In cooperation with the Texas Commission on Environmental Quality

\title{
Summary of Percentages of Zero Daily Mean Streamflow for 712 U.S. Geological Survey Streamflow-Gaging Stations in Texas Through 2003
}

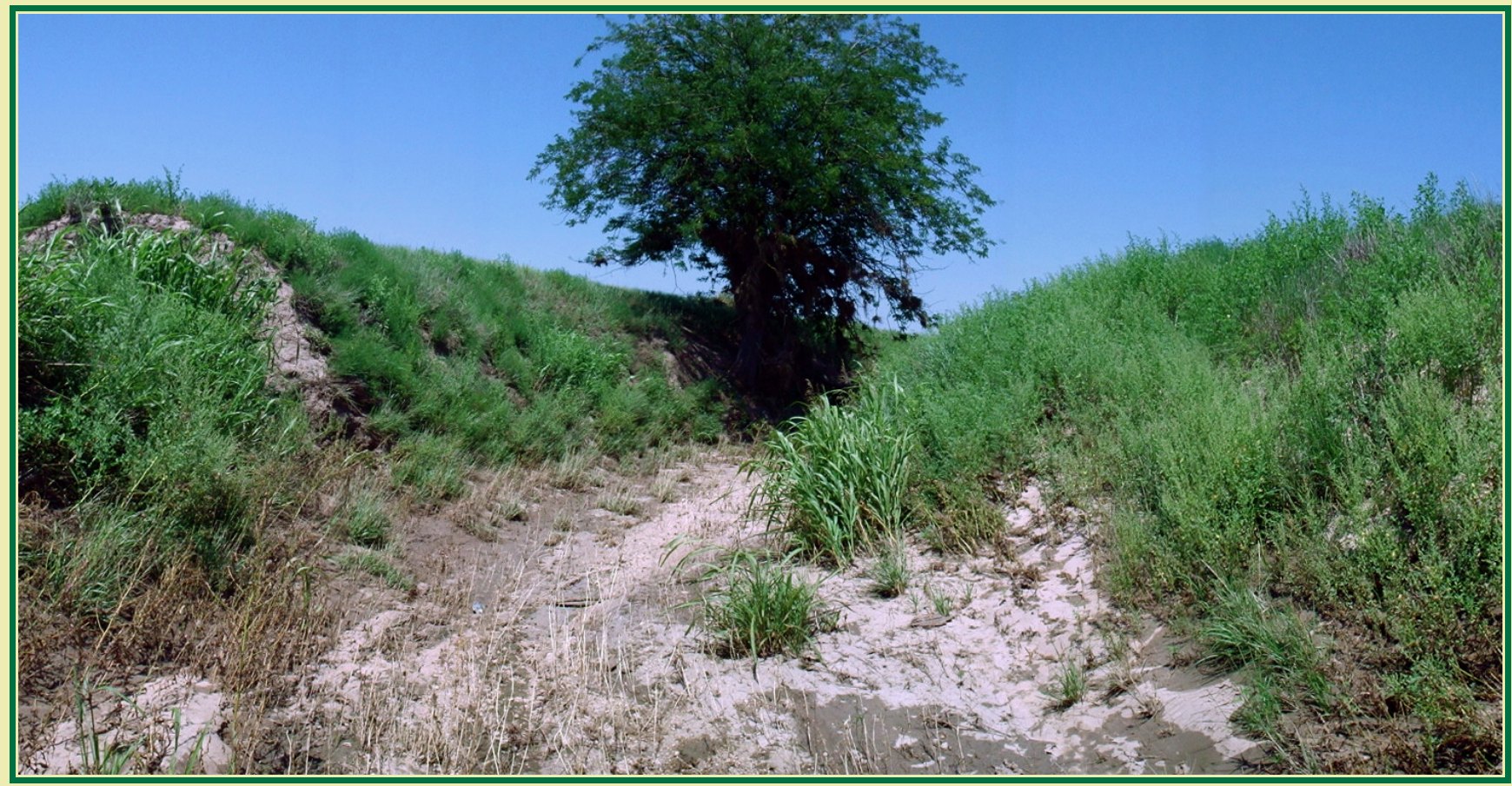

Data Series 247 
Cover. Photo of dry creek bed at station 07233500 Palo Duro Creek near Spearman, Texas, on July 7, 2004 (see page 10 


\section{Summary of Percentages of Zero Daily Mean Streamflow for 712 U.S. Geological Survey Streamflow-Gaging Stations in Texas Through 2003}

By William H. Asquith, Joseph Vrabel, and Meghan C. Roussel

In cooperation with the Texas Commission on Environmental Quality

Data Series 247

U.S. Department of the Interior

U.S. Geological Survey 


\section{U.S. Department of the Interior DIRK KEMPTHORNE, Secretary}

\section{U.S. Geological Survey \\ Mark D. Myers, Director}

U.S. Geological Survey, Reston, Virginia: 2007

For more information aboutthe USGS and its products:

Telephone: 1-888-ASK-USGS

World Wide Web: http://www.usgs.gov/

Any use of trade, product, or firm names in this publication is for descriptive purposes only and does not imply endorsement by the U.S. Government.

Although this report is in the public domain, permission must be secured from the individual copyright owners to reproduce any copyrighted materials contained within this report.

Suggested citation:

Asquith, W.H., Vrabel, Joseph, and Roussel, M.C., 2007, Summary of percentages of zero daily mean streamflow for 712 U.S. Geological Survey streamflow-gaging stations in Texas through 2003: U.S. Geological Survey Data Series 247, 721 p.

Also available at:

http://pubs.usgs.gov/ds/2007/247/ 


\section{Contents}

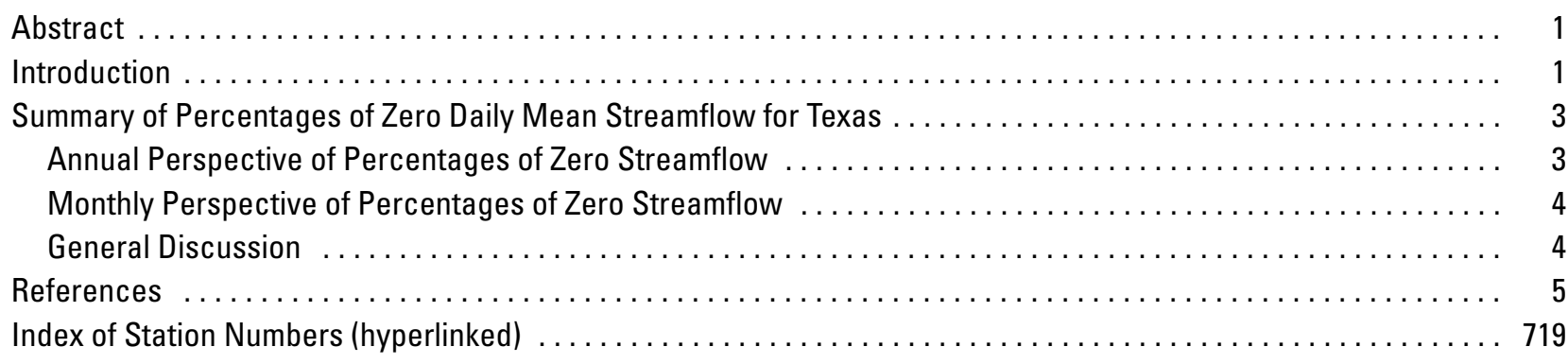

\section{Figures}

1. Maps showing locations of U.S. Geological Survey streamflow-gaging stations in Texas with at least 1 year

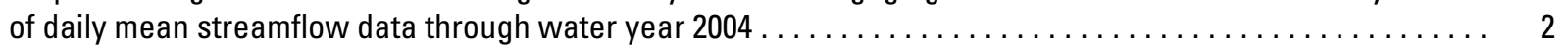

27713 Graphs showing:

2. Analysis of percentage of zero daily mean streamflow for U.S. Geological Survey streamflow-gaging

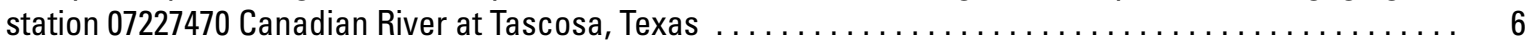

3. Analysis of percentage of zero daily mean streamflow for U.S. Geological Survey streamflow-gaging

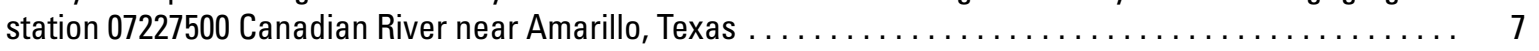

4. Analysis of percentage of zero daily mean streamflow for U.S. Geological Survey streamflow-gaging

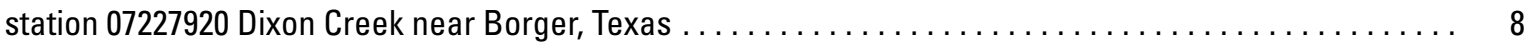

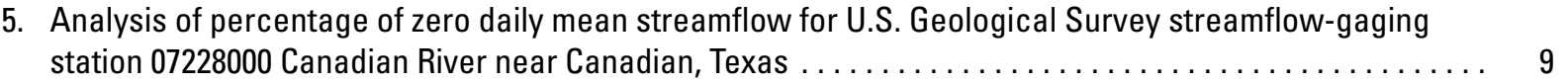

6. Analysis of percentage of zero daily mean streamflow for U.S. Geological Survey streamflow-gaging station 07233500 Palo Duro Creek near Spearman, Texas $\ldots \ldots \ldots, \ldots, \ldots, \ldots \ldots \ldots \ldots \ldots, 10$

7. Analysis of percentage of zero daily mean streamflow for U.S. Geological Survey streamflow-gaging

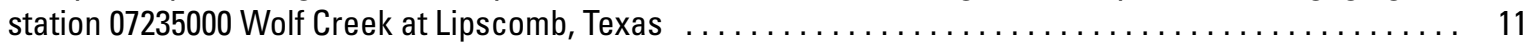

8. Analysis of percentage of zero daily mean streamflow for U.S. Geological Survey streamflow-gaging station 07295500 Tierra Blanca Creek above Buffalo Lake near Umbarger, Texas $\mid \ldots \ldots \ldots \ldots \ldots \ldots \ldots, 12$

9. Analysis of percentage of zero daily mean streamflow for U.S. Geological Survey streamflow-gaging station 07296100 Tierra Blanca Creek below Buffalo Lake near Umbarger, Texas $\ldots \ldots \ldots \ldots \ldots \ldots \ldots \ldots, 13$

10. Analysis of percentage of zero daily mean streamflow for U.S. Geological Survey streamflow-gaging station 07297500 Prairie Dog Town Fork Red River near Canyon, Texas $\ldots \ldots \ldots \ldots \ldots \ldots \ldots \ldots \ldots \ldots \ldots$

11. Analysis of percentage of zero daily mean streamflow for U.S. Geological Survey streamflow-gaging station 07297910 Prairie Dog Town Fork Red River near Wayside, Texas $\ldots \ldots \ldots \ldots \ldots \ldots \ldots \ldots \ldots \ldots$ is

12. Analysis of percentage of zero daily mean streamflow for U.S. Geological Survey streamflow-gaging station 07298000 North Tule Draw at Reservoir near Tulia, Texas $\ldots \ldots \ldots \ldots \ldots \ldots \ldots \ldots \ldots \ldots \ldots \ldots, 16$

13. Analysis of percentage of zero daily mean streamflow for U.S. Geological Survey streamflow-gaging

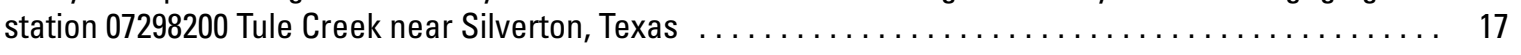

14. Analysis of percentage of zero daily mean streamflow for U.S. Geological Survey streamflow-gaging station 07298500 Prairie Dog Town Fork Red River near Brice, Texas $\ldots \ldots \ldots \ldots \ldots \ldots \ldots \ldots \ldots \ldots, 18$

15. Analysis of percentage of zero daily mean streamflow for U.S. Geological Survey streamflow-gaging station 07299000 Mulberry Creek near Brice, lexas $\ldots \ldots \ldots \ldots \ldots \ldots \ldots \ldots \ldots \ldots \ldots \ldots, 19$

16. Analysis of percentage of zero daily mean streamflow for U.S. Geological Survey streamflow-gaging

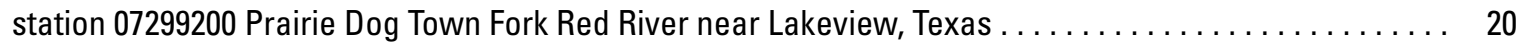

17. Analysis of percentage of zero daily mean streamflow for U.S. Geological Survey streamflow-gaging

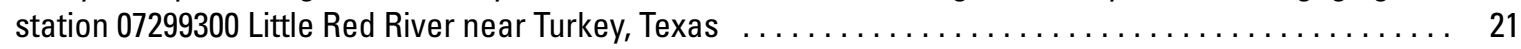


18. Analysis of percentage of zero daily mean streamflow for U.S. Geological Survey streamflow-gaging station 07299500 Prairie Dog lown fork Red River near Estelline, Texas $\ldots \ldots \ldots \ldots \ldots \ldots \ldots \ldots \ldots$

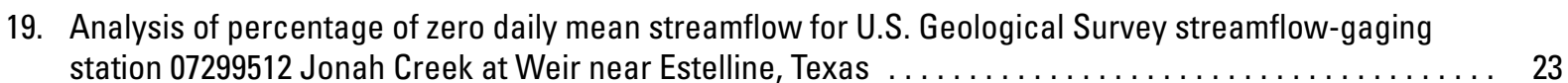

20. Analysis of percentage of zero daily mean streamflow for U.S. Geological Survey streamflow-gaging station 07299514 Jonah Creek below Weir near Estelline, Texas $\ldots \ldots \ldots \ldots \ldots \ldots \ldots \ldots \ldots \ldots \ldots$

21. Analysis of percentage of zero daily mean streamflow for U.S. Geological Survey streamflow-gaging

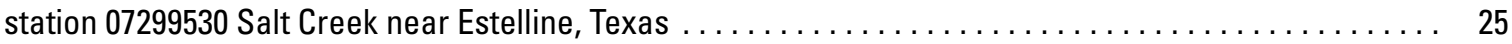

22. Analysis of percentage of zero daily mean streamflow for U.S. Geological Survey streamflow-gaging station 07299540 Prairie Dog Town Fork Red River near Chiddress, Texas $\ldots \ldots \ldots \ldots \ldots \ldots \ldots \ldots \ldots \ldots$

23. Analysis of percentage of zero daily mean streamflow for U.S. Geological Survey streamflow-gaging station 07299570 Red River near Quanah, texas $\ldots \ldots \ldots \ldots \ldots \ldots \ldots \ldots \ldots \ldots \ldots \ldots \ldots \ldots \ldots \ldots$

24. Analysis of percentage of zero daily mean streamflow for U.S. Geological Survey streamflow-gaging station 07299670 Groesbeck Creek at State Highway 6 near Quanah, Texas $\ldots \ldots \ldots \ldots \ldots \ldots \ldots$

25. Analysis of percentage of zero daily mean streamflow for U.S. Geological Survey streamflow-gaging station 07299850 Salt Fork Red River near Clarendon, Texas $\ldots \ldots \ldots \ldots \ldots \ldots \ldots \ldots \ldots \ldots \ldots \ldots \ldots$

26. Analysis of percentage of zero daily mean streamflow for U.S. Geological Survey streamflow-gaging station 07299890 Lelia Lake Creek below Bell Creek near Hedley, Texas $\ldots \ldots \ldots \ldots \ldots \ldots \ldots \ldots \ldots$

27. Analysis of percentage of zero daily mean streamflow for U.S. Geological Survey streamflow-gaging station 07300000 Salt Fork Red River near Wellington, Texas $\ldots \ldots \ldots \ldots \ldots \ldots \ldots \ldots \ldots \ldots \ldots \ldots \ldots$

28. Analysis of percentage of zero daily mean streamflow for U.S. Geological Survey streamflow-gaging

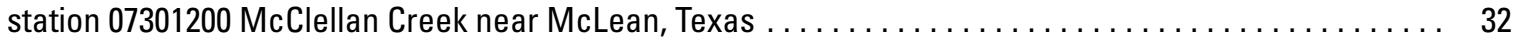

29. Analysis of percentage of zero daily mean streamflow for U.S. Geological Survey streamflow-gaging station 07301300 North Fork Red River near Shamrock, Texas $\ldots \ldots \ldots \ldots \ldots \ldots \ldots \ldots \ldots \ldots \ldots \ldots$

30. Analysis of percentage of zero daily mean streamflow for U.S. Geological Survey streamflow-gaging

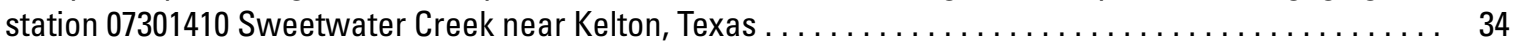

31. Analysis of percentage of zero daily mean streamflow for U.S. Geological Survey streamflow-gaging

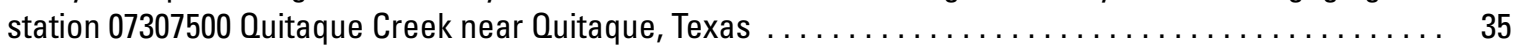

32. Analysis of percentage of zero daily mean streamflow for U.S. Geological Survey streamflow-gaging station 07307600 North Pease River near Childress, Texas $\ldots \ldots \ldots \ldots \ldots \ldots \ldots \ldots \ldots \ldots \ldots \ldots \ldots \ldots$ 33. Analysis of percentage of zero daily mean streamflow for U.S. Geological Survey streamflow-gaging
station 07307750 Middle Pease River at U. S. Highways 62 and 83 near Paducah, Texas $\ldots \ldots \ldots \ldots$. $\ldots \ldots \ldots$

34. Analysis of percentage of zero daily mean streamflow for U.S. Geological Survey streamflow-gaging station 07307760 Middle Pease River near Paducah, Texas $\ldots \ldots \ldots \ldots \ldots \ldots \ldots \ldots \ldots \ldots \ldots \ldots$

35. Analysis of percentage of zero daily mean streamflow for U.S. Geological Survey streamflow-gaging

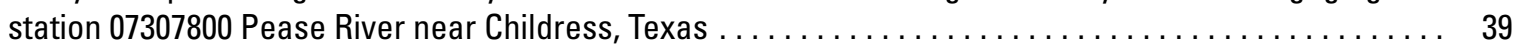

36. Analysis of percentage of zero daily mean streamflow for U.S. Geological Survey streamflow-gaging

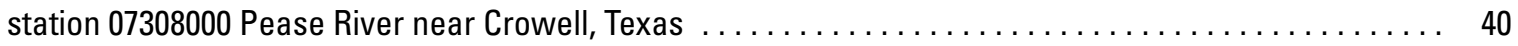

37. Analysis of percentage of zero daily mean streamflow for U.S. Geological Survey streamflow-gaging

38. Analysis of percentage of zero daily mean streamflow for U.S. Geological Survey streamflow-gaging station 07308500 Red River near Burkburnett, Texas $\mid \ldots \ldots \ldots \ldots \ldots \ldots \ldots \ldots \ldots \ldots \ldots \ldots \ldots \ldots$

39. Analysis of percentage of zero daily mean streamflow for U.S. Geological Survey streamflow-gaging

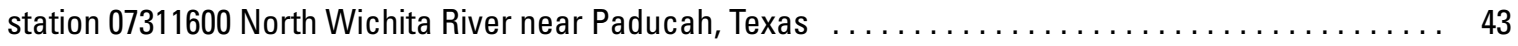

40. Analysis of percentage of zero daily mean streamflow for U.S. Geological Survey streamflow-gaging station 07311622 North Wichita River near Crowell, Texas $\ldots \ldots \ldots \ldots \ldots \ldots \ldots \ldots \ldots \ldots \ldots \ldots \ldots$

41. Analysis of percentage of zero daily mean streamflow for U.S. Geological Survey streamflow-gaging station 07311630 Middle Wichita River near Guthrie, Texas $\ldots \ldots \ldots \ldots \ldots \ldots \ldots \ldots \ldots \ldots \ldots \ldots$ 
42. Analysis of percentage of zero daily mean streamflow for U.S. Geological Survey streamflow-gaging station 07311648 Middle Wichita River near Truscott, Texas $\ldots \ldots \ldots \ldots \ldots \ldots \ldots \ldots \ldots \ldots \ldots, 46$

43. Analysis of percentage of zero daily mean streamflow for U.S. Geological Survey streamflow-gaging

44. Analysis of percentage of zero daily mean streamflow for U.S. Geological Survey streamflow-gaging station 07311780 South Wichita River near Guthrie, Texas $\ldots \ldots \ldots \ldots \ldots \ldots \ldots \ldots \ldots \ldots \ldots \ldots, 48$

45. Analysis of percentage of zero daily mean streamflow for U.S. Geological Survey streamflow-gaging station 07311782 South Wichita River at Low How Dam near Guthrie, lexas $\ldots \ldots \ldots \ldots \ldots \ldots \ldots \ldots$. 49

46. Analysis of percentage of zero daily mean streamflow for U.S. Geological Survey streamflow-gaging station 07311783 South Wichita River below Low How Dam near Guthrie, lexas $\ldots \ldots \ldots \ldots \ldots \ldots \ldots$

47. Analysis of percentage of zero daily mean streamflow for U.S. Geological Survey streamflow-gaging station 07311790 South Wichita River at Ross Ranch near Benjamin, Texas $\ldots \ldots \ldots \ldots \ldots \ldots \ldots \ldots$ 51

48. Analysis of percentage of zero daily mean streamflow for U.S. Geological Survey streamflow-gaging

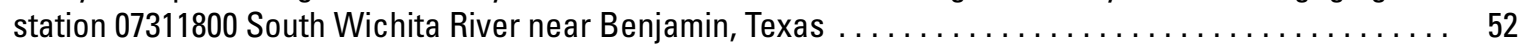

49. Analysis of percentage of zero daily mean streamflow for U.S. Geological Survey streamflow-gaging

50. Analysis of percentage of zero daily mean streamflow for U.S. Geological Survey streamflow-gaging

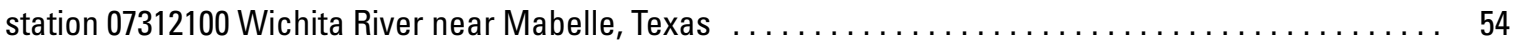

51. Analysis of percentage of zero daily mean streamflow for U.S. Geological Survey streamflow-gaging

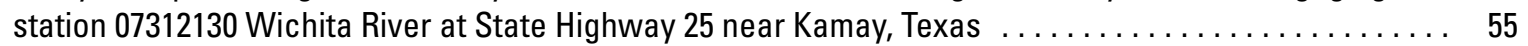

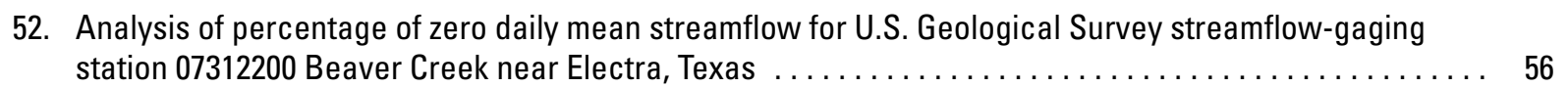

53. Analysis of percentage of zero daily mean streamflow for U.S. Geological Survey streamflow-gaging

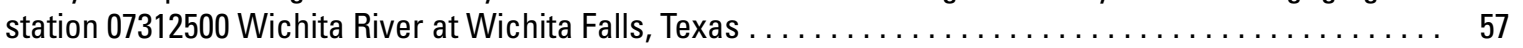

54. Analysis of percentage of zero daily mean streamflow for U.S. Geological Survey streamflow-gaging

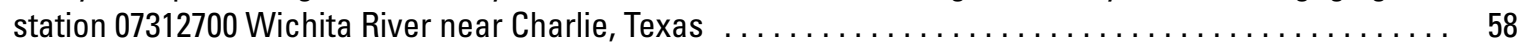

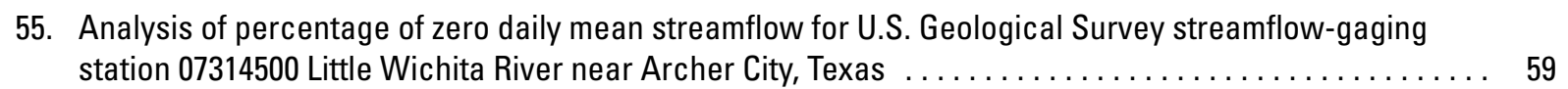

56. Analysis of percentage of zero daily mean streamflow for U.S. Geological Survey streamflow-gaging station 07314900 Little Wichita River above Henrietta, Texas $\ldots \ldots \ldots \ldots \ldots \ldots \ldots \ldots \ldots \ldots \ldots, 60$

57. Analysis of percentage of zero daily mean streamflow for U.S. Geological Survey streamflow-gaging station 07315200 East Fork Little Wichita River near Henrietta, Texas $\ldots \ldots \ldots \ldots \ldots \ldots \ldots \ldots \ldots, 61$

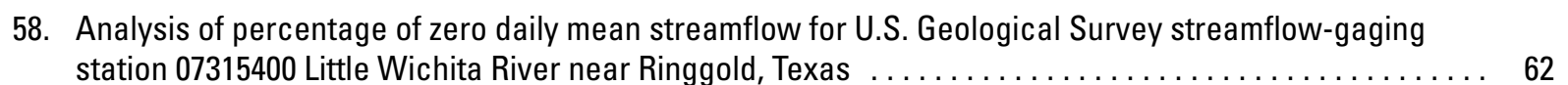

59. Analysis of percentage of zero daily mean streamflow for U.S. Geological Survey streamflow-gaging

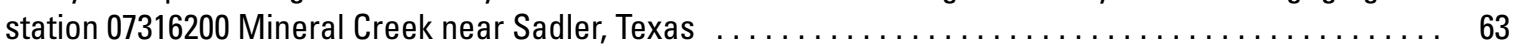

60. Analysis of percentage of zero daily mean streamflow for U.S. Geological Survey streamflow-gaging station 07332600 Bois d'Arc Creek near Randolph, lexas $\ldots \ldots \ldots \ldots \ldots \ldots \ldots \ldots \ldots \ldots \ldots \ldots, 64$

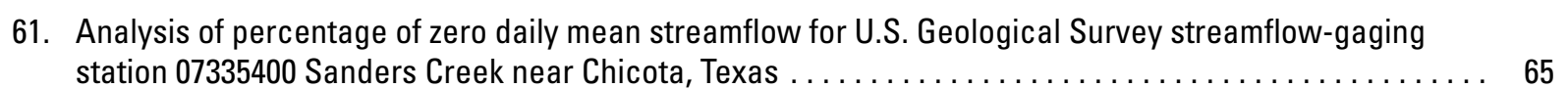

62. Analysis of percentage of zero daily mean streamflow for U.S. Geological Survey streamflow-gaging

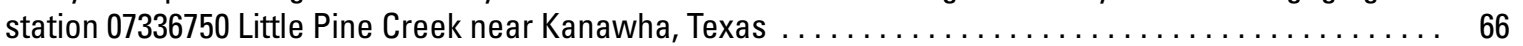

63. Analysis of percentage of zero daily mean streamflow for U.S. Geological Survey streamflow-gaging

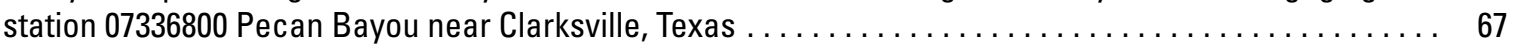

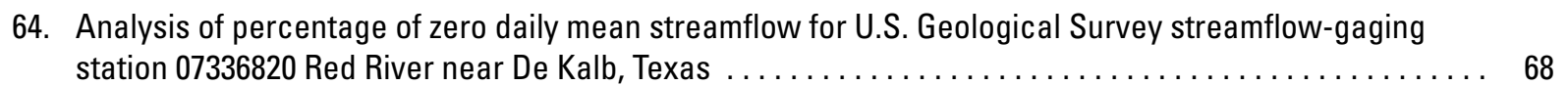

65. Analysis of percentage of zero daily mean streamflow for U.S. Geological Survey streamflow-gaging station 07342465 South Sulphur River at Commerce, Texas $\ldots \ldots \ldots \ldots \ldots \ldots \ldots \ldots \ldots \ldots \ldots, 69$ 
66. Analysis of percentage of zero daily mean streamflow for U.S. Geological Survey streamflow-gaging station 07342470 South Sulphur River near Commerce, Texas $\ldots \ldots \ldots \ldots \ldots \ldots \ldots \ldots \ldots \ldots \ldots, 70$

67. Analysis of percentage of zero daily mean streamflow for U.S. Geological Survey streamflow-gaging

68. Analysis of percentage of zero daily mean streamflow for U.S. Geological Survey streamflow-gaging station 07342500 South Sulphur River near Cooper, Texas $\mid \ldots \ldots \ldots \ldots \ldots \ldots \ldots \ldots \ldots \ldots \ldots, 72$

69. Analysis of percentage of zero daily mean streamflow for U.S. Geological Survey streamflow-gaging station 07343000 North Sulphur River near Cooper, Texas $\ldots \ldots \ldots \ldots \ldots \ldots \ldots \ldots \ldots \ldots \ldots \ldots, 73$

70. Analysis of percentage of zero daily mean streamflow for U.S. Geological Survey streamflow-gaging station 07343200 Sulphur River near Talco, Texas

71. Analysis of percentage of zero daily mean streamflow for U.S. Geological Survey streamflow-gaging station 07343300 Cuthand Creek near Bogata, Texas $\ldots \ldots \ldots \ldots \ldots \ldots \ldots \ldots \ldots \ldots \ldots \ldots \ldots \ldots \ldots, 75$

72. Analysis of percentage of zero daily mean streamflow for U.S. Geological Survey streamflow-gaging

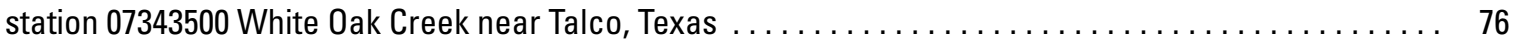

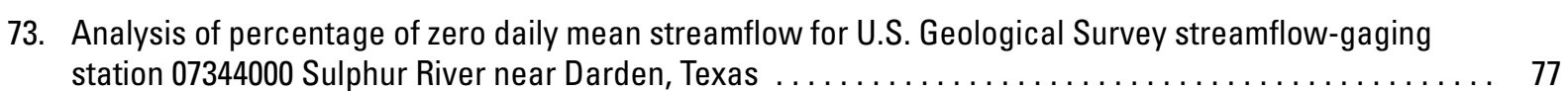

74. Analysis of percentage of zero daily mean streamflow for U.S. Geological Survey streamflow-gaging station 07344482 Big Cypress Creek near Winnsboro, Texas $\ldots \ldots \ldots \ldots \ldots \ldots \ldots \ldots \ldots \ldots \ldots \ldots \ldots, 78$

75. Analysis of percentage of zero daily mean streamflow for U.S. Geological Survey streamflow-gaging station 07344486 Brushy Creek at Scroggins, lexas $\ldots \ldots \ldots \ldots \ldots \ldots \ldots \ldots \ldots \ldots \ldots \ldots \ldots \ldots, 79$

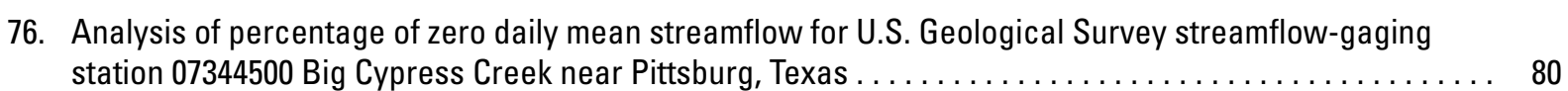

77. Analysis of percentage of zero daily mean streamflow for U.S. Geological Survey streamflow-gaging station 07345000 Boggy Creek near Daingerfield, Texas $\ldots \ldots \ldots \ldots \ldots \ldots \ldots \ldots \ldots \ldots \ldots \ldots \ldots \ldots \ldots \ldots, \quad 81$ 78. Analysis of percentage of zero daily mean streamflow for U.S. Geological Survey streamflow-gaging

79. Analysis of percentage of zero daily mean streamflow for U.S. Geological Survey streamflow-gaging station 07346045 Black Cypress Bayou at Jefferson, Texas $\ldots \ldots \ldots \ldots \ldots \ldots \ldots \ldots \ldots \ldots \ldots \ldots, 83$

80. Analysis of percentage of zero daily mean streamflow for U.S. Geological Survey streamflow-gaging station 07346050 Little Cypress Creek near Ore City, lexas $\ldots \ldots \ldots \ldots \ldots \ldots \ldots \ldots \ldots \ldots \ldots \ldots \ldots \ldots, 84$

81. Analysis of percentage of zero daily mean streamflow for U.S. Geological Survey streamflow-gaging station 07346070 Little Cypress Creek near Jefferson, lexas $\ldots \ldots \ldots \ldots \ldots \ldots \ldots \ldots \ldots \ldots \ldots, 85$

82. Analysis of percentage of zero daily mean streamflow for U.S. Geological Survey streamflow-gaging

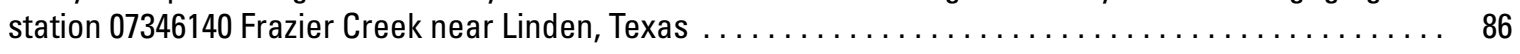

83. Analysis of percentage of zero daily mean streamflow for U.S. Geological Survey streamflow-gaging station 08017200 Cowleech Fork Sabine River at Greenville, Texas $\ldots \ldots \ldots \ldots \ldots \ldots \ldots \ldots \ldots \ldots, 87$

84. Analysis of percentage of zero daily mean streamflow for U.S. Geological Survey streamflow-gaging station 08017300 South Fork Sabine River near Quinlan, lexas $\ldots \ldots \ldots \ldots \ldots \ldots \ldots \ldots \ldots \ldots \ldots, 88$

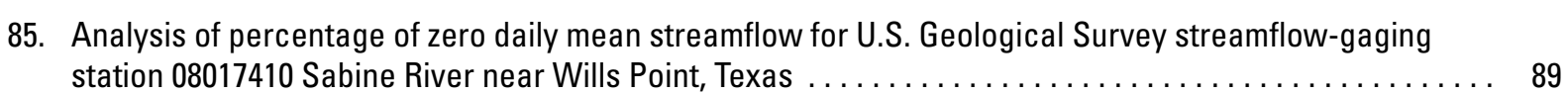

86. Analysis of percentage of zero daily mean streamflow for U.S. Geological Survey streamflow-gaging

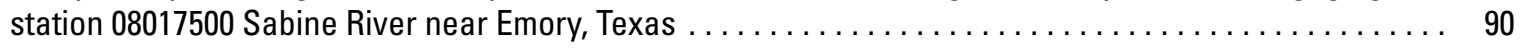
87. \begin{tabular}{l} 
Analysis of percentage of zero daily mean streamflow for U.S. Geological Survey streamflow-gaging \\
\hline station 08018500 Sabine River near Mineola, Texas $\ldots \ldots \ldots \ldots \ldots \ldots \ldots \ldots \ldots \ldots \ldots \ldots \ldots \ldots \ldots$
\end{tabular}

88. Analysis of percentage of zero daily mean streamflow for U.S. Geological Survey streamflow-gaging

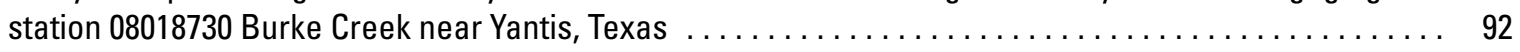

89. Analysis of percentage of zero daily mean streamflow for U.S. Geological Survey streamflow-gaging

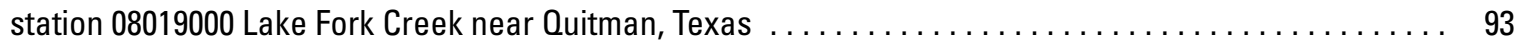


90. Analysis of percentage of zero daily mean streamflow for U.S. Geological Survey streamflow-gaging

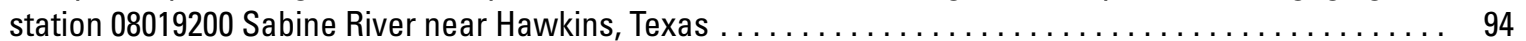

91. Analysis of percentage of zero daily mean streamflow for U.S. Geological Survey streamflow-gaging

92. Analysis of percentage of zero daily mean streamflow for U.S. Geological Survey streamflow-gaging

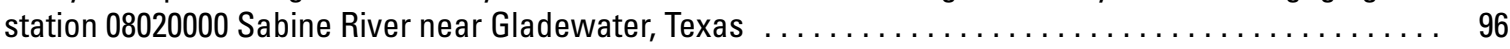

93. Analysis of percentage of zero daily mean streamflow for U.S. Geological Survey streamflow-gaging

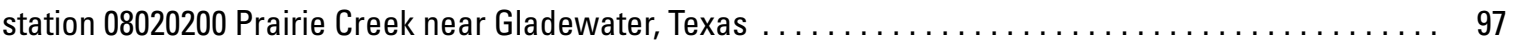

94. Analysis of percentage of zero daily mean streamflow for U.S. Geological Survey streamflow-gaging station 08020450 Sabine River above Longview, lexas $\ldots \ldots \ldots \ldots \ldots \ldots \ldots \ldots \ldots \ldots \ldots \ldots \ldots \ldots \ldots \ldots$

95. Analysis of percentage of zero daily mean streamflow for U.S. Geological Survey streamflow-gaging

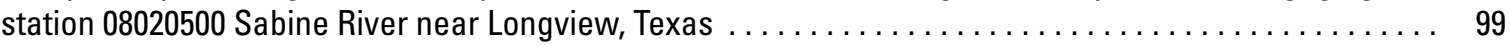

96. Analysis of percentage of zero daily mean streamflow for U.S. Geological Survey streamflow-gaging

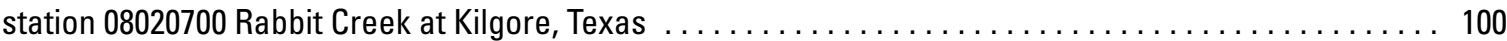

97. Analysis of percentage of zero daily mean streamflow for U.S. Geological Survey streamflow-gaging

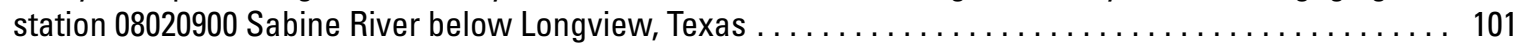

98. Analysis of percentage of zero daily mean streamflow for U.S. Geological Survey streamflow-gaging station 08020960 Mill Creek near Henderson, lexas $\ldots \ldots \ldots \ldots \ldots \ldots \ldots \ldots \ldots \ldots \ldots \ldots \ldots \ldots, 102$

99. Analysis of percentage of zero daily mean streamflow for U.S. Geological Survey streamflow-gaging

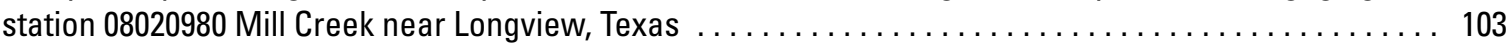

100. Analysis of percentage of zero daily mean streamflow for U.S. Geological Survey streamflow-gaging station 08020990 liawichi Creek near Longview, lexas $\ldots \ldots \ldots \ldots \ldots \ldots \ldots \ldots \ldots \ldots \ldots \ldots, 104$

101. Analysis of percentage of zero daily mean streamflow for U.S. Geological Survey streamflow-gaging

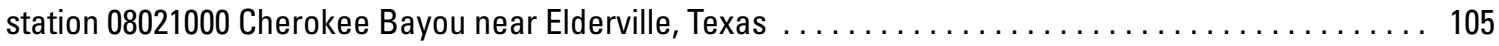

102. Analysis of percentage of zero daily mean streamflow for U.S. Geological Survey streamflow-gaging

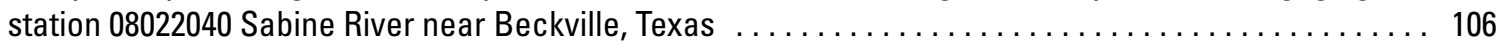

103. Analysis of percentage of zero daily mean streamflow for U.S. Geological Survey streamflow-gaging

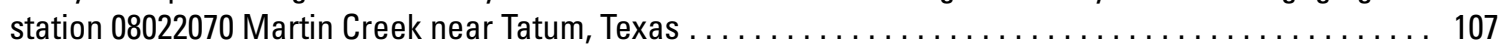

104. Analysis of percentage of zero daily mean streamflow for U.S. Geological Survey streamflow-gaging

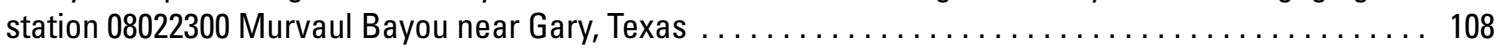

105. Analysis of percentage of zero daily mean streamflow for U.S. Geological Survey streamflow-gaging

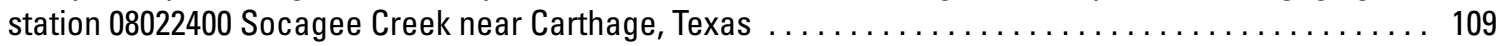

106. Analysis of percentage of zero daily mean streamflow for U.S. Geological Survey streamflow-gaging station 08022500 Sabine River at Logansport, Louisiana $\ldots \ldots \ldots \ldots \ldots \ldots \ldots \ldots \ldots \ldots \ldots \ldots \ldots \ldots \ldots \ldots \ldots$

107. Analysis of percentage of zero daily mean streamflow for U.S. Geological Survey streamflow-gaging

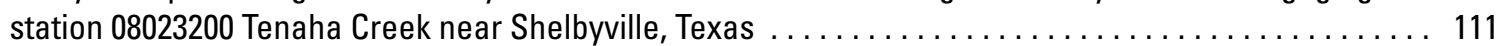

108. Analysis of percentage of zero daily mean streamflow for U.S. Geological Survey streamflow-gaging station 08024400 Sabine River near Milam, Texas $\ldots \ldots \ldots \ldots \ldots \ldots \ldots \ldots \ldots \ldots \ldots, 112$

109. Analysis of percentage of zero daily mean streamflow for U.S. Geological Survey streamflow-gaging

110. Analysis of percentage of zero daily mean streamflow for U.S. Geological Survey streamflow-gaging station 08025307 Mill Creek near Burkeville, Texas $\ldots \ldots \ldots \ldots \ldots \ldots \ldots \ldots \ldots \ldots \ldots \ldots \ldots \ldots, 114$

111. Analysis of percentage of zero daily mean streamflow for U.S. Geological Survey streamflow-gaging station 08025360 Sabine River at Toledo Bend Reservoir near Burkeville, Texas $\ldots \ldots \ldots \ldots \ldots \ldots \ldots 115$

112. Analysis of percentage of zero daily mean streamflow for U.S. Geological Survey streamflow-gaging station 08026000 Sabine River near Burkeville, Texas $\ldots \ldots \ldots \ldots \ldots \ldots \ldots \ldots \ldots \ldots \ldots \ldots \ldots \ldots \ldots, 116$

113. Analysis of percentage of zero daily mean streamflow for U.S. Geological Survey streamflow-gaging station 08028500 Sabine River near Bon Wier, lexas $\ldots \ldots \ldots \ldots \ldots \ldots \ldots \ldots \ldots \ldots \ldots \ldots, 117$ 
viii

114. Analysis of percentage of zero daily mean streamflow for U.S. Geological Survey streamflow-gaging station 08029500 Big Cow Creek near Newton, Texas $\ldots \ldots \ldots, \ldots, \ldots, \ldots, \ldots, \ldots, \ldots, \ldots, 18$

115. Analysis of percentage of zero daily mean streamflow for U.S. Geological Survey streamflow-gaging

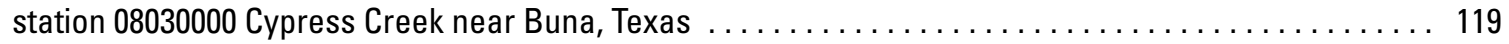

116. Analysis of percentage of zero daily mean streamflow for U.S. Geological Survey streamflow-gaging

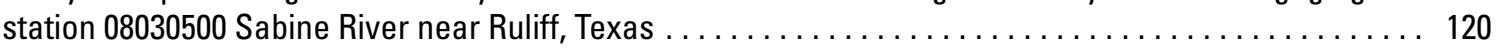

117. Analysis of percentage of zero daily mean streamflow for U.S. Geological Survey streamflow-gaging

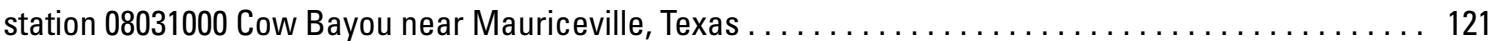

118. Analysis of percentage of zero daily mean streamflow for U.S. Geological Survey streamflow-gaging station 08031200 Kickapoo Creek near Brownsboro, lexas $\ldots \ldots \ldots \ldots \ldots \ldots \ldots \ldots \ldots \ldots \ldots \ldots \ldots \ldots \ldots \ldots, 122$

119. Analysis of percentage of zero daily mean streamflow for U.S. Geological Survey streamflow-gaging

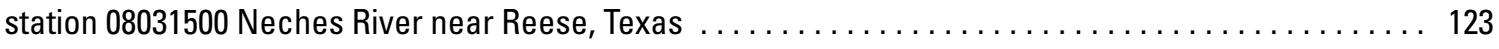

120. Analysis of percentage of zero daily mean streamflow for U.S. Geological Survey streamflow-gaging

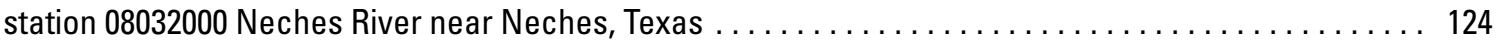

121. Analysis of percentage of zero daily mean streamflow for U.S. Geological Survey streamflow-gaging station 08032500 Neches River near Alto, Texas $\ldots \ldots \ldots \ldots \ldots \ldots \ldots \ldots \ldots \ldots \ldots \ldots \ldots \ldots \ldots \ldots \ldots \ldots \ldots \ldots, 125$

122. Analysis of percentage of zero daily mean streamflow for U.S. Geological Survey streamflow-gaging station 08033000 Neches River near Diboll, Texas $\ldots \ldots \ldots \ldots \ldots \ldots \ldots \ldots \ldots \ldots \ldots \ldots \ldots \ldots \ldots \ldots \ldots, 126$

123. Analysis of percentage of zero daily mean streamflow for U.S. Geological Survey streamflow-gaging

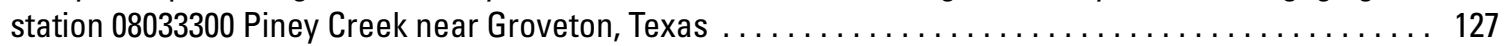

124. Analysis of percentage of zero daily mean streamflow for U.S. Geological Survey streamflow-gaging station 08033500 Neches River near Rockland, lexas $\ldots \ldots \ldots \ldots \ldots \ldots \ldots \ldots \ldots \ldots \ldots \ldots \ldots \ldots, 128$

125. Analysis of percentage of zero daily mean streamflow for U.S. Geological Survey streamflow-gaging

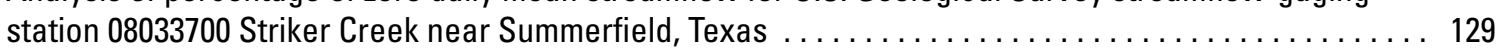

126. Analysis of percentage of zero daily mean streamflow for U.S. Geological Survey streamflow-gaging station 08033900 East Fork Angelina River near Cushing, lexas $\ldots \ldots \ldots \ldots \ldots \ldots \ldots \ldots \ldots \ldots, 130$

127. Analysis of percentage of zero daily mean streamflow for U.S. Geological Survey streamflow-gaging

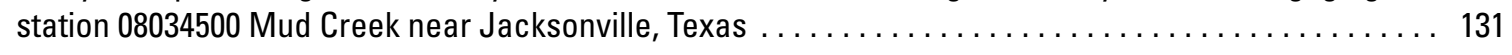

128. Analysis of percentage of zero daily mean streamflow for U.S. Geological Survey streamflow-gaging station 08035000 Mud Creek at Ponta, lexas $\ldots \ldots \ldots \ldots \ldots \ldots \ldots \ldots \ldots \ldots \ldots \ldots \ldots \ldots \ldots \ldots \ldots, 132$

129. Analysis of percentage of zero daily mean streamflow for U.S. Geological Survey streamflow-gaging

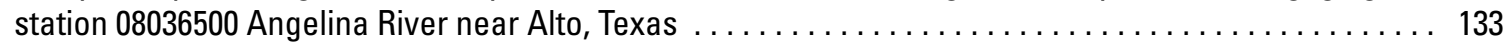

130. Analysis of percentage of zero daily mean streamflow for U.S. Geological Survey streamflow-gaging station 08037000 Angelina River near Lufkin, Texas $\ldots \ldots \ldots \ldots \ldots \ldots \ldots \ldots \ldots \ldots \ldots \ldots \ldots \ldots \ldots \ldots \ldots, 134$

131. Analysis of percentage of zero daily mean streamflow for U.S. Geological Survey streamflow-gaging station 08037050 Bayou Lanana at Nacogdoches, lexas $\ldots \ldots \ldots \ldots \ldots \ldots \ldots \ldots \ldots \ldots \ldots \ldots \ldots, 135$

132. Analysis of percentage of zero daily mean streamflow for U.S. Geological Survey streamflow-gaging station 08037500 Arenoso Creek near San Augustine, lexas $\ldots \ldots \ldots \ldots \ldots \ldots \ldots \ldots \ldots \ldots \ldots \ldots, 136$

133. Analysis of percentage of zero daily mean streamflow for U.S. Geological Survey streamflow-gaging

134. Analysis of percentage of zero daily mean streamflow for U.S. Geological Survey streamflow-gaging station 08038500 Angelina River near Zavalla, Texas $\ldots \ldots \ldots \ldots \ldots \ldots \ldots \ldots \ldots \ldots, 138$ 135. Analysis of percentage of zero daily mean streamflow for U.S. Geological Survey streamflow-gaging

136. Analysis of percentage of zero daily mean streamflow for U.S. Geological Survey streamflow-gaging station 08039500 Angelina River near Ebenezer, Texas $\ldots \ldots \ldots \ldots \ldots \ldots \ldots \ldots \ldots \ldots \ldots \ldots, 140$

137. Analysis of percentage of zero daily mean streamflow for U.S. Geological Survey streamflow-gaging station 08040600 Neches River near Town Bluff, Texas $\ldots \ldots \ldots \ldots \ldots \ldots \ldots \ldots \ldots \ldots \ldots \ldots \ldots, 141$ 
138. Analysis of percentage of zero daily mean streamflow for U.S. Geological Survey streamflow-gaging station 08041000 Neches River at Evadale, Texas $\ldots \ldots \ldots \ldots \ldots \ldots \ldots \ldots \ldots \ldots \ldots \ldots \ldots \ldots \ldots \ldots 142$

139. Analysis of percentage of zero daily mean streamflow for U.S. Geological Survey streamflow-gaging station 08041500 Village Creek near Kountze, Texas $\ldots \ldots \ldots \ldots \ldots \ldots \ldots \ldots \ldots \ldots \ldots \ldots \ldots \ldots \ldots 143$

140. Analysis of percentage of zero daily mean streamflow for U.S. Geological Survey streamflow-gaging station 08041700 Pine sland Bayou near Sour Lake, Texas $\ldots \ldots \ldots \ldots \ldots \ldots \ldots \ldots \ldots \ldots \ldots \ldots \ldots$

141. Analysis of percentage of zero daily mean streamflow for U.S. Geological Survey streamflow-gaging station 08042000 Taylor Bayou near LaBelle, Texas $\ldots \ldots \ldots \ldots \ldots \ldots \ldots \ldots \ldots \ldots \ldots \ldots \ldots \ldots \ldots 145$

142. Analysis of percentage of zero daily mean streamflow for U.S. Geological Survey streamflow-gaging station 08042500 Hillebrandt Bayou near Lovell Lake, Texas $\ldots \ldots \ldots \ldots \ldots \ldots \ldots \ldots \ldots \ldots \ldots \ldots$

143. Analysis of percentage of zero daily mean streamflow for U.S. Geological Survey streamflow-gaging station 08042700 North Creek near Jacksboro, Texas $\ldots \ldots \ldots \ldots \ldots \ldots \ldots \ldots \ldots \ldots \ldots \ldots \ldots \ldots 14$

144. Analysis of percentage of zero daily mean streamflow for U.S. Geological Survey streamflow-gaging station 08042800 West Fork Trinity River near Jacksboro, Texas $\ldots \ldots \ldots \ldots \ldots \ldots \ldots \ldots \ldots \ldots \ldots \ldots$

145. Analysis of percentage of zero daily mean streamflow for U.S. Geological Survey streamflow-gaging station 08042900 Beans Creek at Wizard Wells, Texas $\ldots \ldots \ldots \ldots \ldots \ldots \ldots \ldots \ldots \ldots \ldots \ldots \ldots \ldots$

146. Analysis of percentage of zero daily mean streamflow for U.S. Geological Survey streamflow-gaging station 08043500 West Fork Trinity River at Bridgeport, Texas $\ldots \ldots \ldots \ldots \ldots \ldots \ldots \ldots \ldots \ldots \ldots \ldots$

147. $\frac{\text { Analysis of percentage of zero daily mean streamflow for U.S. Geological Survey streamflow-gaging }}{\text { station 08043950 Big Sandy Creek near Chico, Texas } \ldots \ldots \ldots \ldots \ldots \ldots \ldots \ldots \ldots \ldots \ldots \ldots \ldots \ldots \ldots \ldots \ldots}$

148. Analysis of percentage of zero daily mean streamflow for U.S. Geological Survey streamflow-gaging station 08044000 Big Sandy Creek near Bridgeport, Texas $\ldots \ldots \ldots \ldots \ldots \ldots \ldots \ldots \ldots \ldots \ldots \ldots \ldots 152$

149. Analysis of percentage of zero daily mean streamflow for U.S. Geological Survey streamflow-gaging station 08044135 Garrett Creek near Paradise, Texas $\ldots \ldots \ldots \ldots \ldots \ldots \ldots \ldots \ldots \ldots \ldots \ldots \ldots \ldots$

150. Analysis of percentage of zero daily mean streamflow for U.S. Geological Survey streamflow-gaging

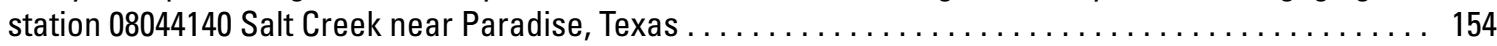

151. Analysis of percentage of zero daily mean streamflow for U.S. Geological Survey streamflow-gaging station 08044500 West fork Trinity River near Boyd, Texas $\ldots \ldots \ldots \ldots \ldots \ldots \ldots \ldots \ldots \ldots \ldots$

152. Analysis of percentage of zero daily mean streamflow for U.S. Geological Survey streamflow-gaging

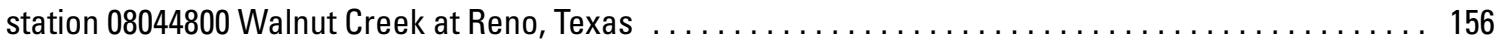

153. Analysis of percentage of zero daily mean streamflow for U.S. Geological Survey streamflow-gaging station 08045500 West Fork Trinity River at Lake Worth Dam above Fort Worth, Texas $\ldots \ldots \ldots \ldots \ldots 157$

154. Analysis of percentage of zero daily mean streamflow for U.S. Geological Survey streamflow-gaging station 08045850 Clear Fork Trinity River near Weatherford, Texas $\ldots \ldots \ldots \ldots \ldots \ldots \ldots \ldots \ldots \ldots \ldots$

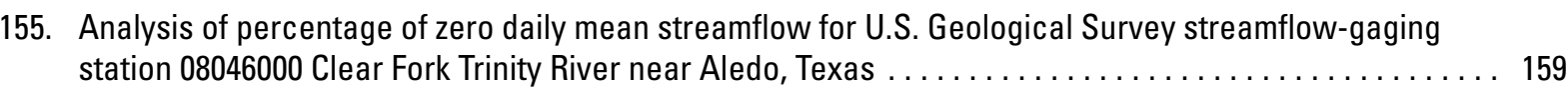

156. Analysis of percentage of zero daily mean streamflow for U.S. Geological Survey streamflow-gaging station 08047000 Clear Fork Trinity River near Benbrook, Texas $\ldots \ldots \ldots \ldots \ldots \ldots \ldots \ldots \ldots \ldots \ldots \ldots$

157. Analysis of percentage of zero daily mean streamflow for U.S. Geological Survey streamflow-gaging

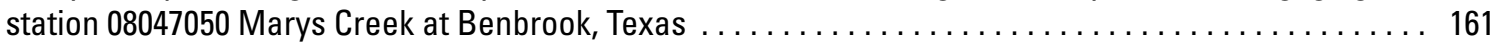

158. Analysis of percentage of zero daily mean streamflow for U.S. Geological Survey streamflow-gaging station 08047500 Clear Fork Trinity River at Fort Worth, Texas $\ldots \ldots \ldots \ldots \ldots \ldots \ldots \ldots \ldots \ldots \ldots \ldots 162$

159. Analysis of percentage of zero daily mean streamflow for U.S. Geological Survey streamflow-gaging station 08048000 West Fork Trinity River at Fort Worth, Texas $\ldots \ldots \ldots \ldots \ldots \ldots \ldots \ldots \ldots \ldots \ldots \ldots$

160. Analysis of percentage of zero daily mean streamflow for U.S. Geological Survey streamflow-gaging station 08048520 Sycamore Creek at Interstate Highway 35 West, Fort Worth, Texas $\ldots \ldots \ldots \ldots \ldots$

161. Analysis of percentage of zero daily mean streamflow for U.S. Geological Survey streamflow-gaging station 08048530 Sycamore Creek Tributary above Semenary South Shopping Center, Fort Worth,

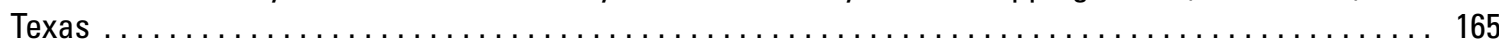


162. Analysis of percentage of zero daily mean streamflow for U.S. Geological Survey streamflow-gaging station 08048540 Sycamore Creek Tributary at Interstate Highway 35West, Fort Worth, Texas $\ldots \ldots \ldots 166$

163. Analysis of percentage of zero daily mean streamflow for U.S. Geological Survey streamflow-gaging station 08048543 West Fork Trinity River at Beach Street, Fort Worth, Texas $\ldots \ldots \ldots \ldots \ldots \ldots \ldots$

164. Analysis of percentage of zero daily mean streamflow for U.S. Geological Survey streamflow-gaging station 08048600 Dry Branch at Fain Street, Fort Worth, Texas $\mid \ldots \ldots \ldots \ldots \ldots \ldots \ldots \ldots \ldots \ldots \ldots$

165. Analysis of percentage of zero daily mean streamflow for U.S. Geological Survey streamflow-gaging station 08048800 Big Fossil Creek at Haltom City, Texas $\ldots \ldots \ldots \ldots \ldots \ldots \ldots \ldots \ldots \ldots \ldots \ldots \ldots$

166. Analysis of percentage of zero daily mean streamflow for U.S. Geological Survey streamflow-gaging station 08048850 Little Fossit Creek at Mesquite Street, Fort Worth, Texas $\ldots \ldots \ldots \ldots \ldots \ldots \ldots \ldots$

167. Analysis of percentage of zero daily mean streamflow for U.S. Geological Survey streamflow-gaging station 08048970 Village Creek at Everman, Texas $\ldots \ldots \ldots \ldots \ldots \ldots \ldots \ldots \ldots \ldots \ldots \ldots \ldots \ldots \ldots$

168. Analysis of percentage of zero daily mean streamflow for U.S. Geological Survey streamflow-gaging station 08048980 Village Creek at Kennedale, Texas $\ldots \ldots \ldots \ldots \ldots \ldots \ldots \ldots \ldots \ldots \ldots \ldots \ldots \ldots \ldots 172$

169. Analysis of percentage of zero daily mean streamflow for U.S. Geological Survey streamflow-gaging station 08049000 Village Creek near Handley, Texas $\ldots \ldots \ldots \ldots \ldots \ldots \ldots \ldots \ldots \ldots \ldots \ldots \ldots \ldots$

170. Analysis of percentage of zero daily mean streamflow for U.S. Geological Survey streamflow-gaging station 08049500 West Fork Trinity River at Grand Prairie, Texas $\ldots \ldots \ldots \ldots \ldots \ldots \ldots \ldots \ldots \ldots \ldots 174$

171. Analysis of percentage of zero daily mean streamflow for U.S. Geological Survey streamflow-gaging station 08049550 Big Bear Creek near Grapevine, Texas $\ldots \ldots \ldots \ldots \ldots \ldots \ldots \ldots \ldots \ldots \ldots \ldots \ldots 175$

172. Analysis of percentage of zero daily mean streamflow for U.S. Geological Survey streamflow-gaging station 08049553 Big Bear Creek at Euless/Grapevine Road near Grapevine, Texas $\ldots \ldots \ldots \ldots \ldots \ldots$

173. Analysis of percentage of zero daily mean streamflow for U.S. Geological Survey streamflow-gaging station 08049556 Unnamed Tributary Big Bear Creek (Outflow 19) near Euless, Texas $\ldots \ldots \ldots \ldots \ldots 177$

174. Analysis of percentage of zero daily mean streamflow for U.S. Geological Survey streamflow-gaging station 08049565 Trigg Branch at DFW Airport near Euless, Texas $\ldots \ldots \ldots \ldots \ldots \ldots \ldots \ldots \ldots \ldots$

175. Analysis of percentage of zero daily mean streamflow for U.S. Geological Survey streamflow-gaging station $08049569 \mathrm{Big}$ Bear Creek at State Highway 183 near Euless, Texas $\ldots \ldots \ldots \ldots \ldots \ldots$

176. Analysis of percentage of zero daily mean streamflow for U.S. Geological Survey streamflow-gaging station 08049580 Mountain Creek near Venus, Texas $\ldots \ldots \ldots \ldots \ldots \ldots \ldots \ldots \ldots \ldots \ldots \ldots \ldots$

177. Analysis of percentage of zero daily mean streamflow for U.S. Geological Survey streamflow-gaging

178. Analysis of percentage of zero daily mean streamflow for U.S. Geological Survey streamflow-gaging station 08049700 Walnut Creek near Mansfield, Texas $\ldots \ldots \ldots \ldots \ldots \ldots \ldots \ldots \ldots \ldots \ldots \ldots \ldots \ldots$

179. Analysis of percentage of zero daily mean streamflow for U.S. Geological Survey streamflow-gaging station 08050000 Mountain Creek near Grand Prairie, Texas $\ldots \ldots \ldots \ldots \ldots \ldots \ldots \ldots \ldots \ldots$

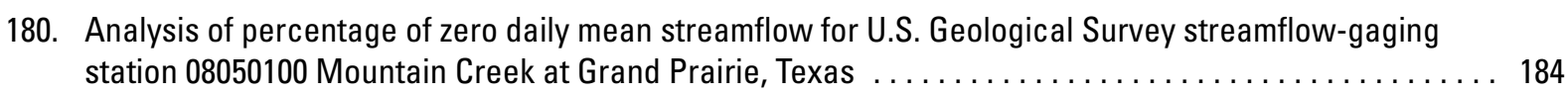

181. Analysis of percentage of zero daily mean streamflow for U.S. Geological Survey streamflow-gaging

182. Analysis of percentage of zero daily mean streamflow for U.S. Geological Survey streamflow-gaging station 08050400 Elm Fork Trinity River at Gainesville, Texas $\ldots \ldots \ldots \ldots \ldots \ldots \ldots \ldots \ldots \ldots$

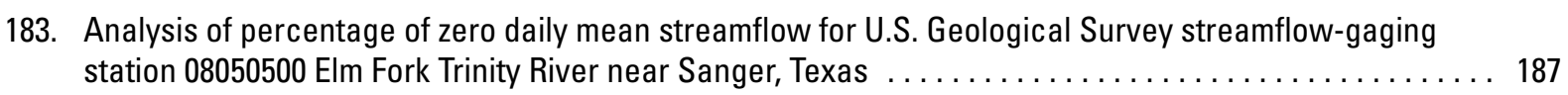

184. Analysis of percentage of zero daily mean streamflow for U.S. Geological Survey streamflow-gaging station 08050800 Timber Creek near Collinsville, Texas $\ldots \ldots \ldots \ldots \ldots \ldots \ldots \ldots \ldots \ldots \ldots \ldots \ldots$

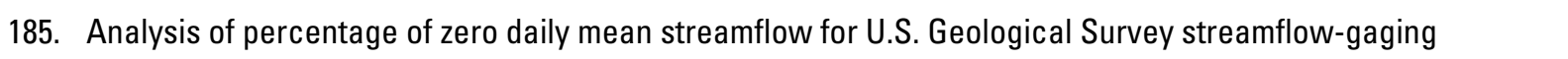
station 08050840 Range Creek near Collinsville, lexas $\ldots \ldots \ldots \ldots \ldots \ldots \ldots \ldots \ldots \ldots \ldots \ldots$ 
186. Analysis of percentage of zero daily mean streamflow for U.S. Geological Survey streamflow-gaging station 08051000 sle du Bois Creek near Pilot Point, Texas $\ldots \ldots \ldots \ldots \ldots \ldots \ldots \ldots \ldots \ldots \ldots \ldots$

187. Analysis of percentage of zero daily mean streamflow for U.S. Geological Survey streamflow-gaging station 08051130 Elm Fork Trinity River near Pilot Point, Texas $\ldots \ldots \ldots \ldots \ldots \ldots \ldots \ldots \ldots \ldots \ldots \ldots 1$

188. Analysis of percentage of zero daily mean streamflow for U.S. Geological Survey streamflow-gaging station 08051500 Clear Creek near Sanger, Texas $\ldots \ldots \ldots \ldots \ldots \ldots \ldots \ldots \ldots \ldots \ldots \ldots \ldots \ldots \ldots$

189. Analysis of percentage of zero daily mean streamflow for U.S. Geological Survey streamflow-gaging station 08052000 Elm Fork Trinity River near Denton, lexas $\ldots \ldots \ldots \ldots \ldots \ldots \ldots \ldots \ldots \ldots \ldots \ldots \ldots$

190. Analysis of percentage of zero daily mean streamflow for U.S. Geological Survey streamflow-gaging station 08052650 Little Elm Creek near Celina, Texas $\ldots \ldots \ldots \ldots \ldots \ldots \ldots \ldots \ldots \ldots \ldots \ldots \ldots \ldots 194$

191. Analysis of percentage of zero daily mean streamflow for U.S. Geological Survey streamflow-gaging station 08052700 Little Elm Creek near Aubrey, Texas $\ldots \ldots \ldots \ldots \ldots \ldots \ldots \ldots \ldots \ldots \ldots \ldots \ldots \ldots$

192. Analysis of percentage of zero daily mean streamflow for U.S. Geological Survey streamflow-gaging station 08052780 Hickory Creek at Denton, Texas $\ldots \ldots \ldots \ldots \ldots \ldots \ldots \ldots \ldots \ldots \ldots \ldots \ldots \ldots$

193. Analysis of percentage of zero daily mean streamflow for U.S. Geological Survey streamflow-gaging station 08053000 Elm Fork Trinity River near Lewisville, Texas $\ldots \ldots \ldots \ldots \ldots \ldots \ldots \ldots \ldots \ldots \ldots \ldots 19 \ldots \ldots$

194. Analysis of percentage of zero daily mean streamflow for U.S. Geological Survey streamflow-gaging station 08053500 Denton Creek near Justin, Texas $\ldots \ldots \ldots \ldots \ldots \ldots \ldots \ldots \ldots \ldots \ldots \ldots \ldots \ldots \ldots$

195. Analysis of percentage of zero daily mean streamflow for U.S. Geological Survey streamflow-gaging station 08054000 Denton Creek near Roanoke, lexas $\ldots \ldots \ldots \ldots \ldots \ldots \ldots \ldots \ldots \ldots \ldots \ldots \ldots \ldots$

196. Analysis of percentage of zero daily mean streamflow for U.S. Geological Survey streamflow-gaging

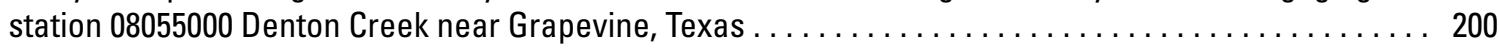

197. Analysis of percentage of zero daily mean streamflow for U.S. Geological Survey streamflow-gaging station 08055500 Elm Fork Trinity River near Carrollton, Texas $\ldots \ldots \ldots \ldots \ldots \ldots \ldots \ldots \ldots \ldots \ldots \ldots 201$

198. Analysis of percentage of zero daily mean streamflow for U.S. Geological Survey streamflow-gaging

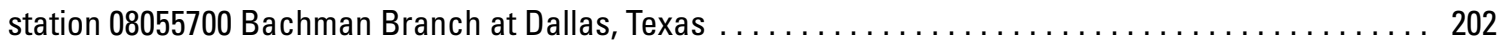

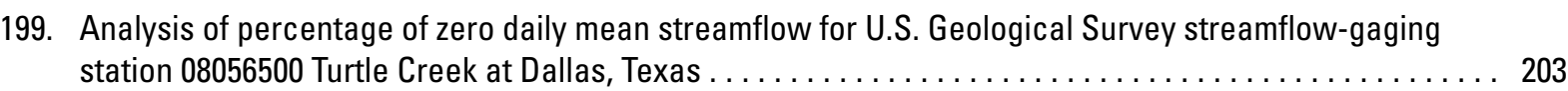

200. Analysis of percentage of zero daily mean streamflow for U.S. Geological Survey streamflow-gaging

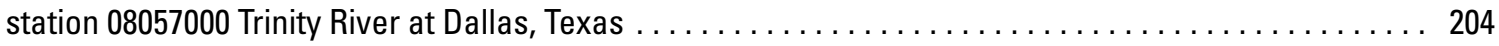

201. Analysis of percentage of zero daily mean streamflow for U.S. Geological Survey streamflow-gaging station 08057100White Rock Creek at Keller Springs Road, Dallas, lexas $\ldots \ldots \ldots \ldots \ldots \ldots \ldots \ldots$

202. Analysis of percentage of zero daily mean streamflow for U.S. Geological Survey streamflow-gaging station 08057200 White Rock Creek at Greenville Avenue, Dallas, Texas $\ldots \ldots \ldots \ldots \ldots \ldots \ldots \ldots$

203. Analysis of percentage of zero daily mean streamflow for U.S. Geological Survey streamflow-gaging station 08057300White Rock Creek at White Rock Lake, Dallas, Texas $\ldots \ldots \ldots \ldots \ldots \ldots \ldots \ldots$

204. Analysis of percentage of zero daily mean streamflow for U.S. Geological Survey streamflow-gaging

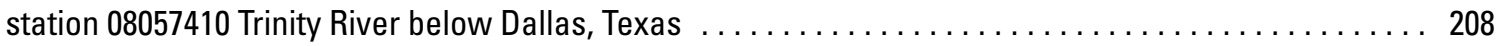

205. Analysis of percentage of zero daily mean streamflow for U.S. Geological Survey streamflow-gaging station 08057445 Prairie Creek at U. S. Highway 175 , Dallas, Texas $\ldots \ldots \ldots \ldots \ldots \ldots \ldots \ldots \ldots \ldots$

206. Analysis of percentage of zero daily mean streamflow for U.S. Geological Survey streamflow-gaging station 08057448 Trinity River near Wilmer, Texas $\ldots \ldots \ldots \ldots \ldots \ldots \ldots \ldots \ldots \ldots \ldots \ldots \ldots \ldots$

207. Analysis of percentage of zero daily mean streamflow for U.S. Geological Survey streamflow-gaging station 08057450 Tenmile Creek at State Highway 342, Lancaster, Texas $\ldots \ldots \ldots \ldots \ldots \ldots \ldots \ldots \ldots$

208. Analysis of percentage of zero daily mean streamflow for U.S. Geological Survey streamflow-gaging station 08058500 Honey Creek near McKinney, texas $\ldots \ldots \ldots \ldots \ldots \ldots \ldots \ldots \ldots \ldots \ldots \ldots \ldots \ldots 212$

209. Analysis of percentage of zero daily mean streamflow for U.S. Geological Survey streamflow-gaging station 08058900 East Fork Trinity River at McKinney, Texas $\ldots \ldots \ldots \ldots \ldots \ldots \ldots \ldots \ldots \ldots \ldots \ldots$ 
210. Analysis of percentage of zero daily mean streamflow for U.S. Geological Survey streamflow-gaging station 08059000 East Fork Trinity River near McKinney, Texas $\ldots \ldots \ldots \ldots \ldots \ldots \ldots \ldots \ldots \ldots \ldots \ldots \ldots \ldots \ldots \ldots$

211. Analysis of percentage of zero daily mean streamflow for U.S. Geological Survey streamflow-gaging

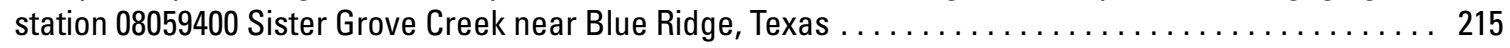

212. Analysis of percentage of zero daily mean streamflow for U.S. Geological Survey streamflow-gaging

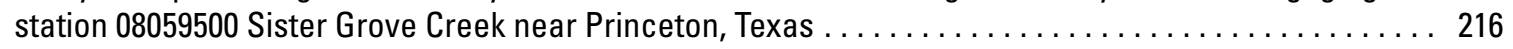

213. Analysis of percentage of zero daily mean streamflow for U.S. Geological Survey streamflow-gaging station 08060000 East Fork Trinity River above Pilot Grove near Lavon, Texas $\ldots \ldots \ldots \ldots \ldots \ldots \ldots \ldots, 217$

214. Analysis of percentage of zero daily mean streamflow for U.S. Geological Survey streamflow-gaging station 08061000 East Fork Trinity River near Lavon, Texas $\ldots \ldots \ldots \ldots \ldots \ldots \ldots \ldots \ldots \ldots \ldots \ldots \ldots \ldots, 218$ 215. Analysis of percentage of zero daily mean streamflow for U.S. Geological Survey streamflow-gaging

216. Analysis of percentage of zero daily mean streamflow for U.S. Geological Survey streamflow-gaging

217. Analysis of percentage of zero daily mean streamflow for U.S. Geological Survey streamflow-gaging

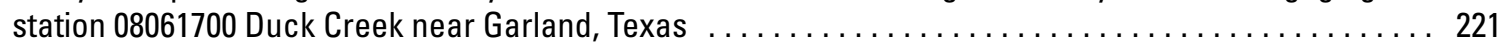

218. Analysis of percentage of zero daily mean streamflow for U.S. Geological Survey streamflow-gaging

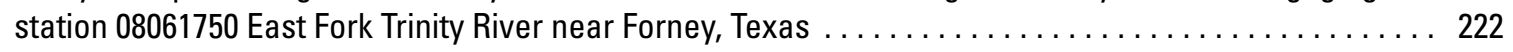
219. $\frac{\text { Analysis of percentage of zero daily mean streamflow for U.S. Geological Survey streamflow-gaging }}{\text { station 08061950 South Mesquite Creek at Mercury Road, North Mesquite, lexas } \ldots \ldots \ldots \ldots \ldots \ldots \ldots 223}$

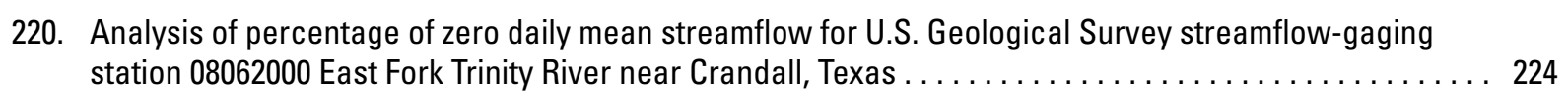

221. Analysis of percentage of zero daily mean streamflow for U.S. Geological Survey streamflow-gaging

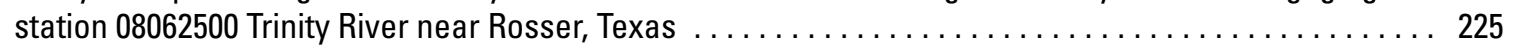

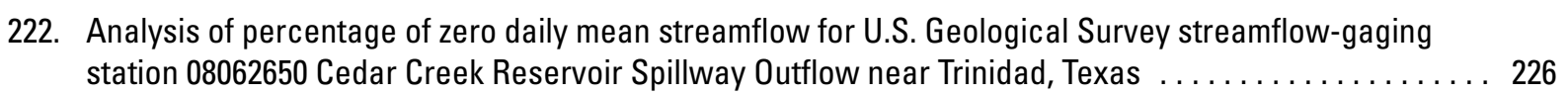

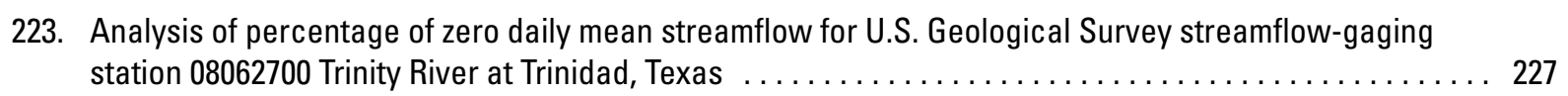

224. Analysis of percentage of zero daily mean streamflow for U.S. Geological Survey streamflow-gaging station 08062800 Cedar Creek near Kemp, lexas $\ldots \ldots \ldots \ldots \ldots \ldots \ldots \ldots \ldots \ldots \ldots \ldots \ldots \ldots \ldots, 228$

225. Analysis of percentage of zero daily mean streamflow for U.S. Geological Survey streamflow-gaging

226. Analysis of percentage of zero daily mean streamflow for U.S. Geological Survey streamflow-gaging

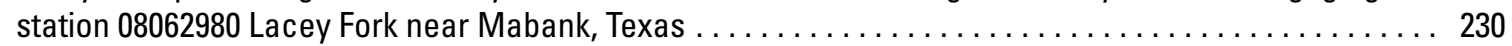

227. Analysis of percentage of zero daily mean streamflow for U.S. Geological Survey streamflow-gaging

228. Analysis of percentage of zero daily mean streamflow for U.S. Geological Survey streamflow-gaging station 08063003 South Twin Creek near Eustace, lexas $\ldots \ldots \ldots \ldots \ldots \ldots \ldots \ldots \ldots \ldots \ldots \ldots \ldots \ldots \ldots \ldots, 232$

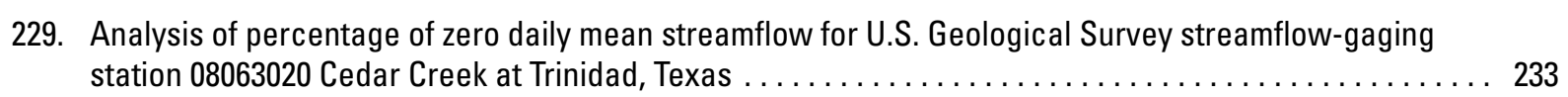

230. Analysis of percentage of zero daily mean streamflow for U.S. Geological Survey streamflow-gaging

231. Analysis of percentage of zero daily mean streamflow for U.S. Geological Survey streamflow-gaging station 08063200 Pin 0ak Creek near Hubbard, Texas $\ldots \ldots \ldots \ldots \ldots \ldots \ldots \ldots \ldots \ldots \ldots \ldots \ldots \ldots \ldots \ldots \ldots \ldots, 235$

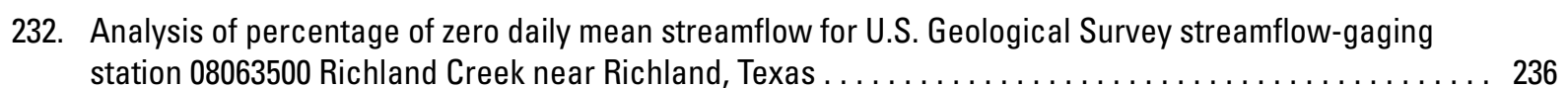

233. Analysis of percentage of zero daily mean streamflow for U.S. Geological Survey streamflow-gaging station 08063800 Waxahachie Creek near Bardwell, Texas $\ldots \ldots \ldots \ldots \ldots \ldots \ldots \ldots \ldots \ldots \ldots \ldots, 237$ 
234. Analysis of percentage of zero daily mean streamflow for U.S. Geological Survey streamflow-gaging station 08064100 Chambers Creek near Rice, Texas $\ldots \ldots \ldots \ldots \ldots \ldots \ldots \ldots \ldots \ldots \ldots \ldots \ldots \ldots \ldots \ldots, 238$

235. Analysis of percentage of zero daily mean streamflow for U.S. Geological Survey streamflow-gaging station 08064500 Chambers Creek near Corsicana, Texas $\ldots \ldots \ldots \ldots \ldots \ldots \ldots \ldots \ldots \ldots \ldots \ldots \ldots \ldots \ldots \ldots, 239$

236. Analysis of percentage of zero daily mean streamflow for U.S. Geological Survey streamflow-gaging

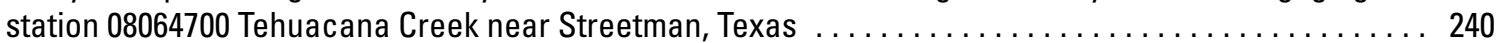

237. Analysis of percentage of zero daily mean streamflow for U.S. Geological Survey streamflow-gaging station 08064800 Cattish Creek near Tennessee Colony, Texas $\ldots \ldots \ldots \ldots \ldots \ldots \ldots \ldots \ldots \ldots \ldots, 241$

238. Analysis of percentage of zero daily mean streamflow for U.S. Geological Survey streamflow-gaging

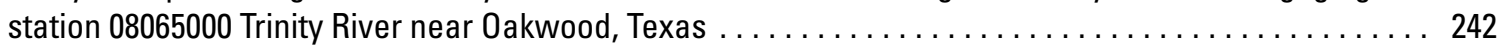

239. Analysis of percentage of zero daily mean streamflow for U.S. Geological Survey streamflow-gaging station 08065200 upper Keechi Creek near 0akwood, lexas $\ldots \ldots \ldots \ldots \ldots \ldots \ldots \ldots \ldots \ldots \ldots, 243$

240. Analysis of percentage of zero daily mean streamflow for U.S. Geological Survey streamflow-gaging station 08065350 Trinity River near Crockett, Texas $\ldots \ldots \ldots \ldots \ldots \ldots \ldots \ldots \ldots \ldots \ldots \ldots \ldots \ldots \ldots, 244$

241. Analysis of percentage of zero daily mean streamflow for U.S. Geological Survey streamflow-gaging

242. Analysis of percentage of zero daily mean streamflow for U.S. Geological Survey streamflow-gaging station 08065700 Caney Creek near Madisonville, Texas $\ldots \ldots \ldots \ldots \ldots \ldots \ldots \ldots \ldots \ldots \ldots \ldots \ldots \ldots \ldots, 246$

243. Analysis of percentage of zero daily mean streamflow for U.S. Geological Survey streamflow-gaging station 08065800 Bedias Creek near Madisonville, Texas $\ldots \ldots \ldots \ldots \ldots \ldots \ldots \ldots \ldots \ldots \ldots \ldots \ldots \ldots, 247$

244. Analysis of percentage of zero daily mean streamflow for U.S. Geological Survey streamflow-gaging

245. Analysis of percentage of zero daily mean streamflow for U.S. Geological Survey streamflow-gaging

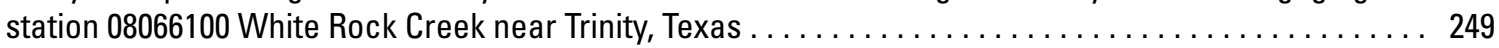

246. Analysis of percentage of zero daily mean streamflow for U.S. Geological Survey streamflow-gaging

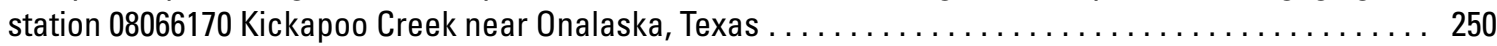

247. Analysis of percentage of zero daily mean streamflow for U.S. Geological Survey streamflow-gaging

248. Analysis of percentage of zero daily mean streamflow for U.S. Geological Survey streamflow-gaging

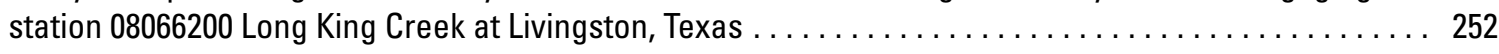

249. Analysis of percentage of zero daily mean streamflow for U.S. Geological Survey streamflow-gaging

250. Analysis of percentage of zero daily mean streamflow for U.S. Geological Survey streamflow-gaging

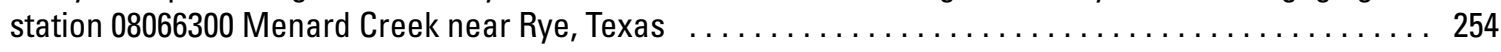

251. Analysis of percentage of zero daily mean streamflow for U.S. Geological Survey streamflow-gaging

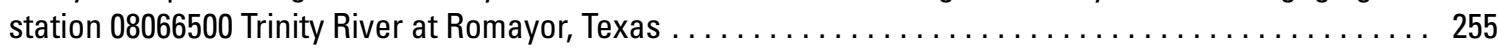

252. Analysis of percentage of zero daily mean streamflow for U.S. Geological Survey streamflow-gaging

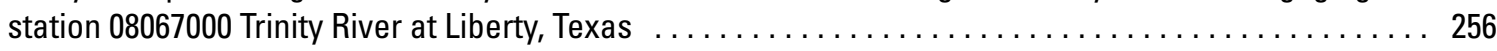

253. Analysis of percentage of zero daily mean streamflow for U.S. Geological Survey streamflow-gaging

254. Analysis of percentage of zero daily mean streamflow for U.S. Geological Survey streamflow-gaging

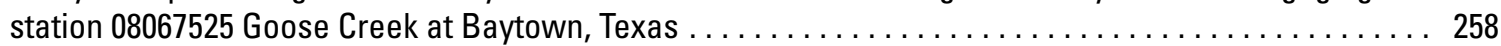

255. Analysis of percentage of zero daily mean streamflow for U.S. Geological Survey streamflow-gaging station 08067610 Lake Conroe Outflow Weir near Conroe, Texas $\ldots \ldots \ldots \ldots \ldots \ldots \ldots \ldots \ldots \ldots \ldots \ldots \ldots \ldots$

256. Analysis of percentage of zero daily mean streamflow for U.S. Geological Survey streamflow-gaging station 08067650West Fork San Jacinto River below Lake Conroe near Conroe, Texas $\ldots \ldots \ldots \ldots \ldots 260$

257. Analysis of percentage of zero daily mean streamflow for U.S. Geological Survey streamflow-gaging

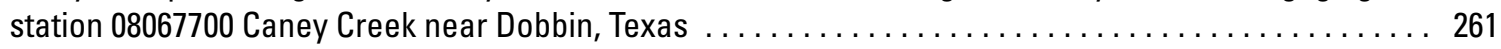


258. Analysis of percentage of zero daily mean streamflow for U.S. Geological Survey streamflow-gaging

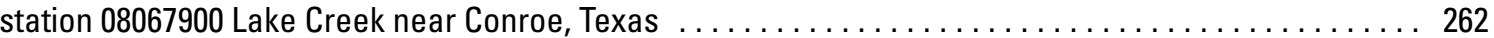

259. Analysis of percentage of zero daily mean streamflow for U.S. Geological Survey streamflow-gaging station 08068000 West Fork San Jacinto River near Conroe, Texas $\ldots \ldots \ldots \ldots \ldots \ldots \ldots \ldots \ldots \ldots$

260. Analysis of percentage of zero daily mean streamflow for U.S. Geological Survey streamflow-gaging station 08068090 West Fork San Jacinto River above Lake Houston near Porter, Texas $\ldots \ldots \ldots \ldots \ldots 264$

261. Analysis of percentage of zero daily mean streamflow for U.S. Geological Survey streamflow-gaging station 08068275 Spring Creek near Tomball, Texas $\ldots \ldots \ldots \ldots \ldots \ldots \ldots \ldots \ldots \ldots \ldots \ldots \ldots \ldots \ldots \ldots$

262. Analysis of percentage of zero daily mean streamflow for U.S. Geological Survey streamflow-gaging station 08068325 Willow Creek near Tomball, Texas $\ldots \ldots \ldots \ldots \ldots \ldots \ldots \ldots \ldots \ldots \ldots \ldots \ldots \ldots 266$

263. Analysis of percentage of zero daily mean streamflow for U.S. Geological Survey streamflow-gaging station 08068390 Bear Branch at Research Boulevard, The Woodlands, Texas $\ldots \ldots \ldots \ldots \ldots \ldots \ldots$

264. Analysis of percentage of zero daily mean streamflow for U.S. Geological Survey streamflow-gaging station 08068400 Panther Branch at Gosling Road, The Woodlands, Texas $\ldots \ldots \ldots \ldots \ldots \ldots \ldots$

$265 . \quad$ Analysis of percentage of zero daily mean streamflow for U.S. Geological Survey streamflow-gaging station 08068450 Panther Branch near Spring, Texas $\ldots \ldots \ldots \ldots \ldots \ldots \ldots \ldots \ldots \ldots \ldots \ldots \ldots \ldots \ldots$

266. Analysis of percentage of zero daily mean streamflow for U.S. Geological Survey streamflow-gaging

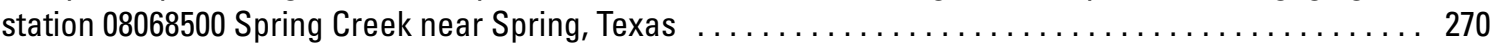

267. Analysis of percentage of zero daily mean streamflow for U.S. Geological Survey streamflow-gaging station 08068520 Spring Creek at Spring, Texas $\ldots \ldots \ldots \ldots \ldots \ldots \ldots \ldots \ldots \ldots \ldots \ldots \ldots \ldots \ldots \ldots$

268. Analysis of percentage of zero daily mean streamflow for U.S. Geological Survey streamflow-gaging station 08068720 Cypress Creek at Katy-Hockley Road near Hockley, Texas $\ldots \ldots \ldots \ldots \ldots \ldots \ldots \ldots$

269. Analysis of percentage of zero daily mean streamflow for U.S. Geological Survey streamflow-gaging station 08068740 Cypress Creek at House-Haht Road near Cypress, Texas $\ldots \ldots \ldots \ldots \ldots \ldots \ldots$

270. Analysis of percentage of zero daily mean streamflow for U.S. Geological Survey streamflow-gaging station 08068780 Little Cypress Creek near Cypress, Texas $\ldots \ldots \ldots \ldots \ldots \ldots \ldots \ldots \ldots \ldots \ldots \ldots \ldots$

271. Analysis of percentage of zero daily mean streamflow for U.S. Geological Survey streamflow-gaging station 08068800 Cypress Creek at Grant Road near Cypress, Texas $\ldots \ldots \ldots \ldots \ldots \ldots \ldots \ldots \ldots \ldots 275$

272. Analysis of percentage of zero daily mean streamflow for U.S. Geological Survey streamflow-gaging station 08068900 Cypress Creek at Stuebner-Airline Road near Westfield, Texas $\ldots \ldots \ldots \ldots \ldots \ldots$

273. Analysis of percentage of zero daily mean streamflow for U.S. Geological Survey streamflow-gaging station 08069000 Cypress Creek near Westfield, Texas $\ldots \ldots \ldots \ldots \ldots \ldots \ldots \ldots \ldots \ldots \ldots \ldots$

274. Analysis of percentage of zero daily mean streamflow for U.S. Geological Survey streamflow-gaging station 08069500 West Fork San Jacinto River near Humble, Texas $\ldots \ldots \ldots \ldots \ldots \ldots \ldots \ldots \ldots$

275. Analysis of percentage of zero daily mean streamflow for U.S. Geological Survey streamflow-gaging station 08070000 East Fork San Jacinto River near Cleveland, Texas $\ldots \ldots \ldots \ldots \ldots \ldots \ldots \ldots$

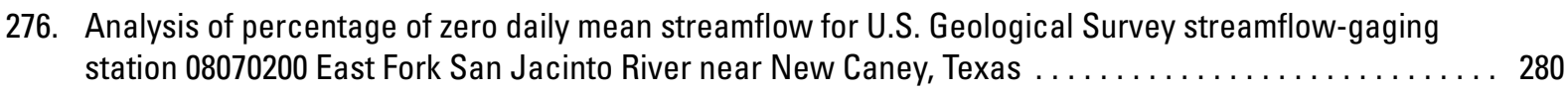

277. Analysis of percentage of zero daily mean streamflow for U.S. Geological Survey streamflow-gaging

278. Analysis of percentage of zero daily mean streamflow for U.S. Geological Survey streamflow-gaging station 08071000 Peach Creek at Splendora, Texas $\ldots \ldots \ldots \ldots \ldots \ldots \ldots \ldots \ldots \ldots \ldots \ldots \ldots \ldots$

279. Analysis of percentage of zero daily mean streamflow for U.S. Geological Survey streamflow-gaging station 08071280 Luce Bayou above Lake Houston near Huffman, Texas $\ldots \ldots \ldots \ldots \ldots \ldots \ldots \ldots \ldots$

280. Analysis of percentage of zero daily mean streamflow for U.S. Geological Survey streamflow-gaging station 08071500 San Jacinto River near Huffman, texas $\ldots \ldots \ldots \ldots \ldots \ldots \ldots \ldots \ldots \ldots \ldots \ldots \ldots$

281. Analysis of percentage of zero daily mean streamflow for U.S. Geological Survey streamflow-gaging station 08072300 Buffalo Bayou near Katy, Texas $\ldots \ldots \ldots \ldots \ldots \ldots \ldots \ldots \ldots \ldots \ldots \ldots \ldots \ldots$ 
282. Analysis of percentage of zero daily mean streamflow for U.S. Geological Survey streamflow-gaging

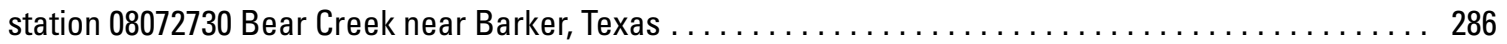

283. Analysis of percentage of zero daily mean streamflow for U.S. Geological Survey streamflow-gaging station 08072760 Langham Creek at West Little York Road near Addicks, Texas $\ldots \ldots \ldots \ldots \ldots \ldots \ldots$

284. Analysis of percentage of zero daily mean streamflow for U.S. Geological Survey streamflow-gaging station 08073500 Buffalo Bayou near Addicks, Texas $\ldots \ldots \ldots \ldots \ldots \ldots \ldots \ldots \ldots \ldots \ldots \ldots \ldots \ldots, 288$

285. Analysis of percentage of zero daily mean streamflow for U.S. Geological Survey streamflow-gaging station 08073600 Buffalo Bayou at West Belt Drive, Houston, lexas $\ldots \ldots \ldots \ldots \ldots \ldots \ldots \ldots \ldots \ldots, 289$

286. Analysis of percentage of zero daily mean streamflow for U.S. Geological Survey streamflow-gaging

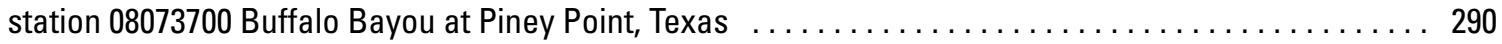

287. Analysis of percentage of zero daily mean streamflow for U.S. Geological Survey streamflow-gaging

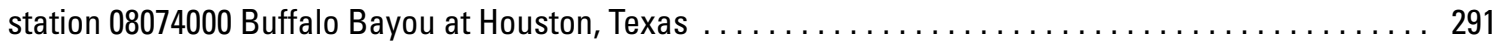

288. Analysis of percentage of zero daily mean streamflow for U.S. Geological Survey streamflow-gaging station 08074020 Whiteoak Bayou at Alabonson Road, Houston, Texas $\ldots \ldots \ldots \ldots \ldots \ldots \ldots \ldots \ldots 292$

289. Analysis of percentage of zero daily mean streamflow for U.S. Geological Survey streamflow-gaging station 08074150 Cole Creek at Deint Road, Houston, Texas $\ldots \ldots \ldots \ldots \ldots \ldots \ldots \ldots \ldots \ldots \ldots \ldots, 293$

290. Analysis of percentage of zero daily mean streamflow for U.S. Geological Survey streamflow-gaging station 08074250 Brickhouse Gully at Costa Rica Street, Houston, Texas $\ldots \ldots \ldots \ldots \ldots \ldots \ldots \ldots \ldots 294$

291. Analysis of percentage of zero daily mean streamflow for U.S. Geological Survey streamflow-gaging station 08074500 Whiteoak Bayou at Houston, Texas $\ldots \ldots \ldots \ldots \ldots \ldots \ldots \ldots \ldots \ldots \ldots \ldots \ldots \ldots, 295$

292. Analysis of percentage of zero daily mean streamflow for U.S. Geological Survey streamflow-gaging

293. Analysis of percentage of zero daily mean streamflow for U.S. Geological Survey streamflow-gaging station 08074780 Keegans Bayou at Keegan Road near Houston, Texas $\mid \ldots \ldots \ldots \ldots \ldots \ldots \ldots \ldots \ldots 297$

294. Analysis of percentage of zero daily mean streamflow for U.S. Geological Survey streamflow-gaging station 08074800 Keegans Bayou at Roark Road near Houston, Texas $\ldots \ldots \ldots \ldots \ldots \ldots \ldots \ldots \ldots \ldots \ldots$

295. Analysis of percentage of zero daily mean streamflow for U.S. Geological Survey streamflow-gaging station 08074810 Brays Bayou at Gessner Drive, Houston, lexas $\ldots \ldots \ldots \ldots \ldots \ldots \ldots \ldots \ldots \ldots \ldots \ldots \ldots$

296. Analysis of percentage of zero daily mean streamflow for U.S. Geological Survey streamflow-gaging

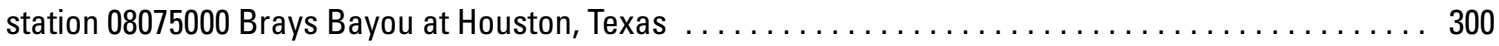

297. Analysis of percentage of zero daily mean streamflow for U.S. Geological Survey streamflow-gaging

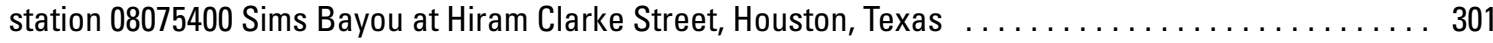

298. Analysis of percentage of zero daily mean streamflow for U.S. Geological Survey streamflow-gaging

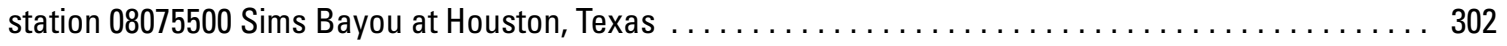

299. Analysis of percentage of zero daily mean streamflow for U.S. Geological Survey streamflow-gaging station 08075650 Berry Bayou at Forest 0 aks Street, Houston, lexas $\ldots \ldots \ldots \ldots \ldots \ldots \ldots \ldots \ldots \ldots, 303$

300. Analysis of percentage of zero daily mean streamflow for U.S. Geological Survey streamflow-gaging

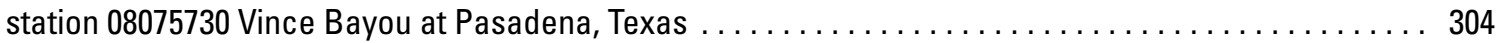

301. Analysis of percentage of zero daily mean streamflow for U.S. Geological Survey streamflow-gaging

302. Analysis of percentage of zero daily mean streamflow for U.S. Geological Survey streamflow-gaging station 08075780 Greens Bayou at Cutten Road near Houston, lexas $\ldots \ldots \ldots \ldots \ldots \ldots \ldots \ldots \ldots \ldots \ldots$

303. Analysis of percentage of zero daily mean streamflow for U.S. Geological Survey streamflow-gaging station 08075900 Greens Bayou near U. S. Highway 75 near Houston, Texas $\ldots \ldots \ldots \ldots \ldots \ldots \ldots \ldots, 307$

304. Analysis of percentage of zero daily mean streamflow for U.S. Geological Survey streamflow-gaging

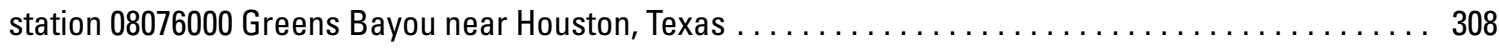

305. Analysis of percentage of zero daily mean streamflow for U.S. Geological Survey streamflow-gaging

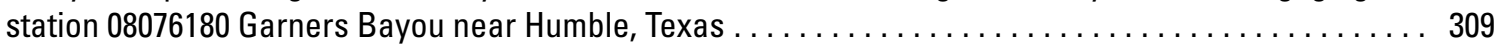


306. Analysis of percentage of zero daily mean streamflow for U.S. Geological Survey streamflow-gaging station 08076500 Halls Bayou at Houston, Texas $\ldots \ldots \ldots \ldots \ldots \ldots \ldots \ldots \ldots \ldots \ldots \ldots \ldots \ldots, 310$

307. Analysis of percentage of zero daily mean streamflow for U.S. Geological Survey streamflow-gaging station 08076700 Greens Bayou at Ley Road, Houston, Texas $\ldots \ldots \ldots \ldots \ldots \ldots \ldots \ldots \ldots \ldots \ldots \ldots \ldots \ldots \ldots$

308. Analysis of percentage of zero daily mean streamflow for U.S. Geological Survey streamflow-gaging

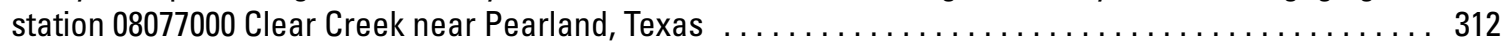

309. Analysis of percentage of zero daily mean streamflow for U.S. Geological Survey streamflow-gaging station 08077540 Clear Creek at Friendswood, Texas $\ldots \ldots \ldots \ldots \ldots \ldots \ldots \ldots \ldots \ldots \ldots \ldots \ldots, 313$

310. Analysis of percentage of zero daily mean streamflow for U.S. Geological Survey streamflow-gaging

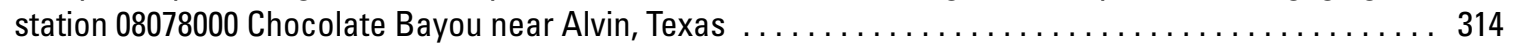

311. Analysis of percentage of zero daily mean streamflow for U.S. Geological Survey streamflow-gaging

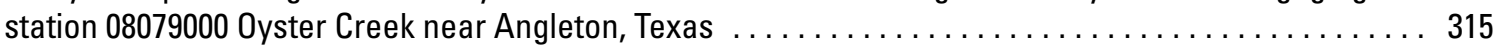

312. Analysis of percentage of zero daily mean streamflow for U.S. Geological Survey streamflow-gaging station 08079500 North Fork Double Mountain Fork Brazos River at Lubbock, Texas $\ldots \ldots \ldots \ldots \ldots \ldots .316$

313. Analysis of percentage of zero daily mean streamflow for U.S. Geological Survey streamflow-gaging station 08079575 North Fork Double Mountain Fork Brazos River near Post, Texas $\ldots \ldots \ldots \ldots \ldots \ldots \ldots \ldots \ldots$

314. Analysis of percentage of zero daily mean streamflow for U.S. Geological Survey streamflow-gaging station 08079600 Double Mountain Fork Brazos River at Justic eburg, Texas $\ldots \ldots \ldots \ldots \ldots \ldots \ldots \ldots, 318$

315. Analysis of percentage of zero daily mean streamflow for U.S. Geological Survey streamflow-gaging station 08080000 Double Mountain Fork Brazos River near Rotan, Texas $\ldots \ldots \ldots \ldots \ldots \ldots \ldots \ldots \ldots \ldots \ldots$

316. Analysis of percentage of zero daily mean streamflow for U.S. Geological Survey streamflow-gaging station 08080500 Double Mountain Fork Brazos River near Aspermont, Texas $\ldots \ldots \ldots \ldots \ldots \ldots \ldots, 320$

317. Analysis of percentage of zero daily mean streamflow for U.S. Geological Survey streamflow-gaging

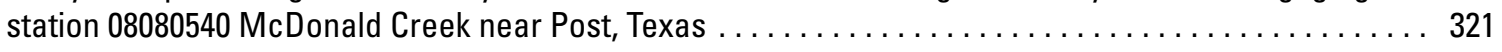

318. Analysis of percentage of zero daily mean streamflow for U.S. Geological Survey streamflow-gaging station 08080700 Running Water Draw at Plainview, Texas $\ldots \ldots \ldots \ldots \ldots \ldots \ldots \ldots \ldots \ldots \ldots, 322$

319. Analysis of percentage of zero daily mean streamflow for U.S. Geological Survey streamflow-gaging station 08080950 Duck Creek near Girard, Texas $\ldots \ldots \ldots \ldots \ldots \ldots \ldots \ldots \ldots \ldots \ldots \ldots \ldots \ldots \ldots \ldots \ldots, 323$

320. Analysis of percentage of zero daily mean streamflow for U.S. Geological Survey streamflow-gaging

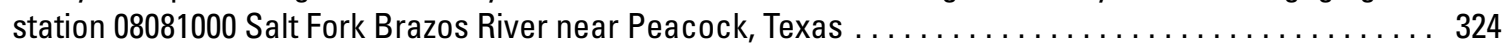

321. Analysis of percentage of zero daily mean streamflow for U.S. Geological Survey streamflow-gaging

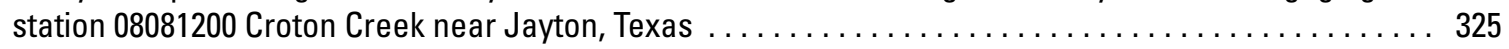

322. Analysis of percentage of zero daily mean streamflow for U.S. Geological Survey streamflow-gaging

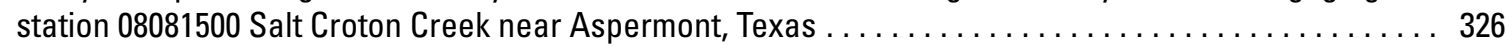

323. Analysis of percentage of zero daily mean streamflow for U.S. Geological Survey streamflow-gaging

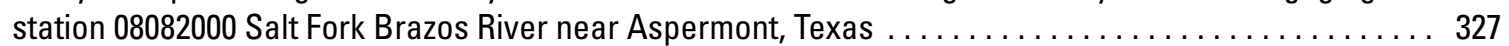
$324 . \quad$ Analysis of percentage of zero daily mean streamflow for U.S. Geological Survey streamflow-gaging

325. Analysis of percentage of zero daily mean streamflow for U.S. Geological Survey streamflow-gaging

326. Analysis of percentage of zero daily mean streamflow for U.S. Geological Survey streamflow-gaging

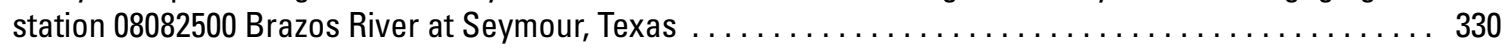

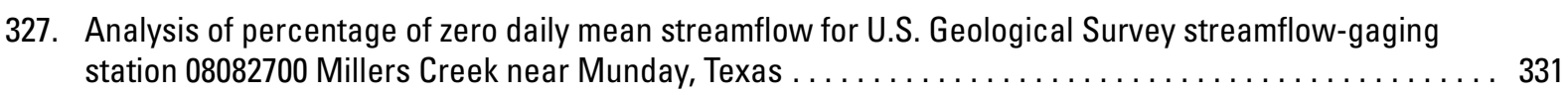

328. Analysis of percentage of zero daily mean streamflow for U.S. Geological Survey streamflow-gaging

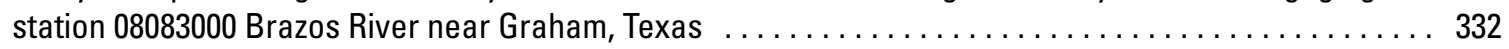

329. Analysis of percentage of zero daily mean streamflow for U.S. Geological Survey streamflow-gaging station 08083100 Clear Fork Brazos River near Roby, lexas $\ldots \ldots \ldots \ldots \ldots \ldots \ldots \ldots \ldots \ldots \ldots \ldots \ldots, 333$ 
330. Analysis of percentage of zero daily mean streamflow for U.S. Geological Survey streamflow-gaging station 08083230 Clear Fork Brazos River near Noodle, lexas $\ldots \ldots \ldots \ldots \ldots \ldots \ldots \ldots \ldots \ldots \ldots, 334$

331. Analysis of percentage of zero daily mean streamflow for U.S. Geological Survey streamflow-gaging

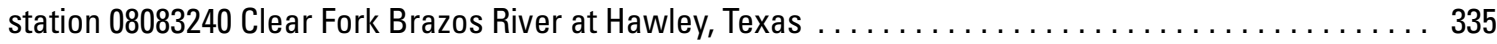

332. Analysis of percentage of zero daily mean streamflow for U.S. Geological Survey streamflow-gaging station 08083245 Mulberry Creek near Hawley, Texas $\mid \ldots \ldots \ldots \ldots \ldots \ldots \ldots \ldots \ldots \ldots \ldots, 336$

333. Analysis of percentage of zero daily mean streamflow for U.S. Geological Survey streamflow-gaging

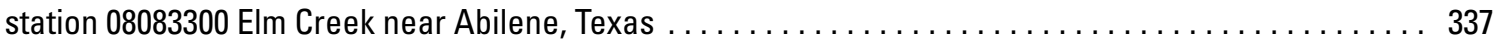

334. Analysis of percentage of zero daily mean streamflow for U.S. Geological Survey streamflow-gaging station 08083400 Little Elm Creek near Abilene, lexas $\ldots \ldots \ldots \ldots \ldots \ldots \ldots \ldots \ldots \ldots \ldots \ldots \ldots \ldots \ldots \ldots \ldots \ldots$

335. Analysis of percentage of zero daily mean streamflow for U.S. Geological Survey streamflow-gaging station 08083420 Cat Claw Creek at Abilene, Texas $\ldots \ldots \ldots \ldots \ldots \ldots \ldots \ldots \ldots \ldots \ldots \ldots \ldots \ldots \ldots \ldots, 339$

336. Analysis of percentage of zero daily mean streamflow for U.S. Geological Survey streamflow-gaging

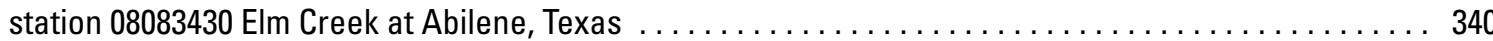

337. Analysis of percentage of zero daily mean streamflow for U.S. Geological Survey streamflow-gaging

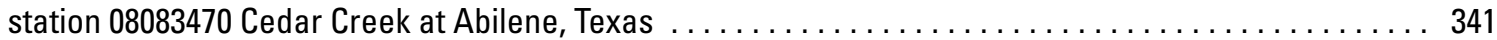

338. Analysis of percentage of zero daily mean streamflow for U.S. Geological Survey streamflow-gaging station 08083480 Cedar Creek at Interstate Highway 20, Abilene, lexas $\ldots \ldots \ldots \ldots \ldots \ldots \ldots \ldots \ldots, 342$

339. Analysis of percentage of zero daily mean streamflow for U.S. Geological Survey streamflow-gaging

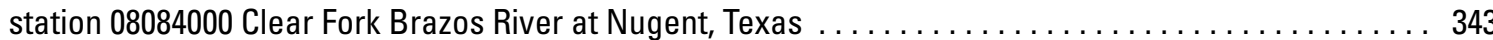

340. Analysis of percentage of zero daily mean streamflow for U.S. Geological Survey streamflow-gaging station 08084800 California Creek near Stamford, Texas $\ldots \ldots \ldots \ldots \ldots \ldots \ldots \ldots \ldots \ldots \ldots \ldots \ldots, 344$

341. Analysis of percentage of zero daily mean streamflow for U.S. Geological Survey streamflow-gaging

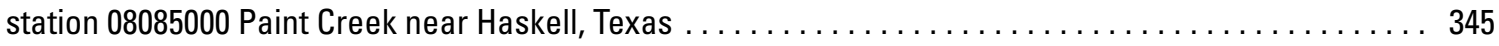

342. Analysis of percentage of zero daily mean streamflow for U.S. Geological Survey streamflow-gaging station 08085500 Clear Fork Brazos River at Fort Griffin, Texas $\mid \ldots \ldots \ldots \ldots \ldots \ldots \ldots \ldots \ldots \ldots \ldots, 346$

343. Analysis of percentage of zero daily mean streamflow for U.S. Geological Survey streamflow-gaging station 08086000 Clear Fork Brazos River at Crystalfalls, Texas $\ldots \ldots \ldots \ldots \ldots \ldots \ldots \ldots \ldots \ldots \ldots \ldots \ldots, 347$

344. Analysis of percentage of zero daily mean streamflow for U.S. Geological Survey streamflow-gaging

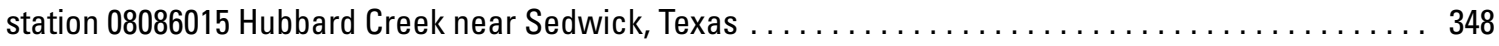

345. Analysis of percentage of zero daily mean streamflow for U.S. Geological Survey streamflow-gaging station 08086050 Deep Creek at Moran, lexas $\ldots \ldots \ldots \ldots \ldots \ldots \ldots \ldots \ldots \ldots \ldots \ldots \ldots \ldots \ldots \ldots \ldots, 349$

346. Analysis of percentage of zero daily mean streamflow for U.S. Geological Survey streamflow-gaging

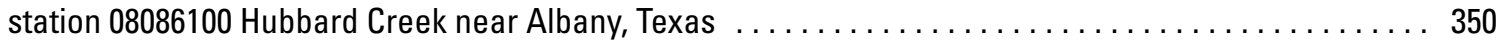

347. Analysis of percentage of zero daily mean streamflow for U.S. Geological Survey streamflow-gaging station 08086120 Salt Prong HubbardCreek at U.S. Highway 380 near Albany, Texas $\ldots \ldots \ldots \ldots \ldots \ldots$ 351

348. Analysis of percentage of zero daily mean streamflow for U.S. Geological Survey streamflow-gaging station 08086150 North Fork Hubbard Creek near Albany, lexas $\ldots \ldots \ldots \ldots \ldots \ldots \ldots \ldots \ldots \ldots \ldots, 352$

349. Analysis of percentage of zero daily mean streamflow for U.S. Geological Survey streamflow-gaging

350. Analysis of percentage of zero daily mean streamflow for U.S. Geological Survey streamflow-gaging

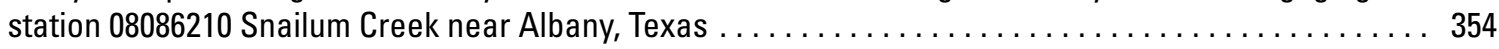

351. Analysis of percentage of zero daily mean streamflow for U.S. Geological Survey streamflow-gaging

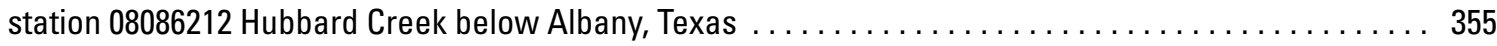

352. Analysis of percentage of zero daily mean streamflow for U.S. Geological Survey streamflow-gaging

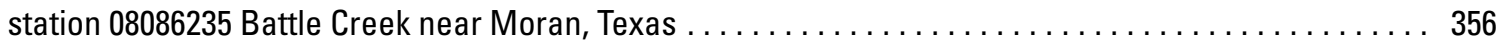

353. Analysis of percentage of zero daily mean streamflow for U.S. Geological Survey streamflow-gaging

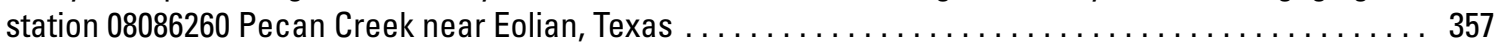


354. Analysis of percentage of zero daily mean streamflow for U.S. Geological Survey streamflow-gaging station 08086290 Big Sandy Creek above Breckenridge, Texas $\ldots \ldots \ldots \ldots \ldots \ldots \ldots \ldots \ldots \ldots \ldots \ldots$

355. Analysis of percentage of zero daily mean streamflow for U.S. Geological Survey streamflow-gaging station 08086500 Hubbard Creek near Breckenridge, Texas $\ldots \ldots \ldots \ldots \ldots \ldots \ldots \ldots \ldots \ldots \ldots \ldots$

356. Analysis of percentage of zero daily mean streamflow for U.S. Geological Survey streamflow-gaging station 08087300 Clear Fork Brazos River at Eliasville, Texas $\ldots \ldots \ldots \ldots \ldots \ldots \ldots \ldots \ldots \ldots \ldots \ldots$

357. Analysis of percentage of zero daily mean streamflow for U.S. Geological Survey streamflow-gaging station 08088000 Brazos River near South Bend, Texas $\ldots \ldots \ldots \ldots \ldots \ldots \ldots \ldots \ldots \ldots \ldots \ldots \ldots \ldots 1$

358. Analysis of percentage of zero daily mean streamflow for U.S. Geological Survey streamflow-gaging

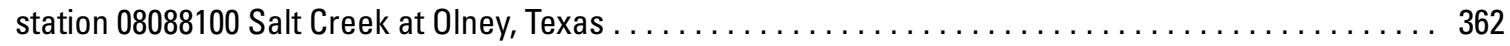

359. Analysis of percentage of zero daily mean streamflow for U.S. Geological Survey streamflow-gaging

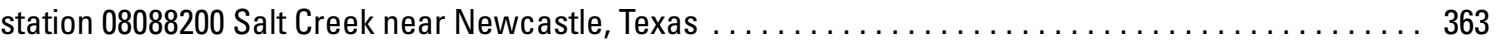

360. Analysis of percentage of zero daily mean streamflow for U.S. Geological Survey streamflow-gaging station 08088300 Briar Creek near Graham, Texas $\ldots \ldots \ldots \ldots \ldots \ldots \ldots \ldots \ldots \ldots \ldots \ldots \ldots \ldots \ldots \ldots$

361. Analysis of percentage of zero daily mean streamflow for U.S. Geological Survey streamflow-gaging

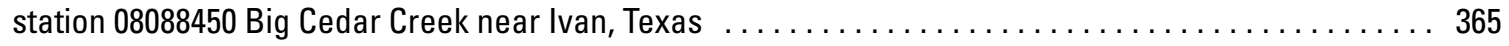

362. Analysis of percentage of zero daily mean streamflow for U.S. Geological Survey streamflow-gaging station 08088600 Brazos River at Morris Sheppard Dam near Graford, Texas $\ldots \ldots \ldots \ldots \ldots \ldots$

363. Analysis of percentage of zero daily mean streamflow for U.S. Geological Survey streamflow-gaging station 08088610 Brazos River near Graford, Texas $\ldots \ldots \ldots \ldots \ldots \ldots \ldots \ldots \ldots \ldots \ldots \ldots \ldots \ldots$

364. Analysis of percentage of zero daily mean streamflow for U.S. Geological Survey streamflow-gaging station 08089000 Brazos River near Palo Pinto, texas $\ldots \ldots \ldots \ldots \ldots \ldots \ldots \ldots \ldots \ldots \ldots \ldots \ldots$

365. Analysis of percentage of zero daily mean streamflow for U.S. Geological Survey streamflow-gaging station 08090500 Palo Pinto Creek near Santo, Texas $\ldots \ldots \ldots \ldots \ldots \ldots \ldots \ldots \ldots \ldots \ldots \ldots \ldots \ldots \ldots$

366. Analysis of percentage of zero daily mean streamflow for U.S. Geological Survey streamflow-gaging station 08090800 Brazos River near Dennis, Texas $\ldots \ldots \ldots \ldots \ldots \ldots \ldots \ldots \ldots \ldots \ldots \ldots \ldots \ldots$

367. Analysis of percentage of zero daily mean streamflow for U.S. Geological Survey streamflow-gaging station 08091000 Brazos River near Glen Rose, Texas $\ldots \ldots \ldots \ldots \ldots \ldots \ldots \ldots \ldots \ldots \ldots \ldots \ldots \ldots$

368. Analysis of percentage of zero daily mean streamflow for U.S. Geological Survey streamflow-gaging

369. $\frac{\text { Analysis of percentage of zero daily mean streamflow for U.S. Geological Survey streamflow-gaging }}{\text { station } 08091750 \text { Squaw Creek near Glen Rose, Texas } \ldots \ldots \ldots \ldots \ldots \ldots \ldots \ldots \ldots \ldots \ldots \ldots \ldots \ldots \ldots \ldots \ldots \ldots \ldots \ldots}$

370. Analysis of percentage of zero daily mean streamflow for U.S. Geological Survey streamflow-gaging station 08092000 Nolan River at Blum, Texas $\ldots \ldots \ldots \ldots \ldots \ldots \ldots \ldots \ldots \ldots \ldots \ldots \ldots \ldots \ldots \ldots \ldots$

371. Analysis of percentage of zero daily mean streamflow for U.S. Geological Survey streamflow-gaging station 08092600 Brazos River at Whitney Dam near Whitney, Texas $\ldots \ldots \ldots \ldots \ldots \ldots \ldots \ldots \ldots \ldots$

372. Analysis of percentage of zero daily mean streamflow for U.S. Geological Survey streamflow-gaging station 08093100 Brazos River near Aquilla, Texas $\ldots \ldots \ldots \ldots \ldots \ldots \ldots \ldots \ldots \ldots \ldots \ldots \ldots \ldots \ldots$

373. Analysis of percentage of zero daily mean streamflow for U.S. Geological Survey streamflow-gaging

374. Analysis of percentage of zero daily mean streamflow for U.S. Geological Survey streamflow-gaging station 08093360 Aquilla Creek above Aquilla, Texas $\ldots \ldots \ldots \ldots \ldots \ldots \ldots \ldots \ldots \ldots \ldots \ldots$ 375. Analysis of percentage of zero daily mean streamflow for U.S. Geological Survey streamflow-gaging

376. Analysis of percentage of zero daily mean streamflow for U.S. Geological Survey streamflow-gaging

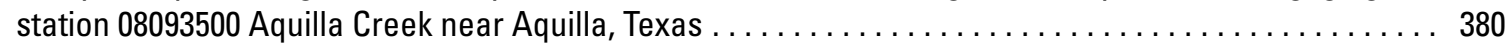

377. Analysis of percentage of zero daily mean streamflow for U.S. Geological Survey streamflow-gaging station 08093700 North Bosque River at Stephenville, Texas $\ldots \ldots \ldots \ldots \ldots \ldots \ldots \ldots \ldots \ldots \ldots$. 
378. Analysis of percentage of zero daily mean streamflow for U.S. Geological Survey streamflow-gaging

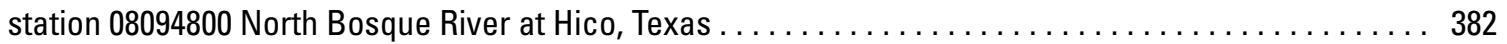

379. Analysis of percentage of zero daily mean streamflow for U.S. Geological Survey streamflow-gaging station 08095000 North Bosque River near Clifton, Texas $\ldots \ldots \ldots \ldots \ldots \ldots \ldots \ldots \ldots \ldots \ldots \ldots \ldots 3$

380. Analysis of percentage of zero daily mean streamflow for U.S. Geological Survey streamflow-gaging station 08095200 North Bosque River at Valley Mills, Texas $\ldots \ldots \ldots \ldots \ldots \ldots \ldots \ldots \ldots \ldots \ldots \ldots$

381. Analysis of percentage of zero daily mean streamflow for U.S. Geological Survey streamflow-gaging station 08095300 Middle Bosque River near McGregor, Texas $\ldots \ldots \ldots \ldots \ldots \ldots \ldots \ldots \ldots \ldots \ldots \ldots 38$

382. Analysis of percentage of zero daily mean streamflow for U.S. Geological Survey streamflow-gaging station 08095400 Hog Creek near Crawford, Texas $\ldots \ldots \ldots \ldots \ldots \ldots \ldots \ldots \ldots \ldots \ldots \ldots \ldots \ldots$

383. Analysis of percentage of zero daily mean streamflow for U.S. Geological Survey streamflow-gaging station 08095500 South Bosque River near Speegleville, Texas $\ldots \ldots \ldots \ldots \ldots \ldots \ldots \ldots \ldots \ldots \ldots$

384. Analysis of percentage of zero daily mean streamflow for U.S. Geological Survey streamflow-gaging station 08095600 Bosque River near Wac0, Texas $\ldots \ldots \ldots \ldots \ldots \ldots \ldots \ldots \ldots \ldots \ldots \ldots \ldots \ldots$

385. Analysis of percentage of zero daily mean streamflow for U.S. Geological Survey streamflow-gaging station 08096500 Brazos River at Wac0, Texas $\ldots \ldots \ldots \ldots \ldots \ldots \ldots \ldots \ldots \ldots \ldots \ldots \ldots \ldots \ldots$

386. Analysis of percentage of zero daily mean streamflow for U.S. Geological Survey streamflow-gaging station 08097500 Brazos River near Marlin, Texas $\ldots \ldots \ldots \ldots \ldots \ldots \ldots \ldots \ldots \ldots \ldots \ldots \ldots \ldots$

387. Analysis of percentage of zero daily mean streamflow for U.S. Geological Survey streamflow-gaging

388. Analysis of percentage of zero daily mean streamflow for U.S. Geological Survey streamflow-gaging station 08098290 Brazos River near Highbank, lexas $\ldots \ldots \ldots \ldots \ldots \ldots \ldots \ldots \ldots \ldots \ldots \ldots \ldots \ldots \ldots$

389. Analysis of percentage of zero daily mean streamflow for U.S. Geological Survey streamflow-gaging station 08098300 Little Pond Creek near Burlington, Texas $\ldots \ldots \ldots \ldots \ldots \ldots \ldots \ldots \ldots \ldots \ldots \ldots$

390. Analysis of percentage of zero daily mean streamflow for U.S. Geological Survey streamflow-gaging

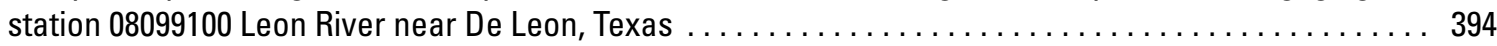

391. Analysis of percentage of zero daily mean streamflow for U.S. Geological Survey streamflow-gaging station 08099300 Sabana River near De Leon, Texas $\ldots \ldots \ldots \ldots \ldots \ldots \ldots \ldots \ldots \ldots \ldots \ldots \ldots \ldots$

392. Analysis of percentage of zero daily mean streamflow for U.S. Geological Survey streamflow-gaging

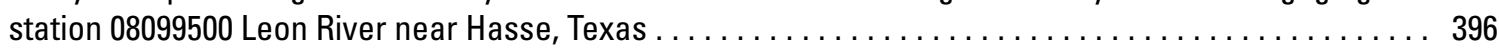

393. Analysis of percentage of zero daily mean streamflow for U.S. Geological Survey streamflow-gaging

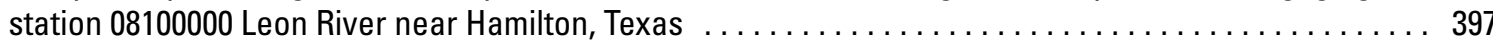

394. Analysis of percentage of zero daily mean streamflow for U.S. Geological Survey streamflow-gaging station 08100500 Leon River at Gatesville, Texas $\ldots \ldots \ldots \ldots \ldots \ldots \ldots \ldots \ldots \ldots \ldots \ldots \ldots \ldots$

395. Analysis of percentage of zero daily mean streamflow for U.S. Geological Survey streamflow-gaging station 08101000 Cowhouse Creek at Pidcoke, Texas $\ldots \ldots \ldots \ldots \ldots \ldots \ldots \ldots \ldots \ldots \ldots \ldots$

396. Analysis of percentage of zero daily mean streamflow for U.S. Geological Survey streamflow-gaging station 08101500 Cowhouse Creek near Killeen, Texas $\ldots \ldots \ldots \ldots \ldots \ldots \ldots \ldots \ldots \ldots \ldots \ldots \ldots$

397. Analysis of percentage of zero daily mean streamflow for U.S. Geological Survey streamflow-gaging

398. Analysis of percentage of zero daily mean streamflow for U.S. Geological Survey streamflow-gaging station 08102600 Nolan Creek at Belton, Texas $\ldots \ldots \ldots \ldots \ldots \ldots \ldots \ldots \ldots \ldots \ldots \ldots \ldots \ldots \ldots$

399. Analysis of percentage of zero daily mean streamflow for U.S. Geological Survey streamflow-gaging station 08103800 Lampasas River near Kempner, Texas $\ldots \ldots \ldots \ldots \ldots \ldots \ldots \ldots \ldots \ldots \ldots \ldots \ldots$

400. Analysis of percentage of zero daily mean streamflow for U.S. Geological Survey streamflow-gaging station 08103900 South Fork Rocky Creek near Briggs, Texas $\ldots \ldots \ldots \ldots \ldots \ldots \ldots \ldots \ldots \ldots \ldots$

401. Analysis of percentage of zero daily mean streamflow for U.S. Geological Survey streamflow-gaging station 08104000 Lampasas River at Youngsport, Texas $\ldots \ldots \ldots \ldots \ldots \ldots \ldots \ldots \ldots \ldots \ldots \ldots$ 
402. Analysis of percentage of zero daily mean streamflow for U.S. Geological Survey streamflow-gaging station 08104100 Lampasas River near Belton, lexas $\ldots \ldots \ldots \ldots \ldots \ldots \ldots \ldots \ldots \ldots \ldots \ldots \ldots \ldots .406$

403. Analysis of percentage of zero daily mean streamflow for U.S. Geological Survey streamflow-gaging station 08104310 Salado Creek below Salado Springs at Salado, Texas $\ldots \ldots \ldots \ldots \ldots \ldots \ldots \ldots \ldots$

404. Analysis of percentage of zero daily mean streamflow for U.S. Geological Survey streamflow-gaging station 08104500 Little River near Little River, Texas $\ldots \ldots \ldots \ldots \ldots \ldots \ldots \ldots \ldots \ldots \ldots \ldots \ldots \ldots \ldots$

405. Analysis of percentage of zero daily mean streamflow for U.S. Geological Survey streamflow-gaging station 08104700 North Fork San Gabriel River near Georgetown, Texas $\ldots \ldots \ldots \ldots \ldots \ldots \ldots \ldots$

406. Analysis of percentage of zero daily mean streamflow for U.S. Geological Survey streamflow-gaging station 08104900 South Fork San Gabriel River at Georgetown, Texas $\ldots \ldots \ldots \ldots \ldots \ldots \ldots \ldots \ldots$

407. Analysis of percentage of zero daily mean streamflow for U.S. Geological Survey streamflow-gaging station 08105000 San Gabriel River at Georgetown, Texas $\ldots \ldots \ldots \ldots \ldots \ldots \ldots \ldots \ldots \ldots \ldots \ldots \ldots 11$

408. Analysis of percentage of zero daily mean streamflow for U.S. Geological Survey streamflow-gaging station 08105095 Berry Creek at Airport Road near Georgetown, Texas $\ldots \ldots \ldots \ldots \ldots \ldots \ldots \ldots \ldots .412$

409. Analysis of percentage of zero daily mean streamflow for U.S. Geological Survey streamflow-gaging station 08105100 Berry Creek near Georgetown, Texas $\ldots \ldots \ldots \ldots \ldots \ldots \ldots \ldots \ldots \ldots \ldots \ldots \ldots \ldots$

410. Analysis of percentage of zero daily mean streamflow for U.S. Geological Survey streamflow-gaging station 08105200 Berry Creek at State Highway 971 near Georgetown, Texas $\ldots \ldots \ldots \ldots \ldots \ldots \ldots$

411. Analysis of percentage of zero daily mean streamflow for U.S. Geological Survey streamflow-gaging station 08105300 San Gabriel River near Weir, Texas $\ldots \ldots \ldots \ldots \ldots \ldots \ldots \ldots \ldots \ldots \ldots \ldots \ldots \ldots \ldots 415$

412. Analysis of percentage of zero daily mean streamflow for U.S. Geological Survey streamflow-gaging station 08105400 San Gabriel River near Circleville, Texas $\ldots \ldots \ldots \ldots \ldots \ldots \ldots \ldots \ldots \ldots \ldots \ldots \ldots$

413. Analysis of percentage of zero daily mean streamflow for U.S. Geological Survey streamflow-gaging station 08105700 San Gabriel River at Laneport, Texas $\ldots \ldots \ldots \ldots \ldots \ldots \ldots \ldots \ldots \ldots \ldots \ldots \ldots \ldots 417$

414. Analysis of percentage of zero daily mean streamflow for U.S. Geological Survey streamflow-gaging station 08106300 Brushy Creek near Rockdale, Texas $\ldots \ldots \ldots \ldots \ldots \ldots \ldots \ldots \ldots \ldots \ldots \ldots \ldots \ldots 418$

415. Analysis of percentage of zero daily mean streamflow for U.S. Geological Survey streamflow-gaging station 08106310 San Gabriel River near Rockdale, Texas $\ldots \ldots \ldots \ldots \ldots \ldots \ldots \ldots \ldots \ldots \ldots \ldots \ldots 419$

416. Analysis of percentage of zero daily mean streamflow for U.S. Geological Survey streamflow-gaging station 08106350 Little River near Rockdale, Texas $\ldots \ldots \ldots \ldots \ldots \ldots \ldots \ldots \ldots \ldots \ldots \ldots \ldots \ldots$

417. Analysis of percentage of zero daily mean streamflow for U.S. Geological Survey streamflow-gaging station 08106500 Little River at Cameron, Texas $\ldots \ldots \ldots \ldots \ldots \ldots \ldots \ldots \ldots \ldots \ldots \ldots \ldots \ldots \ldots \ldots \ldots$

418. Analysis of percentage of zero daily mean streamflow for U.S. Geological Survey streamflow-gaging station 08107000 Big Elm Creek near Temple, Texas $\ldots \ldots \ldots \ldots \ldots \ldots \ldots \ldots \ldots \ldots \ldots \ldots \ldots \ldots 422$

419. Analysis of percentage of zero daily mean streamflow for U.S. Geological Survey streamflow-gaging station 08107500 Big Elm Creek near Buckholts, Texas $\ldots \ldots \ldots \ldots \ldots \ldots \ldots \ldots \ldots \ldots \ldots \ldots \ldots$ 420. $\frac{\text { Analysis of percentage of zero daily mean streamflow for U.S. Geological Survey streamflow-gaging }}{\text { station 08108000 North Elm Creek near Ben Arnold, Texas } \ldots \ldots \ldots \ldots \ldots \ldots \ldots \ldots \ldots \ldots \ldots \ldots \ldots \ldots \ldots \ldots}$

421. Analysis of percentage of zero daily mean streamflow for U.S. Geological Survey streamflow-gaging

422. Analysis of percentage of zero daily mean streamflow for U.S. Geological Survey streamflow-gaging station 08108700 Brazos River at State Highway 21 near Bryan, Texas $\ldots \ldots \ldots \ldots \ldots \ldots \ldots \ldots$

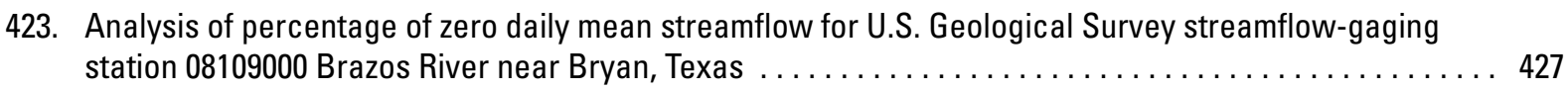

424. Analysis of percentage of zero daily mean streamflow for U.S. Geological Survey streamflow-gaging station 08109700 Middle Yegua Creek near Dime Box, Texas $\ldots \ldots \ldots \ldots \ldots \ldots \ldots \ldots \ldots \ldots \ldots \ldots$

425. Analysis of percentage of zero daily mean streamflow for U.S. Geological Survey streamflow-gaging station 08109800 East Yegua Creek near Dime Box, Texas $\ldots \ldots \ldots \ldots \ldots \ldots \ldots \ldots \ldots \ldots \ldots \ldots$ 
426. Analysis of percentage of zero daily mean streamflow for U.S. Geological Survey streamflow-gaging station 08110000 Yegua Creek near Somerville, Texas $\ldots \ldots \ldots \ldots \ldots \ldots \ldots \ldots \ldots \ldots \ldots \ldots \ldots \ldots$

427. Analysis of percentage of zero daily mean streamflow for U.S. Geological Survey streamflow-gaging station 08110100 Davidson Creek near Lyons, Texas $\ldots \ldots \ldots \ldots \ldots \ldots \ldots \ldots \ldots \ldots \ldots \ldots \ldots \ldots \ldots$

428. Analysis of percentage of zero daily mean streamflow for U.S. Geological Survey streamflow-gaging station 08110200 Brazos River at Washington, Texas $\ldots \ldots \ldots \ldots \ldots \ldots \ldots \ldots \ldots \ldots \ldots \ldots \ldots \ldots 432$

429. Analysis of percentage of zero daily mean streamflow for U.S. Geological Survey streamflow-gaging station 08110325 Navasota River above Groesbeck, Texas $\ldots \ldots \ldots \ldots \ldots \ldots \ldots \ldots \ldots \ldots \ldots \ldots .433$

430. Analysis of percentage of zero daily mean streamflow for U.S. Geological Survey streamflow-gaging station 08110400 Navasota River near Groesbeck, Texas $\ldots \ldots \ldots \ldots \ldots \ldots \ldots \ldots \ldots \ldots \ldots \ldots \ldots 434$

431. Analysis of percentage of zero daily mean streamflow for U.S. Geological Survey streamflow-gaging station 08110430 Big Creek near Freestone, Texas $\ldots \ldots \ldots \ldots \ldots \ldots \ldots \ldots \ldots \ldots \ldots \ldots \ldots \ldots 435$

432. Analysis of percentage of zero daily mean streamflow for U.S. Geological Survey streamflow-gaging station 08110500 Navasota River near Easterly, Texas $\ldots \ldots \ldots \ldots \ldots \ldots \ldots \ldots \ldots \ldots \ldots \ldots \ldots .436$

433. Analysis of percentage of zero daily mean streamflow for U.S. Geological Survey streamflow-gaging station 08110800 Navasota River at Old Spanish Road near Bryan, Texas $\ldots \ldots \ldots \ldots \ldots \ldots \ldots$

434. Analysis of percentage of zero daily mean streamflow for U.S. Geological Survey streamflow-gaging station 08111000 Navasota River near Bryan, Texas $\ldots \ldots \ldots \ldots \ldots \ldots \ldots \ldots \ldots \ldots \ldots \ldots \ldots$

435. Analysis of percentage of zero daily mean streamflow for U.S. Geological Survey streamflow-gaging station 08111010 Navasota River near College Station, Texas $\ldots \ldots \ldots \ldots \ldots \ldots \ldots \ldots \ldots \ldots \ldots \ldots 439$

436. Analysis of percentage of zero daily mean streamflow for U.S. Geological Survey streamflow-gaging station 08111025 Burton Creek at Villa Maria Road, Bryan, Texas $\ldots \ldots \ldots \ldots \ldots \ldots \ldots \ldots \ldots \ldots \ldots$

437. Analysis of percentage of zero daily mean streamflow for U.S. Geological Survey streamflow-gaging station 08111050 Hudson Creek near Bryan, Texas $\ldots \ldots \ldots \ldots \ldots \ldots \ldots \ldots \ldots \ldots \ldots \ldots \ldots \ldots$

438. Analysis of percentage of zero daily mean streamflow for U.S. Geological Survey streamflow-gaging station 08111500 Brazos River near Hempstead, Texas $\ldots \ldots \ldots \ldots \ldots \ldots \ldots \ldots \ldots \ldots \ldots \ldots \ldots \ldots 442$

439. Analysis of percentage of zero daily mean streamflow for U.S. Geological Survey streamflow-gaging station 08111700 Mill Creek near Bellville, Texas $\ldots \ldots \ldots \ldots \ldots \ldots \ldots \ldots \ldots \ldots \ldots \ldots \ldots \ldots \ldots$

440. Analysis of percentage of zero daily mean streamflow for U.S. Geological Survey streamflow-gaging station 08114000 Brazos River at Richmond, Texas $\ldots \ldots \ldots \ldots \ldots \ldots \ldots \ldots \ldots \ldots \ldots \ldots \ldots \ldots 444$

441. Analysis of percentage of zero daily mean streamflow for U.S. Geological Survey streamflow-gaging station 08114500 Brazos River near Juliff, texas $\ldots \ldots \ldots \ldots \ldots \ldots \ldots \ldots \ldots \ldots \ldots \ldots \ldots \ldots \ldots 445$

442. Analysis of percentage of zero daily mean streamflow for U.S. Geological Survey streamflow-gaging station 08115000 Big Creek near Needville, Texas $\ldots \ldots \ldots \ldots \ldots \ldots \ldots \ldots \ldots \ldots \ldots \ldots \ldots \ldots$

443. Analysis of percentage of zero daily mean streamflow for U.S. Geological Survey streamflow-gaging station 08115500 Fairchild Creek near Needville, Texas $\ldots \ldots \ldots \ldots \ldots \ldots \ldots \ldots \ldots \ldots \ldots \ldots \ldots$

444. Analysis of percentage of zero daily mean streamflow for U.S. Geological Survey streamflow-gaging station 08116000 Big Creek near Guy, Texas $\ldots \ldots \ldots \ldots \ldots \ldots \ldots \ldots \ldots \ldots \ldots \ldots \ldots \ldots \ldots$

445. Analysis of percentage of zero daily mean streamflow for U.S. Geological Survey streamflow-gaging

446. Analysis of percentage of zero daily mean streamflow for U.S. Geological Survey streamflow-gaging station 08116500 Dry Creek near Richmond, Texas $\ldots \ldots \ldots \ldots \ldots \ldots \ldots \ldots \ldots \ldots \ldots \ldots \ldots$

447. Analysis of percentage of zero daily mean streamflow for U.S. Geological Survey streamflow-gaging station 08116650 Brazos River near Rosharon, Texas $\ldots \ldots \ldots \ldots \ldots \ldots \ldots \ldots \ldots \ldots \ldots \ldots \ldots \ldots 451$

448. Analysis of percentage of zero daily mean streamflow for U.S. Geological Survey streamflow-gaging station 08117500 San Bernard River near Boling, Texas $\ldots \ldots \ldots \ldots \ldots \ldots \ldots \ldots \ldots \ldots \ldots \ldots \ldots 452$

449. Analysis of percentage of zero daily mean streamflow for U.S. Geological Survey streamflow-gaging station 08117900 Big Boggy Creek near Wadsworth, Texas $\ldots \ldots \ldots \ldots \ldots \ldots \ldots \ldots \ldots \ldots \ldots \ldots 45$ 
xxii

450. Analysis of percentage of zero daily mean streamflow for U.S. Geological Survey streamflow-gaging station 08117995 Colorado River near Gail, Texas $\ldots \ldots \ldots \ldots \ldots \ldots \ldots \ldots \ldots \ldots \ldots \ldots \ldots \ldots \ldots 454$

451. Analysis of percentage of zero daily mean streamflow for U.S. Geological Survey streamflow-gaging station 08118500 Bull Creek near Ira, Texas $\ldots \ldots \ldots \ldots \ldots \ldots \ldots \ldots \ldots \ldots \ldots \ldots \ldots \ldots \ldots \ldots \ldots$

452. Analysis of percentage of zero daily mean streamflow for U.S. Geological Survey streamflow-gaging

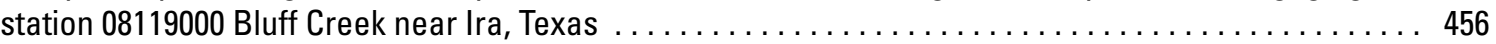

453. Analysis of percentage of zero daily mean streamflow for U.S. Geological Survey streamflow-gaging station 08119500 Colorado River near Ira, Texas $\ldots \ldots \ldots \ldots \ldots \ldots \ldots \ldots \ldots \ldots \ldots \ldots \ldots \ldots \ldots \ldots \ldots$

454. Analysis of percentage of zero daily mean streamflow for U.S. Geological Survey streamflow-gaging station 08120500 Deep Creek near Dunn, Texas $\ldots \ldots \ldots \ldots \ldots \ldots \ldots \ldots \ldots \ldots \ldots \ldots \ldots \ldots \ldots$

455. Analysis of percentage of zero daily mean streamflow for U.S. Geological Survey streamflow-gaging station 08120700 Colorado River near Cuthbert, Texas $\ldots \ldots \ldots \ldots \ldots \ldots \ldots \ldots \ldots \ldots \ldots \ldots \ldots \ldots$

456. Analysis of percentage of zero daily mean streamflow for U.S. Geological Survey streamflow-gaging station 08121000 Colorado River at Colorado City, Texas $\ldots \ldots \ldots \ldots \ldots \ldots \ldots \ldots \ldots \ldots \ldots \ldots \ldots 460$

457. Analysis of percentage of zero daily mean streamflow for U.S. Geological Survey streamflow-gaging station 08121500 Morgan Creek near Westbrook, Texas $\ldots \ldots \ldots \ldots \ldots \ldots \ldots \ldots \ldots \ldots \ldots \ldots \ldots$

458. Analysis of percentage of zero daily mean streamflow for U.S. Geological Survey streamflow-gaging station 08122000 Graze Creek near Westbrook, Texas $\ldots \ldots \ldots \ldots \ldots \ldots \ldots \ldots \ldots \ldots \ldots \ldots \ldots \ldots 2$

459. Analysis of percentage of zero daily mean streamflow for U.S. Geological Survey streamflow-gaging station 08122500 Morgan Creek near Colorado City, Texas $\ldots \ldots \ldots \ldots \ldots \ldots \ldots \ldots \ldots \ldots \ldots \ldots \ldots$

460. Analysis of percentage of zero daily mean streamflow for U.S. Geological Survey streamflow-gaging station 08123500 Champion Creek near Colorado City, Texas $\ldots \ldots \ldots \ldots \ldots \ldots \ldots \ldots \ldots \ldots \ldots \ldots 4$

461. Analysis of percentage of zero daily mean streamflow for U.S. Geological Survey streamflow-gaging station 08123650 Beals Creek above Big Spring, Texas $\ldots \ldots \ldots \ldots \ldots \ldots \ldots \ldots \ldots \ldots \ldots \ldots \ldots 46 \ldots \ldots \ldots$

462. Analysis of percentage of zero daily mean streamflow for U.S. Geological Survey streamflow-gaging

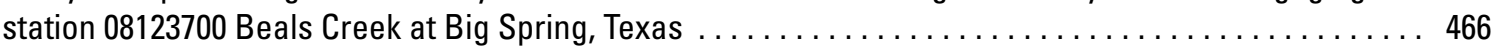

463. Analysis of percentage of zero daily mean streamflow for U.S. Geological Survey streamflow-gaging station 08123720 Beals Creek near Coahoma, Texas $\ldots \ldots \ldots \ldots \ldots \ldots \ldots \ldots \ldots \ldots \ldots \ldots \ldots \ldots$

464. Analysis of percentage of zero daily mean streamflow for U.S. Geological Survey streamflow-gaging station 08123800 Beals Creek near Westbrook, Texas $\ldots \ldots \ldots \ldots \ldots \ldots \ldots \ldots \ldots \ldots \ldots \ldots \ldots \ldots$

465. Analysis of percentage of zero daily mean streamflow for U.S. Geological Survey streamflow-gaging station 08123850 Colorado River above Silver, Texas $\ldots \ldots \ldots \ldots \ldots \ldots \ldots \ldots \ldots \ldots \ldots \ldots \ldots \ldots 469$

466. Analysis of percentage of zero daily mean streamflow for U.S. Geological Survey streamflow-gaging station 08123900 Colorado River near Silver, Texas $\ldots \ldots \ldots \ldots \ldots \ldots \ldots \ldots \ldots \ldots \ldots \ldots \ldots \ldots$

467. Analysis of percentage of zero daily mean streamflow for U.S. Geological Survey streamflow-gaging station 08124000 Colorado River at Robert Lee, Texas $\ldots \ldots \ldots \ldots \ldots \ldots \ldots \ldots \ldots \ldots \ldots \ldots \ldots$

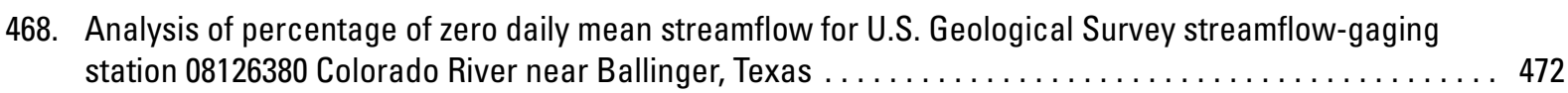

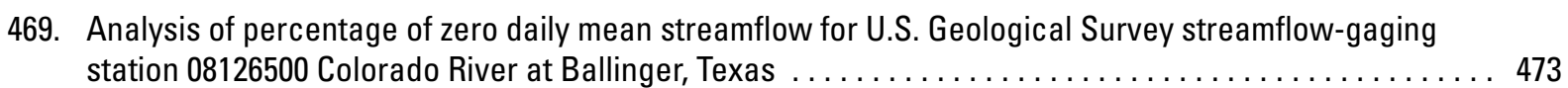

470. Analysis of percentage of zero daily mean streamflow for U.S. Geological Survey streamflow-gaging station 08127000 Elm Creek at Ballinger, Texas $\ldots \ldots \ldots \ldots \ldots \ldots \ldots \ldots \ldots \ldots \ldots \ldots \ldots \ldots$

471. Analysis of percentage of zero daily mean streamflow for U.S. Geological Survey streamflow-gaging station 08128000 South Concho River at Christoval, Texas $\ldots \ldots \ldots \ldots \ldots \ldots \ldots \ldots \ldots \ldots \ldots \ldots \ldots 475$

472. Analysis of percentage of zero daily mean streamflow for U.S. Geological Survey streamflow-gaging station 08128400 Middle Concho River above Tankersley, Texas $\ldots \ldots \ldots \ldots \ldots \ldots \ldots \ldots \ldots \ldots \ldots$

473. Analysis of percentage of zero daily mean streamflow for U.S. Geological Survey streamflow-gaging station 08128500 Middle Concho River near Tankersley, texas $\ldots \ldots \ldots \ldots \ldots \ldots \ldots \ldots \ldots \ldots \ldots$ 
474. Analysis of percentage of zero daily mean streamflow for U.S. Geological Survey streamflow-gaging station 08129300 Spring Creek above Tankersley, texas $\ldots \ldots \ldots \ldots \ldots \ldots \ldots \ldots \ldots \ldots \ldots \ldots \ldots 478$

475. Analysis of percentage of zero daily mean streamflow for U.S. Geological Survey streamflow-gaging station 08130500 Dove Creek at Knickerbocker, Texas $\ldots \ldots \ldots \ldots \ldots \ldots \ldots \ldots \ldots \ldots \ldots \ldots \ldots \ldots$

476. Analysis of percentage of zero daily mean streamflow for U.S. Geological Survey streamflow-gaging station 08130700 Spring Creek above Twin Buttes Reservoir near San Angelo, Texas $\ldots \ldots \ldots \ldots \ldots .480$

477. Analysis of percentage of zero daily mean streamflow for U.S. Geological Survey streamflow-gaging station 08131000 Spring Creek near Tankersley, Texas $\ldots \ldots \ldots \ldots \ldots \ldots \ldots \ldots \ldots \ldots \ldots \ldots \ldots \ldots$

478. Analysis of percentage of zero daily mean streamflow for U.S. Geological Survey streamflow-gaging station 08131400 Pecan Creek near San Angelo, texas $\ldots \ldots \ldots \ldots \ldots \ldots \ldots \ldots \ldots \ldots \ldots \ldots \ldots 48$

479. Analysis of percentage of zero daily mean streamflow for U.S. Geological Survey streamflow-gaging station 08132500 South Concho River at San Angelo, Texas $\ldots \ldots \ldots \ldots \ldots \ldots \ldots \ldots \ldots \ldots \ldots \ldots 483$

480. Analysis of percentage of zero daily mean streamflow for U.S. Geological Survey streamflow-gaging station 08133250 North Concho River above Sterling City, Texas $\ldots \ldots \ldots \ldots \ldots \ldots \ldots \ldots \ldots \ldots \ldots$

481. Analysis of percentage of zero daily mean streamflow for U.S. Geological Survey streamflow-gaging station 08133500 North Concho River at Sterling City, Texas

482. Analysis of percentage of zero daily mean streamflow for U.S. Geological Survey streamflow-gaging station 08133900 Chalk Creek near Water Valley, texas $\ldots \ldots \ldots \ldots \ldots \ldots \ldots \ldots \ldots \ldots \ldots \ldots \ldots$

483. Analysis of percentage of zero daily mean streamflow for U.S. Geological Survey streamflow-gaging station 08134000 North Concho River near Carlsbad, Texas $\ldots \ldots \ldots \ldots \ldots \ldots \ldots \ldots \ldots \ldots \ldots \ldots \ldots 48$

484. Analysis of percentage of zero daily mean streamflow for U.S. Geological Survey streamflow-gaging station 08134230 Grape Creek near Grape Creek, Texas $\ldots \ldots \ldots \ldots \ldots \ldots \ldots \ldots \ldots \ldots \ldots \ldots \ldots$

485. Analysis of percentage of zero daily mean streamflow for U.S. Geological Survey streamflow-gaging station 08134250 North Concho River near Grape Creek, Texas $\ldots \ldots \ldots \ldots \ldots \ldots \ldots \ldots \ldots \ldots \ldots 489$

486. Analysis of percentage of zero daily mean streamflow for U.S. Geological Survey streamflow-gaging station 08135000 North Concho River at San Angelo, Texas $\ldots \ldots \ldots \ldots \ldots \ldots \ldots \ldots \ldots \ldots \ldots \ldots$

487. Analysis of percentage of zero daily mean streamflow for U.S. Geological Survey streamflow-gaging station 08136000 Concho River at San Angelo, Texas $\ldots \ldots \ldots \ldots \ldots \ldots \ldots \ldots \ldots \ldots \ldots \ldots \ldots \ldots$ 491

488. Analysis of percentage of zero daily mean streamflow for U.S. Geological Survey streamflow-gaging station 08136500 Concho River at Paint Rock, Texas $\ldots \ldots \ldots \ldots \ldots \ldots \ldots \ldots \ldots \ldots \ldots \ldots \ldots \ldots \ldots 2$

489. Analysis of percentage of zero daily mean streamflow for U.S. Geological Survey streamflow-gaging station 08136700 Colorado River near Stacy, Texas $\ldots \ldots \ldots \ldots \ldots \ldots \ldots \ldots \ldots \ldots \ldots \ldots \ldots \ldots 49 \ldots \ldots$

490. Analysis of percentage of zero daily mean streamflow for U.S. Geological Survey streamflow-gaging station 08138000 Colorado River at Winchell, Texas $\ldots \ldots \ldots \ldots \ldots \ldots \ldots \ldots \ldots \ldots \ldots \ldots \ldots \ldots 49 \ldots \ldots \ldots$

491. Analysis of percentage of zero daily mean streamflow for U.S. Geological Survey streamflow-gaging station 08139500 Deep Creek near Mercury, Texas $\ldots \ldots \ldots \ldots \ldots \ldots \ldots \ldots \ldots \ldots \ldots \ldots \ldots \ldots \ldots$

492. Analysis of percentage of zero daily mean streamflow for U.S. Geological Survey streamflow-gaging station 08140500 Dry Prong Deep Creek near Mercury, Texas $\ldots \ldots \ldots \ldots \ldots \ldots \ldots \ldots \ldots \ldots \ldots \ldots 496$

493. Analysis of percentage of zero daily mean streamflow for U.S. Geological Survey streamflow-gaging station 08140700 Pecan Bayou near Cross Cut, Texas $\ldots \ldots \ldots \ldots \ldots \ldots \ldots \ldots \ldots \ldots \ldots \ldots \ldots \ldots$

494. Analysis of percentage of zero daily mean streamflow for U.S. Geological Survey streamflow-gaging station $08140800 \mathrm{Jim} N$ d Creek near Coleman, Texas $\ldots \ldots \ldots \ldots \ldots \ldots \ldots \ldots \ldots \ldots \ldots \ldots \ldots \ldots$

495. Analysis of percentage of zero daily mean streamflow for U.S. Geological Survey streamflow-gaging station 08141500 Hords Creek near Valera, Texas $\ldots \ldots \ldots \ldots \ldots \ldots \ldots \ldots \ldots \ldots \ldots \ldots \ldots \ldots \ldots 9$

496. Analysis of percentage of zero daily mean streamflow for U.S. Geological Survey streamflow-gaging

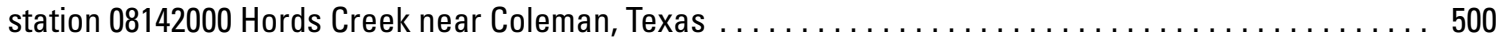

497. Analysis of percentage of zero daily mean streamflow for U.S. Geological Survey streamflow-gaging station 08143500 Pecan Bayou at Brownwood, Texas $\ldots \ldots \ldots \ldots \ldots \ldots \ldots \ldots \ldots \ldots \ldots \ldots \ldots$ 
498. Analysis of percentage of zero daily mean streamflow for U.S. Geological Survey streamflow-gaging

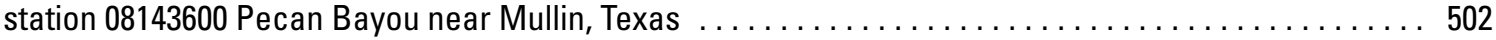

499. Analysis of percentage of zero daily mean streamflow for U.S. Geological Survey streamflow-gaging station 08144500 San Saba River at Menard, Texas $\ldots \ldots \ldots \ldots \ldots \ldots \ldots \ldots \ldots \ldots \ldots \ldots \ldots \ldots$

500. Analysis of percentage of zero daily mean streamflow for U.S. Geological Survey streamflow-gaging

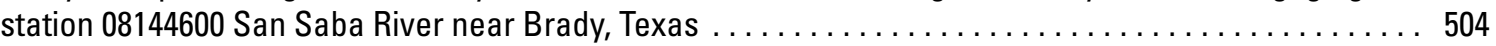

501. Analysis of percentage of zero daily mean streamflow for U.S. Geological Survey streamflow-gaging

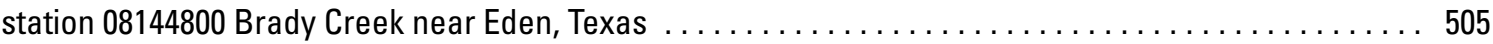

502. Analysis of percentage of zero daily mean streamflow for U.S. Geological Survey streamflow-gaging

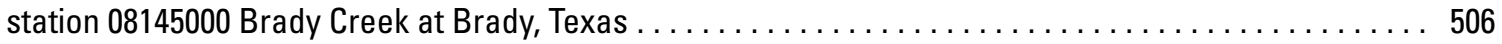

503. Analysis of percentage of zero daily mean streamflow for U.S. Geological Survey streamflow-gaging station 08146000 San Saba River at San Saba, Texas $\ldots \ldots \ldots \ldots \ldots \ldots \ldots \ldots \ldots \ldots \ldots \ldots \ldots \ldots$

504. Analysis of percentage of zero daily mean streamflow for U.S. Geological Survey streamflow-gaging station 08147000 Colorado River near San Saba, Texas $\ldots \ldots \ldots \ldots \ldots \ldots \ldots \ldots \ldots \ldots \ldots \ldots \ldots \ldots$

505. Analysis of percentage of zero daily mean streamflow for U.S. Geological Survey streamflow-gaging station 08148500 North Llano River near Junction, Texas $\ldots \ldots \ldots \ldots \ldots \ldots \ldots \ldots \ldots \ldots \ldots \ldots \ldots$

506. Analysis of percentage of zero daily mean streamflow for U.S. Geological Survey streamflow-gaging

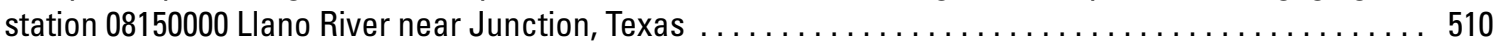

507. Analysis of percentage of zero daily mean streamflow for U.S. Geological Survey streamflow-gaging station 08150700 Llano River near Mason, Texas $\ldots \ldots \ldots \ldots \ldots \ldots \ldots \ldots \ldots \ldots \ldots \ldots \ldots \ldots \ldots \ldots \ldots$

508. Analysis of percentage of zero daily mean streamflow for U.S. Geological Survey streamflow-gaging station 08150800 Beaver Creek near Mason, Texas $\ldots \ldots \ldots \ldots \ldots \ldots \ldots \ldots \ldots \ldots \ldots \ldots \ldots \ldots \ldots 12$

509. Analysis of percentage of zero daily mean streamflow for U.S. Geological Survey streamflow-gaging station 08151000 Llano River near Castell, Texas $\ldots \ldots \ldots \ldots \ldots \ldots \ldots \ldots \ldots \ldots \ldots \ldots \ldots \ldots \ldots \ldots$

510. Analysis of percentage of zero daily mean streamflow for U.S. Geological Survey streamflow-gaging

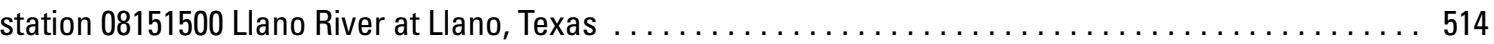

511. Analysis of percentage of zero daily mean streamflow for U.S. Geological Survey streamflow-gaging station 08152000 Sandy Creek near Kingsland, Texas $\ldots \ldots \ldots \ldots \ldots \ldots \ldots \ldots \ldots \ldots \ldots \ldots \ldots \ldots$

512. Analysis of percentage of zero daily mean streamflow for U.S. Geological Survey streamflow-gaging station 08152900 Pedernales River near Fredericksburg, Texas $\ldots \ldots \ldots \ldots \ldots \ldots \ldots \ldots \ldots \ldots \ldots$

513. Analysis of percentage of zero daily mean streamflow for U.S. Geological Survey streamflow-gaging station 08153000 Pedernales River at Stonewall, texas $\ldots \ldots \ldots \ldots \ldots \ldots \ldots \ldots \ldots \ldots \ldots \ldots \ldots \ldots$

514. Analysis of percentage of zero daily mean streamflow for U.S. Geological Survey streamflow-gaging station 08153500 Pedernales River near Johnson City, Texas $\ldots \ldots \ldots \ldots \ldots \ldots \ldots \ldots \ldots \ldots \ldots \ldots$

515. $\quad$ Analysis of percentage of zero daily mean streamflow for U.S. Geological Survey streamflow-gaging station 08154000 Pedernales River near Spicew00d, Texas $\ldots \ldots \ldots \ldots \ldots \ldots \ldots \ldots \ldots \ldots \ldots \ldots \ldots$

516. Analysis of percentage of zero daily mean streamflow for U.S. Geological Survey streamflow-gaging station 08154510 Colorado River below Mansfield Dam, Austin, Texas $\ldots \ldots \ldots \ldots \ldots \ldots \ldots \ldots \ldots$

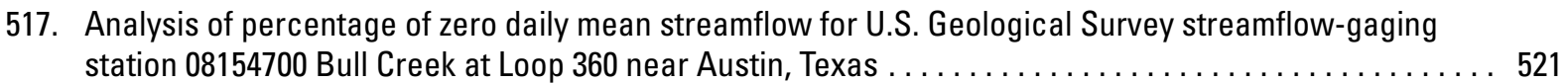

518. Analysis of percentage of zero daily mean streamflow for U.S. Geological Survey streamflow-gaging station 08155200 Barton Creek at State Highway 71 near 0ak Hill, Texas $\ldots \ldots \ldots \ldots \ldots \ldots \ldots \ldots$

519. Analysis of percentage of zero daily mean streamflow for U.S. Geological Survey streamflow-gaging station 08155240 Barton Creek at Lost Creek Boulevard near Austin, Texas $\ldots \ldots \ldots \ldots \ldots \ldots \ldots \ldots$

520. Analysis of percentage of zero daily mean streamflow for U.S. Geological Survey streamflow-gaging station 08155260 Barton Creek near Camp Craft Road near Austin, Texas $\ldots \ldots \ldots \ldots \ldots \ldots \ldots \ldots$

521. Analysis of percentage of zero daily mean streamflow for U.S. Geological Survey streamflow-gaging station 08155300 Barton Creek at Loop 360, Austin, Texas $\ldots \ldots \ldots \ldots \ldots \ldots \ldots \ldots \ldots \ldots \ldots \ldots$ 
522. Analysis of percentage of zero daily mean streamflow for U.S. Geological Survey streamflow-gaging station 08155400 Barton Creek above Barton Springs at Austin, Texas $\ldots \ldots \ldots \ldots \ldots \ldots \ldots \ldots \ldots \ldots 526$

523. Analysis of percentage of zero daily mean streamflow for U.S. Geological Survey streamflow-gaging station 08156700 Shoal Creek at Northwest Park at Austin, Texas $\ldots \ldots \ldots \ldots \ldots \ldots \ldots \ldots \ldots \ldots \ldots$

524. Analysis of percentage of zero daily mean streamflow for U.S. Geological Survey streamflow-gaging station 08156800 Shoal Creek at West 12th Street, Austin, Texas $\ldots \ldots \ldots \ldots \ldots \ldots \ldots \ldots \ldots \ldots \ldots$

525. Analysis of percentage of zero daily mean streamflow for U.S. Geological Survey streamflow-gaging station 08157000 Waller Creek at 38th Street, Austin, Texas $\ldots \ldots \ldots \ldots \ldots \ldots \ldots \ldots \ldots \ldots \ldots \ldots \ldots 29$

526. $\quad$ Analysis of percentage of zero daily mean streamflow for U.S. Geological Survey streamflow-gaging station 08157500 Waller Creek at 23rd Street, Austin, Texas $\ldots \ldots \ldots \ldots \ldots \ldots \ldots \ldots \ldots \ldots \ldots \ldots$

527. Analysis of percentage of zero daily mean streamflow for U.S. Geological Survey streamflow-gaging station 08157600 East Bouldin Creek at South 1st Street, Austin, Texas $\ldots \ldots \ldots \ldots \ldots \ldots \ldots \ldots \ldots$

528. Analysis of percentage of zero daily mean streamflow for U.S. Geological Survey streamflow-gaging station 08157700 Blunn Creek near Little Stacy Park, Austin, Texas $\quad \ldots \ldots \ldots \ldots \ldots \ldots \ldots \ldots \ldots \ldots \ldots 32$

529. Analysis of percentage of zero daily mean streamflow for U.S. Geological Survey streamflow-gaging

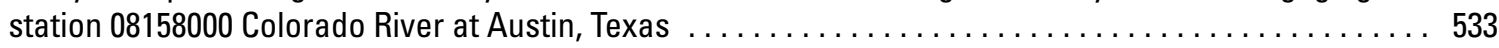

530. Analysis of percentage of zero daily mean streamflow for U.S. Geological Survey streamflow-gaging station 08158050 Boggy Creek at U. S. Highway 183, Austin, Texas $\ldots \ldots \ldots \ldots \ldots \ldots \ldots \ldots \ldots \ldots \ldots 34$

531. Analysis of percentage of zero daily mean streamflow for U.S. Geological Survey streamflow-gaging station 08158600 Walnut Creek at Webberville Road, Austin, Texas $\ldots \ldots \ldots \ldots \ldots \ldots \ldots \ldots \ldots \ldots$

532. Analysis of percentage of zero daily mean streamflow for U.S. Geological Survey streamflow-gaging station 08158700 0nion Creek near Driftwood, lexas $\ldots \ldots \ldots \ldots \ldots \ldots \ldots \ldots \ldots \ldots \ldots \ldots \ldots \ldots$

533. Analysis of percentage of zero daily mean streamflow for U.S. Geological Survey streamflow-gaging

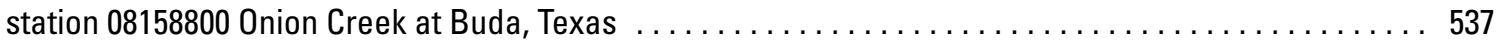

534. Analysis of percentage of zero daily mean streamflow for U.S. Geological Survey streamflow-gaging station 08158810 Bear Creek below Farm to Market Road 1826 near Driftwood, Texas $\ldots \ldots \ldots \ldots \ldots$

535. Analysis of percentage of zero daily mean streamflow for U.S. Geological Survey streamflow-gaging station 08158840 Slaughter Creek at Farm to Market Road 1826 near Austin, Texas $\ldots \ldots \ldots \ldots \ldots \ldots$

536. Analysis of percentage of zero daily mean streamflow for U.S. Geological Survey streamflow-gaging station 08158920Williamson Creek at 0ak Hill, Texas $\ldots \ldots \ldots \ldots \ldots \ldots \ldots \ldots \ldots \ldots \ldots \ldots \ldots \ldots$. 540

537. Analysis of percentage of zero daily mean streamflow for U.S. Geological Survey streamflow-gaging station 08158922 Williamson Creek at Brush Country Boulevard, 0ak Hill, Texas $\ldots \ldots \ldots \ldots \ldots \ldots$.

538. Analysis of percentage of zero daily mean streamflow for U.S. Geological Survey streamflow-gaging station 08158930 Williamson Creek at Manchaca Road, Austin, Texas $\ldots \ldots \ldots \ldots \ldots \ldots \ldots \ldots \ldots$

539. Analysis of percentage of zero daily mean streamflow for U.S. Geological Survey streamflow-gaging station 08158970Williamson Creek at Jimmy Clay Road, Austin, Texas $\ldots \ldots \ldots \ldots \ldots \ldots \ldots \ldots \ldots$

540. Analysis of percentage of zero daily mean streamflow for U.S. Geological Survey streamflow-gaging station 08159000 0nion Creek at U. S. Highway 183, Austin, Texas $\ldots \ldots \ldots \ldots \ldots \ldots \ldots \ldots \ldots \ldots \ldots 44$

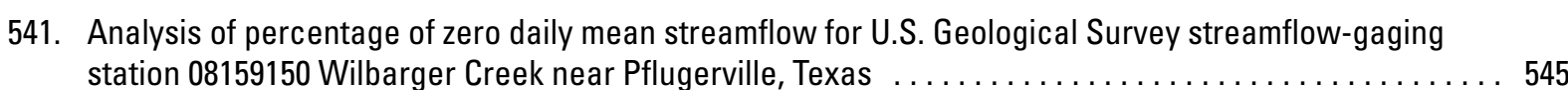

542. Analysis of percentage of zero daily mean streamflow for U.S. Geological Survey streamflow-gaging station 08159165 Big Sandy Creek near McDade, Texas $\ldots \ldots \ldots \ldots \ldots \ldots \ldots \ldots \ldots \ldots \ldots \ldots$

543. Analysis of percentage of zero daily mean streamflow for U.S. Geological Survey streamflow-gaging station 08159170 Big Sandy Creek near Elgin, Texas $\ldots \ldots \ldots \ldots \ldots \ldots \ldots \ldots \ldots \ldots \ldots \ldots \ldots \ldots \ldots 47$

544. Analysis of percentage of zero daily mean streamflow for U.S. Geological Survey streamflow-gaging station 08159200 Colorado River at Bastrop, Texas $\ldots \ldots \ldots \ldots \ldots \ldots \ldots \ldots \ldots \ldots \ldots \ldots \ldots$

545. Analysis of percentage of zero daily mean streamflow for U.S. Geological Survey streamflow-gaging station 08159500 Colorado River at Smithville, Texas $\ldots \ldots \ldots \ldots \ldots \ldots \ldots \ldots \ldots \ldots \ldots \ldots \ldots \ldots$ 
546. Analysis of percentage of zero daily mean streamflow for U.S. Geological Survey streamflow-gaging

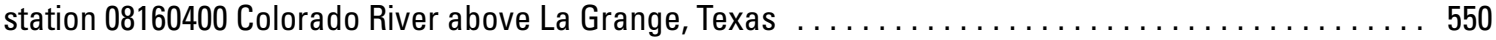

547. Analysis of percentage of zero daily mean streamflow for U.S. Geological Survey streamflow-gaging

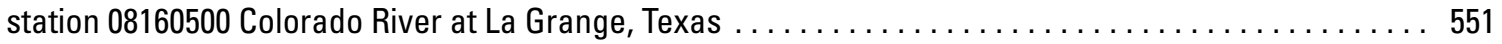

548. Analysis of percentage of zero daily mean streamflow for U.S. Geological Survey streamflow-gaging

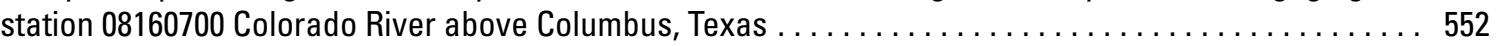

549. Analysis of percentage of zero daily mean streamflow for U.S. Geological Survey streamflow-gaging

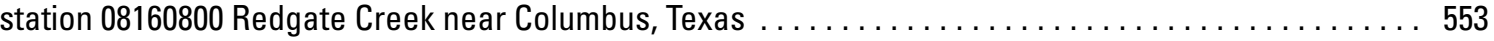

550. Analysis of percentage of zero daily mean streamflow for U.S. Geological Survey streamflow-gaging

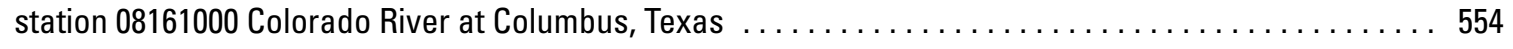

551. Analysis of percentage of zero daily mean streamflow for U.S. Geological Survey streamflow-gaging

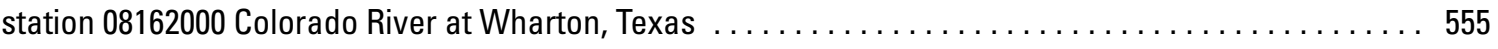

552. Analysis of percentage of zero daily mean streamflow for U.S. Geological Survey streamflow-gaging

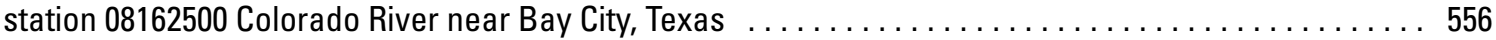

553. Analysis of percentage of zero daily mean streamflow for U.S. Geological Survey streamflow-gaging

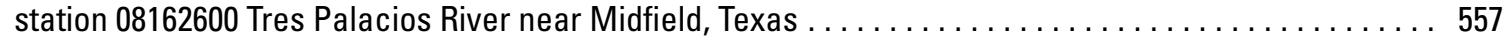

554. Analysis of percentage of zero daily mean streamflow for U.S. Geological Survey streamflow-gaging

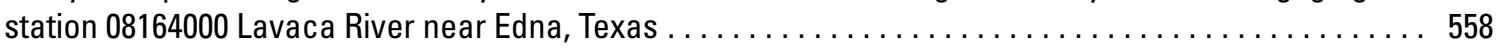

555. Analysis of percentage of zero daily mean streamflow for U.S. Geological Survey streamflow-gaging station 08164300 Navidad River near Hallettsville, lexas $\ldots \ldots \ldots \ldots \ldots \ldots \ldots \ldots \ldots \ldots \ldots \ldots \ldots \ldots, \ldots \ldots \ldots$

556. Analysis of percentage of zero daily mean streamflow for U.S. Geological Survey streamflow-gaging

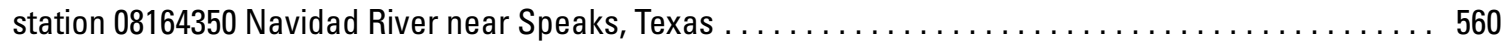

557. Analysis of percentage of zero daily mean streamflow for U.S. Geological Survey streamflow-gaging

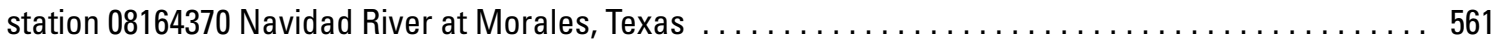

558. Analysis of percentage of zero daily mean streamflow for U.S. Geological Survey streamflow-gaging

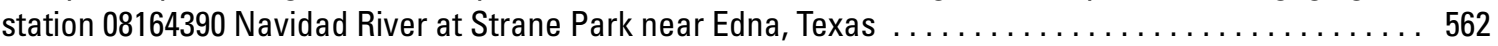

559. Analysis of percentage of zero daily mean streamflow for U.S. Geological Survey streamflow-gaging

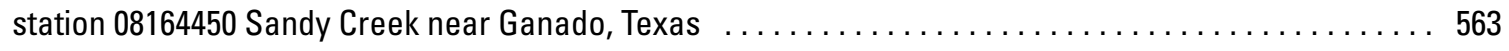

560. Analysis of percentage of zero daily mean streamflow for U.S. Geological Survey streamflow-gaging

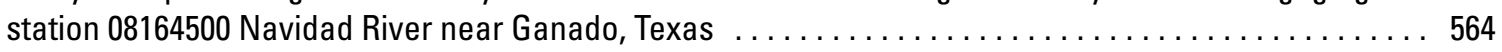

561. Analysis of percentage of zero daily mean streamflow for U.S. Geological Survey streamflow-gaging

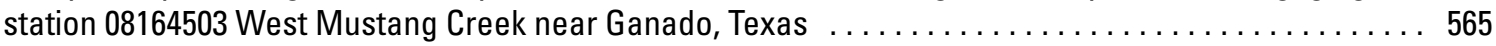

562. Analysis of percentage of zero daily mean streamflow for U.S. Geological Survey streamflow-gaging

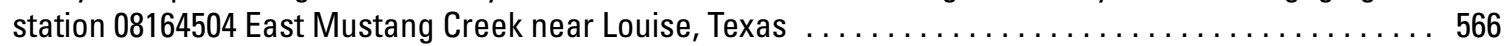

563. Analysis of percentage of zero daily mean streamflow for U.S. Geological Survey streamflow-gaging

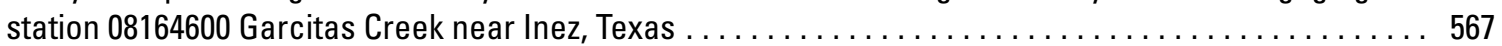

564. Analysis of percentage of zero daily mean streamflow for U.S. Geological Survey streamflow-gaging station 08164800 Placedo Creek near Placedo, lexas $\ldots \ldots \ldots \ldots \ldots \ldots \ldots \ldots \ldots \ldots \ldots \ldots \ldots \ldots, 568$

565. Analysis of percentage of zero daily mean streamflow for U.S. Geological Survey streamflow-gaging

566. Analysis of percentage of zero daily mean streamflow for U.S. Geological Survey streamflow-gaging

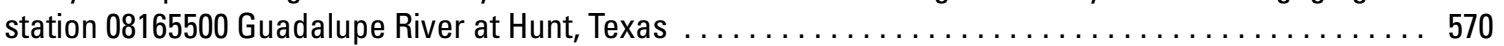
567. Analysis of percentage of zero daily mean streamflow for U.S. Geological Survey streamflow-gaging

568. Analysis of percentage of zero daily mean streamflow for U.S. Geological Survey streamflow-gaging station 08166140 Guadalupe River above Bear Creek at Kerrville, lexas $\ldots \ldots \ldots \ldots \ldots \ldots \ldots \ldots, 512$

569. Analysis of percentage of zero daily mean streamflow for U.S. Geological Survey streamflow-gaging station 08166200 Guadalupe River at Kerrville, lexas $\ldots \ldots \ldots \ldots \ldots \ldots \ldots \ldots \ldots \ldots \ldots \ldots \ldots, 573$ 
570. Analysis of percentage of zero daily mean streamflow for U.S. Geological Survey streamflow-gaging

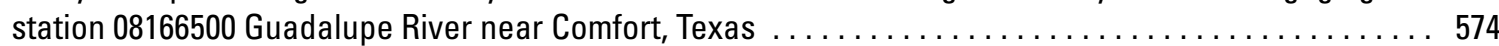

571. Analysis of percentage of zero daily mean streamflow for U.S. Geological Survey streamflow-gaging

572. Analysis of percentage of zero daily mean streamflow for U.S. Geological Survey streamflow-gaging station 08167500 Guadalupe River near Spring Branch, Texas $\ldots \ldots \ldots \ldots \ldots \ldots \ldots \ldots \ldots \ldots \ldots, \quad 576$

573. Analysis of percentage of zero daily mean streamflow for U.S. Geological Survey streamflow-gaging

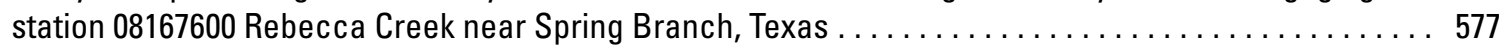

574. Analysis of percentage of zero daily mean streamflow for U.S. Geological Survey streamflow-gaging

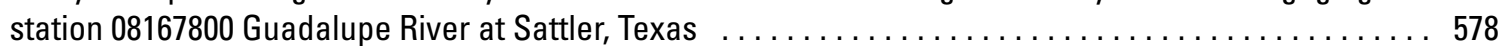

575. Analysis of percentage of zero daily mean streamflow for U.S. Geological Survey streamflow-gaging station 08168500 Guadalupe River above Comal River at New Braunfels, Texas $\ldots \ldots \ldots \ldots \ldots \ldots \ldots, 579$

576. Analysis of percentage of zero daily mean streamflow for U.S. Geological Survey streamflow-gaging

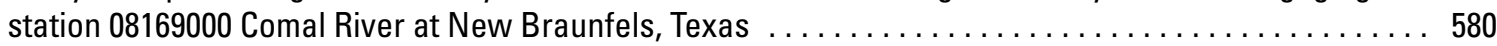

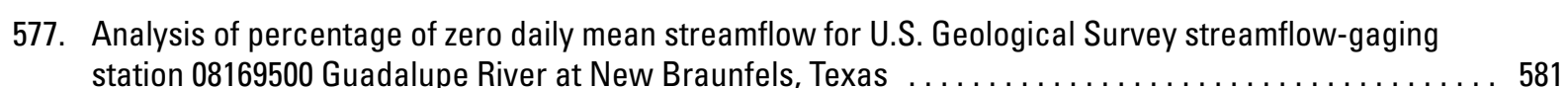

578. Analysis of percentage of zero daily mean streamflow for U.S. Geological Survey streamflow-gaging

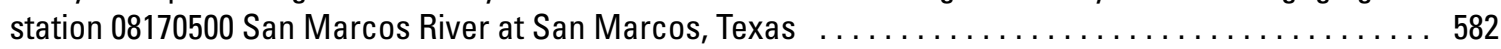

579. Analysis of percentage of zero daily mean streamflow for U.S. Geological Survey streamflow-gaging

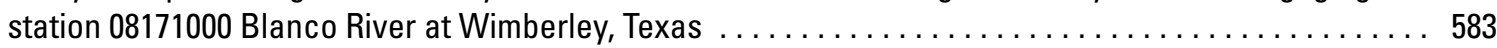

580. Analysis of percentage of zero daily mean streamflow for U.S. Geological Survey streamflow-gaging

581. Analysis of percentage of zero daily mean streamflow for U.S. Geological Survey streamflow-gaging

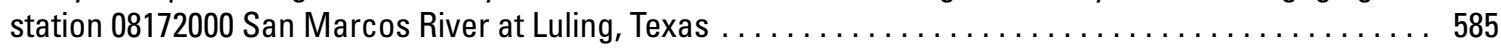

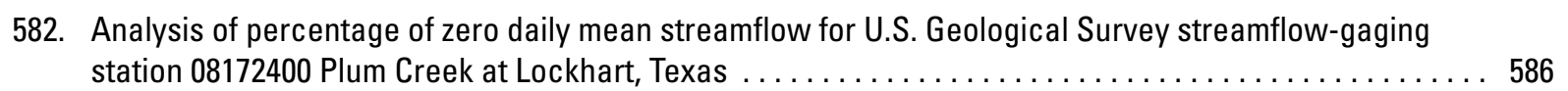

583. Analysis of percentage of zero daily mean streamflow for U.S. Geological Survey streamflow-gaging

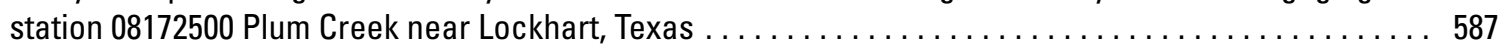

584. Analysis of percentage of zero daily mean streamflow for U.S. Geological Survey streamflow-gaging

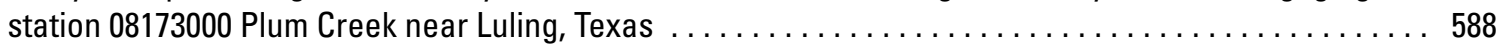

585. Analysis of percentage of zero daily mean streamflow for U.S. Geological Survey streamflow-gaging

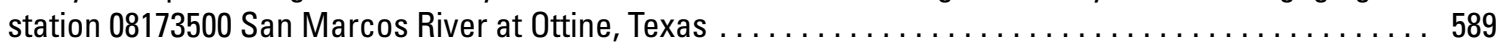

586. Analysis of percentage of zero daily mean streamflow for U.S. Geological Survey streamflow-gaging

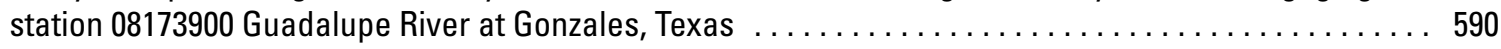

587. Analysis of percentage of zero daily mean streamflow for U.S. Geological Survey streamflow-gaging

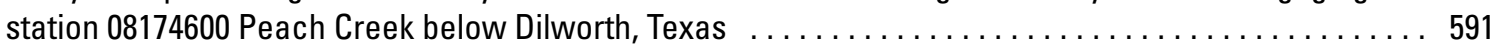

588. Analysis of percentage of zero daily mean streamflow for U.S. Geological Survey streamflow-gaging station 08175000 Sandies Creek near Westhoff, Texas $\ldots \ldots \ldots \ldots \ldots \ldots \ldots \ldots \ldots \ldots \ldots \ldots \ldots, 592$

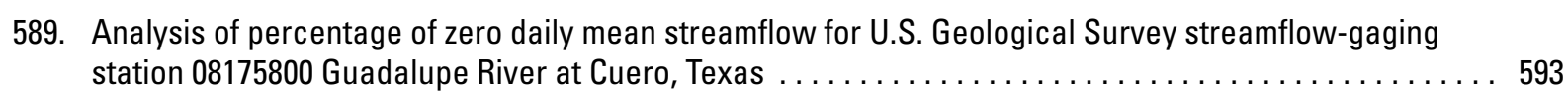

590. Analysis of percentage of zero daily mean streamflow for U.S. Geological Survey streamflow-gaging station 08176000 Guadalupe River below Cuero, Texas $\ldots \ldots \ldots \ldots \ldots \ldots \ldots \ldots \ldots \ldots \ldots \ldots, 594$

591. Analysis of percentage of zero daily mean streamflow for U.S. Geological Survey streamflow-gaging

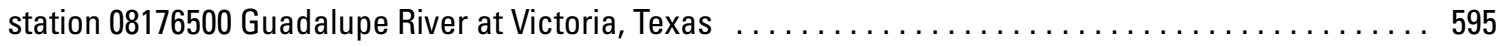

592. Analysis of percentage of zero daily mean streamflow for U.S. Geological Survey streamflow-gaging

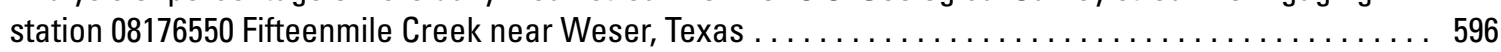

593. Analysis of percentage of zero daily mean streamflow for U.S. Geological Survey streamflow-gaging station 08176900 Coleto Creek at Arnold hoad near Schroeder, Texas $\ldots \ldots \ldots \ldots \ldots \ldots \ldots \ldots \ldots$. 597 
594. Analysis of percentage of zero daily mean streamflow for U.S. Geological Survey streamflow-gaging station 08176990 Coleto Creek Reservoir Inflow (Guadalupe Diversion) near Schroeder, Texas $\ldots \ldots \ldots 598$

595. Analysis of percentage of zero daily mean streamflow for U.S. Geological Survey streamflow-gaging station 08177000 Coleto Creek near Schroeder, Texas $\ldots \ldots \ldots \ldots \ldots \ldots \ldots \ldots \ldots \ldots \ldots \ldots \ldots \ldots 9$

596. Analysis of percentage of zero daily mean streamflow for U.S. Geological Survey streamflow-gaging station 08177300 Perdido Creek at Farm to Market Road 622 near Fannin, Texas $\ldots \ldots \ldots \ldots \ldots$

597. Analysis of percentage of zero daily mean streamflow for U.S. Geological Survey streamflow-gaging station 08177500 Coleto Creek near Victoria, Texas $\ldots \ldots \ldots \ldots \ldots \ldots \ldots \ldots \ldots \ldots \ldots \ldots \ldots \ldots$ 601

598. Analysis of percentage of zero daily mean streamflow for U.S. Geological Survey streamflow-gaging station $0817770001 m 0 s$ Creek at Dresden Drive, San Antonio, Texas $\ldots \ldots \ldots \ldots \ldots \ldots \ldots \ldots \ldots \ldots 6$

599. Analysis of percentage of zero daily mean streamflow for U.S. Geological Survey streamflow-gaging station 08177860 San Antonio River at Woodlawn Avenue, San Antonio, Texas $\ldots \ldots \ldots \ldots \ldots \ldots$

600. Analysis of percentage of zero daily mean streamflow for U.S. Geological Survey streamflow-gaging station 08178000 San Antonio River at San Antonio, Texas $\ldots \ldots \ldots \ldots \ldots \ldots \ldots \ldots \ldots \ldots \ldots \ldots \ldots$

601. Analysis of percentage of zero daily mean streamflow for U.S. Geological Survey streamflow-gaging station 08178050 San Antonio River at Mitchell Street, San Antonio, Texas $\ldots \ldots \ldots \ldots \ldots \ldots \ldots \ldots$

602. Analysis of percentage of zero daily mean streamflow for U.S. Geological Survey streamflow-gaging station 08178500 San Pedro Creek at Furnish Street, San Antonio, Texas $\ldots \ldots \ldots \ldots \ldots \ldots \ldots \ldots 66$

603. Analysis of percentage of zero daily mean streamflow for U.S. Geological Survey streamflow-gaging station 08178565 San Antonio River at Loop 410, San Antonio, Texas $\ldots \ldots \ldots \ldots \ldots \ldots \ldots \ldots \ldots \ldots 606$

604. Analysis of percentage of zero daily mean streamflow for U.S. Geological Survey streamflow-gaging station 08178585 Salado Creek at Wilderness Road, San Antonio, Texas $\ldots \ldots \ldots \ldots \ldots \ldots \ldots \ldots \ldots 60$

605. Analysis of percentage of zero daily mean streamflow for U.S. Geological Survey streamflow-gaging station 08178700 Salado Creek at Loop 410, San Antonio, Texas $\ldots \ldots \ldots \ldots \ldots \ldots \ldots \ldots \ldots \ldots \ldots$

606. Analysis of percentage of zero daily mean streamflow for U.S. Geological Survey streamflow-gaging station 08178800 Salado Creek at Loop 13, San Antonio, Texas $\ldots \ldots \ldots \ldots \ldots \ldots \ldots \ldots \ldots \ldots \ldots \ldots 610$

607. Analysis of percentage of zero daily mean streamflow for U.S. Geological Survey streamflow-gaging station 08178880 Medina River at Bandera, Texas $\ldots \ldots \ldots \ldots \ldots \ldots \ldots \ldots \ldots \ldots \ldots \ldots \ldots \ldots \ldots$

608. Analysis of percentage of zero daily mean streamflow for U.S. Geological Survey streamflow-gaging station 08179000 Medina River near Pipe Creek, Texas $\ldots \ldots \ldots \ldots \ldots \ldots \ldots \ldots \ldots \ldots \ldots \ldots \ldots \ldots 612$

609. Analysis of percentage of zero daily mean streamflow for U.S. Geological Survey streamflow-gaging station 08179100 Red Bluff Creek near Pipe Creek, lexas $\ldots \ldots \ldots \ldots \ldots \ldots \ldots \ldots \ldots \ldots \ldots \ldots \ldots 613$

610. Analysis of percentage of zero daily mean streamflow for U.S. Geological Survey streamflow-gaging station 08179520 Medina River below Medina Lake near San Antonio, Texas $\ldots \ldots \ldots \ldots \ldots \ldots \ldots$

611. Analysis of percentage of zero daily mean streamflow for U.S. Geological Survey streamflow-gaging station 08180500 Medina River near Riomedina, Texas $\ldots \ldots \ldots \ldots \ldots \ldots \ldots \ldots \ldots \ldots \ldots \ldots \ldots \ldots 6$

612. Analysis of percentage of zero daily mean streamflow for U.S. Geological Survey streamflow-gaging station 08180640 Medina River at La Coste, lexas $\ldots \ldots \ldots \ldots \ldots \ldots \ldots \ldots \ldots \ldots \ldots \ldots \ldots \ldots \ldots$

613. Analysis of percentage of zero daily mean streamflow for U.S. Geological Survey streamflow-gaging station 08180700 Medina River near Macdona, Texas $\ldots \ldots \ldots \ldots \ldots \ldots \ldots \ldots \ldots \ldots \ldots \ldots \ldots$ 617

614. Analysis of percentage of zero daily mean streamflow for U.S. Geological Survey streamflow-gaging station 08180750 Medio Creek at Pearsall Road, San Antonio, Texas $\ldots \ldots \ldots \ldots \ldots \ldots \ldots \ldots \ldots$

615. Analysis of percentage of zero daily mean streamflow for U.S. Geological Survey streamflow-gaging station 08180800 Medina River near Somerset, Texas $\ldots \ldots \ldots \ldots \ldots \ldots \ldots \ldots \ldots \ldots \ldots \ldots \ldots \ldots$

616. Analysis of percentage of zero daily mean streamflow for U.S. Geological Survey streamflow-gaging

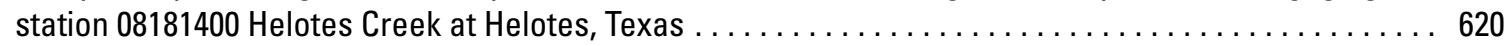

617. Analysis of percentage of zero daily mean streamflow for U.S. Geological Survey streamflow-gaging station 08181410 Ranch Creek near Helotes, lexas $\ldots \ldots \ldots \ldots \ldots \ldots \ldots \ldots \ldots \ldots \ldots \ldots \ldots \ldots$ 621 
618. Analysis of percentage of zero daily mean streamflow for U.S. Geological Survey streamflow-gaging station 08181450 Leon Creek Tributary at Kelly Air Force Base, lexas $\ldots \ldots \ldots \ldots \ldots \ldots \ldots \ldots \ldots, 622$

619. Analysis of percentage of zero daily mean streamflow for U.S. Geological Survey streamflow-gaging station 08181480 Leon Creek at Interstate Highway 35, San Antonio, Texas $\ldots \ldots \ldots \ldots \ldots \ldots \ldots \ldots 623$

620. Analysis of percentage of zero daily mean streamflow for U.S. Geological Survey streamflow-gaging

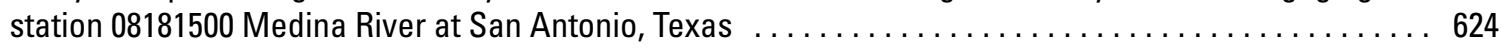

621. Analysis of percentage of zero daily mean streamflow for U.S. Geological Survey streamflow-gaging

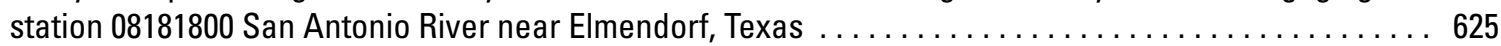

622. Analysis of percentage of zero daily mean streamflow for U.S. Geological Survey streamflow-gaging

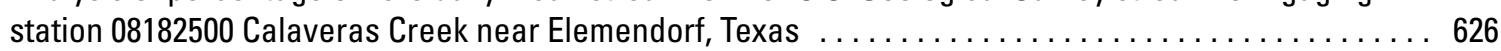

623. Analysis of percentage of zero daily mean streamflow for U.S. Geological Survey streamflow-gaging

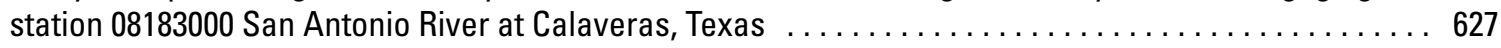

624. Analysis of percentage of zero daily mean streamflow for U.S. Geological Survey streamflow-gaging

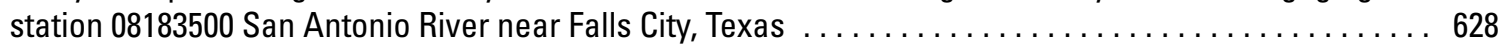

625. Analysis of percentage of zero daily mean streamflow for U.S. Geological Survey streamflow-gaging station 08183850 Cibolo Creek at Interstate Highway 10 above Boerne, Texas $\ldots \ldots \ldots \ldots \ldots \ldots \ldots 629$

626. Analysis of percentage of zero daily mean streamflow for U.S. Geological Survey streamflow-gaging

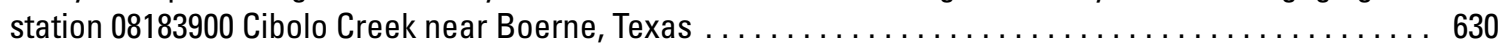

627. Analysis of percentage of zero daily mean streamflow for U.S. Geological Survey streamflow-gaging

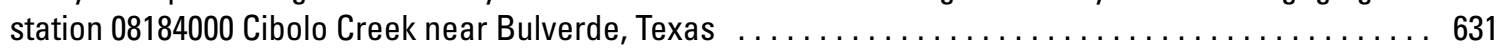

628. Analysis of percentage of zero daily mean streamflow for U.S. Geological Survey streamflow-gaging

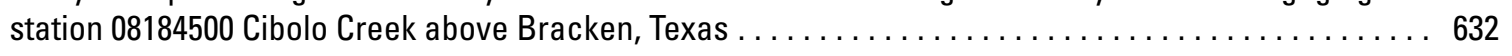

629. Analysis of percentage of zero daily mean streamflow for U.S. Geological Survey streamflow-gaging

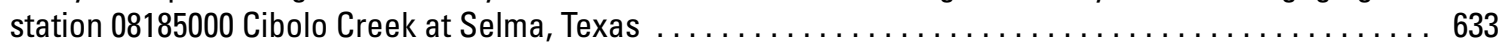

630. Analysis of percentage of zero daily mean streamflow for U.S. Geological Survey streamflow-gaging

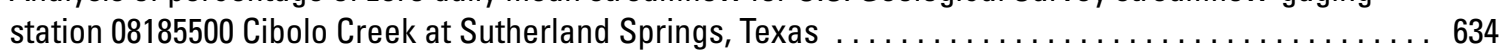

631. Analysis of percentage of zero daily mean streamflow for U.S. Geological Survey streamflow-gaging

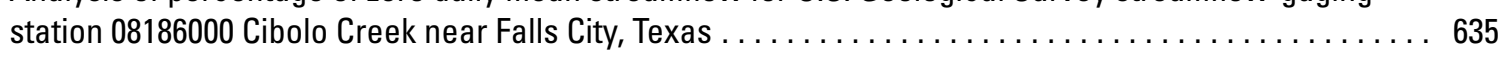

632. Analysis of percentage of zero daily mean streamflow for U.S. Geological Survey streamflow-gaging

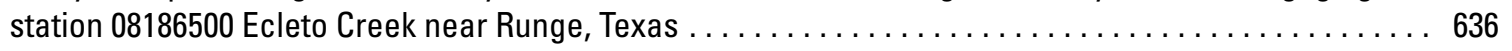

633. Analysis of percentage of zero daily mean streamflow for U.S. Geological Survey streamflow-gaging

634. Analysis of percentage of zero daily mean streamflow for U.S. Geological Survey streamflow-gaging

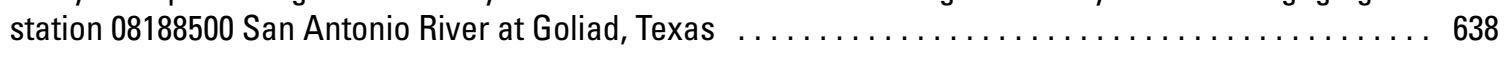

635. Analysis of percentage of zero daily mean streamflow for U.S. Geological Survey streamflow-gaging

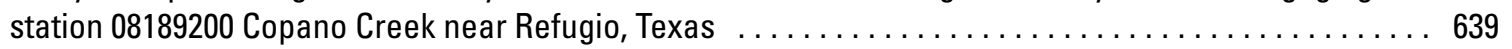

636. Analysis of percentage of zero daily mean streamflow for U.S. Geological Survey streamflow-gaging station 08189300 Medio Creek near Beeville, lexas $\ldots \ldots \ldots \ldots \ldots \ldots \ldots \ldots \ldots \ldots \ldots \ldots \ldots, 640$

637. Analysis of percentage of zero daily mean streamflow for U.S. Geological Survey streamflow-gaging

638. Analysis of percentage of zero daily mean streamflow for U.S. Geological Survey streamflow-gaging

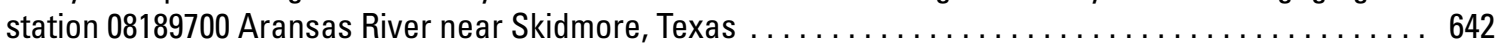

639. Analysis of percentage of zero daily mean streamflow for U.S. Geological Survey streamflow-gaging station 08189800 Chiltipin Creek at Sinton, Texas $\quad \ldots \ldots \ldots \ldots \ldots \ldots \ldots \ldots \ldots \ldots \ldots \ldots \ldots \ldots, 643$

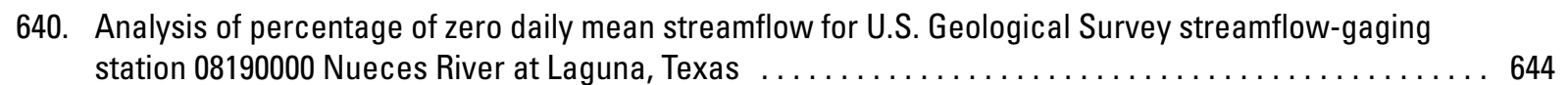

641. \begin{tabular}{l} 
Analysis of percentage of zero daily mean streamflow for U.S. Geological Survey streamflow-gaging \\
\hline station 08190500West Nueces River near Brackettville, Texas $\ldots \ldots \ldots \ldots \ldots \ldots \ldots \ldots \ldots \ldots \ldots \ldots$
\end{tabular} 
642. Analysis of percentage of zero daily mean streamflow for U.S. Geological Survey streamflow-gaging station 08191500 Nueces River near Uvalde, Texas $\ldots \ldots \ldots \ldots \ldots \ldots \ldots \ldots \ldots \ldots \ldots \ldots \ldots \ldots \ldots 646$

643. Analysis of percentage of zero daily mean streamflow for U.S. Geological Survey streamflow-gaging station 08192000 Nueces River below Uvalde, Texas $\ldots \ldots \ldots \ldots \ldots \ldots \ldots \ldots \ldots \ldots \ldots \ldots \ldots \ldots$

644. Analysis of percentage of zero daily mean streamflow for U.S. Geological Survey streamflow-gaging

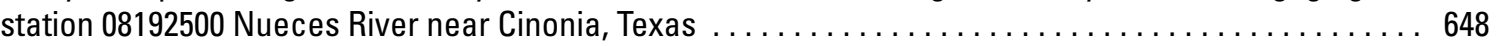

645. Analysis of percentage of zero daily mean streamflow for U.S. Geological Survey streamflow-gaging station 08193000 Nueces River near Asherton, Texas $\ldots \ldots \ldots \ldots \ldots \ldots \ldots \ldots \ldots \ldots \ldots \ldots \ldots, 649$

646. Analysis of percentage of zero daily mean streamflow for U.S. Geological Survey streamflow-gaging

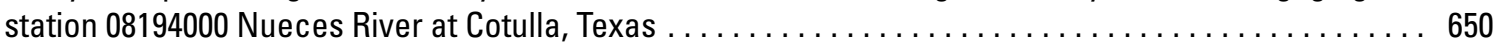

647. Analysis of percentage of zero daily mean streamflow for U.S. Geological Survey streamflow-gaging station 08194200 San Casimiro Creek near Freer, lexas $\ldots \ldots \ldots \ldots \ldots \ldots \ldots \ldots \ldots \ldots \ldots \ldots \ldots$ 651

648. Analysis of percentage of zero daily mean streamflow for U.S. Geological Survey streamflow-gaging station 08194500 Nueces River near Tilden, Texas $\ldots \ldots \ldots \ldots \ldots \ldots \ldots \ldots \ldots \ldots \ldots \ldots \ldots \ldots \ldots 62$

649. Analysis of percentage of zero daily mean streamflow for U.S. Geological Survey streamflow-gaging station 08194600 Nueces River at Simmons, Texas $\ldots \ldots \ldots \ldots \ldots \ldots \ldots \ldots \ldots \ldots \ldots \ldots \ldots \ldots \ldots$

650. Analysis of percentage of zero daily mean streamflow for U.S. Geological Survey streamflow-gaging

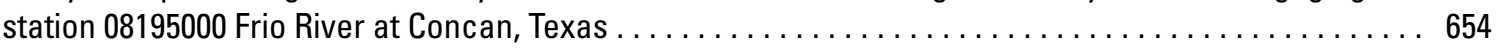

651. Analysis of percentage of zero daily mean streamflow for U.S. Geological Survey streamflow-gaging station 08196000 Dry Frio River near Reagan Wells, Texas $\ldots \ldots \ldots \ldots \ldots \ldots \ldots \ldots \ldots \ldots \ldots \ldots \ldots 55$

652. Analysis of percentage of zero daily mean streamflow for U.S. Geological Survey streamflow-gaging

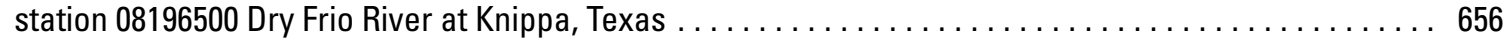

653. Analysis of percentage of zero daily mean streamflow for U.S. Geological Survey streamflow-gaging station 08197500 Frio River below Dry Frio River near Uvalde, Texas $\ldots \ldots \ldots \ldots \ldots \ldots \ldots \ldots \ldots \ldots 67$

654. Analysis of percentage of zero daily mean streamflow for U.S. Geological Survey streamflow-gaging station 08198000 Sabinal River near Sabinal, texas $\ldots \ldots \ldots \ldots \ldots \ldots \ldots \ldots \ldots \ldots \ldots \ldots \ldots \ldots 6$

655. Analysis of percentage of zero daily mean streamflow for U.S. Geological Survey streamflow-gaging station 08198500 Sabinal River at Sabinal, Texas $\ldots \ldots \ldots \ldots \ldots \ldots \ldots \ldots \ldots \ldots \ldots \ldots \ldots \ldots \ldots$

656. Analysis of percentage of zero daily mean streamflow for U.S. Geological Survey streamflow-gaging station 08199700 frio River near frio Town, Texas $\ldots \ldots \ldots \ldots \ldots \ldots \ldots \ldots \ldots \ldots \ldots \ldots \ldots \ldots \ldots 60$

657. Analysis of percentage of zero daily mean streamflow for U.S. Geological Survey streamflow-gaging station 08200000 Hondo Creek near Tarpley, texas $\ldots \ldots \ldots \ldots \ldots \ldots \ldots \ldots \ldots \ldots \ldots \ldots \ldots \ldots \ldots$

658. Analysis of percentage of zero daily mean streamflow for U.S. Geological Survey streamflow-gaging

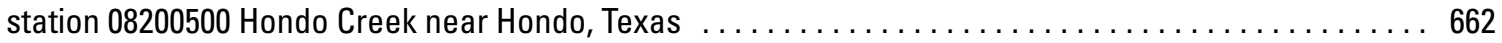

659. Analysis of percentage of zero daily mean streamflow for U.S. Geological Survey streamflow-gaging station 08200700 Hondo Creek at King Waterhole near Hondo, Texas $\ldots \ldots \ldots \ldots \ldots \ldots \ldots \ldots \ldots$

660. Analysis of percentage of zero daily mean streamflow for U.S. Geological Survey streamflow-gaging station 08201500 Seco Creek at Miller Ranch near Utopia, Texas $\ldots \ldots \ldots \ldots \ldots \ldots \ldots \ldots \ldots \ldots \ldots 64$

661. Analysis of percentage of zero daily mean streamflow for U.S. Geological Survey streamflow-gaging station 08202000 Seco Creek near Utopia, Texas $\ldots \ldots \ldots \ldots \ldots \ldots \ldots \ldots \ldots \ldots \ldots \ldots \ldots \ldots \ldots 6$

662. Analysis of percentage of zero daily mean streamflow for U.S. Geological Survey streamflow-gaging station 08202500 Seco Creek near D'Hanis, Texas $\ldots \ldots \ldots \ldots \ldots \ldots \ldots \ldots \ldots \ldots \ldots \ldots \ldots \ldots 66$

663. Analysis of percentage of zero daily mean streamflow for U.S. Geological Survey streamflow-gaging station 08202700 Seco Creek at Rowe Ranch near D'Hanis, Texas $\ldots \ldots \ldots \ldots \ldots \ldots \ldots \ldots \ldots \ldots \ldots 67$

664. Analysis of percentage of zero daily mean streamflow for U.S. Geological Survey streamflow-gaging

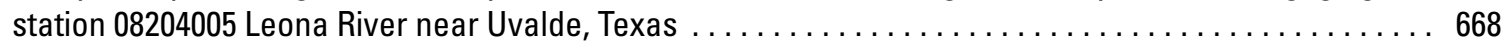

665. Analysis of percentage of zero daily mean streamflow for U.S. Geological Survey streamflow-gaging station 08204500 Leona River near Divot, Texas $\ldots \ldots \ldots \ldots \ldots \ldots \ldots \ldots \ldots \ldots \ldots \ldots \ldots \ldots 6$ 
666. Analysis of percentage of zero daily mean streamflow for U.S. Geological Survey streamflow-gaging station 08205500 Frio River near Derby, lexas $\ldots \ldots \ldots \ldots \ldots \ldots \ldots \ldots \ldots \ldots \ldots \ldots \ldots \ldots \ldots \ldots 60$

667. Analysis of percentage of zero daily mean streamflow for U.S. Geological Survey streamflow-gaging

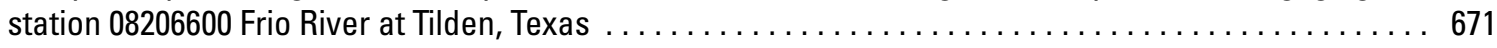

668. Analysis of percentage of zero daily mean streamflow for U.S. Geological Survey streamflow-gaging station 08206700 San Miguel Creek near Tiden, Texas $\ldots \ldots \ldots \ldots \ldots \ldots \ldots \ldots \ldots \ldots \ldots \ldots \ldots \ldots 6$

669. Analysis of percentage of zero daily mean streamflow for U.S. Geological Survey streamflow-gaging station 08206910 Choke Canyon Reservoir (Outlet Works Control) near Three Rivers, Texas $\ldots \ldots \ldots \ldots 673$

670. Analysis of percentage of zero daily mean streamflow for U.S. Geological Survey streamflow-gaging station 08207000 frio River at Calliham, texas $\ldots \ldots \ldots \ldots \ldots \ldots \ldots \ldots \ldots \ldots \ldots \ldots \ldots \ldots \ldots \ldots$

671. Analysis of percentage of zero daily mean streamflow for U.S. Geological Survey streamflow-gaging station 08207500 Atascosa River near McCoy, Texas $\ldots \ldots \ldots \ldots \ldots \ldots \ldots \ldots \ldots \ldots \ldots \ldots \ldots \ldots 675$

672. Analysis of percentage of zero daily mean streamflow for U.S. Geological Survey streamflow-gaging station 08208000 Atascosa River at Whitsett, Texas $\ldots \ldots \ldots \ldots \ldots \ldots \ldots \ldots \ldots \ldots \ldots \ldots \ldots \ldots$

673. Analysis of percentage of zero daily mean streamflow for U.S. Geological Survey streamflow-gaging station 08210000 Nueces River near Three Rivers, Texas $\ldots \ldots \ldots \ldots \ldots \ldots \ldots \ldots \ldots \ldots \ldots \ldots \ldots$

674. Analysis of percentage of zero daily mean streamflow for U.S. Geological Survey streamflow-gaging station 08210300 Ramirena Creek near George West, Texas $\ldots \ldots \ldots \ldots \ldots \ldots \ldots \ldots \ldots \ldots \ldots \ldots 678$

675. Analysis of percentage of zero daily mean streamflow for U.S. Geological Survey streamflow-gaging station 08210400 Lagarto Creek near George West, Texas $\ldots \ldots \ldots \ldots \ldots \ldots \ldots \ldots \ldots \ldots \ldots \ldots \ldots$

676. Analysis of percentage of zero daily mean streamflow for U.S. Geological Survey streamflow-gaging station 08211000 Nueces River near Mathis, Texas $\ldots \ldots \ldots \ldots \ldots \ldots \ldots \ldots \ldots \ldots \ldots \ldots \ldots$

677. Analysis of percentage of zero daily mean streamflow for U.S. Geological Survey streamflow-gaging

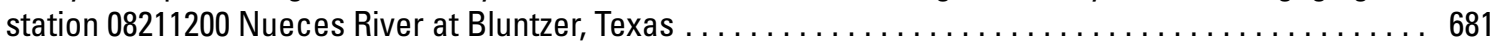

678. Analysis of percentage of zero daily mean streamflow for U.S. Geological Survey streamflow-gaging

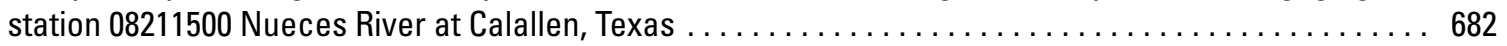

679. Analysis of percentage of zero daily mean streamflow for U.S. Geological Survey streamflow-gaging station 082115200 so Creek at Corpus Christi, Texas $\ldots \ldots \ldots \ldots \ldots \ldots \ldots \ldots \ldots \ldots \ldots \ldots \ldots \ldots 63$

680. Analysis of percentage of zero daily mean streamflow for U.S. Geological Survey streamflow-gaging station 08211800 San Diego Creek at Alice, Texas $\ldots \ldots \ldots \ldots \ldots \ldots \ldots \ldots \ldots \ldots \ldots \ldots \ldots \ldots \ldots$

681. Analysis of percentage of zero daily mean streamflow for U.S. Geological Survey streamflow-gaging station 08211900 San Fernando Creek at Alice, Texas $\ldots \ldots \ldots \ldots \ldots \ldots \ldots \ldots \ldots \ldots \ldots \ldots \ldots 6$

682. Analysis of percentage of zero daily mean streamflow for U.S. Geological Survey streamflow-gaging station 08212000 San Fernando Creek near Alice, Texas $\ldots \ldots \ldots \ldots \ldots \ldots \ldots \ldots \ldots \ldots \ldots \ldots 66$

683. Analysis of percentage of zero daily mean streamflow for U.S. Geological Survey streamflow-gaging station 08212400 Los 0lmos Creek near Falfurrias, Texas $\ldots \ldots \ldots \ldots \ldots \ldots \ldots \ldots \ldots \ldots \ldots \ldots$

684. Analysis of percentage of zero daily mean streamflow for U.S. Geological Survey streamflow-gaging station 08365600 McKelligon Canyon at ETPaso, Texas $\ldots \ldots \ldots \ldots \ldots \ldots \ldots \ldots \ldots \ldots \ldots \ldots \ldots 68$

685. Analysis of percentage of zero daily mean streamflow for U.S. Geological Survey streamflow-gaging

686. Analysis of percentage of zero daily mean streamflow for U.S. Geological Survey streamflow-gaging

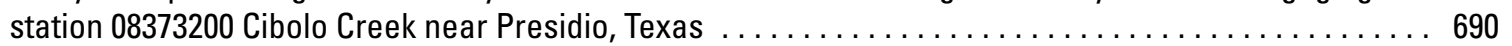

687. Analysis of percentage of zero daily mean streamflow for U.S. Geological Survey streamflow-gaging station 08376300 Sanderson Creek at Sanderson, Texas $\ldots \ldots \ldots \ldots \ldots \ldots \ldots \ldots \ldots \ldots \ldots \ldots \ldots$

688. Analysis of percentage of zero daily mean streamflow for U.S. Geological Survey streamflow-gaging station 08411500 Salt Screwbean Draw near Orla, Texas $\ldots \ldots \ldots \ldots \ldots \ldots \ldots \ldots \ldots \ldots \ldots \ldots \ldots 692$

689. Analysis of percentage of zero daily mean streamflow for U.S. Geological Survey streamflow-gaging station 08412500 Pecos River near Orla, Texas $\ldots \ldots \ldots \ldots \ldots \ldots \ldots \ldots \ldots \ldots \ldots \ldots \ldots \ldots \ldots$ 
690. Analysis of percentage of zero daily mean streamflow for U.S. Geological Survey streamflow-gaging station 08414000 Pecos River near Mentone, Texas $\ldots \ldots \ldots \ldots \ldots \ldots \ldots \ldots \ldots \ldots \ldots \ldots \ldots \ldots .694$

691. Analysis of percentage of zero daily mean streamflow for U.S. Geological Survey streamflow-gaging station 08416500 Pecos River above Barstow (Barstow Canal), Texas $\ldots \ldots \ldots \ldots \ldots \ldots \ldots \ldots \ldots \ldots 6$

692. Analysis of percentage of zero daily mean streamflow for U.S. Geological Survey streamflow-gaging station 08420500 Pecos hiver at Pecos, Texas $\ldots \ldots \ldots \ldots \ldots \ldots \ldots \ldots \ldots \ldots \ldots \ldots \ldots \ldots \ldots \ldots 6$

693. Analysis of percentage of zero daily mean streamflow for U.S. Geological Survey streamflow-gaging station 08424500 Madera Canyon near Toyahvale, Texas $\ldots \ldots \ldots \ldots \ldots \ldots \ldots \ldots \ldots \ldots \ldots \ldots \ldots$

694. Analysis of percentage of zero daily mean streamflow for U.S. Geological Survey streamflow-gaging station 08431000 Toyah Creek near Pecos, Texas $\ldots \ldots \ldots \ldots \ldots \ldots \ldots \ldots \ldots \ldots \ldots \ldots \ldots \ldots \ldots$

695. Analysis of percentage of zero daily mean streamflow for U.S. Geological Survey streamflow-gaging station 08431500 Salt Draw near Pecos, Texas $\ldots \ldots \ldots \ldots \ldots \ldots \ldots \ldots \ldots \ldots \ldots \ldots \ldots \ldots \ldots \ldots 69 \ldots \ldots$

696. Analysis of percentage of zero daily mean streamflow for U.S. Geological Survey streamflow-gaging station 08431700 Limpia Creek above Fort Davis, Texas $\ldots \ldots \ldots \ldots \ldots \ldots \ldots \ldots \ldots \ldots \ldots \ldots \ldots$

697. Analysis of percentage of zero daily mean streamflow for U.S. Geological Survey streamflow-gaging station 08431800 Limpia Creek below Fort Davis, Texas $\ldots \ldots \ldots \ldots \ldots \ldots \ldots \ldots \ldots \ldots \ldots \ldots \ldots$ 701

698. Analysis of percentage of zero daily mean streamflow for U.S. Geological Survey streamflow-gaging station 08432000 Limpia Creek near Fort Davis, Texas $\ldots \ldots \ldots \ldots \ldots \ldots \ldots \ldots \ldots \ldots \ldots \ldots \ldots \ldots$

699. Analysis of percentage of zero daily mean streamflow for U.S. Geological Survey streamflow-gaging station 08433000 Barrilla Draw near Saragosa, Texas $\ldots \ldots \ldots \ldots \ldots \ldots \ldots \ldots \ldots \ldots \ldots \ldots \ldots$

700. Analysis of percentage of zero daily mean streamflow for U.S. Geological Survey streamflow-gaging station 08434000 Toyah Creek below Toyah Lake near Pecos, Texas $\ldots \ldots \ldots \ldots \ldots \ldots \ldots$

701. Analysis of percentage of zero daily mean streamflow for U.S. Geological Survey streamflow-gaging station 08435500 Pecos River below Barstow, Texas $\ldots \ldots \ldots \ldots \ldots \ldots \ldots \ldots \ldots \ldots \ldots \ldots \ldots \ldots$

702. $\quad$ Analysis of percentage of zero daily mean streamflow for U.S. Geological Survey streamflow-gaging station 08435600 Toronto Creek near Alpine, Texas $\ldots \ldots \ldots \ldots \ldots \ldots \ldots \ldots \ldots \ldots \ldots \ldots \ldots \ldots$.

703. Analysis of percentage of zero daily mean streamflow for U.S. Geological Survey streamflow-gaging

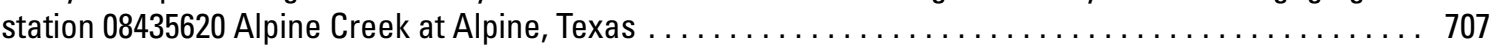

704. Analysis of percentage of zero daily mean streamflow for U.S. Geological Survey streamflow-gaging

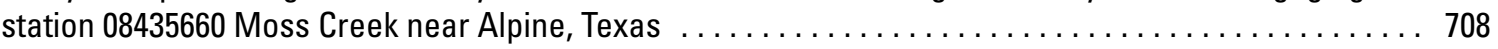

705. Analysis of percentage of zero daily mean streamflow for U.S. Geological Survey streamflow-gaging station 08435700 Sunny Glen Canyon near Alpine, Texas $\ldots \ldots \ldots \ldots \ldots \ldots \ldots \ldots \ldots \ldots \ldots \ldots$

706. Analysis of percentage of zero daily mean streamflow for U.S. Geological Survey streamflow-gaging station 08435800 Coyanosa Draw near Fort Stockton, Texas $\ldots \ldots \ldots \ldots \ldots \ldots \ldots \ldots \ldots \ldots \ldots \ldots$

707. Analysis of percentage of zero daily mean streamflow for U.S. Geological Survey streamflow-gaging station 08438100 Pecos River near Grandfalls, Texas $\ldots \ldots \ldots \ldots \ldots \ldots \ldots \ldots \ldots \ldots \ldots \ldots \ldots \ldots$

708. Analysis of percentage of zero daily mean streamflow for U.S. Geological Survey streamflow-gaging station 08441500 Pecos River below Grandfalls, texas $\ldots \ldots \ldots \ldots \ldots \ldots \ldots \ldots \ldots \ldots \ldots \ldots \ldots \ldots 712$

709. Analysis of percentage of zero daily mean streamflow for U.S. Geological Survey streamflow-gaging station 08446500 Pecos River near Girvin, Texas $\ldots \ldots \ldots \ldots \ldots \ldots \ldots \ldots \ldots \ldots \ldots \ldots \ldots \ldots \ldots$

710. Analysis of percentage of zero daily mean streamflow for U.S. Geological Survey streamflow-gaging station 08447000 Pecos River near Sheffield, Texas $\ldots \ldots \ldots \ldots \ldots \ldots \ldots \ldots \ldots \ldots \ldots \ldots \ldots \ldots 714$

711. Analysis of percentage of zero daily mean streamflow for U.S. Geological Survey streamflow-gaging station 08447020 Independence Creek near Sheffield, Texas $\ldots \ldots \ldots \ldots \ldots \ldots \ldots \ldots \ldots \ldots \ldots \ldots 715$

712. Analysis of percentage of zero daily mean streamflow for U.S. Geological Survey streamflow-gaging station 08449000 Devils River near Juno, Texas $\ldots \ldots \ldots \ldots \ldots \ldots \ldots \ldots \ldots \ldots \ldots \ldots \ldots \ldots \ldots$

713. Analysis of percentage of zero daily mean streamflow for U.S. Geological Survey streamflow-gaging station 08455000 Pinto Creek near DelRio, Texas $\ldots \ldots \ldots \ldots \ldots \ldots \ldots \ldots \ldots \ldots \ldots \ldots \ldots \ldots \ldots 717$ 


\title{
Summary of Percentages of Zero Daily Mean Streamflow for 712 U.S. Geological Survey Streamflow-Gaging Stations in Texas Through 2003
}

\author{
By William H. Asquith, Joseph Vrabel, and Meghan C. Roussel
}

\begin{abstract}
Analysts and managers of surface-water resources might have interest in the zero-flow potential for U.S. Geological Survey (USGS) streamflow-gaging stations in Texas. The USGS, in cooperation with the Texas Commission on Environmental Quality, initiated a data and reporting process to generate summaries of percentages of zero daily mean streamflow for 712 USGS streamflow-gaging stations in Texas. A summary of the percentages of zero daily mean streamflow for most active and inactive, continuous-record gaging stations in Texas provides valuable information by conveying the historical perspective for zero-flow potential for the watershed. The summaries of percentages of zero daily mean streamflow for each station are graphically depicted using two thematic perspectives: annual and monthly. The annual perspective consists of graphs of annual percentages of zero streamflow by year with the addition of lines depicting the mean and median annual percentage of zero streamflow. Monotonic trends in the percentages of zero streamflow also are identified using Kendall's $\tau$. The monthly perspective consists of graphs of the percentage of zero streamflow by month with lines added to indicate the mean and median monthly percentage of zero streamflow. One or more summaries could be used in a watershed, river basin, or other regional context by analysts and managers of surface-water resources to guide scientific, regulatory, or other inquiries of zeroflow or other low-flow conditions in Texas.
\end{abstract}

\section{Introduction}

Analysts and managers of surface-water resources might have interest in the zero-flow potential for U.S. Geological Survey (USGS) streamflow-gaging stations in Texas. To facilitate information transfer, this report provides a historical perspective of zero-flow potential for most of the active and inactive, continuous-record streamflow-gaging stations in Texas. Zero-flow potential refers to the proportion of daily mean streamflow values equal to zero; an alternative interpretation is that the proportion is the probability of zero flow. However, for purposes of this report the zero-flow potential is best interpreted as the percentage of zero daily mean streamflow for a given time period.

A graphical and statistical history of the percentages of zero daily mean streamflow for gaging stations in Texas provides valuable information by conveying the historical perspective for zero-flow potential for a given watershed, in particular, and Texas, in general. Therefore, in 2006 the USGS, in cooperation with the Texas Commission on Environmental Quality (TCEQ), initiated a data and reporting process to generate station-specific summaries of percentages of zero daily mean streamflow in Texas. This report includes graphical depictions of percentages of zero daily mean streamflow for 712 USGS streamflow-gaging stations in Texas with at least 1 year of record through water year 2004 (fig. 11). 


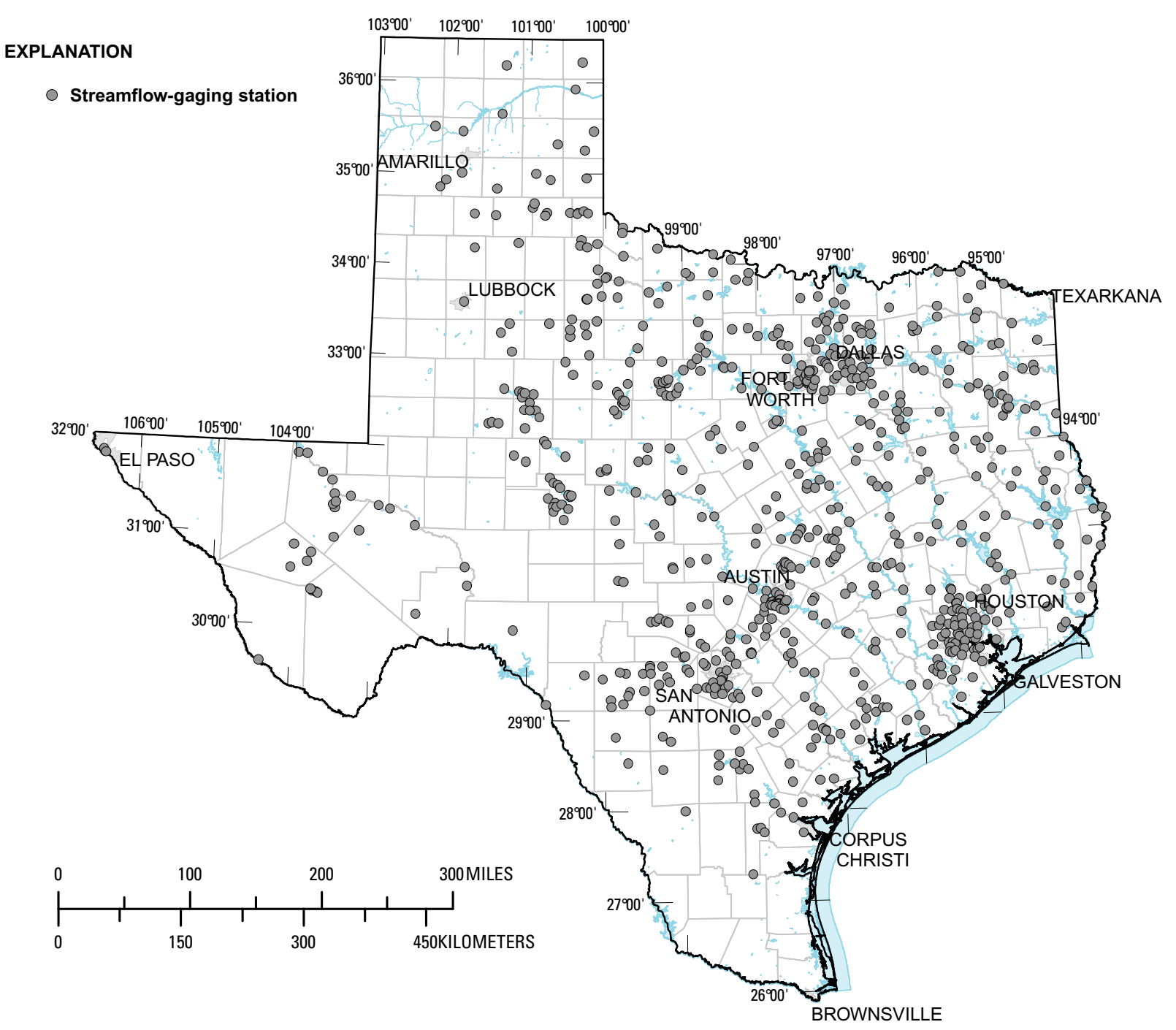

Figure 1. Locations of U.S. Geological Survey streamflow-gaging stations in Texas with at least 1 year of daily mean streamflow data through water year 2004.

Streamflow-gaging stations that monitor spring flow or stage (water level) only were not used. Further, partial-record streamflow-gaging stations were not used because the full range of streamflow at each station was needed. Partial-record streamflow-gaging stations are sites where discrete measurements of streamflow are obtained over a period of time without continuous data being recorded. These stations intrinsically do not monitor the entire range of streamflow. The 712 stations considered in this report were analyzed in Asquith and others (2006) for an evaluation of the drainage-area ratiomethod in Texas. A listing of the station numbers, station names, and ancillary information is available in Asquith and oth- ers (2006, table 1). A companion report (Asquith and thers. 2007) considers four selected annualstatistics of dailly mean streamflow for the same stations and streamflow data.

The data for the 712 stations were obtained from the USGS National Water Information System (U.S. Geological Survey, 2005). The stations have at least 1 year of daily unlean streamflow record through the 2004 water year. A water year is the 12-month period between October 1 and September 30. A water year is designated as the calendar year in which it ends. Thus, the year ending September 30, 2004, is called the "2004 water year." The earliest year of streamflow record is 1898 . The data were trimmed to the 
last complete calendar year (2003). For the analysis reported here the calendar year context is used for statistical computations. Therefore, the last date of daily mean streamflow is December 31, 2003. The total number of daily values processed is $7,748,449$.

\section{Summary of Percentages of Zero Daily Mean Streamflow for Texas}

The summary of percentages of zero daily mean streamflow for each of the 712 stations is provided in figures 2713 (at end of report). Each figure consists of two thematic perspectives: annual and monthly. The annual perspective is shown in the top graph of each the figure, and the monthly perspective is shown in the bottom graph. The monthly perspective facilitates seasonal interpretations of zero-flow potential for a given watershed. Above each figure is the text annotation "U.S. Geological Survey streamflow-gaging station \#," where \# is the eight-digit station identification number. This annotation is included to confirm that the pairing of the two graphs and the figure caption are correct. Some stations have substantial gaps (measured in years) such as those shown in figure 588 on page 592. No special treatment of the streamflow data was applied for stations with gaps in the period of record.

\section{Annual Perspective of Percentages of Zero Streamflow}

The annual perspective consists of four components. First, the annual percentages of zero streamflow are plotted as $n$ open circles ( $n$ represents the number of data points) in the top graph in figures 2713 Each percentage was computed by totaling the number of zero-flow days for the year and dividing by the number of days of observed record for the calendar year. For a full year of record, the number of days for the year was 365 (or 366 for leap years). For the summaries reported here, incomplete years are plotted as well with requisite change in sample size. Second and third, the mean annual percentage and median annual percentage of zero streamflow of the $n$ data points were computed and are illustrated as solid and dashed horizontal lines, respectively. The numeric values of mean and median annual percentage of zero streamflow are shown in the explanation of the graph. The fourth component is the assessment of a monotonic trend in the data.

For the fourth component, Kendall's $\tau$ was computed using an integrated statistical computing environment The MathWorks 2006) for the $n$ annual percentages of zero streamflow. The p-value for $\tau$ also is shown. Hollander and Wolfe 1973, p. 185-199) and Helsel and Hirsch 1992, p. 212 and 216) provide the background and details of computation. Both $\tau$ and the p-value are shown in figures 2713 to three significant figures, except when there is a perfect decreasing or increasing monotonic relation, in which case the exact $\tau$ value of -1 or 1 , respectively, is given. $\mathrm{P}$-values less than .001 are expressed as $<.001$.

Kendall's $\tau$ measures the strength of the monotonic relation between time and annual percentage of zero streamflow. Kendall's $\tau$ is nonparametric, meaning that the statistic is based on the ranks of the data and not the actual data values. Positive $\tau$ values indicate that occurrences of zero streamflow increase with time for the period of record, and negative $\tau$ values indicate that occurrences of zero streamflow decrease with time for the period of record. Perfect monotonically decreasing relations result in $\tau$ values of exactly -1 ; conversely, perfect monotonically increasing relations result in $\tau$ values of exactly 1 . The p-value is a measure of the strength or statistical significance of the relation; small p-values ( $p$-value $\leq .02$ in this report) indicate a strong relation. If all the data values are equal, such as exactly 0 or 100 percent, then $\tau$ and the p-value are listed as "--". Kendall's $\tau$ and the p-value also are listed as "--." for stations with only 1 year of record.

For stations for which Kendall's $\tau$ has a p-value less than or equal to 0.02 , a Theil trend line is superimposed on the top graph as a solid grey line. Thus, the Theil line is not drawn on all the top graphs of the figures. The Theil line, as discussed by Hollander and Wolfe 1973 p. 205) and Helsel and Hirsch 1992, p. 266), is a robust estimator of the slope of a linear relation between time and annual percentage of zero flow. The slope is estimated as the median of all unique $(n \times(n-1) / 2)$ slopes between individual data points. The purpose of the Theil line is to provide a visual cue that a statistically significant trend in annual percentage of zero streamflow was detected. For many 
stations on small watersheds or in generally dry parts of Texas, such as station 07227500 (fig. 3 on page 7), the Theil line is drawn, but not visible-it is masked by the mean annual percentage of zero streamflow line (solid horizontal line). The masking occurs because the median pairwise slope is precisely zero.

In regards to the Theil line, the line could represent an over simplification of the relation between time and annual percentage of zero streamflow for individual watersheds. The actual temporal changes in annual percentage of zero streamflow for individual watersheds could indicate curvilinear or even cyclical variations caused by natural or anthropogenic sources.

\section{Monthly Perspective of Percentages of Zero Streamflow}

The monthly perspective (bottom graph in figs. ⒉ 713 consists of three components. First, the percentage of zero streamflow for the indicated month for an individual year (calendar year) is shown as a grey circle. Considerable overplotting of these symbols can occur if the percentages of zero flow in a given month are 0 or 100 percent. For example, if the period of record contains 15 months of August, then 15 grey circles are plotted. The percentage for each month was computed by totaling the number of zero-flow days for that month for the period of record and dividing by the number of days of observed record for that month. For the summaries in this report, incomplete months are plotted as well with the requisite change in sample size. The second and third components are the mean and median monthly percentage of zero streamflow for each month and are indicated by the solid and dashed "steps," respectively.

\section{General Discussion}

The number of stations summarized in this report is too large for effective discussion and commentary of station-specific results. Conceptually, numerous attributes or factors of a watershed influence the potential for zero daily mean streamflow. These include attributes such as watershed size, climatic setting, geology and soils, and upstream water use or regulation. As a result, specific causes for zero flow for a given station are beyond the scope of this report.
However, some general comments can be made to guide analysts.

Some streamflow-gaging stations, such as those with large watersheds or in parts of the State with abundant rainfall, have few or no occurrences of zero daily mean streamflow (for example, the station in fig. 202 on page 206. Other stations, such as those with small drainage areas or in climatically dry parts of the State, consistently experience zero flow (for example, the station in fig. 48 on page 52. Some stations have definite patterns in monthly zero-flow potential (for example, the station in fig. 316 on page 320 or fig. 453 on page 457), whereas other stations do not (fig. 459 on page 463 .

Some stations have a statistically significant downward trend in percentage of zero daily mean streamflow, which is indicated by the negatively sloped Theil line (for example, the station in fig. 158 on page 162. Other stations have a statistically significant upward trend, which is indicated by the positively sloped Theil line (for example, the station in fig. 56 on page 60. Although trends are not always indicated, the daily mean streamflow at some stations appears to have been driven toward perennial conditions (such as that in fig. 131 on page 135 or conversely toward ephemeral conditions (such as that in fig. 6on page 10 .

The number of stations with statistically significant positive trends, an increase in the percentage of zero streamflow (drier conditions), is 22 (about 3 percent). The number of stations with statistically significant negative trends, a decrease in the percentage of zero streamflow (wetter conditions), is 60 (about 8 percent). No statistically significant trends were detected for 630 stations (about 89 percent).

Finally, each summary provides a compact visual description of the history of zero-flow potential of daily mean streamflow for the watershed monitored by the USGS streamflow-gaging station. Station-specific discussion of climatic, hydrologic, anthropogenic, and other processes potentially influencing the percentages of zero flow can be made. One or more summaries could be used in a watershed, river basin, or other regional context by analysts and managers of surface-water resources to guide scientific, regulatory, or other inquiries of zero-flow or other low-flow conditions in Texas. 


\section{References}

Asquith, W.H., Roussel, M.C., and Vrabel, Joseph, 2006, Statewide analysis of the drainage-area ratio method for 34 streamflow percentile ranges in Texas: U.S. Geological Survey Scientific Investigations Report 2006-5286, 34 p., 1 appendix Available Online

Asquith, W.H., Vrabel, Joseph, and Roussel, M.C., 2007, Summary of annual mean, maximum, minimum, and L-scale statistics of daily mean streamflow for 712 U.S. Geological Survey streamflow-gaging stations in Texas through 2003: U.S. Geological Survey Data Series 248, 721 p. Available Online
Helsel, D.R., and Hirsch, R.M., 1992, Statistical methods in water resources-Studies in environmental science 49: Amsterdam, Elsevier, 529 p.

Hollander, Myles, and Wolfe, D.A., 1973, Nonparametric statistical methods: New York, John Wiley, $503 \mathrm{p}$.

The MathWorks, 2006, MATLAB version 7.2.0.232 (R2006a): Natick, Mass.

U.S. Geological Survey, 2005, National Water Information System: accessed in July 2005 at http: //nwis.waterdata.usgs.gov/nwis/discharge 
U.S. Geological Survey streamflow-gaging station 07227470

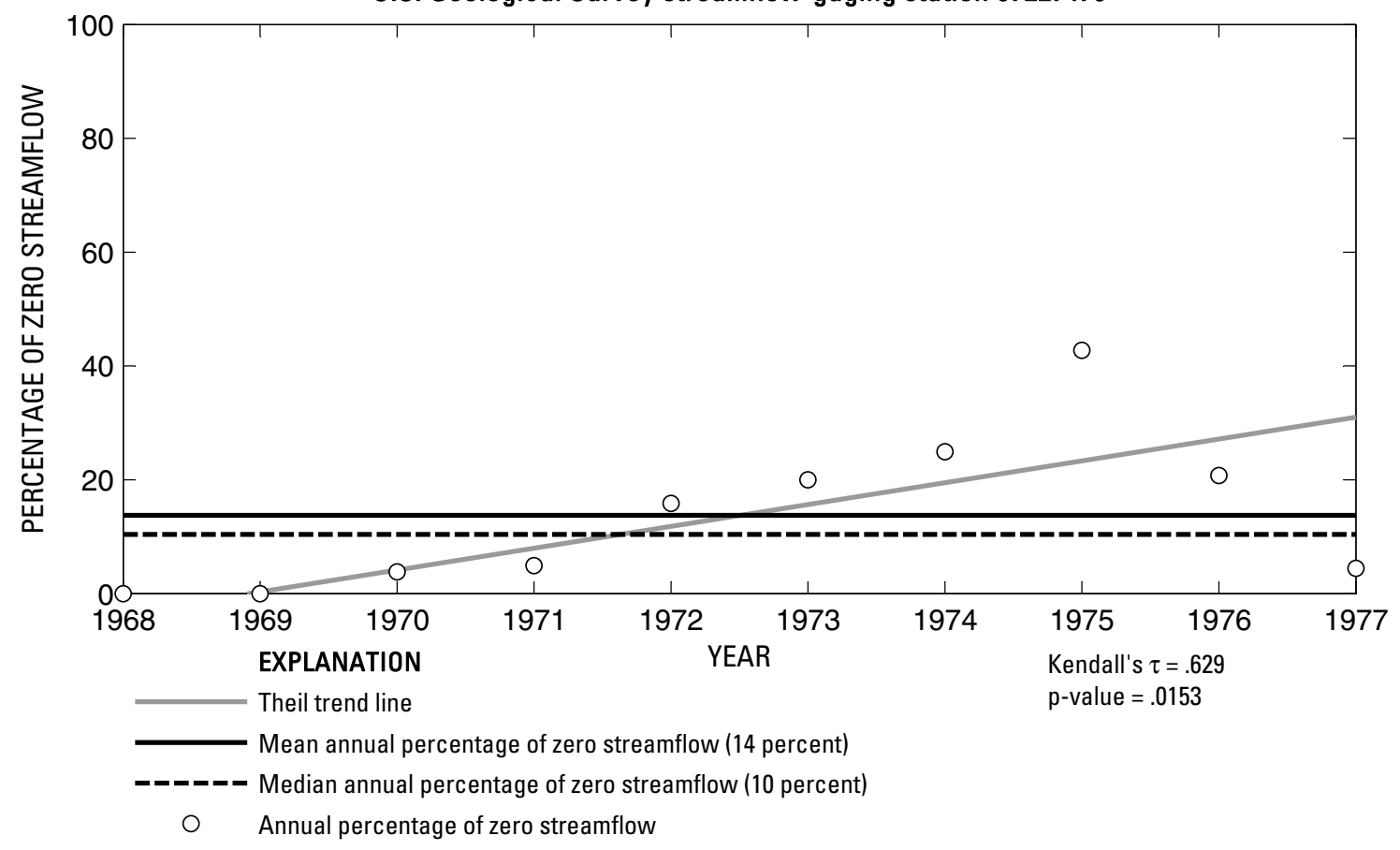

U.S. Geological Survey streamflow-gaging station 07227470

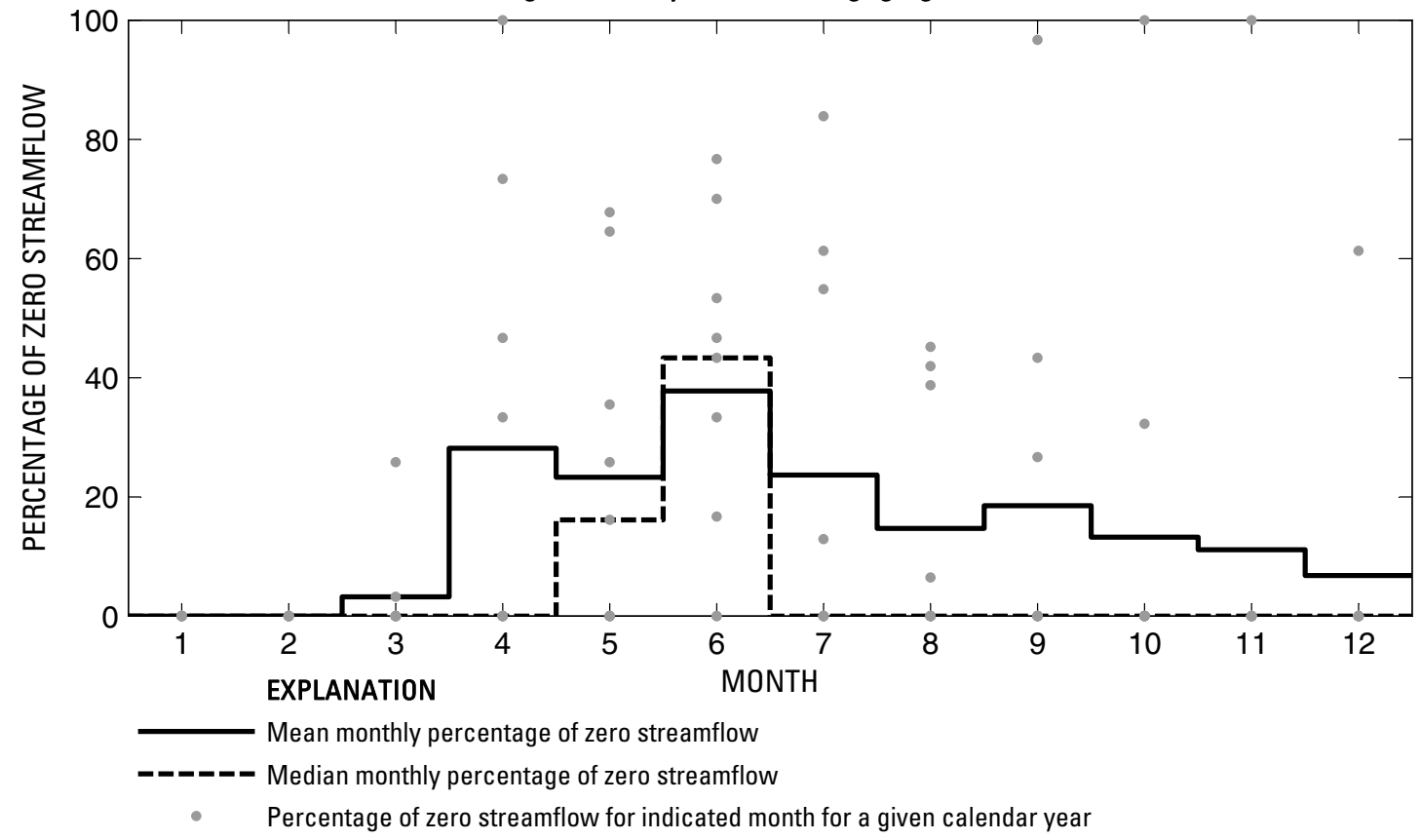

Figure 2. Analysis of percentage of zero daily mean streamflow for U.S. Geological Survey streamflow-gaging station 07227470 Canadian River at Tascosa, Texas. 

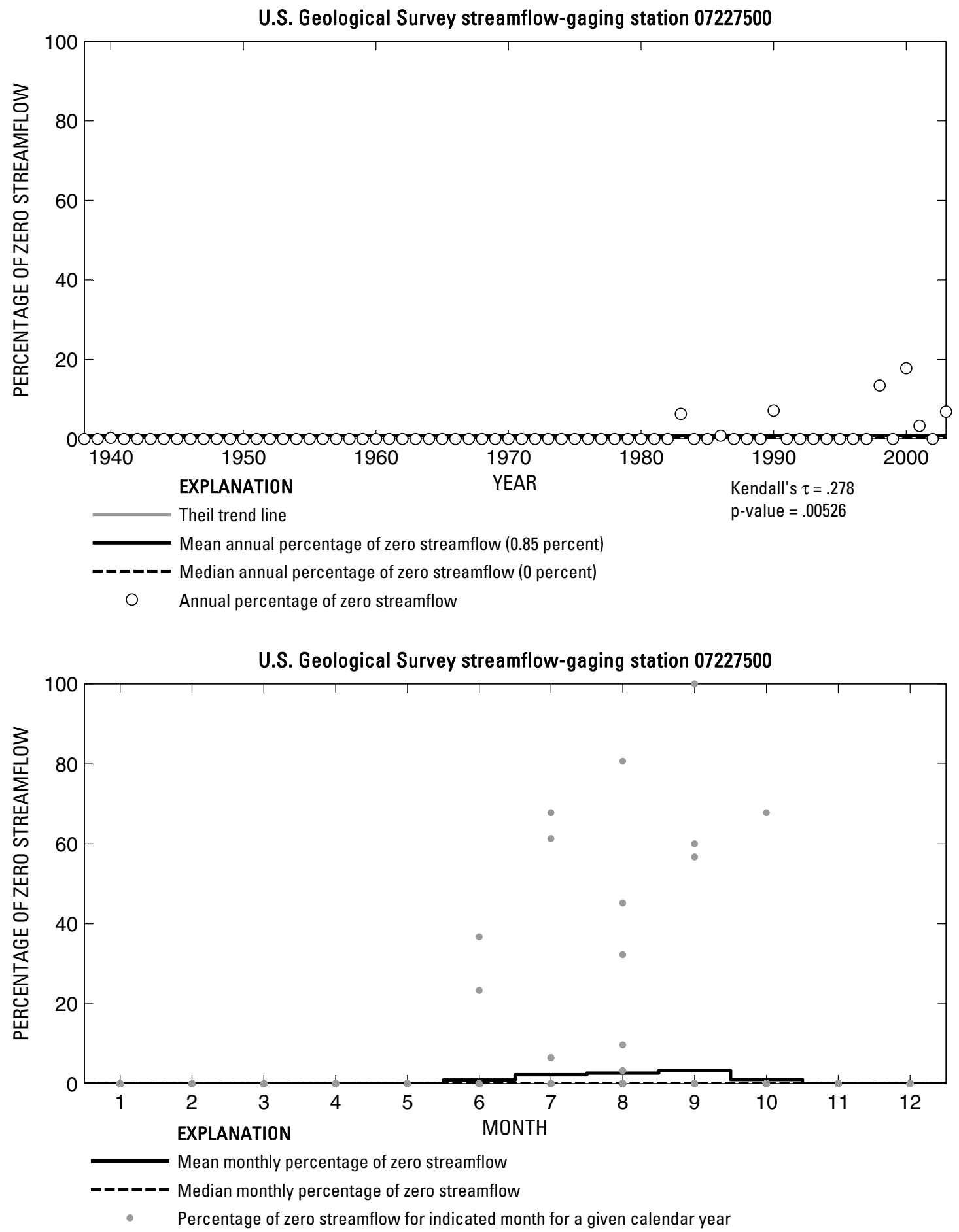

Figure 3. Analysis of percentage of zero daily mean streamflow for U.S. Geological Survey streamflow-gaging station 07227500 Canadian River near Amarillo, Texas. 
U.S. Geological Survey streamflow-gaging station 07227920

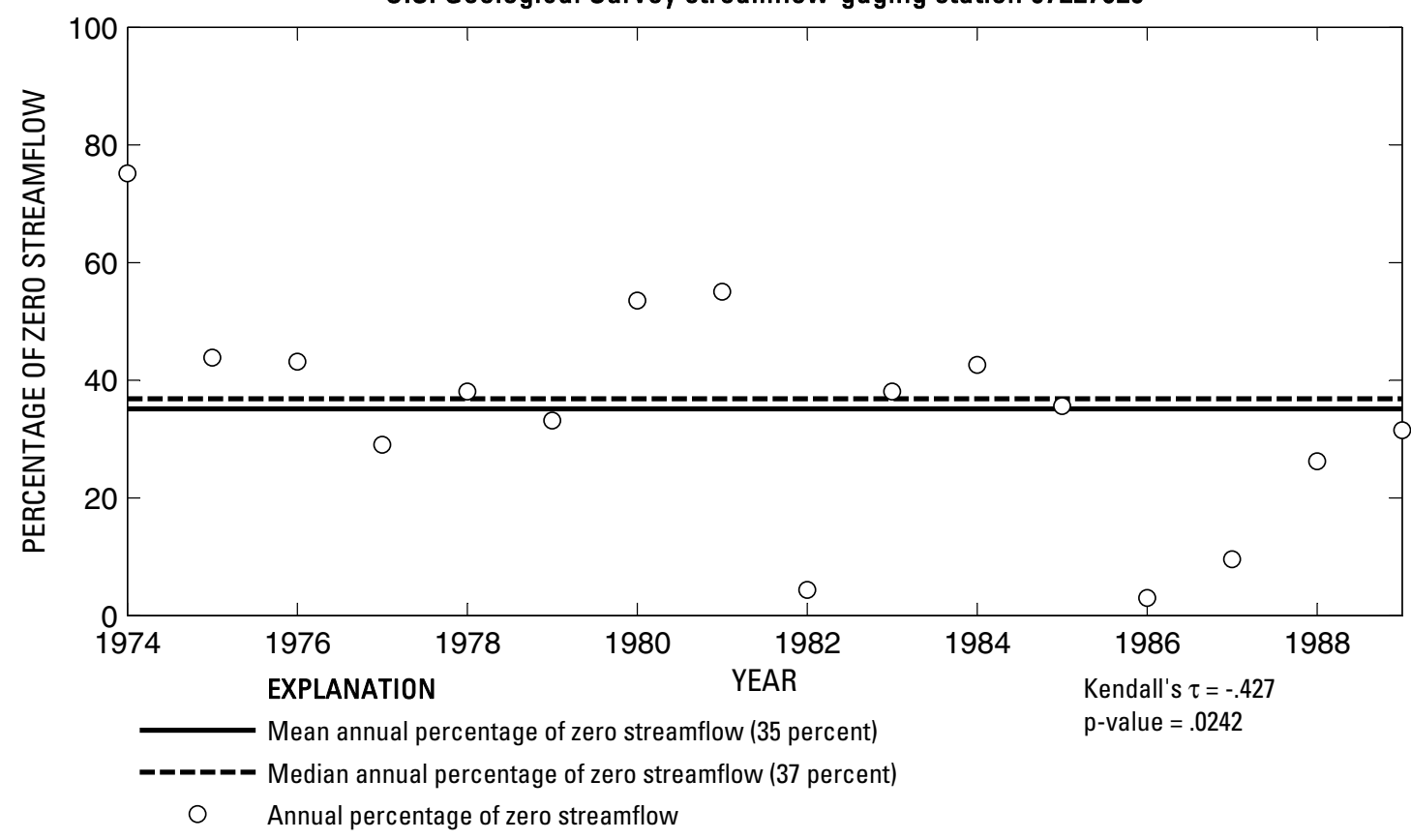

U.S. Geological Survey streamflow-gaging station 07227920

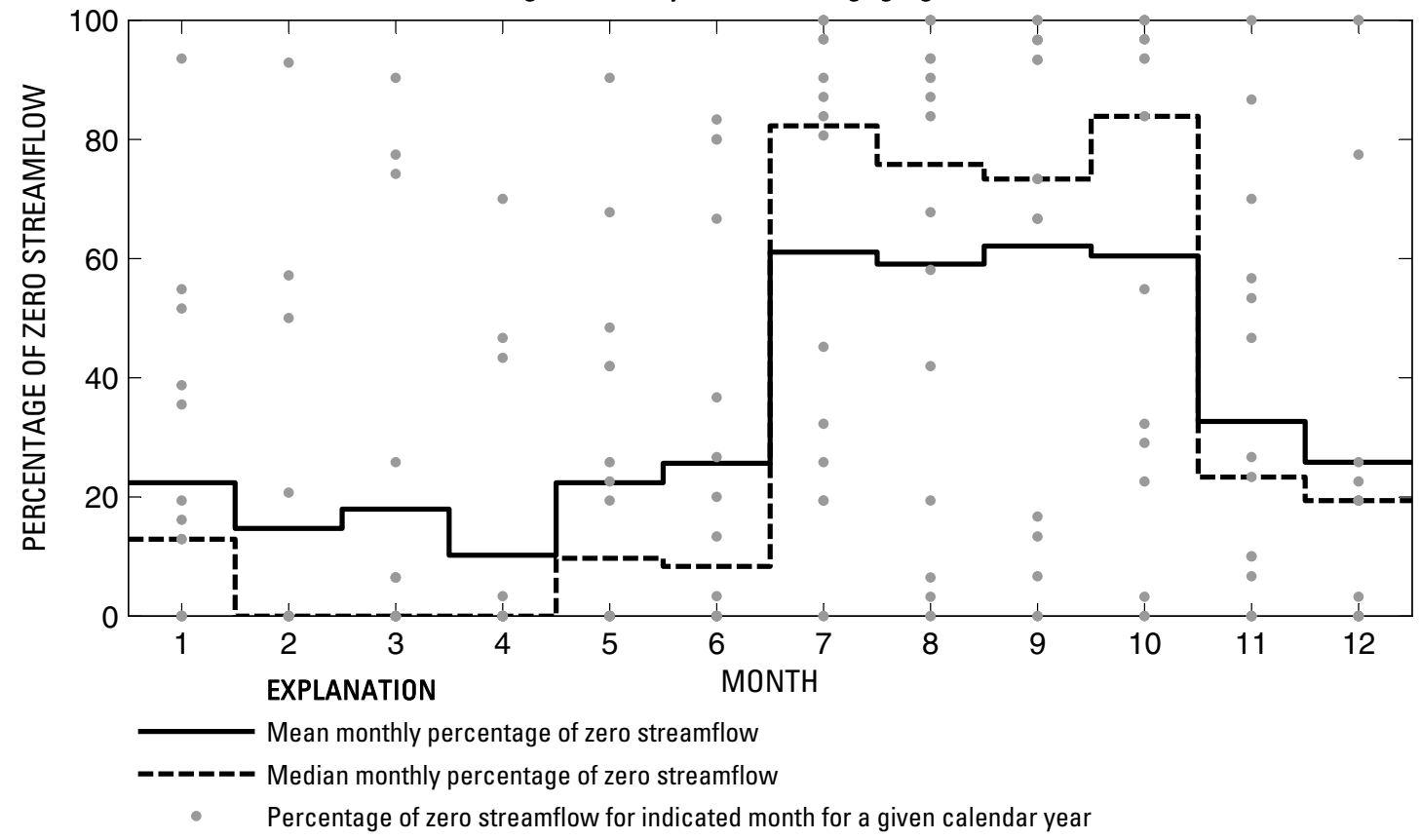

Figure 4. Analysis of percentage of zero daily mean streamflow for U.S. Geological Survey streamflow-gaging station 07227920 Dixon Creek near Borger, Texas.

Index of Station Numbers 719 


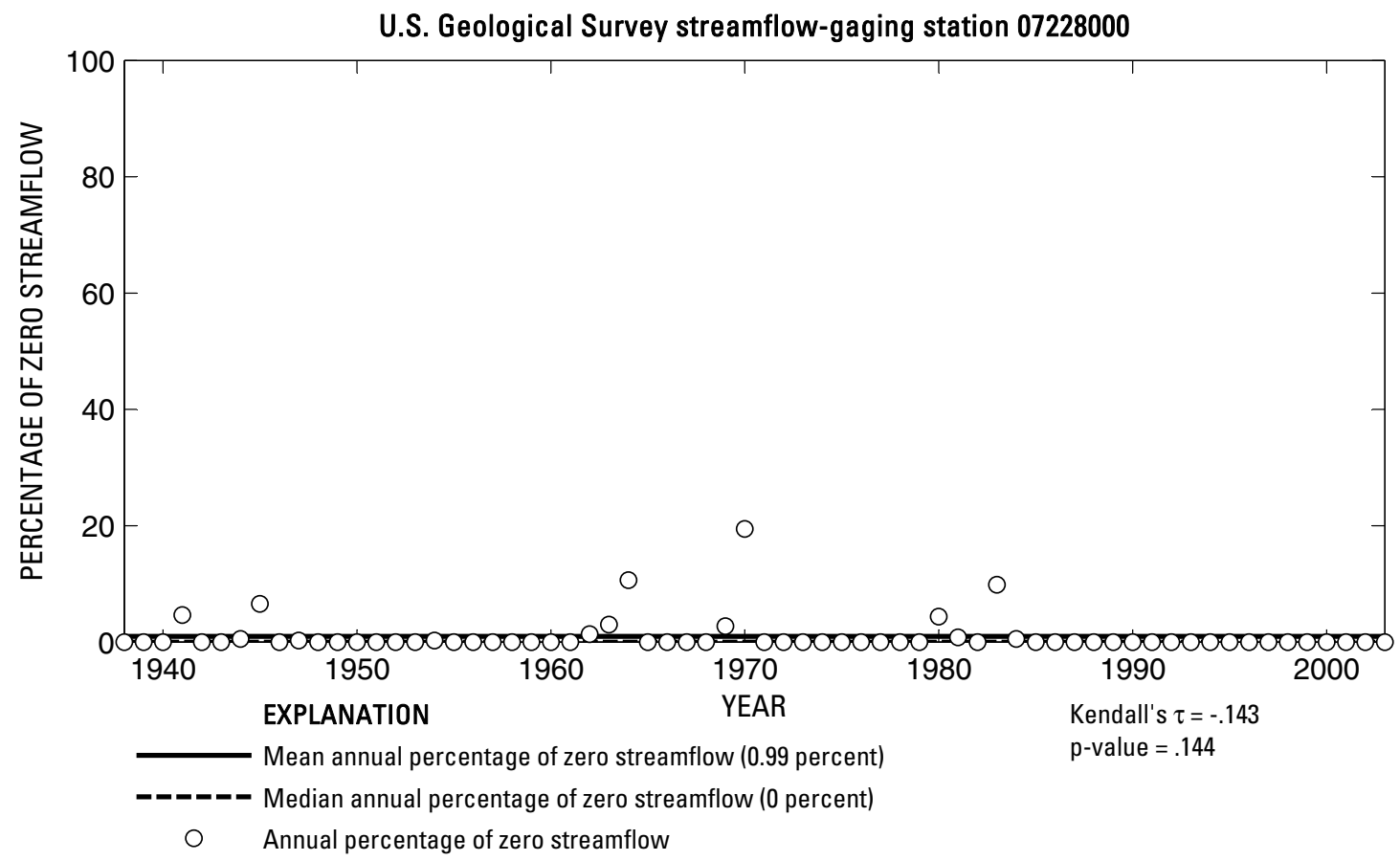

U.S. Geological Survey streamflow-gaging station 07228000

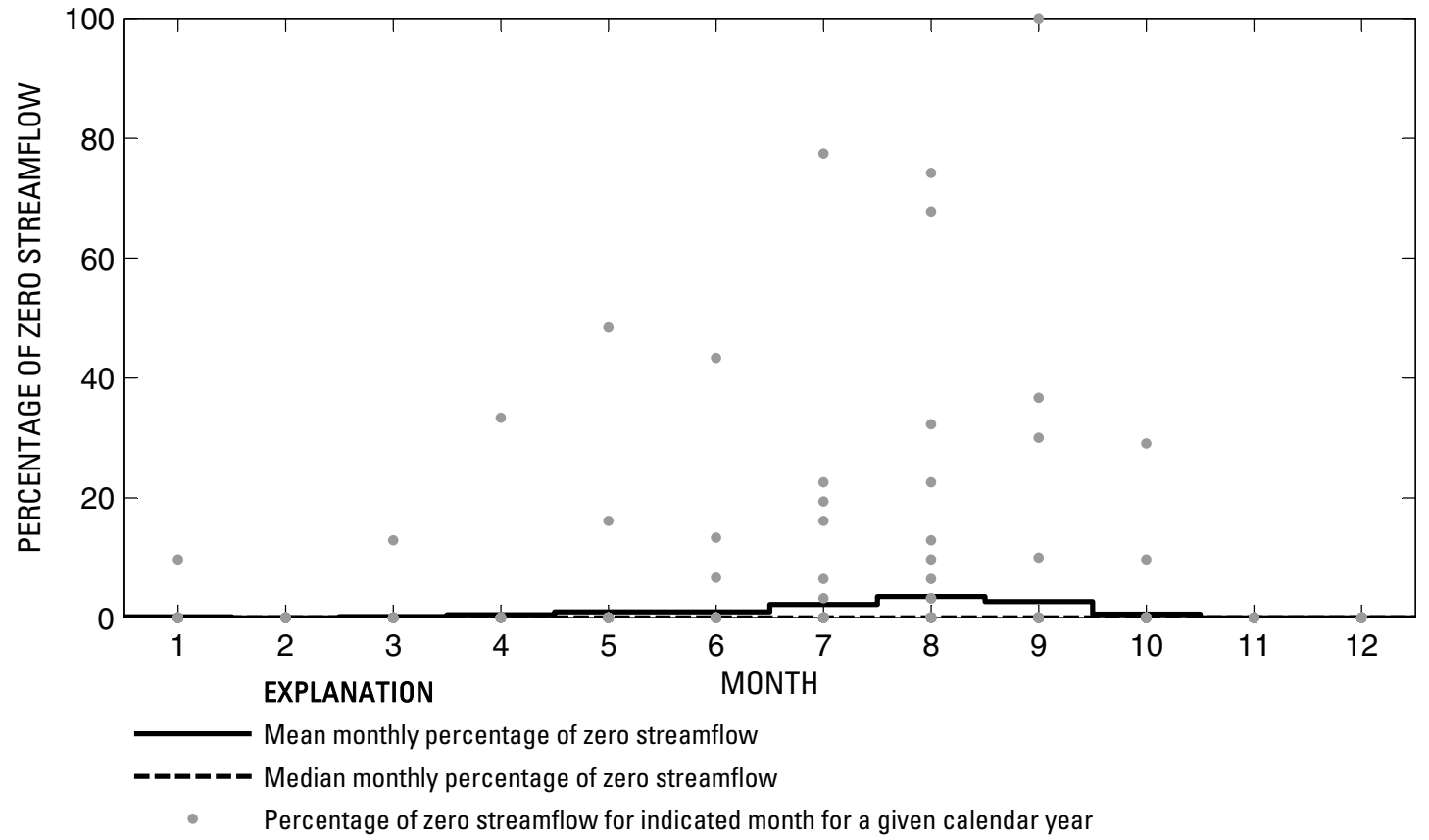

Figure 5. Analysis of percentage of zero daily mean streamflow for U.S. Geological Survey streamflow-gaging station 07228000 Canadian River near Canadian, Texas. 
U.S. Geological Survey streamflow-gaging station 07233500
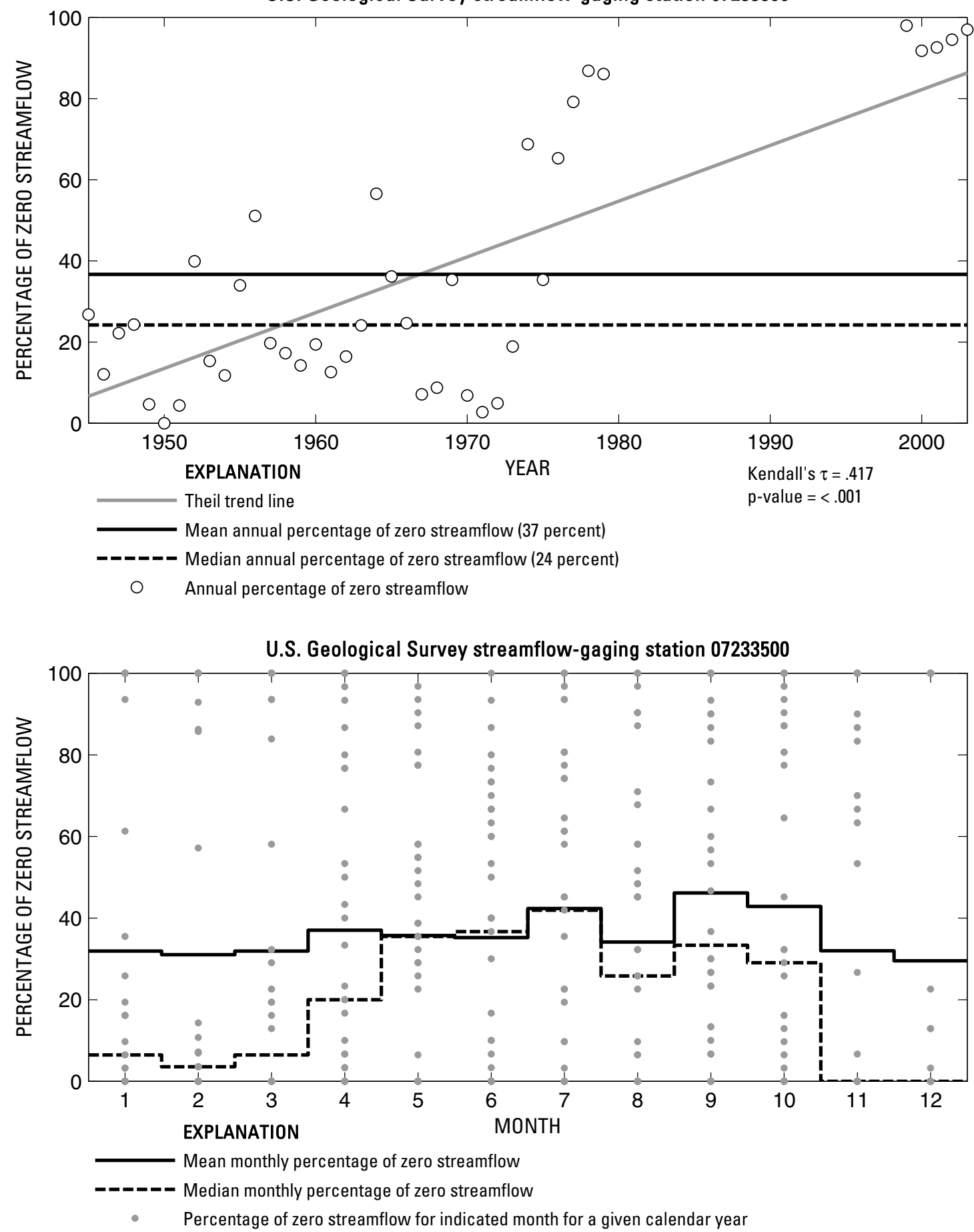

Figure 6. Analysis of percentage of zero daily mean streamflow for U.S. Geological Survey streamflow-gaging station 07233500 Palo Duro Creek near Spearman, Texas. 

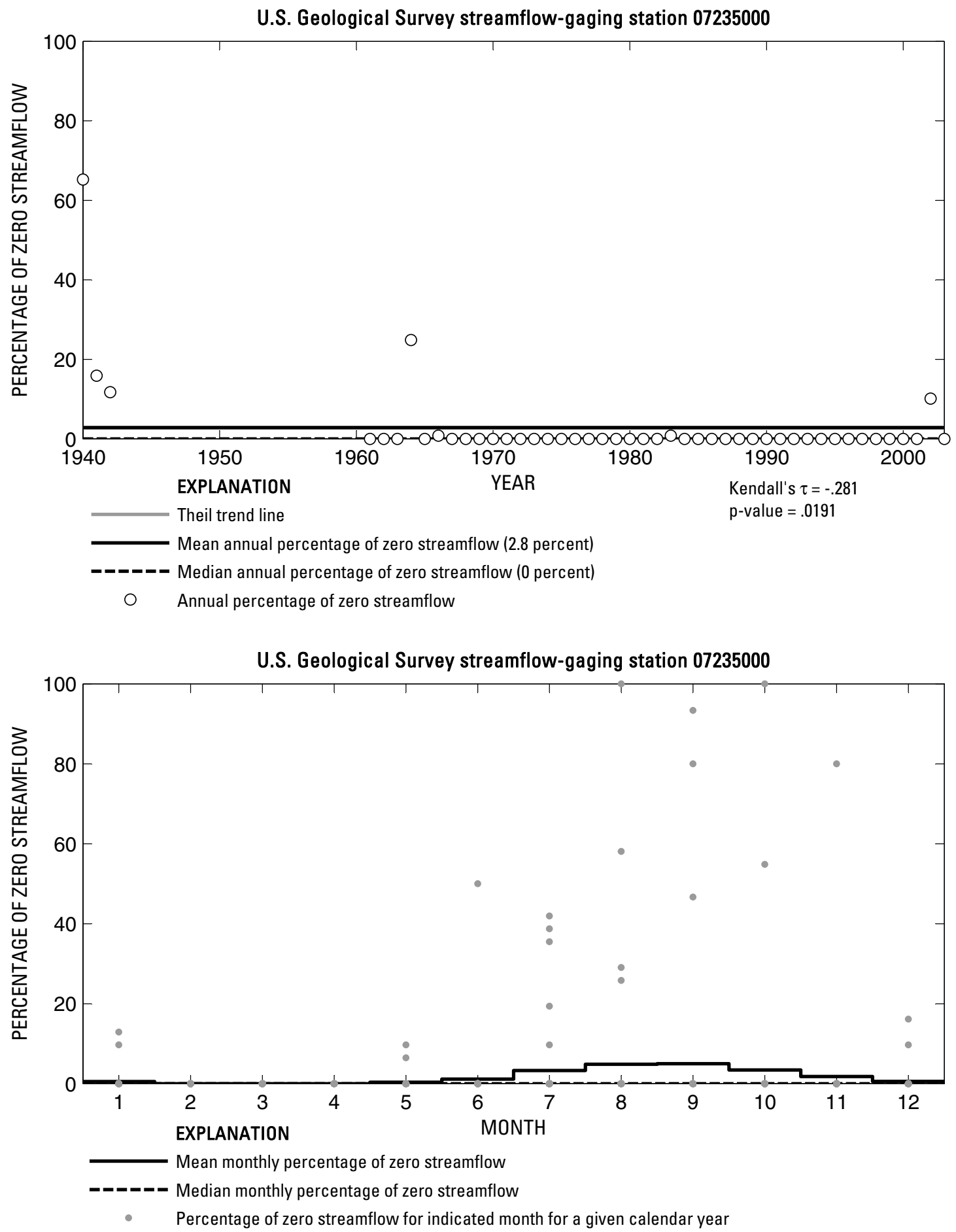

Figure 7. Analysis of percentage of zero daily mean streamflow for U.S. Geological Survey streamflow-gaging station 07235000 Wolf Creek at Lipscomb, Texas. 

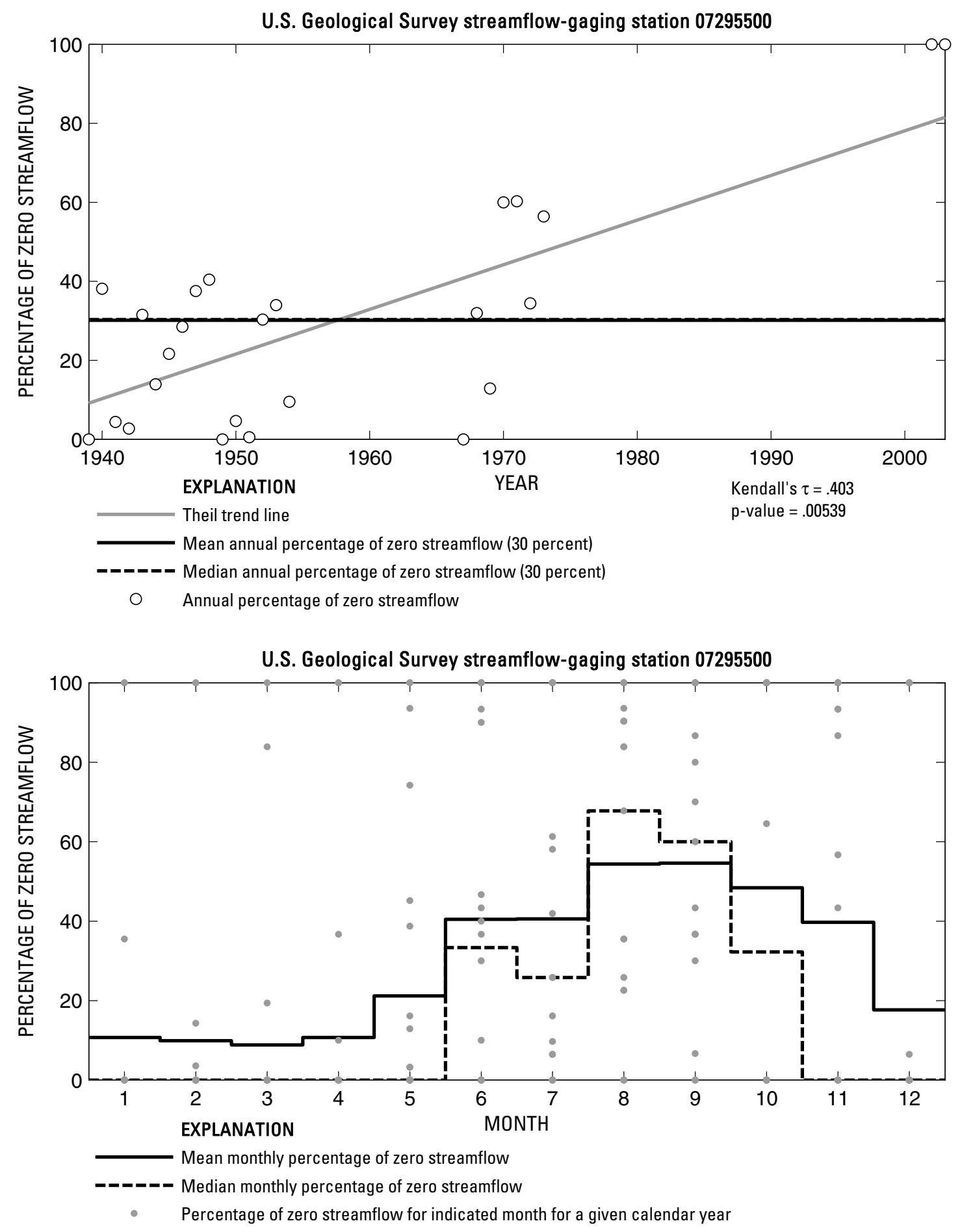

Figure 8. Analysis of percentage of zero daily mean streamflow for U.S. Geological Survey streamflow-gaging station 07295500 Tierra Blanca Creek above Buffalo Lake near Umbarger, Texas. 

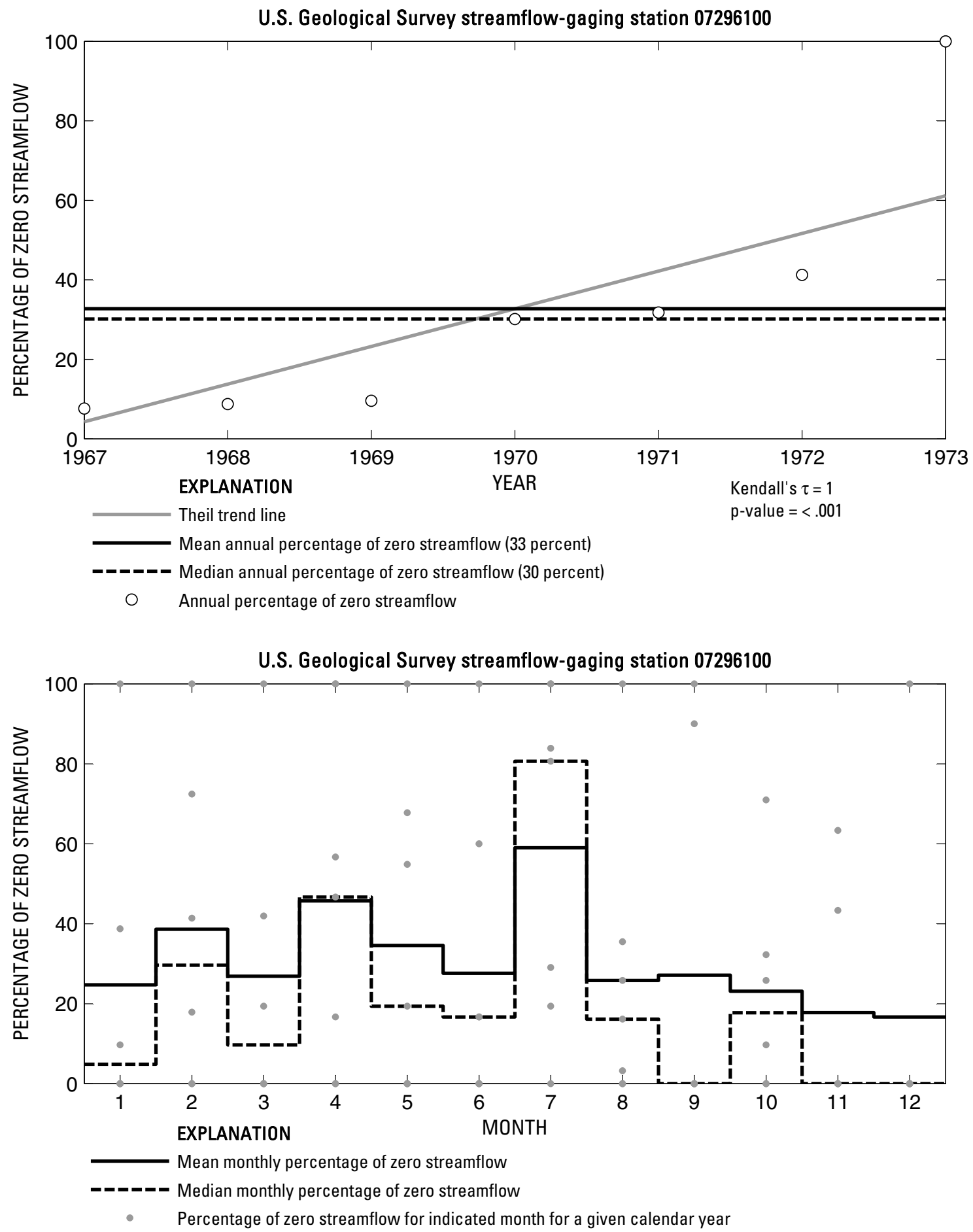

Figure 9. Analysis of percentage of zero daily mean streamflow for U.S. Geological Survey streamflow-gaging station 07296100 Tierra Blanca Creek below Buffalo Lake near Umbarger, Texas. 
U.S. Geological Survey streamflow-gaging station 07297500

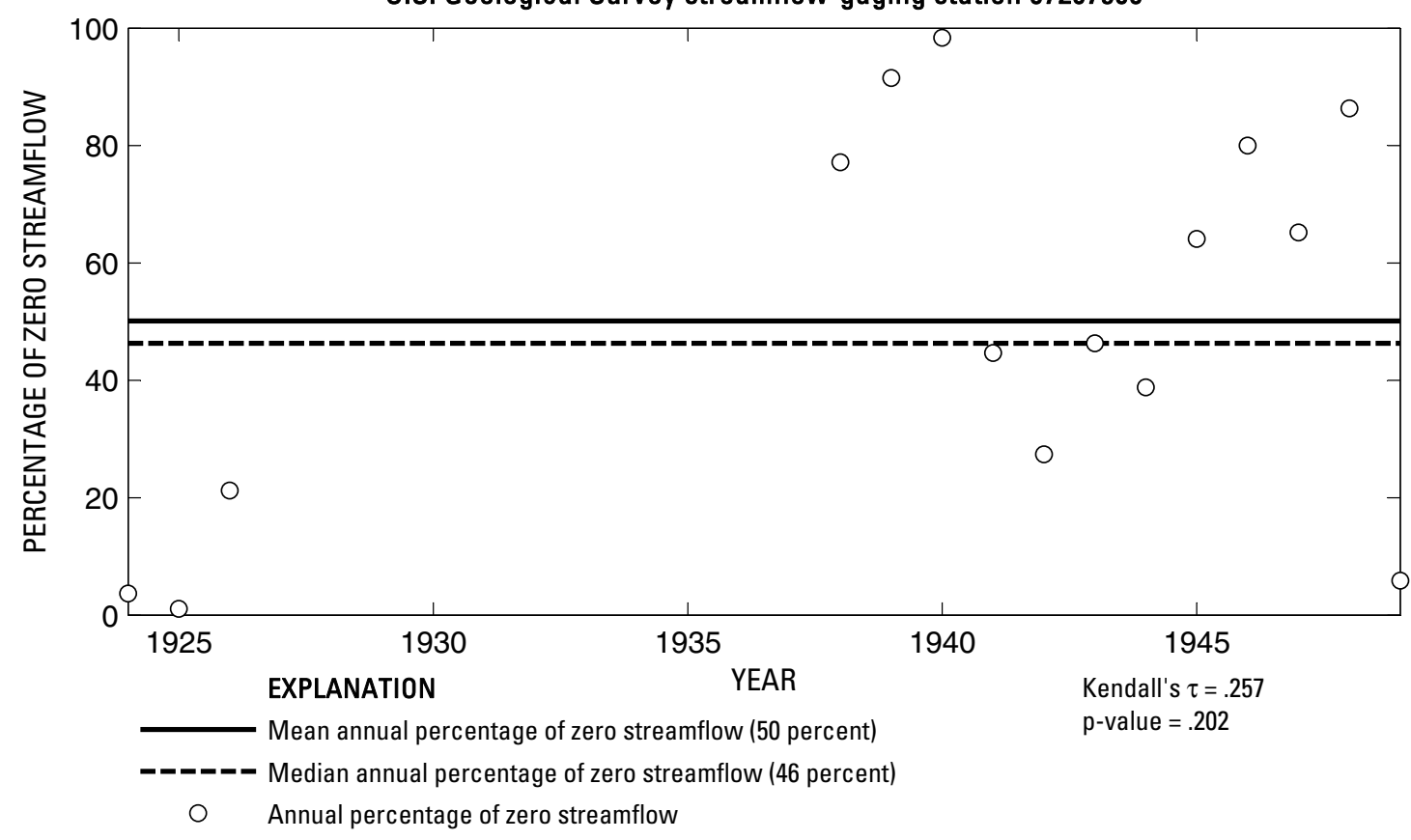

U.S. Geological Survey streamflow-gaging station 07297500

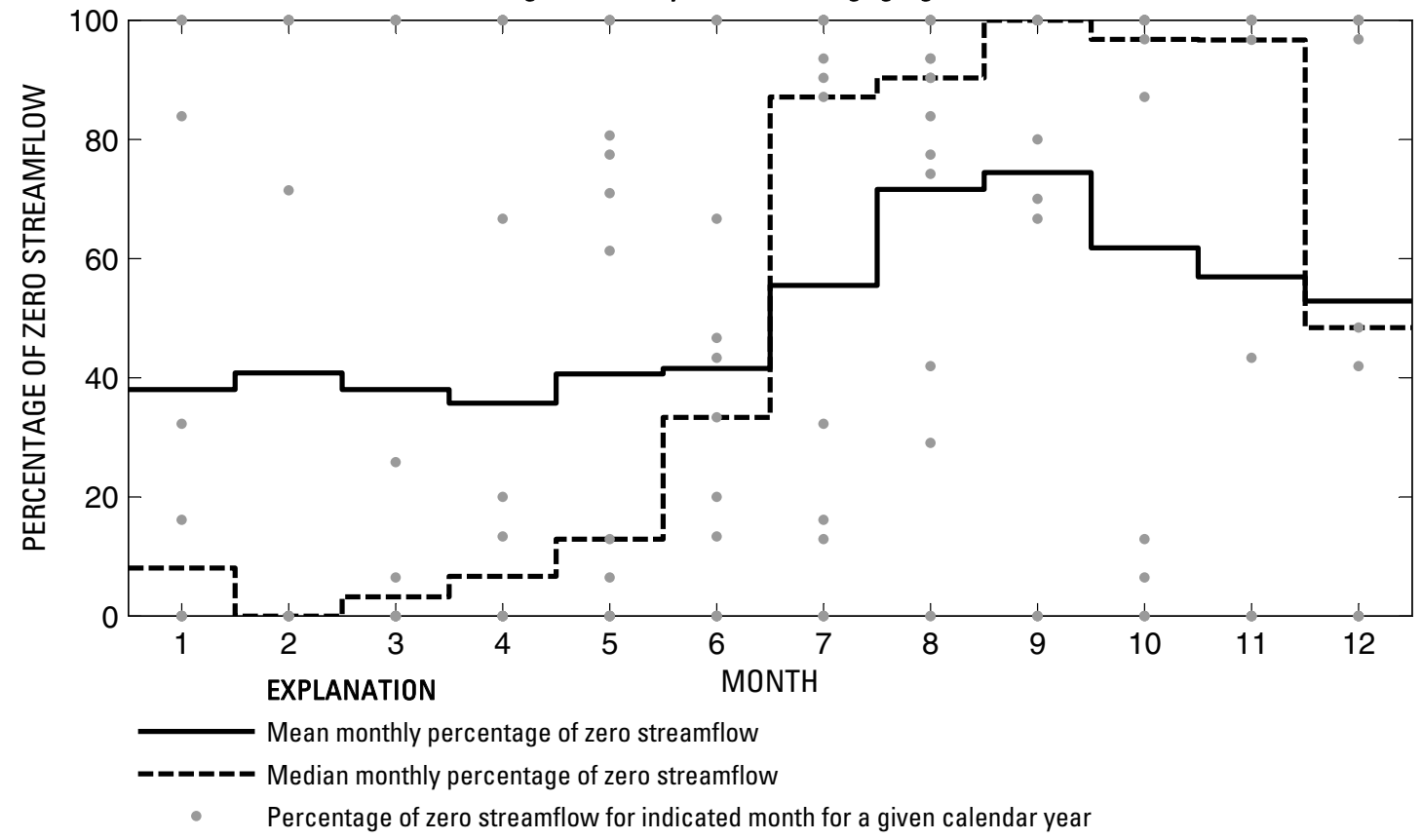

Figure 10. Analysis of percentage of zero daily mean streamflow for U.S. Geological Survey streamflow-gaging station 07297500 Prairie Dog Town Fork Red River near Canyon, Texas. 

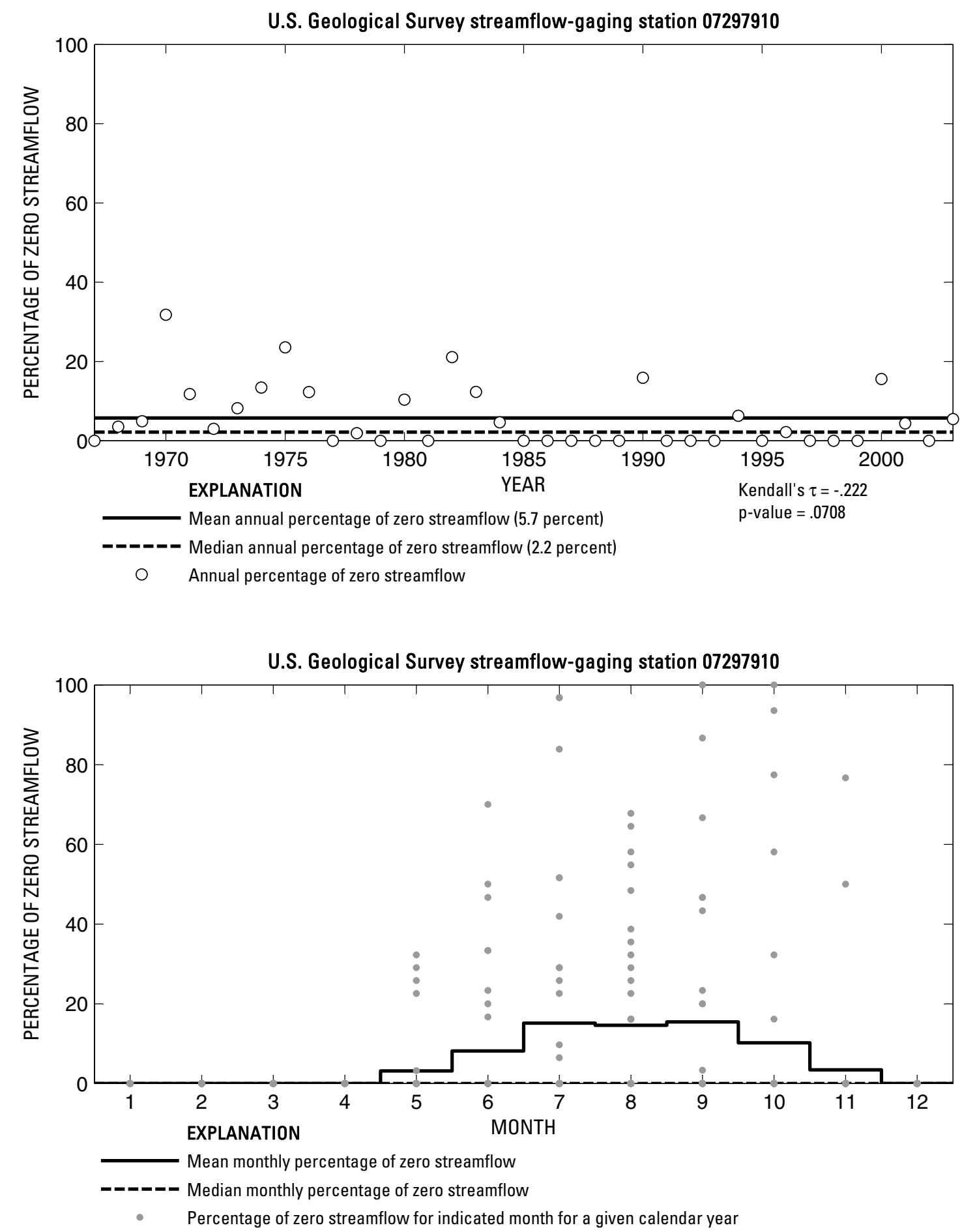

Figure 11. Analysis of percentage of zero daily mean streamflow for U.S. Geological Survey streamflow-gaging station 07297910 Prairie Dog Town Fork Red River near Wayside, Texas. 
U.S. Geological Survey streamflow-gaging station 07298000

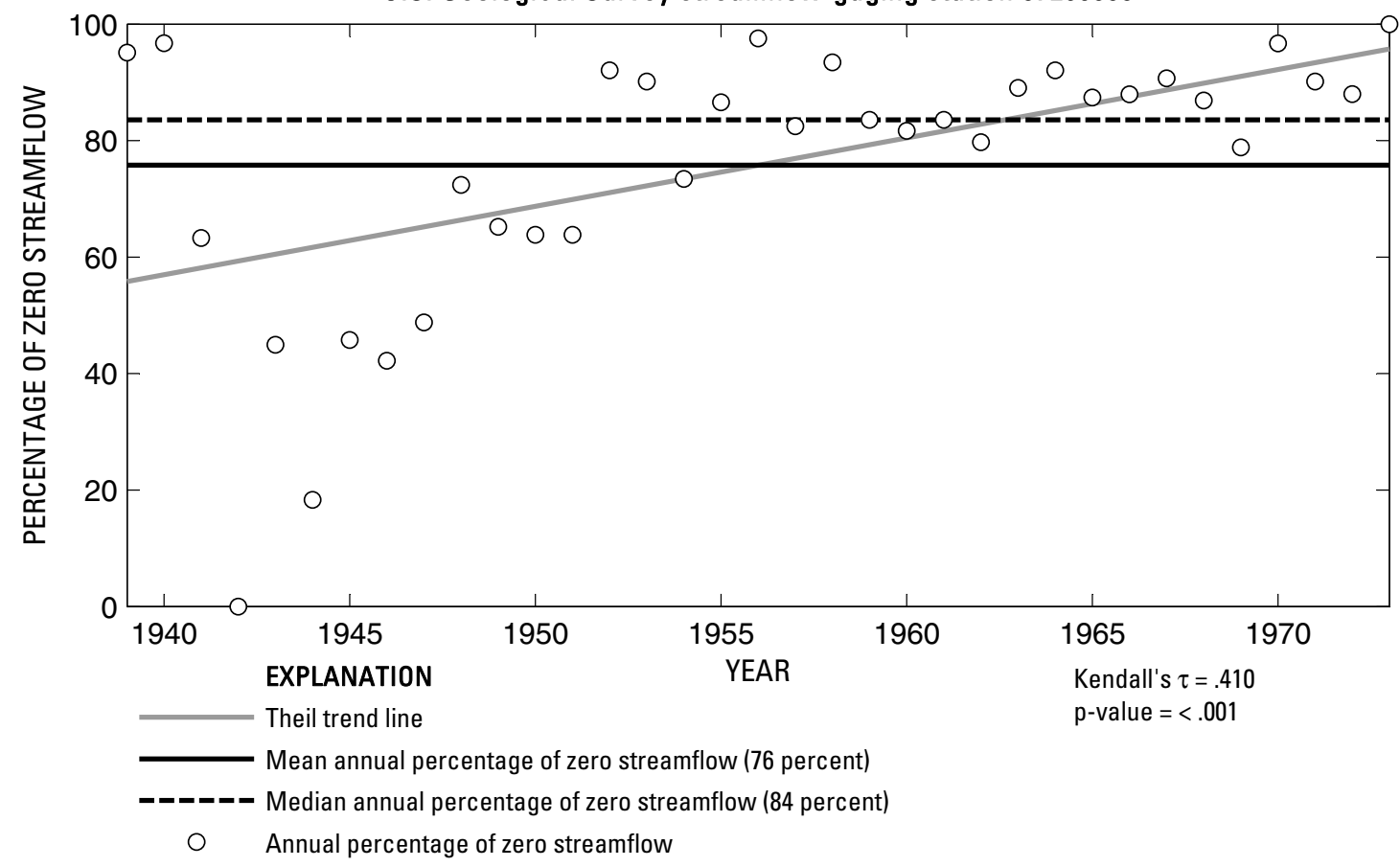

U.S. Geological Survey streamflow-gaging station 07298000

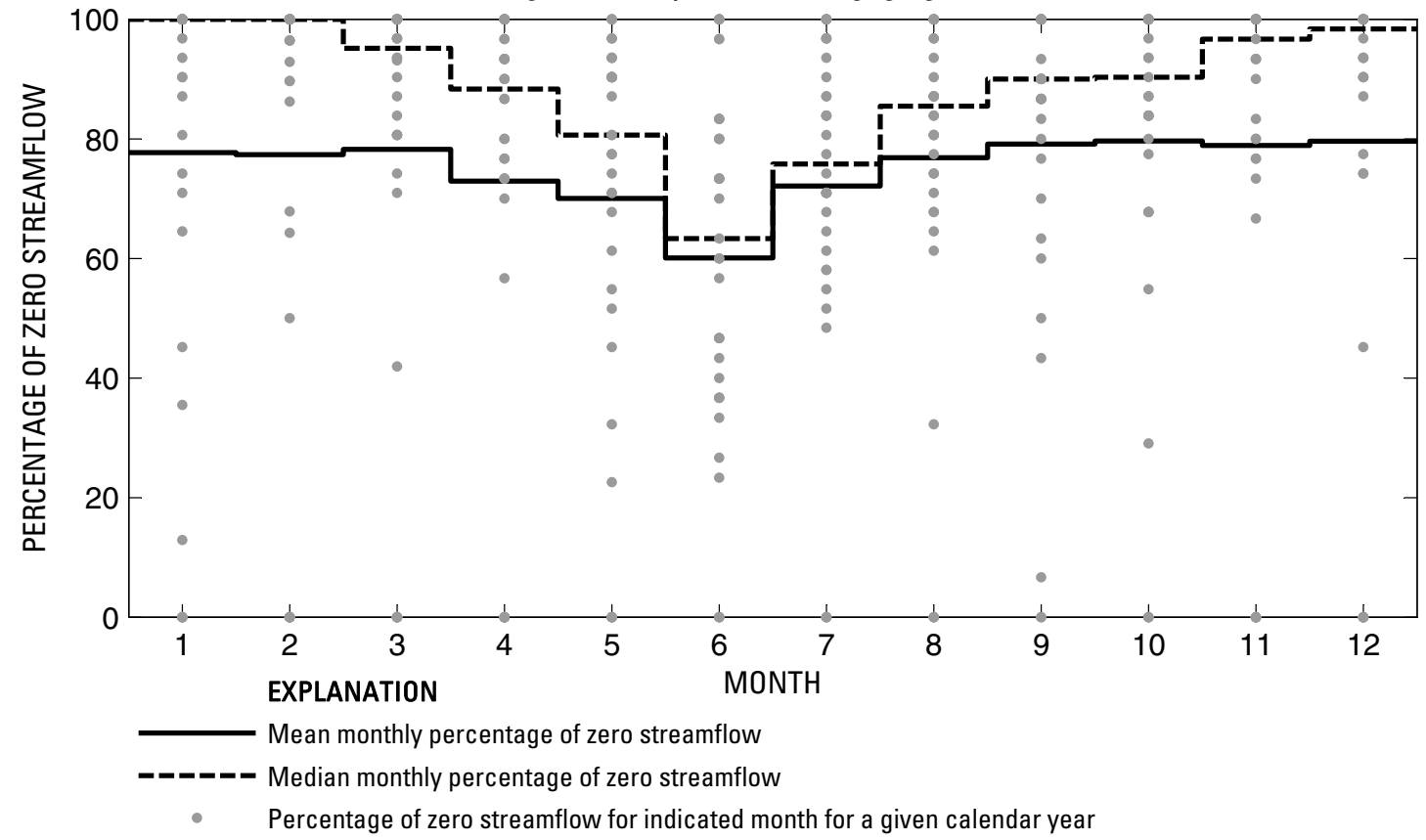

Figure 12. Analysis of percentage of zero daily mean streamflow for U.S. Geological Survey streamflow-gaging station 07298000 North Tule Draw at Reservoir near Tulia, Texas. 


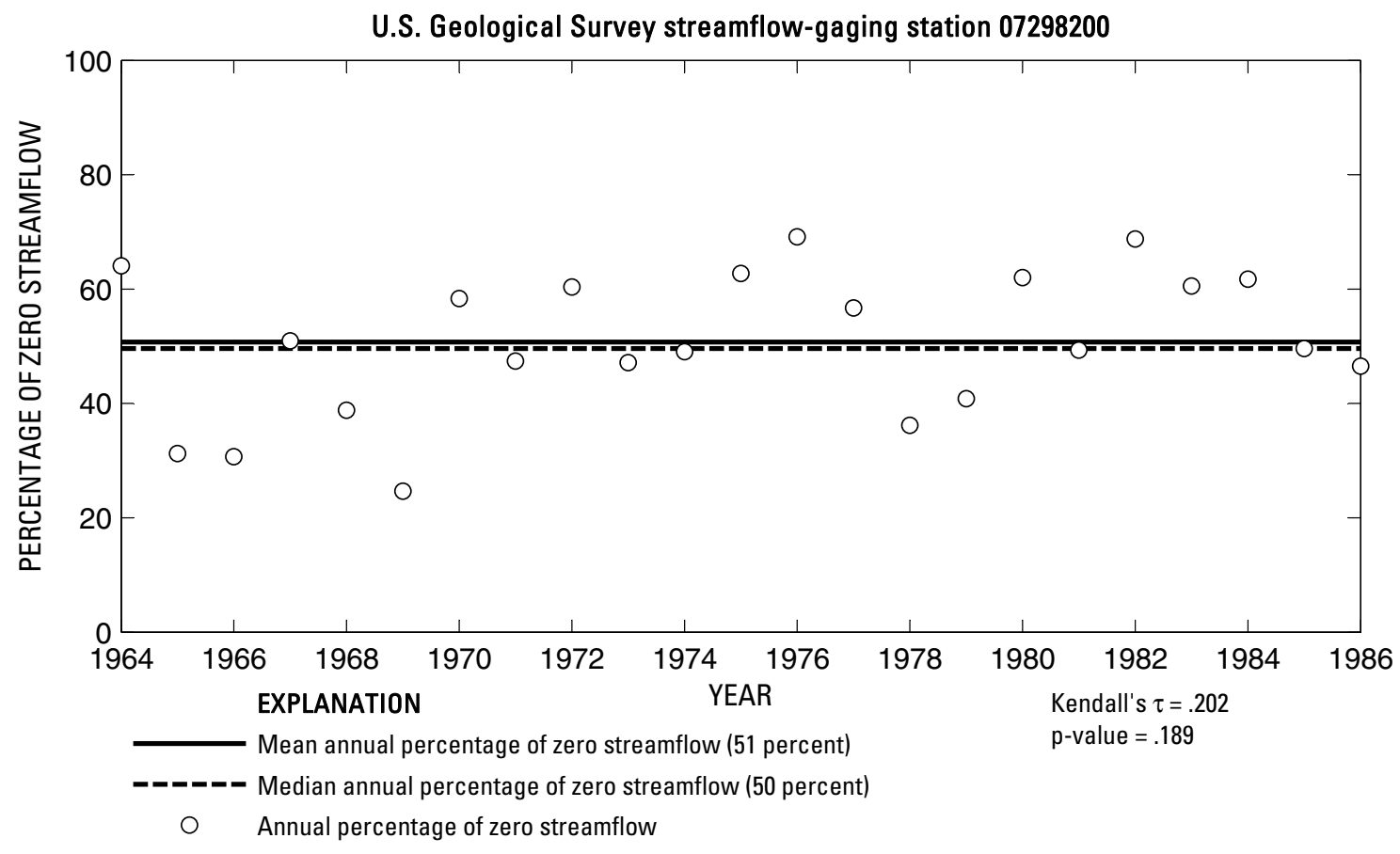

U.S. Geological Survey streamflow-gaging station 07298200

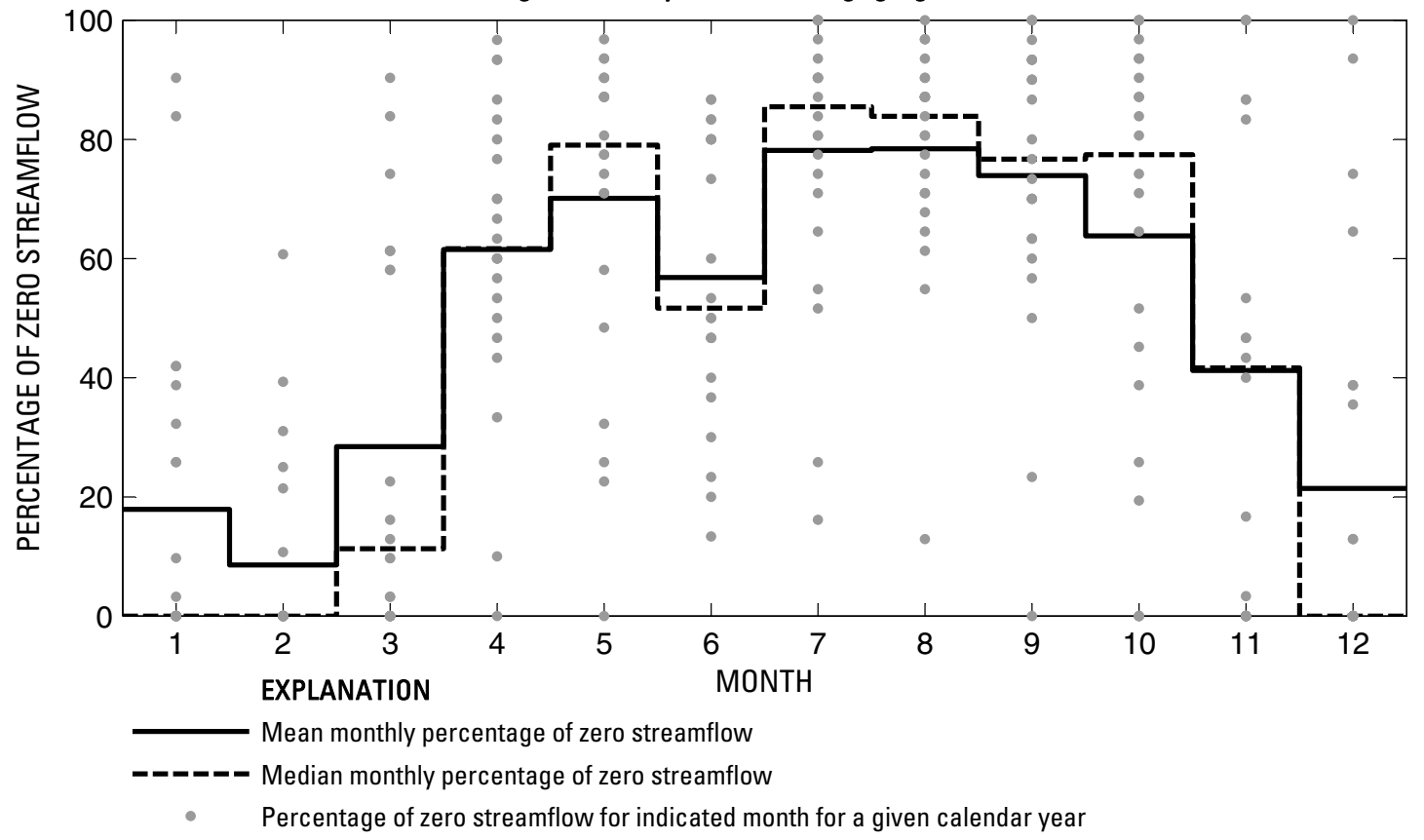

Figure 13. Analysis of percentage of zero daily mean streamflow for U.S. Geological Survey streamflow-gaging station 07298200 Tule Creek near Silverton, Texas. 
U.S. Geological Survey streamflow-gaging station 07298500

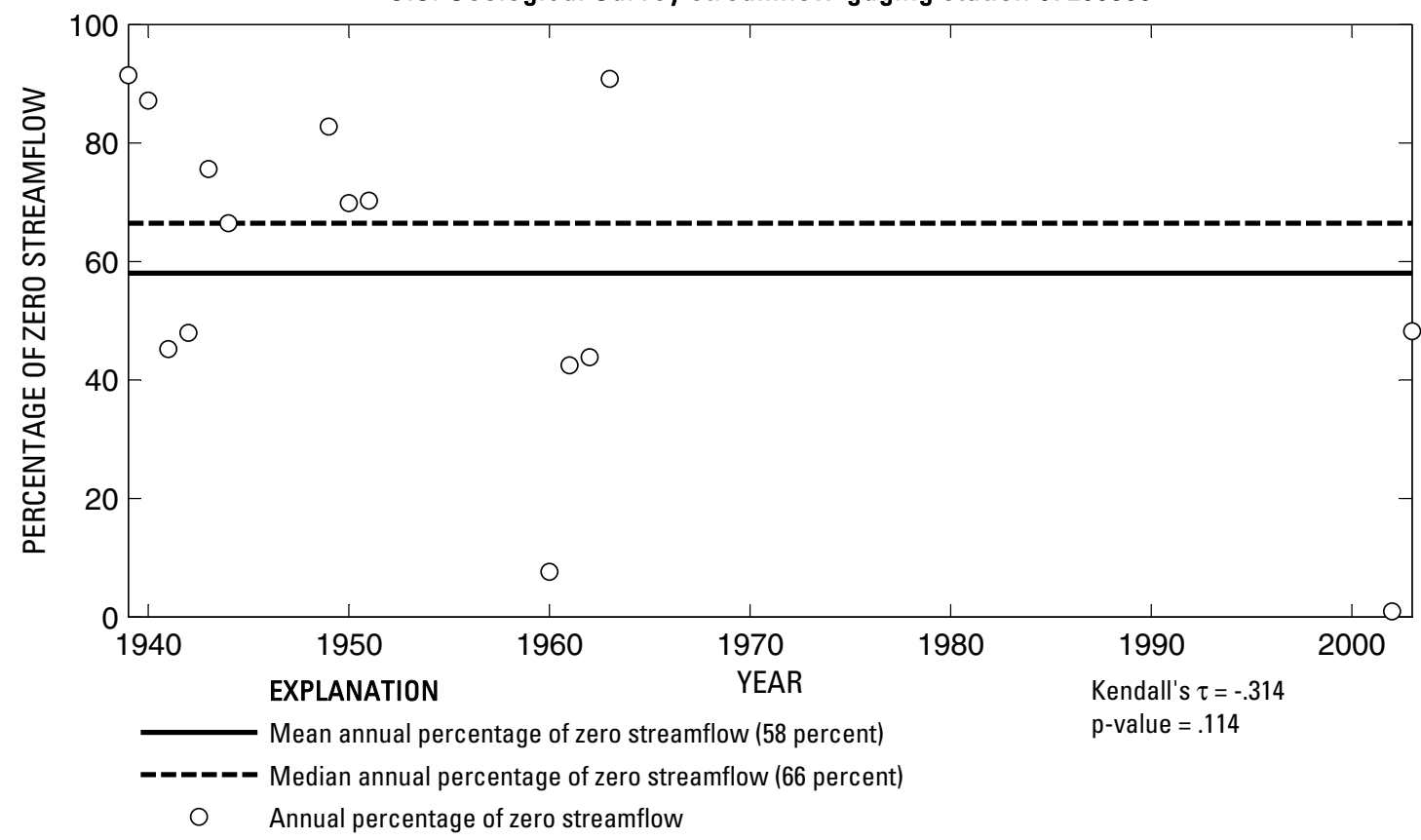

U.S. Geological Survey streamflow-gaging station 07298500

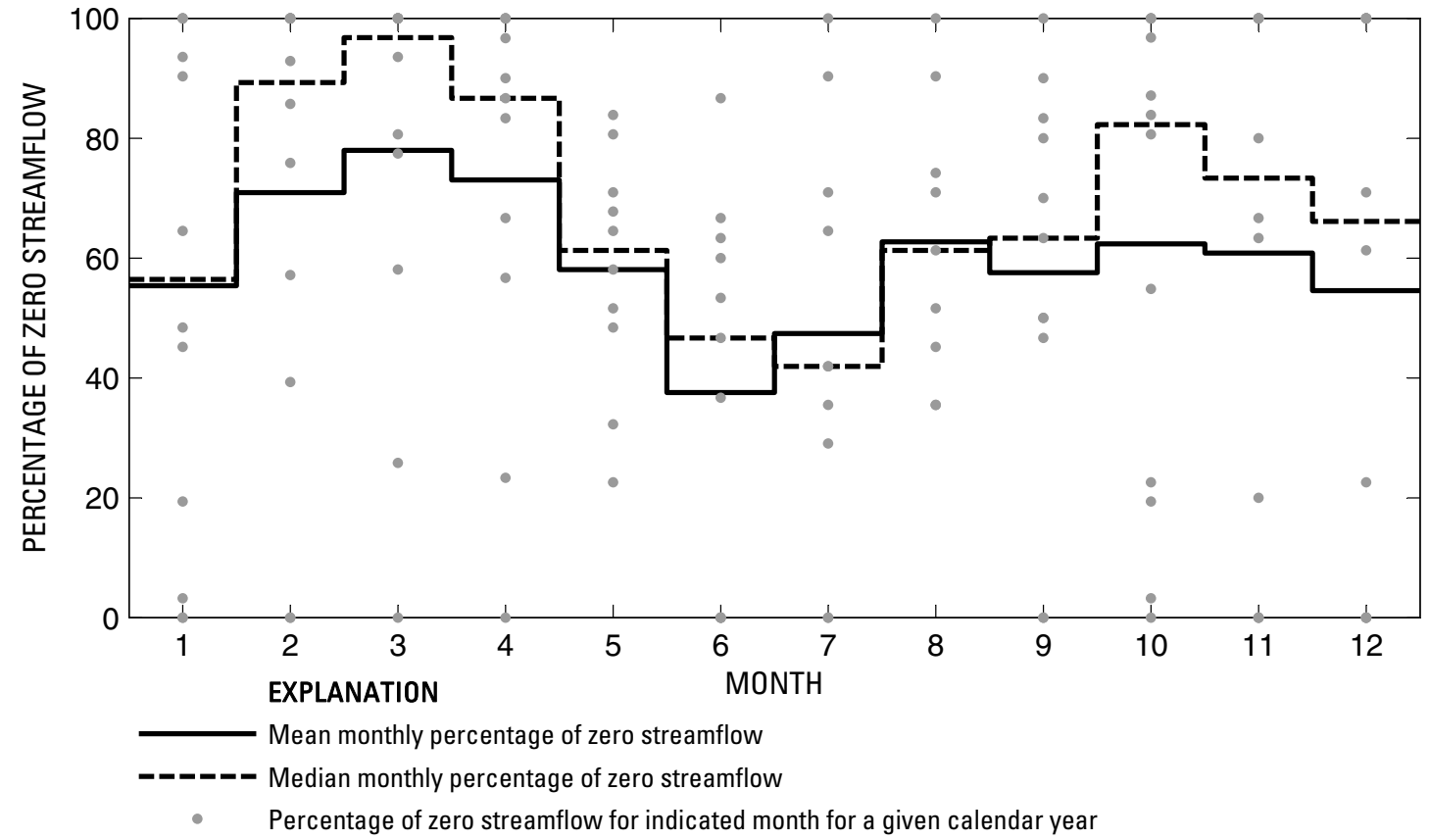

Figure 14. Analysis of percentage of zero daily mean streamflow for U.S. Geological Survey streamflow-gaging station 07298500 Prairie Dog Town Fork Red River near Brice, Texas. 

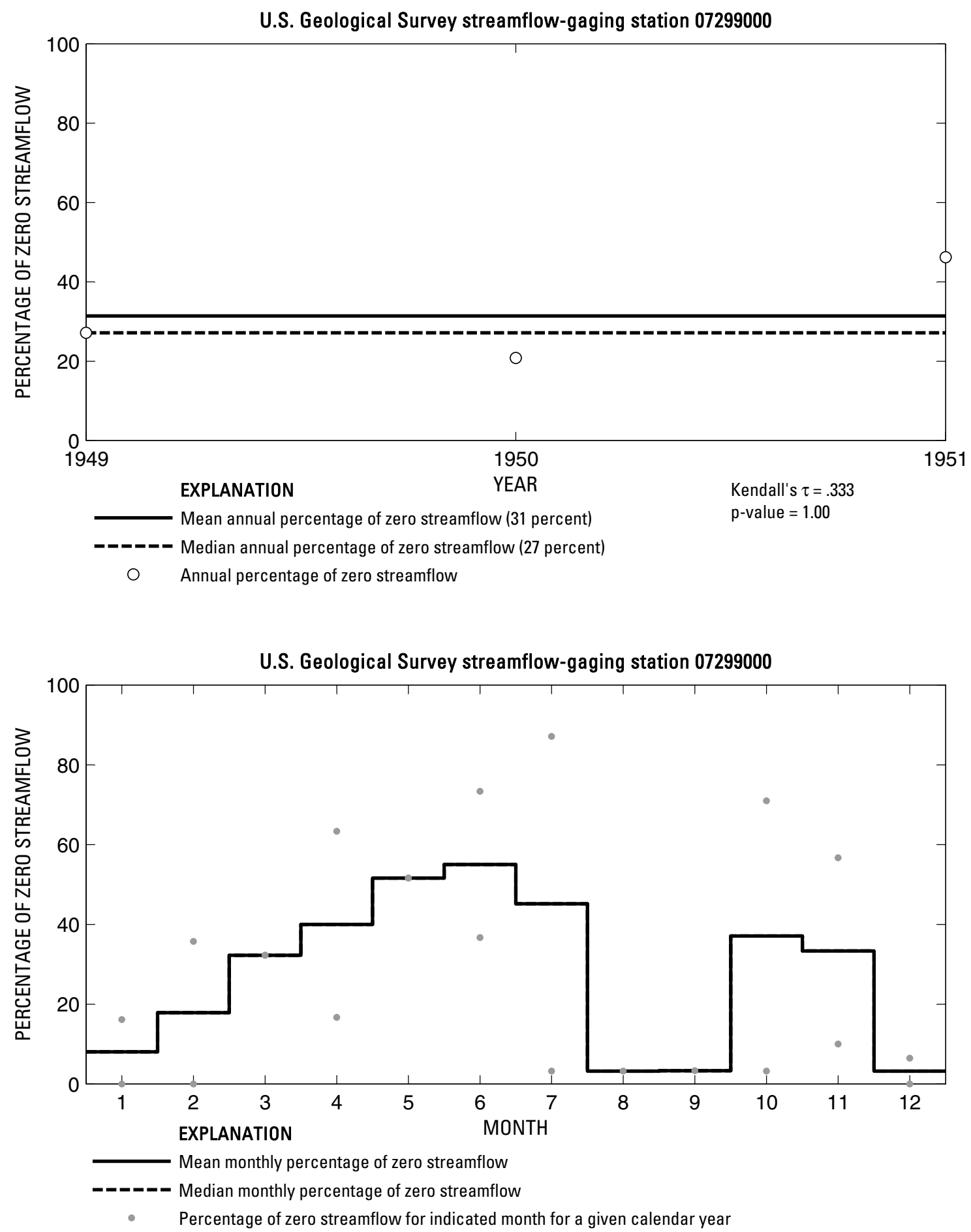

Figure 15. Analysis of percentage of zero daily mean streamflow for U.S. Geological Survey streamflow-gaging station 07299000 Mulberry Creek near Brice, Texas. 
U.S. Geological Survey streamflow-gaging station 07299200

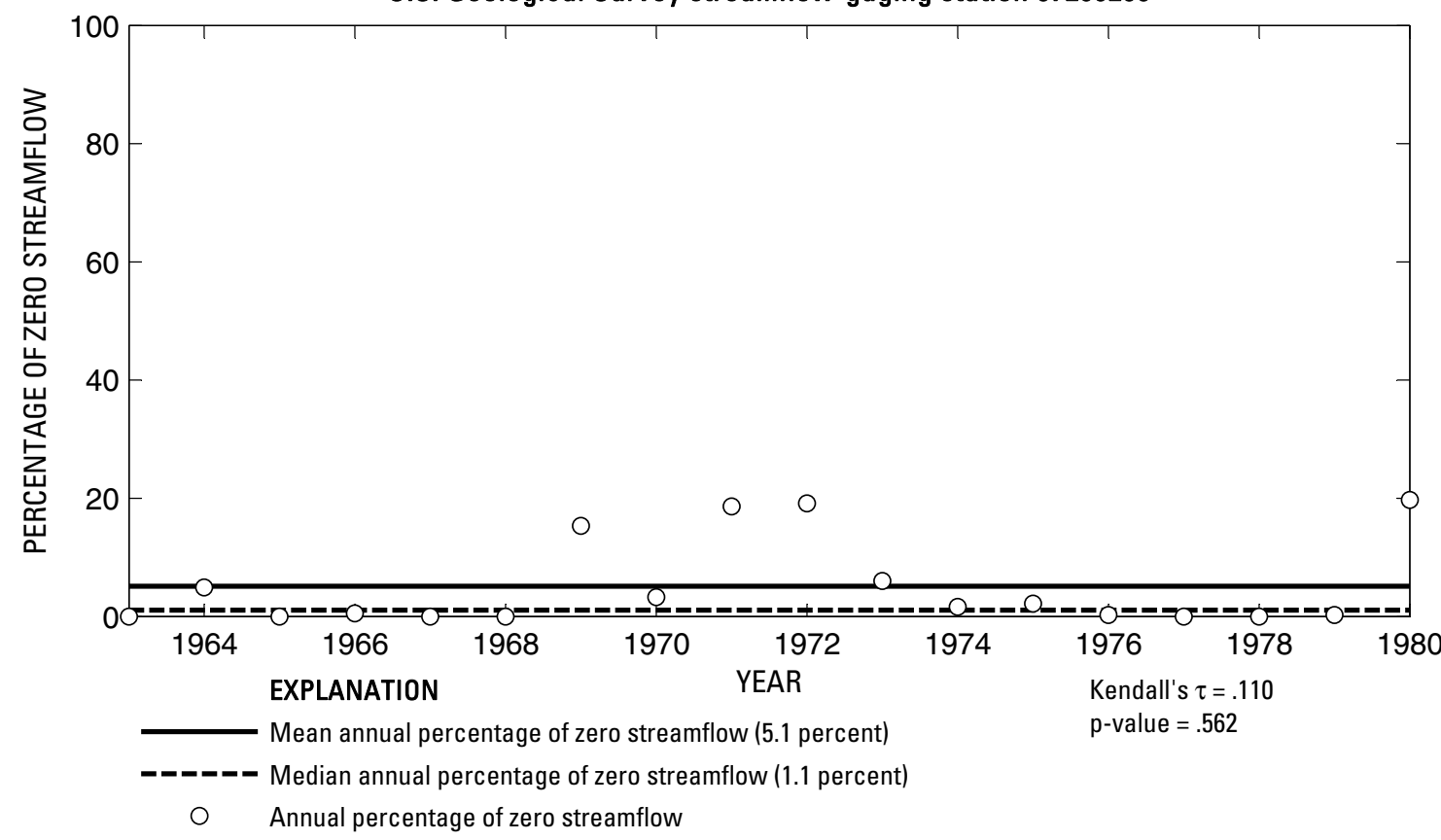

U.S. Geological Survey streamflow-gaging station 07299200

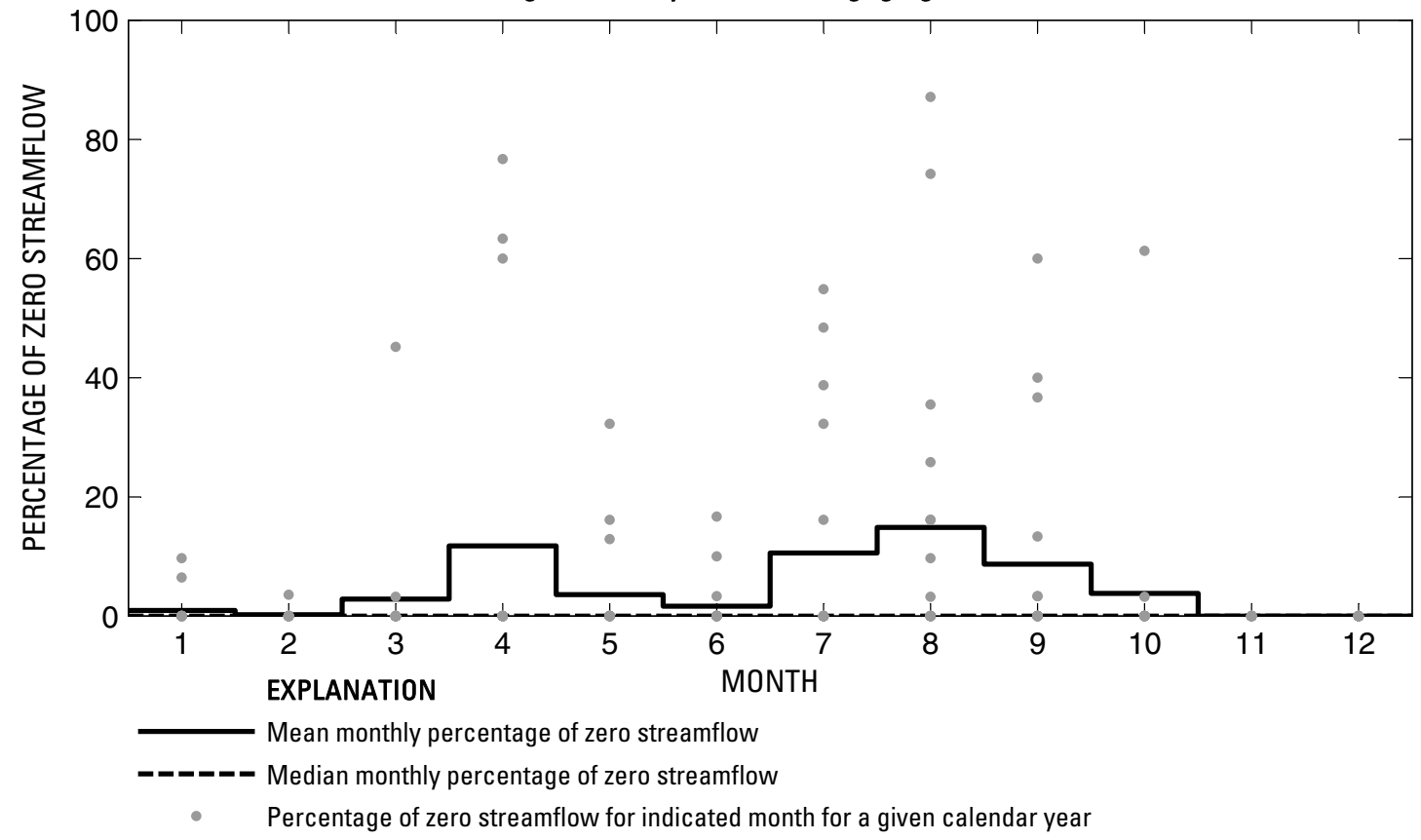

Figure 16. Analysis of percentage of zero daily mean streamflow for U.S. Geological Survey streamflow-gaging station 07299200 Prairie Dog Town Fork Red River near Lakeview, Texas. 

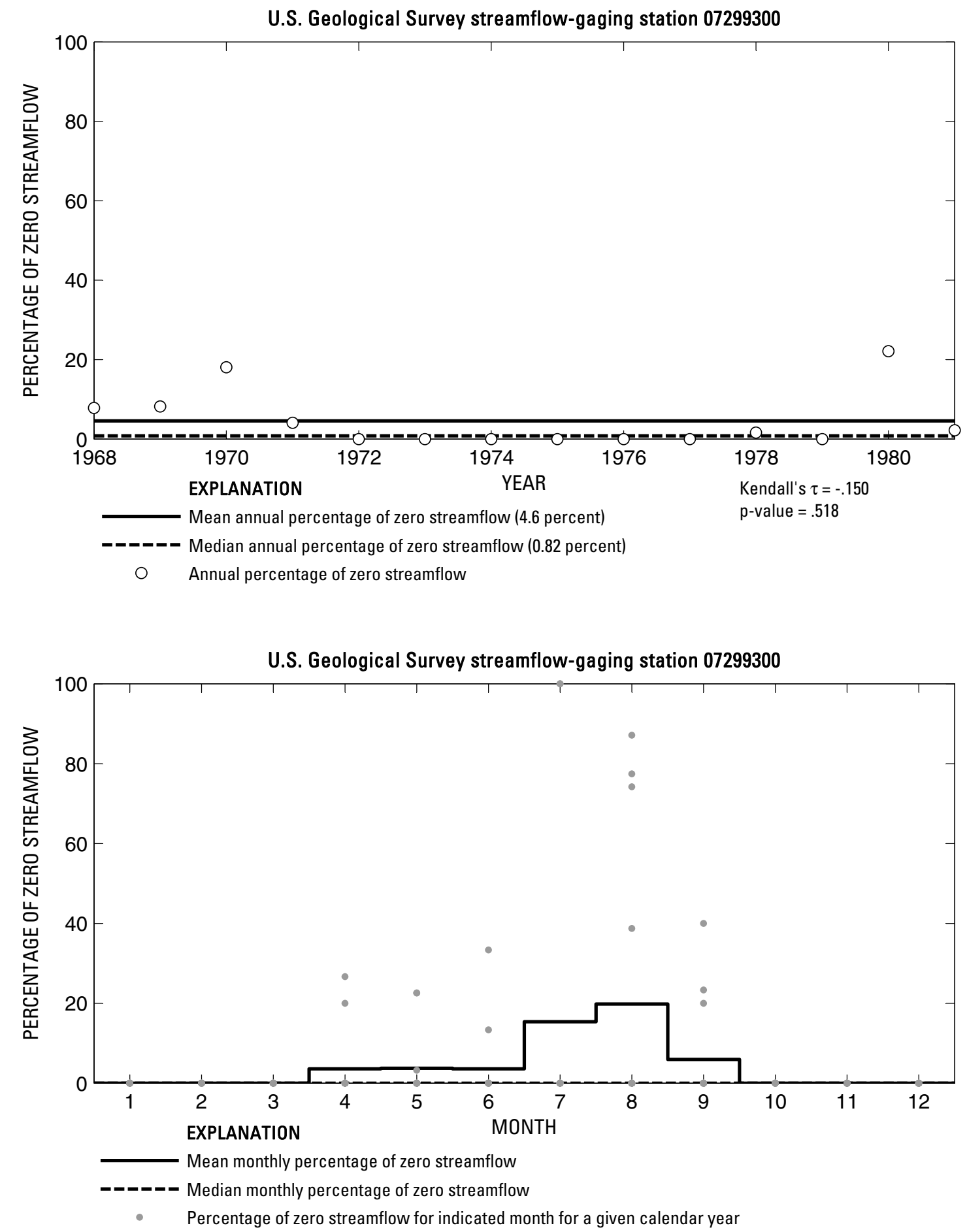

Figure 17. Analysis of percentage of zero daily mean streamflow for U.S. Geological Survey streamflow-gaging station 07299300 Little Red River near Turkey, Texas. 
U.S. Geological Survey streamflow-gaging station 07299500

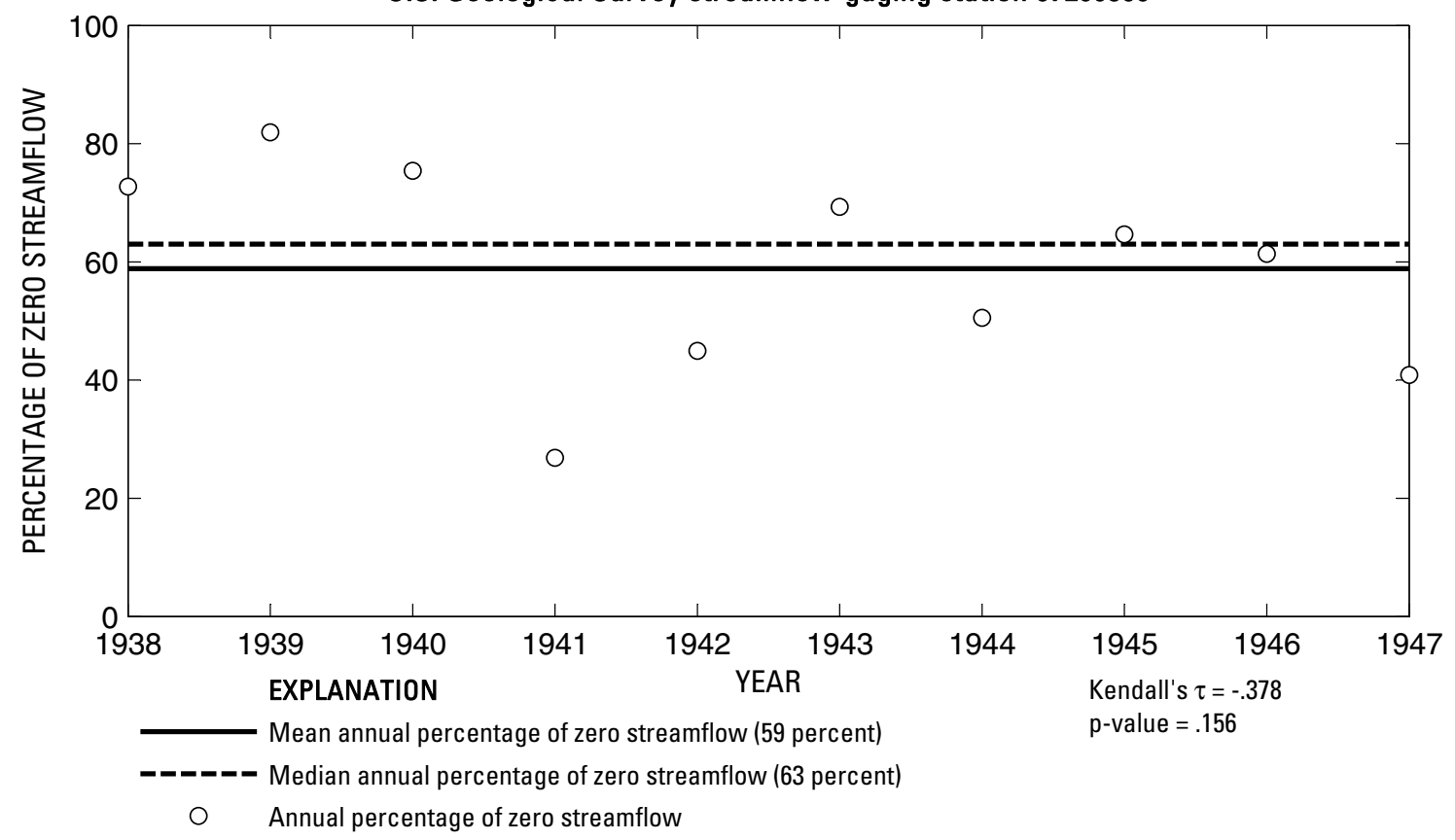

U.S. Geological Survey streamflow-gaging station 07299500

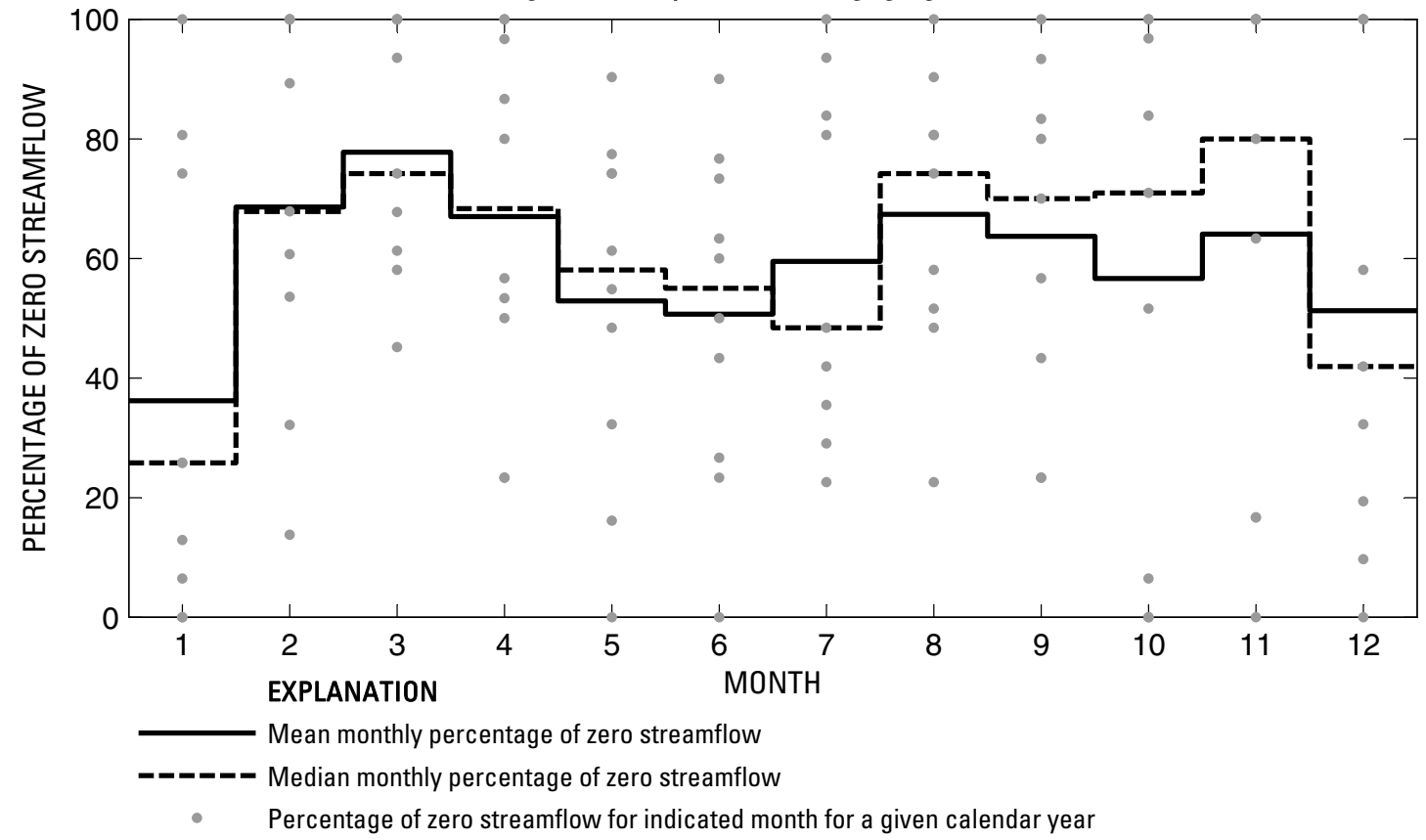

Figure 18. Analysis of percentage of zero daily mean streamflow for U.S. Geological Survey streamflow-gaging station 07299500 Prairie Dog Town Fork Red River near Estelline, Texas. 


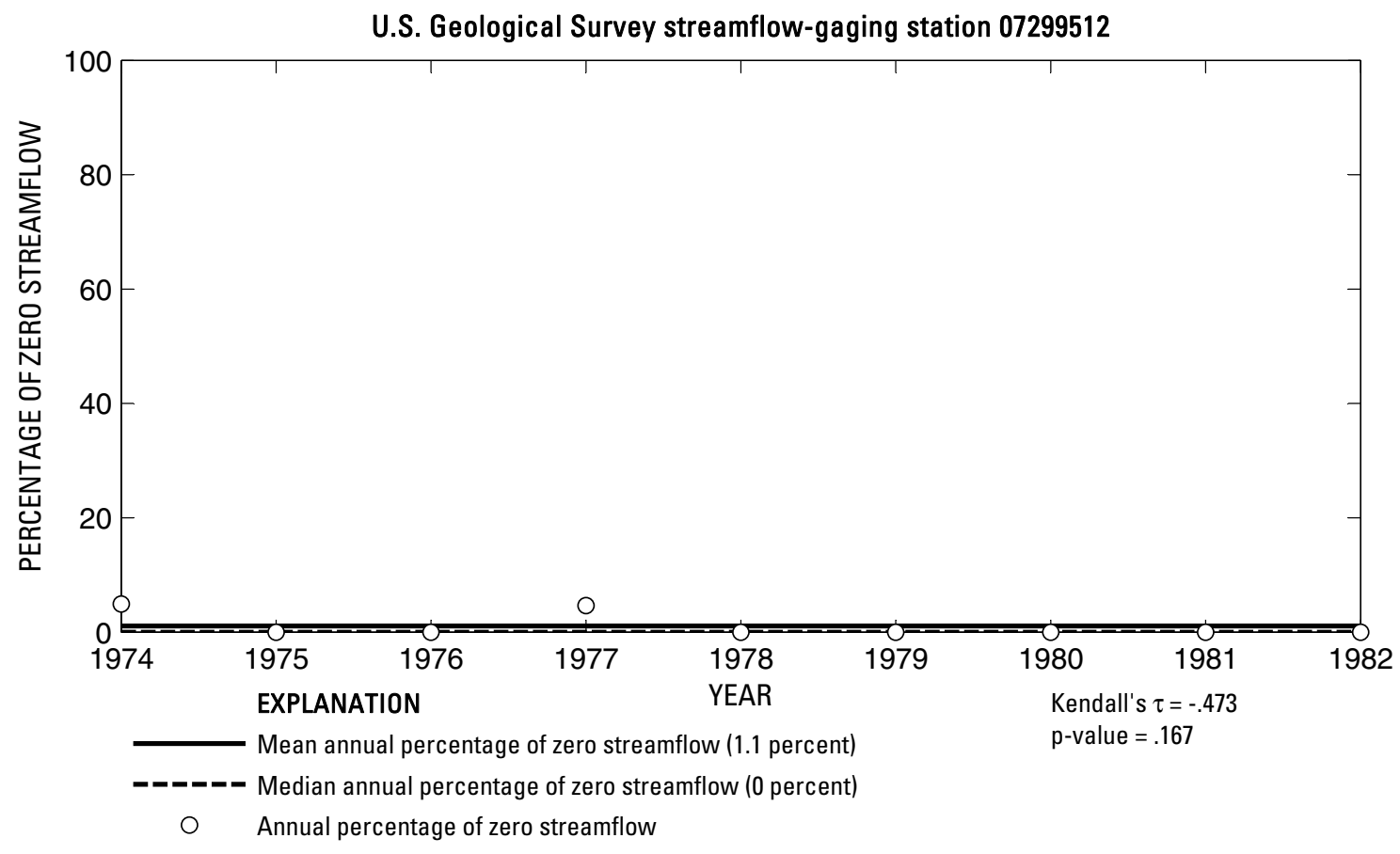

U.S. Geological Survey streamflow-gaging station 07299512

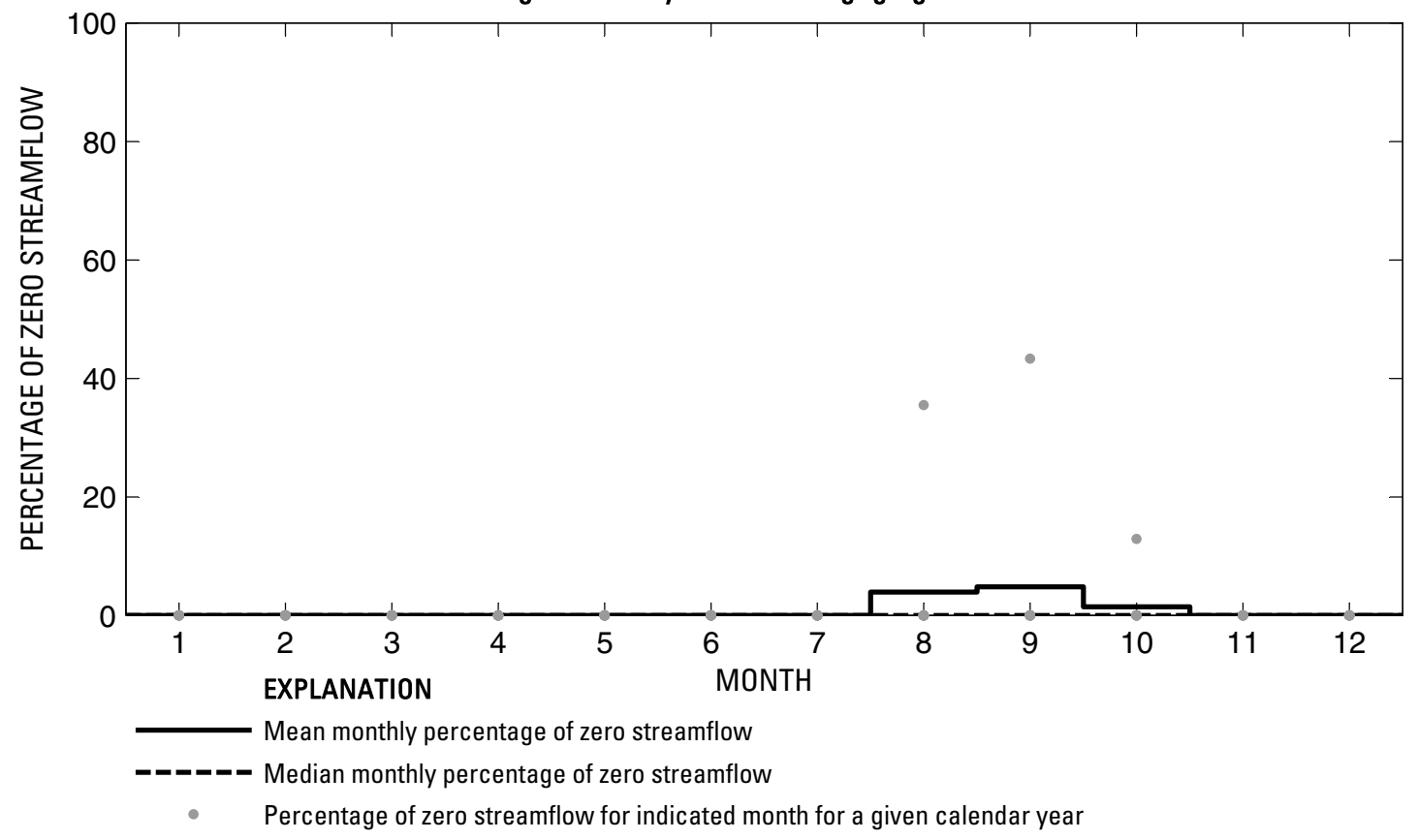

Figure 19. Analysis of percentage of zero daily mean streamflow for U.S. Geological Survey streamflow-gaging station 07299512 Jonah Creek at Weir near Estelline, Texas. 
U.S. Geological Survey streamflow-gaging station 07299514

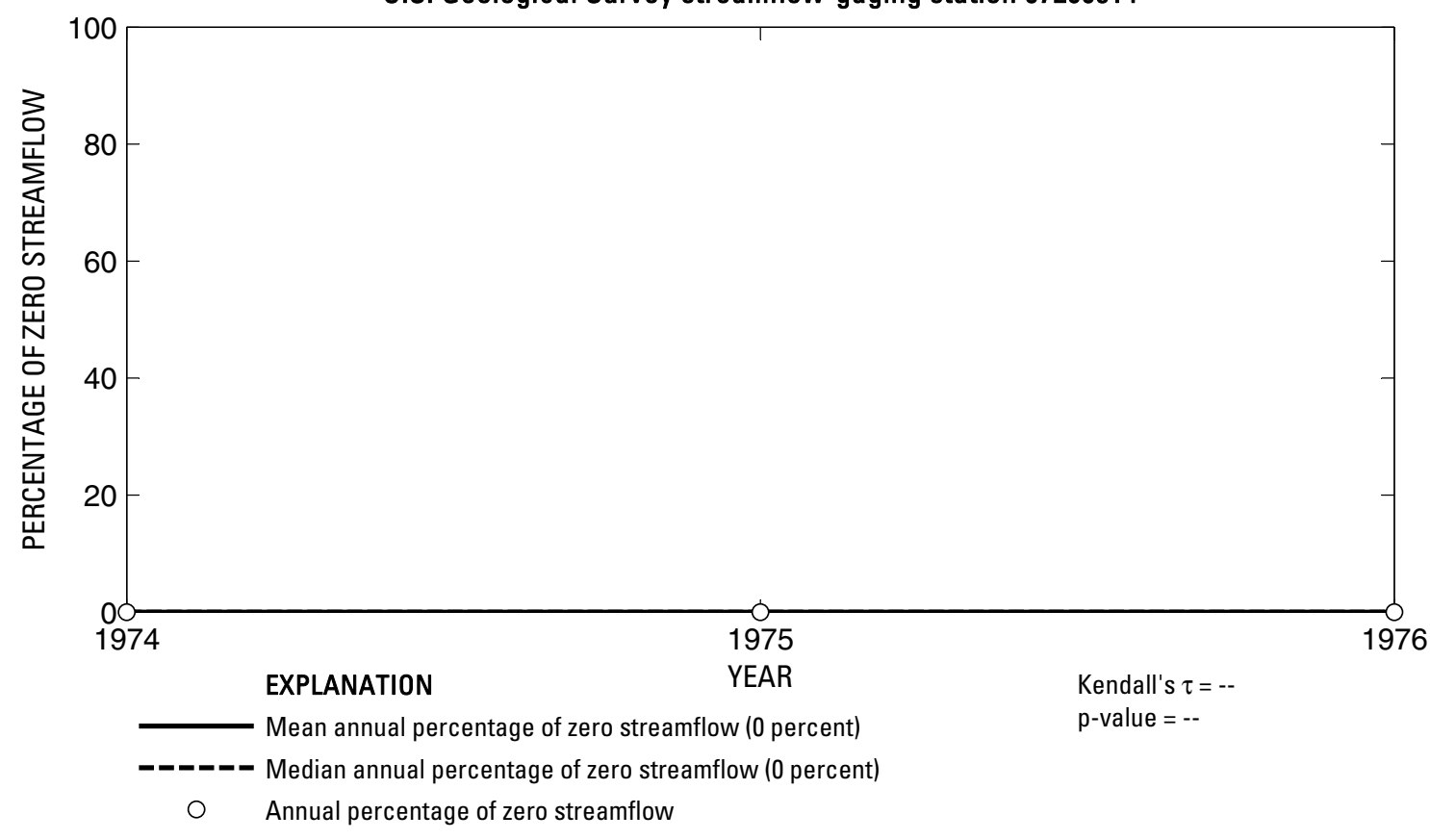

U.S. Geological Survey streamflow-gaging station 07299514

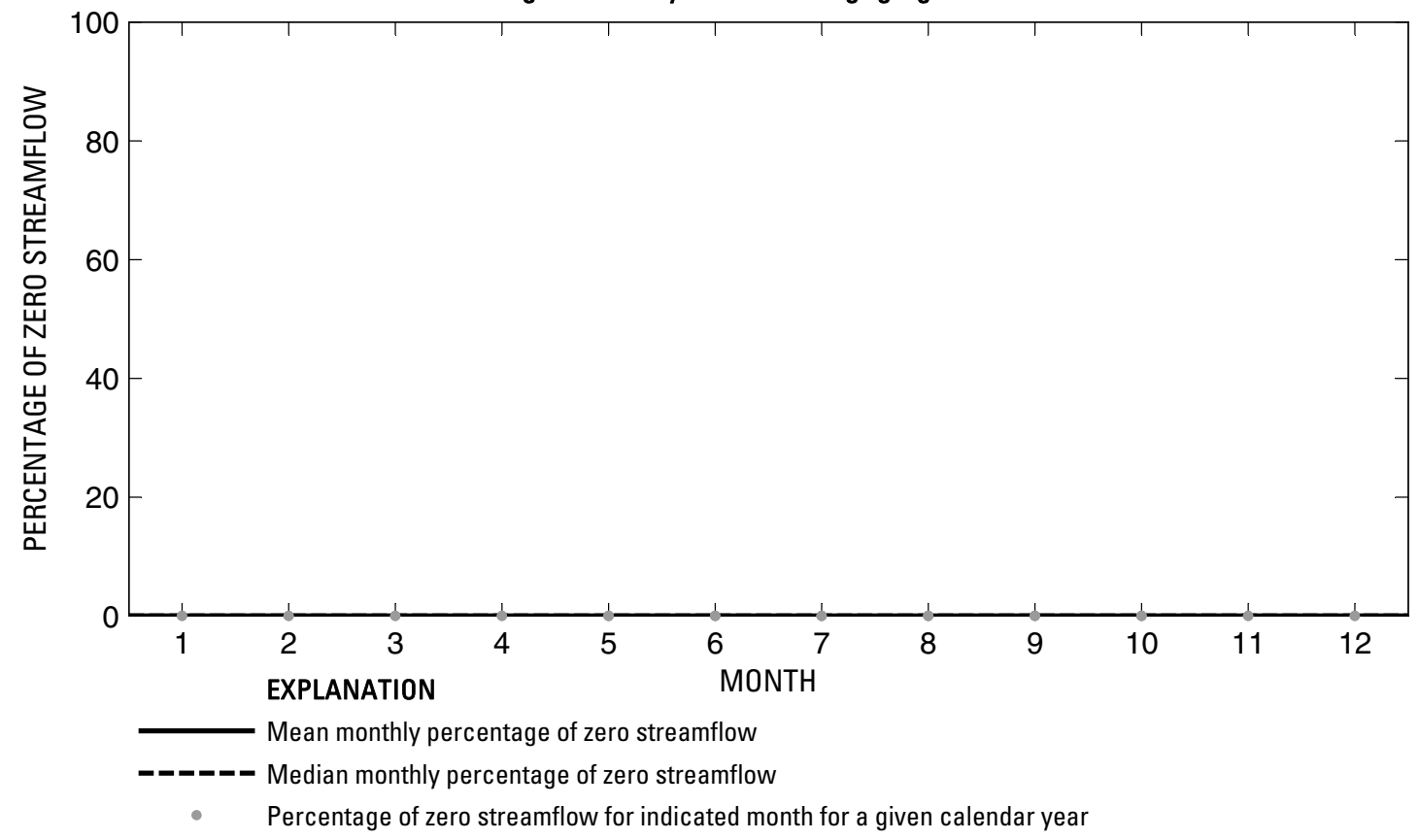

Figure 20. Analysis of percentage of zero daily mean streamflow for U.S. Geological Survey streamflow-gaging station 07299514 Jonah Creek below Weir near Estelline, Texas. 


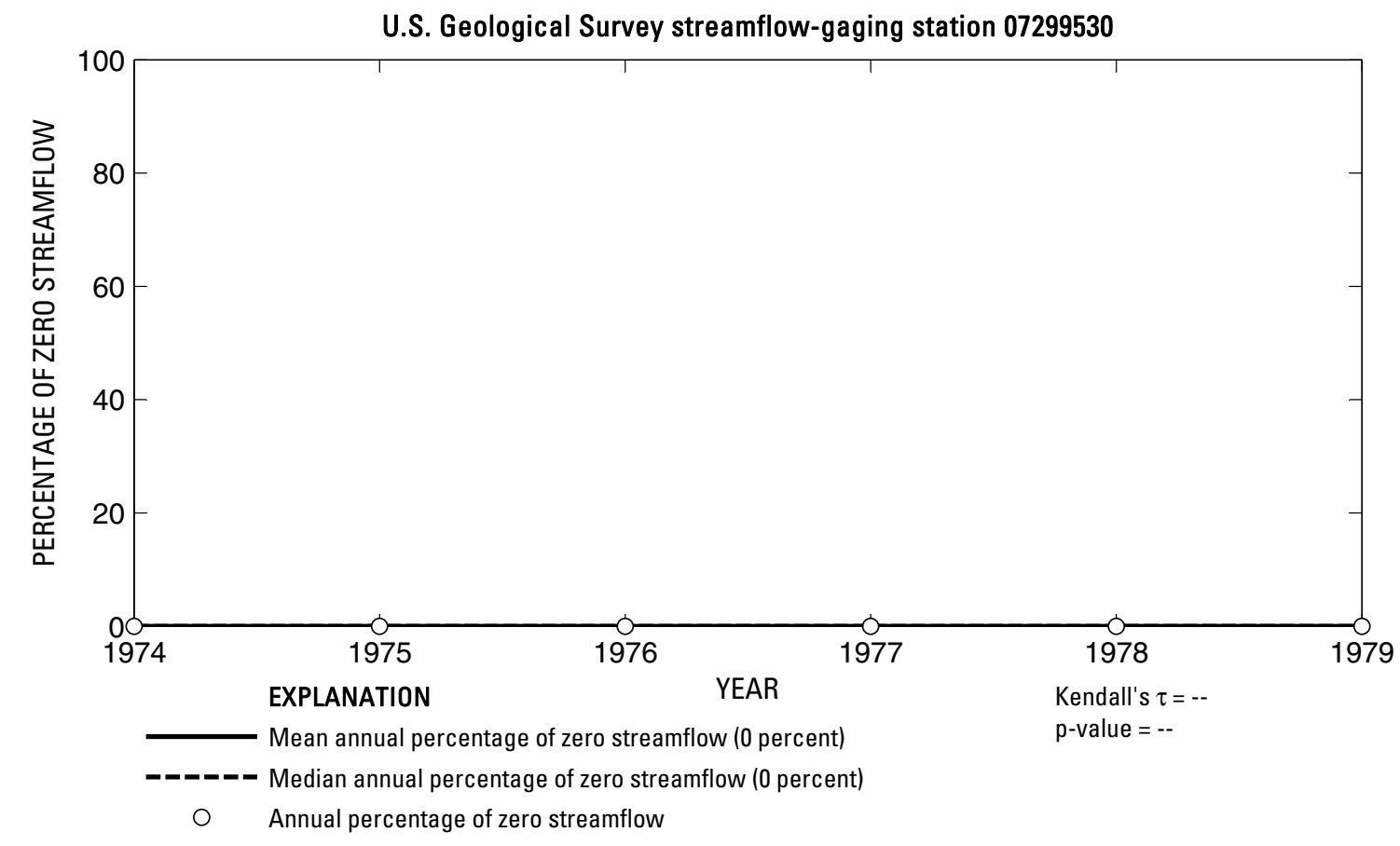

U.S. Geological Survey streamflow-gaging station 07299530

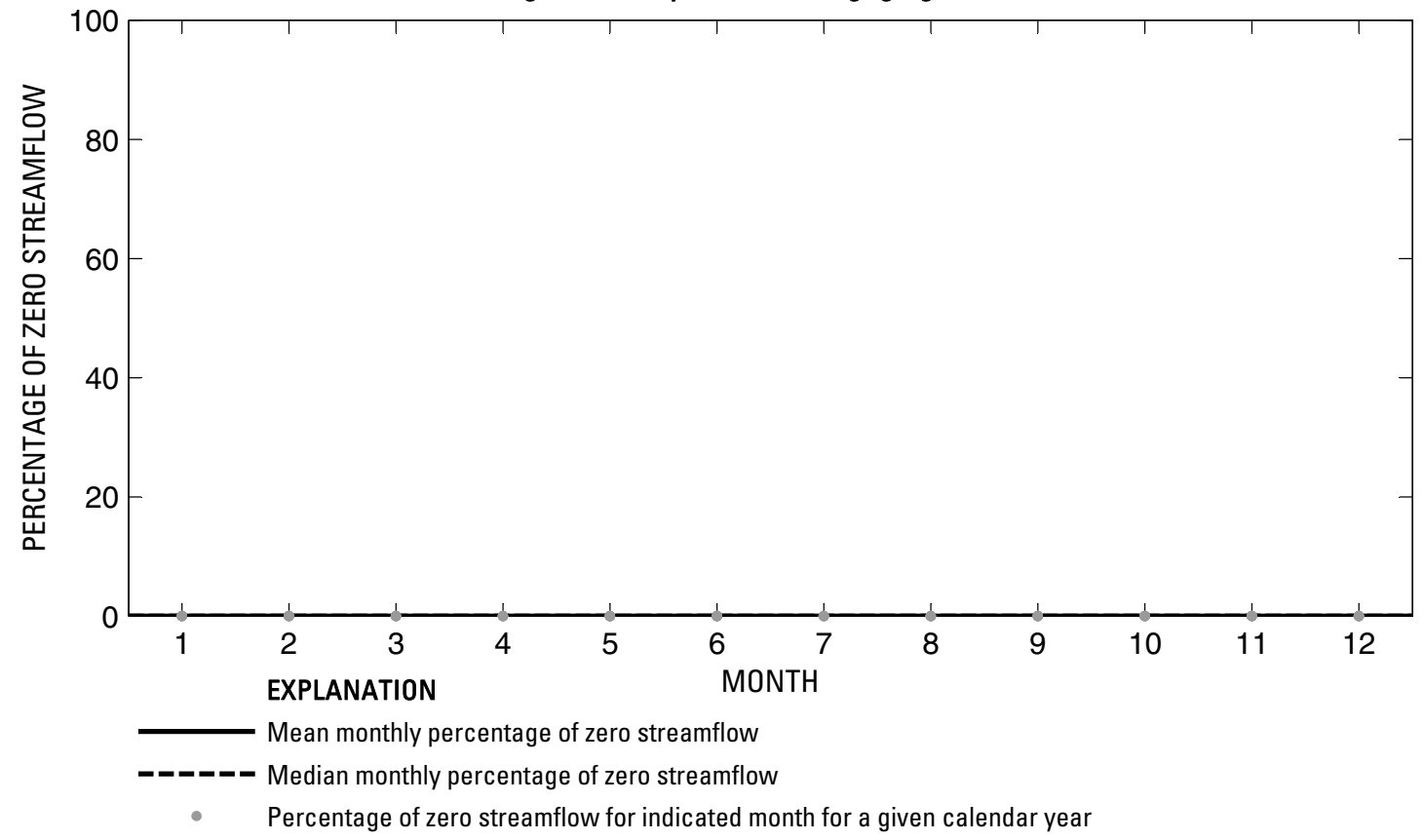

Figure 21. Analysis of percentage of zero daily mean streamflow for U.S. Geological Survey streamflow-gaging station 07299530 Salt Creek near Estelline, Texas. 

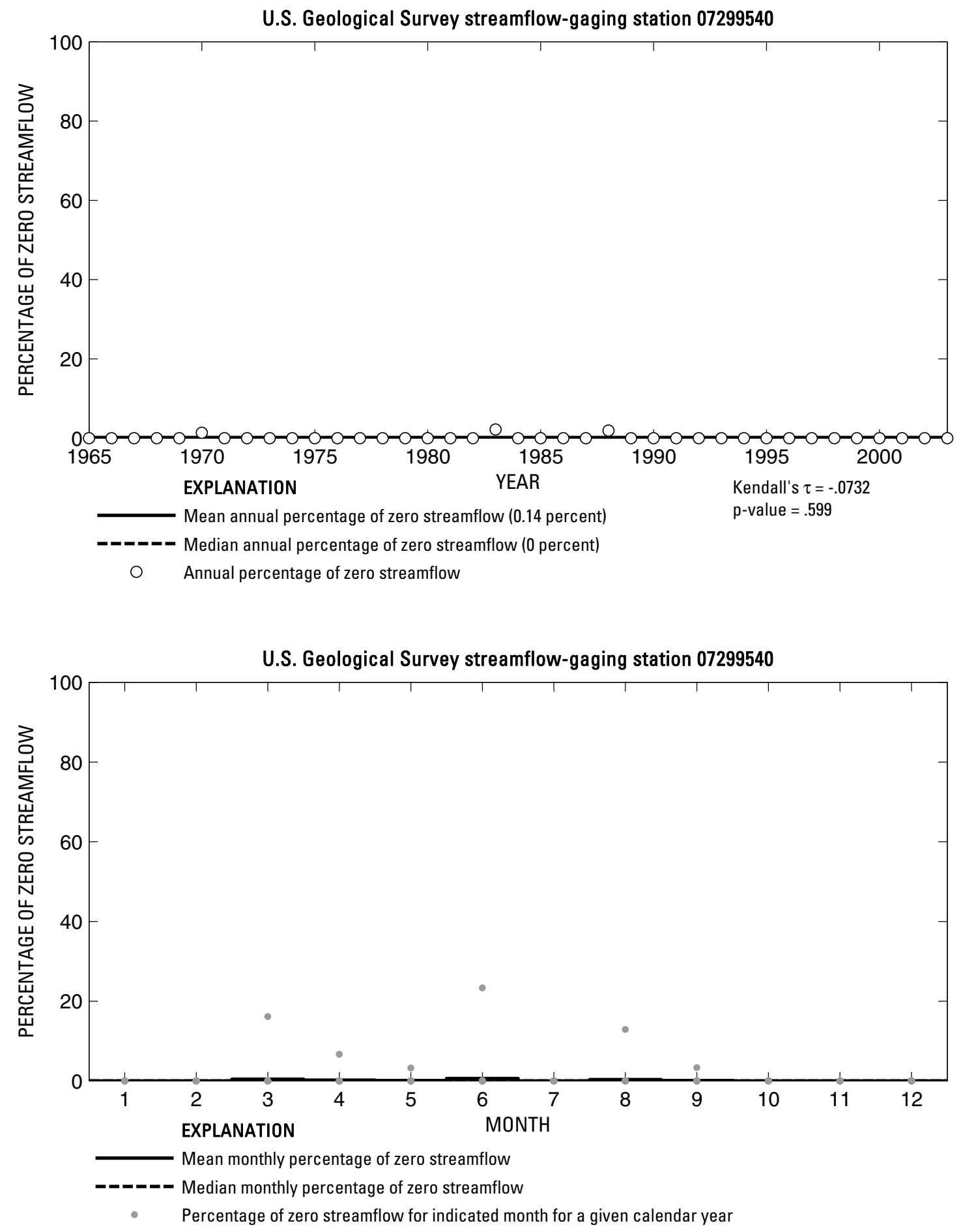

Figure 22. Analysis of percentage of zero daily mean streamflow for U.S. Geological Survey streamflow-gaging station 07299540 Prairie Dog Town Fork Red River near Childress, Texas. 


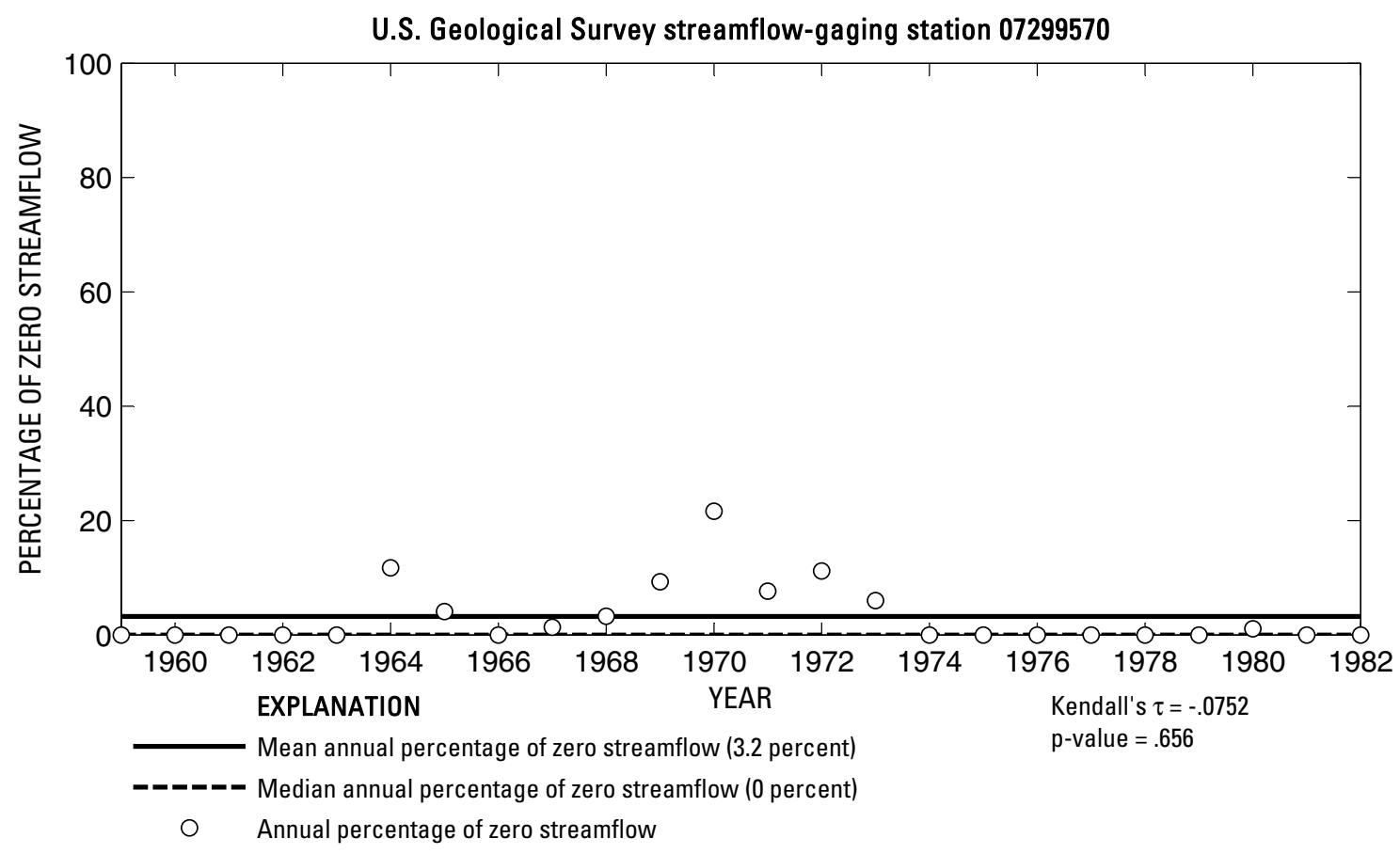

U.S. Geological Survey streamflow-gaging station 07299570

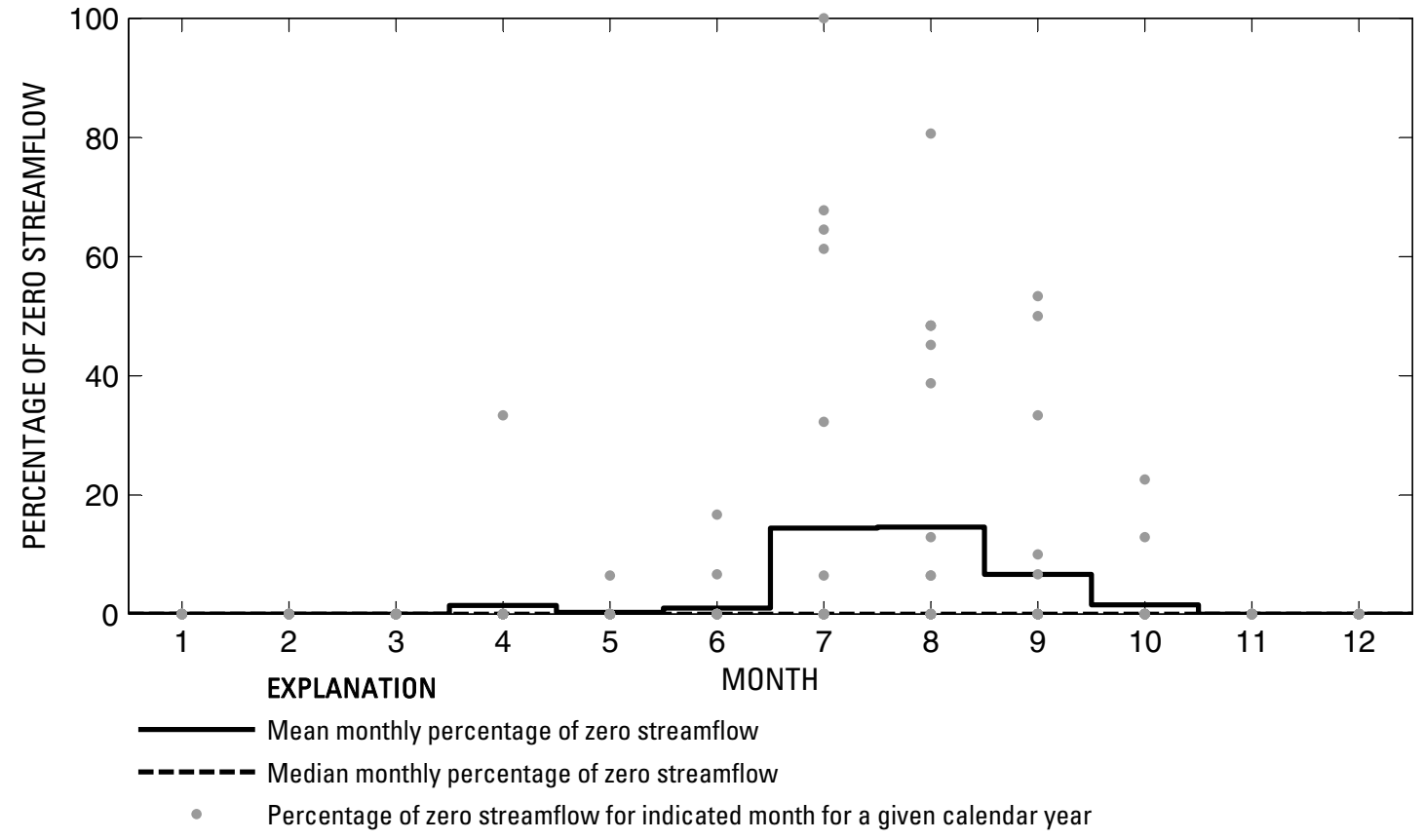

Figure 23. Analysis of percentage of zero daily mean streamflow for U.S. Geological Survey streamflow-gaging station 07299570 Red River near Quanah, Texas. 

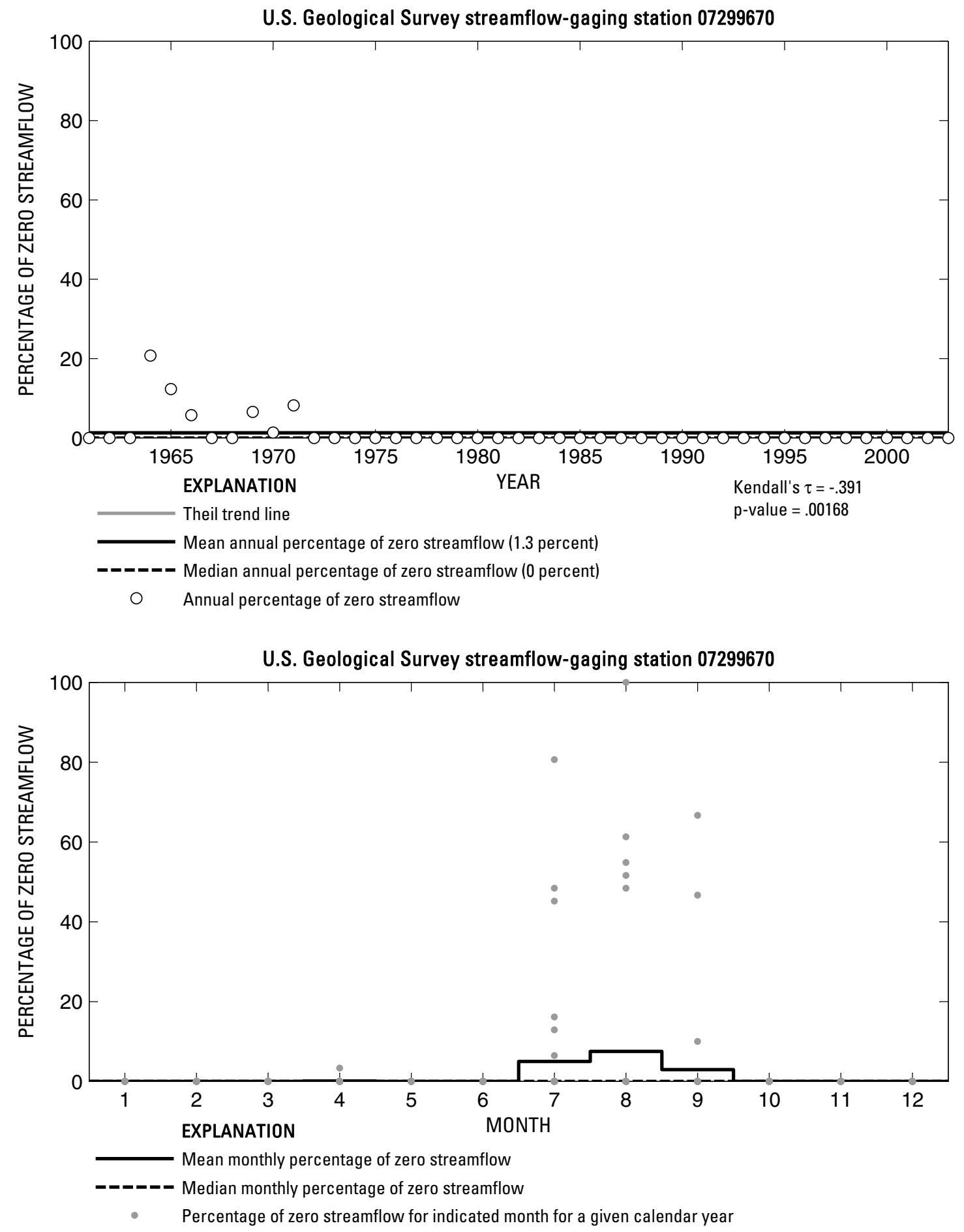

Figure 24. Analysis of percentage of zero daily mean streamflow for U.S. Geological Survey streamflow-gaging station 07299670 Groesbeck Creek at State Highway 6 near Quanah, Texas. 


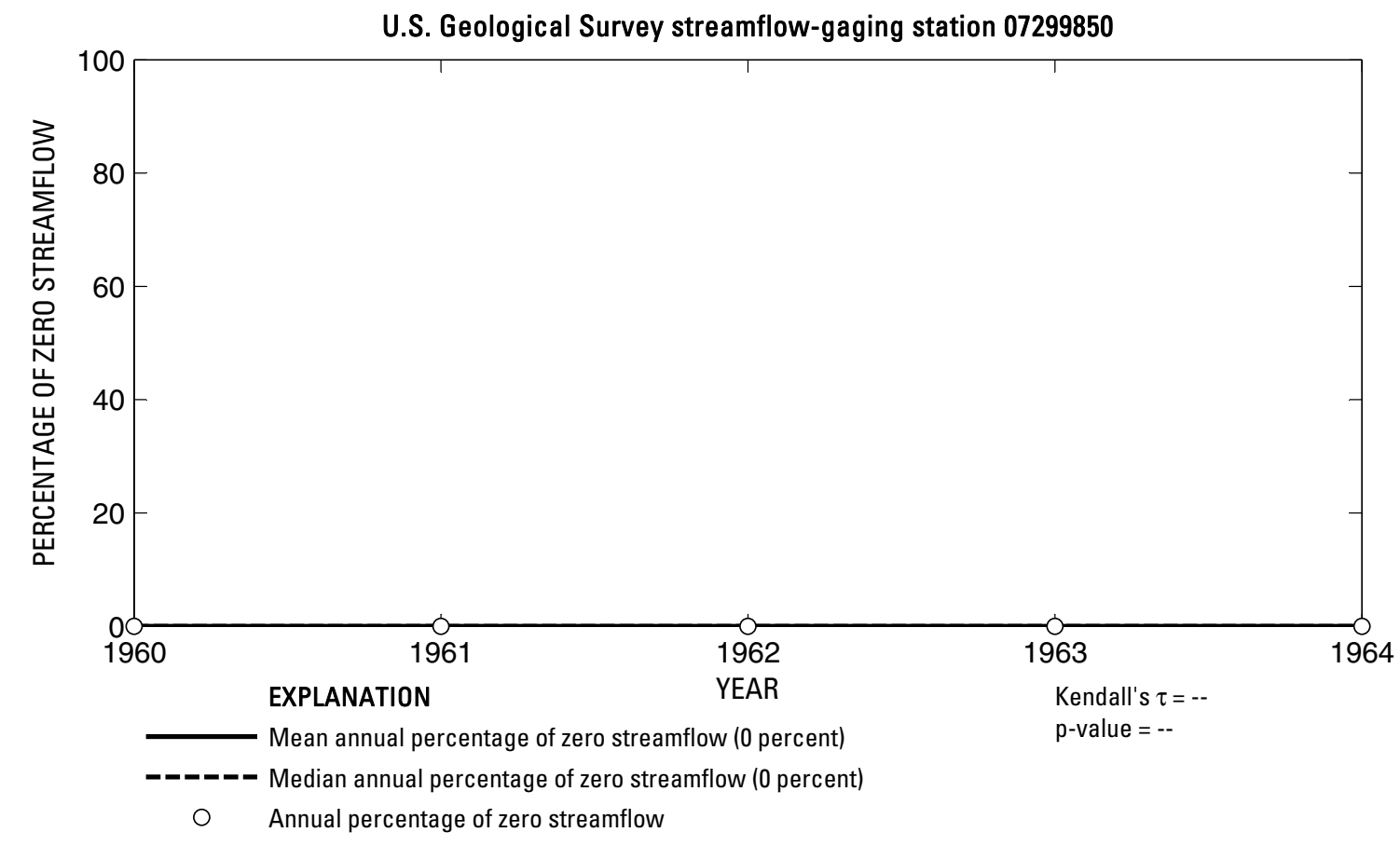

U.S. Geological Survey streamflow-gaging station 07299850

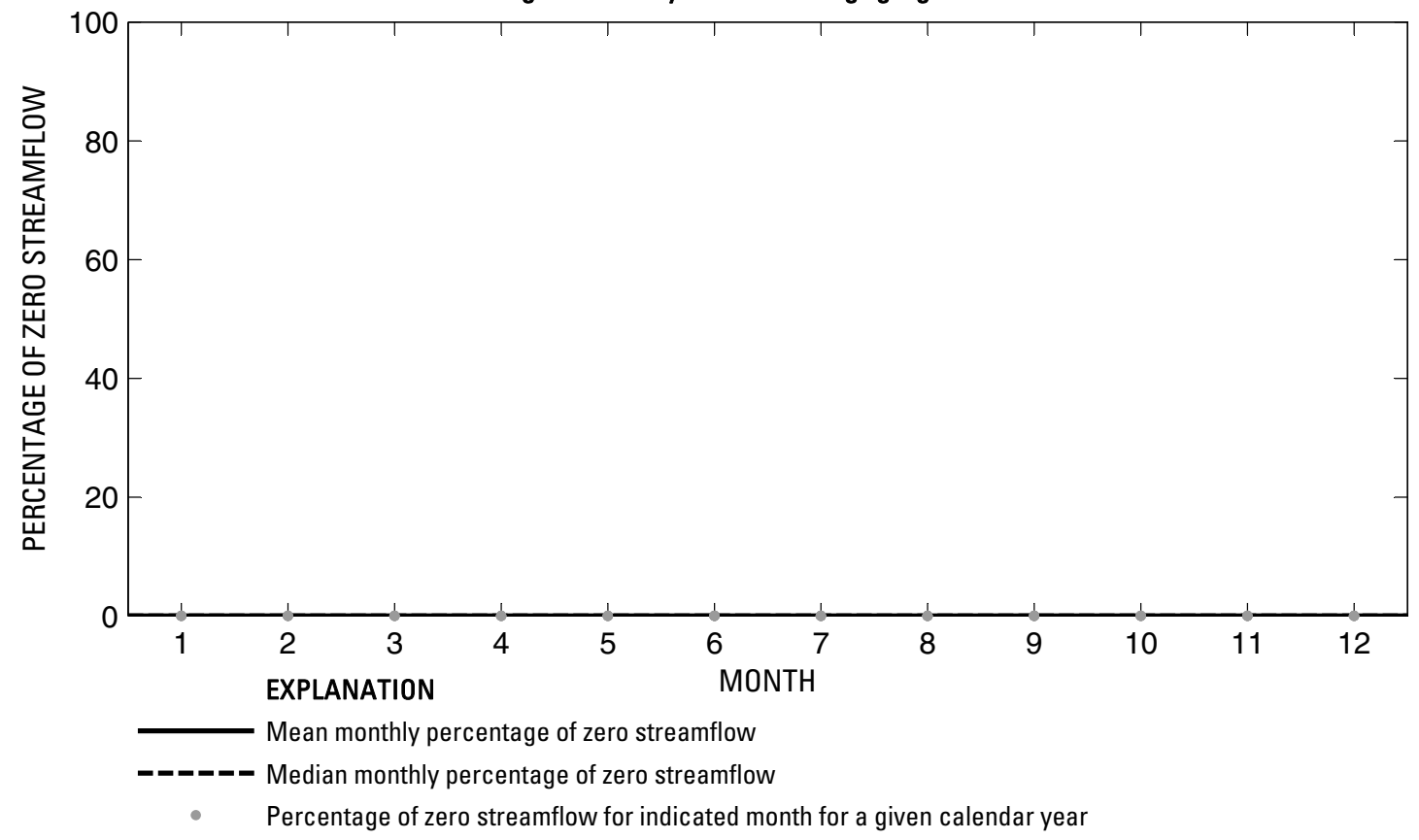

Figure 25. Analysis of percentage of zero daily mean streamflow for U.S. Geological Survey streamflow-gaging station 07299850 Salt Fork Red River near Clarendon, Texas. 
U.S. Geological Survey streamflow-gaging station 07299890

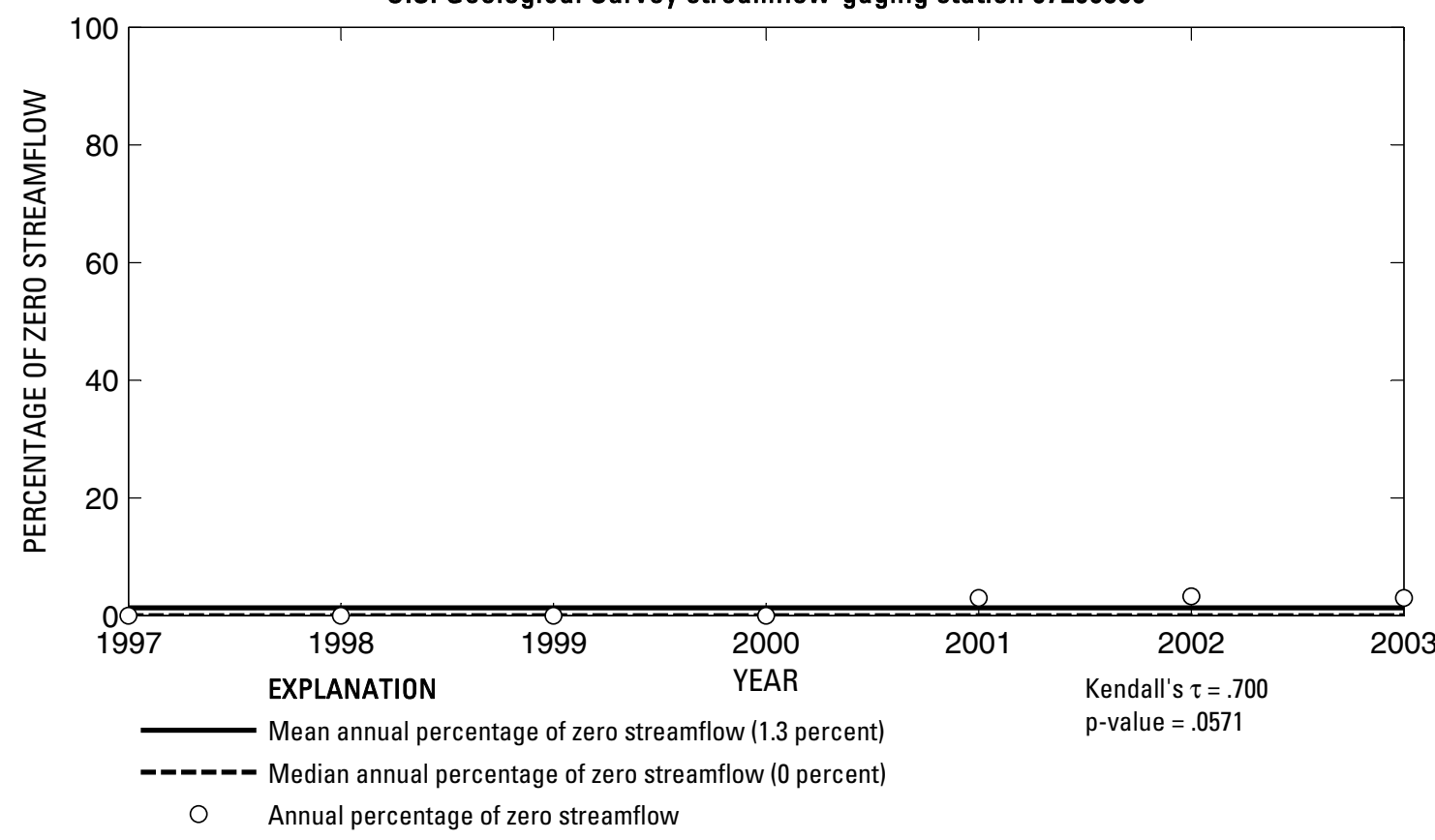

U.S. Geological Survey streamflow-gaging station 07299890

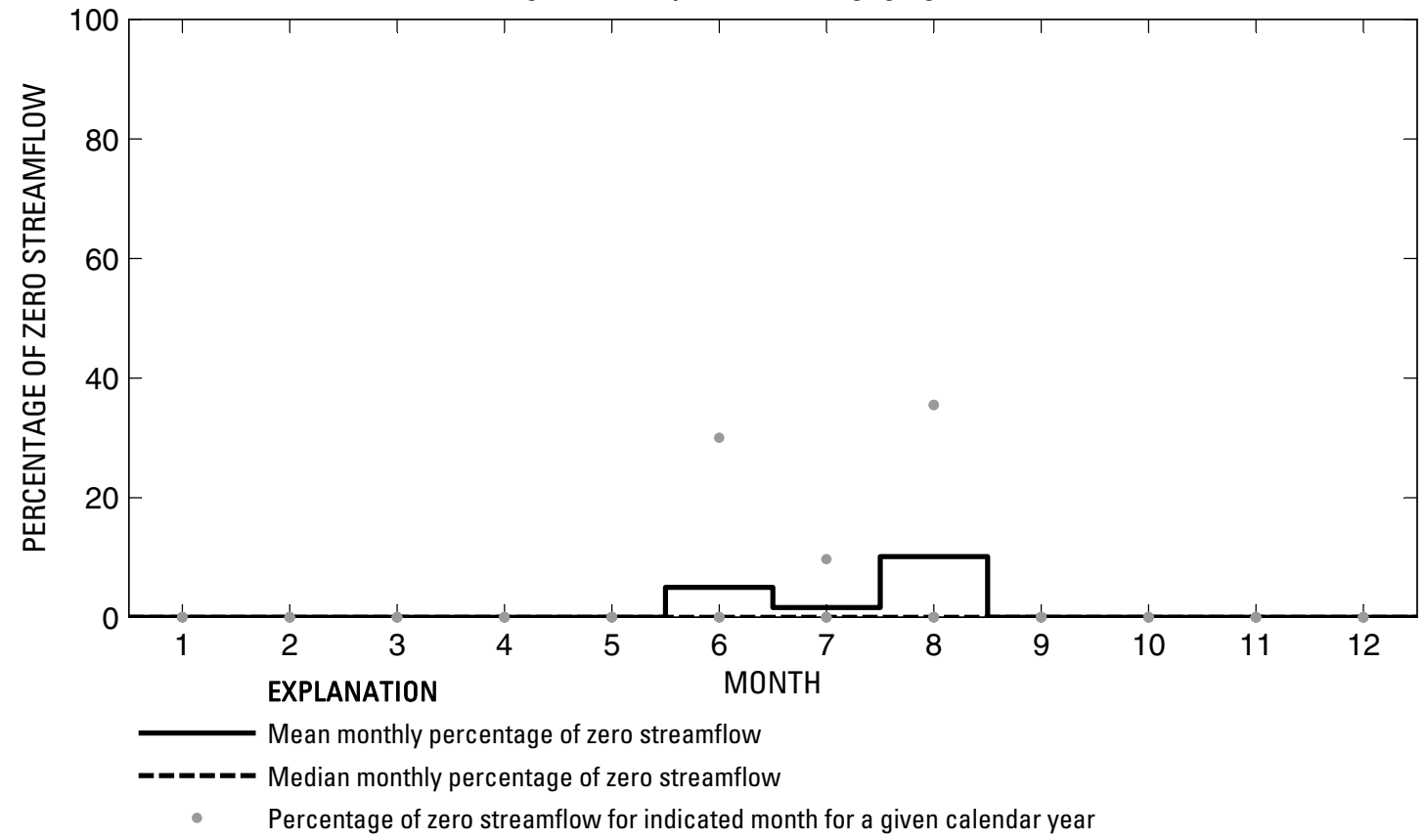

Figure 26. Analysis of percentage of zero daily mean streamflow for U.S. Geological Survey streamflow-gaging station 07299890 Lelia Lake Creek below Bell Creek near Hedley, Texas. 

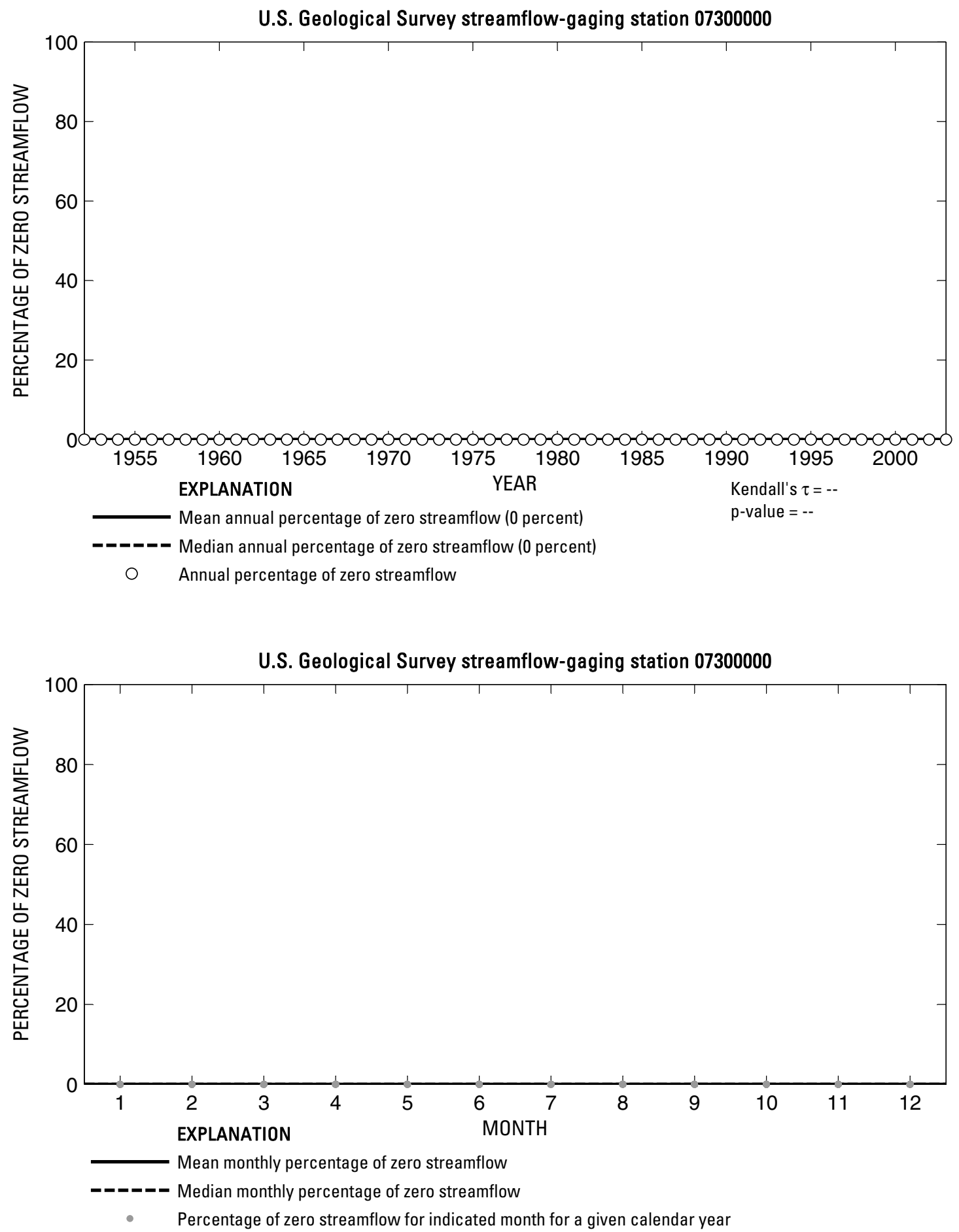

Figure 27. Analysis of percentage of zero daily mean streamflow for U.S. Geological Survey streamflow-gaging station 07300000 Salt Fork Red River near Wellington, Texas. 
U.S. Geological Survey streamflow-gaging station 07301200

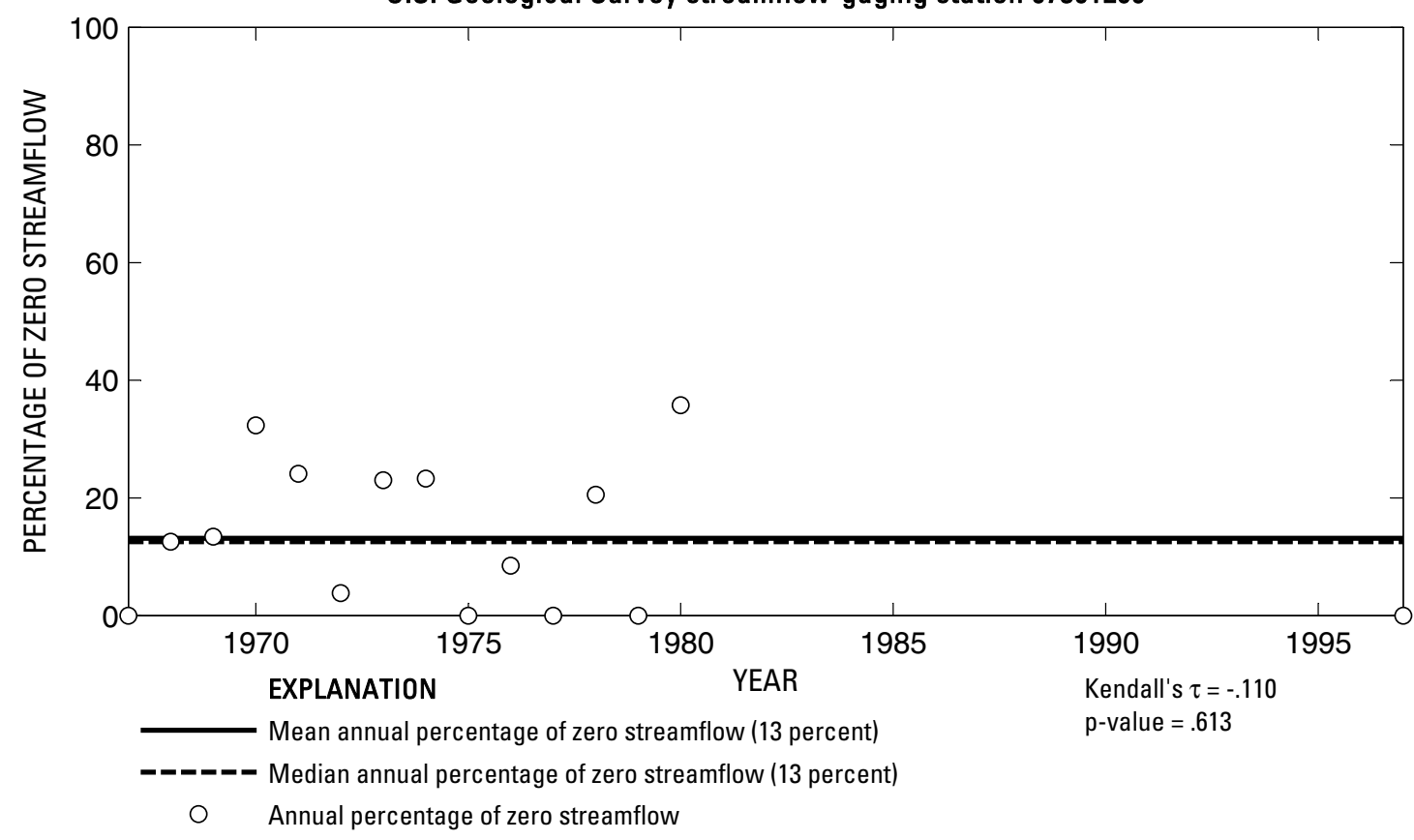

U.S. Geological Survey streamflow-gaging station 07301200

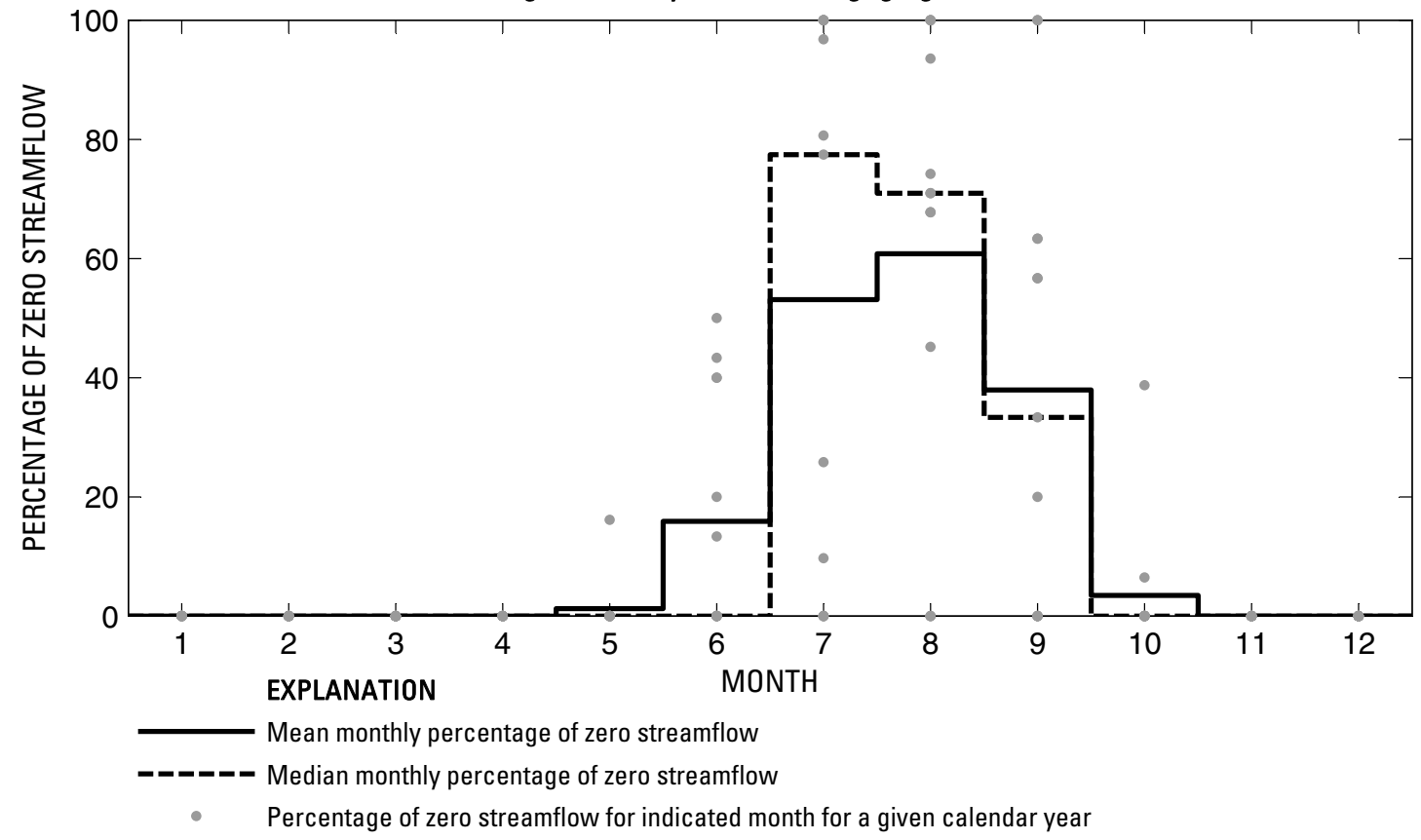

Figure 28. Analysis of percentage of zero daily mean streamflow for U.S. Geological Survey streamflow-gaging station 07301200 McClellan Creek near McLean, Texas. 


\section{U.S. Geological Survey streamflow-gaging station 07301300}

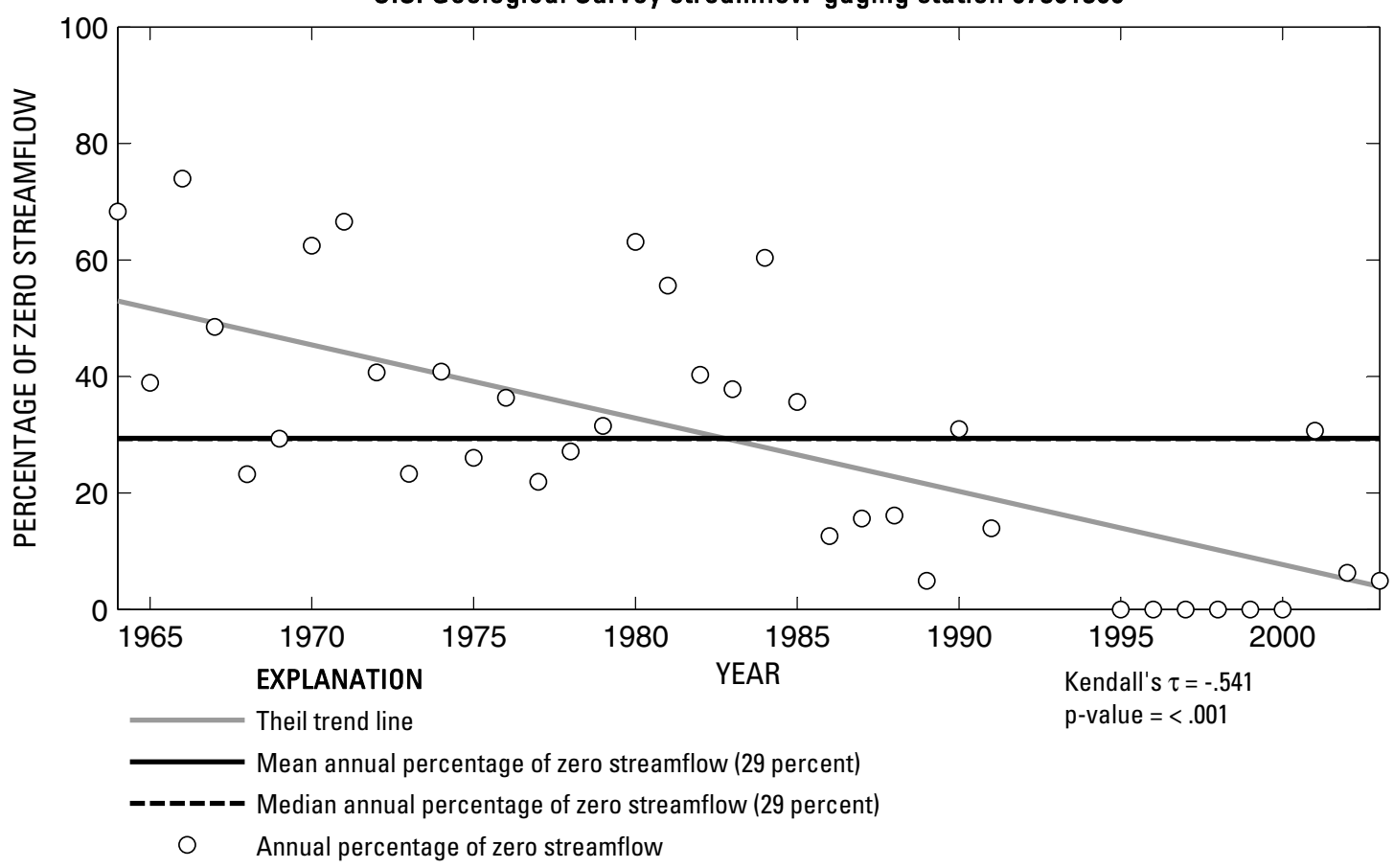

U.S. Geological Survey streamflow-gaging station 07301300

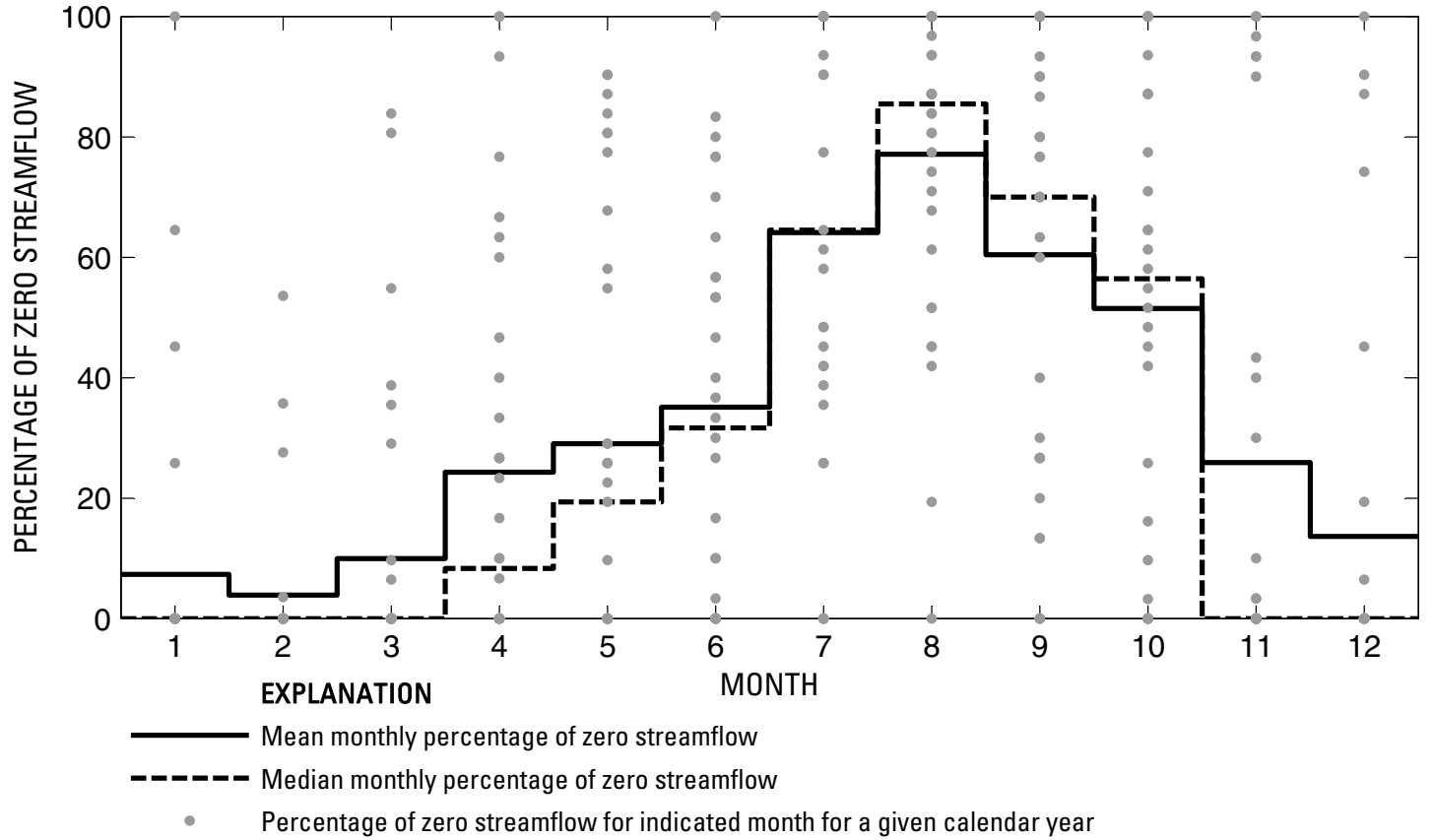

Figure 29. Analysis of percentage of zero daily mean streamflow for U.S. Geological Survey streamflow-gaging station 07301300 North Fork Red River near Shamrock, Texas. 

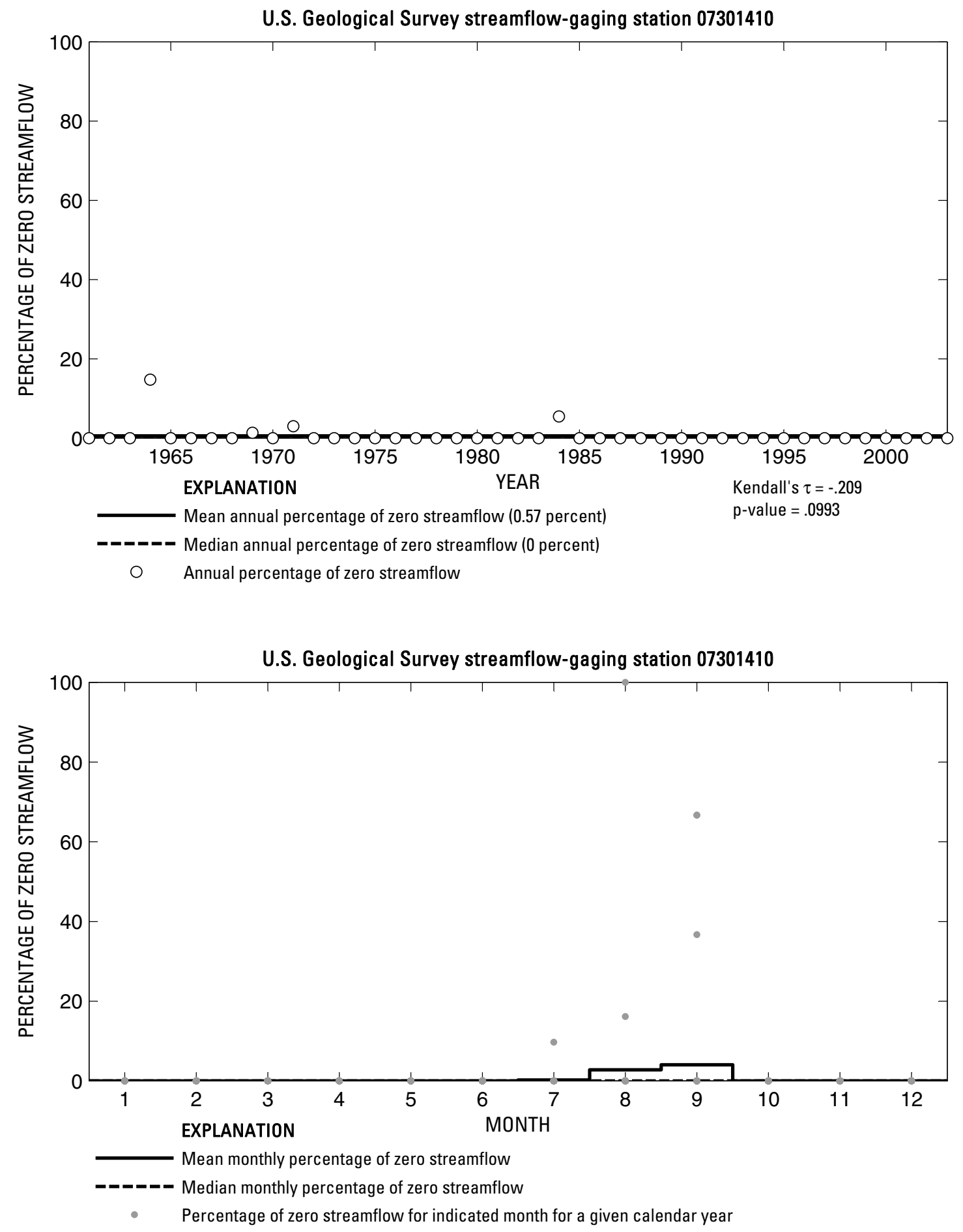

Figure 30. Analysis of percentage of zero daily mean streamflow for U.S. Geological Survey streamflow-gaging station 07301410 Sweetwater Creek near Kelton, Texas. 


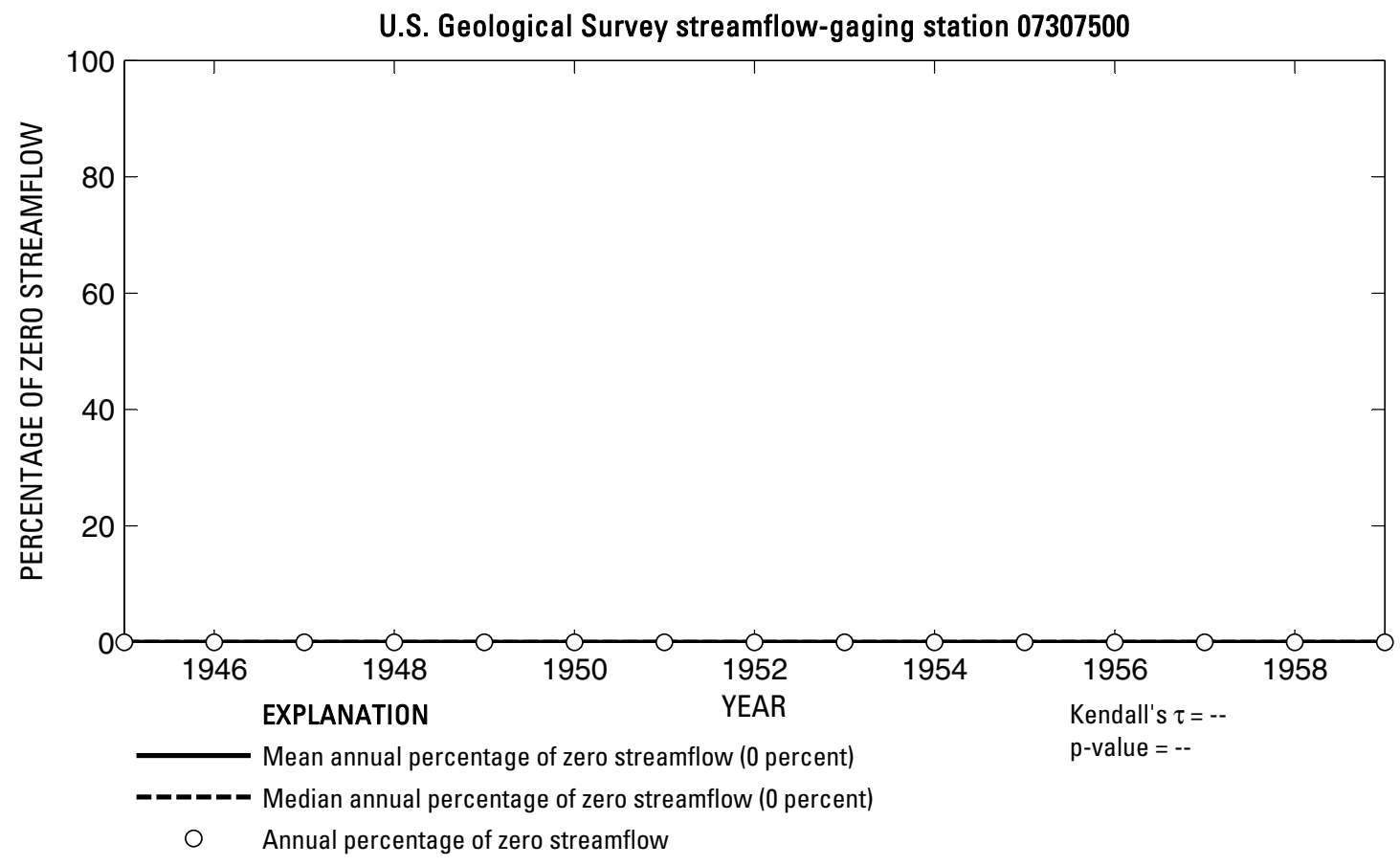

U.S. Geological Survey streamflow-gaging station 07307500

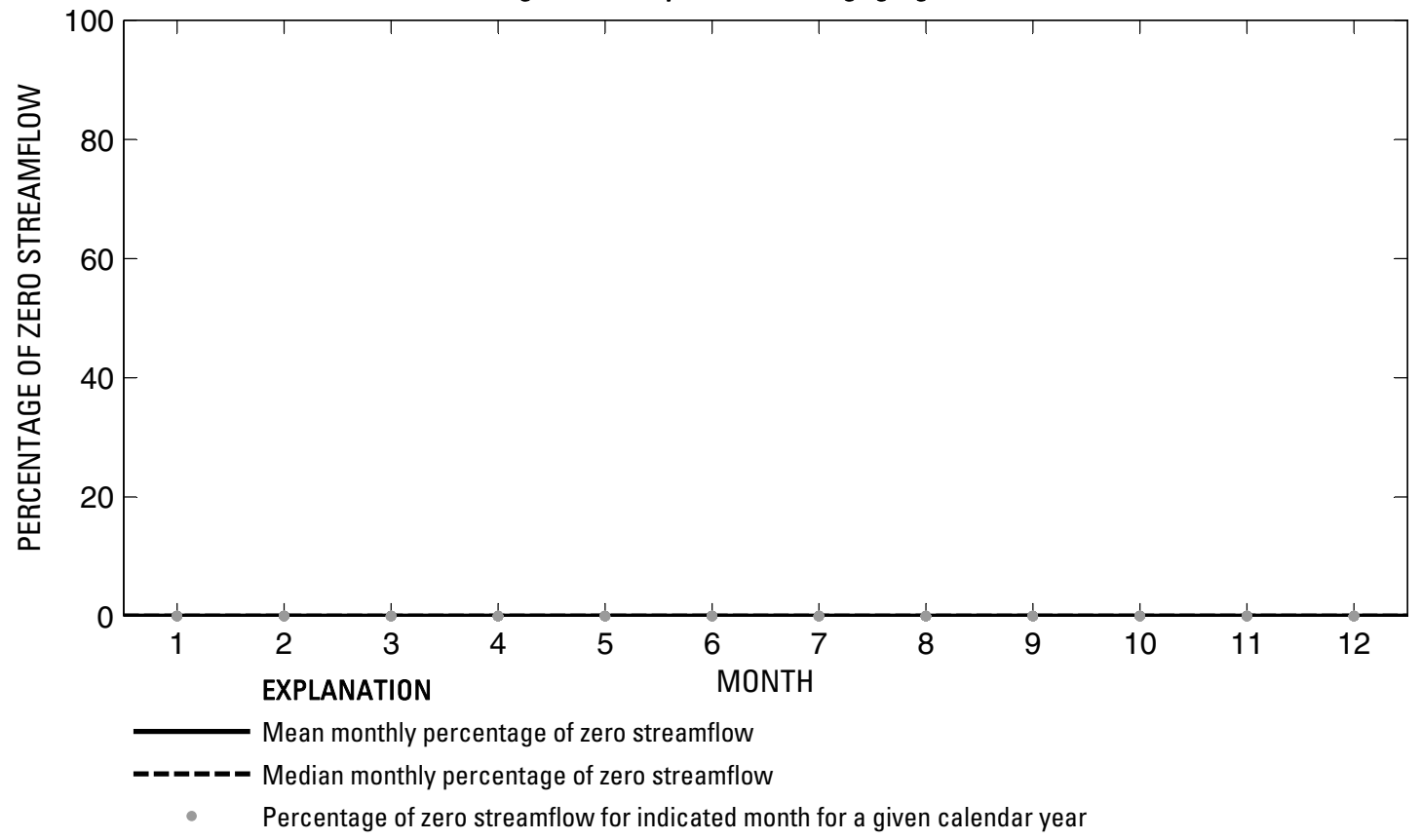

Figure 31. Analysis of percentage of zero daily mean streamflow for U.S. Geological Survey streamflow-gaging station 07307500 Quitaque Creek near Quitaque, Texas. 
U.S. Geological Survey streamflow-gaging station 07307600

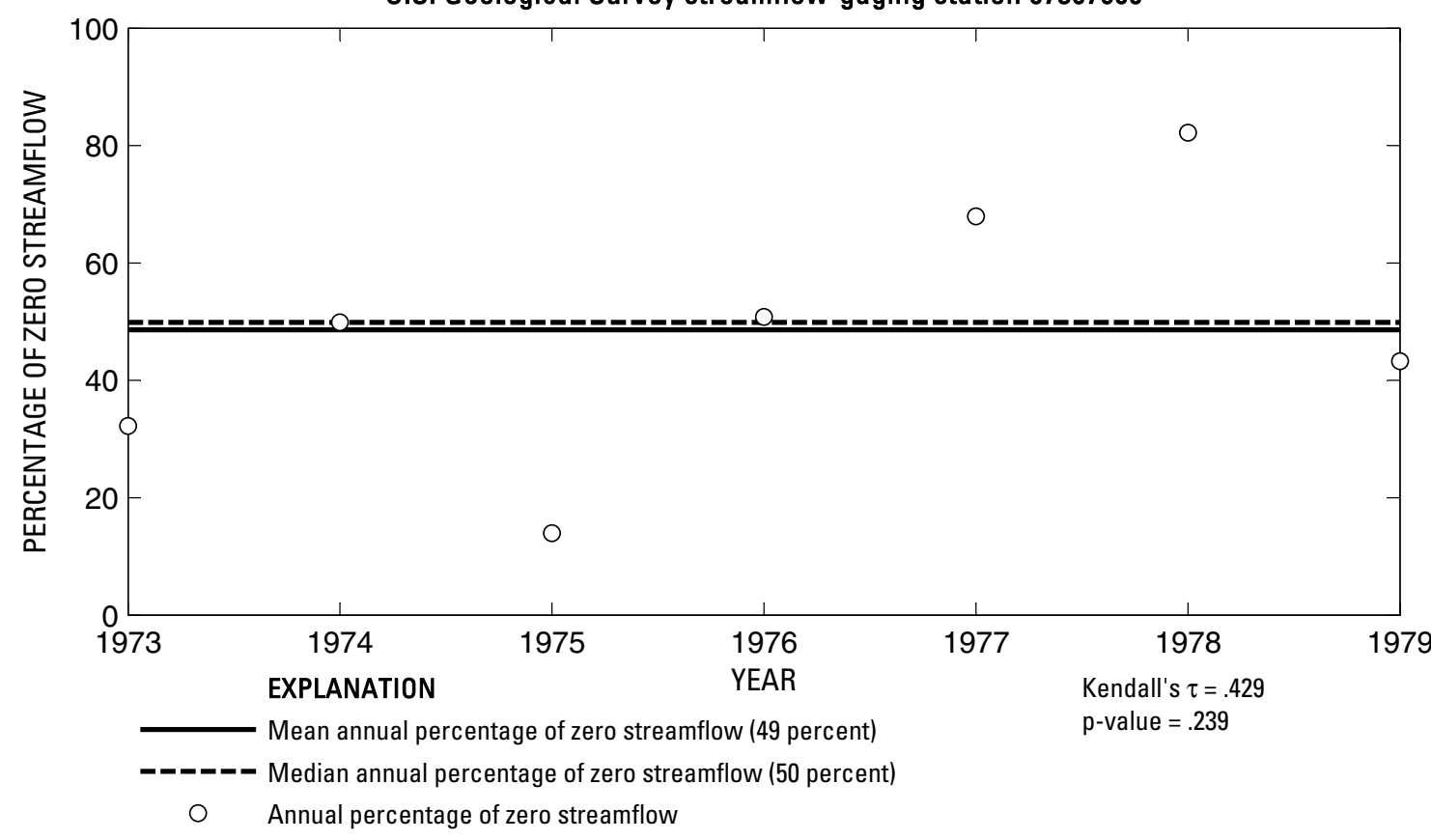

U.S. Geological Survey streamflow-gaging station 07307600

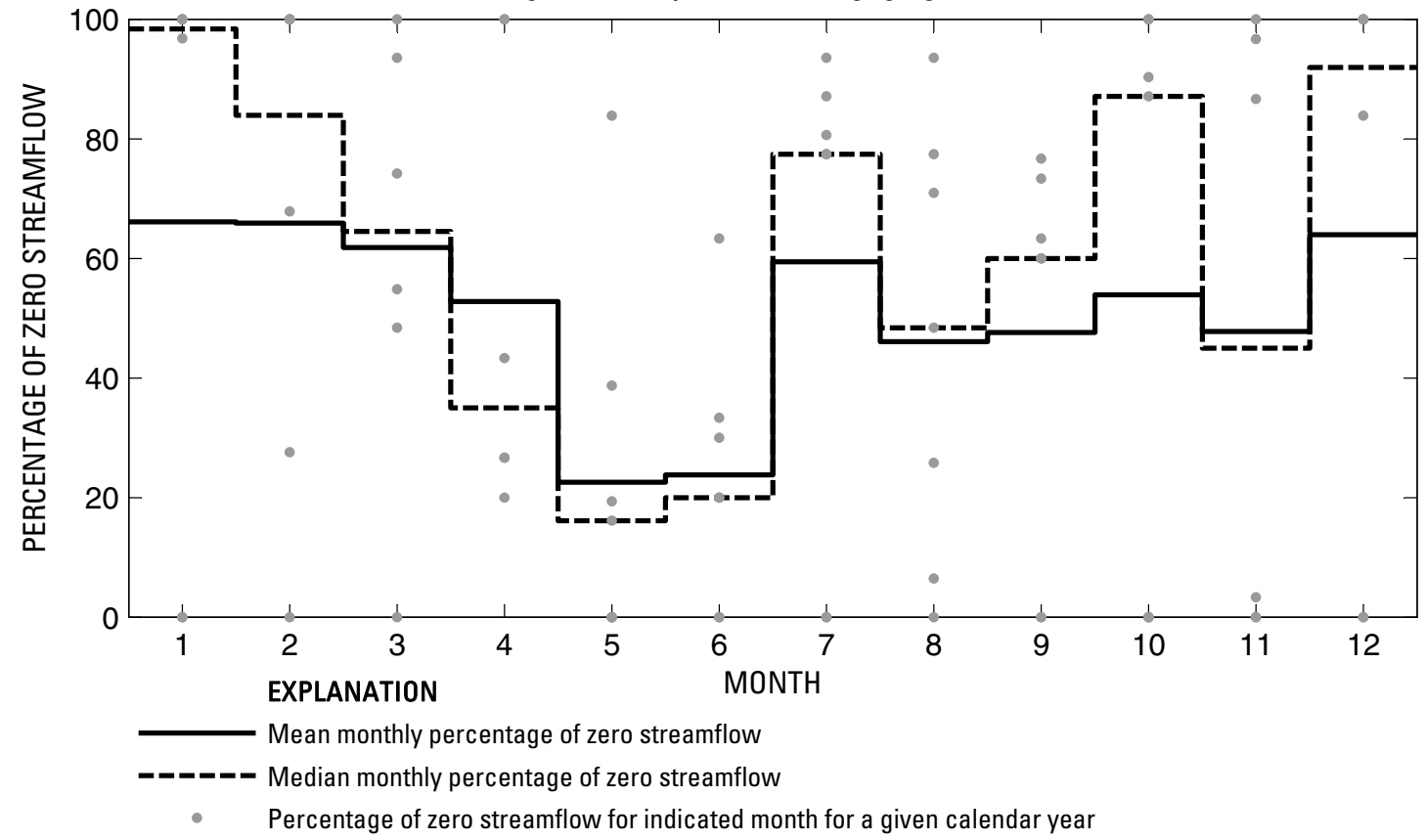

Figure 32. Analysis of percentage of zero daily mean streamflow for U.S. Geological Survey streamflow-gaging station 07307600 North Pease River near Childress, Texas. 


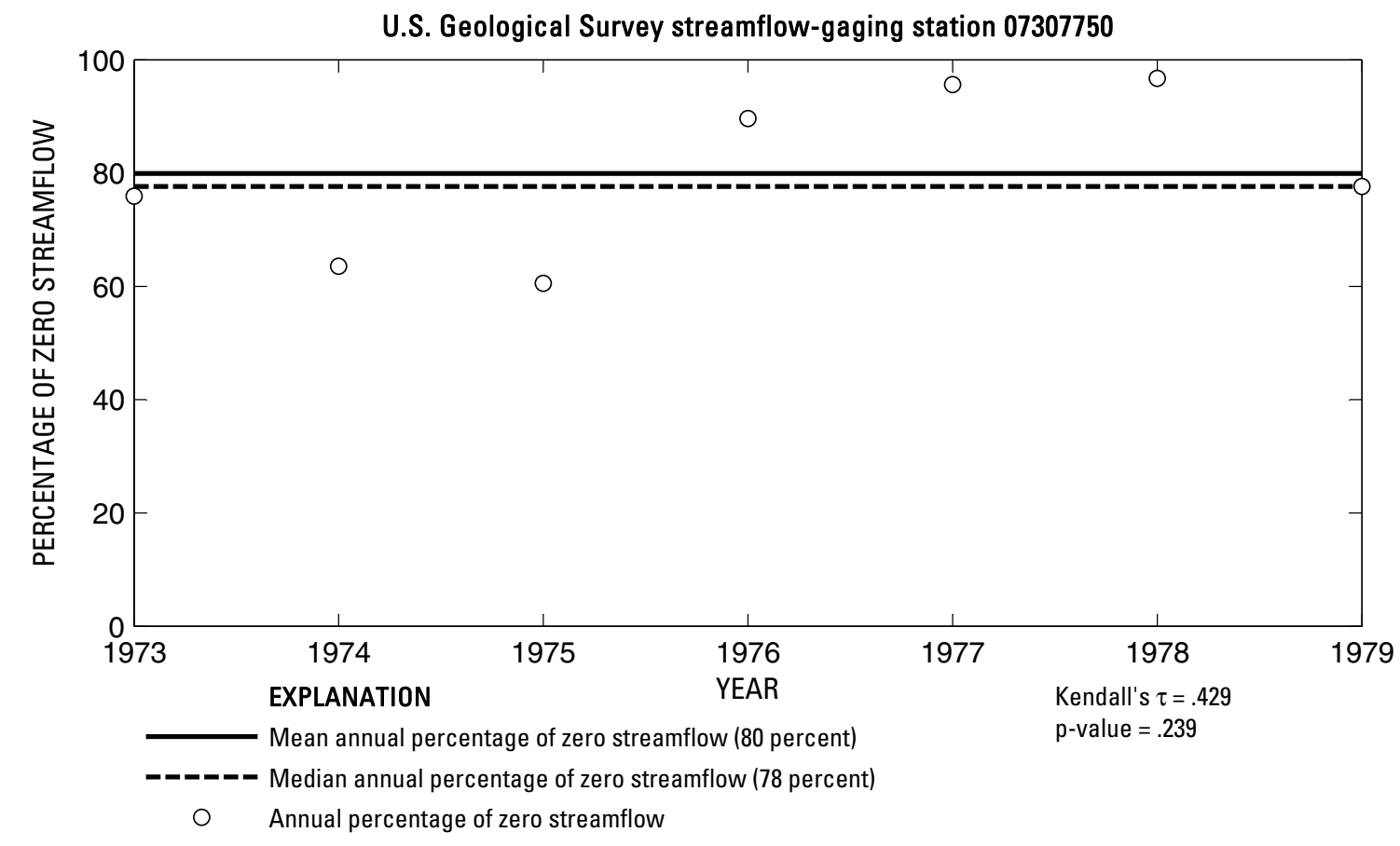

U.S. Geological Survey streamflow-gaging station 07307750

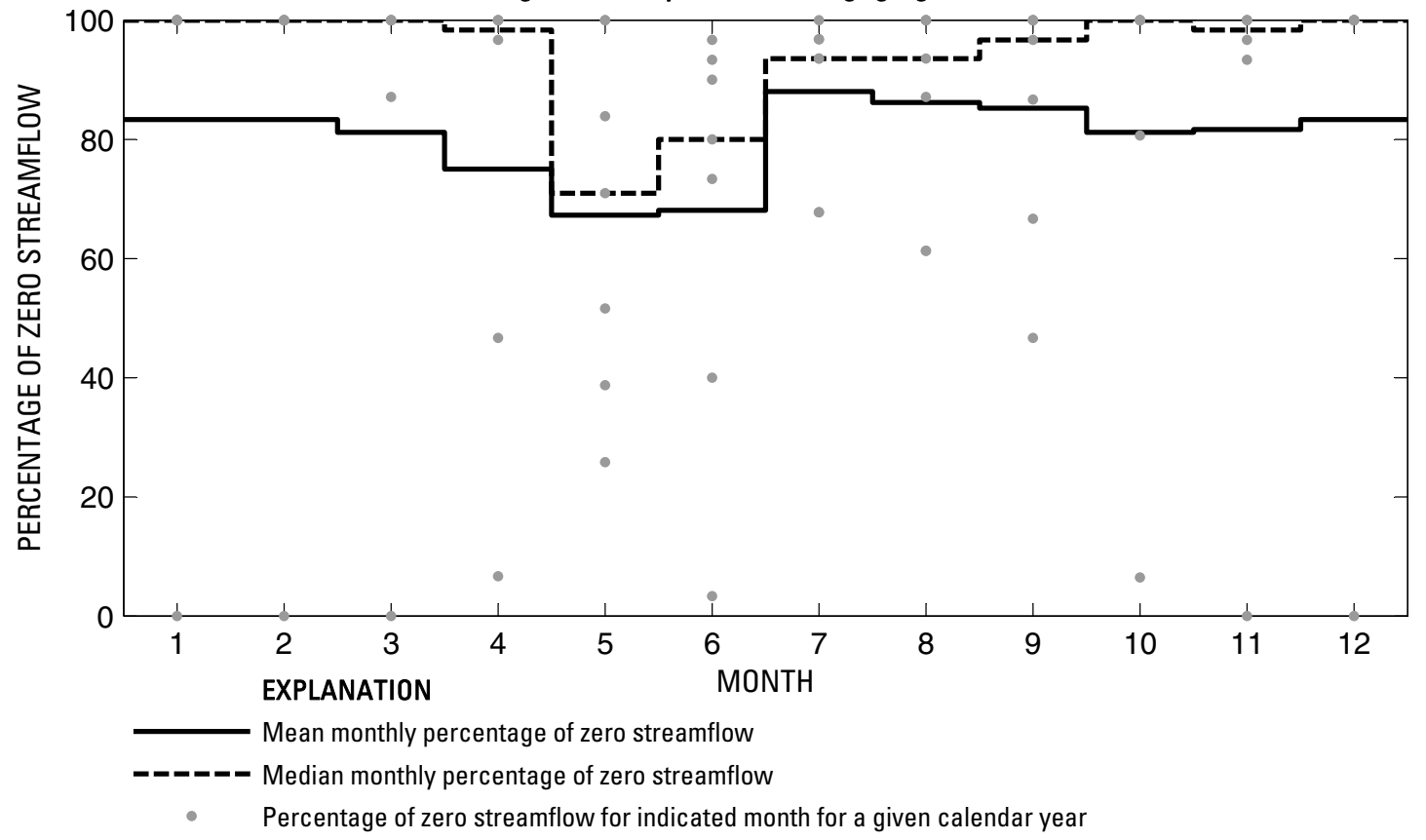

Figure 33. Analysis of percentage of zero daily mean streamflow for U.S. Geological Survey streamflow-gaging station 07307750 Middle Pease River at U. S. Highways 62 and 83 near Paducah, Texas. 

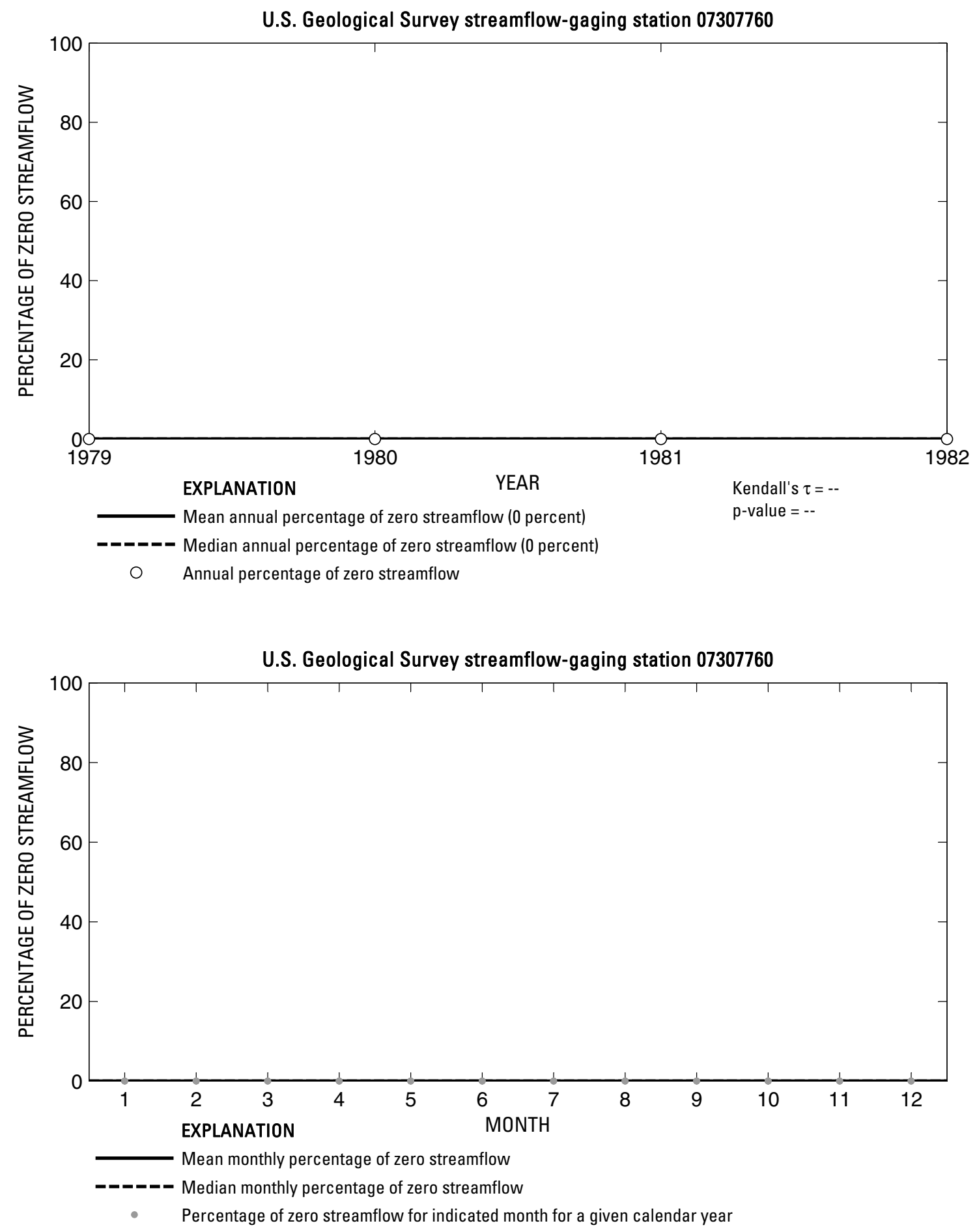

Figure 34. Analysis of percentage of zero daily mean streamflow for U.S. Geological Survey streamflow-gaging station 07307760 Middle Pease River near Paducah, Texas. 


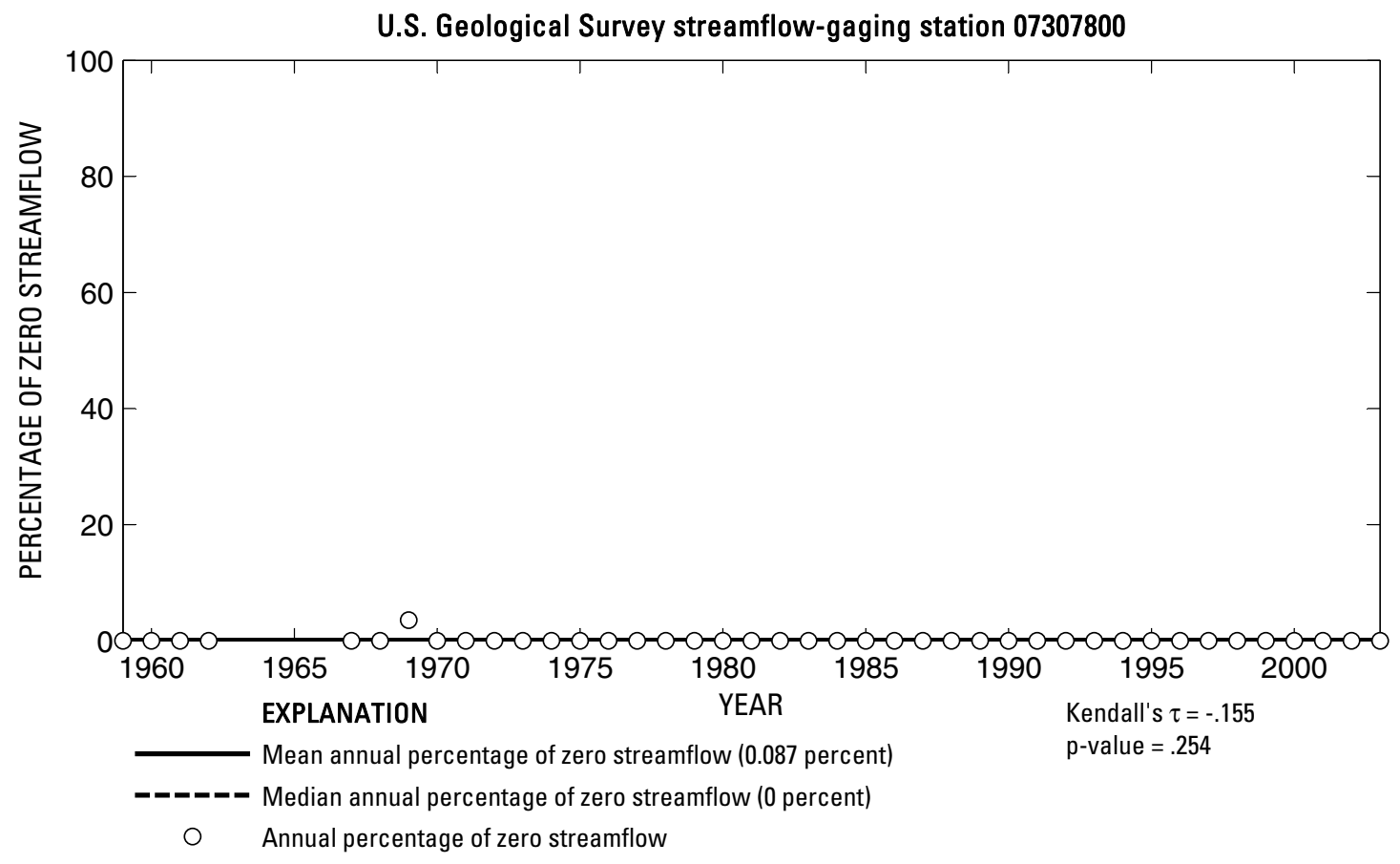

U.S. Geological Survey streamflow-gaging station 07307800

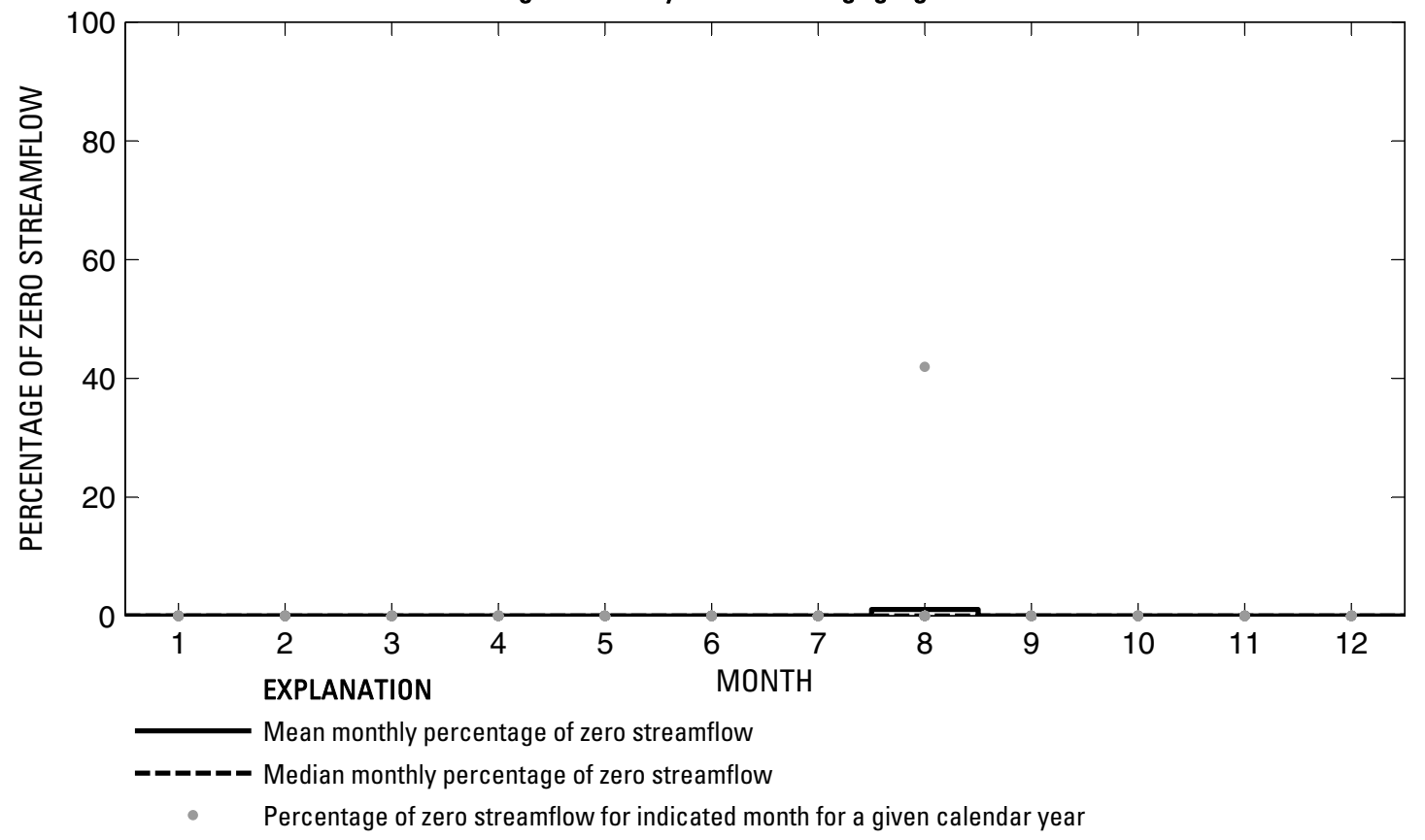

Figure 35. Analysis of percentage of zero daily mean streamflow for U.S. Geological Survey streamflow-gaging station 07307800 Pease River near Childress, Texas. 
U.S. Geological Survey streamflow-gaging station 07308000

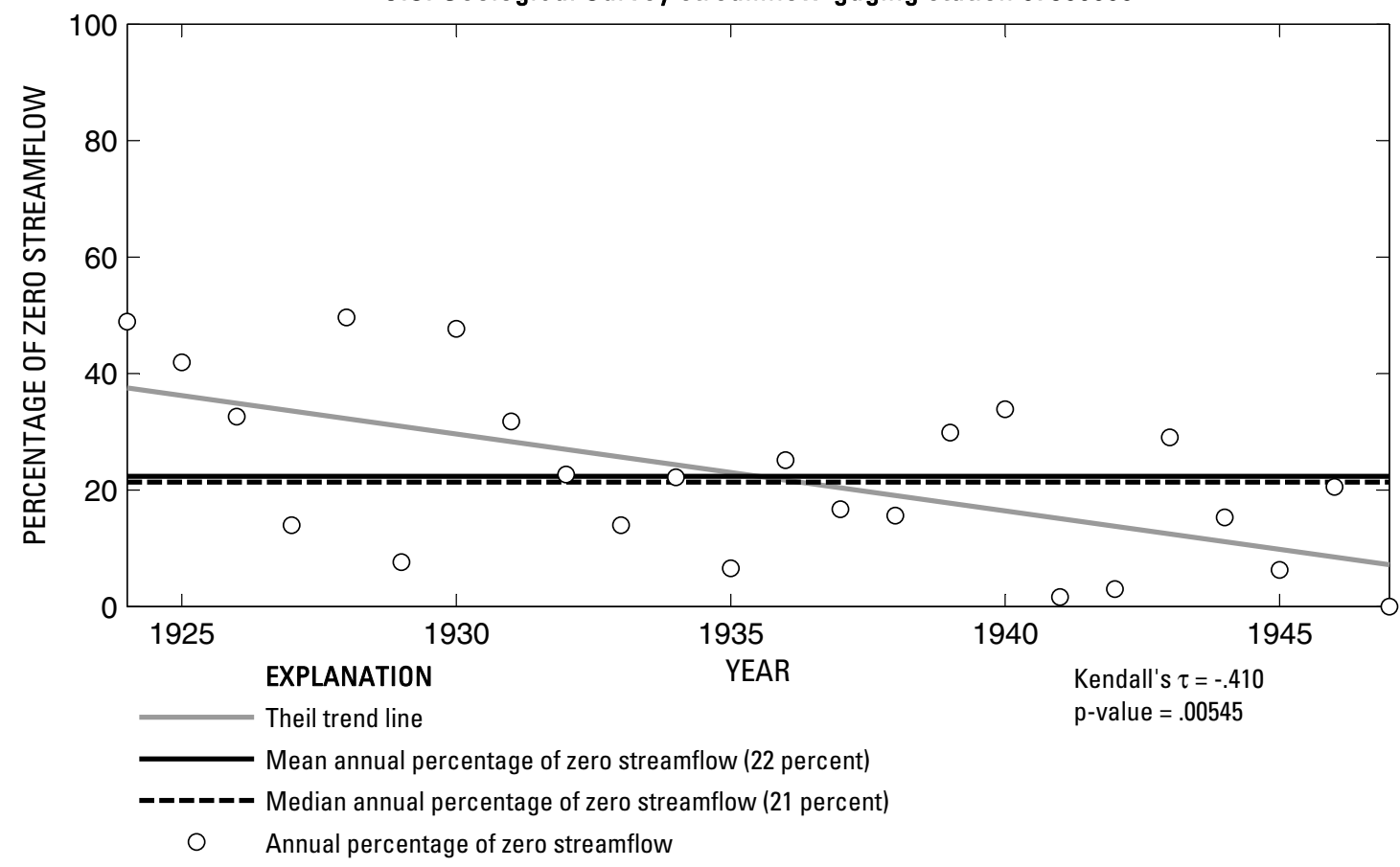

U.S. Geological Survey streamflow-gaging station 07308000

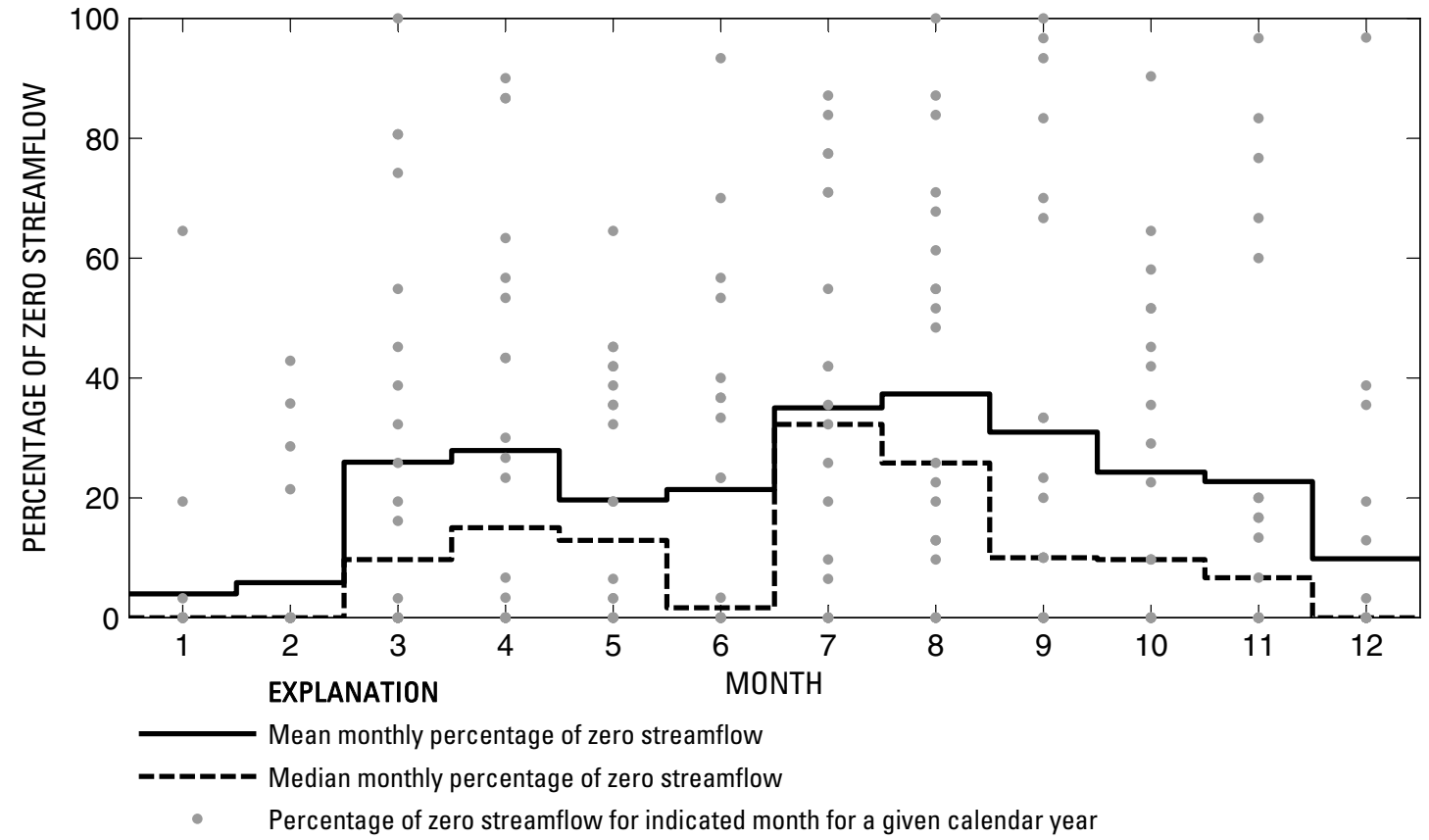

Figure 36. Analysis of percentage of zero daily mean streamflow for U.S. Geological Survey streamflow-gaging station 07308000 Pease River near Crowell, Texas. 

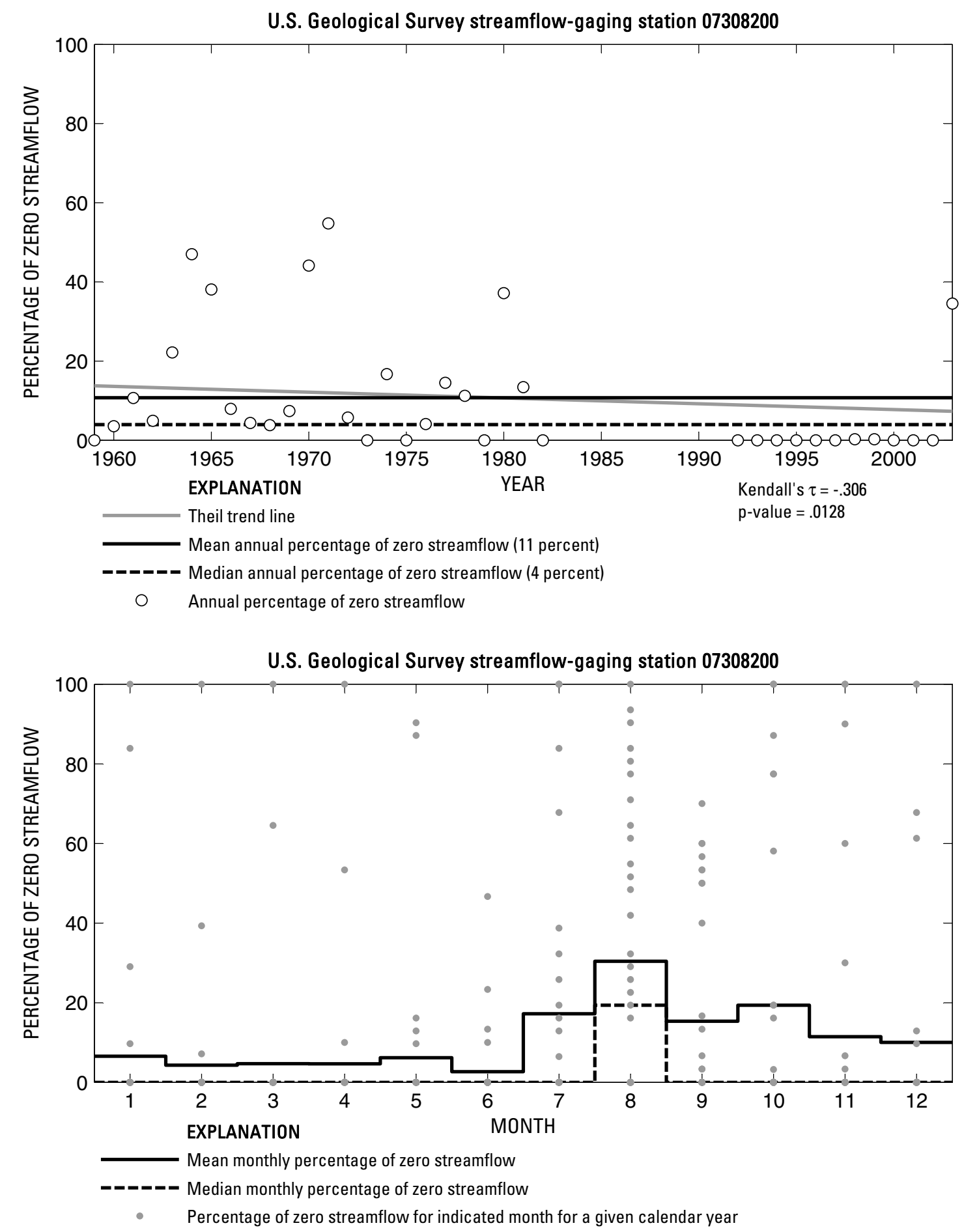

Figure 37. Analysis of percentage of zero daily mean streamflow for U.S. Geological Survey streamflow-gaging station 07308200 Pease River near Vernon, Texas. 

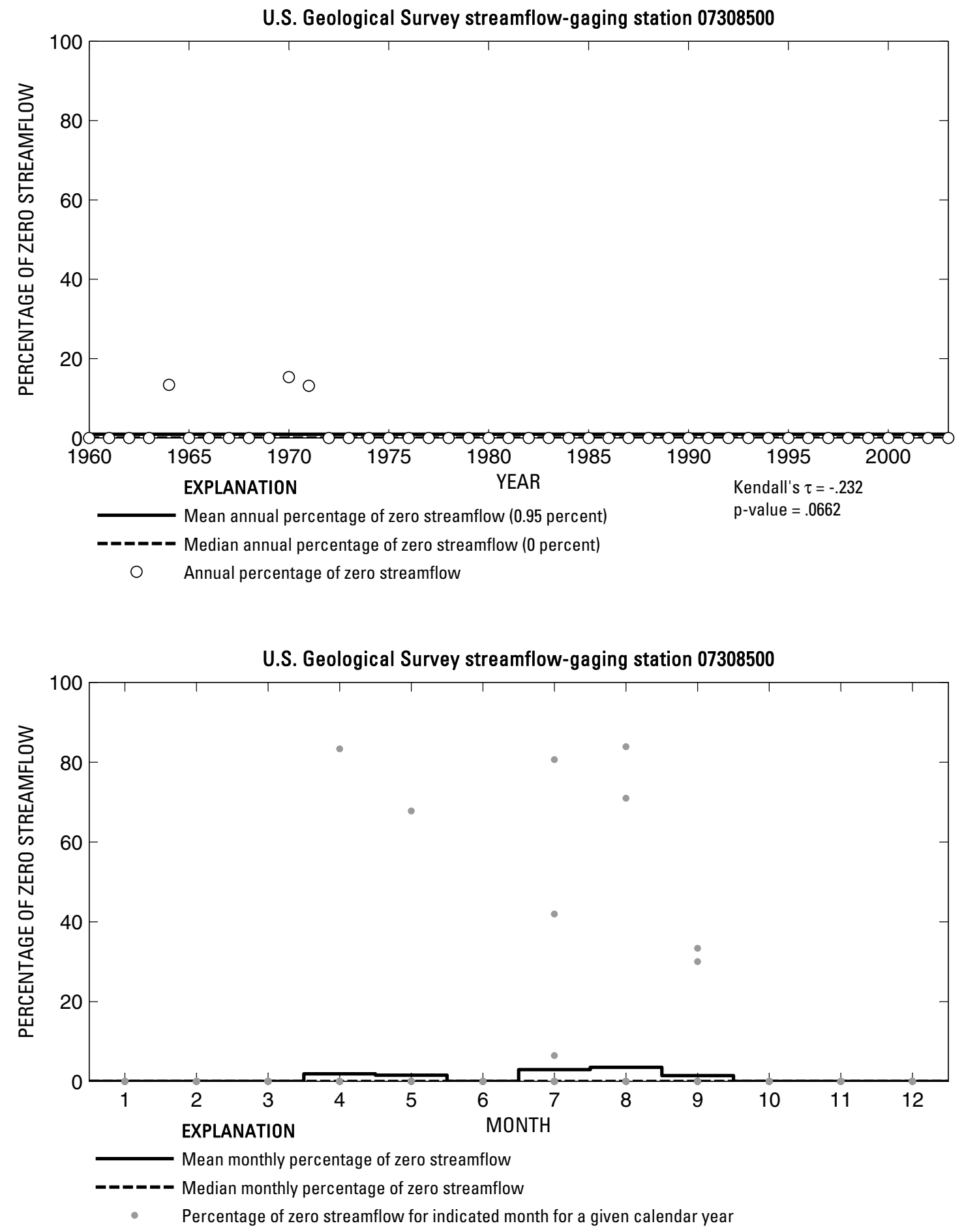

Figure 38. Analysis of percentage of zero daily mean streamflow for U.S. Geological Survey streamflow-gaging station 07308500 Red River near Burkburnett, Texas. 


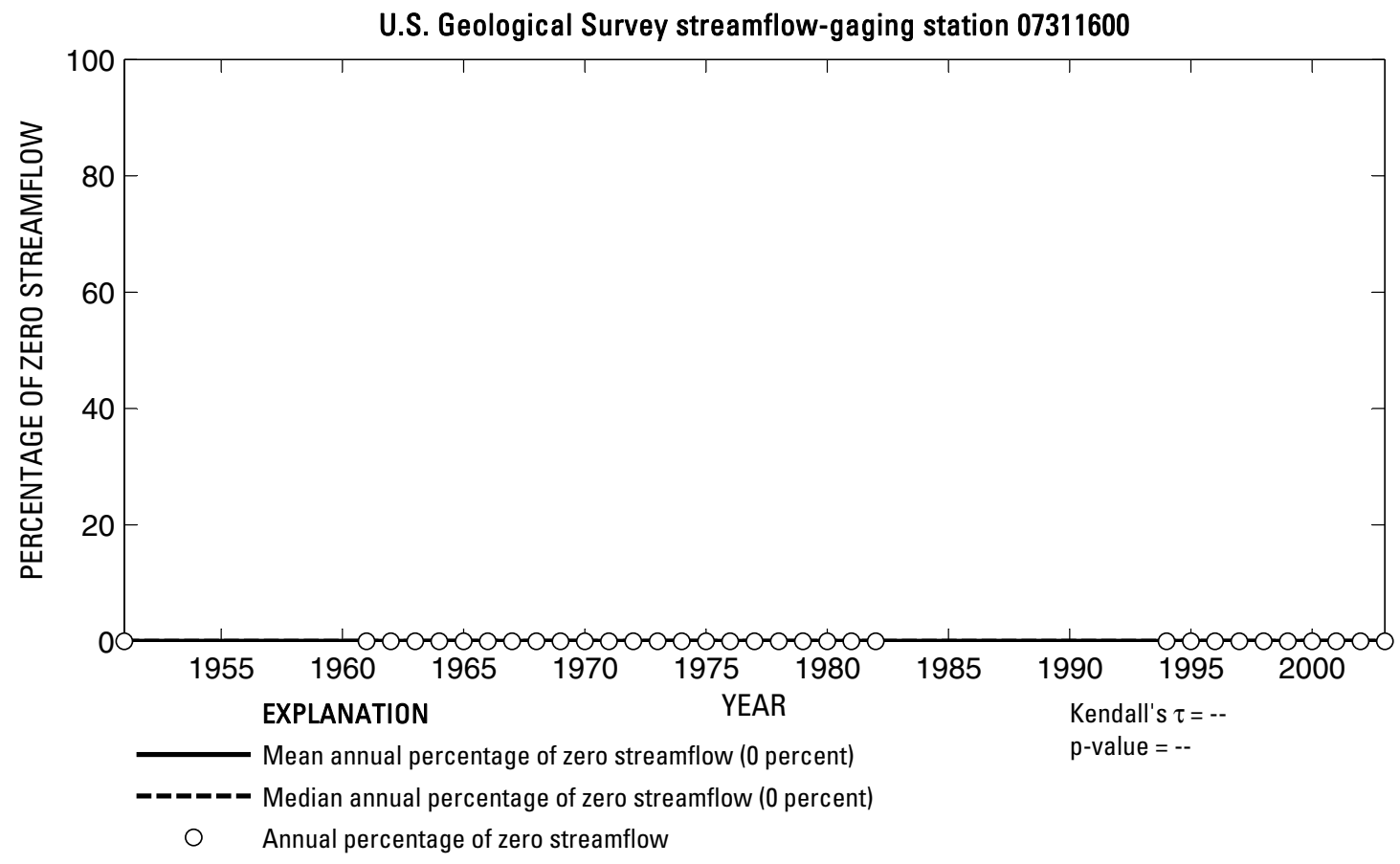

U.S. Geological Survey streamflow-gaging station 07311600

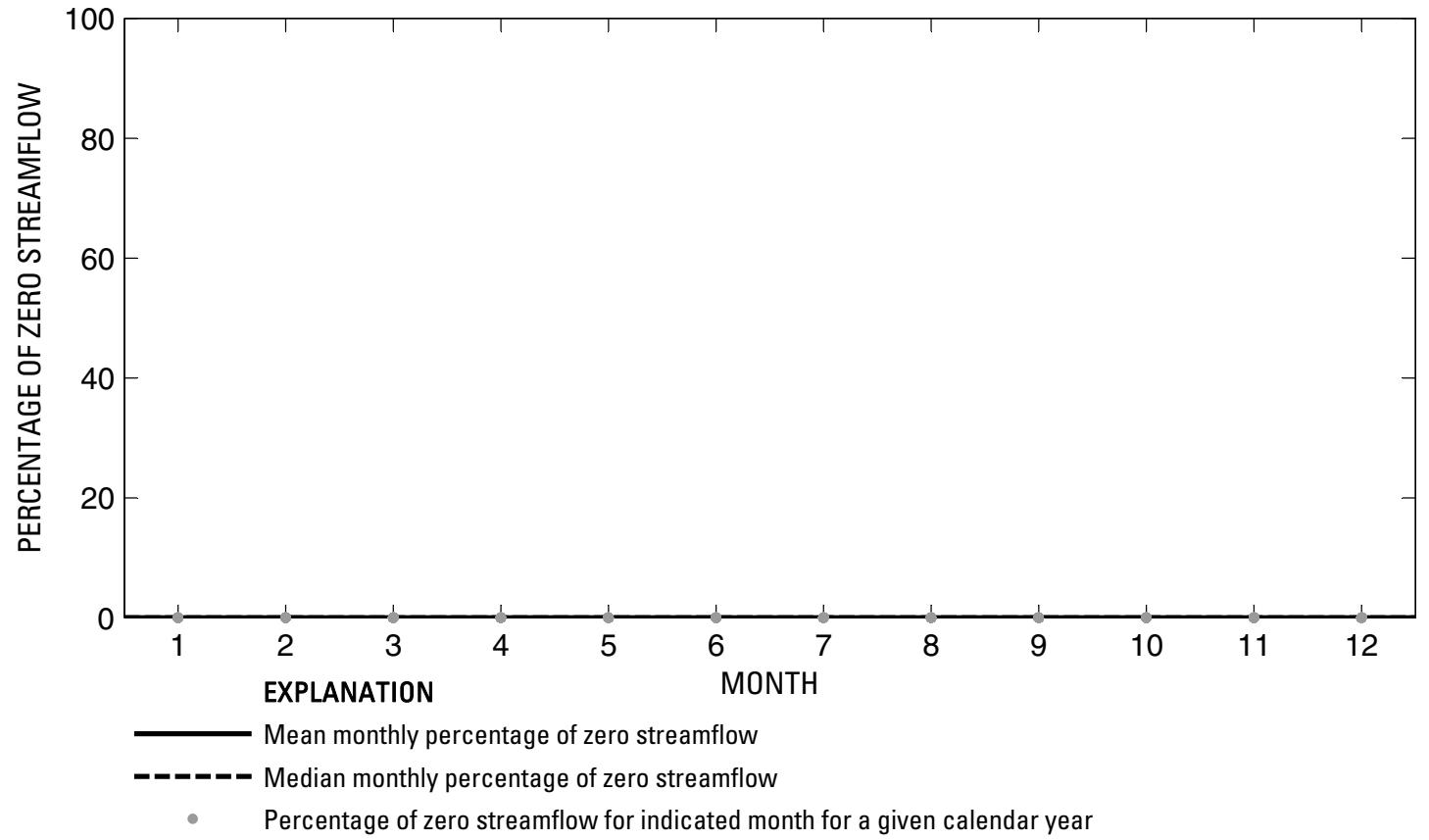

Figure 39. Analysis of percentage of zero daily mean streamflow for U.S. Geological Survey streamflow-gaging station 07311600 North Wichita River near Paducah, Texas. 

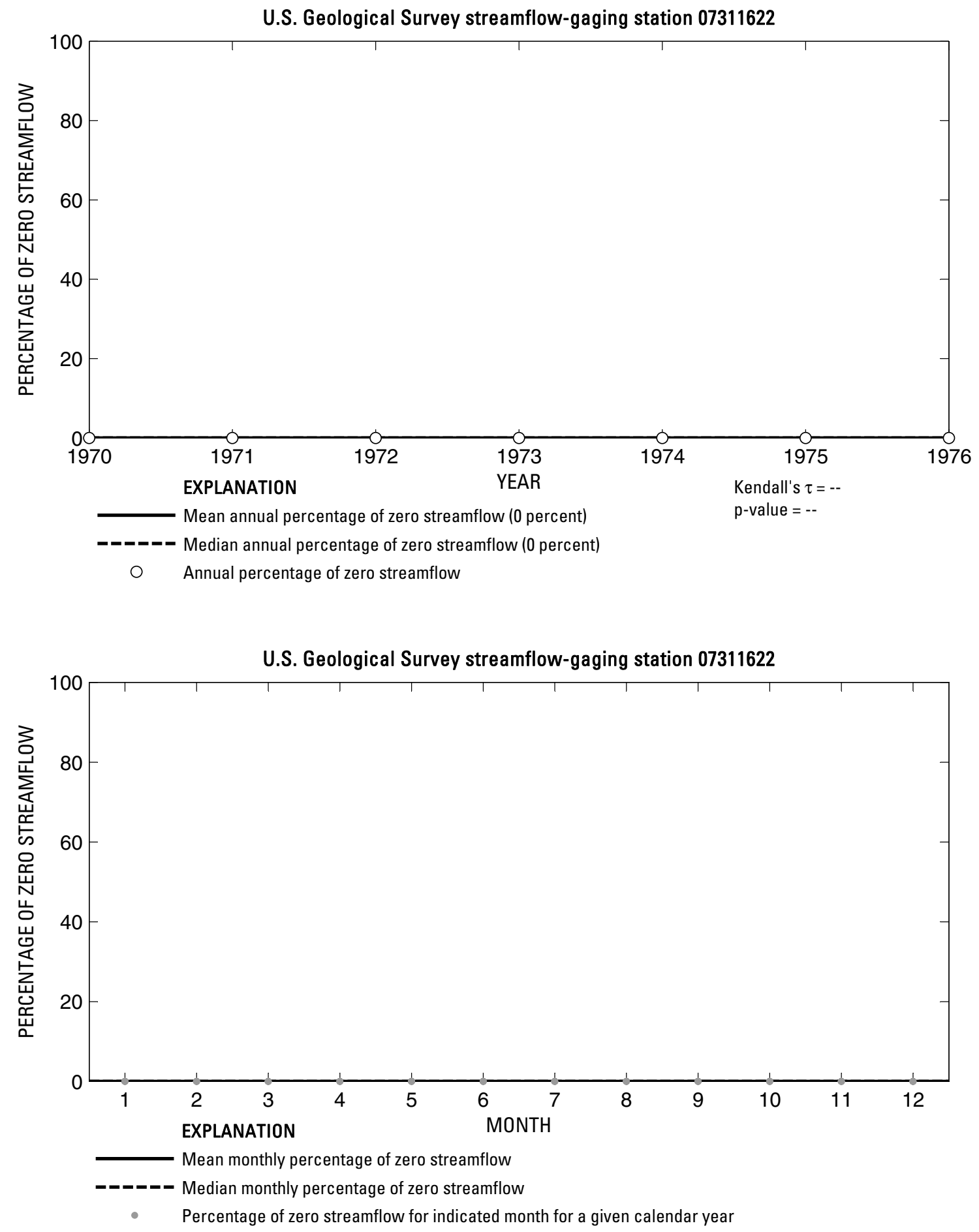

Figure 40. Analysis of percentage of zero daily mean streamflow for U.S. Geological Survey streamflow-gaging station 07311622 North Wichita River near Crowell, Texas. 


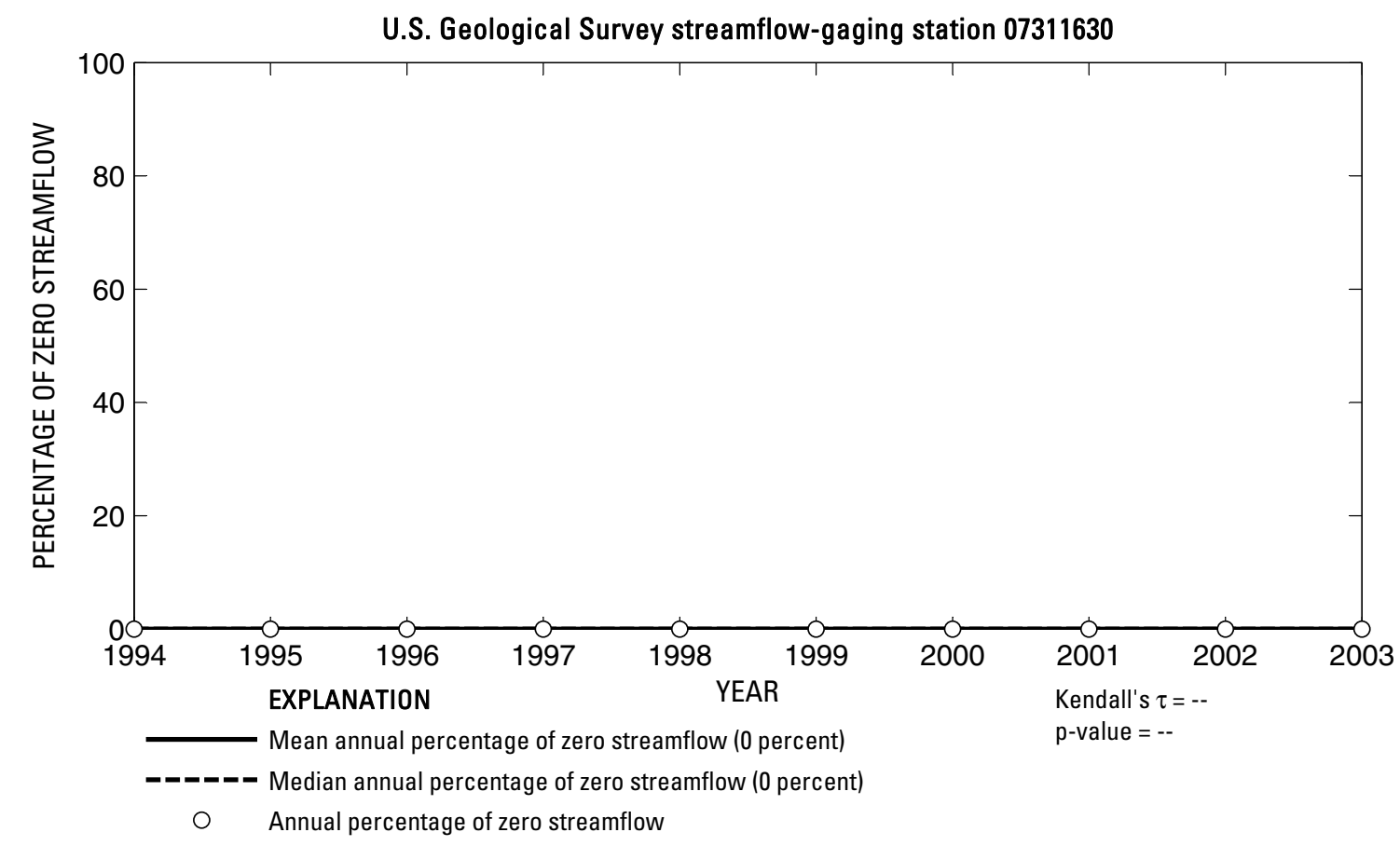

U.S. Geological Survey streamflow-gaging station 07311630

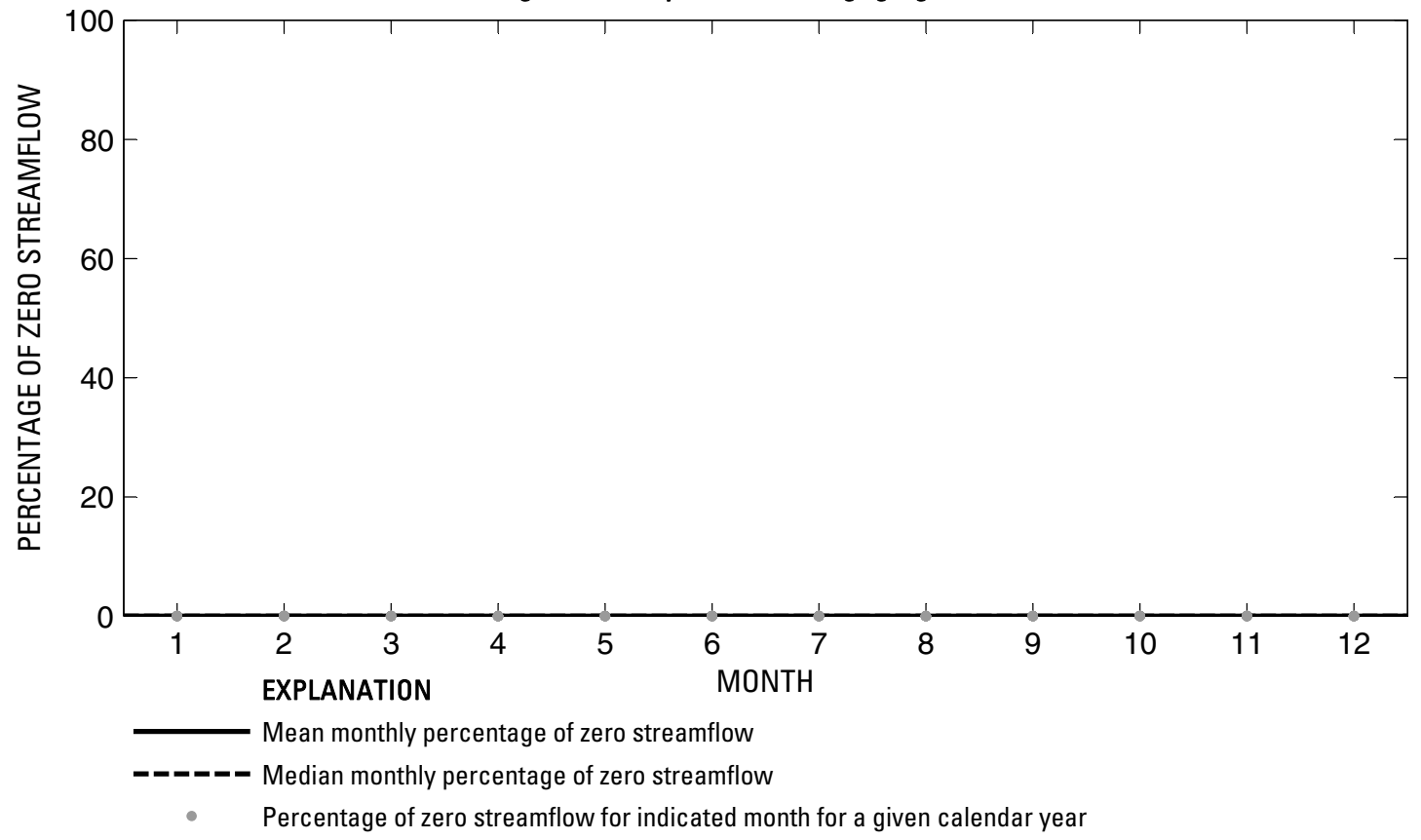

Figure 41. Analysis of percentage of zero daily mean streamflow for U.S. Geological Survey streamflow-gaging station 07311630 Middle Wichita River near Guthrie, Texas. 

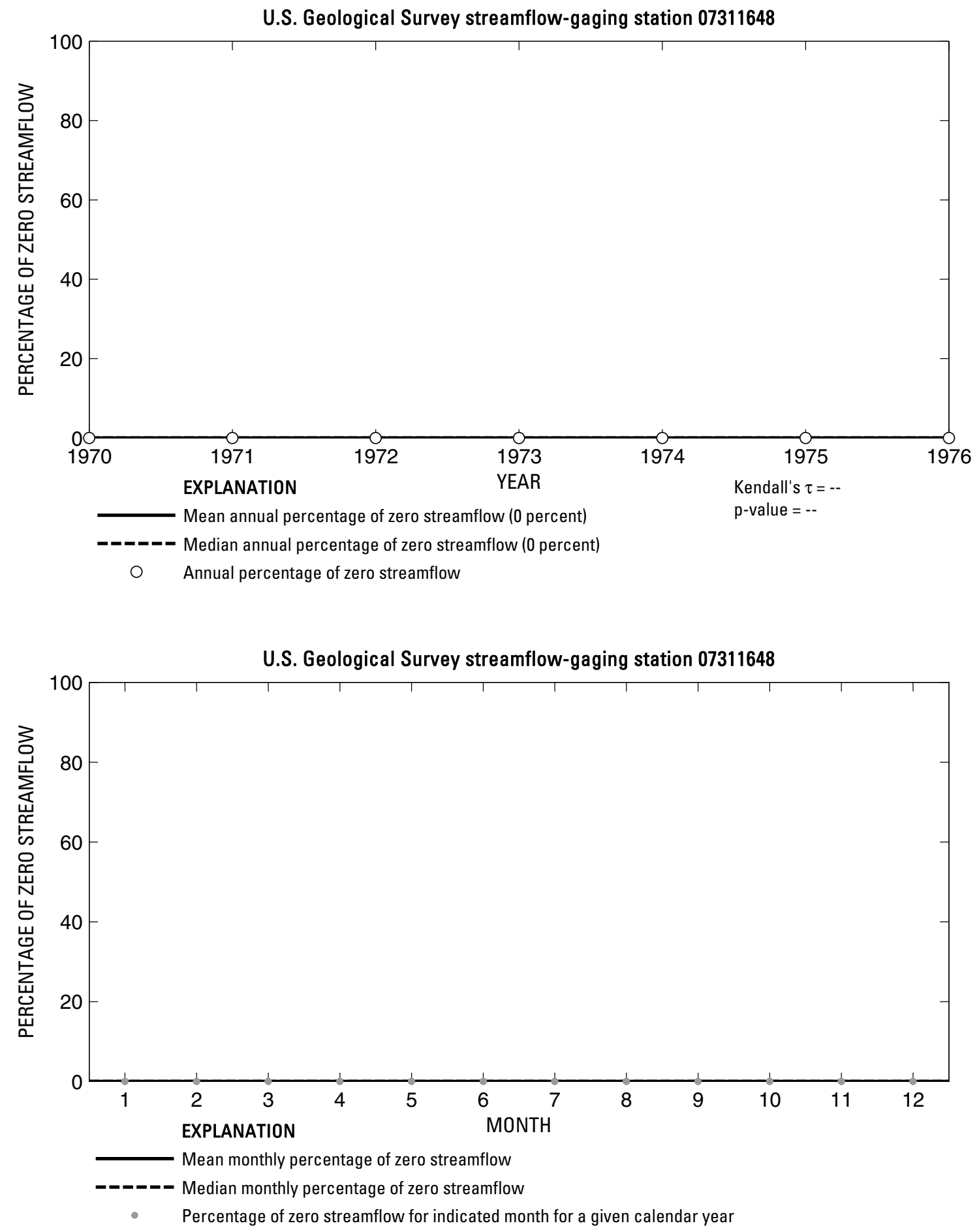

Figure 42. Analysis of percentage of zero daily mean streamflow for U.S. Geological Survey streamflow-gaging station 07311648 Middle Wichita River near Truscott, Texas. 


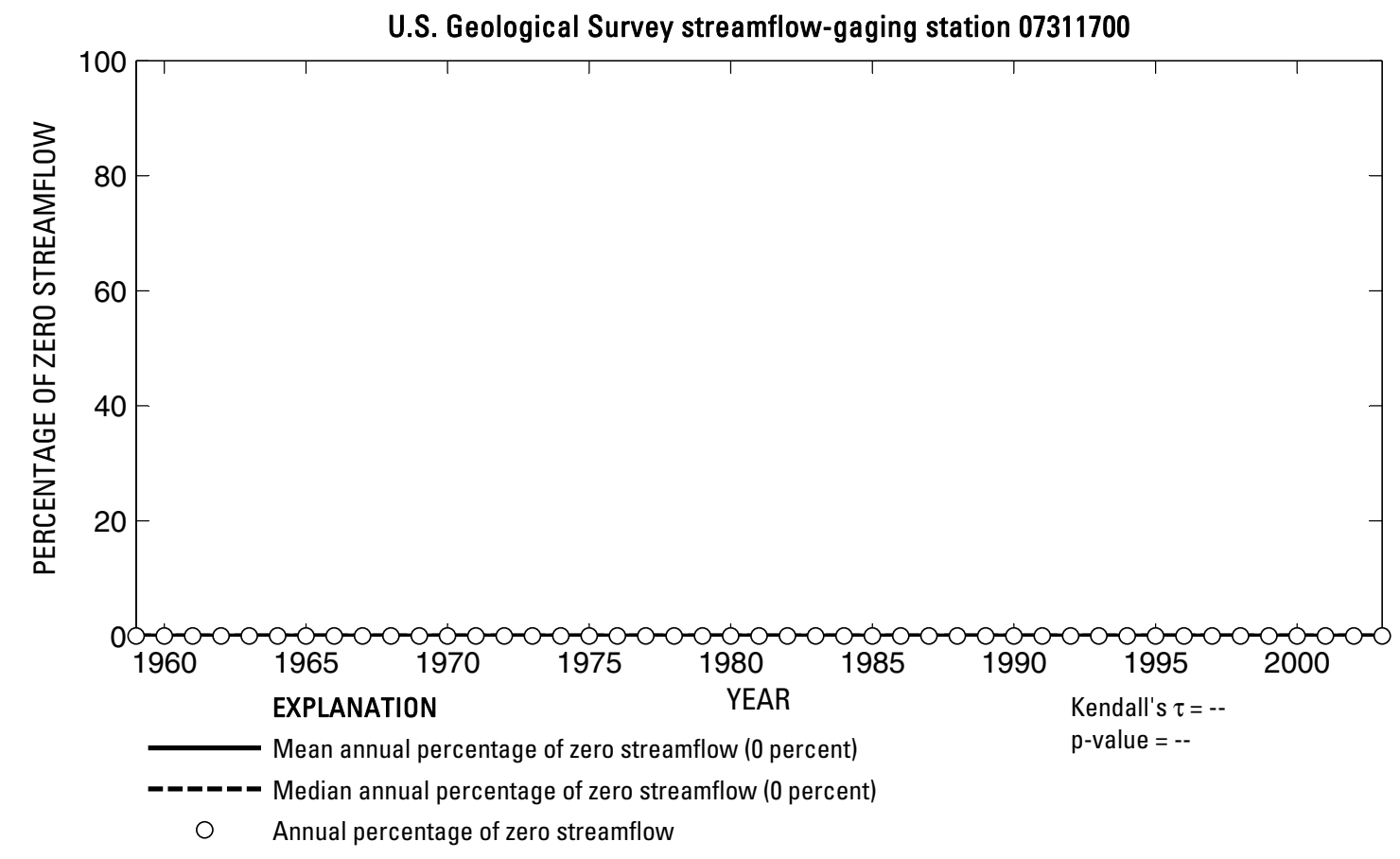

U.S. Geological Survey streamflow-gaging station 07311700

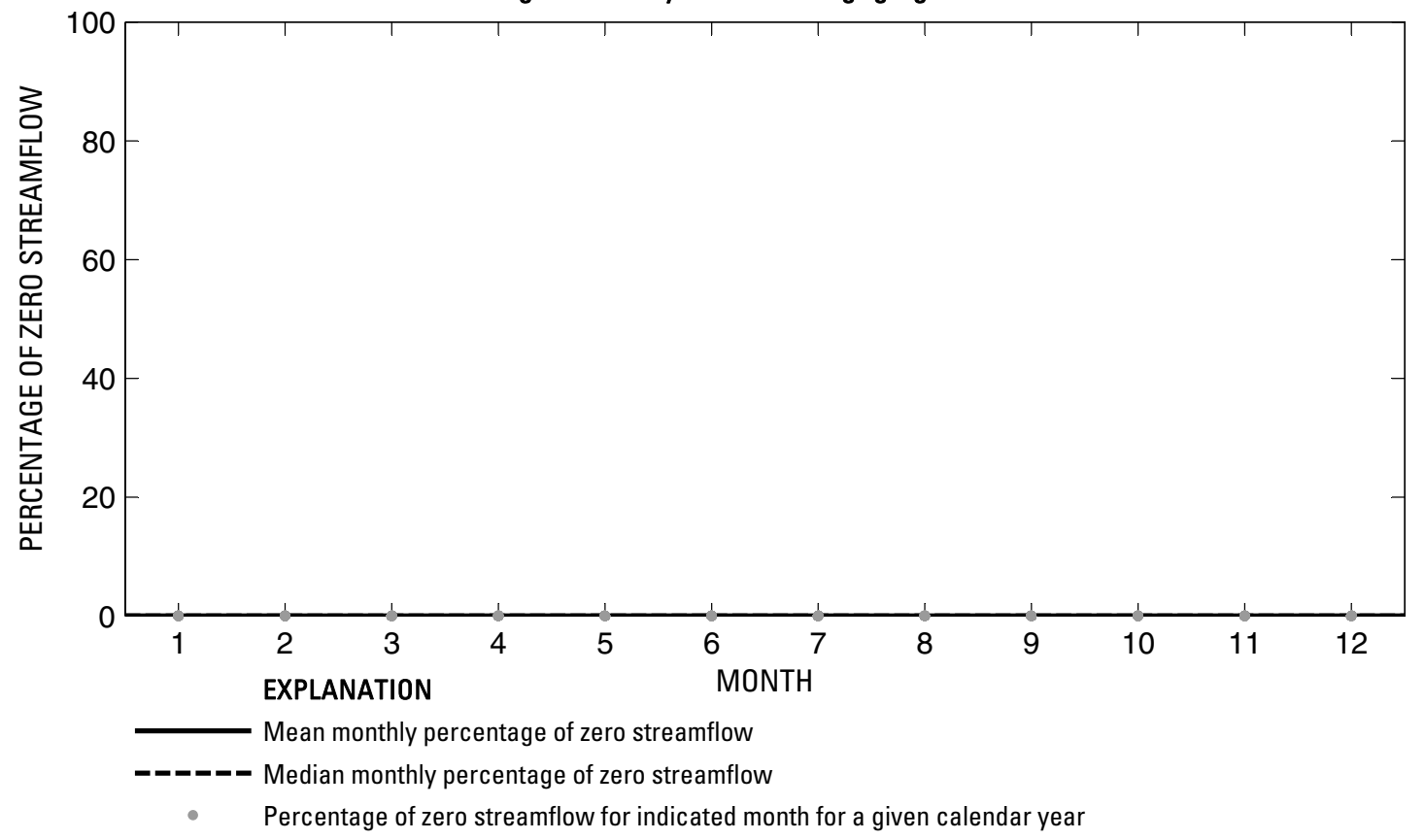

Figure 43. Analysis of percentage of zero daily mean streamflow for U.S. Geological Survey streamflow-gaging station 07311700 North Wichita River near Truscott, Texas. 

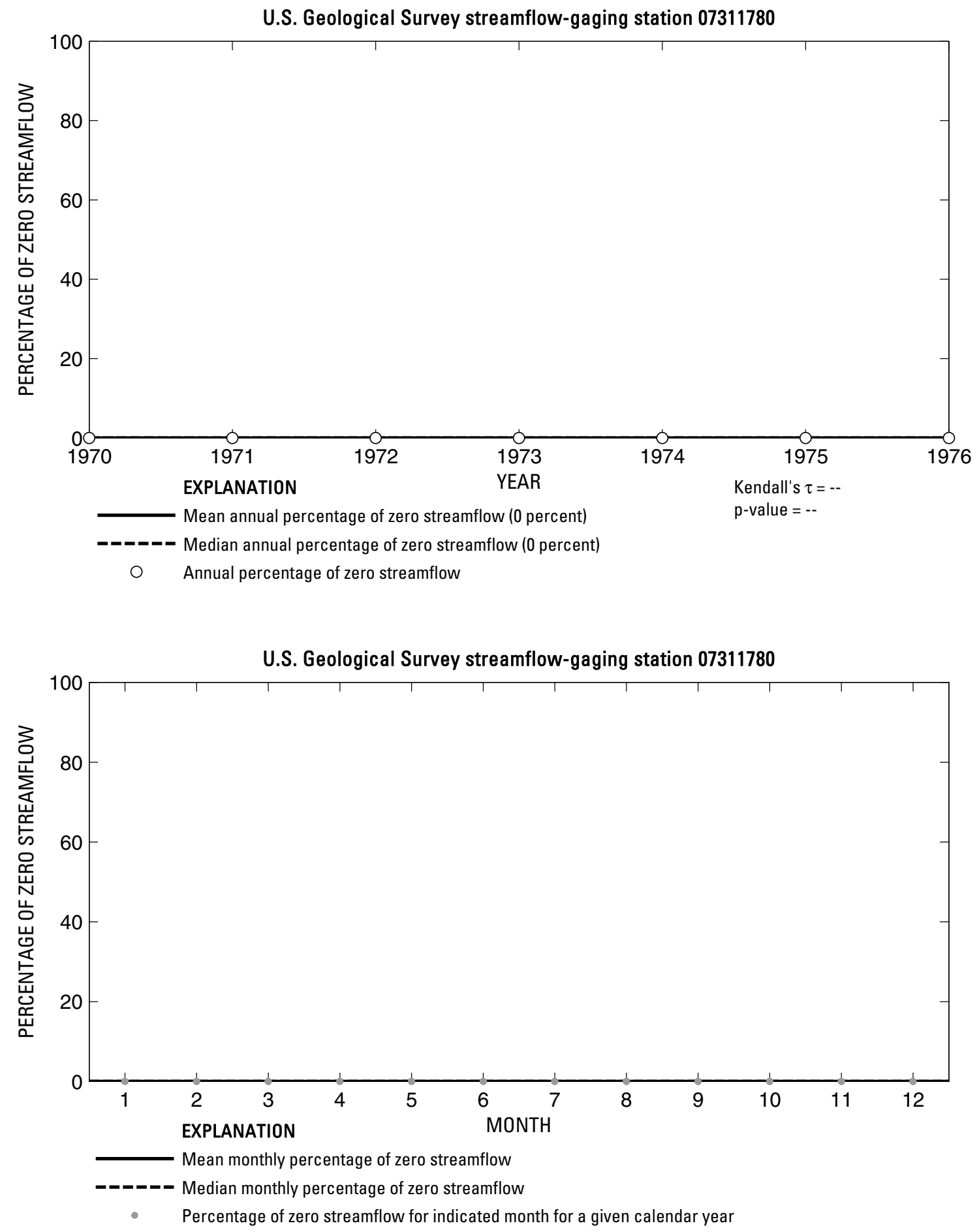

Figure 44. Analysis of percentage of zero daily mean streamflow for U.S. Geological Survey streamflow-gaging station 07311780 South Wichita River near Guthrie, Texas. 
U.S. Geological Survey streamflow-gaging station 07311782

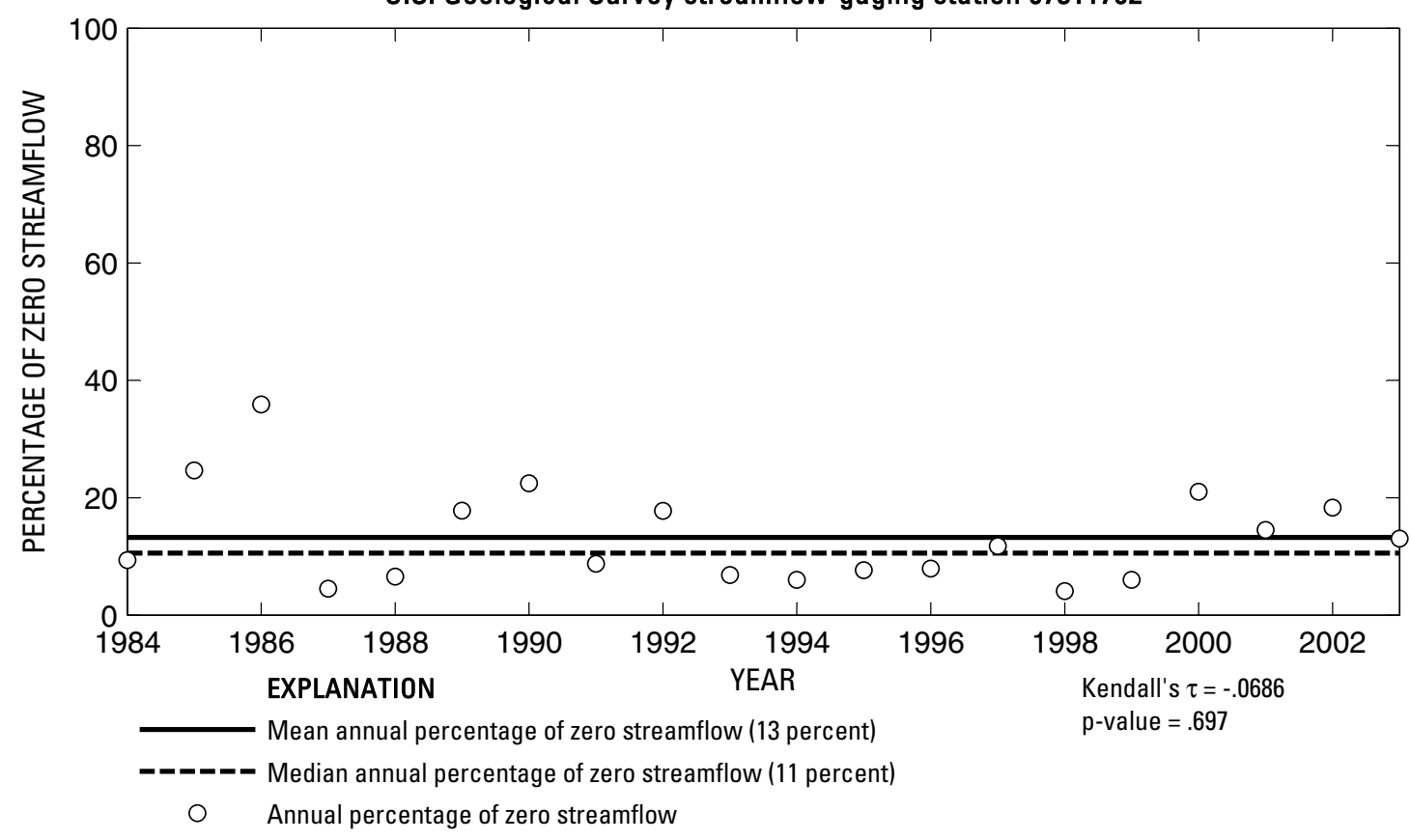

U.S. Geological Survey streamflow-gaging station 07311782

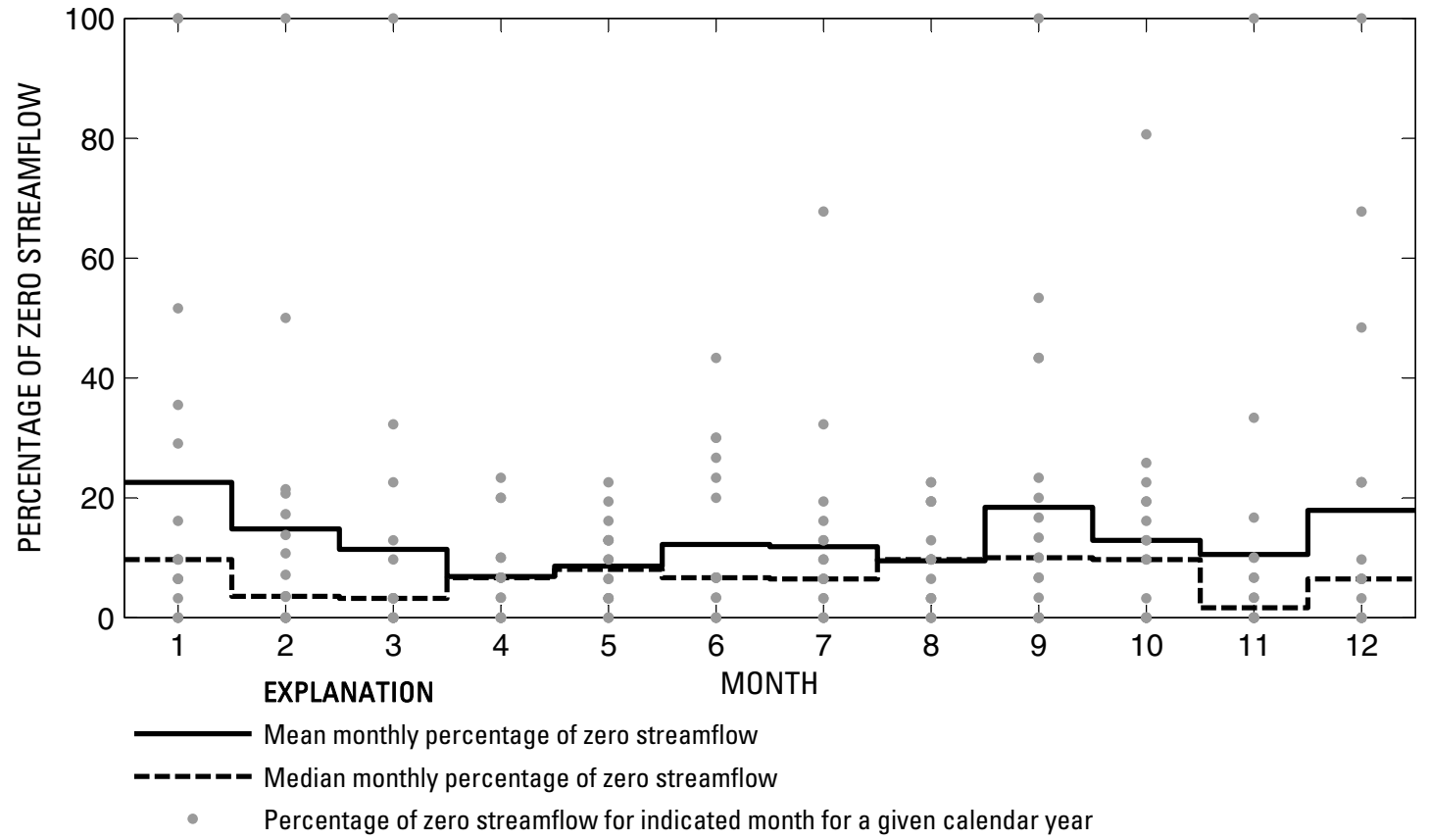

Figure 45. Analysis of percentage of zero daily mean streamflow for U.S. Geological Survey streamflow-gaging station 07311782 South Wichita River at Low Flow Dam near Guthrie, Texas. 
U.S. Geological Survey streamflow-gaging station 07311783

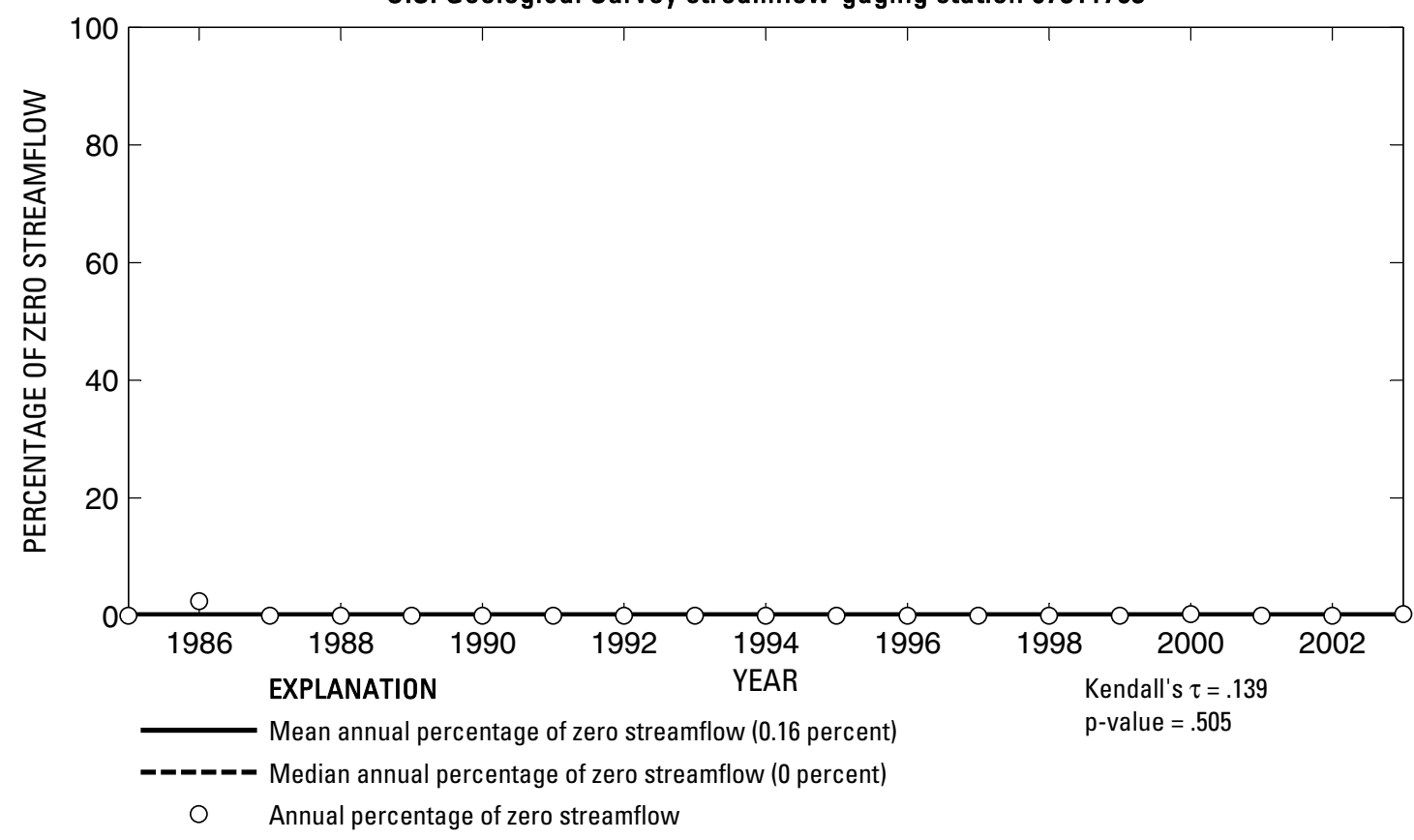

U.S. Geological Survey streamflow-gaging station 07311783

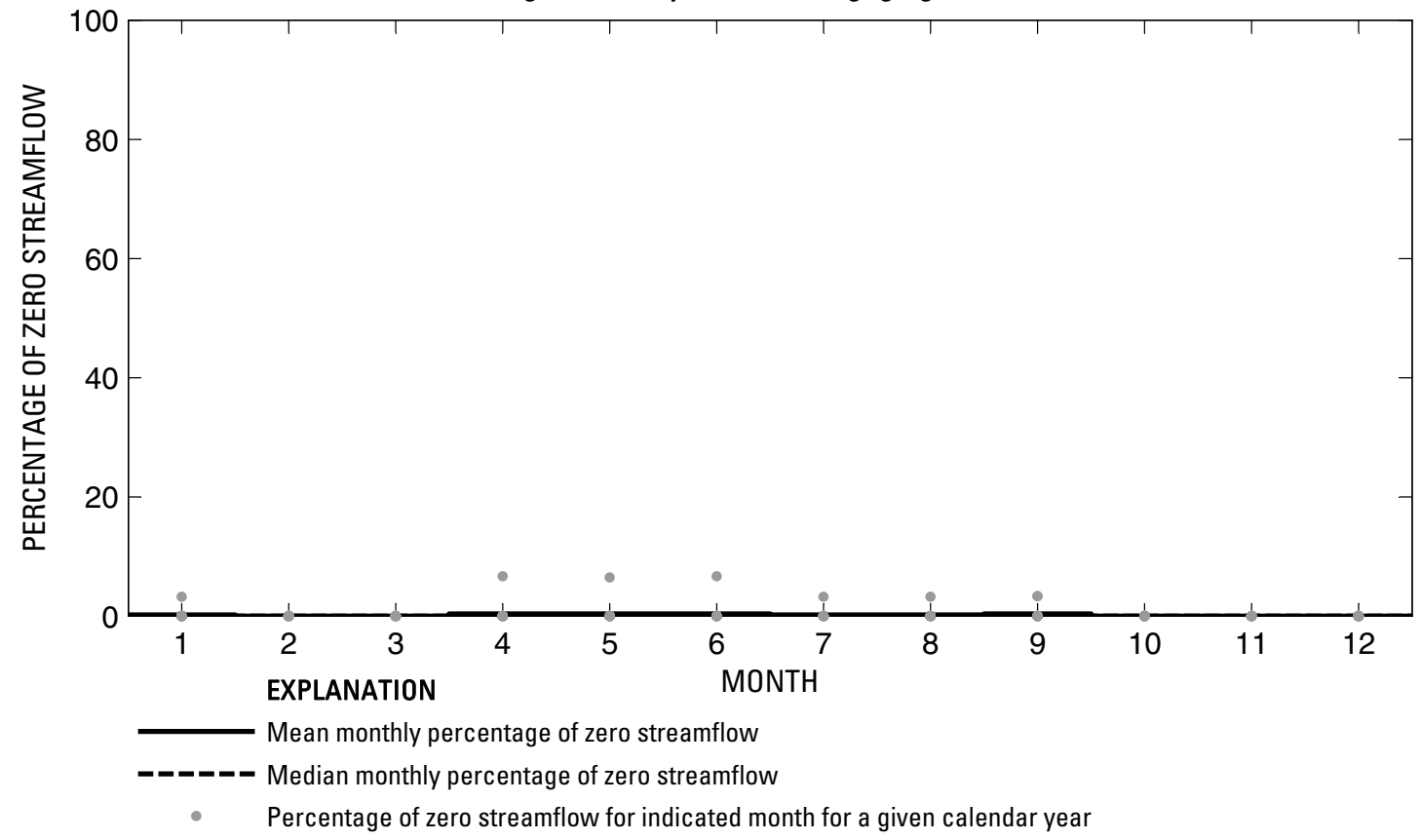

Figure 46. Analysis of percentage of zero daily mean streamflow for U.S. Geological Survey streamflow-gaging station 07311783 South Wichita River below Low Flow Dam near Guthrie, Texas. 


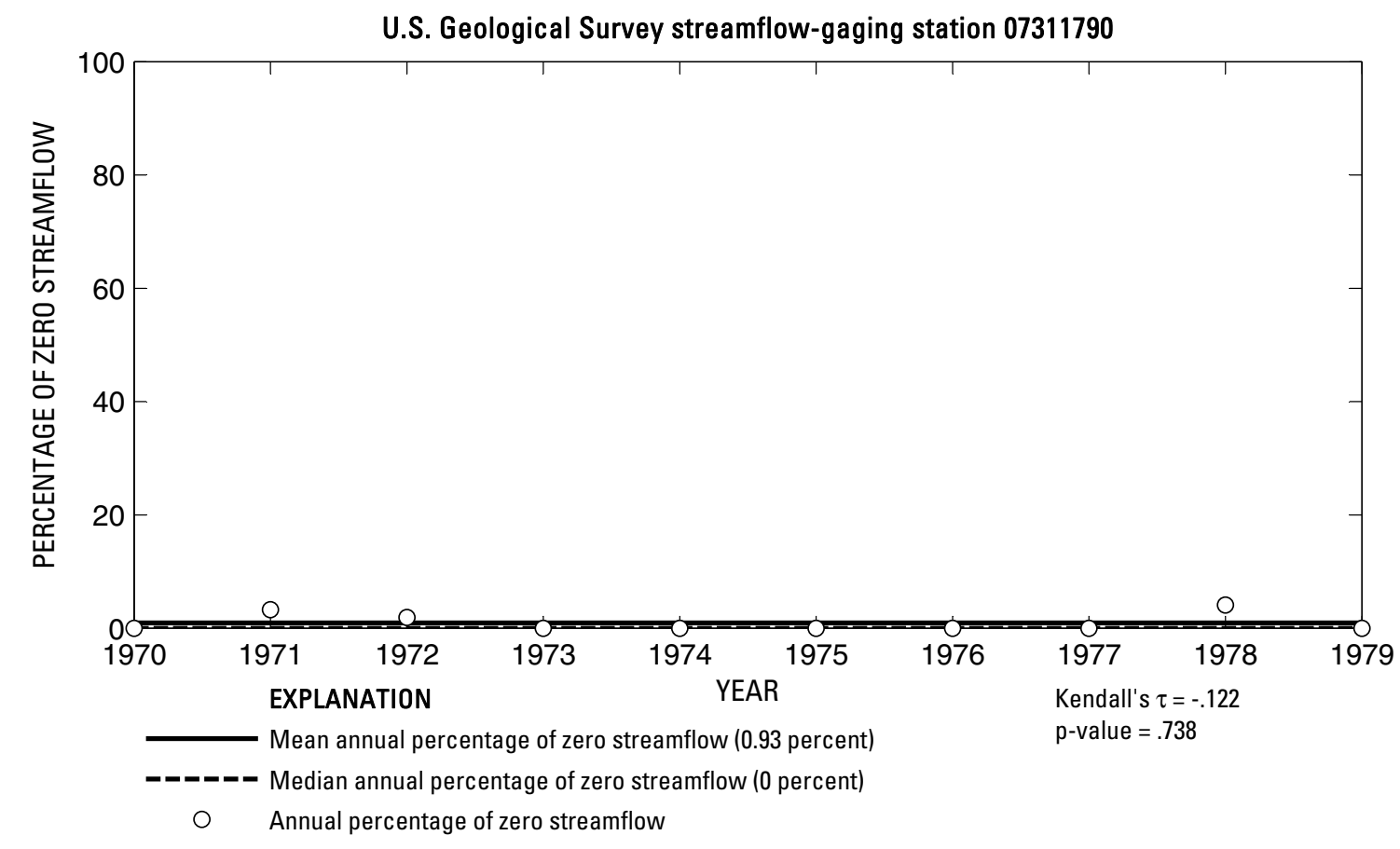

U.S. Geological Survey streamflow-gaging station 07311790

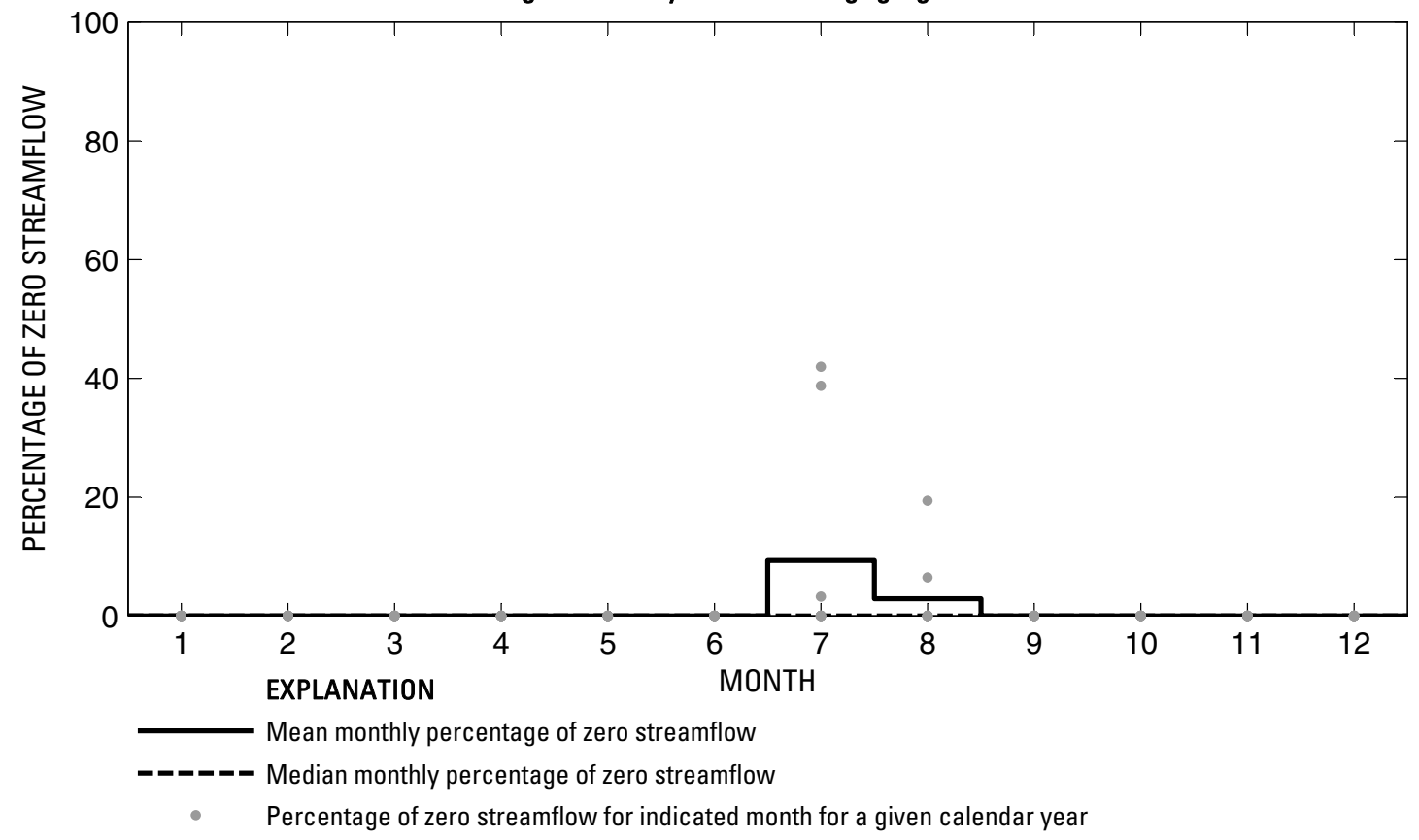

Figure 47. Analysis of percentage of zero daily mean streamflow for U.S. Geological Survey streamflow-gaging station 07311790 South Wichita River at Ross Ranch near Benjamin, Texas. 

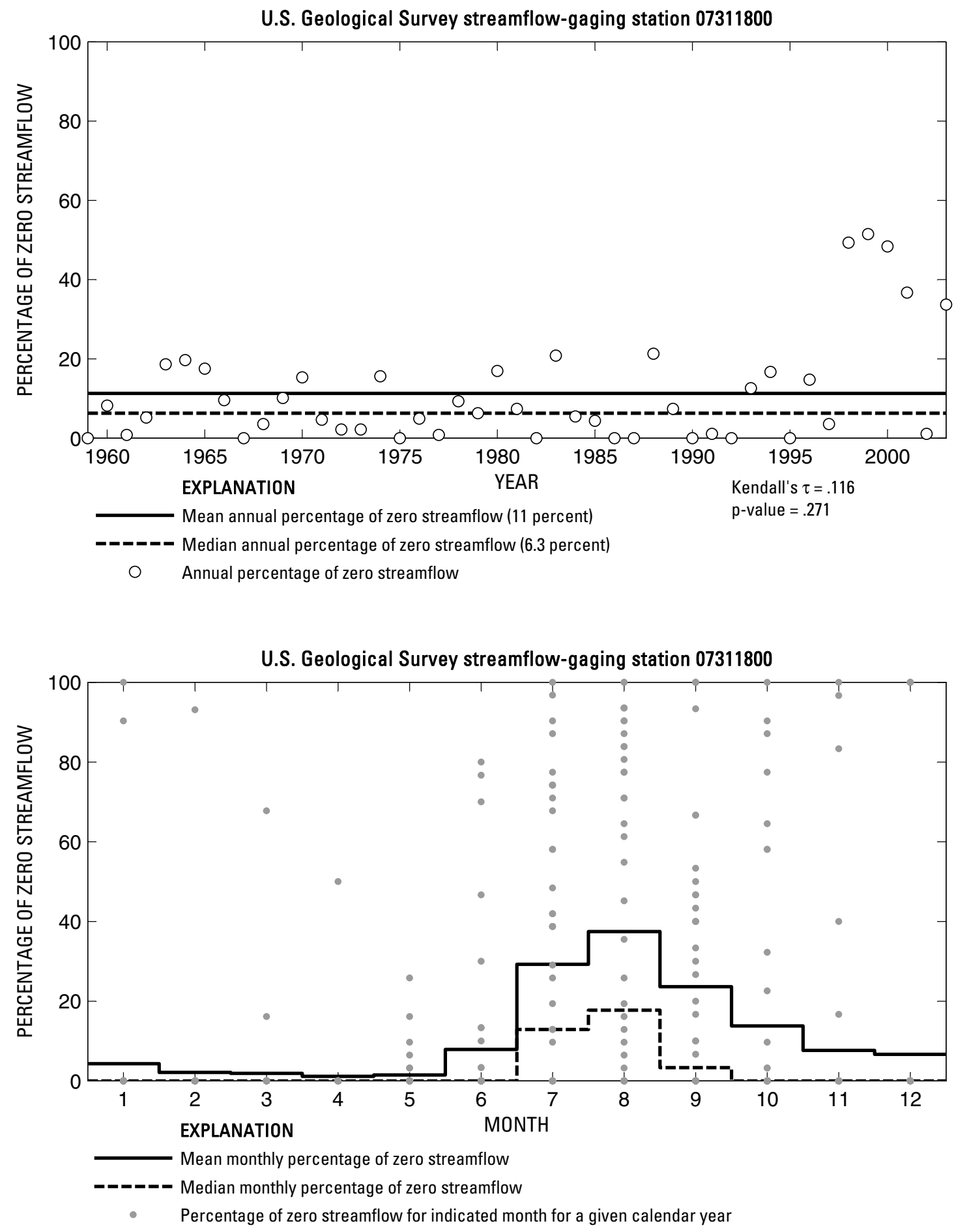

Figure 48. Analysis of percentage of zero daily mean streamflow for U.S. Geological Survey streamflow-gaging station 07311800 South Wichita River near Benjamin, Texas. 


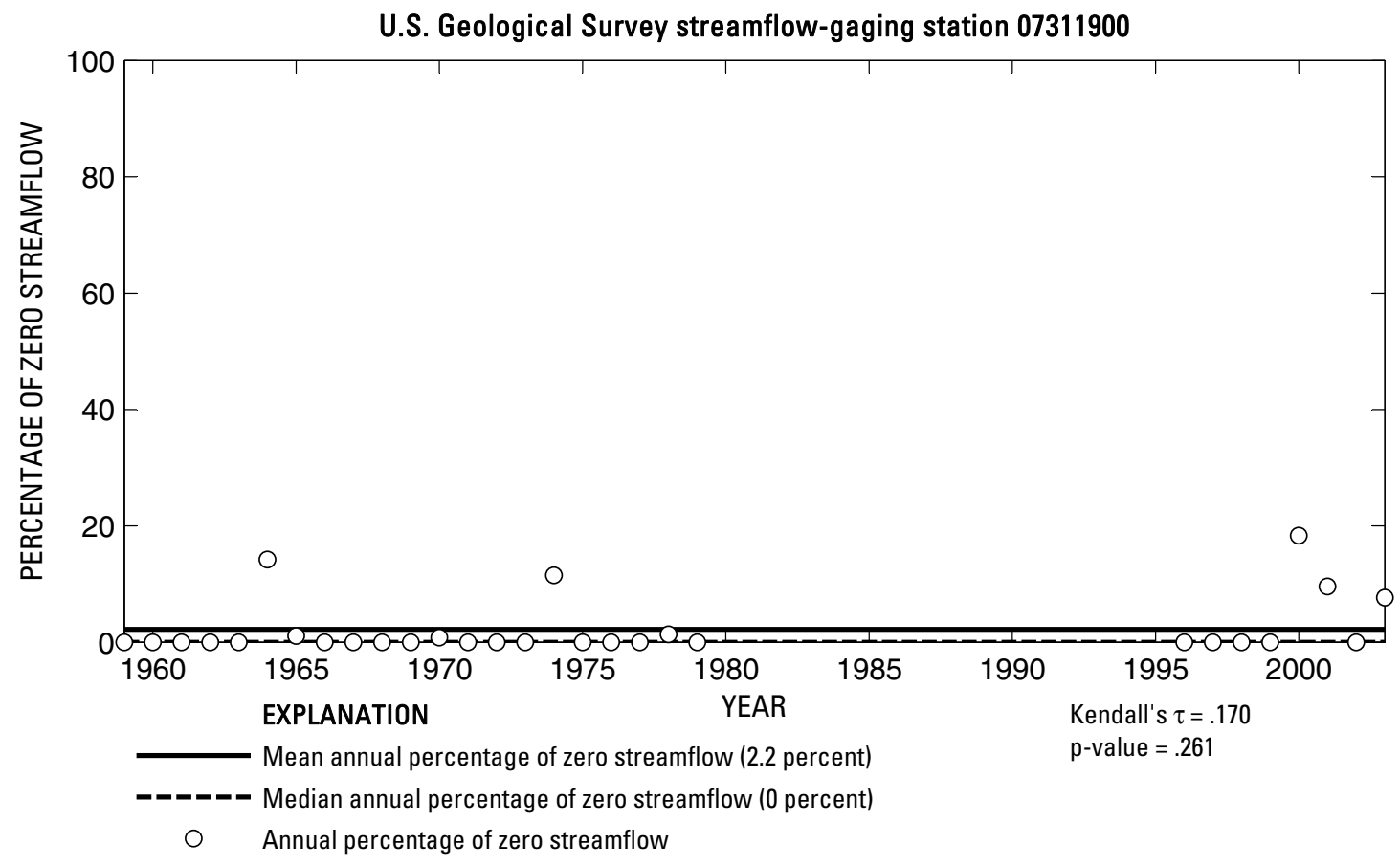

U.S. Geological Survey streamflow-gaging station 07311900

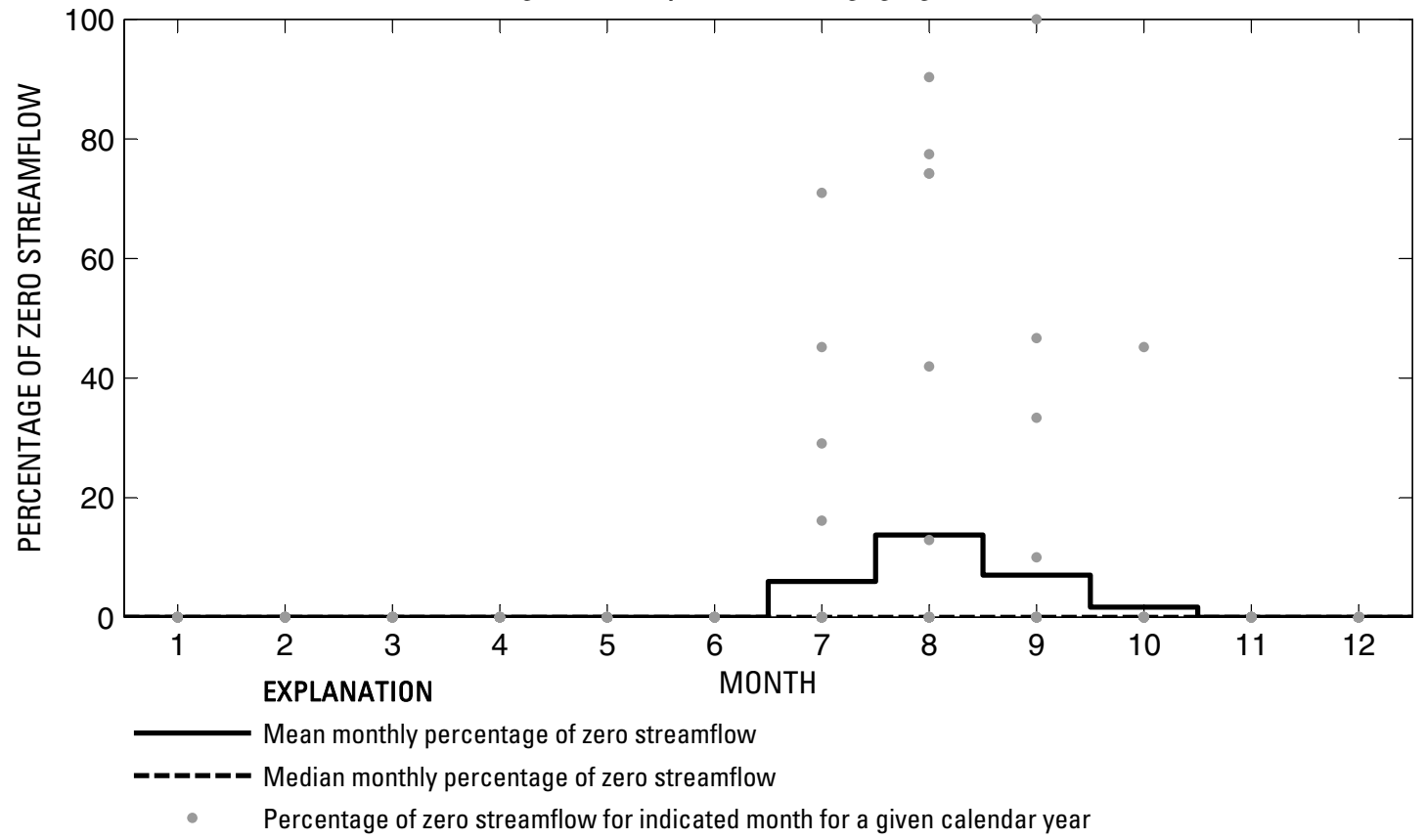

Figure 49. Analysis of percentage of zero daily mean streamflow for U.S. Geological Survey streamflow-gaging station 07311900 Wichita River near Seymour, Texas. 

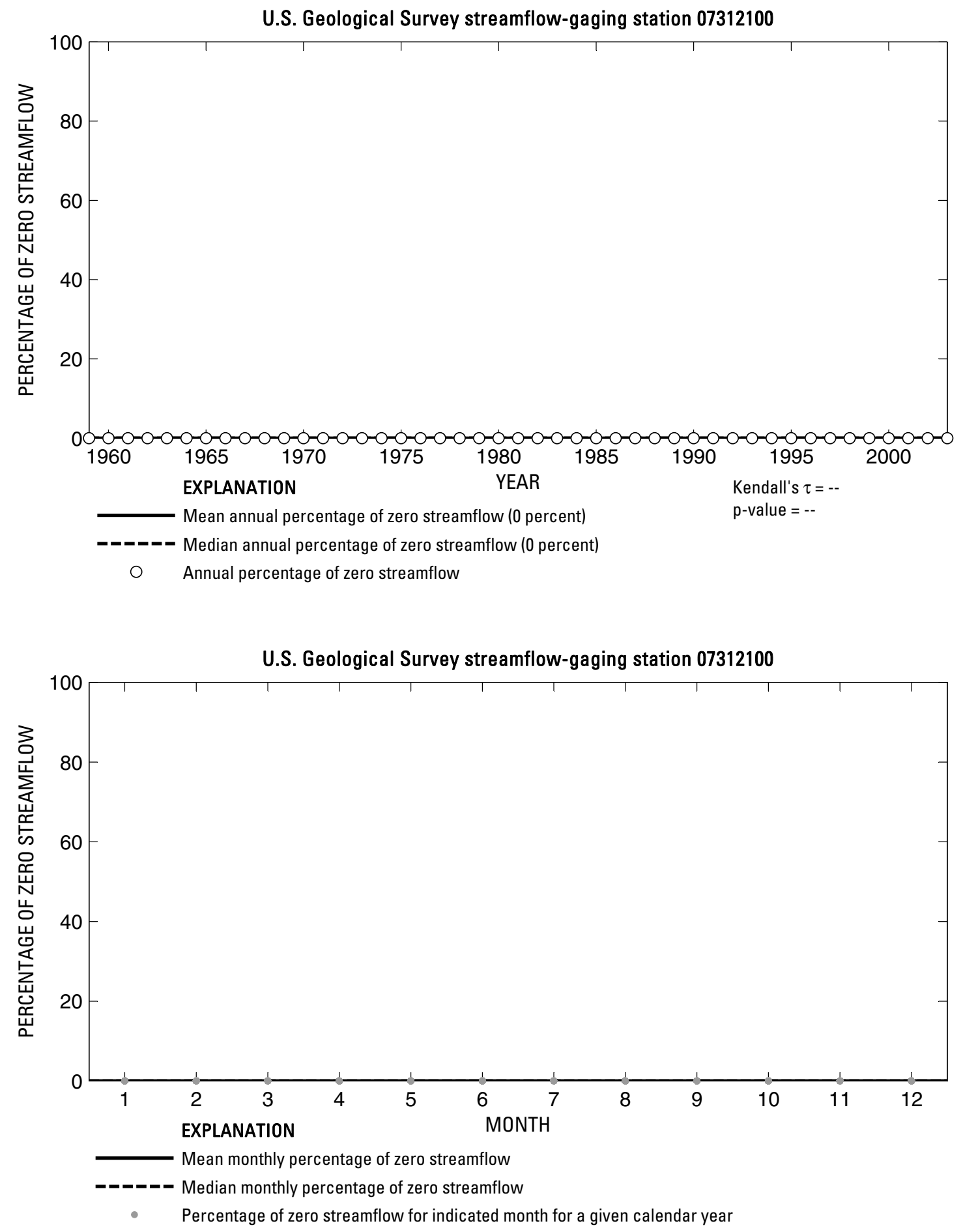

Figure 50. Analysis of percentage of zero daily mean streamflow for U.S. Geological Survey streamflow-gaging station 07312100 Wichita River near Mabelle, Texas. 


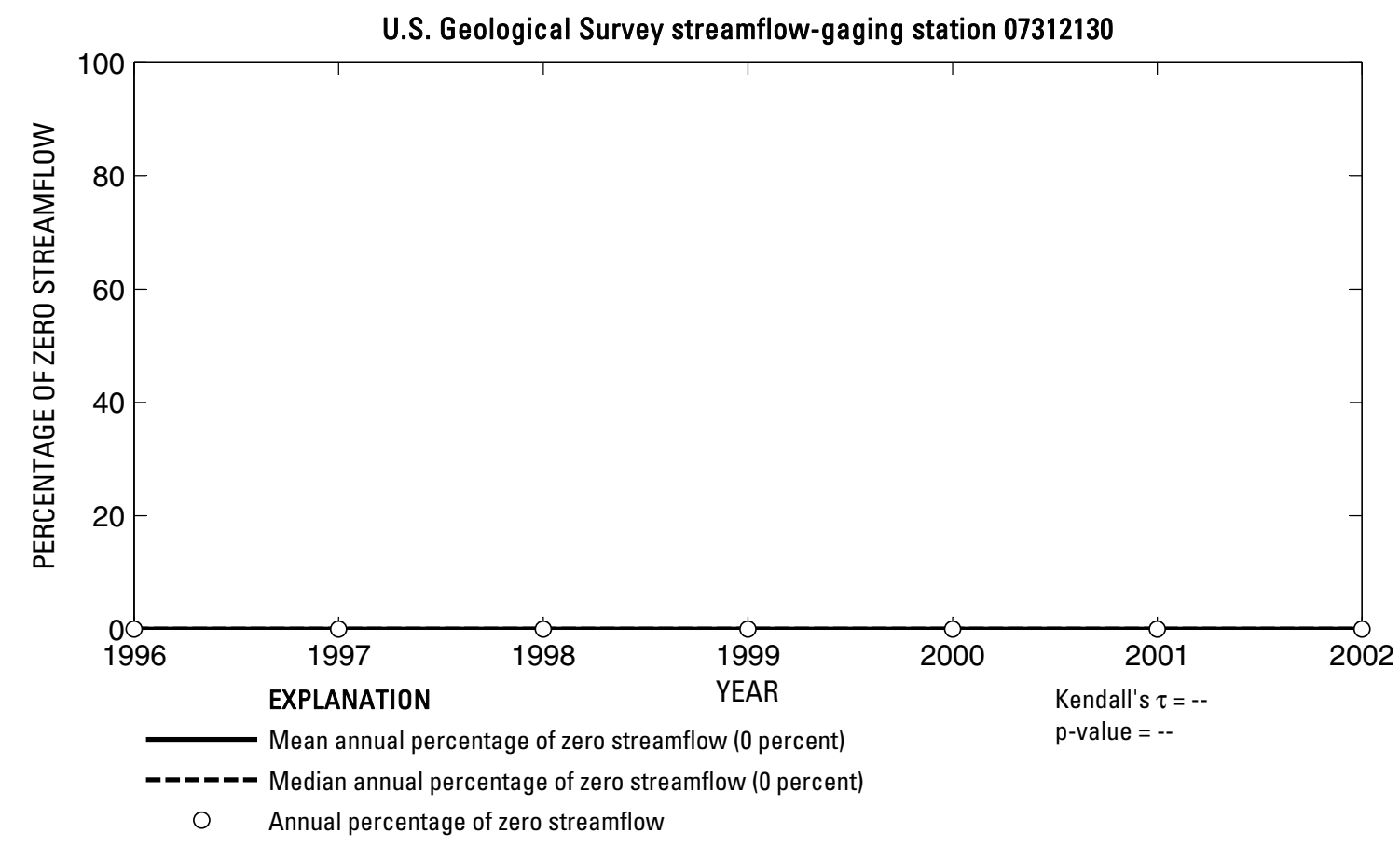

U.S. Geological Survey streamflow-gaging station 07312130

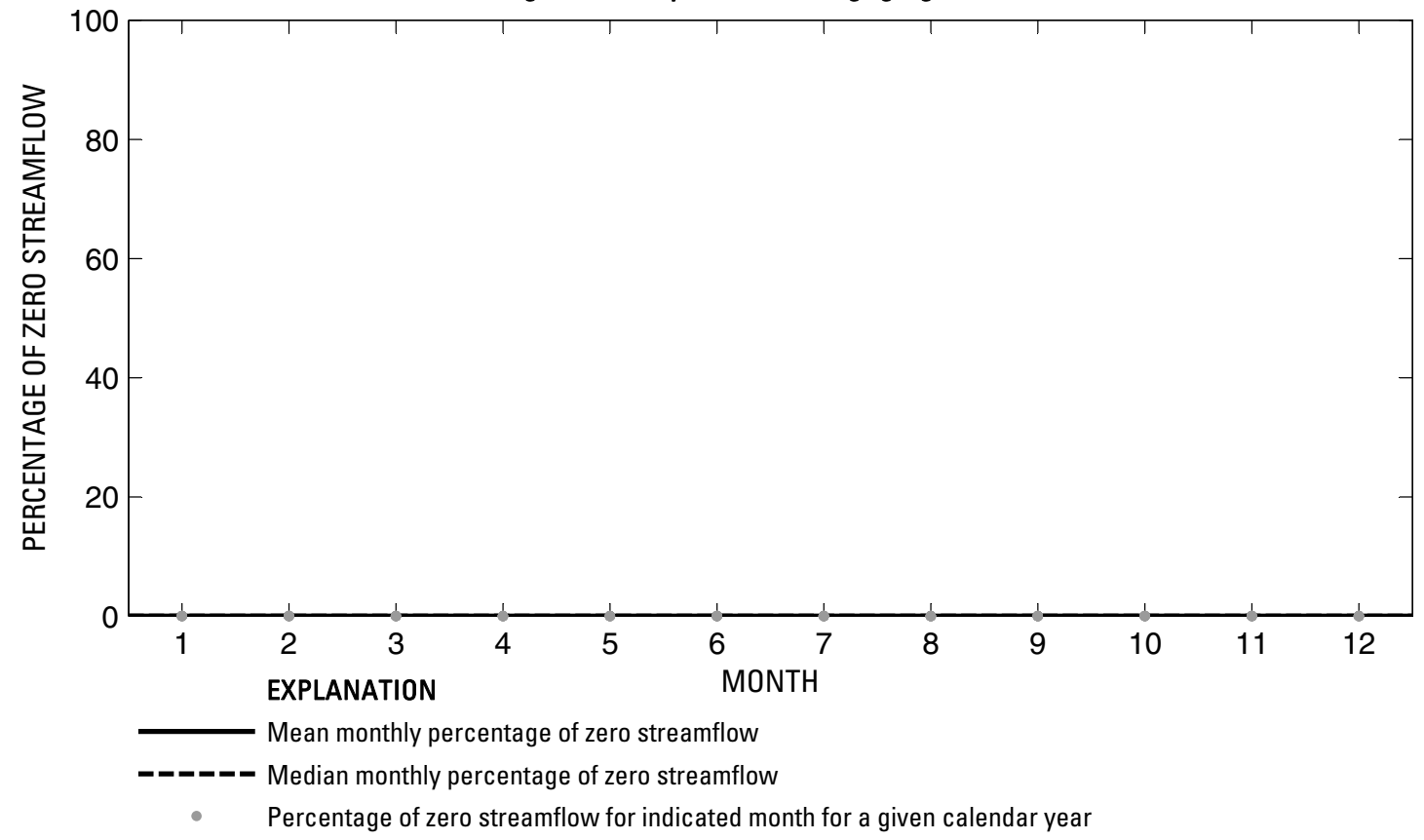

Figure 51. Analysis of percentage of zero daily mean streamflow for U.S. Geological Survey streamflow-gaging station 07312130 Wichita River at State Highway 25 near Kamay, Texas. 

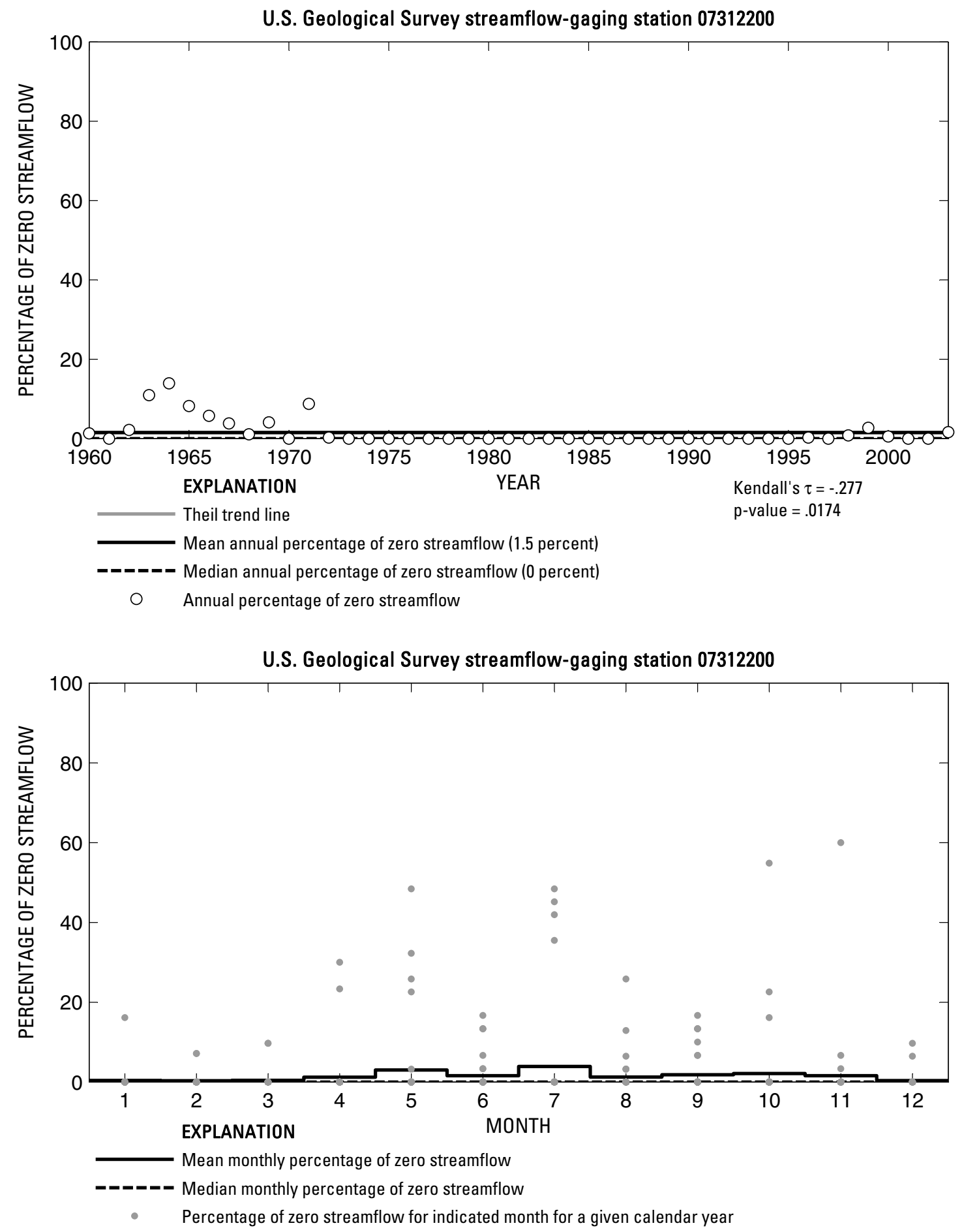

Figure 52. Analysis of percentage of zero daily mean streamflow for U.S. Geological Survey streamflow-gaging station 07312200 Beaver Creek near Electra, Texas. 


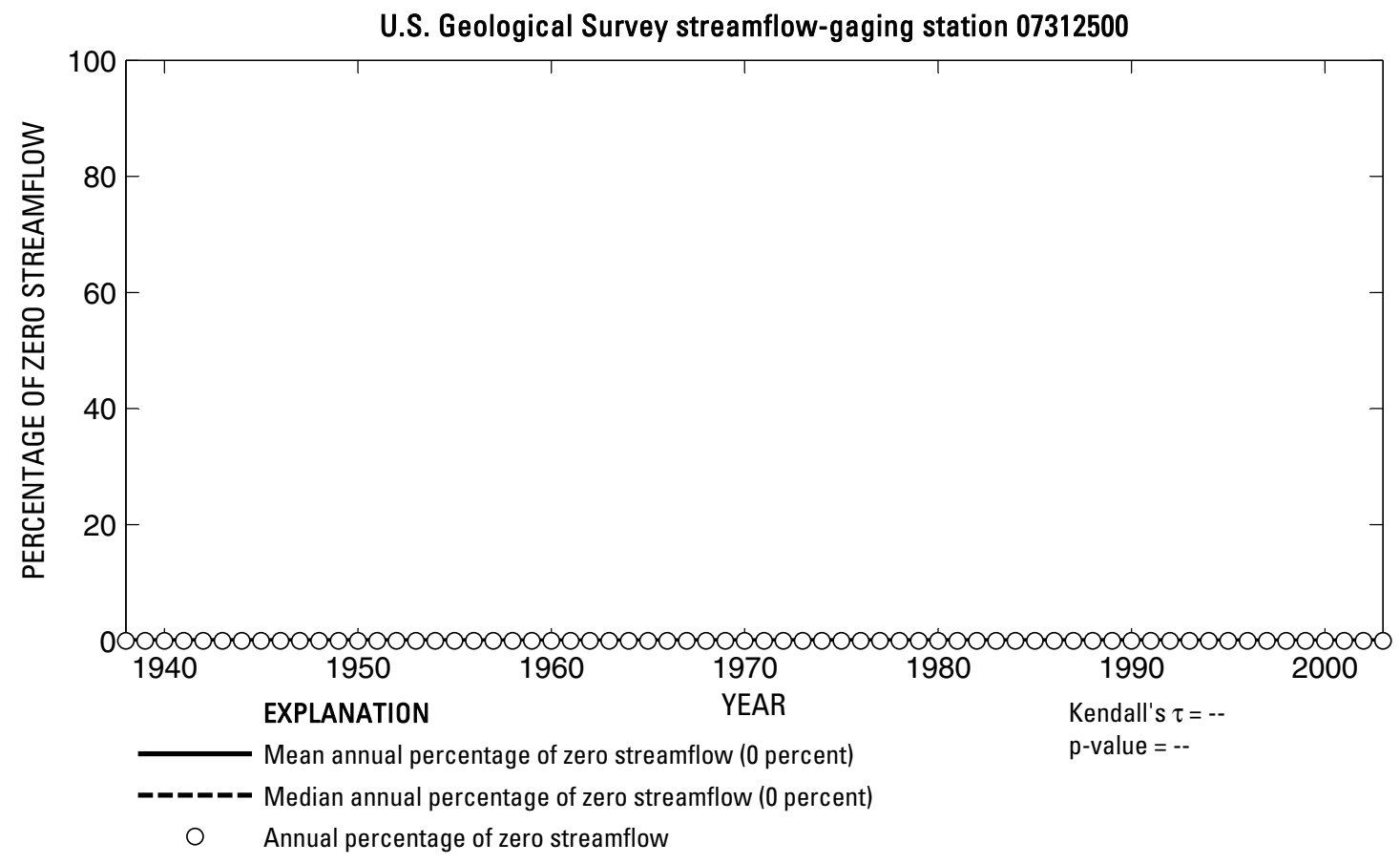

U.S. Geological Survey streamflow-gaging station 07312500

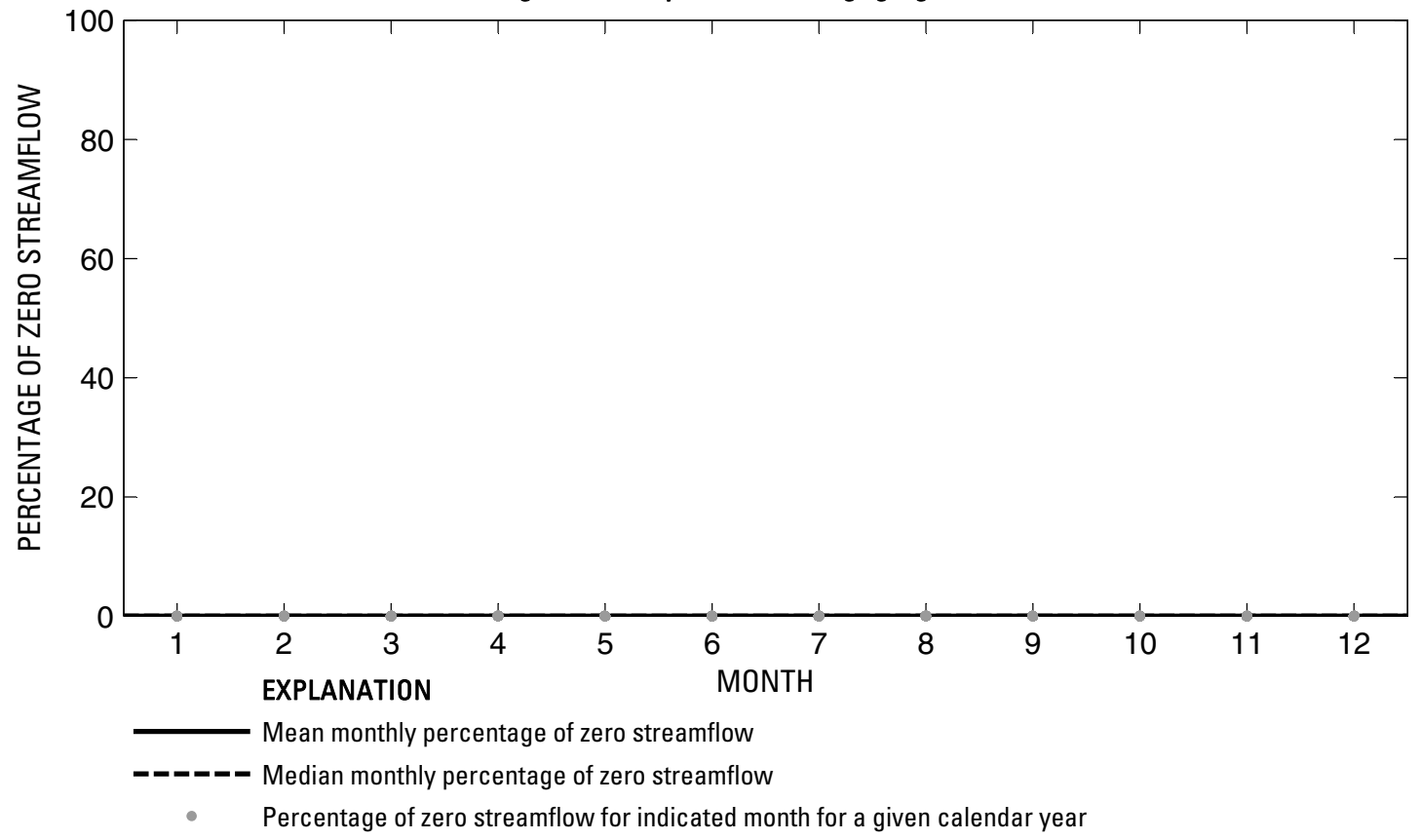

Figure 53. Analysis of percentage of zero daily mean streamflow for U.S. Geological Survey streamflow-gaging station 07312500 Wichita River at Wichita Falls, Texas. 

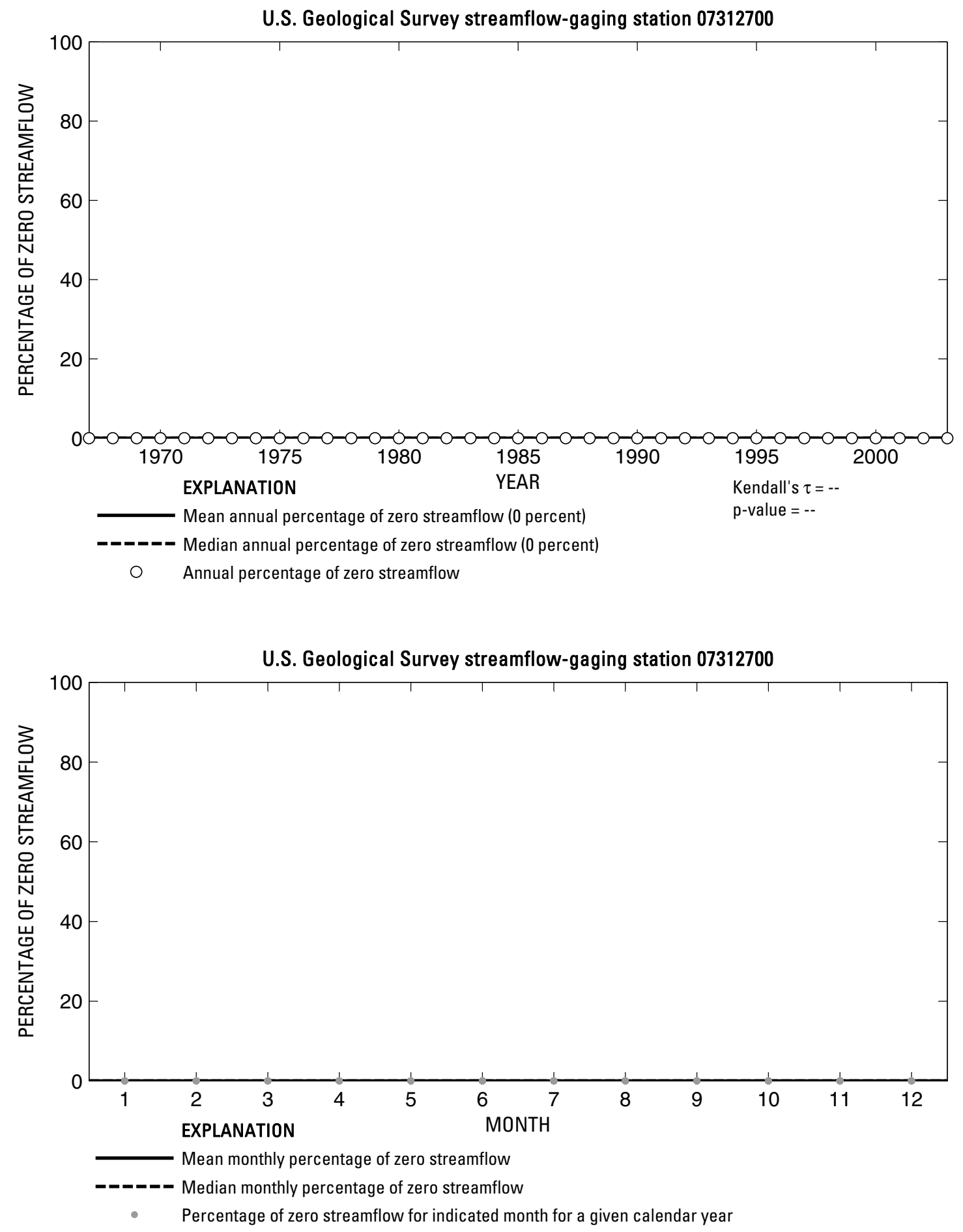

Figure 54. Analysis of percentage of zero daily mean streamflow for U.S. Geological Survey streamflow-gaging station 07312700 Wichita River near Charlie, Texas. 


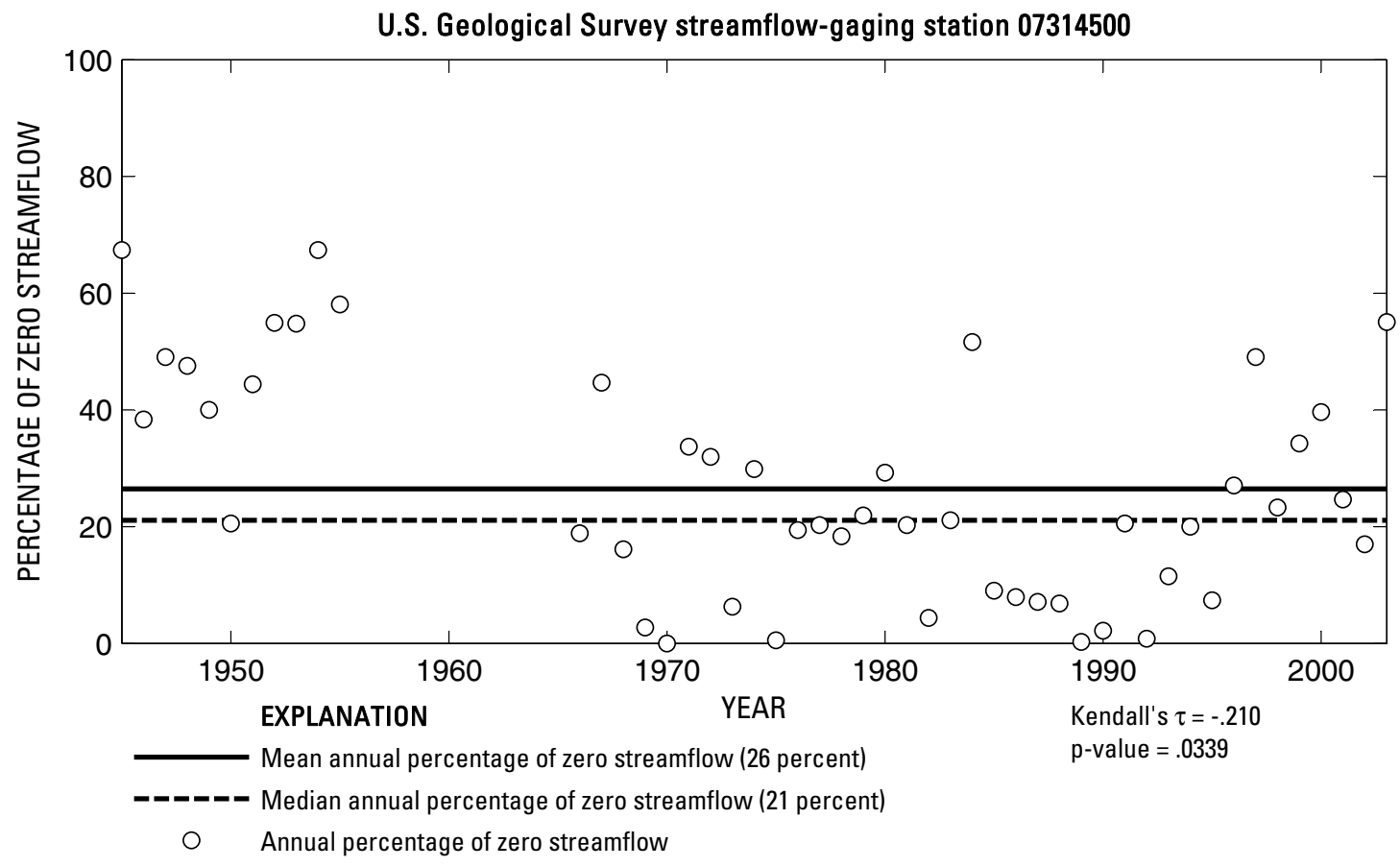

U.S. Geological Survey streamflow-gaging station 07314500

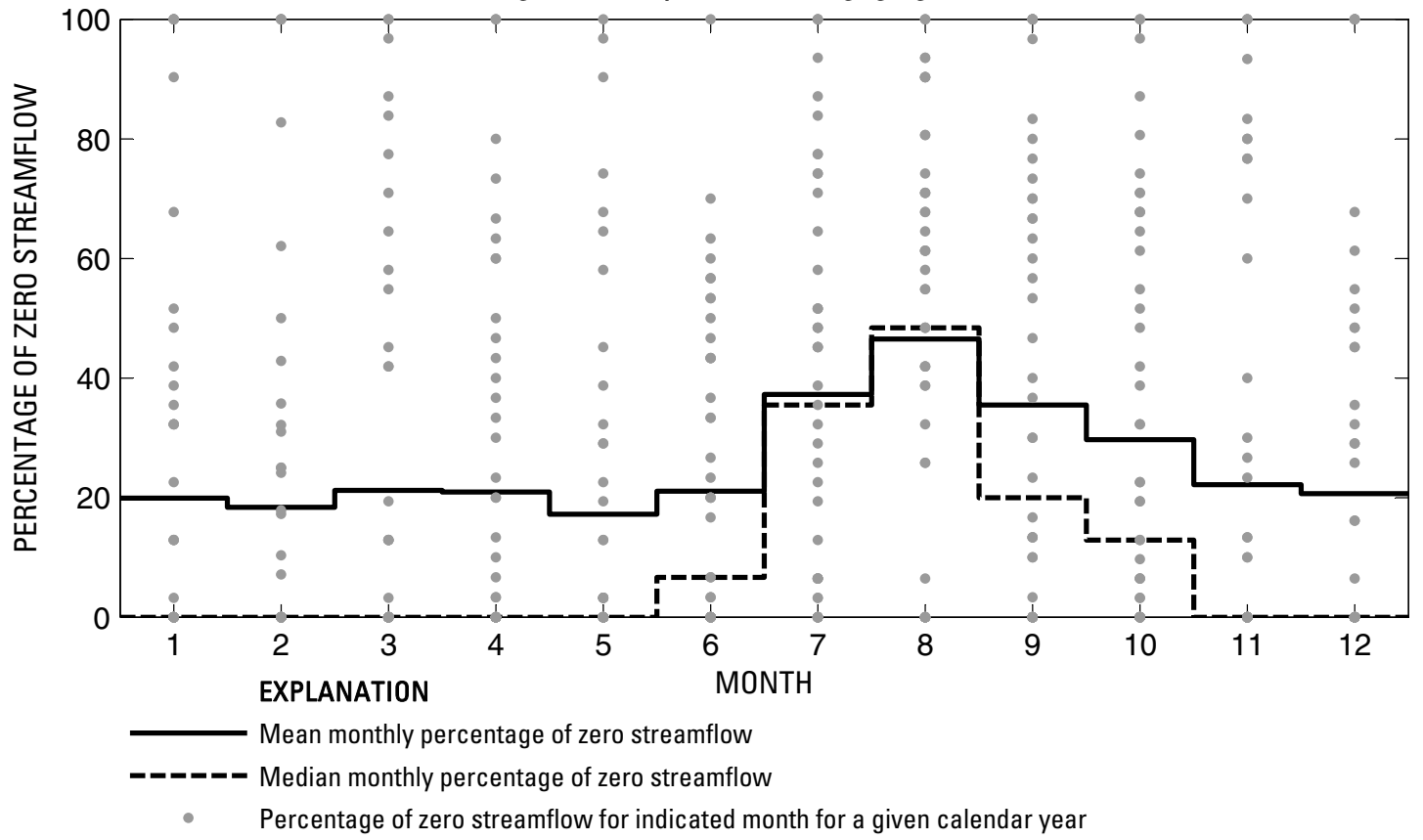

Figure 55. Analysis of percentage of zero daily mean streamflow for U.S. Geological Survey streamflow-gaging station 07314500 Little Wichita River near Archer City, Texas. 
U.S. Geological Survey streamflow-gaging station 07314900

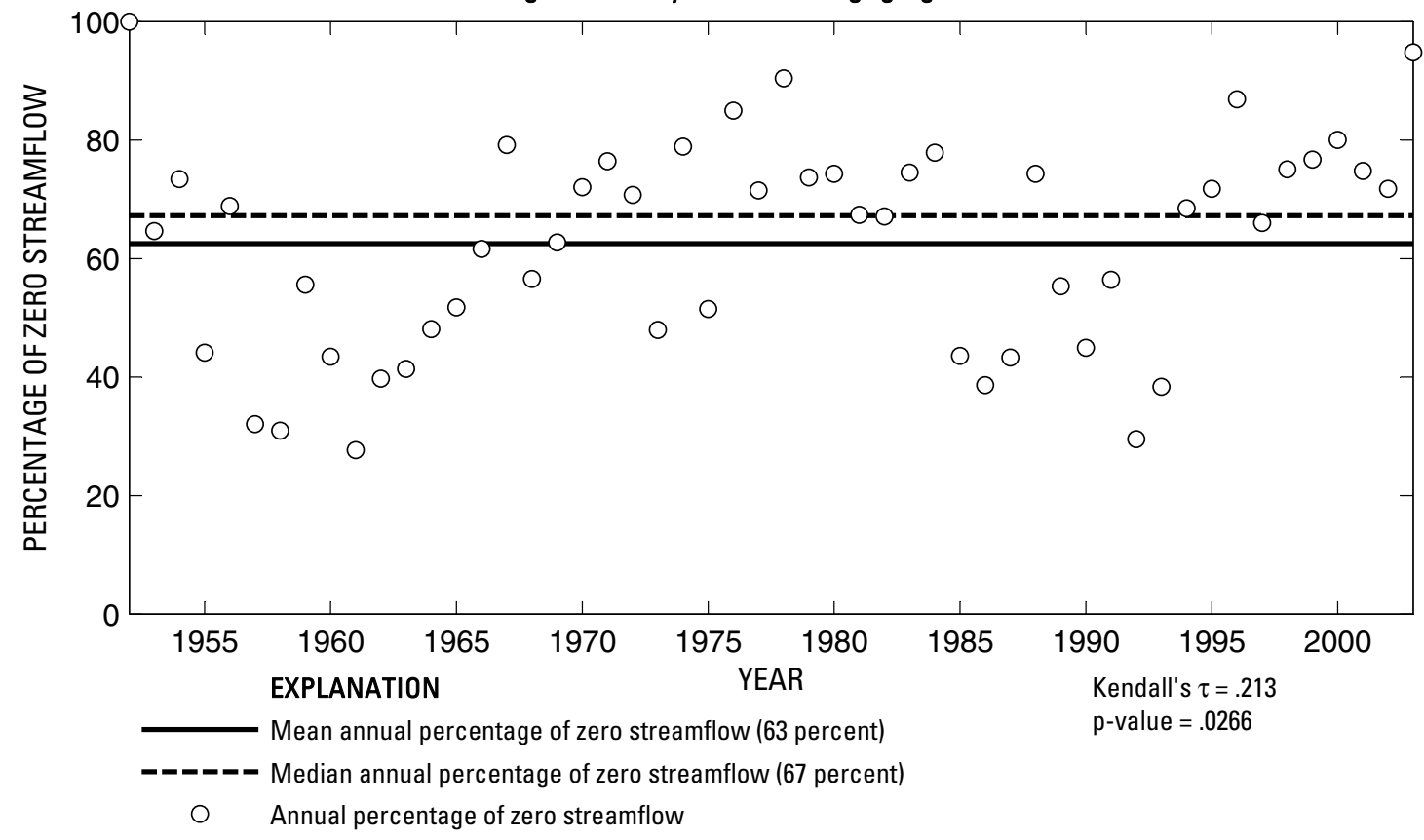

U.S. Geological Survey streamflow-gaging station 07314900

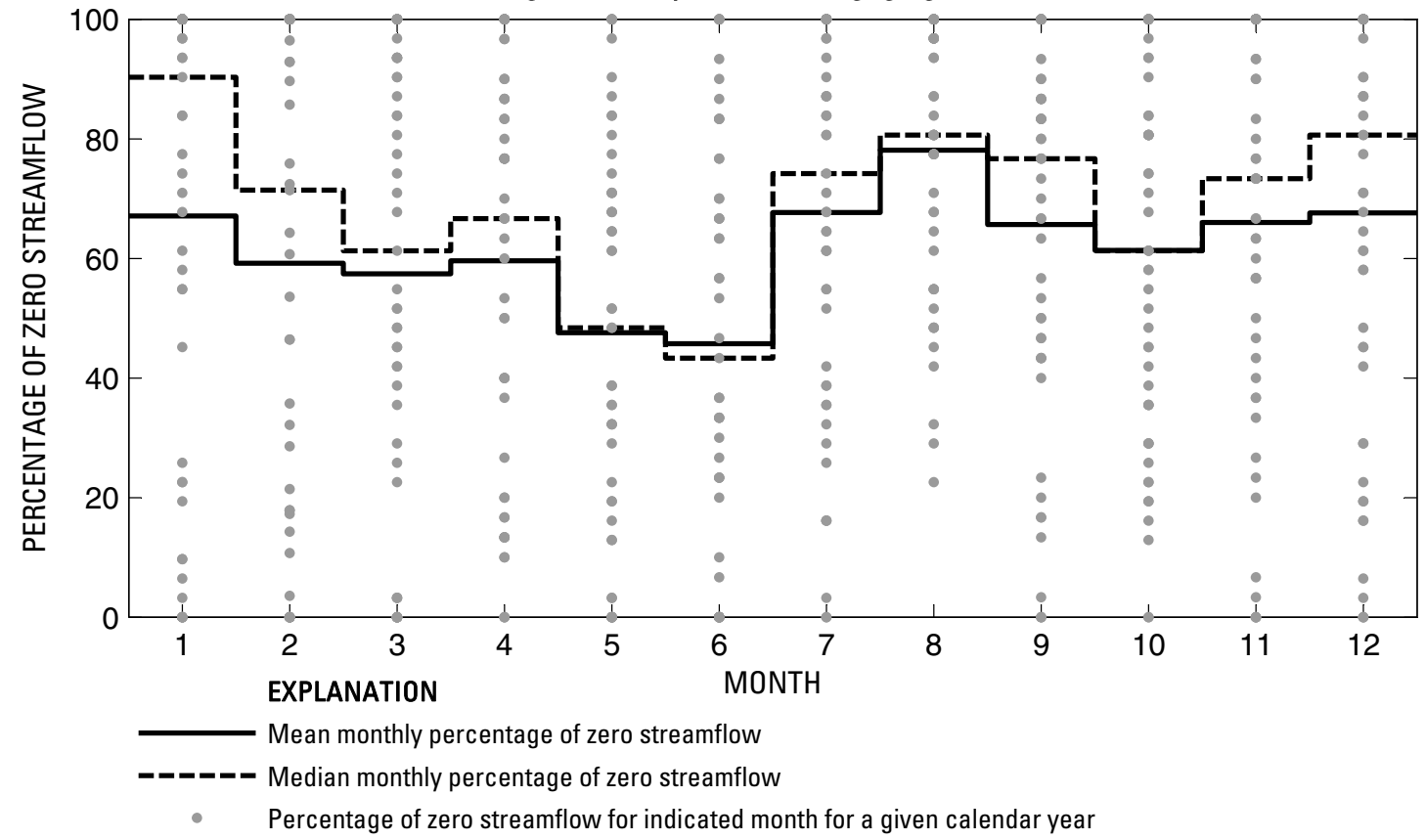

Figure 56. Analysis of percentage of zero daily mean streamflow for U.S. Geological Survey streamflow-gaging station 07314900 Little Wichita River above Henrietta, Texas.

Index of Station Numbers 719 
U.S. Geological Survey streamflow-gaging station 07315200

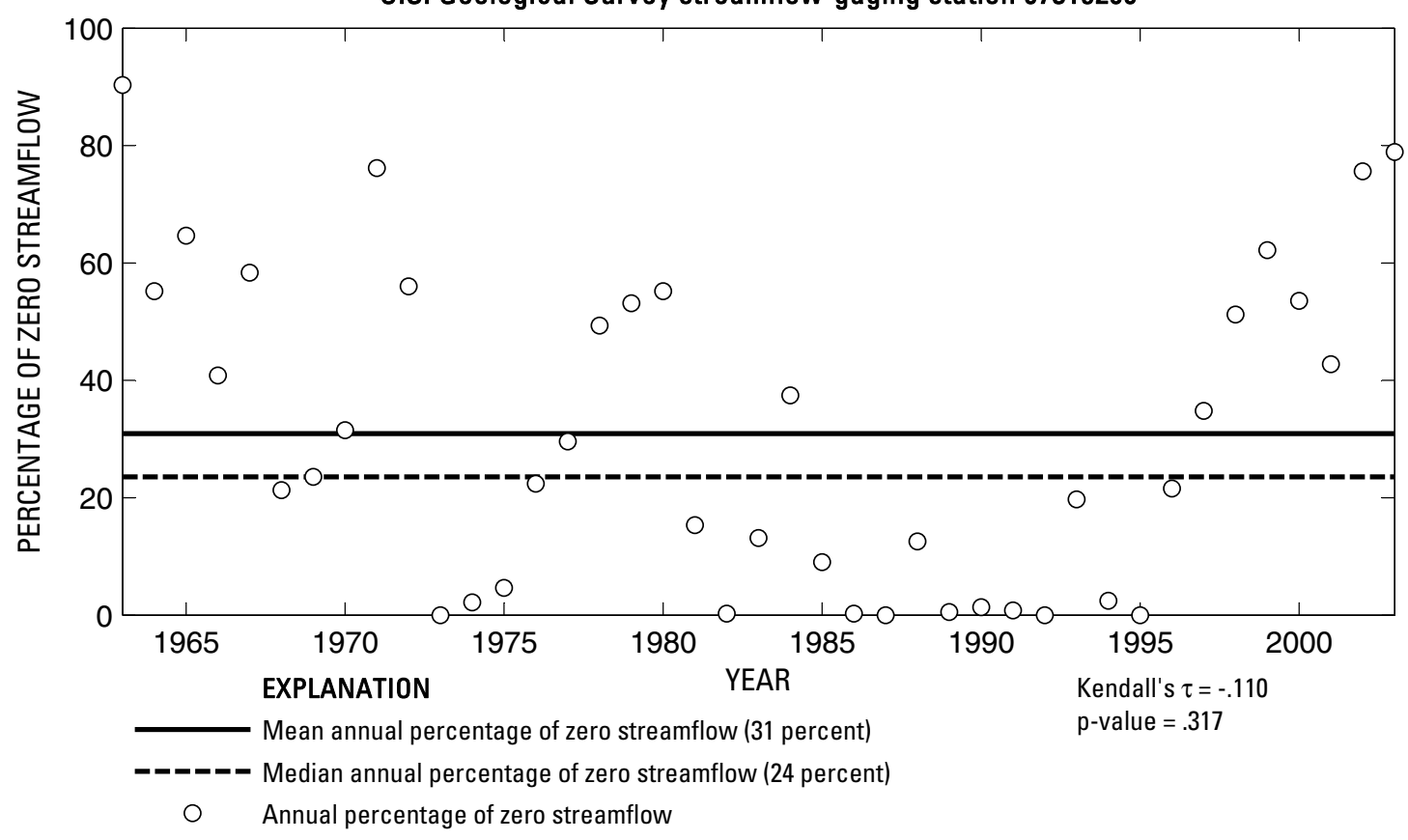

U.S. Geological Survey streamflow-gaging station 07315200

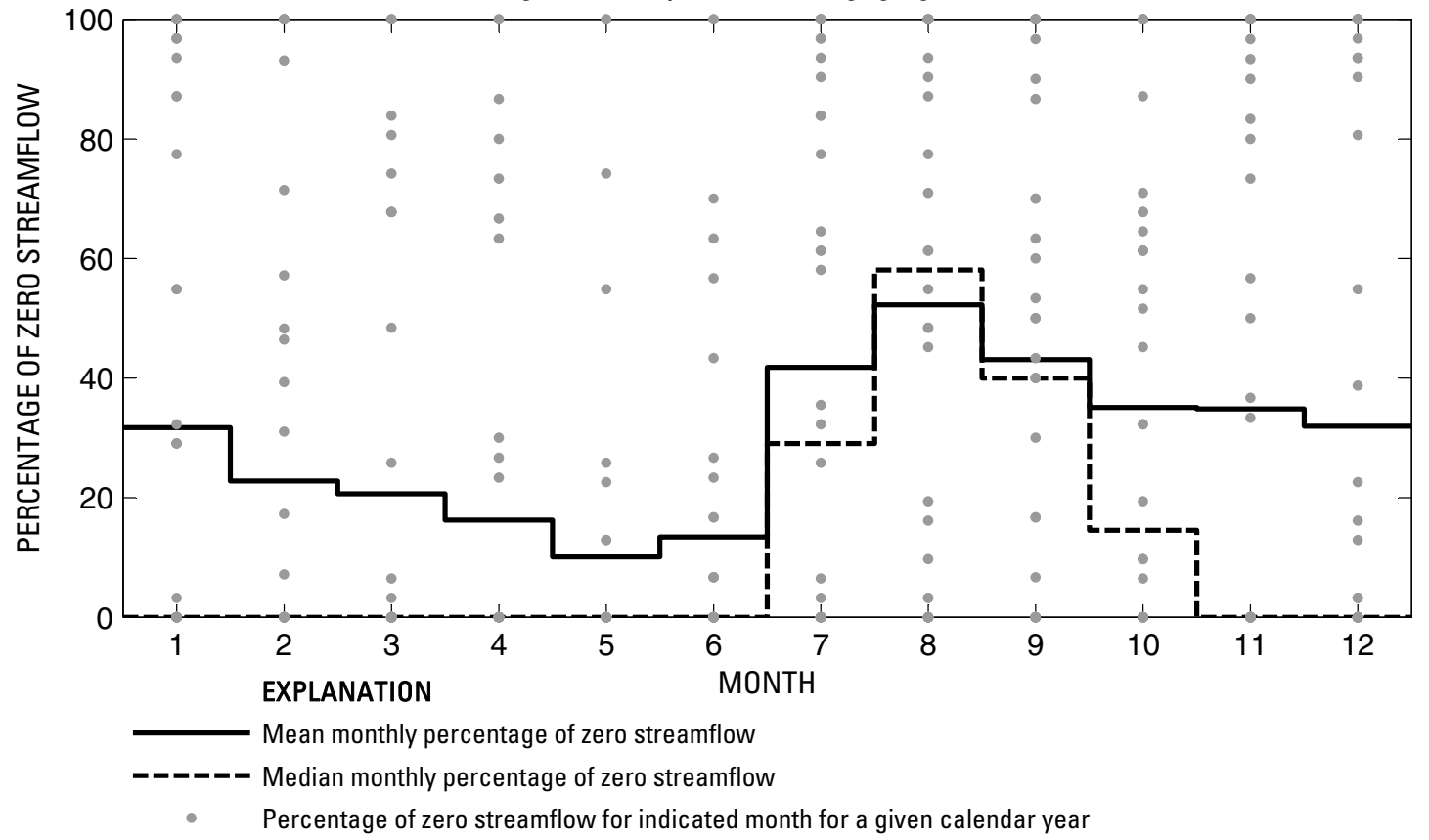

Figure 57. Analysis of percentage of zero daily mean streamflow for U.S. Geological Survey streamflow-gaging station 07315200 East Fork Little Wichita River near Henrietta, Texas. 
U.S. Geological Survey streamflow-gaging station 07315400

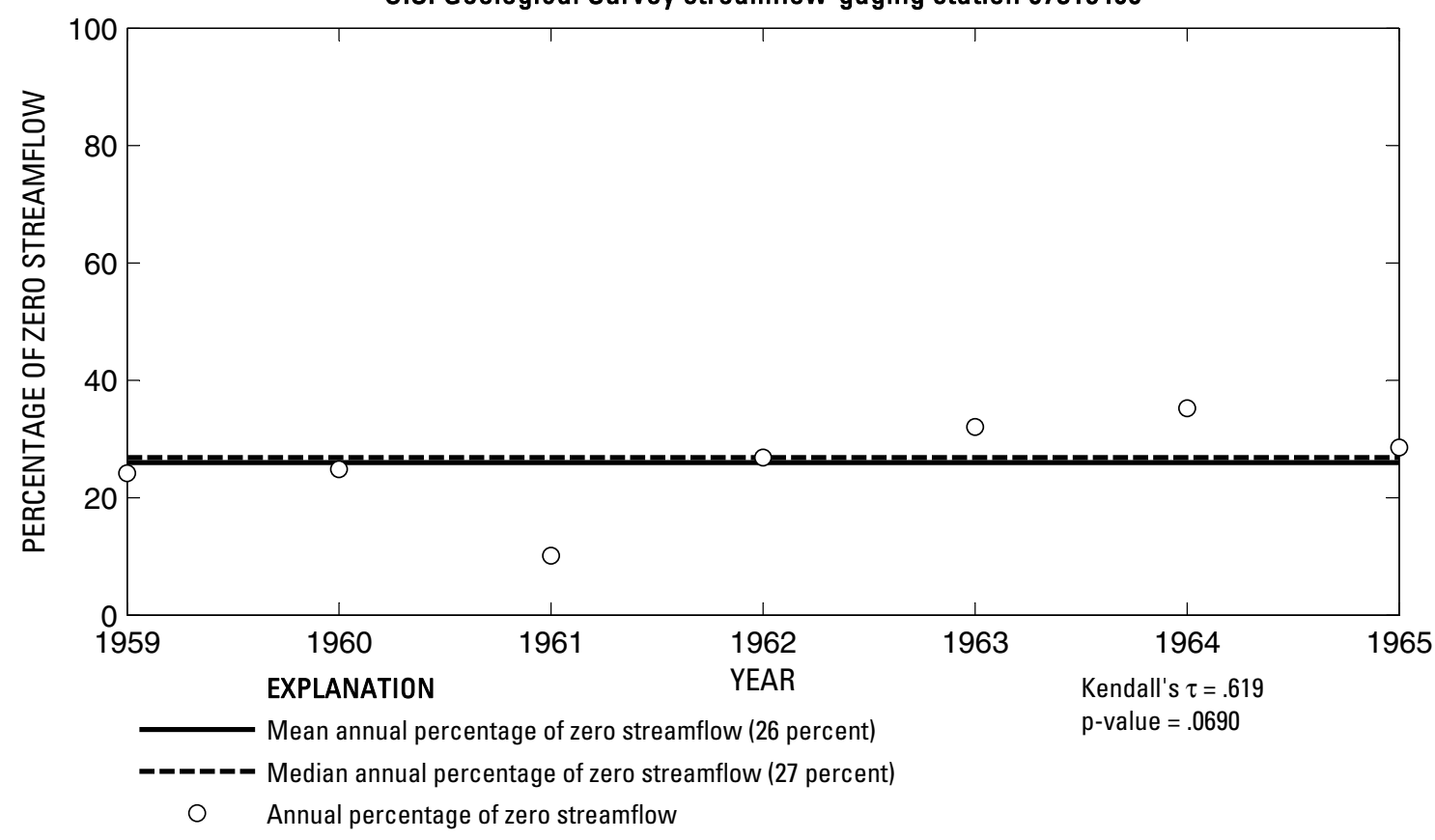

U.S. Geological Survey streamflow-gaging station 07315400

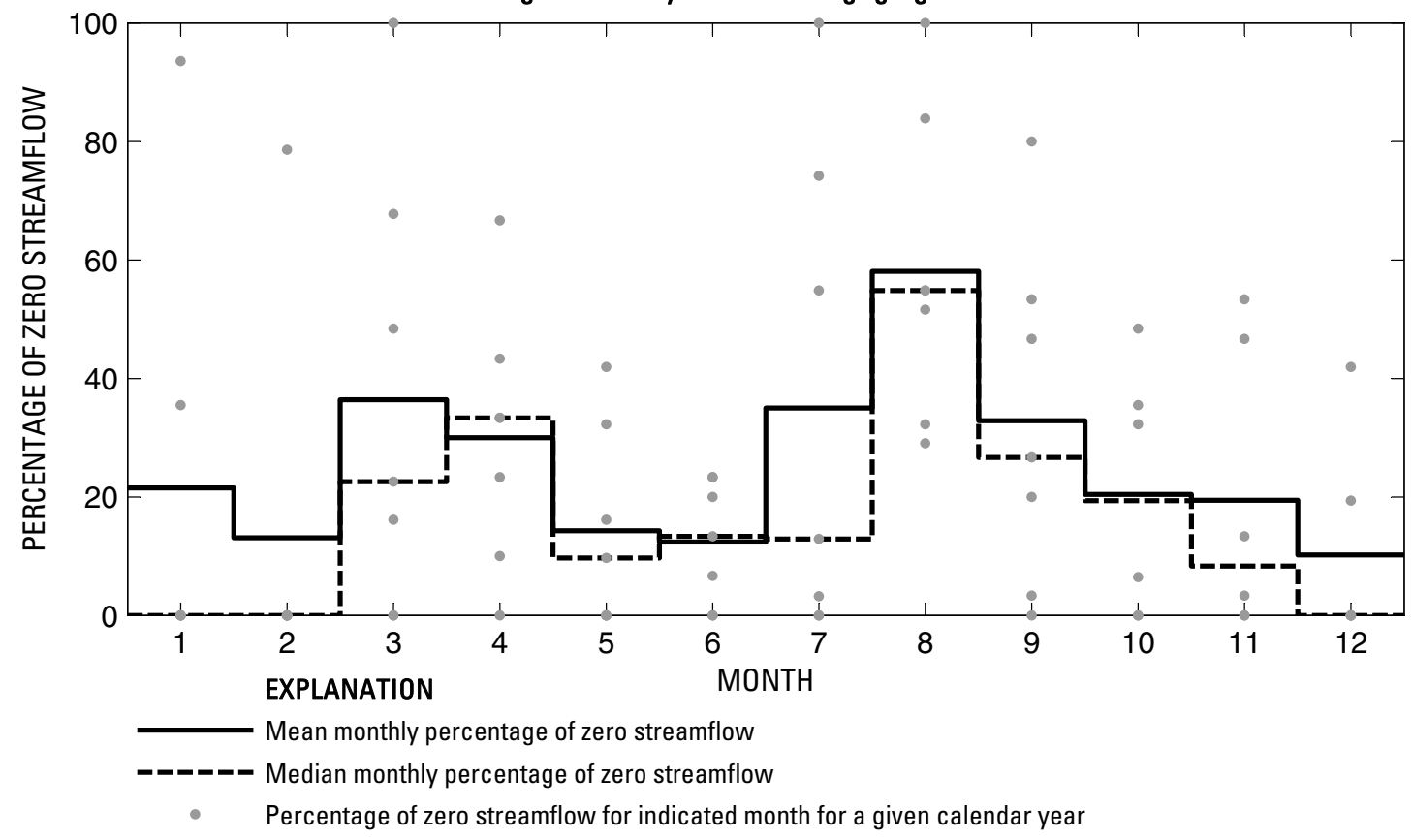

Figure 58. Analysis of percentage of zero daily mean streamflow for U.S. Geological Survey streamflow-gaging station 07315400 Little Wichita River near Ringgold, Texas. 
U.S. Geological Survey streamflow-gaging station 07316200

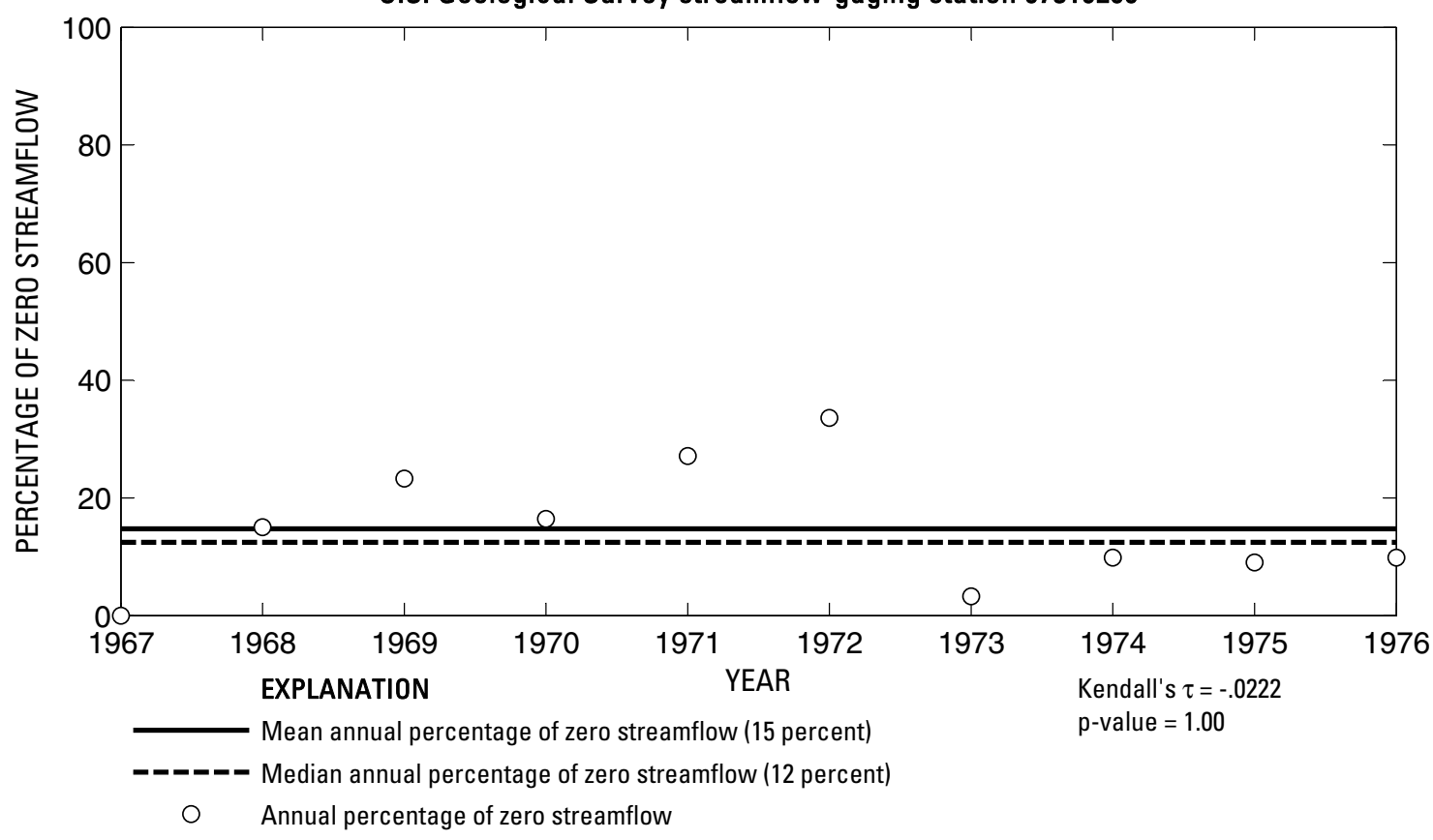

U.S. Geological Survey streamflow-gaging station 07316200

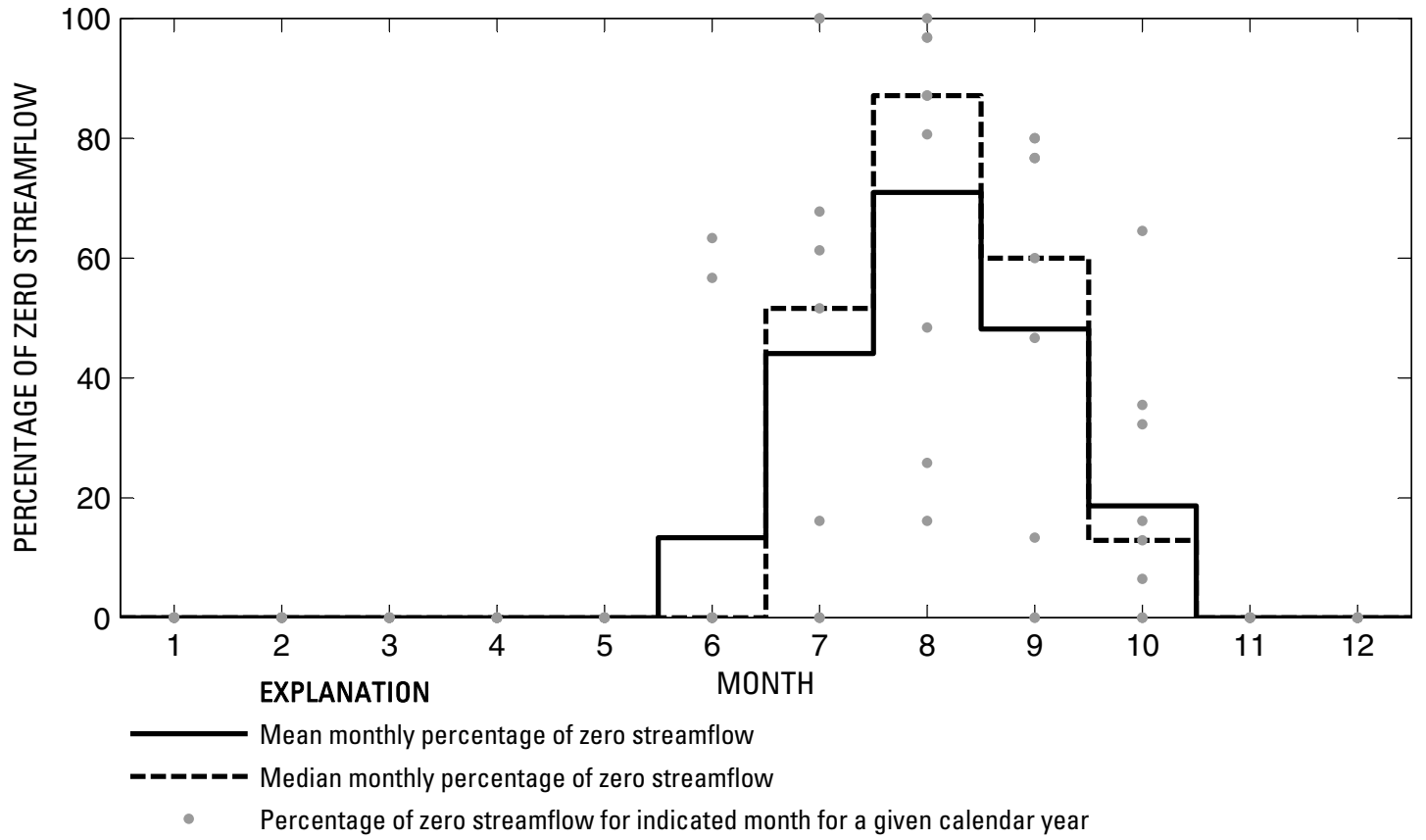

Figure 59. Analysis of percentage of zero daily mean streamflow for U.S. Geological Survey streamflow-gaging station 07316200 Mineral Creek near Sadler, Texas. 

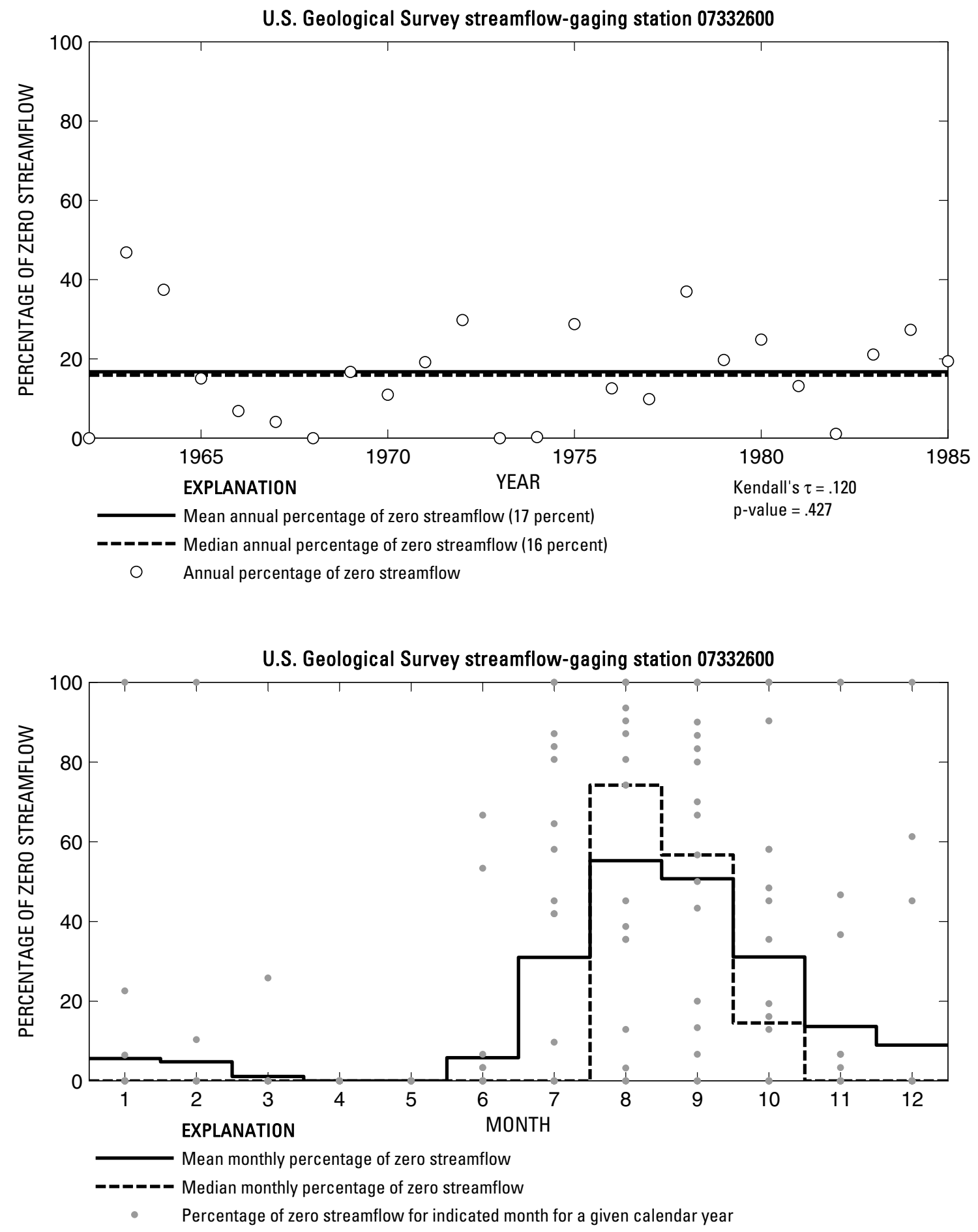

Figure 60. Analysis of percentage of zero daily mean streamflow for U.S. Geological Survey streamflow-gaging station 07332600 Bois d'Arc Creek near Randolph, Texas. 

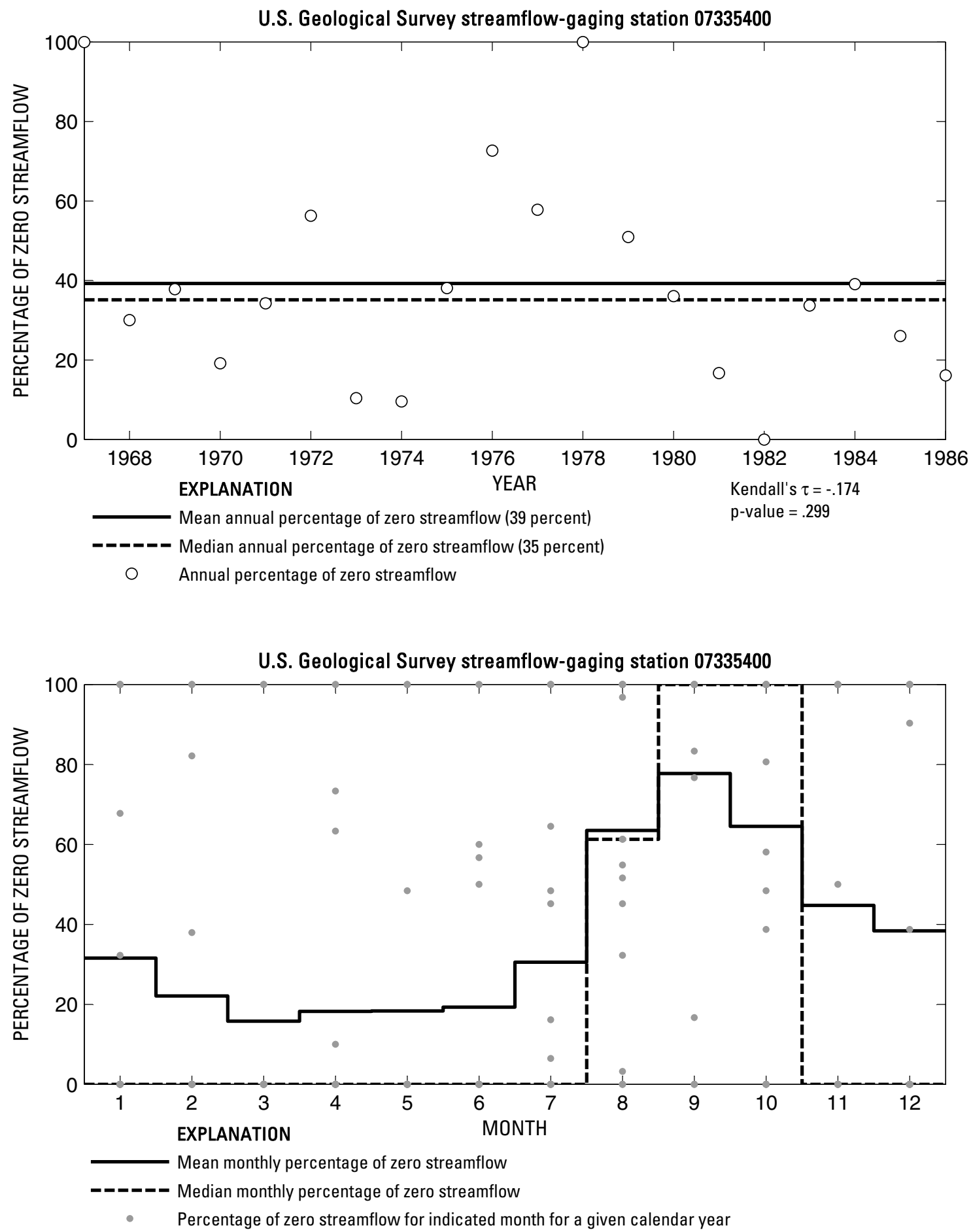

Figure 61. Analysis of percentage of zero daily mean streamflow for U.S. Geological Survey streamflow-gaging station 07335400 Sanders Creek near Chicota, Texas. 
U.S. Geological Survey streamflow-gaging station 07336750

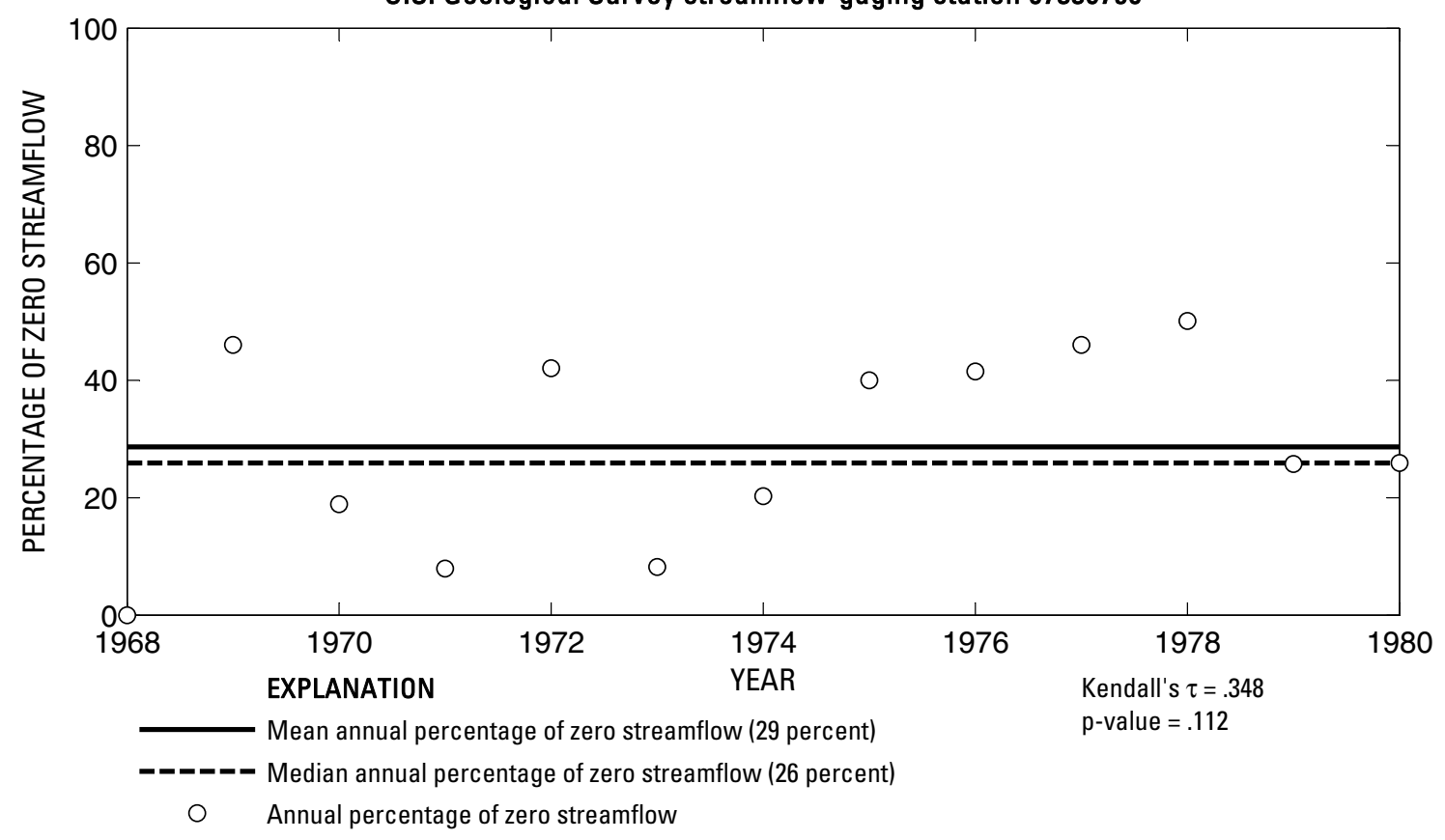

U.S. Geological Survey streamflow-gaging station 07336750

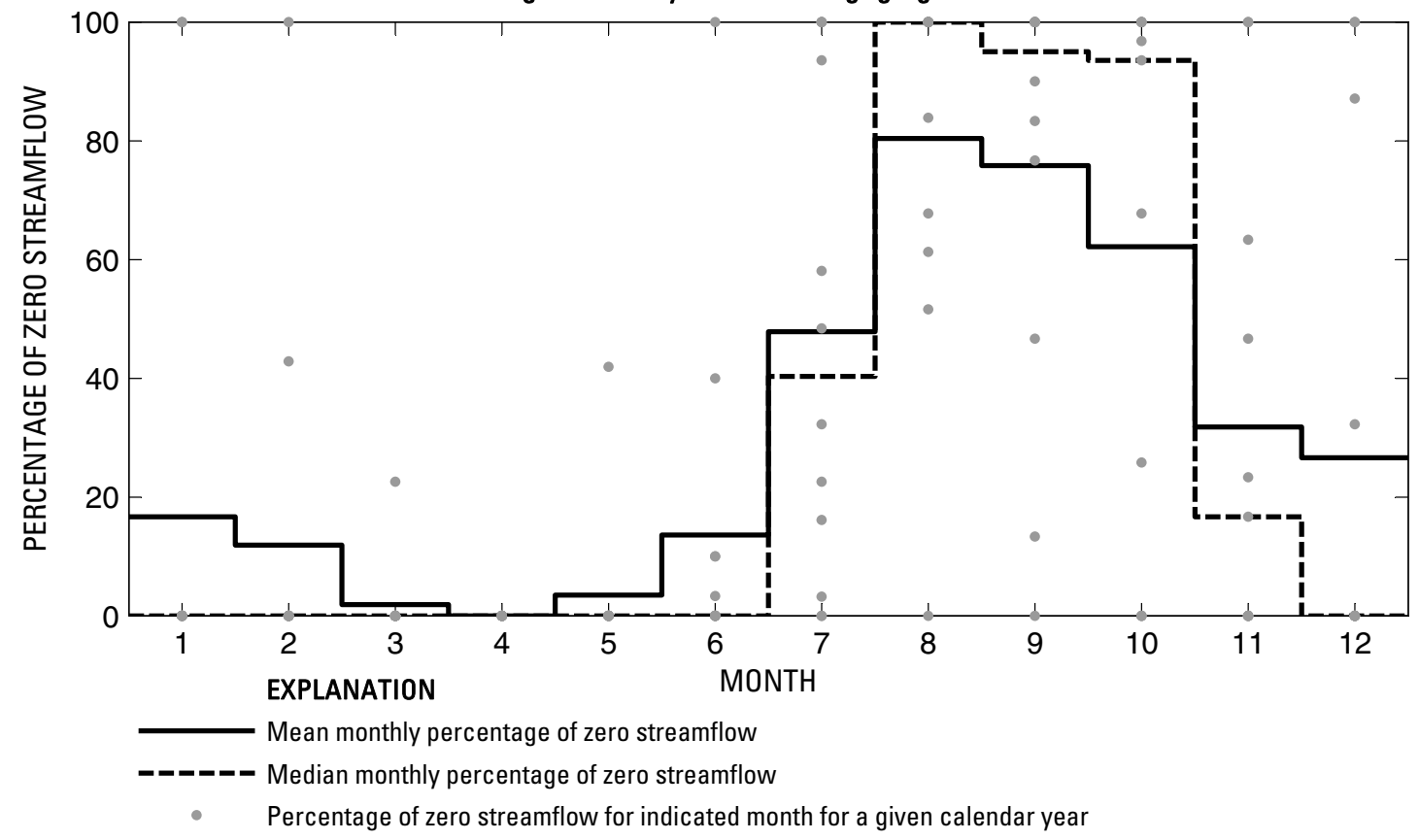

Figure 62. Analysis of percentage of zero daily mean streamflow for U.S. Geological Survey streamflow-gaging station 07336750 Little Pine Creek near Kanawha, Texas. 


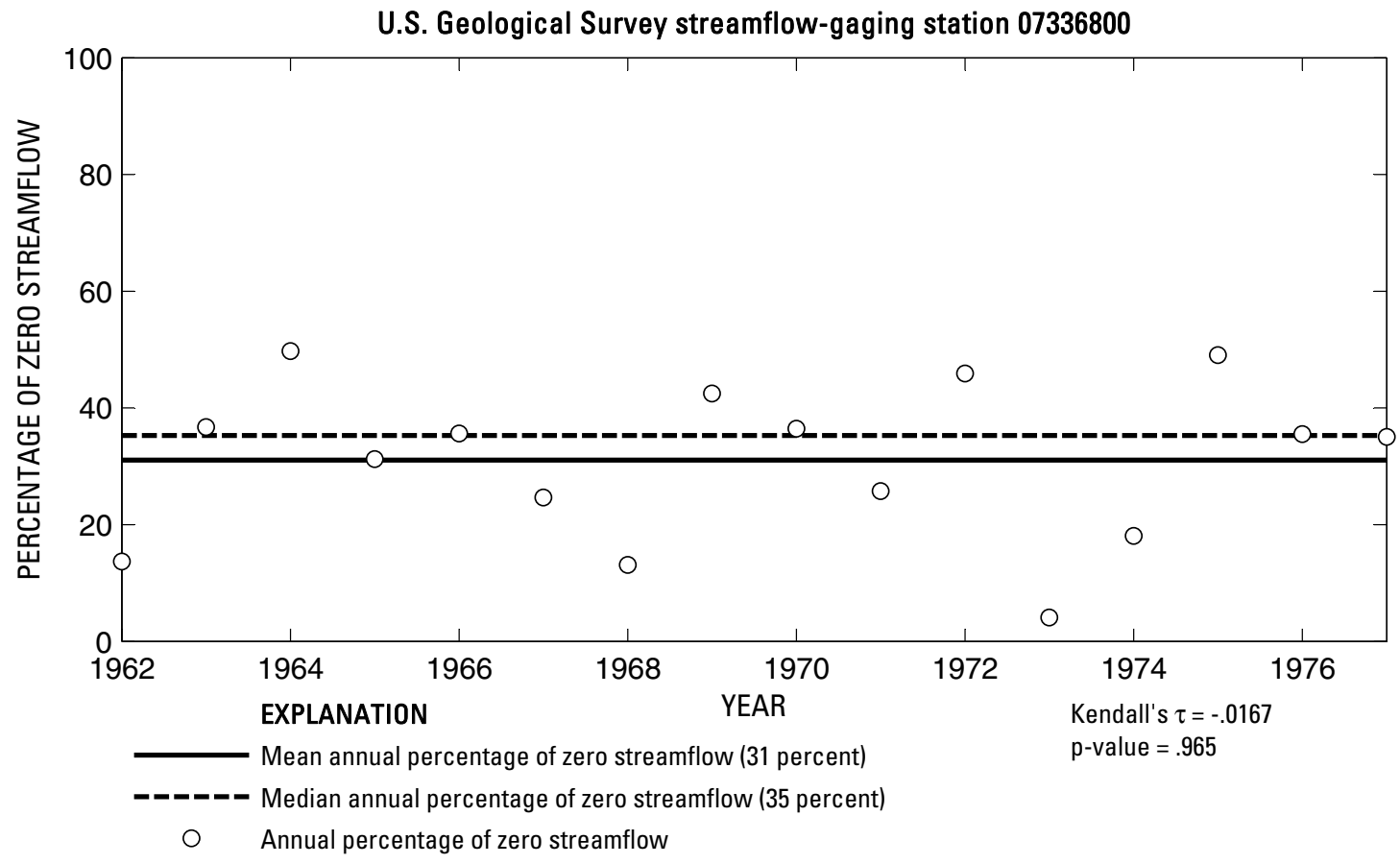

U.S. Geological Survey streamflow-gaging station 07336800

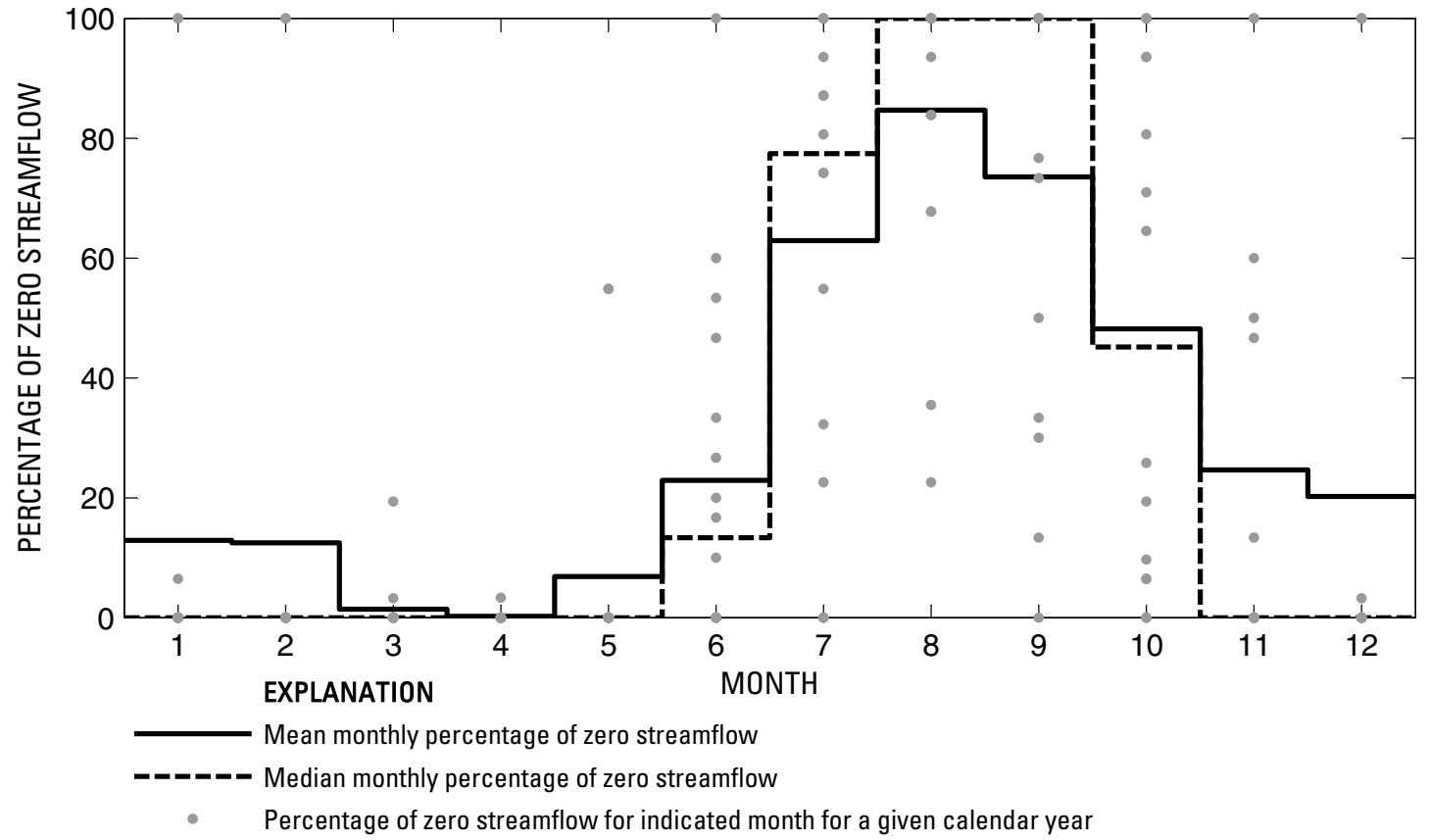

Figure 63. Analysis of percentage of zero daily mean streamflow for U.S. Geological Survey streamflow-gaging station 07336800 Pecan Bayou near Clarksville, Texas. 

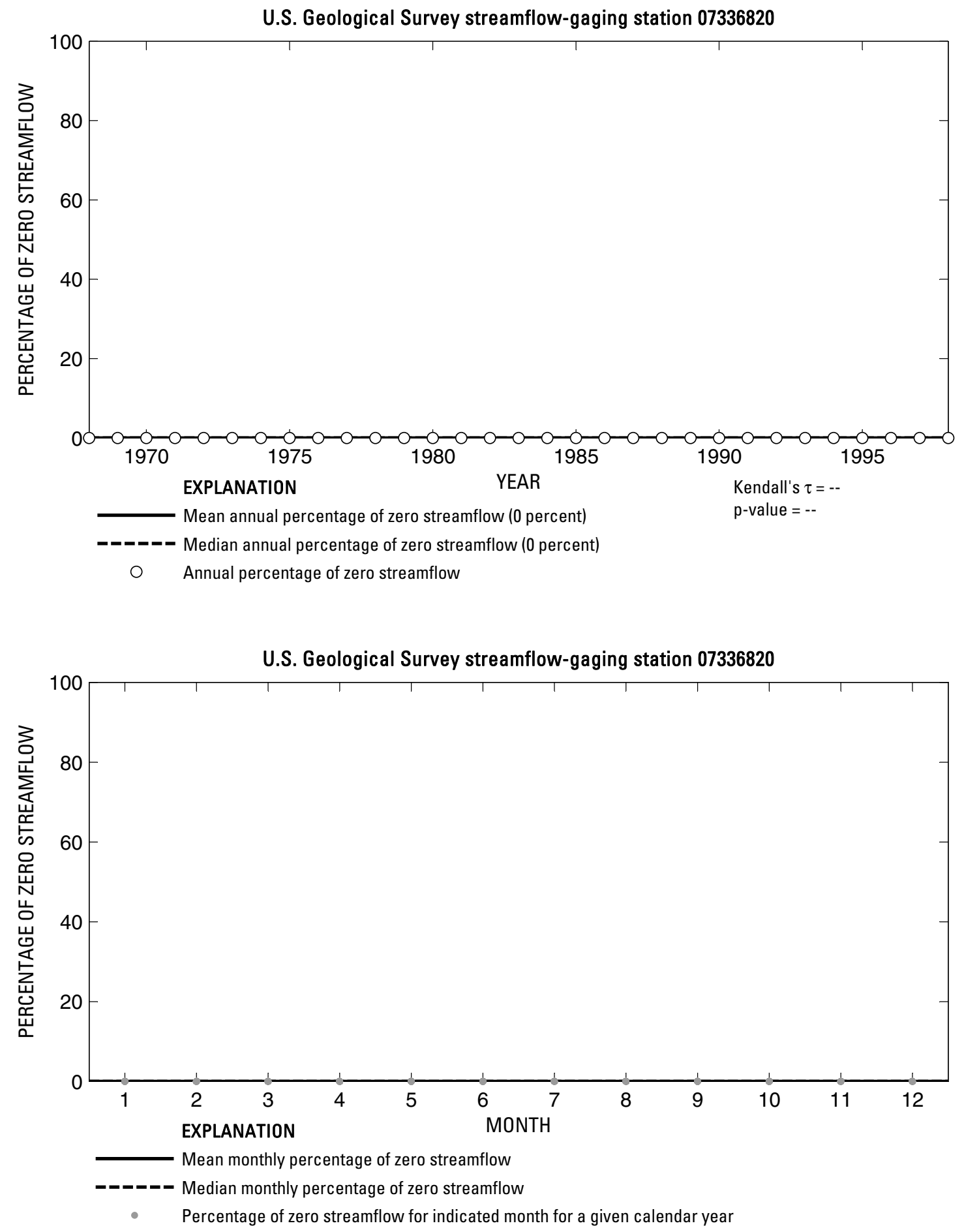

Figure 64. Analysis of percentage of zero daily mean streamflow for U.S. Geological Survey streamflow-gaging station 07336820 Red River near De Kalb, Texas. 


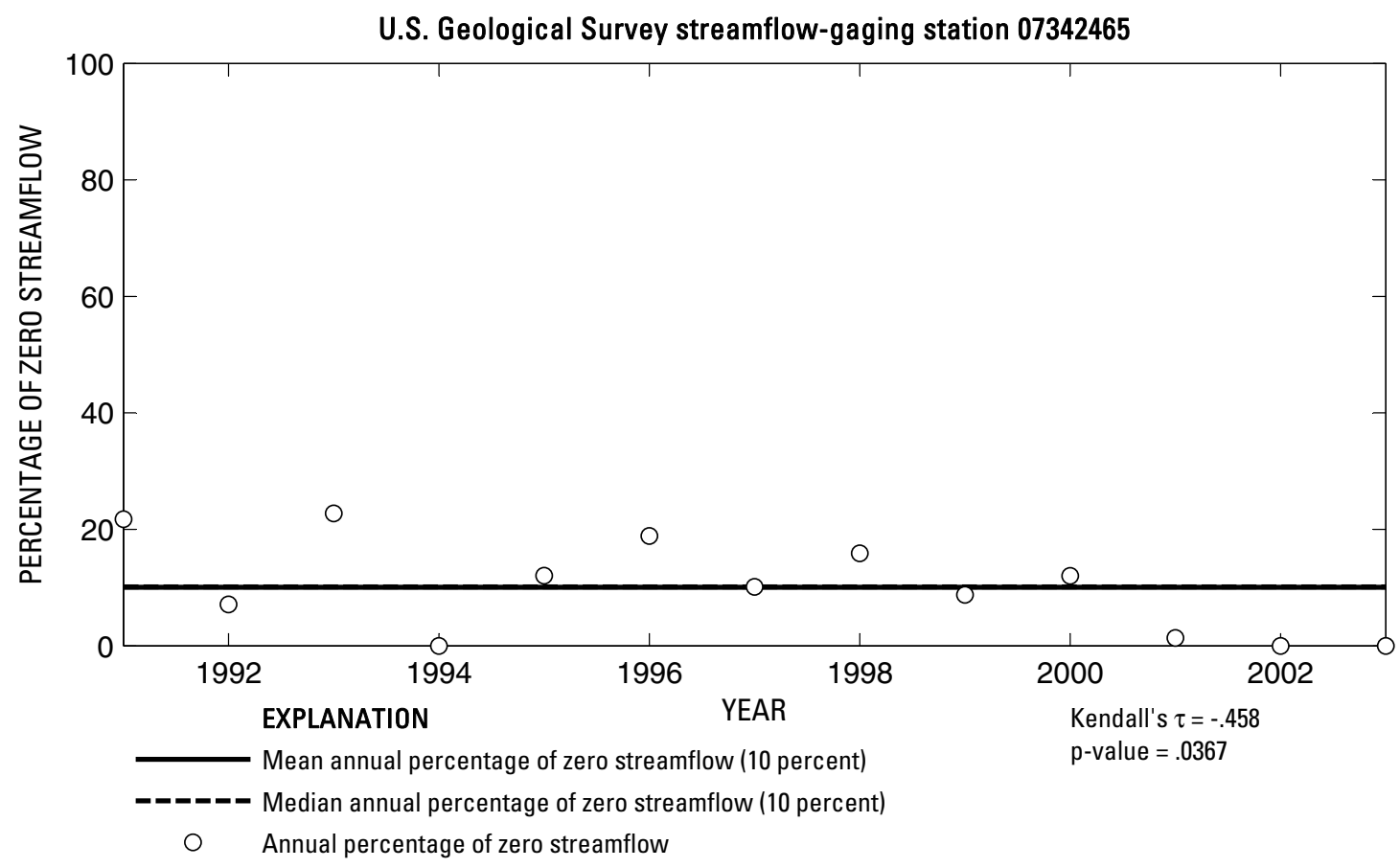

U.S. Geological Survey streamflow-gaging station 07342465

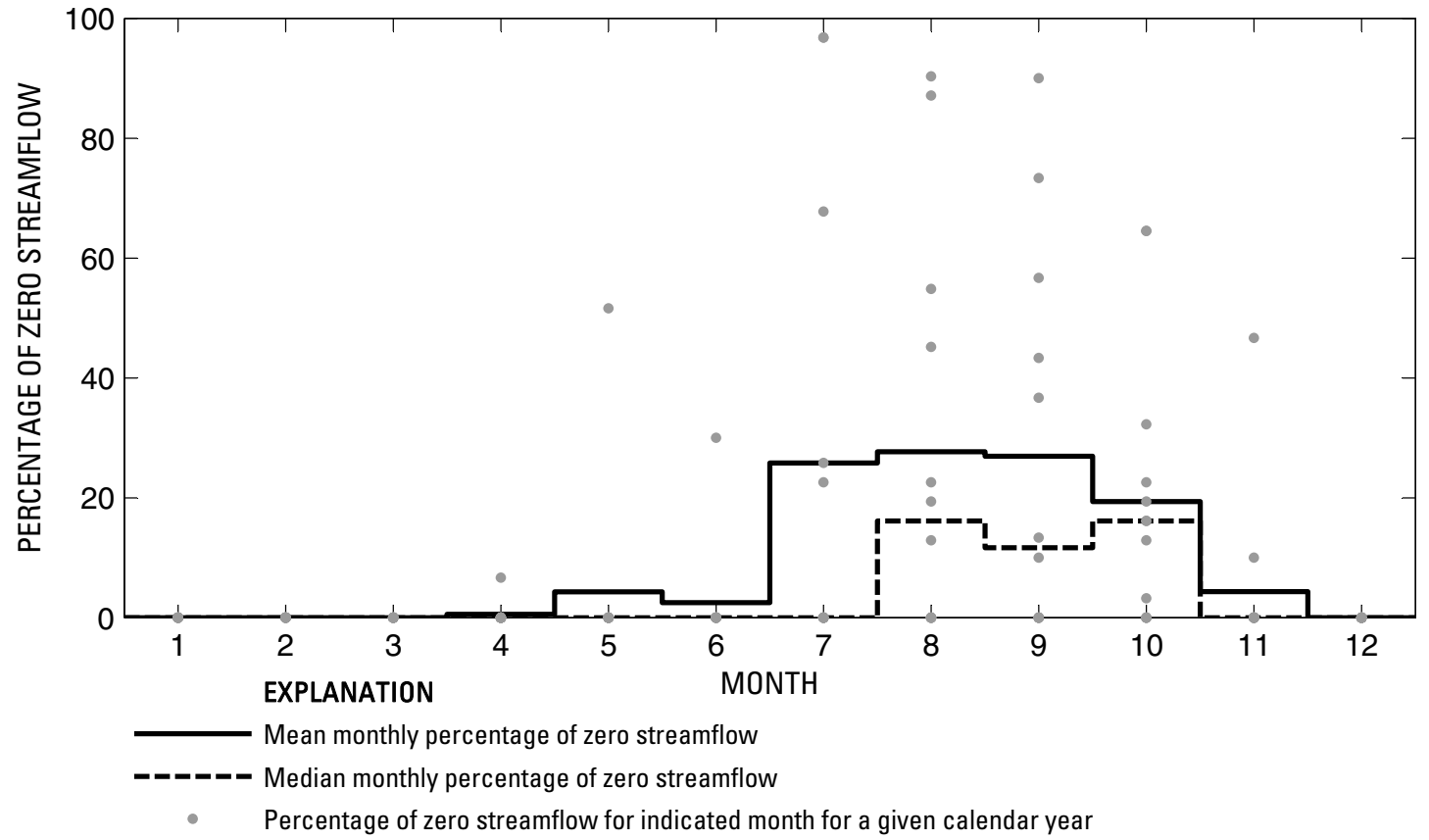

Figure 65. Analysis of percentage of zero daily mean streamflow for U.S. Geological Survey streamflow-gaging station 07342465 South Sulphur River at Commerce, Texas. 

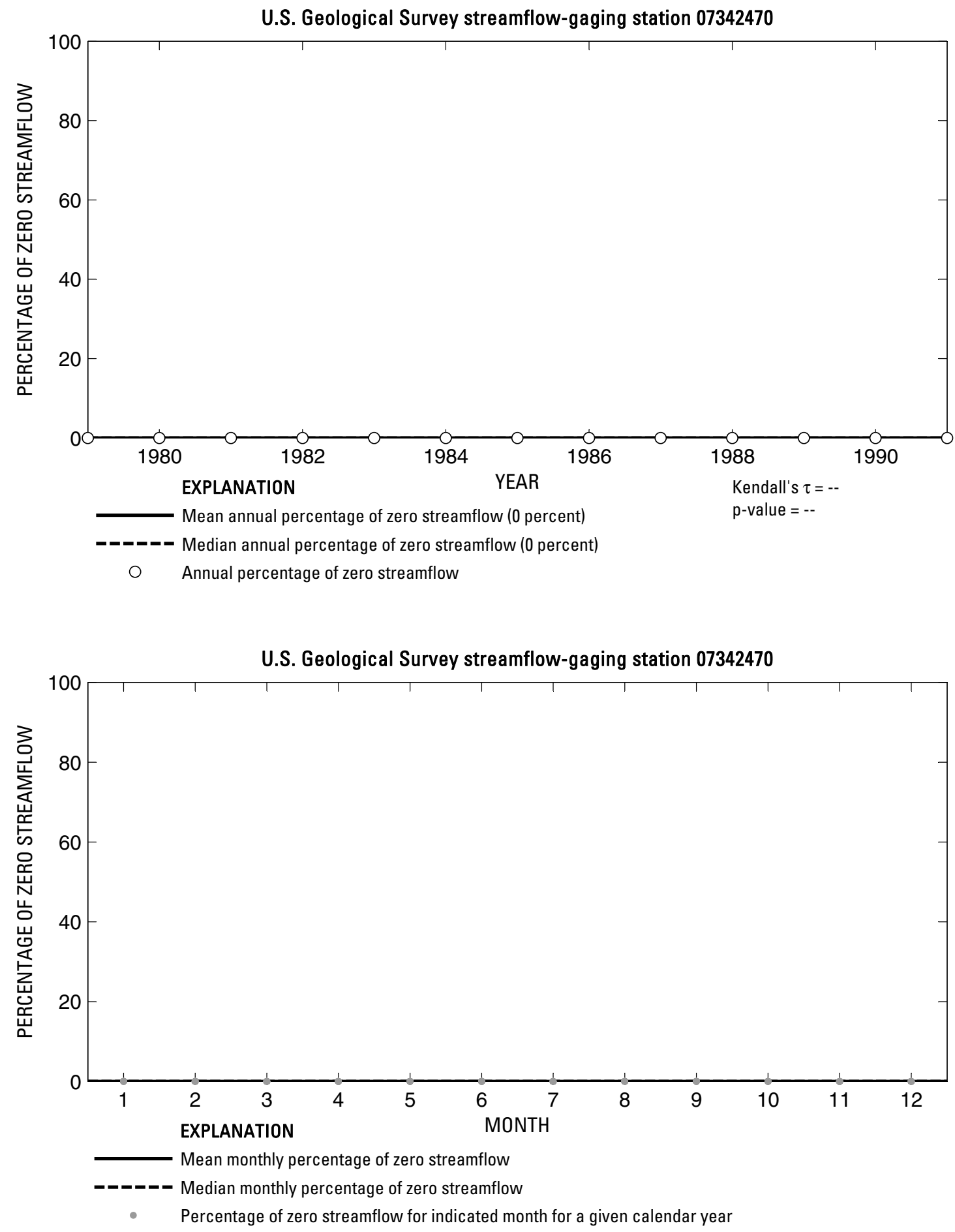

Figure 66. Analysis of percentage of zero daily mean streamflow for U.S. Geological Survey streamflow-gaging station 07342470 South Sulphur River near Commerce, Texas. 

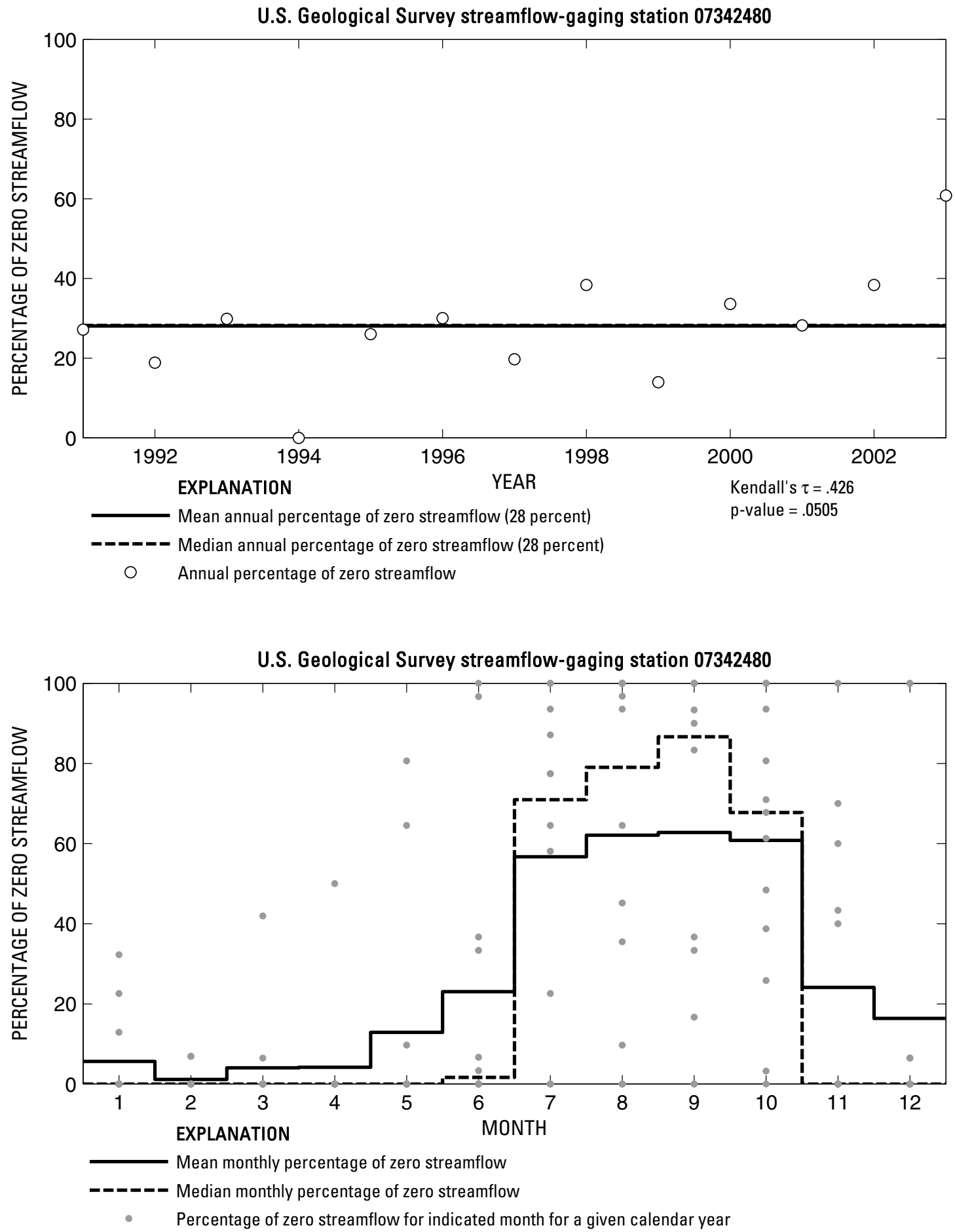

Figure 67. Analysis of percentage of zero daily mean streamflow for U.S. Geological Survey streamflow-gaging station 07342480 Middle Sulphur River at Commerce, Texas. 
U.S. Geological Survey streamflow-gaging station 07342500

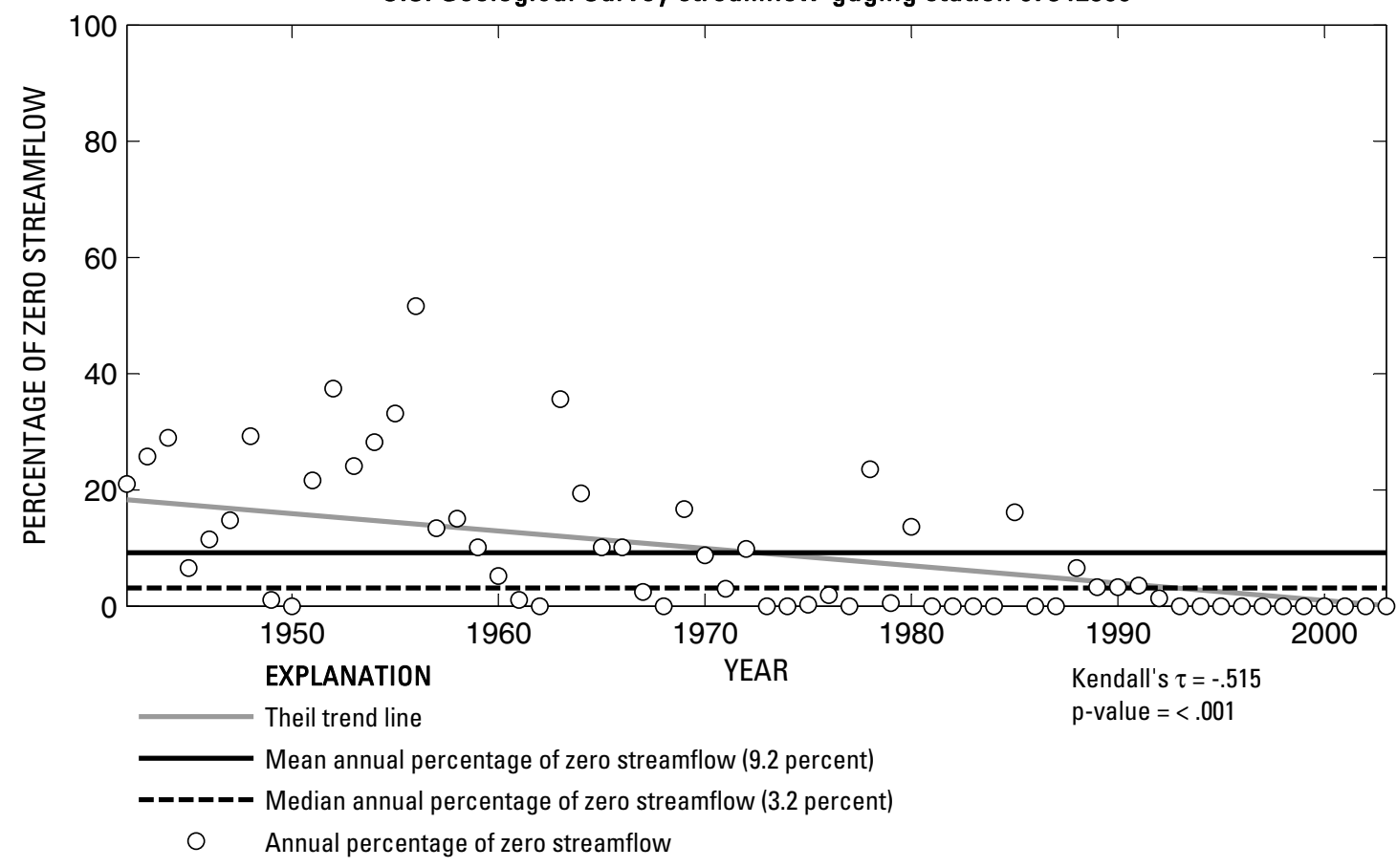

U.S. Geological Survey streamflow-gaging station 07342500

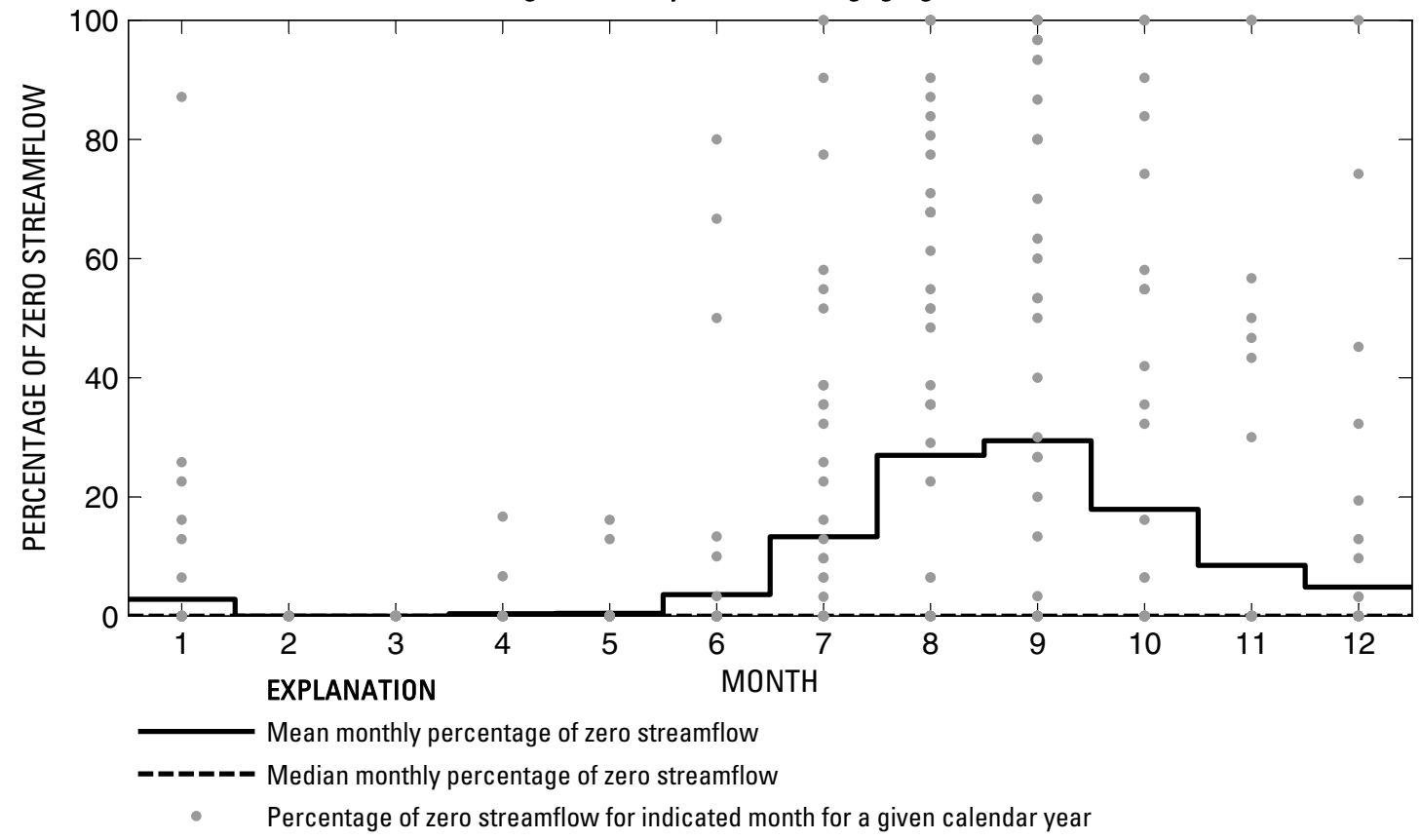

Figure 68. Analysis of percentage of zero daily mean streamflow for U.S. Geological Survey streamflow-gaging station 07342500 South Sulphur River near Cooper, Texas. 


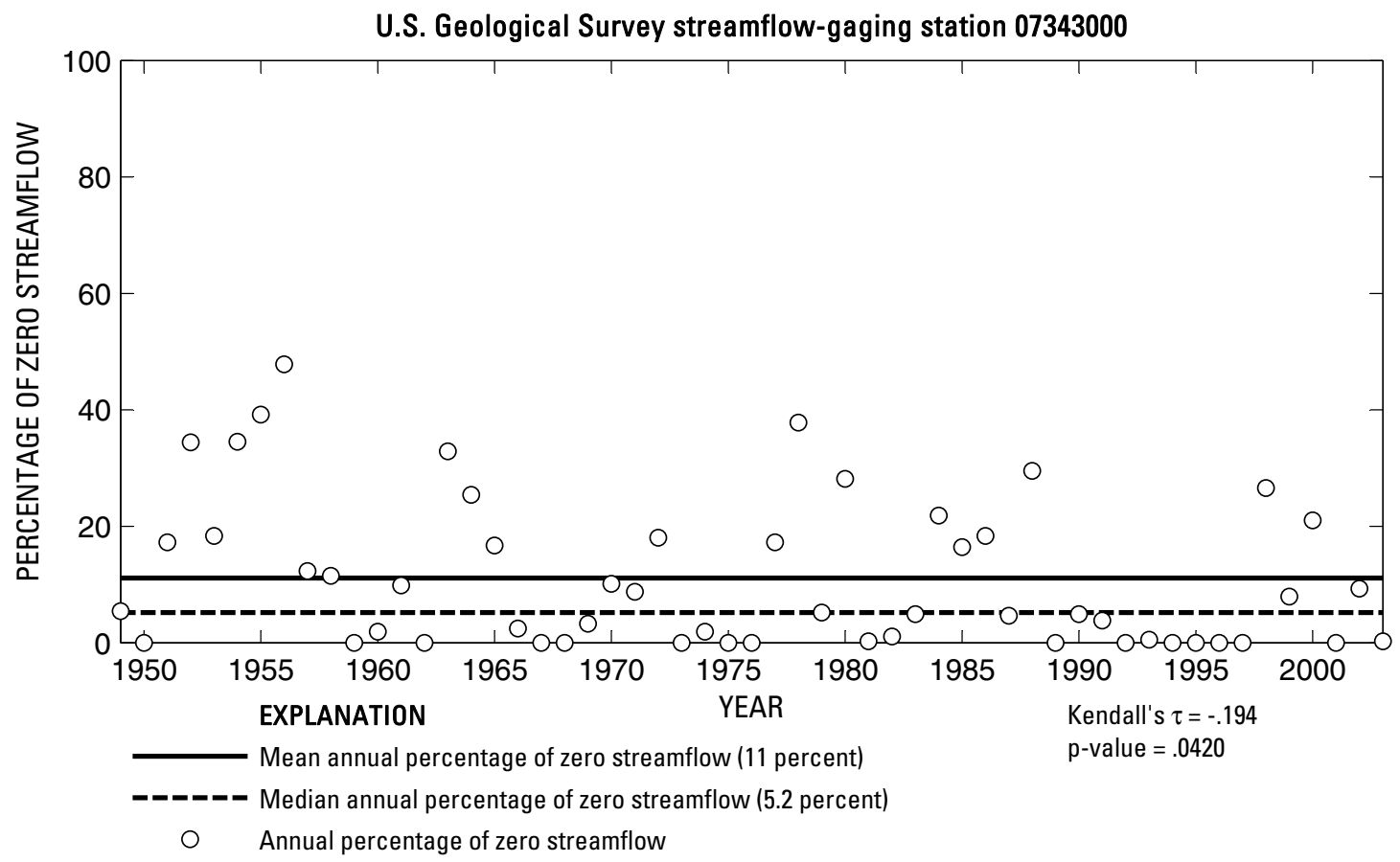

U.S. Geological Survey streamflow-gaging station 07343000

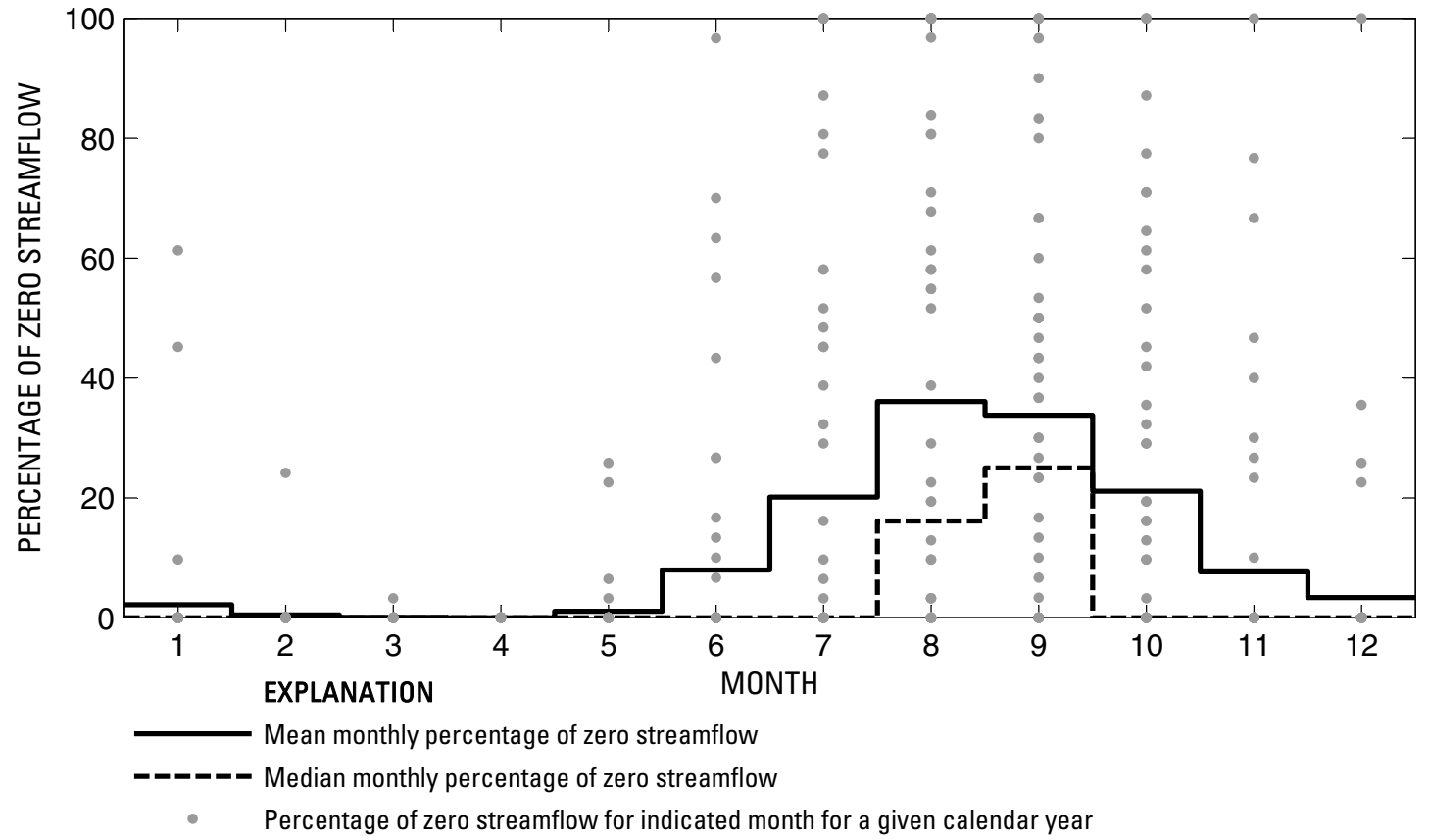

Figure 69. Analysis of percentage of zero daily mean streamflow for U.S. Geological Survey streamflow-gaging station 07343000 North Sulphur River near Cooper, Texas. 
U.S. Geological Survey streamflow-gaging station 07343200

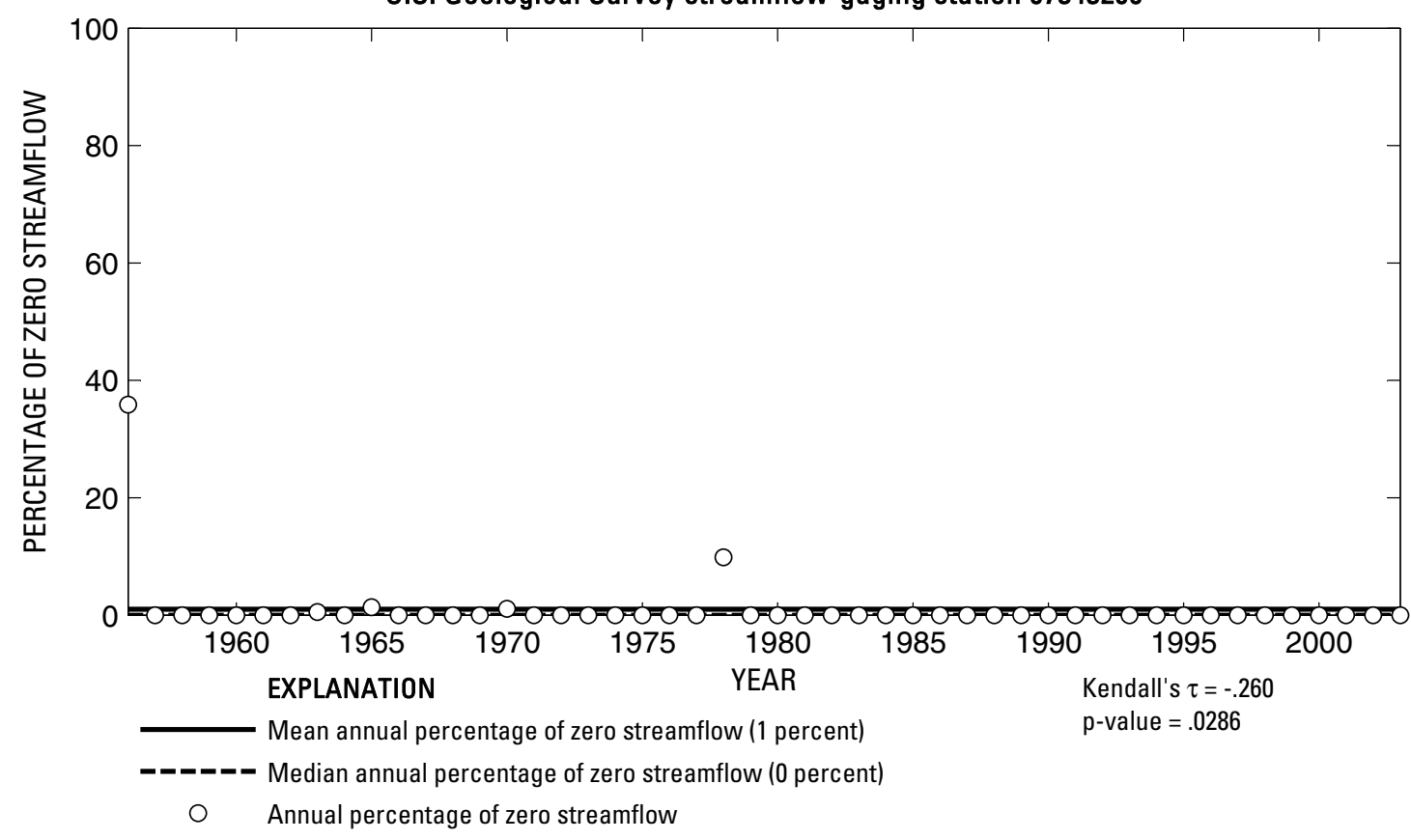

U.S. Geological Survey streamflow-gaging station 07343200

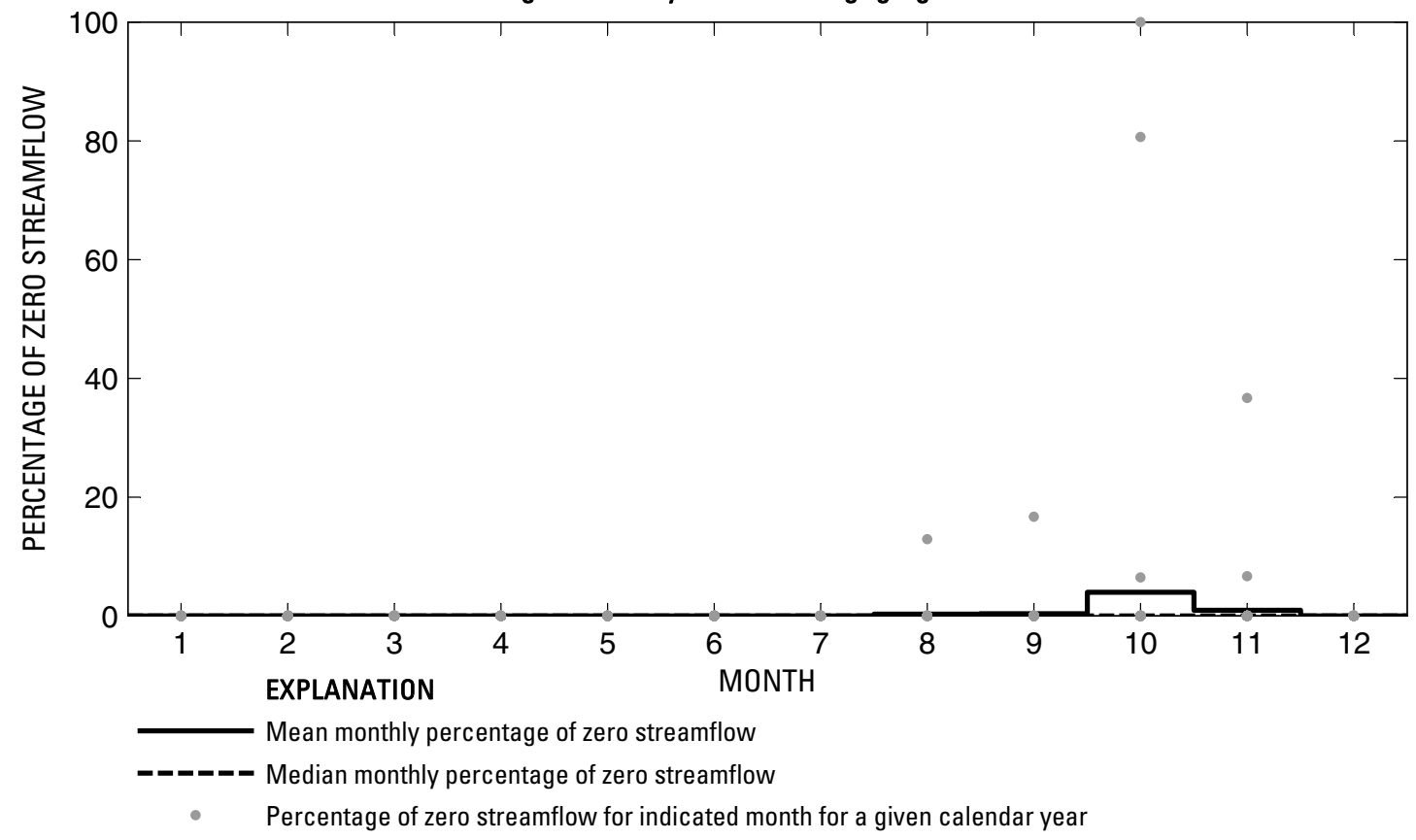

Figure 70. Analysis of percentage of zero daily mean streamflow for U.S. Geological Survey streamflow-gaging station 07343200 Sulphur River near Talco, Texas. 


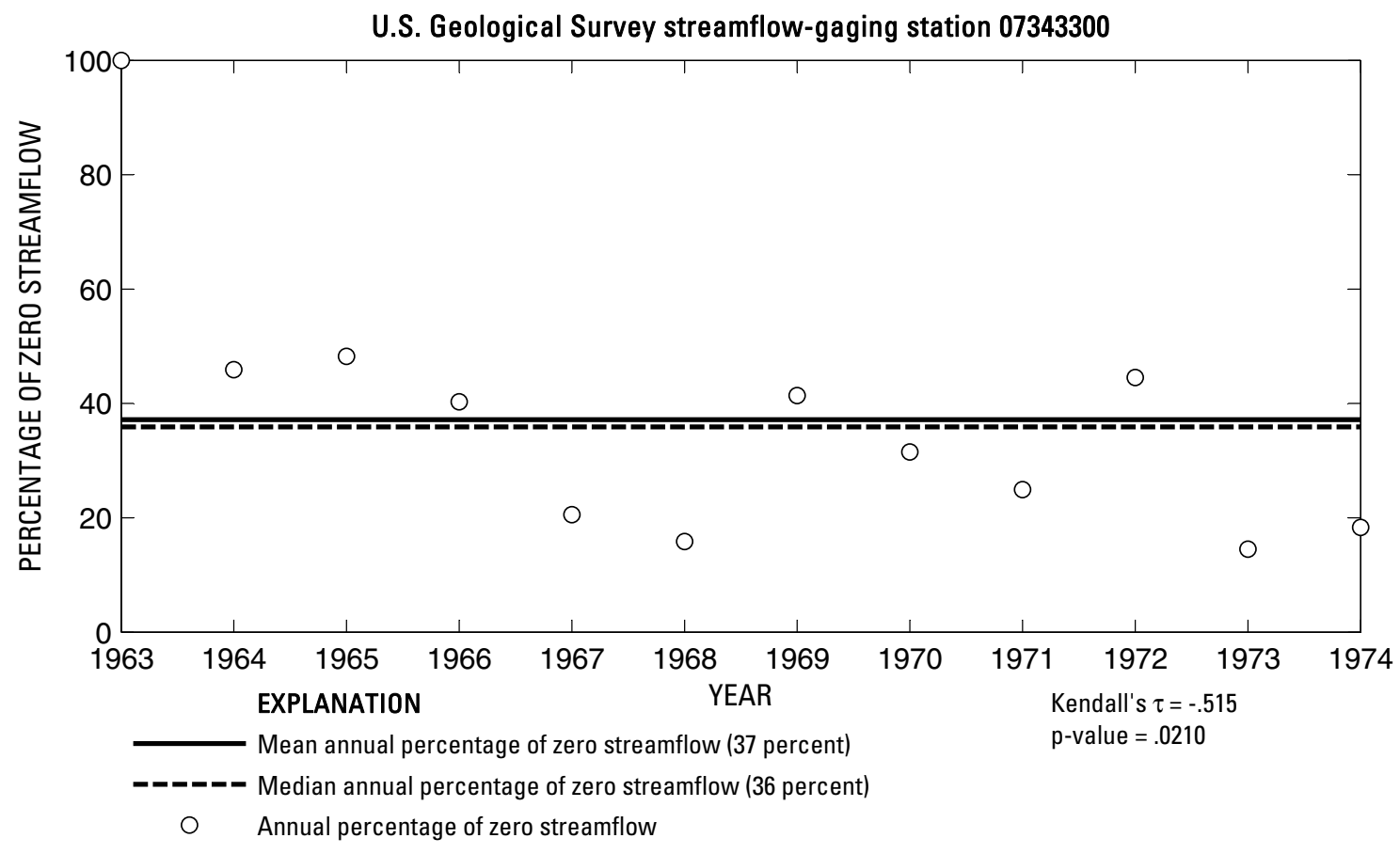

U.S. Geological Survey streamflow-gaging station 07343300

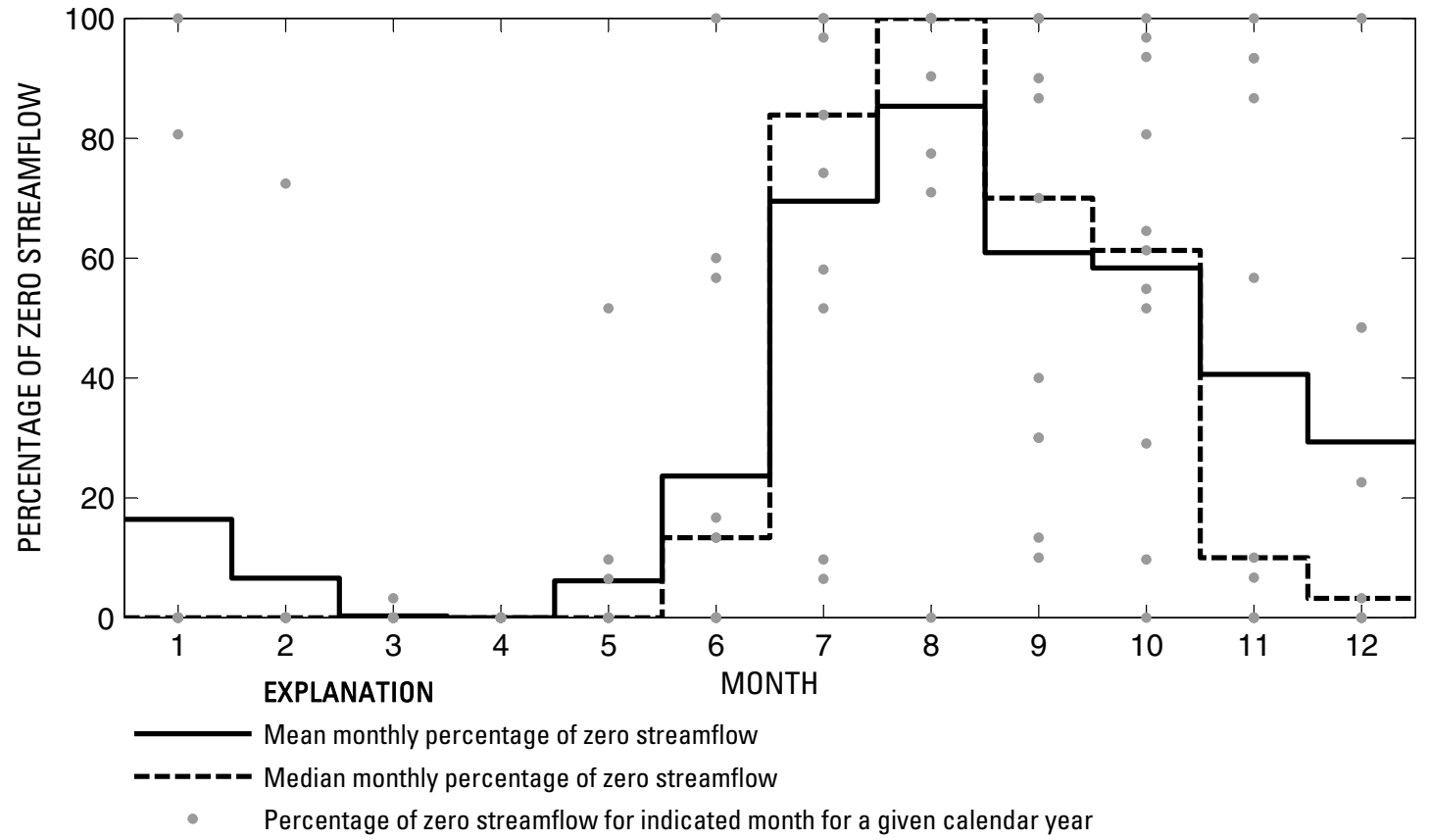

Figure 71. Analysis of percentage of zero daily mean streamflow for U.S. Geological Survey streamflow-gaging station 07343300 Cuthand Creek near Bogata, Texas. 
U.S. Geological Survey streamflow-gaging station 07343500

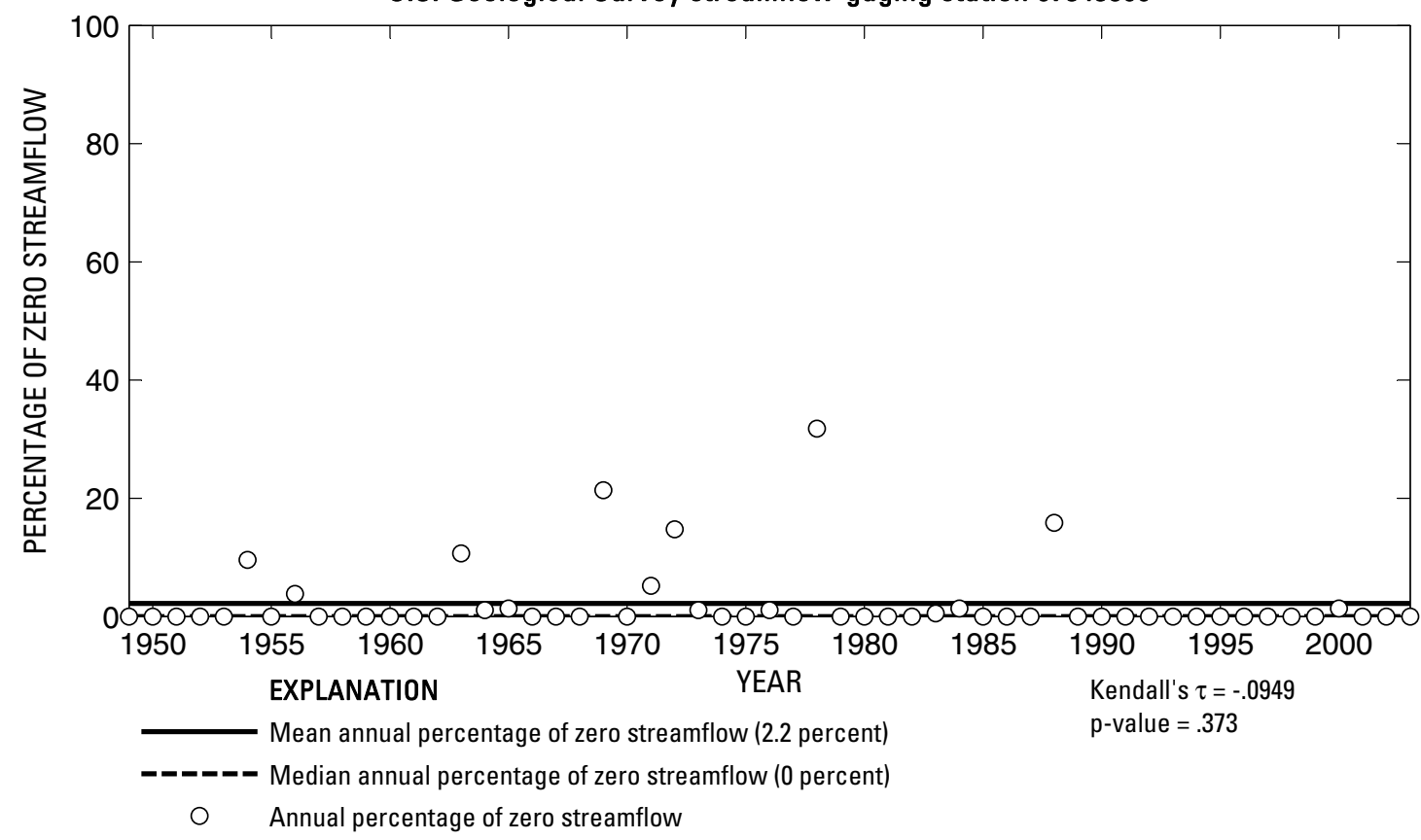

U.S. Geological Survey streamflow-gaging station 07343500

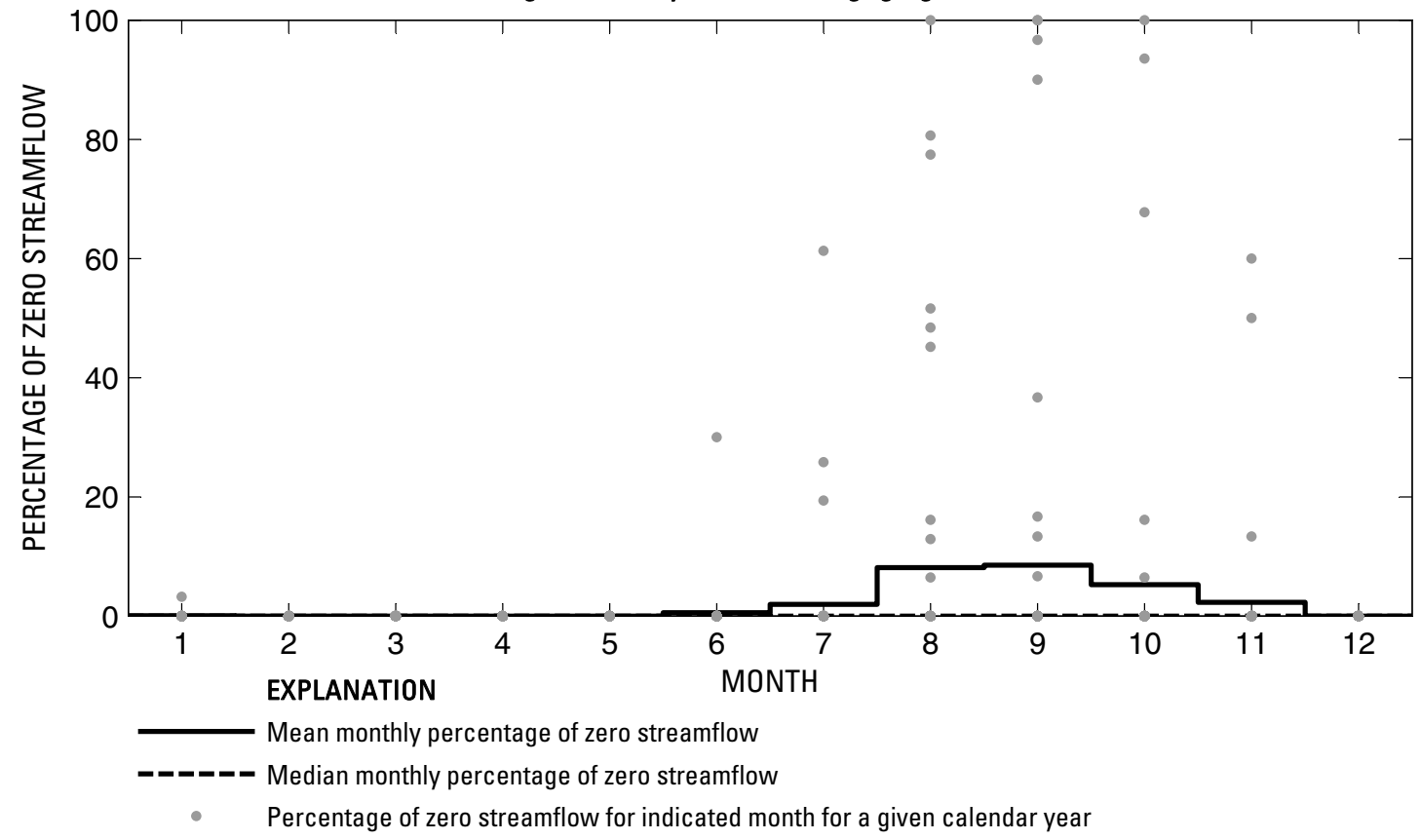

Figure 72. Analysis of percentage of zero daily mean streamflow for U.S. Geological Survey streamflow-gaging station 07343500 White Oak Creek near Talco, Texas. 

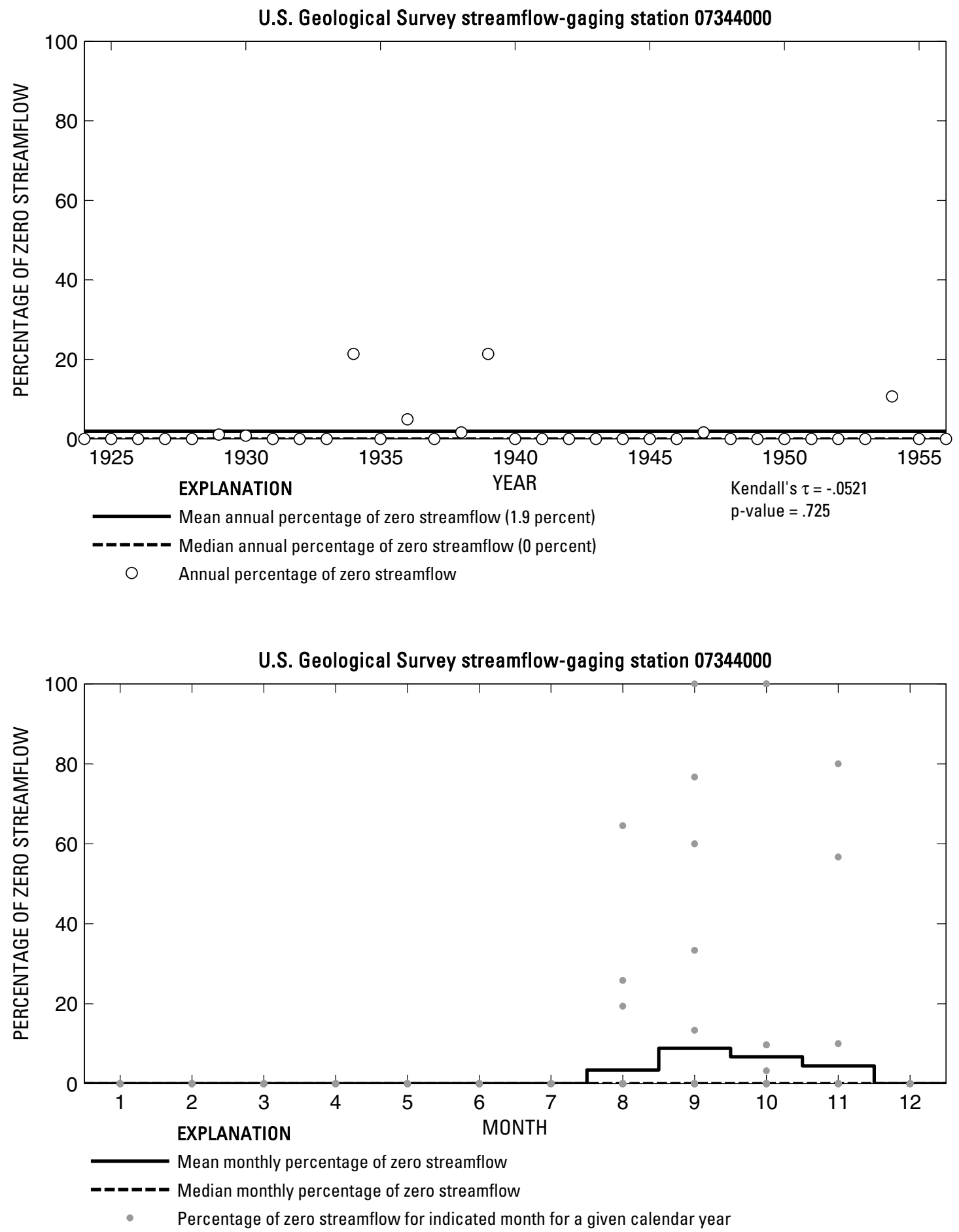

Figure 73. Analysis of percentage of zero daily mean streamflow for U.S. Geological Survey streamflow-gaging station 07344000 Sulphur River near Darden, Texas. 

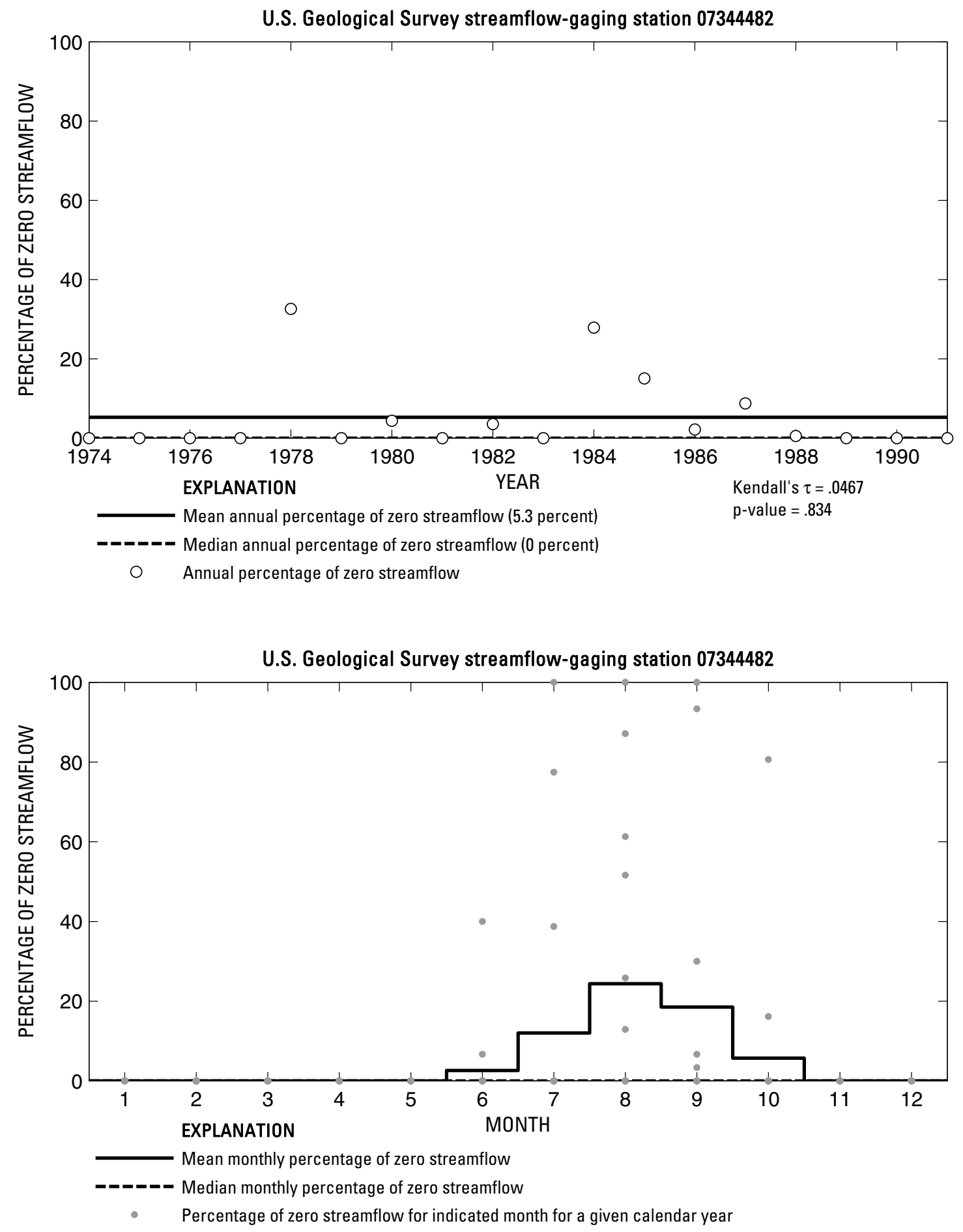

Figure 74. Analysis of percentage of zero daily mean streamflow for U.S. Geological Survey streamflow-gaging station 07344482 Big Cypress Creek near Winnsboro, Texas. 


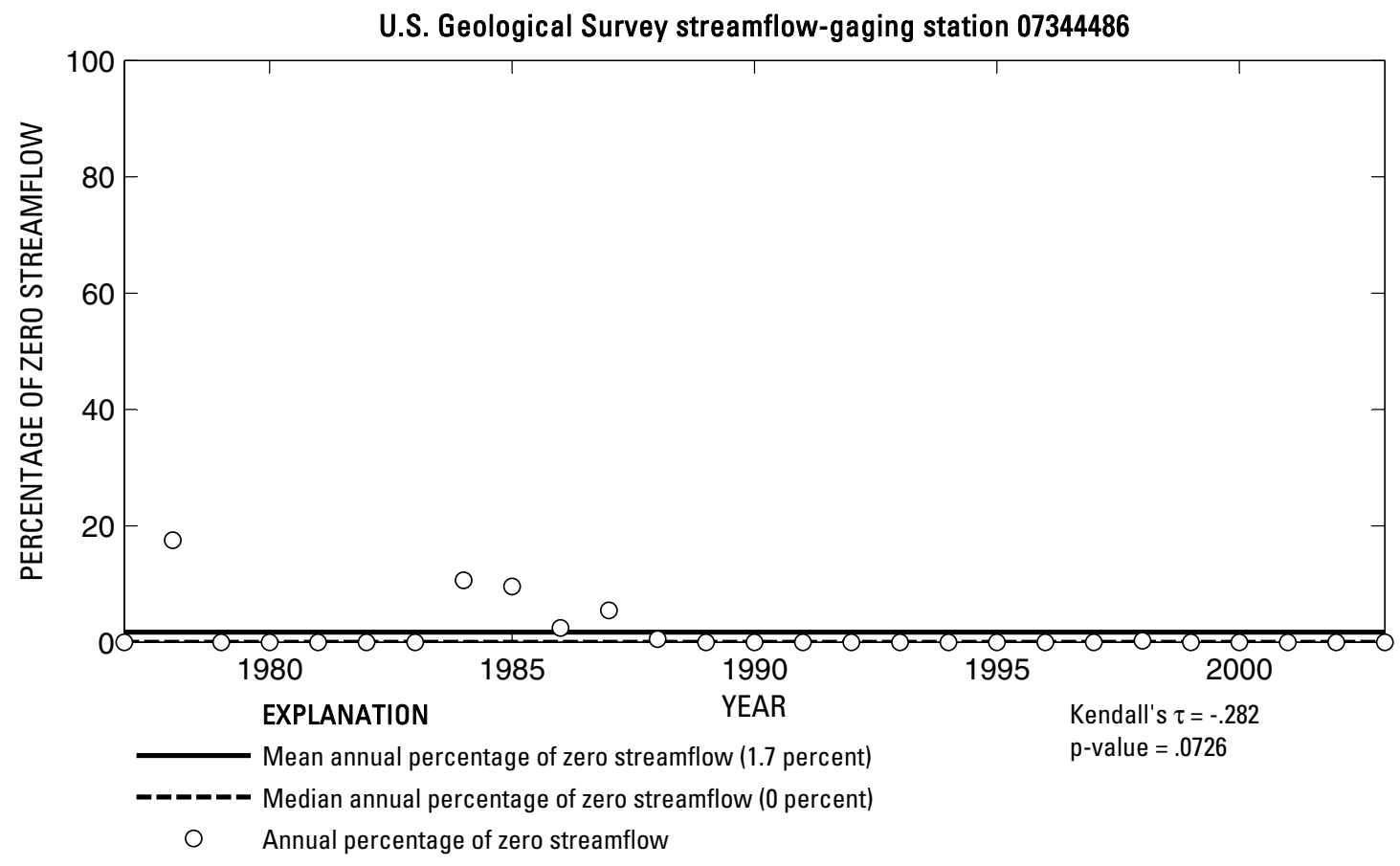

U.S. Geological Survey streamflow-gaging station 07344486

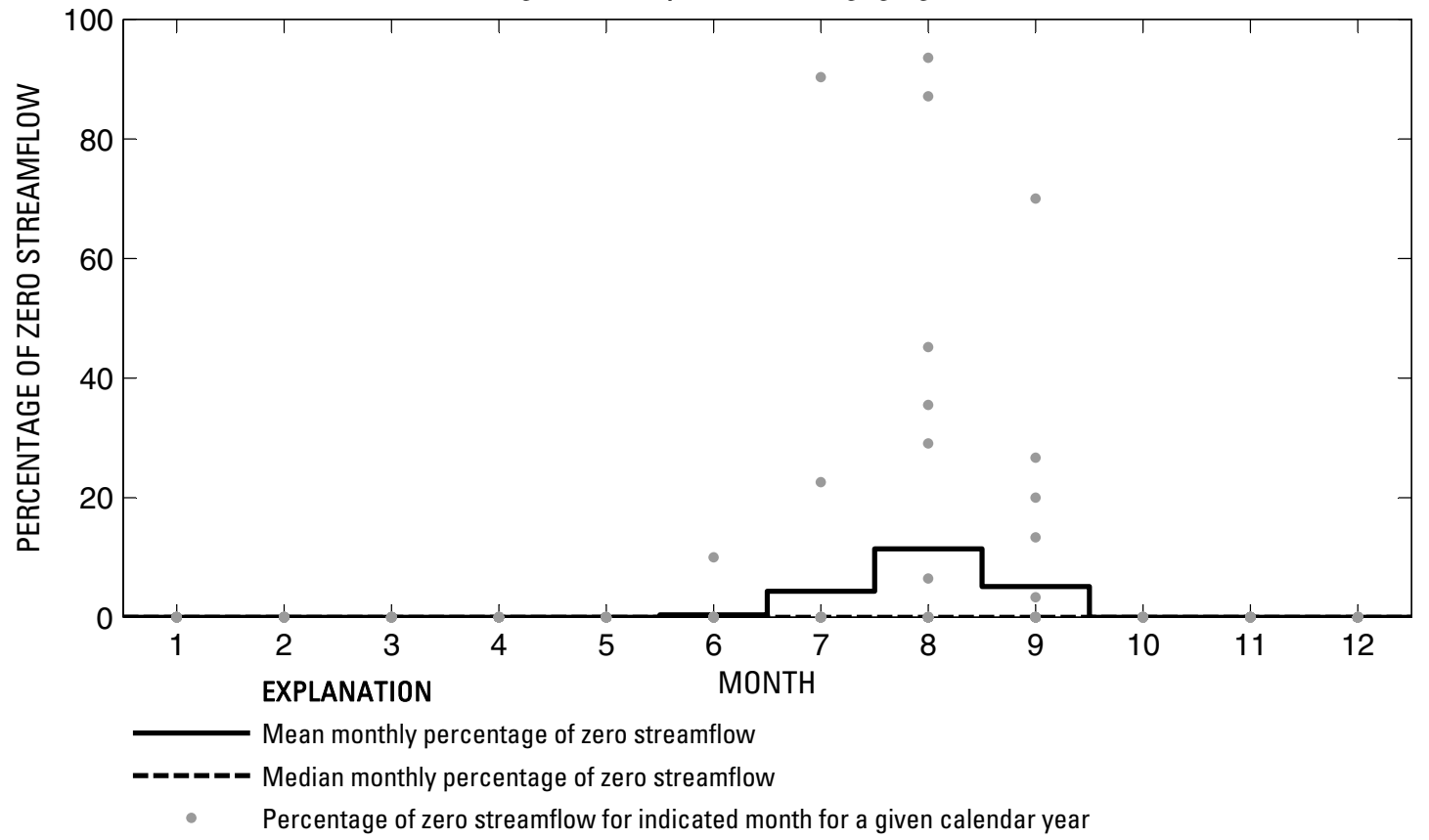

Figure 75. Analysis of percentage of zero daily mean streamflow for U.S. Geological Survey streamflow-gaging station 07344486 Brushy Creek at Scroggins, Texas. 

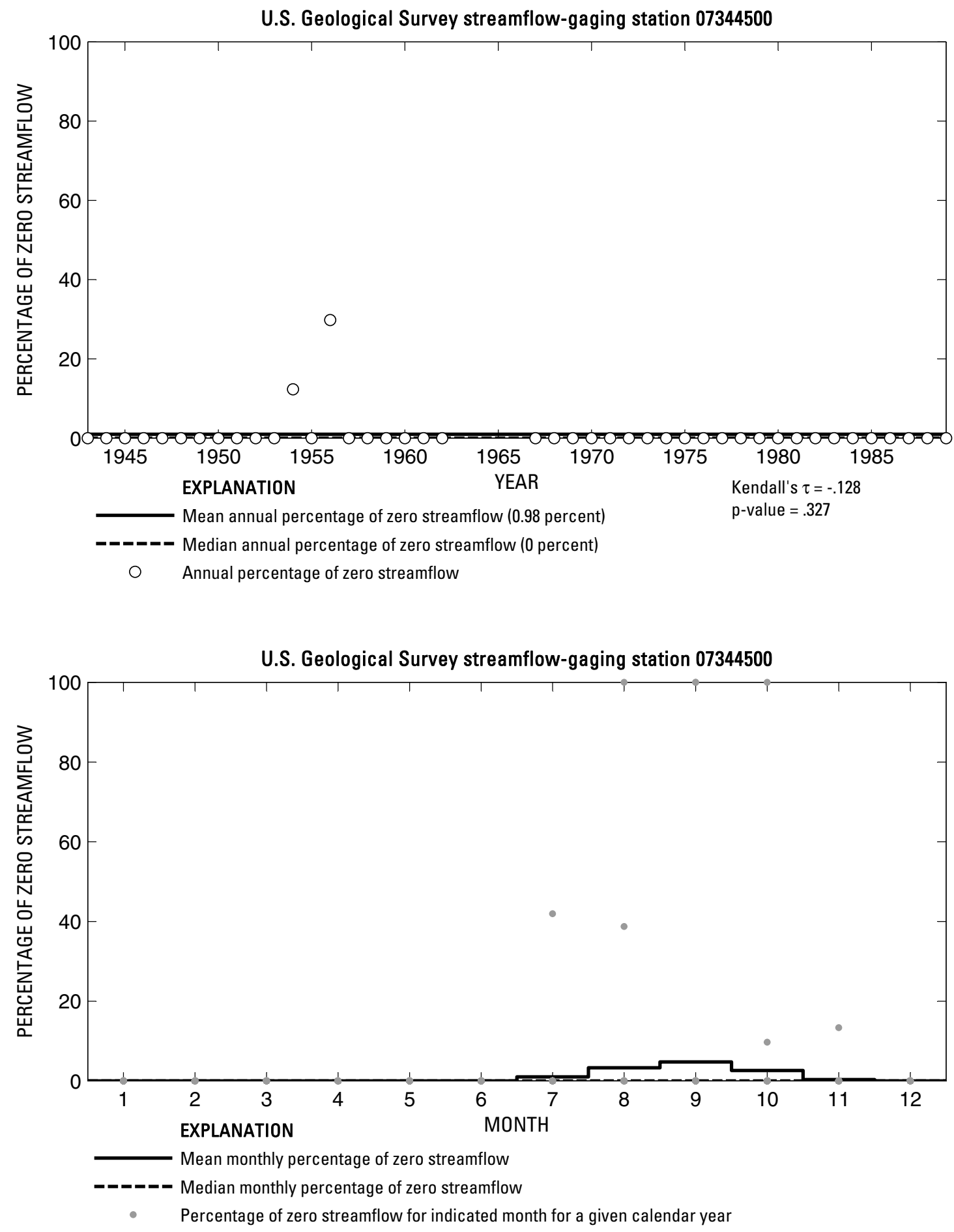

Figure 76. Analysis of percentage of zero daily mean streamflow for U.S. Geological Survey streamflow-gaging station 07344500 Big Cypress Creek near Pittsburg, Texas. 


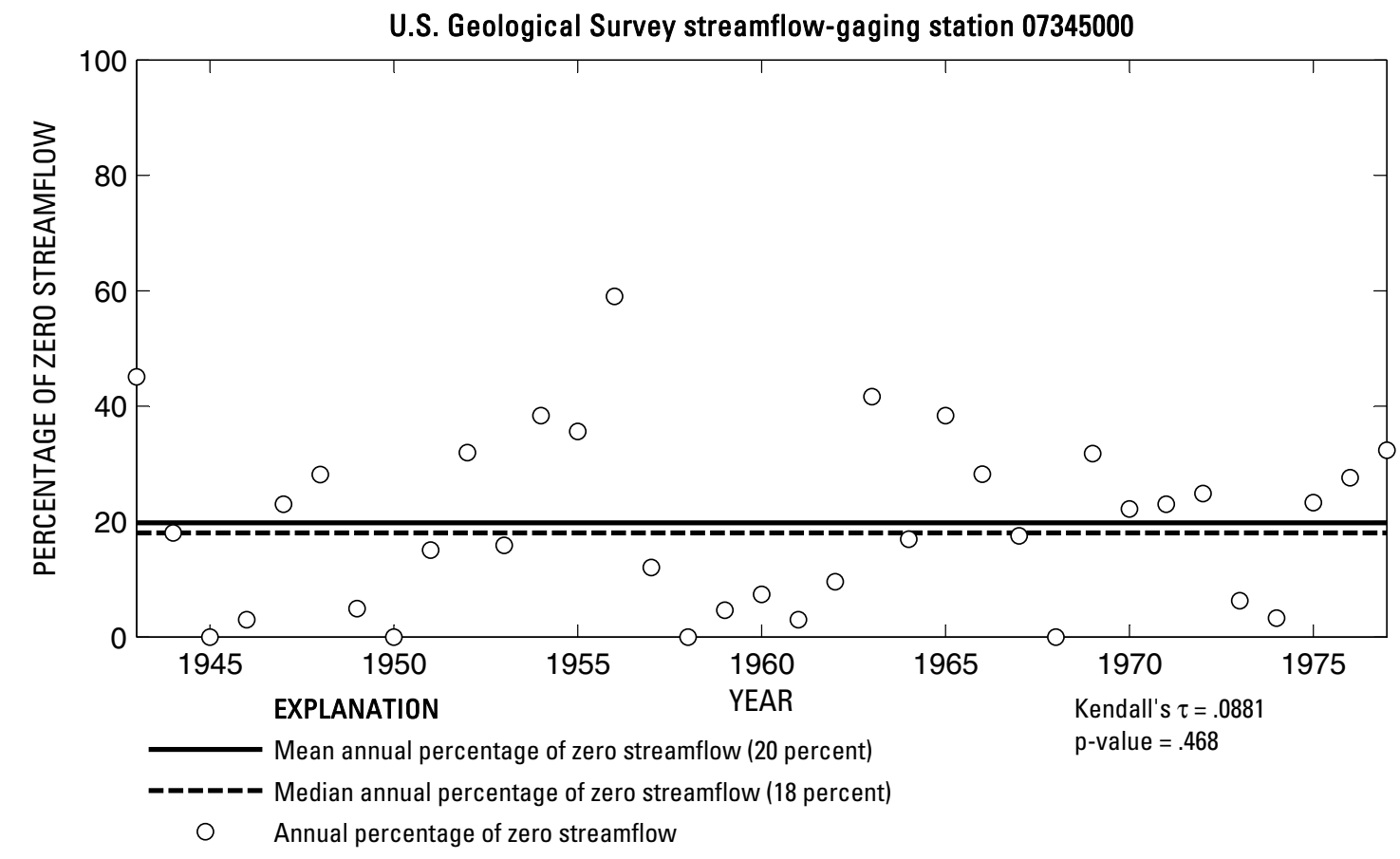

U.S. Geological Survey streamflow-gaging station 07345000

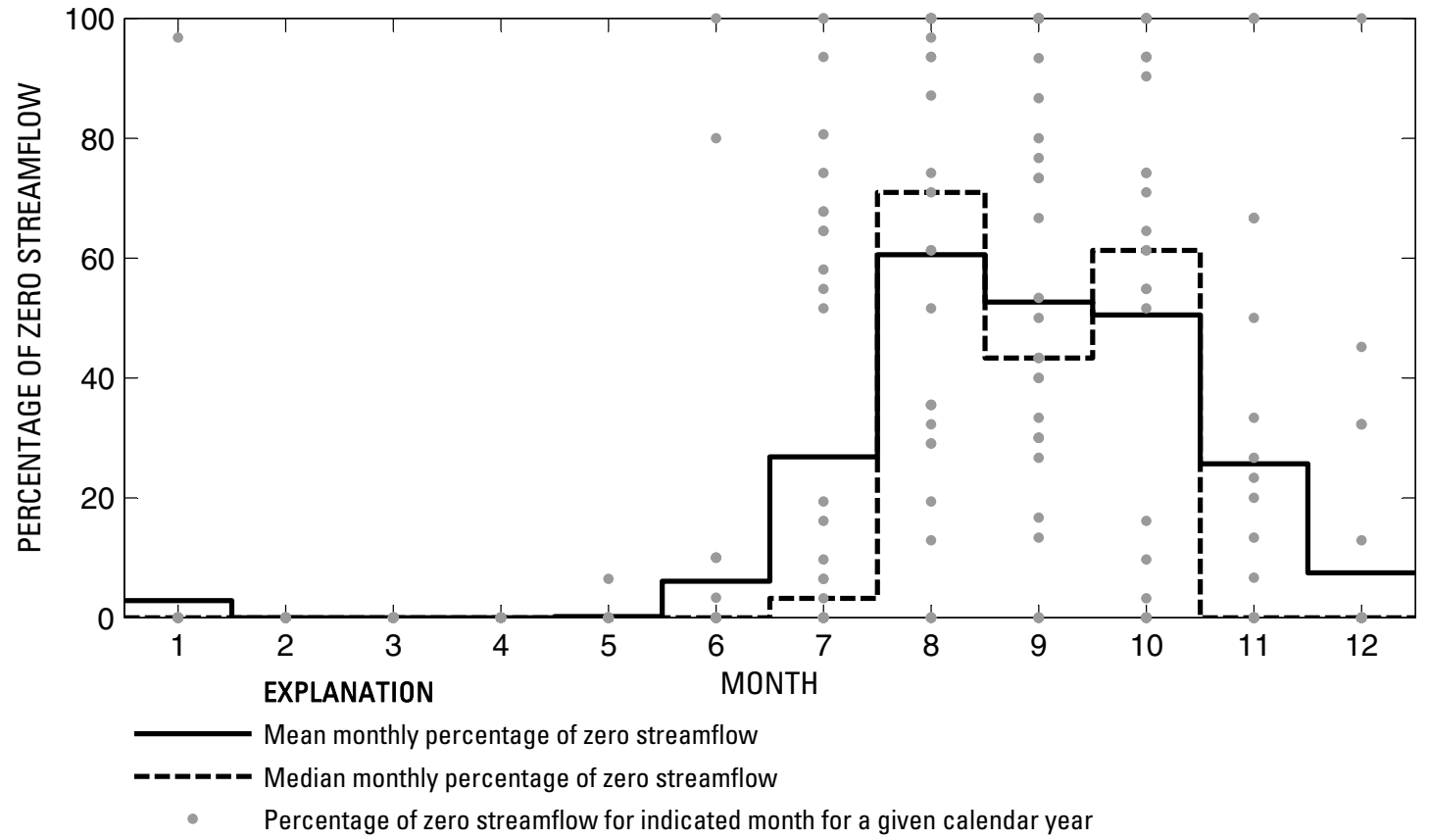

Figure 77. Analysis of percentage of zero daily mean streamflow for U.S. Geological Survey streamflow-gaging station 07345000 Boggy Creek near Daingerfield, Texas. 

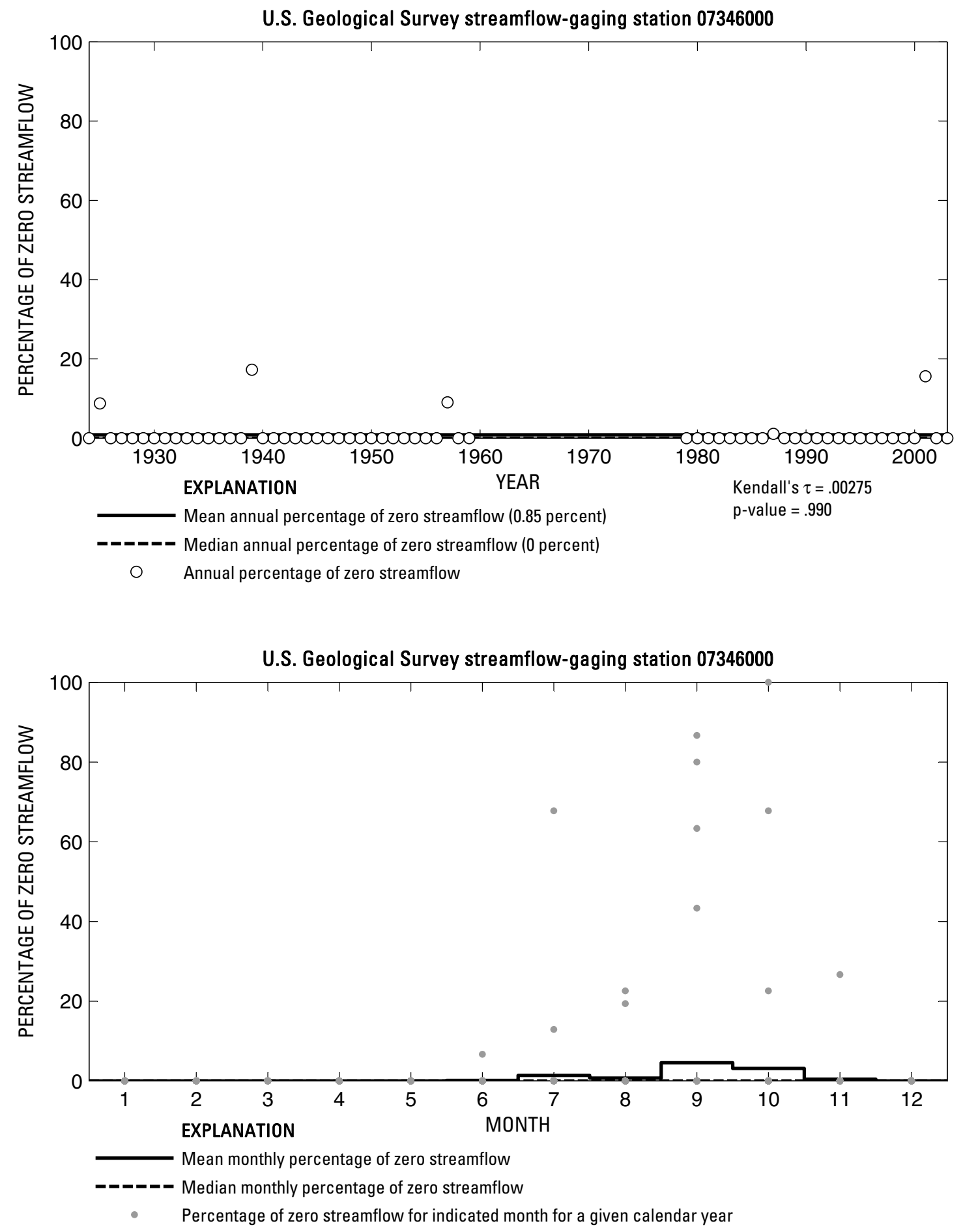

Figure 78. Analysis of percentage of zero daily mean streamflow for U.S. Geological Survey streamflow-gaging station 07346000 Big Cypress Creek near Jefferson, Texas. 

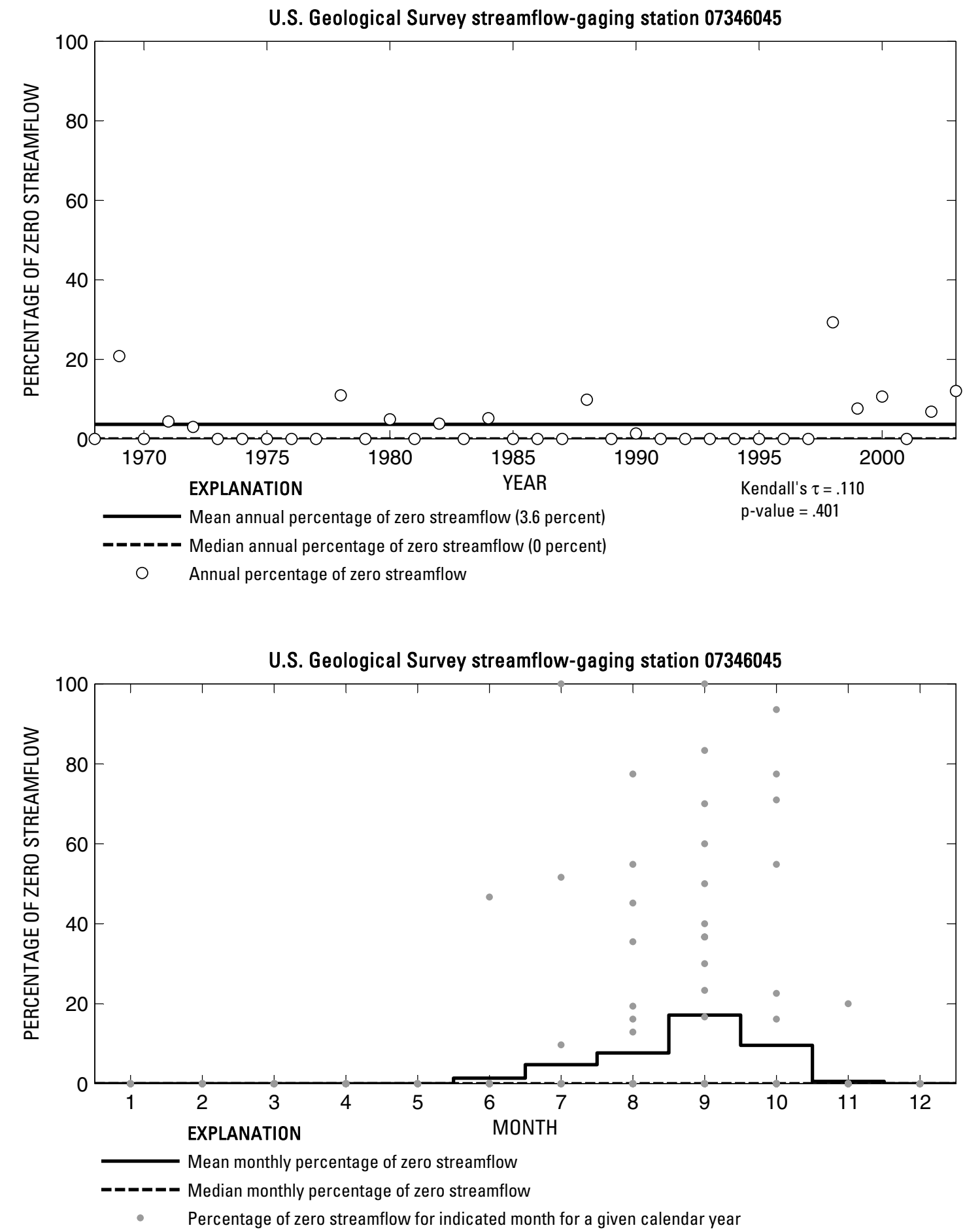

Figure 79. Analysis of percentage of zero daily mean streamflow for U.S. Geological Survey streamflow-gaging station 07346045 Black Cypress Bayou at Jefferson, Texas. 
U.S. Geological Survey streamflow-gaging station 07346050

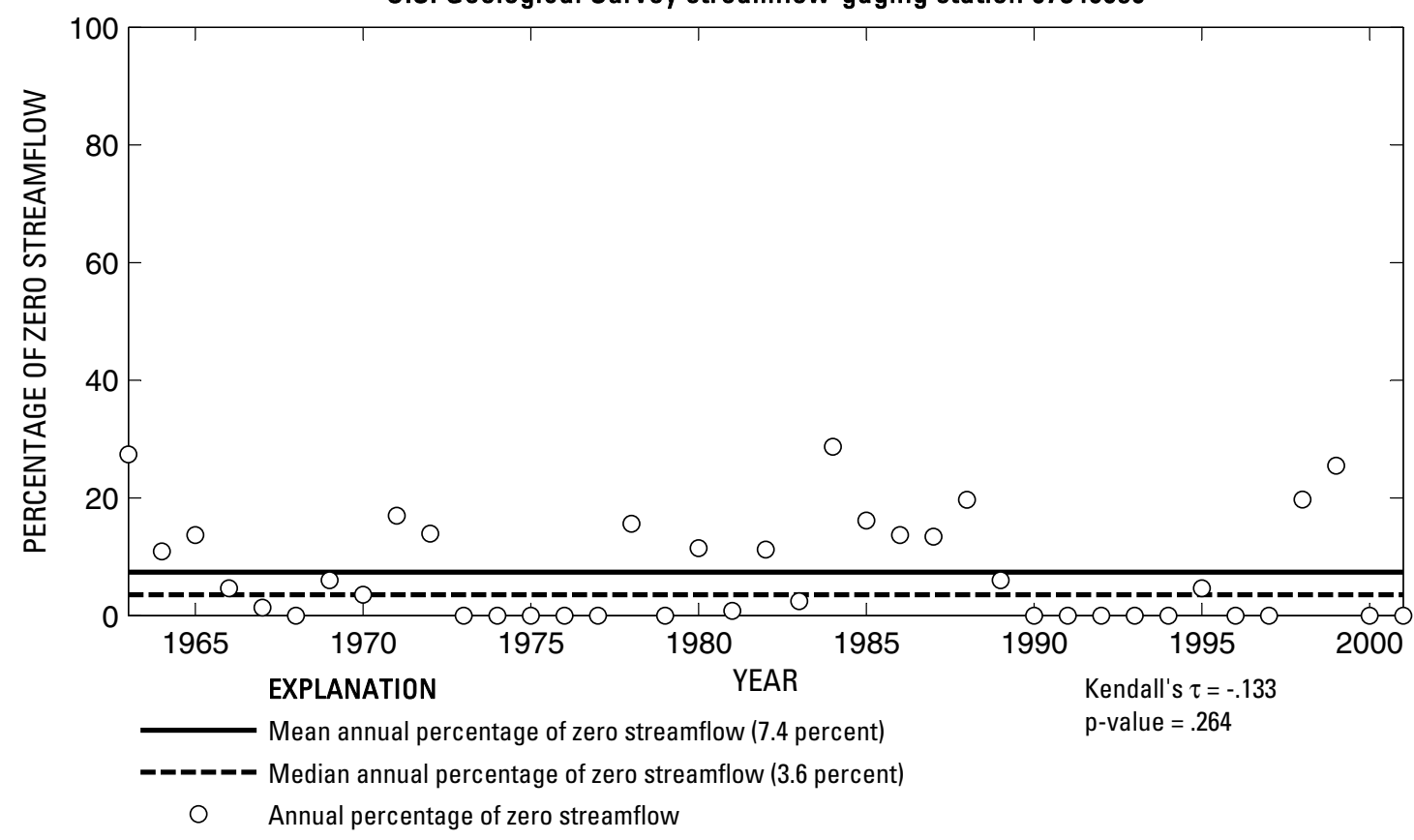

U.S. Geological Survey streamflow-gaging station 07346050

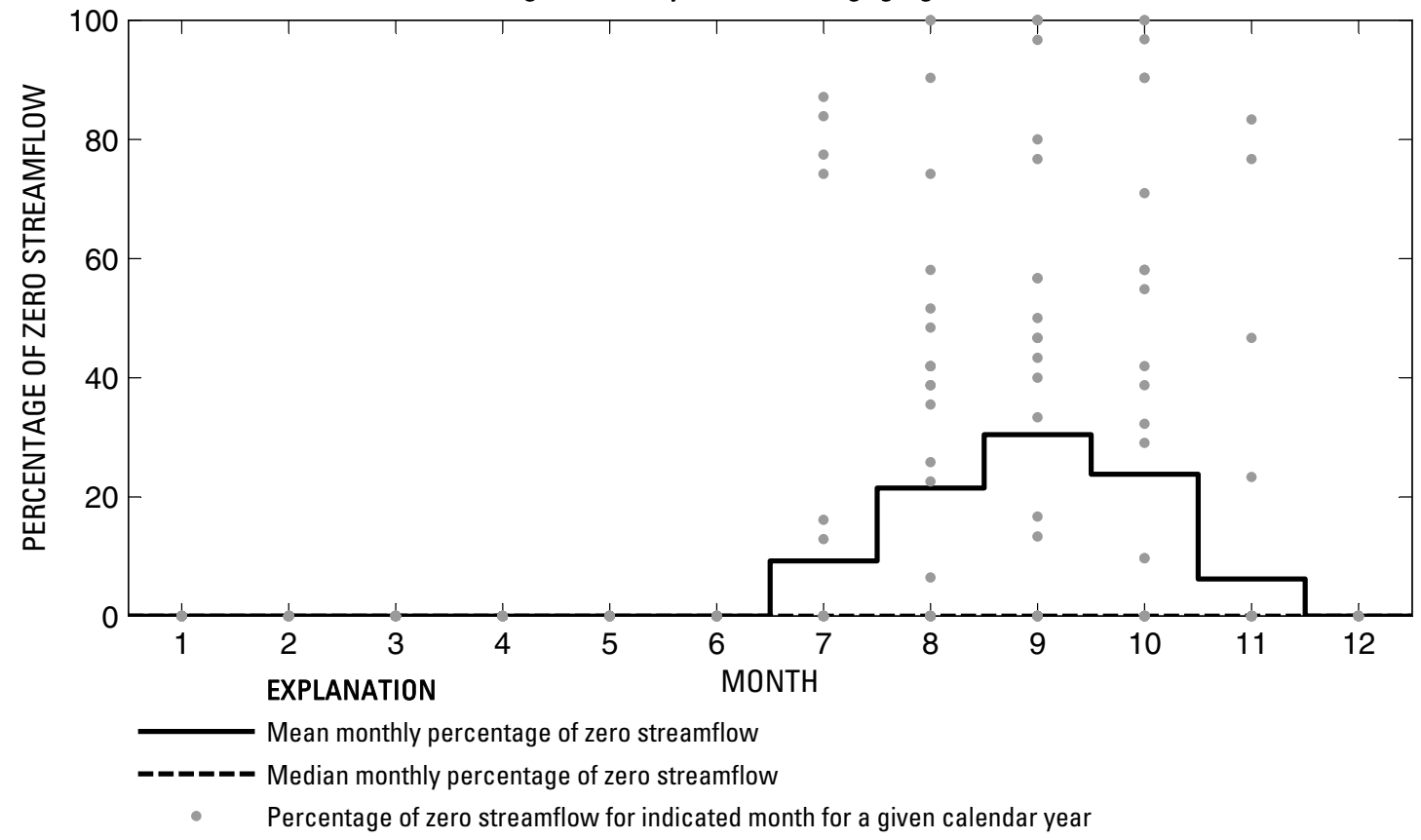

Figure 80. Analysis of percentage of zero daily mean streamflow for U.S. Geological Survey streamflow-gaging station 07346050 Little Cypress Creek near Ore City, Texas. 


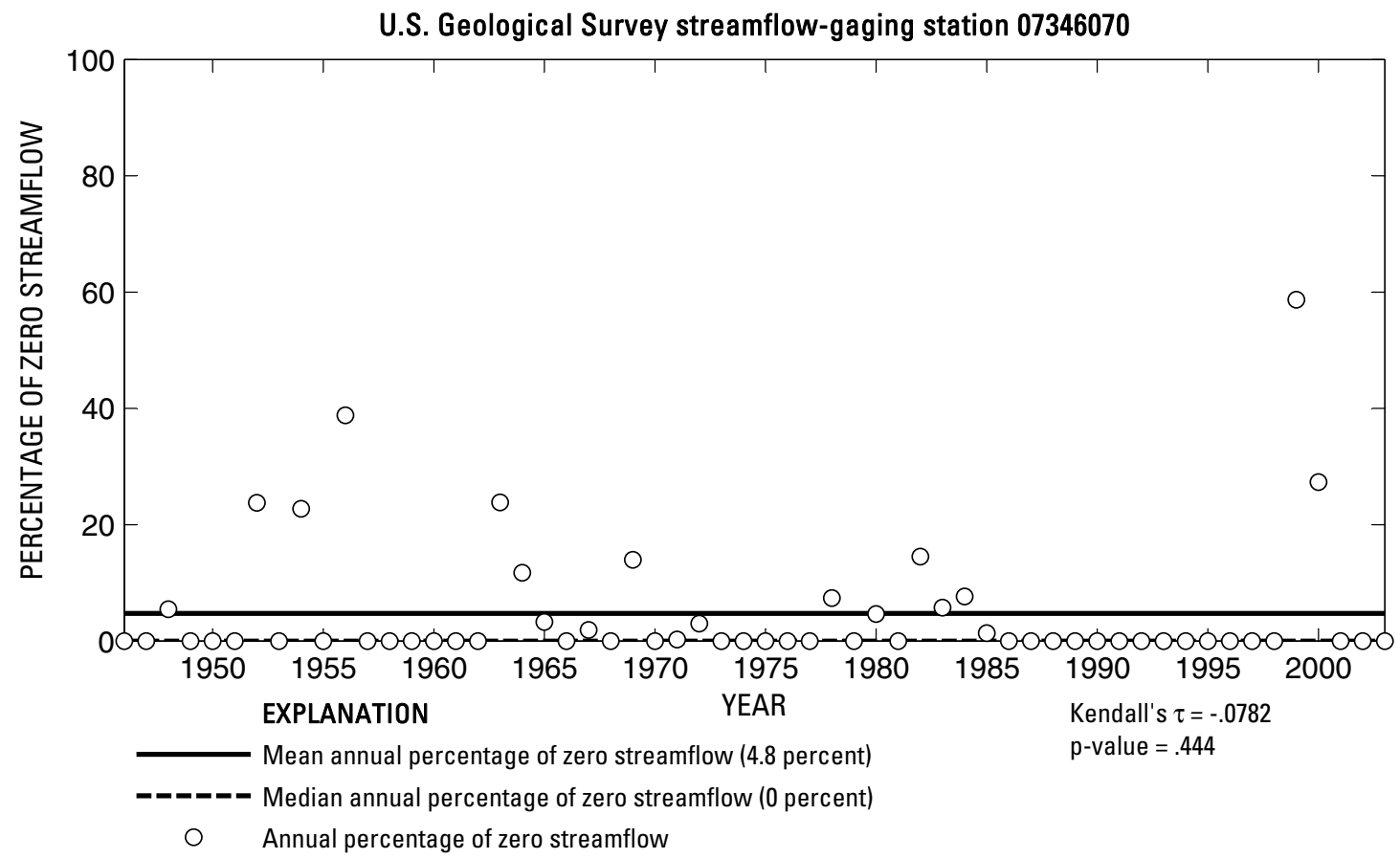

U.S. Geological Survey streamflow-gaging station 07346070

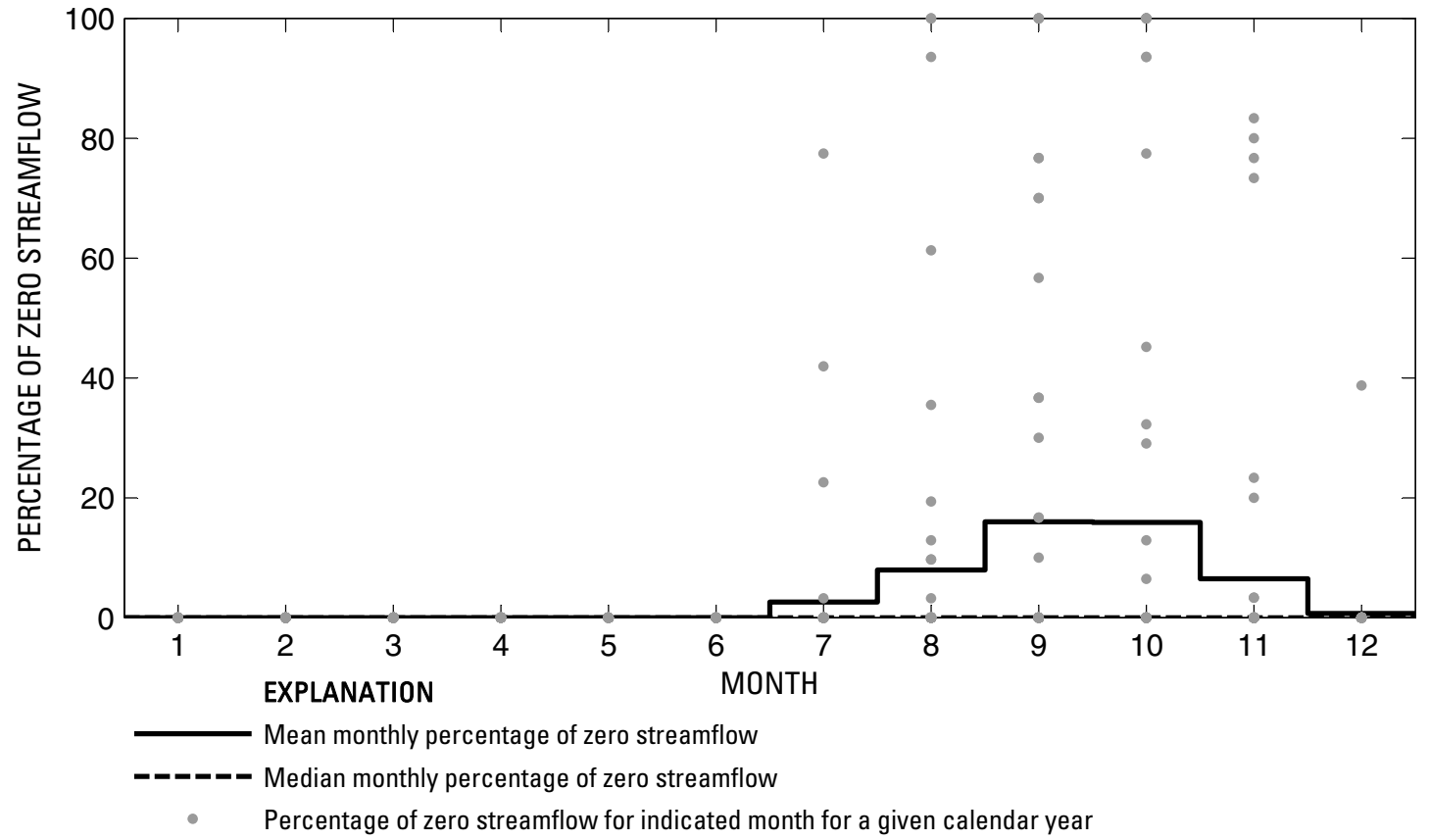

Figure 81. Analysis of percentage of zero daily mean streamflow for U.S. Geological Survey streamflow-gaging station 07346070 Little Cypress Creek near Jefferson, Texas. 
U.S. Geological Survey streamflow-gaging station 07346140

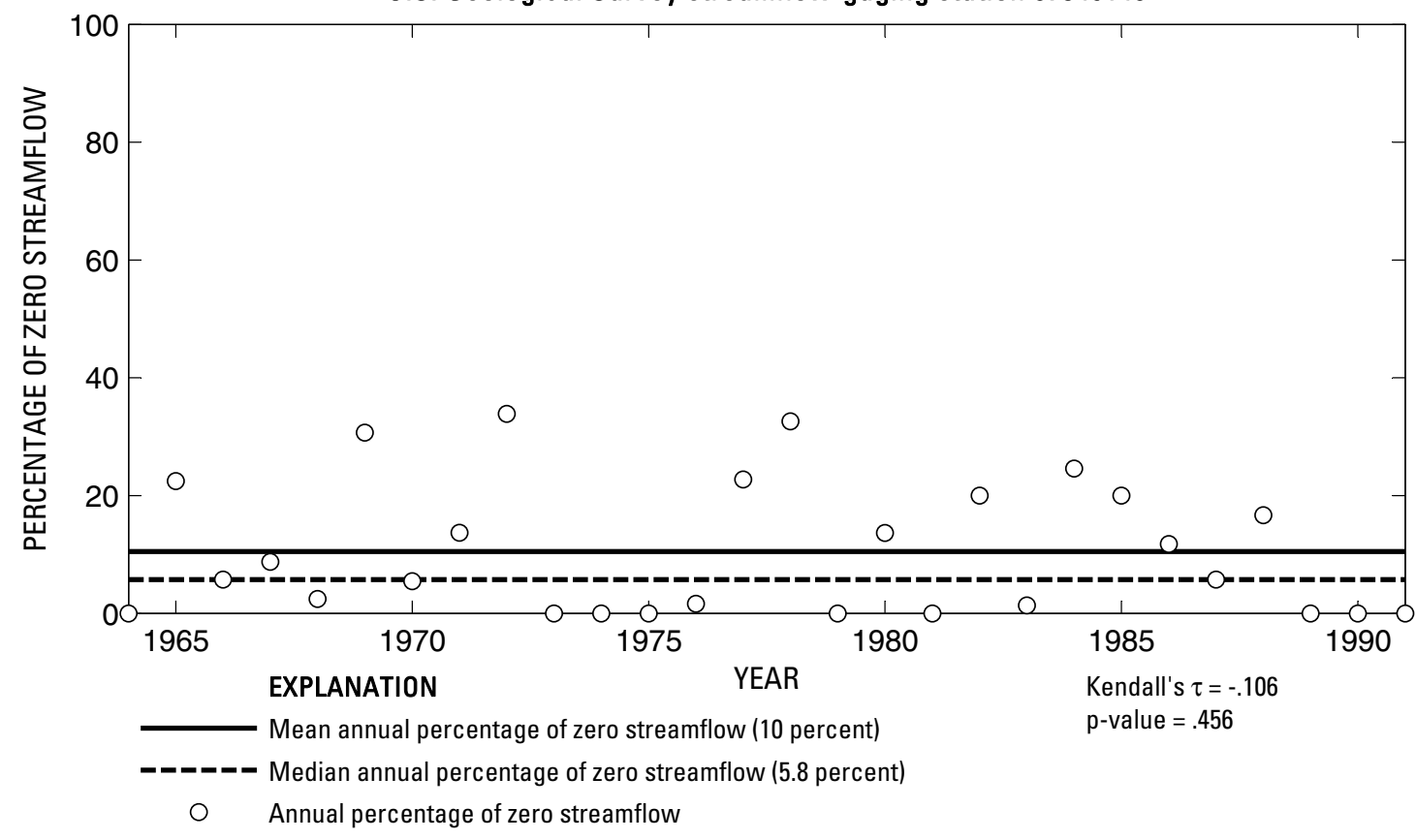

U.S. Geological Survey streamflow-gaging station 07346140

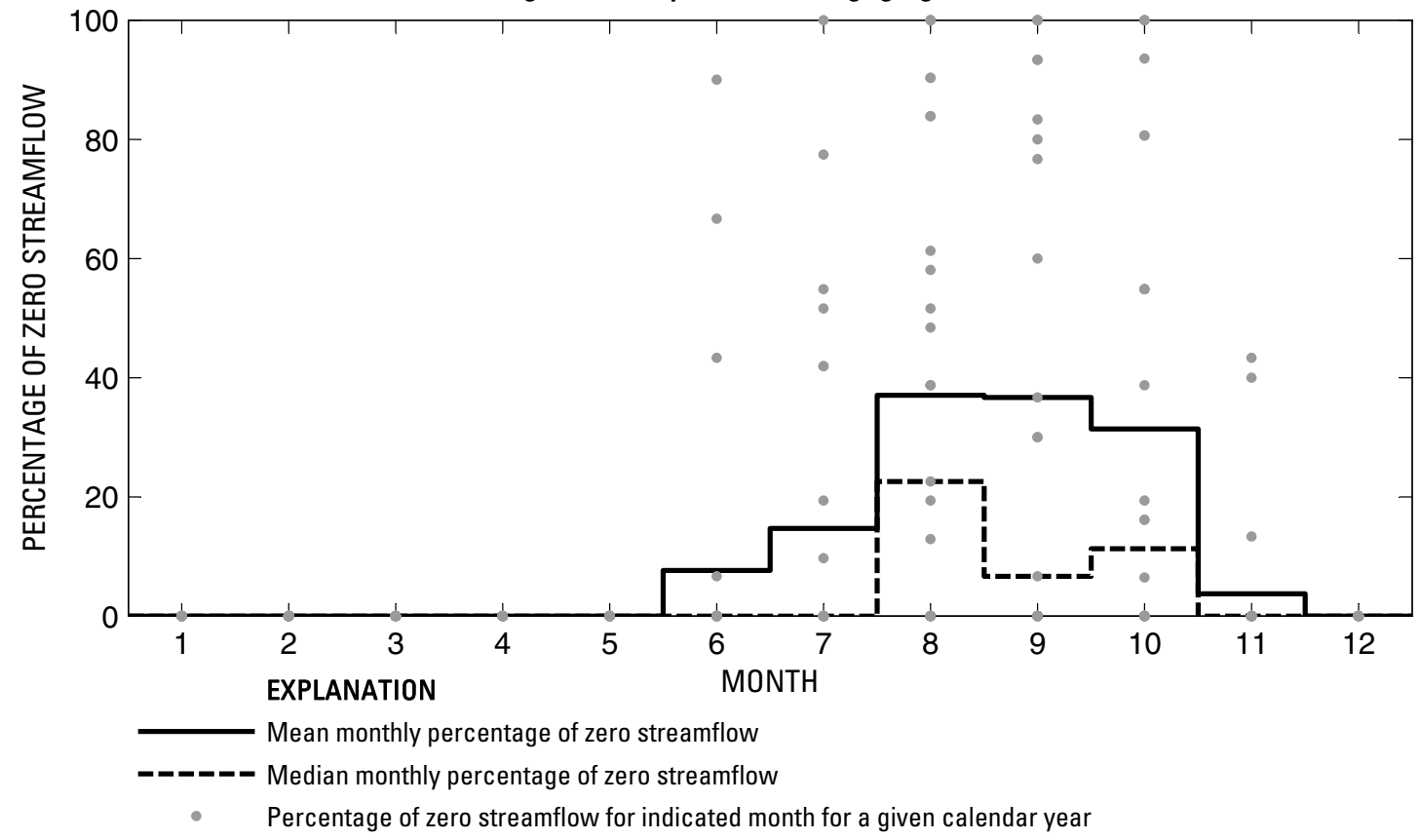

Figure 82. Analysis of percentage of zero daily mean streamflow for U.S. Geological Survey streamflow-gaging station 07346140 Frazier Creek near Linden, Texas. 

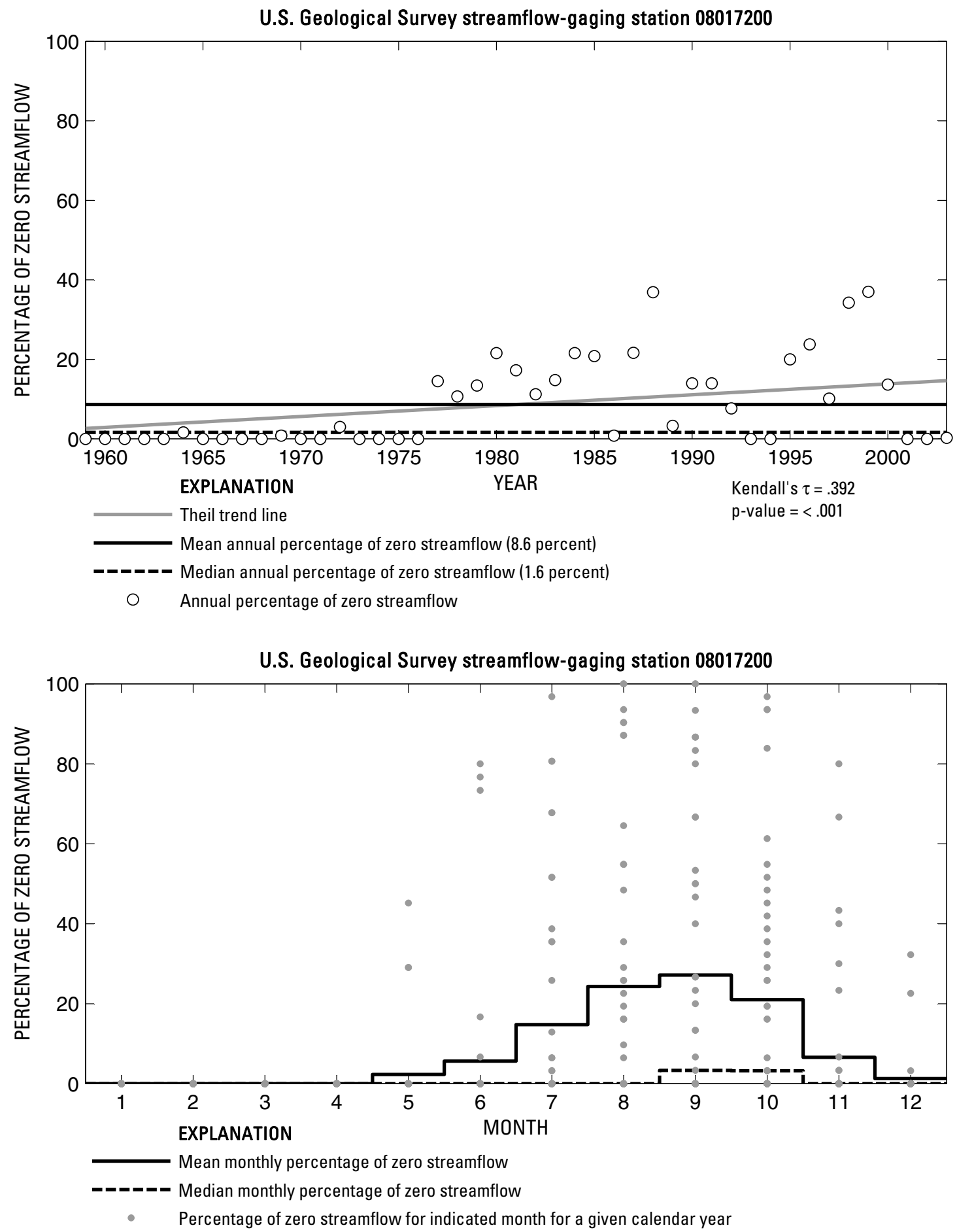

Figure 83. Analysis of percentage of zero daily mean streamflow for U.S. Geological Survey streamflow-gaging station 08017200 Cowleech Fork Sabine River at Greenville, Texas. 
U.S. Geological Survey streamflow-gaging station 08017300
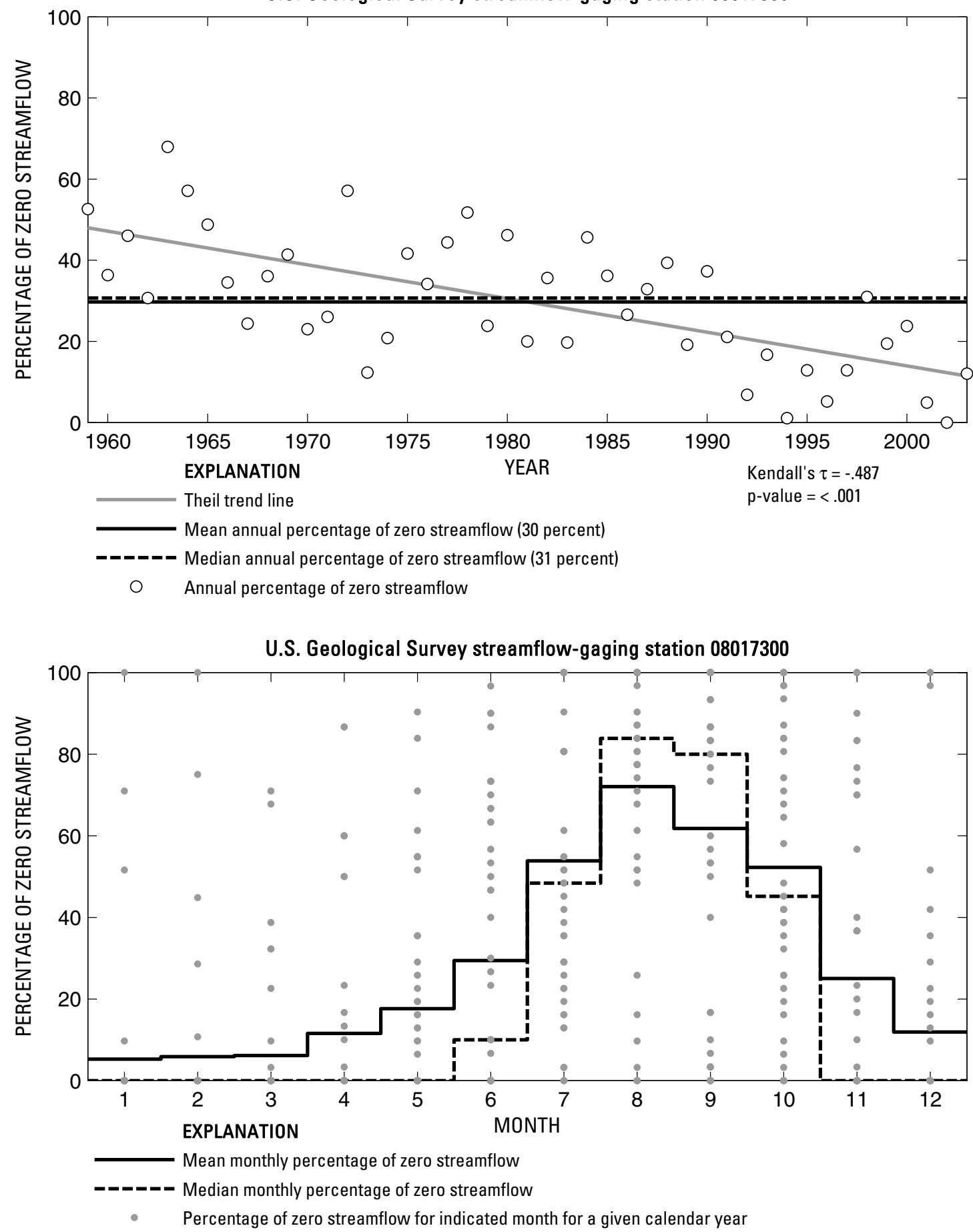

Figure 84. Analysis of percentage of zero daily mean streamflow for U.S. Geological Survey streamflow-gaging station 08017300 South Fork Sabine River near Quinlan, Texas.

Index of Station Numbers 719 


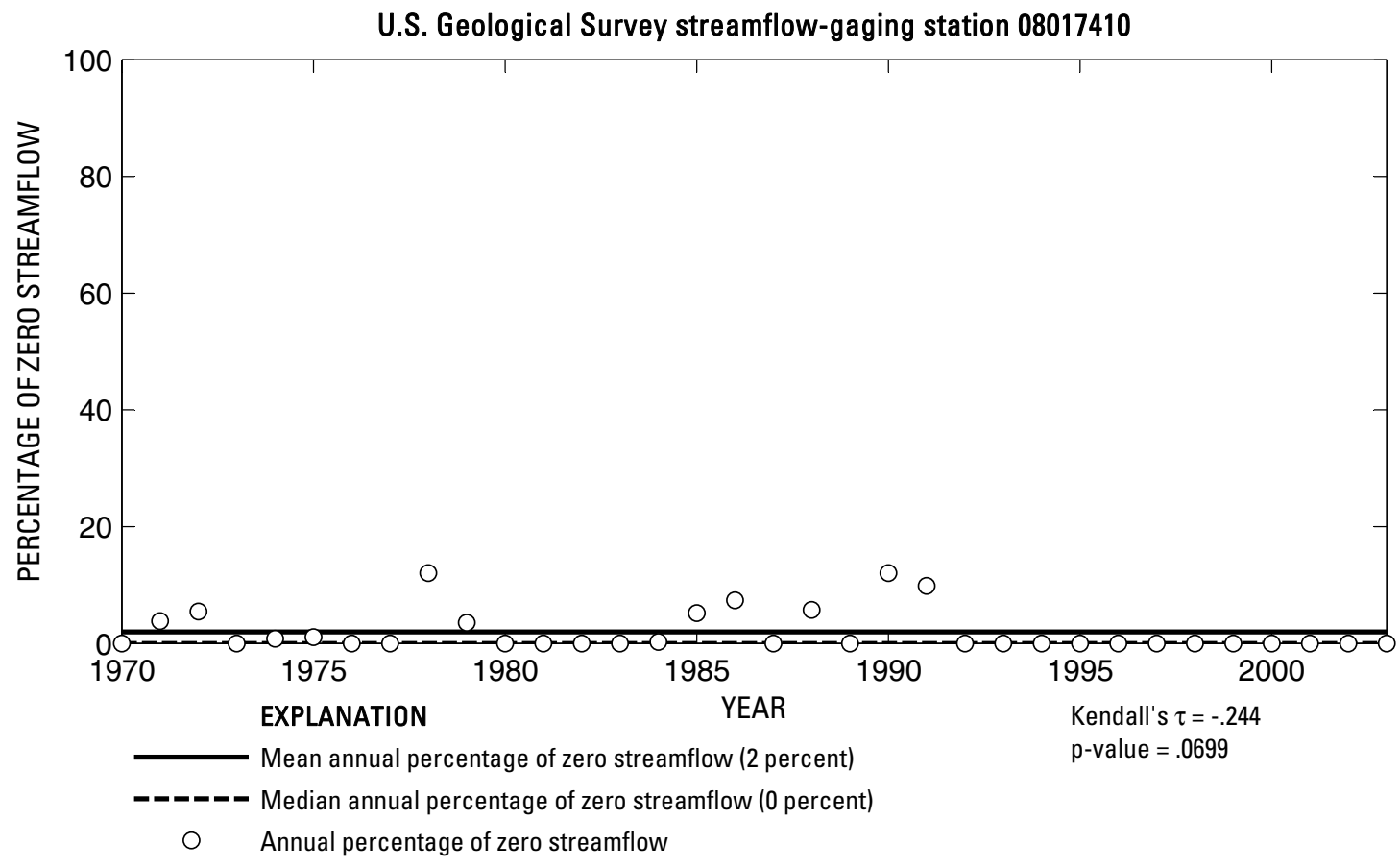

U.S. Geological Survey streamflow-gaging station 08017410

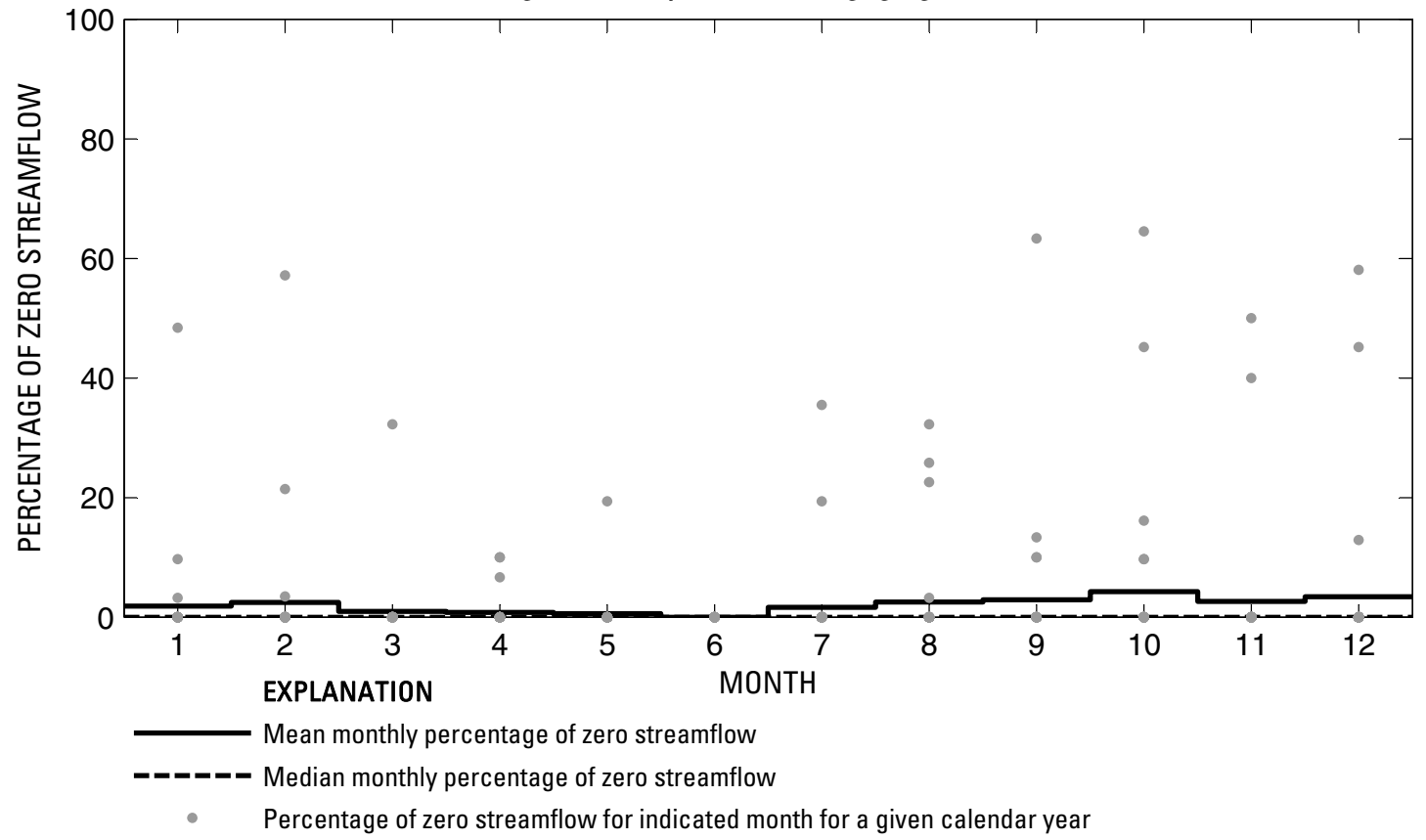

Figure 85. Analysis of percentage of zero daily mean streamflow for U.S. Geological Survey streamflow-gaging station 08017410 Sabine River near Wills Point, Texas. 
U.S. Geological Survey streamflow-gaging station 08017500

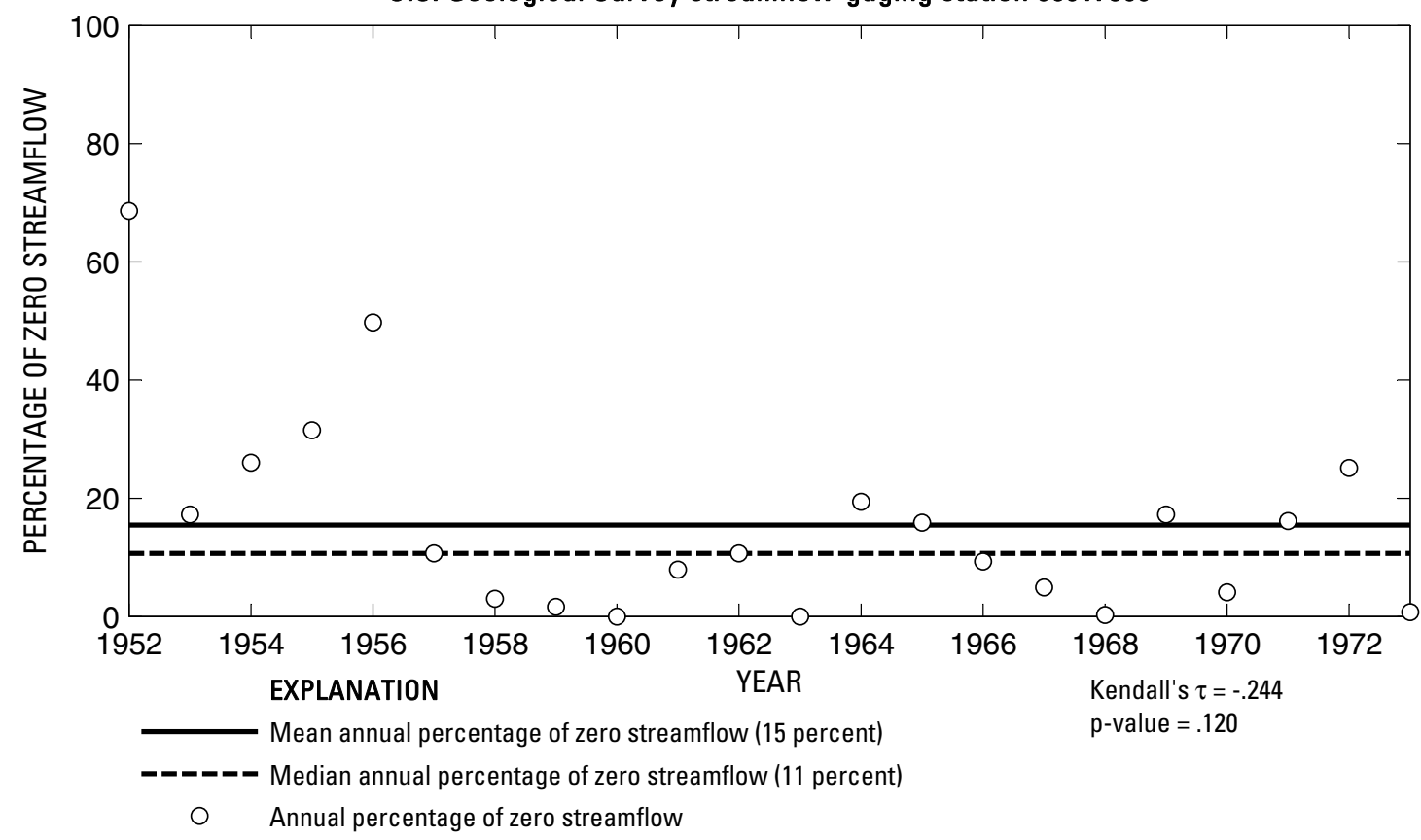

U.S. Geological Survey streamflow-gaging station 08017500

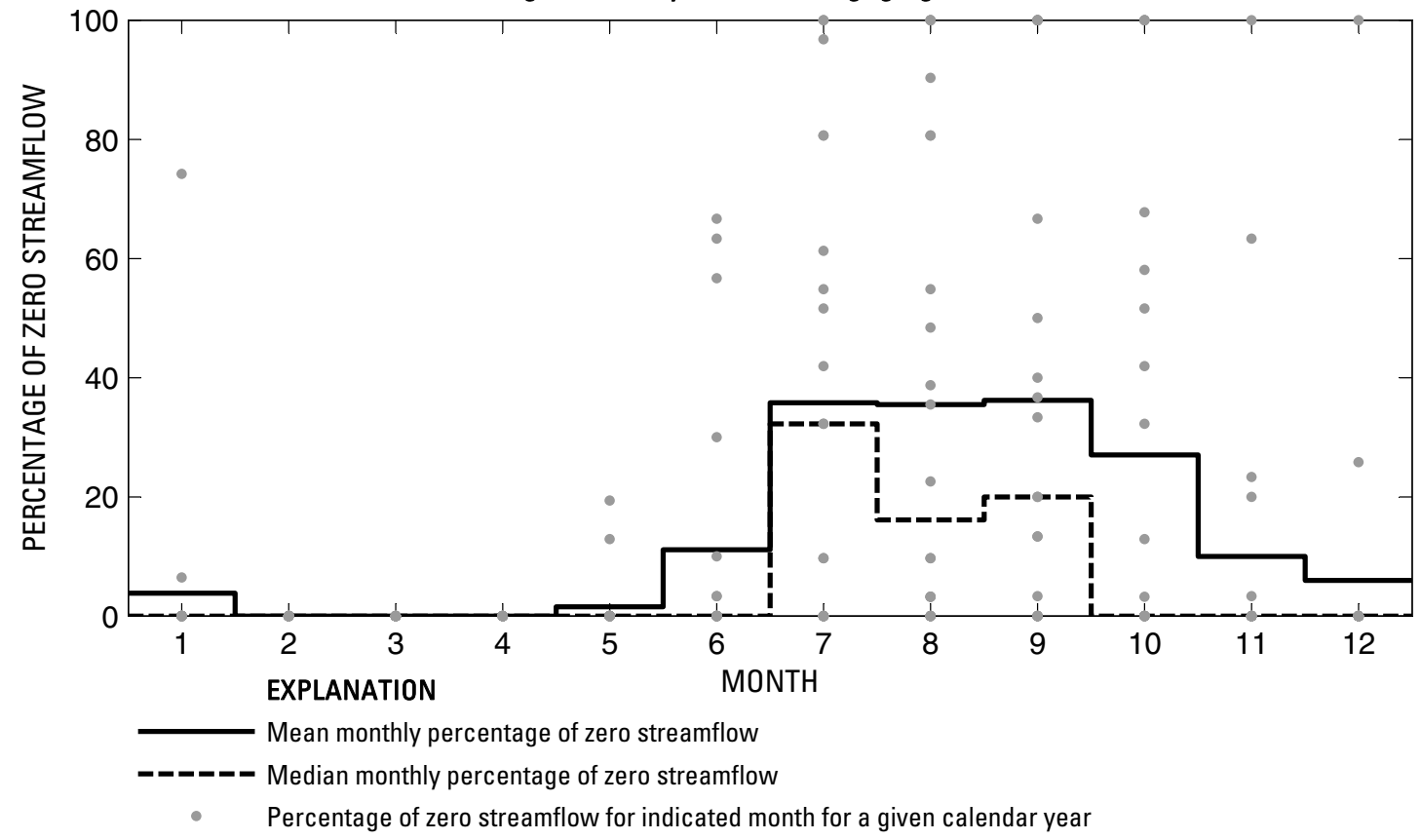

Figure 86. Analysis of percentage of zero daily mean streamflow for U.S. Geological Survey streamflow-gaging station 08017500 Sabine River near Emory, Texas.

Index of Station Numbers 719 


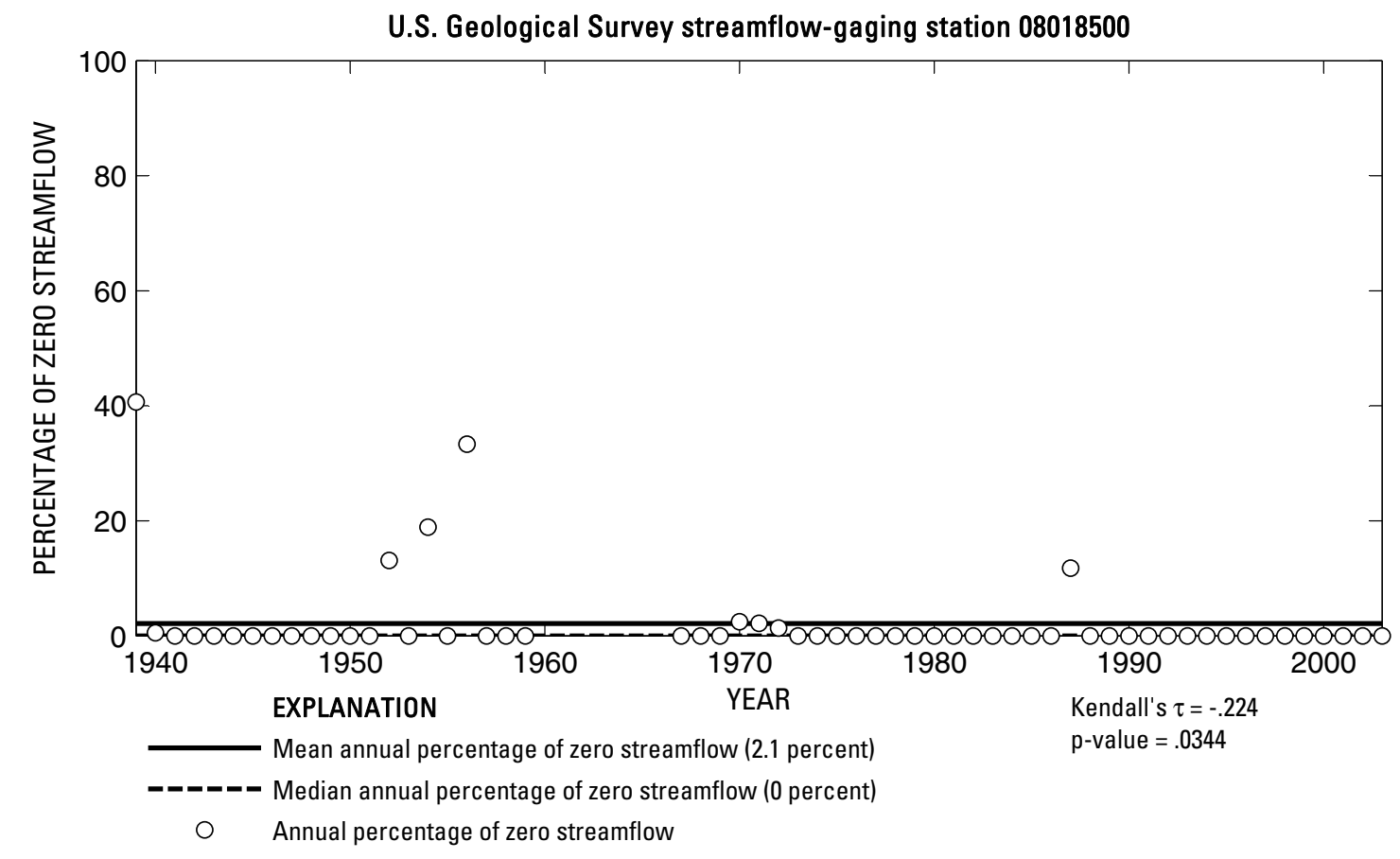

U.S. Geological Survey streamflow-gaging station 08018500

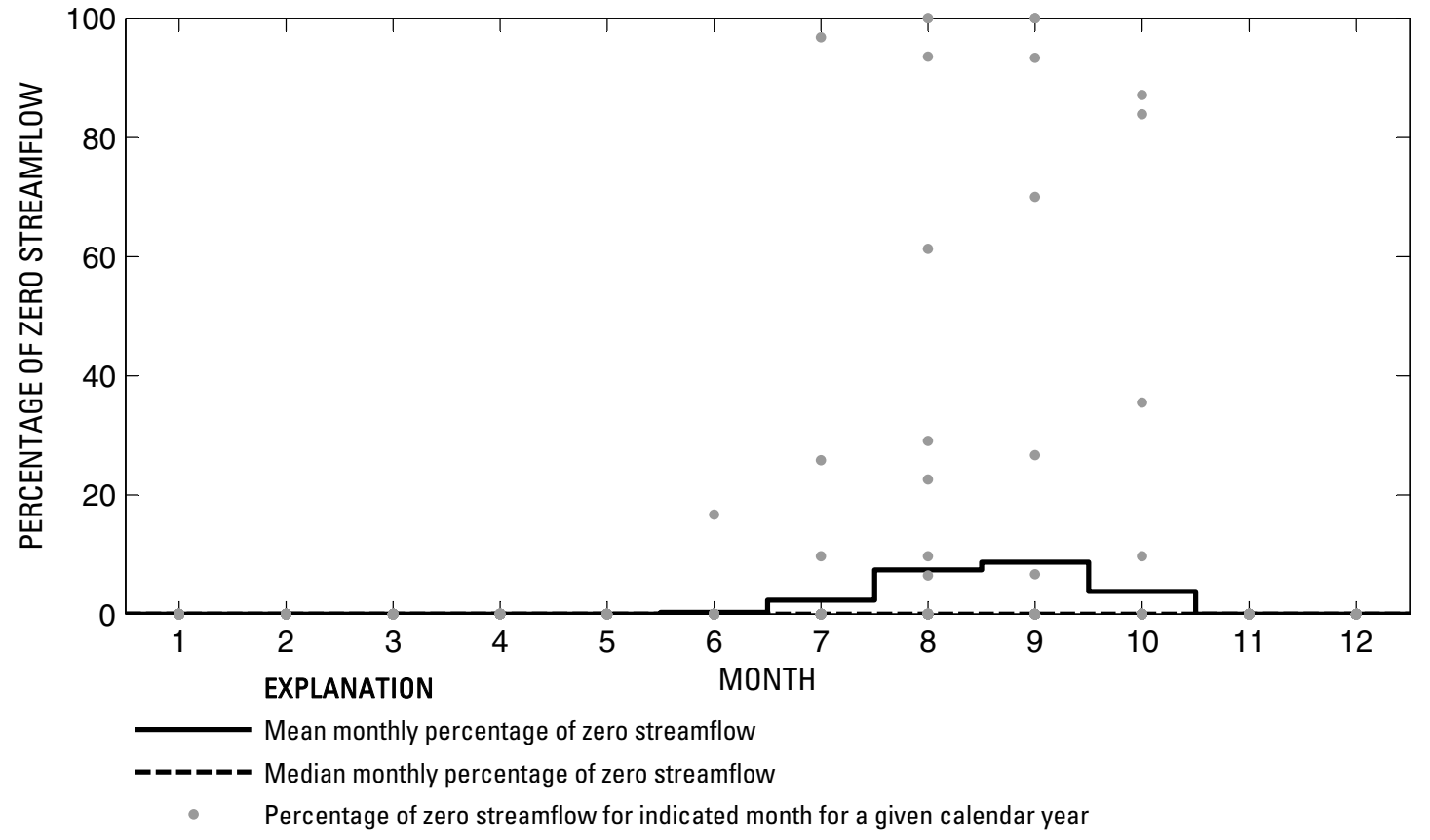

Figure 87. Analysis of percentage of zero daily mean streamflow for U.S. Geological Survey streamflow-gaging station 08018500 Sabine River near Mineola, Texas. 
U.S. Geological Survey streamflow-gaging station 08018730

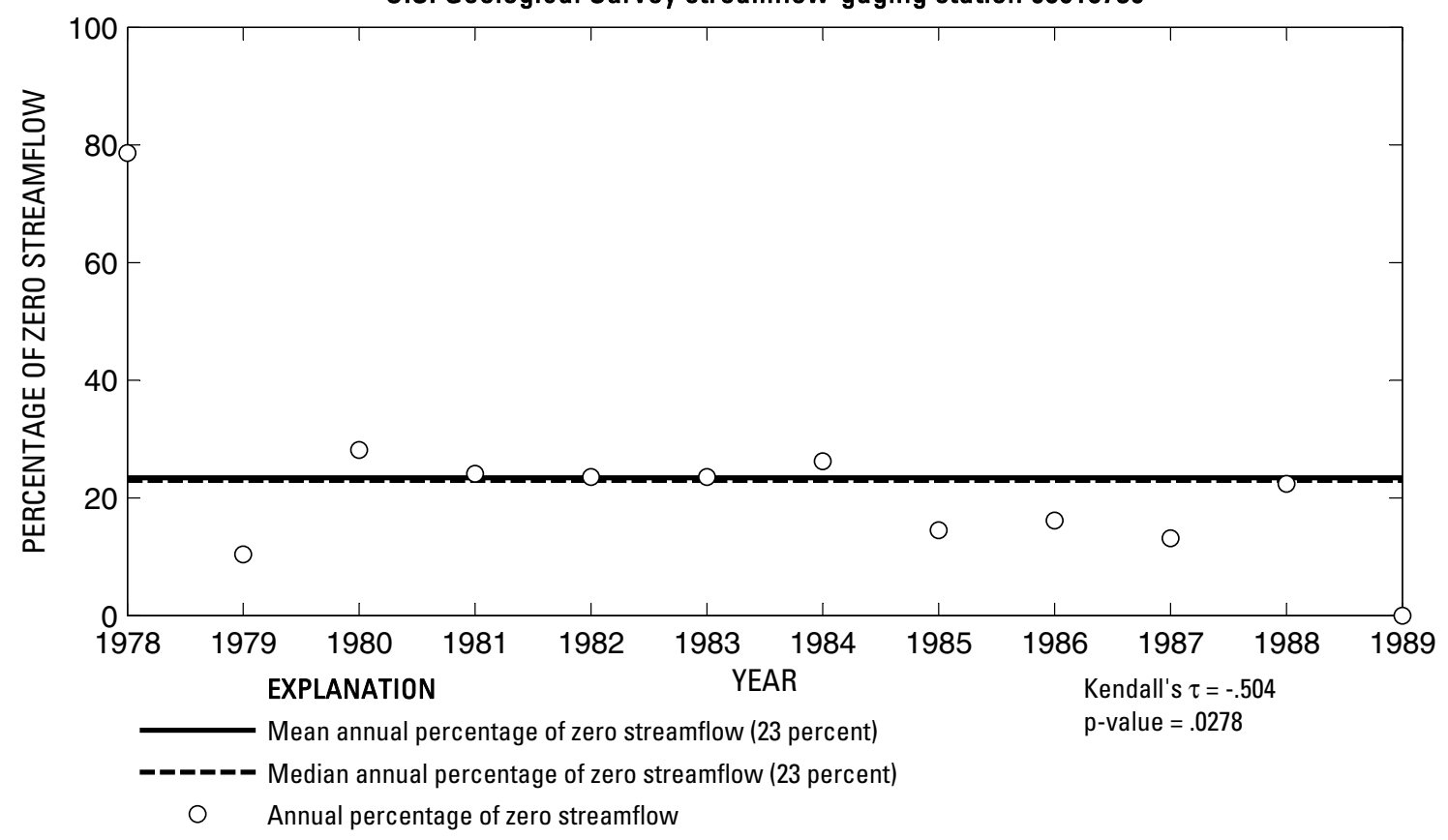

U.S. Geological Survey streamflow-gaging station 08018730

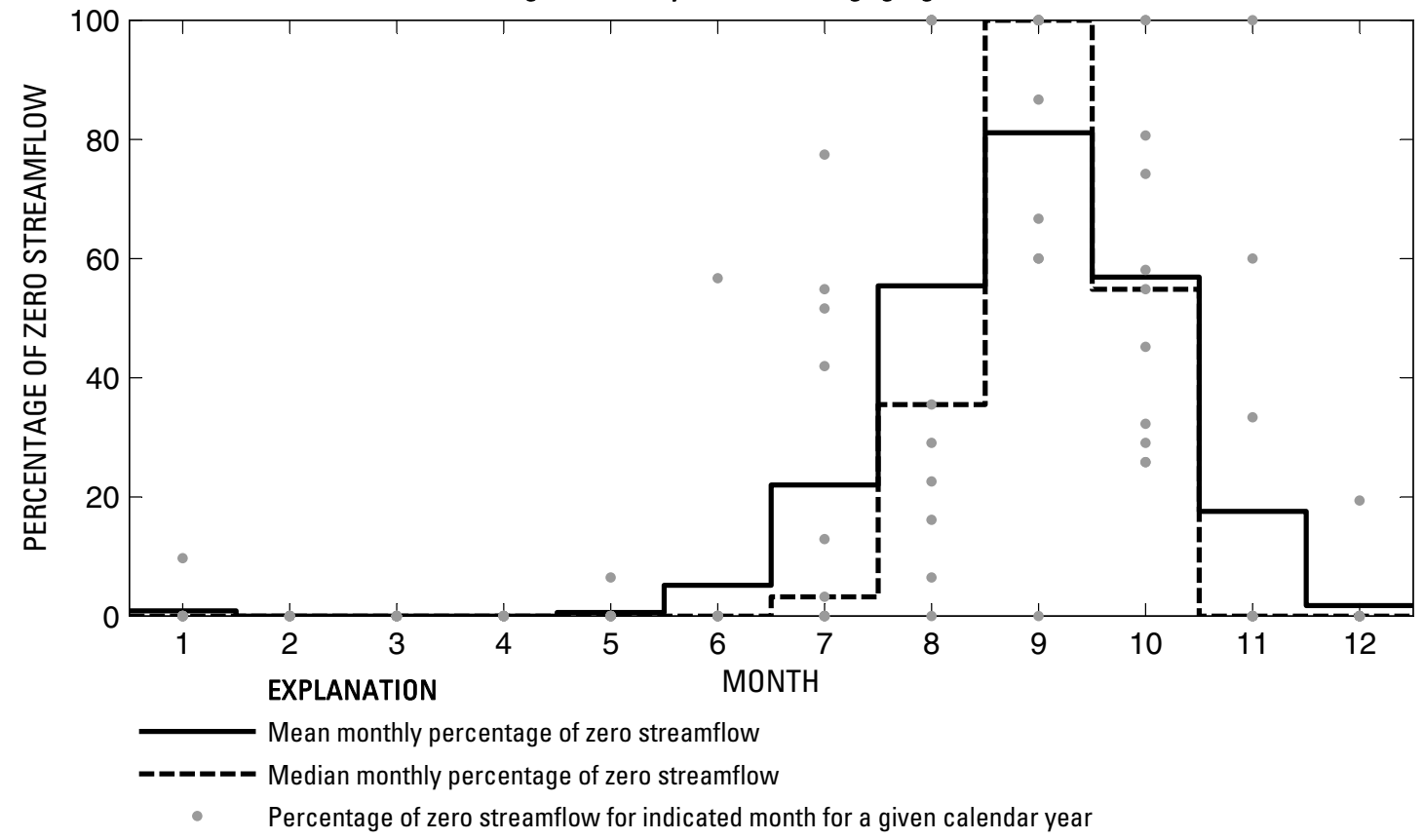

Figure 88. Analysis of percentage of zero daily mean streamflow for U.S. Geological Survey streamflow-gaging station 08018730 Burke Creek near Yantis, Texas. 
U.S. Geological Survey streamflow-gaging station 08019000

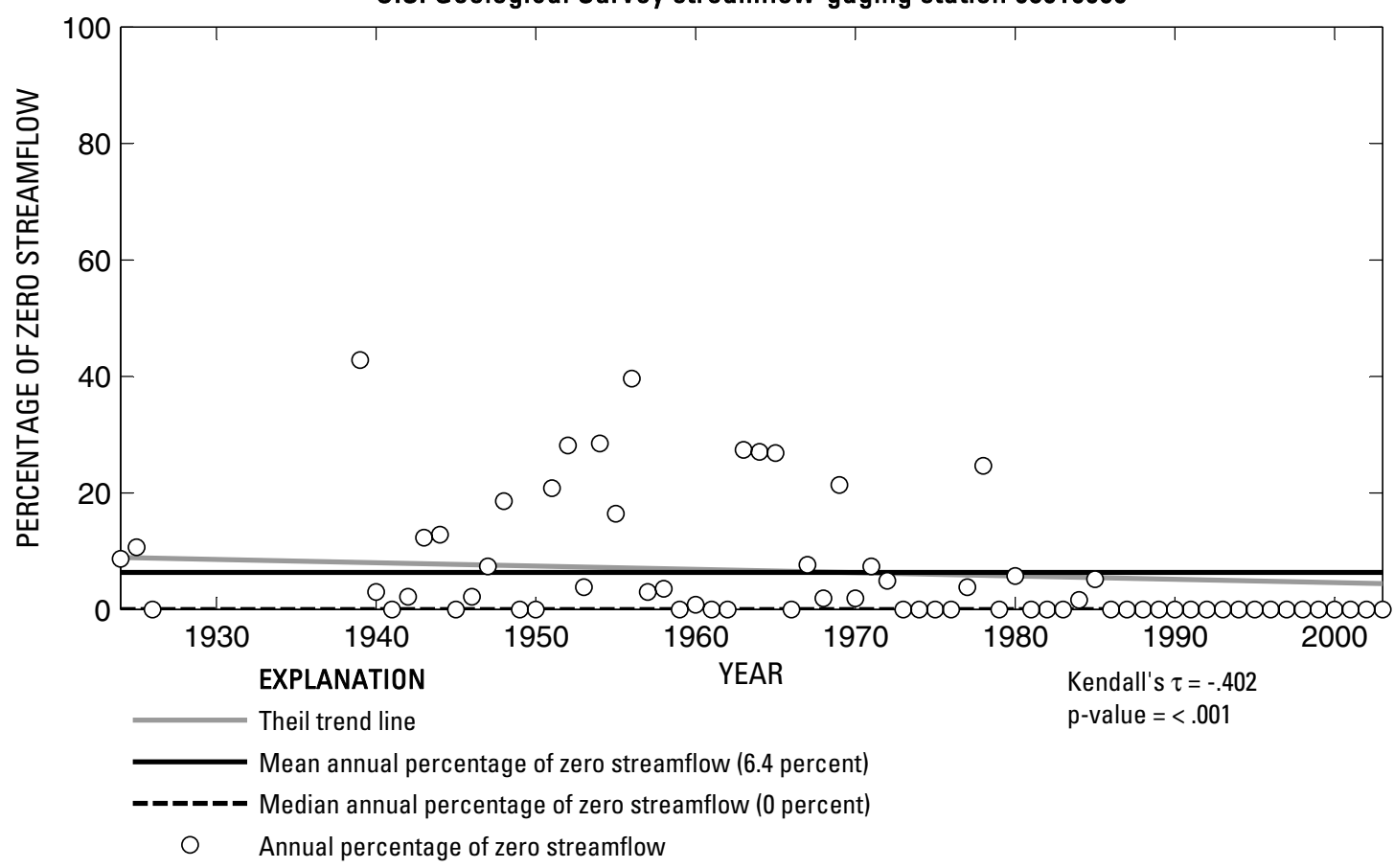

U.S. Geological Survey streamflow-gaging station 08019000

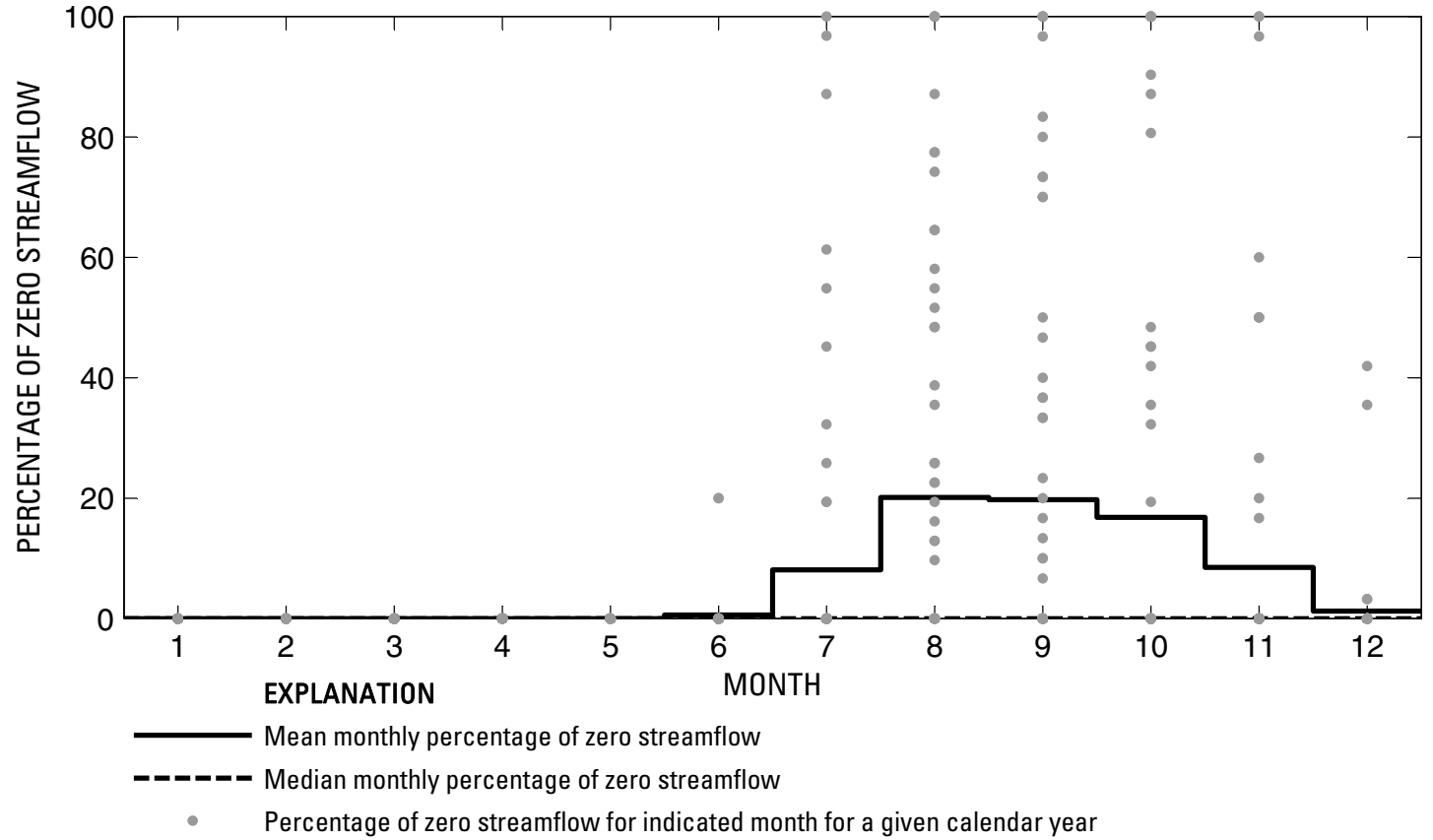

Figure 89. Analysis of percentage of zero daily mean streamflow for U.S. Geological Survey streamflow-gaging station 08019000 Lake Fork Creek near Quitman, Texas. 

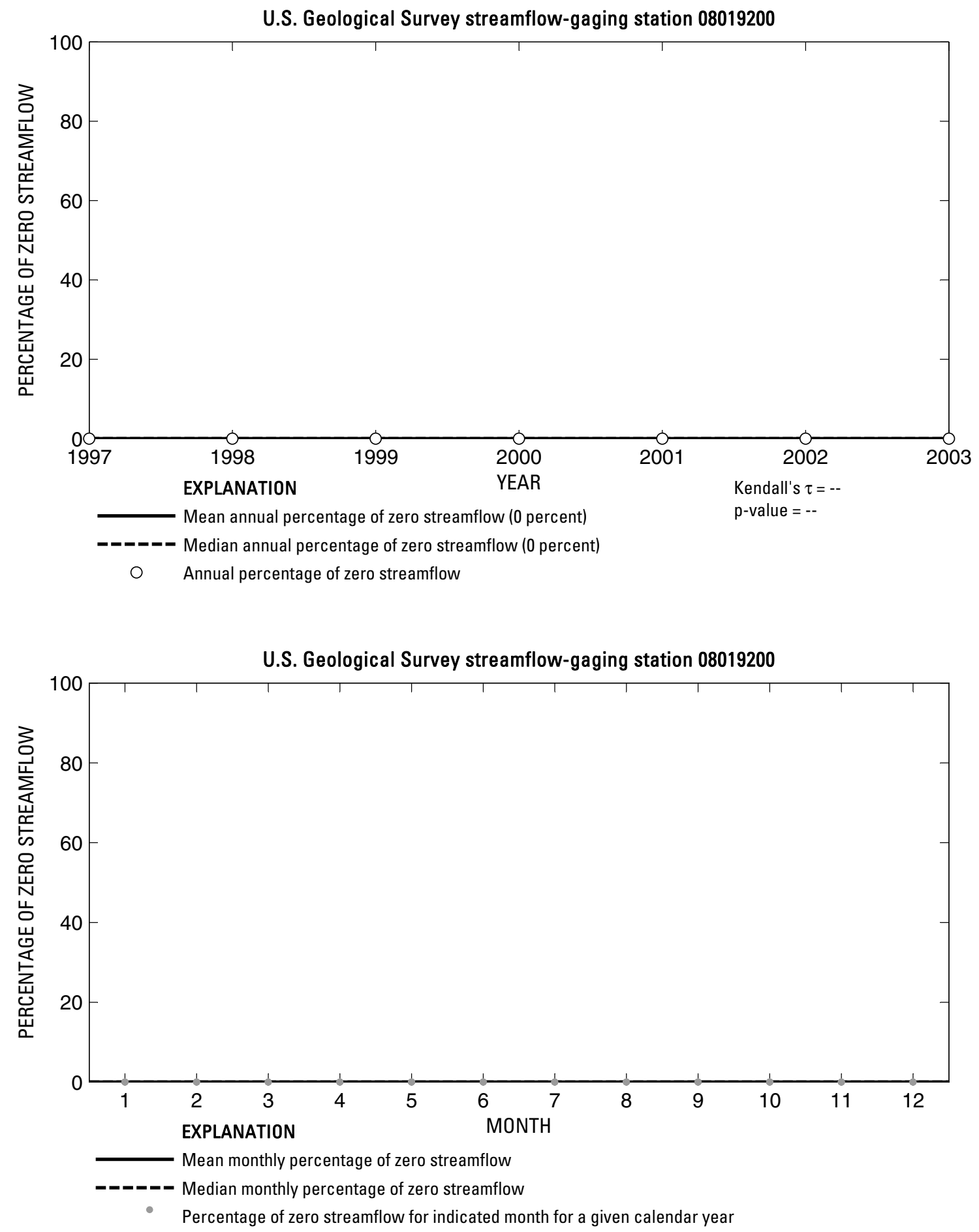

Figure 90. Analysis of percentage of zero daily mean streamflow for U.S. Geological Survey streamflow-gaging station 08019200 Sabine River near Hawkins, Texas. 


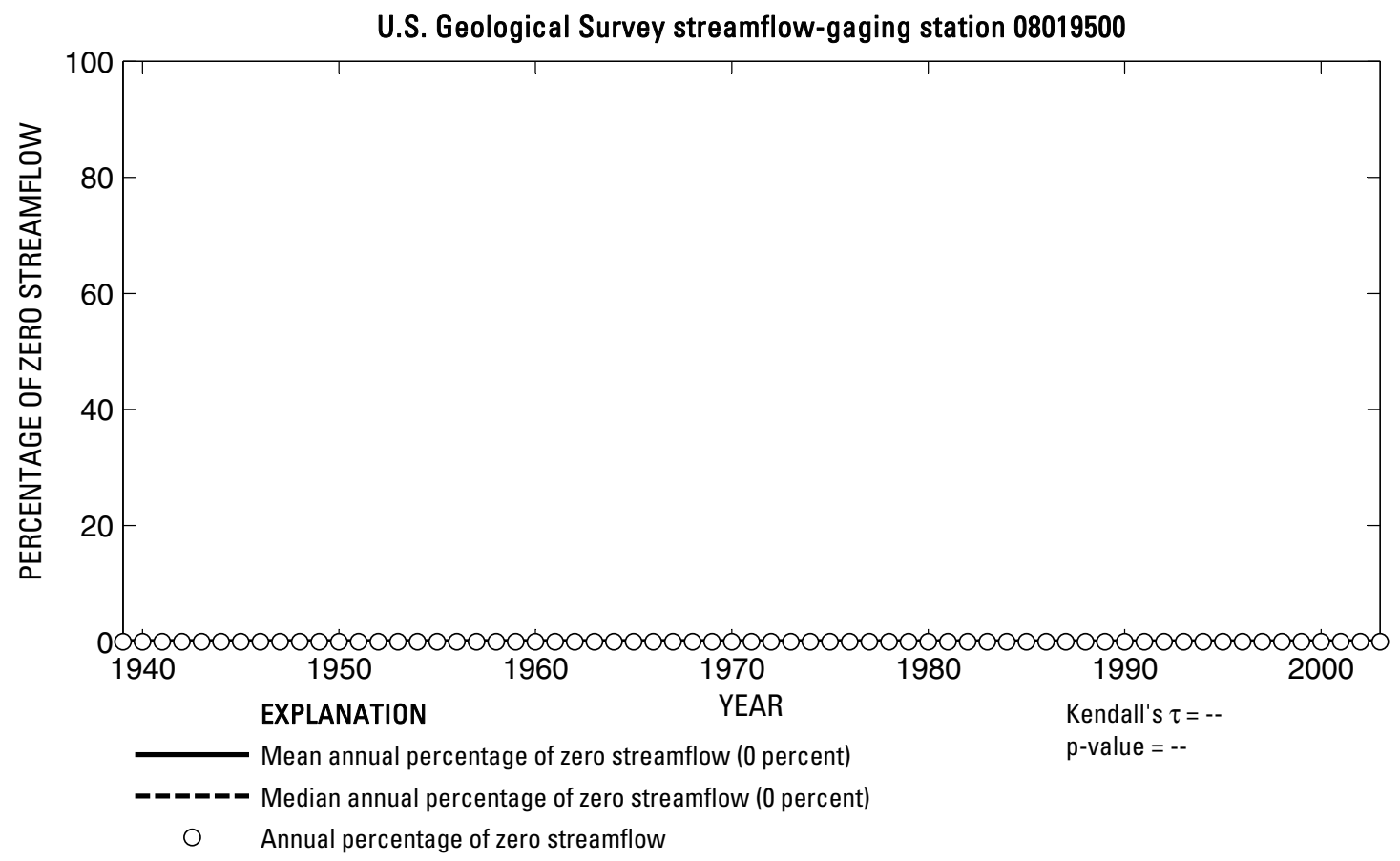

U.S. Geological Survey streamflow-gaging station 08019500

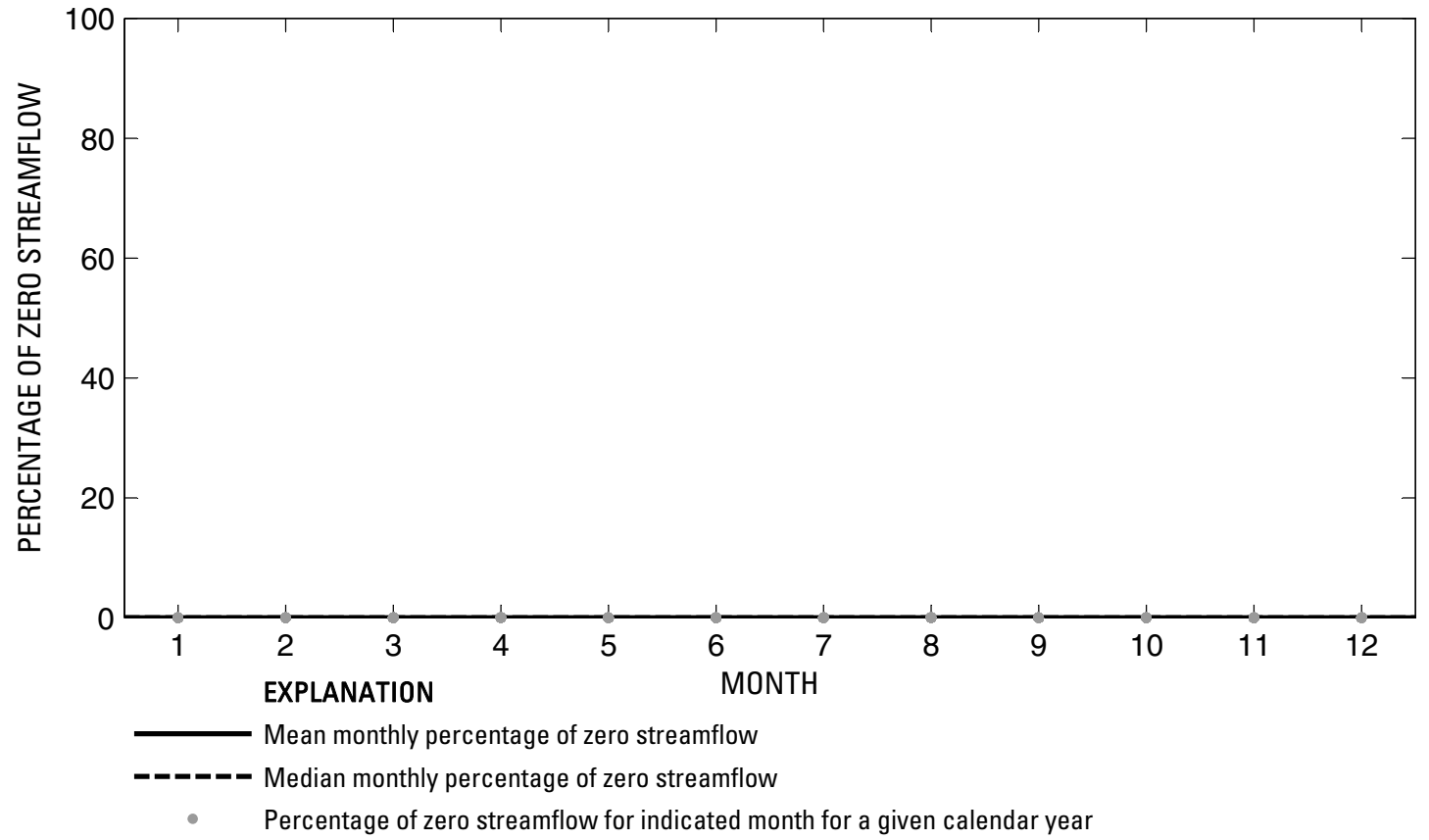

Figure 91. Analysis of percentage of zero daily mean streamflow for U.S. Geological Survey streamflow-gaging station 08019500 Big Sandy Creek near Big Sandy, Texas. 
U.S. Geological Survey streamflow-gaging station 08020000

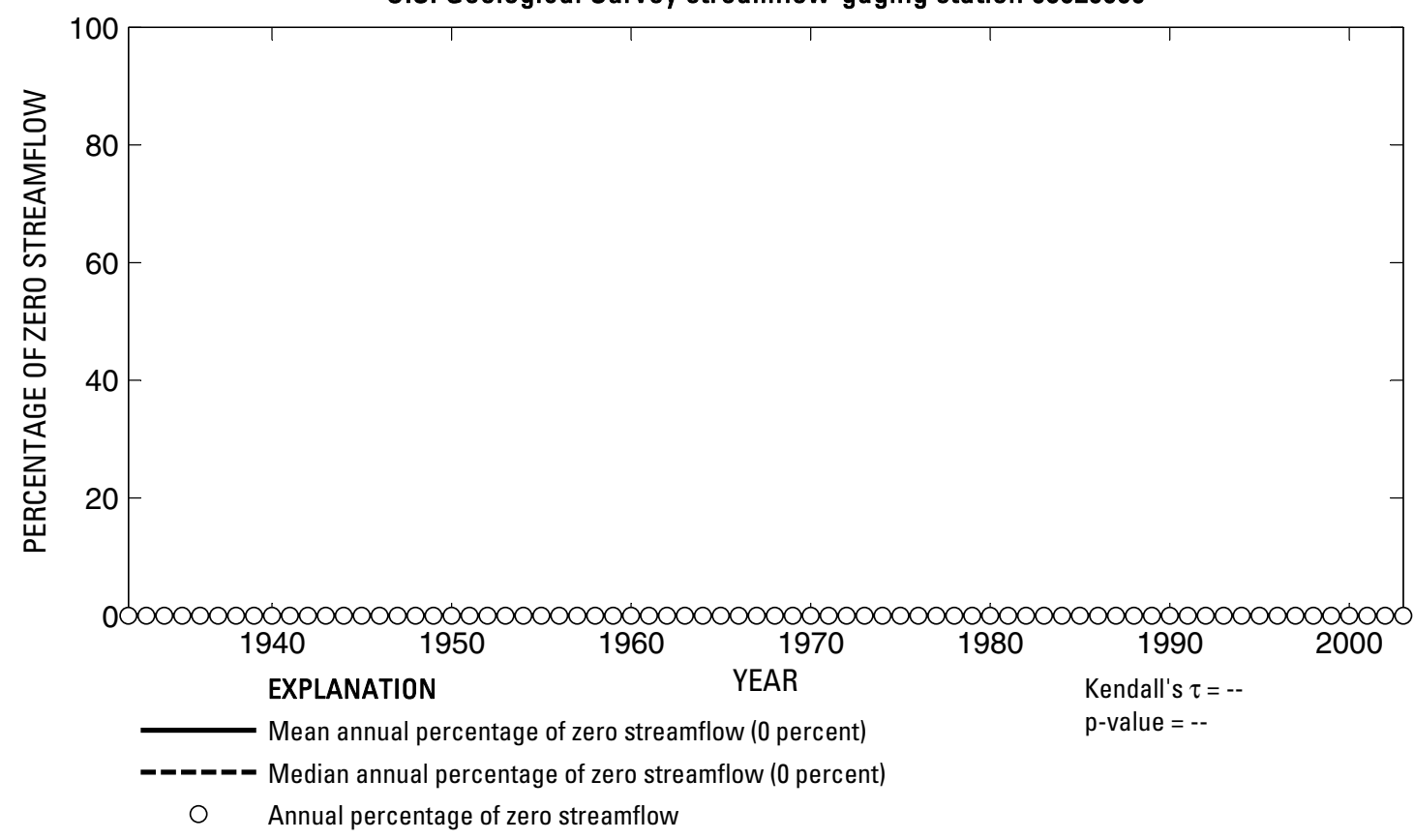

U.S. Geological Survey streamflow-gaging station 08020000

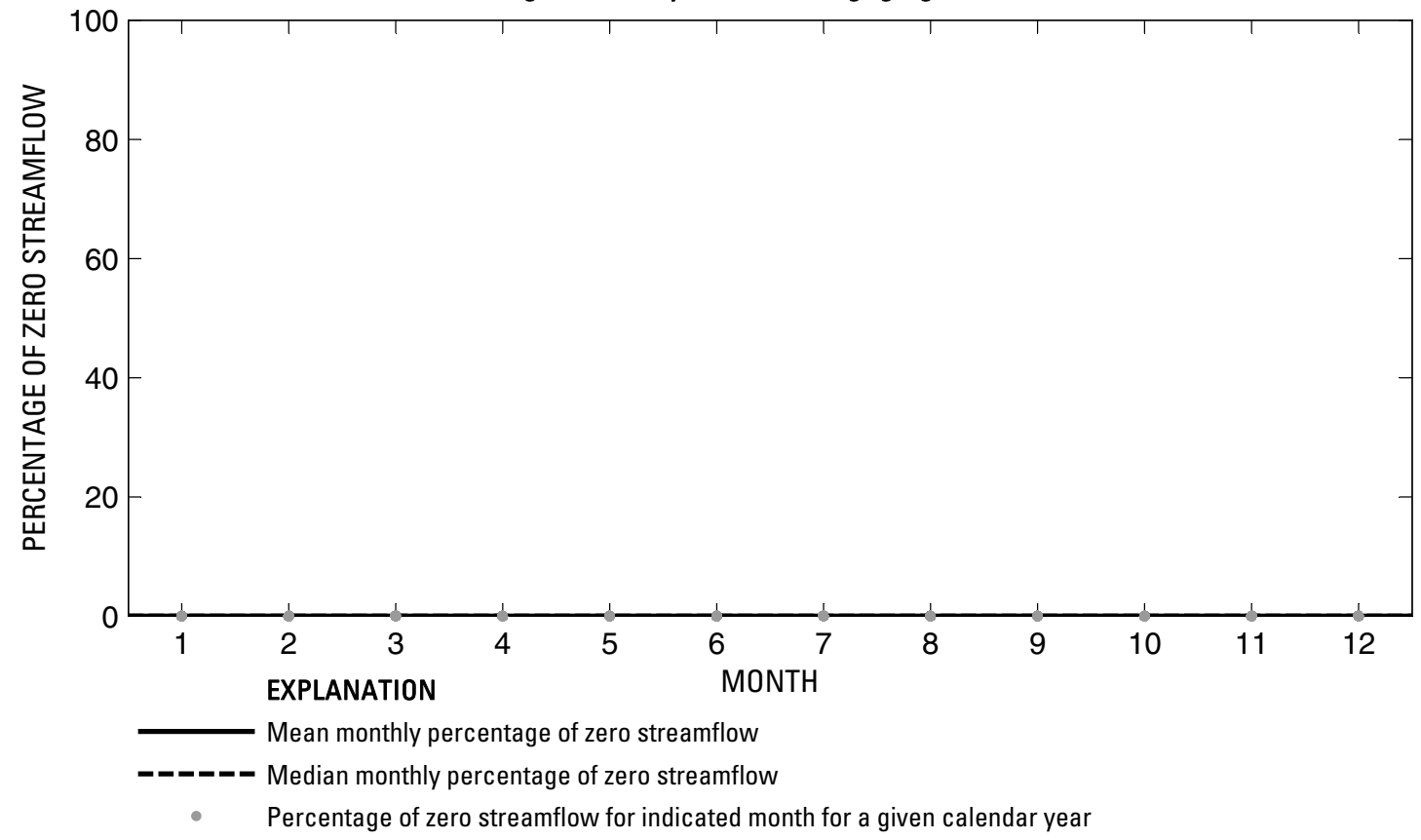

Figure 92. Analysis of percentage of zero daily mean streamflow for U.S. Geological Survey streamflow-gaging station 08020000 Sabine River near Gladewater, Texas. 


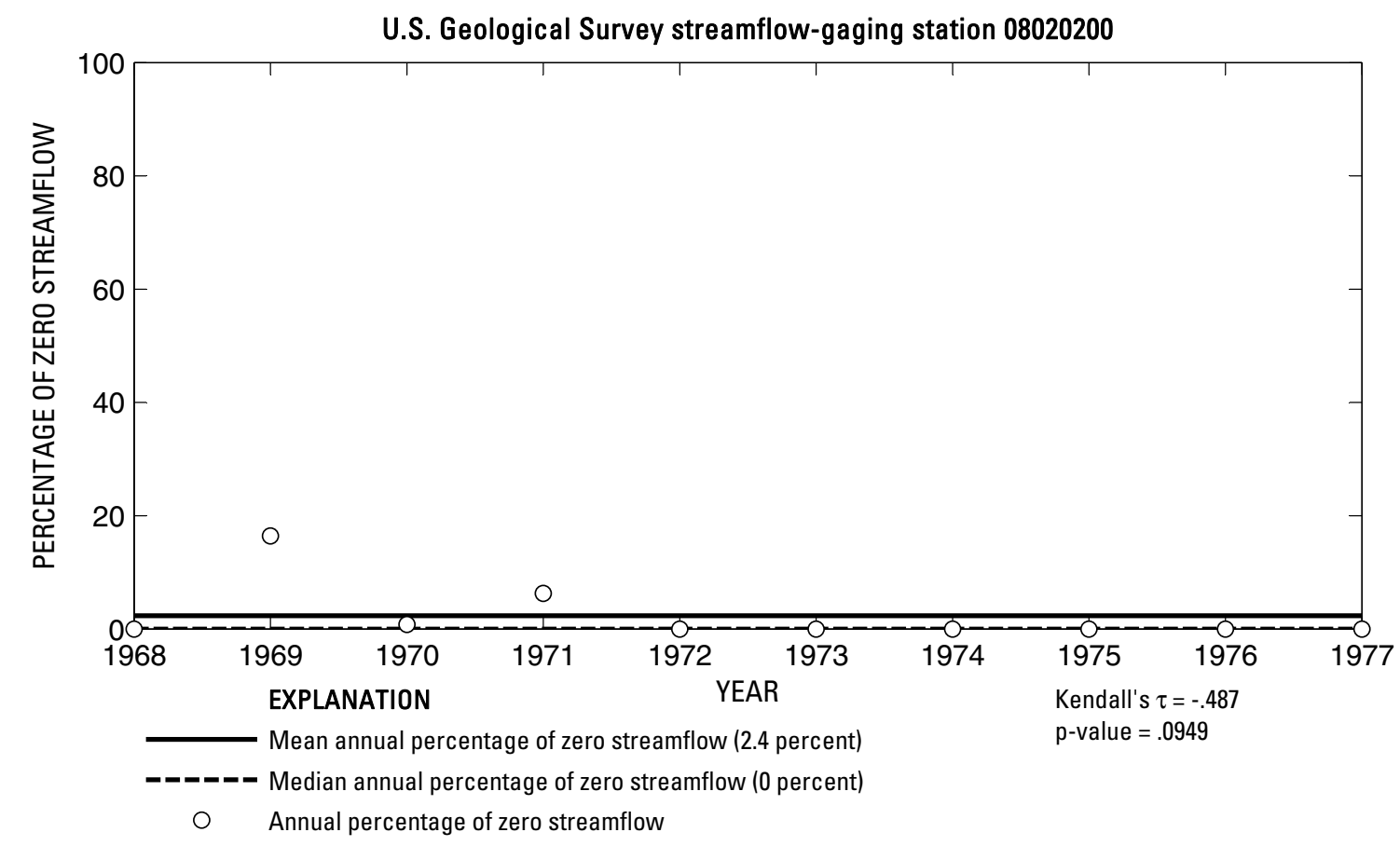

U.S. Geological Survey streamflow-gaging station 08020200

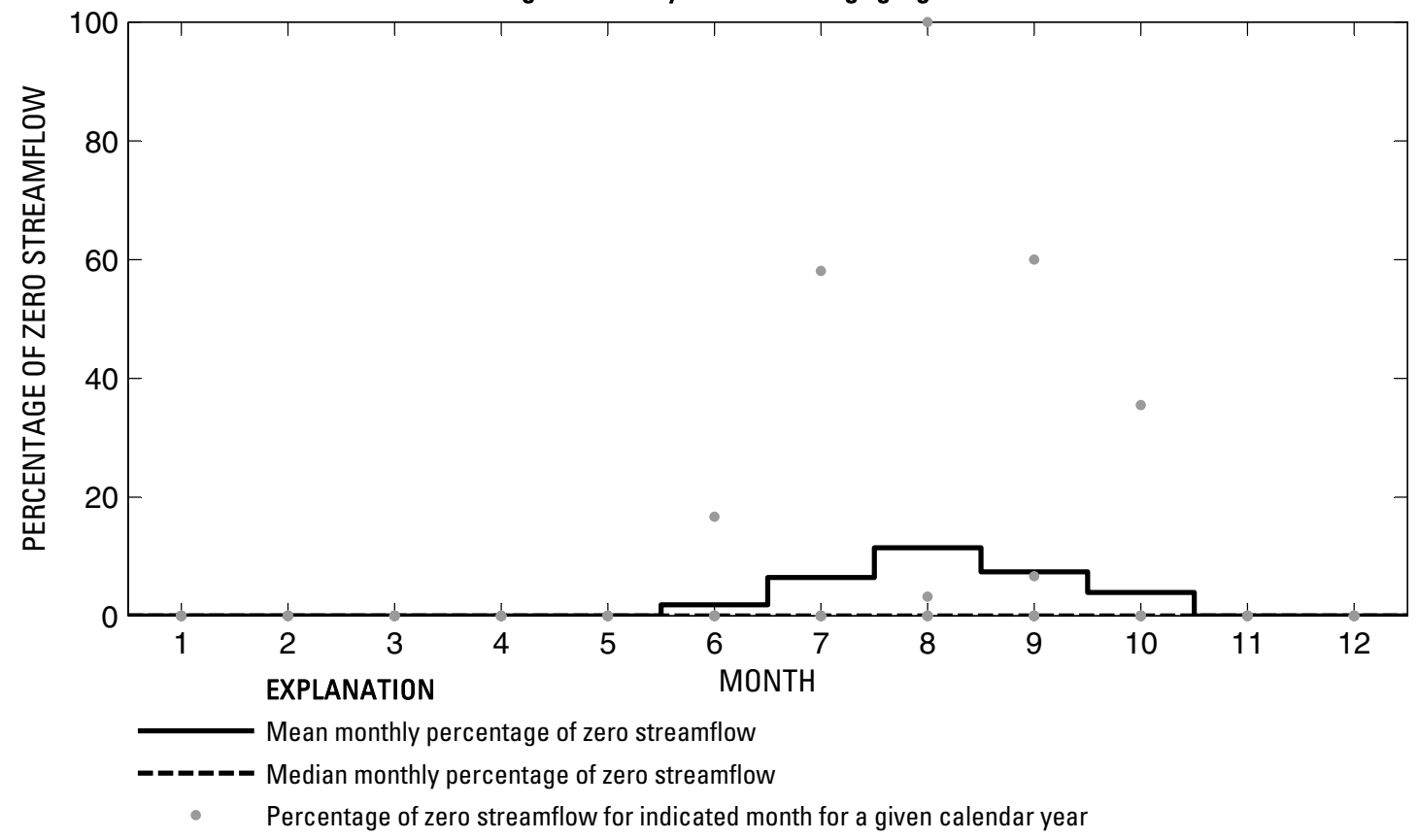

Figure 93. Analysis of percentage of zero daily mean streamflow for U.S. Geological Survey streamflow-gaging station 08020200 Prairie Creek near Gladewater, Texas. 

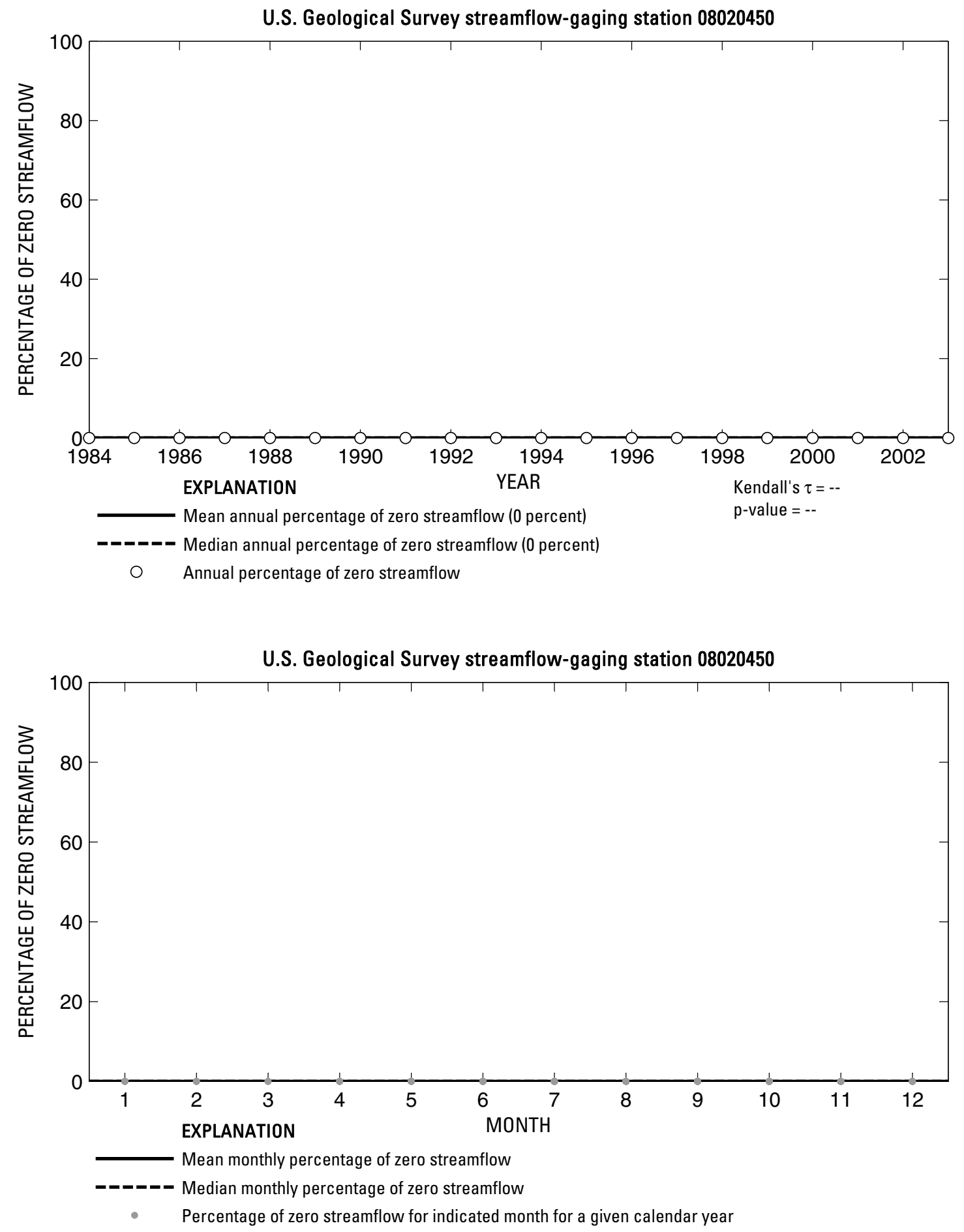

Figure 94. Analysis of percentage of zero daily mean streamflow for U.S. Geological Survey streamflow-gaging station 08020450 Sabine River above Longview, Texas. 


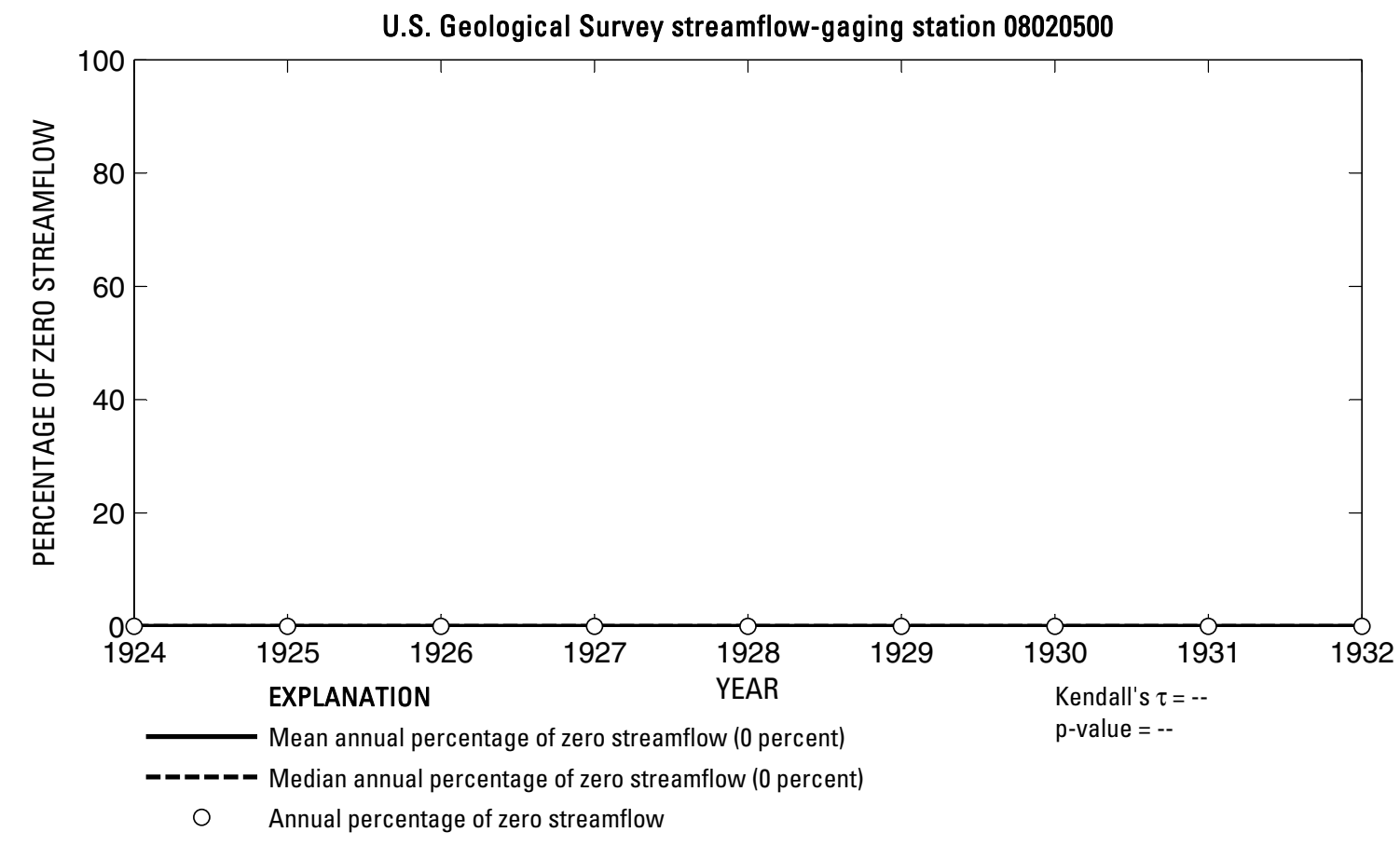

U.S. Geological Survey streamflow-gaging station 08020500

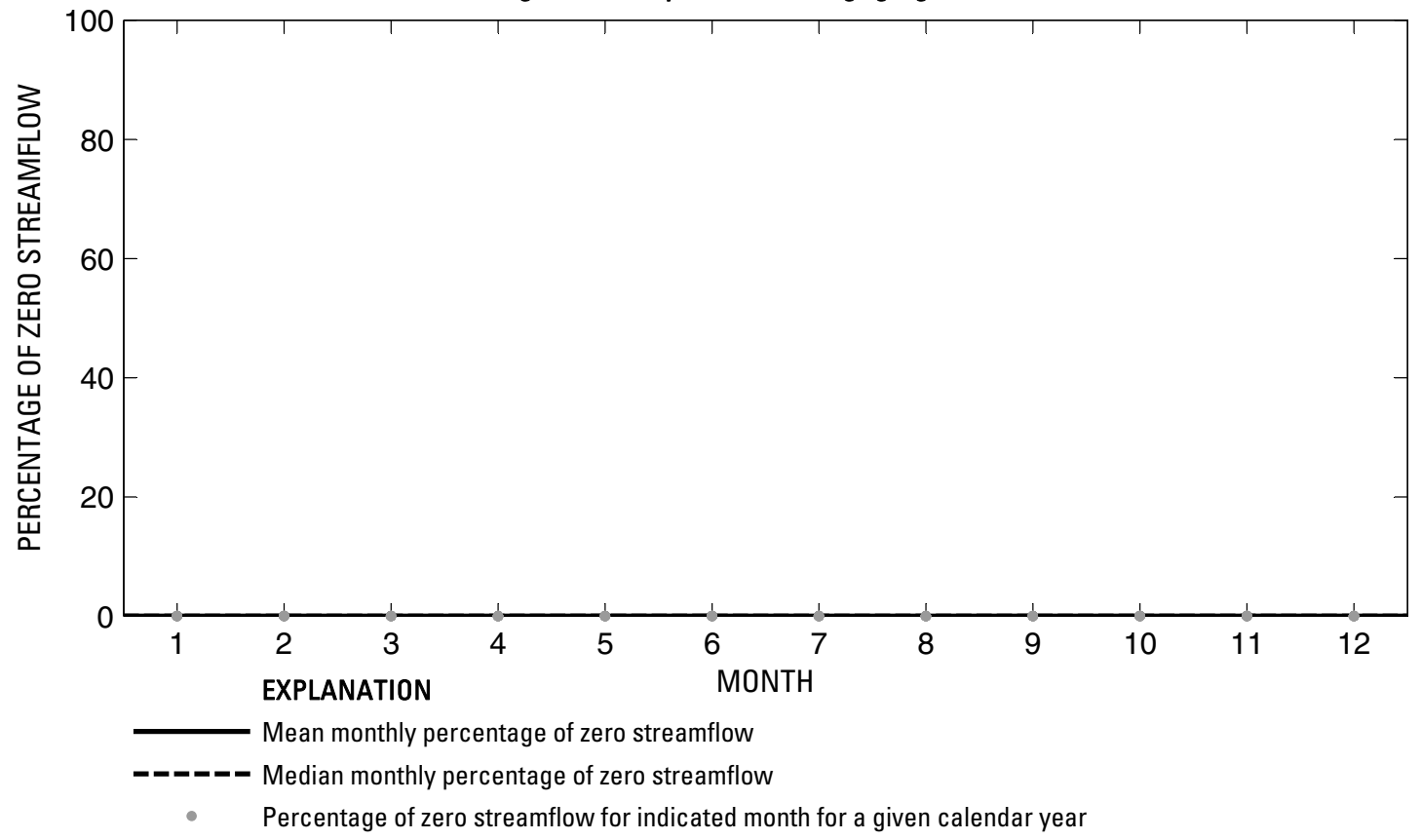

Figure 95. Analysis of percentage of zero daily mean streamflow for U.S. Geological Survey streamflow-gaging station 08020500 Sabine River near Longview, Texas. 
U.S. Geological Survey streamflow-gaging station 08020700

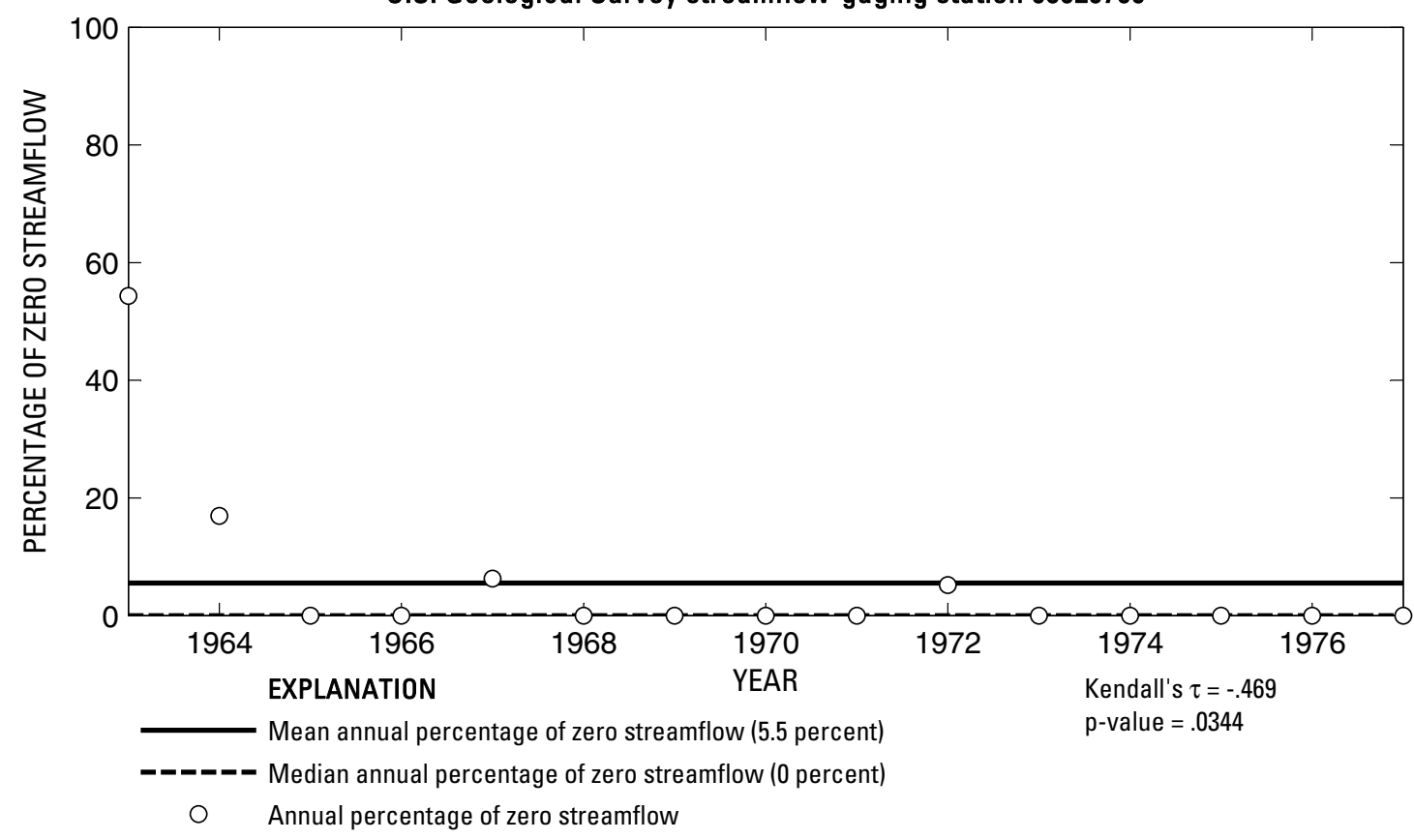

U.S. Geological Survey streamflow-gaging station 08020700

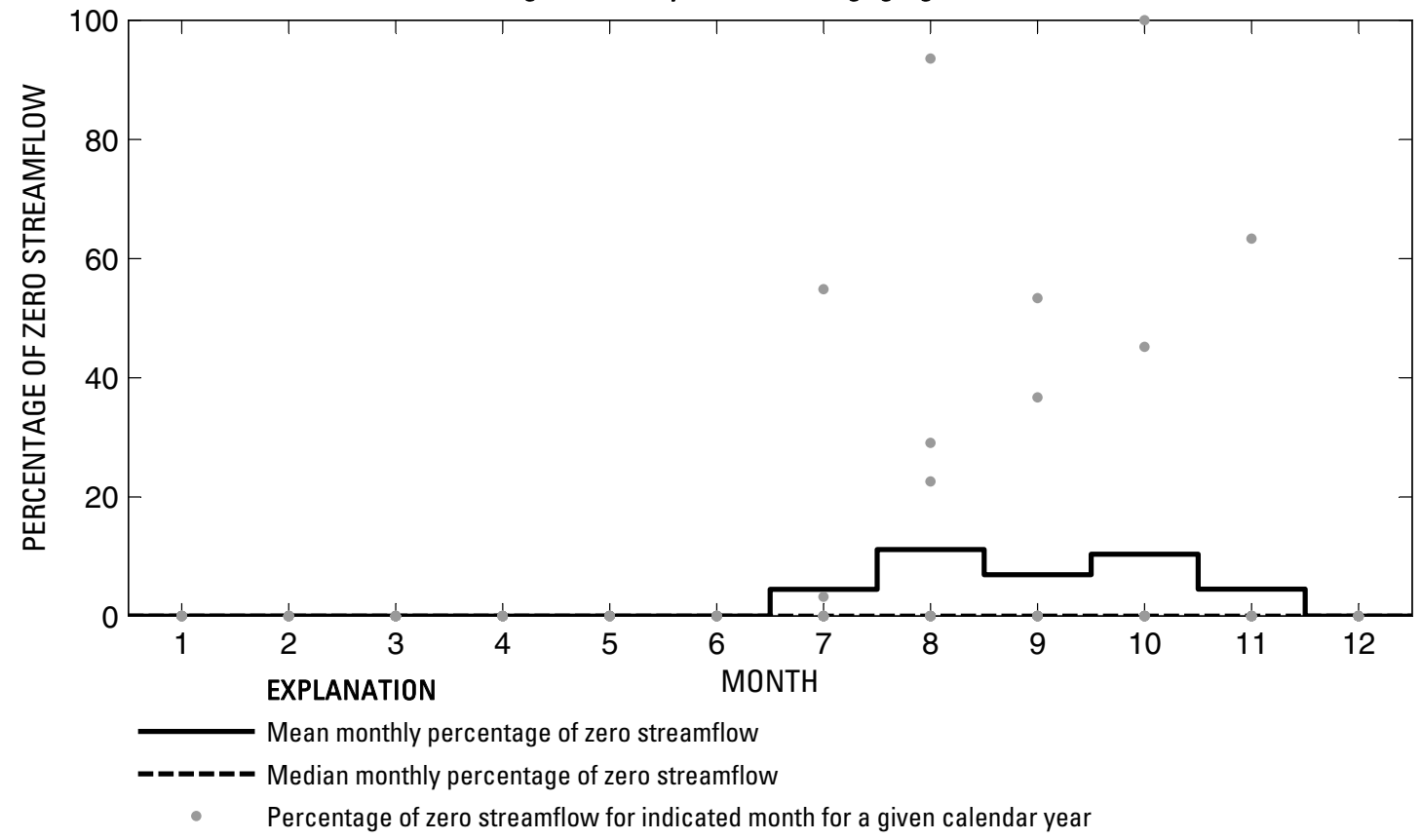

Figure 96. Analysis of percentage of zero daily mean streamflow for U.S. Geological Survey streamflow-gaging station 08020700 Rabbit Creek at Kilgore, Texas. 


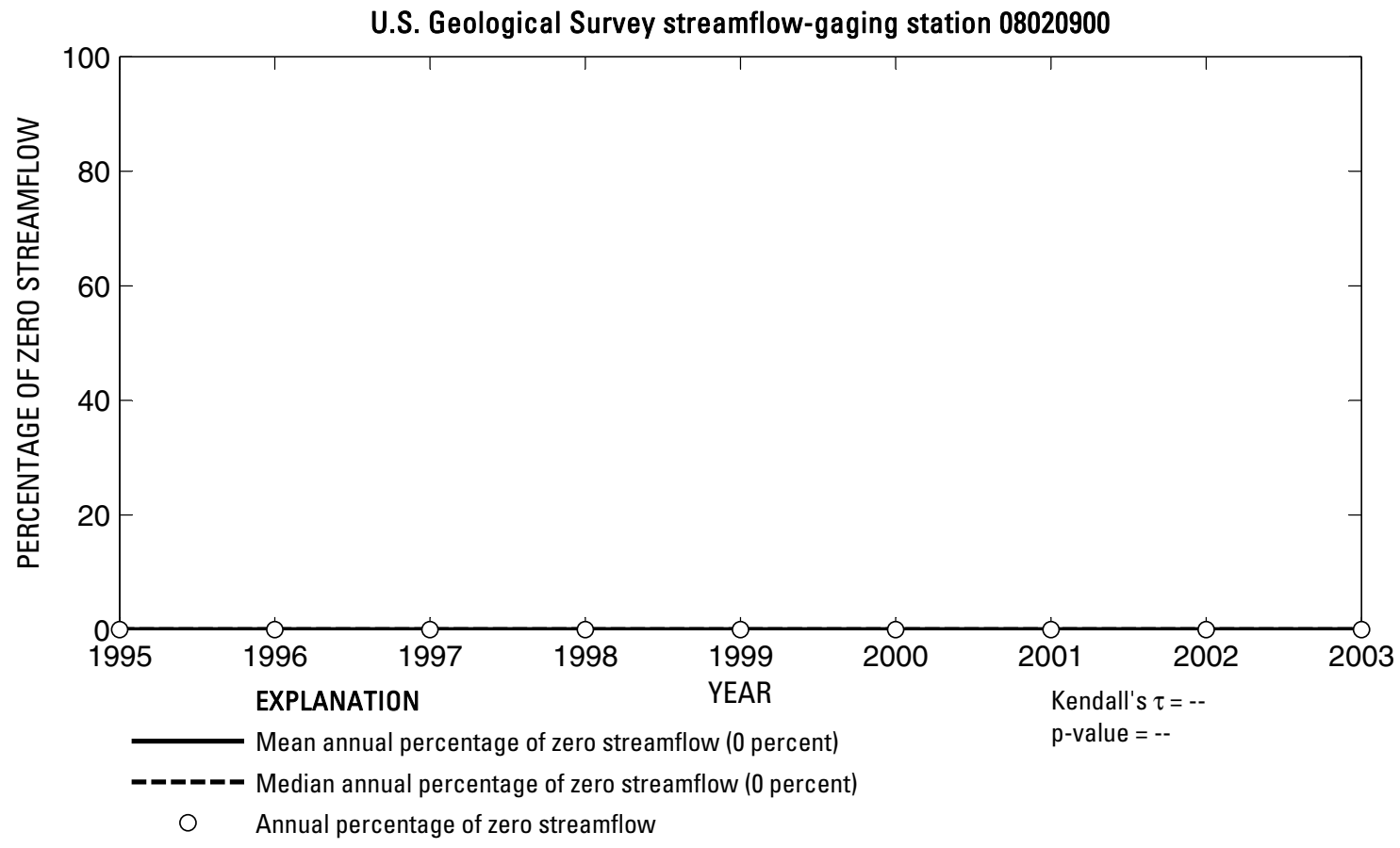

U.S. Geological Survey streamflow-gaging station 08020900

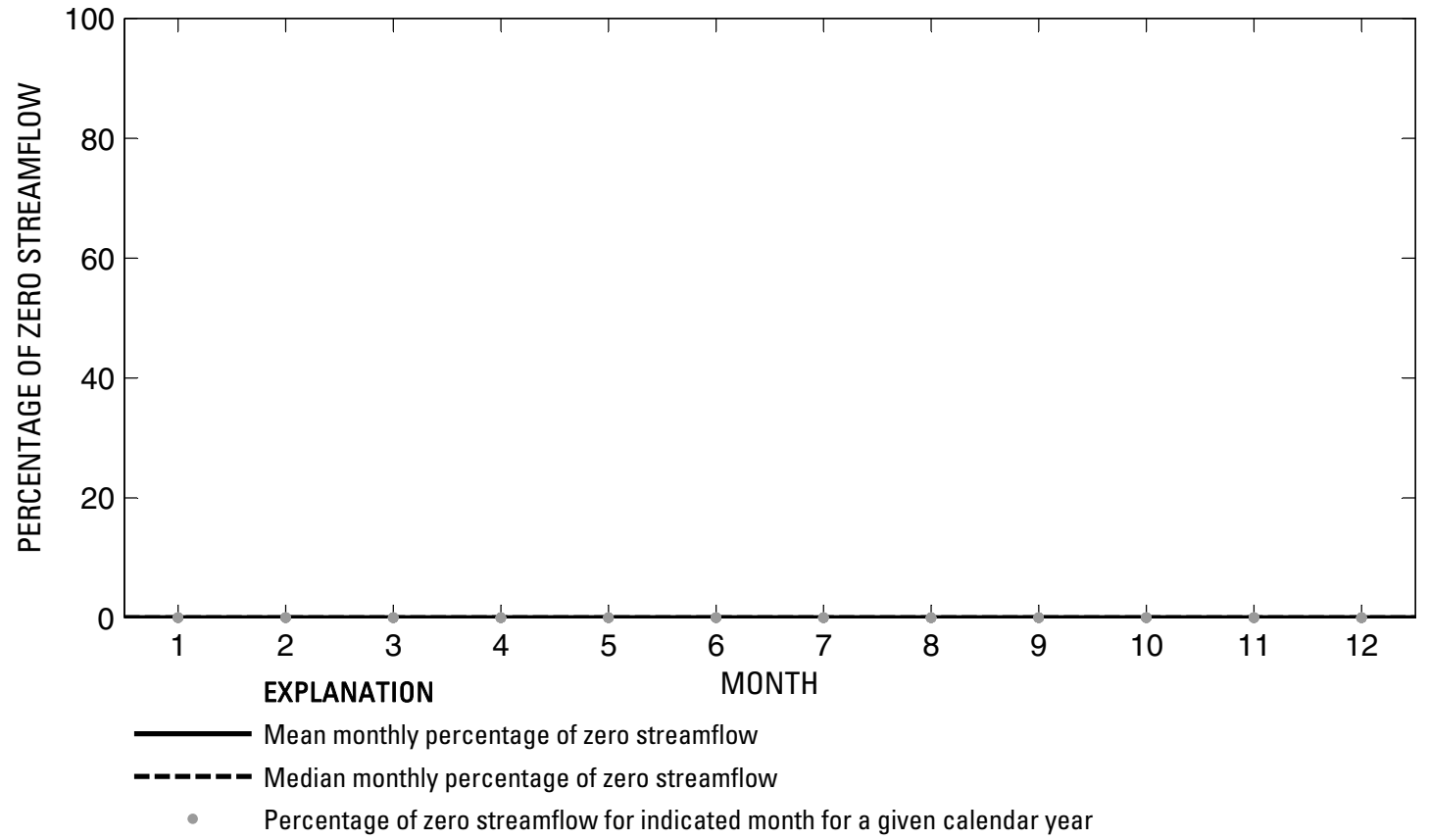

Figure 97. Analysis of percentage of zero daily mean streamflow for U.S. Geological Survey streamflow-gaging station 08020900 Sabine River below Longview, Texas. 
U.S. Geological Survey streamflow-gaging station 08020960

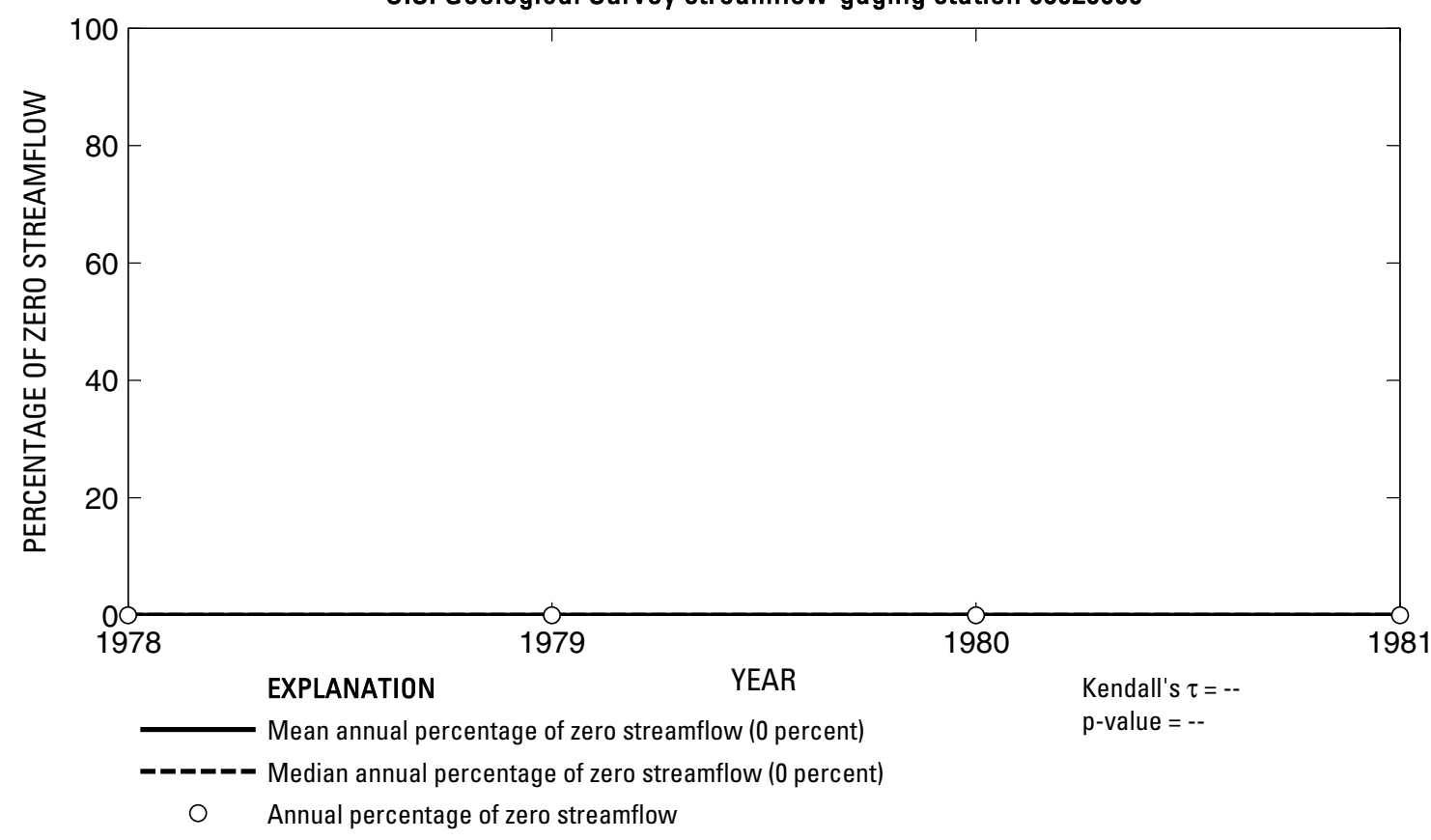

U.S. Geological Survey streamflow-gaging station 08020960

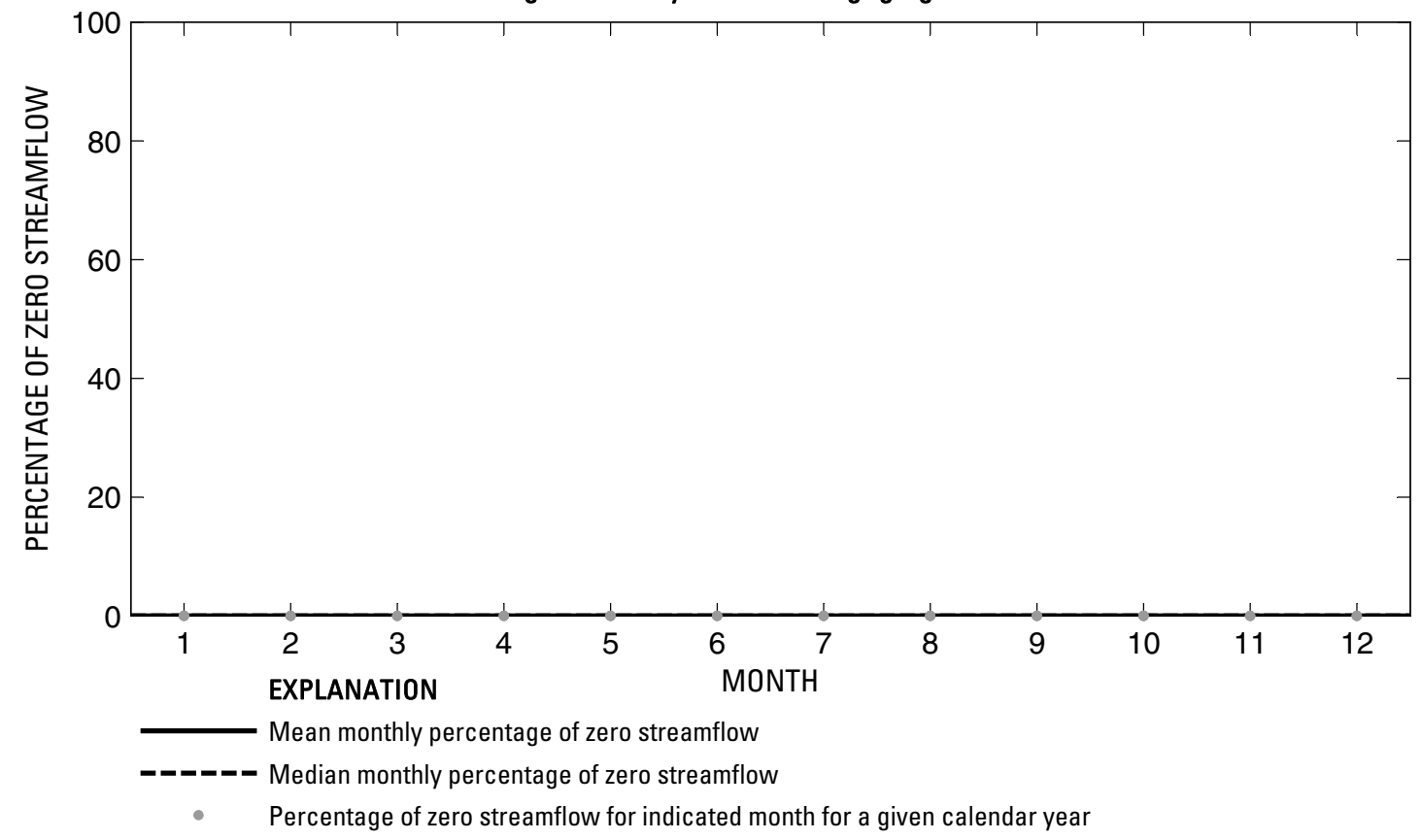

Figure 98. Analysis of percentage of zero daily mean streamflow for U.S. Geological Survey streamflow-gaging station 08020960 Mill Creek near Henderson, Texas. 


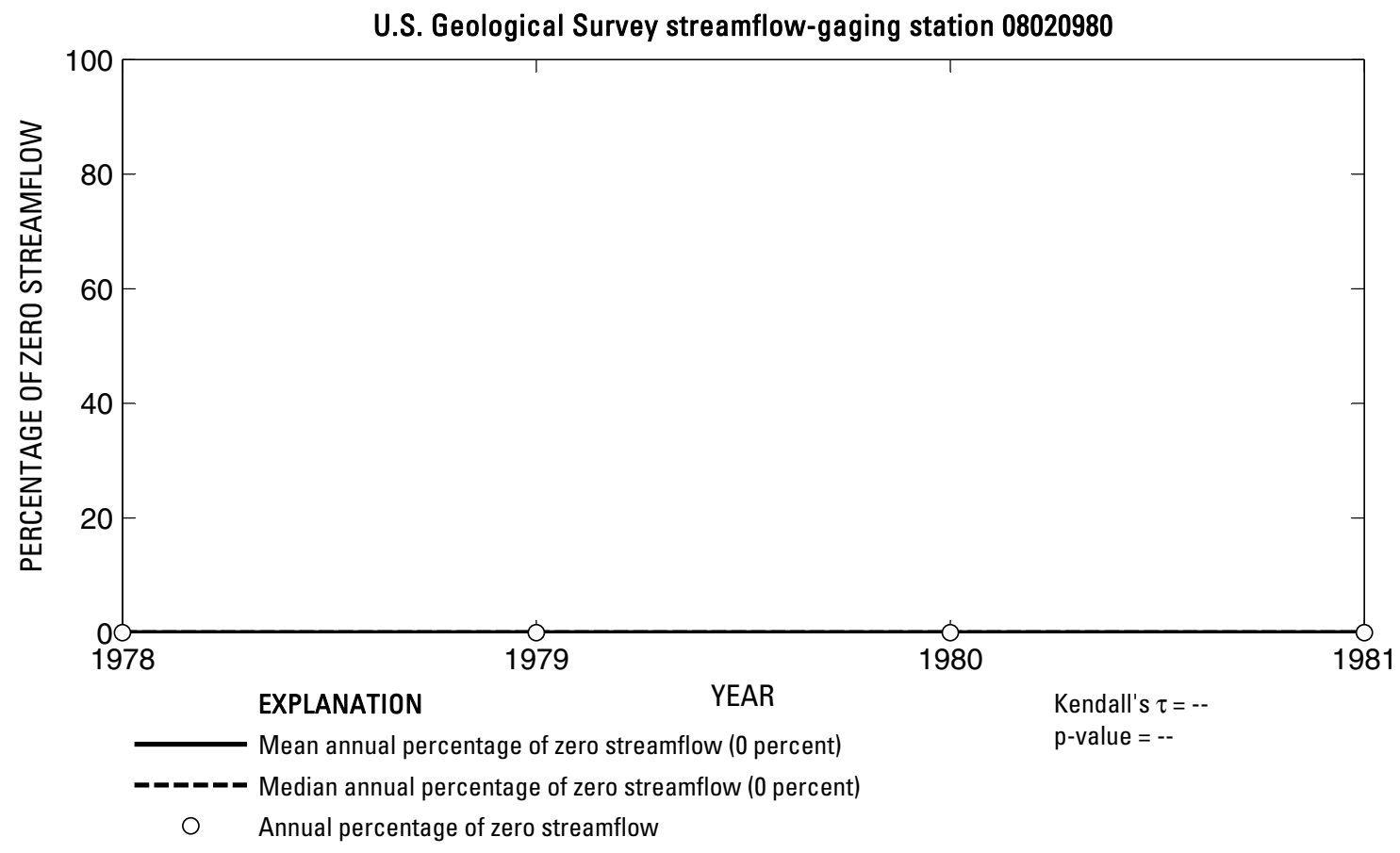

U.S. Geological Survey streamflow-gaging station 08020980

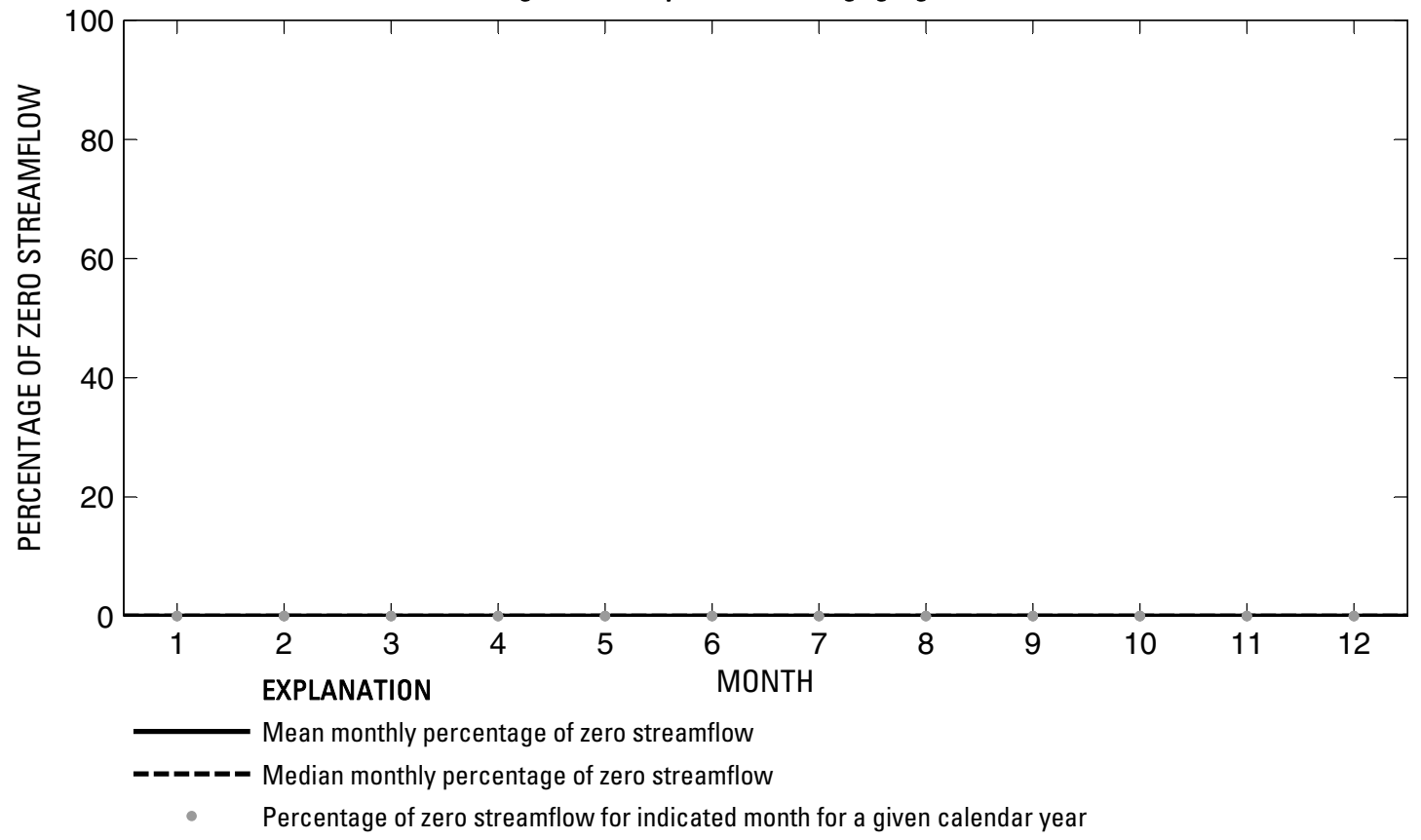

Figure 99. Analysis of percentage of zero daily mean streamflow for U.S. Geological Survey streamflow-gaging station 08020980 Mill Creek near Longview, Texas. 
U.S. Geological Survey streamflow-gaging station 08020990

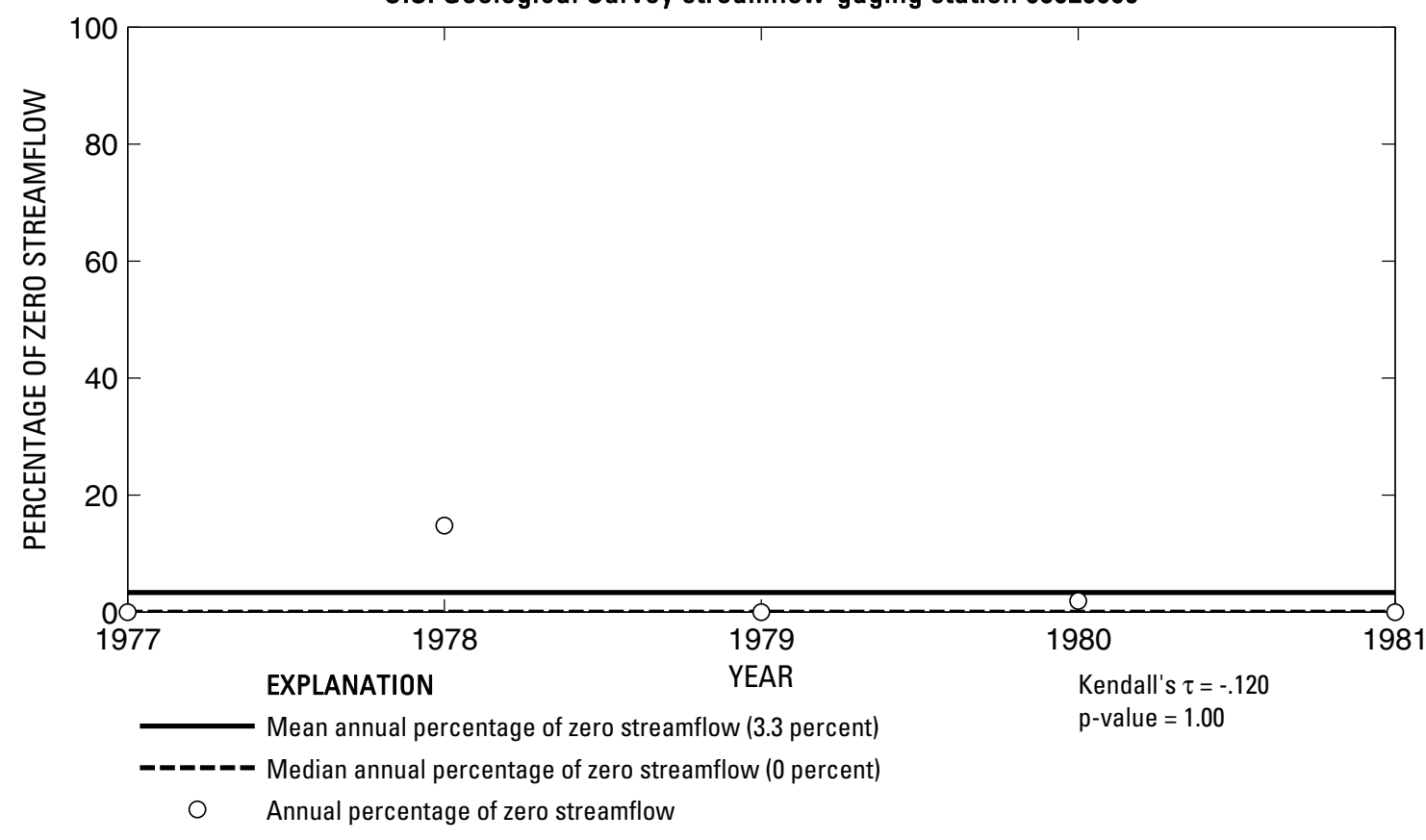

U.S. Geological Survey streamflow-gaging station 08020990

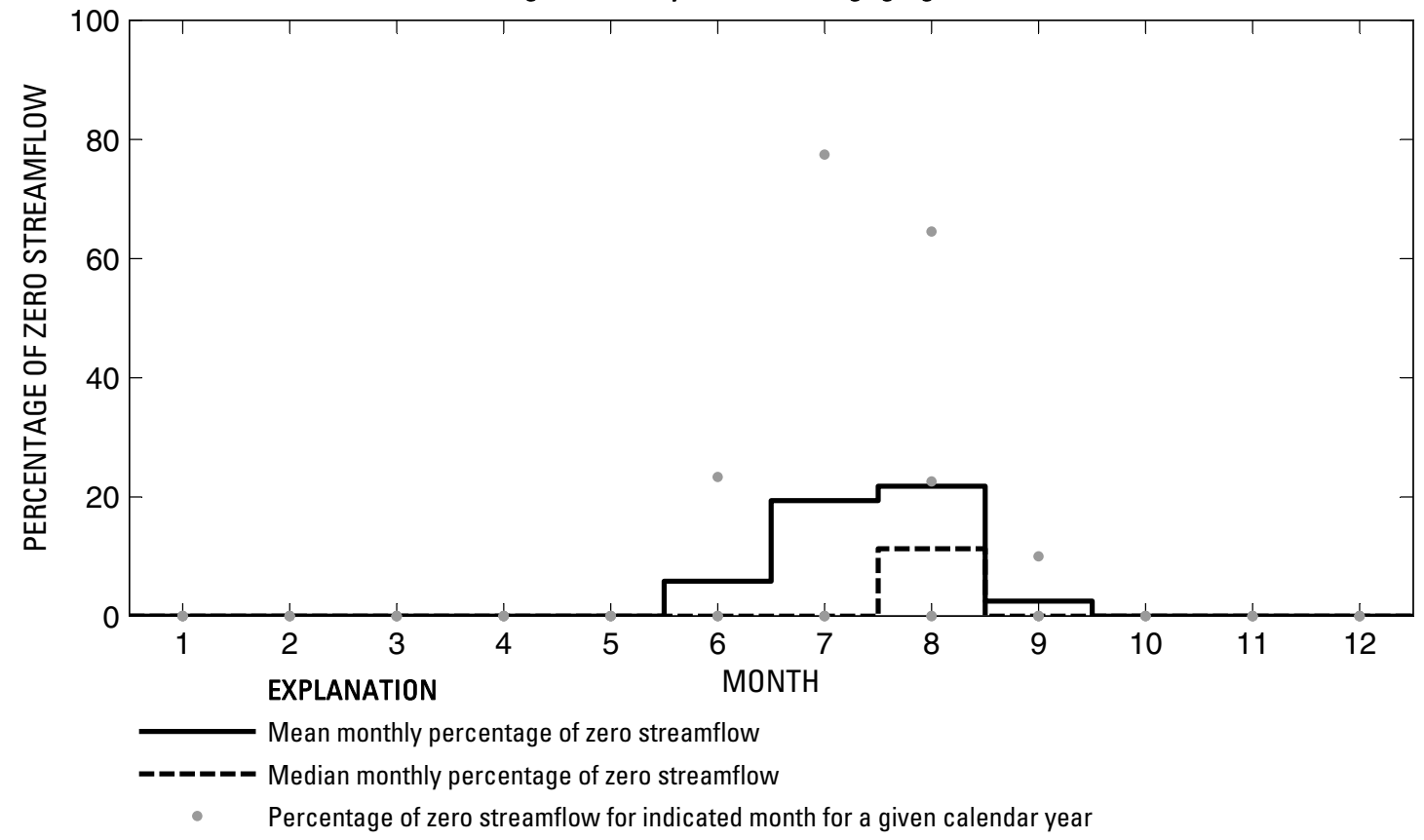

Figure 100. Analysis of percentage of zero daily mean streamflow for U.S. Geological Survey streamflow-gaging station 08020990 Tiawichi Creek near Longview, Texas. 
U.S. Geological Survey streamflow-gaging station 08021000

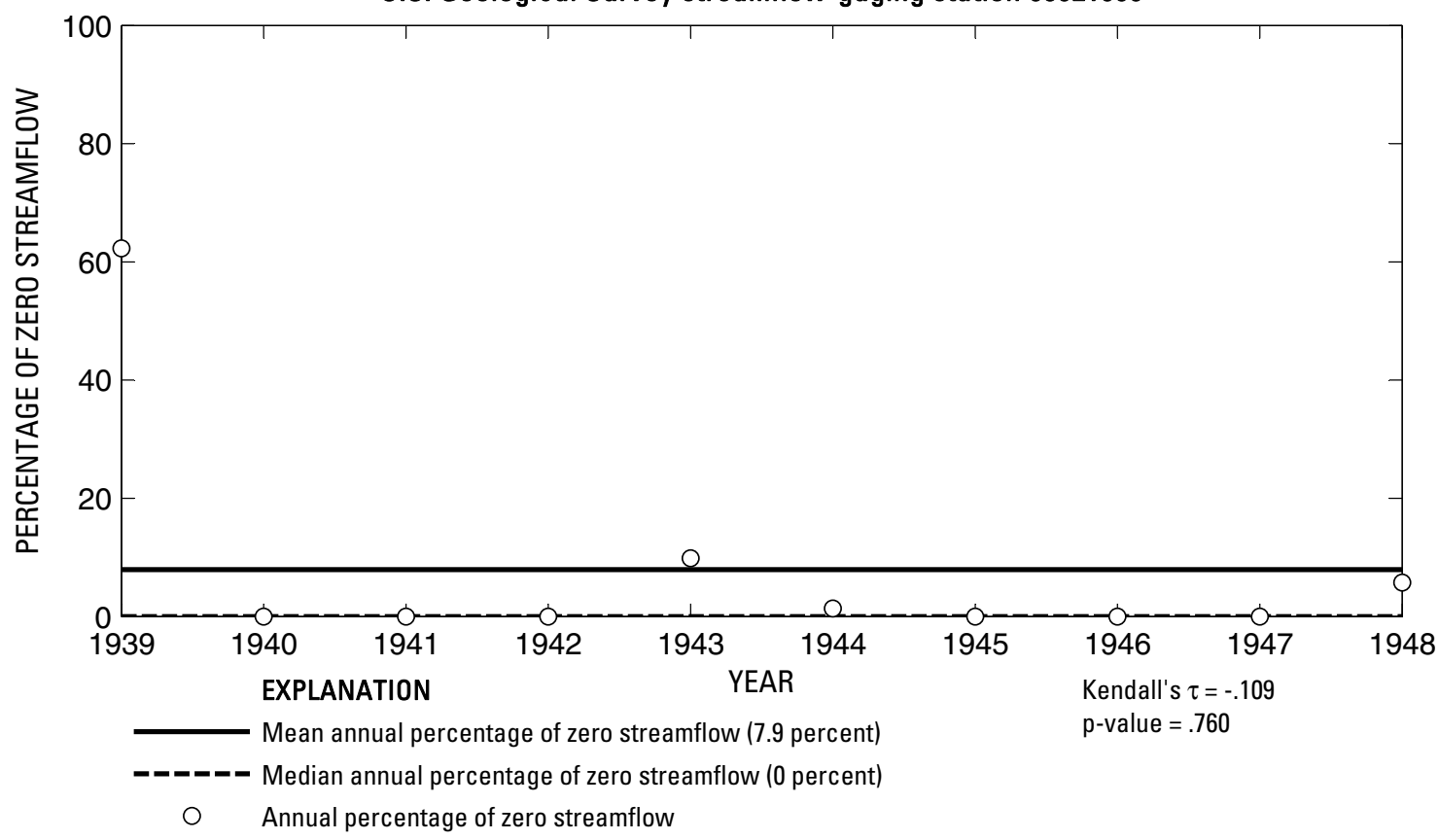

U.S. Geological Survey streamflow-gaging station 08021000

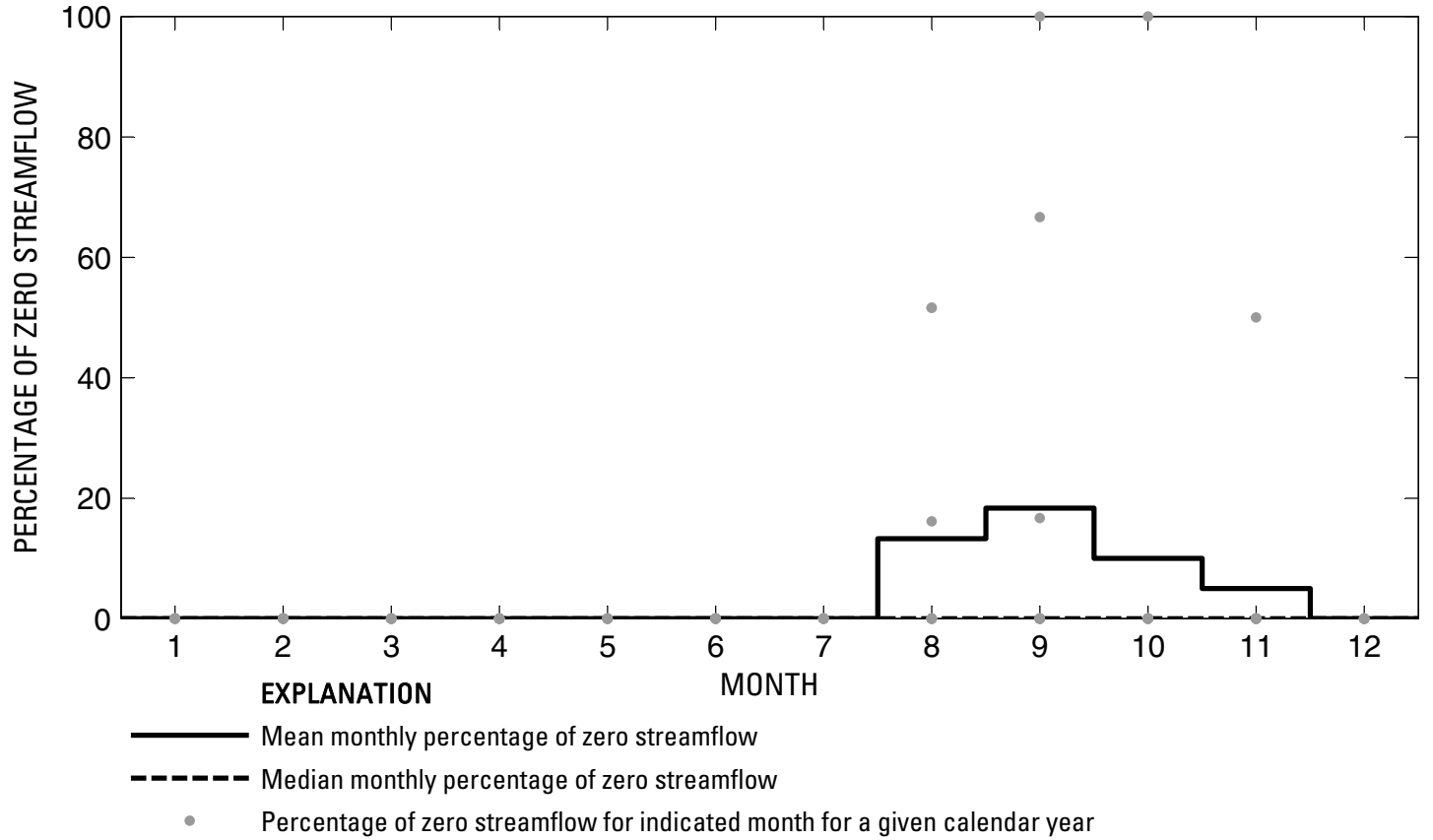

Figure 101. Analysis of percentage of zero daily mean streamflow for U.S. Geological Survey streamflow-gaging station 08021000 Cherokee Bayou near Elderville, Texas. 
U.S. Geological Survey streamflow-gaging station 08022040

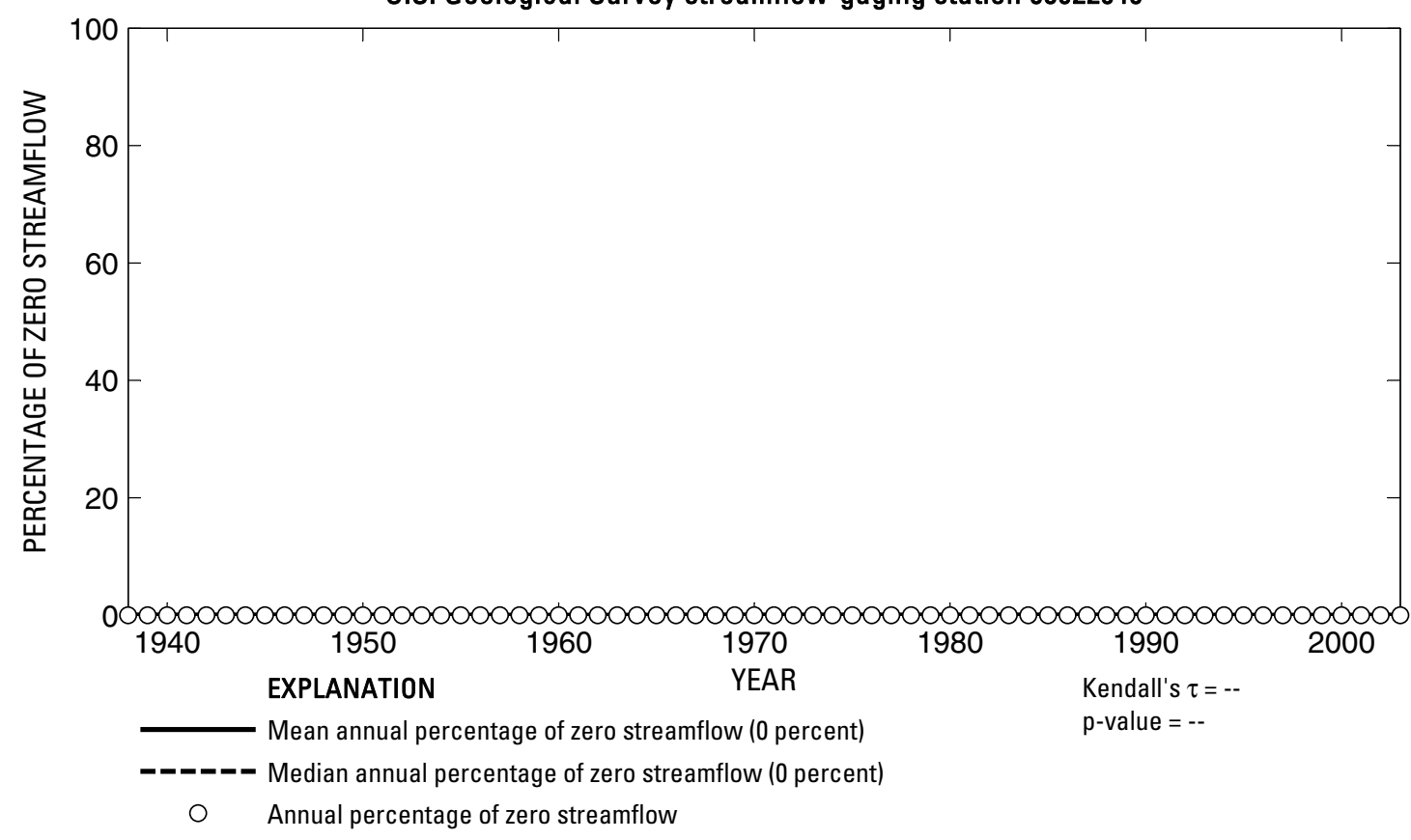

U.S. Geological Survey streamflow-gaging station 08022040

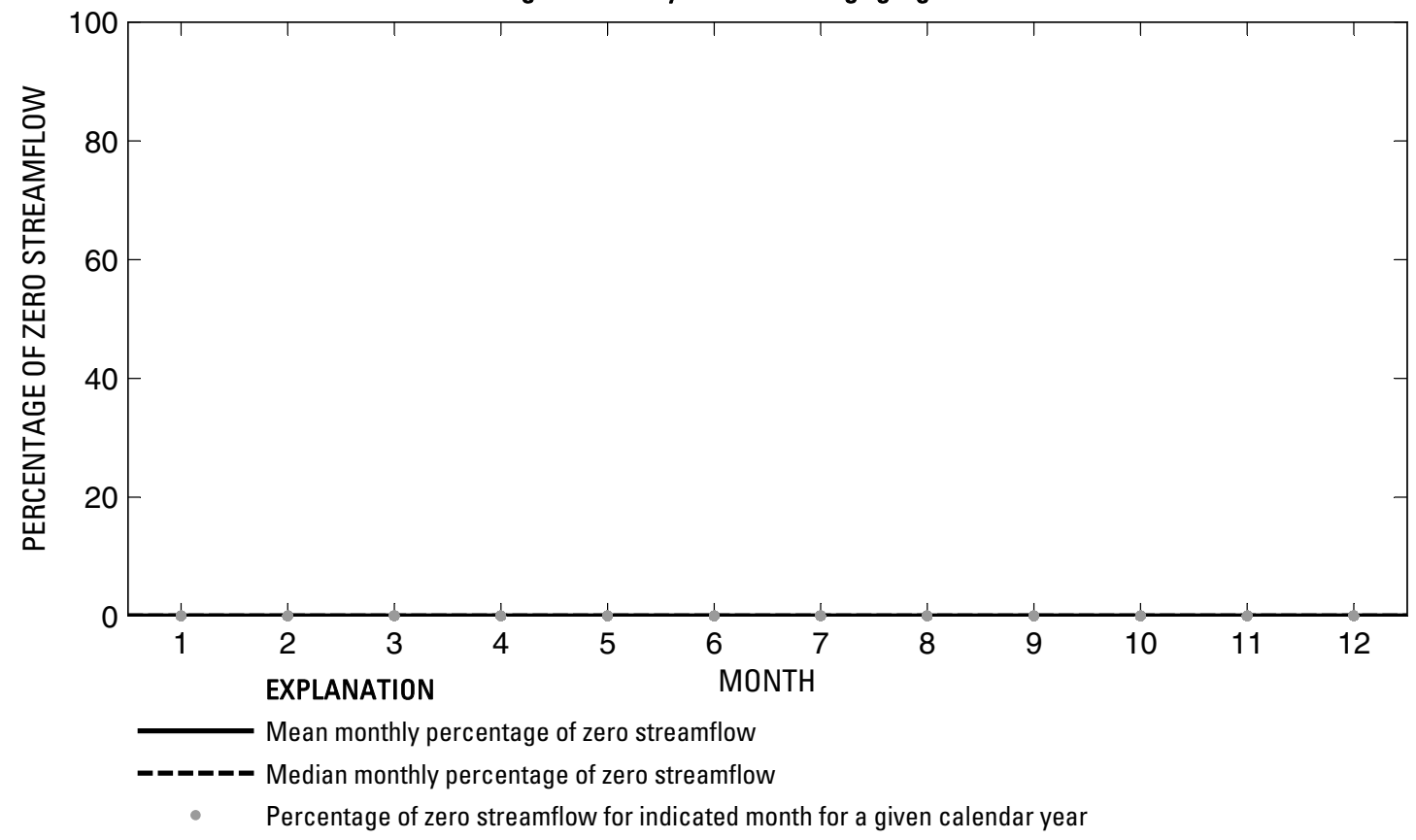

Figure 102. Analysis of percentage of zero daily mean streamflow for U.S. Geological Survey streamflow-gaging station 08022040 Sabine River near Beckville, Texas. 
U.S. Geological Survey streamflow-gaging station 08022070

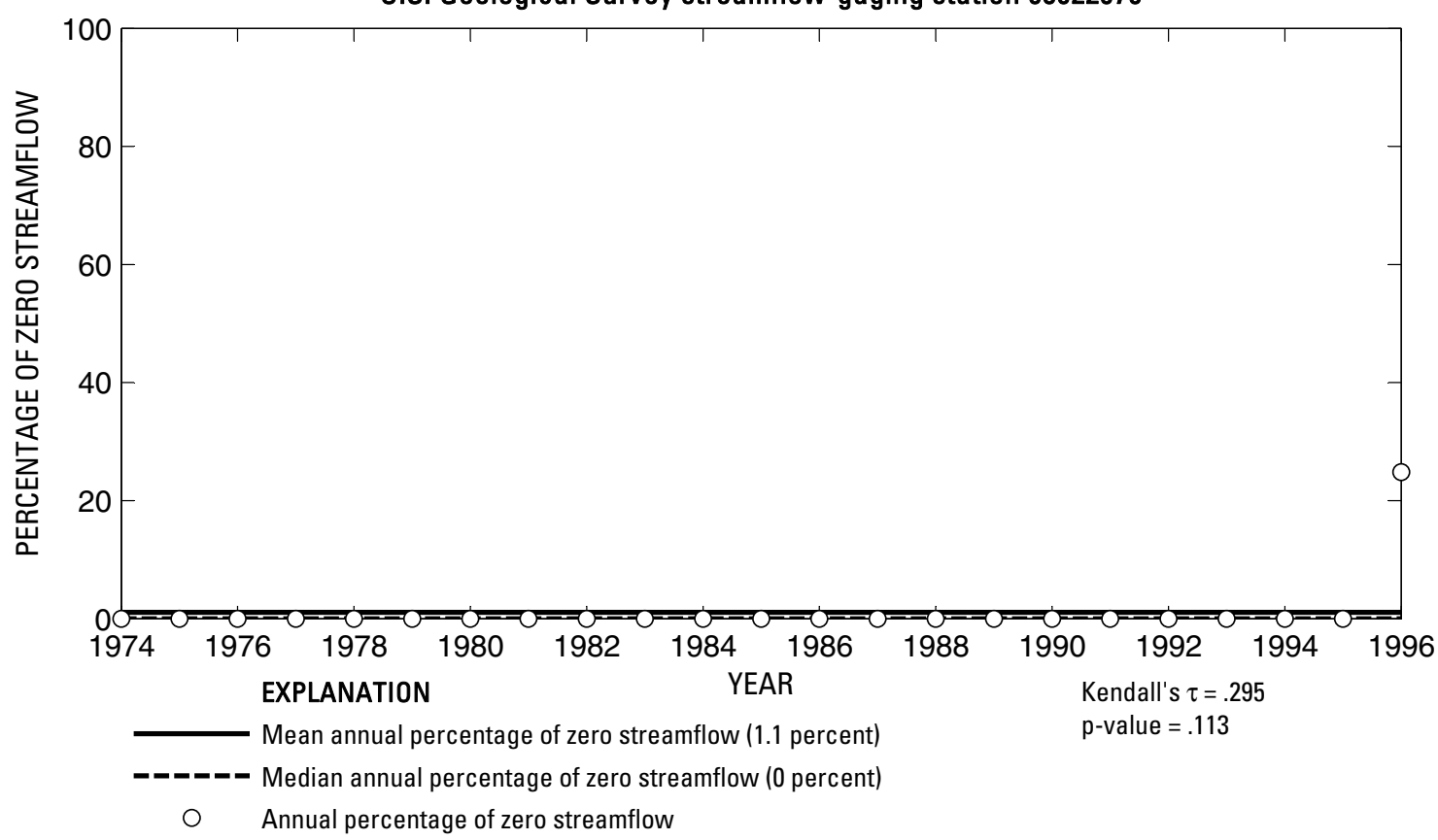

U.S. Geological Survey streamflow-gaging station 08022070

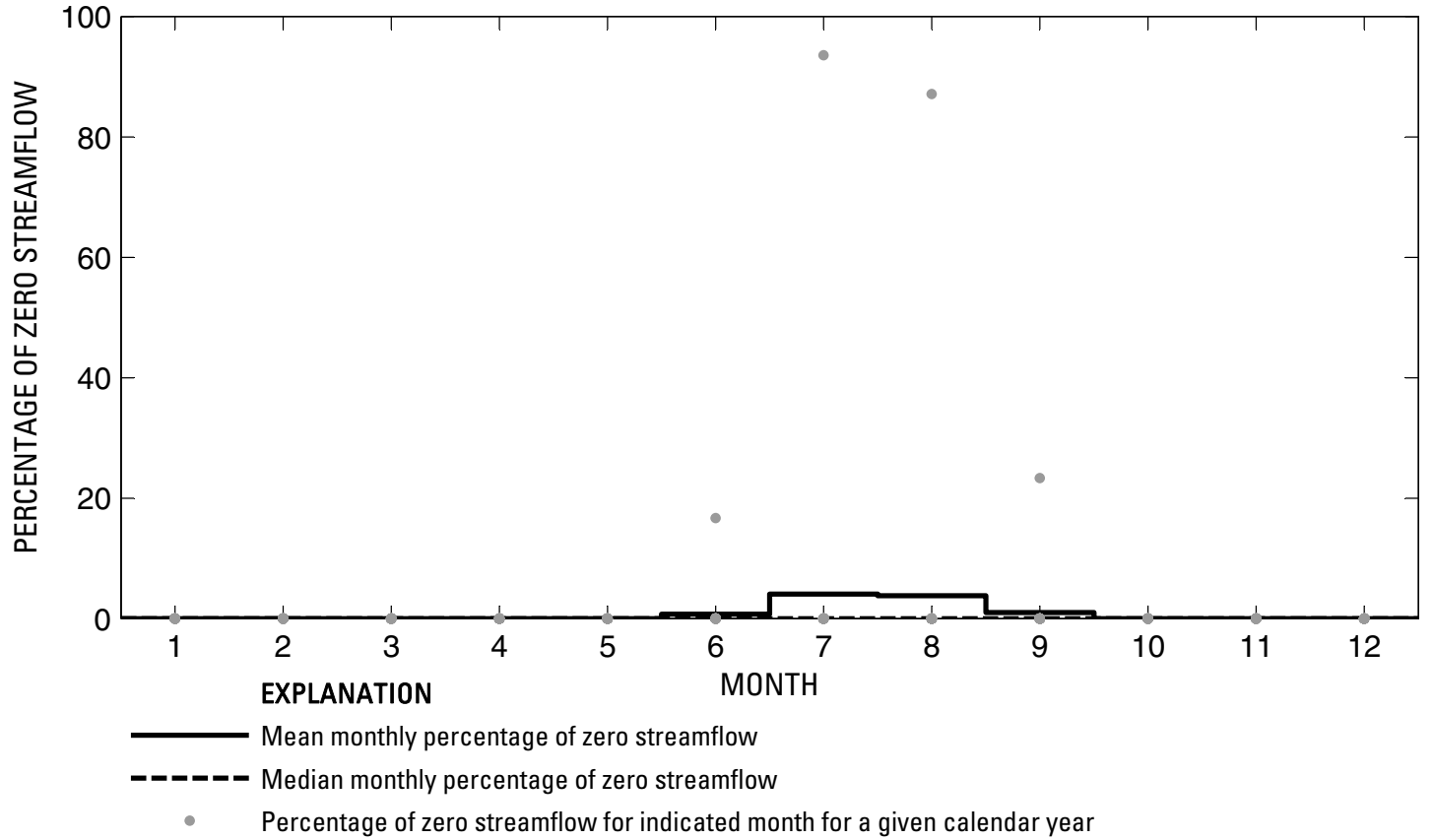

Figure 103. Analysis of percentage of zero daily mean streamflow for U.S. Geological Survey streamflow-gaging station 08022070 Martin Creek near Tatum, Texas. 
U.S. Geological Survey streamflow-gaging station 08022300

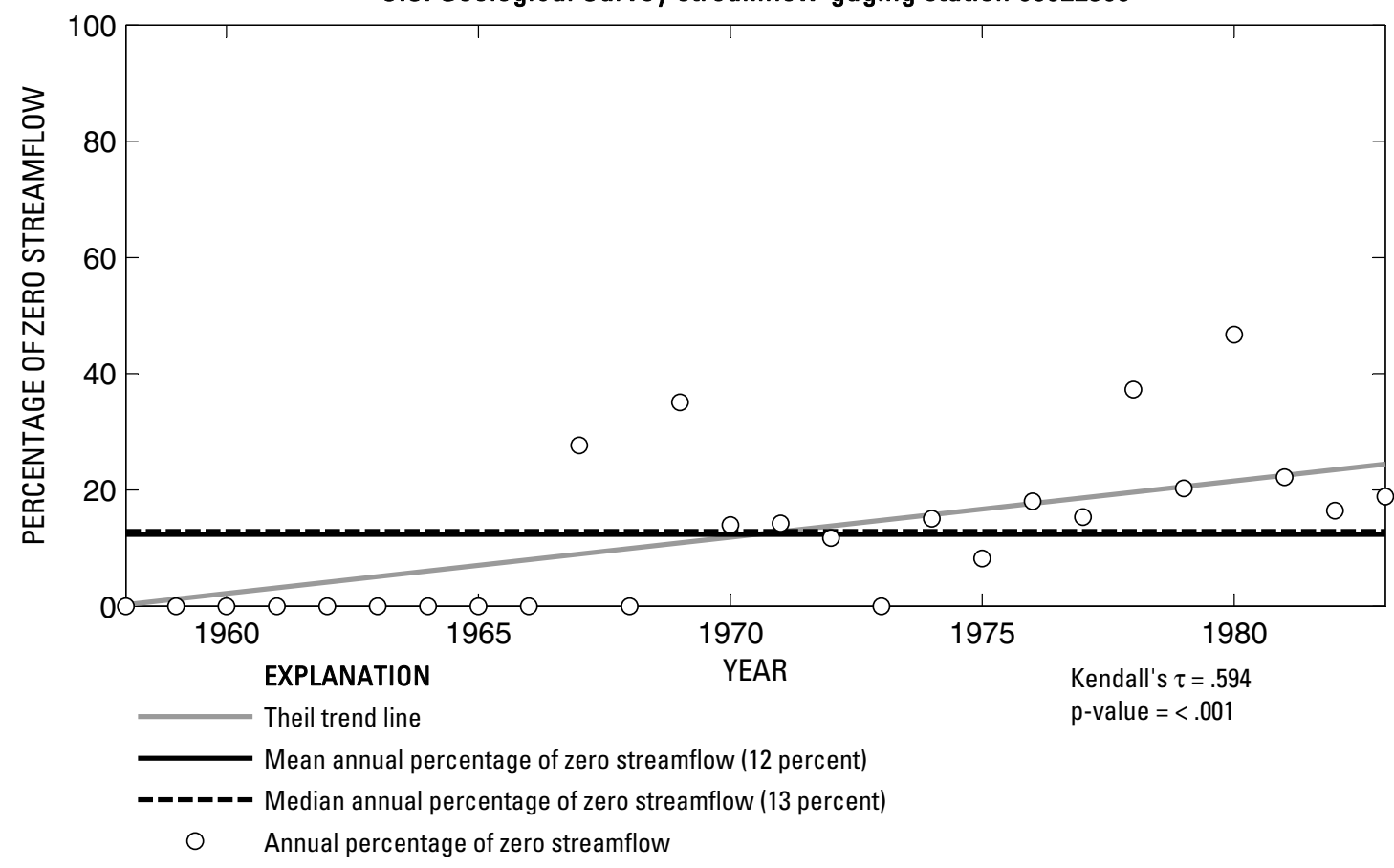

U.S. Geological Survey streamflow-gaging station 08022300

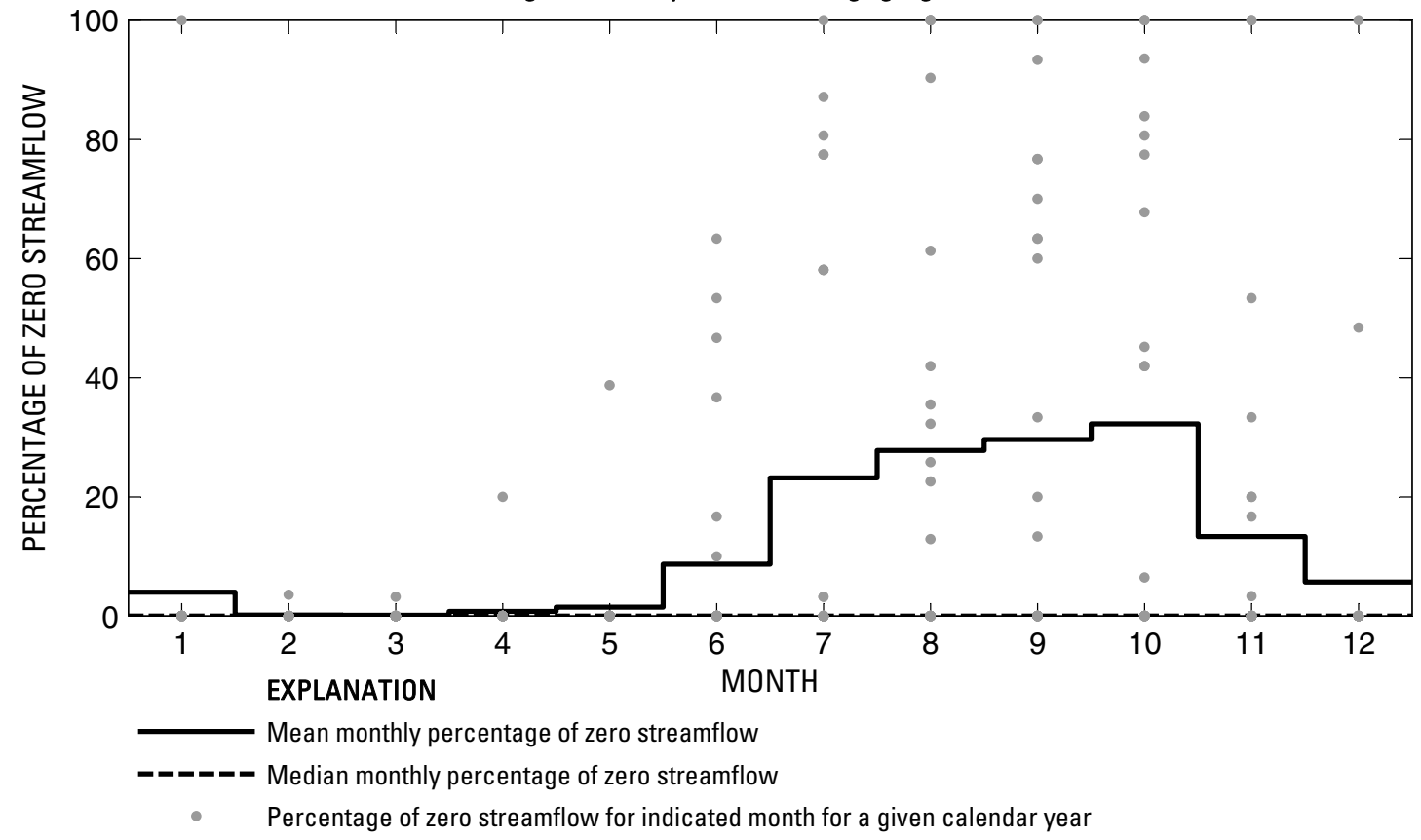

Figure 104. Analysis of percentage of zero daily mean streamflow for U.S. Geological Survey streamflow-gaging station 08022300 Murvaul Bayou near Gary, Texas.

Index of Station Numbers 719 
U.S. Geological Survey streamflow-gaging station 08022400

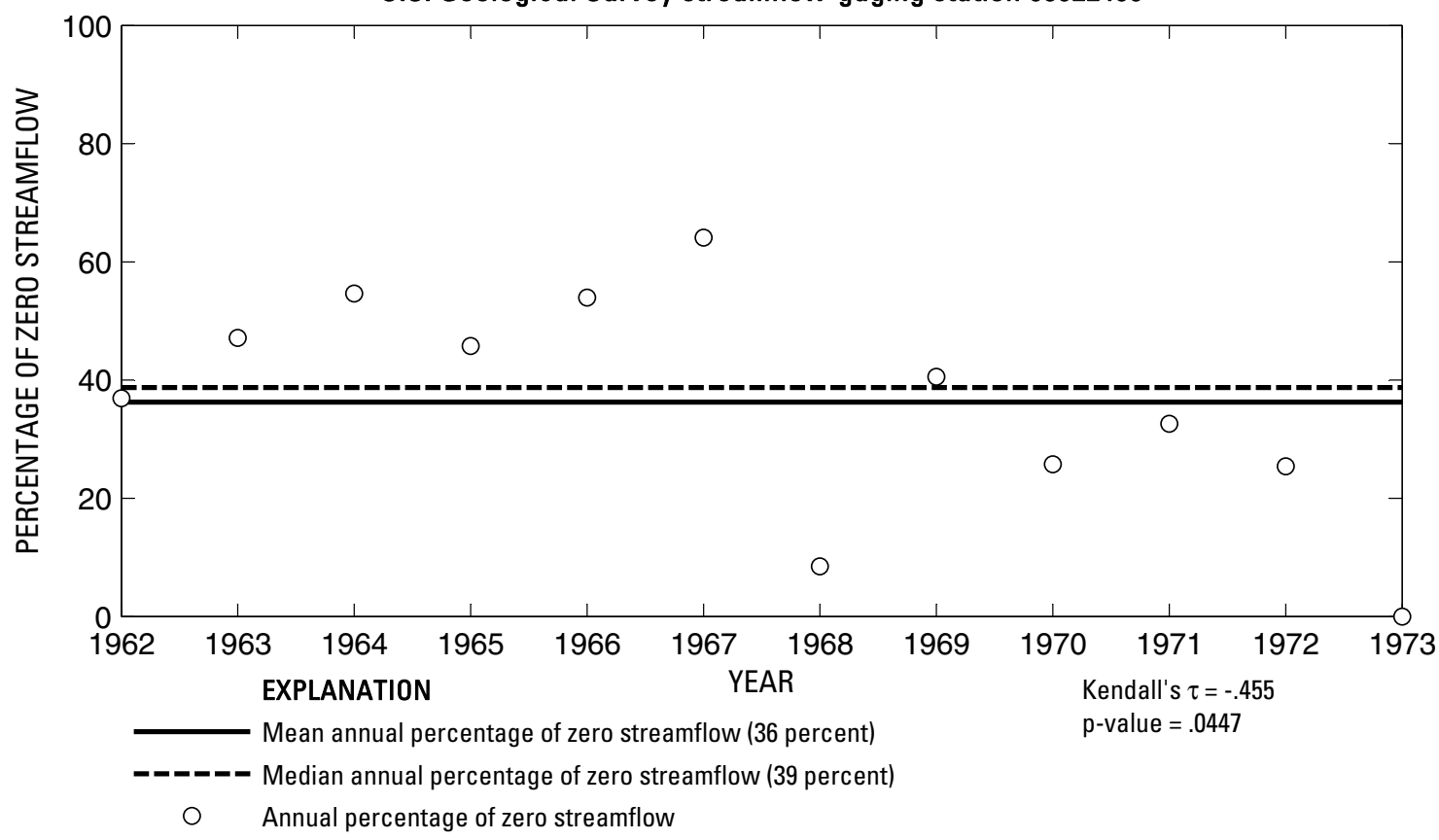

U.S. Geological Survey streamflow-gaging station 08022400

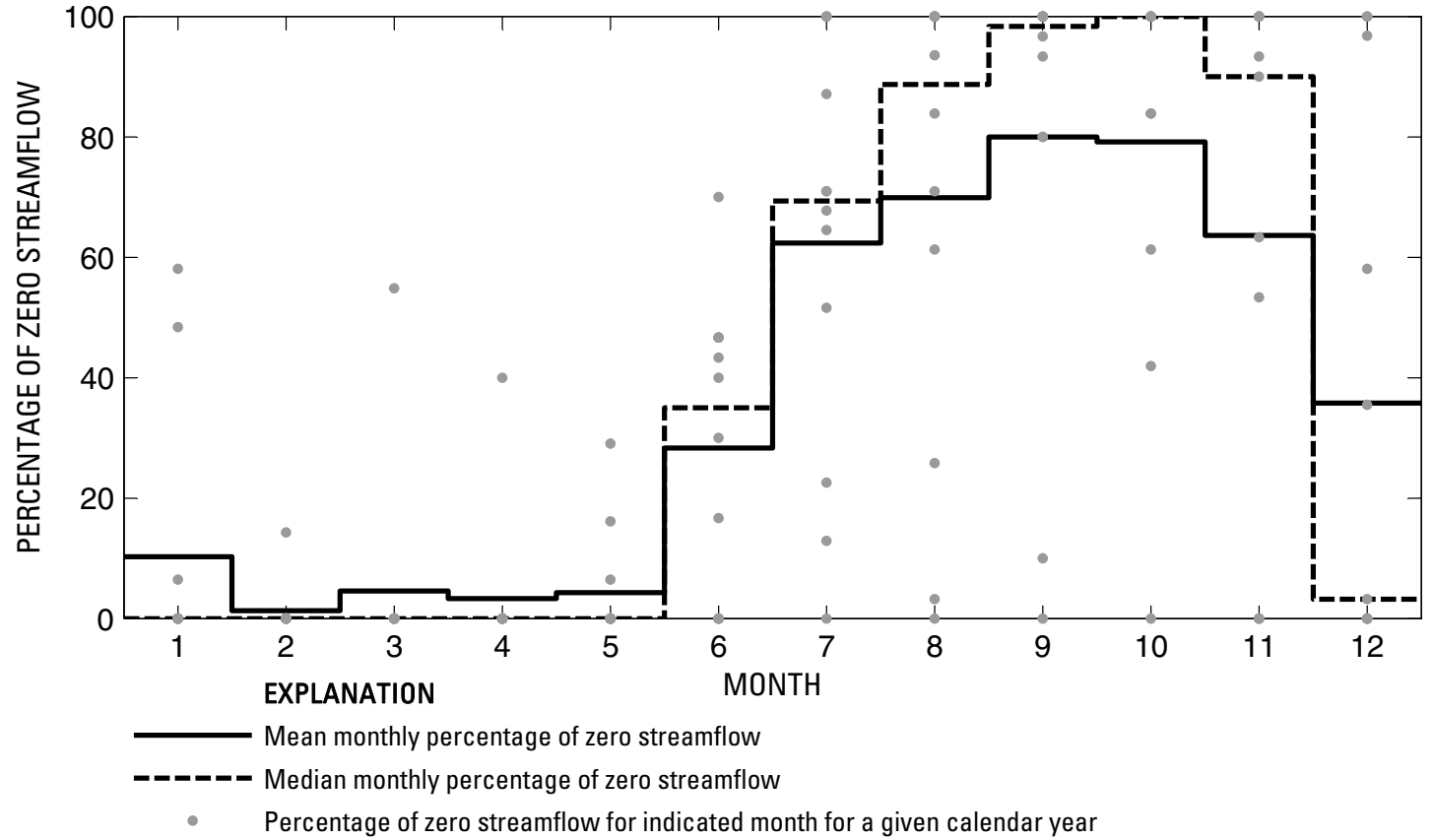

Figure 105. Analysis of percentage of zero daily mean streamflow for U.S. Geological Survey streamflow-gaging station 08022400 Socagee Creek near Carthage, Texas. 
U.S. Geological Survey streamflow-gaging station 08022500

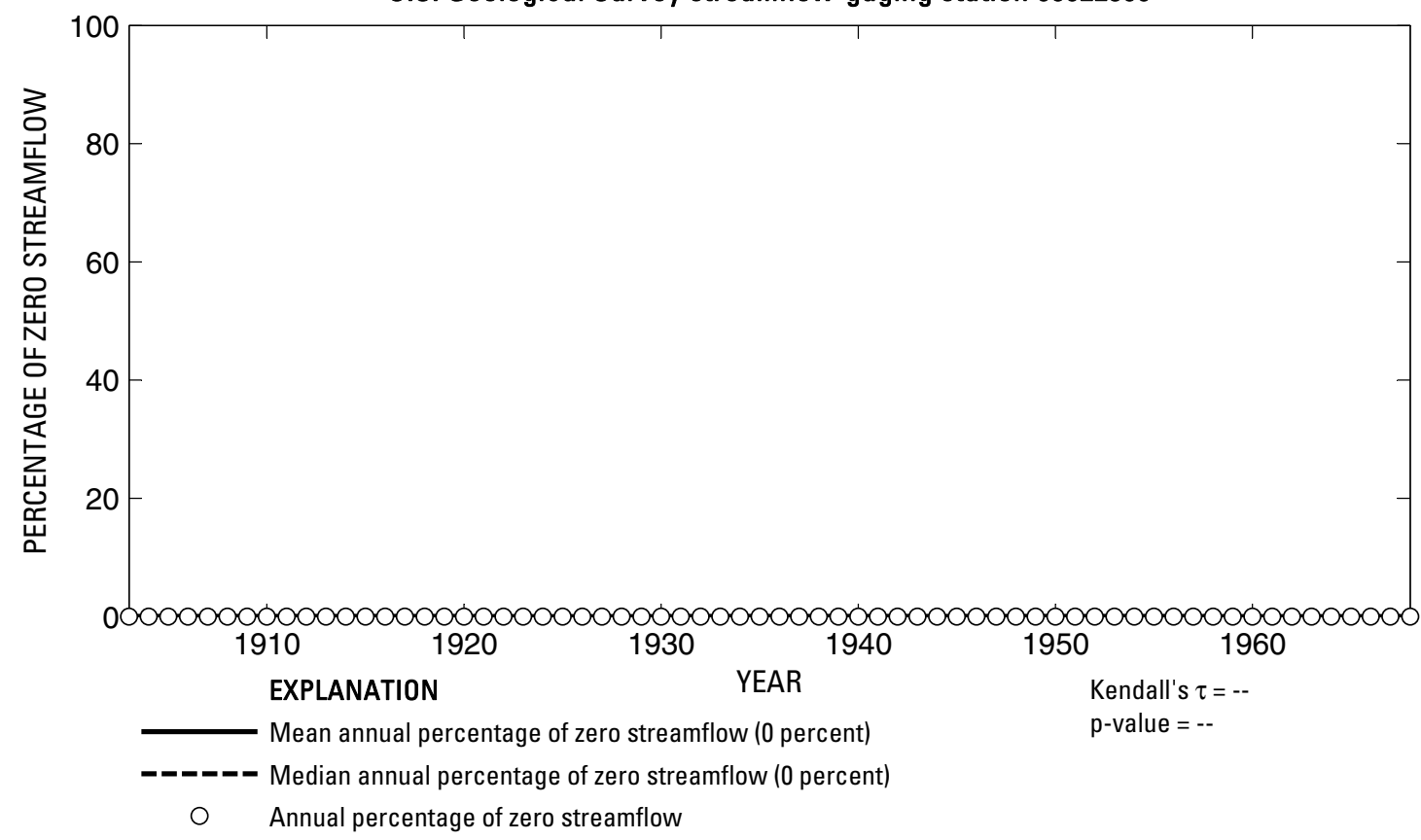

U.S. Geological Survey streamflow-gaging station 08022500

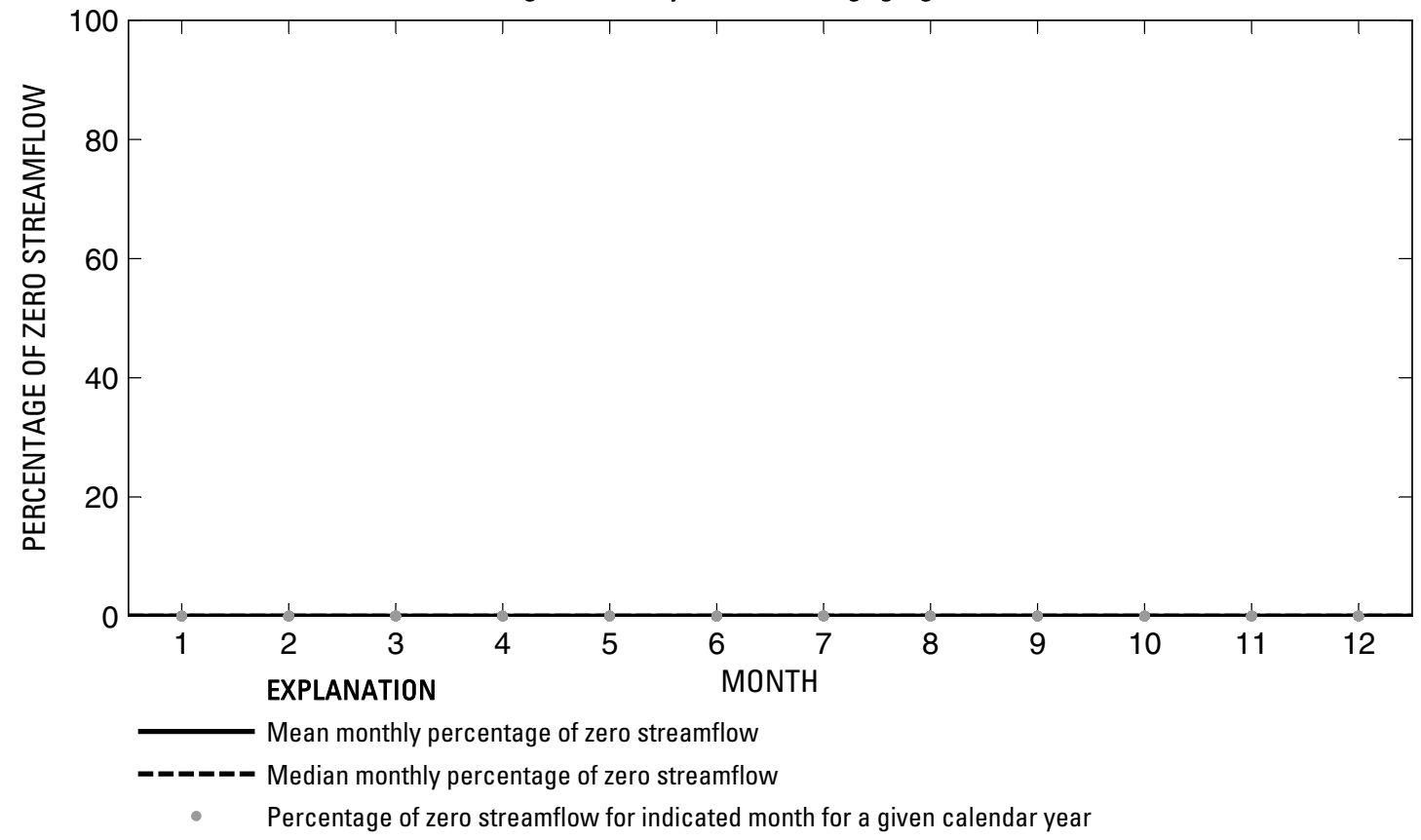

Figure 106. Analysis of percentage of zero daily mean streamflow for U.S. Geological Survey streamflow-gaging station 08022500 Sabine River at Logansport, Louisiana. 
U.S. Geological Survey streamflow-gaging station 08023200

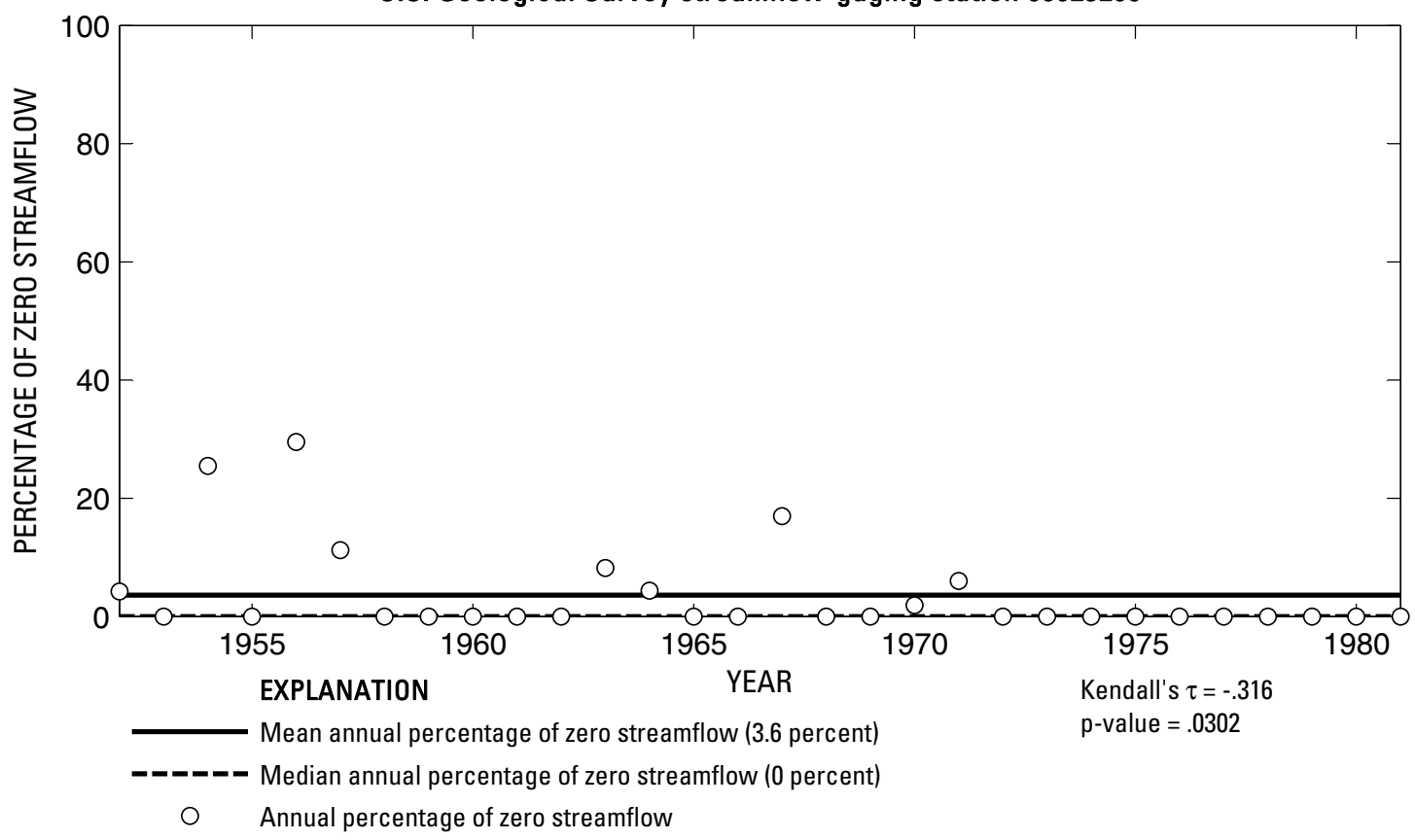

U.S. Geological Survey streamflow-gaging station 08023200

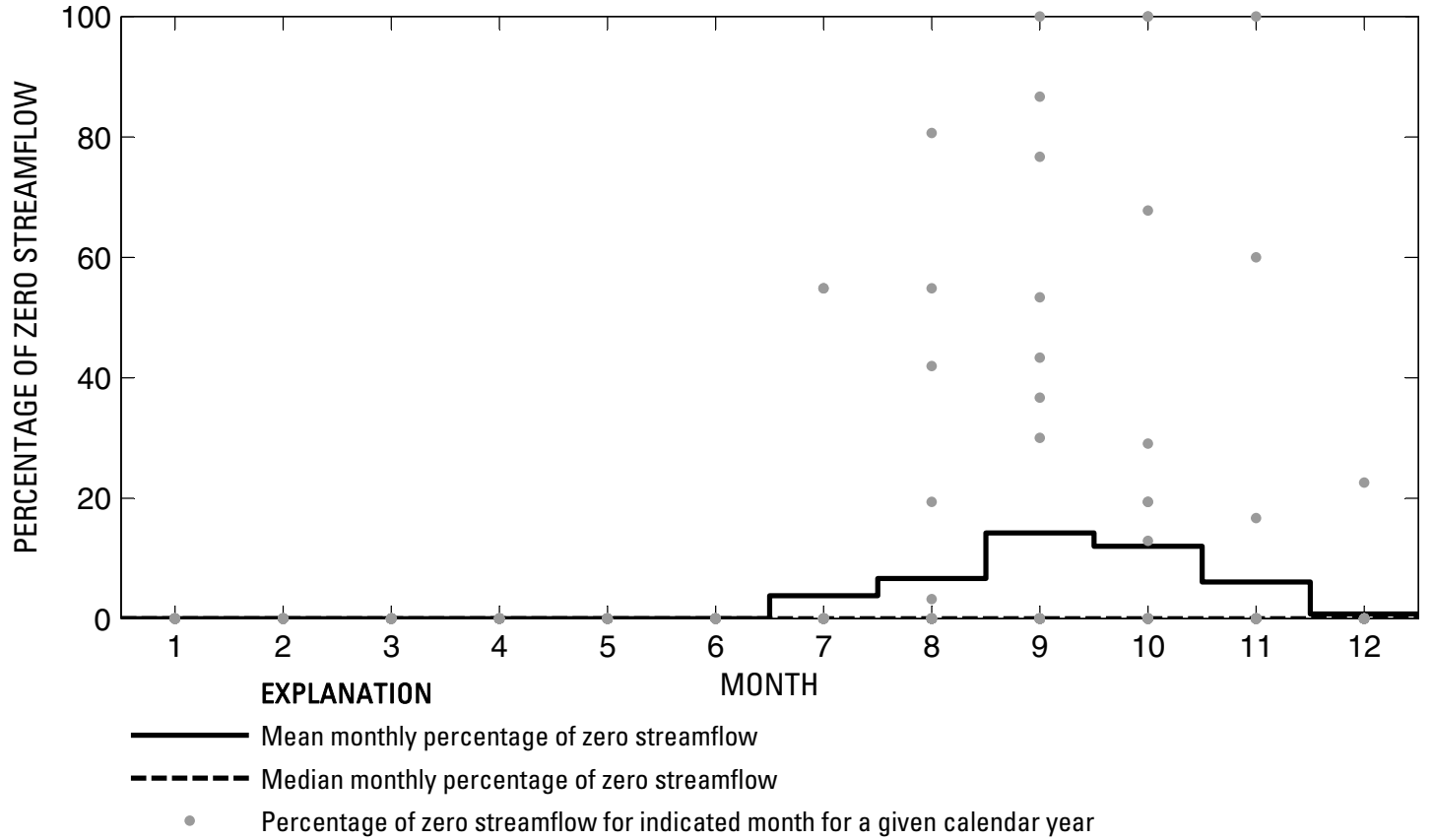

Figure 107. Analysis of percentage of zero daily mean streamflow for U.S. Geological Survey streamflow-gaging station 08023200 Tenaha Creek near Shelbyville, Texas. 
U.S. Geological Survey streamflow-gaging station 08024400

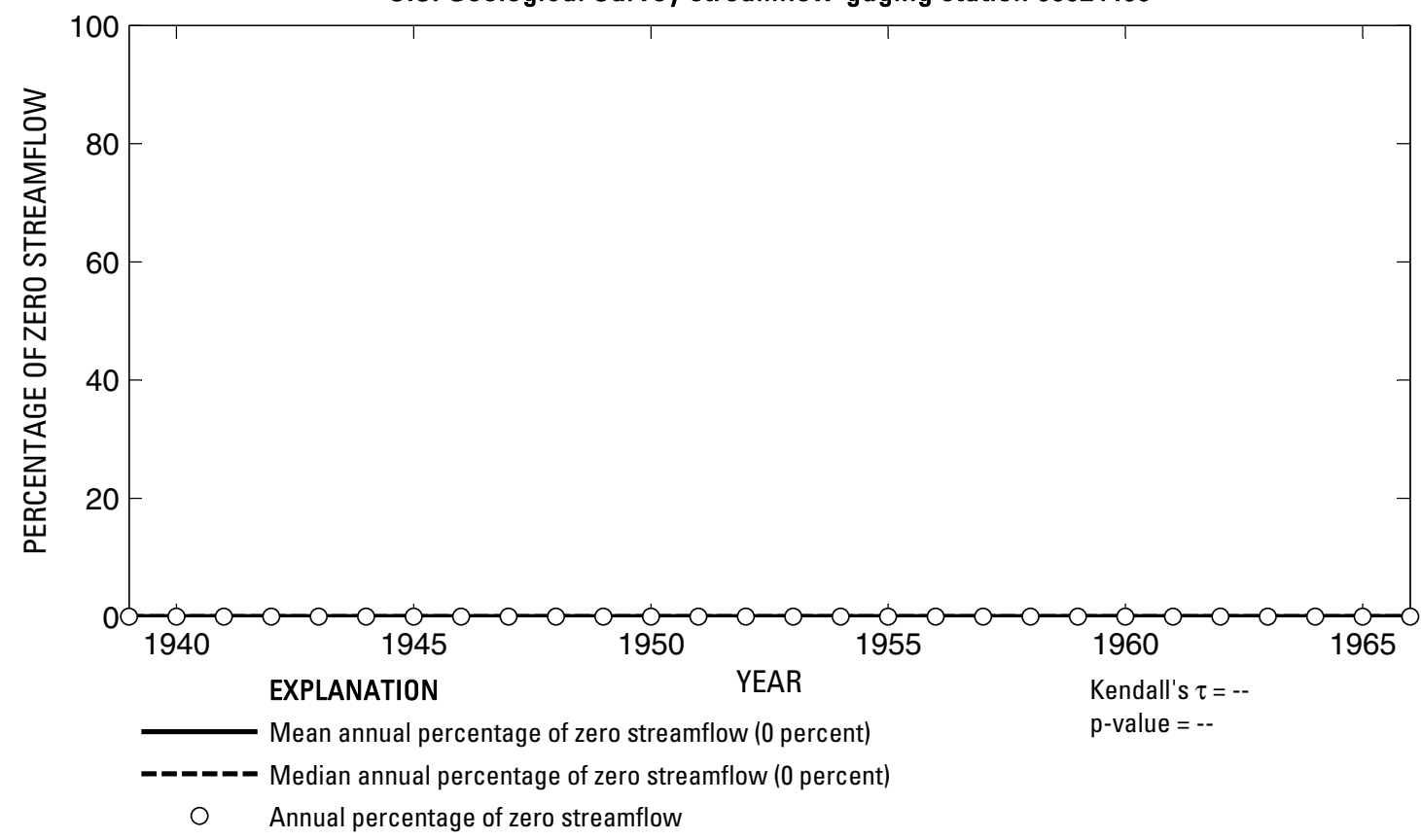

U.S. Geological Survey streamflow-gaging station 08024400

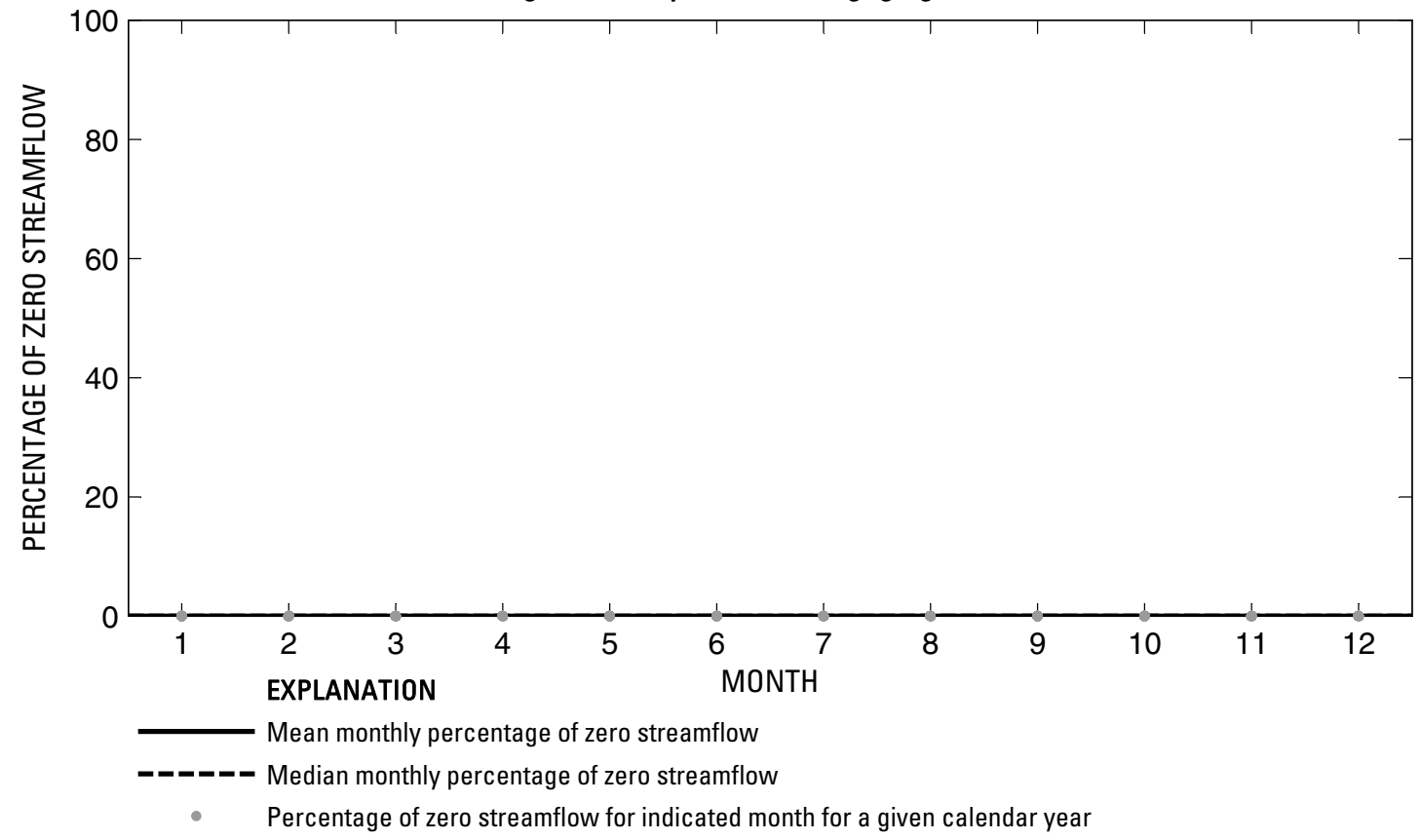

Figure 108. Analysis of percentage of zero daily mean streamflow for U.S. Geological Survey streamflow-gaging station 08024400 Sabine River near Milam, Texas. 


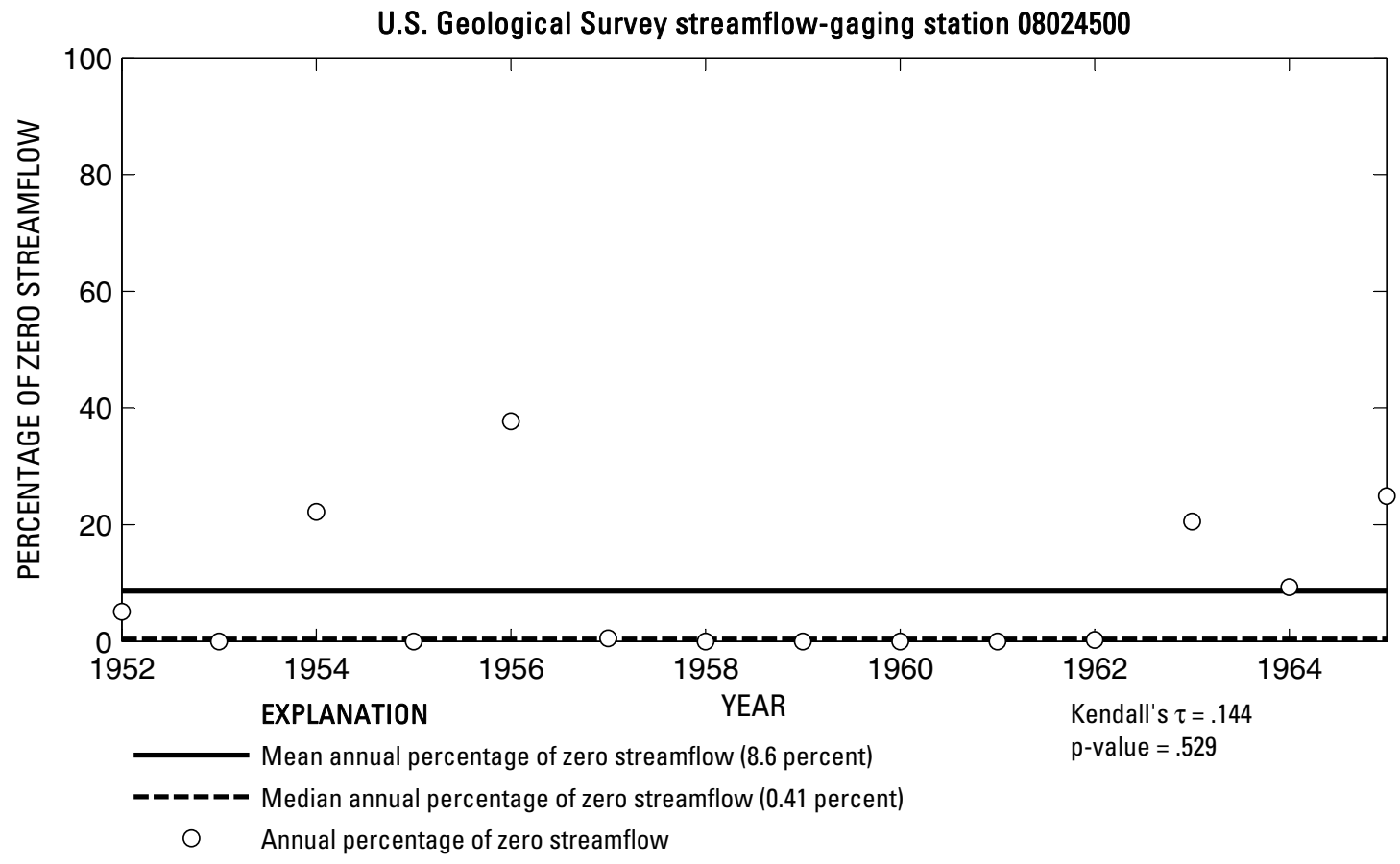

U.S. Geological Survey streamflow-gaging station 08024500

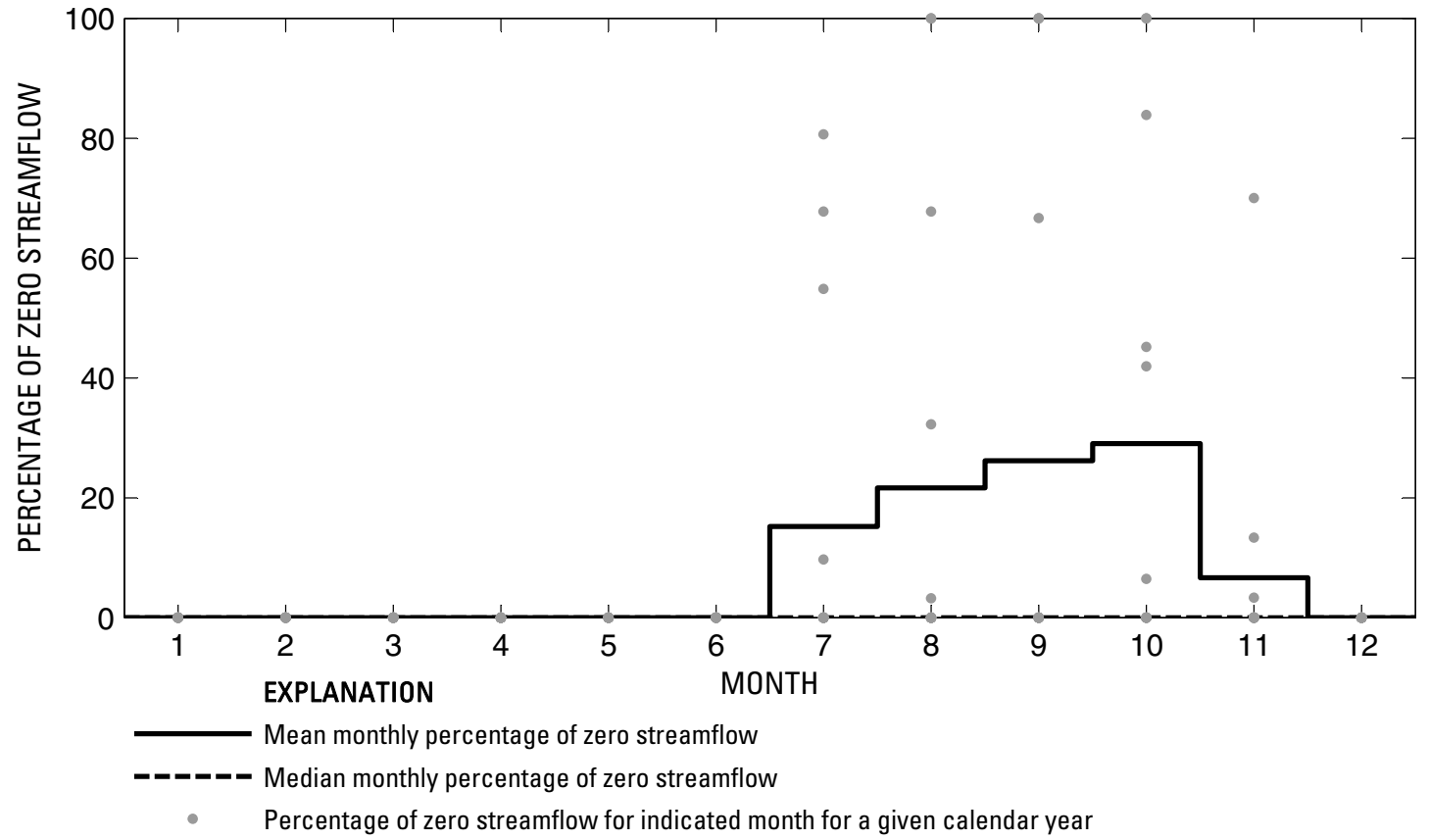

Figure 109. Analysis of percentage of zero daily mean streamflow for U.S. Geological Survey streamflow-gaging station 08024500 Palo Gaucho Bayou near Hemphill, Texas. 
U.S. Geological Survey streamflow-gaging station 08025307

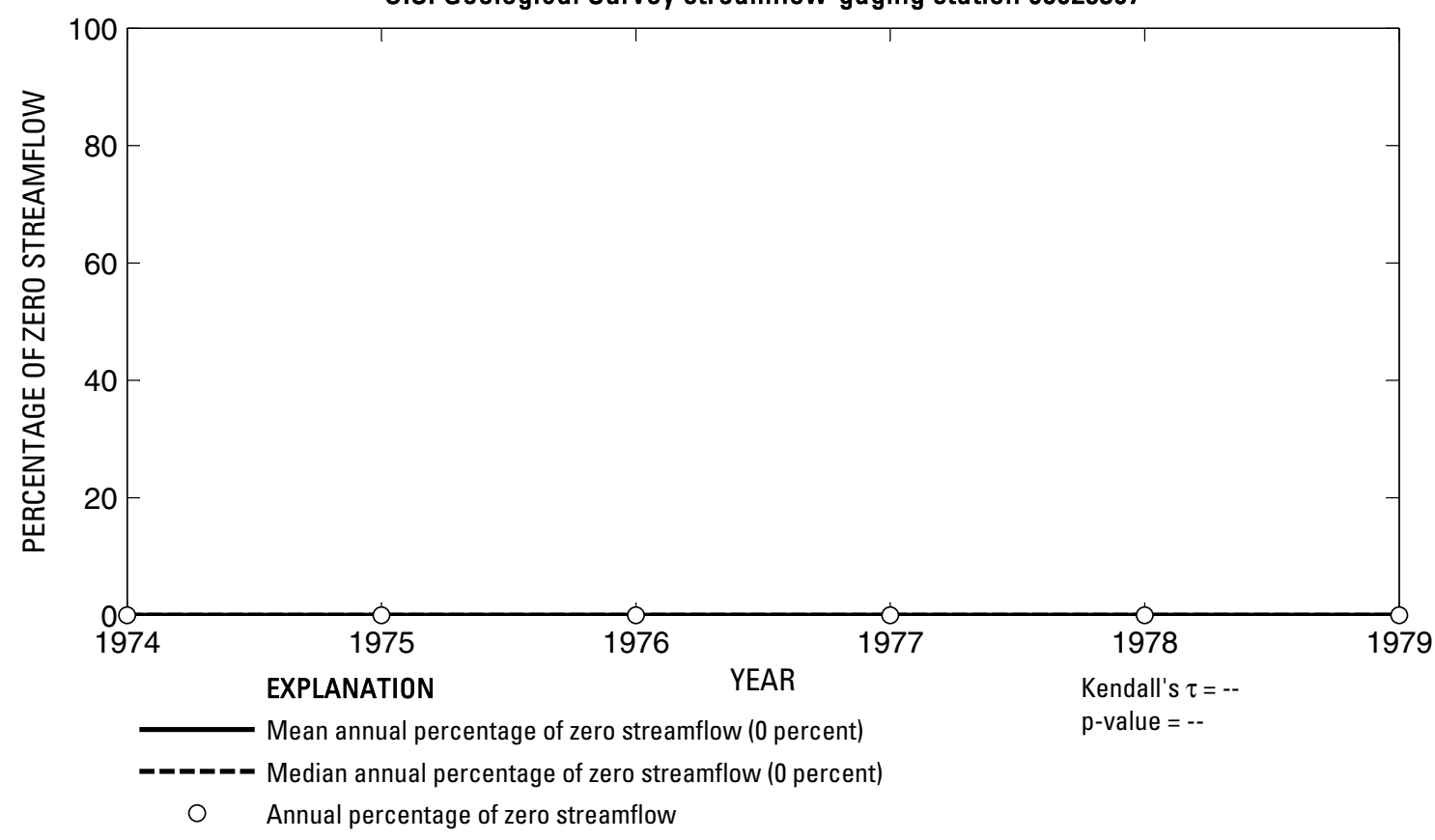

U.S. Geological Survey streamflow-gaging station 08025307

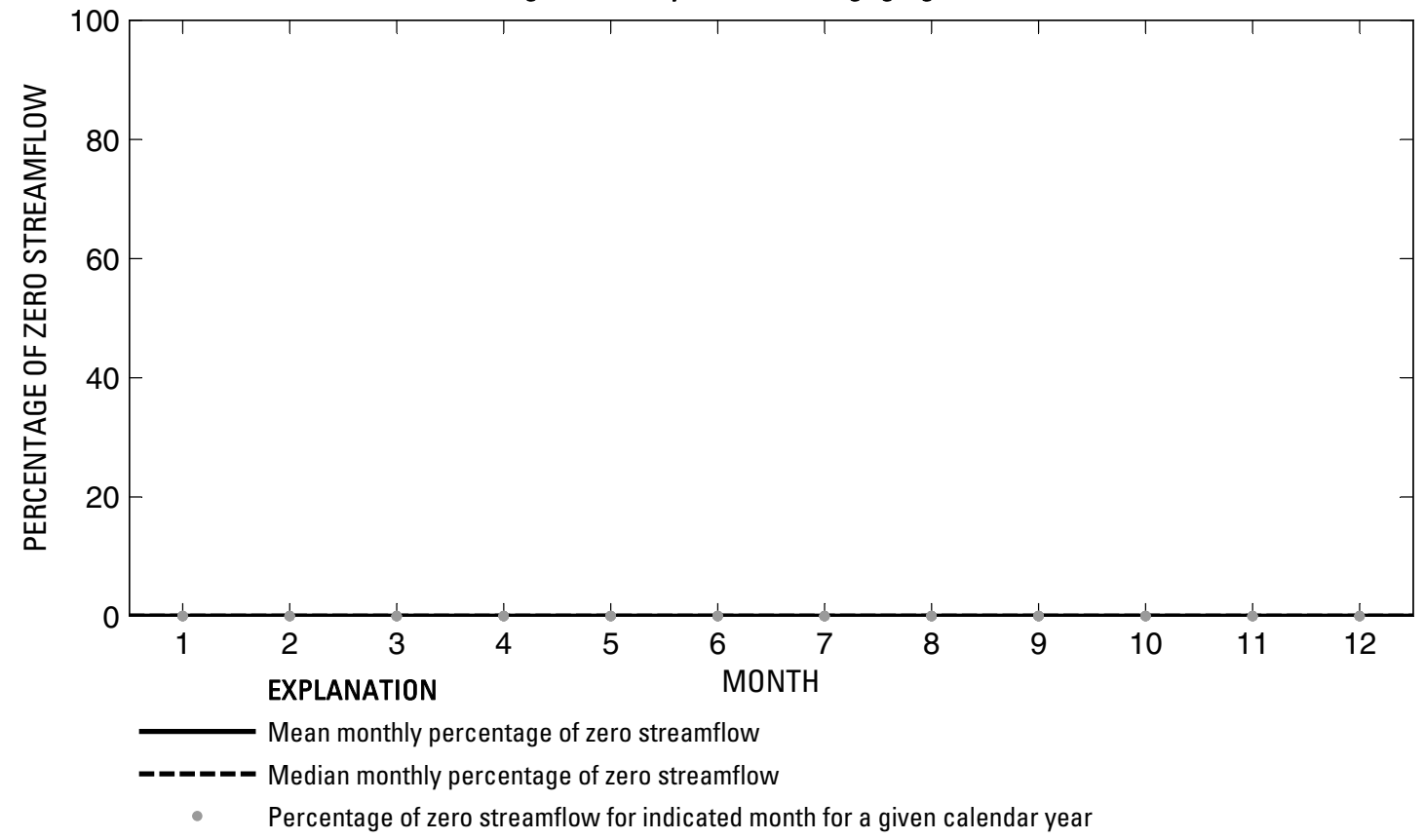

Figure 110. Analysis of percentage of zero daily mean streamflow for U.S. Geological Survey streamflow-gaging station 08025307 Mill Creek near Burkeville, Texas. 
U.S. Geological Survey streamflow-gaging station 08025360

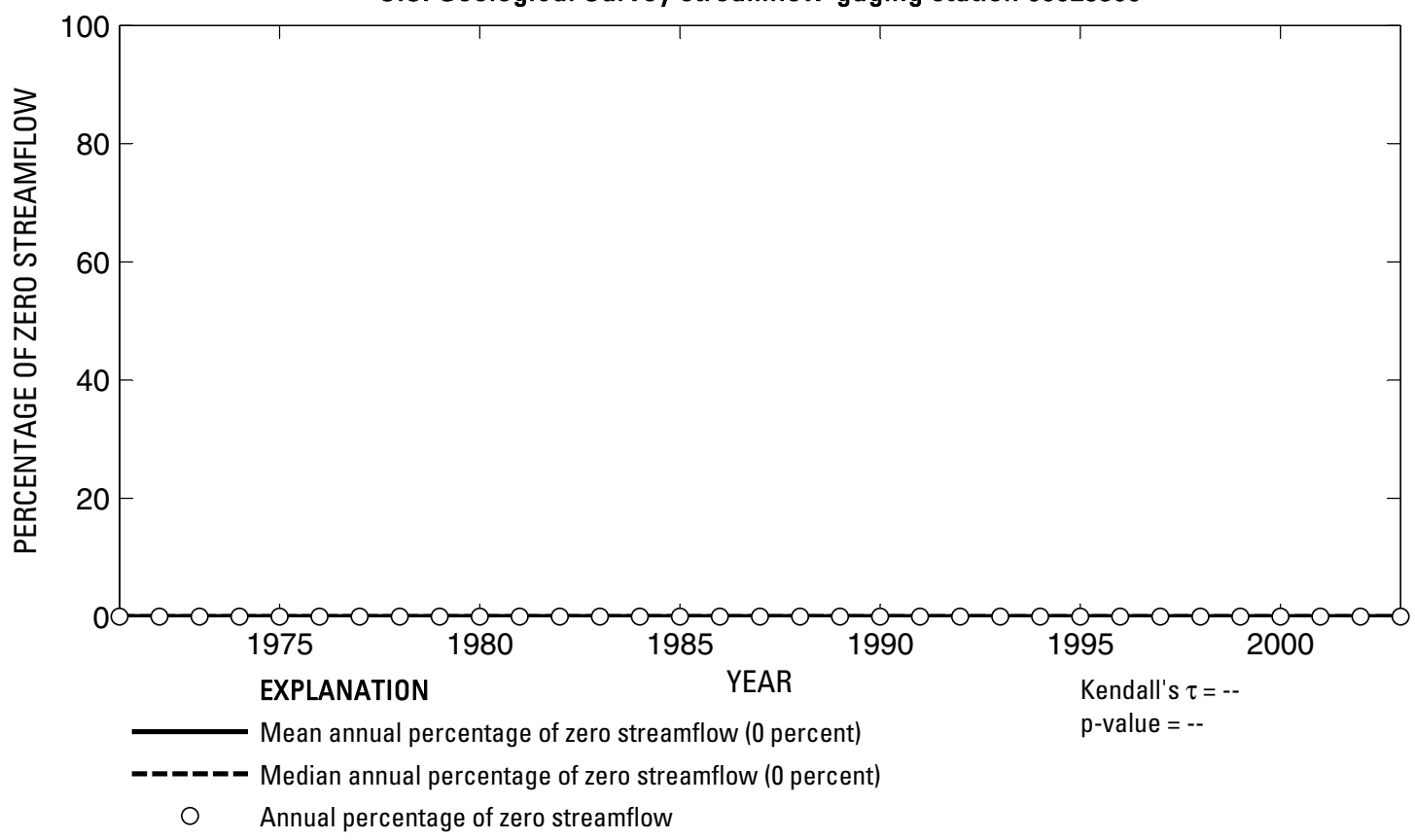

U.S. Geological Survey streamflow-gaging station 08025360

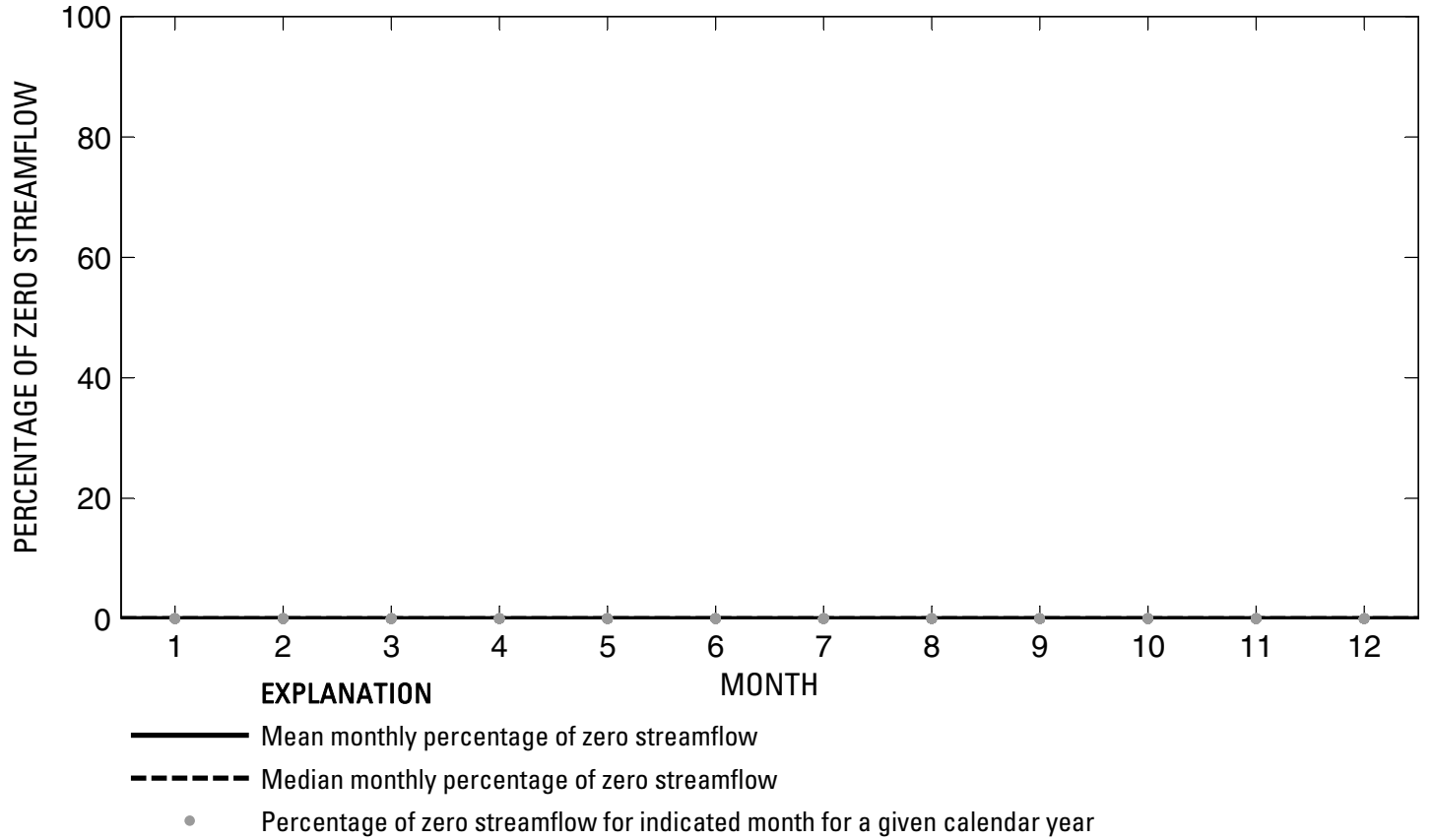

Figure 111. Analysis of percentage of zero daily mean streamflow for U.S. Geological Survey streamflow-gaging station 08025360 Sabine River at Toledo Bend Reservoir near Burkeville, Texas. 
U.S. Geological Survey streamflow-gaging station 08026000

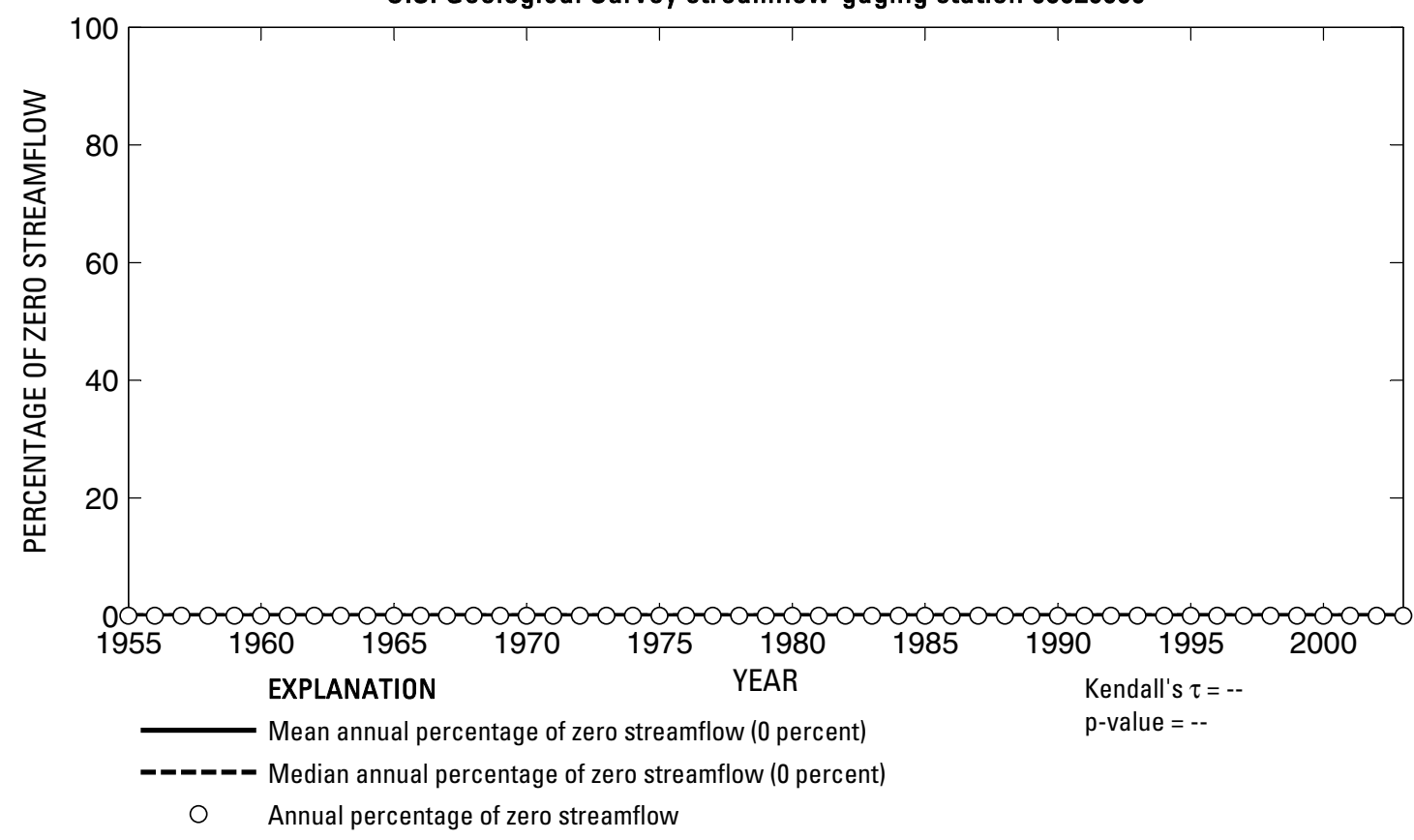

U.S. Geological Survey streamflow-gaging station 08026000

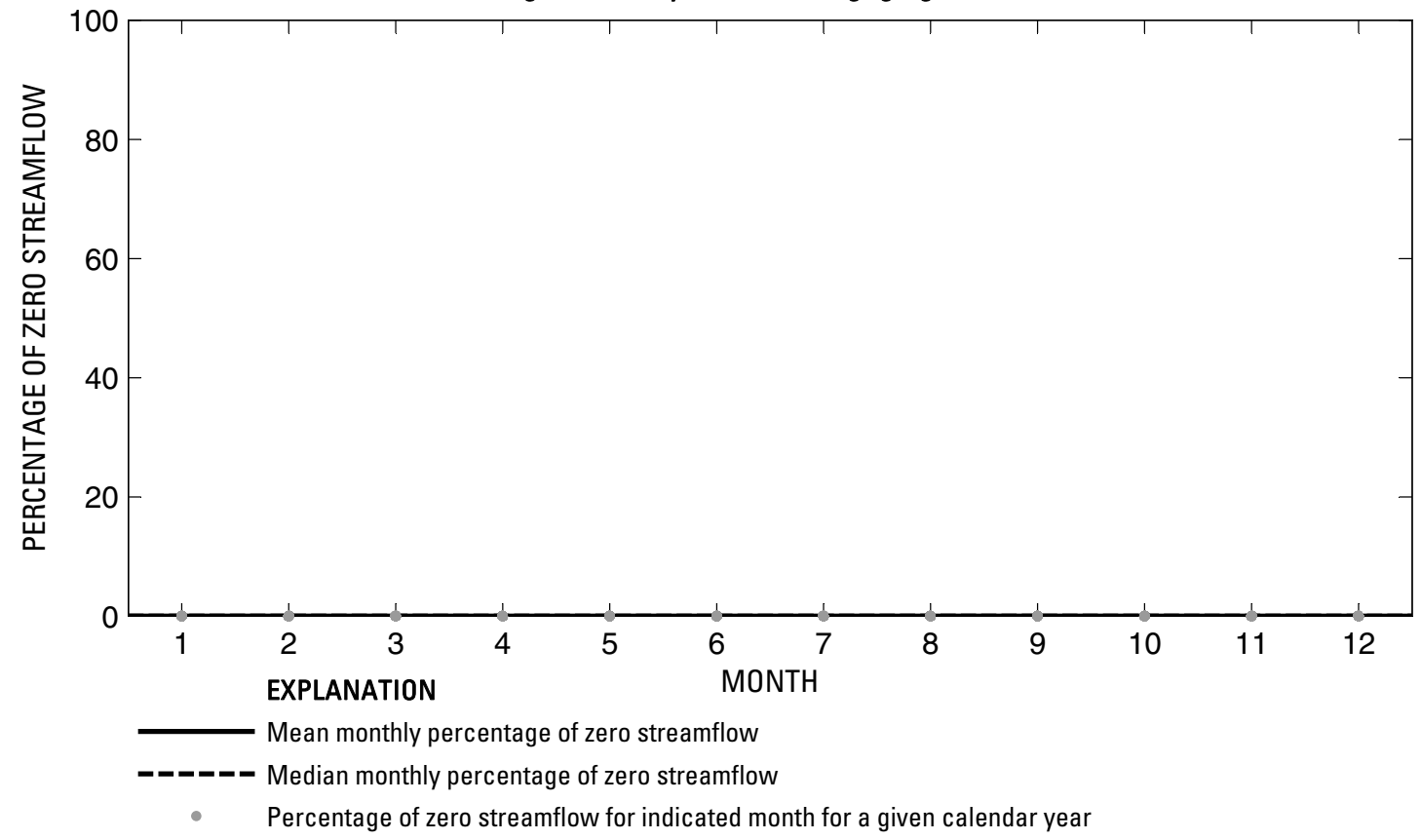

Figure 112. Analysis of percentage of zero daily mean streamflow for U.S. Geological Survey streamflow-gaging station 08026000 Sabine River near Burkeville, Texas. 
U.S. Geological Survey streamflow-gaging station 08028500

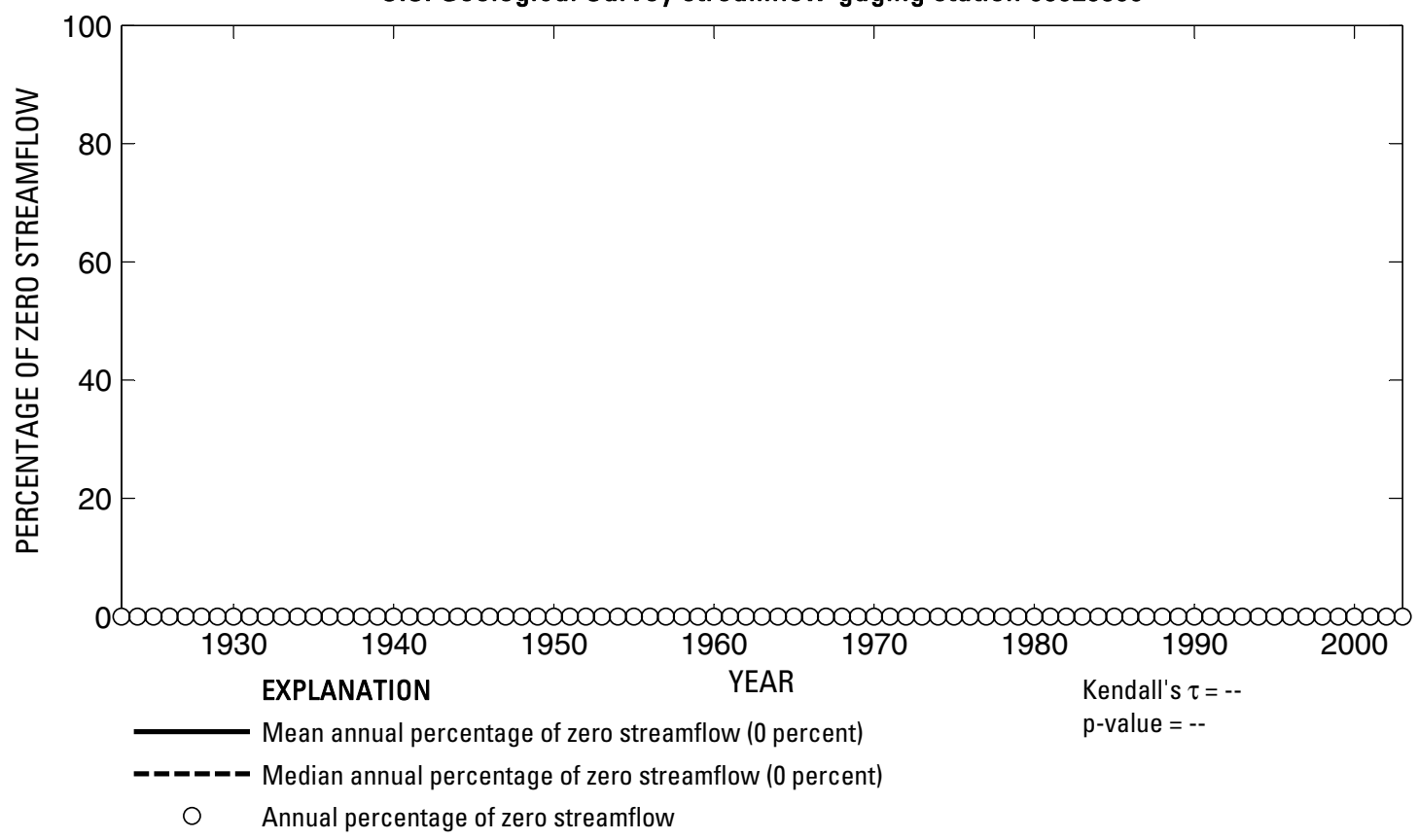

U.S. Geological Survey streamflow-gaging station 08028500

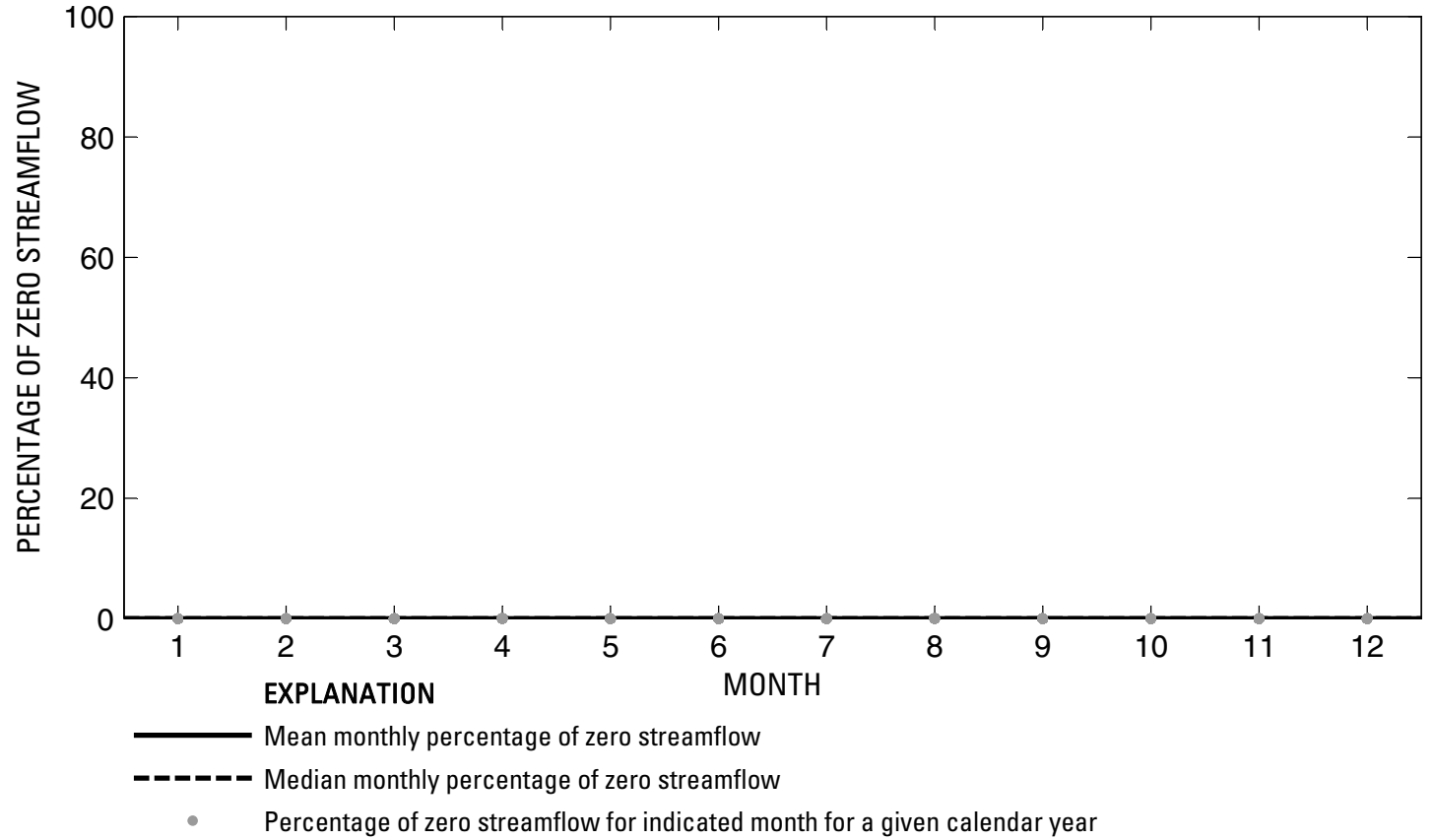

Figure 113. Analysis of percentage of zero daily mean streamflow for U.S. Geological Survey streamflow-gaging station 08028500 Sabine River near Bon Wier, Texas. 
U.S. Geological Survey streamflow-gaging station 08029500

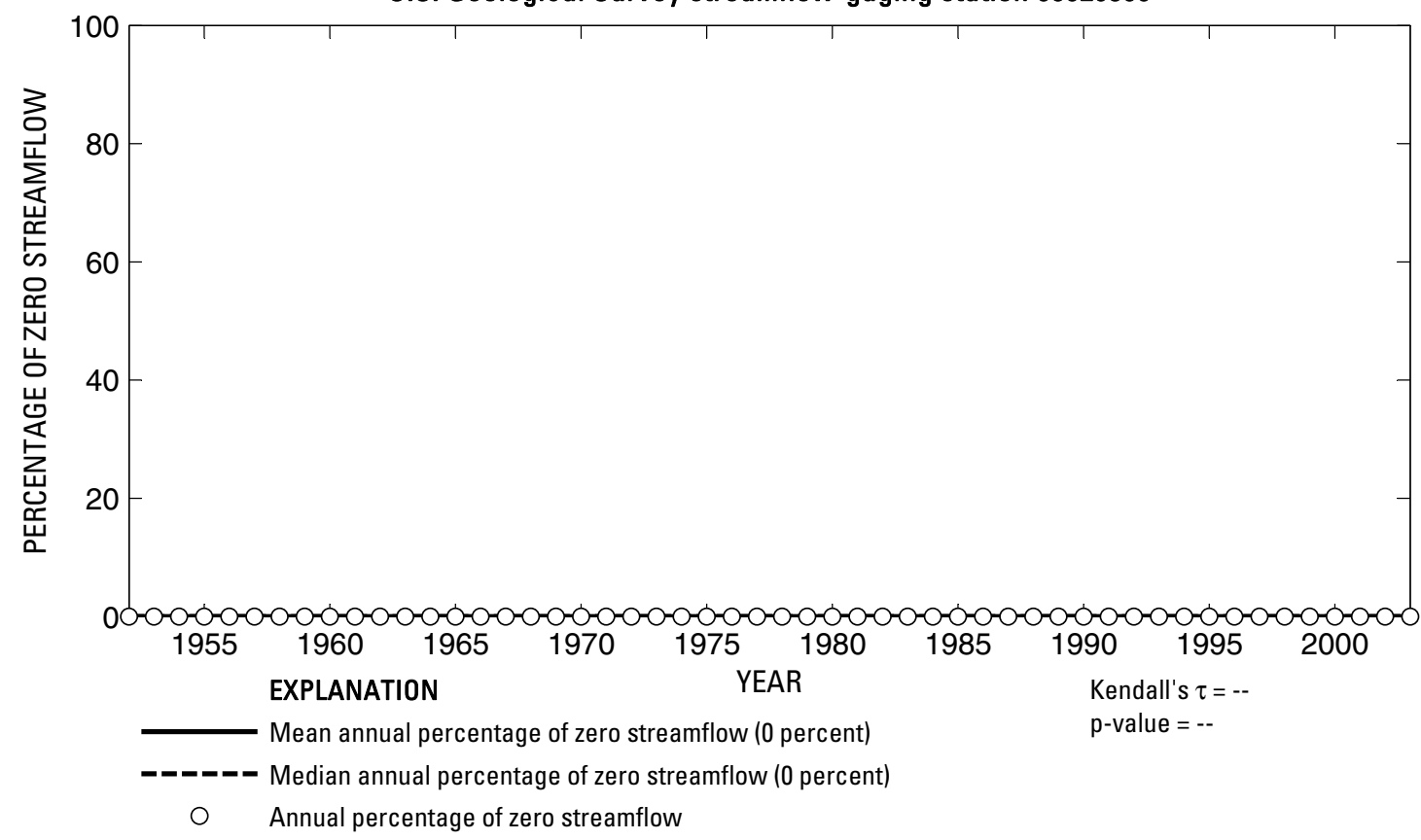

U.S. Geological Survey streamflow-gaging station 08029500

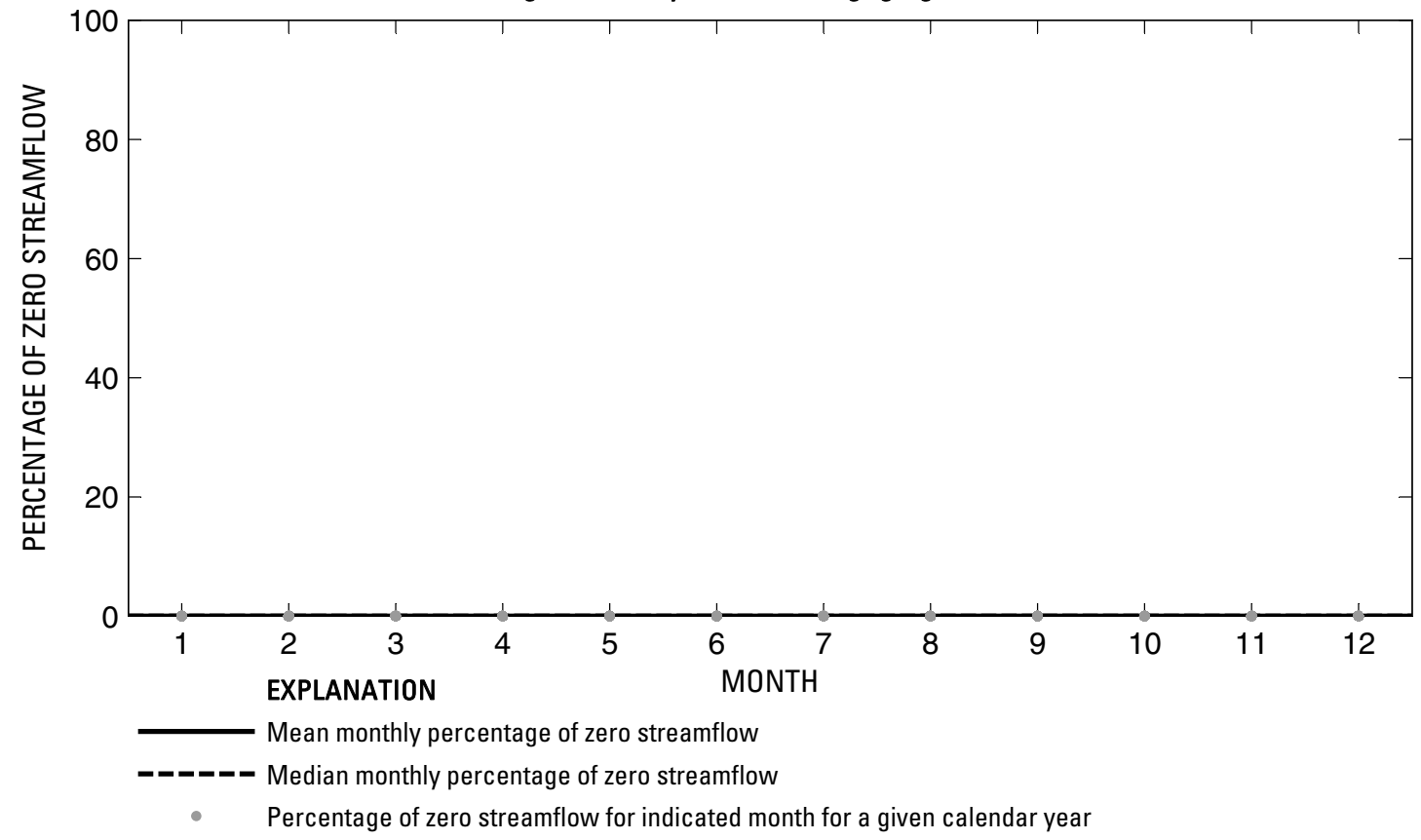

Figure 114. Analysis of percentage of zero daily mean streamflow for U.S. Geological Survey streamflow-gaging station 08029500 Big Cow Creek near Newton, Texas. 
U.S. Geological Survey streamflow-gaging station 08030000

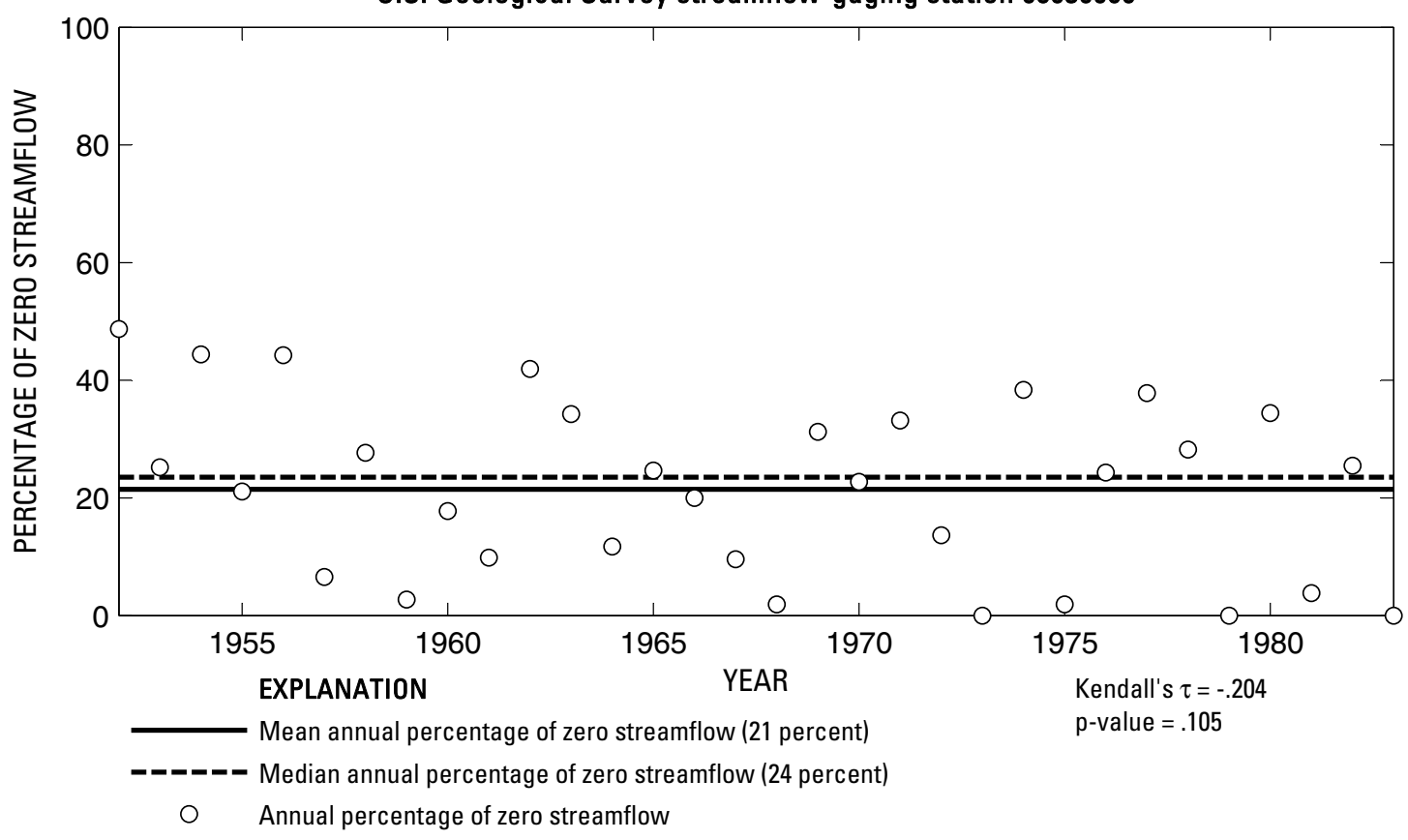

U.S. Geological Survey streamflow-gaging station 08030000

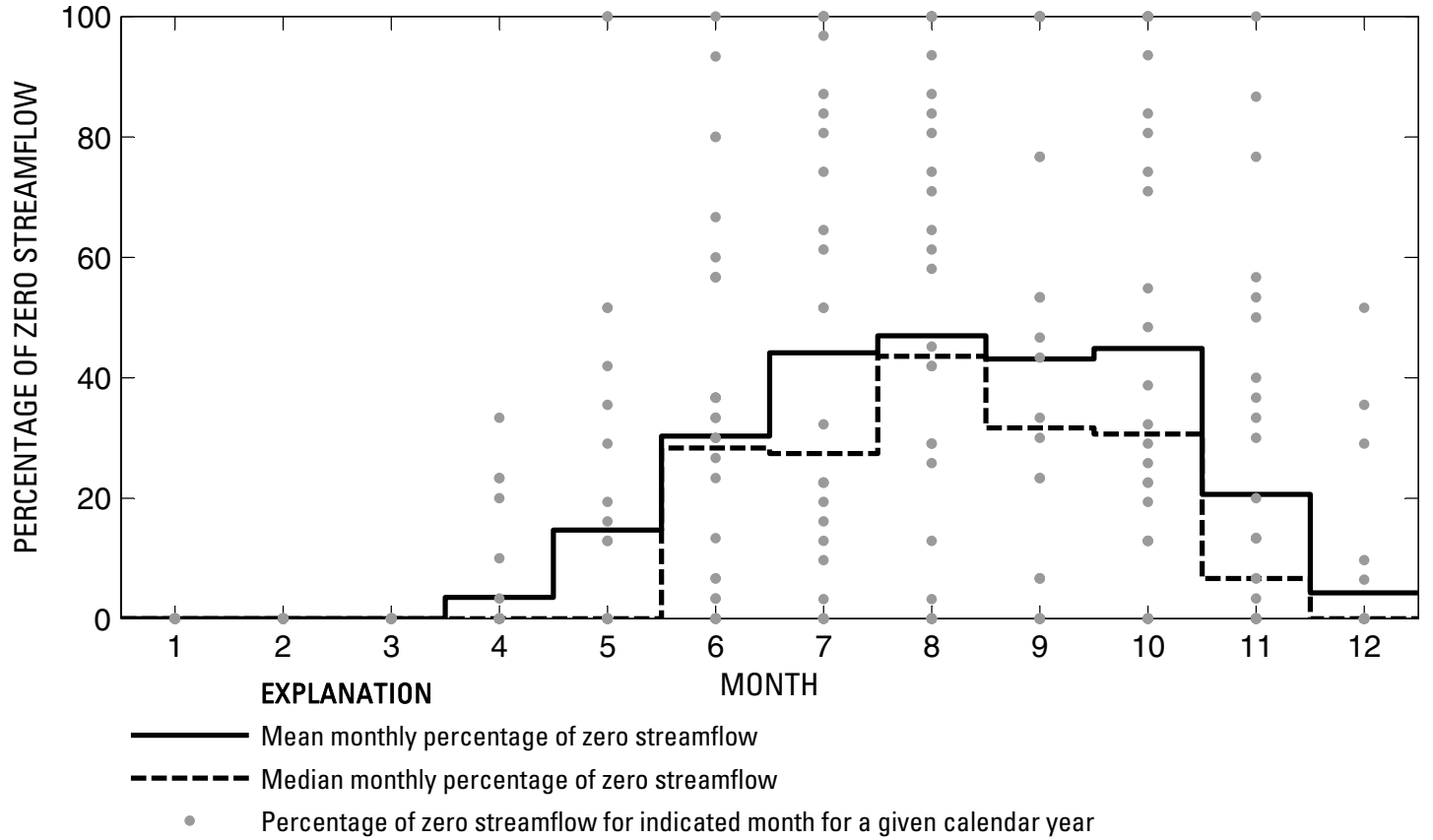

Figure 115. Analysis of percentage of zero daily mean streamflow for U.S. Geological Survey streamflow-gaging station 08030000 Cypress Creek near Buna, Texas. 
U.S. Geological Survey streamflow-gaging station 08030500

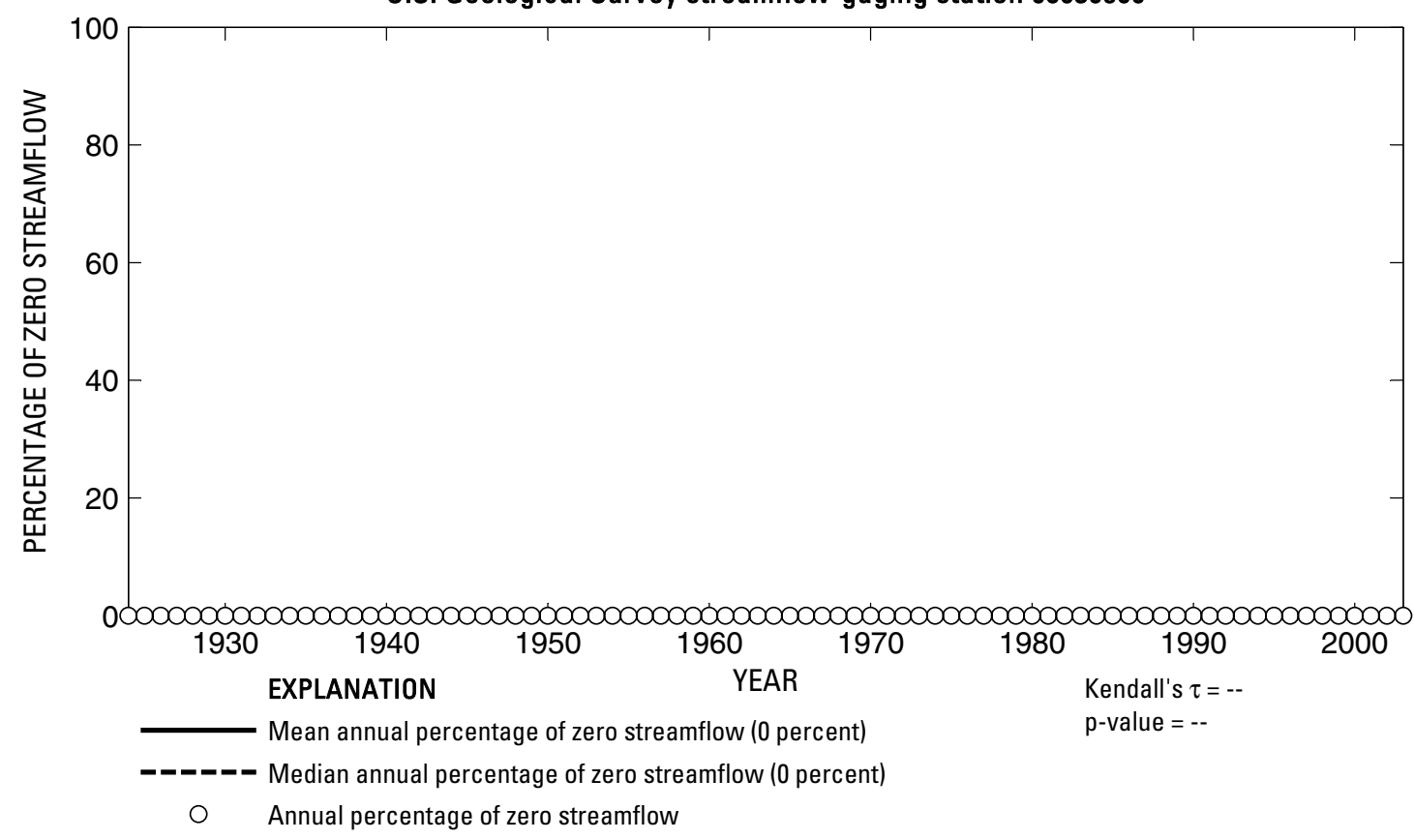

U.S. Geological Survey streamflow-gaging station 08030500

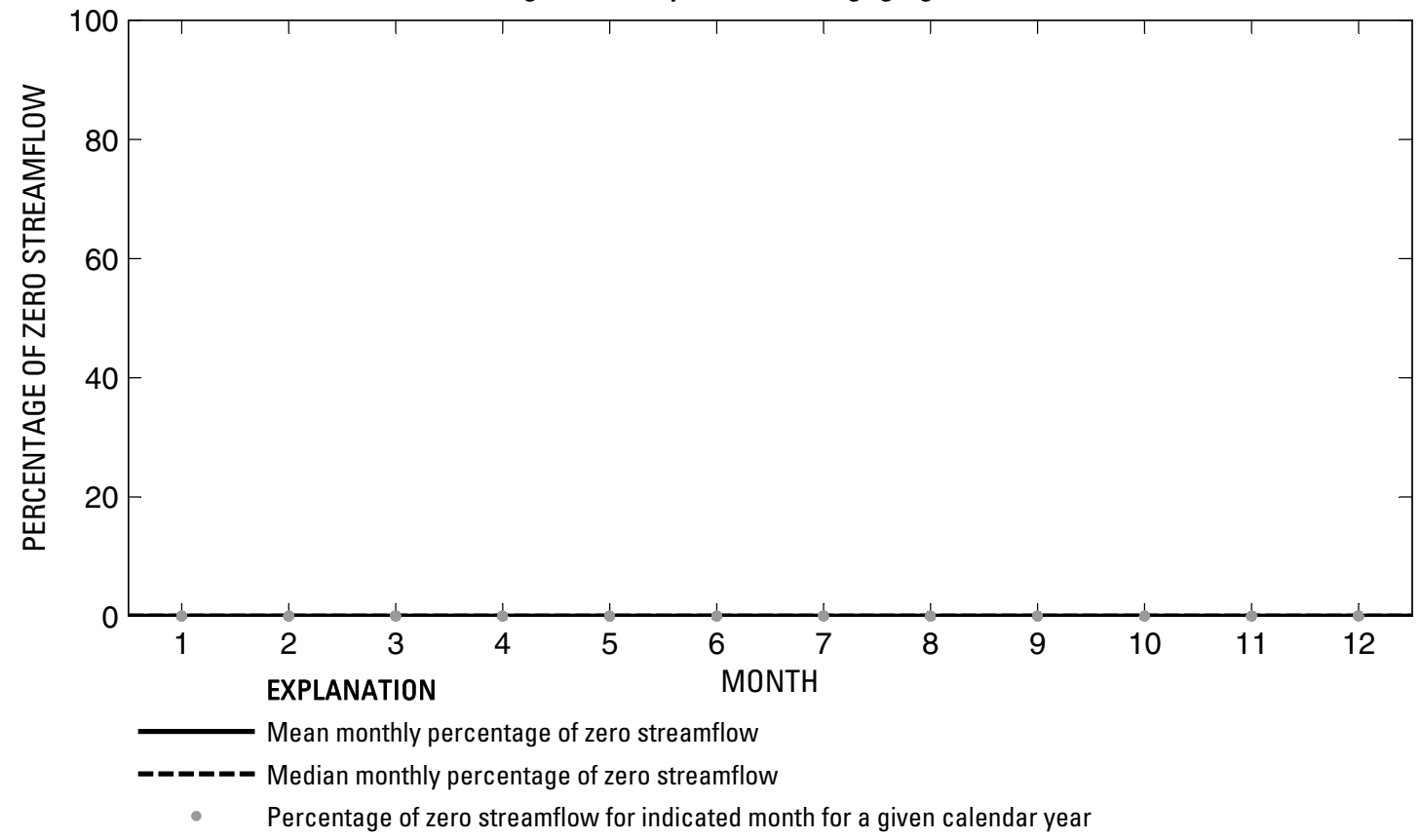

Figure 116. Analysis of percentage of zero daily mean streamflow for U.S. Geological Survey streamflow-gaging station 08030500 Sabine River near Ruliff, Texas. 

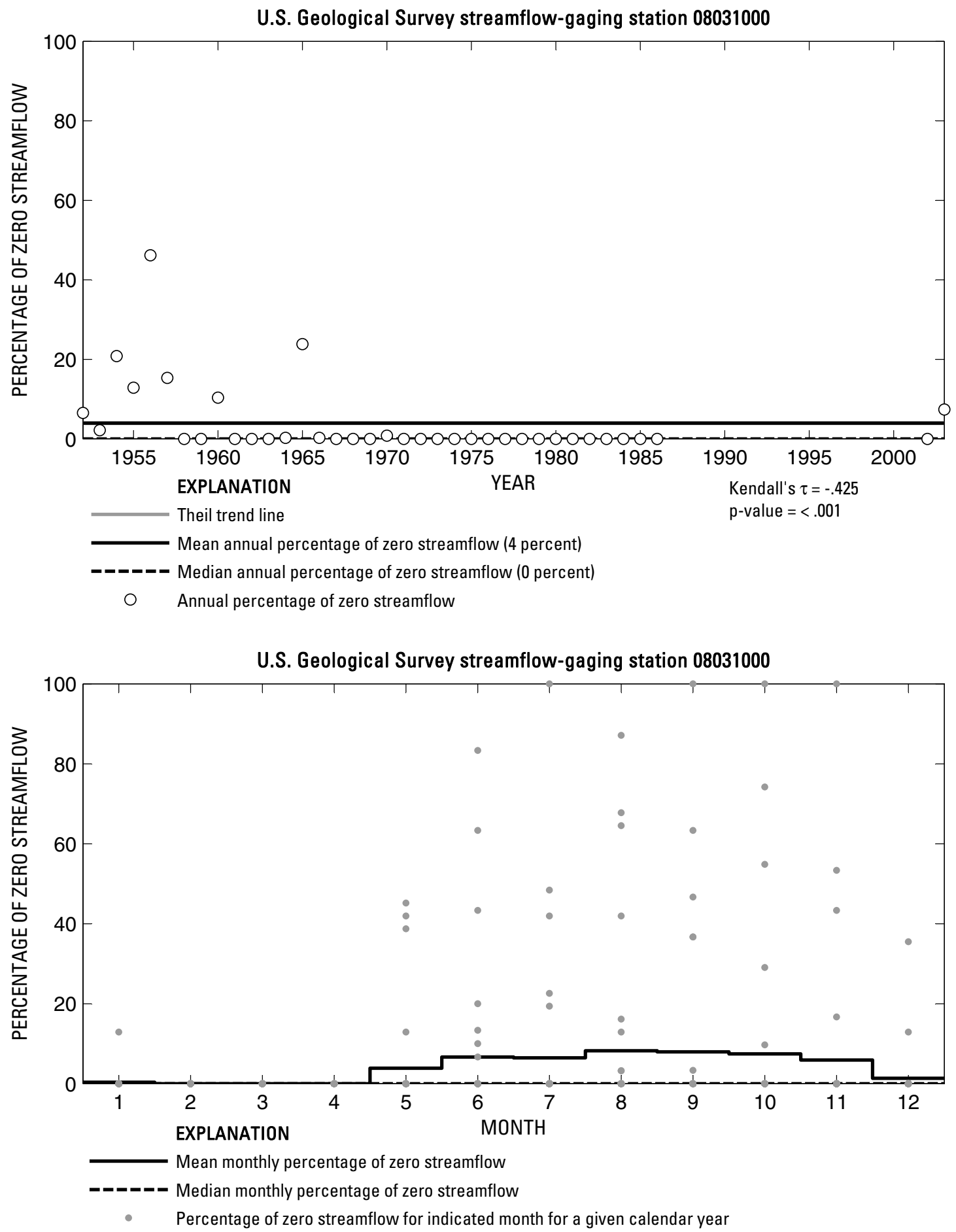

Figure 117. Analysis of percentage of zero daily mean streamflow for U.S. Geological Survey streamflow-gaging station 08031000 Cow Bayou near Mauriceville, Texas. 
U.S. Geological Survey streamflow-gaging station 08031200

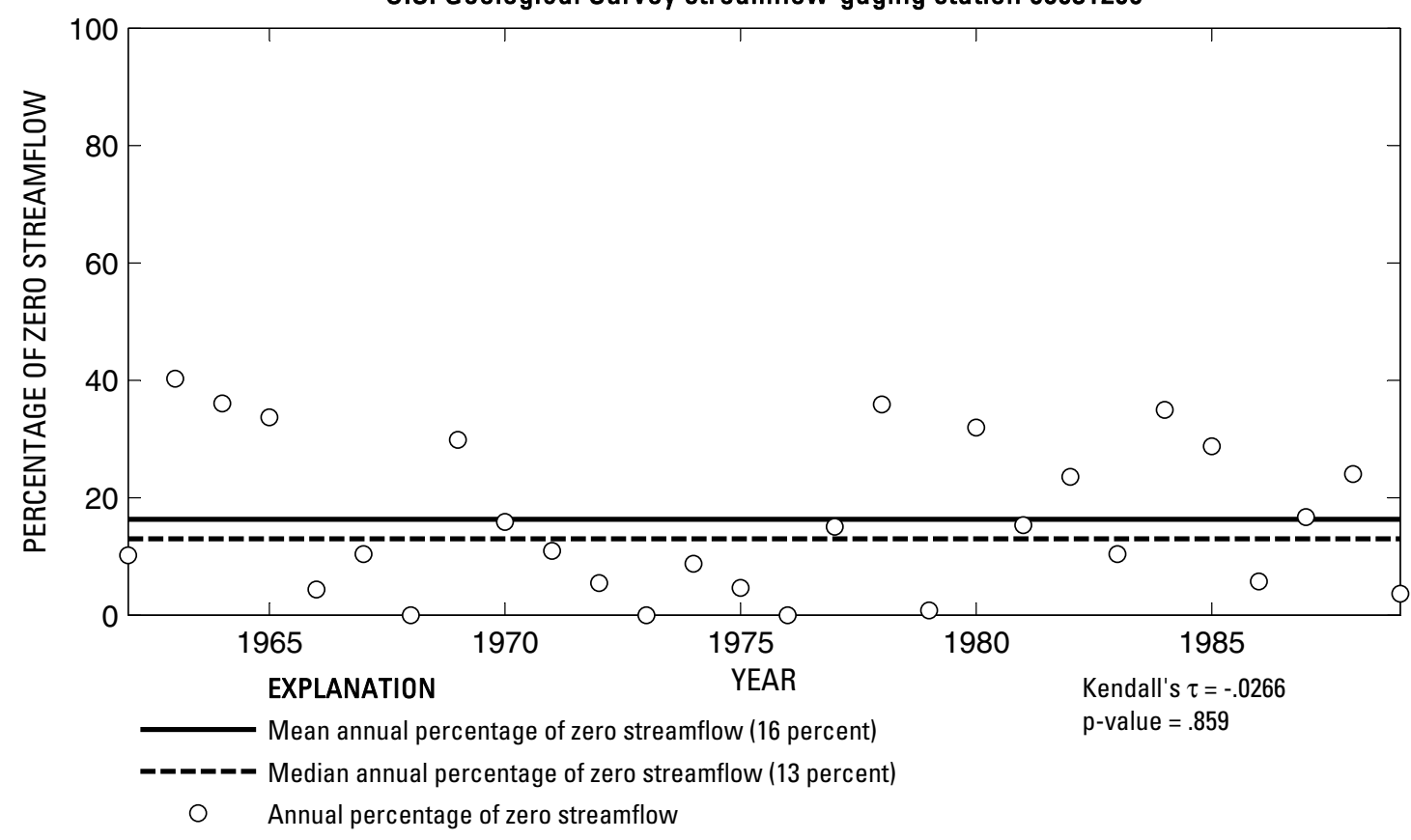

U.S. Geological Survey streamflow-gaging station 08031200

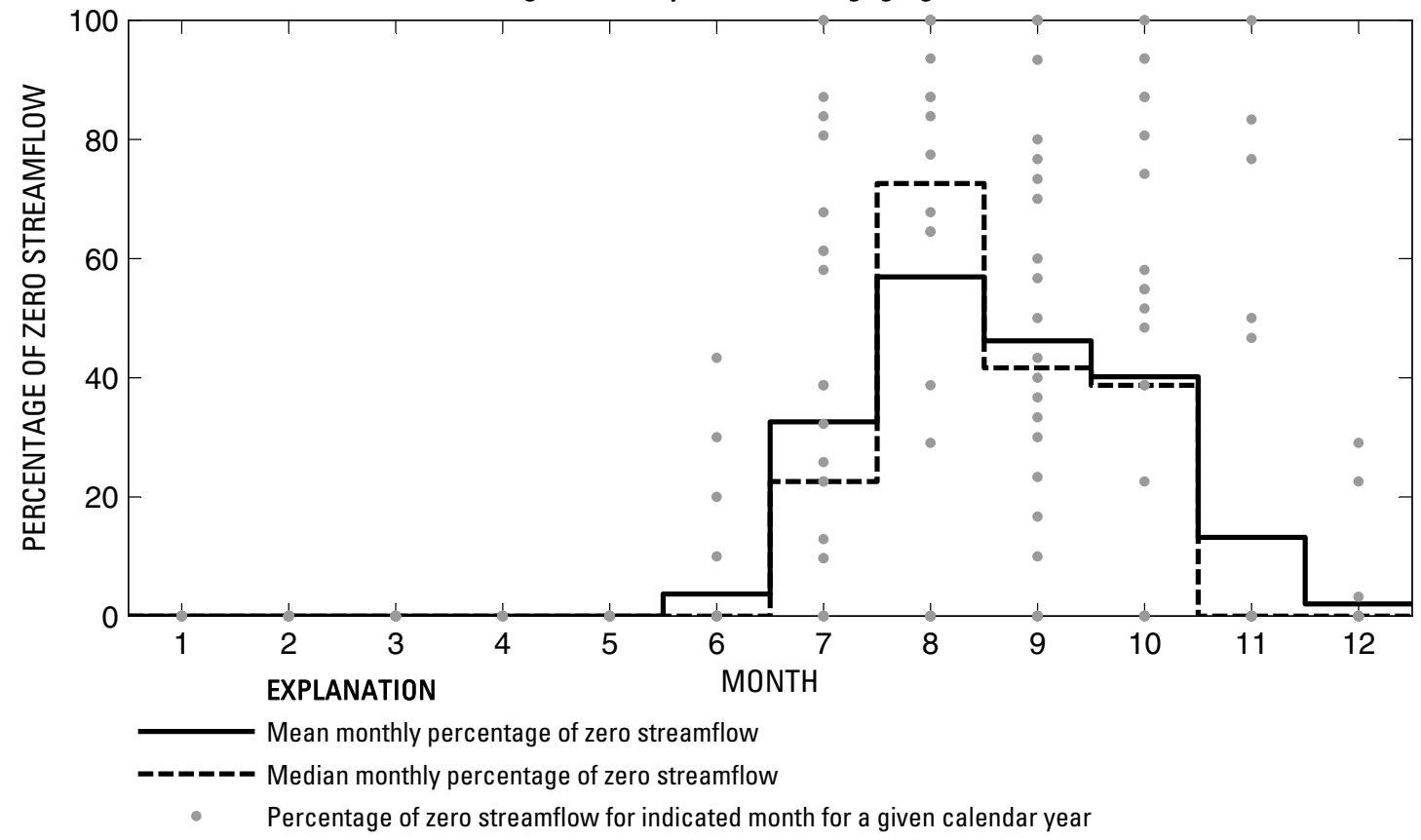

Figure 118. Analysis of percentage of zero daily mean streamflow for U.S. Geological Survey streamflow-gaging station 08031200 Kickapoo Creek near Brownsboro, Texas.

Index of Station Numbers 719 
U.S. Geological Survey streamflow-gaging station 08031500

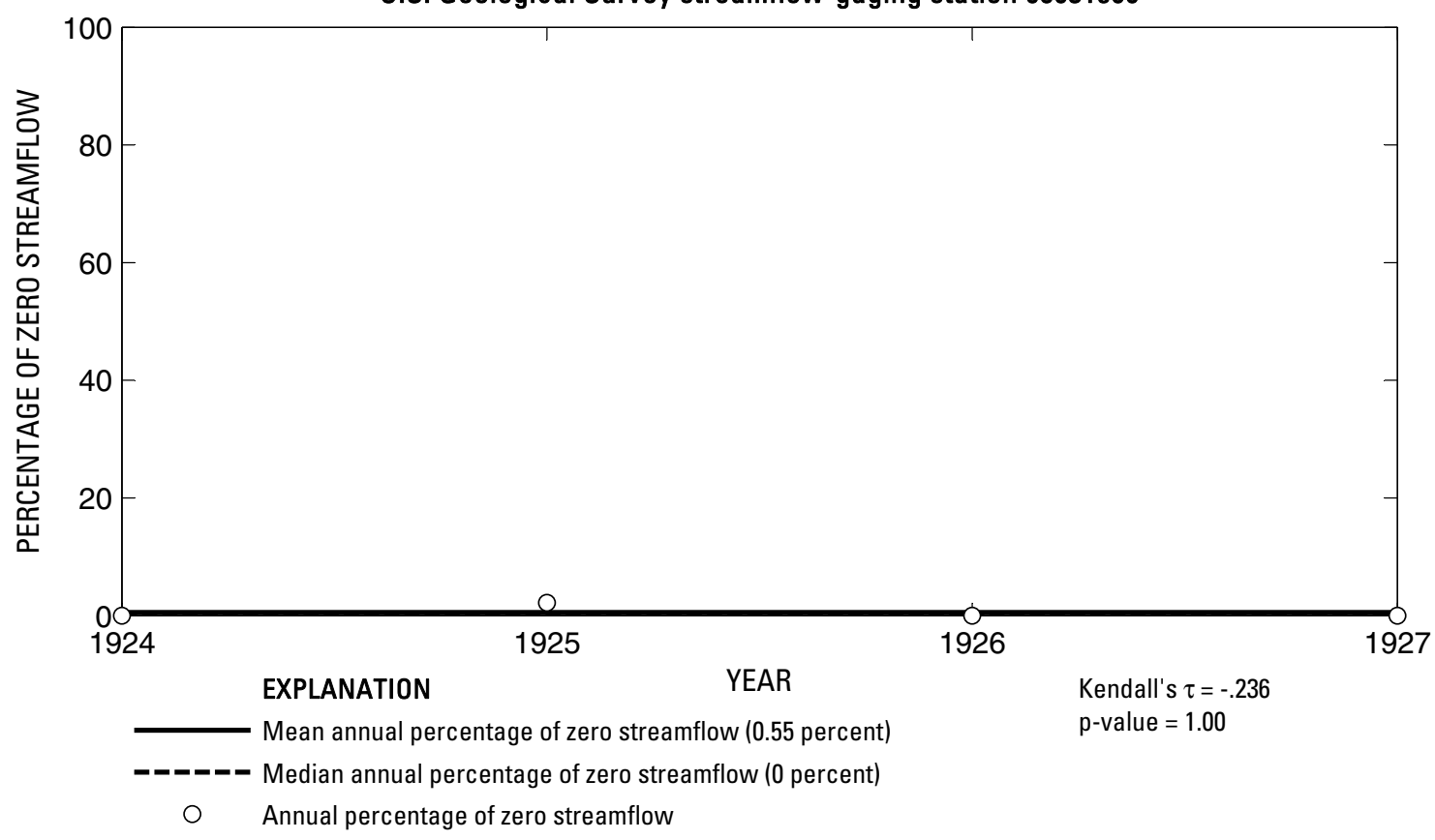

U.S. Geological Survey streamflow-gaging station 08031500

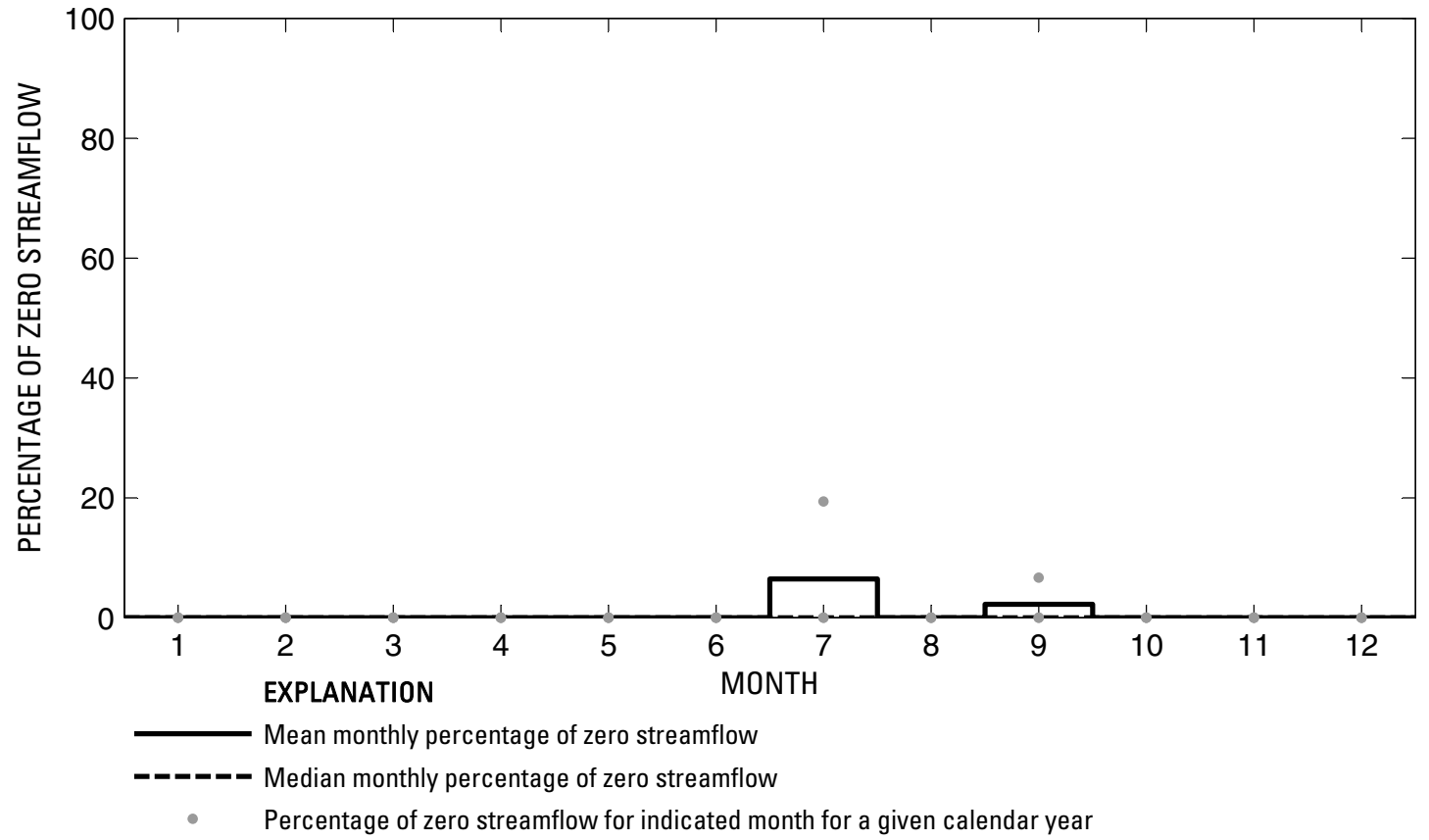

Figure 119. Analysis of percentage of zero daily mean streamflow for U.S. Geological Survey streamflow-gaging station 08031500 Neches River near Reese, Texas. 
U.S. Geological Survey streamflow-gaging station 08032000

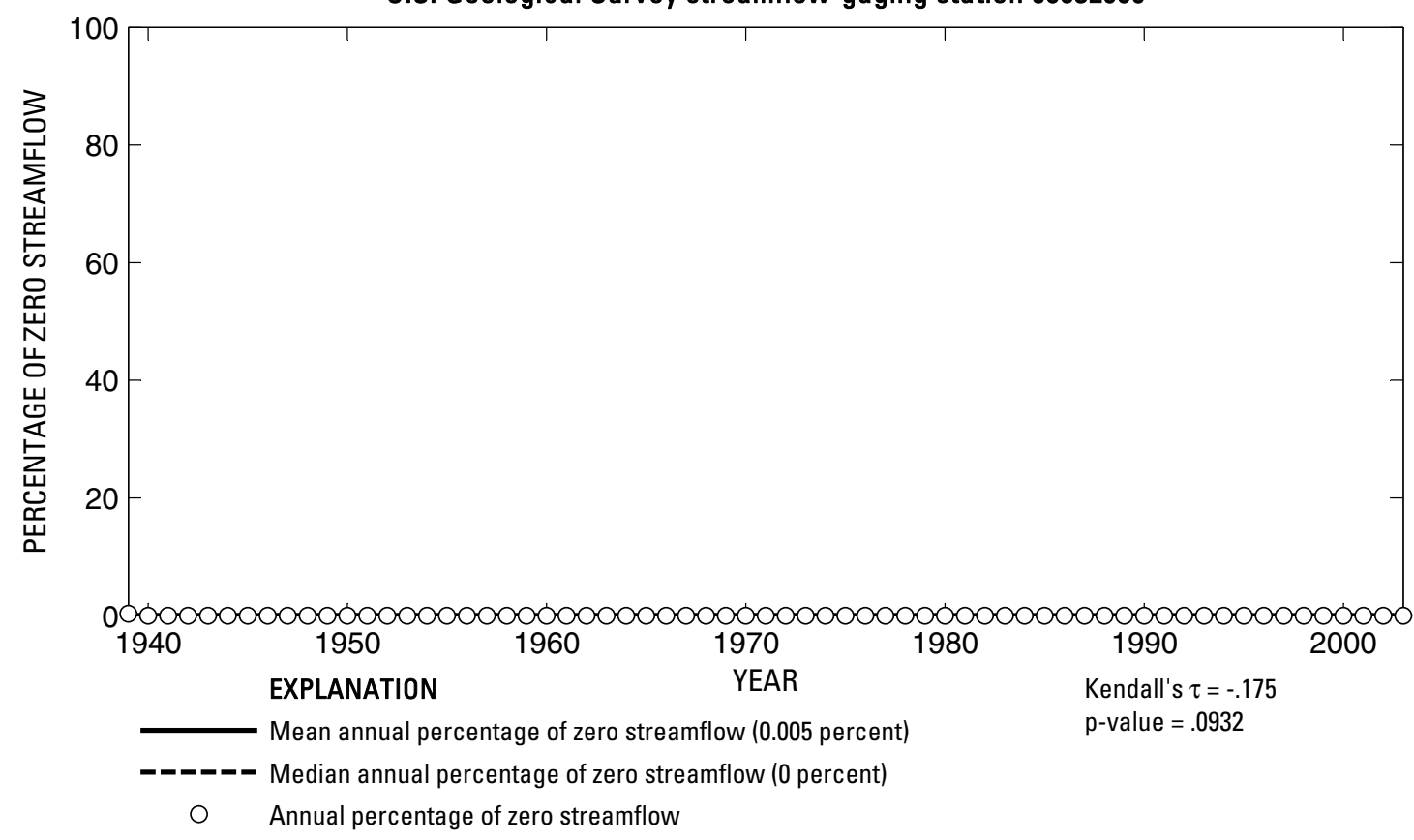

U.S. Geological Survey streamflow-gaging station 08032000

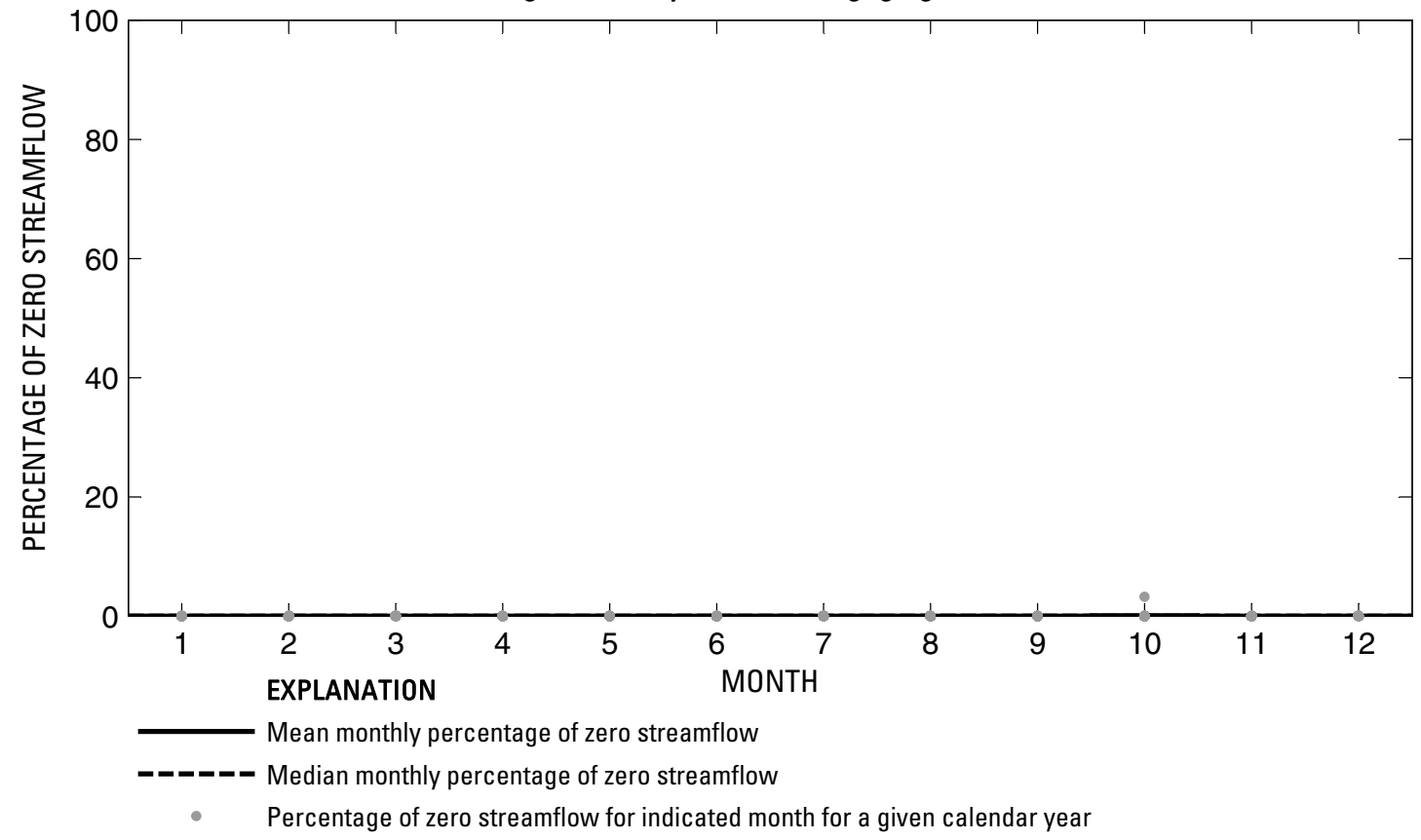

Figure 120. Analysis of percentage of zero daily mean streamflow for U.S. Geological Survey streamflow-gaging station 08032000 Neches River near Neches, Texas. 
U.S. Geological Survey streamflow-gaging station 08032500

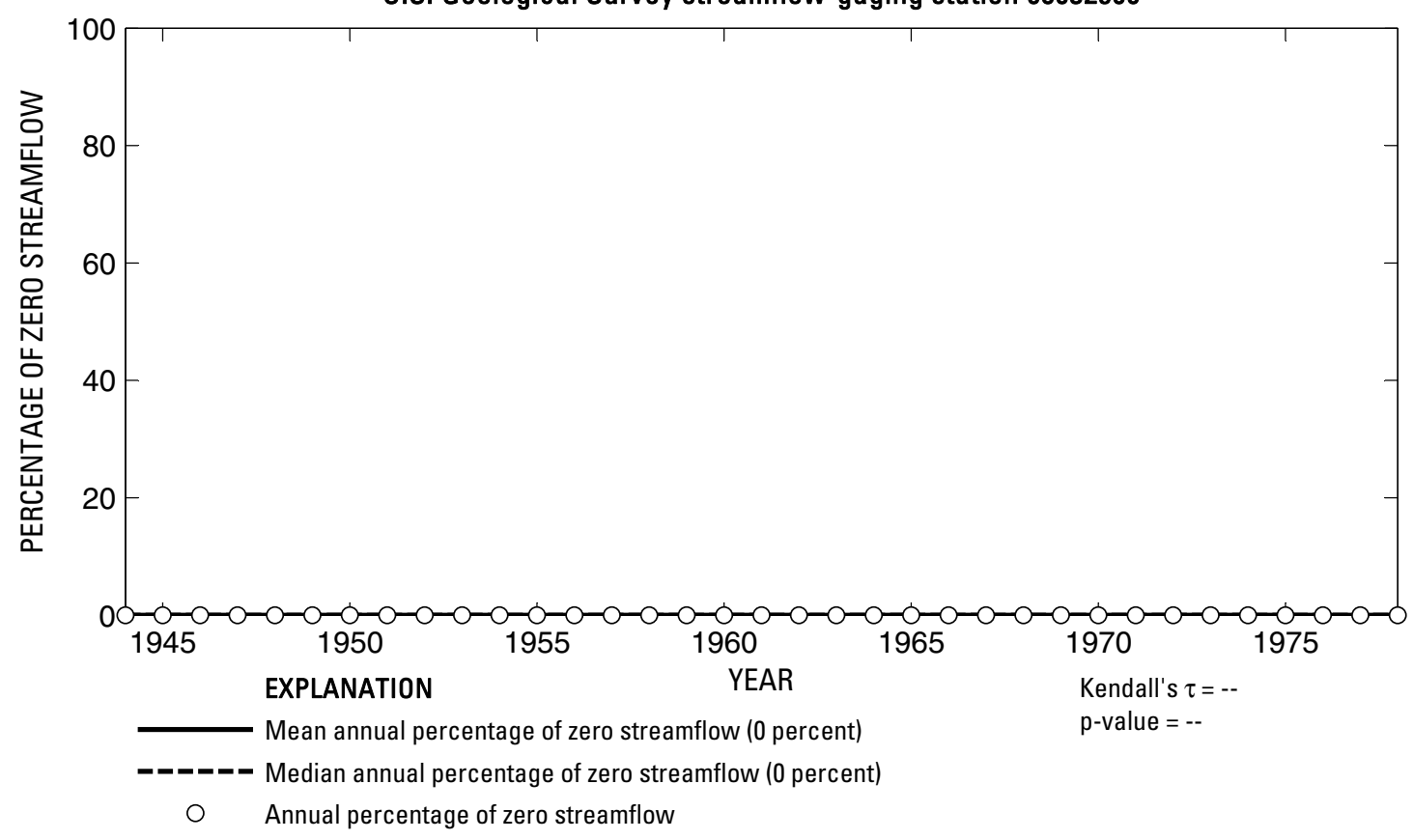

U.S. Geological Survey streamflow-gaging station 08032500

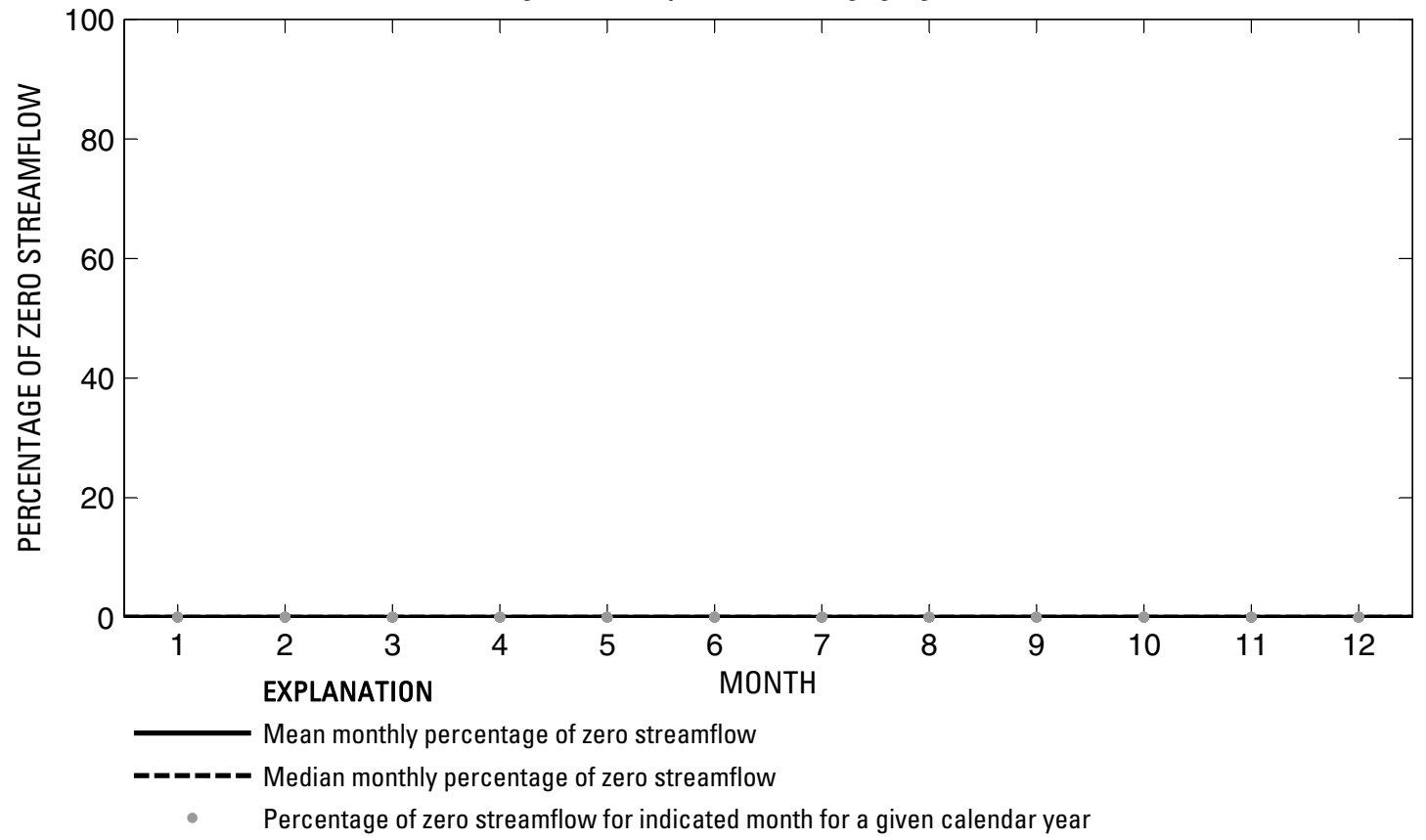

Figure 121. Analysis of percentage of zero daily mean streamflow for U.S. Geological Survey streamflow-gaging station 08032500 Neches River near Alto, Texas. 
U.S. Geological Survey streamflow-gaging station 08033000

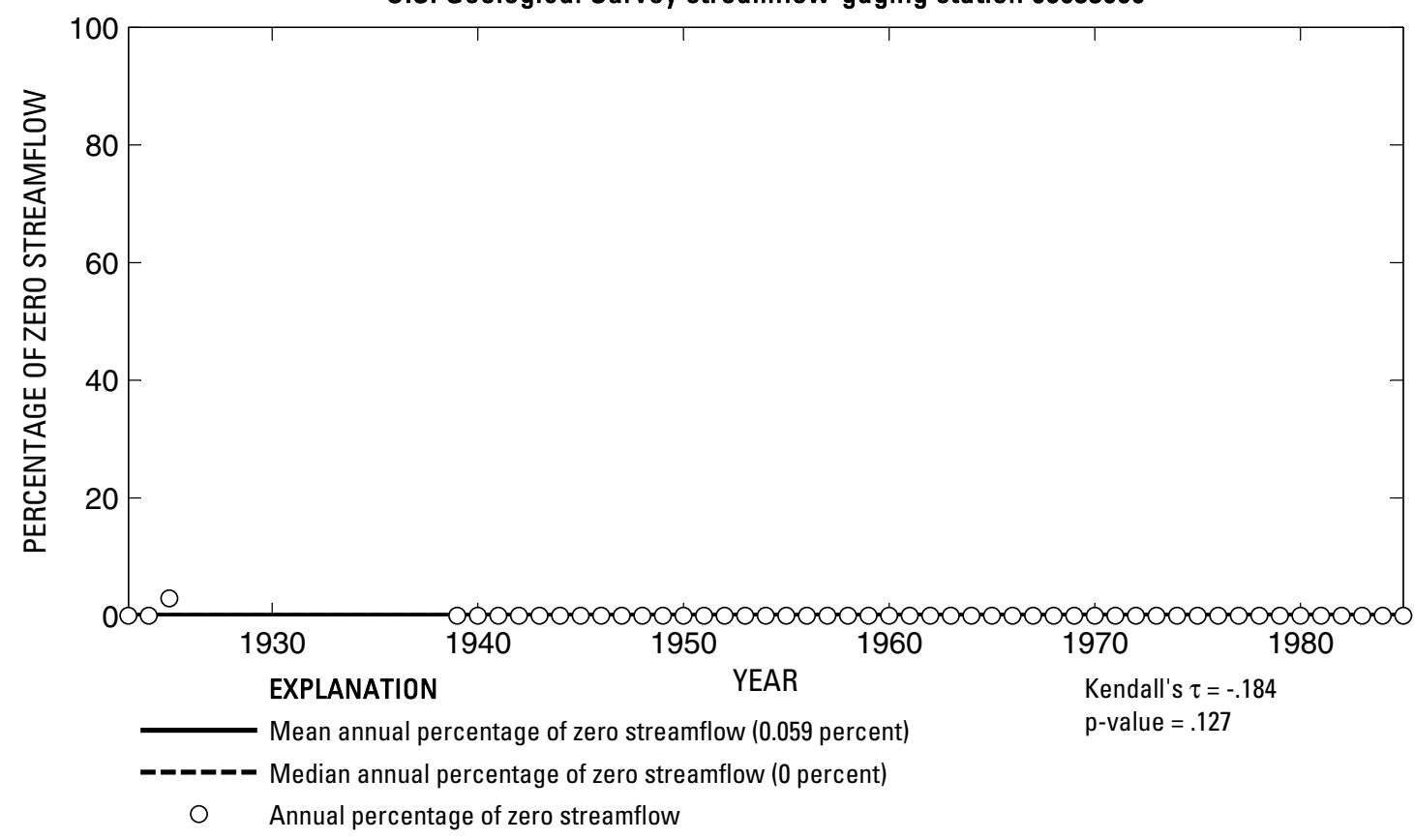

U.S. Geological Survey streamflow-gaging station 08033000

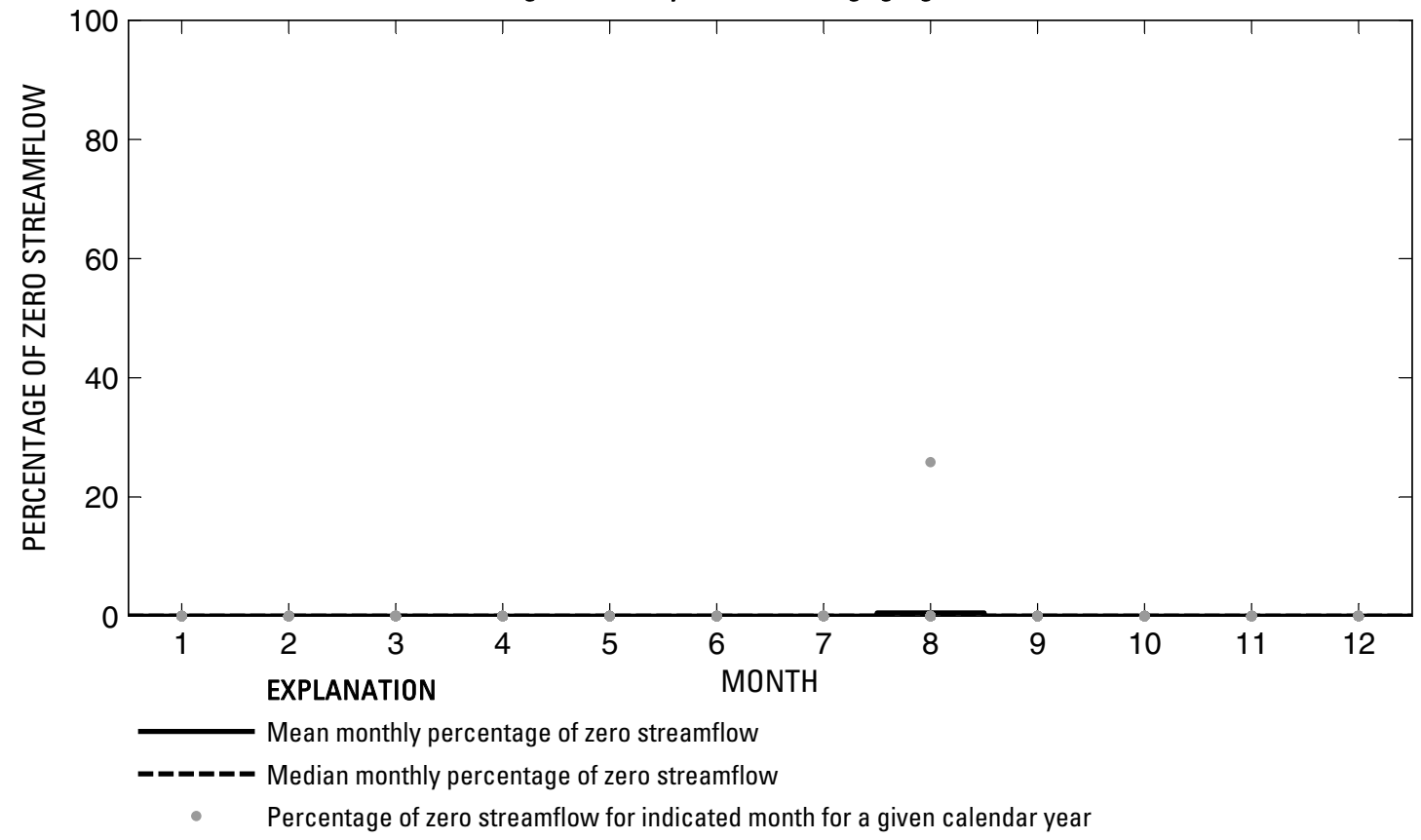

Figure 122. Analysis of percentage of zero daily mean streamflow for U.S. Geological Survey streamflow-gaging station 08033000 Neches River near Diboll, Texas. 

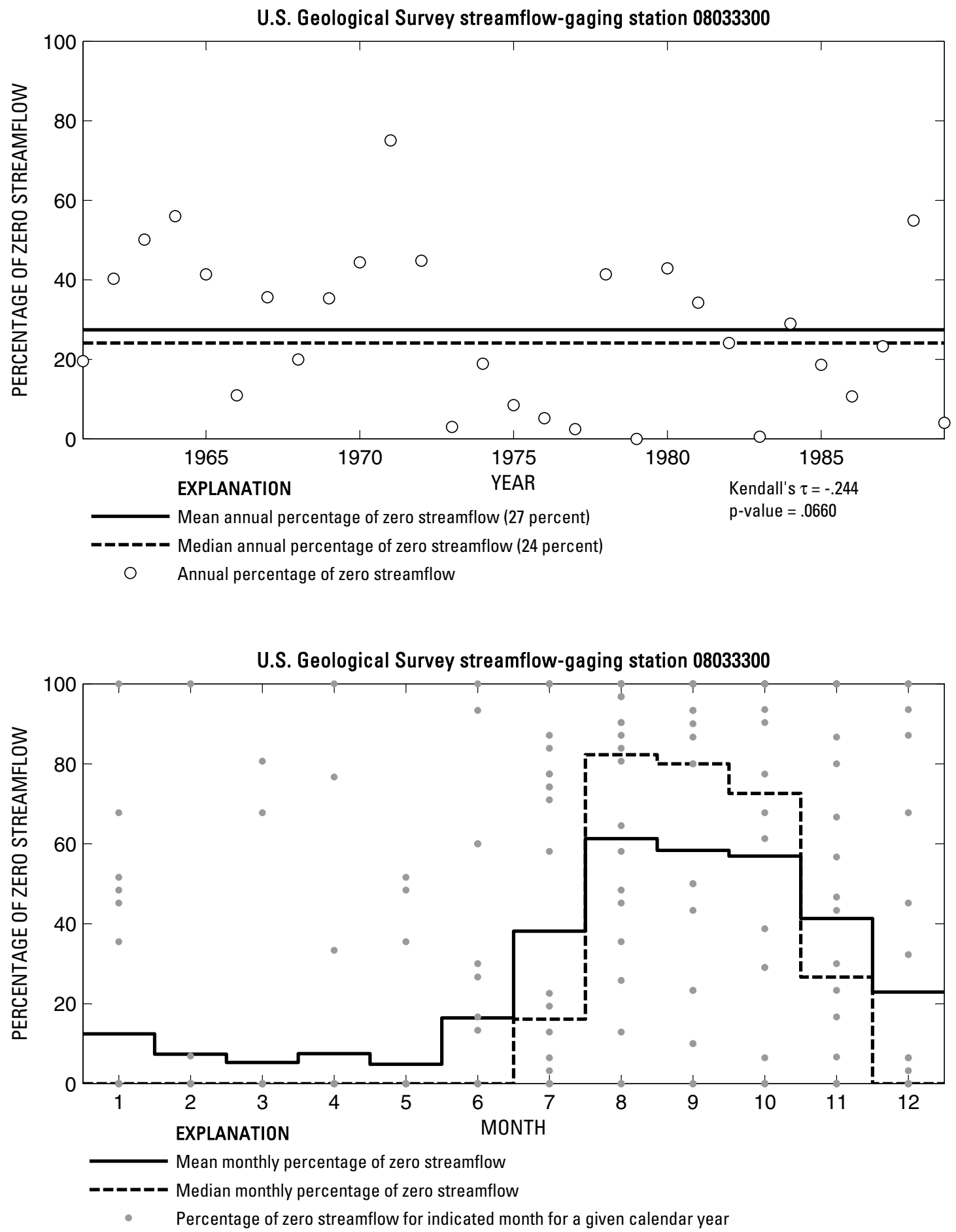

Figure 123. Analysis of percentage of zero daily mean streamflow for U.S. Geological Survey streamflow-gaging station 08033300 Piney Creek near Groveton, Texas. 
U.S. Geological Survey streamflow-gaging station 08033500

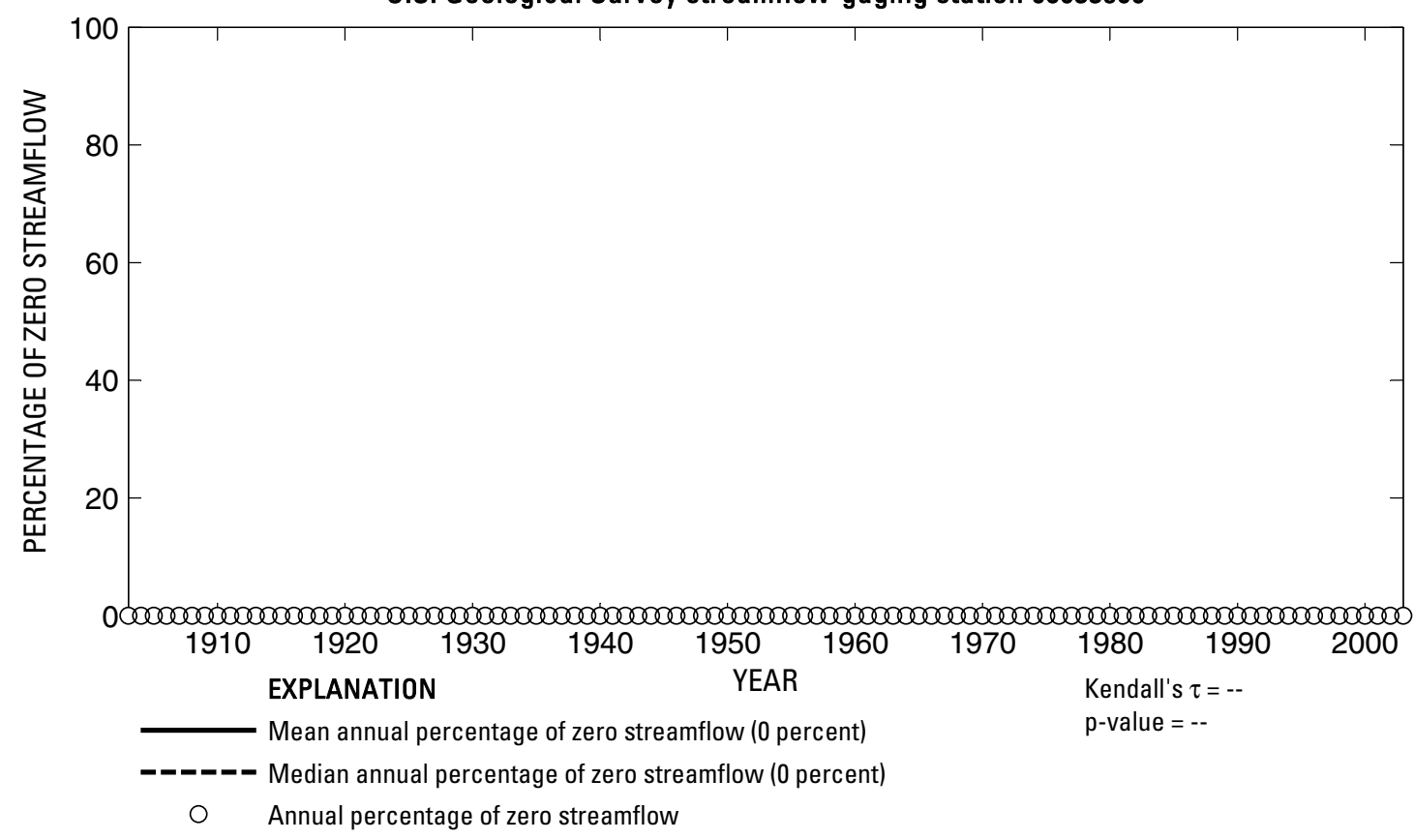

U.S. Geological Survey streamflow-gaging station 08033500

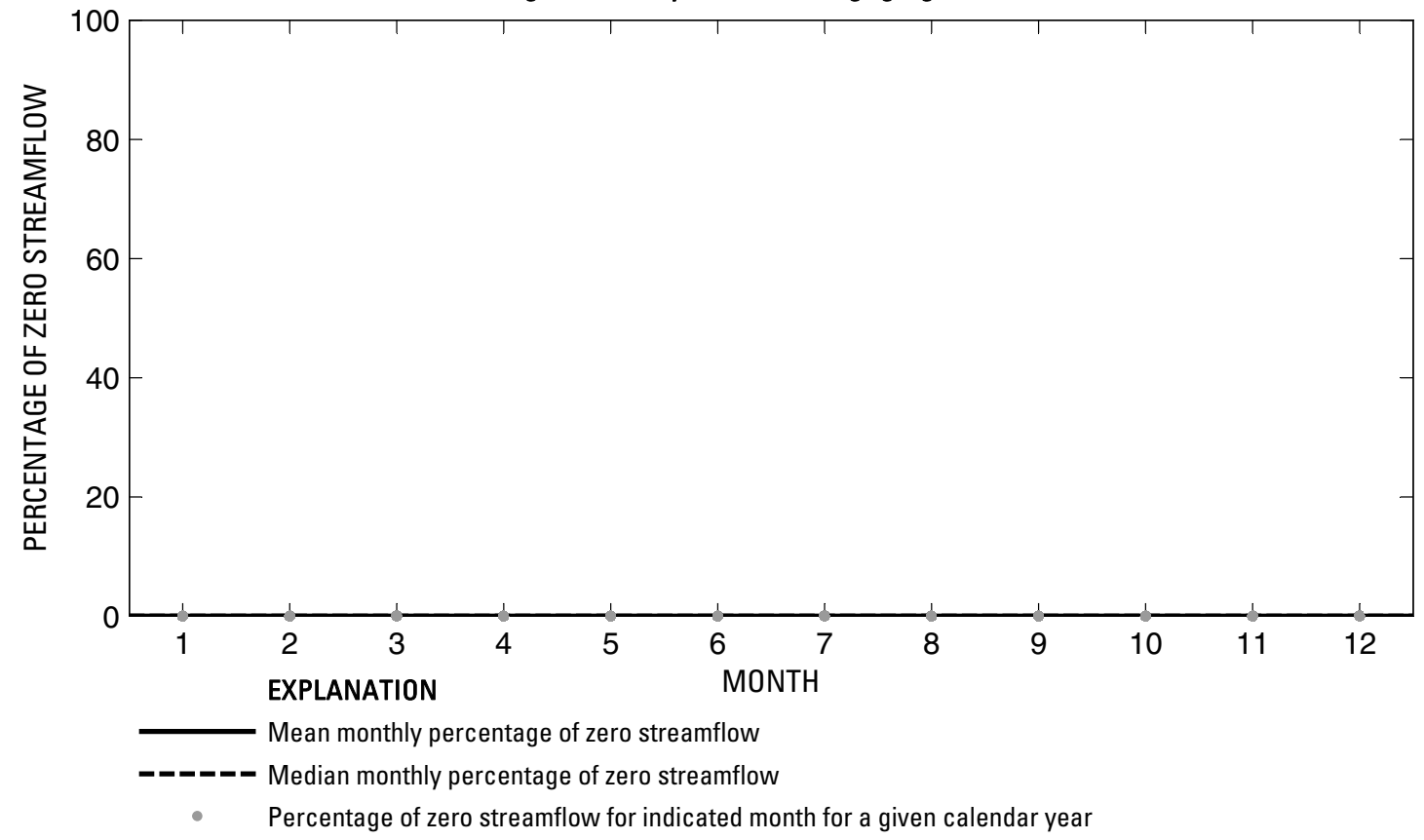

Figure 124. Analysis of percentage of zero daily mean streamflow for U.S. Geological Survey streamflow-gaging station 08033500 Neches River near Rockland, Texas. 
U.S. Geological Survey streamflow-gaging station 08033700

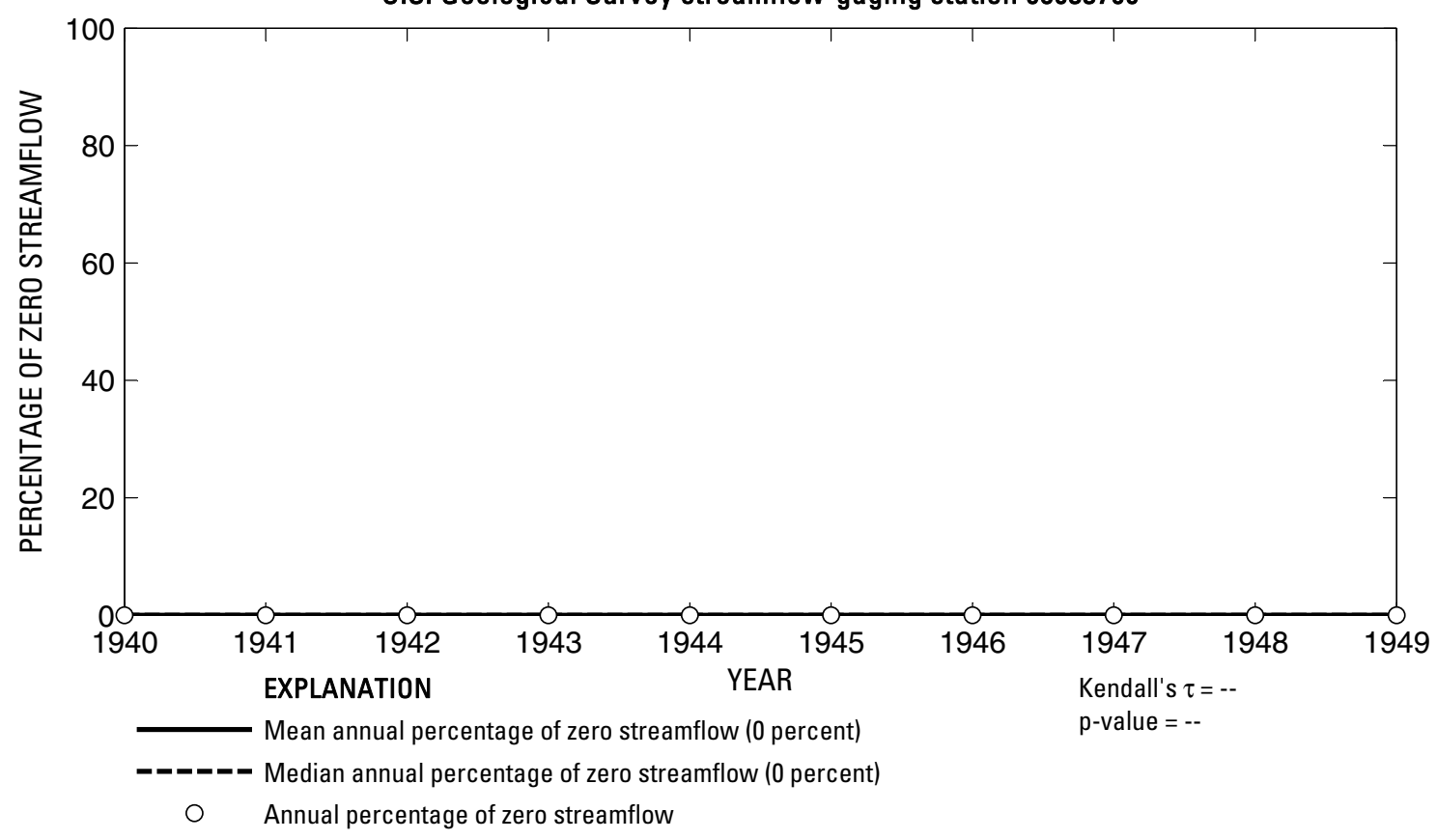

U.S. Geological Survey streamflow-gaging station 08033700

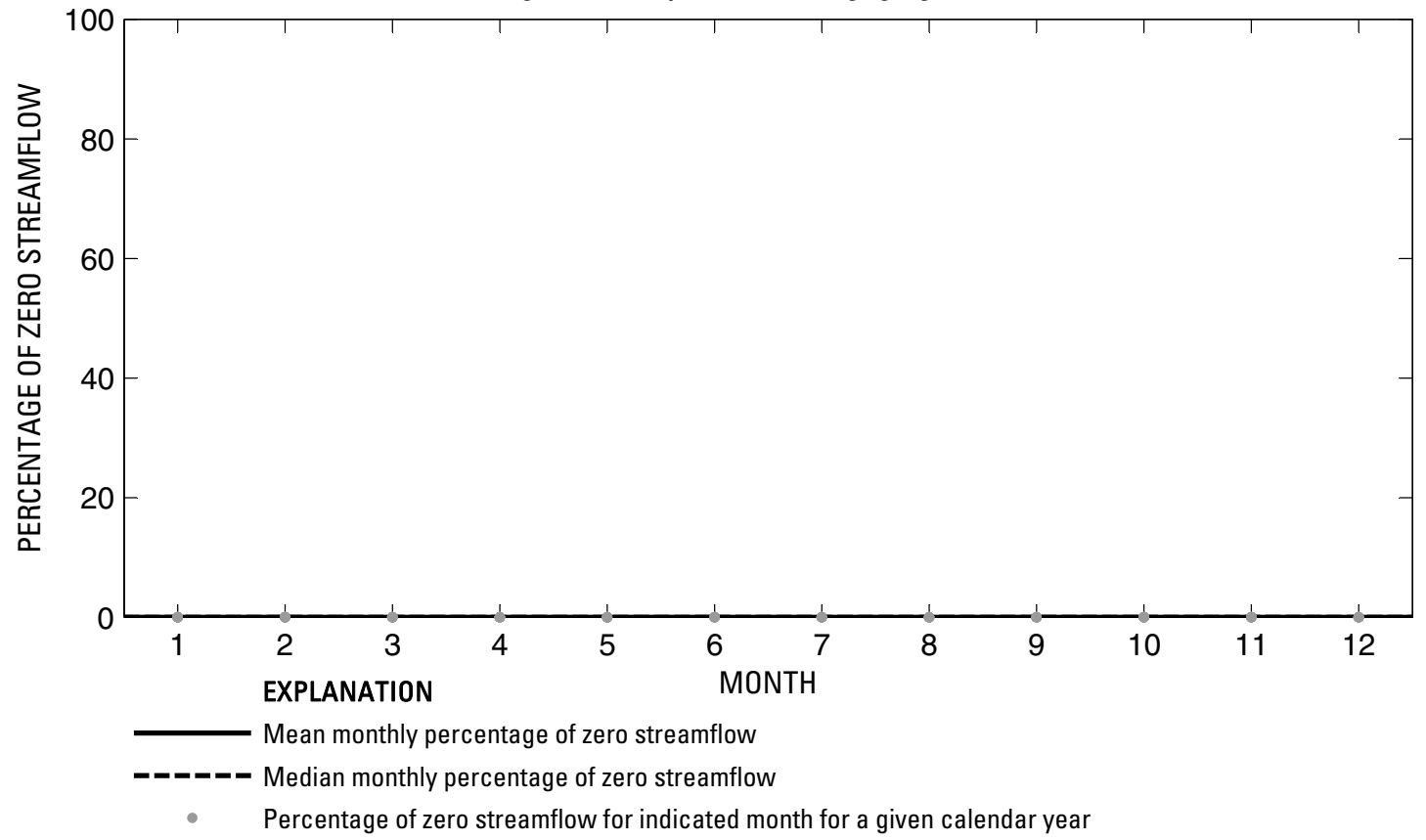

Figure 125. Analysis of percentage of zero daily mean streamflow for U.S. Geological Survey streamflow-gaging station 08033700 Striker Creek near Summerfield, Texas. 
U.S. Geological Survey streamflow-gaging station 08033900

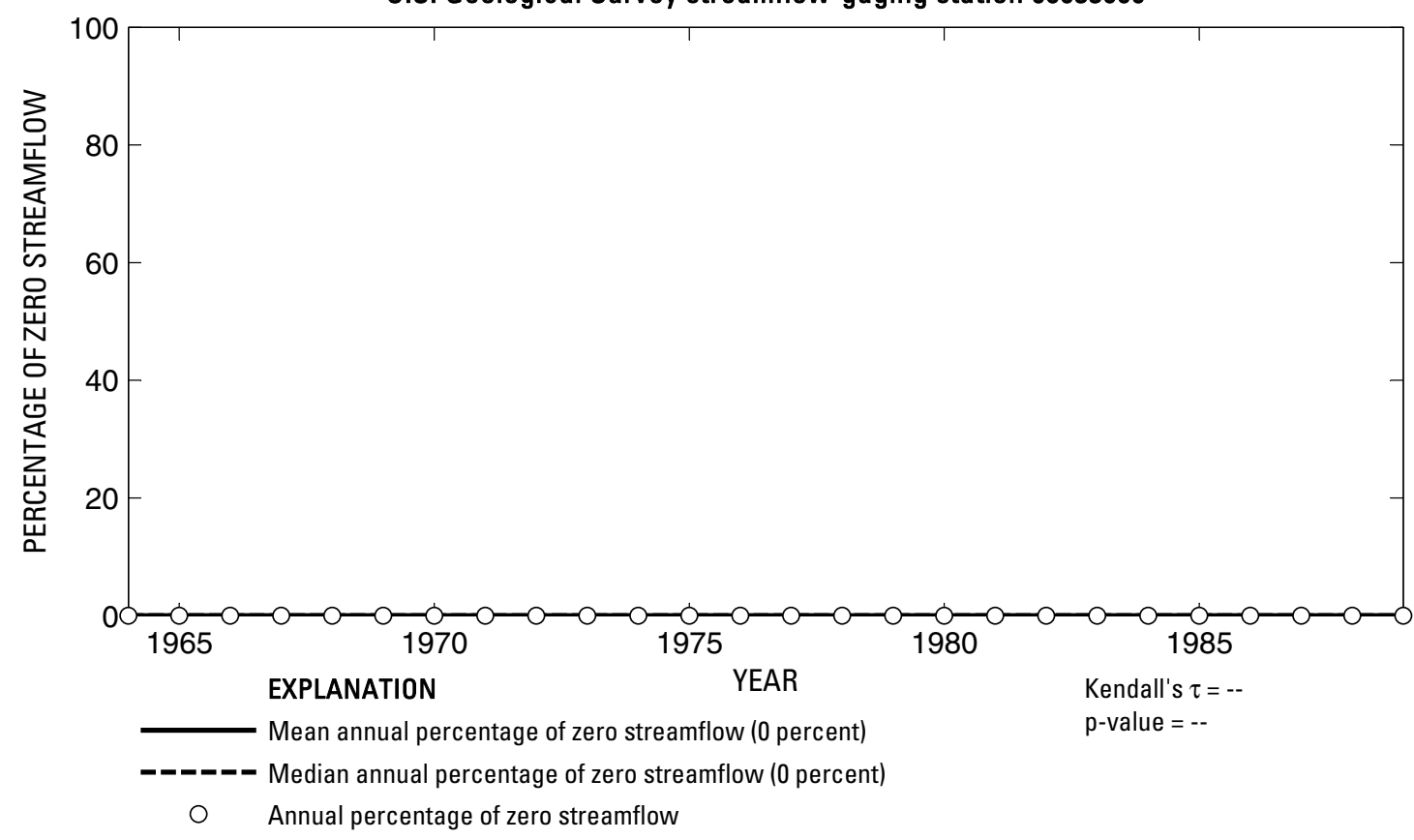

U.S. Geological Survey streamflow-gaging station 08033900

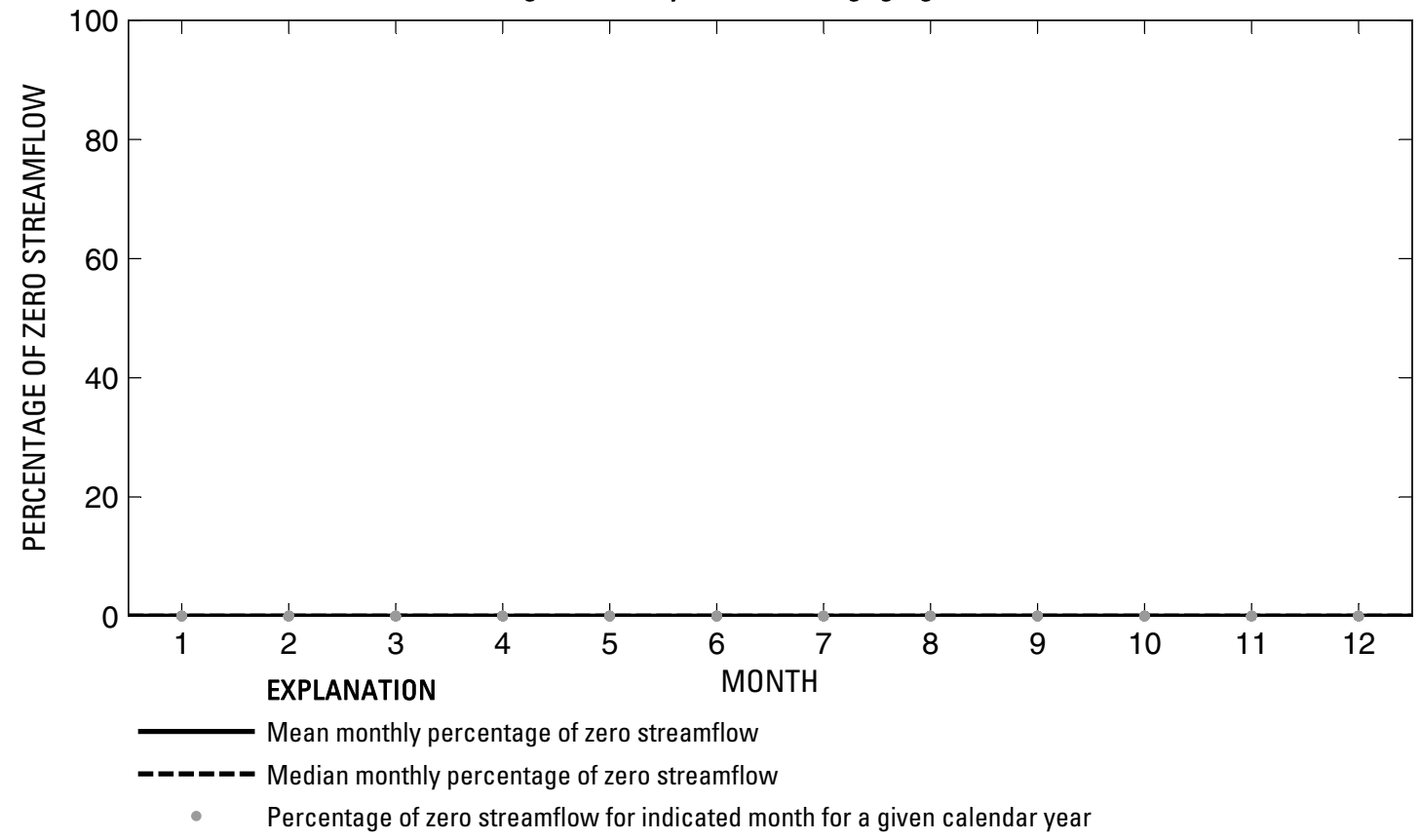

Figure 126. Analysis of percentage of zero daily mean streamflow for U.S. Geological Survey streamflow-gaging station 08033900 East Fork Angelina River near Cushing, Texas. 


\section{U.S. Geological Survey streamflow-gaging station 08034500}

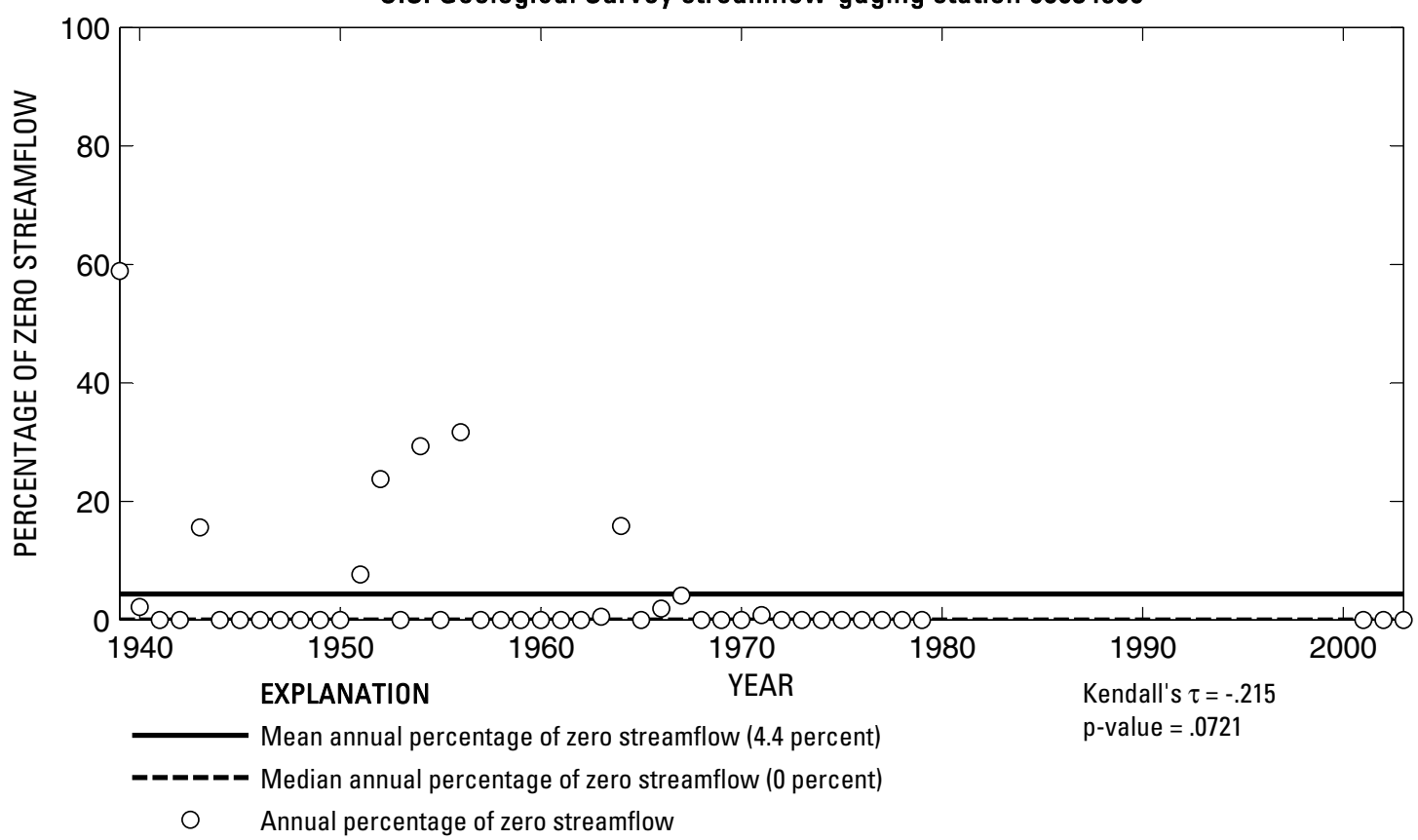

U.S. Geological Survey streamflow-gaging station 08034500

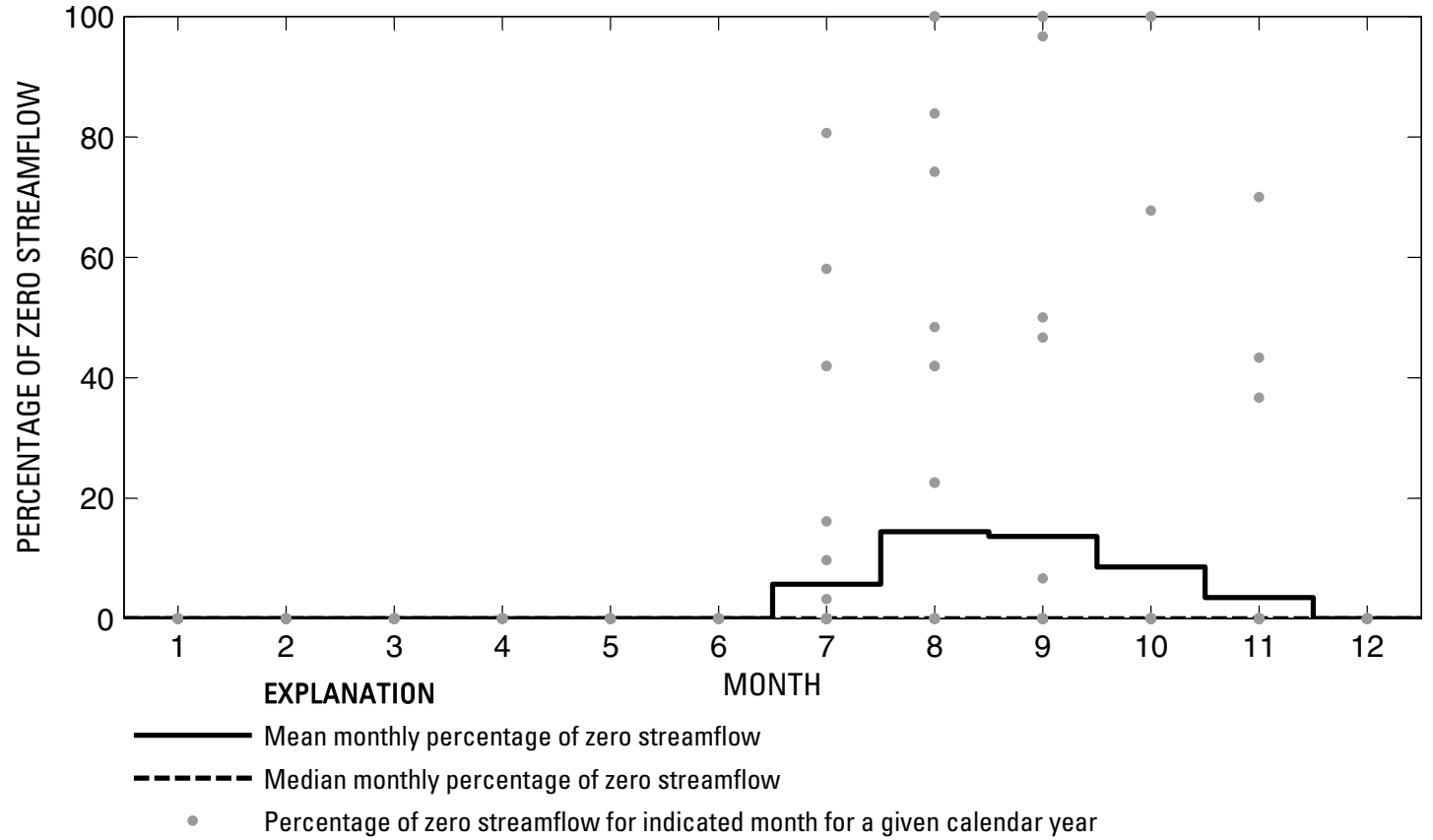

Figure 127. Analysis of percentage of zero daily mean streamflow for U.S. Geological Survey streamflow-gaging station 08034500 Mud Creek near Jacksonville, Texas. 
U.S. Geological Survey streamflow-gaging station 08035000

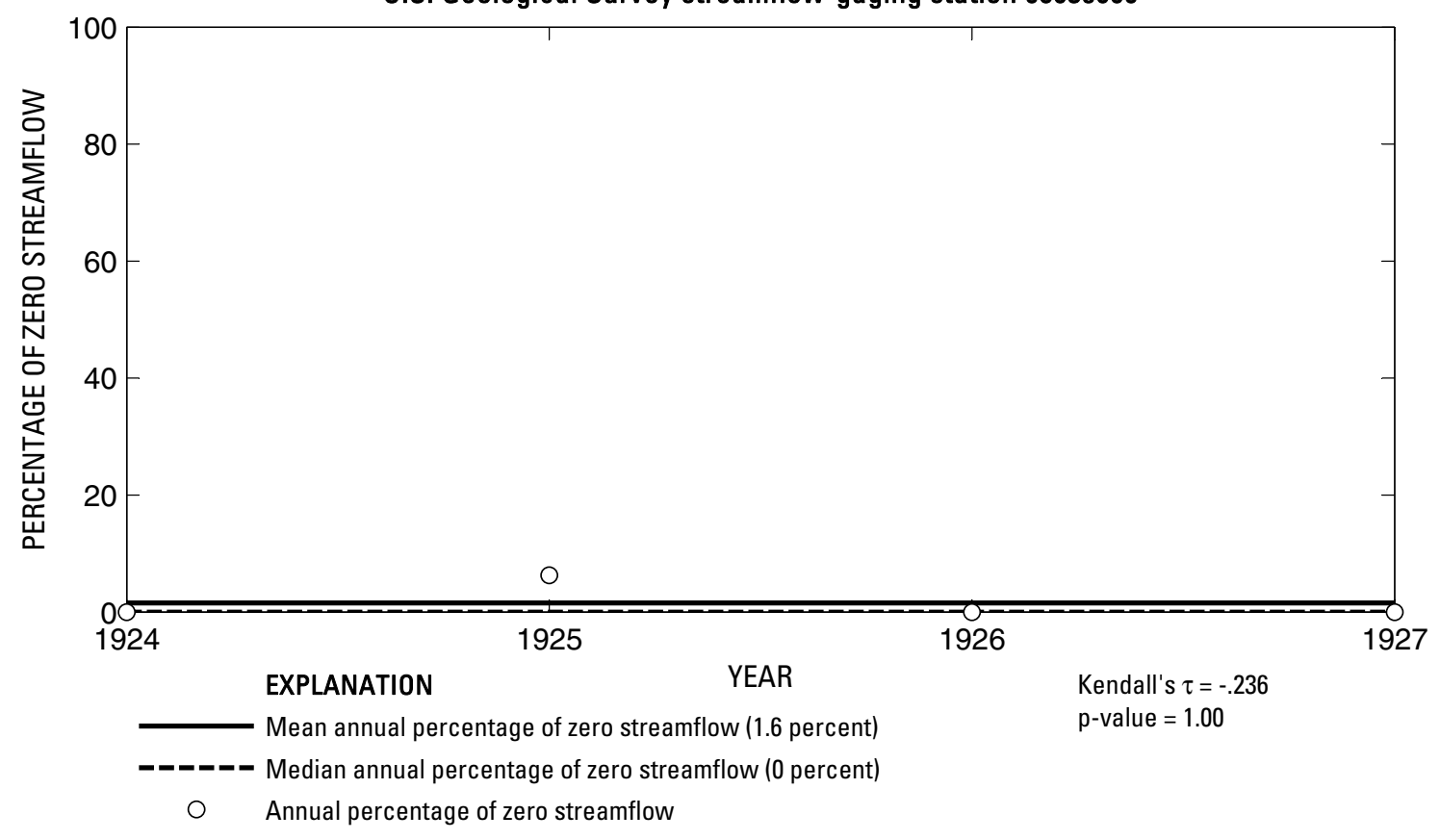

U.S. Geological Survey streamflow-gaging station 08035000

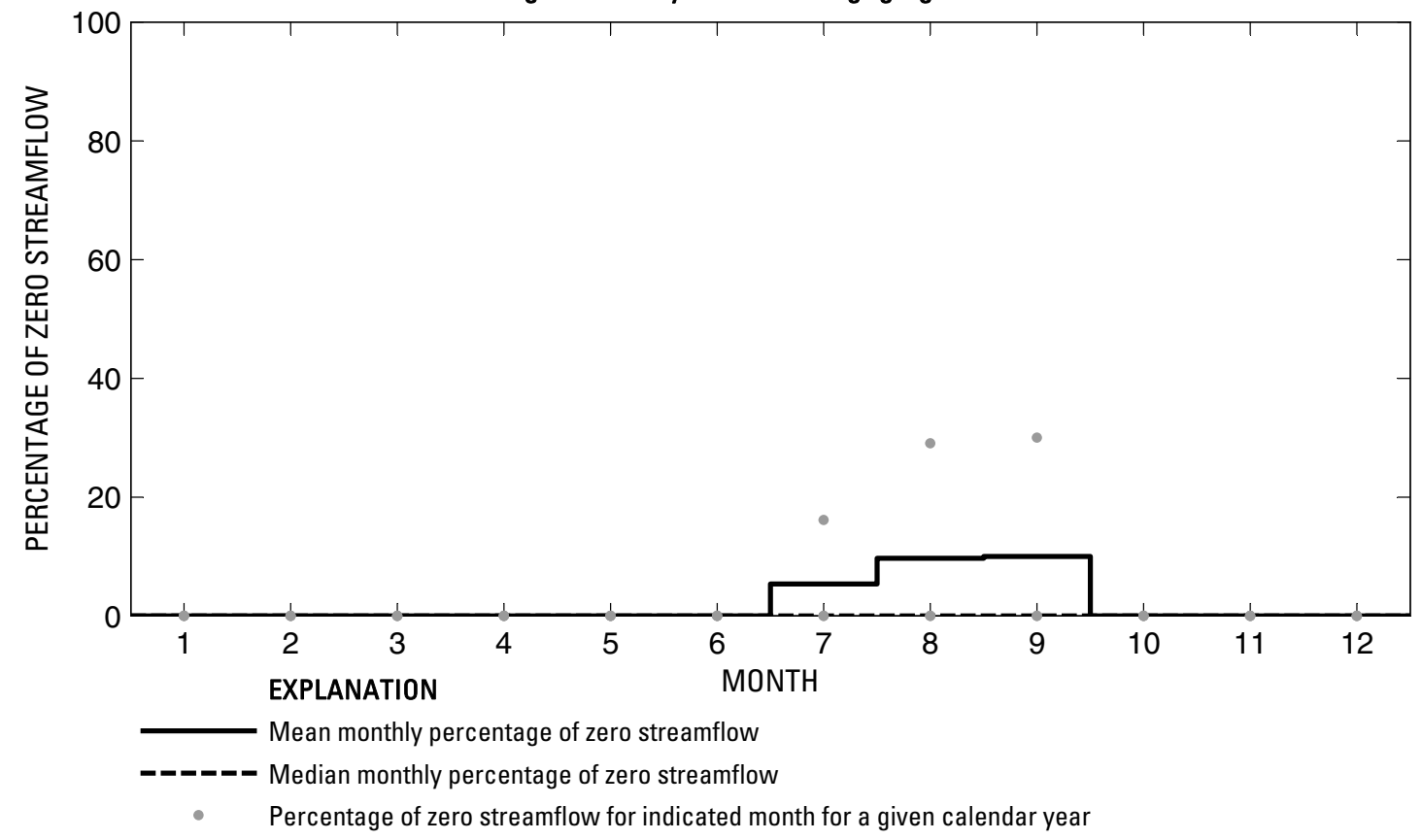

Figure 128. Analysis of percentage of zero daily mean streamflow for U.S. Geological Survey streamflow-gaging station 08035000 Mud Creek at Ponta, Texas. 


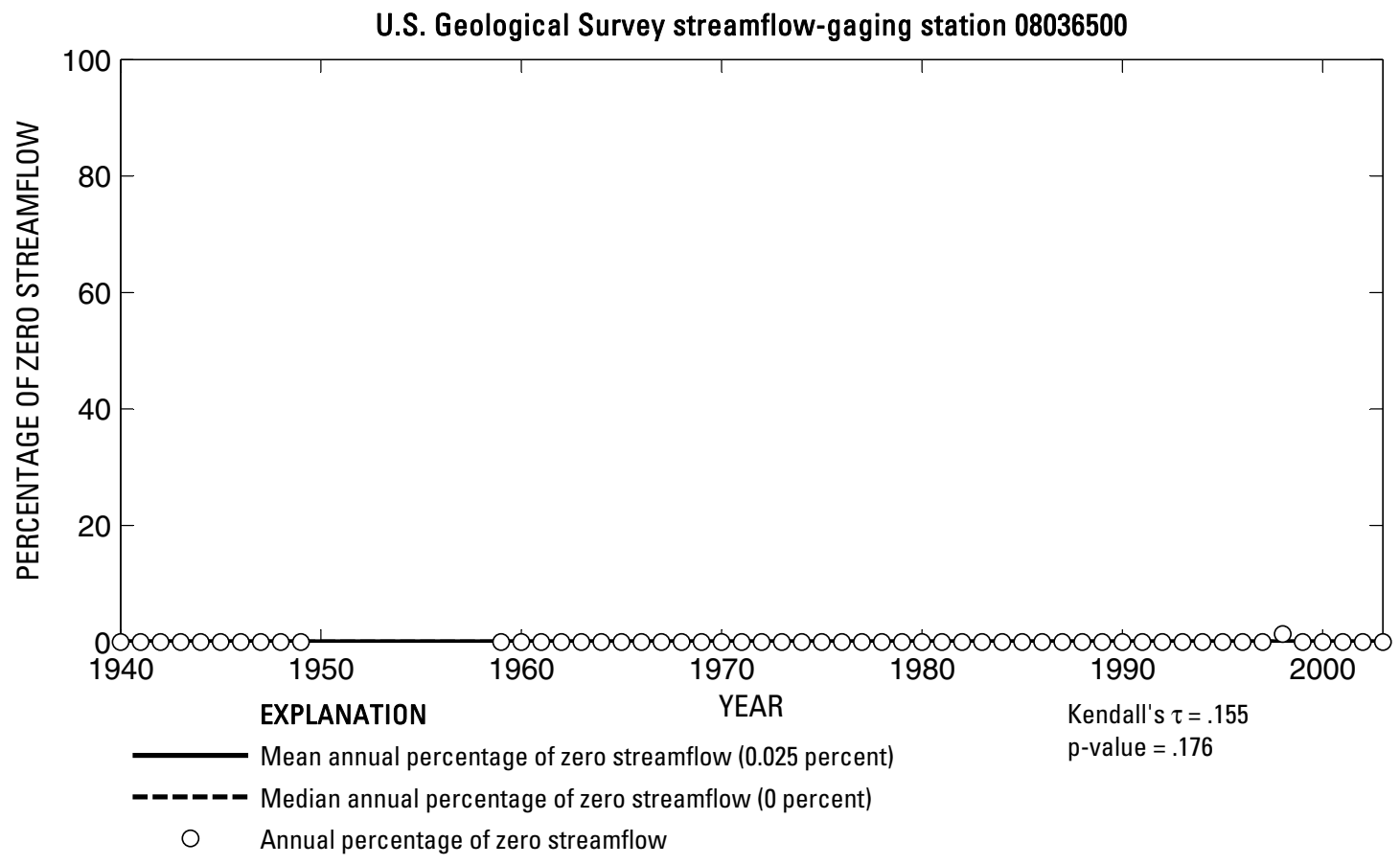

U.S. Geological Survey streamflow-gaging station 08036500

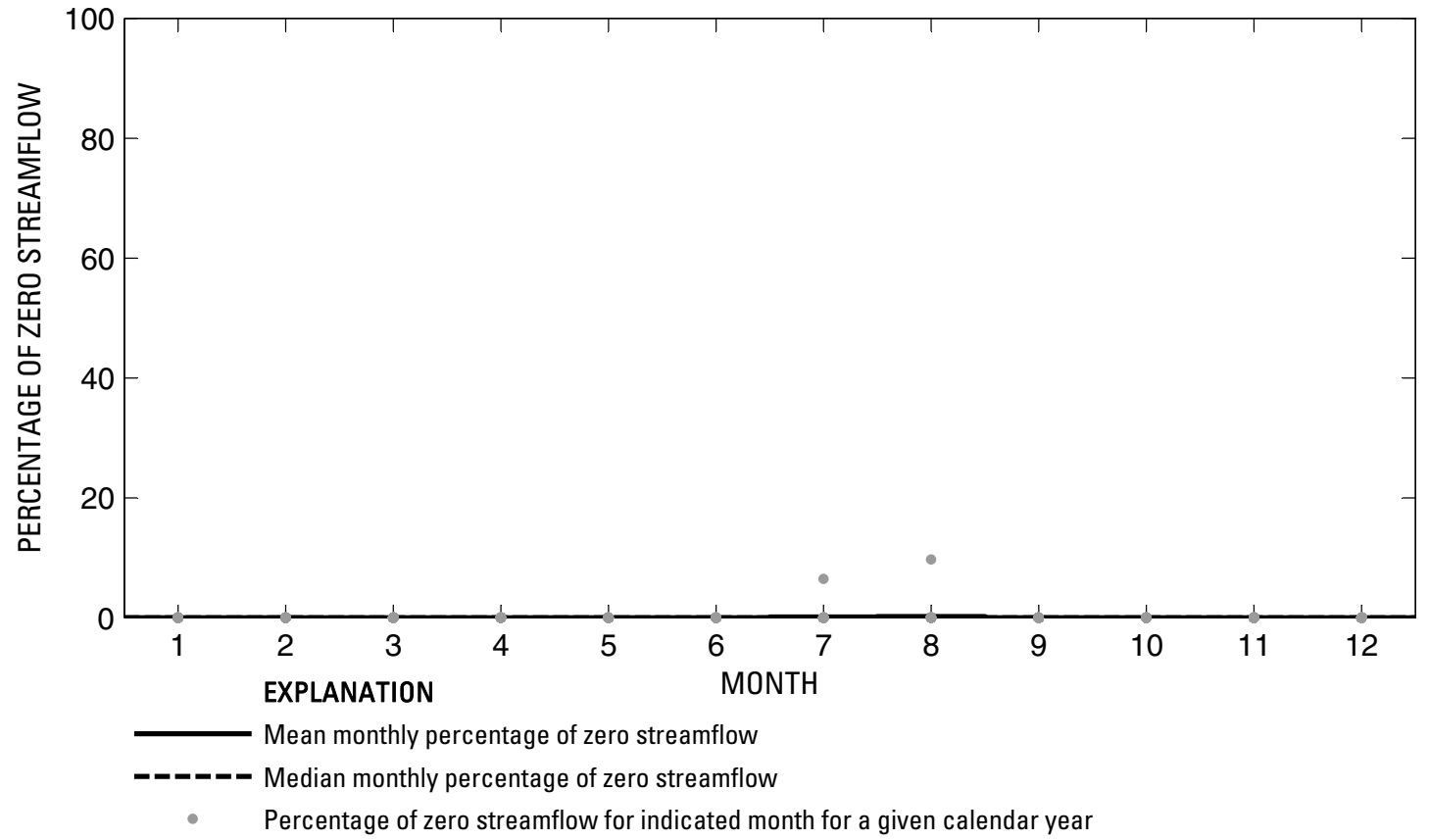

Figure 129. Analysis of percentage of zero daily mean streamflow for U.S. Geological Survey streamflow-gaging station 08036500 Angelina River near Alto, Texas. 

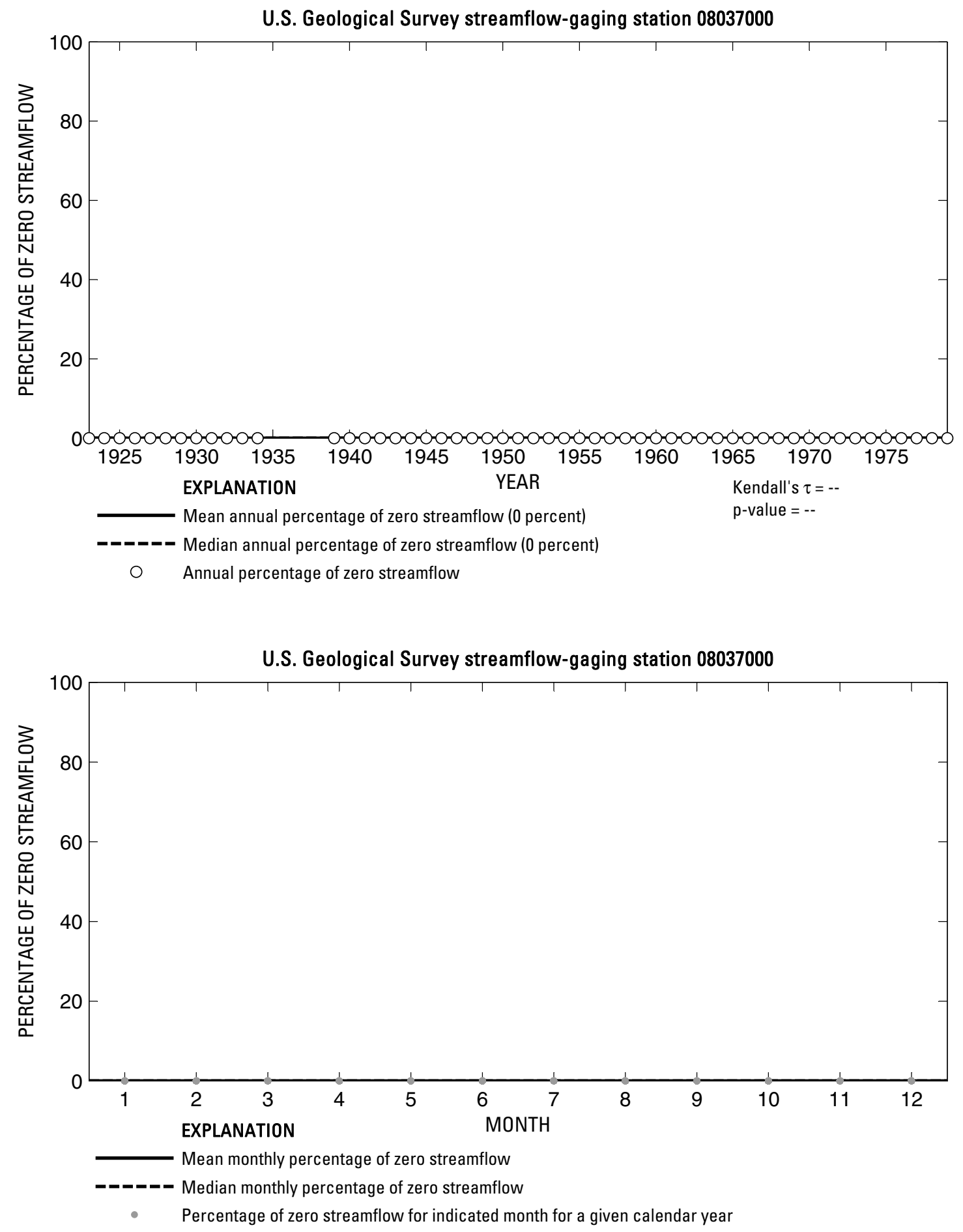

Figure 130. Analysis of percentage of zero daily mean streamflow for U.S. Geological Survey streamflow-gaging station 08037000 Angelina River near Lufkin, Texas. 


\section{U.S. Geological Survey streamflow-gaging station 08037050}

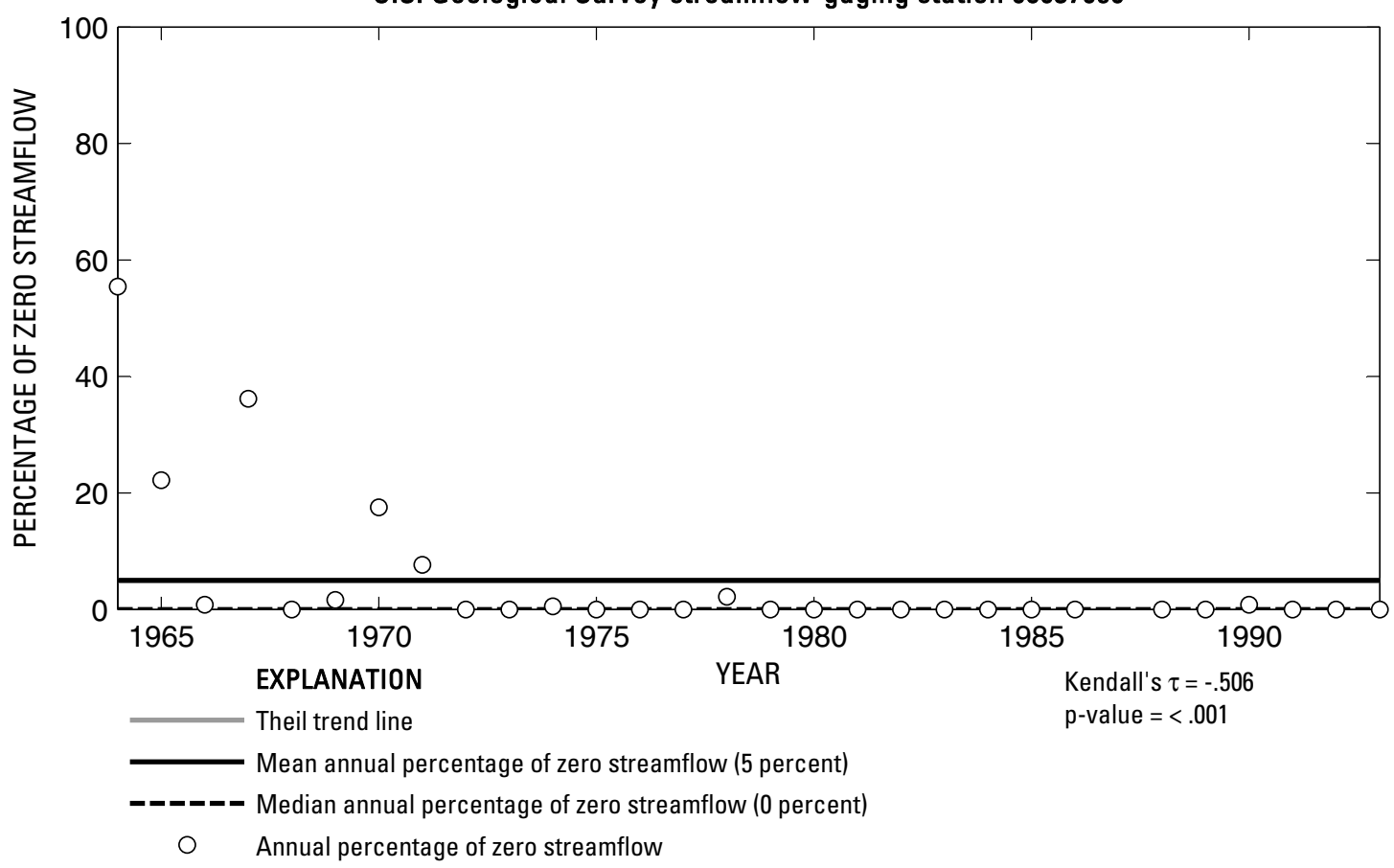

U.S. Geological Survey streamflow-gaging station 08037050

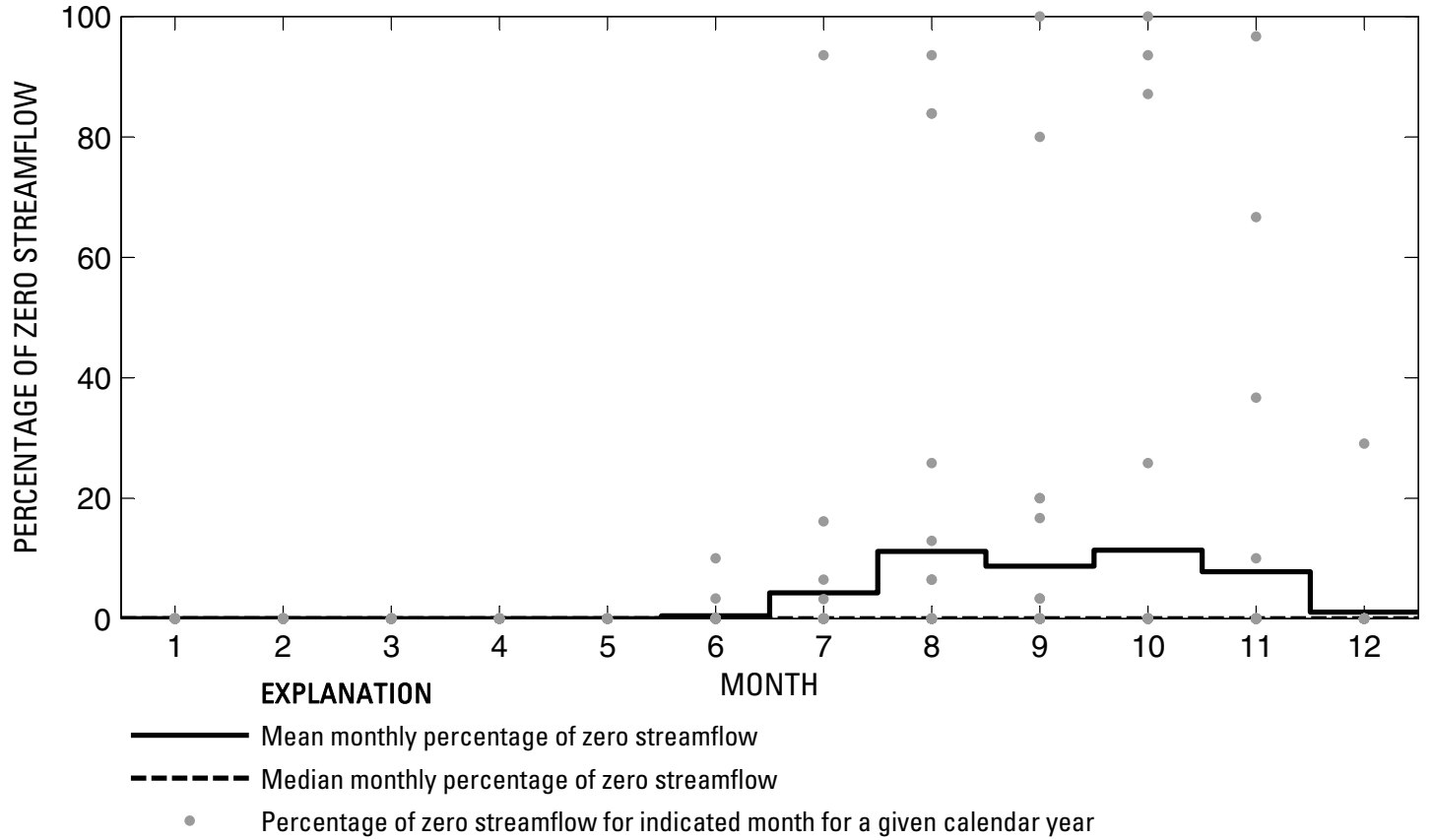

Figure 131. Analysis of percentage of zero daily mean streamflow for U.S. Geological Survey streamflow-gaging station 08037050 Bayou Lanana at Nacogdoches, Texas. 
U.S. Geological Survey streamflow-gaging station 08037500

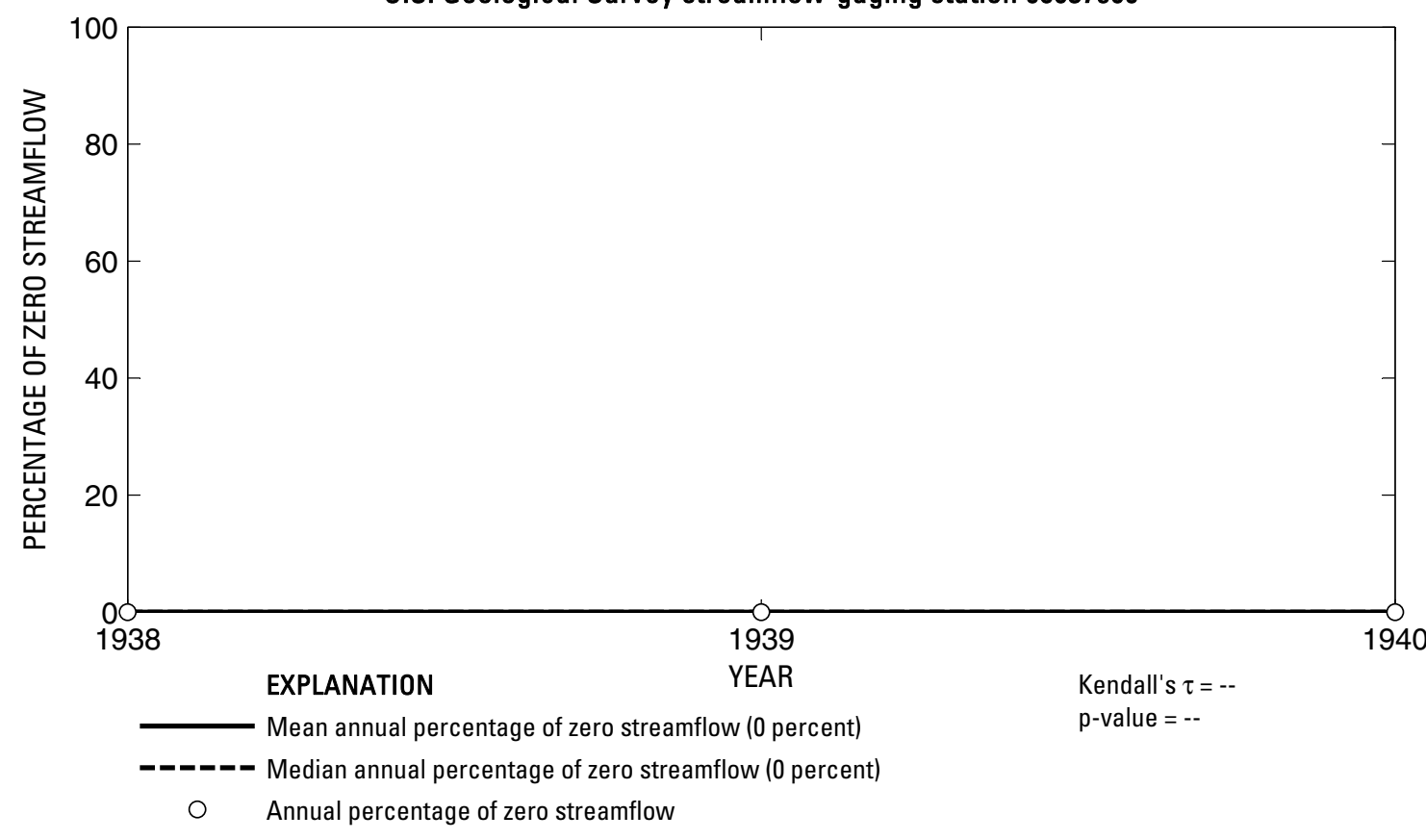

U.S. Geological Survey streamflow-gaging station 08037500

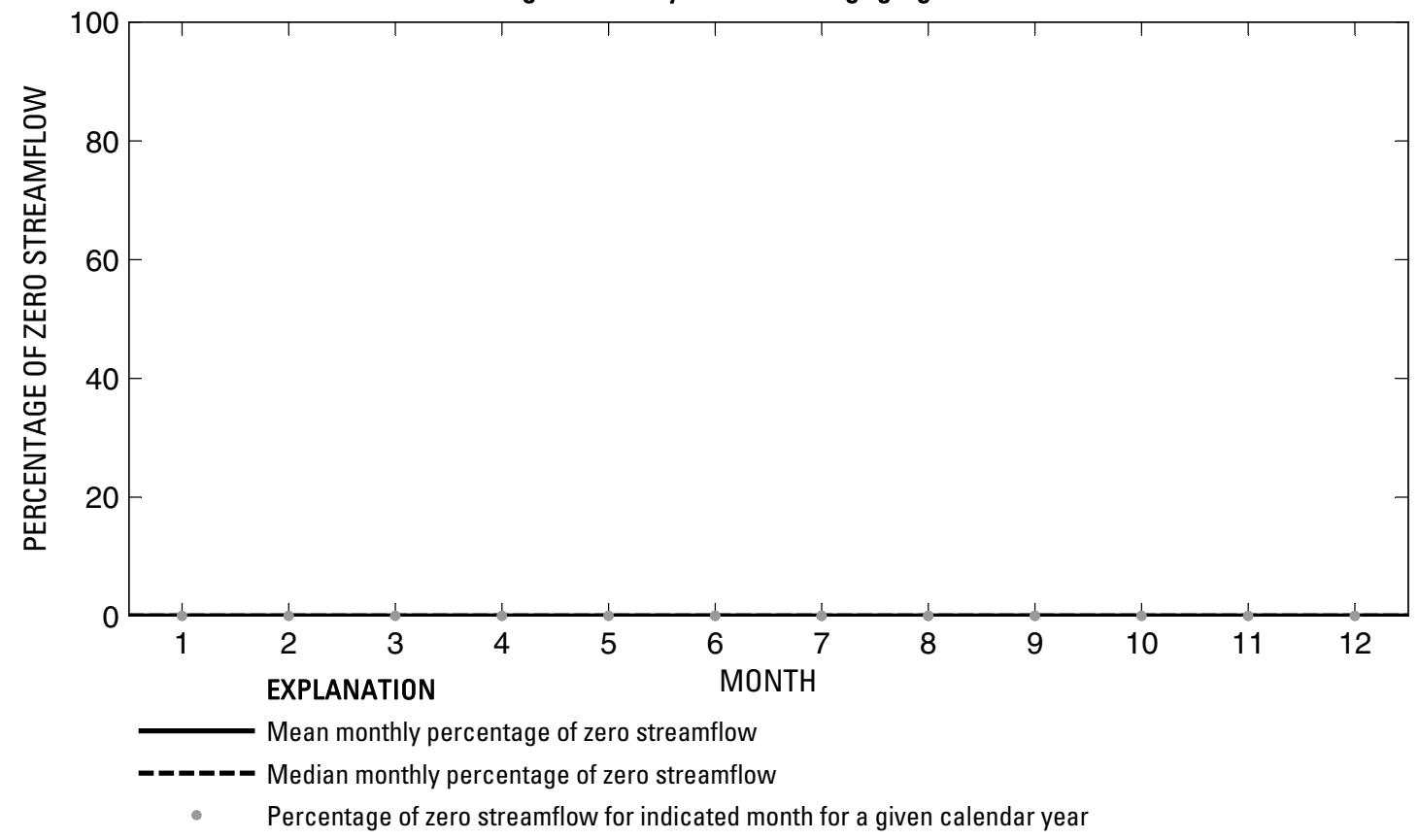

Figure 132. Analysis of percentage of zero daily mean streamflow for U.S. Geological Survey streamflow-gaging station 08037500 Arenoso Creek near San Augustine, Texas. 


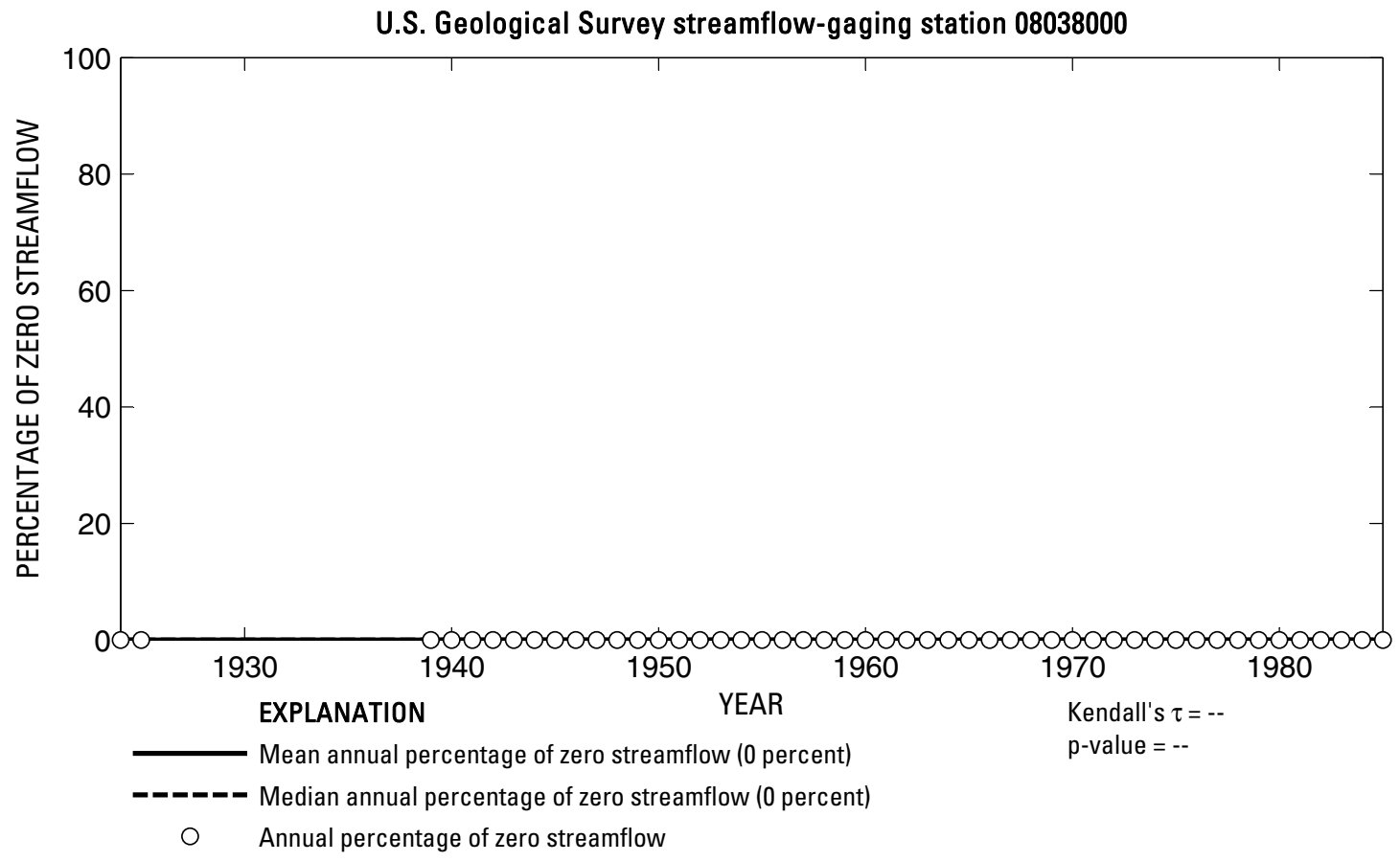

U.S. Geological Survey streamflow-gaging station 08038000

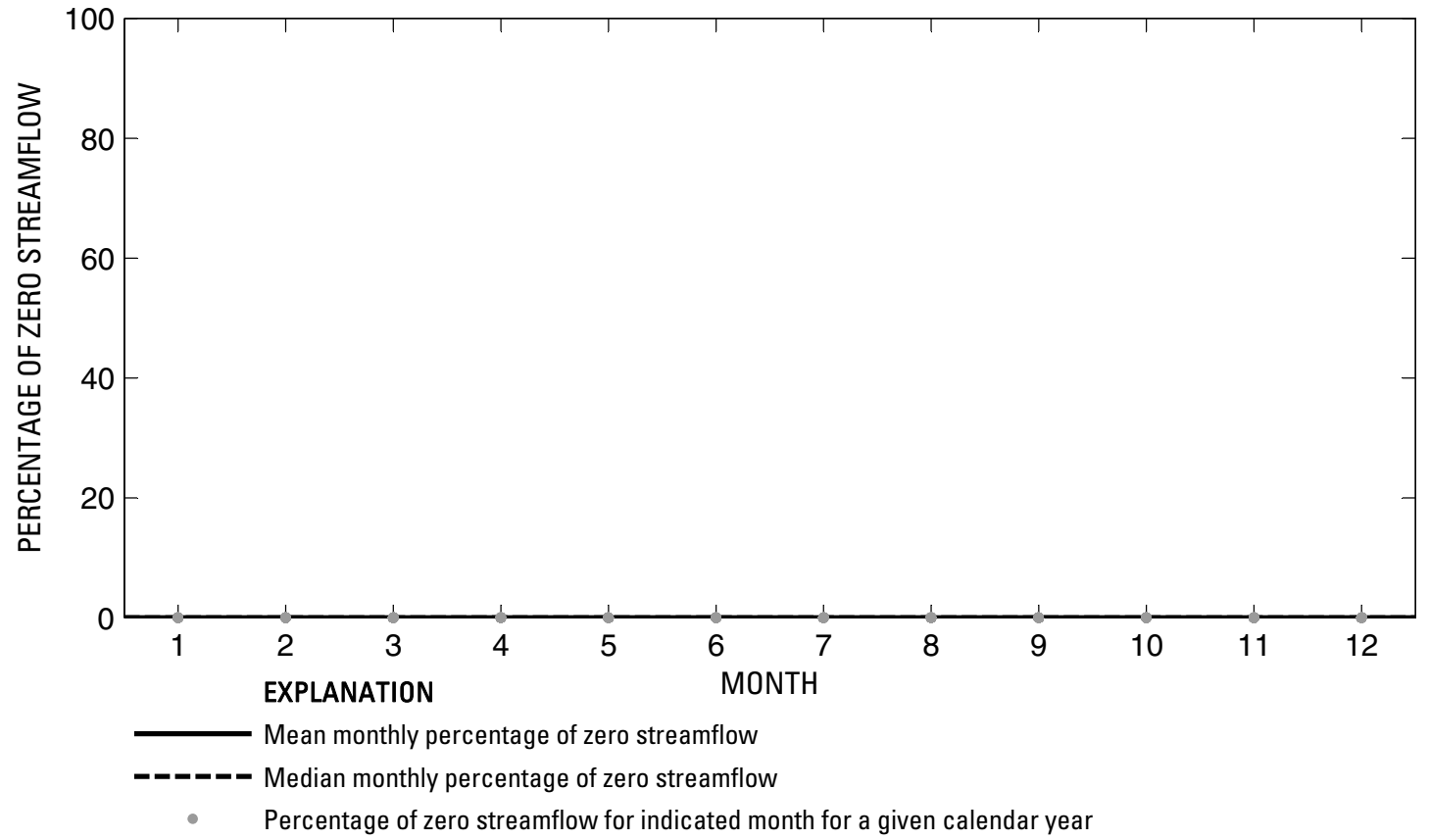

Figure 133. Analysis of percentage of zero daily mean streamflow for U.S. Geological Survey streamflow-gaging station 08038000 Attoyac Bayou near Chireno, Texas. 

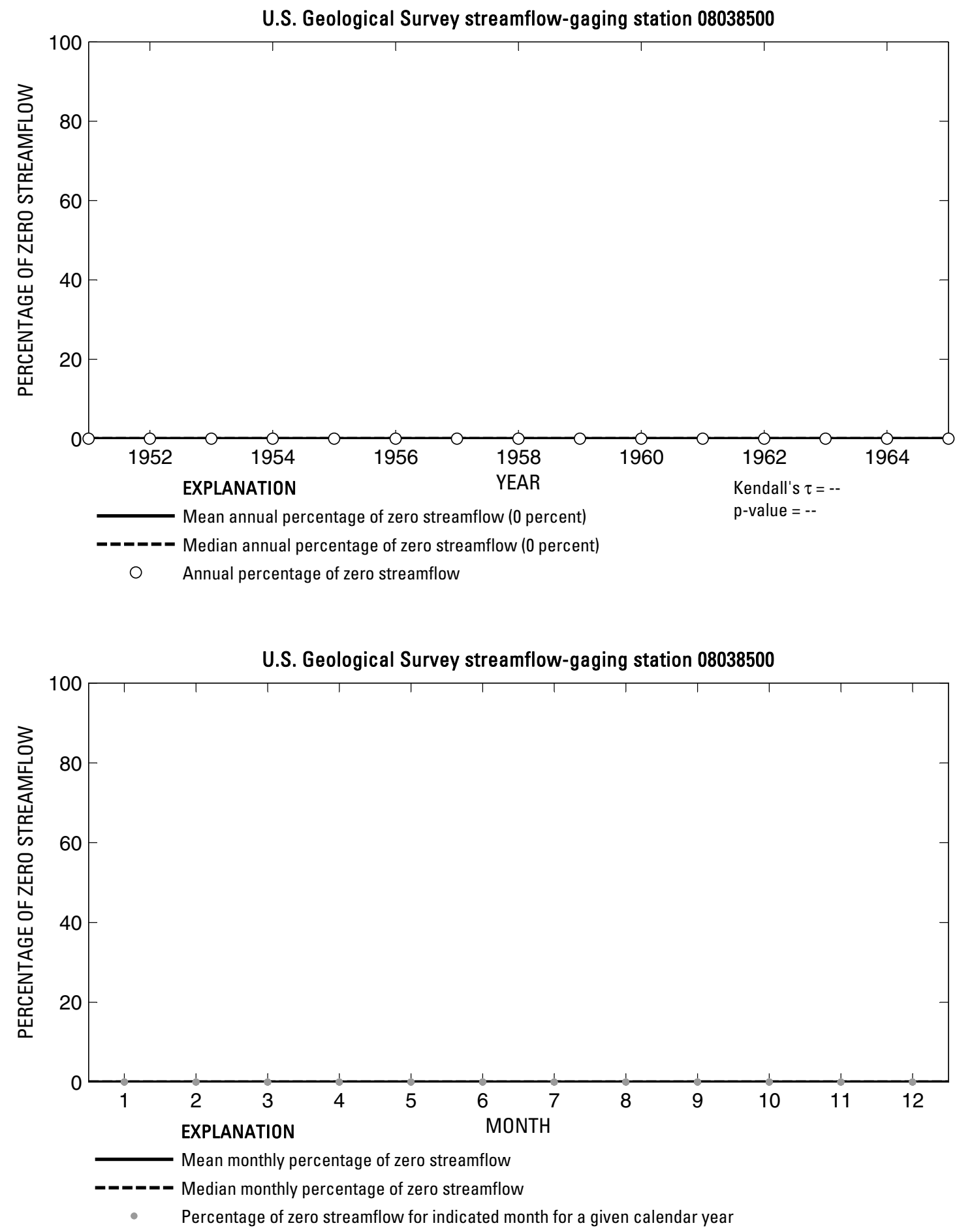

Figure 134. Analysis of percentage of zero daily mean streamflow for U.S. Geological Survey streamflow-gaging station 08038500 Angelina River near Zavalla, Texas. 


\section{U.S. Geological Survey streamflow-gaging station 08039100}

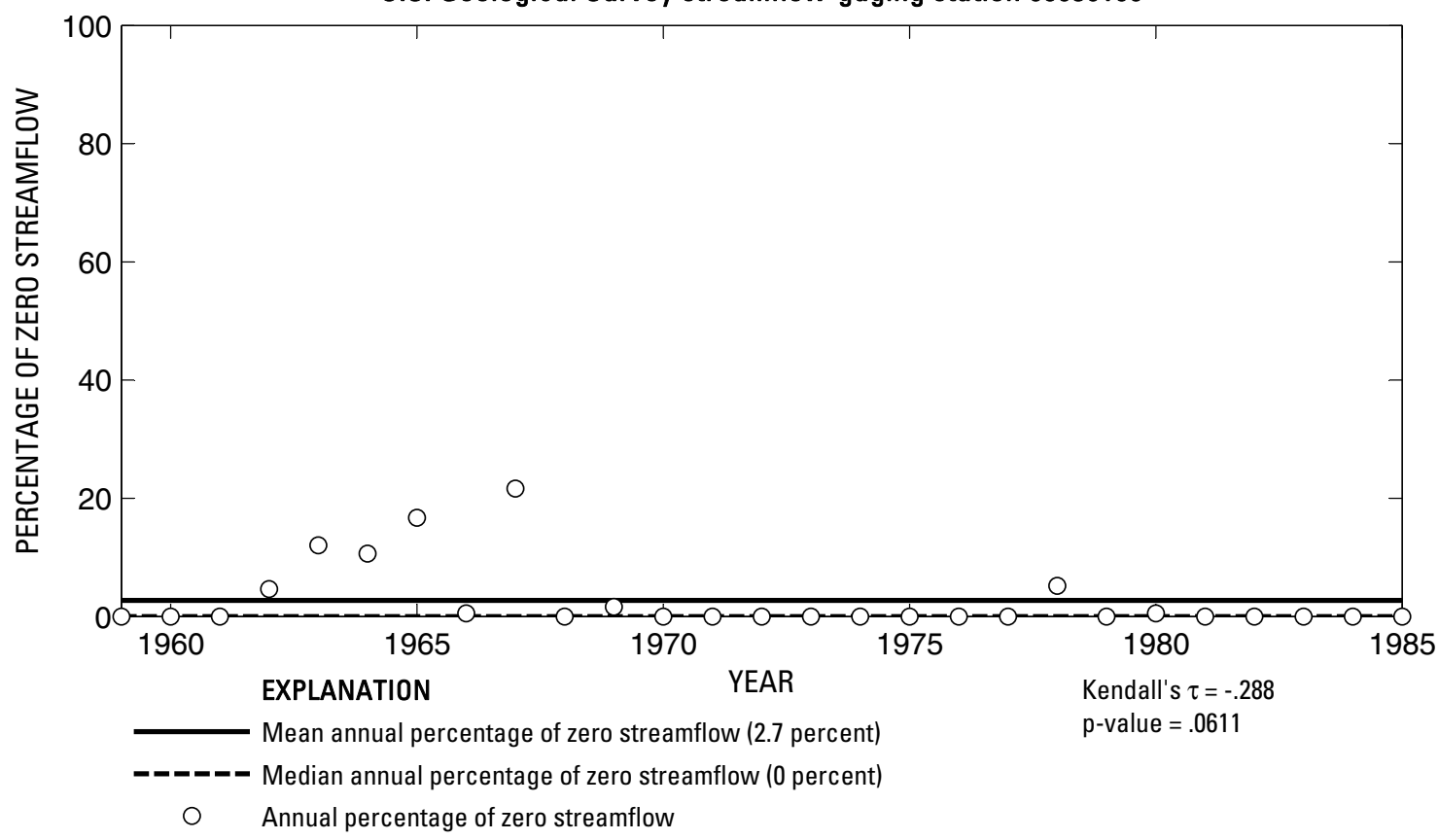

U.S. Geological Survey streamflow-gaging station 08039100

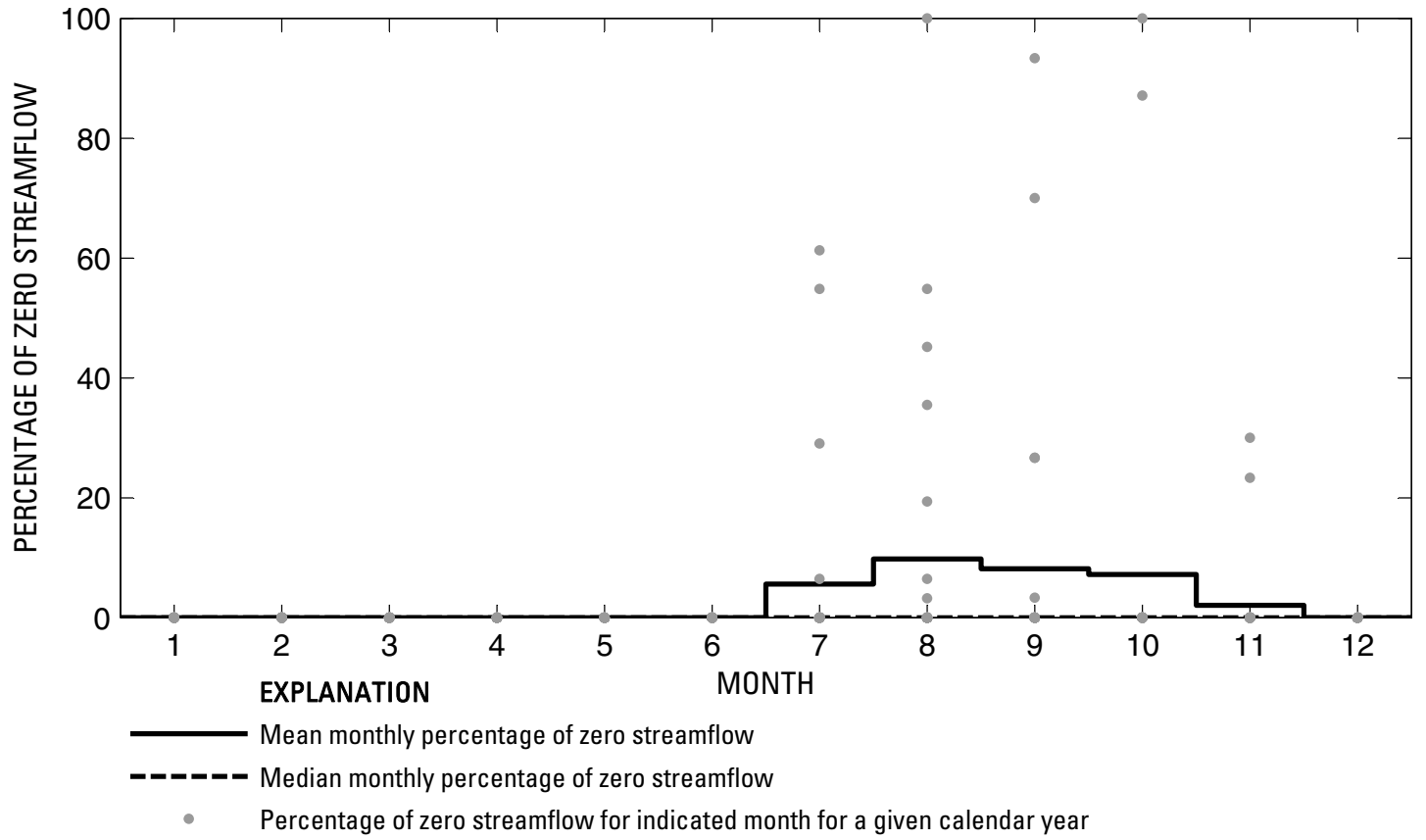

Figure 135. Analysis of percentage of zero daily mean streamflow for U.S. Geological Survey streamflow-gaging station 08039100 Ayish Bayou near San Augustine, Texas. 
U.S. Geological Survey streamflow-gaging station 08039500

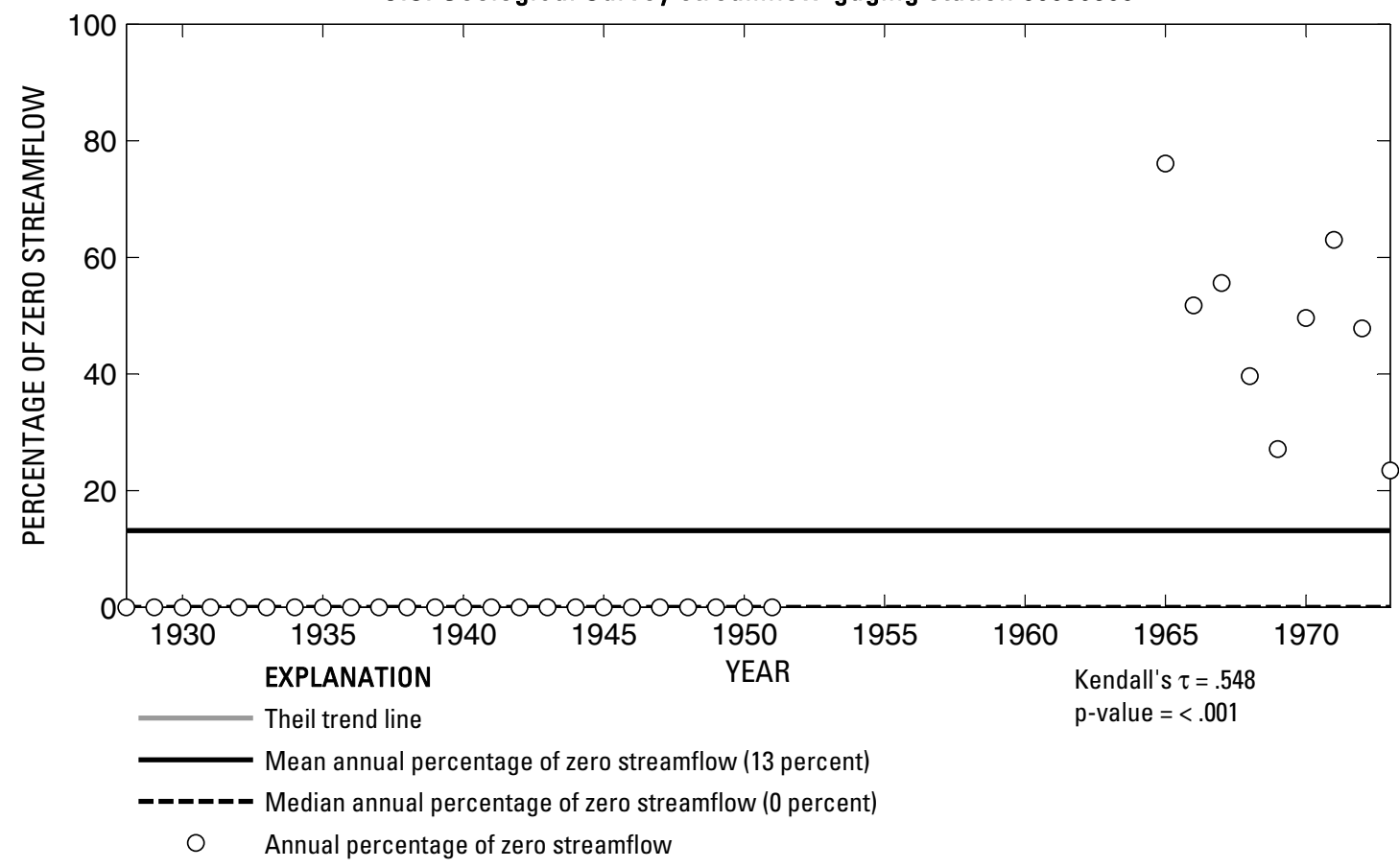

U.S. Geological Survey streamflow-gaging station 08039500

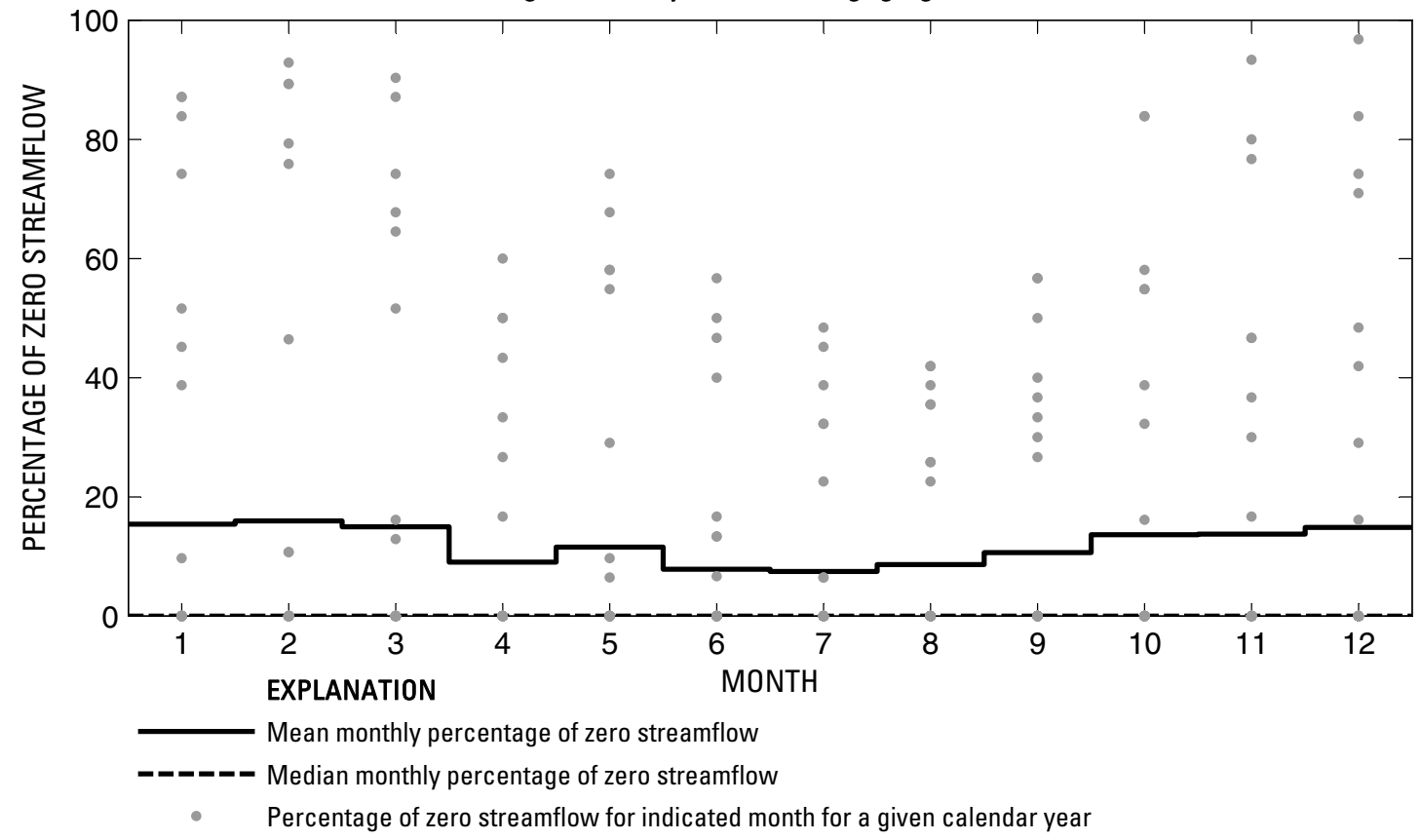

Figure 136. Analysis of percentage of zero daily mean streamflow for U.S. Geological Survey streamflow-gaging station 08039500 Angelina River near Ebenezer, Texas.

Index of Station Numbers 719 


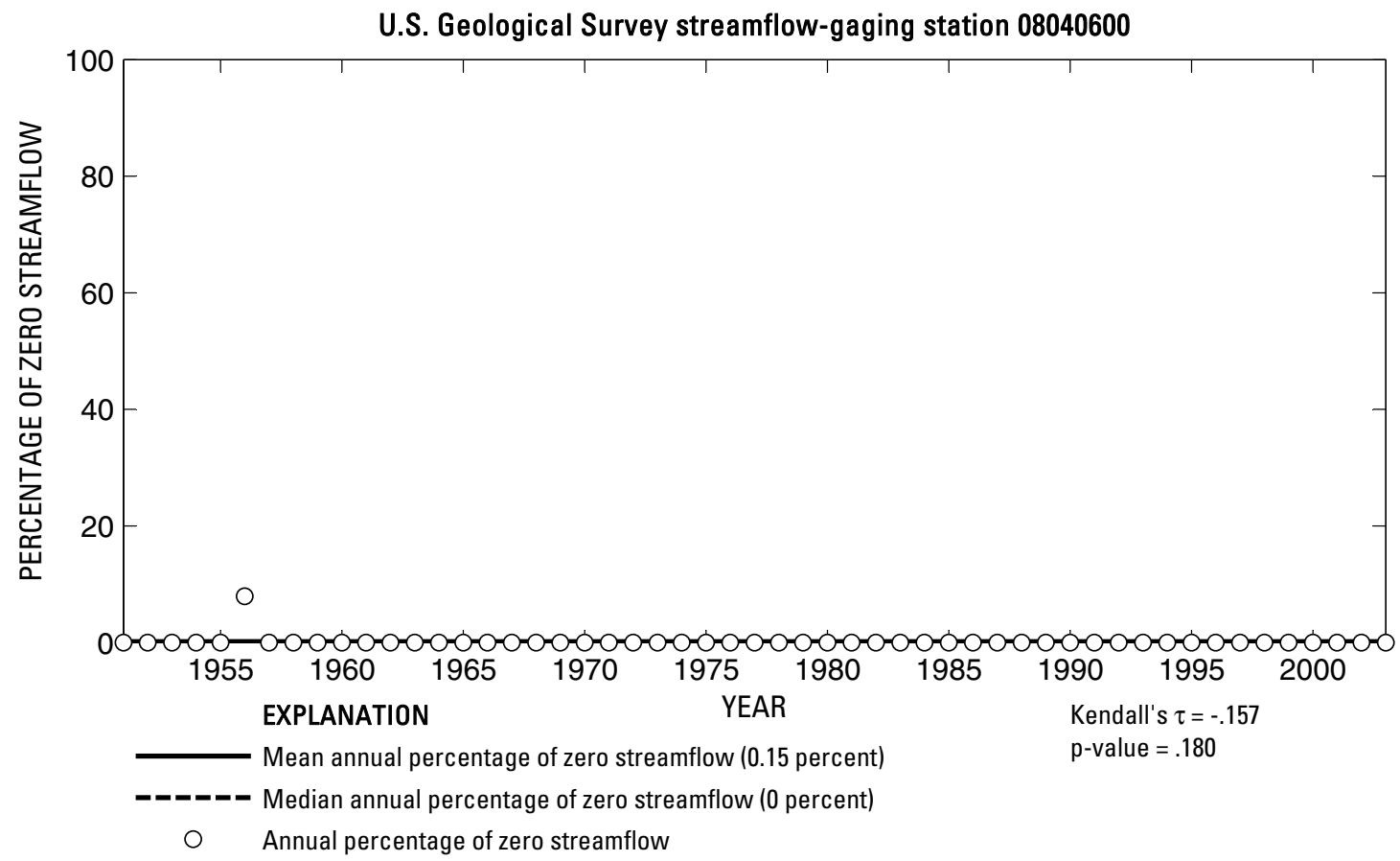

U.S. Geological Survey streamflow-gaging station 08040600

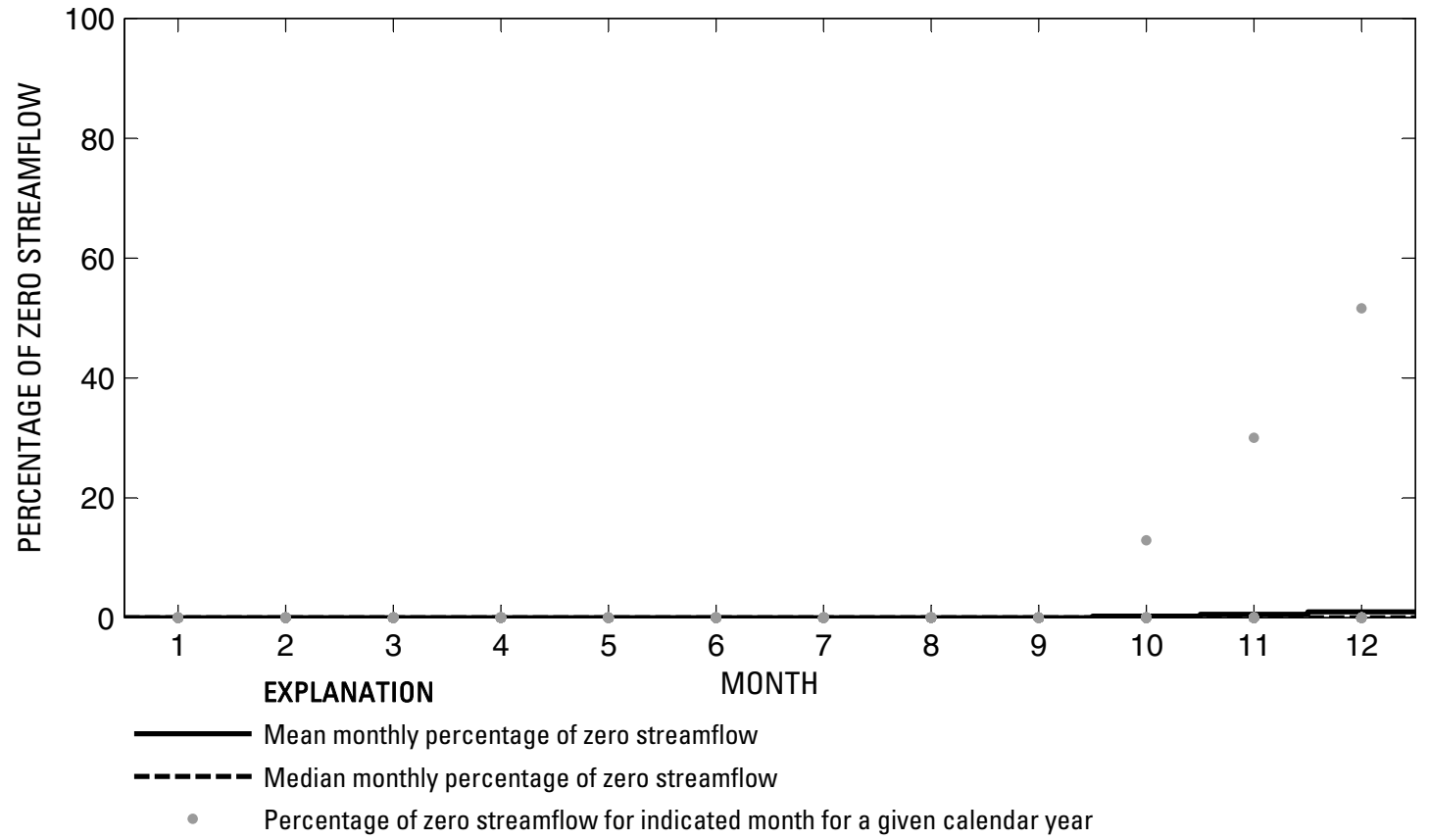

Figure 137. Analysis of percentage of zero daily mean streamflow for U.S. Geological Survey streamflow-gaging station 08040600 Neches River near Town Bluff, Texas. 

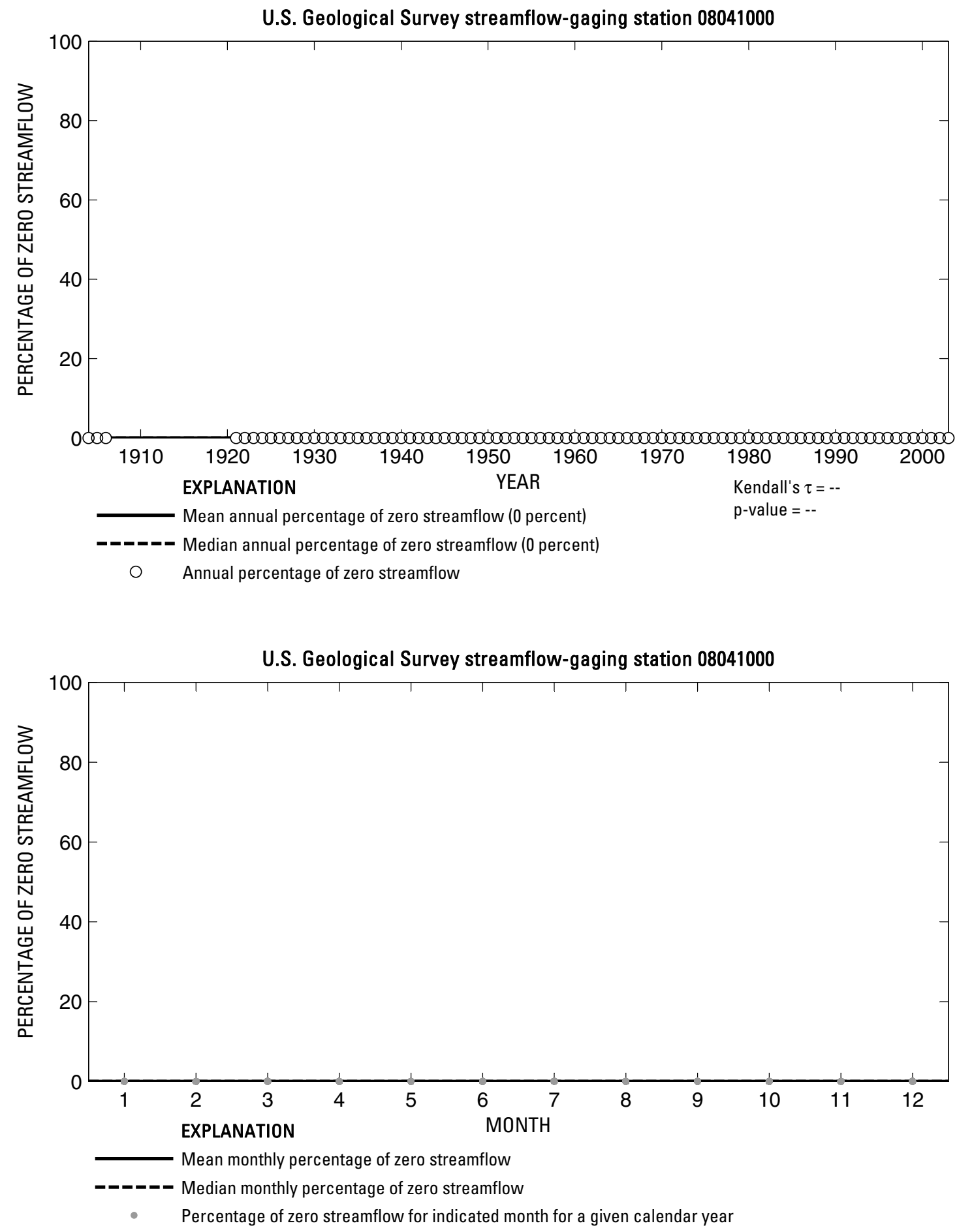

Figure 138. Analysis of percentage of zero daily mean streamflow for U.S. Geological Survey streamflow-gaging station 08041000 Neches River at Evadale, Texas. 


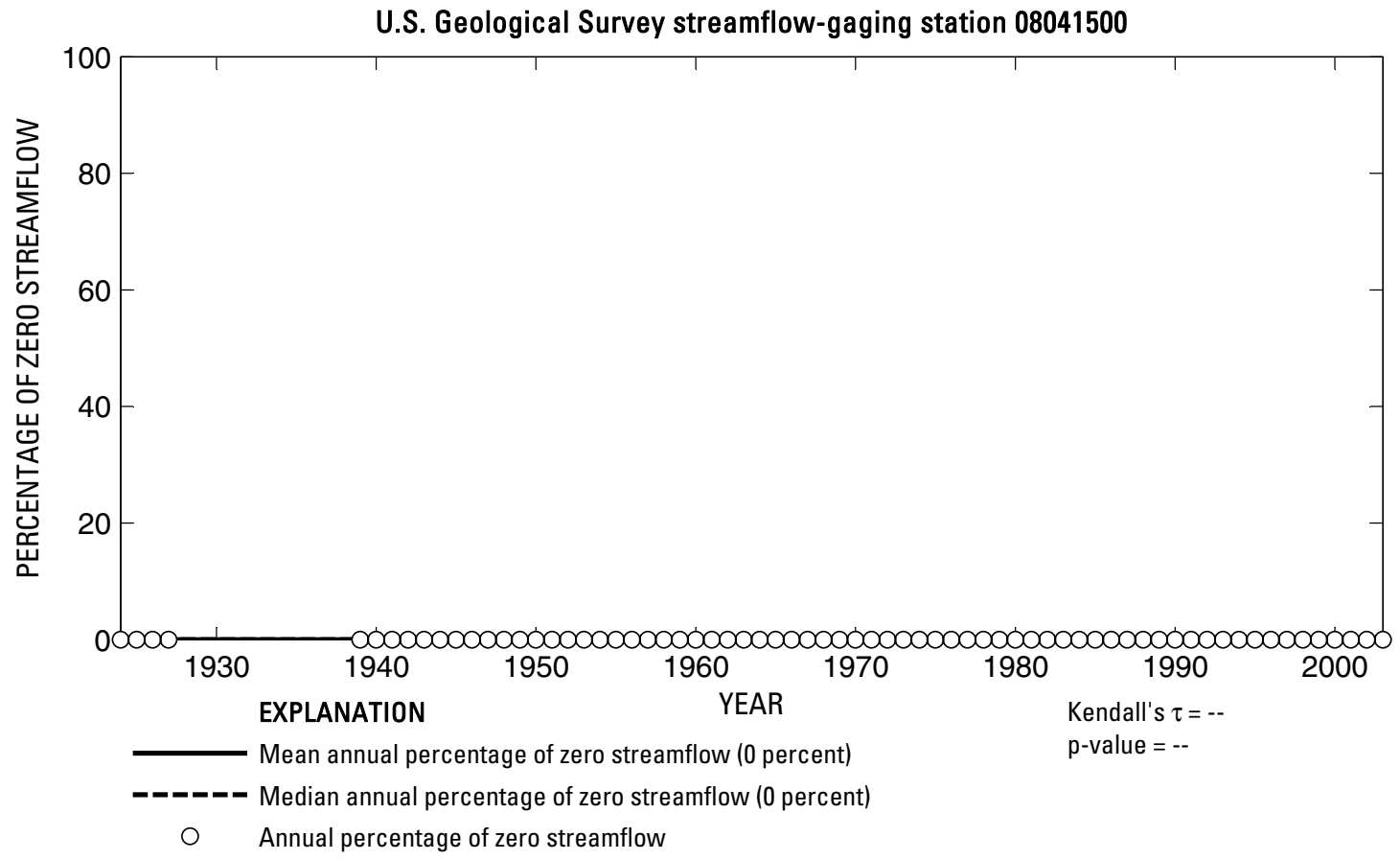

U.S. Geological Survey streamflow-gaging station 08041500

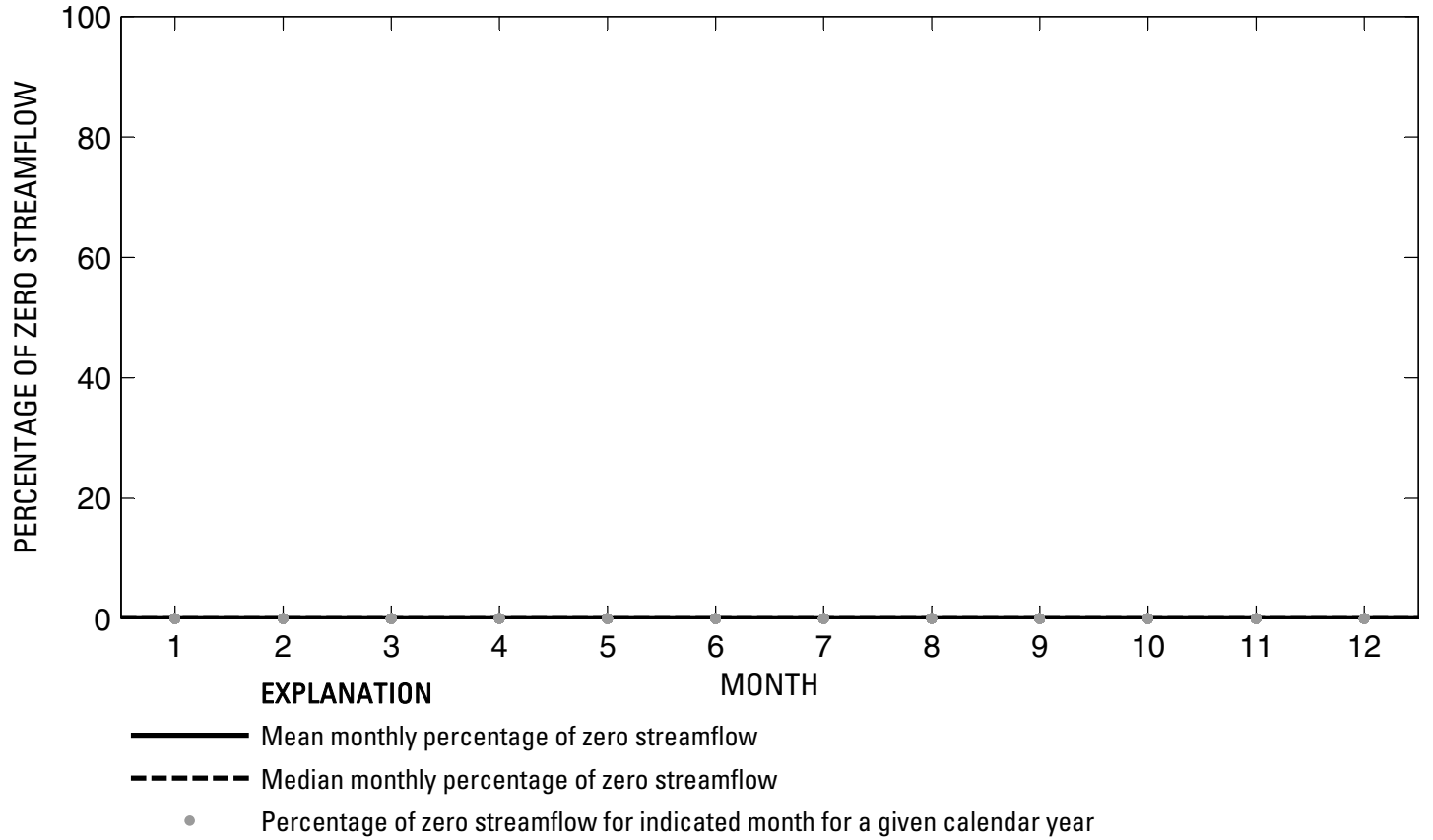

Figure 139. Analysis of percentage of zero daily mean streamflow for U.S. Geological Survey streamflow-gaging station 08041500 Village Creek near Kountze, Texas. 
U.S. Geological Survey streamflow-gaging station 08041700

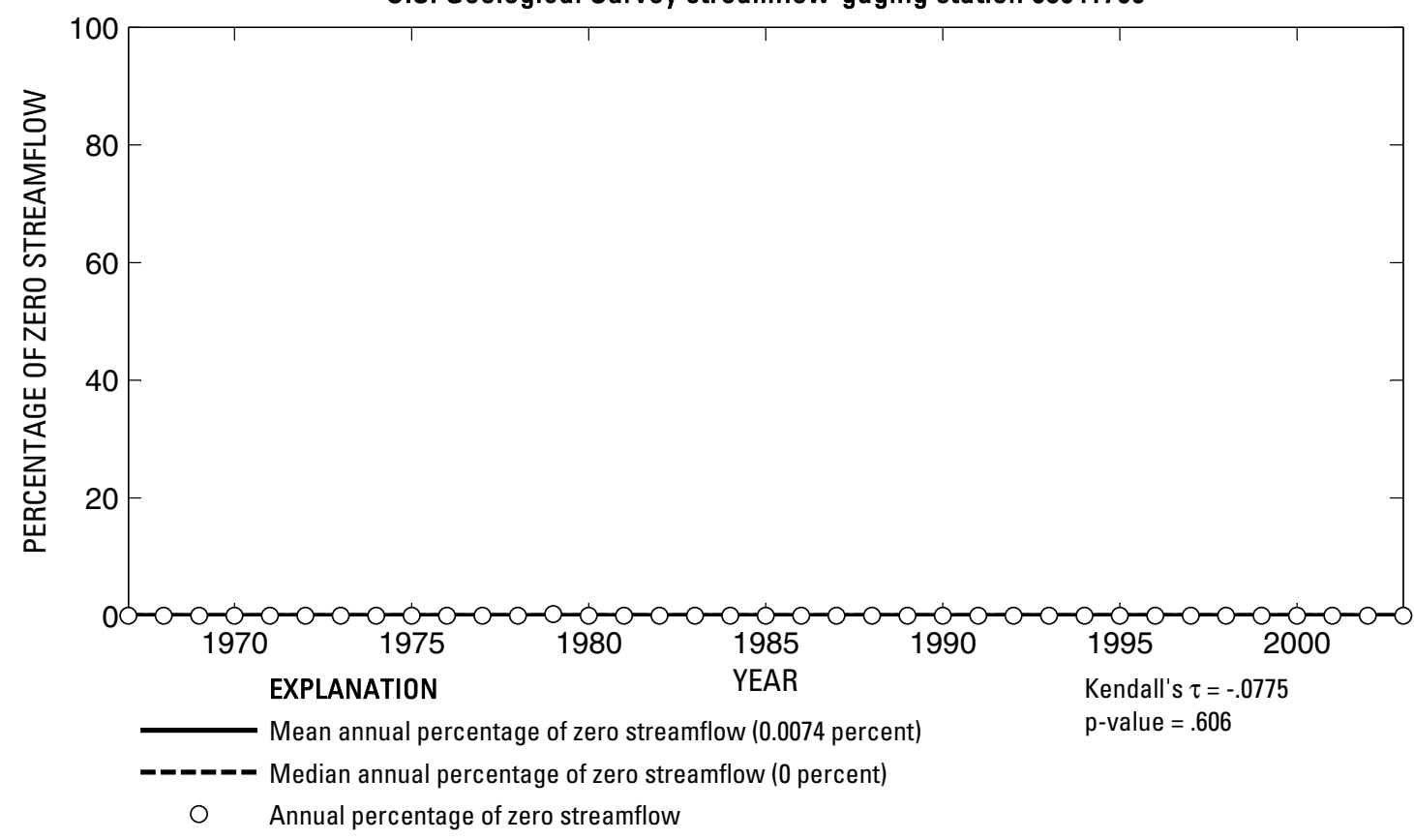

U.S. Geological Survey streamflow-gaging station 08041700

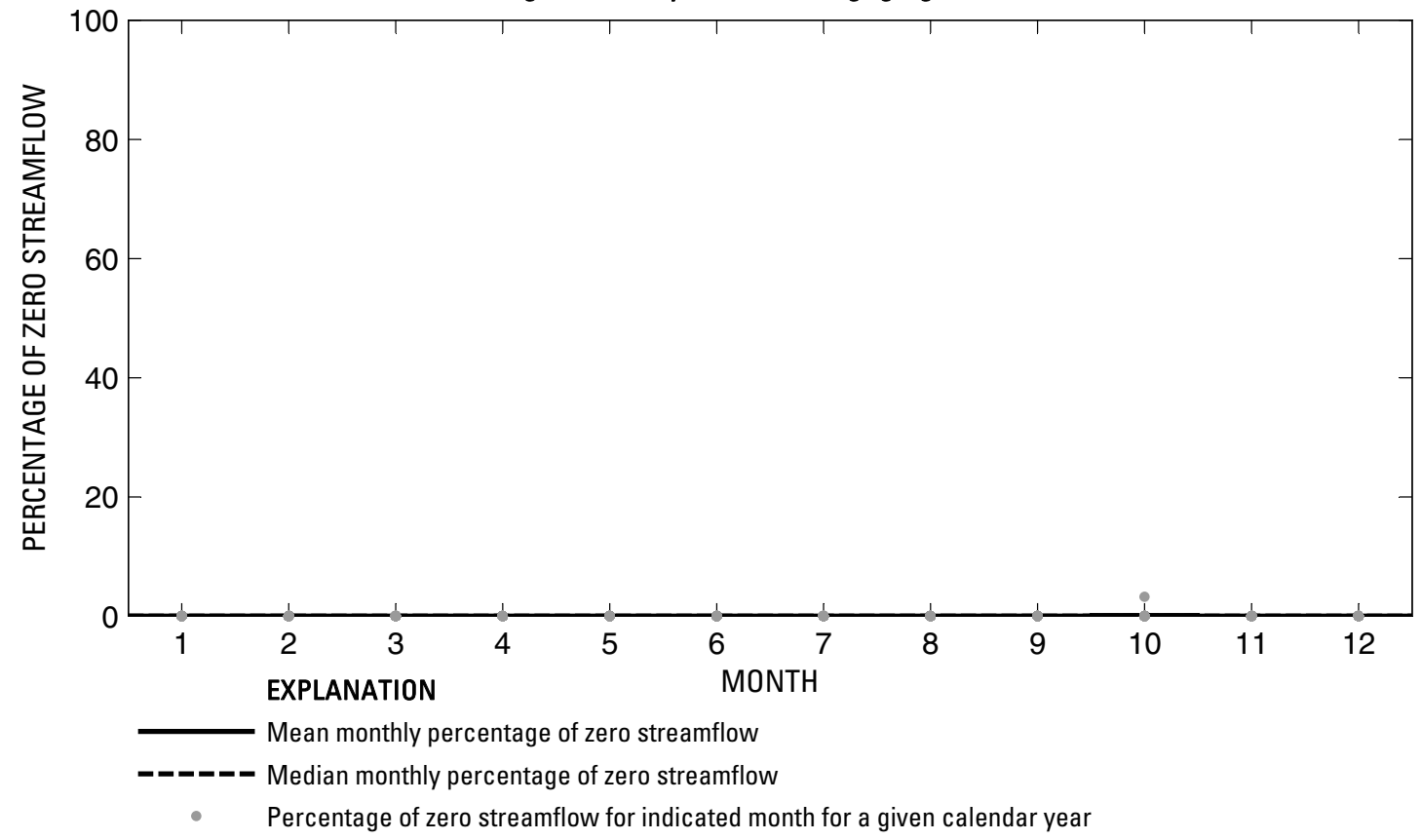

Figure 140. Analysis of percentage of zero daily mean streamflow for U.S. Geological Survey streamflow-gaging station 08041700 Pine Island Bayou near Sour Lake, Texas. 


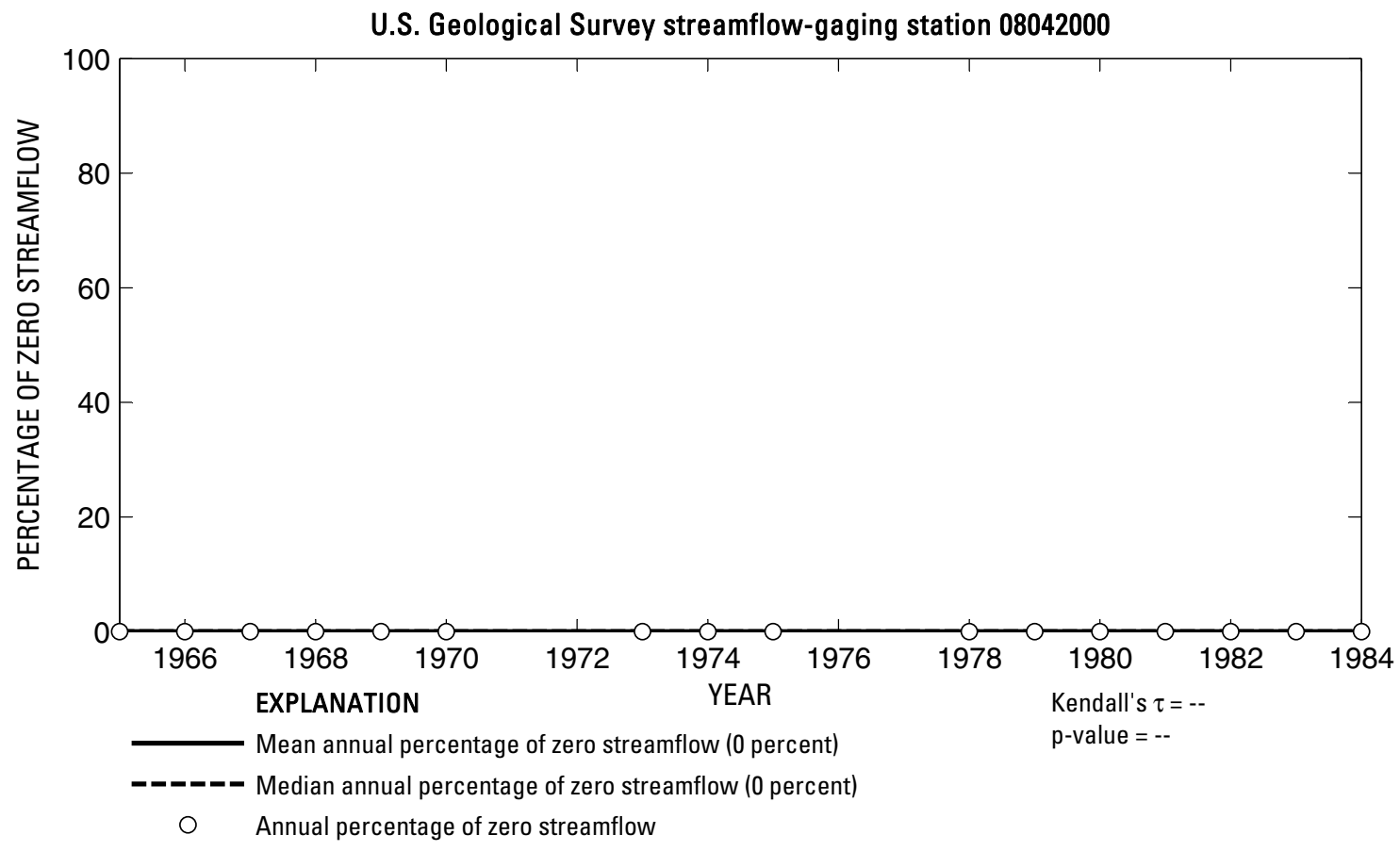

U.S. Geological Survey streamflow-gaging station 08042000

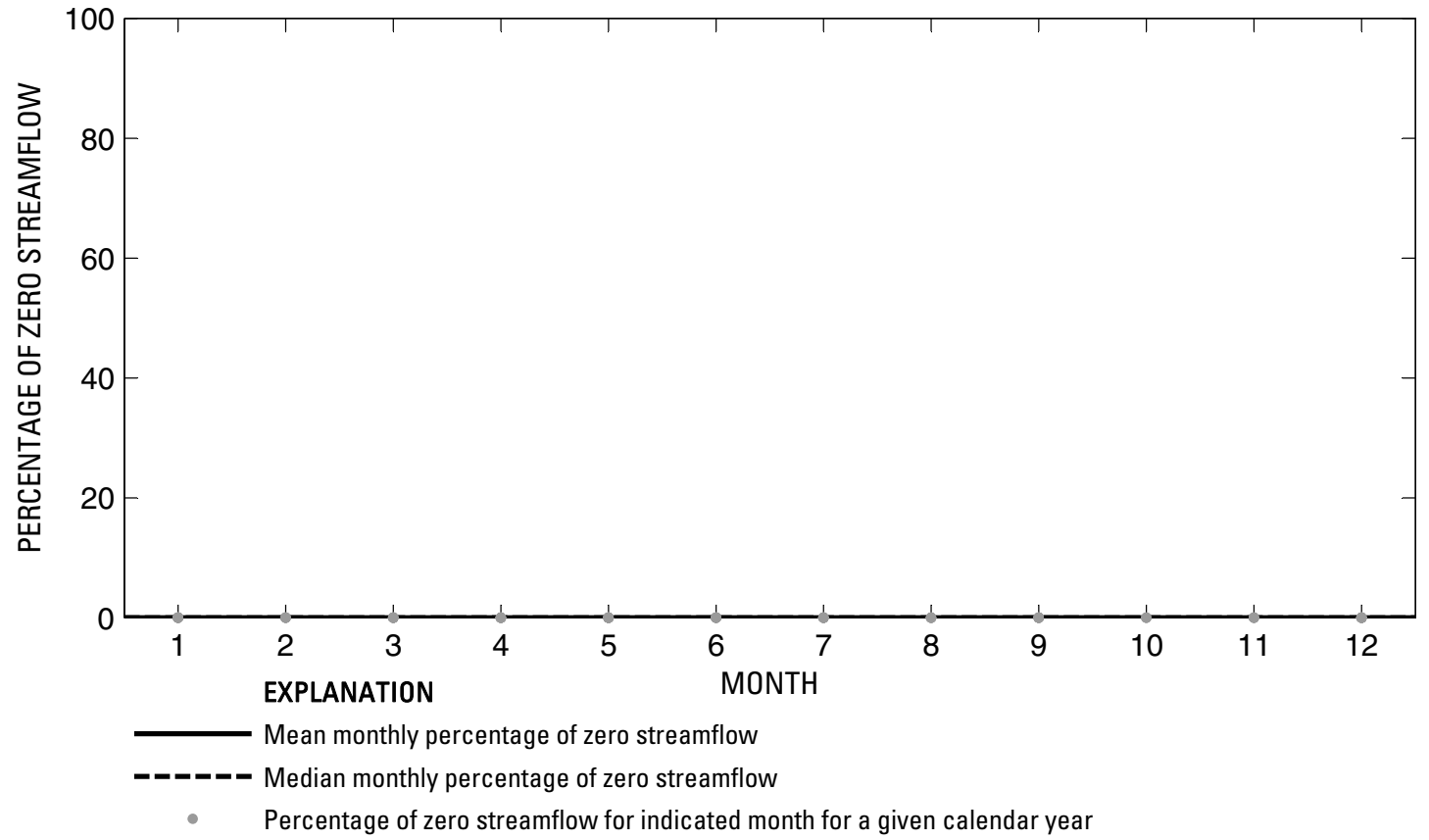

Figure 141. Analysis of percentage of zero daily mean streamflow for U.S. Geological Survey streamflow-gaging station 08042000 Taylor Bayou near LaBelle, Texas. 
U.S. Geological Survey streamflow-gaging station 08042500

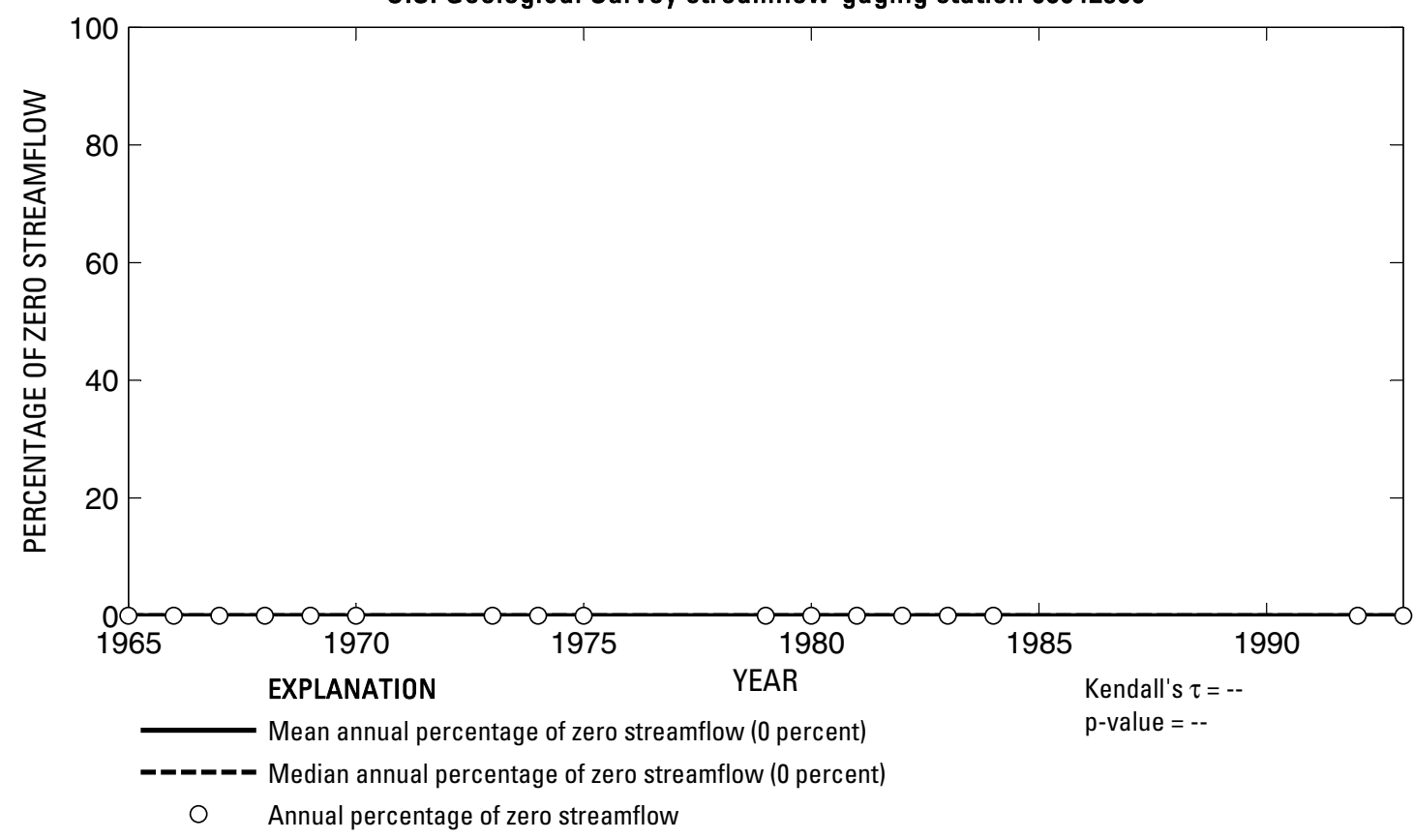

U.S. Geological Survey streamflow-gaging station 08042500

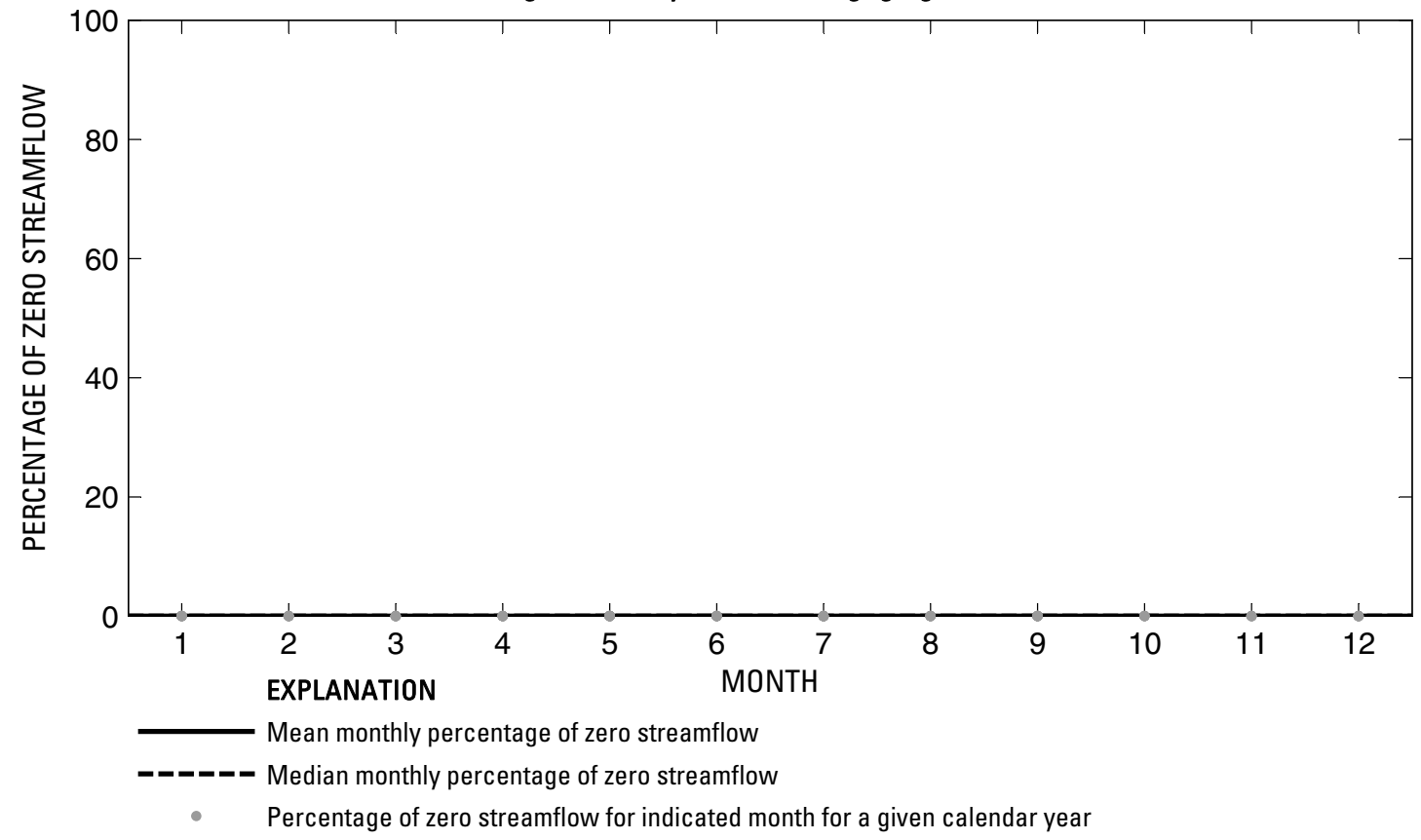

Figure 142. Analysis of percentage of zero daily mean streamflow for U.S. Geological Survey streamflow-gaging station 08042500 Hillebrandt Bayou near Lovell Lake, Texas. 

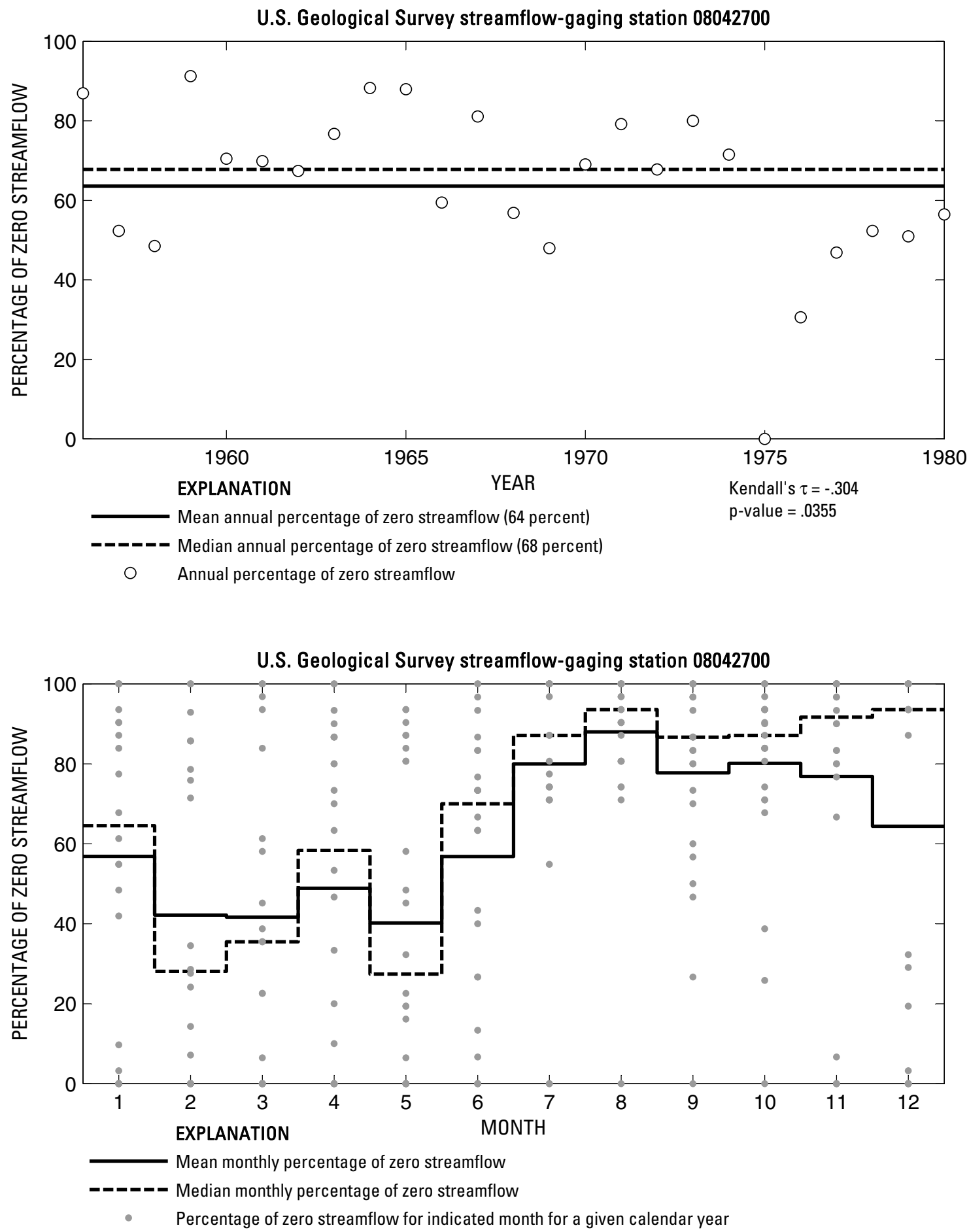

Figure 143. Analysis of percentage of zero daily mean streamflow for U.S. Geological Survey streamflow-gaging station 08042700 North Creek near Jacksboro, Texas. 
U.S. Geological Survey streamflow-gaging station 08042800

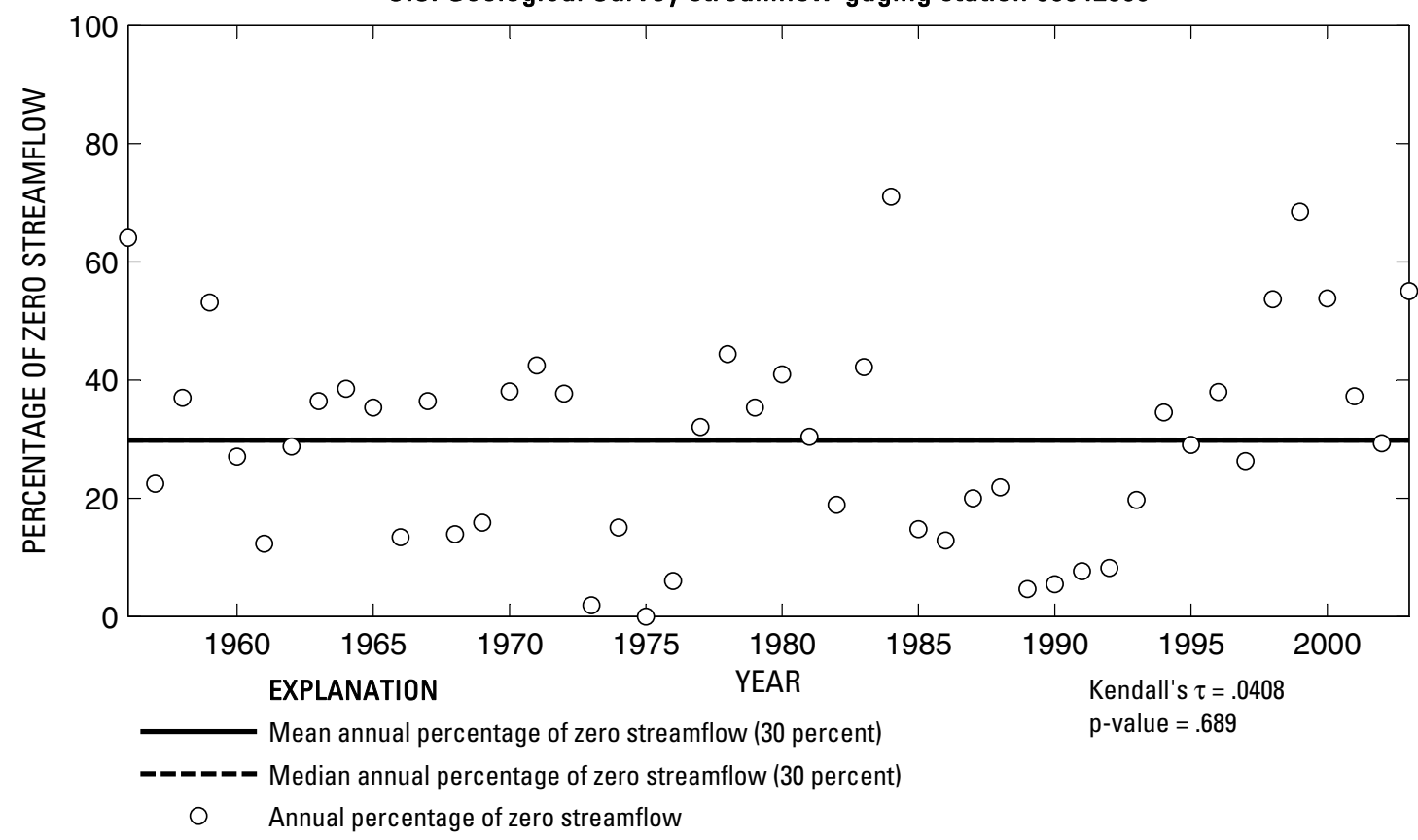

U.S. Geological Survey streamflow-gaging station 08042800

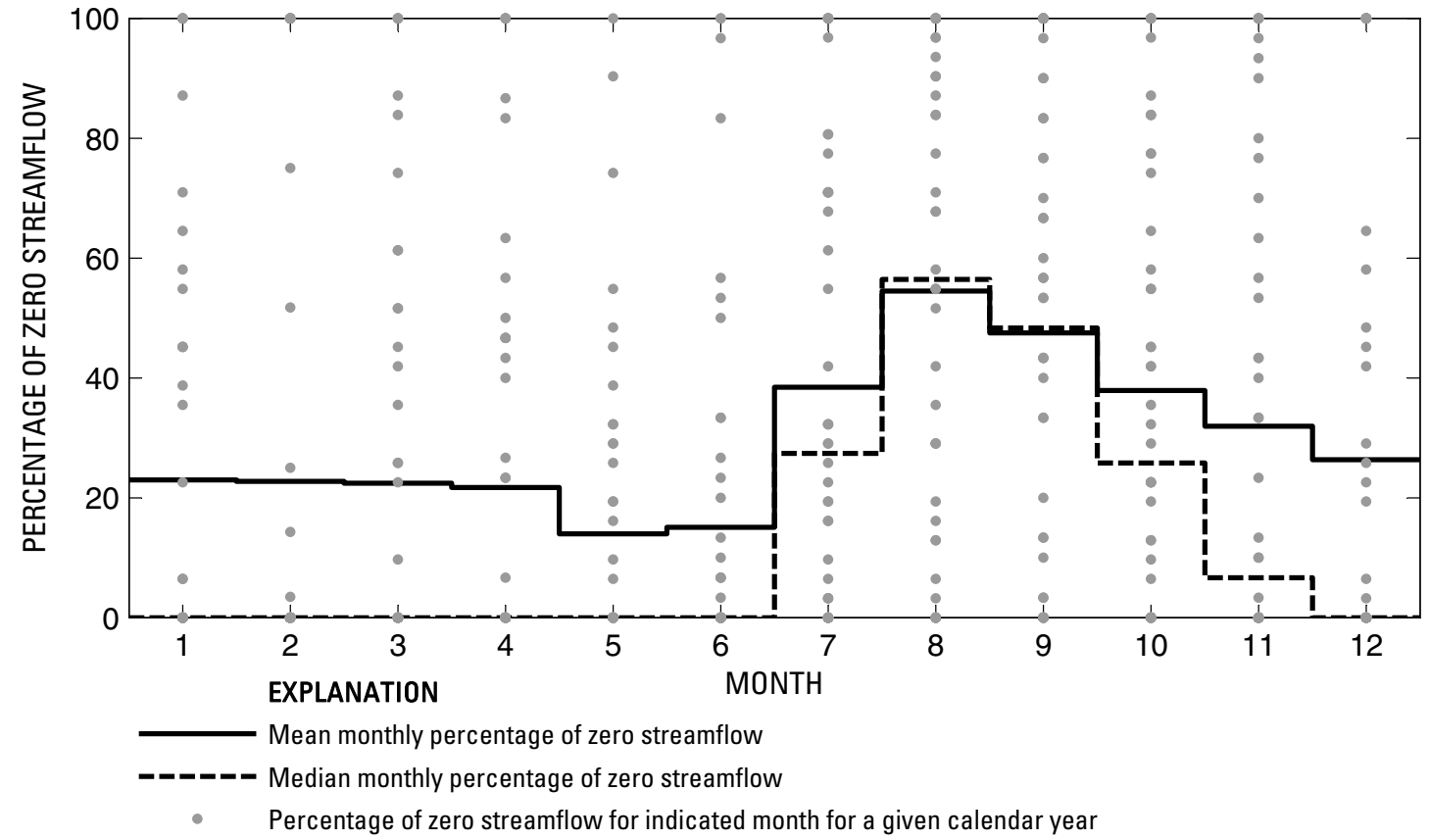

Figure 144. Analysis of percentage of zero daily mean streamflow for U.S. Geological Survey streamflow-gaging station 08042800 West Fork Trinity River near Jacksboro, Texas.

Index of Station Numbers 719 
U.S. Geological Survey streamflow-gaging station 08042900

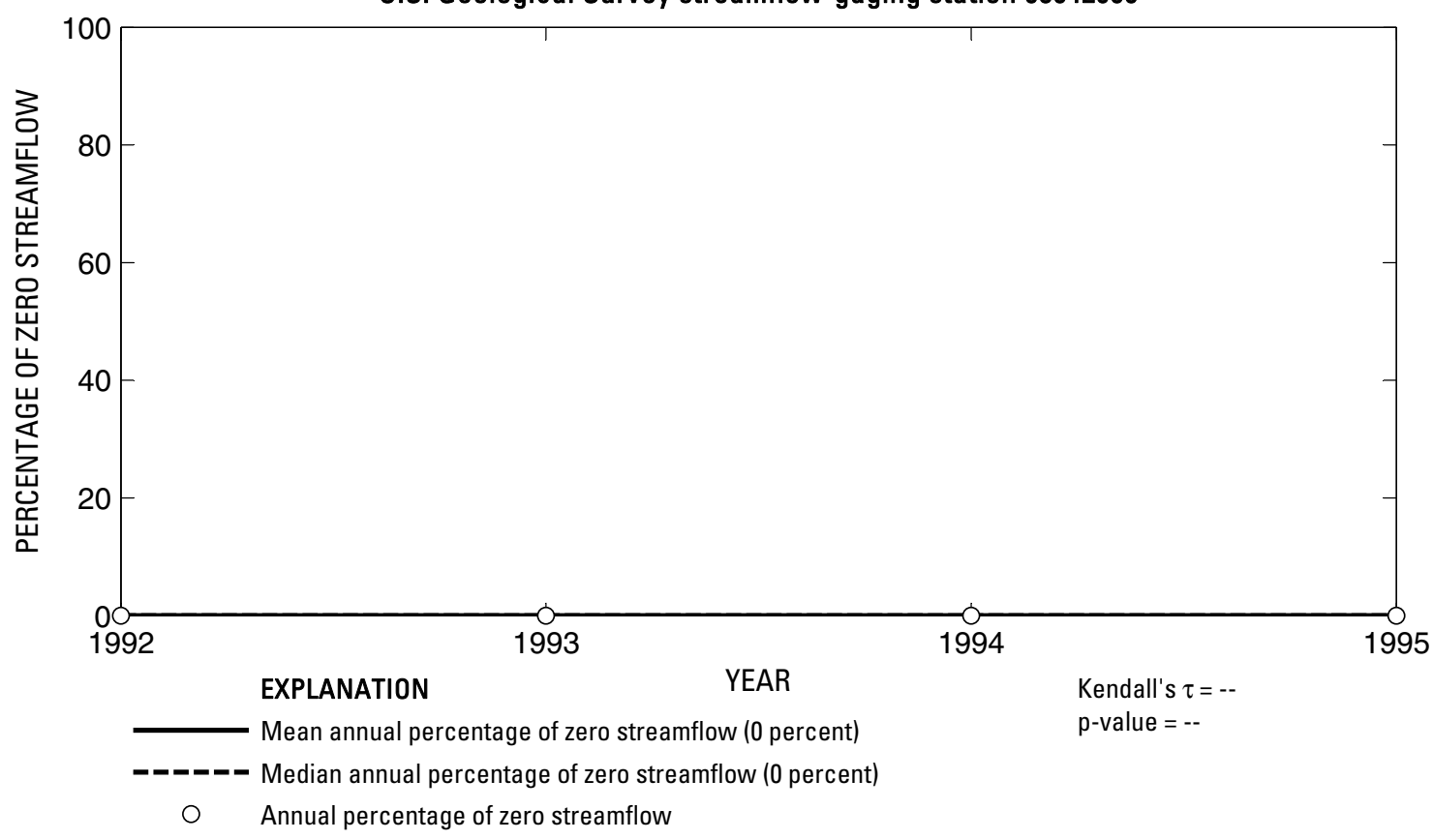

U.S. Geological Survey streamflow-gaging station 08042900

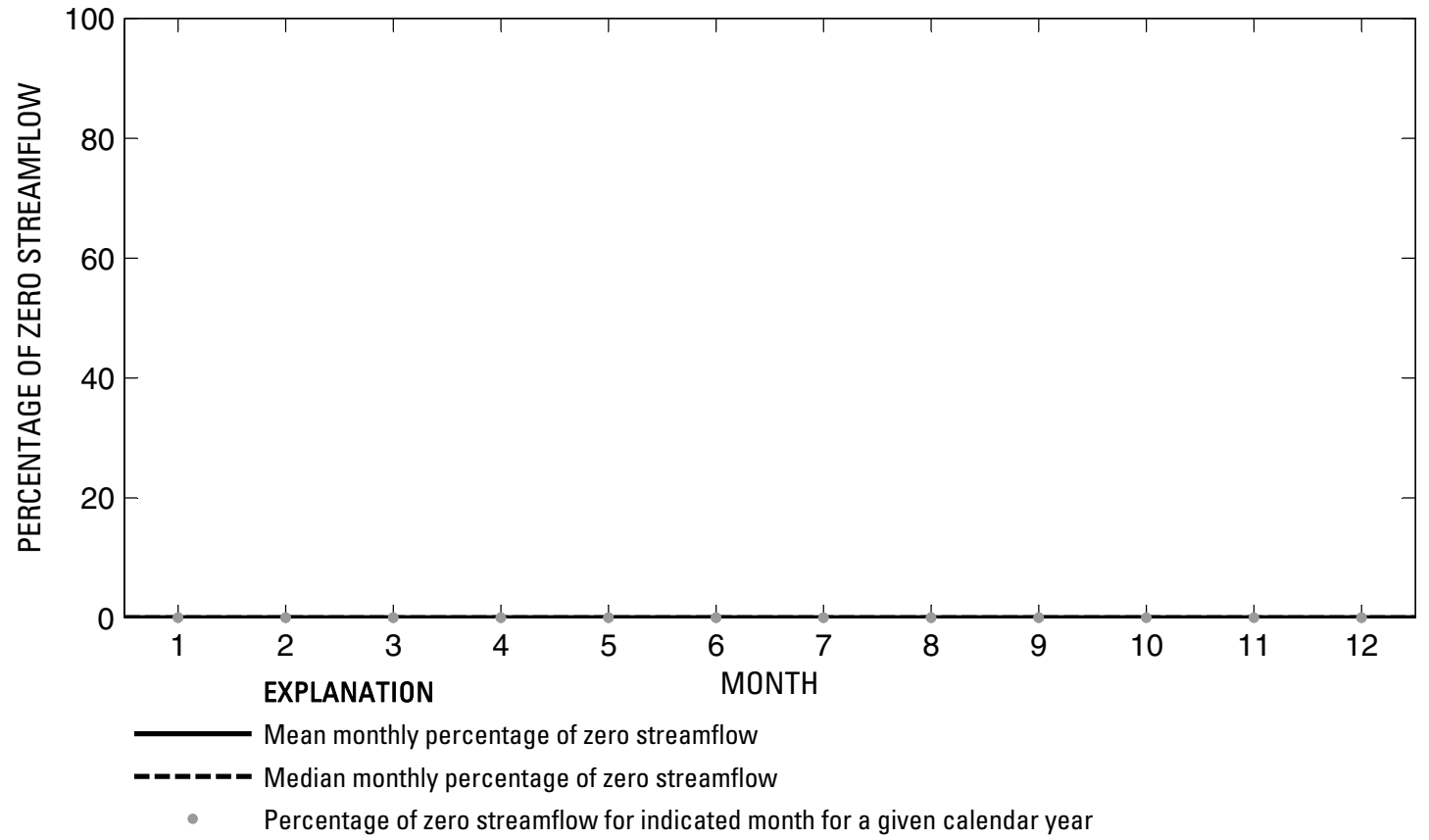

Figure 145. Analysis of percentage of zero daily mean streamflow for U.S. Geological Survey streamflow-gaging station 08042900 Beans Creek at Wizard Wells, Texas. 
U.S. Geological Survey streamflow-gaging station 08043500

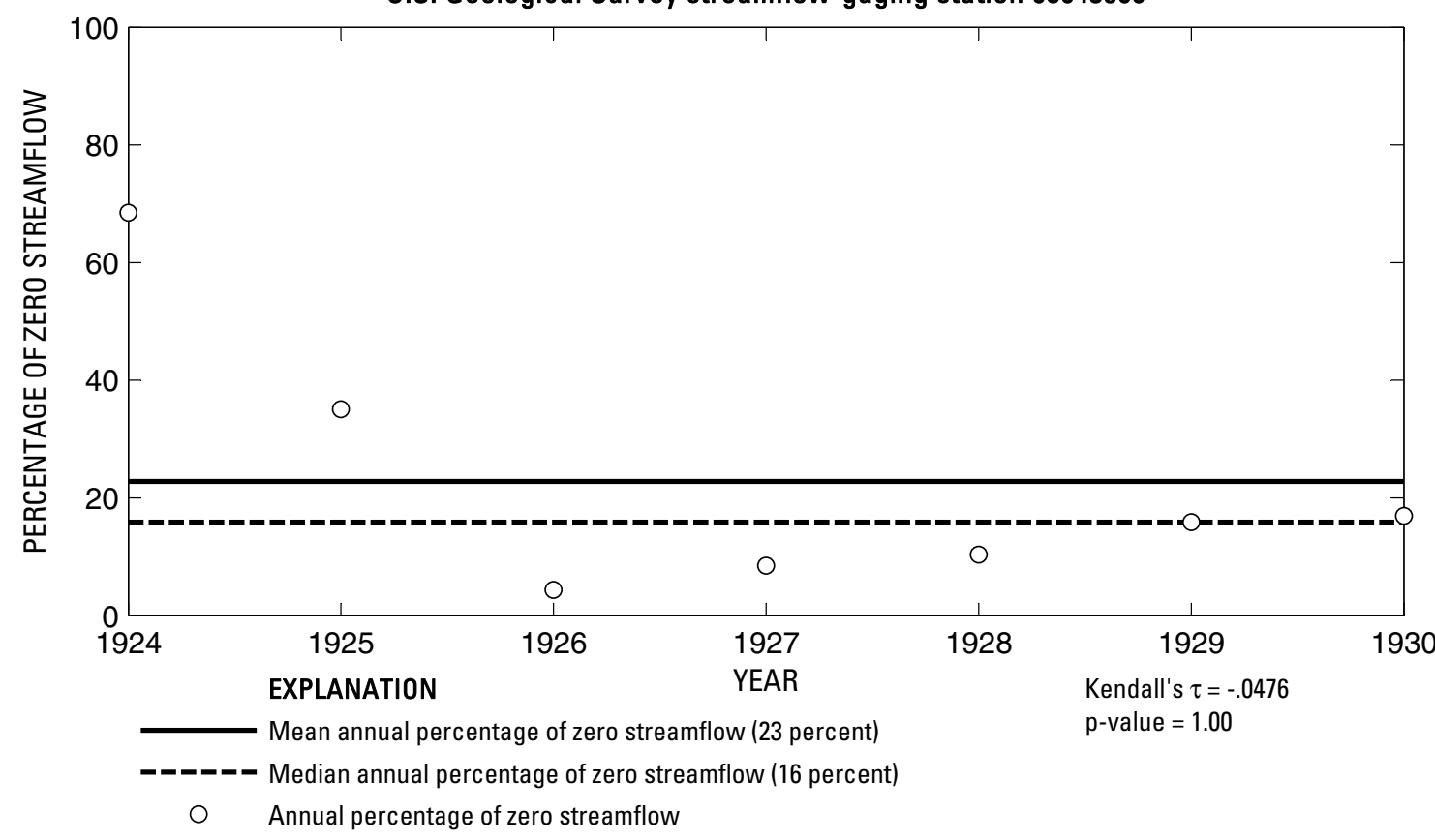

U.S. Geological Survey streamflow-gaging station 08043500

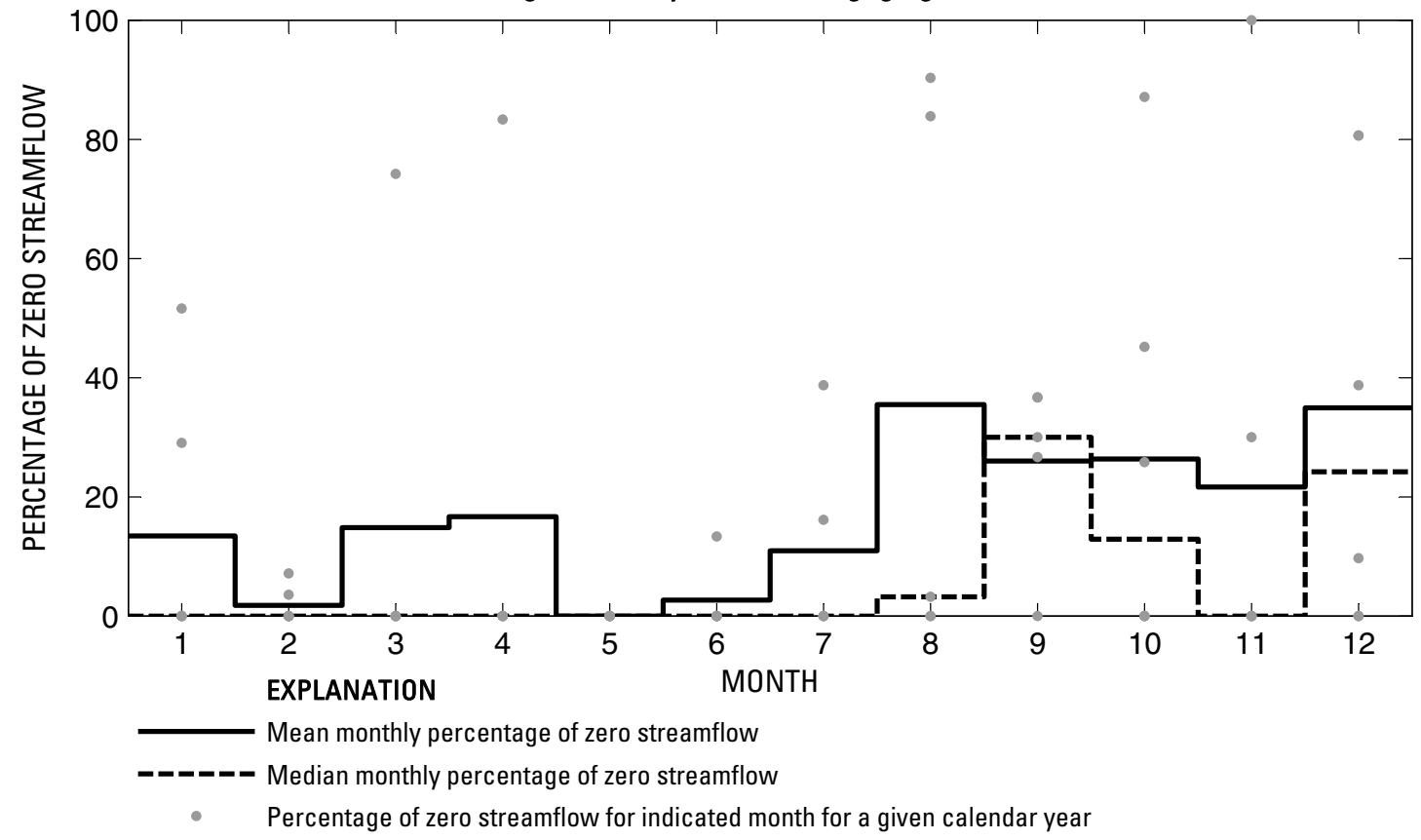

Figure 146. Analysis of percentage of zero daily mean streamflow for U.S. Geological Survey streamflow-gaging station 08043500 West Fork Trinity River at Bridgeport, Texas. 


\section{U.S. Geological Survey streamflow-gaging station 08043950}

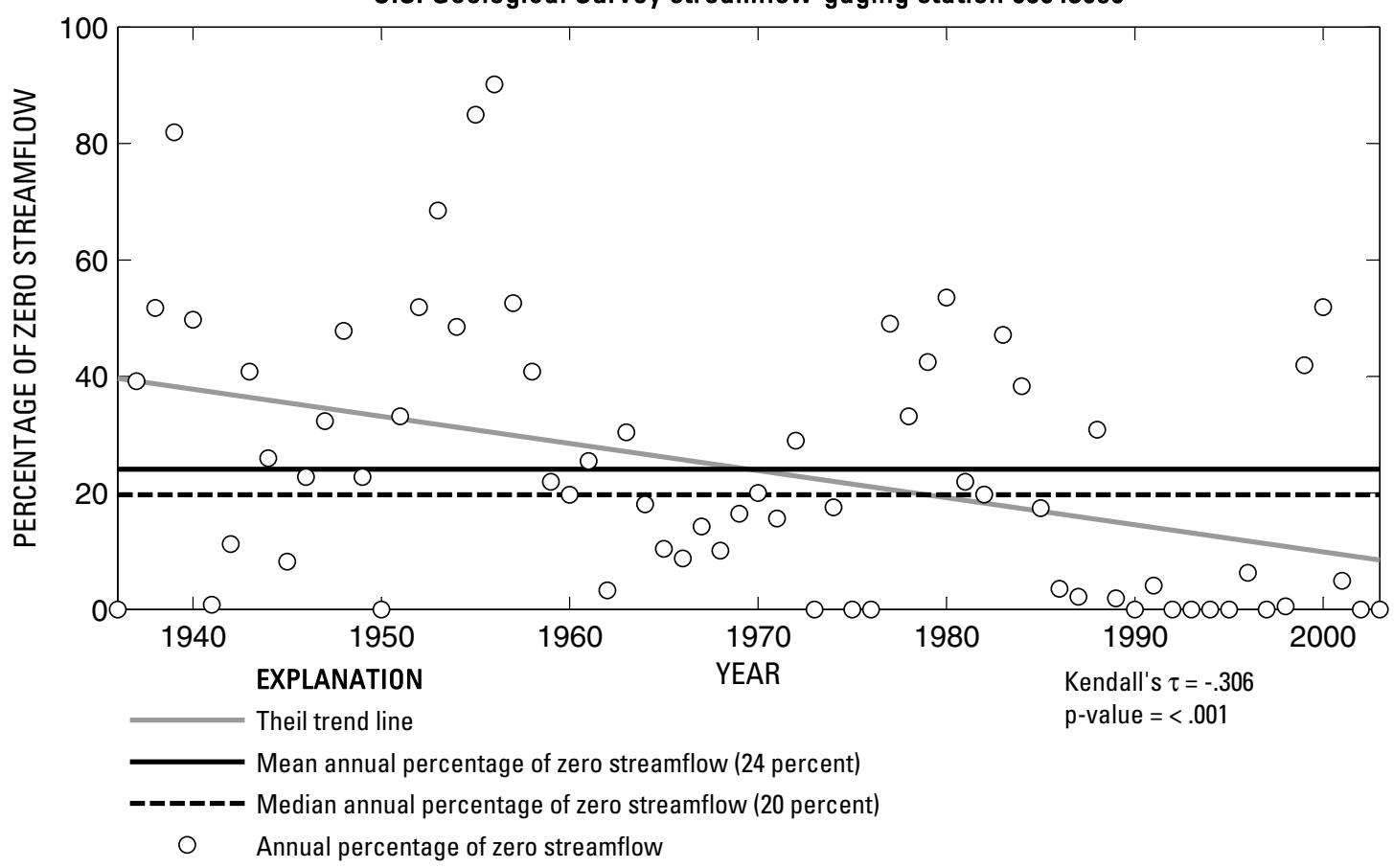

U.S. Geological Survey streamflow-gaging station 08043950

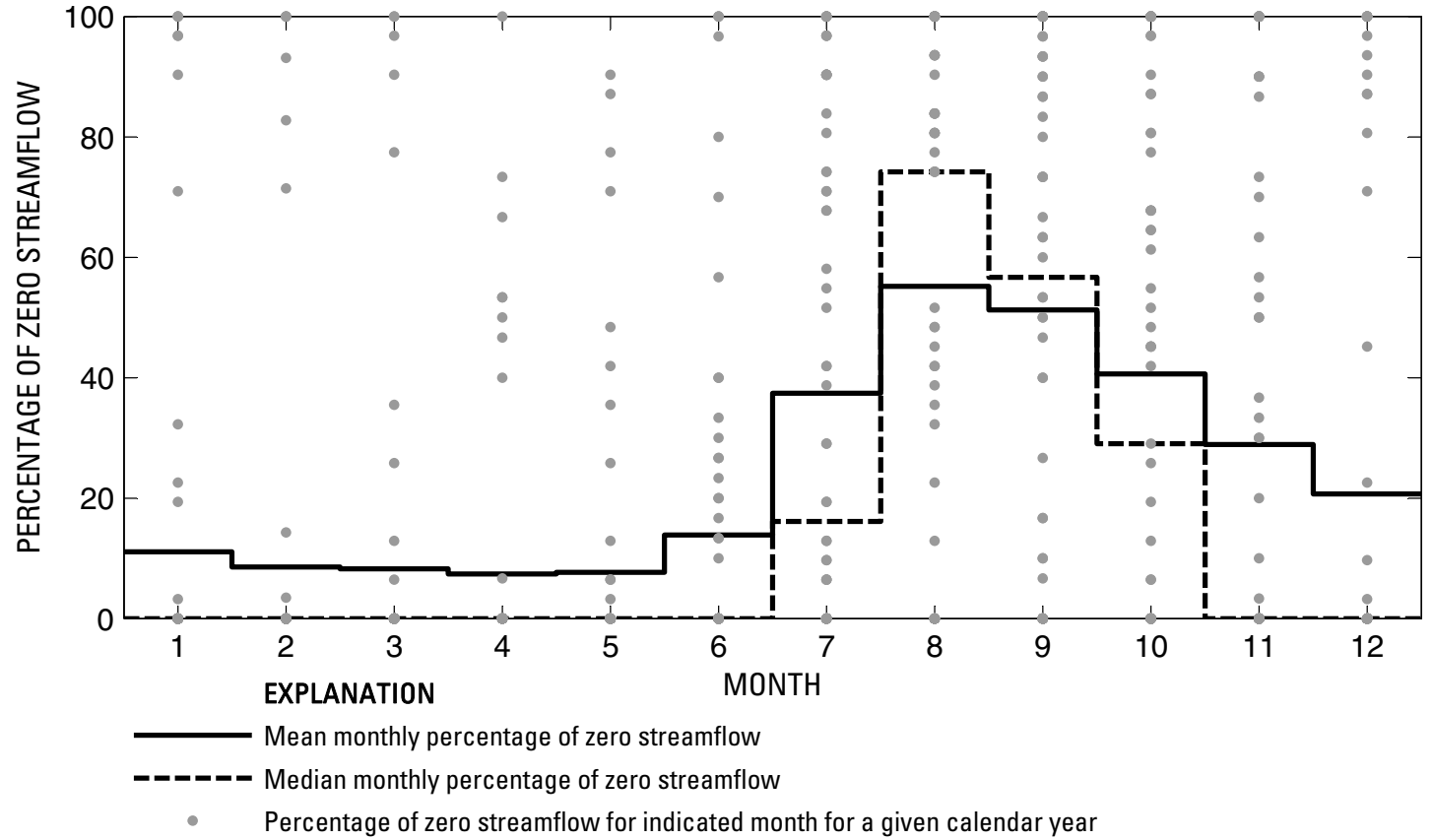

Figure 147. Analysis of percentage of zero daily mean streamflow for U.S. Geological Survey streamflow-gaging station 08043950 Big Sandy Creek near Chico, Texas. 
U.S. Geological Survey streamflow-gaging station 08044000
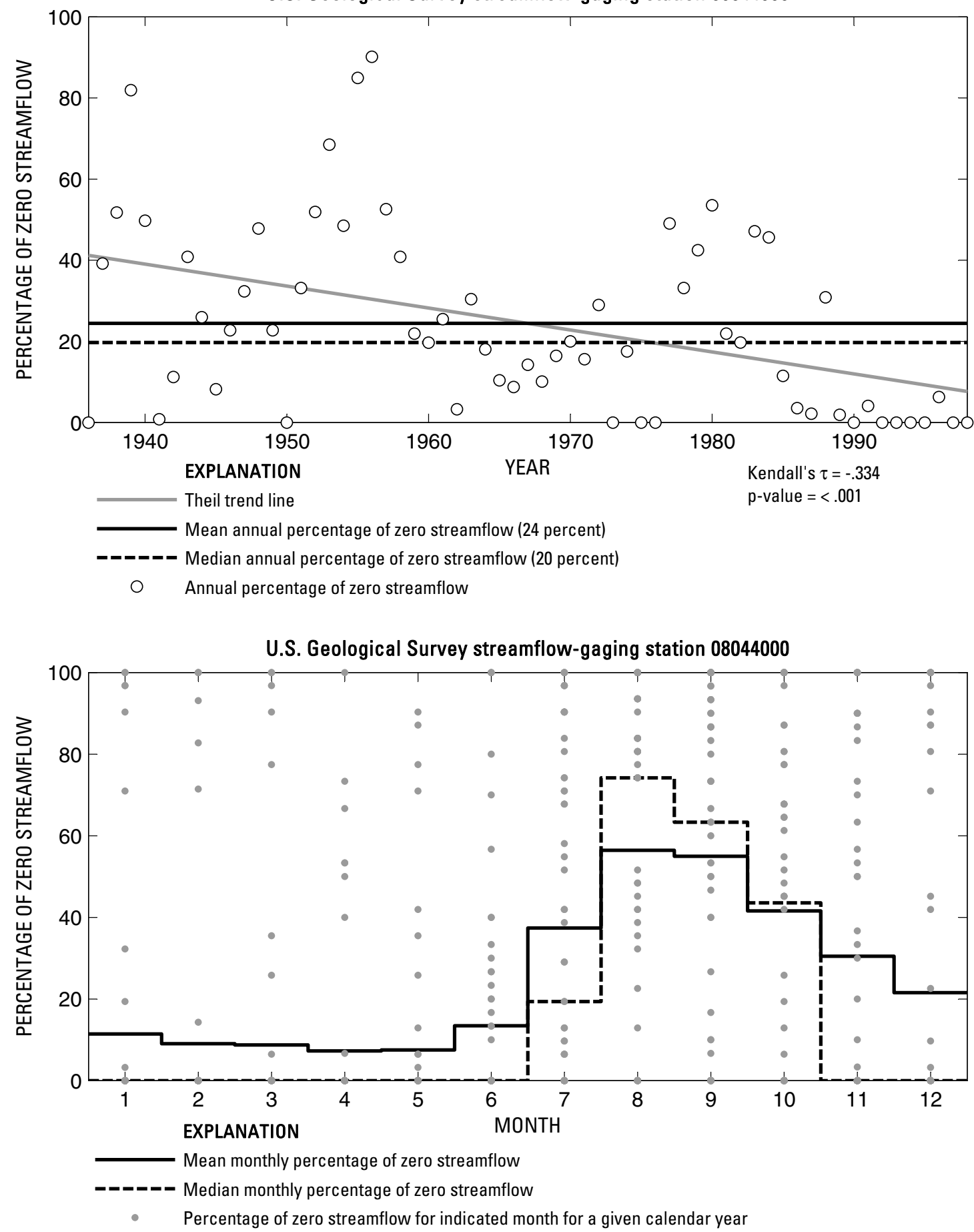

Figure 148. Analysis of percentage of zero daily mean streamflow for U.S. Geological Survey streamflow-gaging station 08044000 Big Sandy Creek near Bridgeport, Texas.

Index of Station Numbers 719 
U.S. Geological Survey streamflow-gaging station 08044135

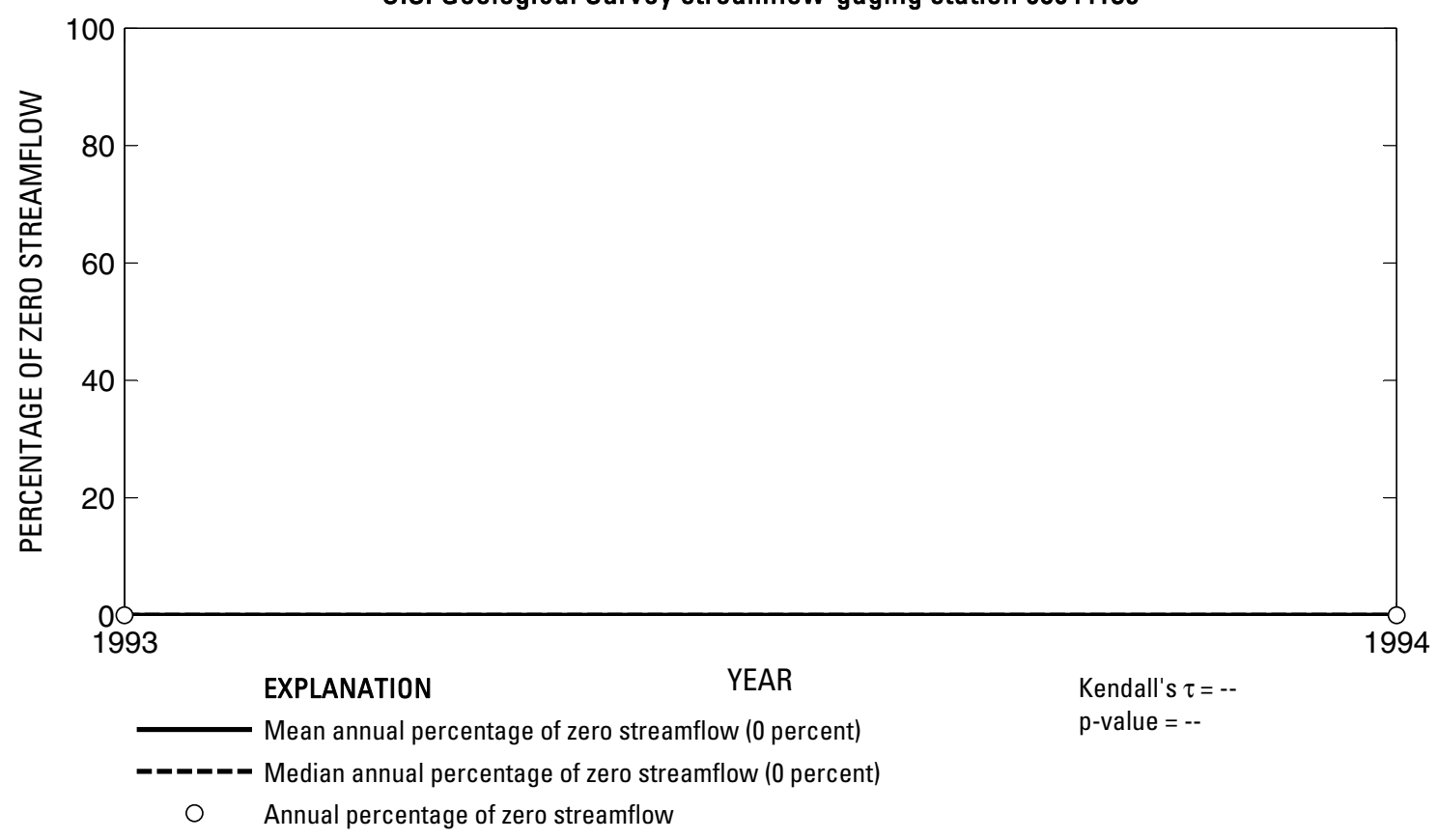

U.S. Geological Survey streamflow-gaging station 08044135

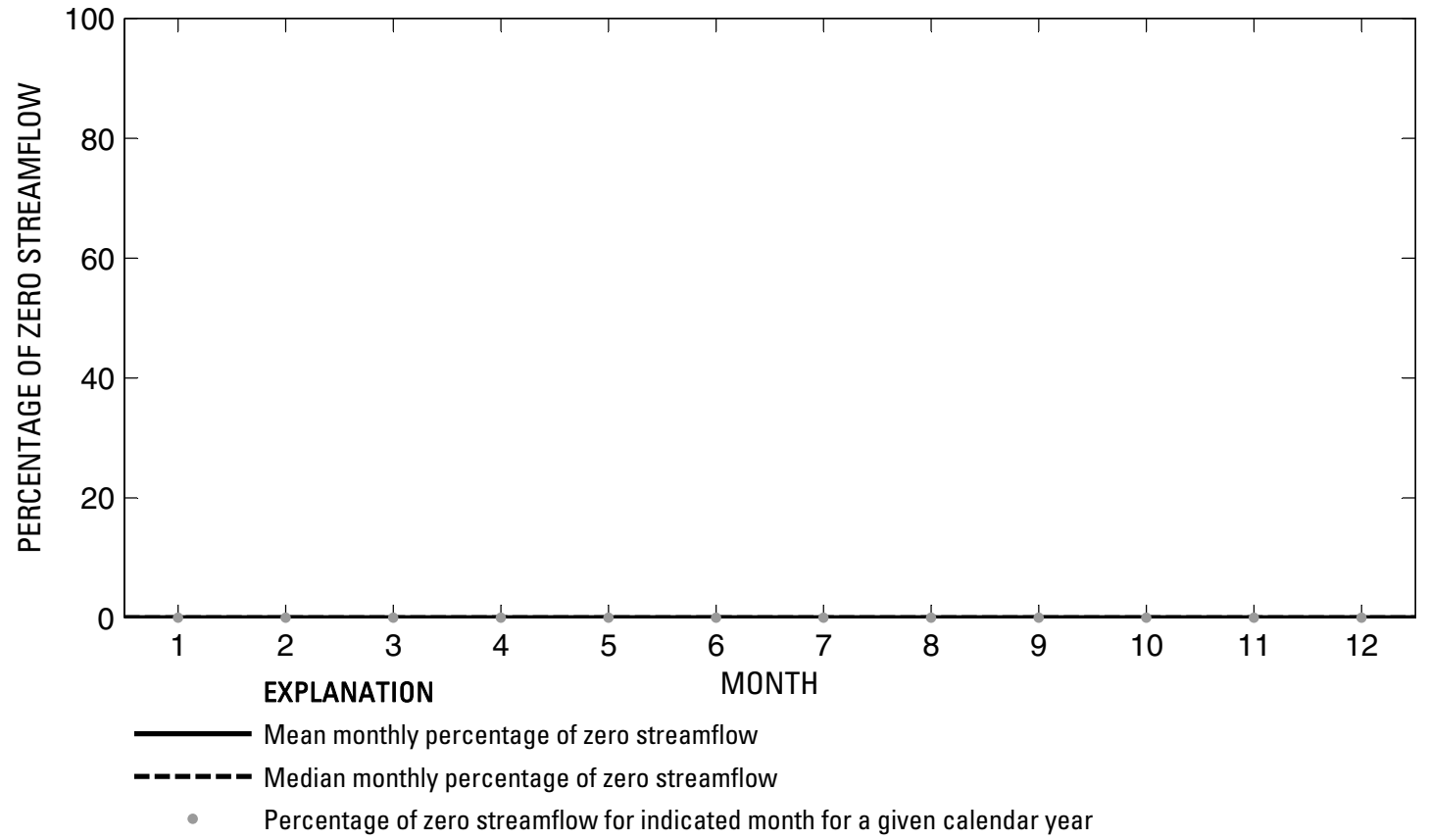

Figure 149. Analysis of percentage of zero daily mean streamflow for U.S. Geological Survey streamflow-gaging station 08044135 Garrett Creek near Paradise, Texas. 
U.S. Geological Survey streamflow-gaging station 08044140

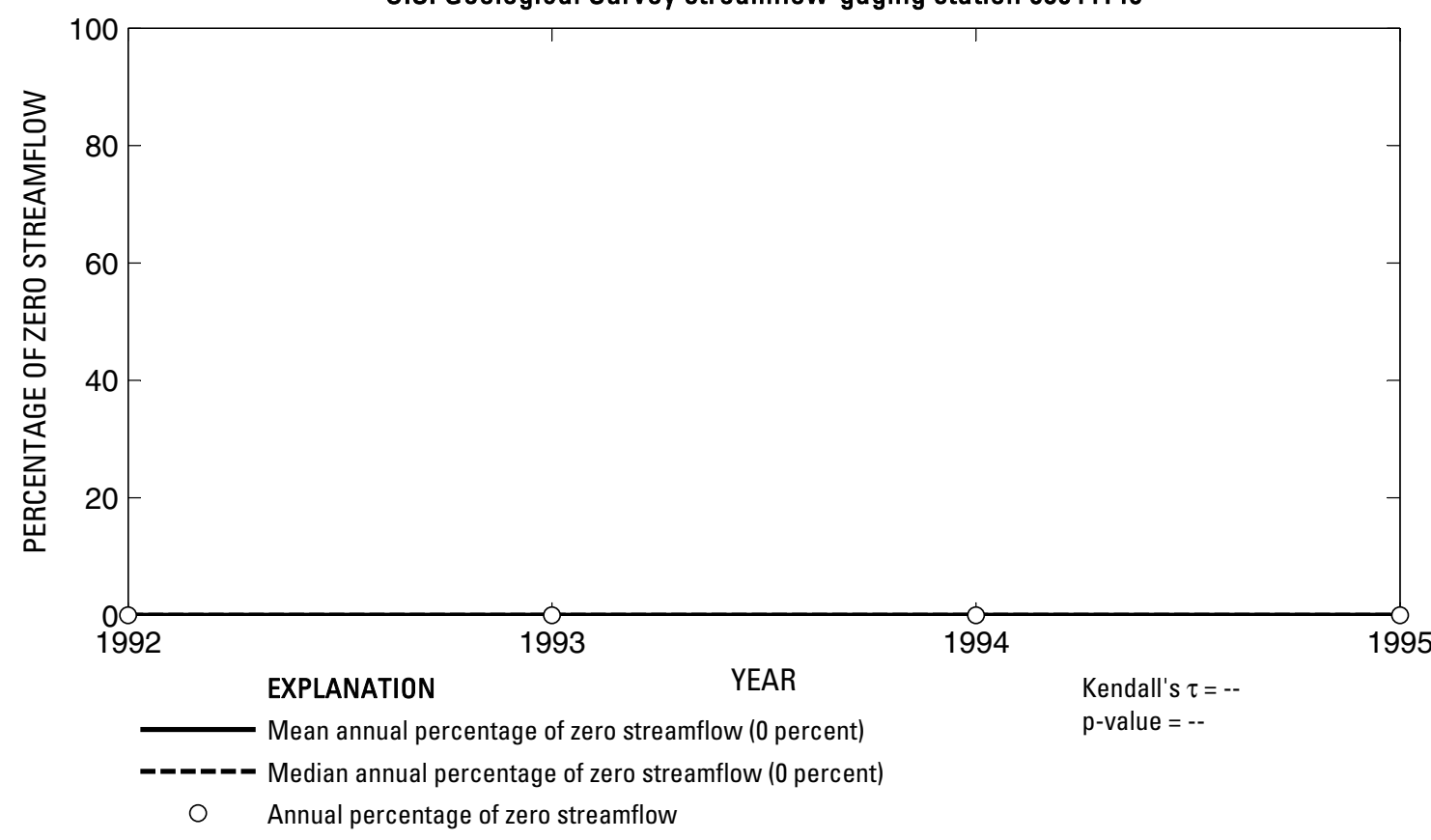

U.S. Geological Survey streamflow-gaging station 08044140

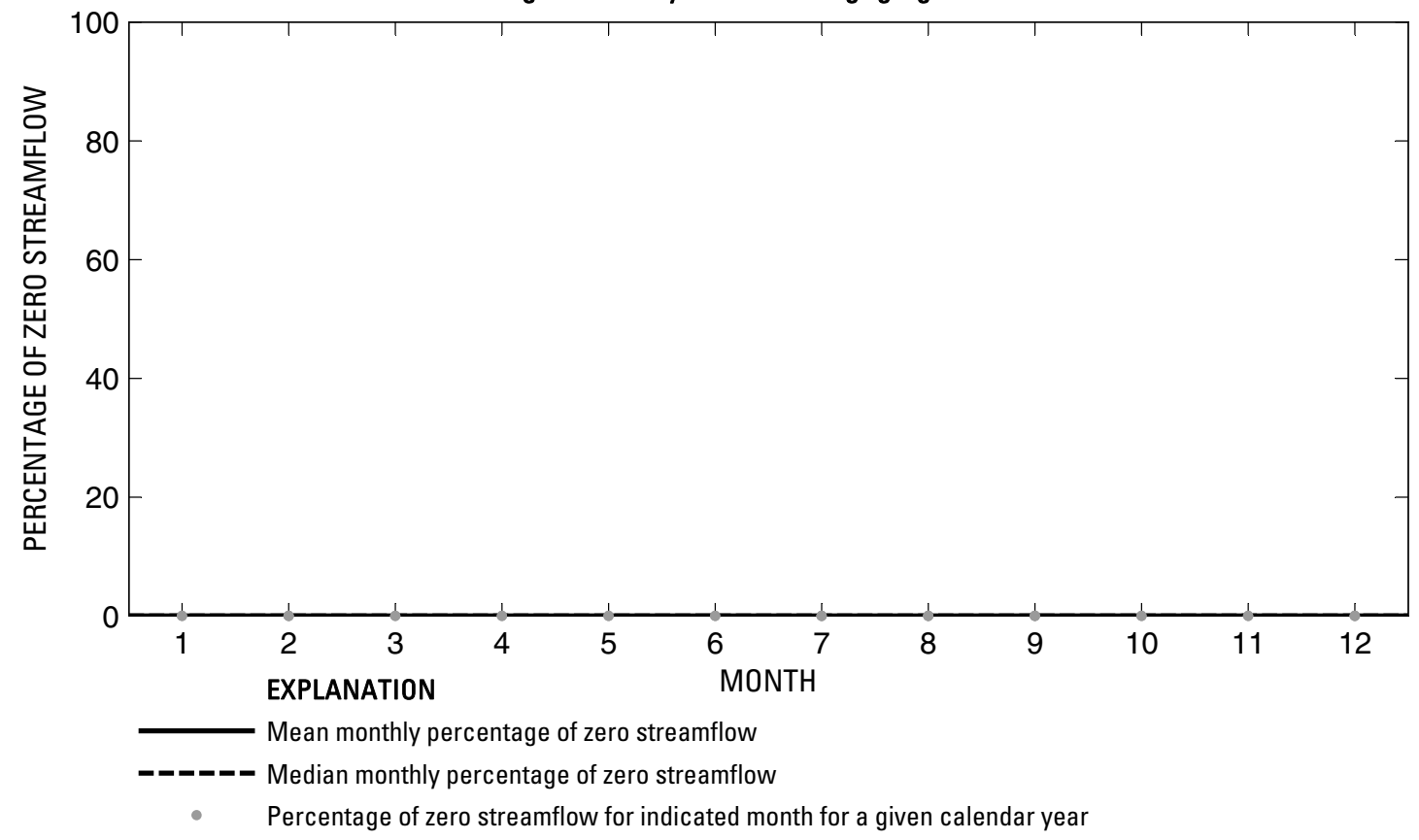

Figure 150. Analysis of percentage of zero daily mean streamflow for U.S. Geological Survey streamflow-gaging station 08044140 Salt Creek near Paradise, Texas. 

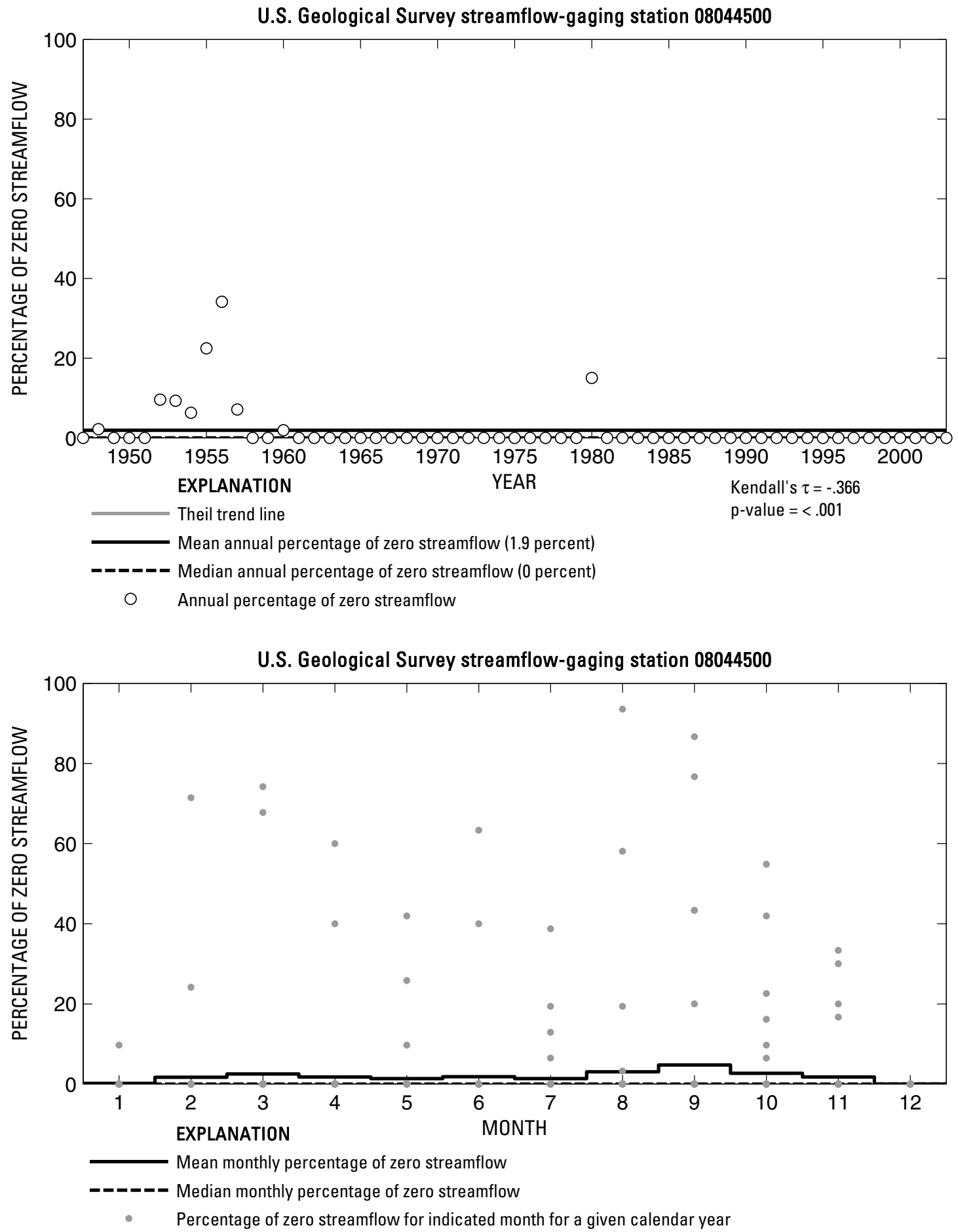

Figure 151. Analysis of percentage of zero daily mean streamflow for U.S. Geological Survey streamflow-gaging station 08044500 West Fork Trinity River near Boyd, Texas. 
U.S. Geological Survey streamflow-gaging station 08044800

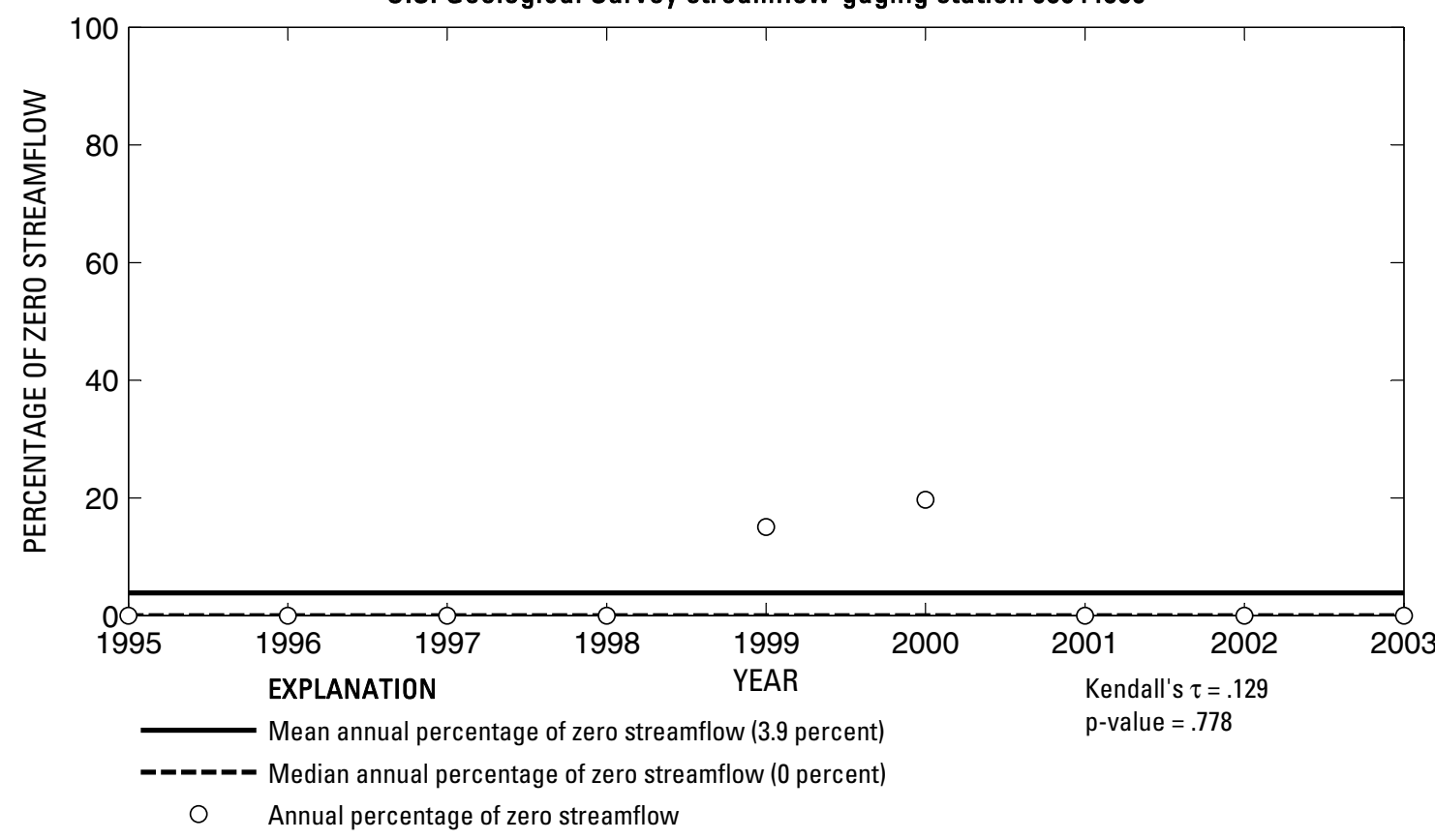

U.S. Geological Survey streamflow-gaging station 08044800

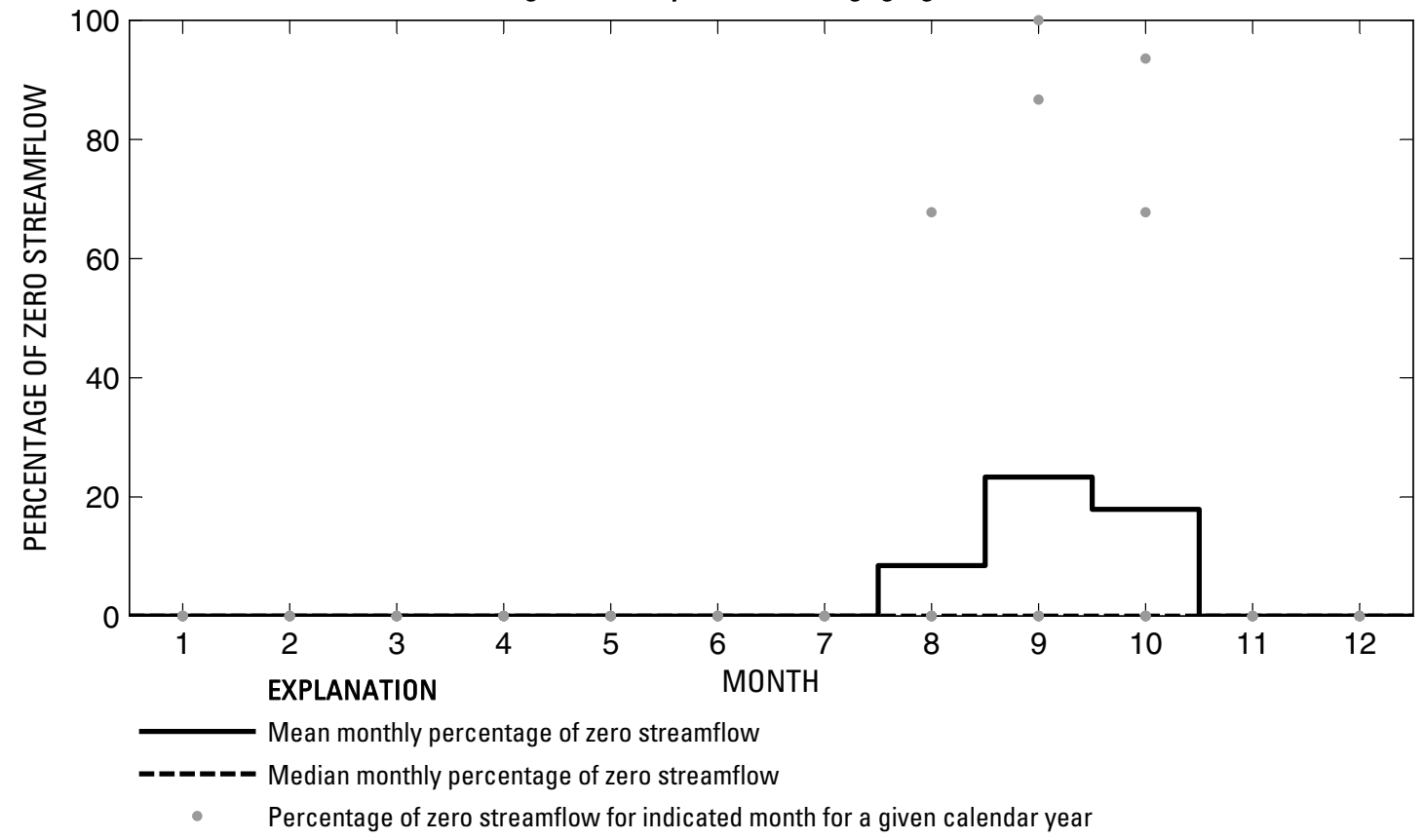

Figure 152. Analysis of percentage of zero daily mean streamflow for U.S. Geological Survey streamflow-gaging station 08044800 Walnut Creek at Reno, Texas.

Index of Station Numbers 719 
U.S. Geological Survey streamflow-gaging station 08045500

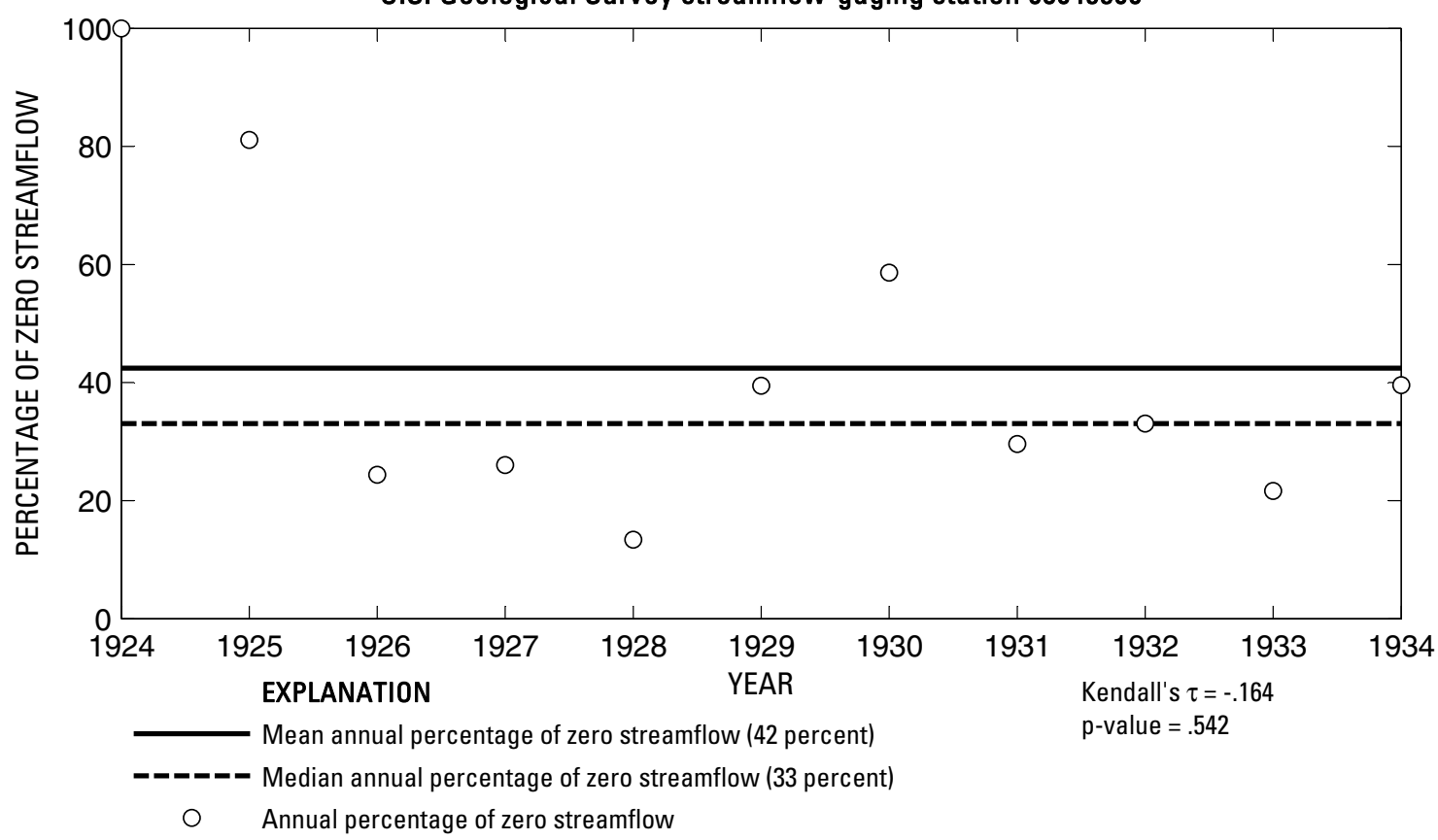

U.S. Geological Survey streamflow-gaging station 08045500

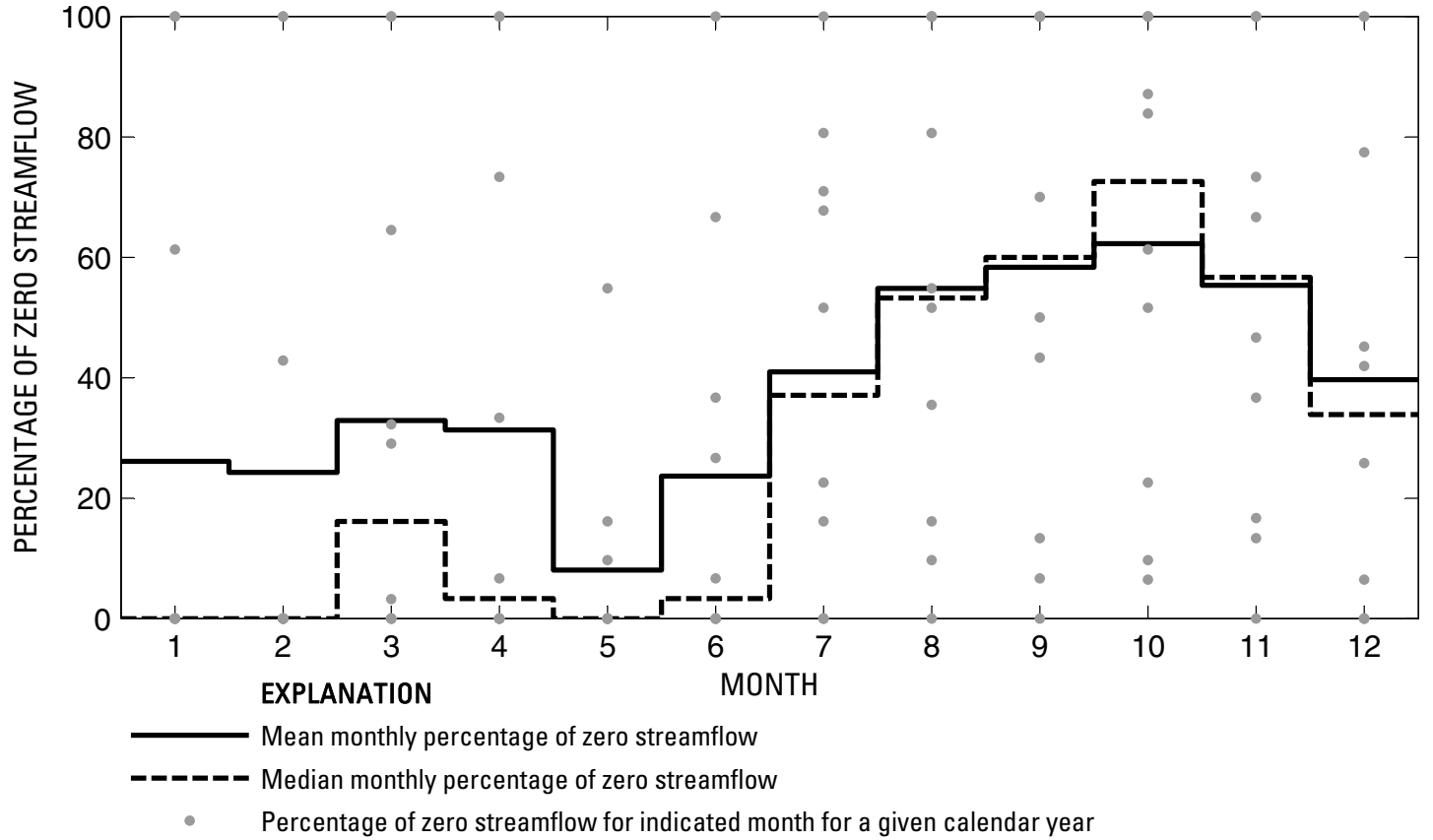

Figure 153. Analysis of percentage of zero daily mean streamflow for U.S. Geological Survey streamflow-gaging station 08045500 West Fork Trinity River at Lake Worth Dam above Fort Worth, Texas. 
U.S. Geological Survey streamflow-gaging station 08045850

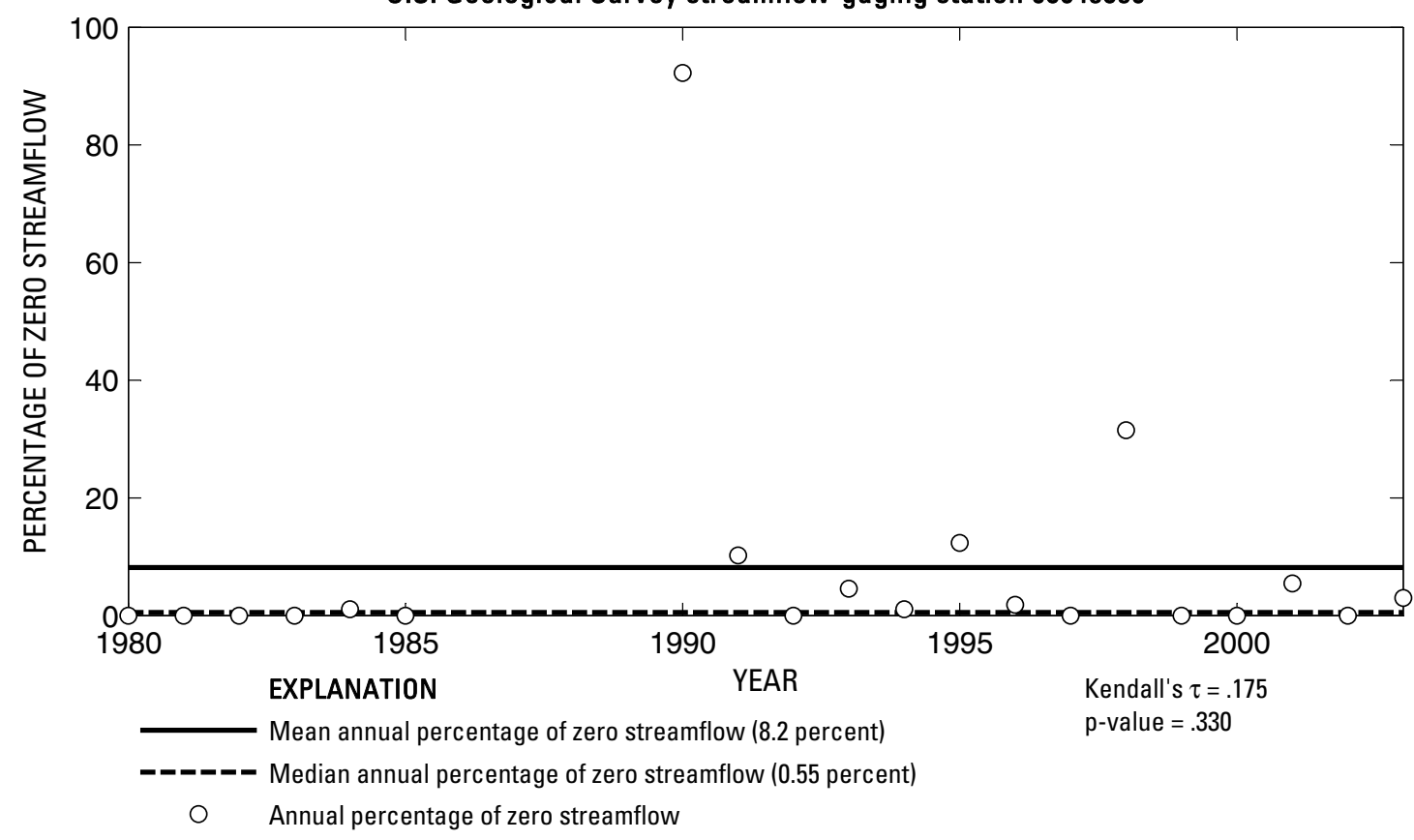

U.S. Geological Survey streamflow-gaging station 08045850

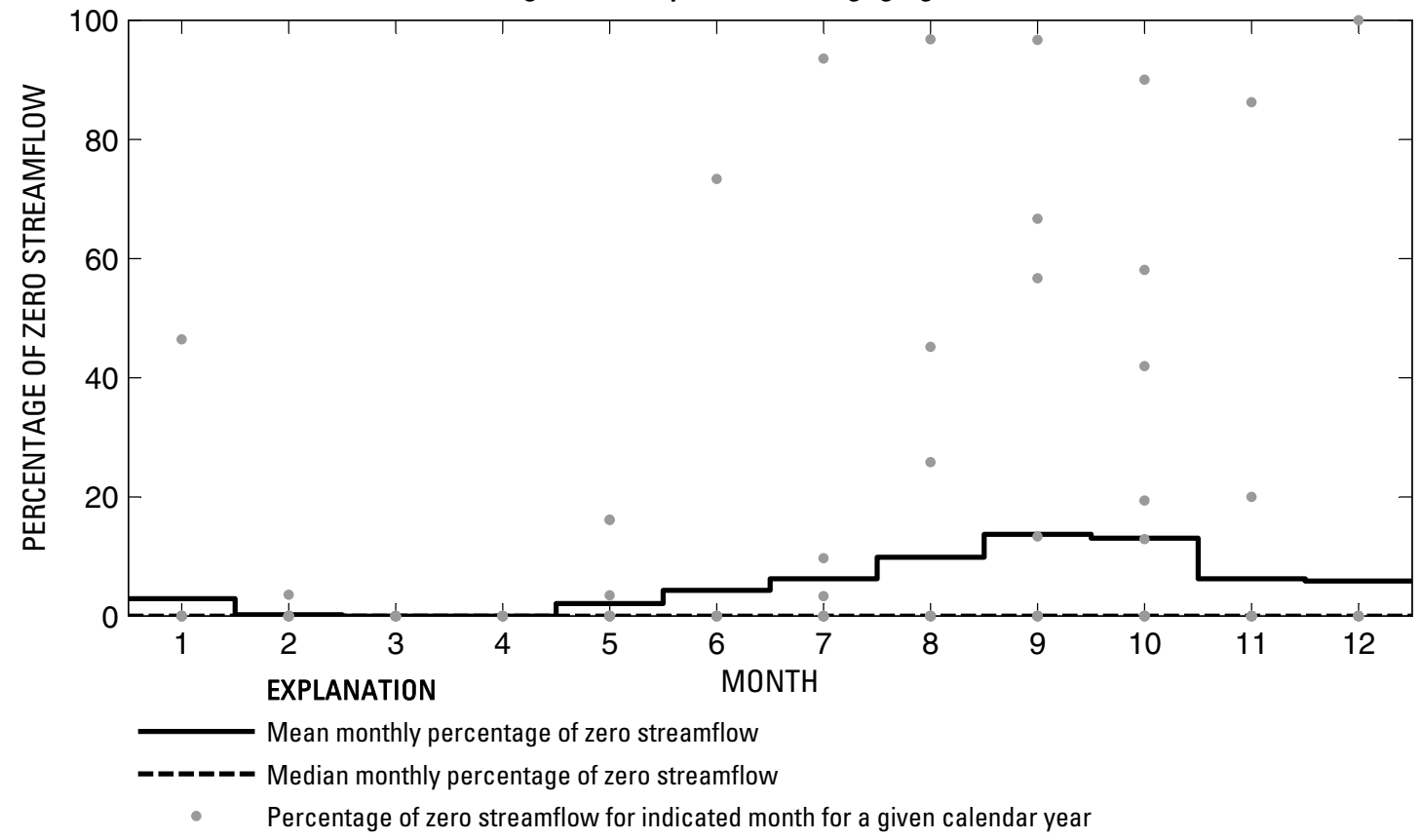

Figure 154. Analysis of percentage of zero daily mean streamflow for U.S. Geological Survey streamflow-gaging station 08045850 Clear Fork Trinity River near Weatherford, Texas. 
U.S. Geological Survey streamflow-gaging station 08046000

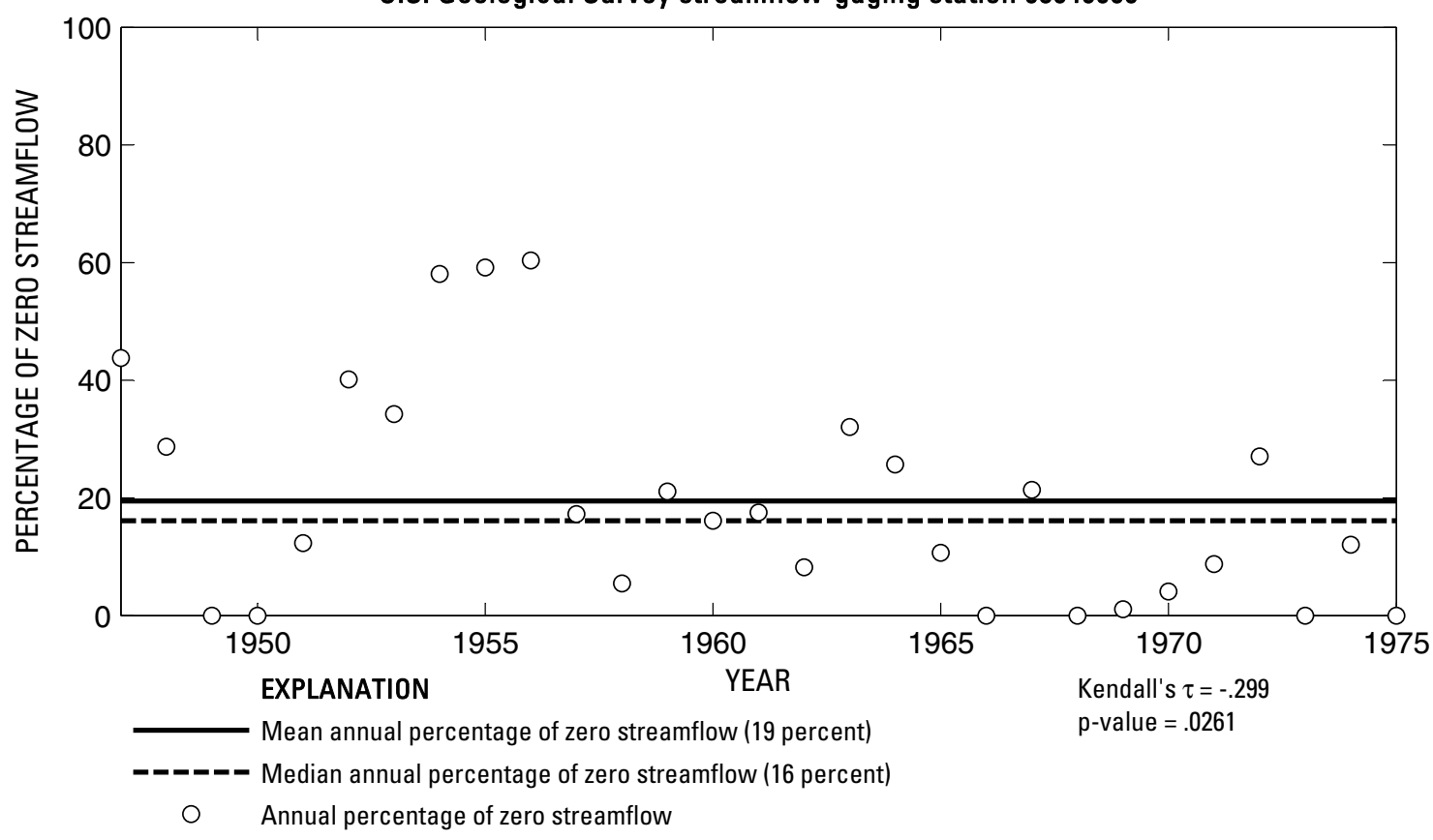

U.S. Geological Survey streamflow-gaging station 08046000

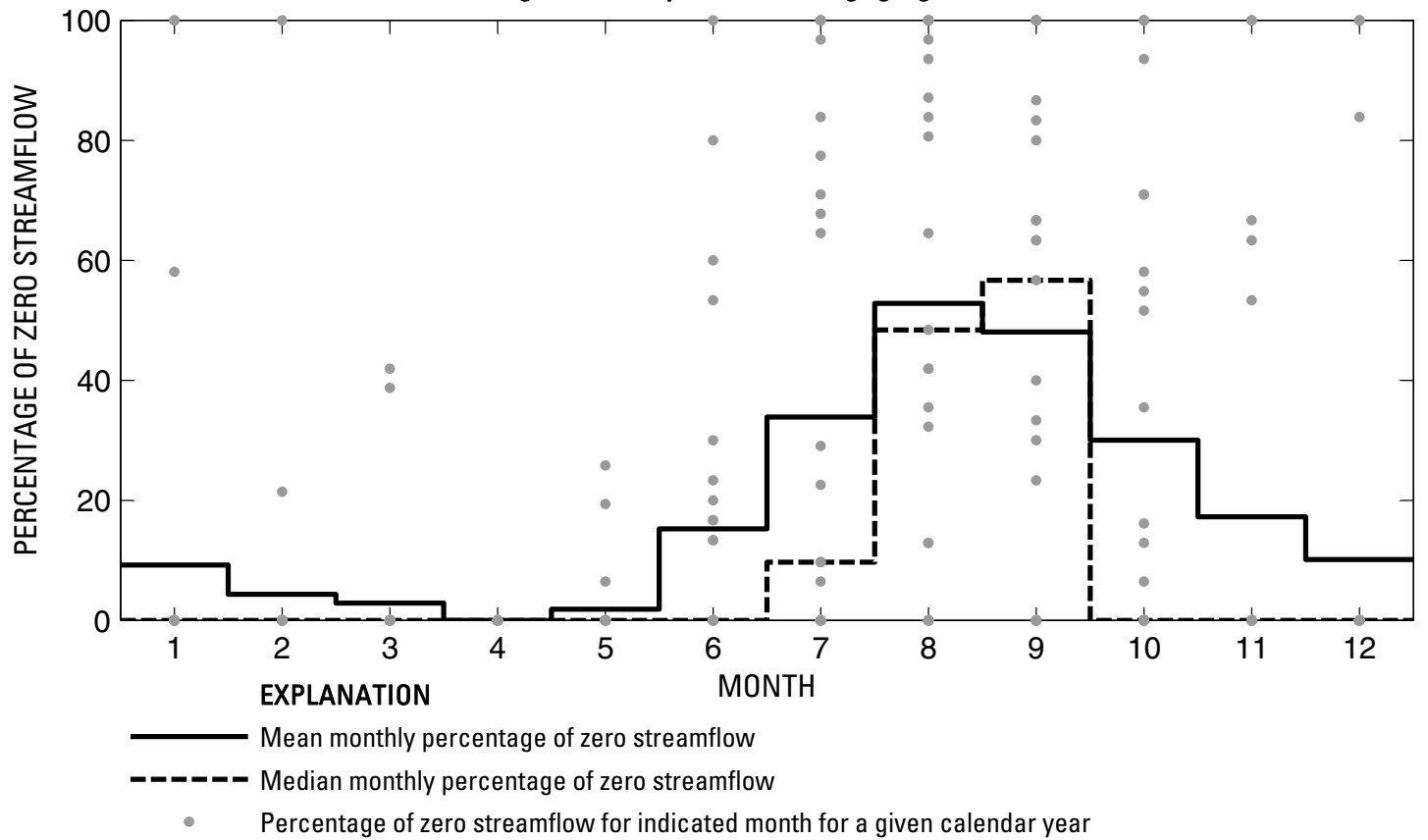

Figure 155. Analysis of percentage of zero daily mean streamflow for U.S. Geological Survey streamflow-gaging station 08046000 Clear Fork Trinity River near Aledo, Texas. 
U.S. Geological Survey streamflow-gaging station 08047000

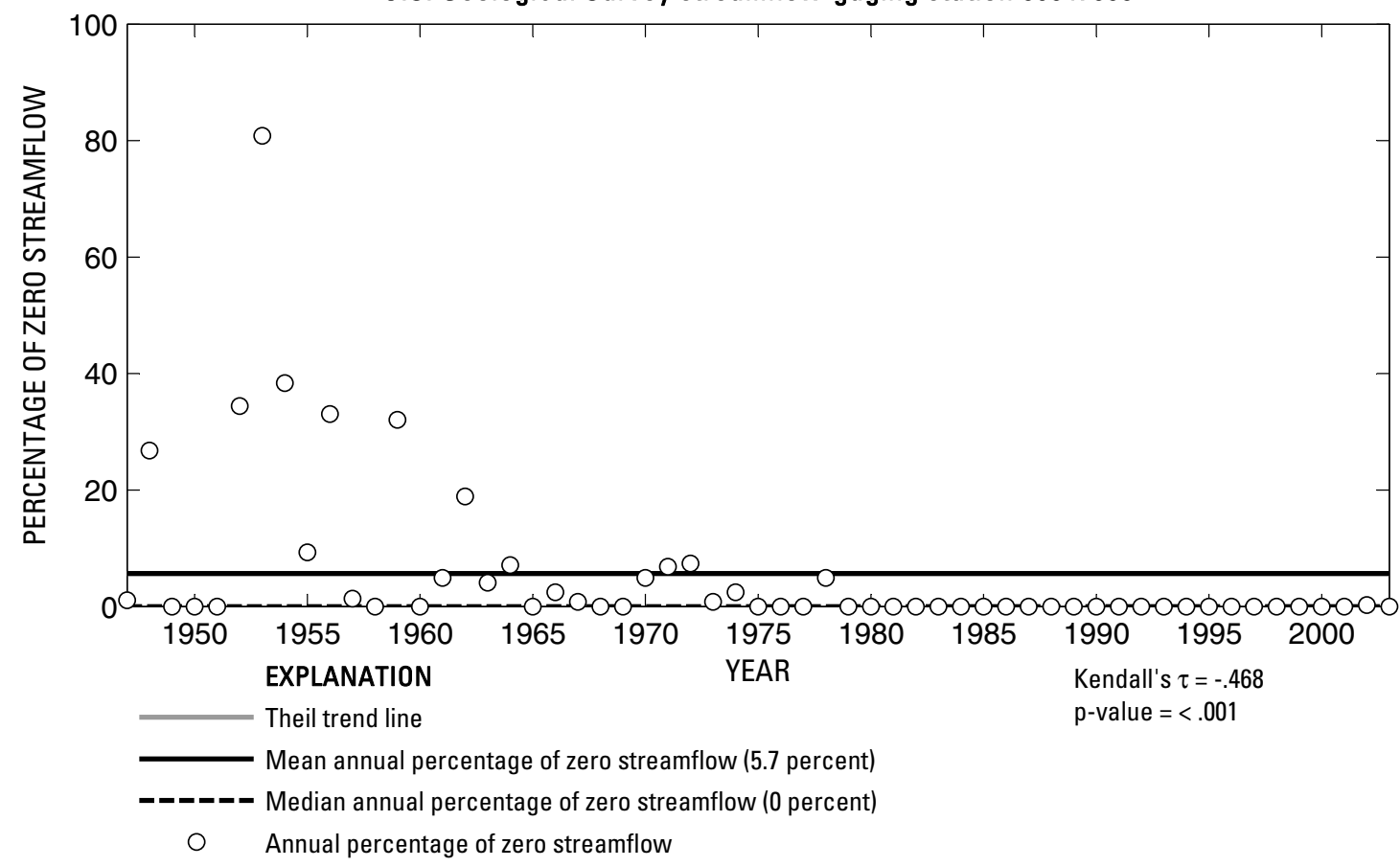

U.S. Geological Survey streamflow-gaging station 08047000

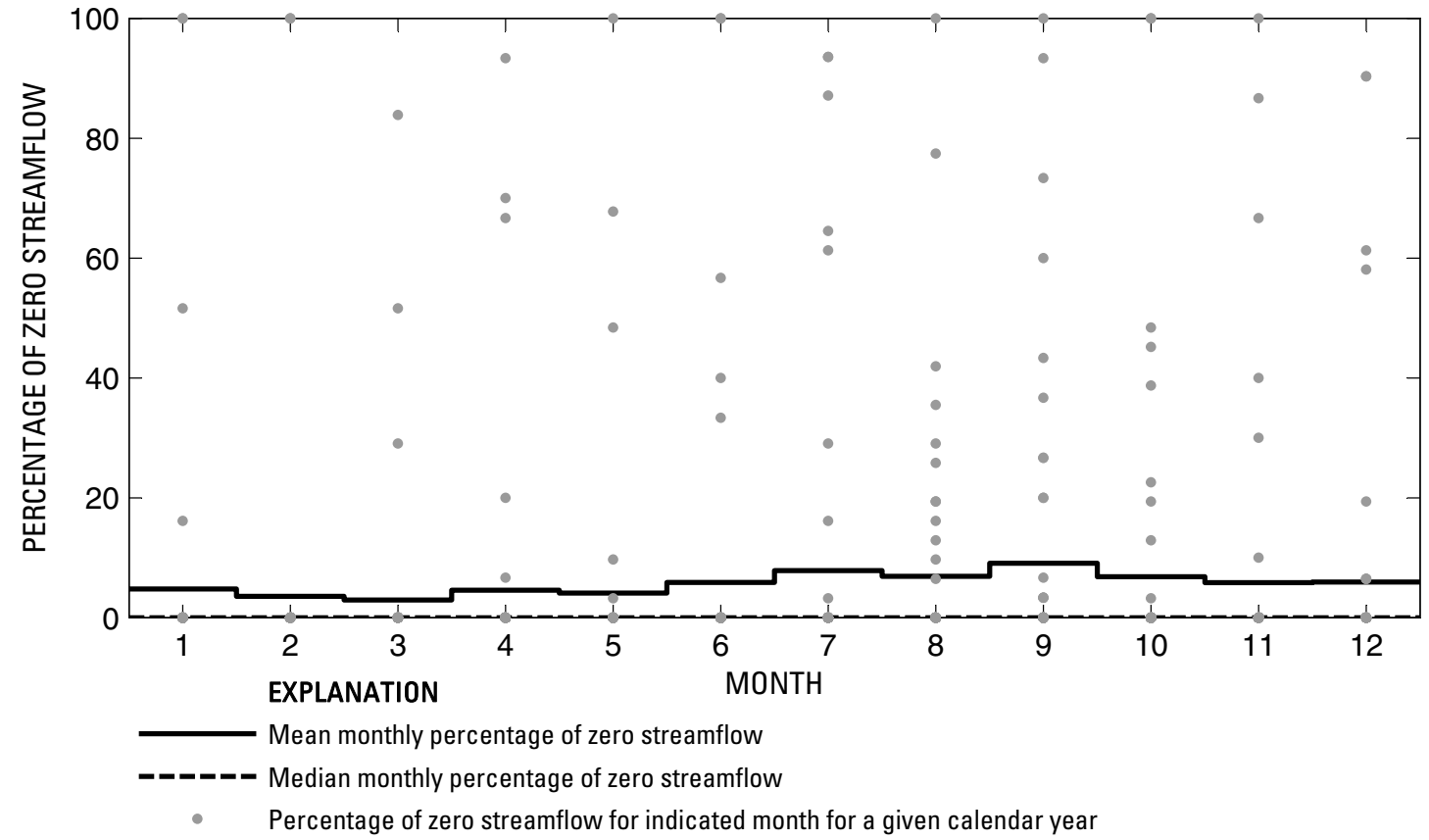

Figure 156. Analysis of percentage of zero daily mean streamflow for U.S. Geological Survey streamflow-gaging station 08047000 Clear Fork Trinity River near Benbrook, Texas.

Index of Station Numbers 719 


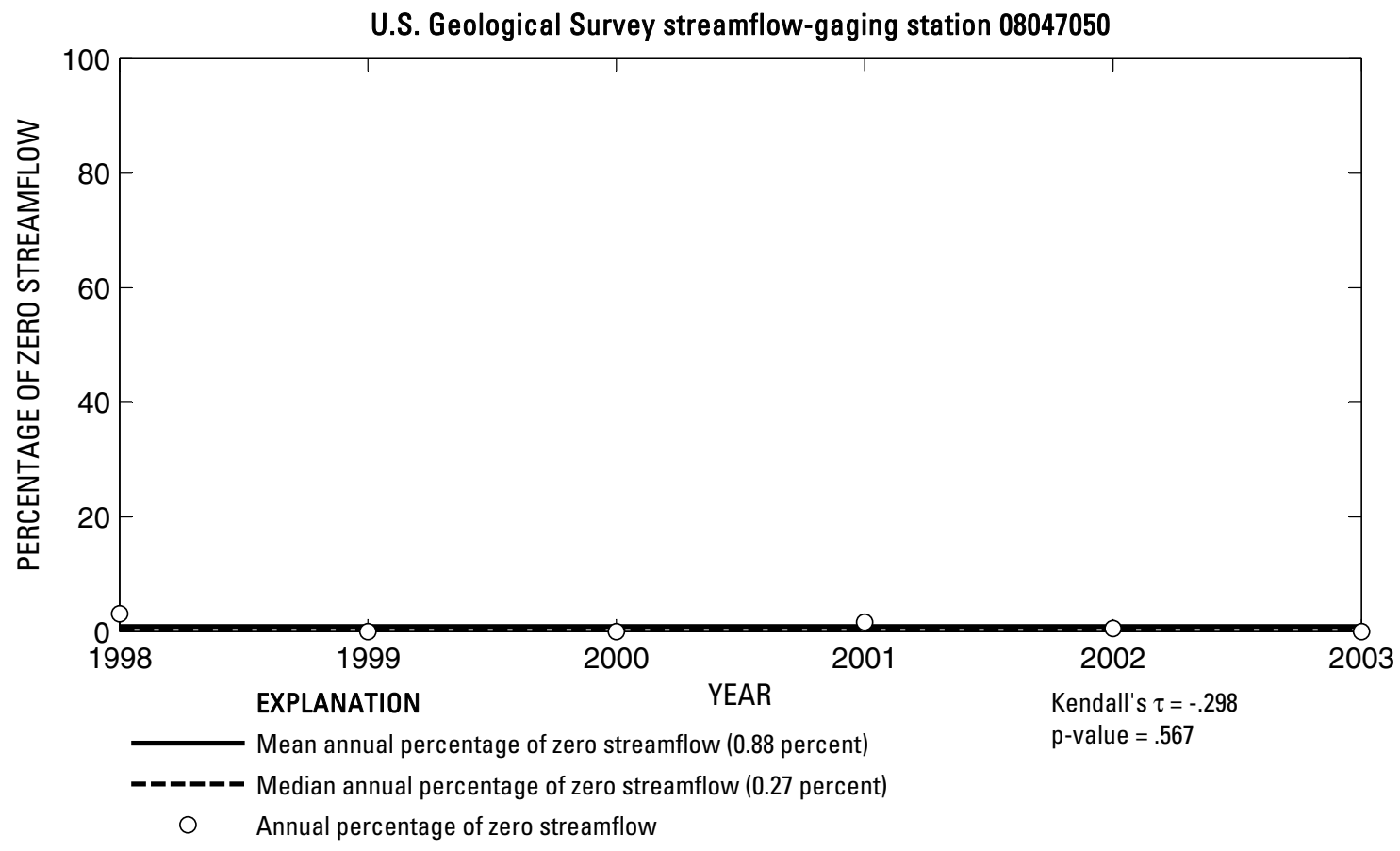

U.S. Geological Survey streamflow-gaging station 08047050

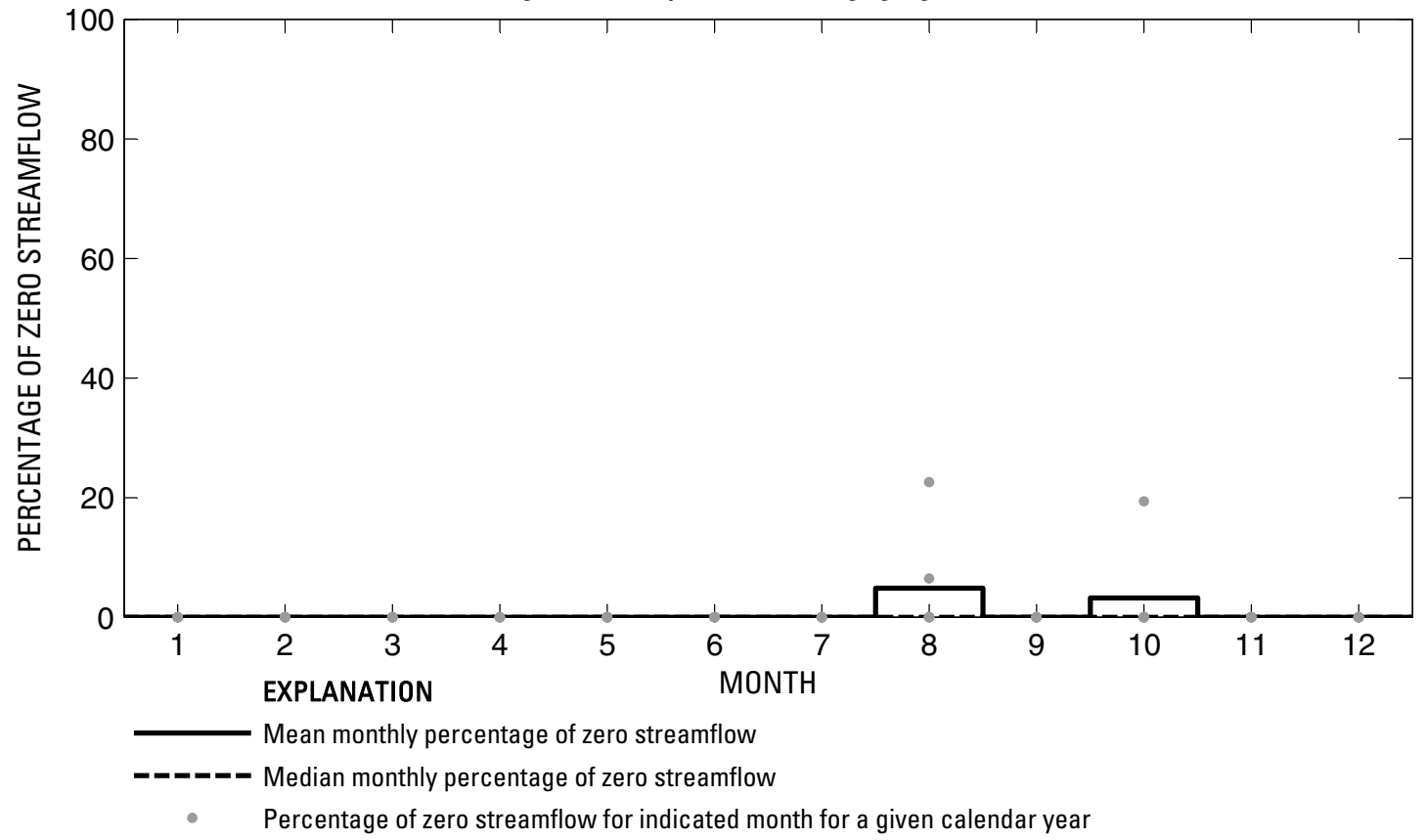

Figure 157. Analysis of percentage of zero daily mean streamflow for U.S. Geological Survey streamflow-gaging station 08047050 Marys Creek at Benbrook, Texas. 
U.S. Geological Survey streamflow-gaging station 08047500

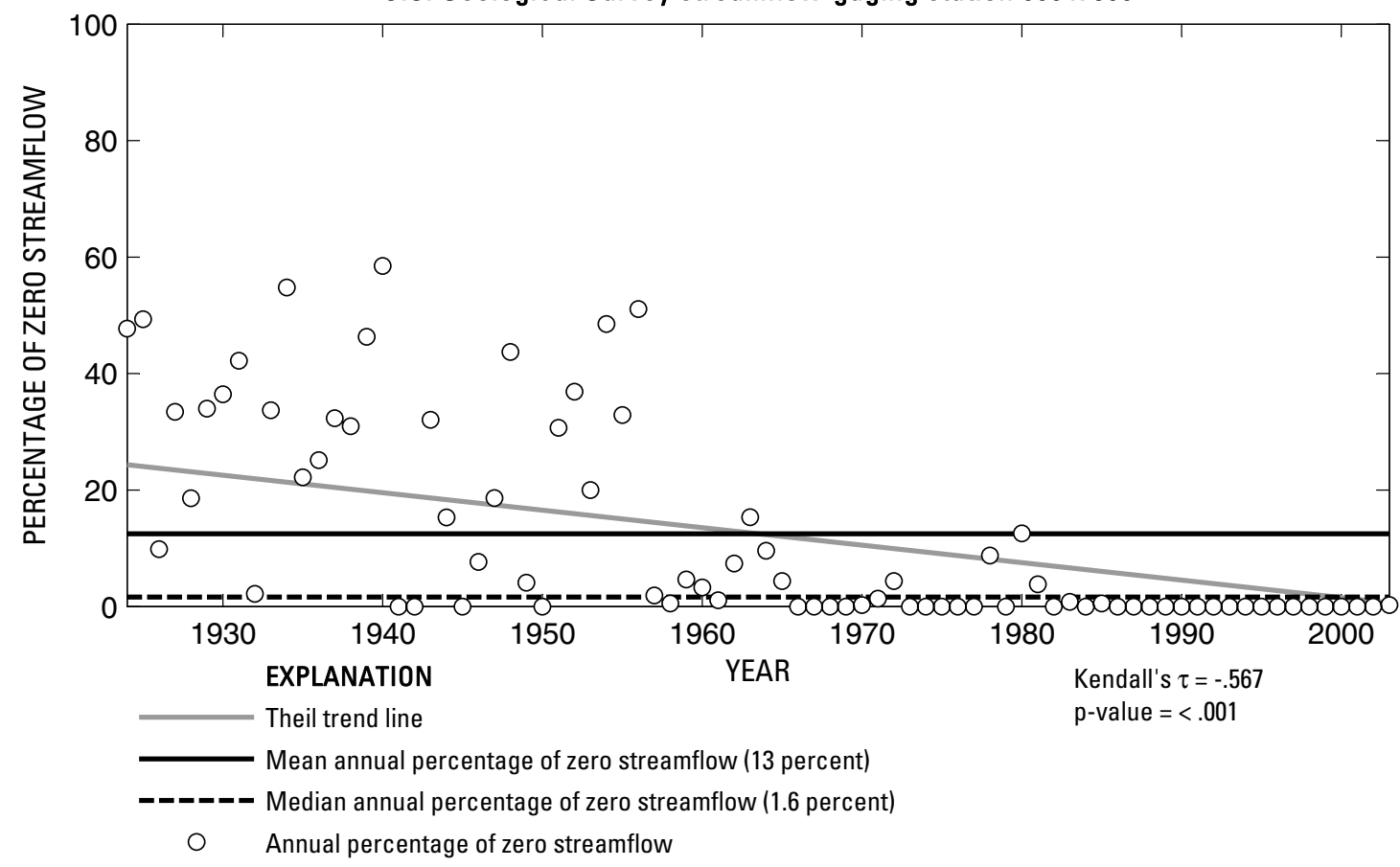

U.S. Geological Survey streamflow-gaging station 08047500

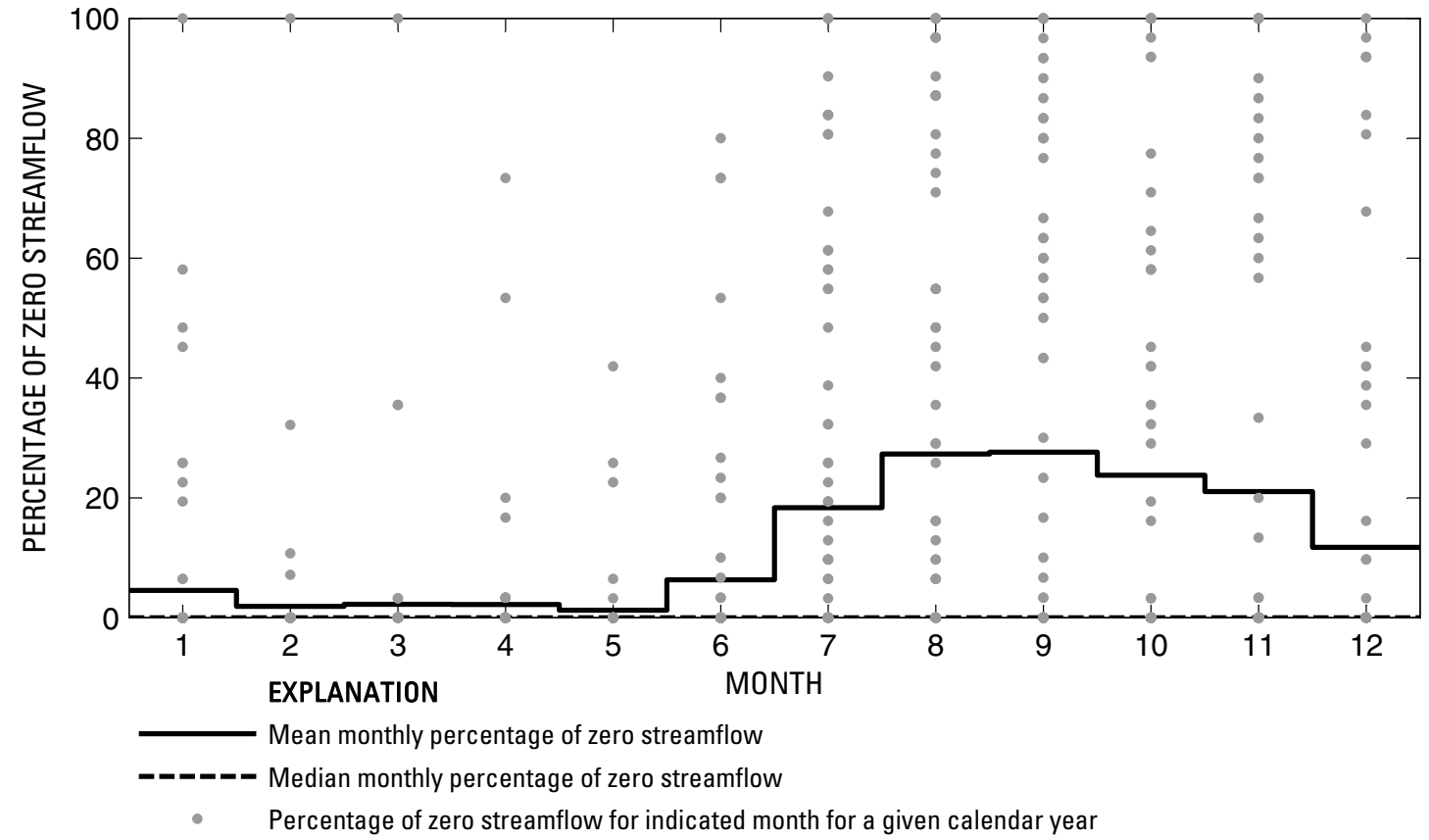

Figure 158. Analysis of percentage of zero daily mean streamflow for U.S. Geological Survey streamflow-gaging station 08047500 Clear Fork Trinity River at Fort Worth, Texas.

Index of Station Numbers 719 
U.S. Geological Survey streamflow-gaging station 08048000

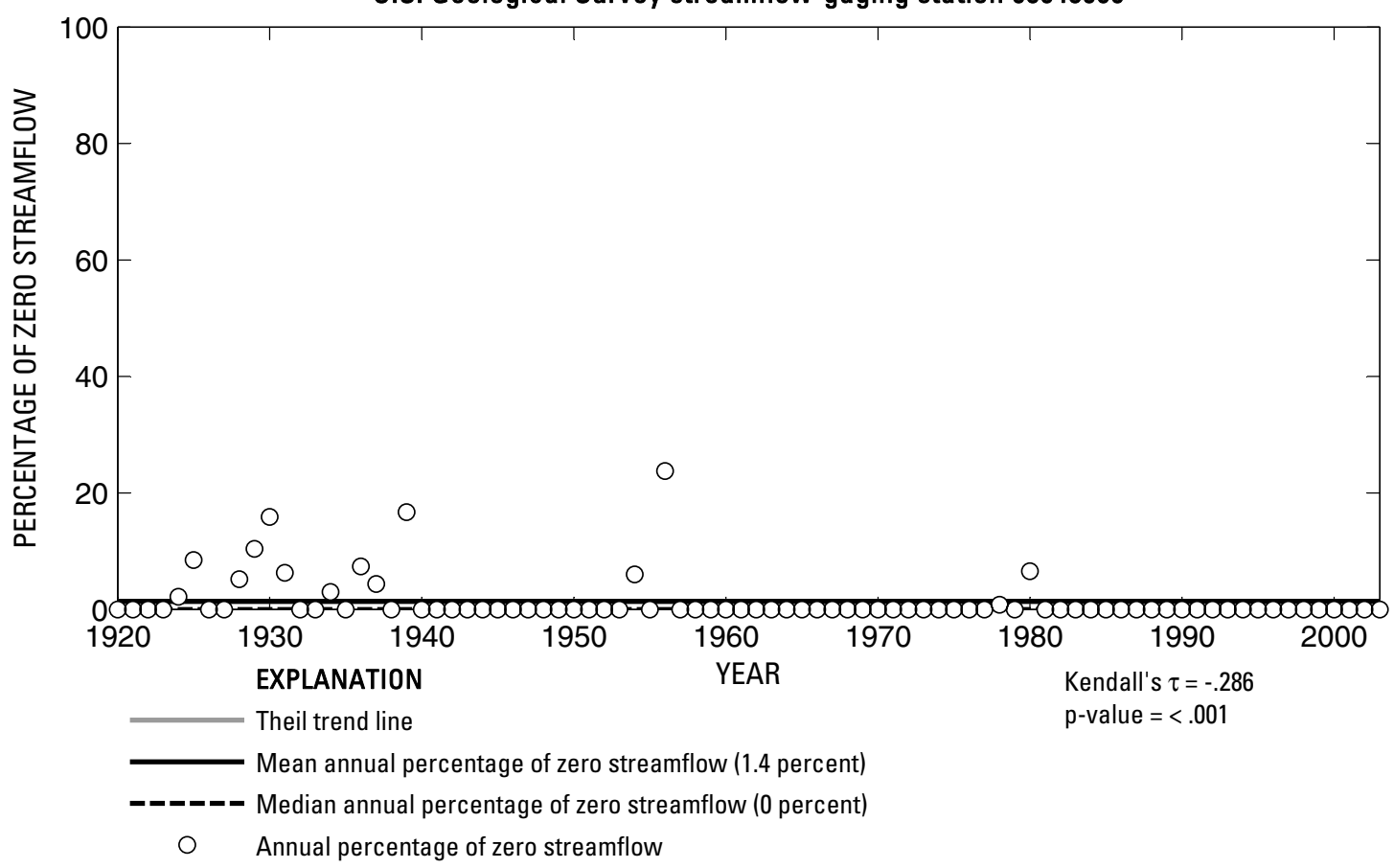

U.S. Geological Survey streamflow-gaging station 08048000

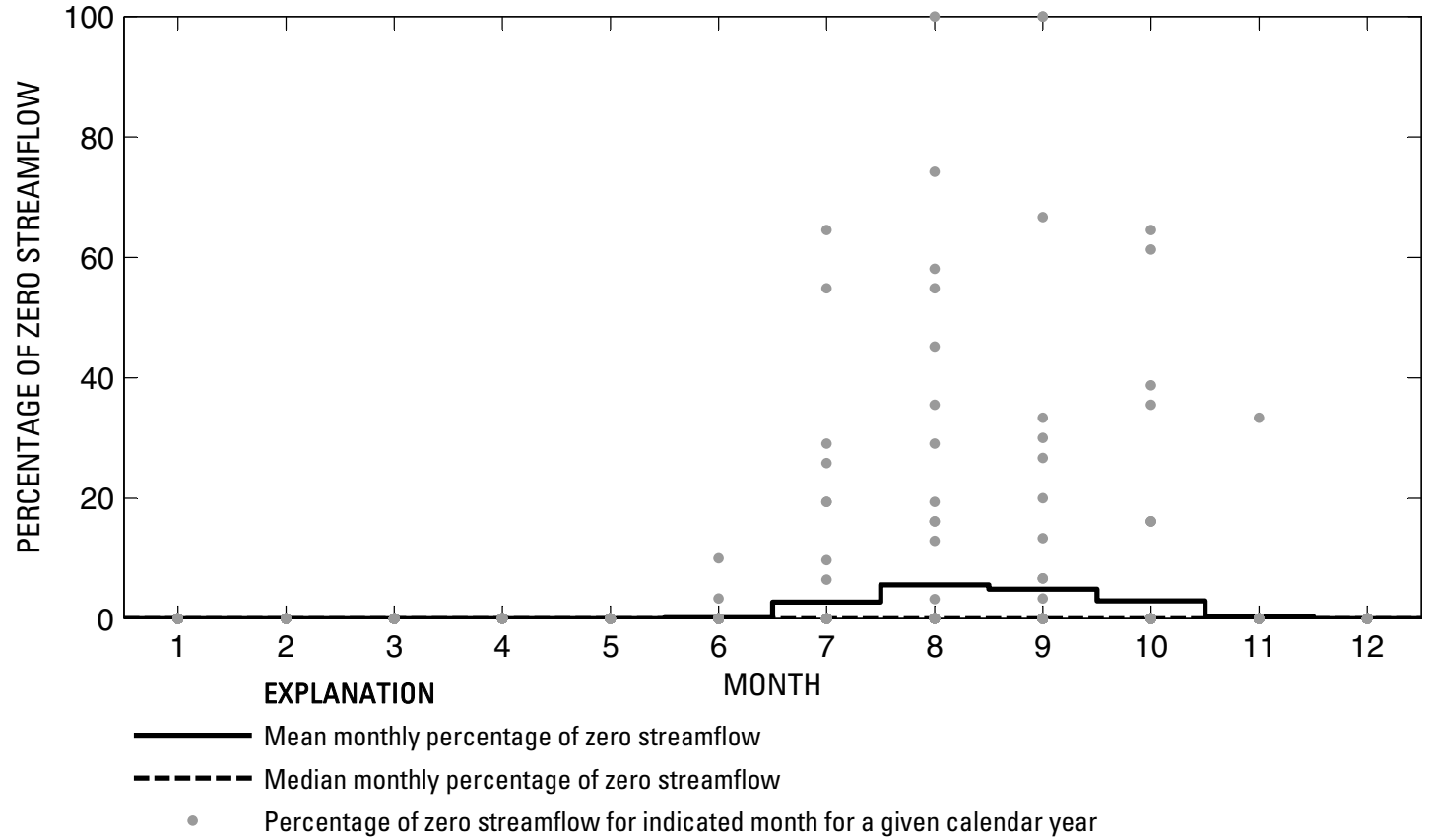

Figure 159. Analysis of percentage of zero daily mean streamflow for U.S. Geological Survey streamflow-gaging station 08048000 West Fork Trinity River at Fort Worth, Texas. 
U.S. Geological Survey streamflow-gaging station 08048520

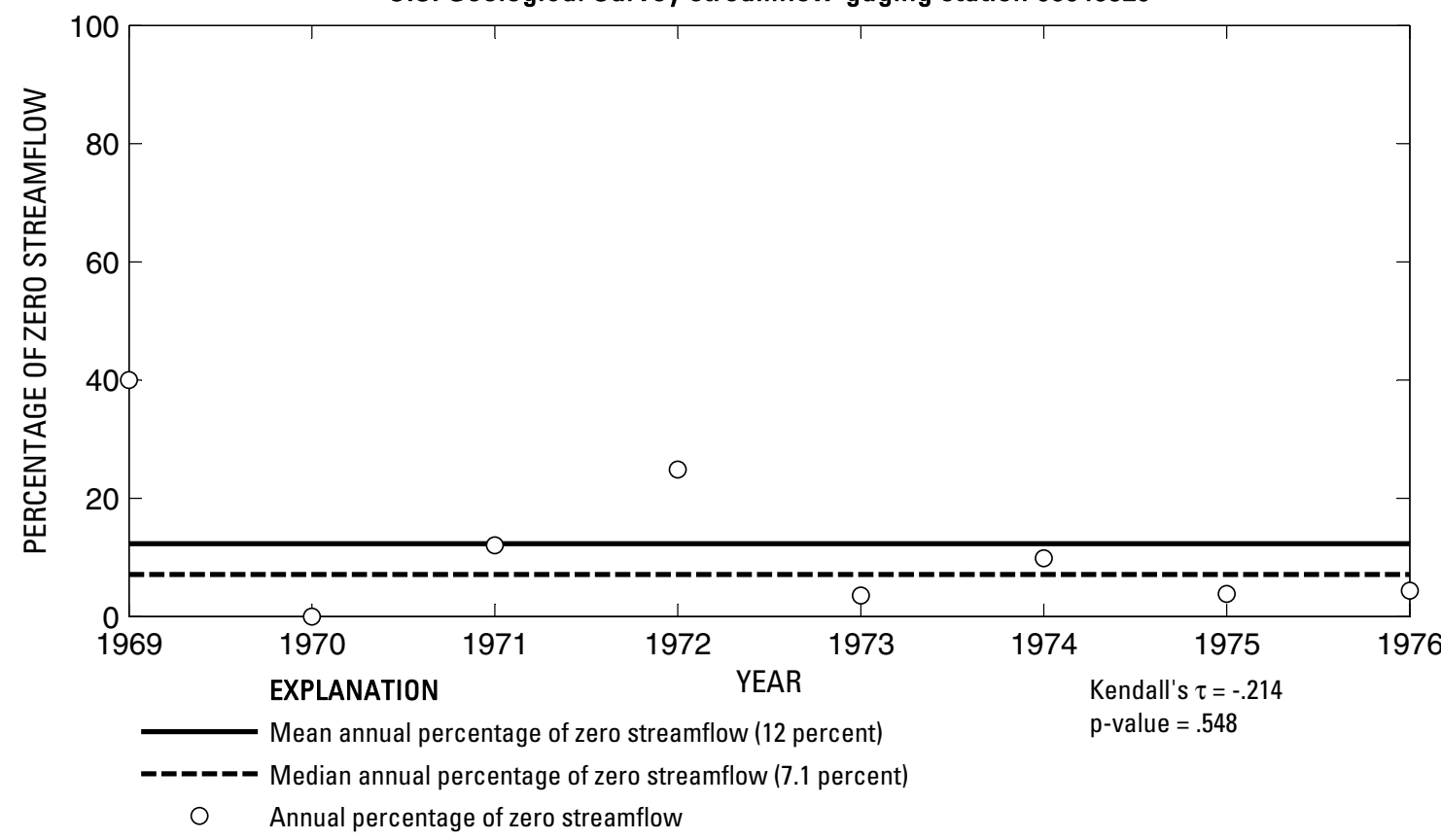

U.S. Geological Survey streamflow-gaging station 08048520

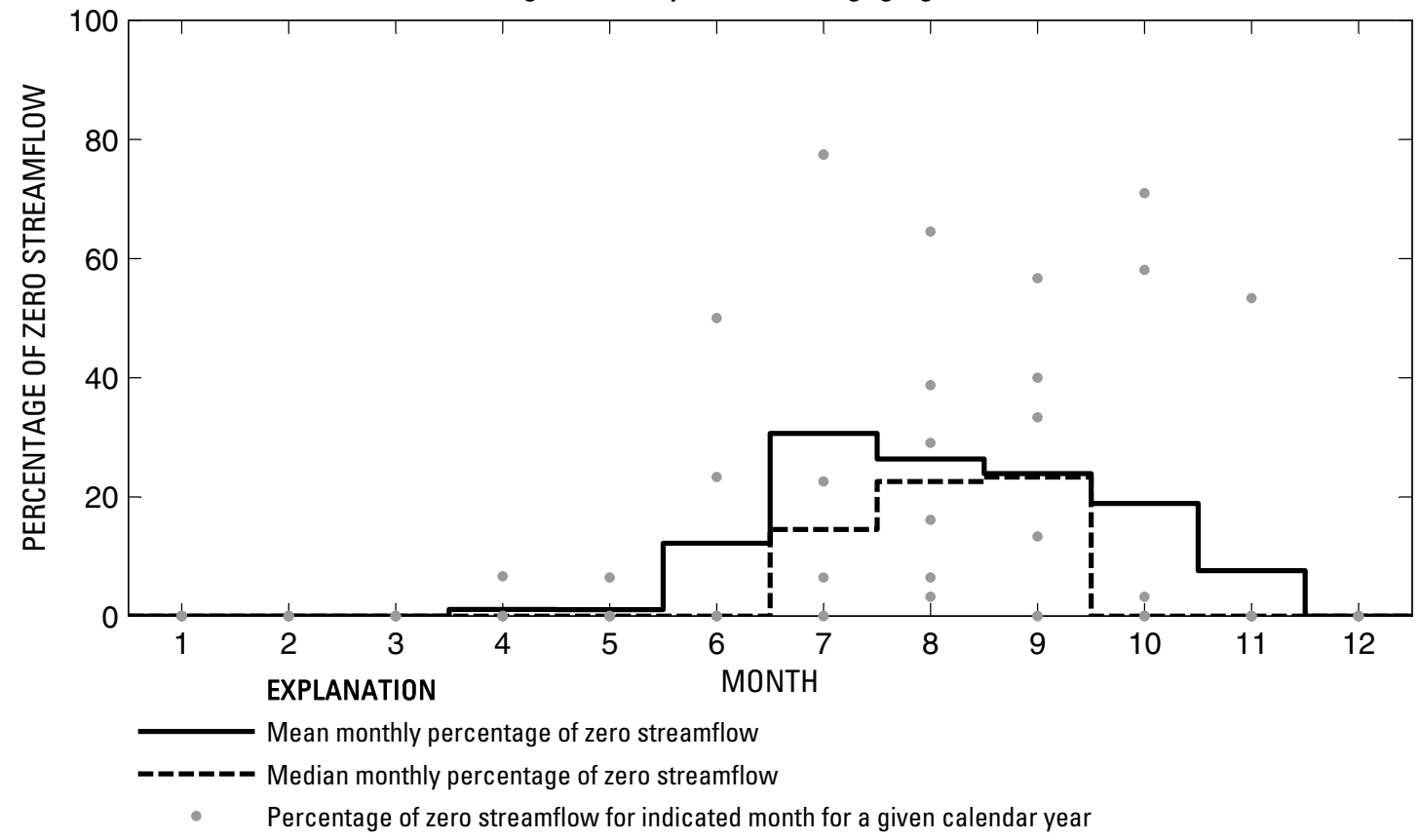

Figure 160. Analysis of percentage of zero daily mean streamflow for U.S. Geological Survey streamflow-gaging station 08048520 Sycamore Creek at Interstate Highway 35 West, Fort Worth, Texas. 


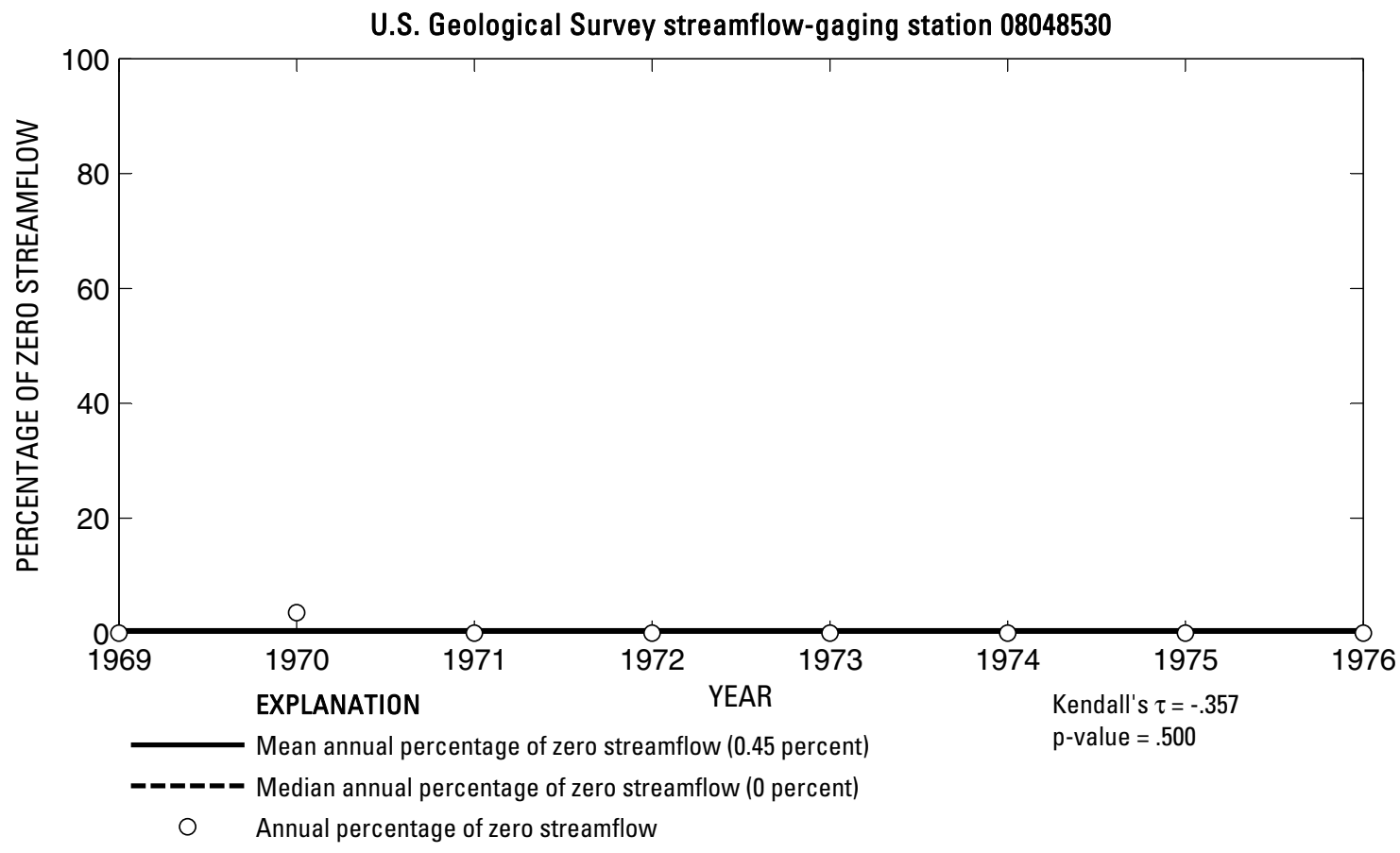

U.S. Geological Survey streamflow-gaging station 08048530

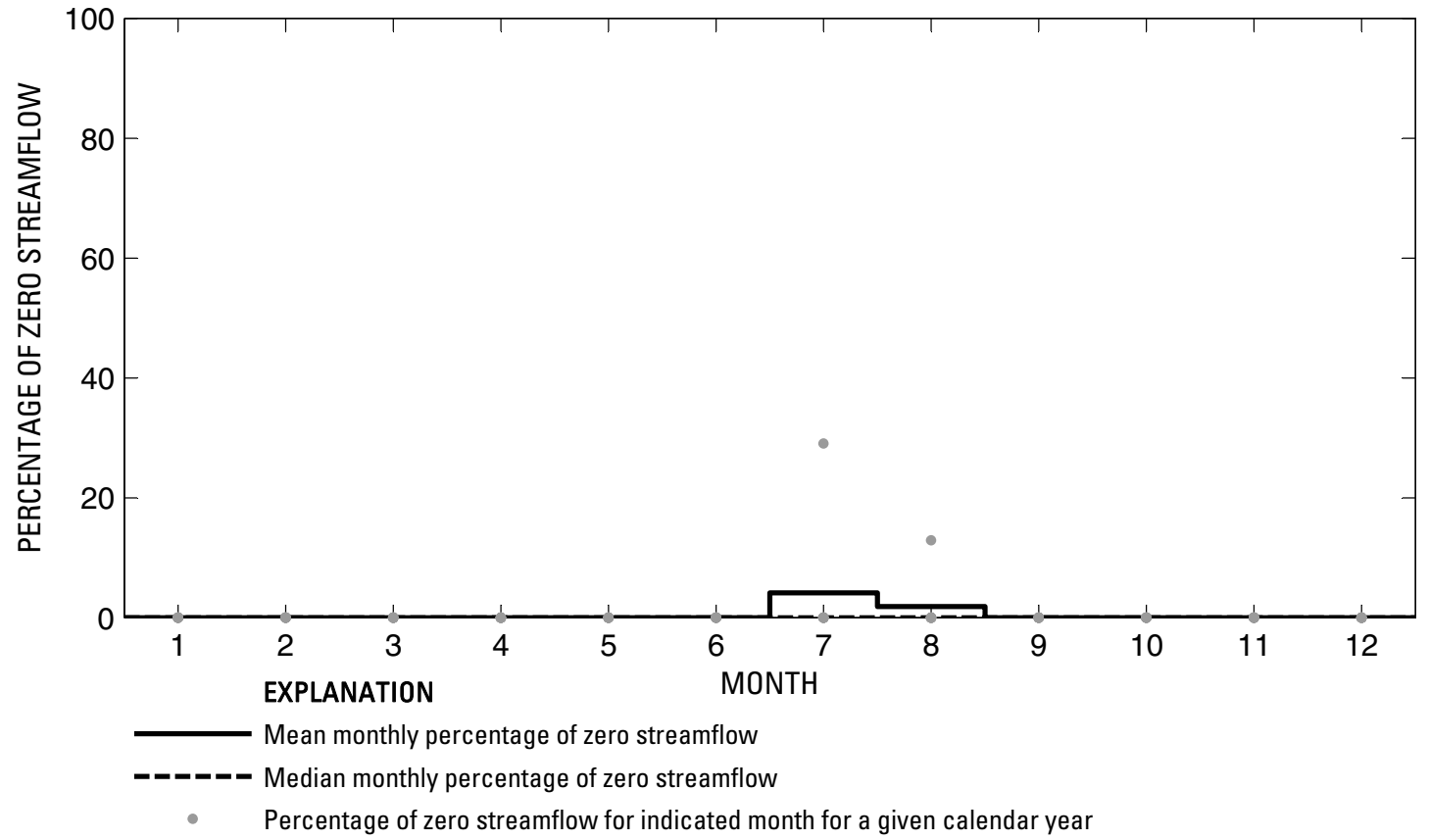

Figure 161. Analysis of percentage of zero daily mean streamflow for U.S. Geological Survey streamflow-gaging station 08048530 Sycamore Creek Tributary above Semenary South Shopping Center, Fort Worth, Texas. 
U.S. Geological Survey streamflow-gaging station 08048540

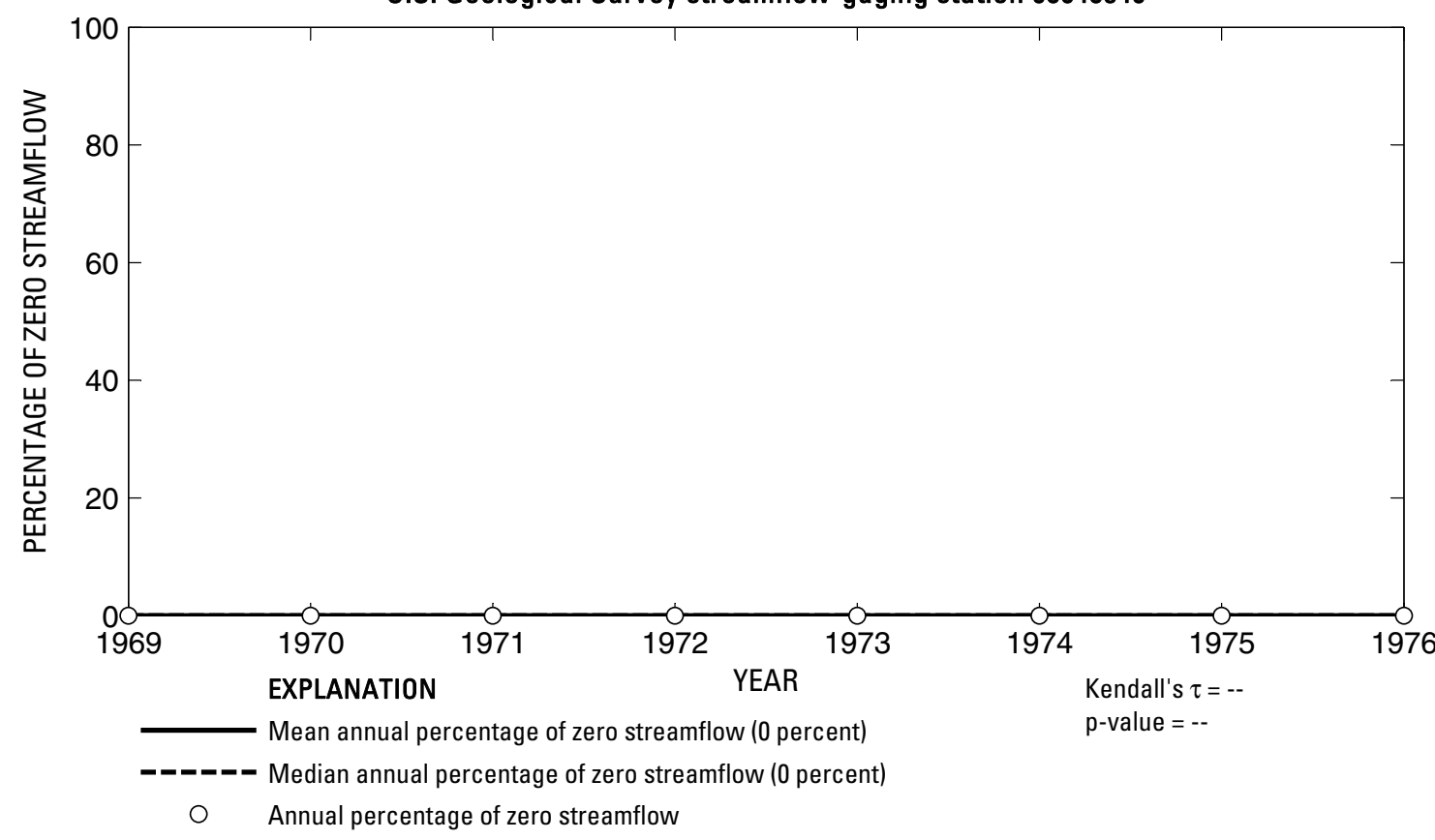

U.S. Geological Survey streamflow-gaging station 08048540

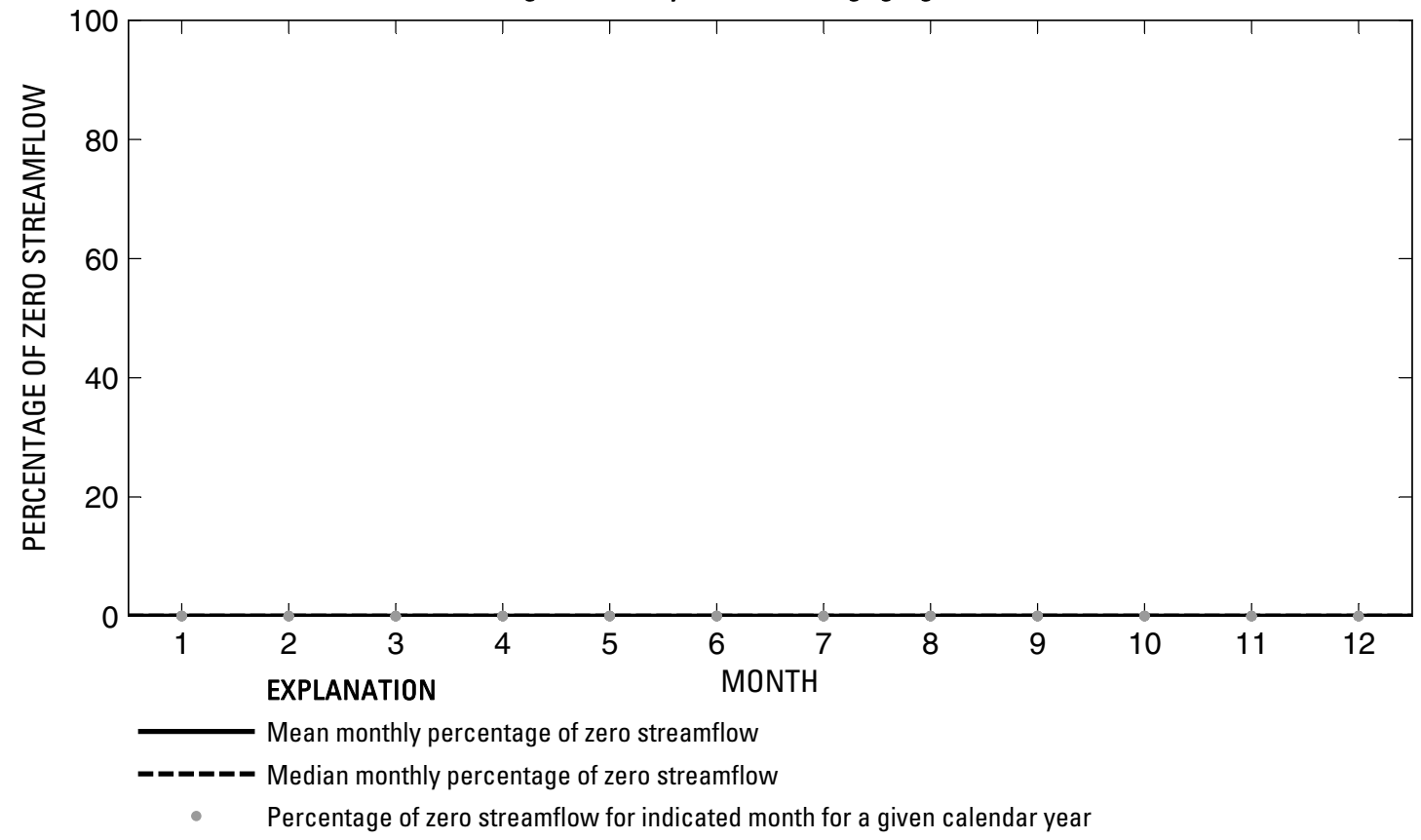

Figure 162. Analysis of percentage of zero daily mean streamflow for U.S. Geological Survey streamflow-gaging station 08048540 Sycamore Creek Tributary at Interstate Highway 35 West, Fort Worth, Texas.

Index of Station Numbers 719 


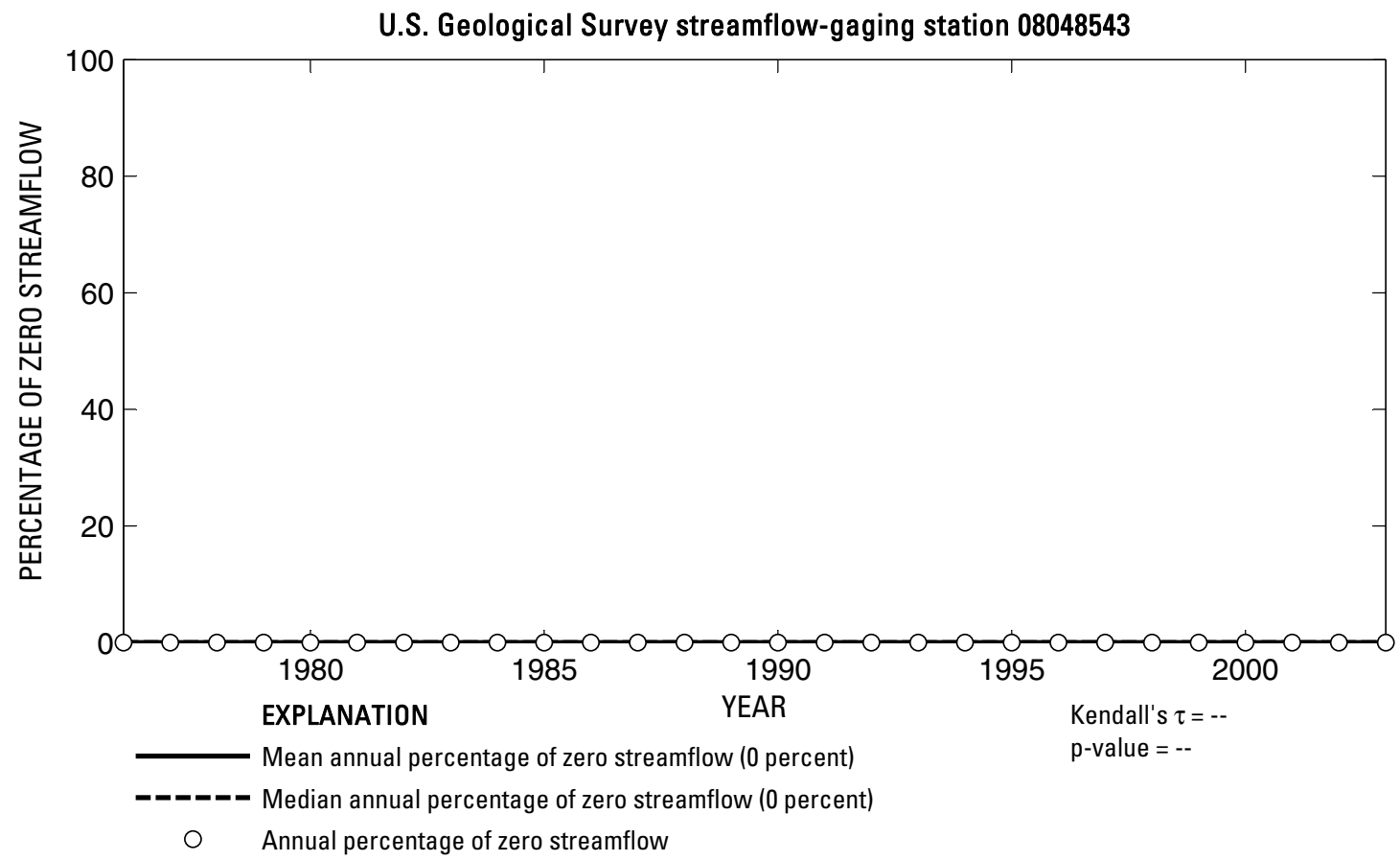

U.S. Geological Survey streamflow-gaging station 08048543

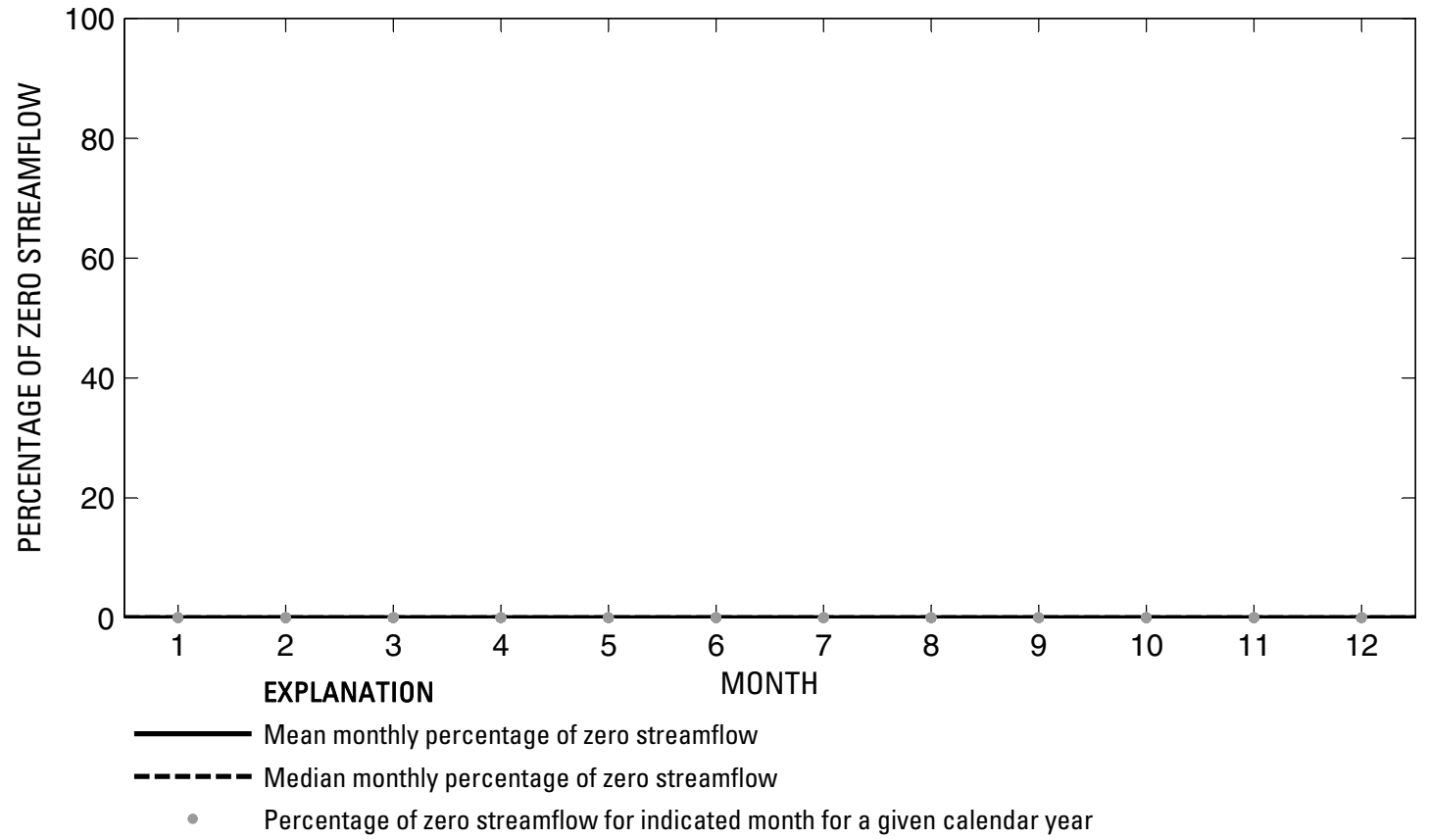

Figure 163. Analysis of percentage of zero daily mean streamflow for U.S. Geological Survey streamflow-gaging station 08048543 West Fork Trinity River at Beach Street, Fort Worth, Texas. 
U.S. Geological Survey streamflow-gaging station 08048600

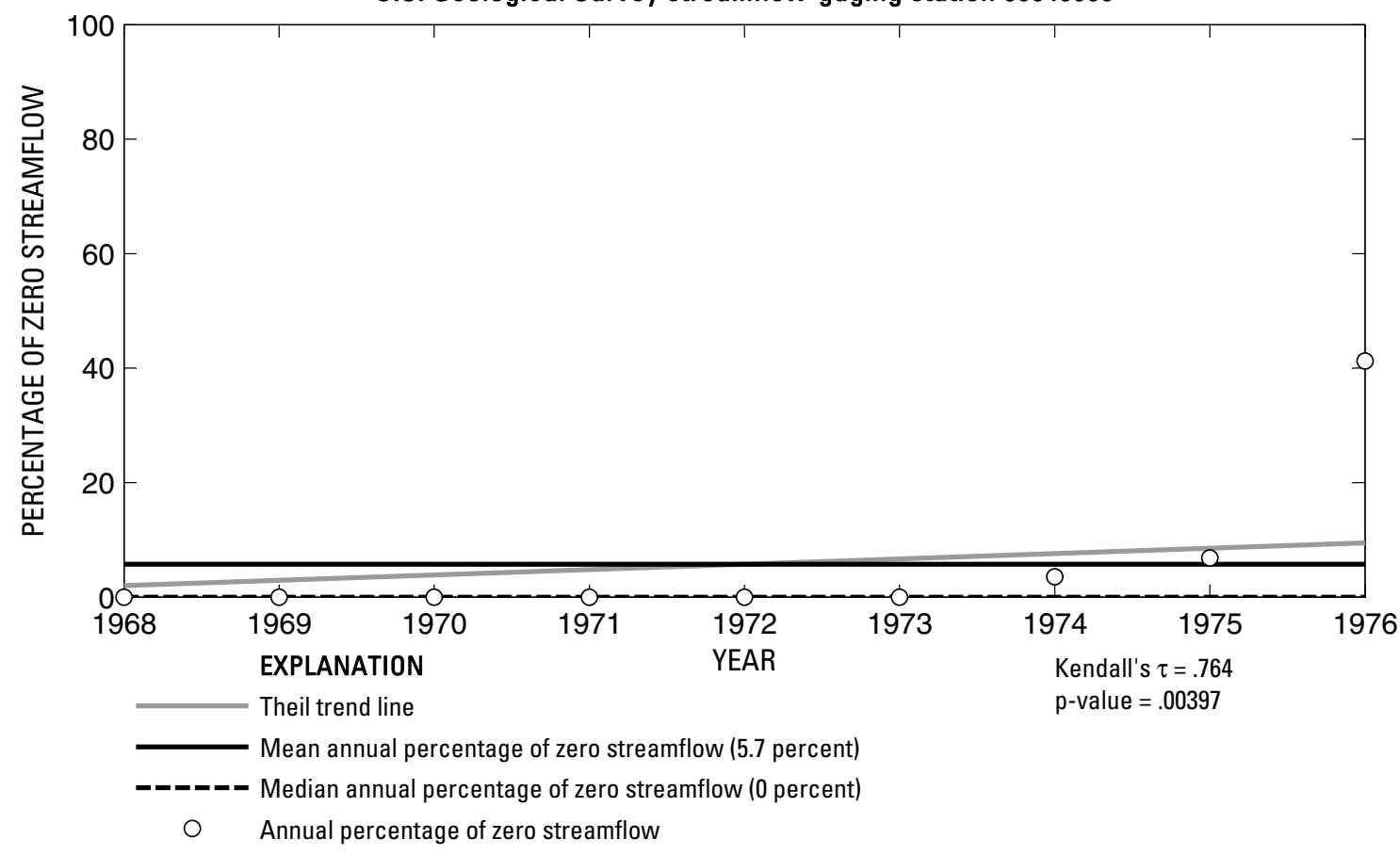

U.S. Geological Survey streamflow-gaging station 08048600

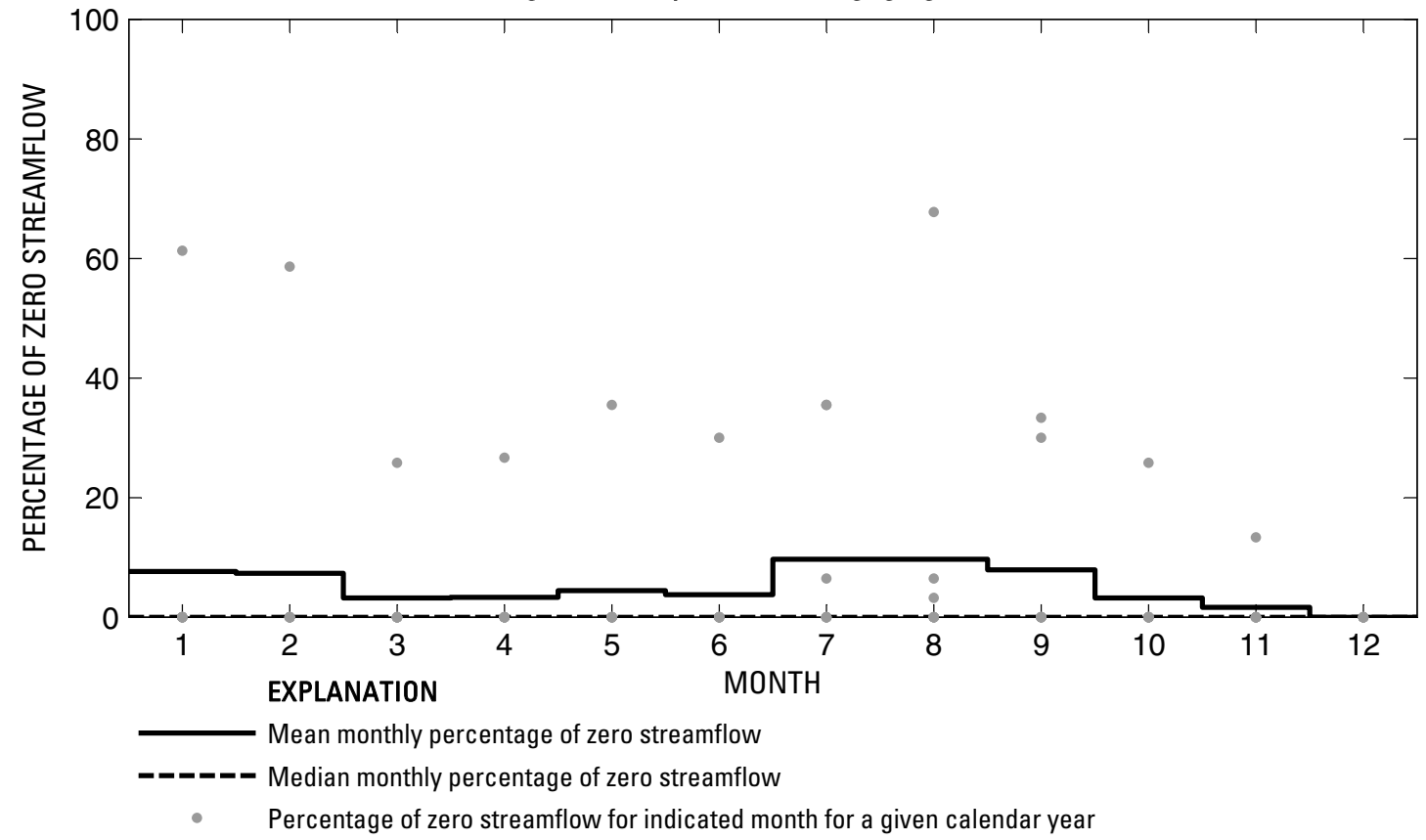

Figure 164. Analysis of percentage of zero daily mean streamflow for U.S. Geological Survey streamflow-gaging station 08048600 Dry Branch at Fain Street, Fort Worth, Texas. 
U.S. Geological Survey streamflow-gaging station 08048800

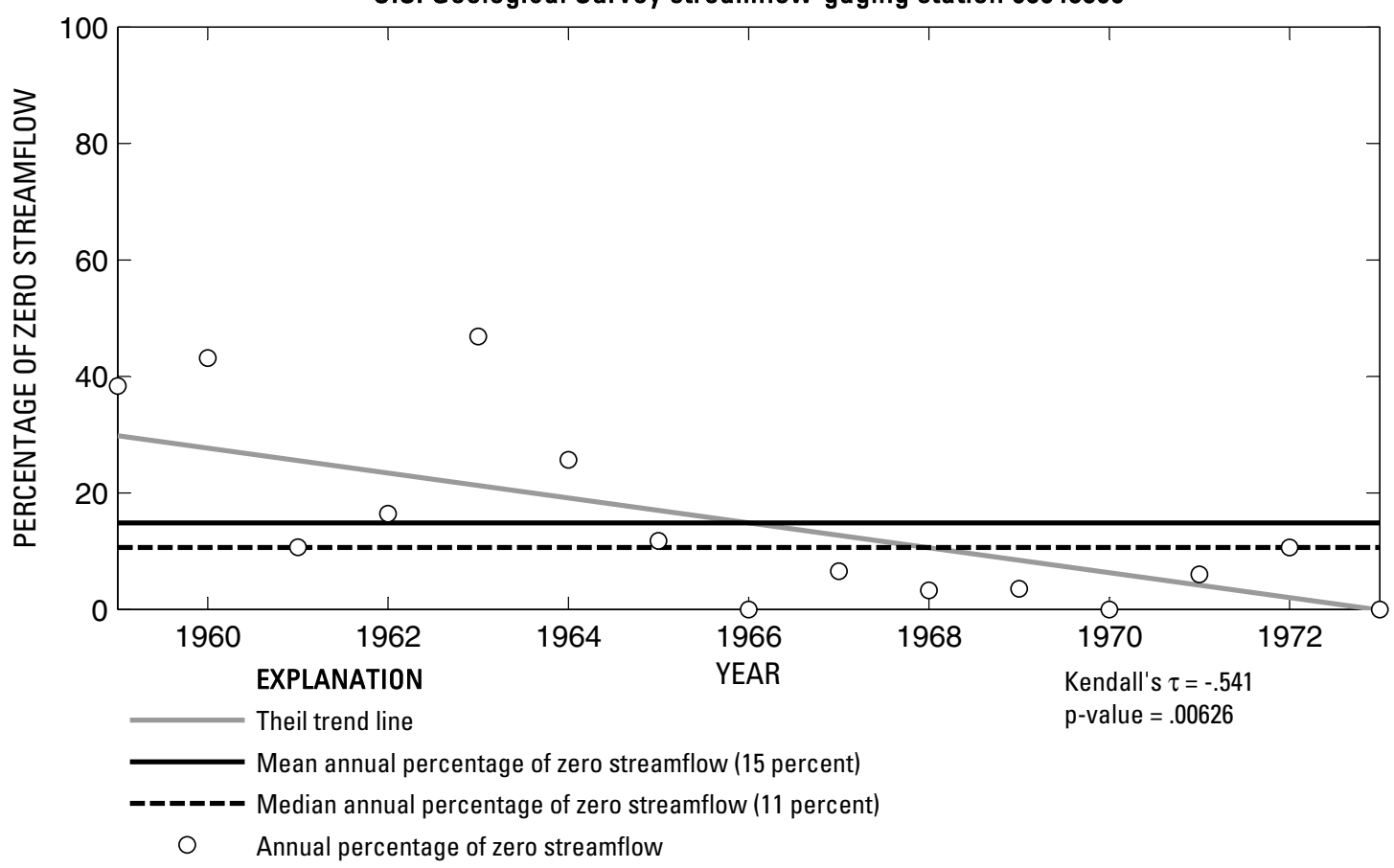

U.S. Geological Survey streamflow-gaging station 08048800

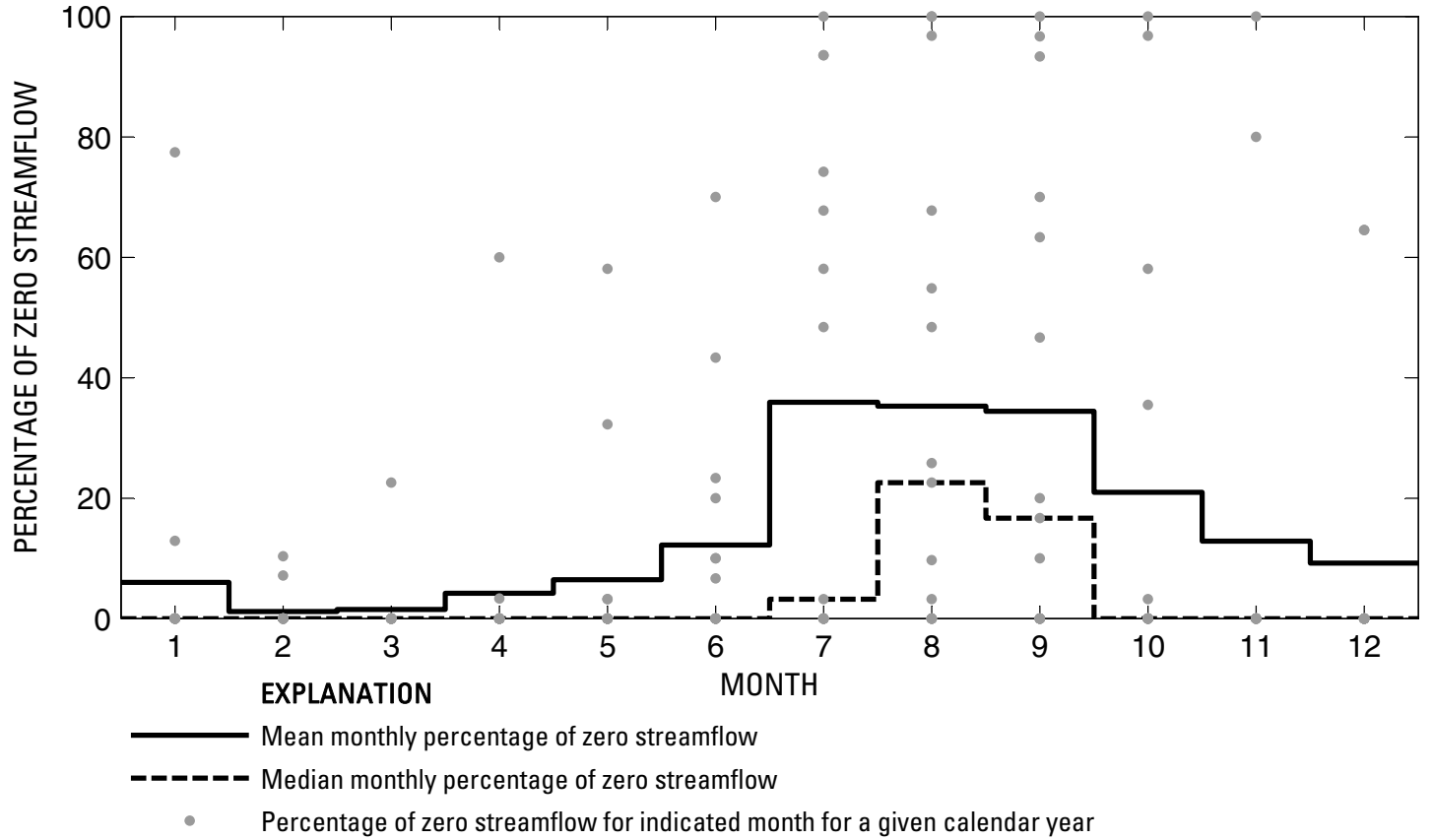

Figure 165. Analysis of percentage of zero daily mean streamflow for U.S. Geological Survey streamflow-gaging station 08048800 Big Fossil Creek at Haltom City, Texas. 
U.S. Geological Survey streamflow-gaging station 08048850

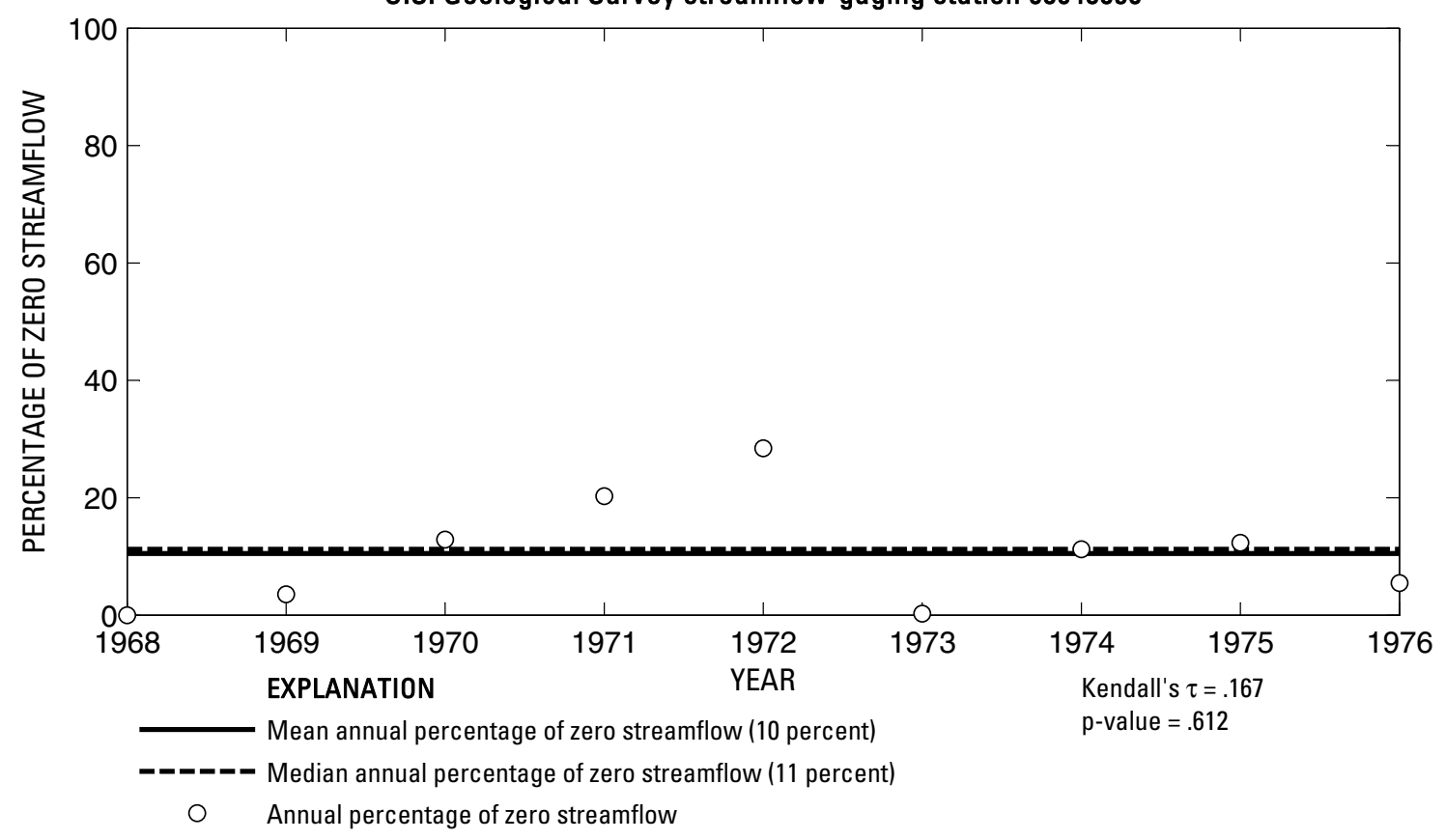

U.S. Geological Survey streamflow-gaging station 08048850

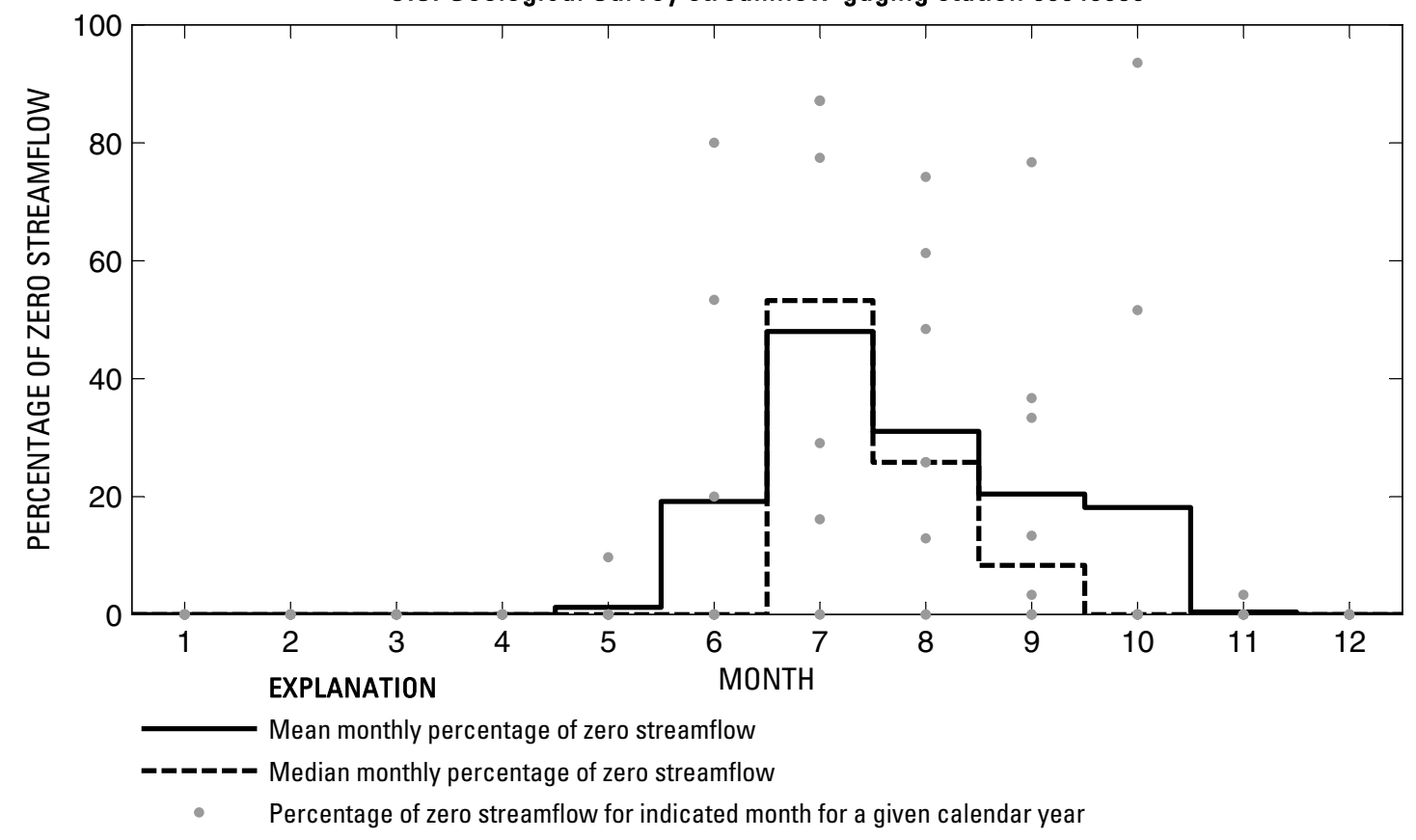

Figure 166. Analysis of percentage of zero daily mean streamflow for U.S. Geological Survey streamflow-gaging station 08048850 Little Fossil Creek at Mesquite Street, Fort Worth, Texas. 
U.S. Geological Survey streamflow-gaging station 08048970

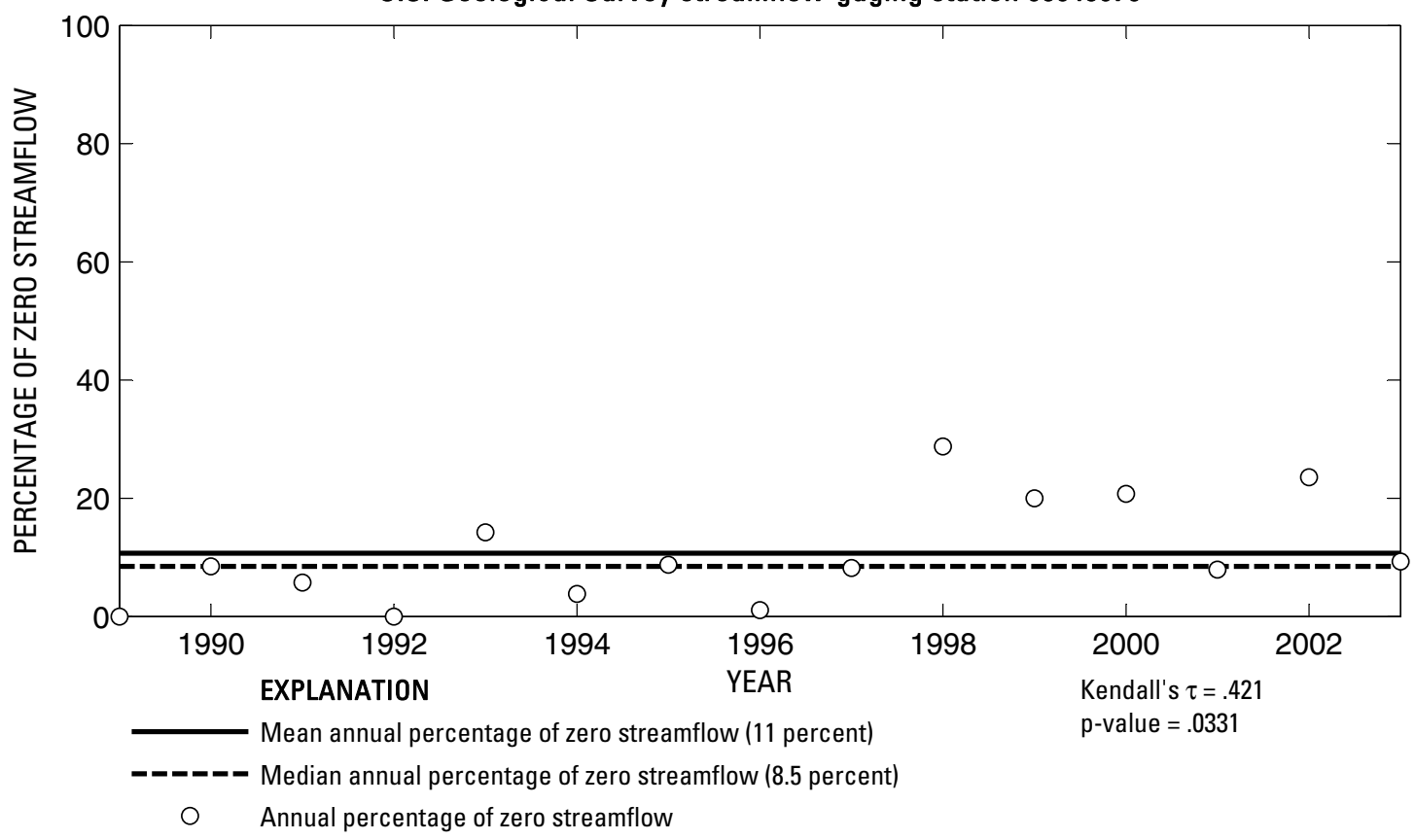

U.S. Geological Survey streamflow-gaging station 08048970

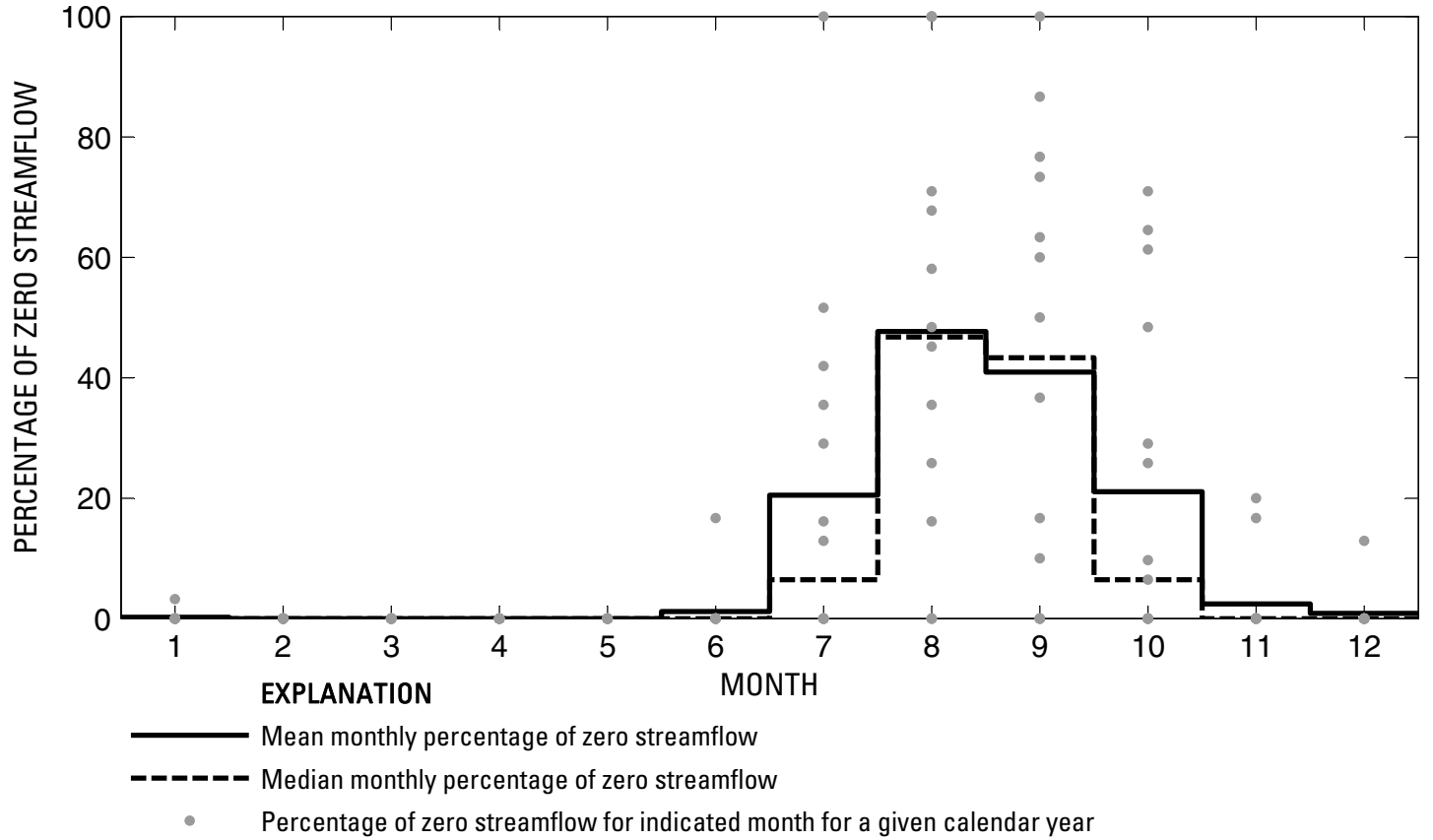

Figure 167. Analysis of percentage of zero daily mean streamflow for U.S. Geological Survey streamflow-gaging station 08048970 Village Creek at Everman, Texas. 
U.S. Geological Survey streamflow-gaging station 08048980

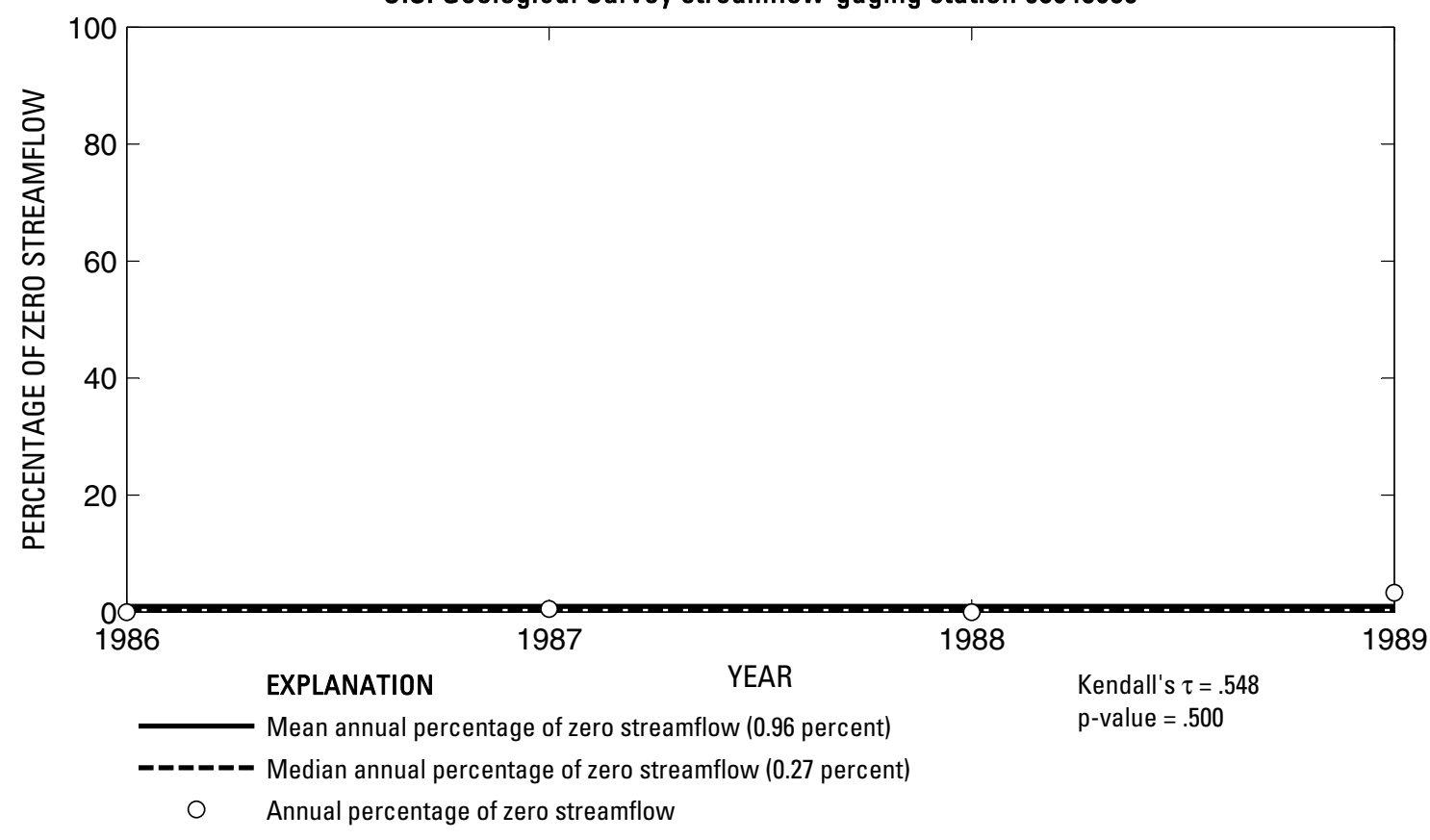

U.S. Geological Survey streamflow-gaging station 08048980

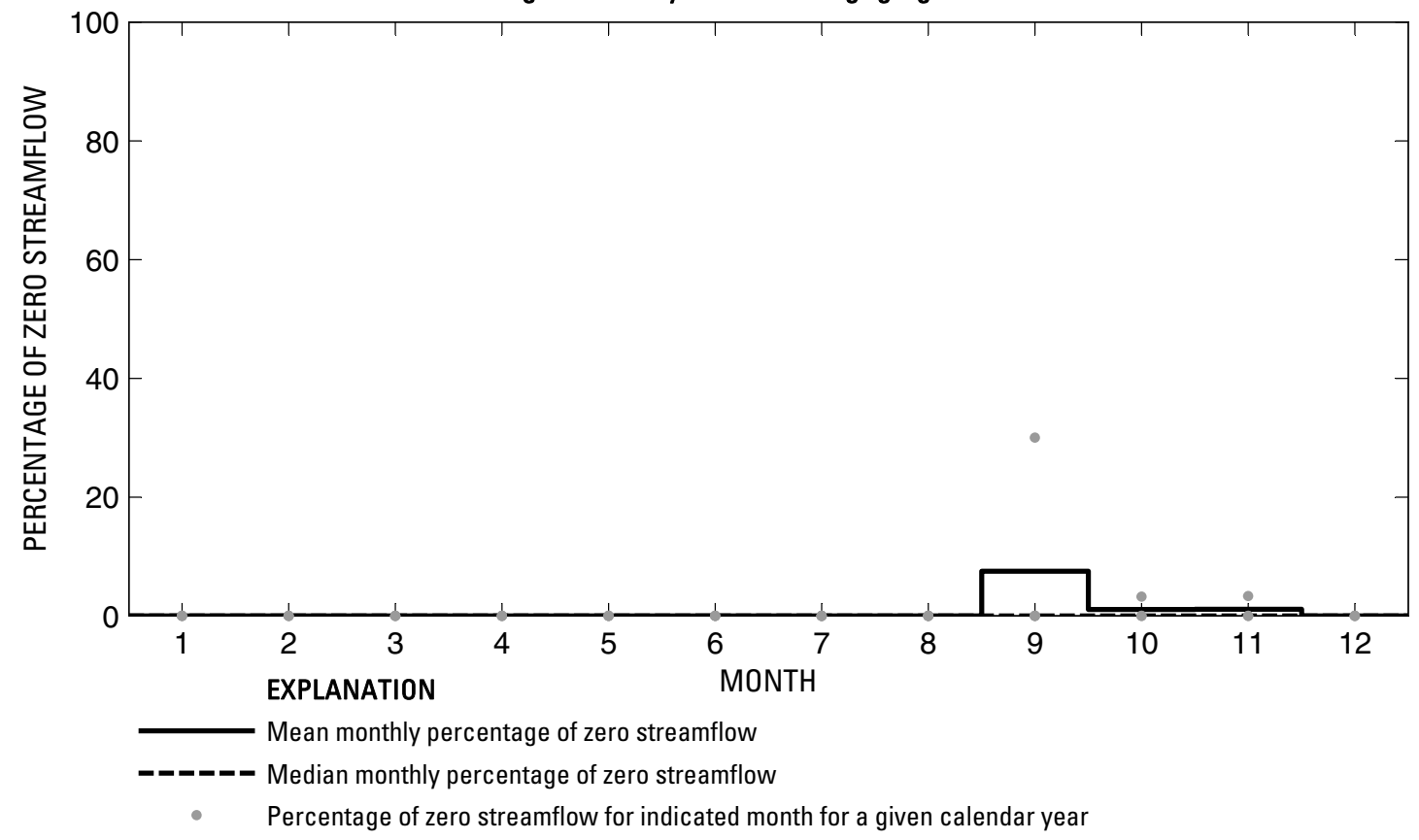

Figure 168. Analysis of percentage of zero daily mean streamflow for U.S. Geological Survey streamflow-gaging station 08048980 Village Creek at Kennedale, Texas. 
U.S. Geological Survey streamflow-gaging station 08049000

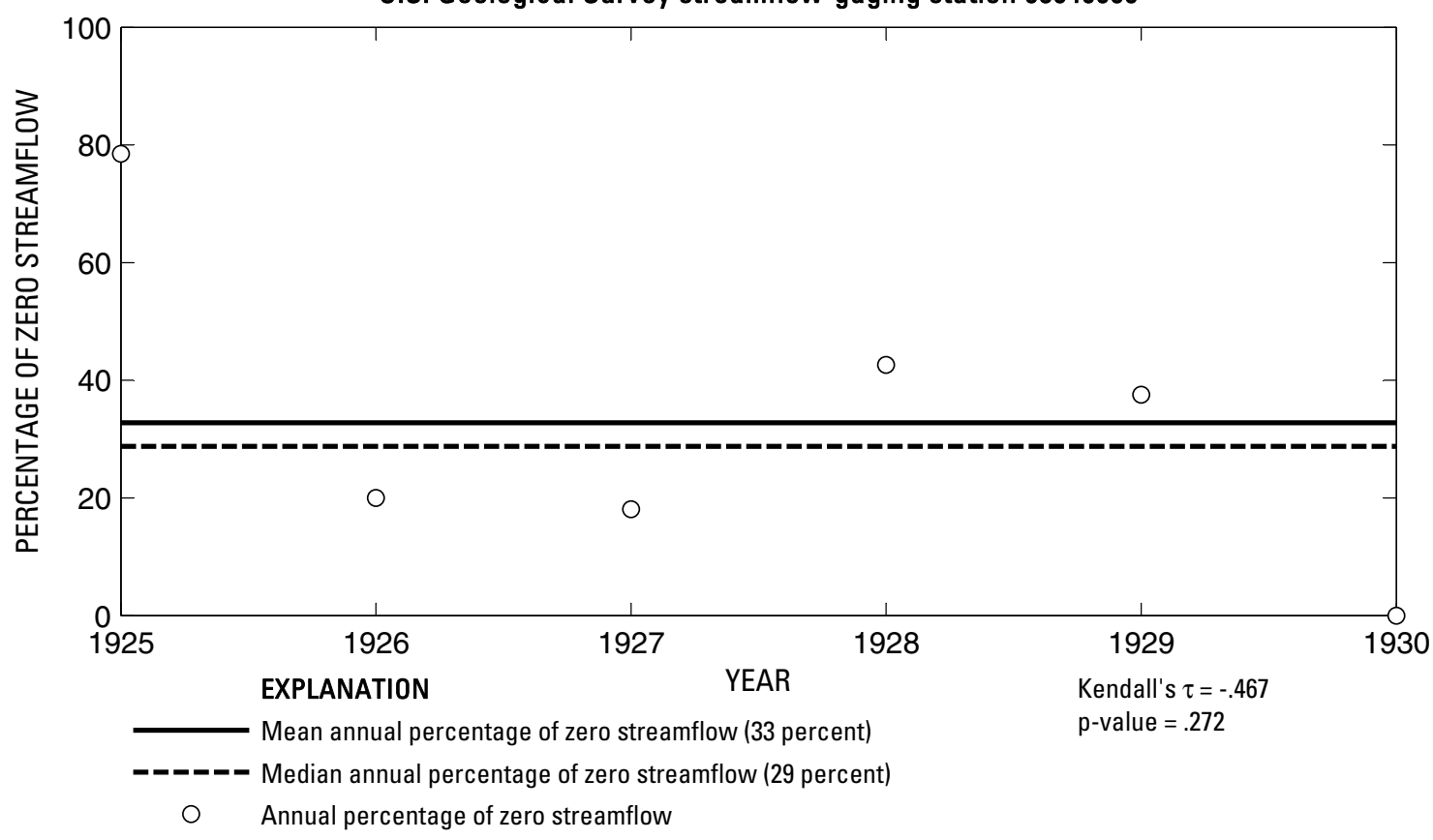

U.S. Geological Survey streamflow-gaging station 08049000

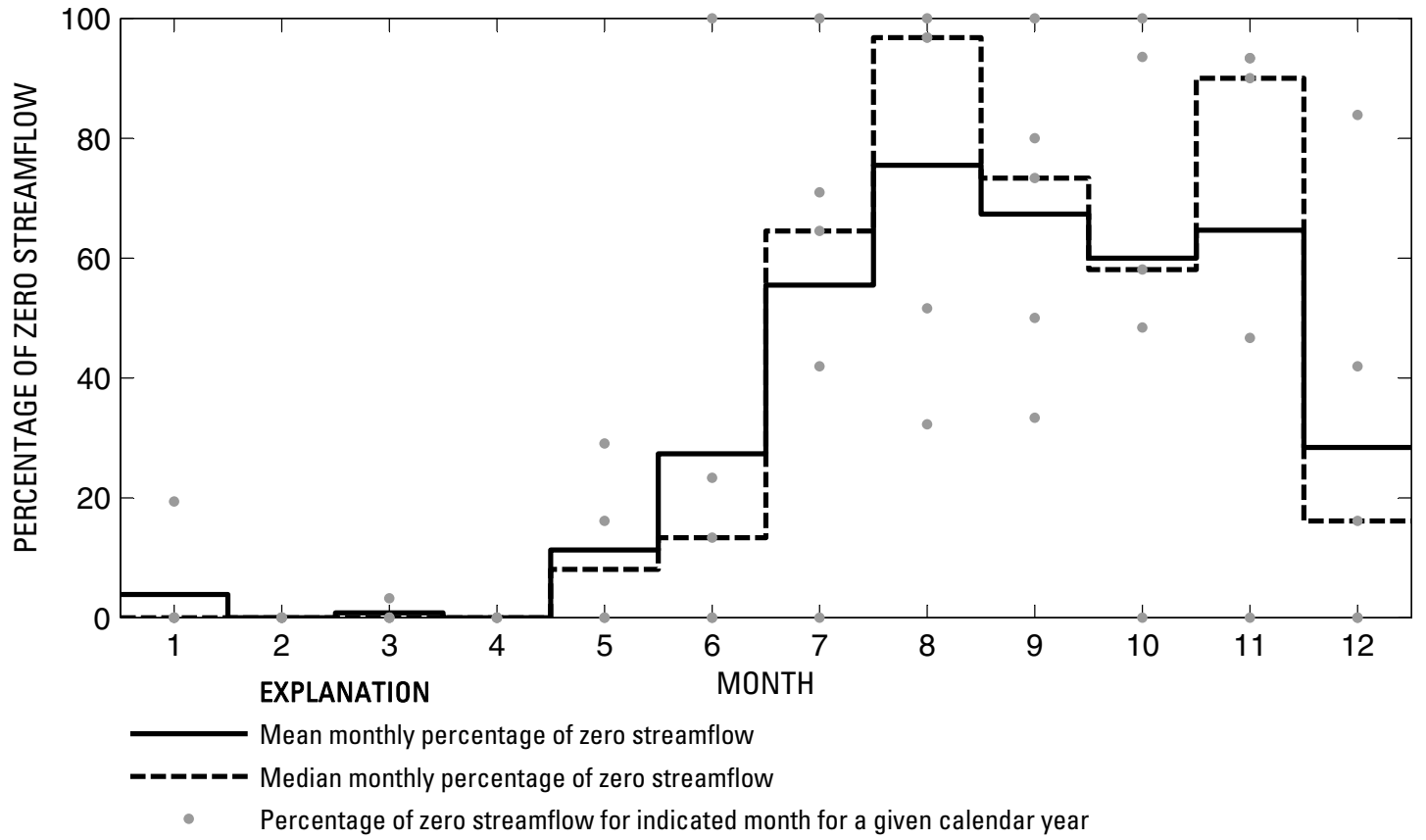

Figure 169. Analysis of percentage of zero daily mean streamflow for U.S. Geological Survey streamflow-gaging station 08049000 Village Creek near Handley, Texas. 
U.S. Geological Survey streamflow-gaging station 08049500

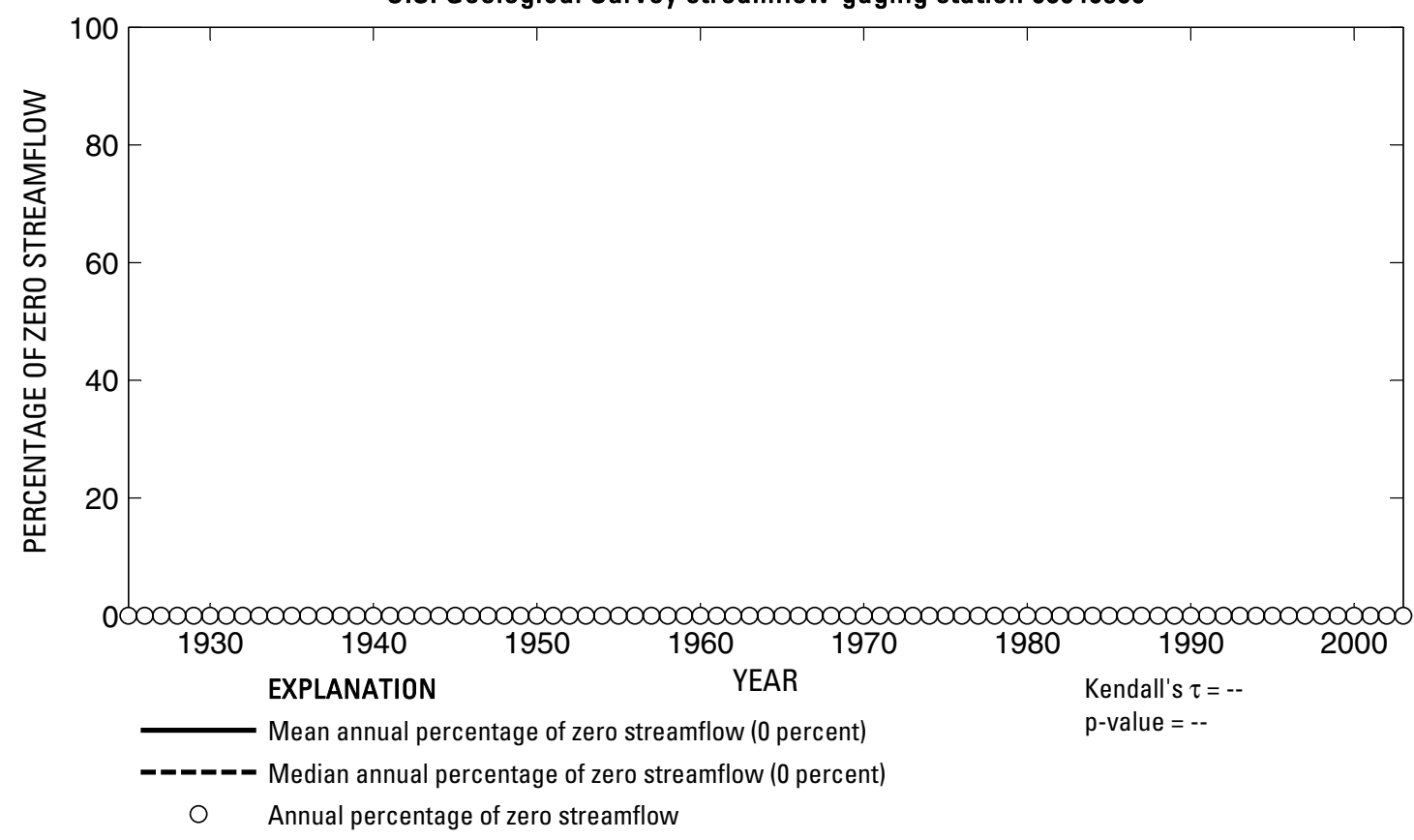

U.S. Geological Survey streamflow-gaging station 08049500

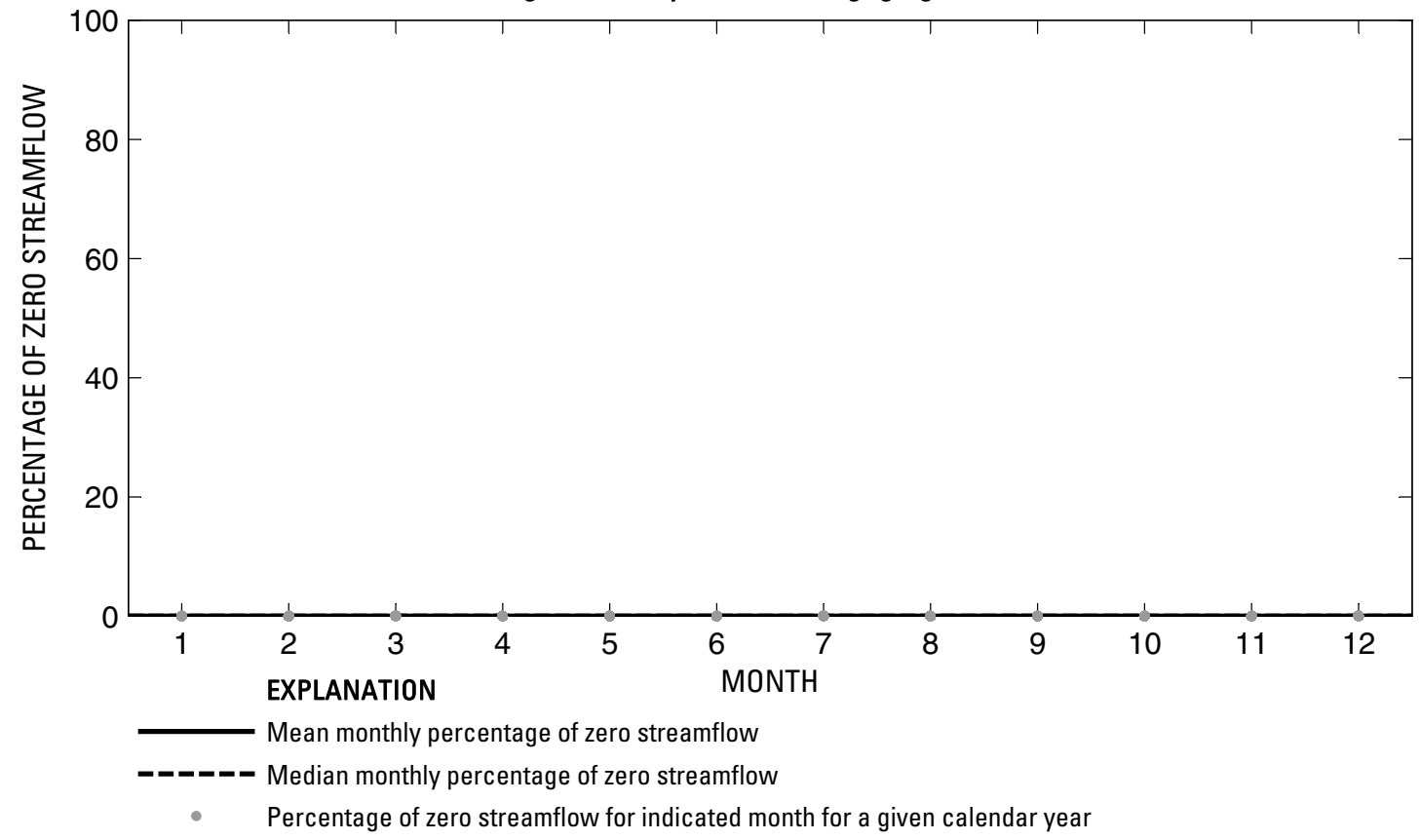

Figure 170. Analysis of percentage of zero daily mean streamflow for U.S. Geological Survey streamflow-gaging station 08049500 West Fork Trinity River at Grand Prairie, Texas. 
U.S. Geological Survey streamflow-gaging station 08049550

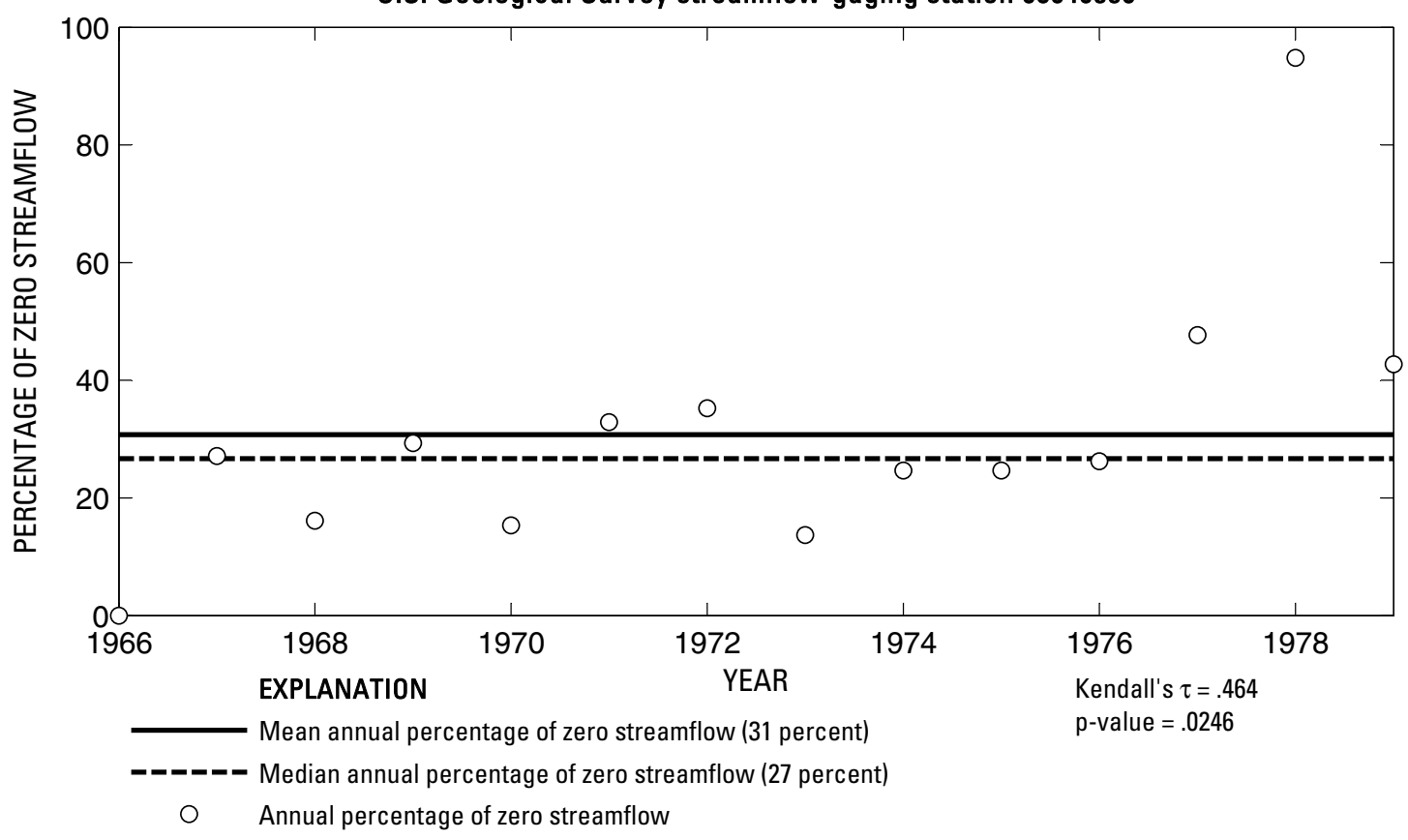

U.S. Geological Survey streamflow-gaging station 08049550

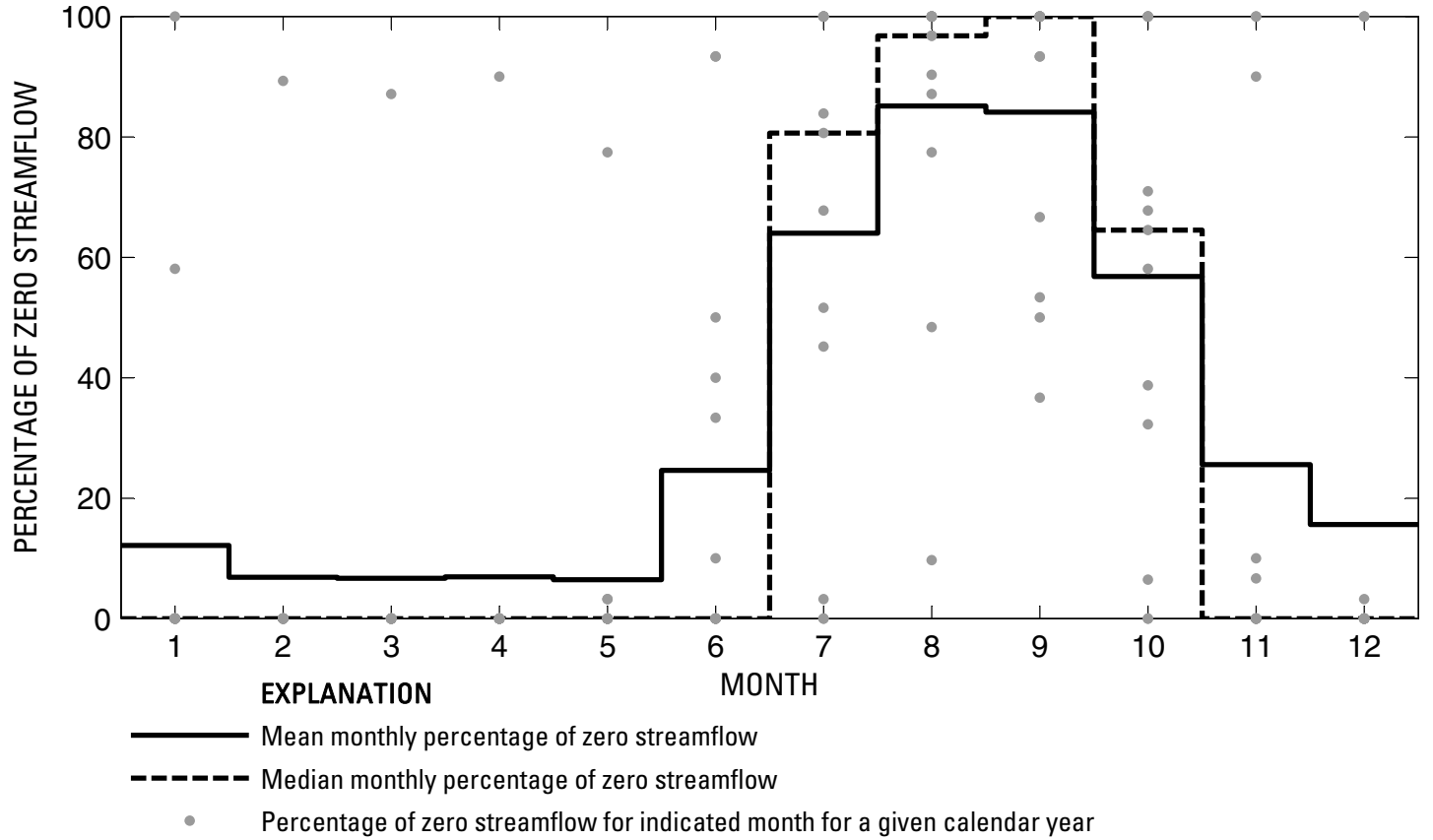

Figure 171. Analysis of percentage of zero daily mean streamflow for U.S. Geological Survey streamflow-gaging station 08049550 Big Bear Creek near Grapevine, Texas. 
U.S. Geological Survey streamflow-gaging station 08049553

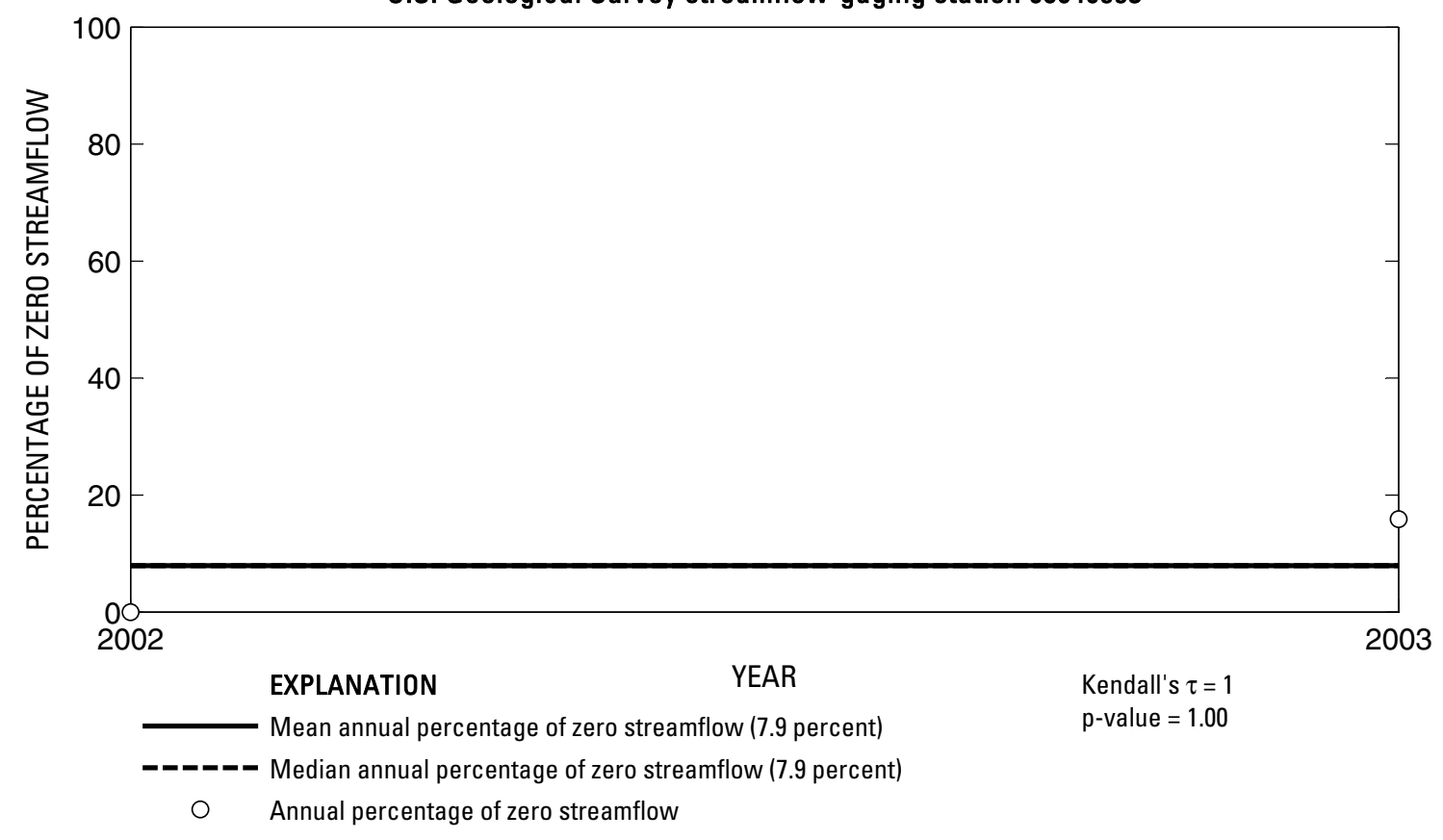

U.S. Geological Survey streamflow-gaging station 08049553

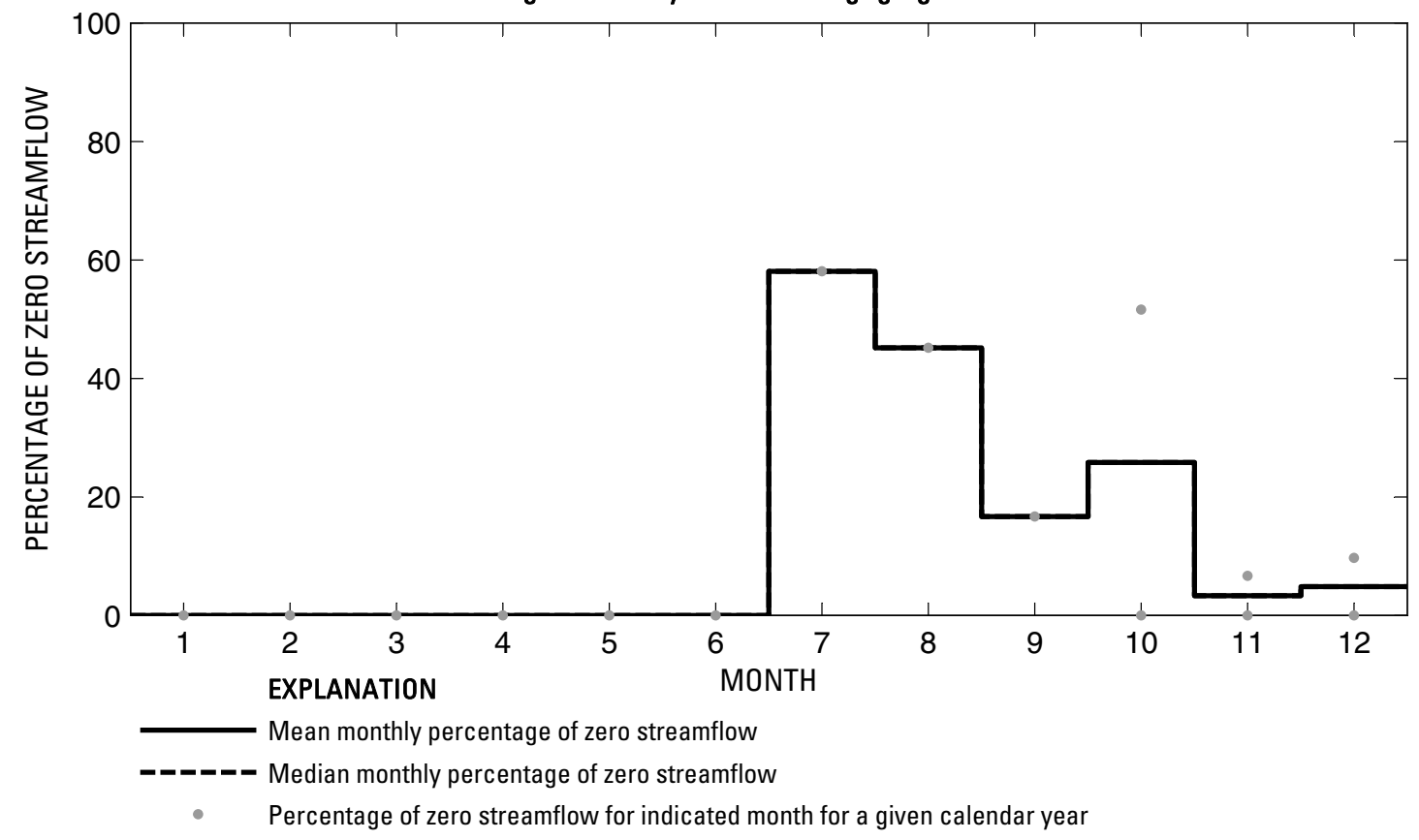

Figure 172. Analysis of percentage of zero daily mean streamflow for U.S. Geological Survey streamflow-gaging station 08049553 Big Bear Creek at Euless/Grapevine Road near Grapevine, Texas. 
U.S. Geological Survey streamflow-gaging station 08049556

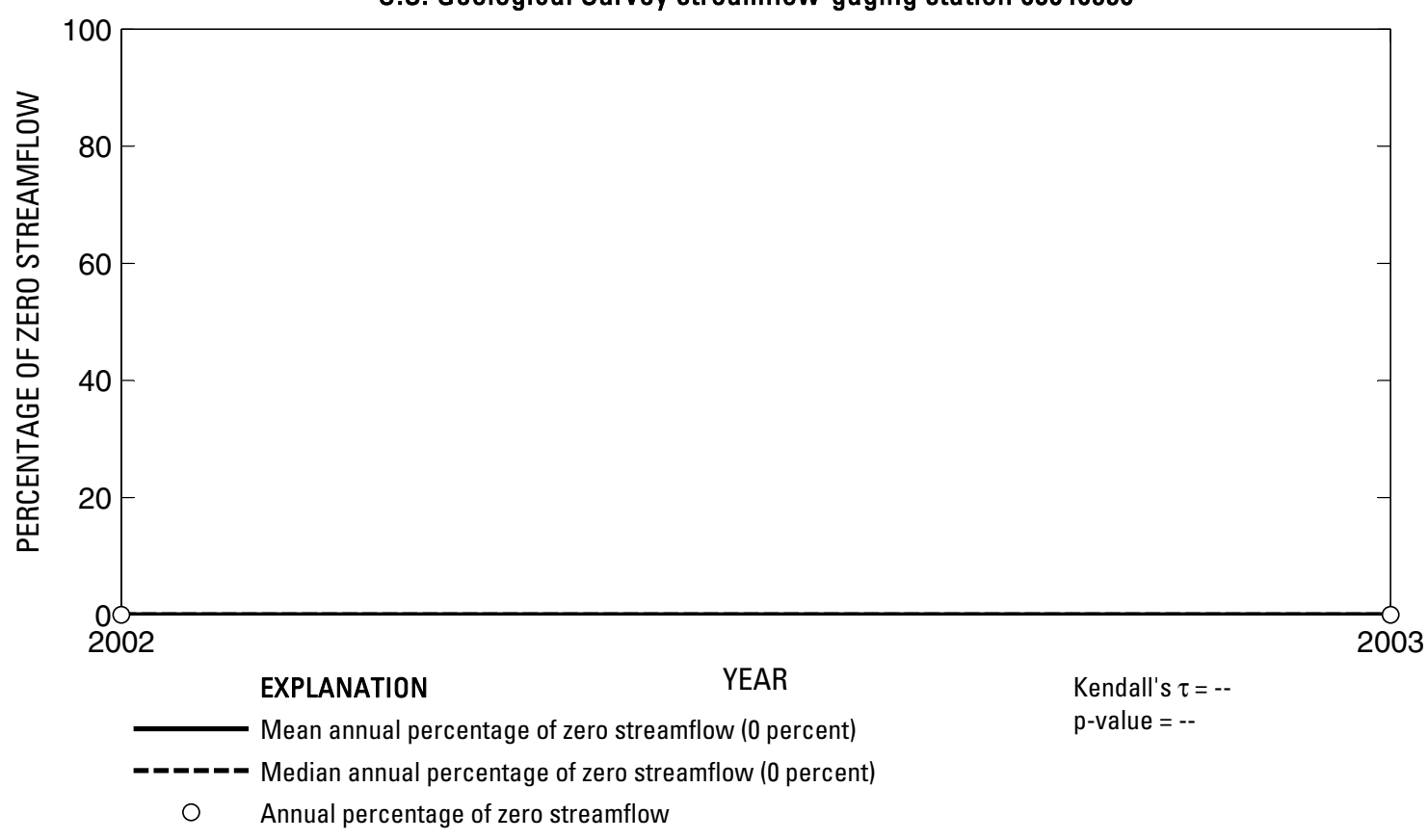

U.S. Geological Survey streamflow-gaging station 08049556

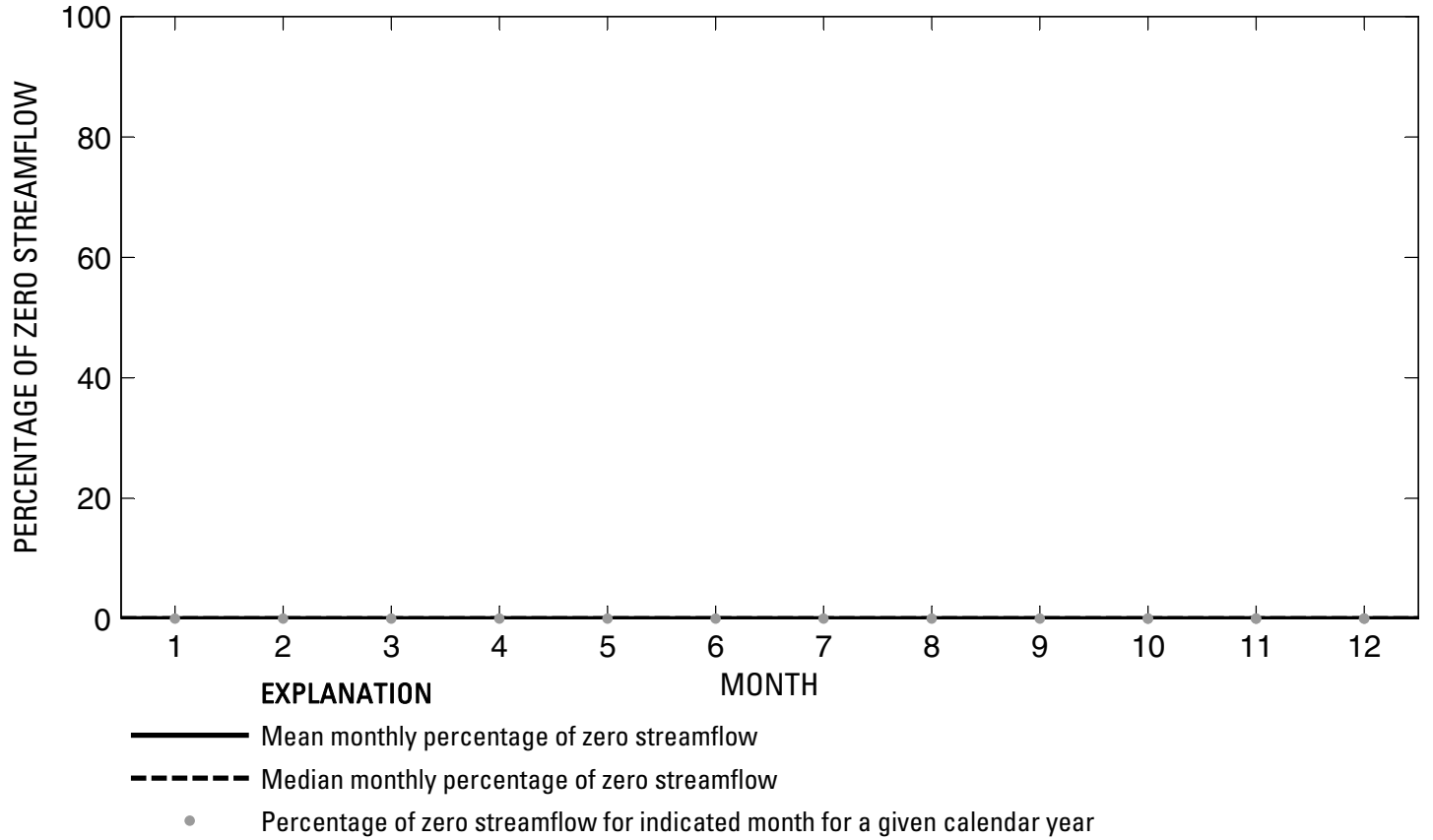

Figure 173. Analysis of percentage of zero daily mean streamflow for U.S. Geological Survey streamflow-gaging station 08049556 Unnamed Tributary Big Bear Creek (Outflow 19) near Euless, Texas. 
U.S. Geological Survey streamflow-gaging station 08049565

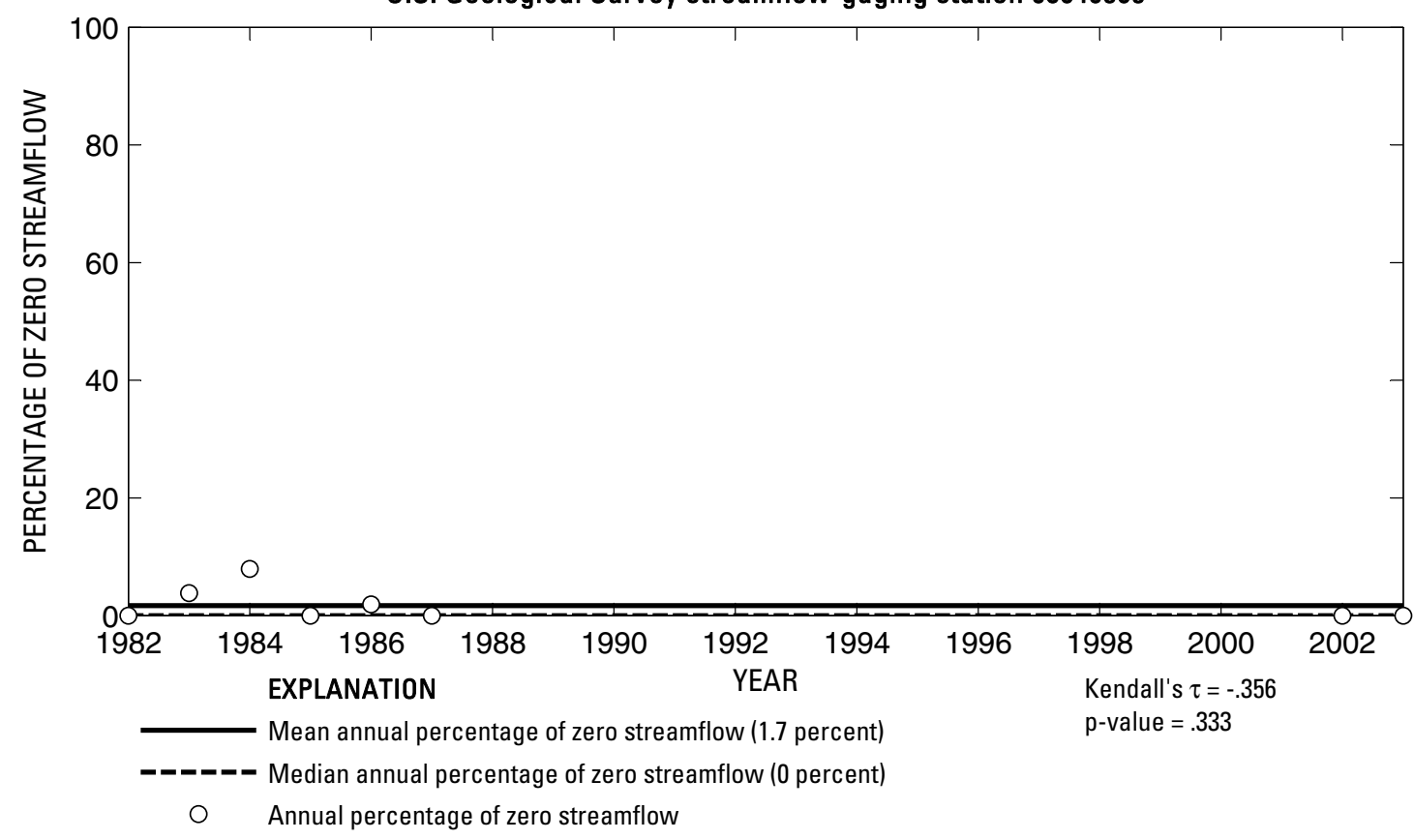

U.S. Geological Survey streamflow-gaging station 08049565

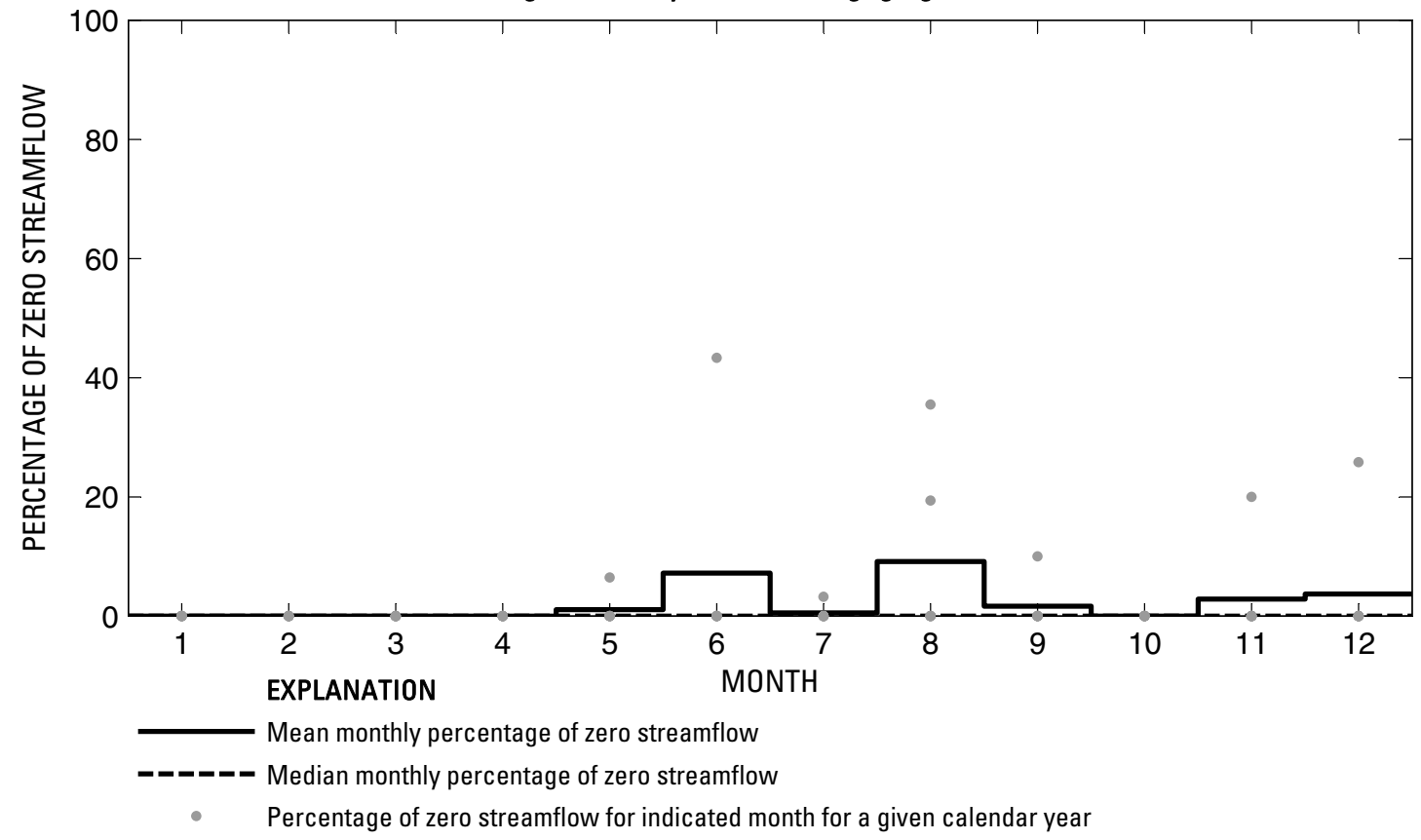

Figure 174. Analysis of percentage of zero daily mean streamflow for U.S. Geological Survey streamflow-gaging station 08049565 Trigg Branch at DFW Airport near Euless, Texas. 
U.S. Geological Survey streamflow-gaging station 08049569

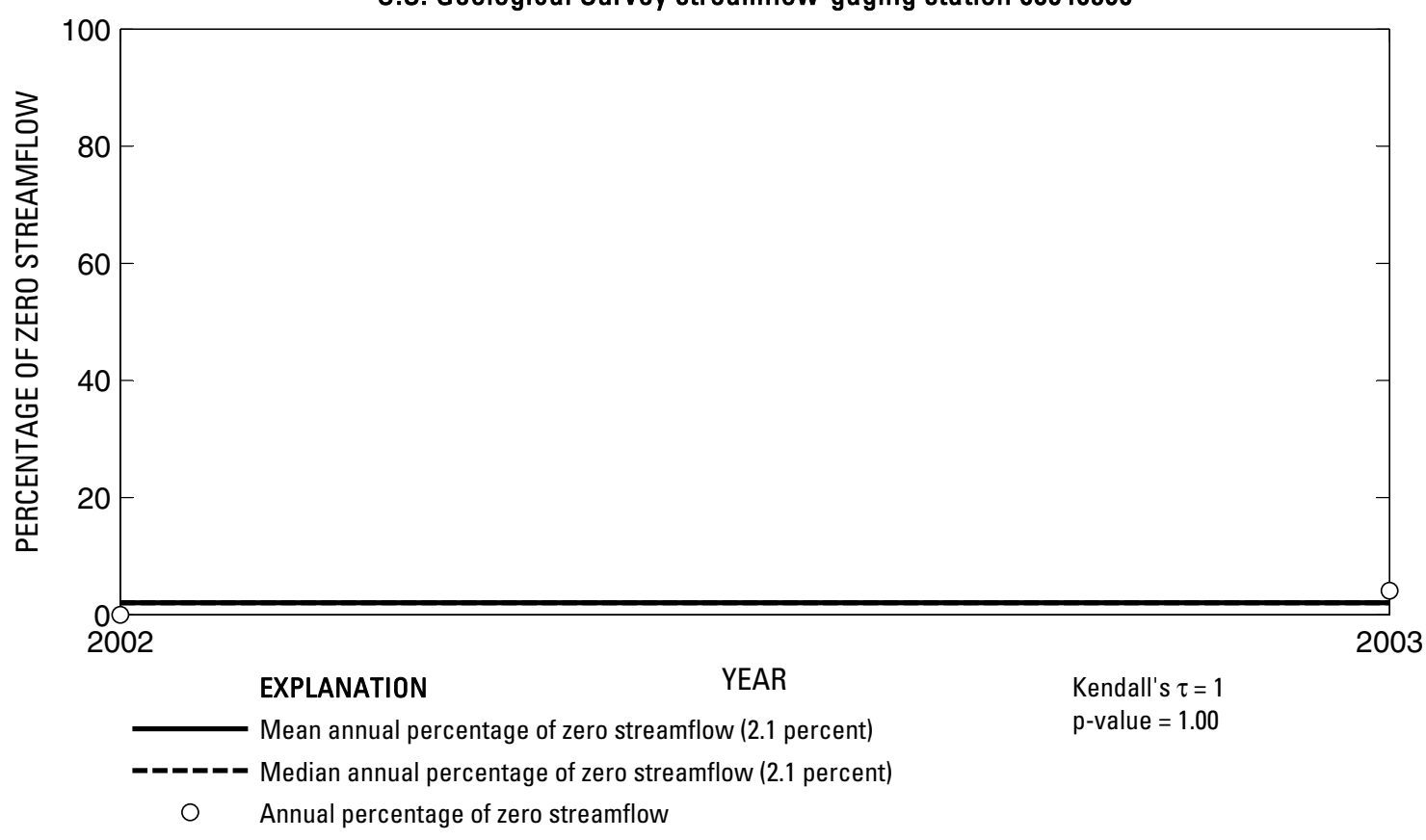

U.S. Geological Survey streamflow-gaging station 08049569

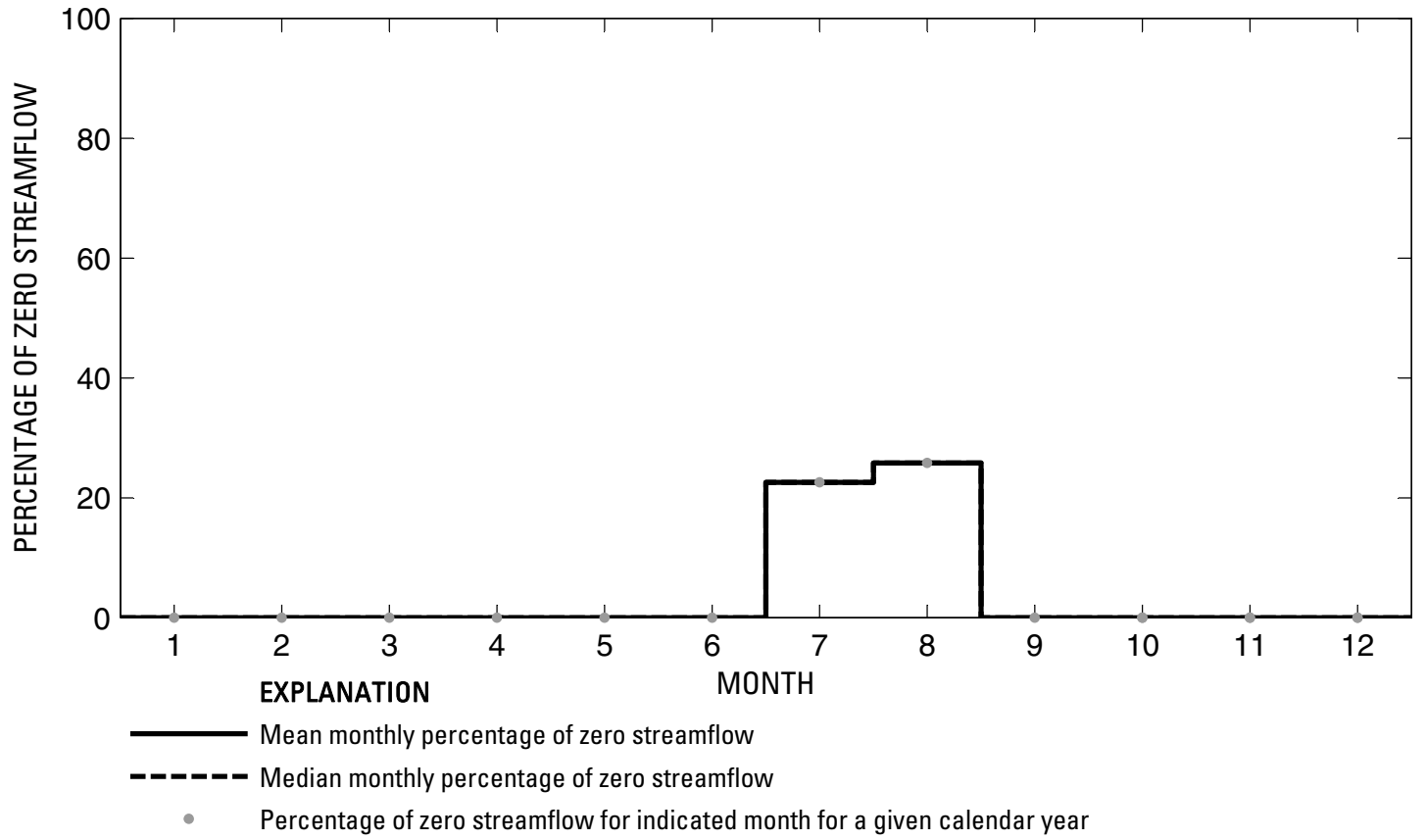

Figure 175. Analysis of percentage of zero daily mean streamflow for U.S. Geological Survey streamflow-gaging station 08049569 Big Bear Creek at State Highway 183 near Euless, Texas. 
U.S. Geological Survey streamflow-gaging station 08049580

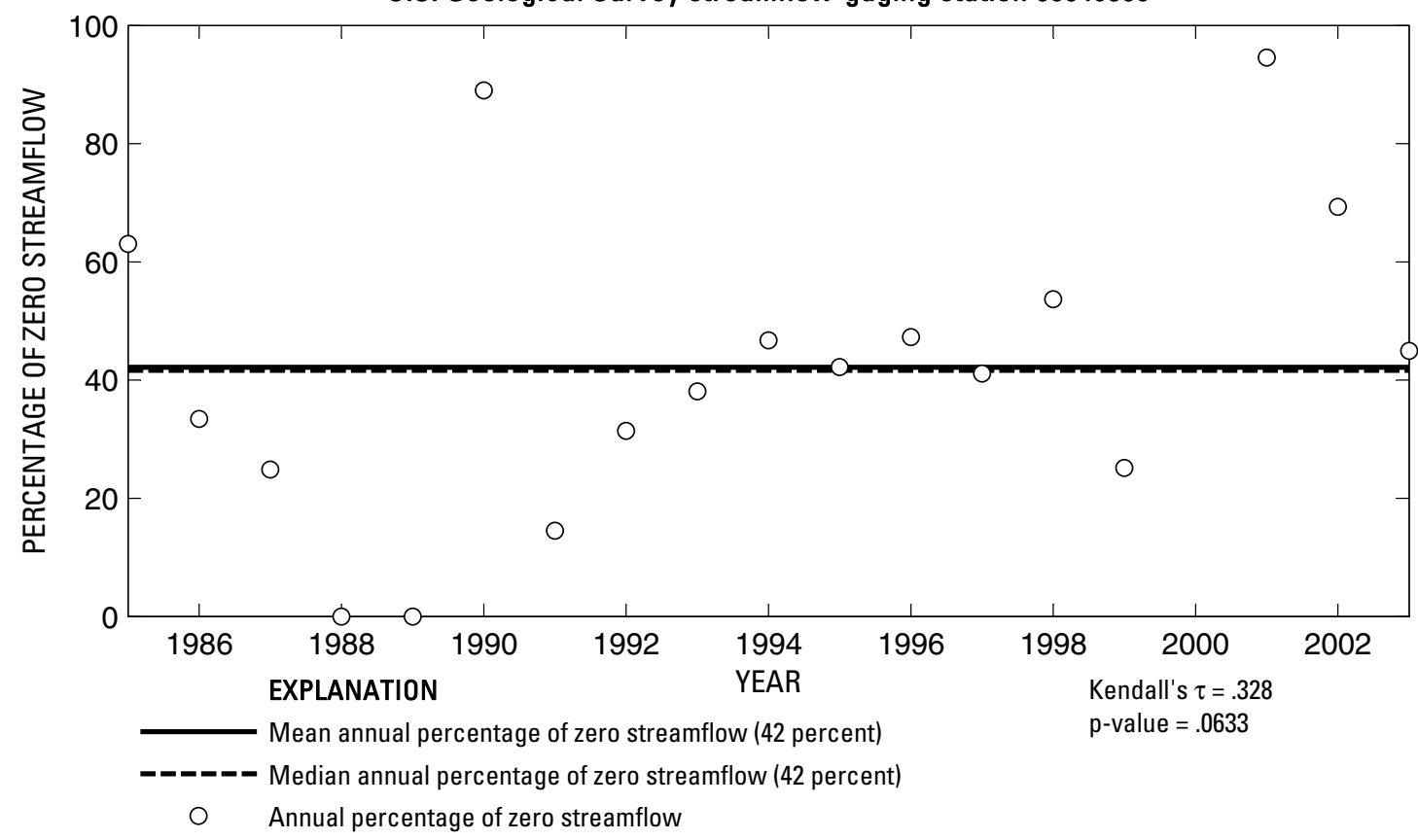

U.S. Geological Survey streamflow-gaging station 08049580

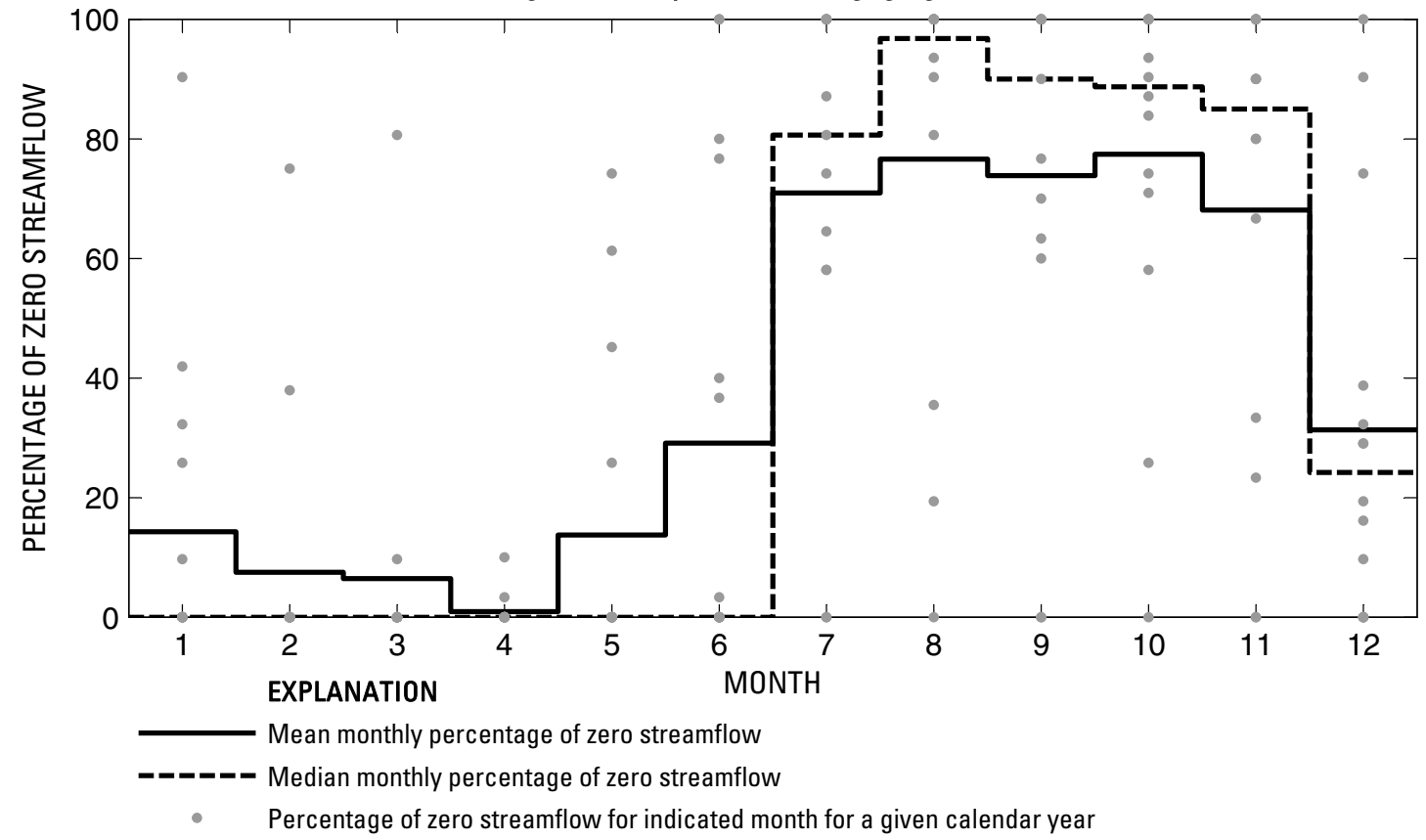

Figure 176. Analysis of percentage of zero daily mean streamflow for U.S. Geological Survey streamflow-gaging station 08049580 Mountain Creek near Venus, Texas. 
U.S. Geological Survey streamflow-gaging station 08049600

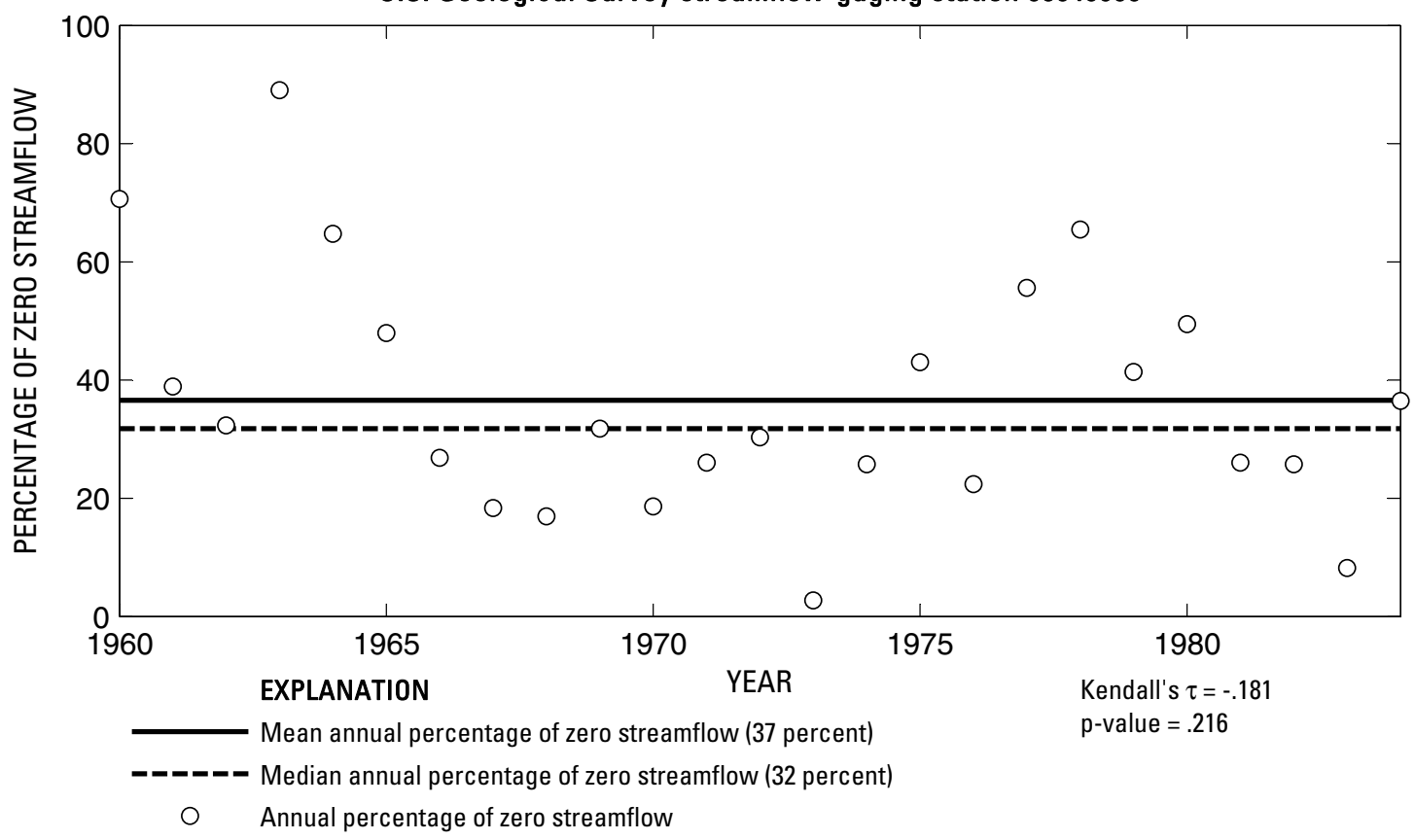

U.S. Geological Survey streamflow-gaging station 08049600

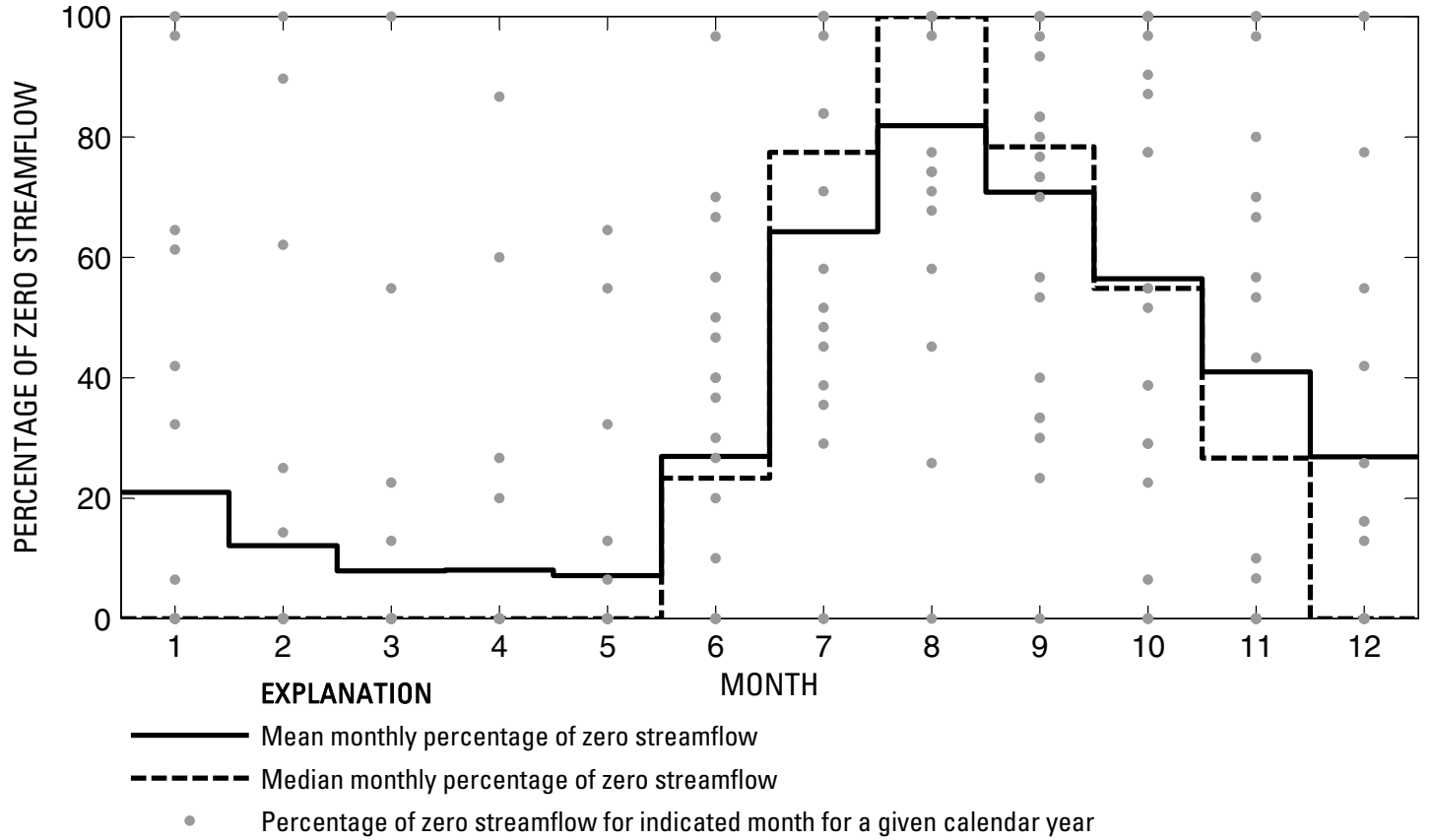

Figure 177. Analysis of percentage of zero daily mean streamflow for U.S. Geological Survey streamflow-gaging station 08049600 Mountain Creek near Cedar Hill, Texas. 
U.S. Geological Survey streamflow-gaging station 08049700

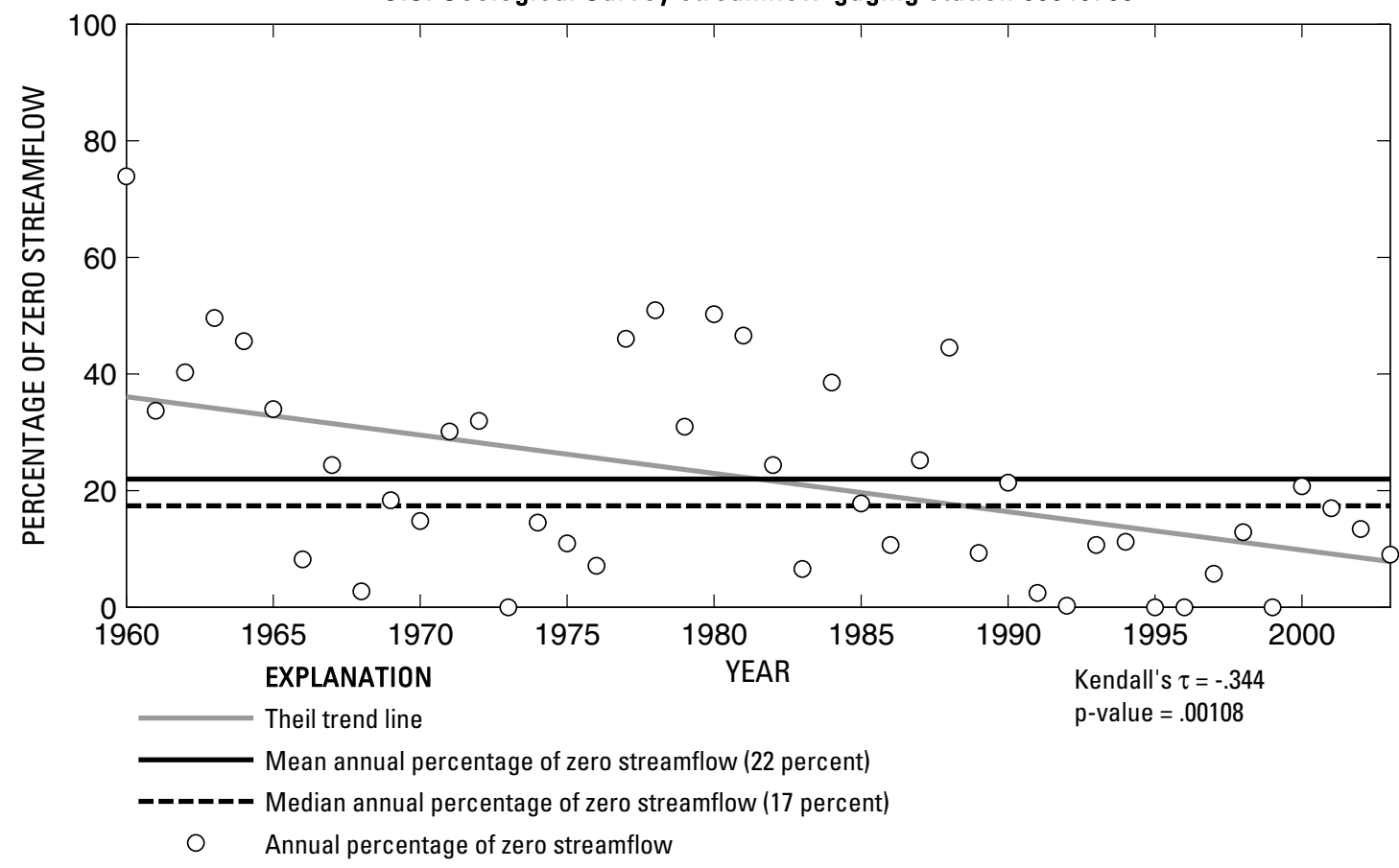

U.S. Geological Survey streamflow-gaging station 08049700

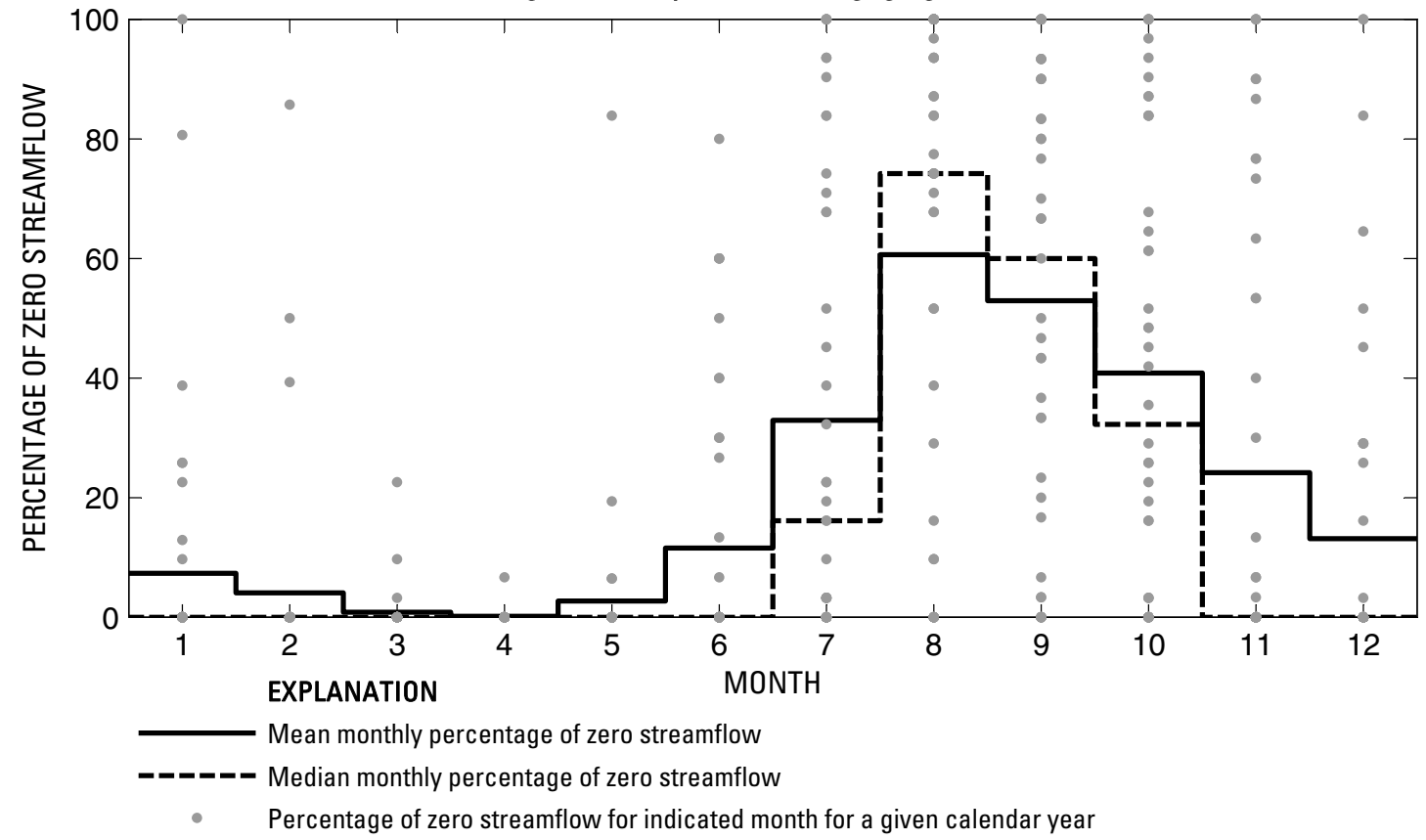

Figure 178. Analysis of percentage of zero daily mean streamflow for U.S. Geological Survey streamflow-gaging station 08049700 Walnut Creek near Mansfield, Texas.

Index of Station Numbers 719 

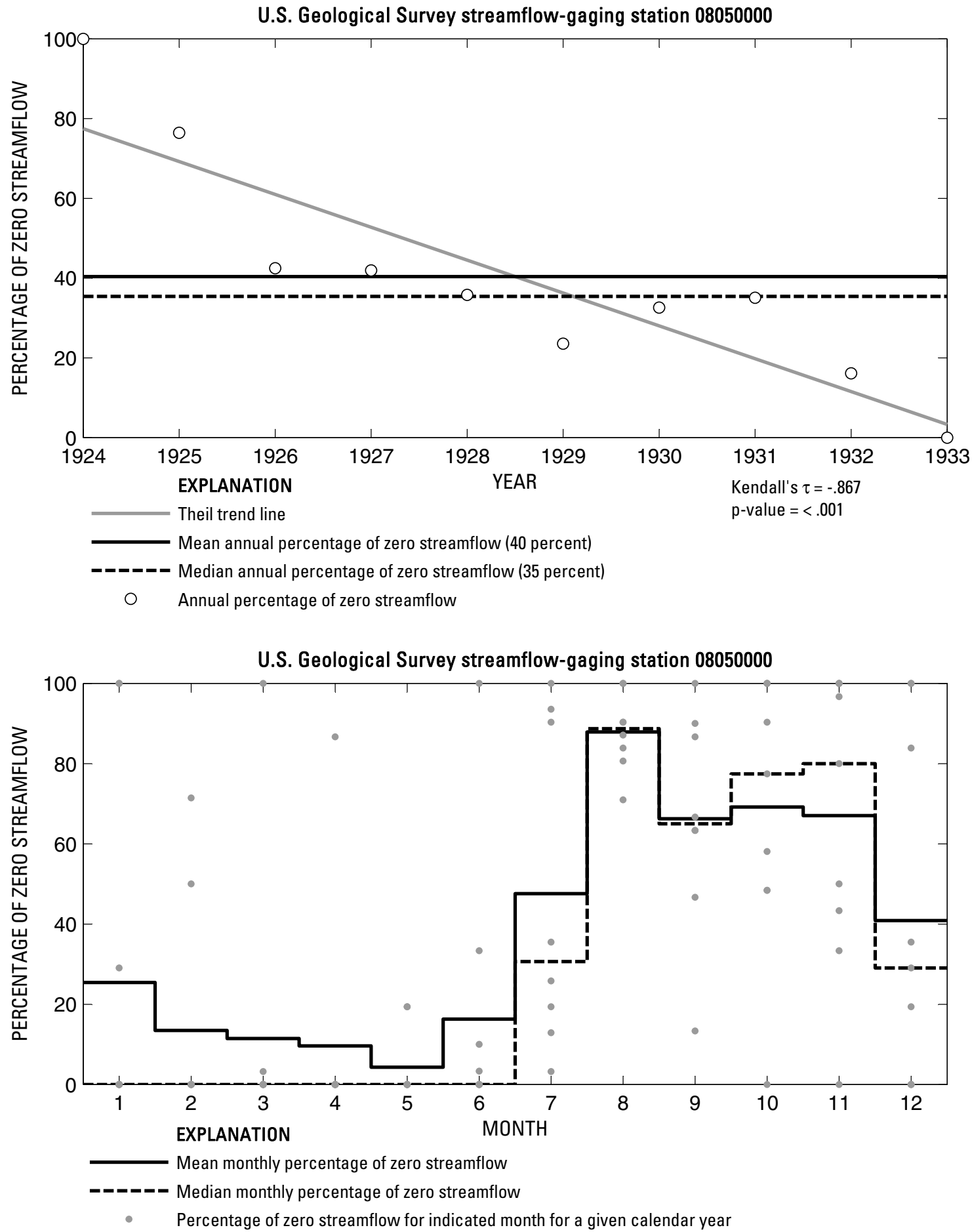

Figure 179. Analysis of percentage of zero daily mean streamflow for U.S. Geological Survey streamflow-gaging station 08050000 Mountain Creek near Grand Prairie, Texas. 
U.S. Geological Survey streamflow-gaging station 08050100

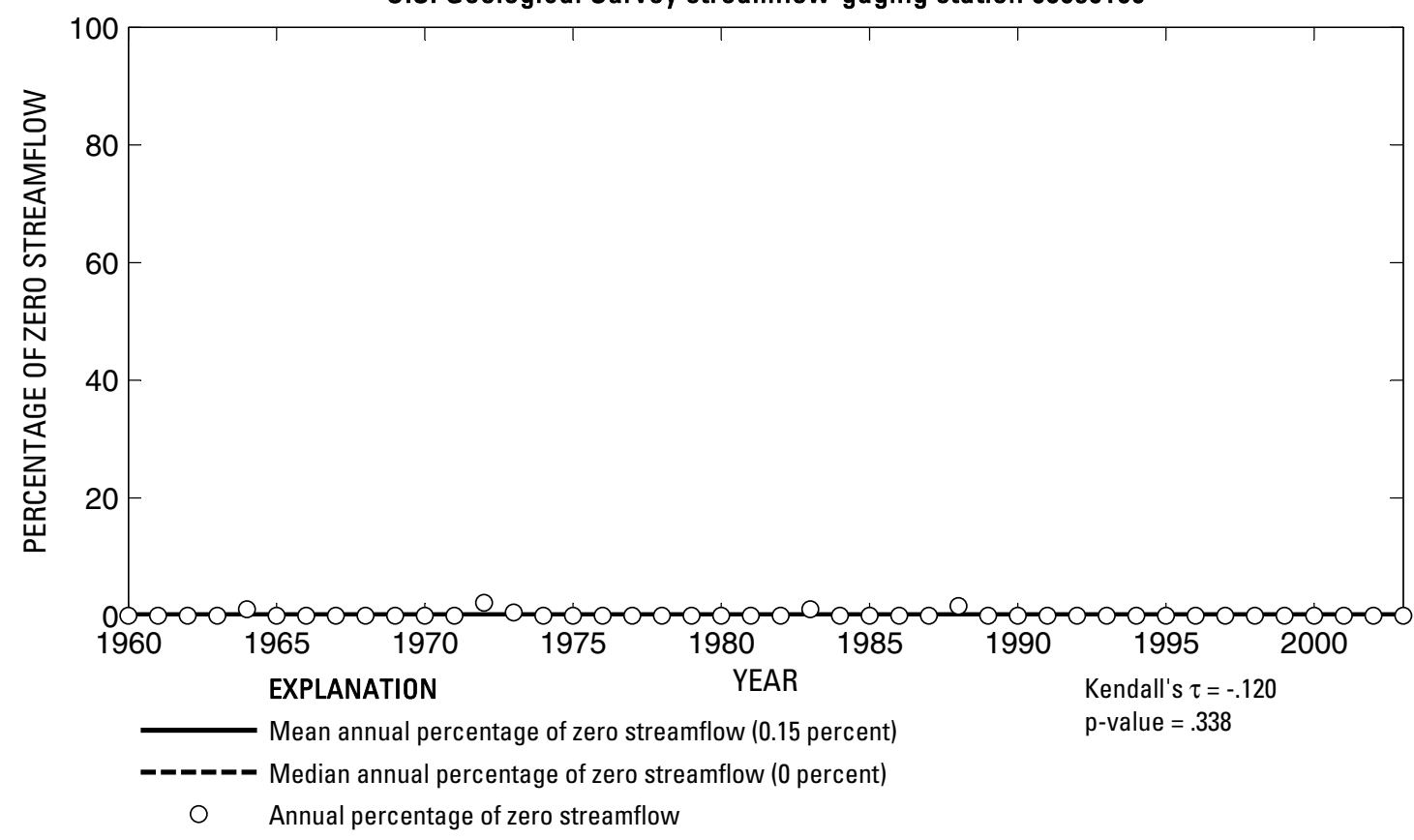

U.S. Geological Survey streamflow-gaging station 08050100

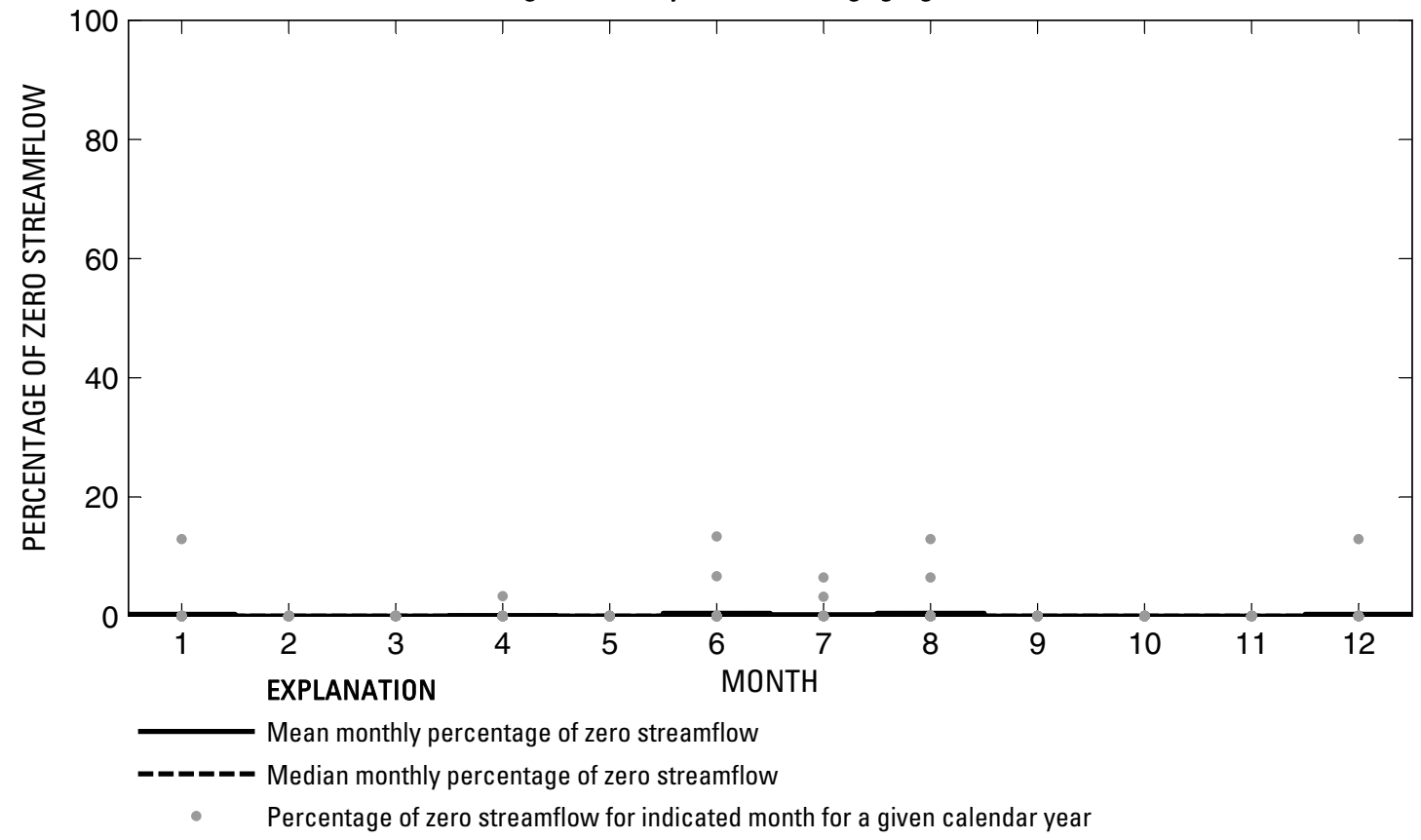

Figure 180. Analysis of percentage of zero daily mean streamflow for U.S. Geological Survey streamflow-gaging station 08050100 Mountain Creek at Grand Prairie, Texas. 
U.S. Geological Survey streamflow-gaging station 08050300

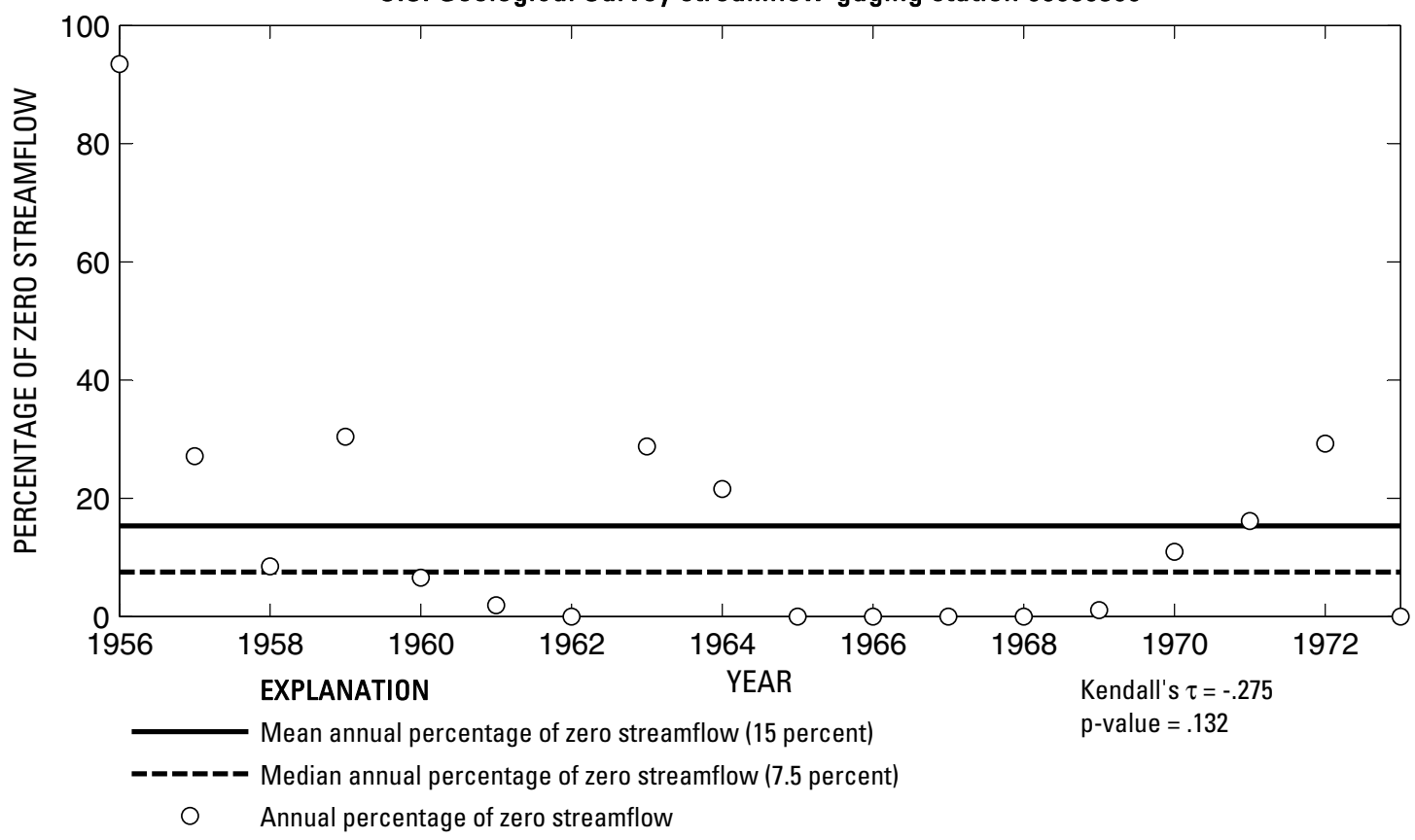

U.S. Geological Survey streamflow-gaging station 08050300

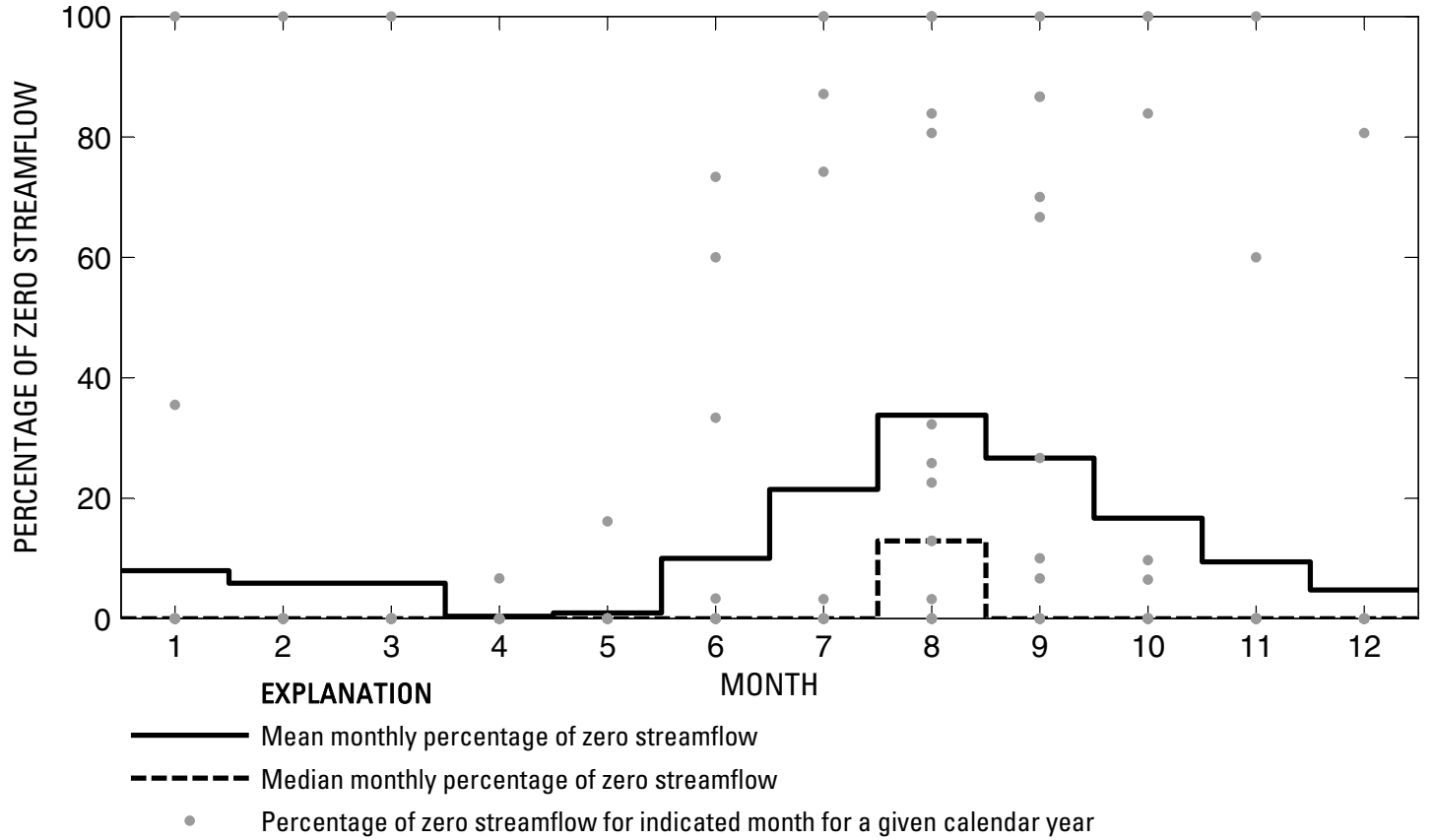

Figure 181. Analysis of percentage of zero daily mean streamflow for U.S. Geological Survey streamflow-gaging station 08050300 Elm Fork Trinity River near Muenster, Texas. 
U.S. Geological Survey streamflow-gaging station 08050400

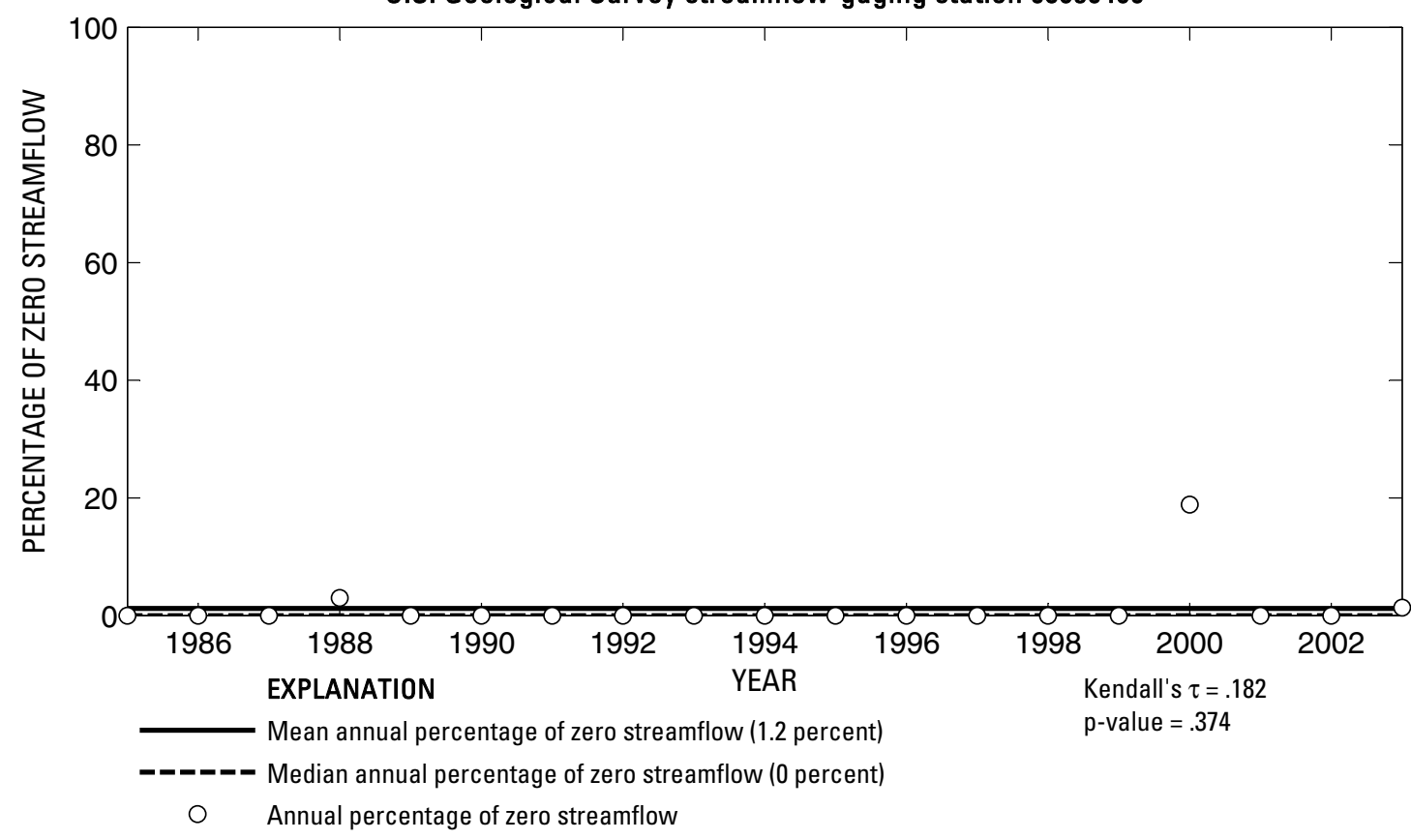

U.S. Geological Survey streamflow-gaging station 08050400

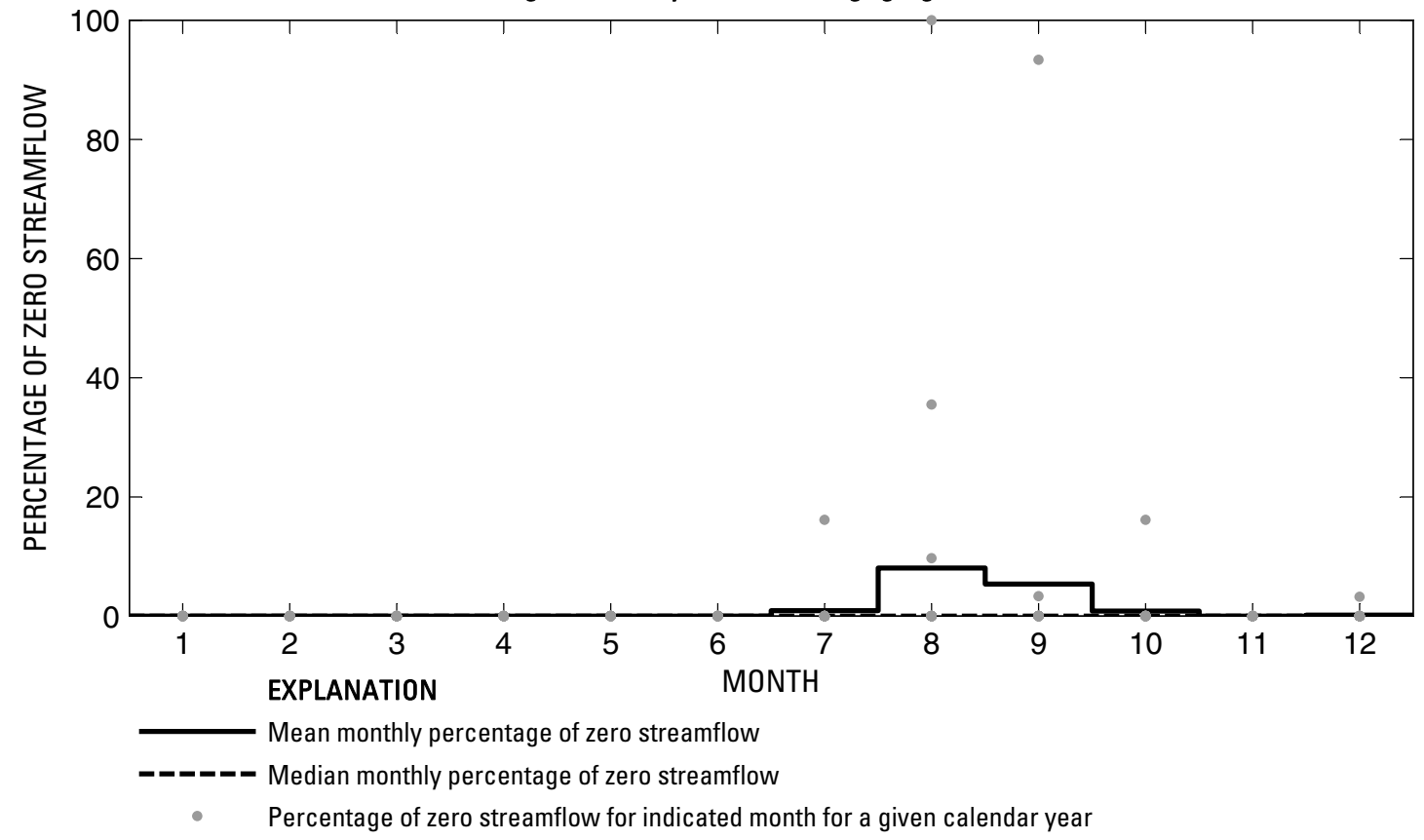

Figure 182. Analysis of percentage of zero daily mean streamflow for U.S. Geological Survey streamflow-gaging station 08050400 Elm Fork Trinity River at Gainesville, Texas. 


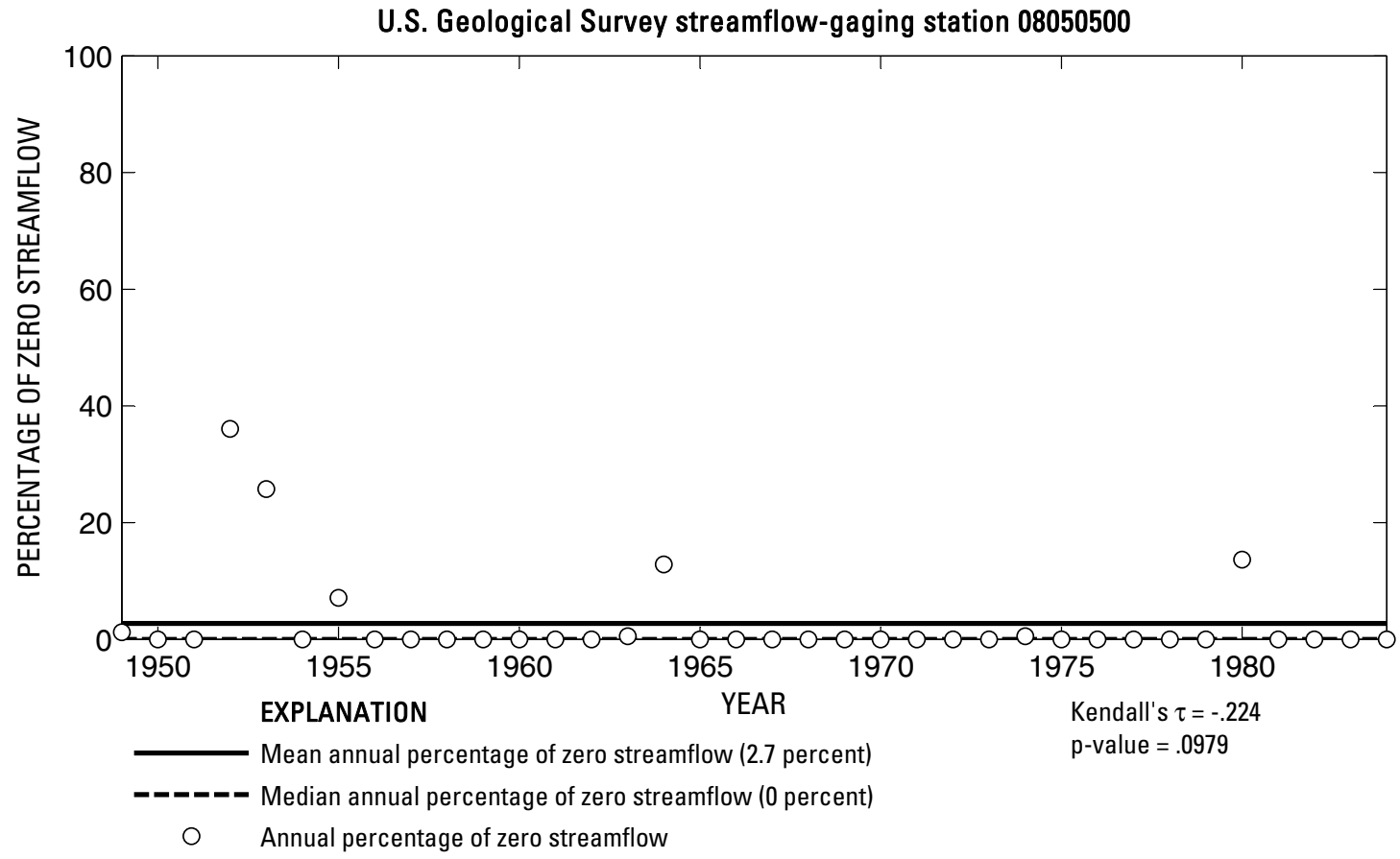

U.S. Geological Survey streamflow-gaging station 08050500

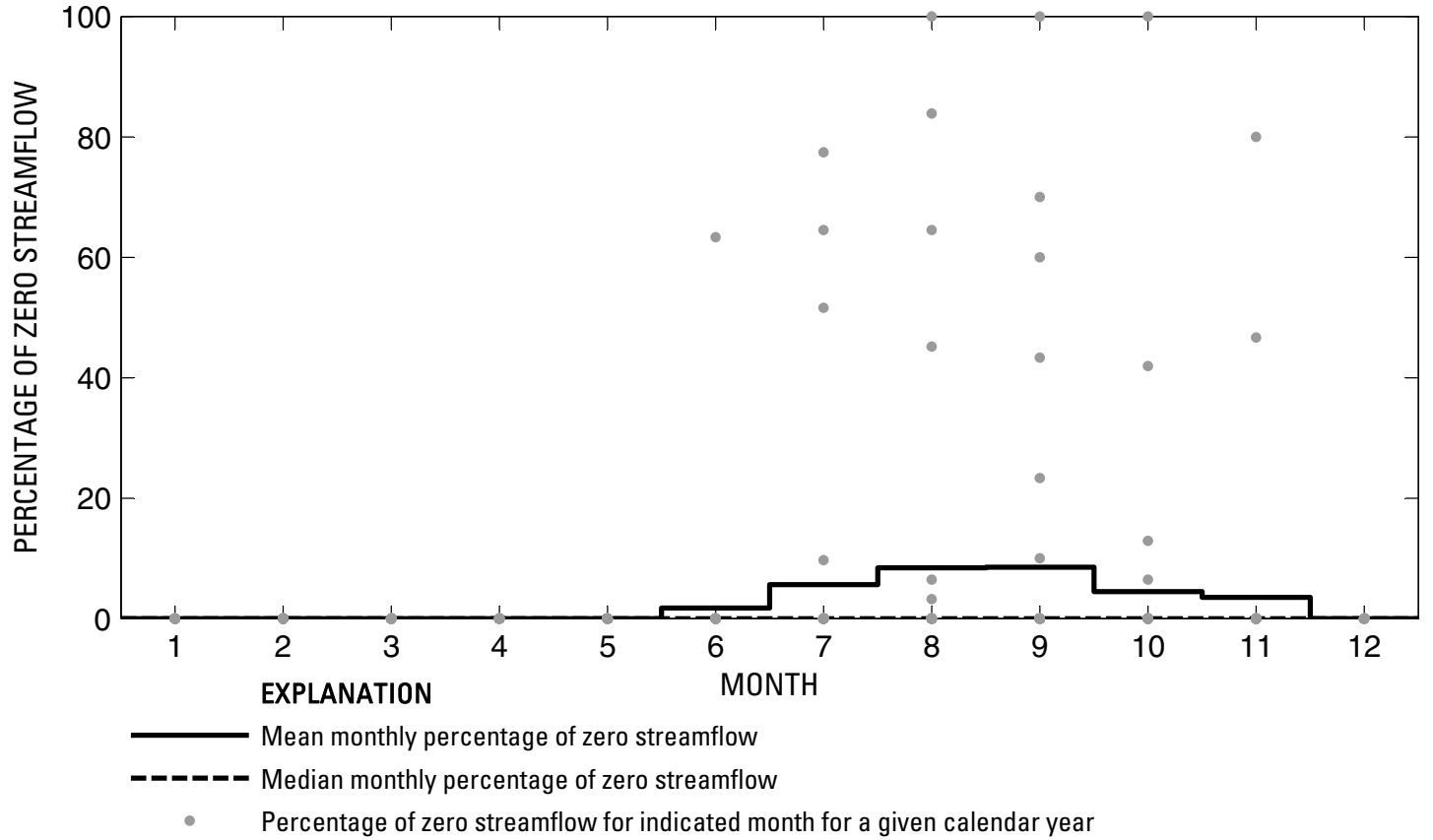

Figure 183. Analysis of percentage of zero daily mean streamflow for U.S. Geological Survey streamflow-gaging station 08050500 Elm Fork Trinity River near Sanger, Texas. 
U.S. Geological Survey streamflow-gaging station 08050800

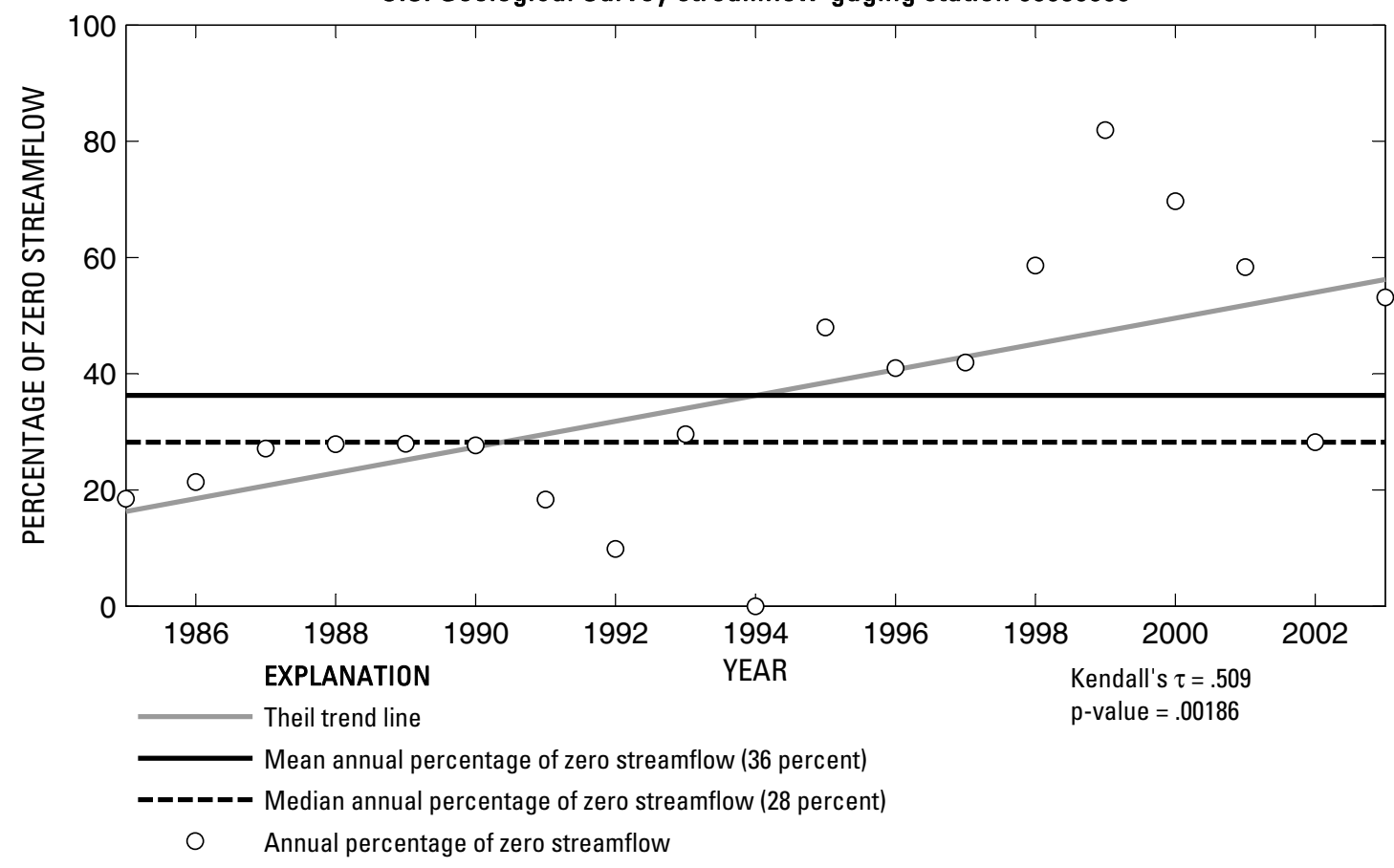

U.S. Geological Survey streamflow-gaging station 08050800

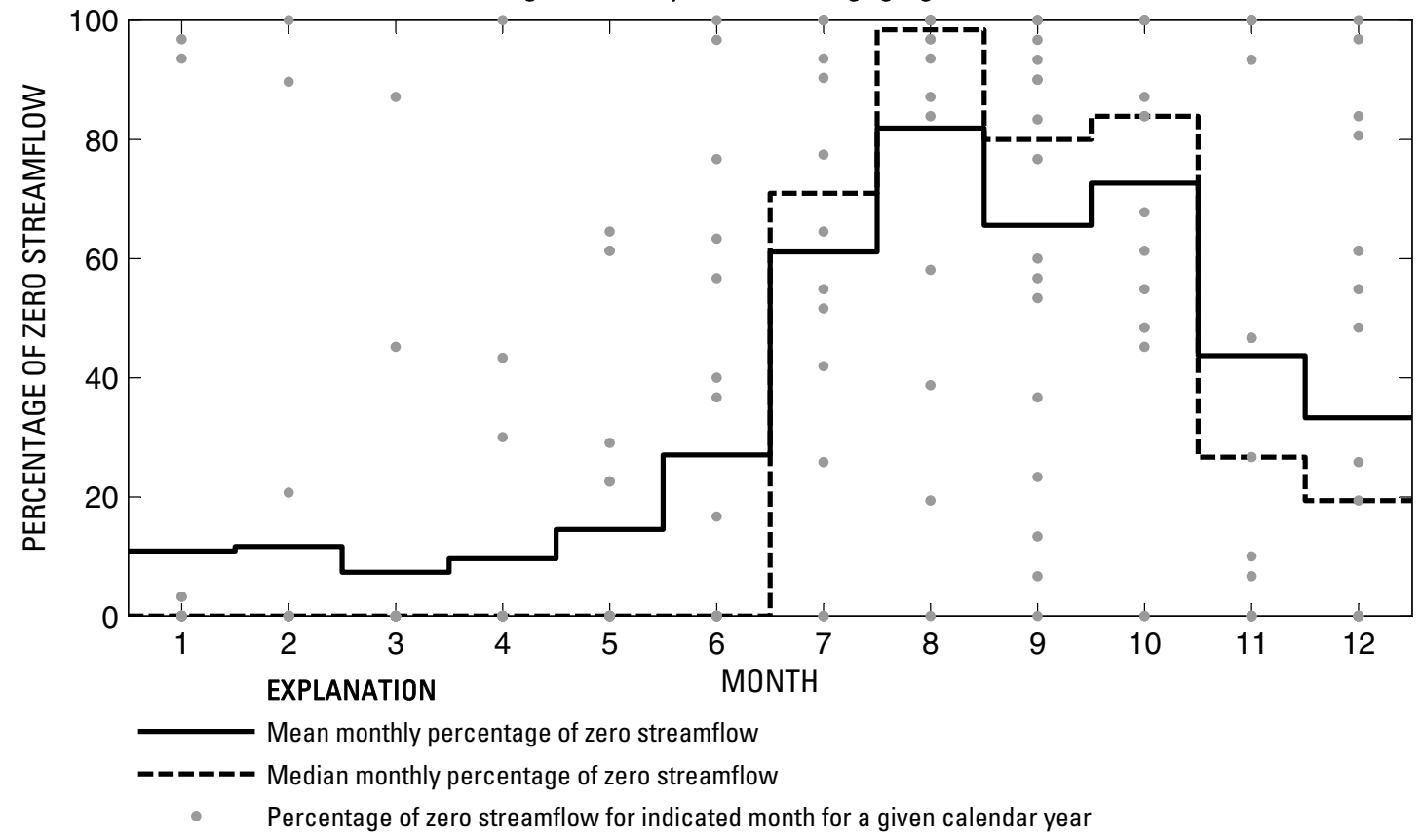

Figure 184. Analysis of percentage of zero daily mean streamflow for U.S. Geological Survey streamflow-gaging station 08050800 Timber Creek near Collinsville, Texas.

Index of Station Numbers 719 
U.S. Geological Survey streamflow-gaging station 08050840

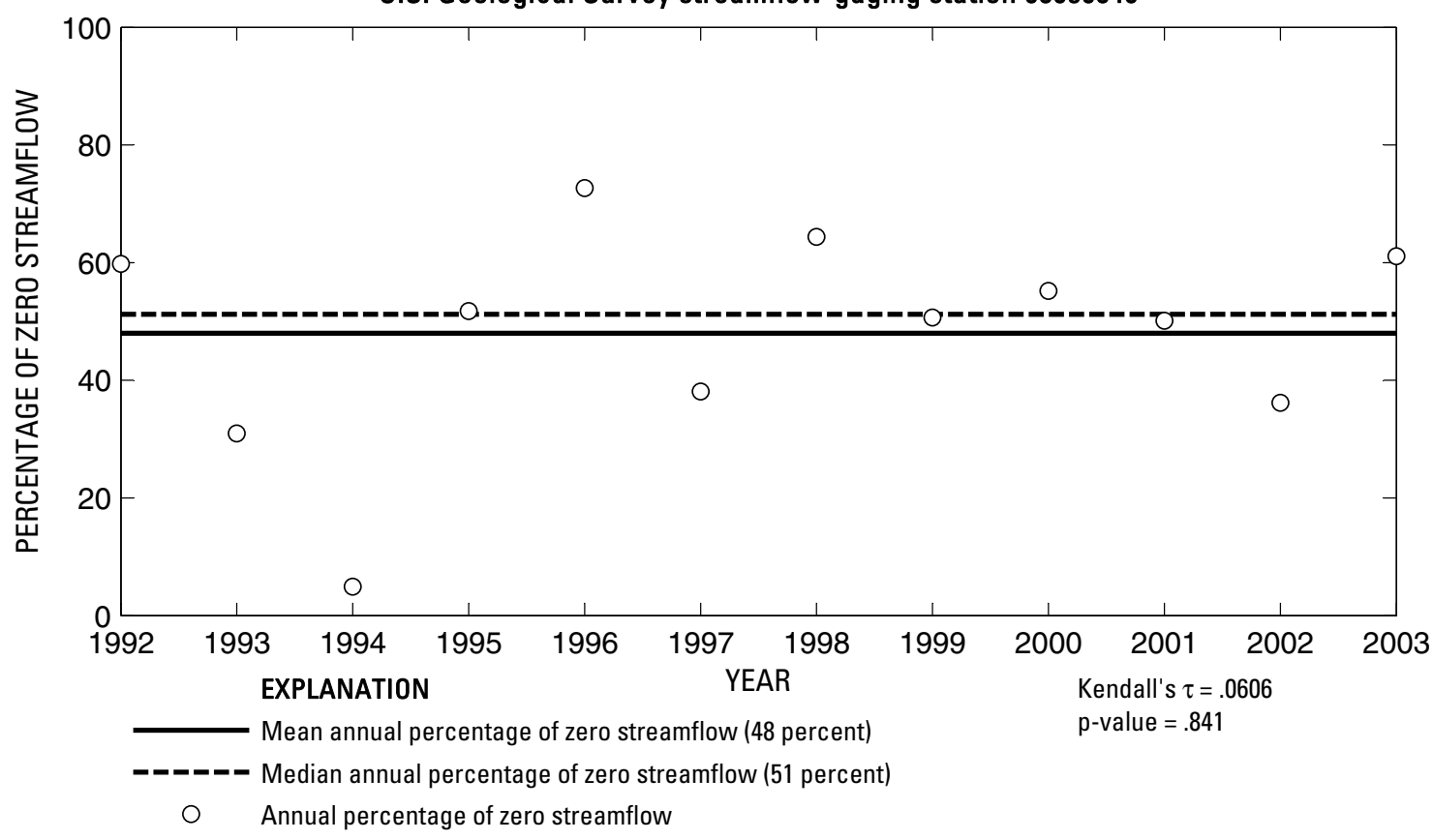

U.S. Geological Survey streamflow-gaging station 08050840

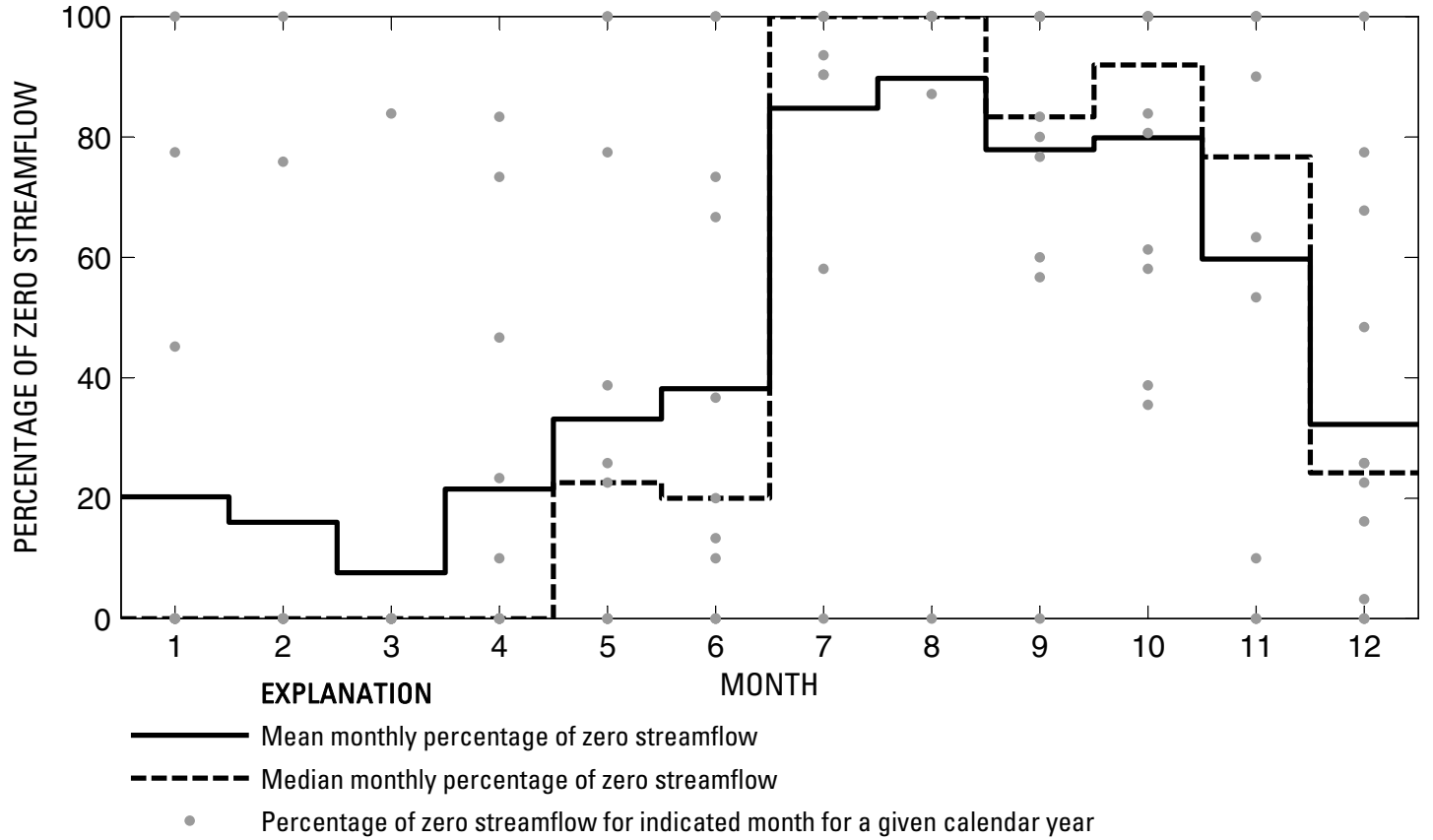

Figure 185. Analysis of percentage of zero daily mean streamflow for U.S. Geological Survey streamflow-gaging station 08050840 Range Creek near Collinsville, Texas. 
U.S. Geological Survey streamflow-gaging station 08051000

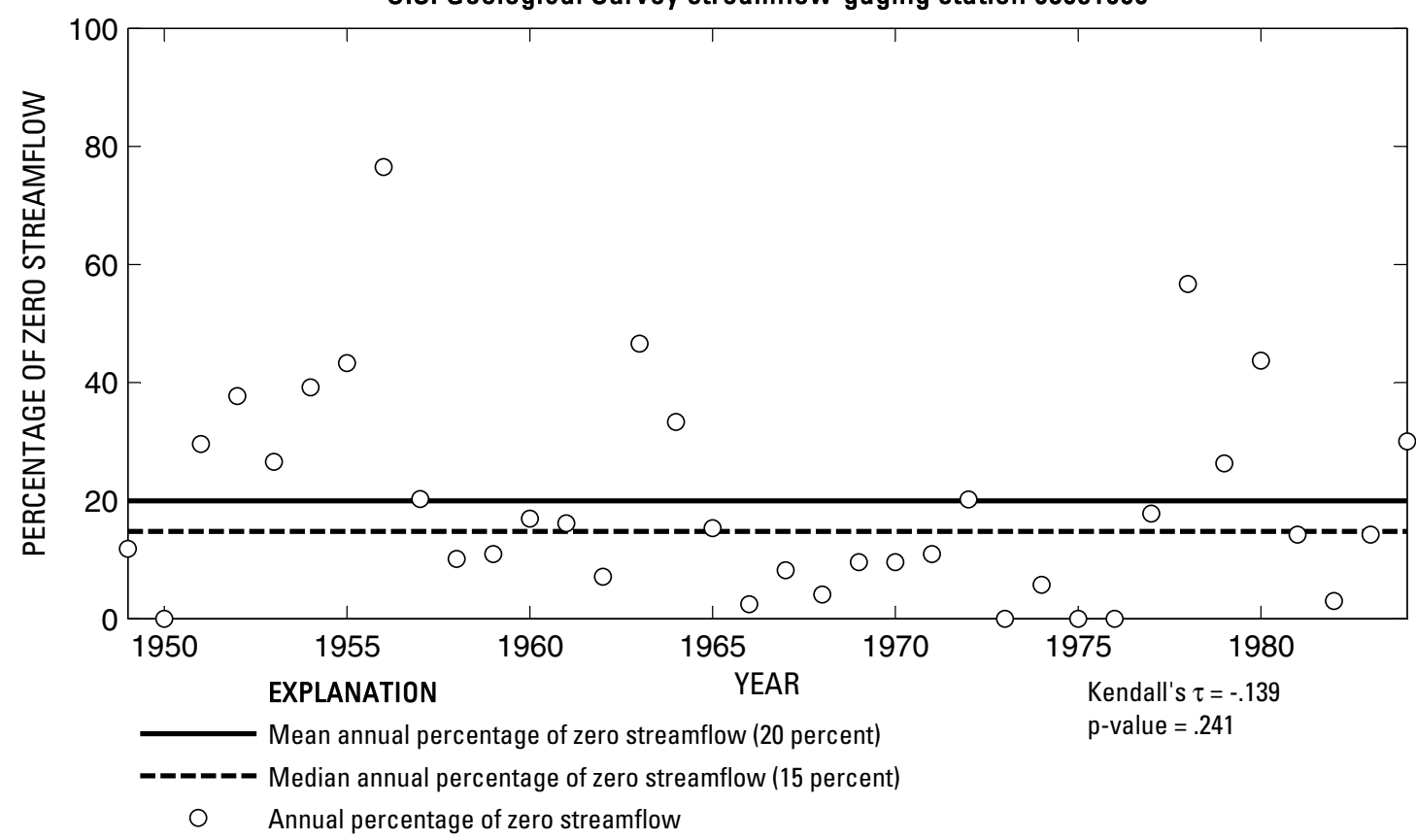

U.S. Geological Survey streamflow-gaging station 08051000

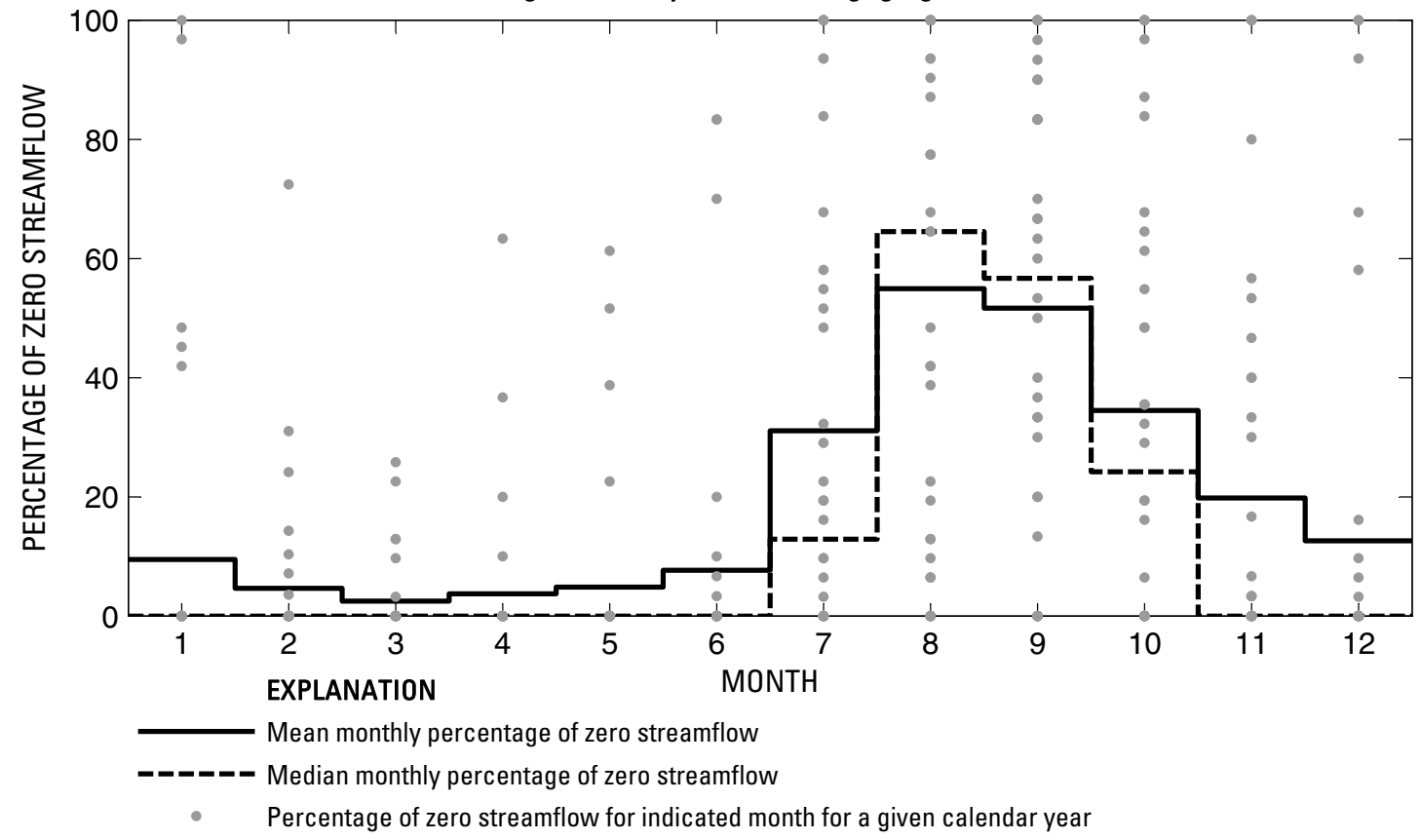

Figure 186. Analysis of percentage of zero daily mean streamflow for U.S. Geological Survey streamflow-gaging station 08051000 Isle du Bois Creek near Pilot Point, Texas. 


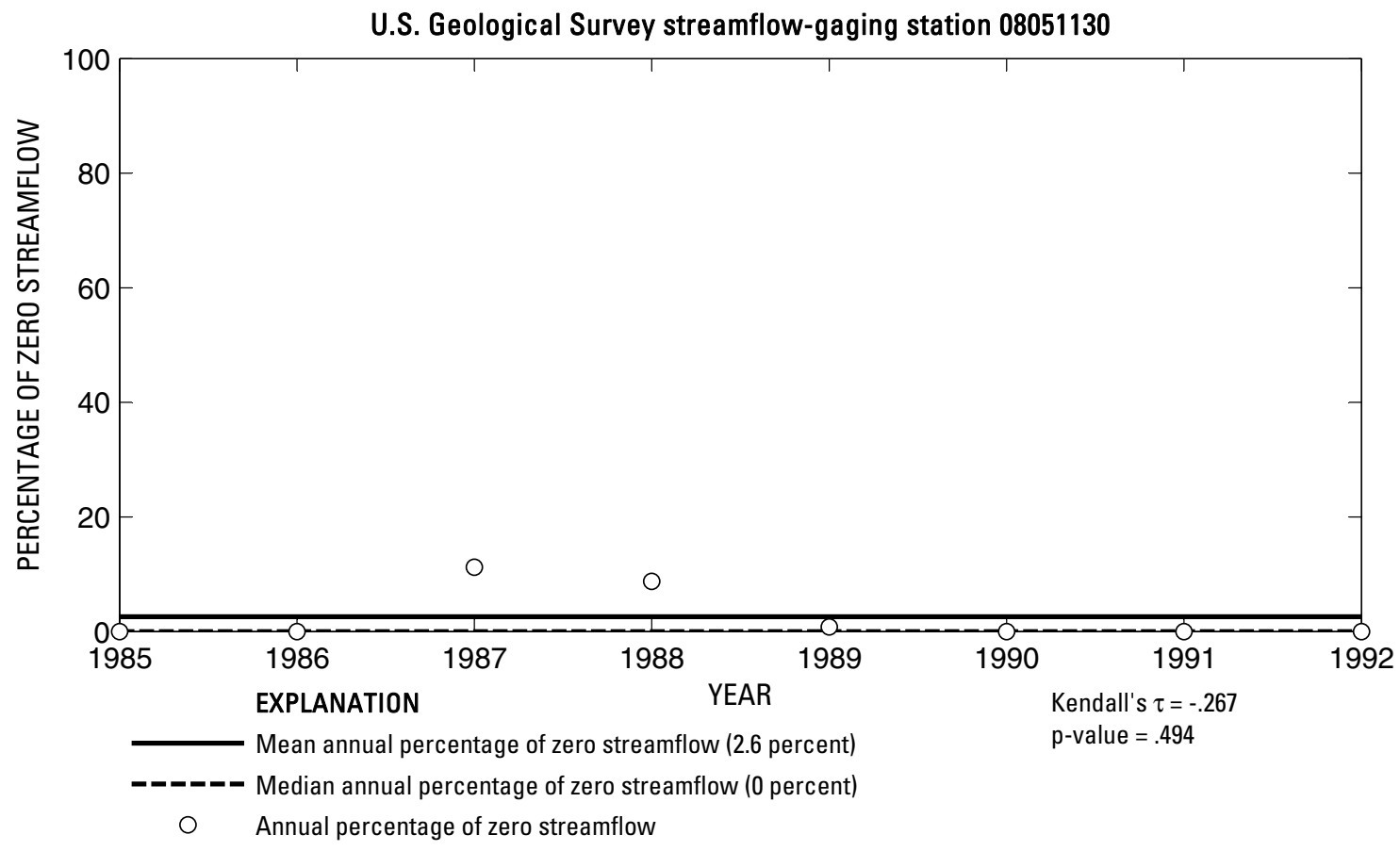

U.S. Geological Survey streamflow-gaging station 08051130

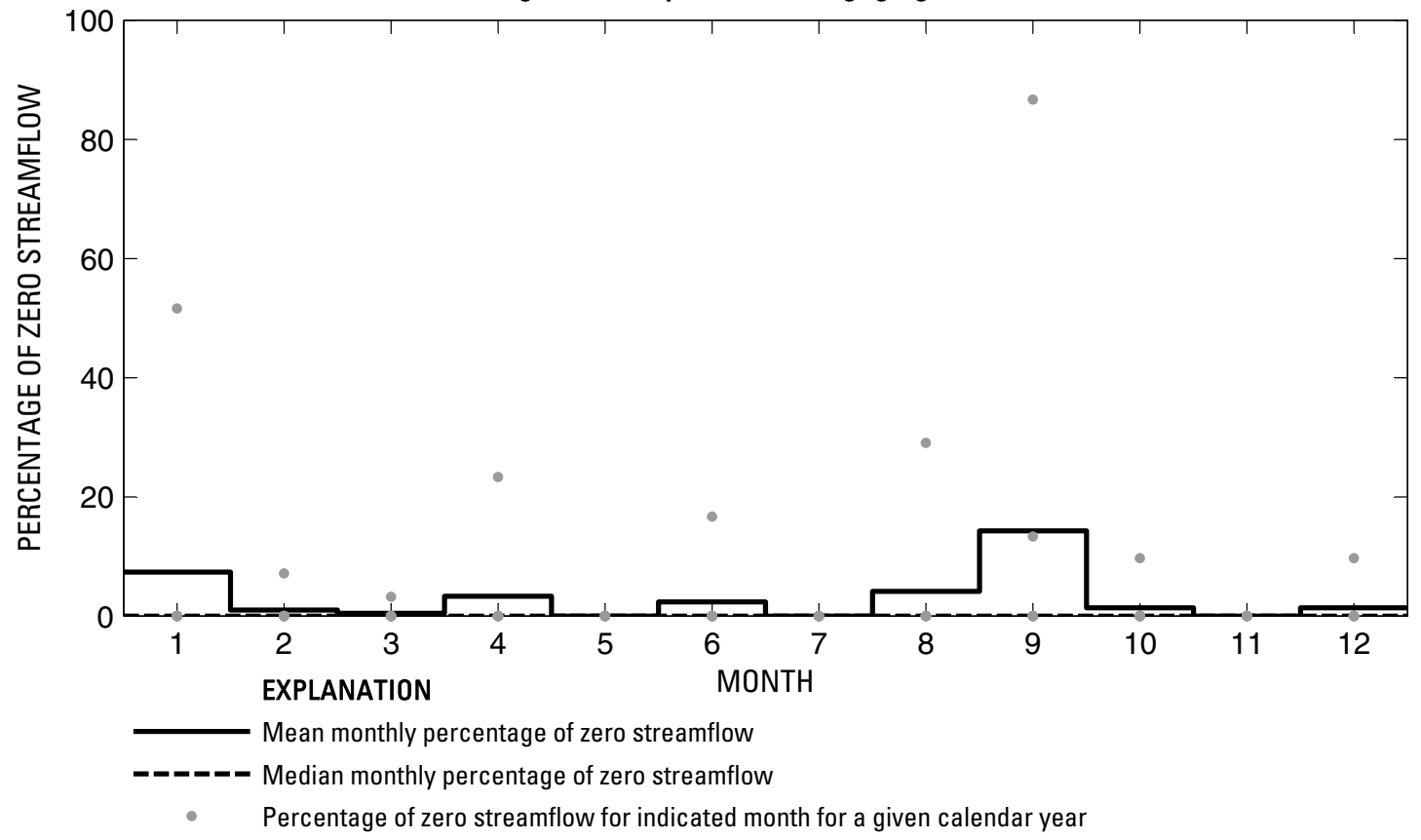

Figure 187. Analysis of percentage of zero daily mean streamflow for U.S. Geological Survey streamflow-gaging station 08051130 Elm Fork Trinity River near Pilot Point, Texas. 
U.S. Geological Survey streamflow-gaging station 08051500

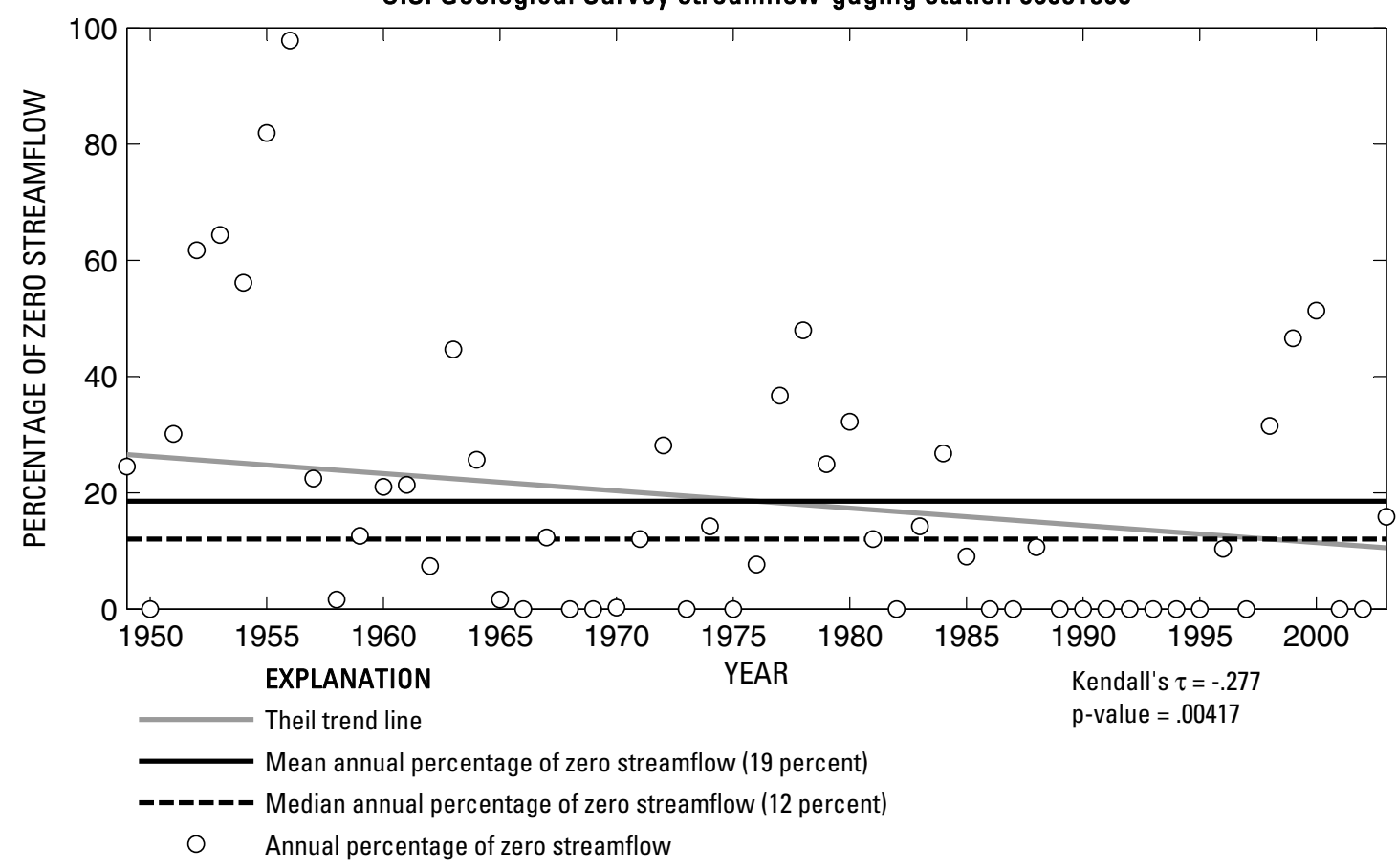

U.S. Geological Survey streamflow-gaging station 08051500

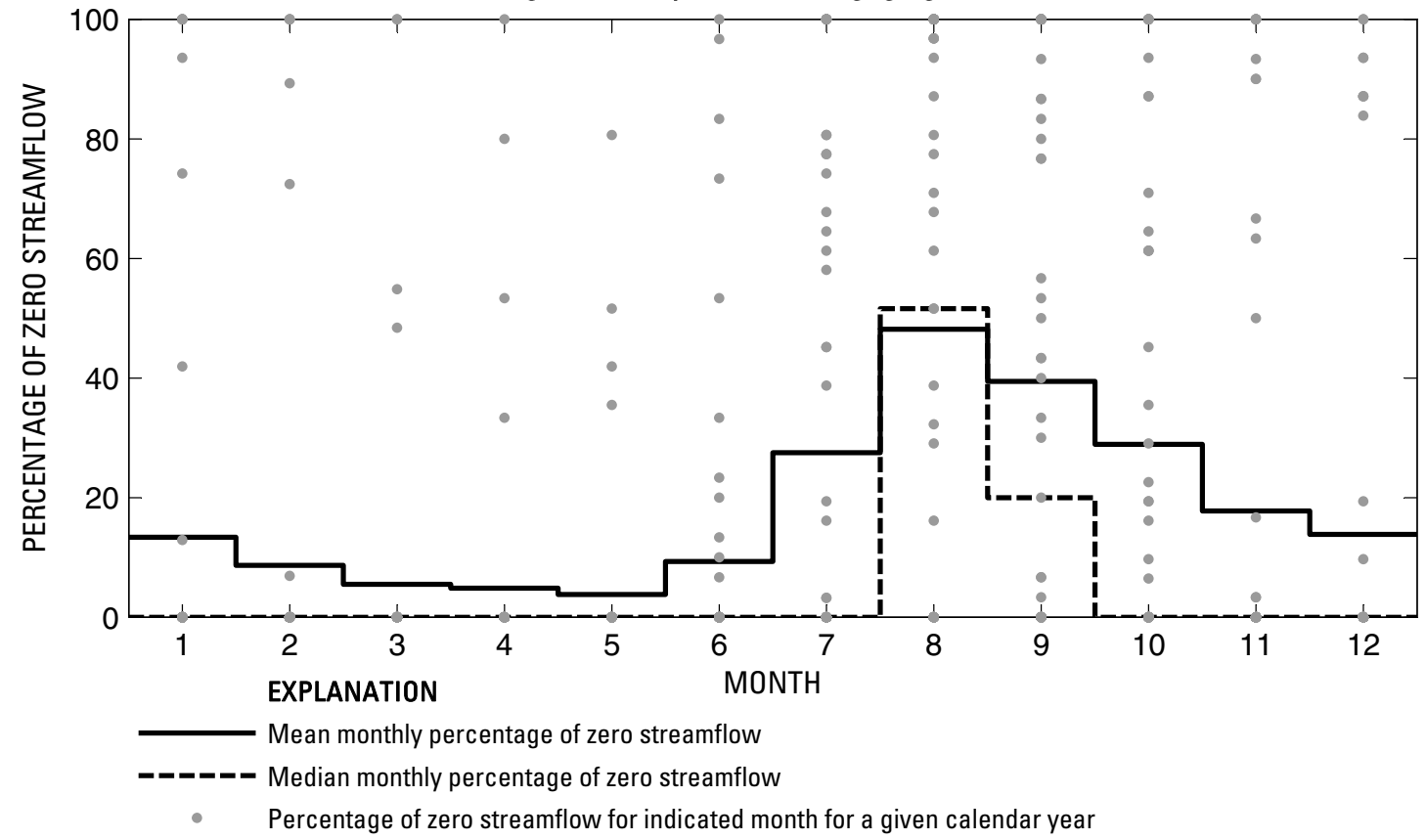

Figure 188. Analysis of percentage of zero daily mean streamflow for U.S. Geological Survey streamflow-gaging station 08051500 Clear Creek near Sanger, Texas.

Index of Station Numbers 719 


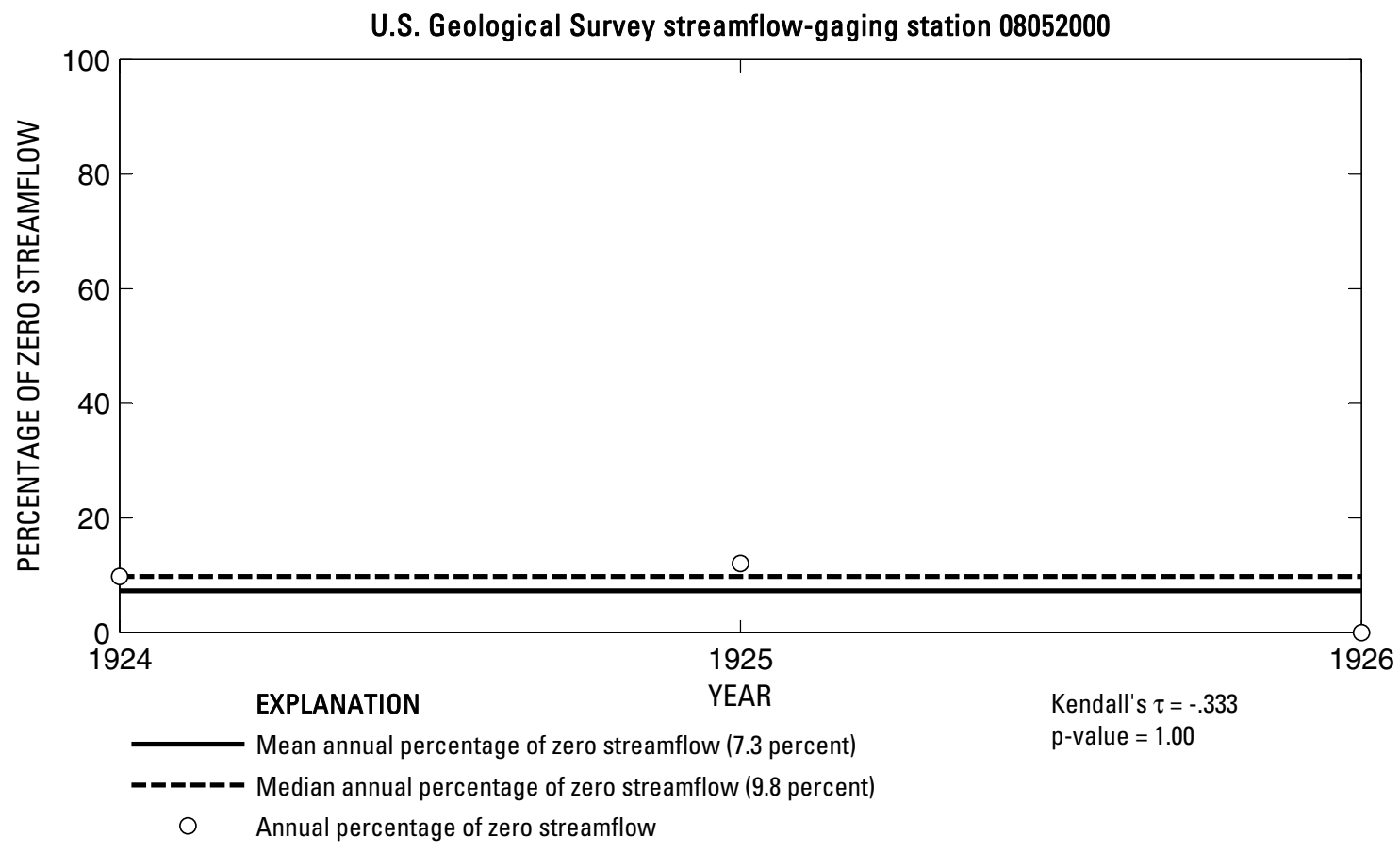

U.S. Geological Survey streamflow-gaging station 08052000

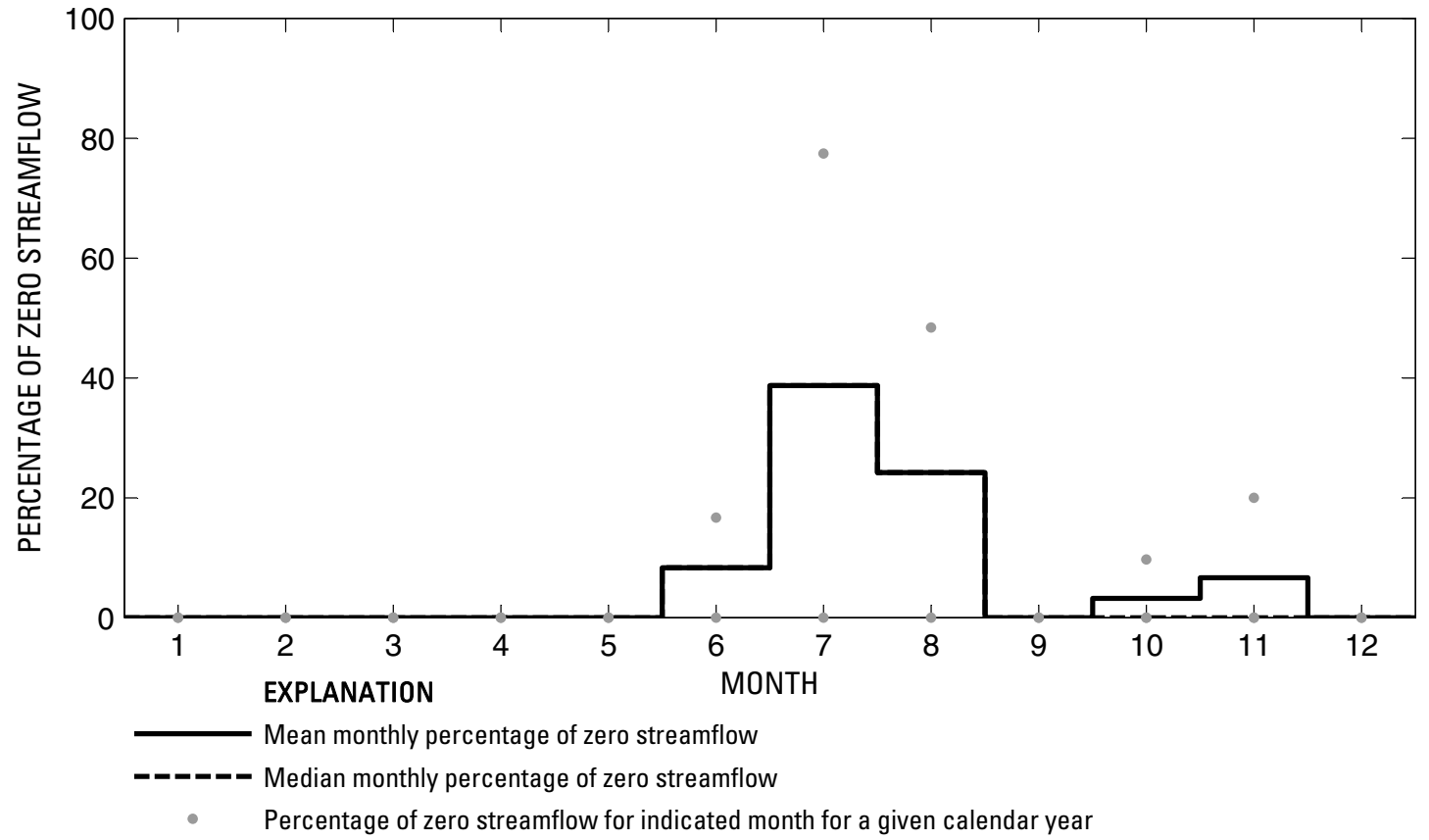

Figure 189. Analysis of percentage of zero daily mean streamflow for U.S. Geological Survey streamflow-gaging station 08052000 Elm Fork Trinity River near Denton, Texas. 
U.S. Geological Survey streamflow-gaging station 08052650

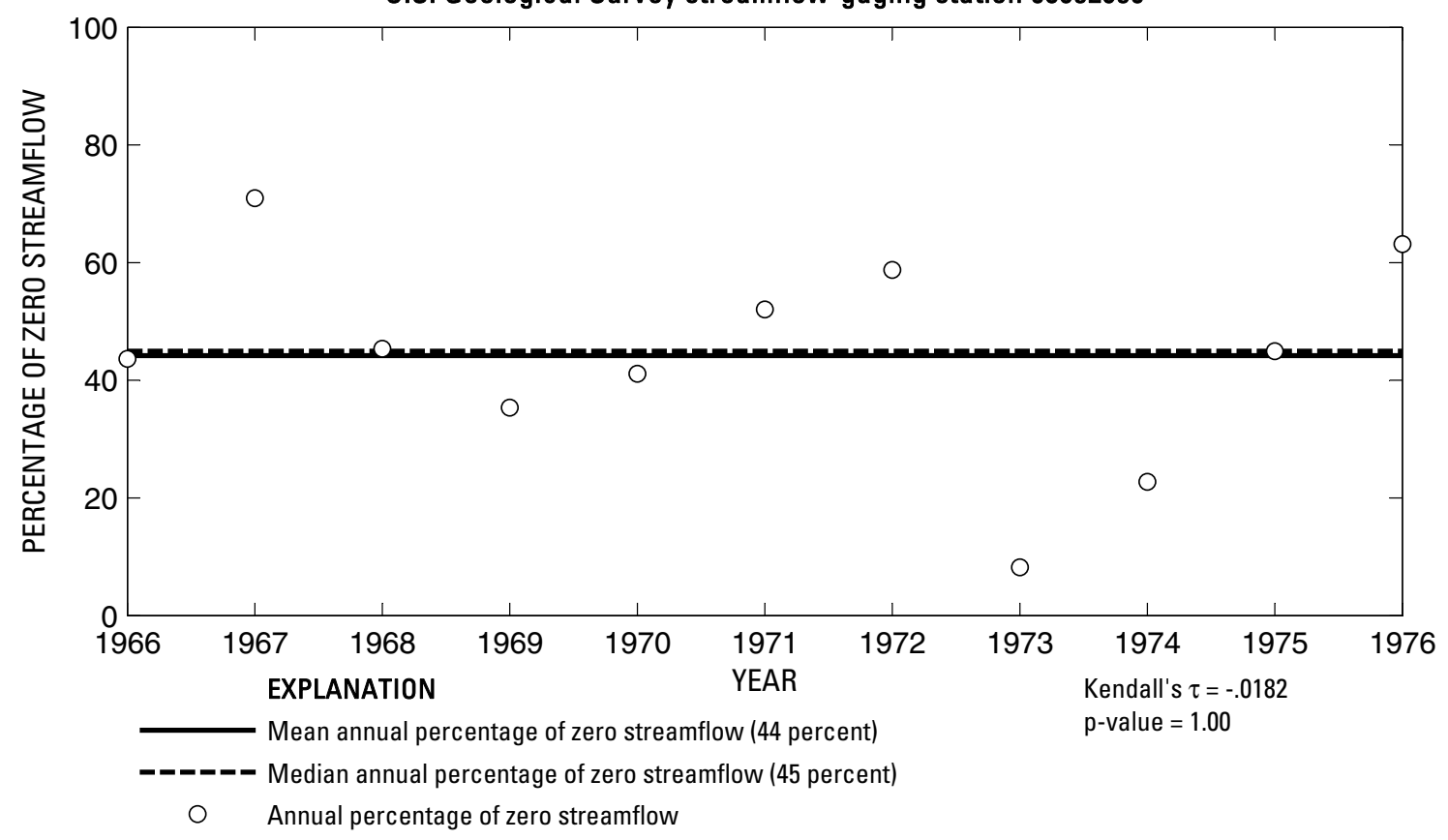

U.S. Geological Survey streamflow-gaging station 08052650

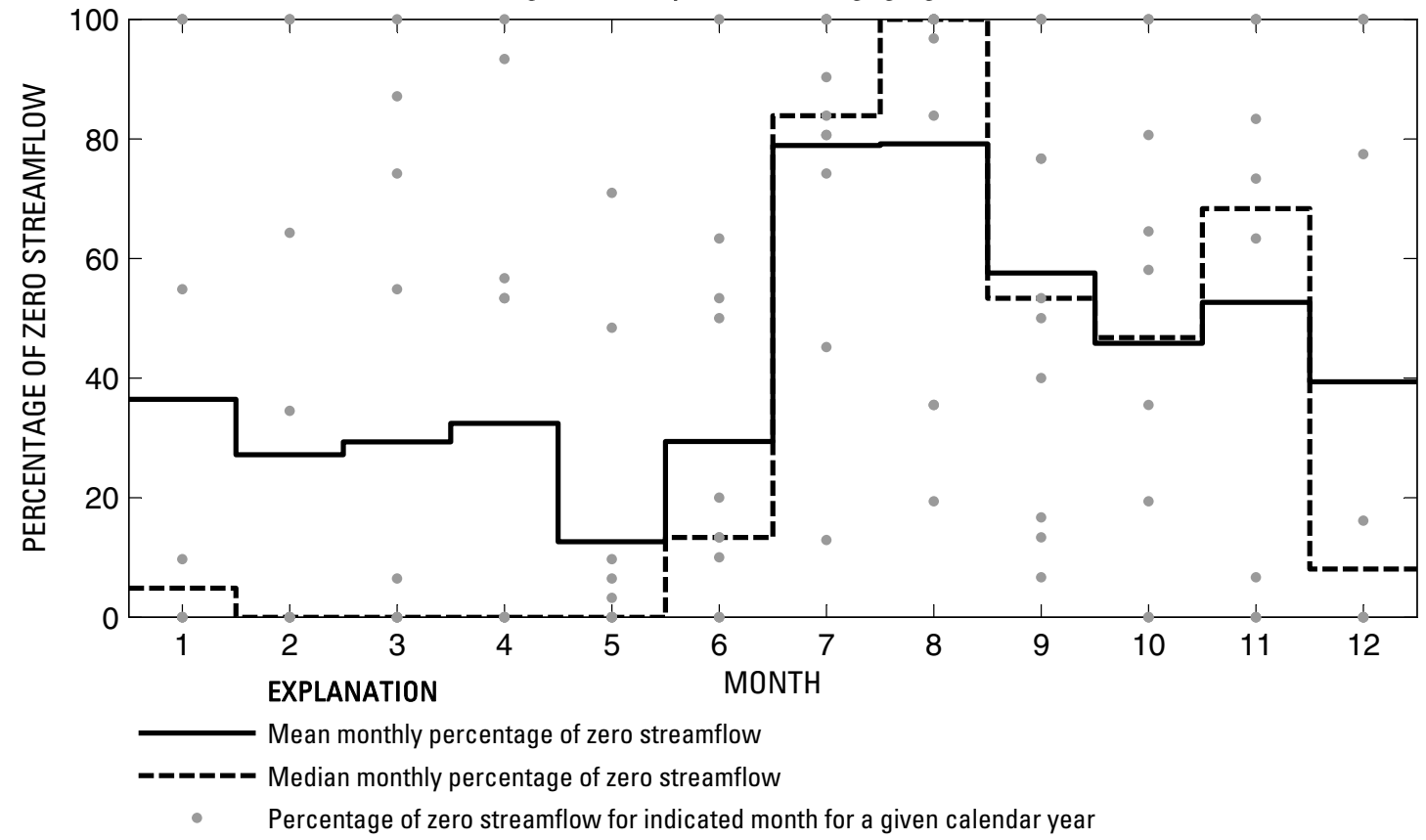

Figure 190. Analysis of percentage of zero daily mean streamflow for U.S. Geological Survey streamflow-gaging station 08052650 Little Elm Creek near Celina, Texas. 


\section{U.S. Geological Survey streamflow-gaging station 08052700}

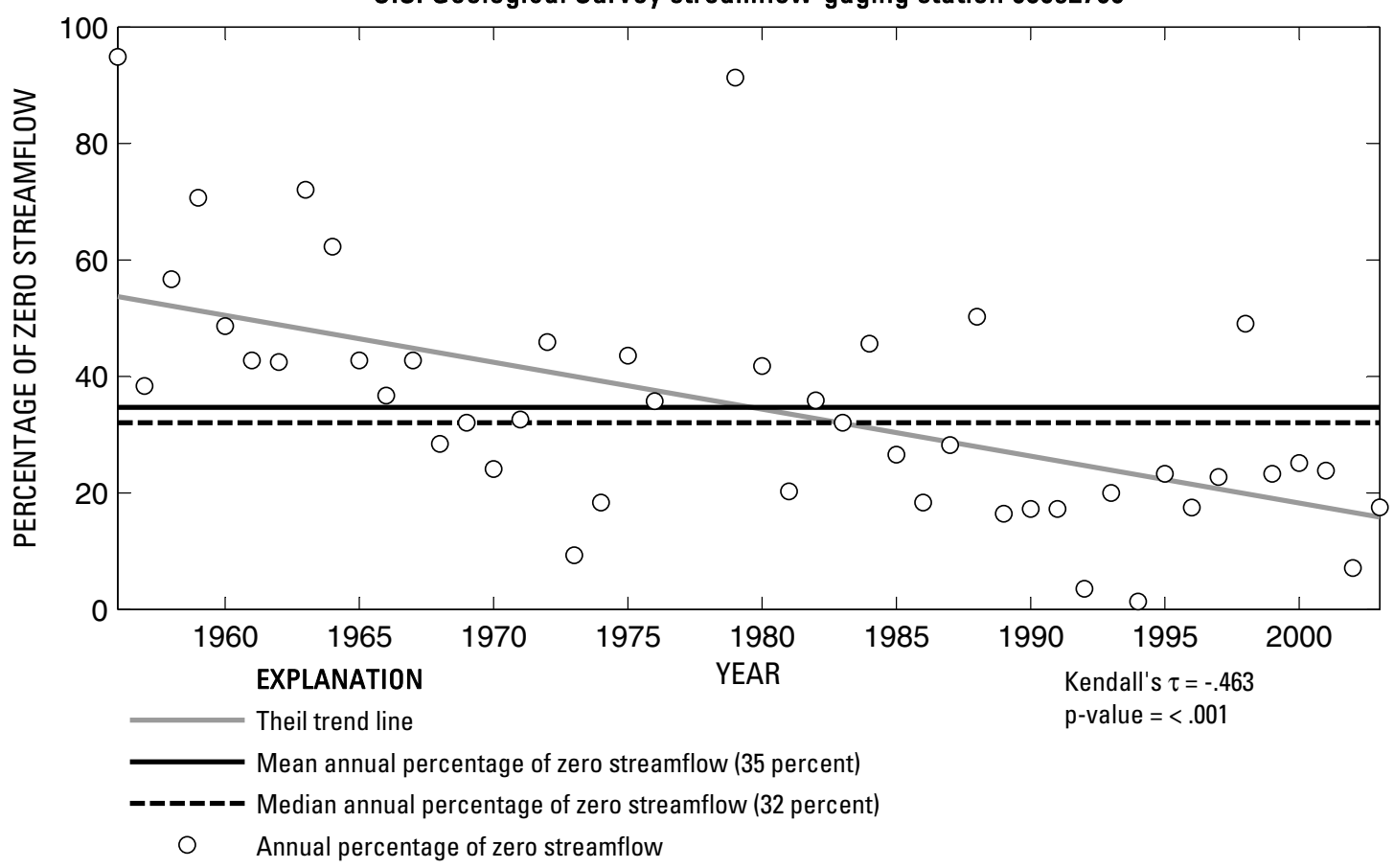

U.S. Geological Survey streamflow-gaging station 08052700

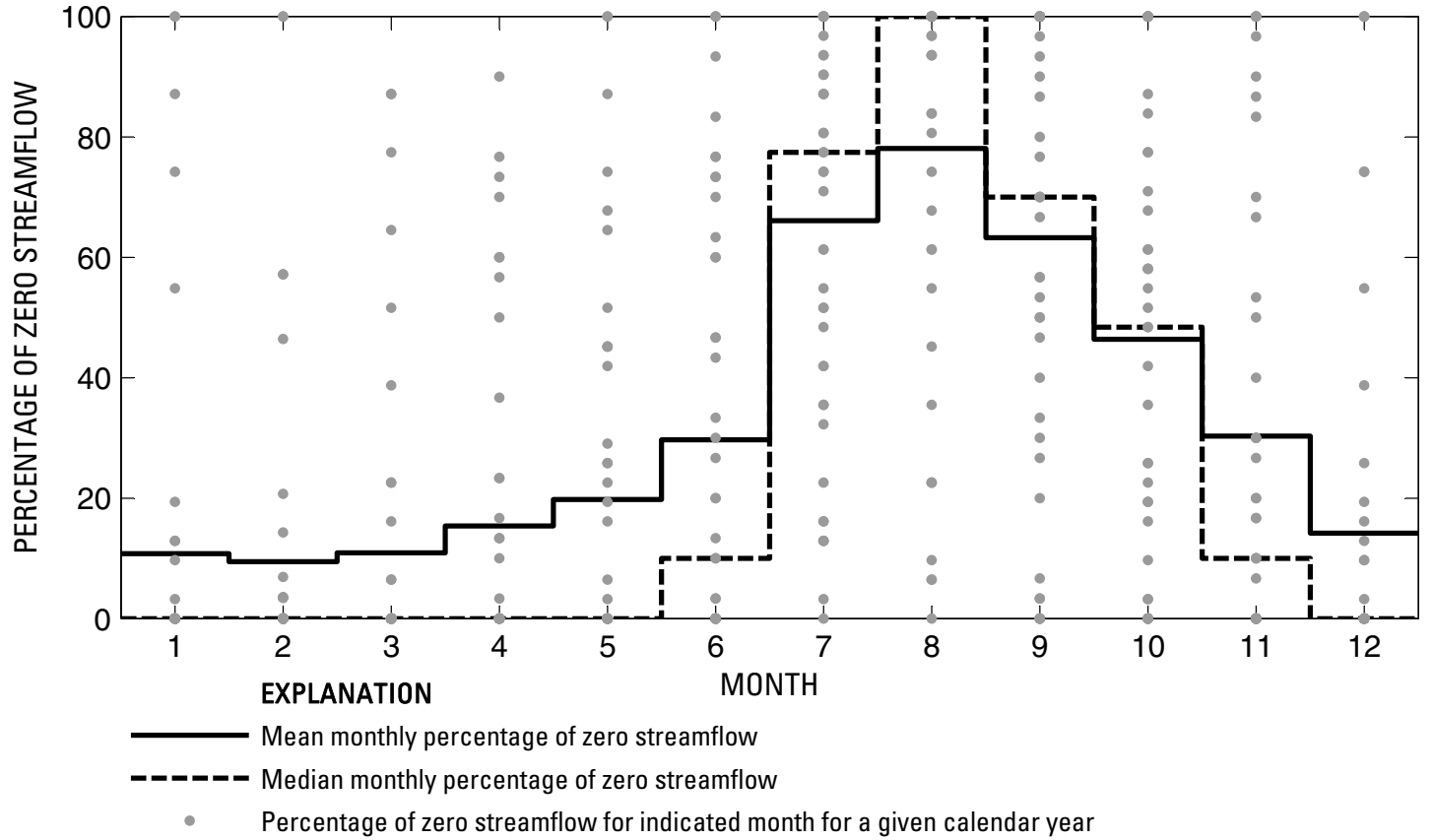

Figure 191. Analysis of percentage of zero daily mean streamflow for U.S. Geological Survey streamflow-gaging station 08052700 Little Elm Creek near Aubrey, Texas. 
U.S. Geological Survey streamflow-gaging station 08052780

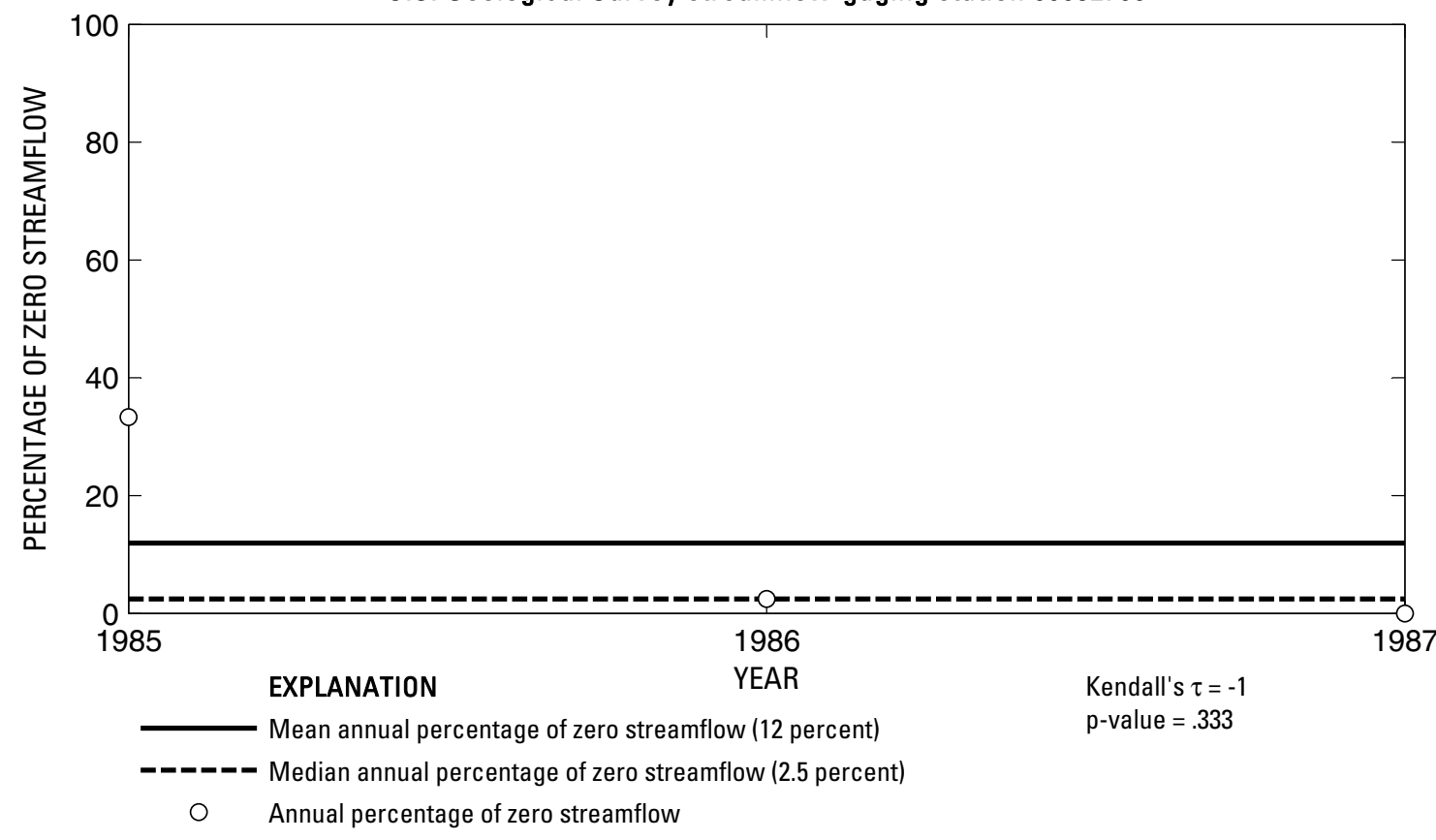

U.S. Geological Survey streamflow-gaging station 08052780

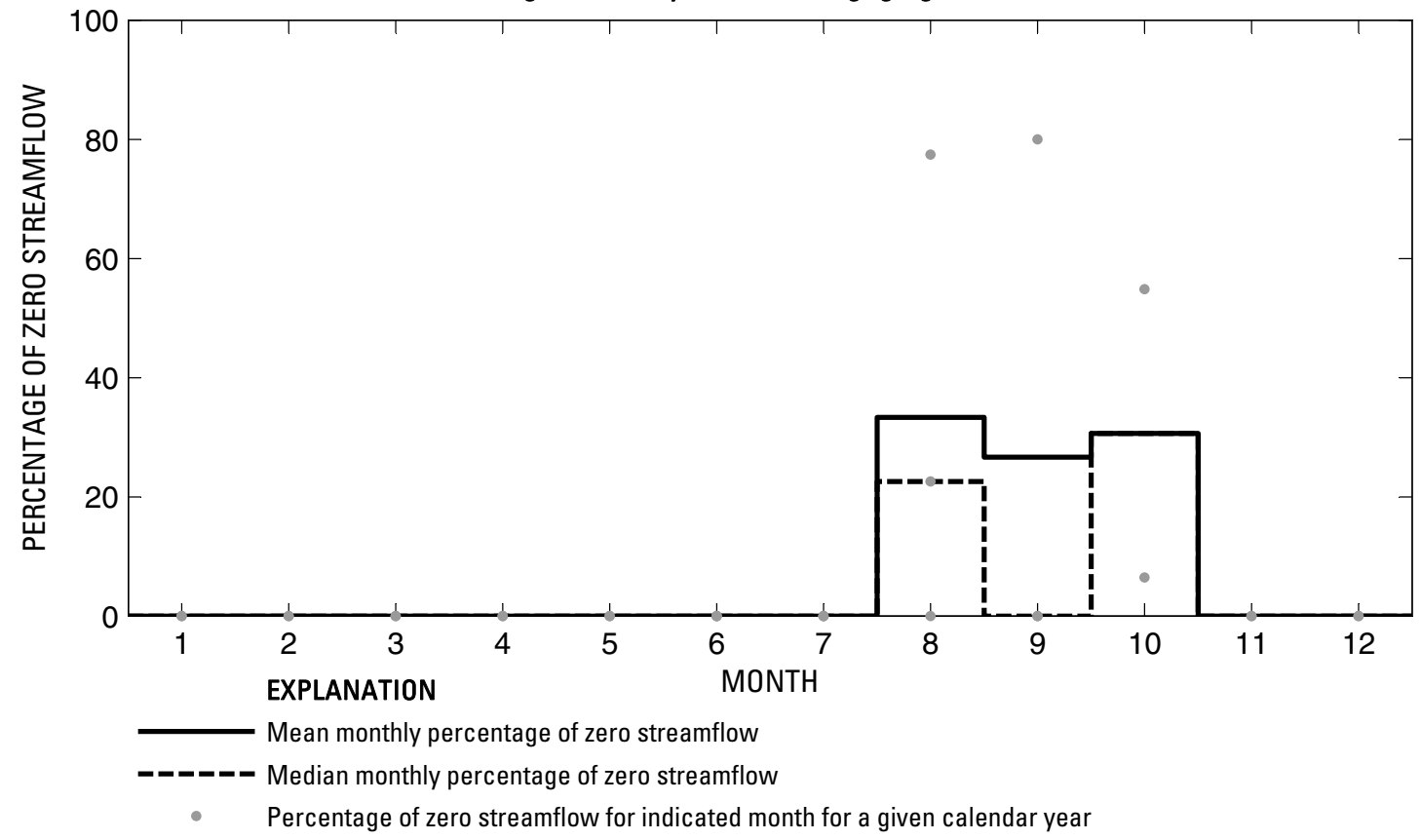

Figure 192. Analysis of percentage of zero daily mean streamflow for U.S. Geological Survey streamflow-gaging station 08052780 Hickory Creek at Denton, Texas. 


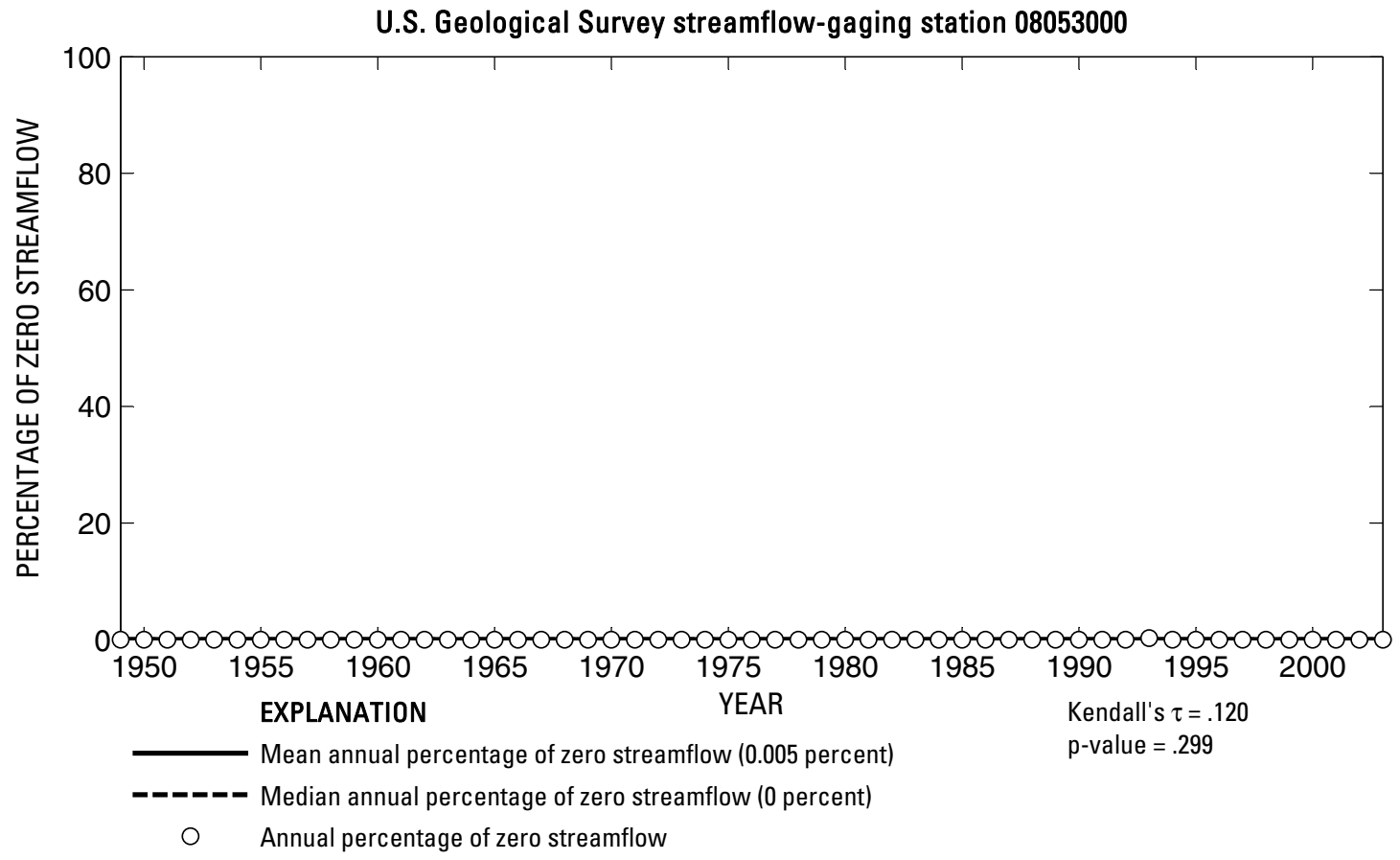

U.S. Geological Survey streamflow-gaging station 08053000

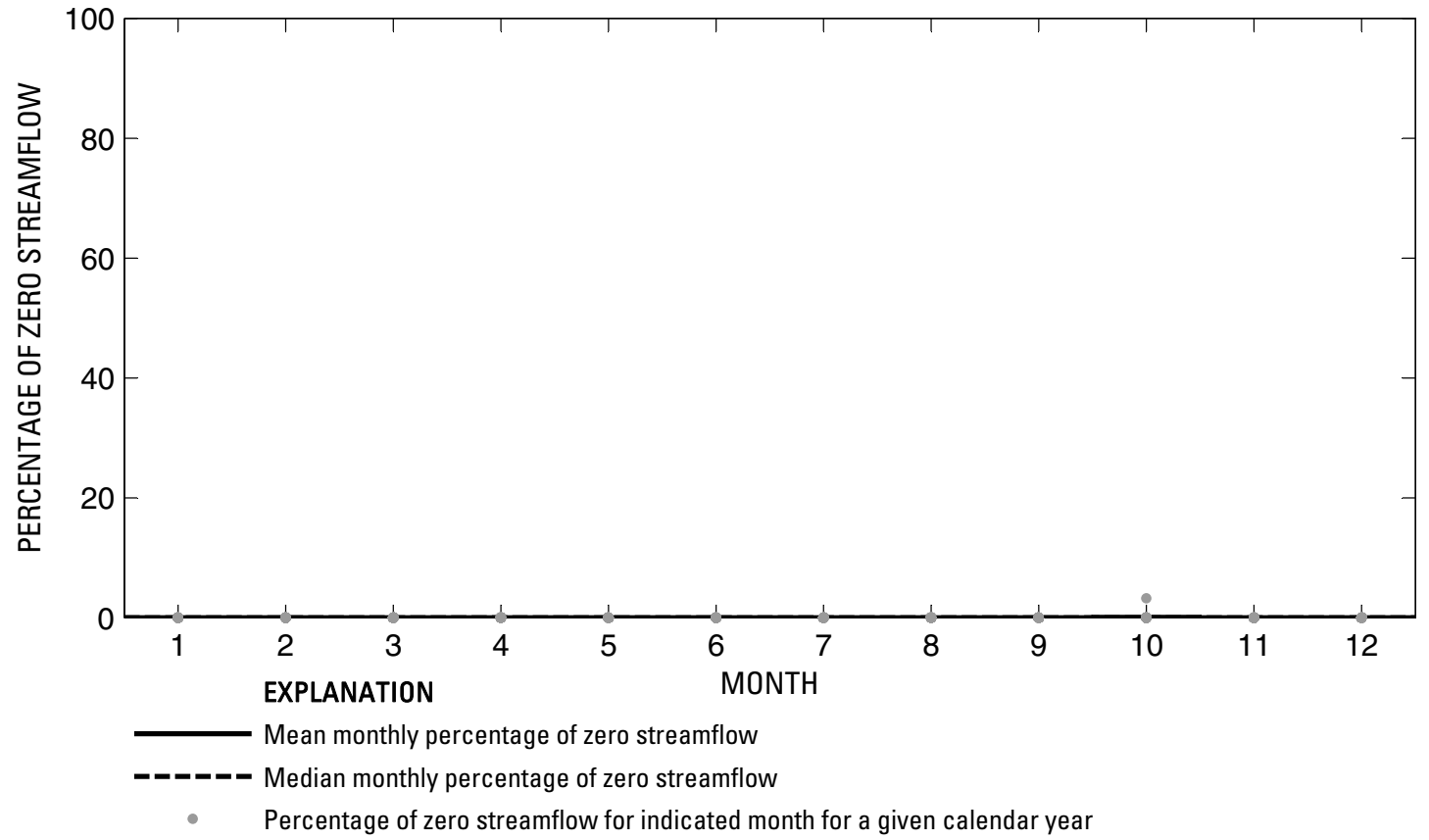

Figure 193. Analysis of percentage of zero daily mean streamflow for U.S. Geological Survey streamflow-gaging station 08053000 Elm Fork Trinity River near Lewisville, Texas. 
U.S. Geological Survey streamflow-gaging station 08053500

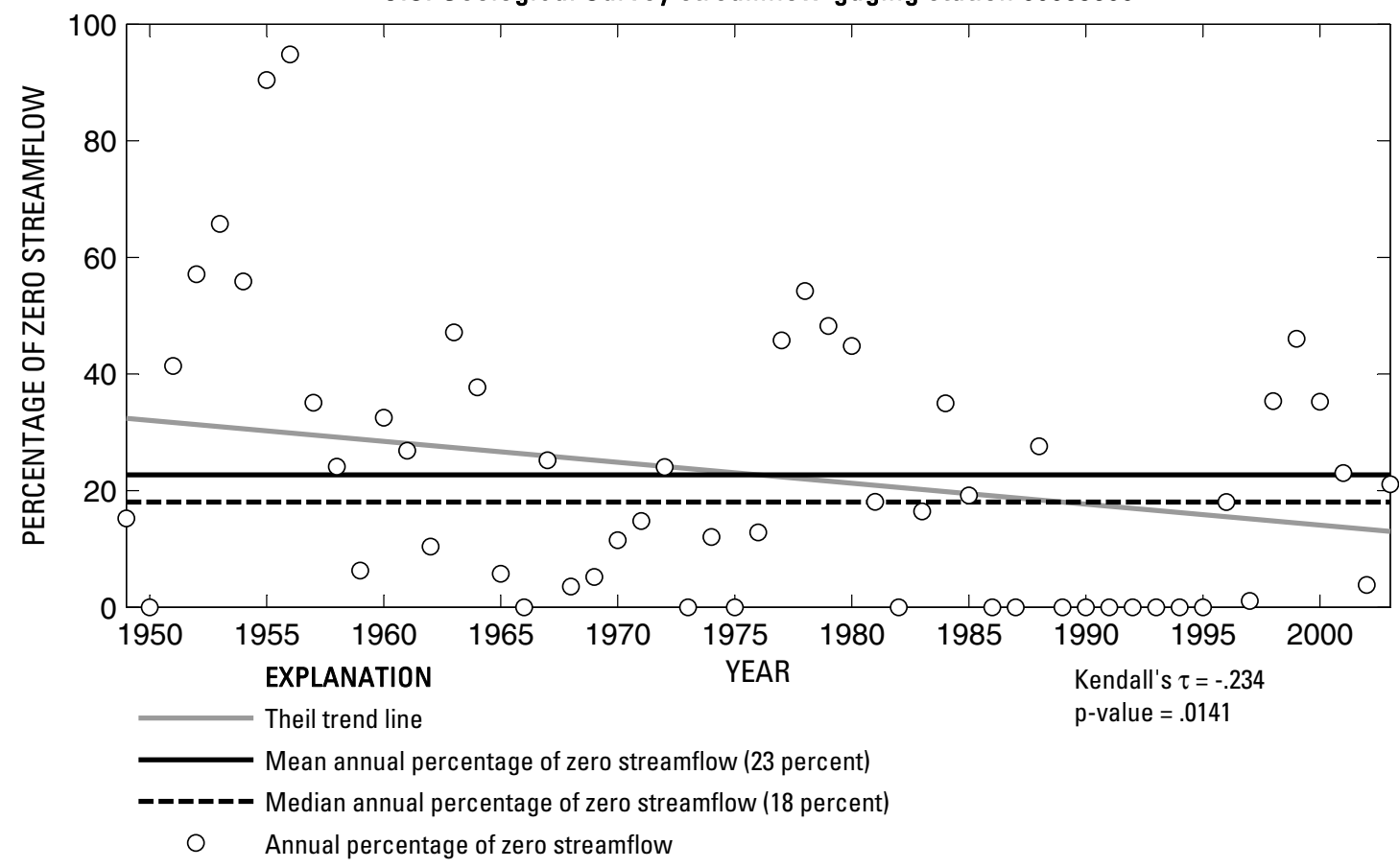

U.S. Geological Survey streamflow-gaging station 08053500

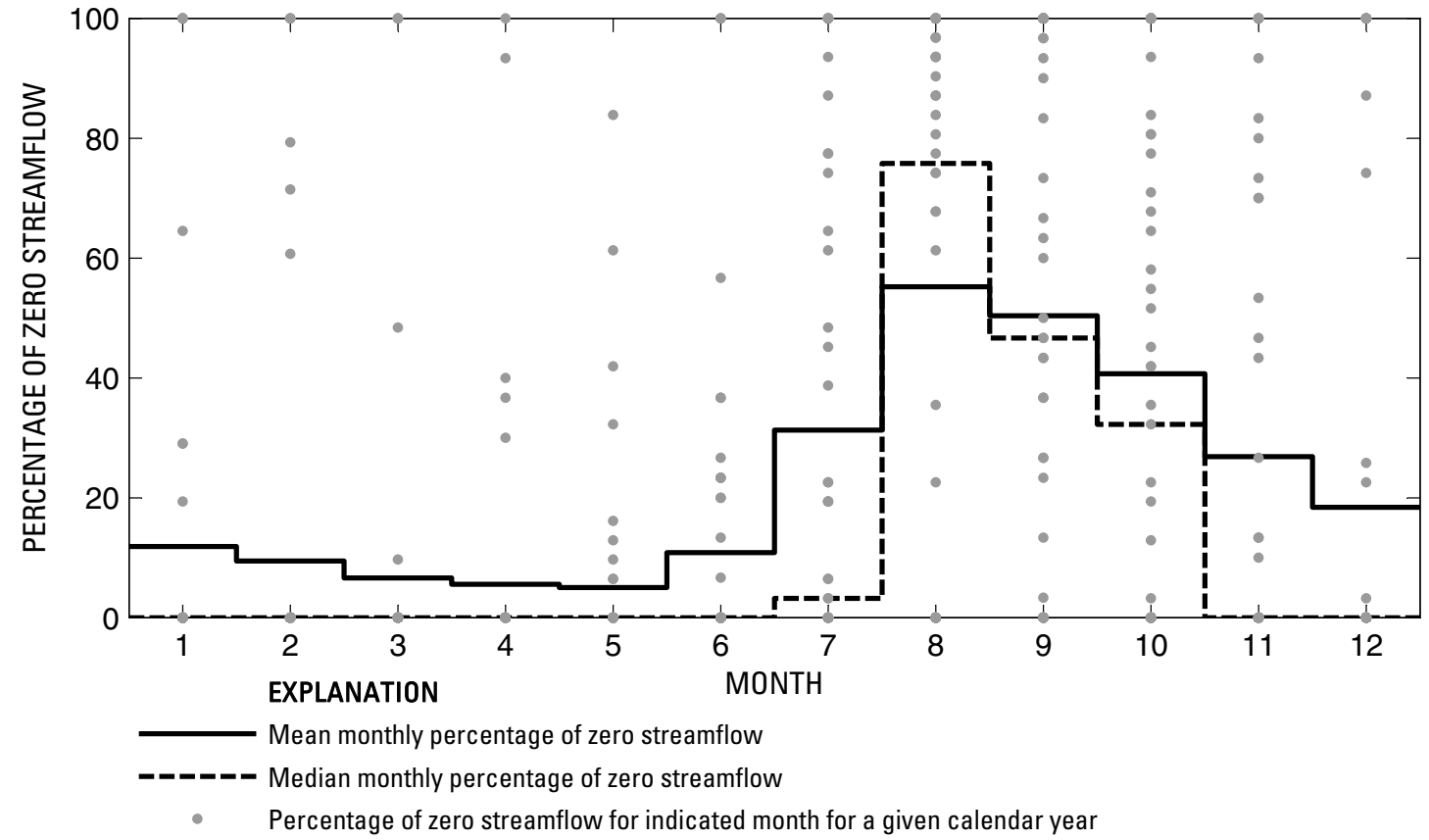

Figure 194. Analysis of percentage of zero daily mean streamflow for U.S. Geological Survey streamflow-gaging station 08053500 Denton Creek near Justin, Texas.

Index of Station Numbers 719 
U.S. Geological Survey streamflow-gaging station 08054000

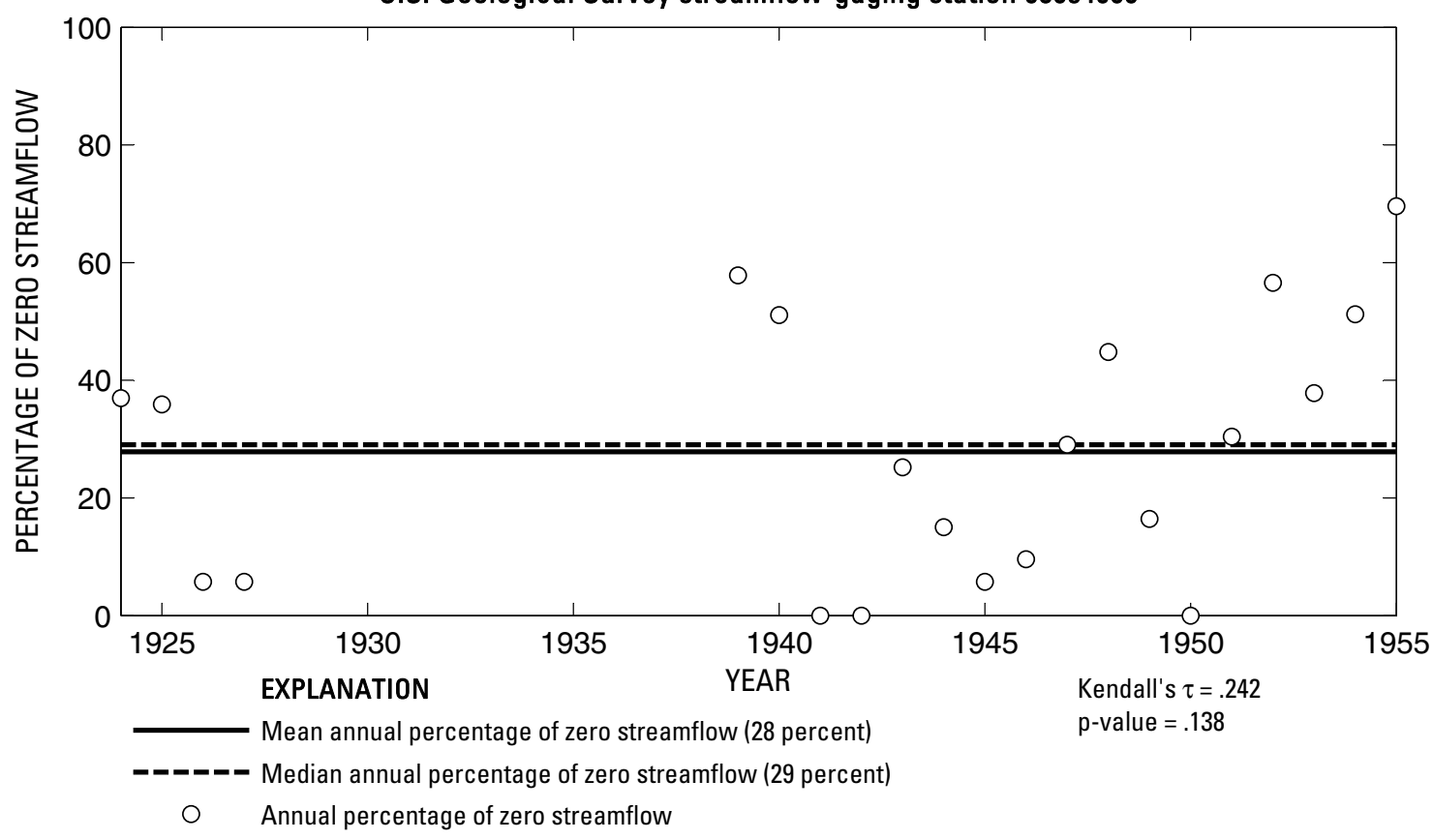

U.S. Geological Survey streamflow-gaging station 08054000

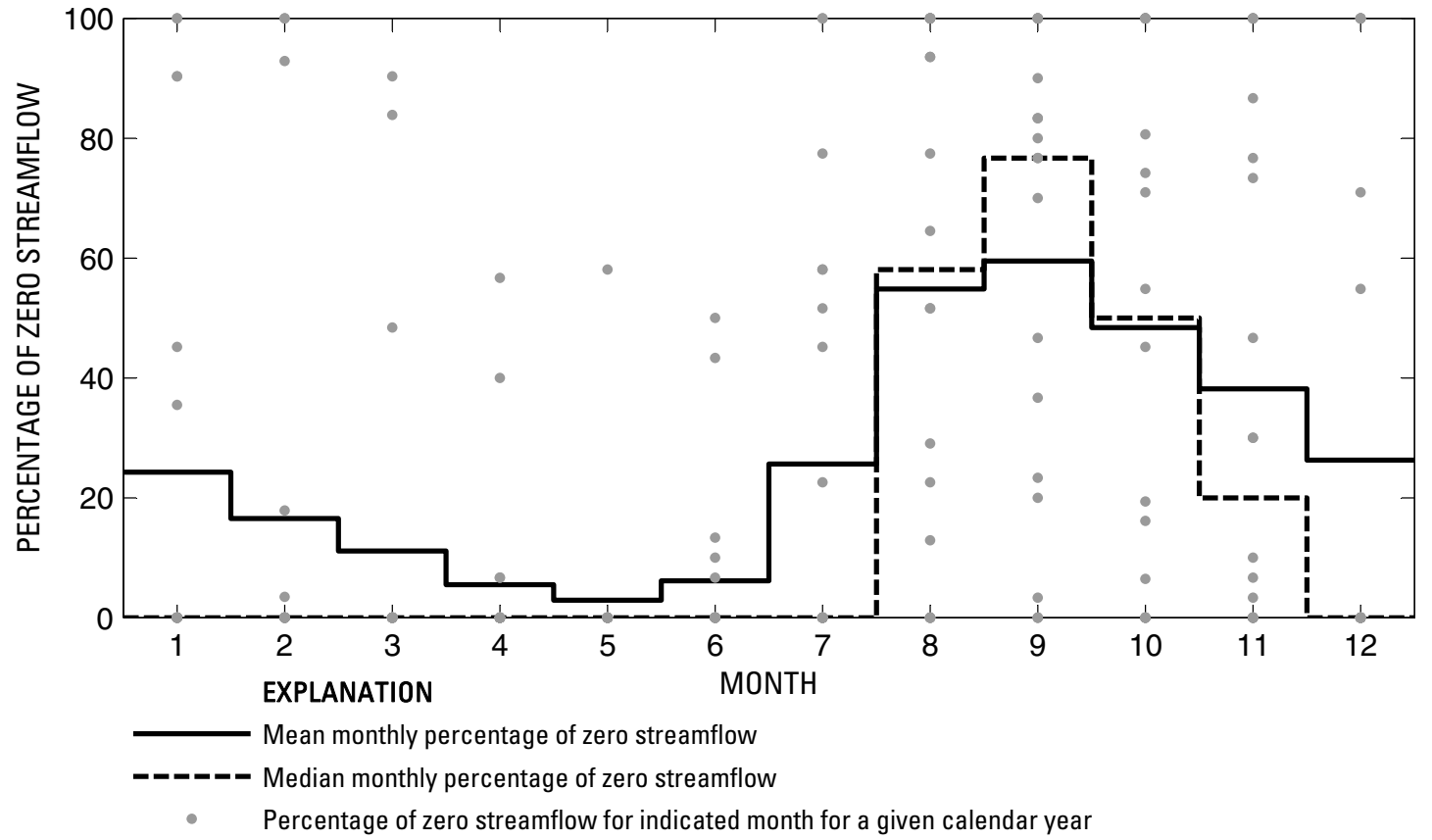

Figure 195. Analysis of percentage of zero daily mean streamflow for U.S. Geological Survey streamflow-gaging station 08054000 Denton Creek near Roanoke, Texas. 
U.S. Geological Survey streamflow-gaging station 08055000
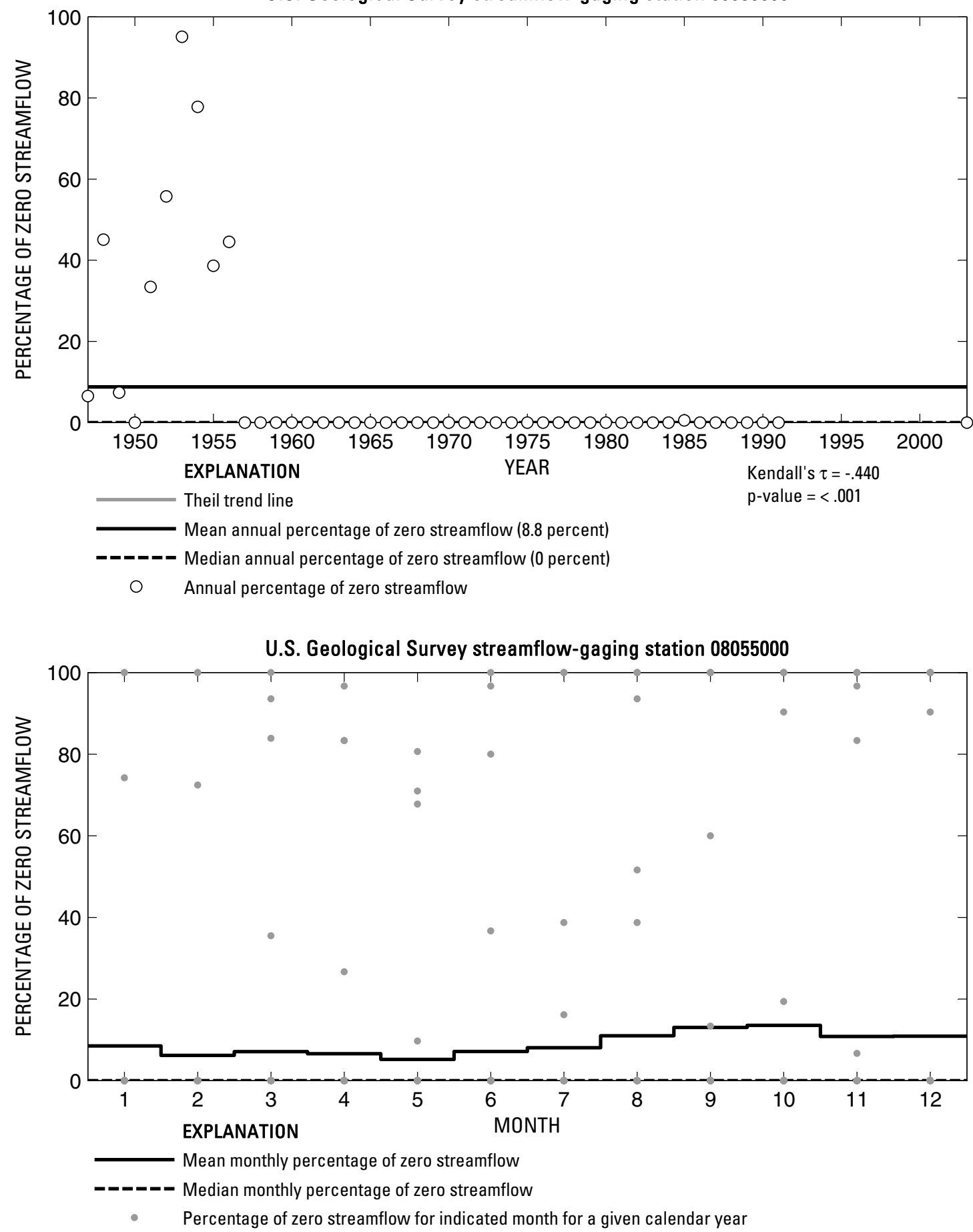

Figure 196. Analysis of percentage of zero daily mean streamflow for U.S. Geological Survey streamflow-gaging station 08055000 Denton Creek near Grapevine, Texas.

Index of Station Numbers 719 
U.S. Geological Survey streamflow-gaging station 08055500

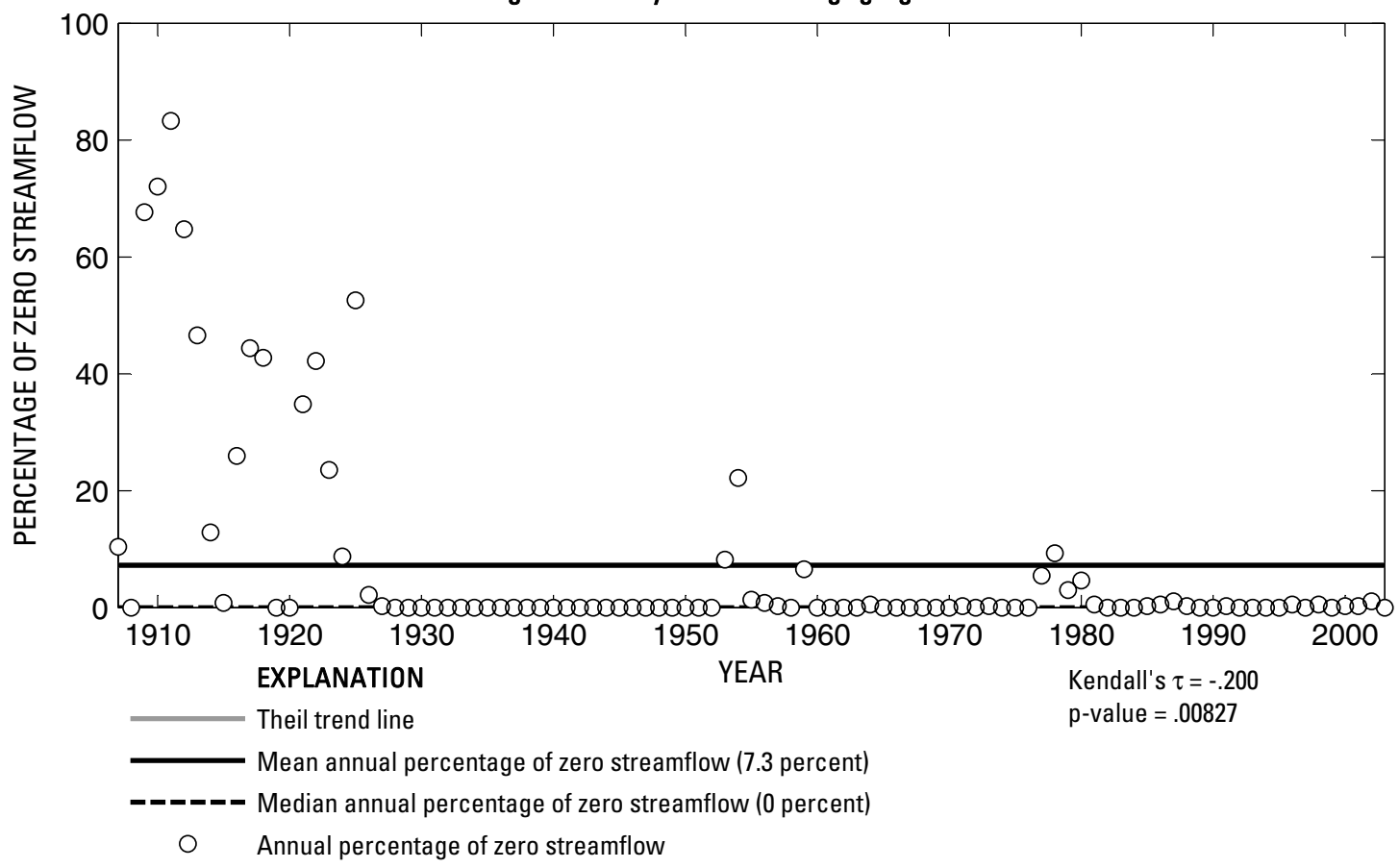

U.S. Geological Survey streamflow-gaging station 08055500

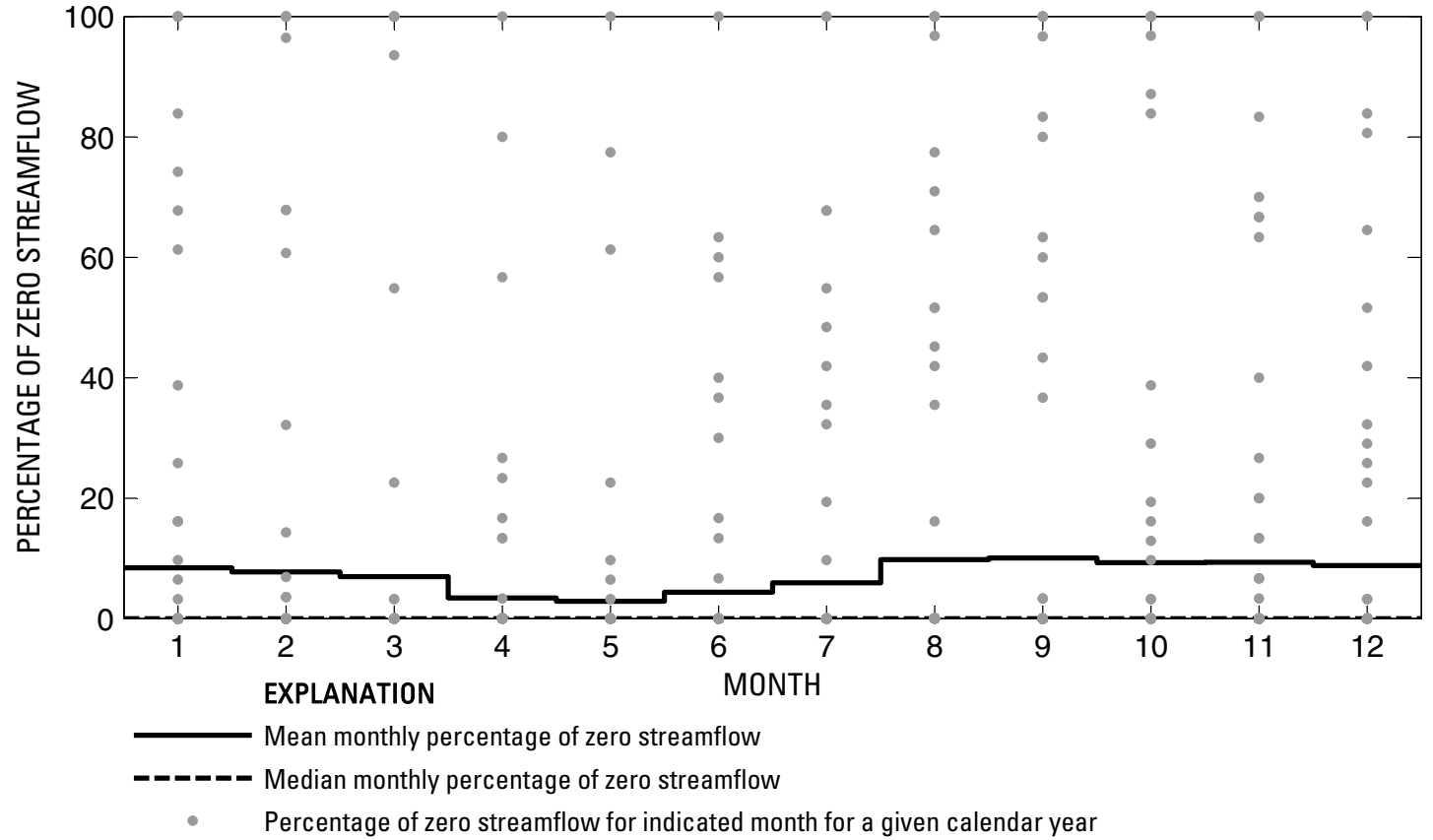

Figure 197. Analysis of percentage of zero daily mean streamflow for U.S. Geological Survey streamflow-gaging station 08055500 Elm Fork Trinity River near Carrollton, Texas. 
U.S. Geological Survey streamflow-gaging station 08055700

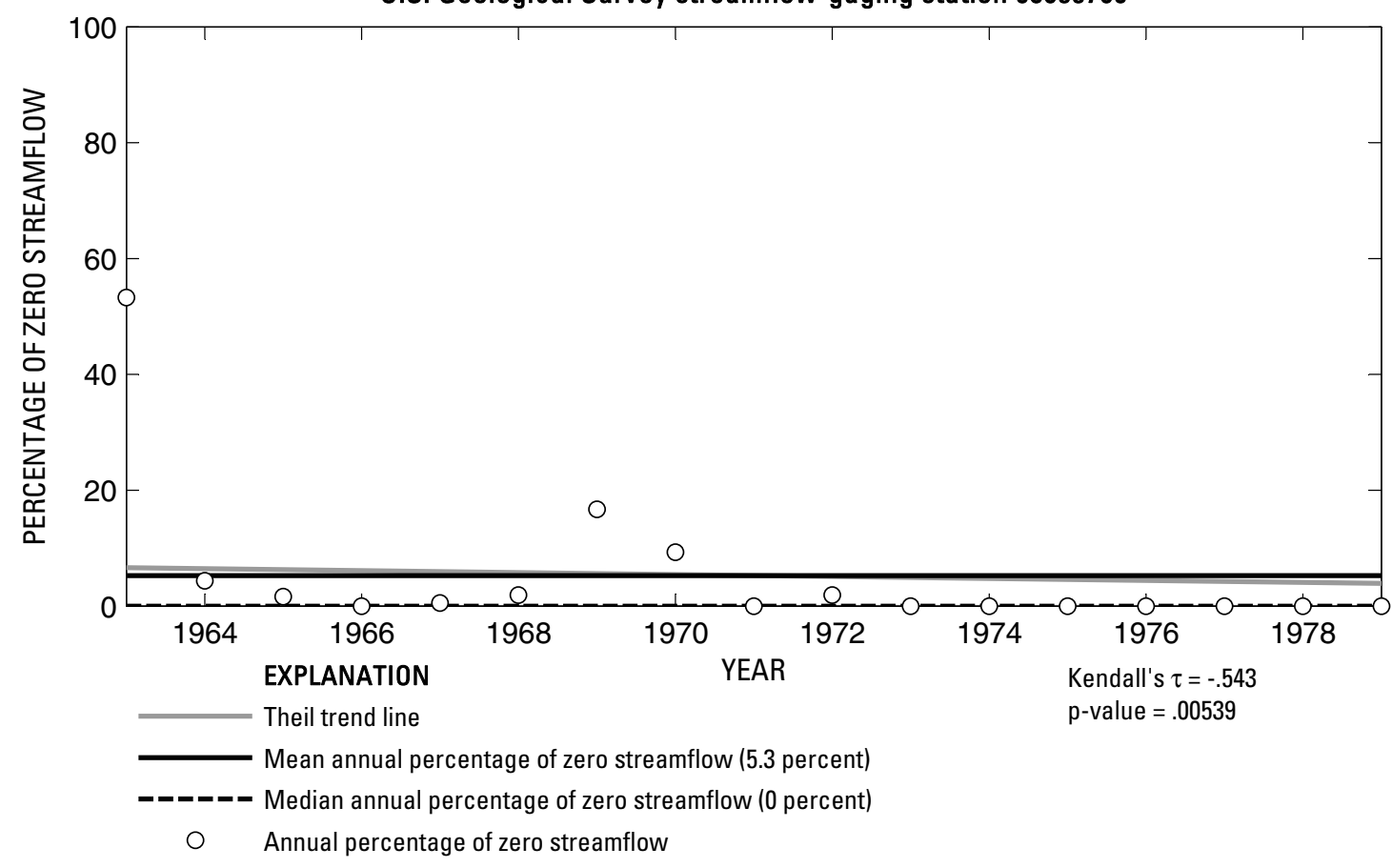

U.S. Geological Survey streamflow-gaging station 08055700

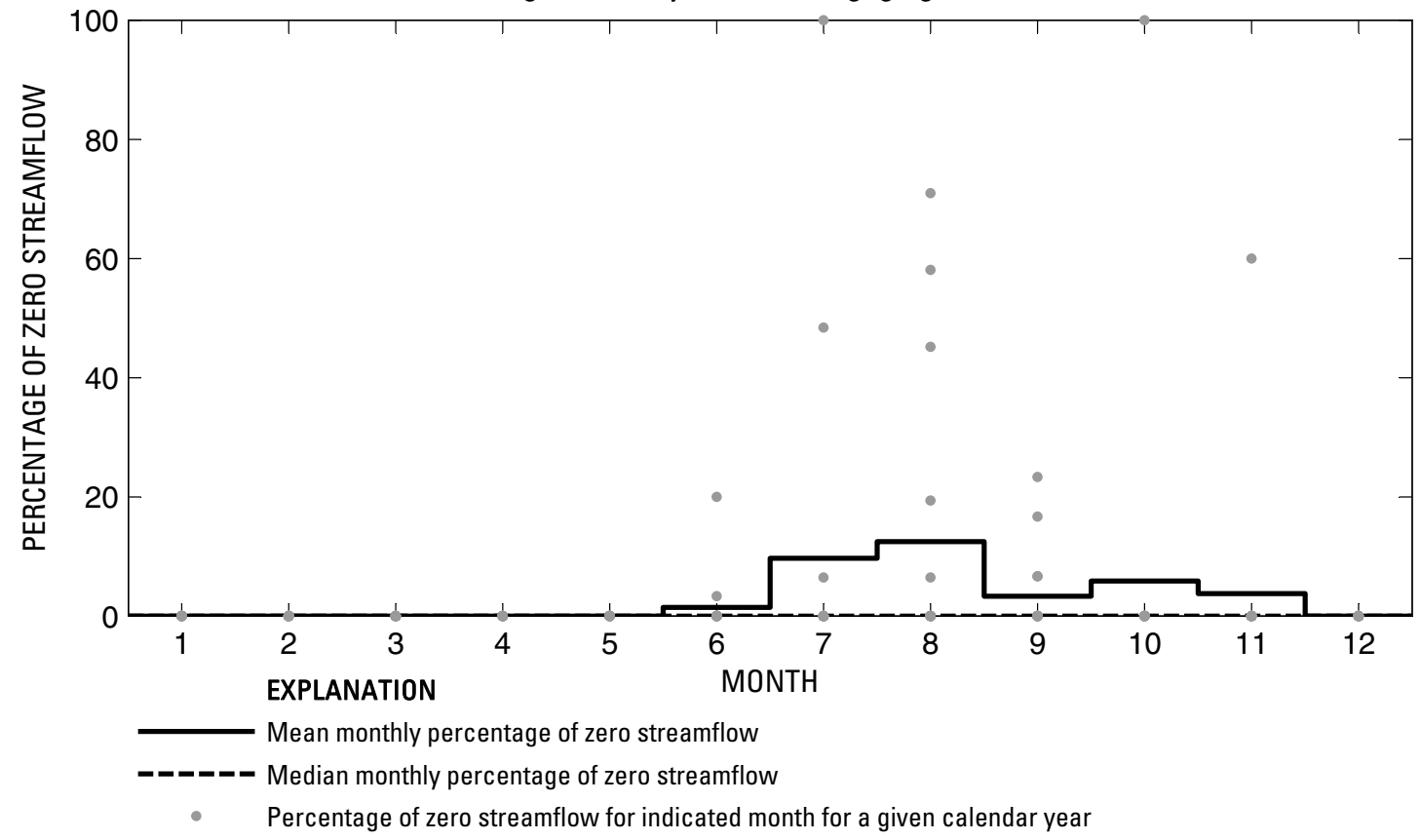

Figure 198. Analysis of percentage of zero daily mean streamflow for U.S. Geological Survey streamflow-gaging station 08055700 Bachman Branch at Dallas, Texas. 


\section{U.S. Geological Survey streamflow-gaging station 08056500}

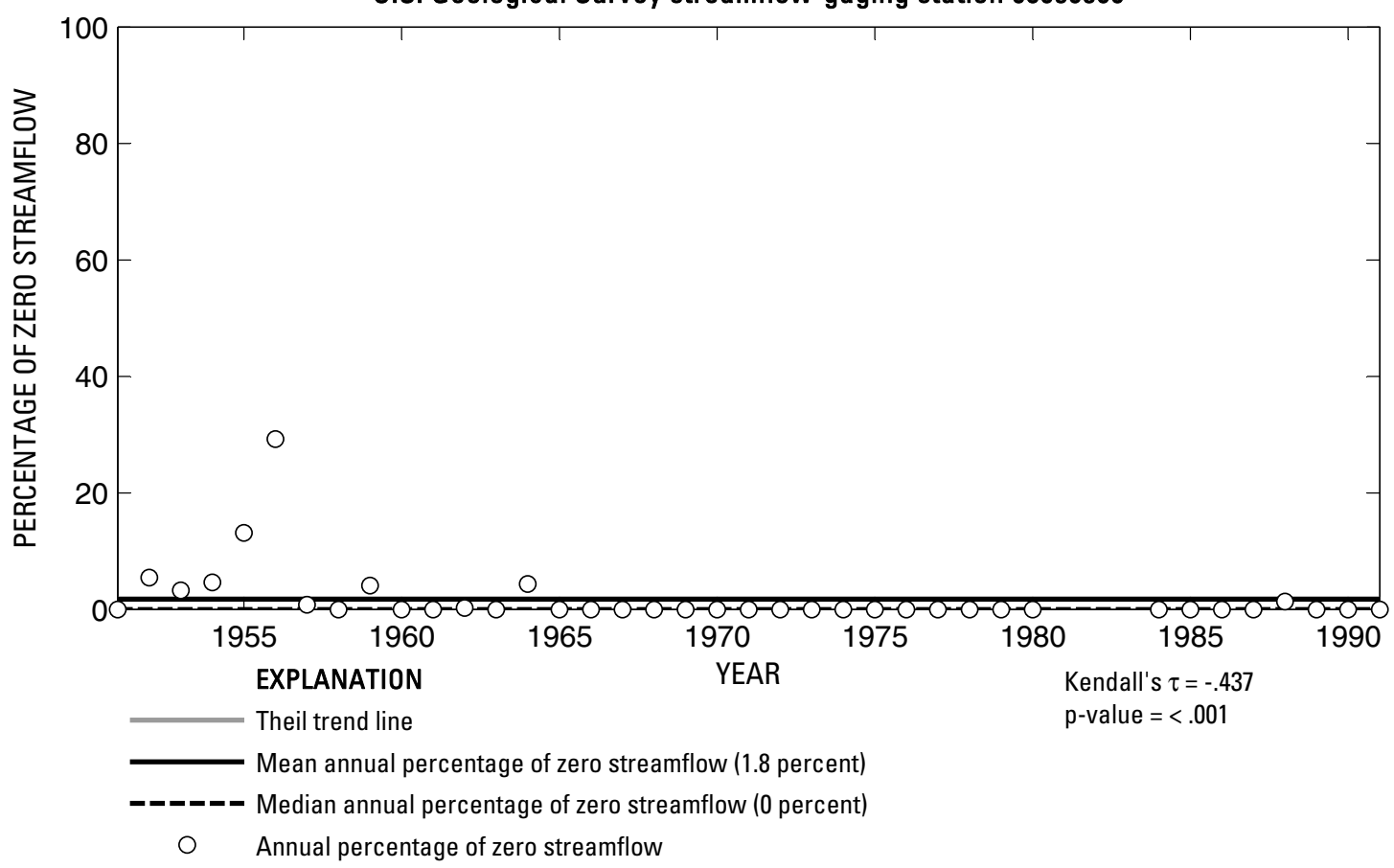

U.S. Geological Survey streamflow-gaging station 08056500

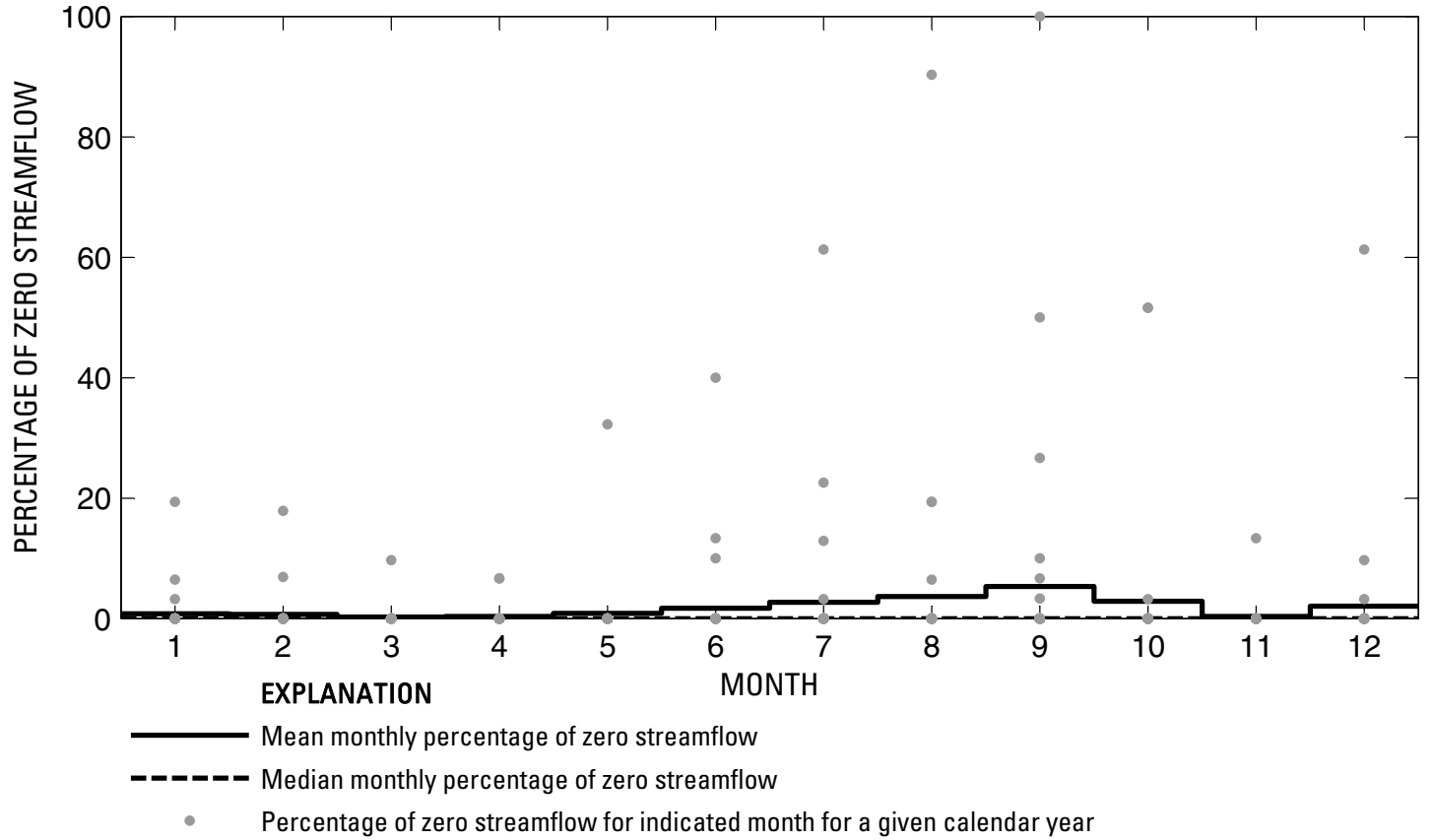

Figure 199. Analysis of percentage of zero daily mean streamflow for U.S. Geological Survey streamflow-gaging station 08056500 Turtle Creek at Dallas, Texas. 
U.S. Geological Survey streamflow-gaging station 08057000

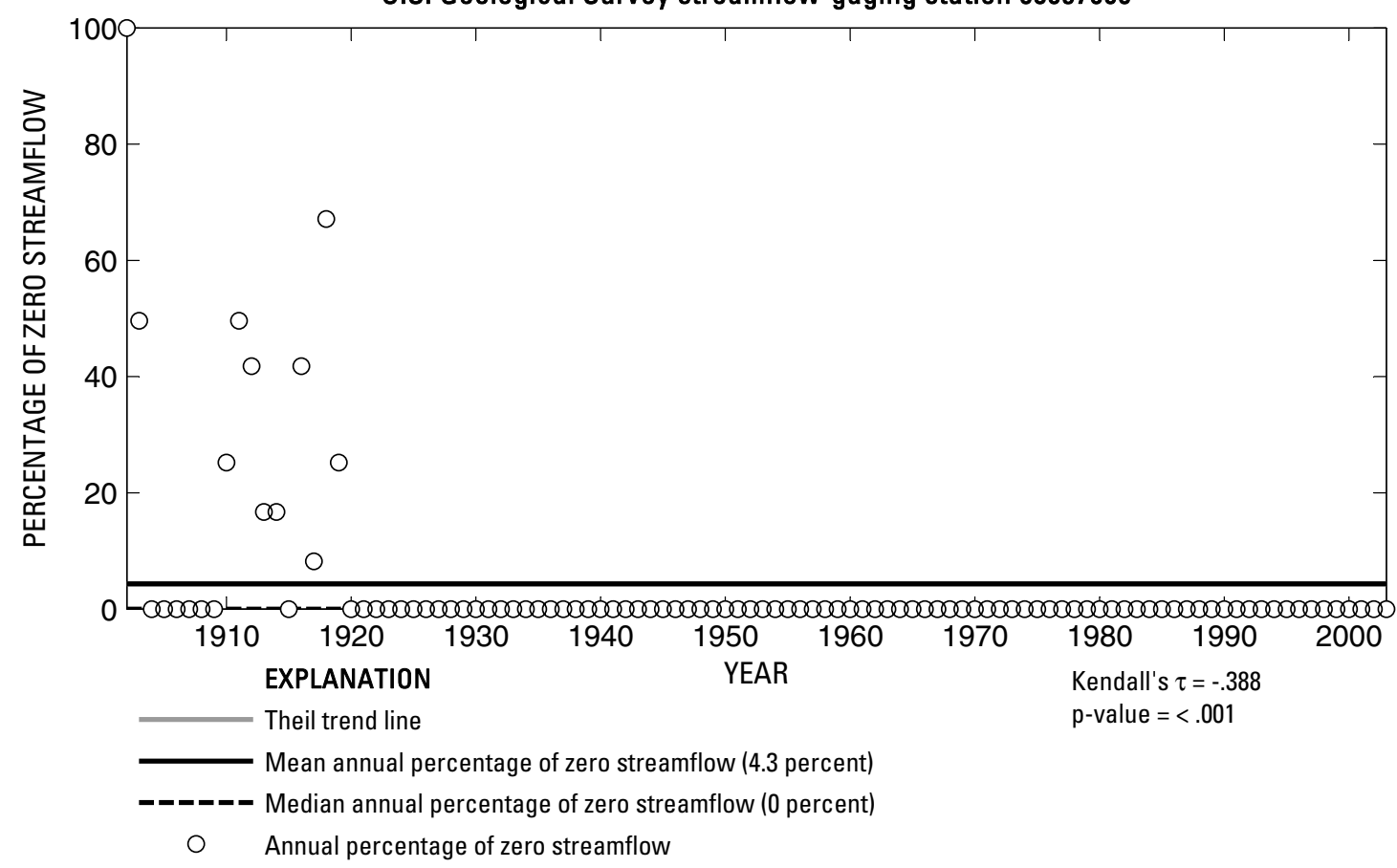

U.S. Geological Survey streamflow-gaging station 08057000

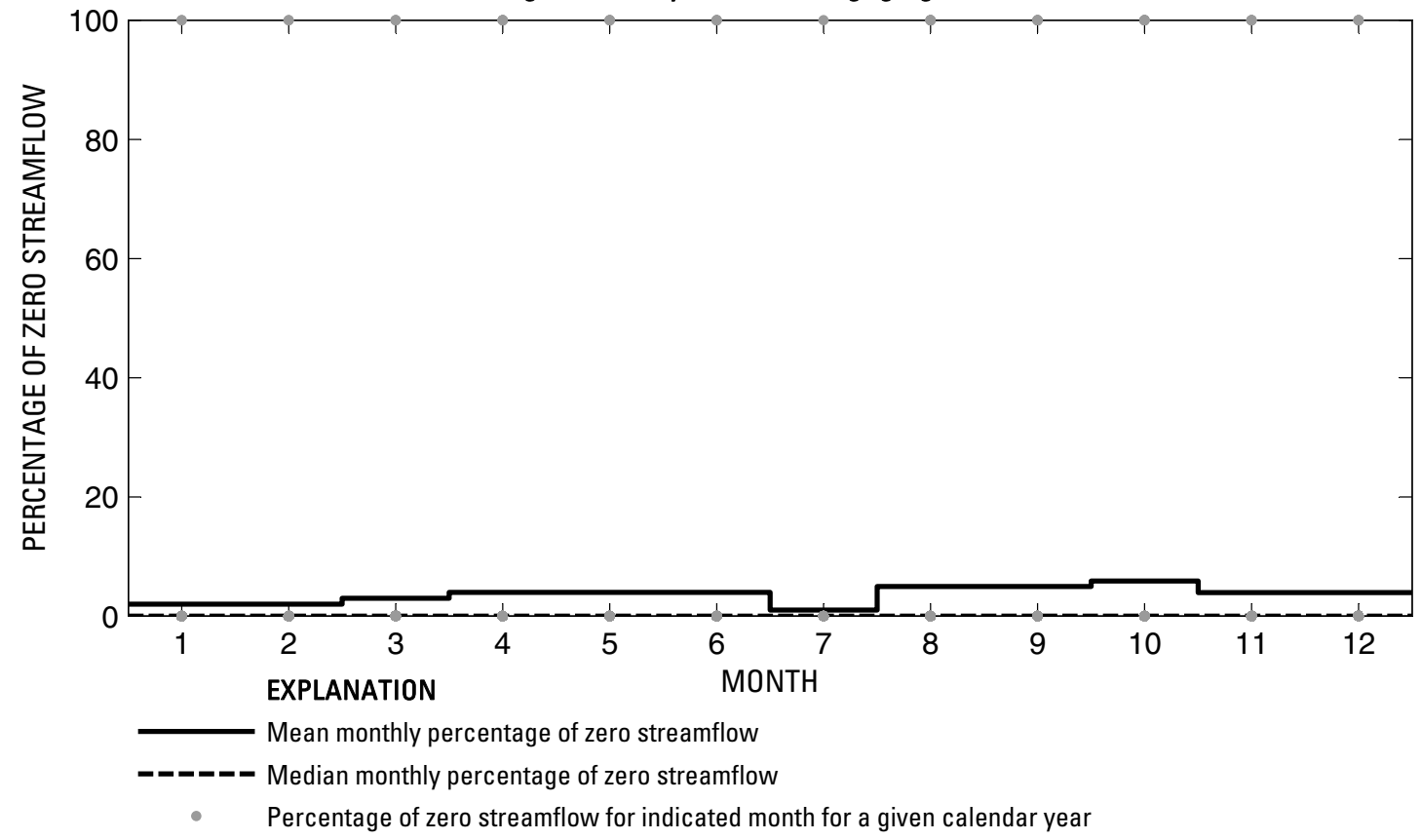

Figure 200. Analysis of percentage of zero daily mean streamflow for U.S. Geological Survey streamflow-gaging station 08057000 Trinity River at Dallas, Texas. 
U.S. Geological Survey streamflow-gaging station 08057100

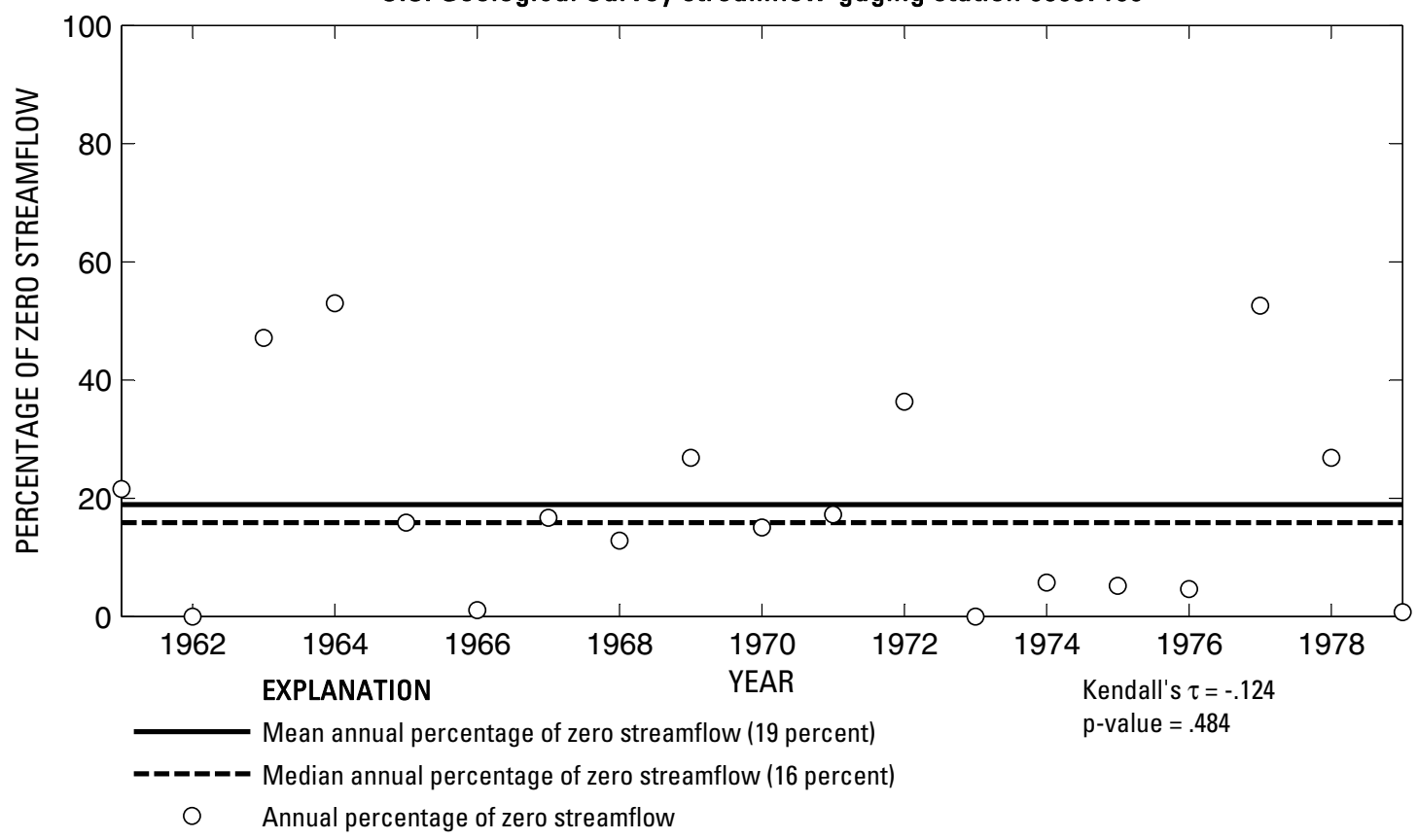

U.S. Geological Survey streamflow-gaging station 08057100

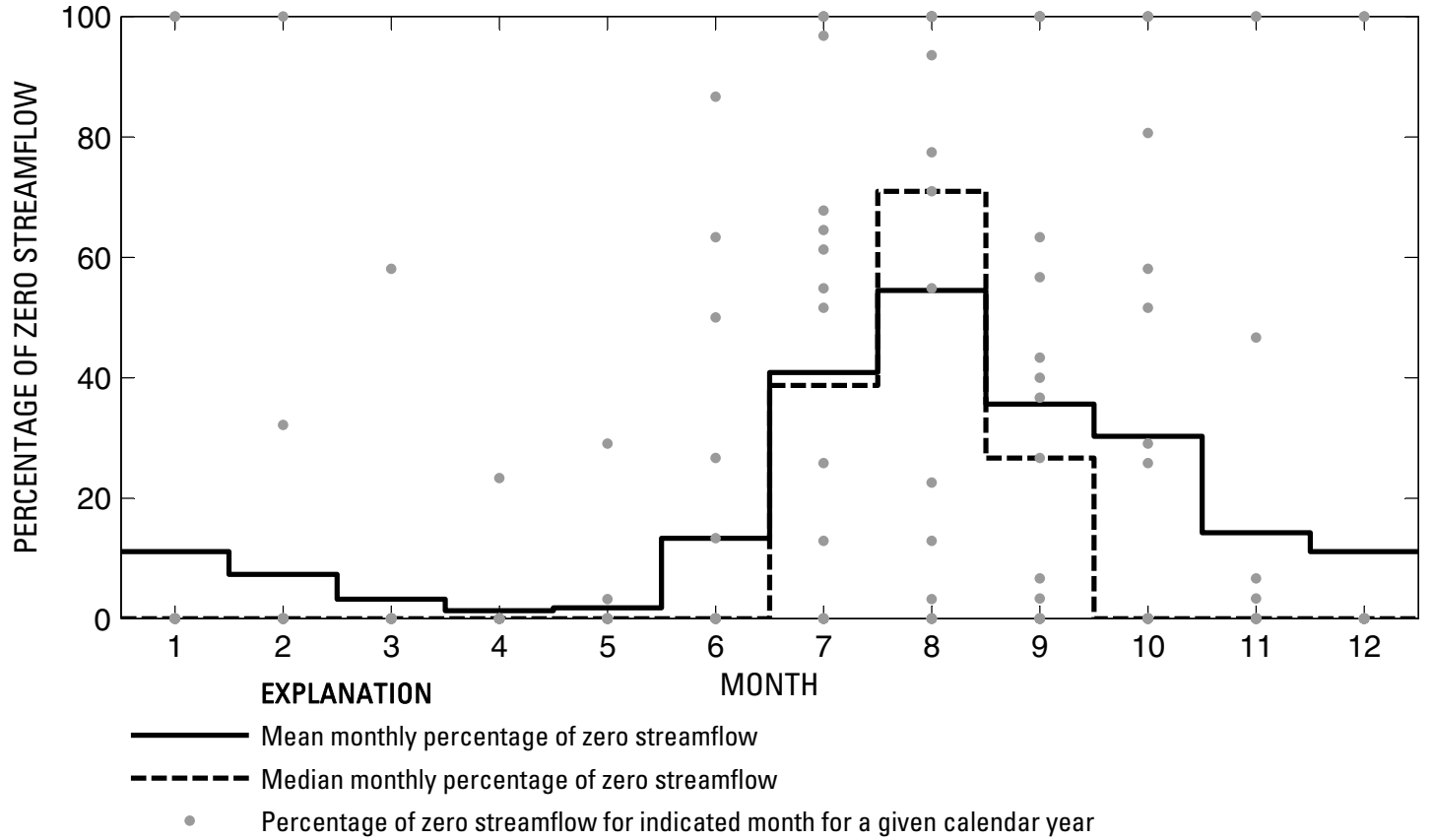

Figure 201. Analysis of percentage of zero daily mean streamflow for U.S. Geological Survey streamflow-gaging station 08057100 White Rock Creek at Keller Springs Road, Dallas, Texas. 
U.S. Geological Survey streamflow-gaging station 08057200

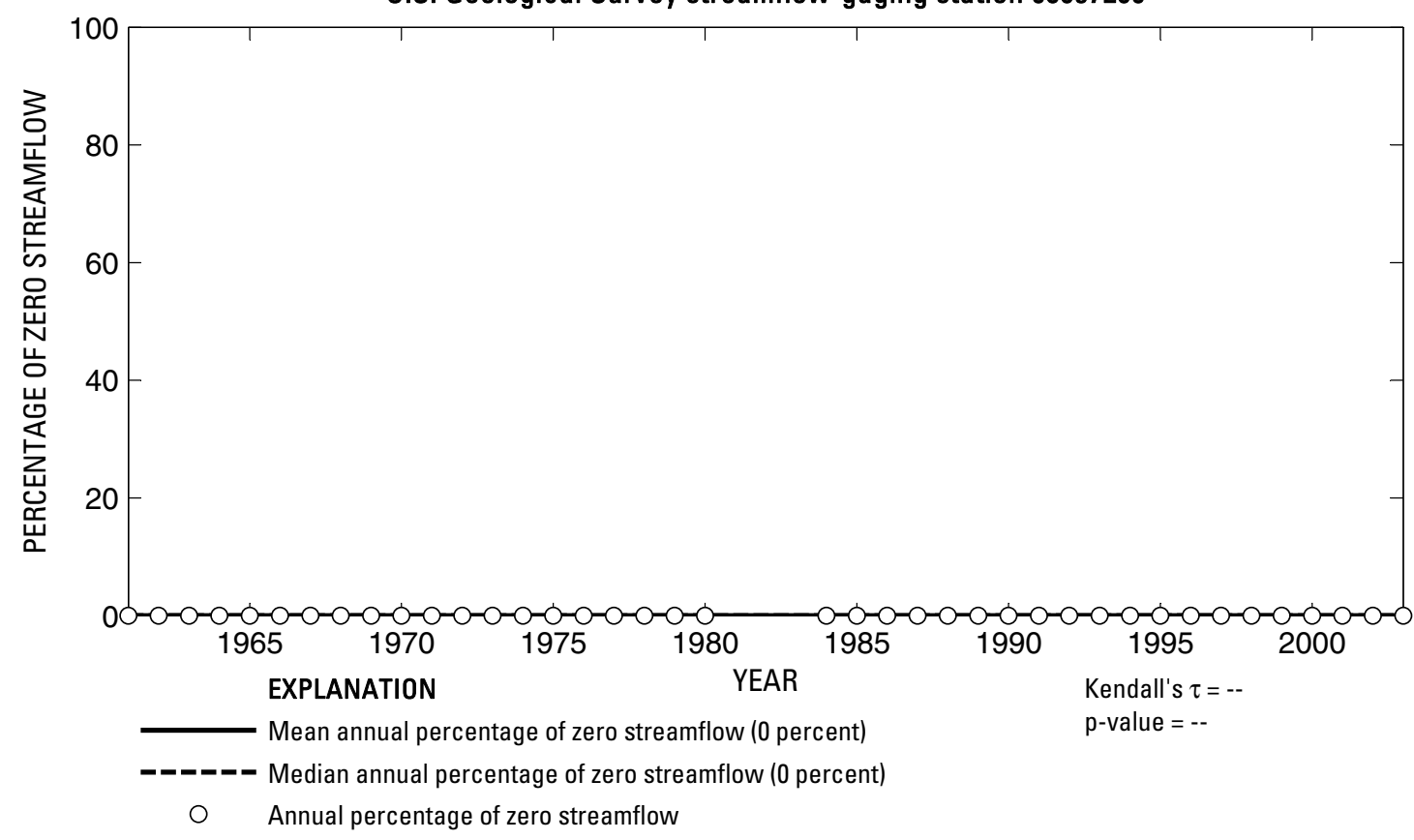

U.S. Geological Survey streamflow-gaging station 08057200

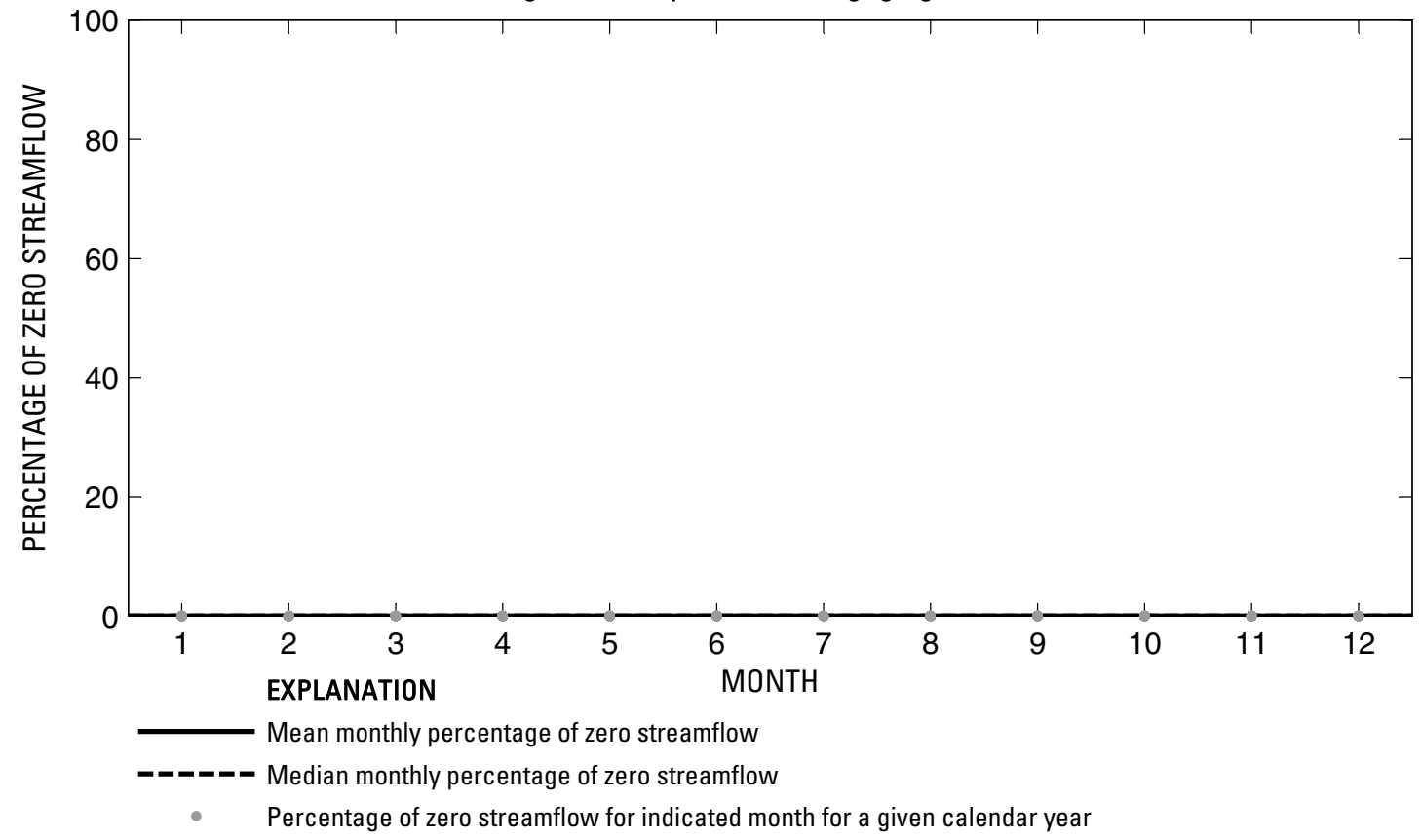

Figure 202. Analysis of percentage of zero daily mean streamflow for U.S. Geological Survey streamflow-gaging station 08057200 White Rock Creek at Greenville Avenue, Dallas, Texas. 
U.S. Geological Survey streamflow-gaging station 08057300

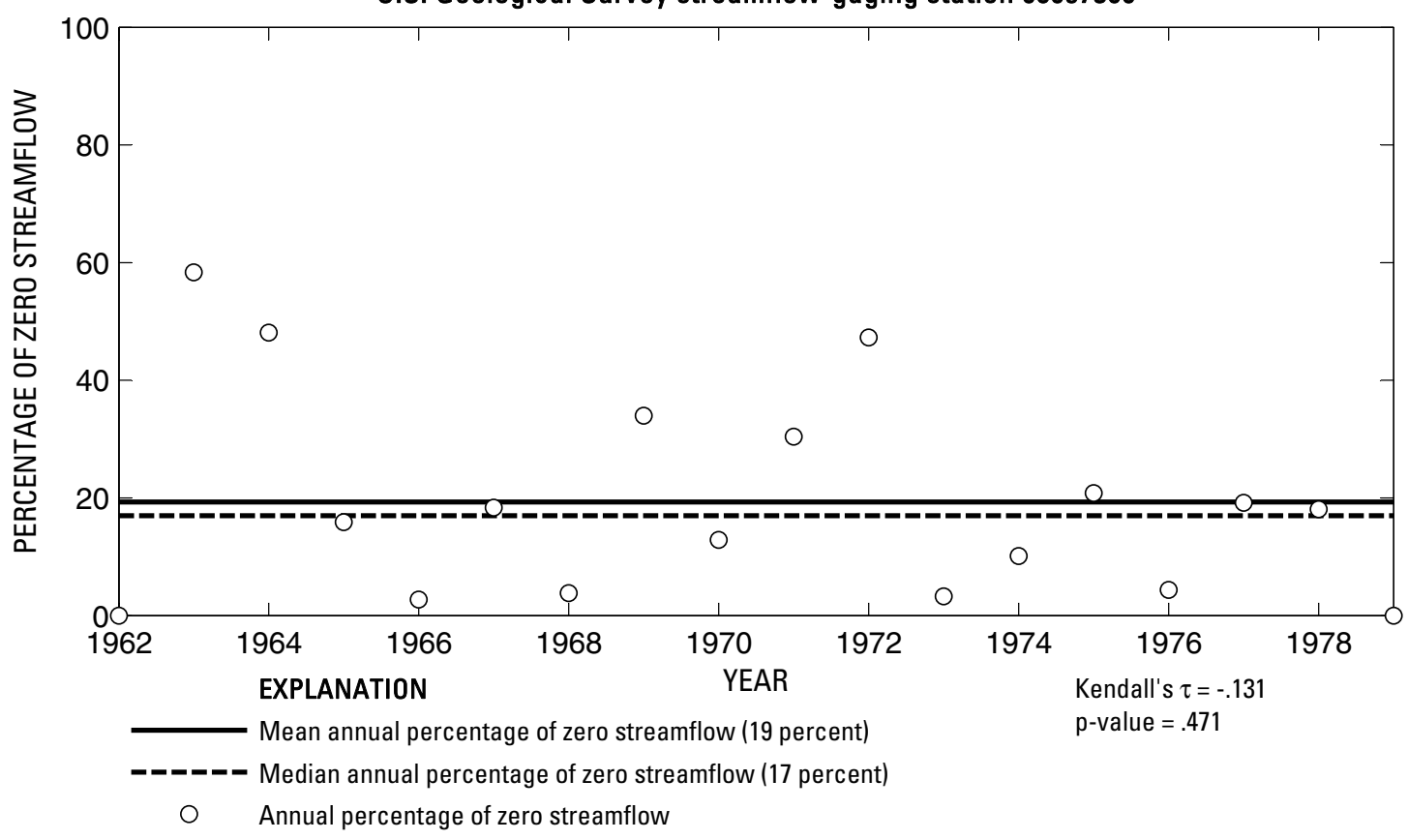

U.S. Geological Survey streamflow-gaging station 08057300

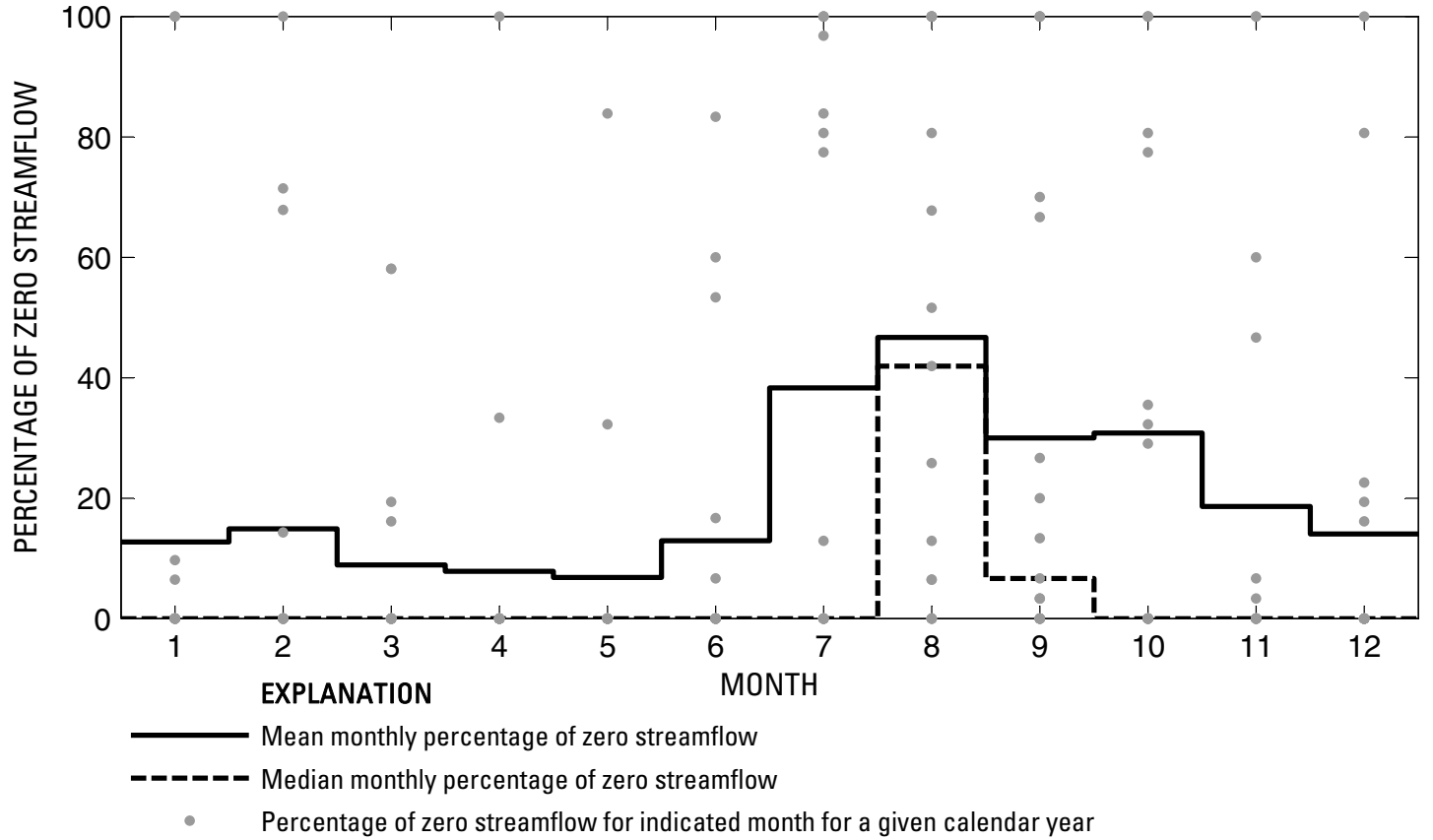

Figure 203. Analysis of percentage of zero daily mean streamflow for U.S. Geological Survey streamflow-gaging station 08057300 White Rock Creek at White Rock Lake, Dallas, Texas. 
U.S. Geological Survey streamflow-gaging station 08057410

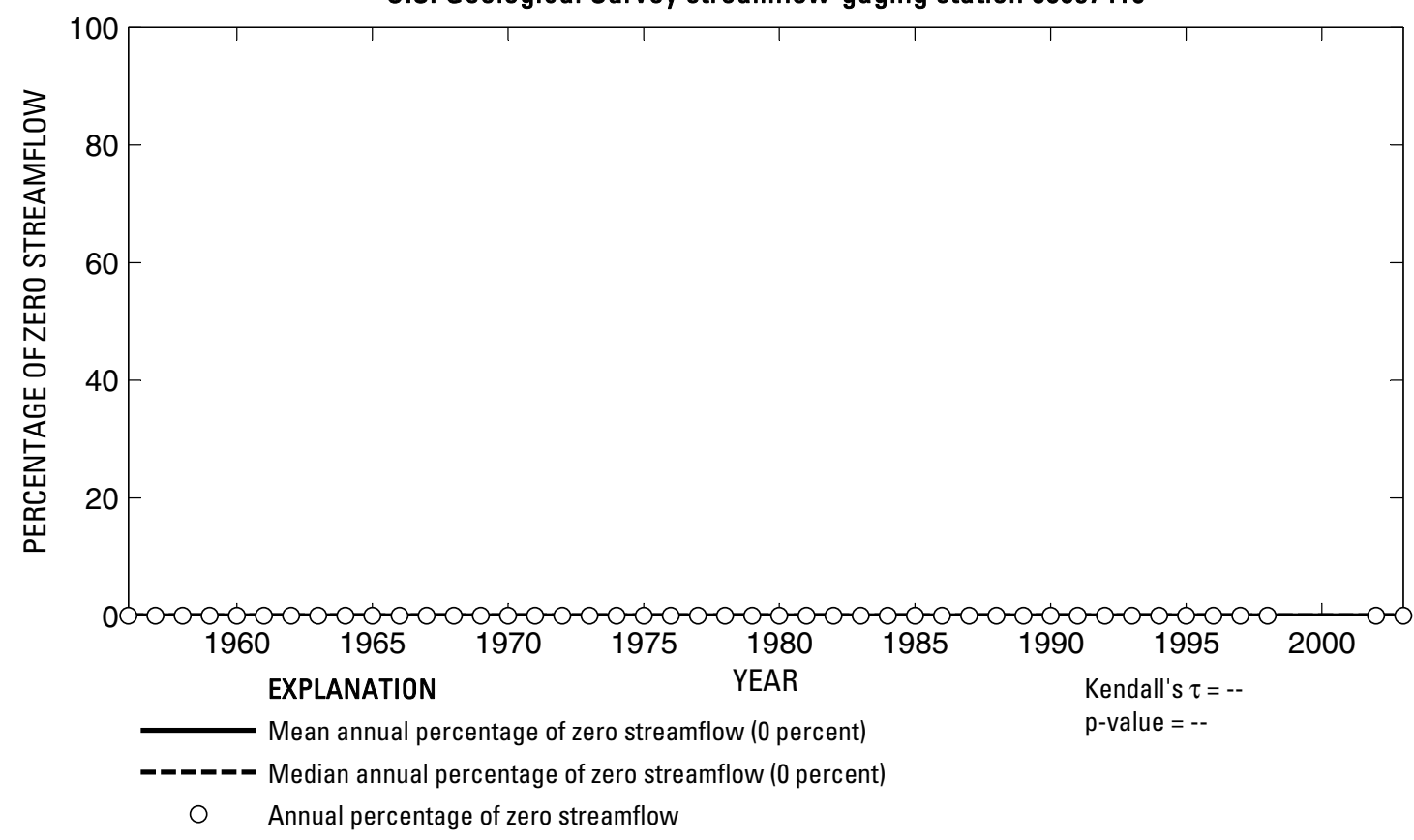

U.S. Geological Survey streamflow-gaging station 08057410

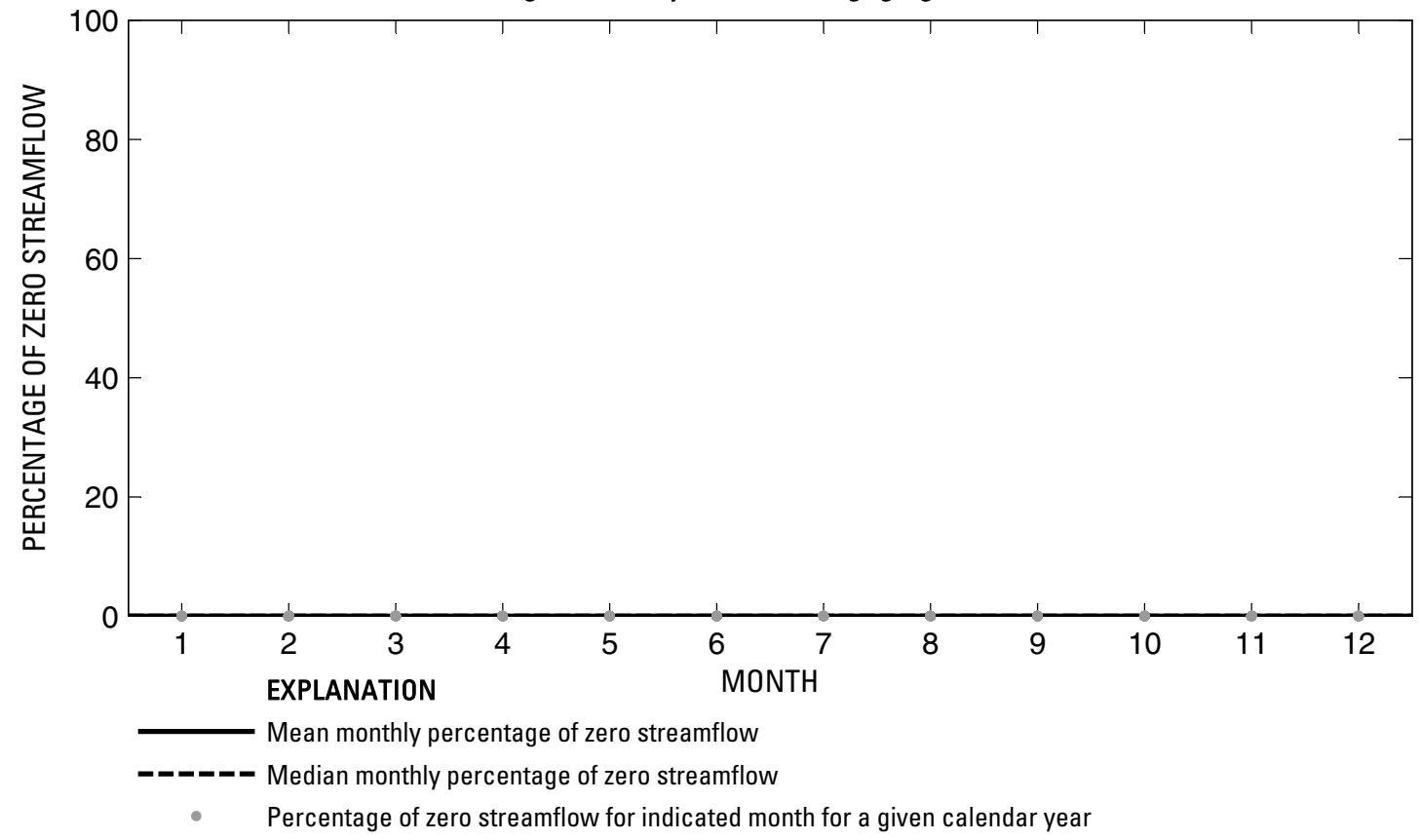

Figure 204. Analysis of percentage of zero daily mean streamflow for U.S. Geological Survey streamflow-gaging station 08057410 Trinity River below Dallas, Texas. 


\section{U.S. Geological Survey streamflow-gaging station 08057445}

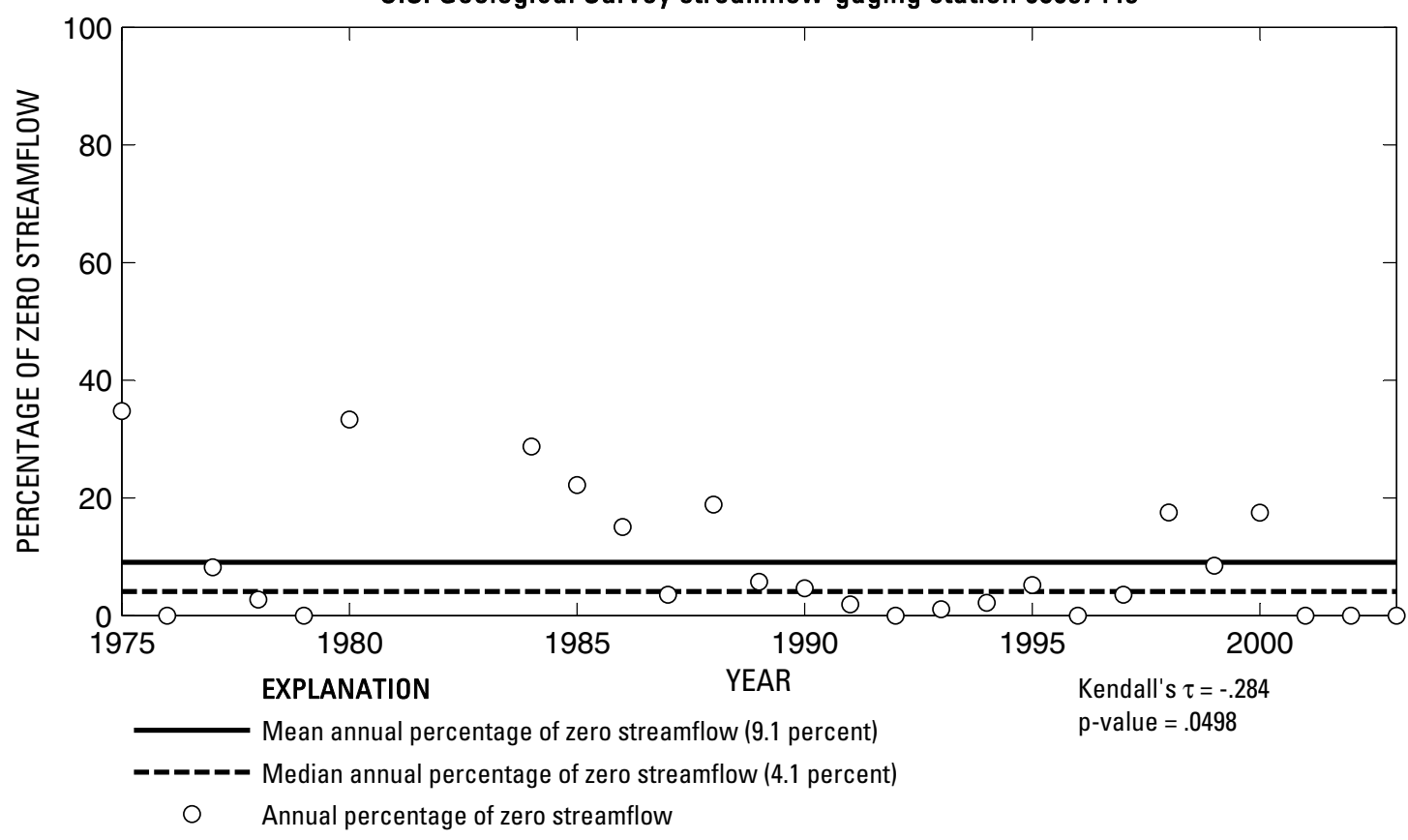

U.S. Geological Survey streamflow-gaging station 08057445

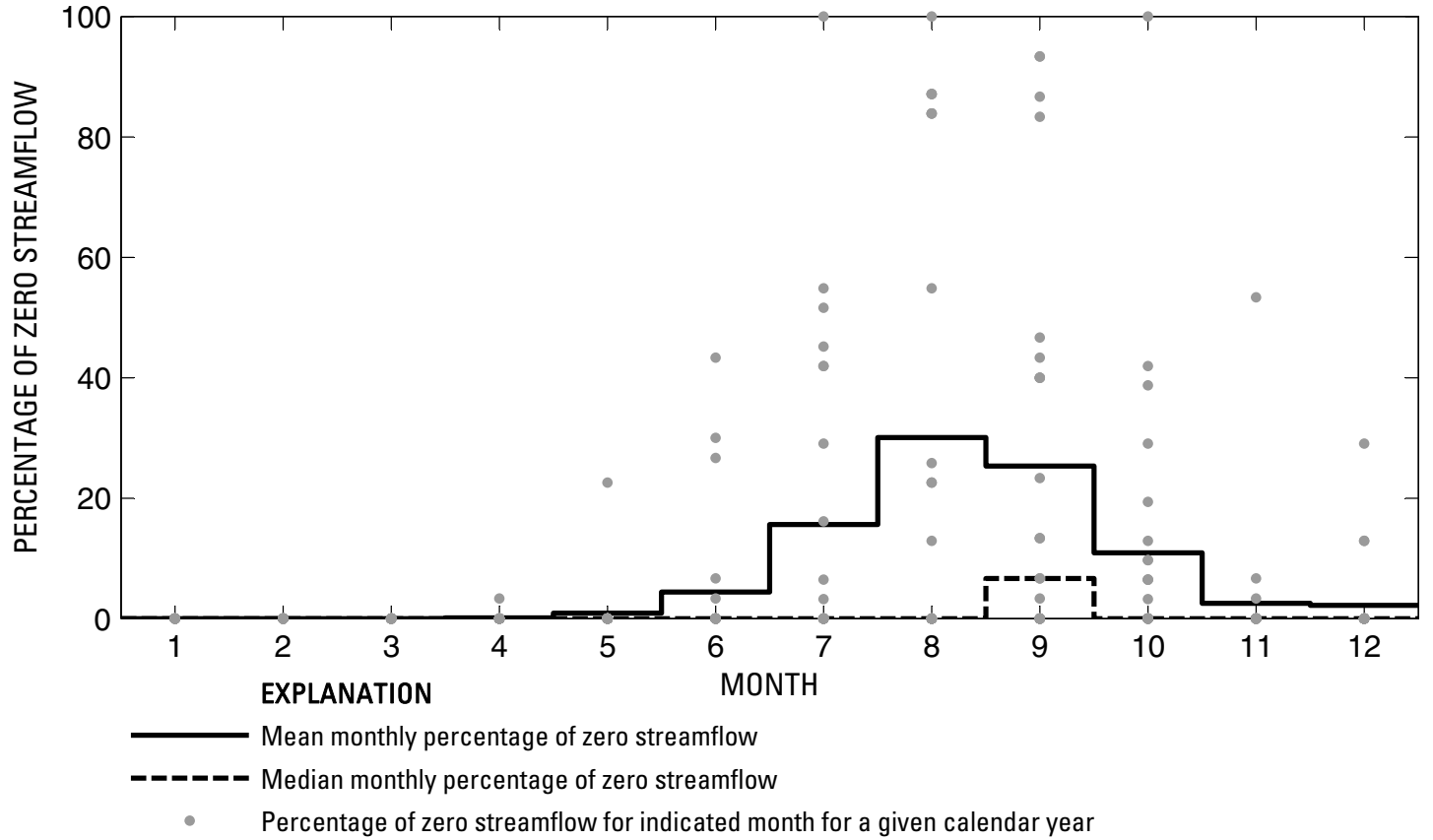

Figure 205. Analysis of percentage of zero daily mean streamflow for U.S. Geological Survey streamflow-gaging station 08057445 Prairie Creek at U. S. Highway 175, Dallas, Texas. 
U.S. Geological Survey streamflow-gaging station 08057448

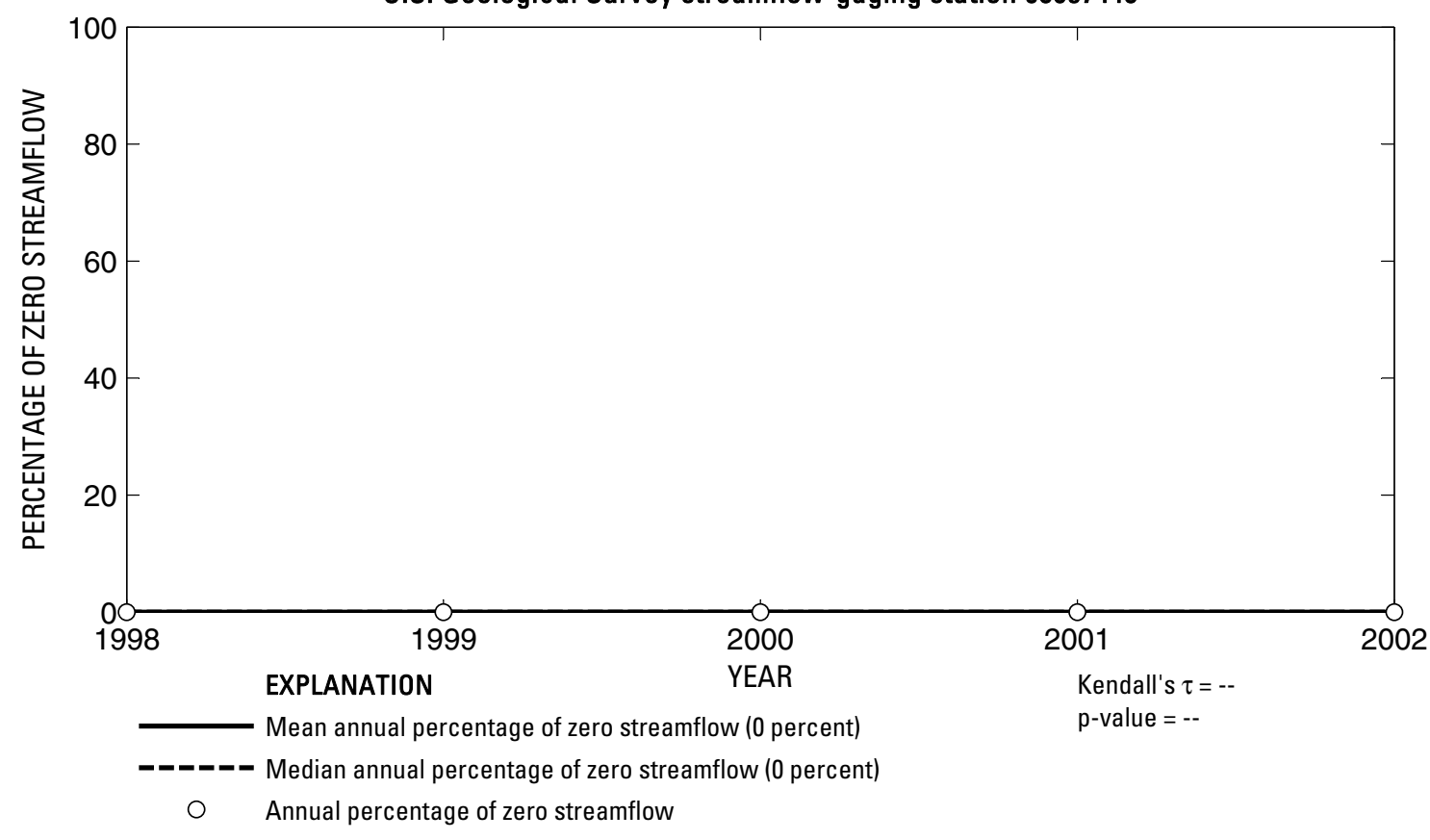

U.S. Geological Survey streamflow-gaging station 08057448

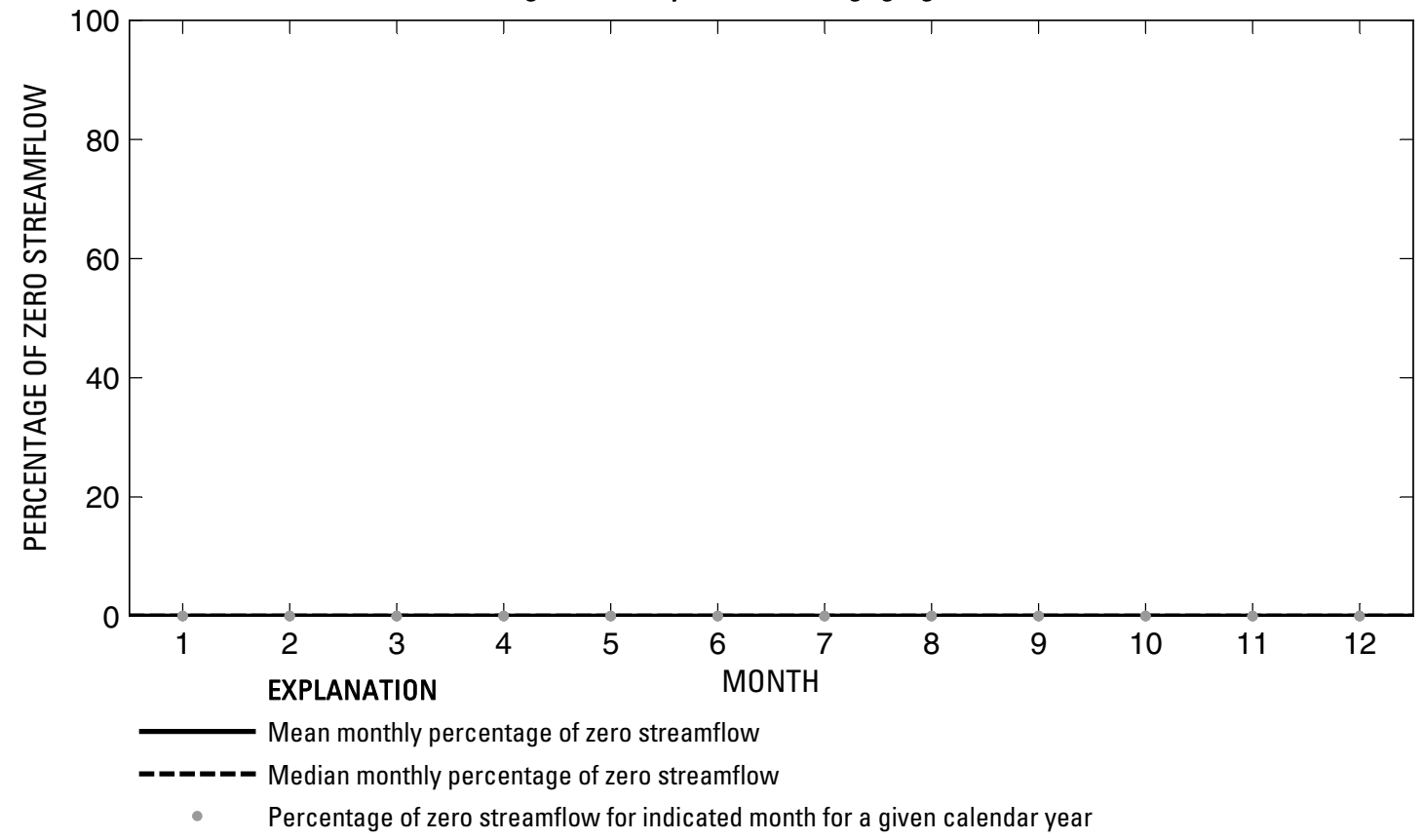

Figure 206. Analysis of percentage of zero daily mean streamflow for U.S. Geological Survey streamflow-gaging station 08057448 Trinity River near Wilmer, Texas. 


\section{U.S. Geological Survey streamflow-gaging station 08057450}

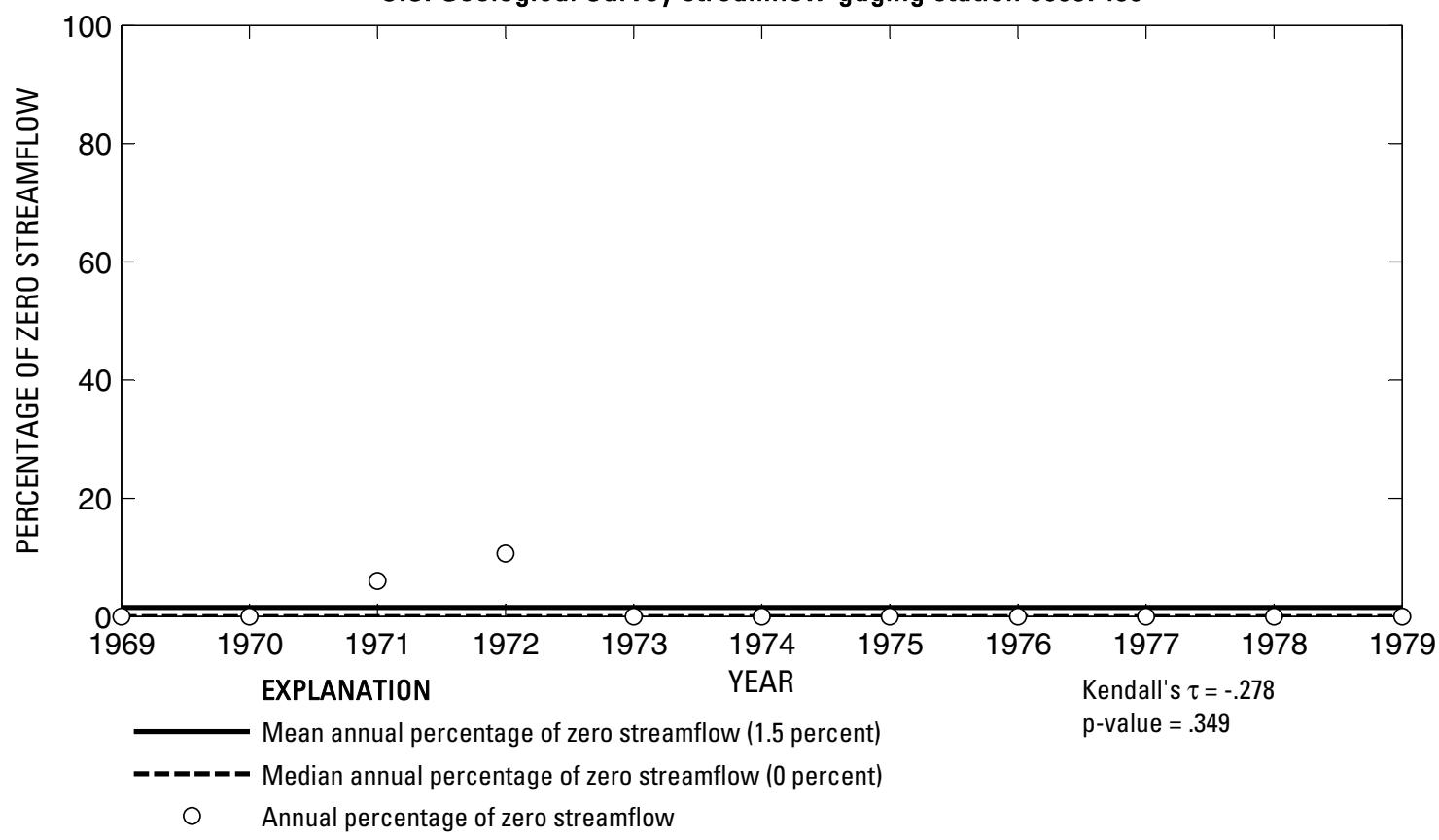

U.S. Geological Survey streamflow-gaging station 08057450

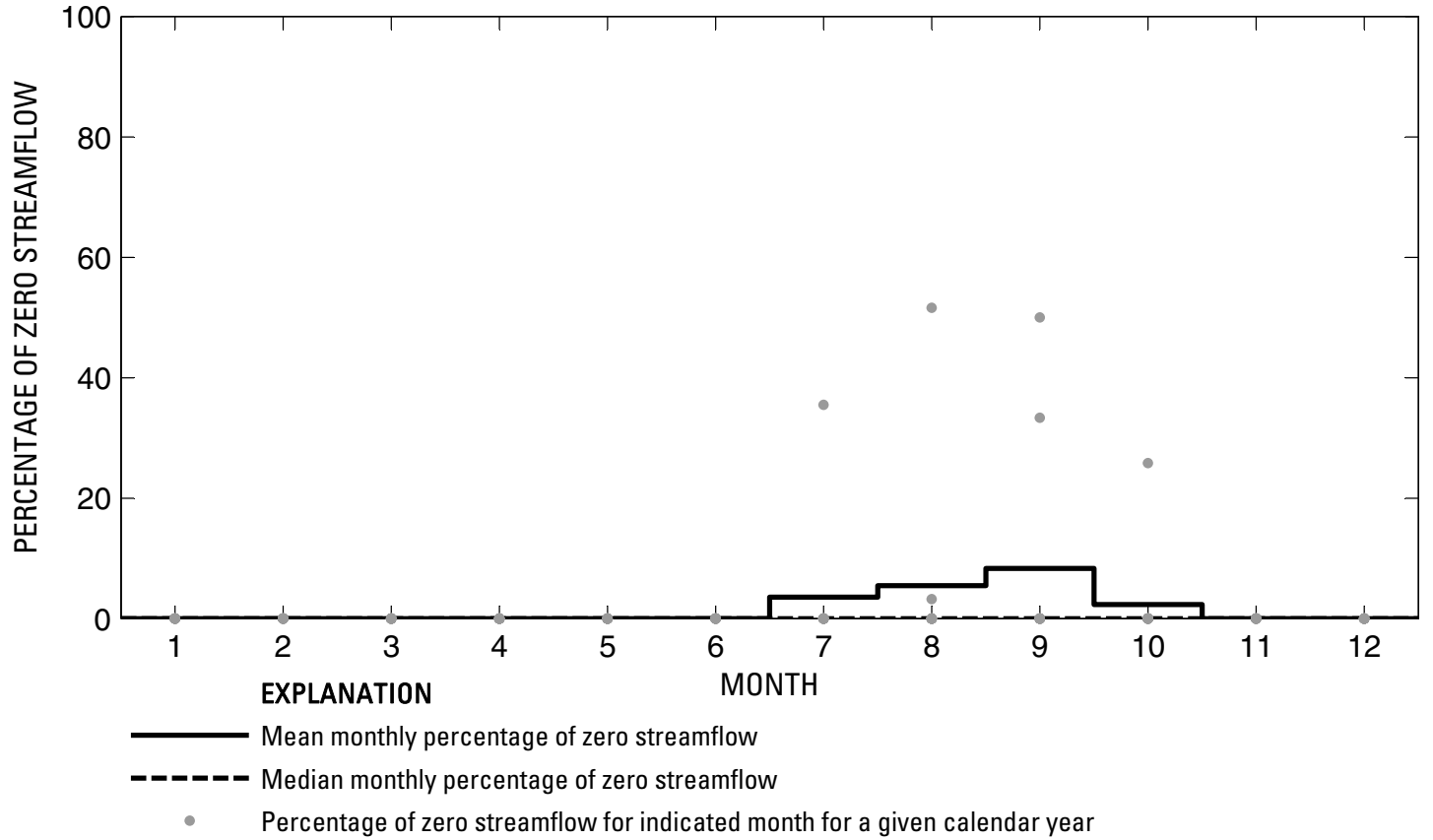

Figure 207. Analysis of percentage of zero daily mean streamflow for U.S. Geological Survey streamflow-gaging station 08057450 Tenmile Creek at State Highway 342, Lancaster, Texas. 
U.S. Geological Survey streamflow-gaging station 08058500

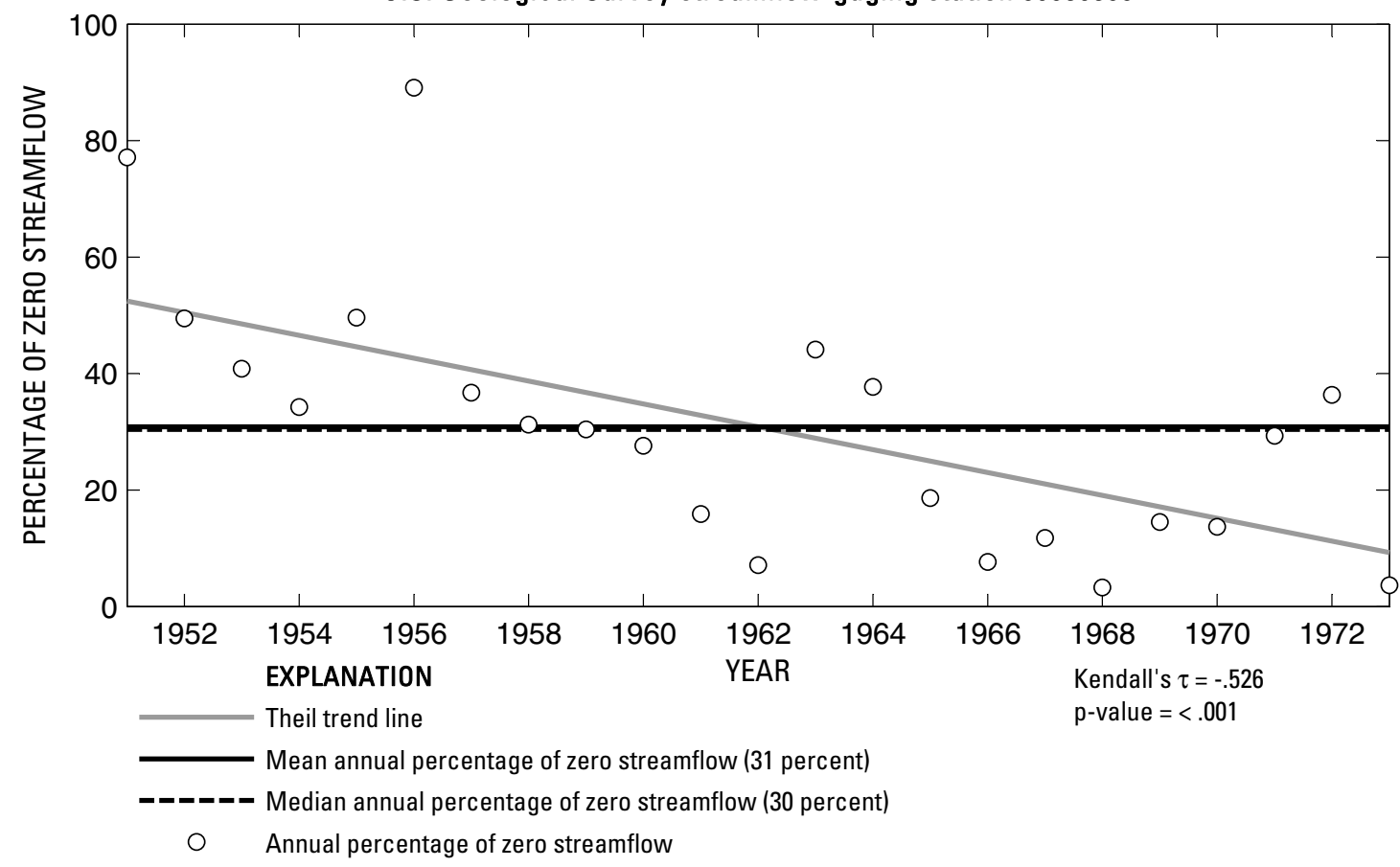

U.S. Geological Survey streamflow-gaging station 08058500

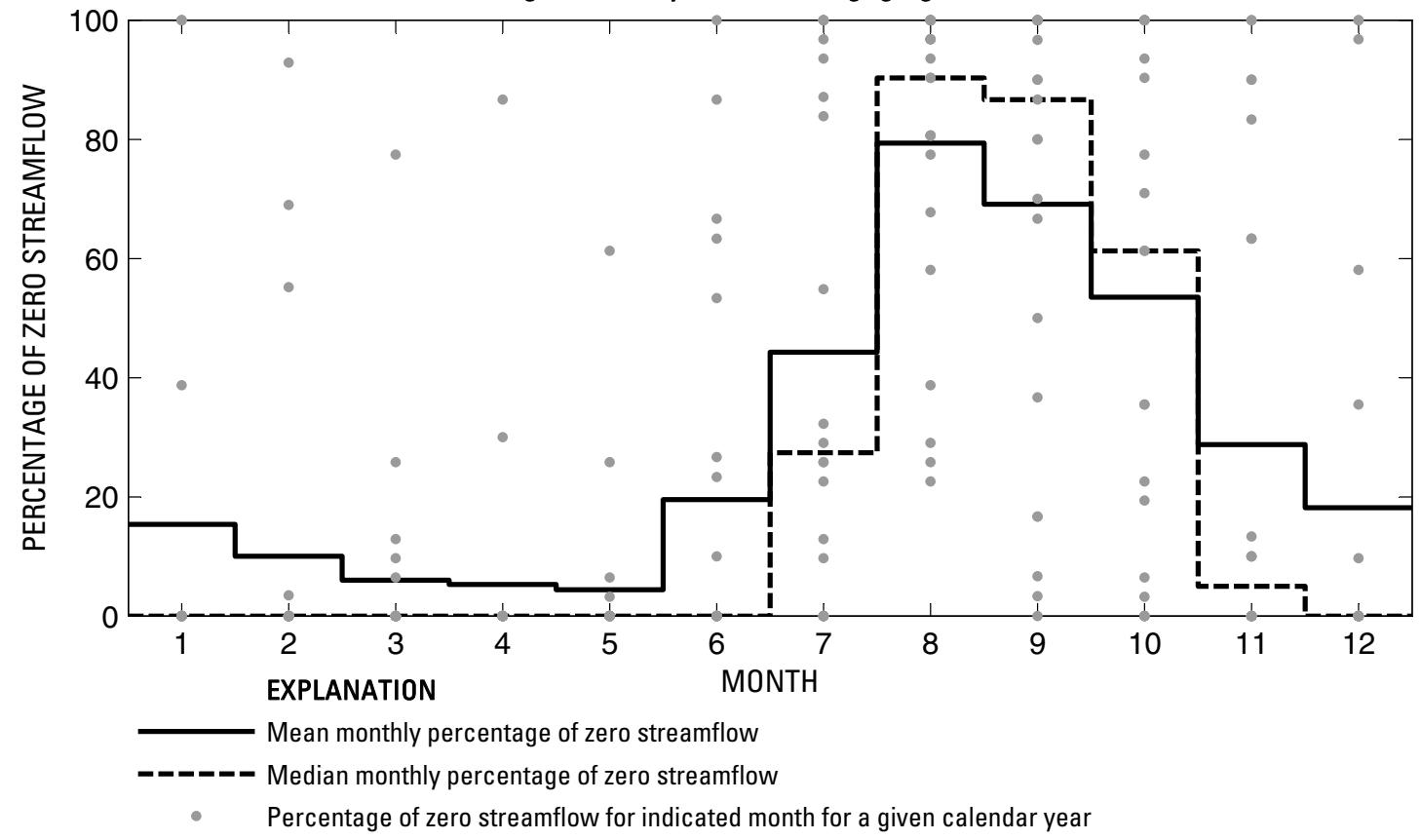

Figure 208. Analysis of percentage of zero daily mean streamflow for U.S. Geological Survey streamflow-gaging station 08058500 Honey Creek near McKinney, Texas.

Index of Station Numbers 719 
U.S. Geological Survey streamflow-gaging station 08058900

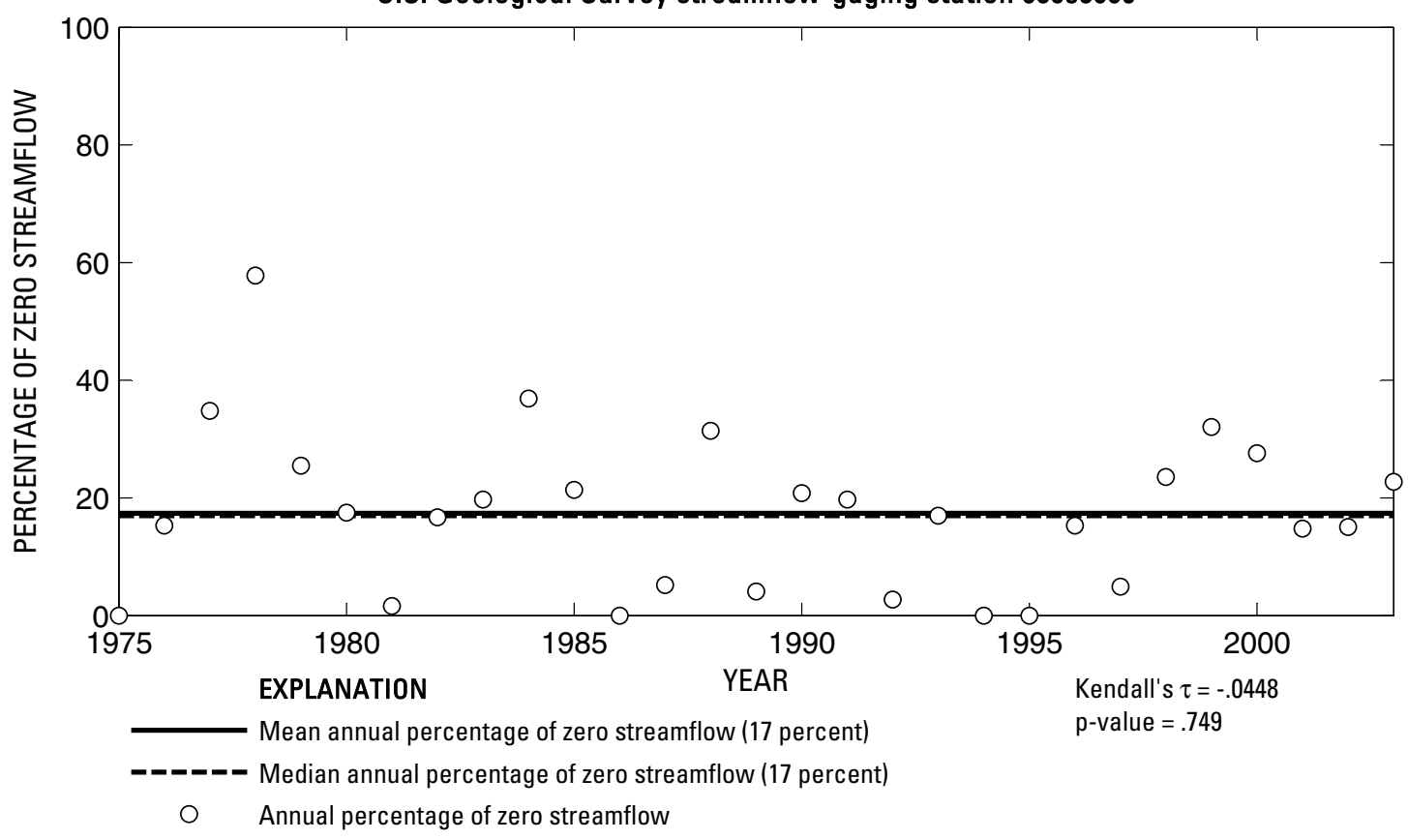

U.S. Geological Survey streamflow-gaging station 08058900

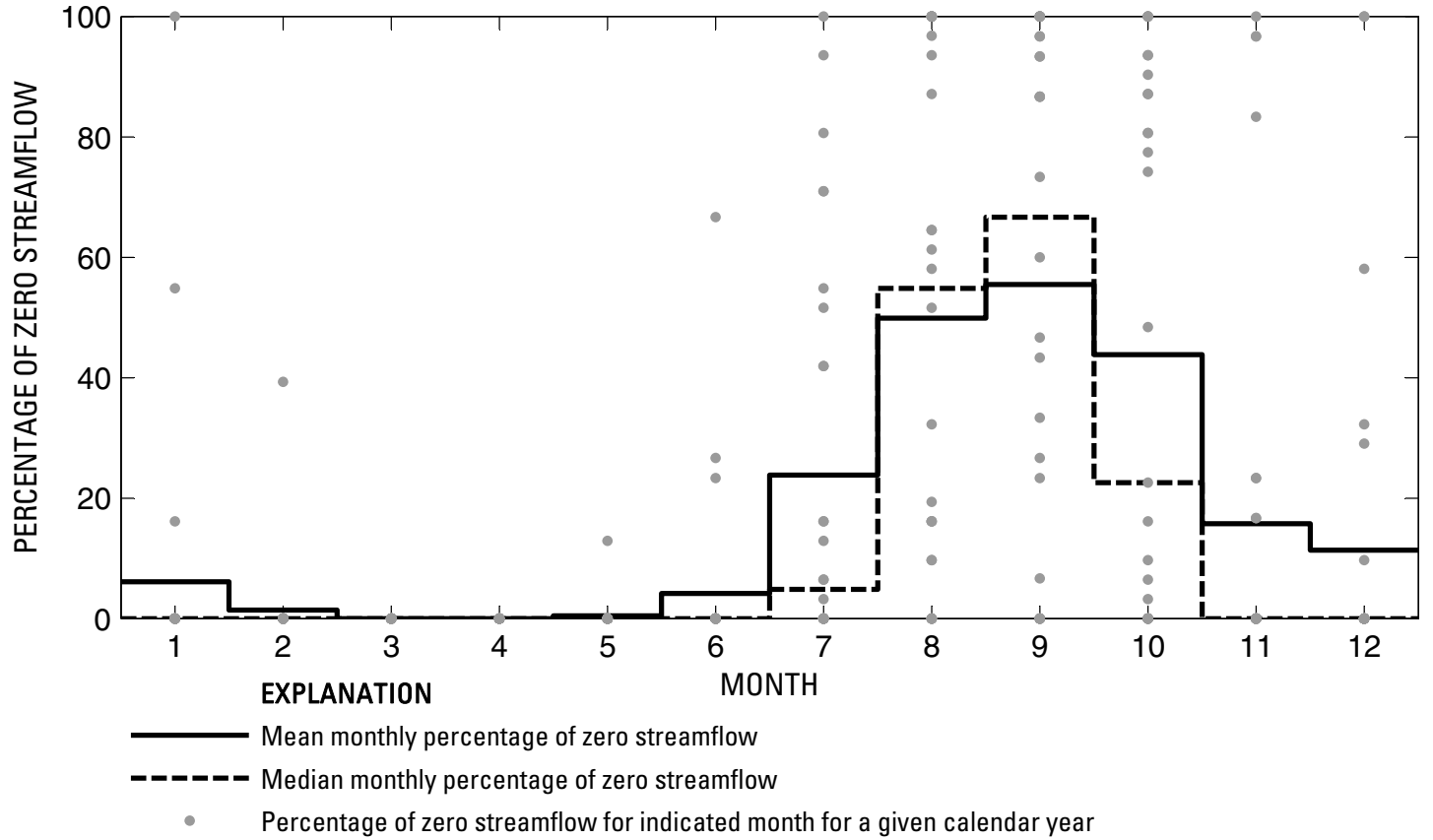

Figure 209. Analysis of percentage of zero daily mean streamflow for U.S. Geological Survey streamflow-gaging station 08058900 East Fork Trinity River at McKinney, Texas. 
U.S. Geological Survey streamflow-gaging station 08059000

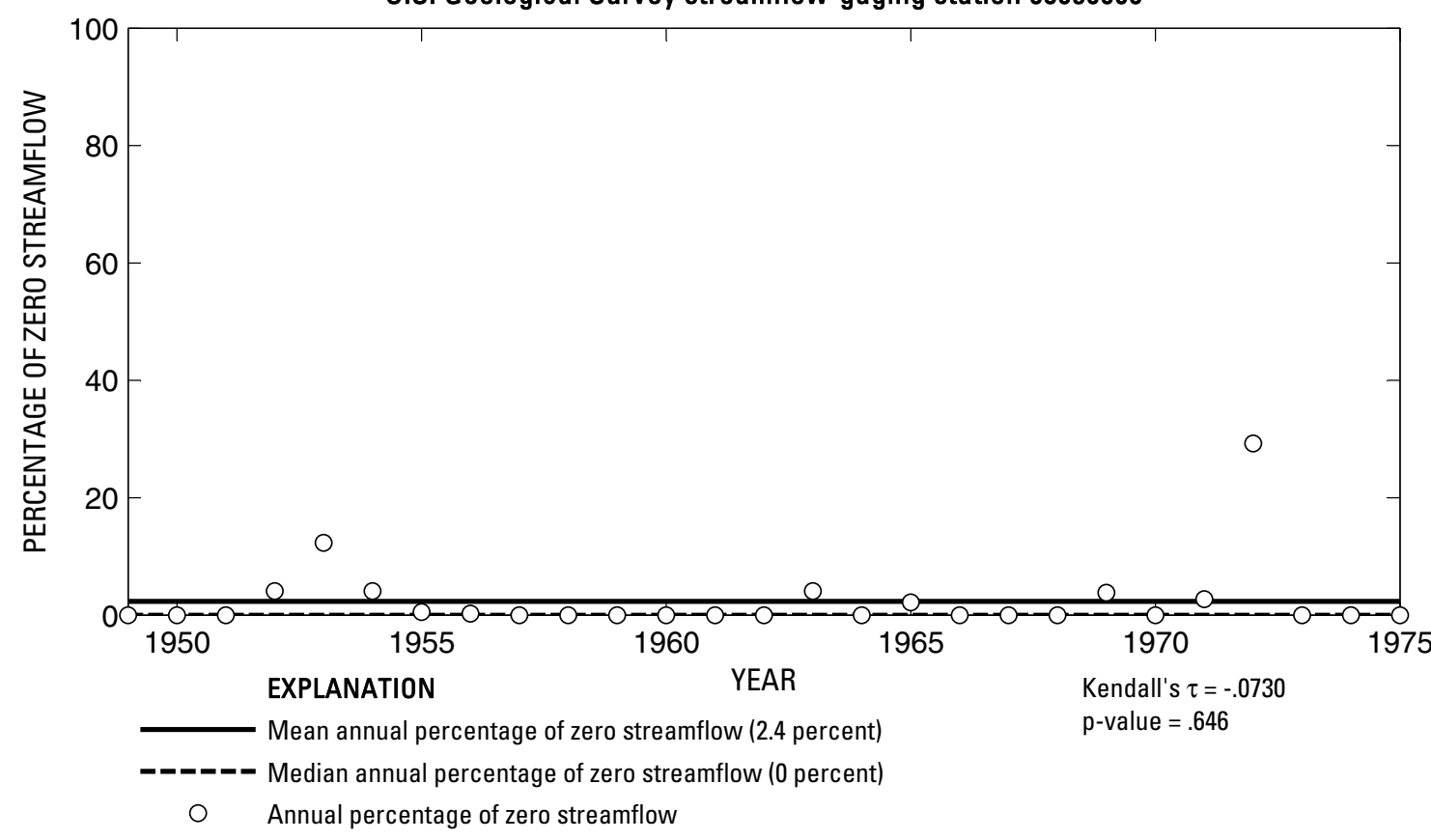

U.S. Geological Survey streamflow-gaging station 08059000

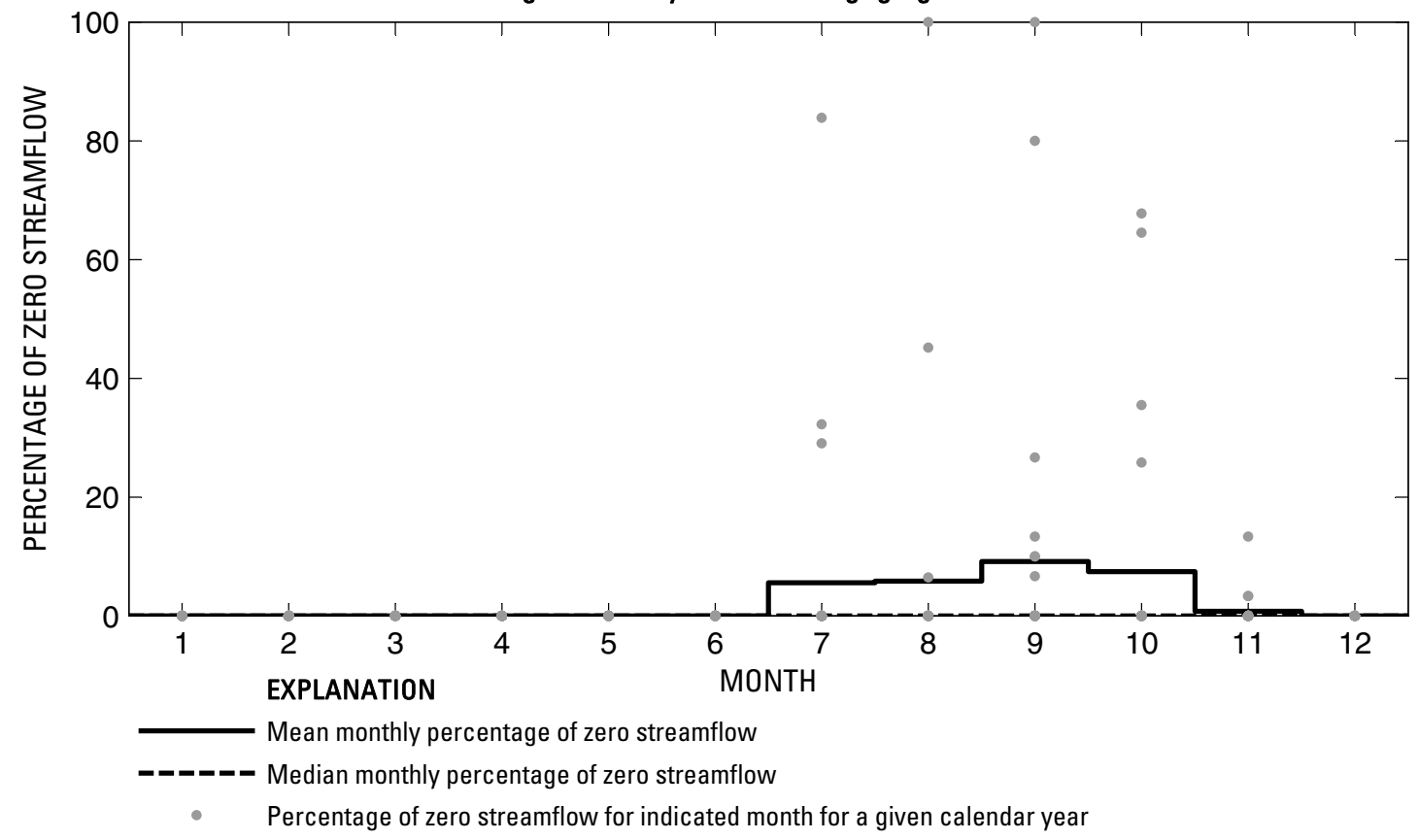

Figure 210. Analysis of percentage of zero daily mean streamflow for U.S. Geological Survey streamflow-gaging station 08059000 East Fork Trinity River near McKinney, Texas. 
U.S. Geological Survey streamflow-gaging station 08059400

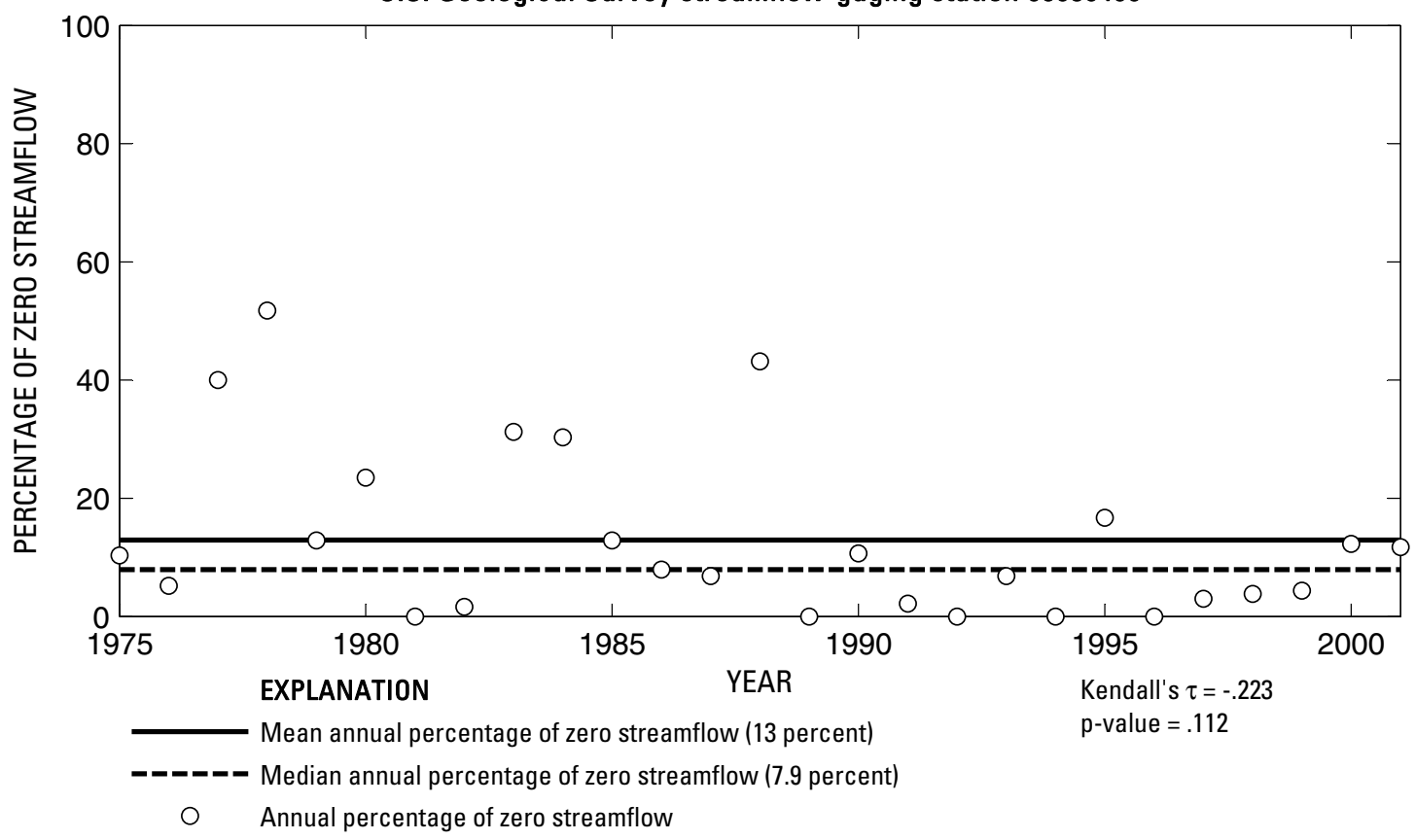

U.S. Geological Survey streamflow-gaging station 08059400

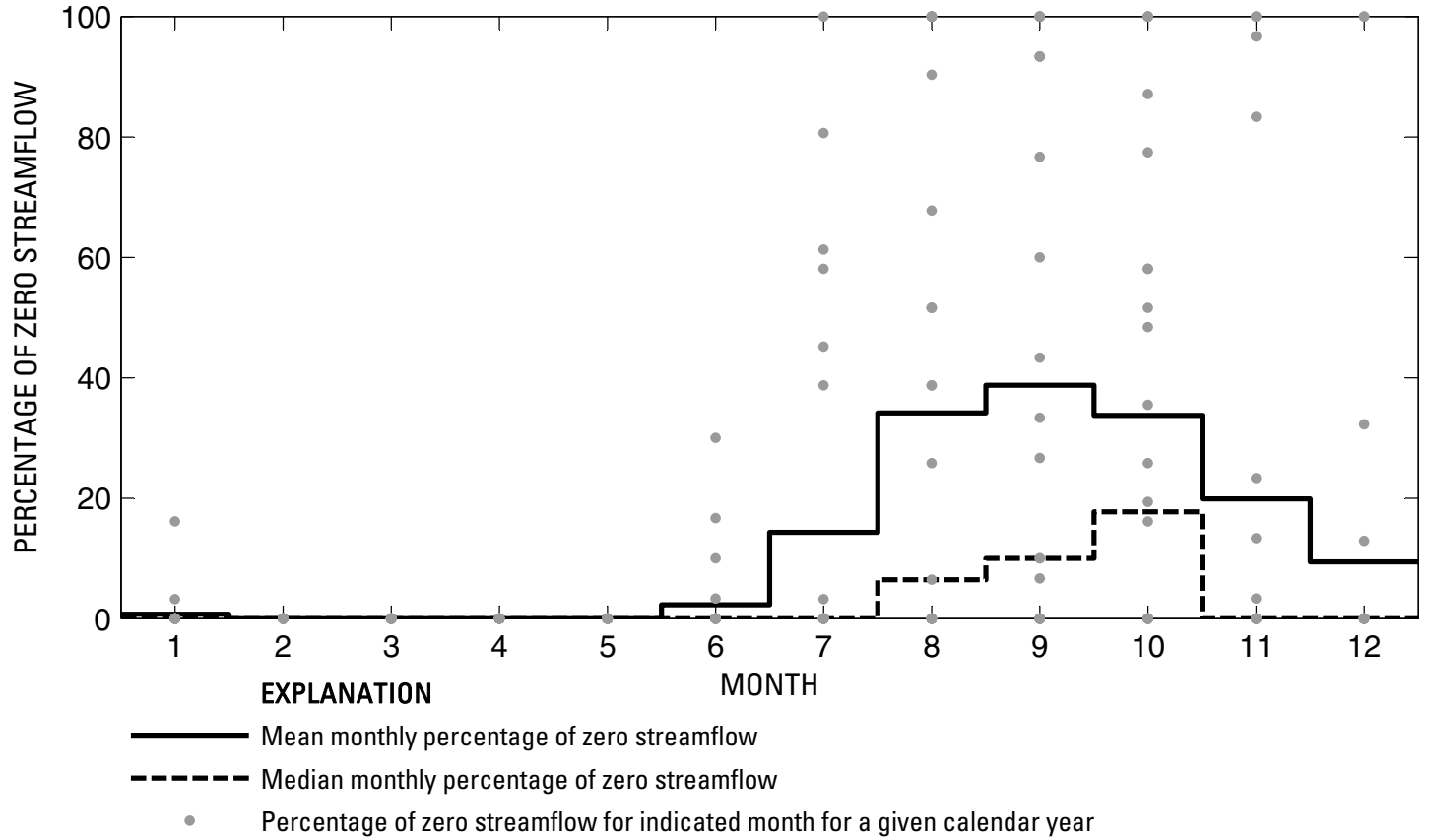

Figure 211. Analysis of percentage of zero daily mean streamflow for U.S. Geological Survey streamflow-gaging station 08059400 Sister Grove Creek near Blue Ridge, Texas. 
U.S. Geological Survey streamflow-gaging station 08059500

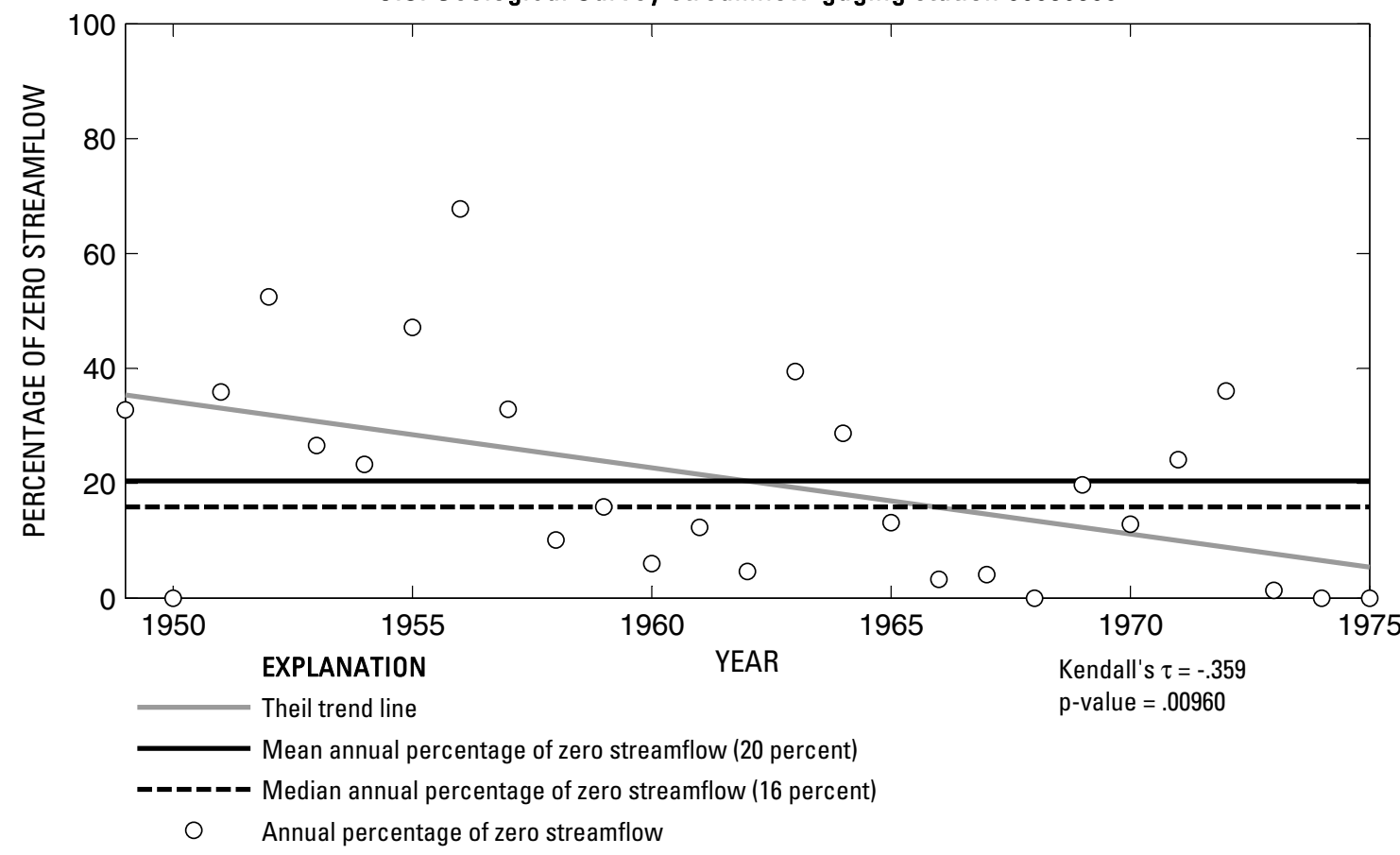

U.S. Geological Survey streamflow-gaging station 08059500

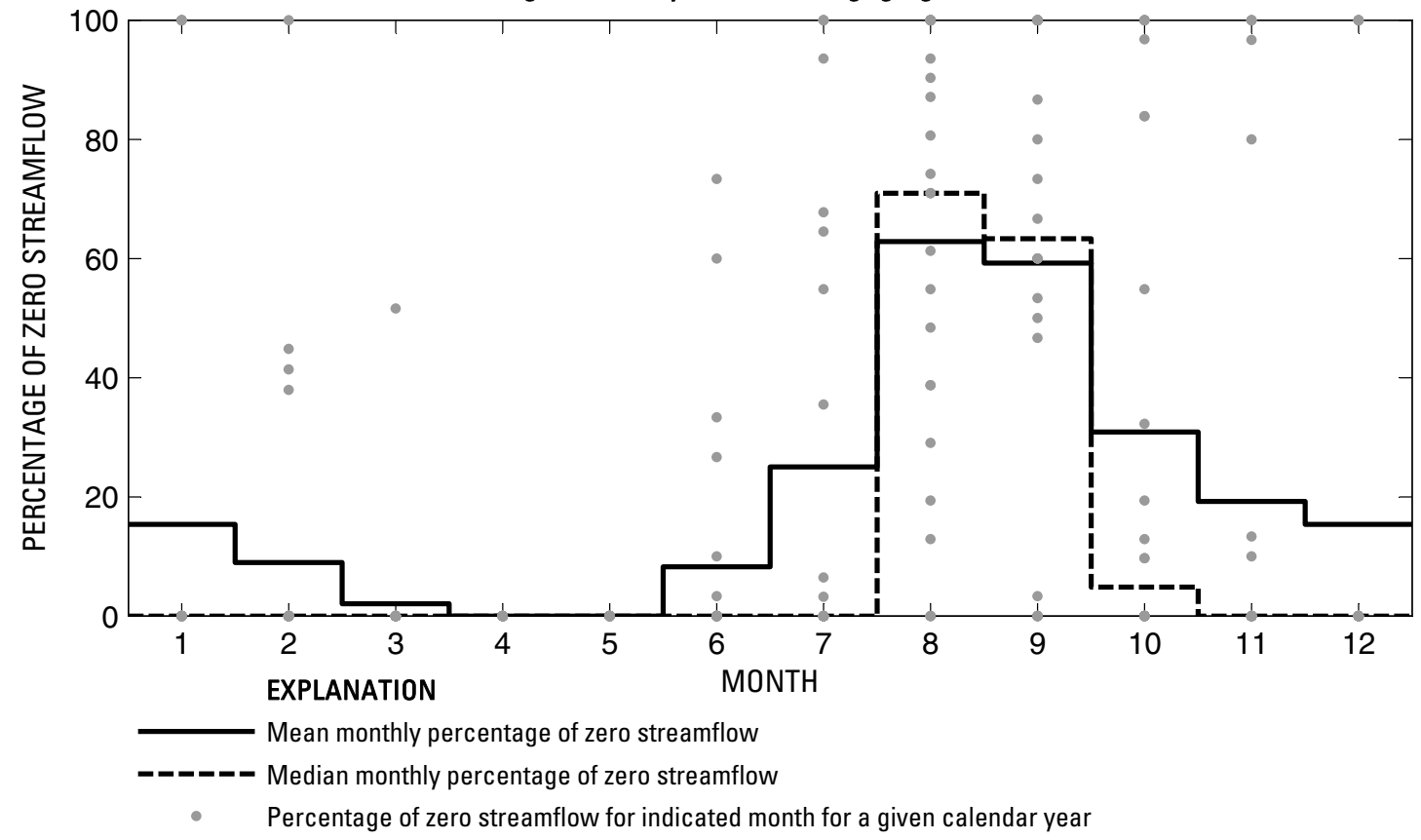

Figure 212. Analysis of percentage of zero daily mean streamflow for U.S. Geological Survey streamflow-gaging station 08059500 Sister Grove Creek near Princeton, Texas. 
U.S. Geological Survey streamflow-gaging station 08060000

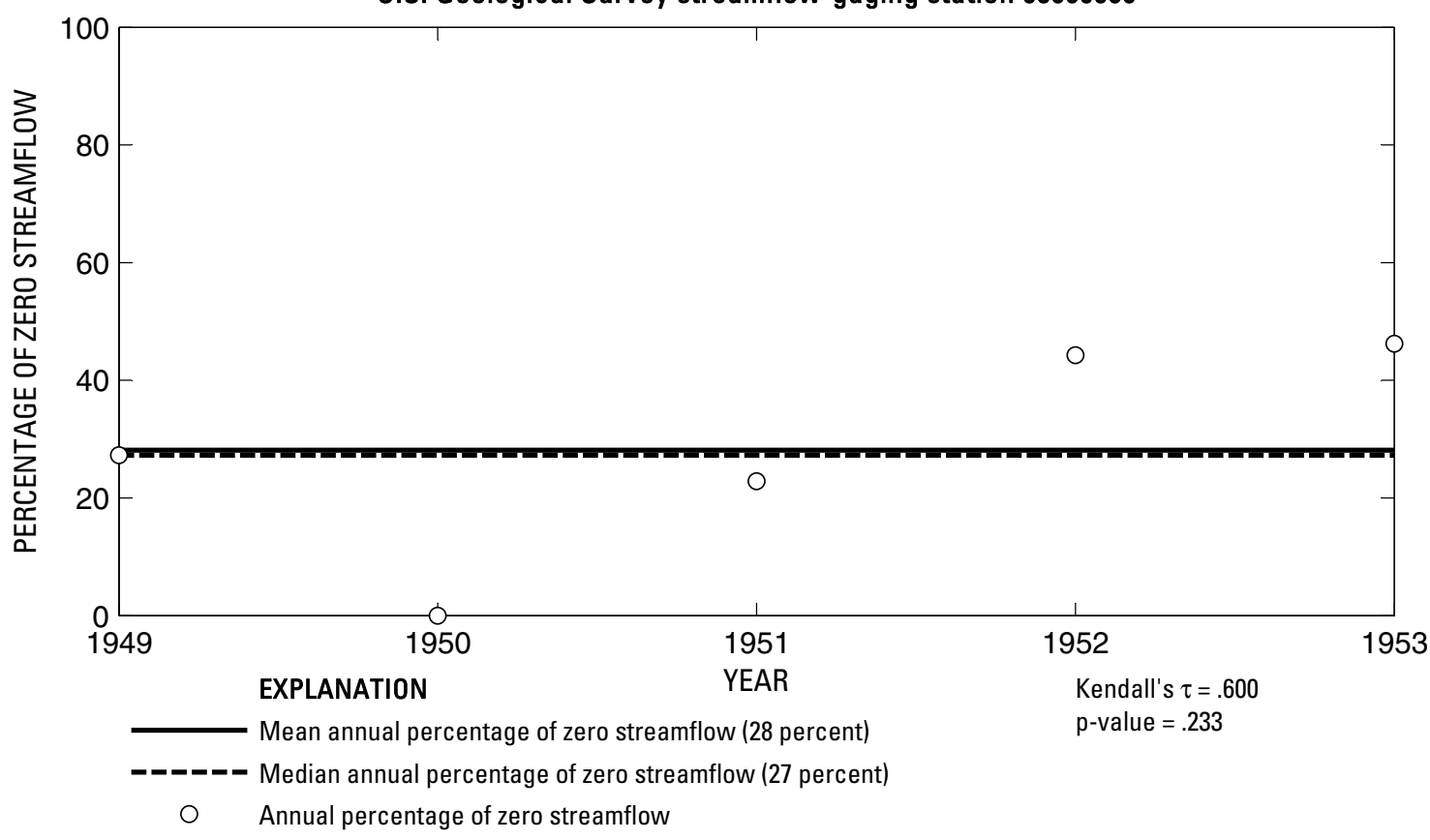

U.S. Geological Survey streamflow-gaging station 08060000

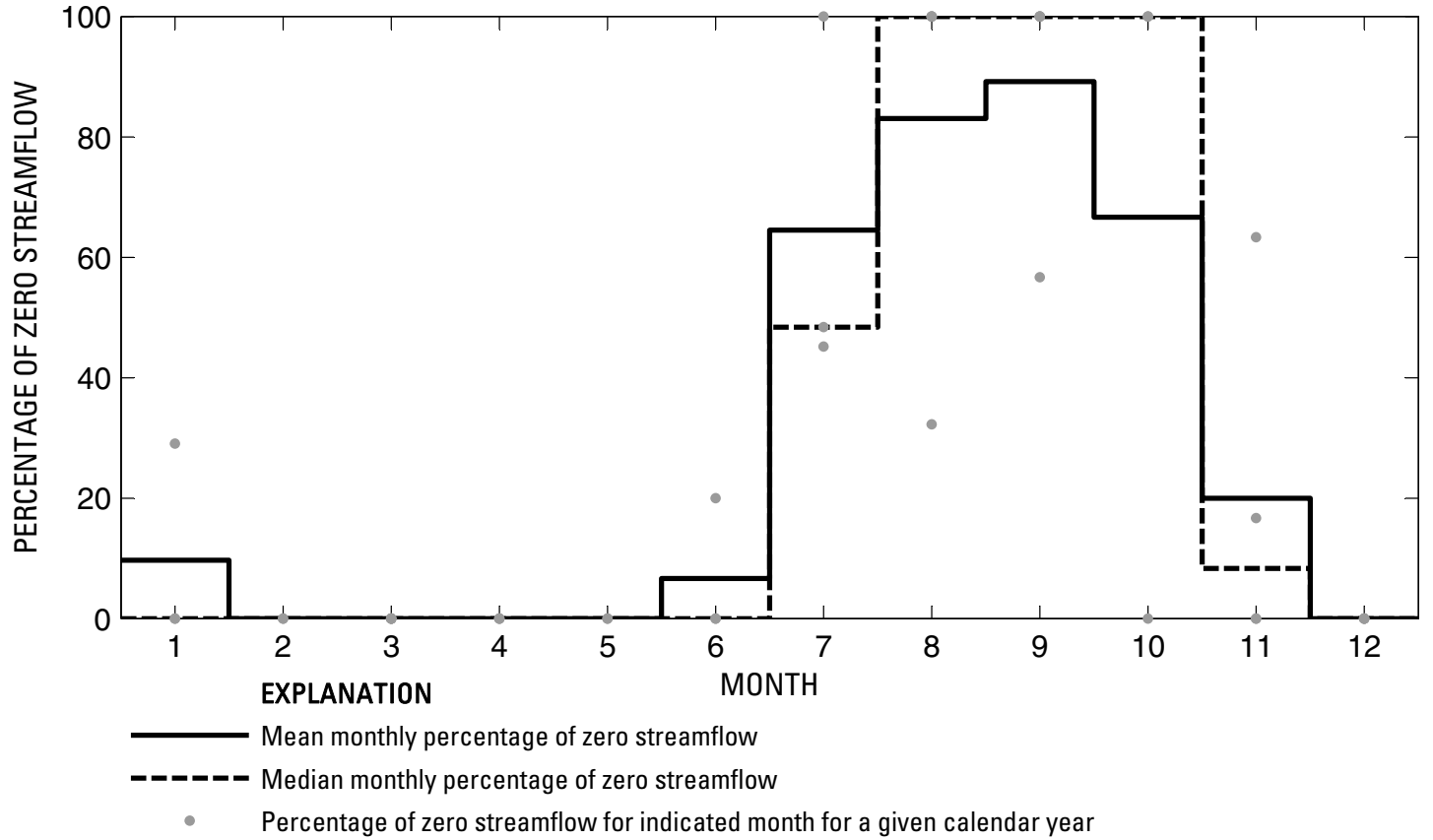

Figure 213. Analysis of percentage of zero daily mean streamflow for U.S. Geological Survey streamflow-gaging station 08060000 East Fork Trinity River above Pilot Grove near Lavon, Texas. 
U.S. Geological Survey streamflow-gaging station 08061000

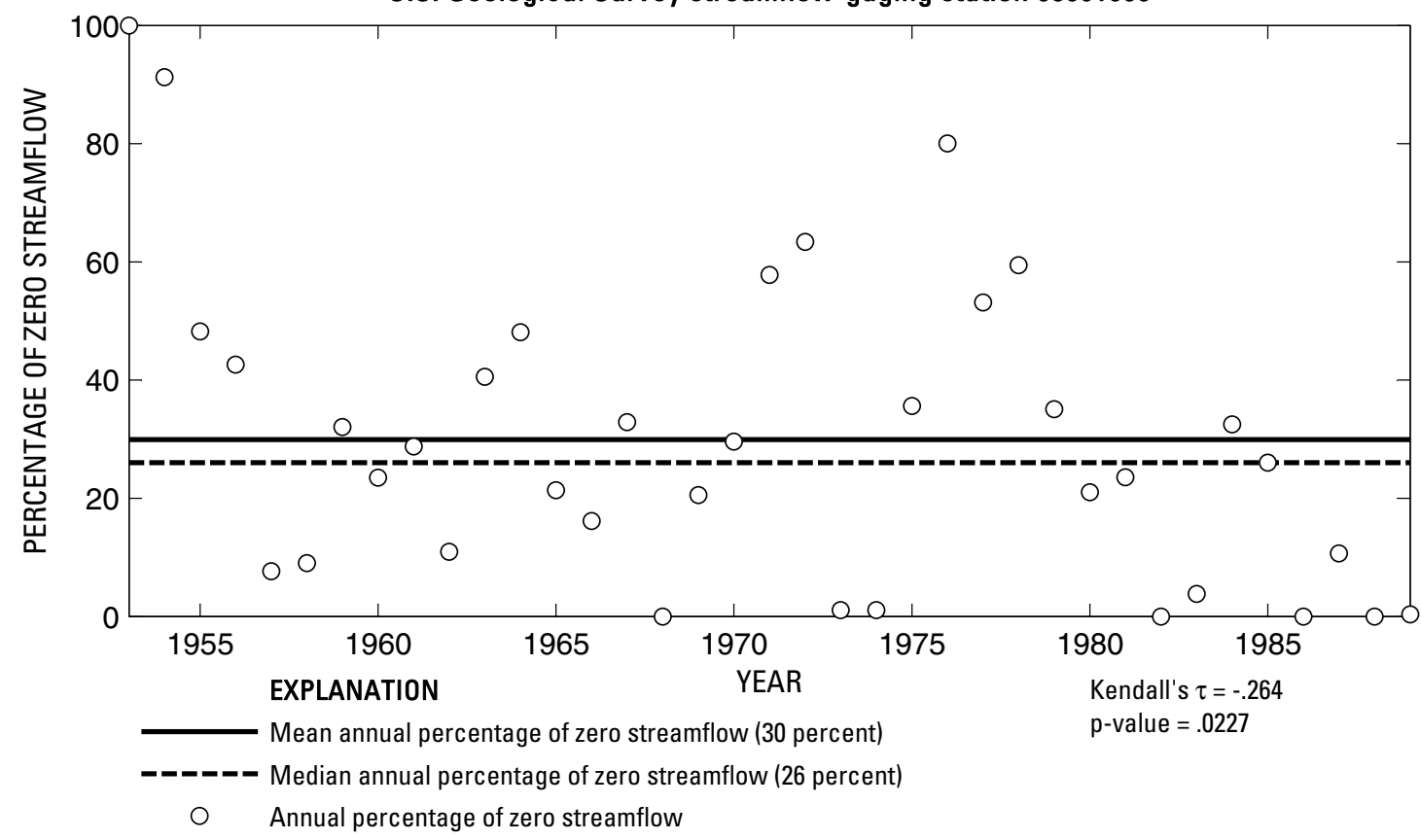

U.S. Geological Survey streamflow-gaging station 08061000

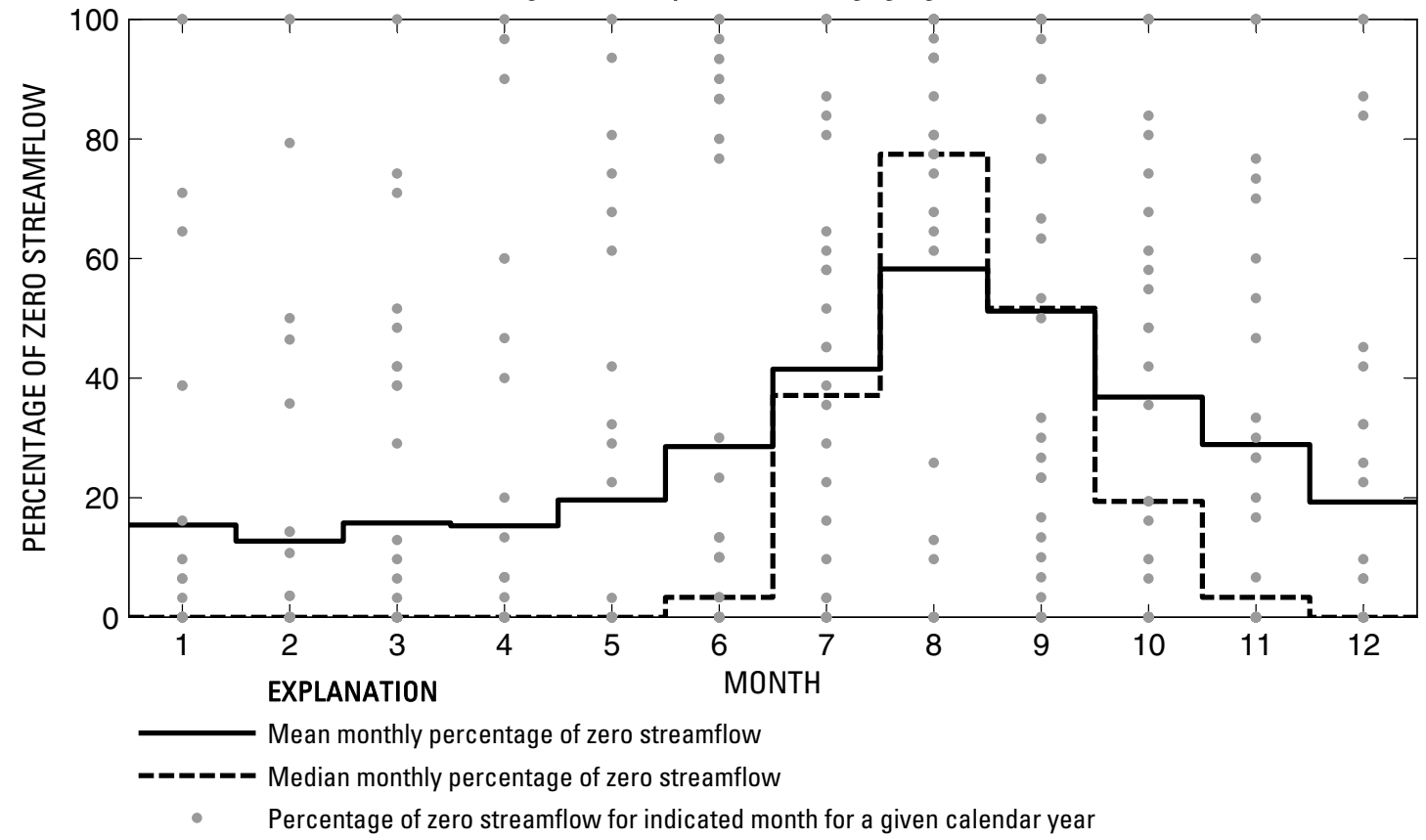

Figure 214. Analysis of percentage of zero daily mean streamflow for U.S. Geological Survey streamflow-gaging station 08061000 East Fork Trinity River near Lavon, Texas.

Index of Station Numbers 719 


\section{U.S. Geological Survey streamflow-gaging station 08061500}

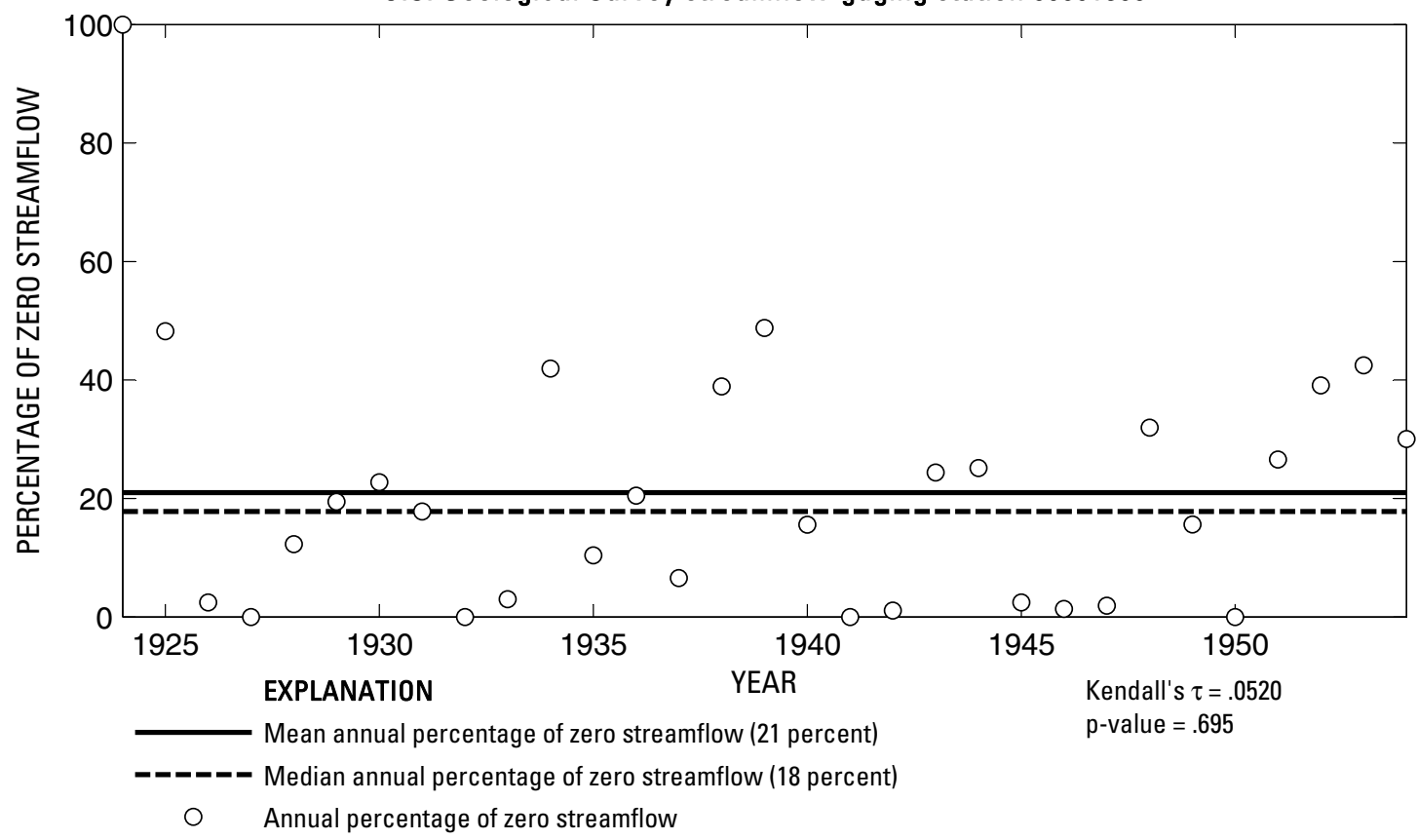

U.S. Geological Survey streamflow-gaging station 08061500

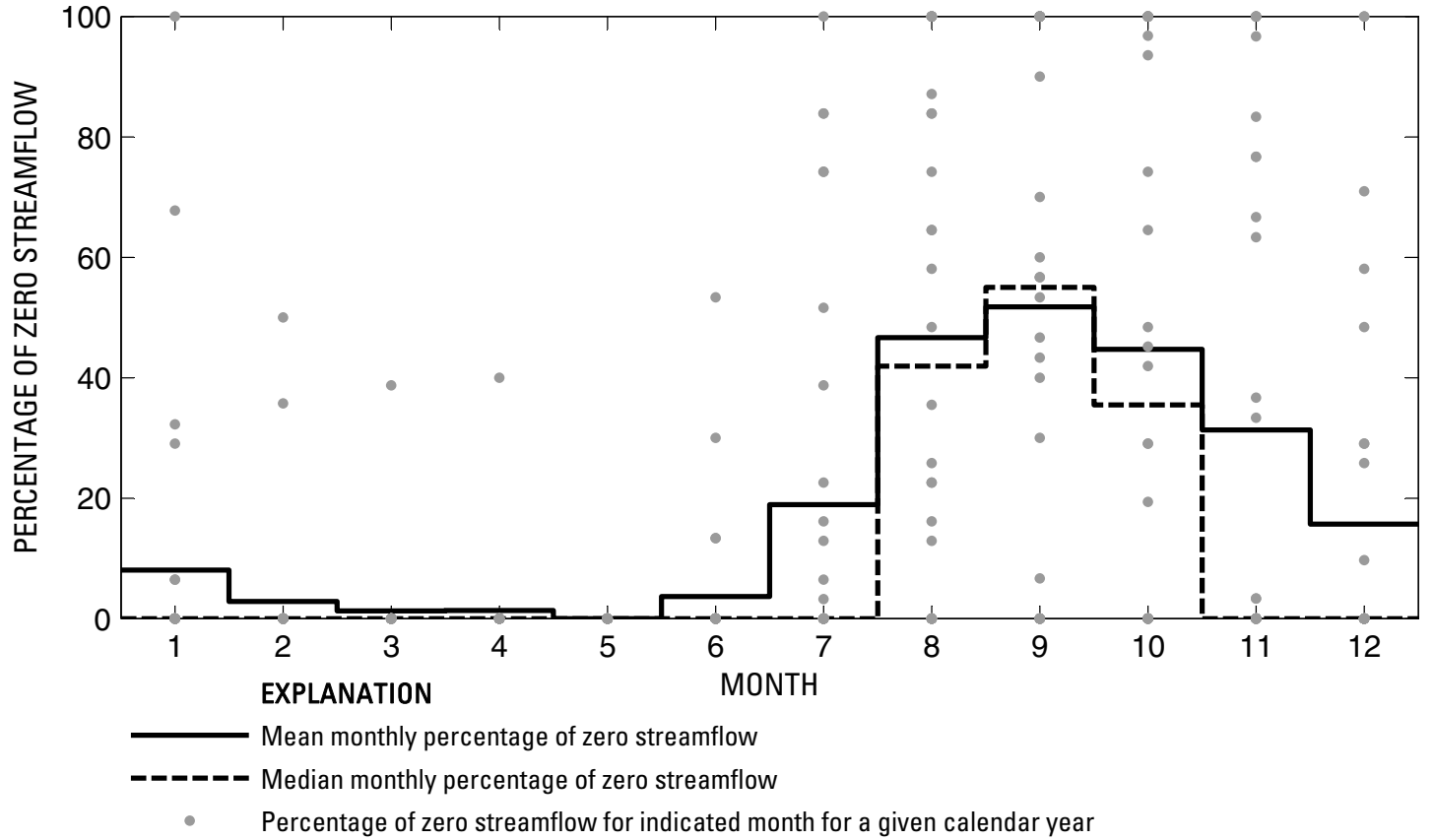

Figure 215. Analysis of percentage of zero daily mean streamflow for U.S. Geological Survey streamflow-gaging station 08061500 East Fork Trinity River near Rockwall, Texas. 
U.S. Geological Survey streamflow-gaging station 08061540

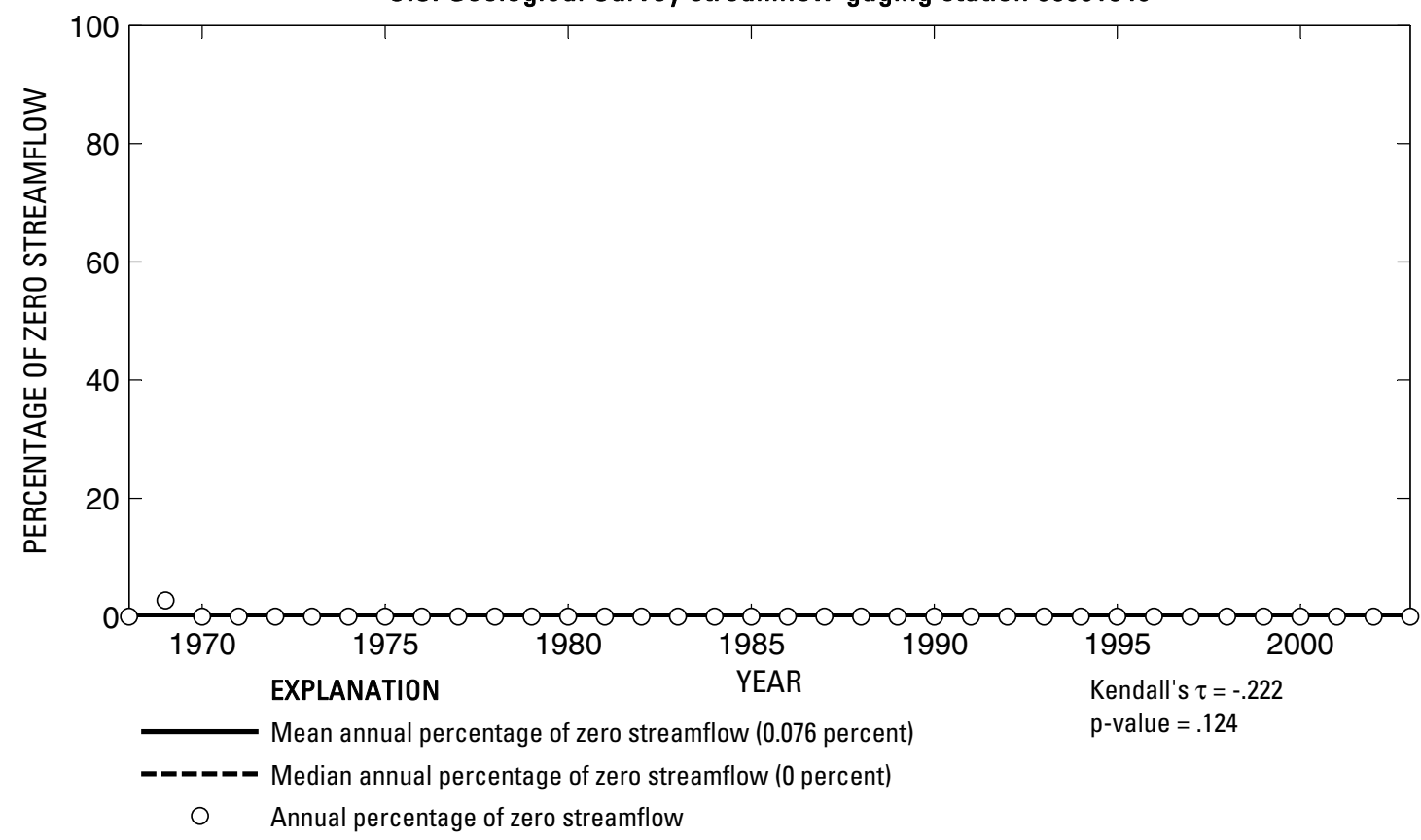

U.S. Geological Survey streamflow-gaging station 08061540

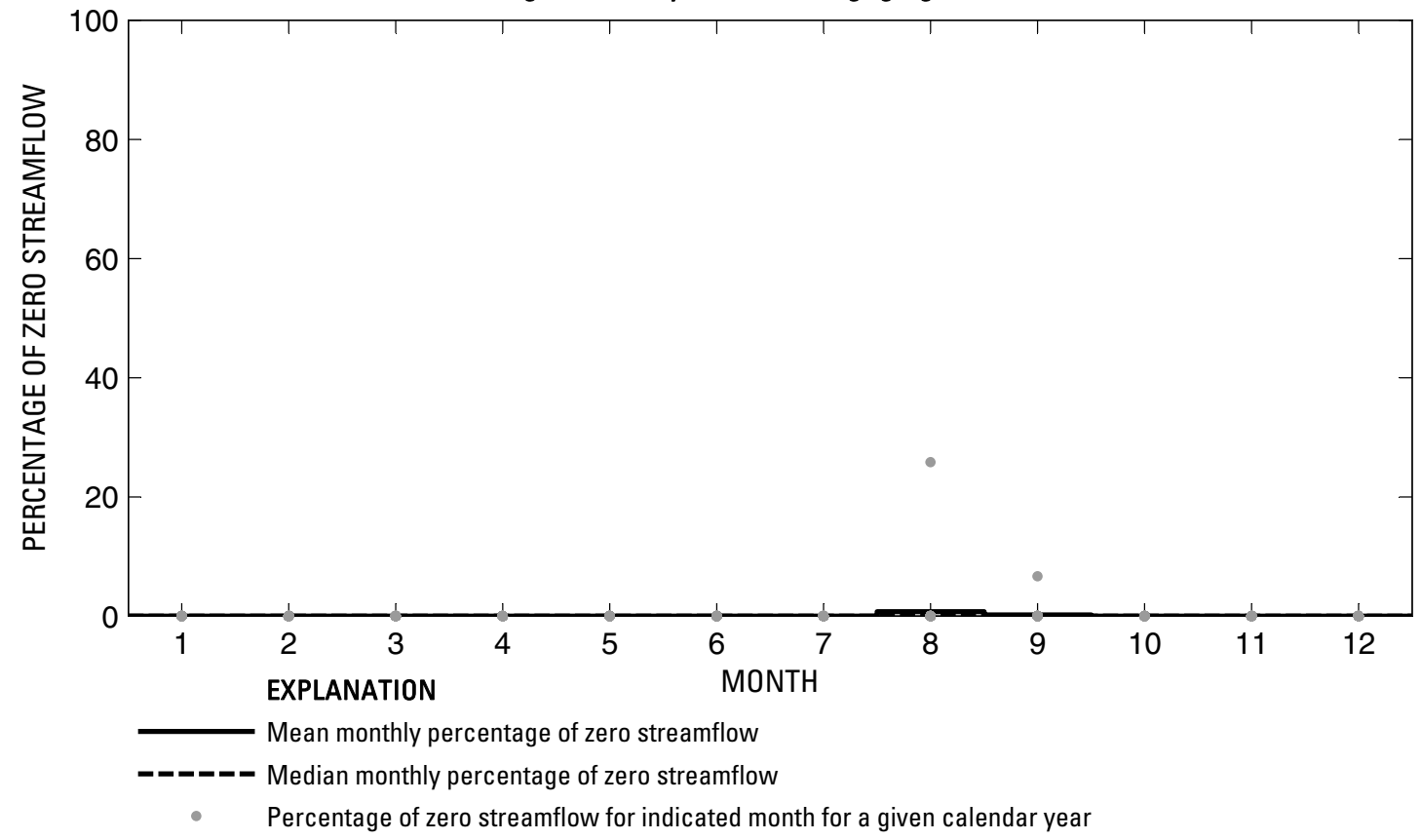

Figure 216. Analysis of percentage of zero daily mean streamflow for U.S. Geological Survey streamflow-gaging station 08061540 Rowlett Creek near Sachse, Texas. 
U.S. Geological Survey streamflow-gaging station 08061700

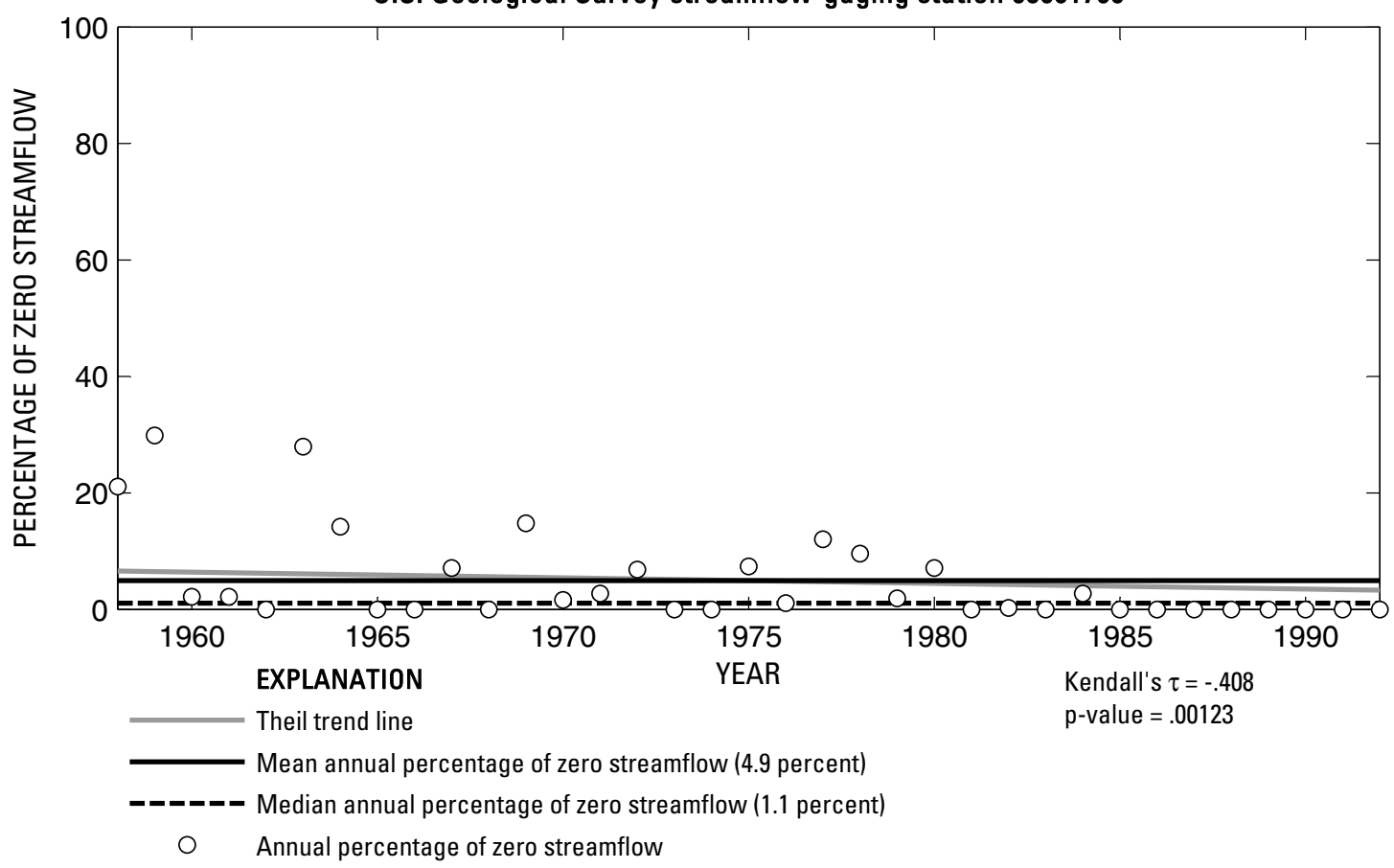

U.S. Geological Survey streamflow-gaging station 08061700

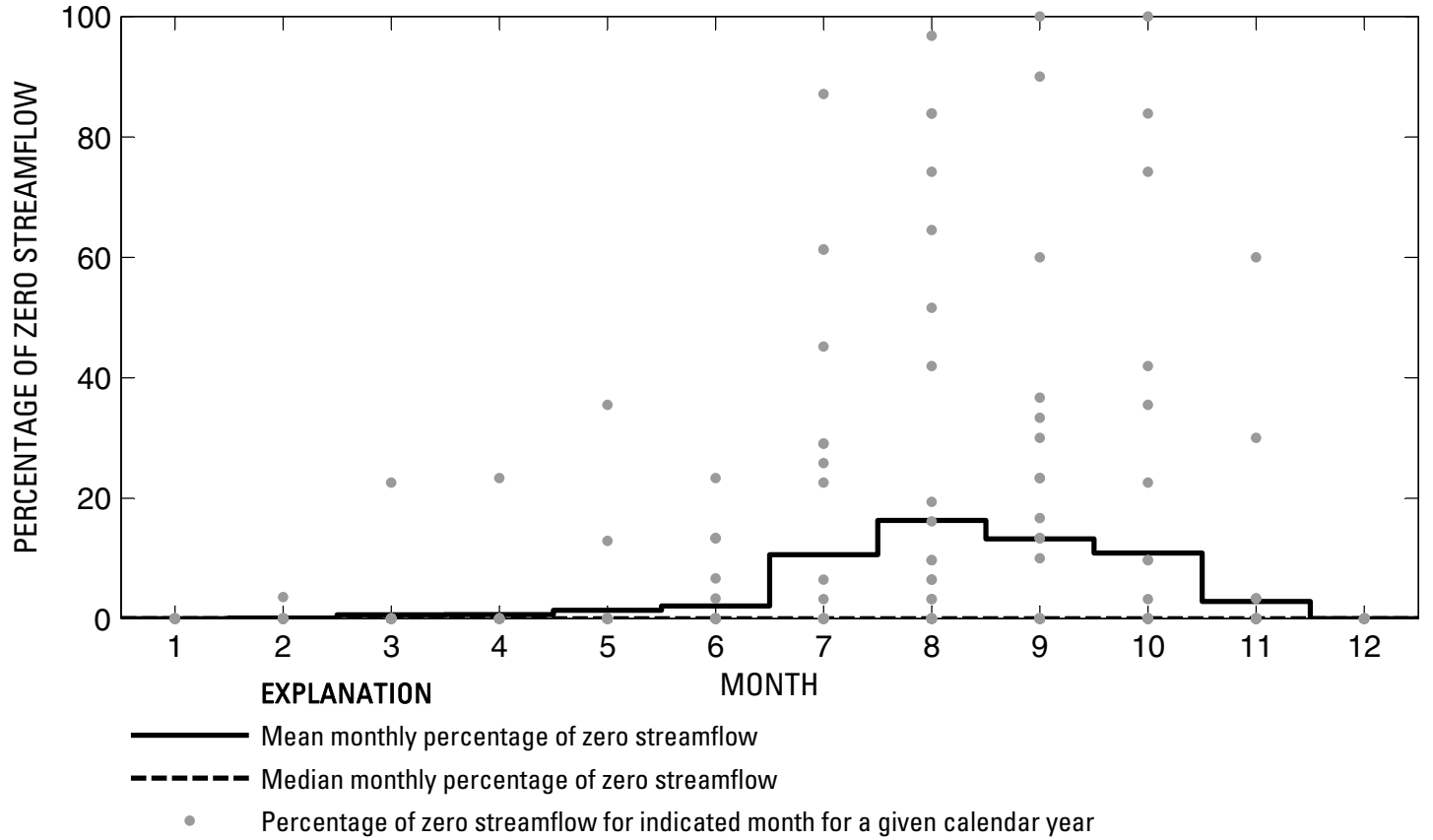

Figure 217. Analysis of percentage of zero daily mean streamflow for U.S. Geological Survey streamflow-gaging station 08061700 Duck Creek near Garland, Texas. 
U.S. Geological Survey streamflow-gaging station 08061750

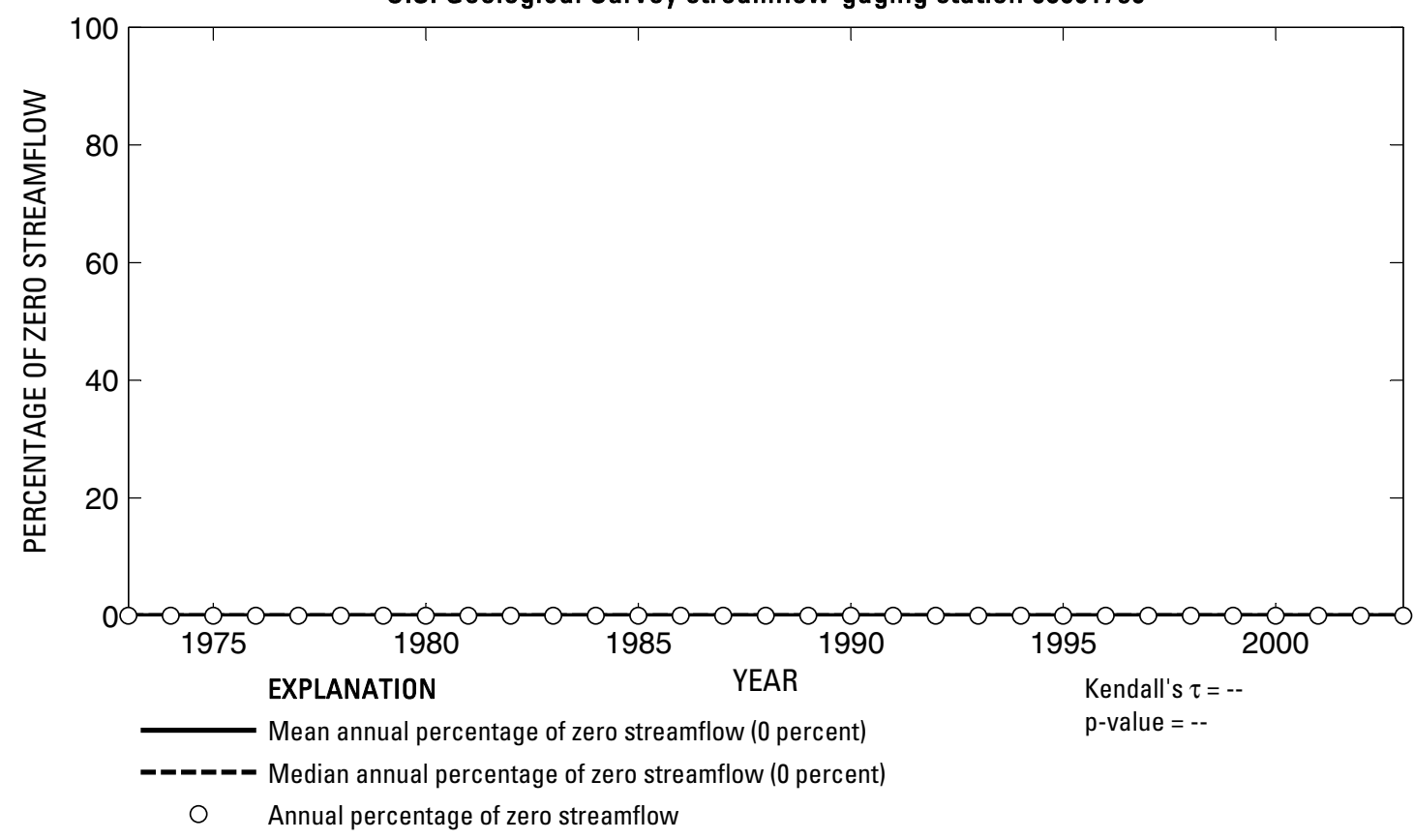

U.S. Geological Survey streamflow-gaging station 08061750

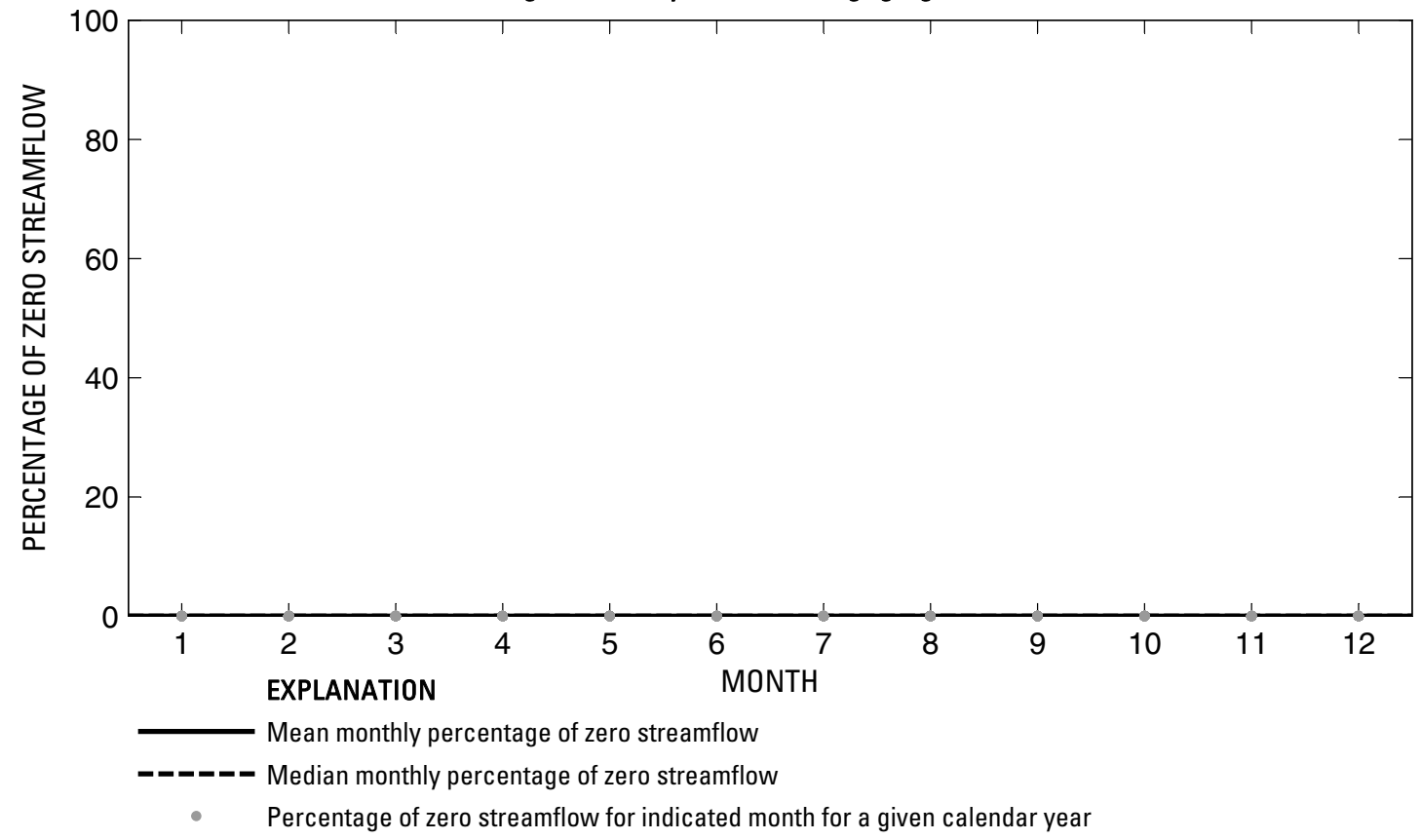

Figure 218. Analysis of percentage of zero daily mean streamflow for U.S. Geological Survey streamflow-gaging station 08061750 East Fork Trinity River near Forney, Texas. 
U.S. Geological Survey streamflow-gaging station 08061950

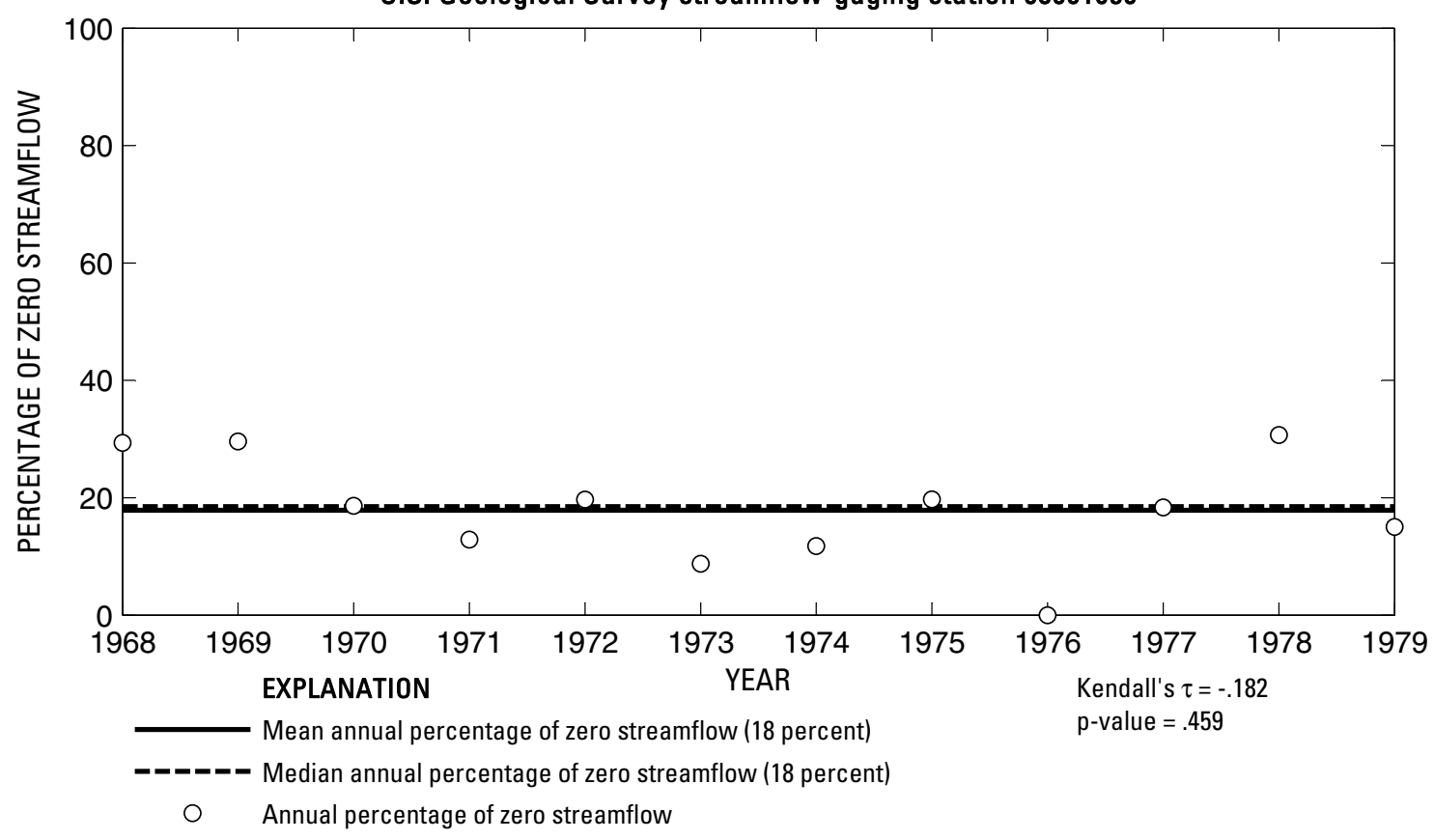

U.S. Geological Survey streamflow-gaging station 08061950

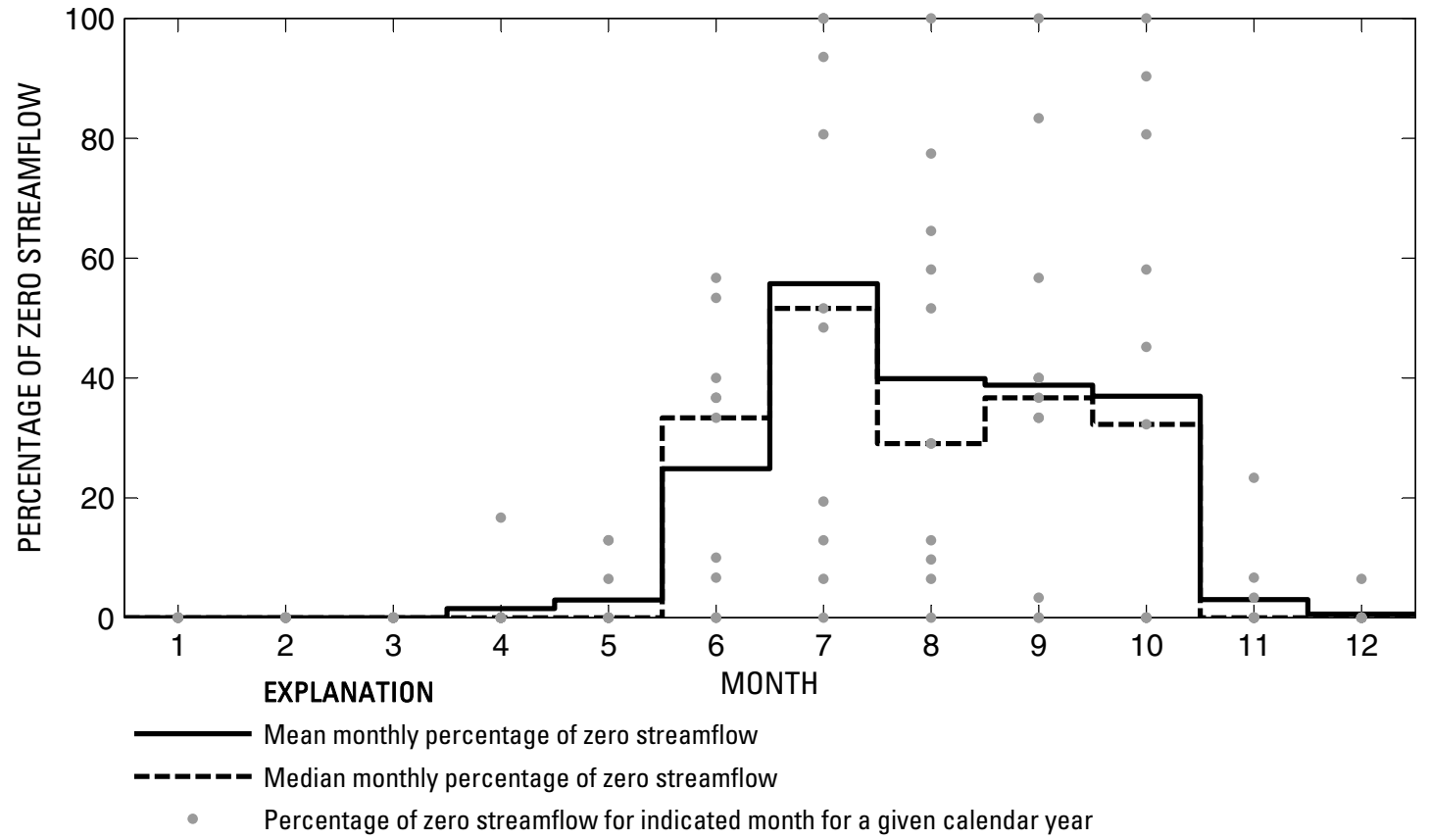

Figure 219. Analysis of percentage of zero daily mean streamflow for U.S. Geological Survey streamflow-gaging station 08061950 South Mesquite Creek at Mercury Road, North Mesquite, Texas. 
U.S. Geological Survey streamflow-gaging station 08062000

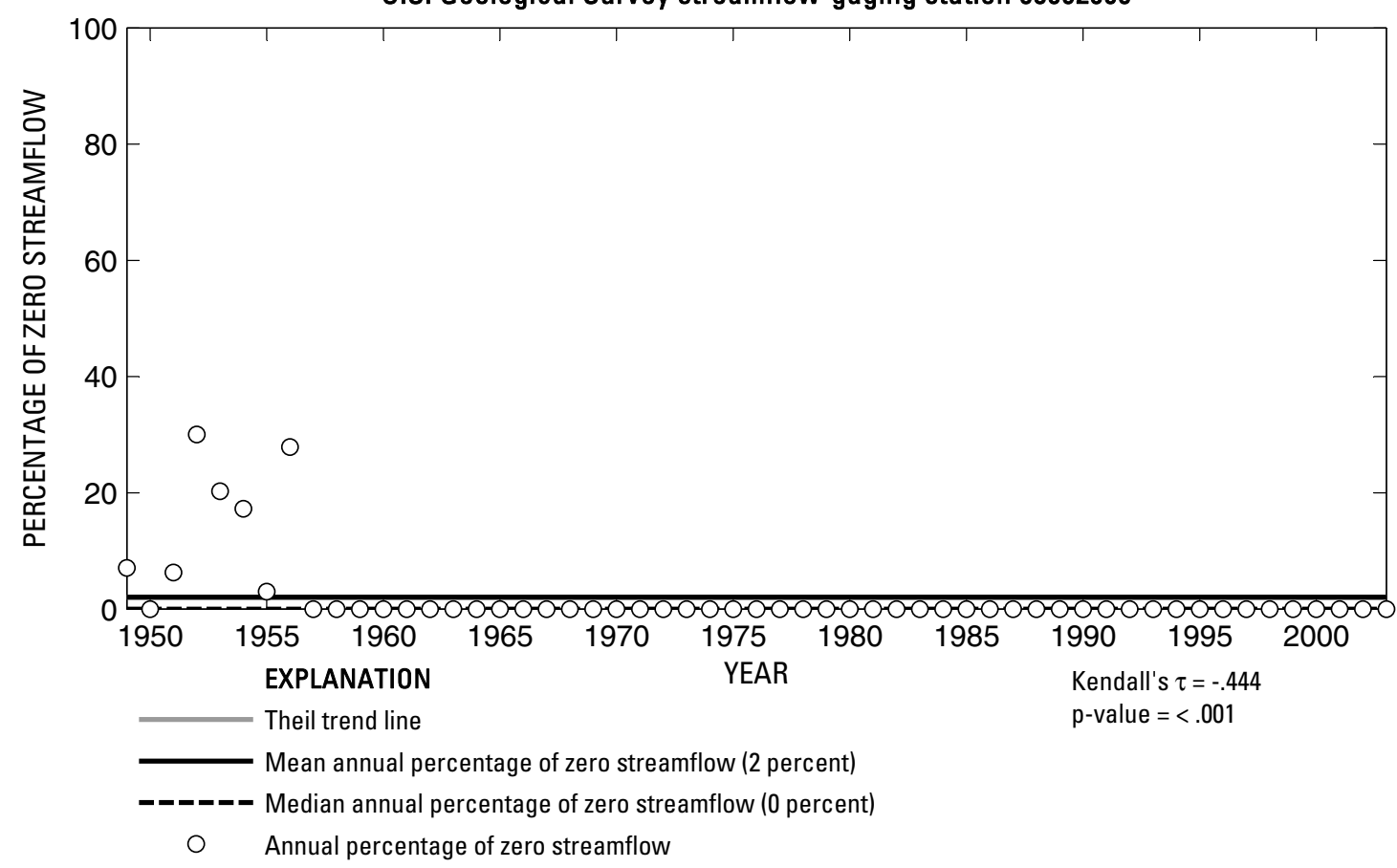

U.S. Geological Survey streamflow-gaging station 08062000

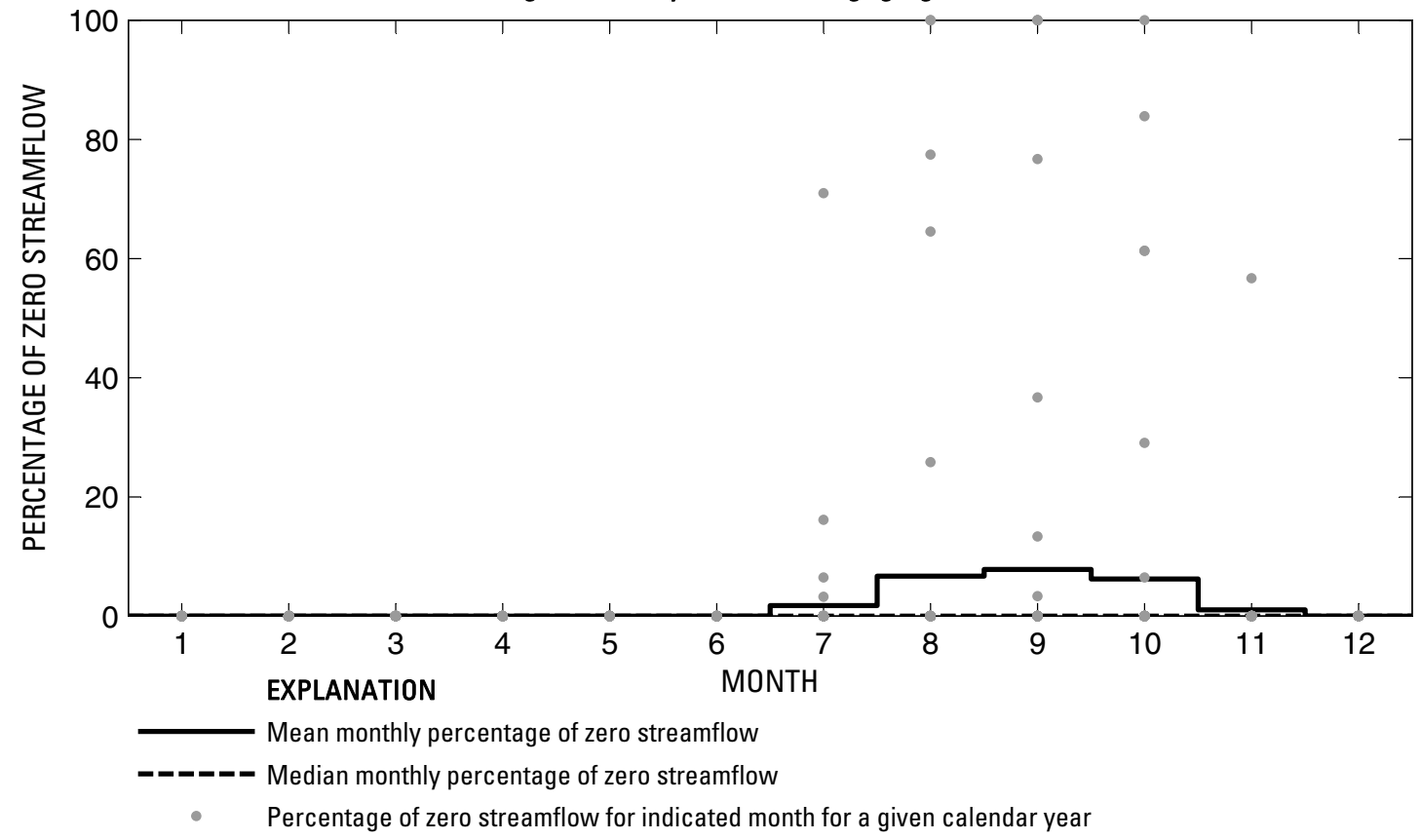

Figure 220. Analysis of percentage of zero daily mean streamflow for U.S. Geological Survey streamflow-gaging station 08062000 East Fork Trinity River near Crandall, Texas. 
U.S. Geological Survey streamflow-gaging station 08062500

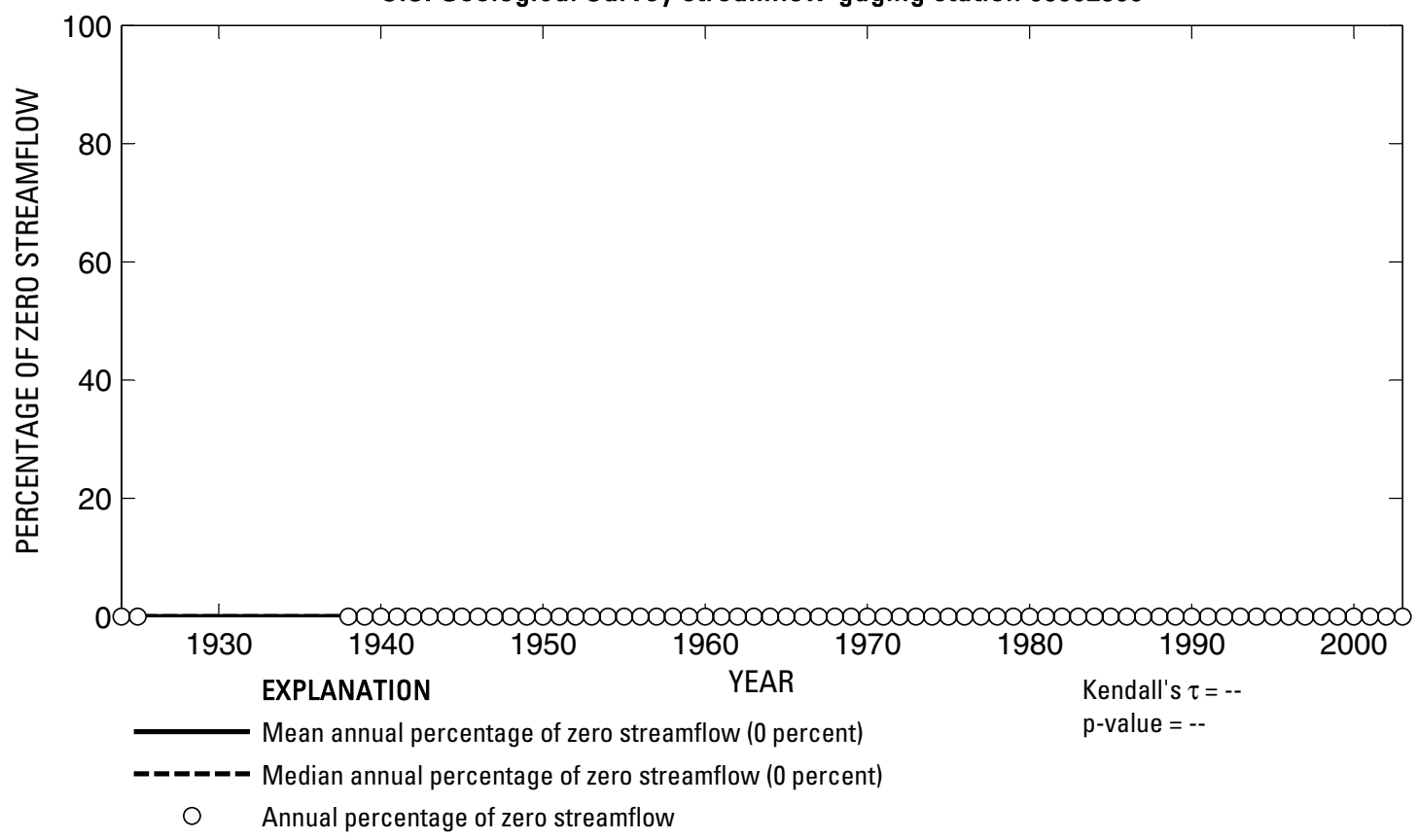

U.S. Geological Survey streamflow-gaging station 08062500

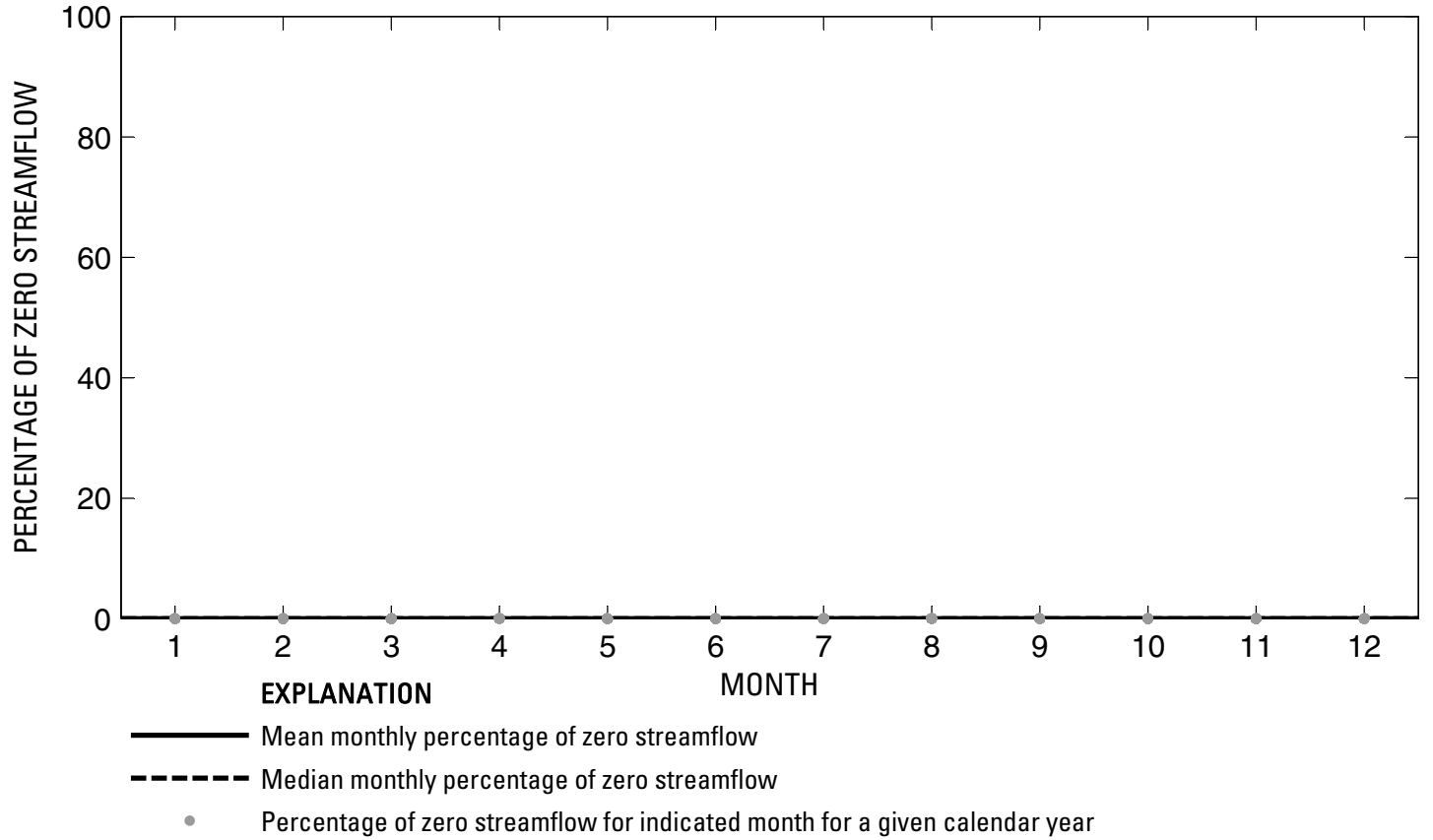

Figure 221. Analysis of percentage of zero daily mean streamflow for U.S. Geological Survey streamflow-gaging station 08062500 Trinity River near Rosser, Texas. 
U.S. Geological Survey streamflow-gaging station 08062650

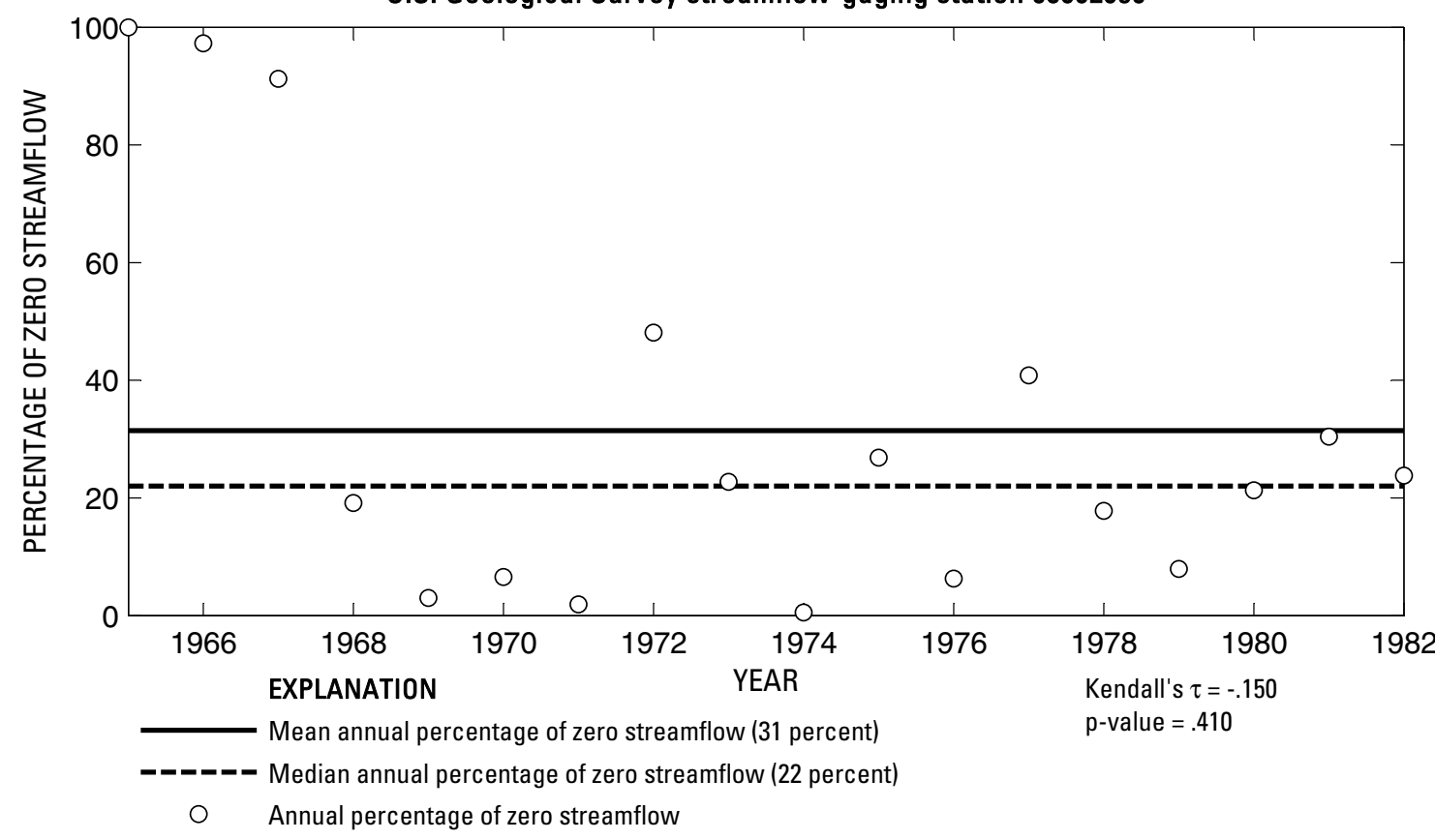

U.S. Geological Survey streamflow-gaging station 08062650

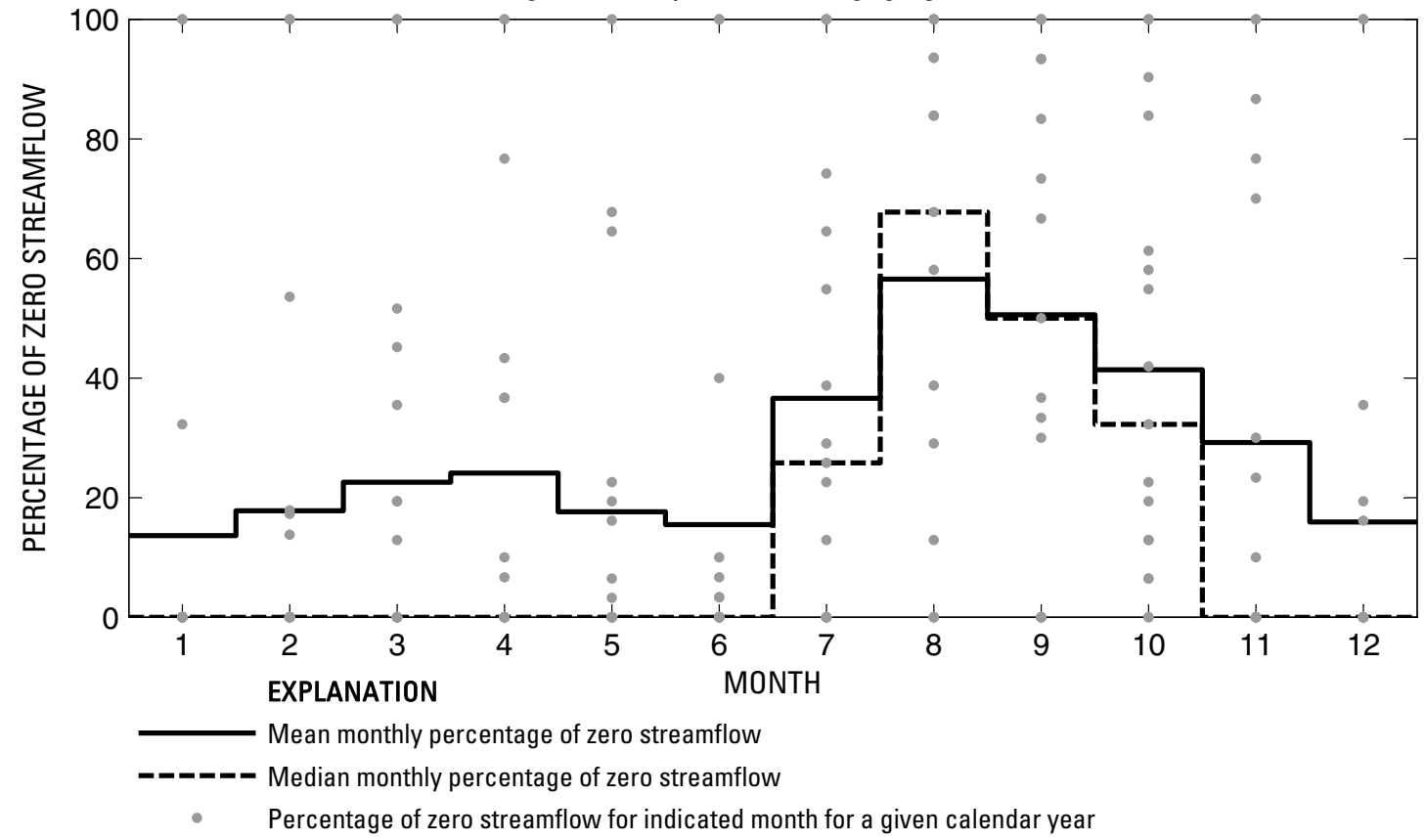

Figure 222. Analysis of percentage of zero daily mean streamflow for U.S. Geological Survey streamflow-gaging station 08062650 Cedar Creek Reservoir Spillway Outflow near Trinidad, Texas.

Index of Station Numbers 719 


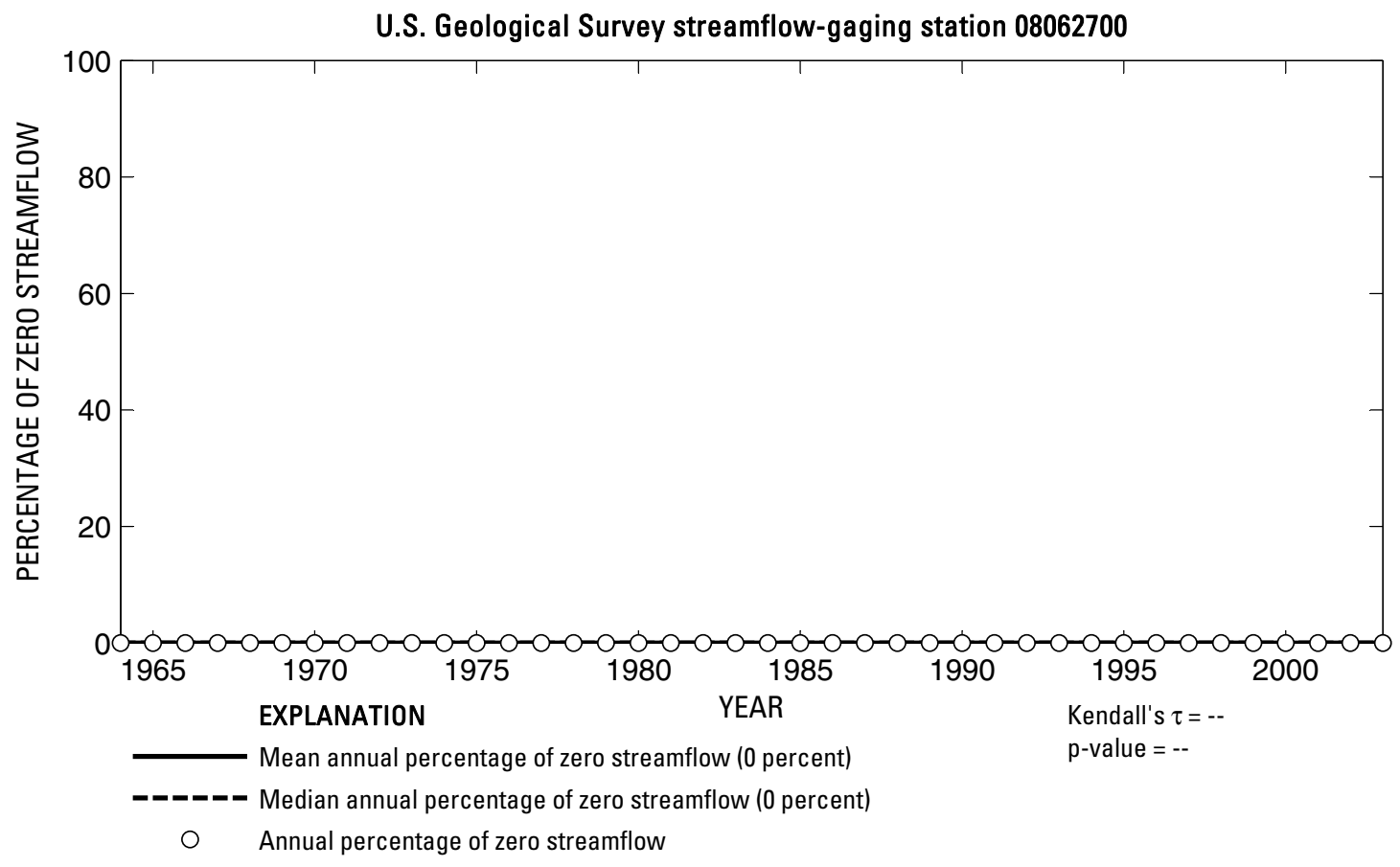

U.S. Geological Survey streamflow-gaging station 08062700

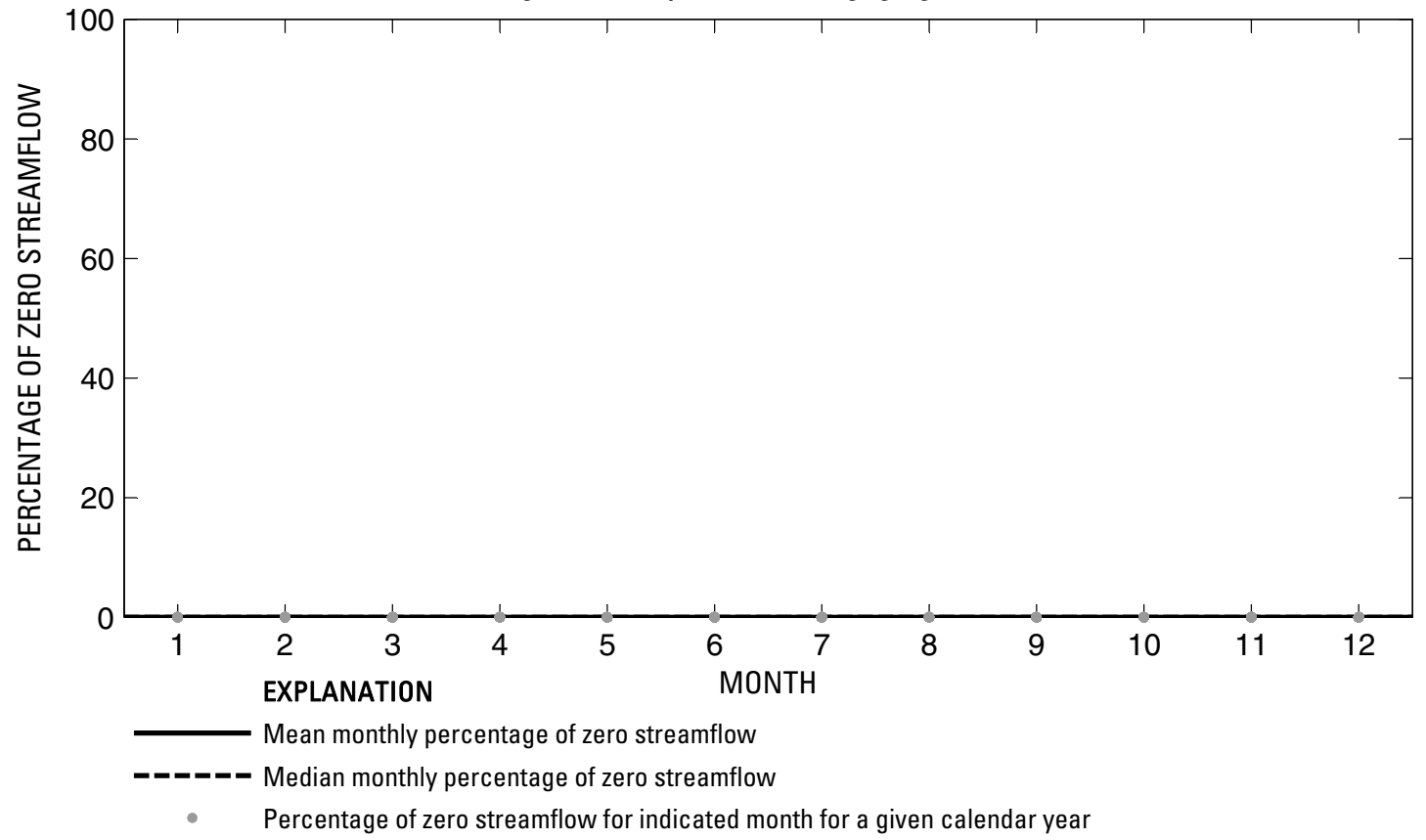

Figure 223. Analysis of percentage of zero daily mean streamflow for U.S. Geological Survey streamflow-gaging station 08062700 Trinity River at Trinidad, Texas. 
U.S. Geological Survey streamflow-gaging station 08062800

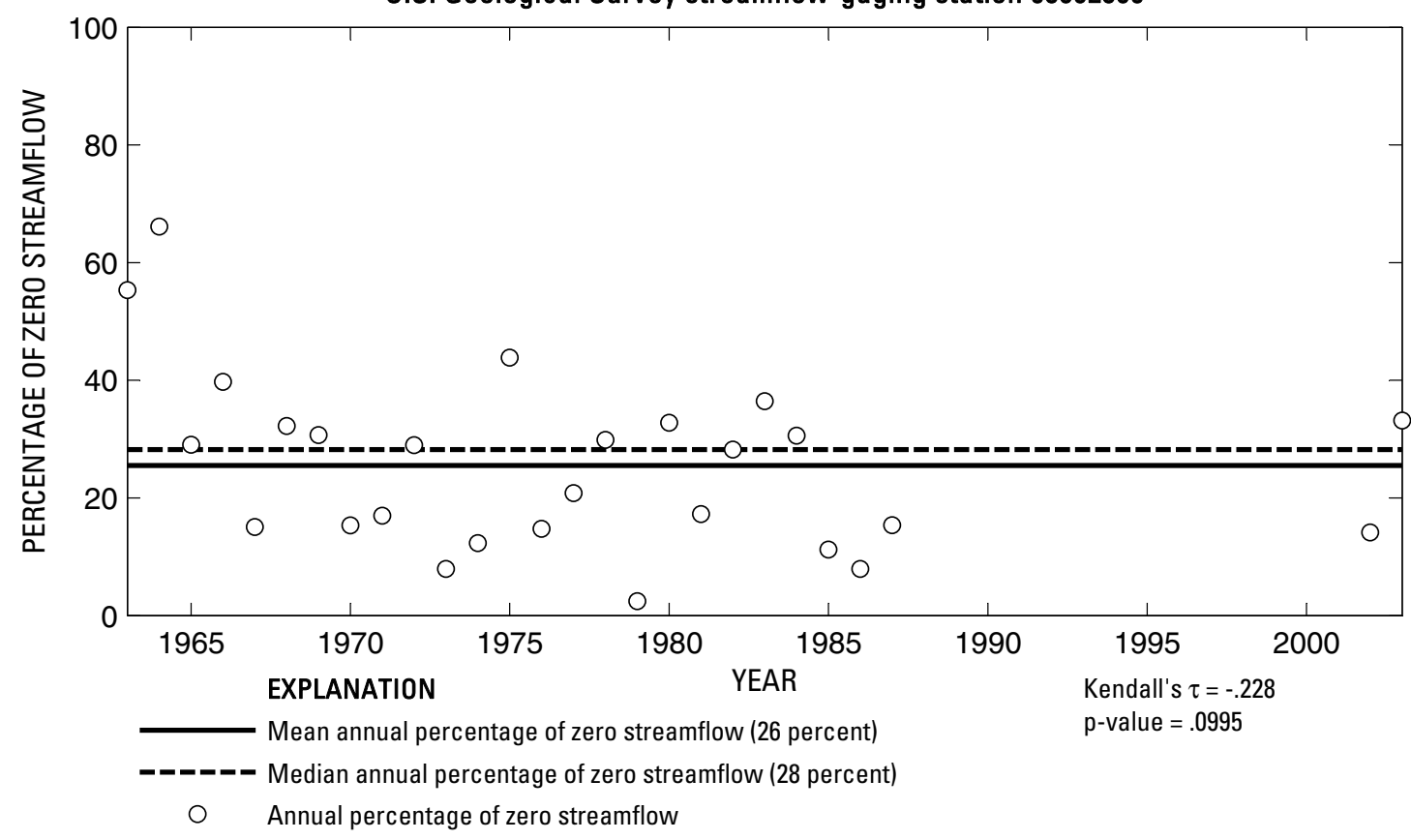

U.S. Geological Survey streamflow-gaging station 08062800

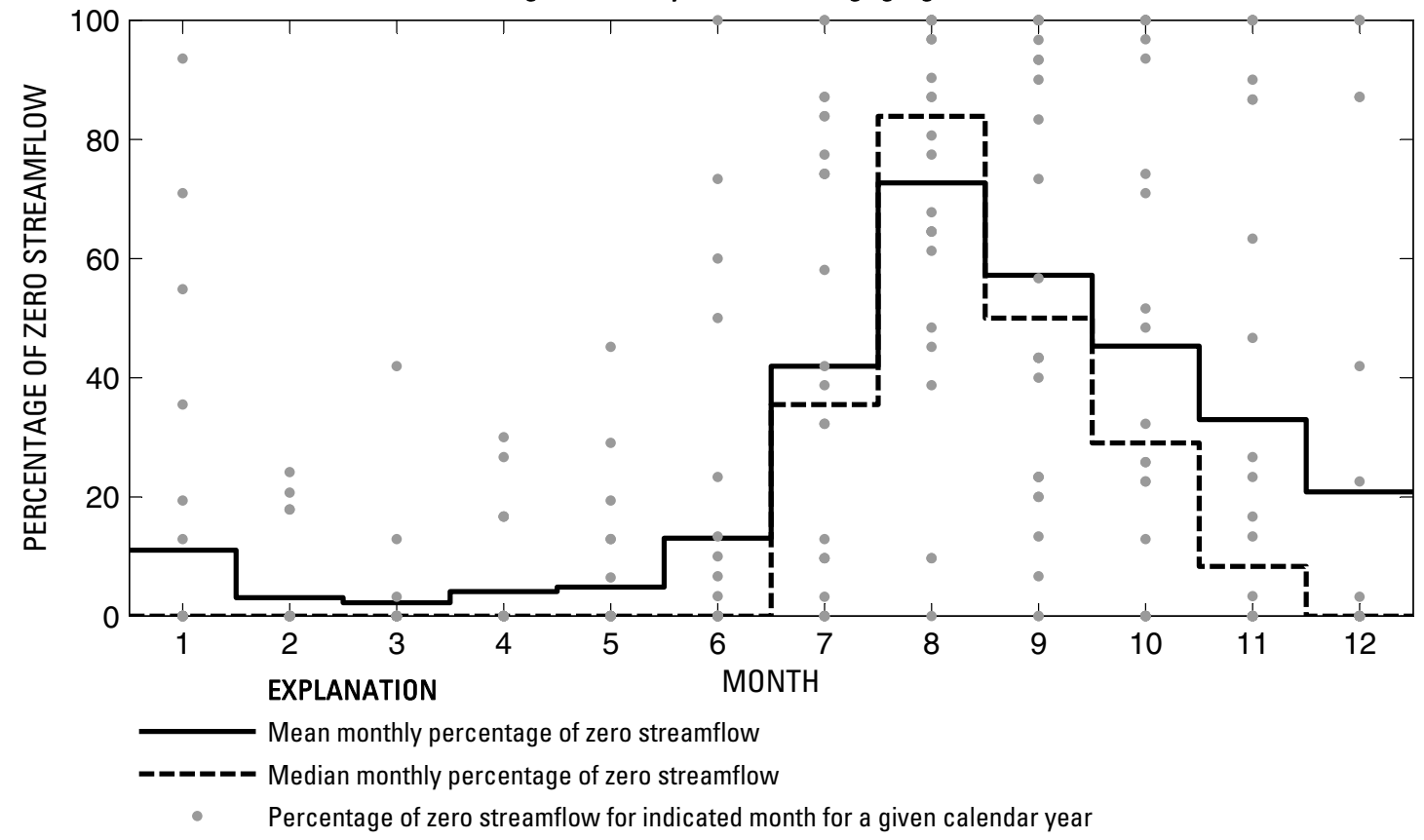

Figure 224. Analysis of percentage of zero daily mean streamflow for U.S. Geological Survey streamflow-gaging station 08062800 Cedar Creek near Kemp, Texas. 


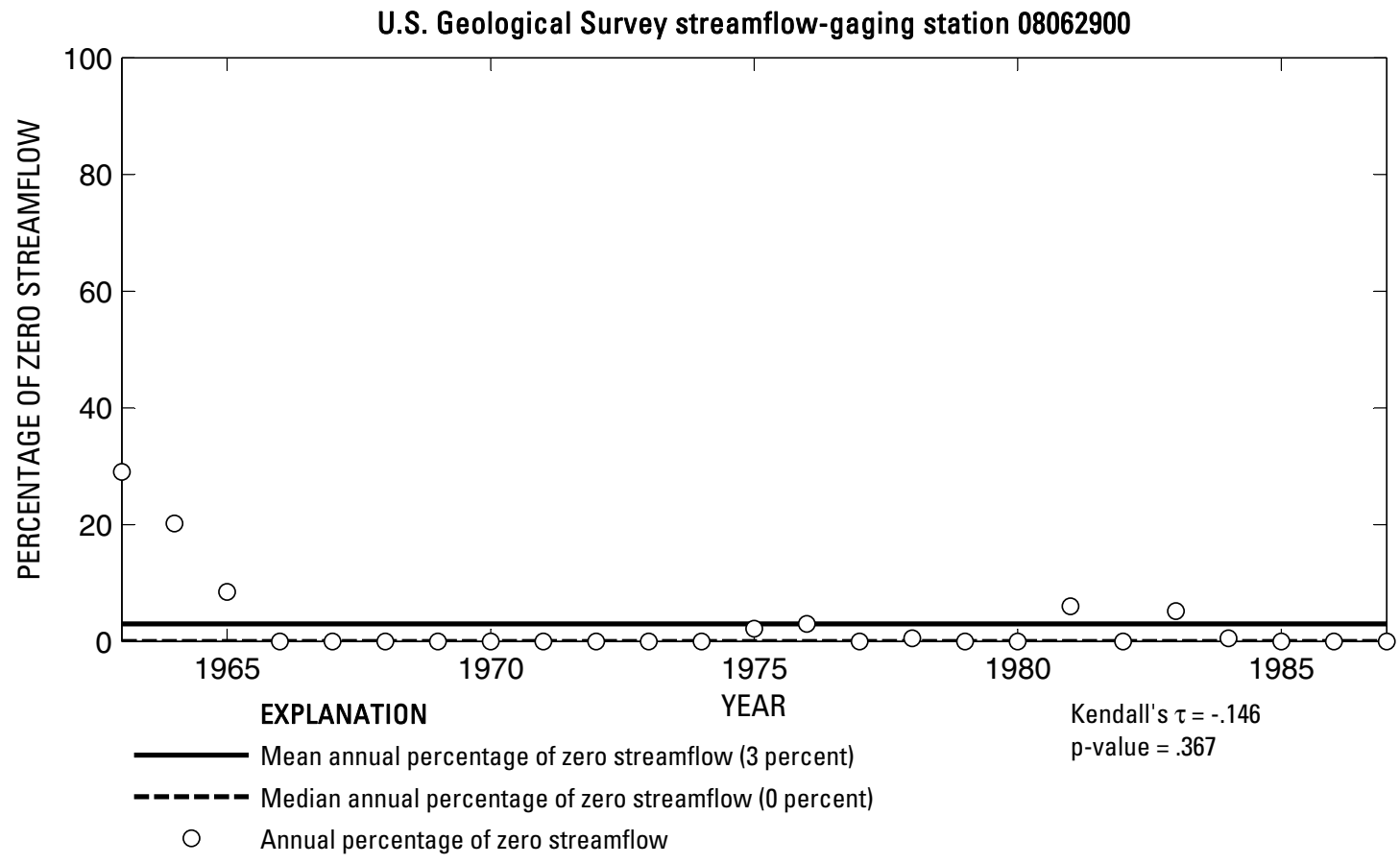

U.S. Geological Survey streamflow-gaging station 08062900

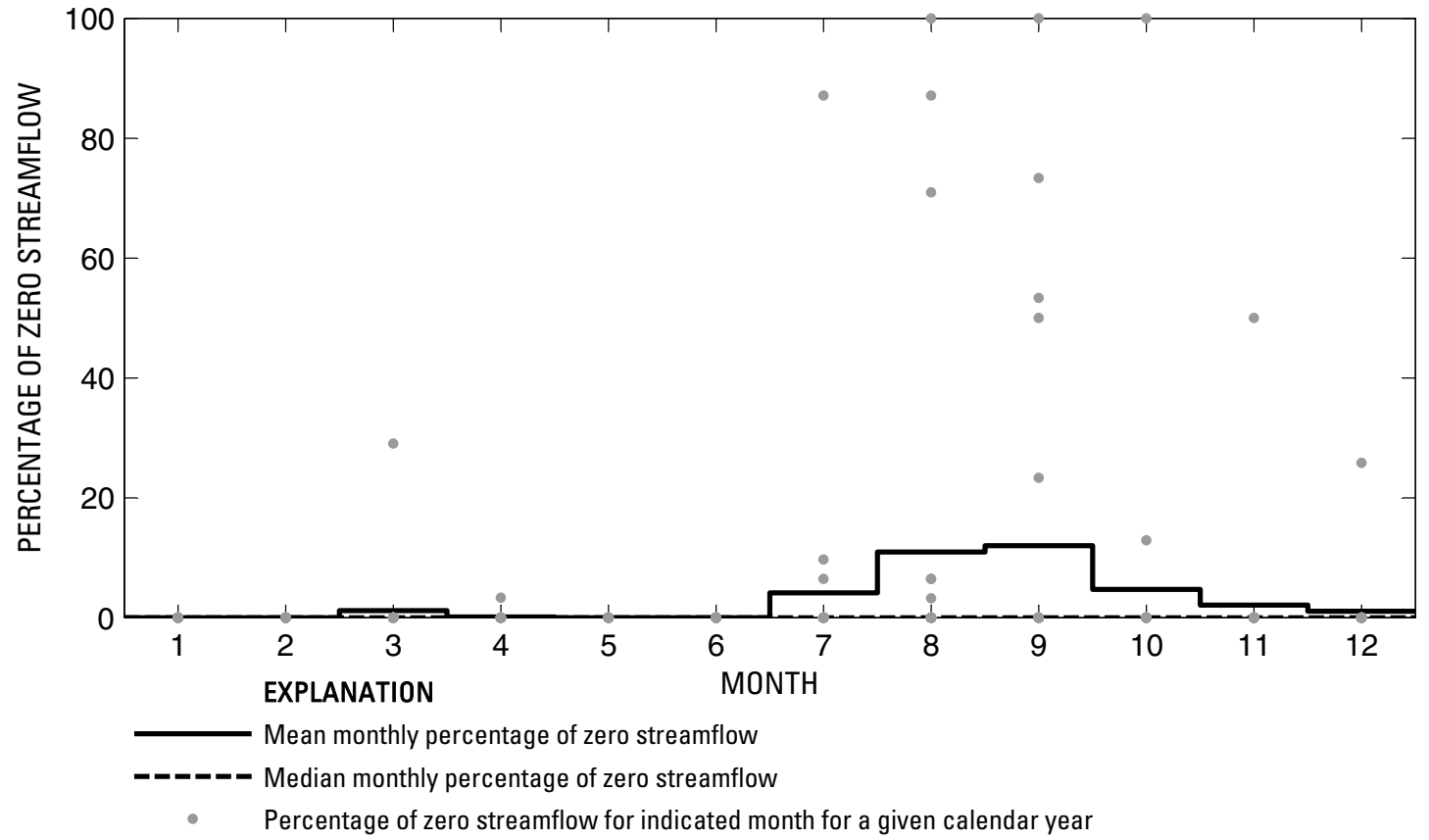

Figure 225. Analysis of percentage of zero daily mean streamflow for U.S. Geological Survey streamflow-gaging station 08062900 Kings Creek near Kaufman, Texas. 
U.S. Geological Survey streamflow-gaging station 08062980

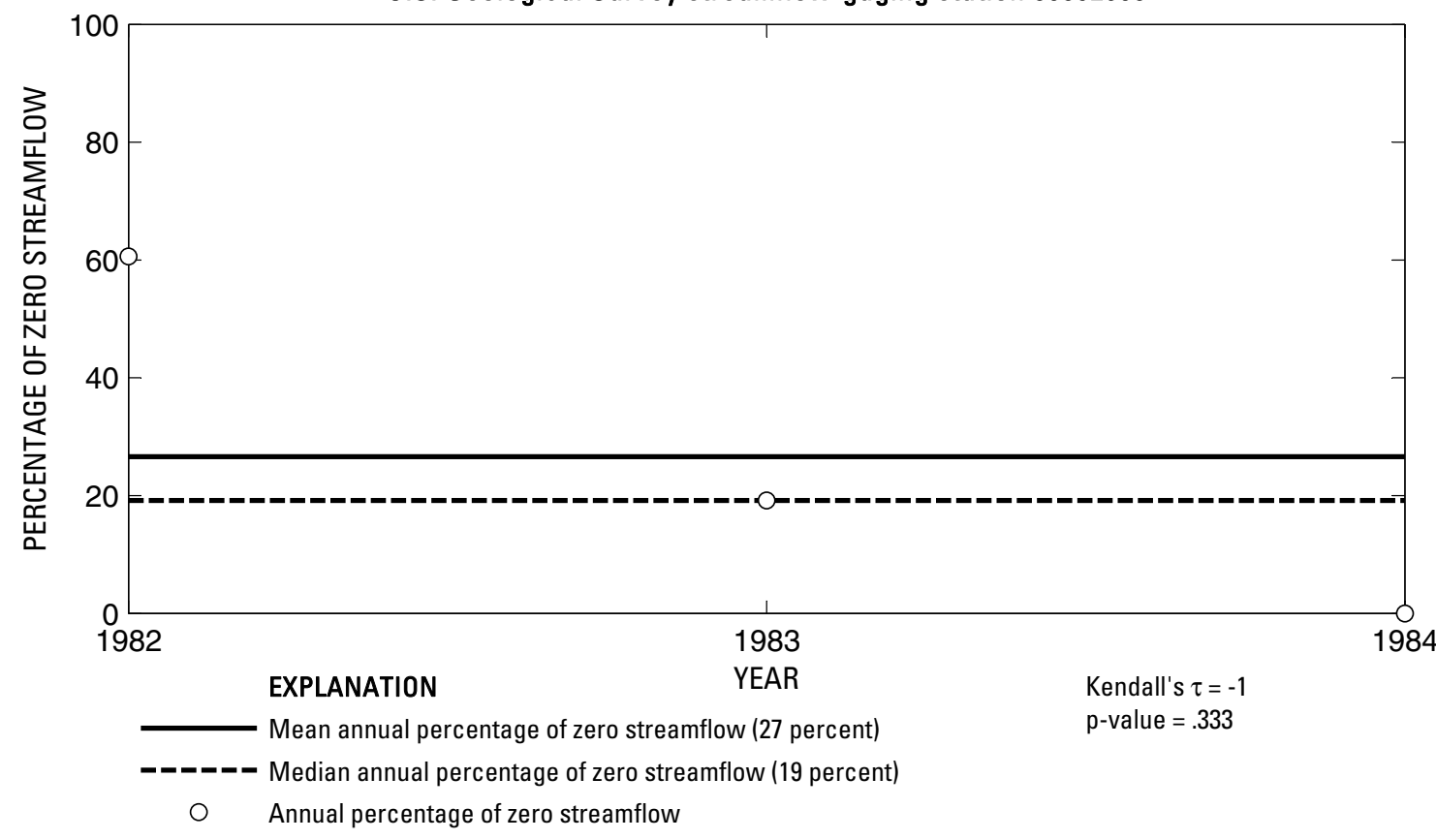

U.S. Geological Survey streamflow-gaging station 08062980

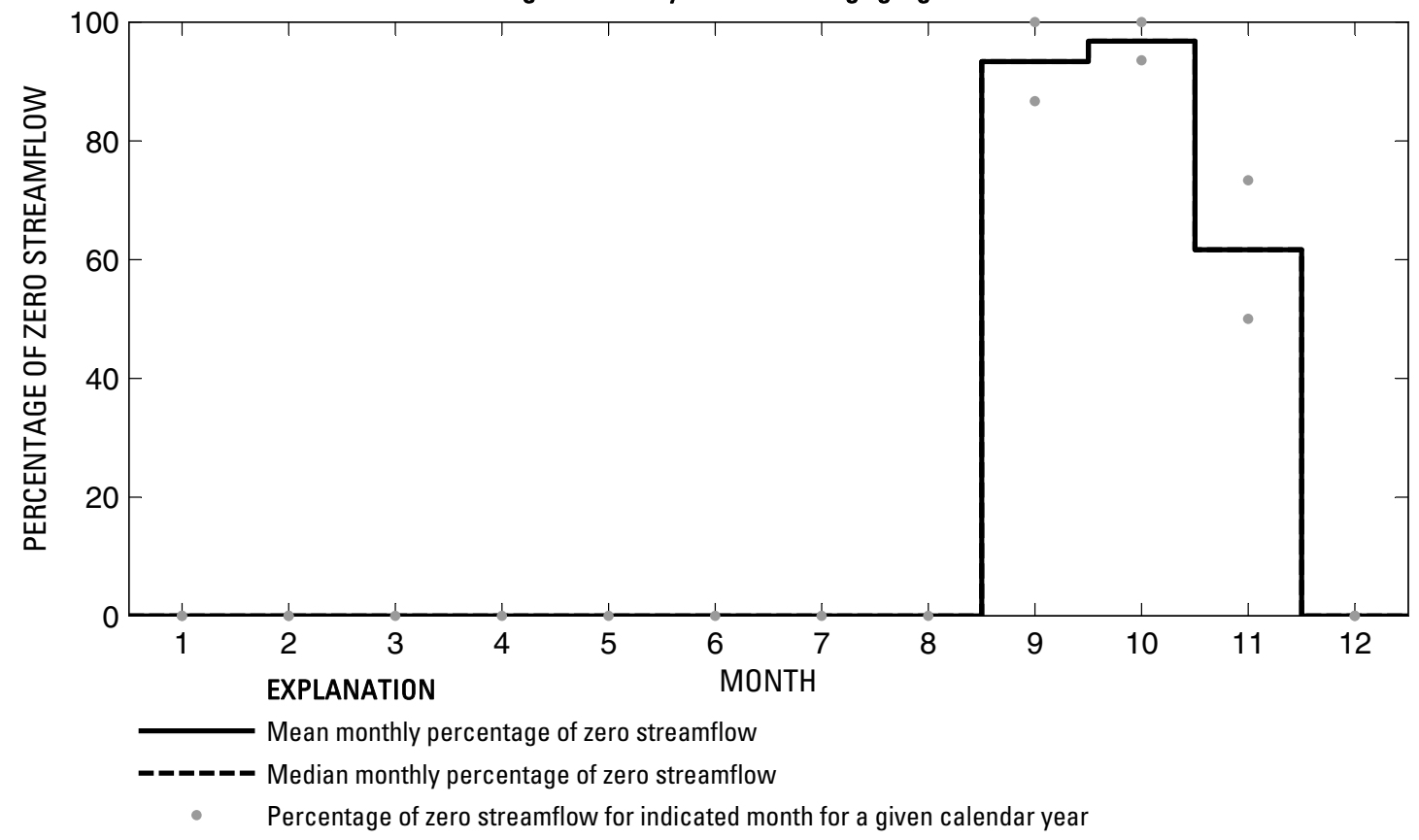

Figure 226. Analysis of percentage of zero daily mean streamflow for U.S. Geological Survey streamflow-gaging station 08062980 Lacey Fork near Mabank, Texas. 


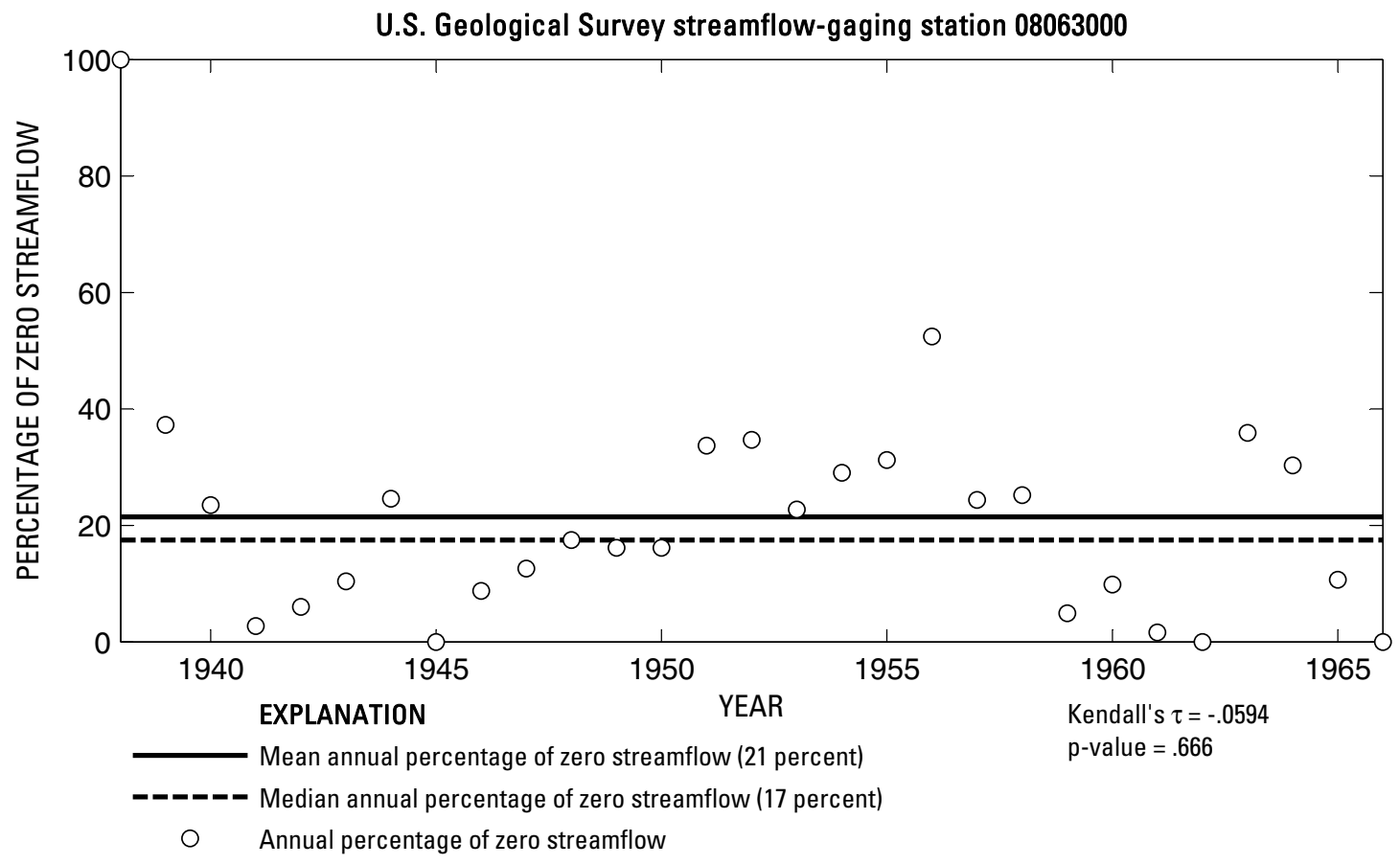

U.S. Geological Survey streamflow-gaging station 08063000

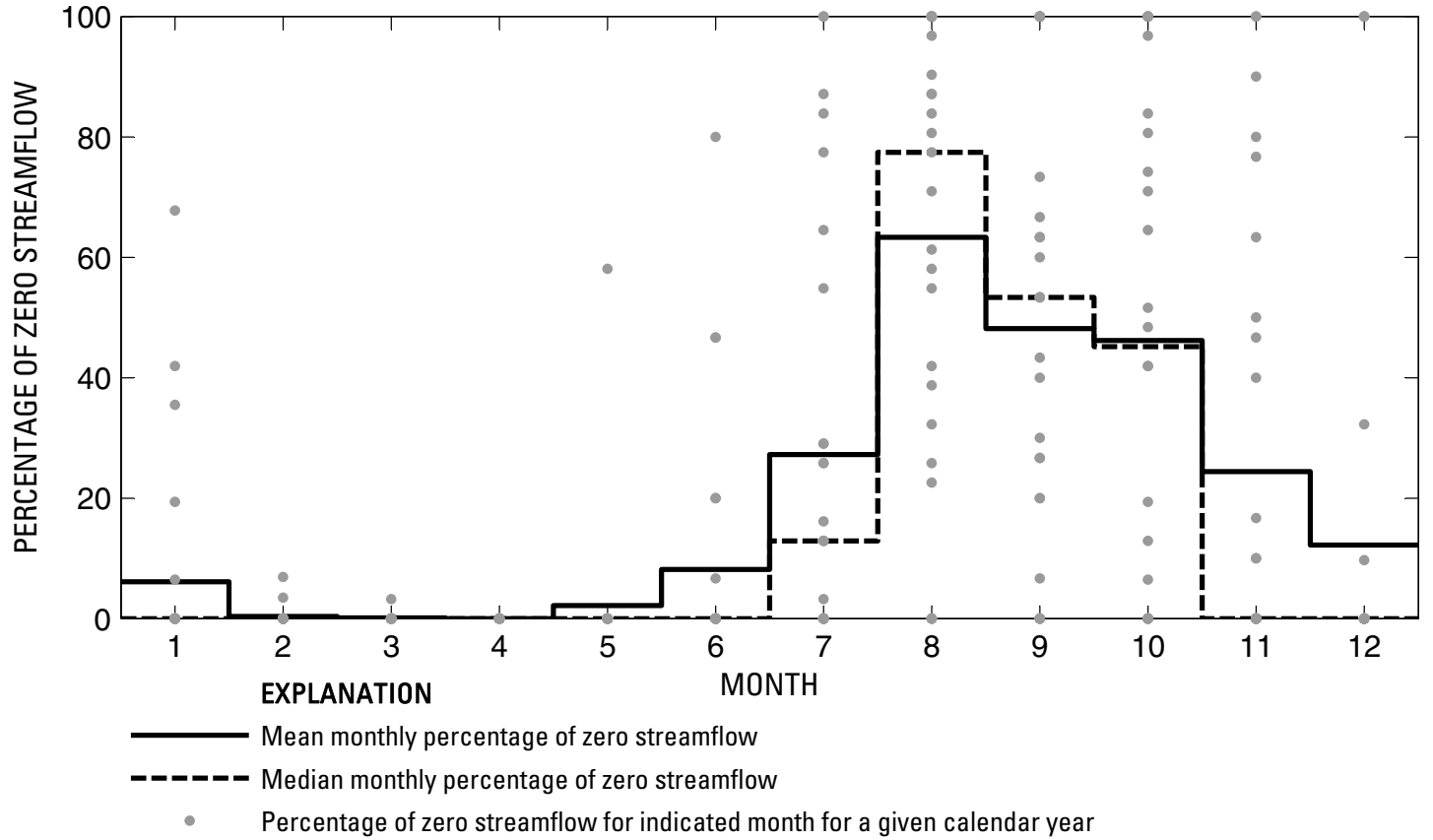

Figure 227. Analysis of percentage of zero daily mean streamflow for U.S. Geological Survey streamflow-gaging station 08063000 Cedar Creek near Mabank, Texas. 
U.S. Geological Survey streamflow-gaging station 08063003

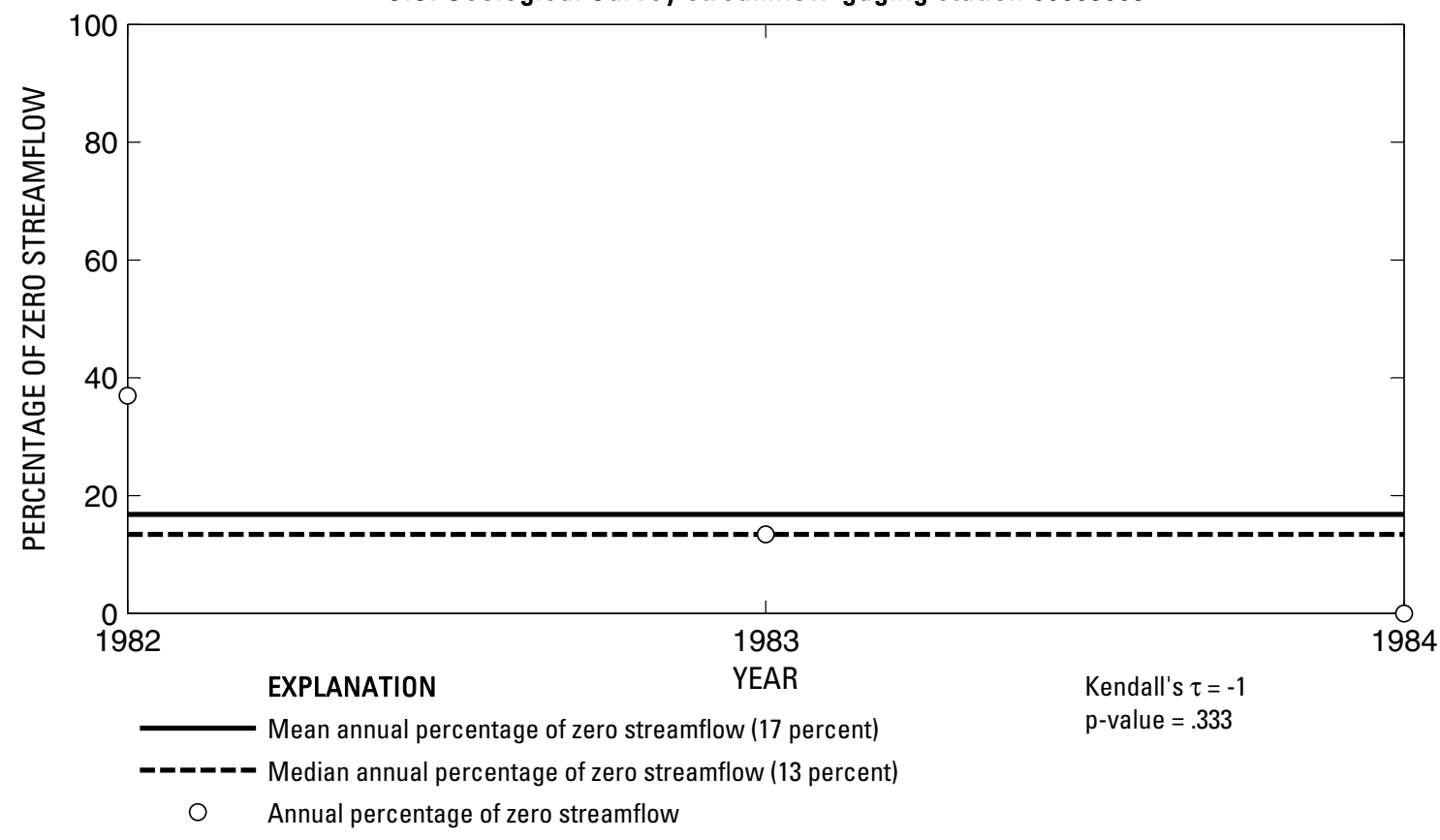

U.S. Geological Survey streamflow-gaging station 08063003

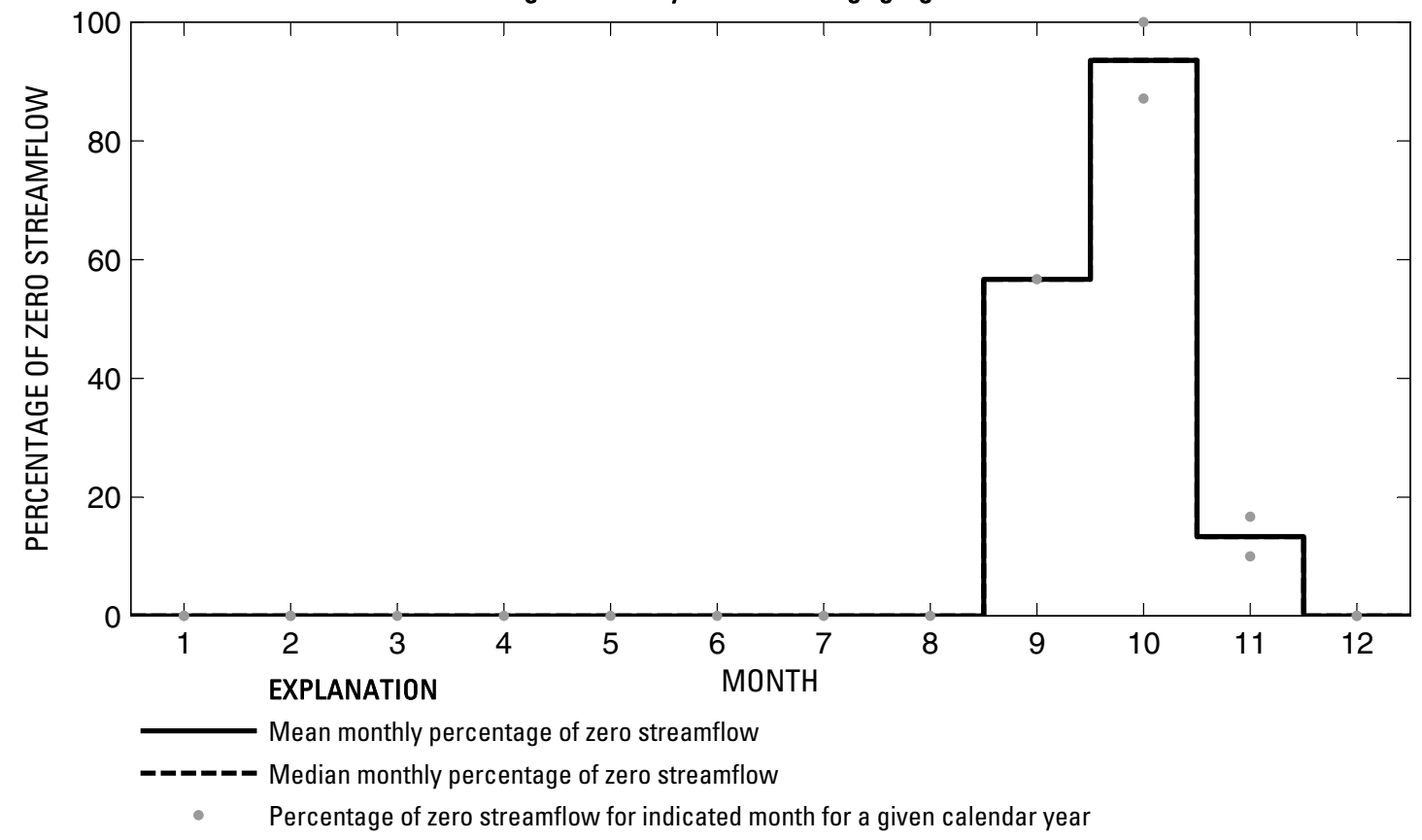

Figure 228. Analysis of percentage of zero daily mean streamflow for U.S. Geological Survey streamflow-gaging station 08063003 South Twin Creek near Eustace, Texas. 

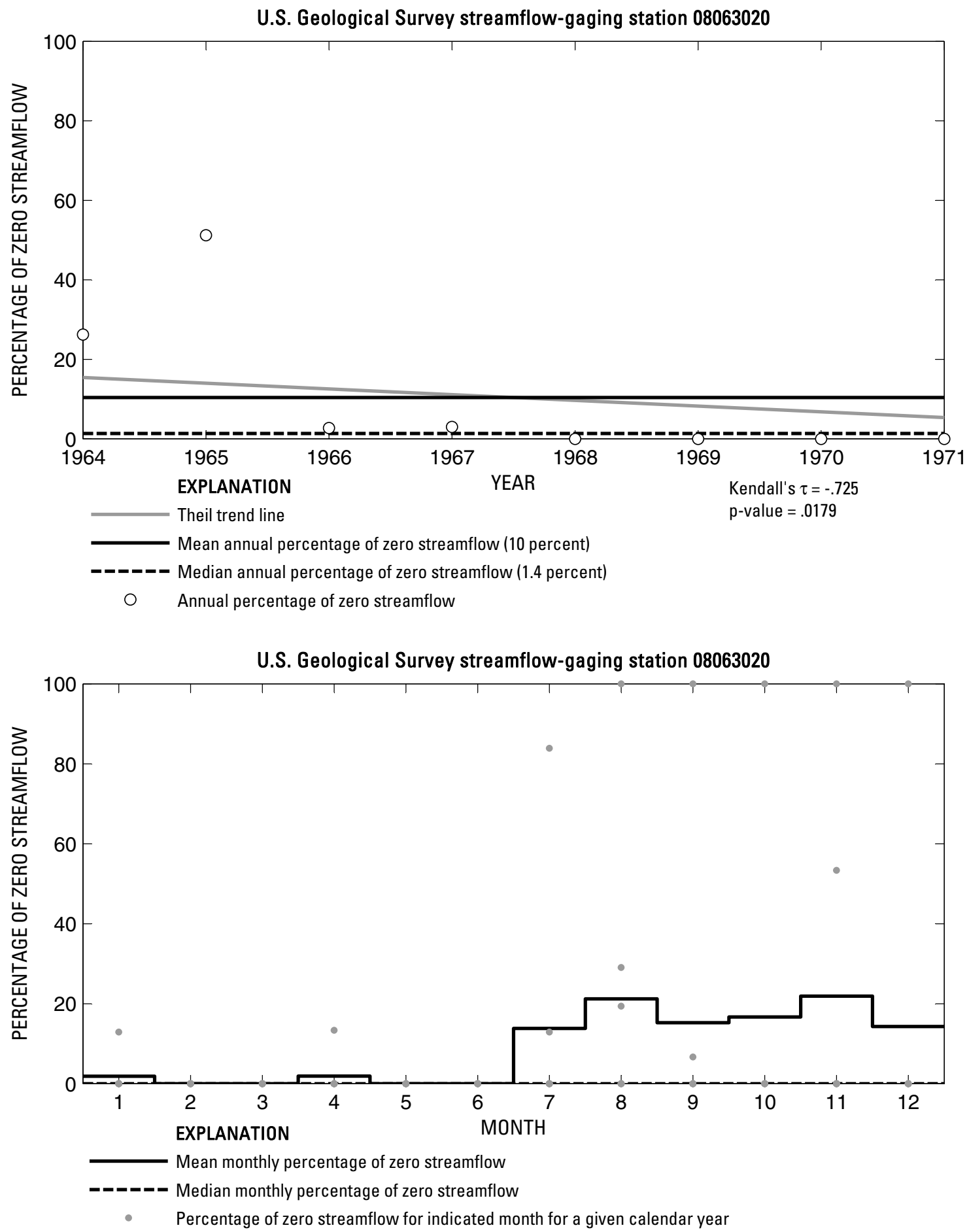

Figure 229. Analysis of percentage of zero daily mean streamflow for U.S. Geological Survey streamflow-gaging station 08063020 Cedar Creek at Trinidad, Texas. 
U.S. Geological Survey streamflow-gaging station 08063100

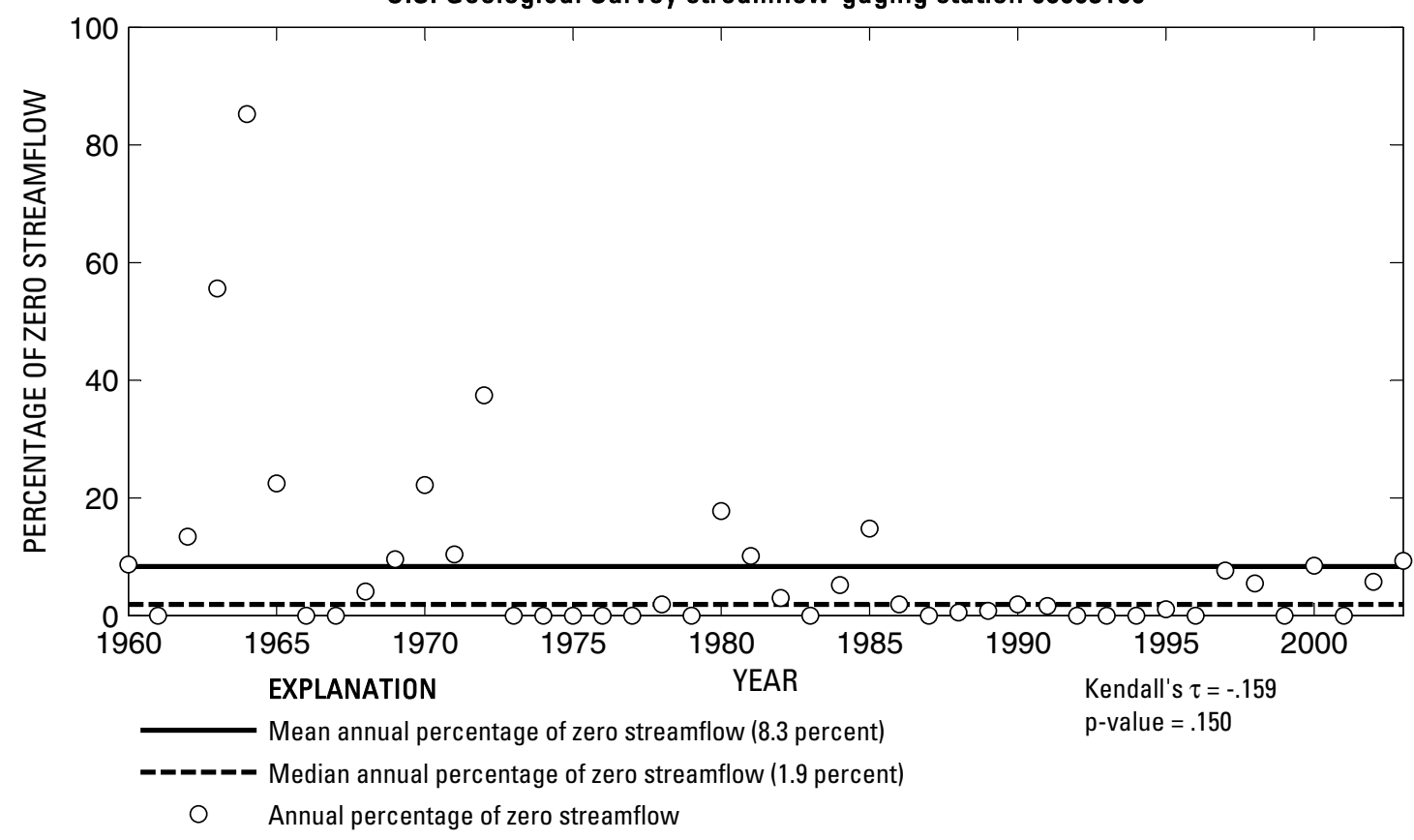

U.S. Geological Survey streamflow-gaging station 08063100

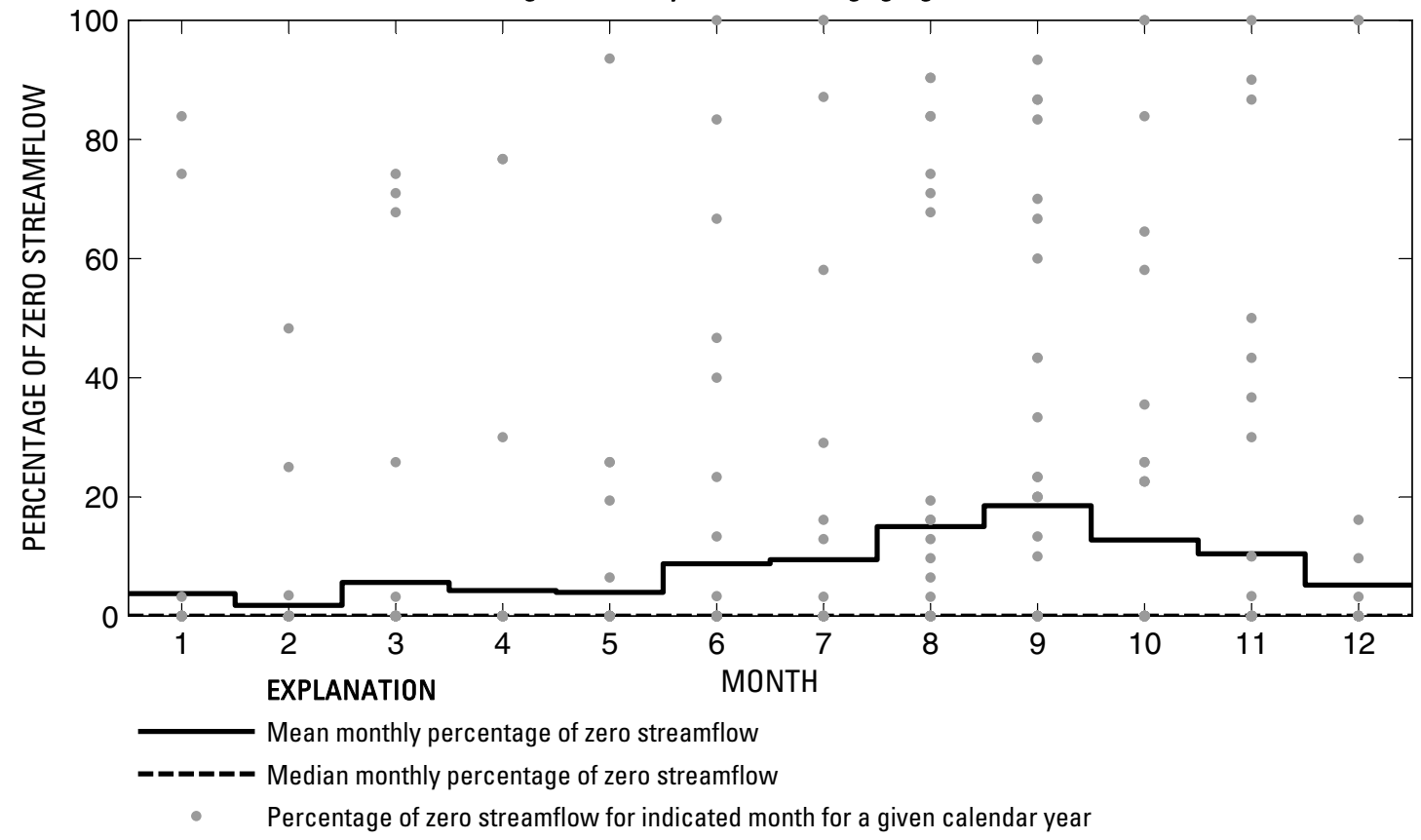

Figure 230. Analysis of percentage of zero daily mean streamflow for U.S. Geological Survey streamflow-gaging station 08063100 Richland Creek near Dawson, Texas. 

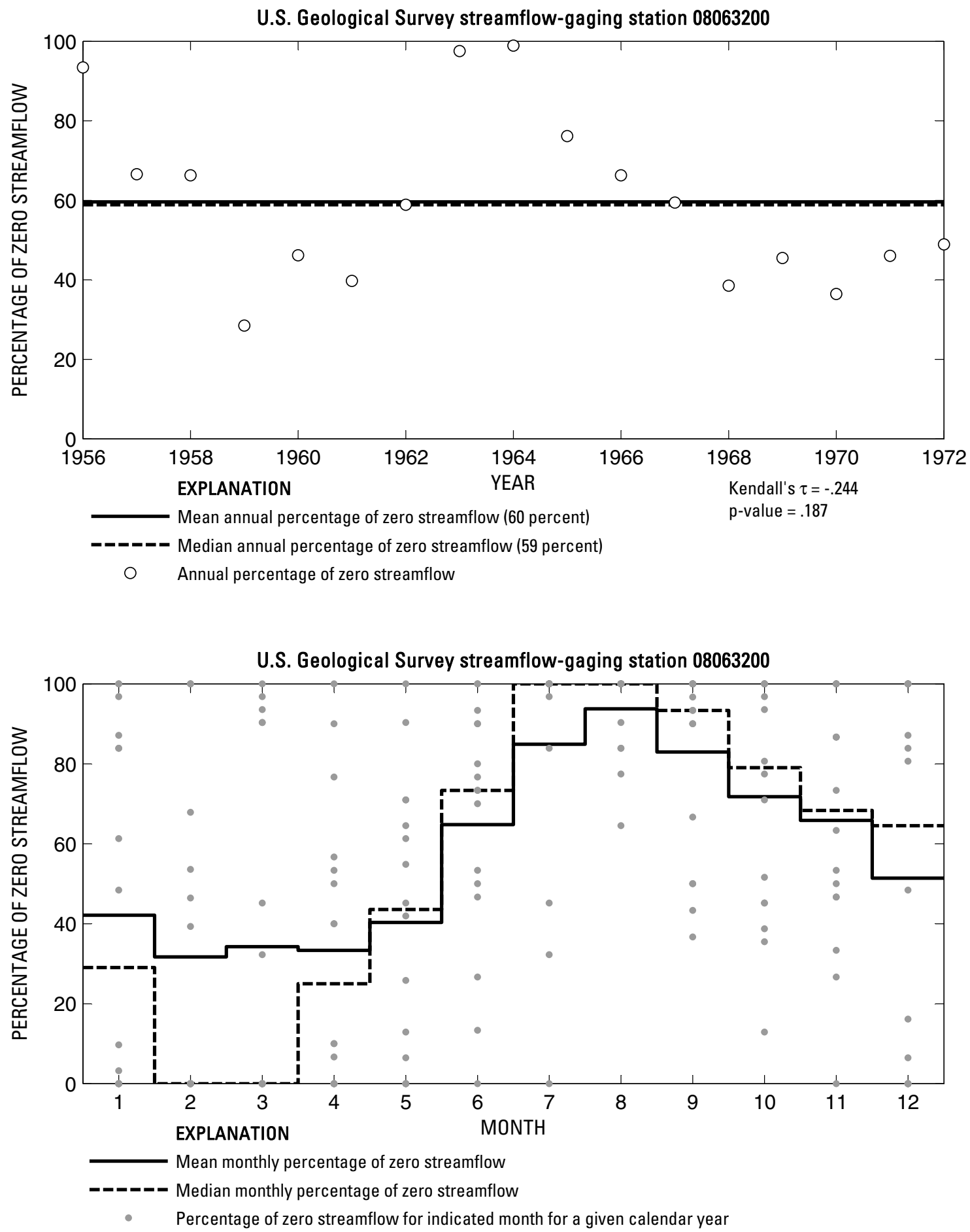

Figure 231. Analysis of percentage of zero daily mean streamflow for U.S. Geological Survey streamflow-gaging station 08063200 Pin Oak Creek near Hubbard, Texas. 
U.S. Geological Survey streamflow-gaging station 08063500

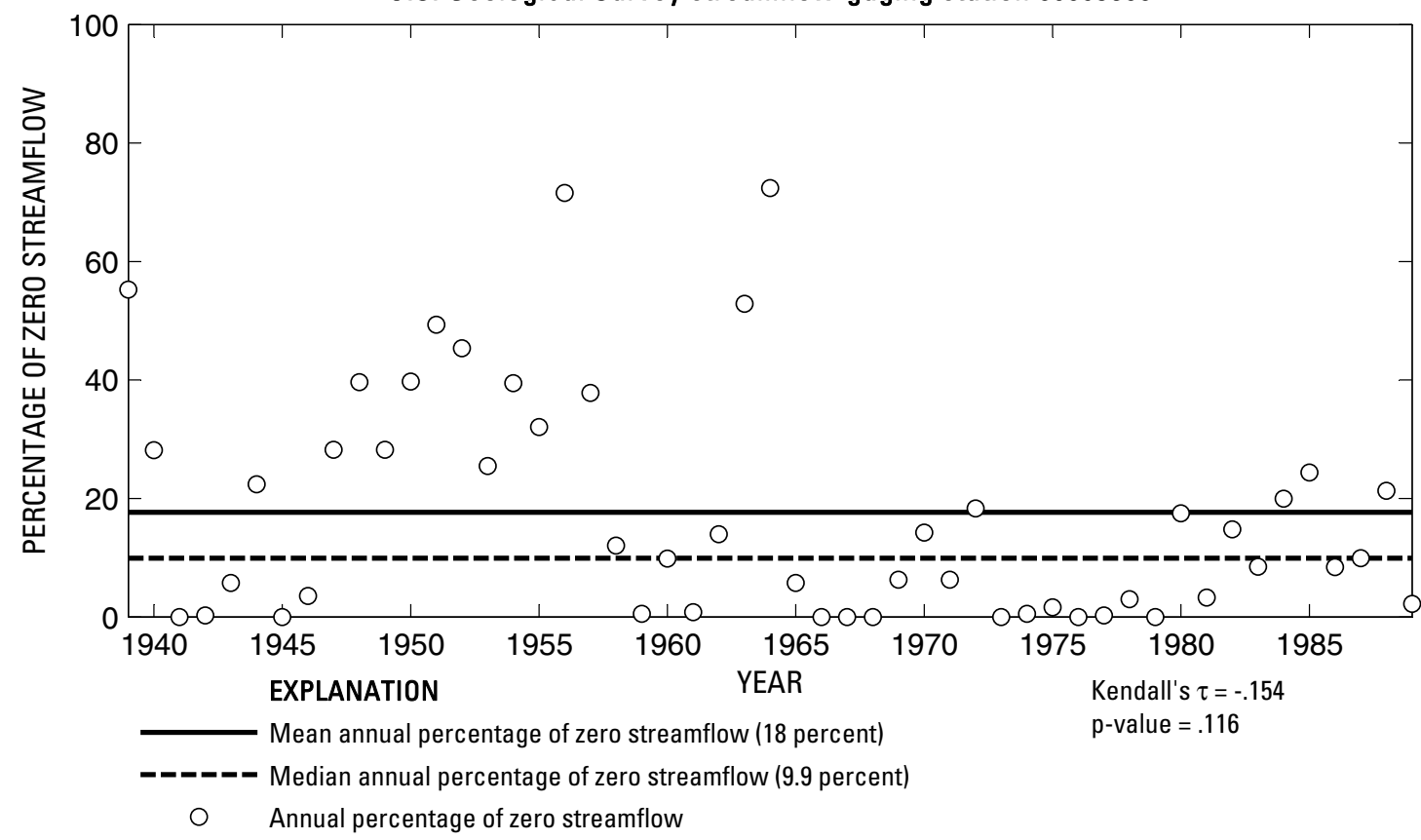

U.S. Geological Survey streamflow-gaging station 08063500

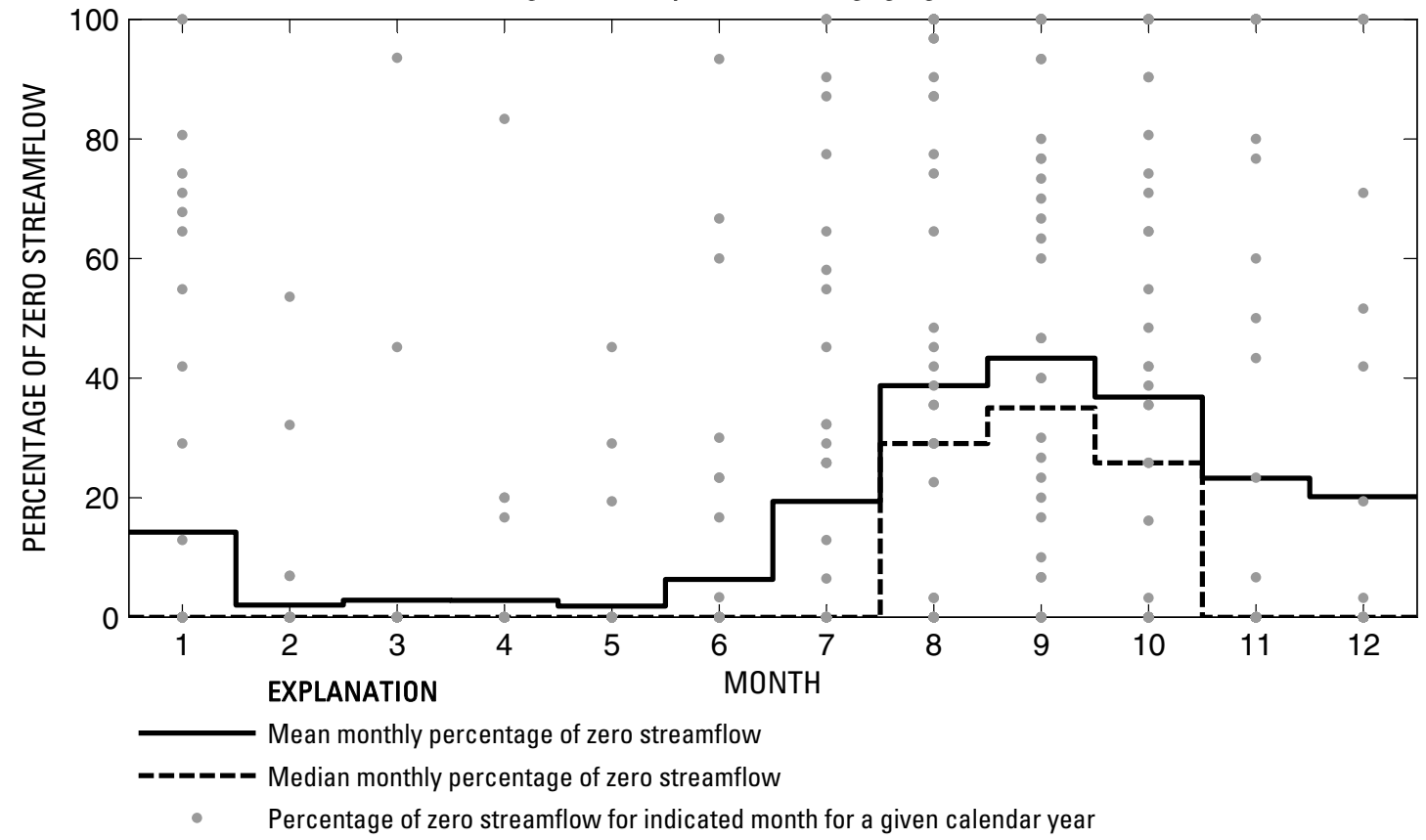

Figure 232. Analysis of percentage of zero daily mean streamflow for U.S. Geological Survey streamflow-gaging station 08063500 Richland Creek near Richland, Texas.

Index of Station Numbers 719 


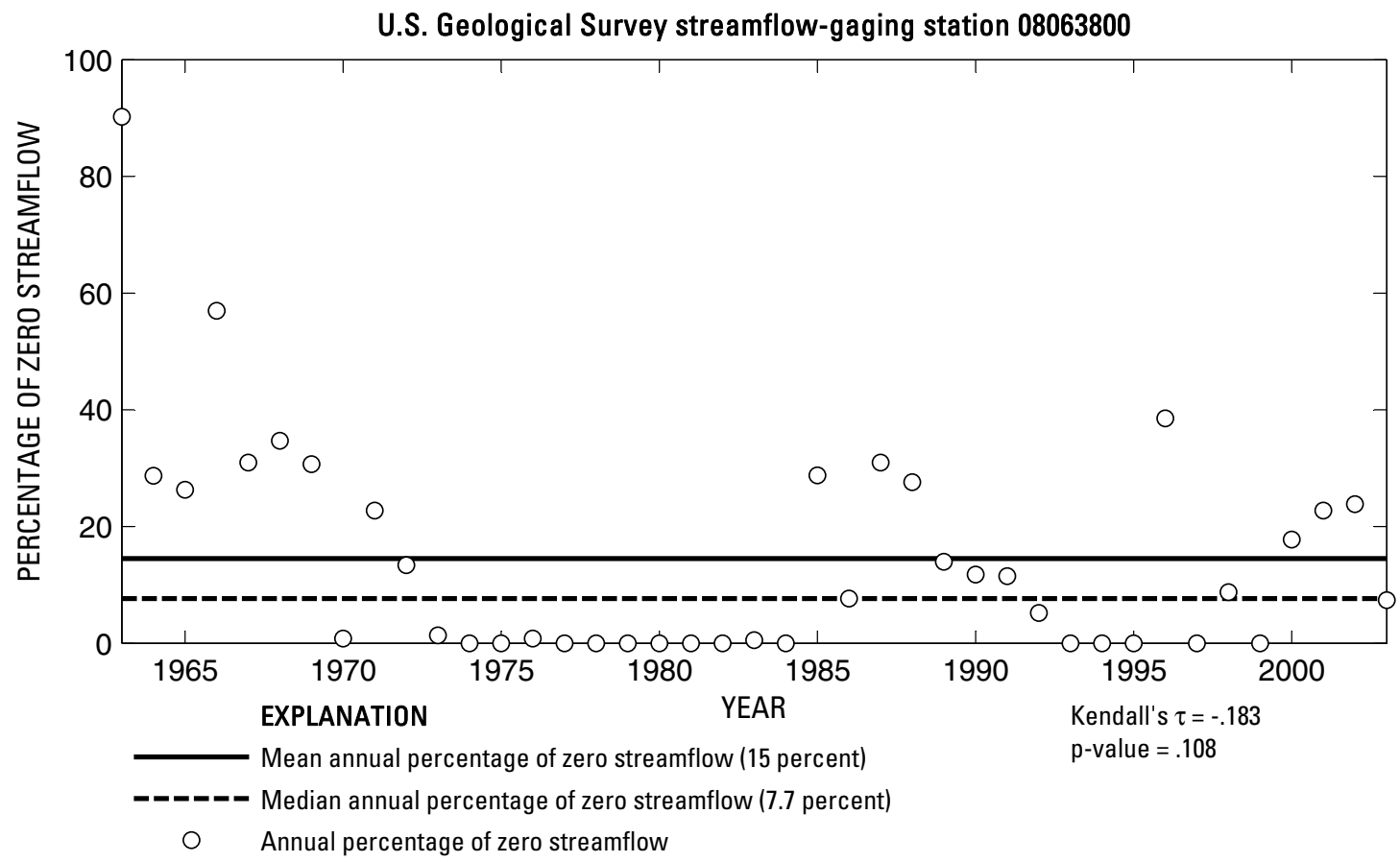

U.S. Geological Survey streamflow-gaging station 08063800

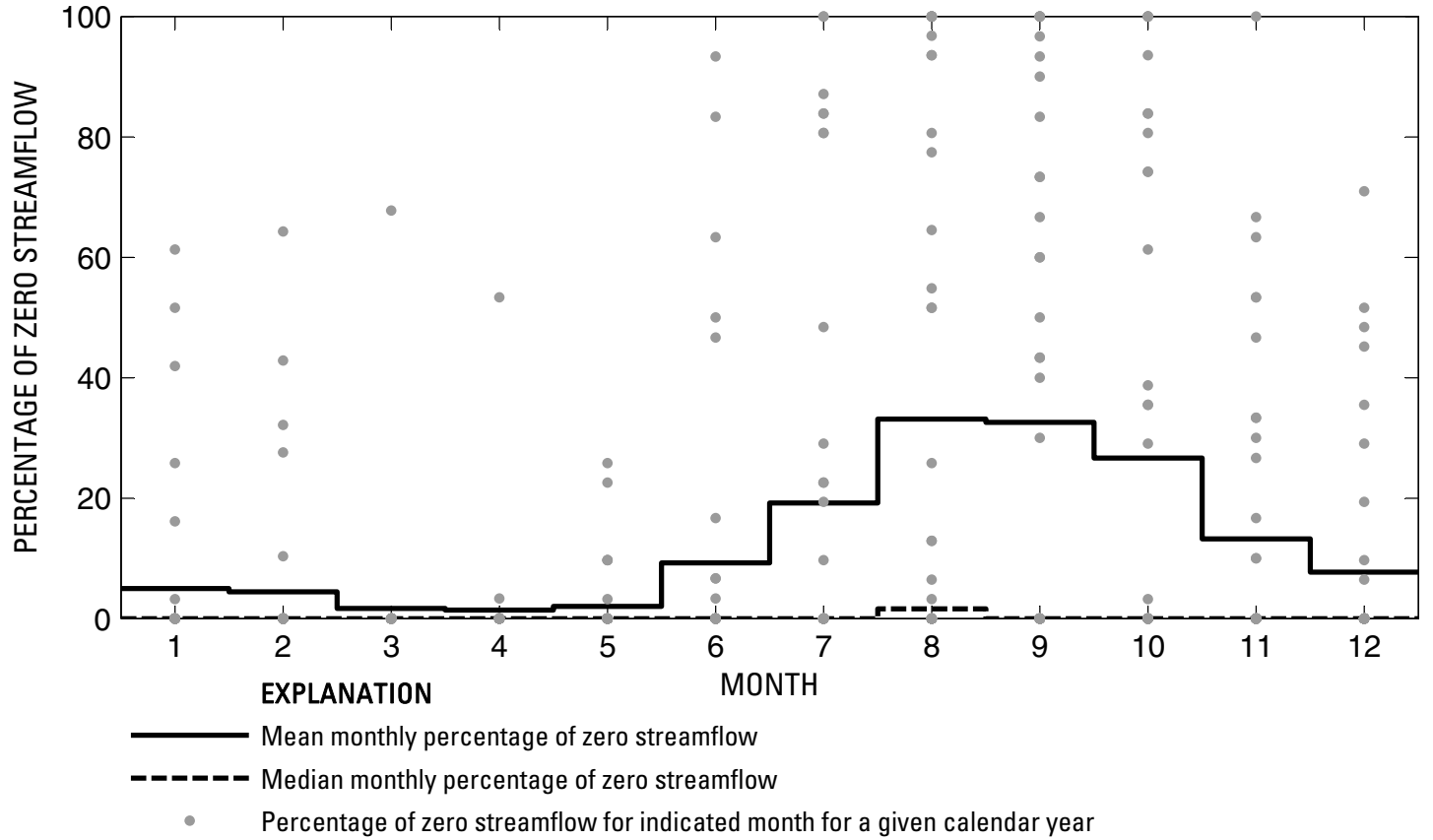

Figure 233. Analysis of percentage of zero daily mean streamflow for U.S. Geological Survey streamflow-gaging station 08063800 Waxahachie Creek near Bardwell, Texas. 
U.S. Geological Survey streamflow-gaging station 08064100

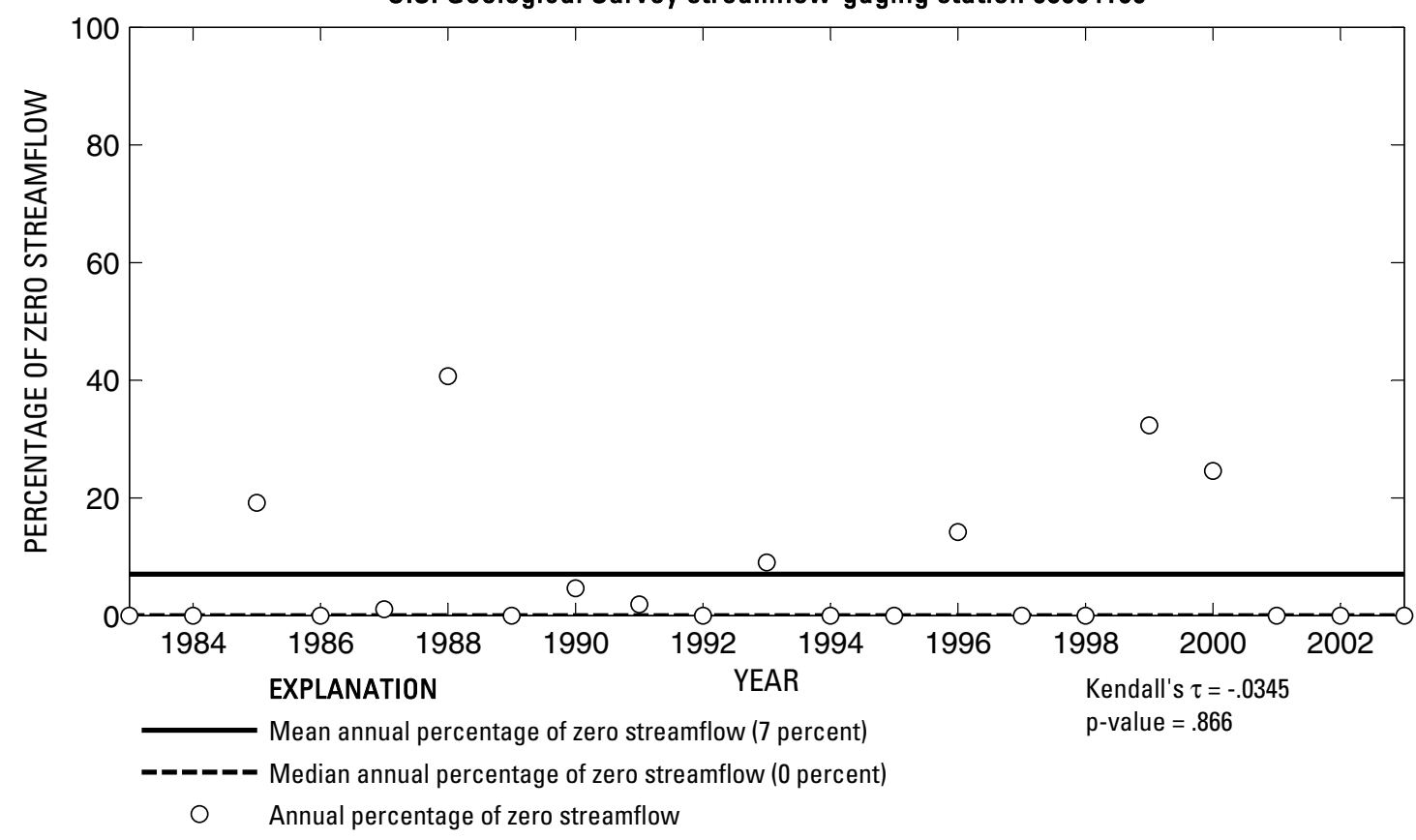

U.S. Geological Survey streamflow-gaging station 08064100

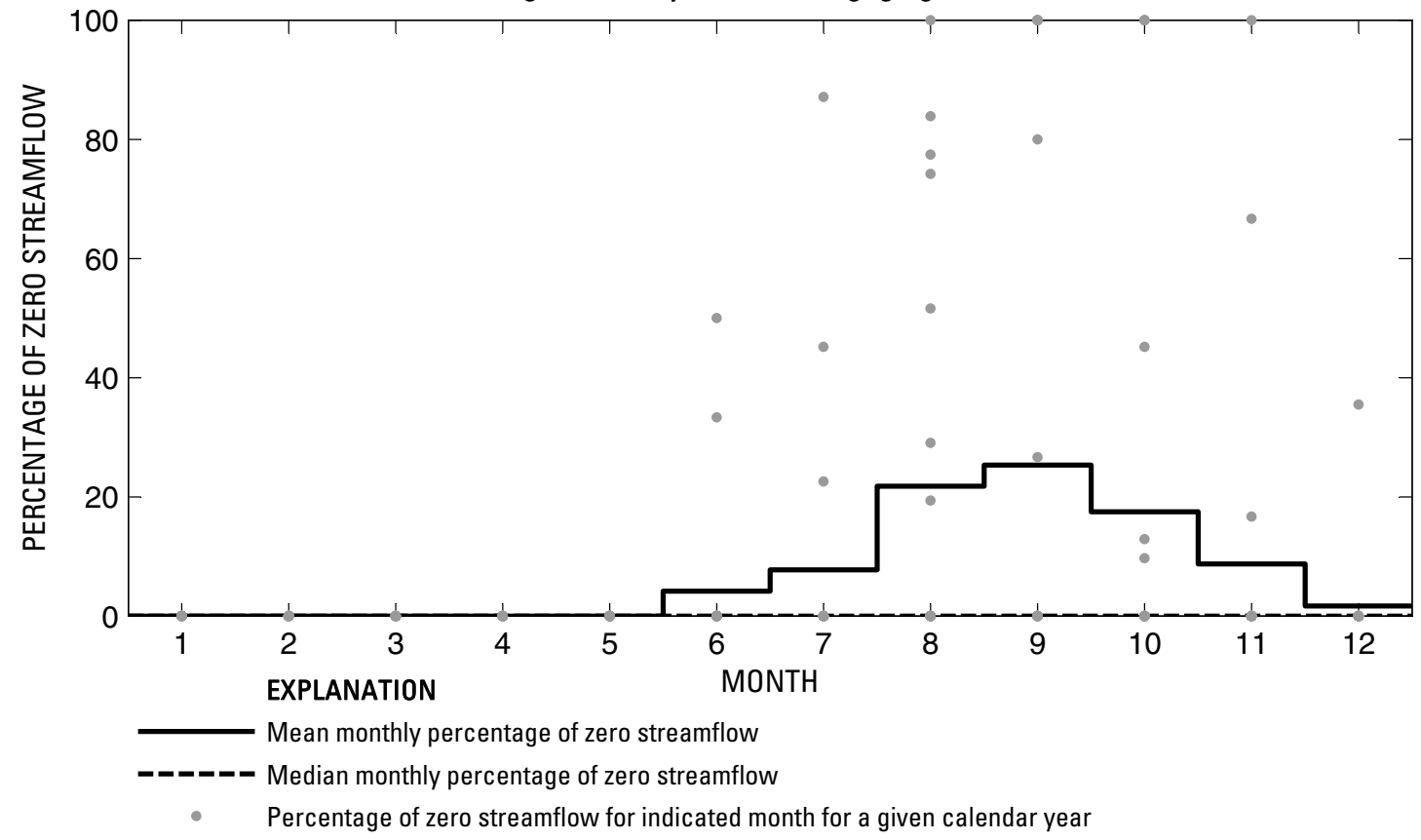

Figure 234. Analysis of percentage of zero daily mean streamflow for U.S. Geological Survey streamflow-gaging station 08064100 Chambers Creek near Rice, Texas. 
U.S. Geological Survey streamflow-gaging station 08064500

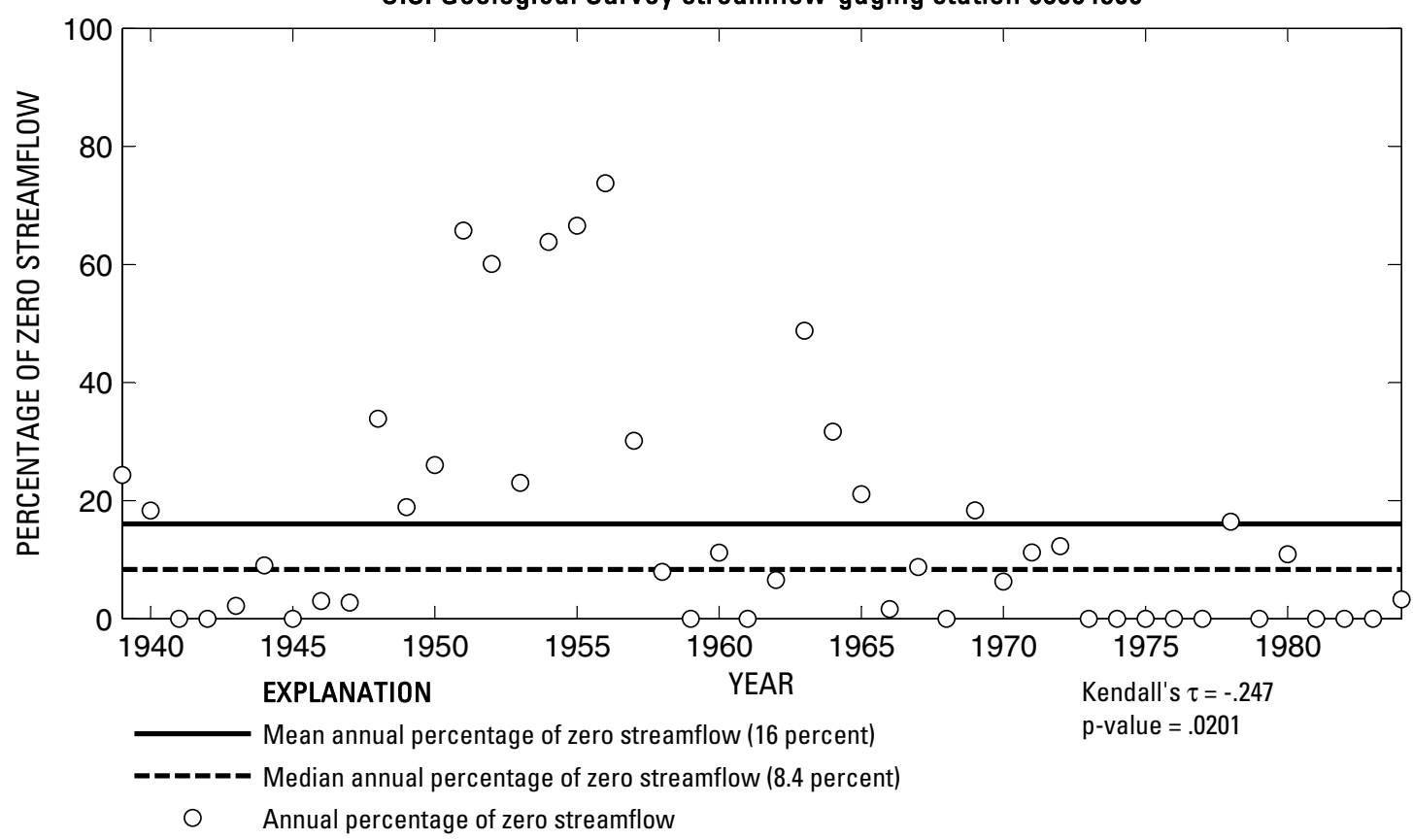

U.S. Geological Survey streamflow-gaging station 08064500

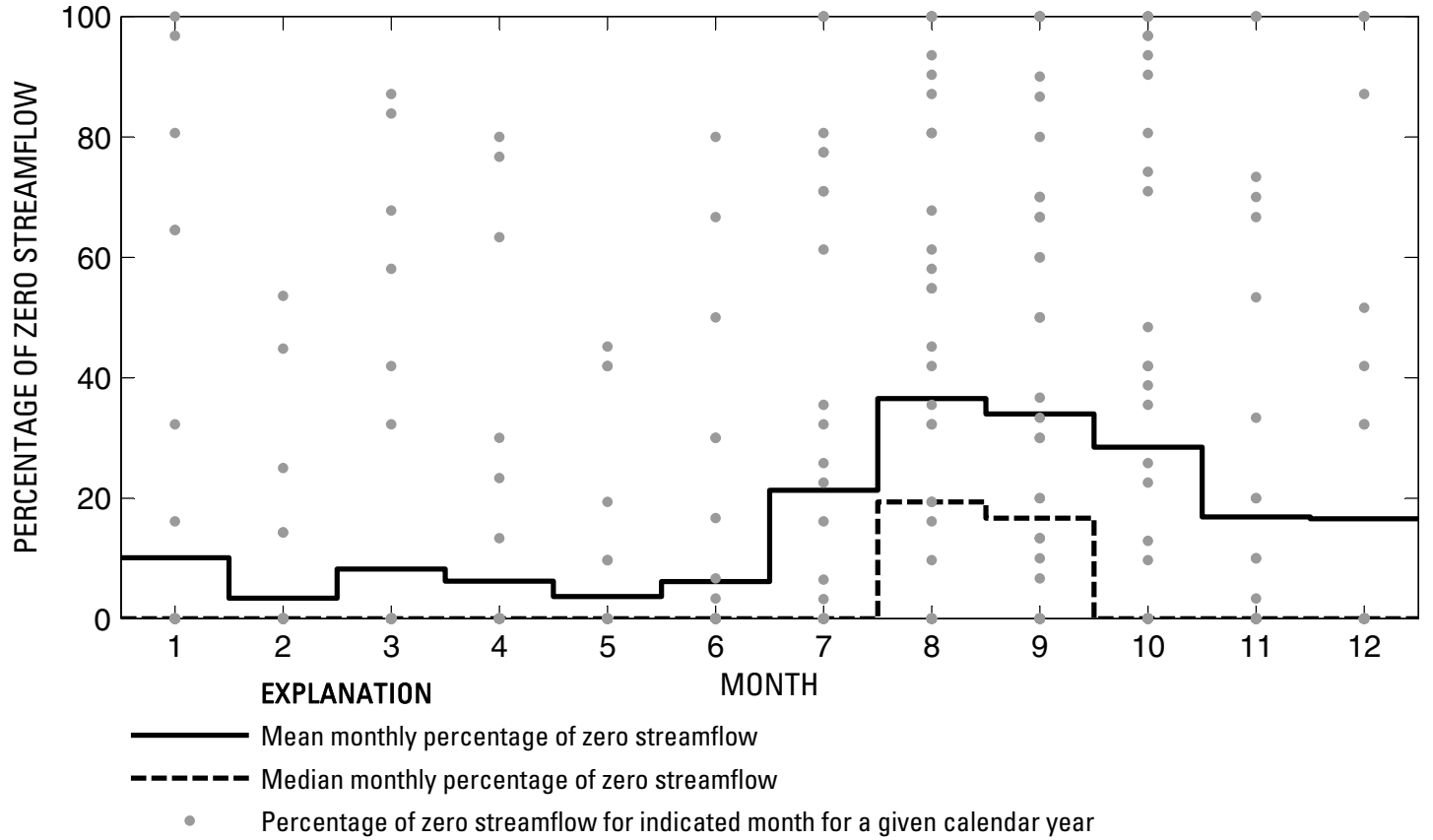

Figure 235. Analysis of percentage of zero daily mean streamflow for U.S. Geological Survey streamflow-gaging station 08064500 Chambers Creek near Corsicana, Texas. 
U.S. Geological Survey streamflow-gaging station 08064700

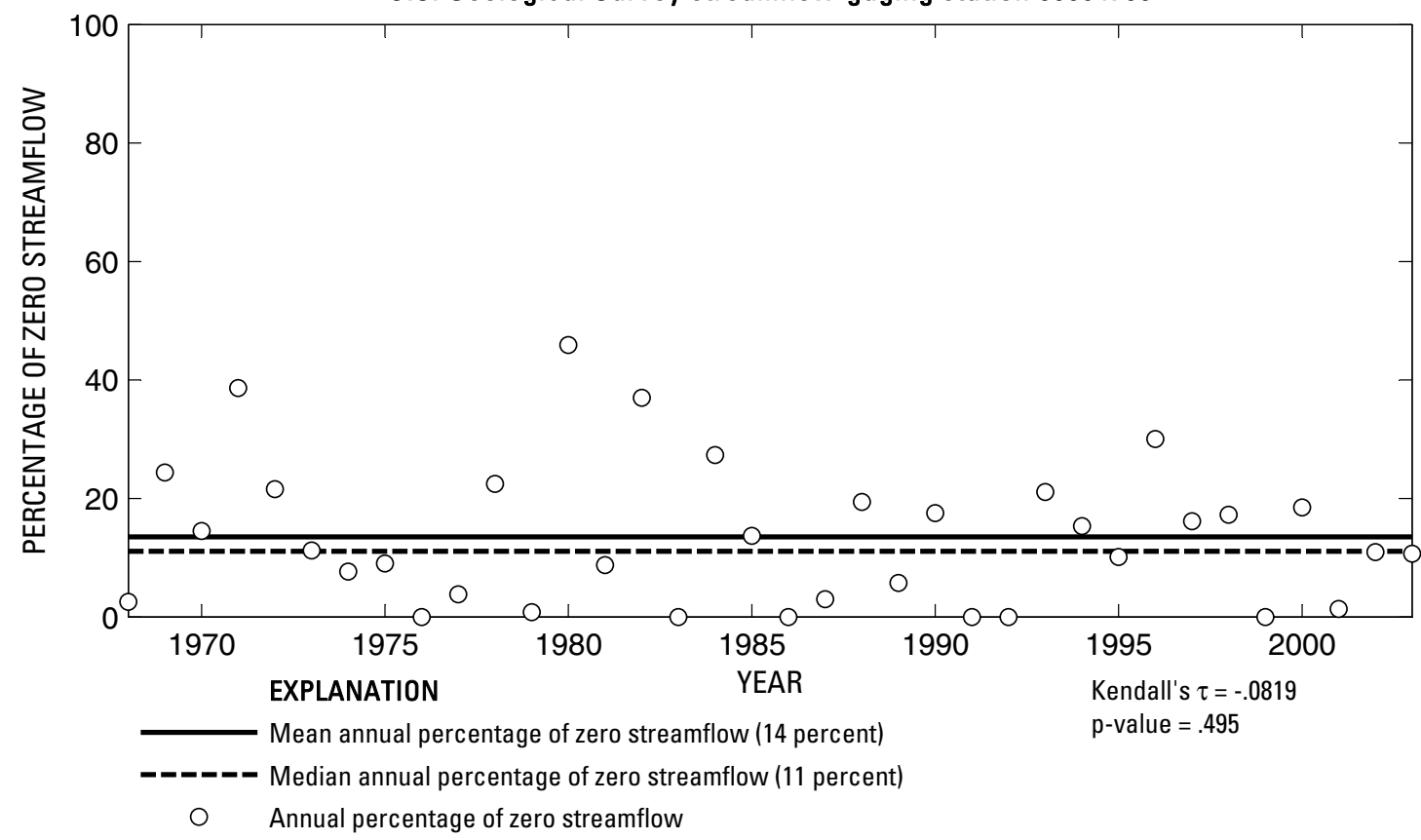

U.S. Geological Survey streamflow-gaging station 08064700

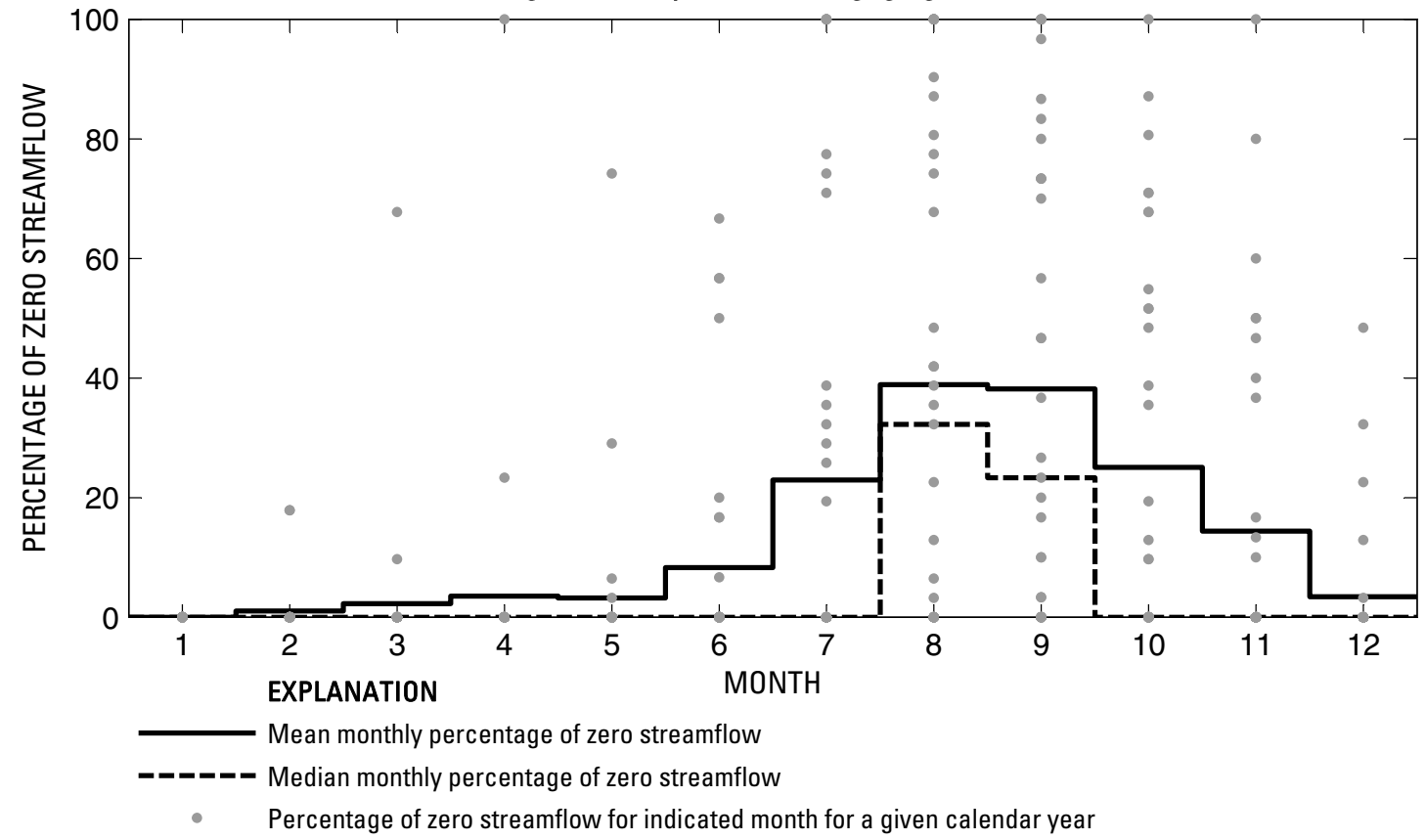

Figure 236. Analysis of percentage of zero daily mean streamflow for U.S. Geological Survey streamflow-gaging station 08064700 Tehuacana Creek near Streetman, Texas.

Index of Station Numbers 719 


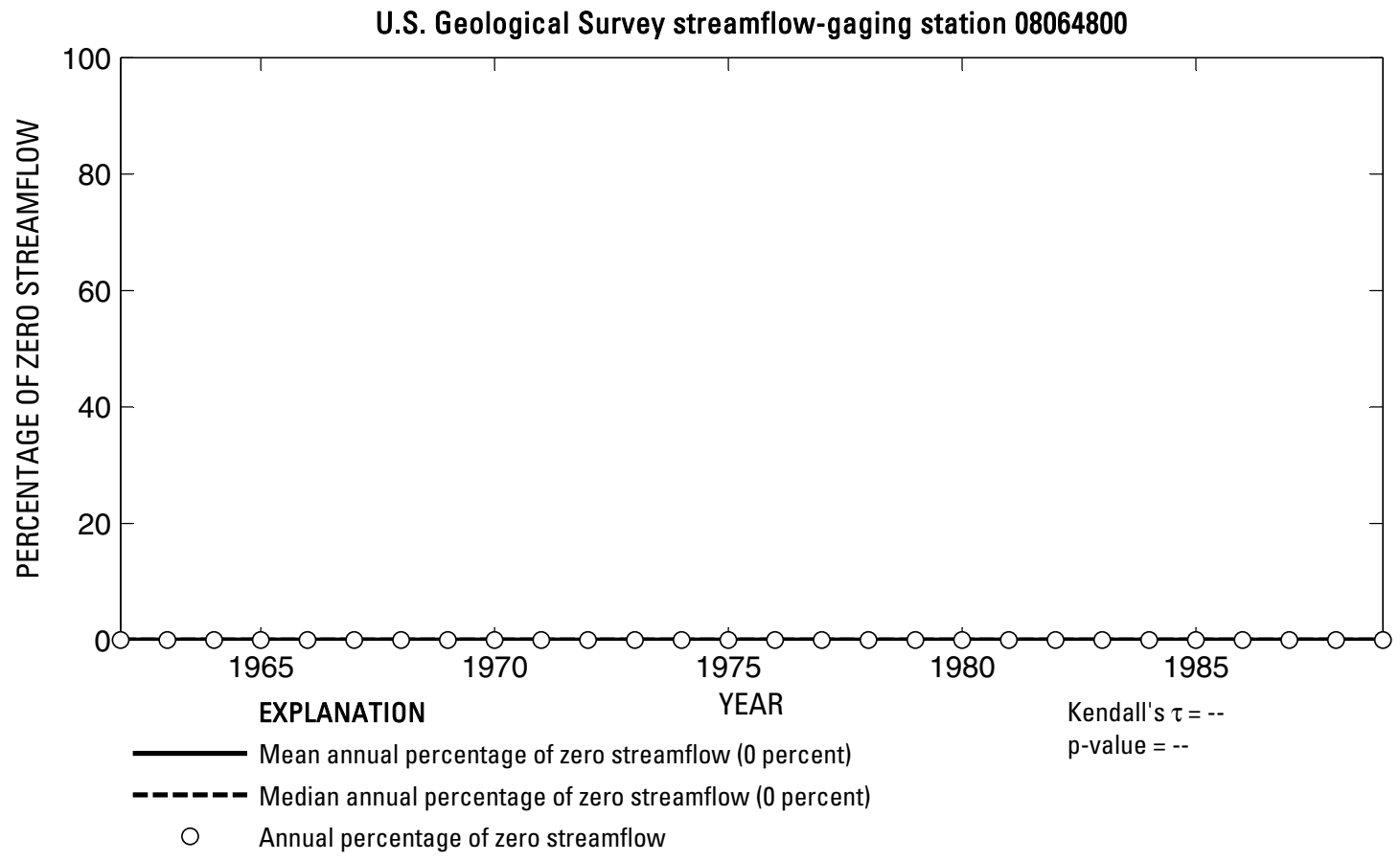

U.S. Geological Survey streamflow-gaging station 08064800

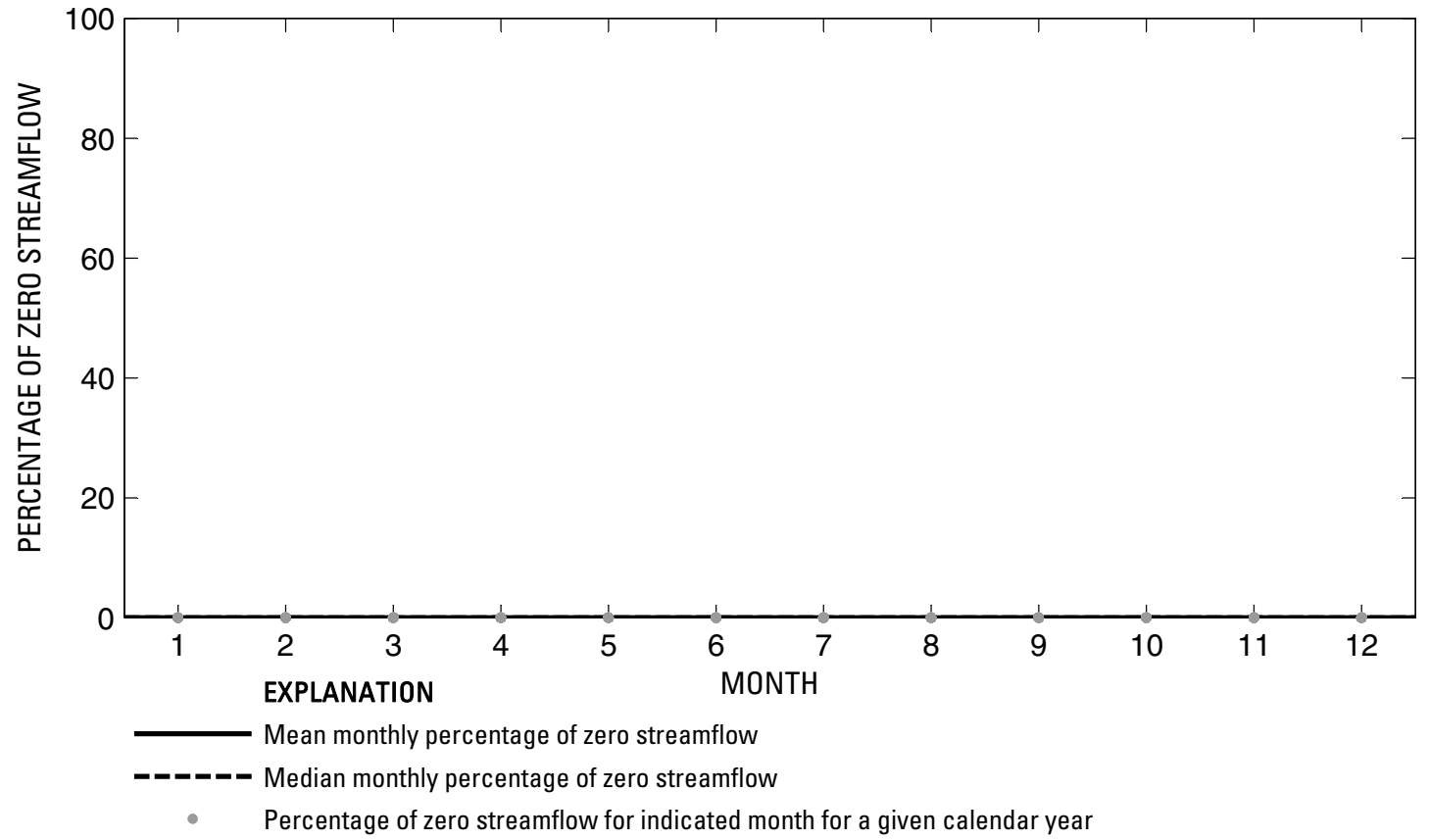

Figure 237. Analysis of percentage of zero daily mean streamflow for U.S. Geological Survey streamflow-gaging station 08064800 Catfish Creek near Tennessee Colony, Texas. 
U.S. Geological Survey streamflow-gaging station 08065000

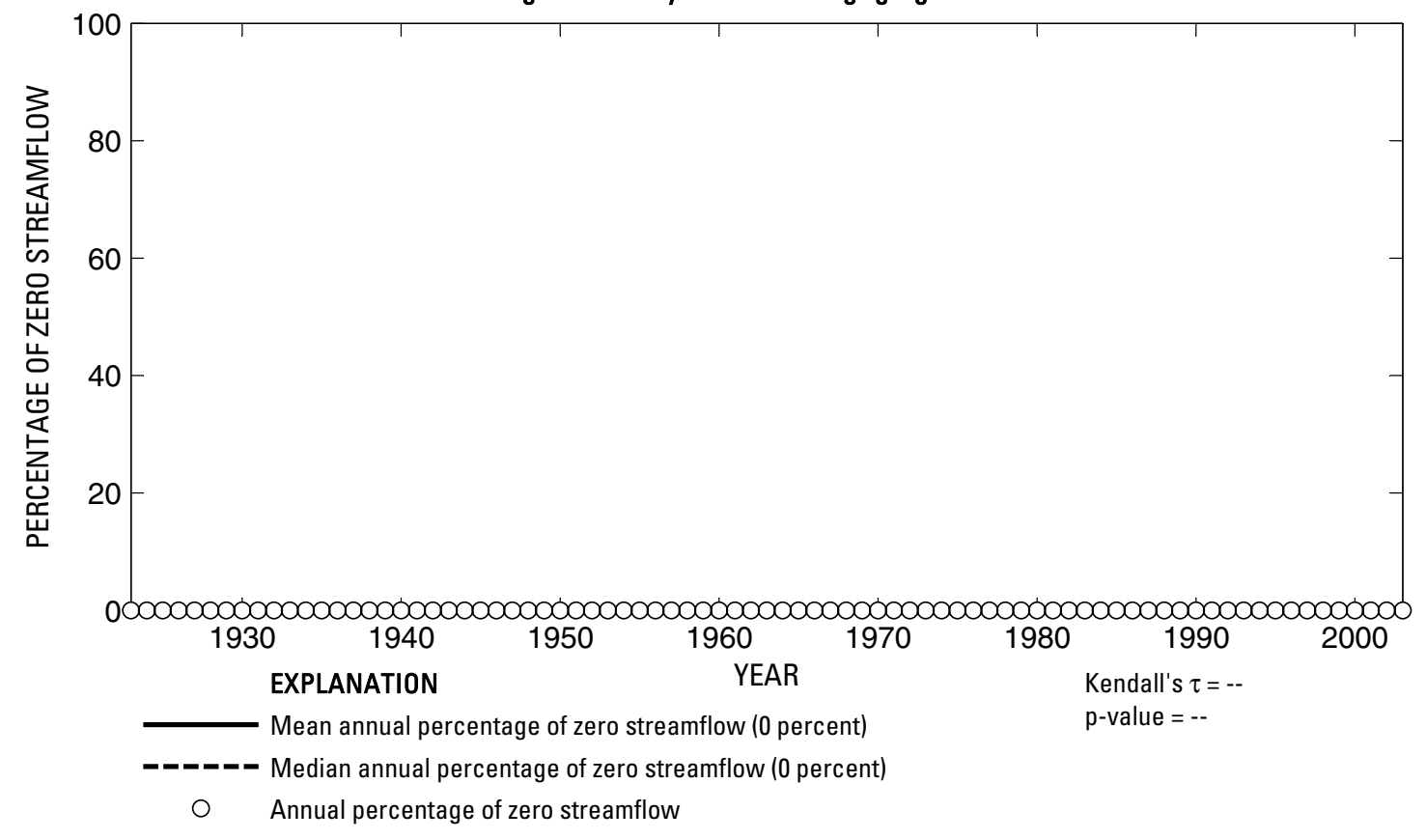

U.S. Geological Survey streamflow-gaging station 08065000

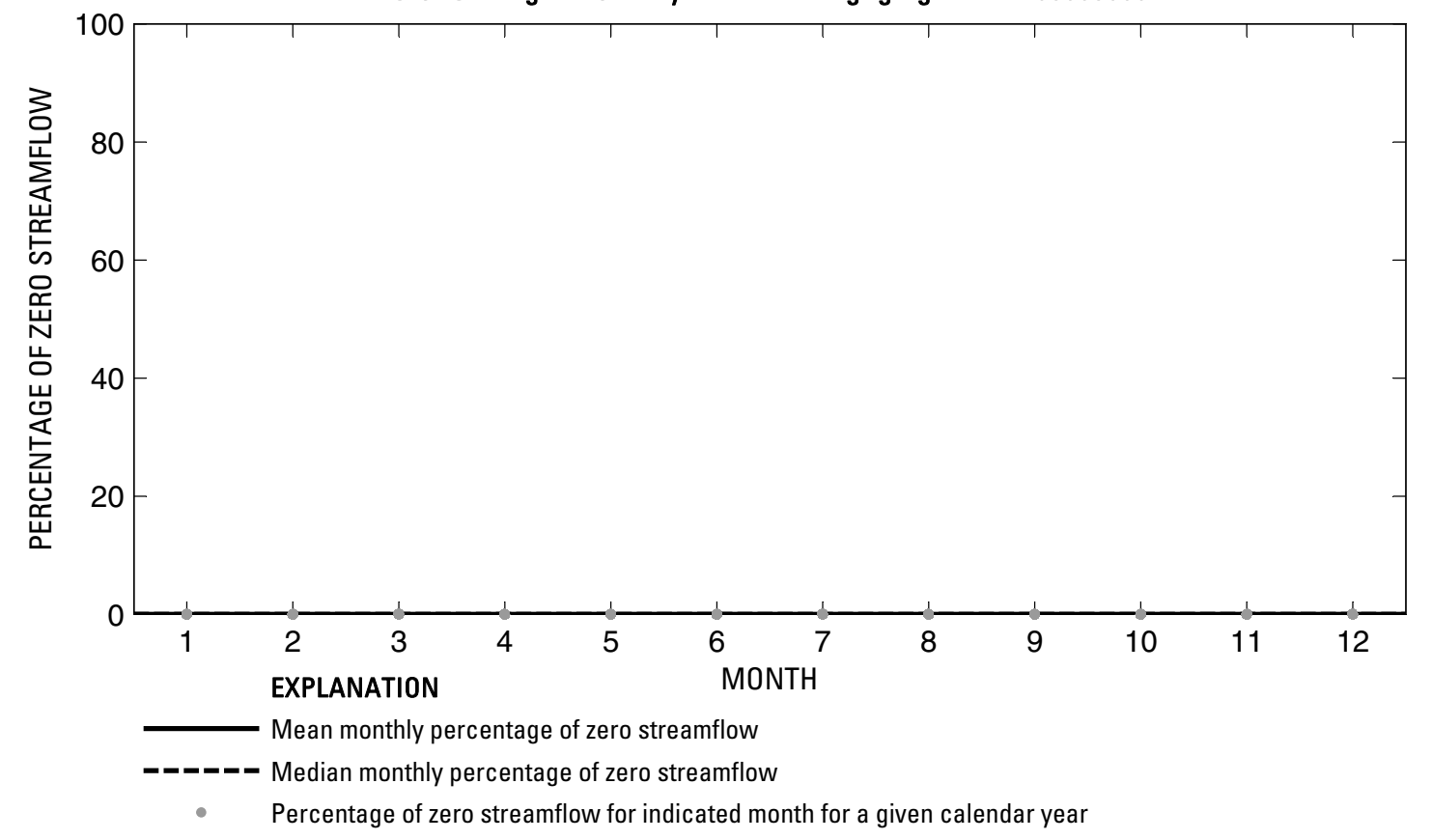

Figure 238. Analysis of percentage of zero daily mean streamflow for U.S. Geological Survey streamflow-gaging station 08065000 Trinity River near Oakwood, Texas. 

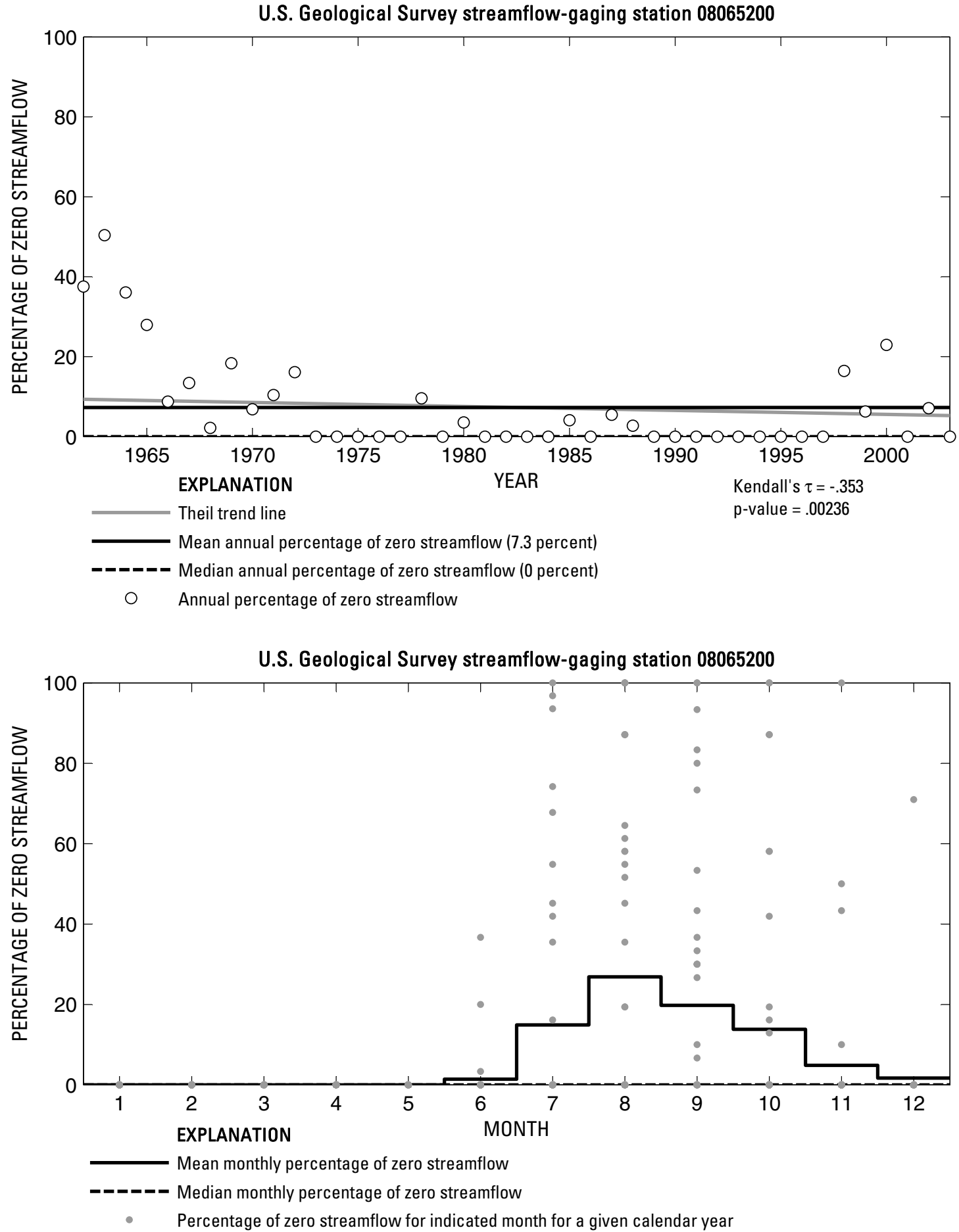

Figure 239. Analysis of percentage of zero daily mean streamflow for U.S. Geological Survey streamflow-gaging station 08065200 Upper Keechi Creek near Oakwood, Texas. 
U.S. Geological Survey streamflow-gaging station 08065350

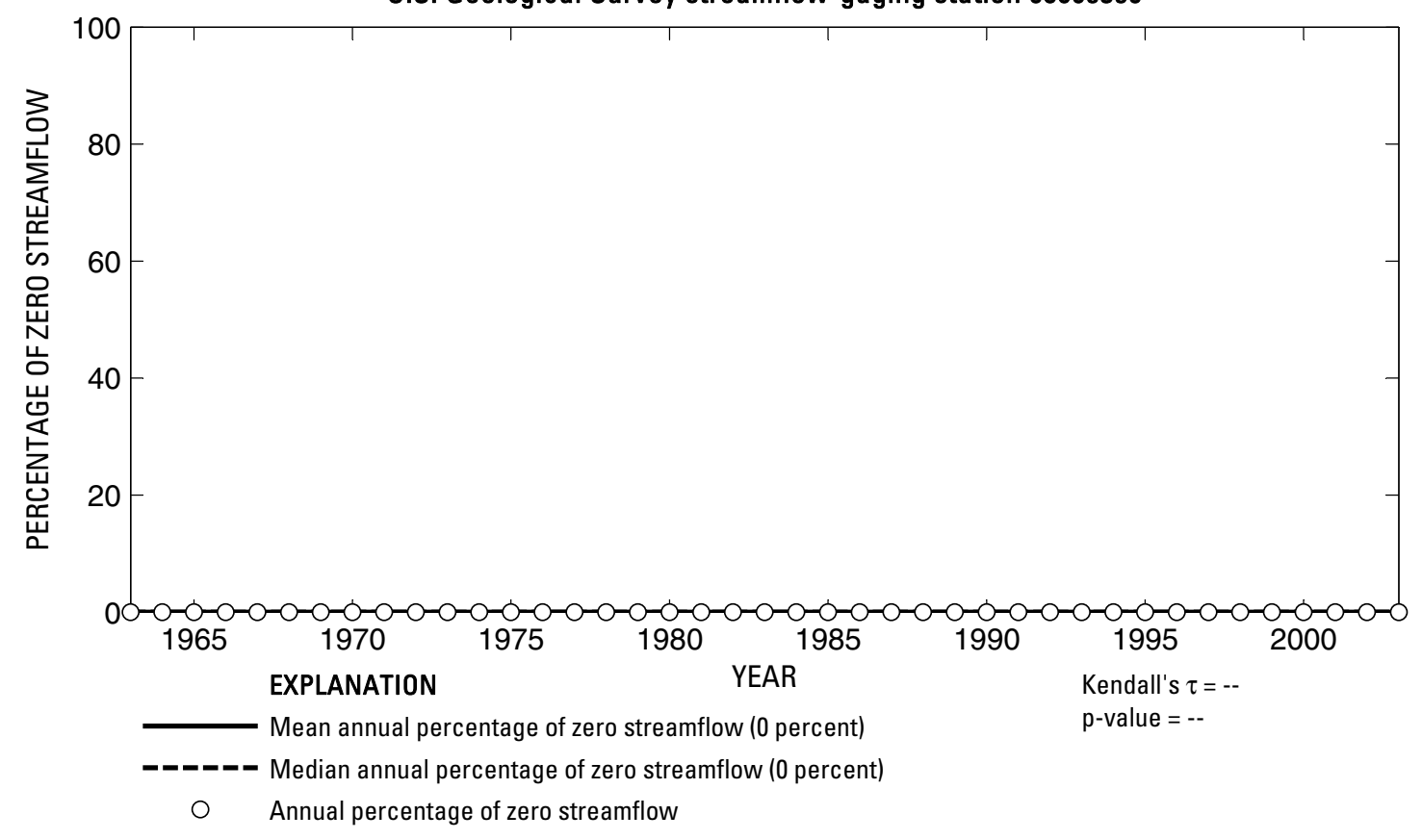

U.S. Geological Survey streamflow-gaging station 08065350

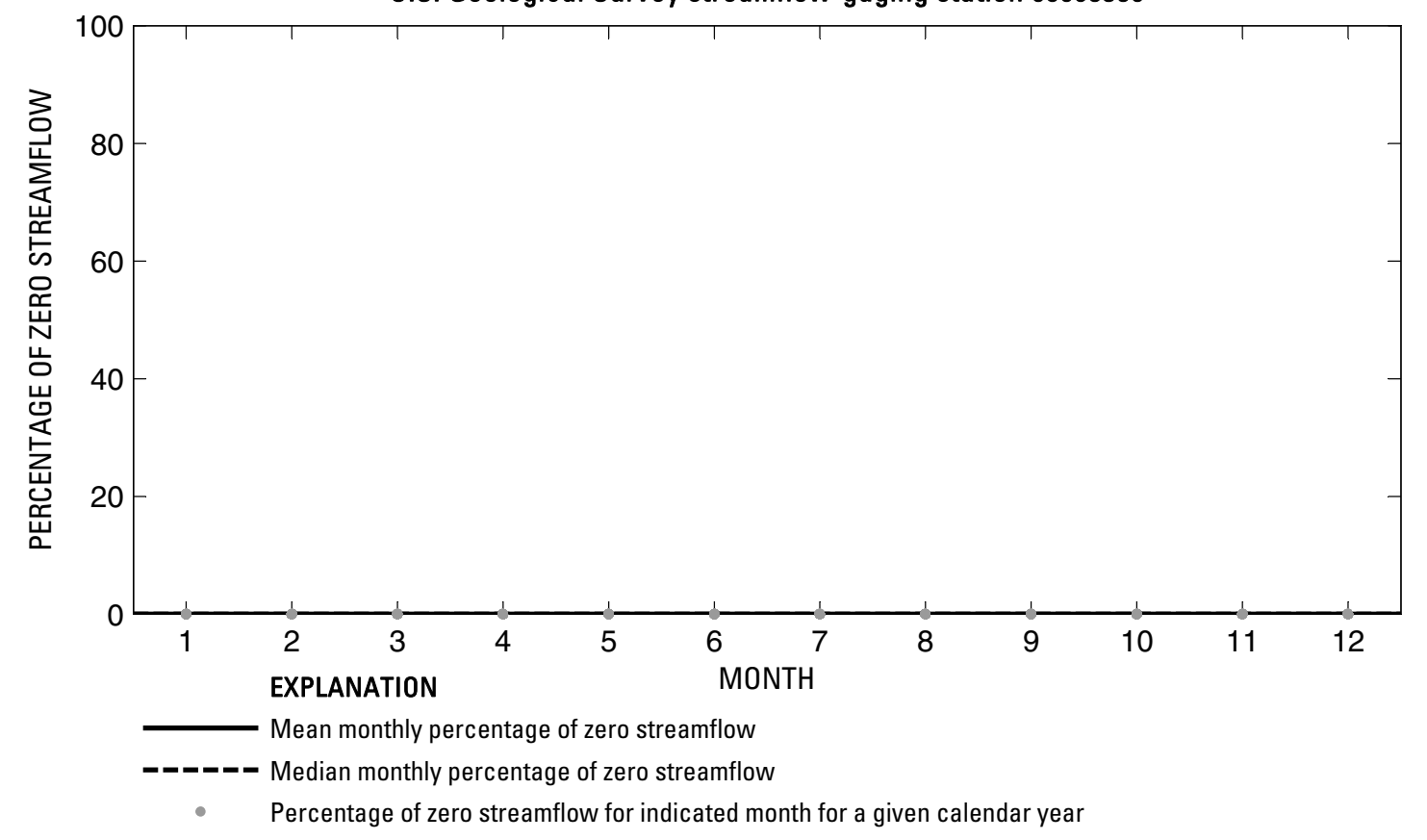

Figure 240. Analysis of percentage of zero daily mean streamflow for U.S. Geological Survey streamflow-gaging station 08065350 Trinity River near Crockett, Texas. 


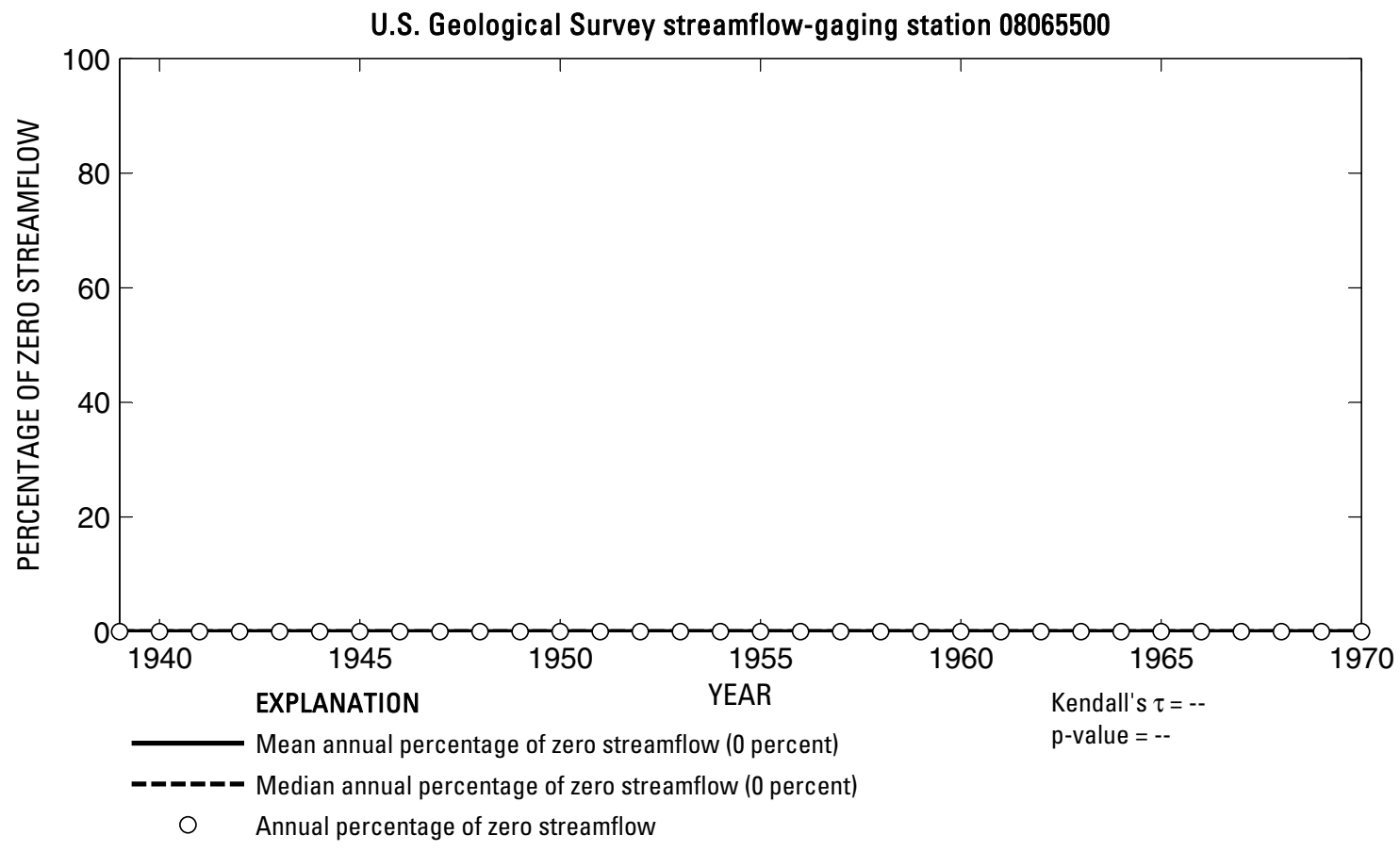

U.S. Geological Survey streamflow-gaging station 08065500

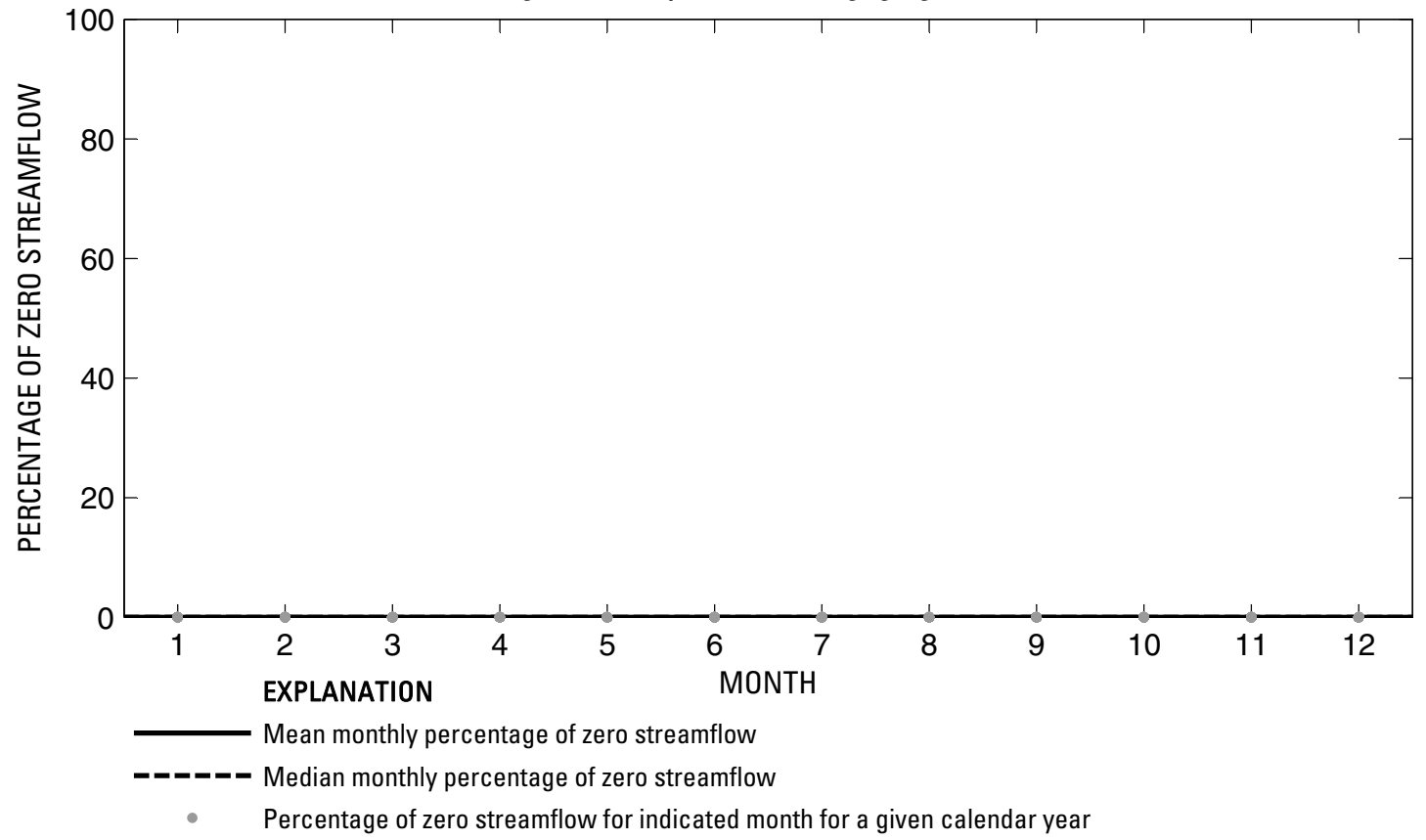

Figure 241. Analysis of percentage of zero daily mean streamflow for U.S. Geological Survey streamflow-gaging station 08065500 Trinity River near Midway, Texas. 
U.S. Geological Survey streamflow-gaging station 08065700

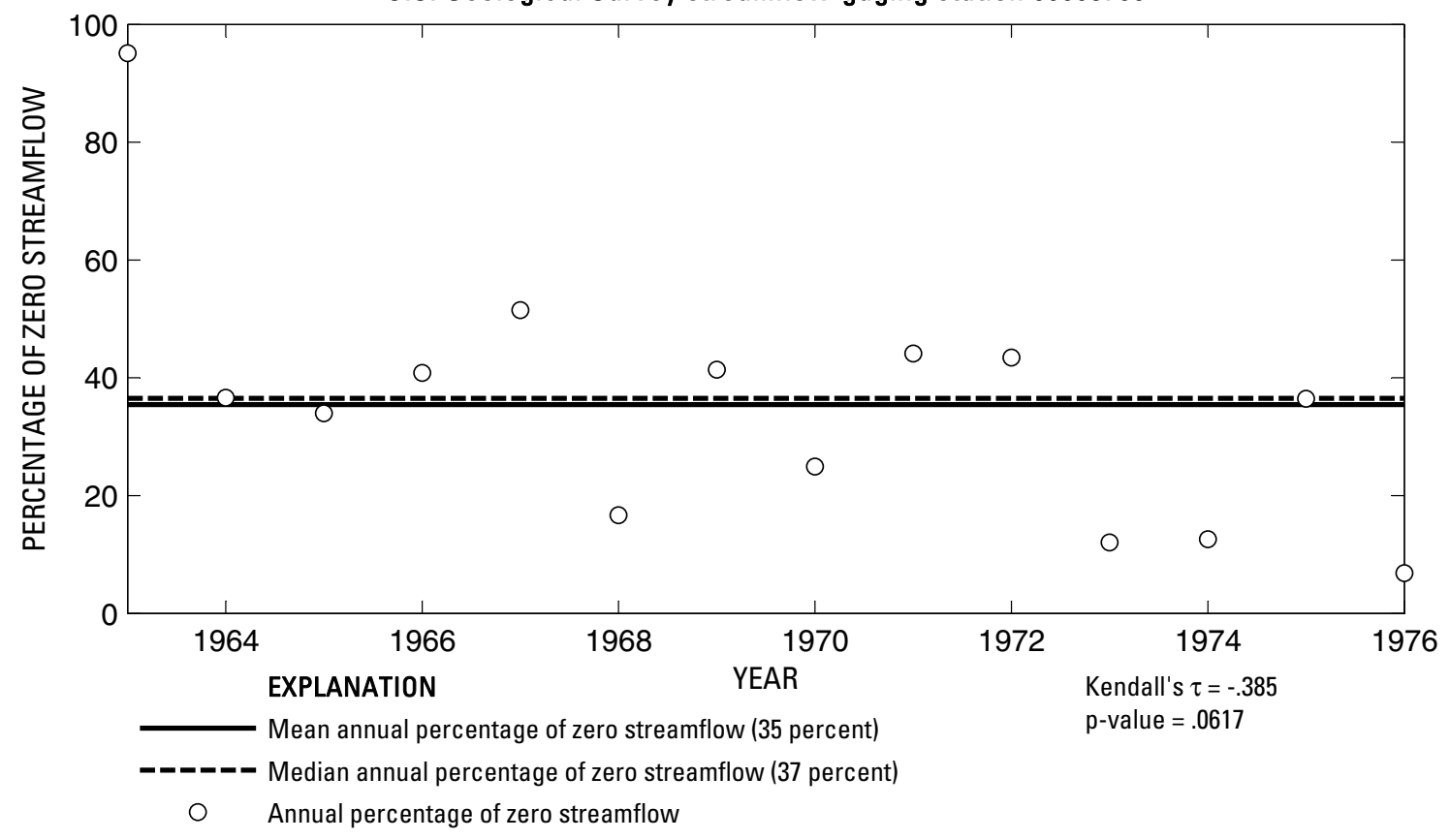

U.S. Geological Survey streamflow-gaging station 08065700

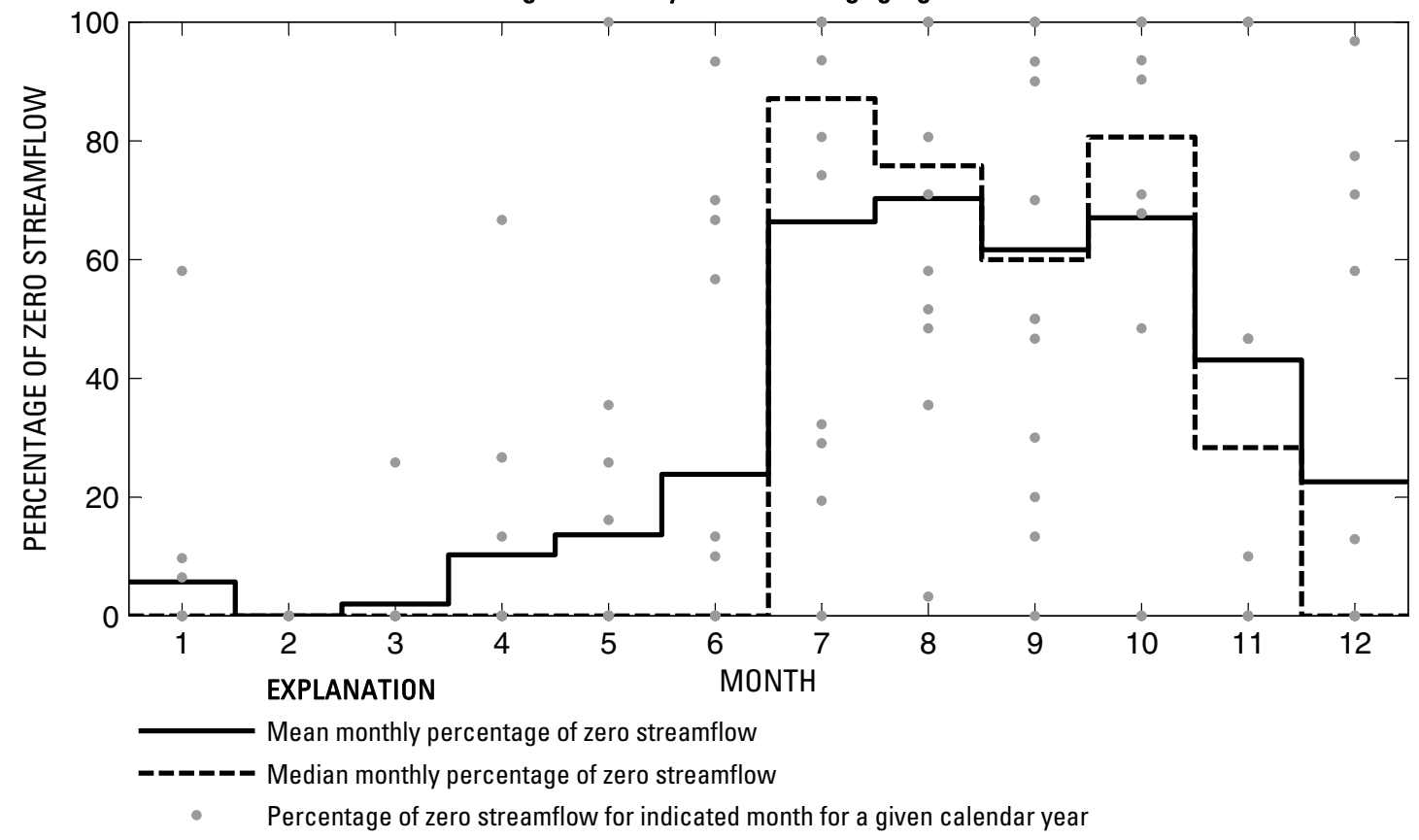

Figure 242. Analysis of percentage of zero daily mean streamflow for U.S. Geological Survey streamflow-gaging station 08065700 Caney Creek near Madisonville, Texas.

Index of Station Numbers 719 

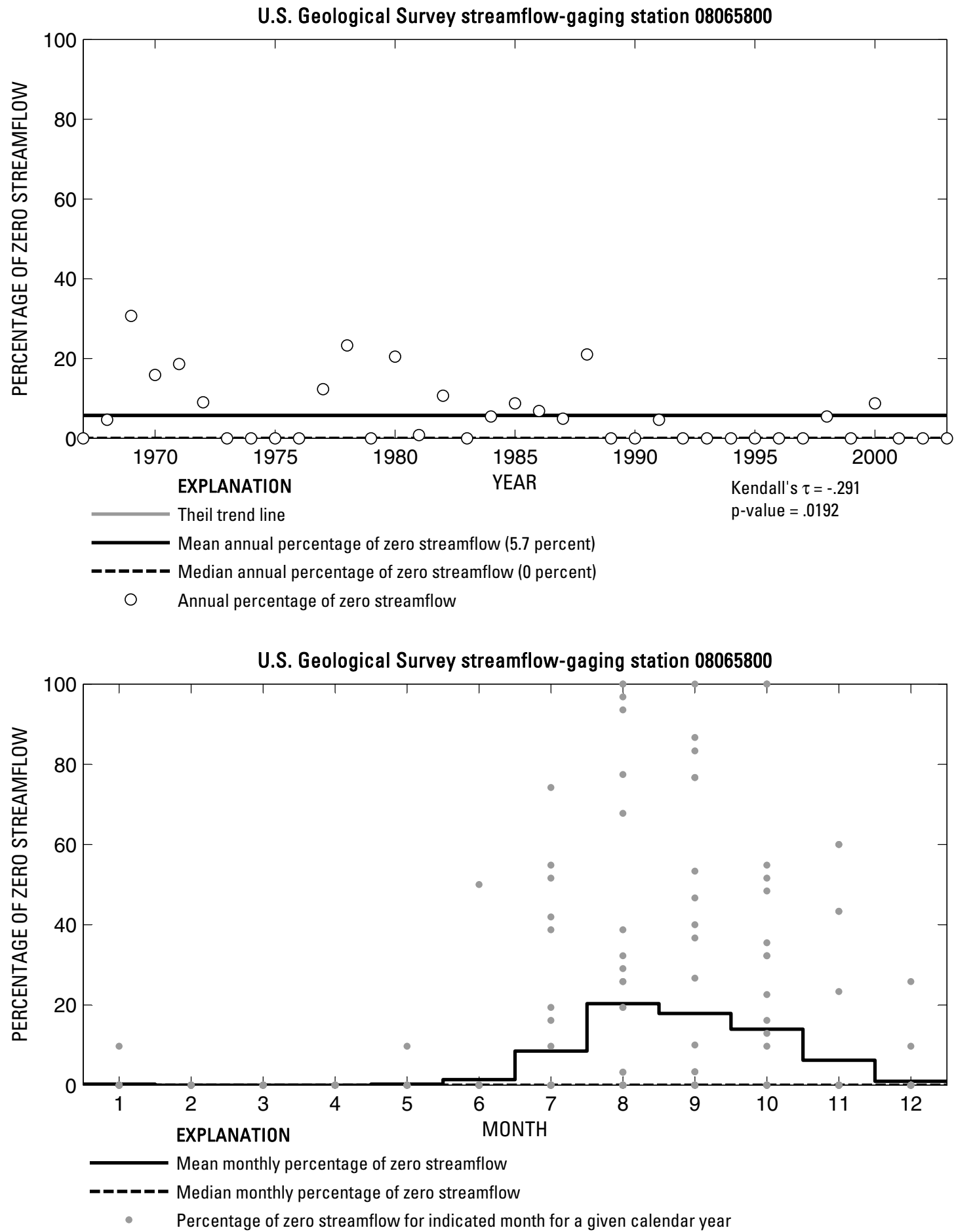

Figure 243. Analysis of percentage of zero daily mean streamflow for U.S. Geological Survey streamflow-gaging station 08065800 Bedias Creek near Madisonville, Texas. 
U.S. Geological Survey streamflow-gaging station 08066000

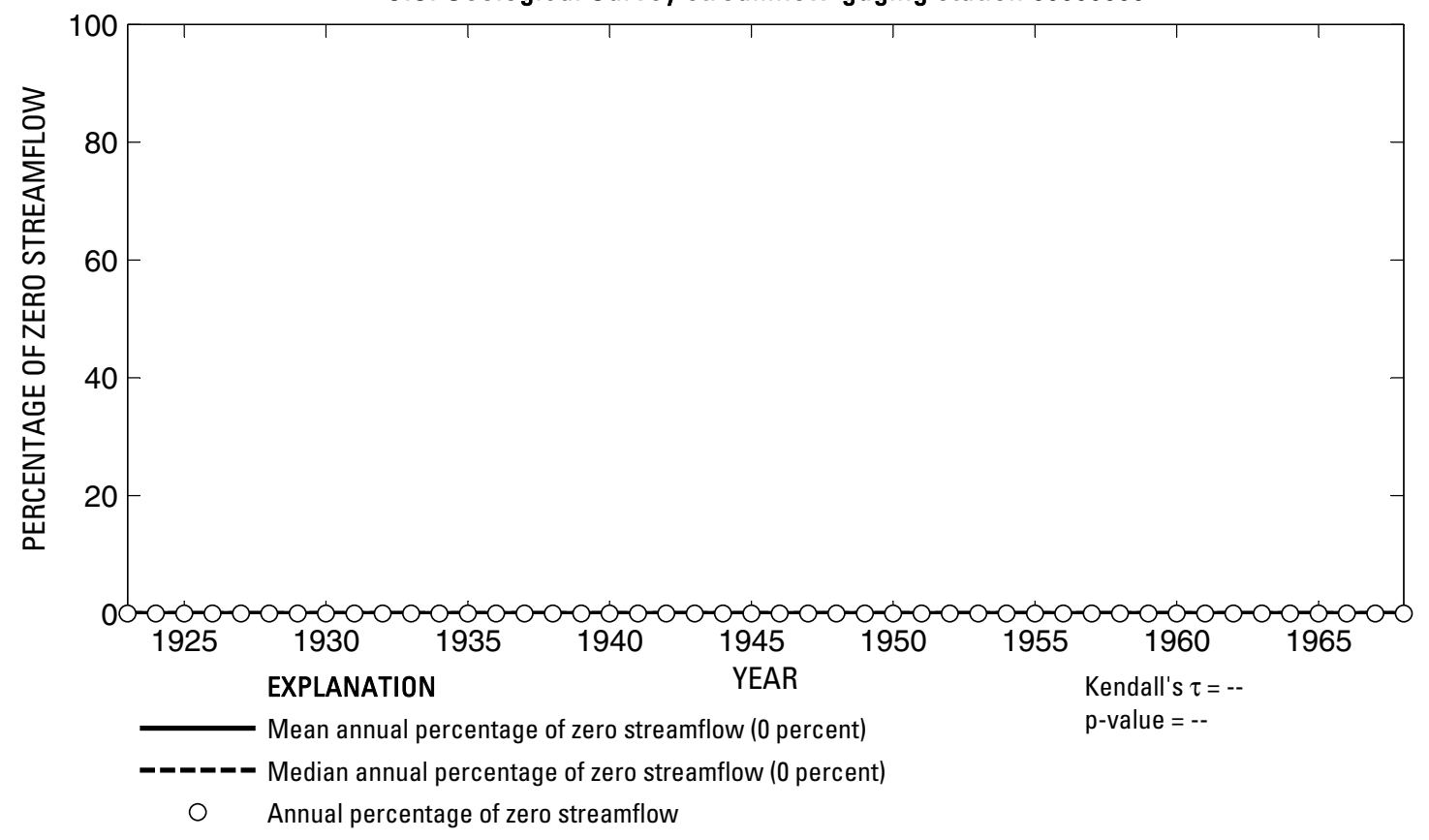

U.S. Geological Survey streamflow-gaging station 08066000

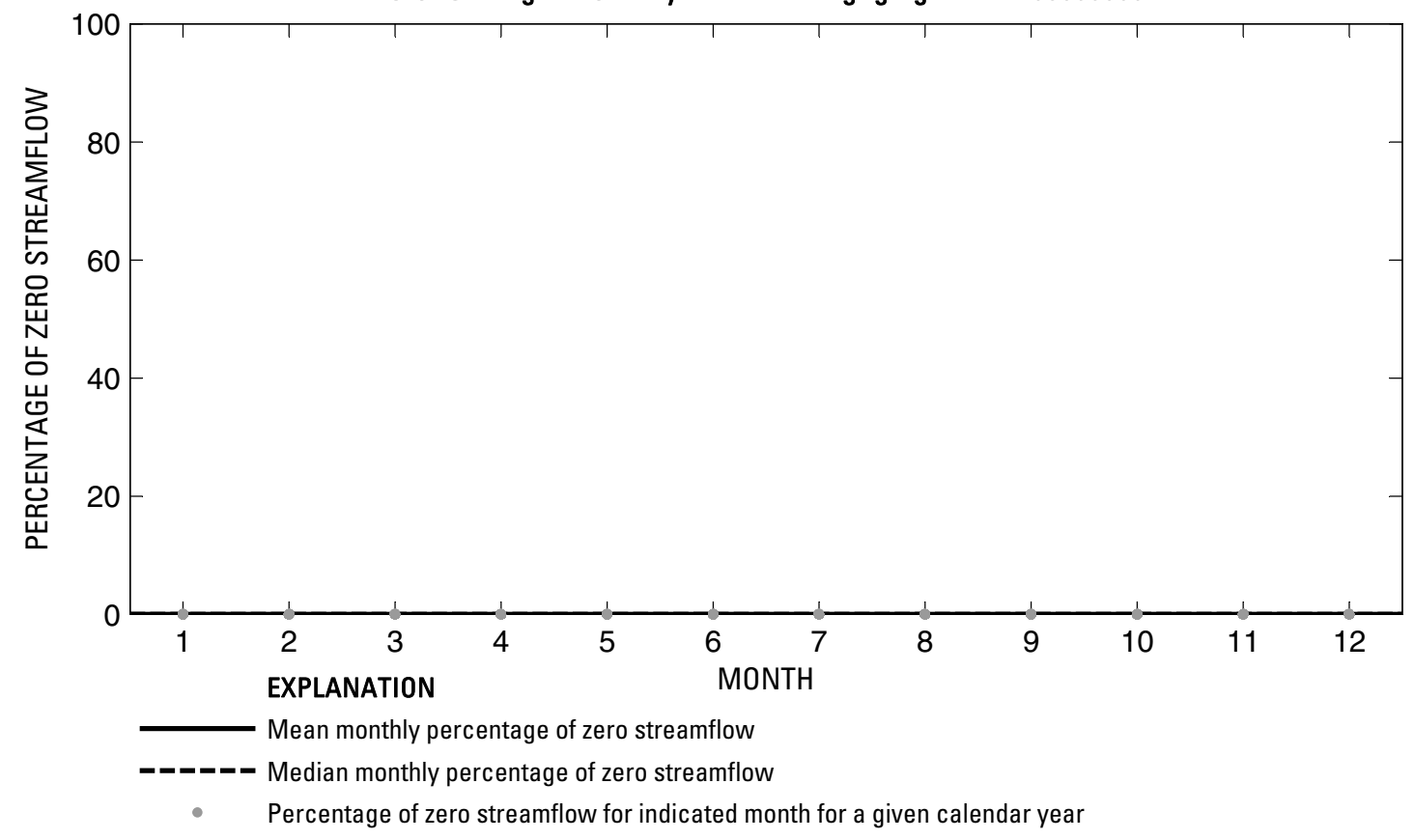

Figure 244. Analysis of percentage of zero daily mean streamflow for U.S. Geological Survey streamflow-gaging station 08066000 Trinity River at Riverside, Texas. 
U.S. Geological Survey streamflow-gaging station 08066100

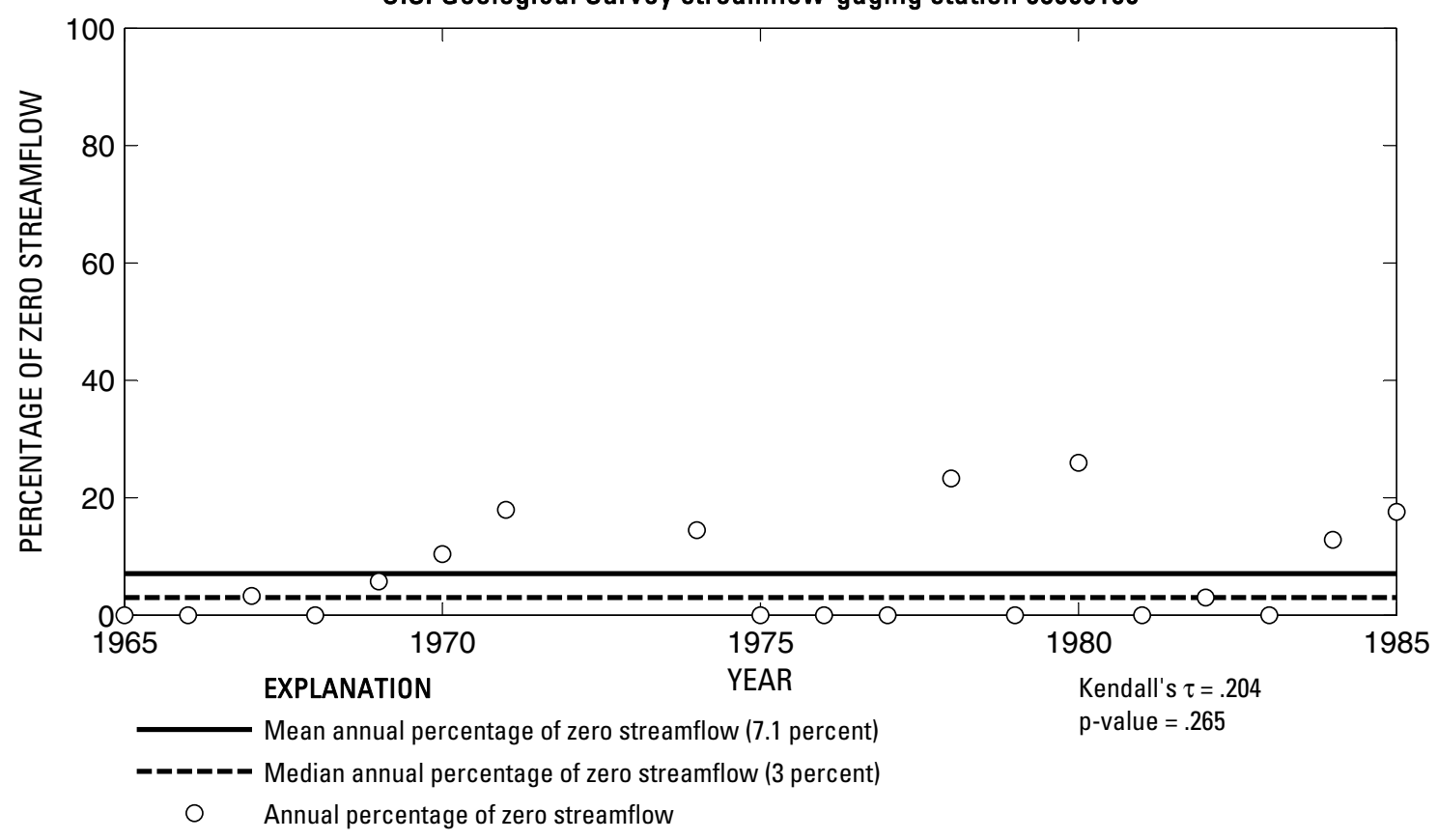

U.S. Geological Survey streamflow-gaging station 08066100

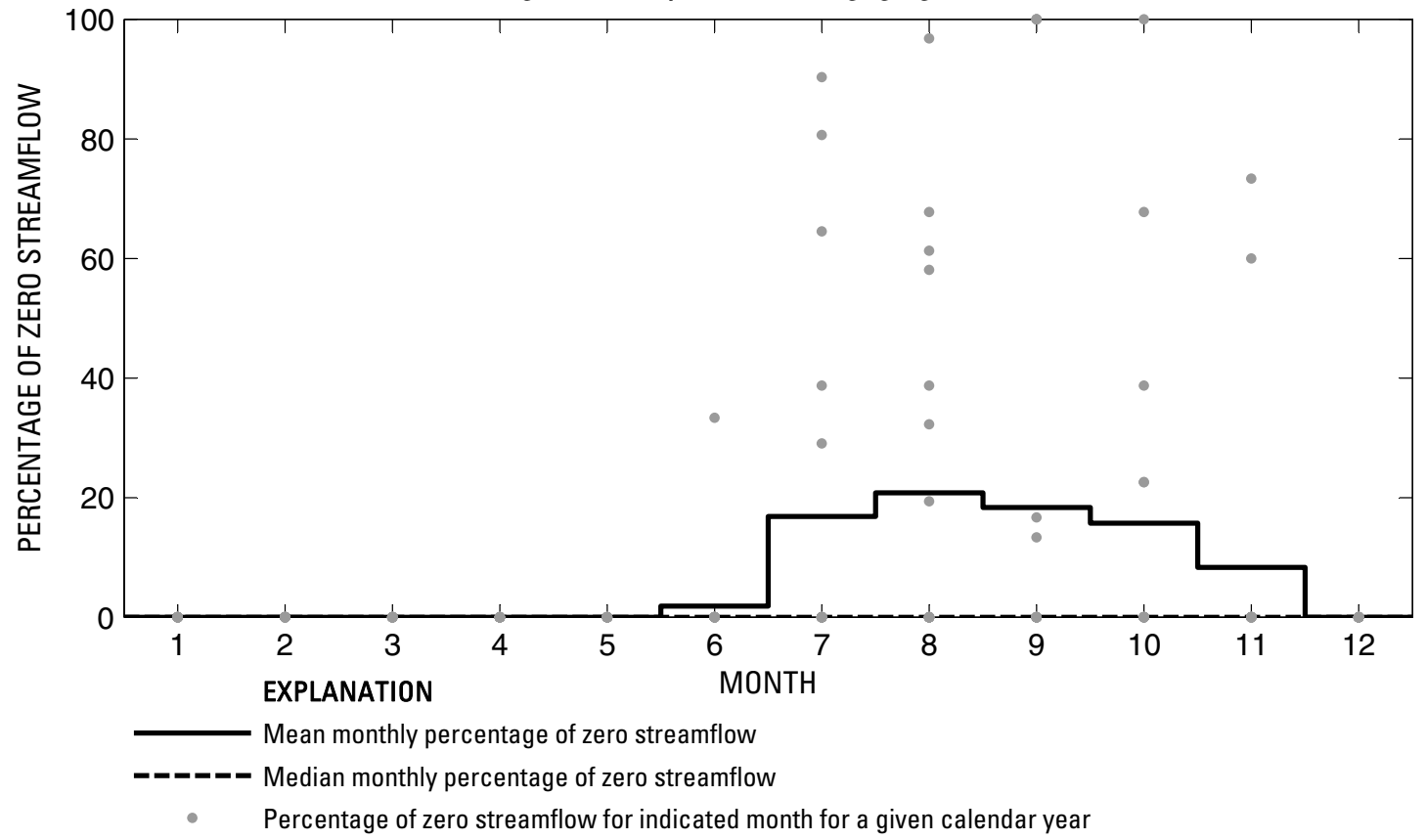

Figure 245. Analysis of percentage of zero daily mean streamflow for U.S. Geological Survey streamflow-gaging station 08066100 White Rock Creek near Trinity, Texas. 
U.S. Geological Survey streamflow-gaging station 08066170

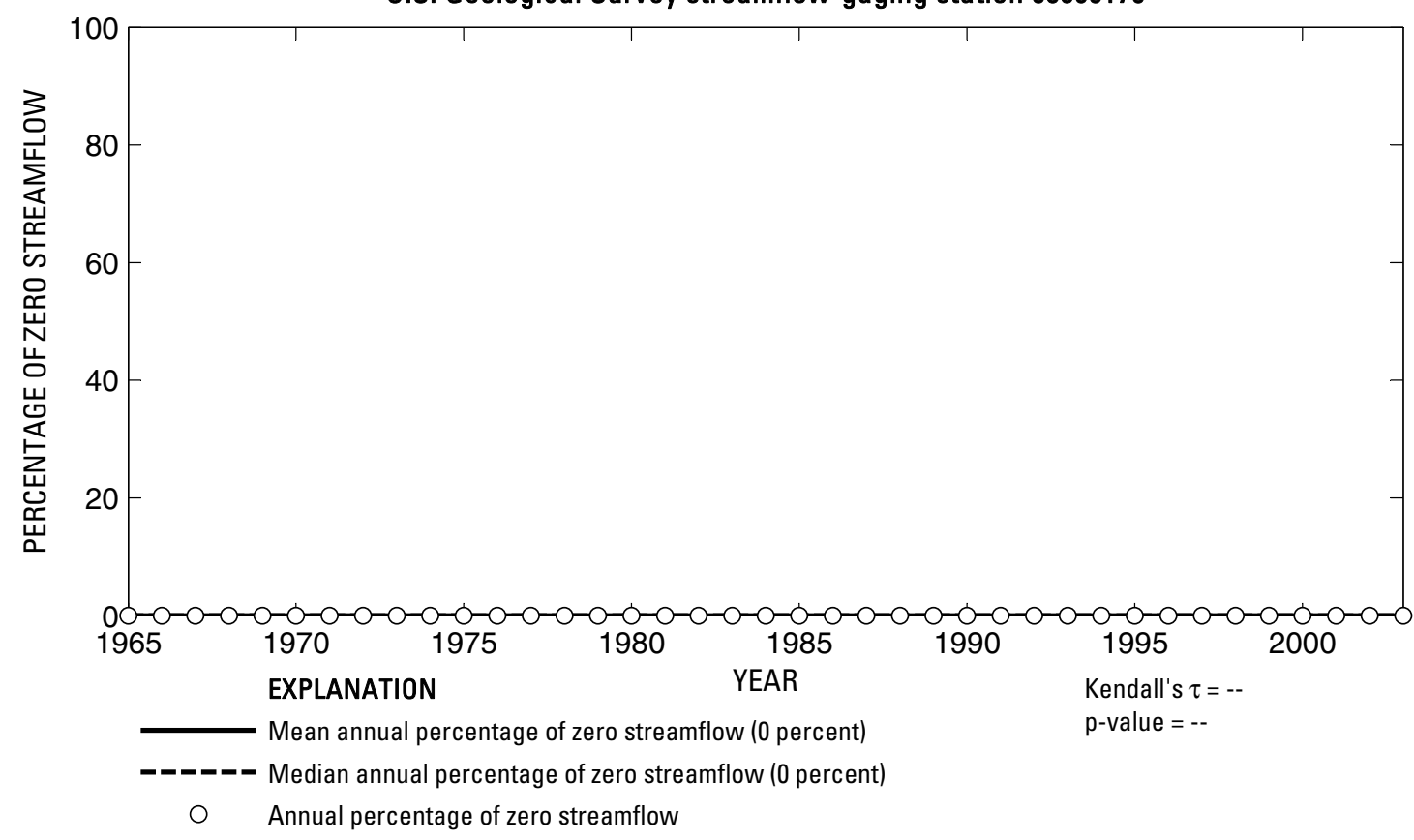

U.S. Geological Survey streamflow-gaging station 08066170

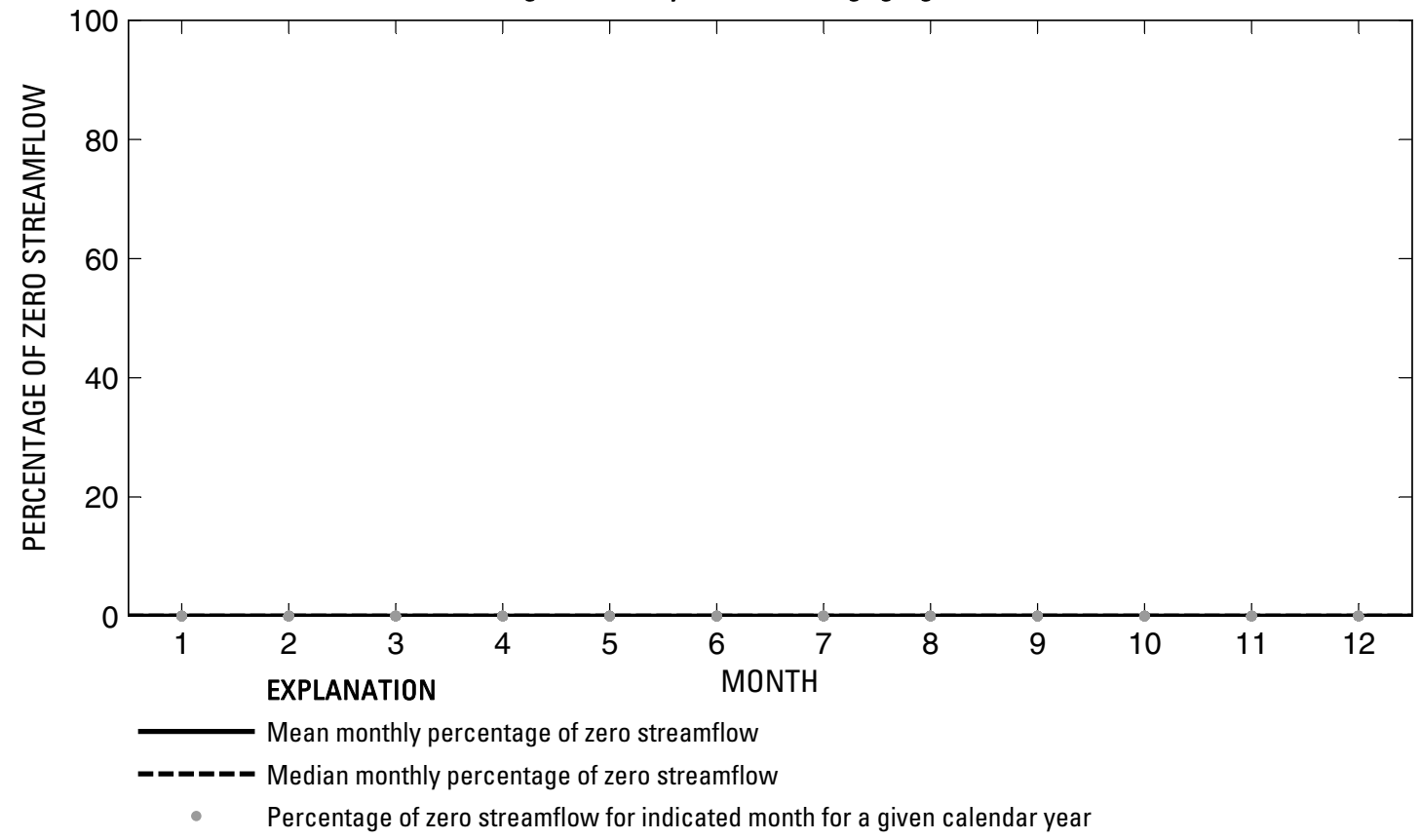

Figure 246. Analysis of percentage of zero daily mean streamflow for U.S. Geological Survey streamflow-gaging station 08066170 Kickapoo Creek near Onalaska, Texas. 
U.S. Geological Survey streamflow-gaging station 08066191

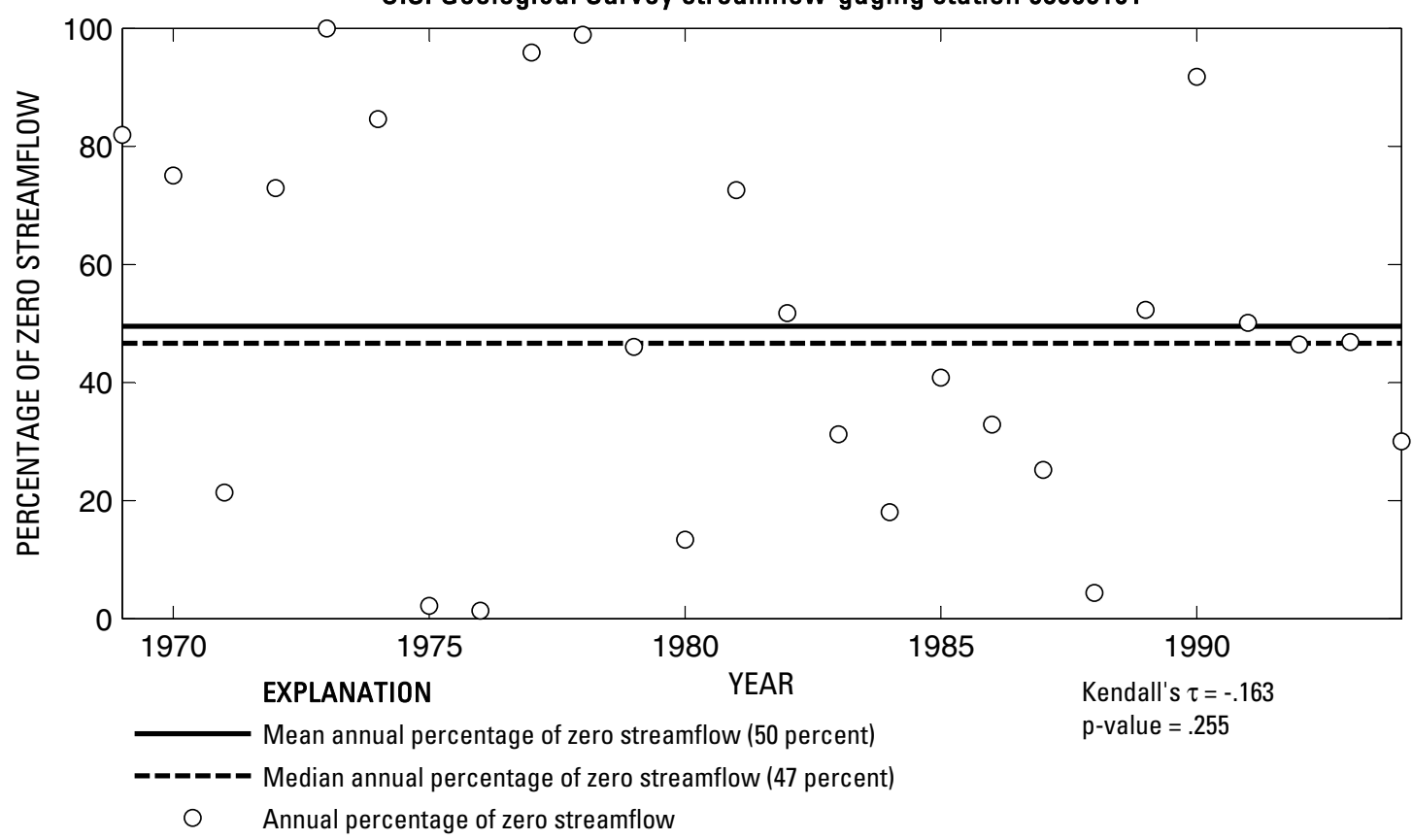

U.S. Geological Survey streamflow-gaging station 08066191

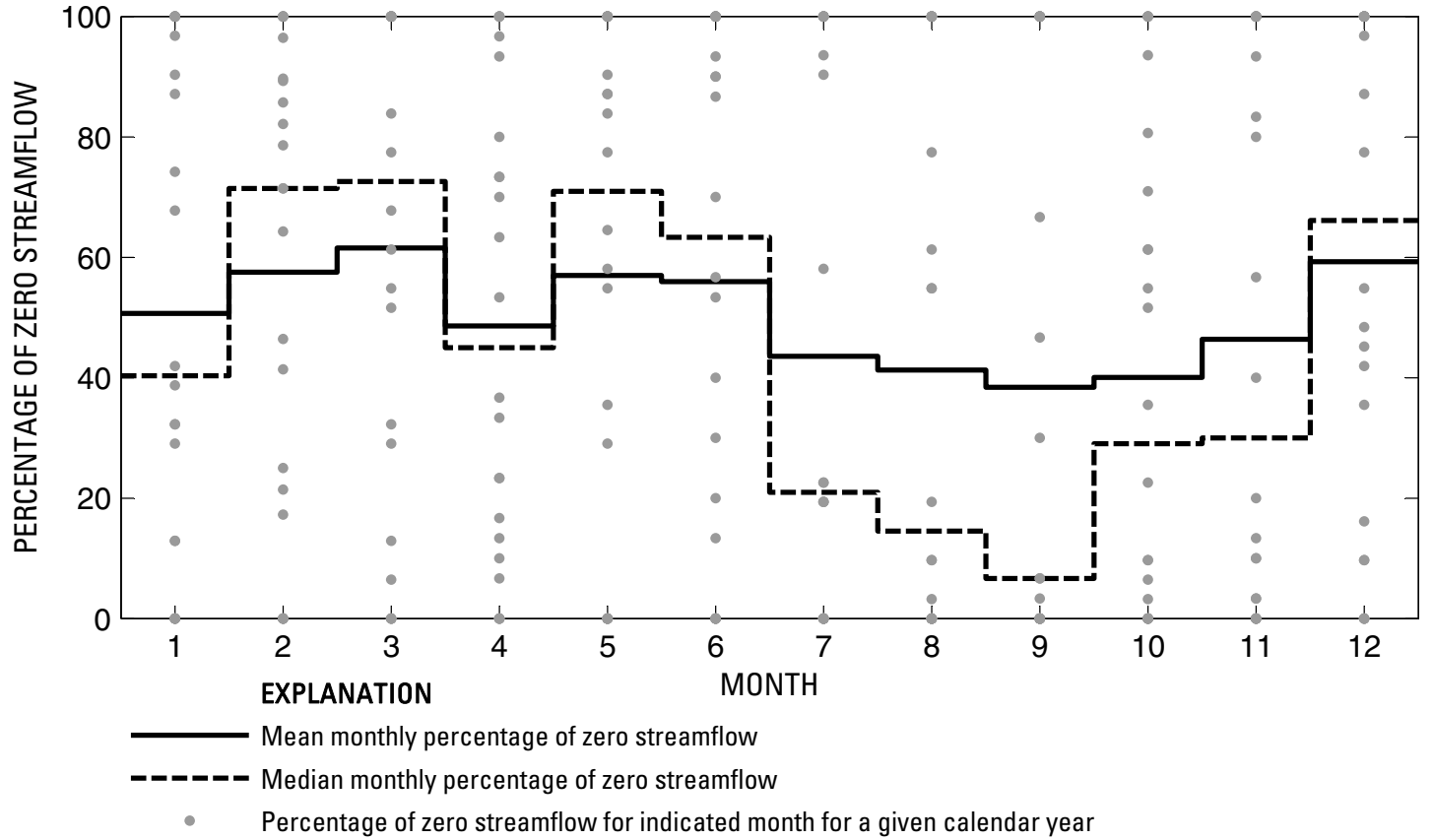

Figure 247. Analysis of percentage of zero daily mean streamflow for U.S. Geological Survey streamflow-gaging station 08066191 Livingston Reservoir Outflow Weir near Goodrich, Texas. 
U.S. Geological Survey streamflow-gaging station 08066200

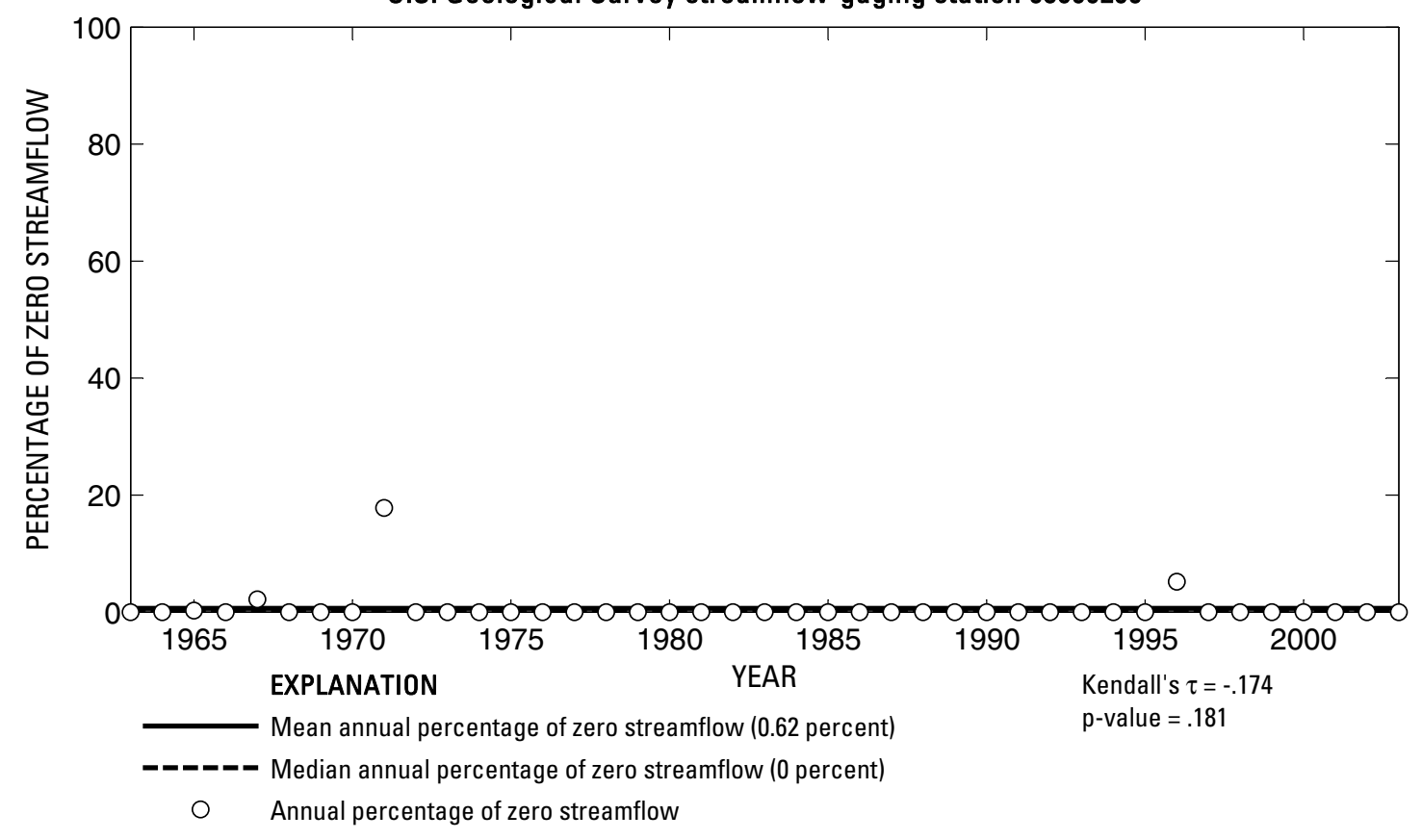

U.S. Geological Survey streamflow-gaging station 08066200

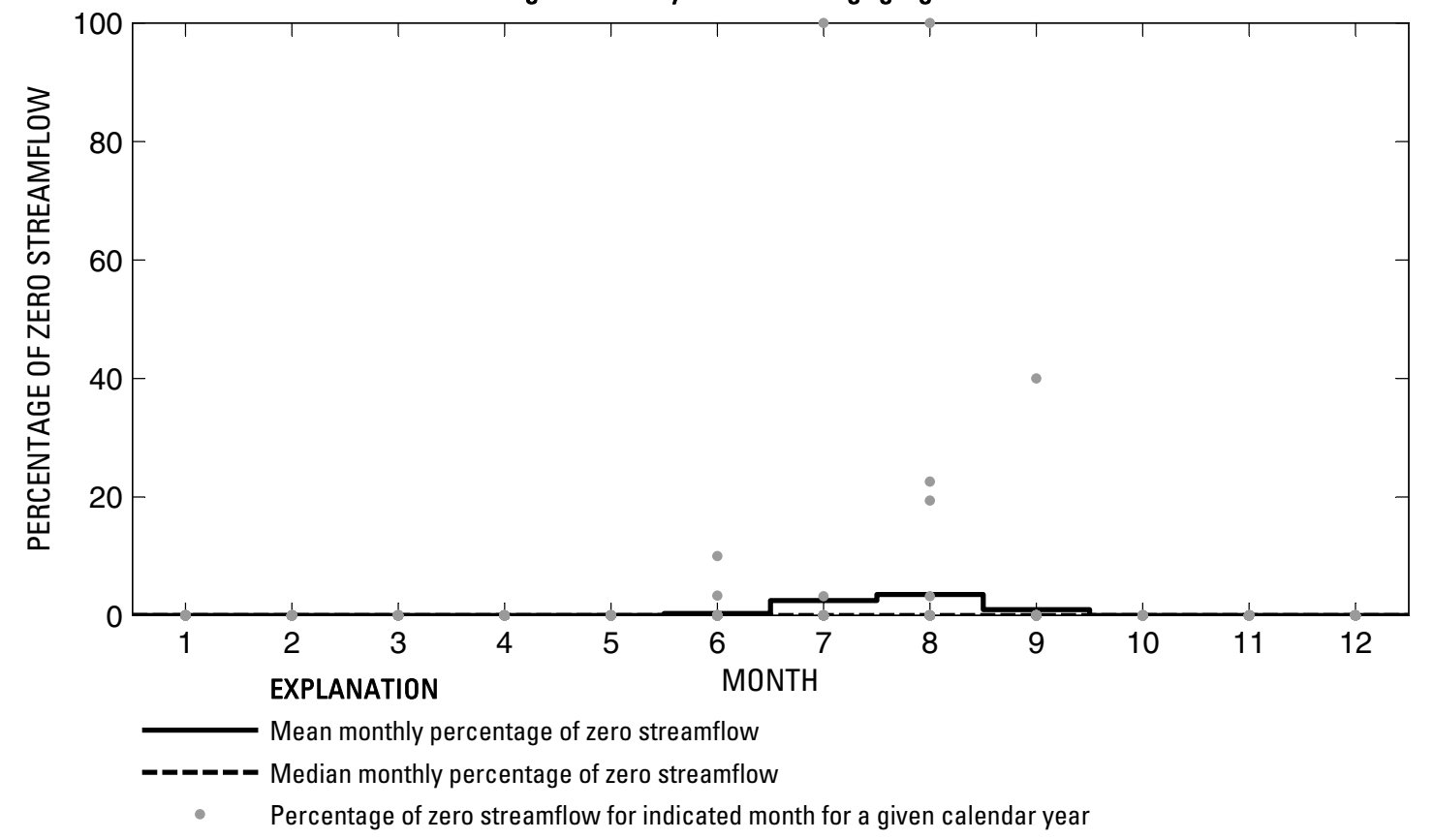

Figure 248. Analysis of percentage of zero daily mean streamflow for U.S. Geological Survey streamflow-gaging station 08066200 Long King Creek at Livingston, Texas. 


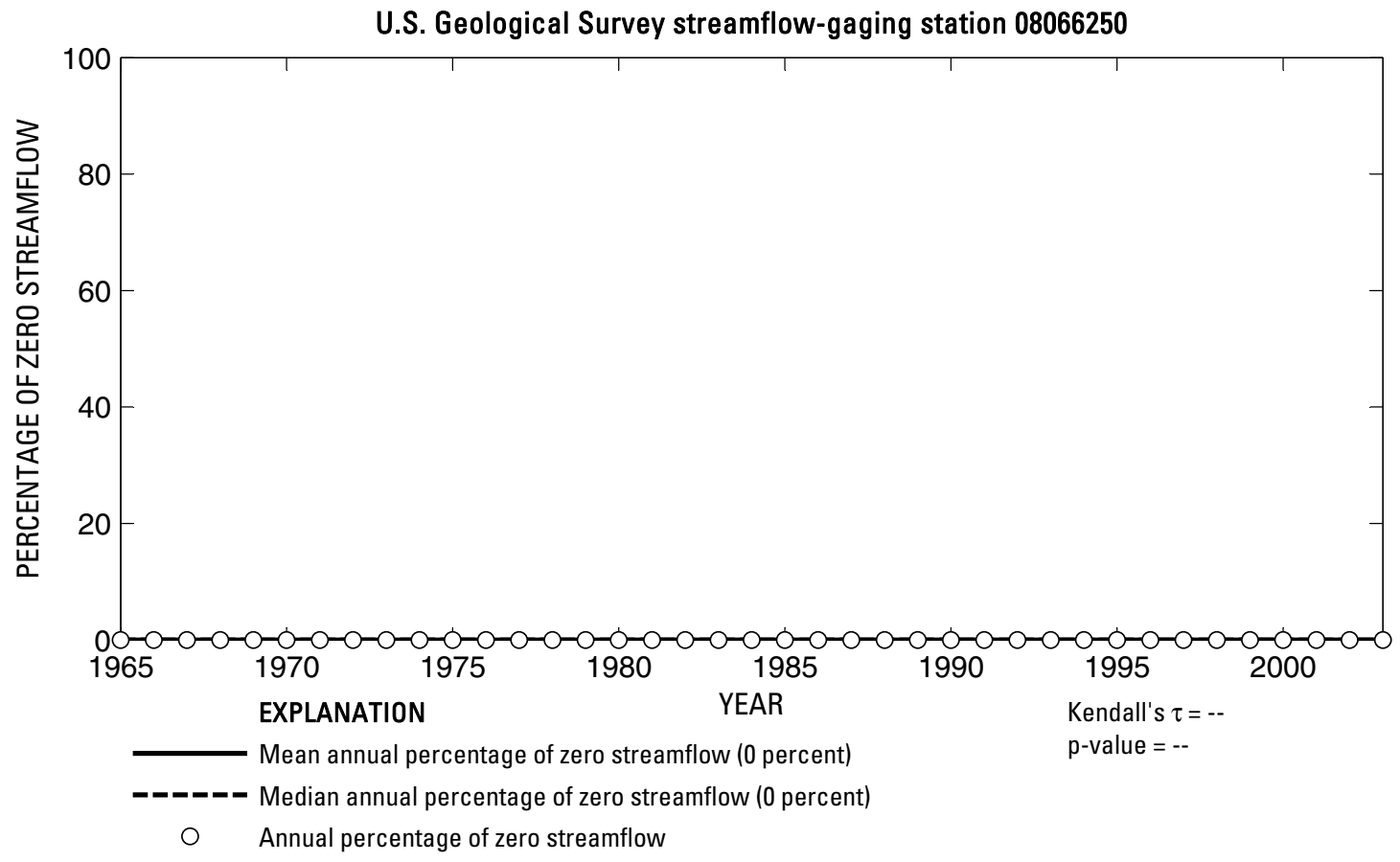

U.S. Geological Survey streamflow-gaging station 08066250

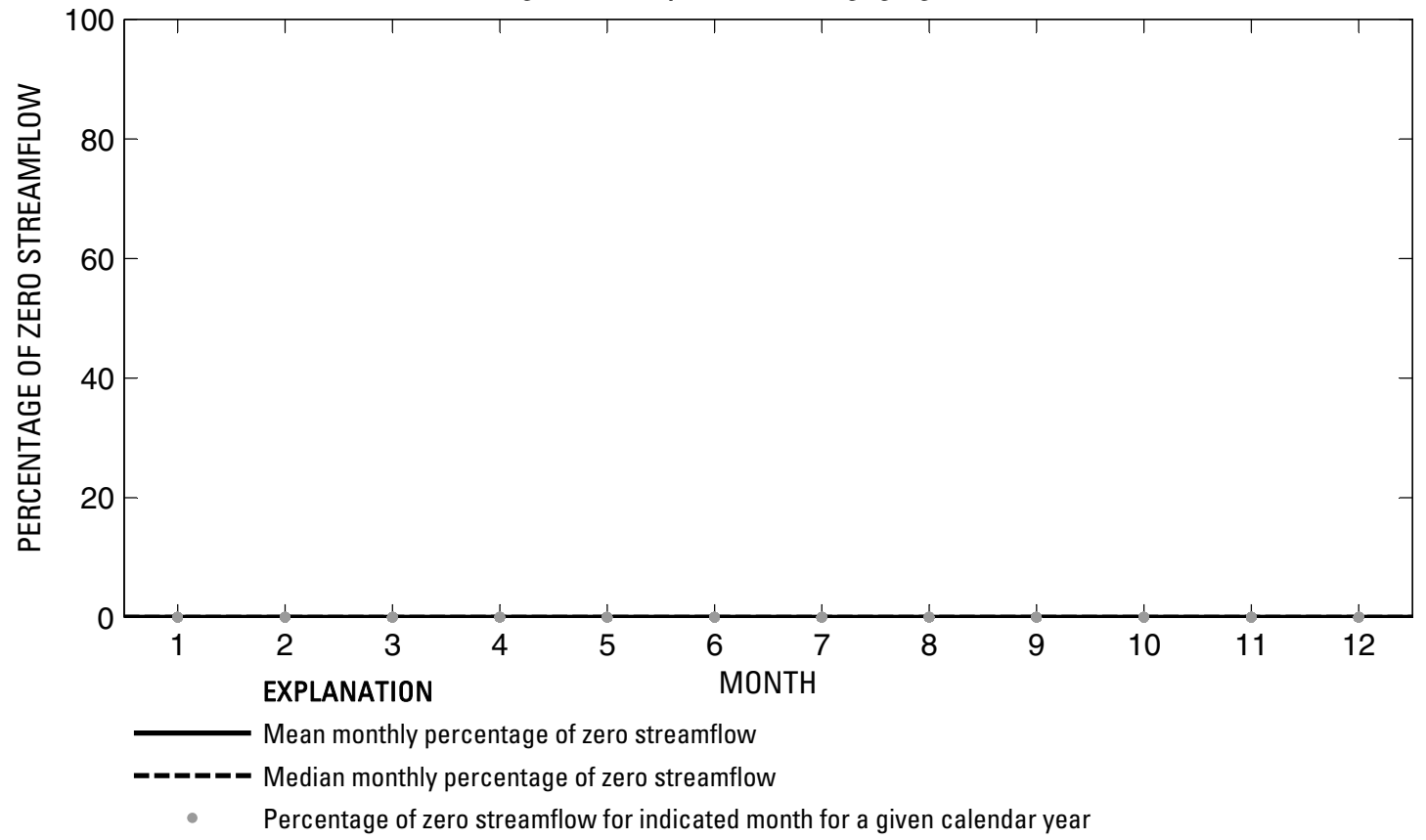

Figure 249. Analysis of percentage of zero daily mean streamflow for U.S. Geological Survey streamflow-gaging station 08066250 Trinity River near Goodrich, Texas. 
U.S. Geological Survey streamflow-gaging station 08066300

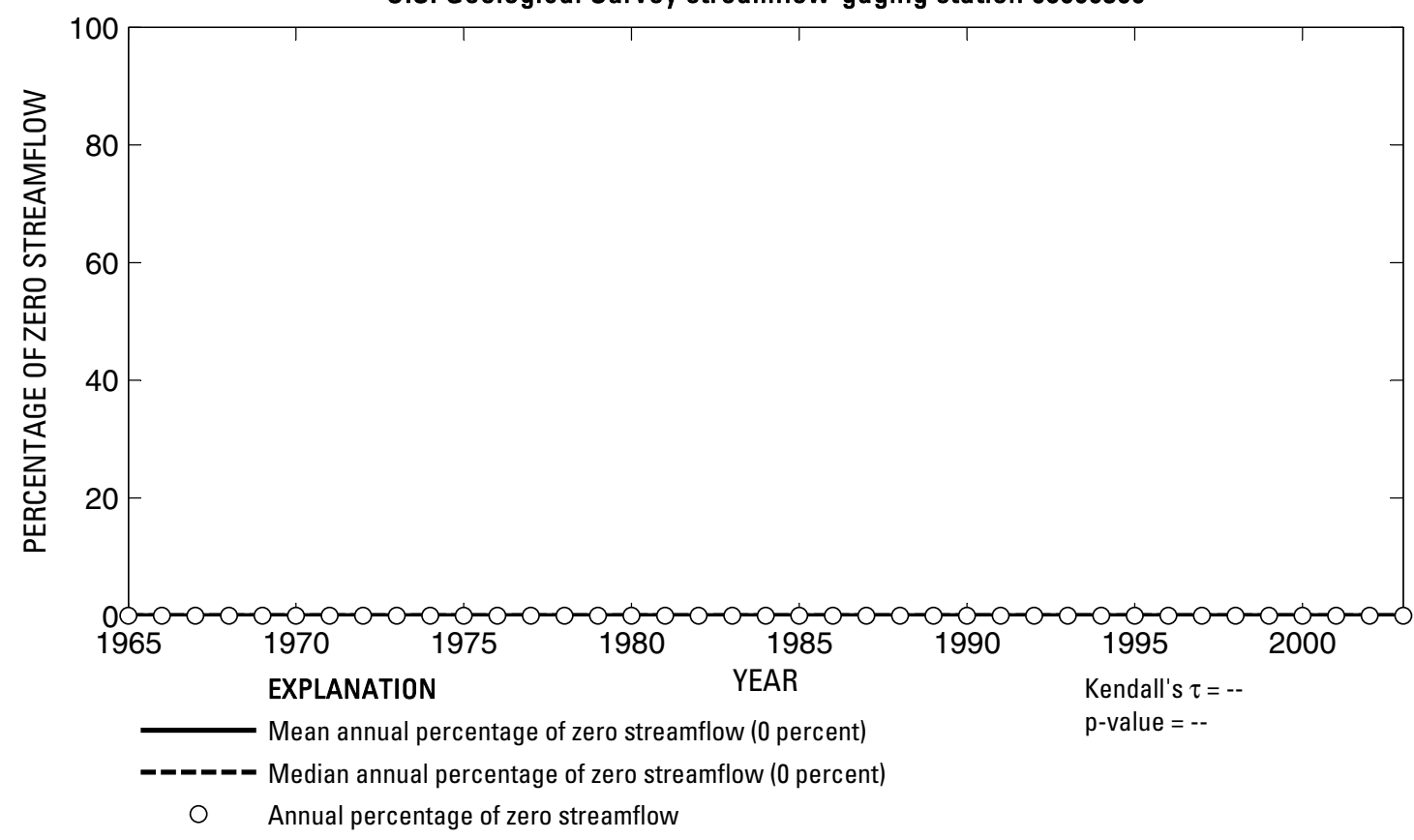

U.S. Geological Survey streamflow-gaging station 08066300

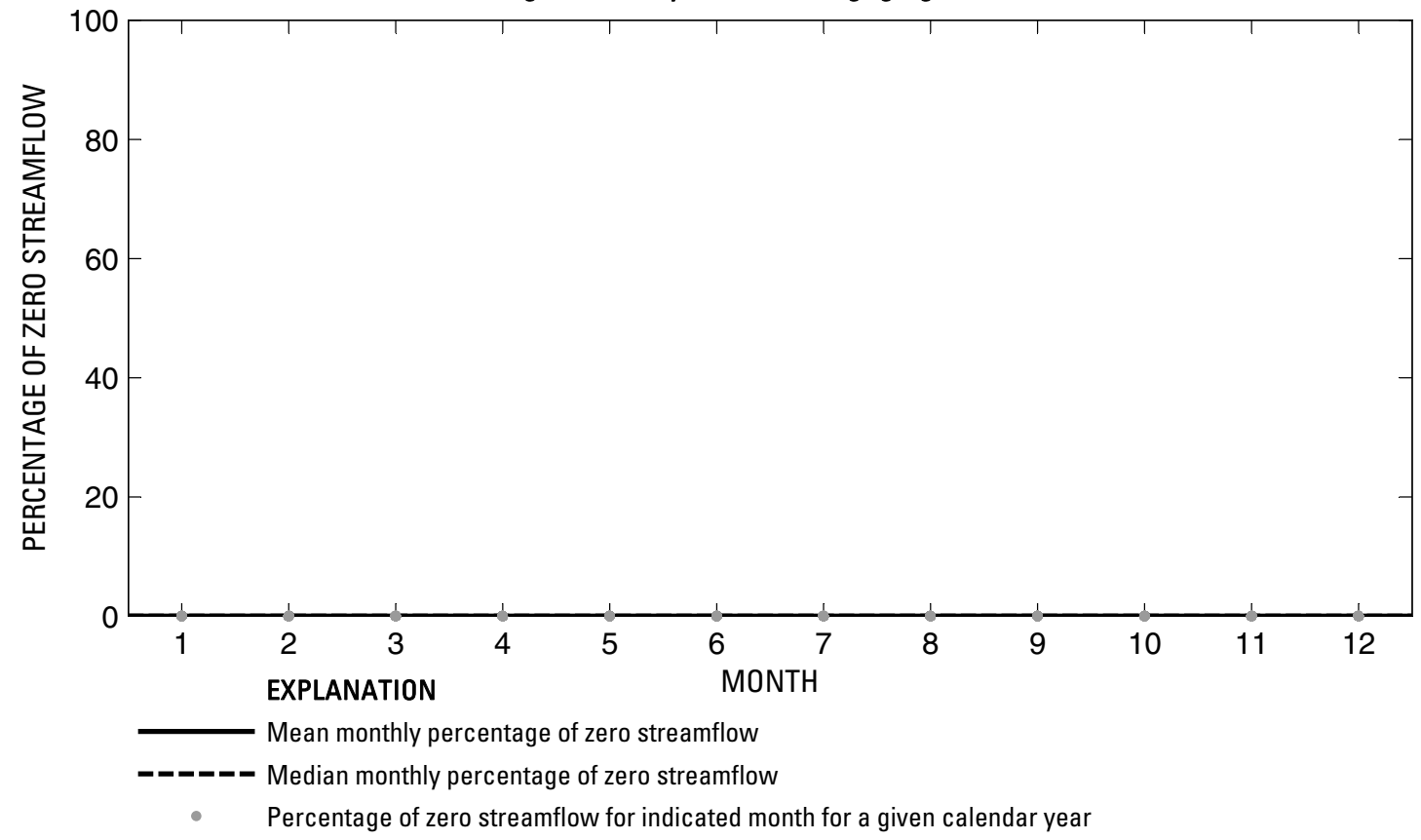

Figure 250. Analysis of percentage of zero daily mean streamflow for U.S. Geological Survey streamflow-gaging station 08066300 Menard Creek near Rye, Texas. 


\section{U.S. Geological Survey streamflow-gaging station 08066500}

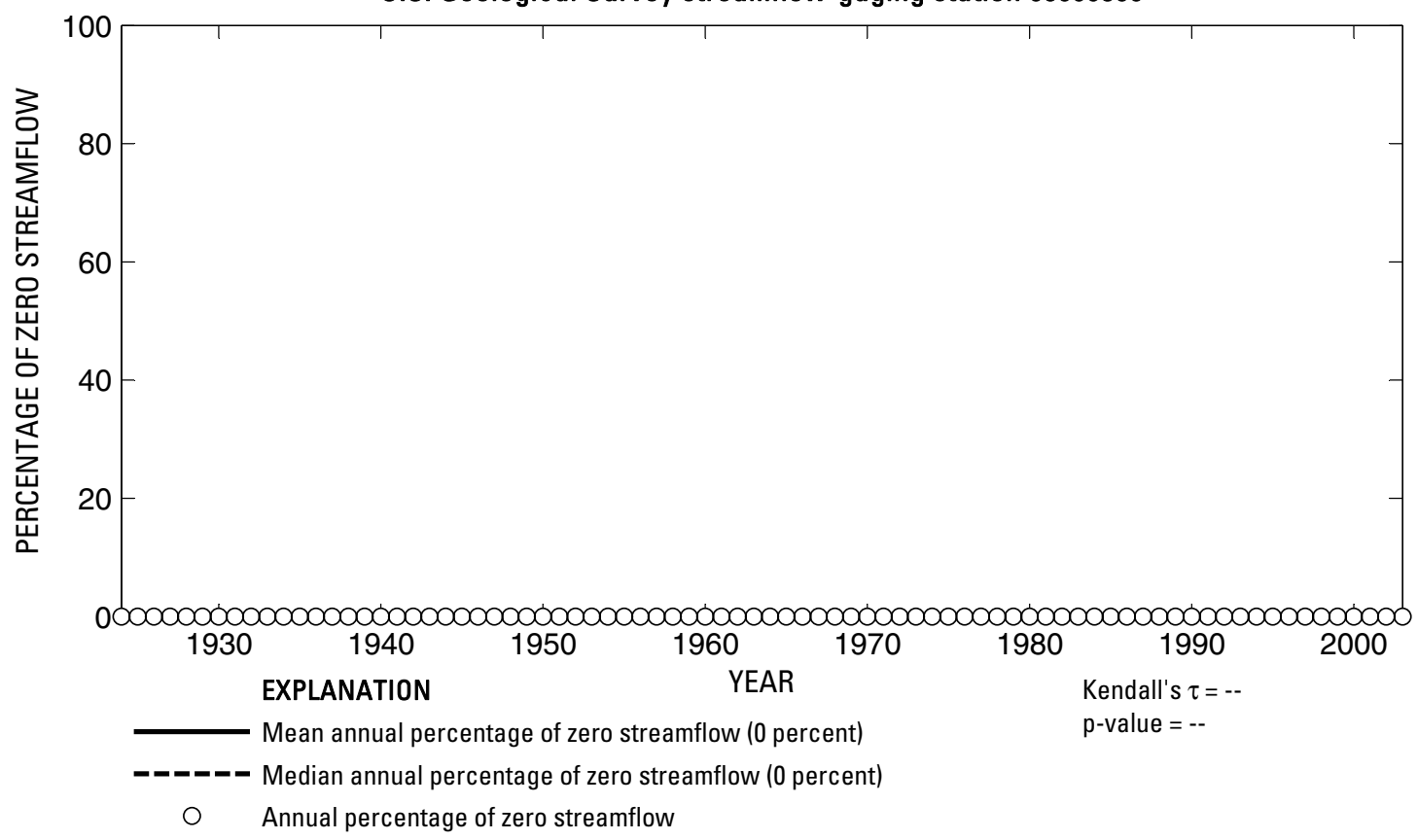

U.S. Geological Survey streamflow-gaging station 08066500

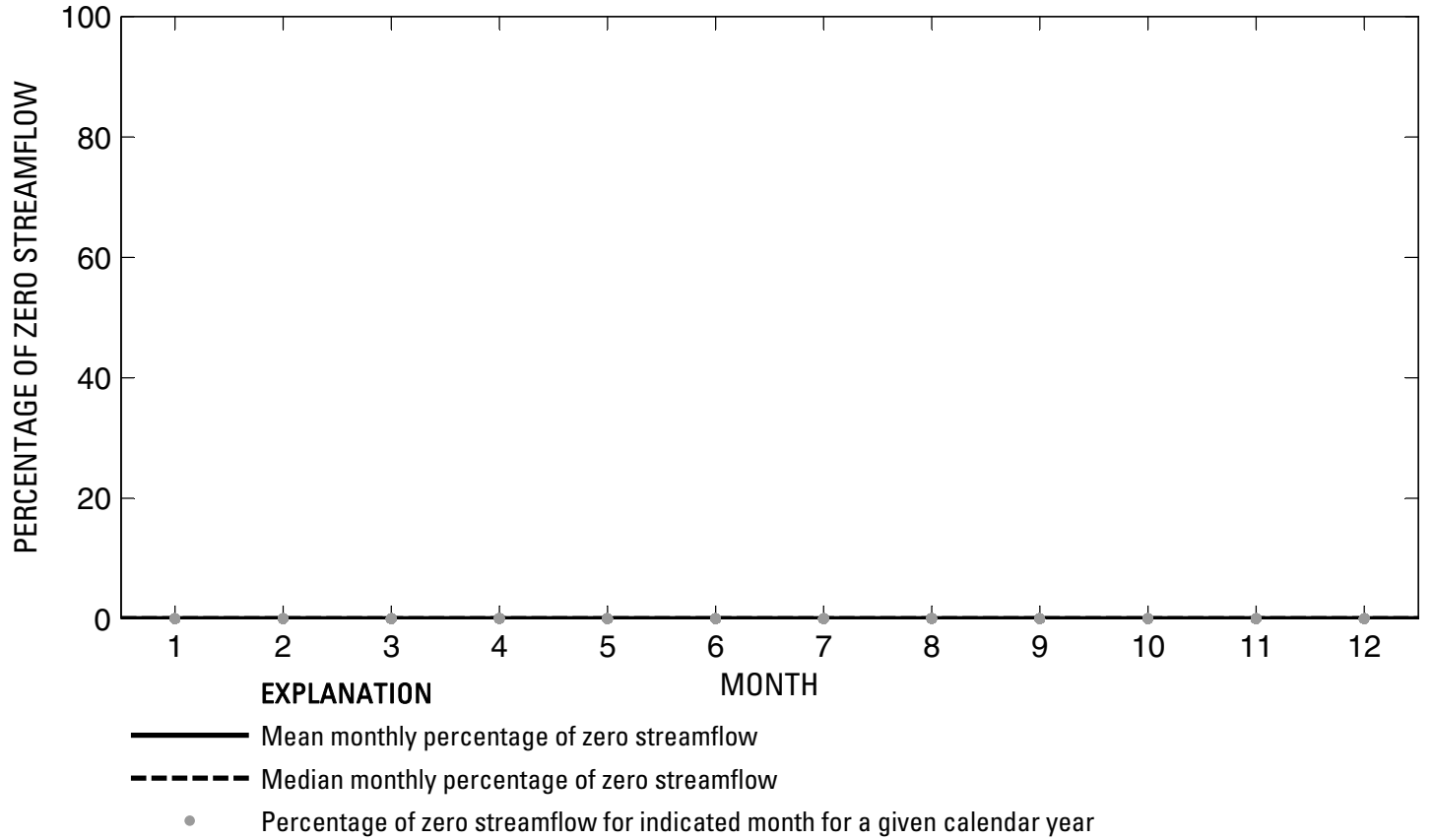

Figure 251. Analysis of percentage of zero daily mean streamflow for U.S. Geological Survey streamflow-gaging station 08066500 Trinity River at Romayor, Texas. 
U.S. Geological Survey streamflow-gaging station 08067000

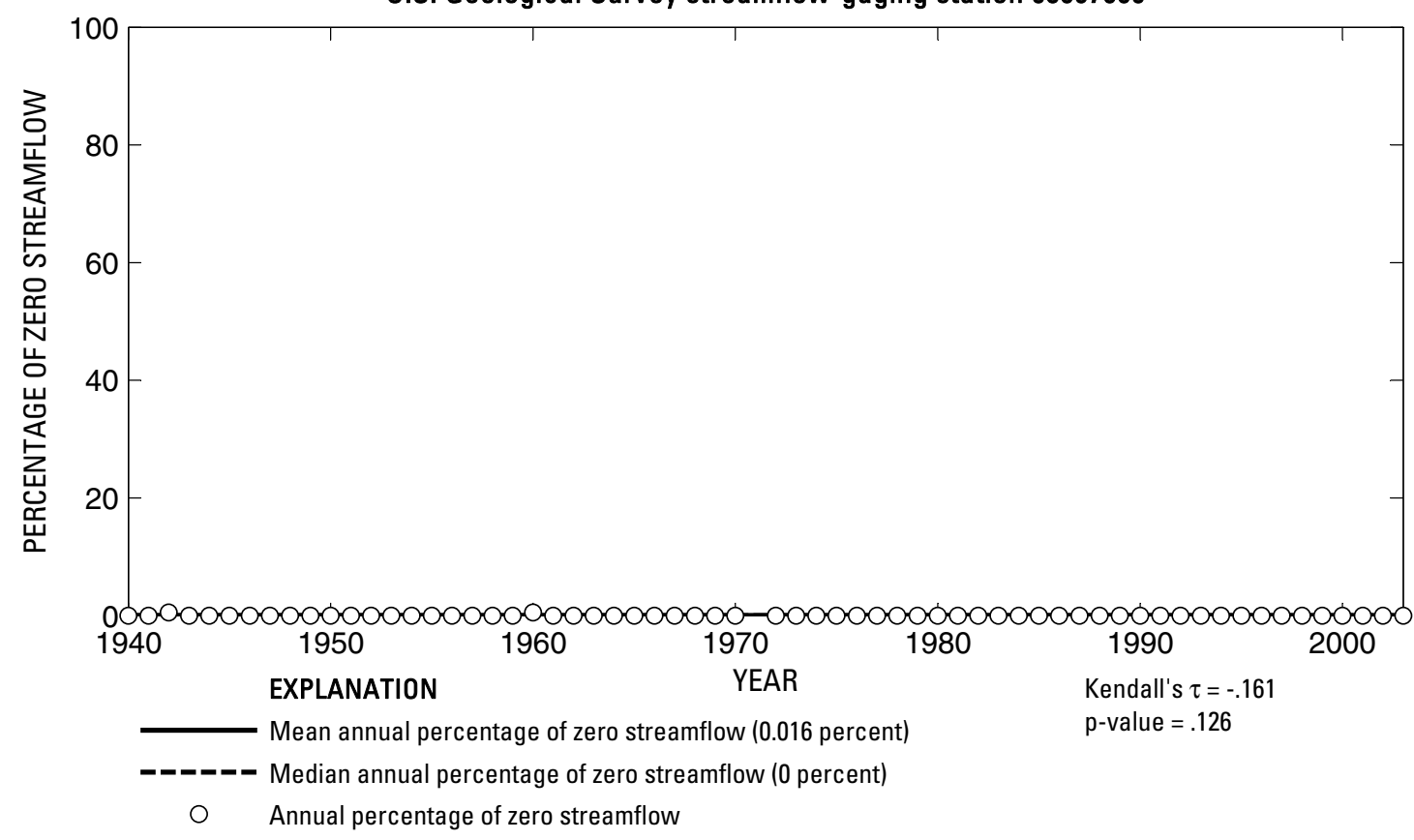

U.S. Geological Survey streamflow-gaging station 08067000

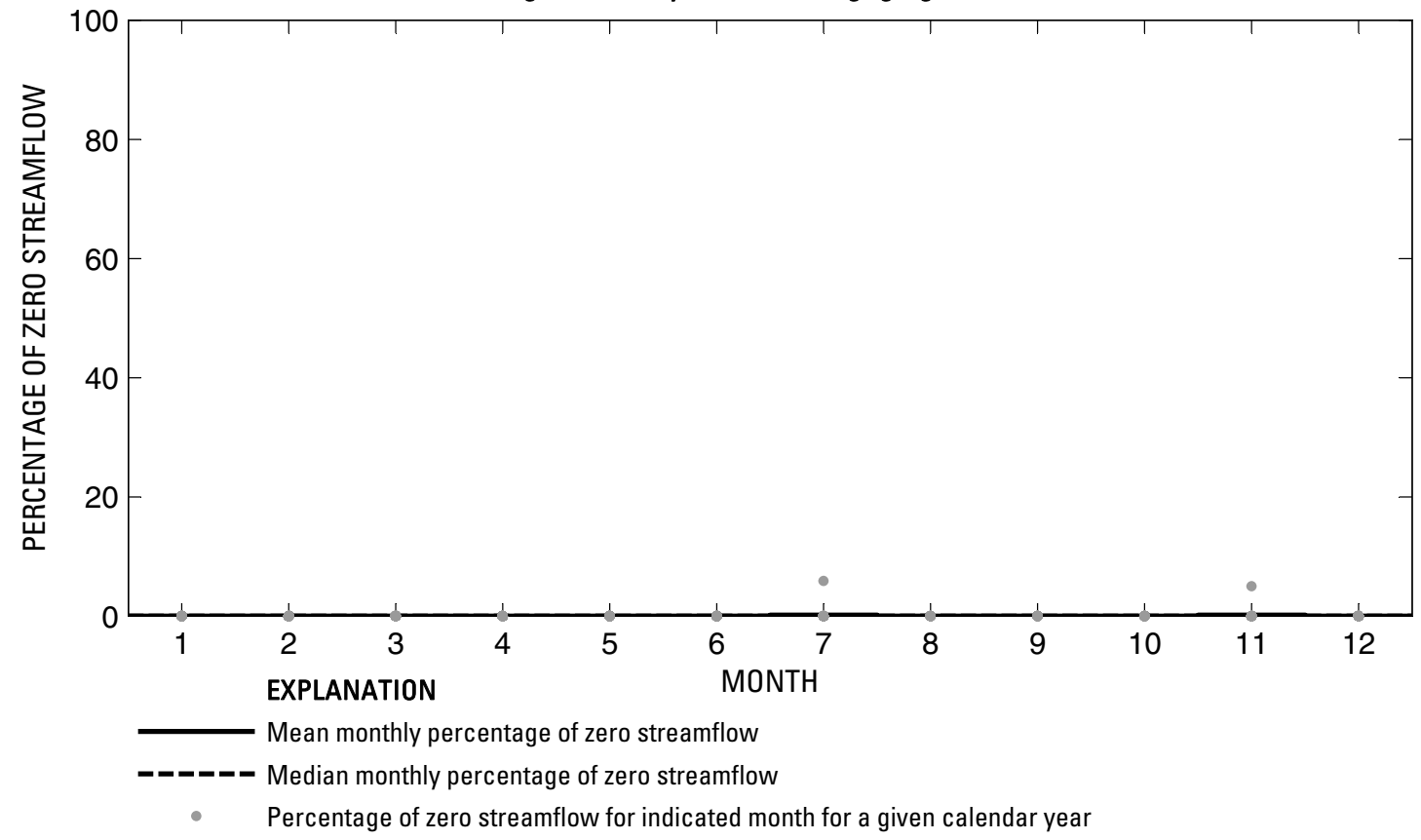

Figure 252. Analysis of percentage of zero daily mean streamflow for U.S. Geological Survey streamflow-gaging station 08067000 Trinity River at Liberty, Texas. 


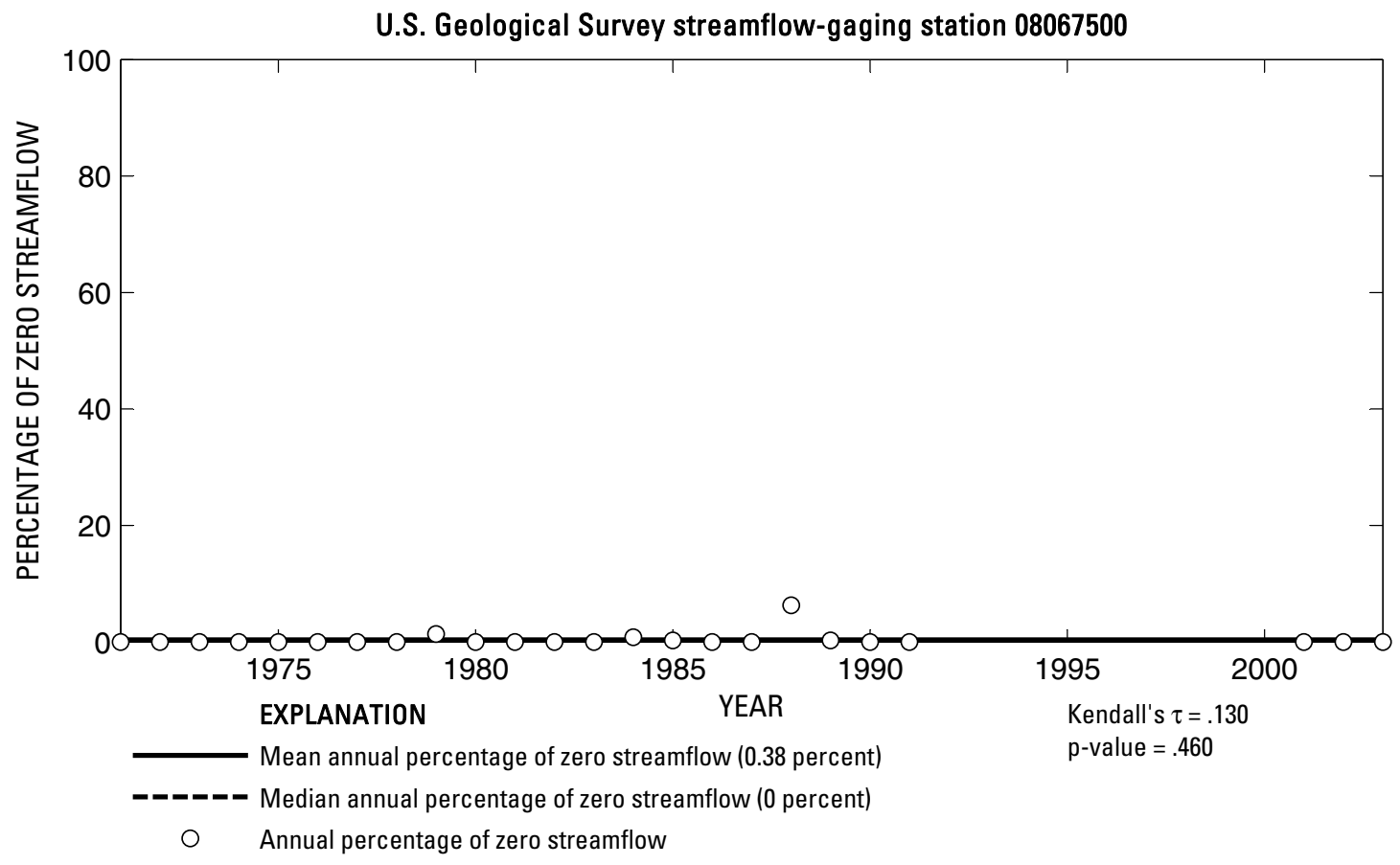

U.S. Geological Survey streamflow-gaging station 08067500

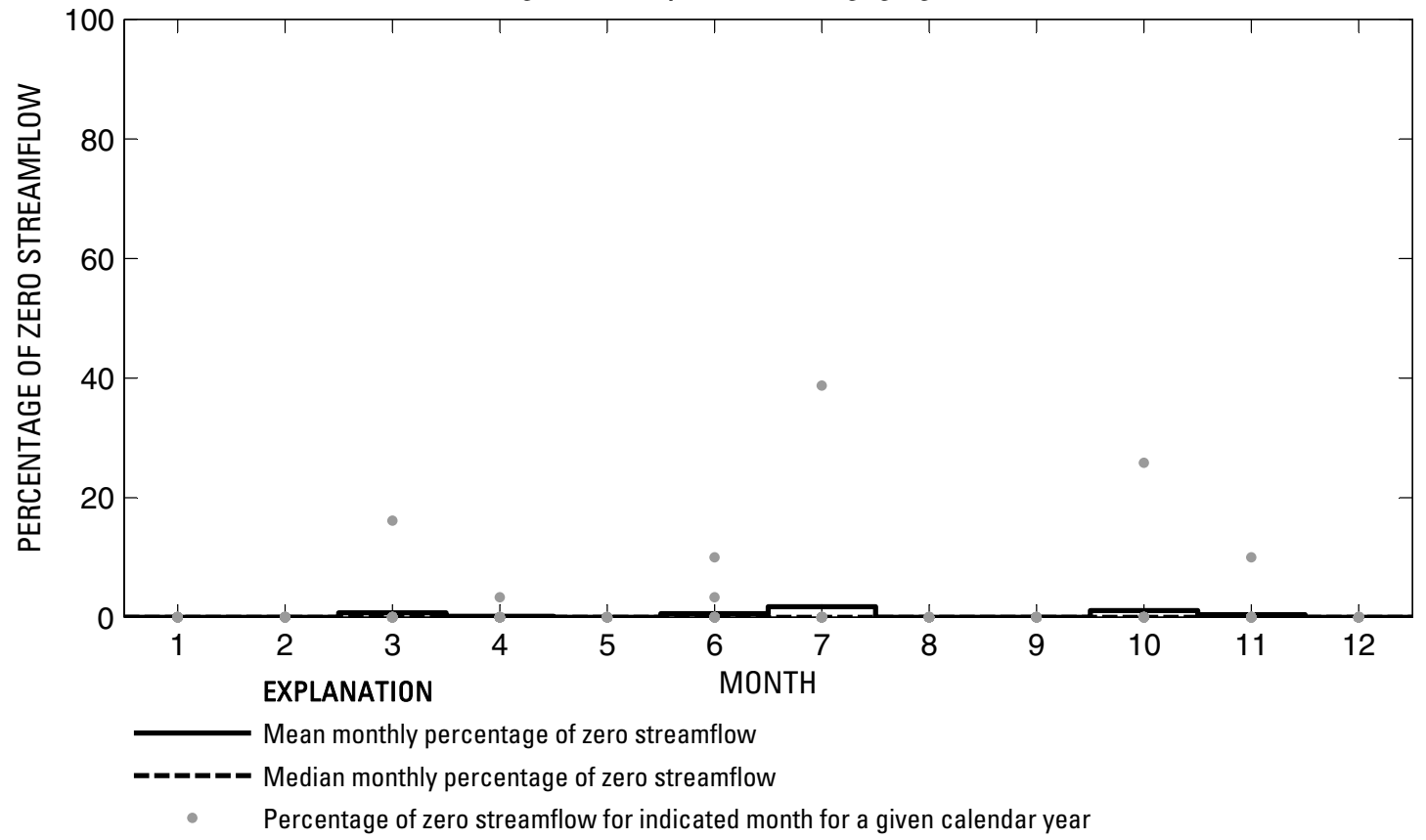

Figure 253. Analysis of percentage of zero daily mean streamflow for U.S. Geological Survey streamflow-gaging station 08067500 Cedar Bayou near Crosby, Texas. 
U.S. Geological Survey streamflow-gaging station 08067525

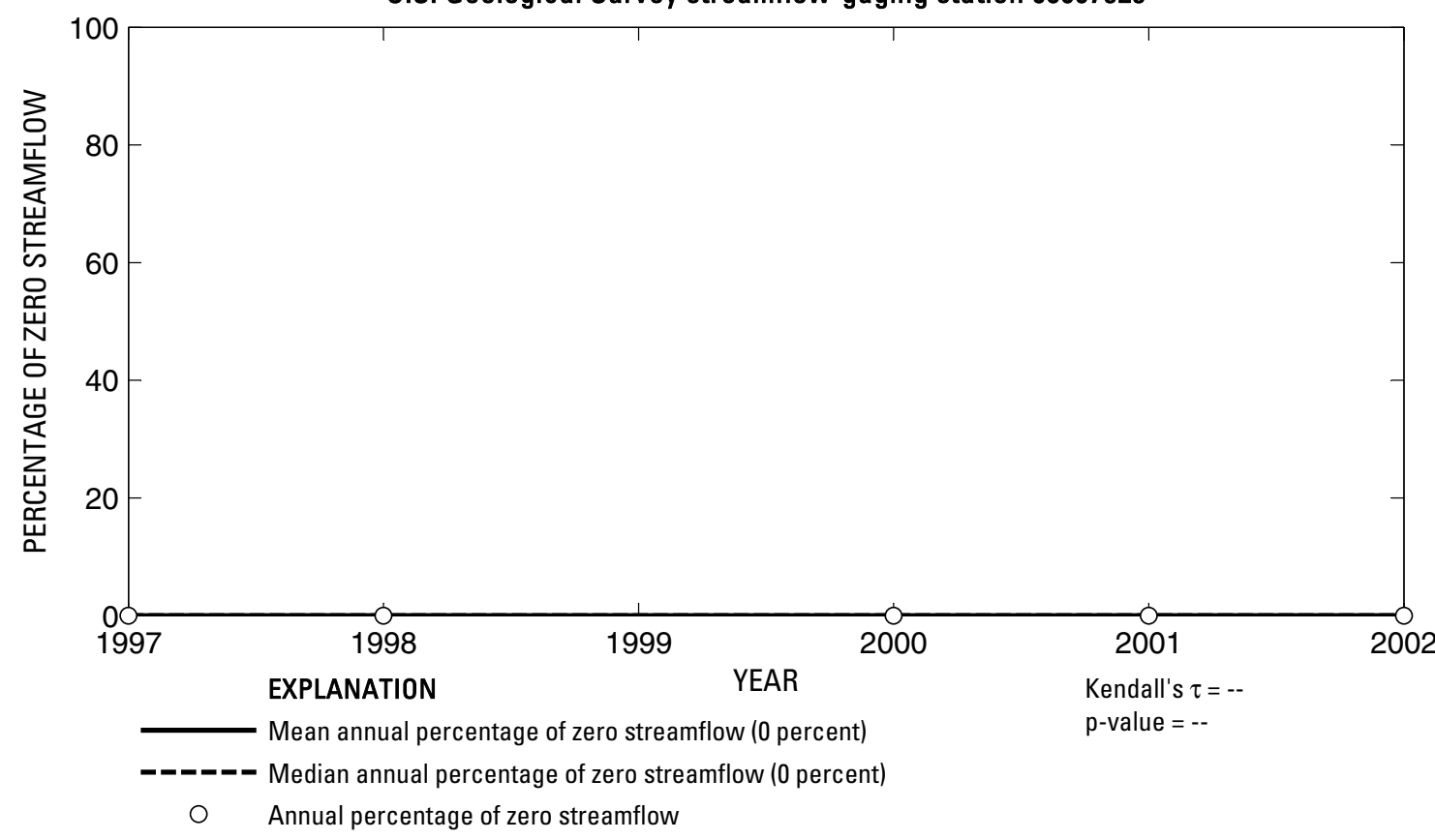

U.S. Geological Survey streamflow-gaging station 08067525

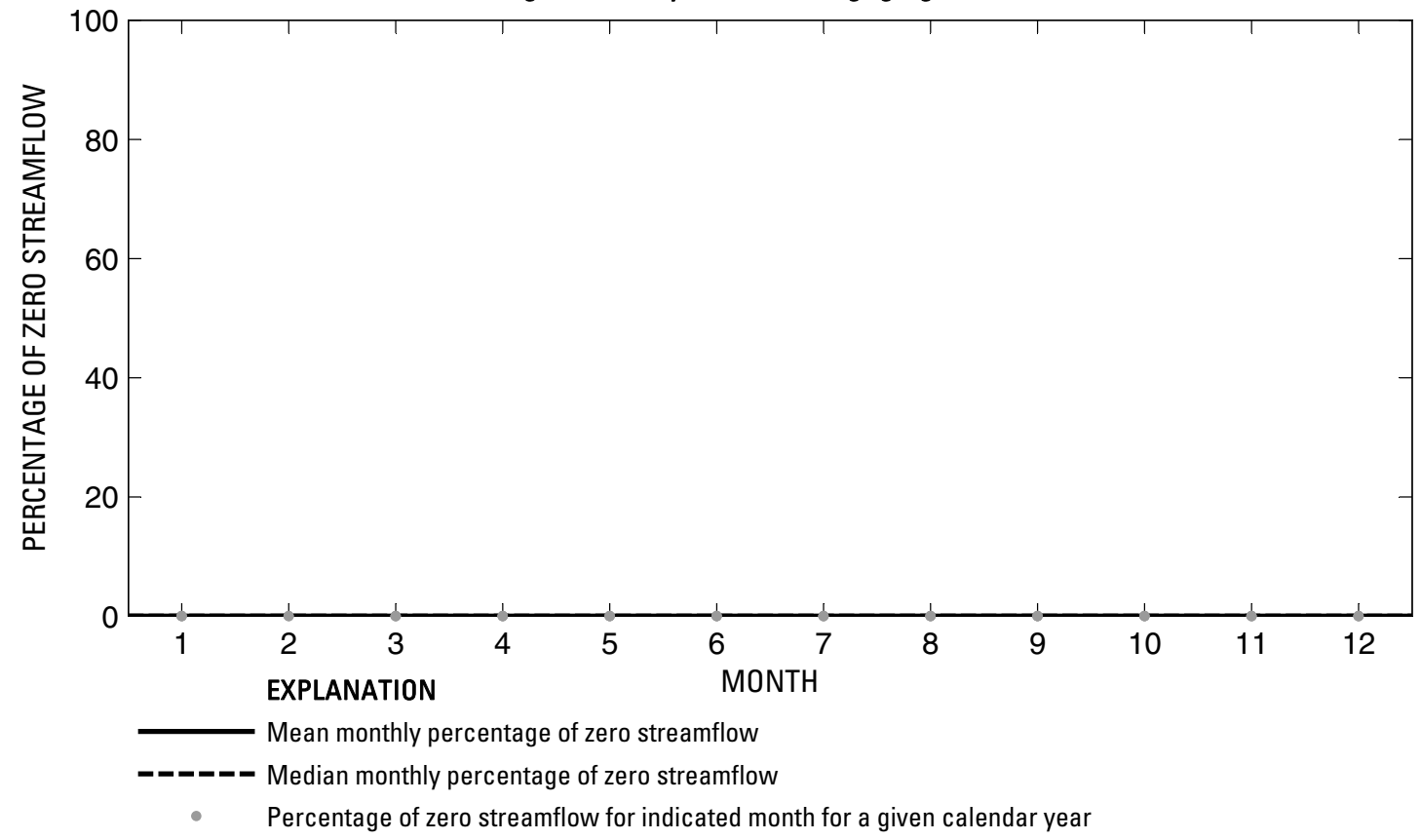

Figure 254. Analysis of percentage of zero daily mean streamflow for U.S. Geological Survey streamflow-gaging station 08067525 Goose Creek at Baytown, Texas. 


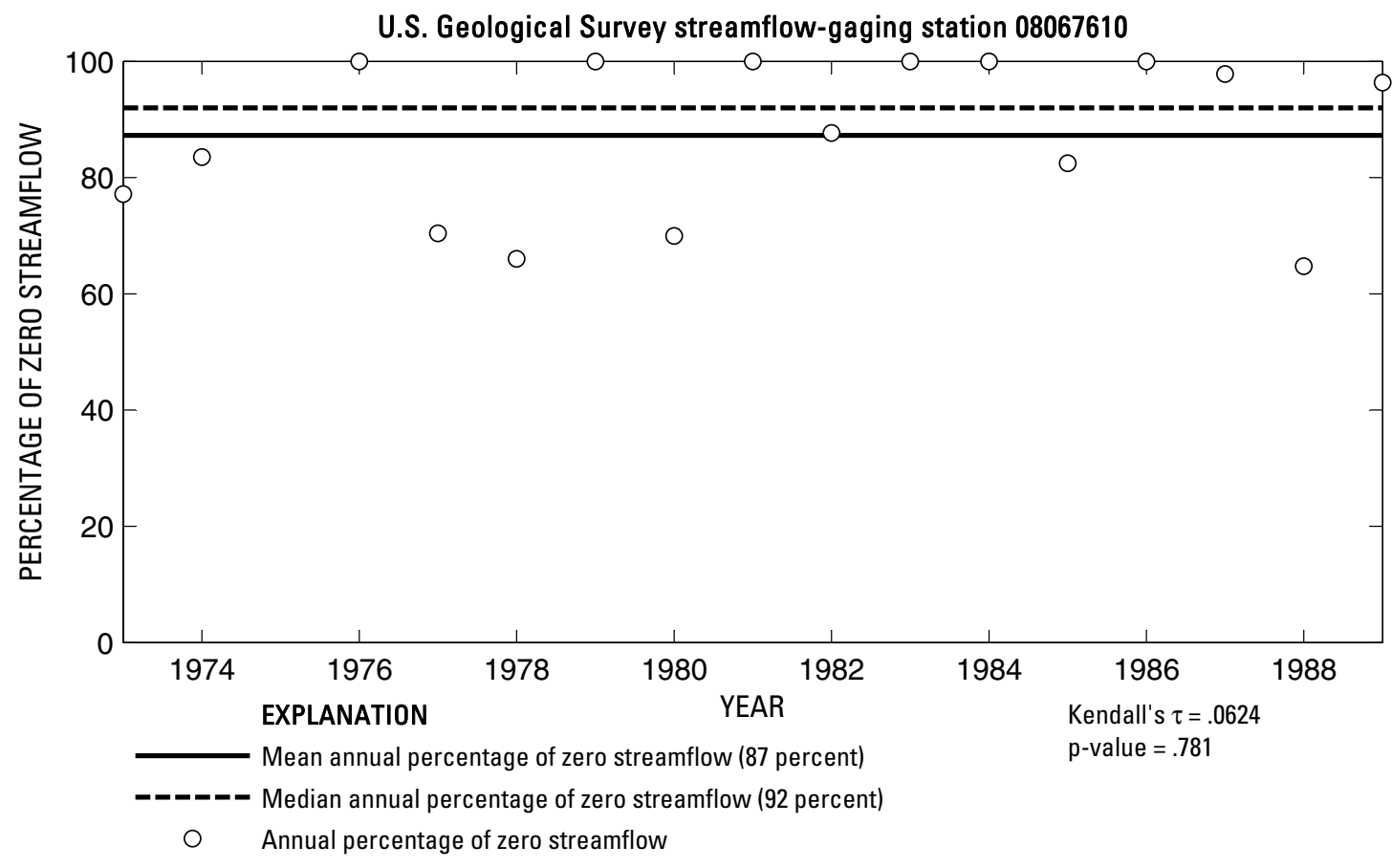

U.S. Geological Survey streamflow-gaging station 08067610

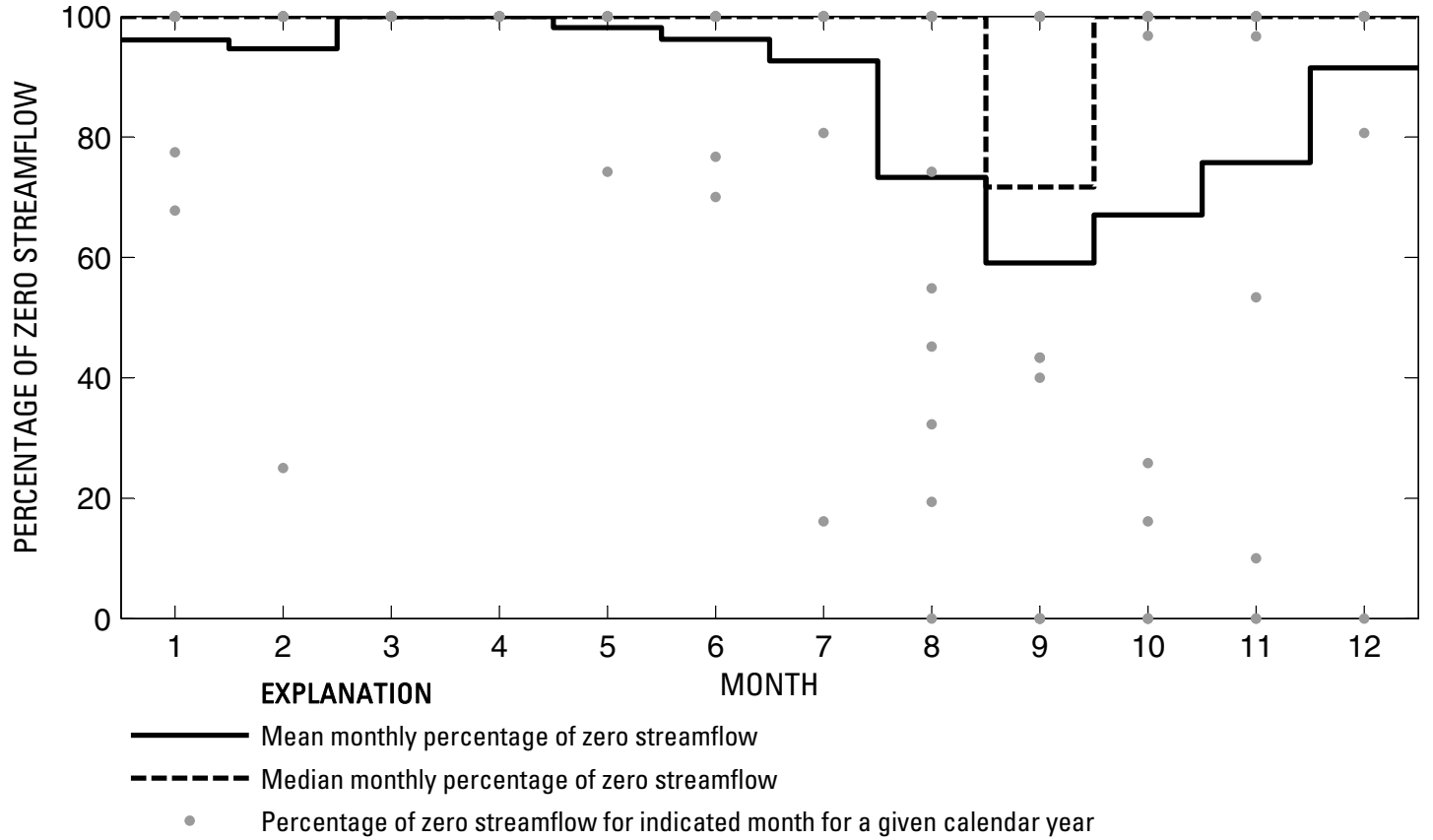

Figure 255. Analysis of percentage of zero daily mean streamflow for U.S. Geological Survey streamflow-gaging station 08067610 Lake Conroe Outflow Weir near Conroe, Texas. 
U.S. Geological Survey streamflow-gaging station 08067650

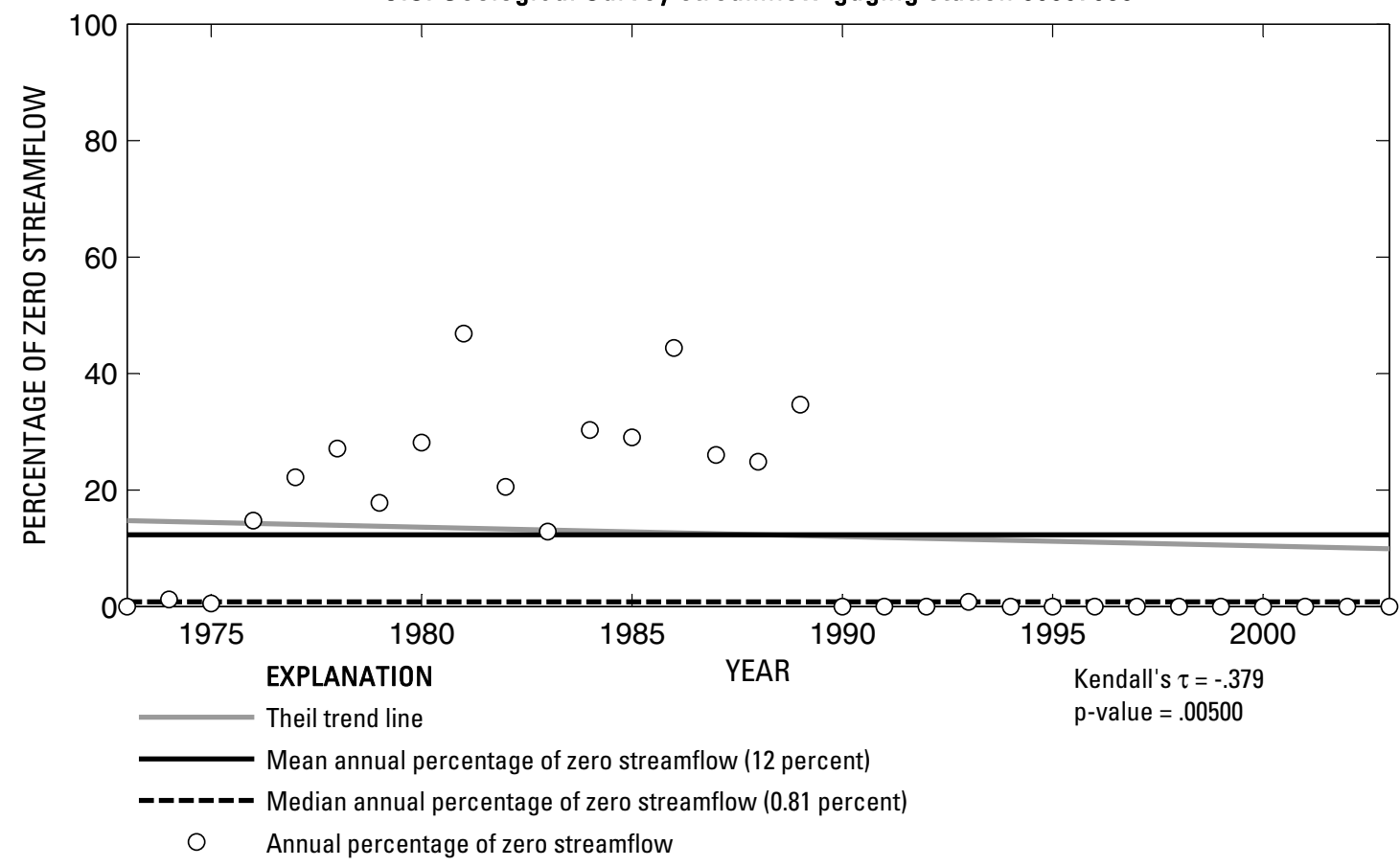

U.S. Geological Survey streamflow-gaging station 08067650

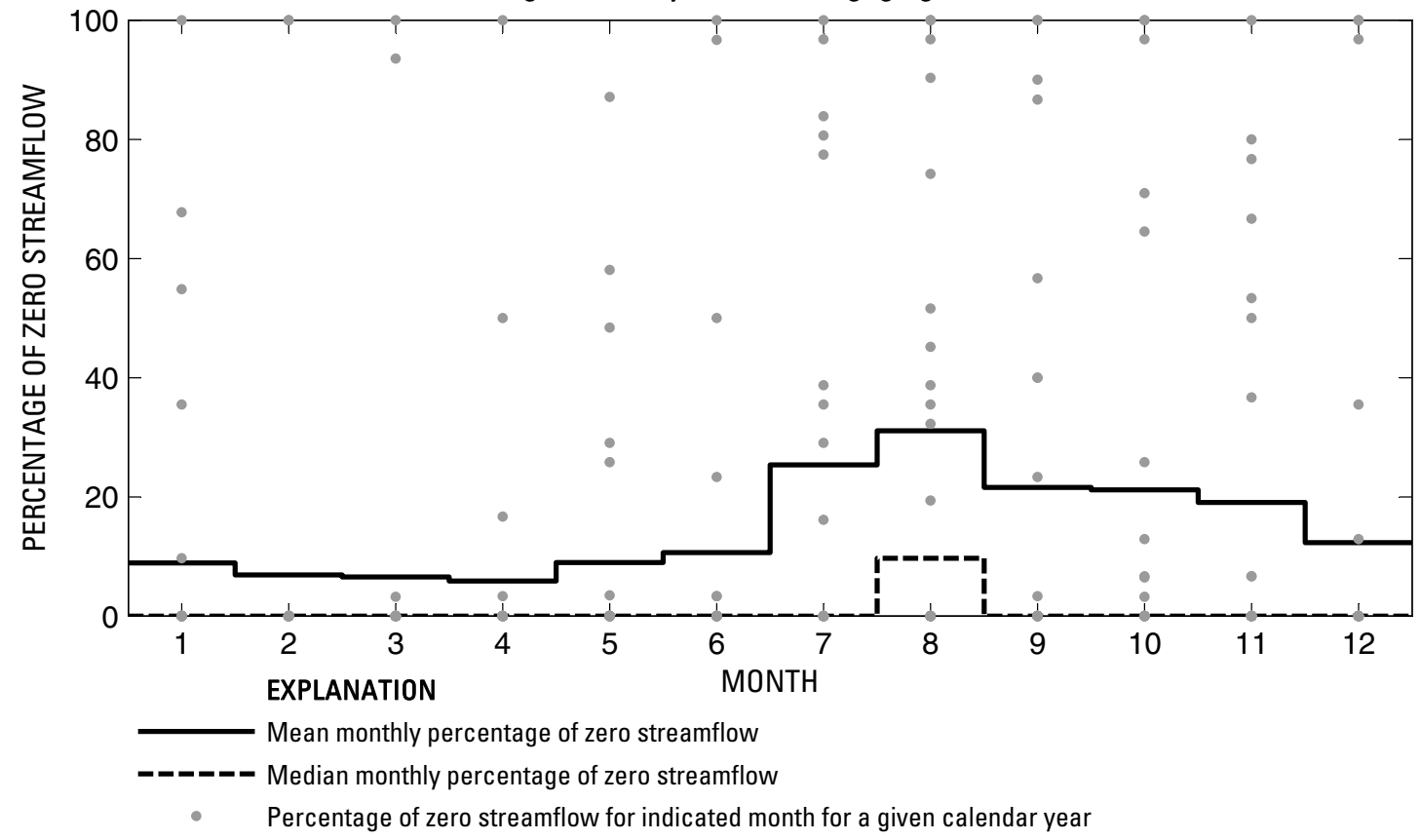

Figure 256. Analysis of percentage of zero daily mean streamflow for U.S. Geological Survey streamflow-gaging station 08067650 West Fork San Jacinto River below Lake Conroe near Conroe, Texas.

Index of Station Numbers 719 
U.S. Geological Survey streamflow-gaging station 08067700

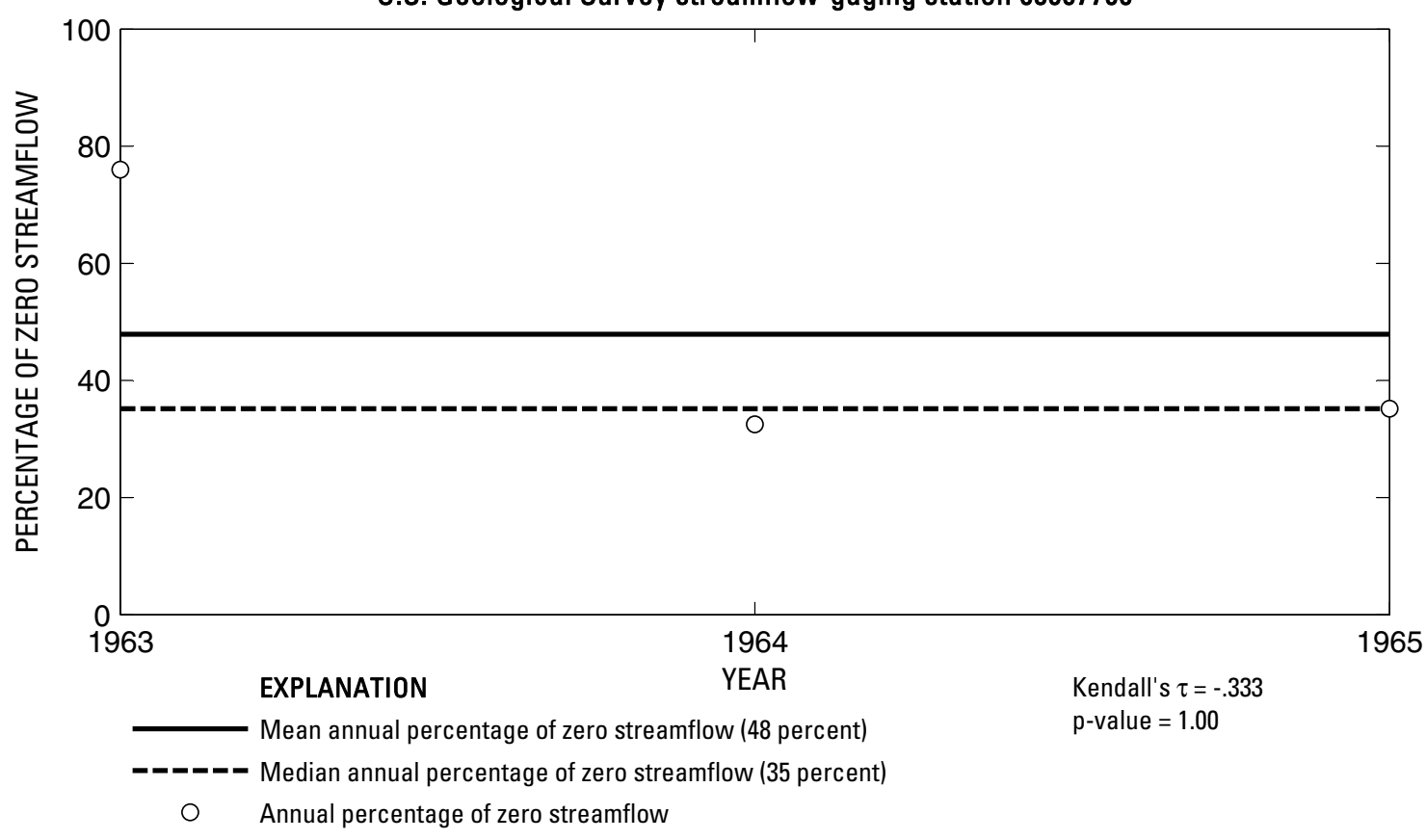

U.S. Geological Survey streamflow-gaging station 08067700

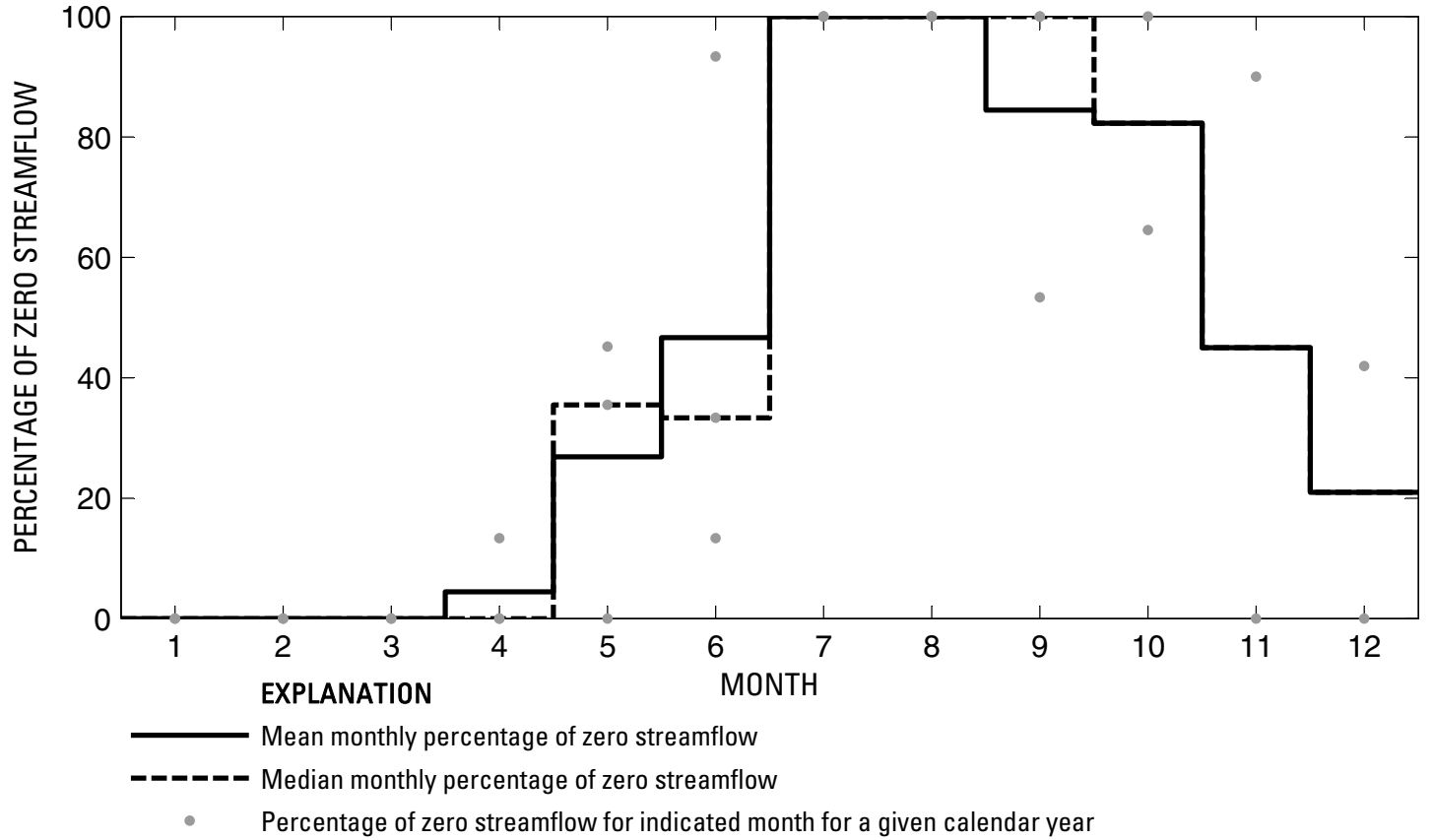

Figure 257. Analysis of percentage of zero daily mean streamflow for U.S. Geological Survey streamflow-gaging station 08067700 Caney Creek near Dobbin, Texas. 
U.S. Geological Survey streamflow-gaging station 08067900

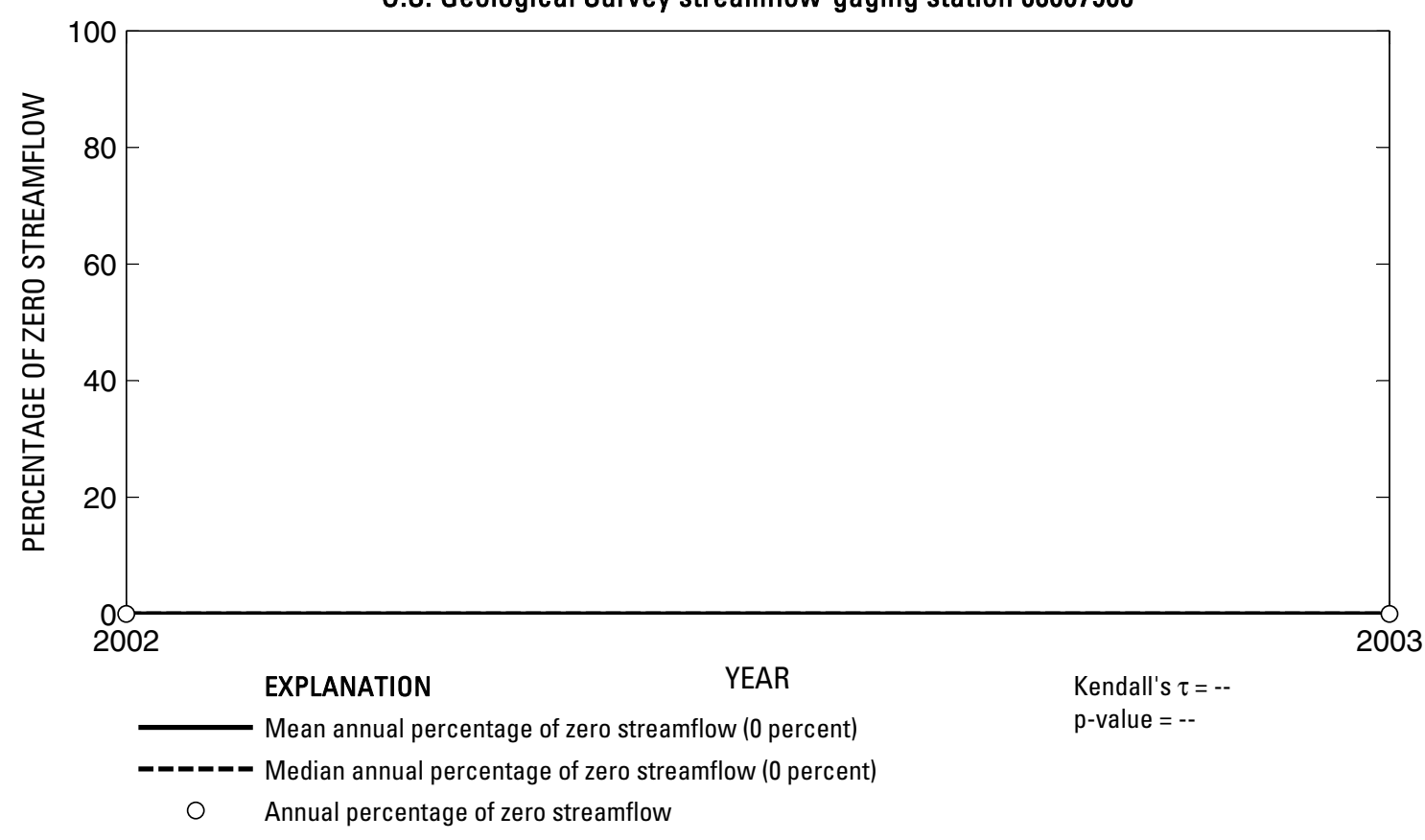

U.S. Geological Survey streamflow-gaging station 08067900

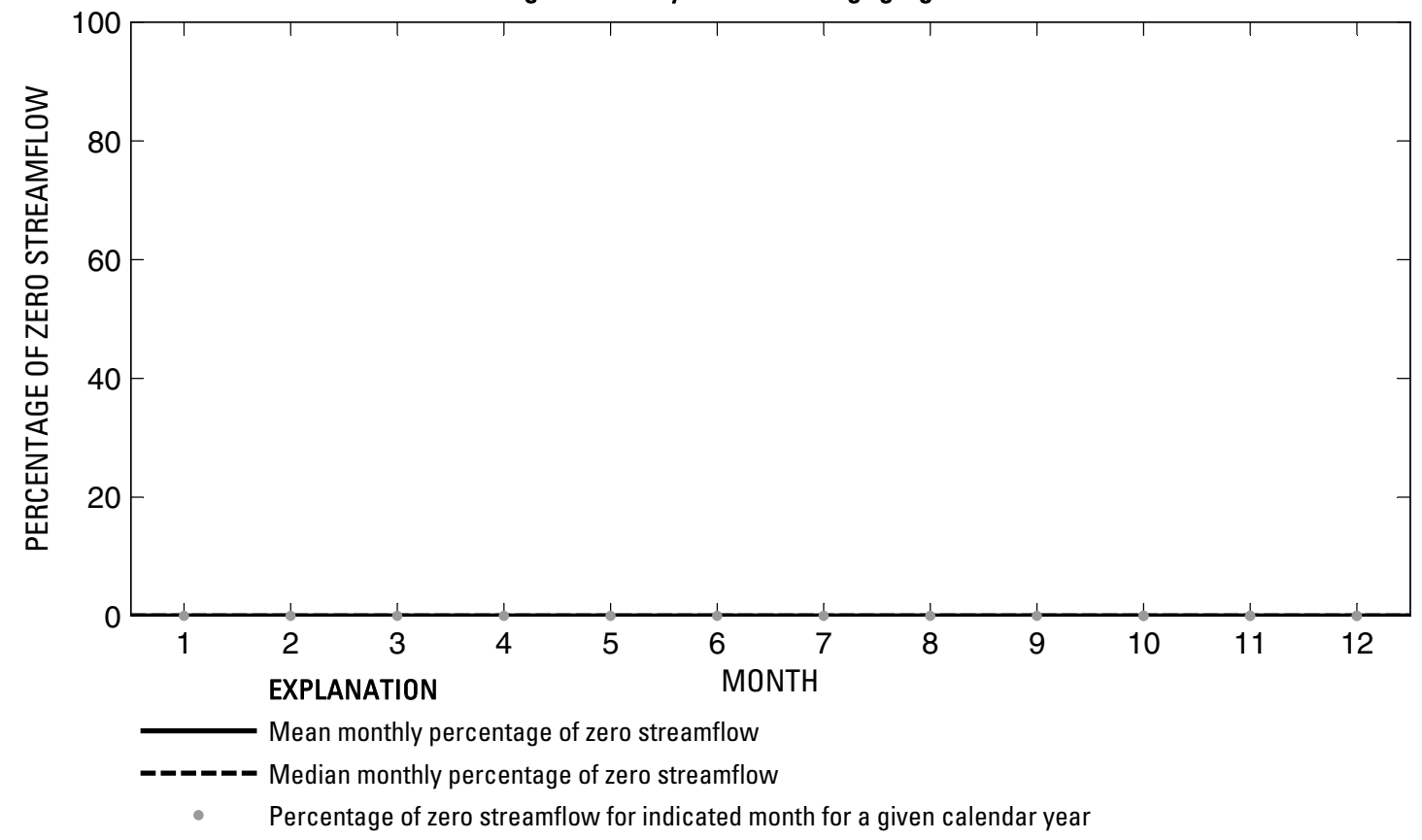

Figure 258. Analysis of percentage of zero daily mean streamflow for U.S. Geological Survey streamflow-gaging station 08067900 Lake Creek near Conroe, Texas. 
U.S. Geological Survey streamflow-gaging station 08068000

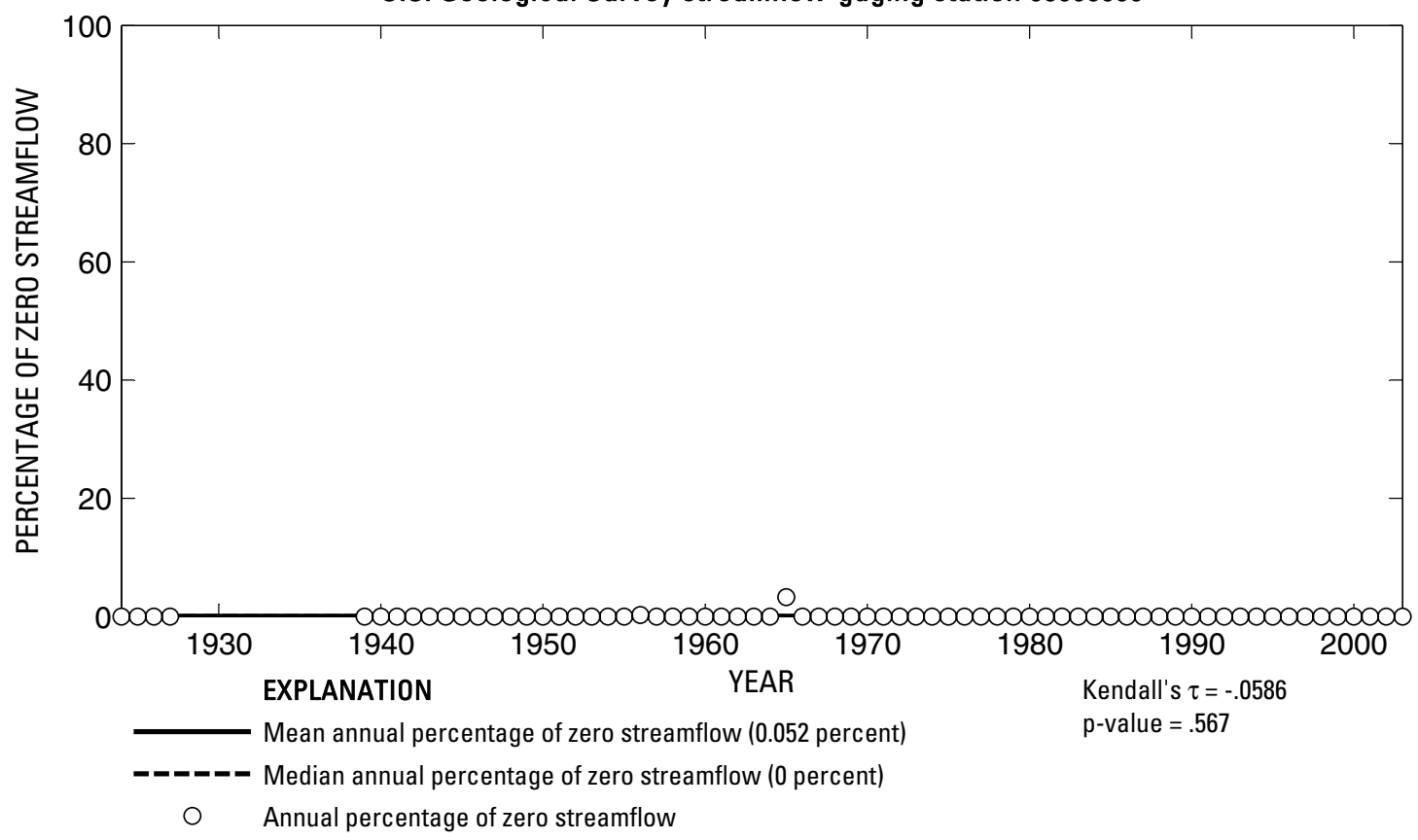

U.S. Geological Survey streamflow-gaging station 08068000

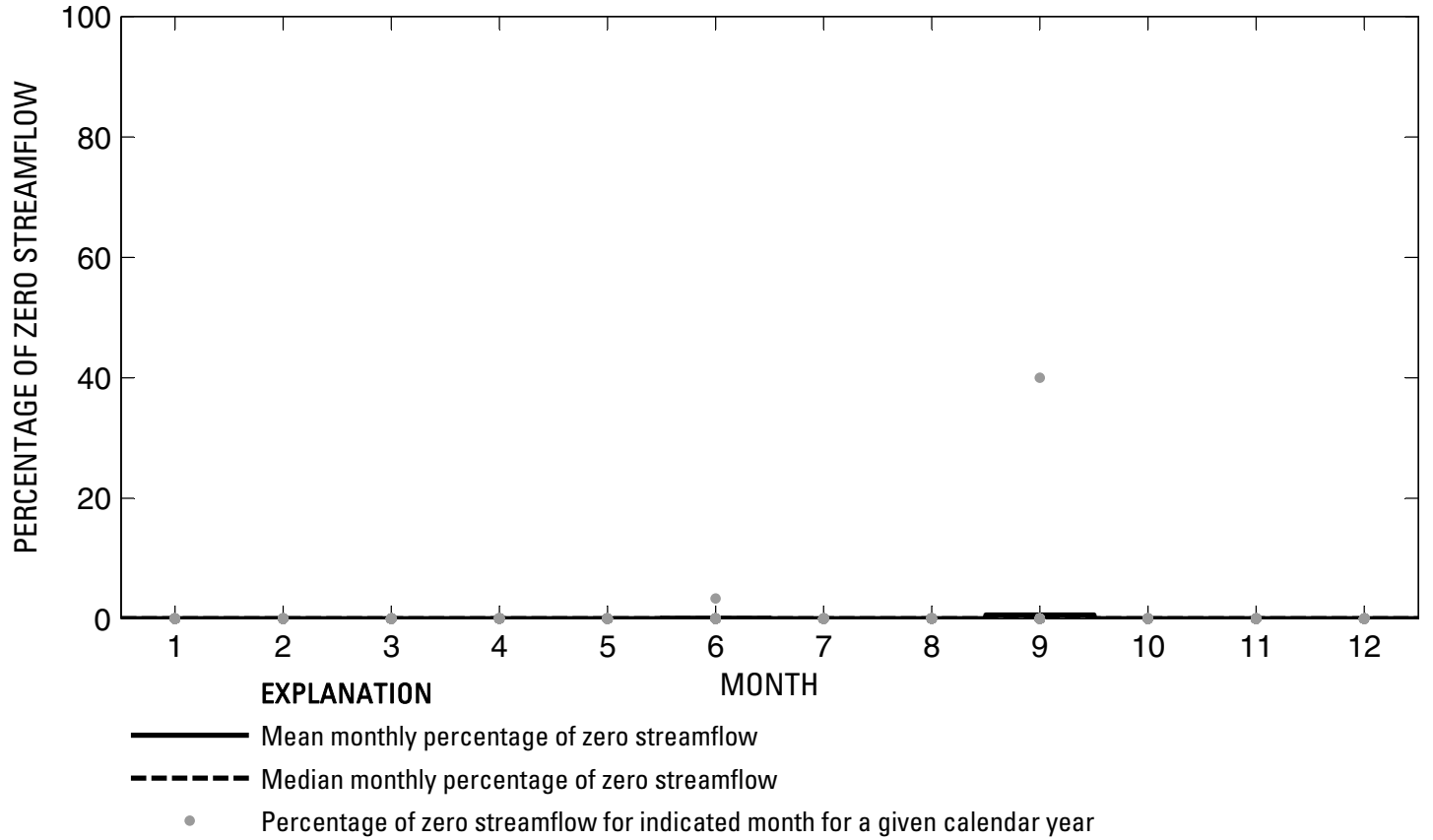

Figure 259. Analysis of percentage of zero daily mean streamflow for U.S. Geological Survey streamflow-gaging station 08068000 West Fork San Jacinto River near Conroe, Texas. 

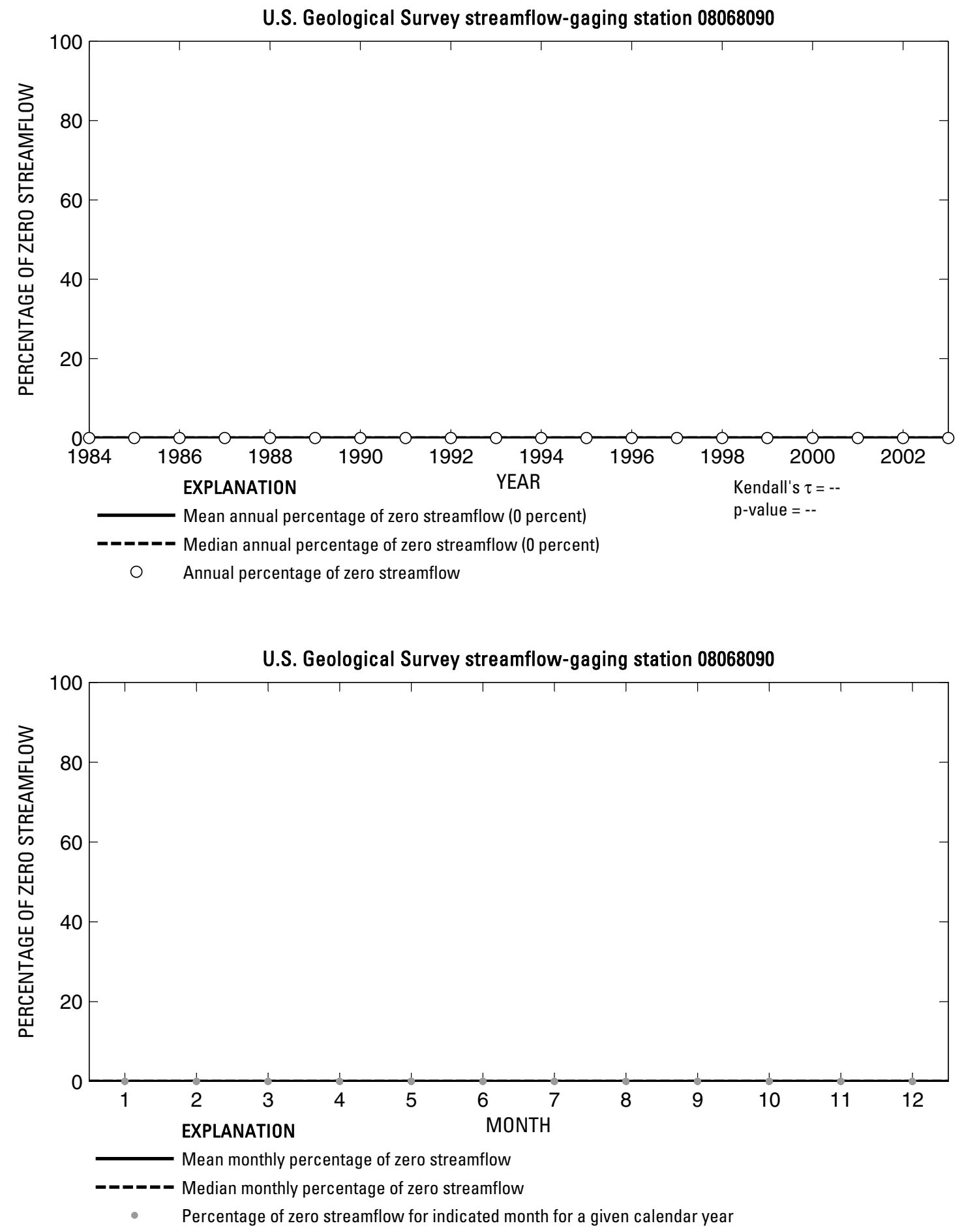

Figure 260. Analysis of percentage of zero daily mean streamflow for U.S. Geological Survey streamflow-gaging station 08068090 West Fork San Jacinto River above Lake Houston near Porter, Texas. 
U.S. Geological Survey streamflow-gaging station 08068275

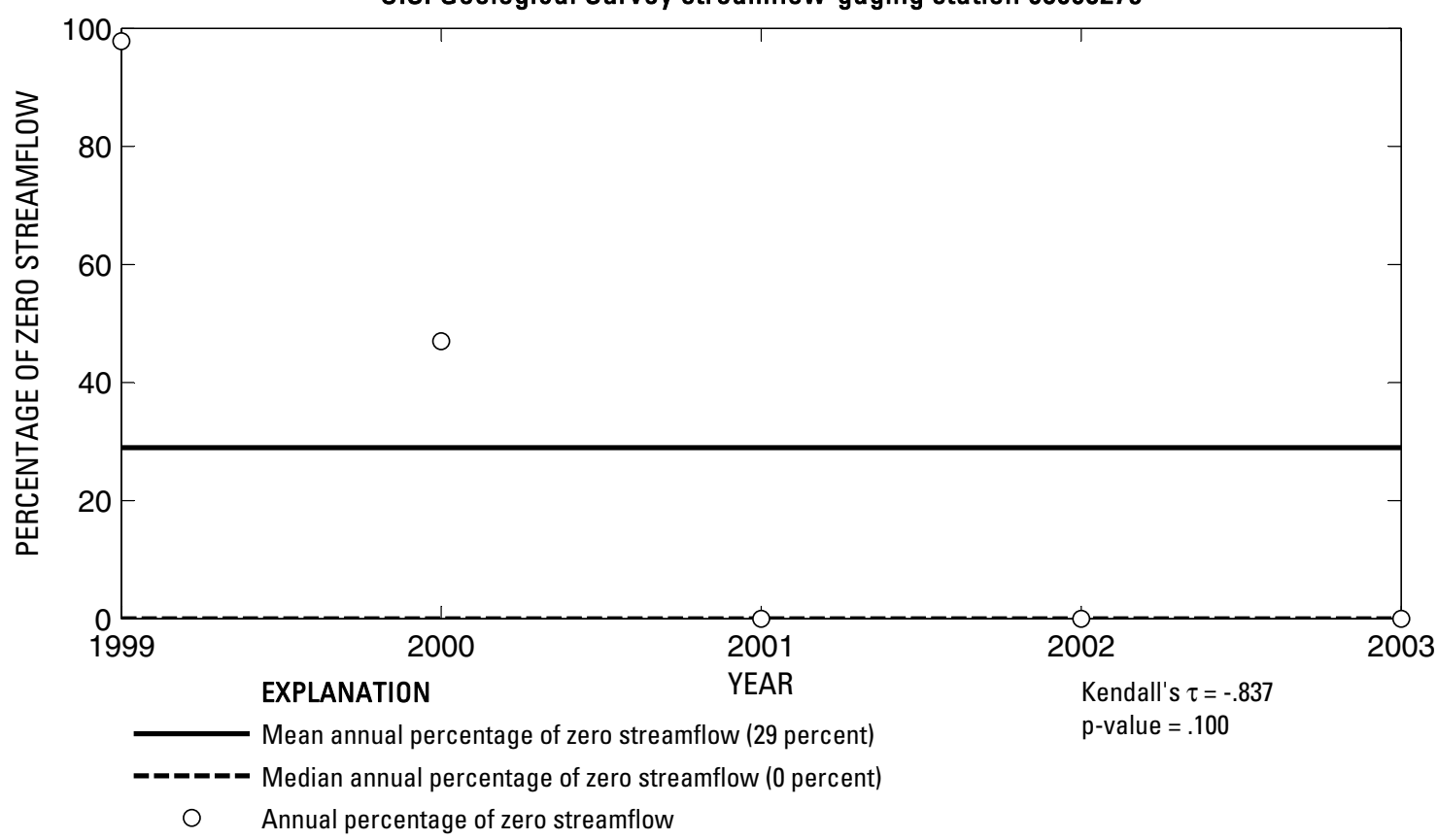

U.S. Geological Survey streamflow-gaging station 08068275

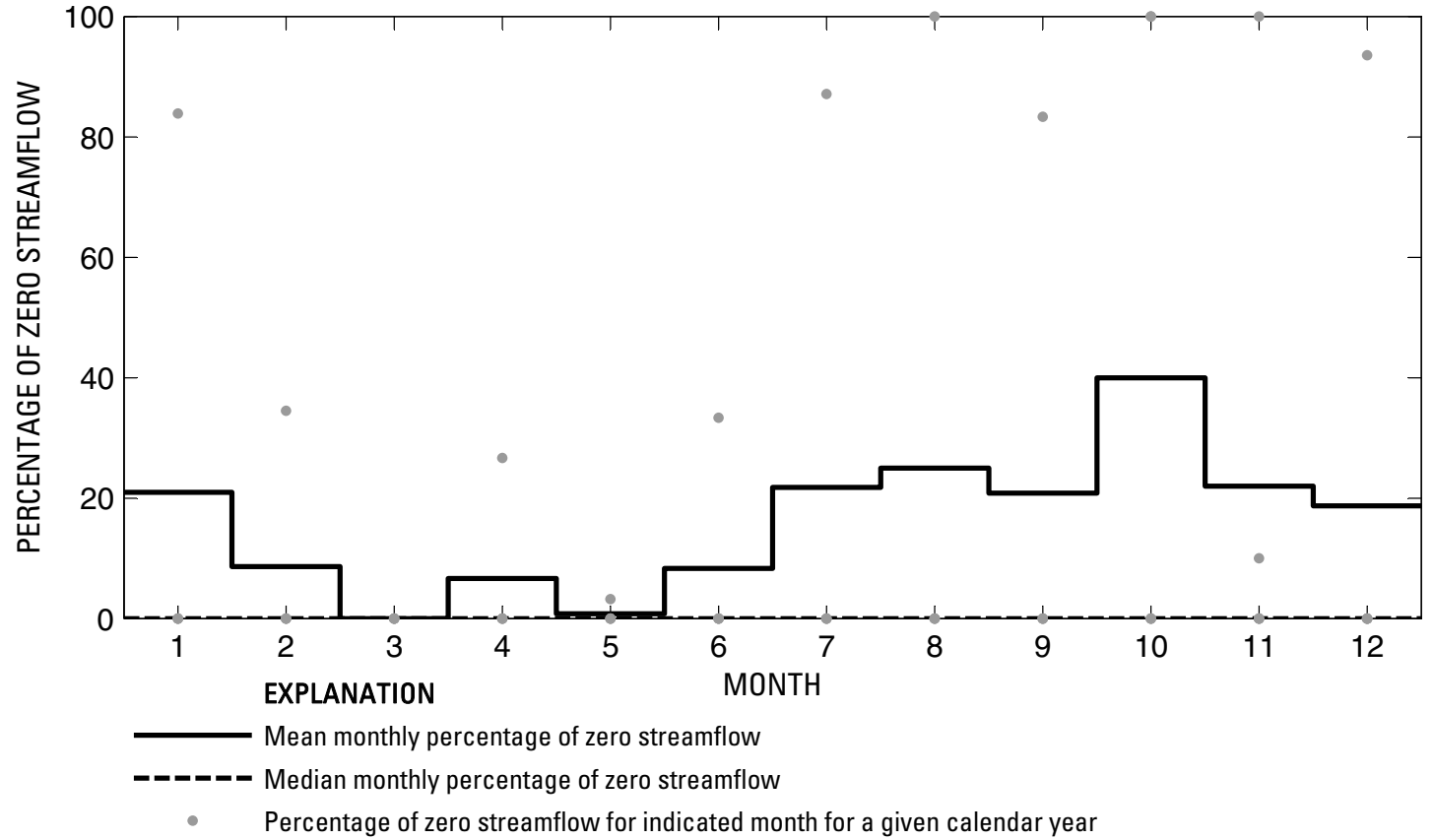

Figure 261. Analysis of percentage of zero daily mean streamflow for U.S. Geological Survey streamflow-gaging station 08068275 Spring Creek near Tomball, Texas. 
U.S. Geological Survey streamflow-gaging station 08068325

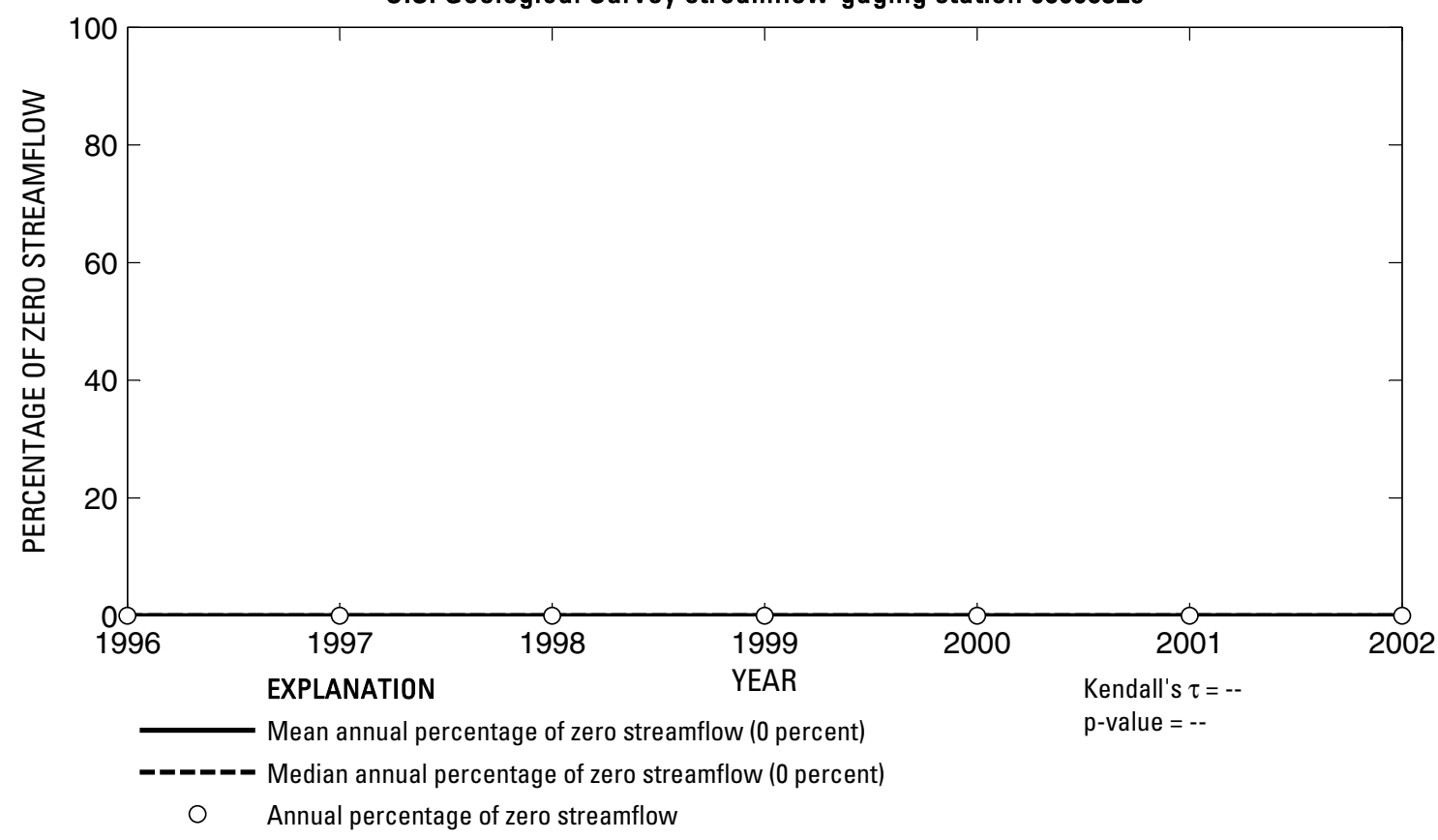

U.S. Geological Survey streamflow-gaging station 08068325

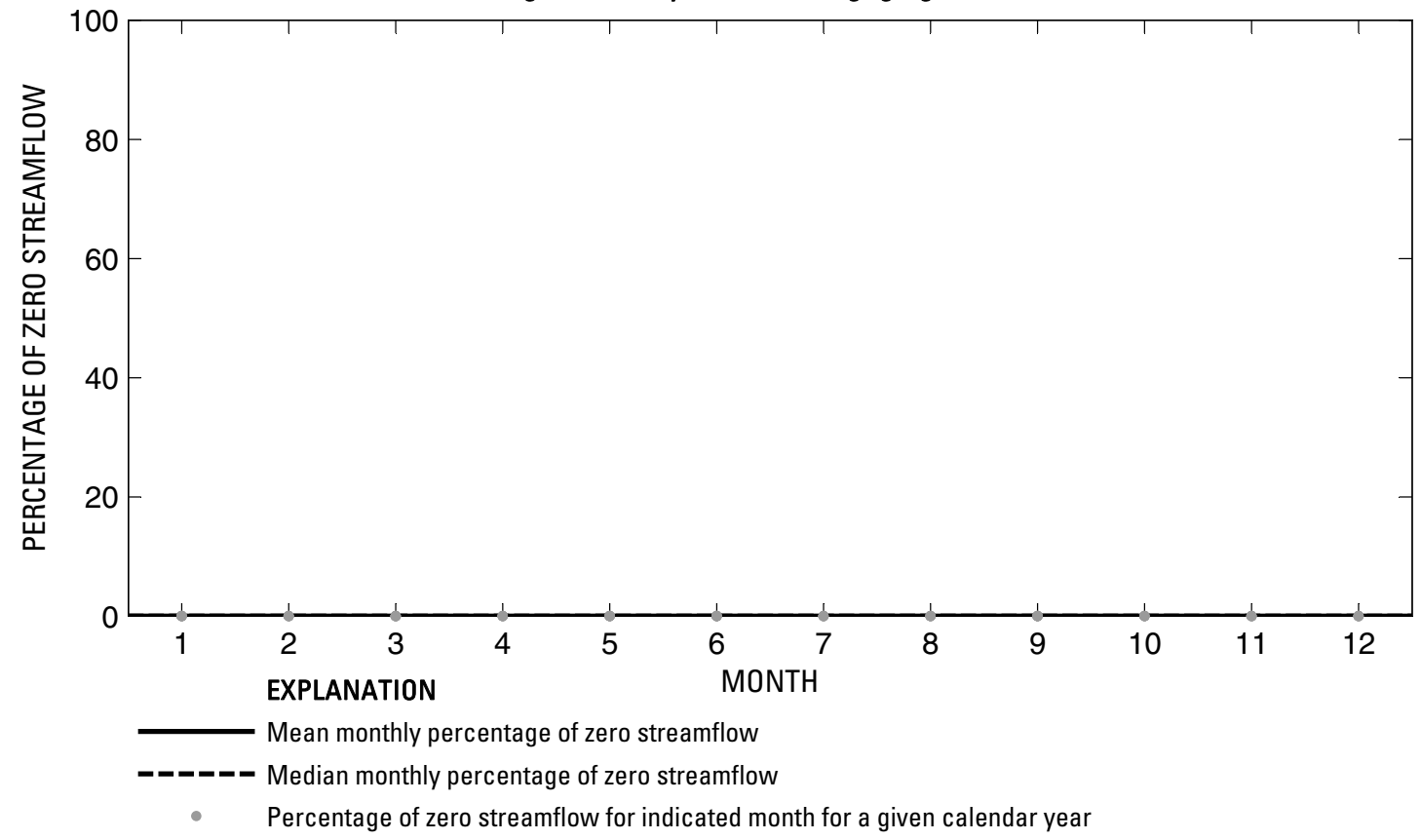

Figure 262. Analysis of percentage of zero daily mean streamflow for U.S. Geological Survey streamflow-gaging station 08068325 Willow Creek near Tomball, Texas. 


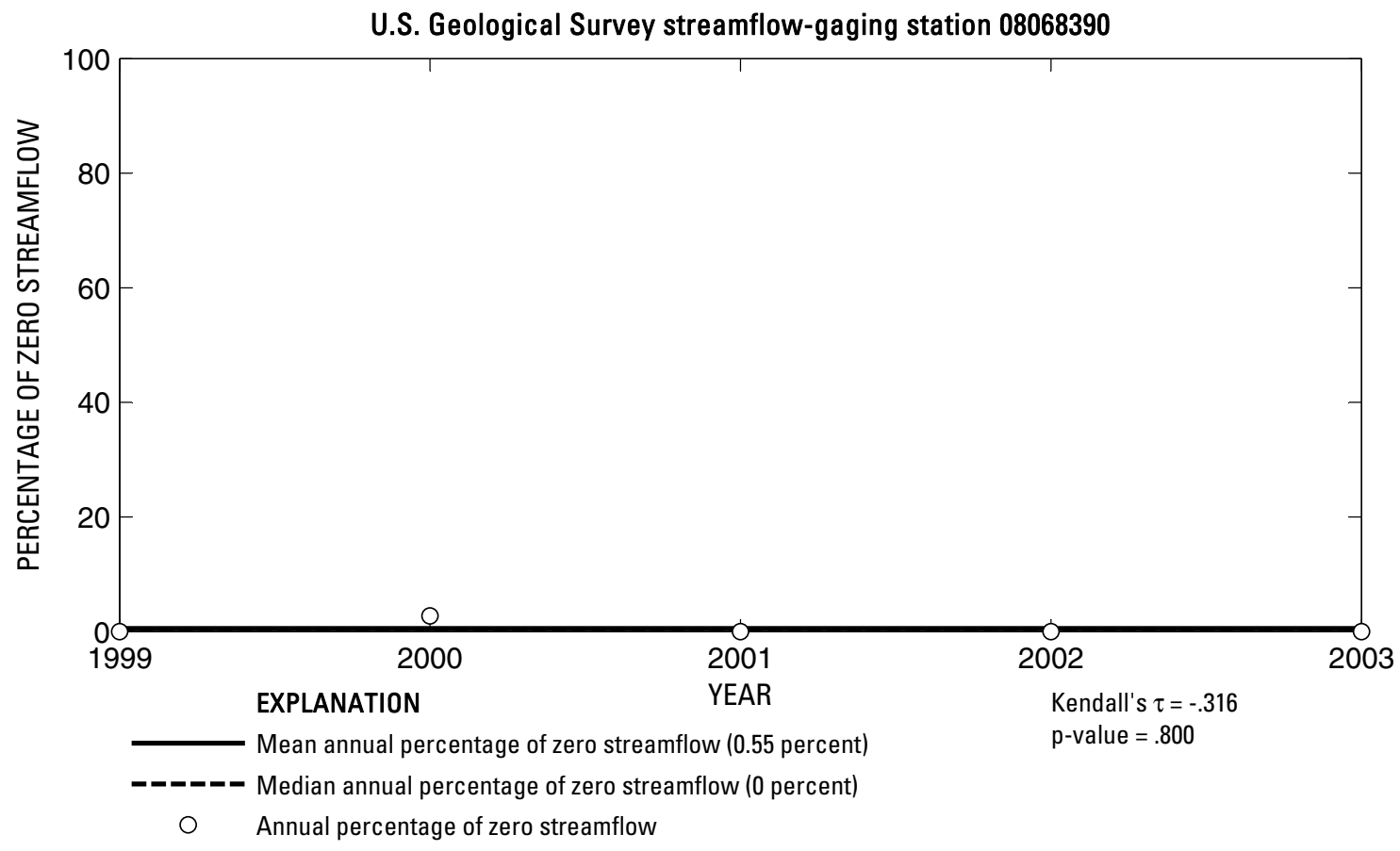

U.S. Geological Survey streamflow-gaging station 08068390

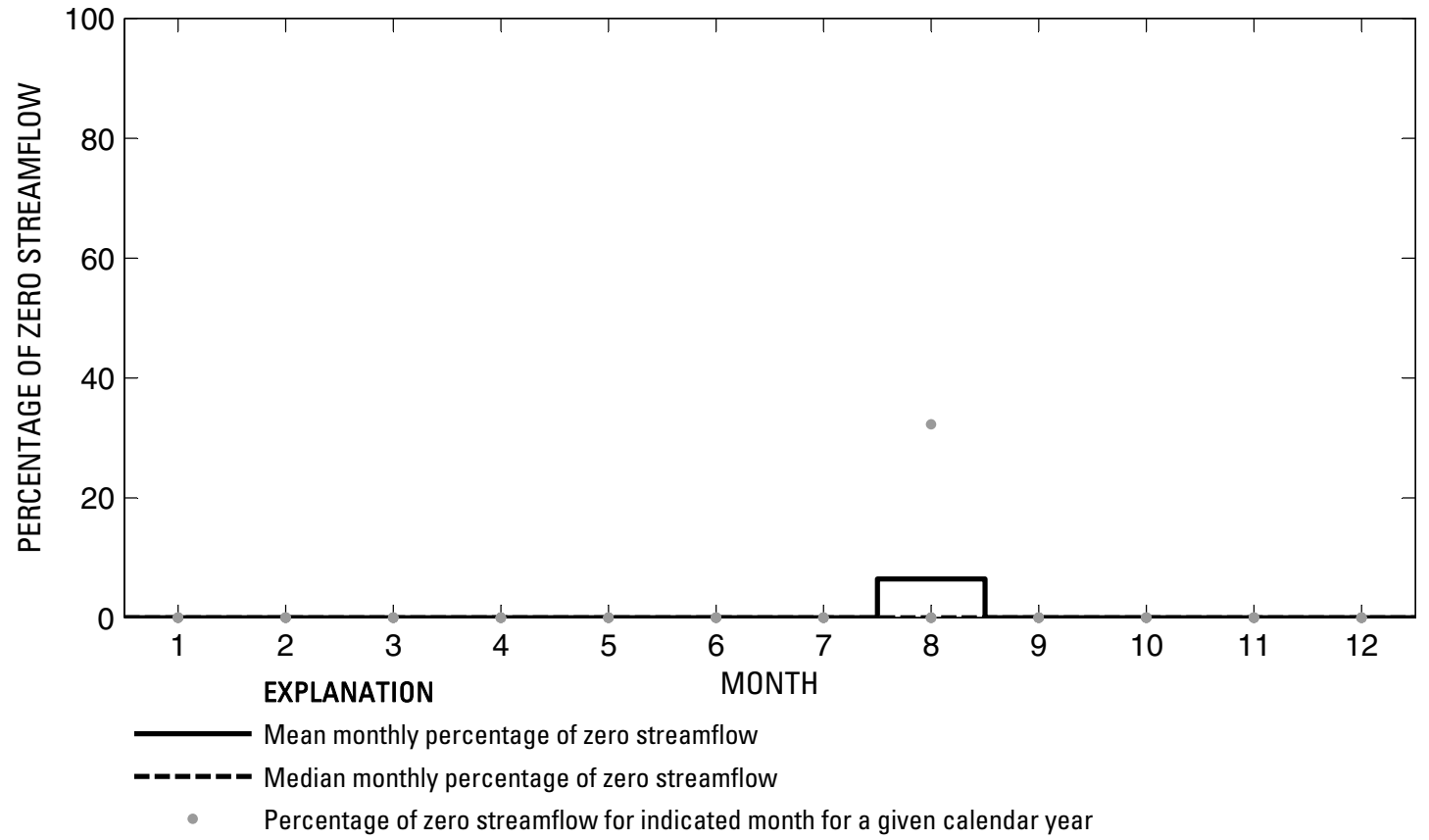

Figure 263. Analysis of percentage of zero daily mean streamflow for U.S. Geological Survey streamflow-gaging station 08068390 Bear Branch at Research Boulevard, The Woodlands, Texas. 
U.S. Geological Survey streamflow-gaging station 08068400

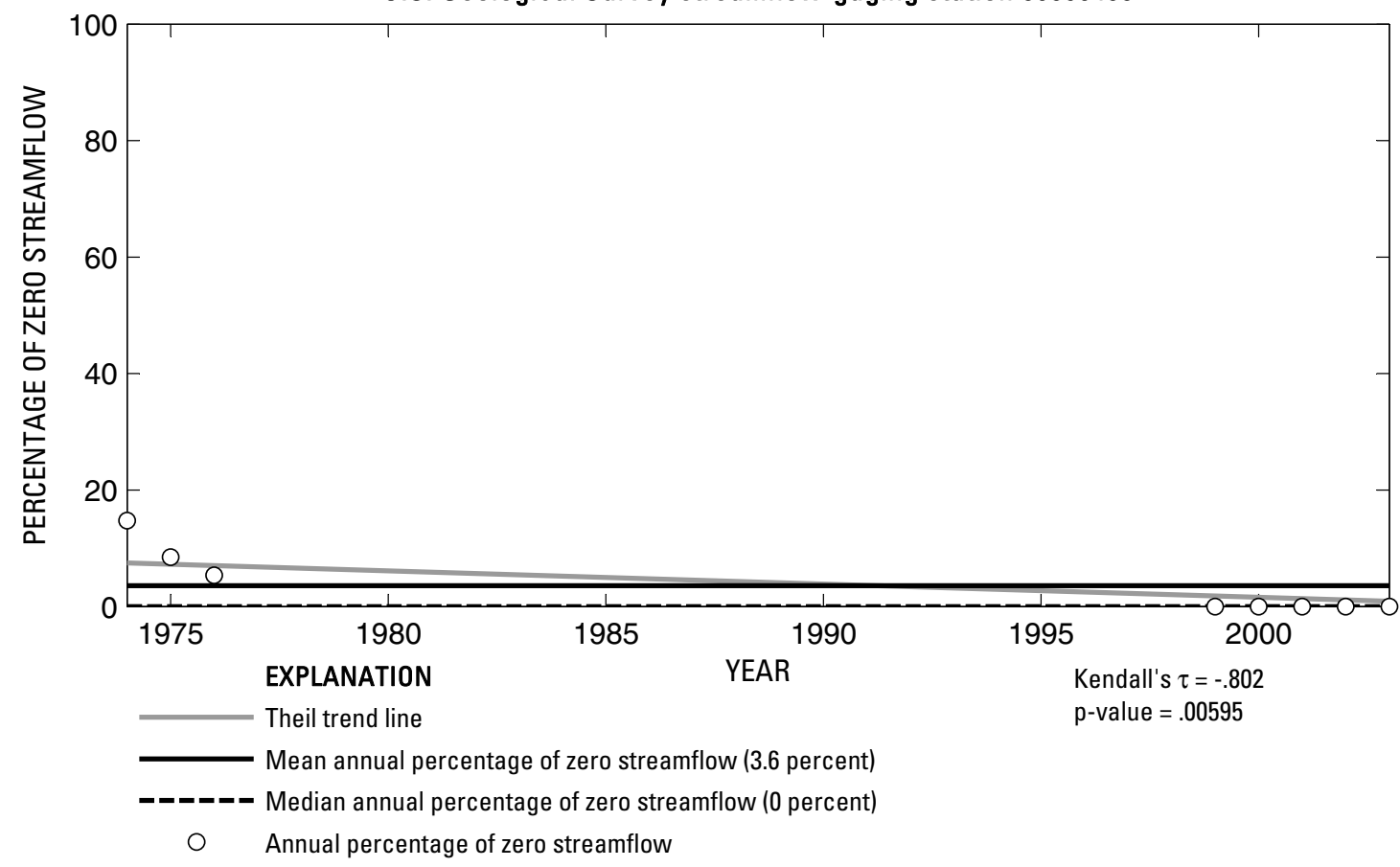

U.S. Geological Survey streamflow-gaging station 08068400

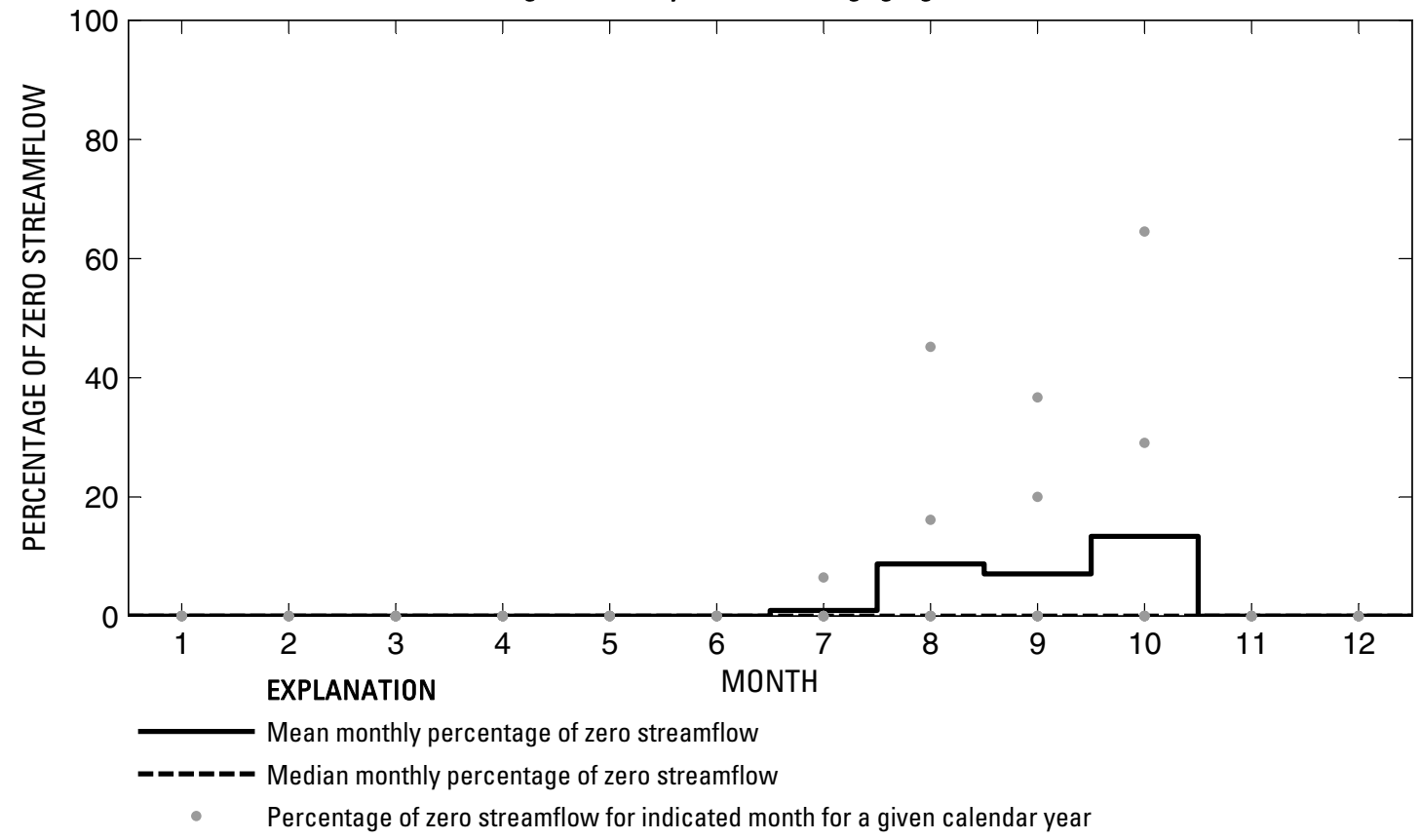

Figure 264. Analysis of percentage of zero daily mean streamflow for U.S. Geological Survey streamflow-gaging station 08068400 Panther Branch at Gosling Road, The Woodlands, Texas. 
U.S. Geological Survey streamflow-gaging station 08068450

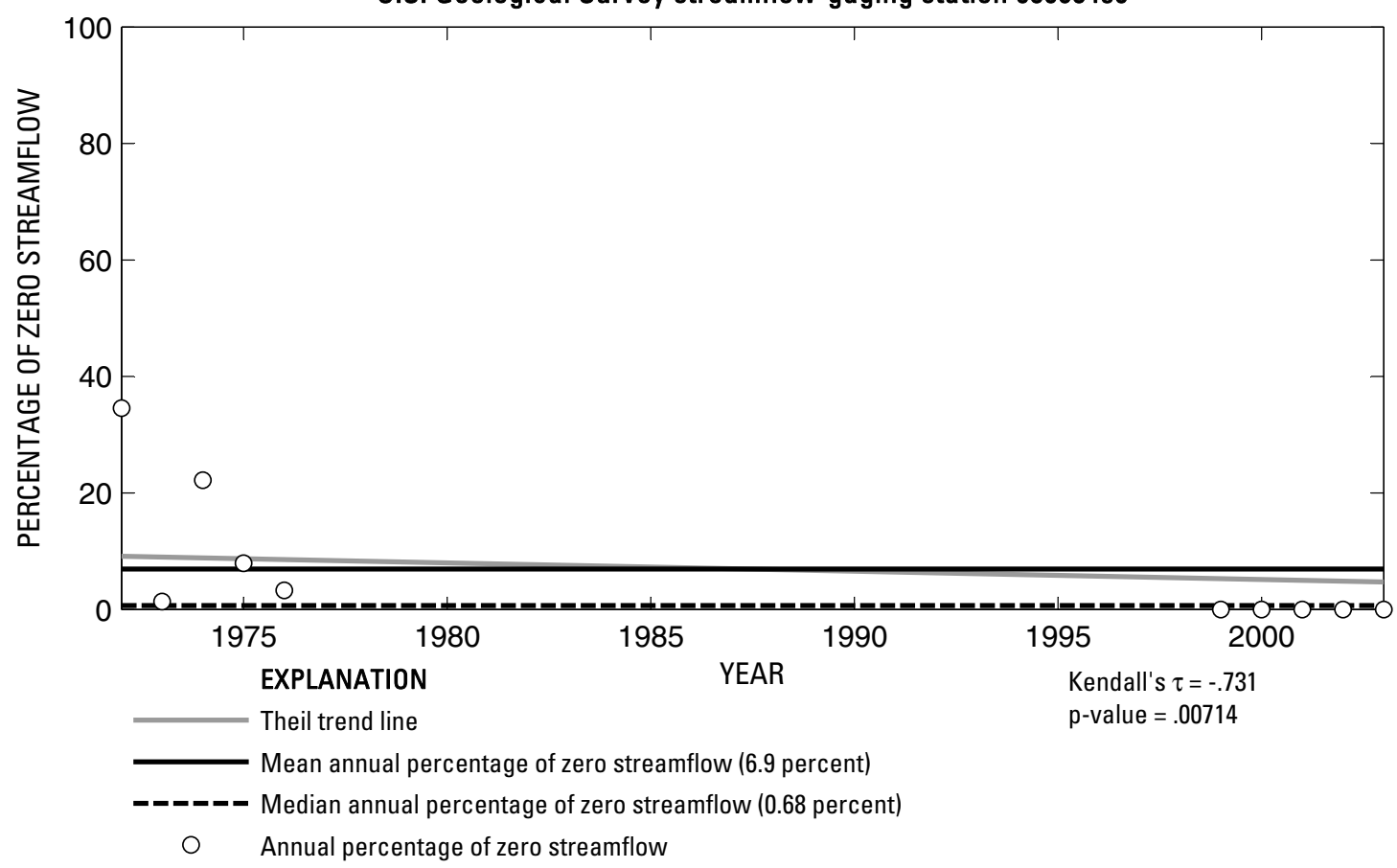

U.S. Geological Survey streamflow-gaging station 08068450

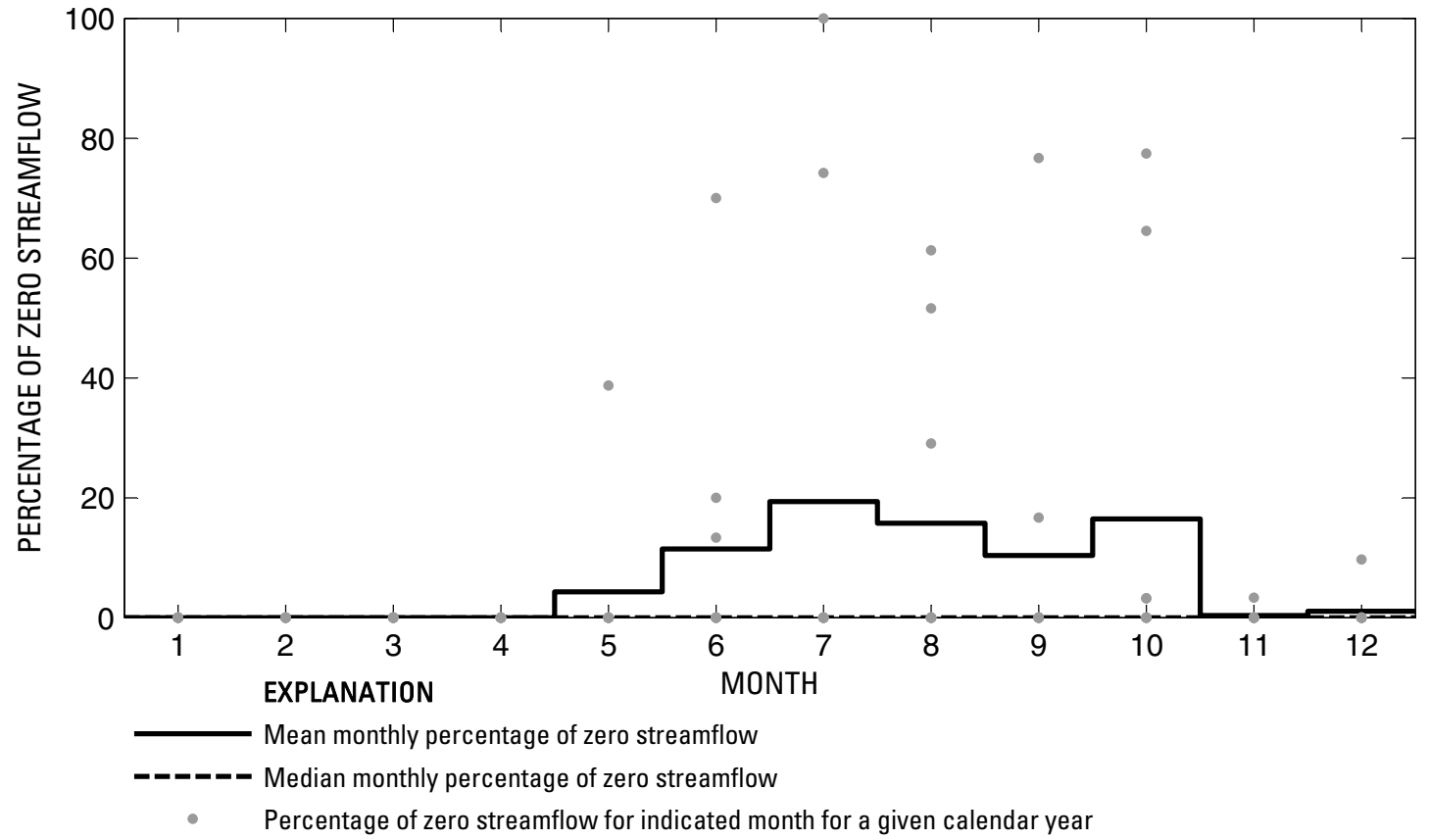

Figure 265. Analysis of percentage of zero daily mean streamflow for U.S. Geological Survey streamflow-gaging station 08068450 Panther Branch near Spring, Texas. 
U.S. Geological Survey streamflow-gaging station 08068500

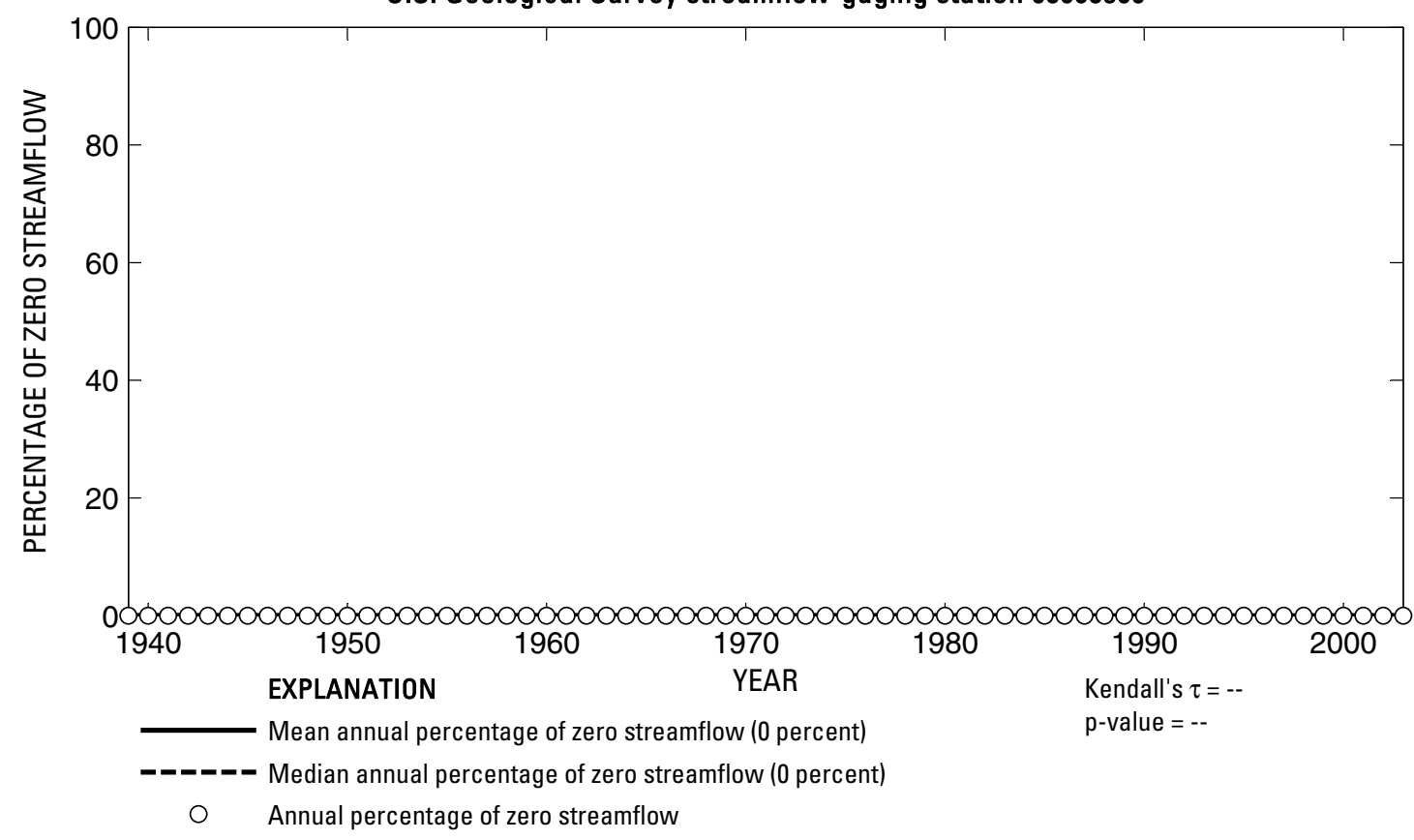

U.S. Geological Survey streamflow-gaging station 08068500

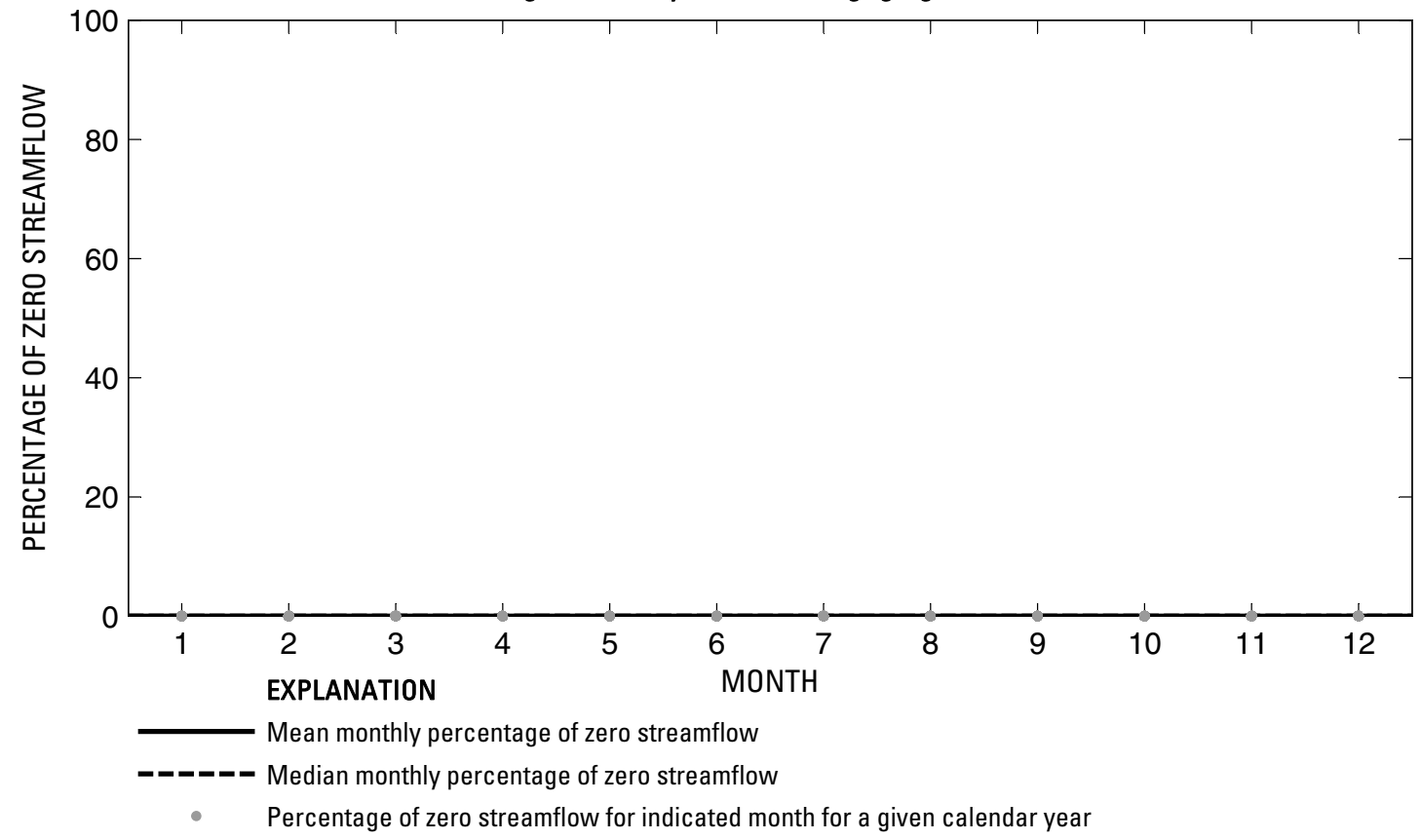

Figure 266. Analysis of percentage of zero daily mean streamflow for U.S. Geological Survey streamflow-gaging station 08068500 Spring Creek near Spring, Texas. 
U.S. Geological Survey streamflow-gaging station 08068520

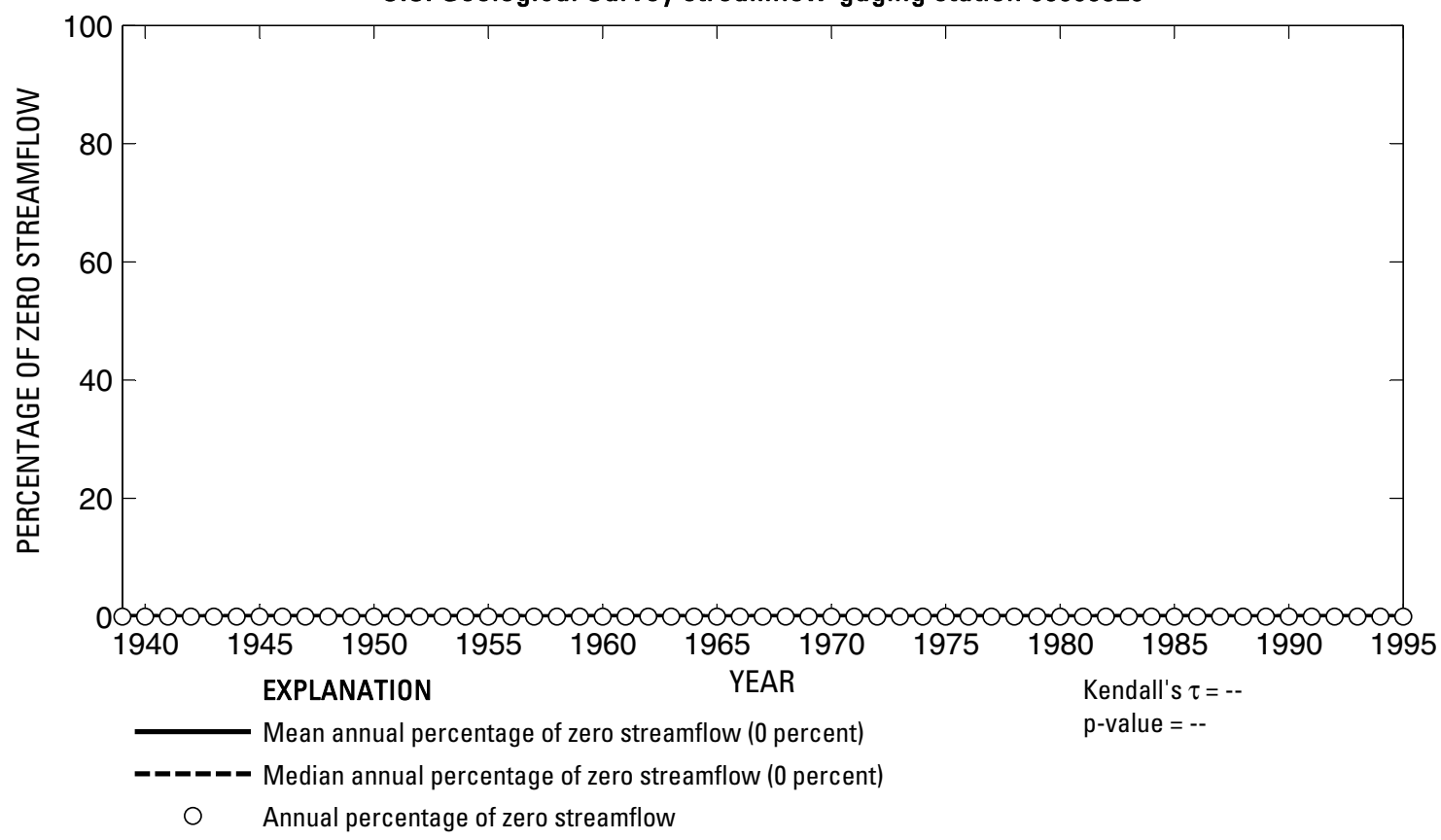

U.S. Geological Survey streamflow-gaging station 08068520

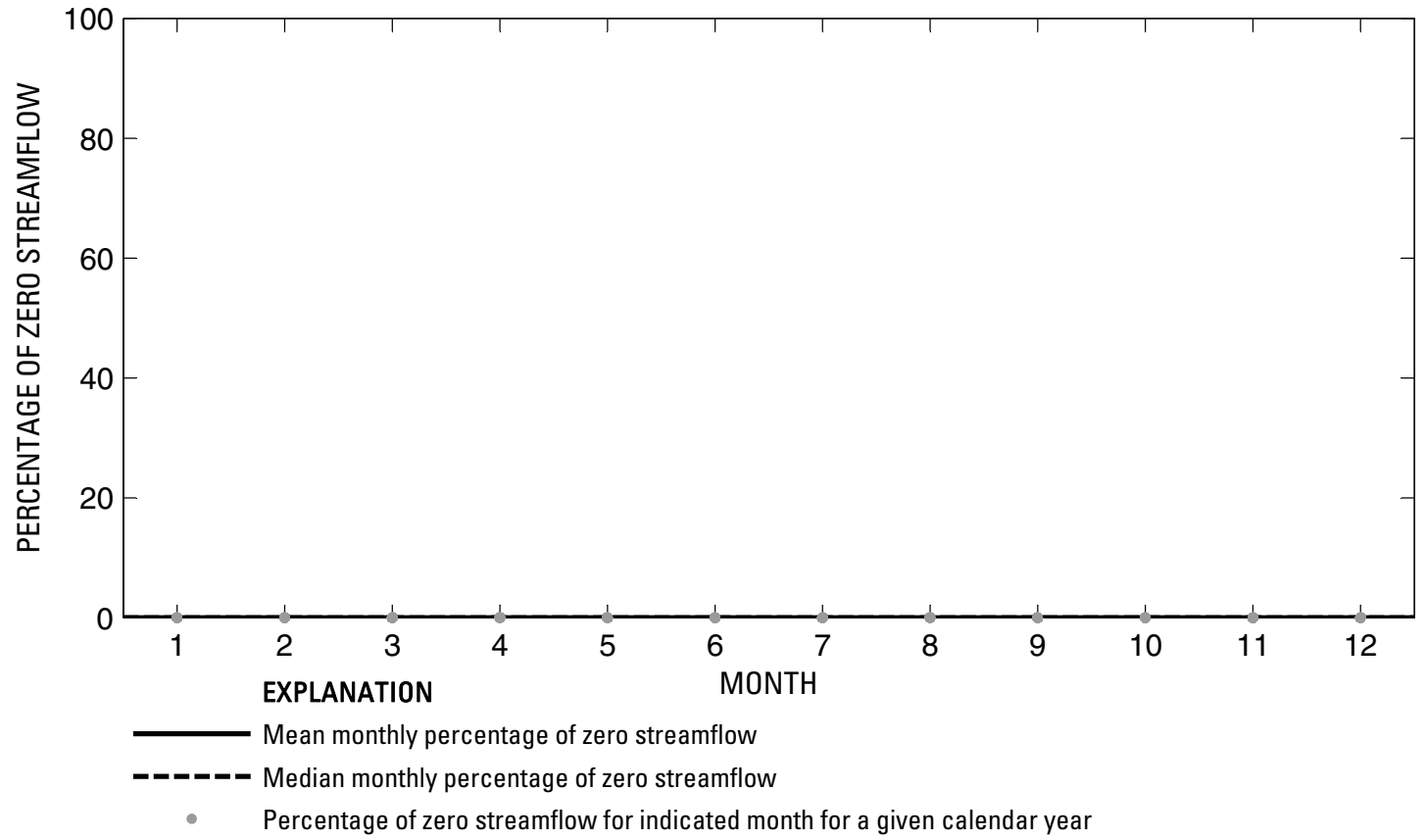

Figure 267. Analysis of percentage of zero daily mean streamflow for U.S. Geological Survey streamflow-gaging station 08068520 Spring Creek at Spring, Texas. 
U.S. Geological Survey streamflow-gaging station 08068720

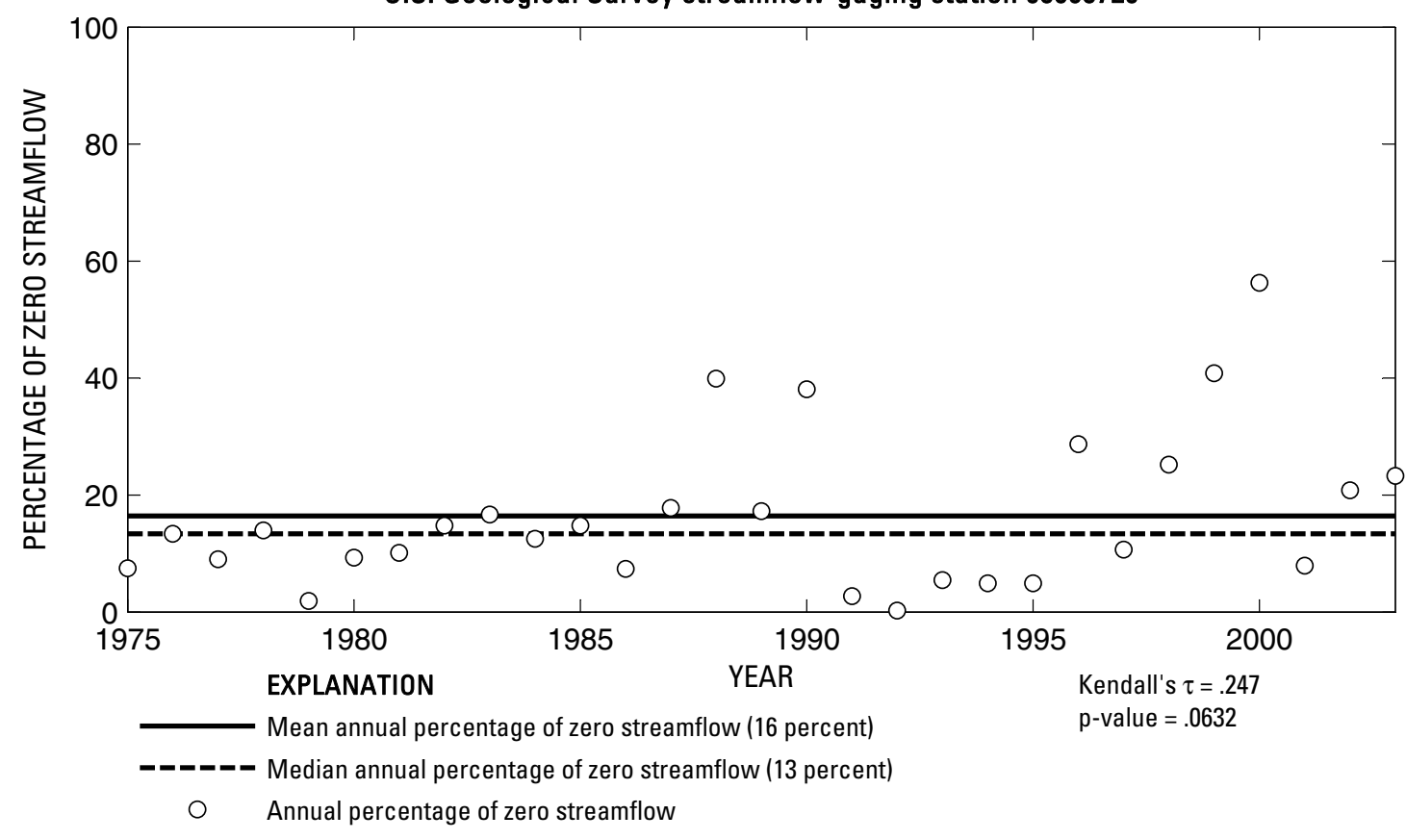

U.S. Geological Survey streamflow-gaging station 08068720

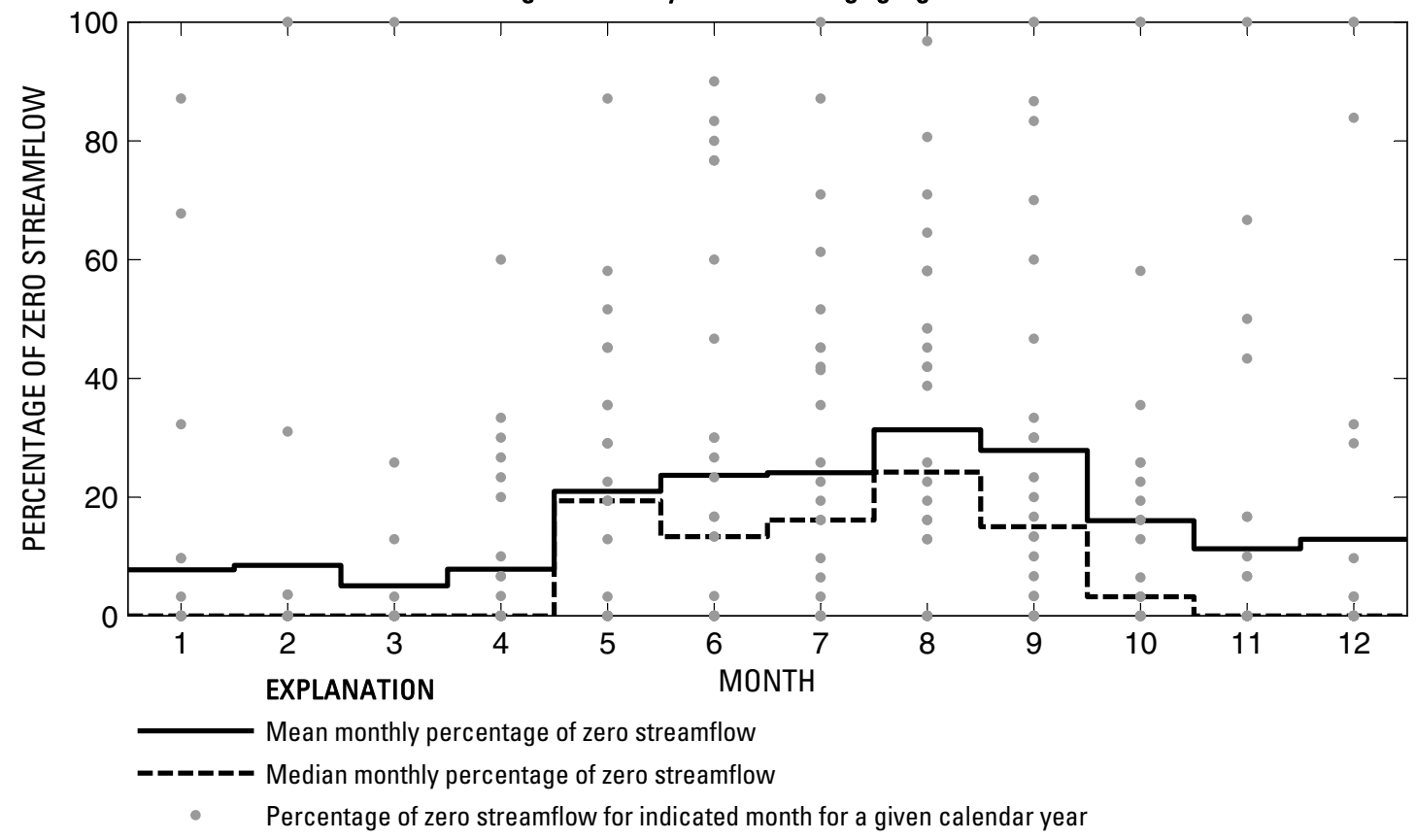

Figure 268. Analysis of percentage of zero daily mean streamflow for U.S. Geological Survey streamflow-gaging station 08068720 Cypress Creek at Katy-Hockley Road near Hockley, Texas.

Index of Station Numbers 719 


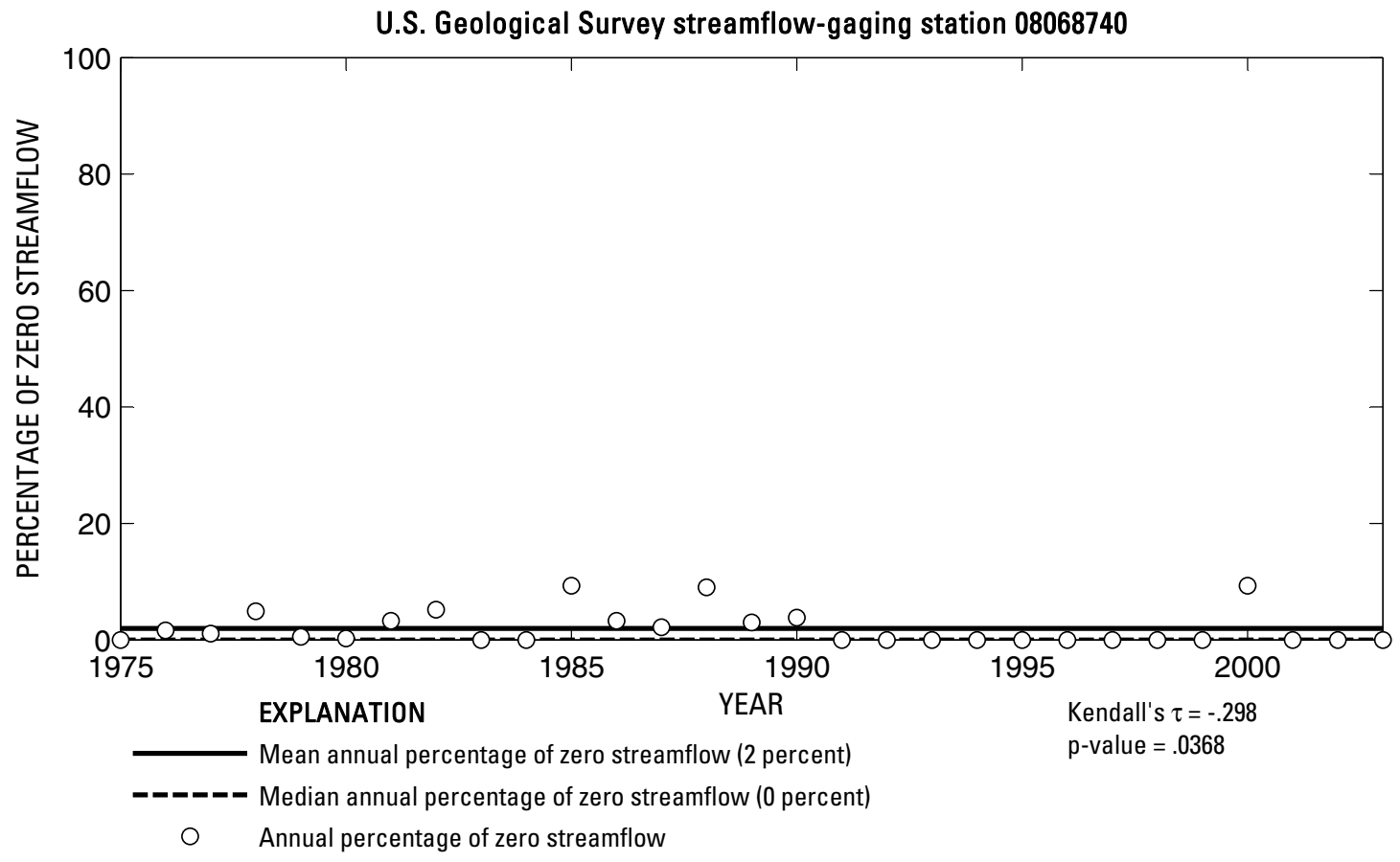

U.S. Geological Survey streamflow-gaging station 08068740

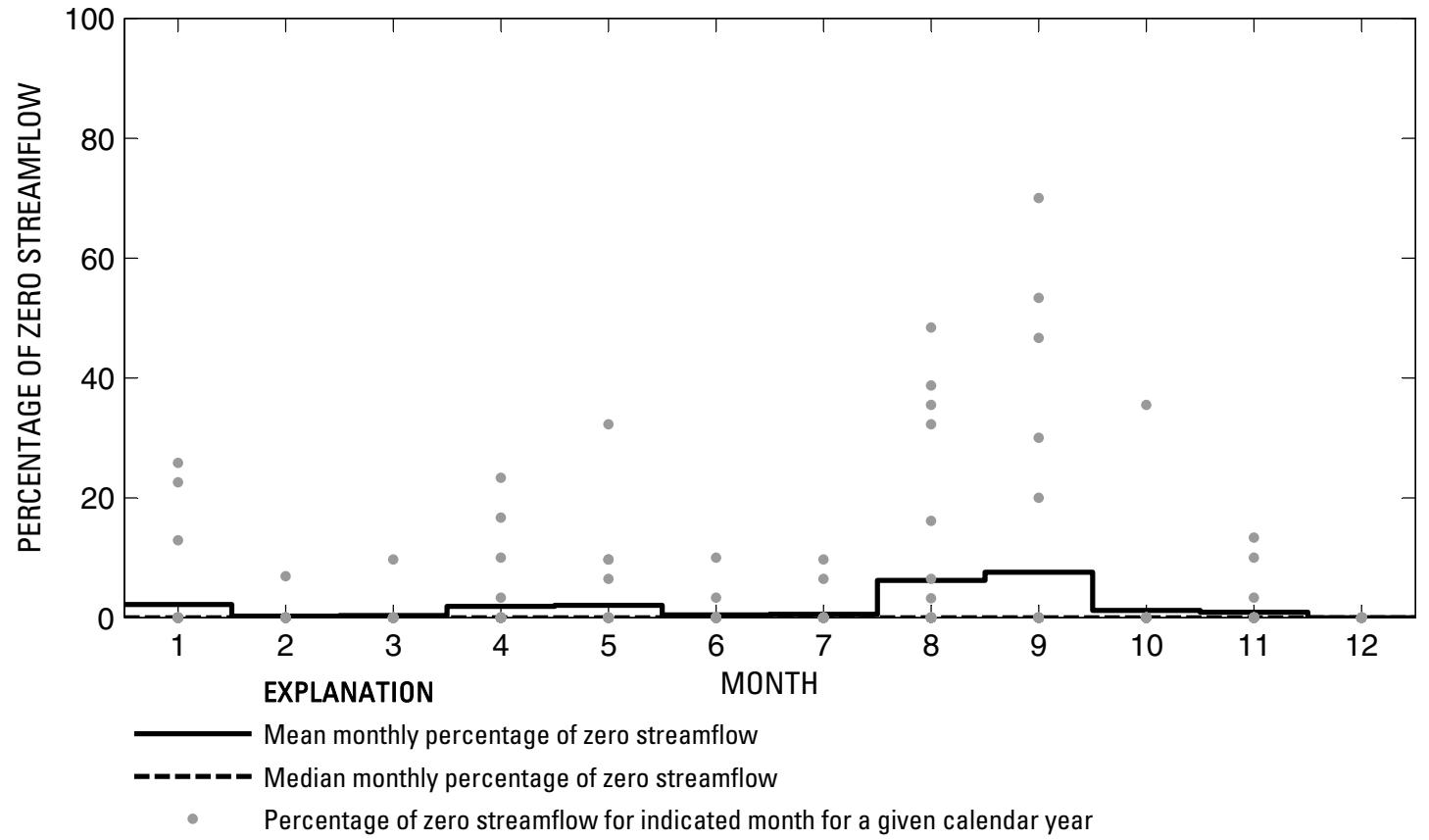

Figure 269. Analysis of percentage of zero daily mean streamflow for U.S. Geological Survey streamflow-gaging station 08068740 Cypress Creek at House-Hahl Road near Cypress, Texas. 
U.S. Geological Survey streamflow-gaging station 08068780

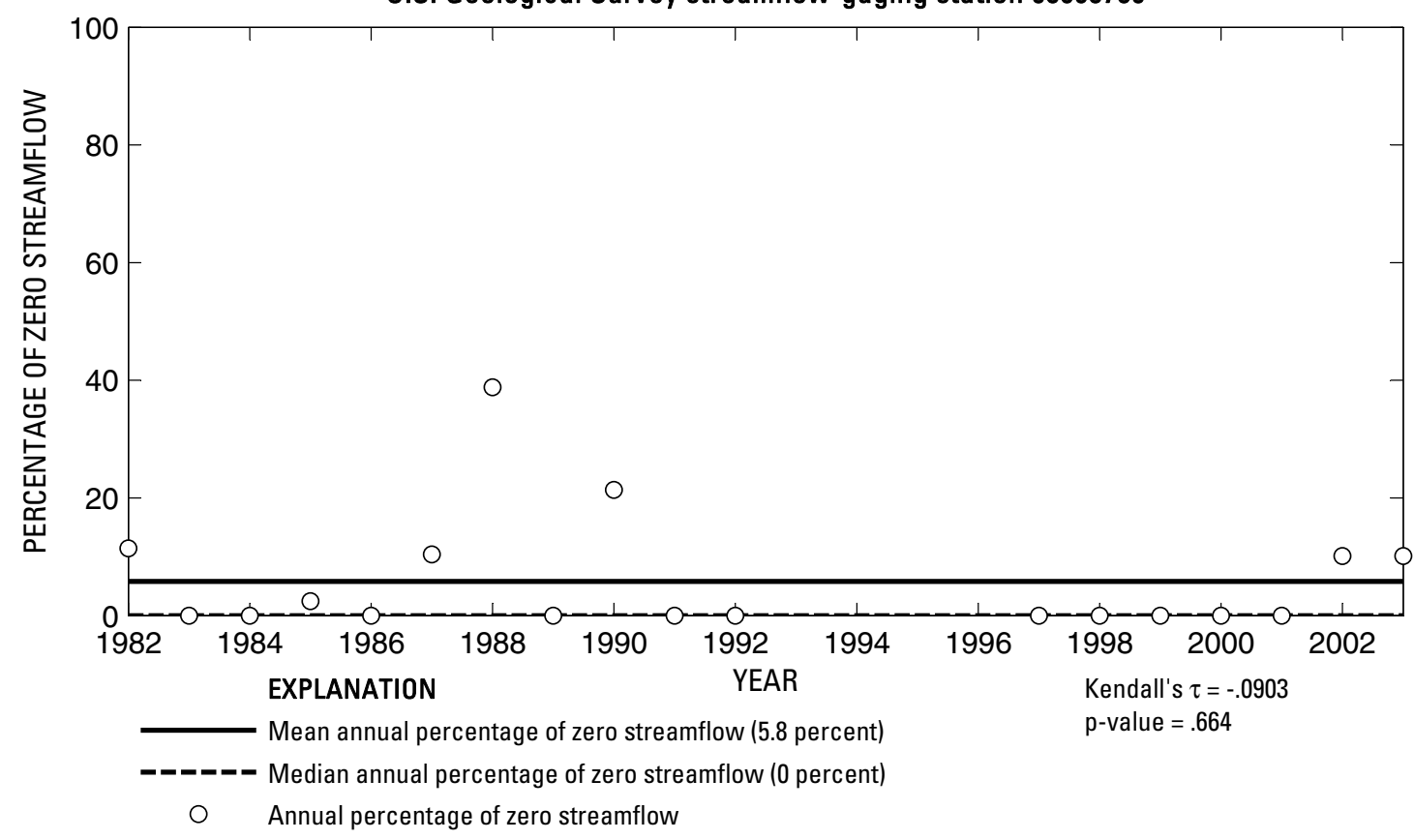

U.S. Geological Survey streamflow-gaging station 08068780

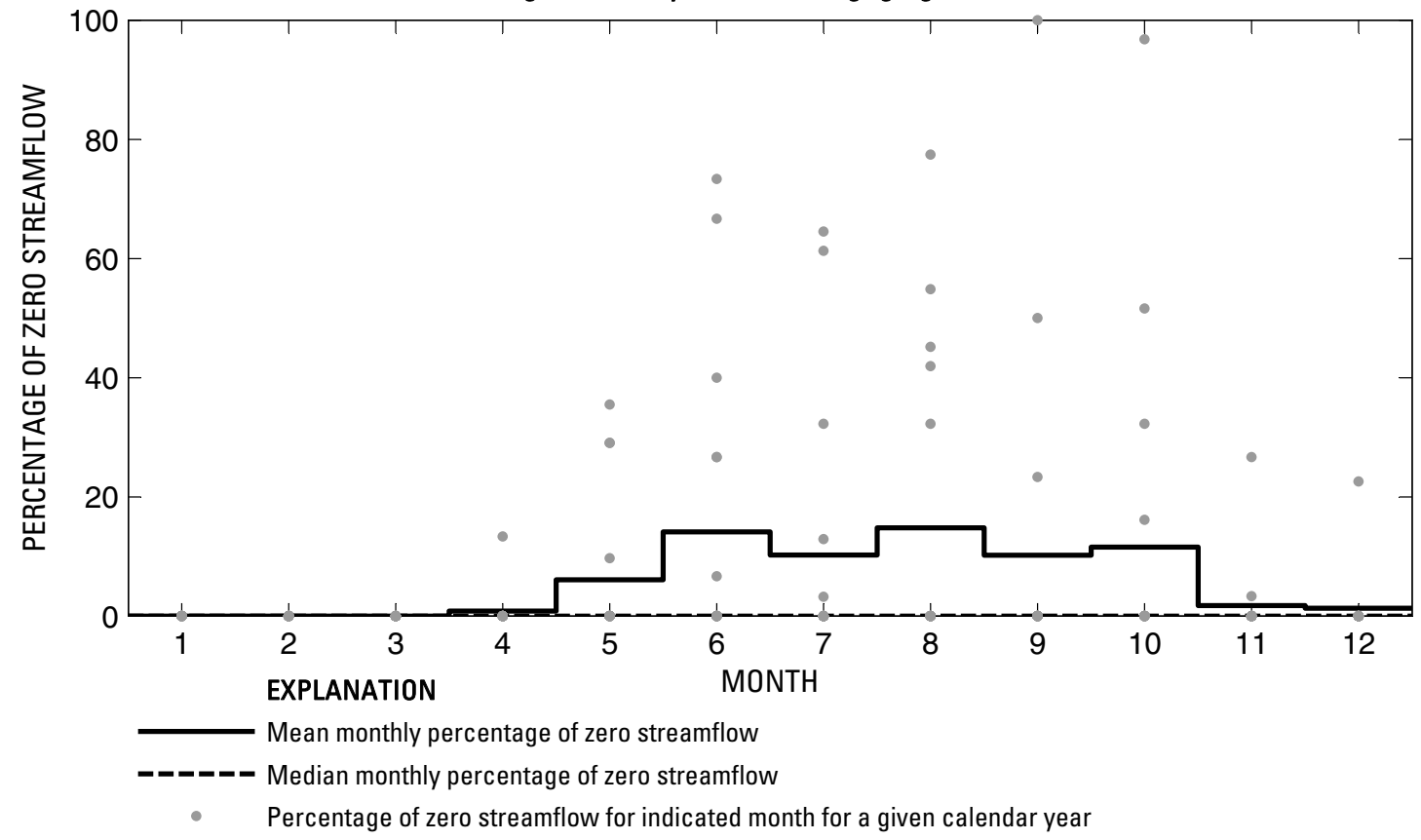

Figure 270. Analysis of percentage of zero daily mean streamflow for U.S. Geological Survey streamflow-gaging station 08068780 Little Cypress Creek near Cypress, Texas. 


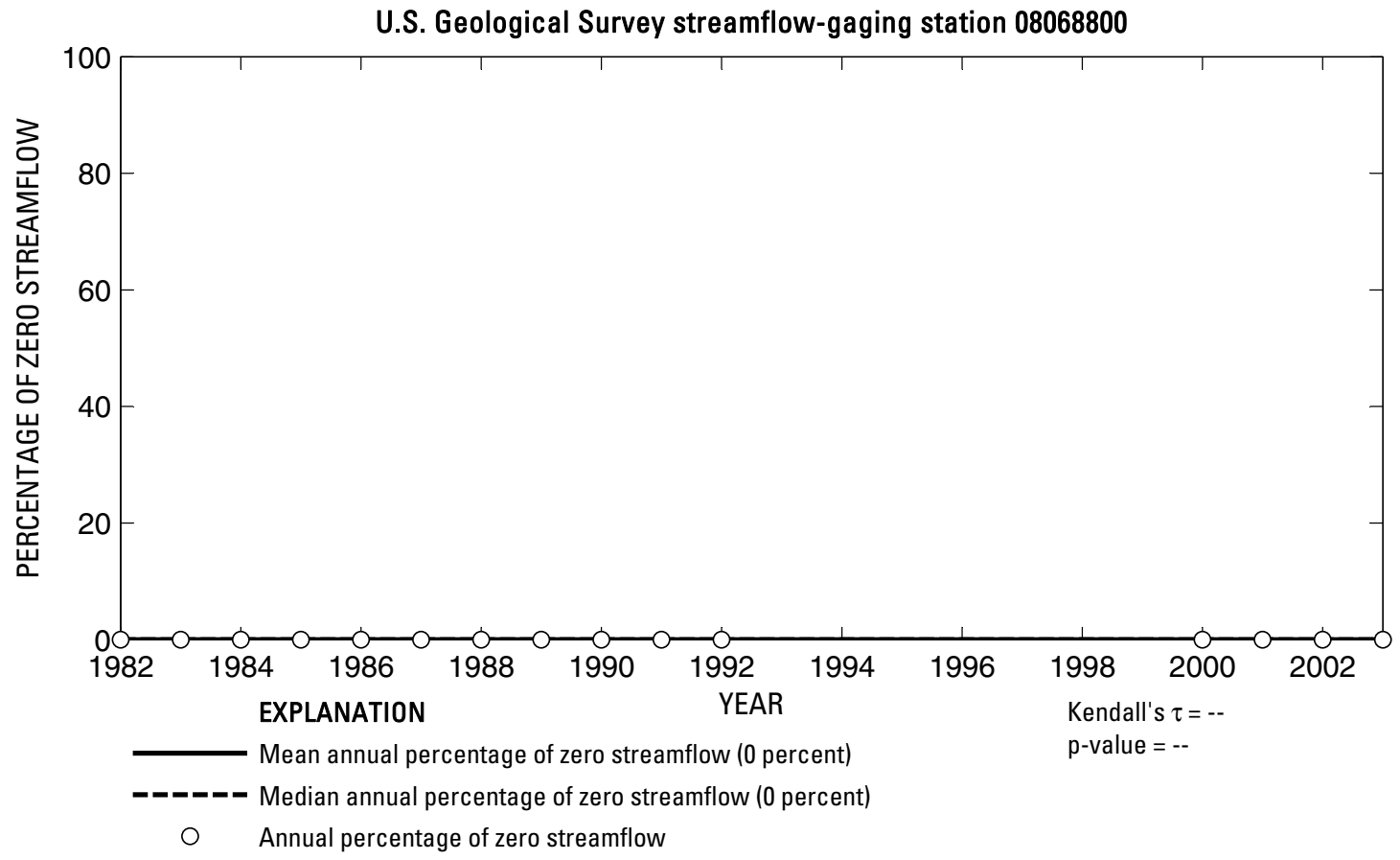

U.S. Geological Survey streamflow-gaging station 08068800

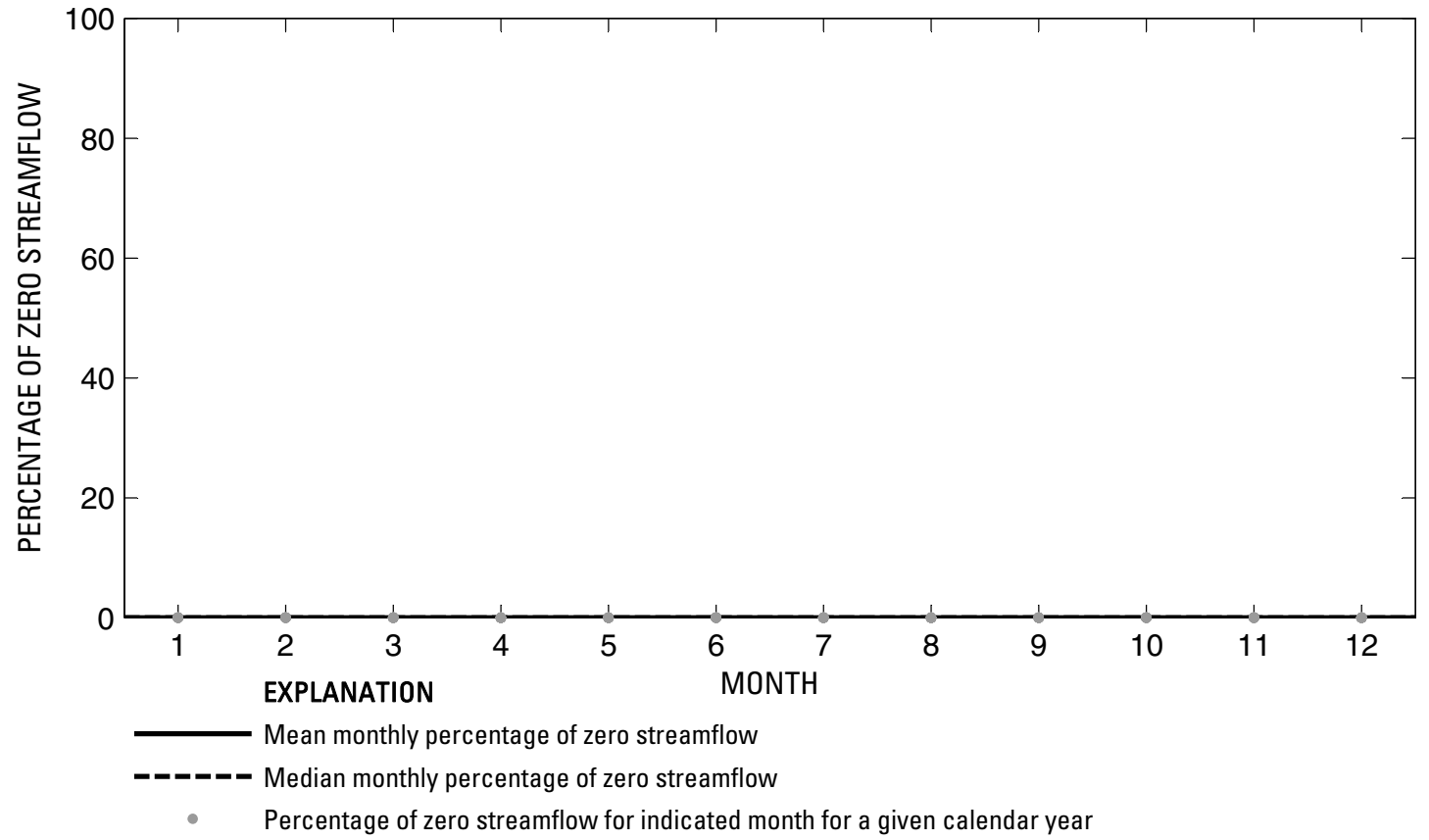

Figure 271. Analysis of percentage of zero daily mean streamflow for U.S. Geological Survey streamflow-gaging station 08068800 Cypress Creek at Grant Road near Cypress, Texas. 

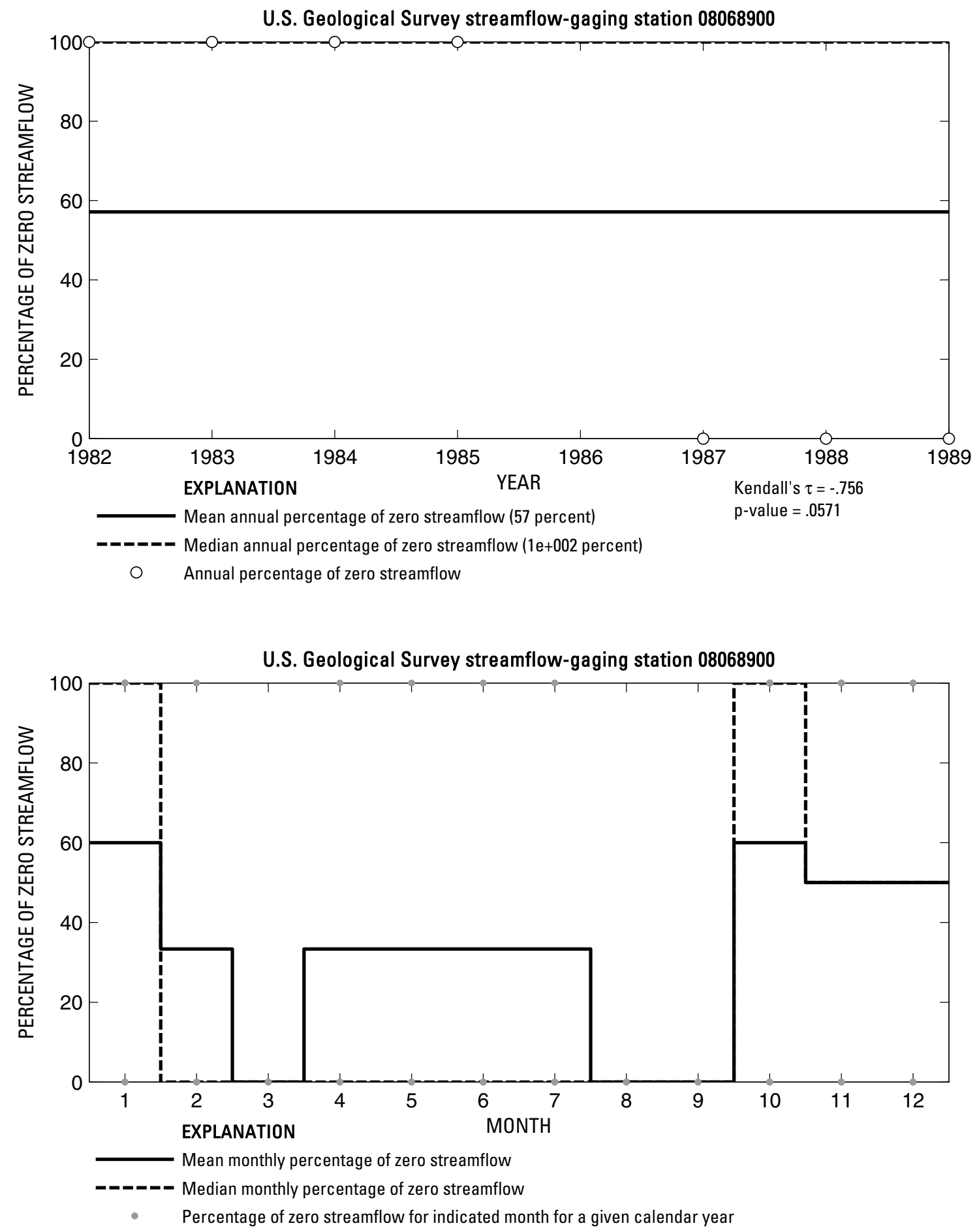

Figure 272. Analysis of percentage of zero daily mean streamflow for U.S. Geological Survey streamflow-gaging station 08068900 Cypress Creek at Stuebner-Airline Road near Westfield, Texas. 

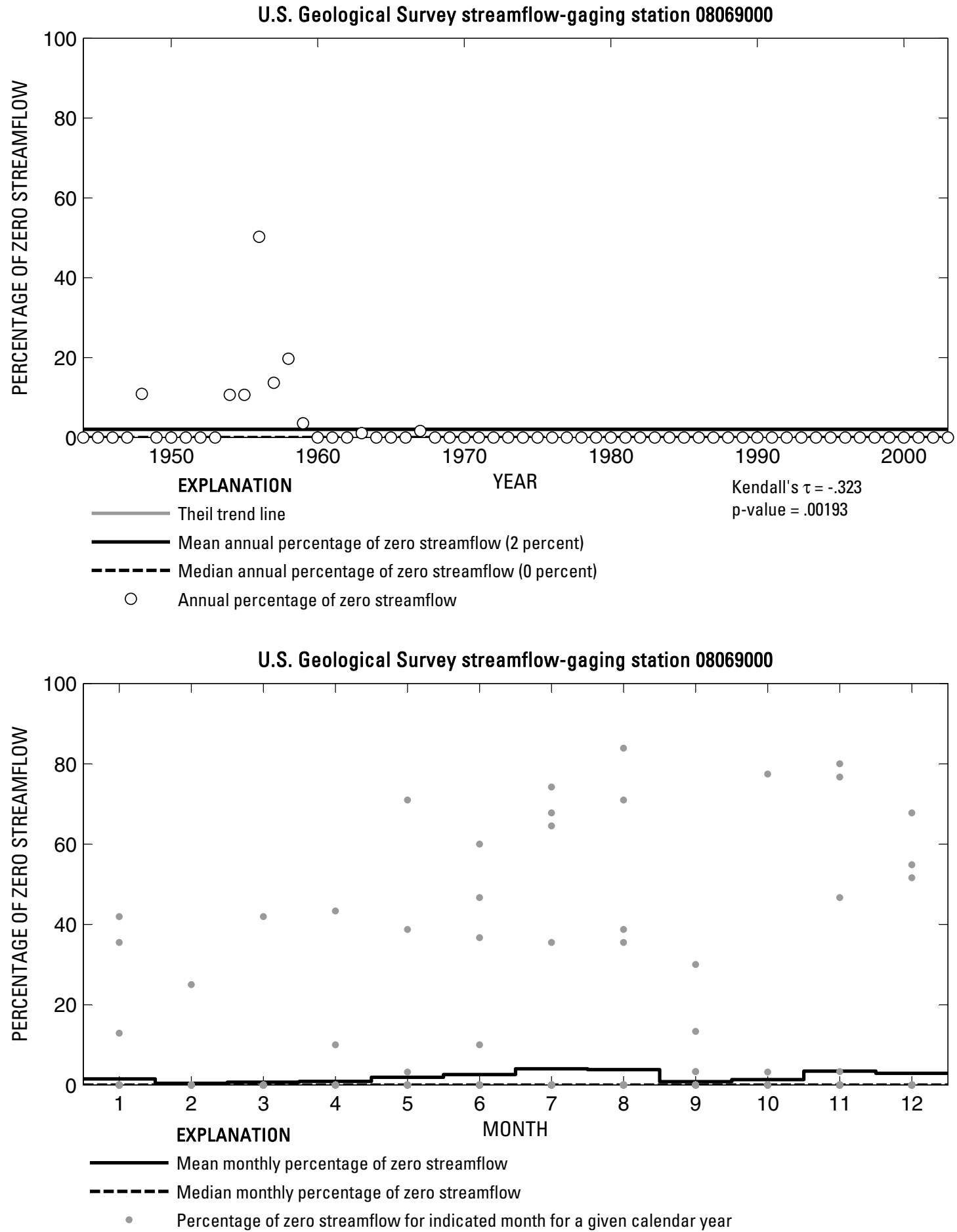

Figure 273. Analysis of percentage of zero daily mean streamflow for U.S. Geological Survey streamflow-gaging station 08069000 Cypress Creek near Westfield, Texas. 
U.S. Geological Survey streamflow-gaging station 08069500

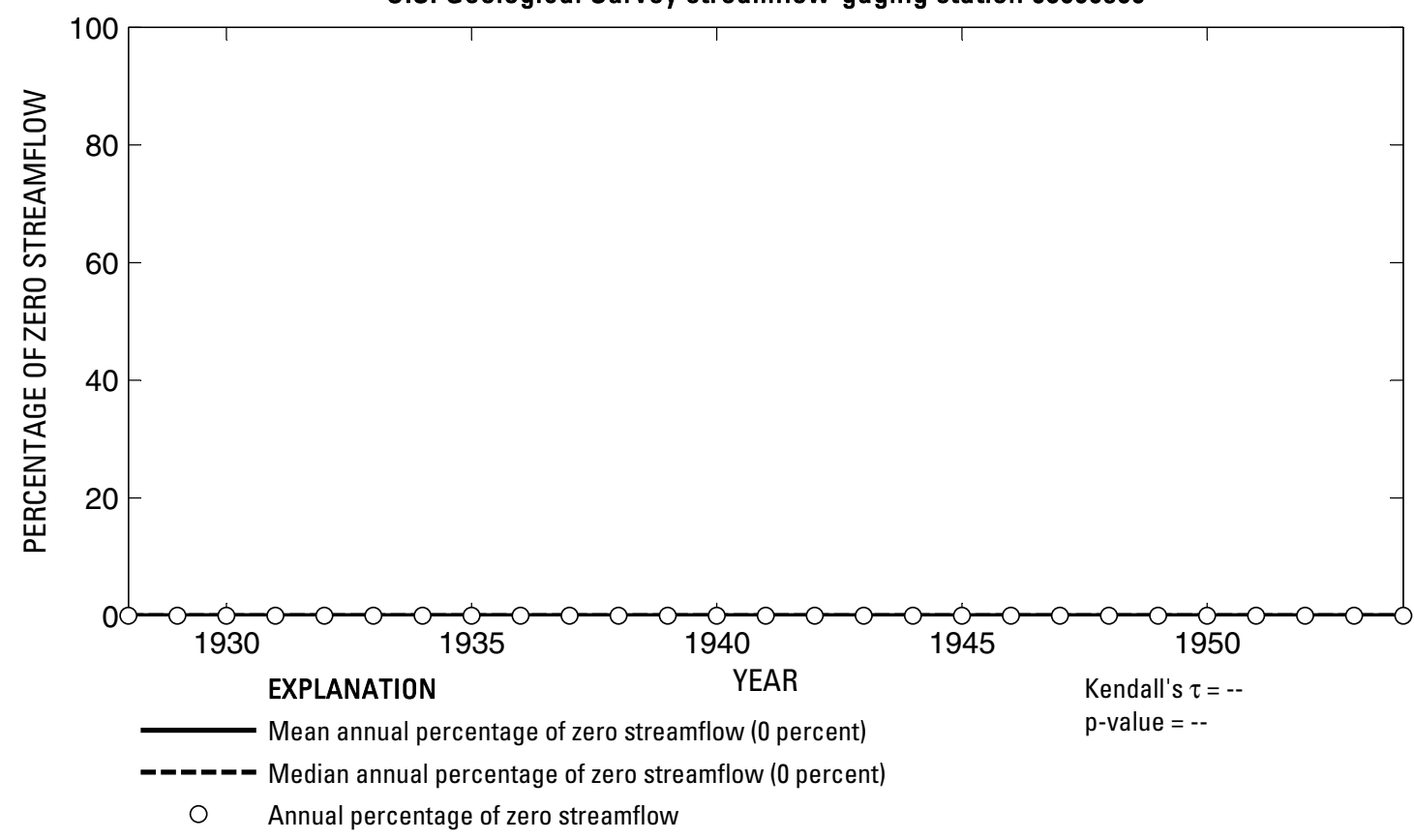

U.S. Geological Survey streamflow-gaging station 08069500

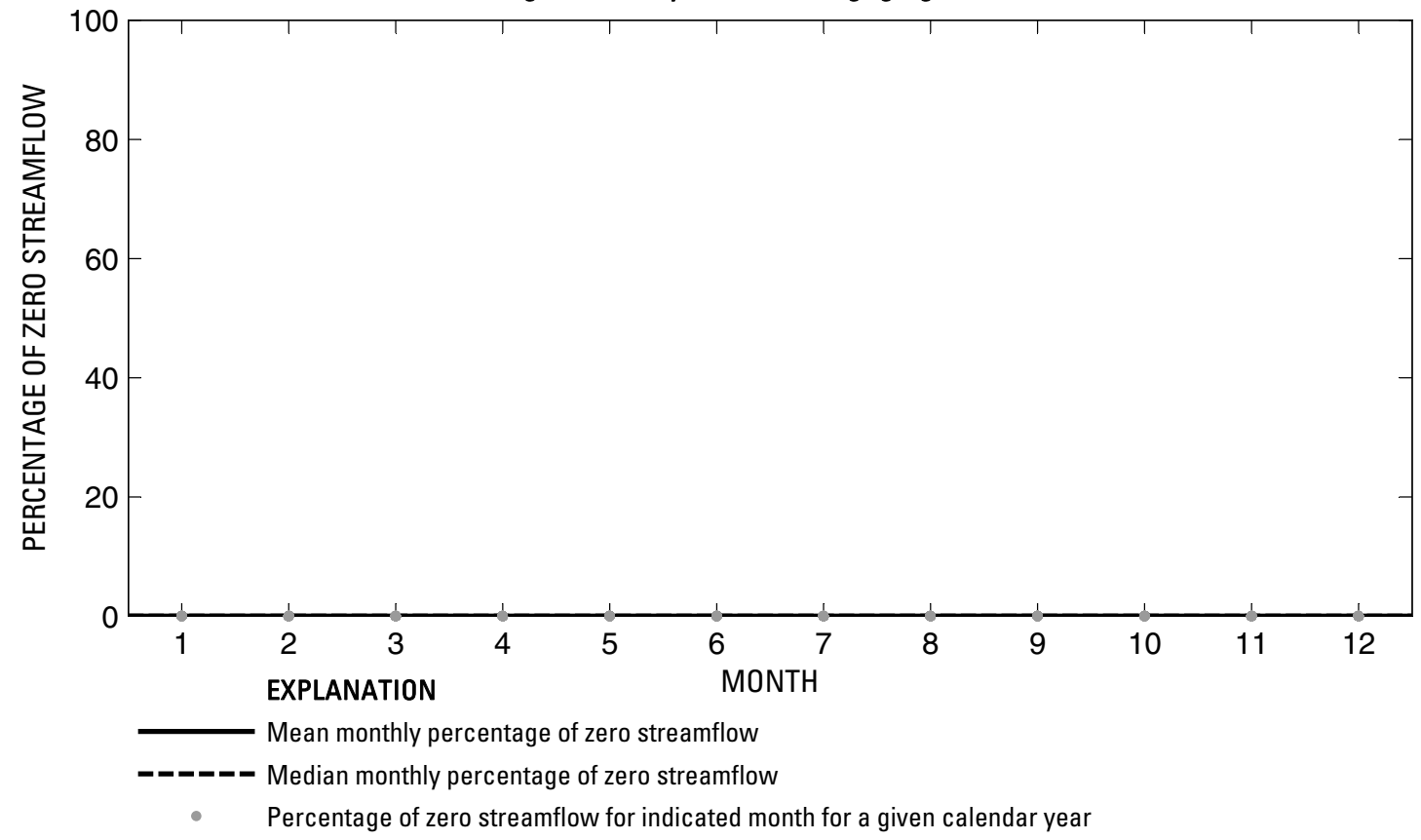

Figure 274. Analysis of percentage of zero daily mean streamflow for U.S. Geological Survey streamflow-gaging station 08069500 West Fork San Jacinto River near Humble, Texas. 
U.S. Geological Survey streamflow-gaging station 08070000

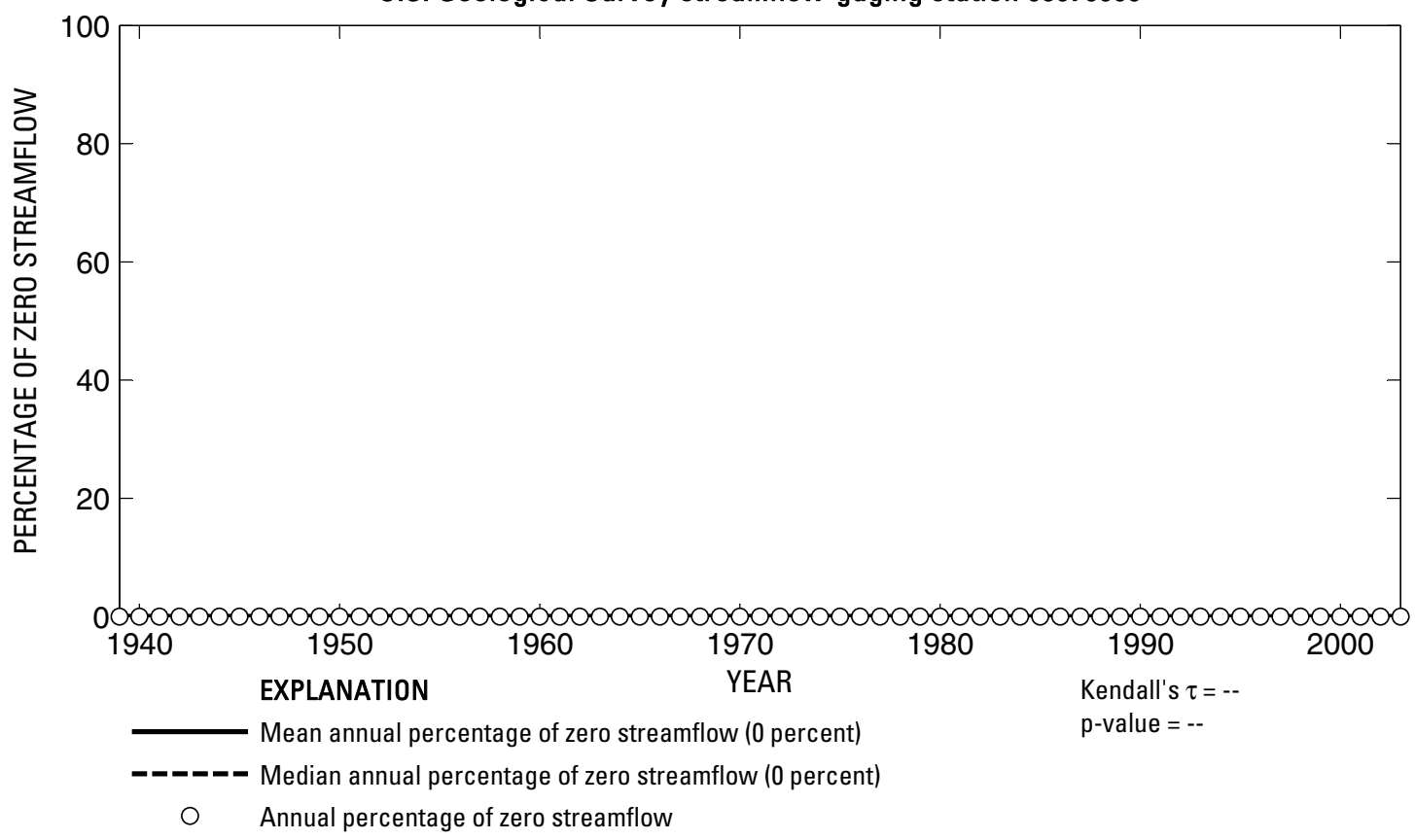

U.S. Geological Survey streamflow-gaging station 08070000

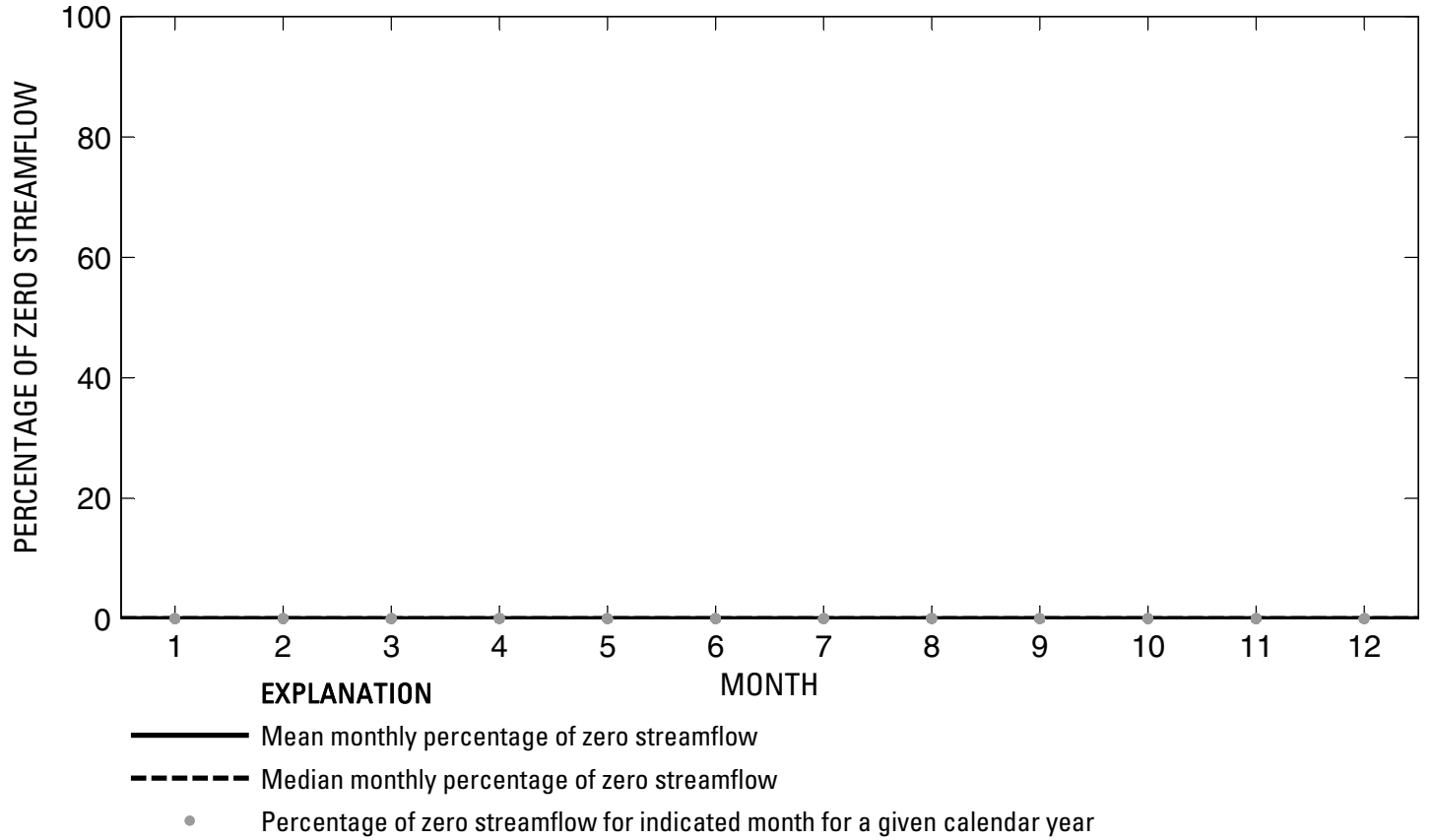

Figure 275. Analysis of percentage of zero daily mean streamflow for U.S. Geological Survey streamflow-gaging station 08070000 East Fork San Jacinto River near Cleveland, Texas. 
U.S. Geological Survey streamflow-gaging station 08070200

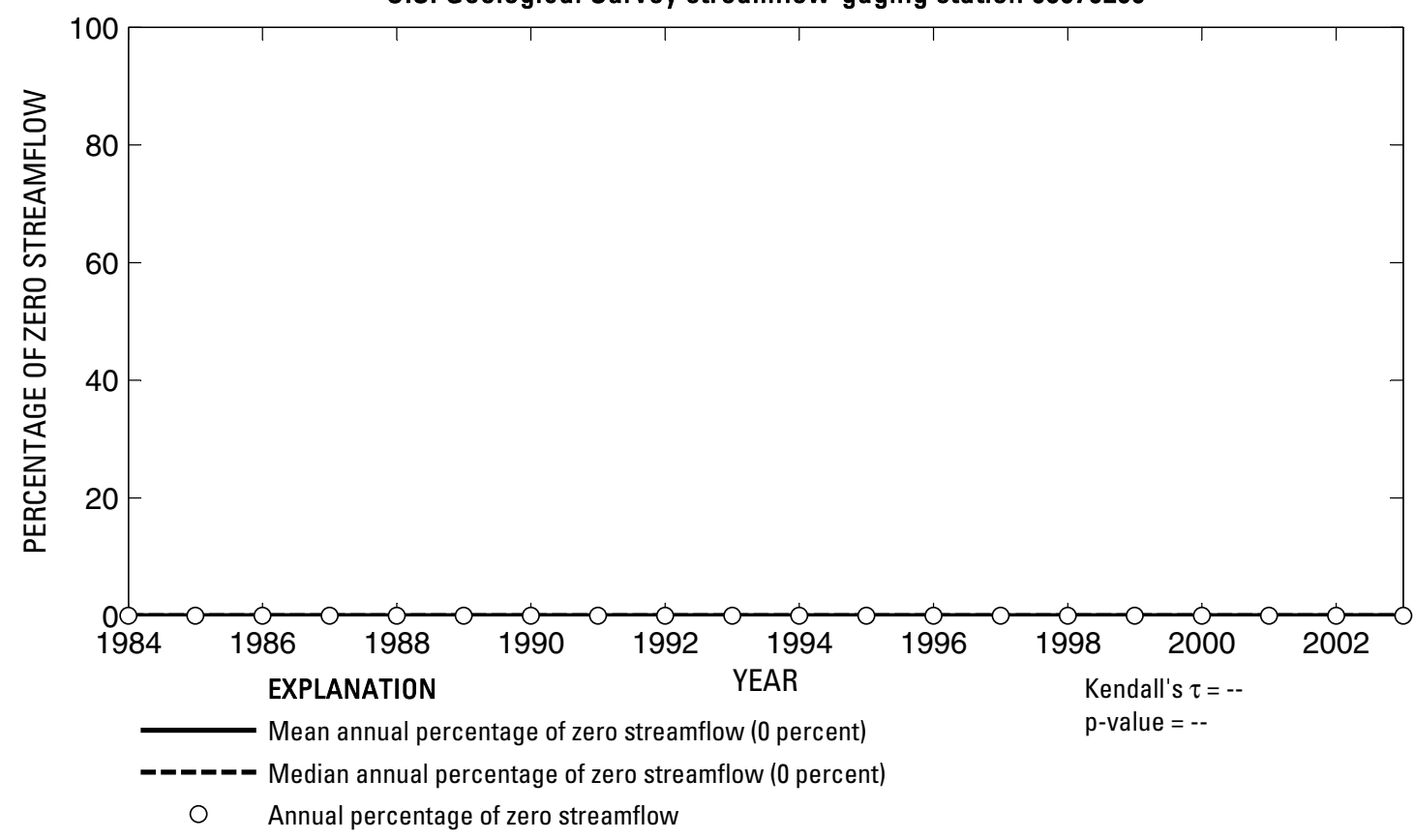

U.S. Geological Survey streamflow-gaging station 08070200

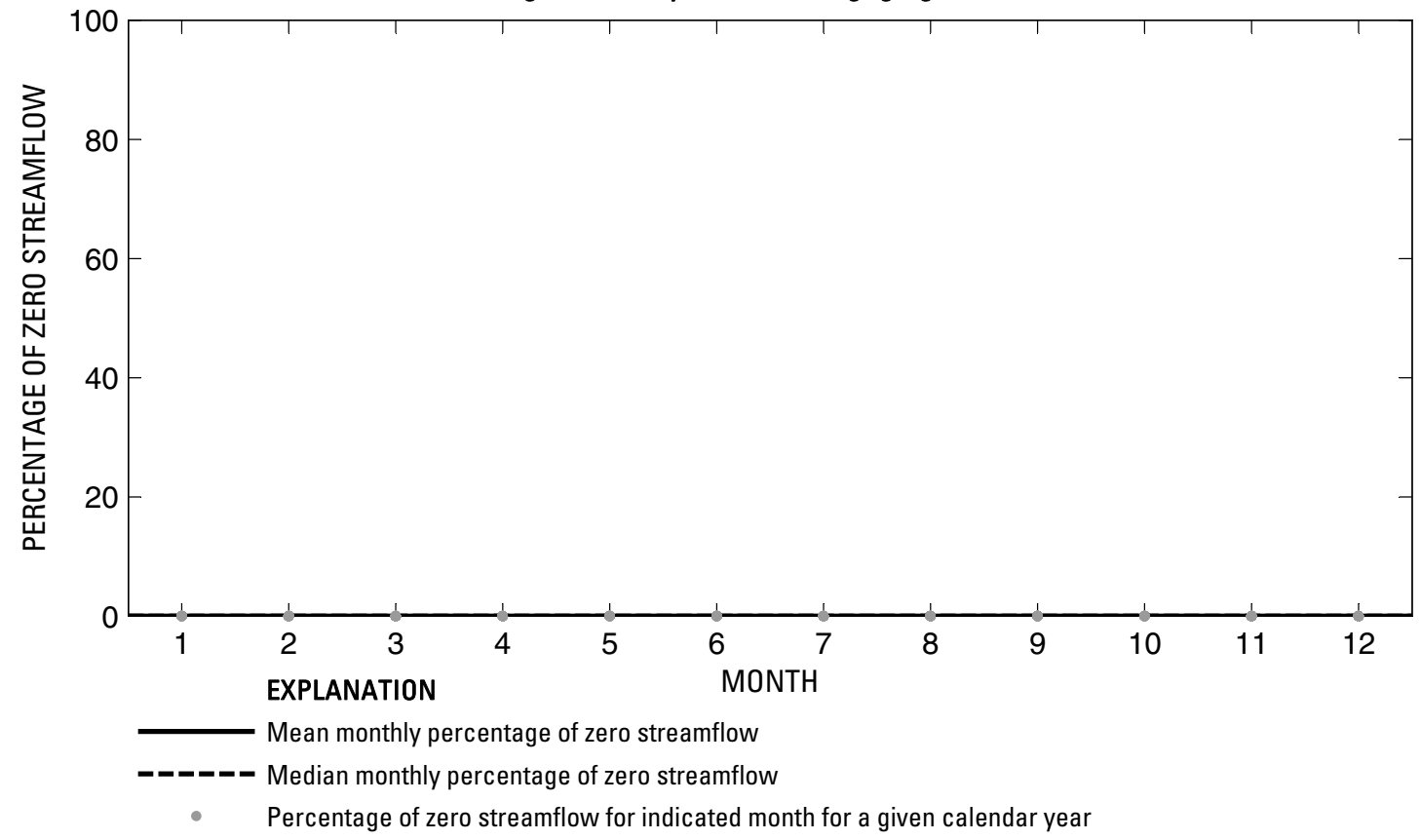

Figure 276. Analysis of percentage of zero daily mean streamflow for U.S. Geological Survey streamflow-gaging station 08070200 East Fork San Jacinto River near New Caney, Texas.

Index of Station Numbers 719 


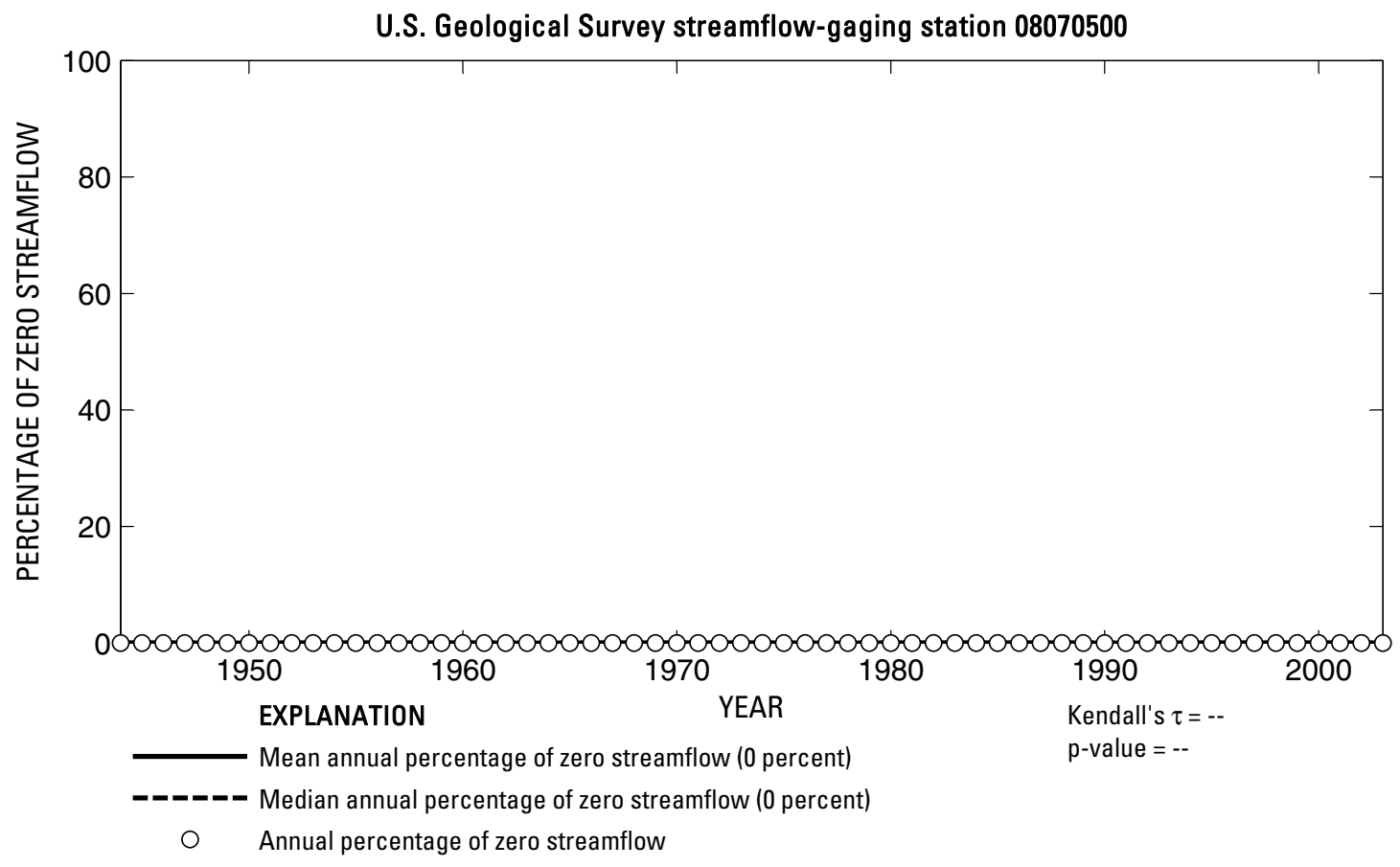

U.S. Geological Survey streamflow-gaging station 08070500

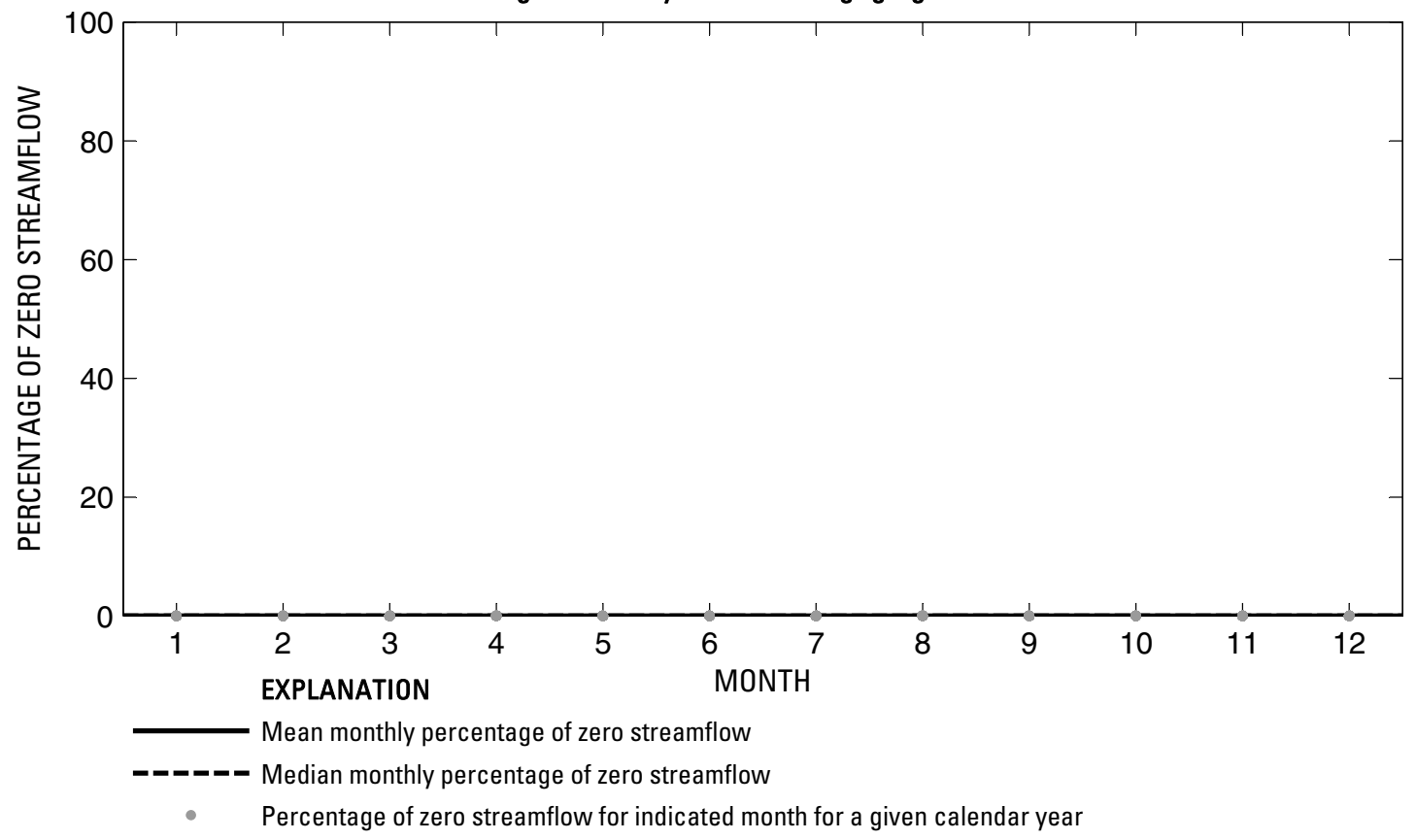

Figure 277. Analysis of percentage of zero daily mean streamflow for U.S. Geological Survey streamflow-gaging station 08070500 Caney Creek near Splendora, Texas. 
U.S. Geological Survey streamflow-gaging station 08071000

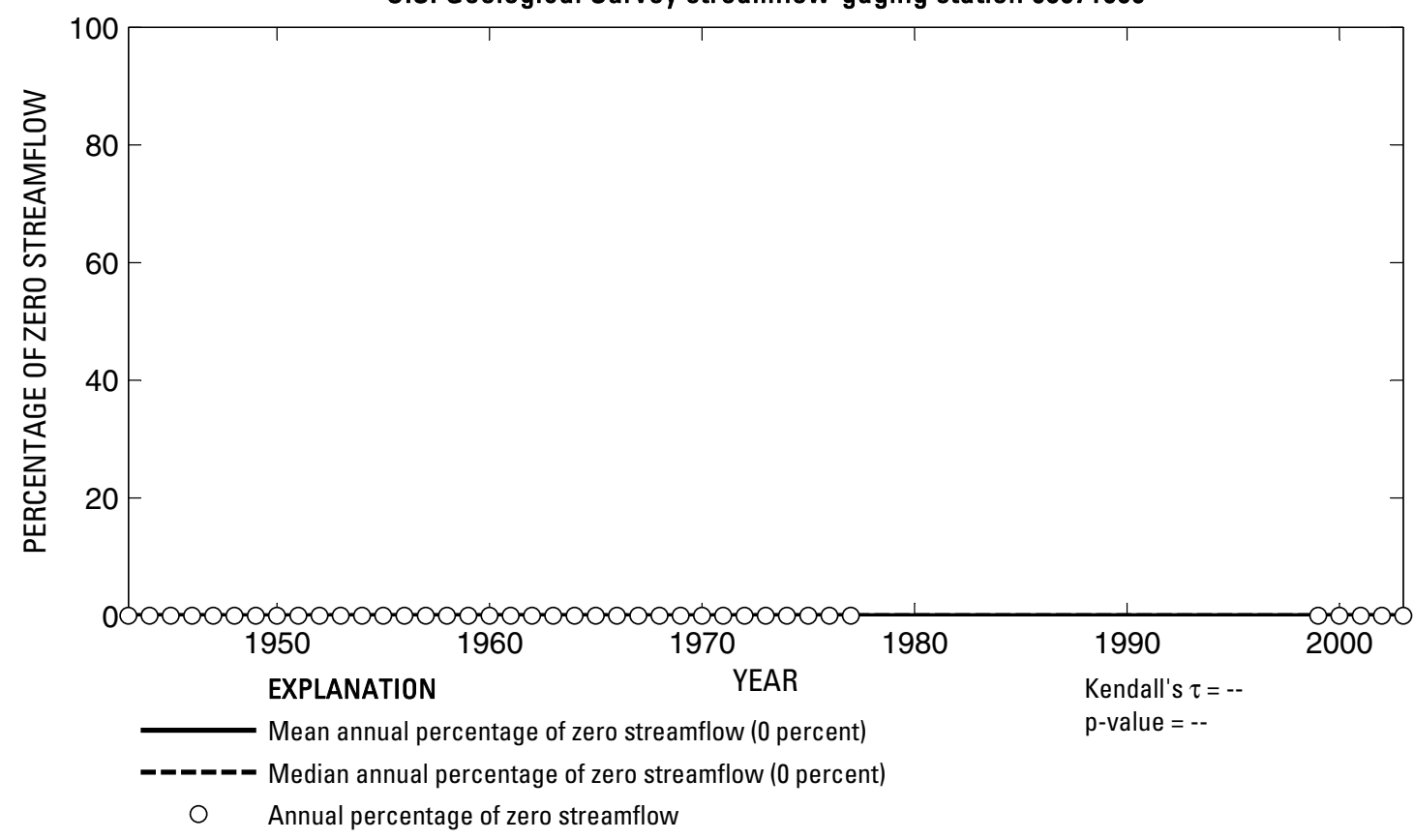

U.S. Geological Survey streamflow-gaging station 08071000

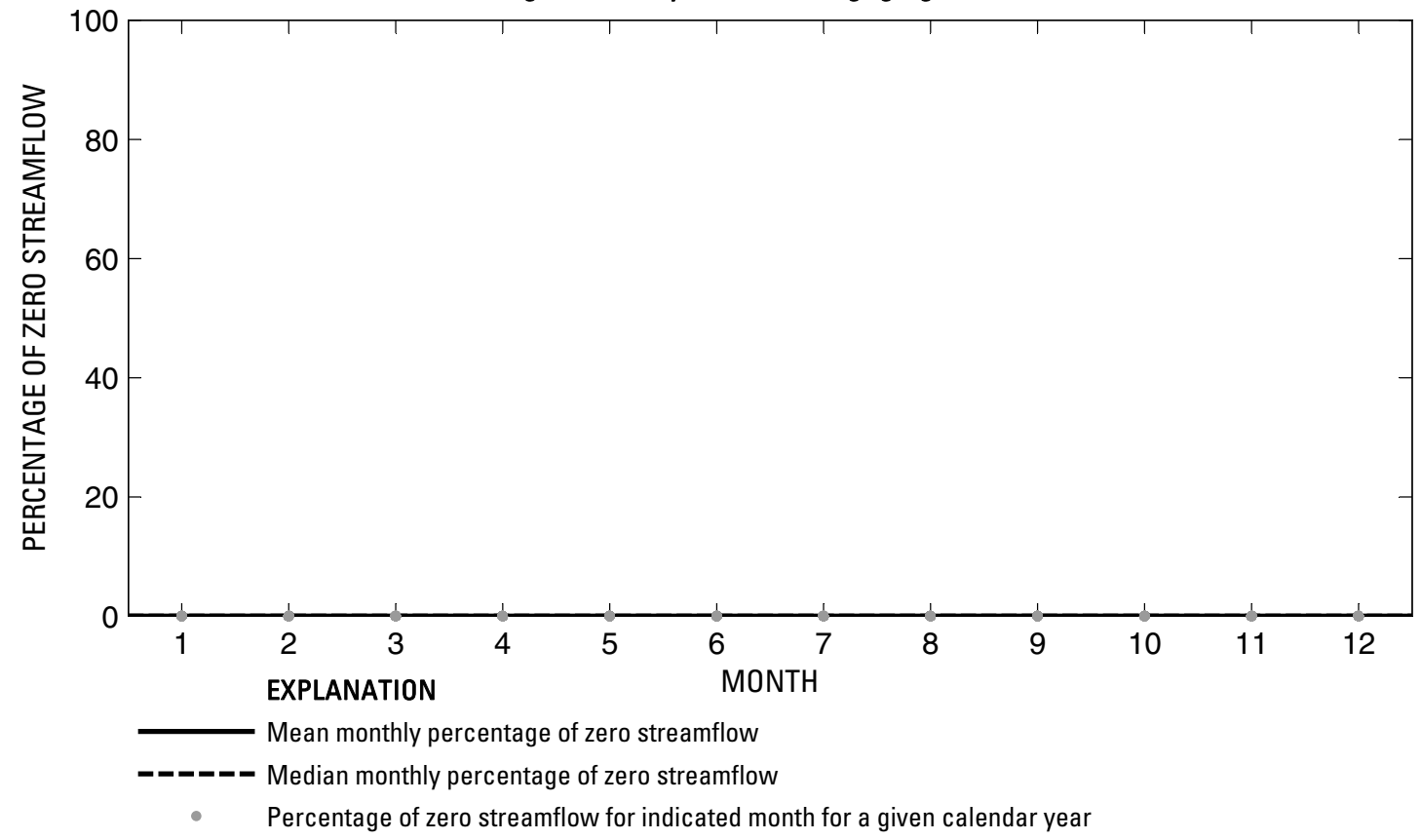

Figure 278. Analysis of percentage of zero daily mean streamflow for U.S. Geological Survey streamflow-gaging station 08071000 Peach Creek at Splendora, Texas. 
U.S. Geological Survey streamflow-gaging station 08071280

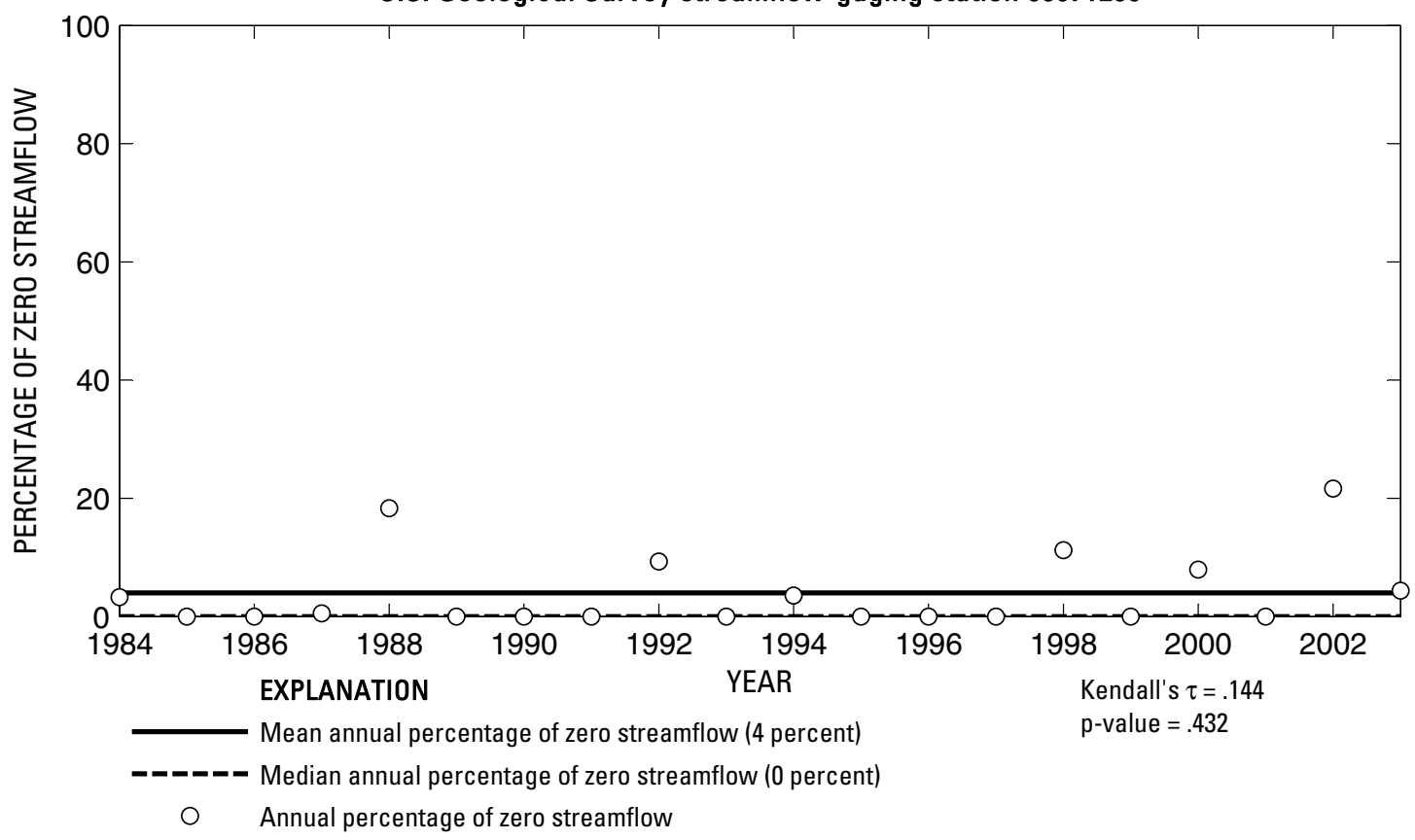

U.S. Geological Survey streamflow-gaging station 08071280

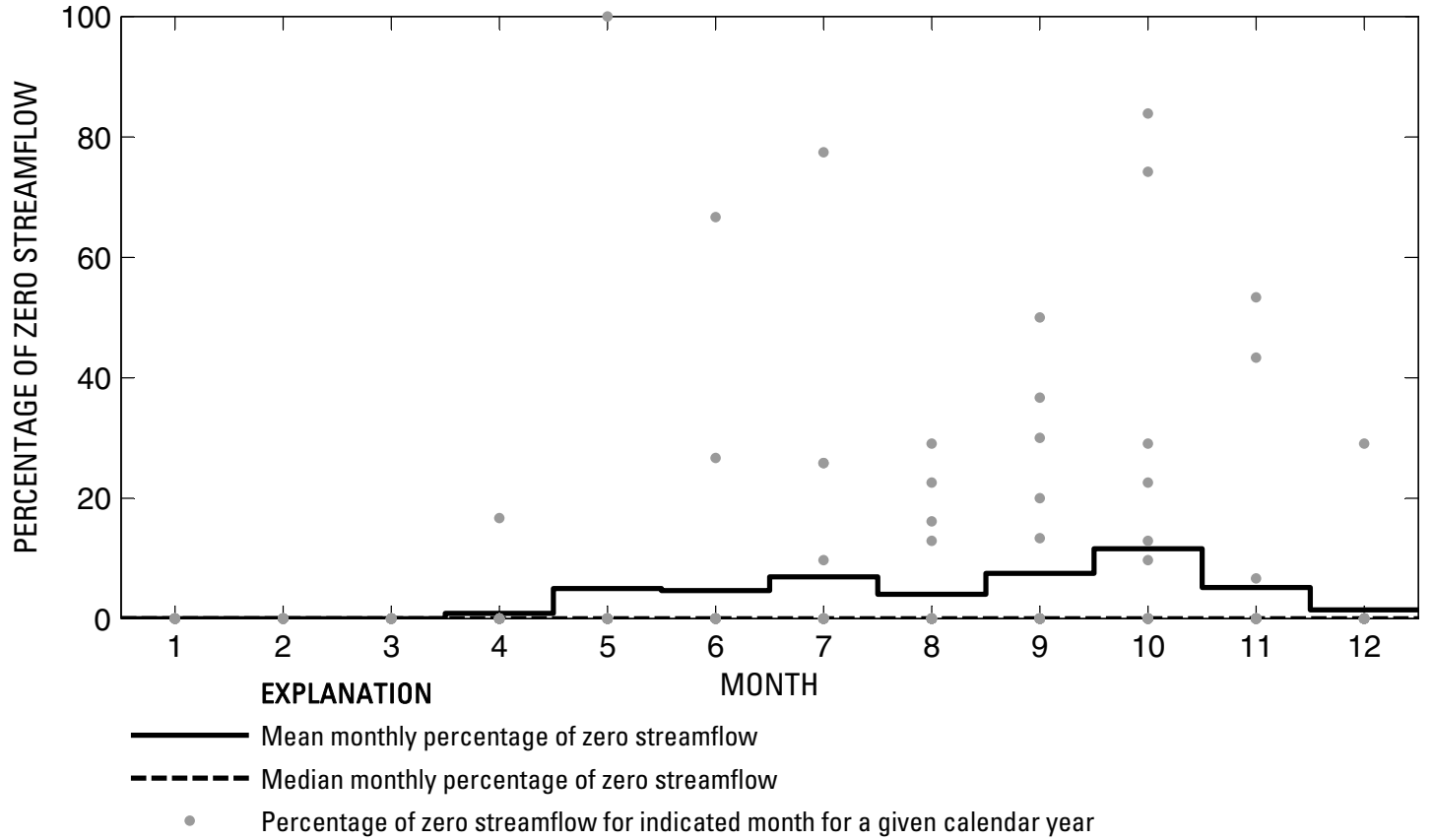

Figure 279. Analysis of percentage of zero daily mean streamflow for U.S. Geological Survey streamflow-gaging station 08071280 Luce Bayou above Lake Houston near Huffman, Texas. 
U.S. Geological Survey streamflow-gaging station 08071500

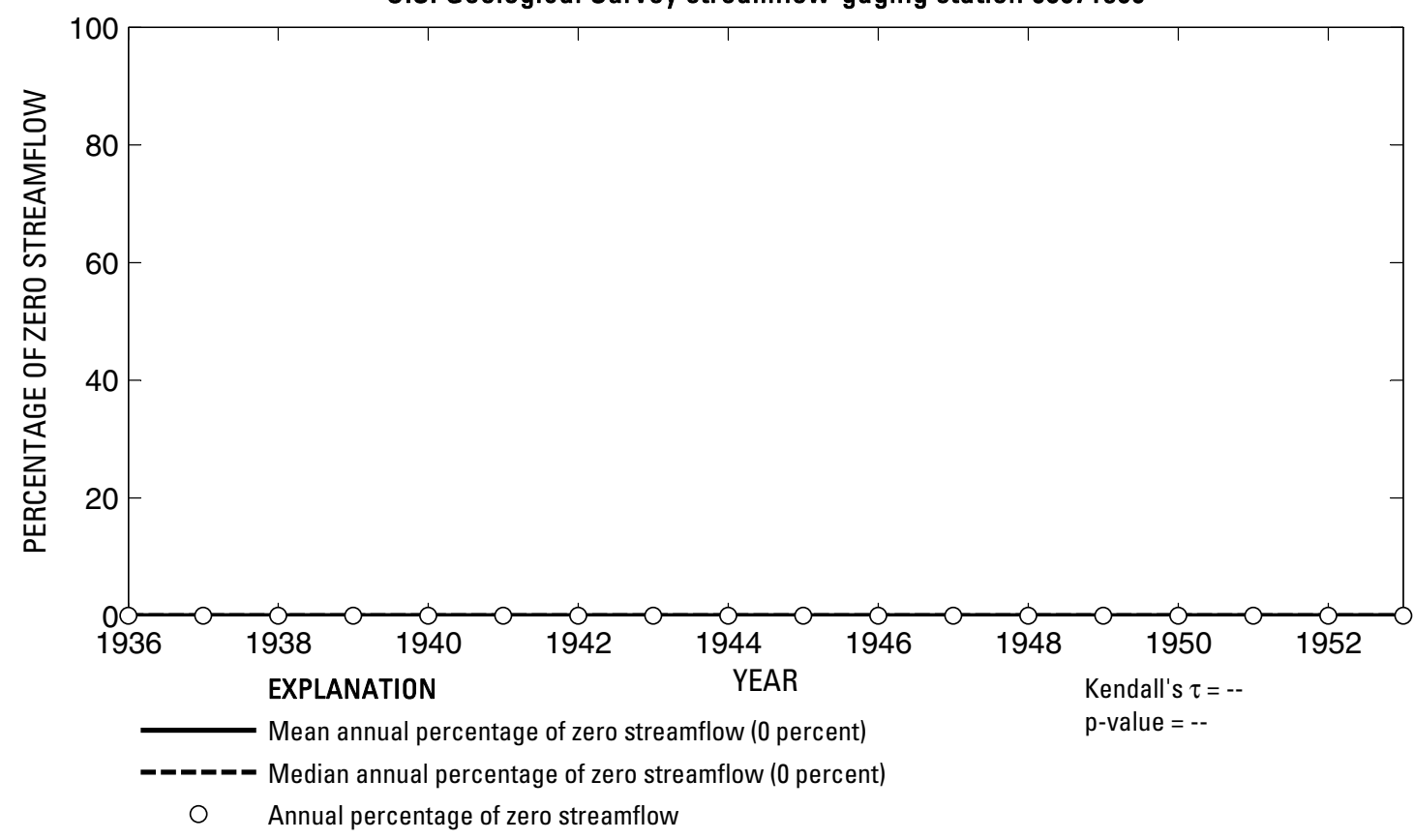

U.S. Geological Survey streamflow-gaging station 08071500

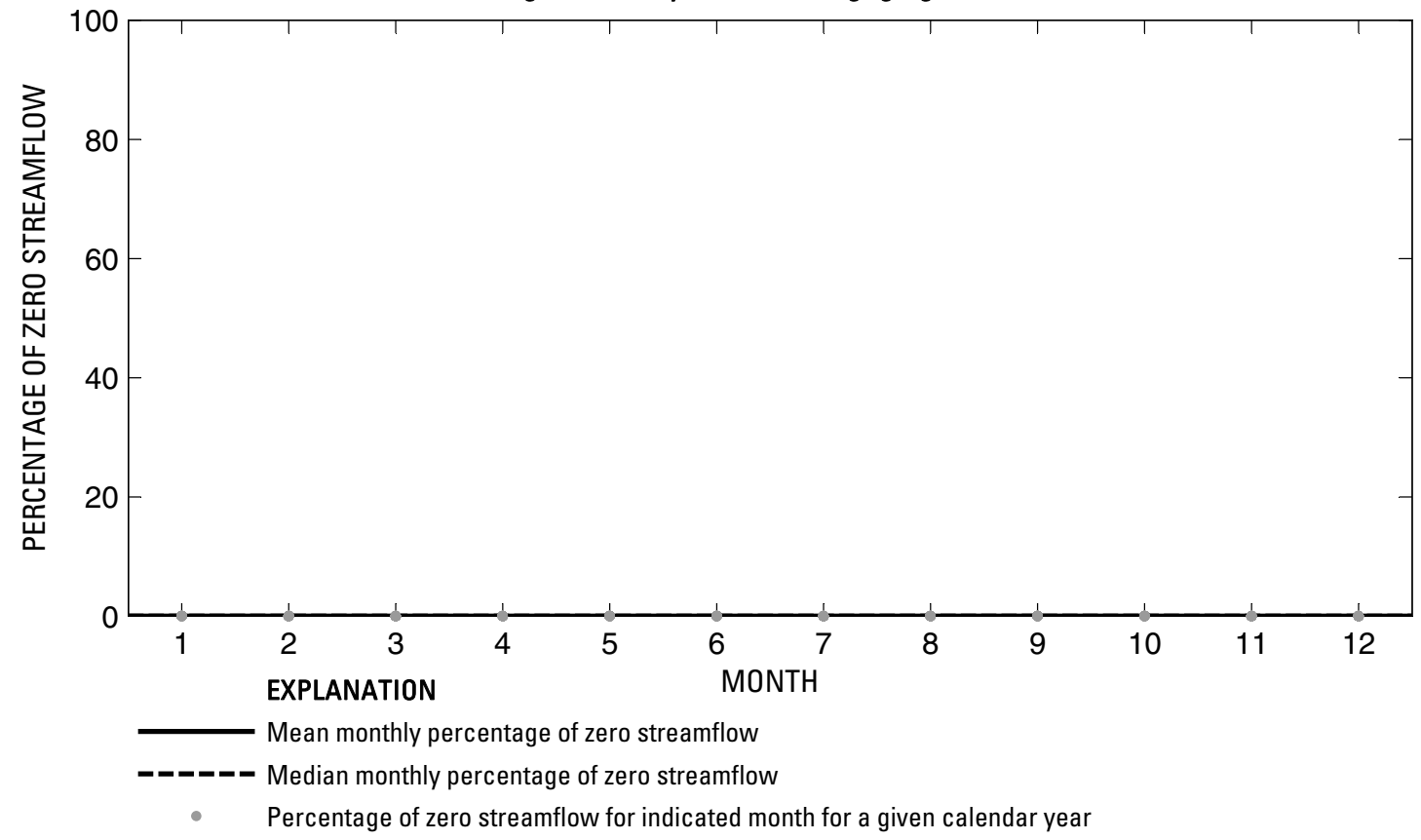

Figure 280. Analysis of percentage of zero daily mean streamflow for U.S. Geological Survey streamflow-gaging station 08071500 San Jacinto River near Huffman, Texas.

Index of Station Numbers 719 
U.S. Geological Survey streamflow-gaging station 08072300

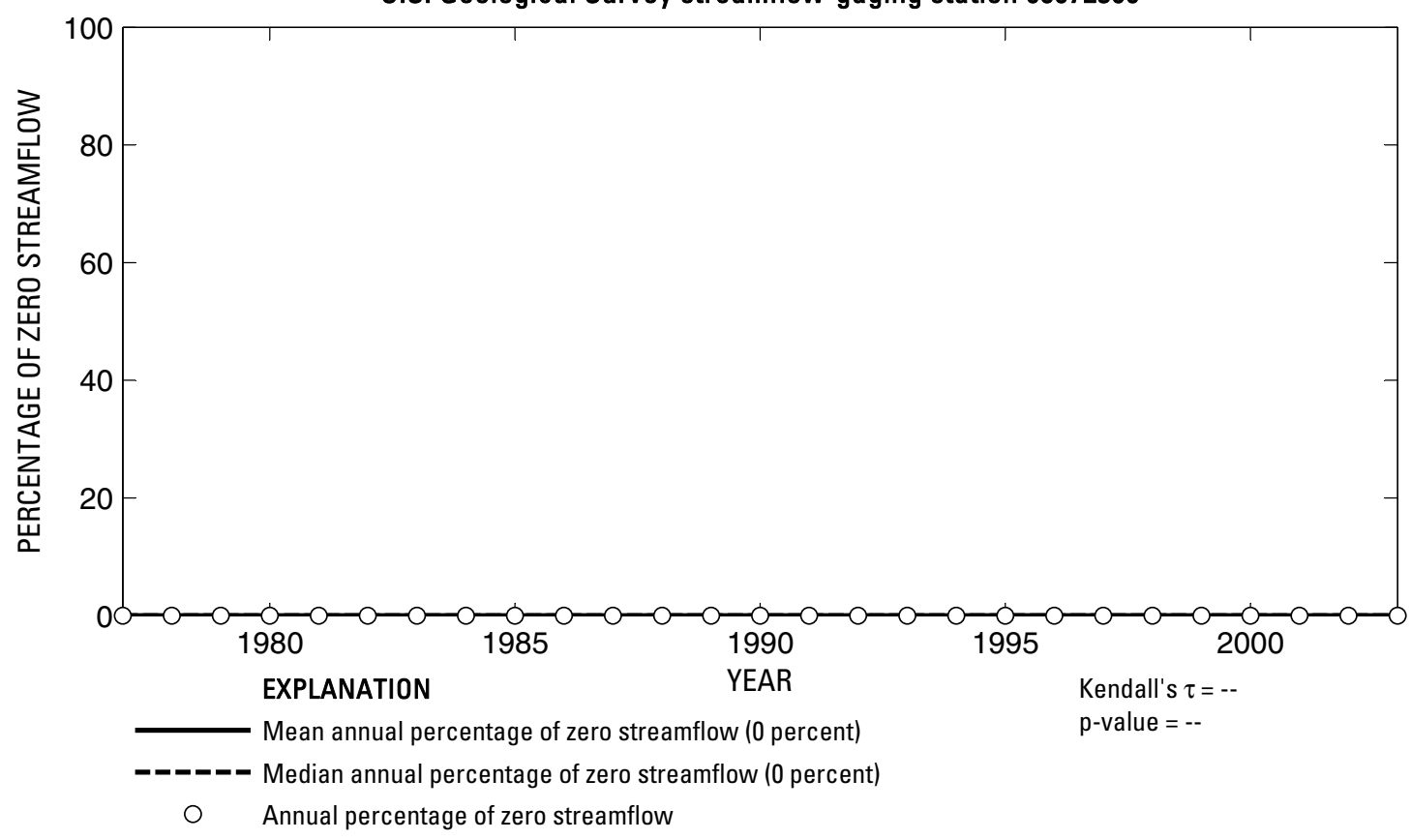

U.S. Geological Survey streamflow-gaging station 08072300

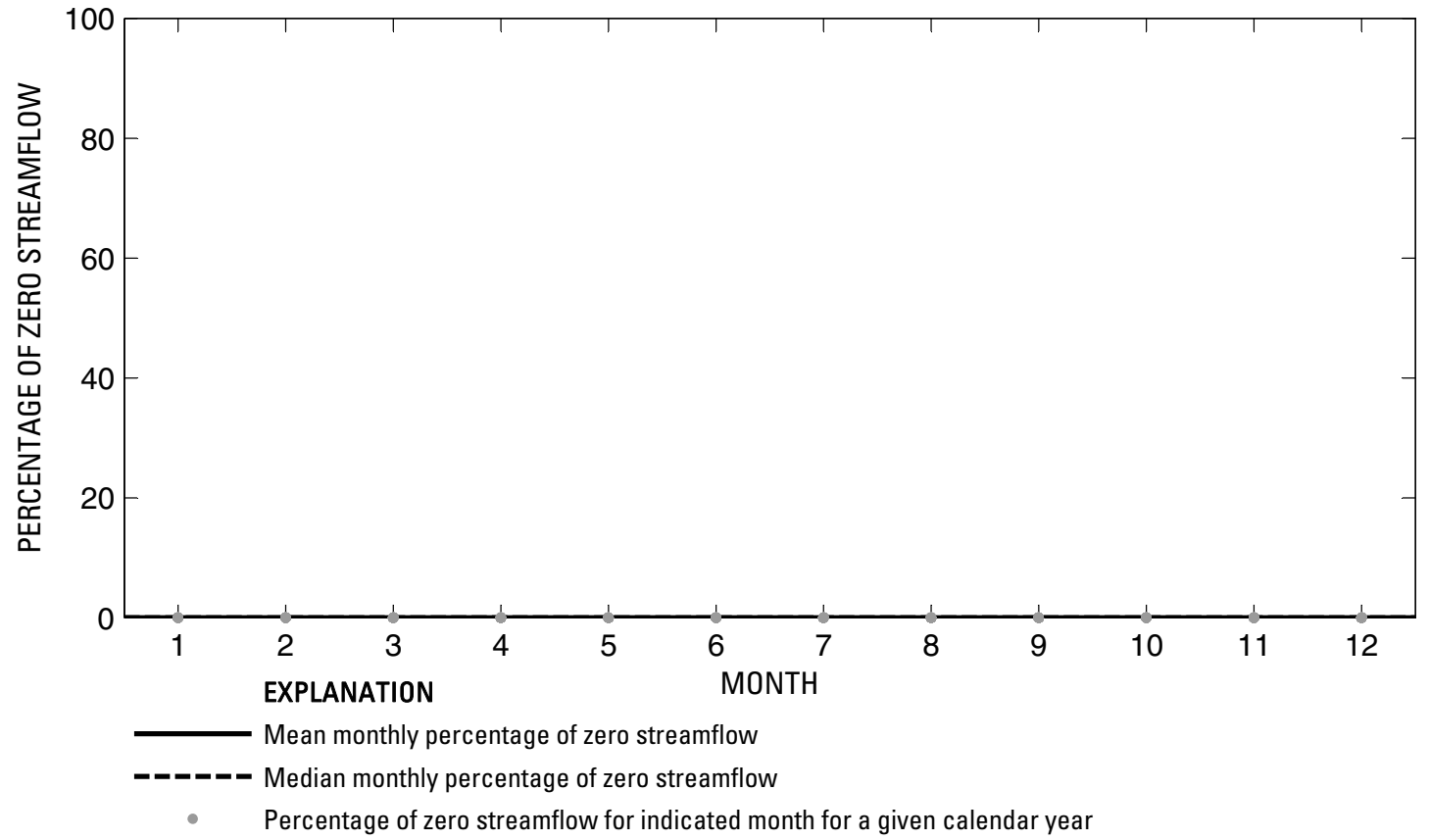

Figure 281. Analysis of percentage of zero daily mean streamflow for U.S. Geological Survey streamflow-gaging station 08072300 Buffalo Bayou near Katy, Texas. 
U.S. Geological Survey streamflow-gaging station 08072730

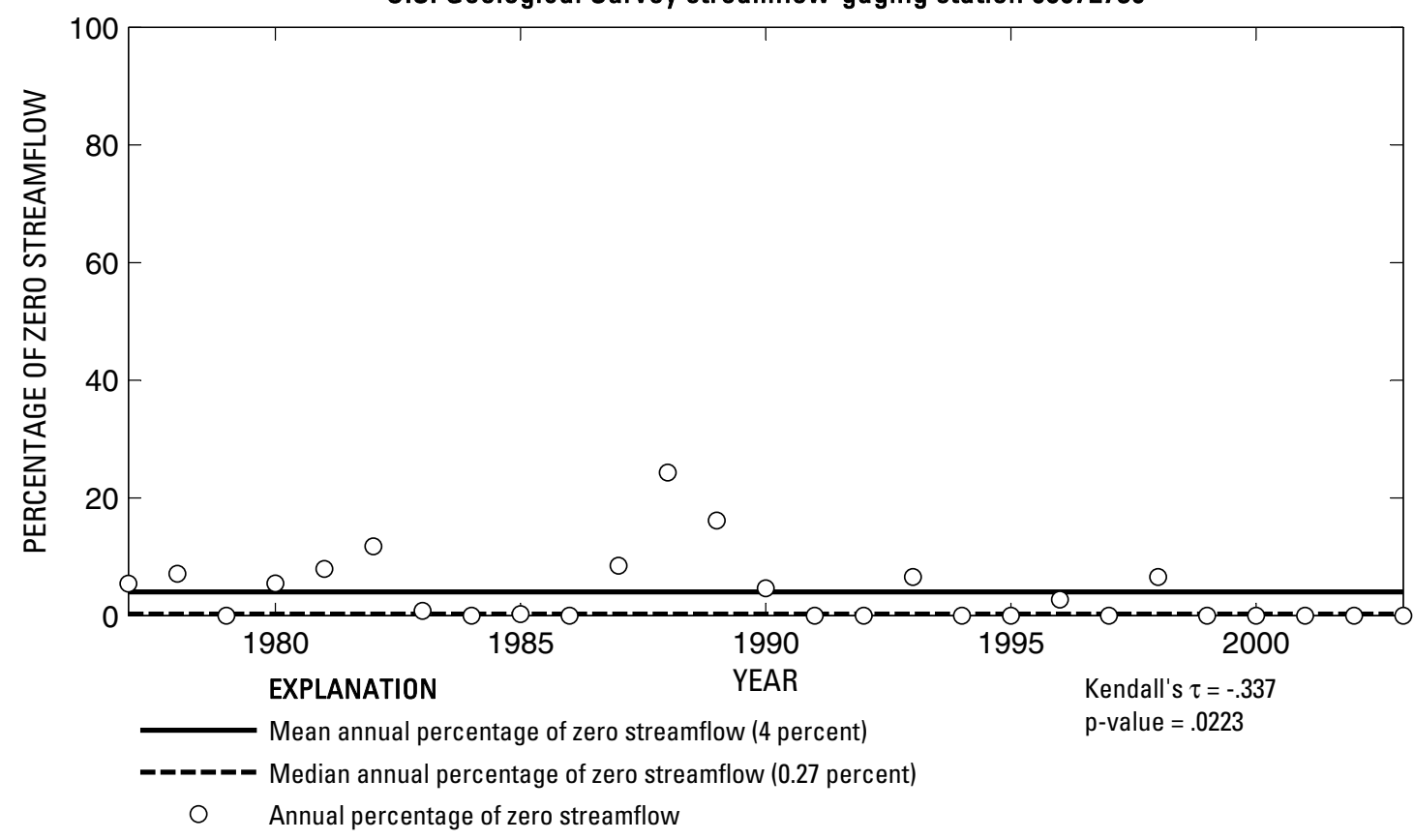

U.S. Geological Survey streamflow-gaging station 08072730

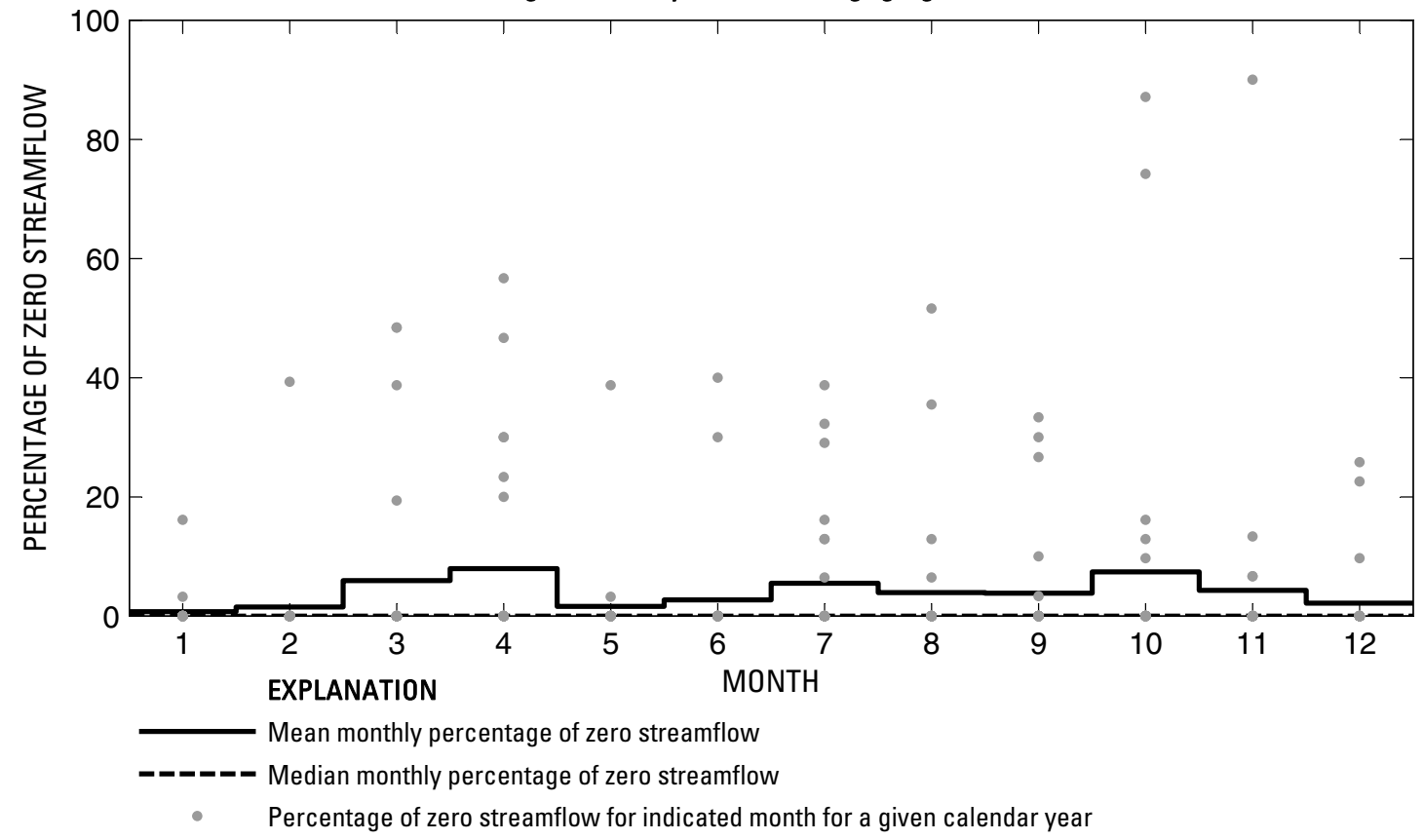

Figure 282. Analysis of percentage of zero daily mean streamflow for U.S. Geological Survey streamflow-gaging station 08072730 Bear Creek near Barker, Texas. 
U.S. Geological Survey streamflow-gaging station 08072760

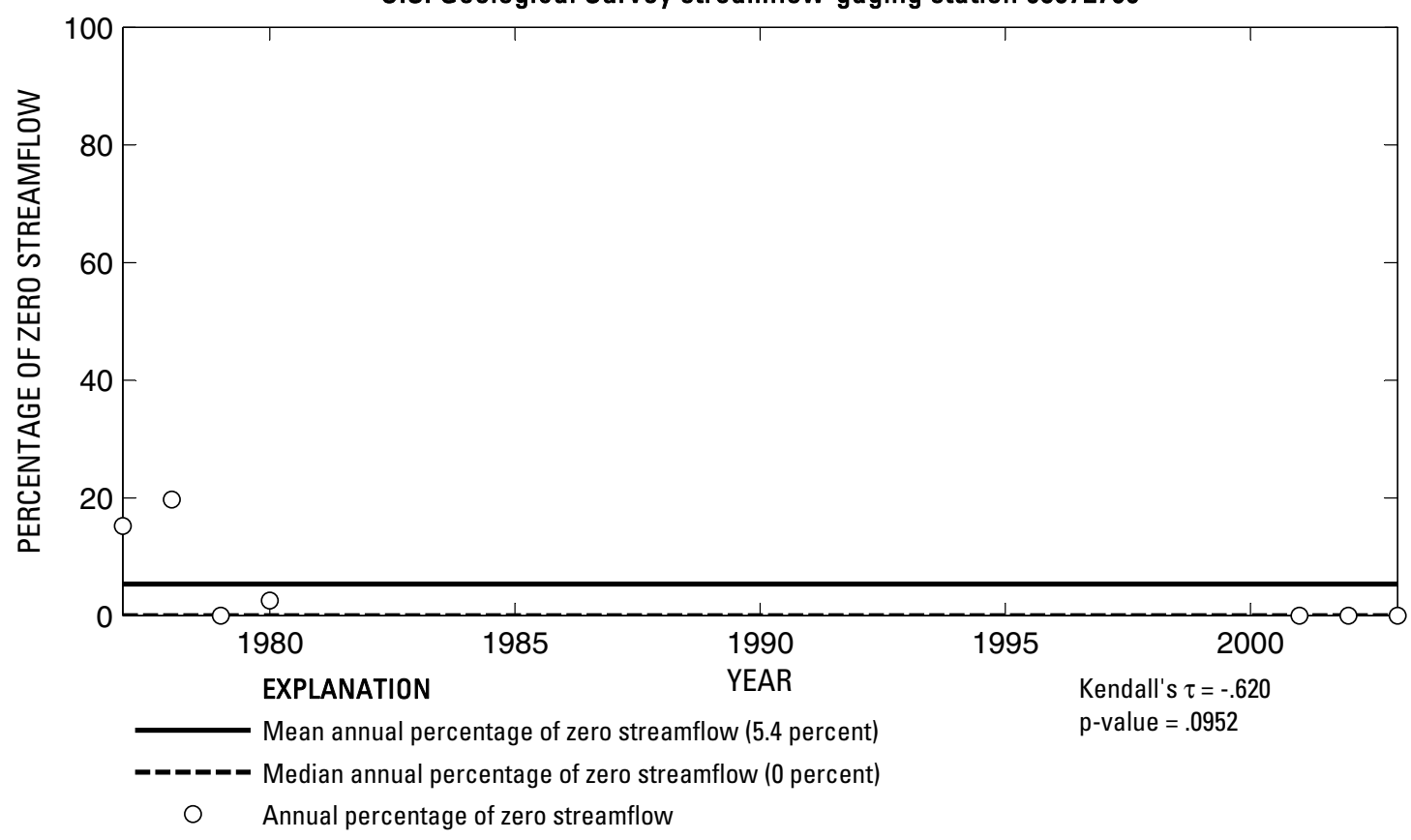

U.S. Geological Survey streamflow-gaging station 08072760

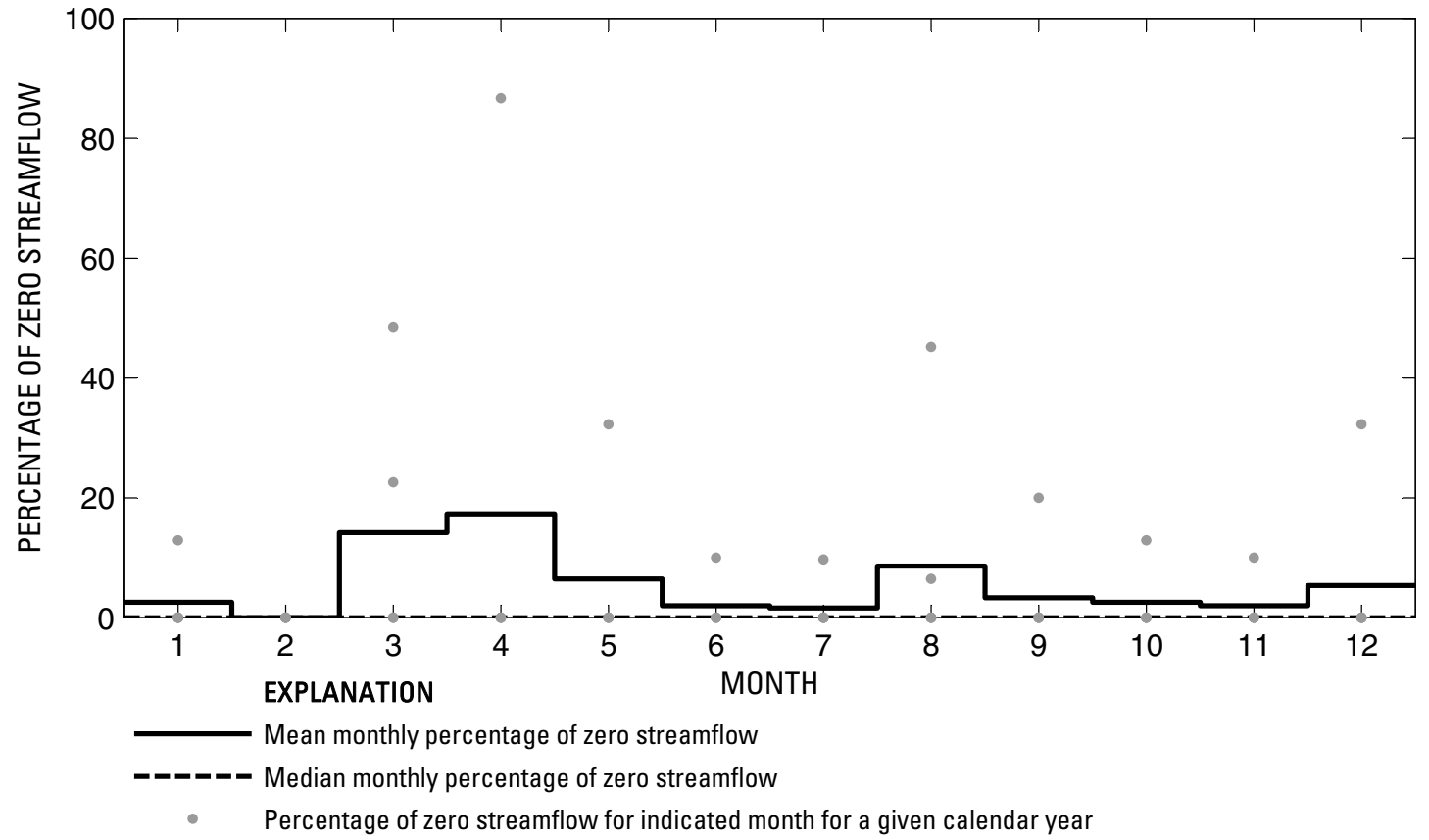

Figure 283. Analysis of percentage of zero daily mean streamflow for U.S. Geological Survey streamflow-gaging station 08072760 Langham Creek at West Little York Road near Addicks, Texas. 
U.S. Geological Survey streamflow-gaging station 08073500

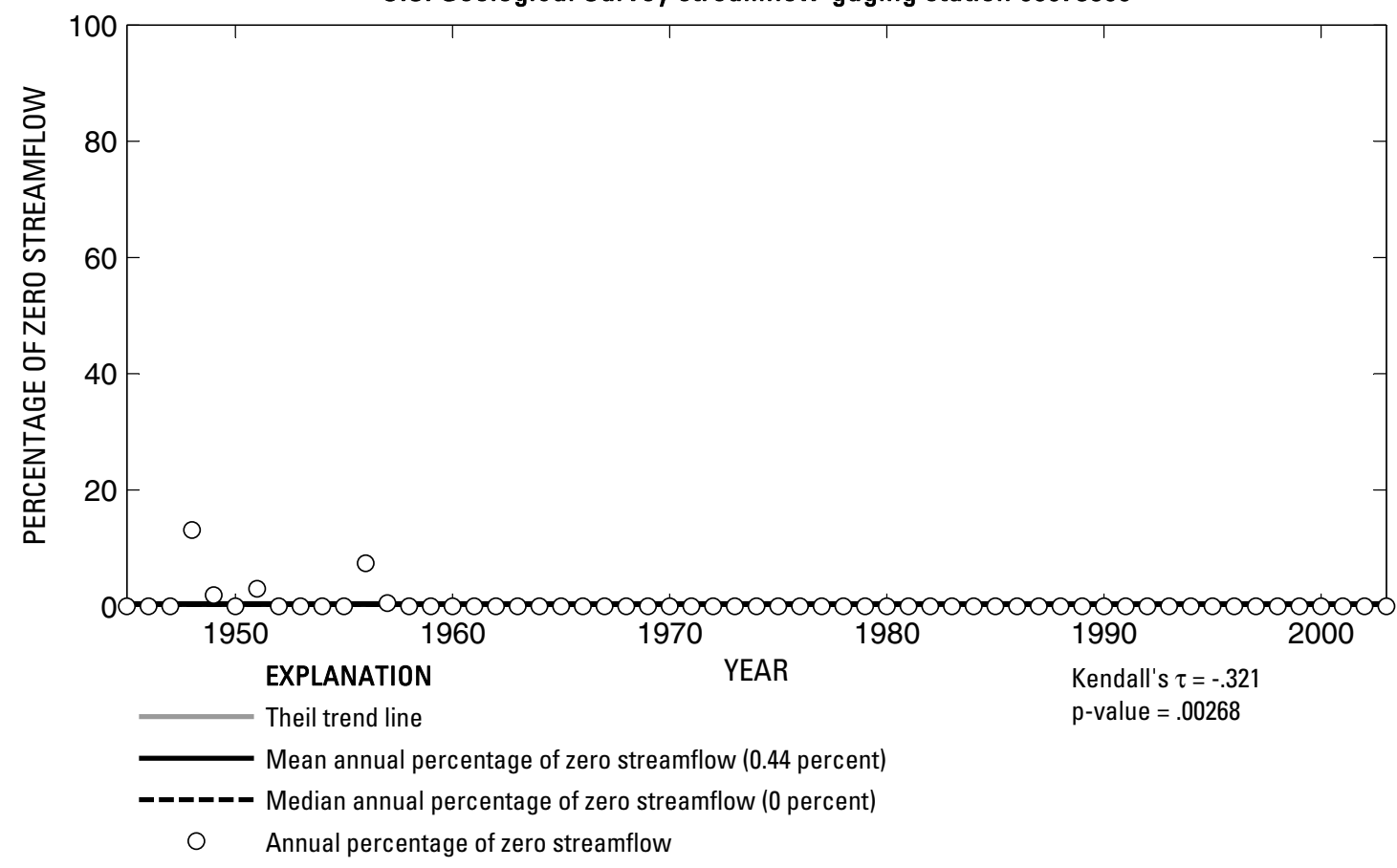

U.S. Geological Survey streamflow-gaging station 08073500

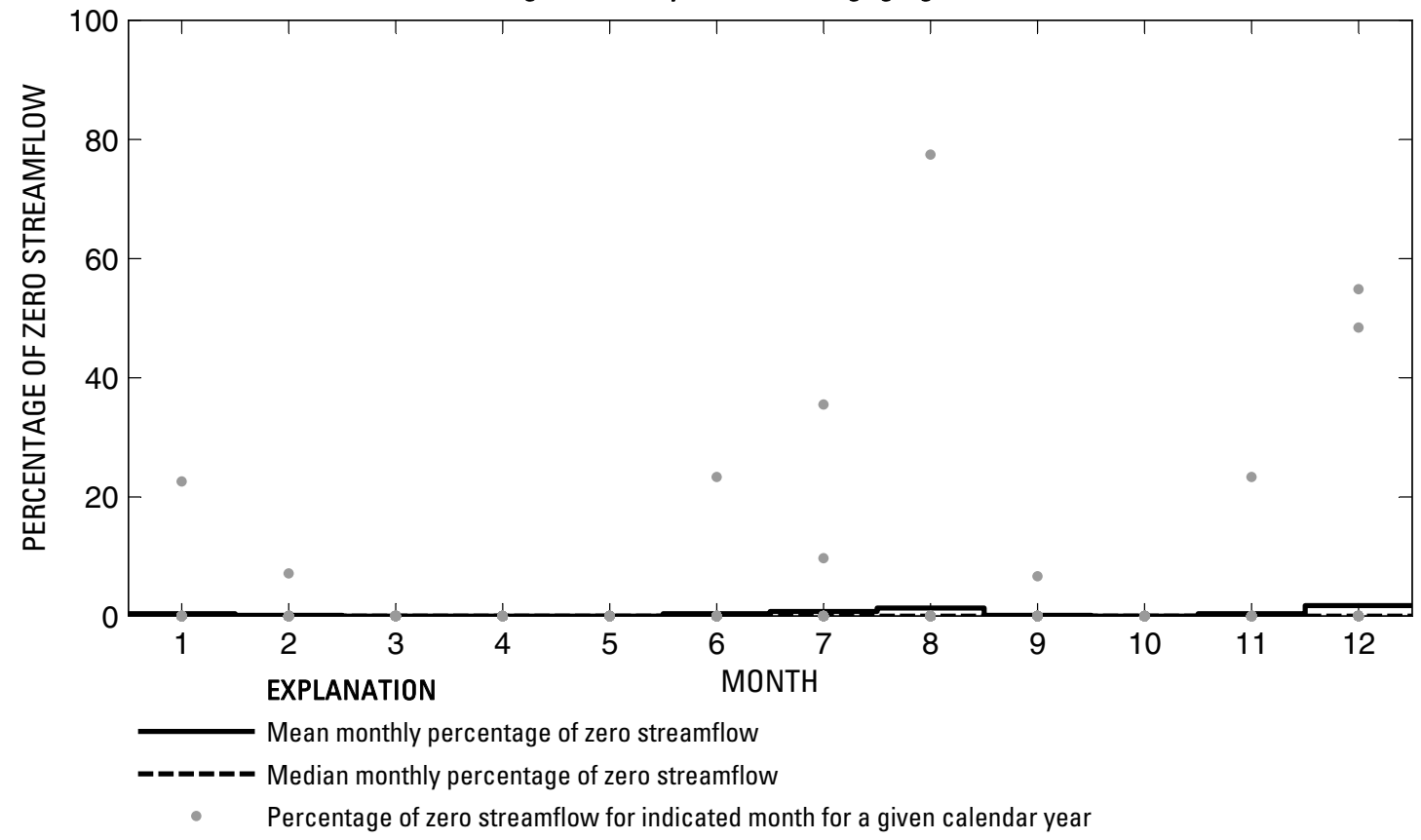

Figure 284. Analysis of percentage of zero daily mean streamflow for U.S. Geological Survey streamflow-gaging station 08073500 Buffalo Bayou near Addicks, Texas.

Index of Station Numbers 719 
U.S. Geological Survey streamflow-gaging station 08073600

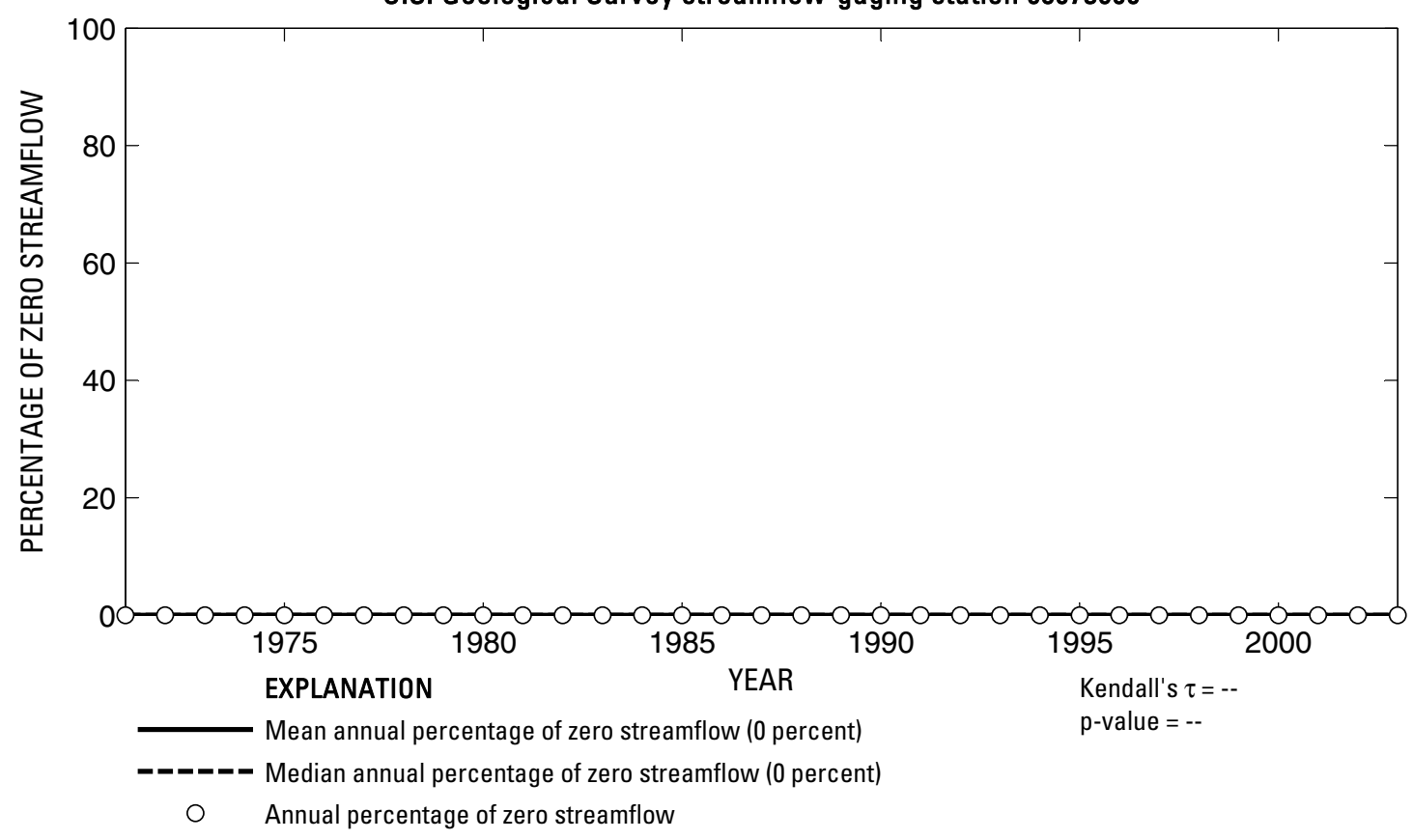

U.S. Geological Survey streamflow-gaging station 08073600

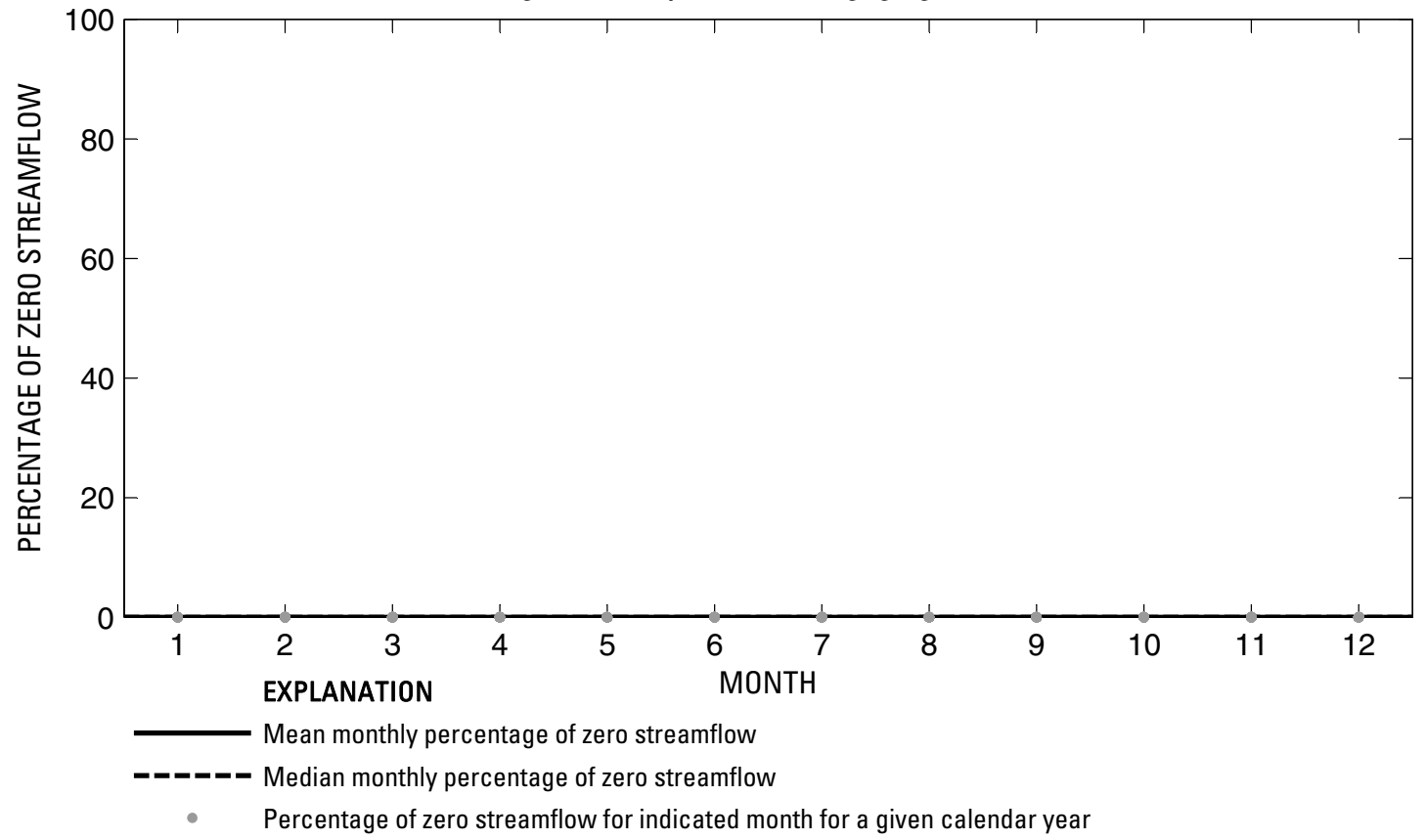

Figure 285. Analysis of percentage of zero daily mean streamflow for U.S. Geological Survey streamflow-gaging station 08073600 Buffalo Bayou at West Belt Drive, Houston, Texas. 
U.S. Geological Survey streamflow-gaging station 08073700

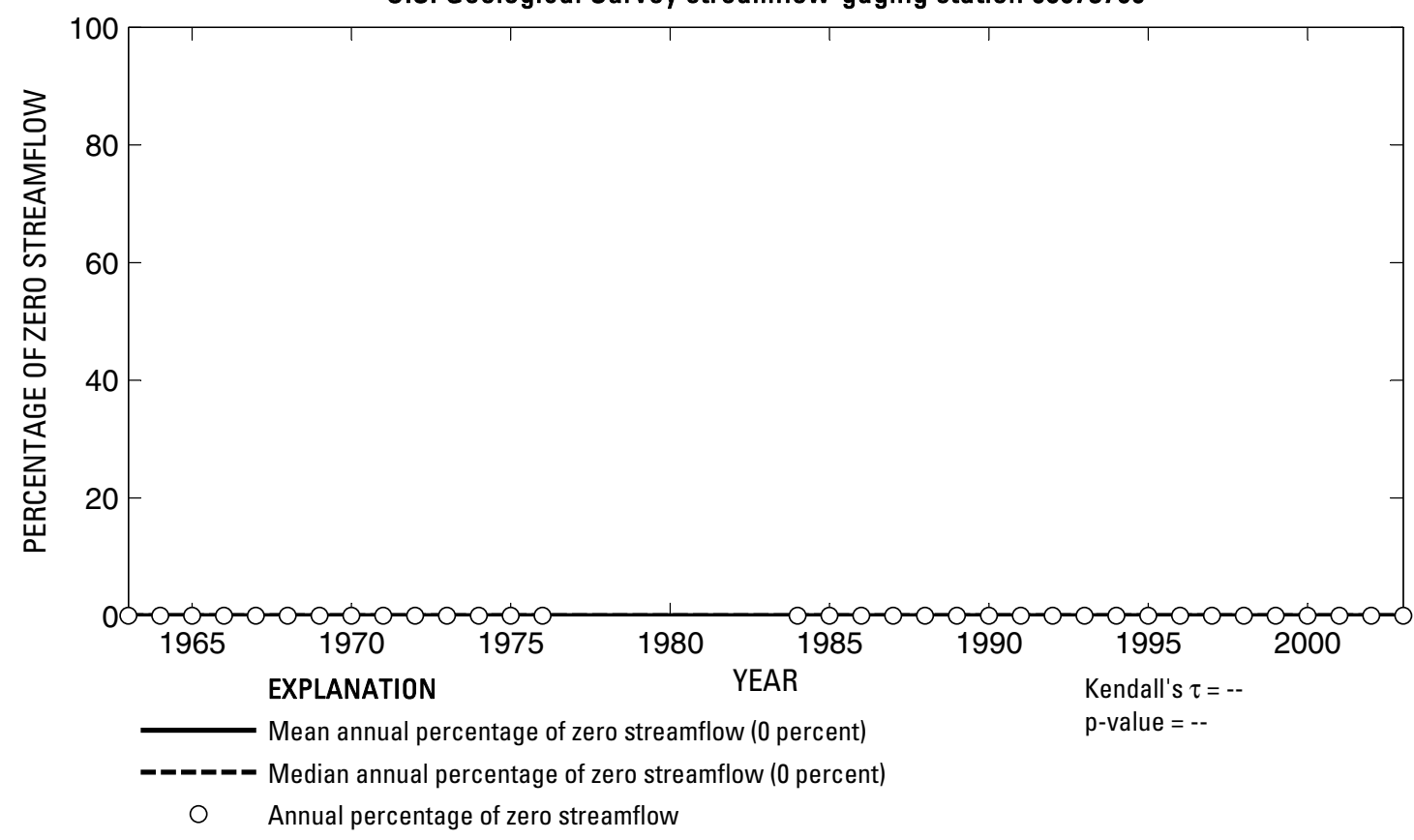

U.S. Geological Survey streamflow-gaging station 08073700

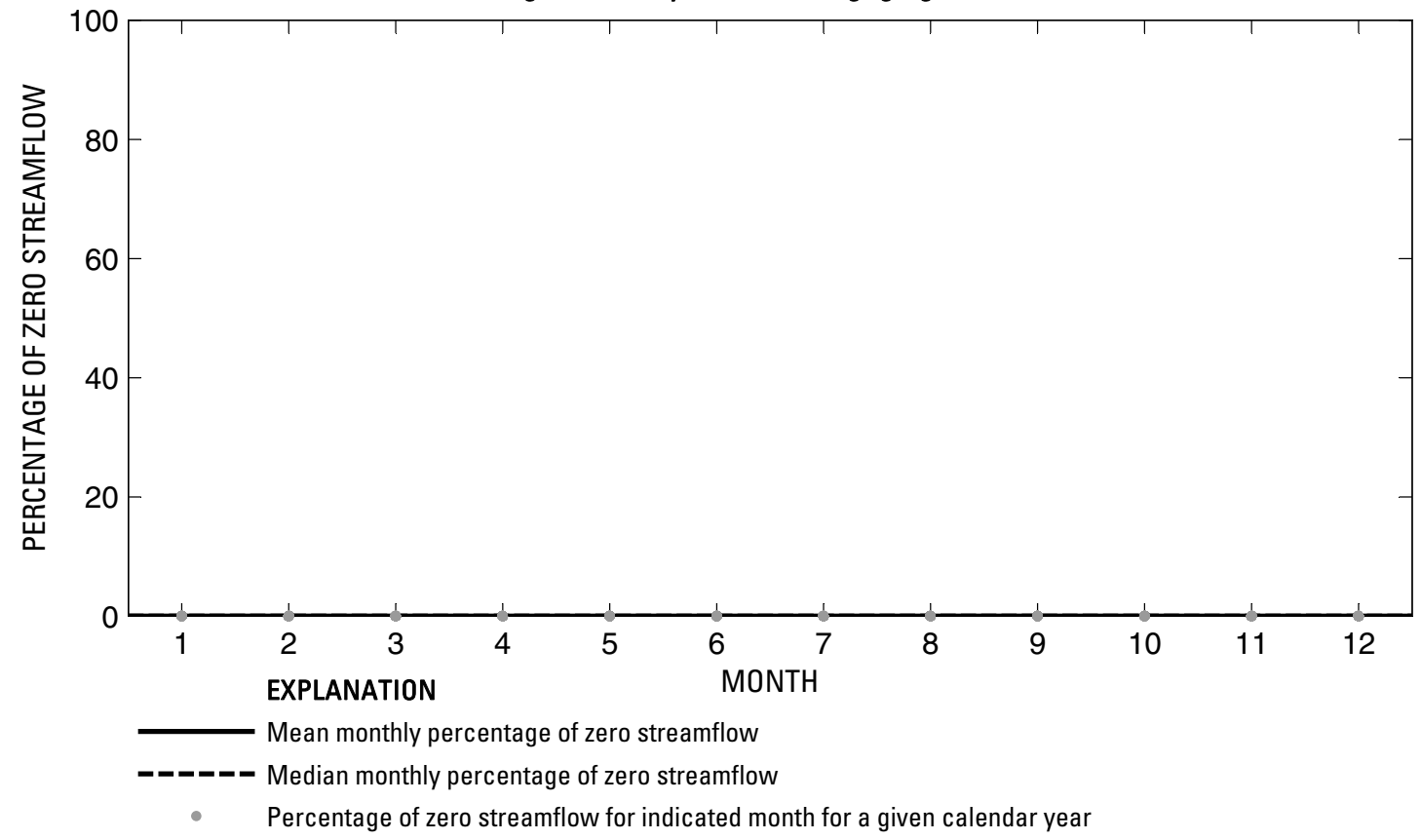

Figure 286. Analysis of percentage of zero daily mean streamflow for U.S. Geological Survey streamflow-gaging station 08073700 Buffalo Bayou at Piney Point, Texas. 
U.S. Geological Survey streamflow-gaging station 08074000

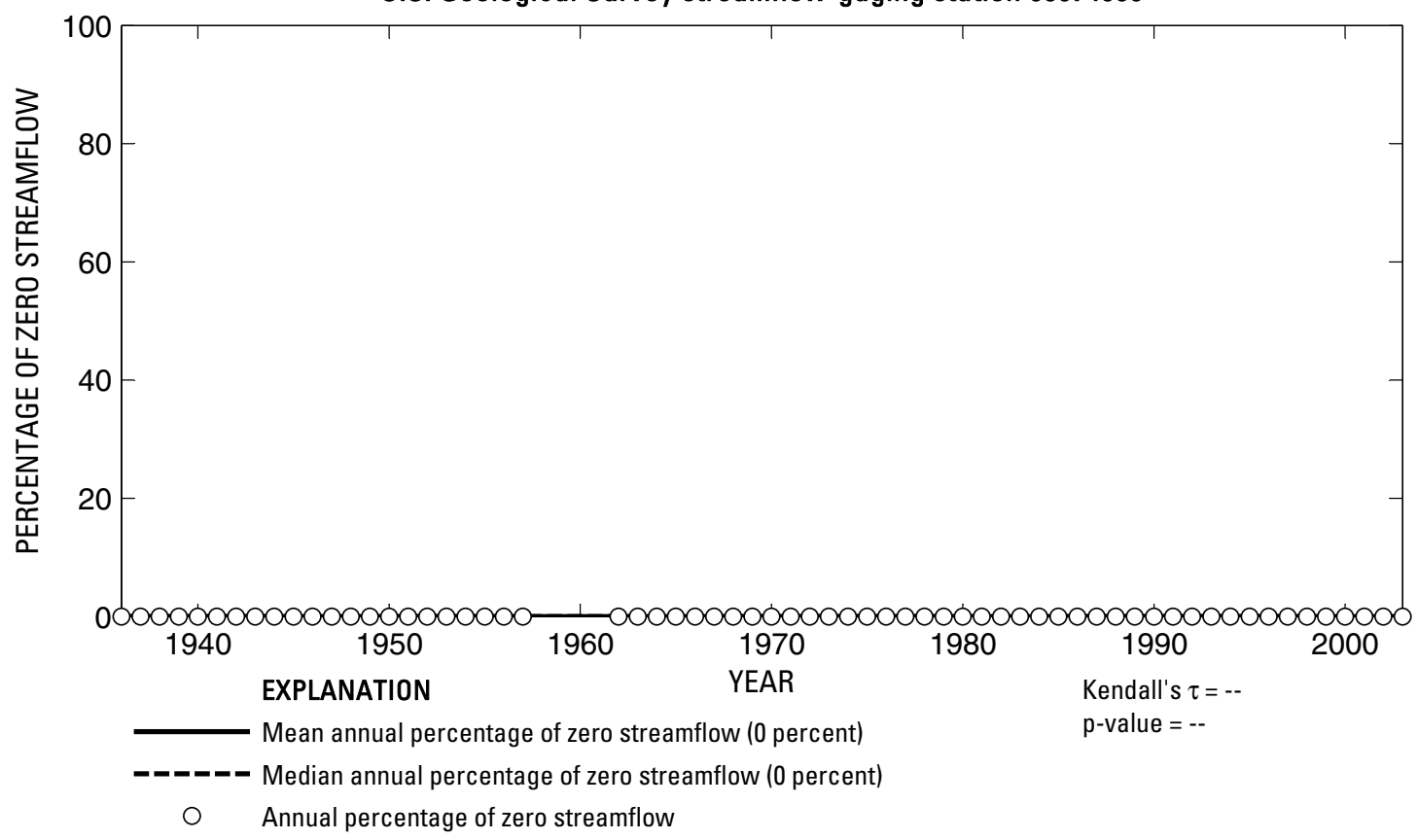

U.S. Geological Survey streamflow-gaging station 08074000

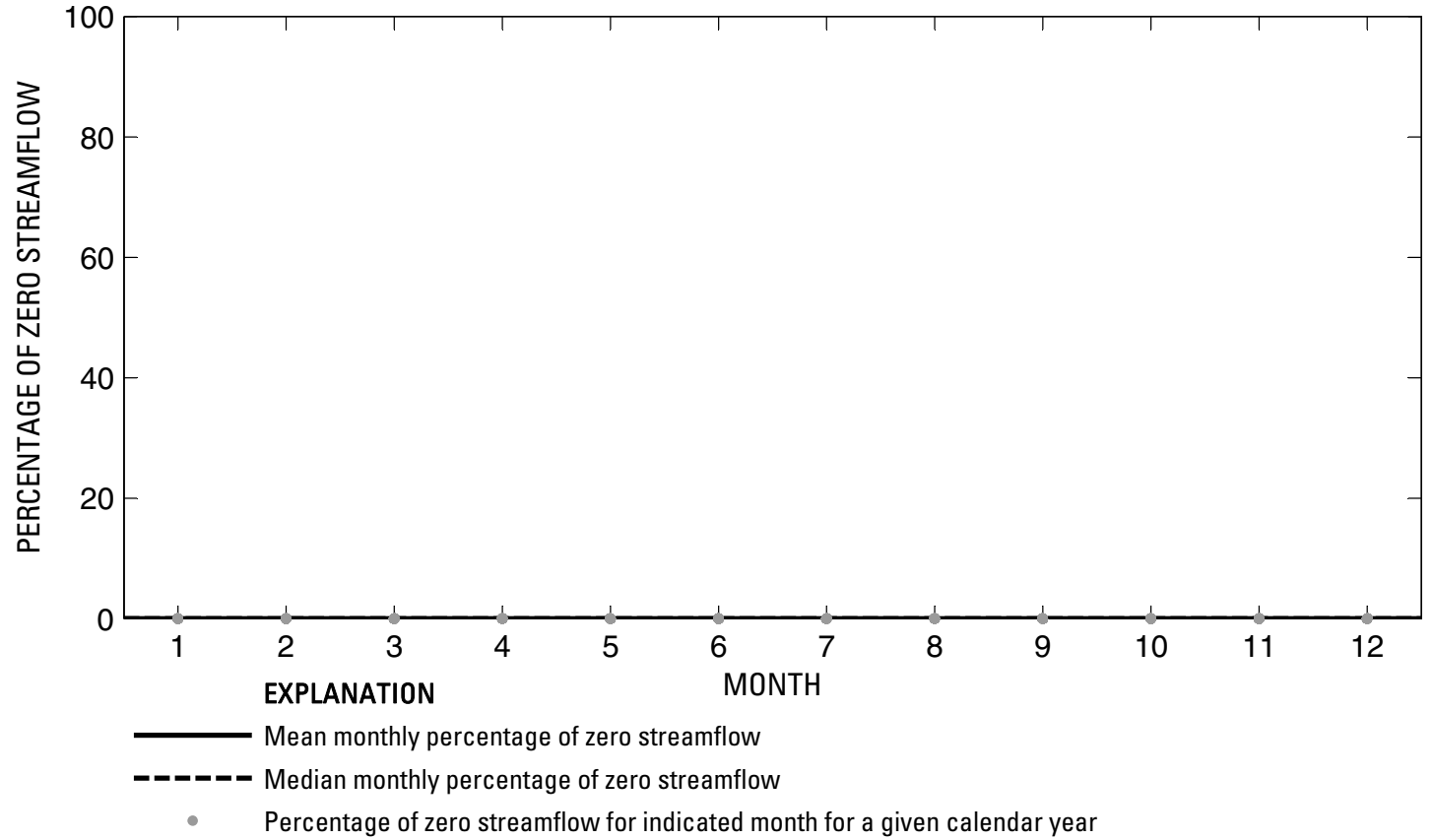

Figure 287. Analysis of percentage of zero daily mean streamflow for U.S. Geological Survey streamflow-gaging station 08074000 Buffalo Bayou at Houston, Texas. 
U.S. Geological Survey streamflow-gaging station 08074020

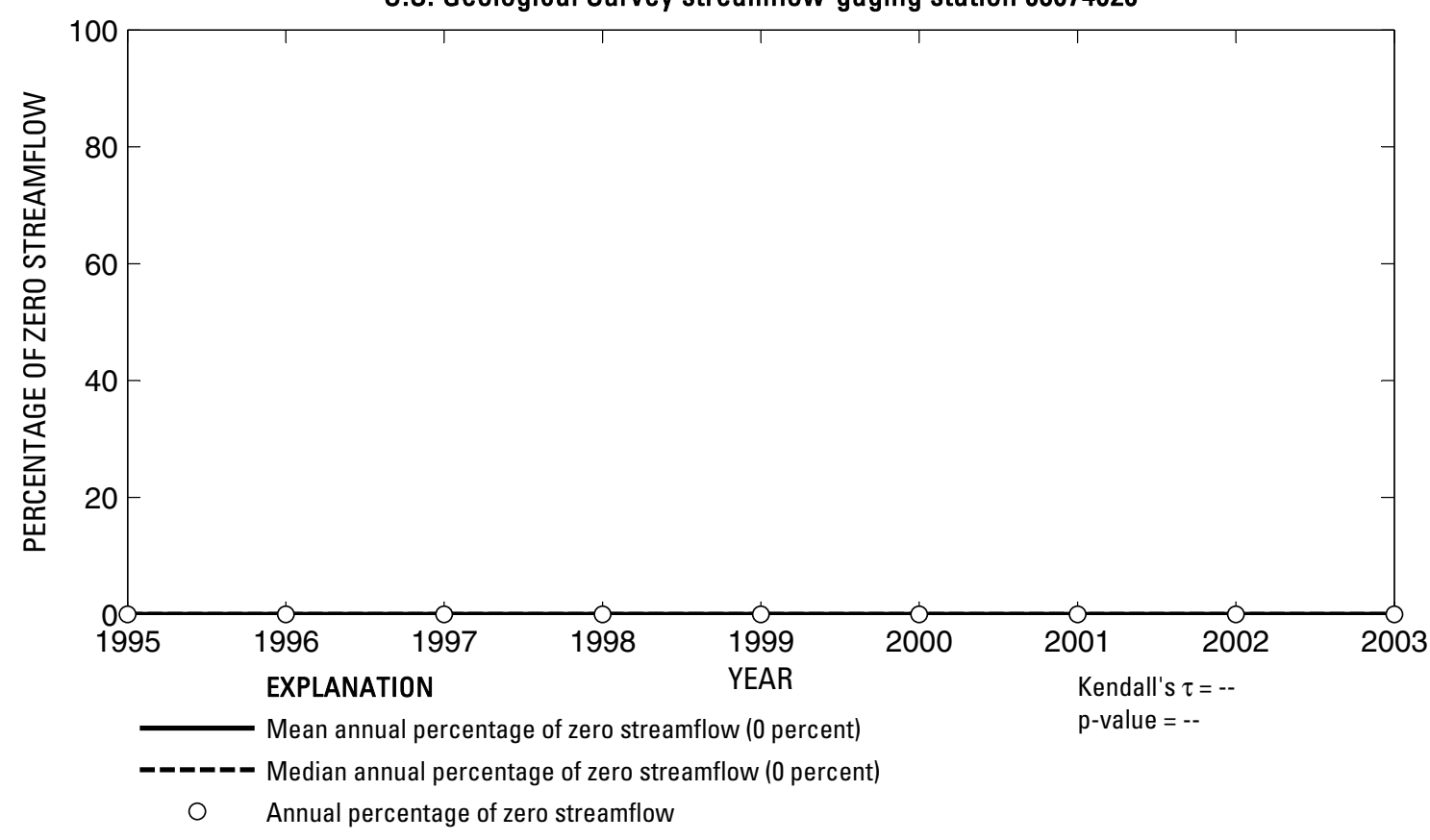

U.S. Geological Survey streamflow-gaging station 08074020

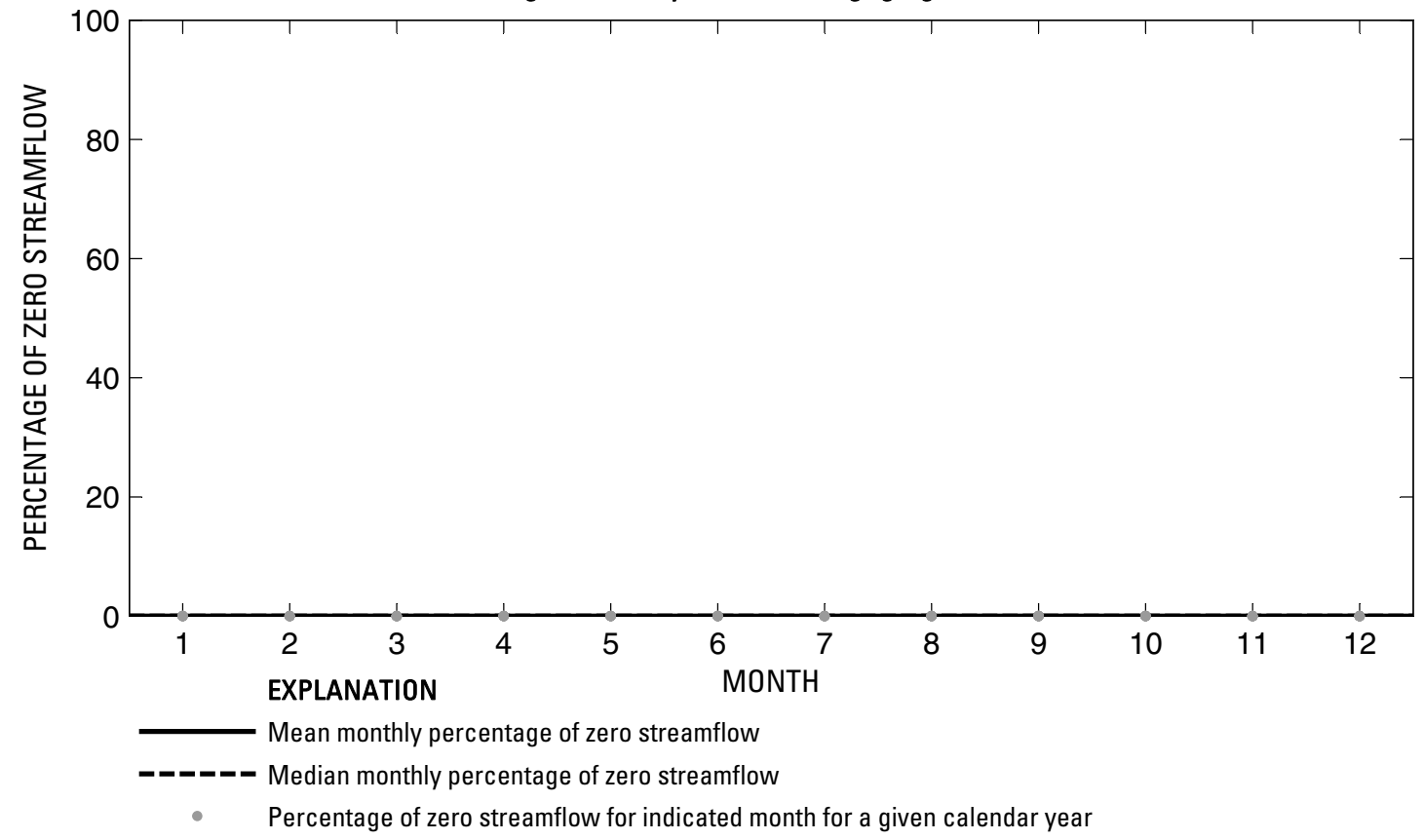

Figure 288. Analysis of percentage of zero daily mean streamflow for U.S. Geological Survey streamflow-gaging station 08074020 Whiteoak Bayou at Alabonson Road, Houston, Texas. 
U.S. Geological Survey streamflow-gaging station 08074150

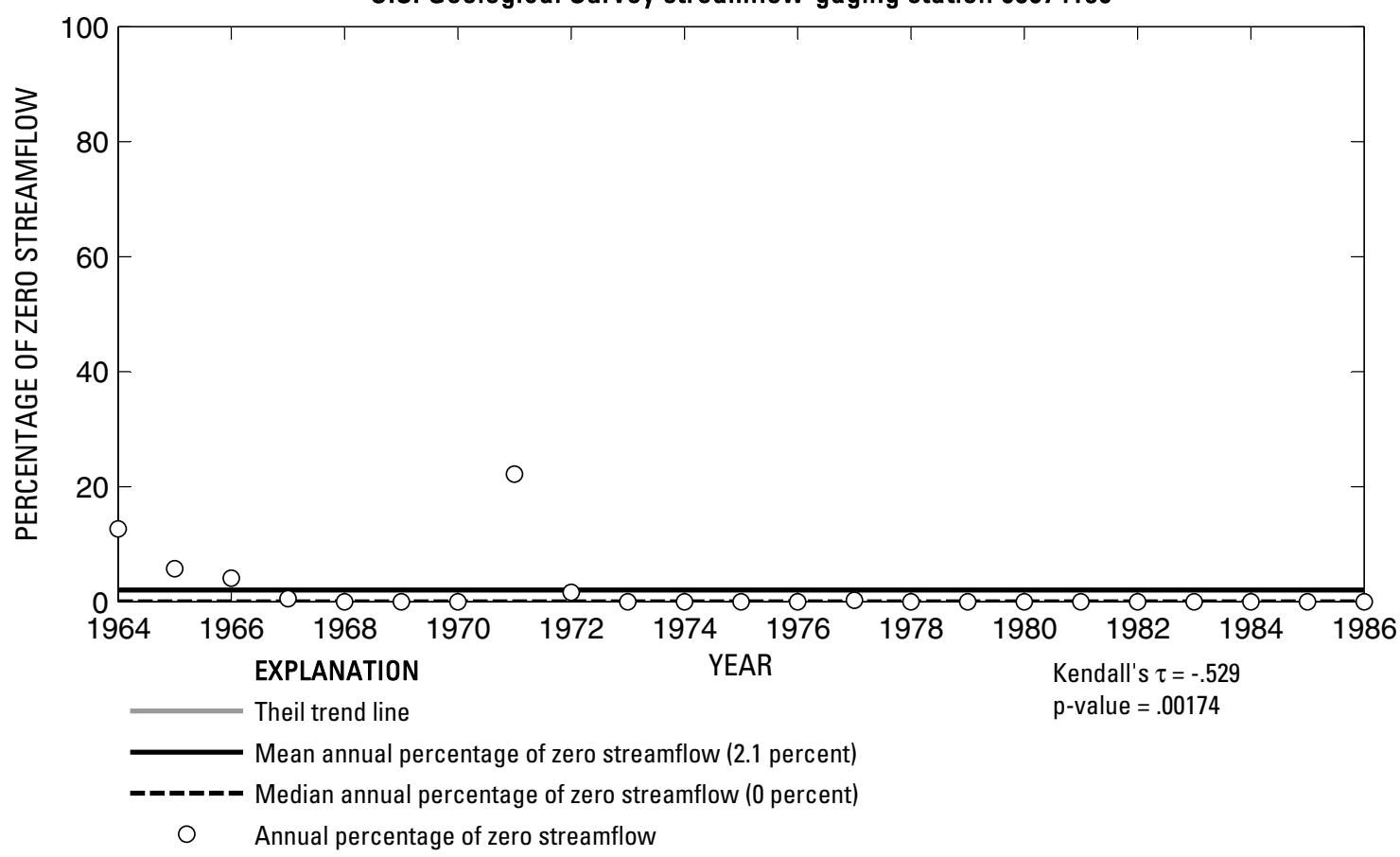

U.S. Geological Survey streamflow-gaging station 08074150

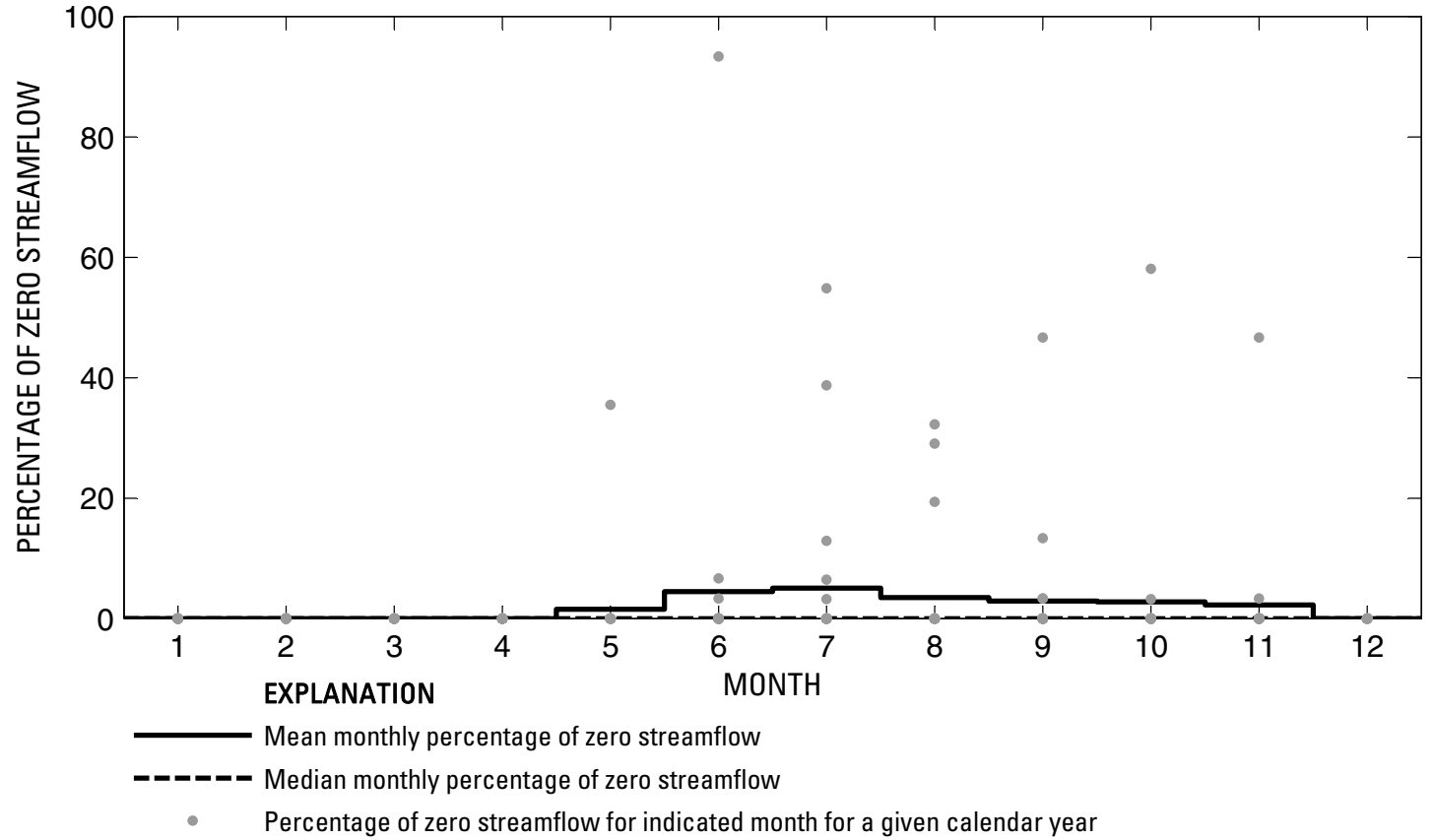

Figure 289. Analysis of percentage of zero daily mean streamflow for U.S. Geological Survey streamflow-gaging station 08074150 Cole Creek at Deihl Road, Houston, Texas. 
U.S. Geological Survey streamflow-gaging station 08074250

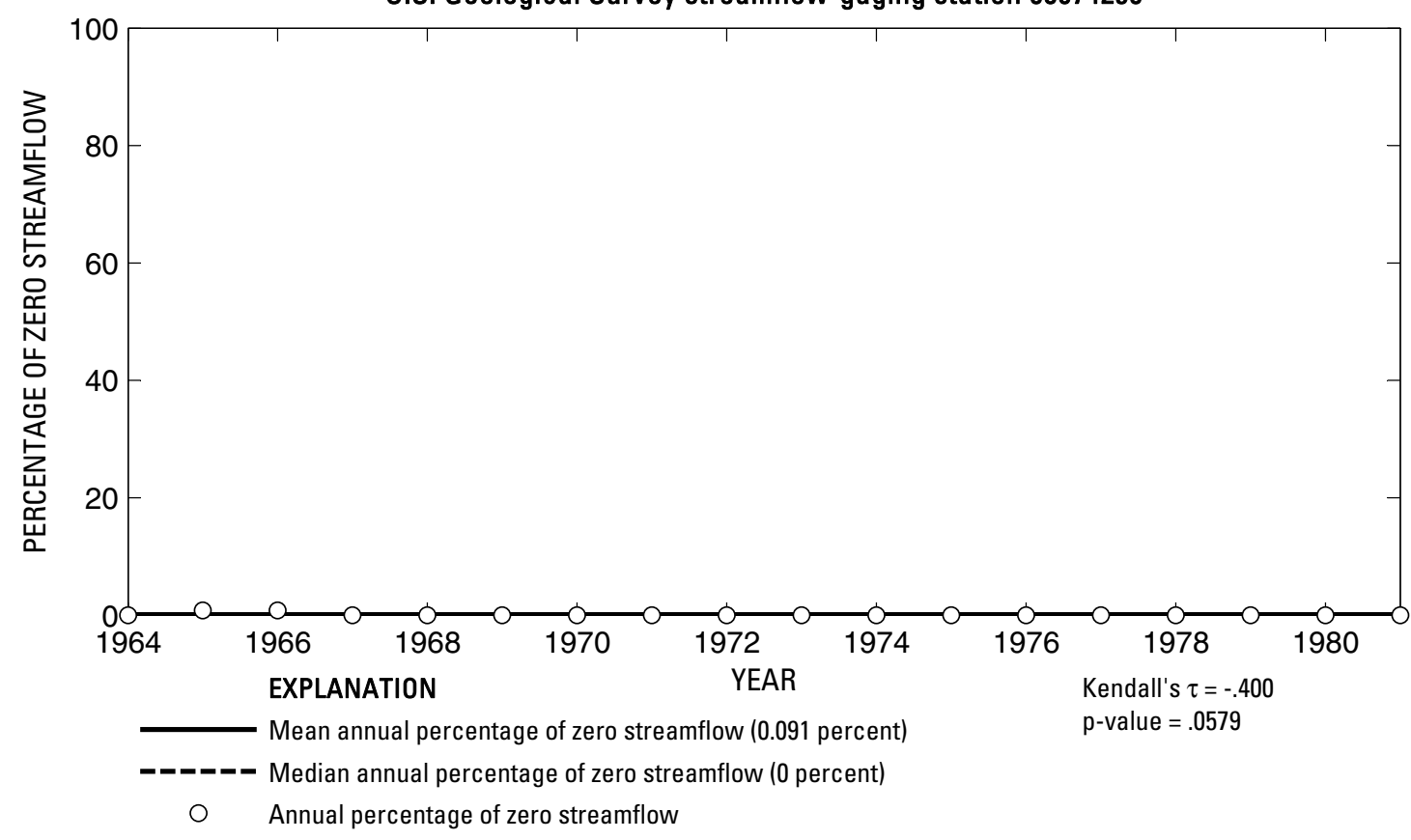

U.S. Geological Survey streamflow-gaging station 08074250

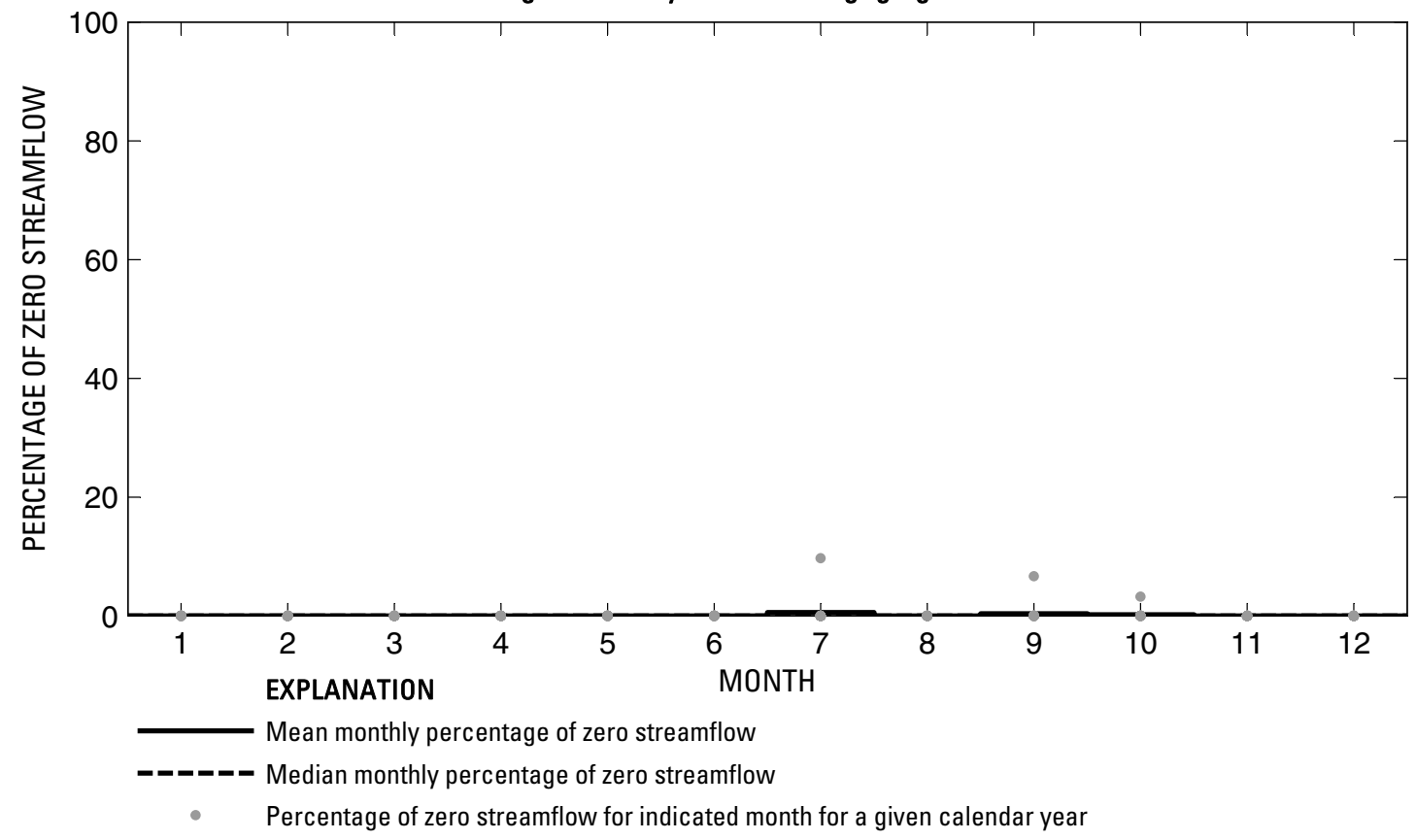

Figure 290. Analysis of percentage of zero daily mean streamflow for U.S. Geological Survey streamflow-gaging station 08074250 Brickhouse Gully at Costa Rica Street, Houston, Texas.

Index of Station Numbers 719 
U.S. Geological Survey streamflow-gaging station 08074500

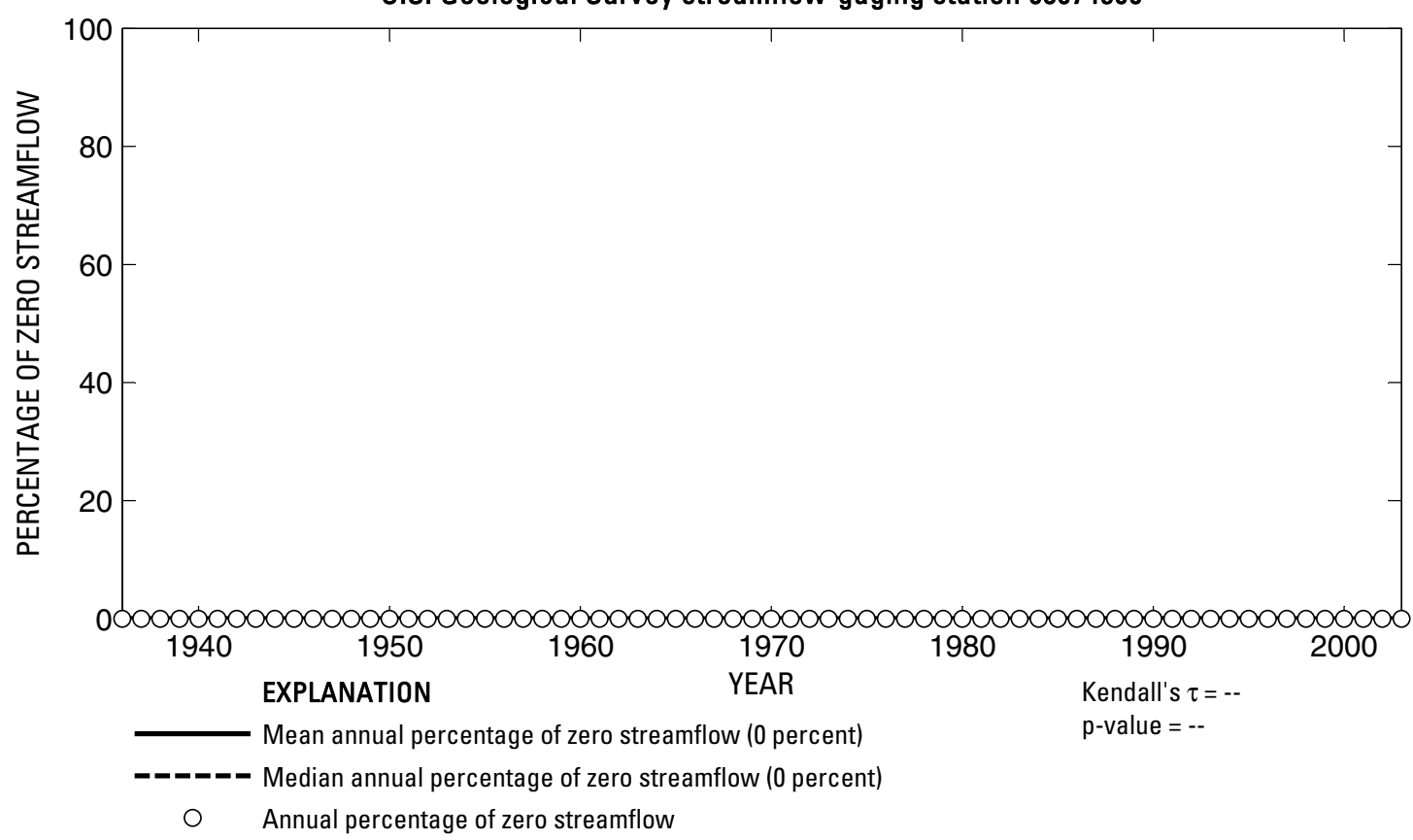

U.S. Geological Survey streamflow-gaging station 08074500

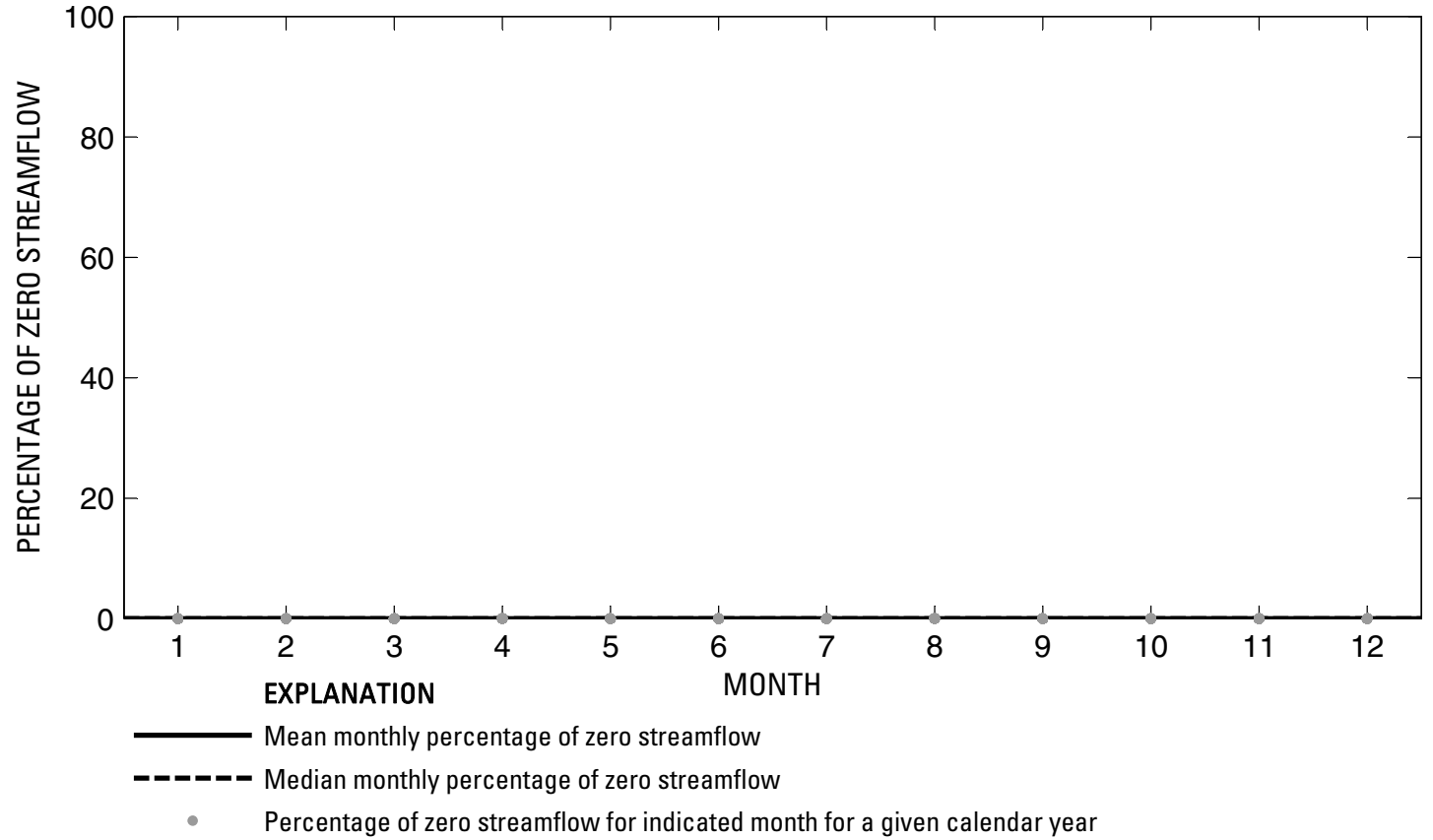

Figure 291. Analysis of percentage of zero daily mean streamflow for U.S. Geological Survey streamflow-gaging station 08074500 Whiteoak Bayou at Houston, Texas. 
U.S. Geological Survey streamflow-gaging station 08074760

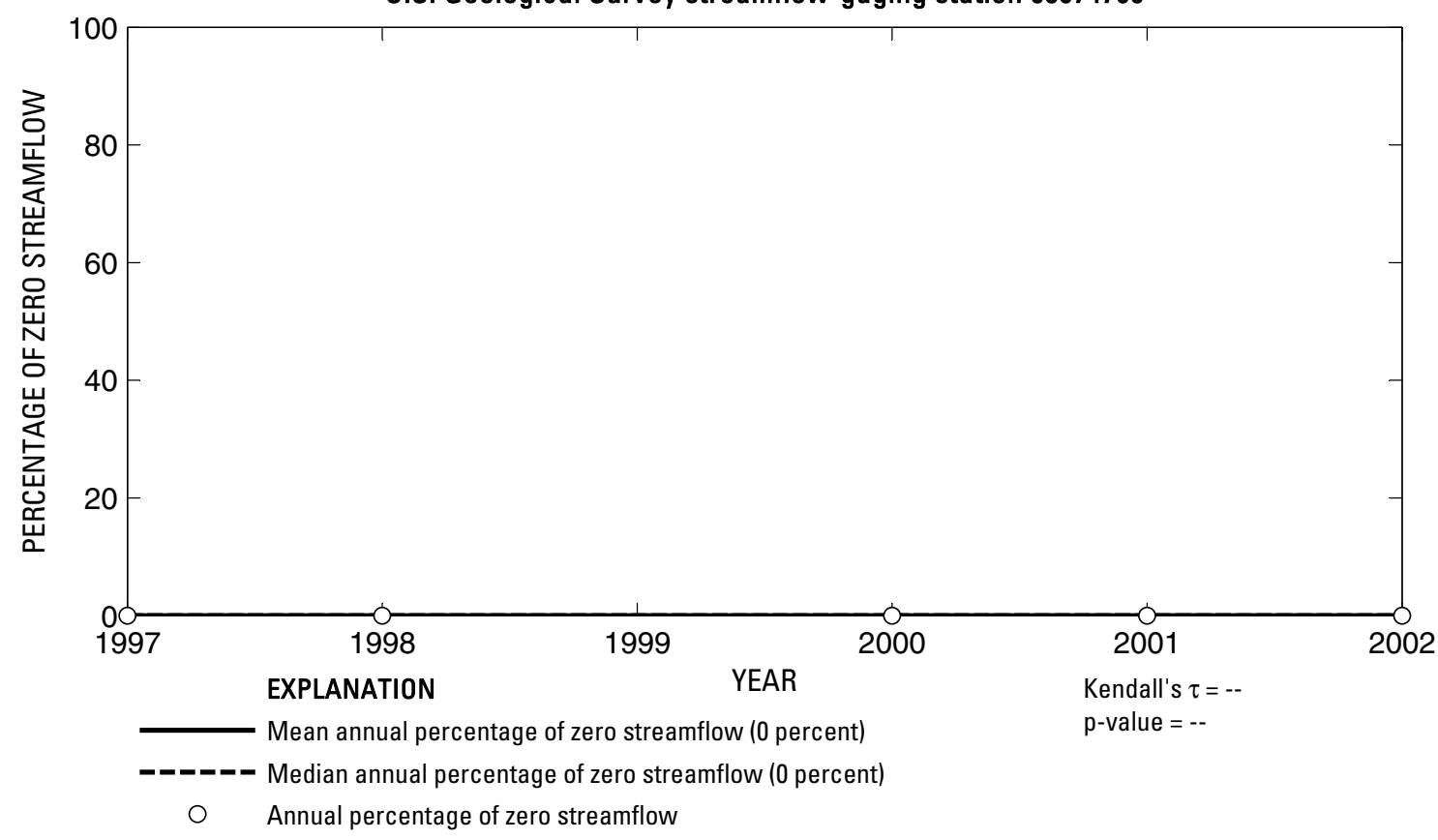

U.S. Geological Survey streamflow-gaging station 08074760

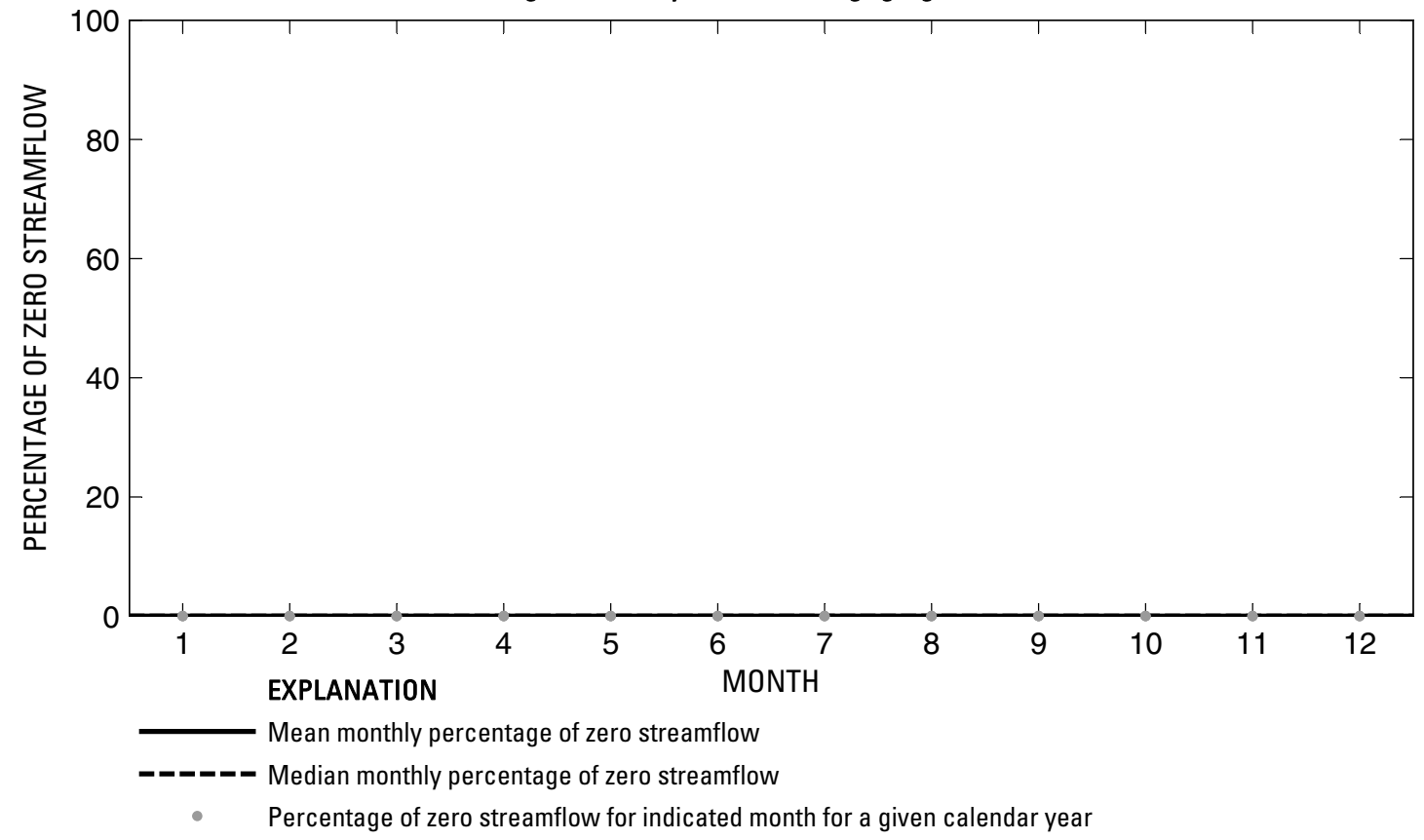

Figure 292. Analysis of percentage of zero daily mean streamflow for U.S. Geological Survey streamflow-gaging station 08074760 Brays Bayou at Alief, Texas. 


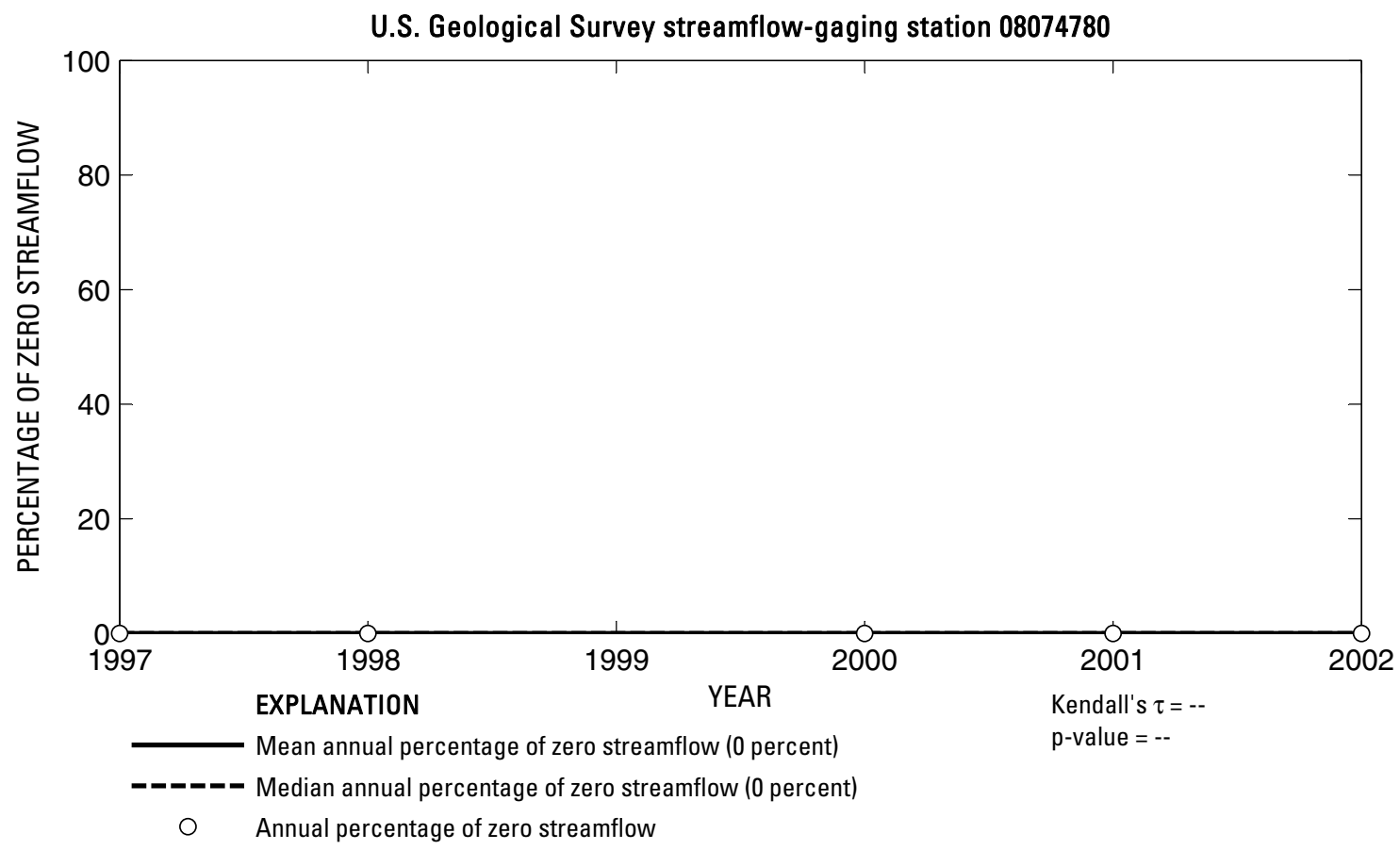

U.S. Geological Survey streamflow-gaging station 08074780

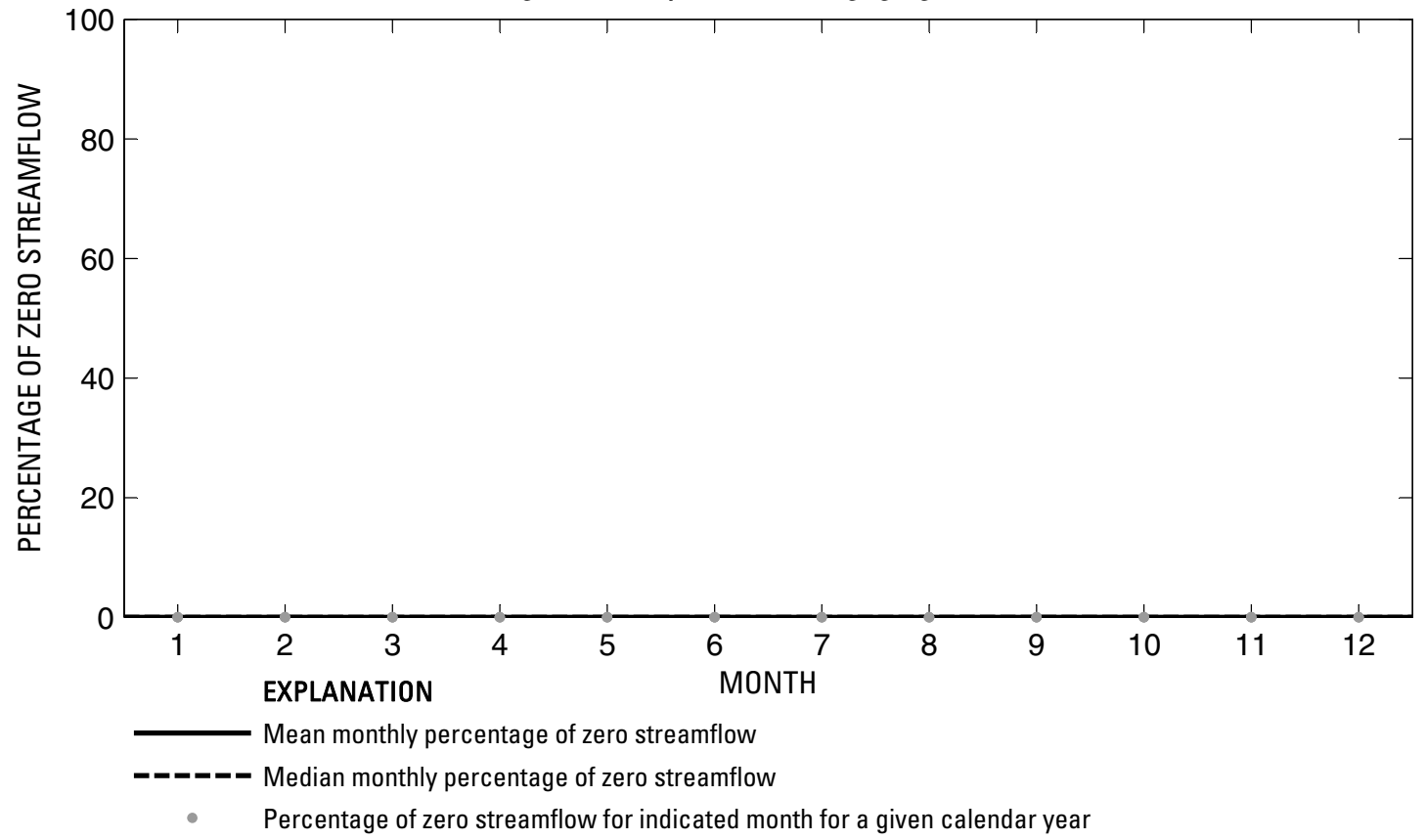

Figure 293. Analysis of percentage of zero daily mean streamflow for U.S. Geological Survey streamflow-gaging station 08074780 Keegans Bayou at Keegan Road near Houston, Texas. 
U.S. Geological Survey streamflow-gaging station 08074800

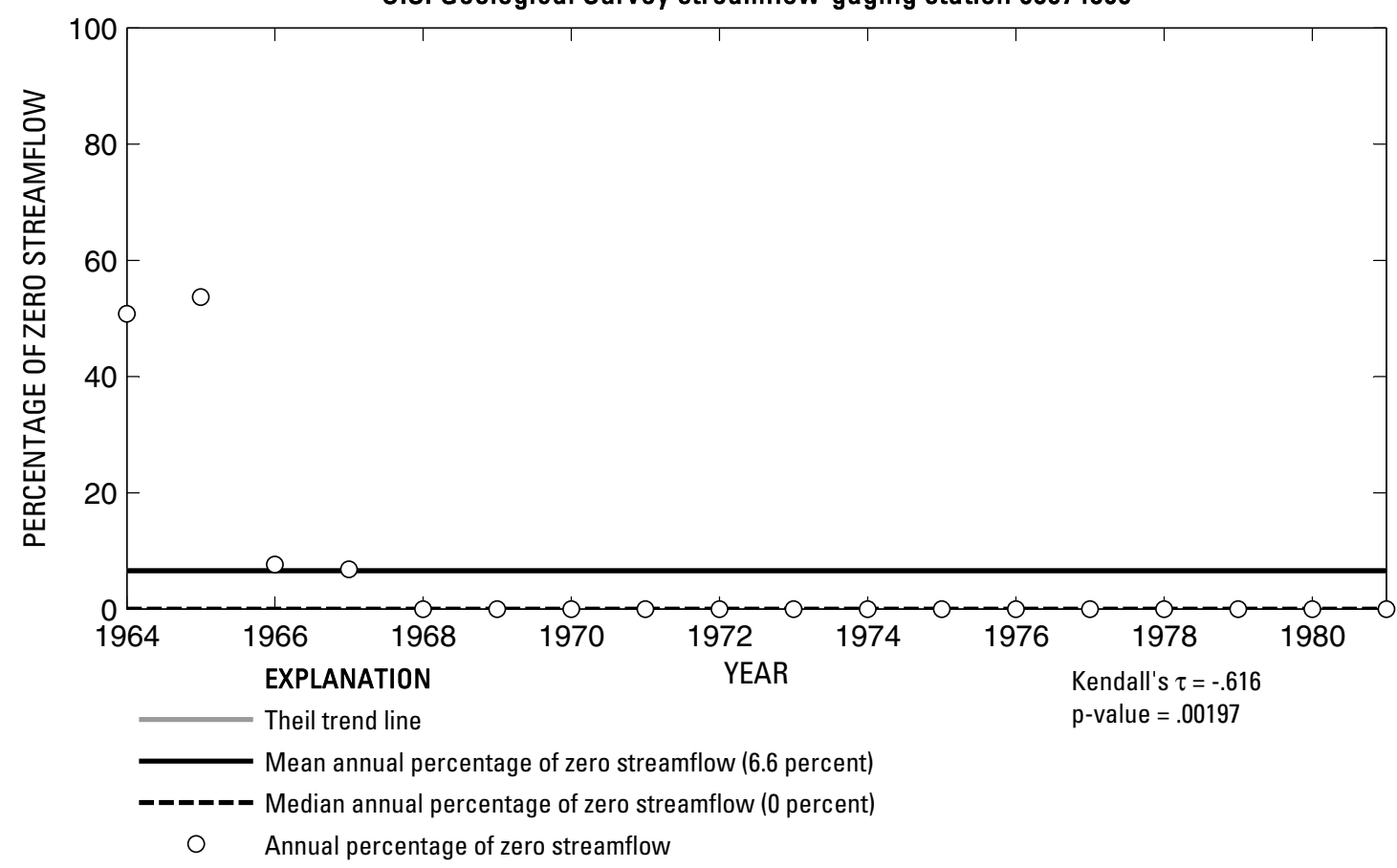

U.S. Geological Survey streamflow-gaging station 08074800

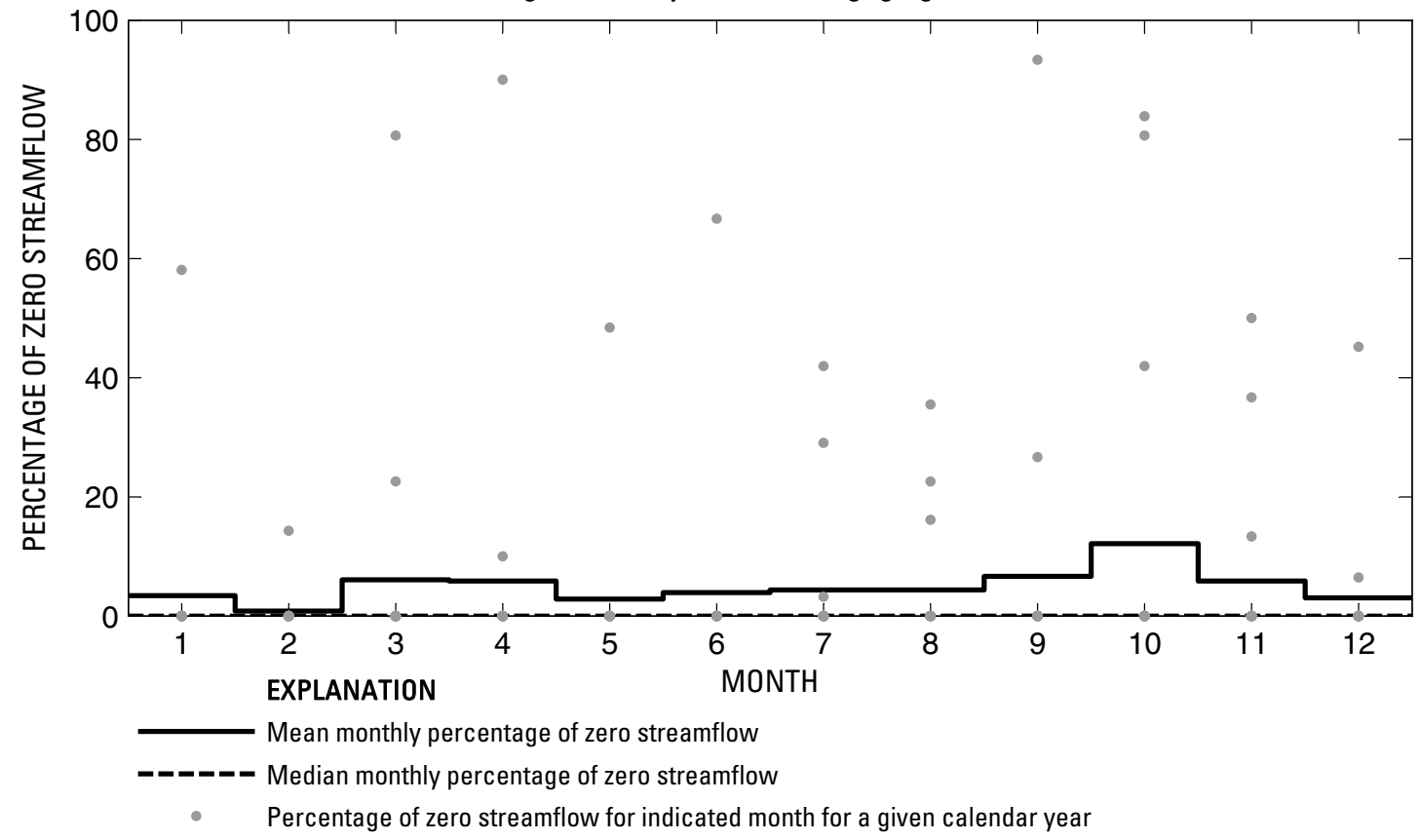

Figure 294. Analysis of percentage of zero daily mean streamflow for U.S. Geological Survey streamflow-gaging station 08074800 Keegans Bayou at Roark Road near Houston, Texas.

Index of Station Numbers 719 
U.S. Geological Survey streamflow-gaging station 08074810

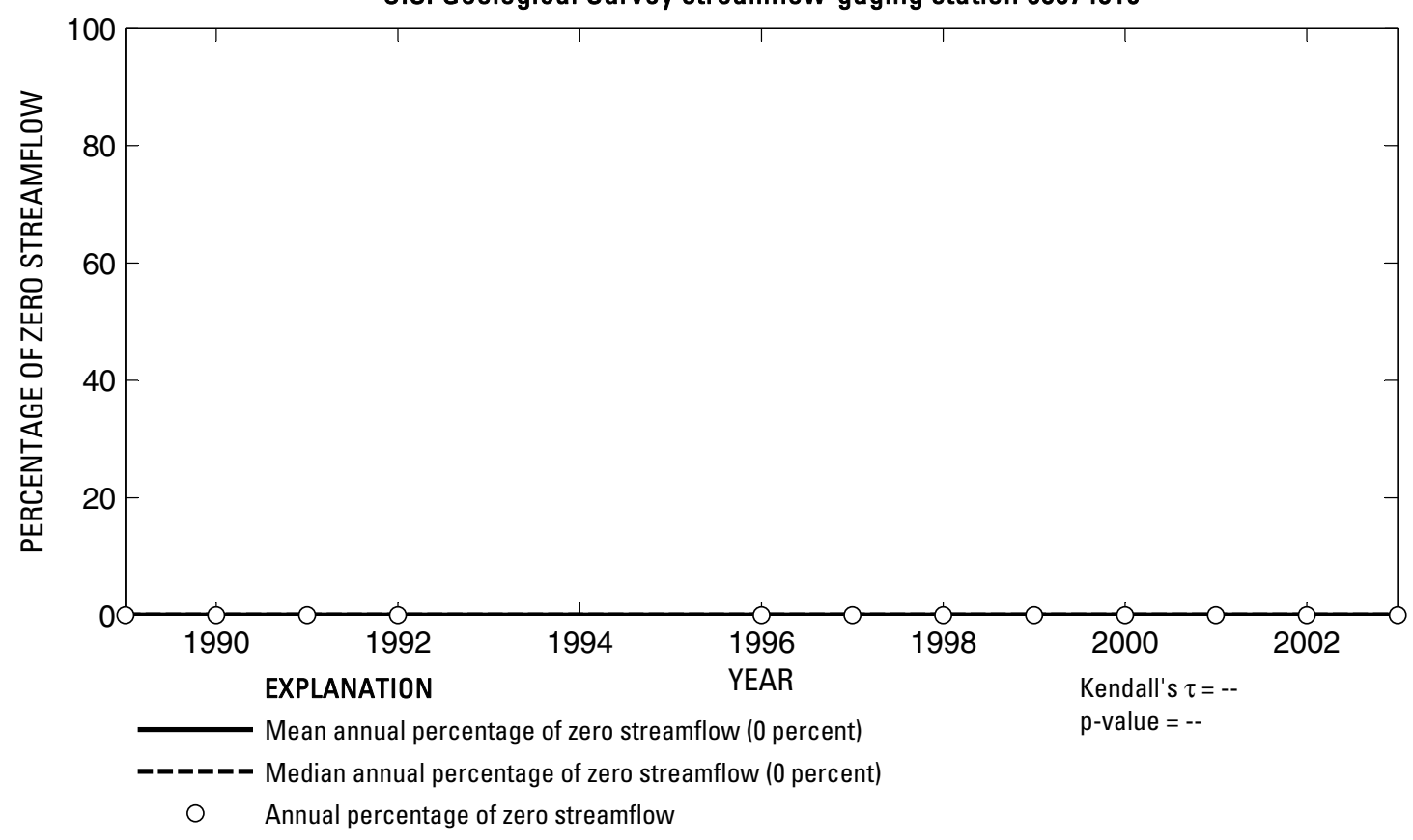

U.S. Geological Survey streamflow-gaging station 08074810

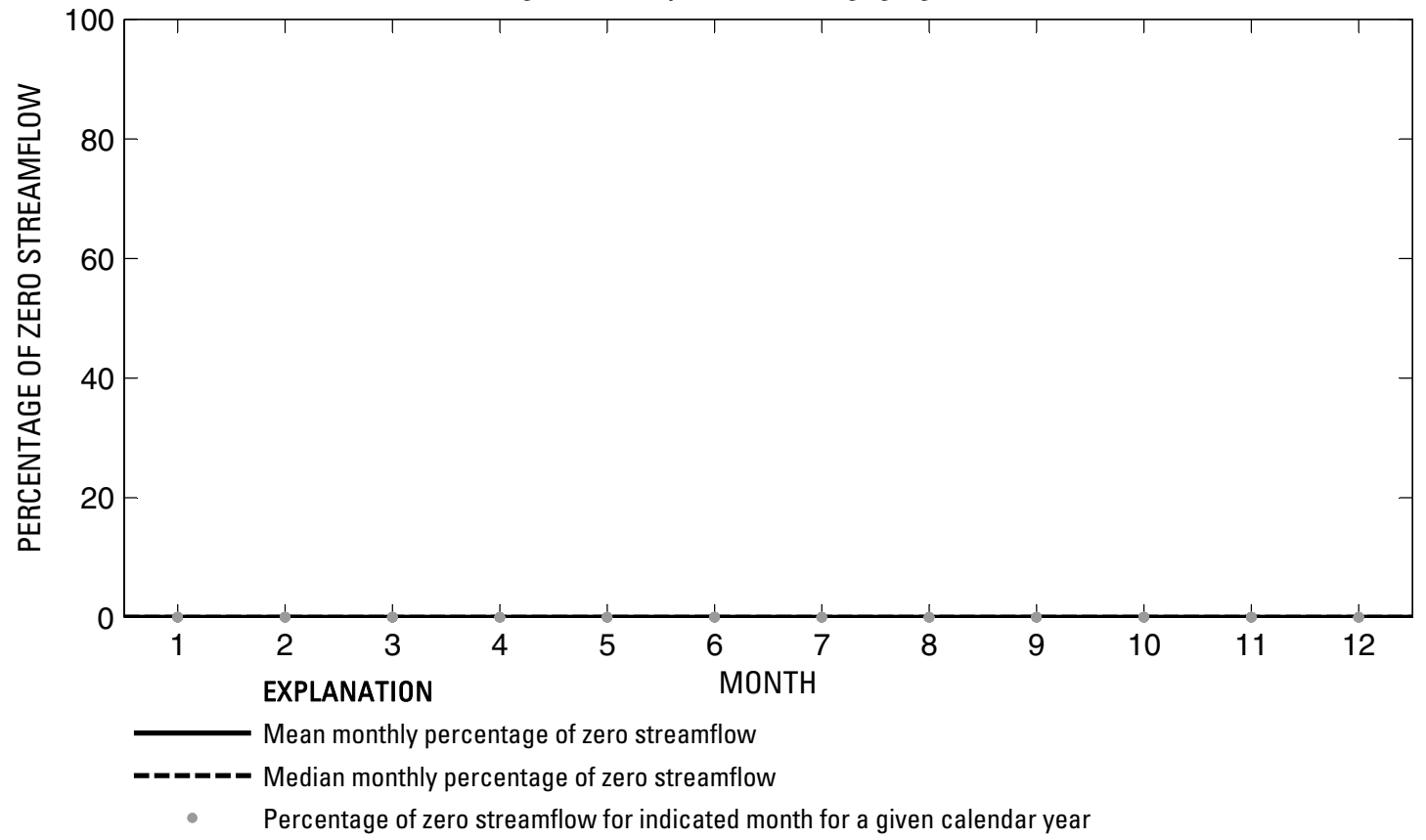

Figure 295. Analysis of percentage of zero daily mean streamflow for U.S. Geological Survey streamflow-gaging station 08074810 Brays Bayou at Gessner Drive, Houston, Texas. 
U.S. Geological Survey streamflow-gaging station 08075000

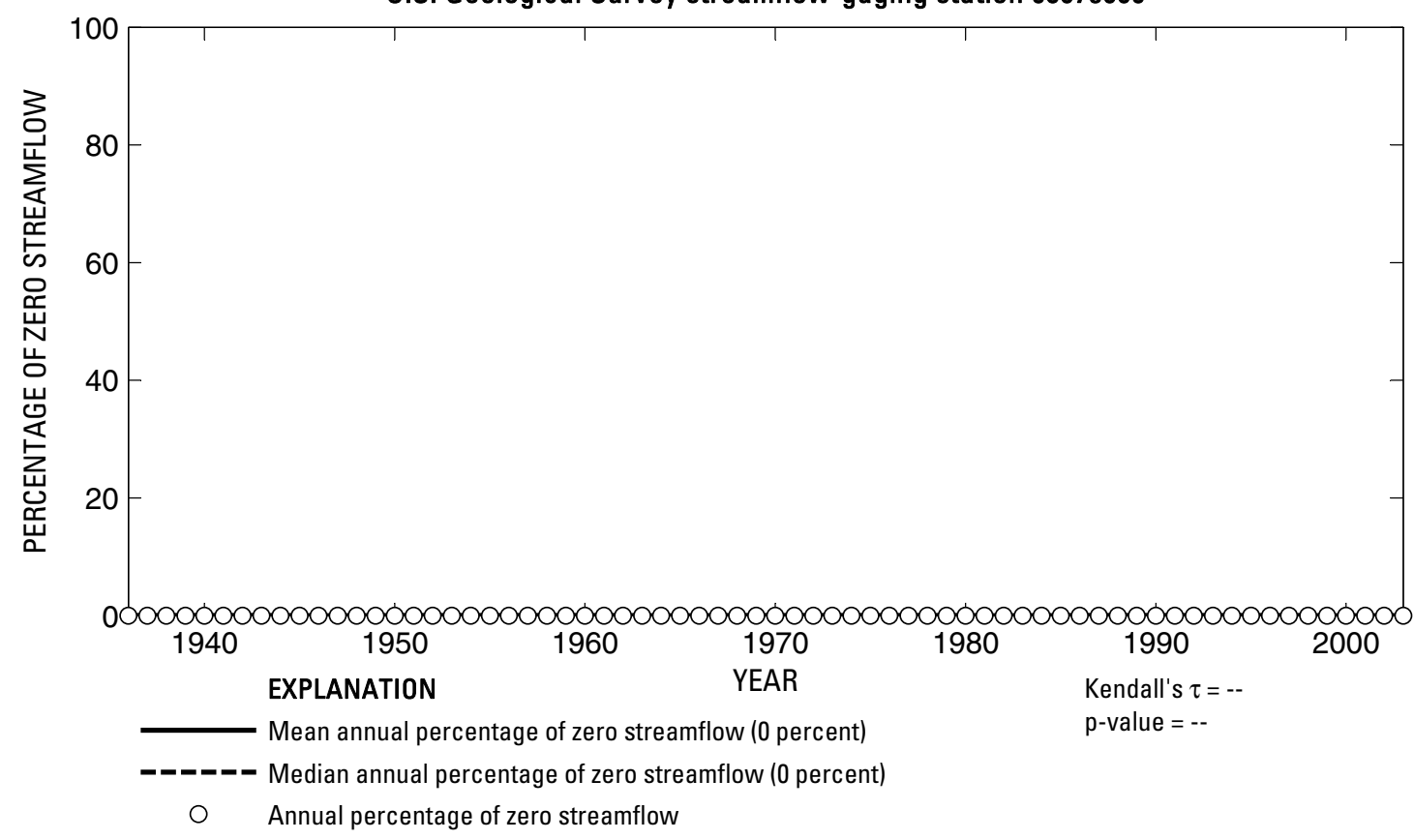

U.S. Geological Survey streamflow-gaging station 08075000

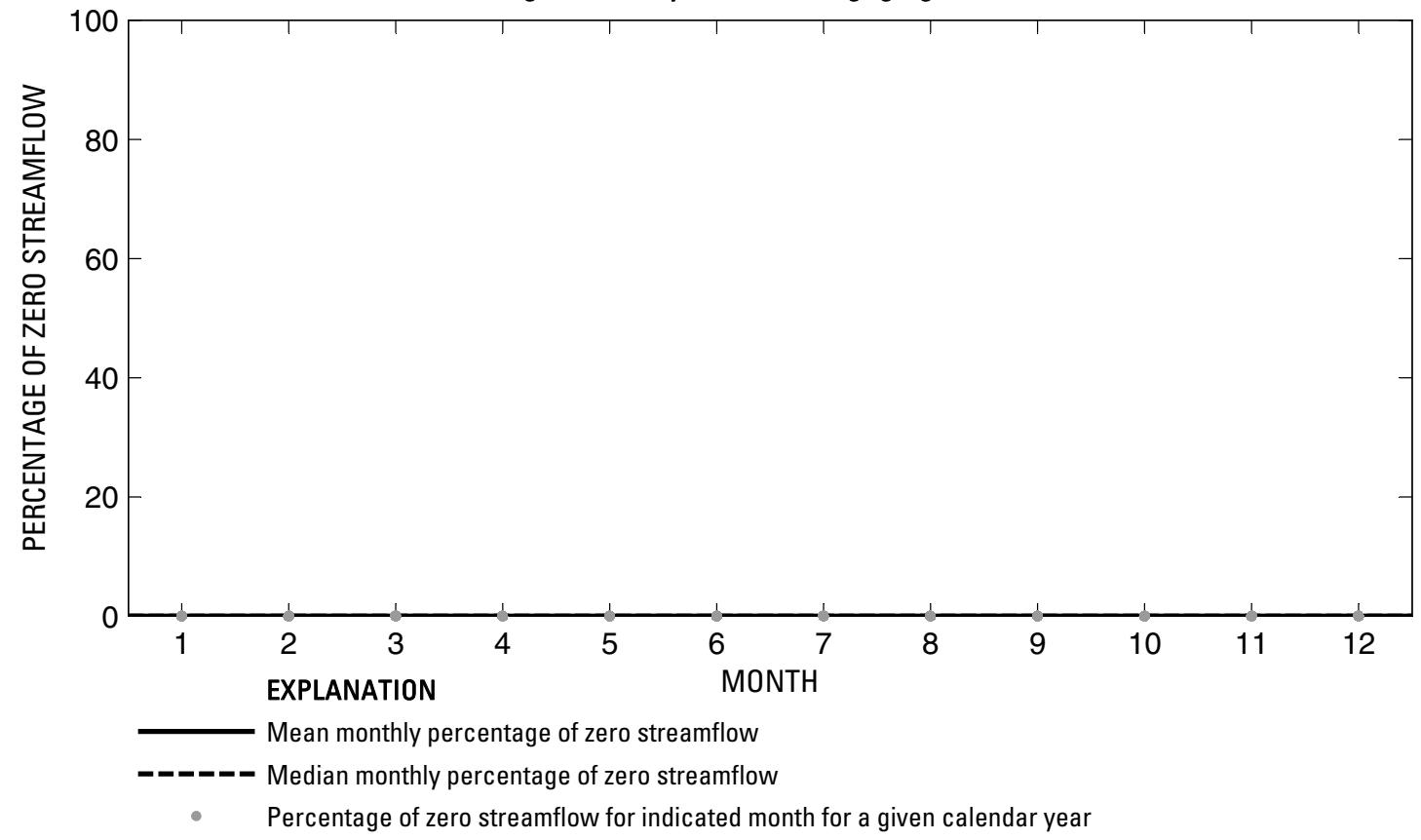

Figure 296. Analysis of percentage of zero daily mean streamflow for U.S. Geological Survey streamflow-gaging station 08075000 Brays Bayou at Houston, Texas. 


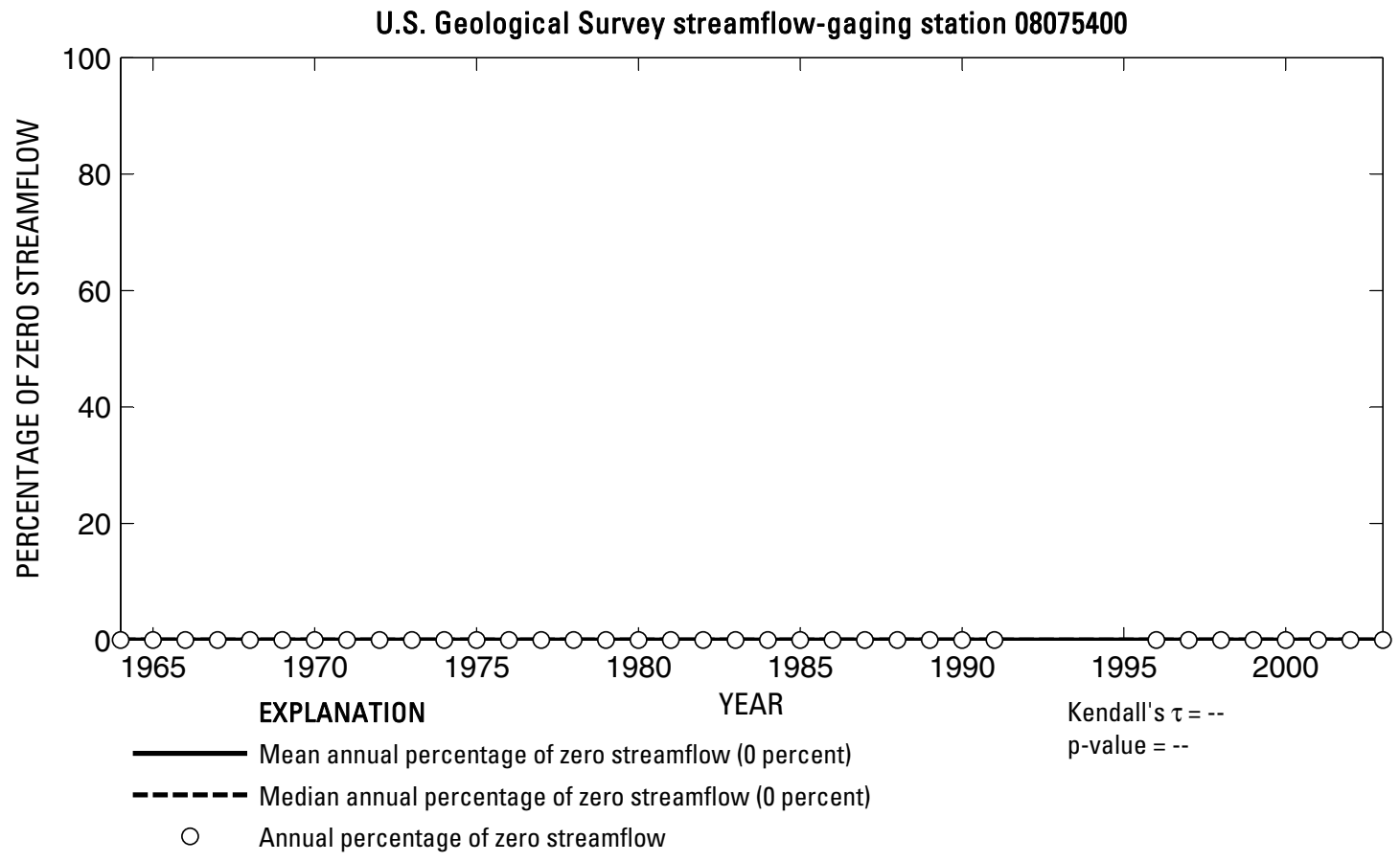

U.S. Geological Survey streamflow-gaging station 08075400

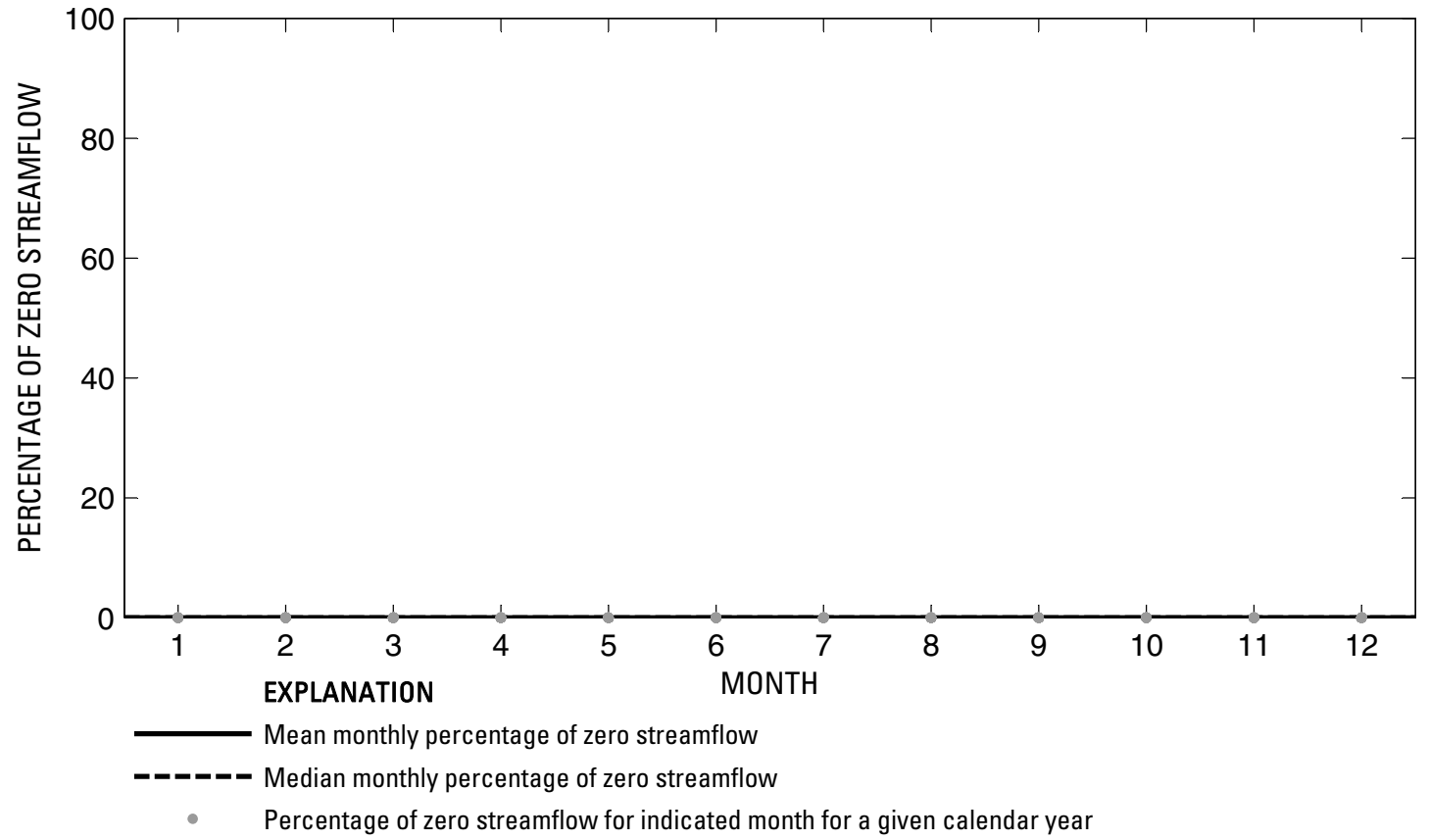

Figure 297. Analysis of percentage of zero daily mean streamflow for U.S. Geological Survey streamflow-gaging station 08075400 Sims Bayou at Hiram Clarke Street, Houston, Texas. 
U.S. Geological Survey streamflow-gaging station 08075500

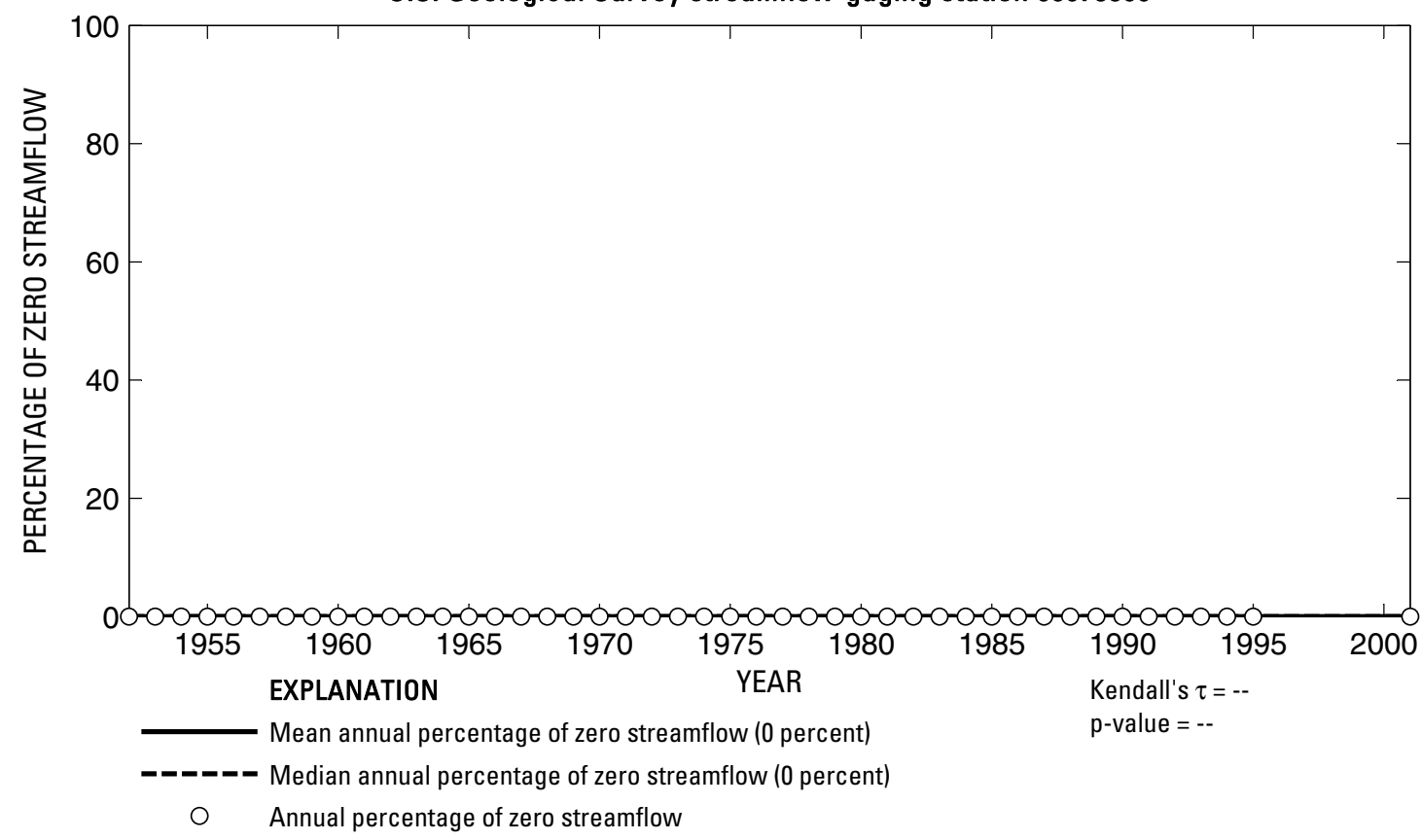

U.S. Geological Survey streamflow-gaging station 08075500

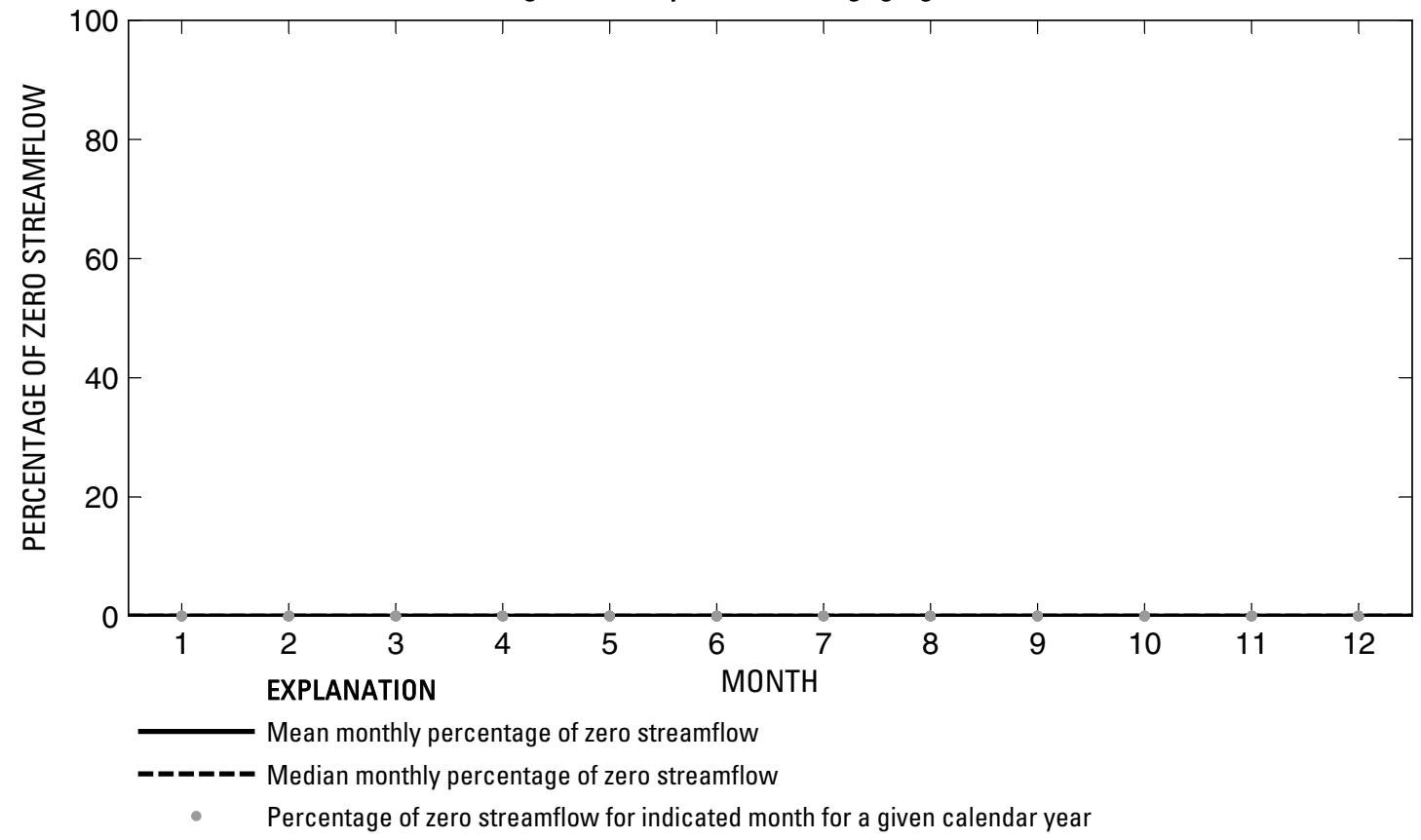

Figure 298. Analysis of percentage of zero daily mean streamflow for U.S. Geological Survey streamflow-gaging station 08075500 Sims Bayou at Houston, Texas. 


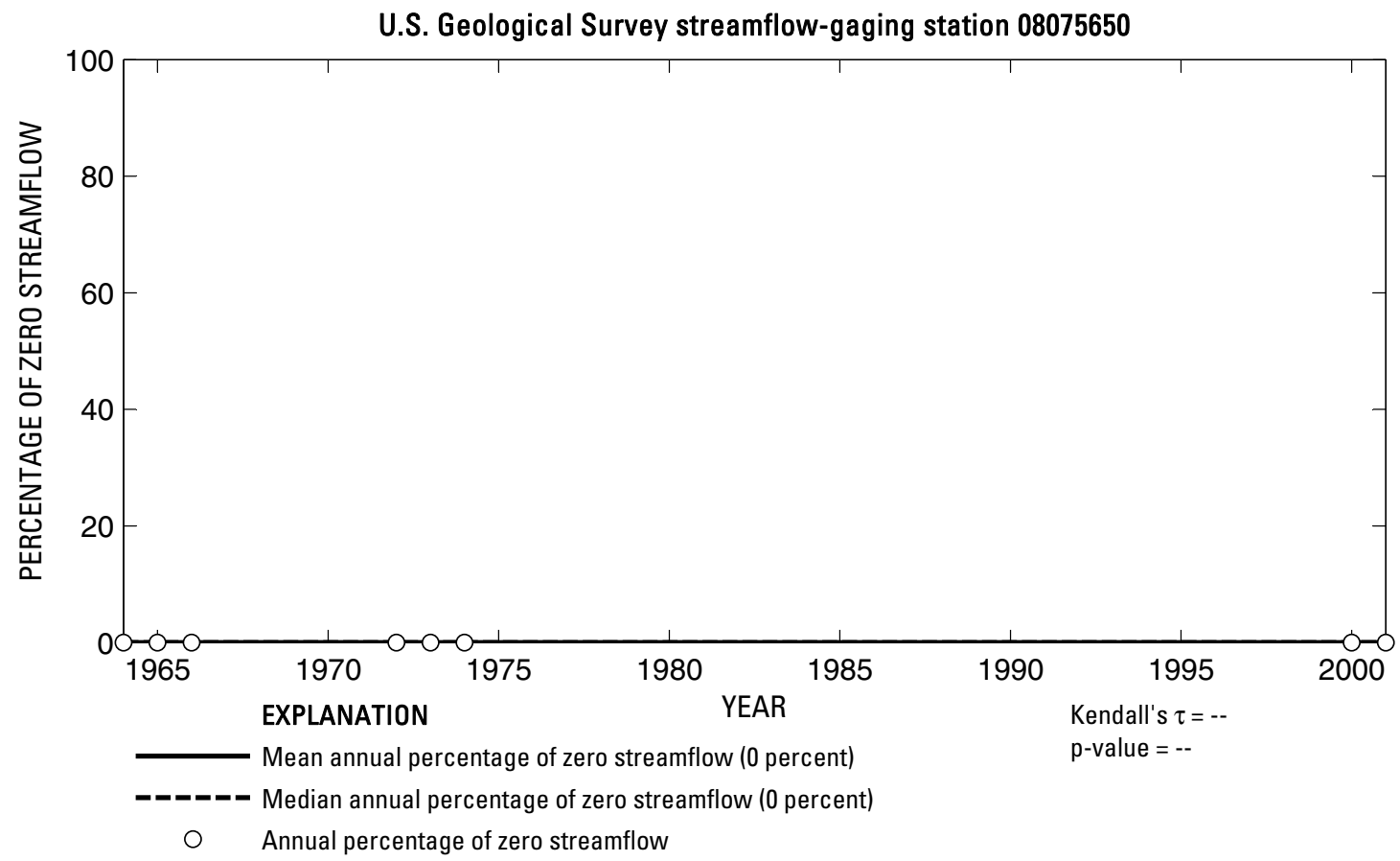

U.S. Geological Survey streamflow-gaging station 08075650

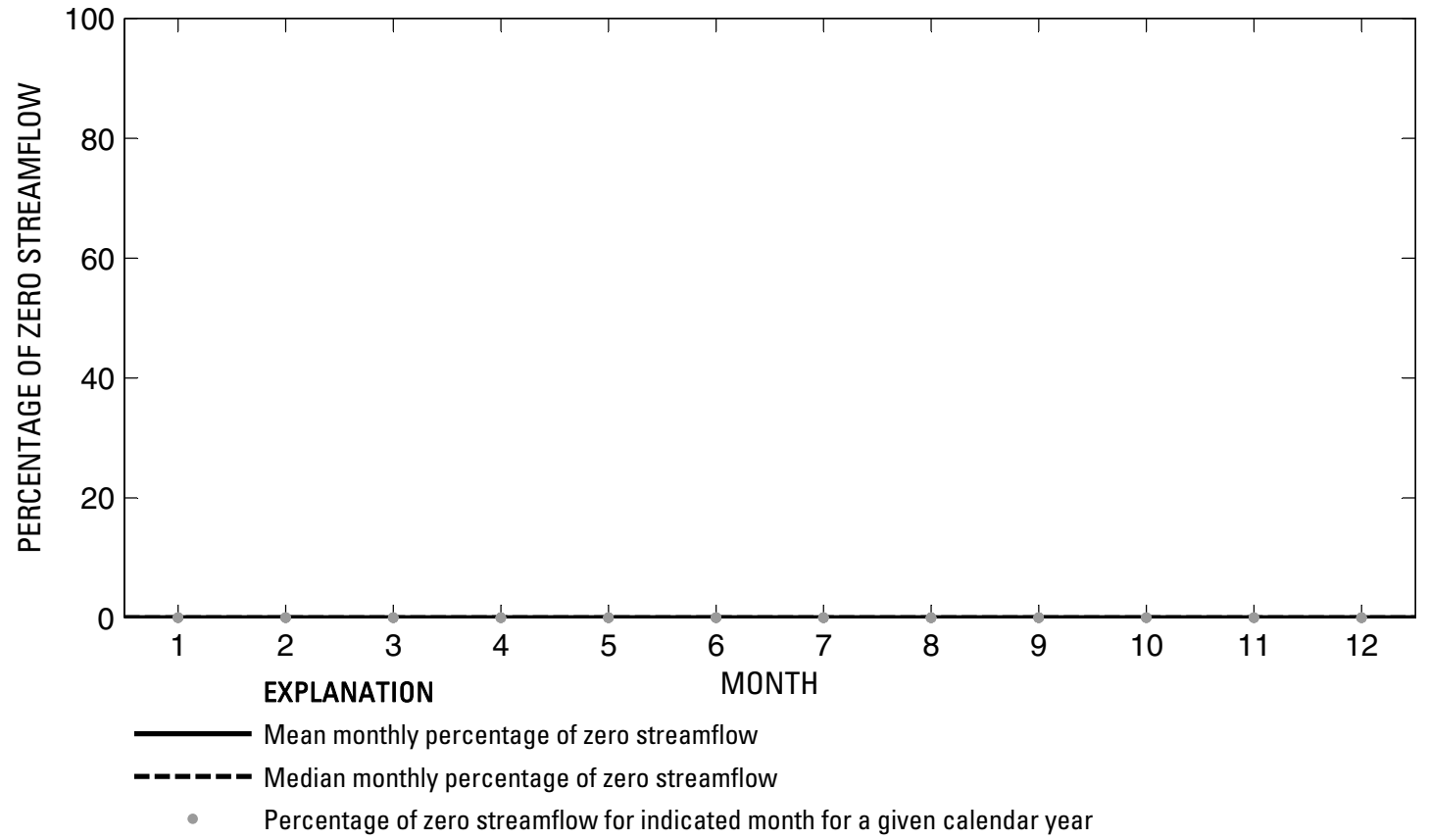

Figure 299. Analysis of percentage of zero daily mean streamflow for U.S. Geological Survey streamflow-gaging station 08075650 Berry Bayou at Forest Oaks Street, Houston, Texas. 
U.S. Geological Survey streamflow-gaging station 08075730

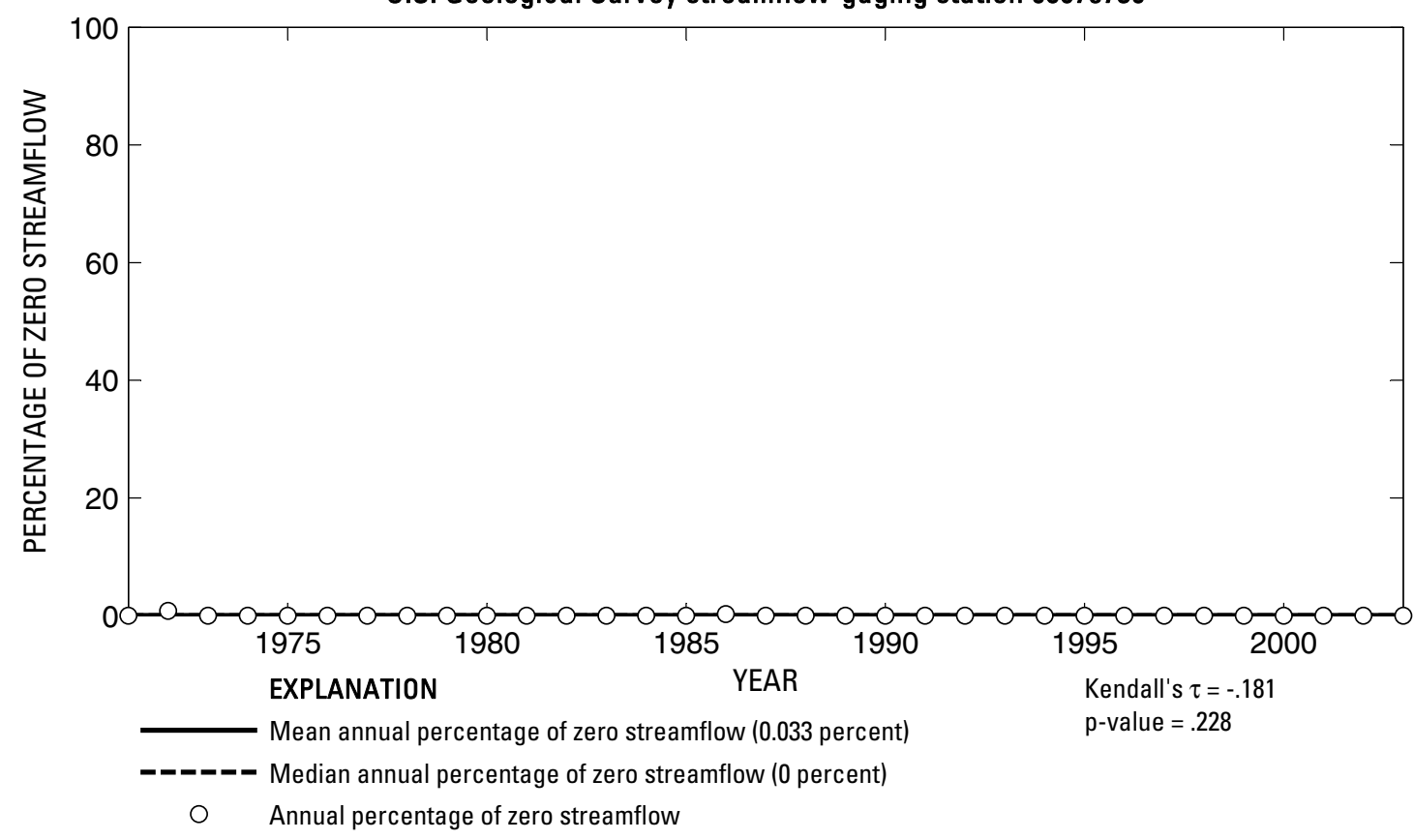

U.S. Geological Survey streamflow-gaging station 08075730

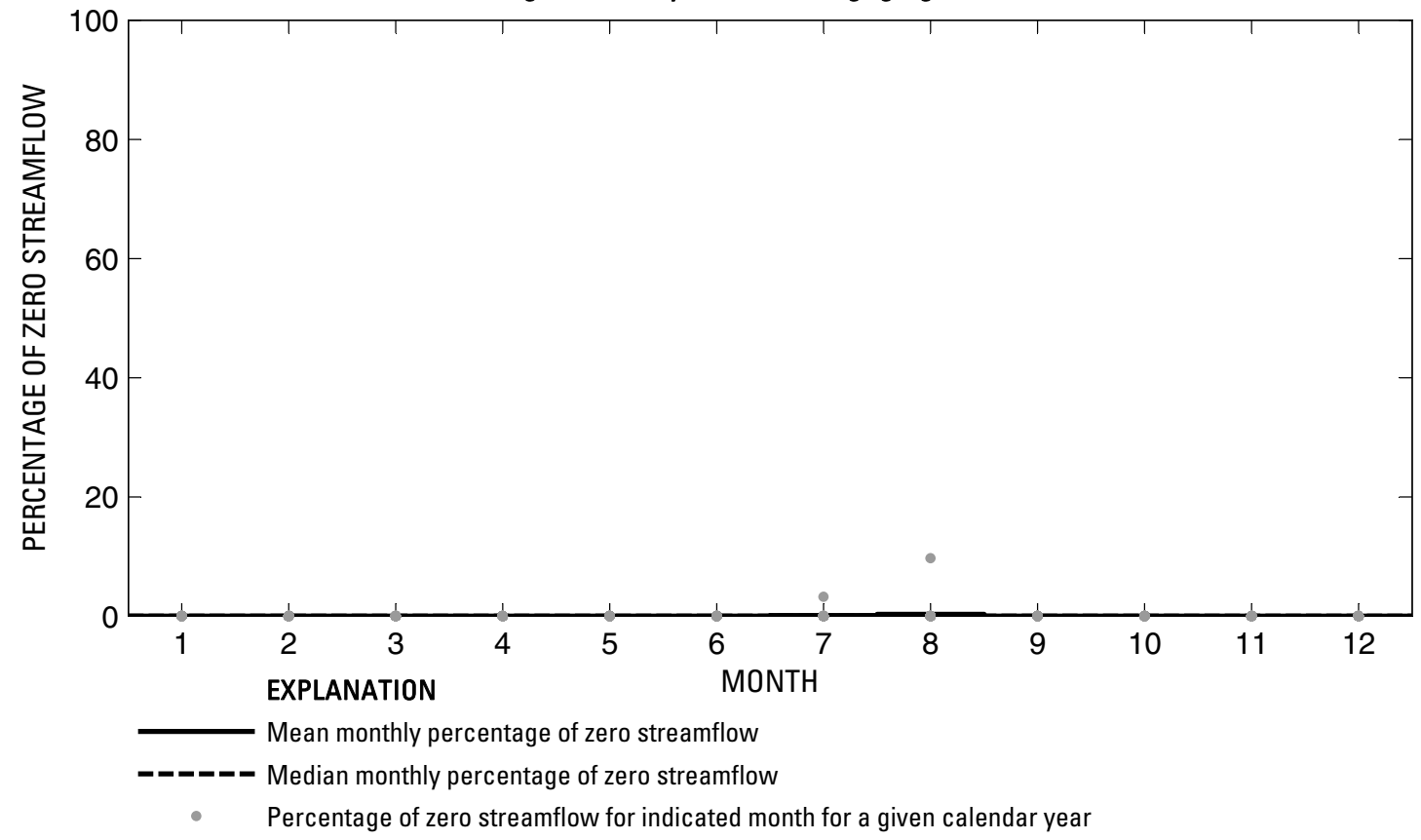

Figure 300. Analysis of percentage of zero daily mean streamflow for U.S. Geological Survey streamflow-gaging station 08075730 Vince Bayou at Pasadena, Texas. 
U.S. Geological Survey streamflow-gaging station 08075770

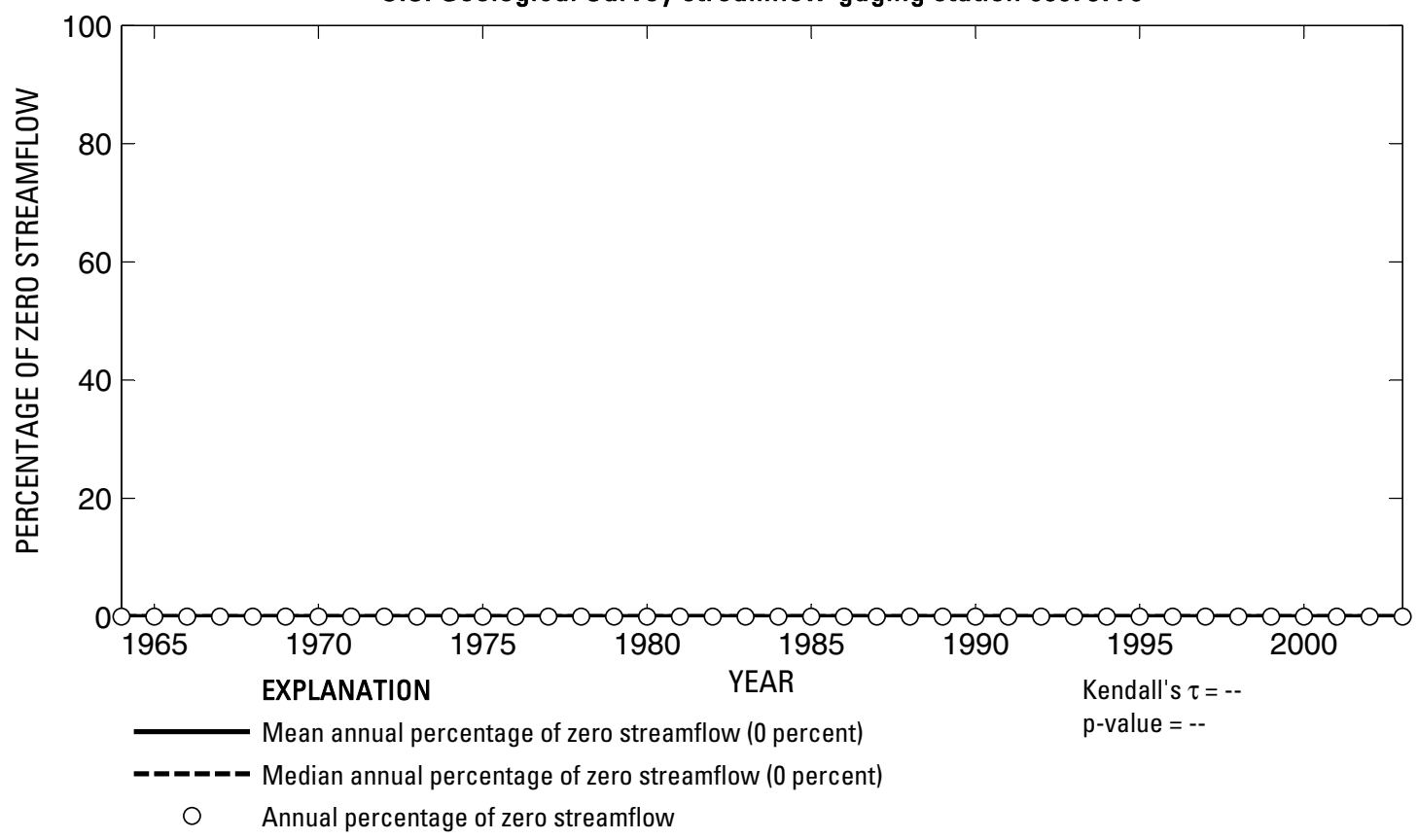

U.S. Geological Survey streamflow-gaging station 08075770

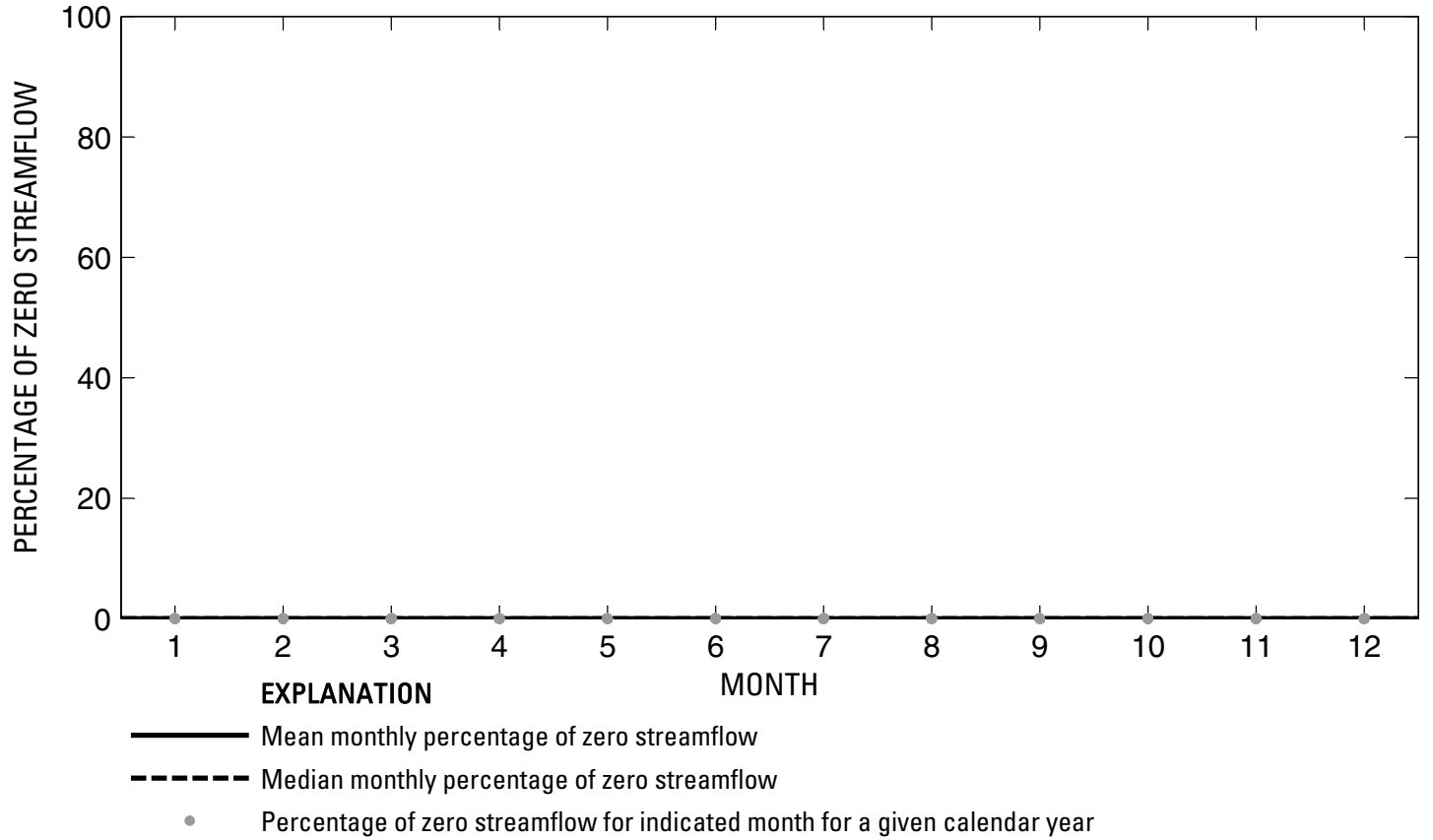

Figure 301. Analysis of percentage of zero daily mean streamflow for U.S. Geological Survey streamflow-gaging station 08075770 Hunting Bayou at Interstate Highway 610, Houston, Texas. 
U.S. Geological Survey streamflow-gaging station 08075780

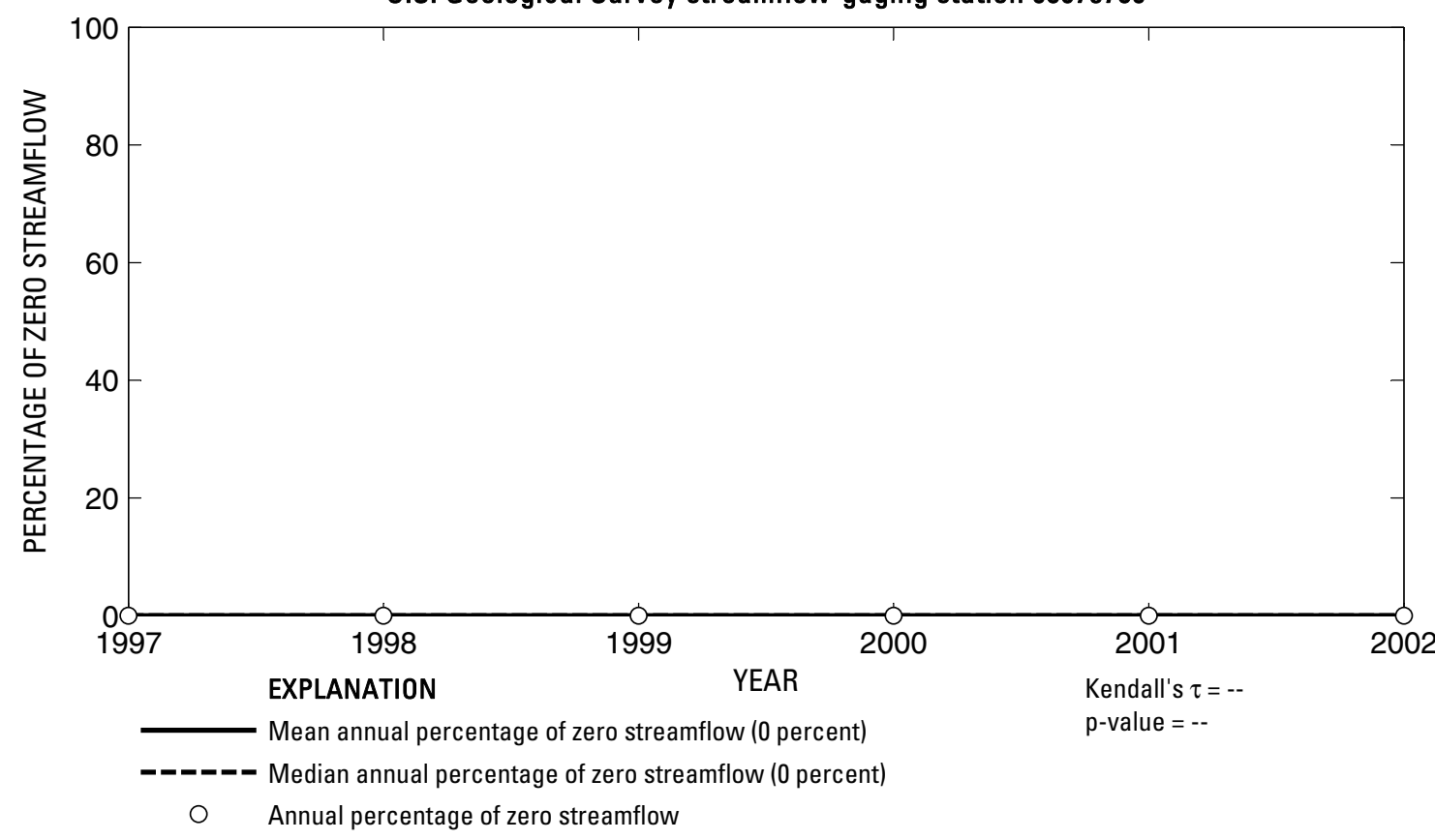

U.S. Geological Survey streamflow-gaging station 08075780

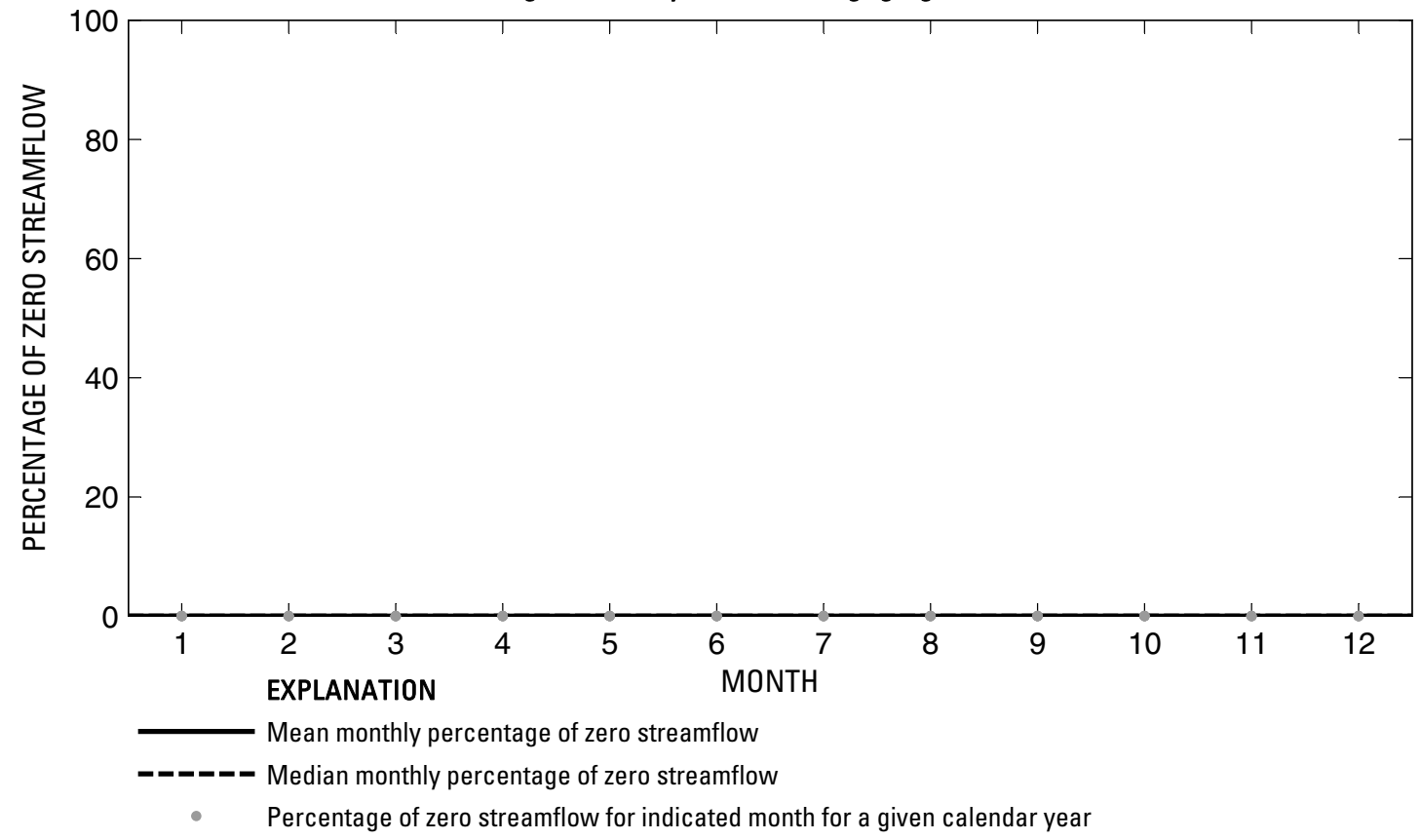

Figure 302. Analysis of percentage of zero daily mean streamflow for U.S. Geological Survey streamflow-gaging station 08075780 Greens Bayou at Cutten Road near Houston, Texas.

Index of Station Numbers 719 


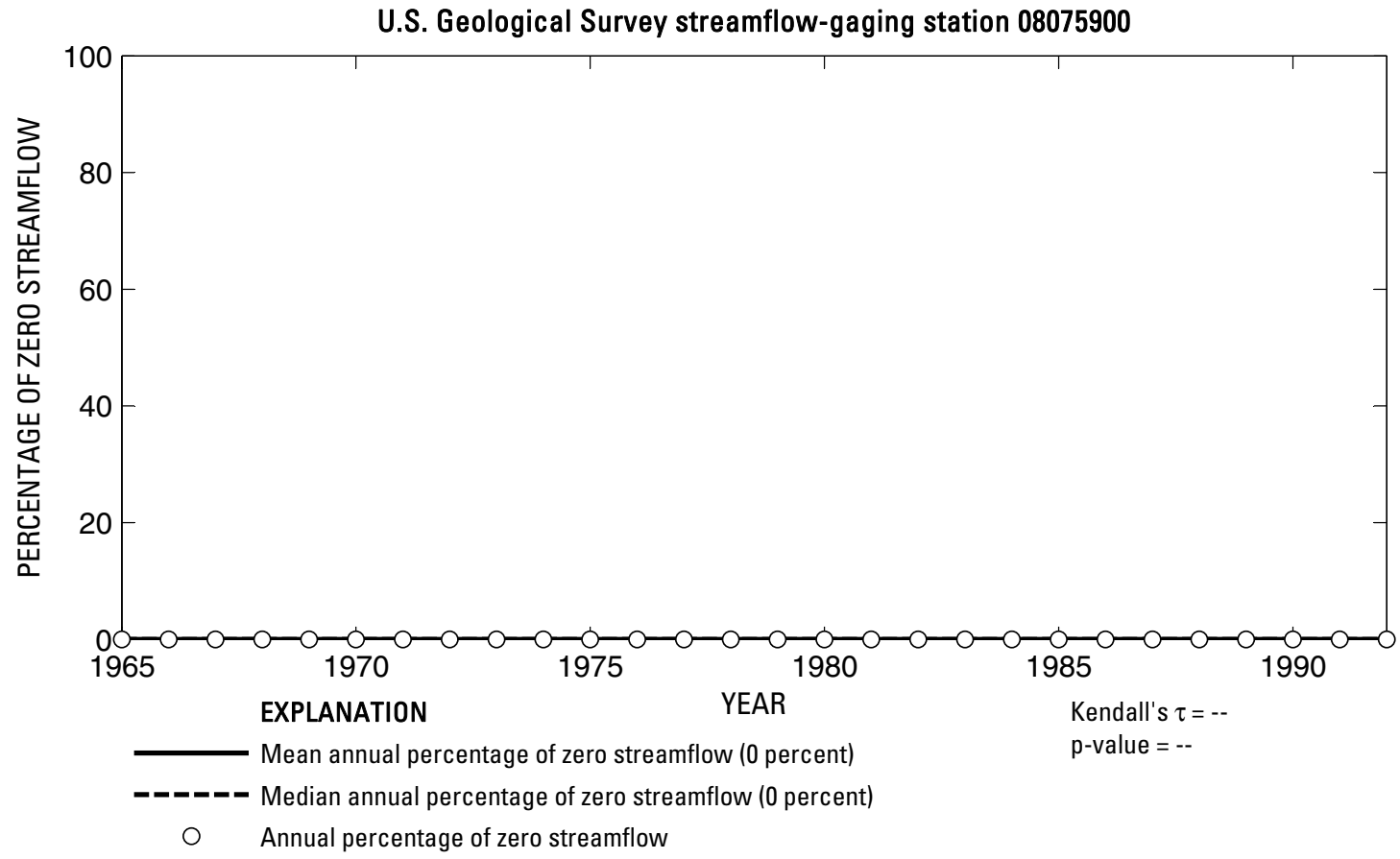

U.S. Geological Survey streamflow-gaging station 08075900

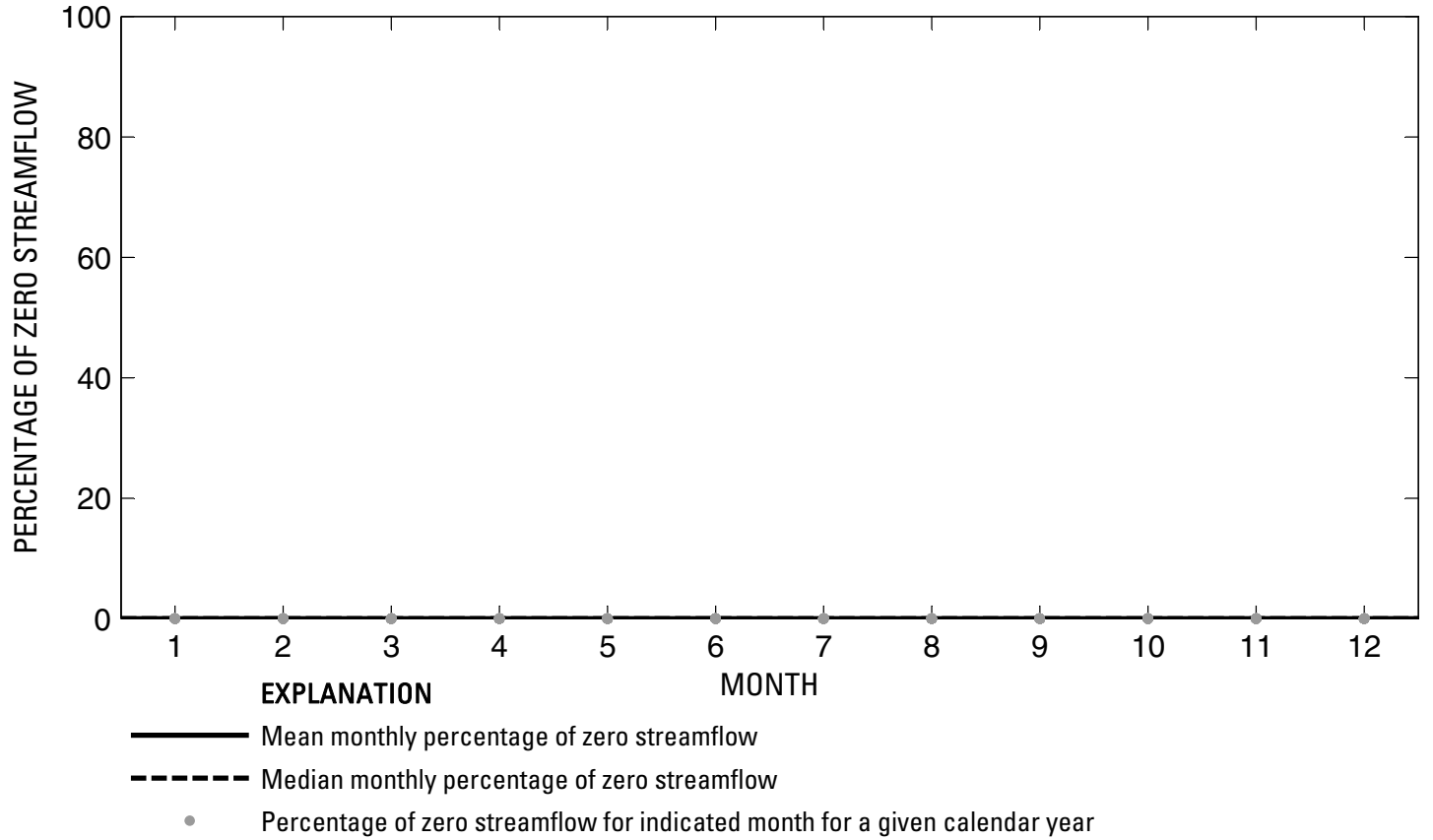

Figure 303. Analysis of percentage of zero daily mean streamflow for U.S. Geological Survey streamflow-gaging station 08075900 Greens Bayou near U. S. Highway 75 near Houston, Texas. 
U.S. Geological Survey streamflow-gaging station 08076000

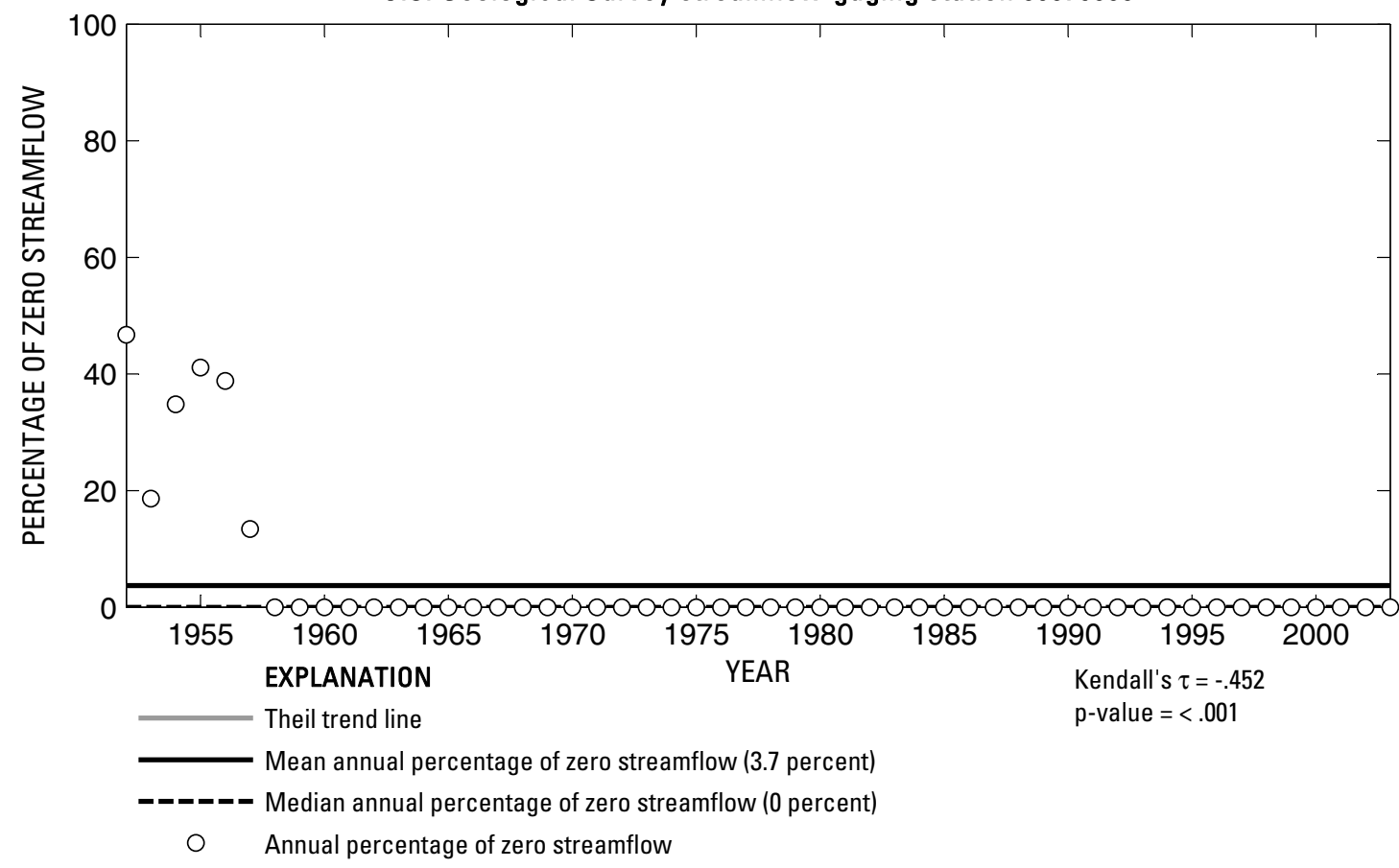

U.S. Geological Survey streamflow-gaging station 08076000

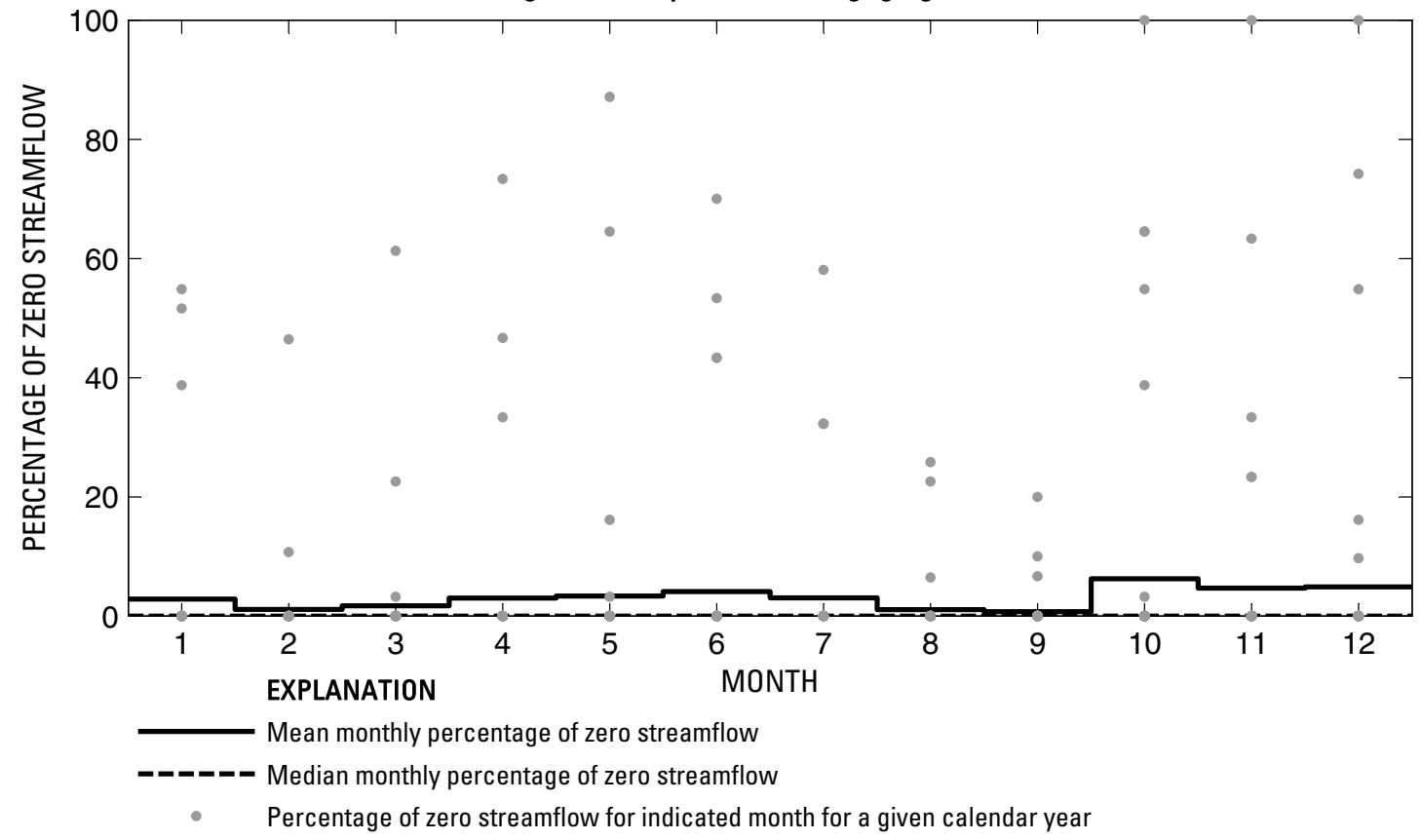

Figure 304. Analysis of percentage of zero daily mean streamflow for U.S. Geological Survey streamflow-gaging station 08076000 Greens Bayou near Houston, Texas.

Index of Station Numbers 719 
U.S. Geological Survey streamflow-gaging station 08076180

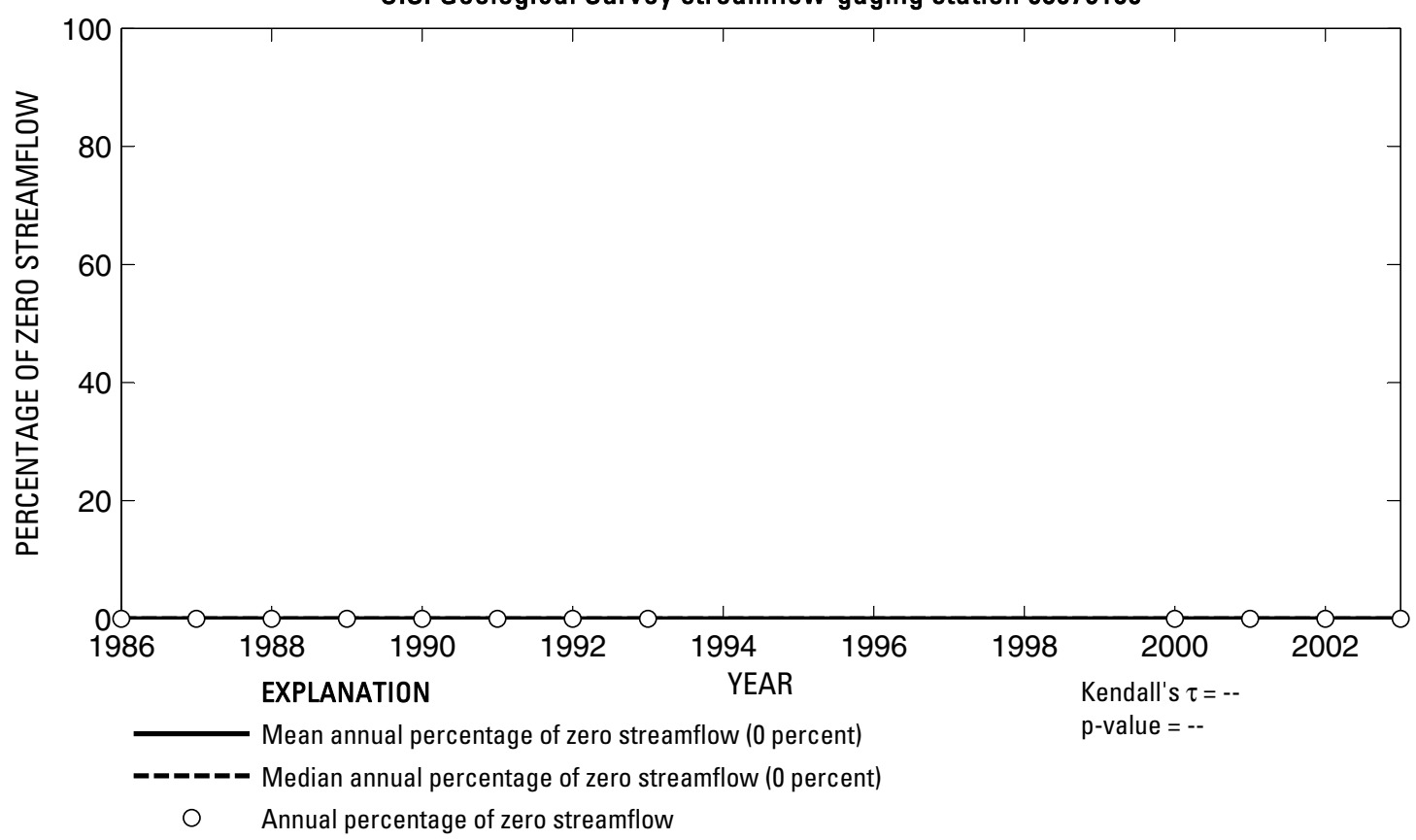

U.S. Geological Survey streamflow-gaging station 08076180

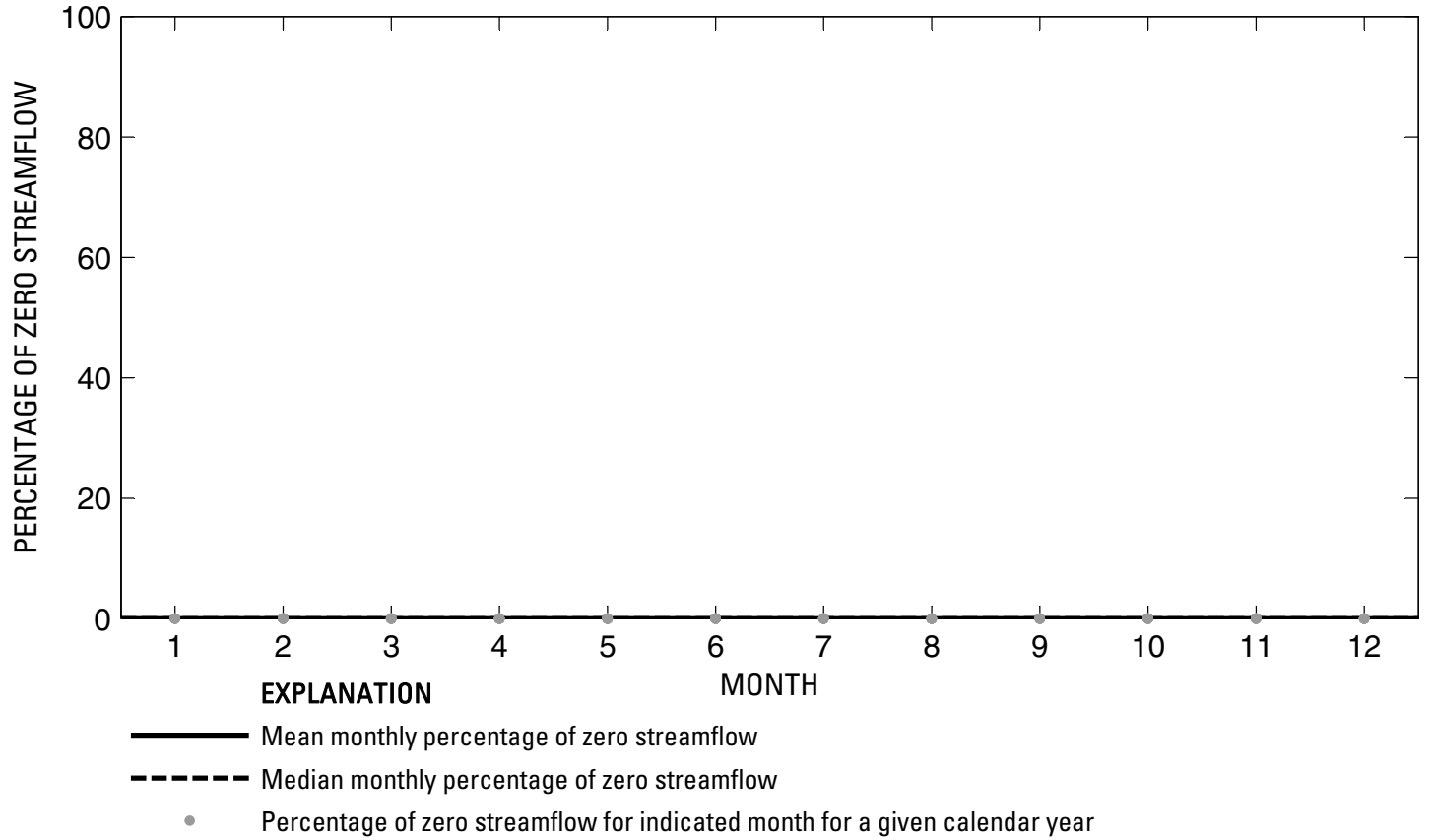

Figure 305. Analysis of percentage of zero daily mean streamflow for U.S. Geological Survey streamflow-gaging station 08076180 Garners Bayou near Humble, Texas. 
U.S. Geological Survey streamflow-gaging station 08076500

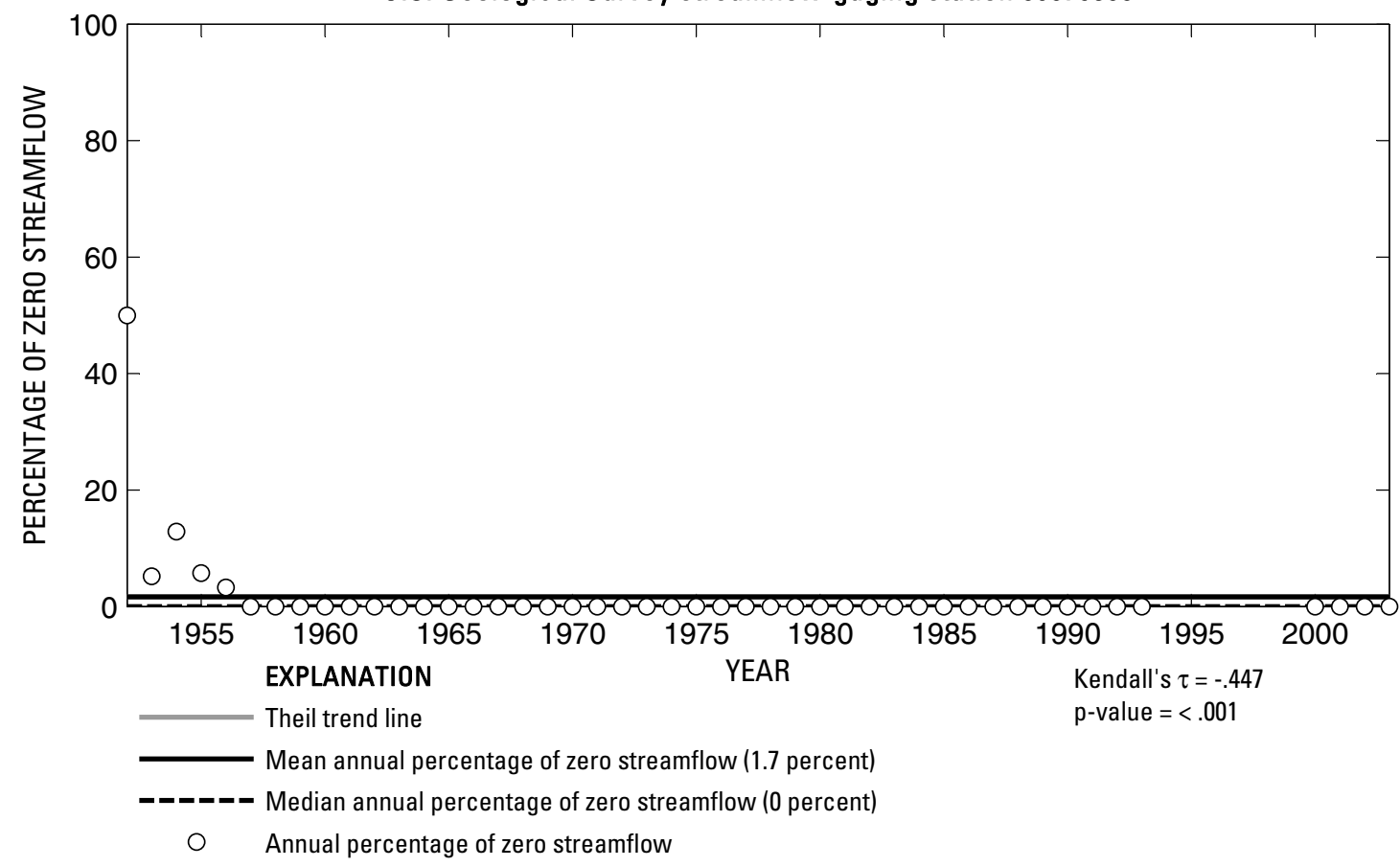

U.S. Geological Survey streamflow-gaging station 08076500

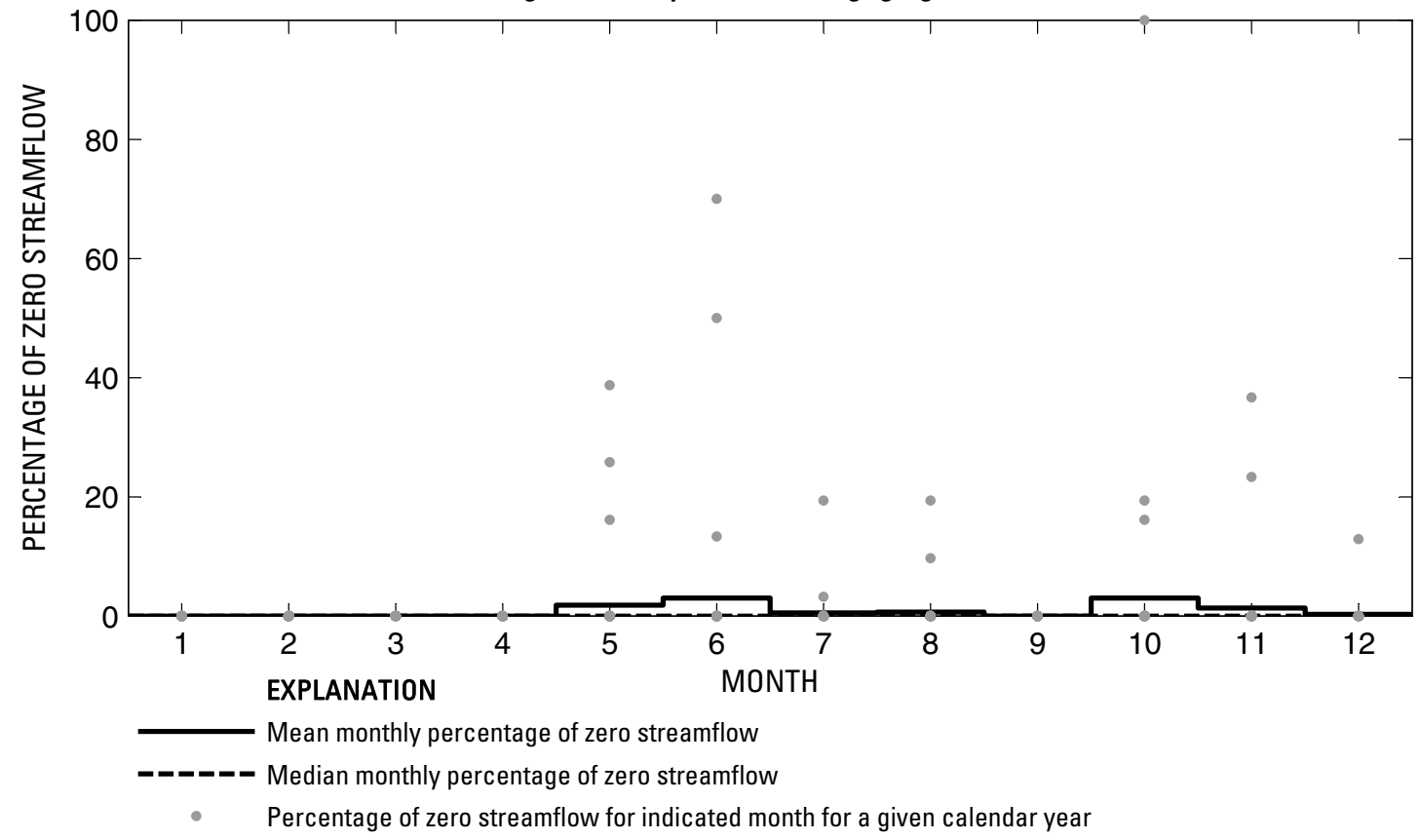

Figure 306. Analysis of percentage of zero daily mean streamflow for U.S. Geological Survey streamflow-gaging station 08076500 Halls Bayou at Houston, Texas.

Index of Station Numbers 719 


\section{U.S. Geological Survey streamflow-gaging station 08076700}

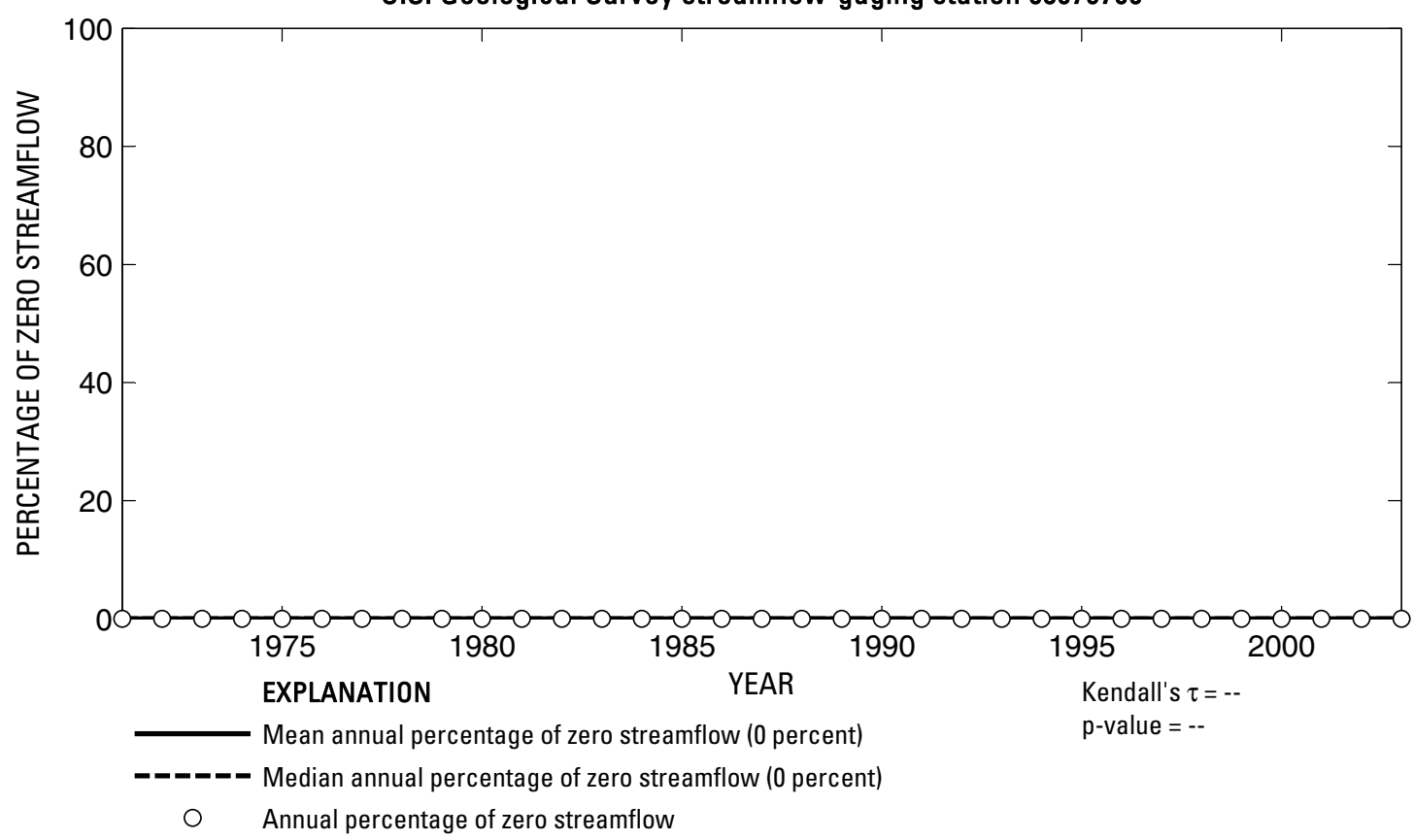

U.S. Geological Survey streamflow-gaging station 08076700

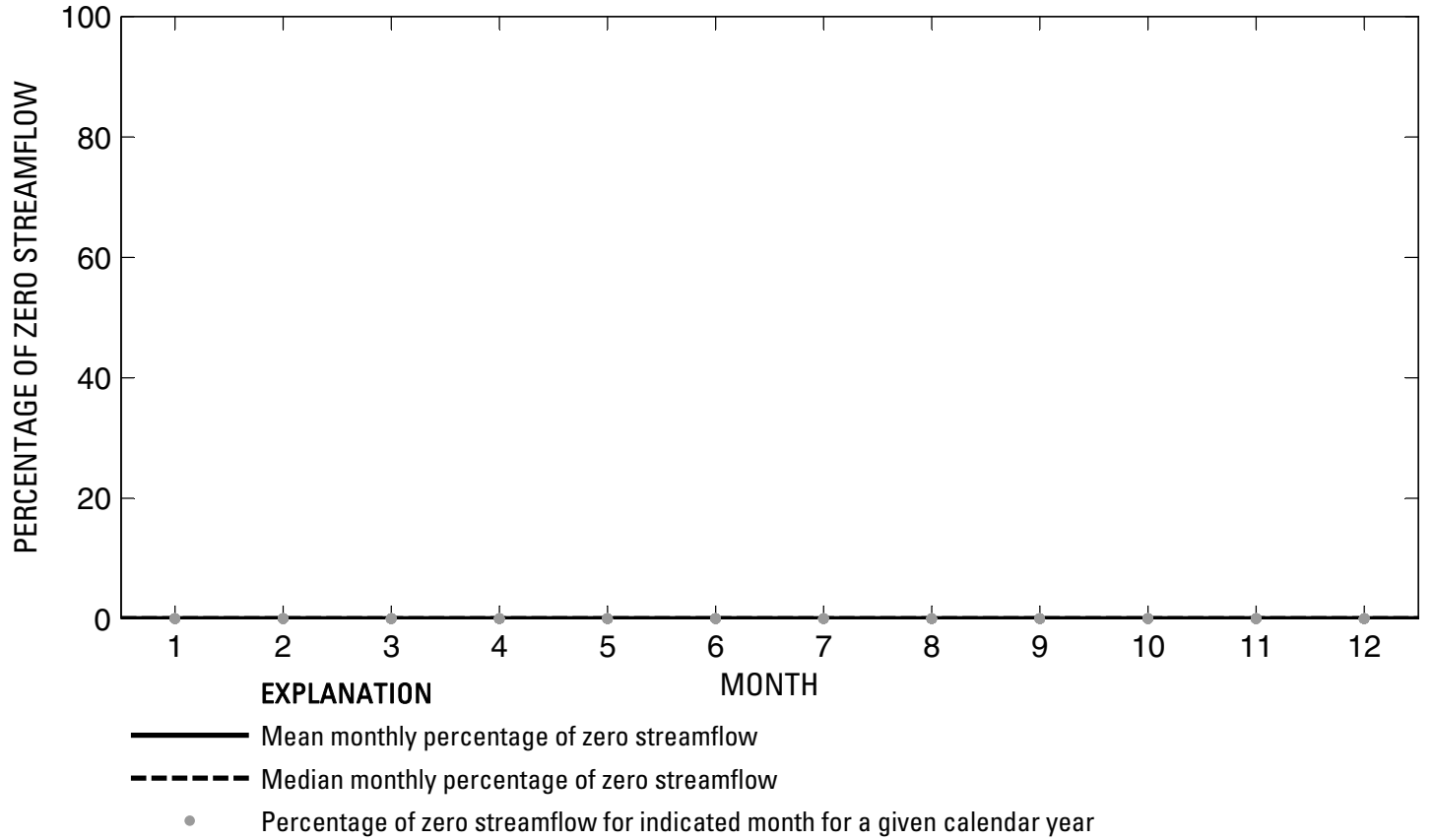

Figure 307. Analysis of percentage of zero daily mean streamflow for U.S. Geological Survey streamflow-gaging station 08076700 Greens Bayou at Ley Road, Houston, Texas. 
U.S. Geological Survey streamflow-gaging station 08077000

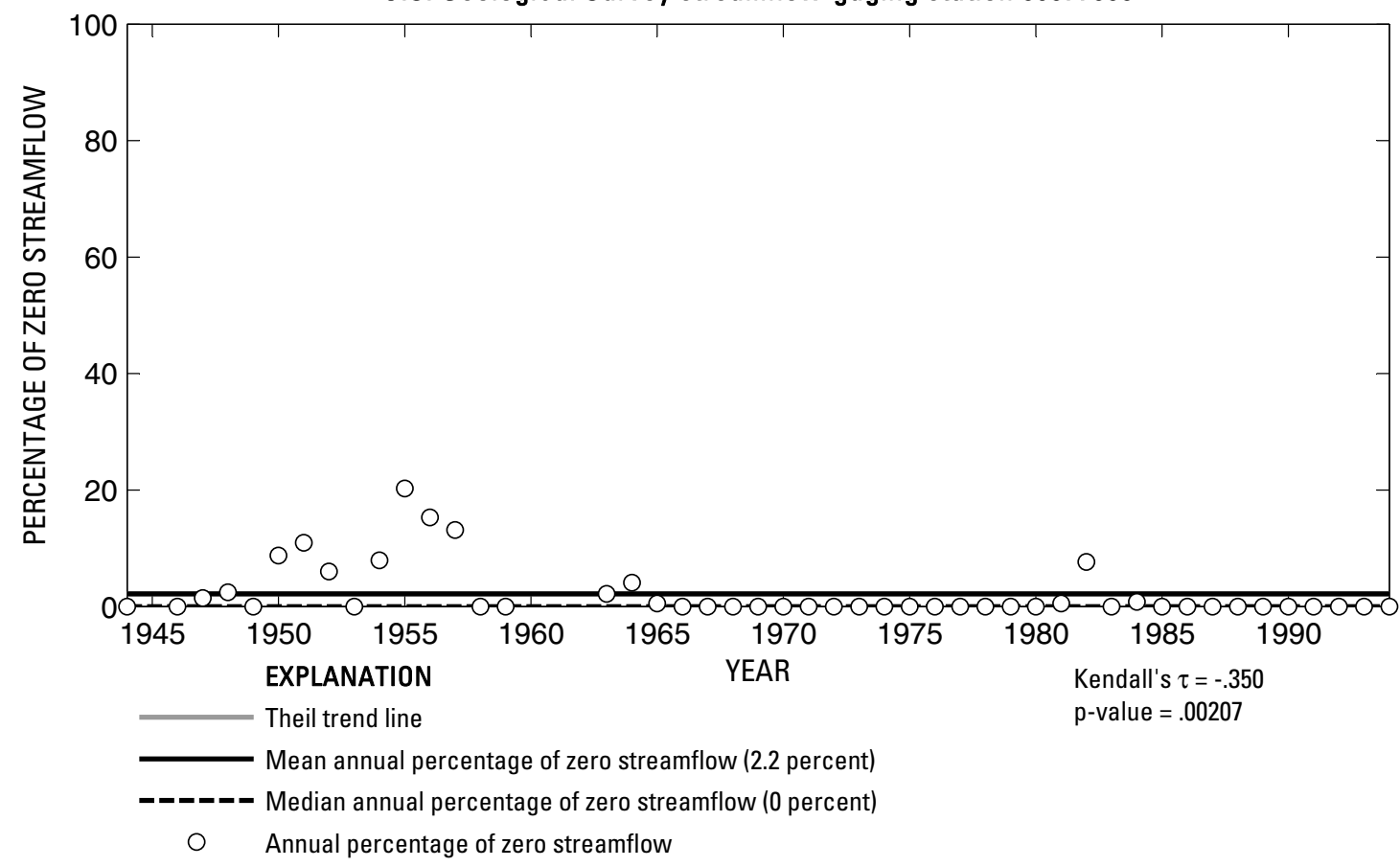

U.S. Geological Survey streamflow-gaging station 08077000

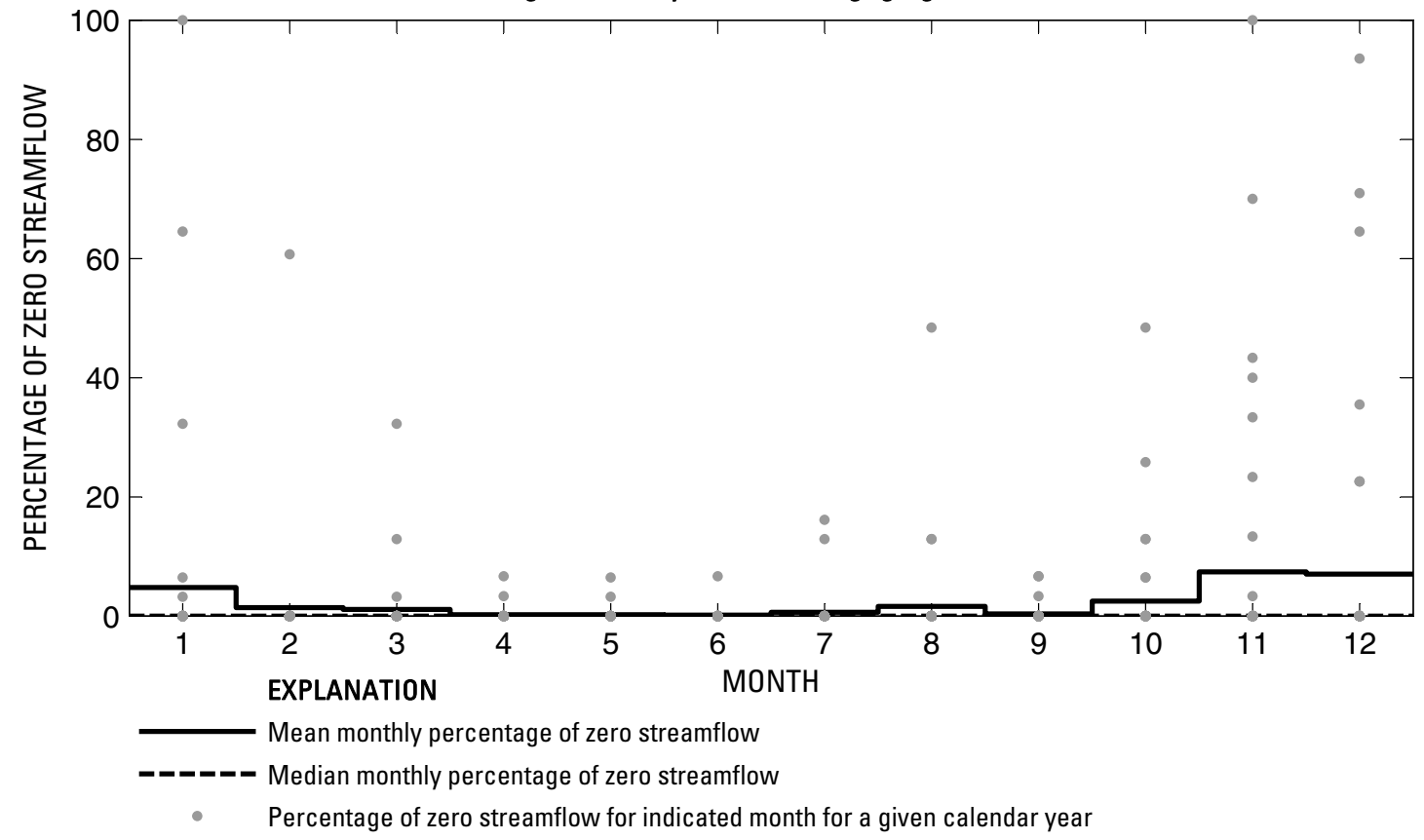

Figure 308. Analysis of percentage of zero daily mean streamflow for U.S. Geological Survey streamflow-gaging station 08077000 Clear Creek near Pearland, Texas.

Index of Station Numbers 719 
U.S. Geological Survey streamflow-gaging station 08077540

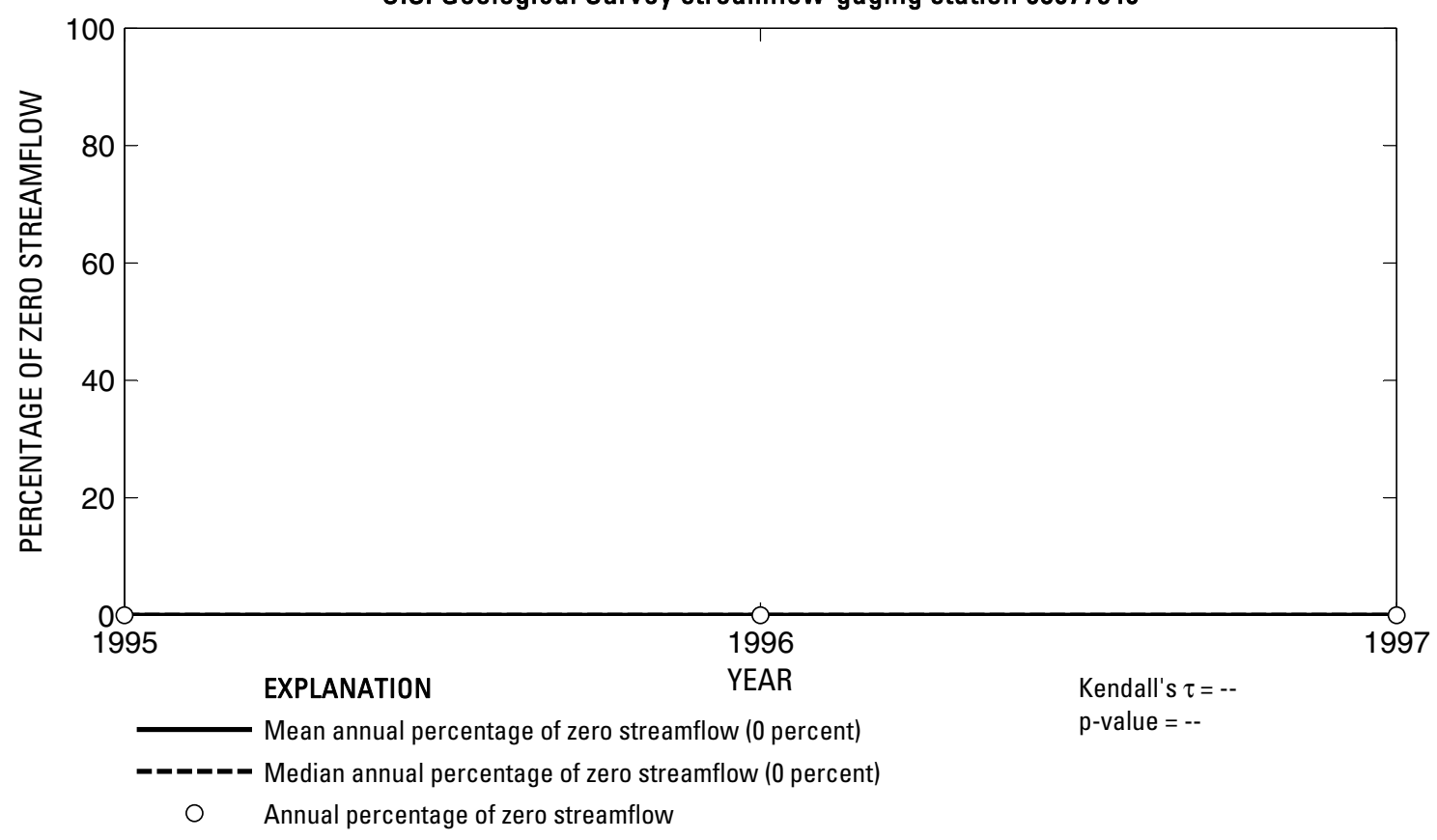

U.S. Geological Survey streamflow-gaging station 08077540

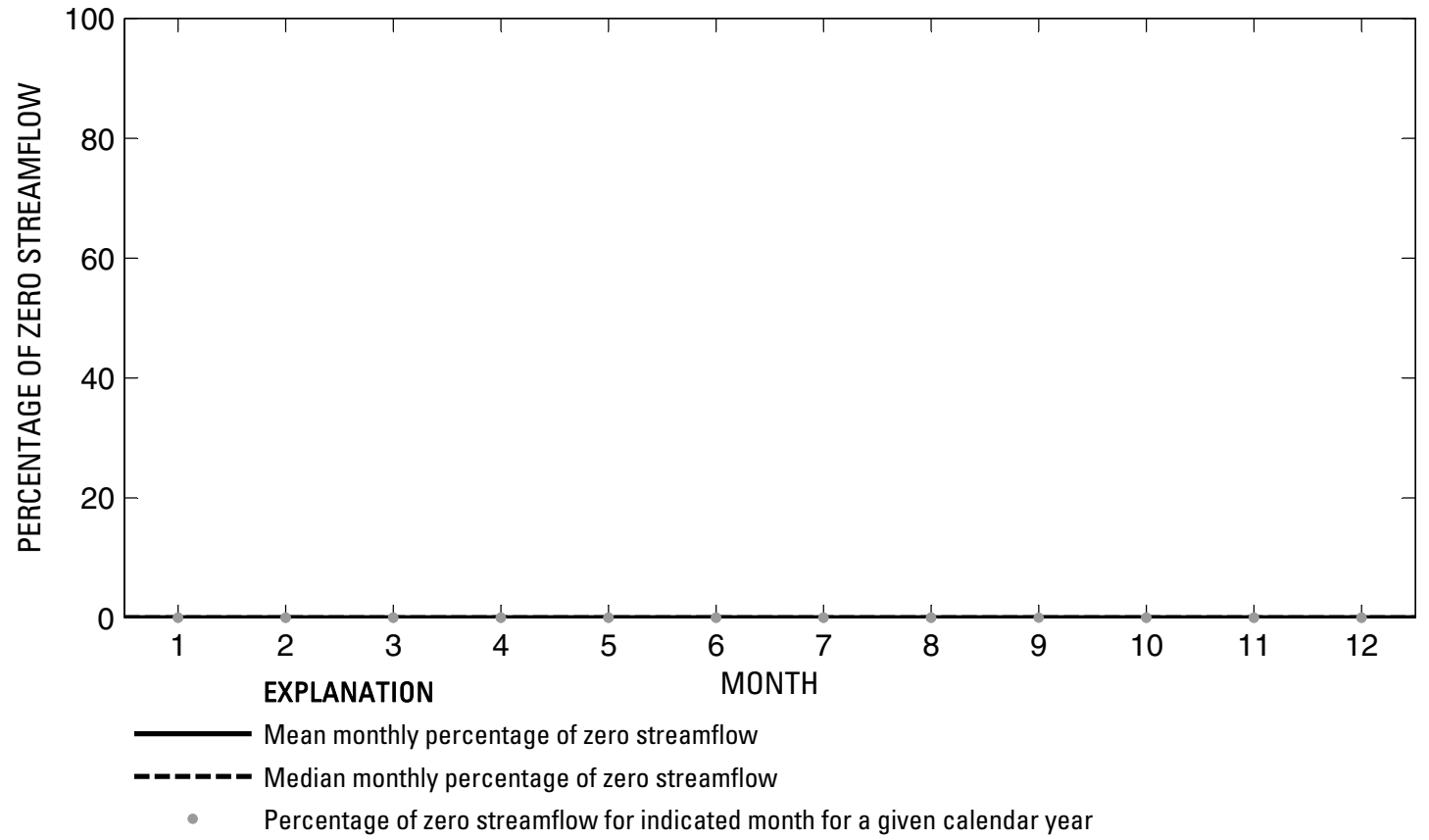

Figure 309. Analysis of percentage of zero daily mean streamflow for U.S. Geological Survey streamflow-gaging station 08077540 Clear Creek at Friendswood, Texas. 
U.S. Geological Survey streamflow-gaging station 08078000

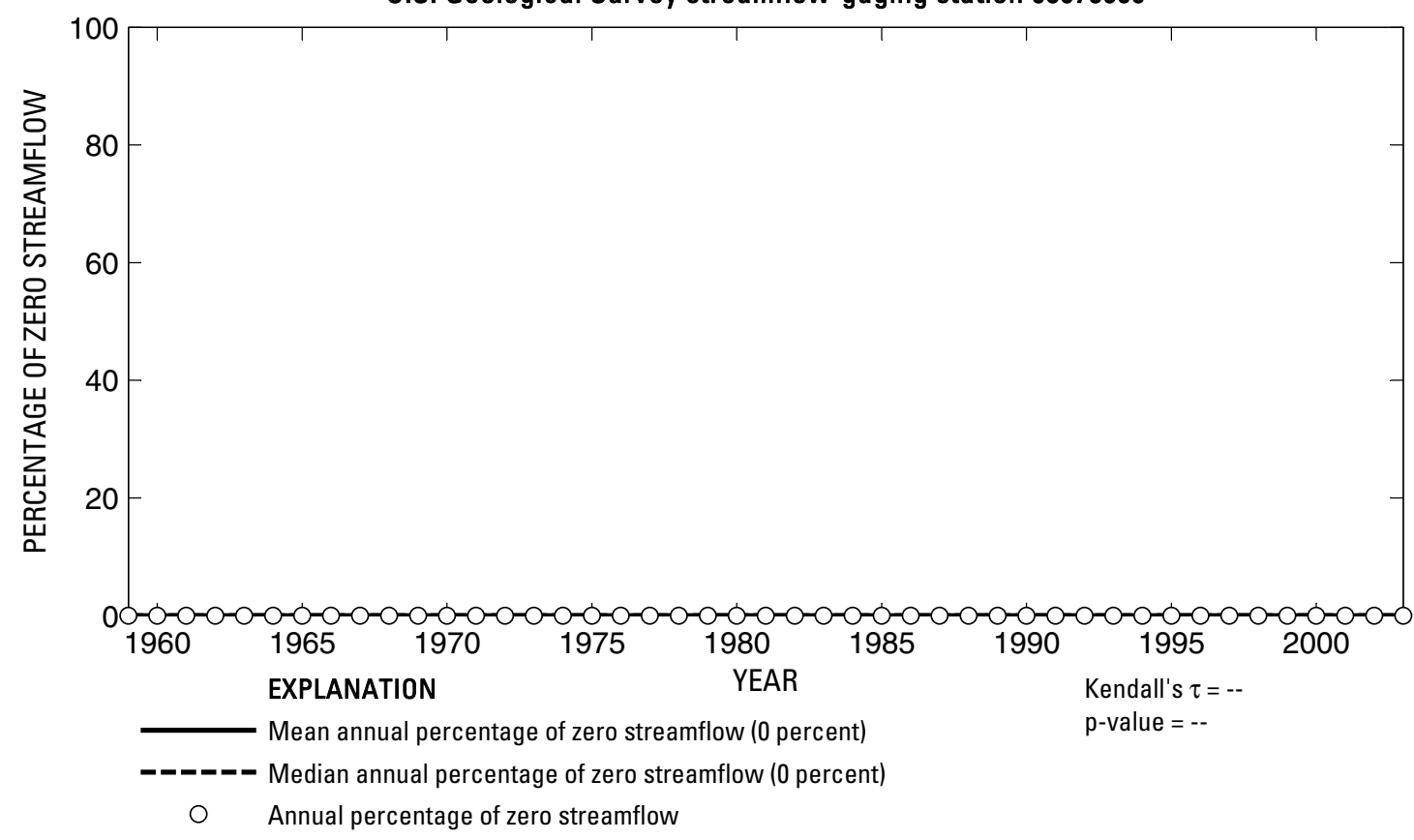

U.S. Geological Survey streamflow-gaging station 08078000

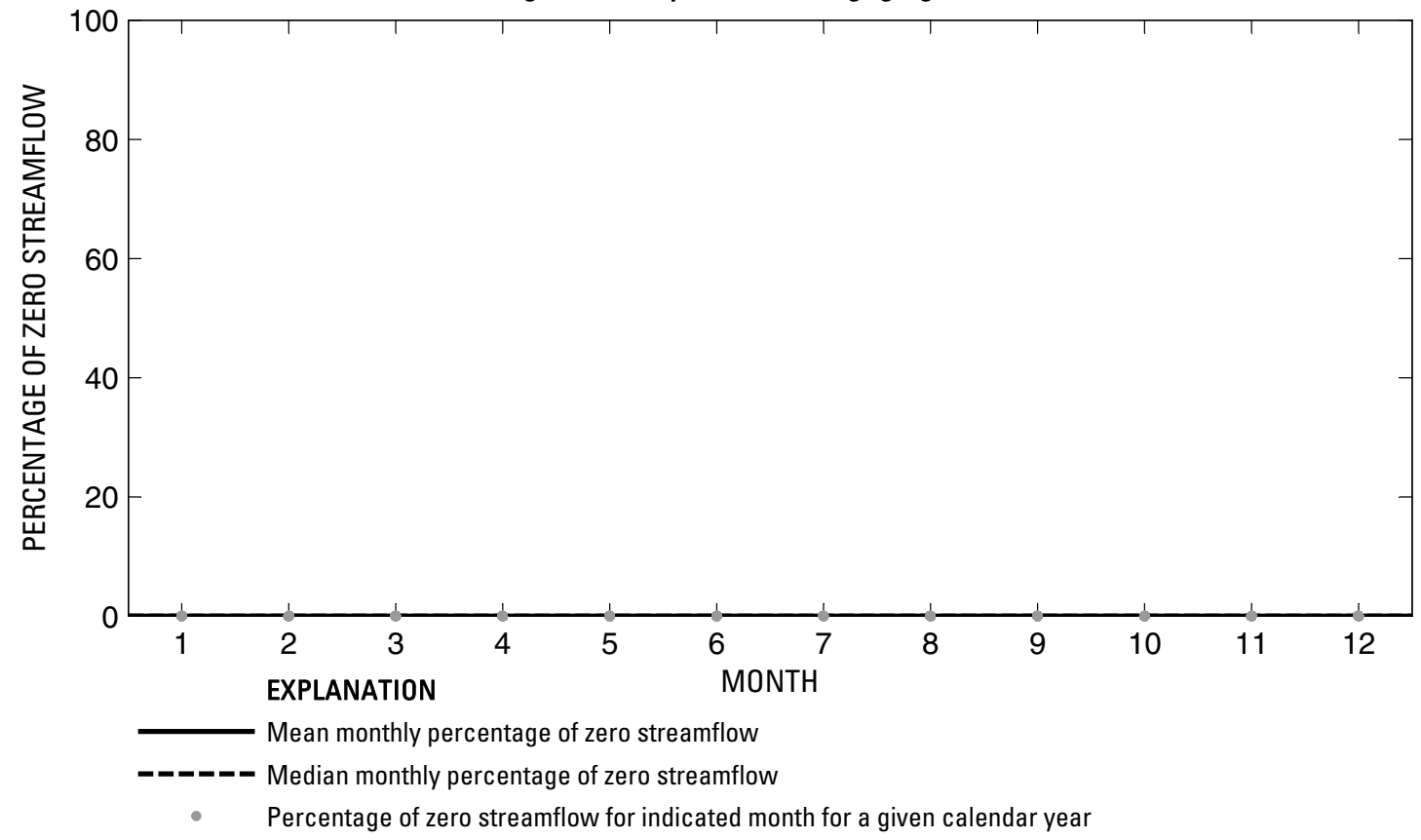

Figure 310. Analysis of percentage of zero daily mean streamflow for U.S. Geological Survey streamflow-gaging station 08078000 Chocolate Bayou near Alvin, Texas. 


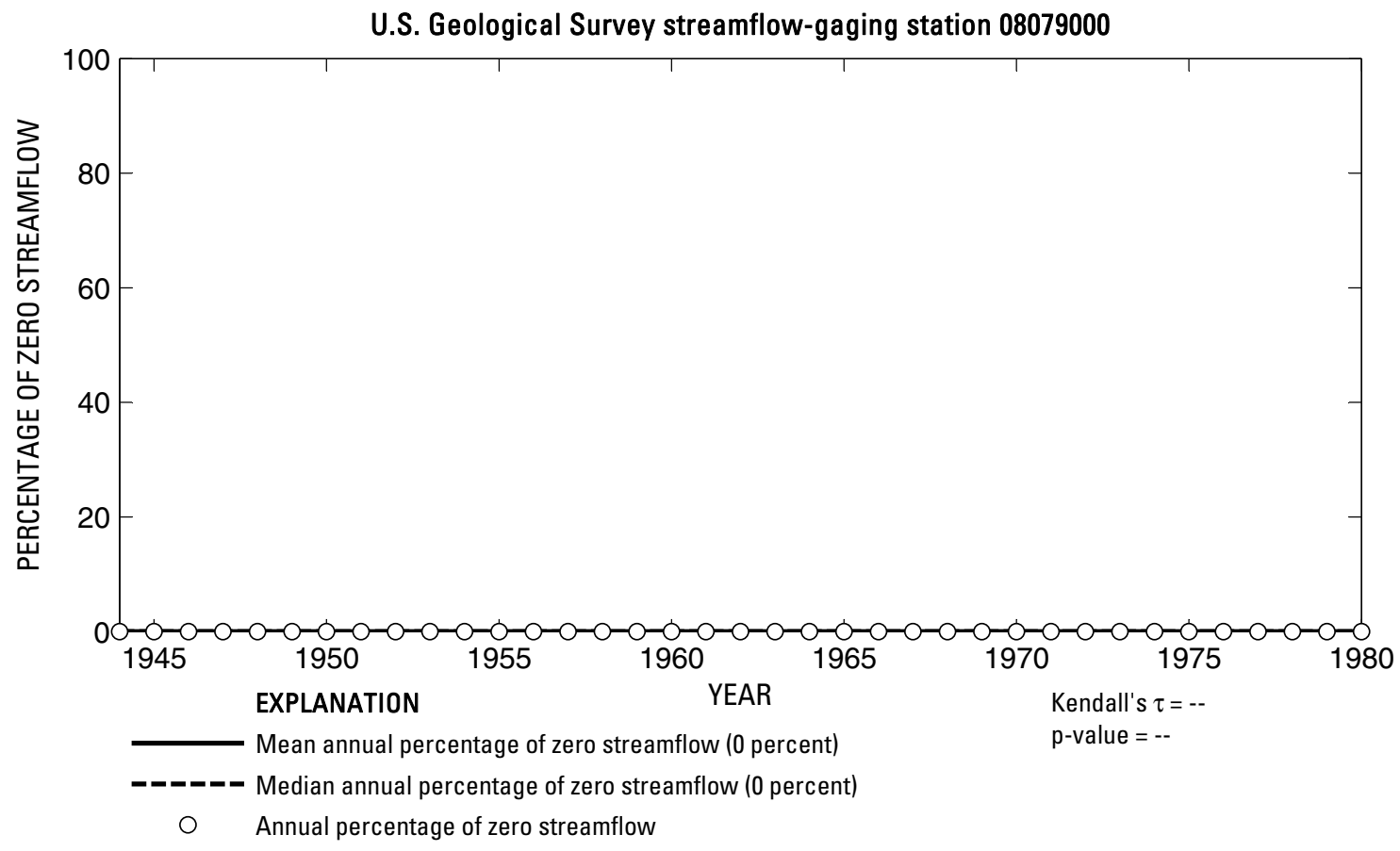

U.S. Geological Survey streamflow-gaging station 08079000

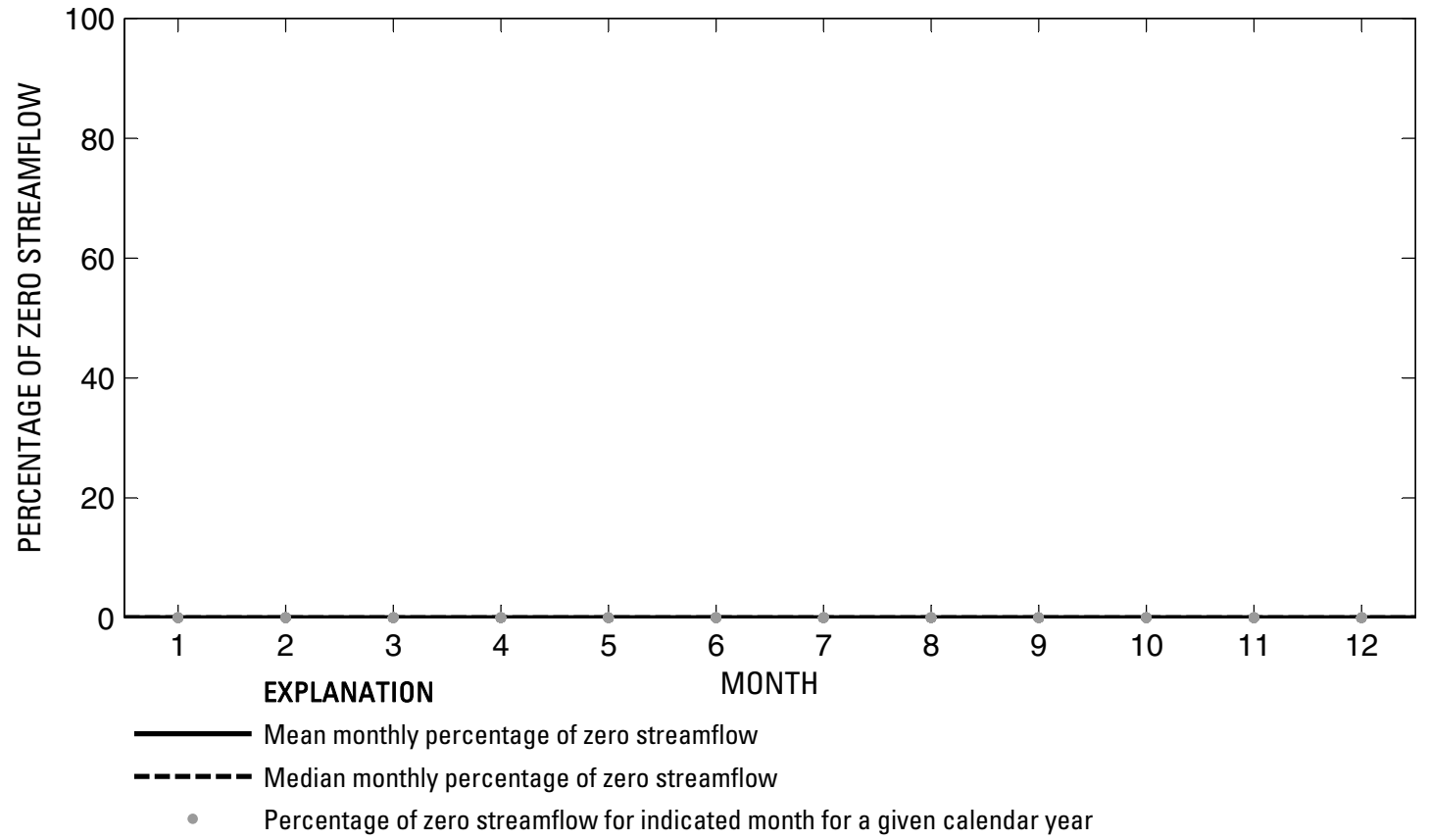

Figure 311. Analysis of percentage of zero daily mean streamflow for U.S. Geological Survey streamflow-gaging station 08079000 Oyster Creek near Angleton, Texas. 
U.S. Geological Survey streamflow-gaging station 08079500

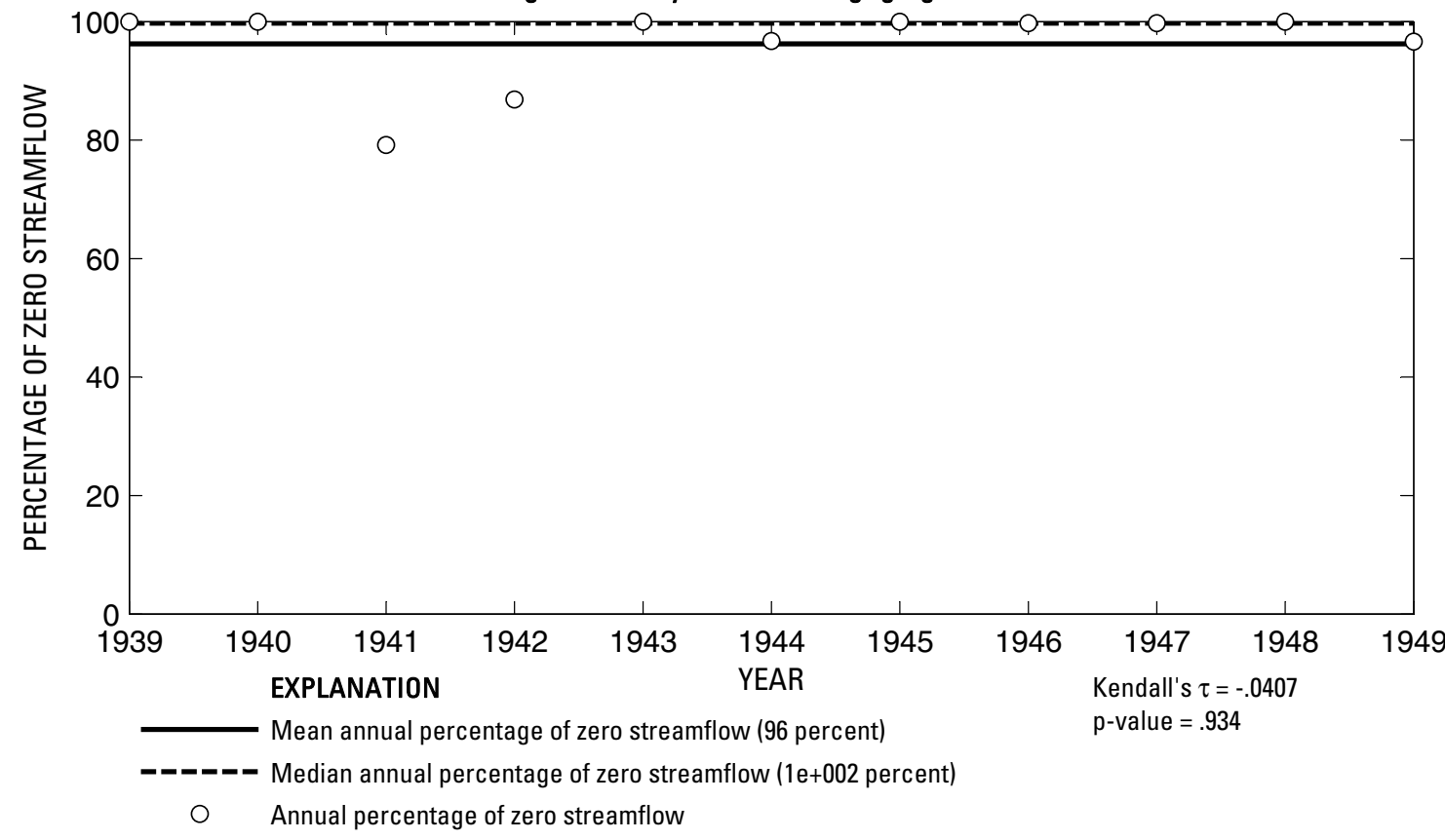

U.S. Geological Survey streamflow-gaging station 08079500

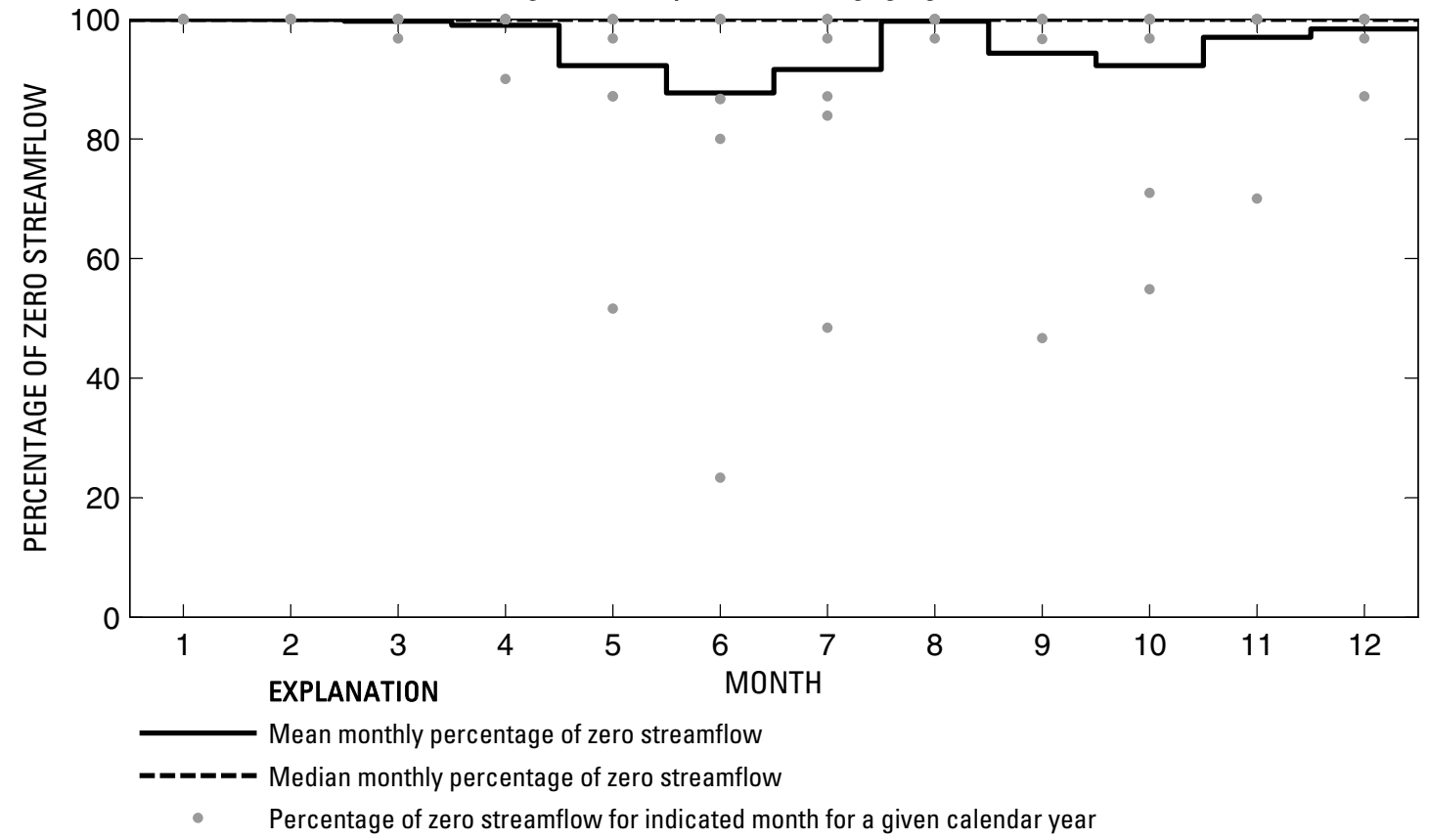

Figure 312. Analysis of percentage of zero daily mean streamflow for U.S. Geological Survey streamflow-gaging station 08079500 North Fork Double Mountain Fork Brazos River at Lubbock, Texas. 
U.S. Geological Survey streamflow-gaging station 08079575

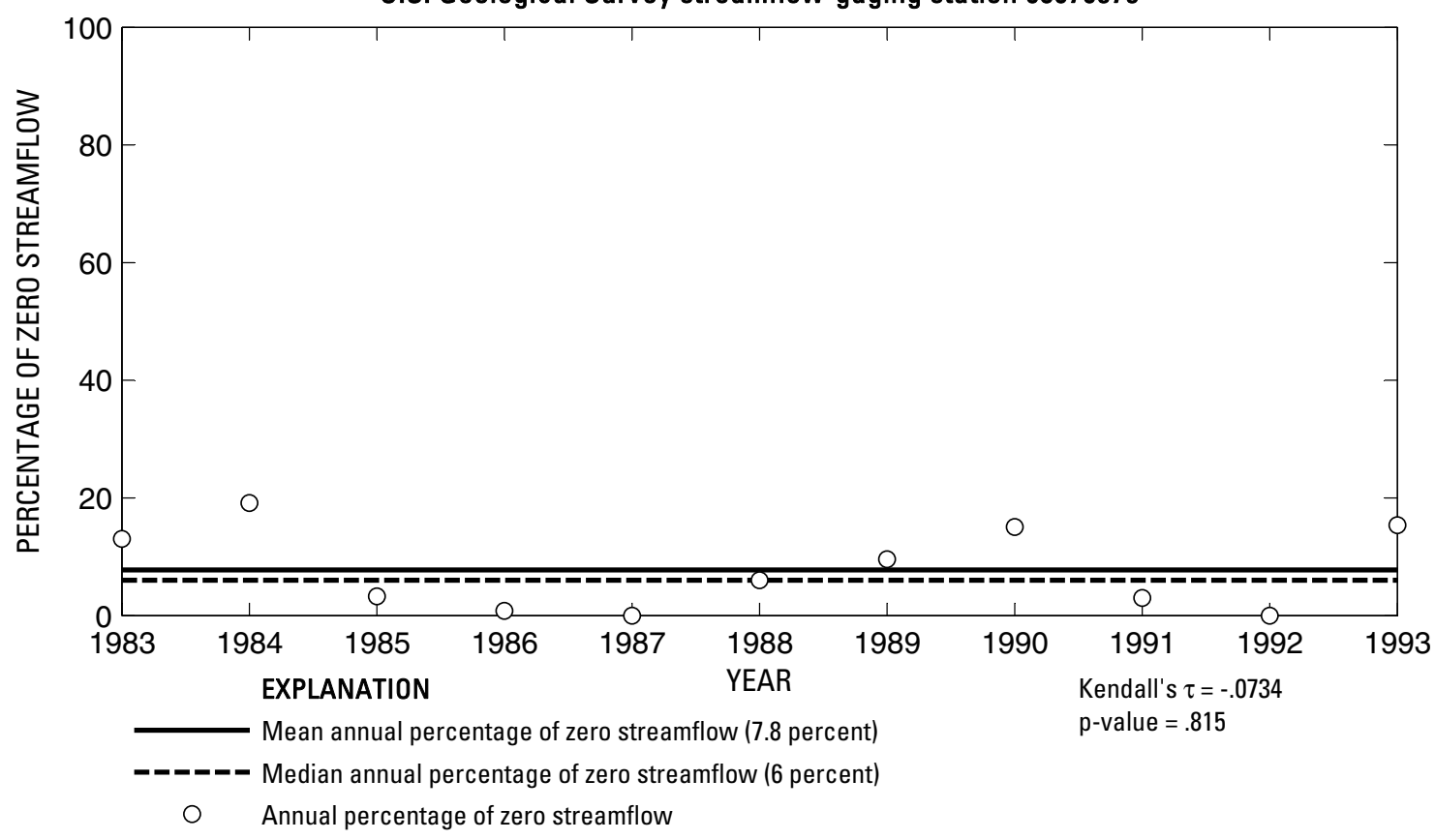

U.S. Geological Survey streamflow-gaging station 08079575

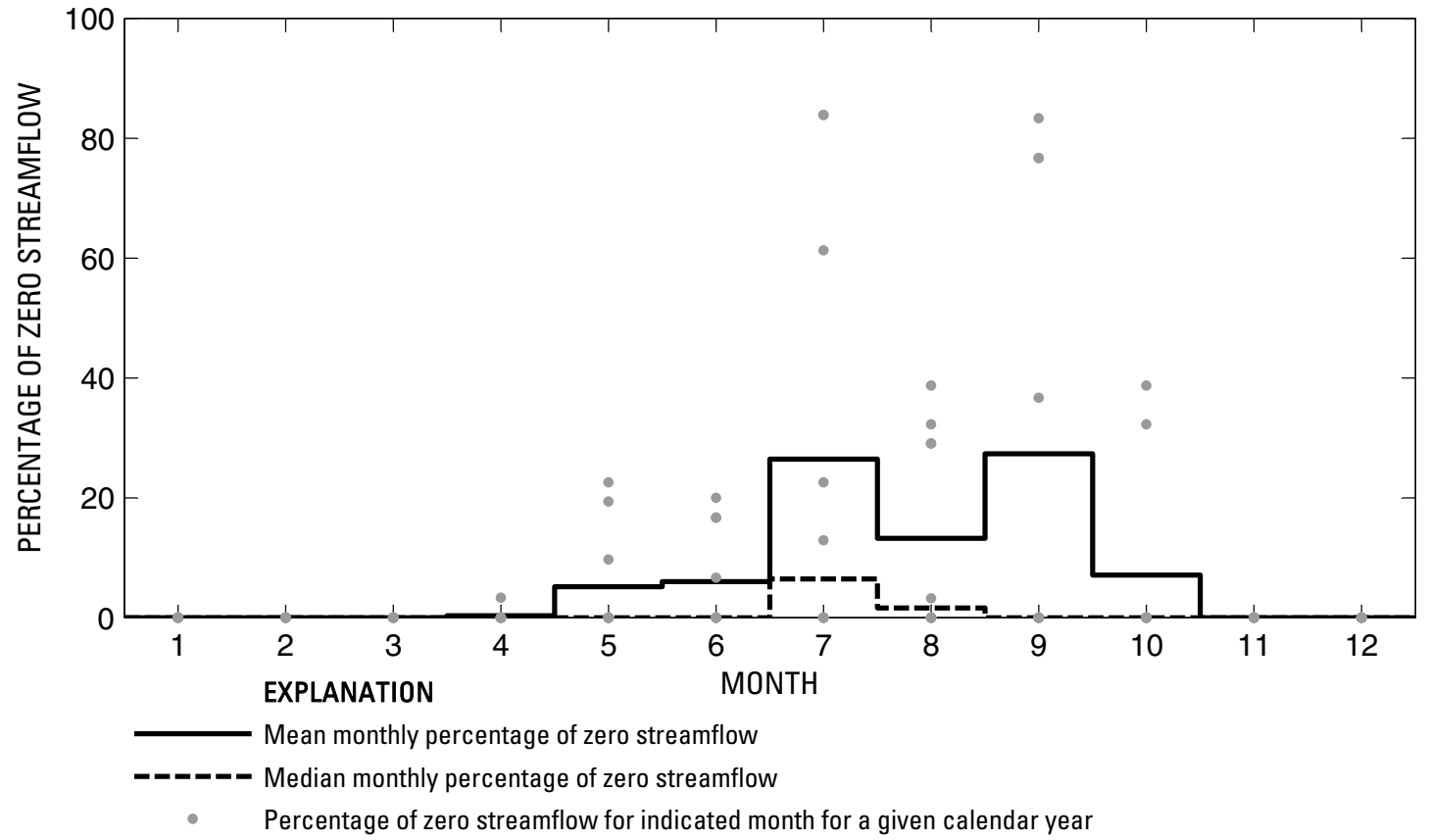

Figure 313. Analysis of percentage of zero daily mean streamflow for U.S. Geological Survey streamflow-gaging station 08079575 North Fork Double Mountain Fork Brazos River near Post, Texas. 
U.S. Geological Survey streamflow-gaging station 08079600

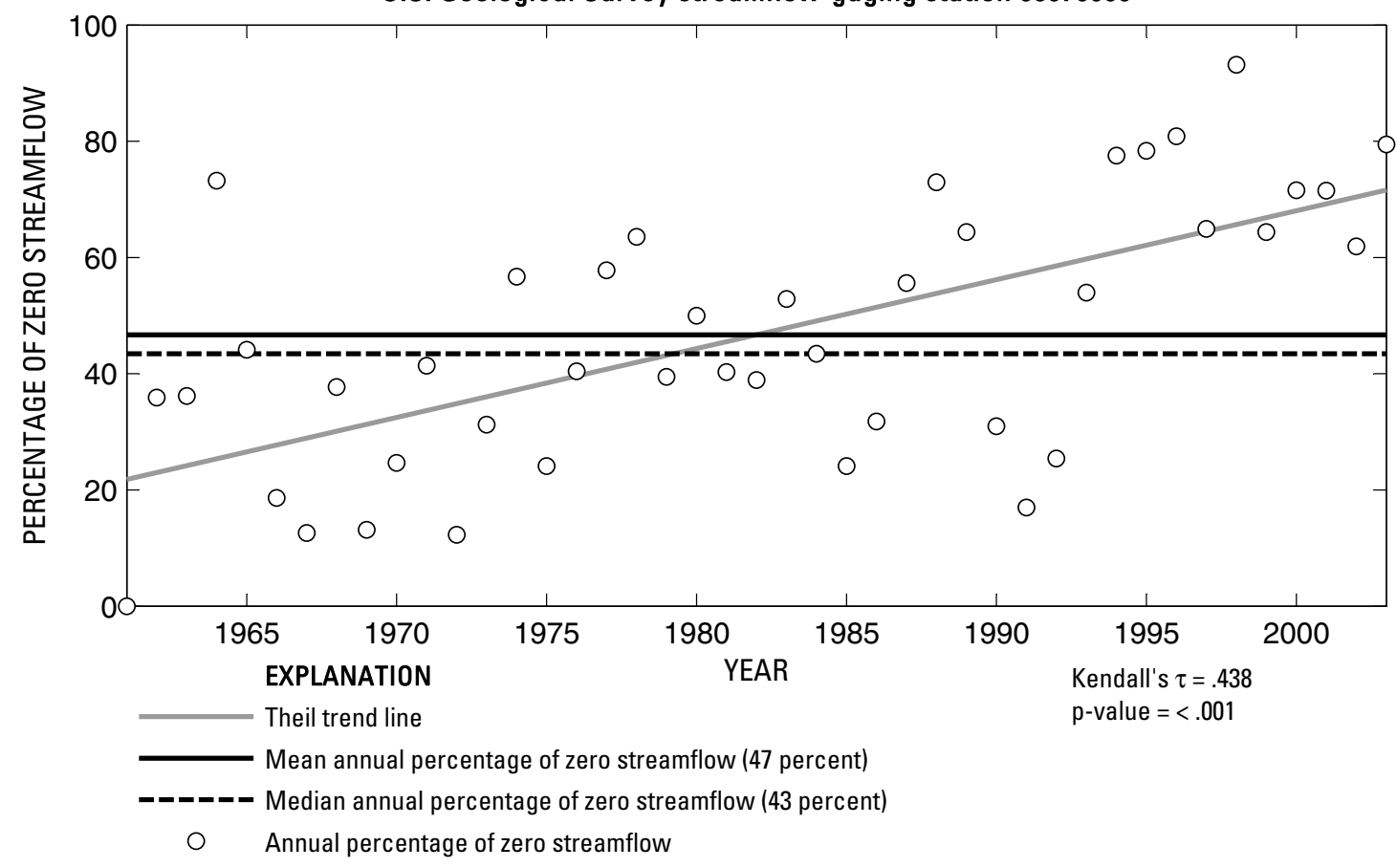

U.S. Geological Survey streamflow-gaging station 08079600

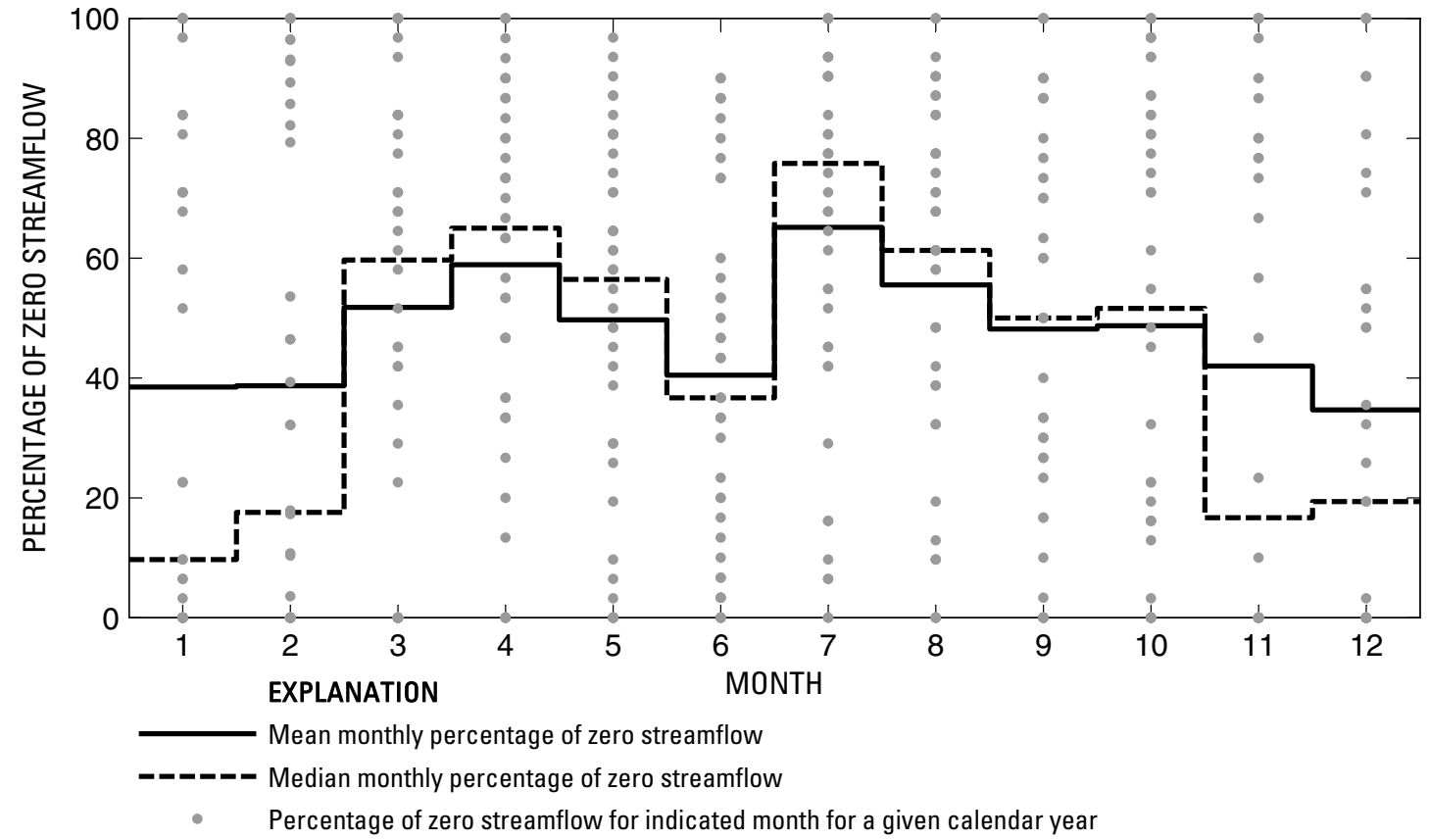

Figure 314. Analysis of percentage of zero daily mean streamflow for U.S. Geological Survey streamflow-gaging station 08079600 Double Mountain Fork Brazos River at Justiceburg, Texas.

Index of Station Numbers 719 
U.S. Geological Survey streamflow-gaging station 08080000

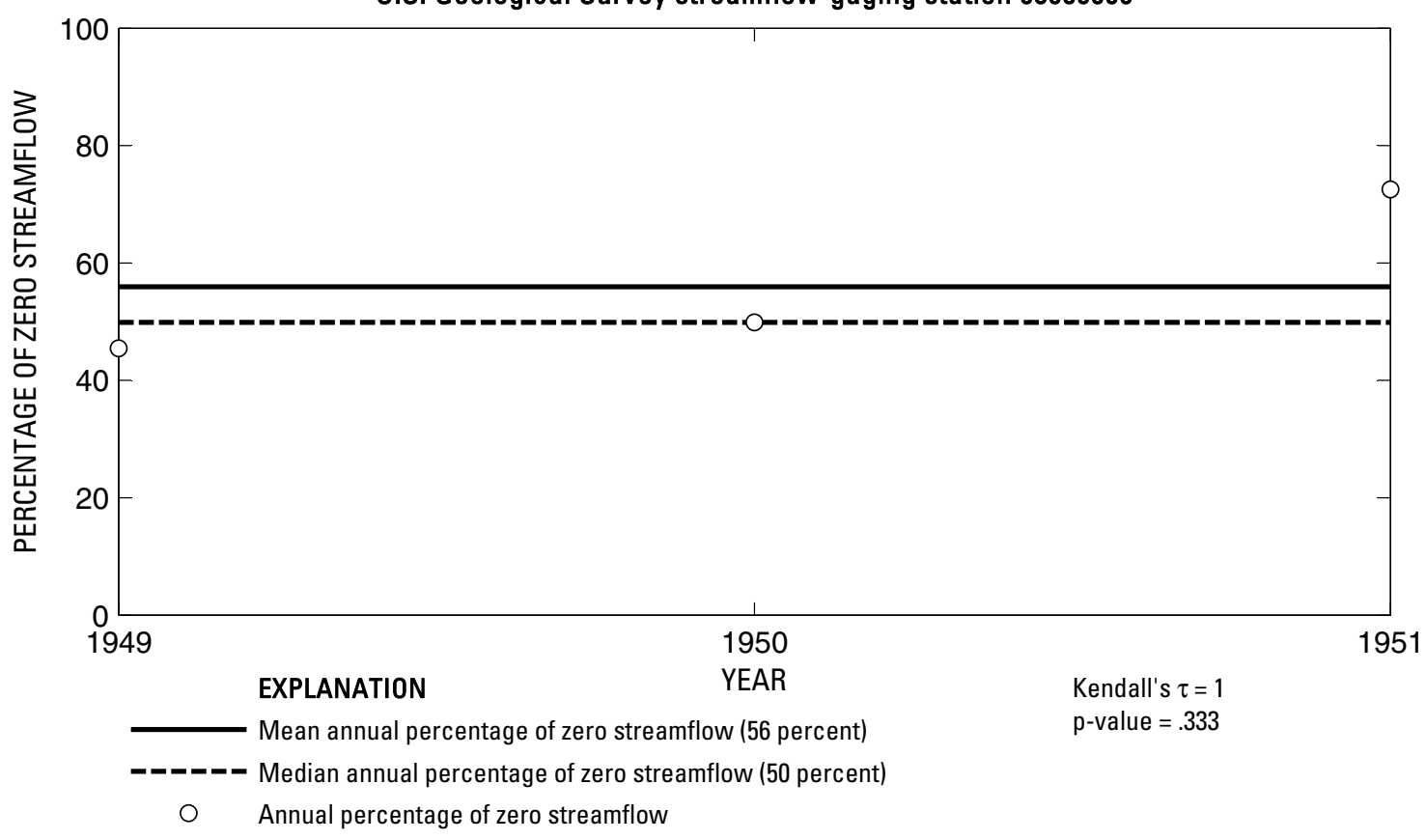

U.S. Geological Survey streamflow-gaging station 08080000

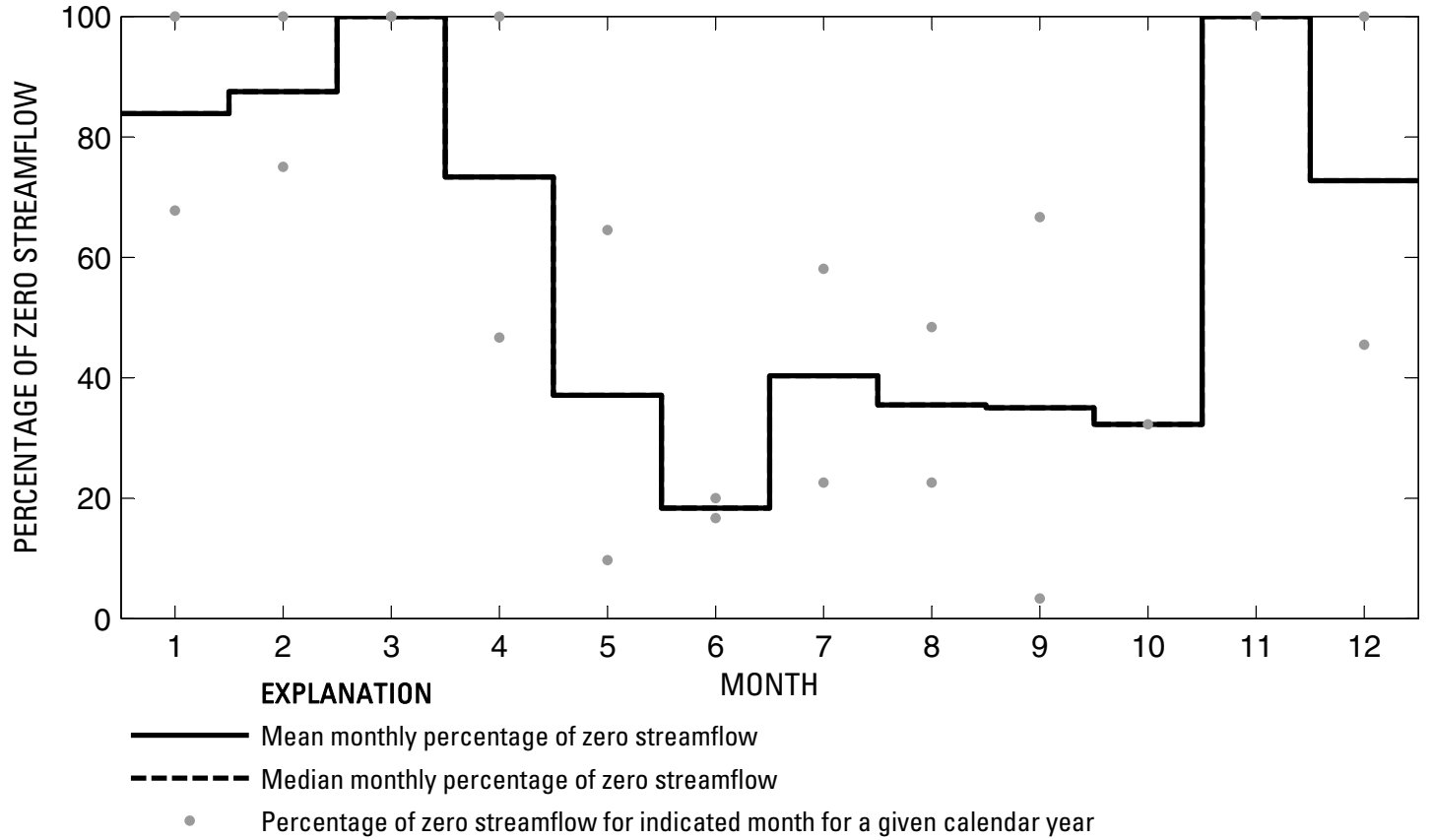

Figure 315. Analysis of percentage of zero daily mean streamflow for U.S. Geological Survey streamflow-gaging station 08080000 Double Mountain Fork Brazos River near Rotan, Texas. 
U.S. Geological Survey streamflow-gaging station 08080500

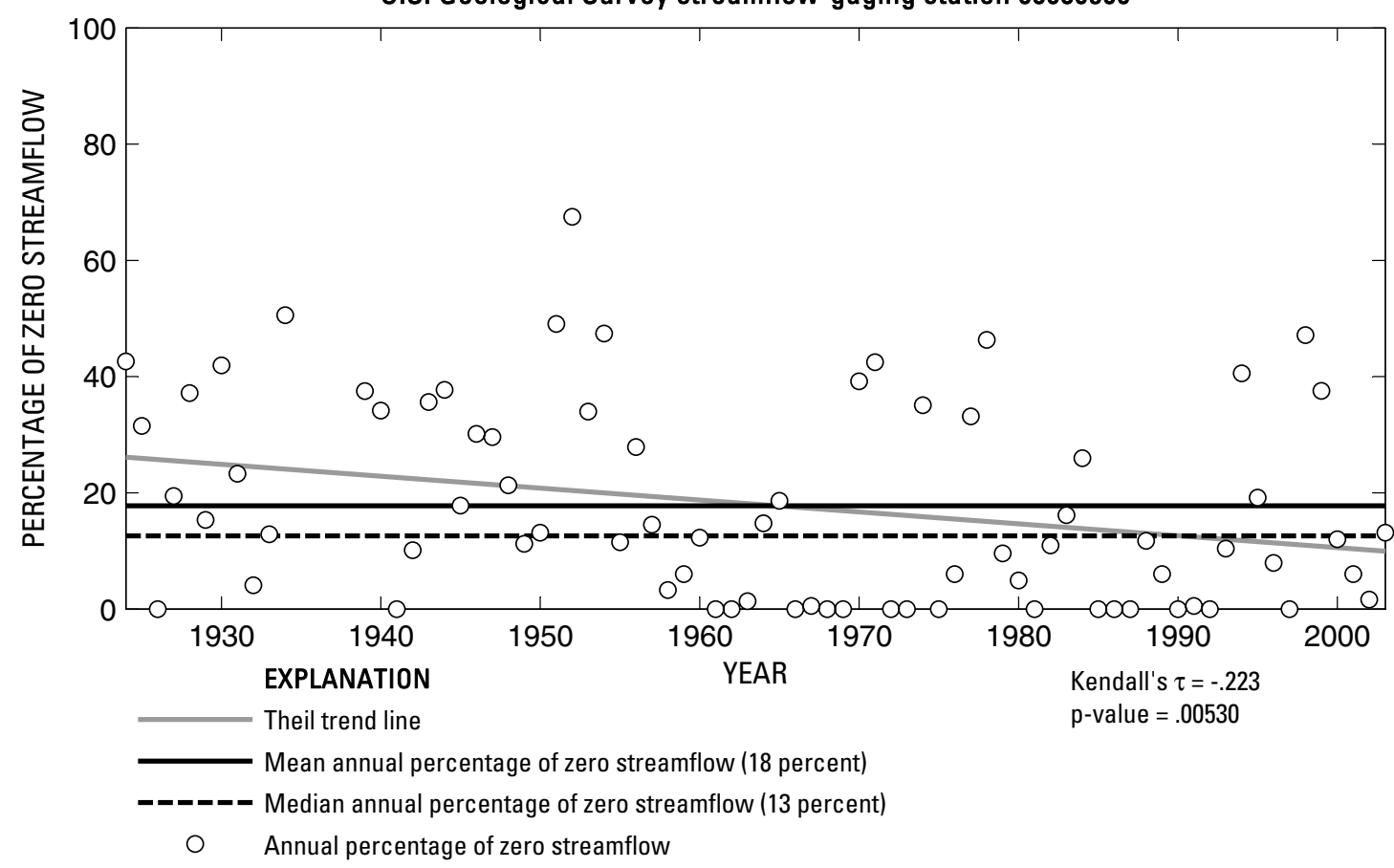

U.S. Geological Survey streamflow-gaging station 08080500

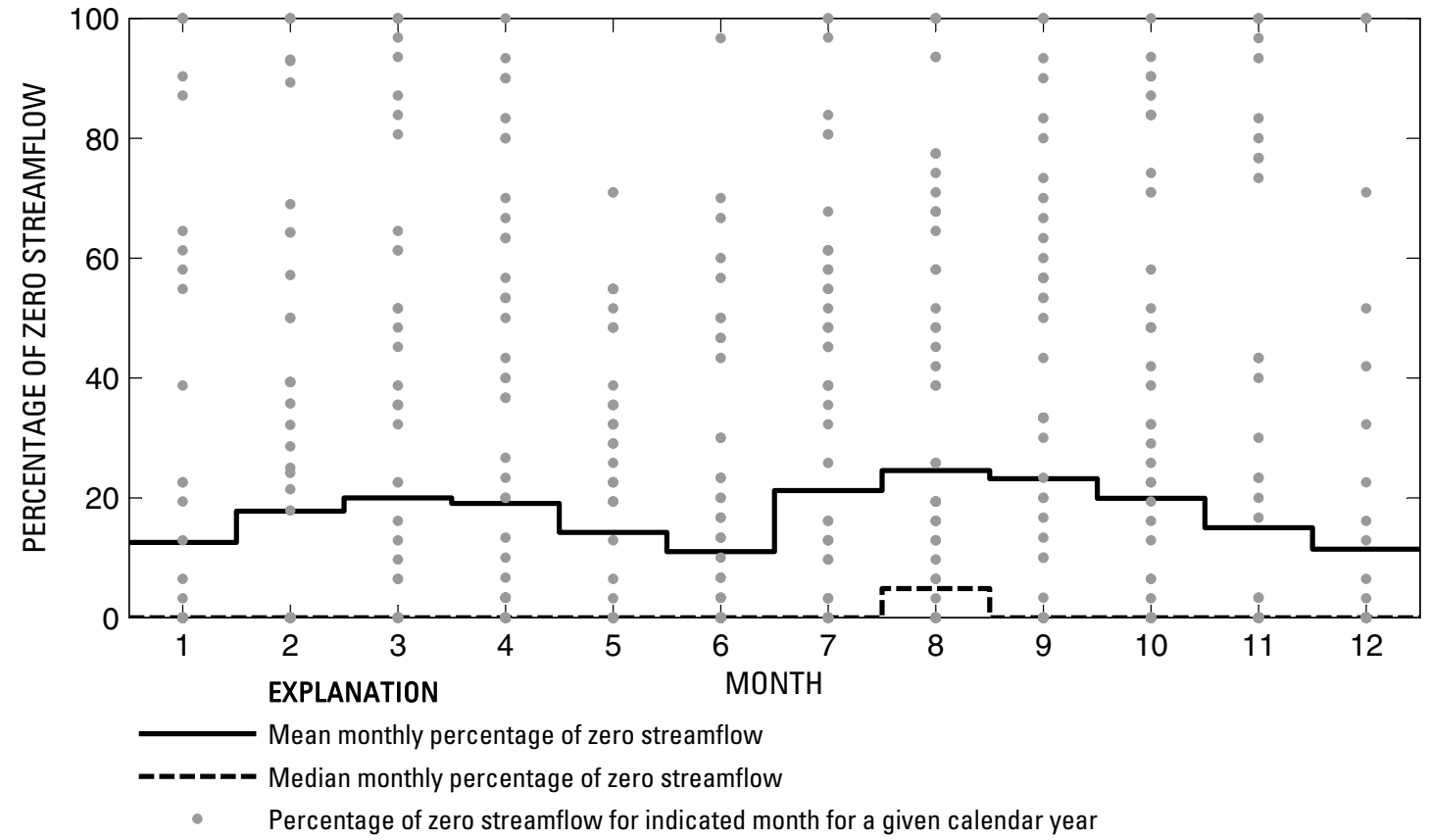

Figure 316. Analysis of percentage of zero daily mean streamflow for U.S. Geological Survey streamflow-gaging station 08080500 Double Mountain Fork Brazos River near Aspermont, Texas.

Index of Station Numbers 719 
U.S. Geological Survey streamflow-gaging station 08080540

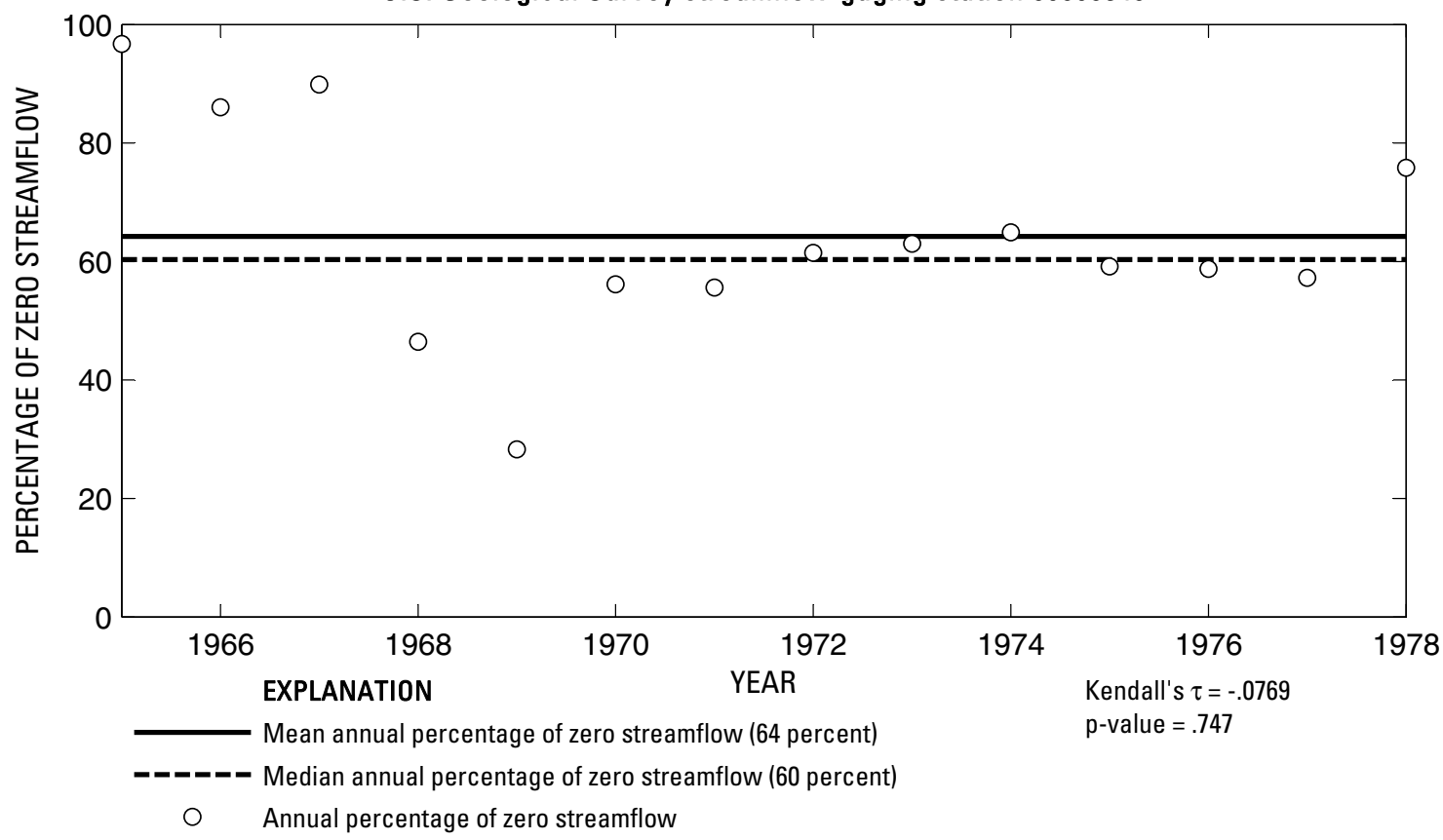

U.S. Geological Survey streamflow-gaging station 08080540

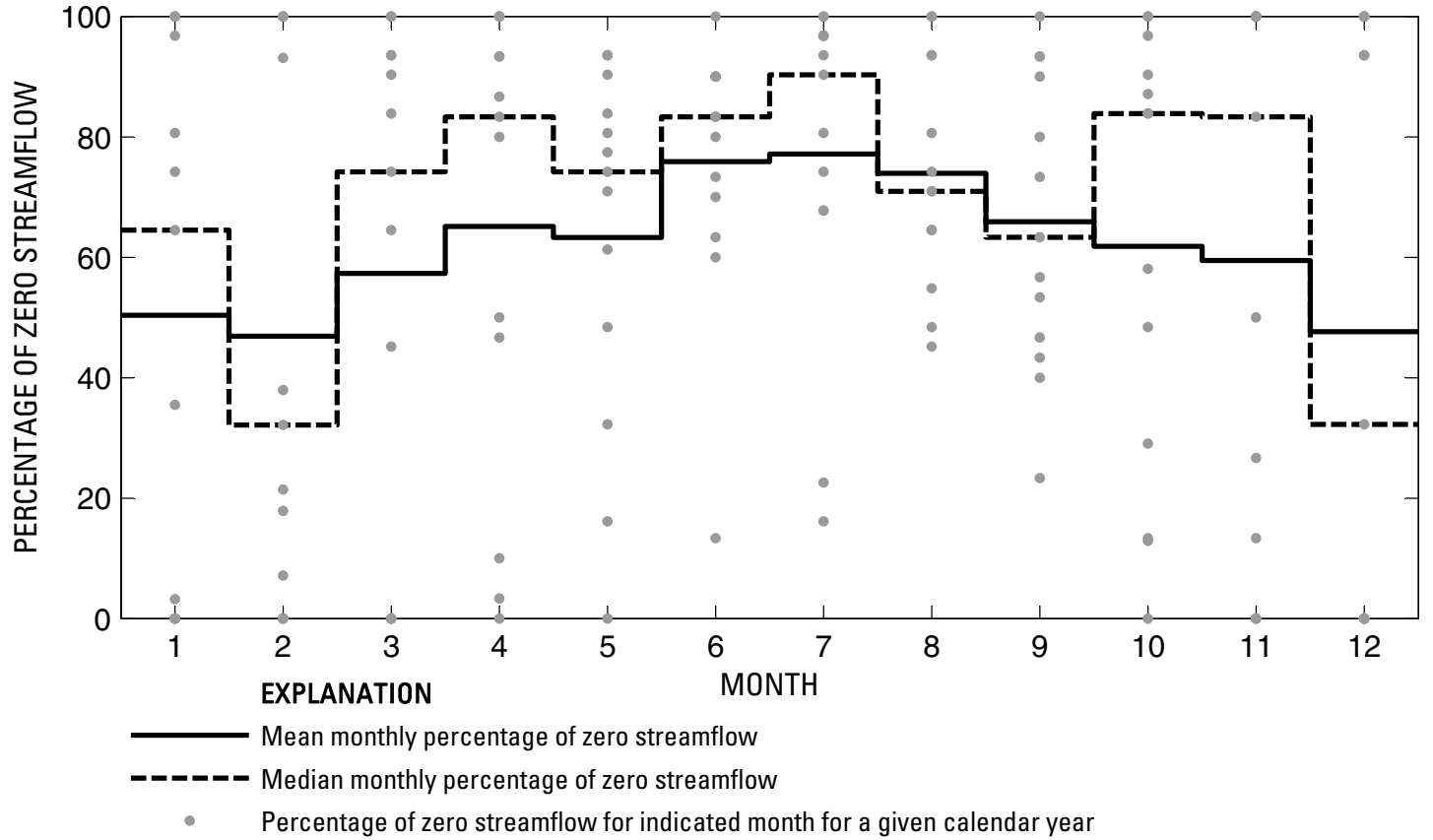

Figure 317. Analysis of percentage of zero daily mean streamflow for U.S. Geological Survey streamflow-gaging station 08080540 McDonald Creek near Post, Texas. 
U.S. Geological Survey streamflow-gaging station 08080700

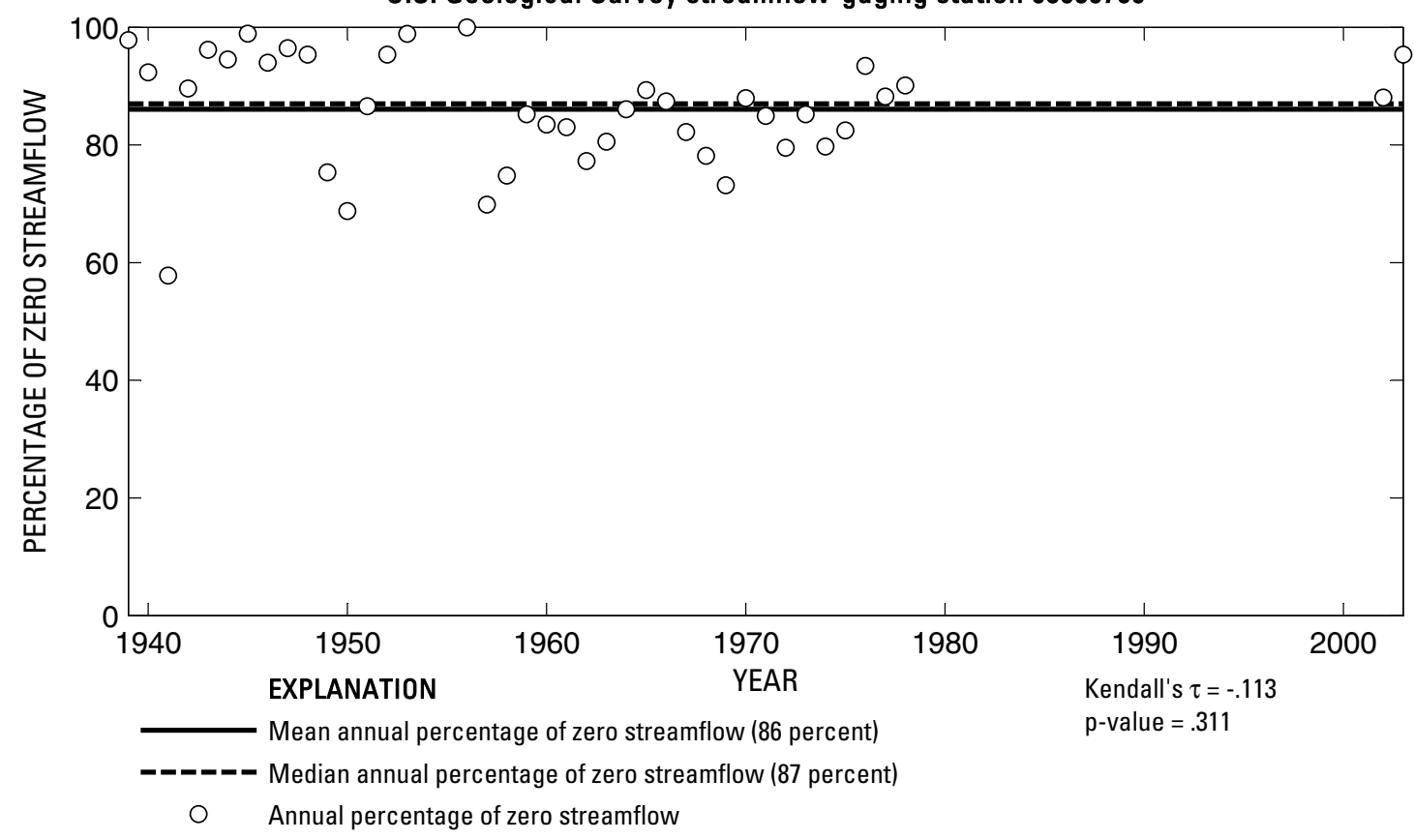

U.S. Geological Survey streamflow-gaging station 08080700

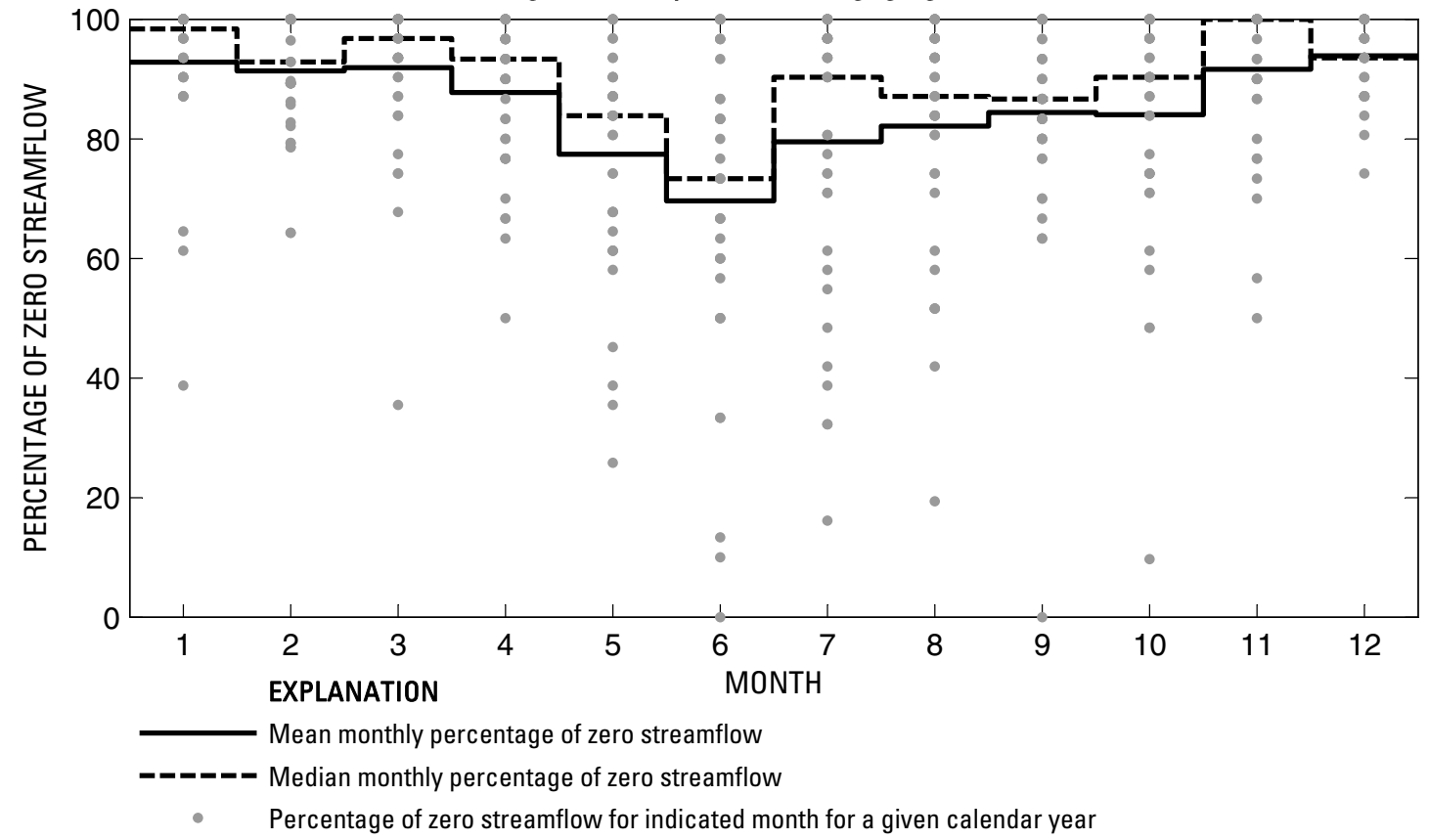

Figure 318. Analysis of percentage of zero daily mean streamflow for U.S. Geological Survey streamflow-gaging station 08080700 Running Water Draw at Plainview, Texas.

Index of Station Numbers 719 


\section{U.S. Geological Survey streamflow-gaging station 08080950}

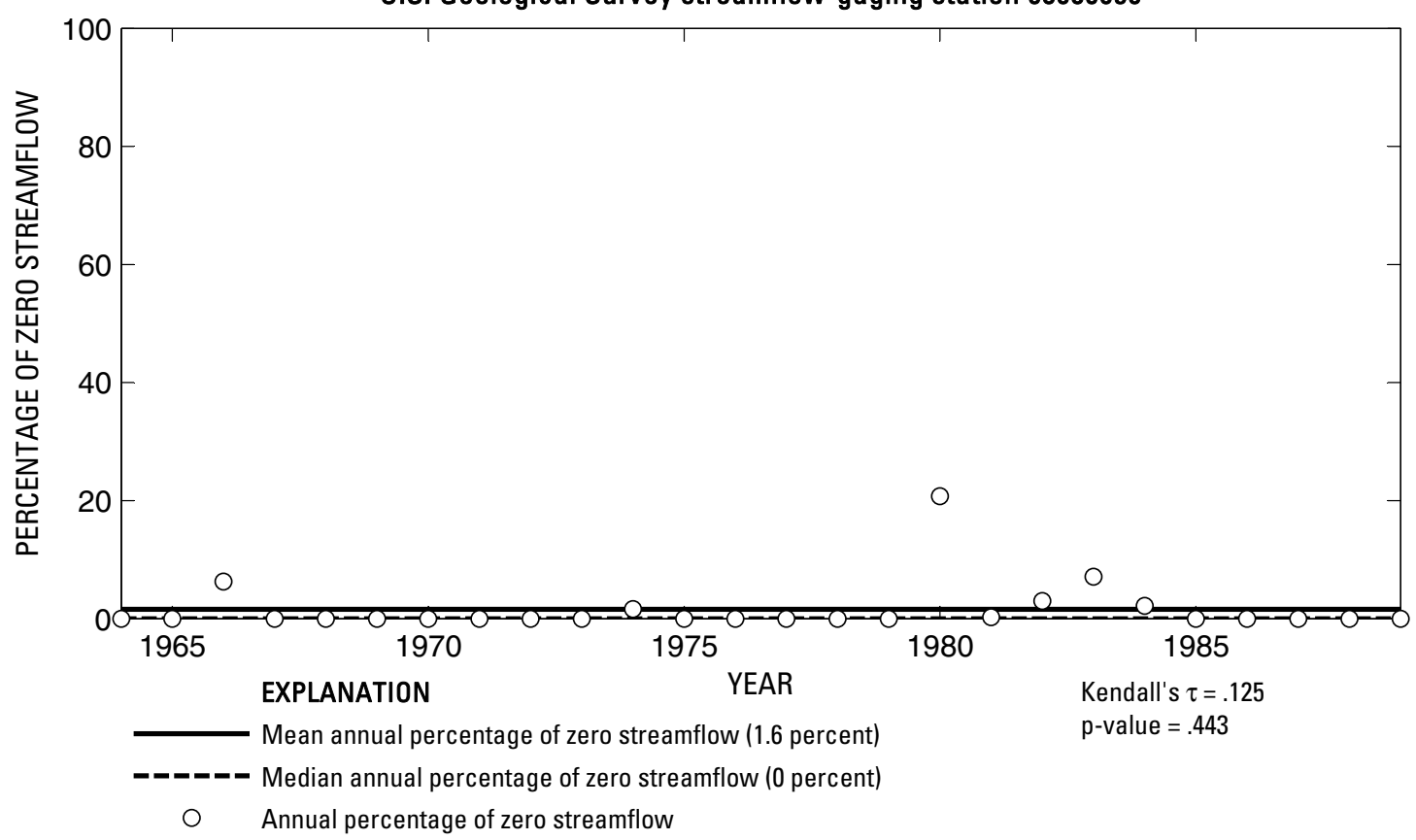

U.S. Geological Survey streamflow-gaging station 08080950

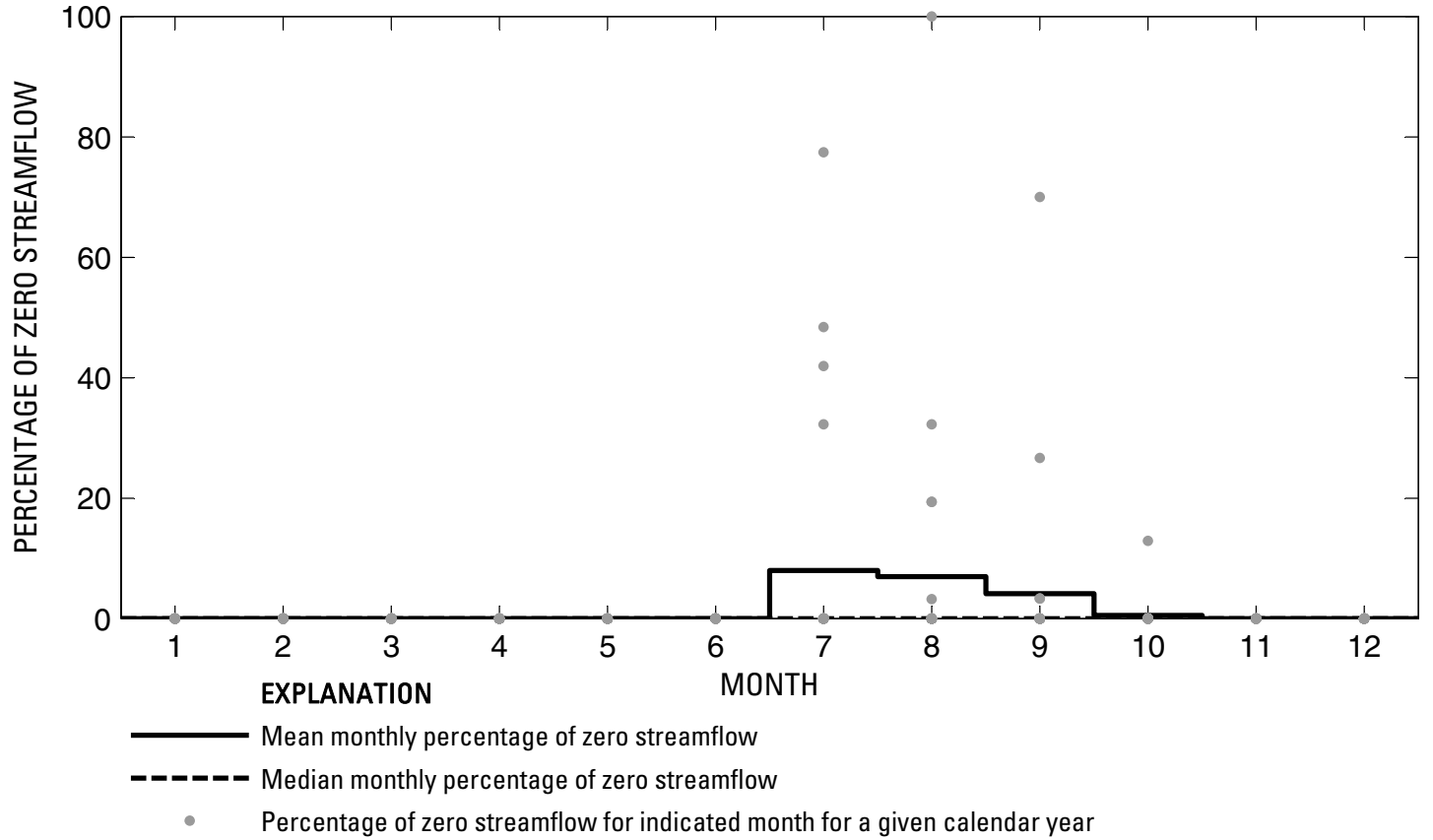

Figure 319. Analysis of percentage of zero daily mean streamflow for U.S. Geological Survey streamflow-gaging station 08080950 Duck Creek near Girard, Texas. 
U.S. Geological Survey streamflow-gaging station 08081000

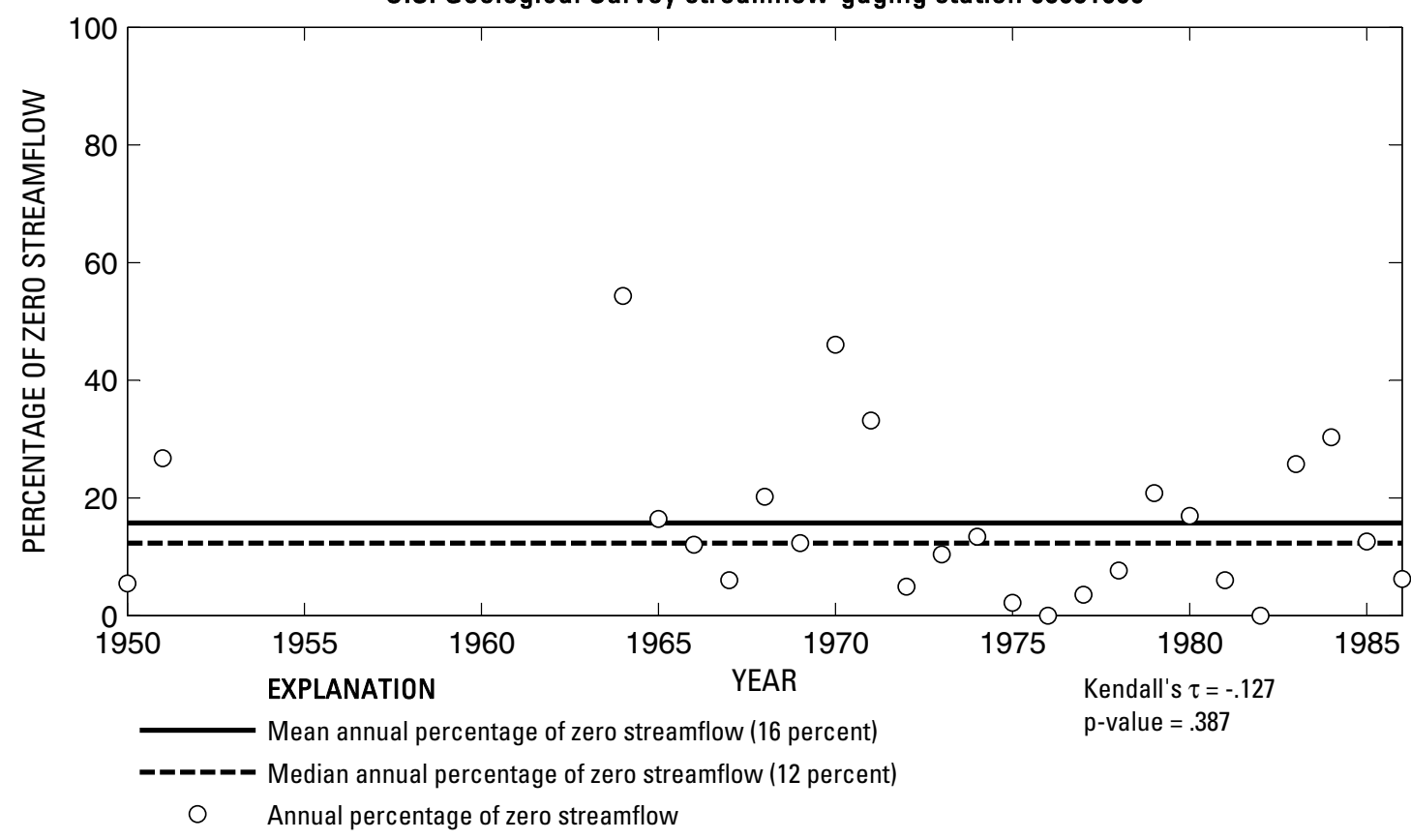

U.S. Geological Survey streamflow-gaging station 08081000

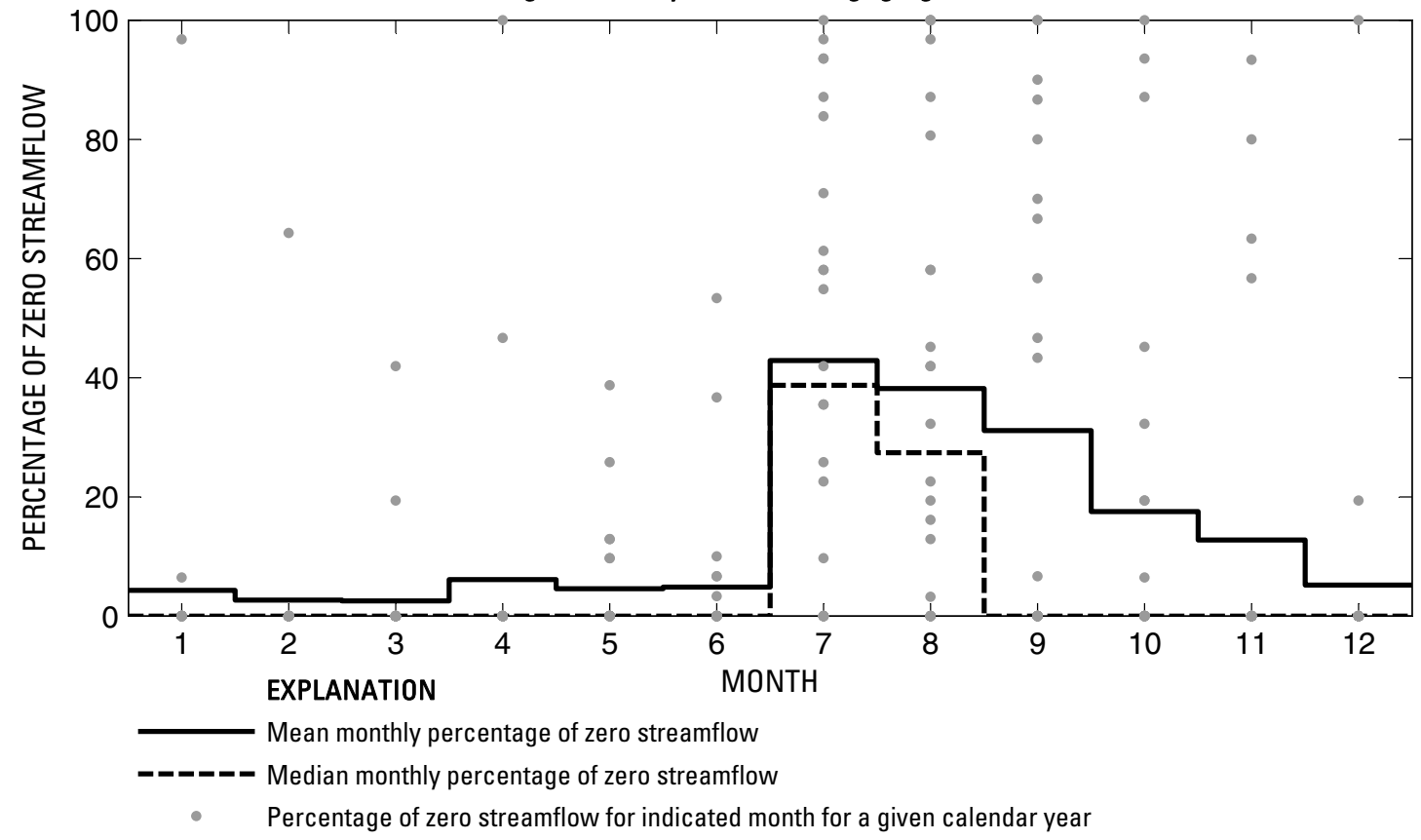

Figure 320. Analysis of percentage of zero daily mean streamflow for U.S. Geological Survey streamflow-gaging station 08081000 Salt Fork Brazos River near Peacock, Texas. 
U.S. Geological Survey streamflow-gaging station 08081200

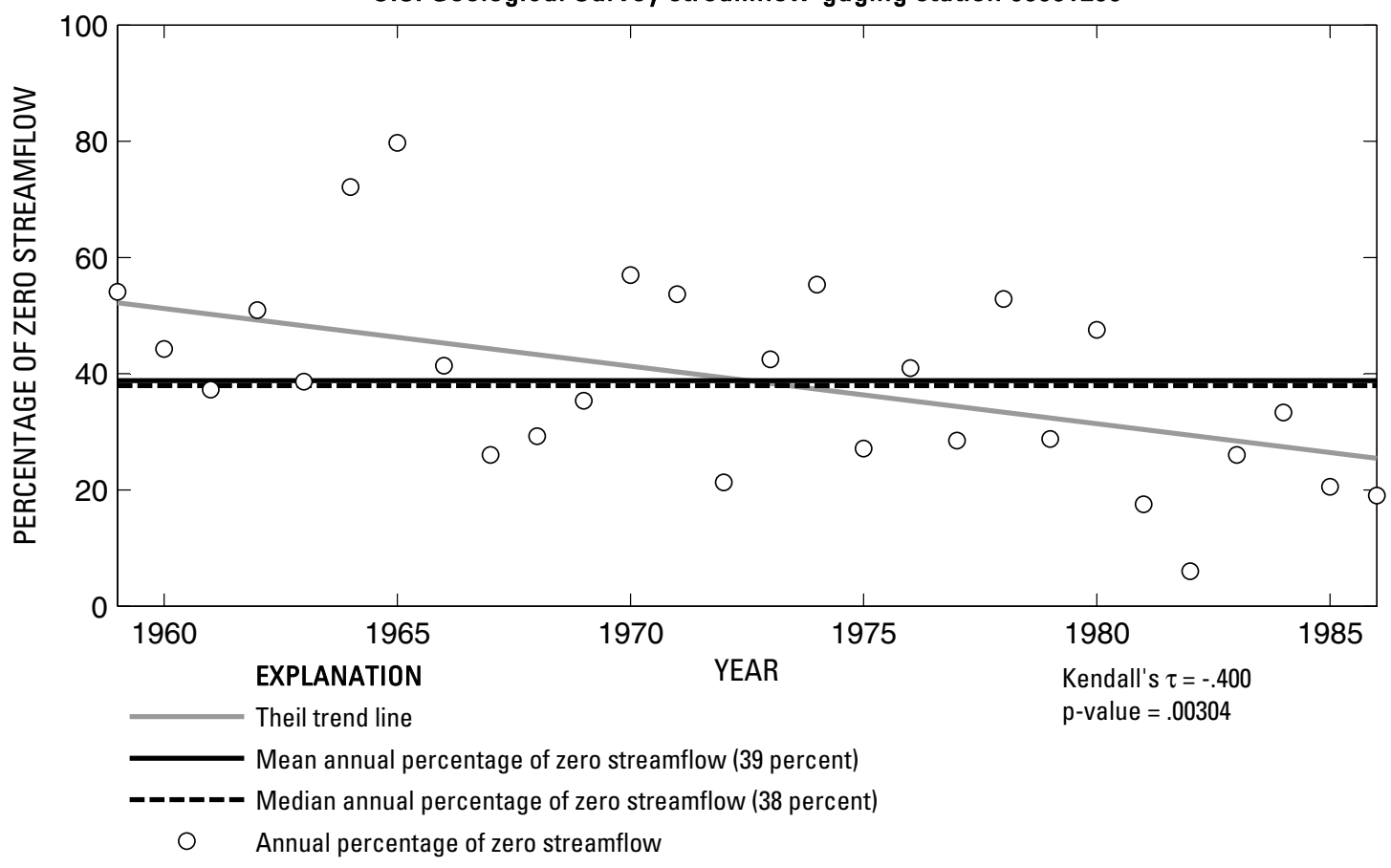

U.S. Geological Survey streamflow-gaging station 08081200

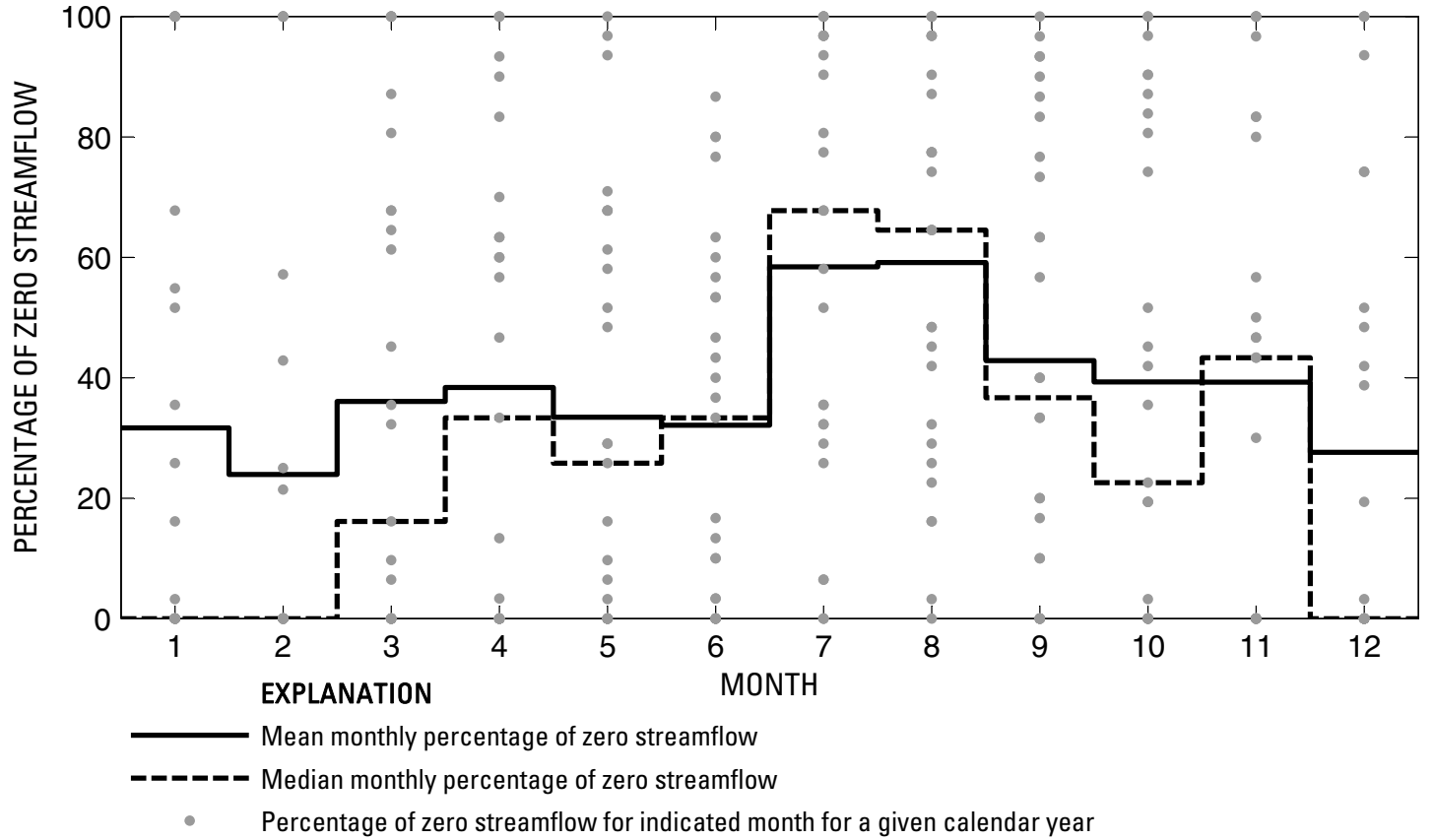

Figure 321. Analysis of percentage of zero daily mean streamflow for U.S. Geological Survey streamflow-gaging station 08081200 Croton Creek near Jayton, Texas. 
U.S. Geological Survey streamflow-gaging station 08081500

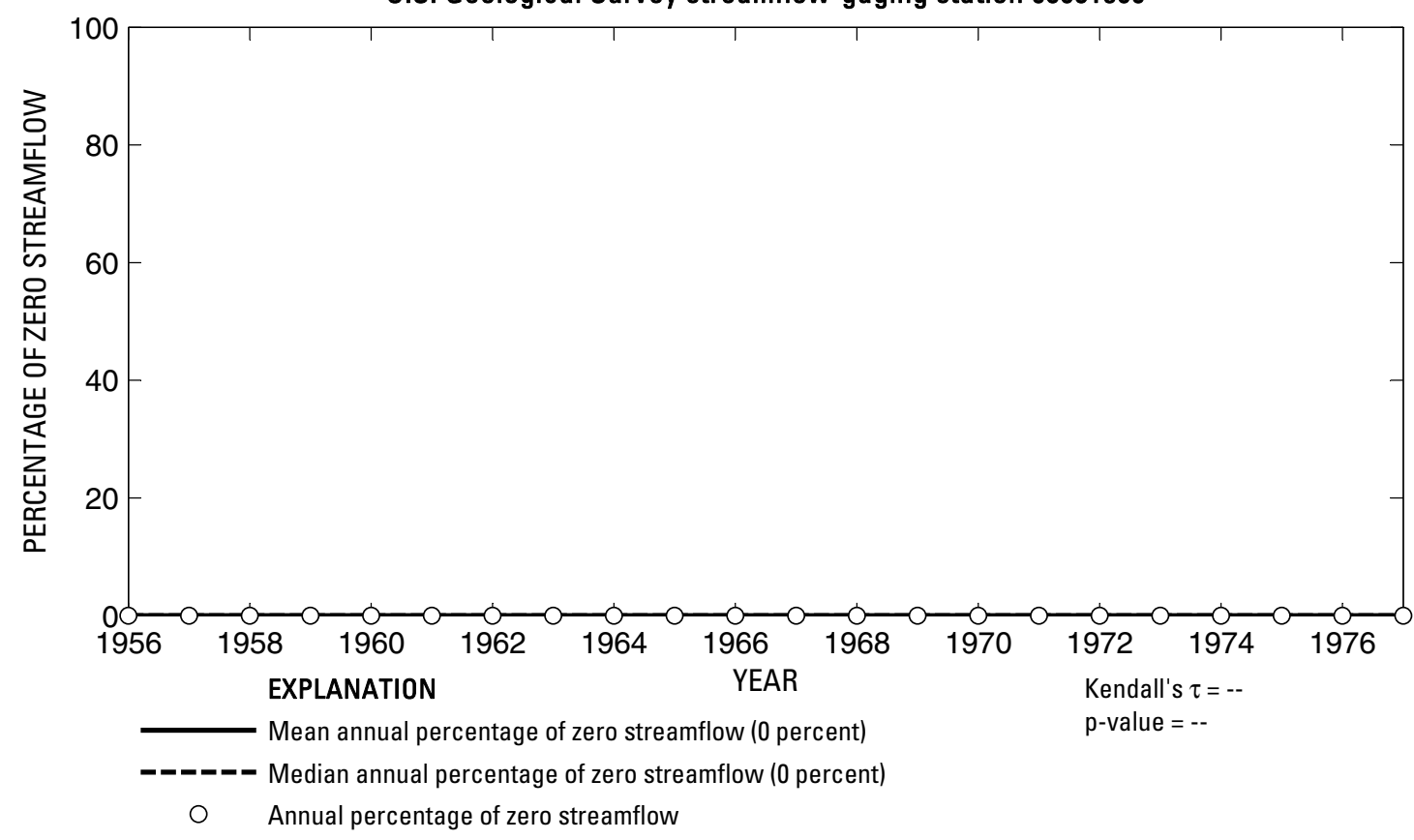

U.S. Geological Survey streamflow-gaging station 08081500

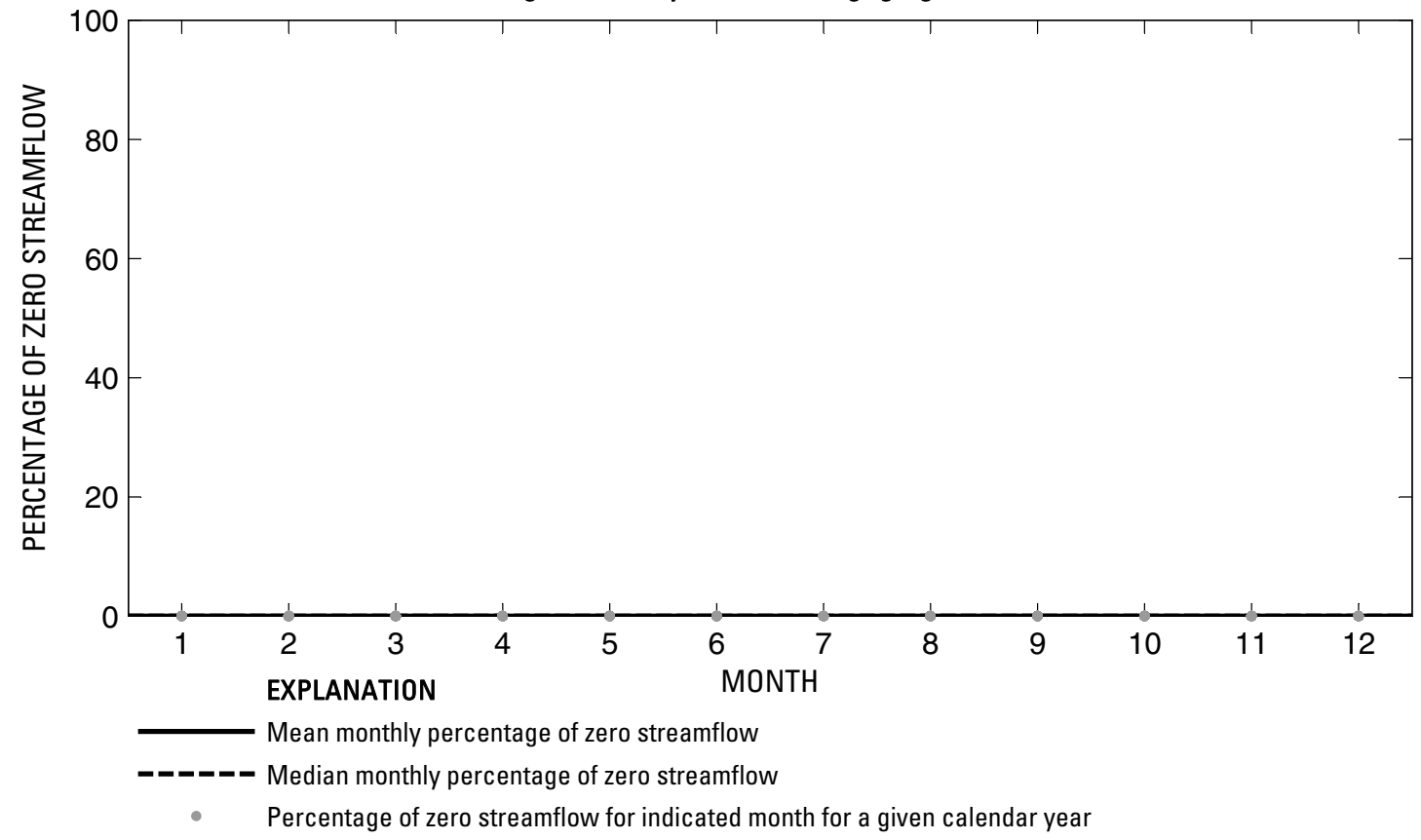

Figure 322. Analysis of percentage of zero daily mean streamflow for U.S. Geological Survey streamflow-gaging station 08081500 Salt Croton Creek near Aspermont, Texas. 
U.S. Geological Survey streamflow-gaging station 08082000

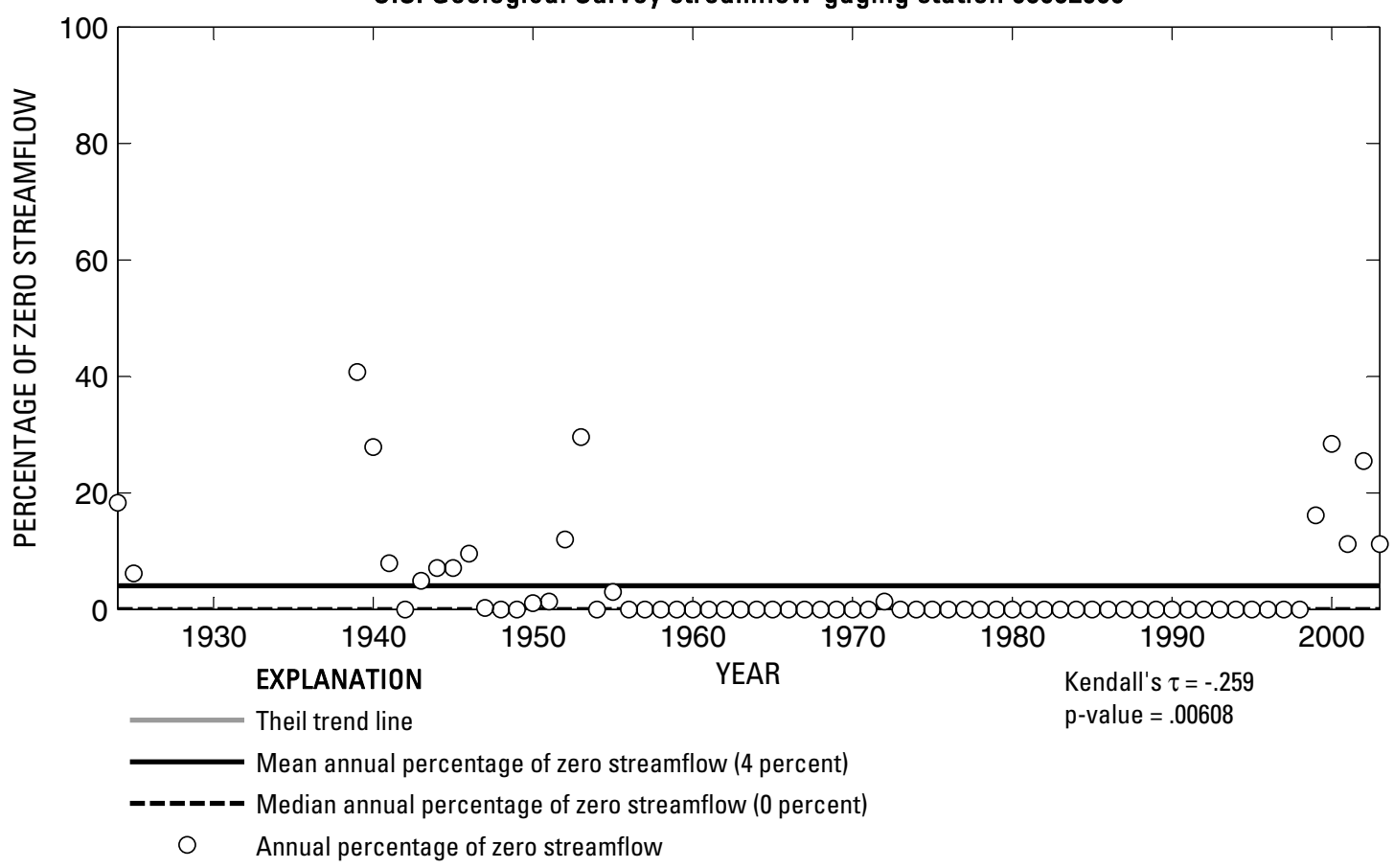

U.S. Geological Survey streamflow-gaging station 08082000

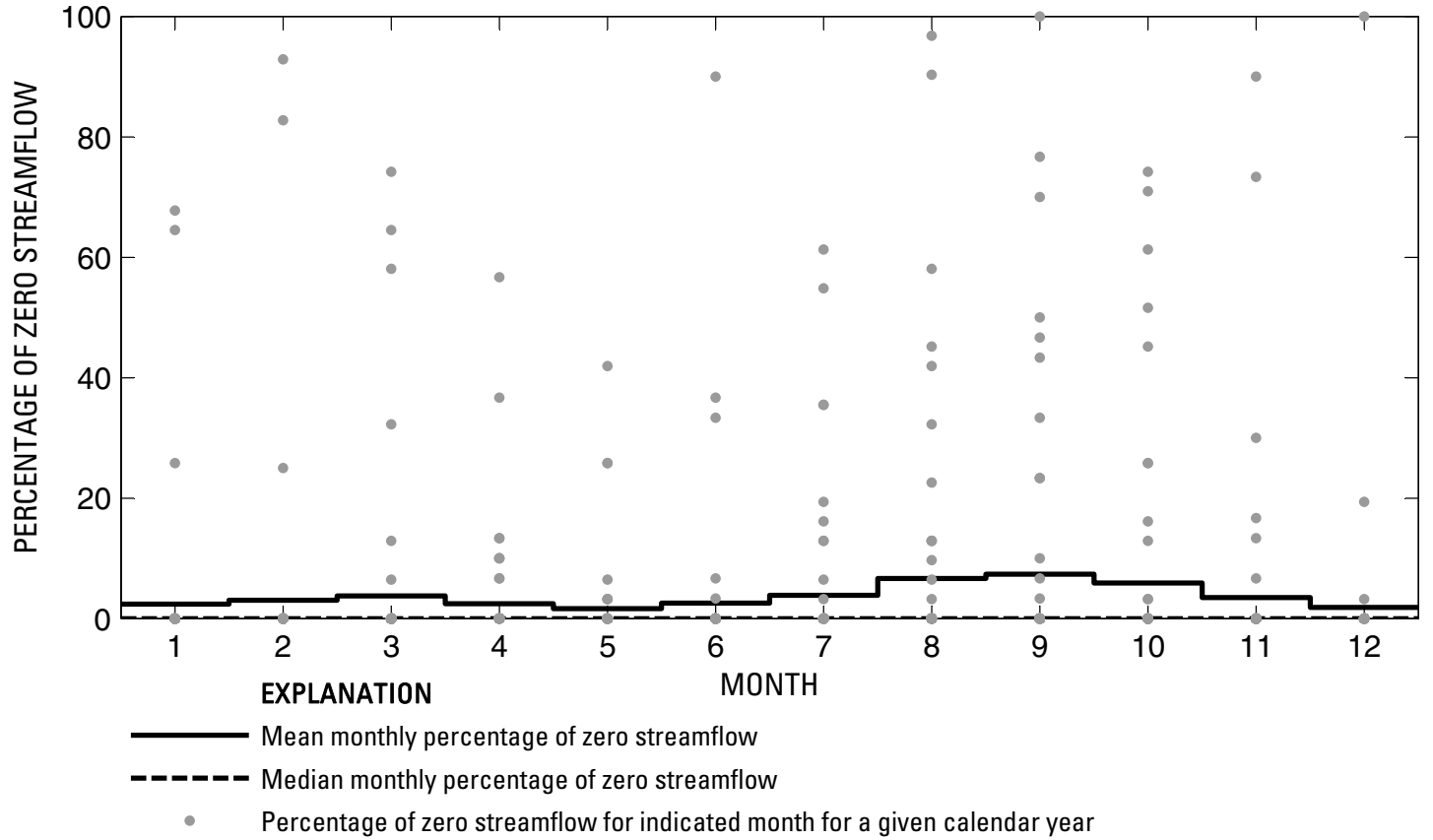

Figure 323. Analysis of percentage of zero daily mean streamflow for U.S. Geological Survey streamflow-gaging station 08082000 Salt Fork Brazos River near Aspermont, Texas. 
U.S. Geological Survey streamflow-gaging station 08082100

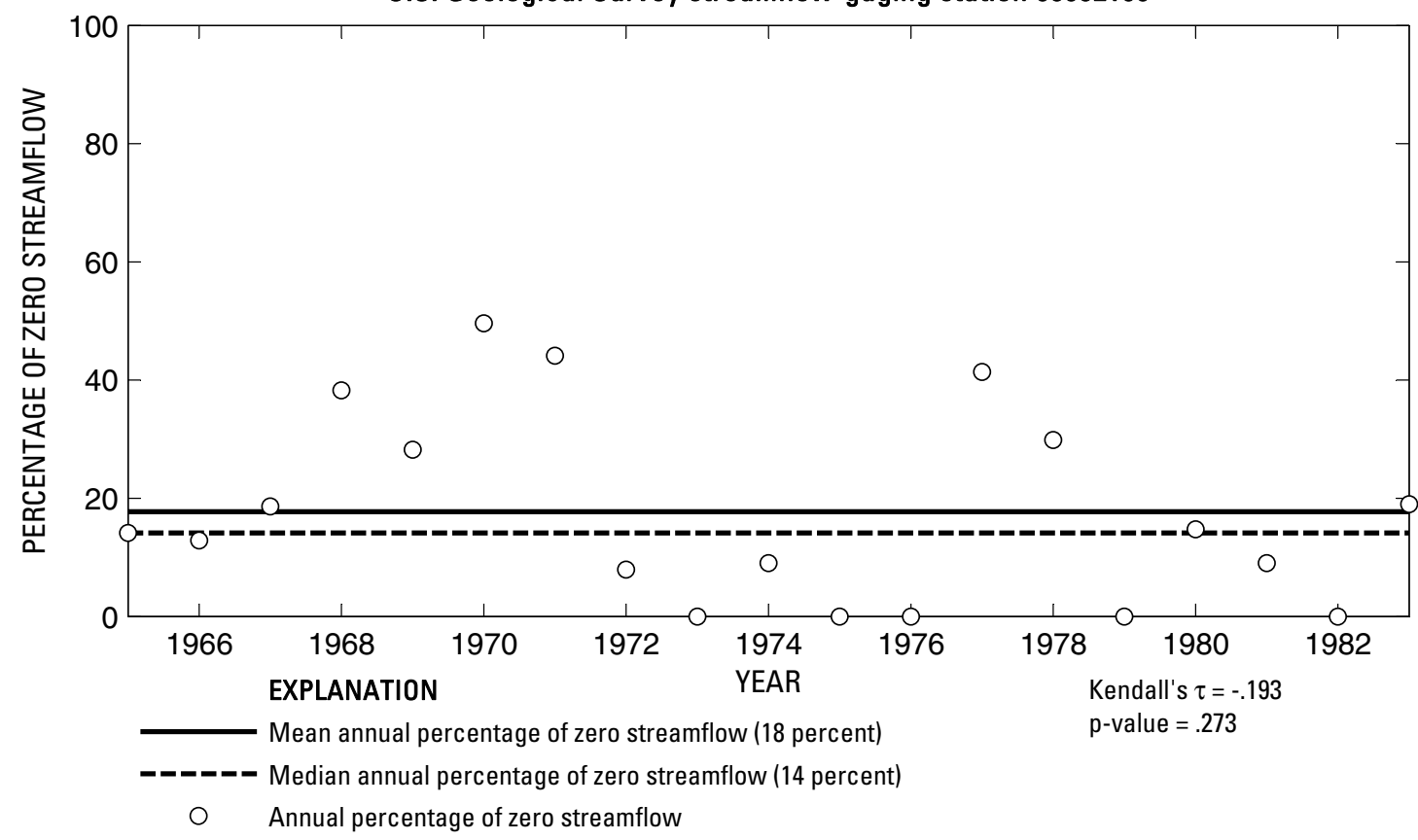

U.S. Geological Survey streamflow-gaging station 08082100

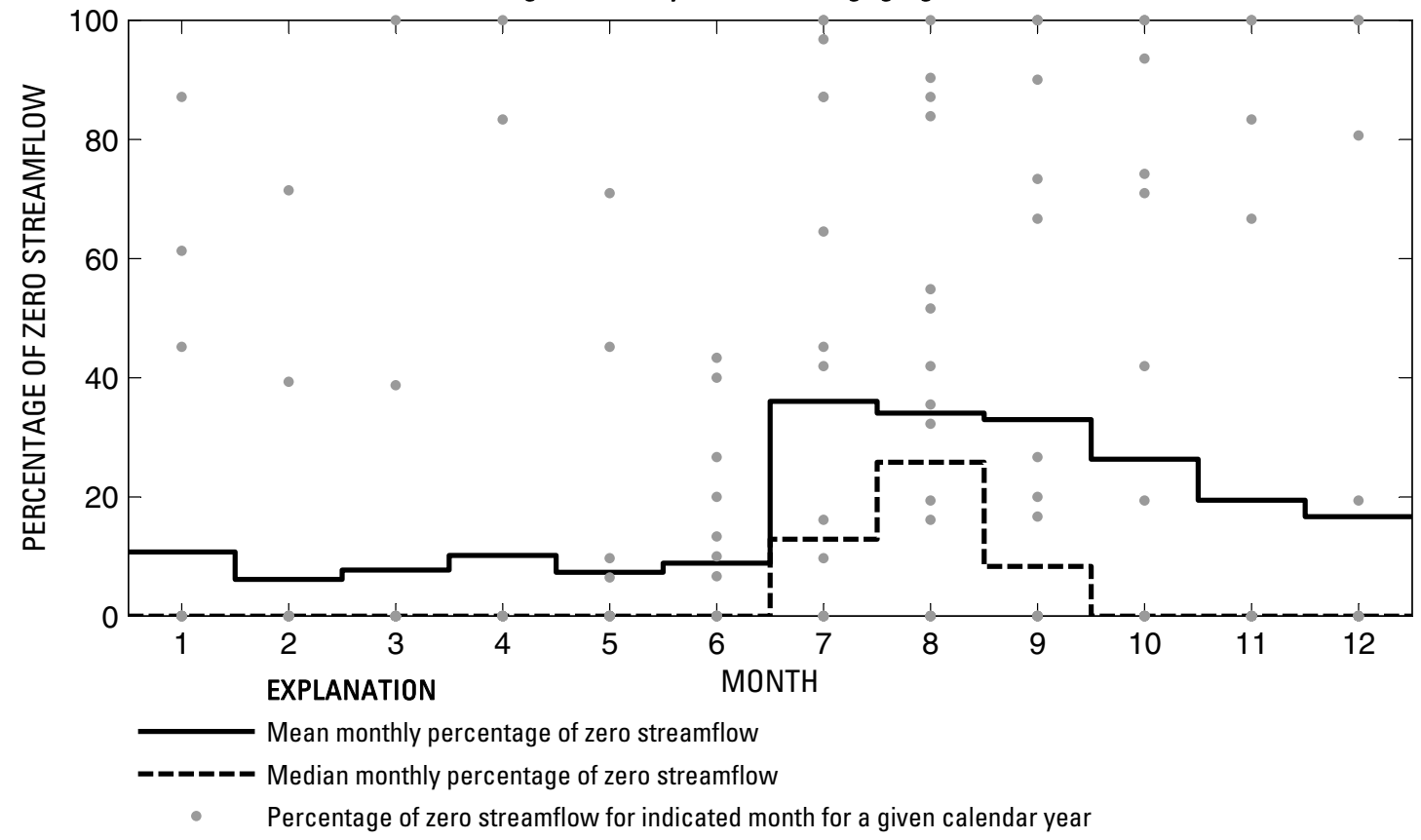

Figure 324. Analysis of percentage of zero daily mean streamflow for U.S. Geological Survey streamflow-gaging station 08082100 Stinking Creek near Aspermont, Texas.

Index of Station Numbers 719 


\section{U.S. Geological Survey streamflow-gaging station 08082180}

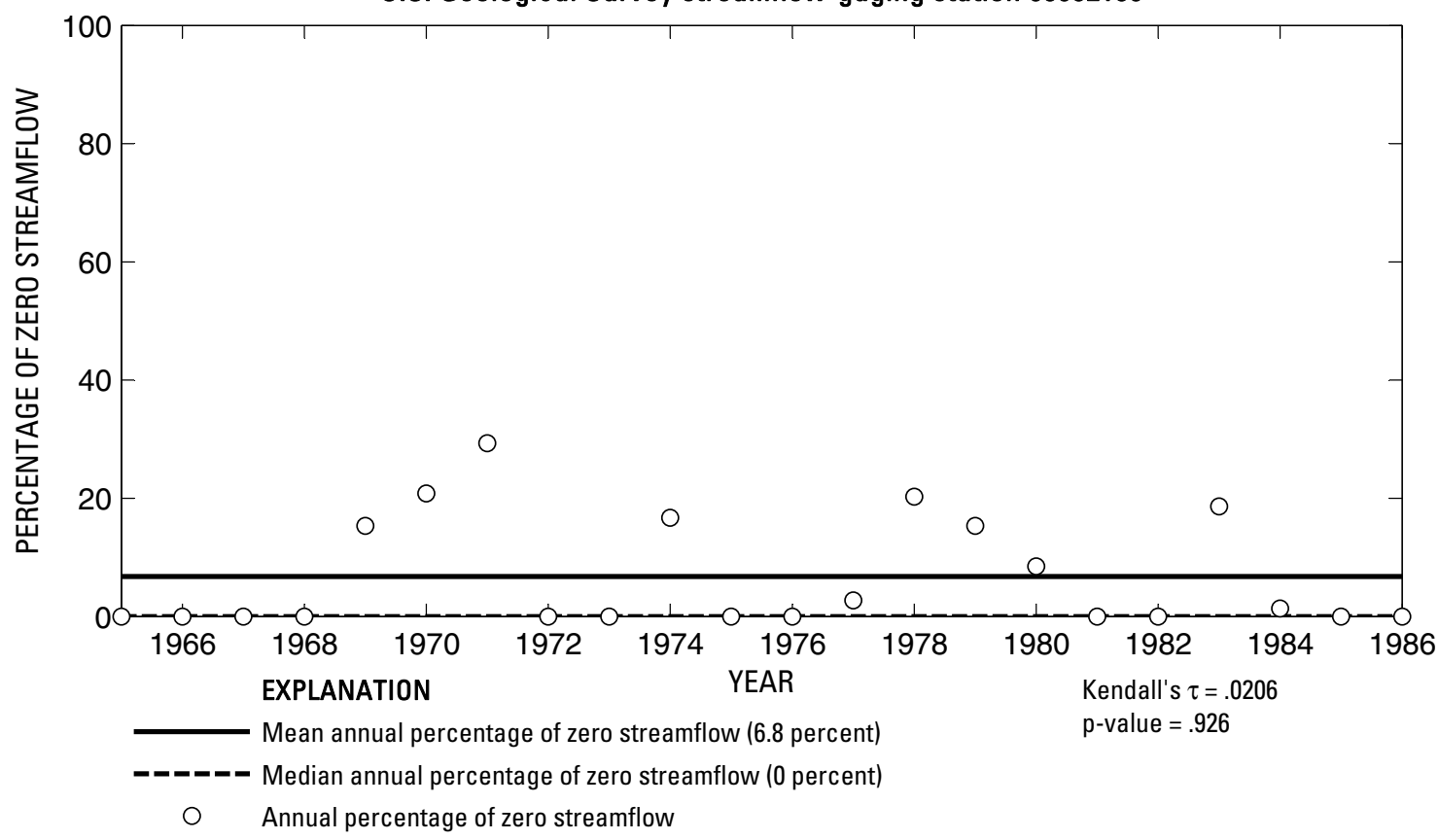

U.S. Geological Survey streamflow-gaging station 08082180

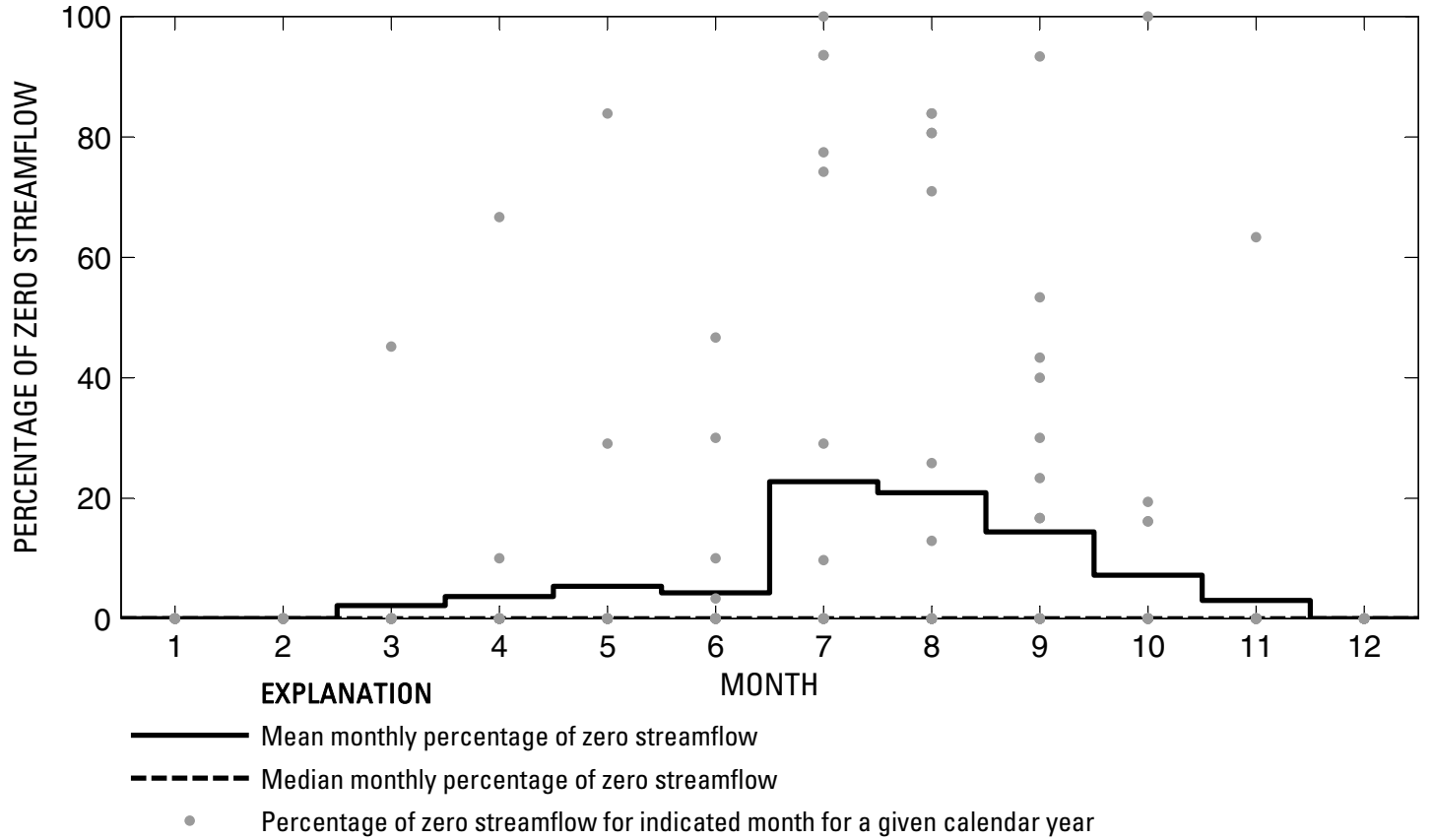

Figure 325. Analysis of percentage of zero daily mean streamflow for U.S. Geological Survey streamflow-gaging station 08082180 North Croton Creek near Knox City, Texas. 
U.S. Geological Survey streamflow-gaging station 08082500

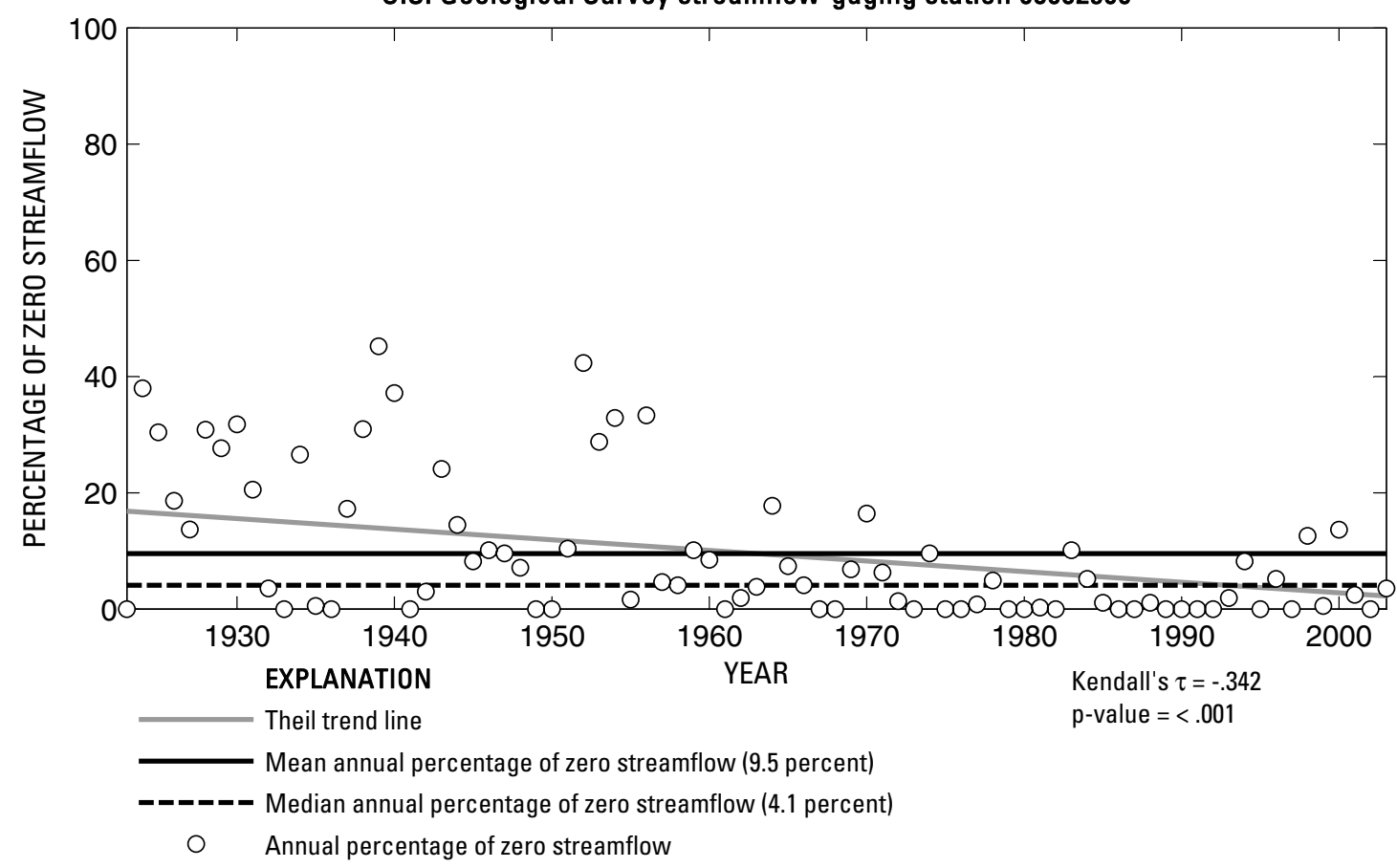

U.S. Geological Survey streamflow-gaging station 08082500

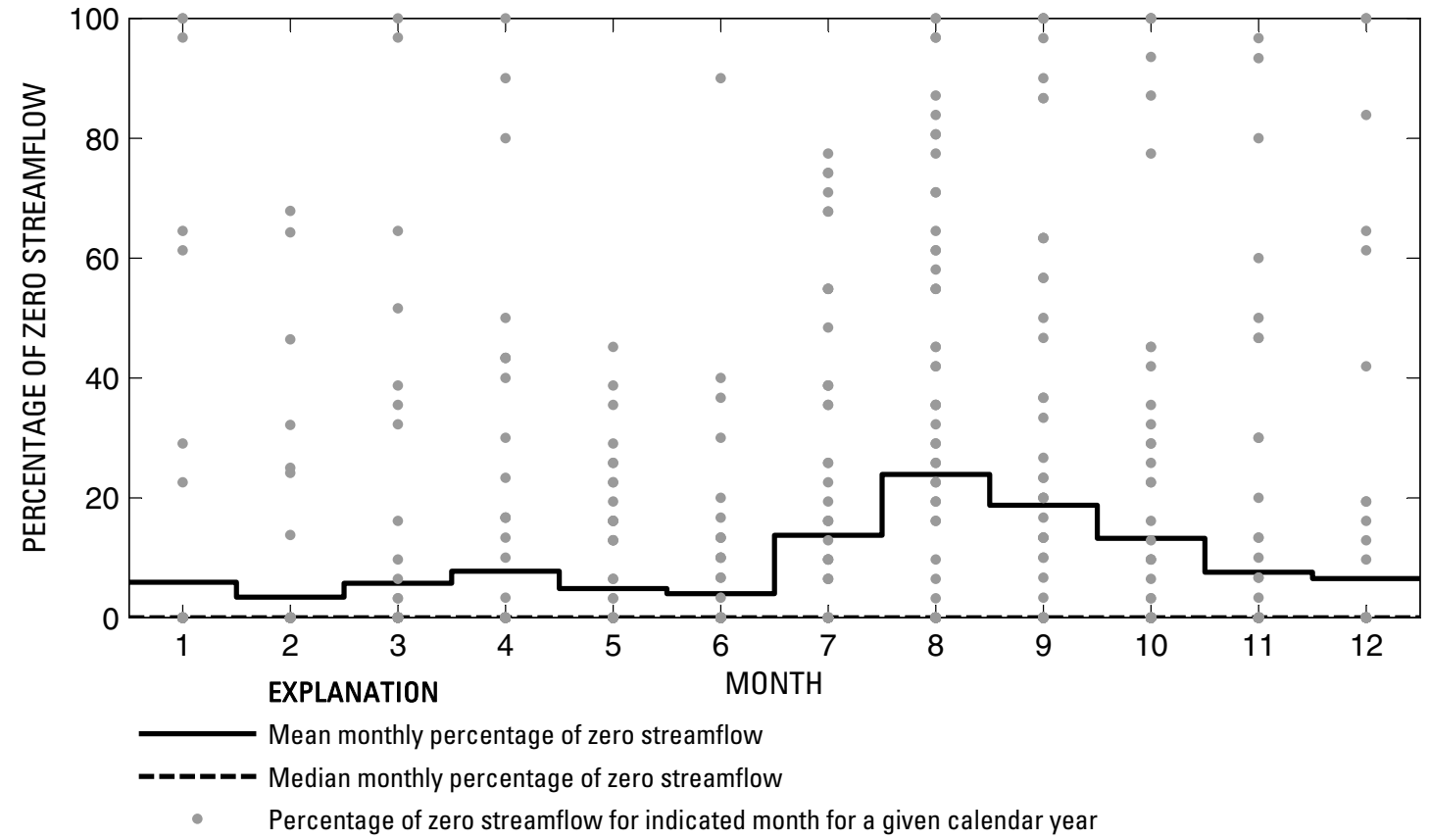

Figure 326. Analysis of percentage of zero daily mean streamflow for U.S. Geological Survey streamflow-gaging station 08082500 Brazos River at Seymour, Texas.

Index of Station Numbers 719 
U.S. Geological Survey streamflow-gaging station 08082700

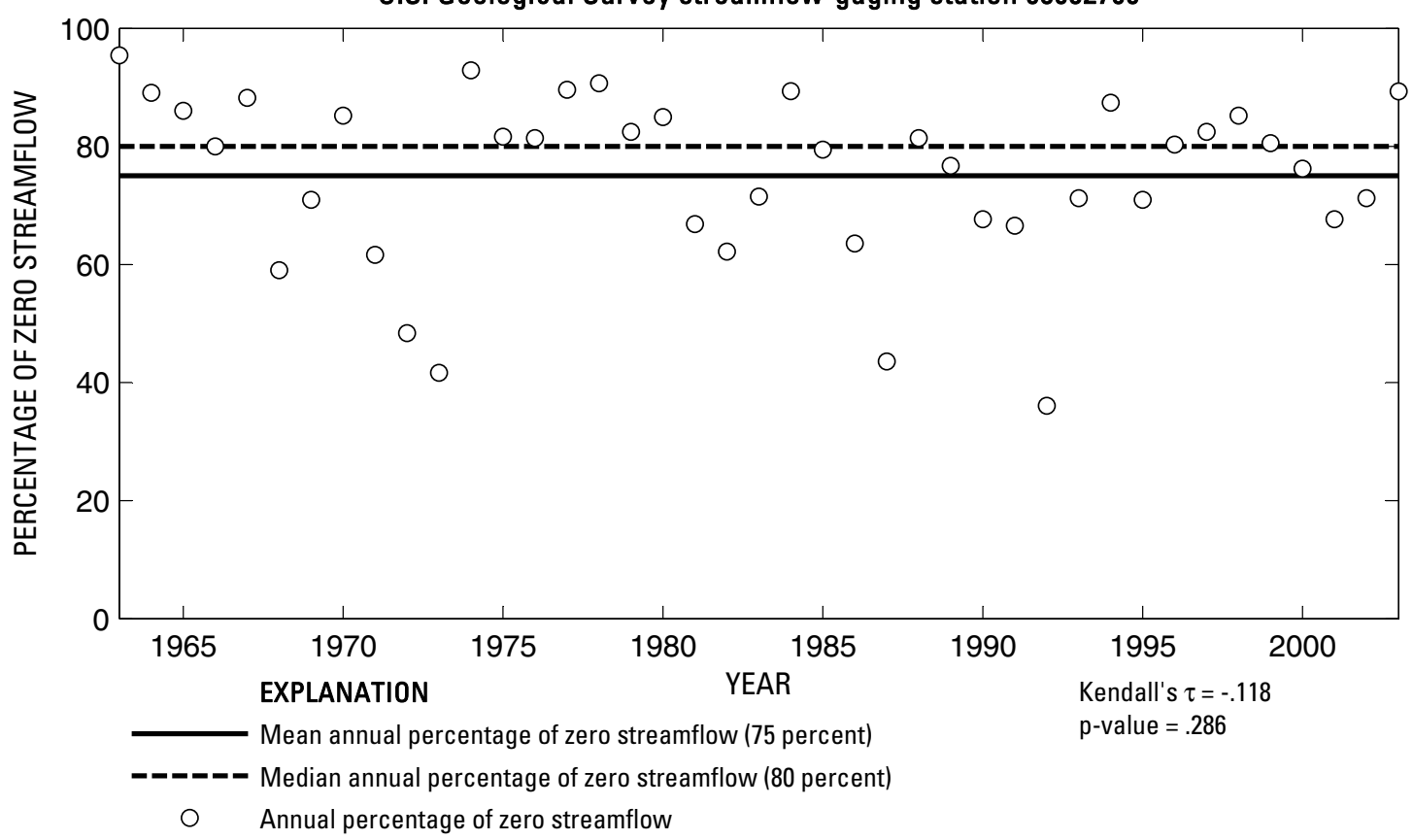

U.S. Geological Survey streamflow-gaging station 08082700

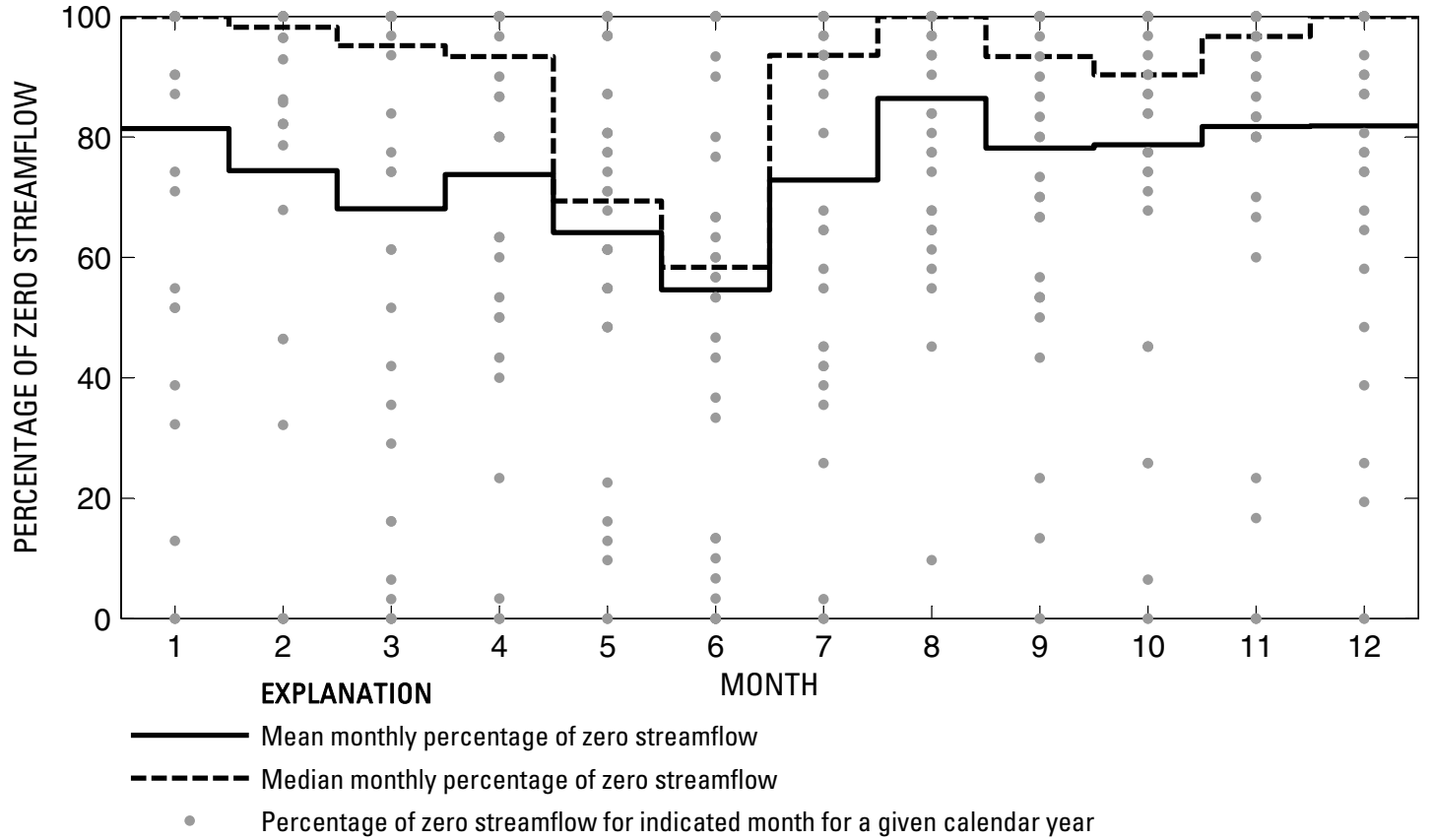

Figure 327. Analysis of percentage of zero daily mean streamflow for U.S. Geological Survey streamflow-gaging station 08082700 Millers Creek near Munday, Texas. 
U.S. Geological Survey streamflow-gaging station 08083000

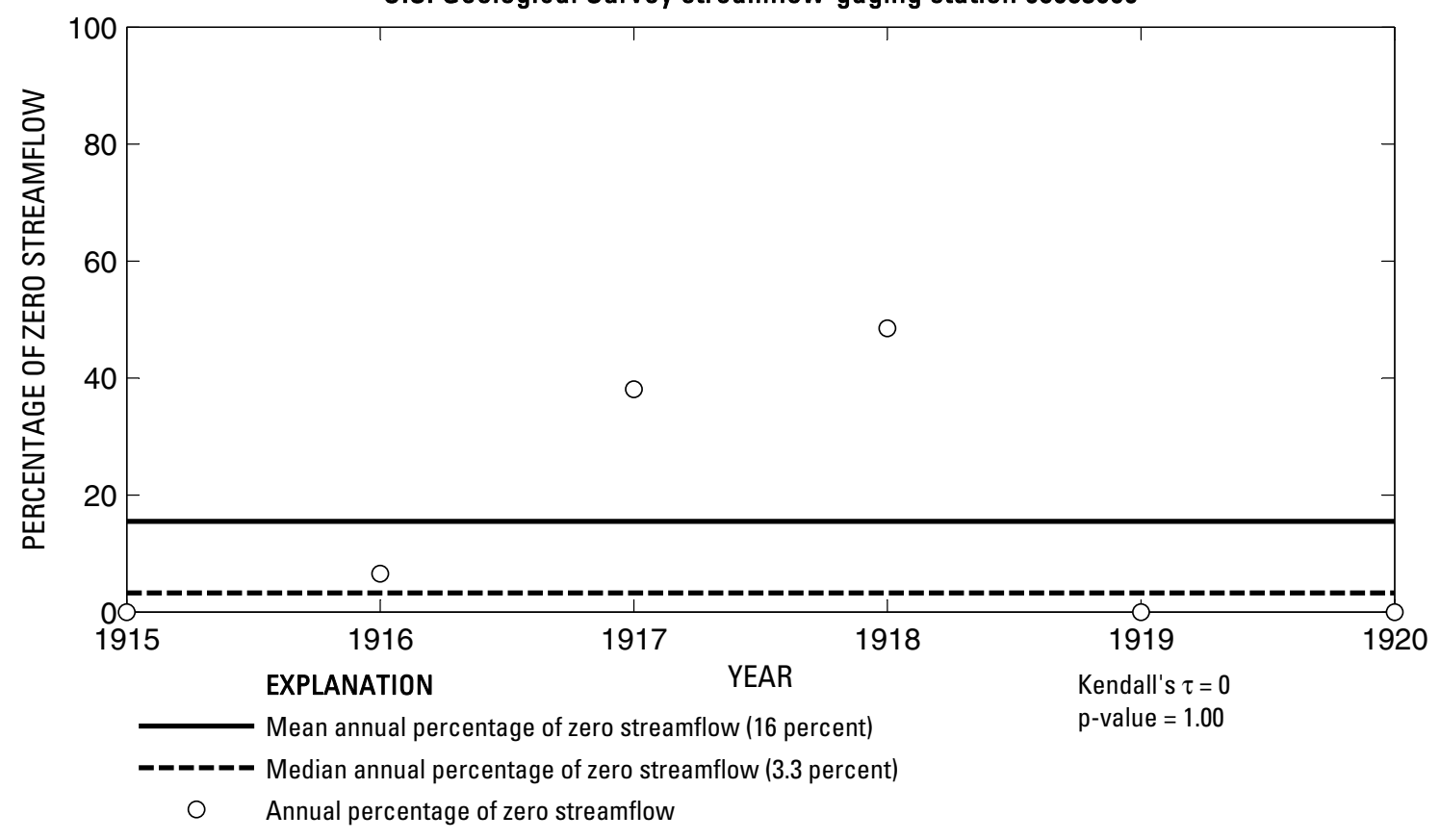

U.S. Geological Survey streamflow-gaging station 08083000

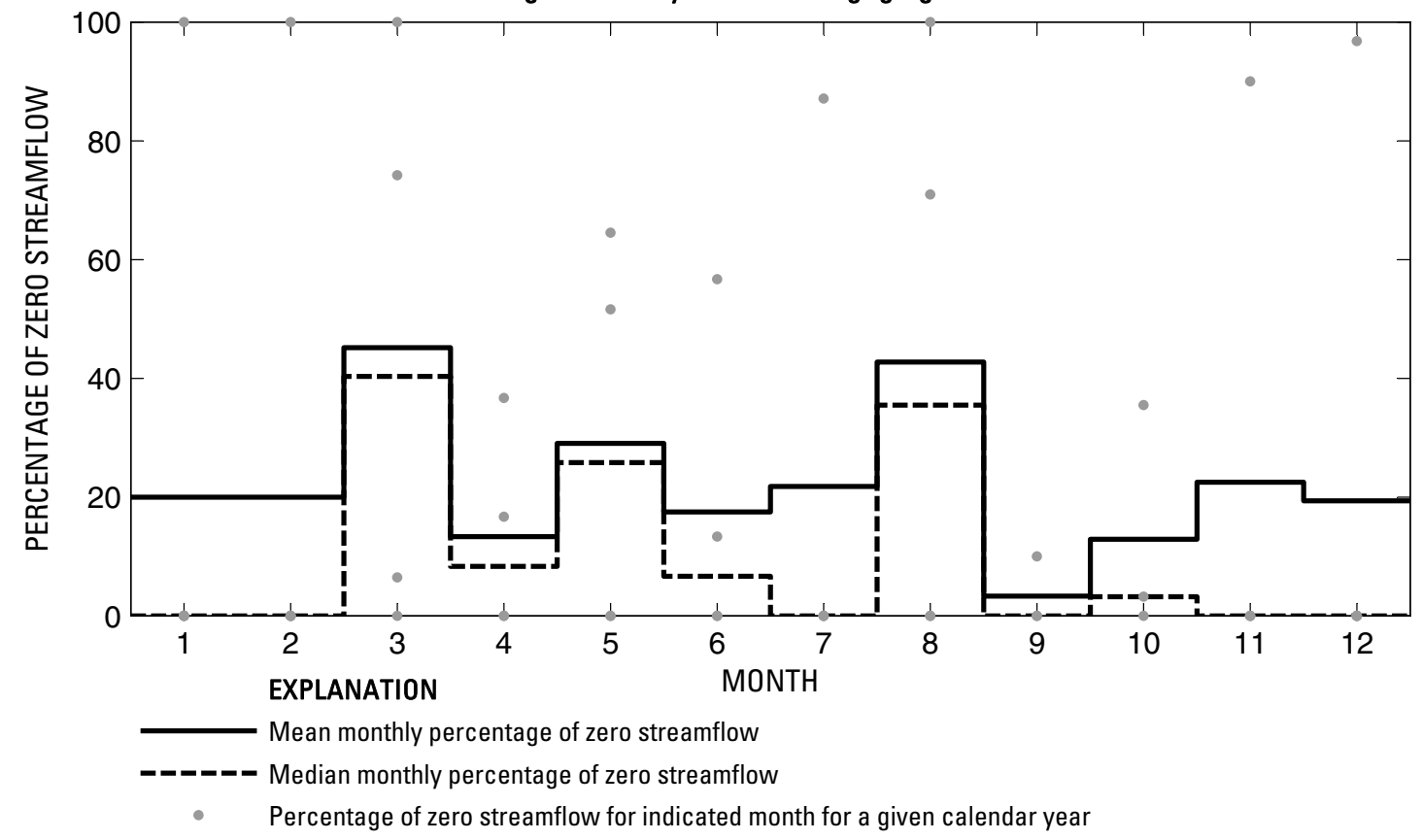

Figure 328. Analysis of percentage of zero daily mean streamflow for U.S. Geological Survey streamflow-gaging station 08083000 Brazos River near Graham, Texas. 
U.S. Geological Survey streamflow-gaging station 08083100

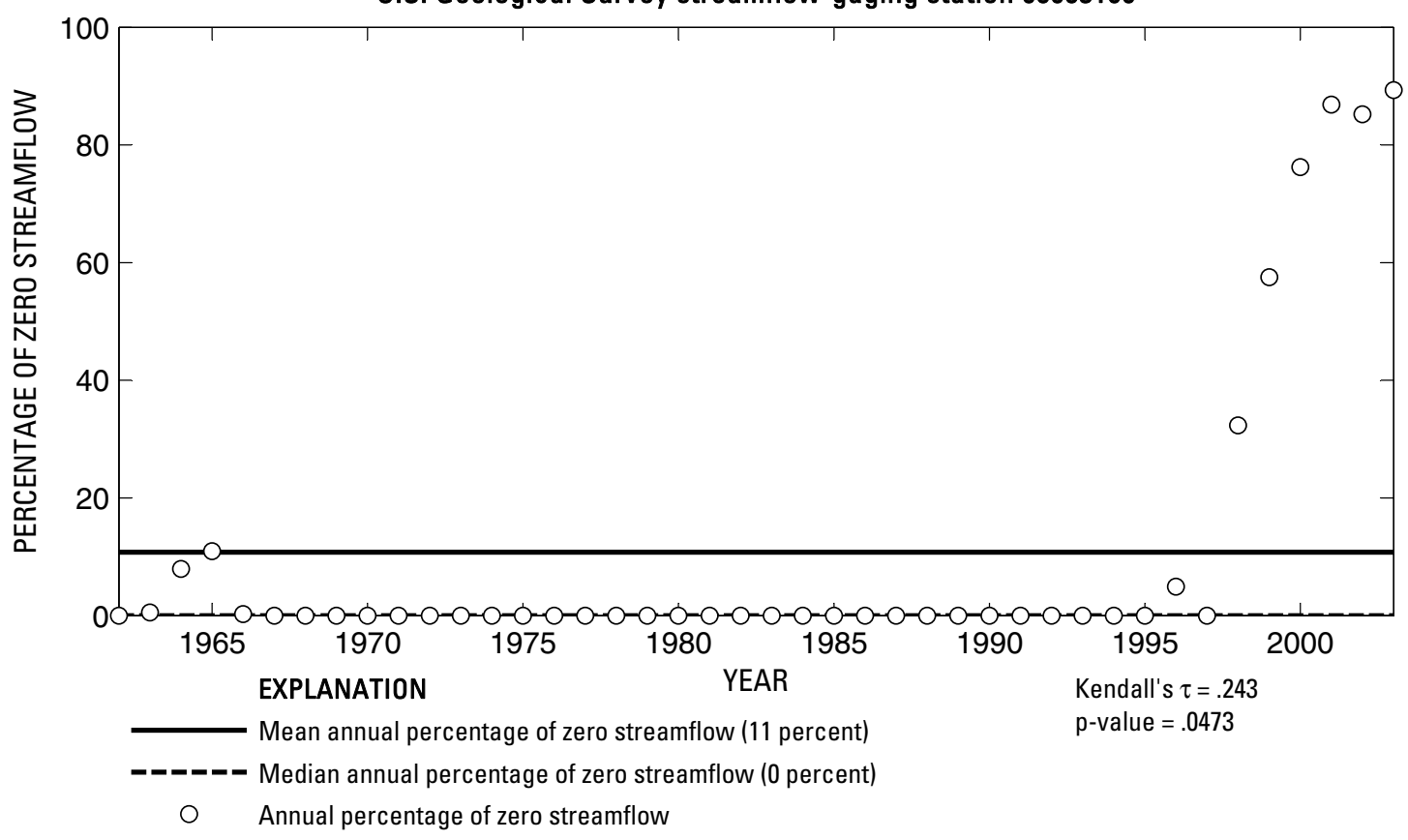

U.S. Geological Survey streamflow-gaging station 08083100

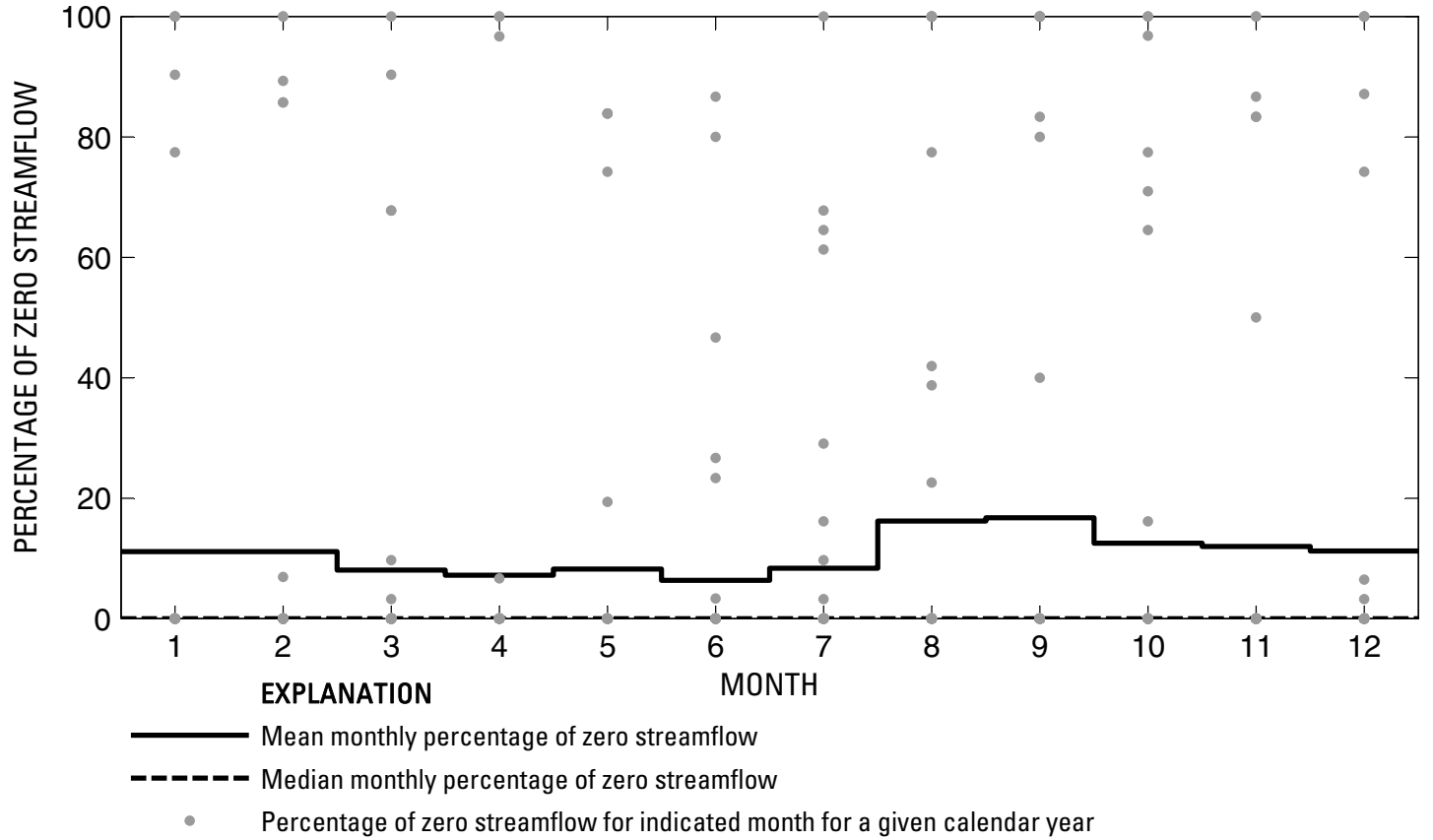

Figure 329. Analysis of percentage of zero daily mean streamflow for U.S. Geological Survey streamflow-gaging station 08083100 Clear Fork Brazos River near Roby, Texas. 
U.S. Geological Survey streamflow-gaging station 08083230

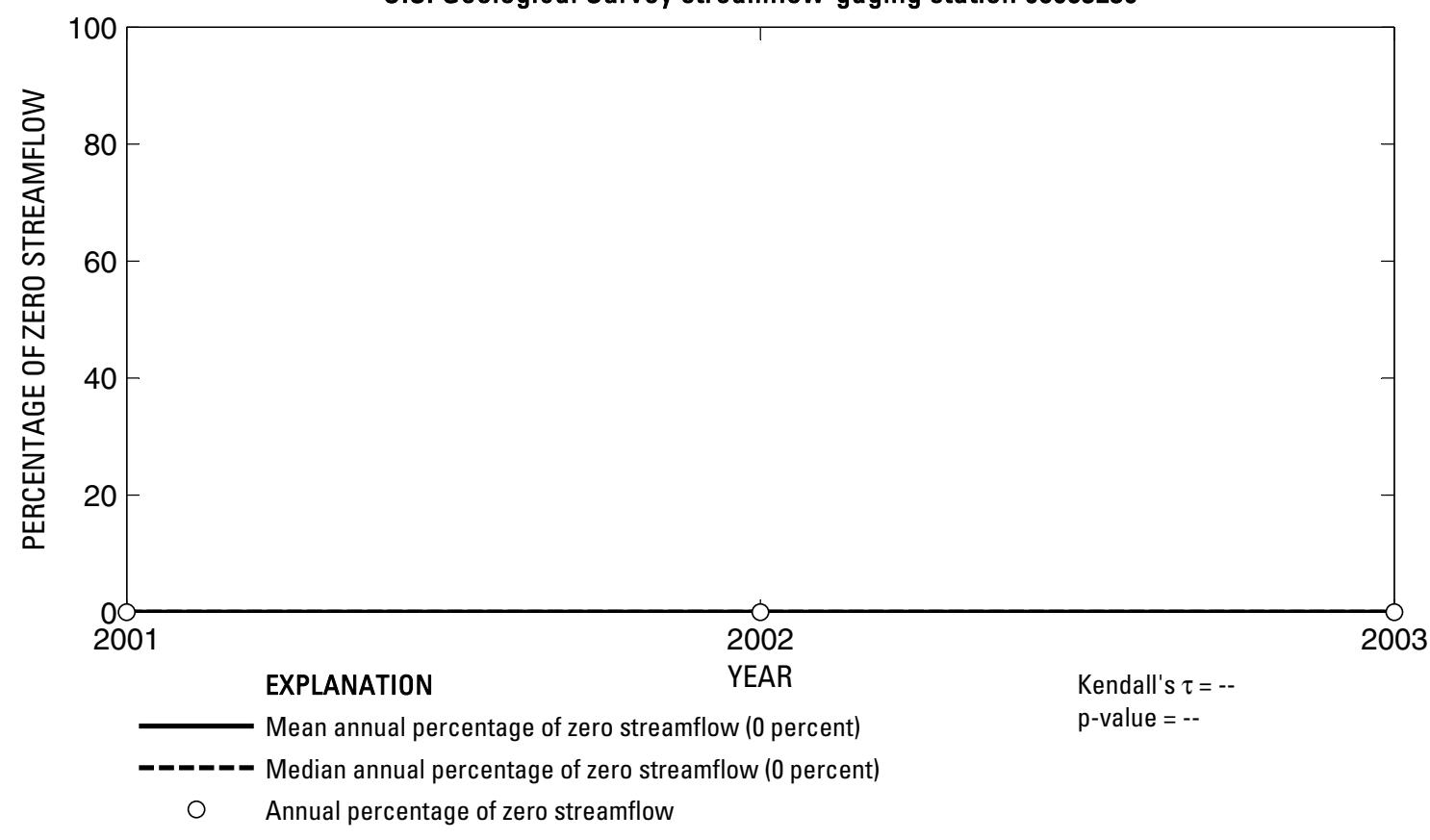

U.S. Geological Survey streamflow-gaging station 08083230

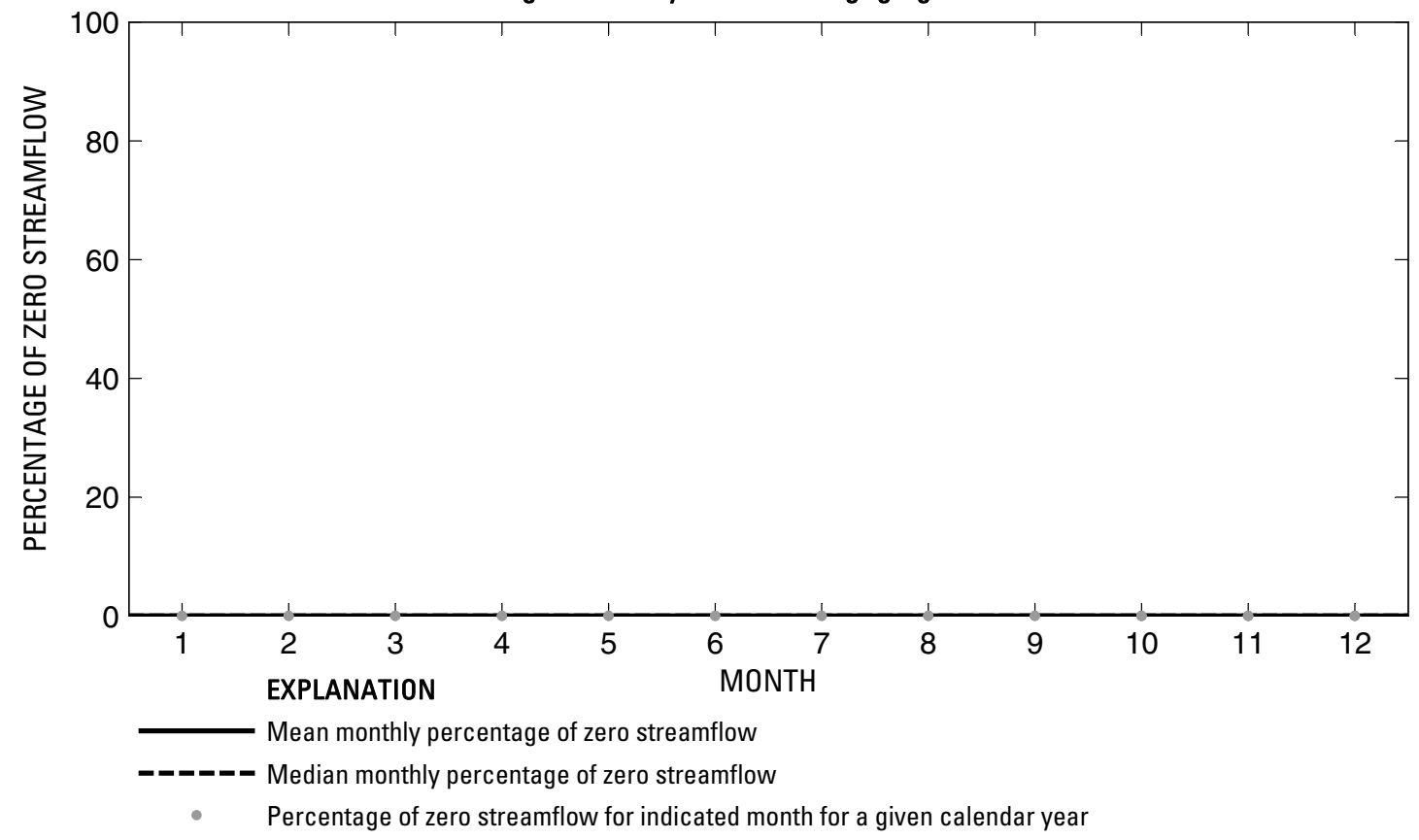

Figure 330. Analysis of percentage of zero daily mean streamflow for U.S. Geological Survey streamflow-gaging station 08083230 Clear Fork Brazos River near Noodle, Texas. 
U.S. Geological Survey streamflow-gaging station 08083240

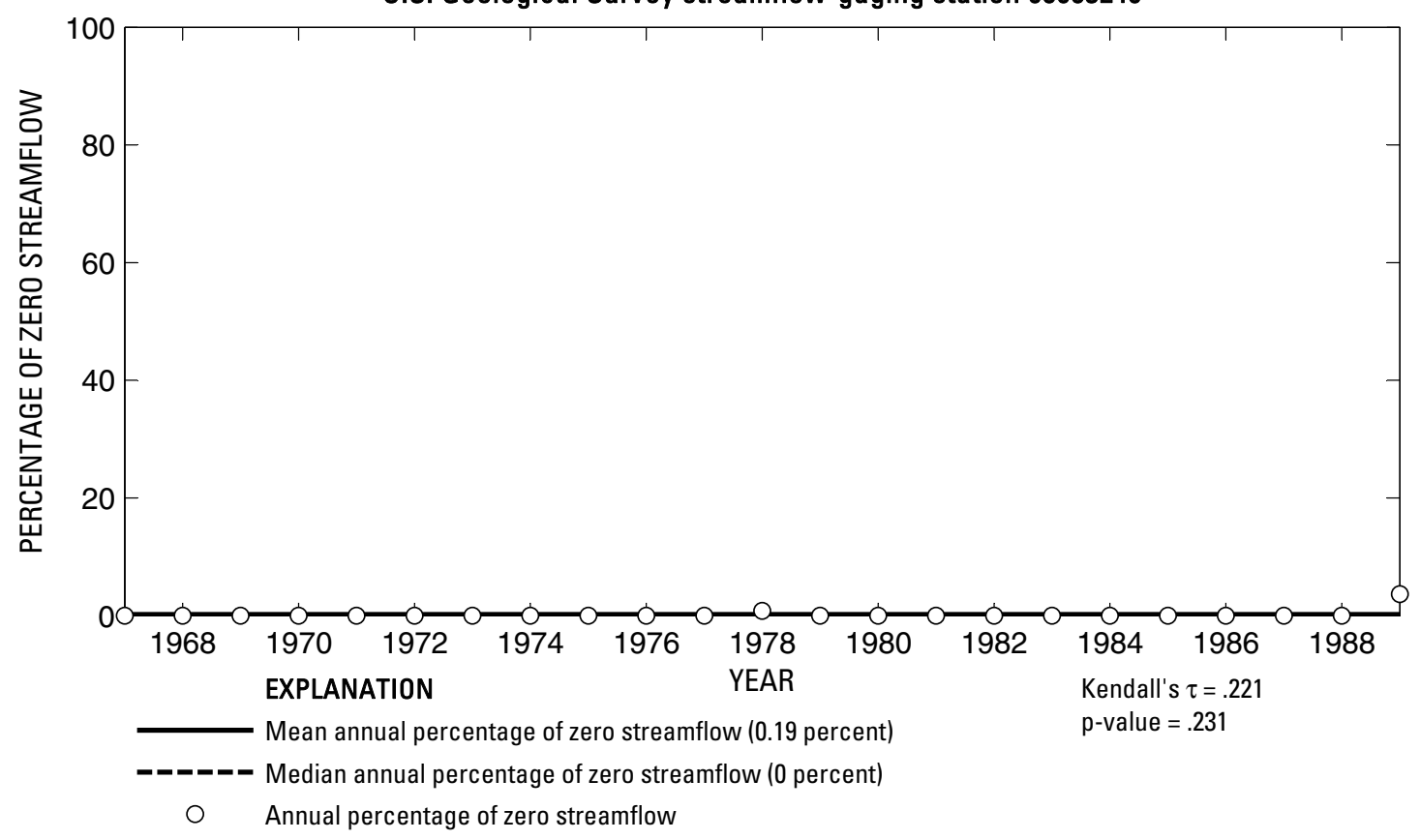

U.S. Geological Survey streamflow-gaging station 08083240

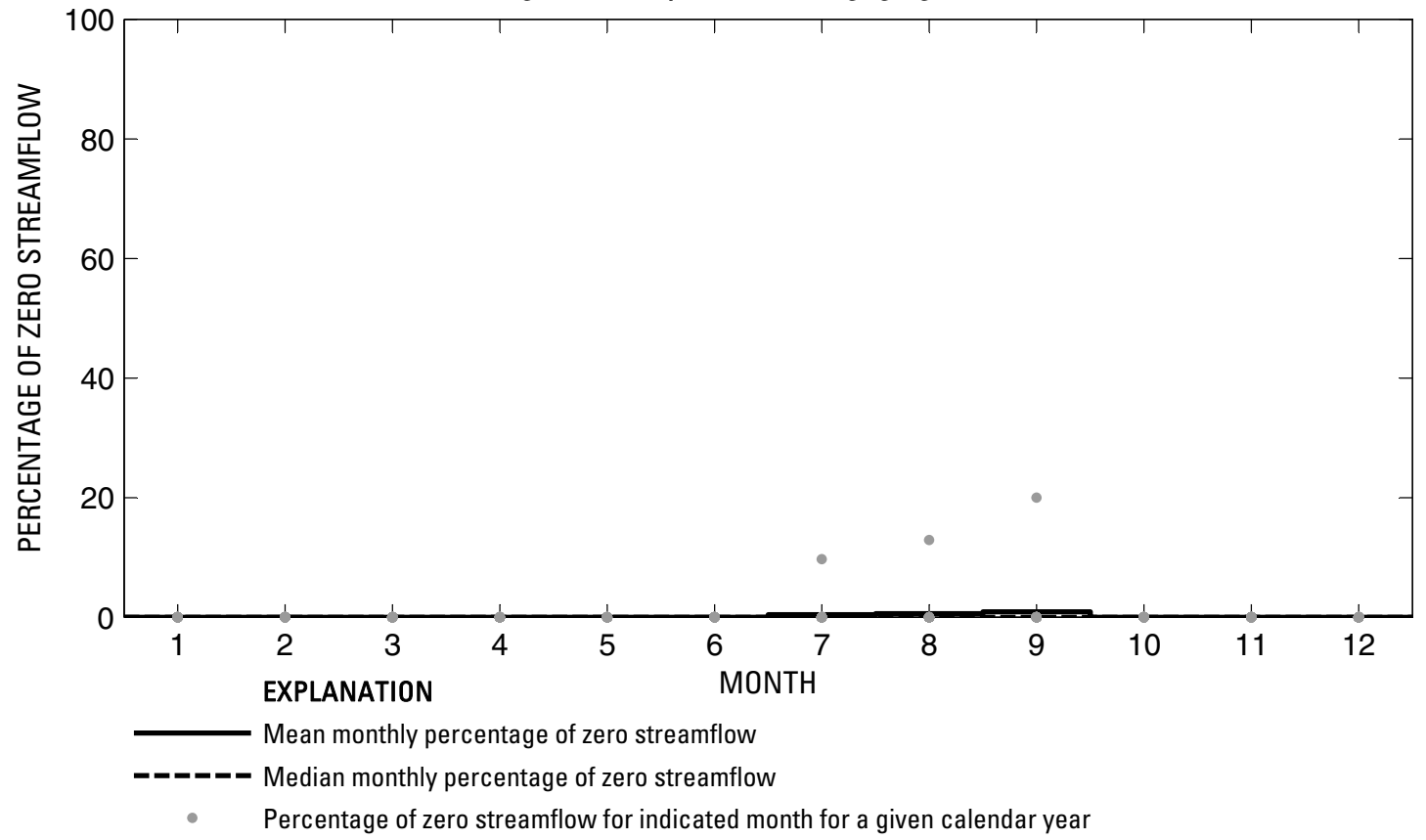

Figure 331. Analysis of percentage of zero daily mean streamflow for U.S. Geological Survey streamflow-gaging station 08083240 Clear Fork Brazos River at Hawley, Texas. 
U.S. Geological Survey streamflow-gaging station 08083245

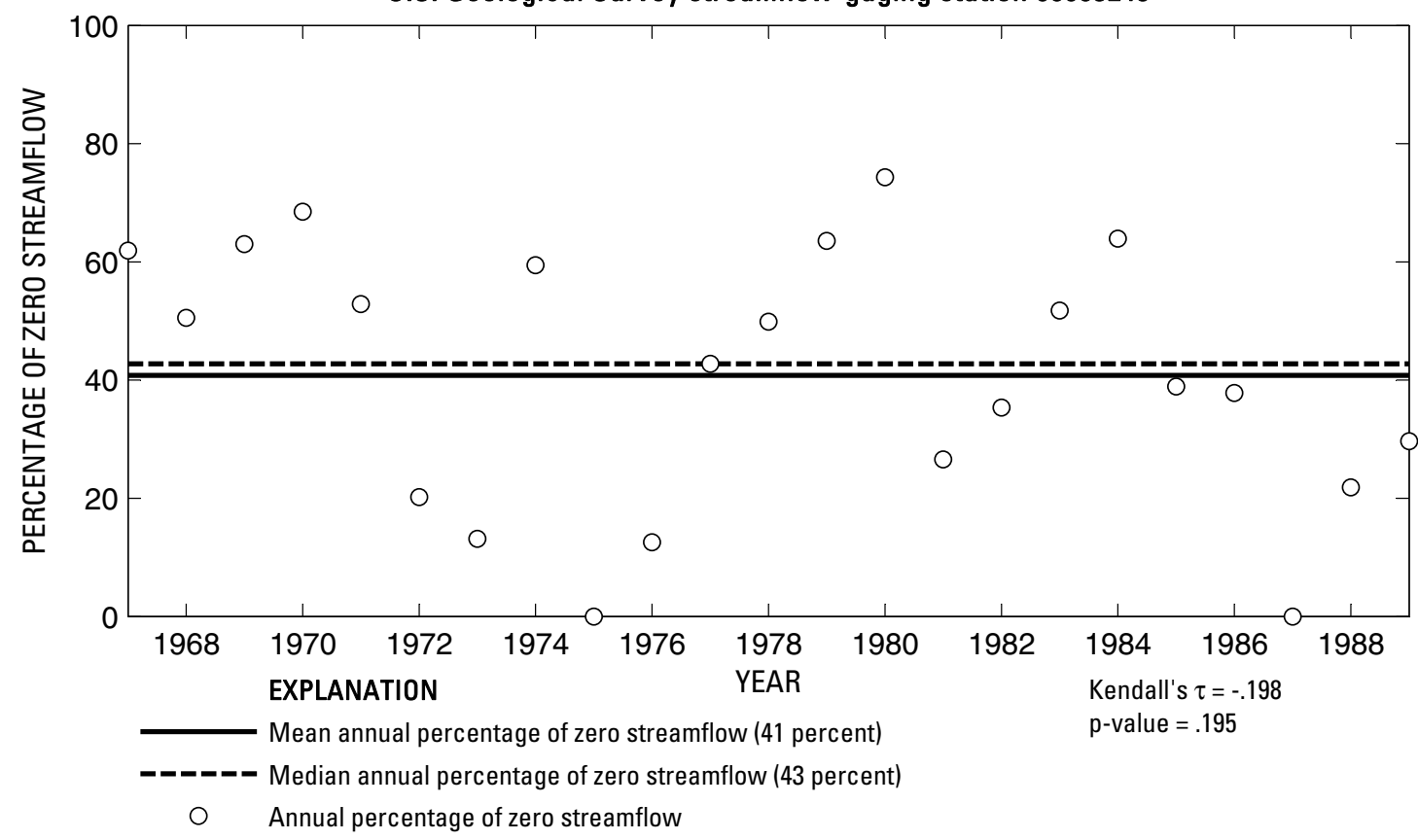

U.S. Geological Survey streamflow-gaging station 08083245

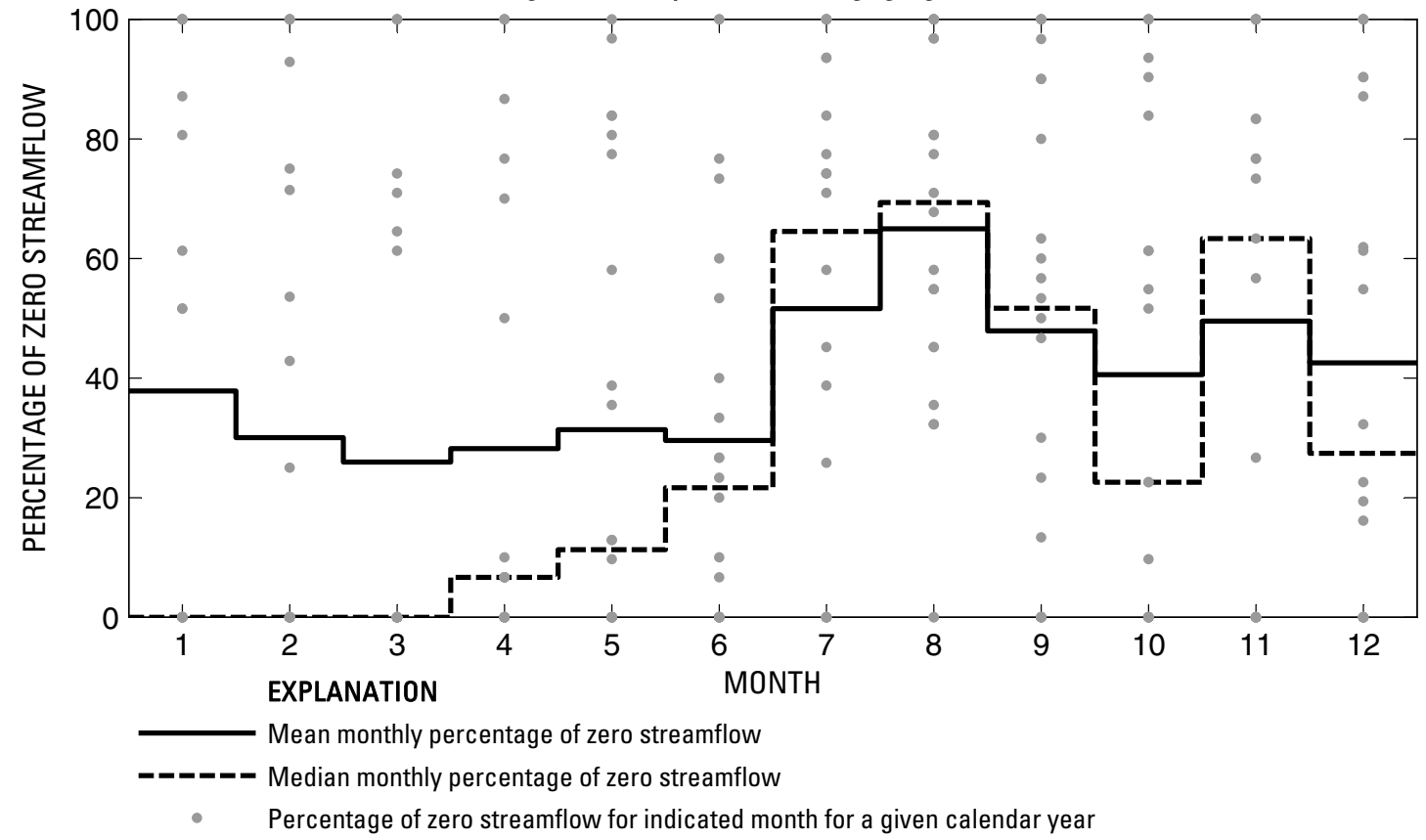

Figure 332. Analysis of percentage of zero daily mean streamflow for U.S. Geological Survey streamflow-gaging station 08083245 Mulberry Creek near Hawley, Texas.

Index of Station Numbers 719 

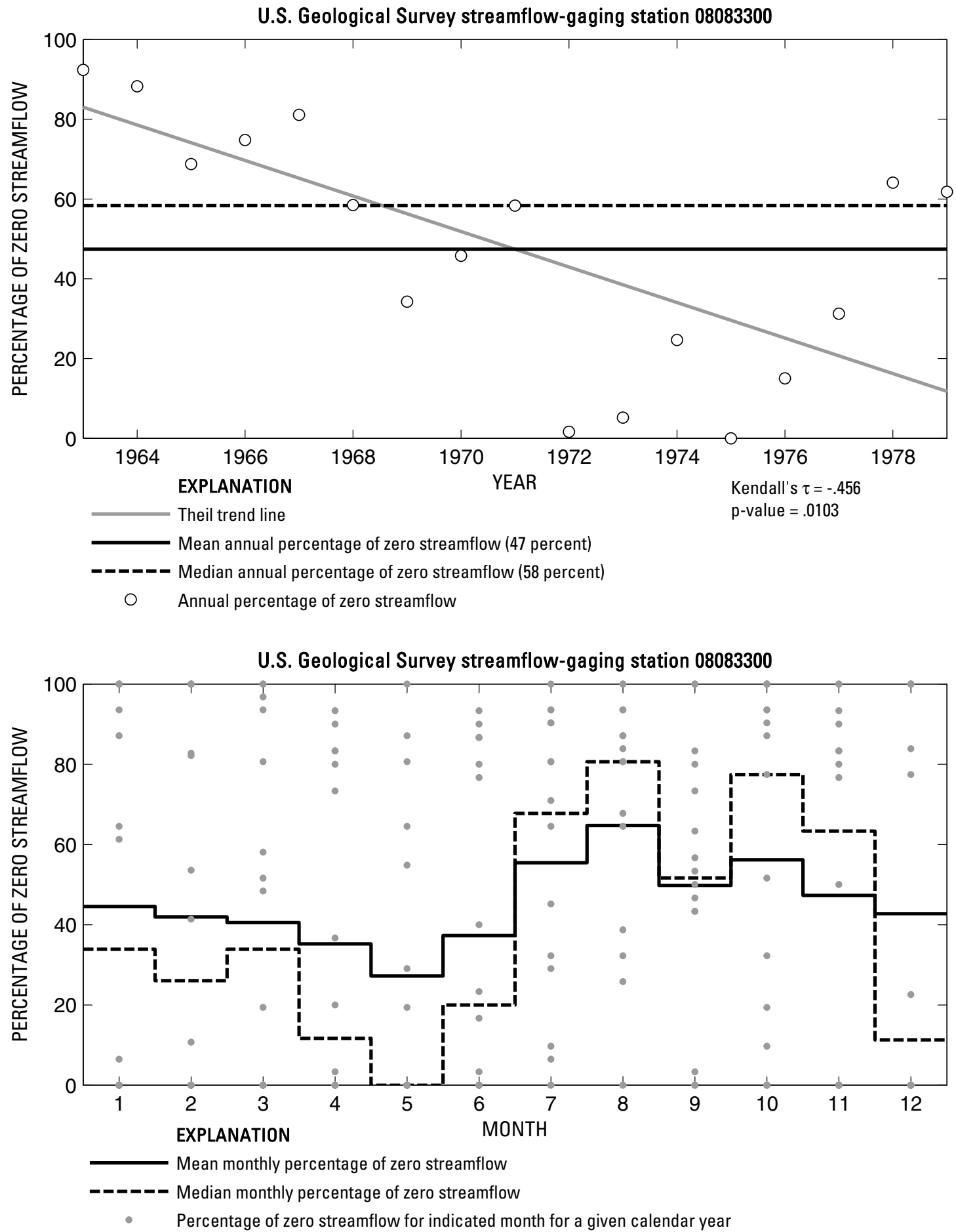

Figure 333. Analysis of percentage of zero daily mean streamflow for U.S. Geological Survey streamflow-gaging station 08083300 Elm Creek near Abilene, Texas. 


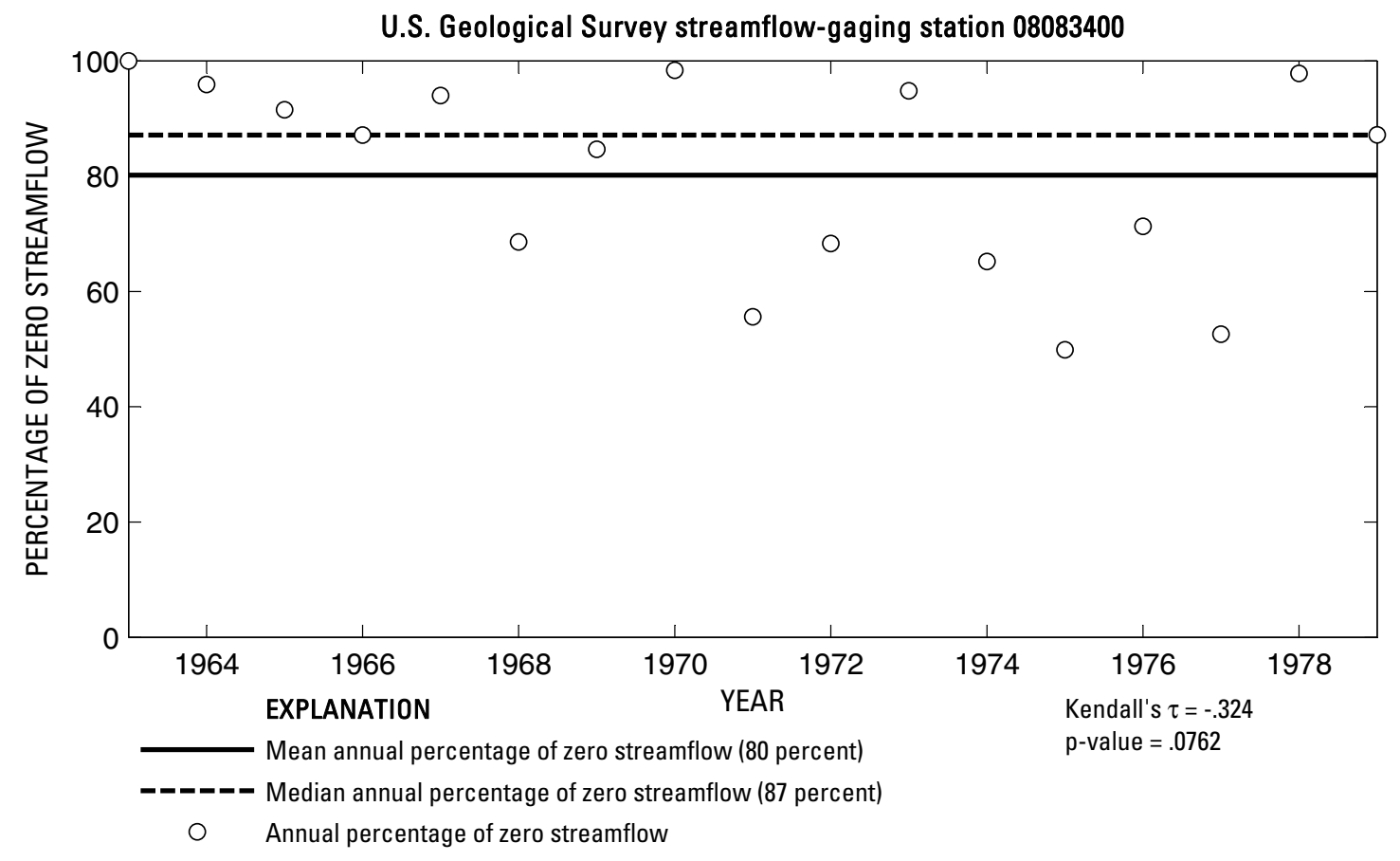

U.S. Geological Survey streamflow-gaging station 08083400

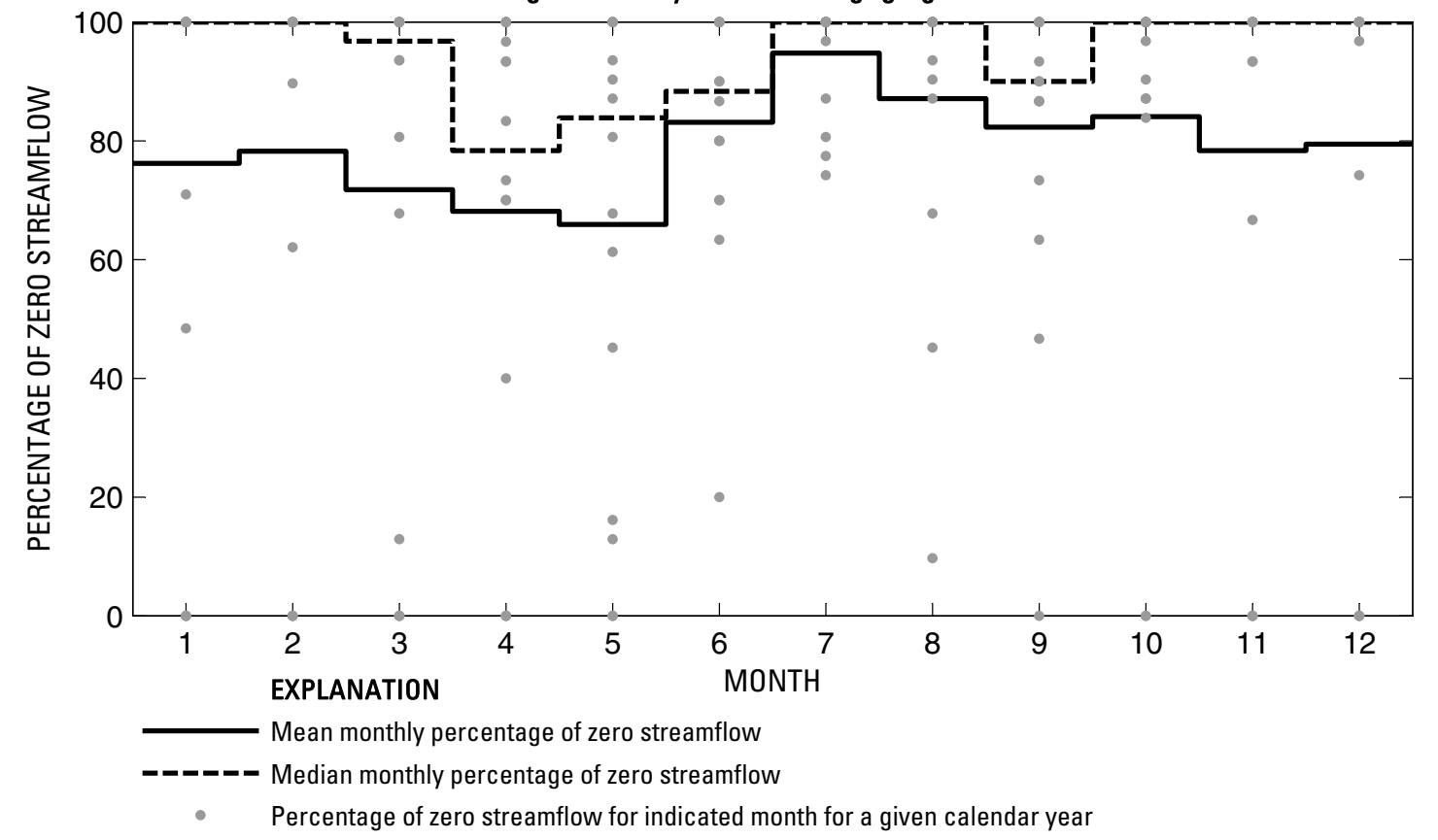

Figure 334. Analysis of percentage of zero daily mean streamflow for U.S. Geological Survey streamflow-gaging station 08083400 Little Elm Creek near Abilene, Texas. 

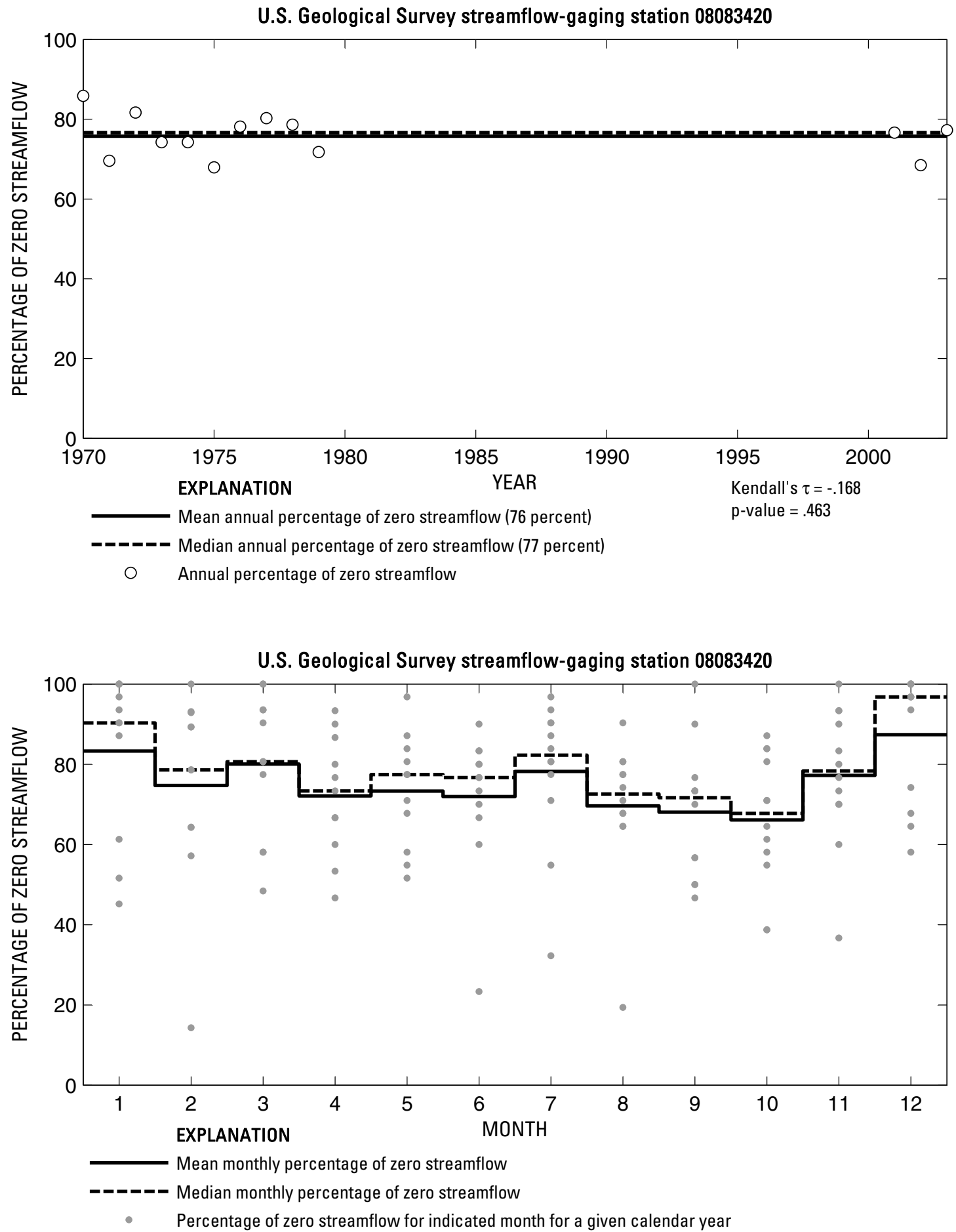

Figure 335. Analysis of percentage of zero daily mean streamflow for U.S. Geological Survey streamflow-gaging station 08083420 Cat Claw Creek at Abilene, Texas. 
U.S. Geological Survey streamflow-gaging station 08083430

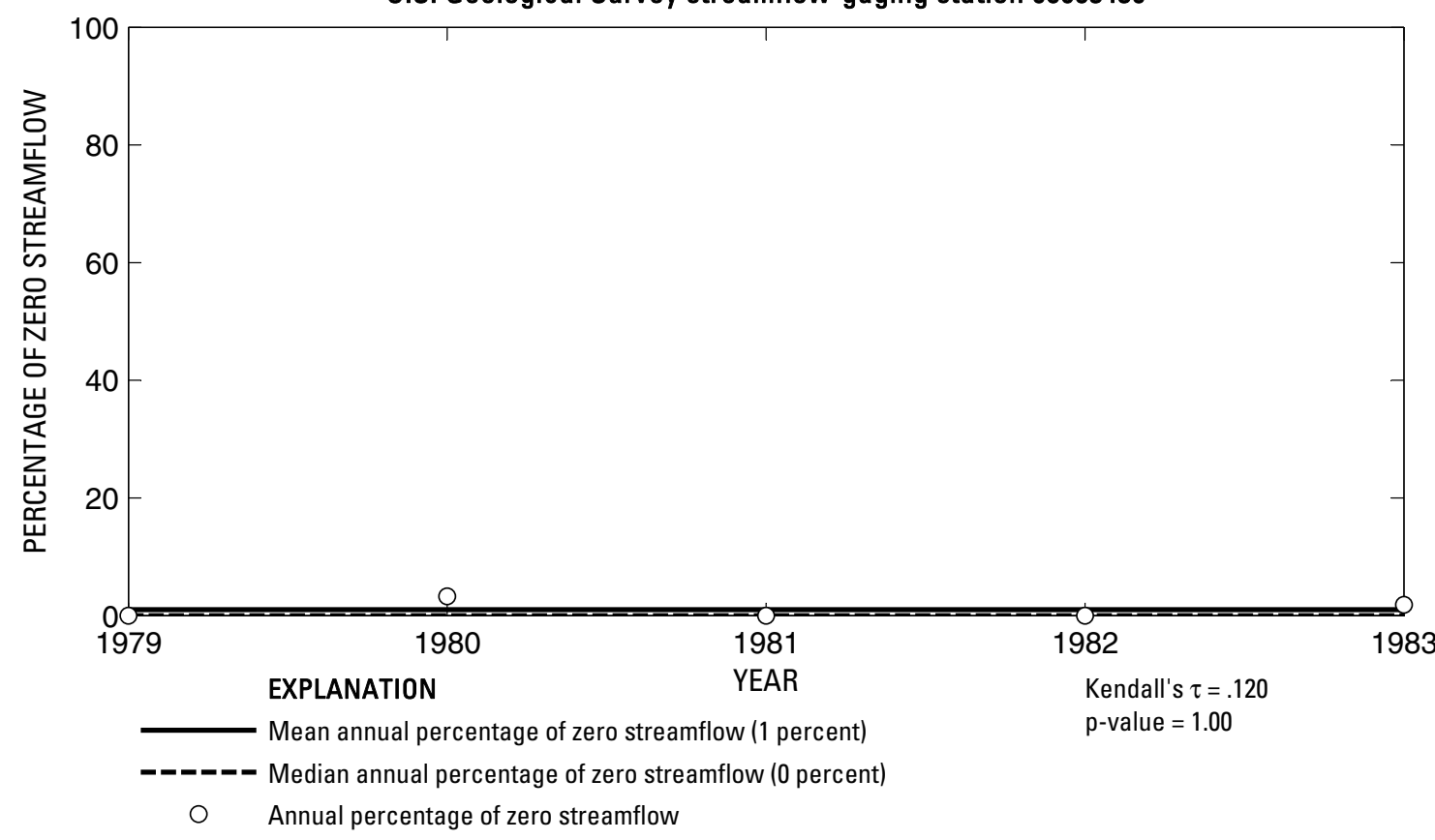

U.S. Geological Survey streamflow-gaging station 08083430

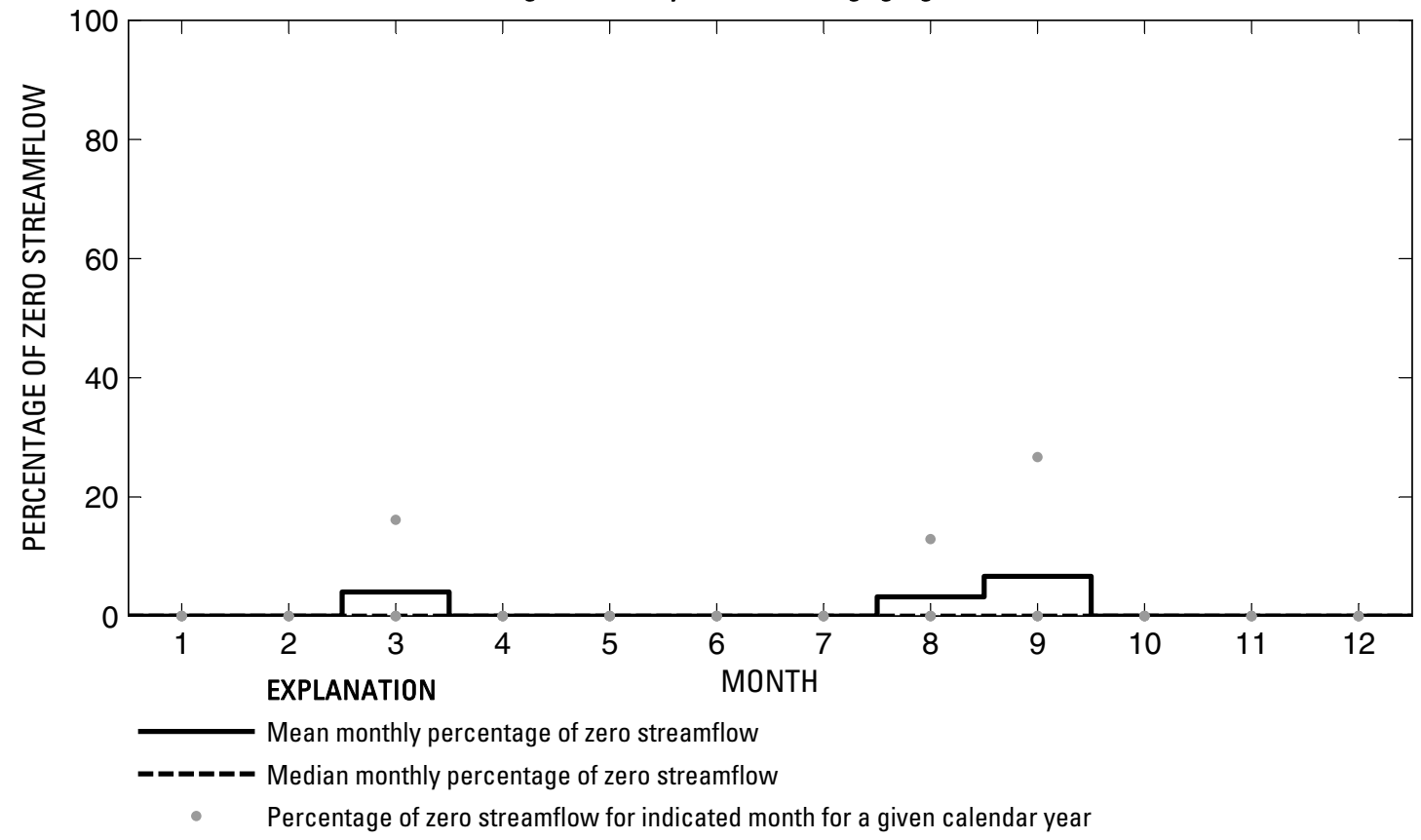

Figure 336. Analysis of percentage of zero daily mean streamflow for U.S. Geological Survey streamflow-gaging station 08083430 Elm Creek at Abilene, Texas. 


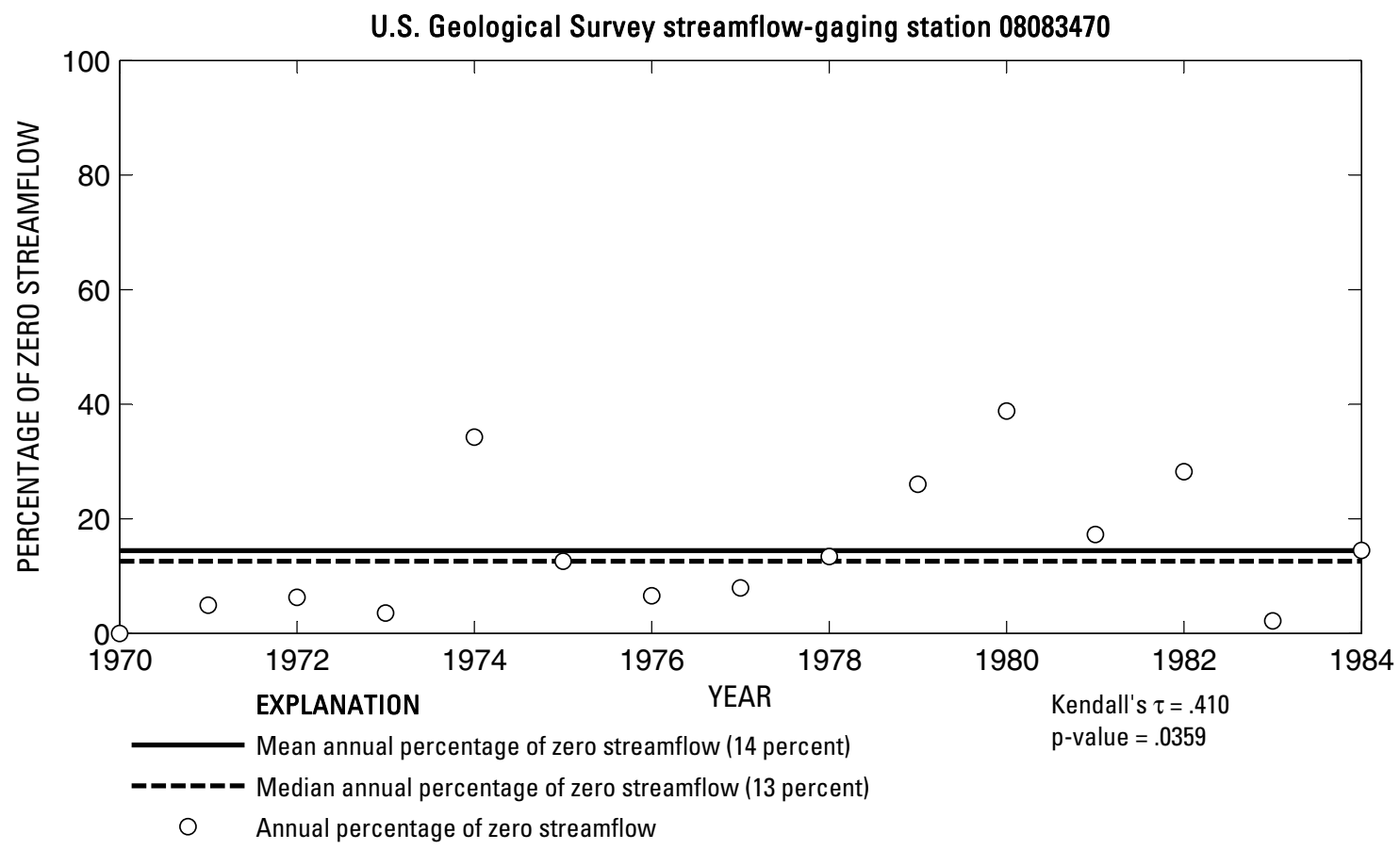

U.S. Geological Survey streamflow-gaging station 08083470

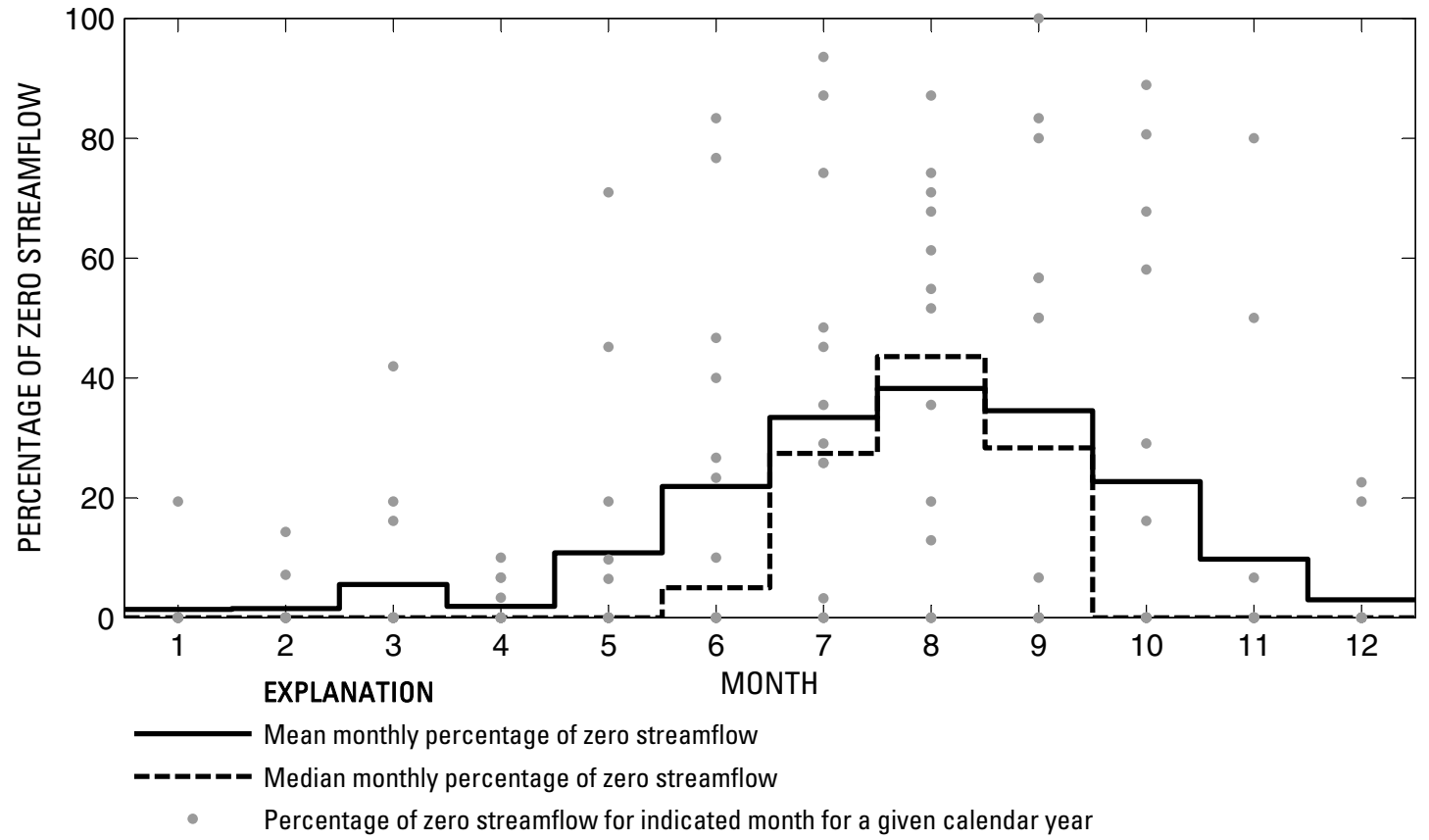

Figure 337. Analysis of percentage of zero daily mean streamflow for U.S. Geological Survey streamflow-gaging station 08083470 Cedar Creek at Abilene, Texas. 
U.S. Geological Survey streamflow-gaging station 08083480

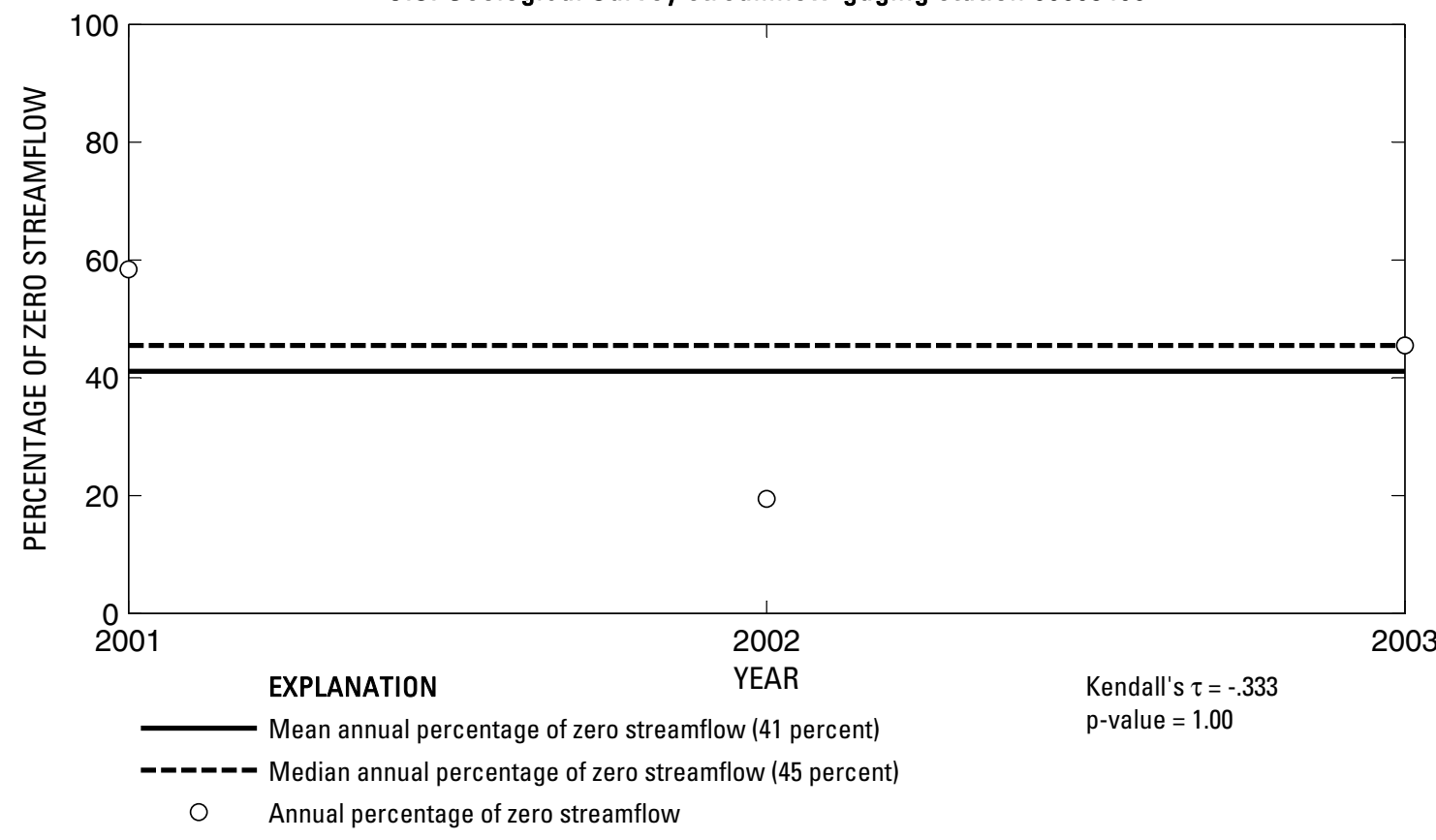

U.S. Geological Survey streamflow-gaging station 08083480

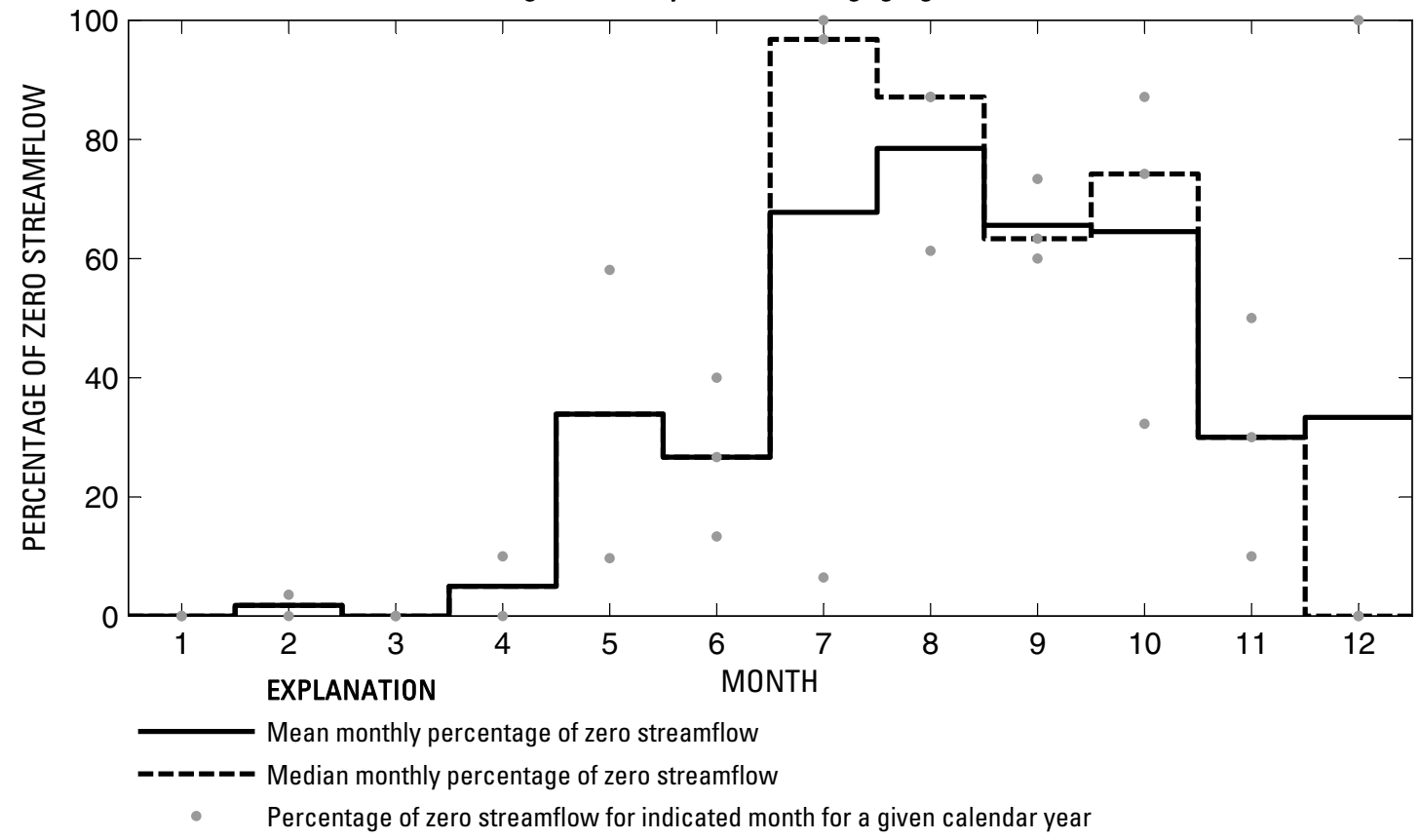

Figure 338. Analysis of percentage of zero daily mean streamflow for U.S. Geological Survey streamflow-gaging station 08083480 Cedar Creek at Interstate Highway 20, Abilene, Texas.

Index of Station Numbers 719 
U.S. Geological Survey streamflow-gaging station 08084000

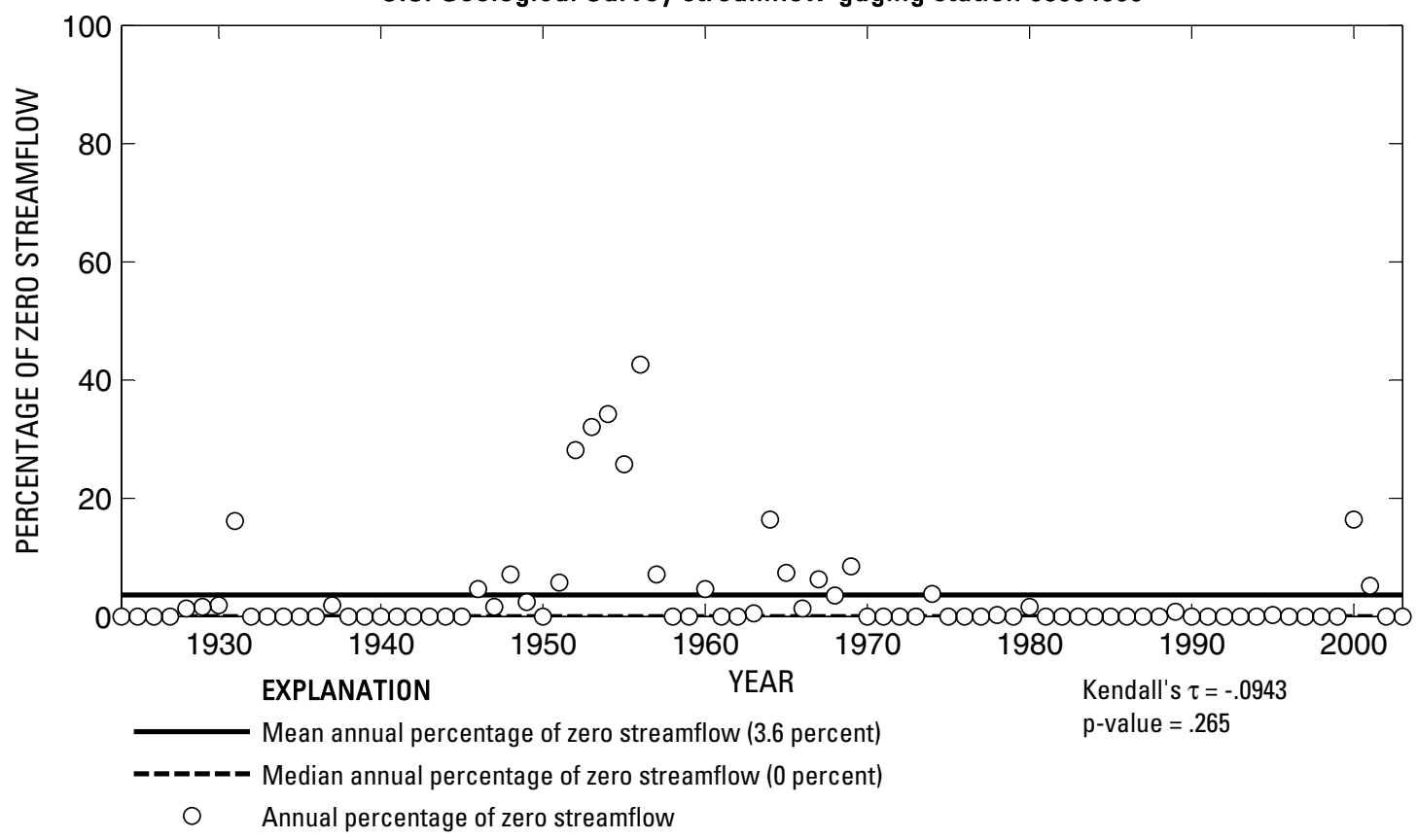

U.S. Geological Survey streamflow-gaging station 08084000

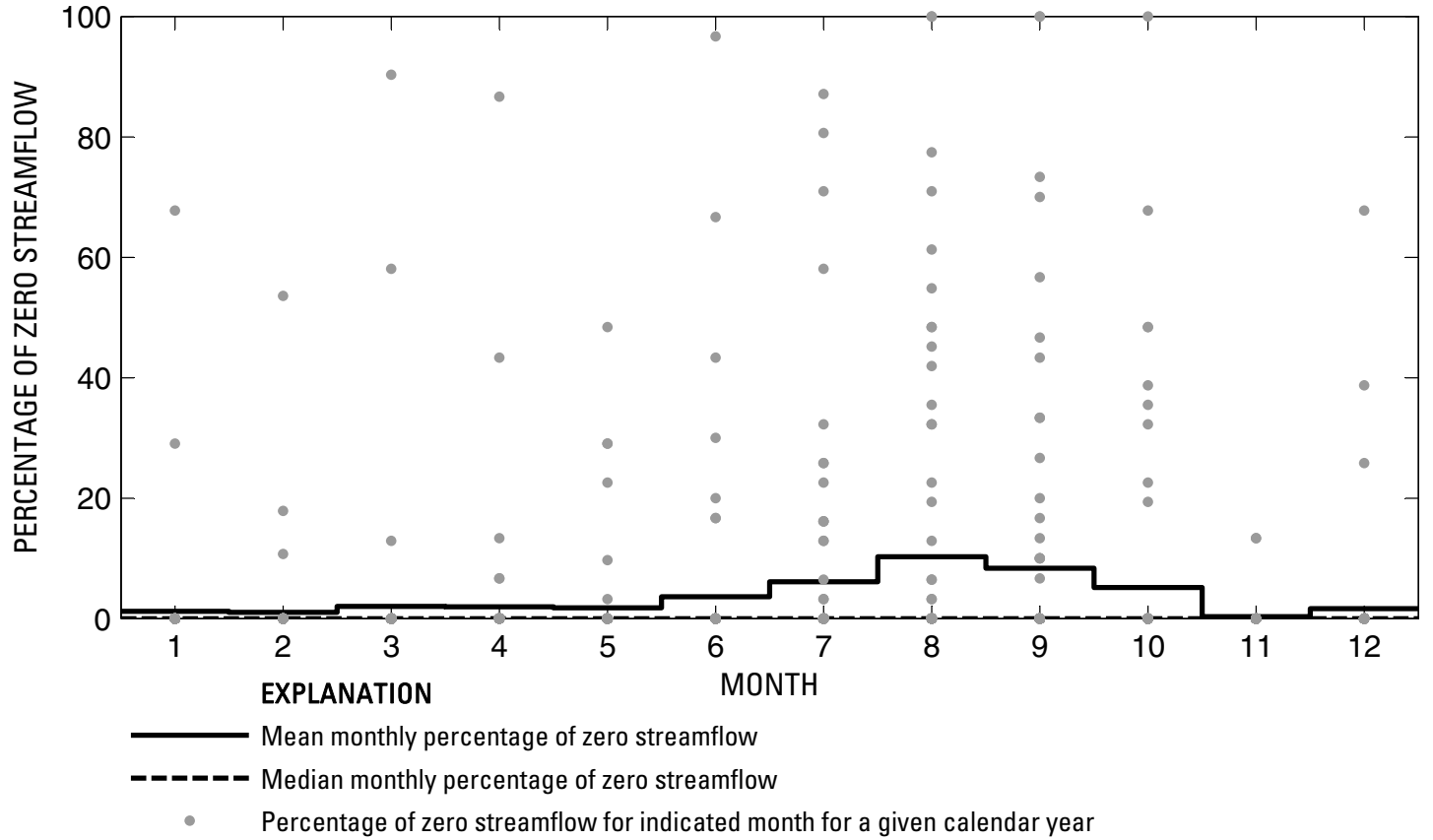

Figure 339. Analysis of percentage of zero daily mean streamflow for U.S. Geological Survey streamflow-gaging station 08084000 Clear Fork Brazos River at Nugent, Texas. 

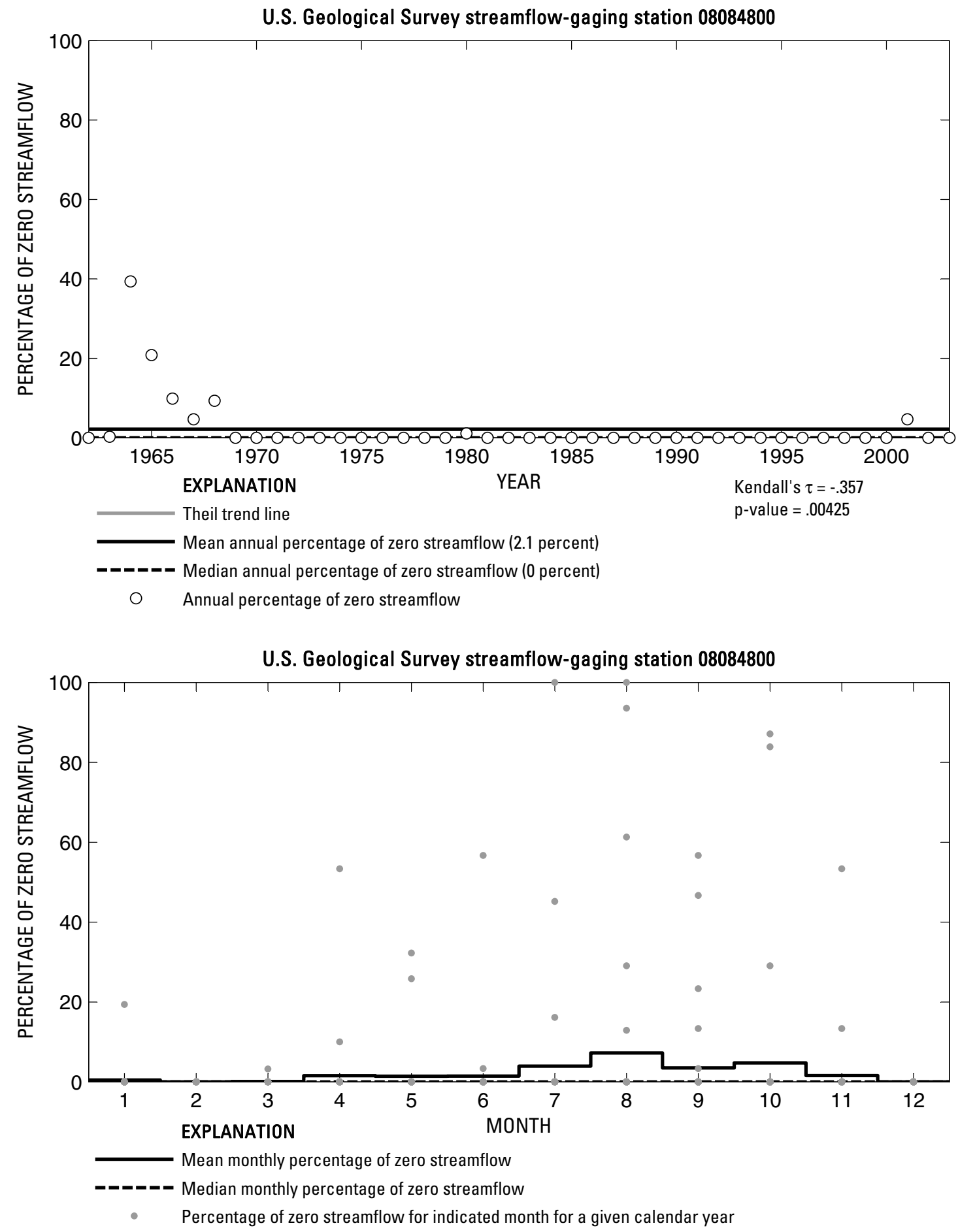

Figure 340. Analysis of percentage of zero daily mean streamflow for U.S. Geological Survey streamflow-gaging station 08084800 California Creek near Stamford, Texas. 
U.S. Geological Survey streamflow-gaging station 08085000

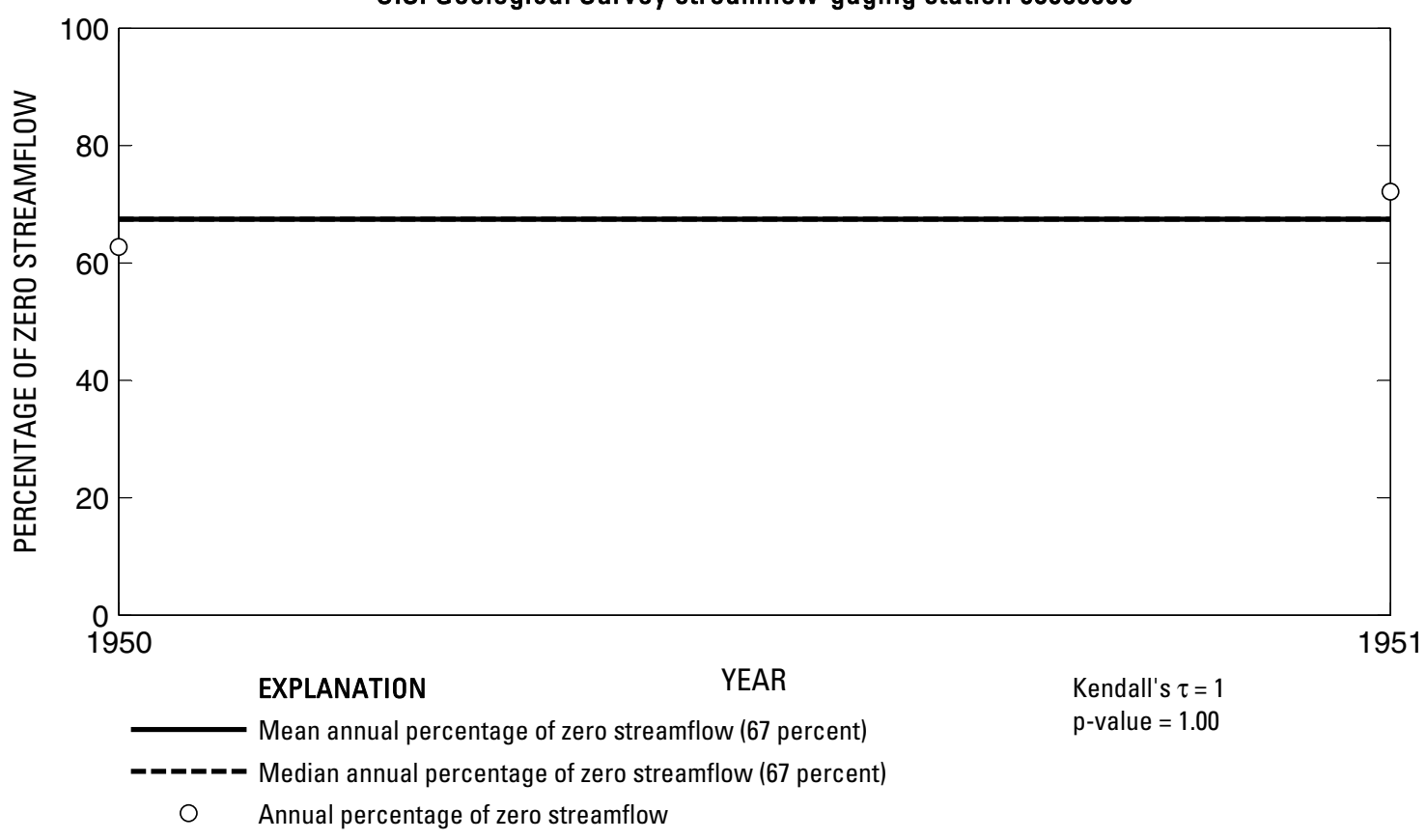

U.S. Geological Survey streamflow-gaging station 08085000

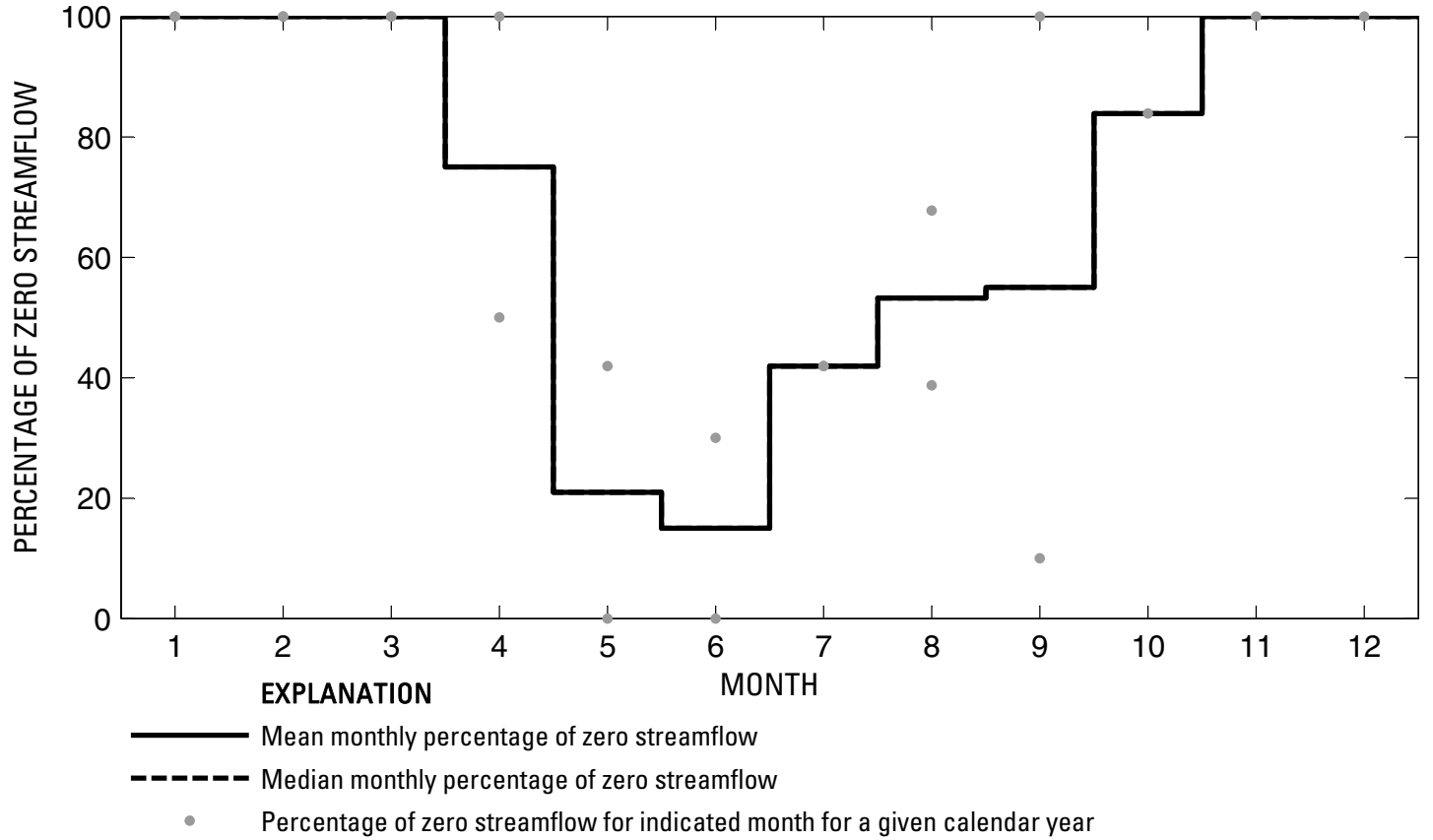

Figure 341. Analysis of percentage of zero daily mean streamflow for U.S. Geological Survey streamflow-gaging station 08085000 Paint Creek near Haskell, Texas. 
U.S. Geological Survey streamflow-gaging station 08085500

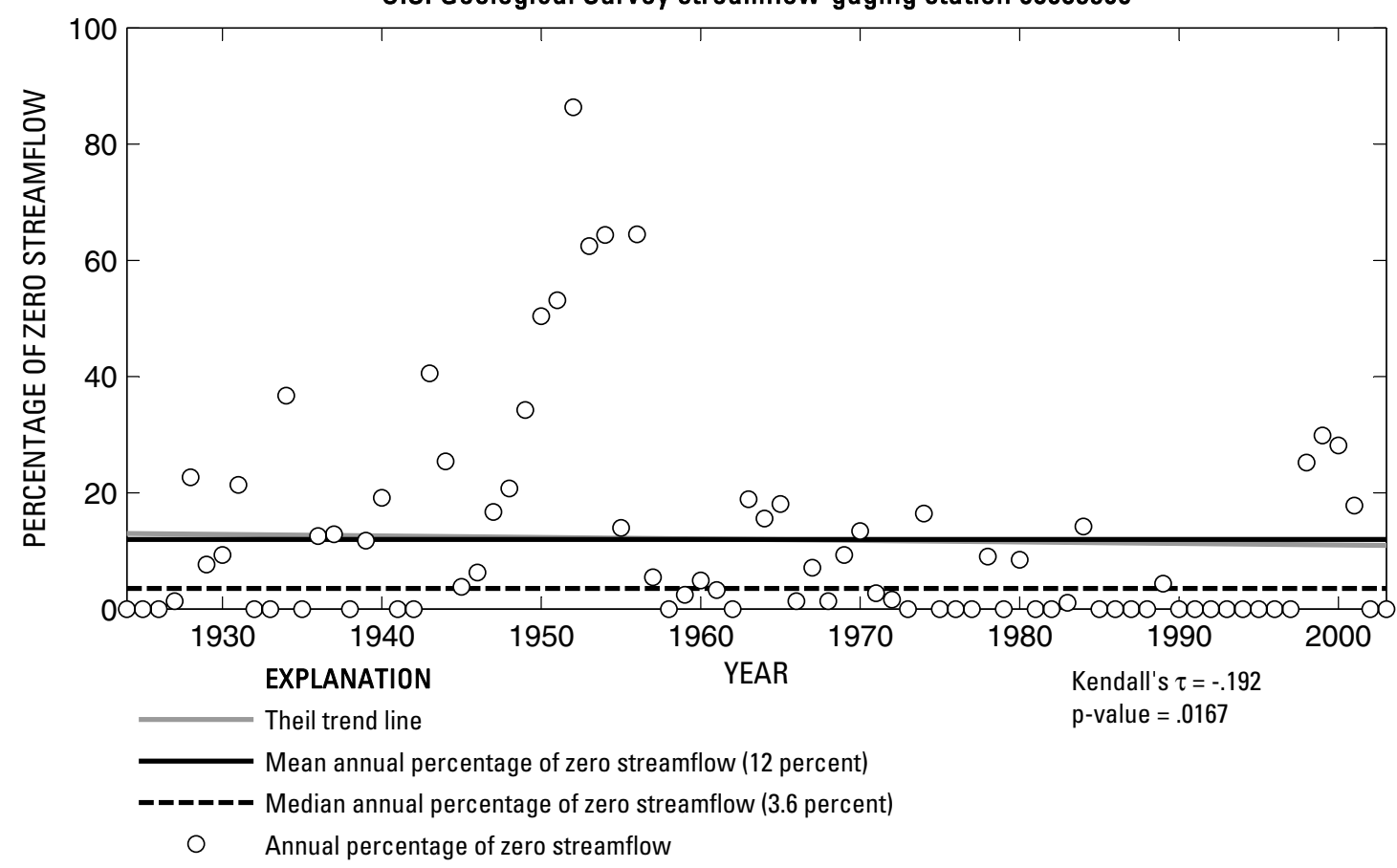

U.S. Geological Survey streamflow-gaging station 08085500

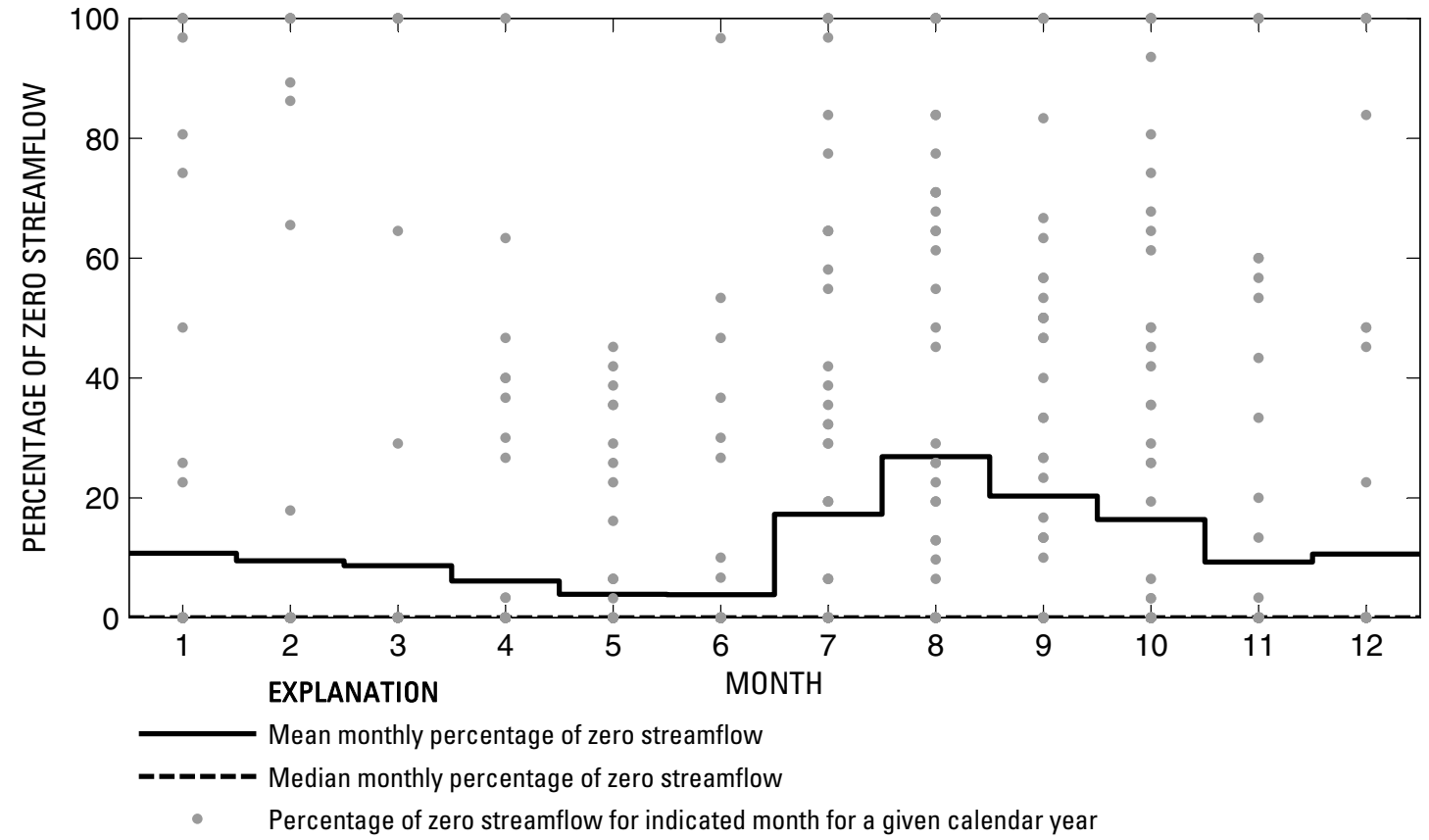

Figure 342. Analysis of percentage of zero daily mean streamflow for U.S. Geological Survey streamflow-gaging station 08085500 Clear Fork Brazos River at Fort Griffin, Texas.

Index of Station Numbers 719 

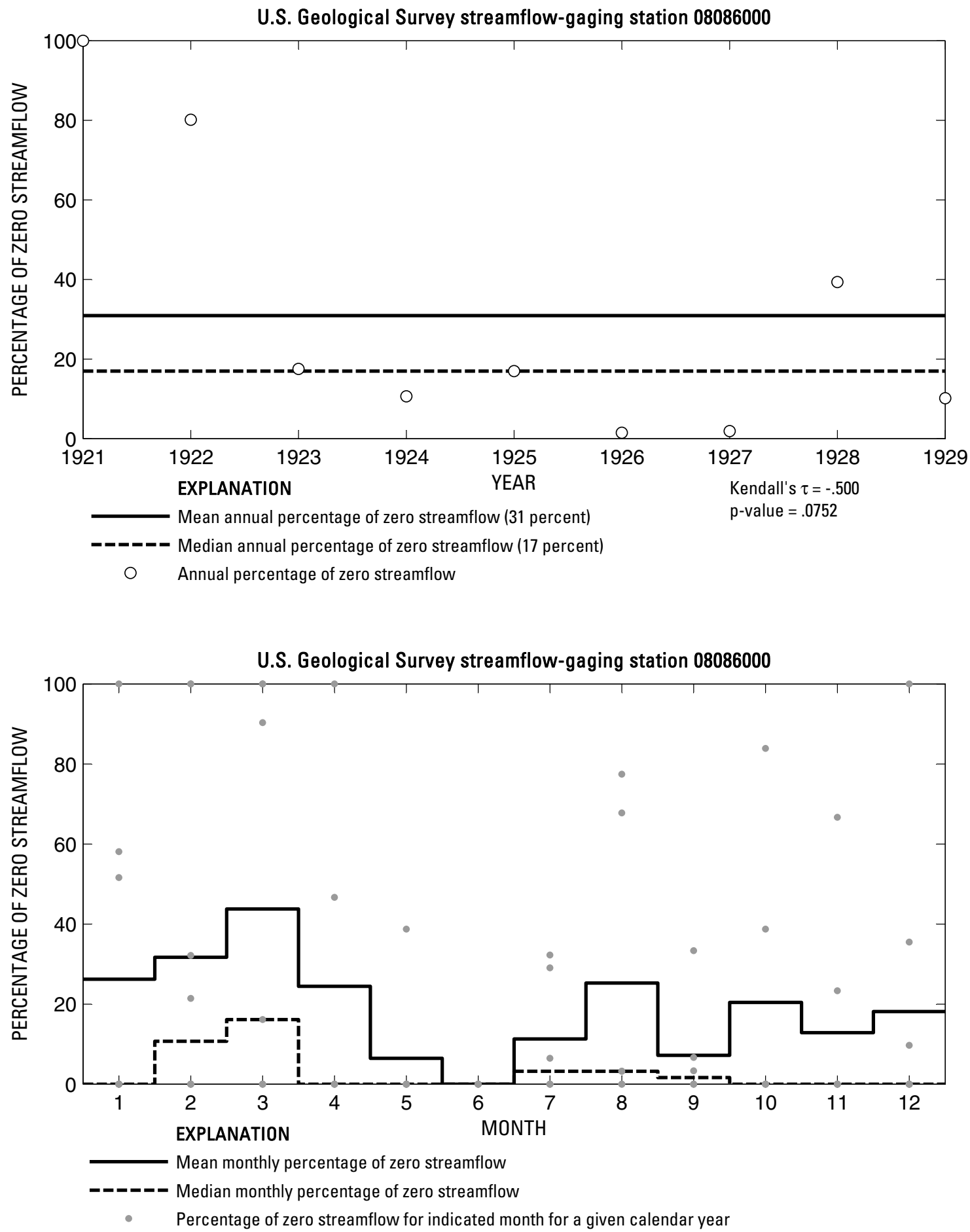

Figure 343. Analysis of percentage of zero daily mean streamflow for U.S. Geological Survey streamflow-gaging station 08086000 Clear Fork Brazos River at Crystal Falls, Texas. 
U.S. Geological Survey streamflow-gaging station 08086015

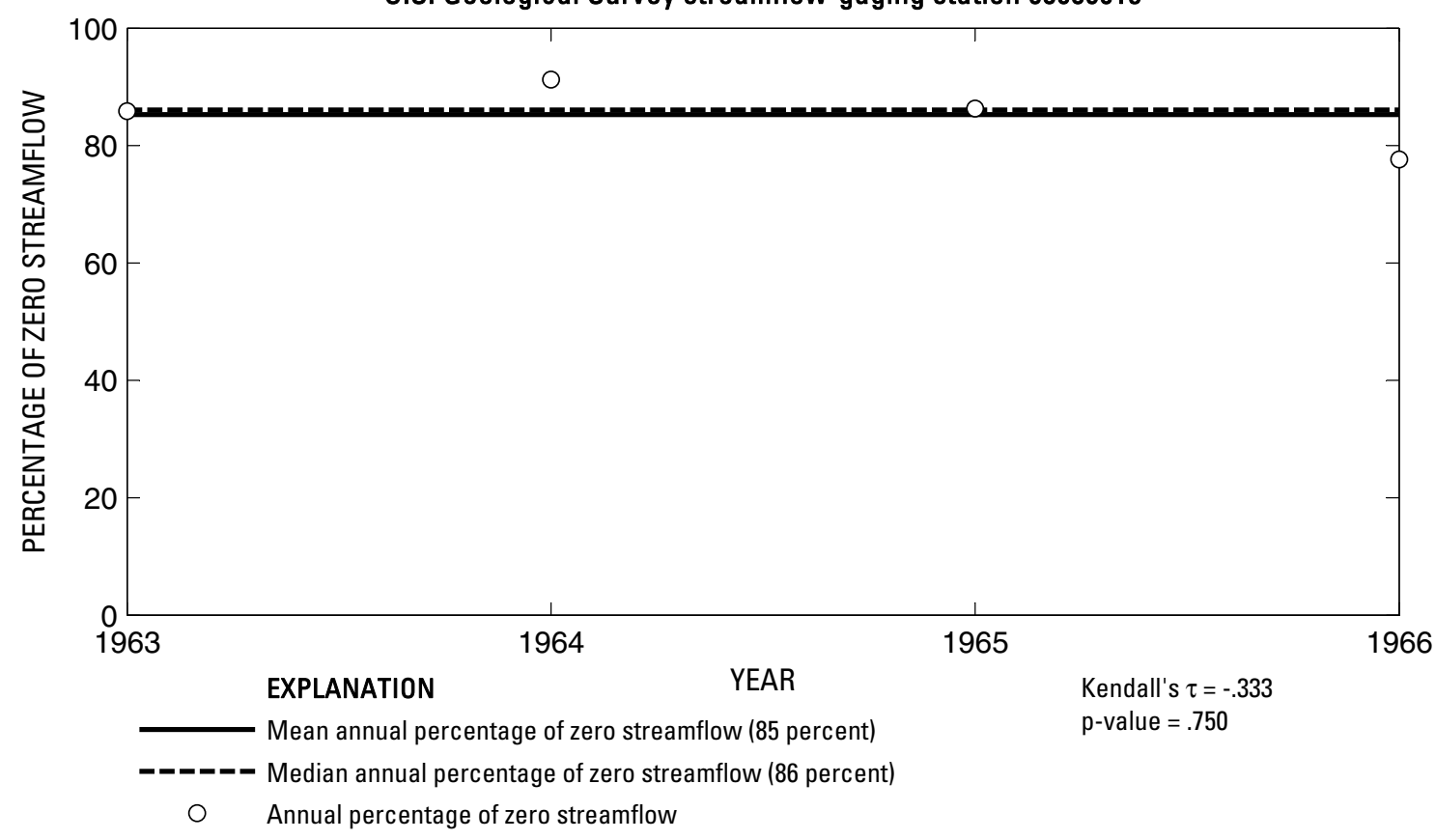

U.S. Geological Survey streamflow-gaging station 08086015

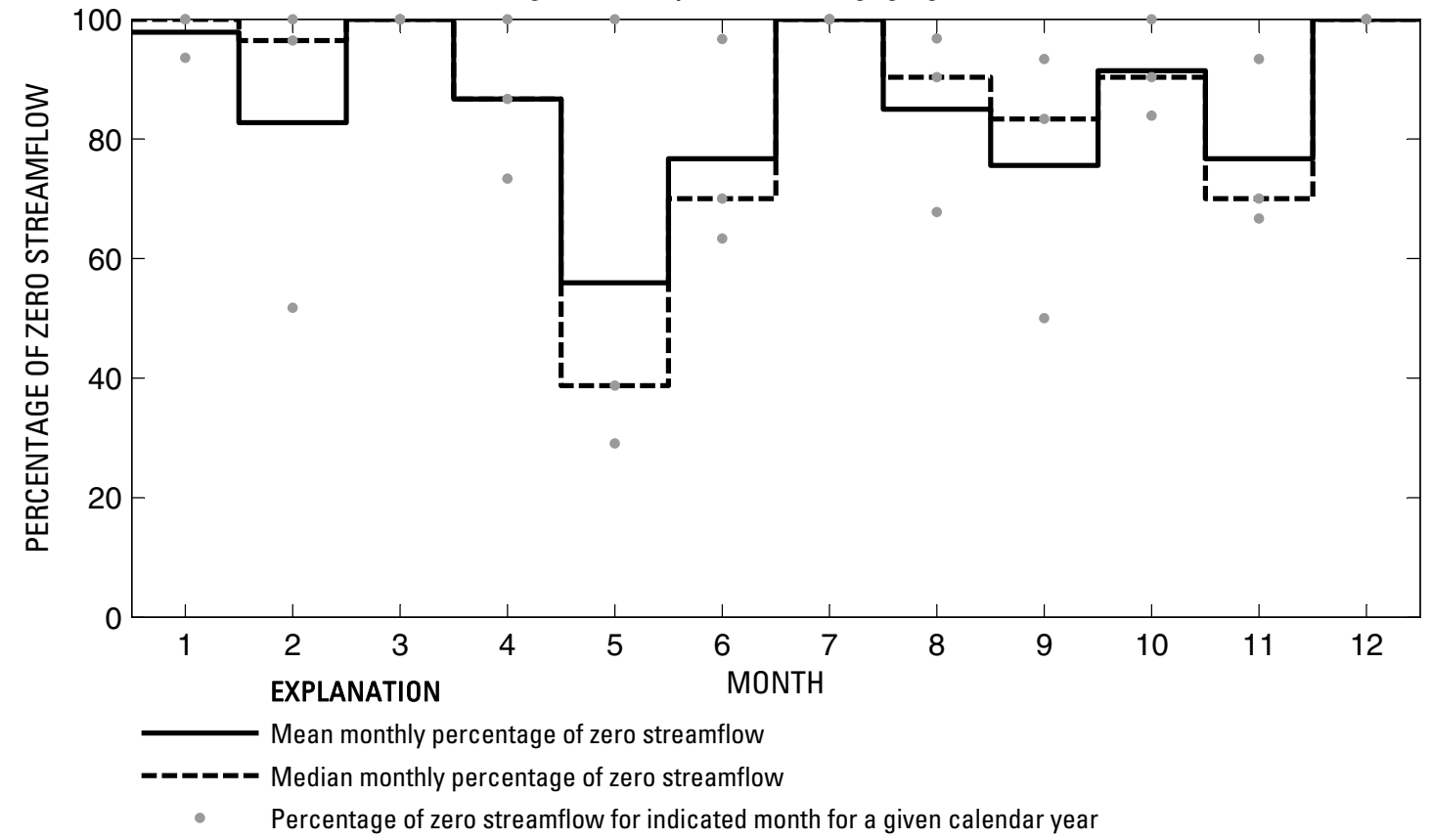

Figure 344. Analysis of percentage of zero daily mean streamflow for U.S. Geological Survey streamflow-gaging station 08086015 Hubbard Creek near Sedwick, Texas.

Index of Station Numbers 719 
U.S. Geological Survey streamflow-gaging station 08086050

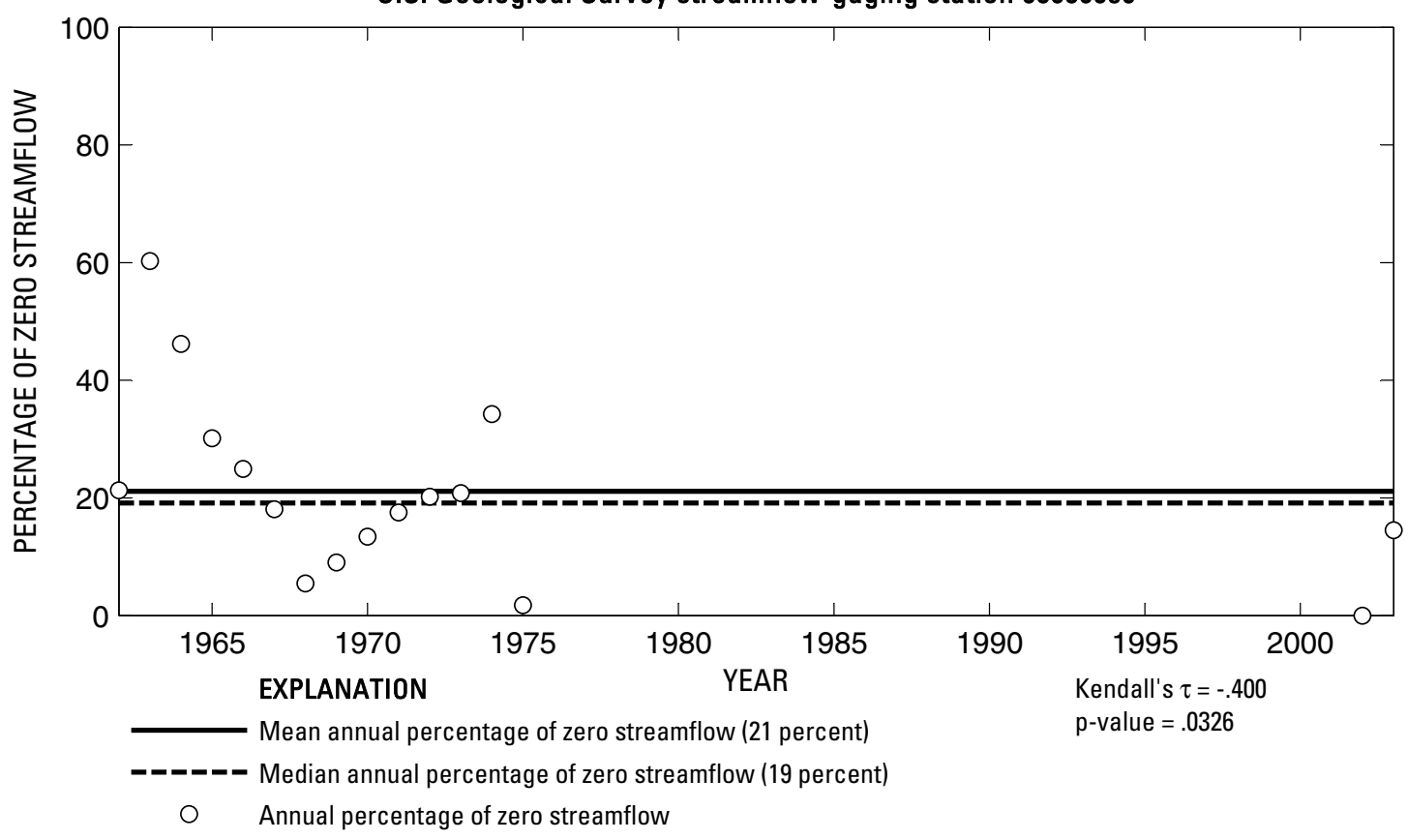

U.S. Geological Survey streamflow-gaging station 08086050

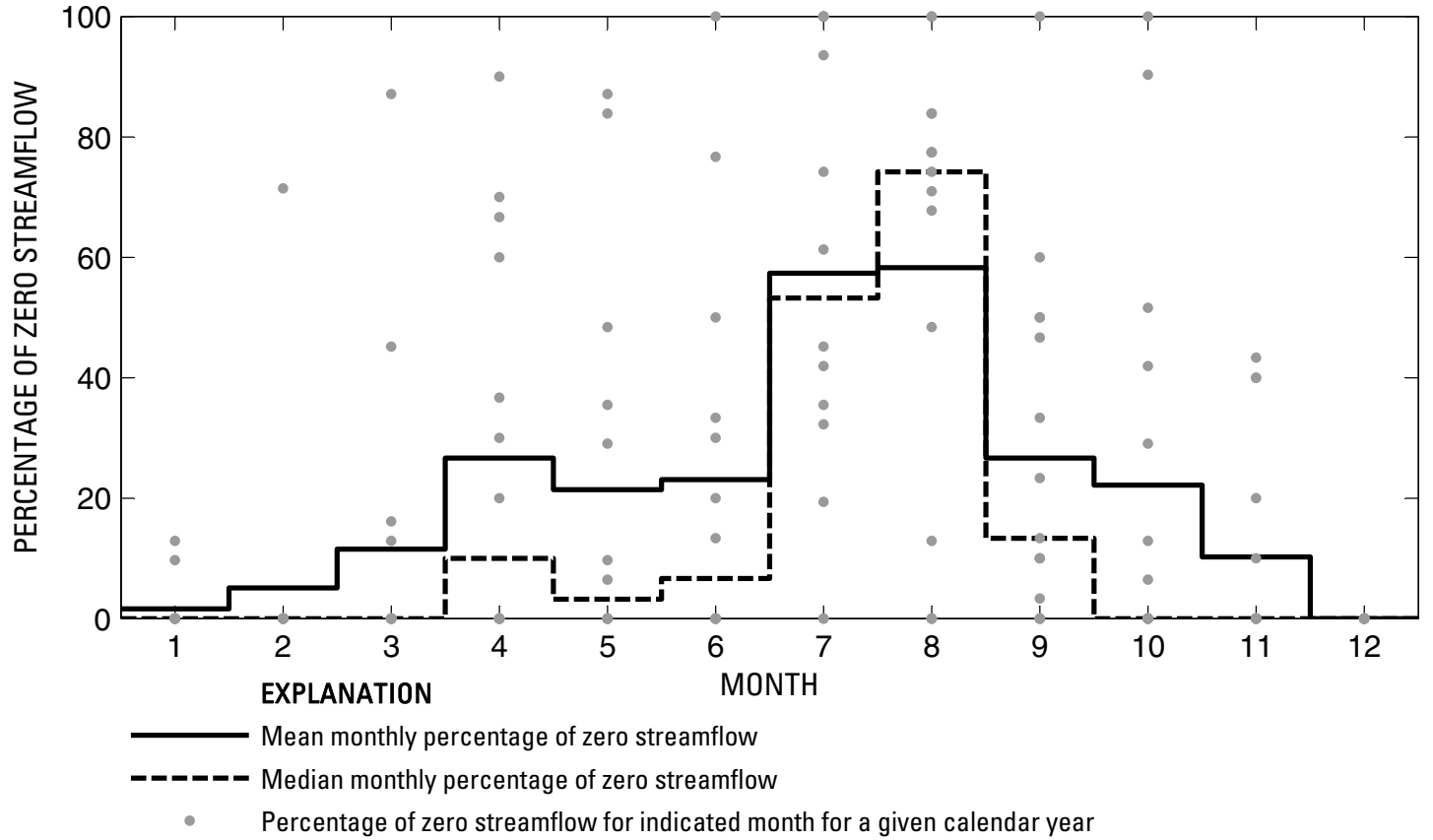

Figure 345. Analysis of percentage of zero daily mean streamflow for U.S. Geological Survey streamflow-gaging station 08086050 Deep Creek at Moran, Texas. 
U.S. Geological Survey streamflow-gaging station 08086100

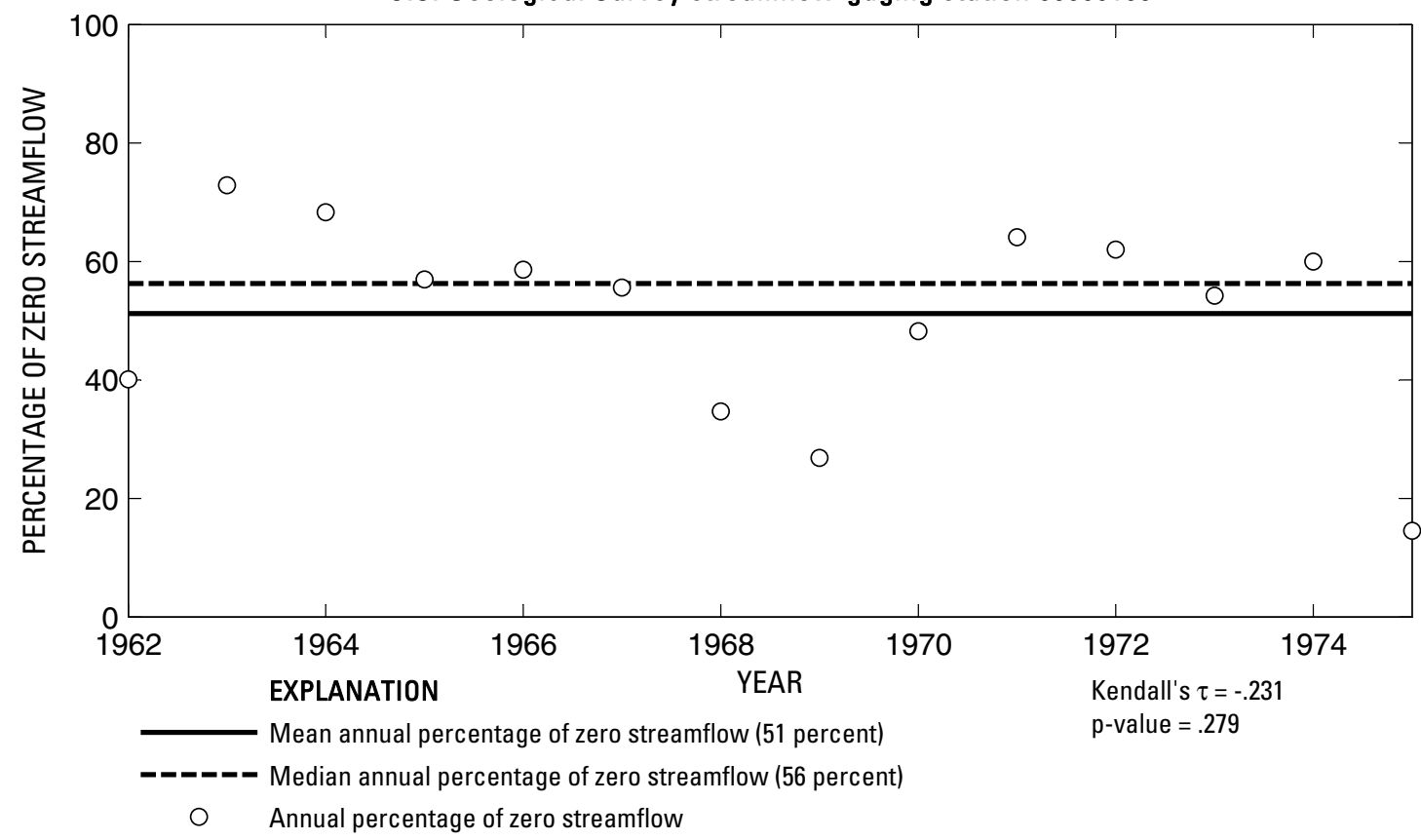

U.S. Geological Survey streamflow-gaging station 08086100

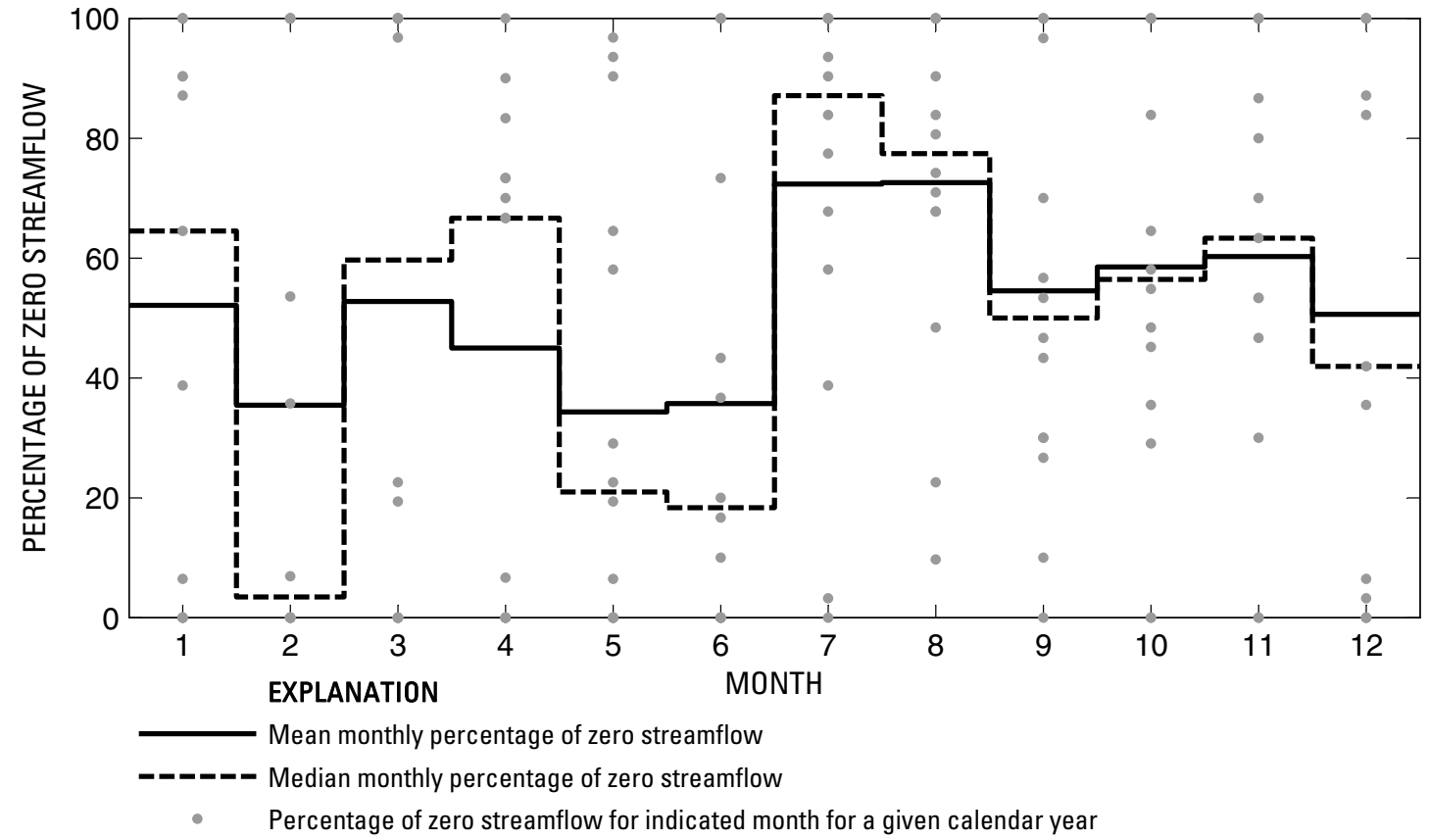

Figure 346. Analysis of percentage of zero daily mean streamflow for U.S. Geological Survey streamflow-gaging station 08086100 Hubbard Creek near Albany, Texas.

Index of Station Numbers 719 
U.S. Geological Survey streamflow-gaging station 08086120

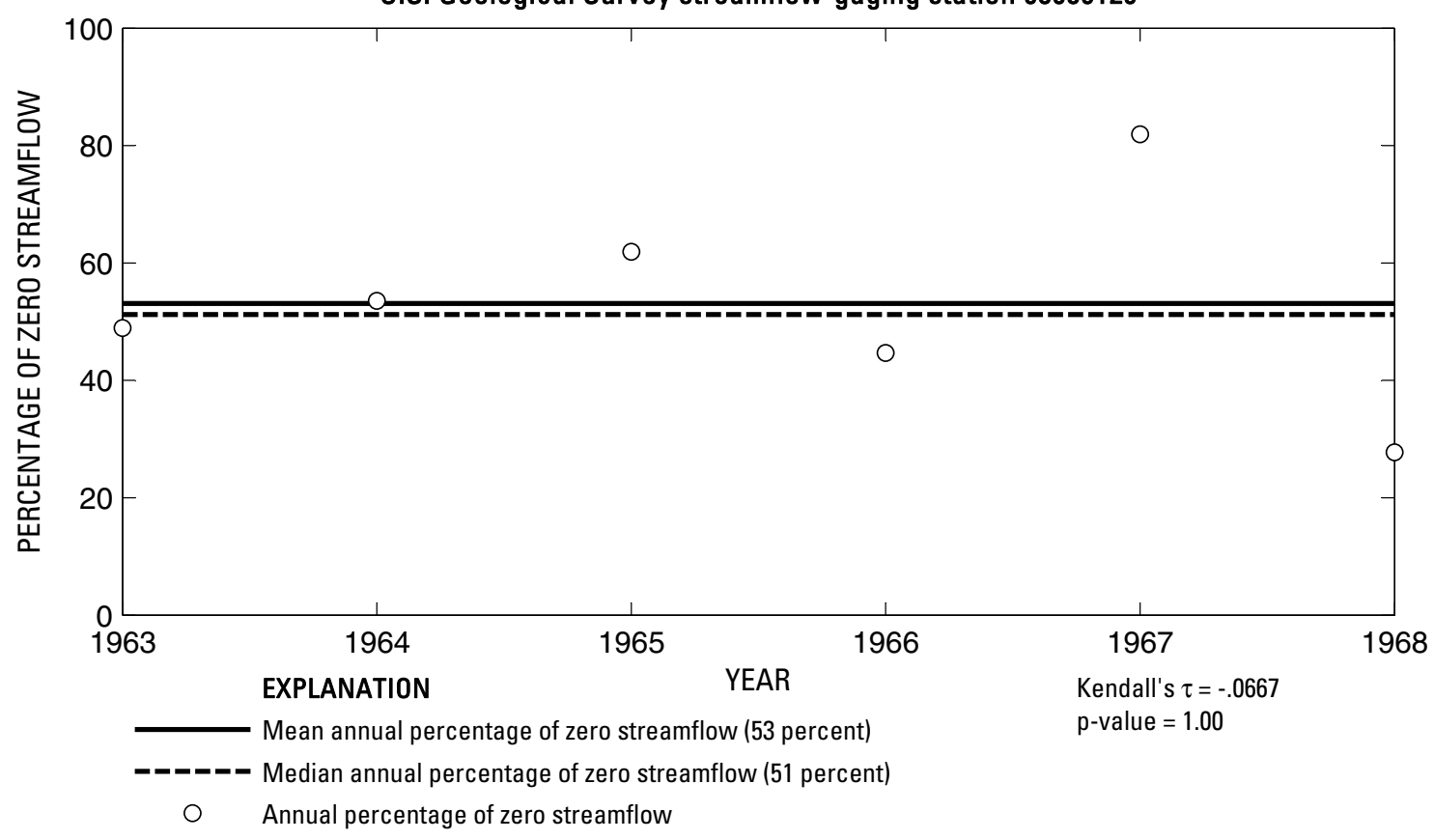

U.S. Geological Survey streamflow-gaging station 08086120

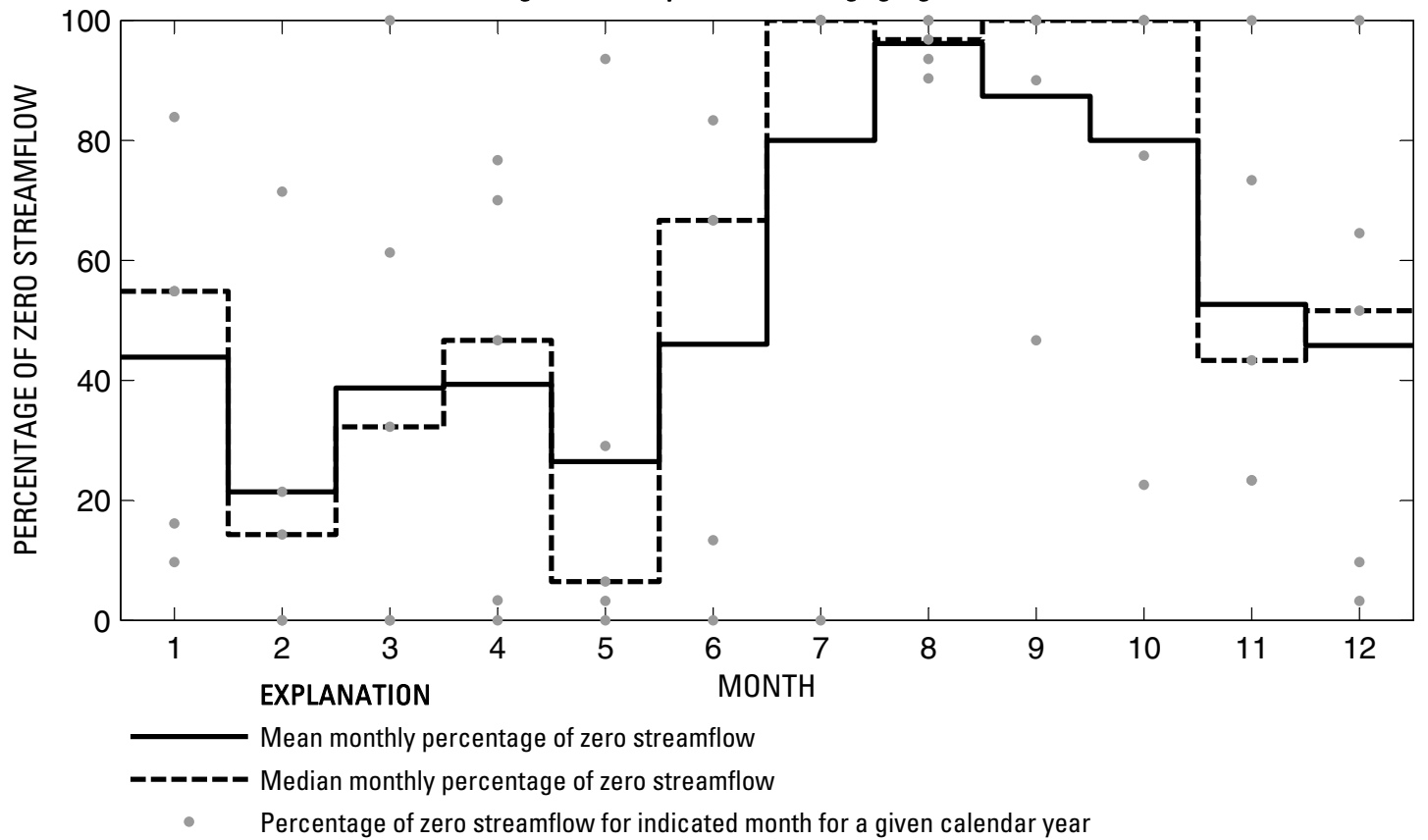

Figure 347. Analysis of percentage of zero daily mean streamflow for U.S. Geological Survey streamflow-gaging station 08086120 Salt Prong Hubbard Creek at U.S. Highway 380 near Albany, Texas. 
U.S. Geological Survey streamflow-gaging station 08086150

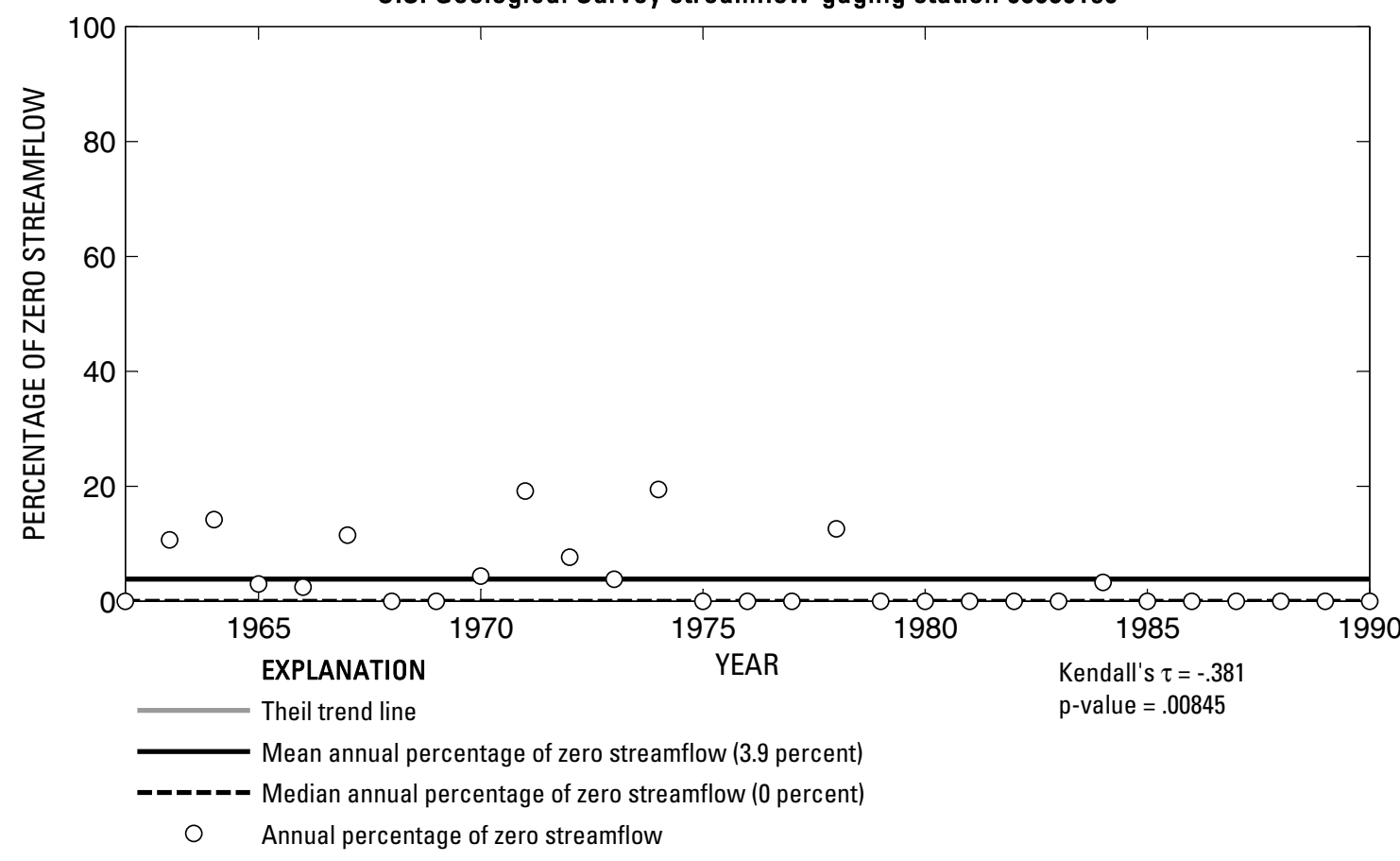

U.S. Geological Survey streamflow-gaging station 08086150

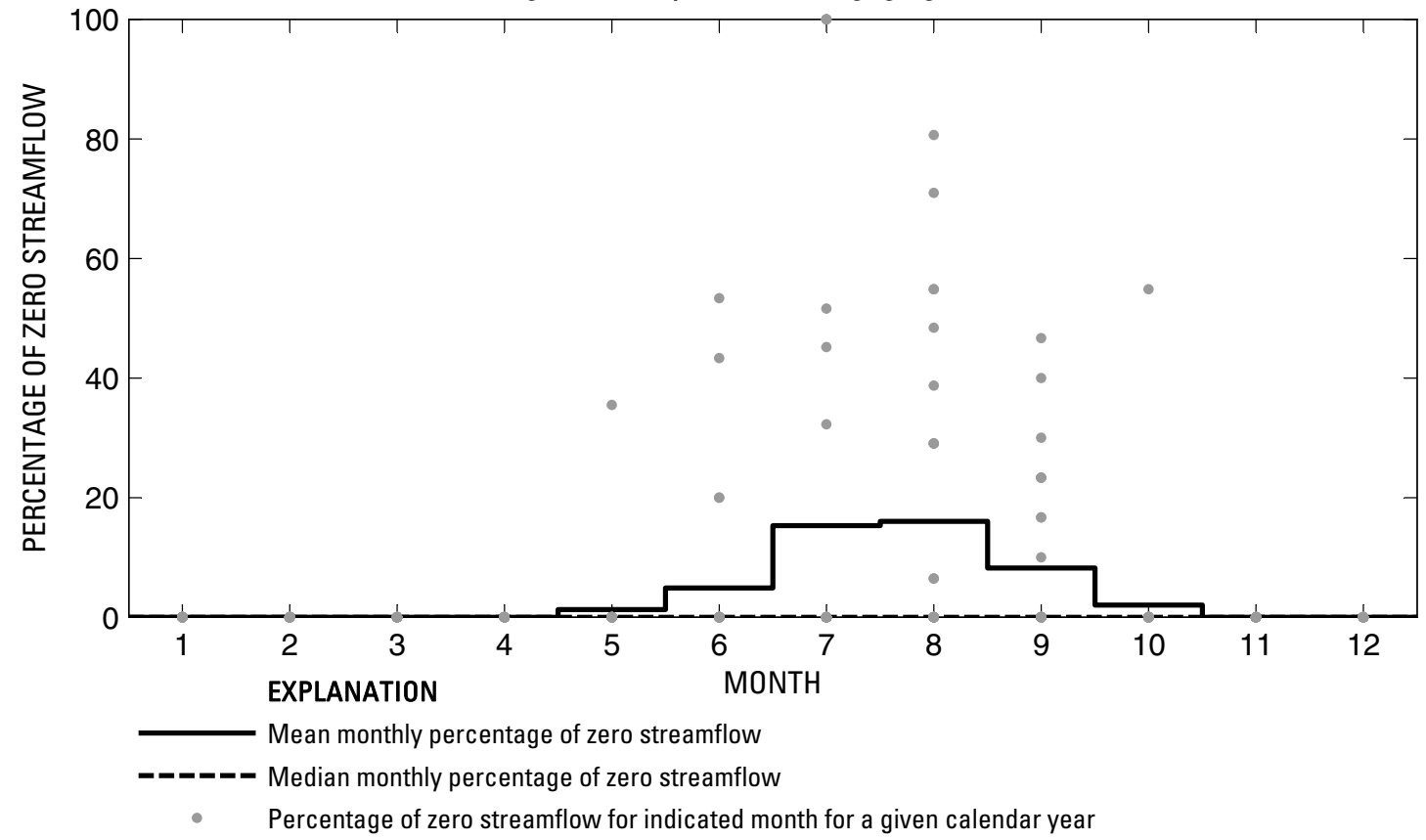

Figure 348. Analysis of percentage of zero daily mean streamflow for U.S. Geological Survey streamflow-gaging station 08086150 North Fork Hubbard Creek near Albany, Texas. 
U.S. Geological Survey streamflow-gaging station 08086200

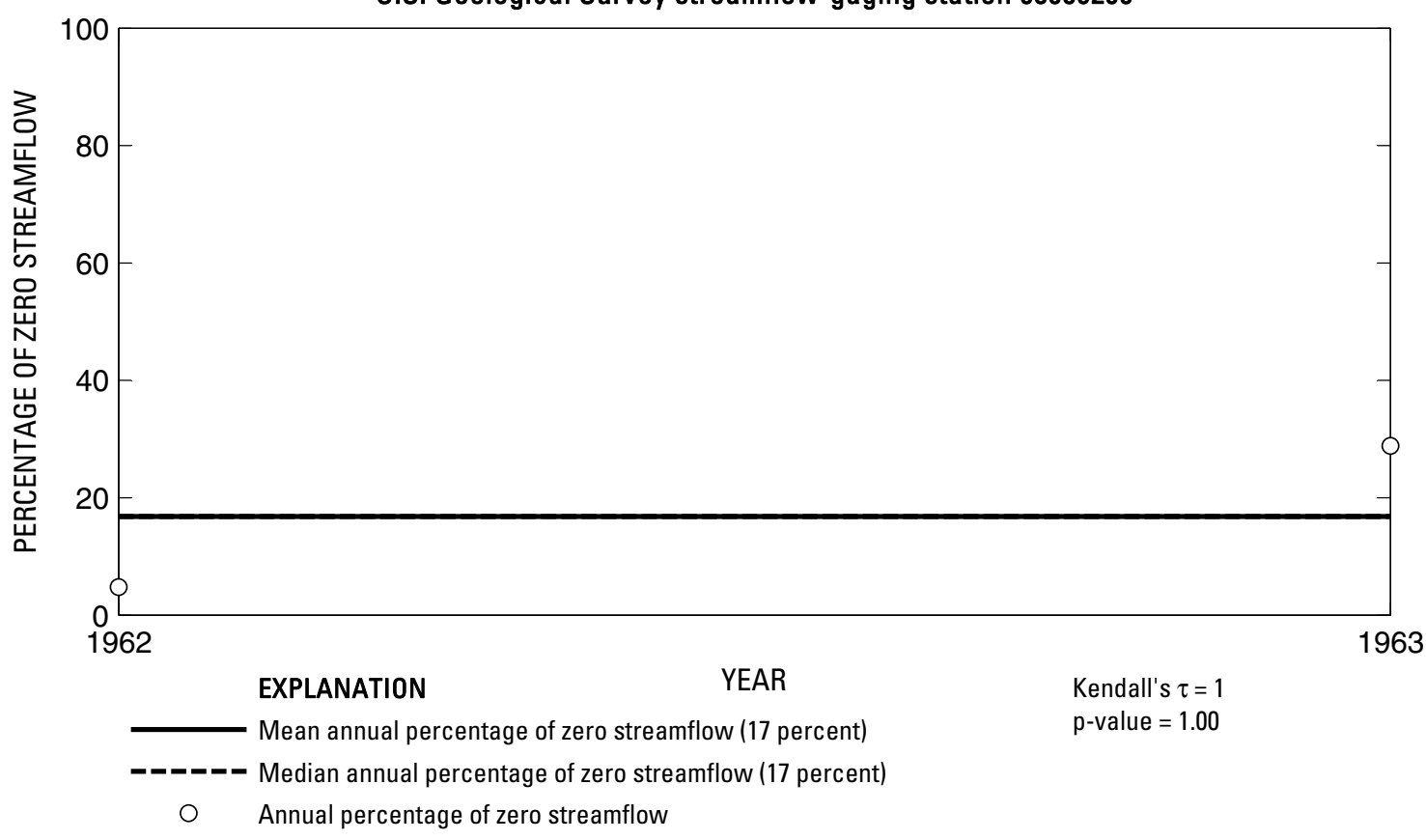

U.S. Geological Survey streamflow-gaging station 08086200

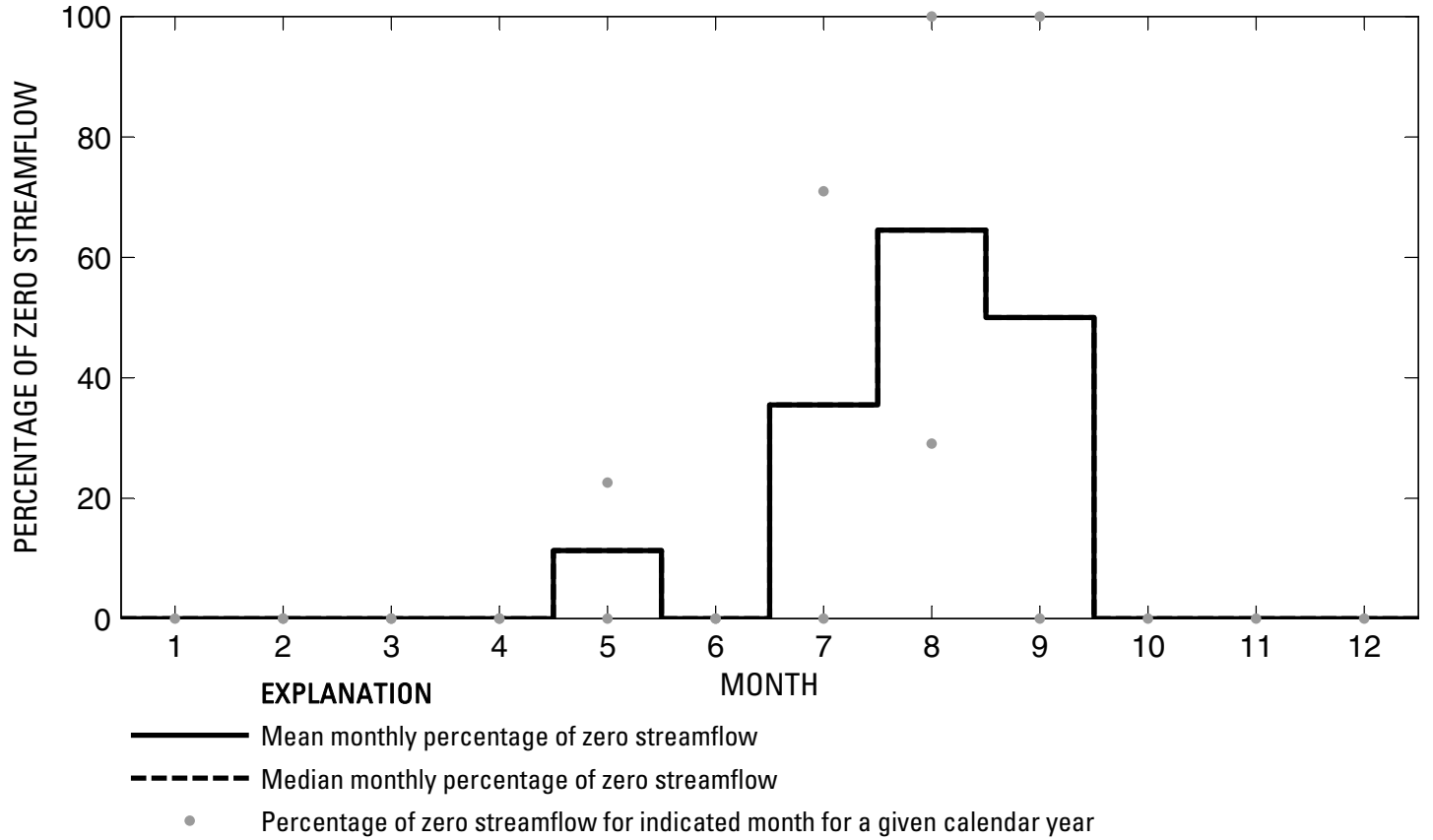

Figure 349. Analysis of percentage of zero daily mean streamflow for U.S. Geological Survey streamflow-gaging station 08086200 Salt Prong Hubbard Creek near Albany, Texas. 
U.S. Geological Survey streamflow-gaging station 08086210

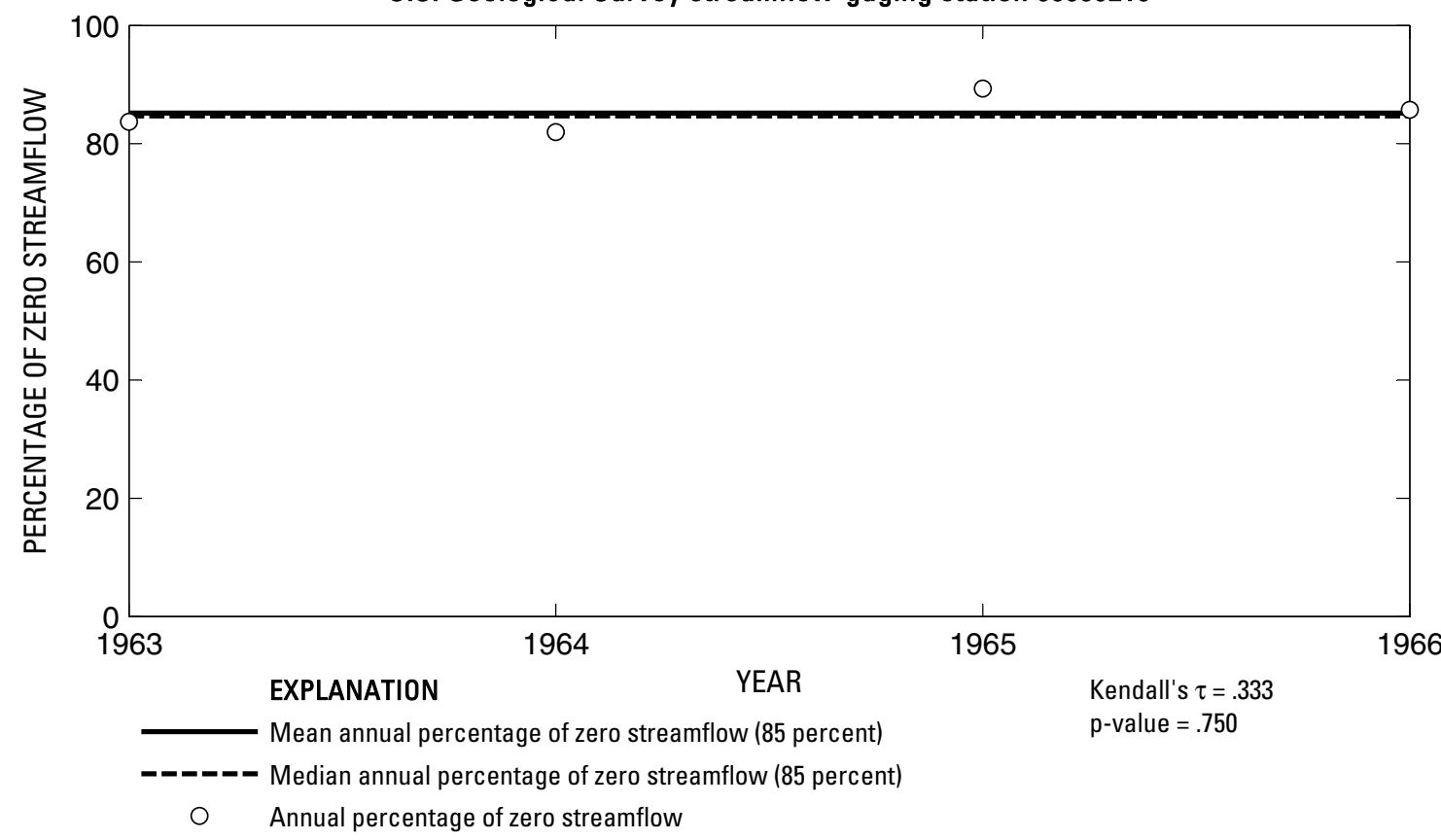

U.S. Geological Survey streamflow-gaging station 08086210

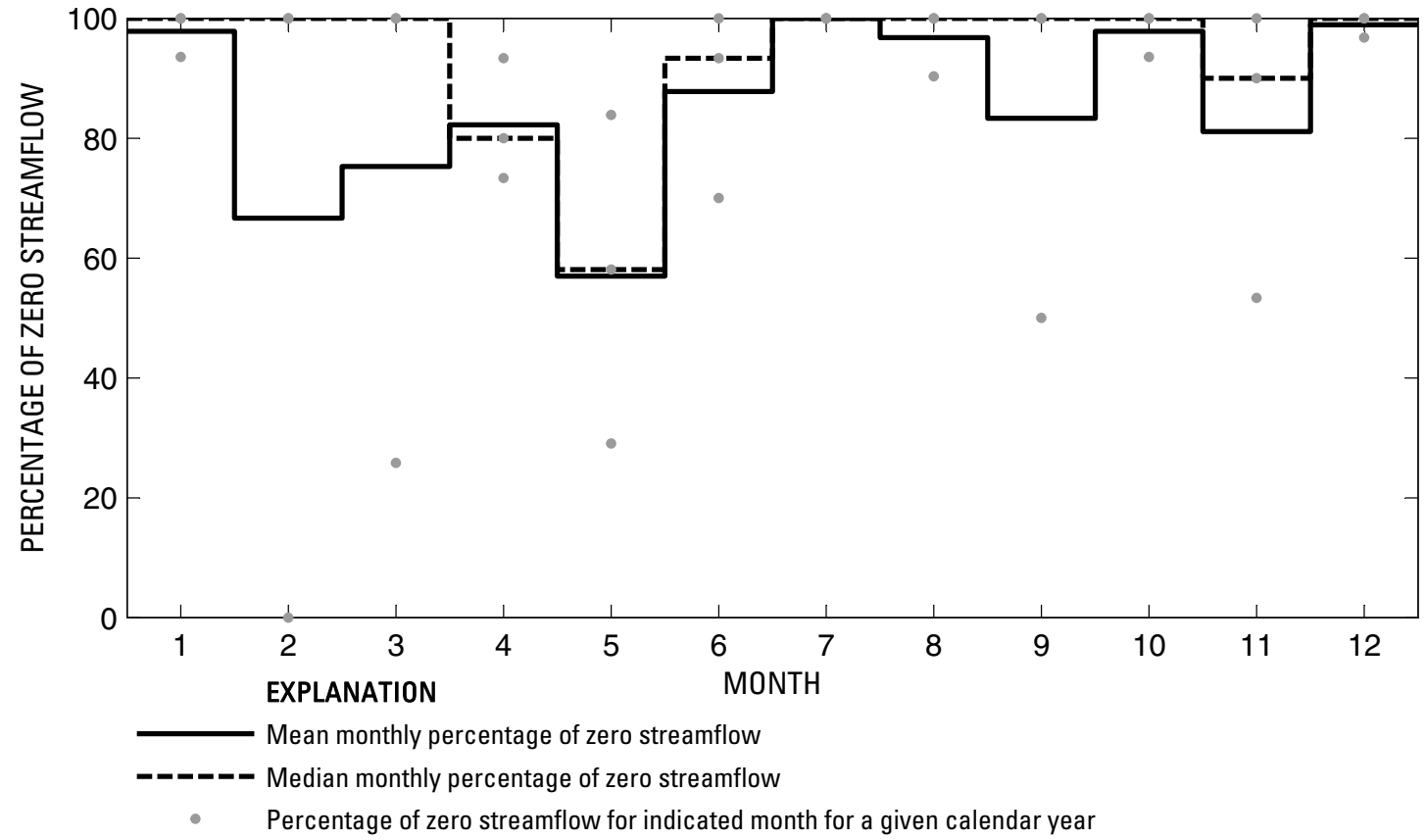

Figure 350. Analysis of percentage of zero daily mean streamflow for U.S. Geological Survey streamflow-gaging station 08086210 Snailum Creek near Albany, Texas.

Index of Station Numbers 719 
U.S. Geological Survey streamflow-gaging station 08086212

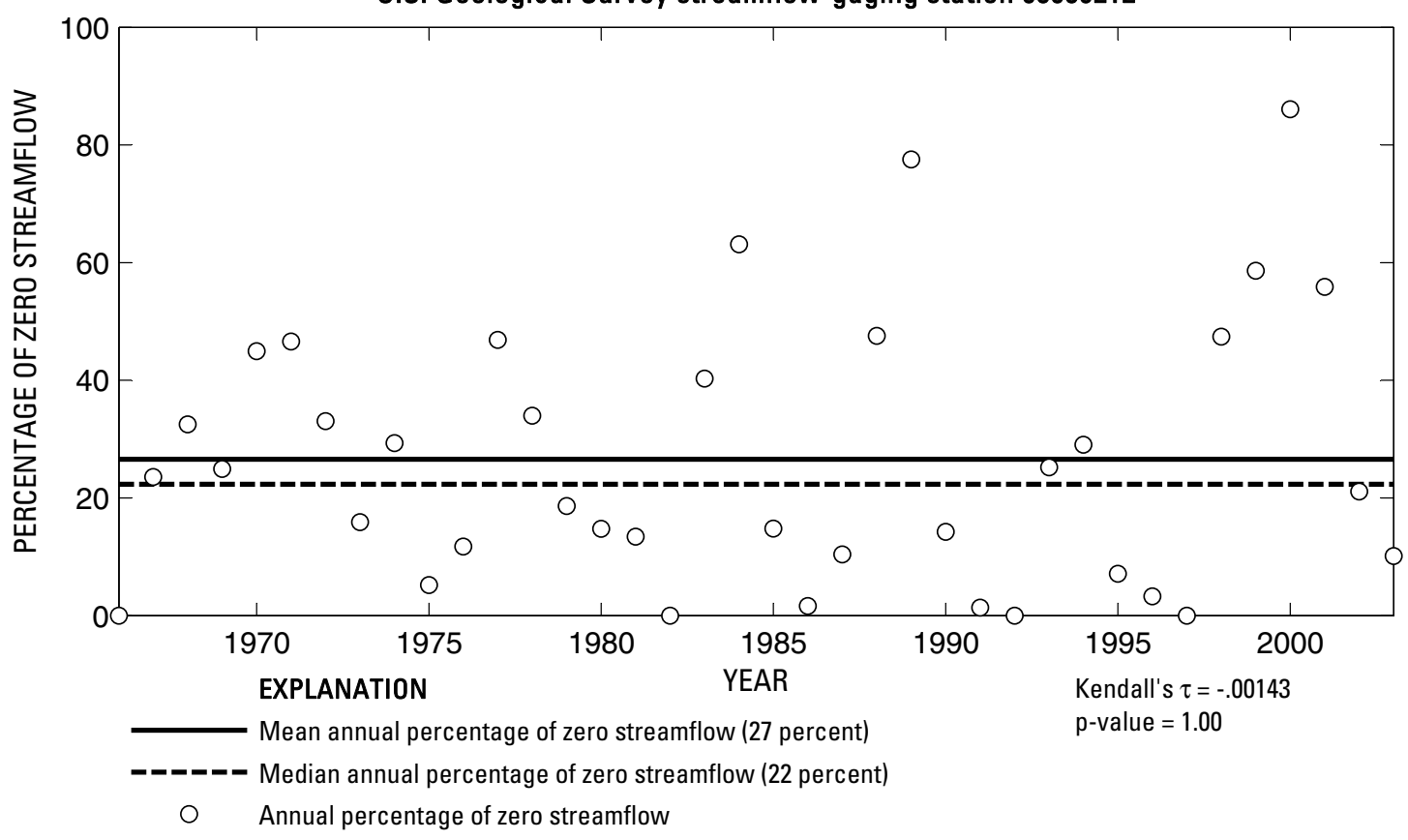

U.S. Geological Survey streamflow-gaging station 08086212

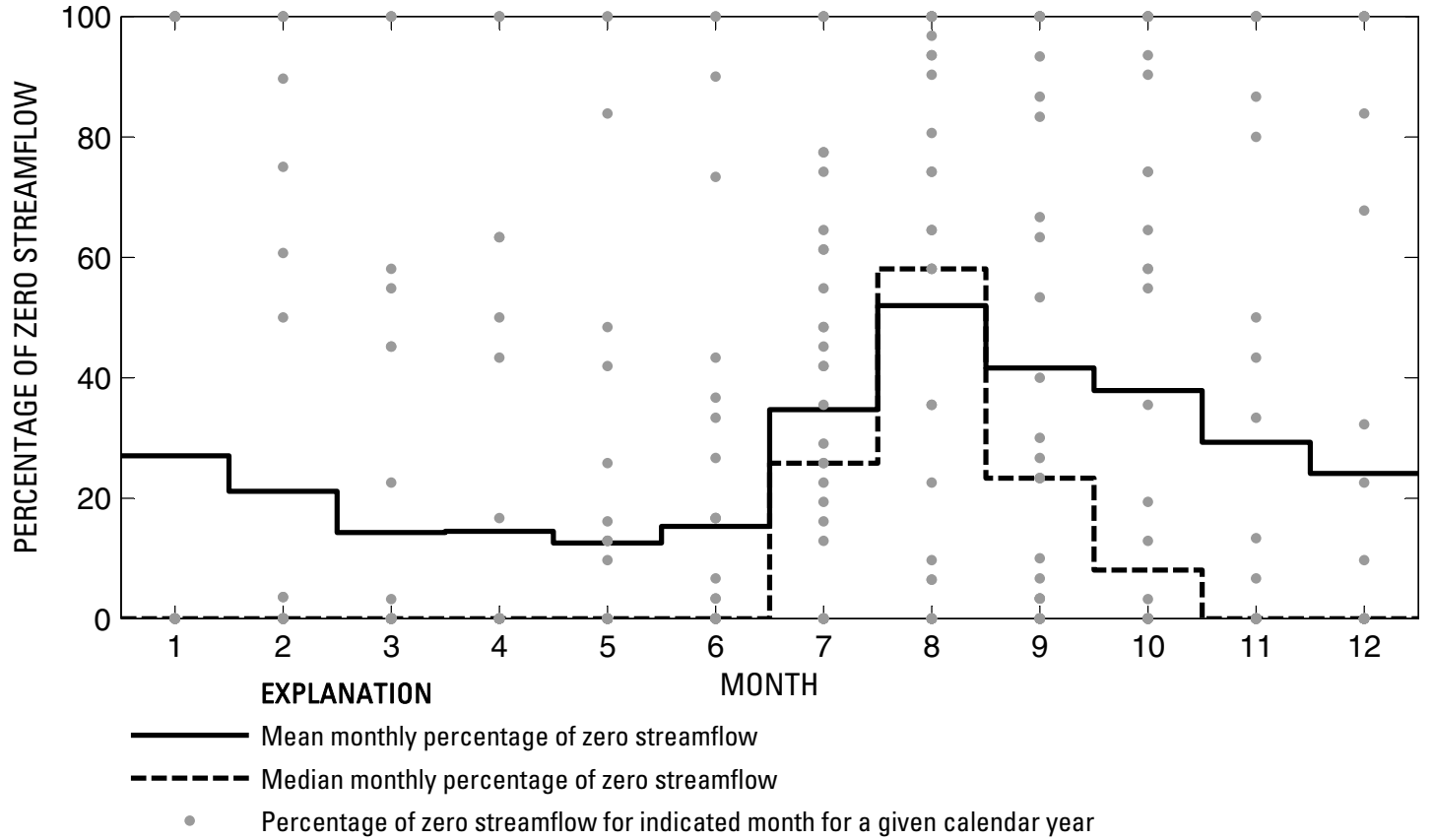

Figure 351. Analysis of percentage of zero daily mean streamflow for U.S. Geological Survey streamflow-gaging station 08086212 Hubbard Creek below Albany, Texas. 
U.S. Geological Survey streamflow-gaging station 08086235

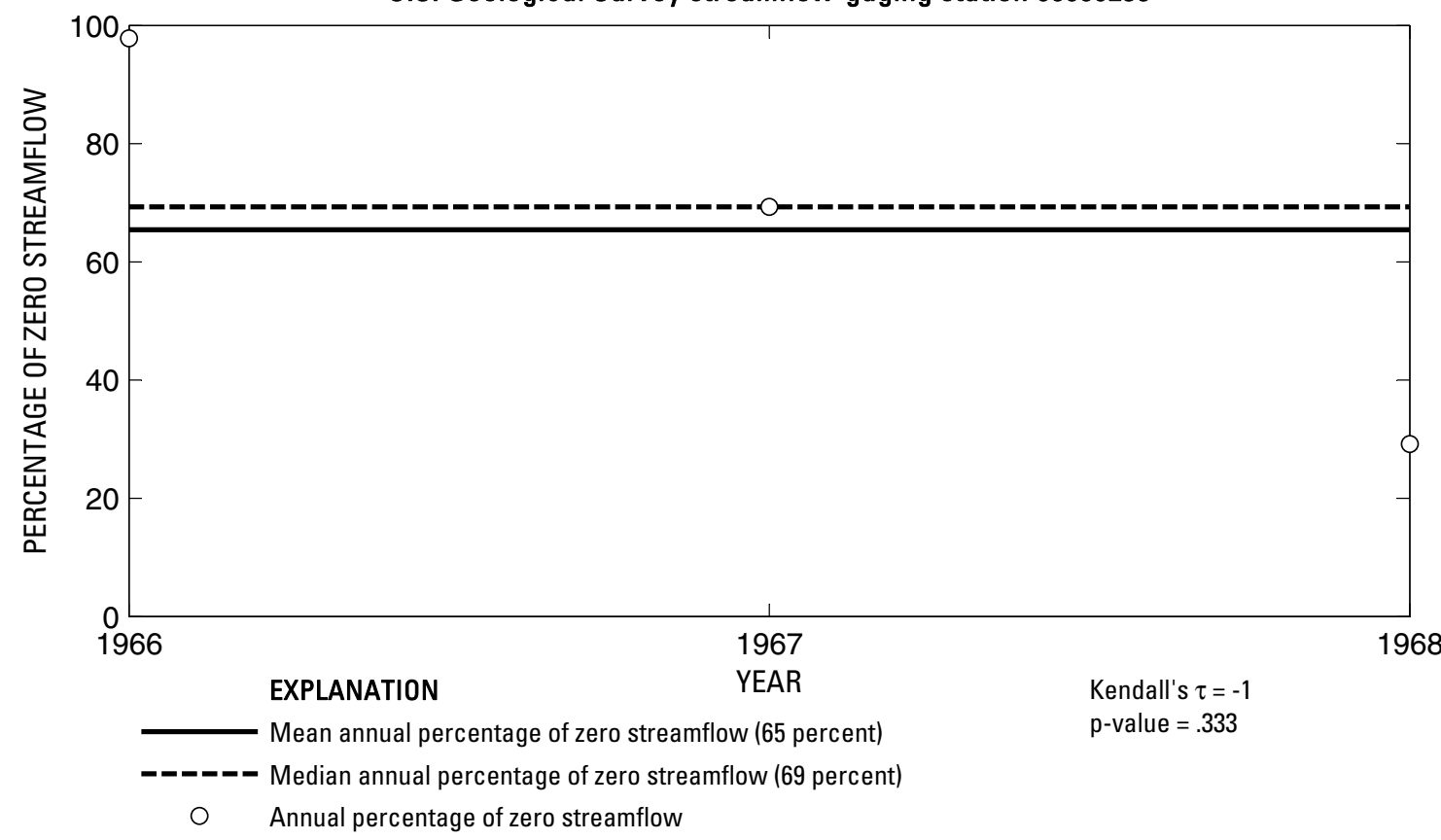

U.S. Geological Survey streamflow-gaging station 08086235

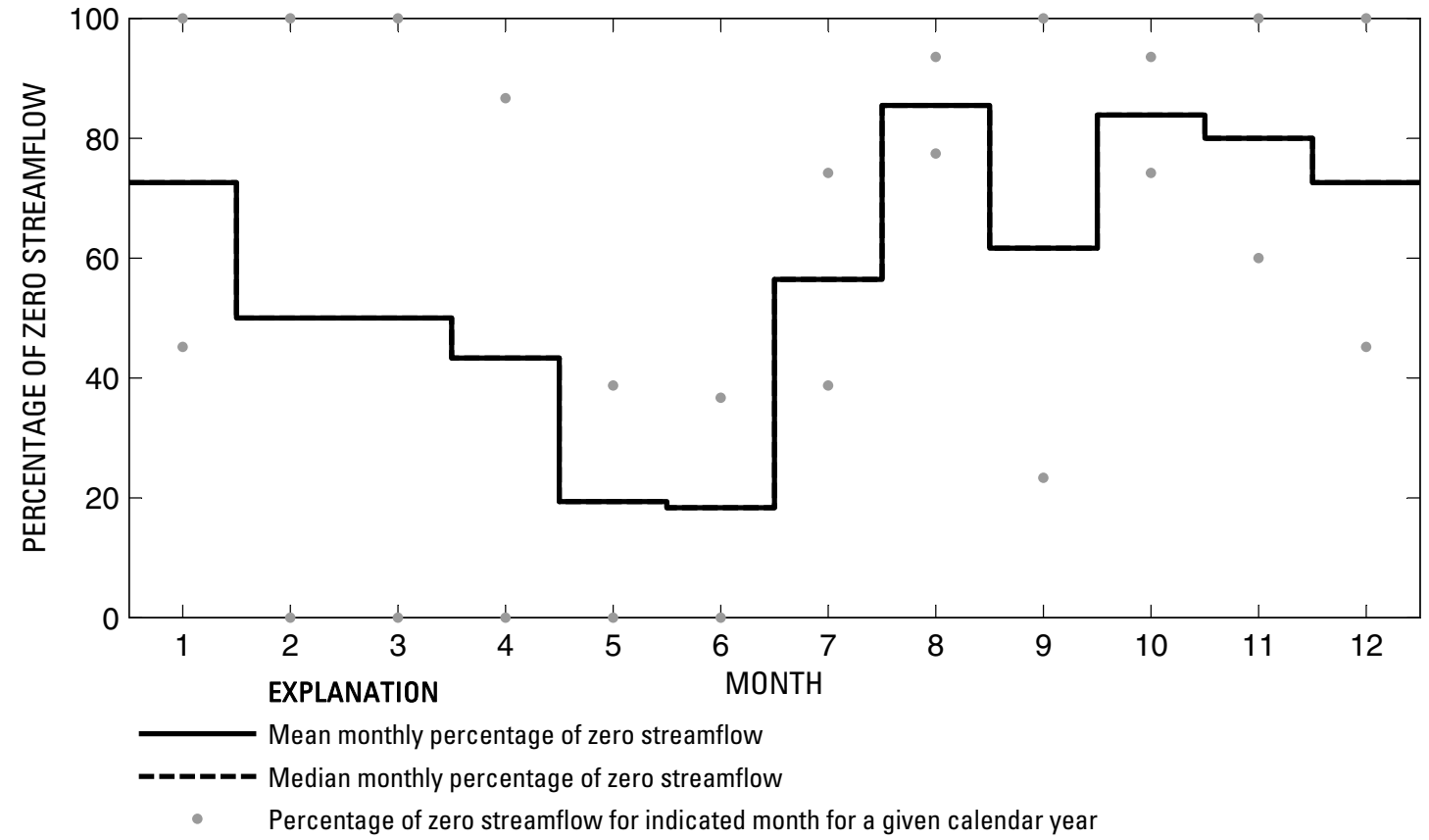

Figure 352. Analysis of percentage of zero daily mean streamflow for U.S. Geological Survey streamflow-gaging station 08086235 Battle Creek near Moran, Texas. 
U.S. Geological Survey streamflow-gaging station 08086260

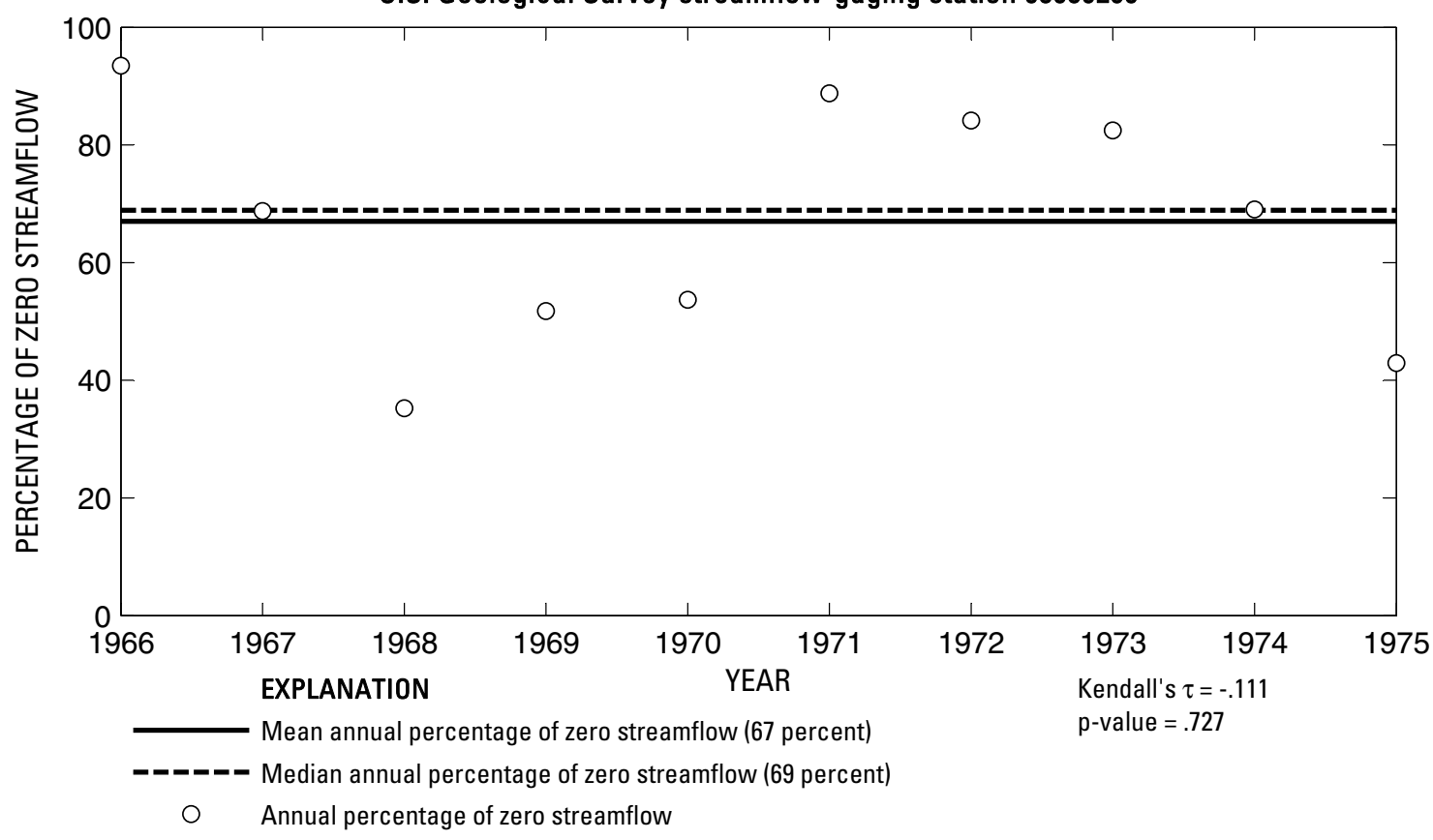

U.S. Geological Survey streamflow-gaging station 08086260

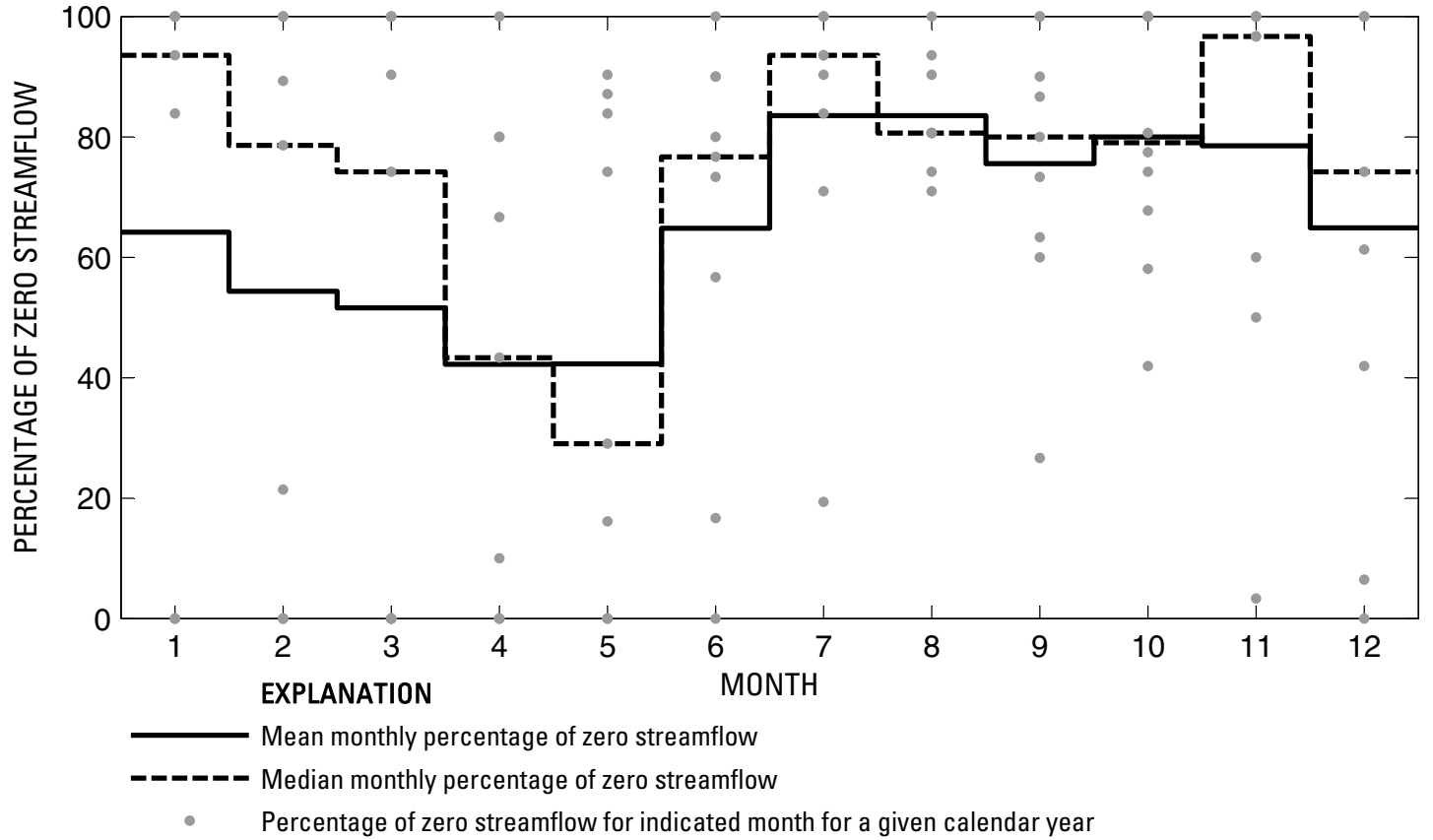

Figure 353. Analysis of percentage of zero daily mean streamflow for U.S. Geological Survey streamflow-gaging station 08086260 Pecan Creek near Eolian, Texas. 
U.S. Geological Survey streamflow-gaging station 08086290

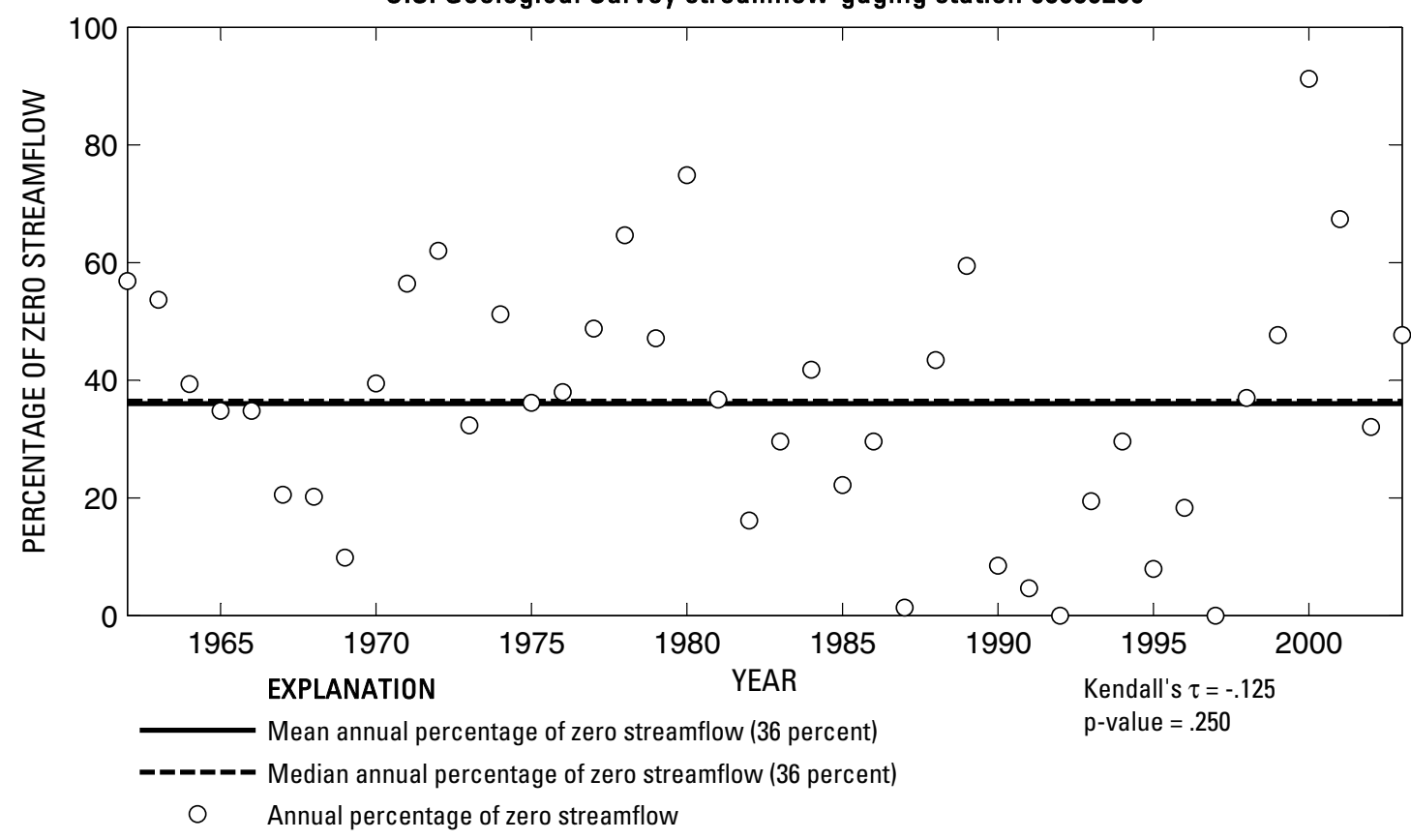

U.S. Geological Survey streamflow-gaging station 08086290

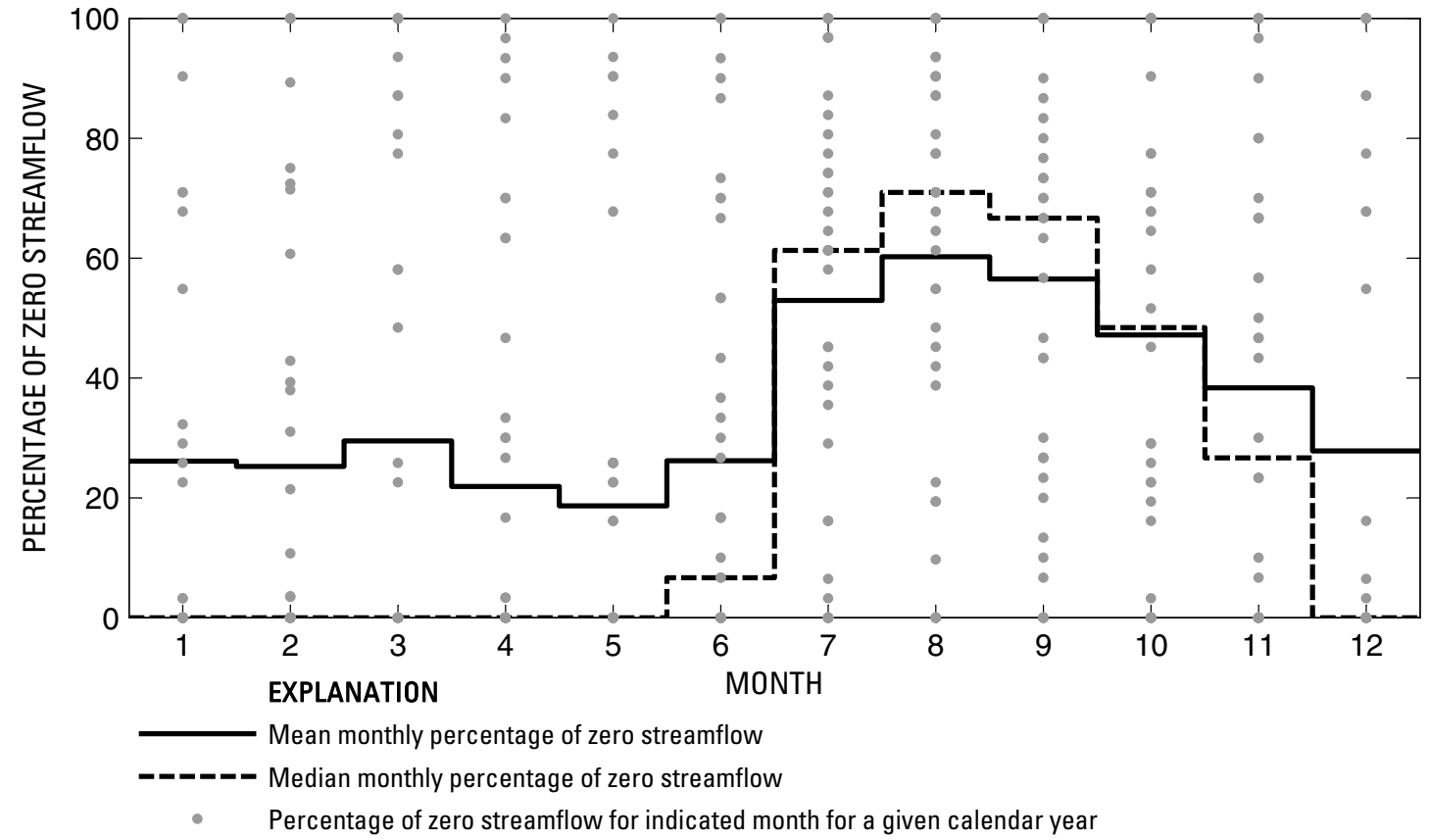

Figure 354. Analysis of percentage of zero daily mean streamflow for U.S. Geological Survey streamflow-gaging station 08086290 Big Sandy Creek above Breckenridge, Texas.

Index of Station Numbers 719 
U.S. Geological Survey streamflow-gaging station 08086500

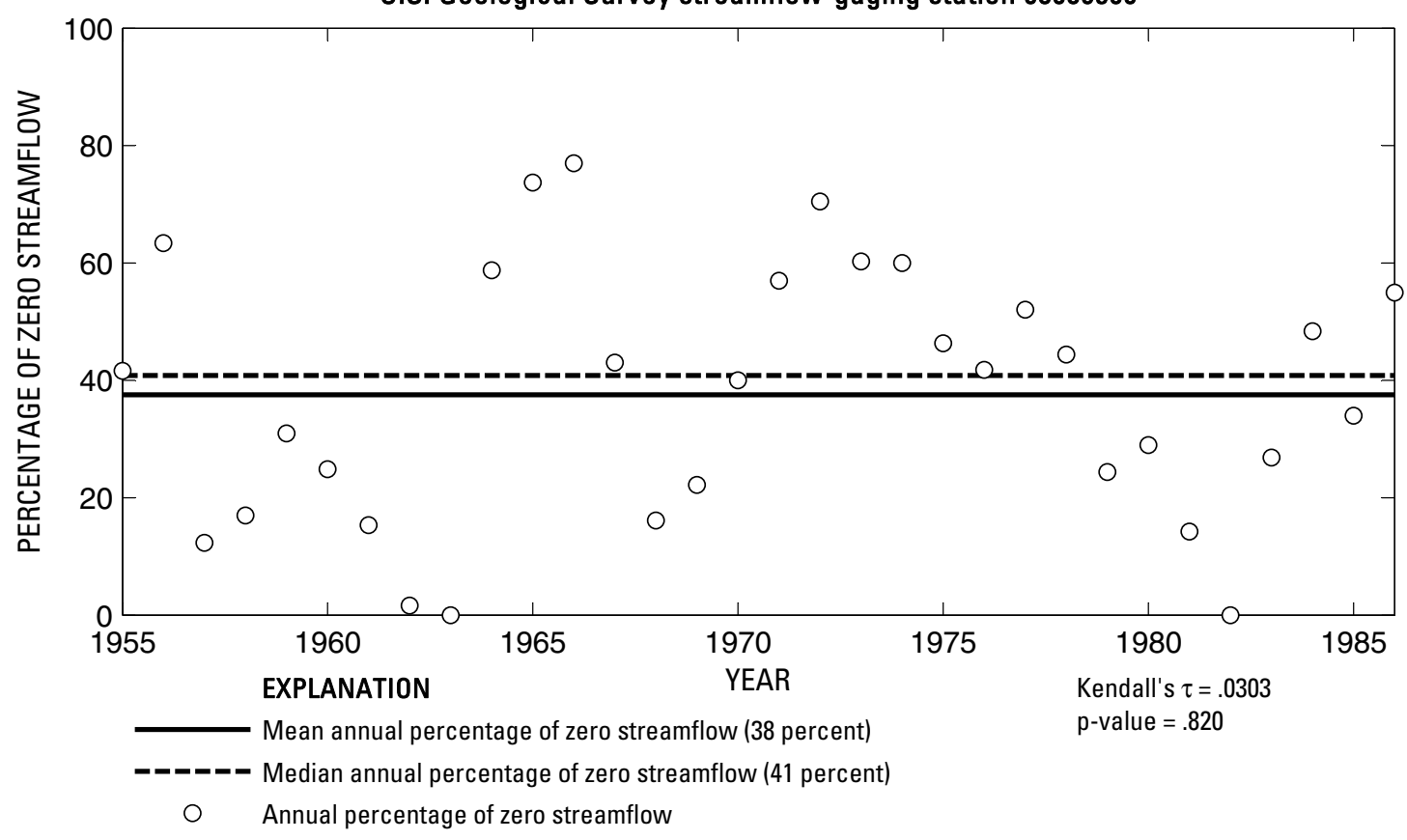

U.S. Geological Survey streamflow-gaging station 08086500

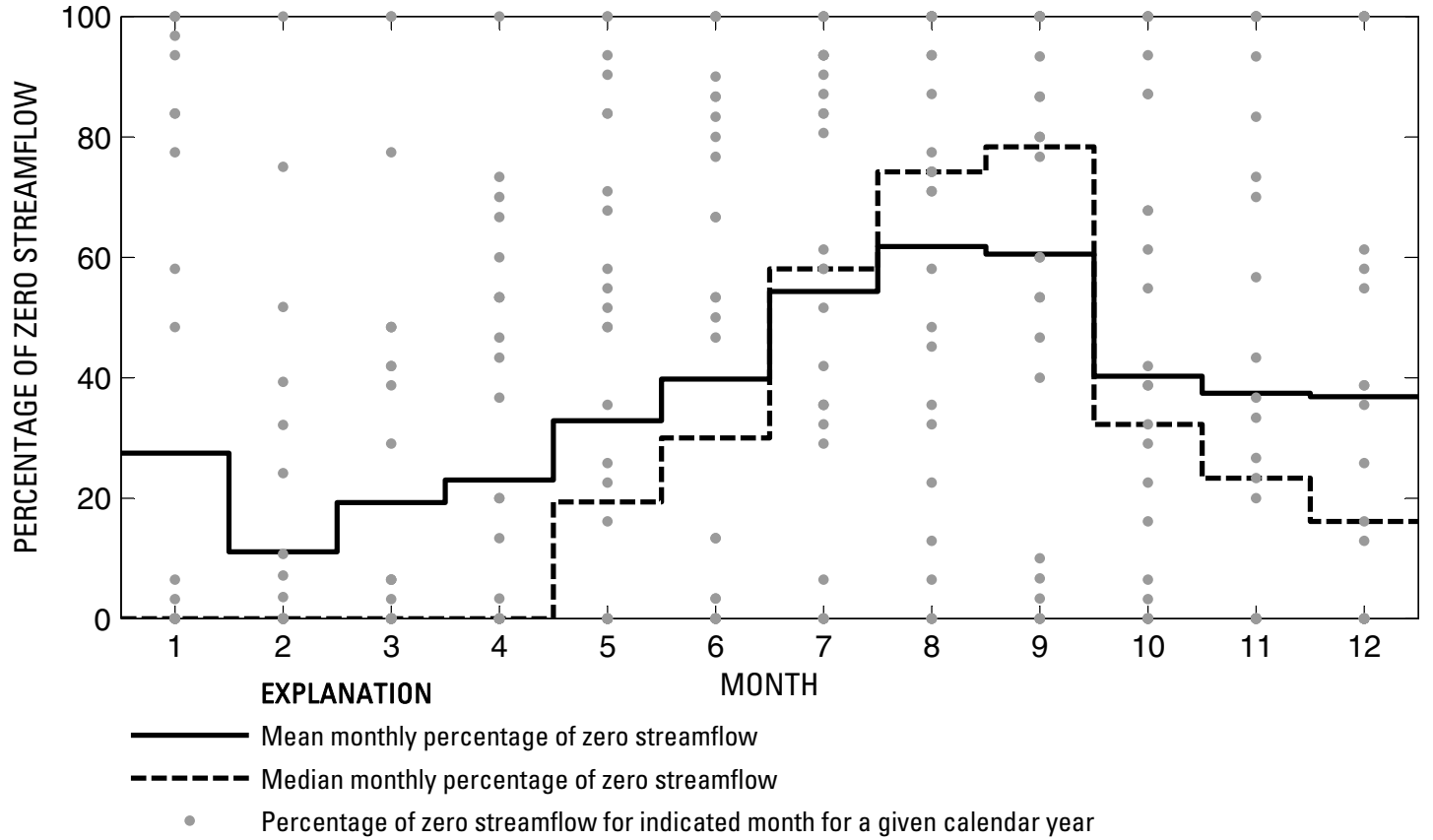

Figure 355. Analysis of percentage of zero daily mean streamflow for U.S. Geological Survey streamflow-gaging station 08086500 Hubbard Creek near Breckenridge, Texas. 
U.S. Geological Survey streamflow-gaging station 08087300

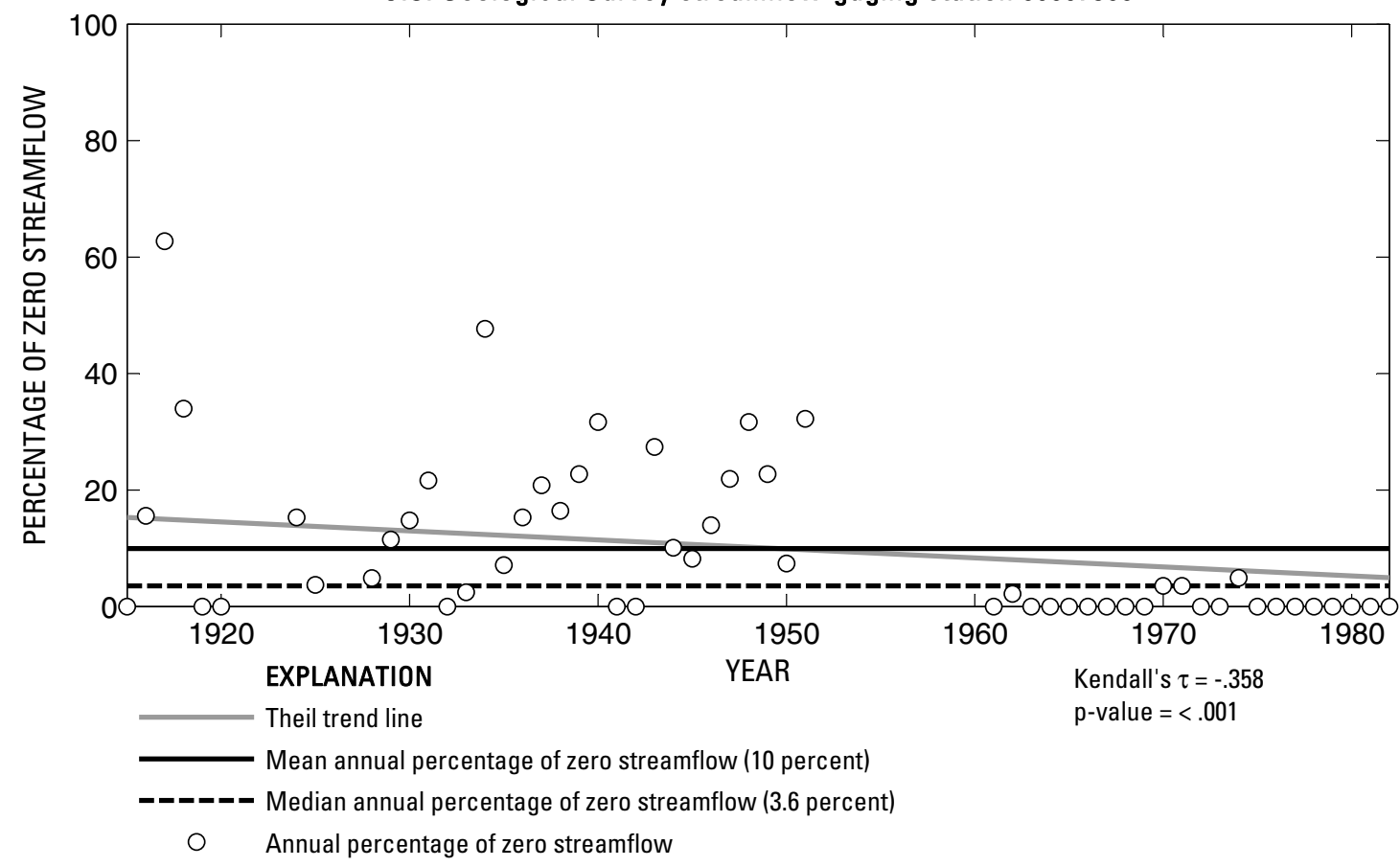

U.S. Geological Survey streamflow-gaging station 08087300

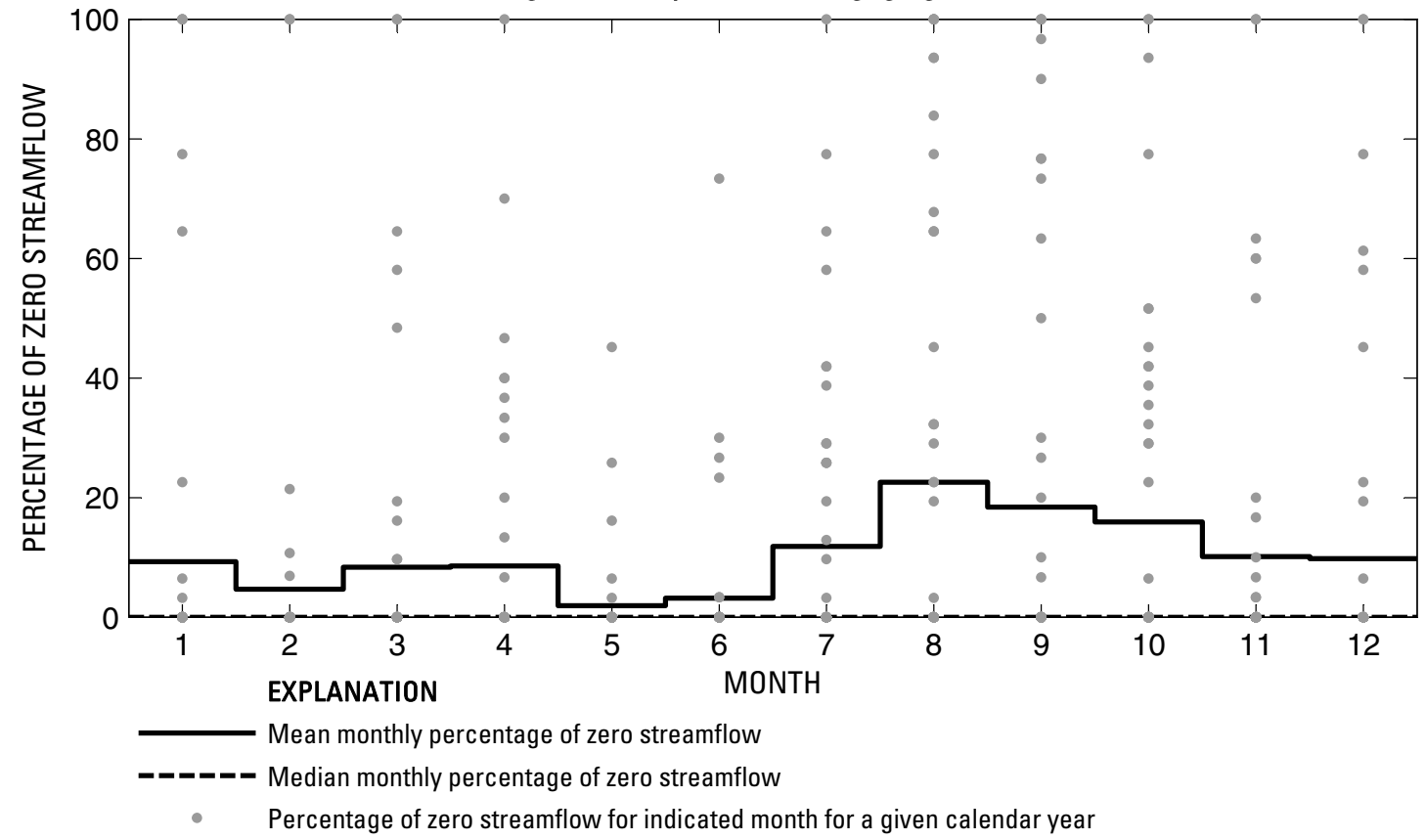

Figure 356. Analysis of percentage of zero daily mean streamflow for U.S. Geological Survey streamflow-gaging station 08087300 Clear Fork Brazos River at Eliasville, Texas.

Index of Station Numbers 719 
U.S. Geological Survey streamflow-gaging station 08088000

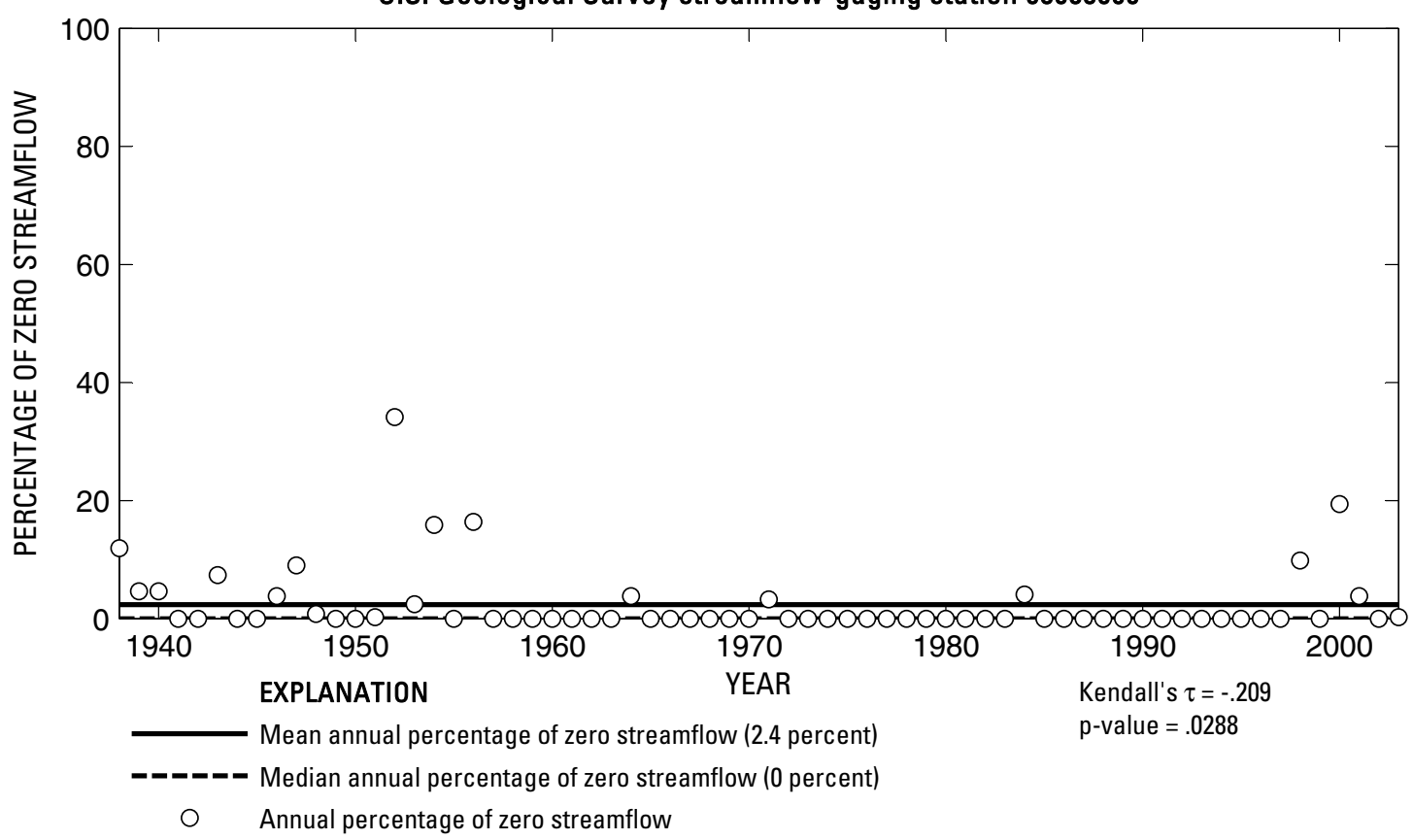

U.S. Geological Survey streamflow-gaging station 08088000

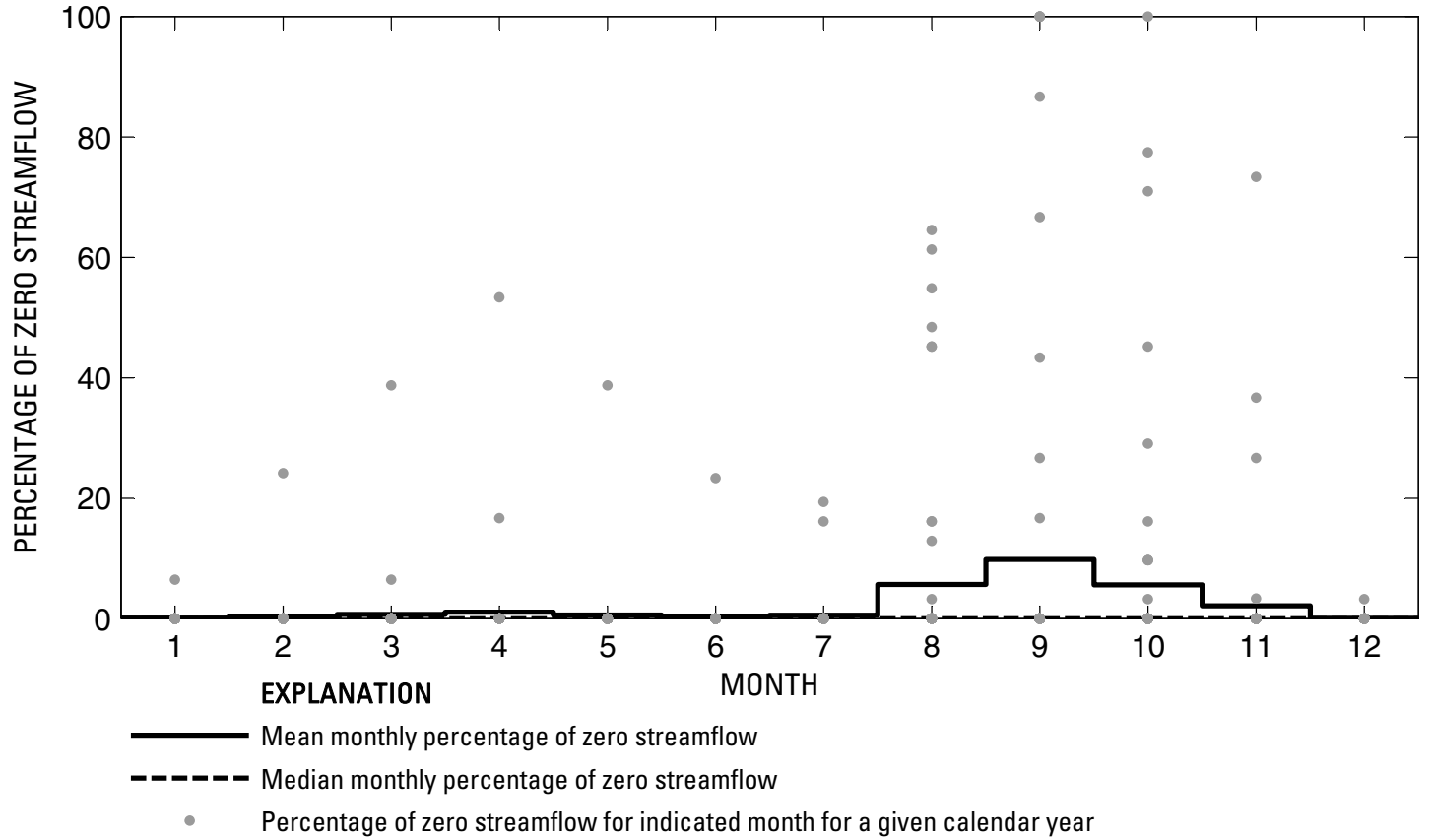

Figure 357. Analysis of percentage of zero daily mean streamflow for U.S. Geological Survey streamflow-gaging station 08088000 Brazos River near South Bend, Texas. 
U.S. Geological Survey streamflow-gaging station 08088100

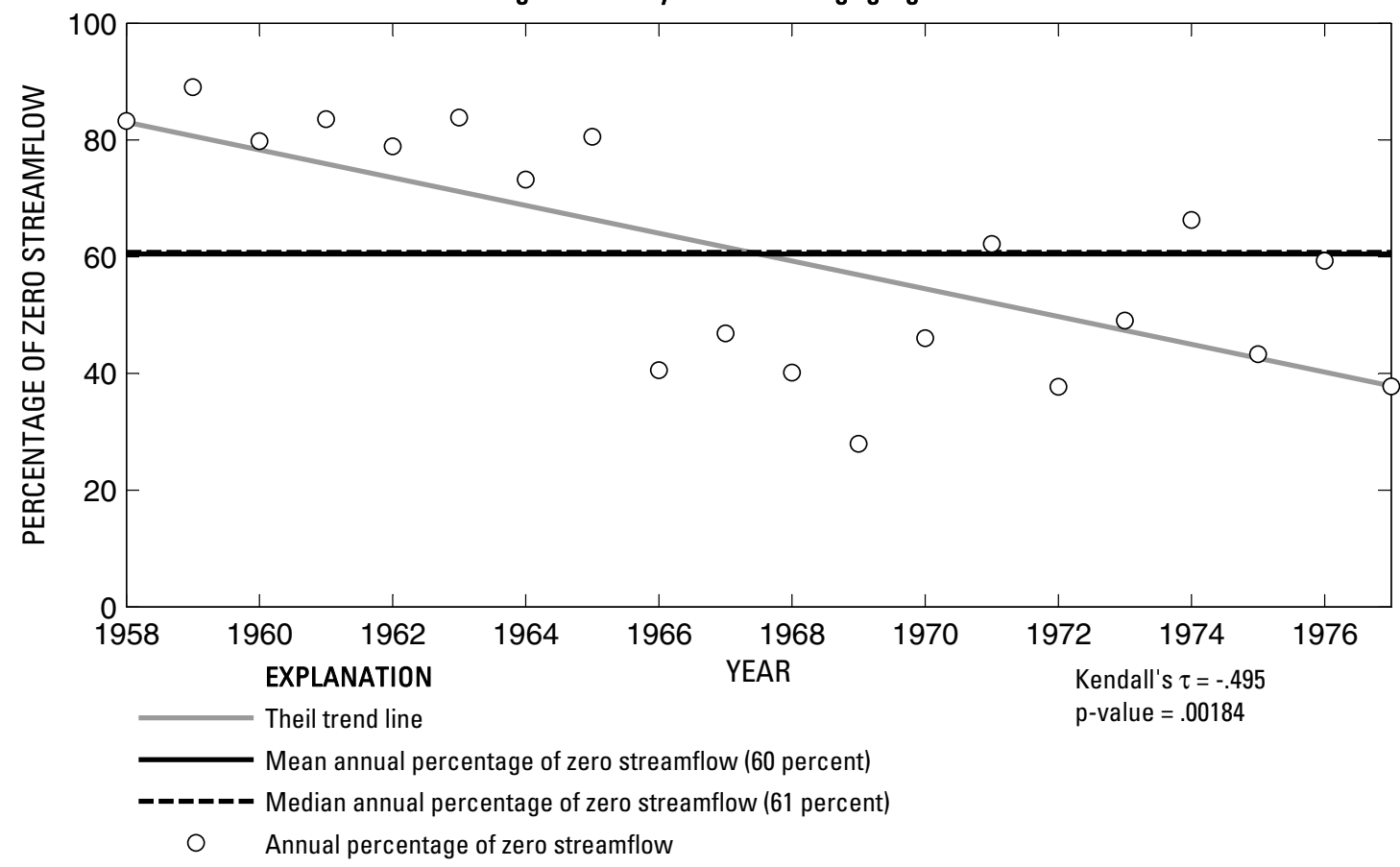

U.S. Geological Survey streamflow-gaging station 08088100

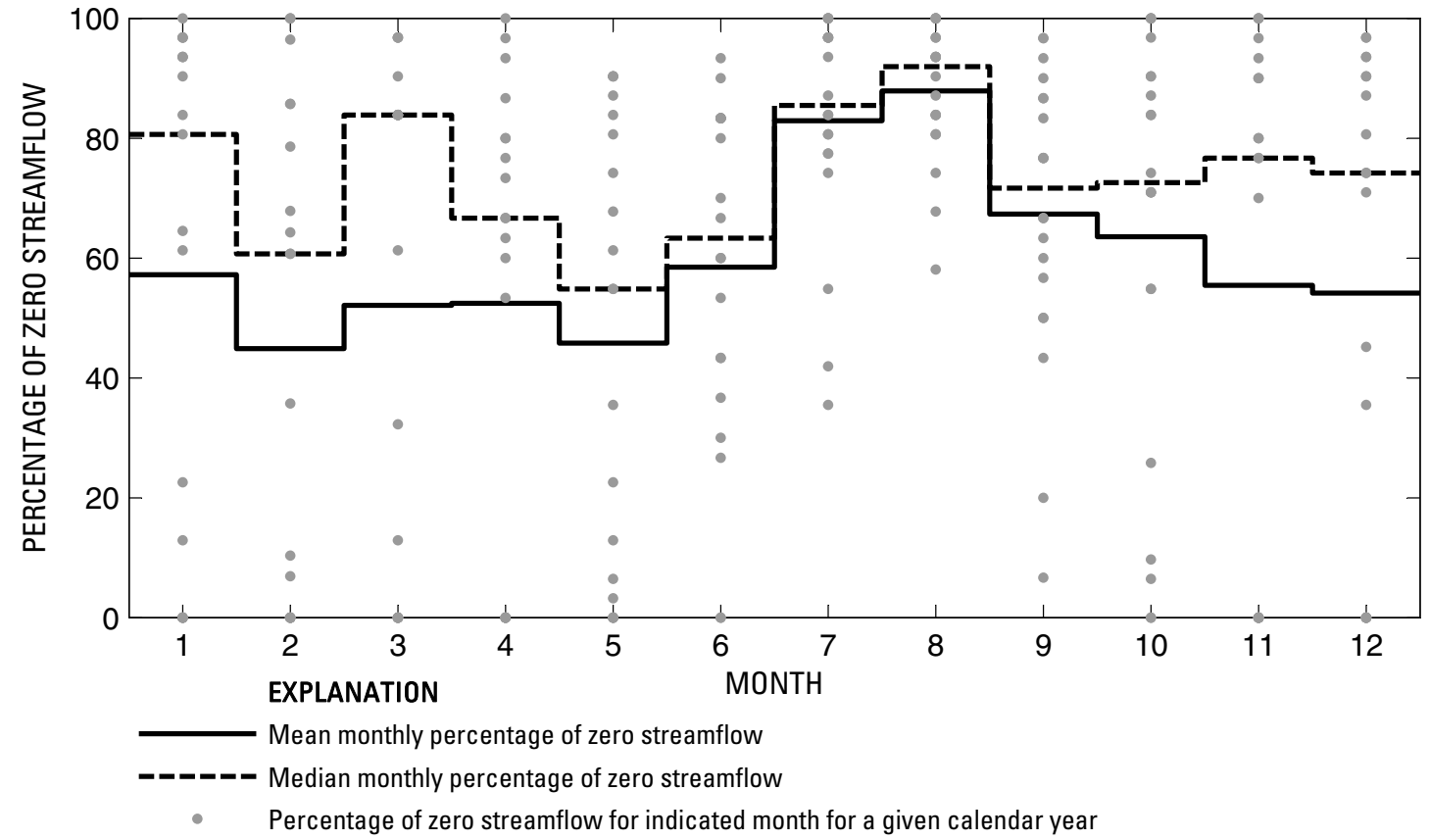

Figure 358. Analysis of percentage of zero daily mean streamflow for U.S. Geological Survey streamflow-gaging station 08088100 Salt Creek at Olney, Texas.

Index of Station Numbers 719 
U.S. Geological Survey streamflow-gaging station 08088200

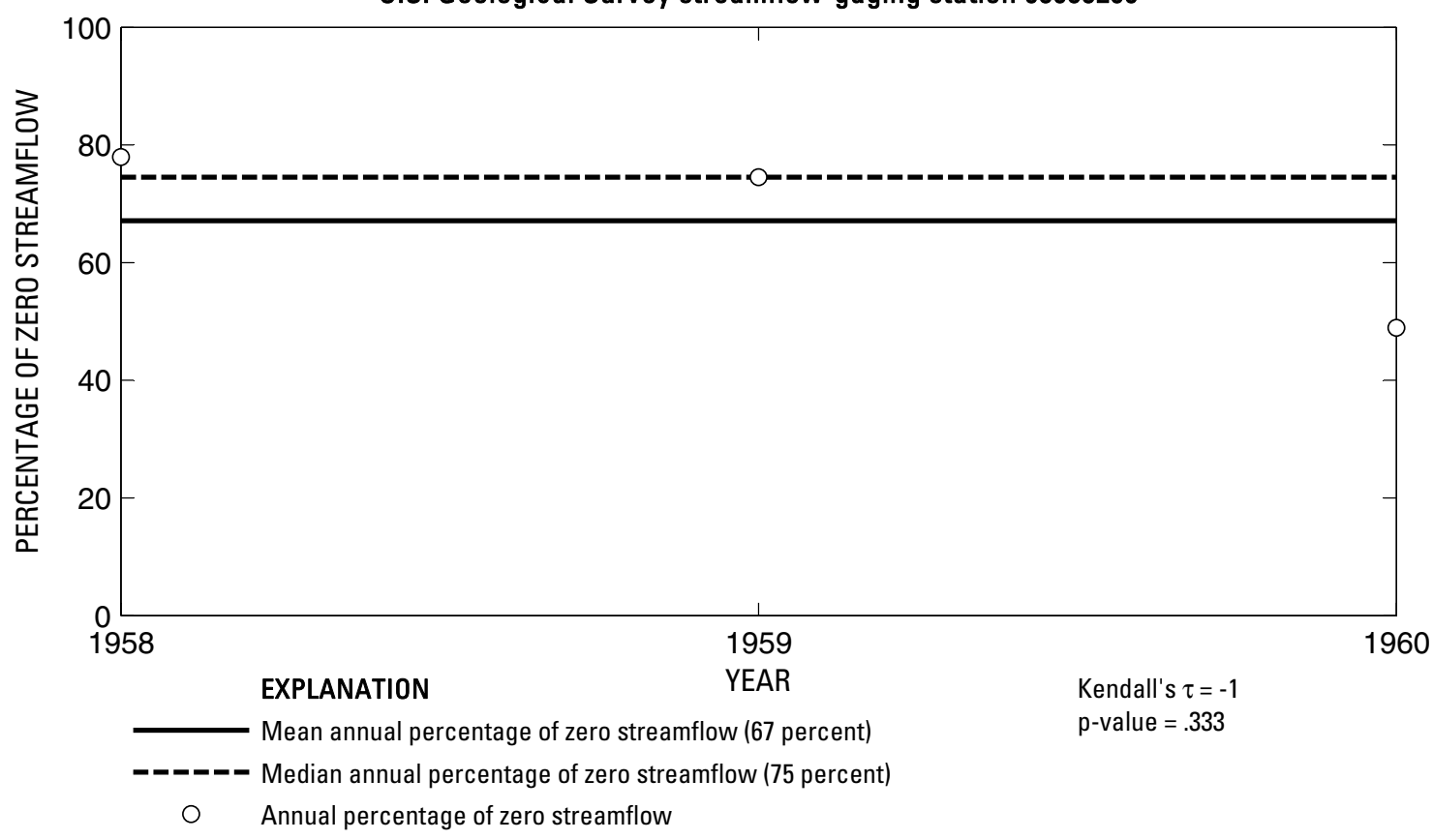

U.S. Geological Survey streamflow-gaging station 08088200

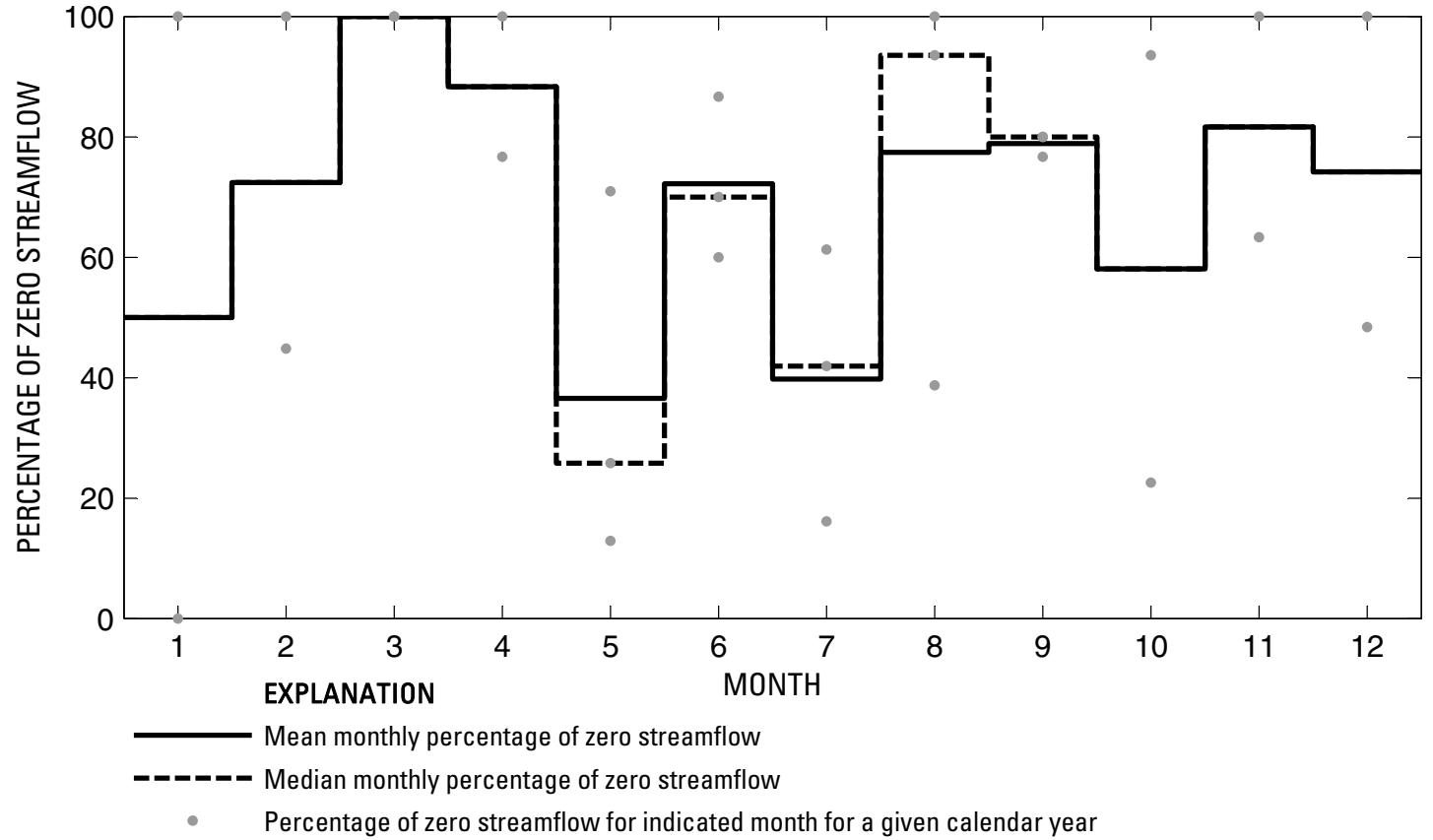

Figure 359. Analysis of percentage of zero daily mean streamflow for U.S. Geological Survey streamflow-gaging station 08088200 Salt Creek near Newcastle, Texas. 
U.S. Geological Survey streamflow-gaging station 08088300

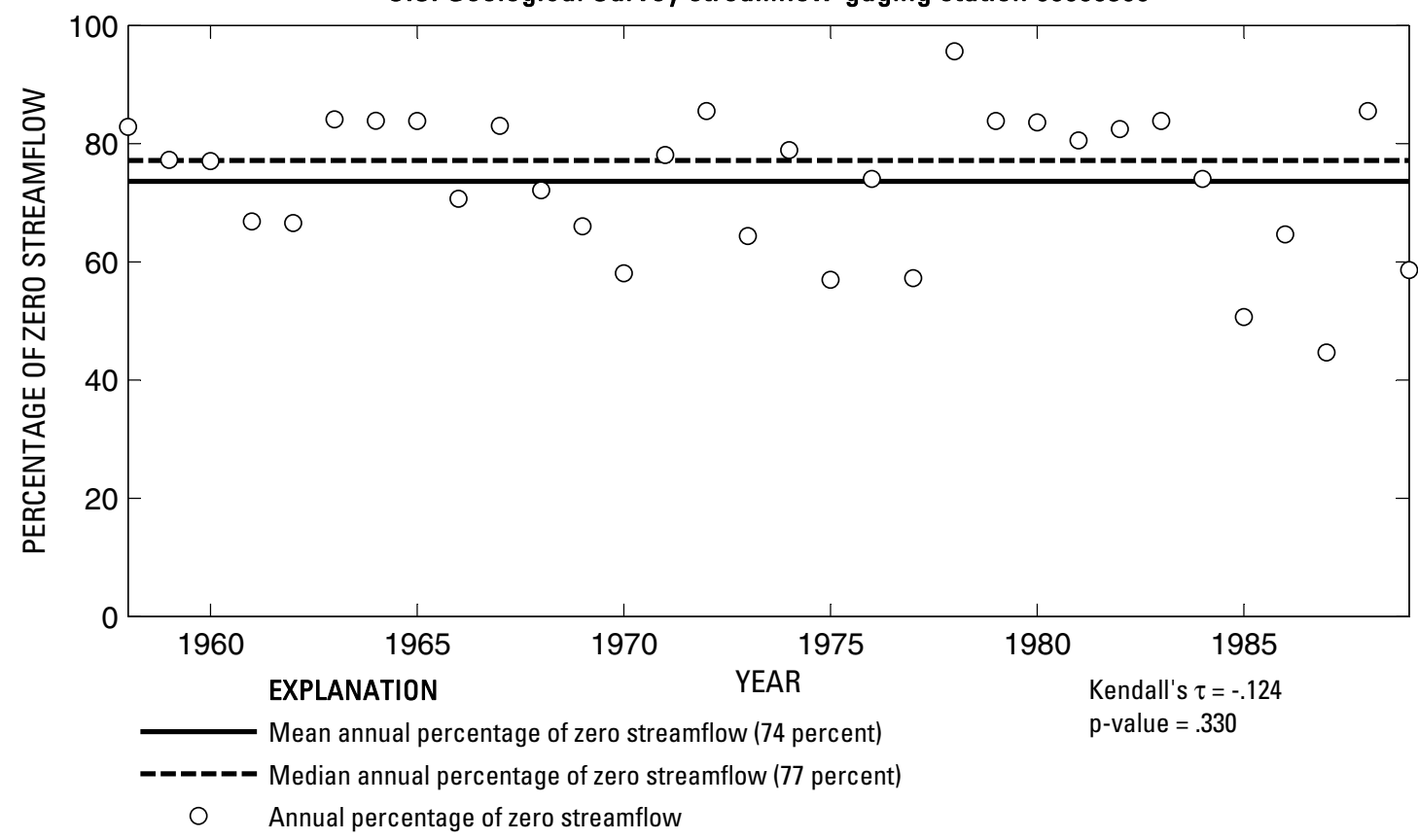

U.S. Geological Survey streamflow-gaging station 08088300

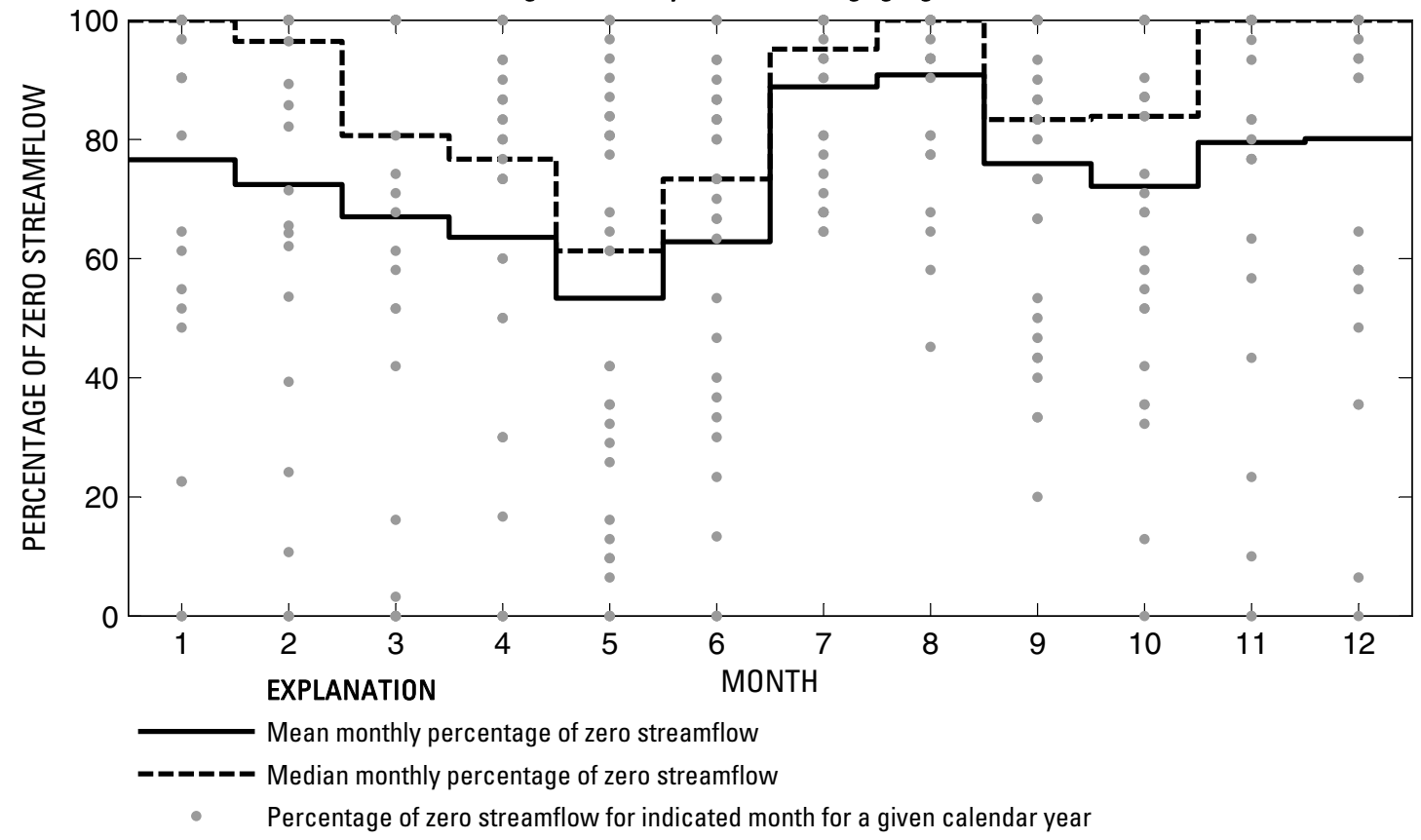

Figure 360. Analysis of percentage of zero daily mean streamflow for U.S. Geological Survey streamflow-gaging station 08088300 Briar Creek near Graham, Texas.

Index of Station Numbers 719 
U.S. Geological Survey streamflow-gaging station 08088450

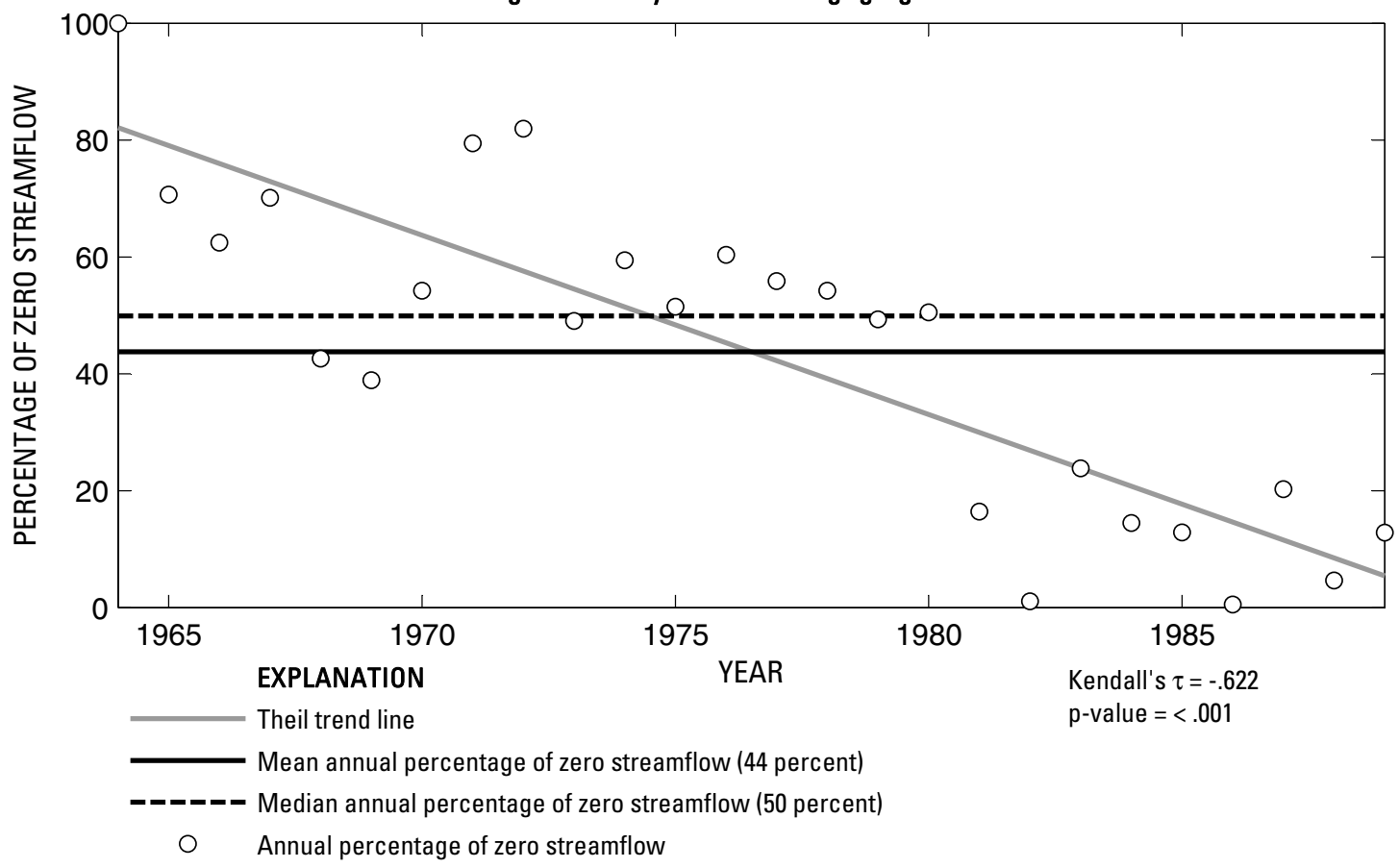

U.S. Geological Survey streamflow-gaging station 08088450

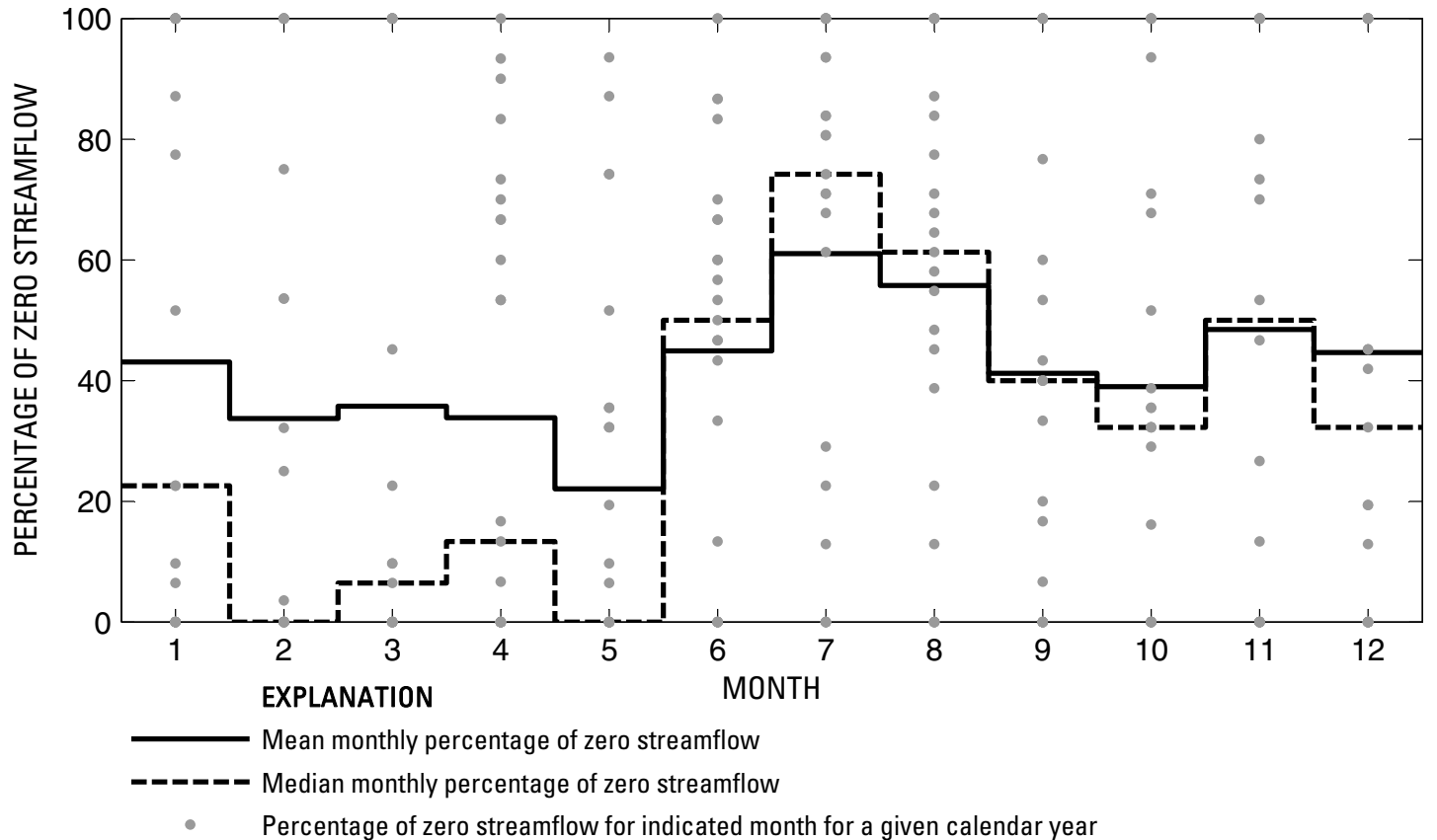

Figure 361. Analysis of percentage of zero daily mean streamflow for U.S. Geological Survey streamflow-gaging station 08088450 Big Cedar Creek near Ivan, Texas. 
U.S. Geological Survey streamflow-gaging station 08088600

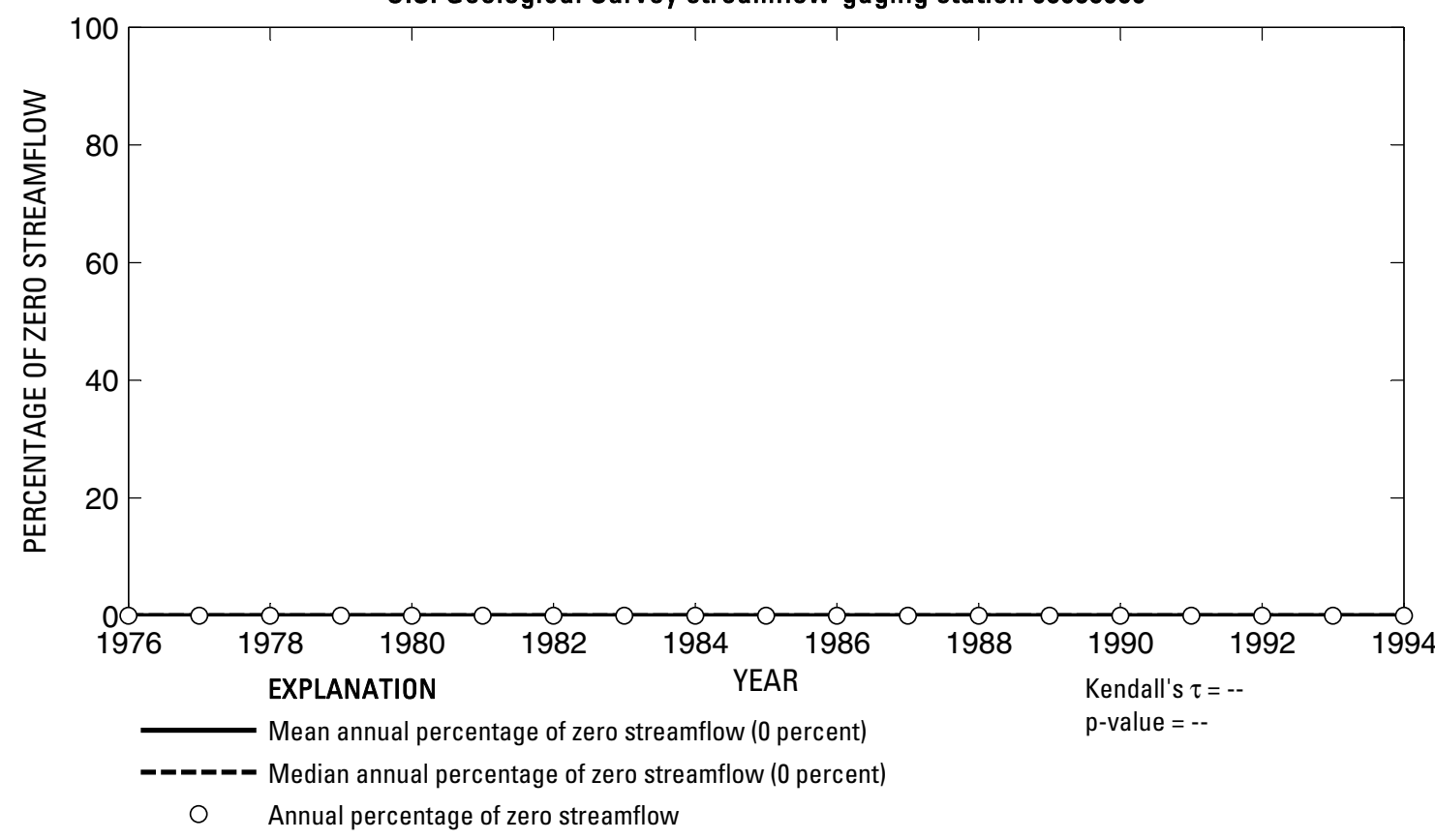

U.S. Geological Survey streamflow-gaging station 08088600

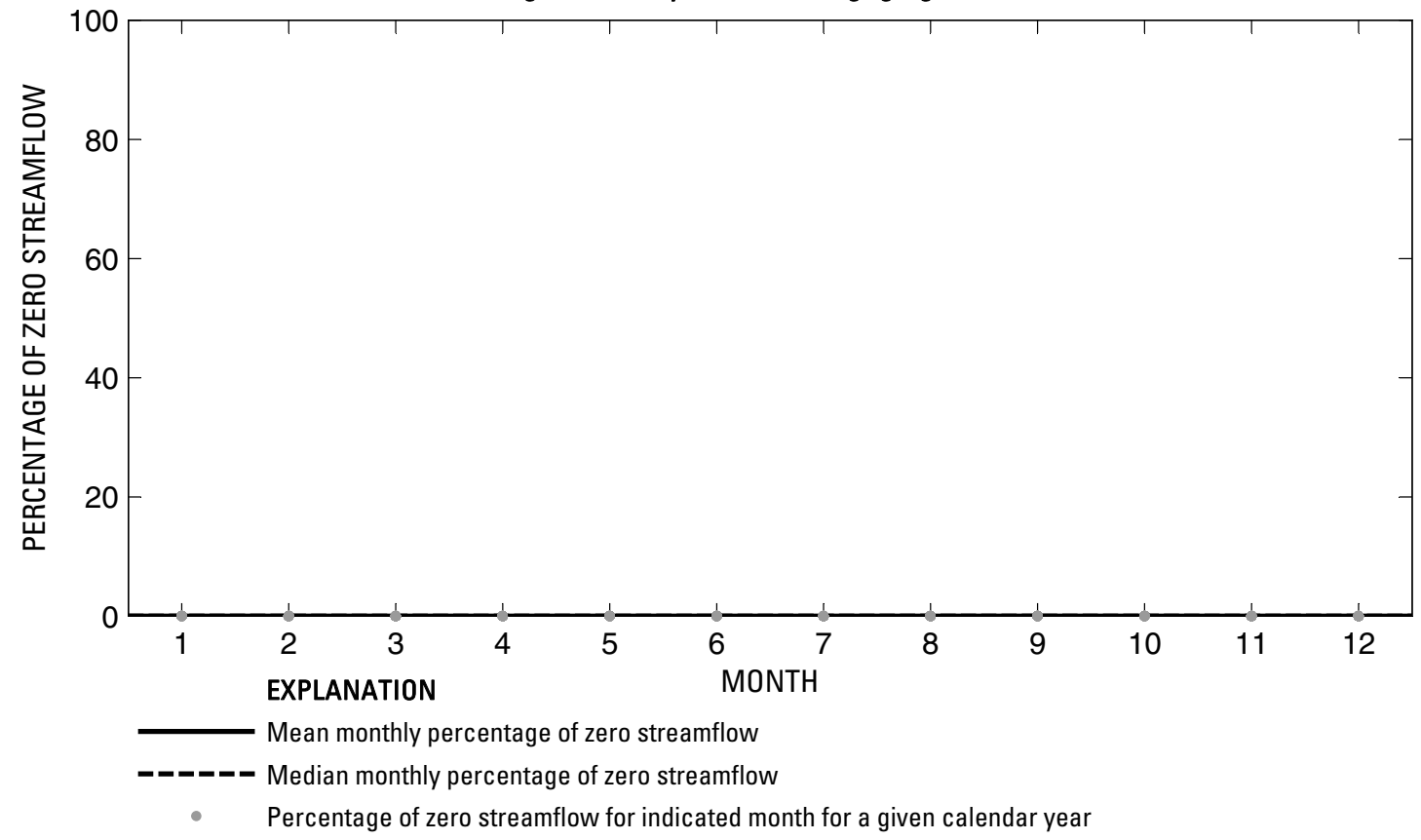

Figure 362. Analysis of percentage of zero daily mean streamflow for U.S. Geological Survey streamflow-gaging station 08088600 Brazos River at Morris Sheppard Dam near Graford, Texas.

Index of Station Numbers 719 
U.S. Geological Survey streamflow-gaging station 08088610

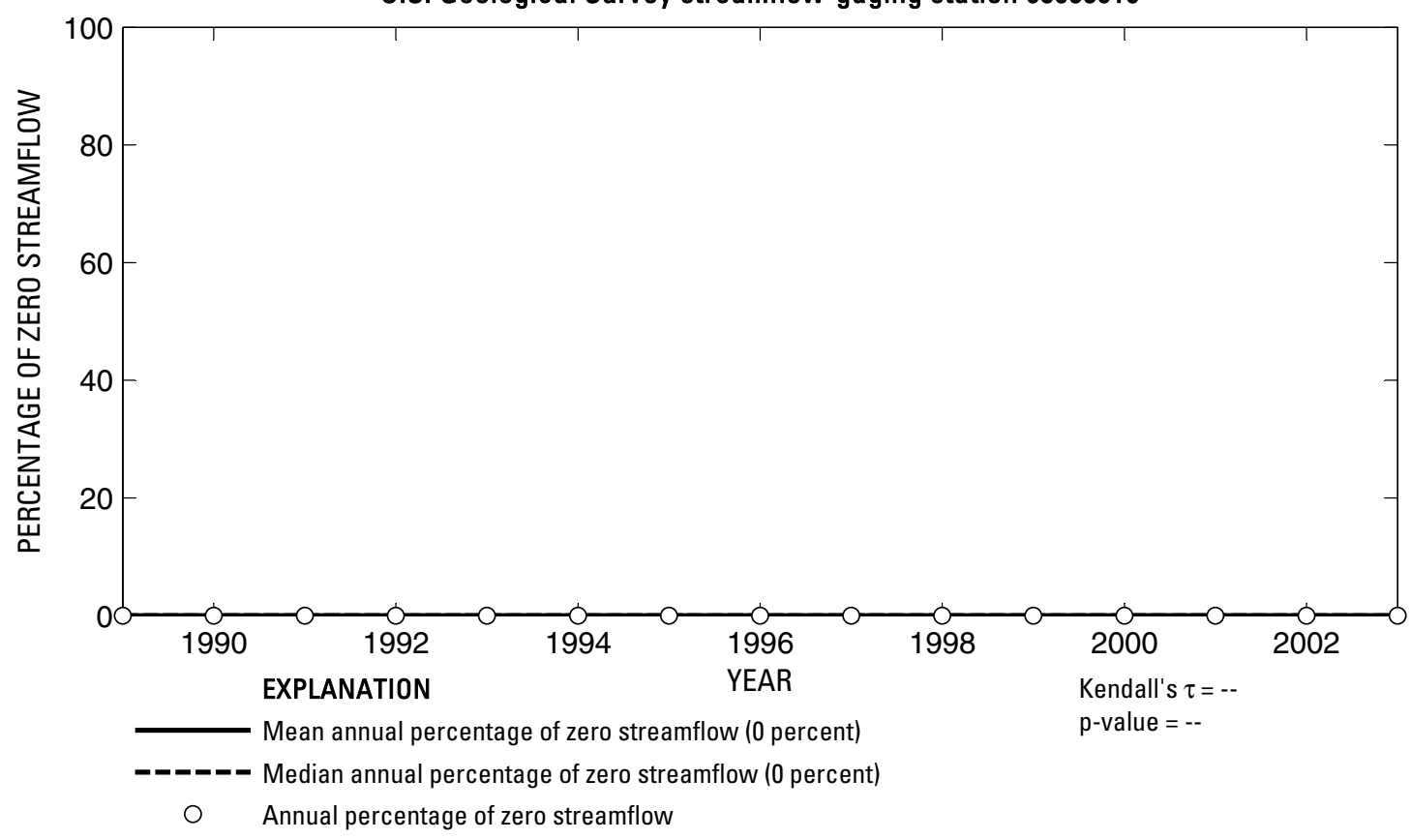

U.S. Geological Survey streamflow-gaging station 08088610

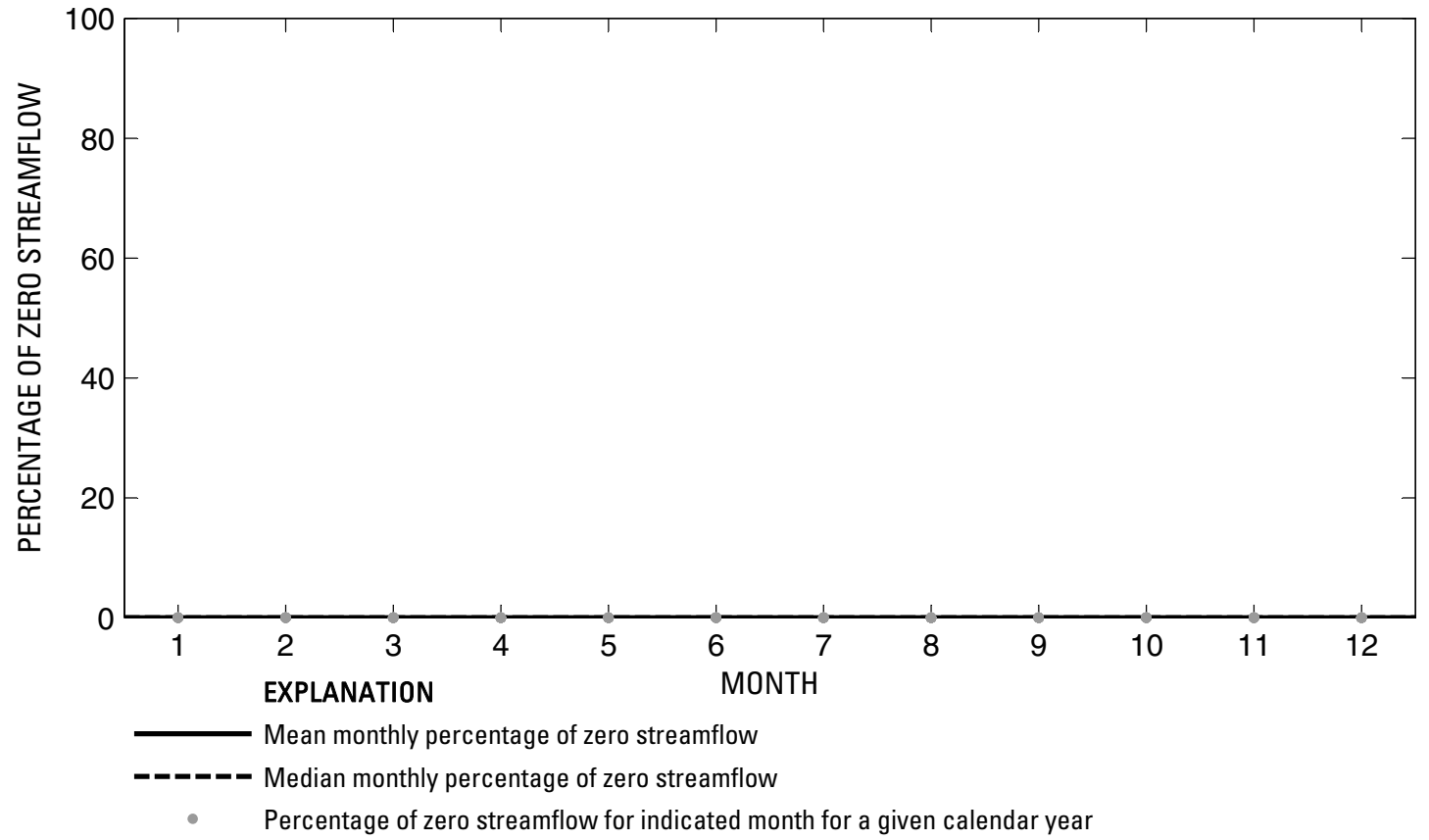

Figure 363. Analysis of percentage of zero daily mean streamflow for U.S. Geological Survey streamflow-gaging station 08088610 Brazos River near Graford, Texas. 
U.S. Geological Survey streamflow-gaging station 08089000

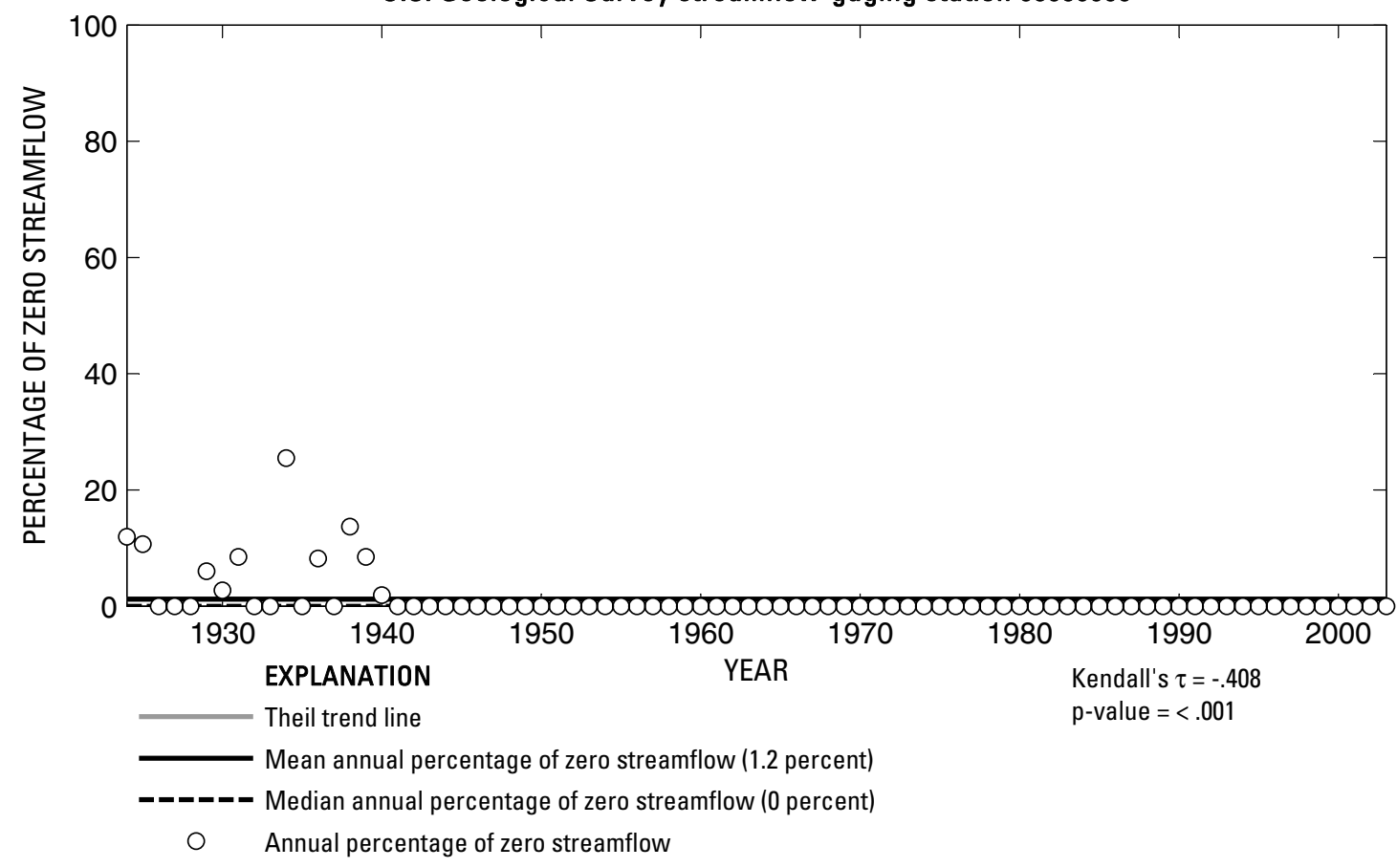

U.S. Geological Survey streamflow-gaging station 08089000

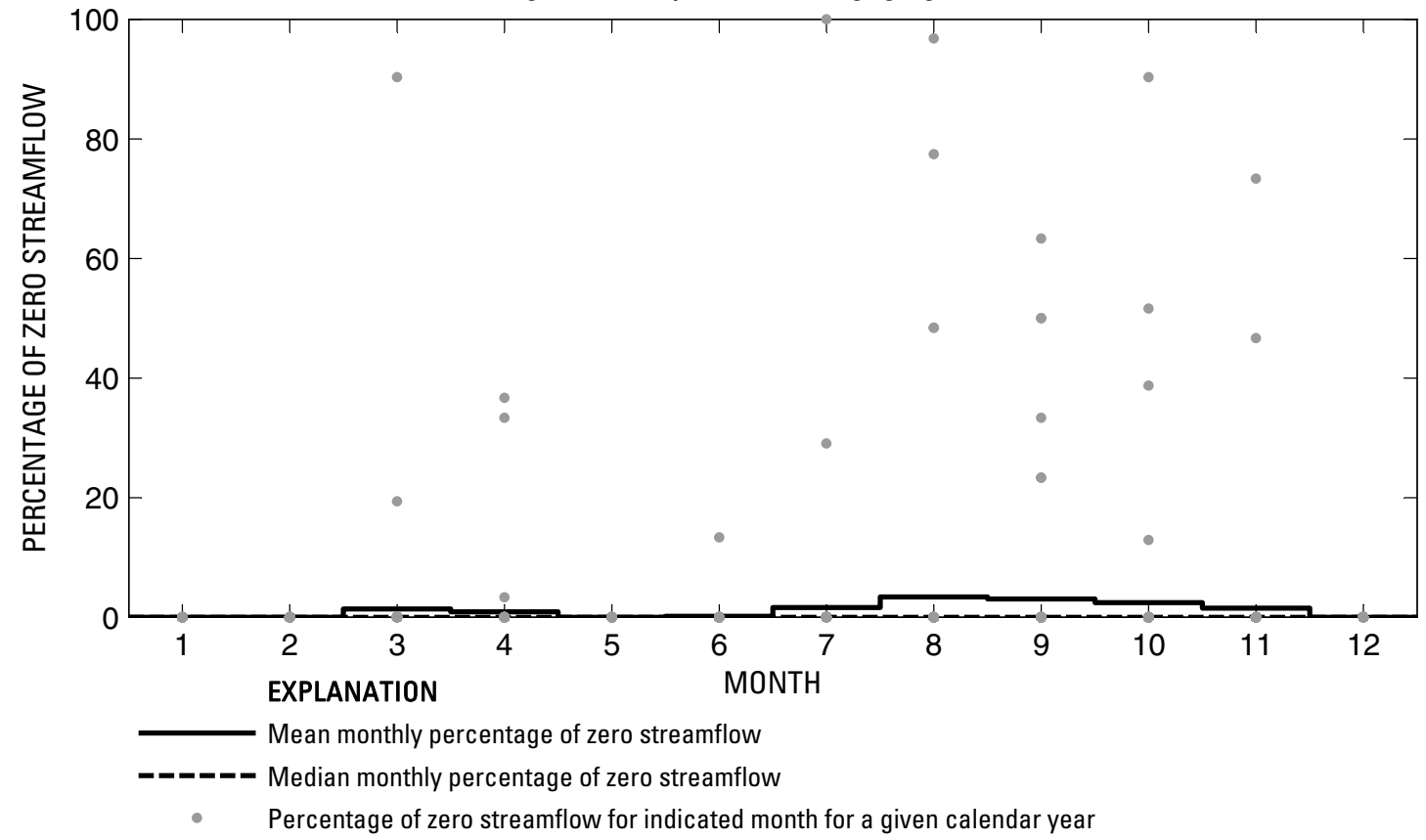

Figure 364. Analysis of percentage of zero daily mean streamflow for U.S. Geological Survey streamflow-gaging station 08089000 Brazos River near Palo Pinto, Texas. 

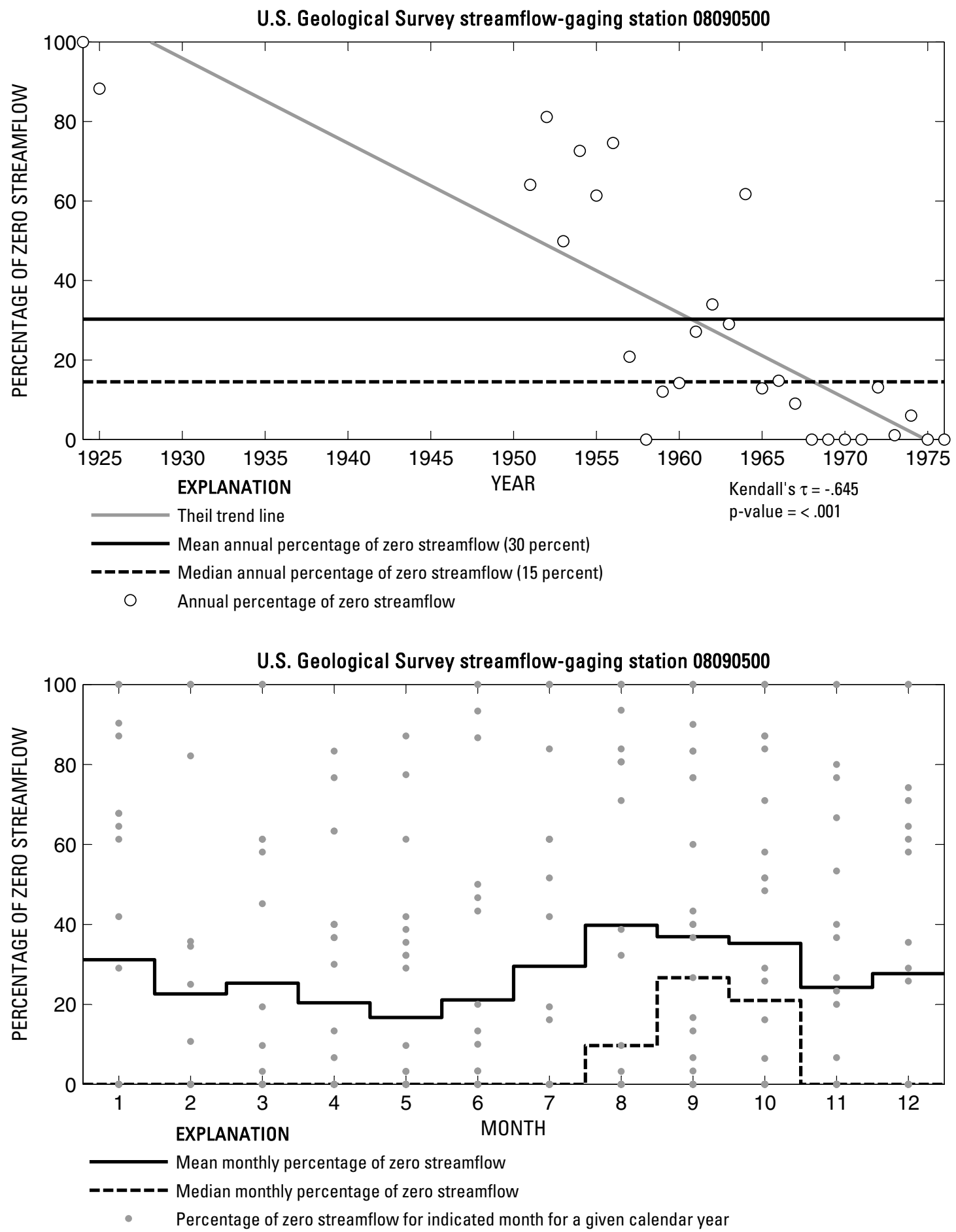

Figure 365. Analysis of percentage of zero daily mean streamflow for U.S. Geological Survey streamflow-gaging station 08090500 Palo Pinto Creek near Santo, Texas. 
U.S. Geological Survey streamflow-gaging station 08090800

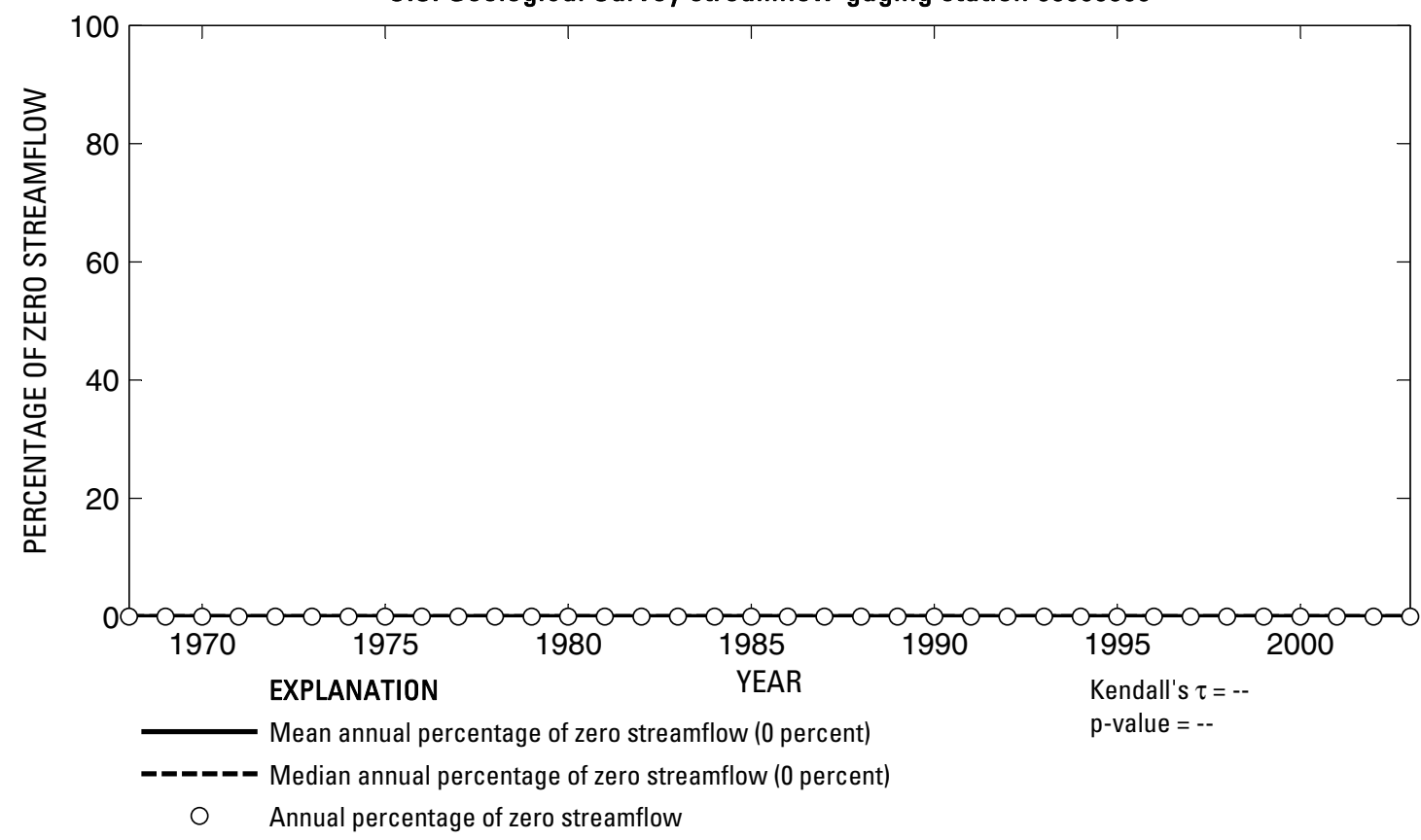

U.S. Geological Survey streamflow-gaging station 08090800

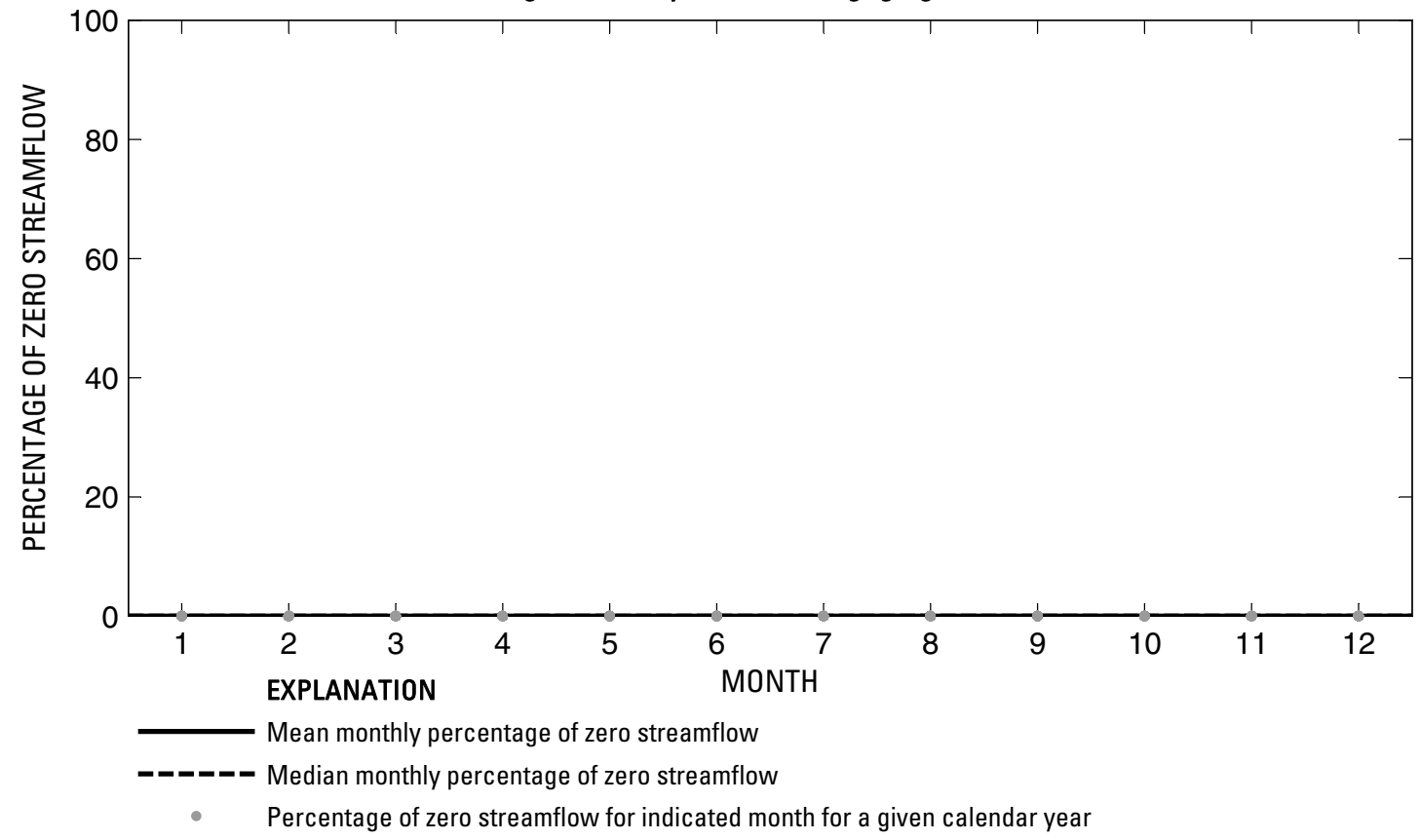

Figure 366. Analysis of percentage of zero daily mean streamflow for U.S. Geological Survey streamflow-gaging station 08090800 Brazos River near Dennis, Texas. 
U.S. Geological Survey streamflow-gaging station 08091000

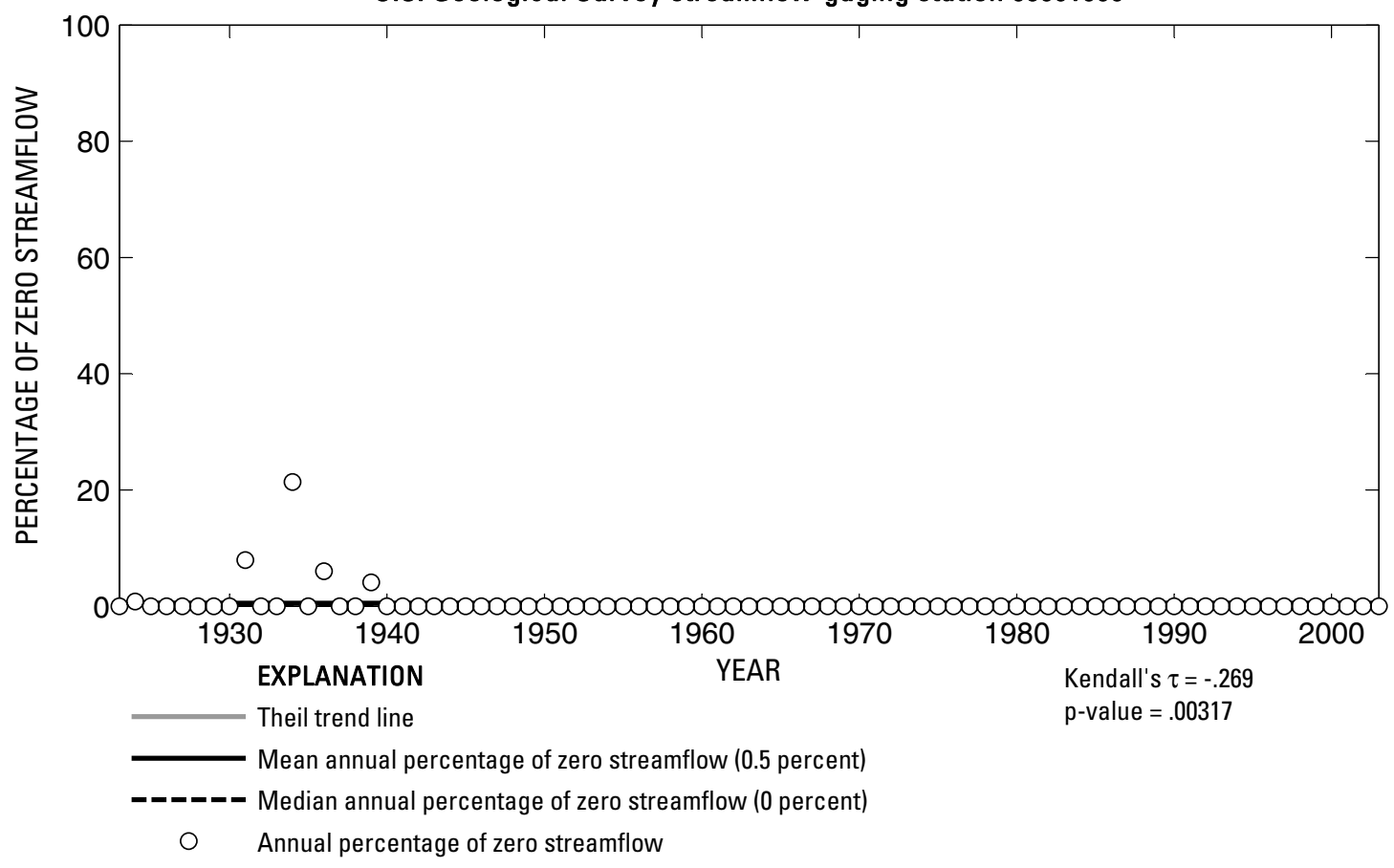

U.S. Geological Survey streamflow-gaging station 08091000

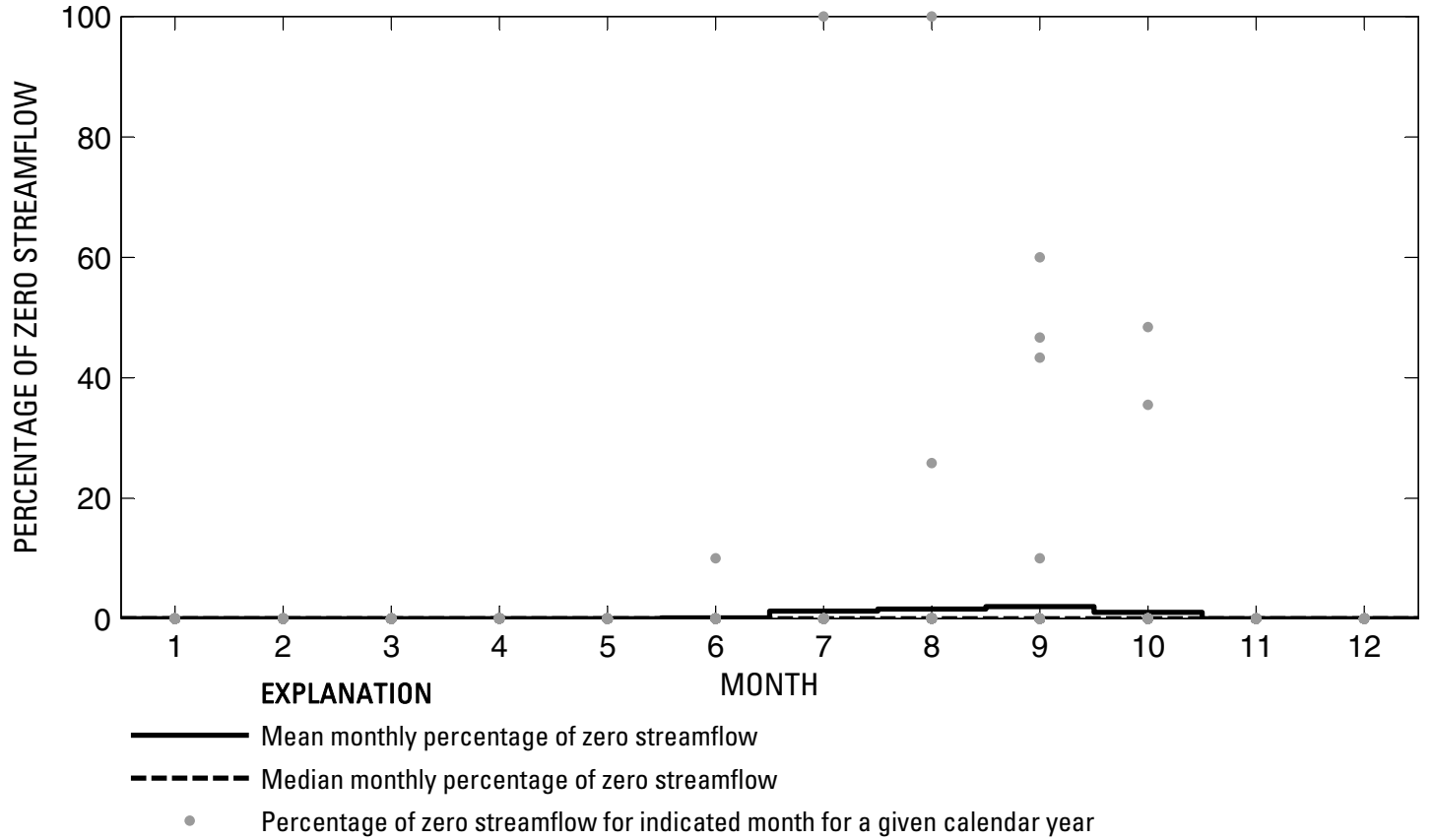

Figure 367. Analysis of percentage of zero daily mean streamflow for U.S. Geological Survey streamflow-gaging station 08091000 Brazos River near Glen Rose, Texas. 
U.S. Geological Survey streamflow-gaging station 08091500

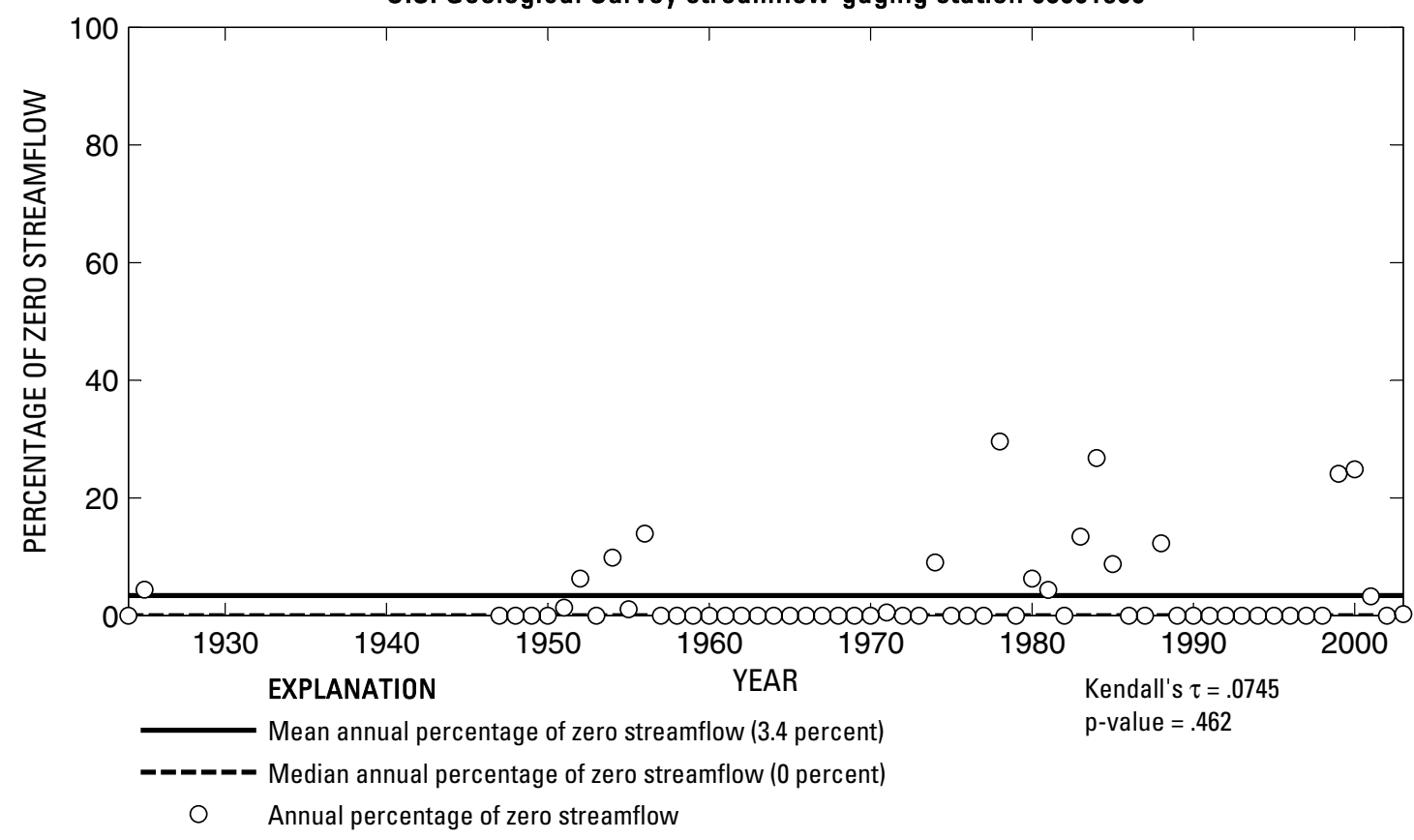

U.S. Geological Survey streamflow-gaging station 08091500

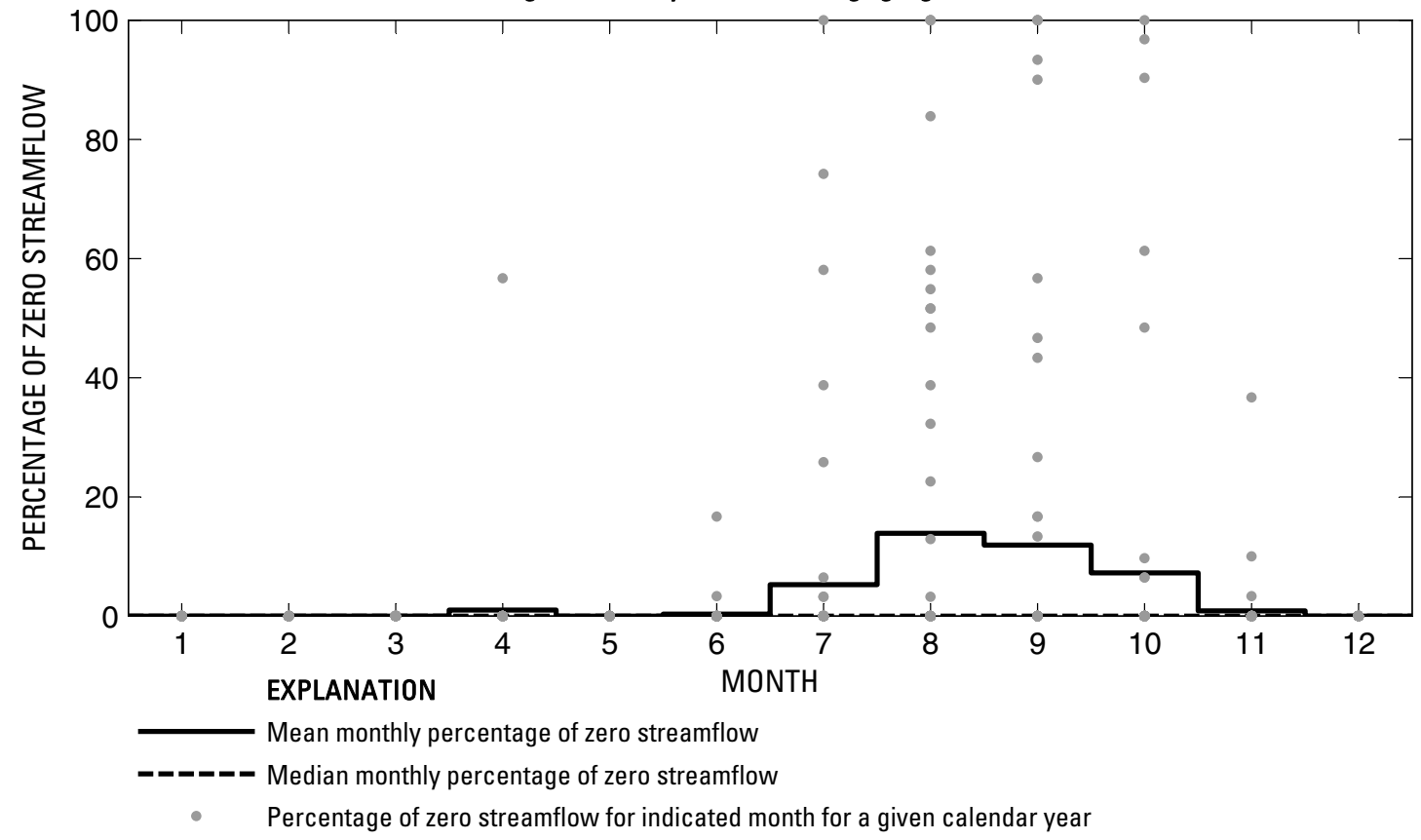

Figure 368. Analysis of percentage of zero daily mean streamflow for U.S. Geological Survey streamflow-gaging station 08091500 Paluxy River at Glen Rose, Texas. 
U.S. Geological Survey streamflow-gaging station 08091750

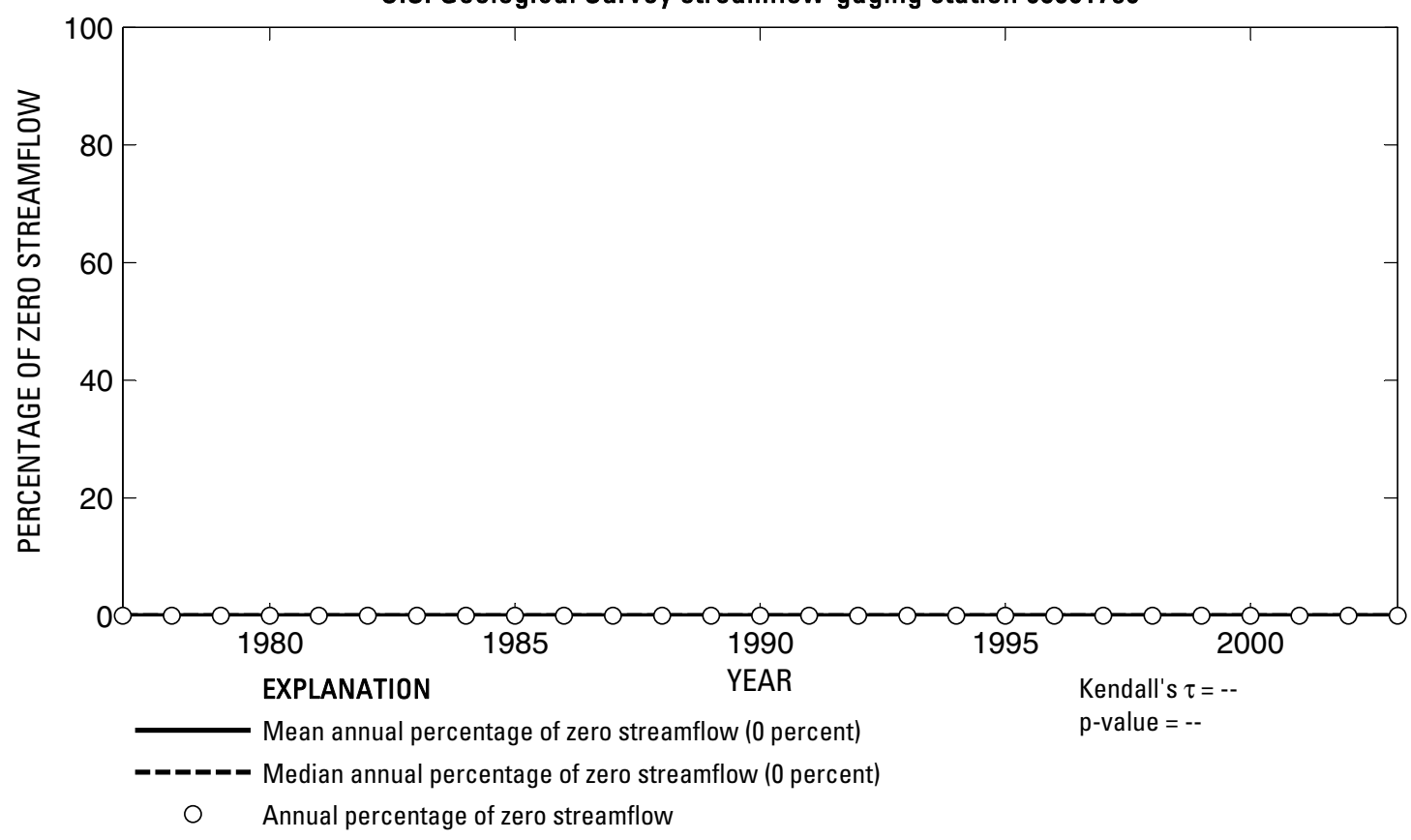

U.S. Geological Survey streamflow-gaging station 08091750

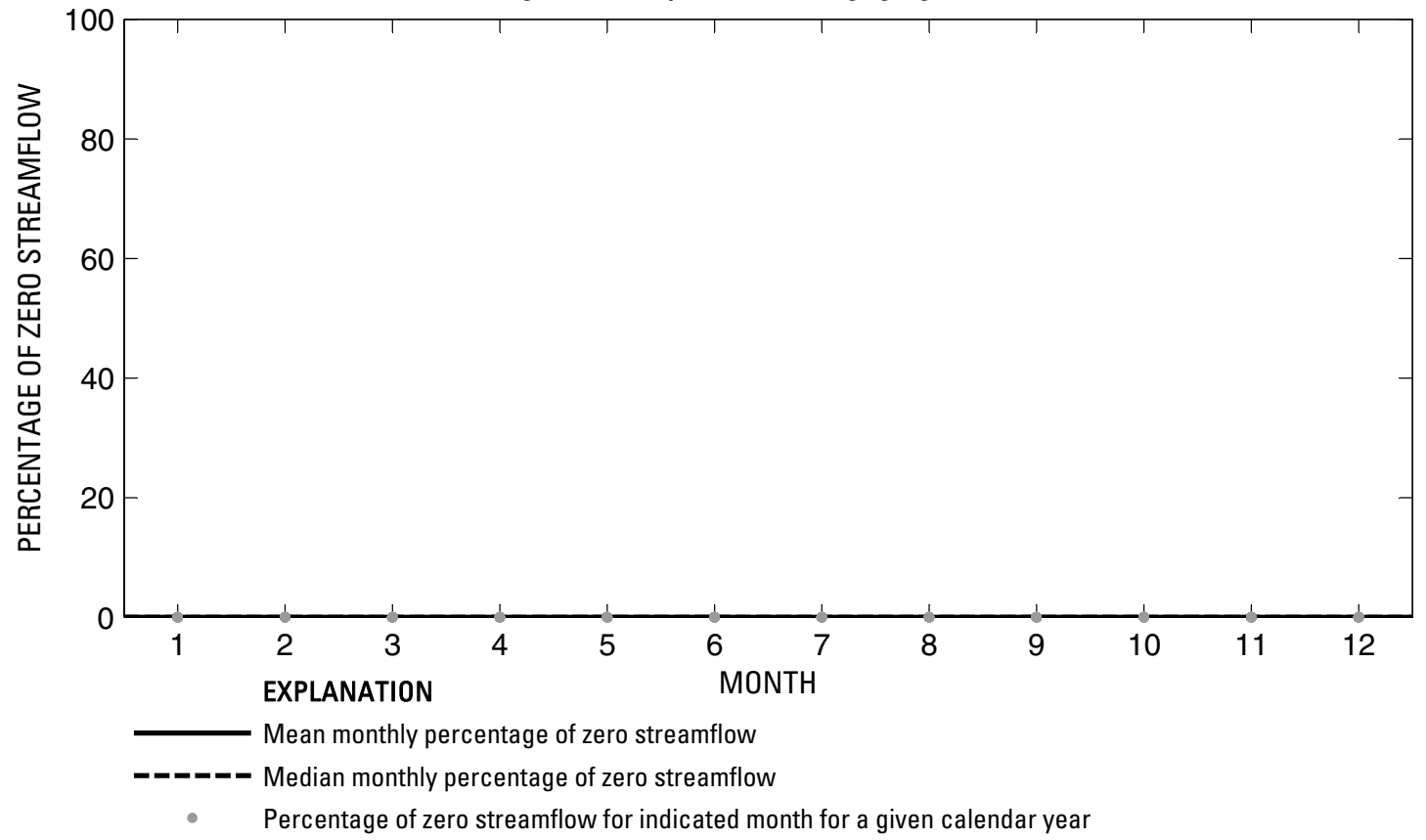

Figure 369. Analysis of percentage of zero daily mean streamflow for U.S. Geological Survey streamflow-gaging station 08091750 Squaw Creek near Glen Rose, Texas. 
U.S. Geological Survey streamflow-gaging station 08092000

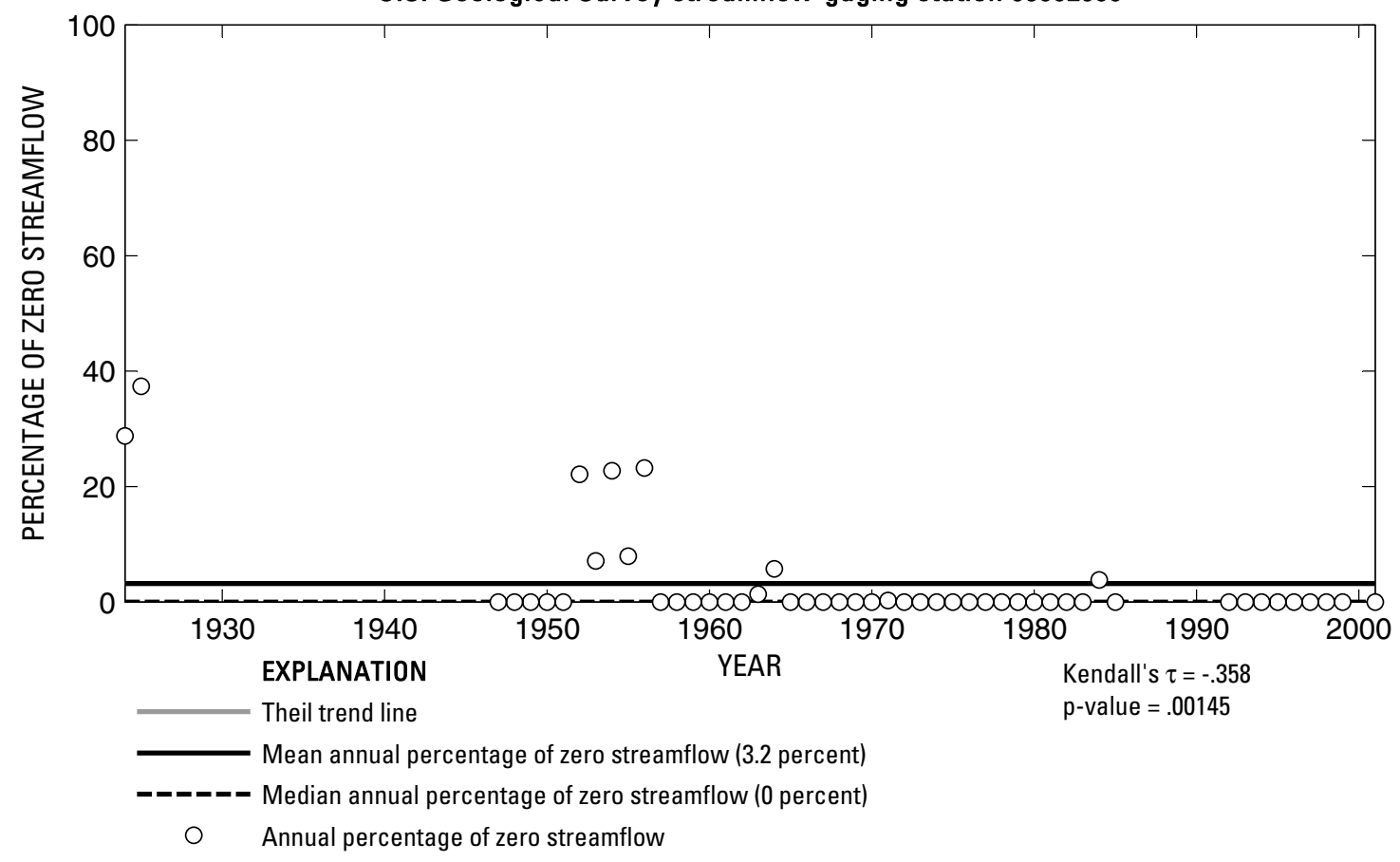

U.S. Geological Survey streamflow-gaging station 08092000

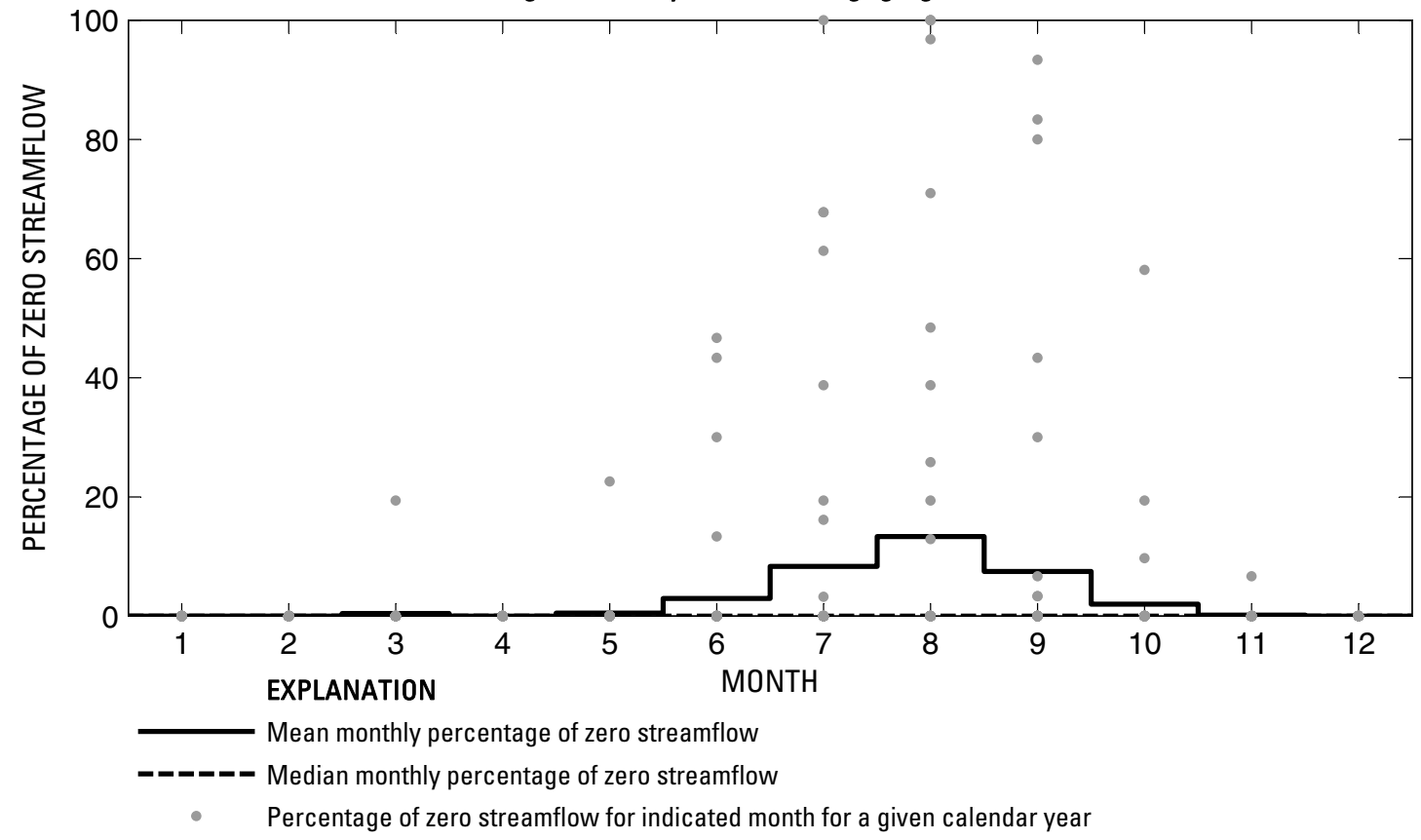

Figure 370. Analysis of percentage of zero daily mean streamflow for U.S. Geological Survey streamflow-gaging station 08092000 Nolan River at Blum, Texas. 
U.S. Geological Survey streamflow-gaging station 08092600

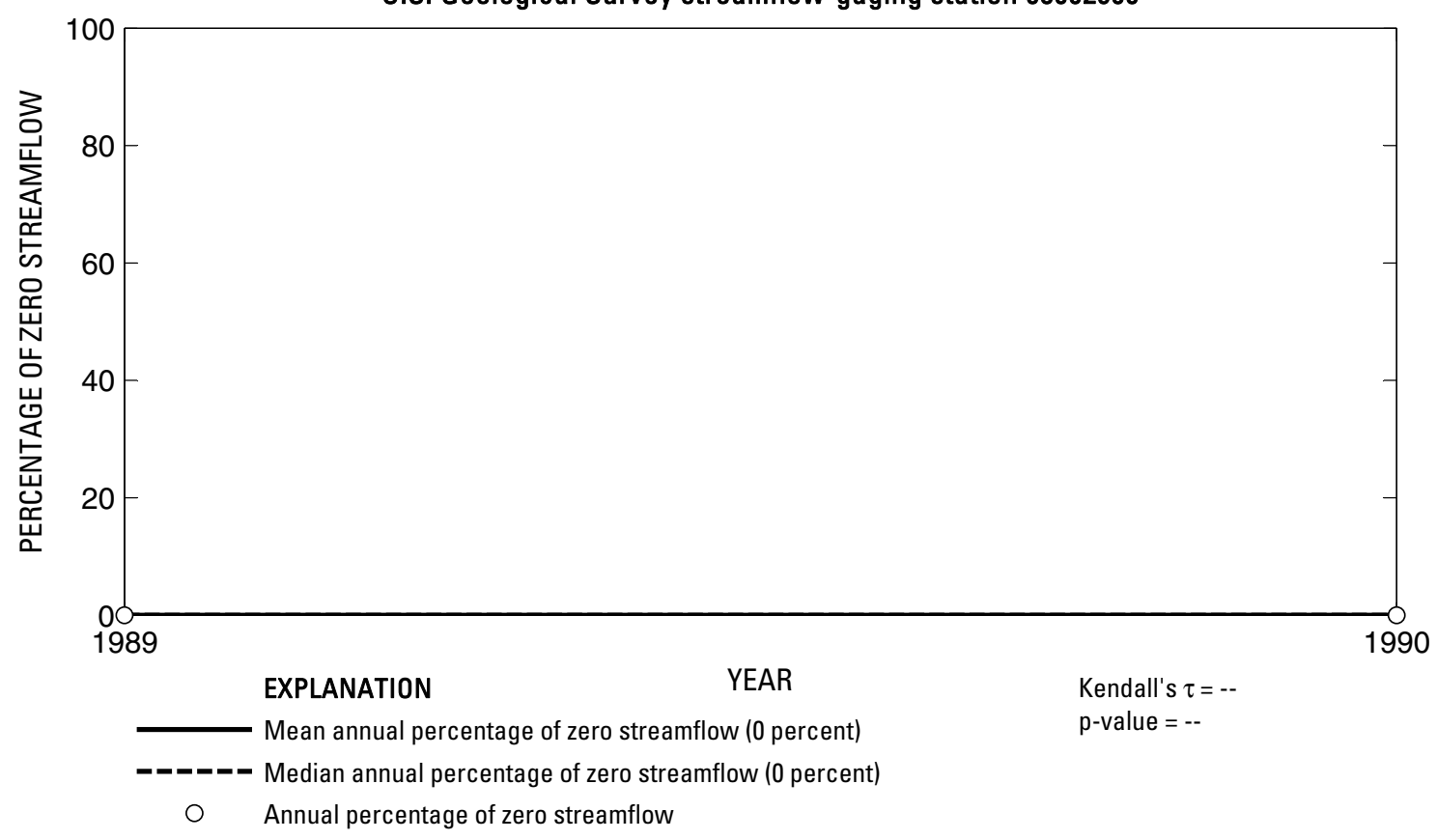

U.S. Geological Survey streamflow-gaging station 08092600

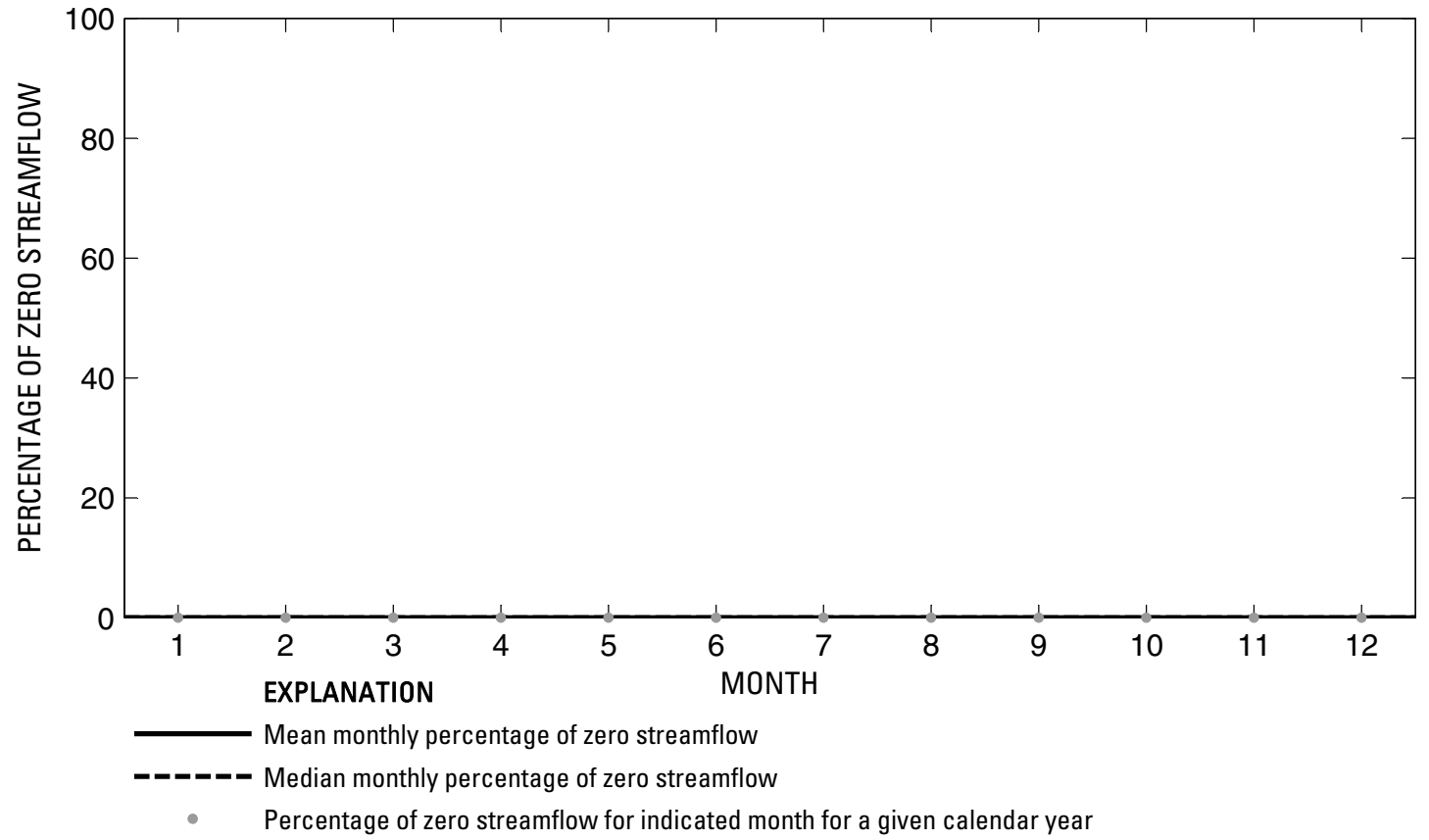

Figure 371. Analysis of percentage of zero daily mean streamflow for U.S. Geological Survey streamflow-gaging station 08092600 Brazos River at Whitney Dam near Whitney, Texas. 
U.S. Geological Survey streamflow-gaging station 08093100

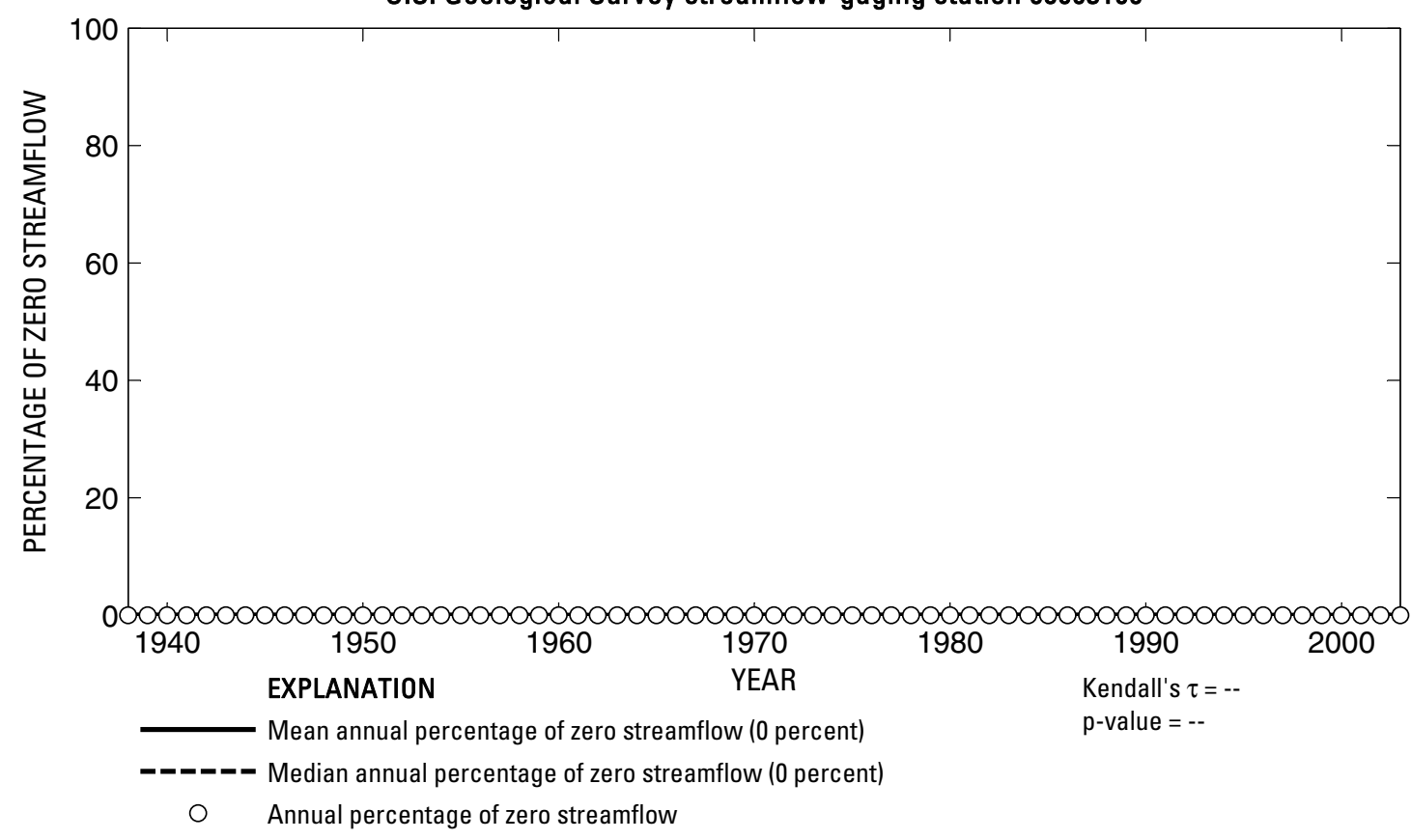

U.S. Geological Survey streamflow-gaging station 08093100

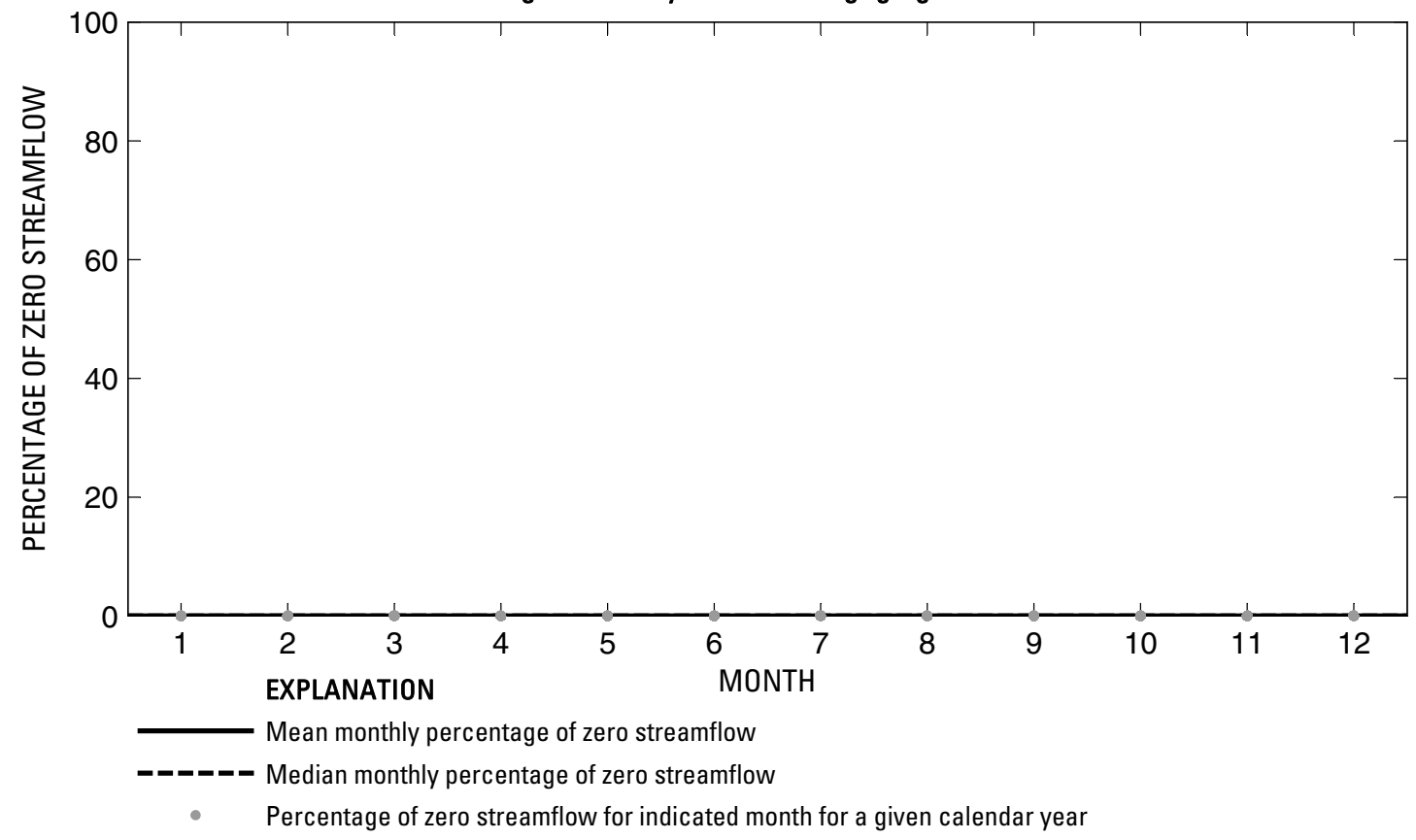

Figure 372. Analysis of percentage of zero daily mean streamflow for U.S. Geological Survey streamflow-gaging station 08093100 Brazos River near Aquilla, Texas. 
U.S. Geological Survey streamflow-gaging station 08093250

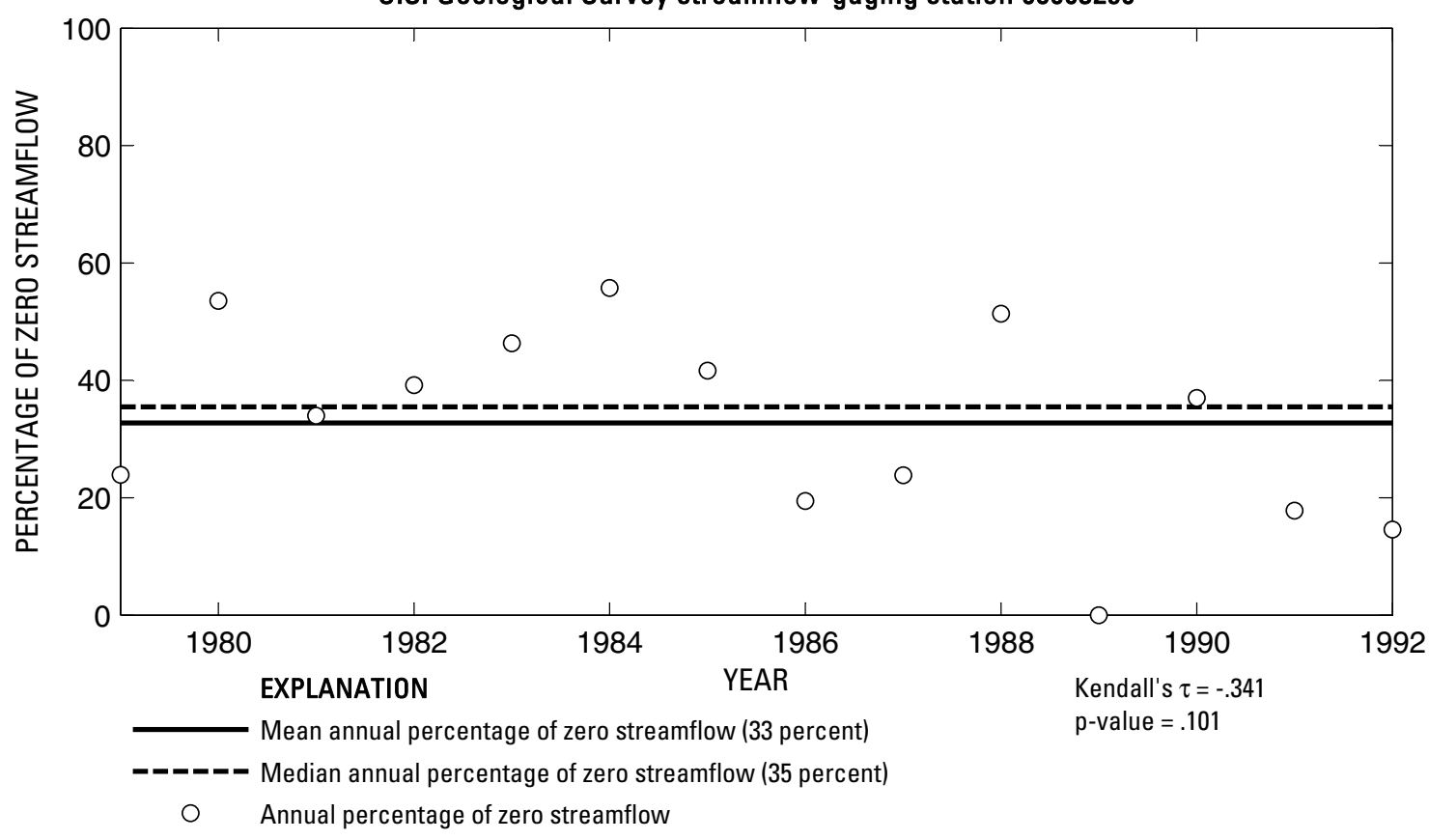

U.S. Geological Survey streamflow-gaging station 08093250

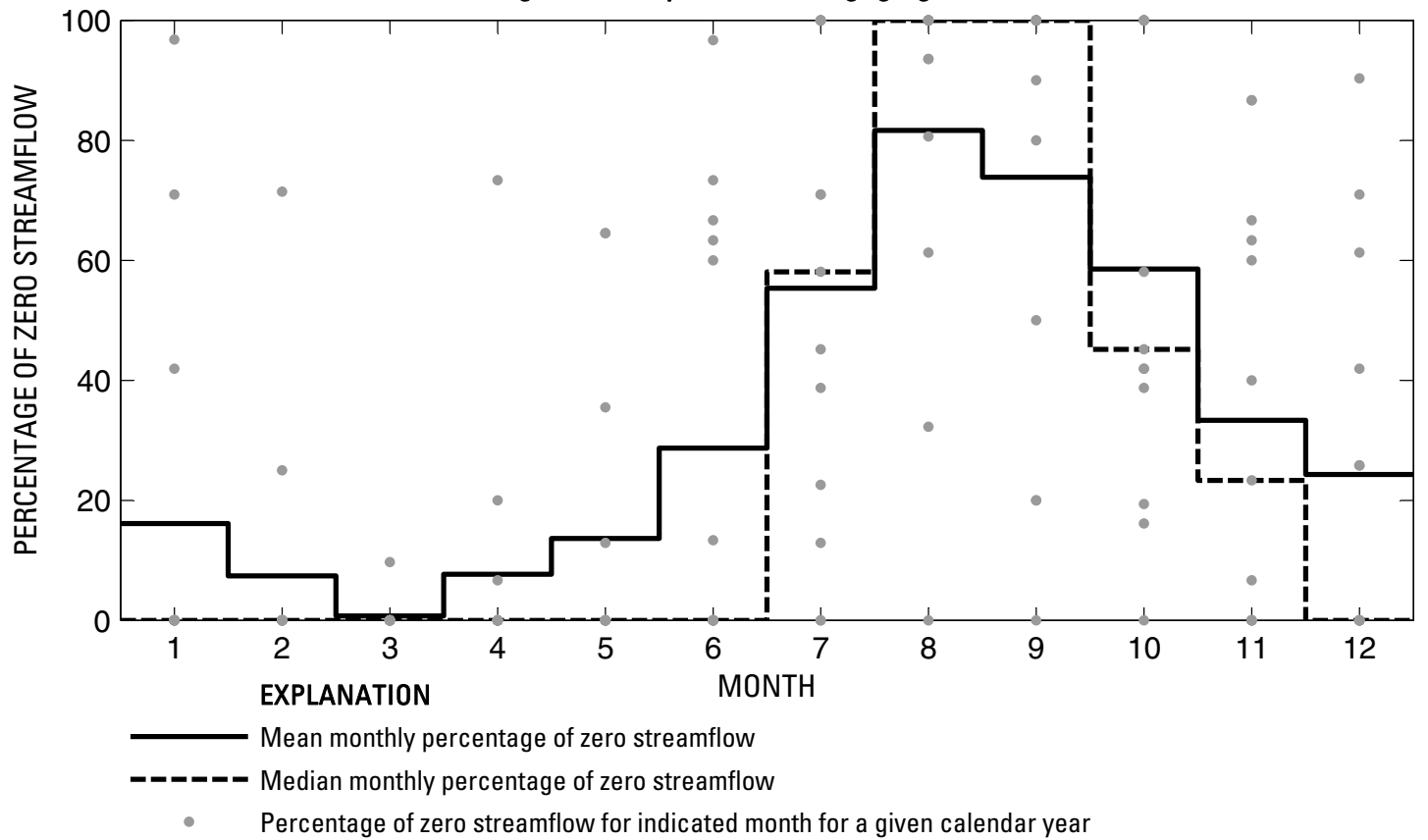

Figure 373. Analysis of percentage of zero daily mean streamflow for U.S. Geological Survey streamflow-gaging station 08093250 Hackberry Creek at Hillsboro, Texas. 
U.S. Geological Survey streamflow-gaging station 08093360

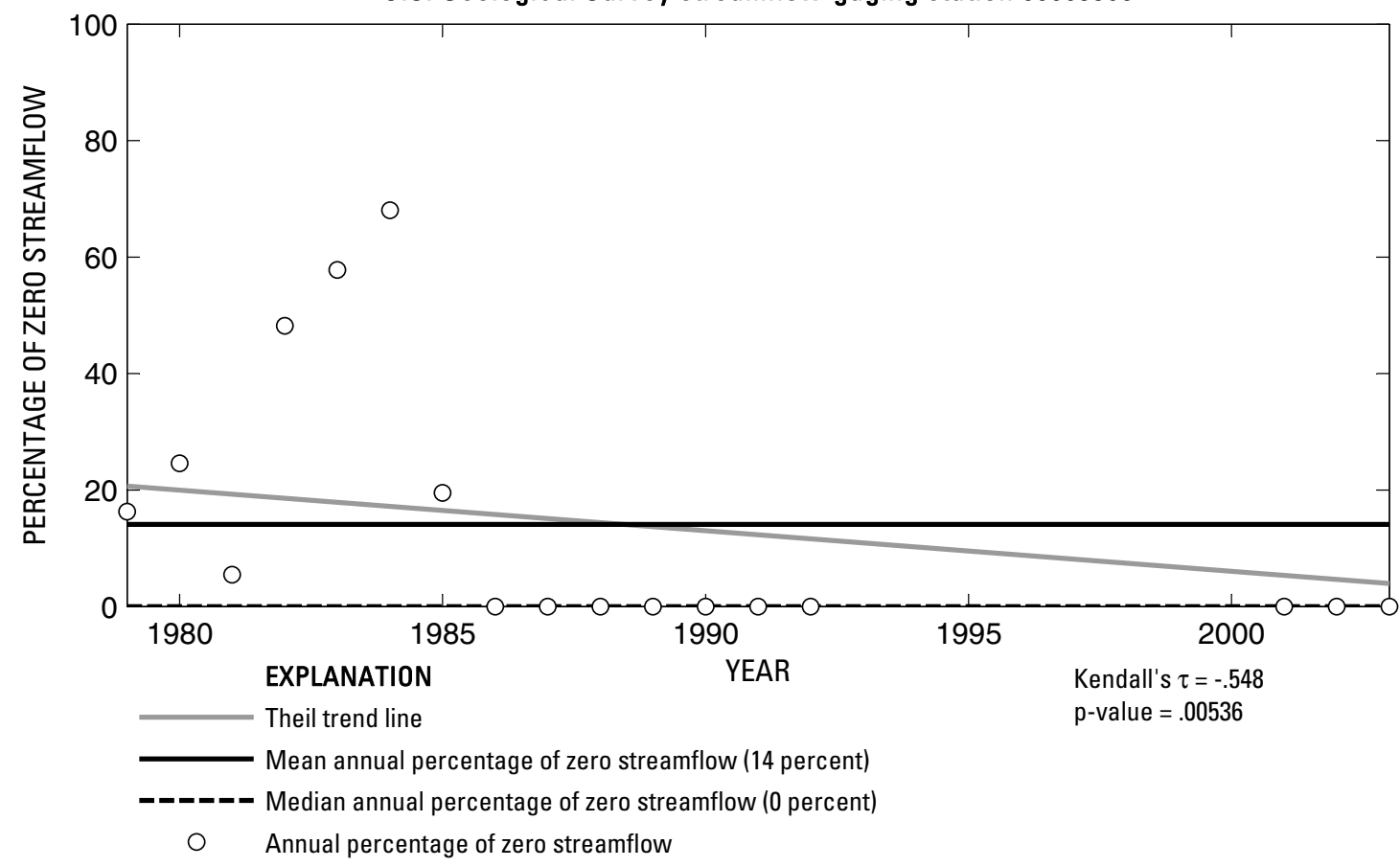

U.S. Geological Survey streamflow-gaging station 08093360

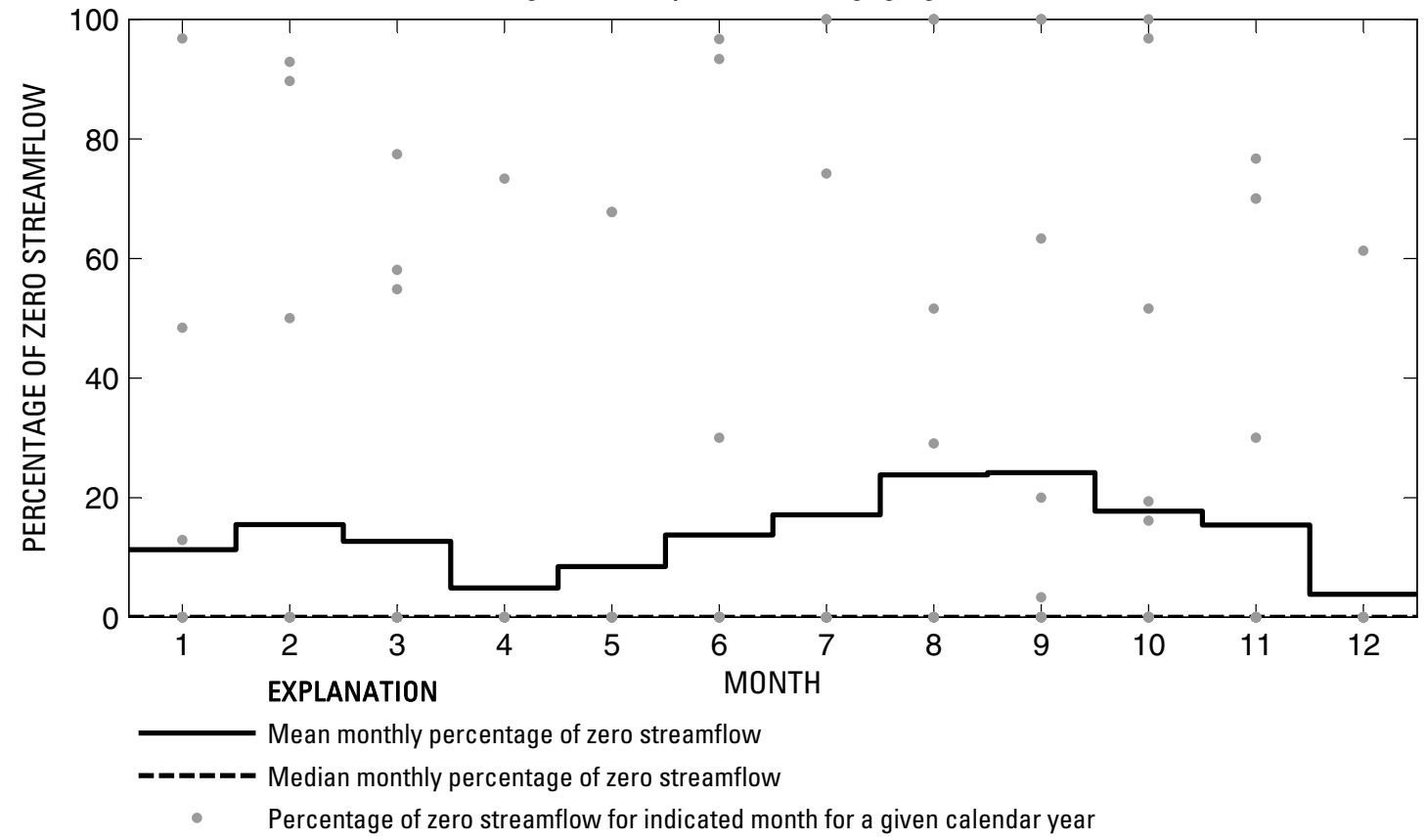

Figure 374. Analysis of percentage of zero daily mean streamflow for U.S. Geological Survey streamflow-gaging station 08093360 Aquilla Creek above Aquilla, Texas. 


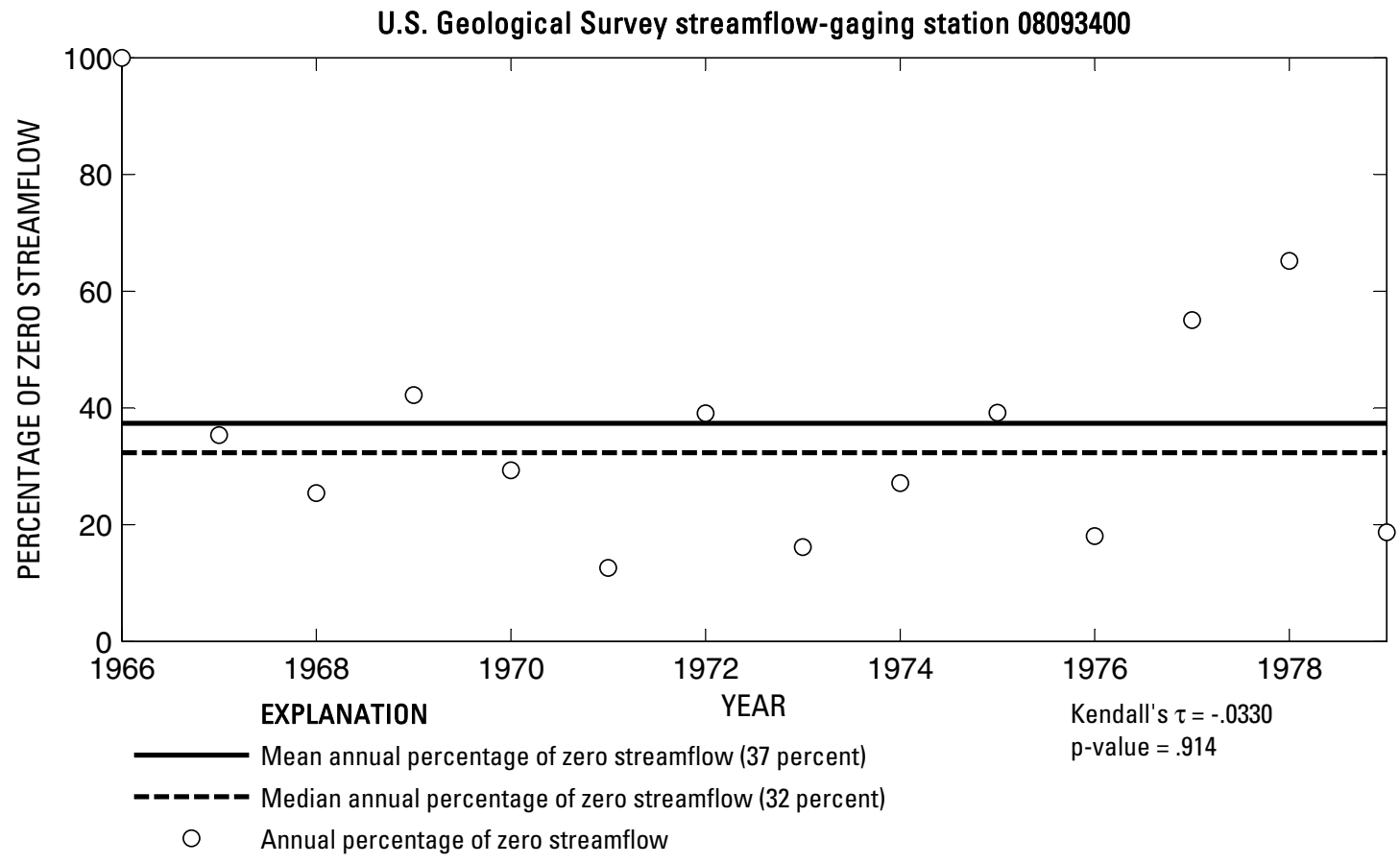

U.S. Geological Survey streamflow-gaging station 08093400

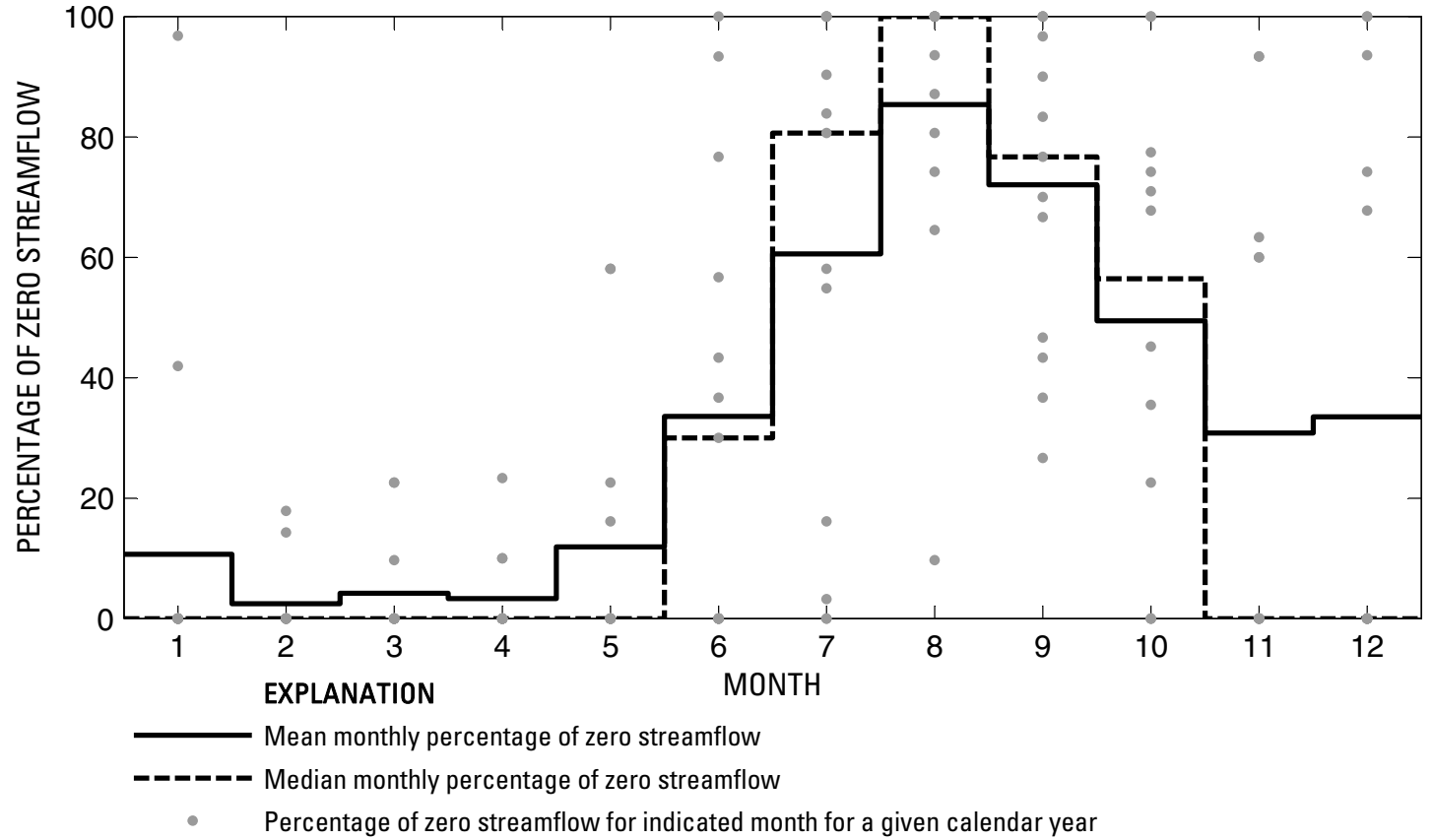

Figure 375. Analysis of percentage of zero daily mean streamflow for U.S. Geological Survey streamflow-gaging station 08093400 Cobb Creek near Abbott, Texas. 
U.S. Geological Survey streamflow-gaging station 08093500

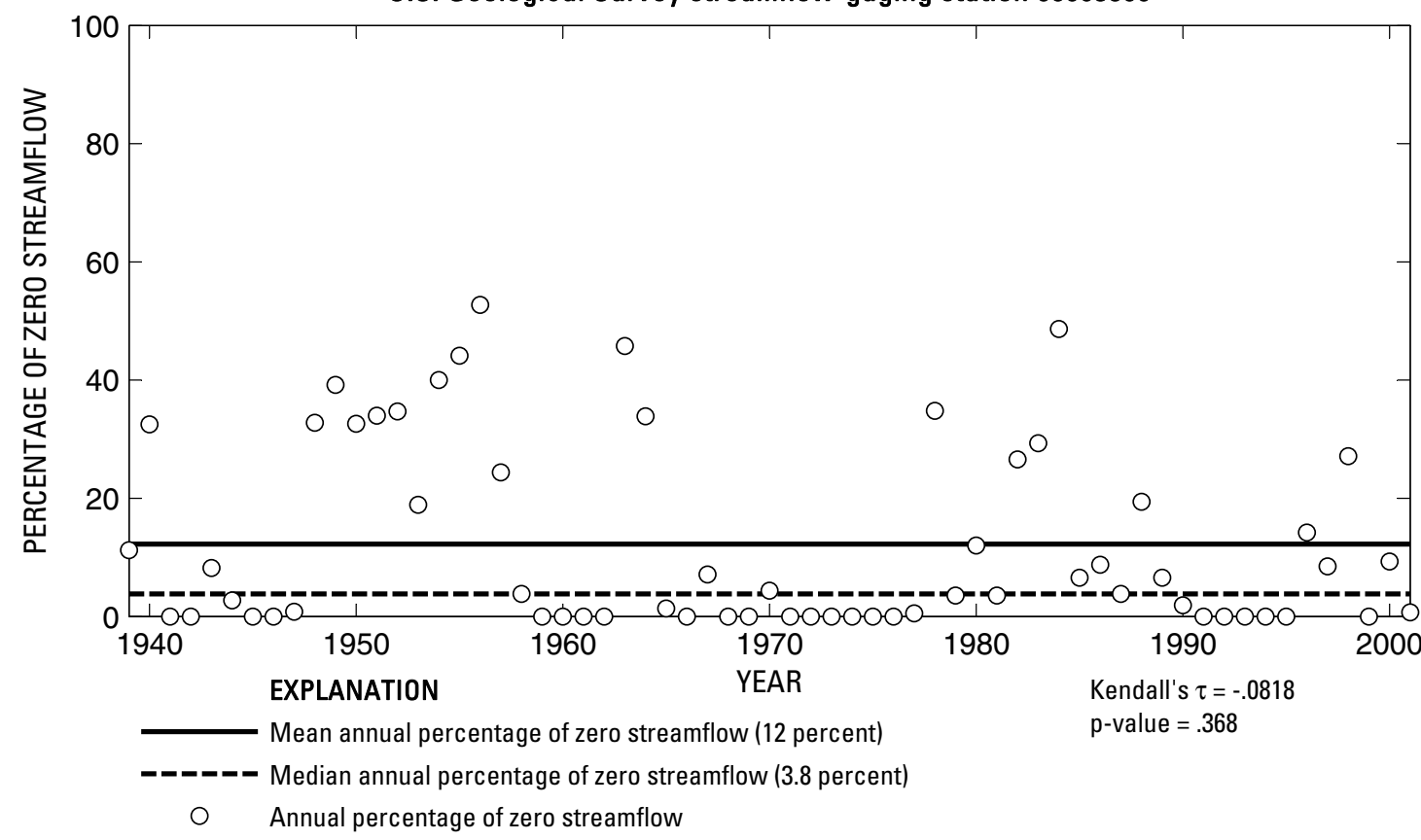

U.S. Geological Survey streamflow-gaging station 08093500

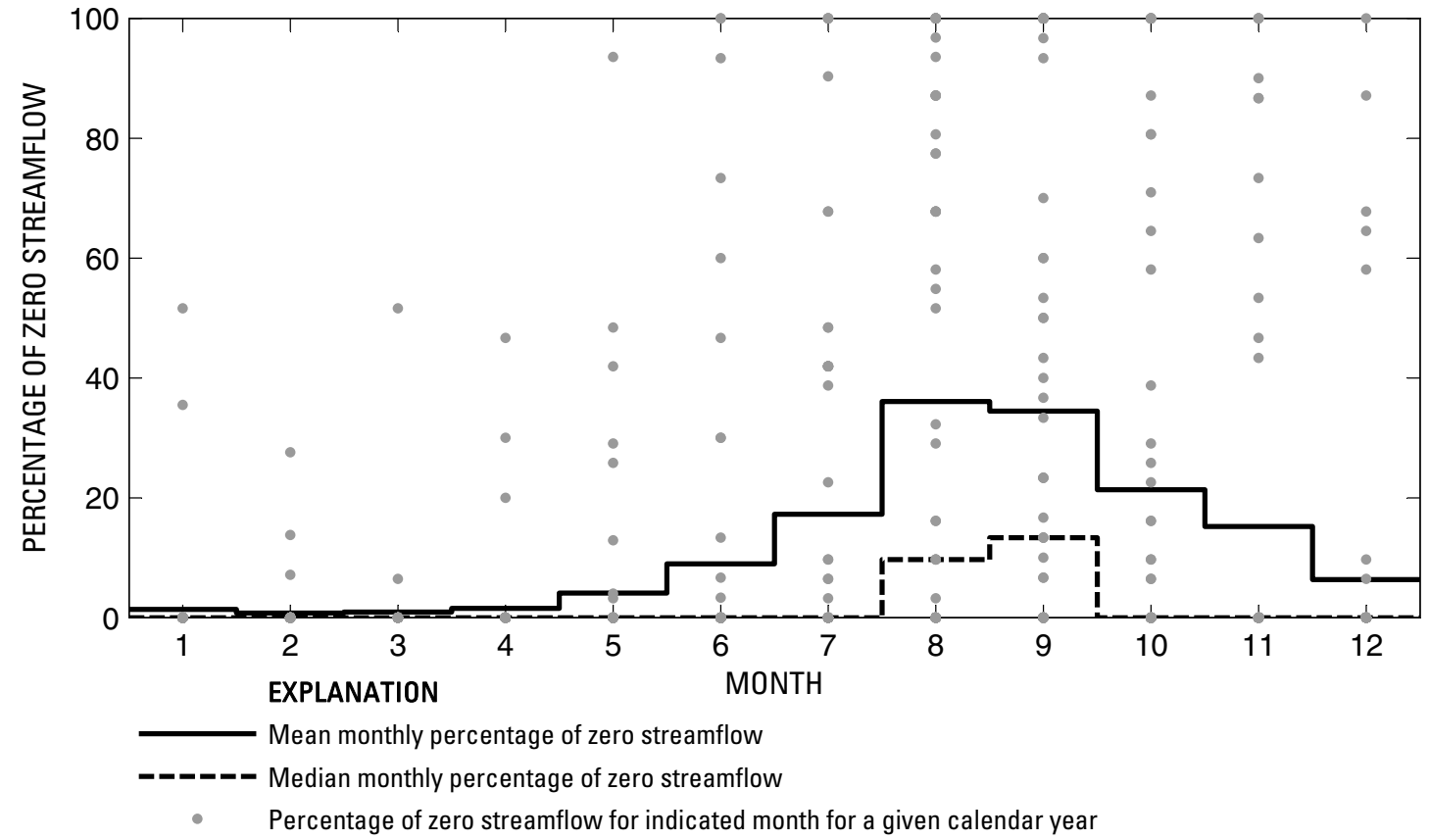

Figure 376. Analysis of percentage of zero daily mean streamflow for U.S. Geological Survey streamflow-gaging station 08093500 Aquilla Creek near Aquilla, Texas.

Index of Station Numbers 719 
U.S. Geological Survey streamflow-gaging station 08093700

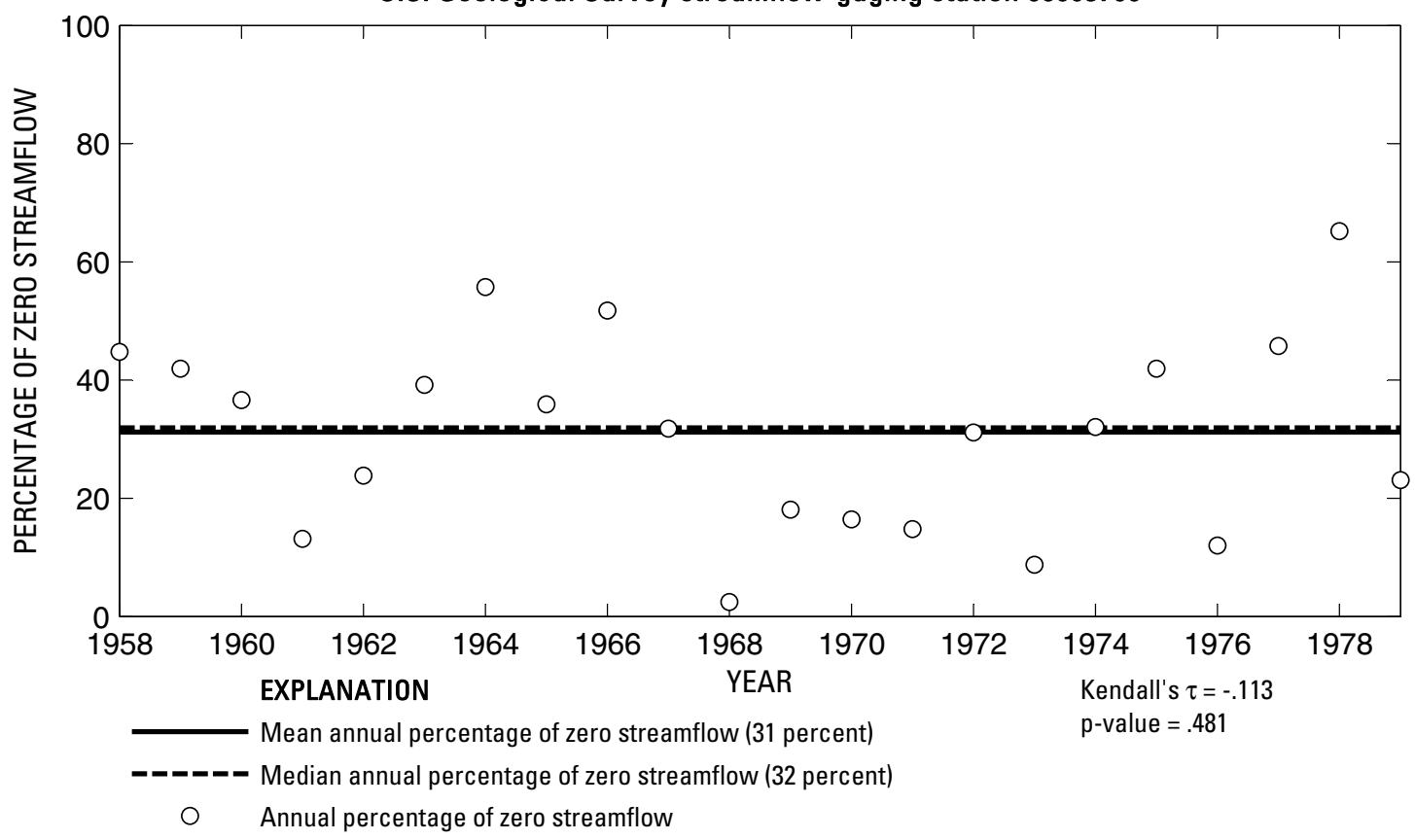

U.S. Geological Survey streamflow-gaging station 08093700

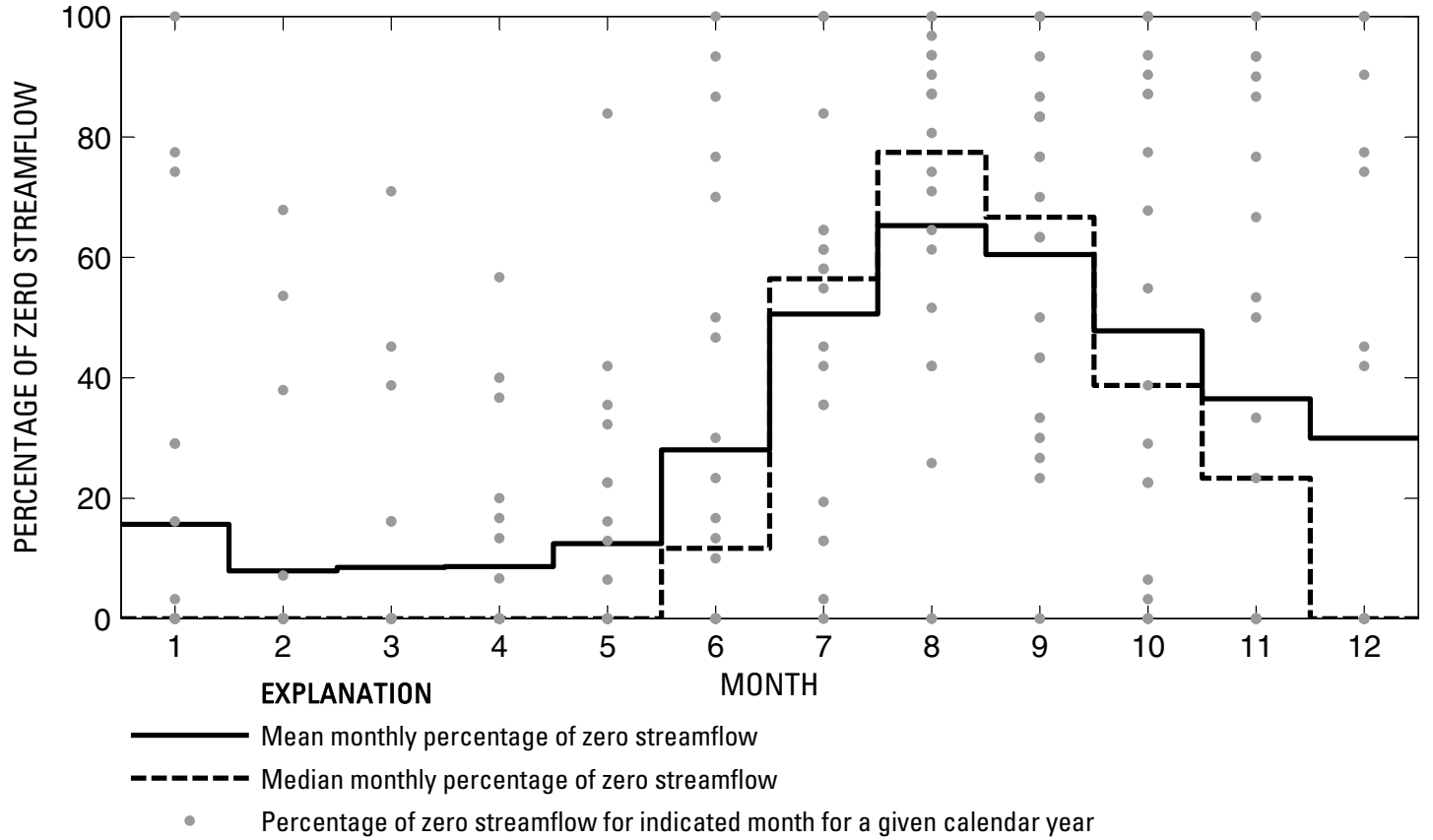

Figure 377. Analysis of percentage of zero daily mean streamflow for U.S. Geological Survey streamflow-gaging station 08093700 North Bosque River at Stephenville, Texas. 
U.S. Geological Survey streamflow-gaging station 08094800

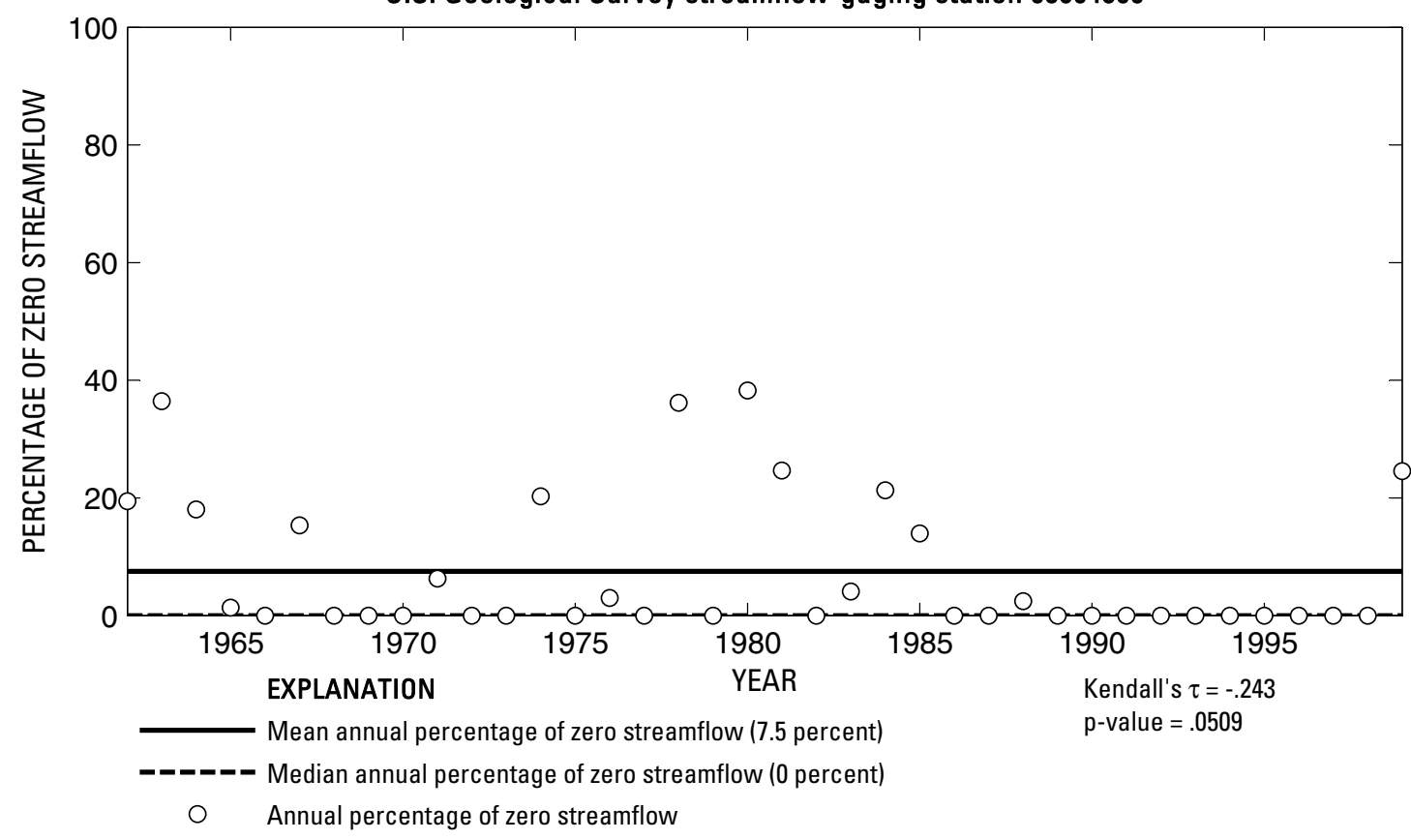

U.S. Geological Survey streamflow-gaging station 08094800

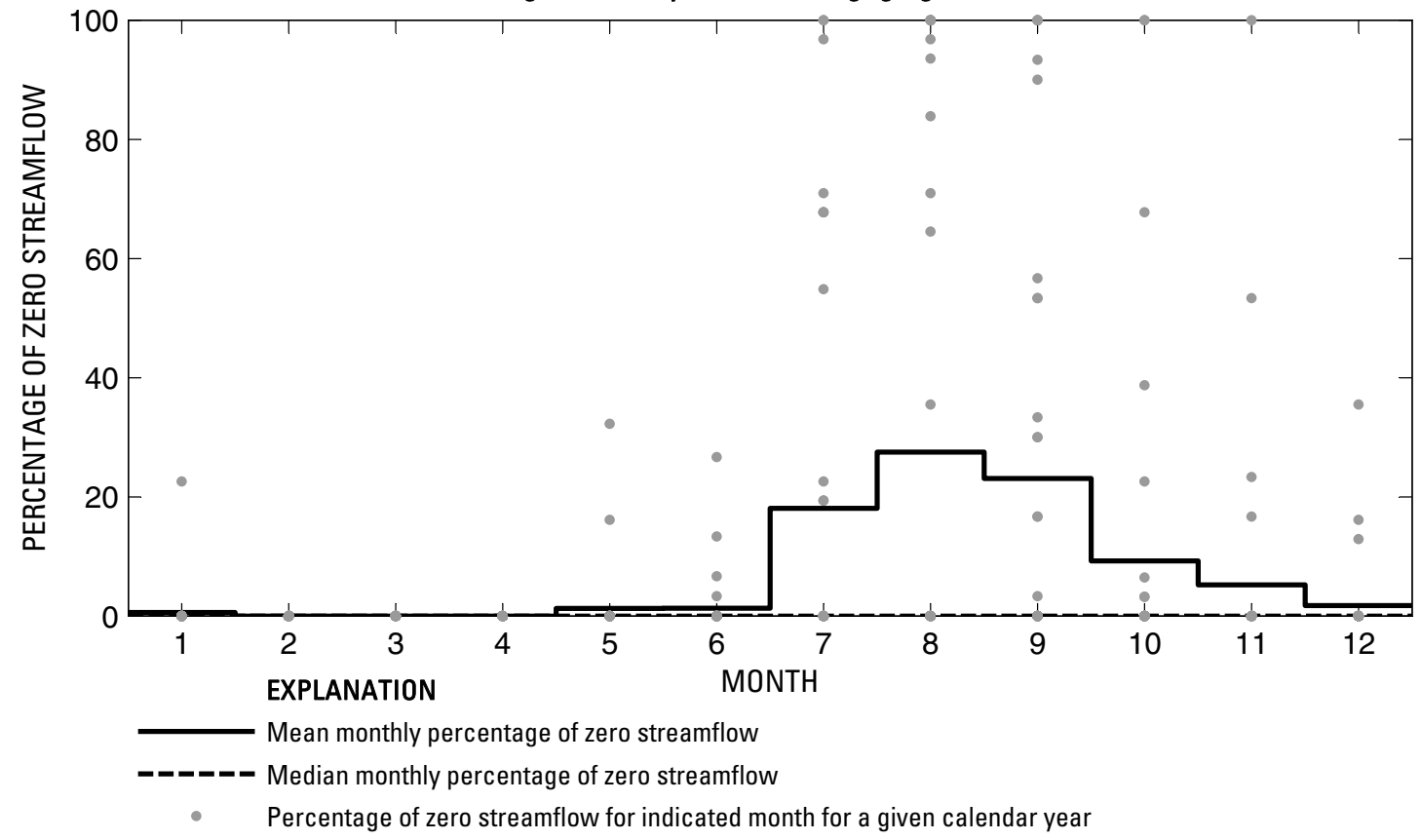

Figure 378. Analysis of percentage of zero daily mean streamflow for U.S. Geological Survey streamflow-gaging station 08094800 North Bosque River at Hico, Texas.

Index of Station Numbers 719 


\section{U.S. Geological Survey streamflow-gaging station 08095000}

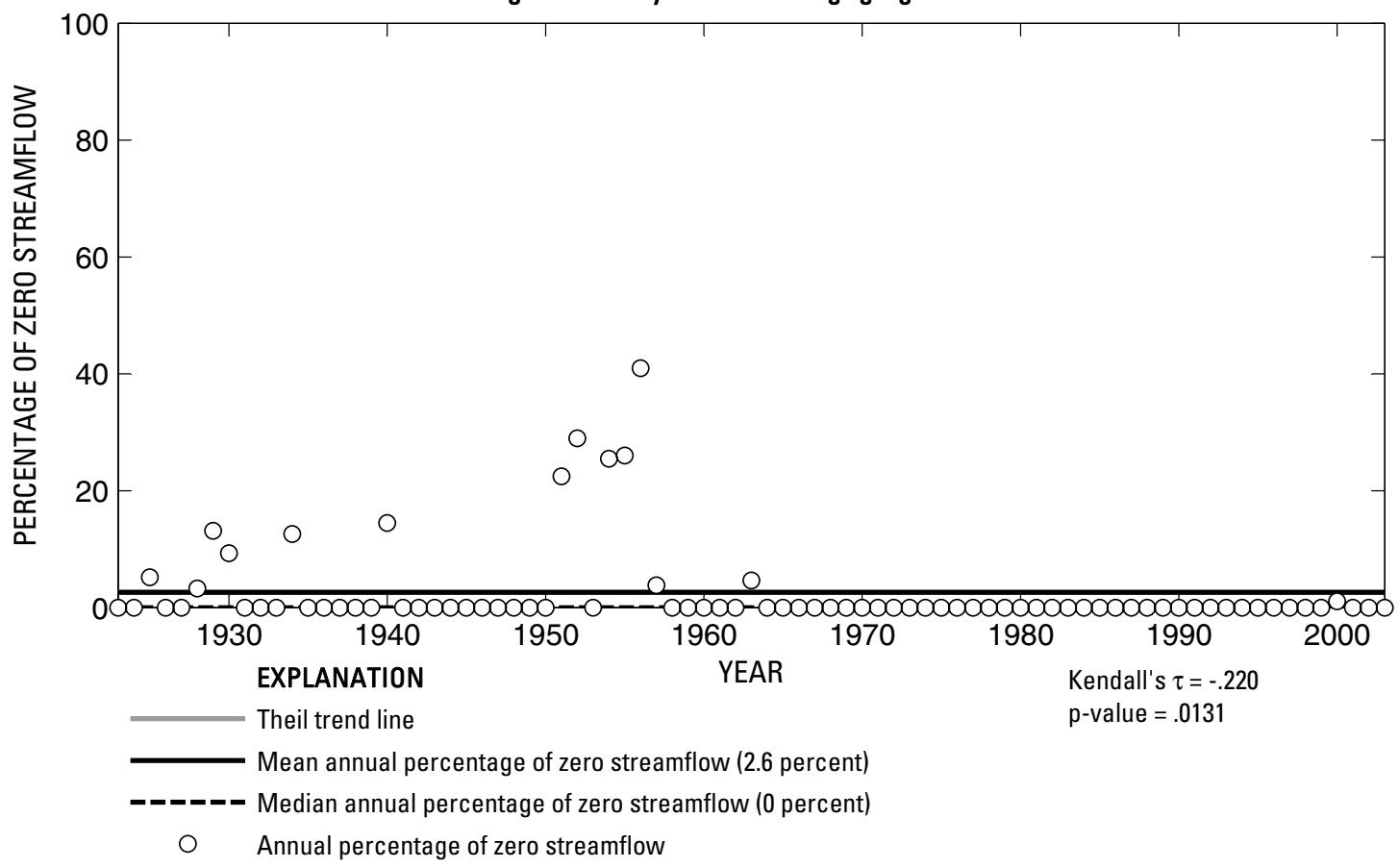

U.S. Geological Survey streamflow-gaging station 08095000

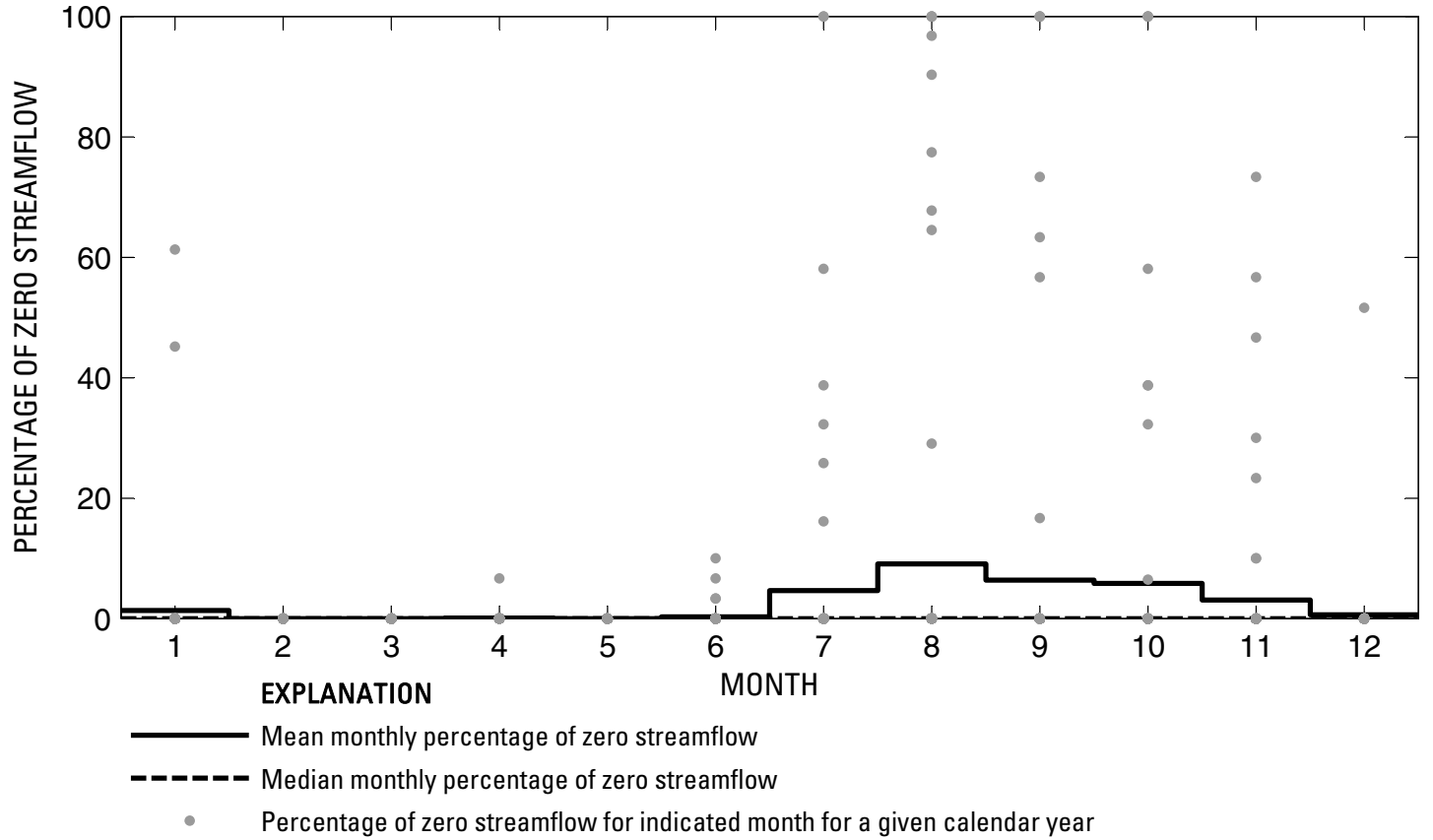

Figure 379. Analysis of percentage of zero daily mean streamflow for U.S. Geological Survey streamflow-gaging station 08095000 North Bosque River near Clifton, Texas. 
U.S. Geological Survey streamflow-gaging station 08095200

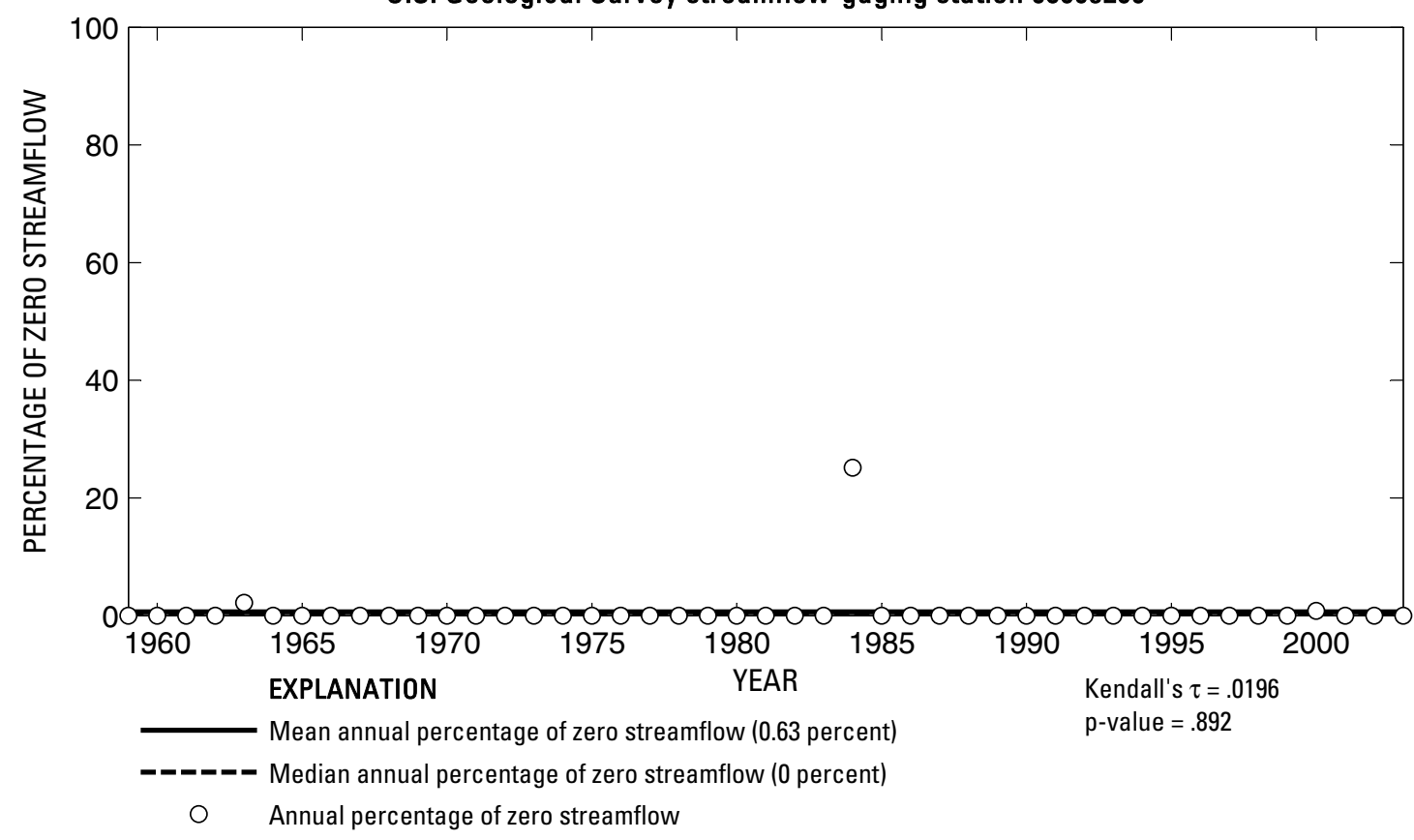

U.S. Geological Survey streamflow-gaging station 08095200

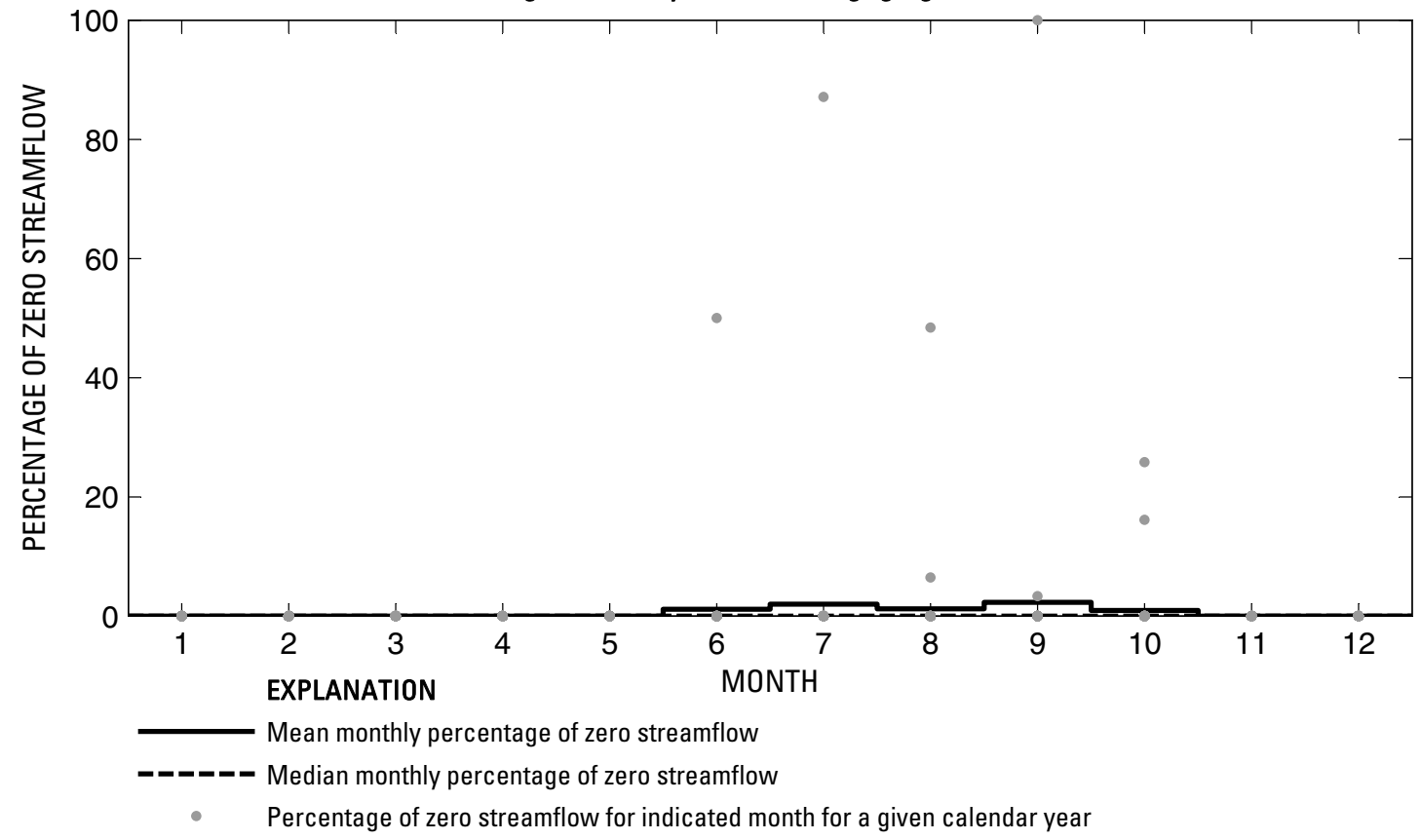

Figure 380. Analysis of percentage of zero daily mean streamflow for U.S. Geological Survey streamflow-gaging station 08095200 North Bosque River at Valley Mills, Texas. 


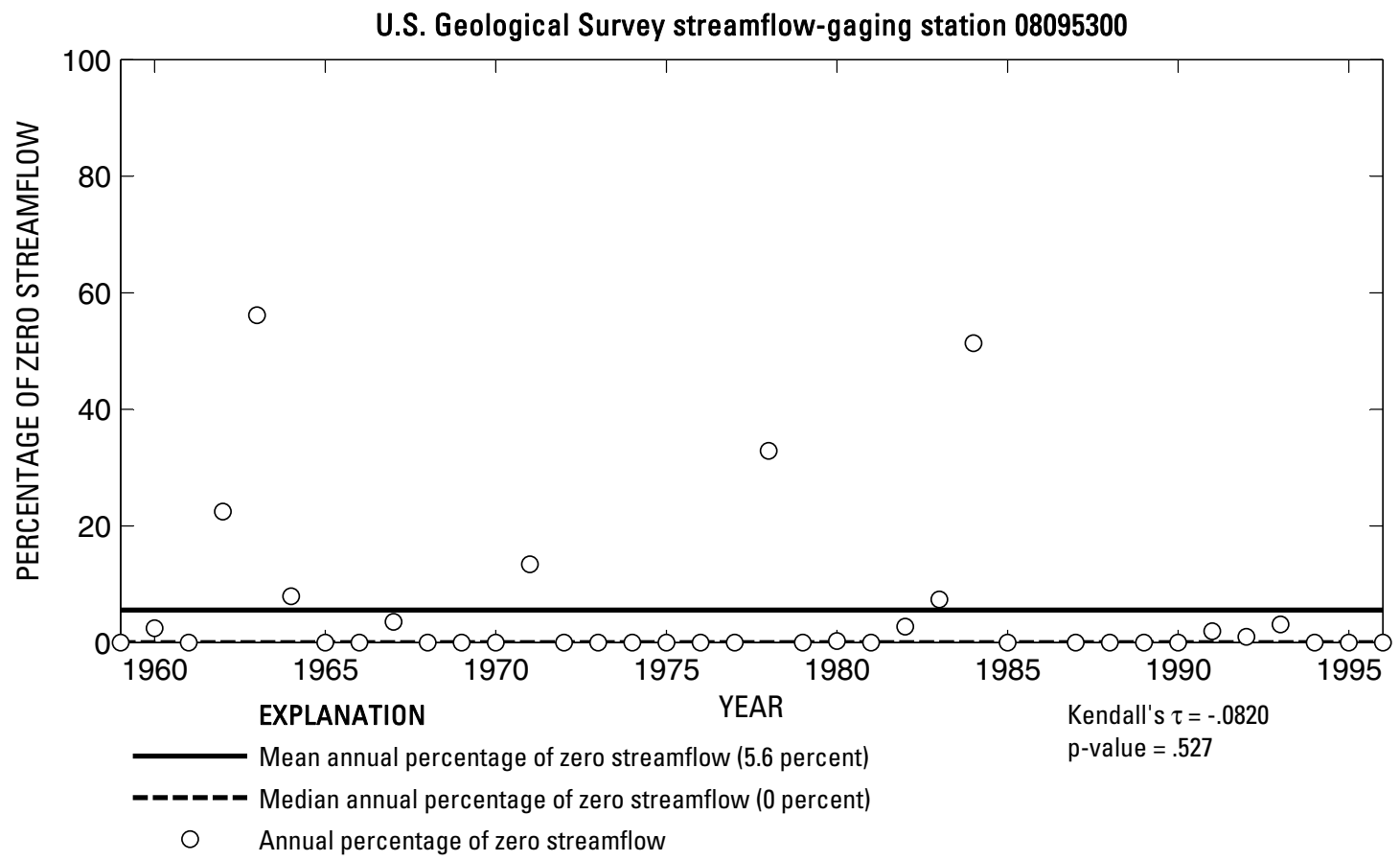

U.S. Geological Survey streamflow-gaging station 08095300

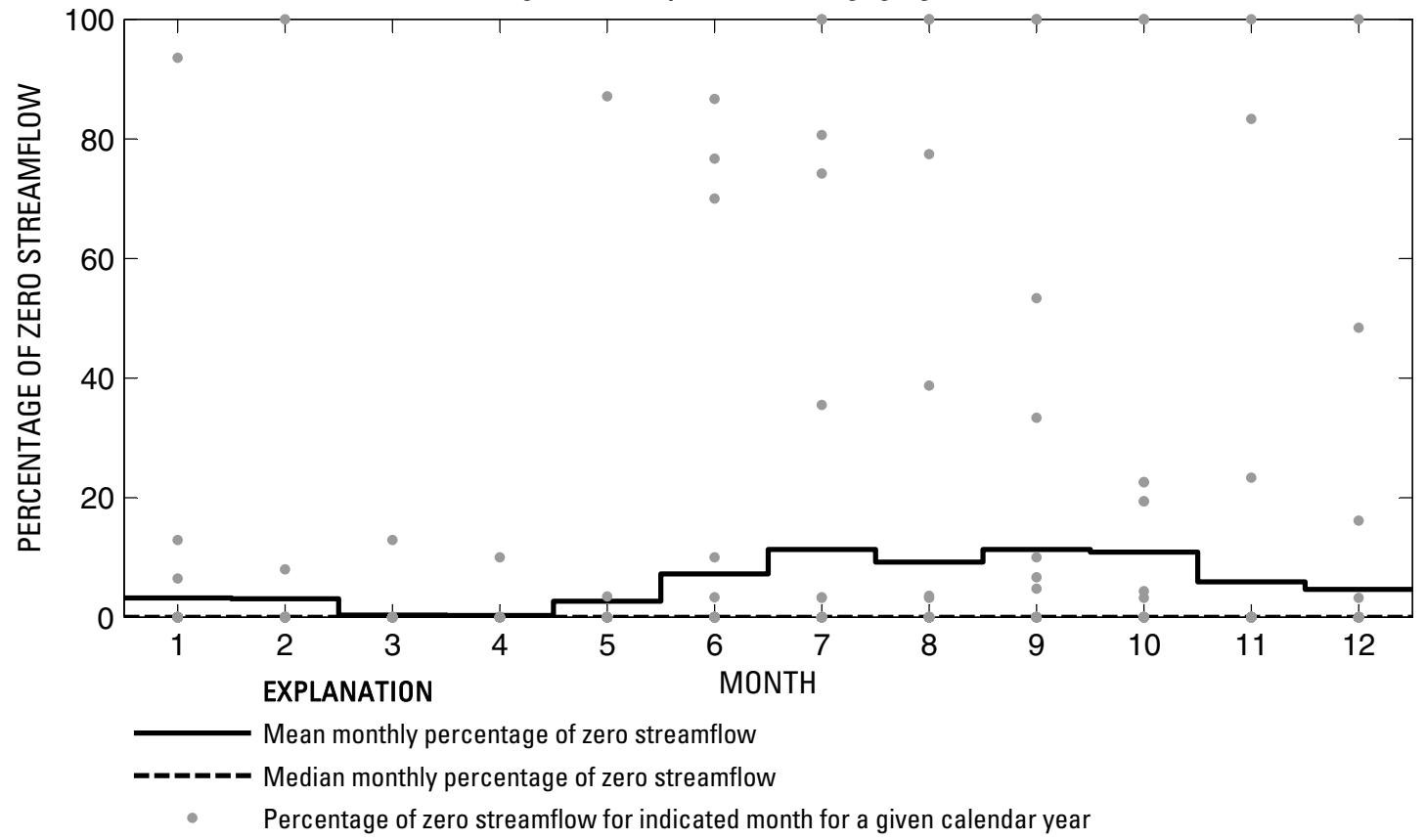

Figure 381. Analysis of percentage of zero daily mean streamflow for U.S. Geological Survey streamflow-gaging station 08095300 Middle Bosque River near McGregor, Texas. 
U.S. Geological Survey streamflow-gaging station 08095400

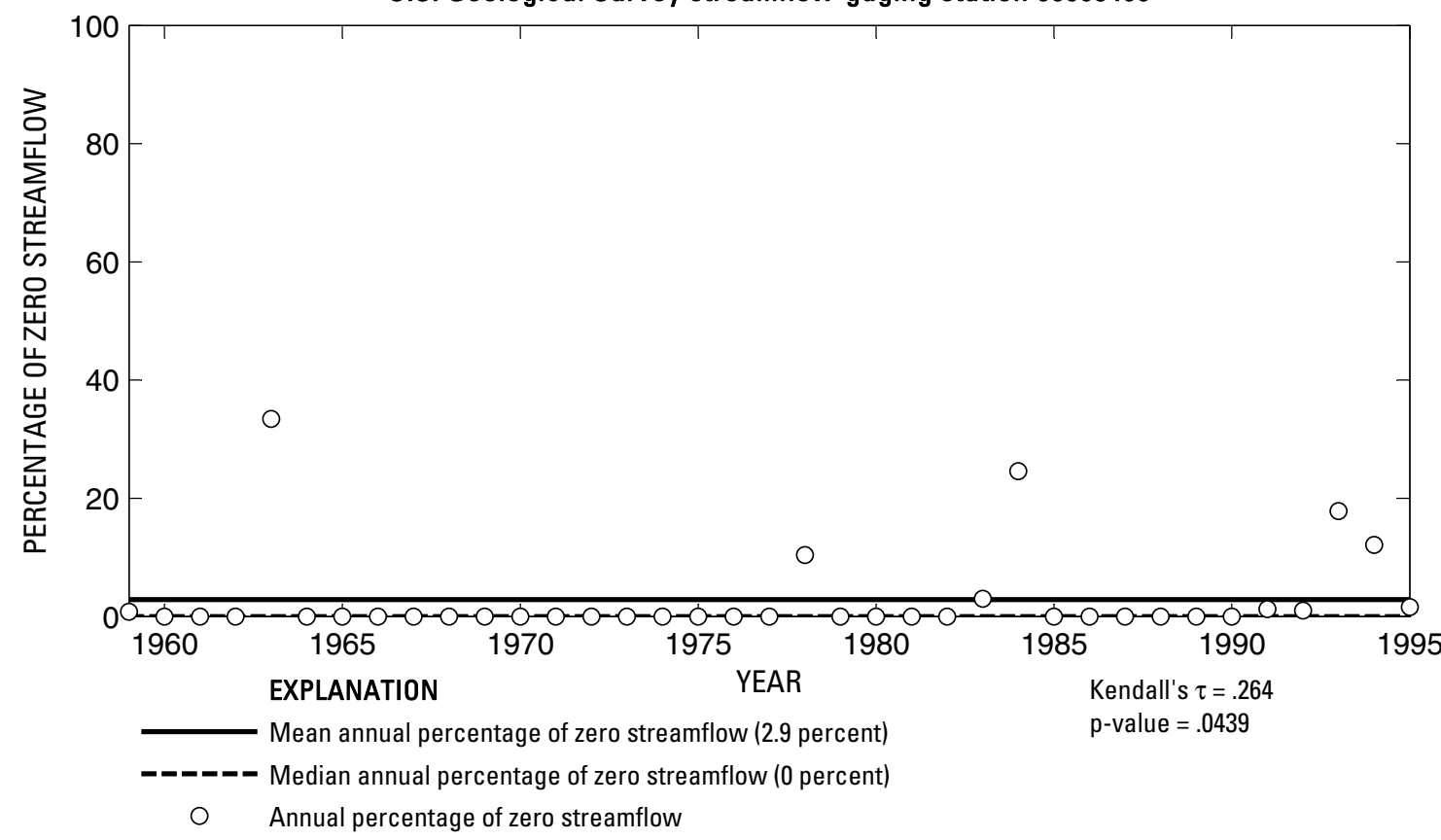

U.S. Geological Survey streamflow-gaging station 08095400

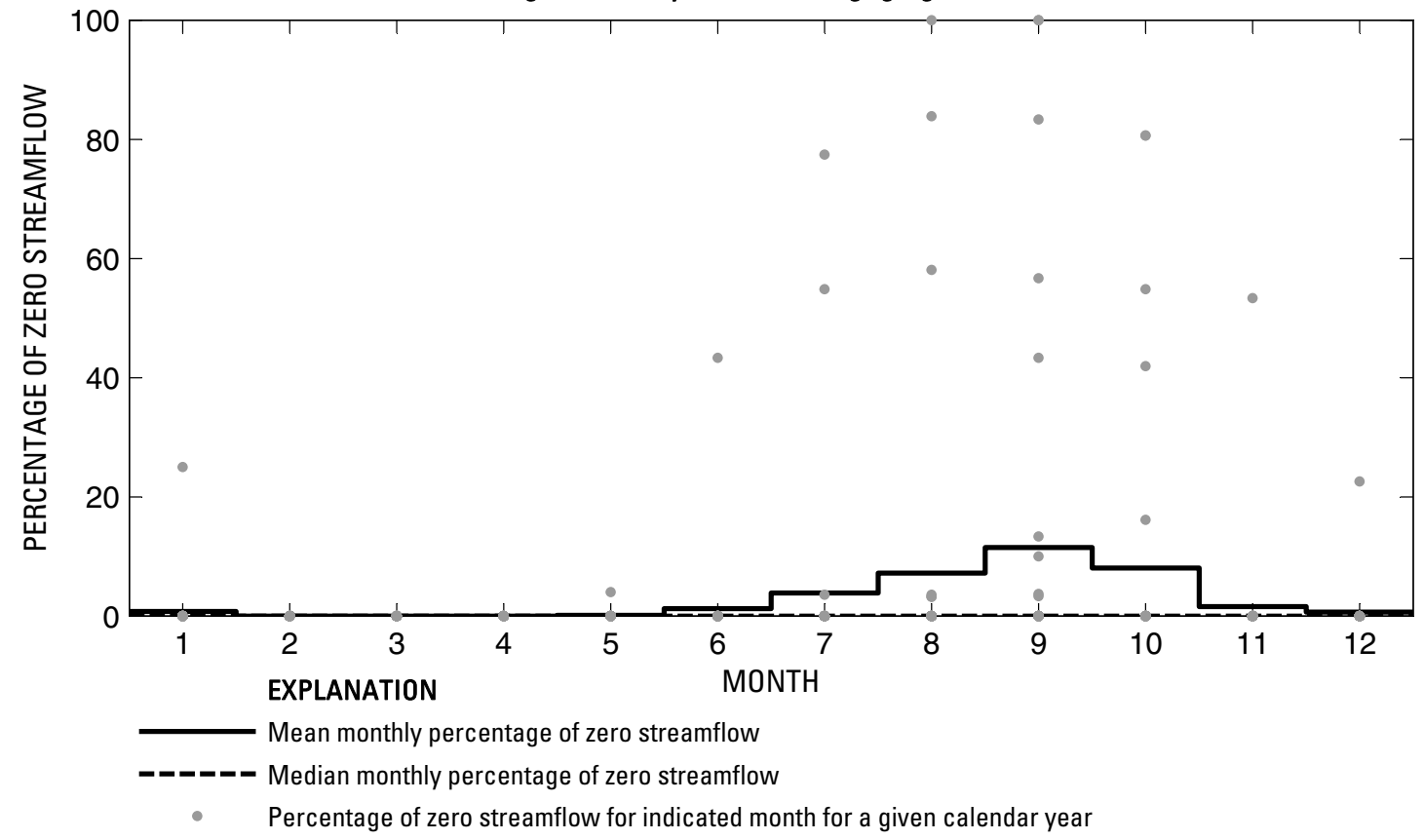

Figure 382. Analysis of percentage of zero daily mean streamflow for U.S. Geological Survey streamflow-gaging station 08095400 Hog Creek near Crawford, Texas. 


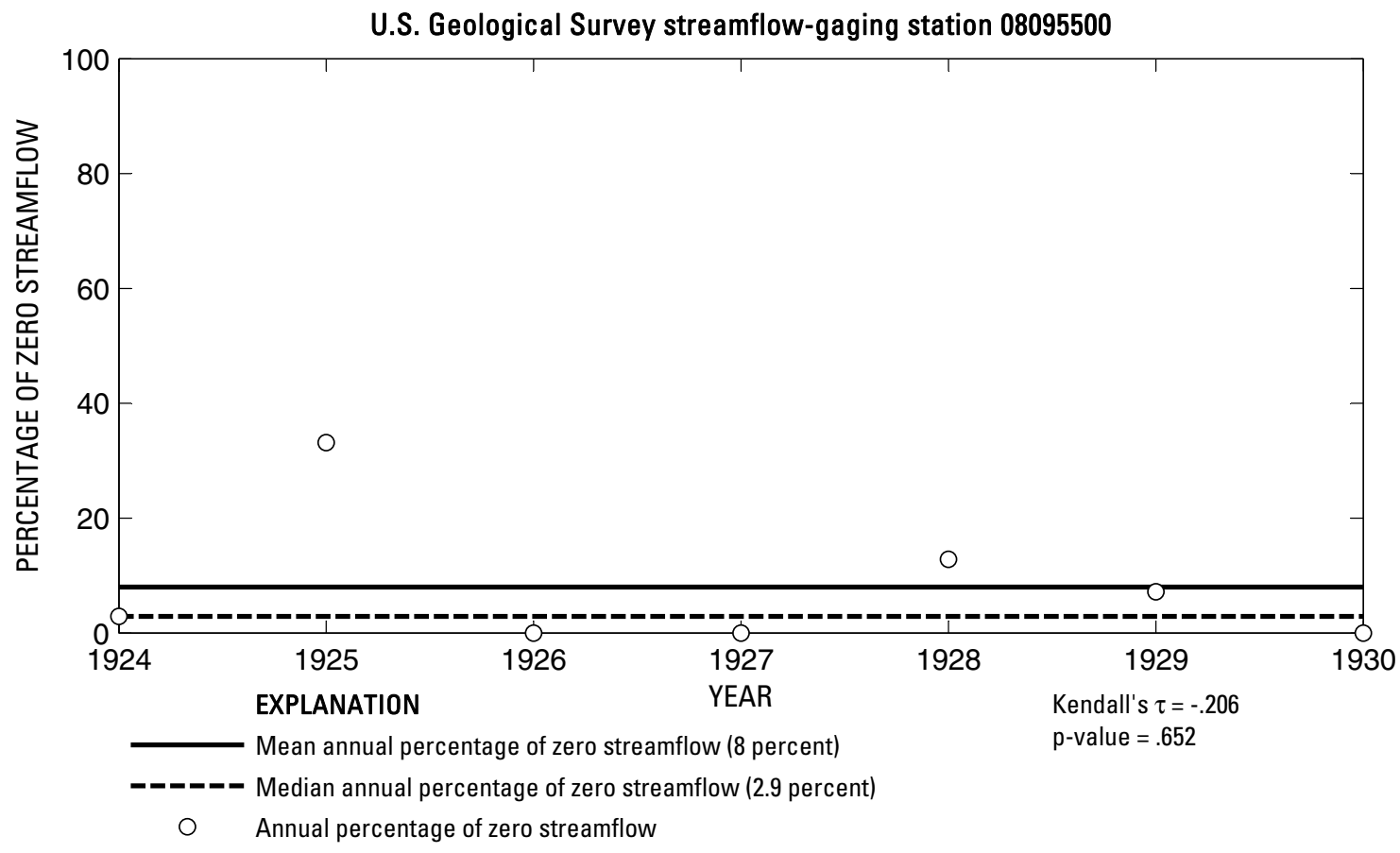

U.S. Geological Survey streamflow-gaging station 08095500

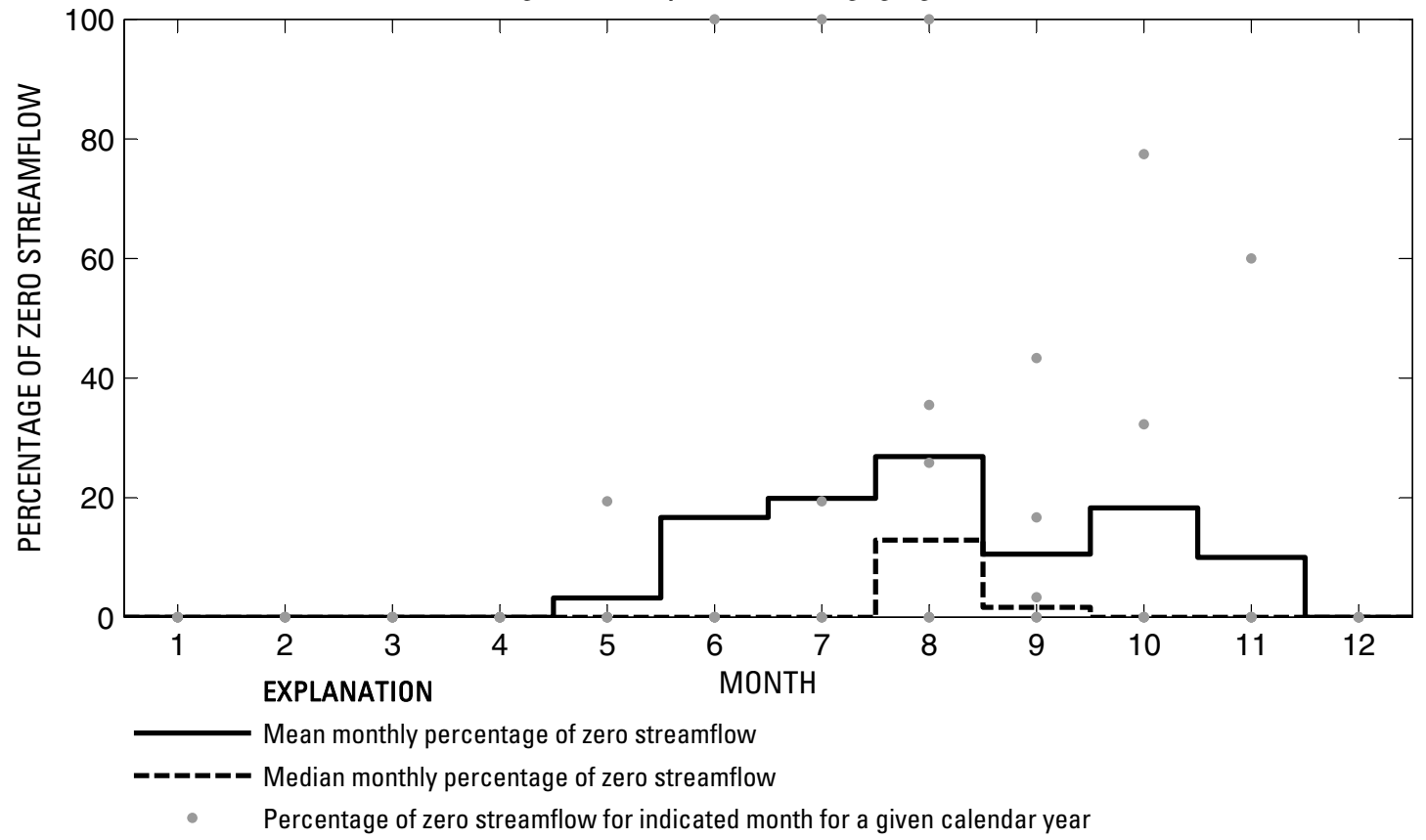

Figure 383. Analysis of percentage of zero daily mean streamflow for U.S. Geological Survey streamflow-gaging station 08095500 South Bosque River near Speegleville, Texas. 
U.S. Geological Survey streamflow-gaging station 08095600

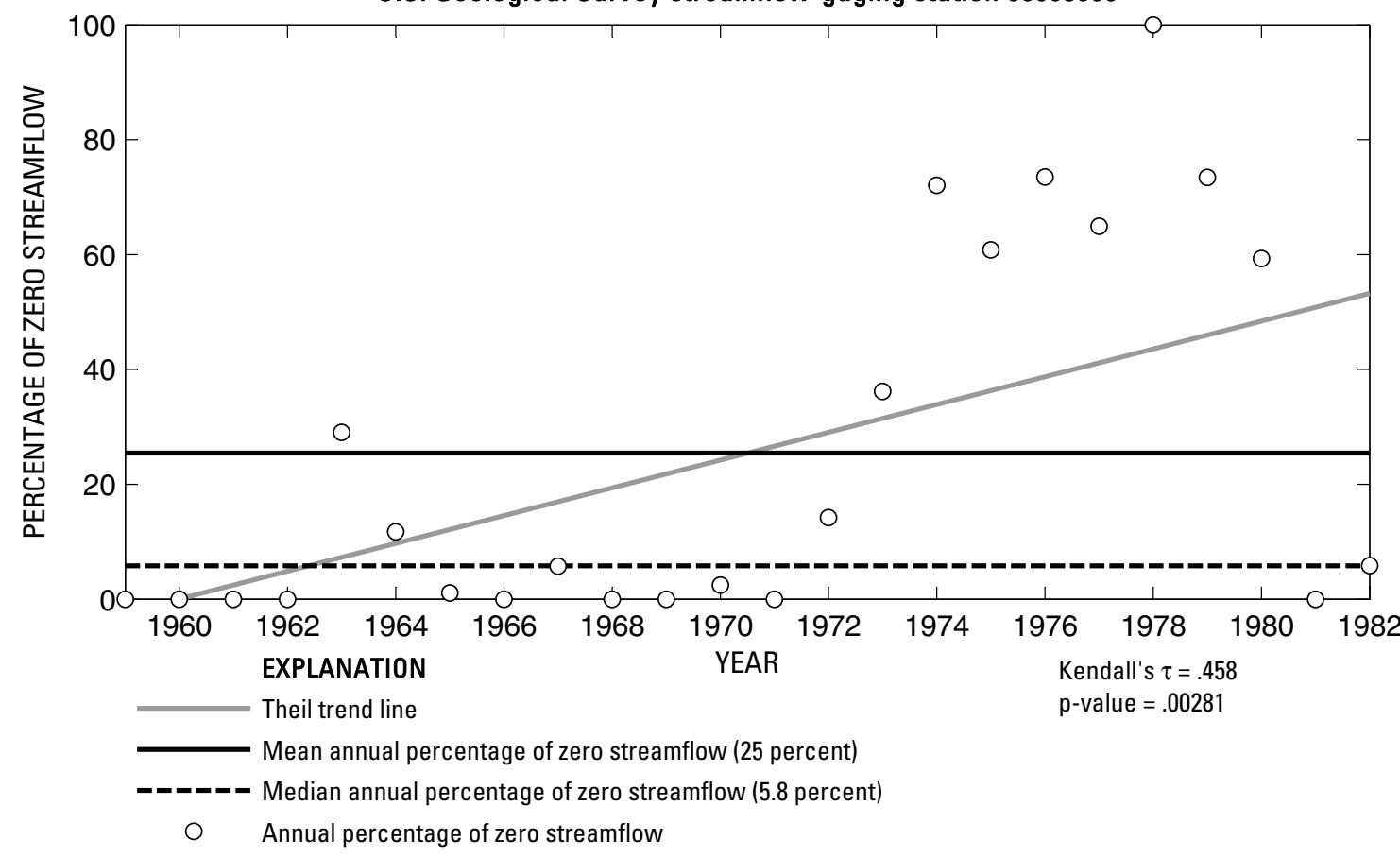

U.S. Geological Survey streamflow-gaging station 08095600

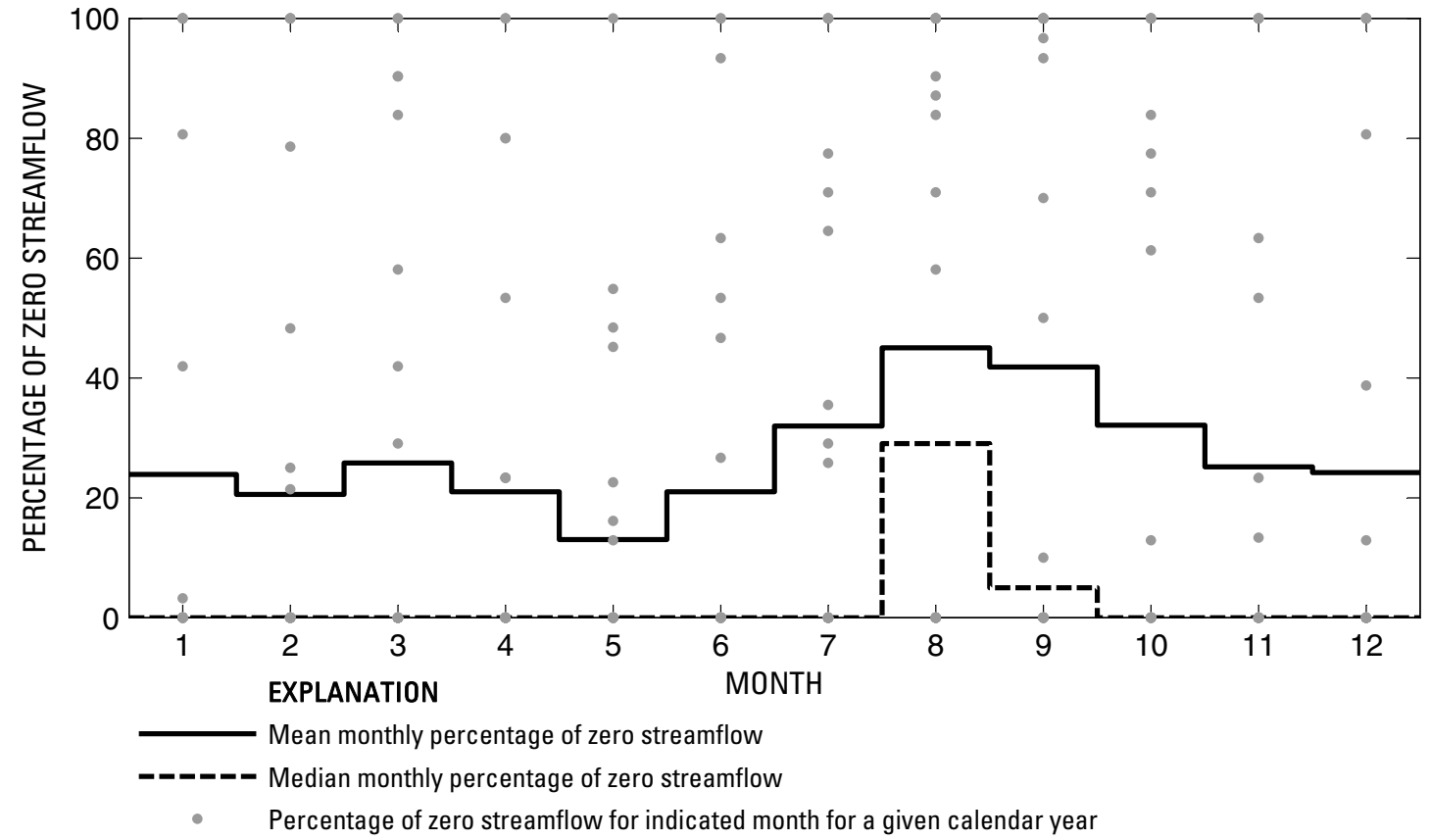

Figure 384. Analysis of percentage of zero daily mean streamflow for U.S. Geological Survey streamflow-gaging station 08095600 Bosque River near Waco, Texas.

Index of Station Numbers 719 
U.S. Geological Survey streamflow-gaging station 08096500

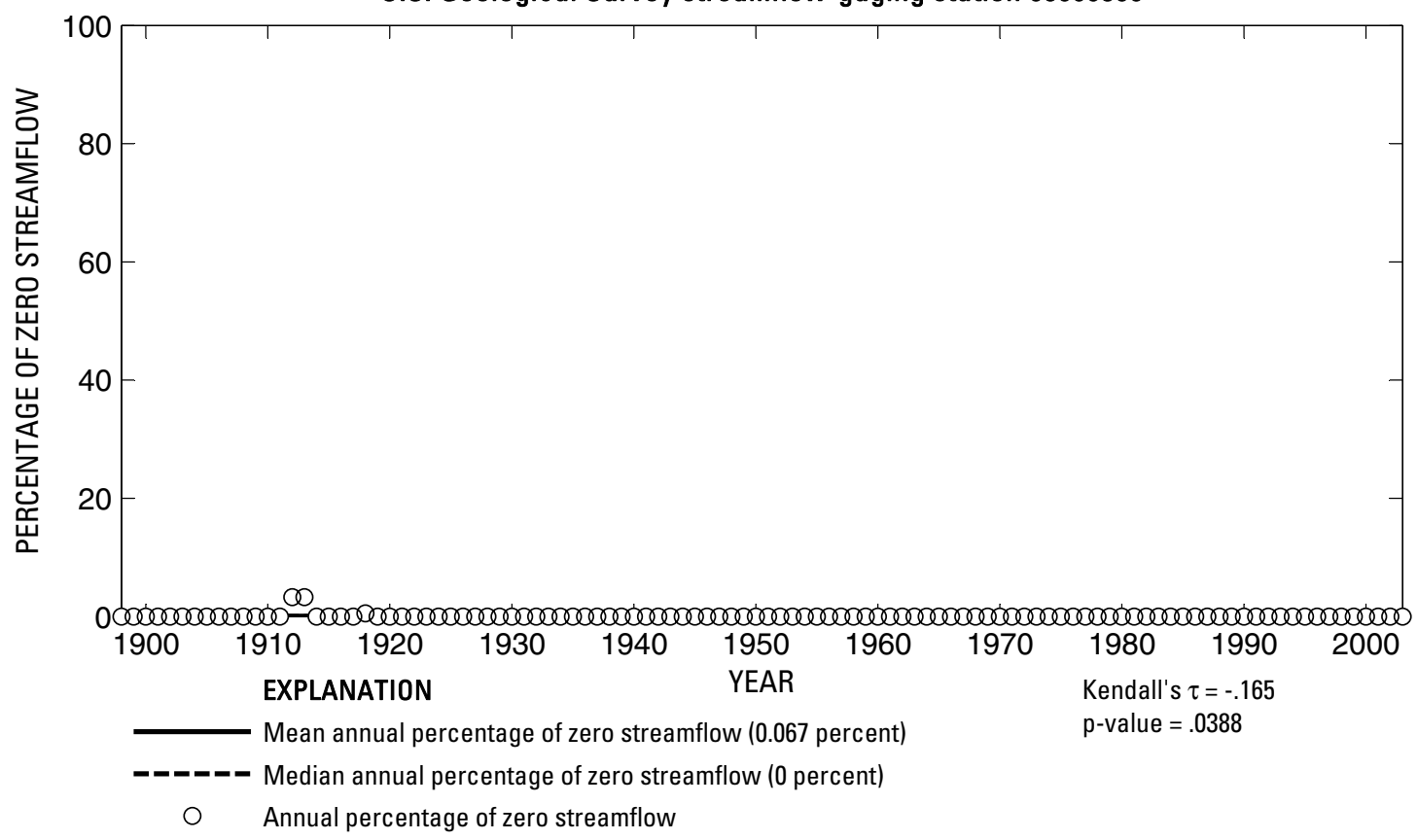

U.S. Geological Survey streamflow-gaging station 08096500

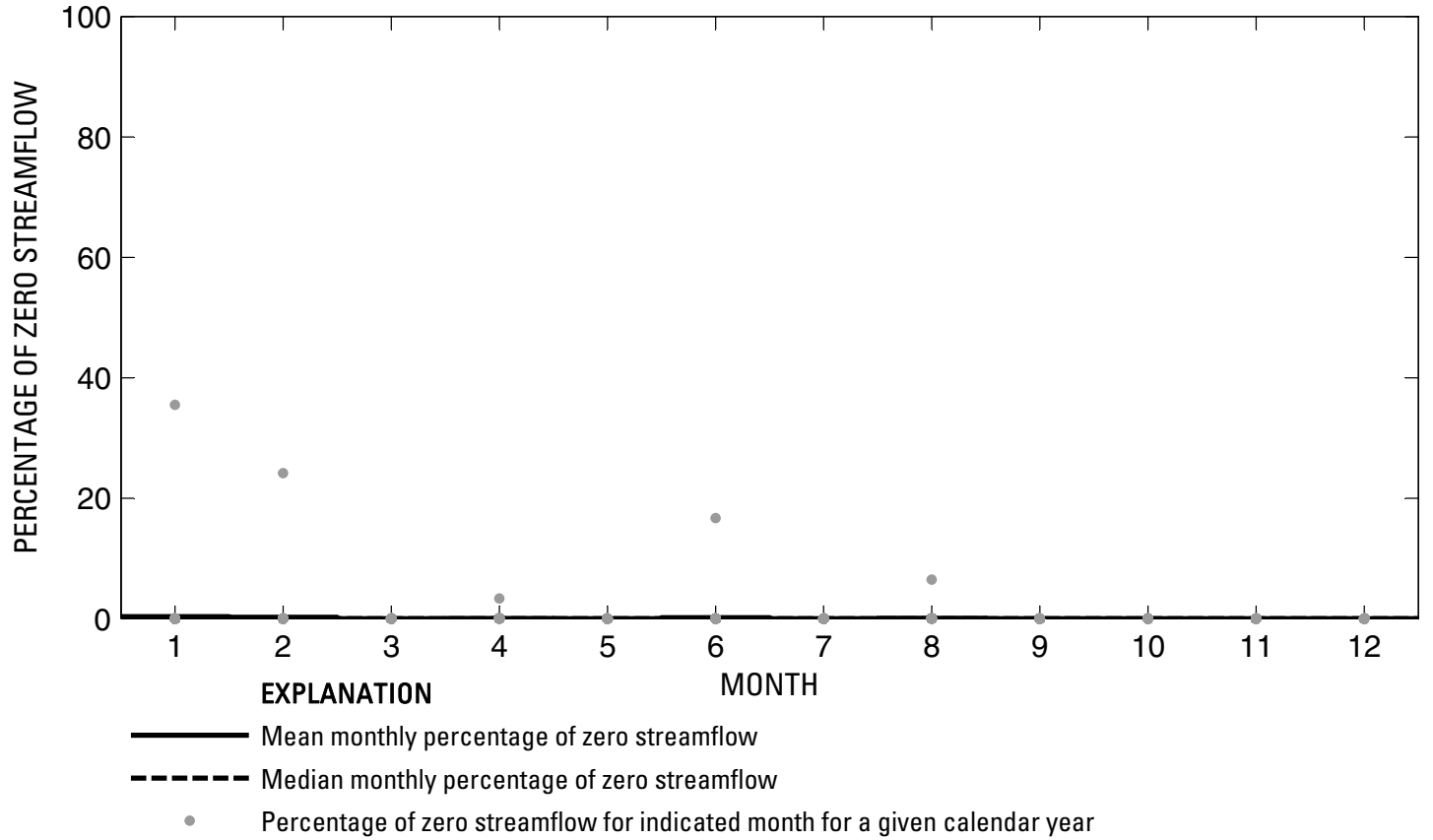

Figure 385. Analysis of percentage of zero daily mean streamflow for U.S. Geological Survey streamflow-gaging station 08096500 Brazos River at Waco, Texas. 
U.S. Geological Survey streamflow-gaging station 08097500

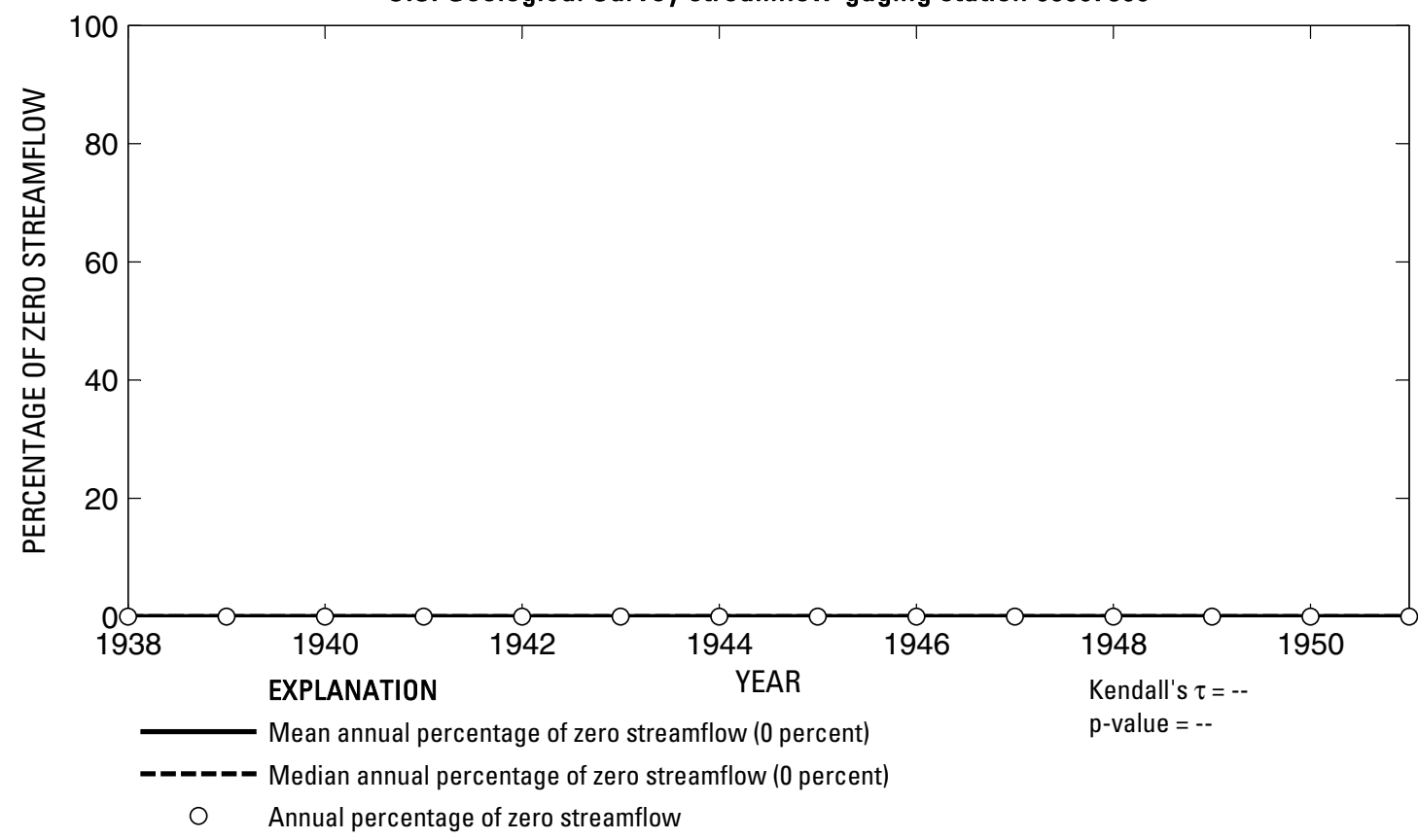

U.S. Geological Survey streamflow-gaging station 08097500

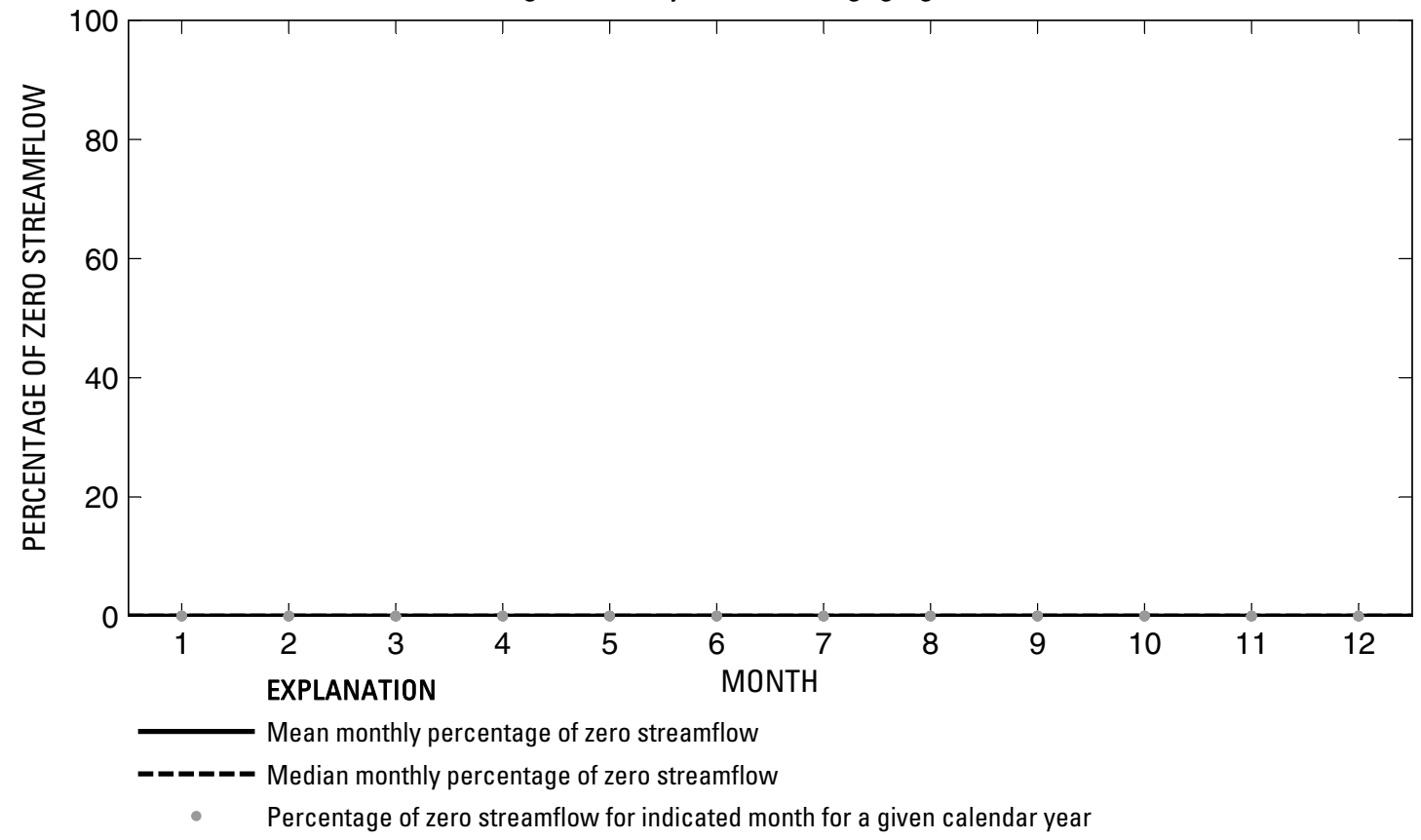

Figure 386. Analysis of percentage of zero daily mean streamflow for U.S. Geological Survey streamflow-gaging station 08097500 Brazos River near Marlin, Texas. 
U.S. Geological Survey streamflow-gaging station 08098000

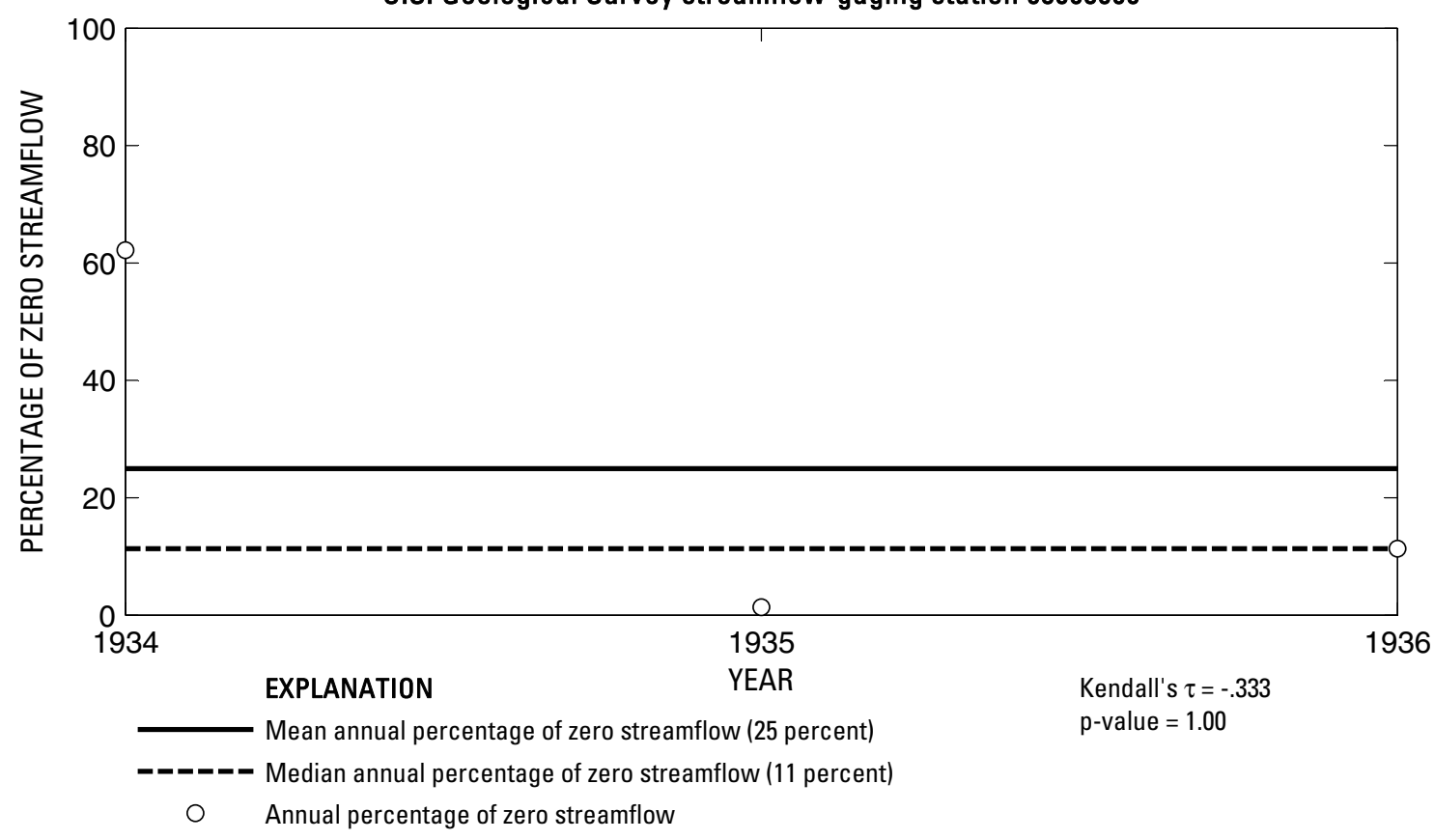

U.S. Geological Survey streamflow-gaging station 08098000

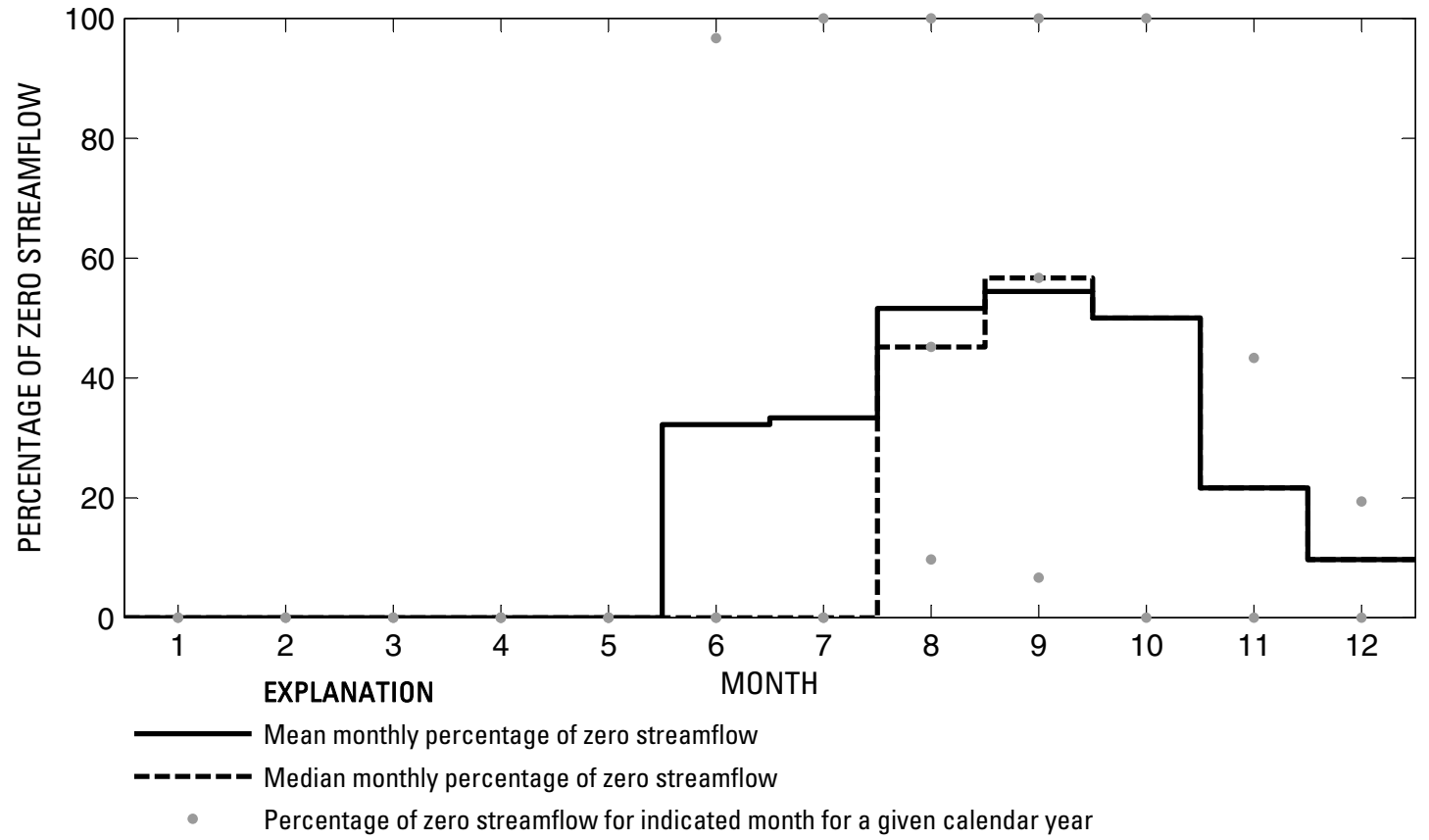

Figure 387. Analysis of percentage of zero daily mean streamflow for U.S. Geological Survey streamflow-gaging station 08098000 Deer Creek at Chilton, Texas. 
U.S. Geological Survey streamflow-gaging station 08098290

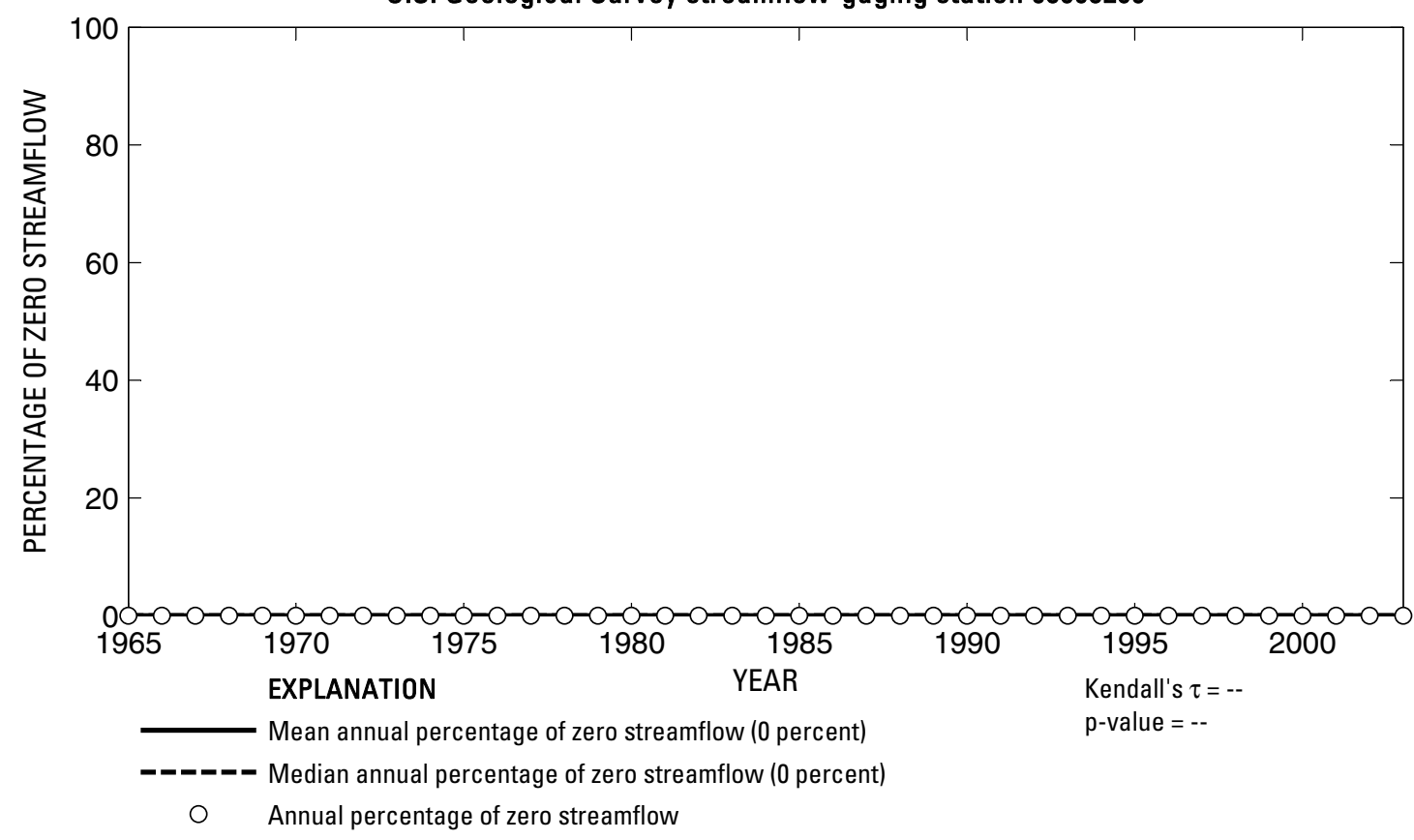

U.S. Geological Survey streamflow-gaging station 08098290

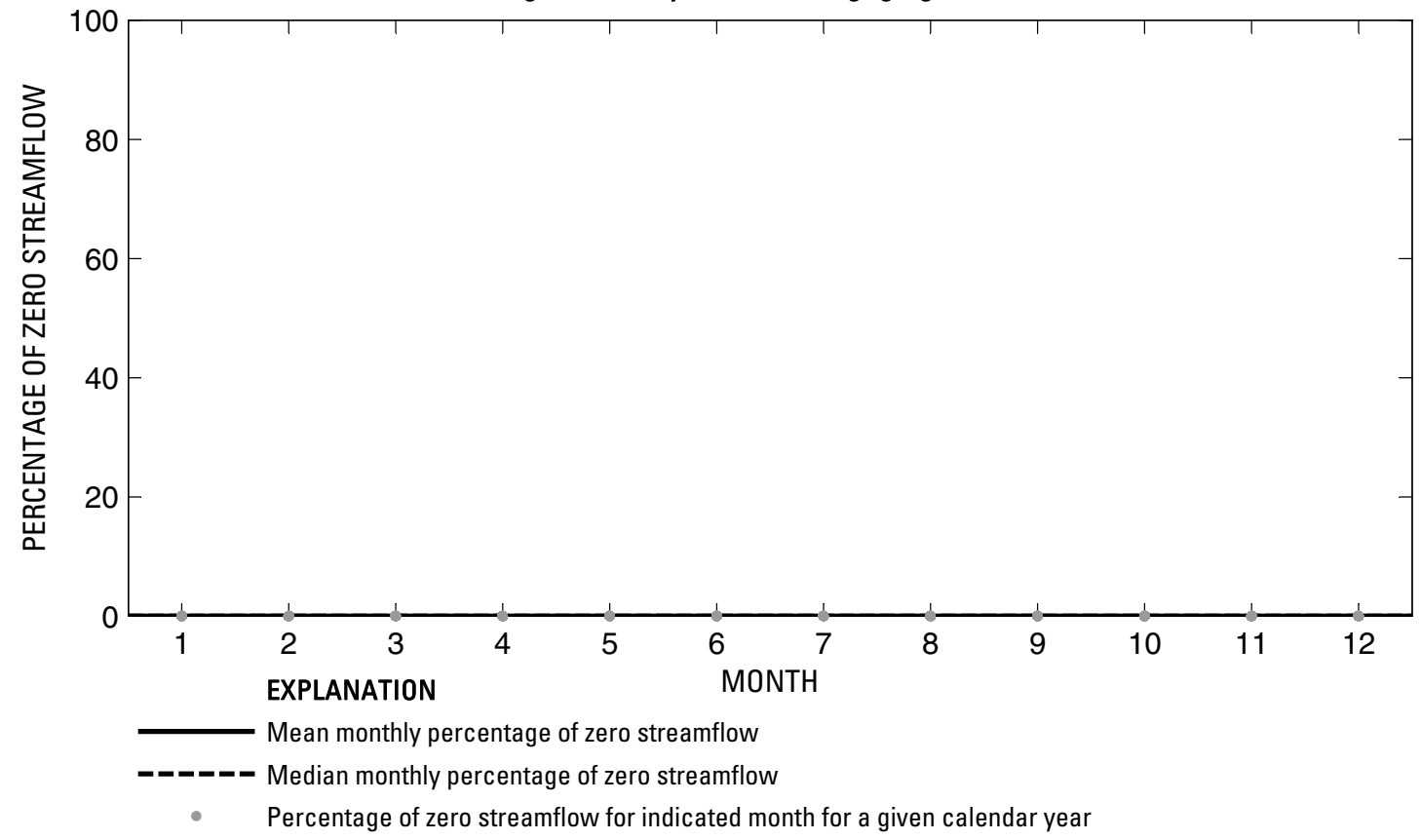

Figure 388. Analysis of percentage of zero daily mean streamflow for U.S. Geological Survey streamflow-gaging station 08098290 Brazos River near Highbank, Texas. 
U.S. Geological Survey streamflow-gaging station 08098300

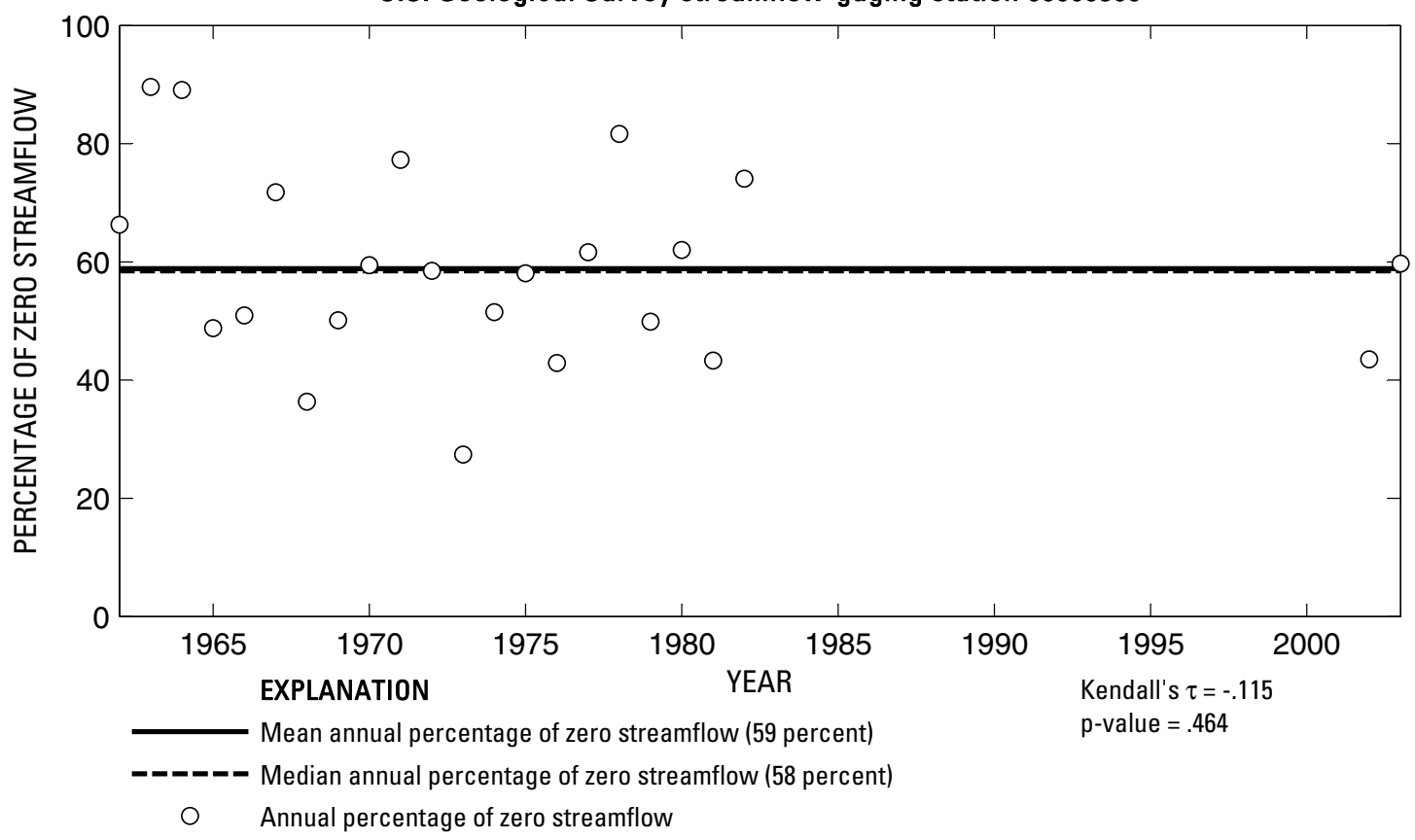

U.S. Geological Survey streamflow-gaging station 08098300

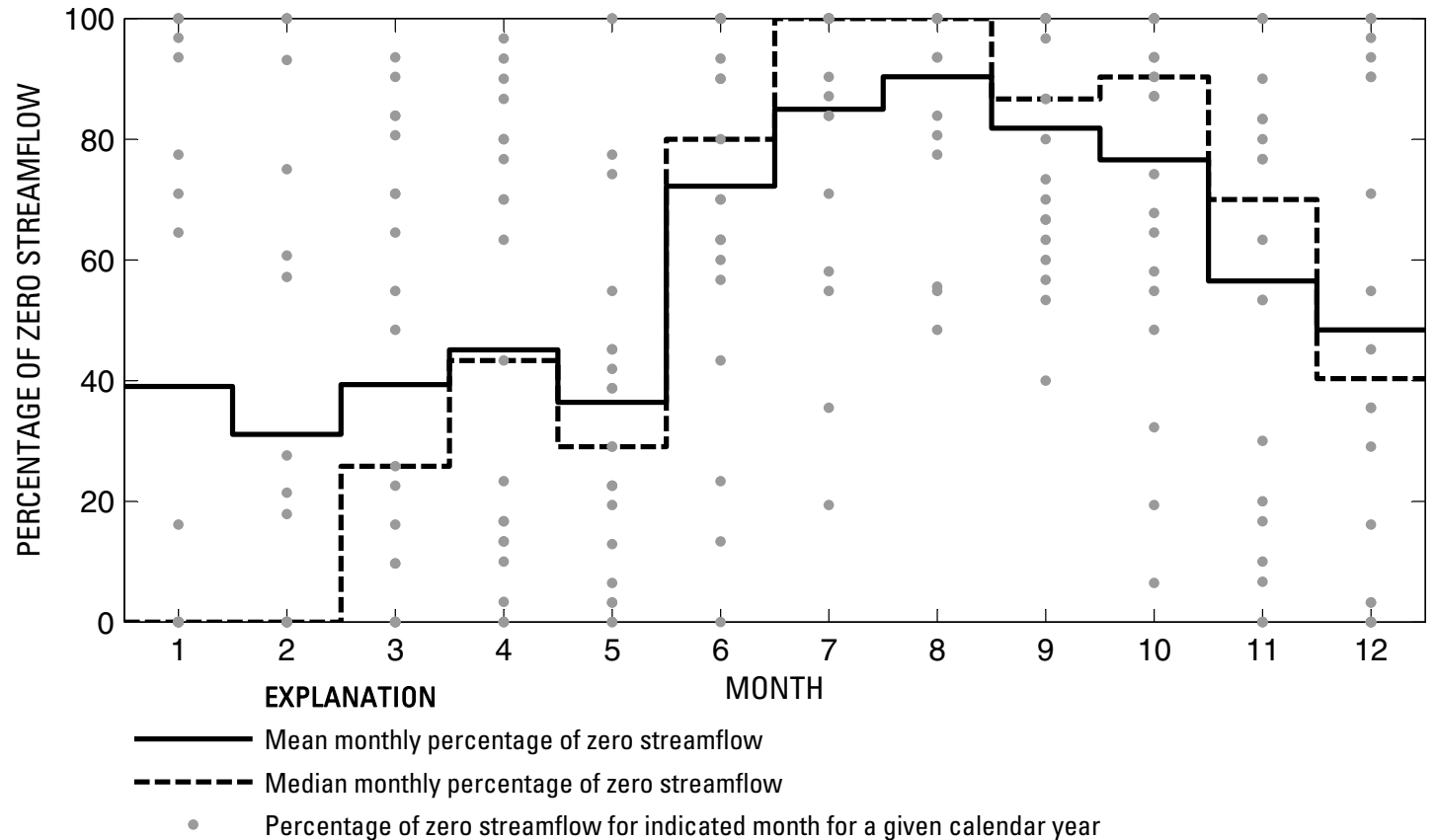

Figure 389. Analysis of percentage of zero daily mean streamflow for U.S. Geological Survey streamflow-gaging station 08098300 Little Pond Creek near Burlington, Texas. 
U.S. Geological Survey streamflow-gaging station 08099100

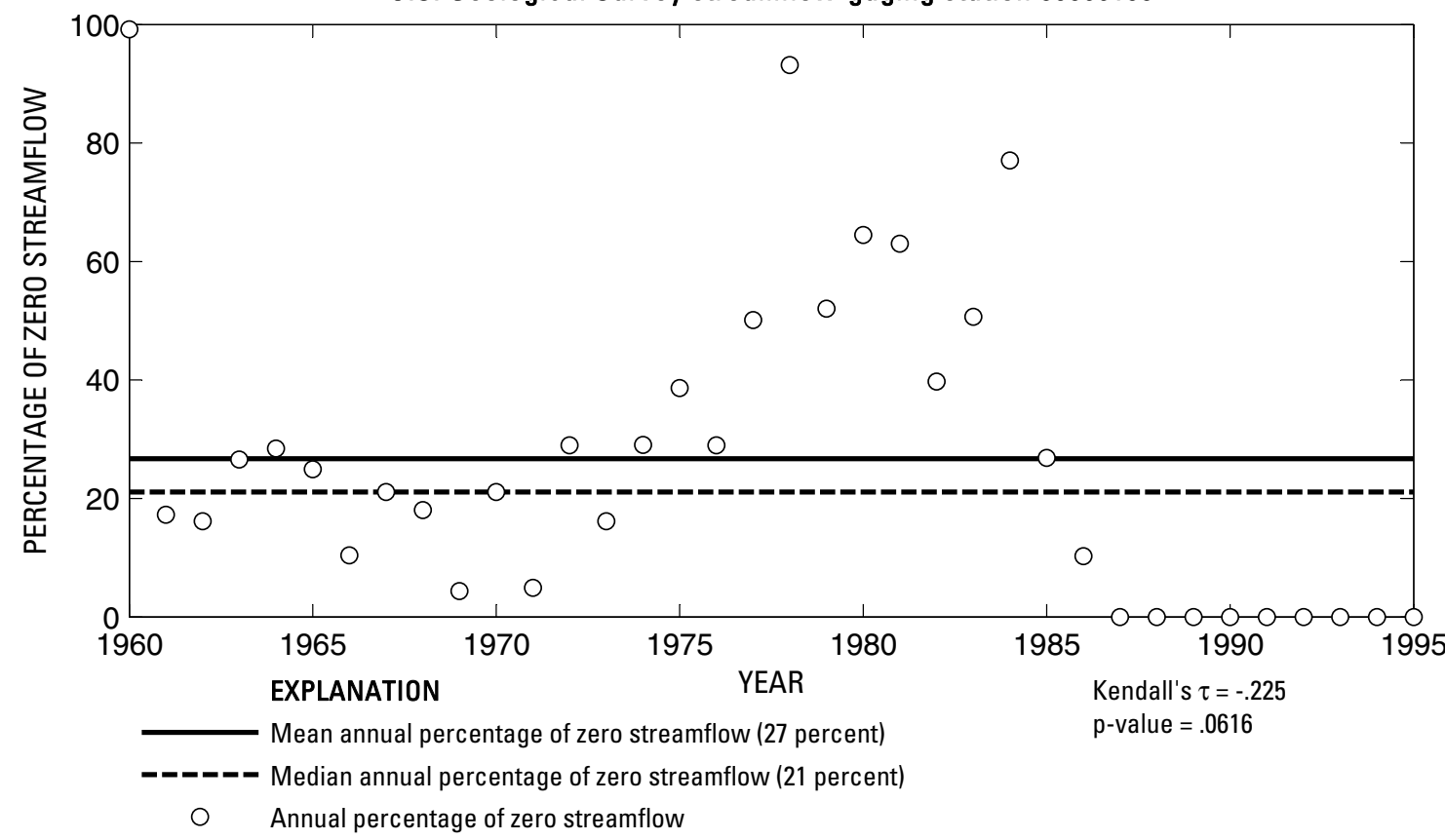

U.S. Geological Survey streamflow-gaging station 08099100

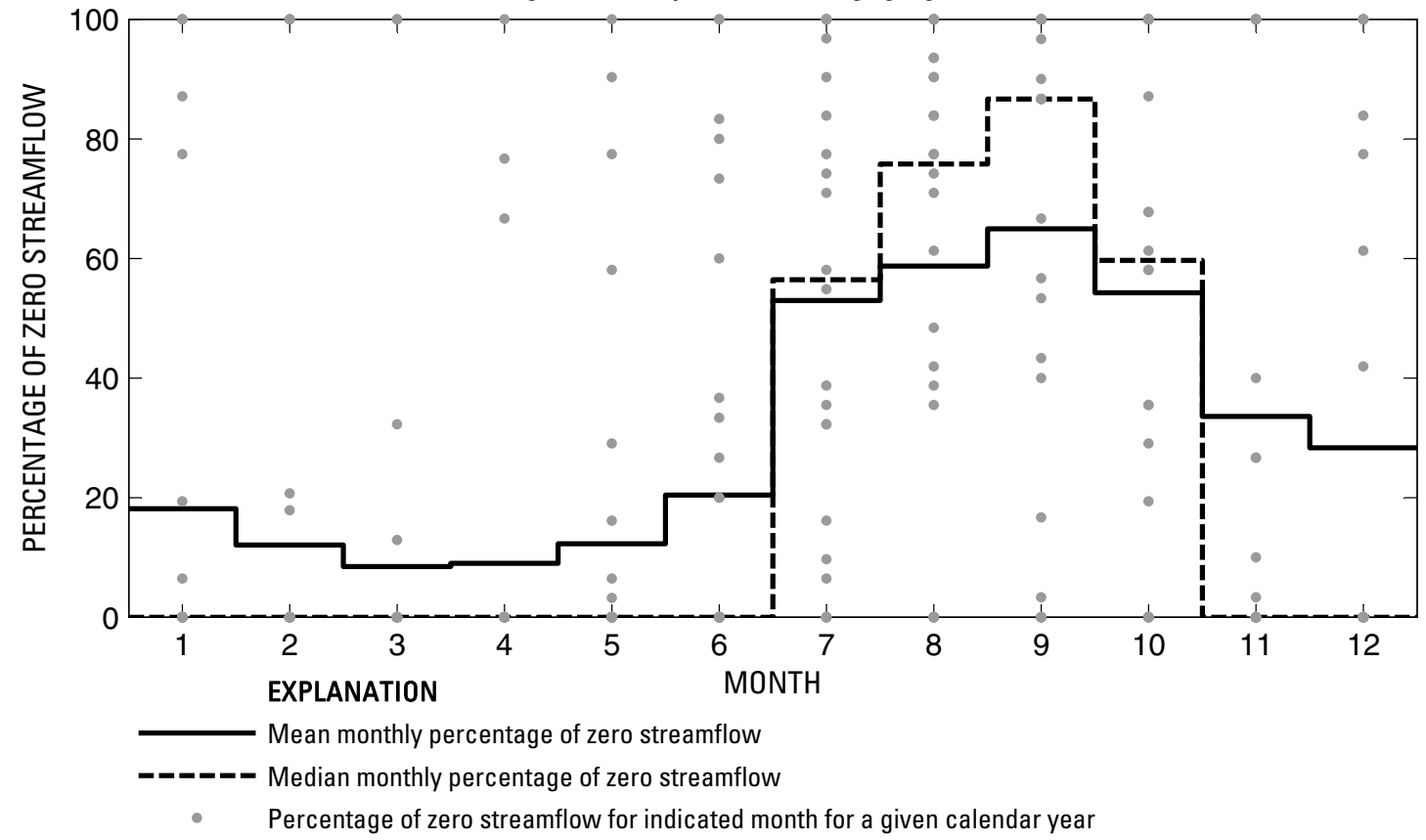

Figure 390. Analysis of percentage of zero daily mean streamflow for U.S. Geological Survey streamflow-gaging station 08099100 Leon River near De Leon, Texas.

Index of Station Numbers 719 


\section{U.S. Geological Survey streamflow-gaging station 08099300}

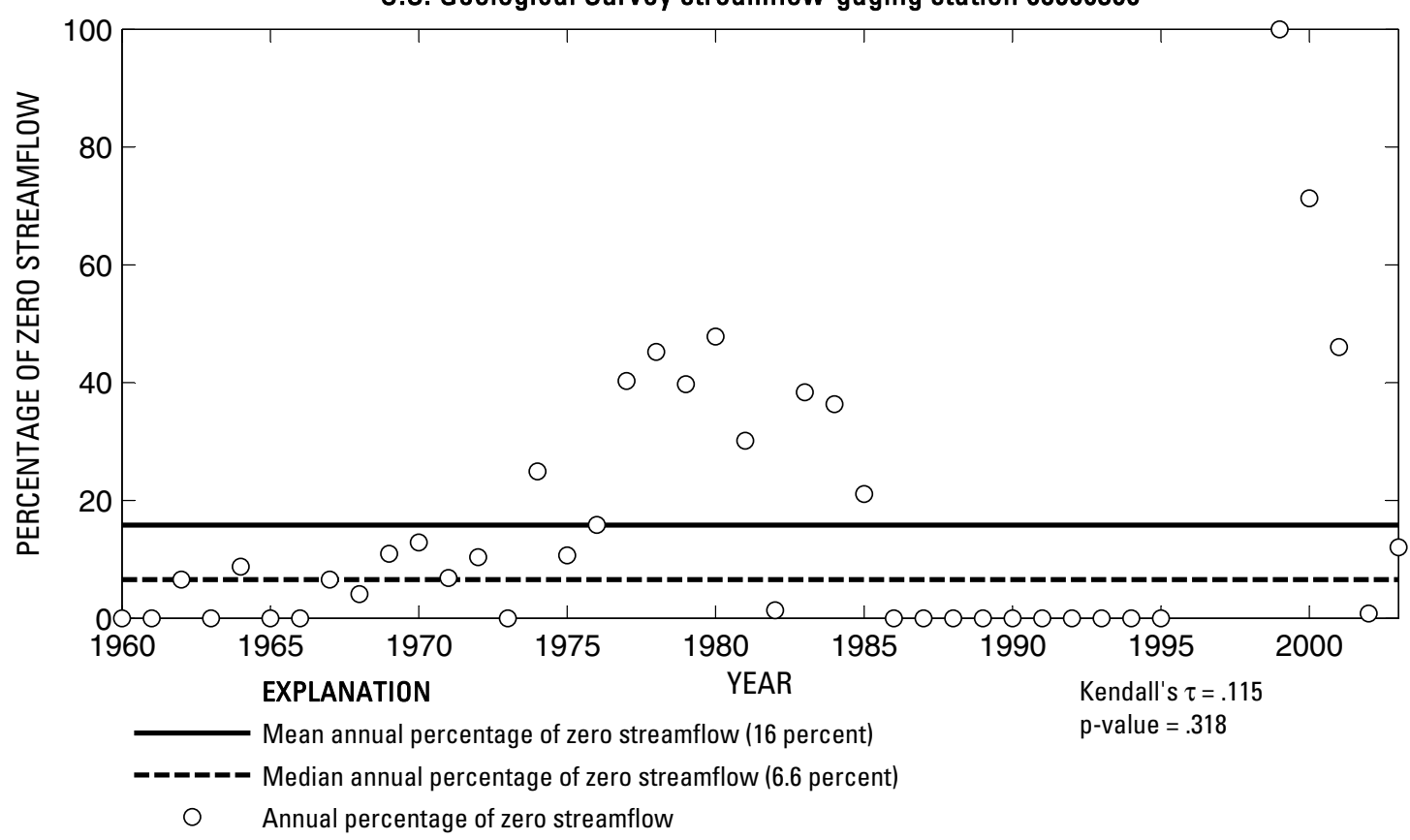

U.S. Geological Survey streamflow-gaging station 08099300

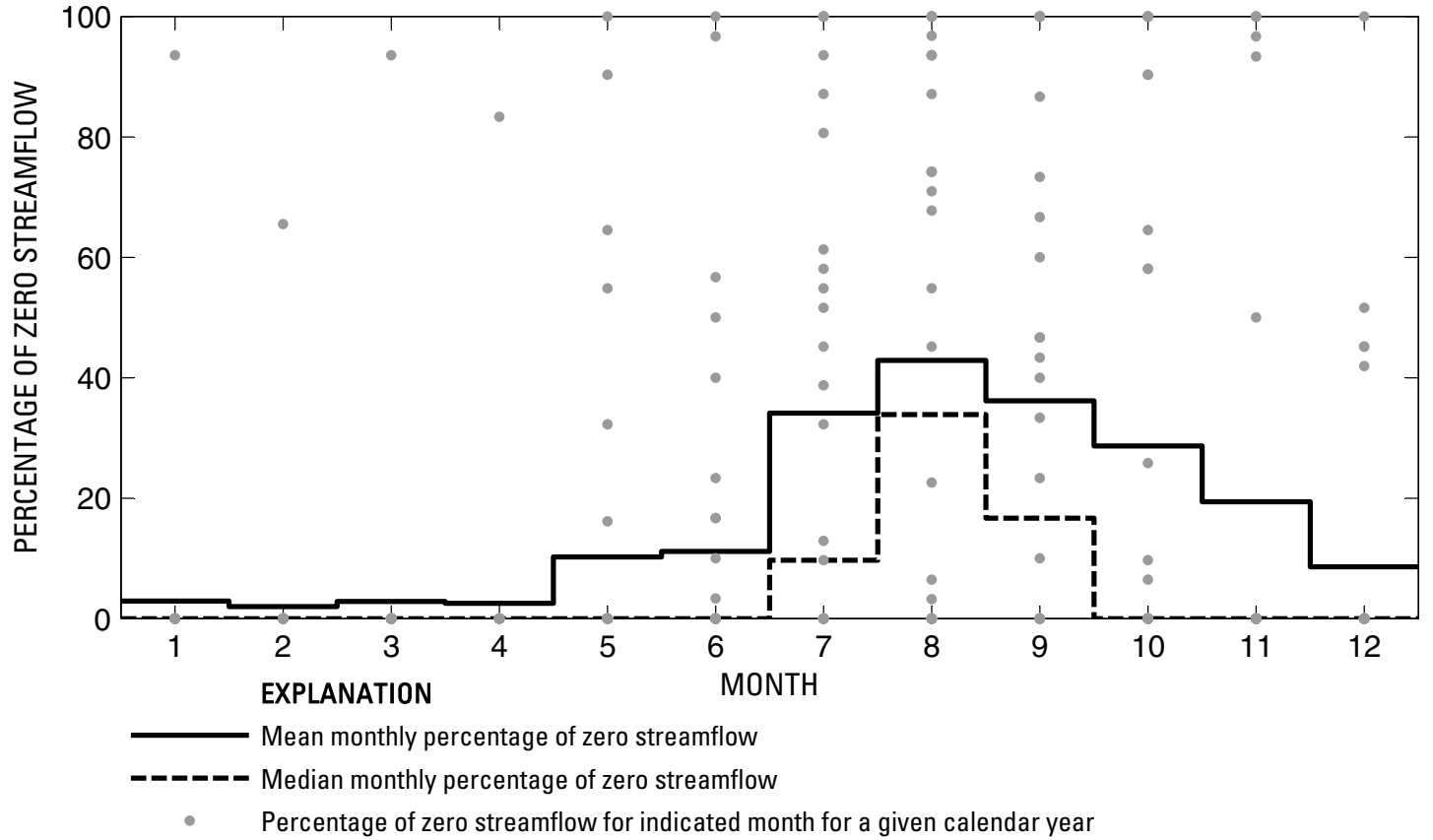

Figure 391. Analysis of percentage of zero daily mean streamflow for U.S. Geological Survey streamflow-gaging station 08099300 Sabana River near De Leon, Texas. 
U.S. Geological Survey streamflow-gaging station 08099500

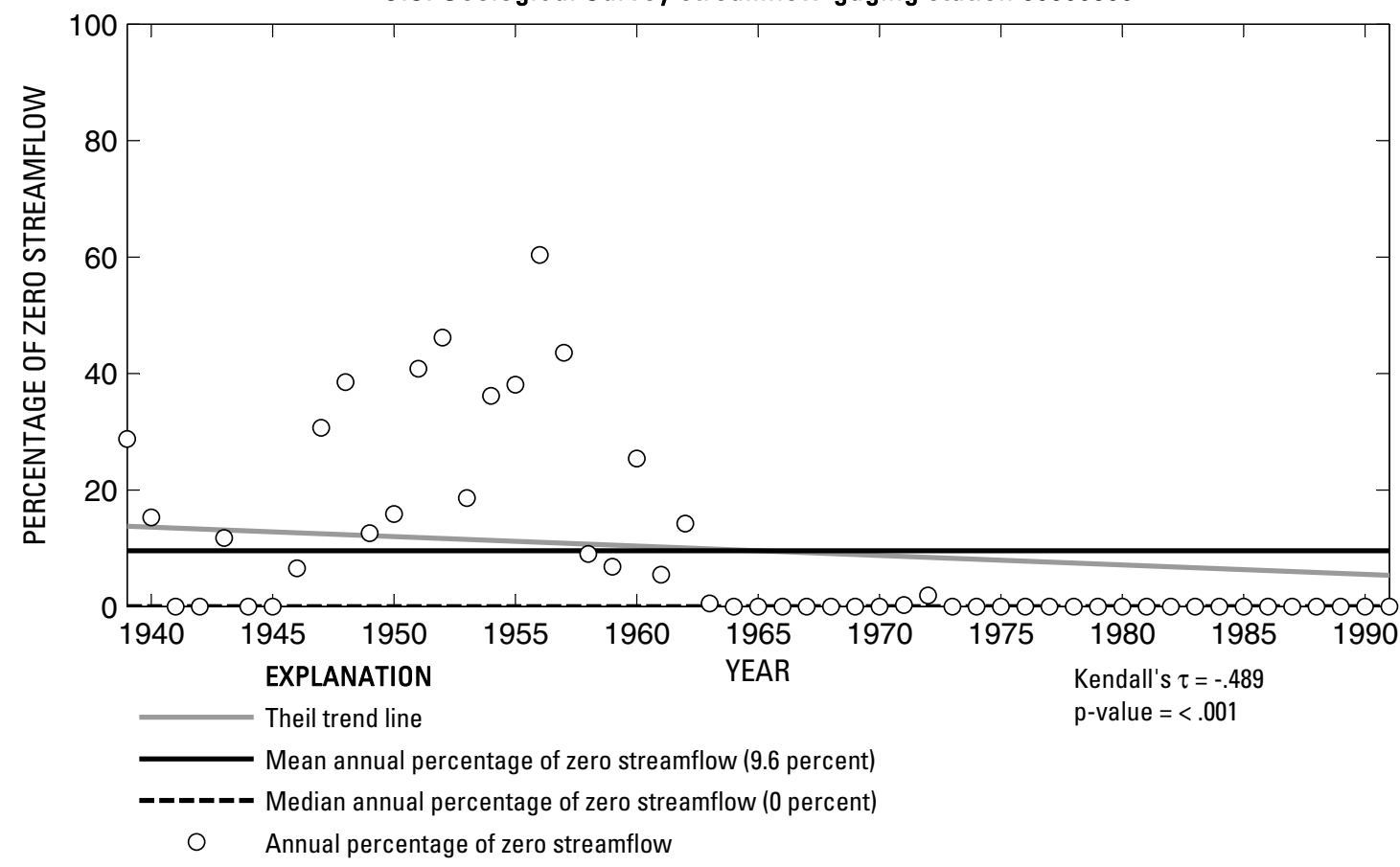

U.S. Geological Survey streamflow-gaging station 08099500

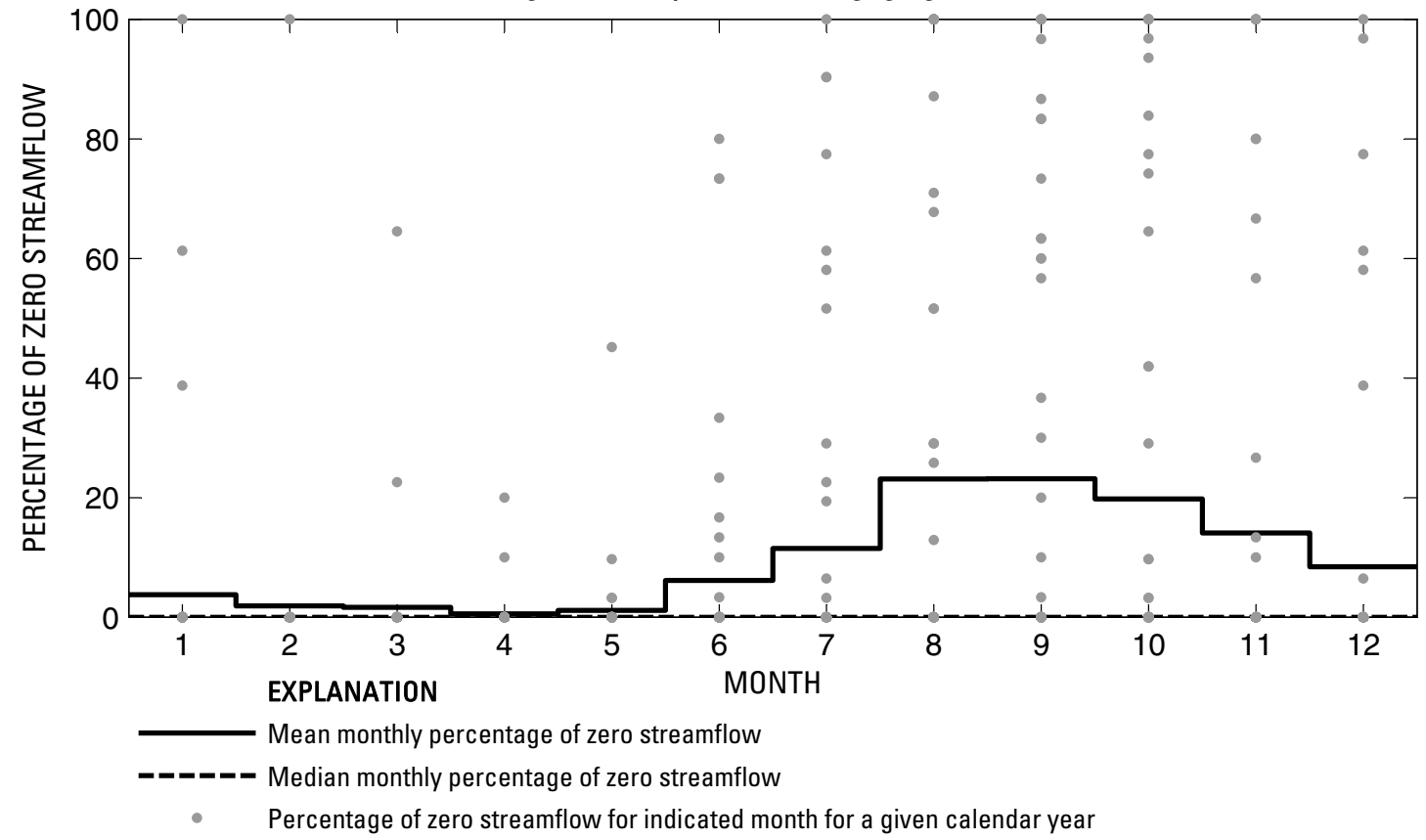

Figure 392. Analysis of percentage of zero daily mean streamflow for U.S. Geological Survey streamflow-gaging station 08099500 Leon River near Hasse, Texas.

Index of Station Numbers 719 

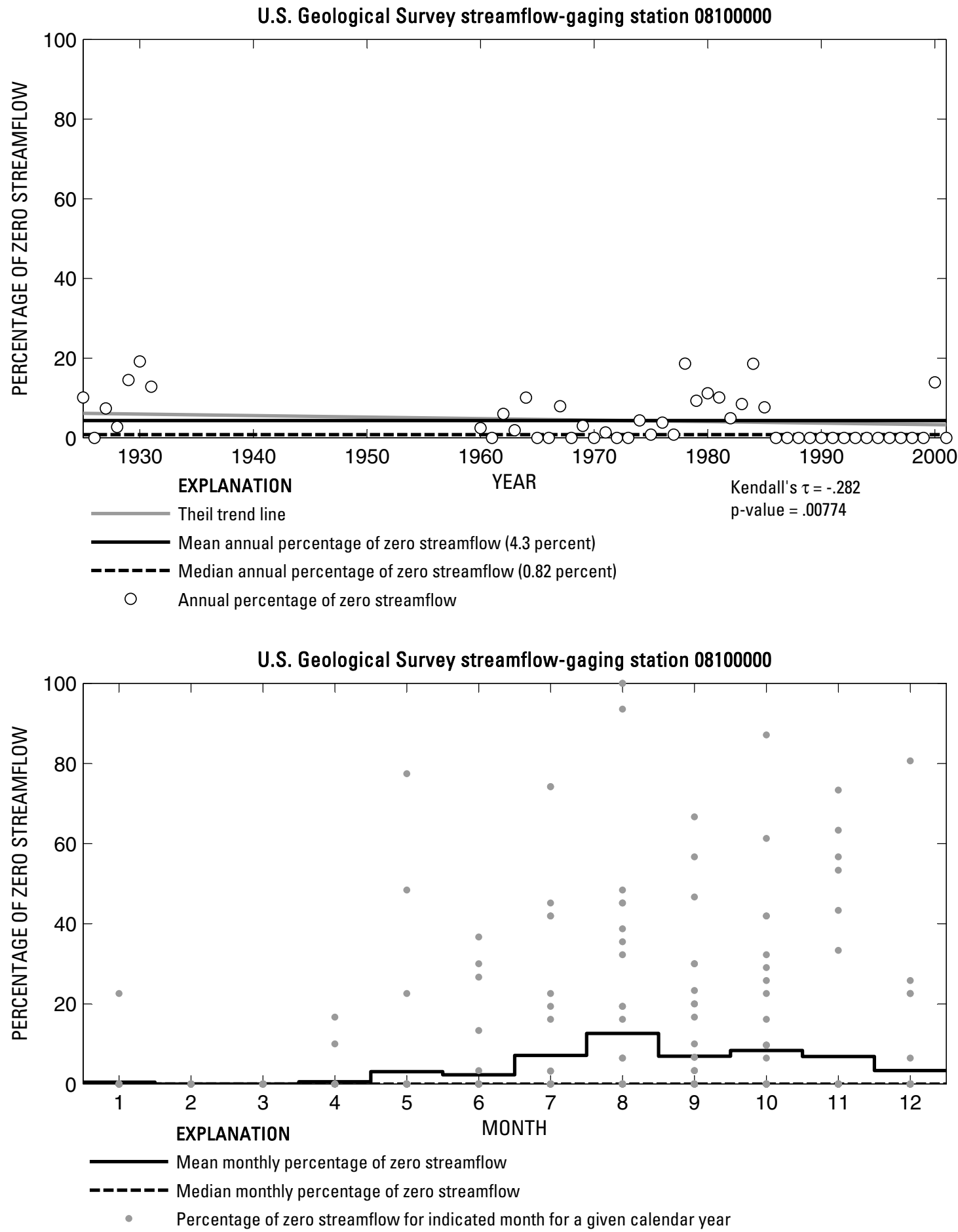

Figure 393. Analysis of percentage of zero daily mean streamflow for U.S. Geological Survey streamflow-gaging station 08100000 Leon River near Hamilton, Texas. 
U.S. Geological Survey streamflow-gaging station 08100500

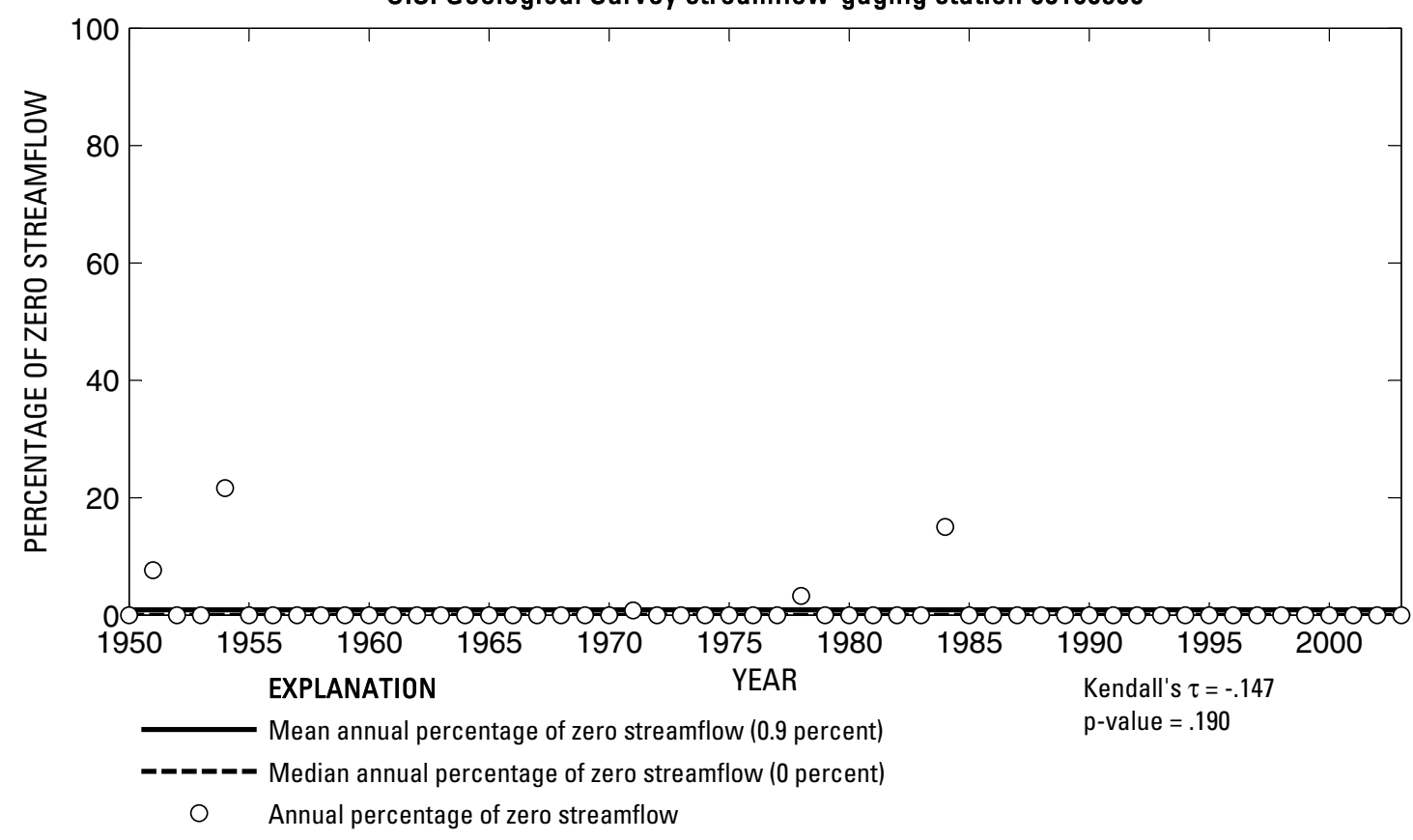

U.S. Geological Survey streamflow-gaging station 08100500

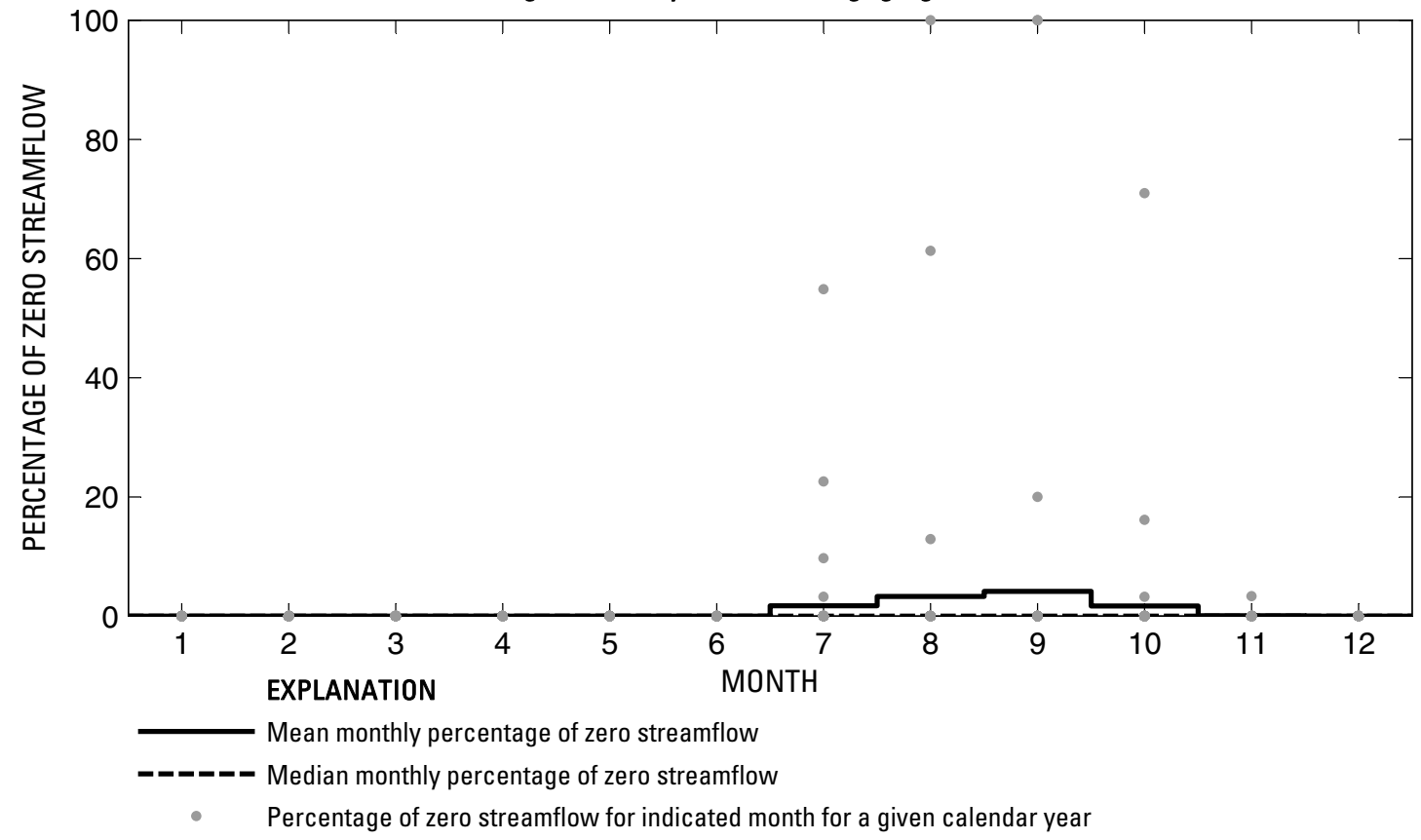

Figure 394. Analysis of percentage of zero daily mean streamflow for U.S. Geological Survey streamflow-gaging station 08100500 Leon River at Gatesville, Texas. 
U.S. Geological Survey streamflow-gaging station 08101000

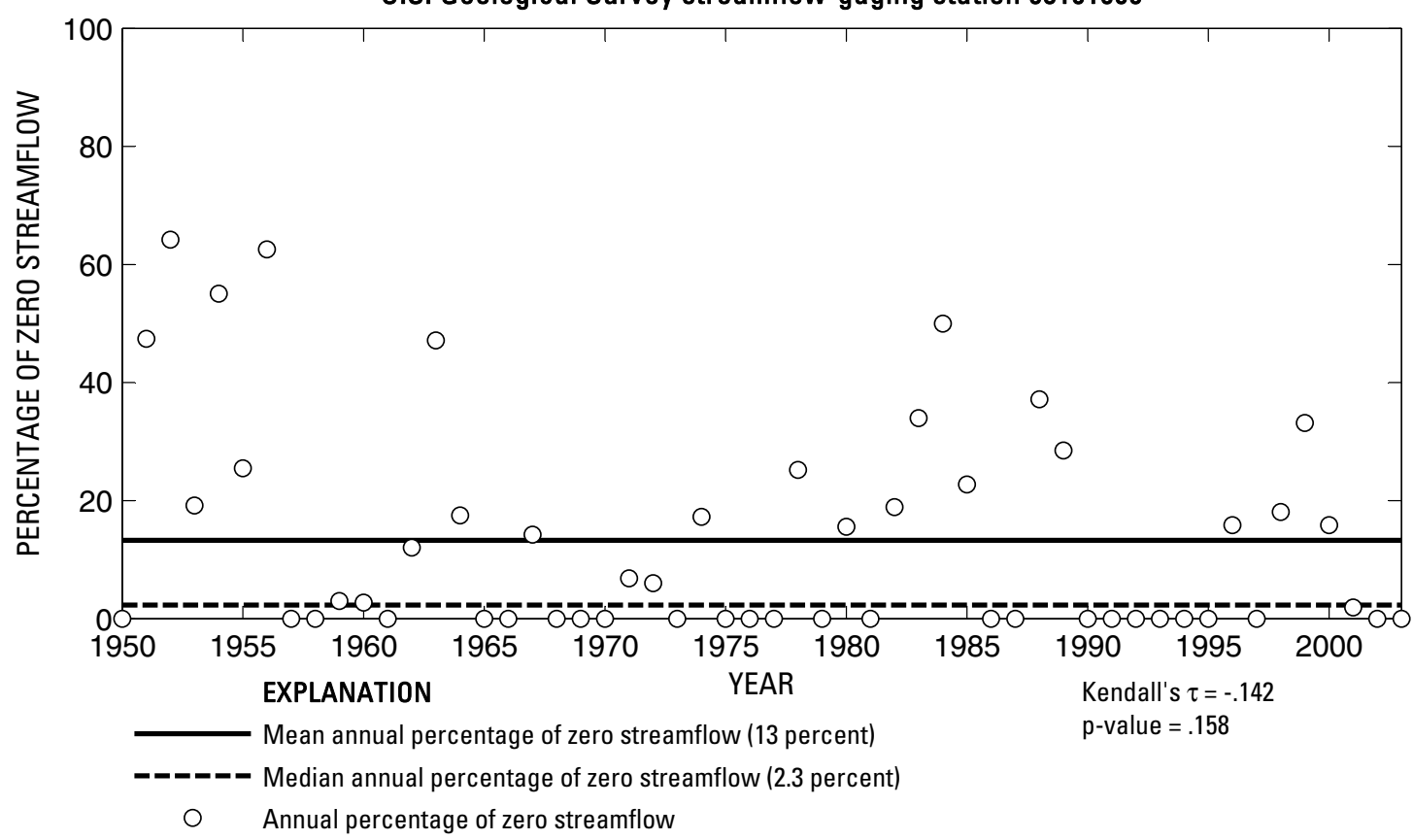

U.S. Geological Survey streamflow-gaging station 08101000

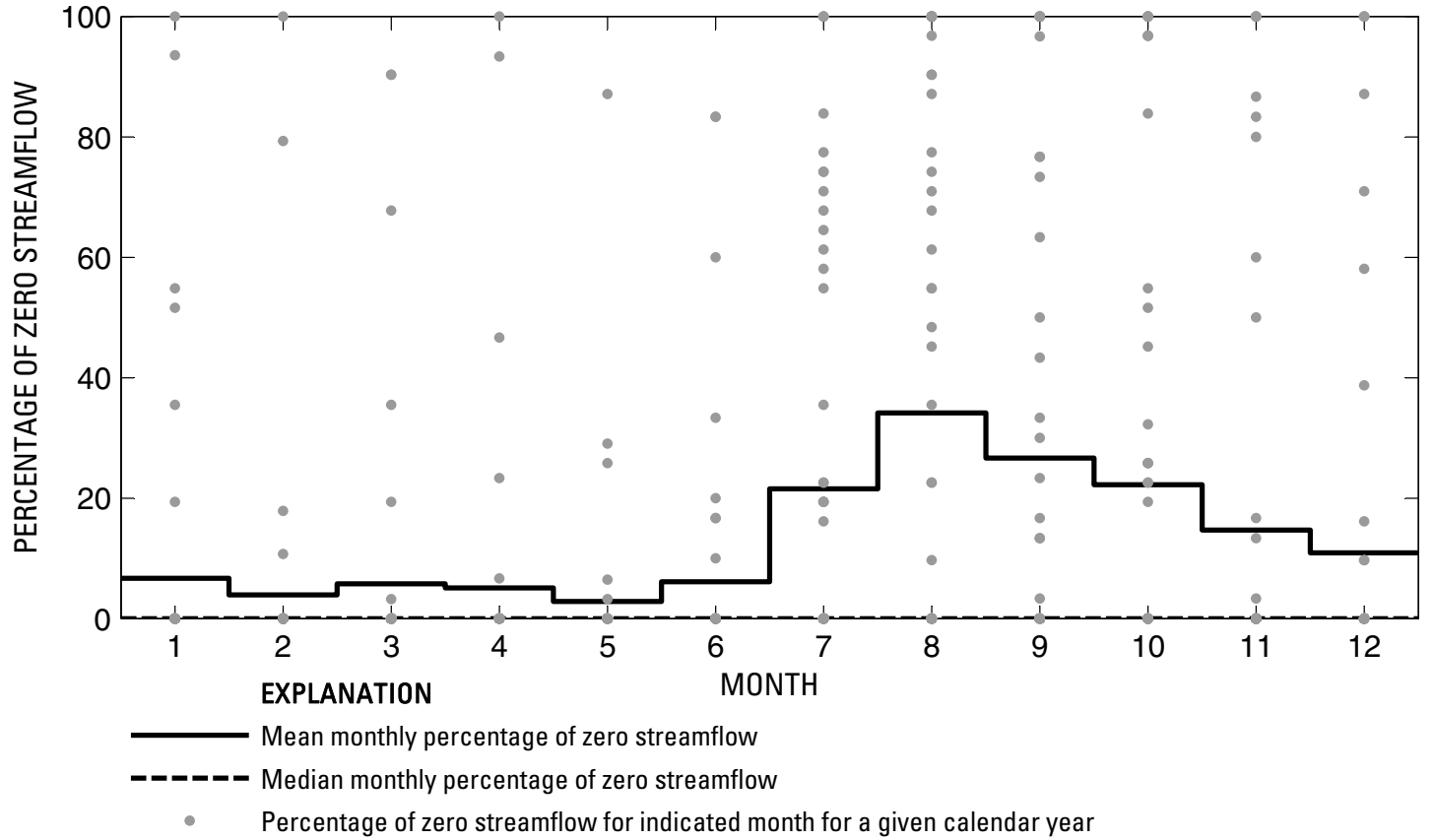

Figure 395. Analysis of percentage of zero daily mean streamflow for U.S. Geological Survey streamflow-gaging station 08101000 Cowhouse Creek at Pidcoke, Texas. 
U.S. Geological Survey streamflow-gaging station 08101500

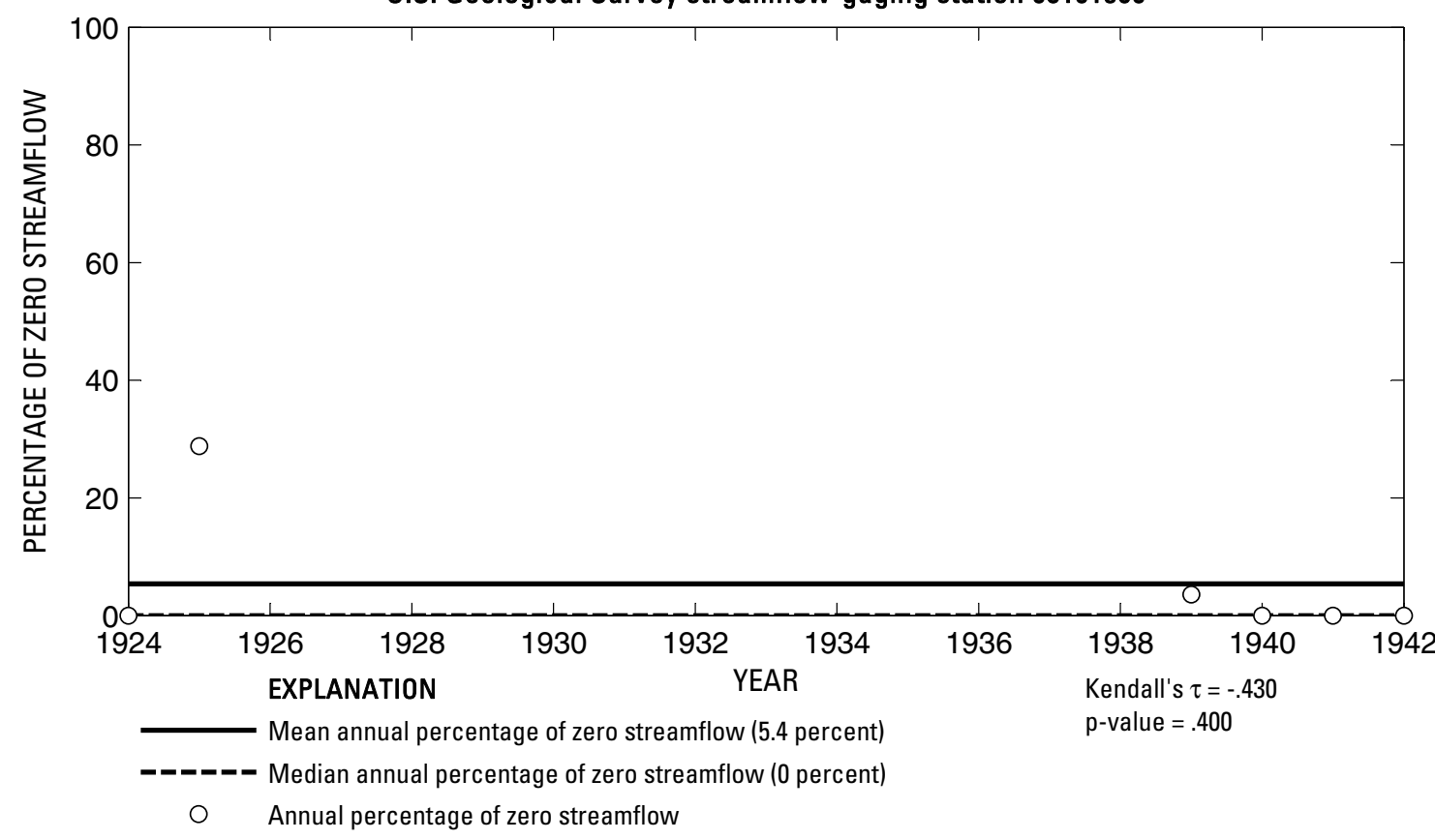

U.S. Geological Survey streamflow-gaging station 08101500

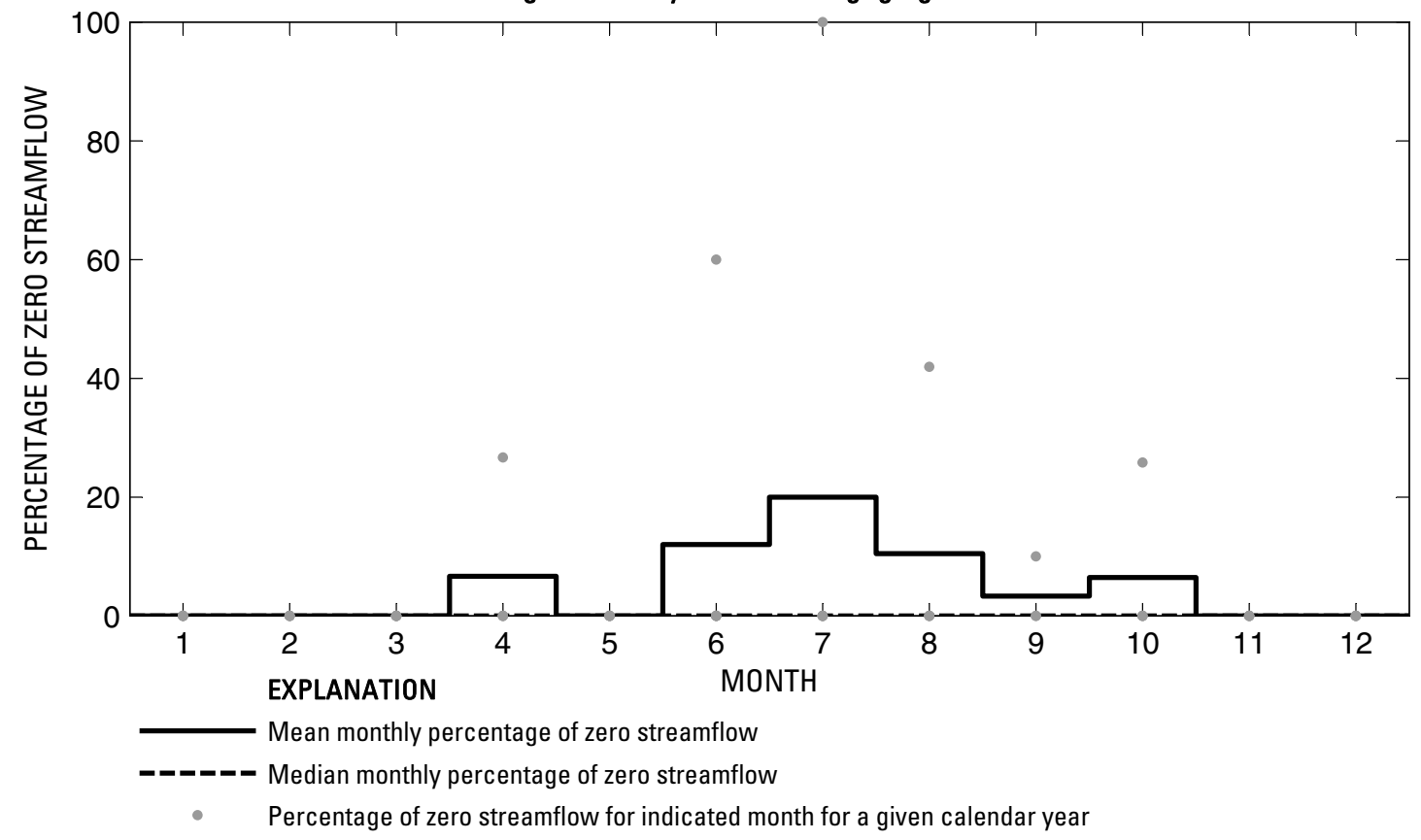

Figure 396. Analysis of percentage of zero daily mean streamflow for U.S. Geological Survey streamflow-gaging station 08101500 Cowhouse Creek near Killeen, Texas.

Index of Station Numbers 719 


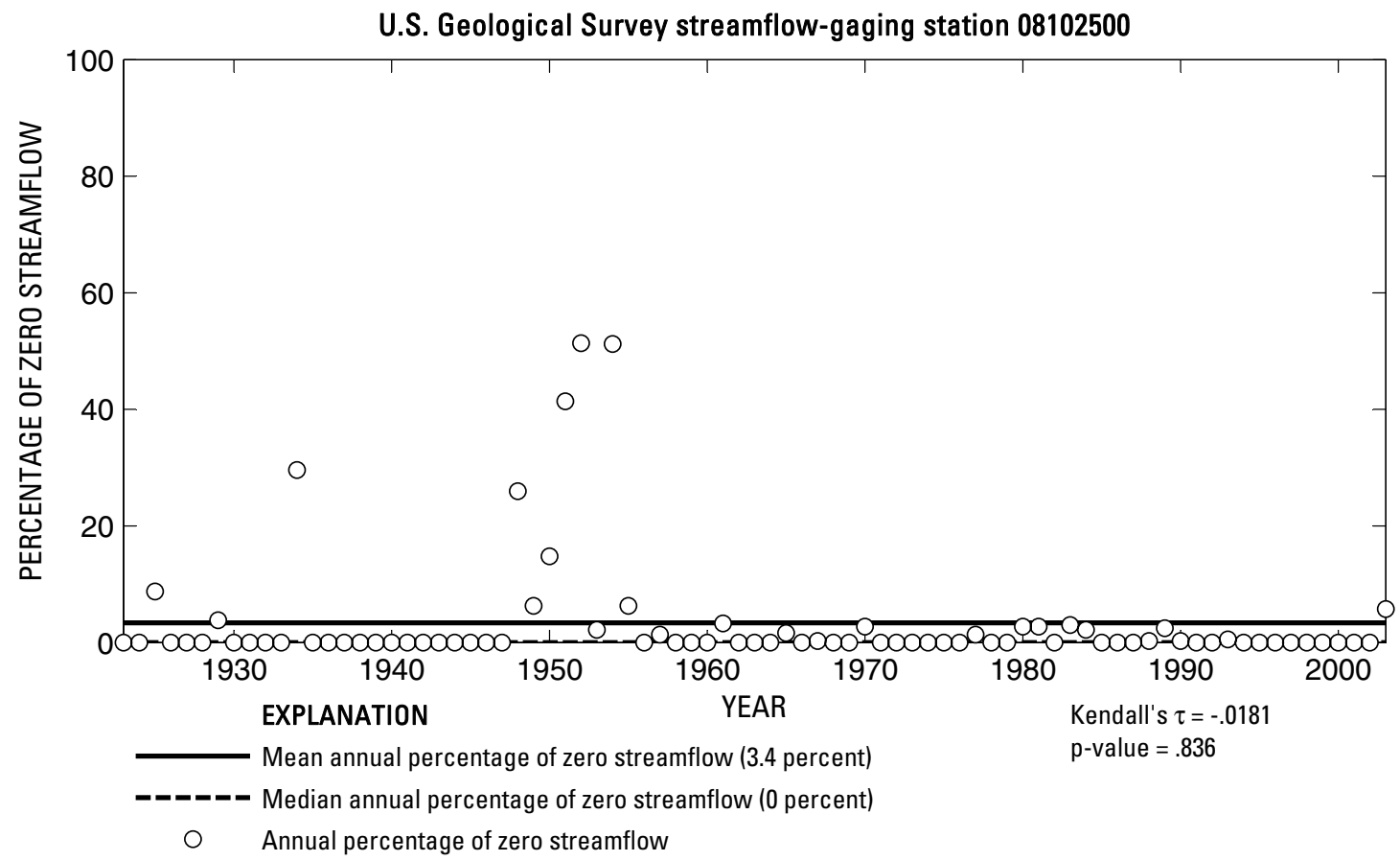

U.S. Geological Survey streamflow-gaging station 08102500

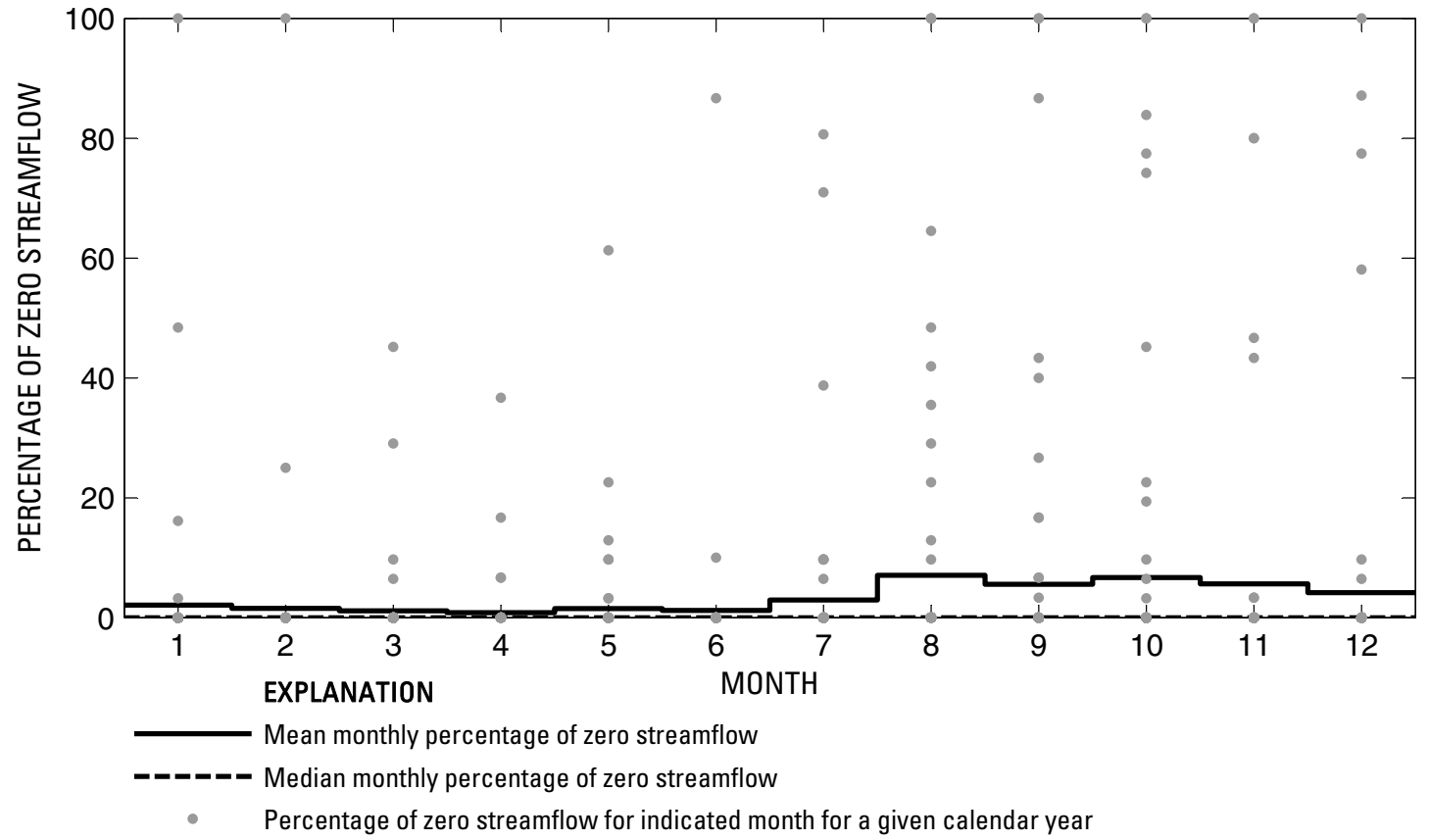

Figure 397. Analysis of percentage of zero daily mean streamflow for U.S. Geological Survey streamflow-gaging station 08102500 Leon River near Belton, Texas. 

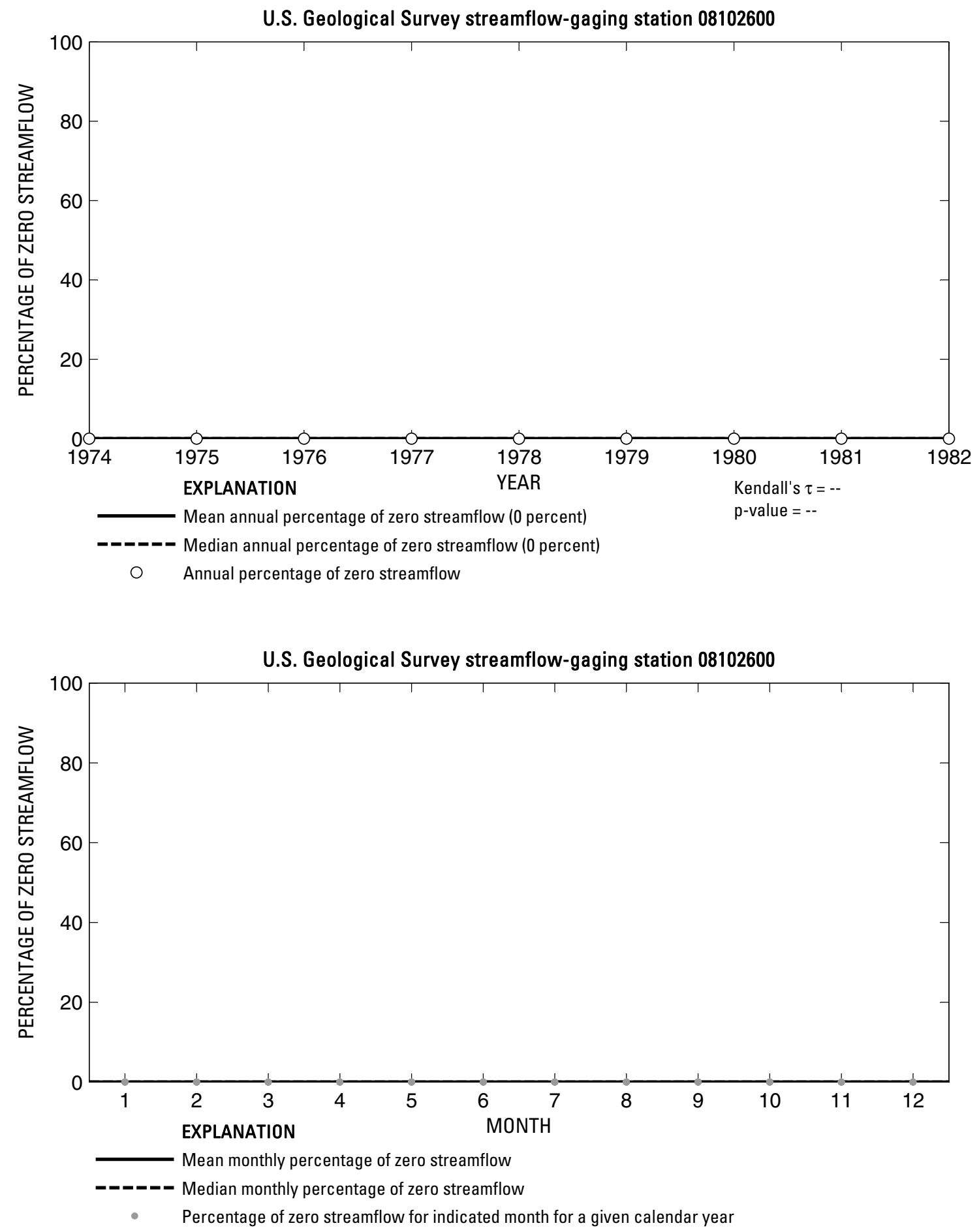

Figure 398. Analysis of percentage of zero daily mean streamflow for U.S. Geological Survey streamflow-gaging station 08102600 Nolan Creek at Belton, Texas. 
U.S. Geological Survey streamflow-gaging station 08103800

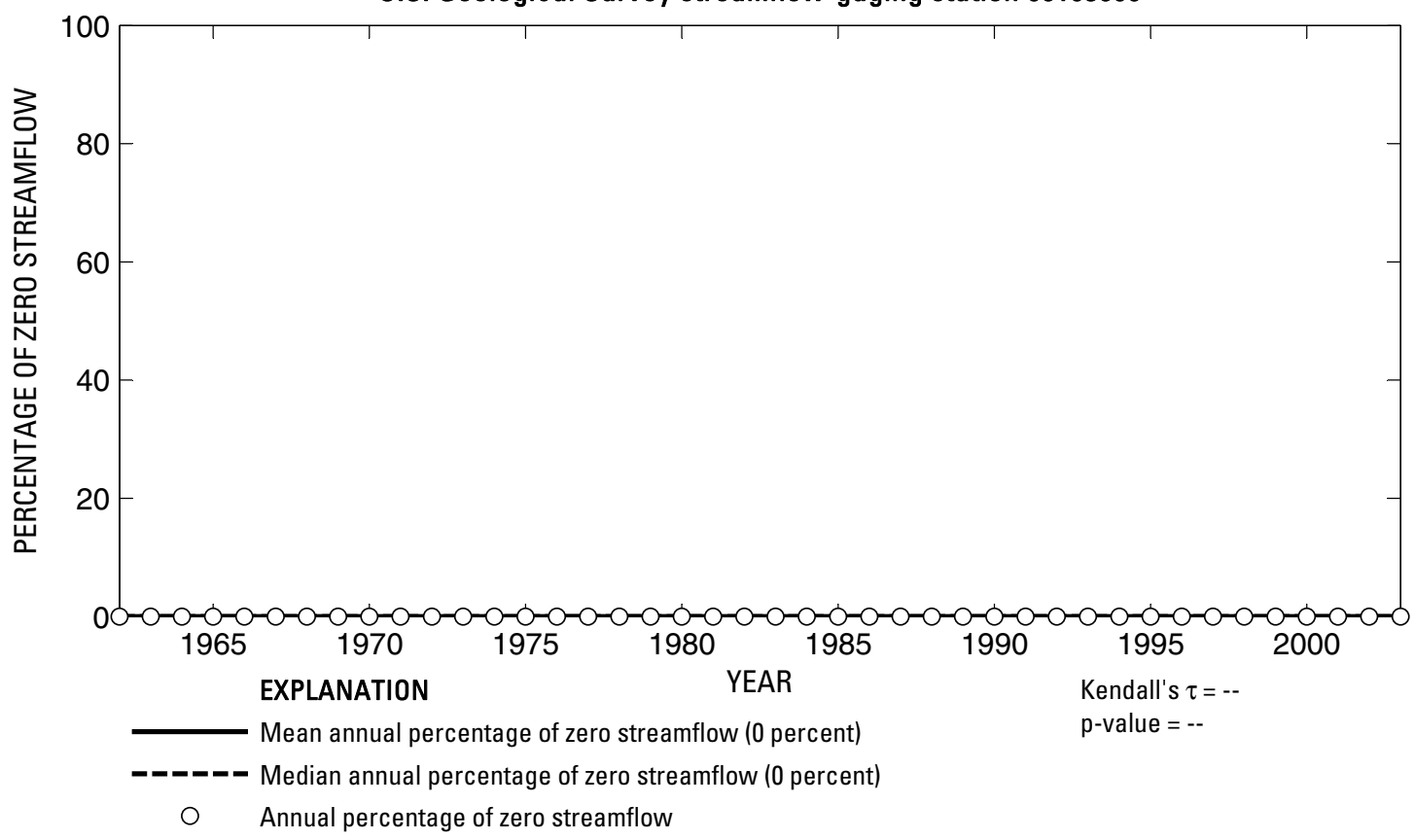

U.S. Geological Survey streamflow-gaging station 08103800

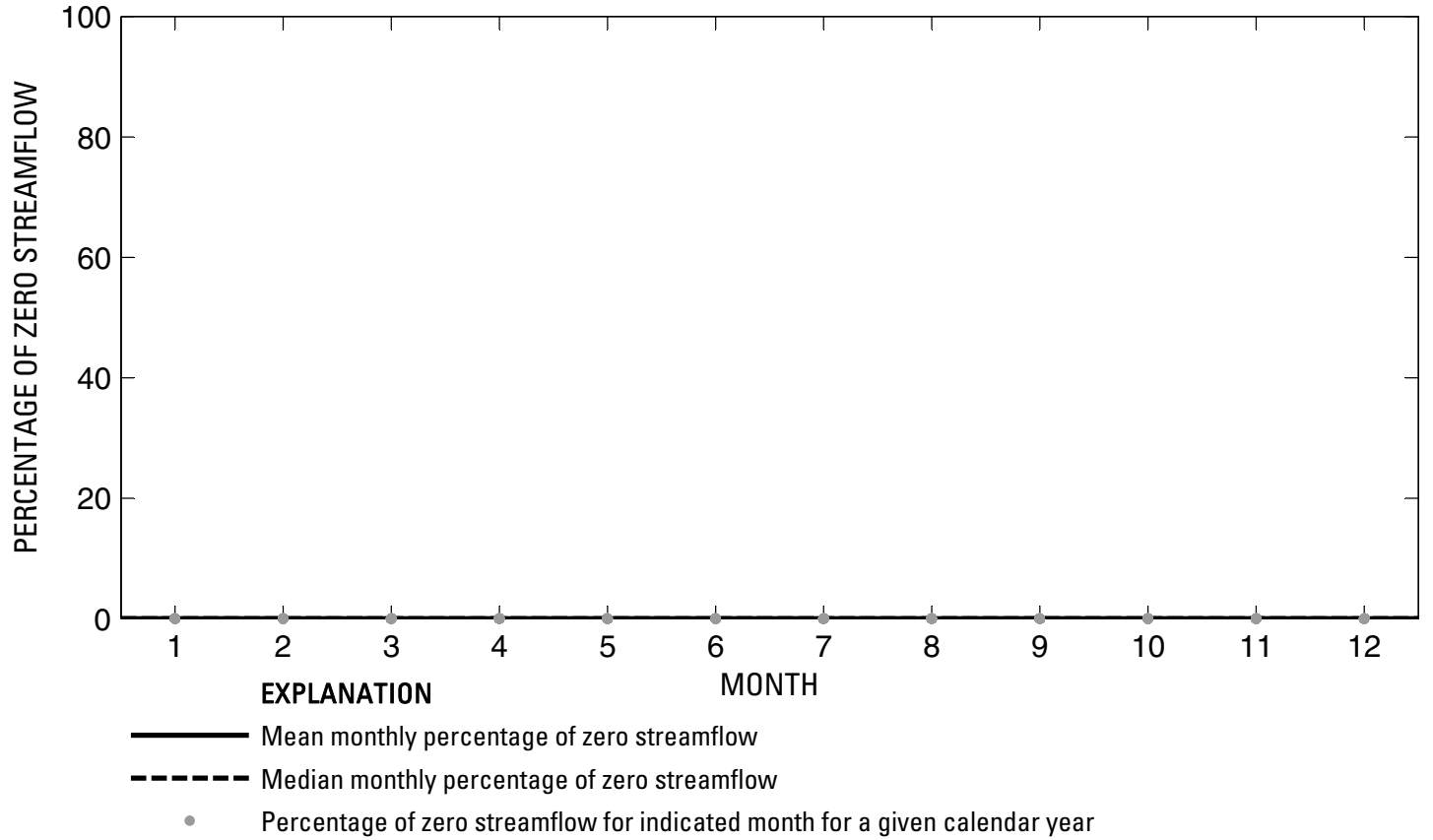

Figure 399. Analysis of percentage of zero daily mean streamflow for U.S. Geological Survey streamflow-gaging station 08103800 Lampasas River near Kempner, Texas. 
U.S. Geological Survey streamflow-gaging station 08103900

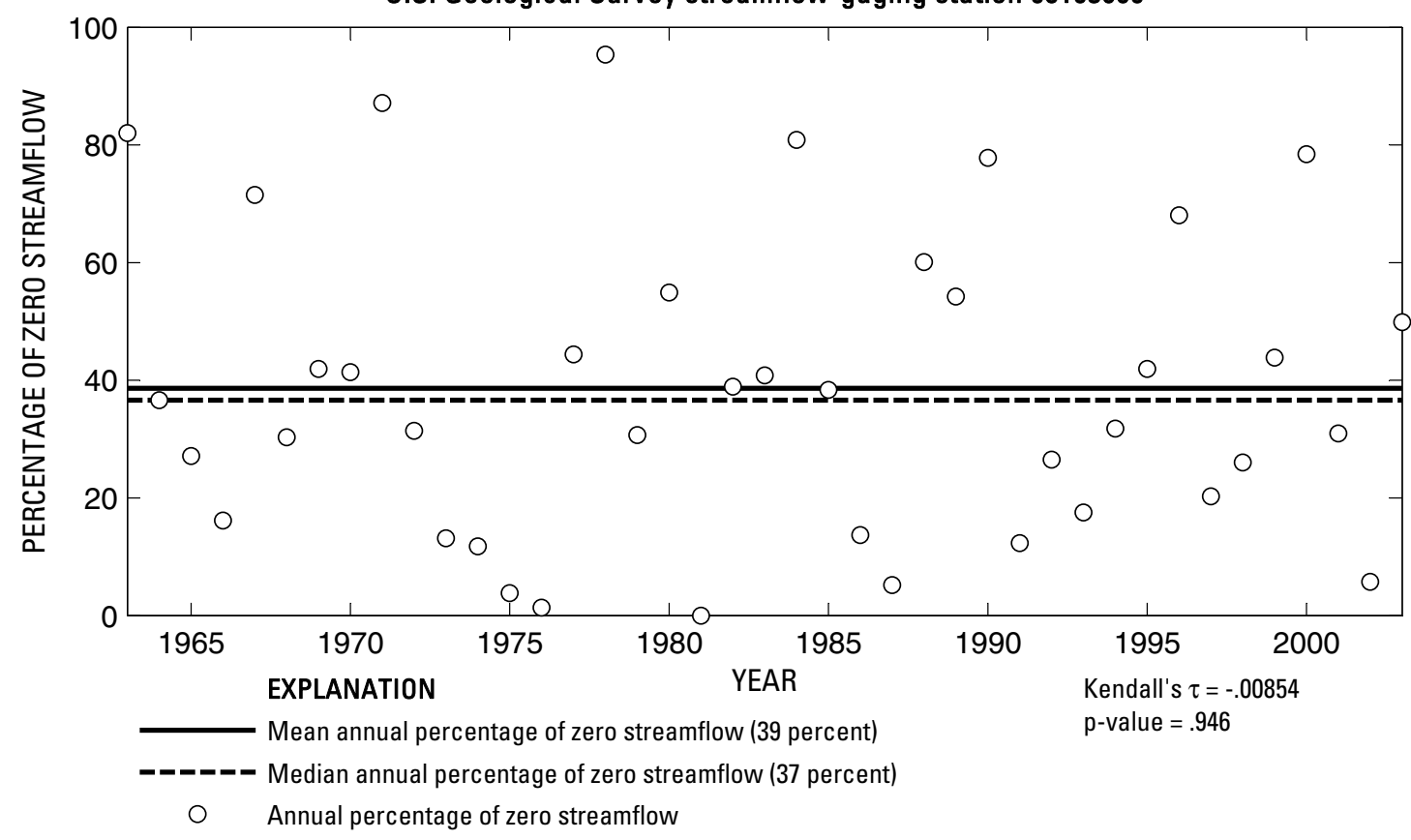

U.S. Geological Survey streamflow-gaging station 08103900

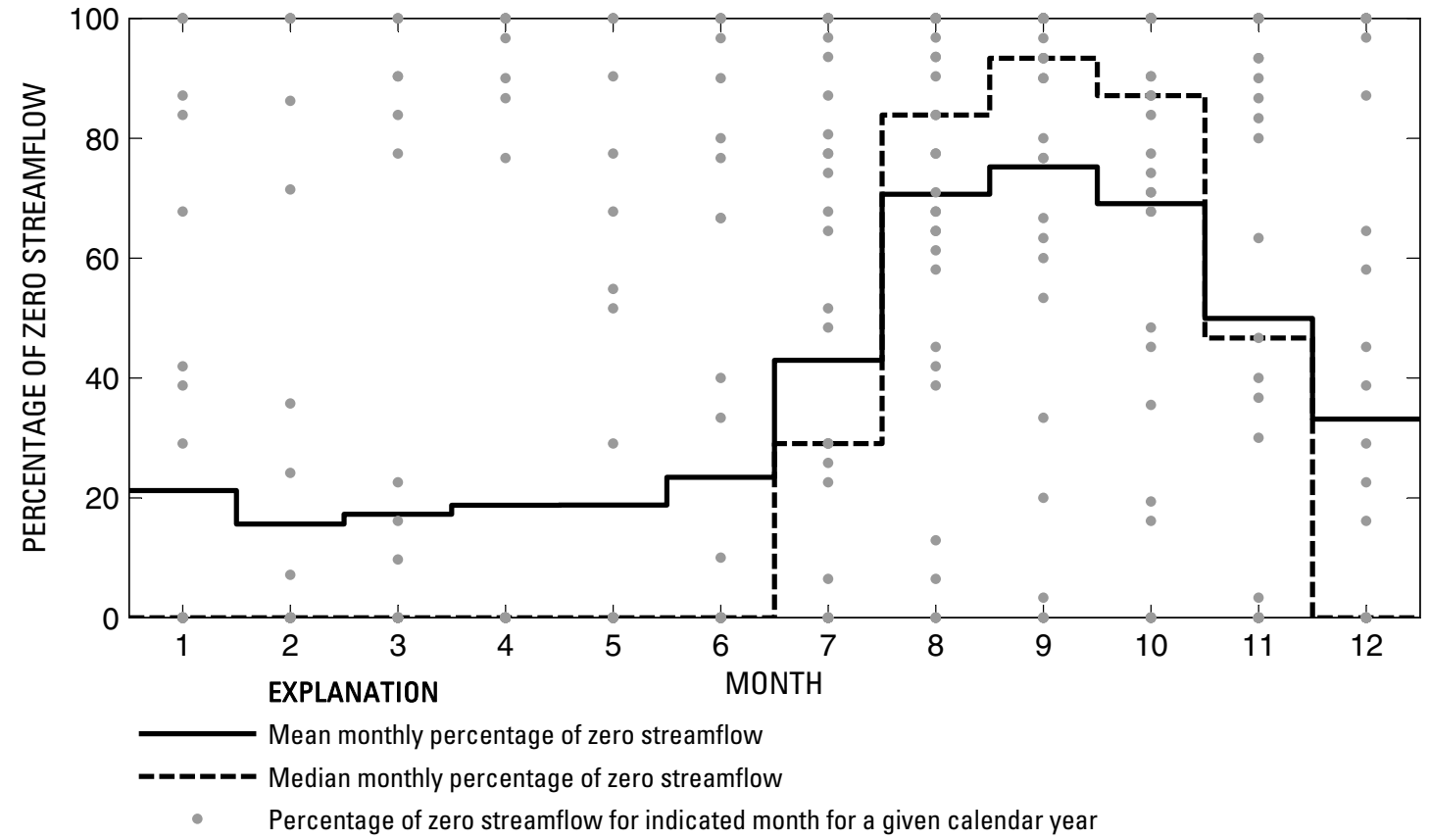

Figure 400. Analysis of percentage of zero daily mean streamflow for U.S. Geological Survey streamflow-gaging station 08103900 South Fork Rocky Creek near Briggs, Texas.

Index of Station Numbers 719 
U.S. Geological Survey streamflow-gaging station 08104000

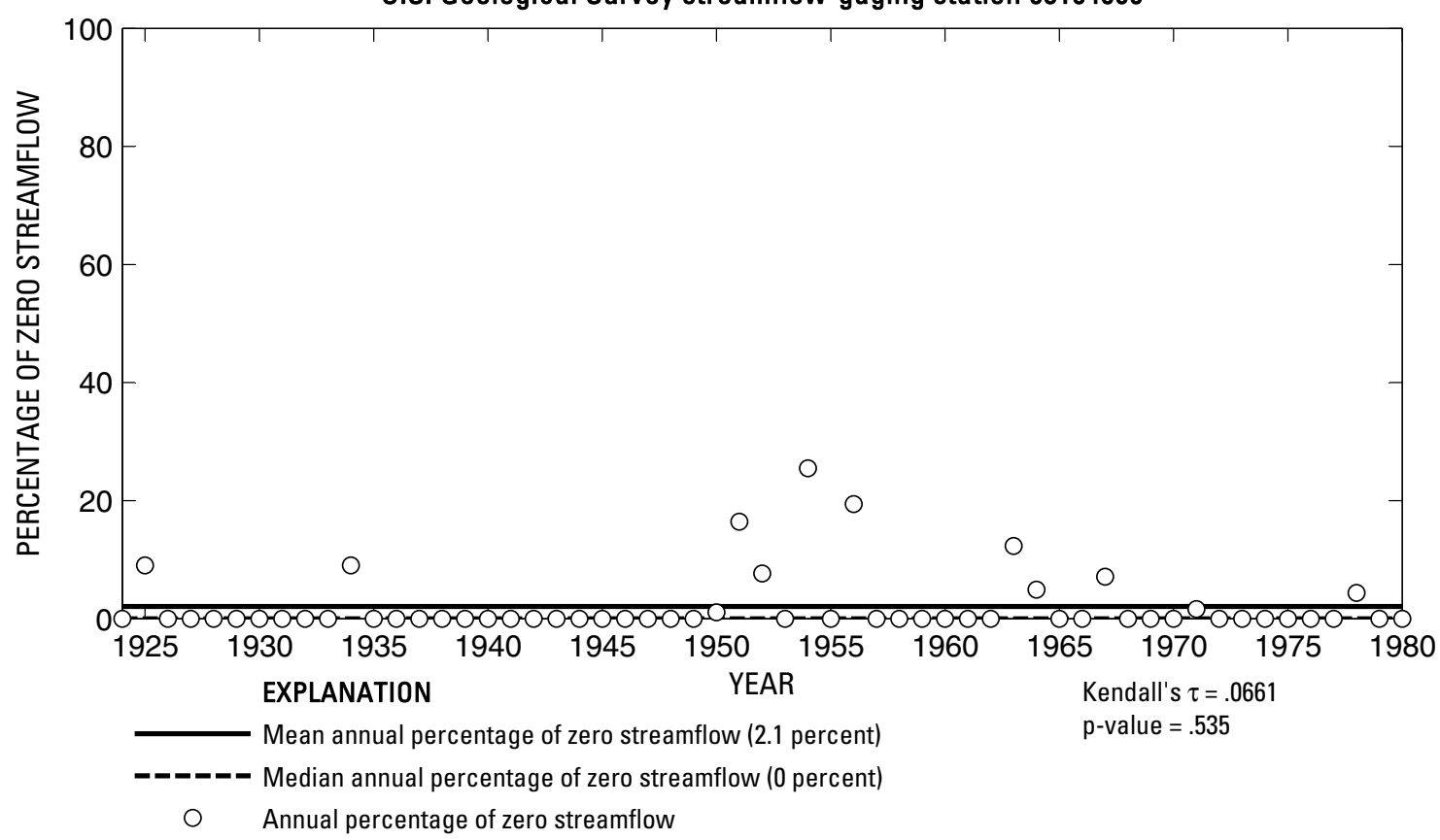

U.S. Geological Survey streamflow-gaging station 08104000

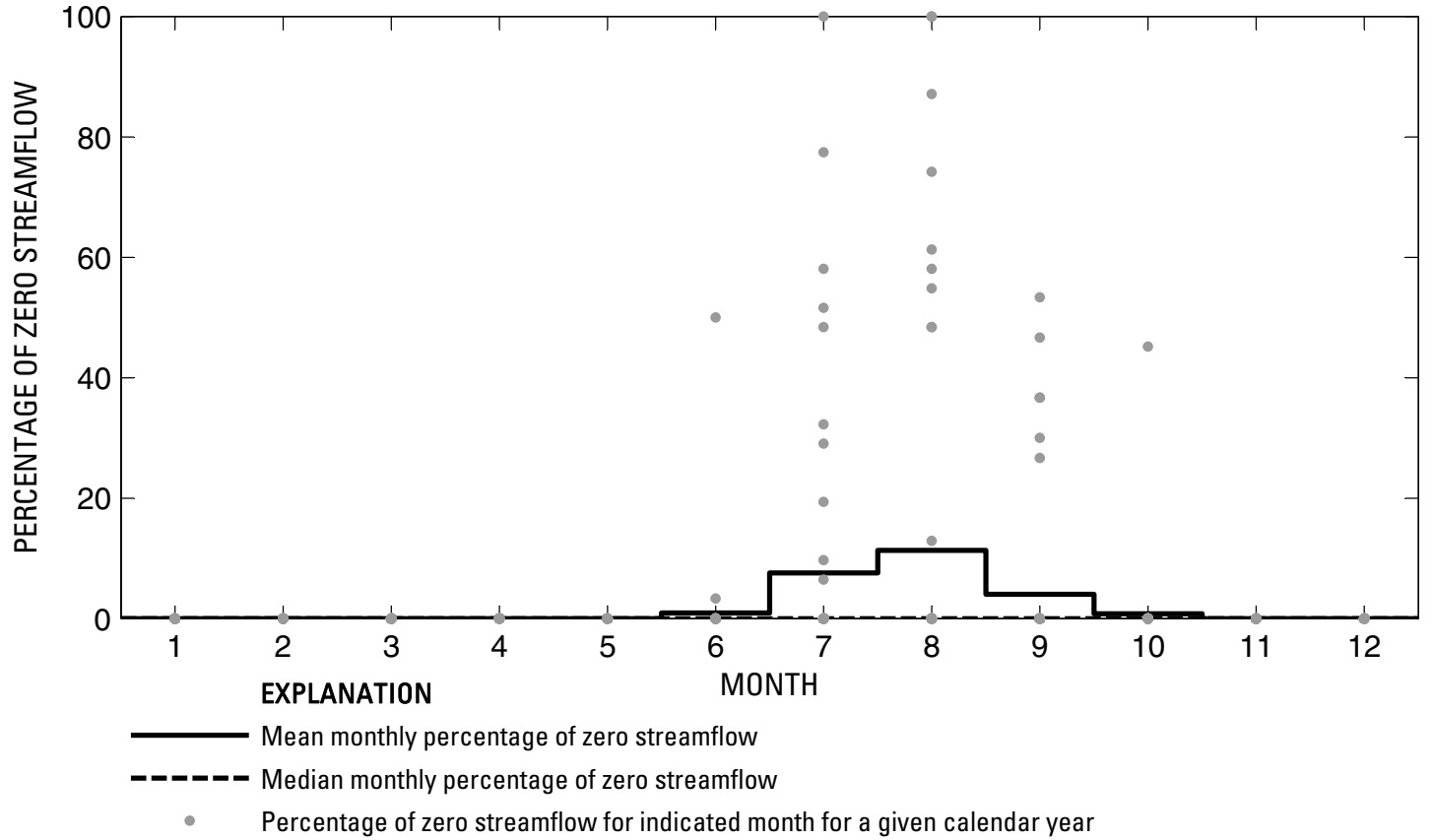

Figure 401. Analysis of percentage of zero daily mean streamflow for U.S. Geological Survey streamflow-gaging station 08104000 Lampasas River at Youngsport, Texas. 
U.S. Geological Survey streamflow-gaging station 08104100

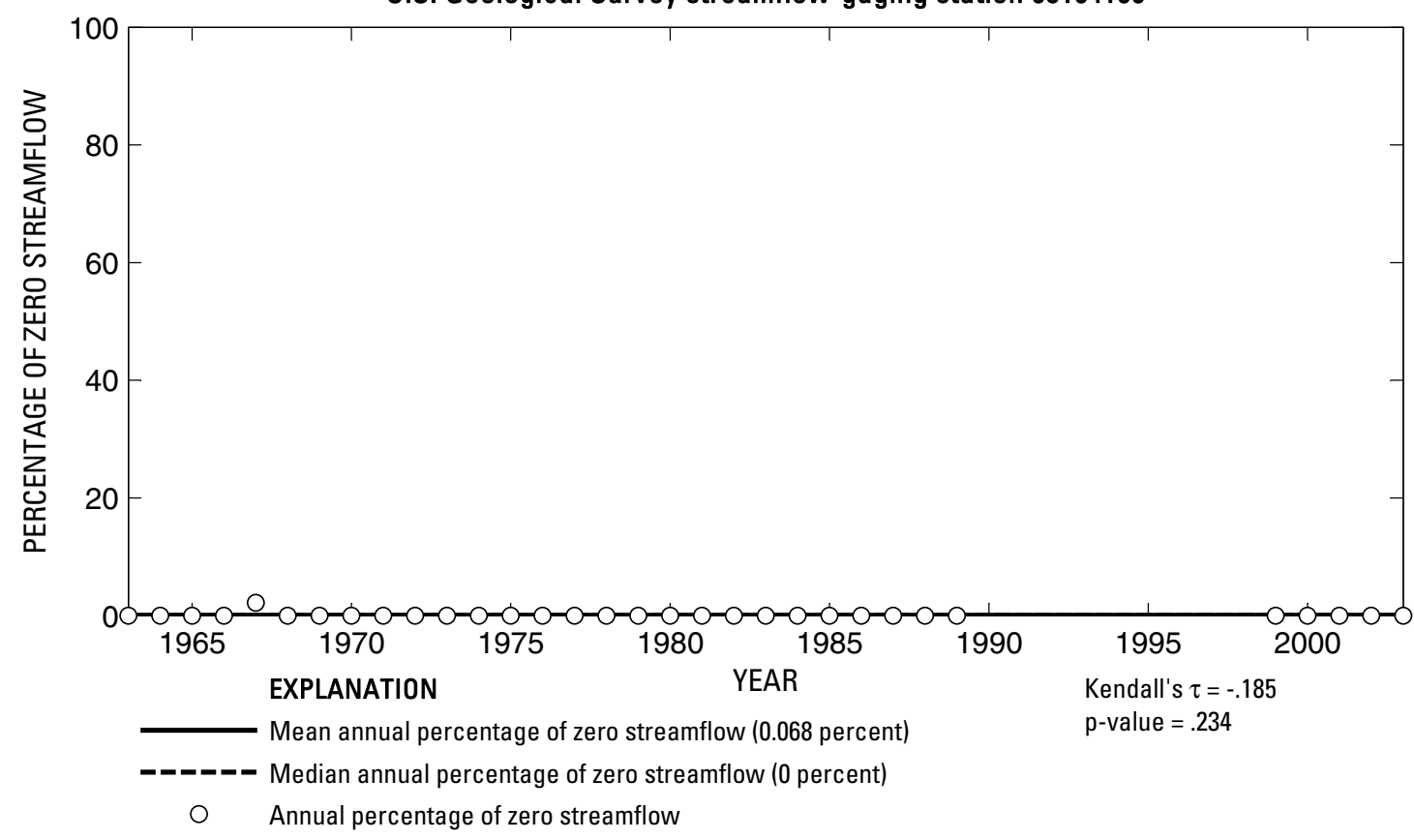

U.S. Geological Survey streamflow-gaging station 08104100

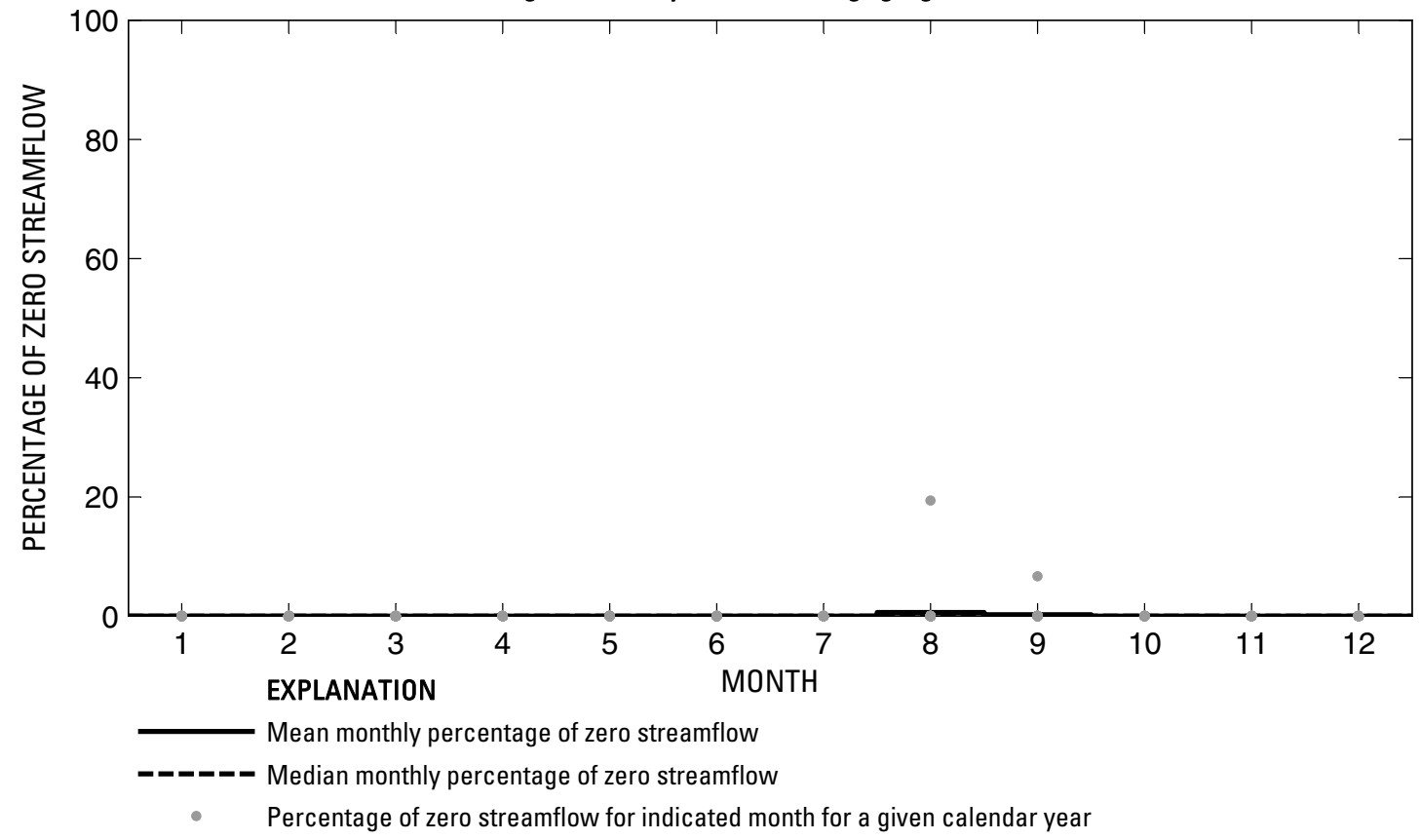

Figure 402. Analysis of percentage of zero daily mean streamflow for U.S. Geological Survey streamflow-gaging station 08104100 Lampasas River near Belton, Texas.

Index of Station Numbers 719 
U.S. Geological Survey streamflow-gaging station 08104310

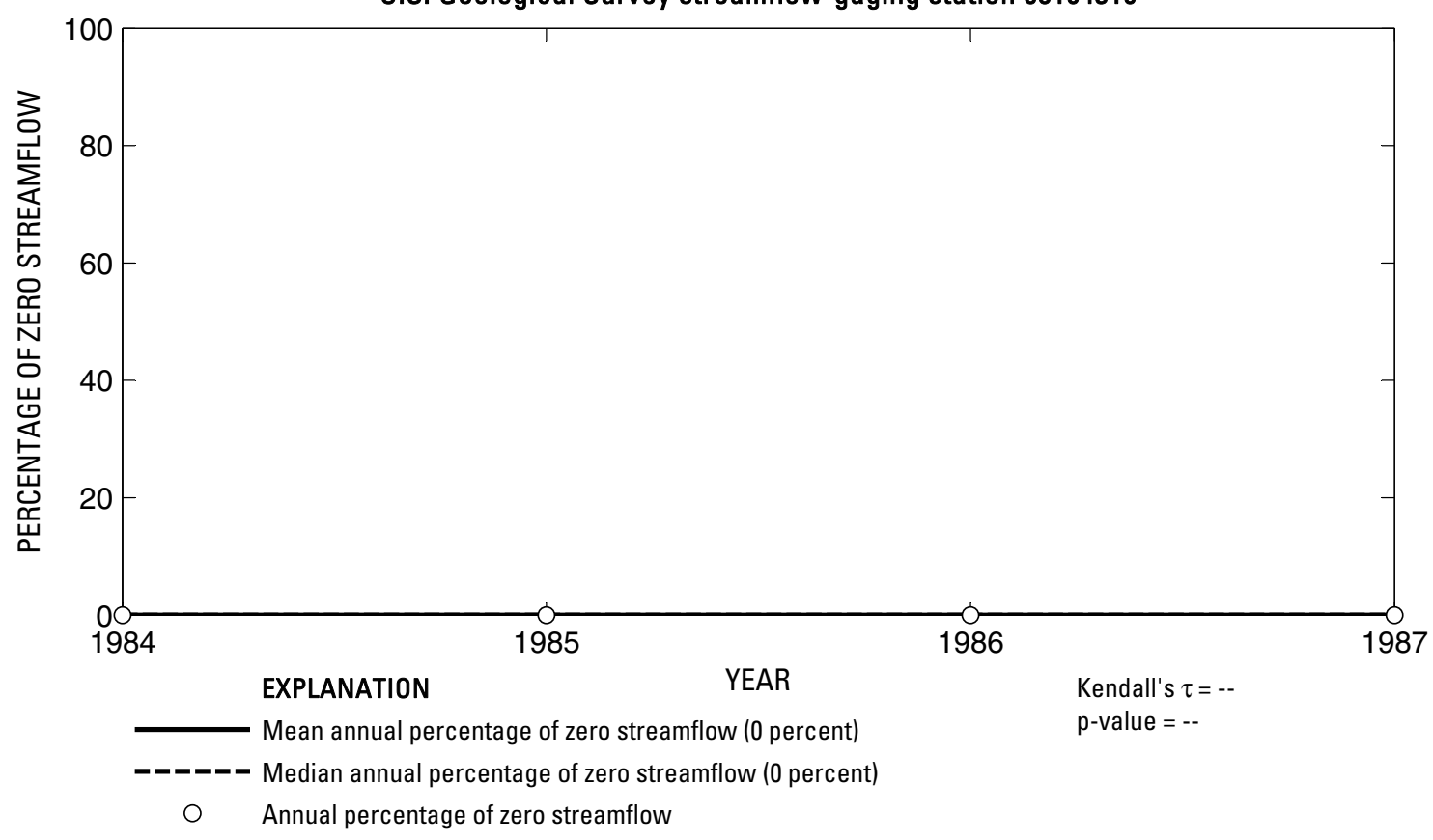

U.S. Geological Survey streamflow-gaging station 08104310

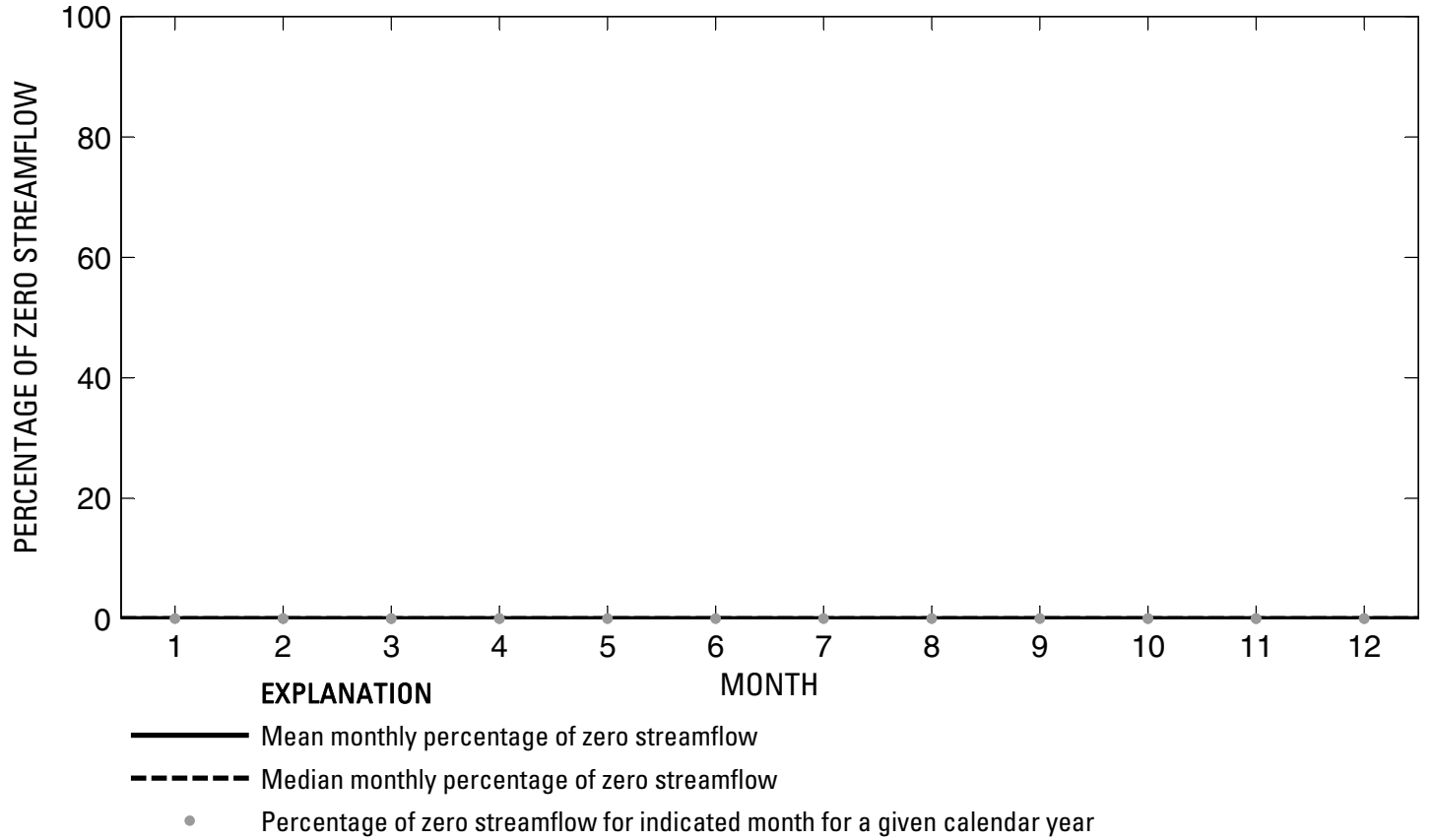

Figure 403. Analysis of percentage of zero daily mean streamflow for U.S. Geological Survey streamflow-gaging station 08104310 Salado Creek below Salado Springs at Salado, Texas. 

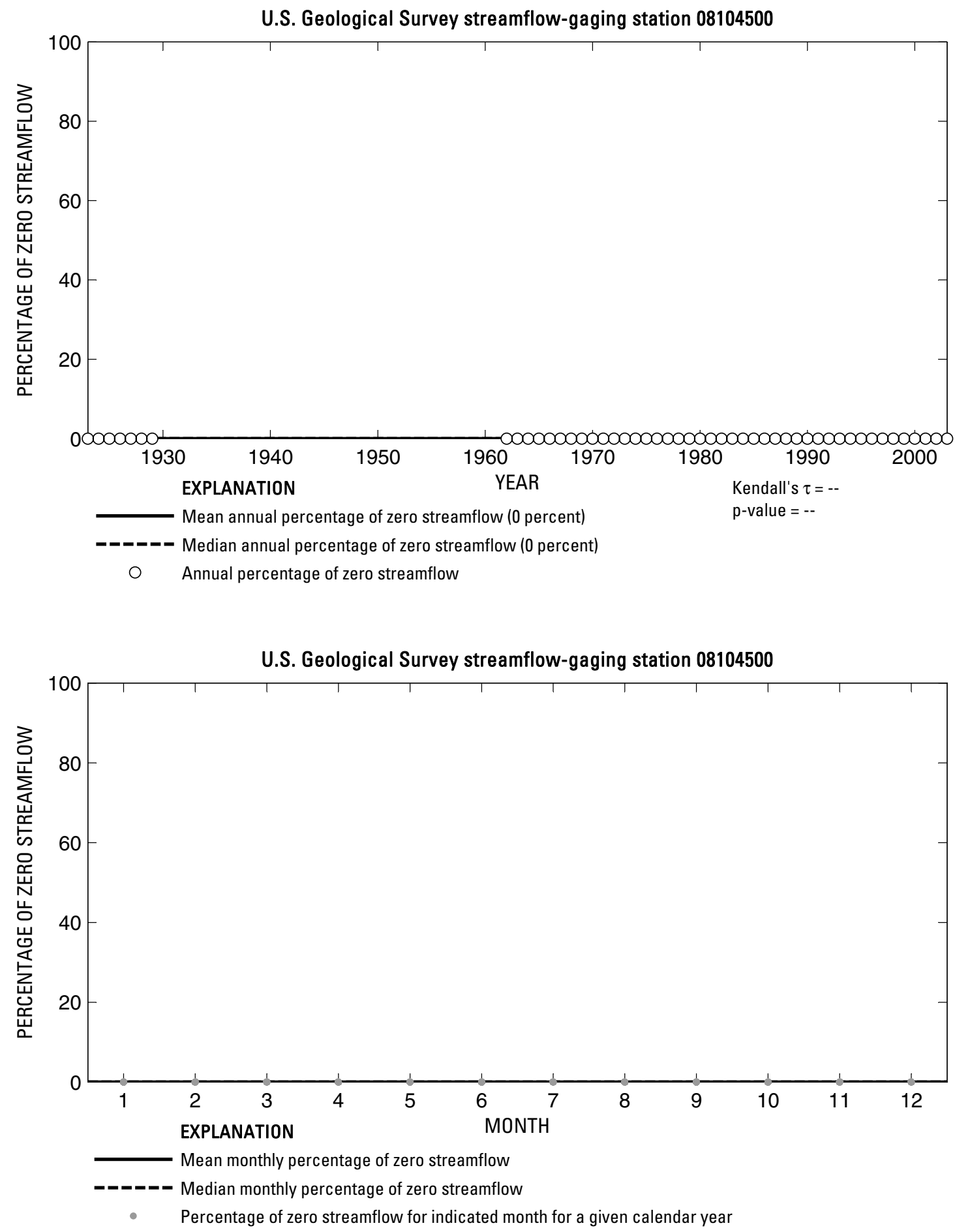

Figure 404. Analysis of percentage of zero daily mean streamflow for U.S. Geological Survey streamflow-gaging station 08104500 Little River near Little River, Texas. 
U.S. Geological Survey streamflow-gaging station 08104700

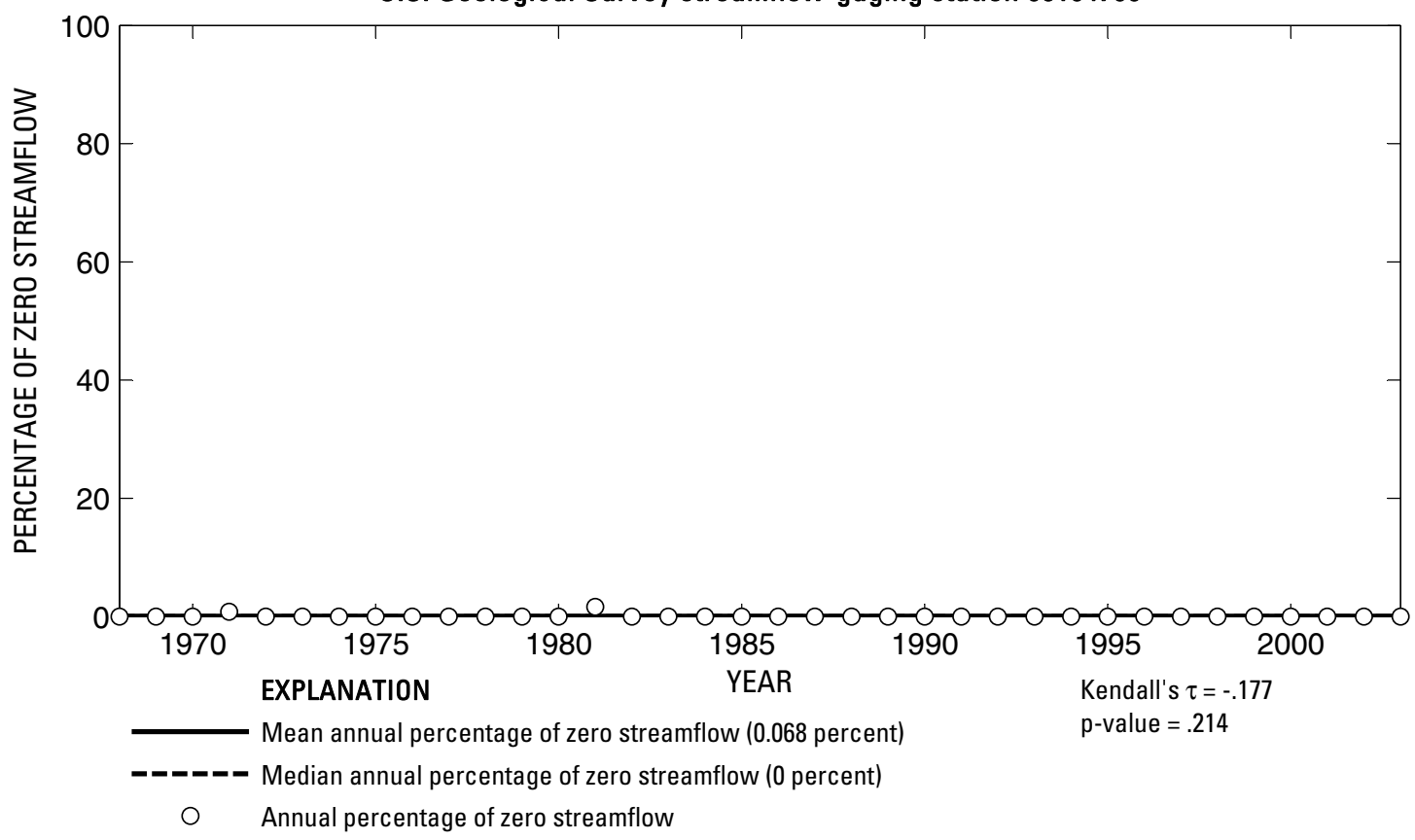

U.S. Geological Survey streamflow-gaging station 08104700

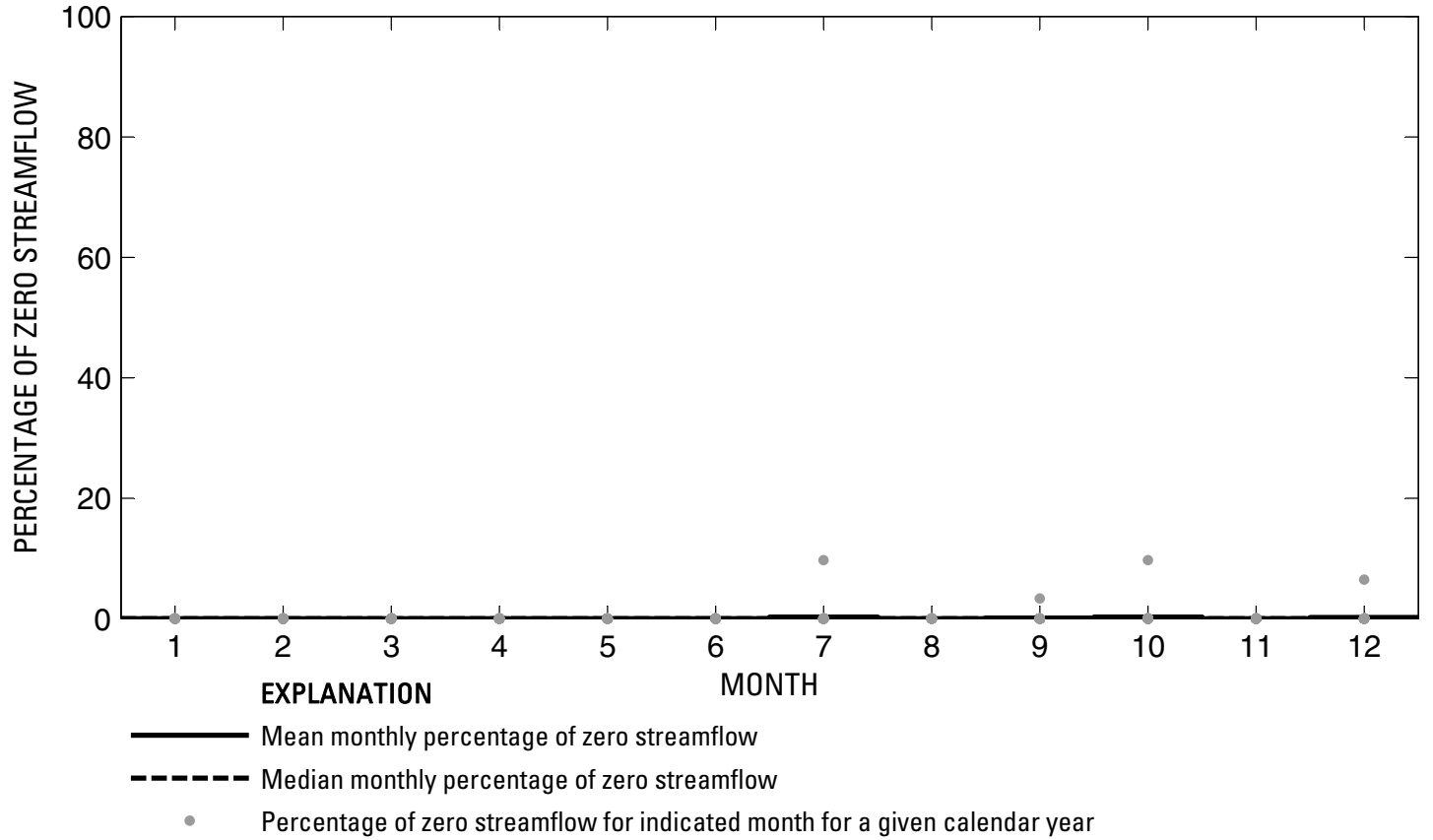

Figure 405. Analysis of percentage of zero daily mean streamflow for U.S. Geological Survey streamflow-gaging station 08104700 North Fork San Gabriel River near Georgetown, Texas. 
U.S. Geological Survey streamflow-gaging station 08104900

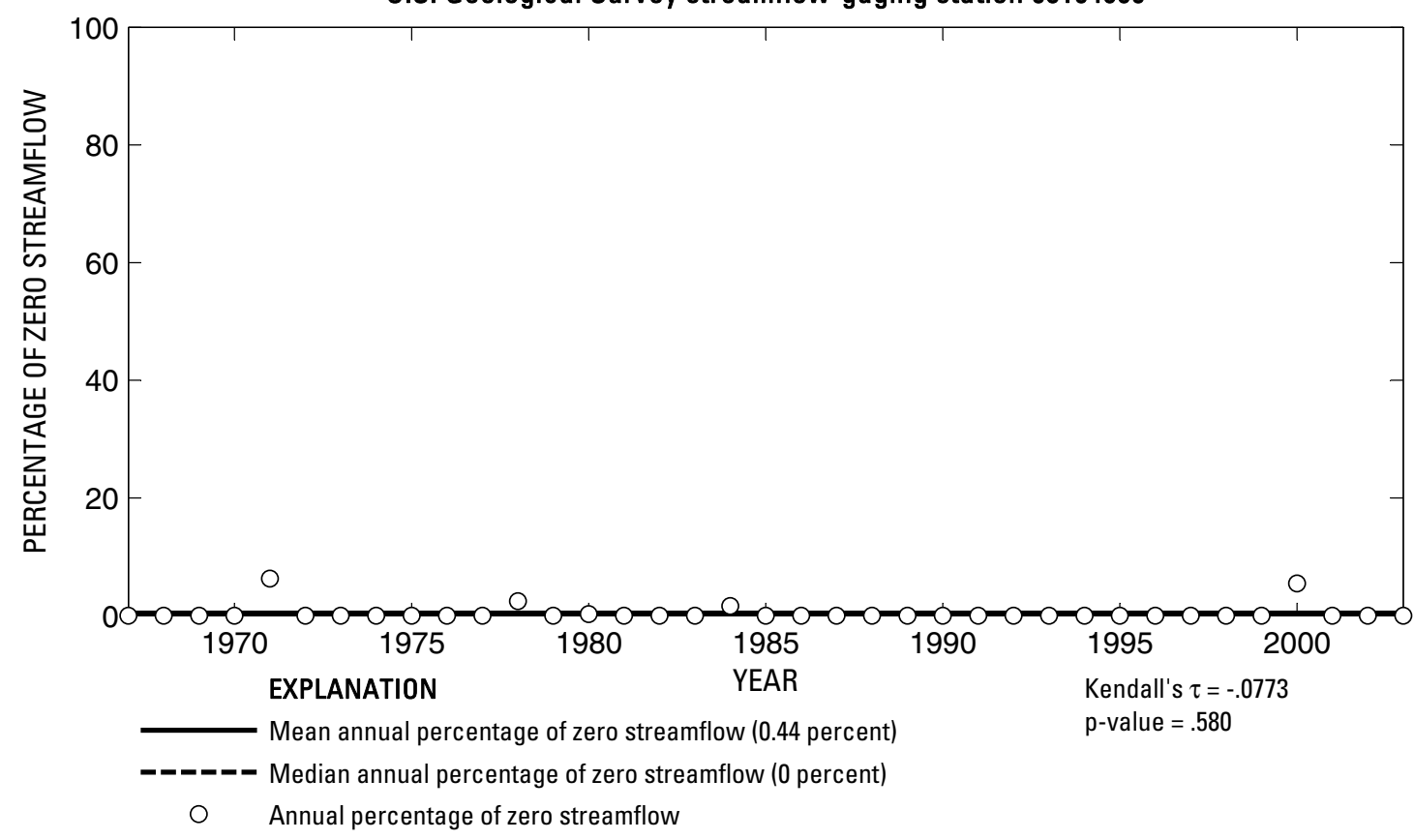

U.S. Geological Survey streamflow-gaging station 08104900

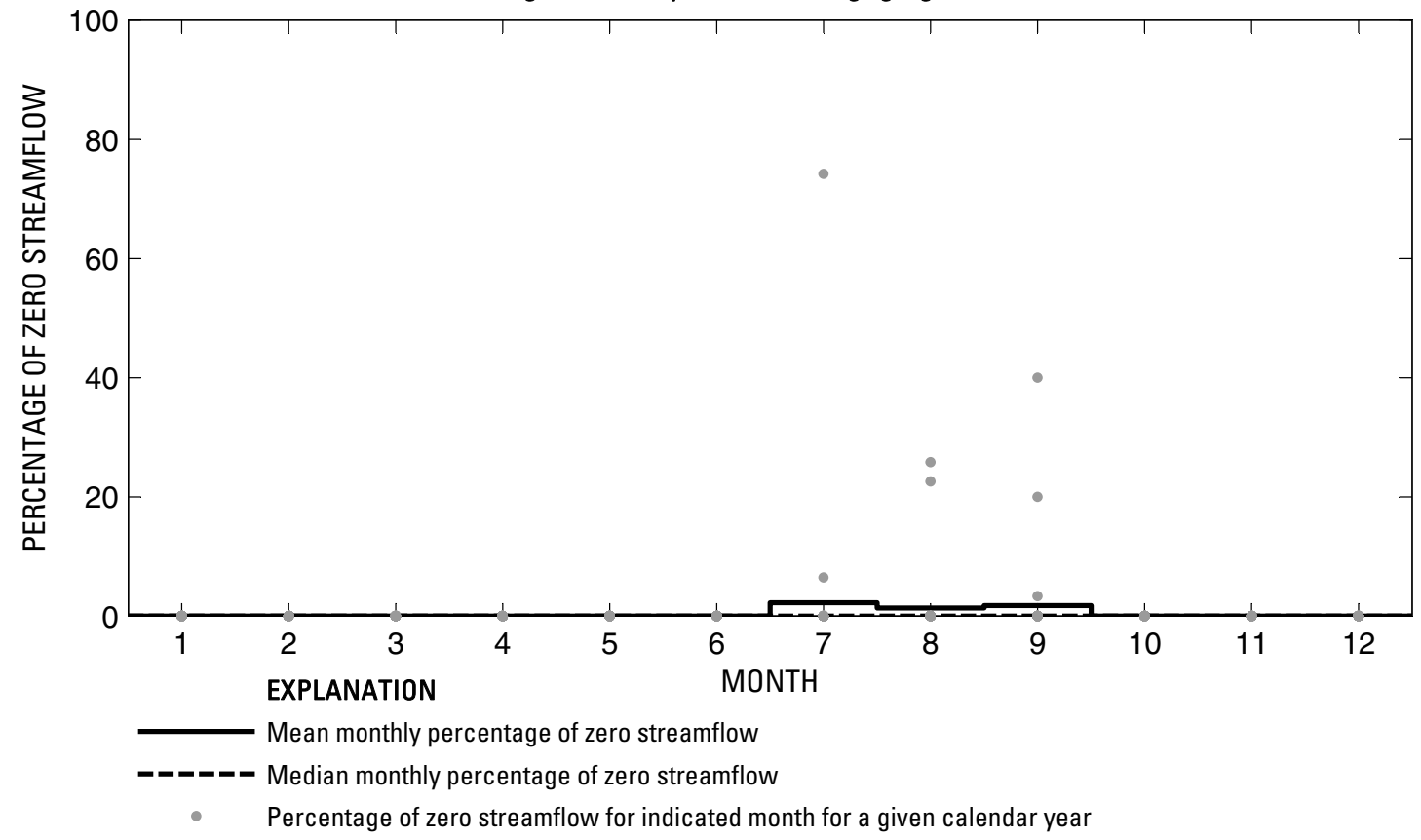

Figure 406. Analysis of percentage of zero daily mean streamflow for U.S. Geological Survey streamflow-gaging station 08104900 South Fork San Gabriel River at Georgetown, Texas. 


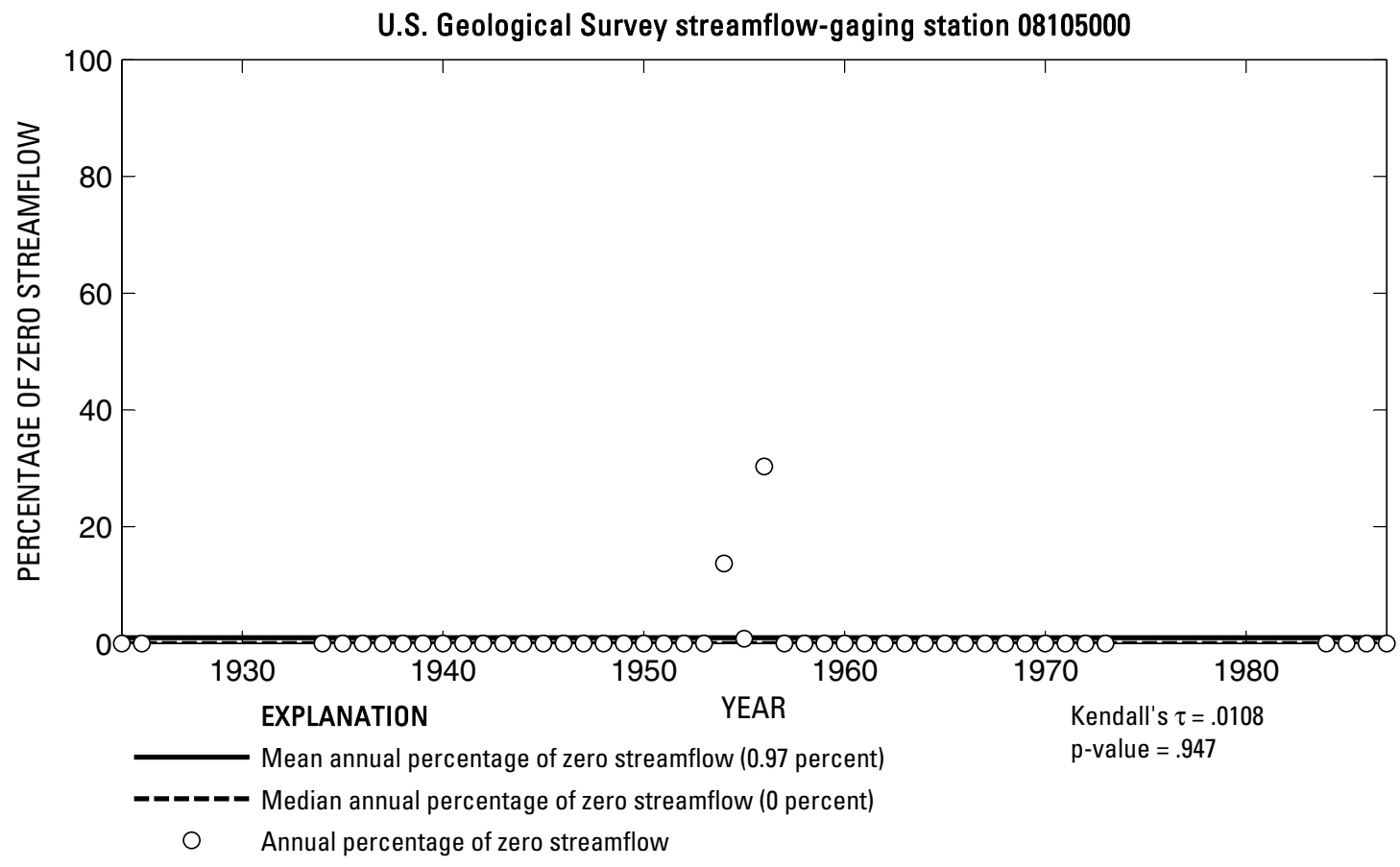

U.S. Geological Survey streamflow-gaging station 08105000

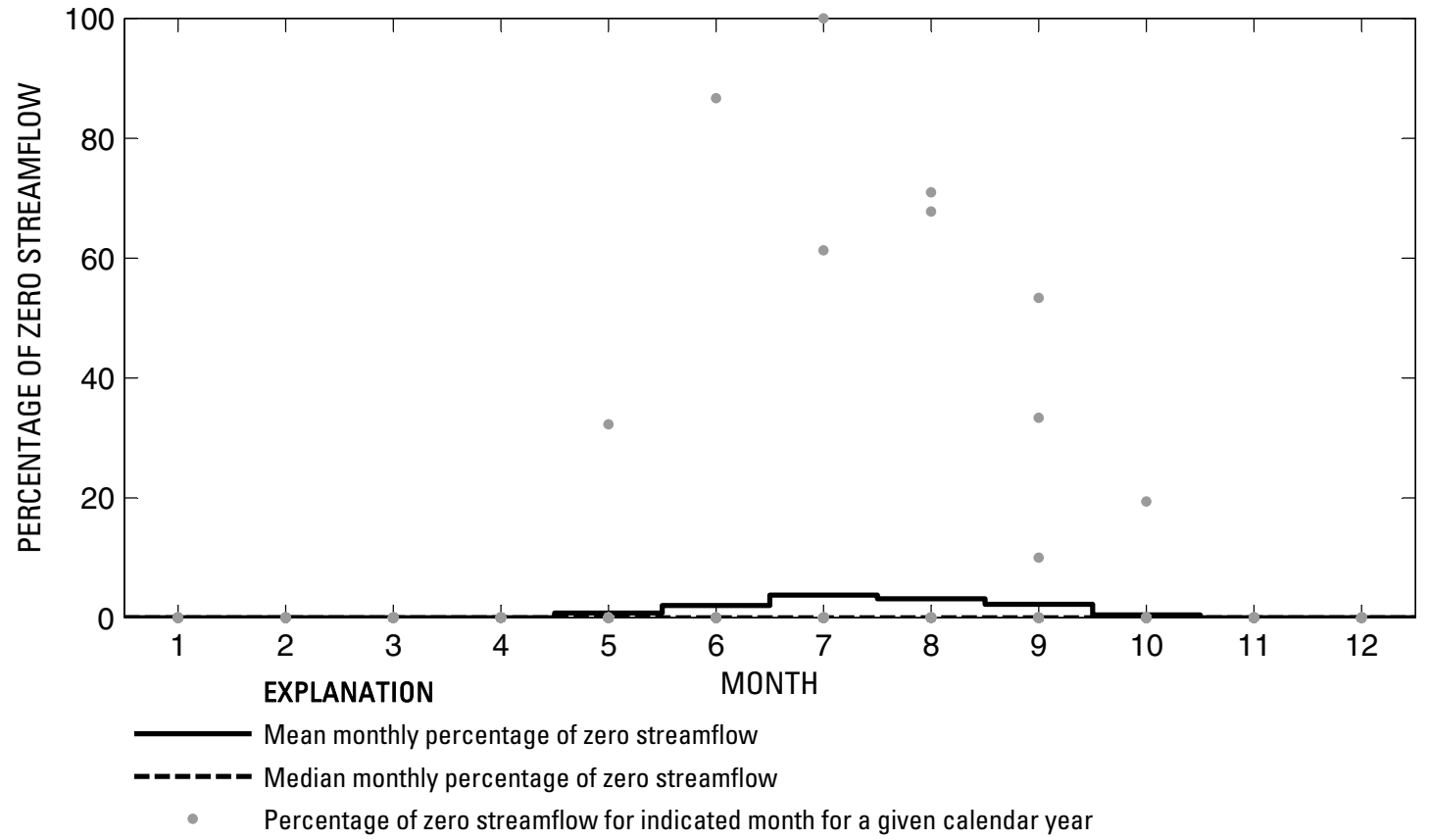

Figure 407. Analysis of percentage of zero daily mean streamflow for U.S. Geological Survey streamflow-gaging station 08105000 San Gabriel River at Georgetown, Texas. 

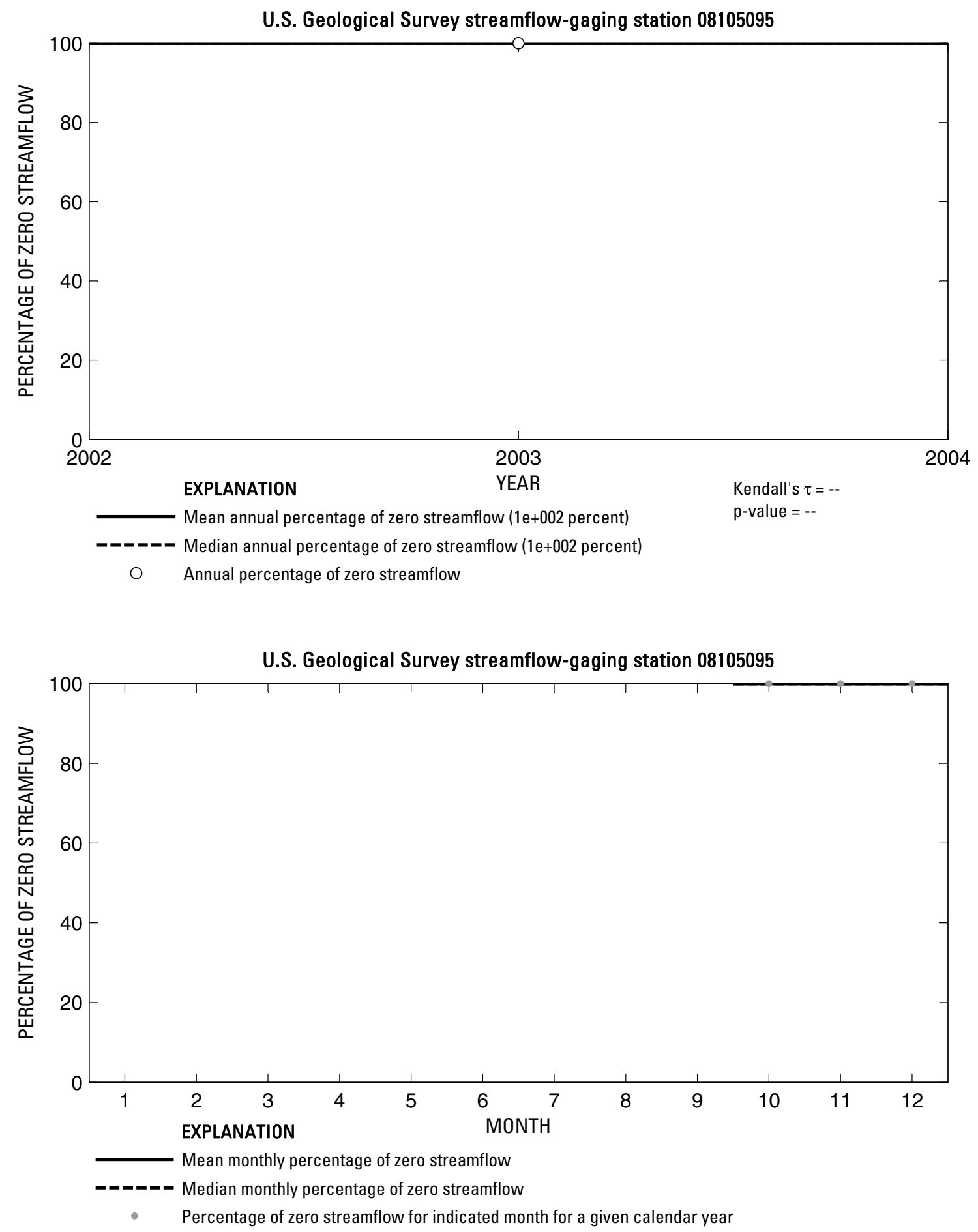

Figure 408. Analysis of percentage of zero daily mean streamflow for U.S. Geological Survey streamflow-gaging station 08105095 Berry Creek at Airport Road near Georgetown, Texas. 
U.S. Geological Survey streamflow-gaging station 08105100

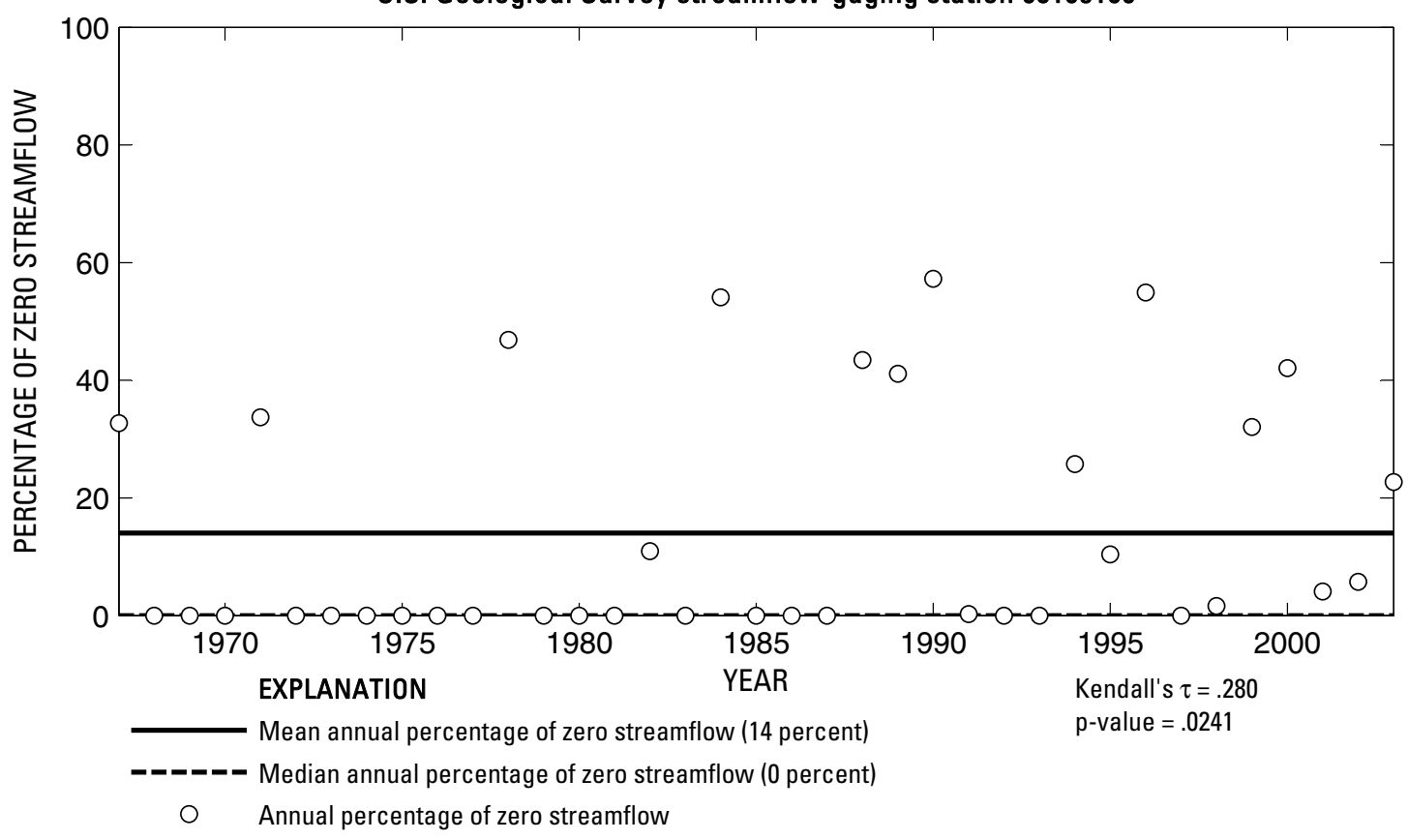

U.S. Geological Survey streamflow-gaging station 08105100

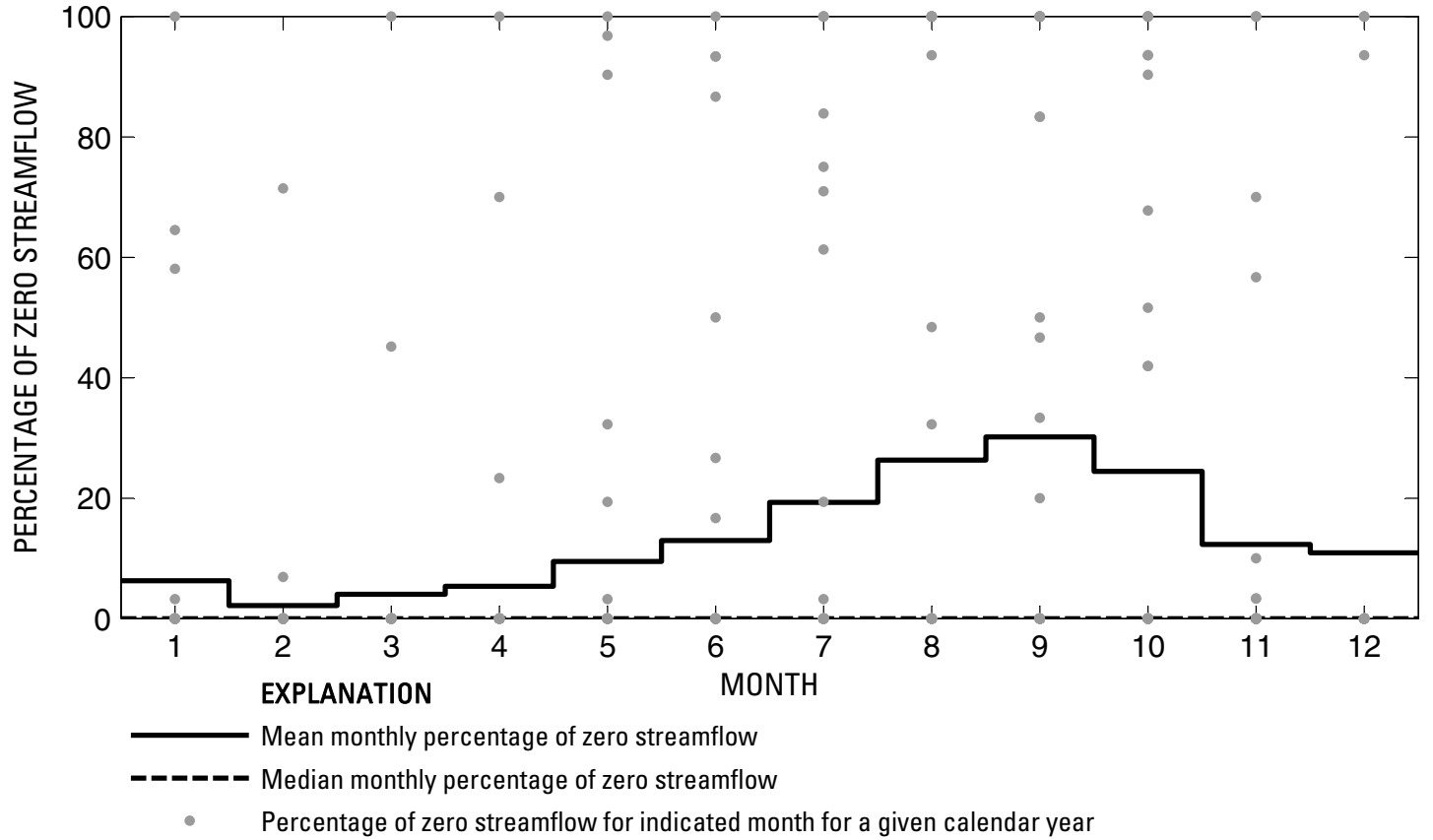

Figure 409. Analysis of percentage of zero daily mean streamflow for U.S. Geological Survey streamflow-gaging station 08105100 Berry Creek near Georgetown, Texas. 
U.S. Geological Survey streamflow-gaging station 08105200

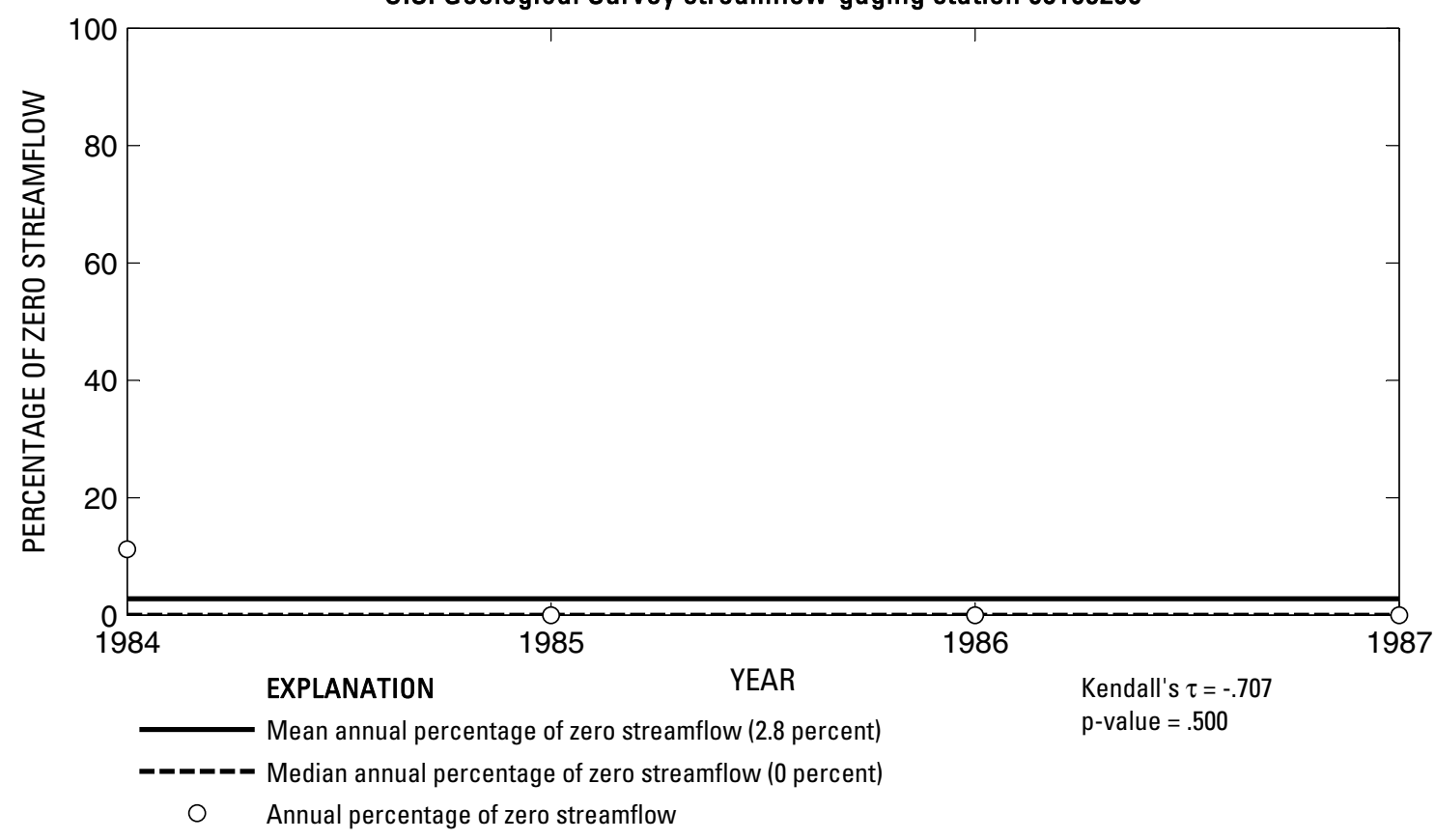

U.S. Geological Survey streamflow-gaging station 08105200

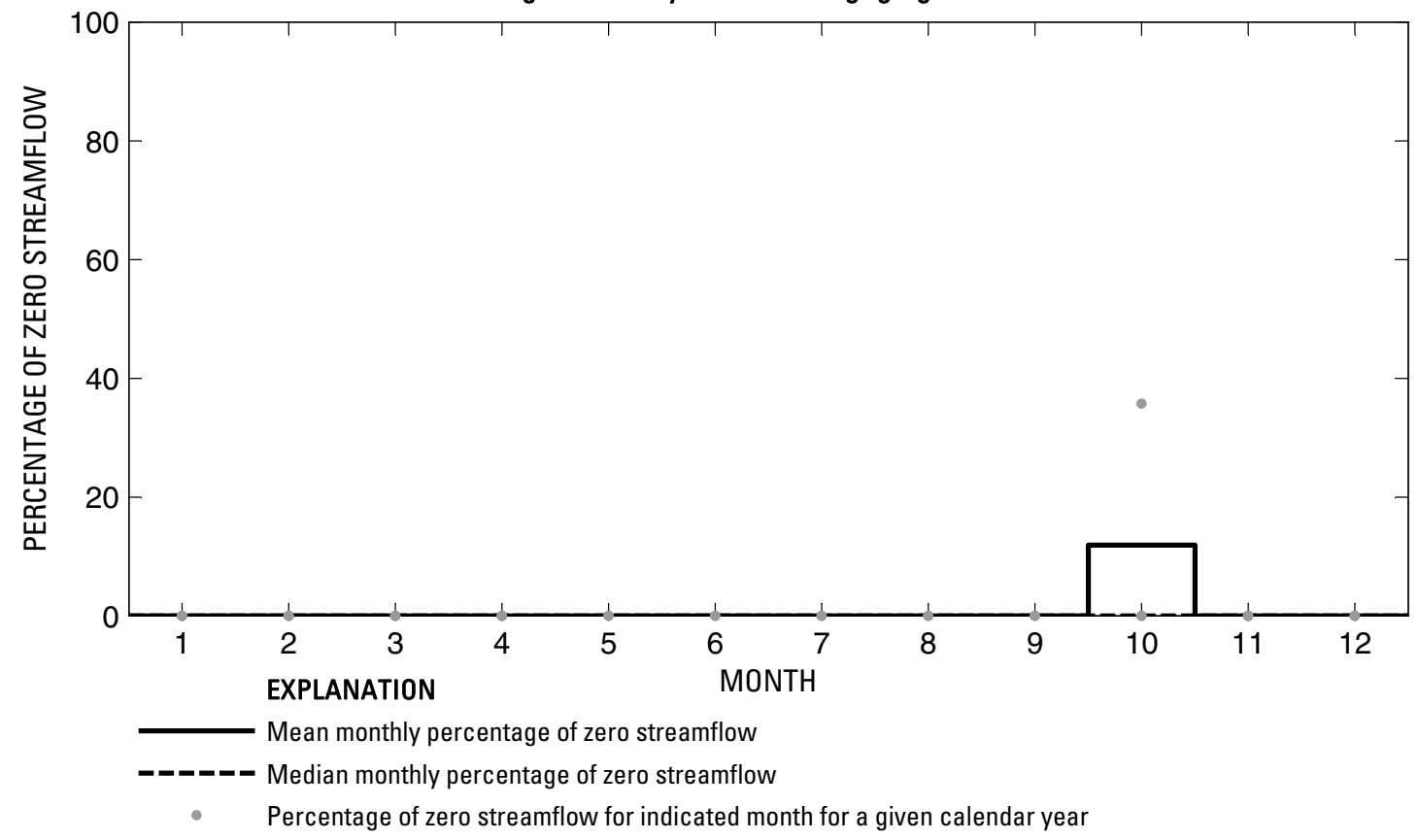

Figure 410. Analysis of percentage of zero daily mean streamflow for U.S. Geological Survey streamflow-gaging station 08105200 Berry Creek at State Highway 971 near Georgetown, Texas.

Index of Station Numbers 719 


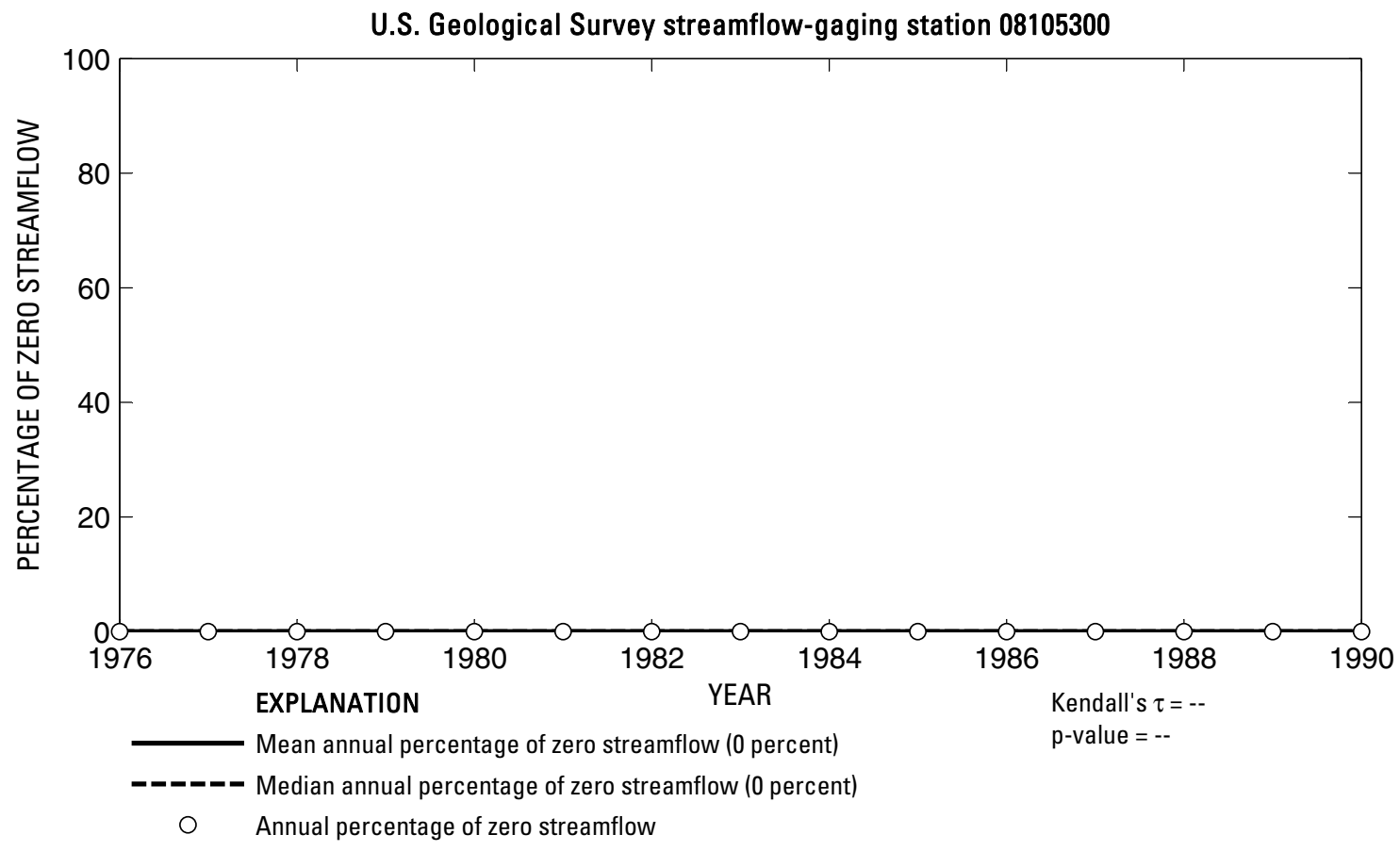

U.S. Geological Survey streamflow-gaging station 08105300

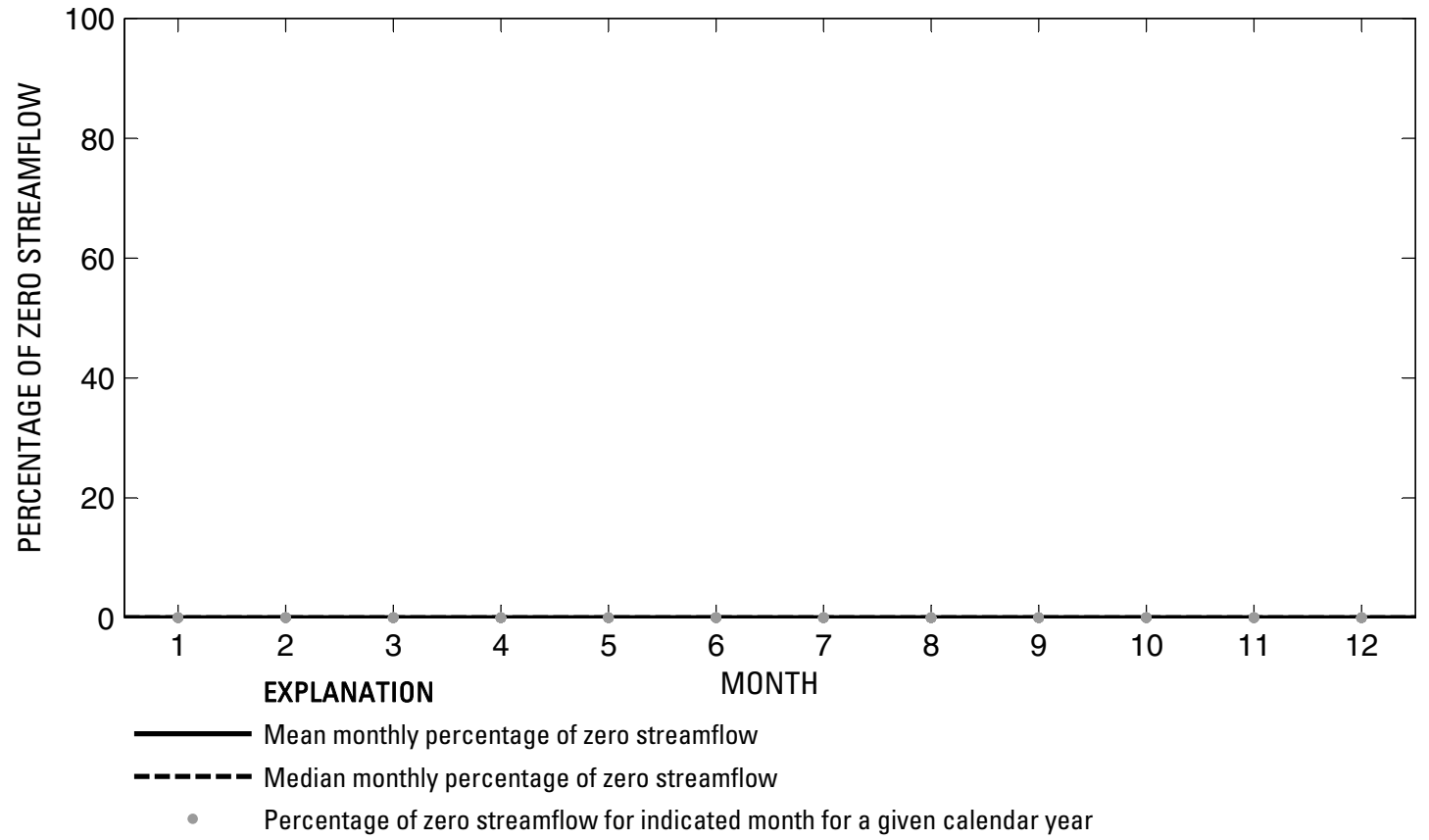

Figure 411. Analysis of percentage of zero daily mean streamflow for U.S. Geological Survey streamflow-gaging station 08105300 San Gabriel River near Weir, Texas. 
U.S. Geological Survey streamflow-gaging station 08105400

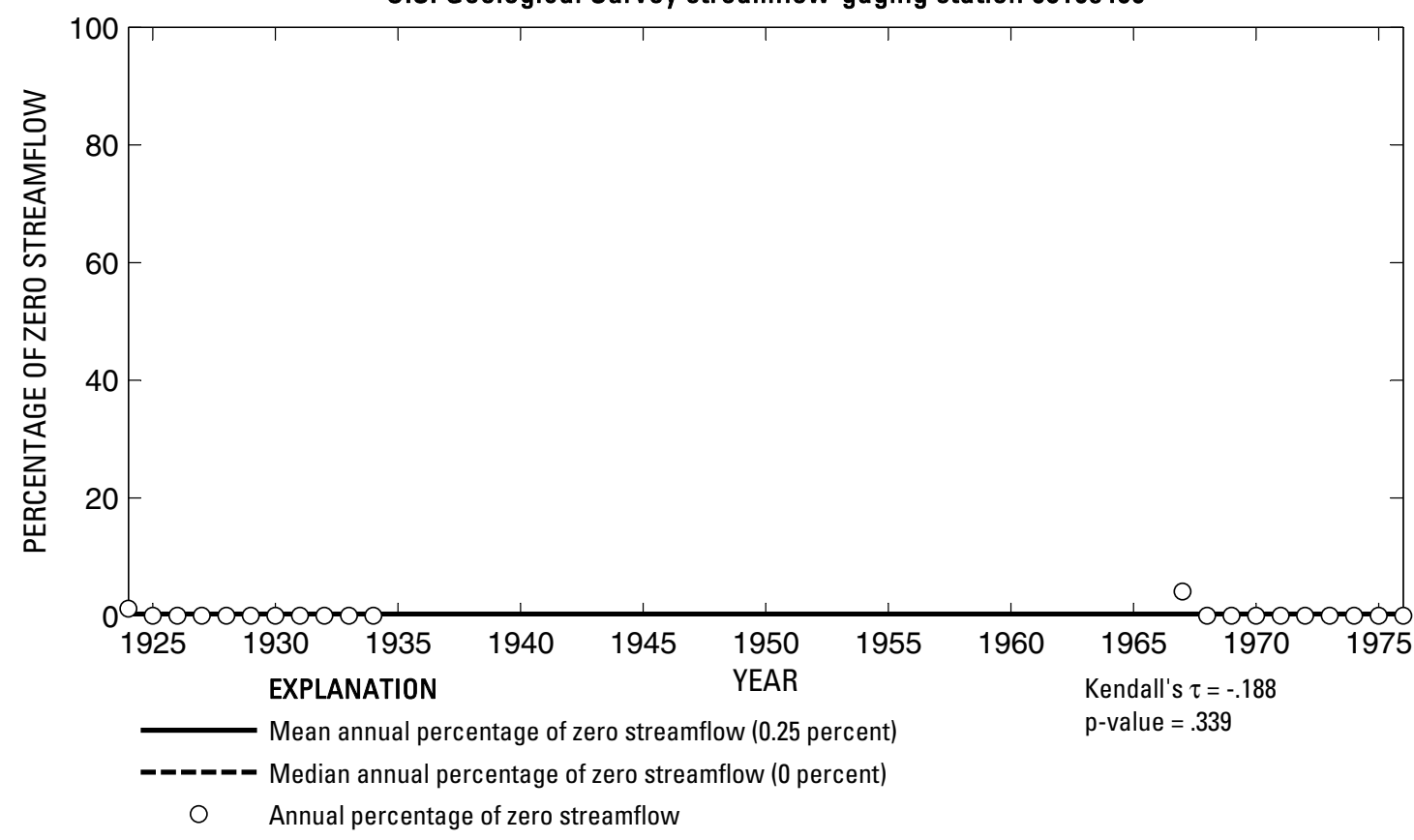

U.S. Geological Survey streamflow-gaging station 08105400

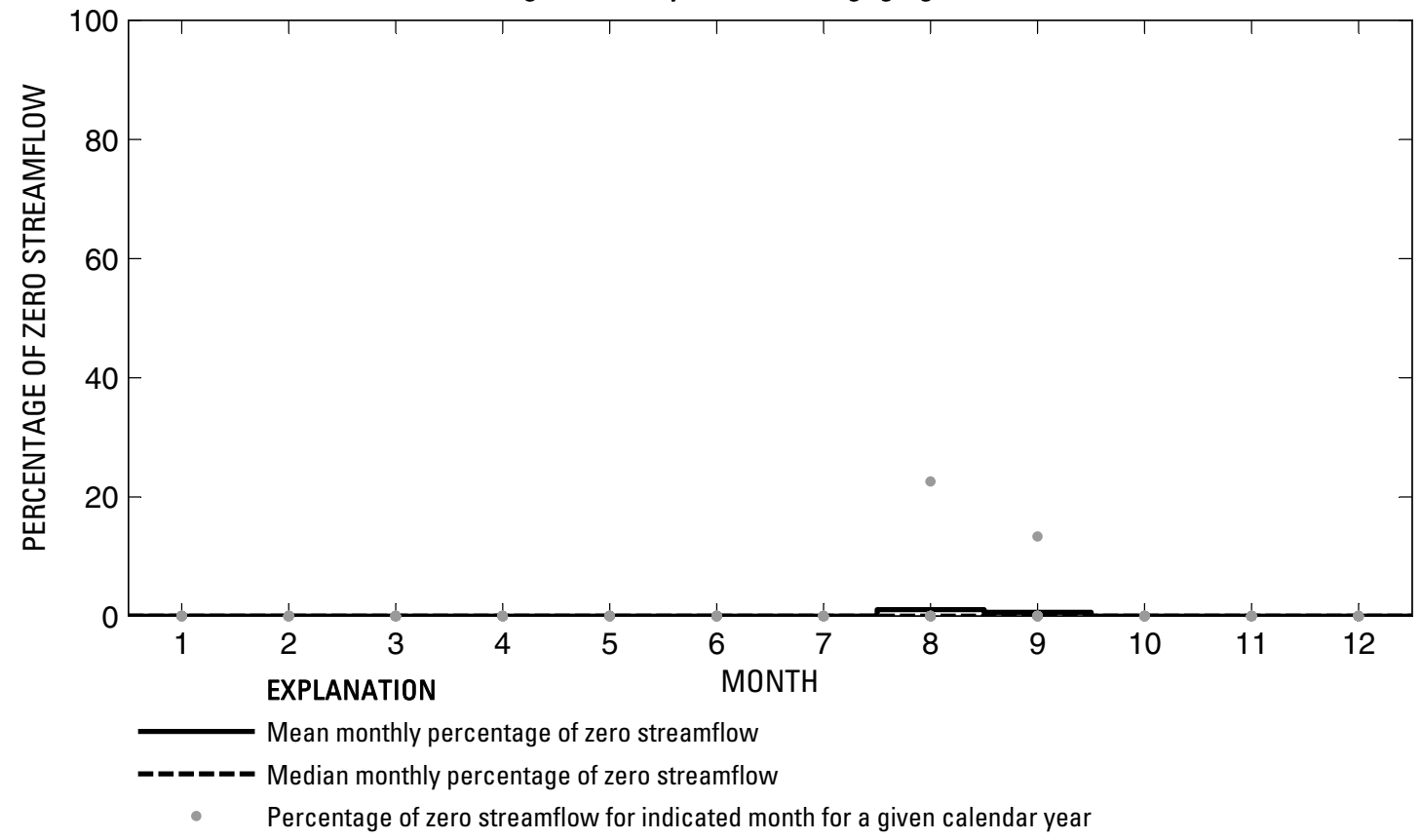

Figure 412. Analysis of percentage of zero daily mean streamflow for U.S. Geological Survey streamflow-gaging station 08105400 San Gabriel River near Circleville, Texas. 


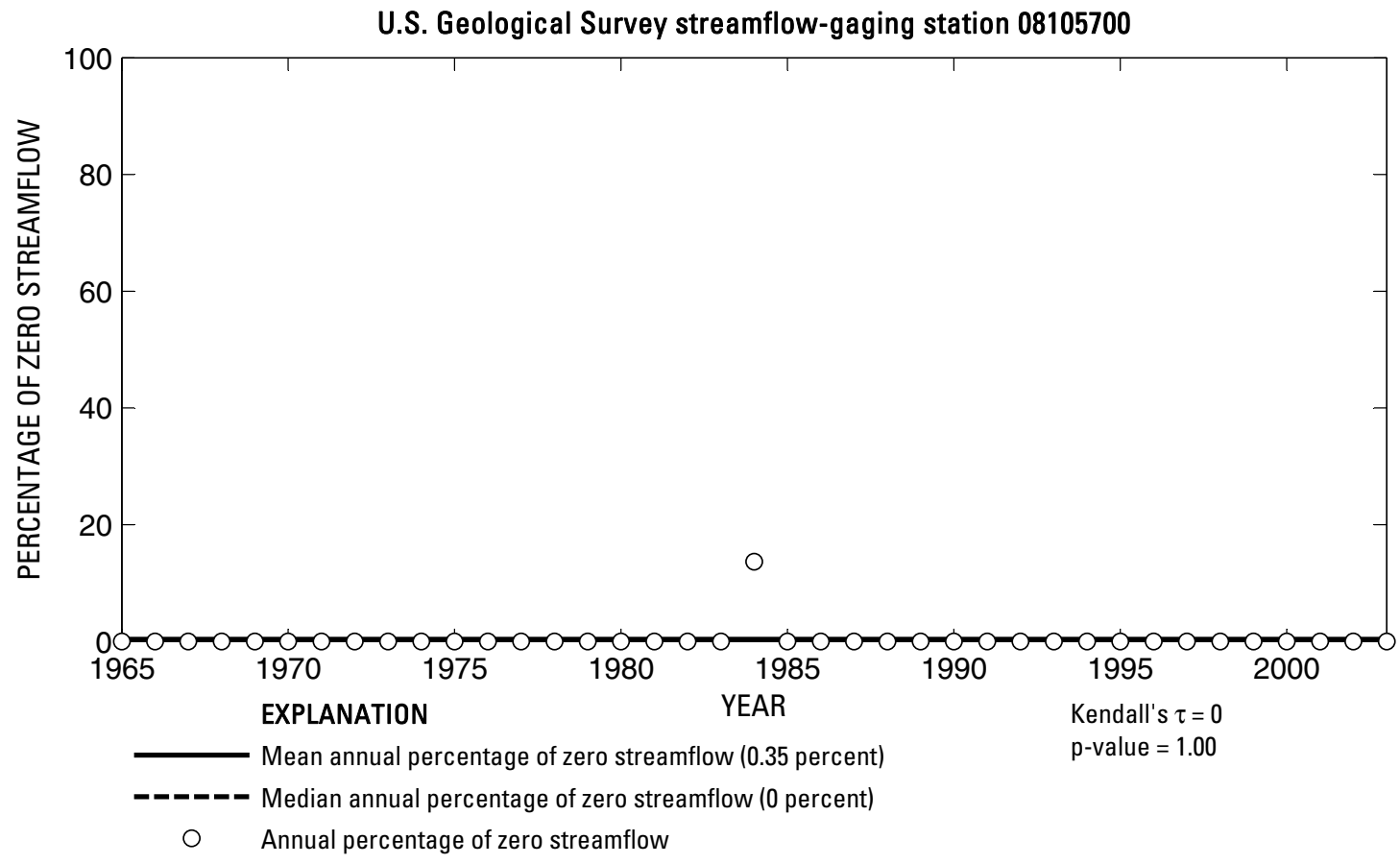

U.S. Geological Survey streamflow-gaging station 08105700

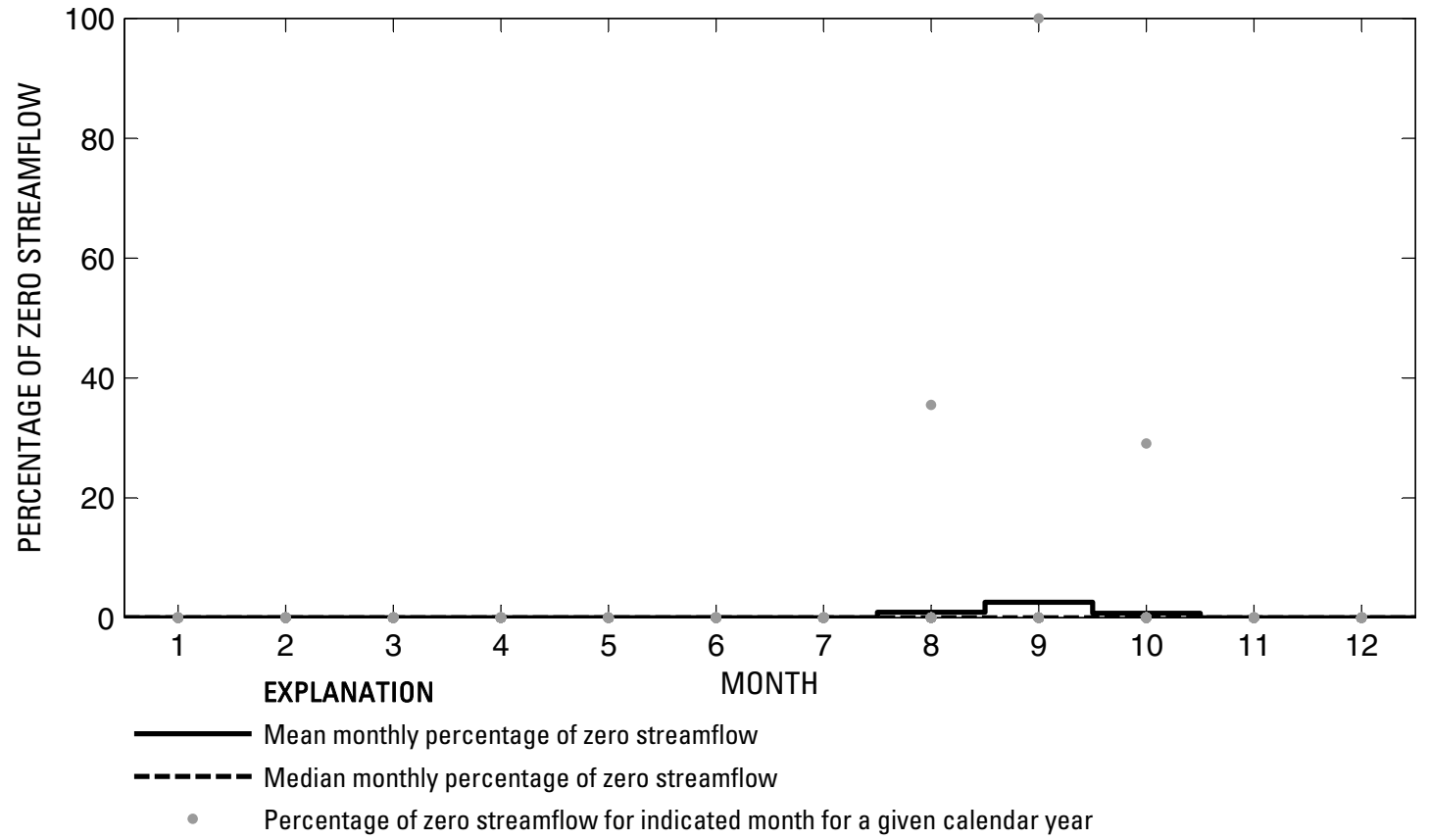

Figure 413. Analysis of percentage of zero daily mean streamflow for U.S. Geological Survey streamflow-gaging station 08105700 San Gabriel River at Laneport, Texas. 

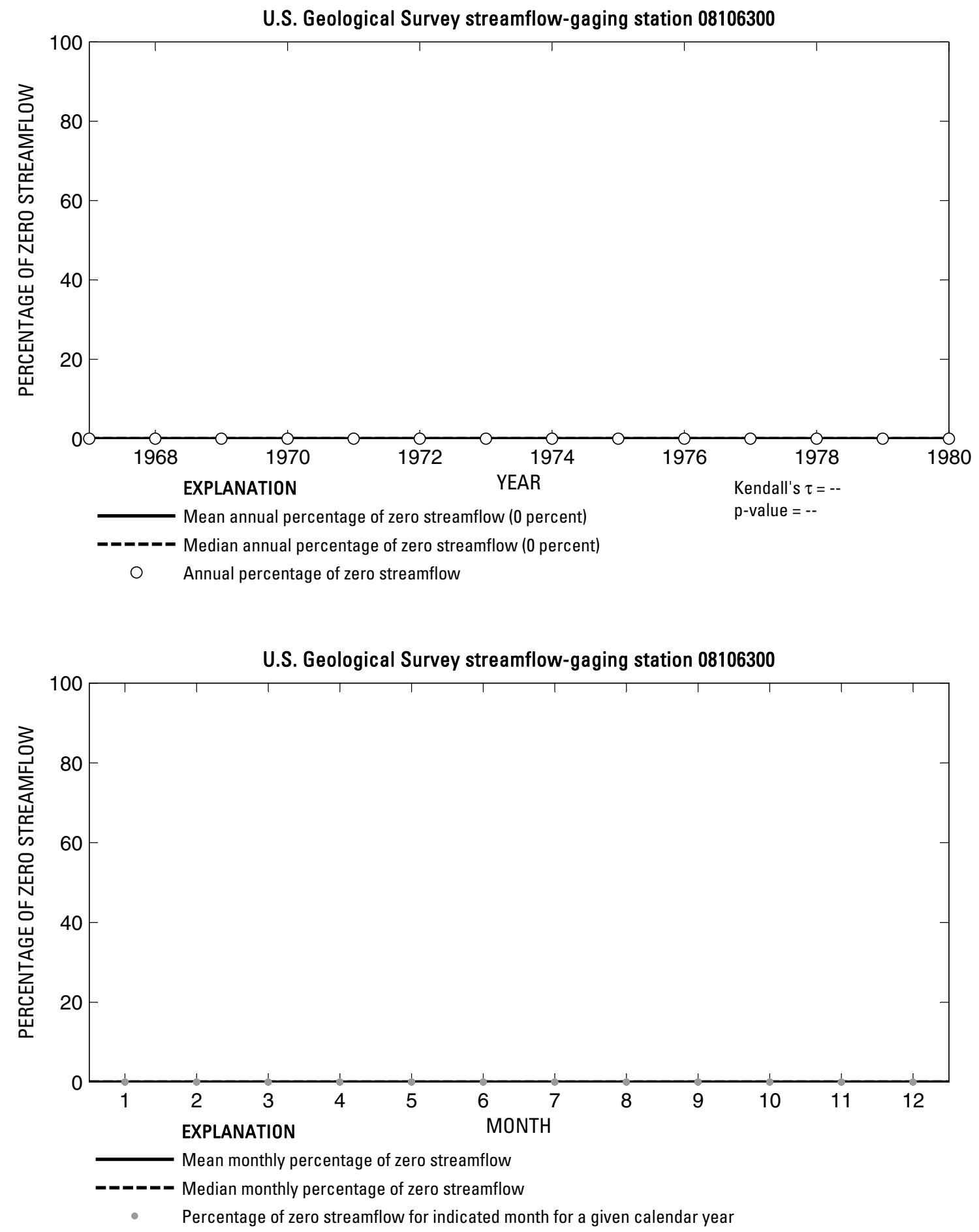

Figure 414. Analysis of percentage of zero daily mean streamflow for U.S. Geological Survey streamflow-gaging station 08106300 Brushy Creek near Rockdale, Texas. 


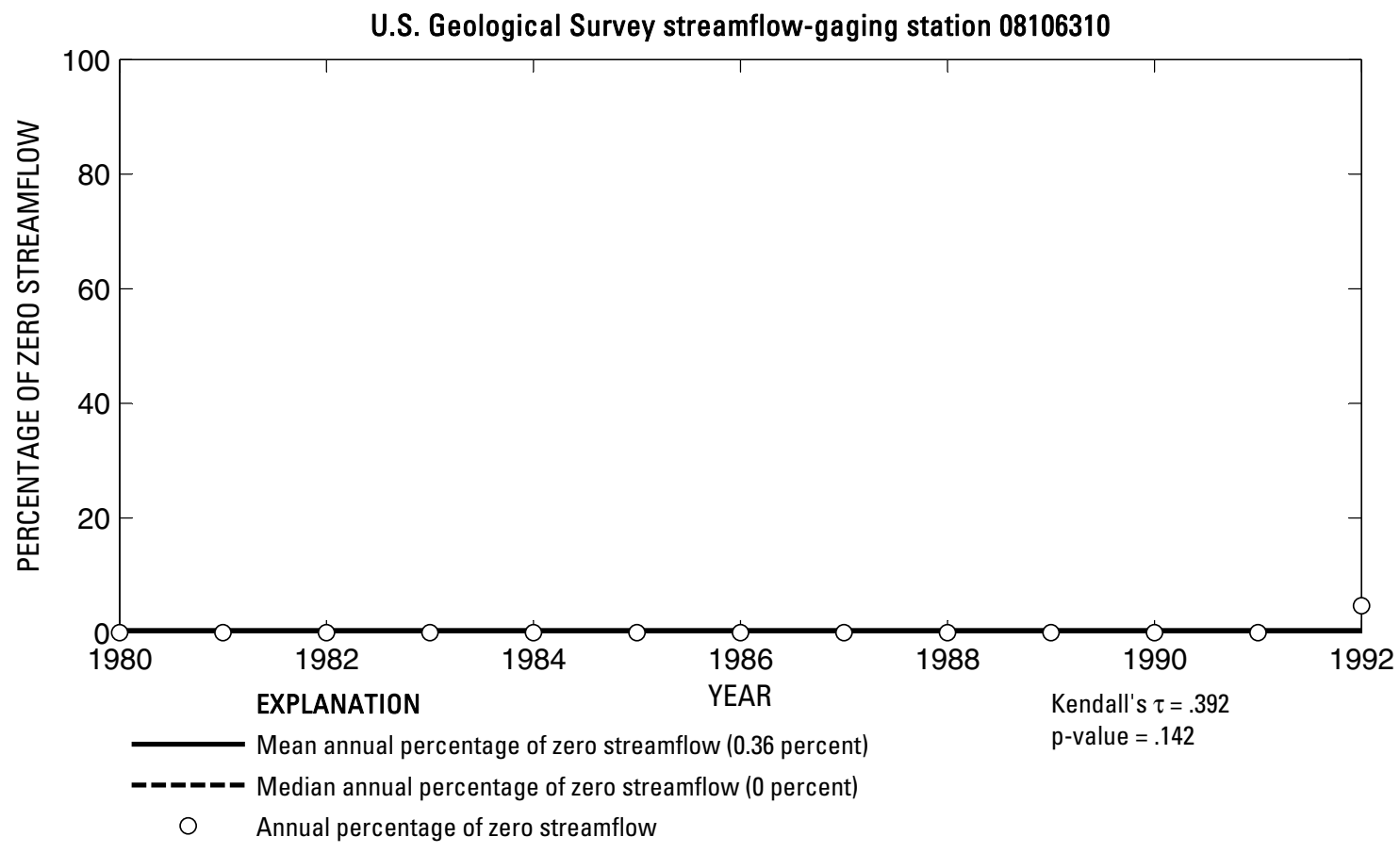

U.S. Geological Survey streamflow-gaging station 08106310

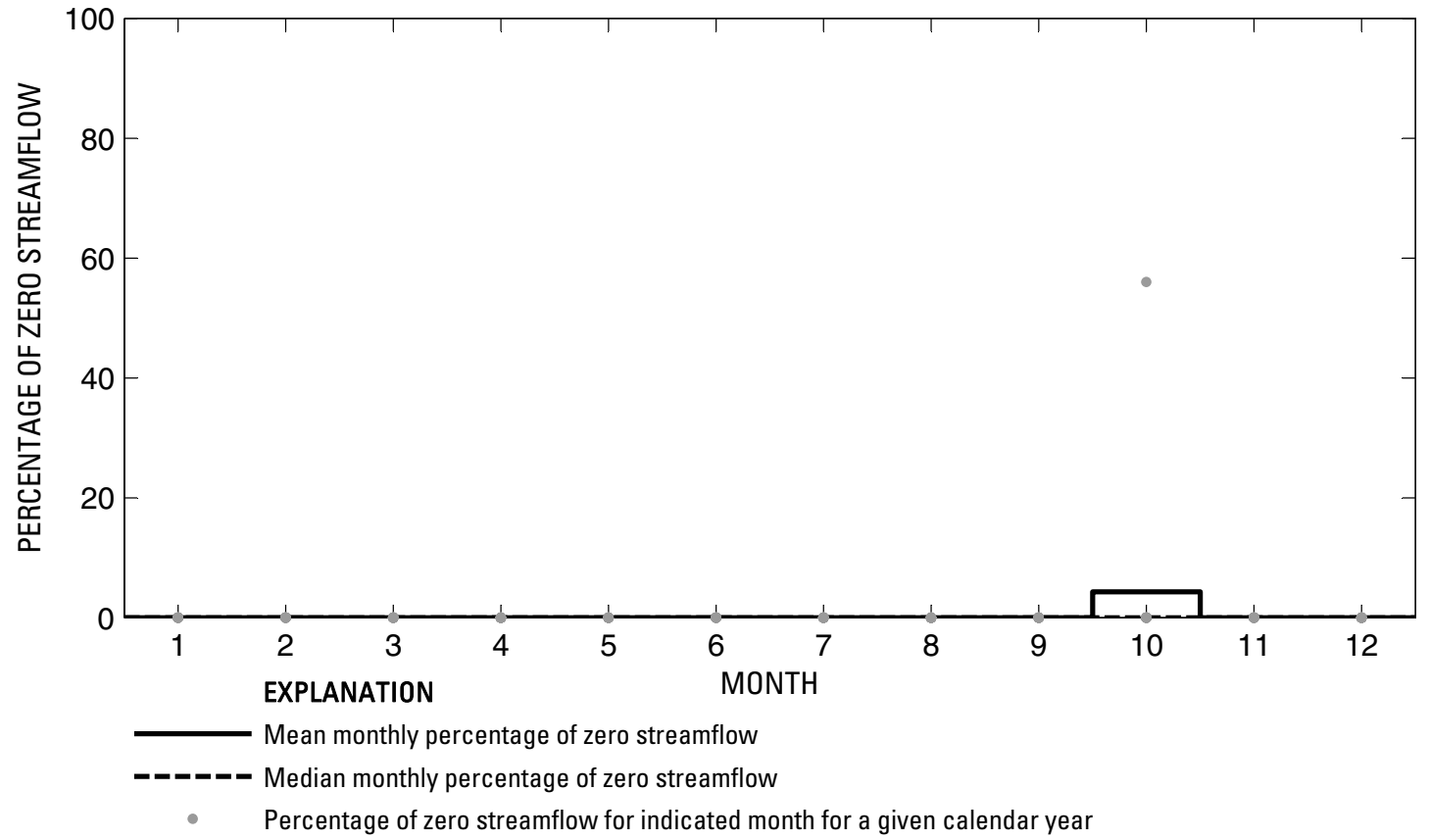

Figure 415. Analysis of percentage of zero daily mean streamflow for U.S. Geological Survey streamflow-gaging station 08106310 San Gabriel River near Rockdale, Texas. 
U.S. Geological Survey streamflow-gaging station 08106350

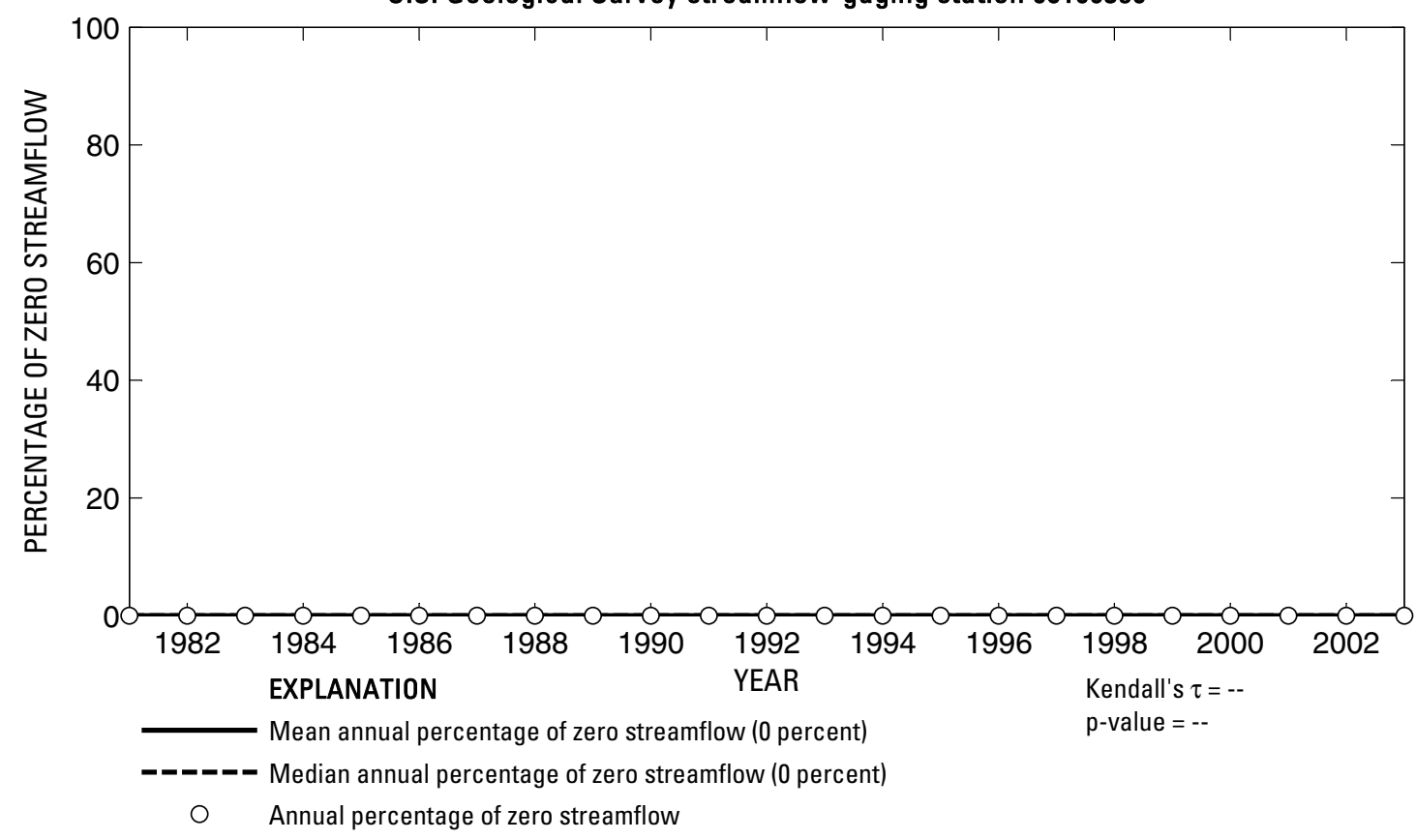

U.S. Geological Survey streamflow-gaging station 08106350

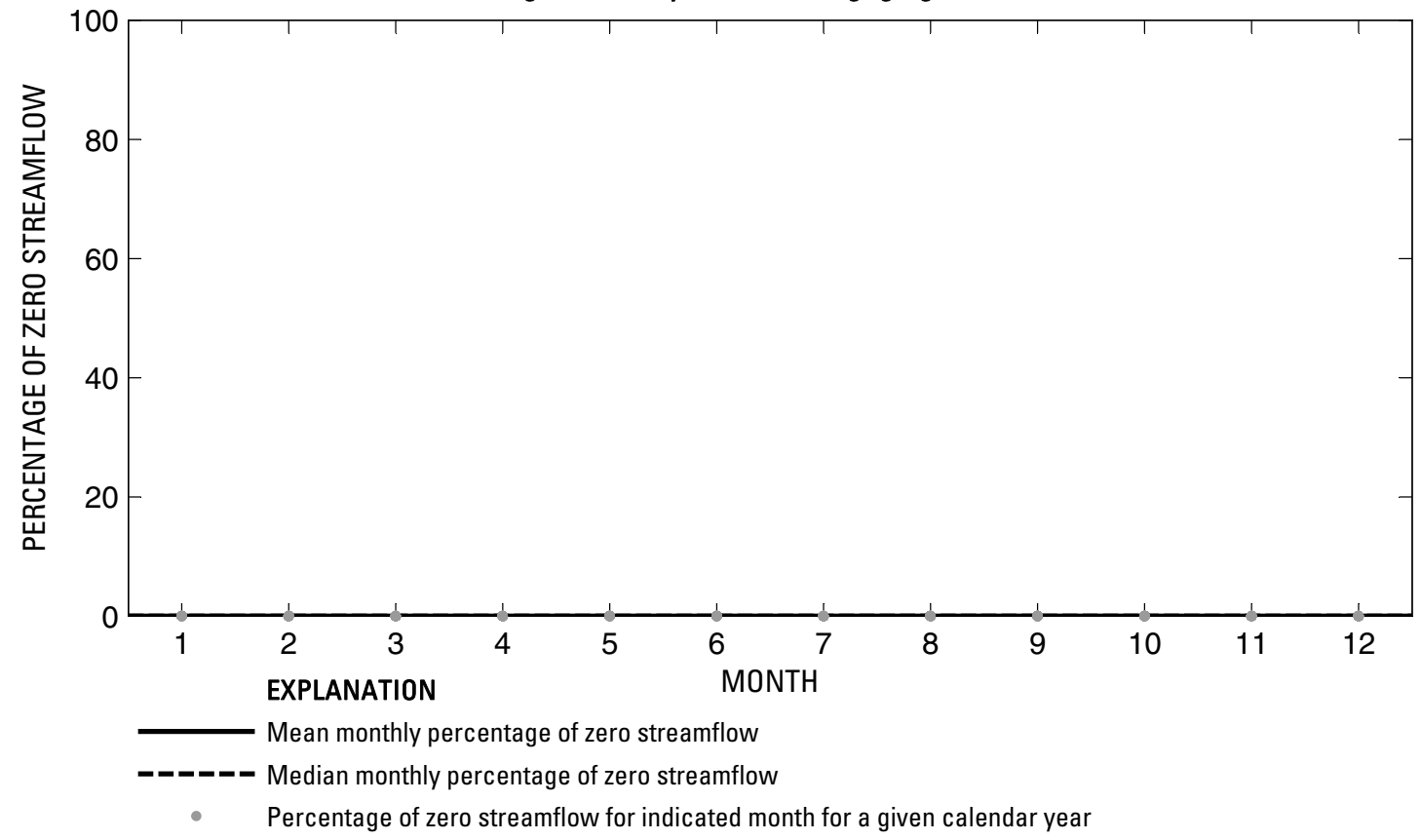

Figure 416. Analysis of percentage of zero daily mean streamflow for U.S. Geological Survey streamflow-gaging station 08106350 Little River near Rockdale, Texas. 


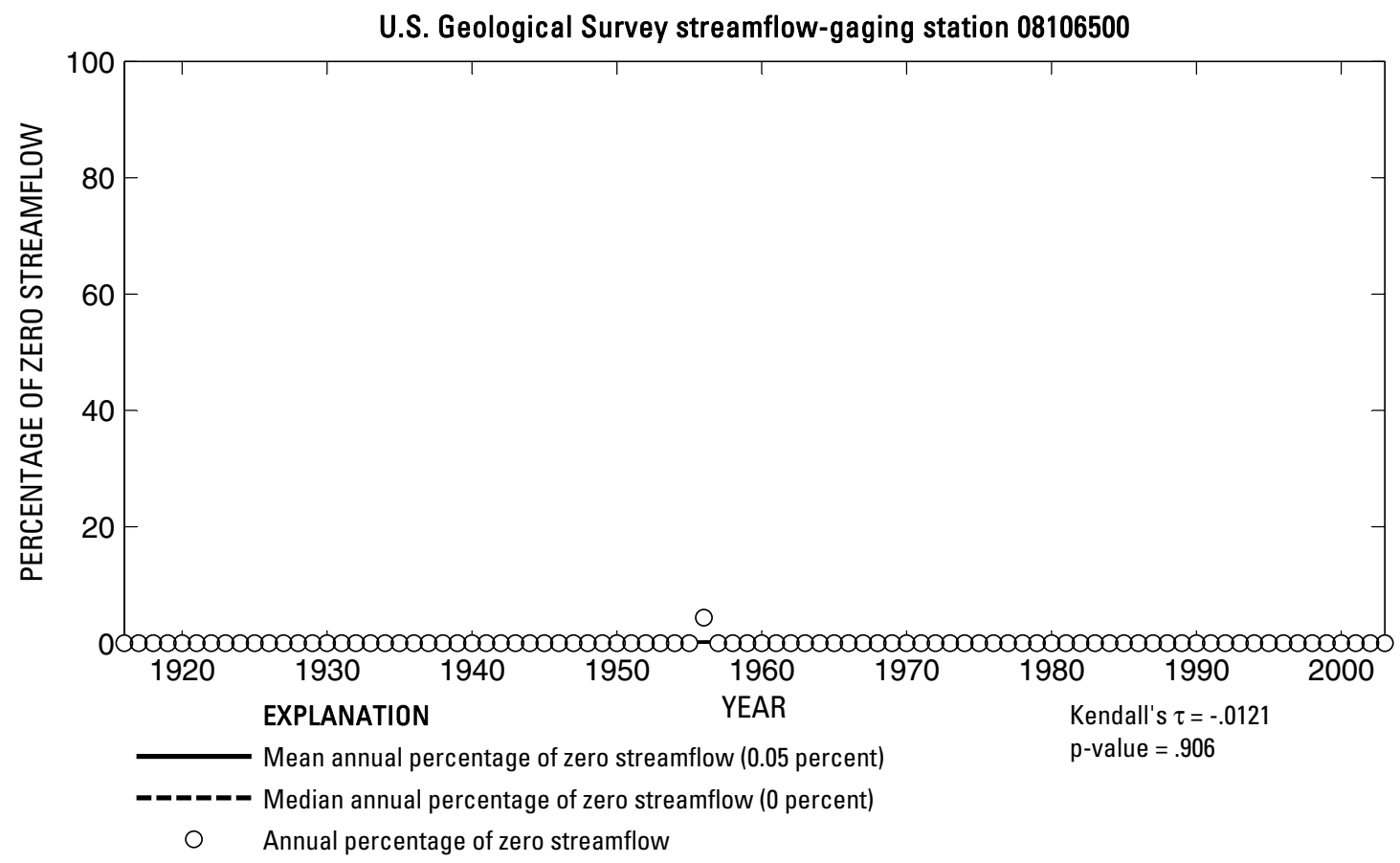

U.S. Geological Survey streamflow-gaging station 08106500

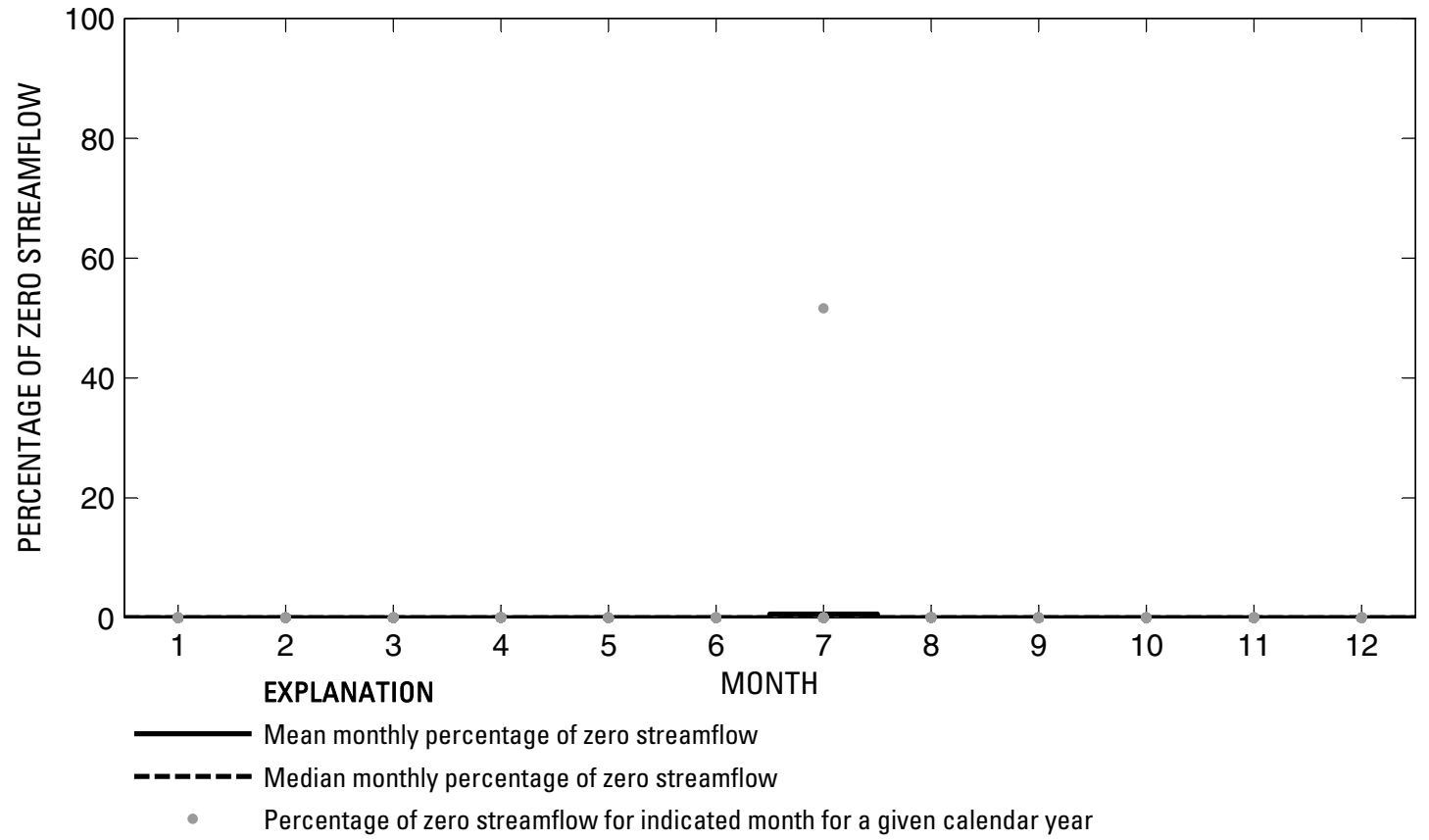

Figure 417. Analysis of percentage of zero daily mean streamflow for U.S. Geological Survey streamflow-gaging station 08106500 Little River at Cameron, Texas. 
U.S. Geological Survey streamflow-gaging station 08107000

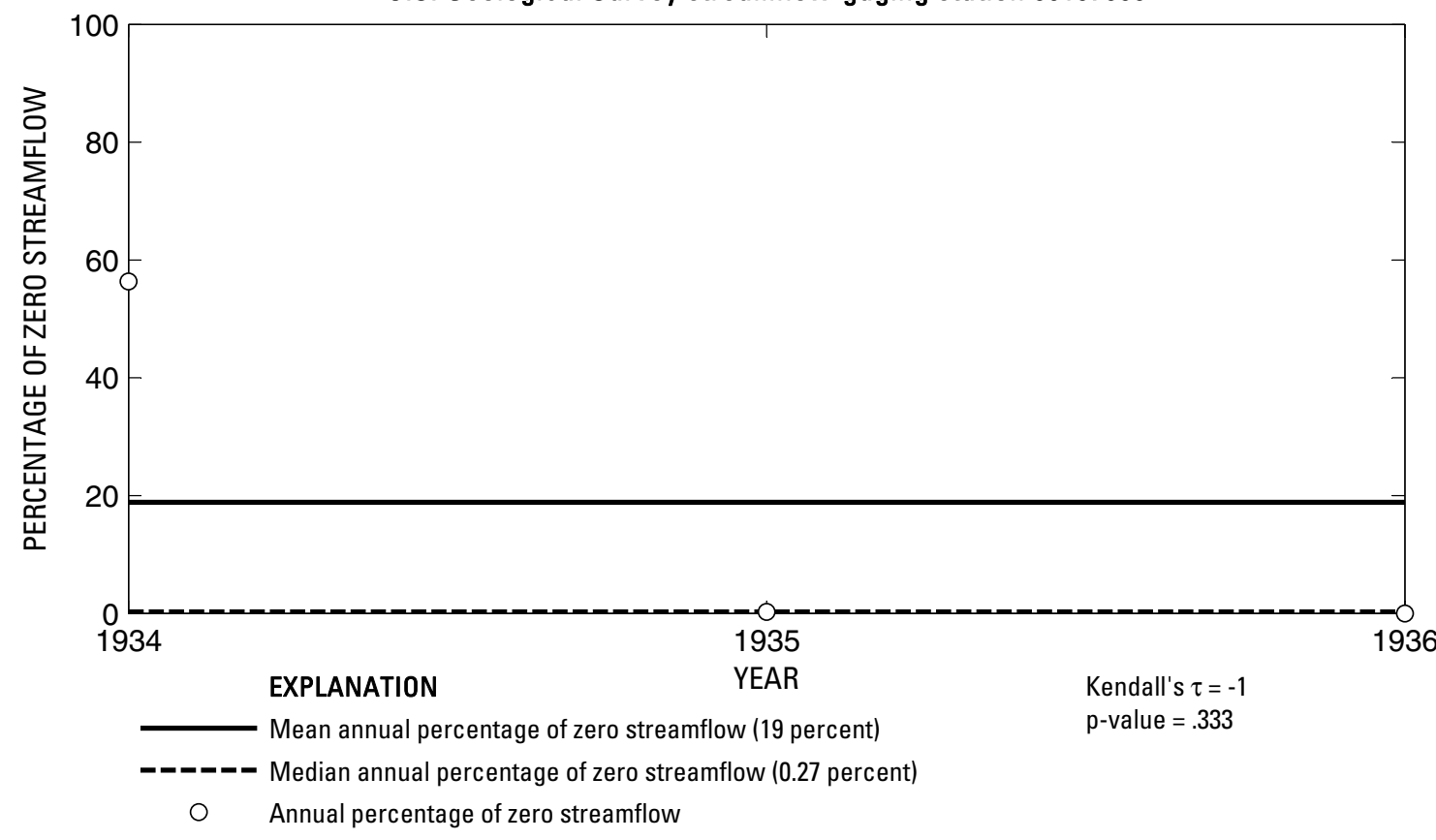

U.S. Geological Survey streamflow-gaging station 08107000

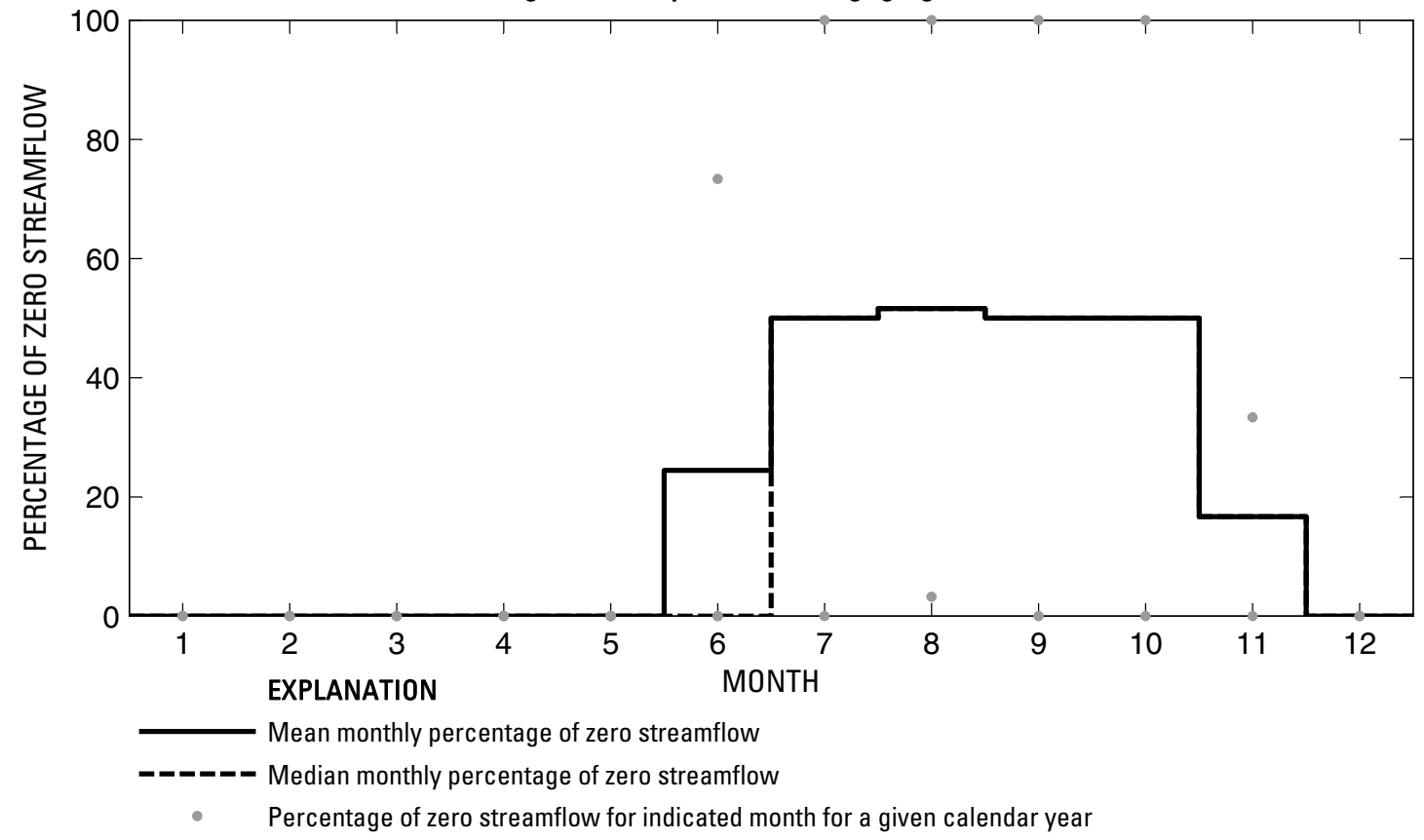

Figure 418. Analysis of percentage of zero daily mean streamflow for U.S. Geological Survey streamflow-gaging station 08107000 Big Elm Creek near Temple, Texas. 
U.S. Geological Survey streamflow-gaging station 08107500

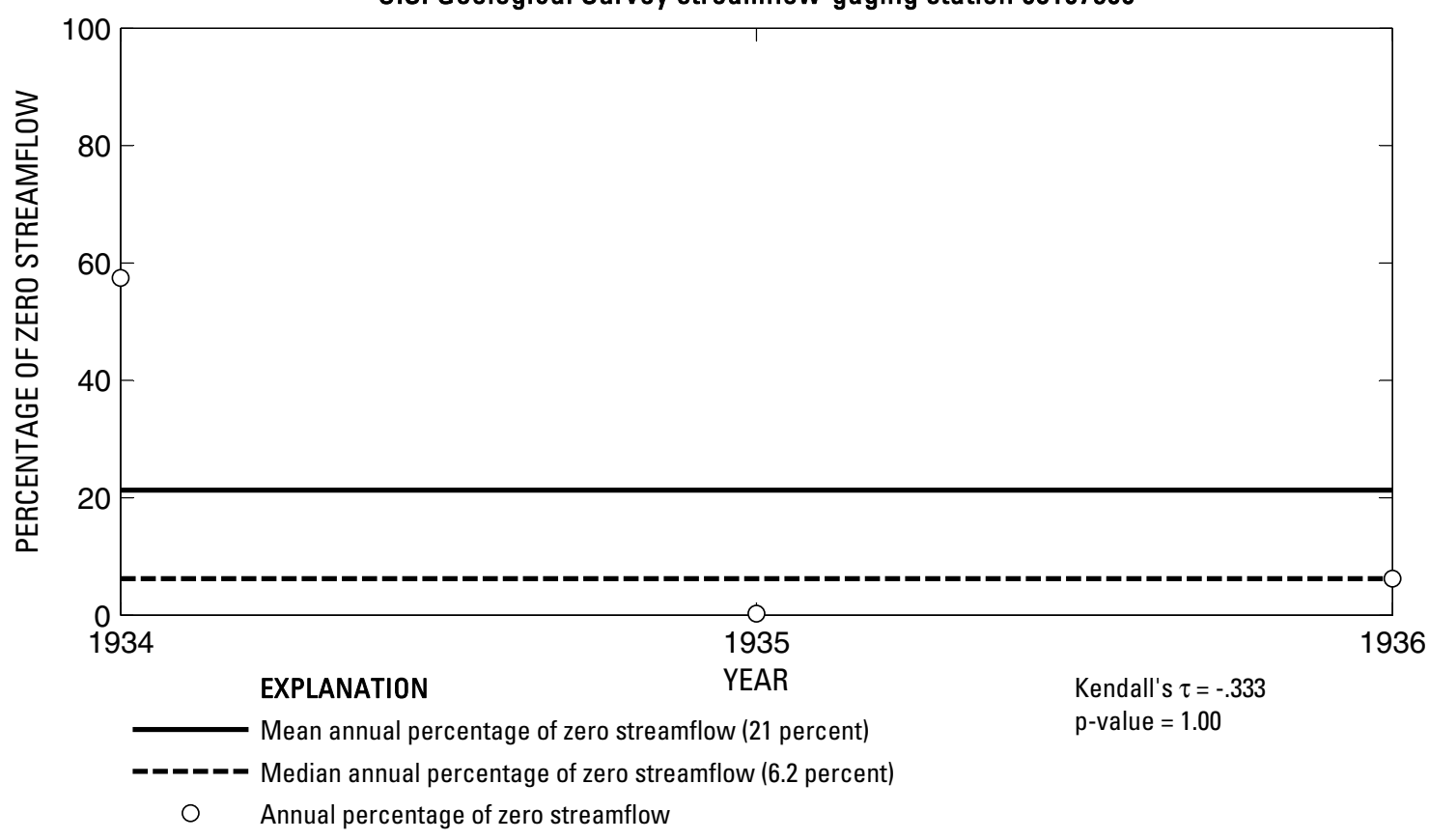

U.S. Geological Survey streamflow-gaging station 08107500

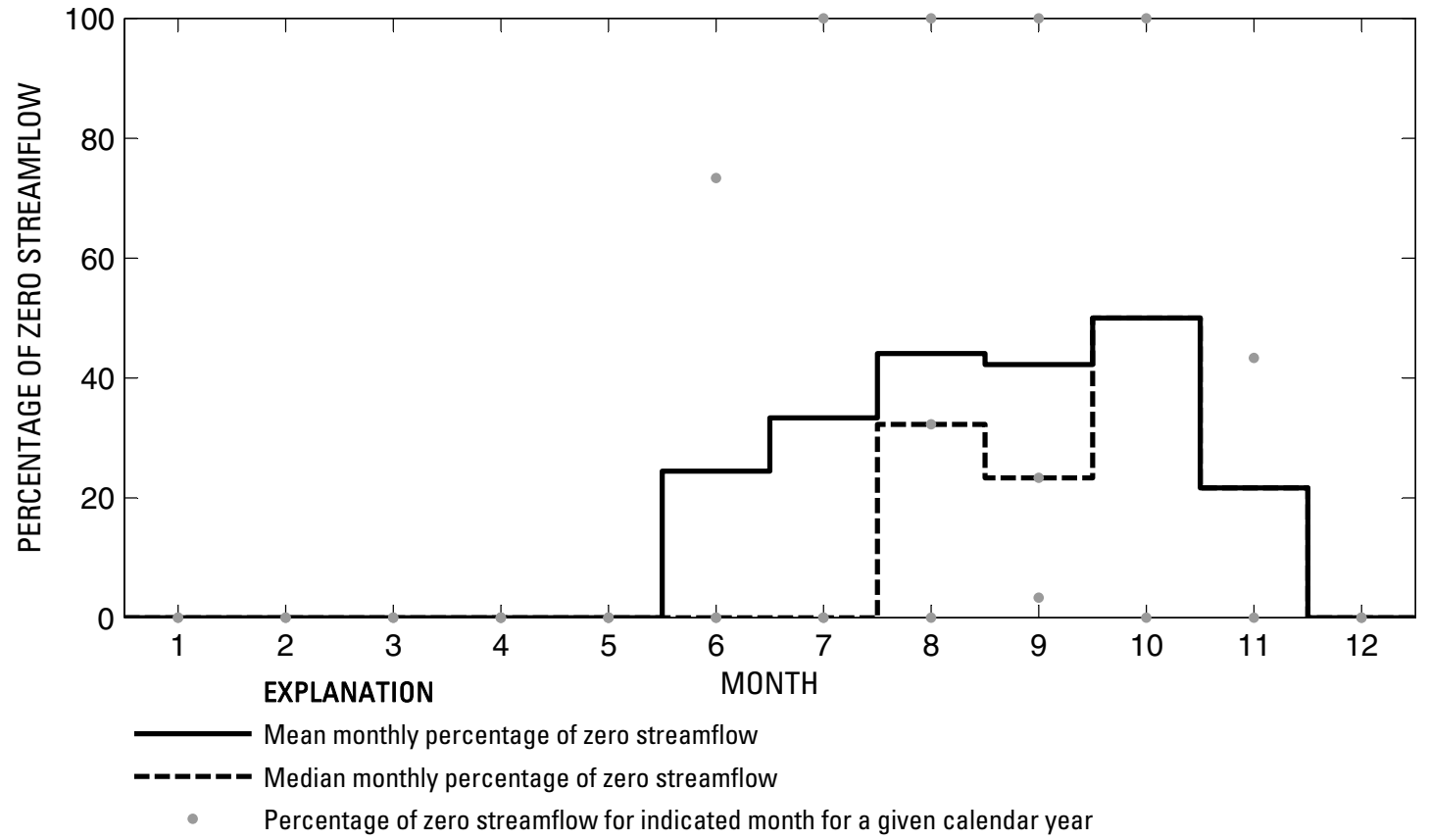

Figure 419. Analysis of percentage of zero daily mean streamflow for U.S. Geological Survey streamflow-gaging station 08107500 Big Elm Creek near Buckholts, Texas. 
U.S. Geological Survey streamflow-gaging station 08108000

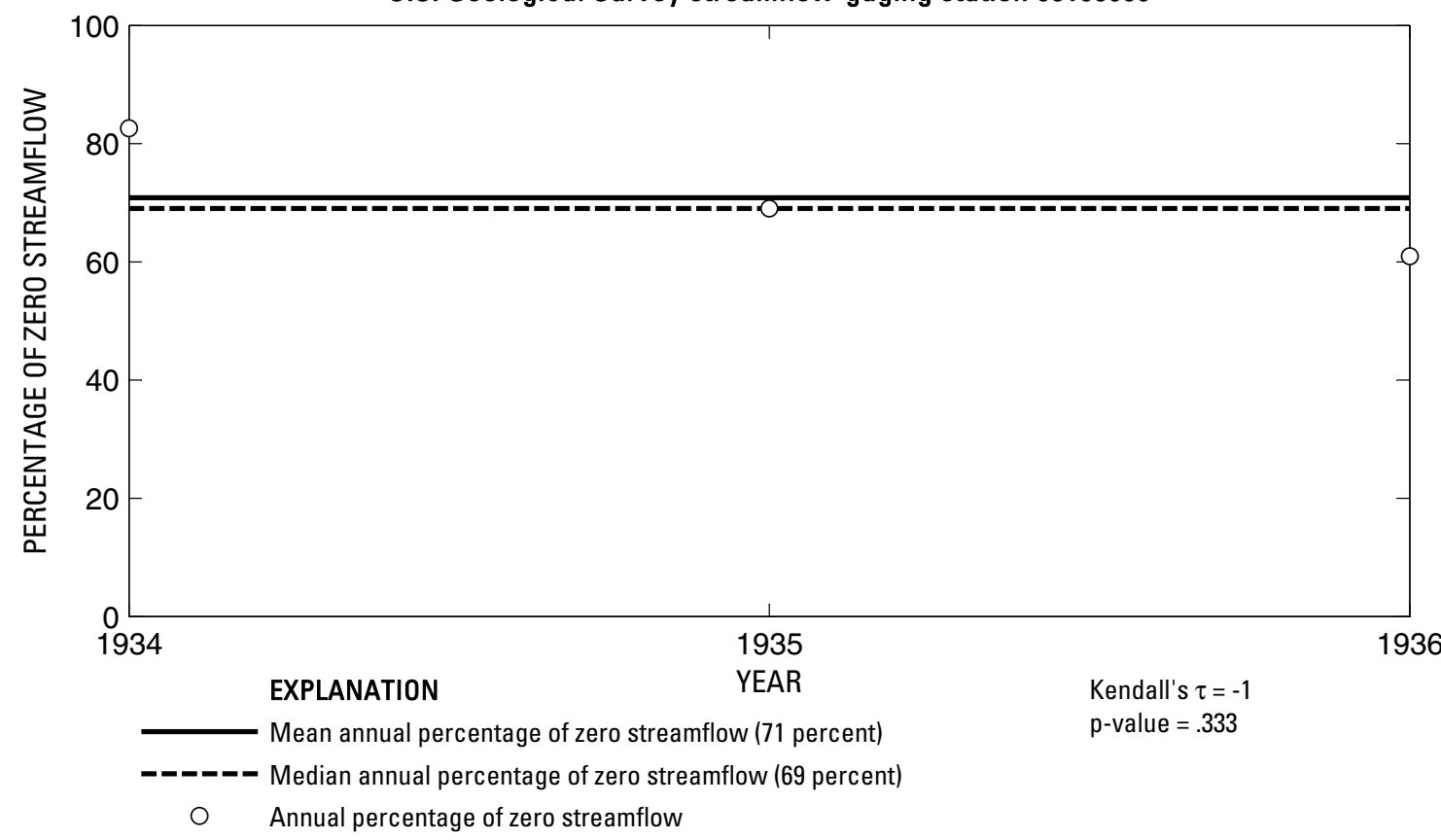

U.S. Geological Survey streamflow-gaging station 08108000

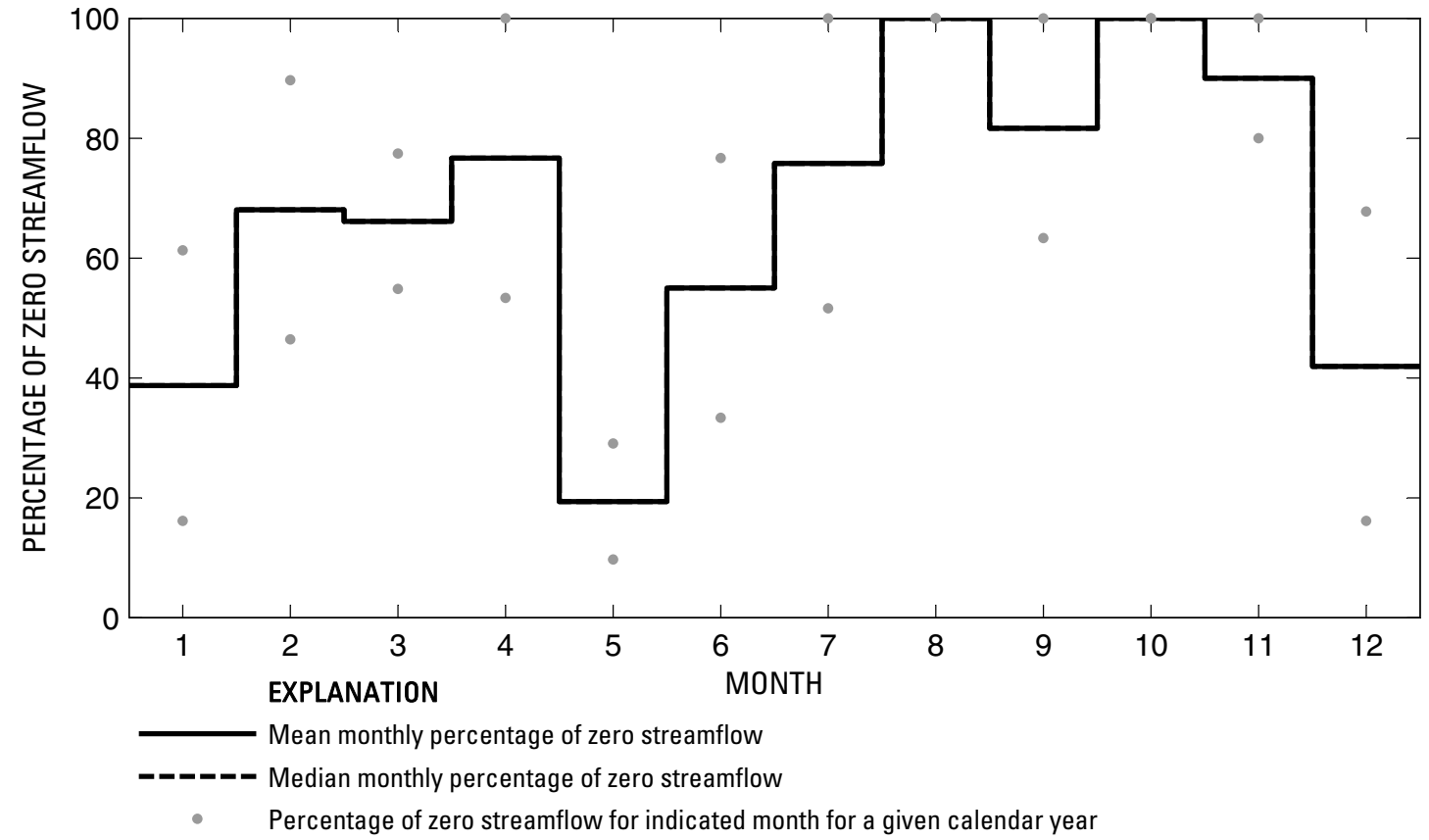

Figure 420. Analysis of percentage of zero daily mean streamflow for U.S. Geological Survey streamflow-gaging station 08108000 North Elm Creek near Ben Arnold, Texas. 
U.S. Geological Survey streamflow-gaging station 08108200

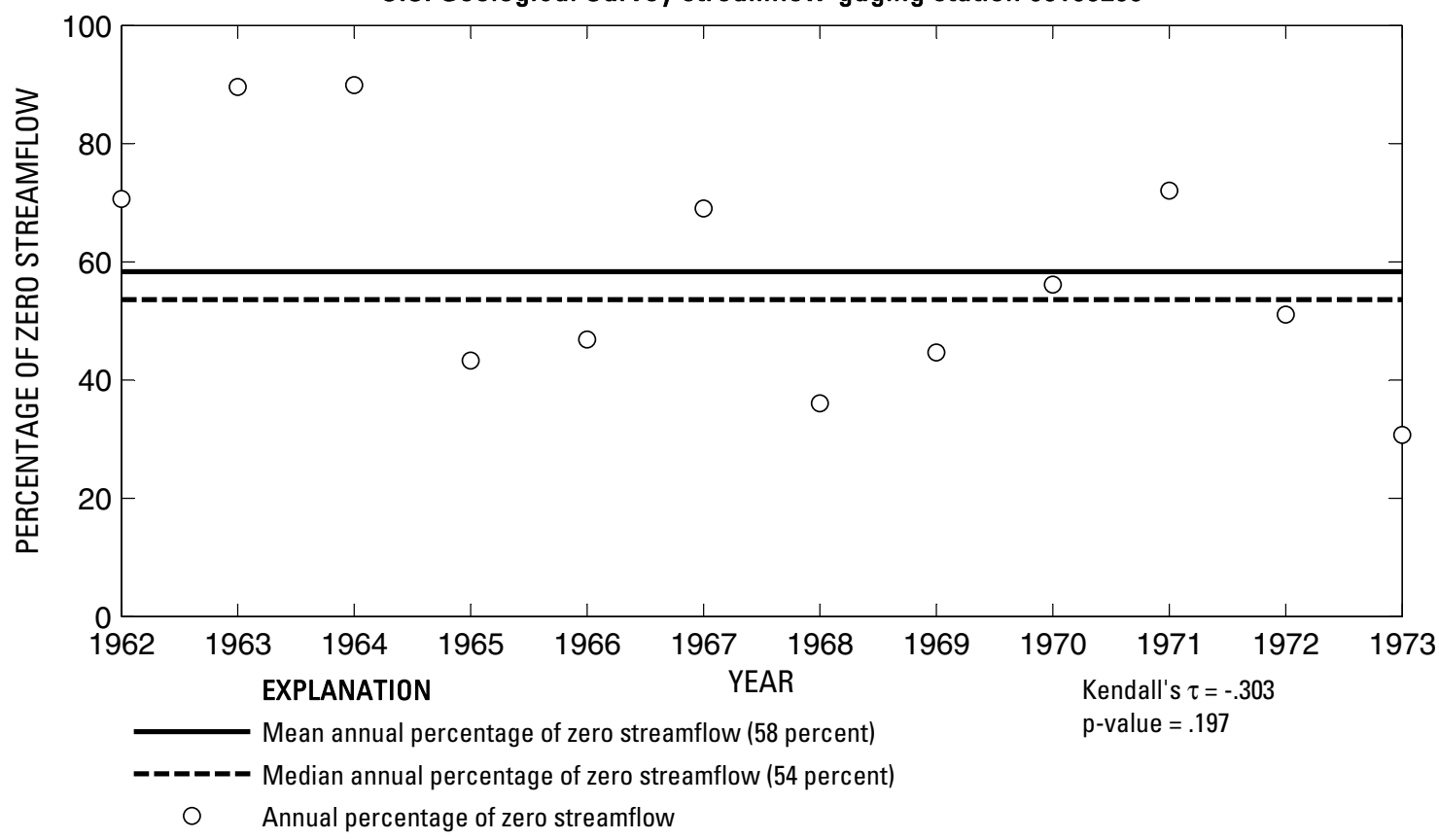

U.S. Geological Survey streamflow-gaging station 08108200

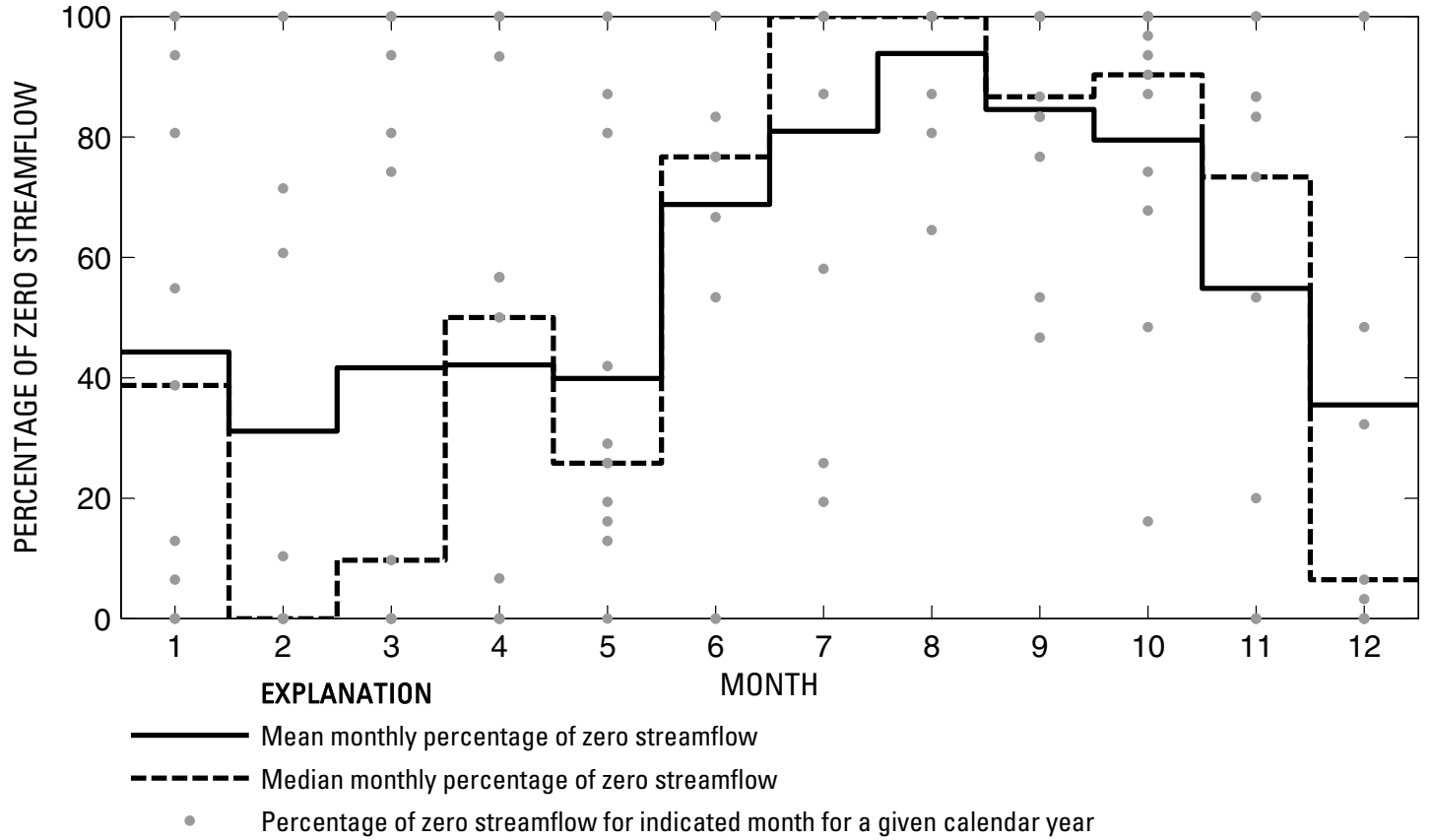

Figure 421. Analysis of percentage of zero daily mean streamflow for U.S. Geological Survey streamflow-gaging station 08108200 North Elm Creek near Cameron, Texas. 
U.S. Geological Survey streamflow-gaging station 08108700

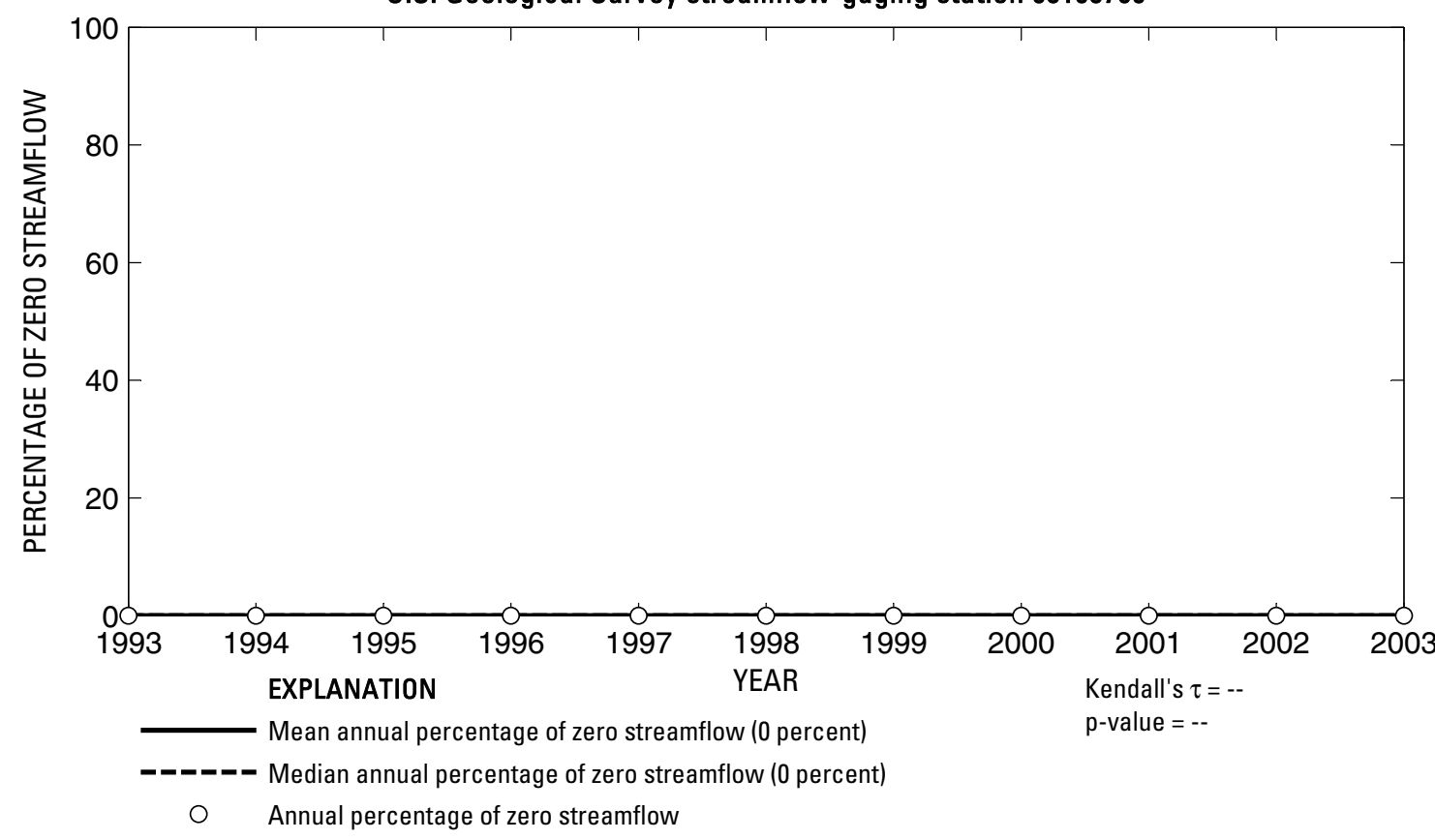

U.S. Geological Survey streamflow-gaging station 08108700

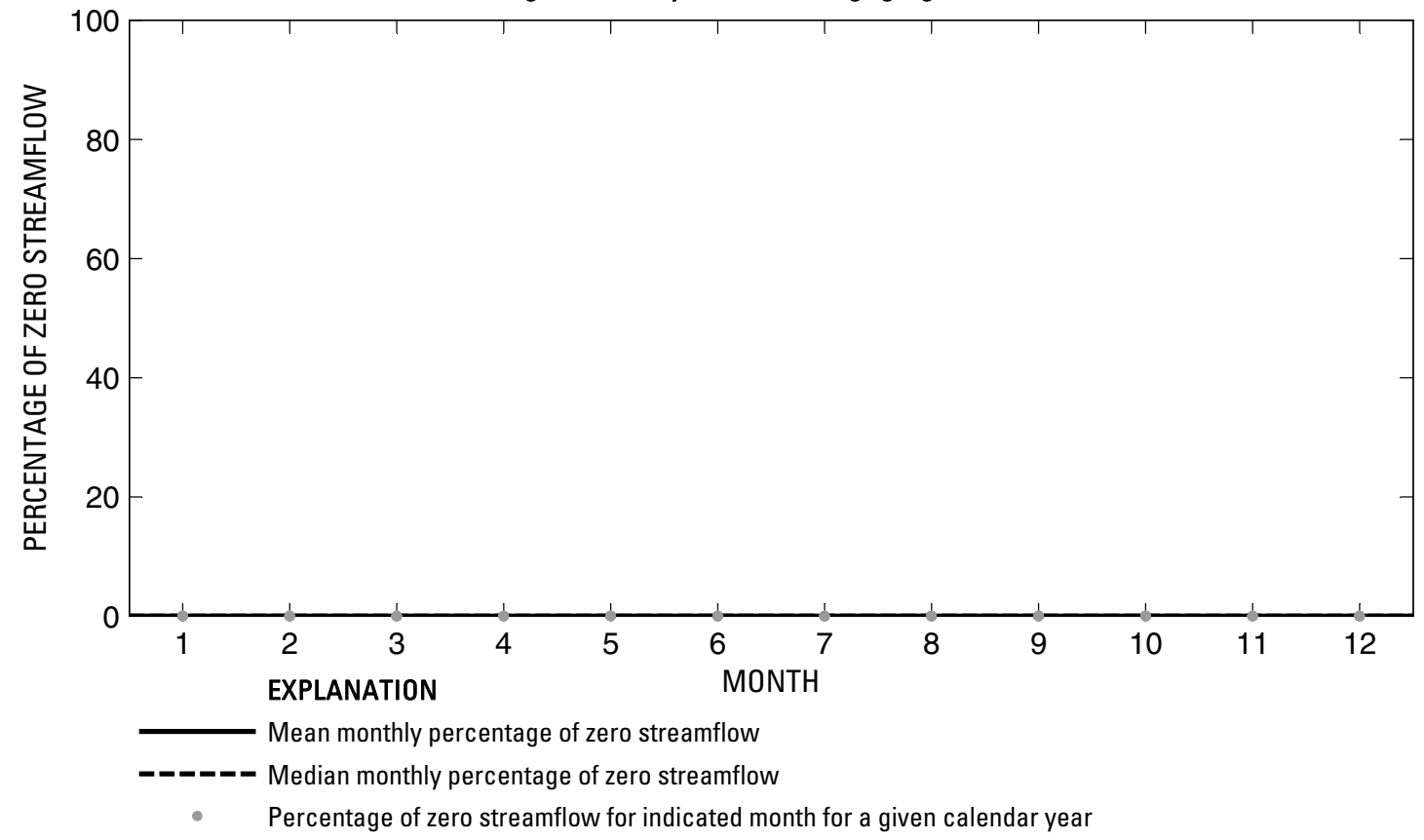

Figure 422. Analysis of percentage of zero daily mean streamflow for U.S. Geological Survey streamflow-gaging station 08108700 Brazos River at State Highway 21 near Bryan, Texas. 


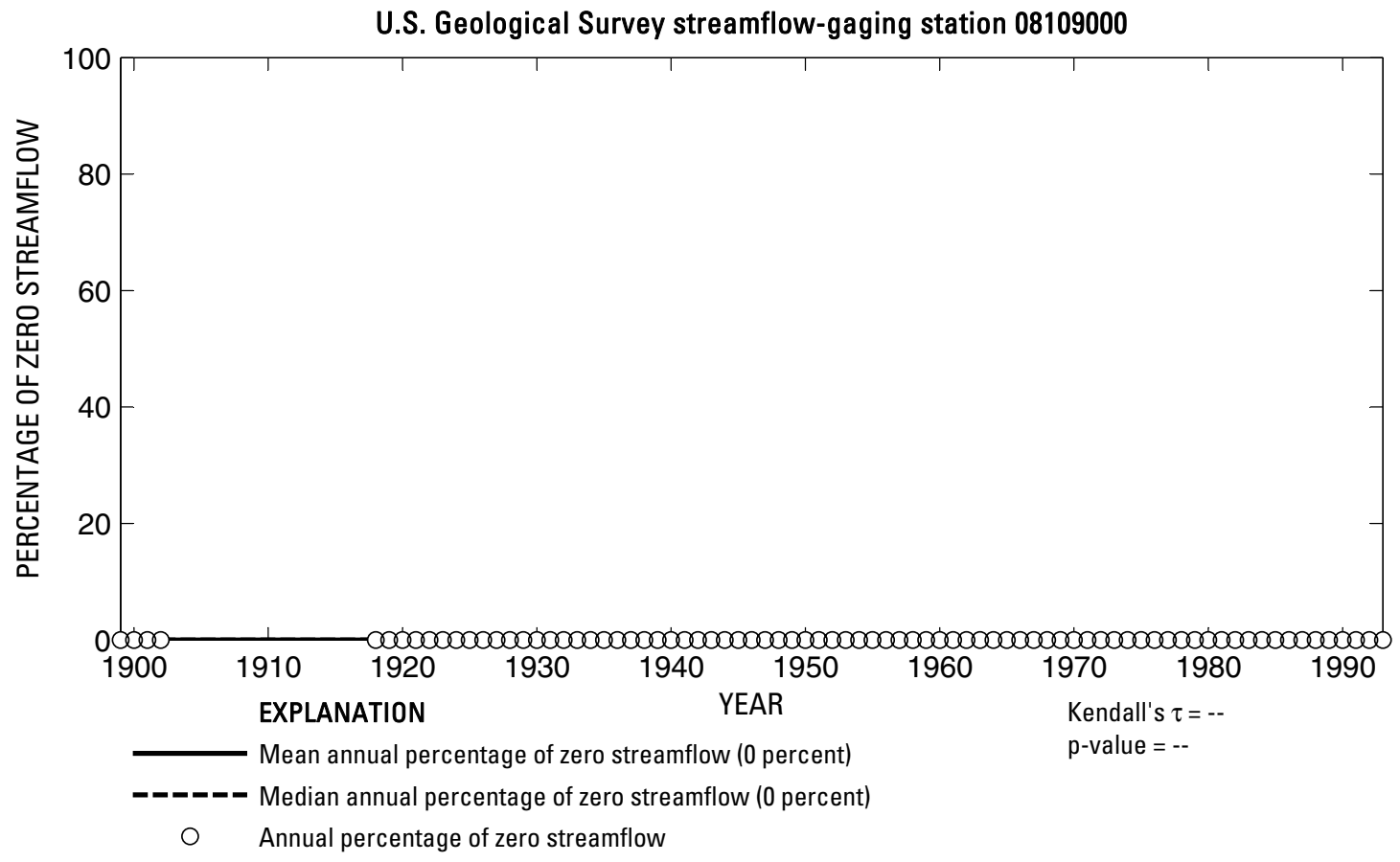

U.S. Geological Survey streamflow-gaging station 08109000

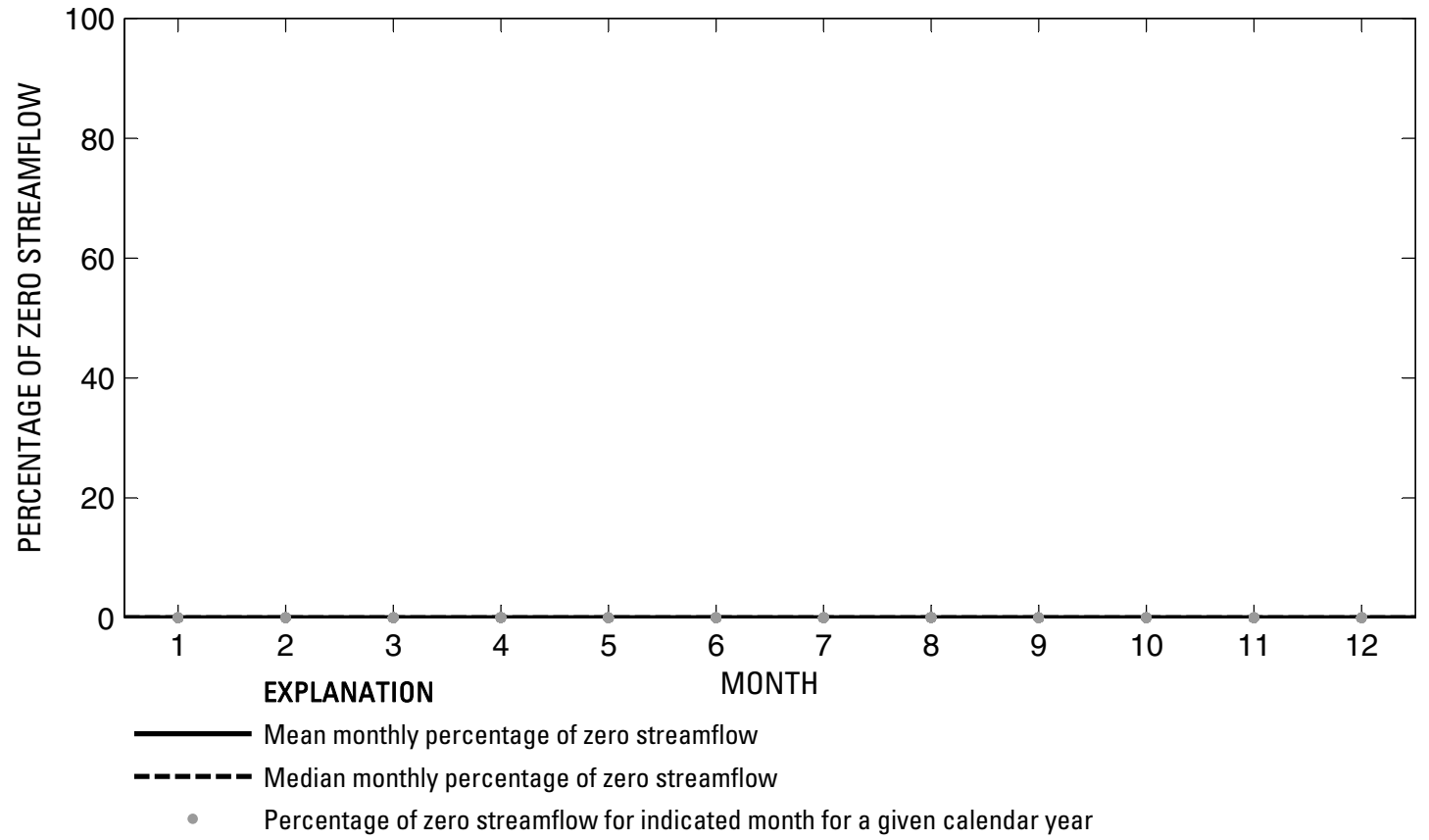

Figure 423. Analysis of percentage of zero daily mean streamflow for U.S. Geological Survey streamflow-gaging station 08109000 Brazos River near Bryan, Texas. 
U.S. Geological Survey streamflow-gaging station 08109700

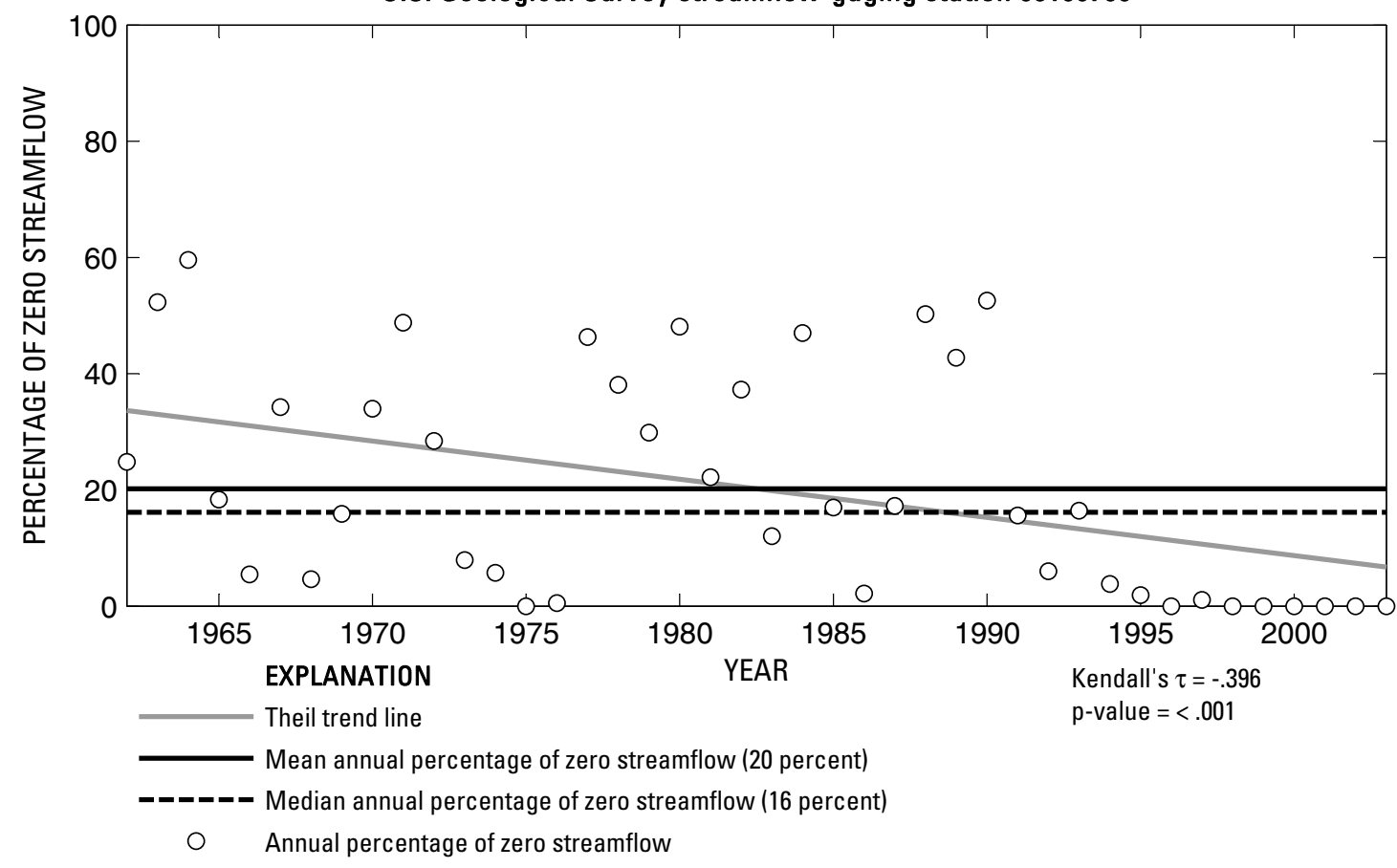

U.S. Geological Survey streamflow-gaging station 08109700

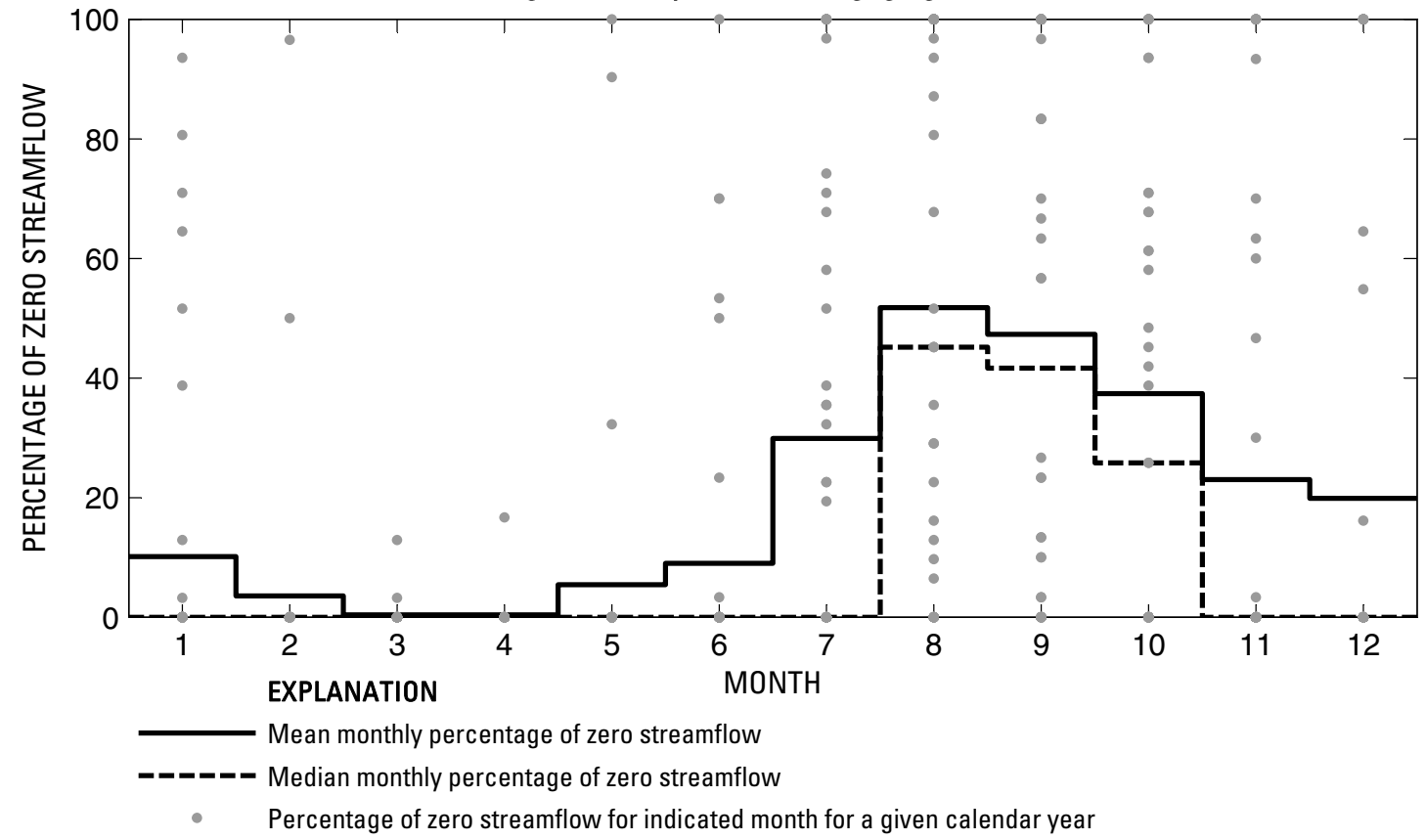

Figure 424. Analysis of percentage of zero daily mean streamflow for U.S. Geological Survey streamflow-gaging station 08109700 Middle Yegua Creek near Dime Box, Texas.

Index of Station Numbers 719 

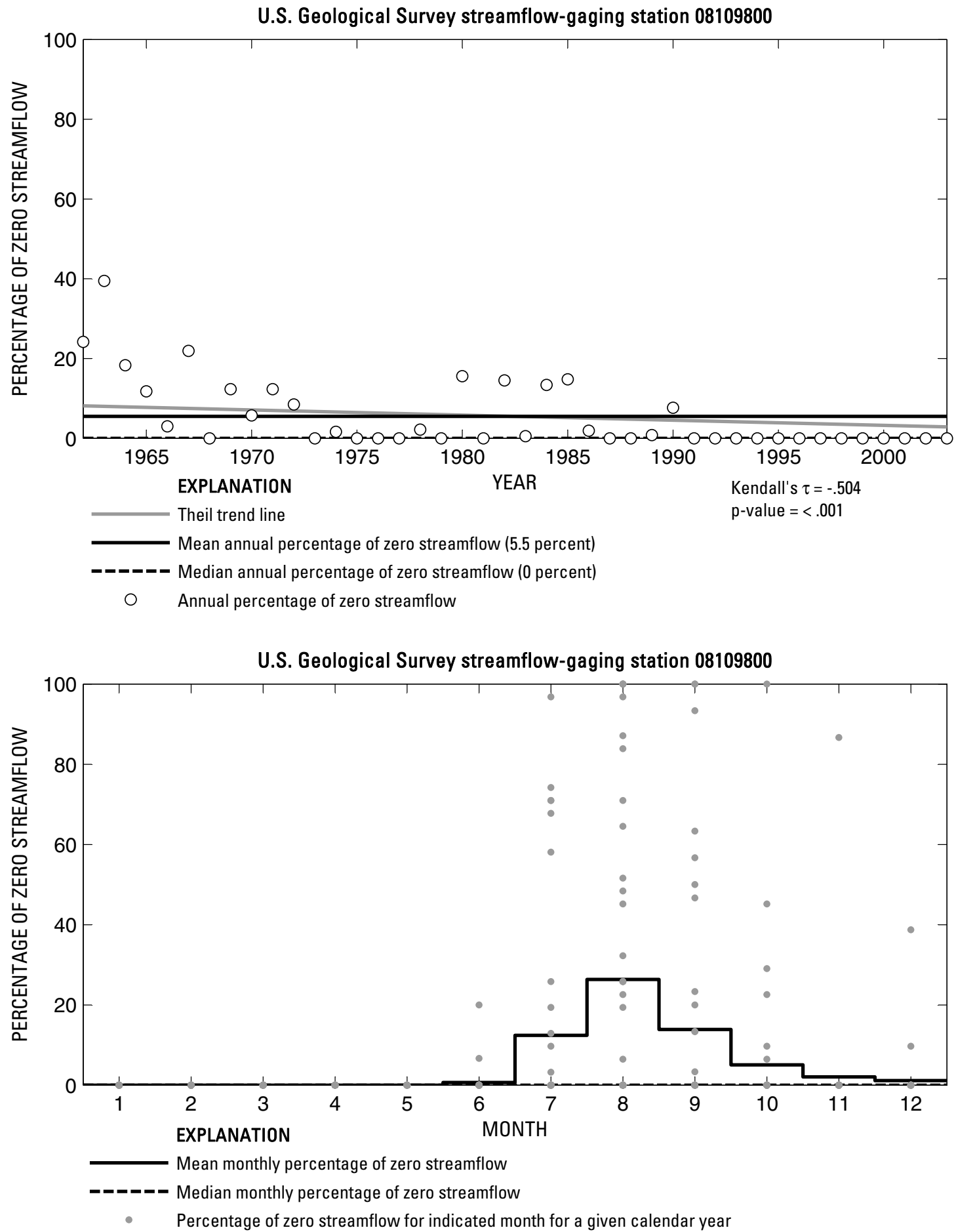

Figure 425. Analysis of percentage of zero daily mean streamflow for U.S. Geological Survey streamflow-gaging station 08109800 East Yegua Creek near Dime Box, Texas. 
U.S. Geological Survey streamflow-gaging station 08110000

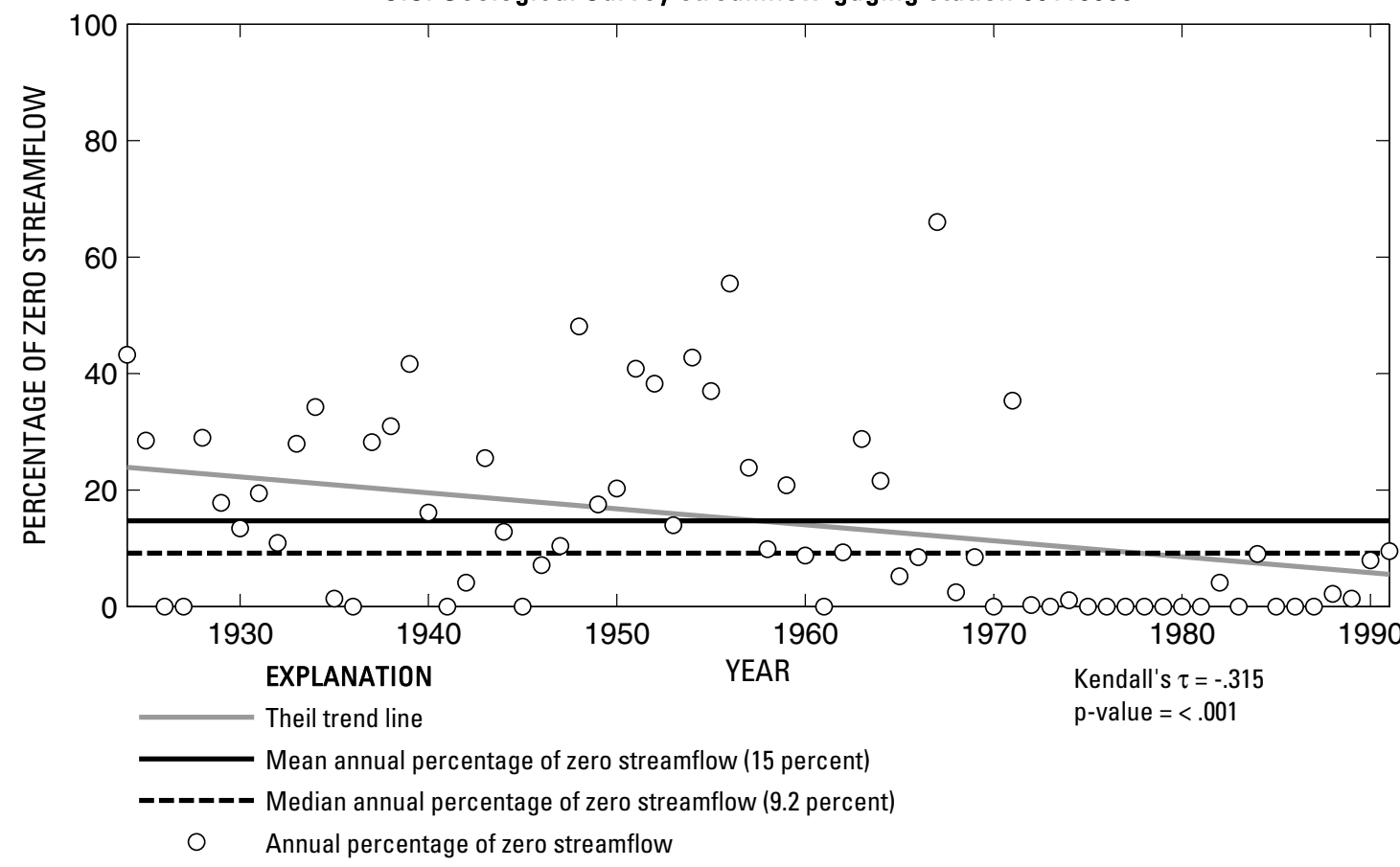

U.S. Geological Survey streamflow-gaging station 08110000

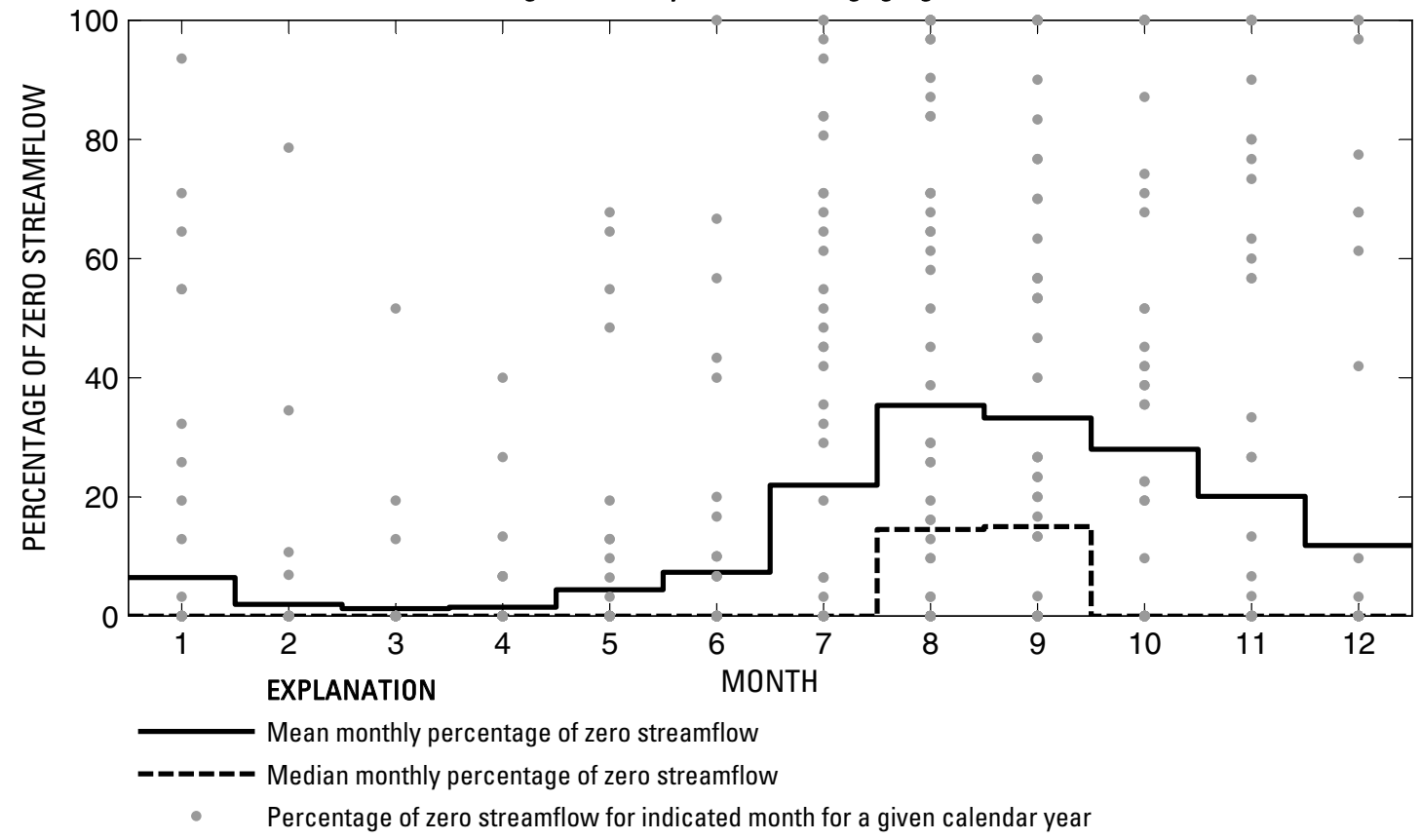

Figure 426. Analysis of percentage of zero daily mean streamflow for U.S. Geological Survey streamflow-gaging station 08110000 Yegua Creek near Somerville, Texas.

Index of Station Numbers 719 


\section{U.S. Geological Survey streamflow-gaging station 08110100}

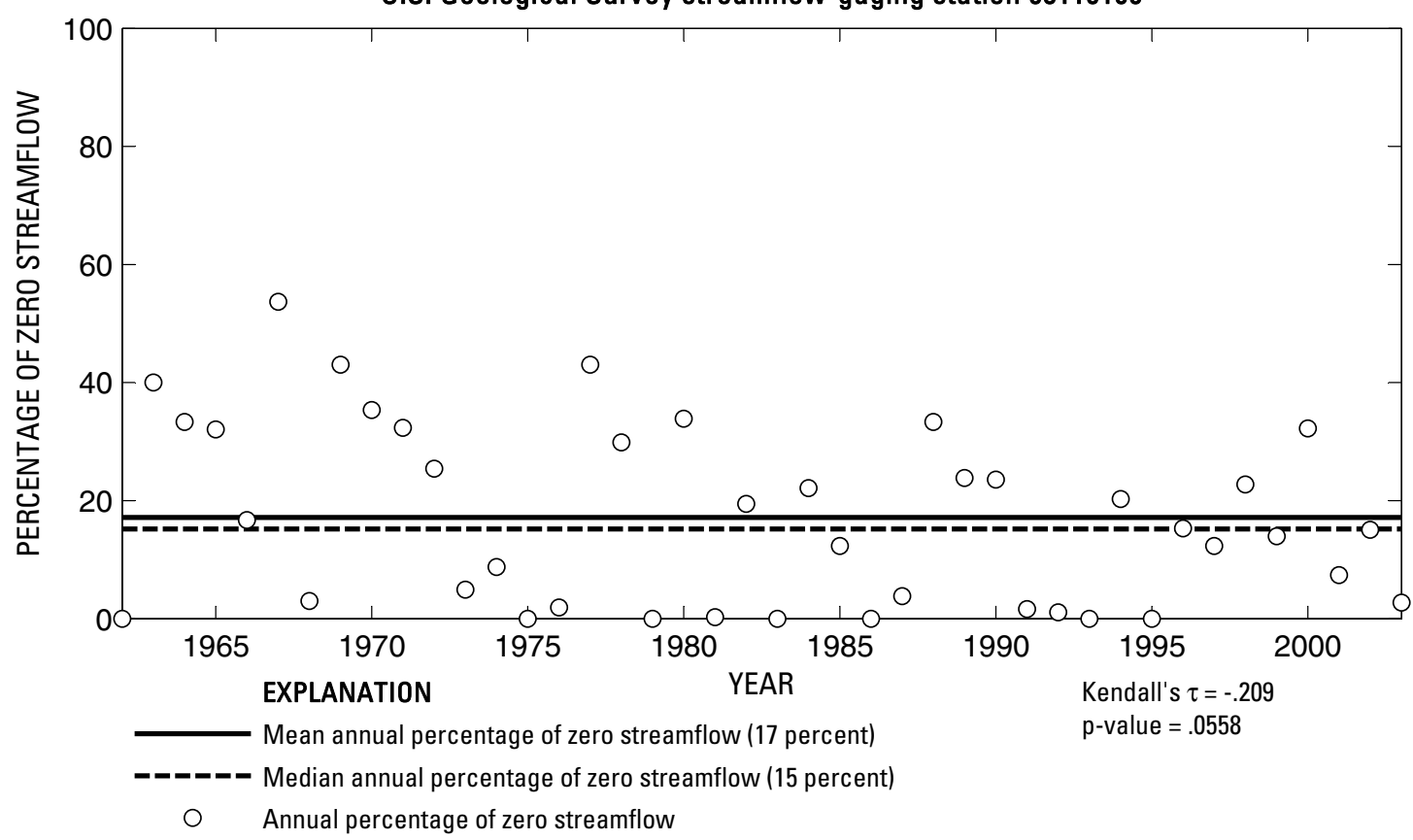

U.S. Geological Survey streamflow-gaging station 08110100

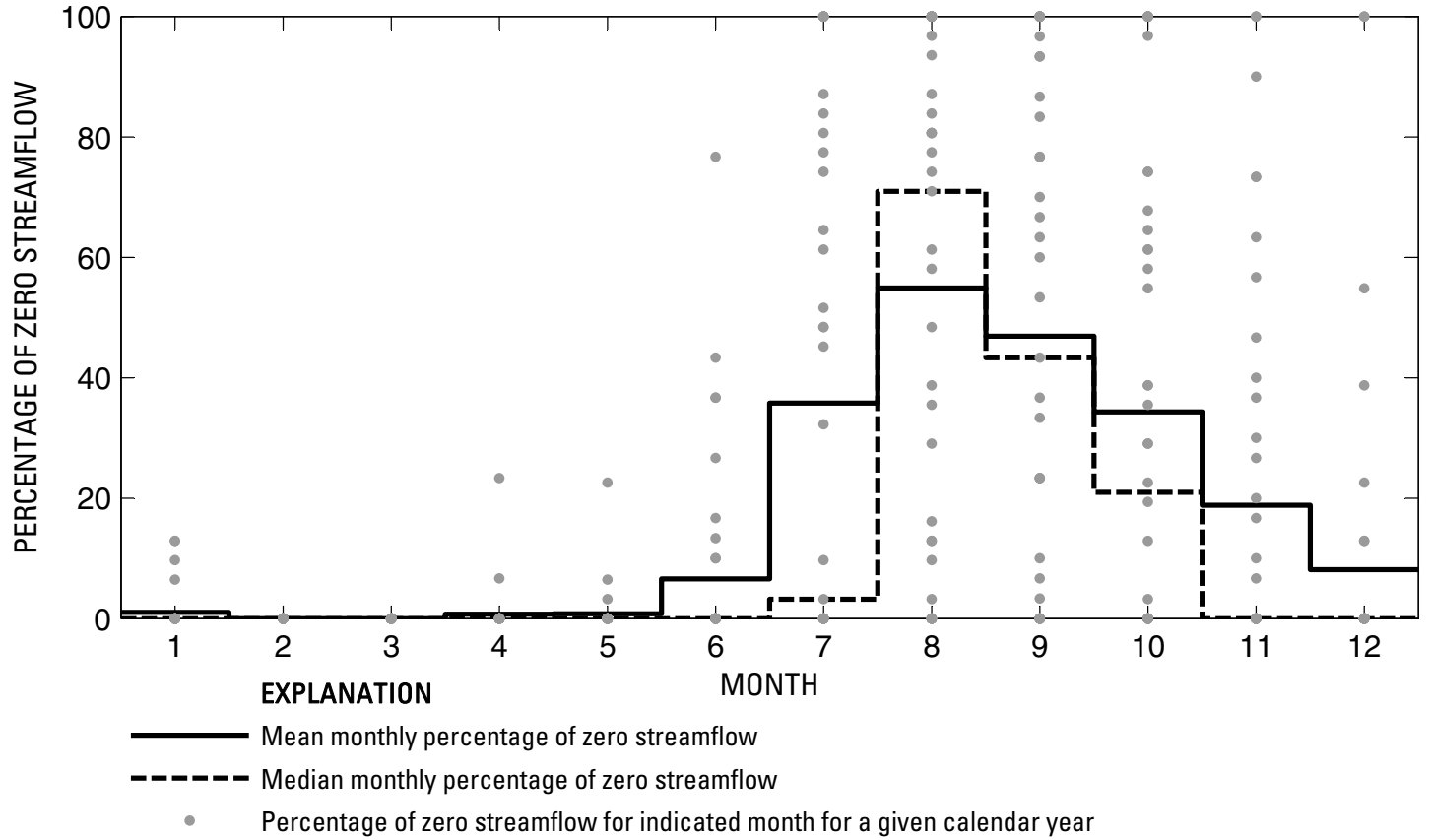

Figure 427. Analysis of percentage of zero daily mean streamflow for U.S. Geological Survey streamflow-gaging station 08110100 Davidson Creek near Lyons, Texas. 
U.S. Geological Survey streamflow-gaging station 08110200

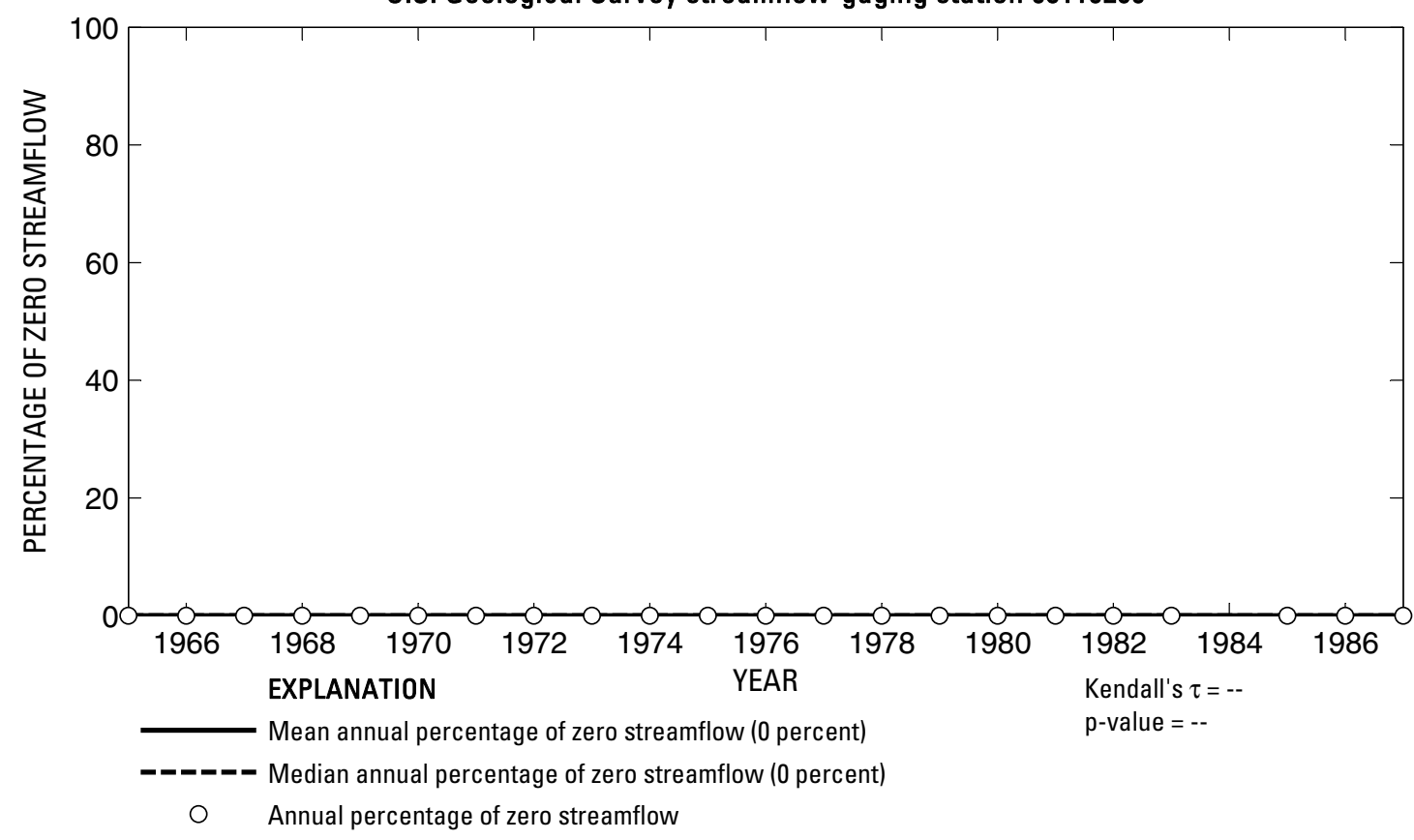

U.S. Geological Survey streamflow-gaging station 08110200

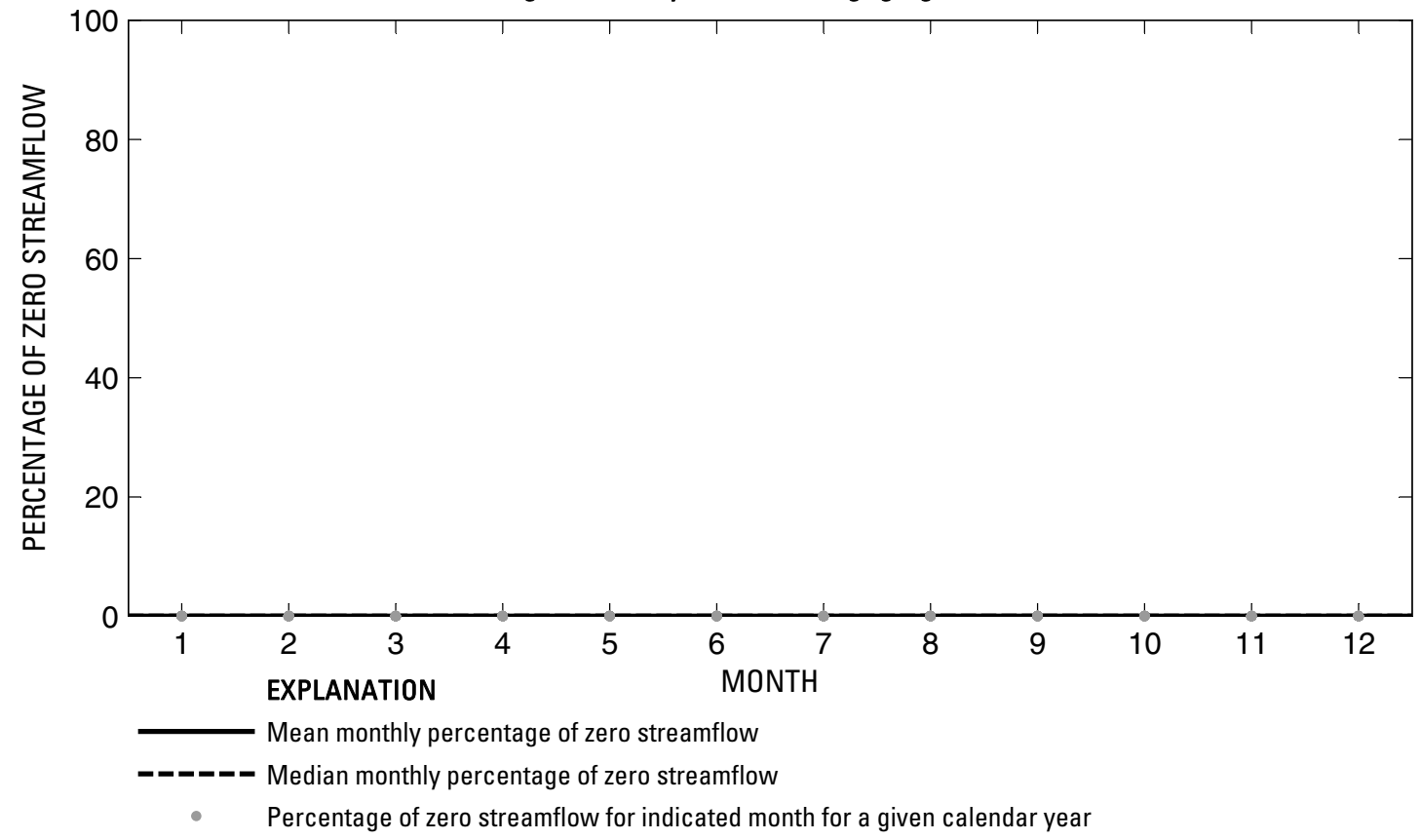

Figure 428. Analysis of percentage of zero daily mean streamflow for U.S. Geological Survey streamflow-gaging station 08110200 Brazos River at Washington, Texas. 


\section{U.S. Geological Survey streamflow-gaging station 08110325}

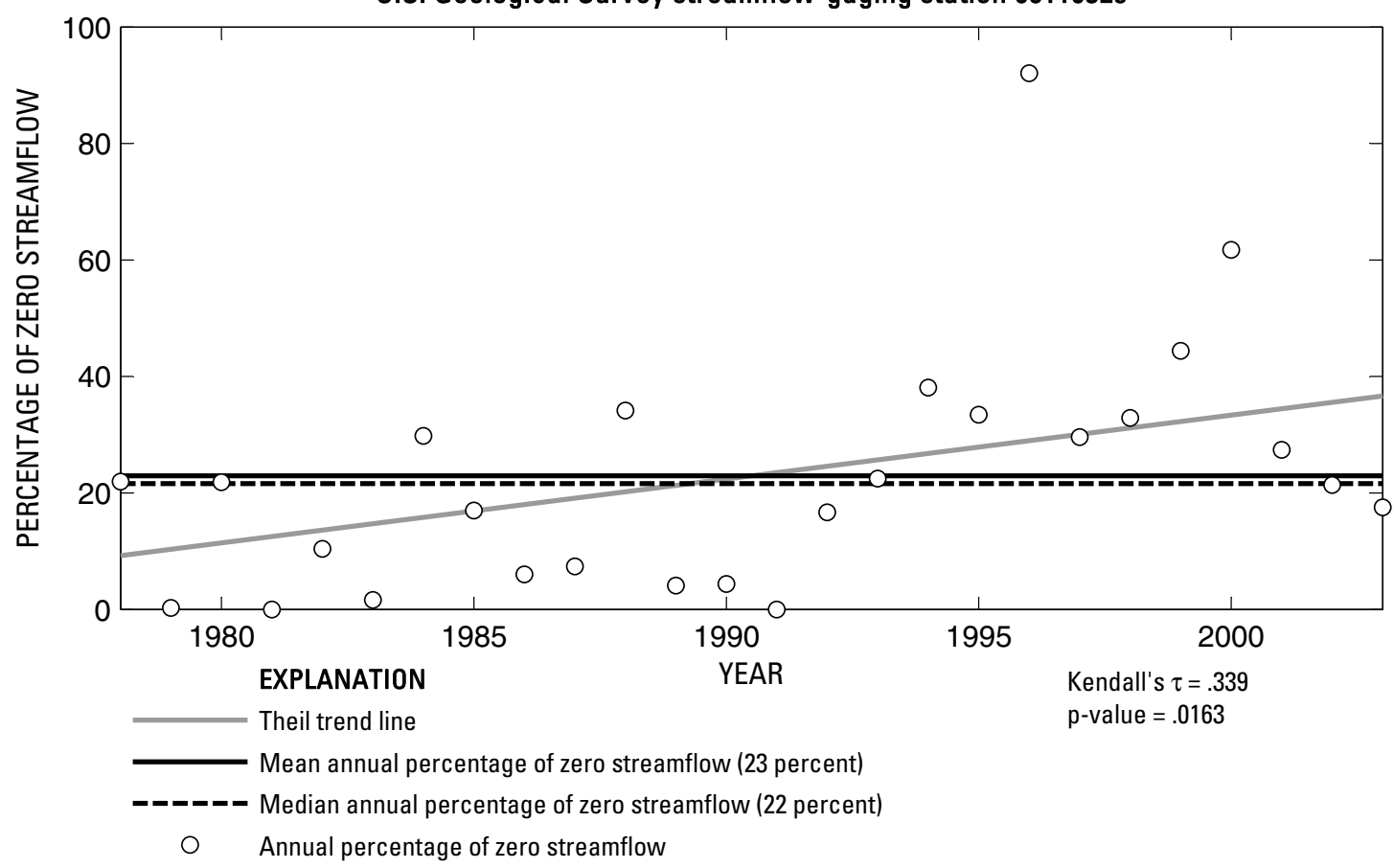

U.S. Geological Survey streamflow-gaging station 08110325

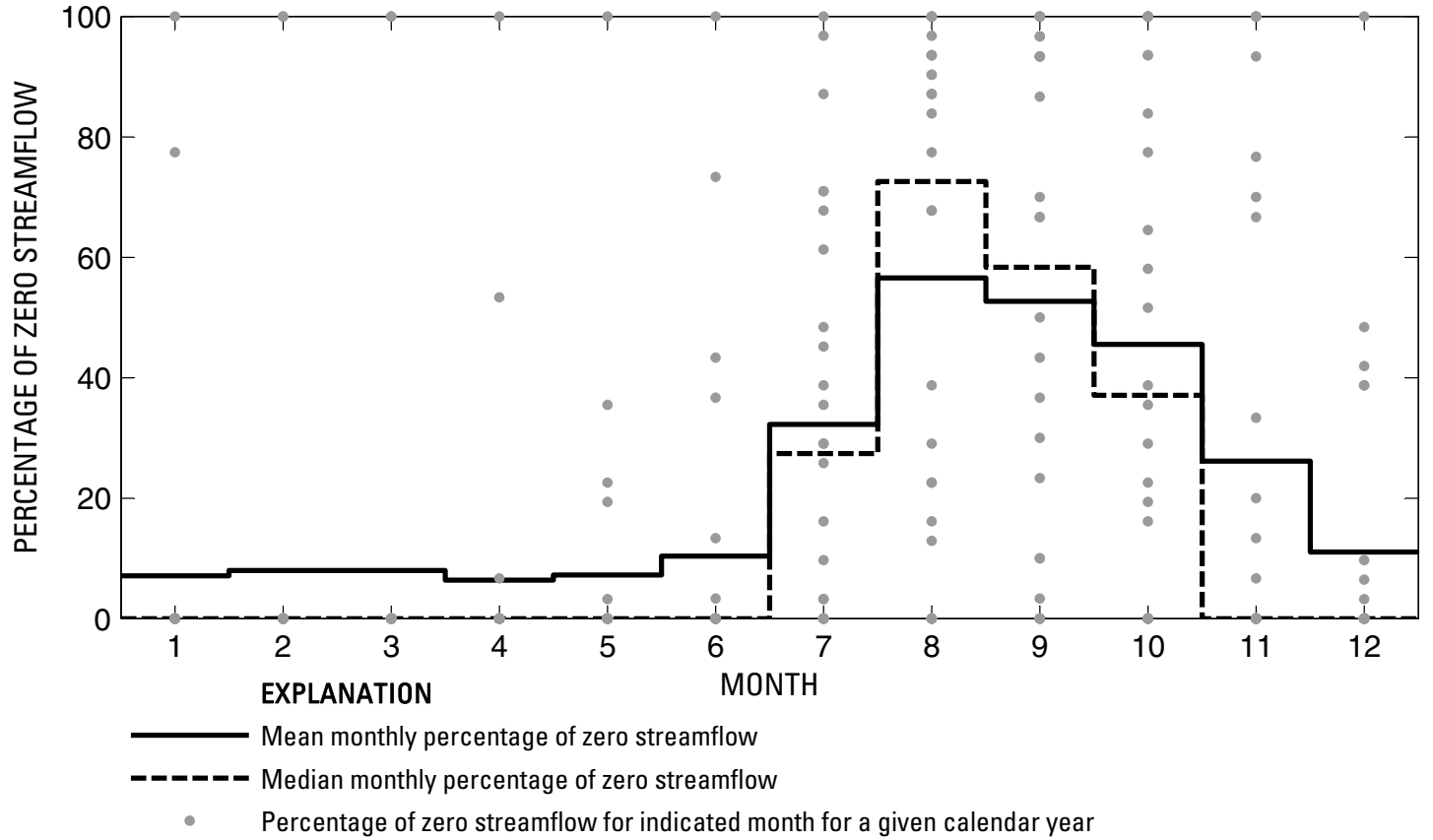

Figure 429. Analysis of percentage of zero daily mean streamflow for U.S. Geological Survey streamflow-gaging station 08110325 Navasota River above Groesbeck, Texas. 
U.S. Geological Survey streamflow-gaging station 08110400

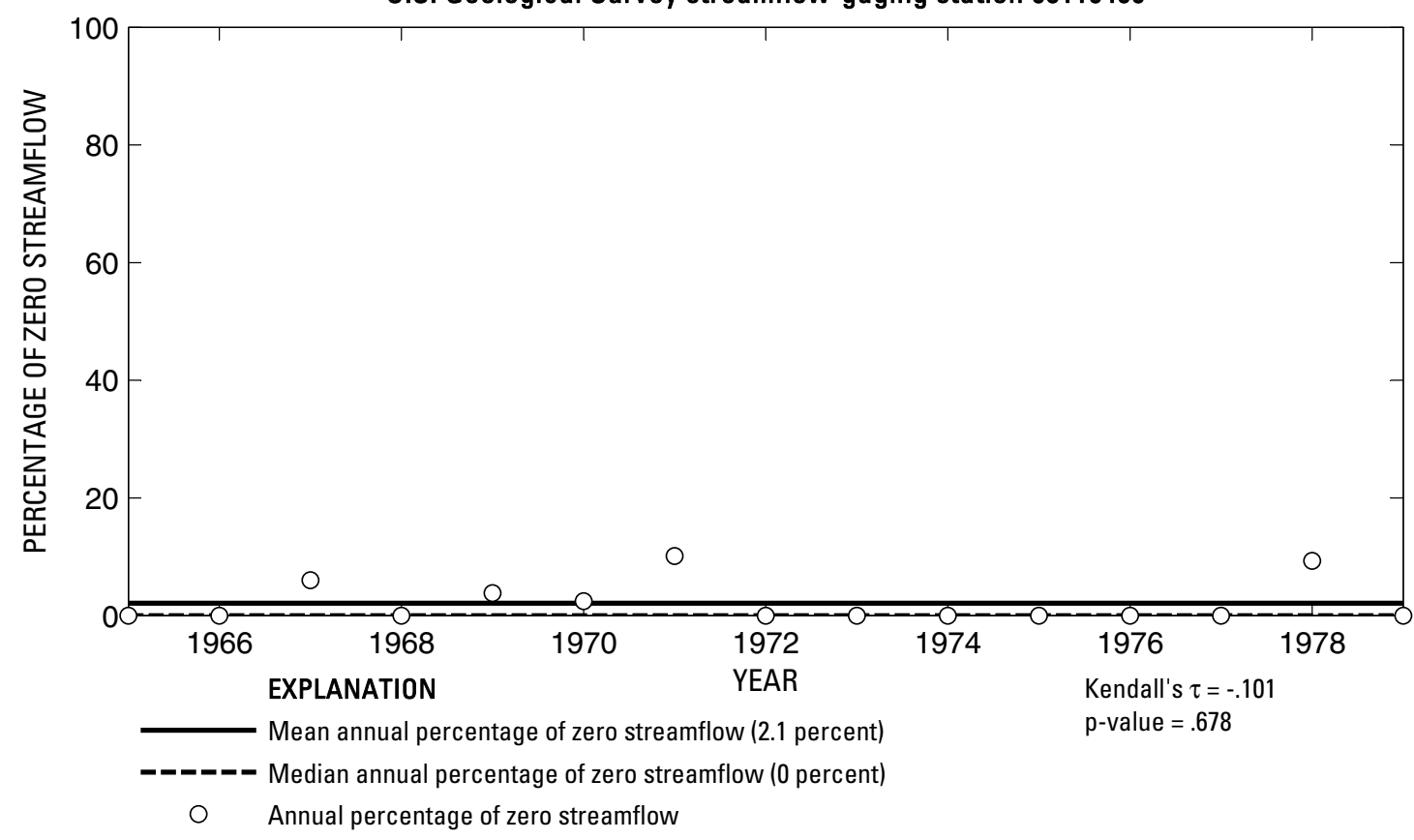

U.S. Geological Survey streamflow-gaging station 08110400

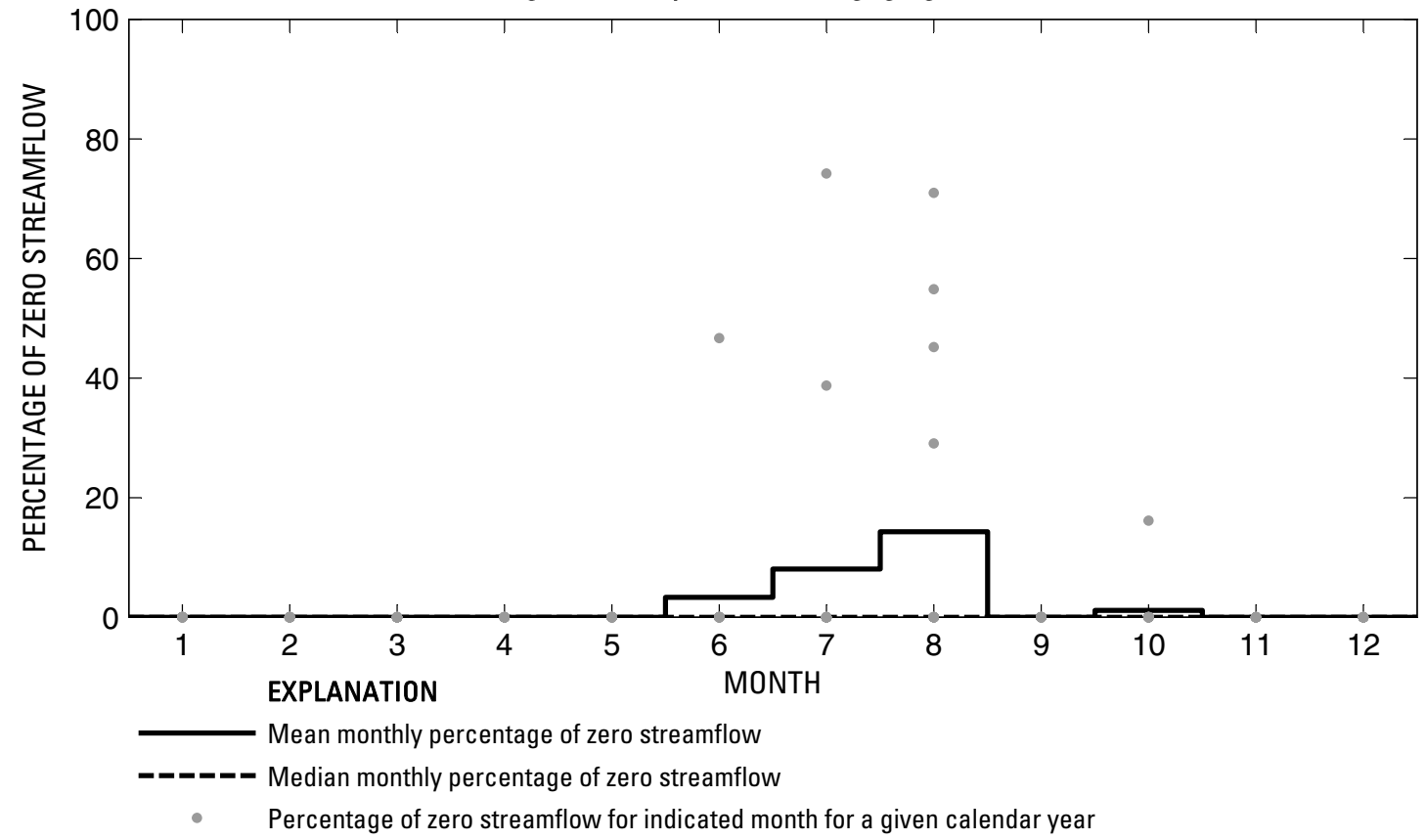

Figure 430. Analysis of percentage of zero daily mean streamflow for U.S. Geological Survey streamflow-gaging station 08110400 Navasota River near Groesbeck, Texas. 
U.S. Geological Survey streamflow-gaging station 08110430

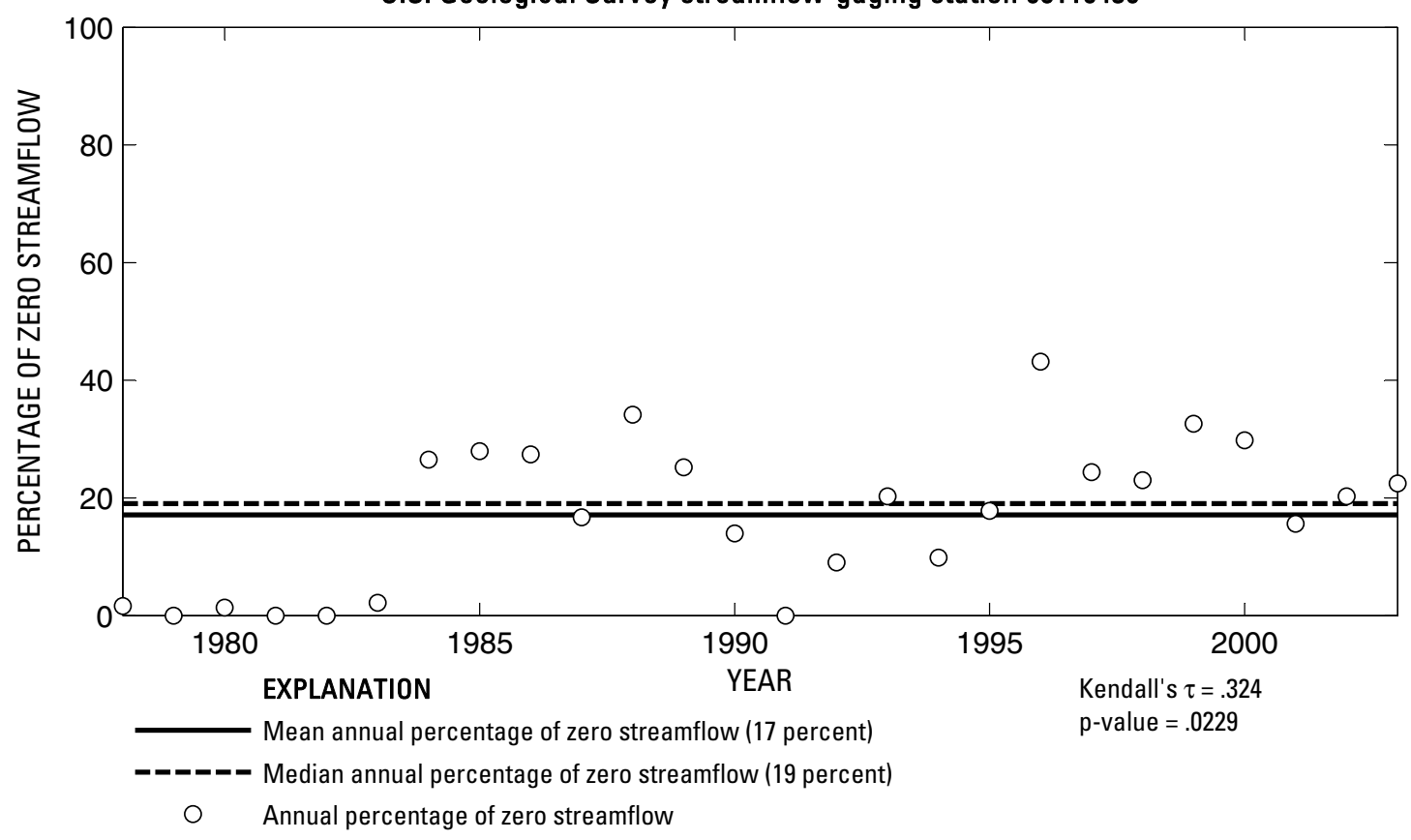

U.S. Geological Survey streamflow-gaging station 08110430

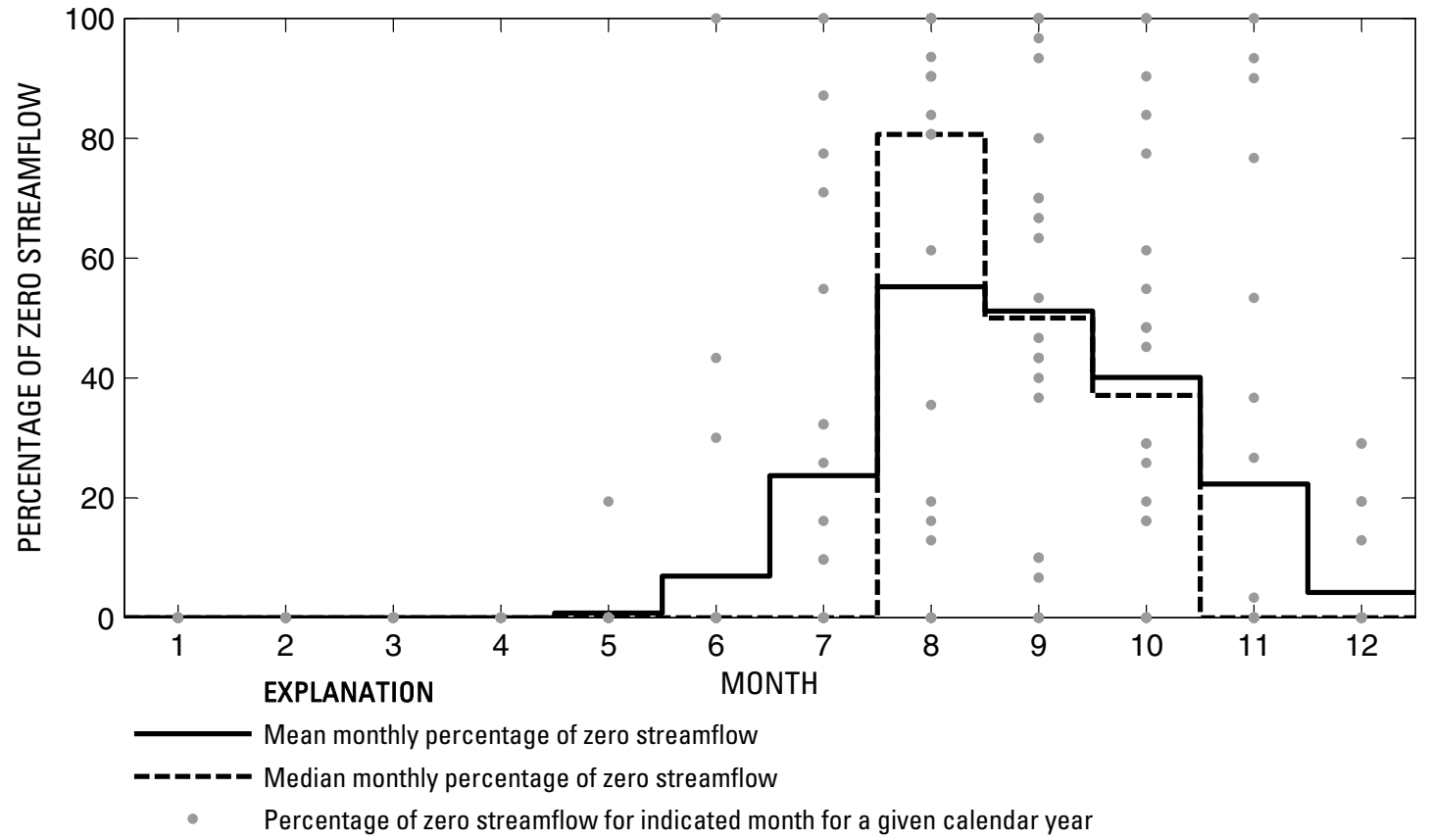

Figure 431. Analysis of percentage of zero daily mean streamflow for U.S. Geological Survey streamflow-gaging station 08110430 Big Creek near Freestone, Texas. 
U.S. Geological Survey streamflow-gaging station 08110500

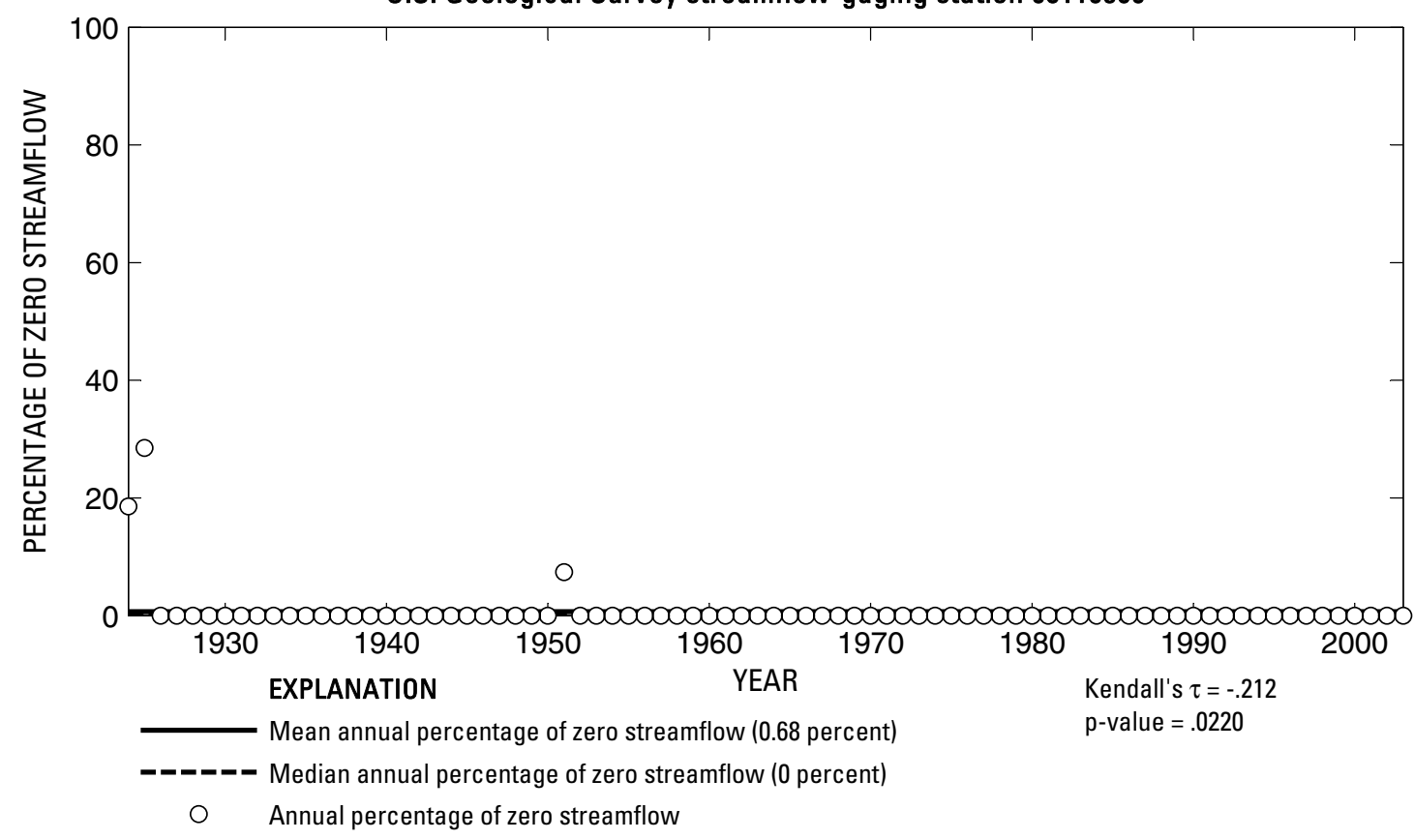

U.S. Geological Survey streamflow-gaging station 08110500

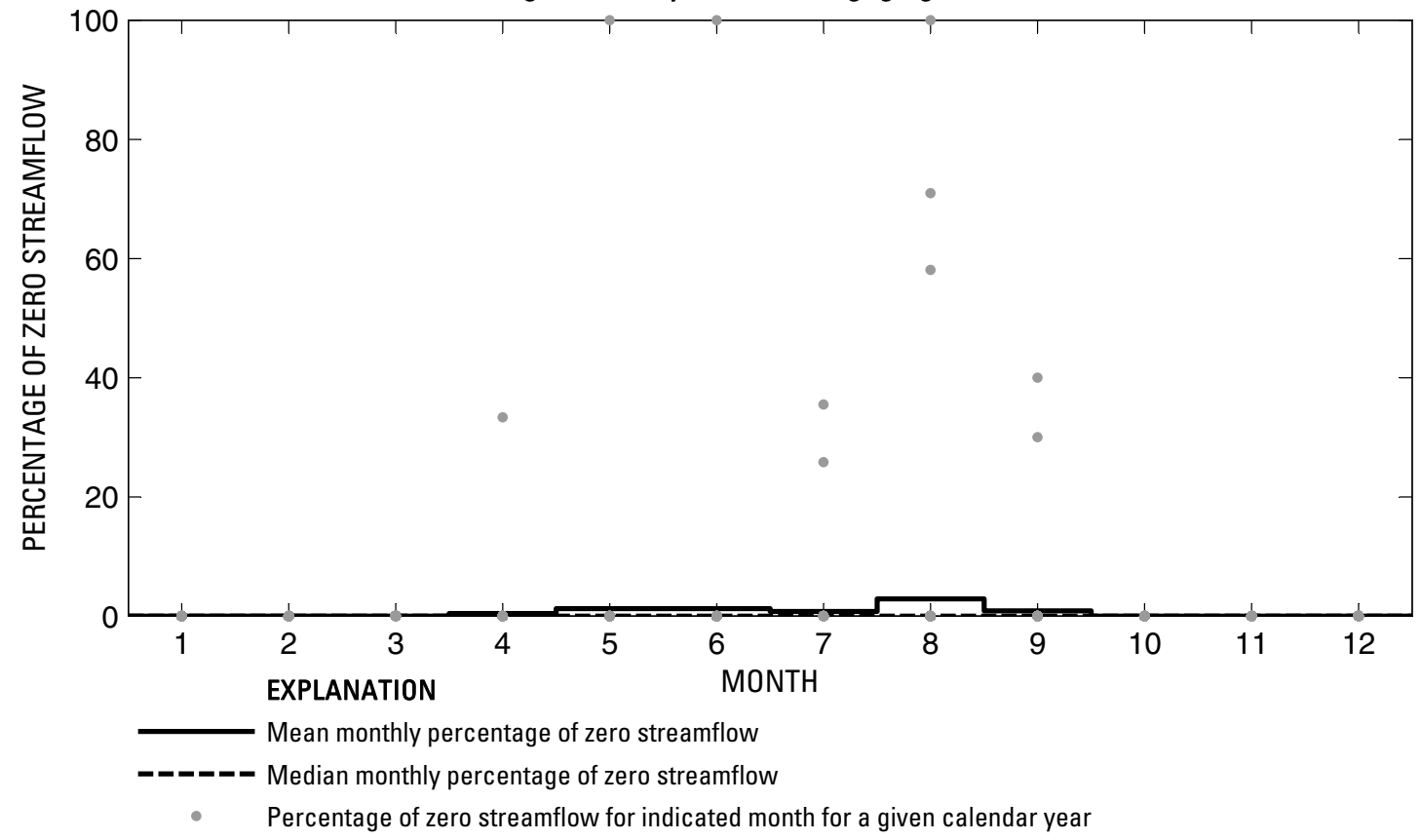

Figure 432. Analysis of percentage of zero daily mean streamflow for U.S. Geological Survey streamflow-gaging station 08110500 Navasota River near Easterly, Texas. 


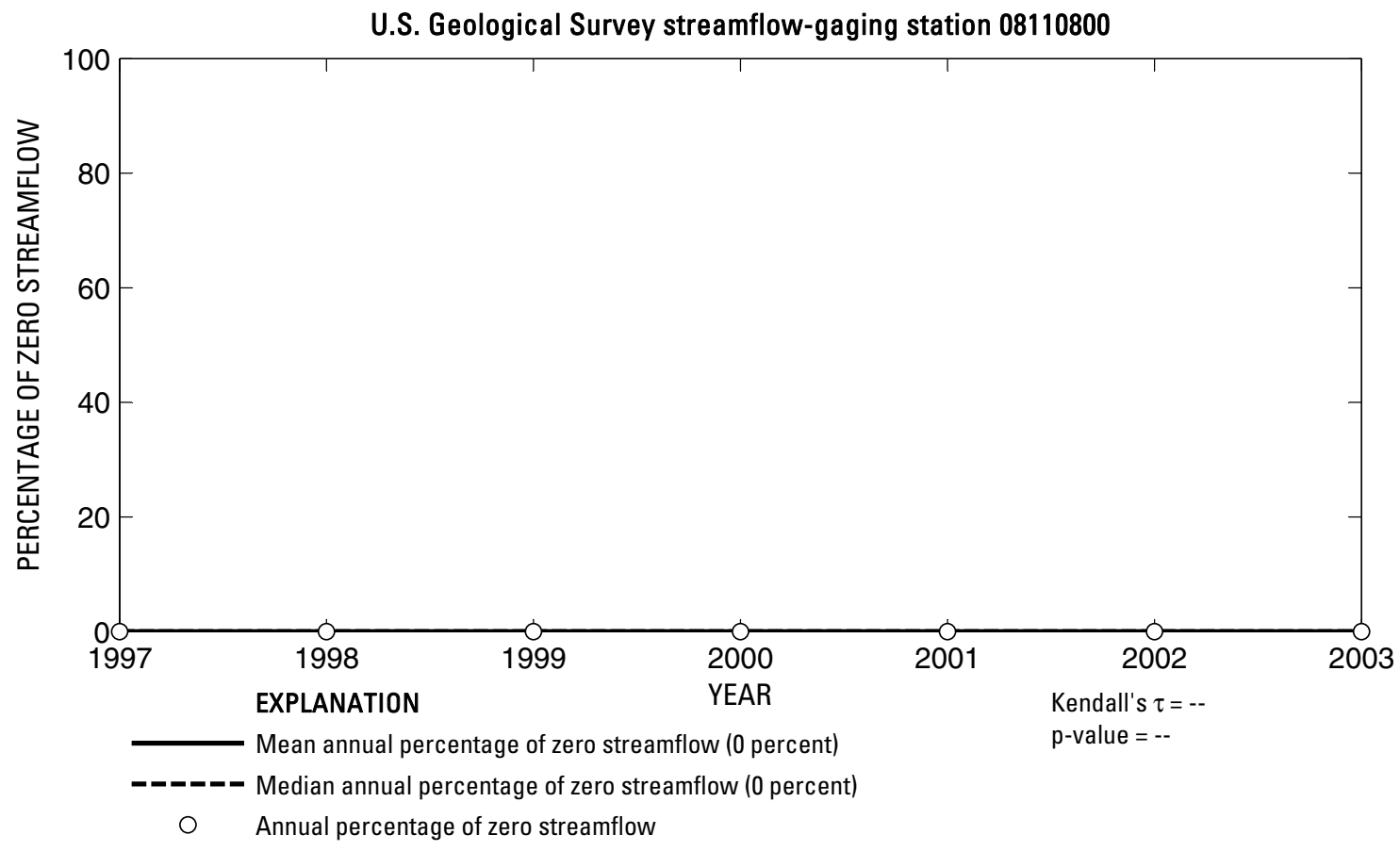

U.S. Geological Survey streamflow-gaging station 08110800

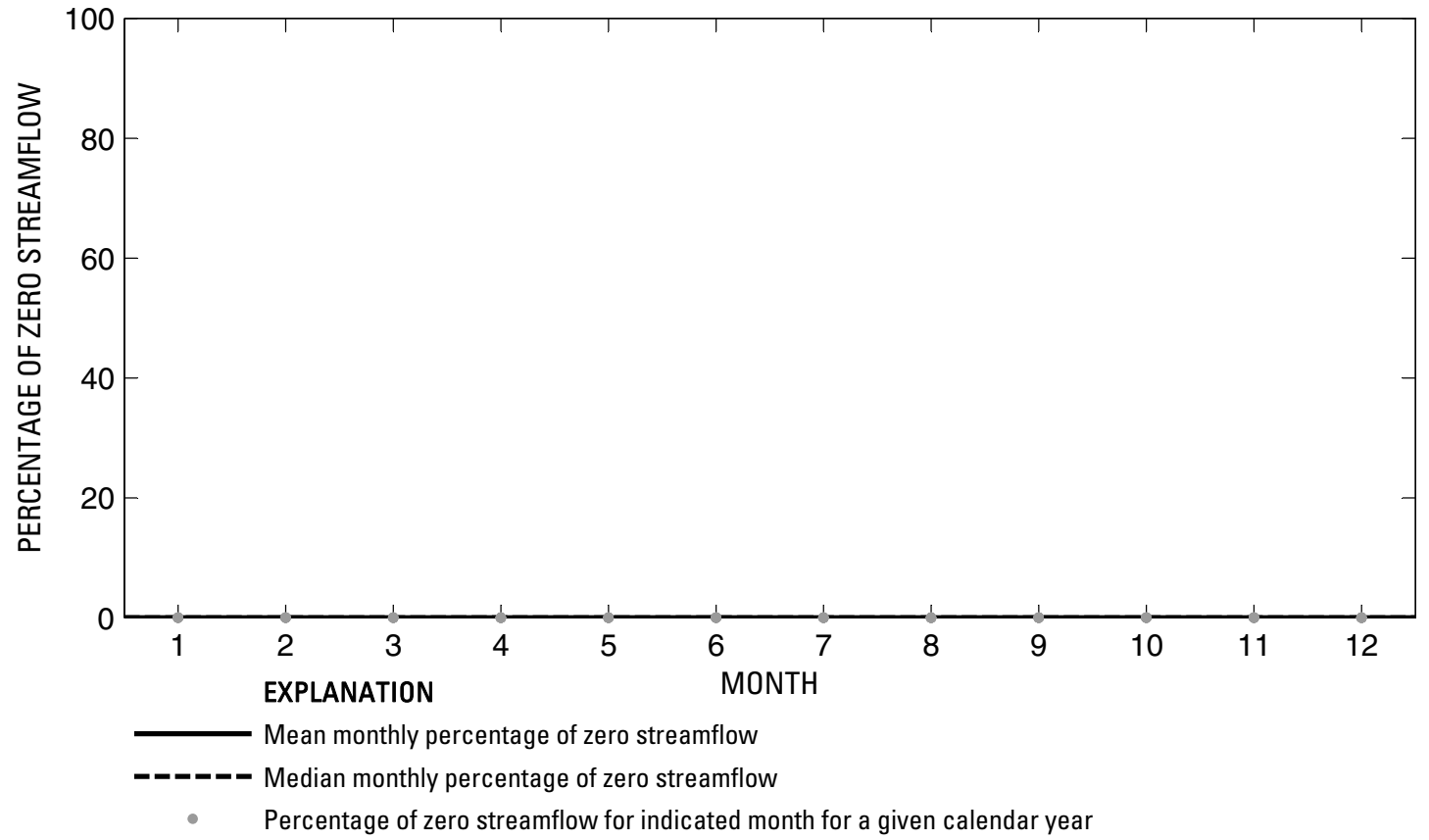

Figure 433. Analysis of percentage of zero daily mean streamflow for U.S. Geological Survey streamflow-gaging station 08110800 Navasota River at Old Spanish Road near Bryan, Texas. 
U.S. Geological Survey streamflow-gaging station 08111000

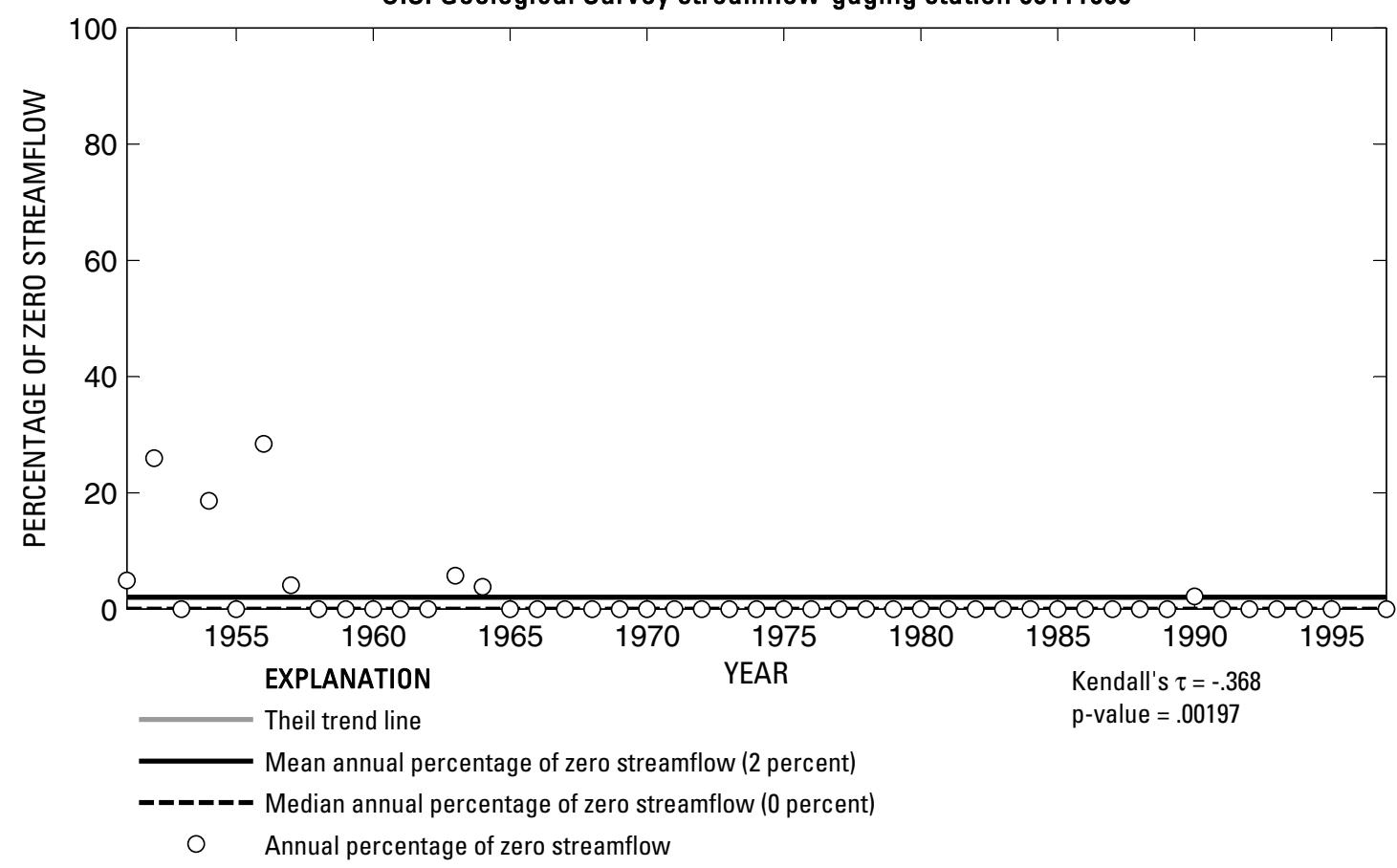

U.S. Geological Survey streamflow-gaging station 08111000

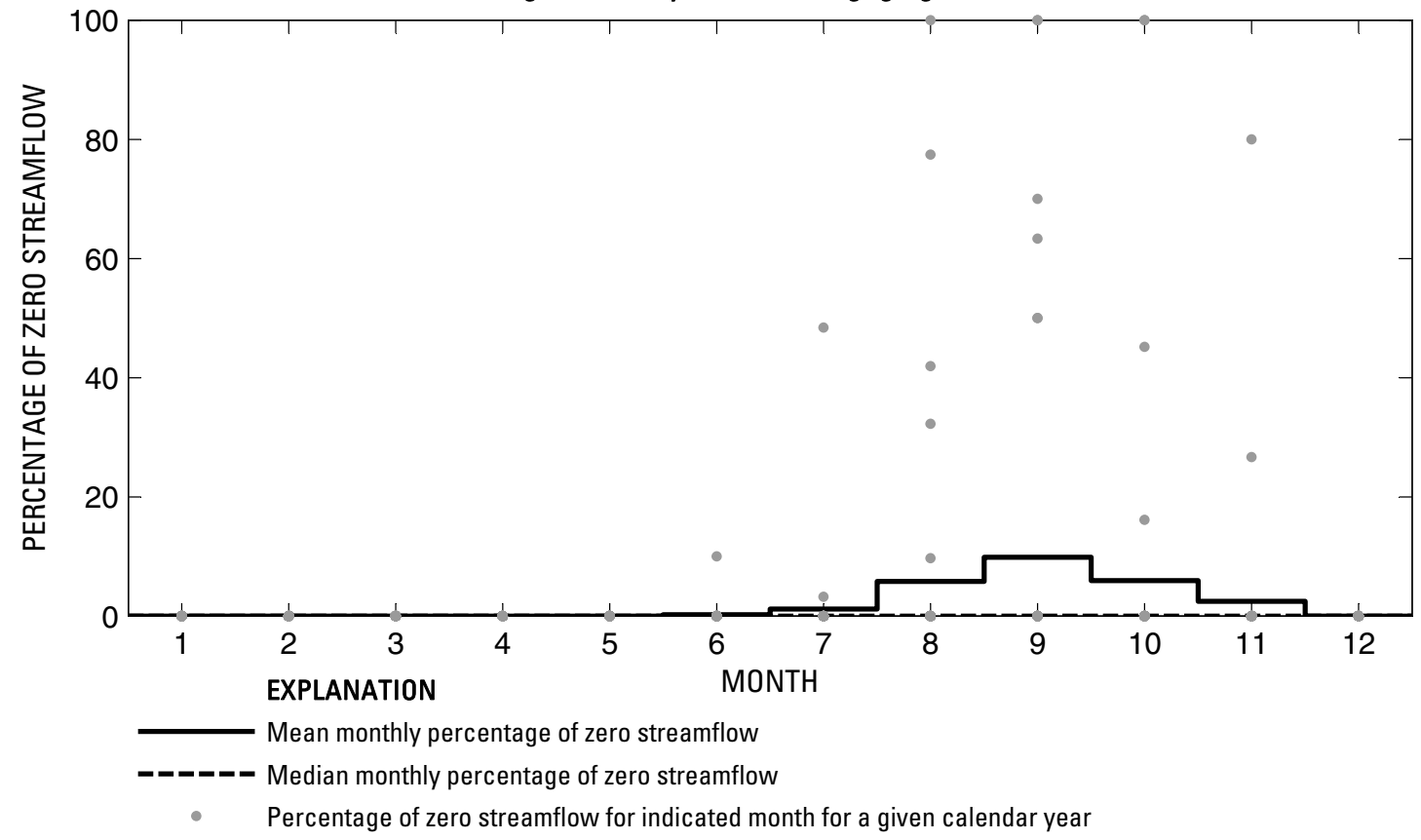

Figure 434. Analysis of percentage of zero daily mean streamflow for U.S. Geological Survey streamflow-gaging station 08111000 Navasota River near Bryan, Texas. 


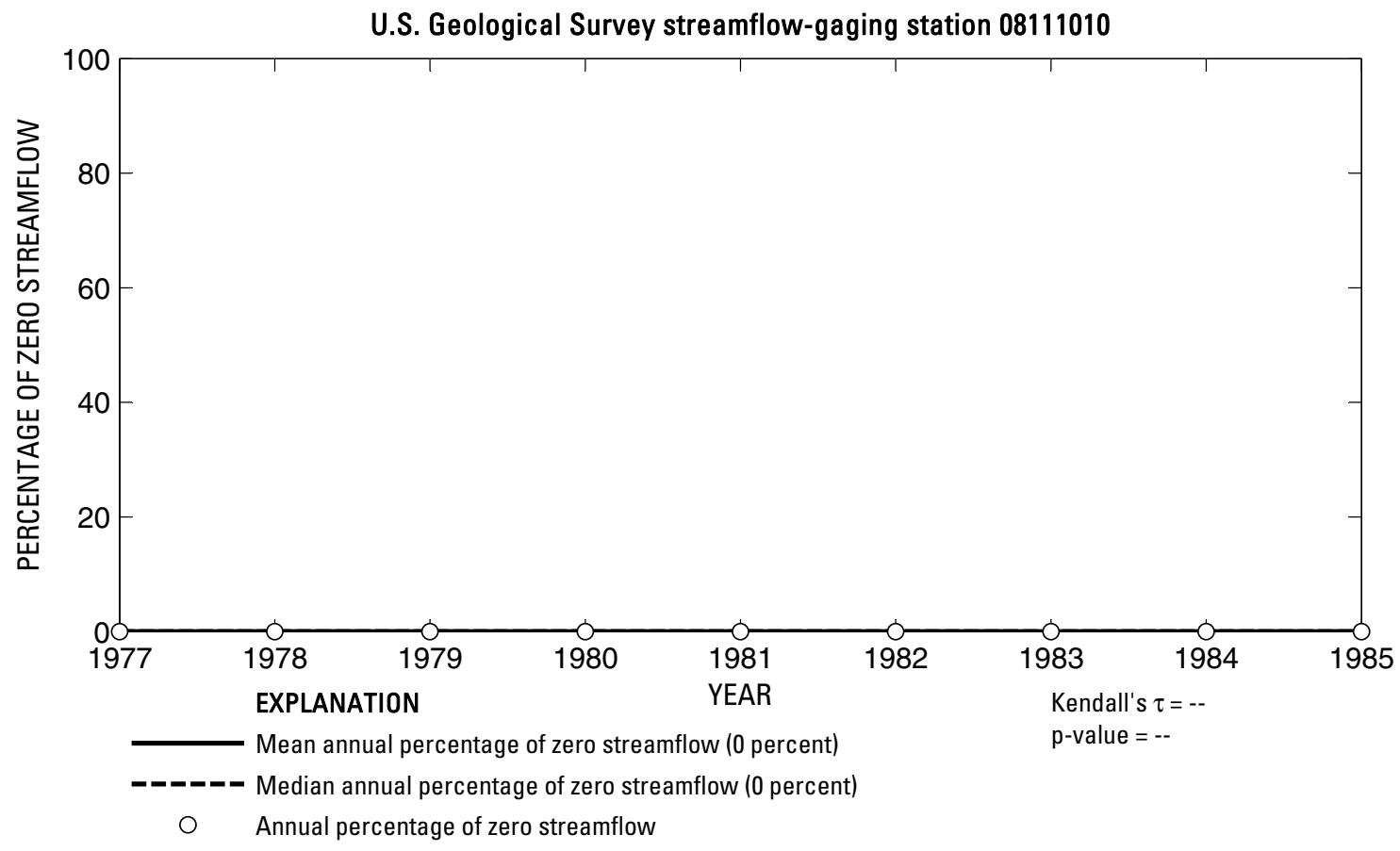

U.S. Geological Survey streamflow-gaging station 08111010

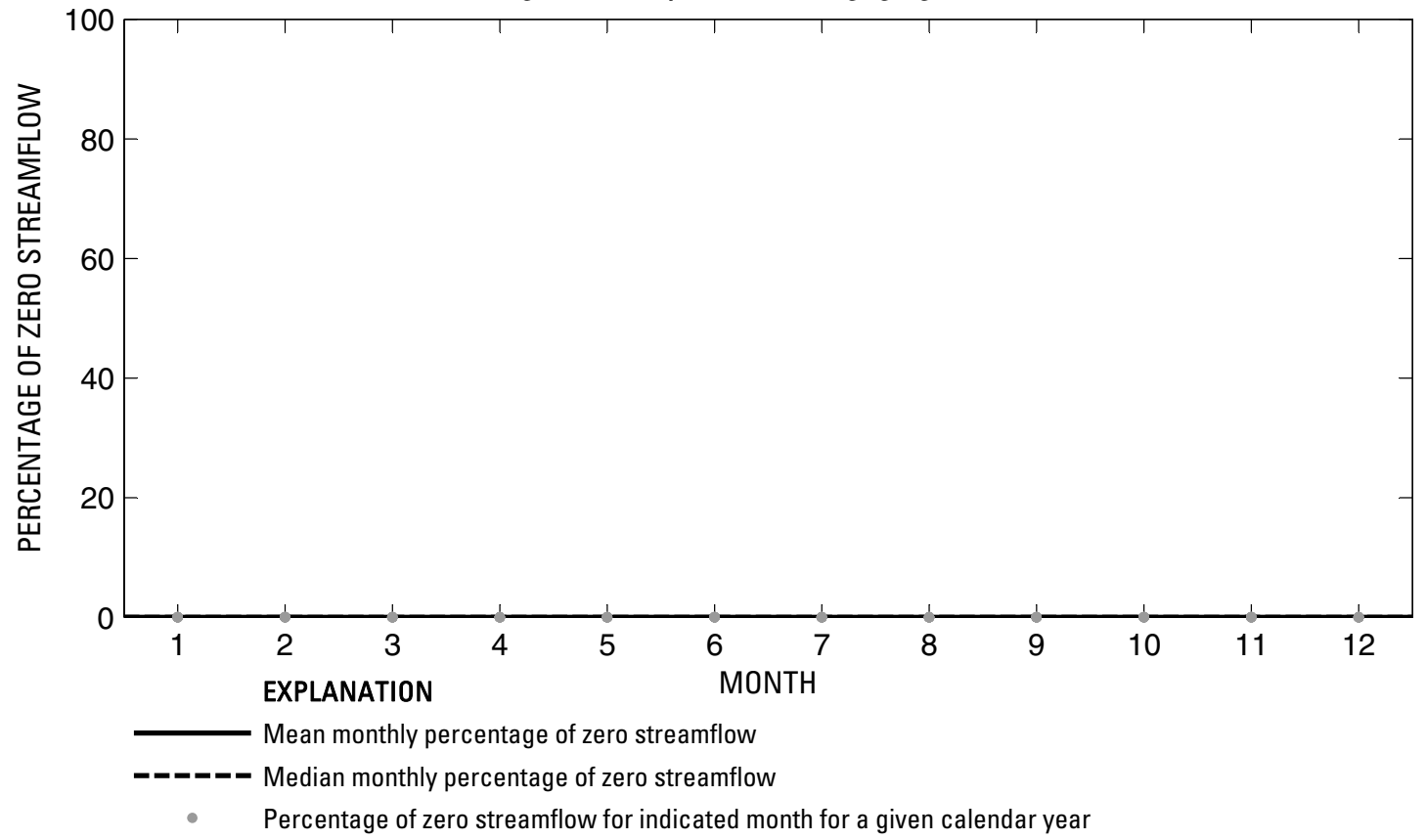

Figure 435. Analysis of percentage of zero daily mean streamflow for U.S. Geological Survey streamflow-gaging station 08111010 Navasota River near College Station, Texas. 
U.S. Geological Survey streamflow-gaging station 08111025

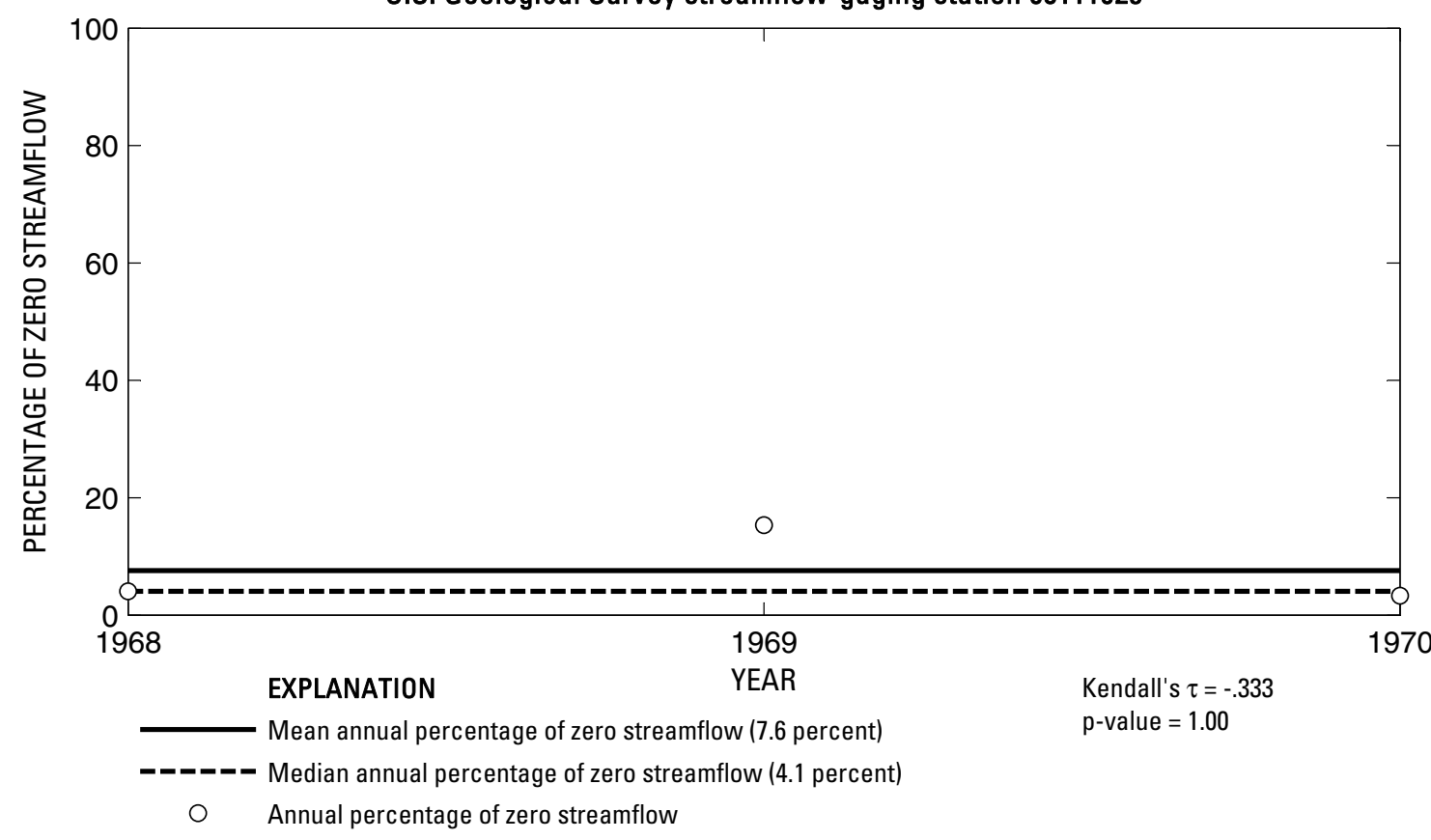

U.S. Geological Survey streamflow-gaging station 08111025

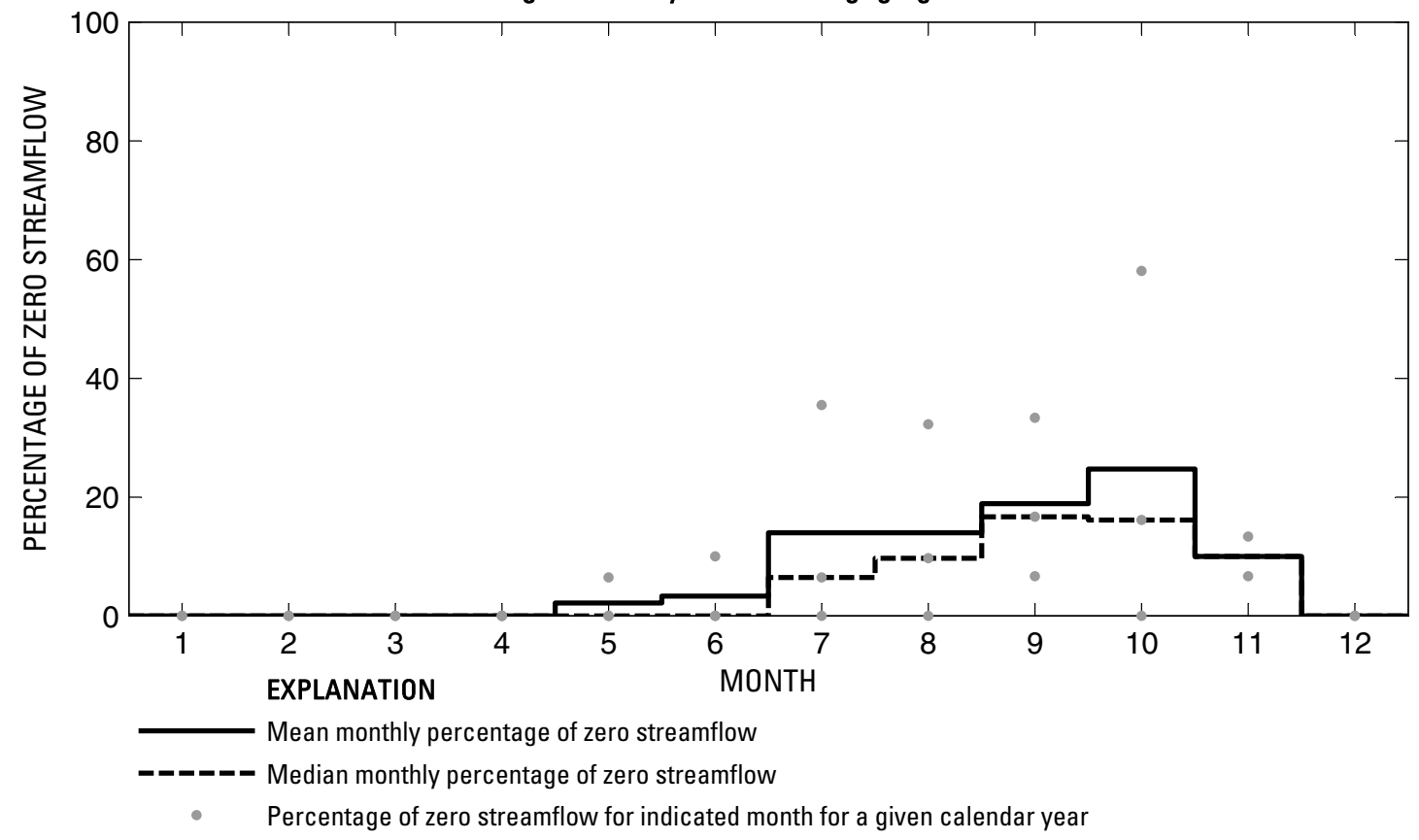

Figure 436. Analysis of percentage of zero daily mean streamflow for U.S. Geological Survey streamflow-gaging station 08111025 Burton Creek at Villa Maria Road, Bryan, Texas. 
U.S. Geological Survey streamflow-gaging station 08111050

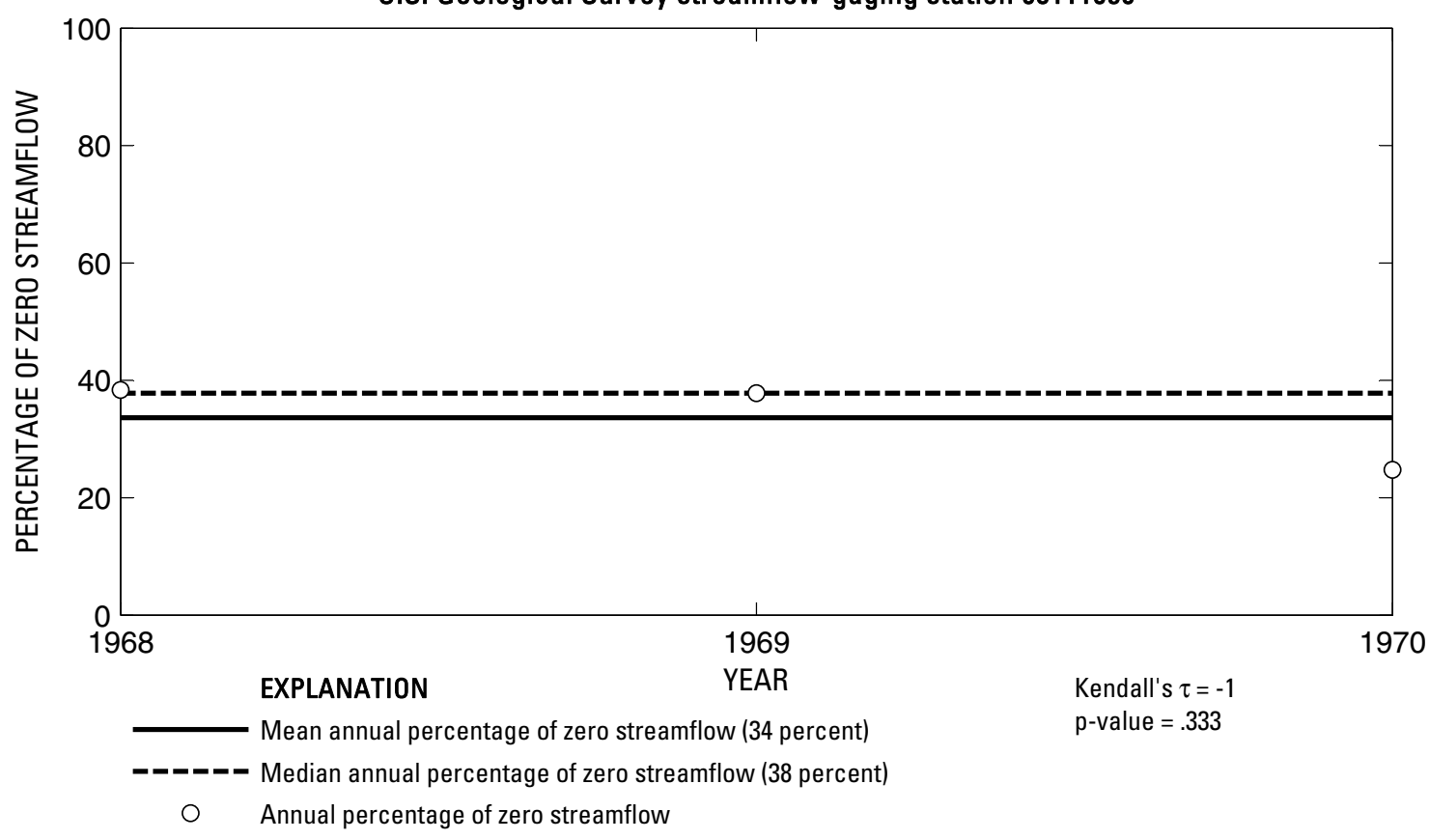

U.S. Geological Survey streamflow-gaging station 08111050

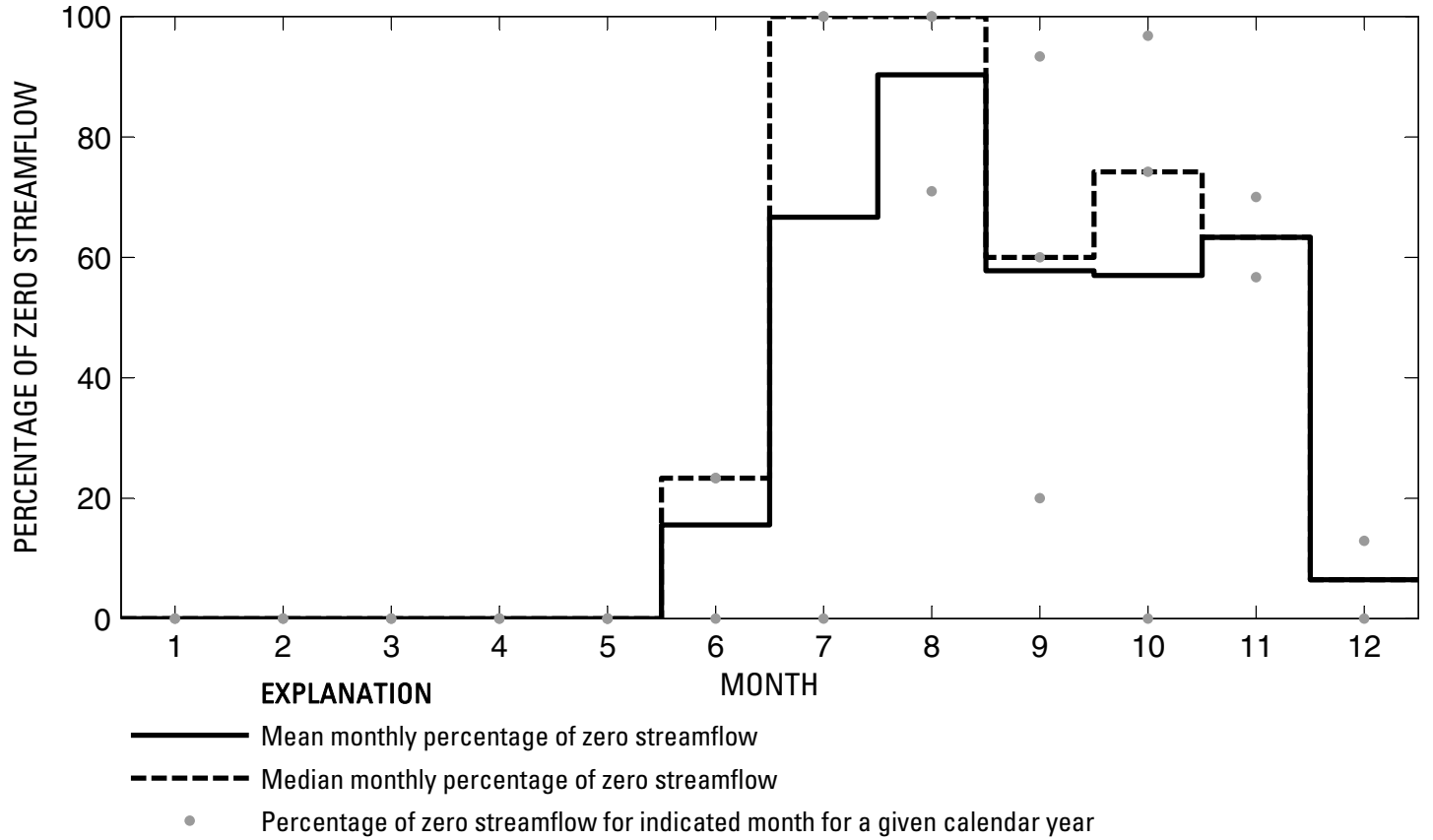

Figure 437. Analysis of percentage of zero daily mean streamflow for U.S. Geological Survey streamflow-gaging station 08111050 Hudson Creek near Bryan, Texas. 
U.S. Geological Survey streamflow-gaging station 08111500

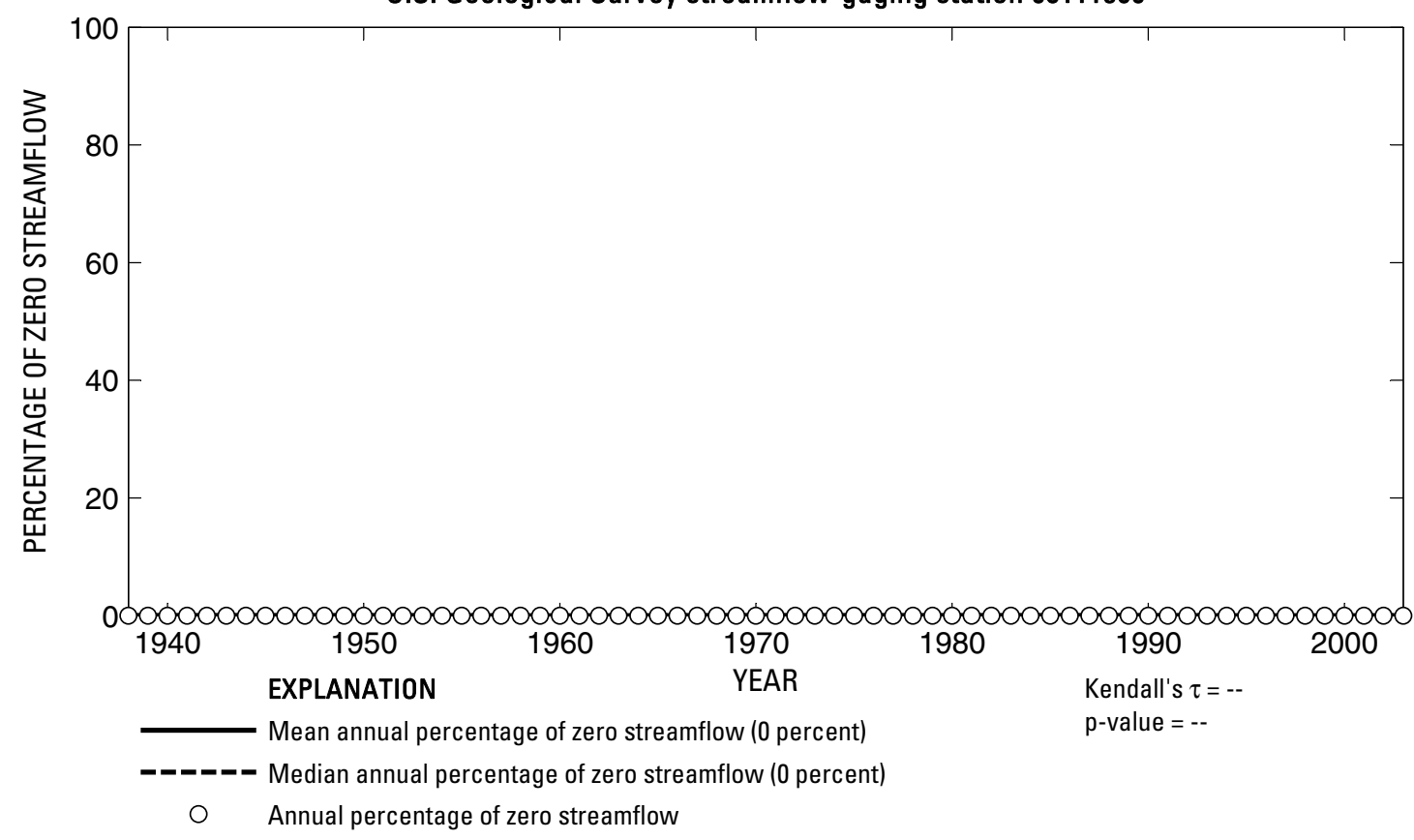

U.S. Geological Survey streamflow-gaging station 08111500

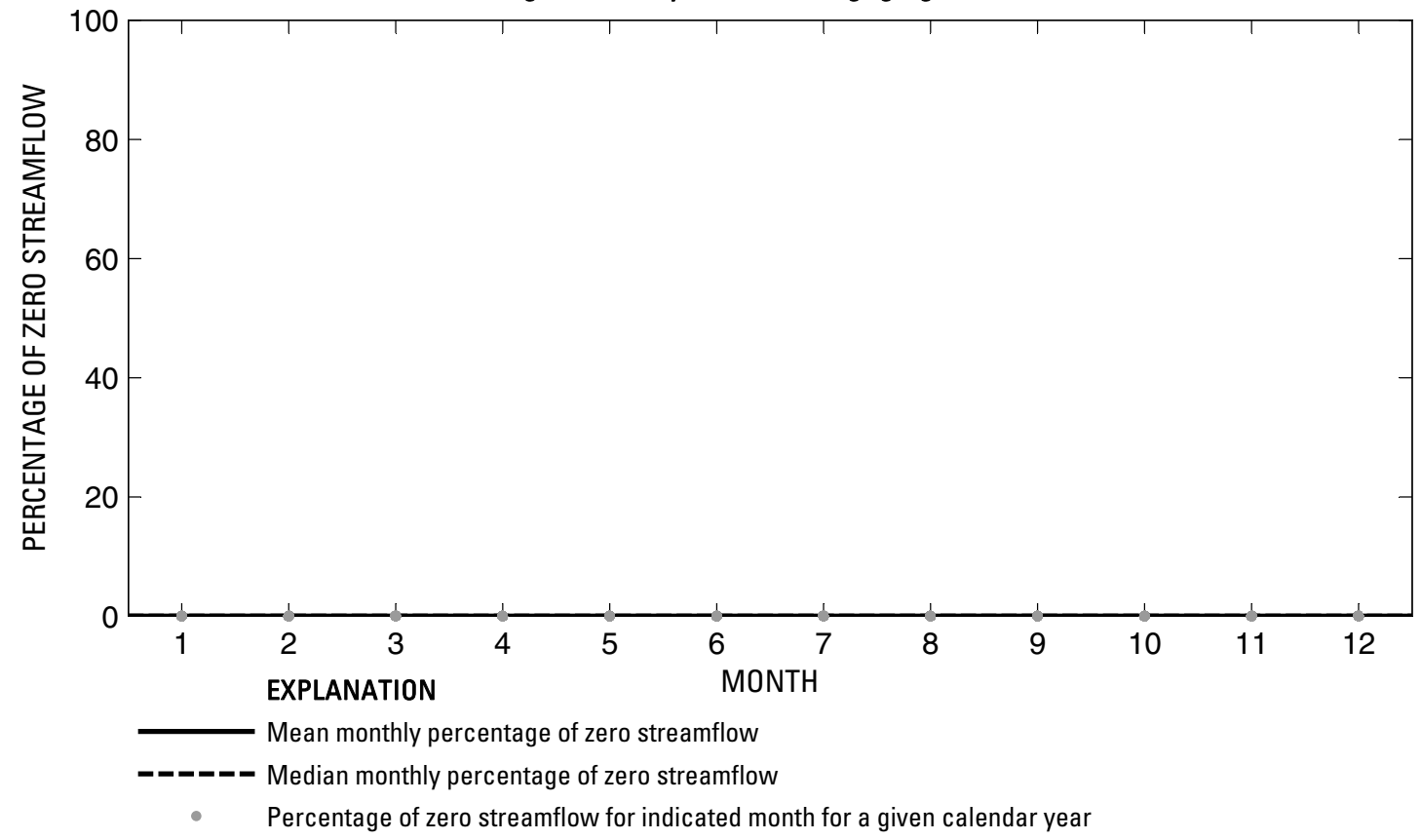

Figure 438. Analysis of percentage of zero daily mean streamflow for U.S. Geological Survey streamflow-gaging station 08111500 Brazos River near Hempstead, Texas. 


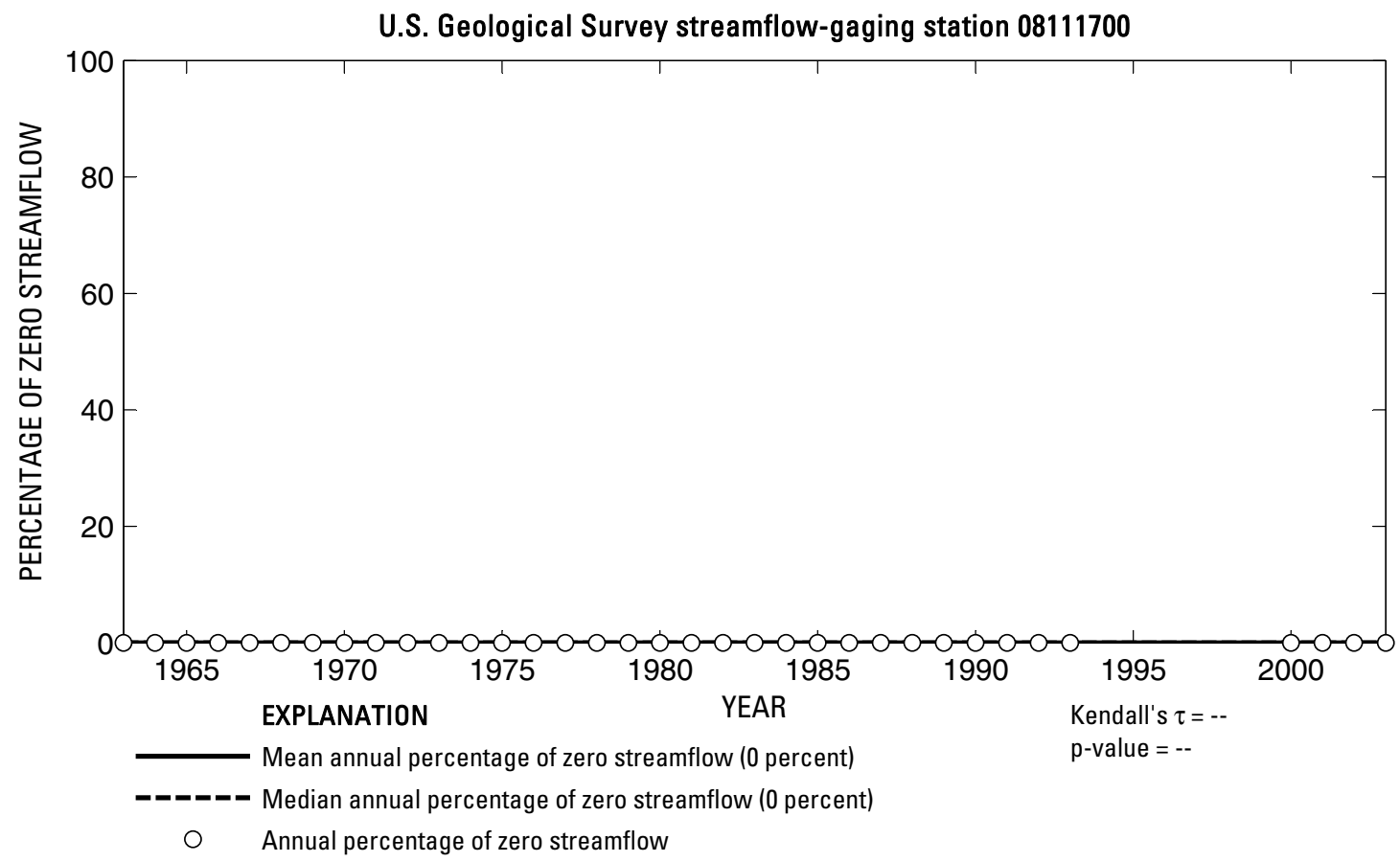

U.S. Geological Survey streamflow-gaging station 08111700

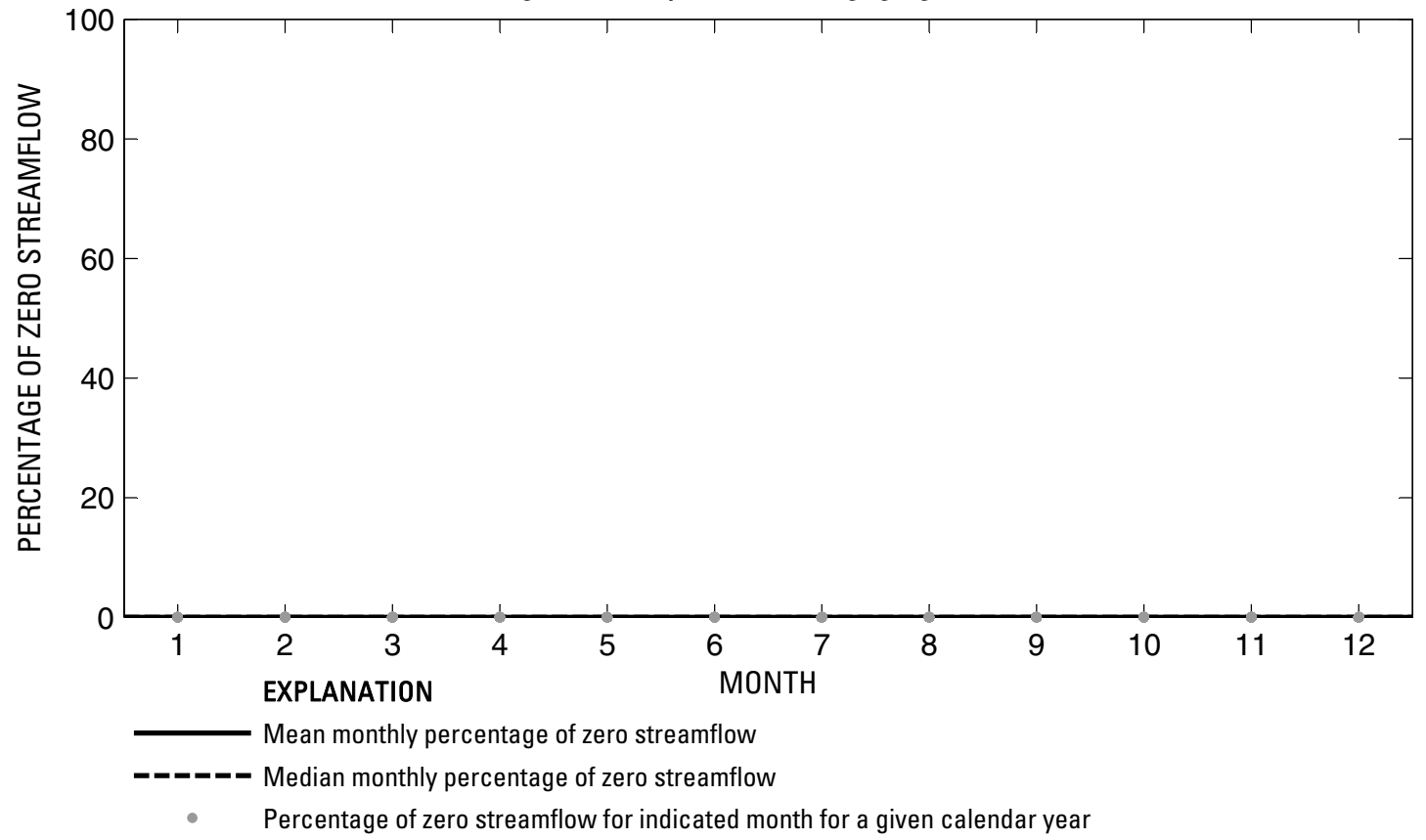

Figure 439. Analysis of percentage of zero daily mean streamflow for U.S. Geological Survey streamflow-gaging station 08111700 Mill Creek near Bellville, Texas. 
U.S. Geological Survey streamflow-gaging station 08114000

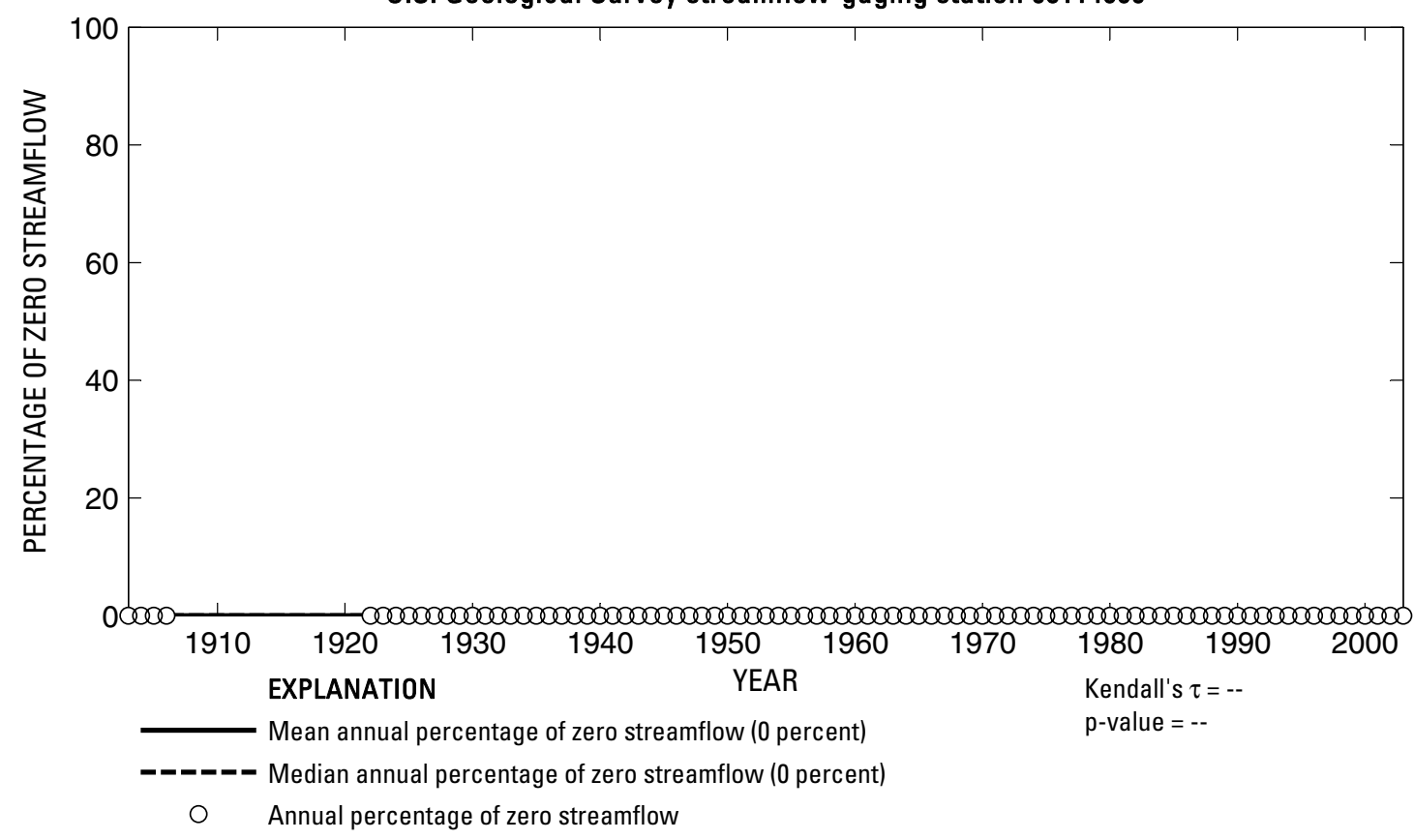

U.S. Geological Survey streamflow-gaging station 08114000

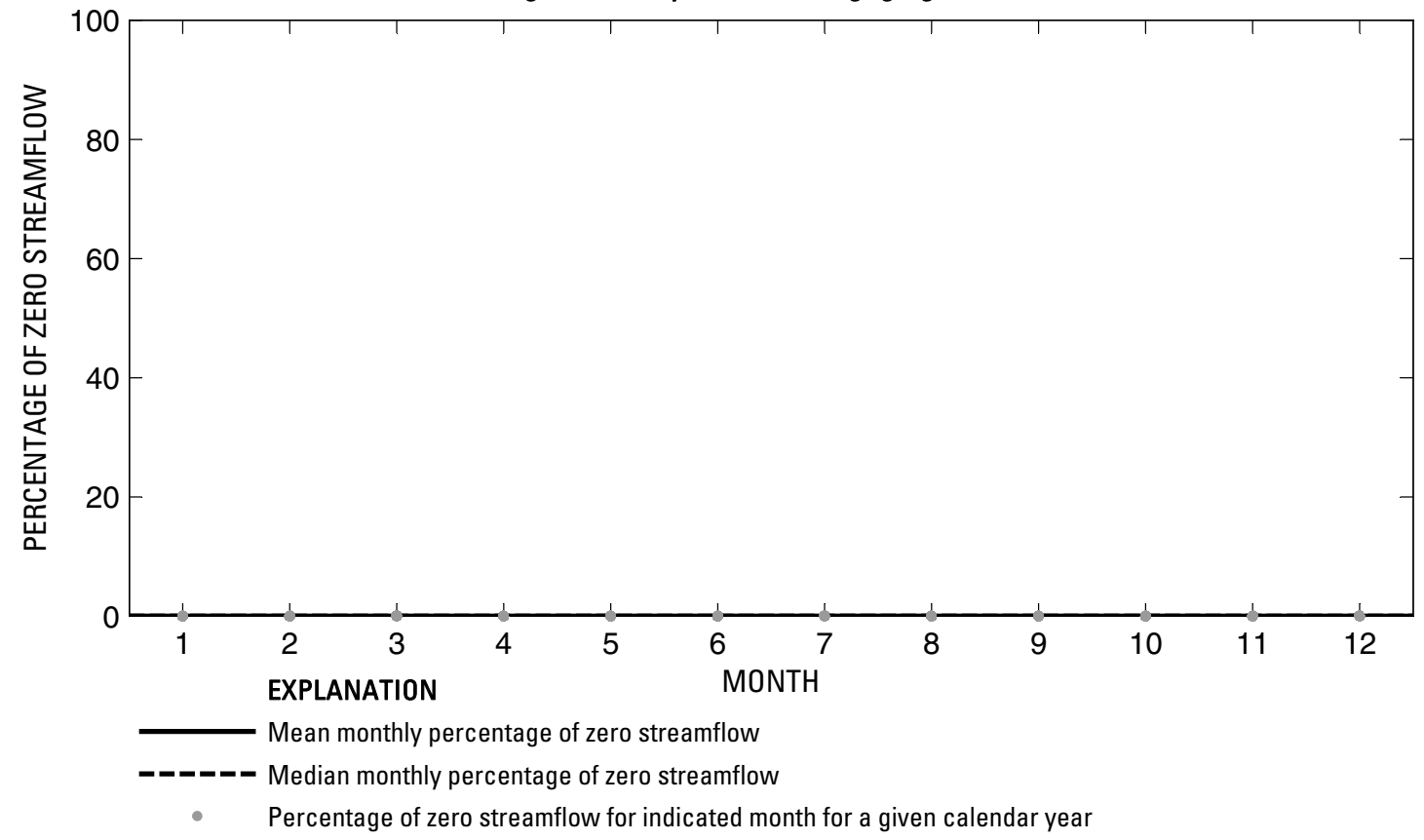

Figure 440. Analysis of percentage of zero daily mean streamflow for U.S. Geological Survey streamflow-gaging station 08114000 Brazos River at Richmond, Texas. 

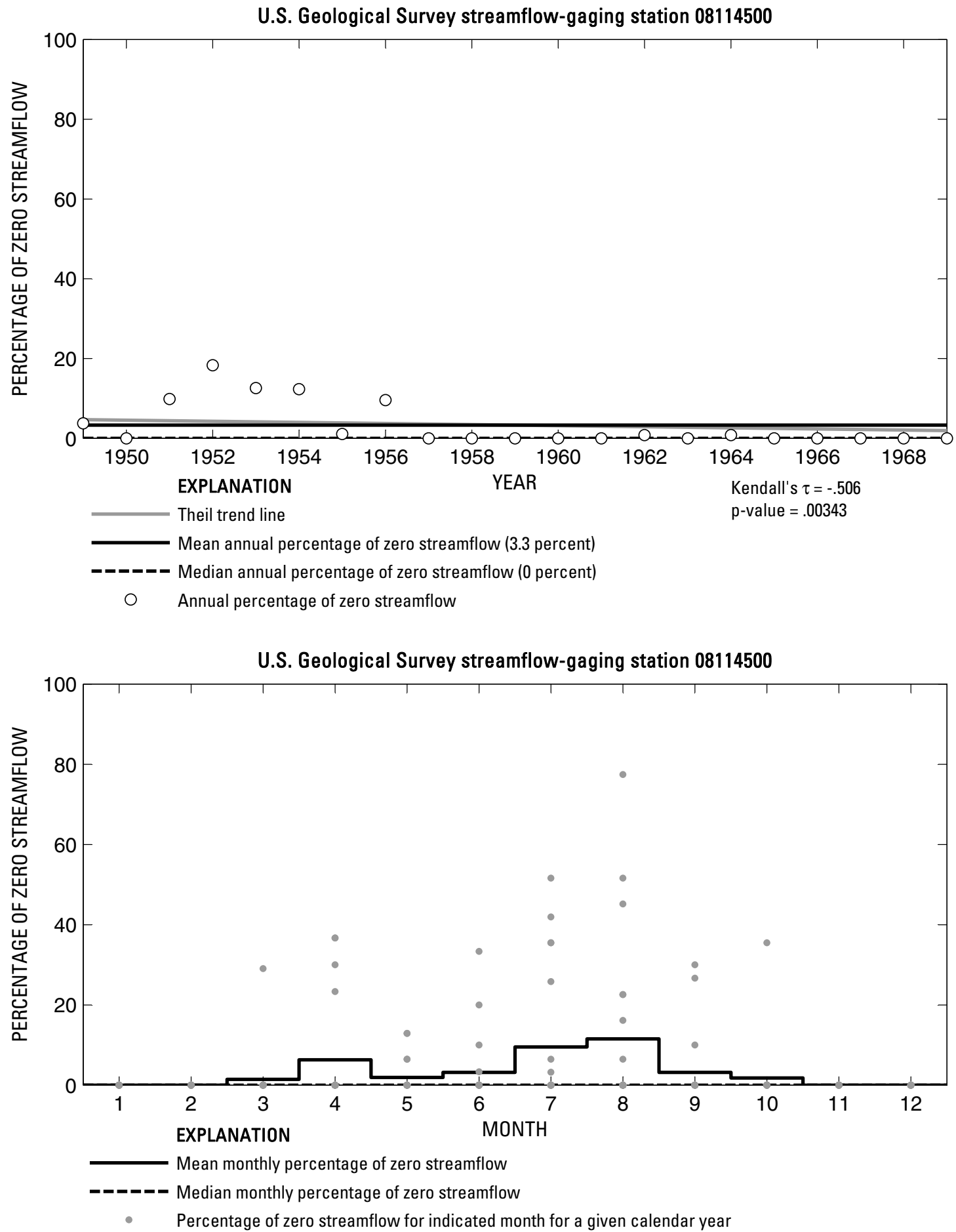

Figure 441. Analysis of percentage of zero daily mean streamflow for U.S. Geological Survey streamflow-gaging station 08114500 Brazos River near Juliff, Texas. 
U.S. Geological Survey streamflow-gaging station 08115000

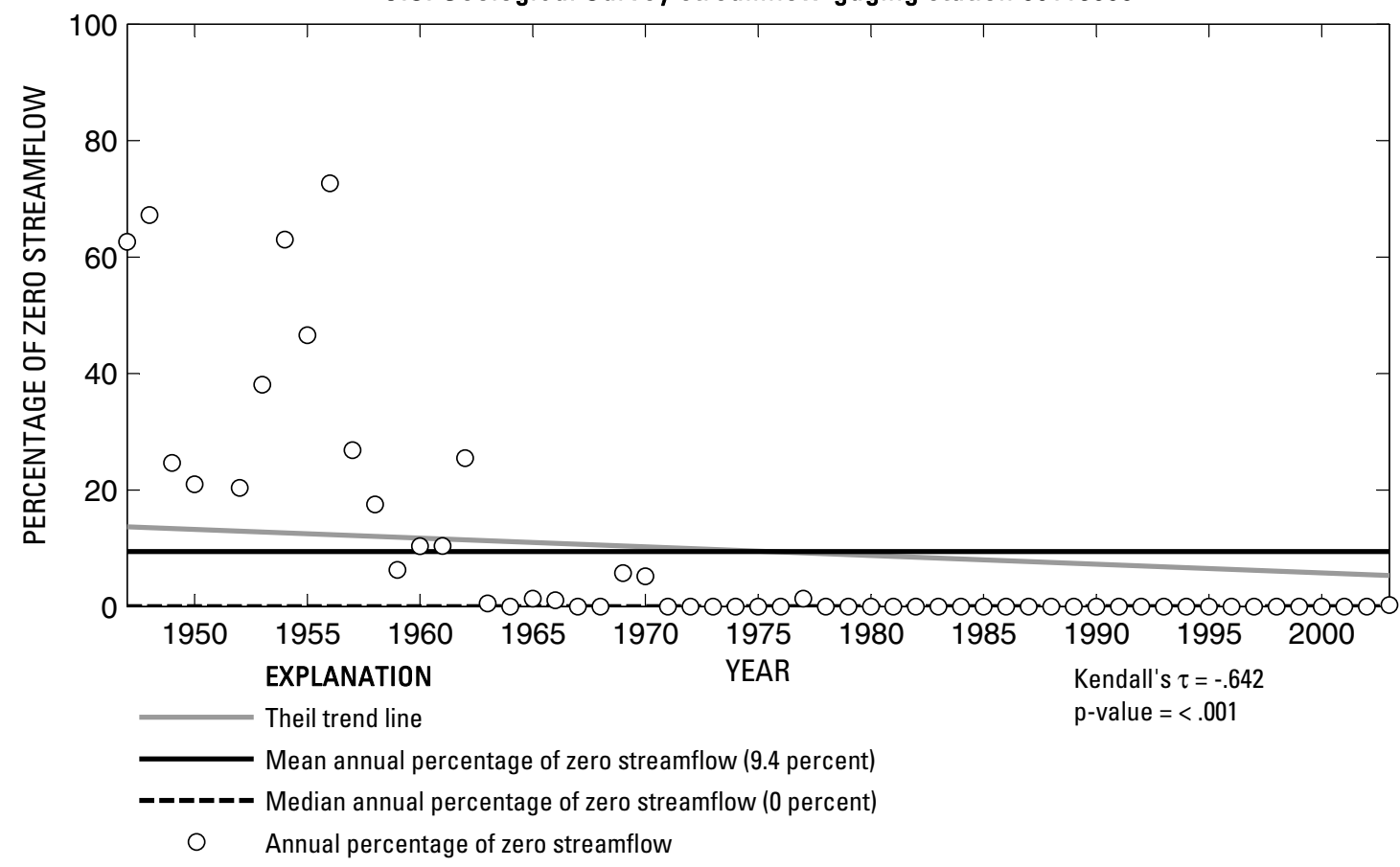

U.S. Geological Survey streamflow-gaging station 08115000

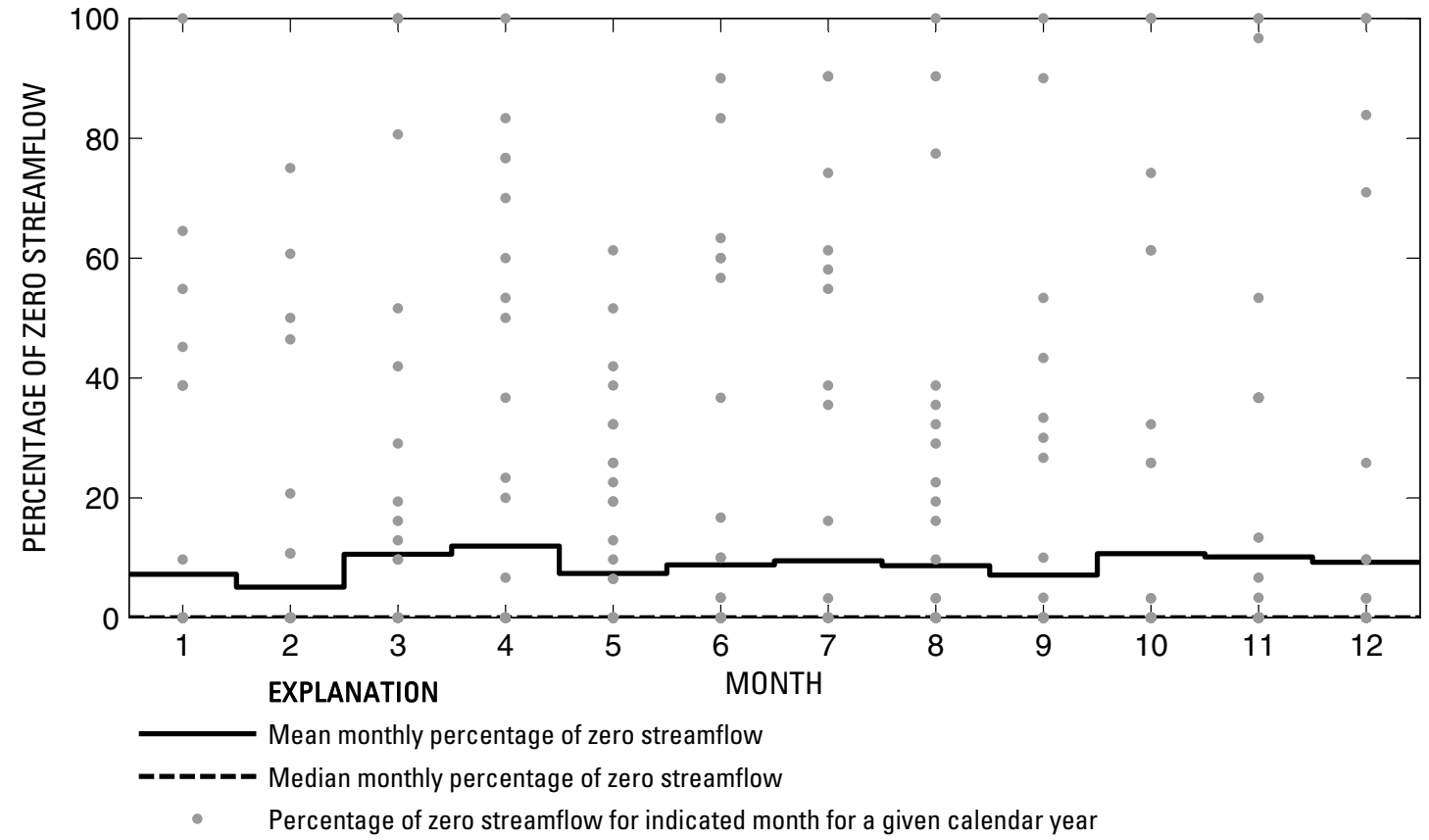

Figure 442. Analysis of percentage of zero daily mean streamflow for U.S. Geological Survey streamflow-gaging station 08115000 Big Creek near Needville, Texas.

Index of Station Numbers 719 


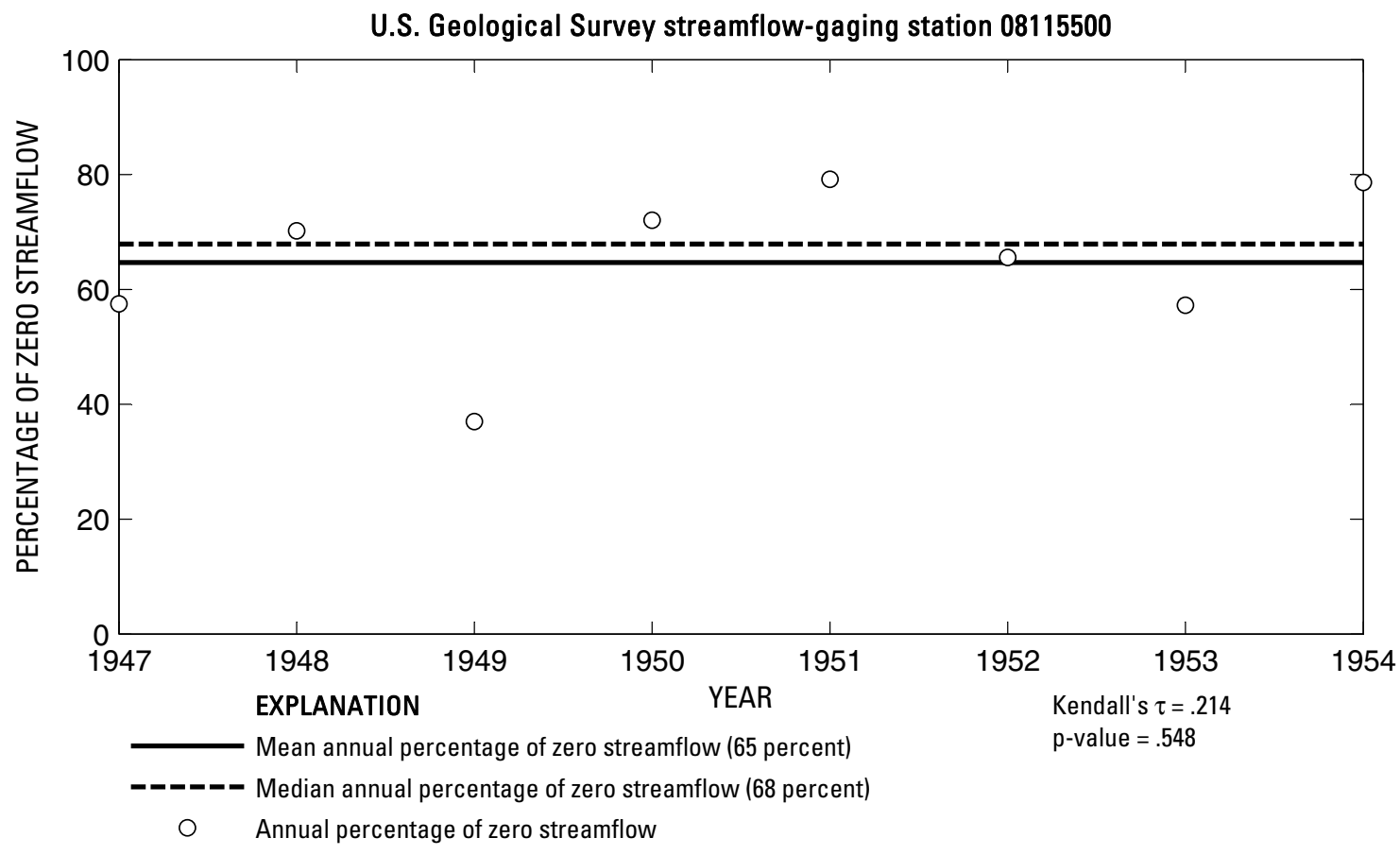

U.S. Geological Survey streamflow-gaging station 08115500

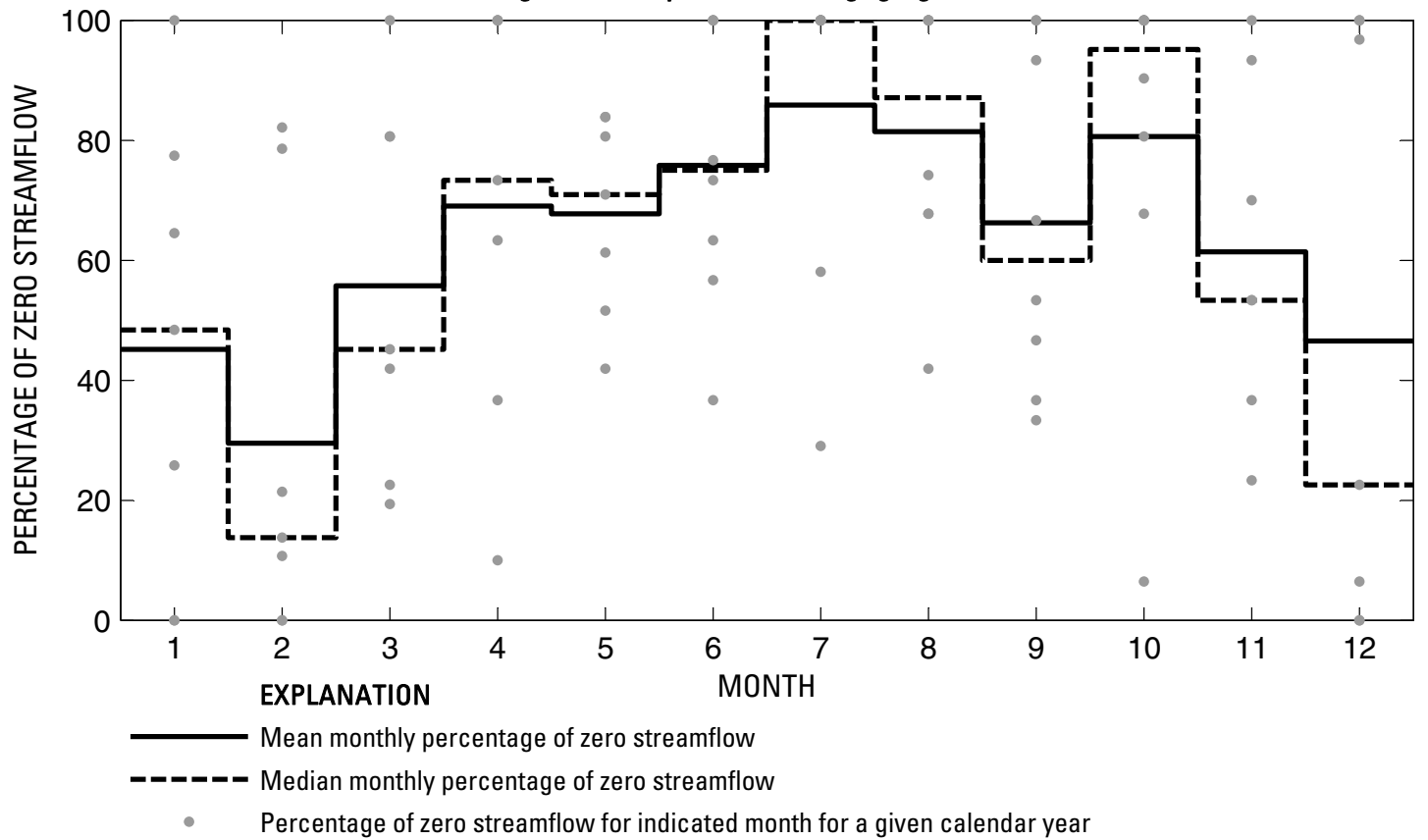

Figure 443. Analysis of percentage of zero daily mean streamflow for U.S. Geological Survey streamflow-gaging station 08115500 Fairchild Creek near Needville, Texas. 
U.S. Geological Survey streamflow-gaging station 08116000

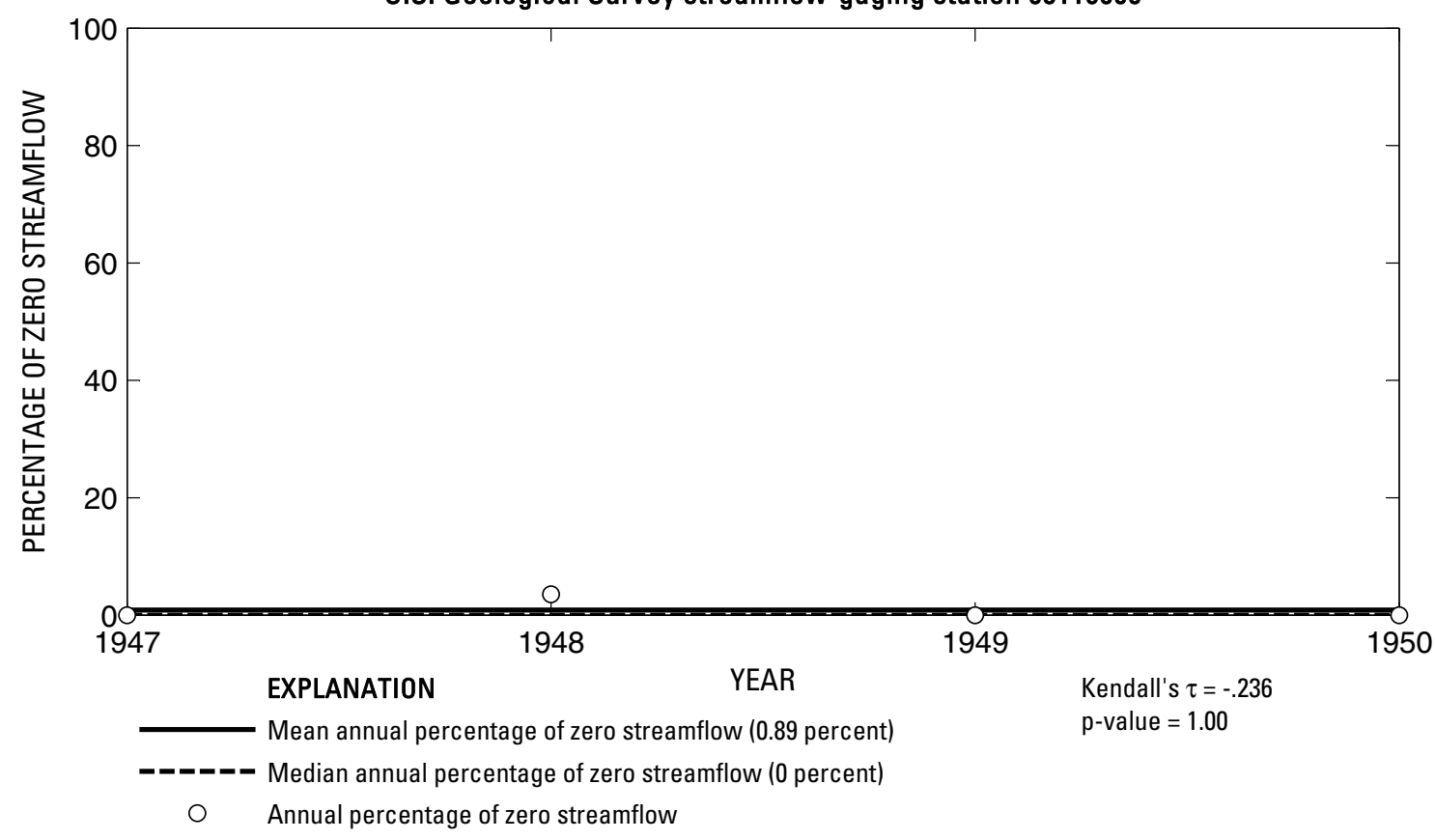

U.S. Geological Survey streamflow-gaging station 08116000

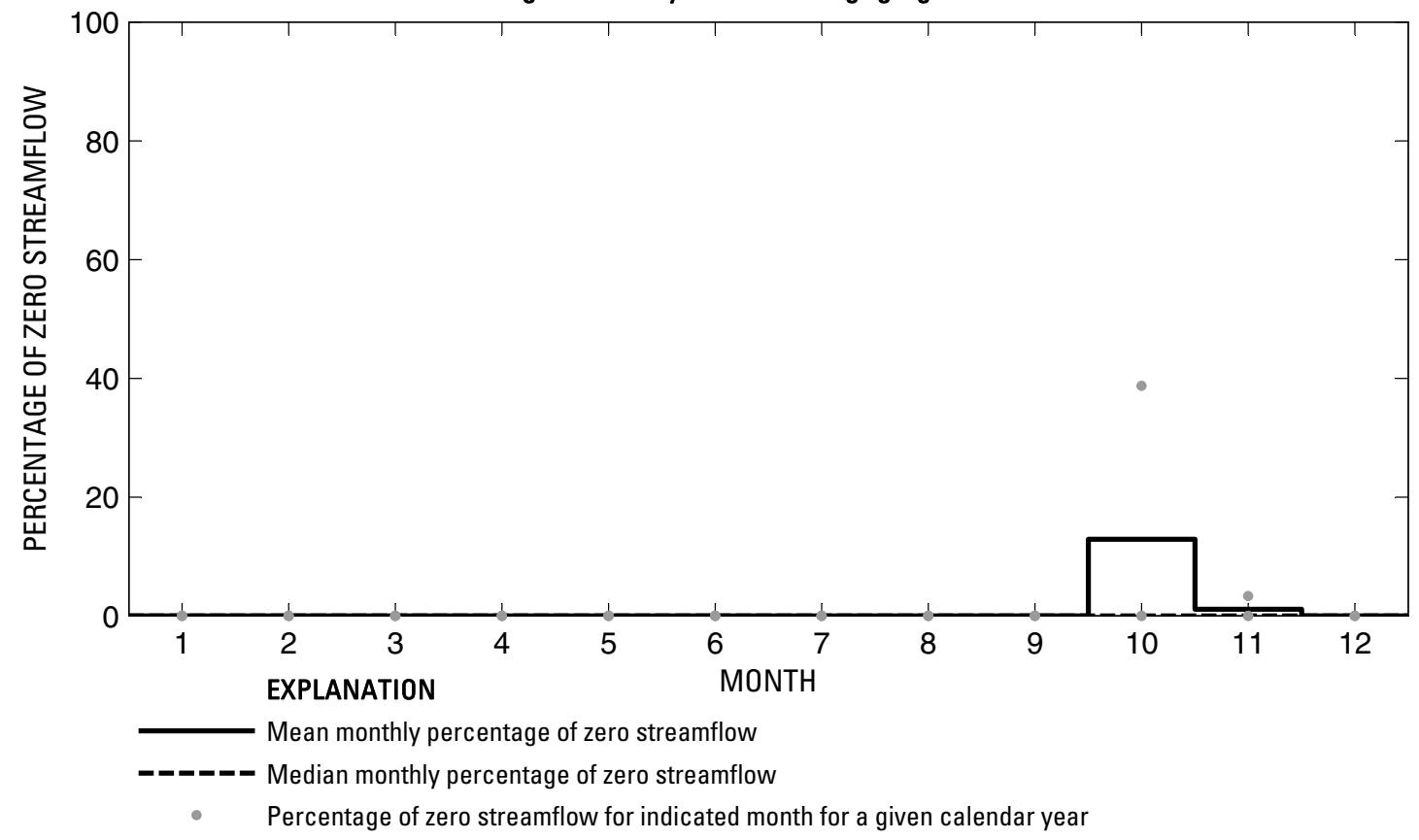

Figure 444. Analysis of percentage of zero daily mean streamflow for U.S. Geological Survey streamflow-gaging station 08116000 Big Creek near Guy, Texas. 
U.S. Geological Survey streamflow-gaging station 08116400

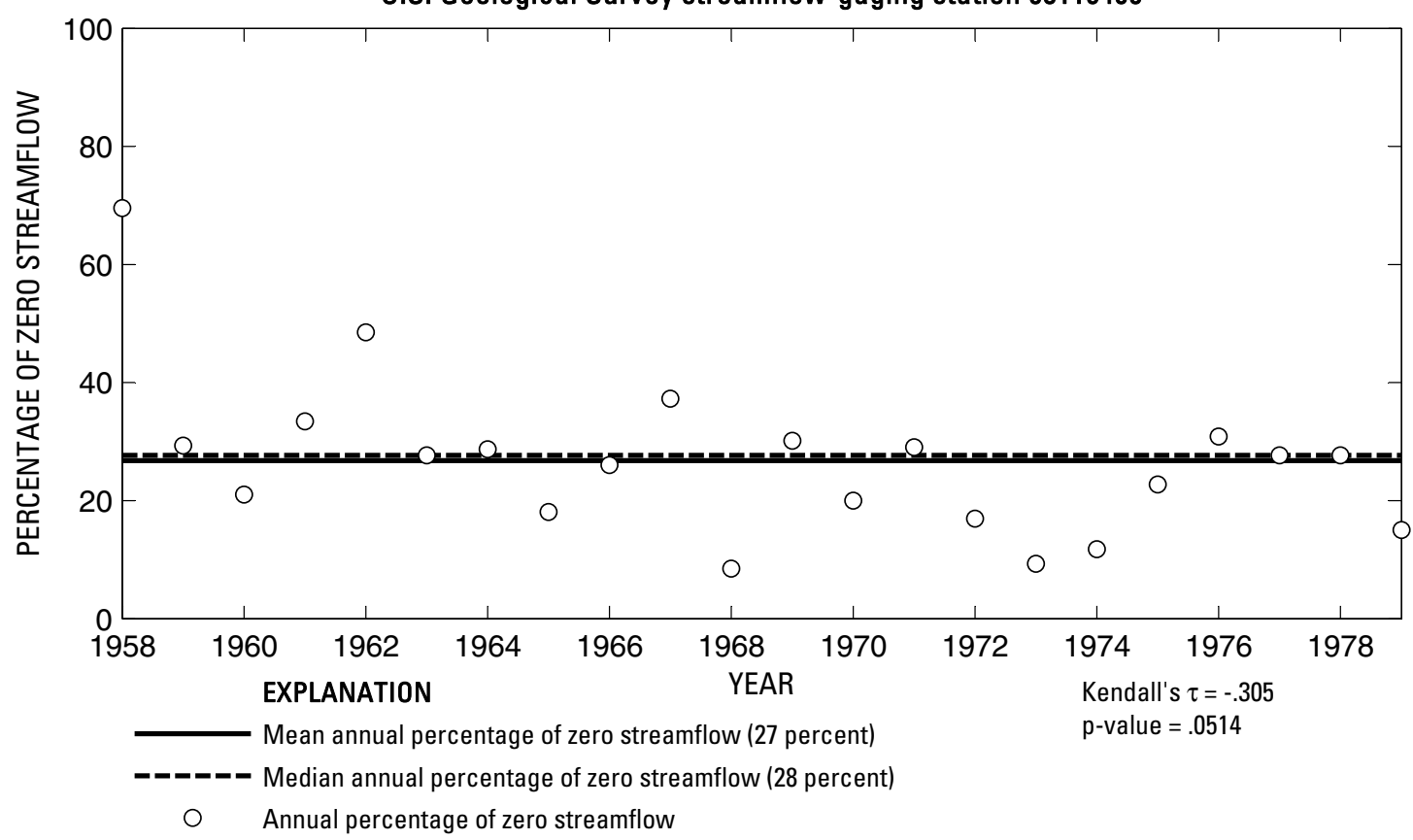

U.S. Geological Survey streamflow-gaging station 08116400

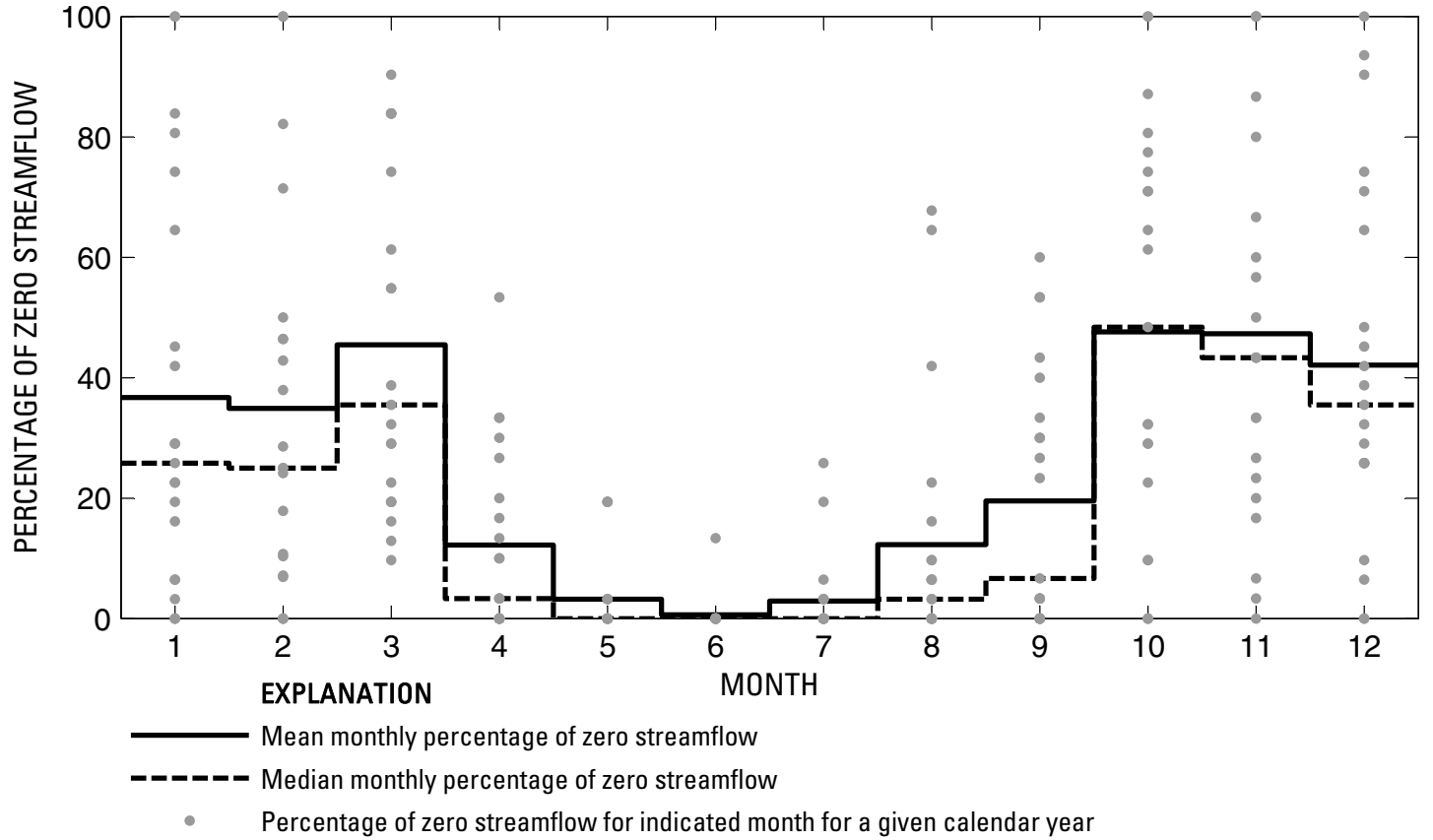

Figure 445. Analysis of percentage of zero daily mean streamflow for U.S. Geological Survey streamflow-gaging station 08116400 Dry Creek near Rosenberg, Texas. 
U.S. Geological Survey streamflow-gaging station 08116500

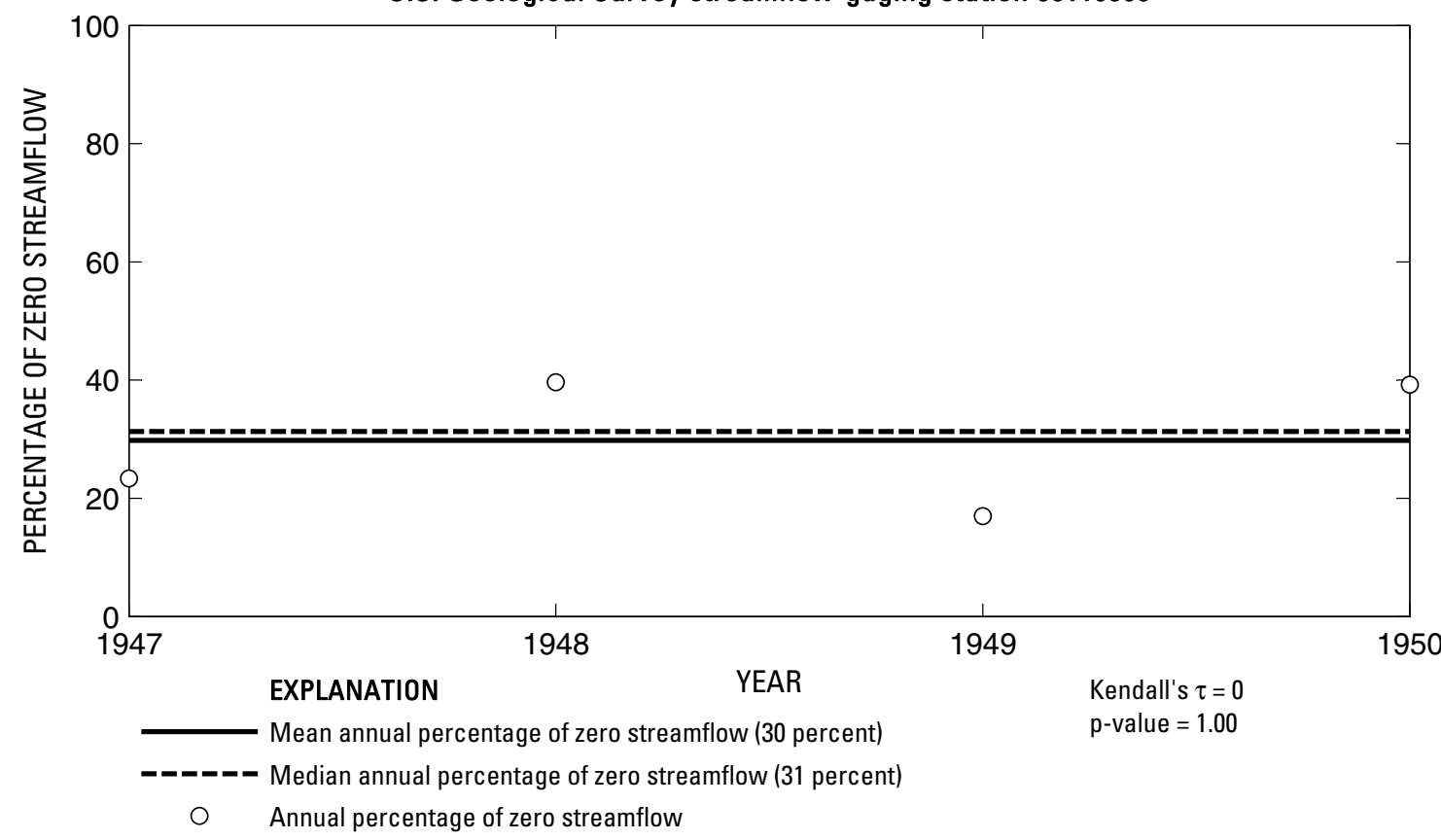

U.S. Geological Survey streamflow-gaging station 08116500

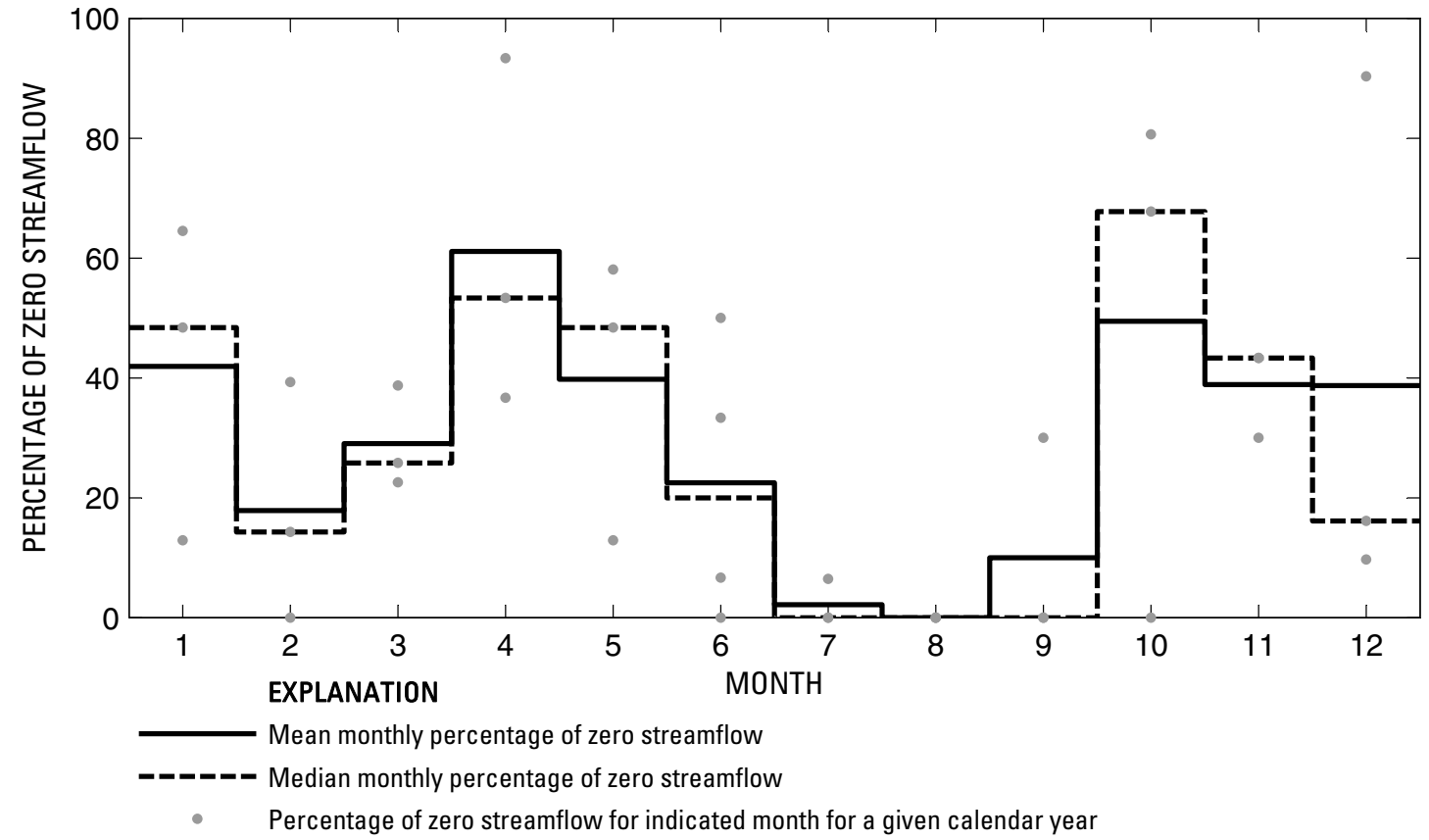

Figure 446. Analysis of percentage of zero daily mean streamflow for U.S. Geological Survey streamflow-gaging station 08116500 Dry Creek near Richmond, Texas. 


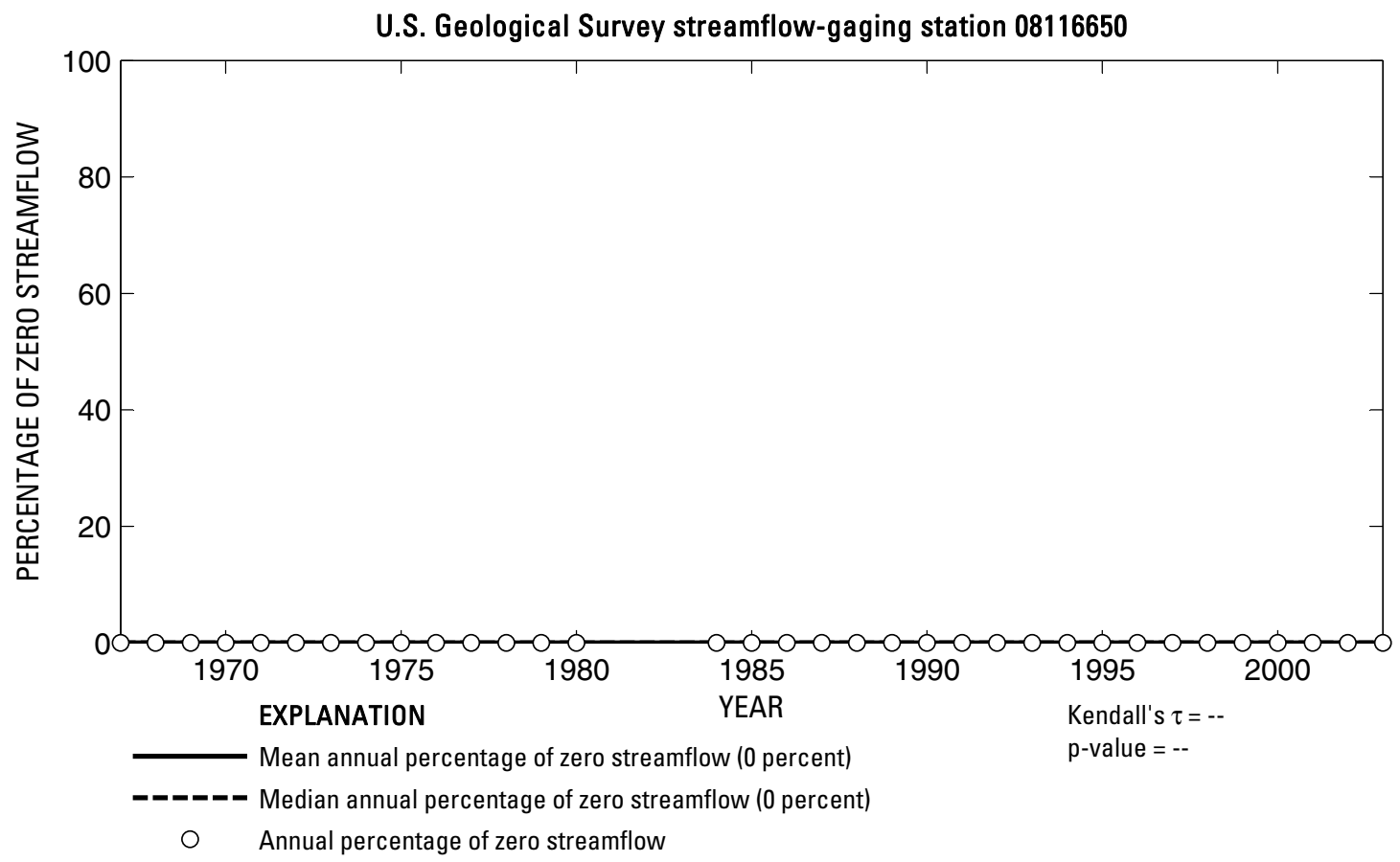

U.S. Geological Survey streamflow-gaging station 08116650

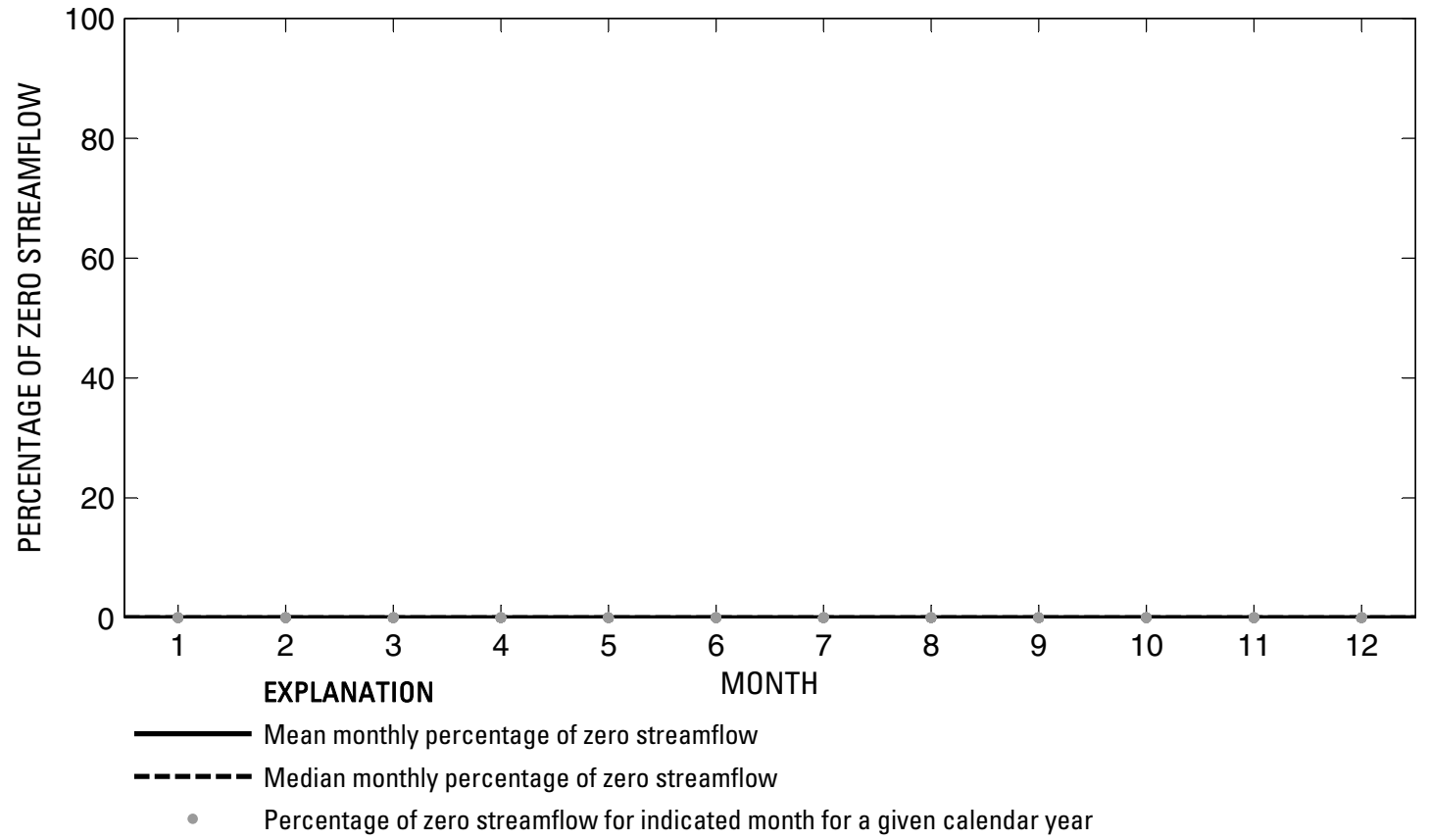

Figure 447. Analysis of percentage of zero daily mean streamflow for U.S. Geological Survey streamflow-gaging station 08116650 Brazos River near Rosharon, Texas. 
U.S. Geological Survey streamflow-gaging station 08117500

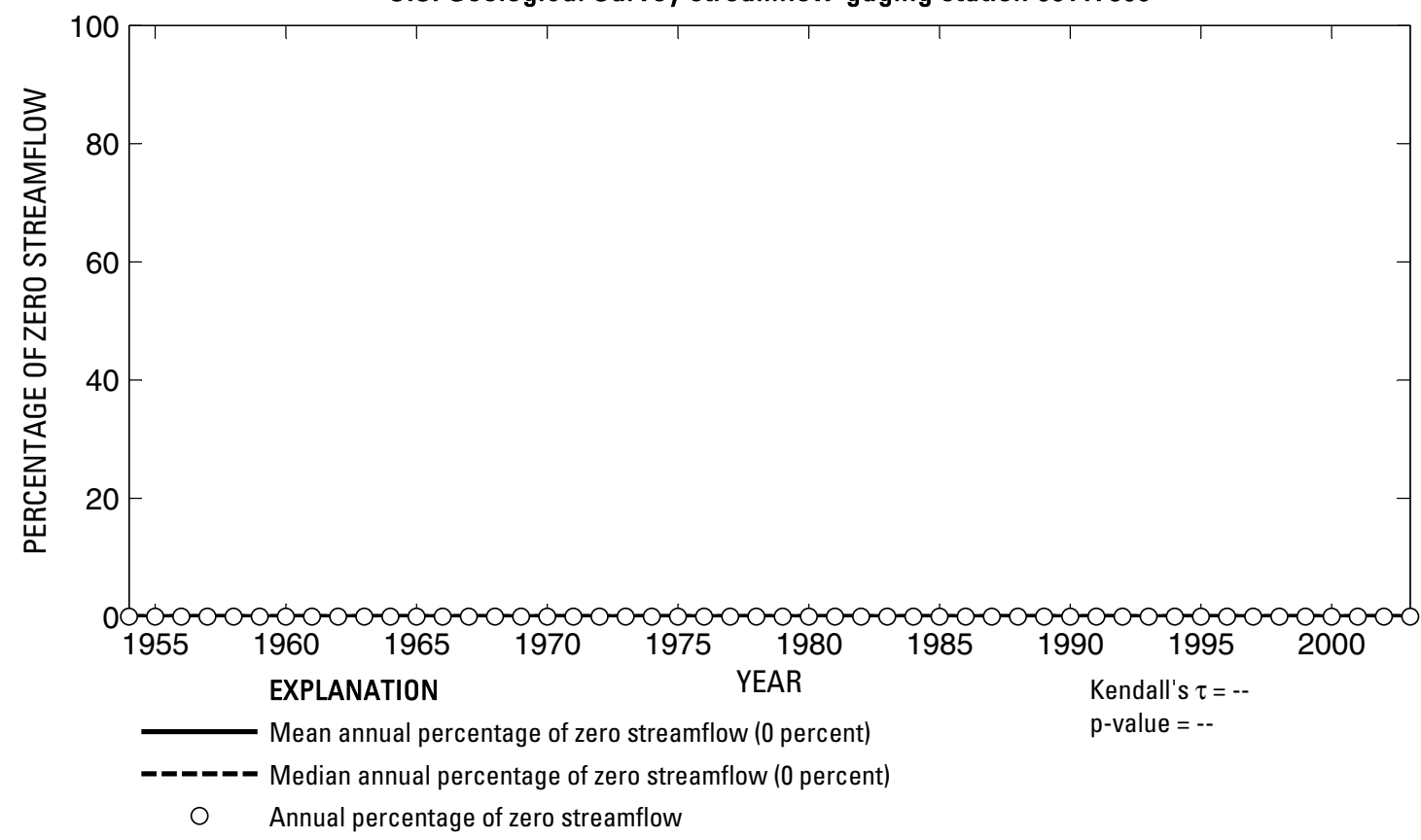

U.S. Geological Survey streamflow-gaging station 08117500

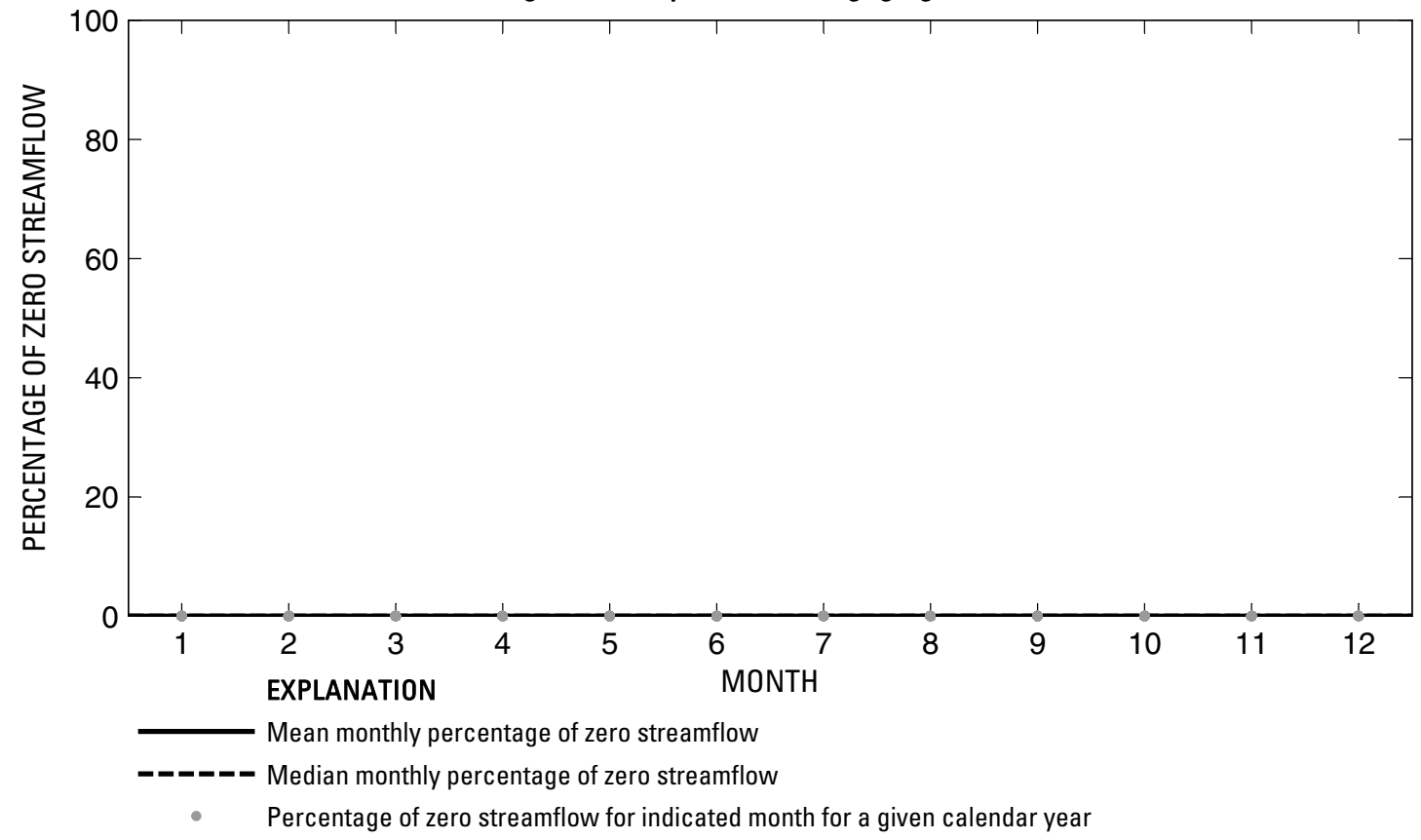

Figure 448. Analysis of percentage of zero daily mean streamflow for U.S. Geological Survey streamflow-gaging station 08117500 San Bernard River near Boling, Texas.

Index of Station Numbers 719 

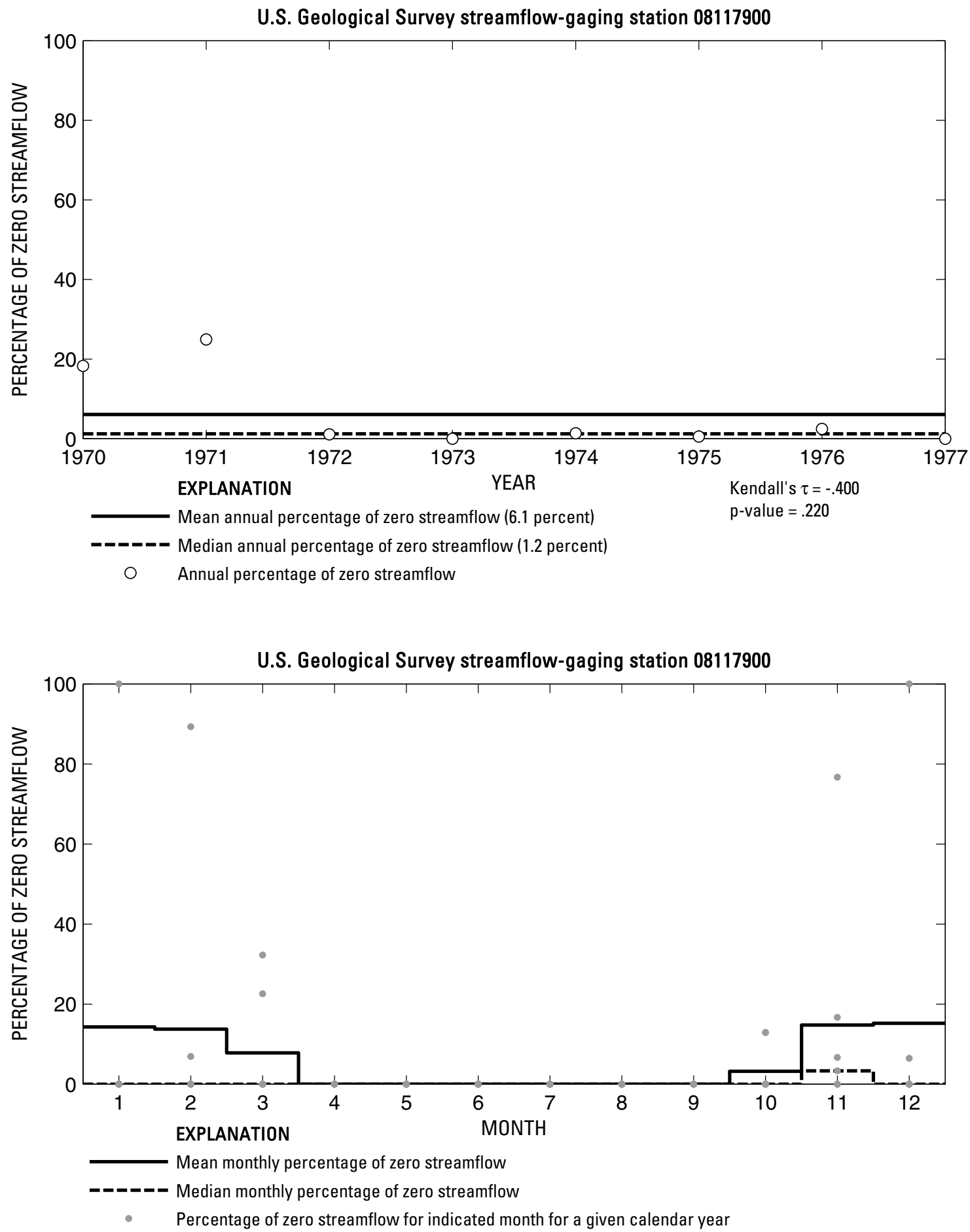

Figure 449. Analysis of percentage of zero daily mean streamflow for U.S. Geological Survey streamflow-gaging station 08117900 Big Boggy Creek near Wadsworth, Texas. 
U.S. Geological Survey streamflow-gaging station 08117995

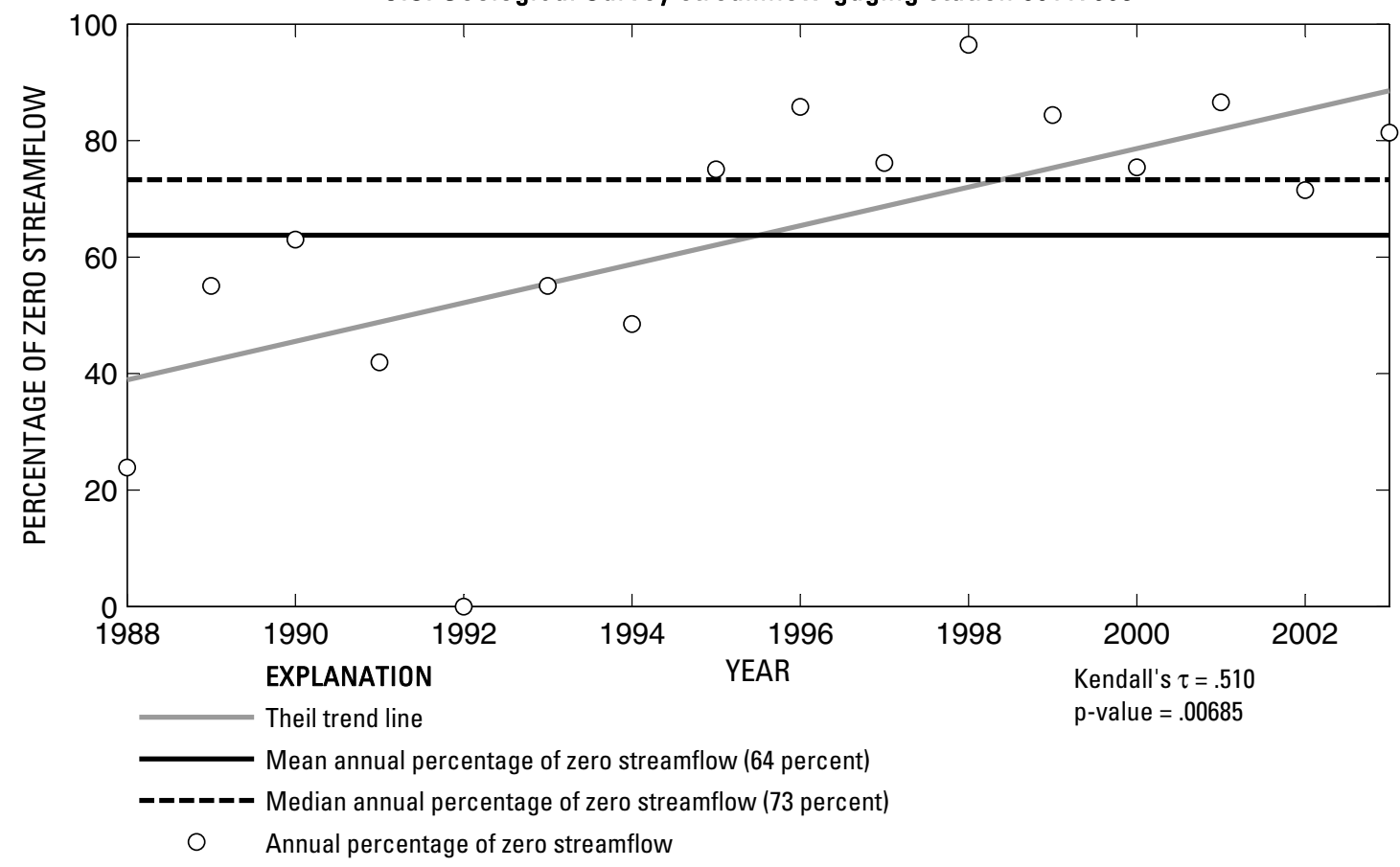

U.S. Geological Survey streamflow-gaging station 08117995

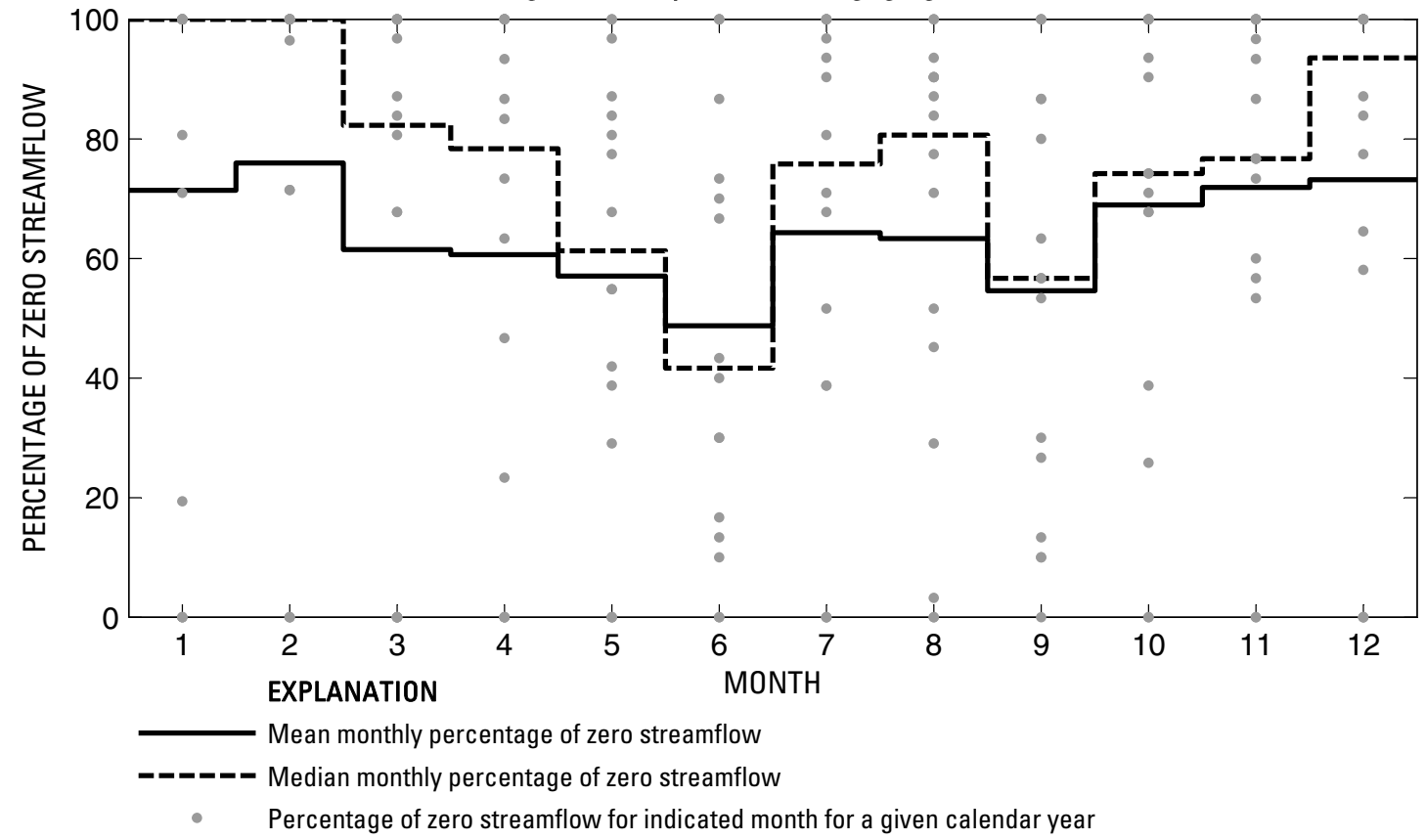

Figure 450. Analysis of percentage of zero daily mean streamflow for U.S. Geological Survey streamflow-gaging station 08117995 Colorado River near Gail, Texas. 
U.S. Geological Survey streamflow-gaging station 08118500

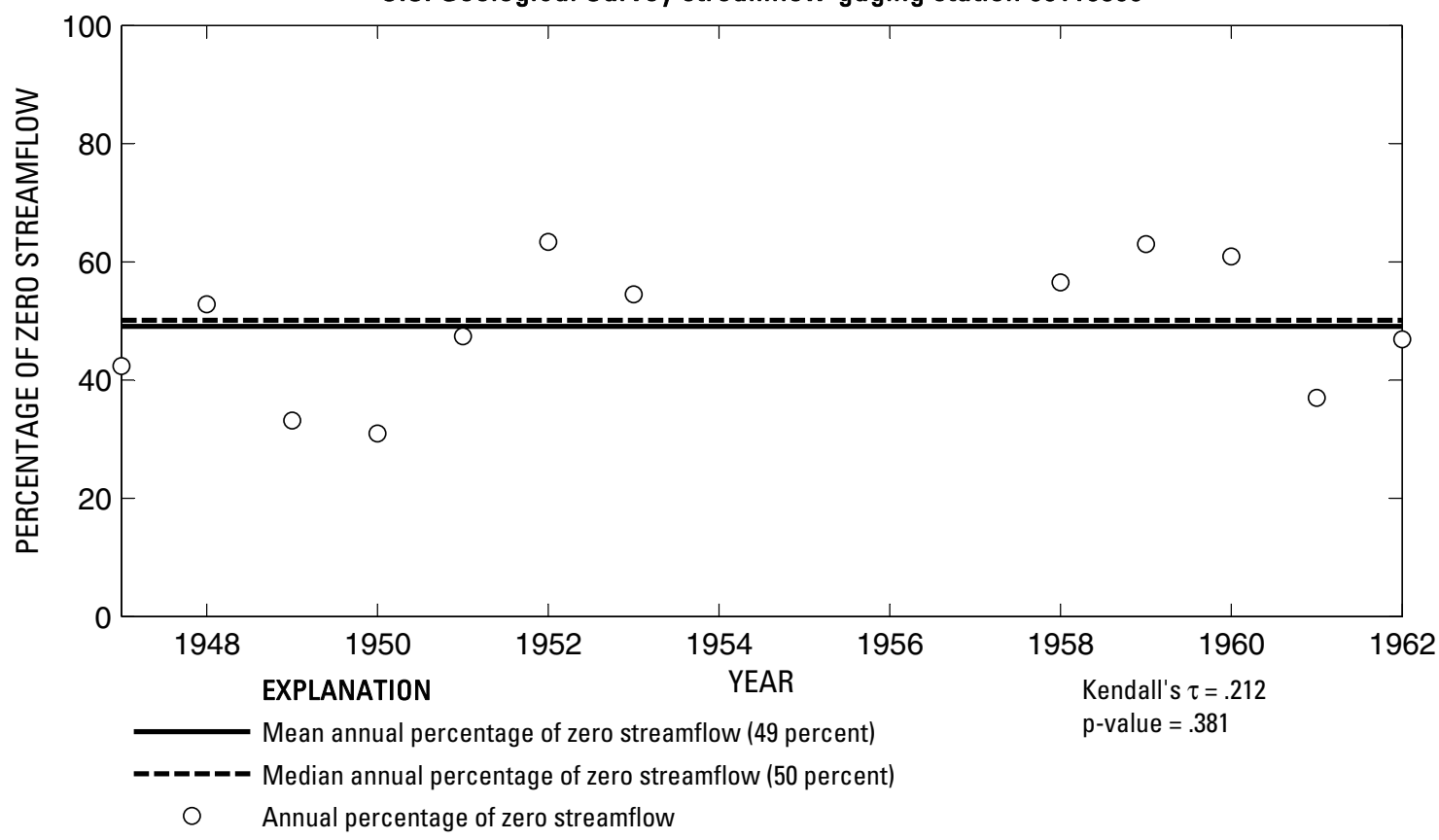

U.S. Geological Survey streamflow-gaging station 08118500

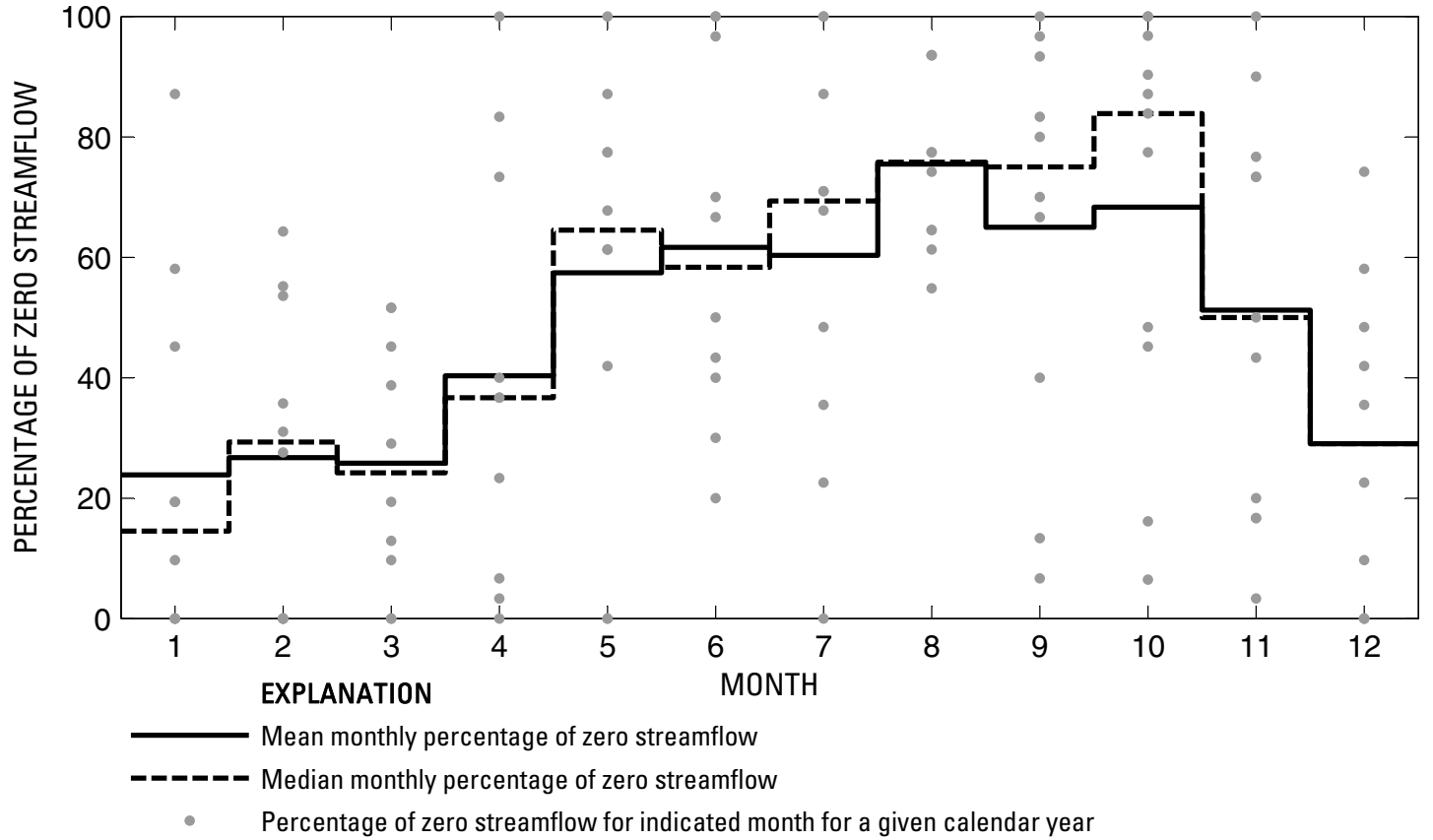

Figure 451. Analysis of percentage of zero daily mean streamflow for U.S. Geological Survey streamflow-gaging station 08118500 Bull Creek near Ira, Texas. 
U.S. Geological Survey streamflow-gaging station 08119000

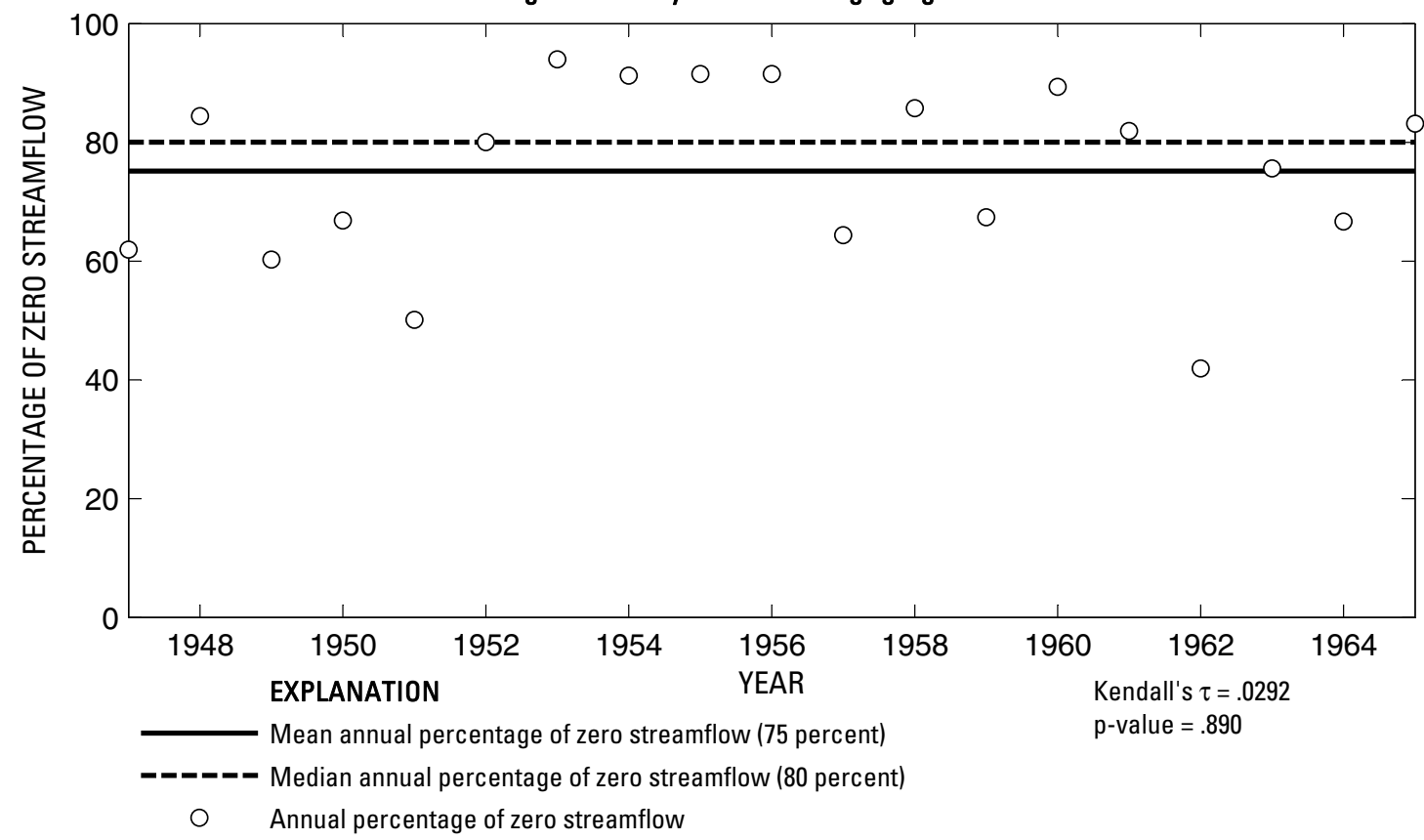

U.S. Geological Survey streamflow-gaging station 08119000

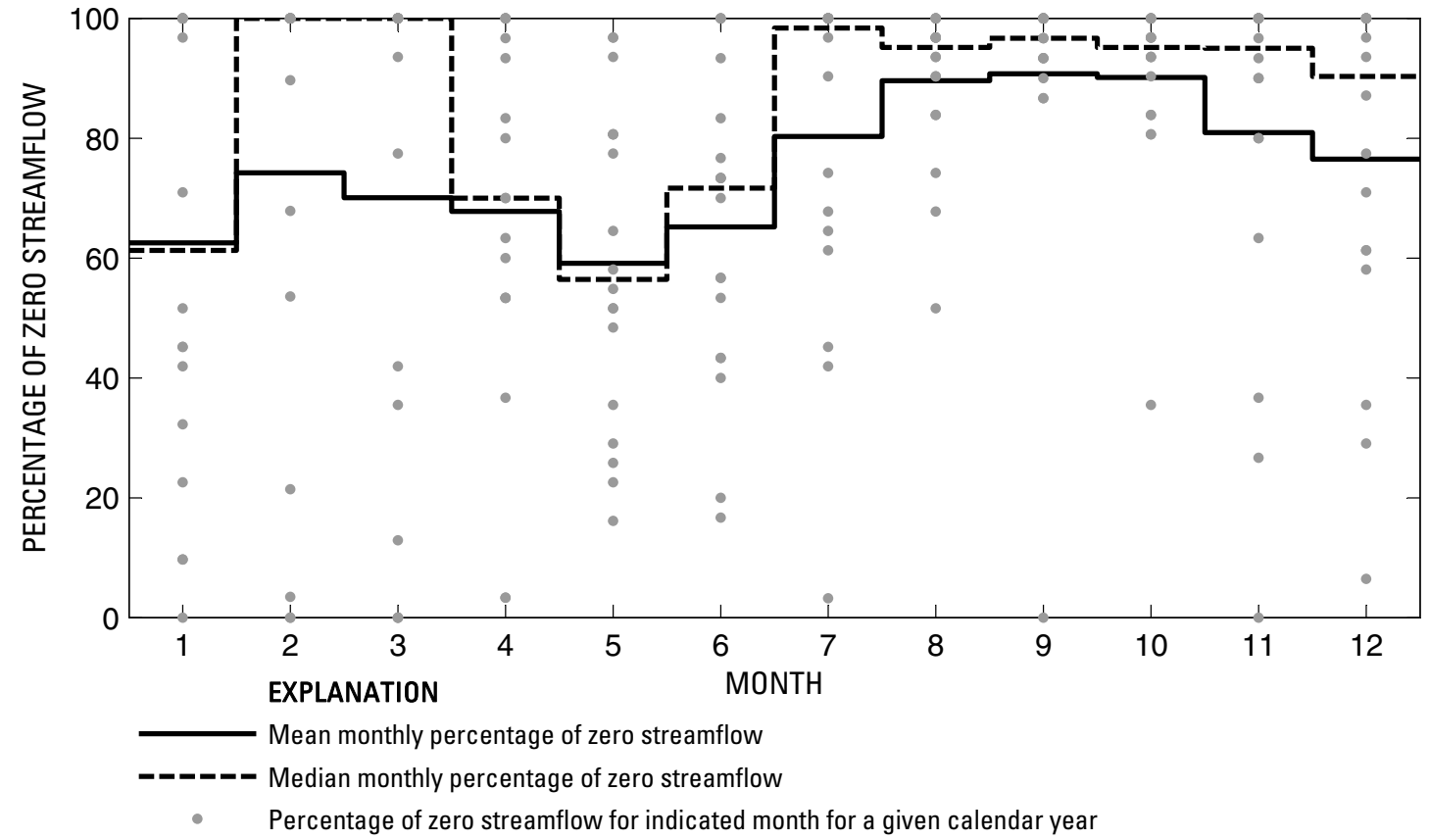

Figure 452. Analysis of percentage of zero daily mean streamflow for U.S. Geological Survey streamflow-gaging station 08119000 Bluff Creek near Ira, Texas. 

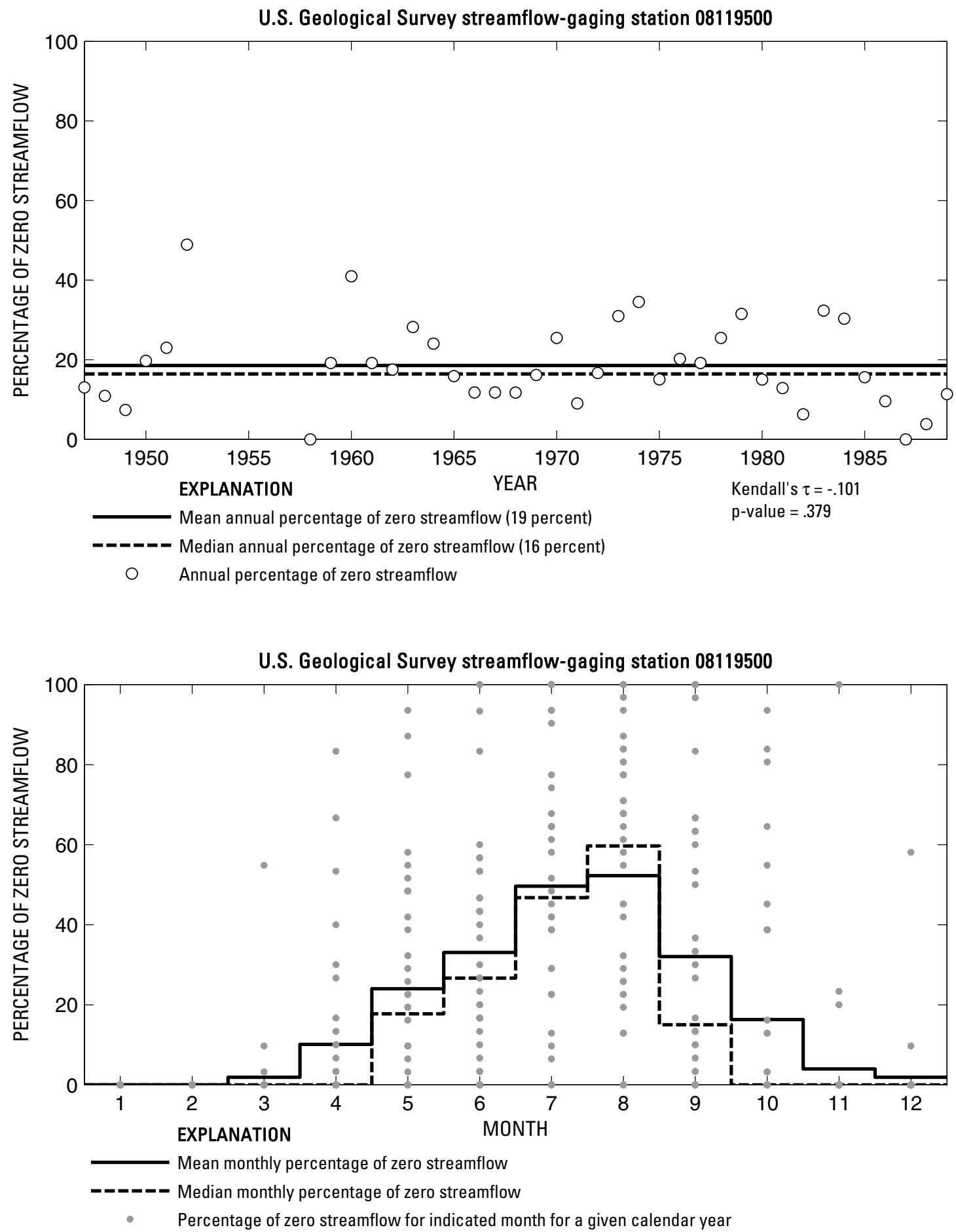

Figure 453. Analysis of percentage of zero daily mean streamflow for U.S. Geological Survey streamflow-gaging station 08119500 Colorado River near Ira, Texas. 
U.S. Geological Survey streamflow-gaging station 08120500

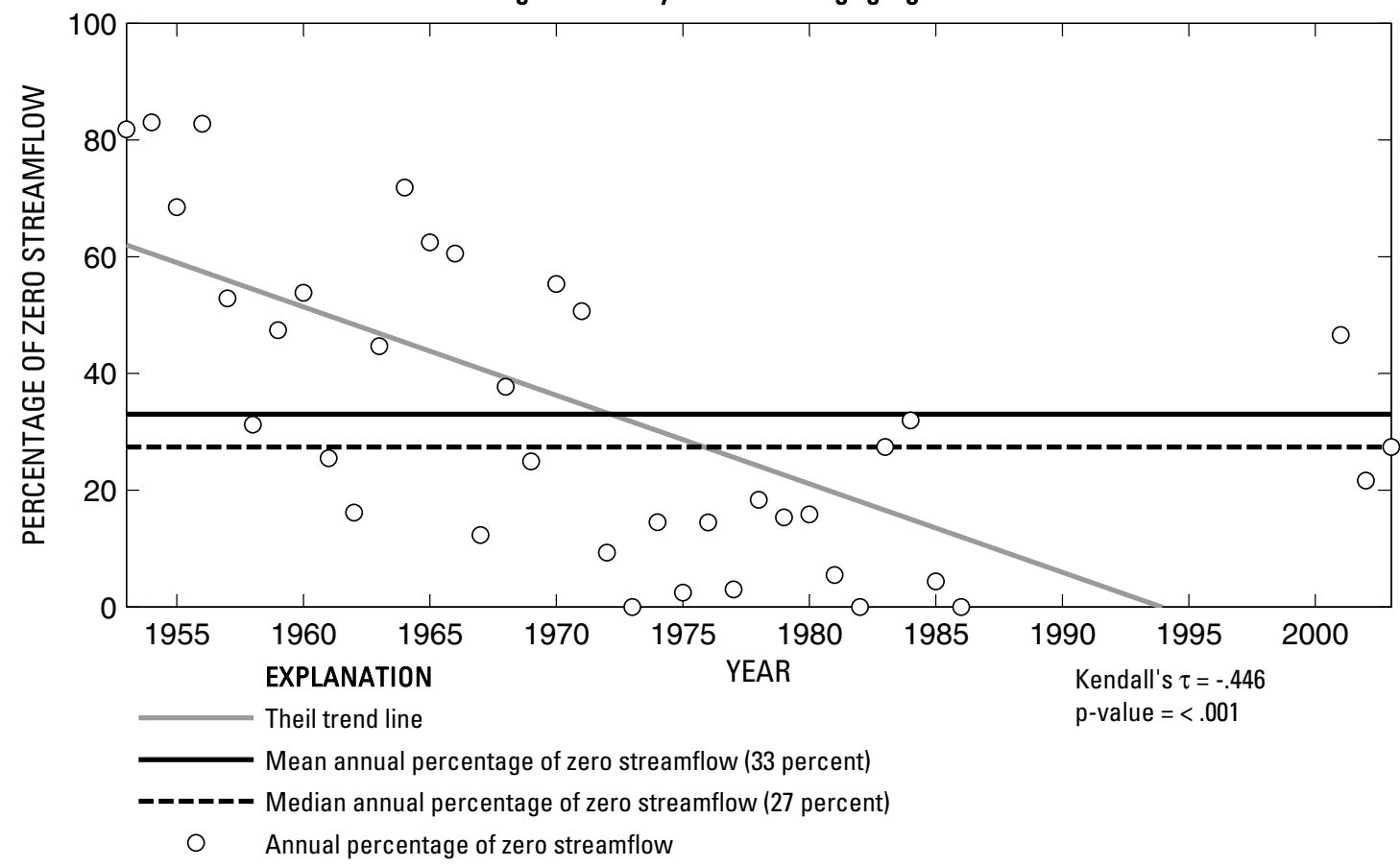

U.S. Geological Survey streamflow-gaging station 08120500

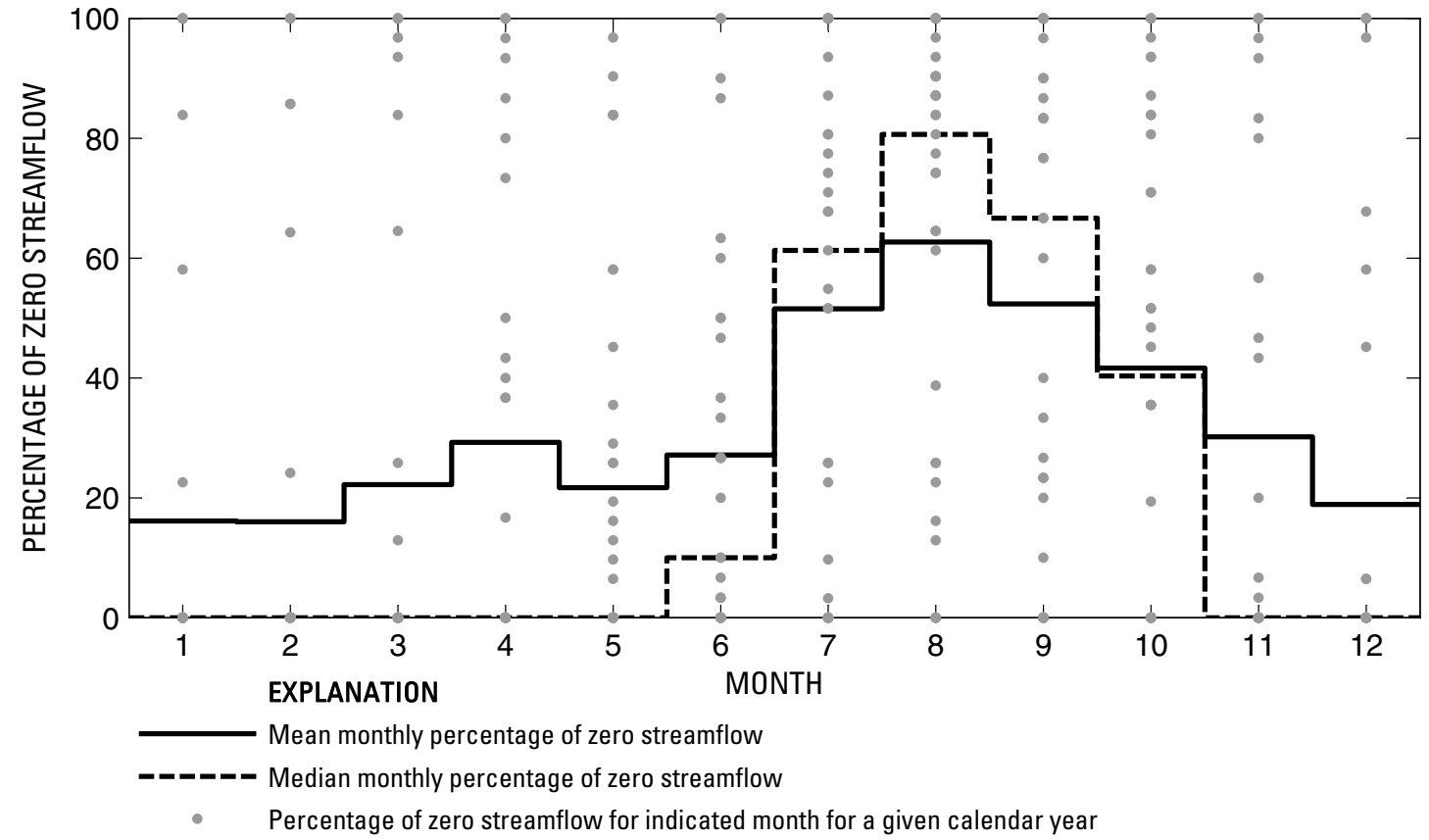

Figure 454. Analysis of percentage of zero daily mean streamflow for U.S. Geological Survey streamflow-gaging station 08120500 Deep Creek near Dunn, Texas.

Index of Station Numbers 719 


\section{U.S. Geological Survey streamflow-gaging station 08120700}

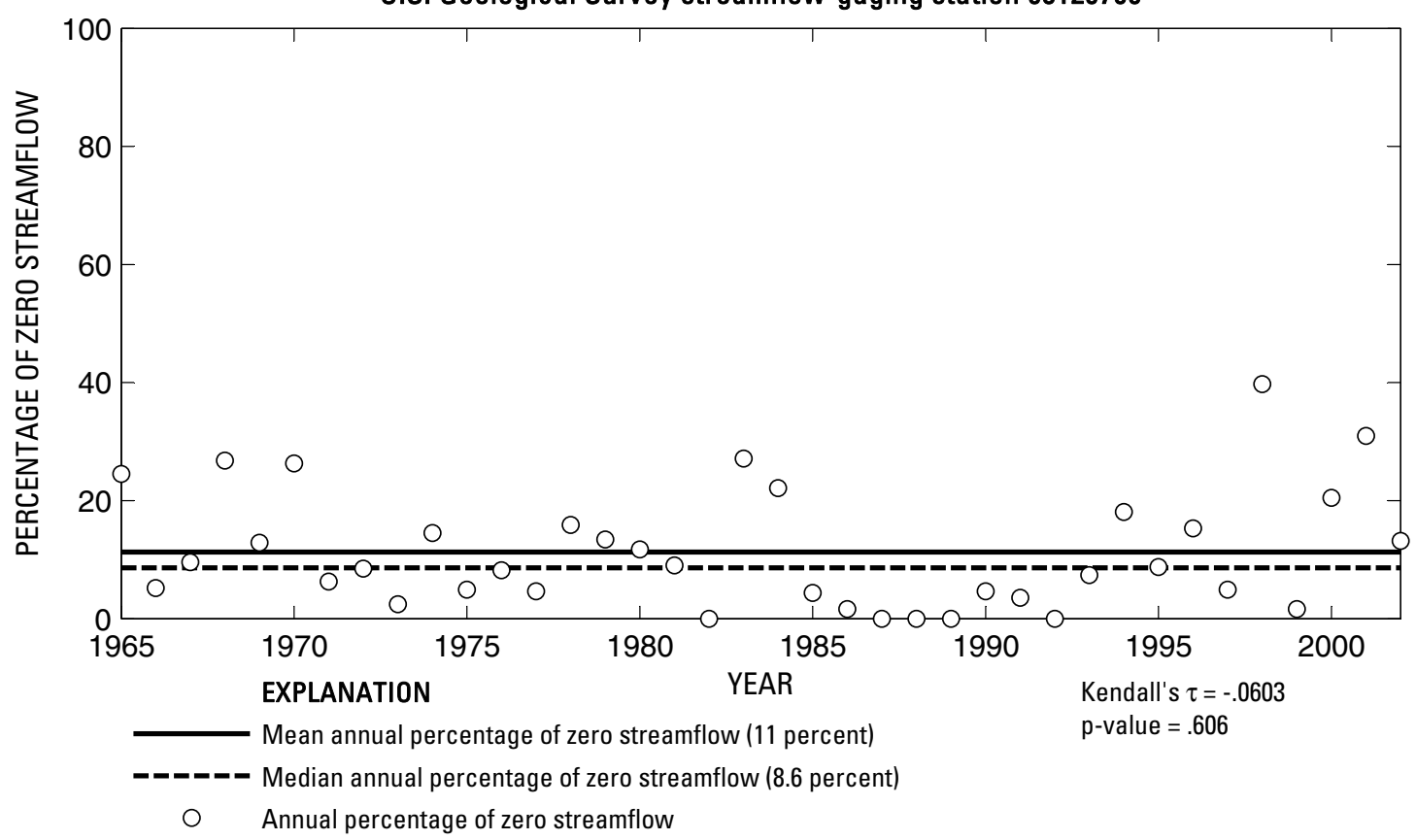

U.S. Geological Survey streamflow-gaging station 08120700

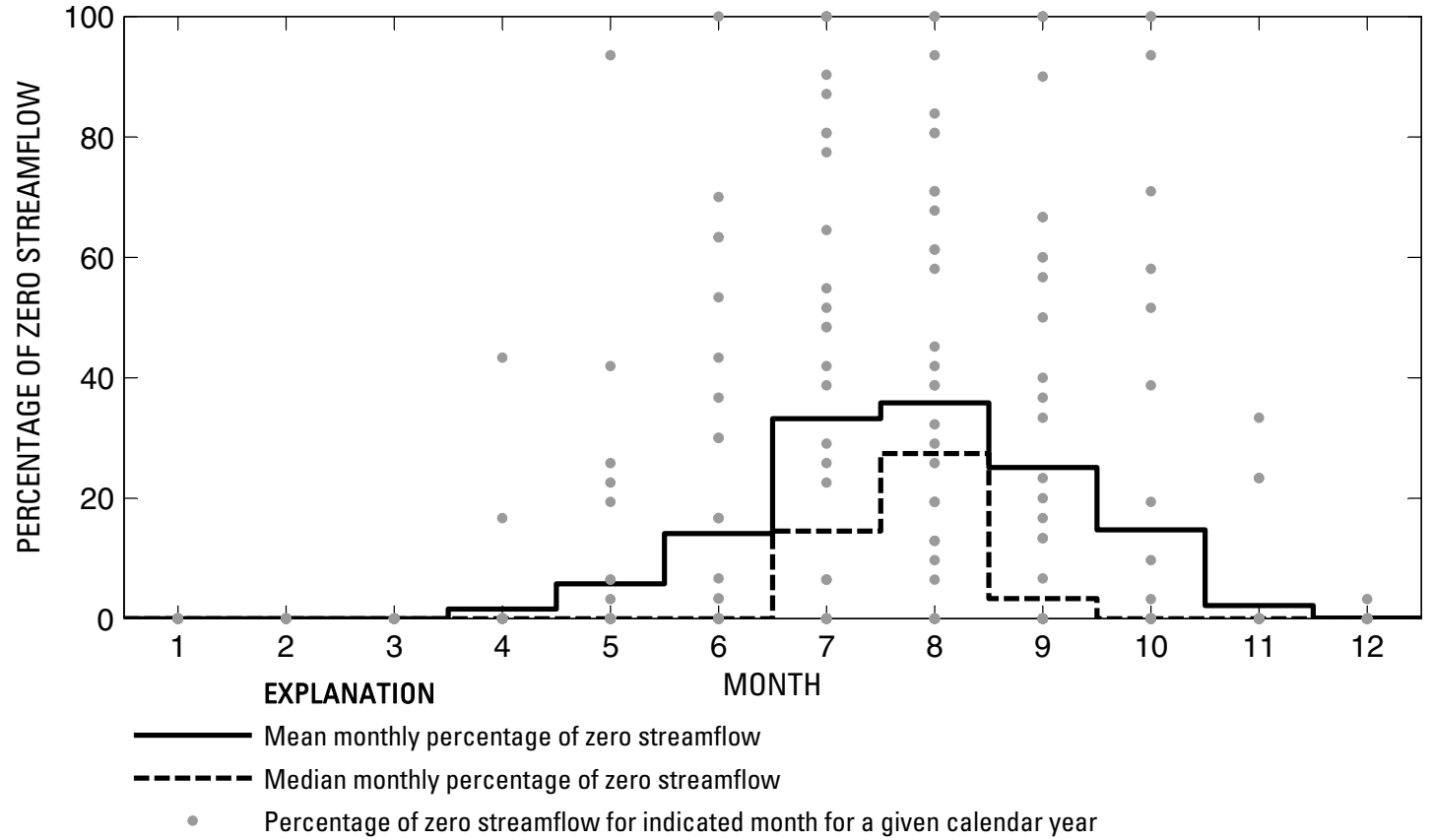

Figure 455. Analysis of percentage of zero daily mean streamflow for U.S. Geological Survey streamflow-gaging station 08120700 Colorado River near Cuthbert, Texas. 
U.S. Geological Survey streamflow-gaging station 08121000

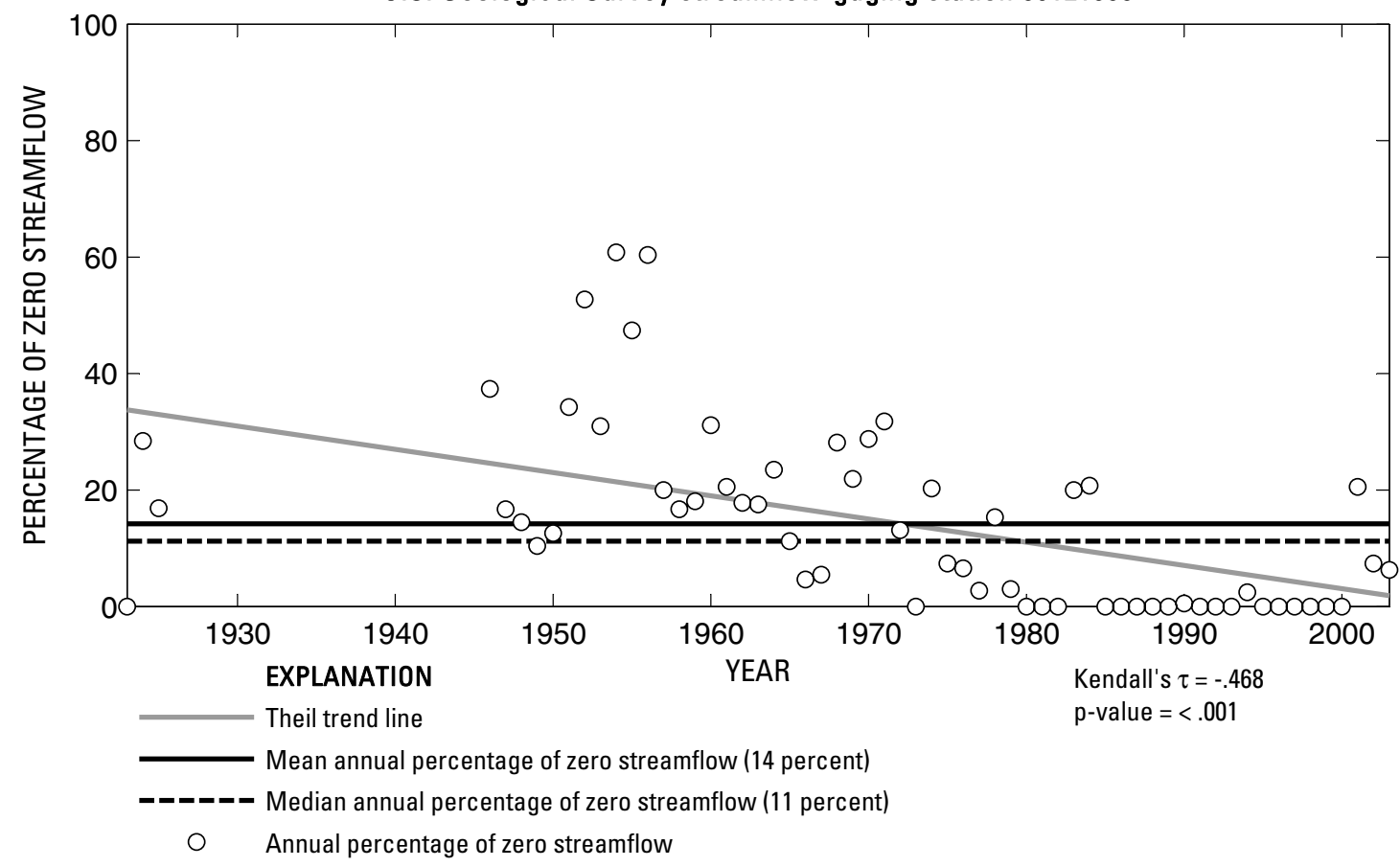

U.S. Geological Survey streamflow-gaging station 08121000

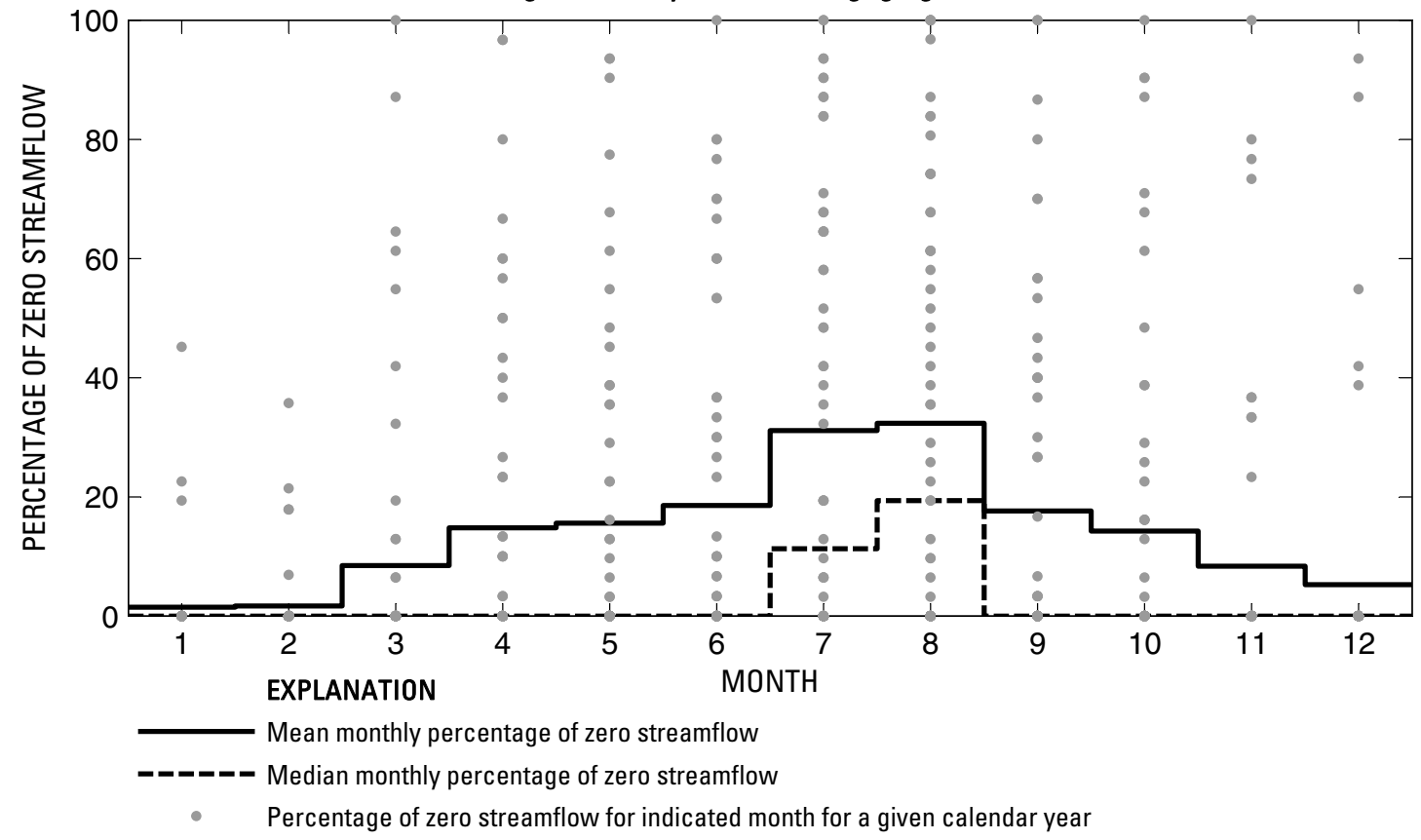

Figure 456. Analysis of percentage of zero daily mean streamflow for U.S. Geological Survey streamflow-gaging station 08121000 Colorado River at Colorado City, Texas.

Index of Station Numbers 719 
U.S. Geological Survey streamflow-gaging station 08121500

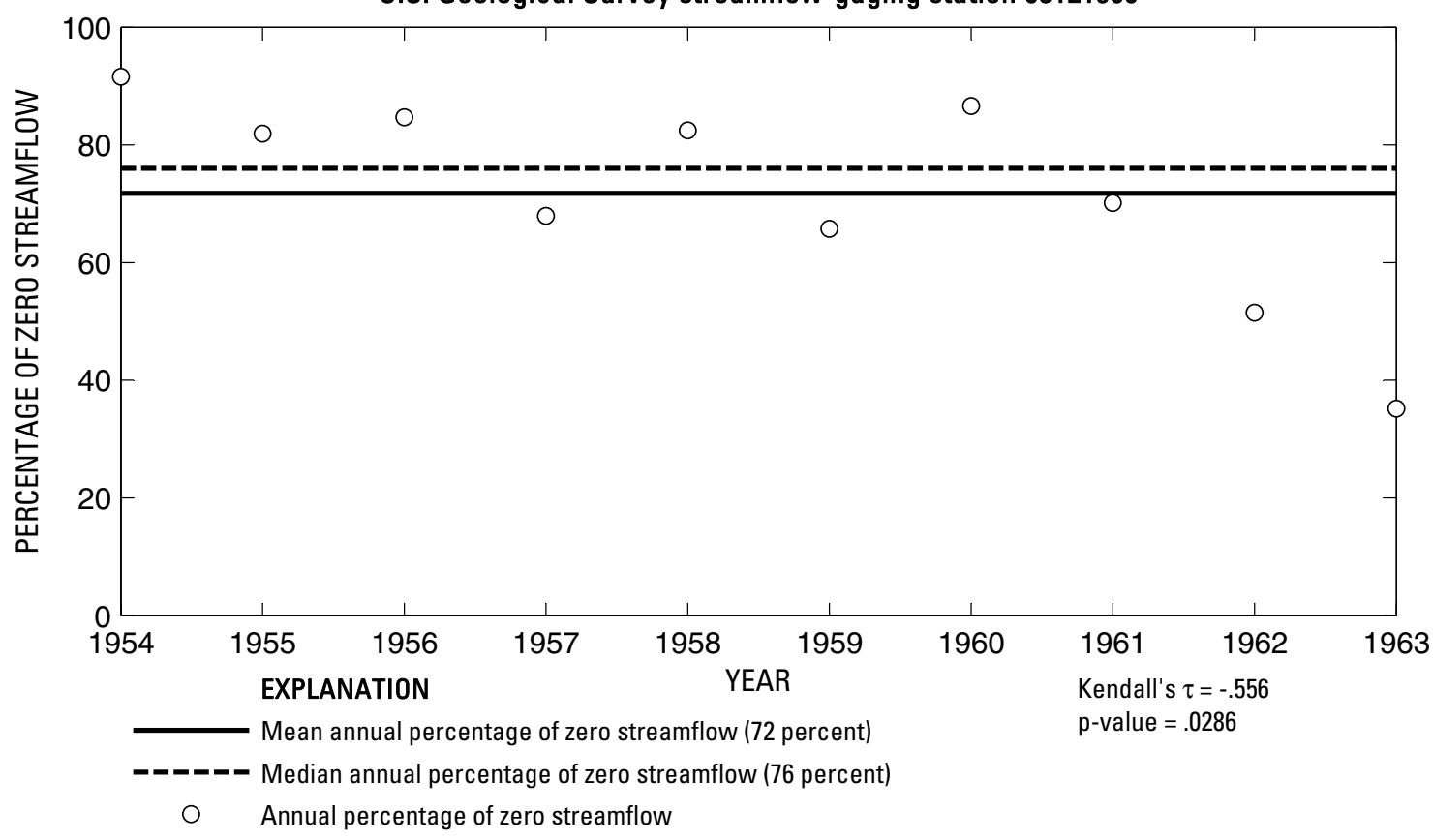

U.S. Geological Survey streamflow-gaging station 08121500

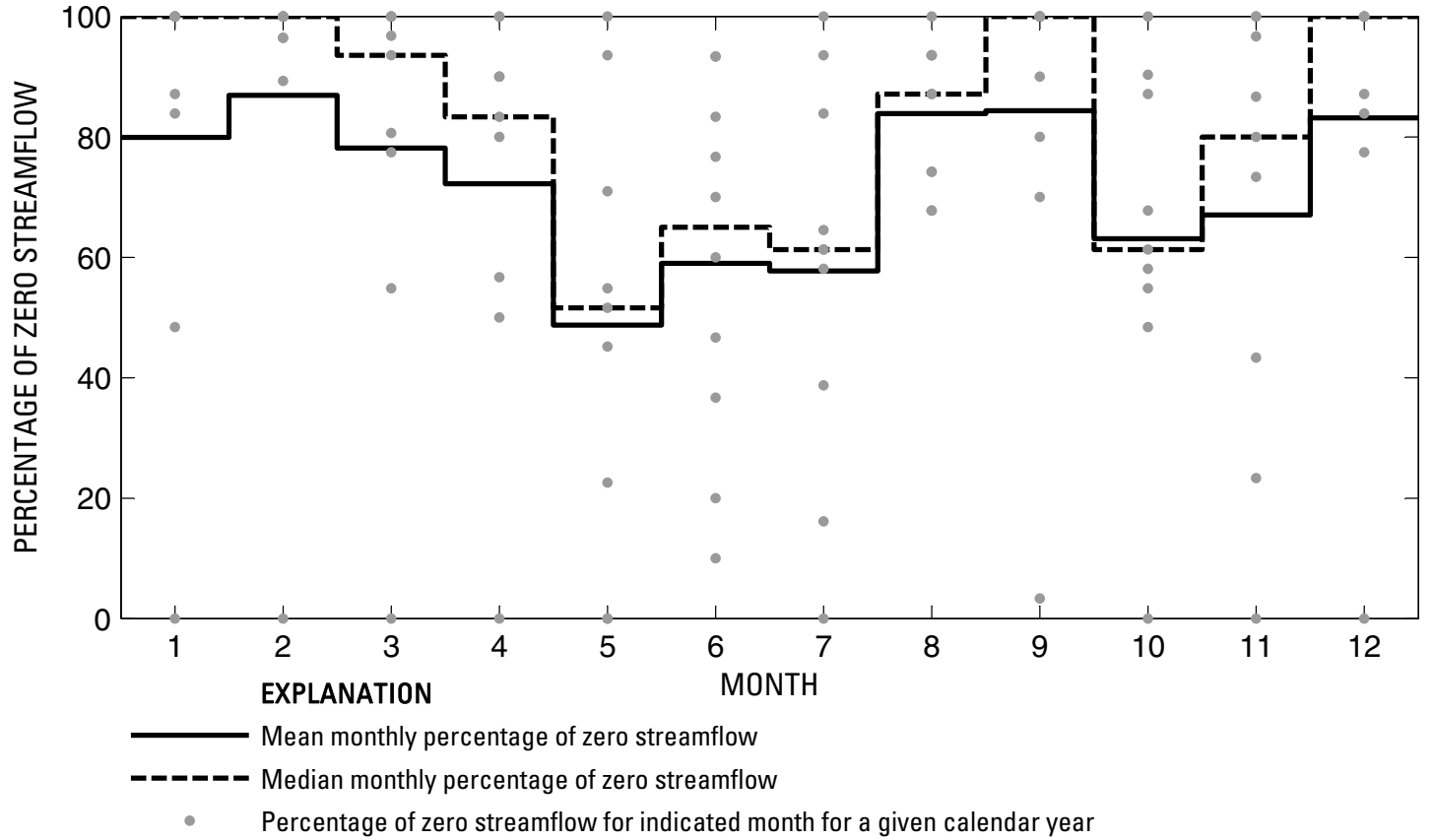

Figure 457. Analysis of percentage of zero daily mean streamflow for U.S. Geological Survey streamflow-gaging station 08121500 Morgan Creek near Westbrook, Texas. 


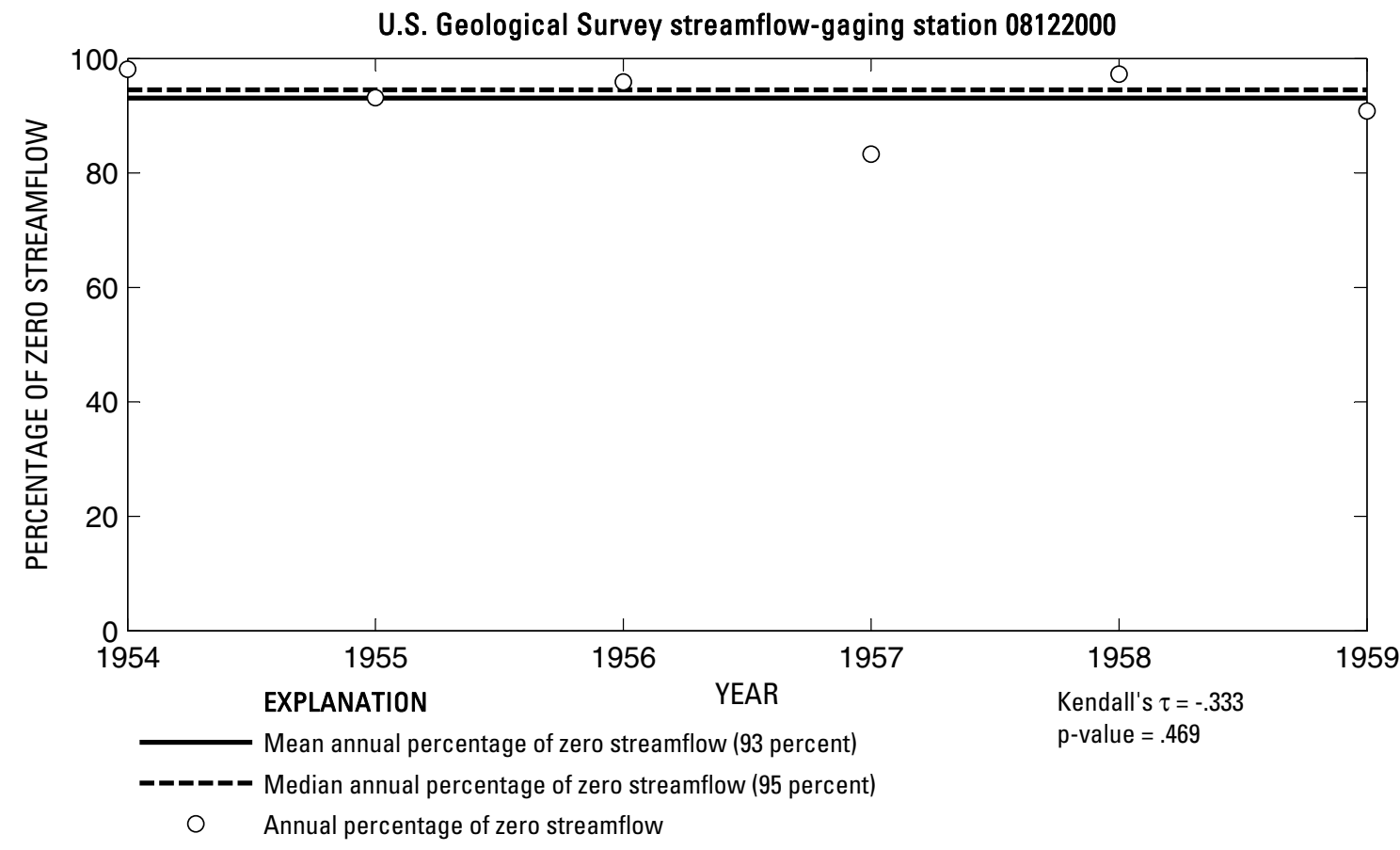

U.S. Geological Survey streamflow-gaging station 08122000

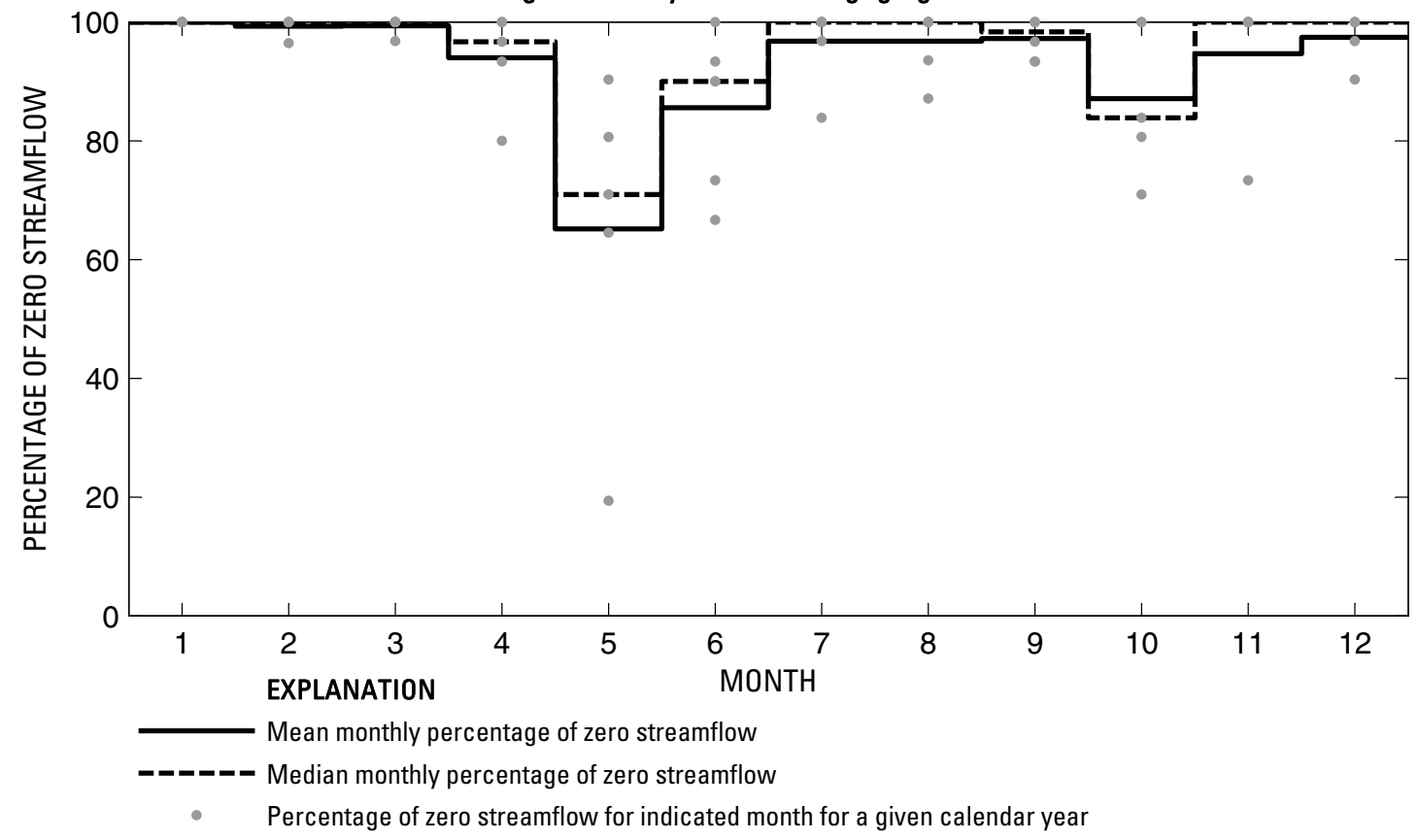

Figure 458. Analysis of percentage of zero daily mean streamflow for U.S. Geological Survey streamflow-gaging station 08122000 Graze Creek near Westbrook, Texas. 
U.S. Geological Survey streamflow-gaging station 08122500

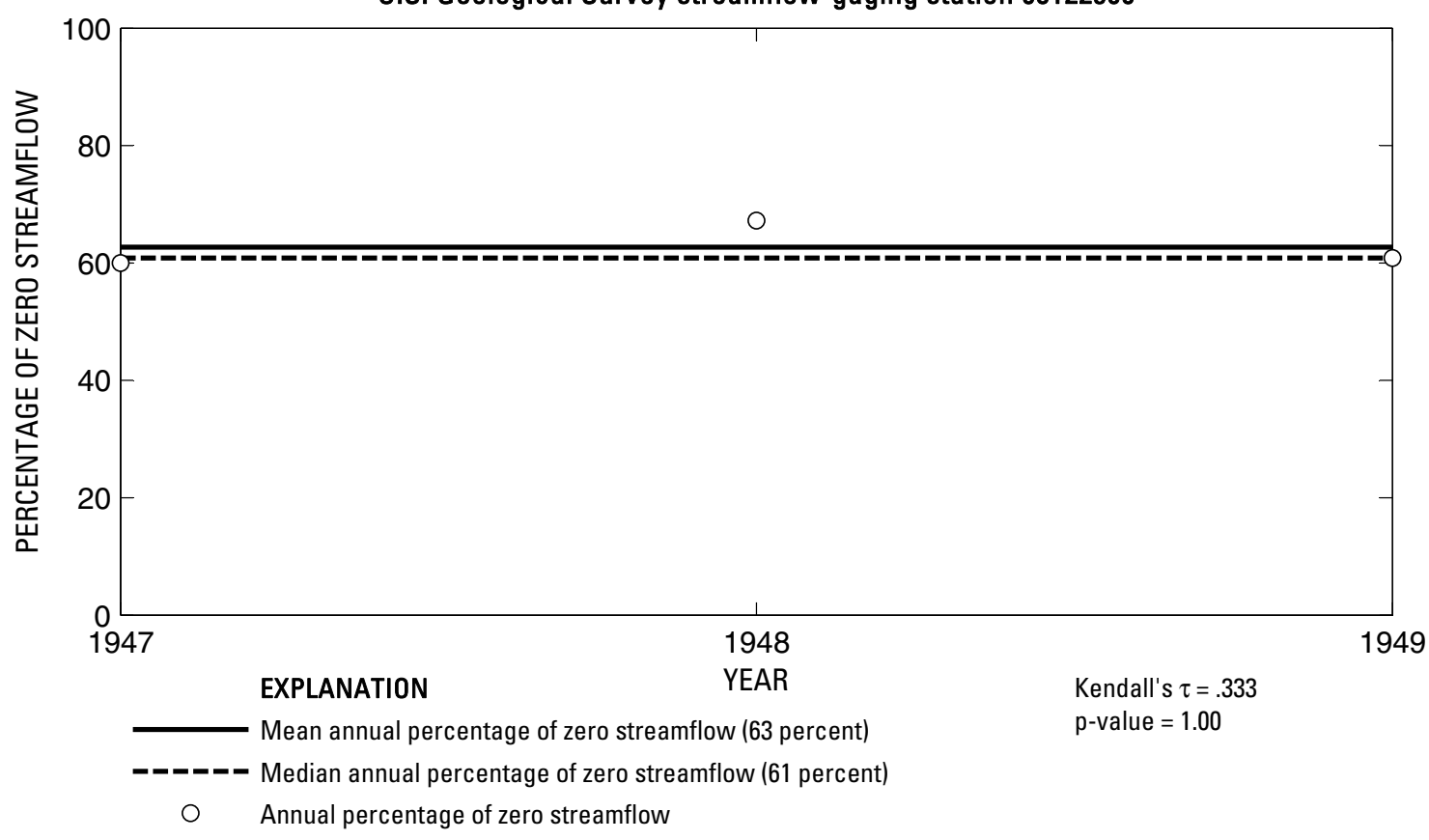

U.S. Geological Survey streamflow-gaging station 08122500

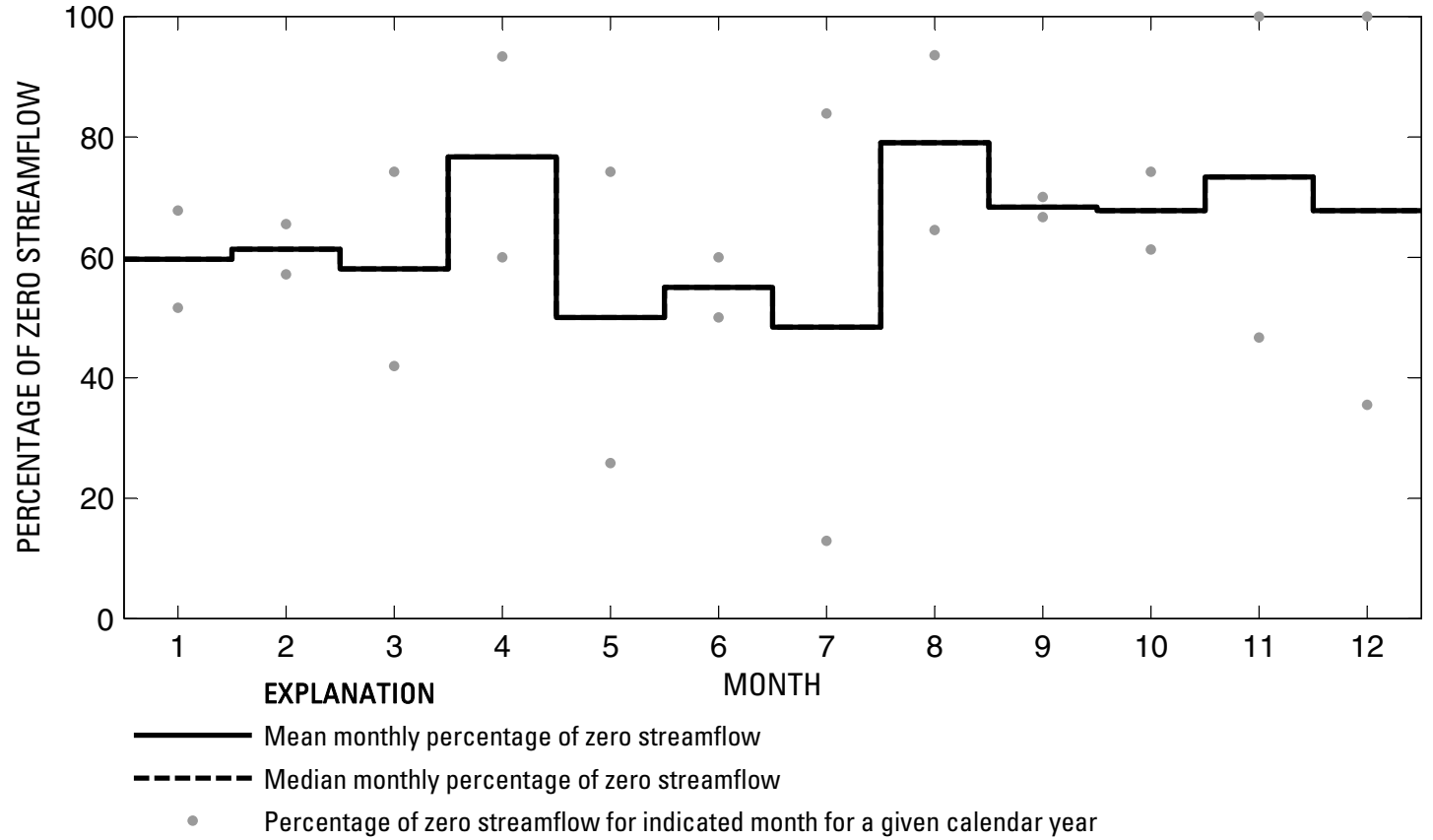

Figure 459. Analysis of percentage of zero daily mean streamflow for U.S. Geological Survey streamflow-gaging station 08122500 Morgan Creek near Colorado City, Texas. 
U.S. Geological Survey streamflow-gaging station 08123500

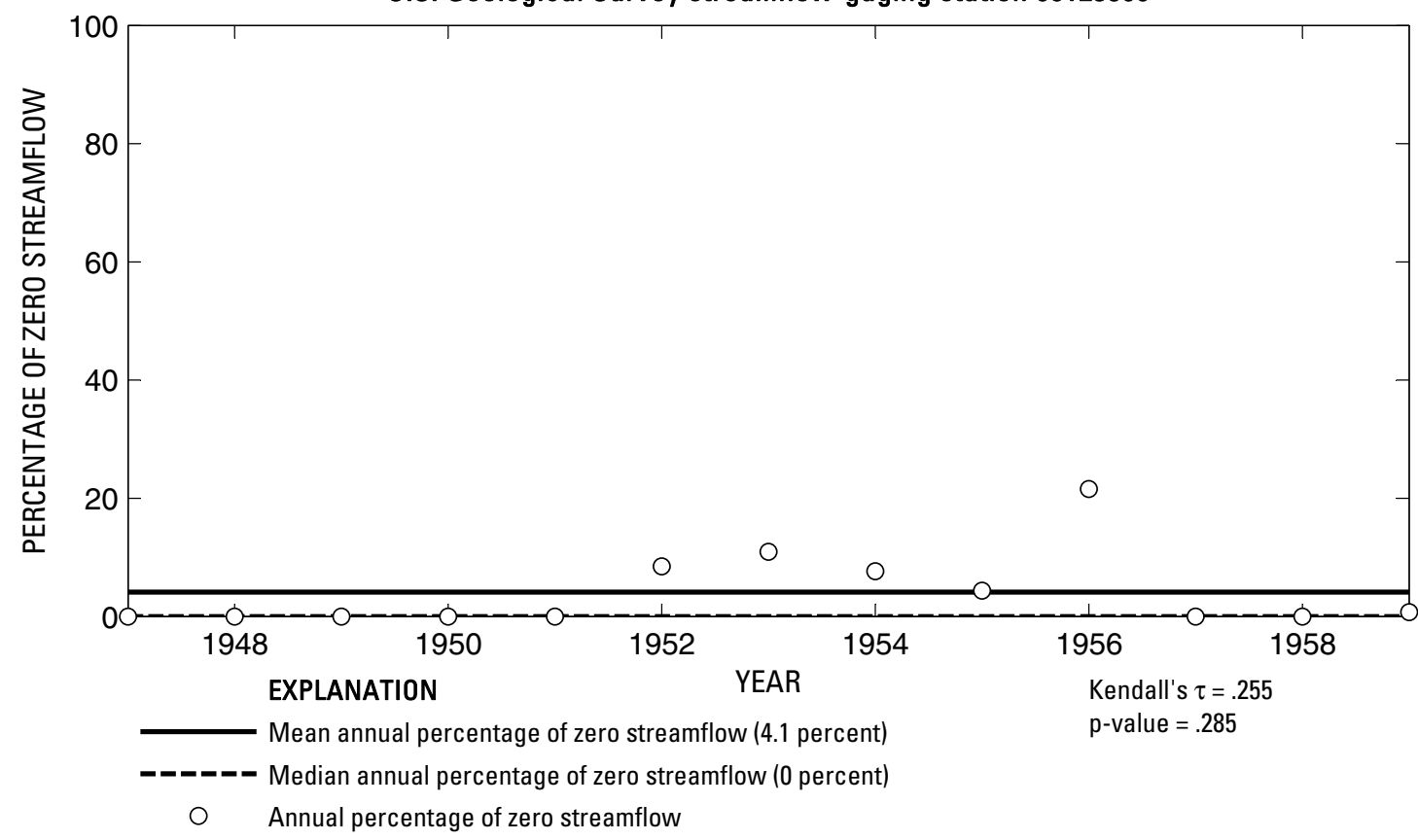

U.S. Geological Survey streamflow-gaging station 08123500

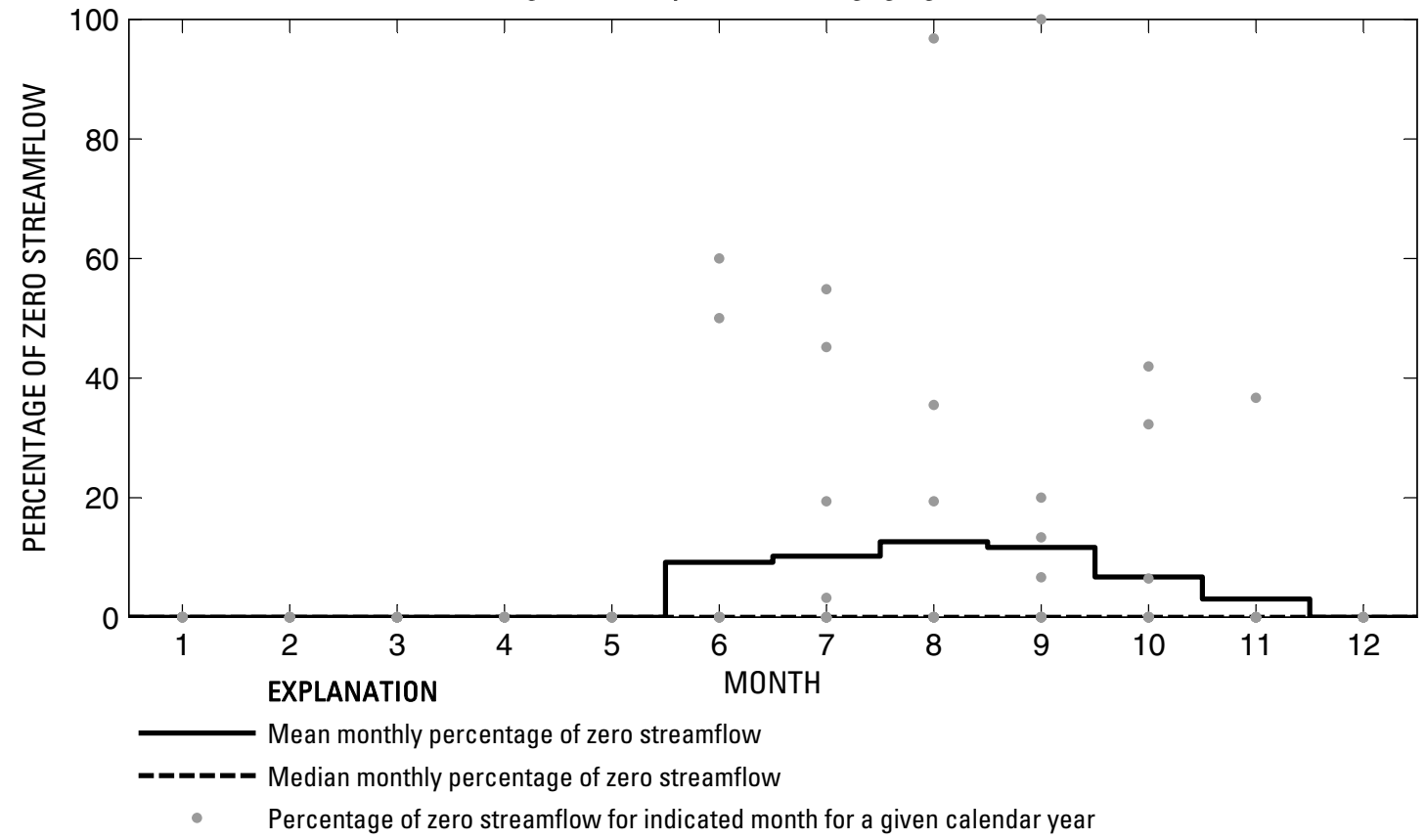

Figure 460. Analysis of percentage of zero daily mean streamflow for U.S. Geological Survey streamflow-gaging station 08123500 Champion Creek near Colorado City, Texas. 

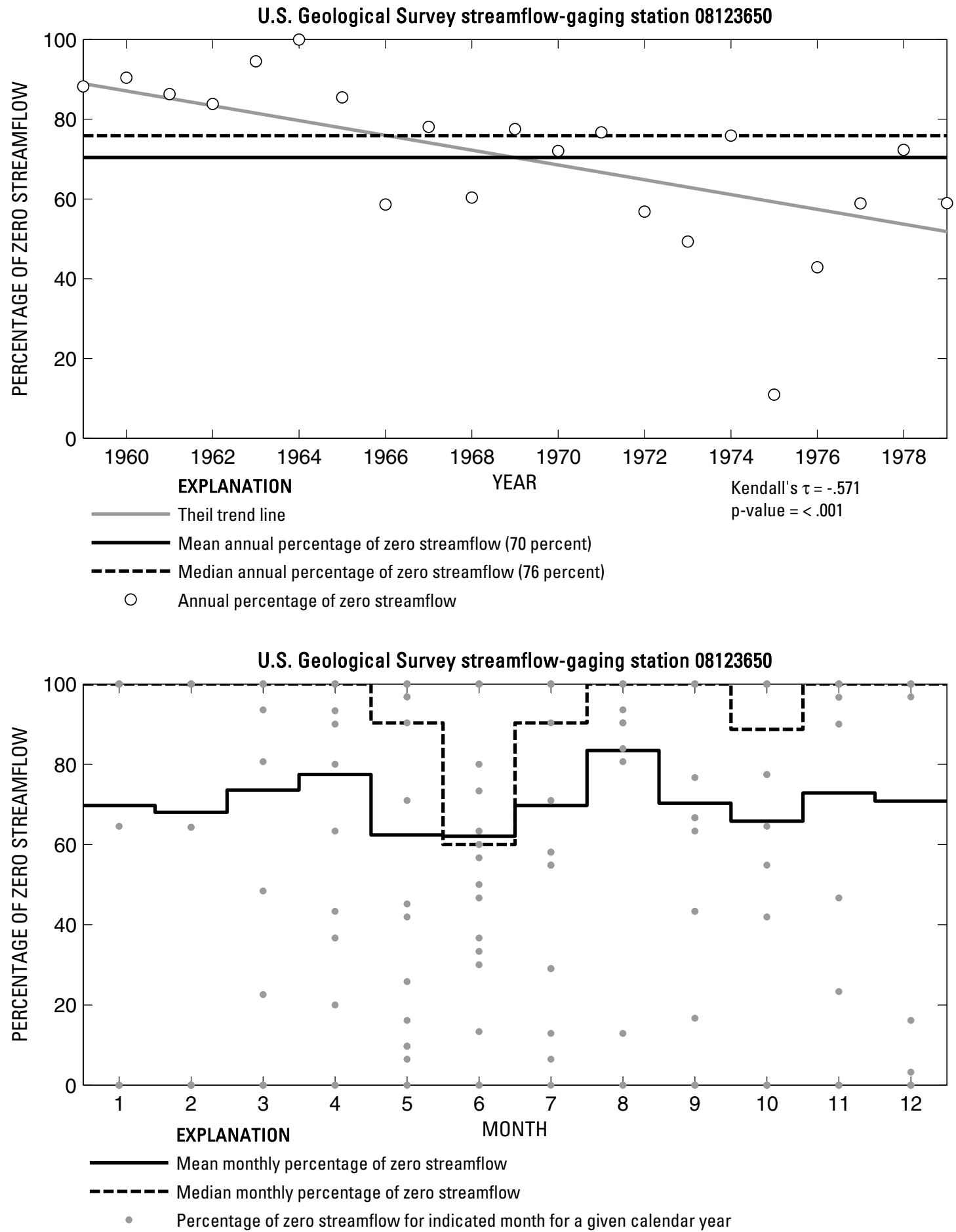

Figure 461. Analysis of percentage of zero daily mean streamflow for U.S. Geological Survey streamflow-gaging station 08123650 Beals Creek above Big Spring, Texas. 
U.S. Geological Survey streamflow-gaging station 08123700

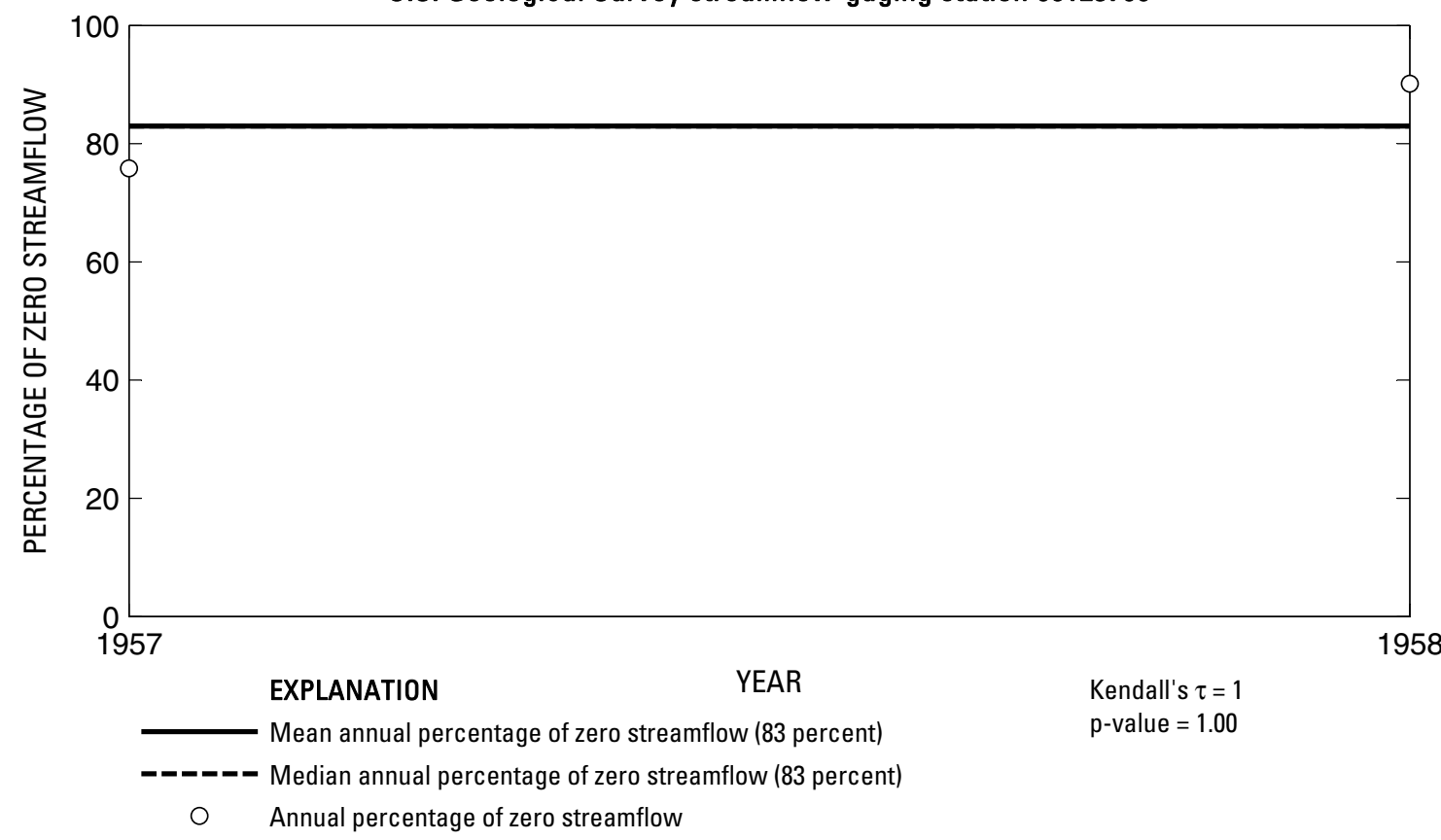

U.S. Geological Survey streamflow-gaging station 08123700

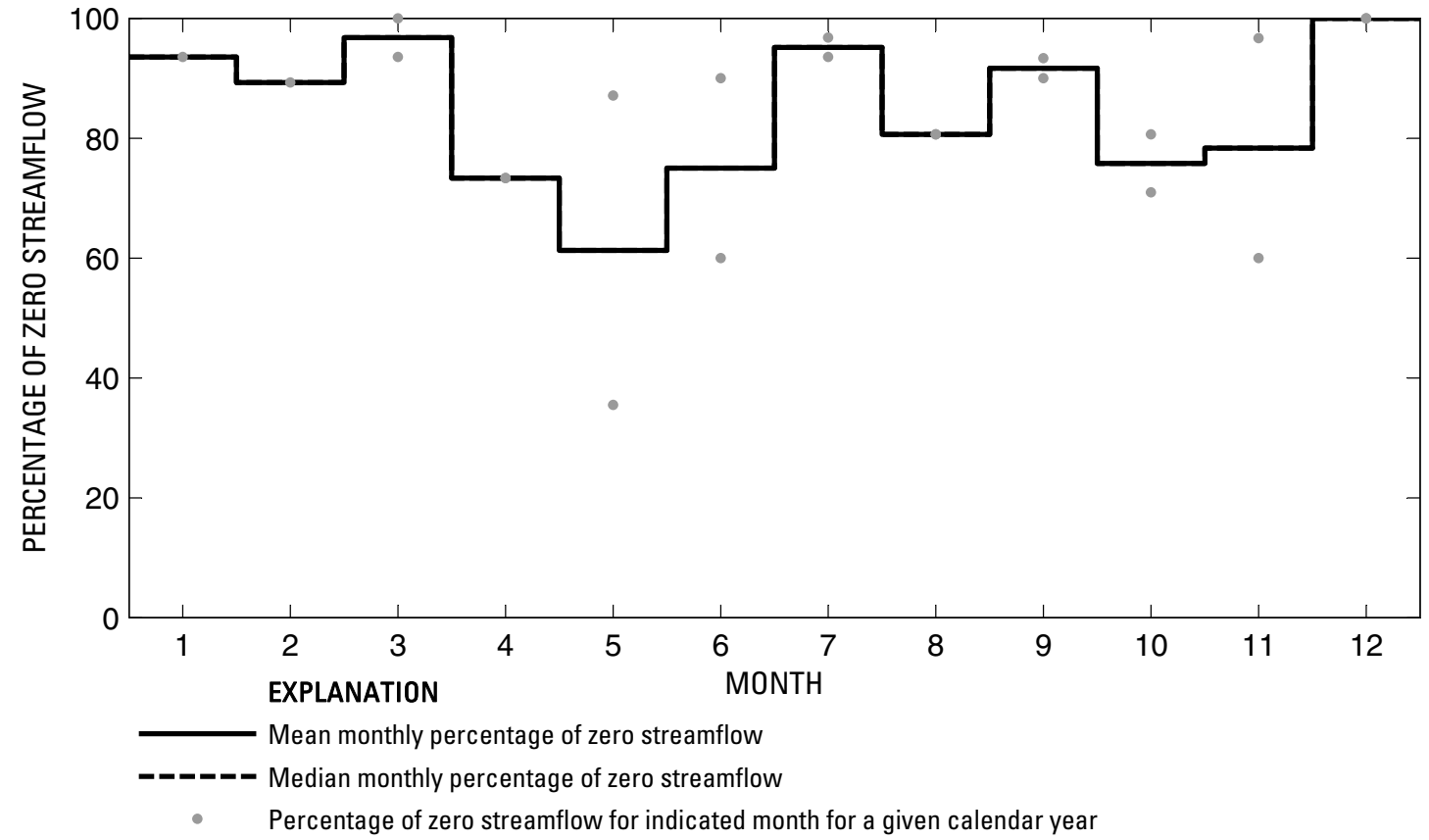

Figure 462. Analysis of percentage of zero daily mean streamflow for U.S. Geological Survey streamflow-gaging station 08123700 Beals Creek at Big Spring, Texas. 
U.S. Geological Survey streamflow-gaging station 08123720

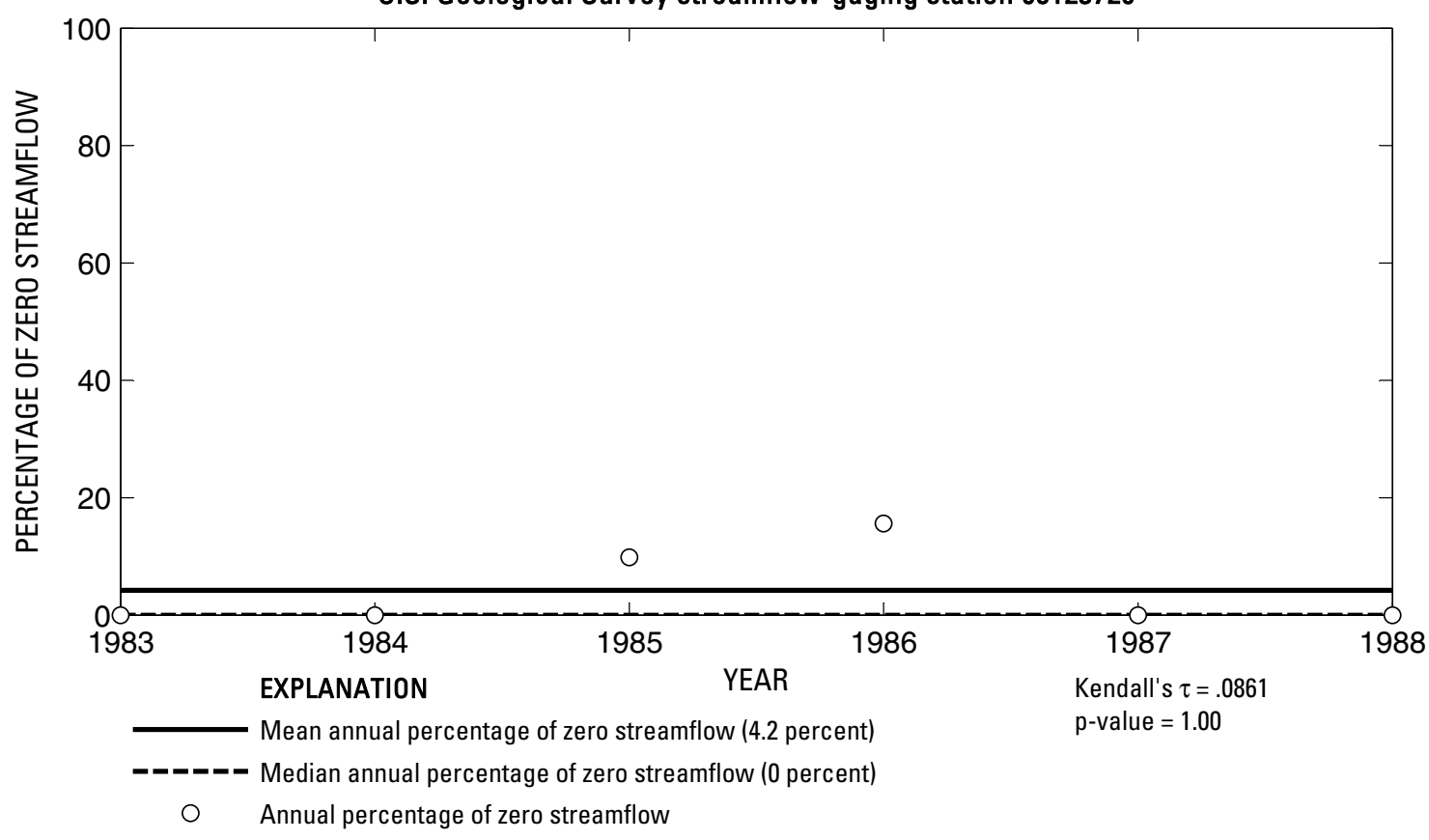

U.S. Geological Survey streamflow-gaging station 08123720

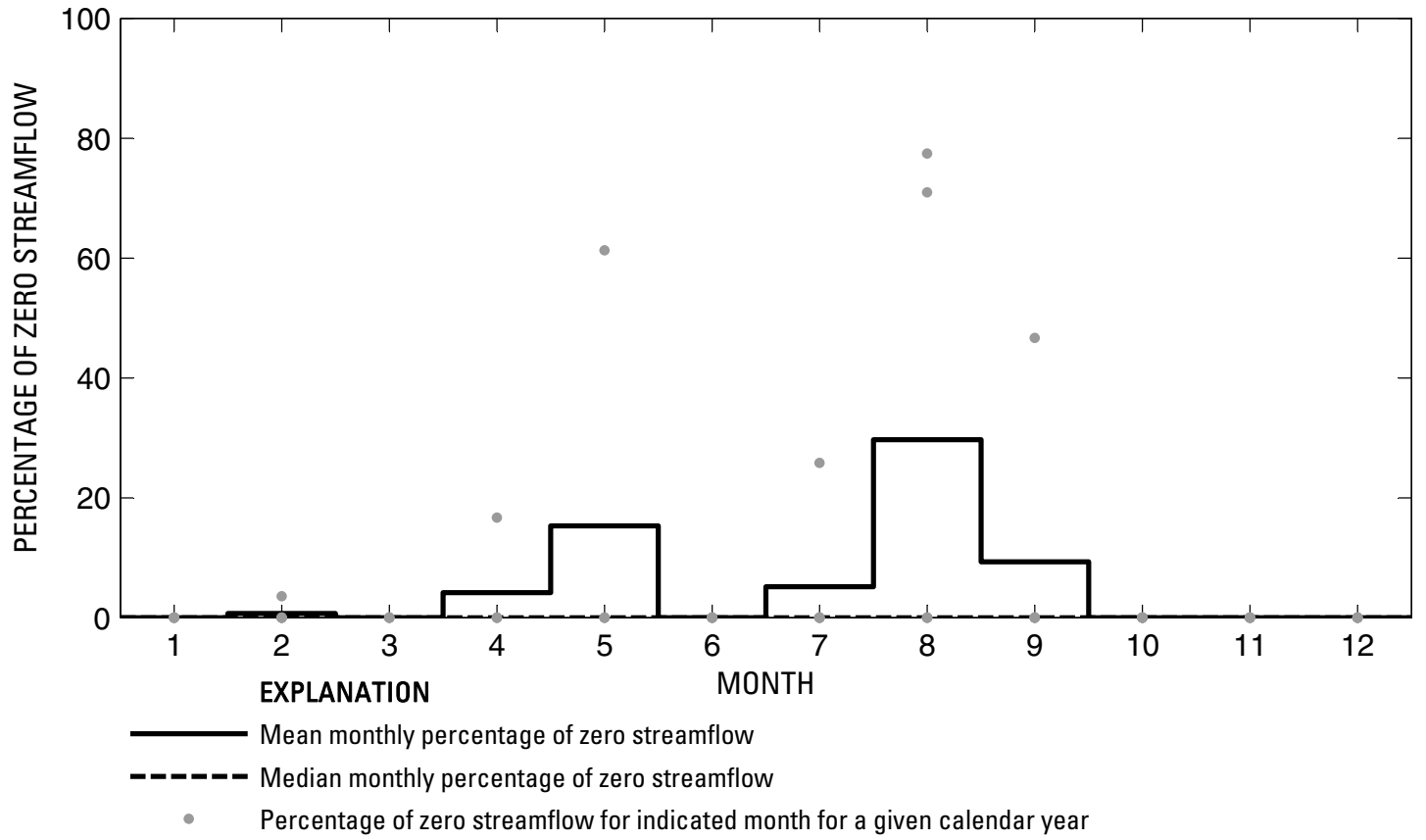

Figure 463. Analysis of percentage of zero daily mean streamflow for U.S. Geological Survey streamflow-gaging station 08123720 Beals Creek near Coahoma, Texas. 
U.S. Geological Survey streamflow-gaging station 08123800

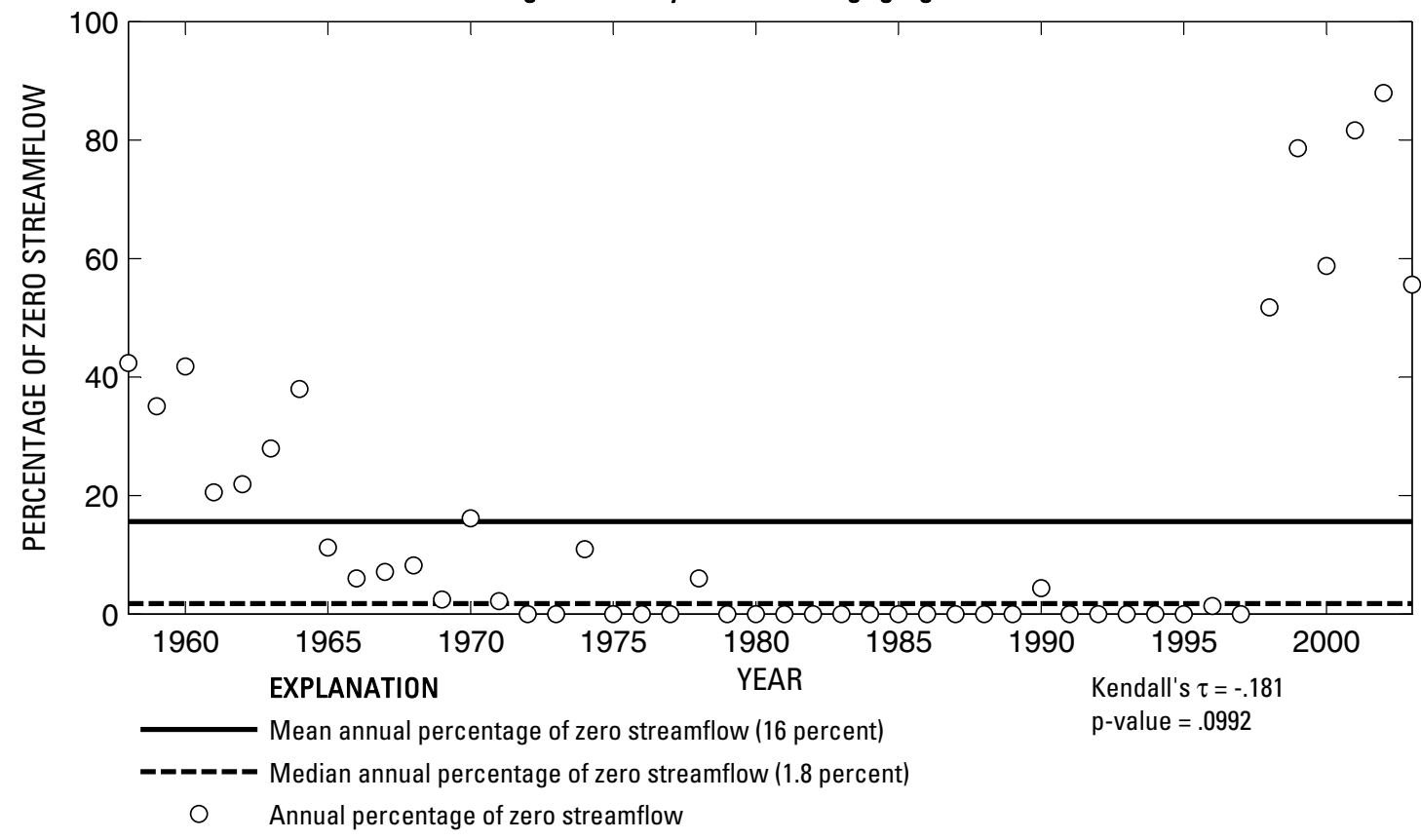

U.S. Geological Survey streamflow-gaging station 08123800

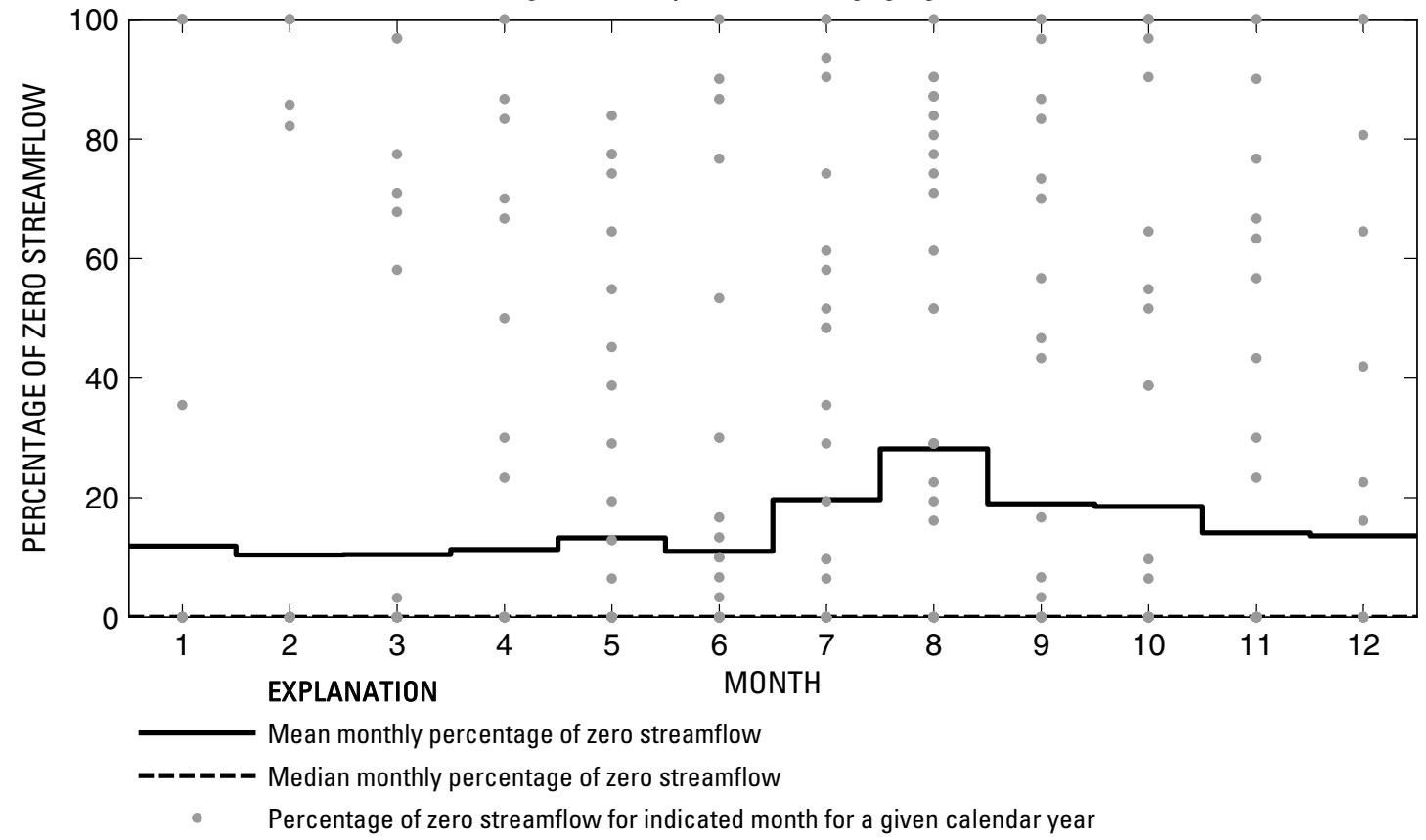

Figure 464. Analysis of percentage of zero daily mean streamflow for U.S. Geological Survey streamflow-gaging station 08123800 Beals Creek near Westbrook, Texas.

Index of Station Numbers 719 
U.S. Geological Survey streamflow-gaging station 08123850

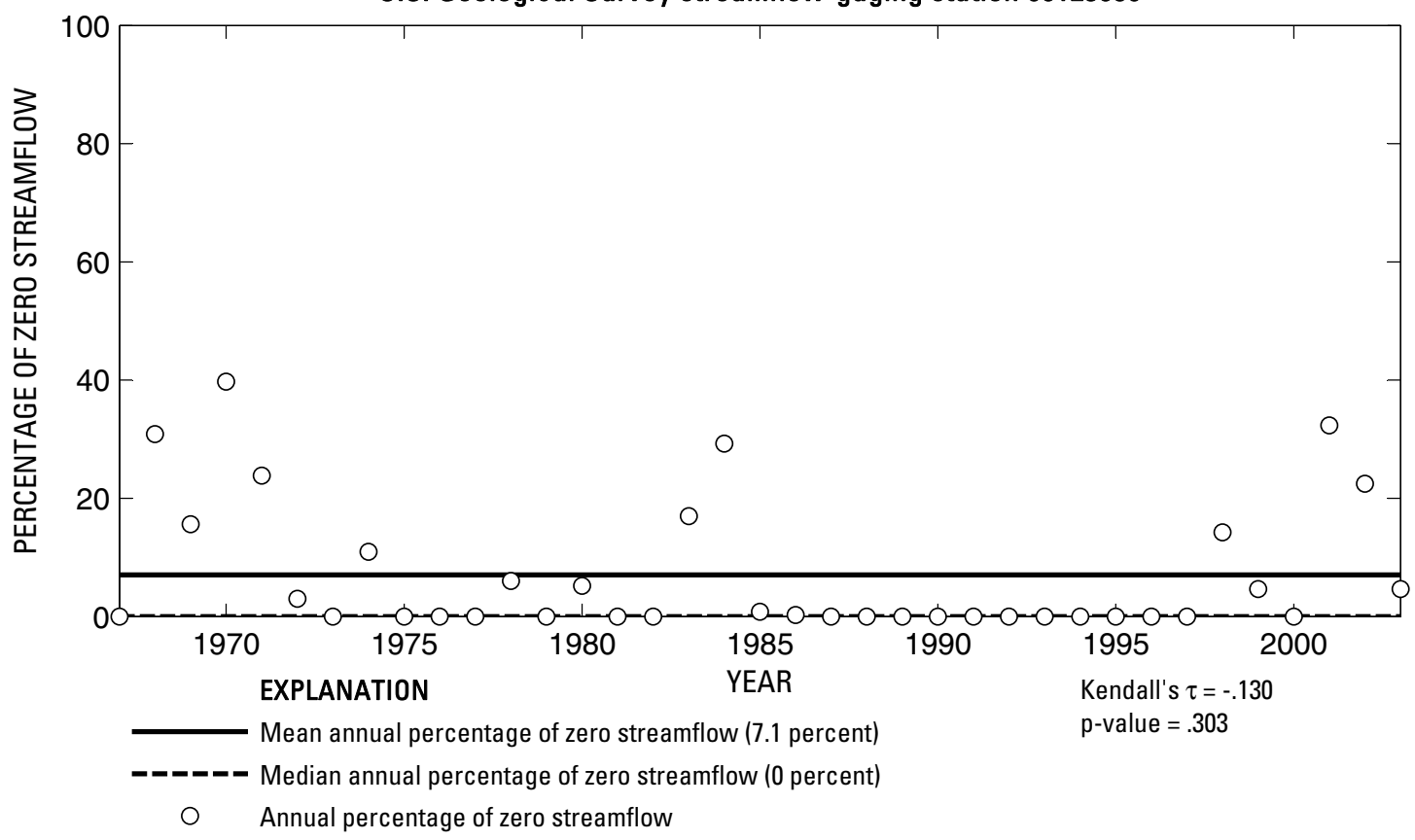

U.S. Geological Survey streamflow-gaging station 08123850

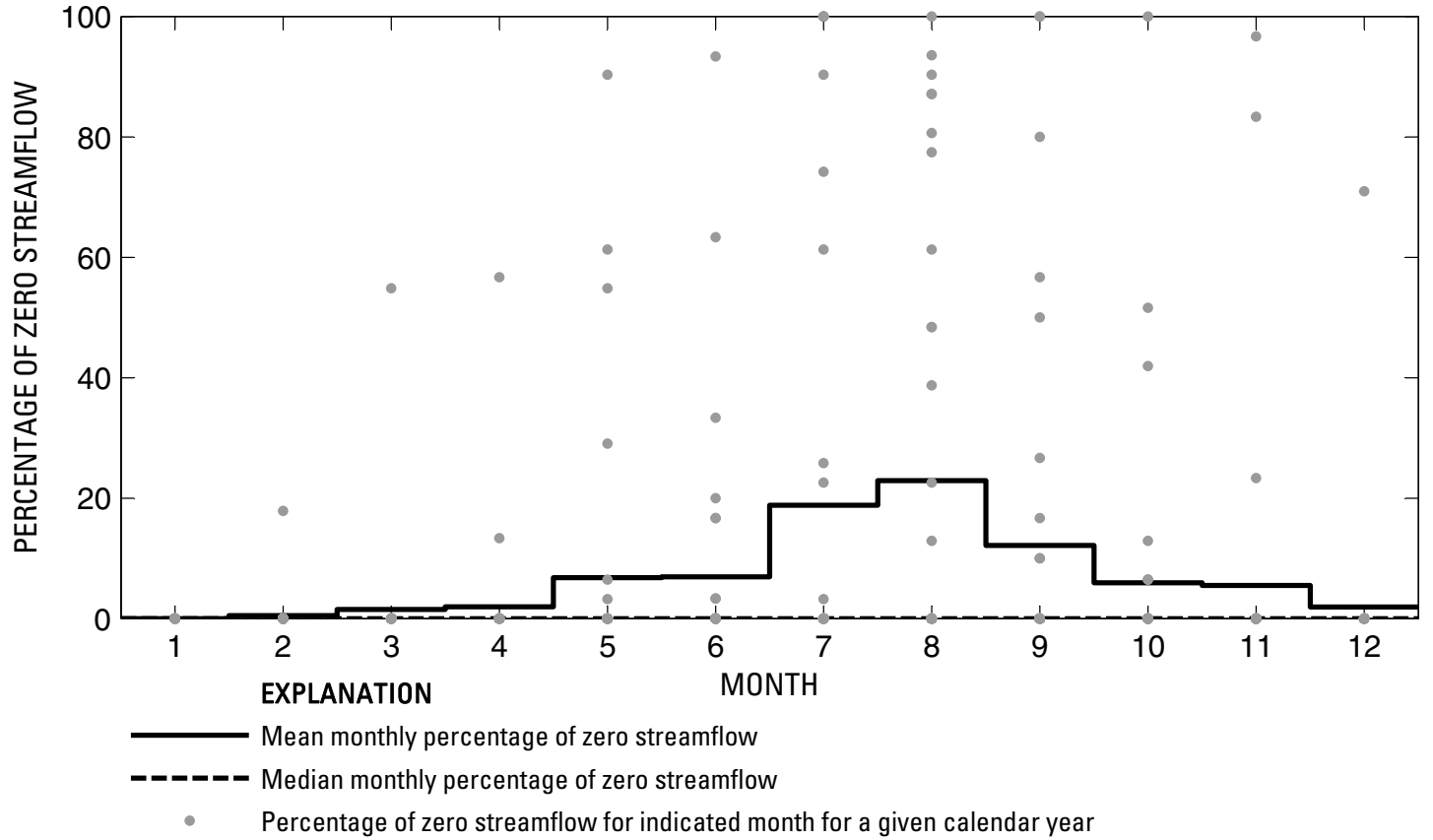

Figure 465. Analysis of percentage of zero daily mean streamflow for U.S. Geological Survey streamflow-gaging station 08123850 Colorado River above Silver, Texas. 
U.S. Geological Survey streamflow-gaging station 08123900

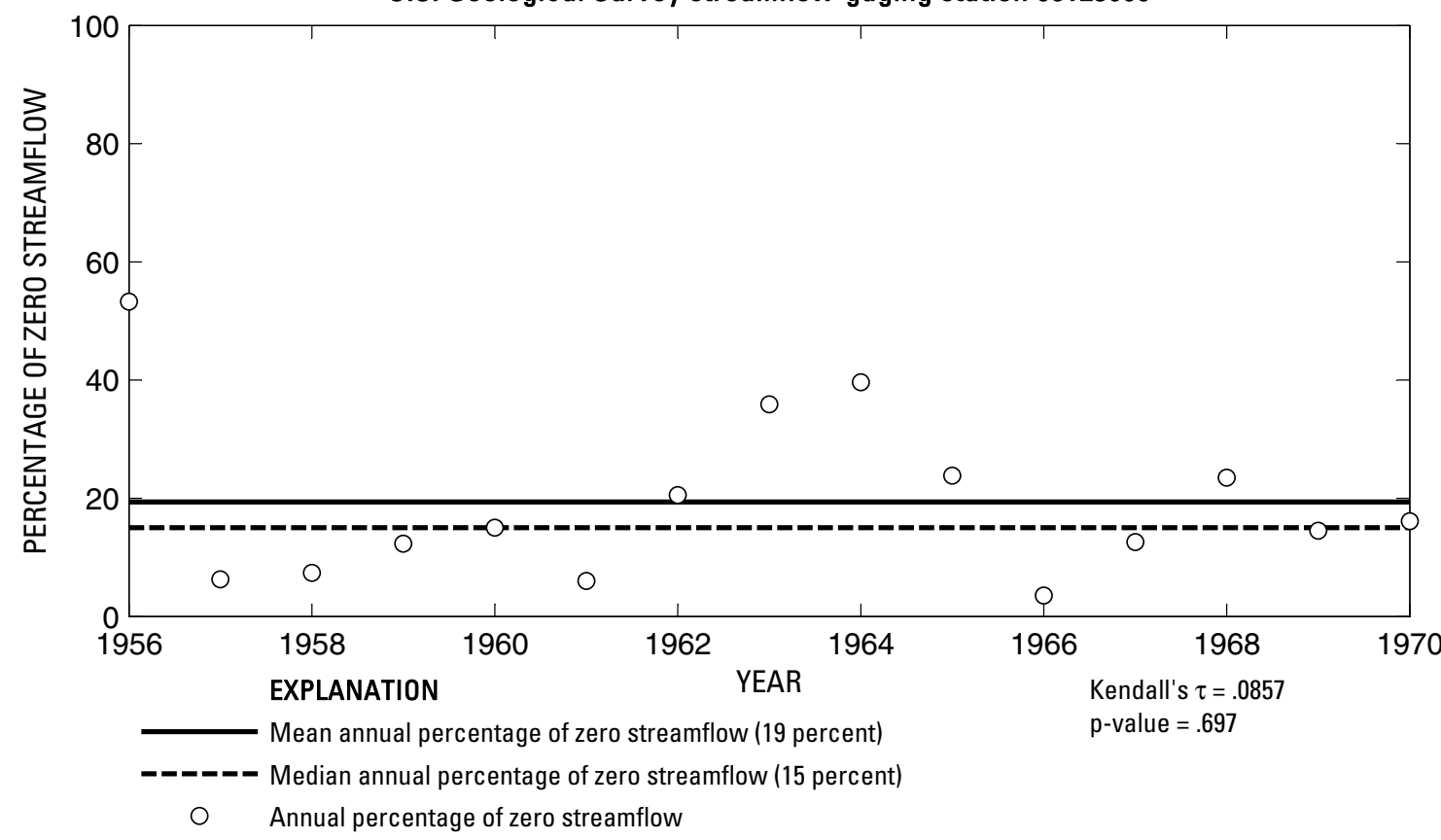

U.S. Geological Survey streamflow-gaging station 08123900

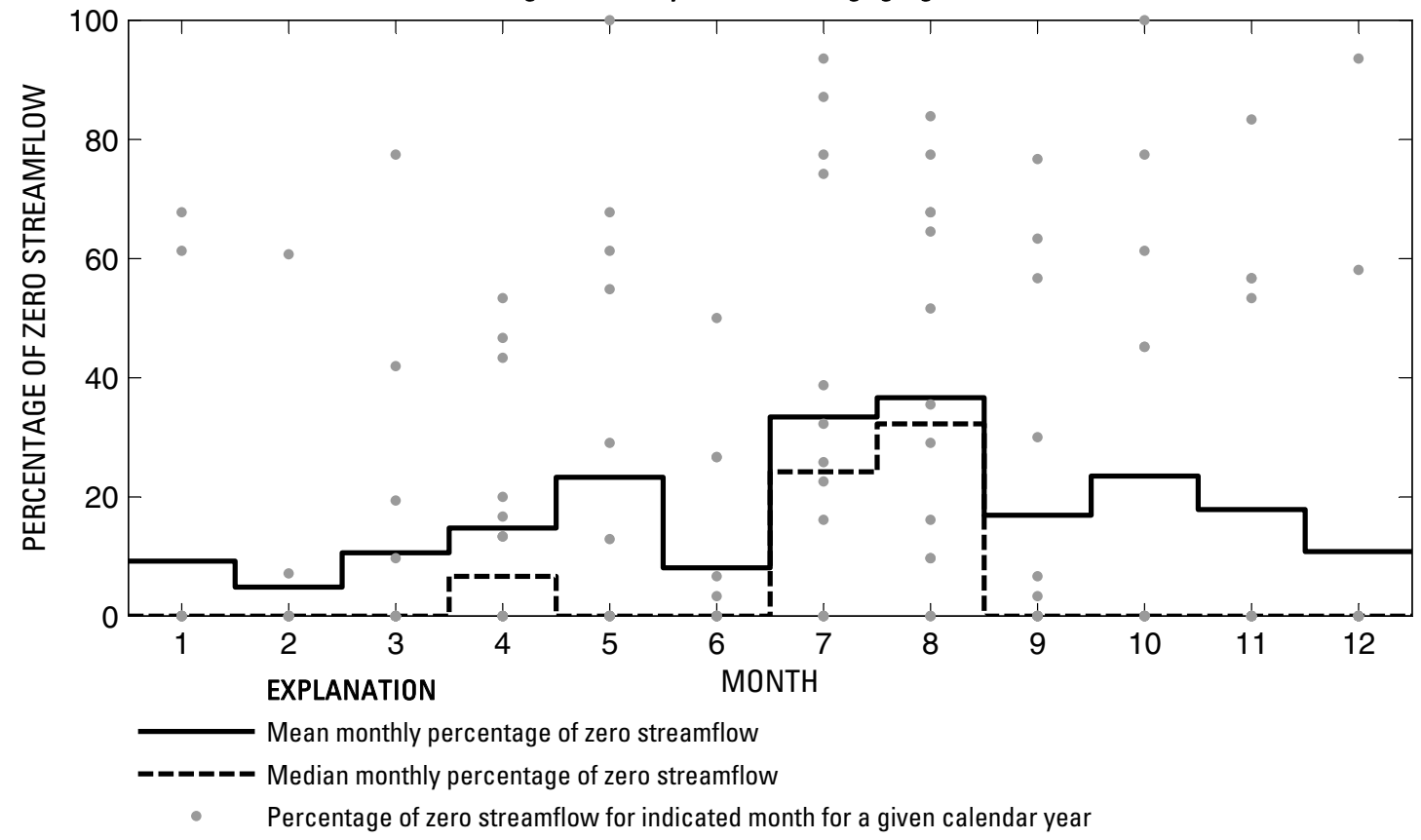

Figure 466. Analysis of percentage of zero daily mean streamflow for U.S. Geological Survey streamflow-gaging station 08123900 Colorado River near Silver, Texas. 

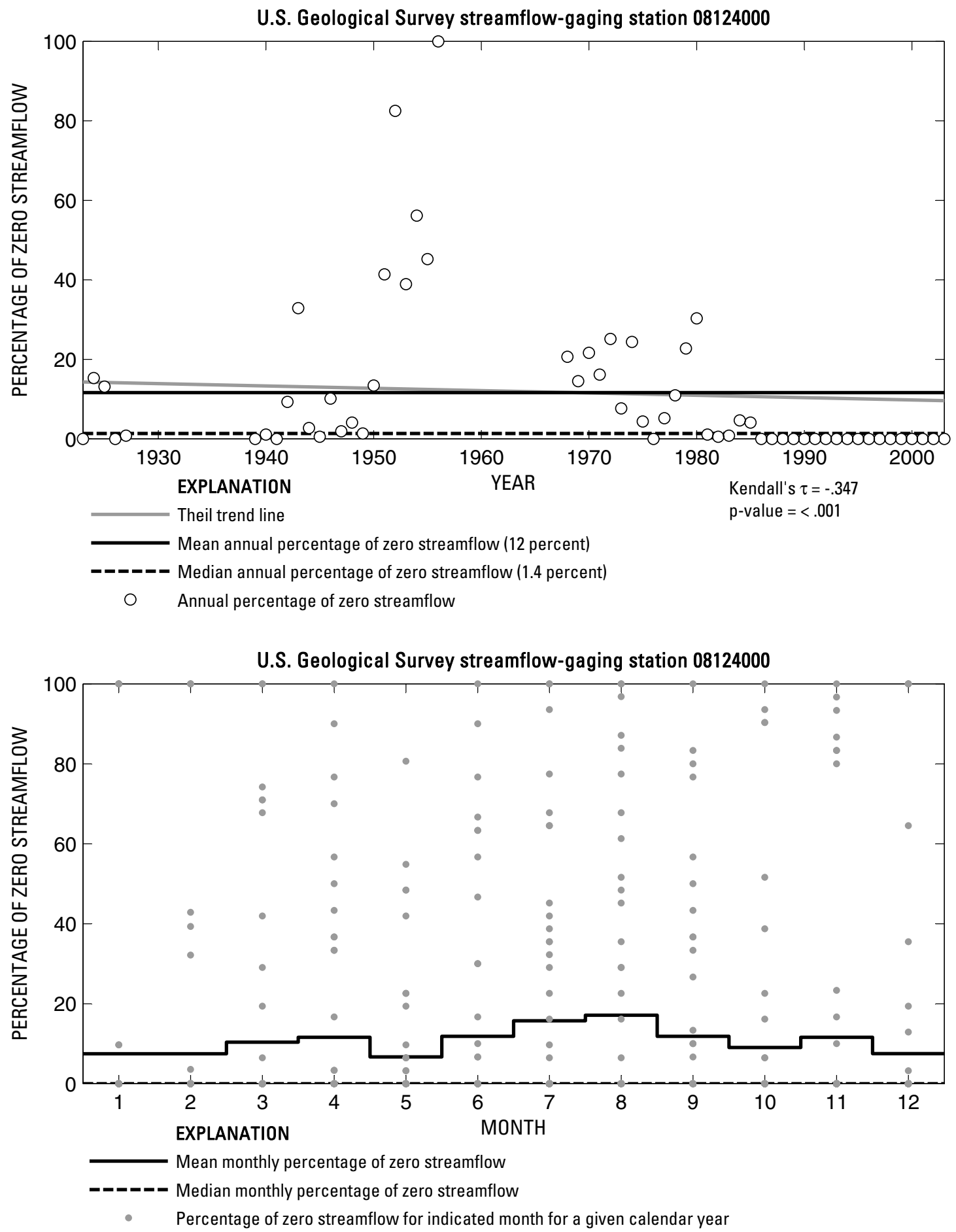

Figure 467. Analysis of percentage of zero daily mean streamflow for U.S. Geological Survey streamflow-gaging station 08124000 Colorado River at Robert Lee, Texas. 
U.S. Geological Survey streamflow-gaging station 08126380

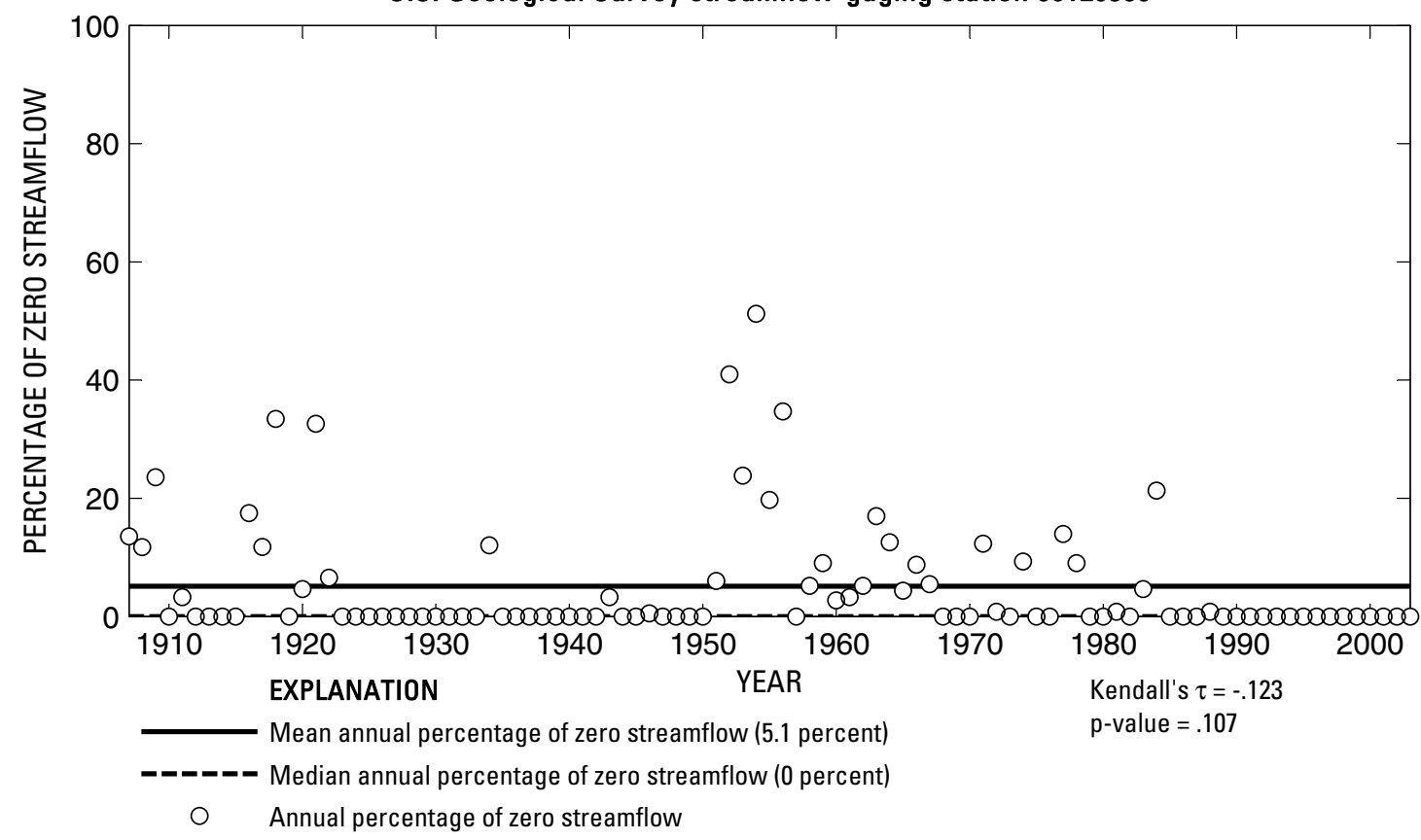

U.S. Geological Survey streamflow-gaging station 08126380

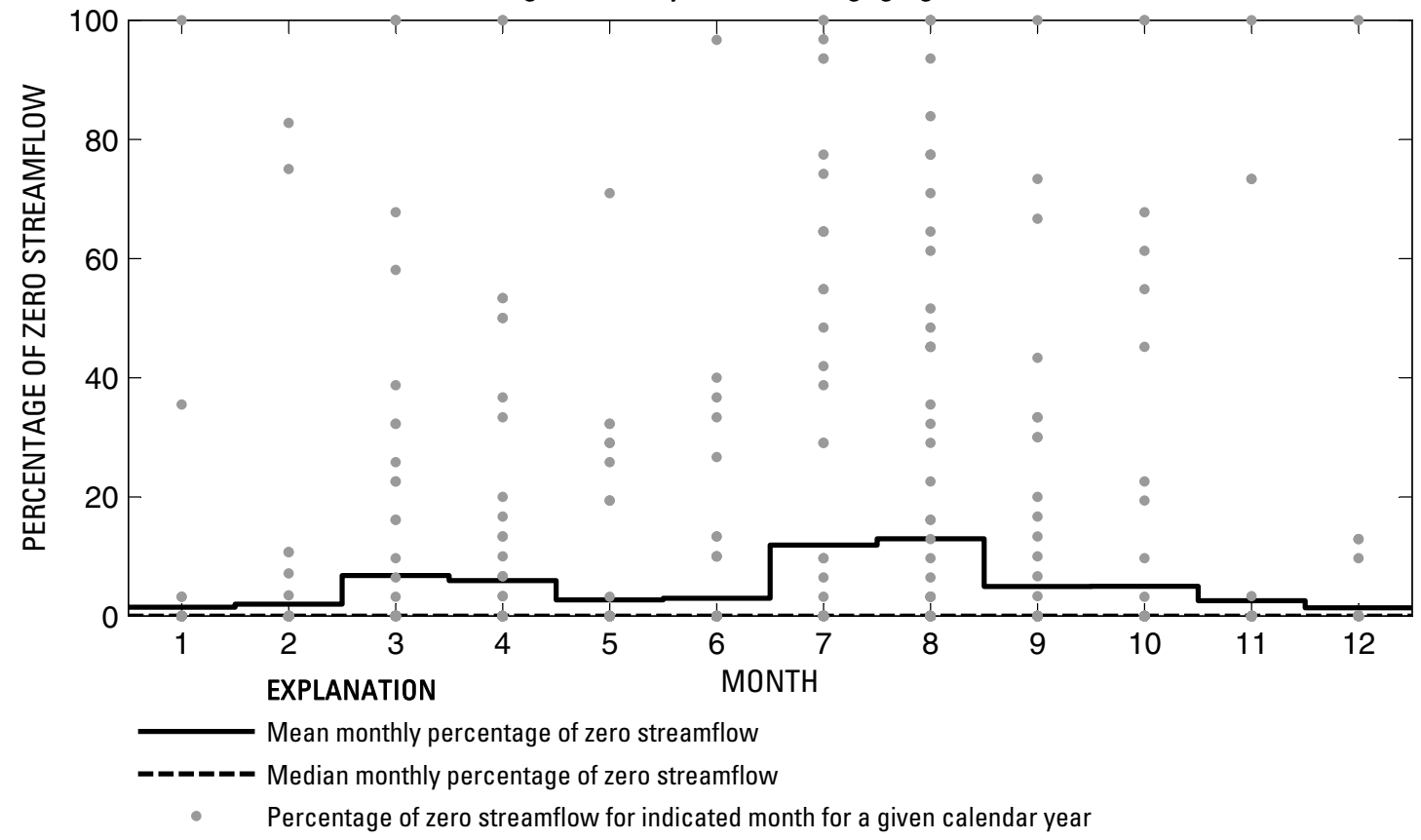

Figure 468. Analysis of percentage of zero daily mean streamflow for U.S. Geological Survey streamflow-gaging station 08126380 Colorado River near Ballinger, Texas.

Index of Station Numbers 719 

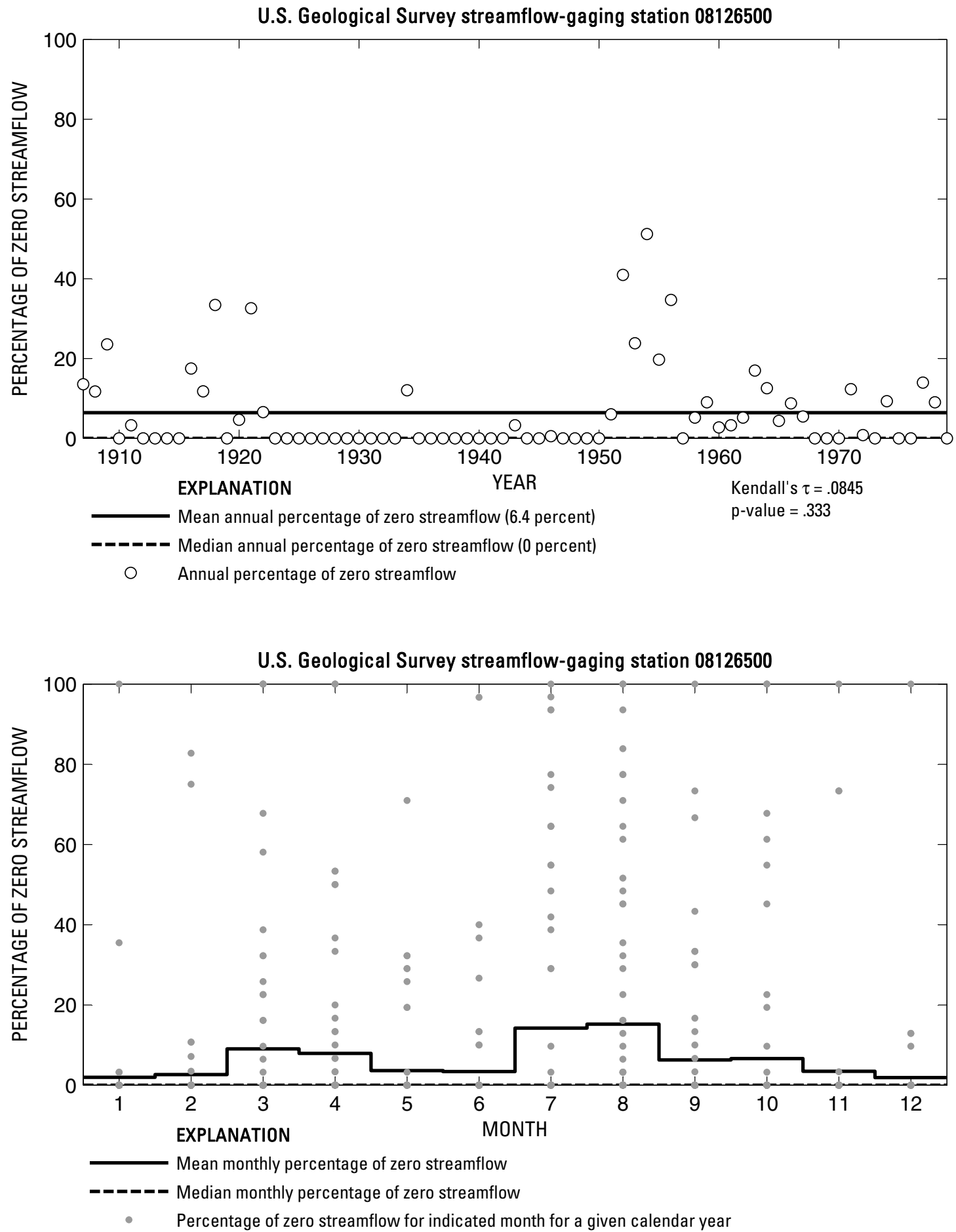

Figure 469. Analysis of percentage of zero daily mean streamflow for U.S. Geological Survey streamflow-gaging station 08126500 Colorado River at Ballinger, Texas. 
U.S. Geological Survey streamflow-gaging station 08127000

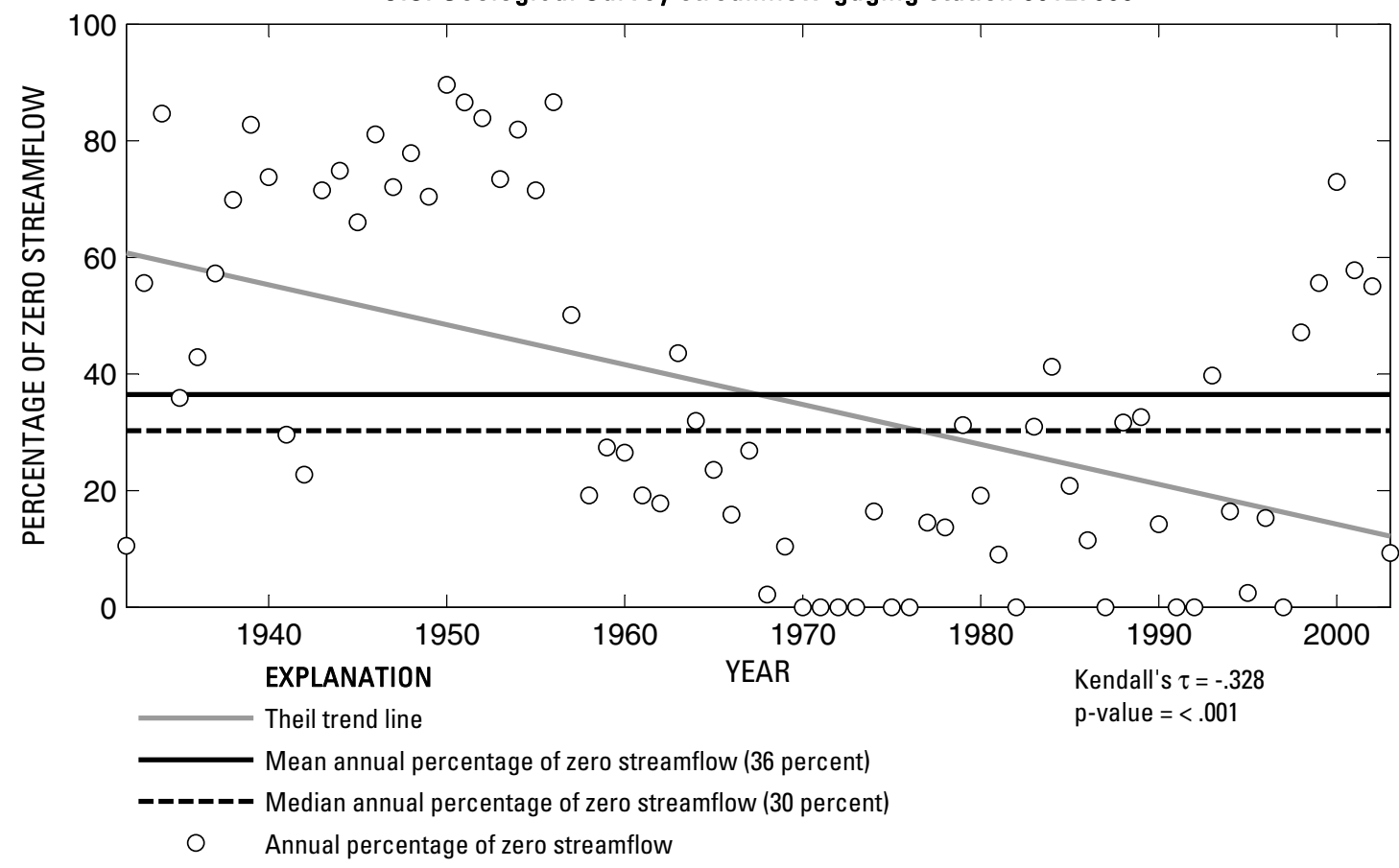

U.S. Geological Survey streamflow-gaging station 08127000

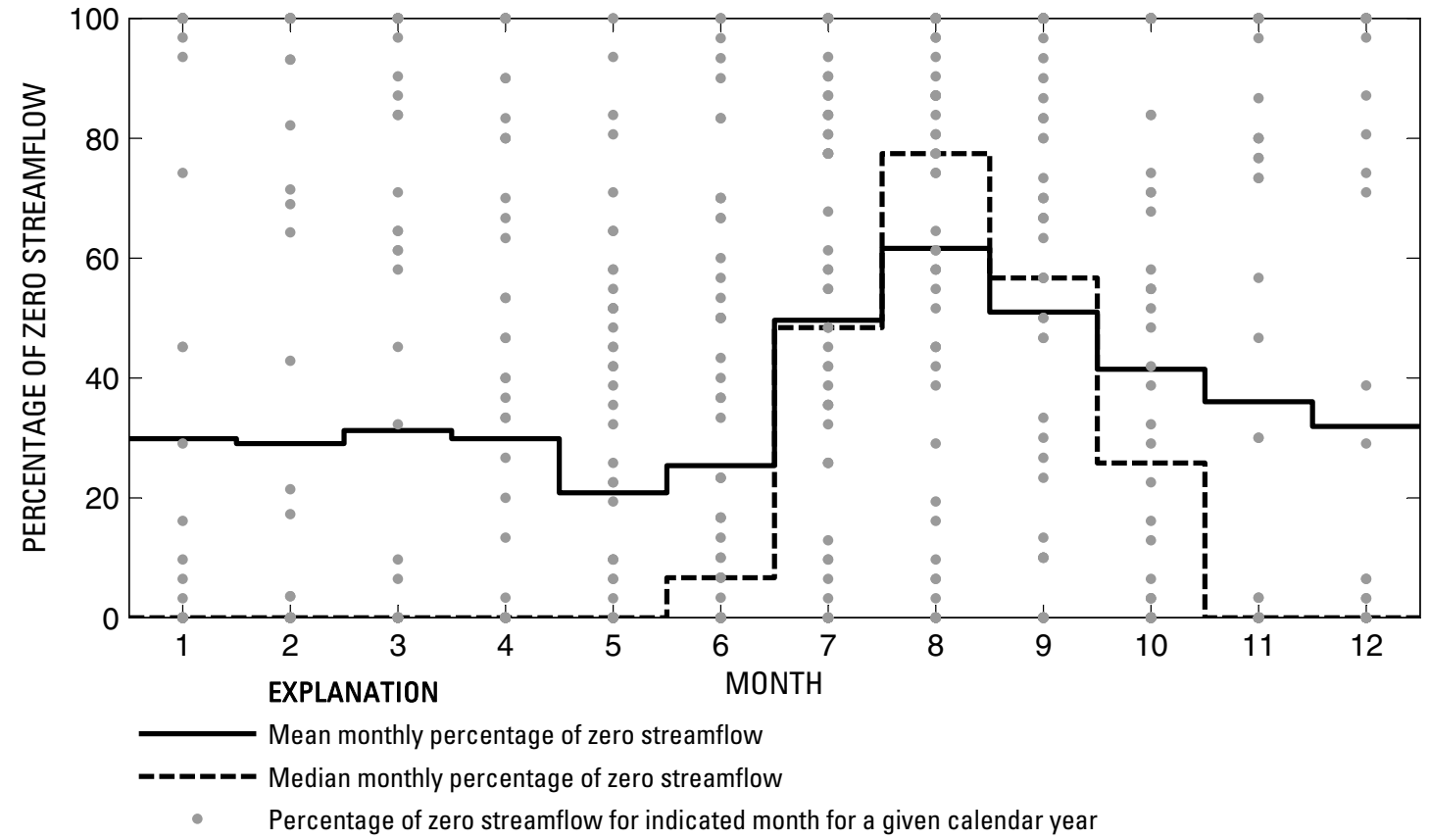

Figure 470. Analysis of percentage of zero daily mean streamflow for U.S. Geological Survey streamflow-gaging station 08127000 Elm Creek at Ballinger, Texas.

Index of Station Numbers 719 


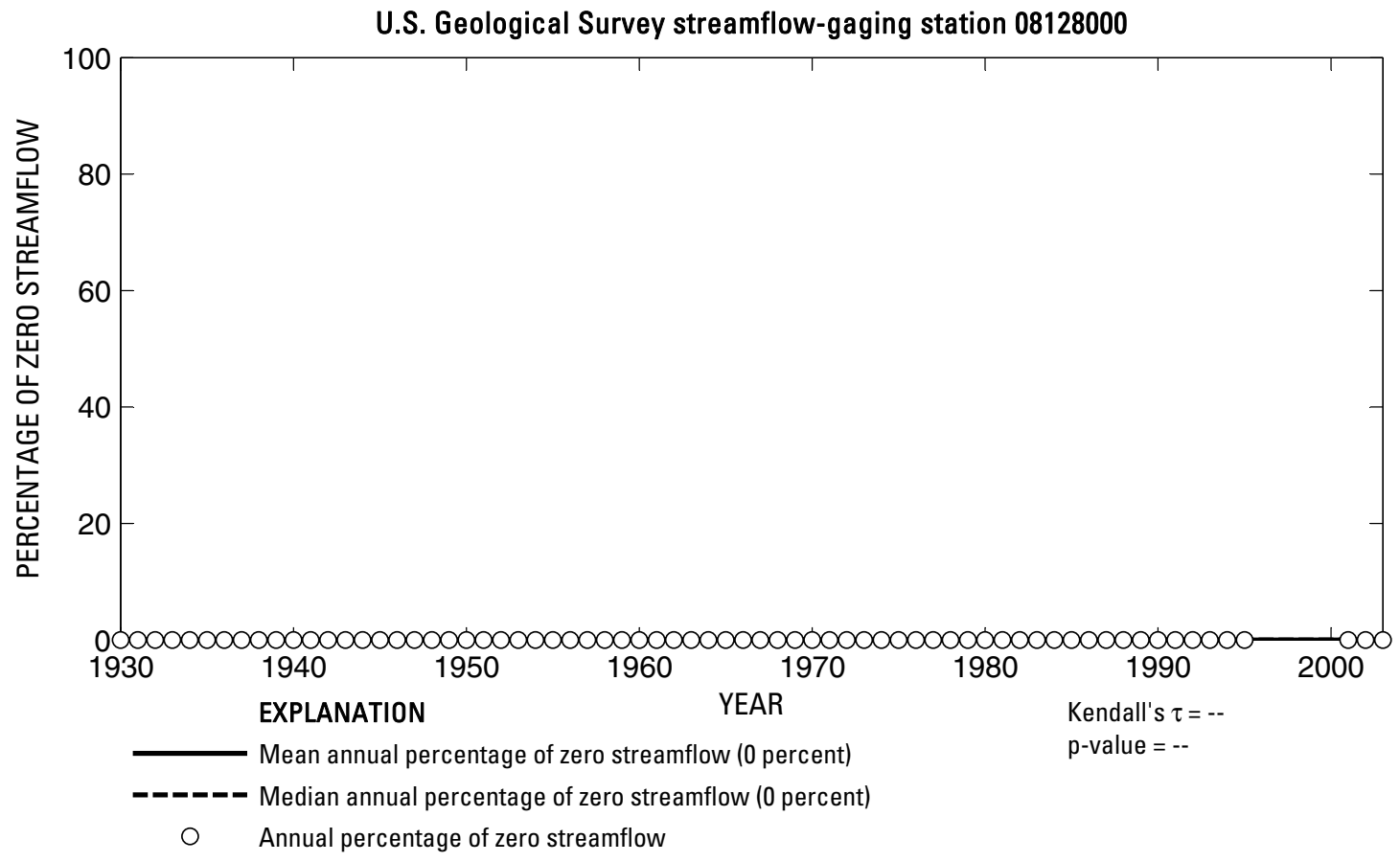

U.S. Geological Survey streamflow-gaging station 08128000

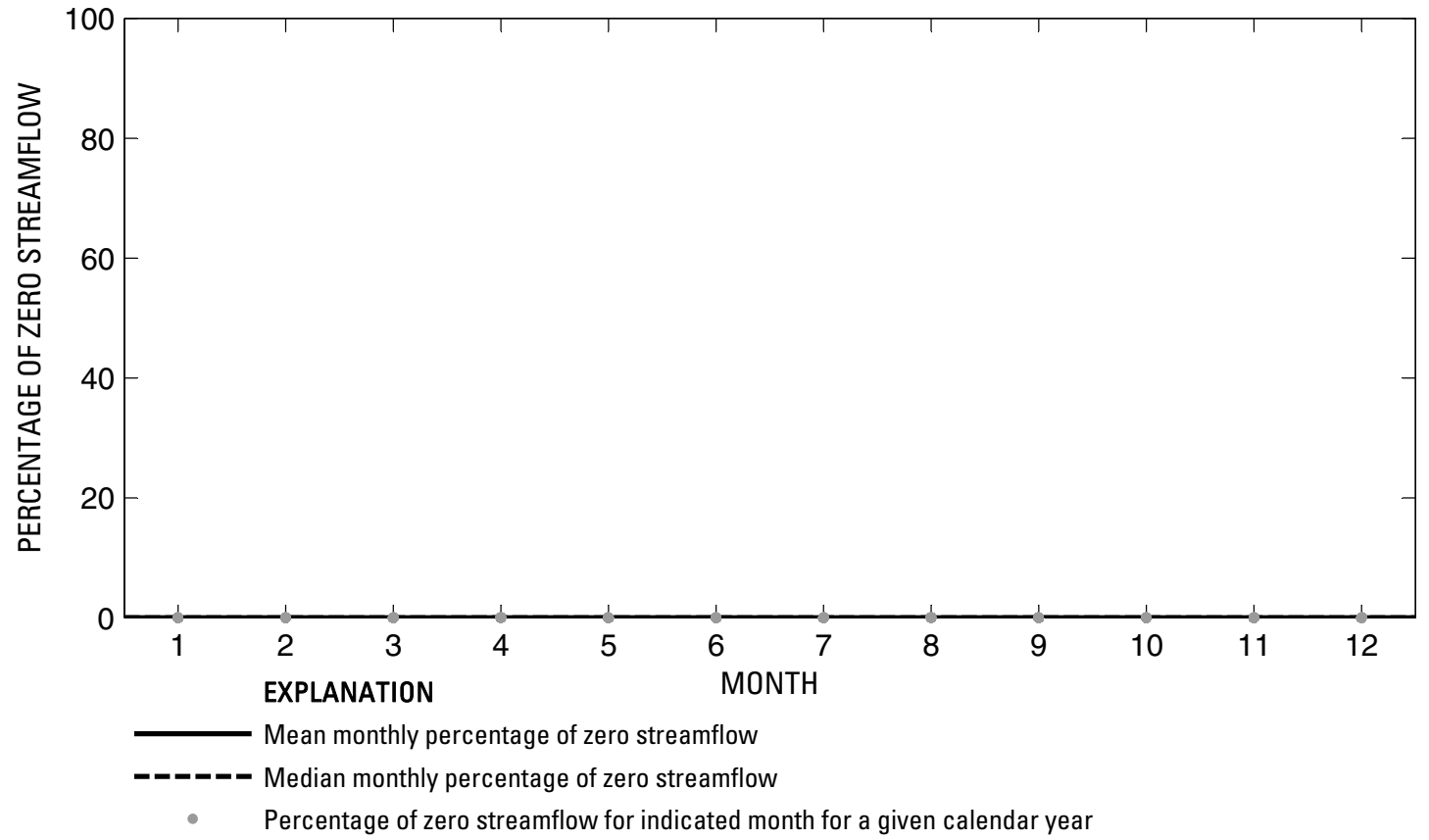

Figure 471. Analysis of percentage of zero daily mean streamflow for U.S. Geological Survey streamflow-gaging station 08128000 South Concho River at Christoval, Texas. 

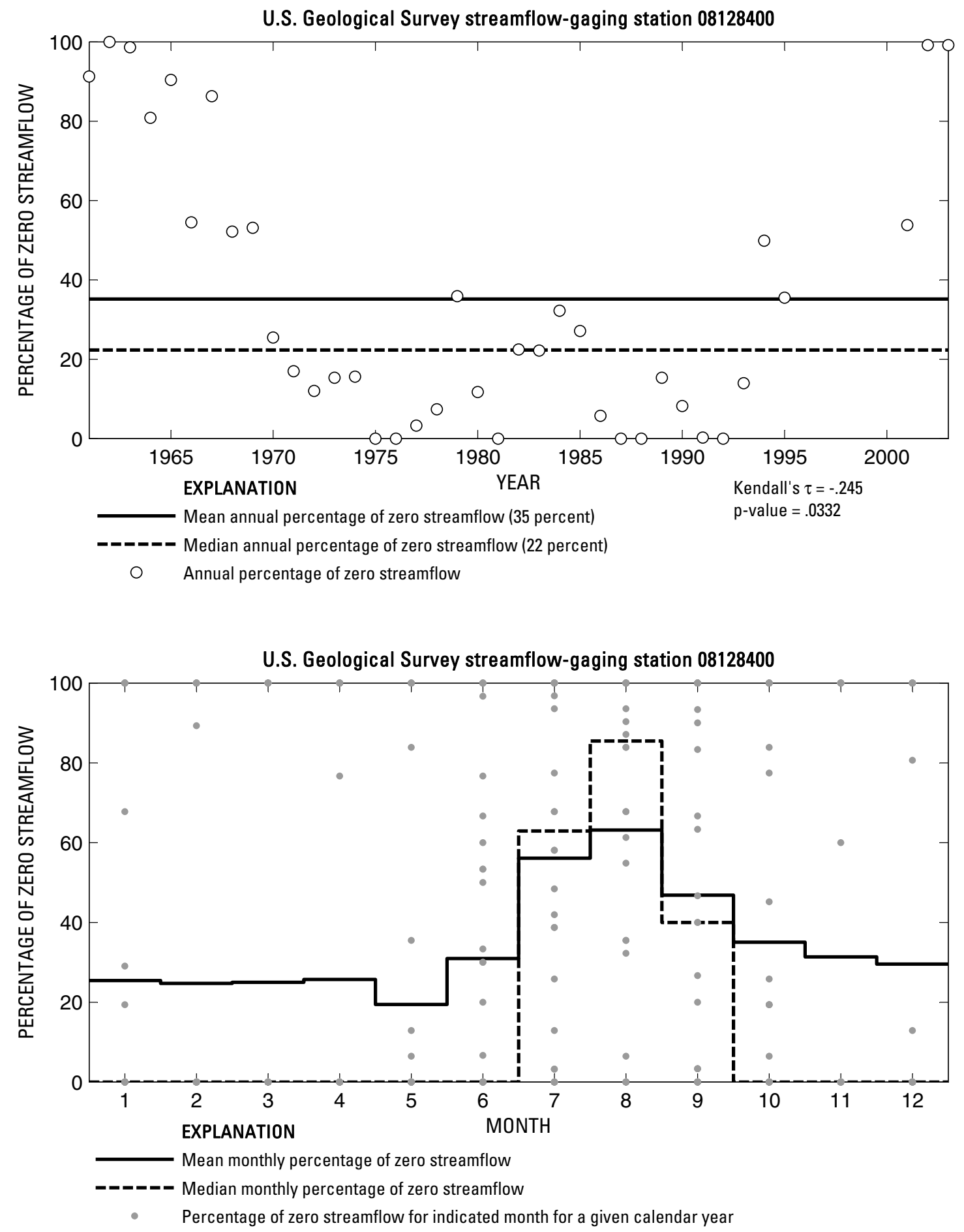

Figure 472. Analysis of percentage of zero daily mean streamflow for U.S. Geological Survey streamflow-gaging station 08128400 Middle Concho River above Tankersley, Texas. 
U.S. Geological Survey streamflow-gaging station 08128500

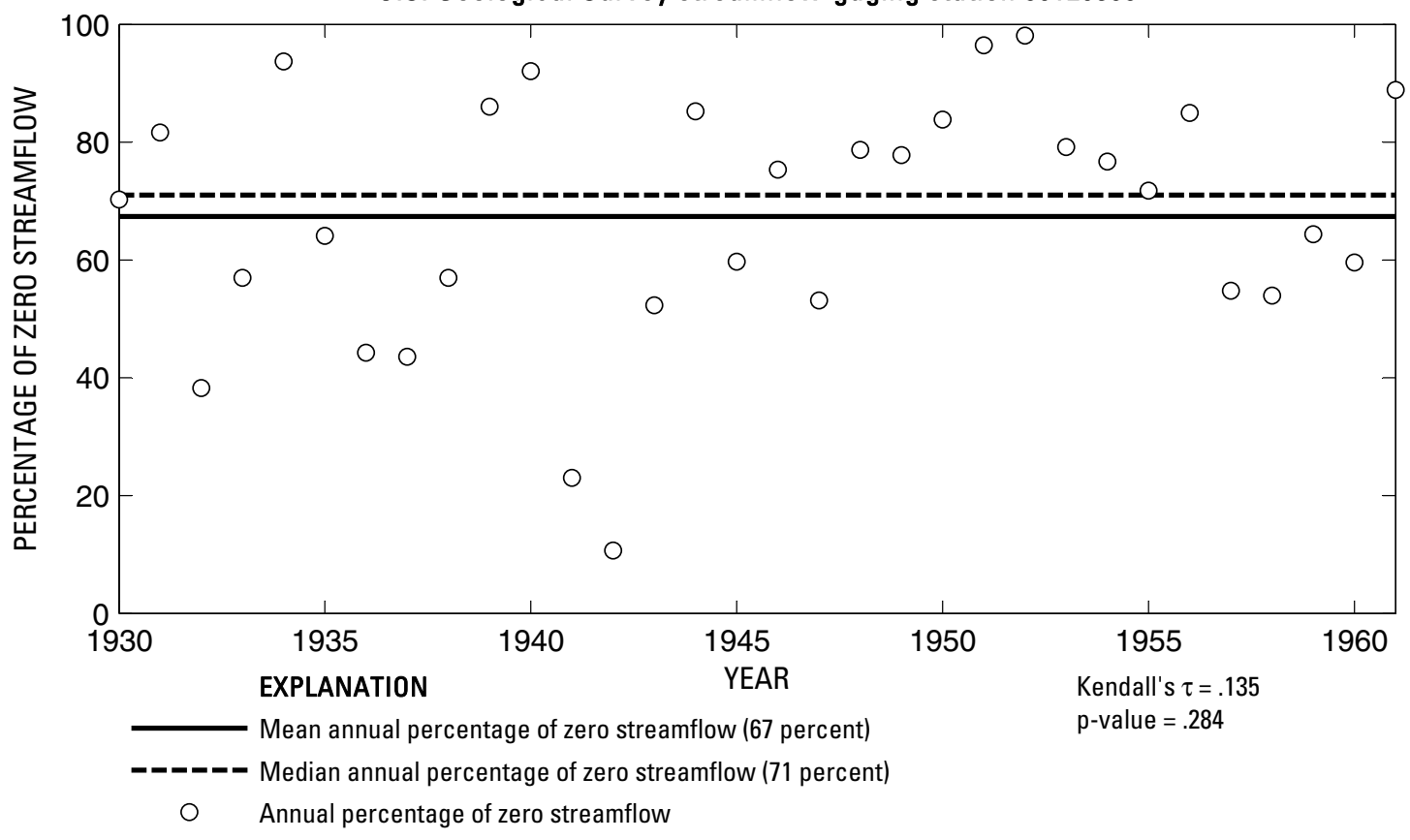

U.S. Geological Survey streamflow-gaging station 08128500

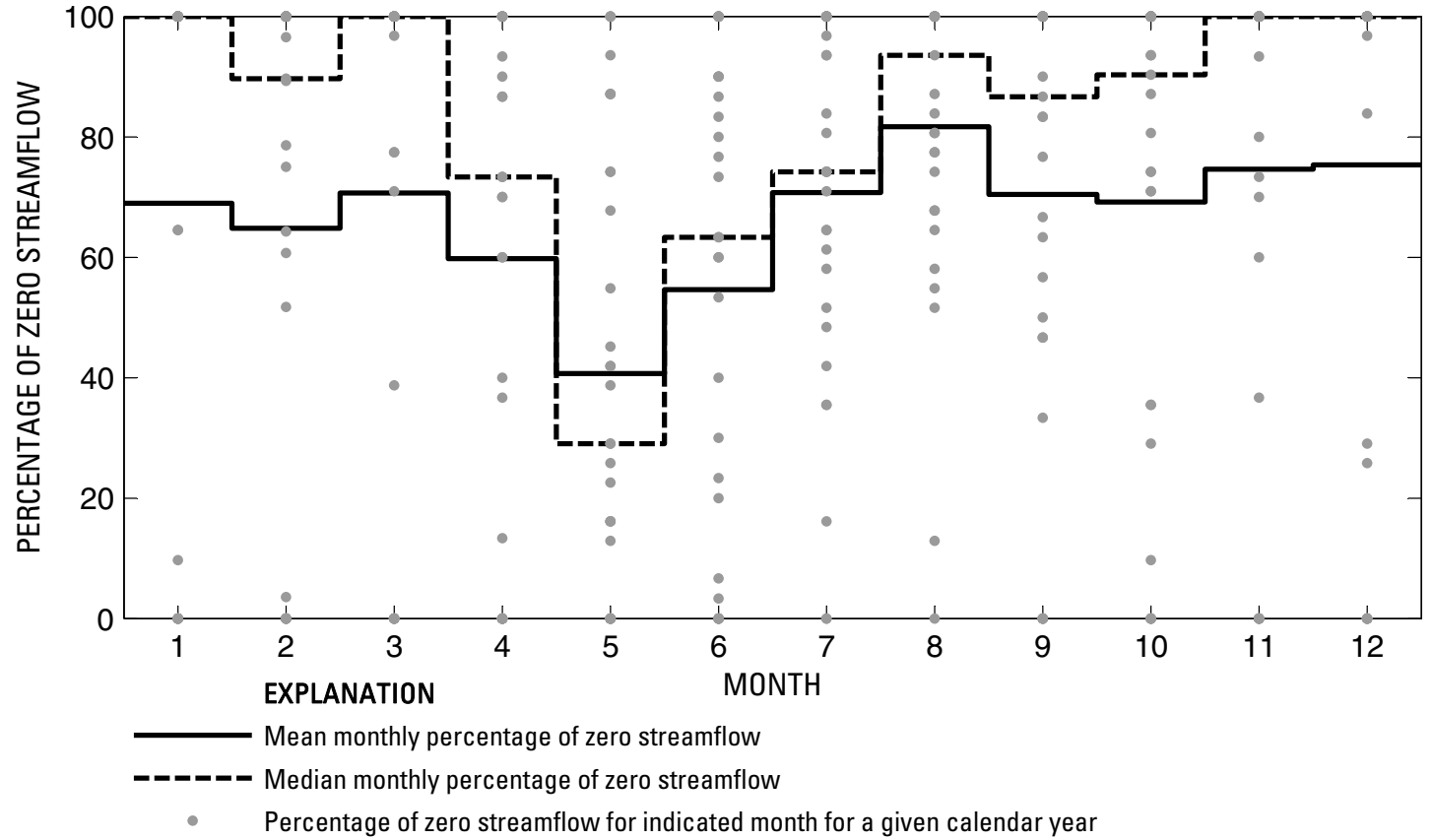

Figure 473. Analysis of percentage of zero daily mean streamflow for U.S. Geological Survey streamflow-gaging station 08128500 Middle Concho River near Tankersley, Texas. 
U.S. Geological Survey streamflow-gaging station 08129300

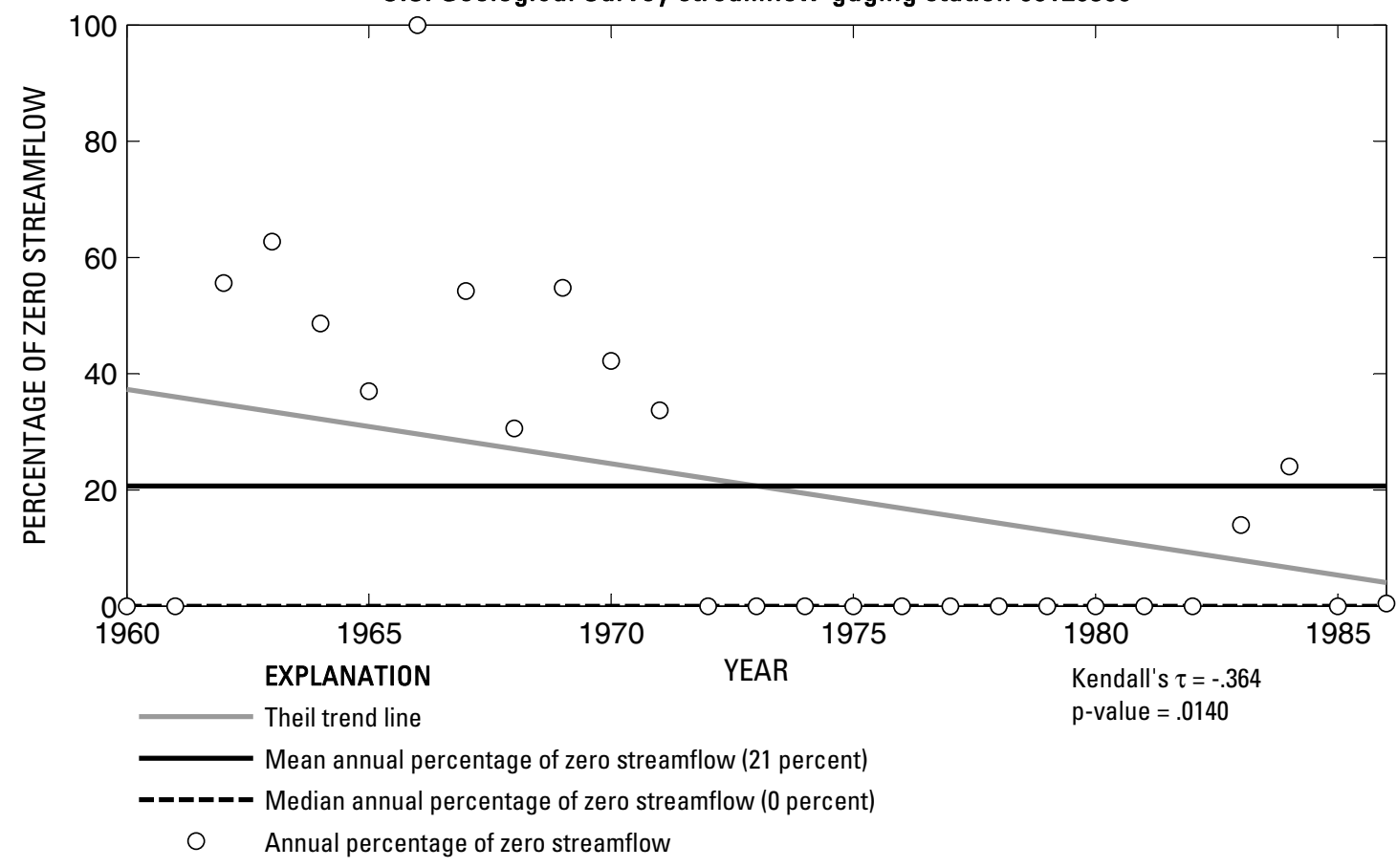

U.S. Geological Survey streamflow-gaging station 08129300

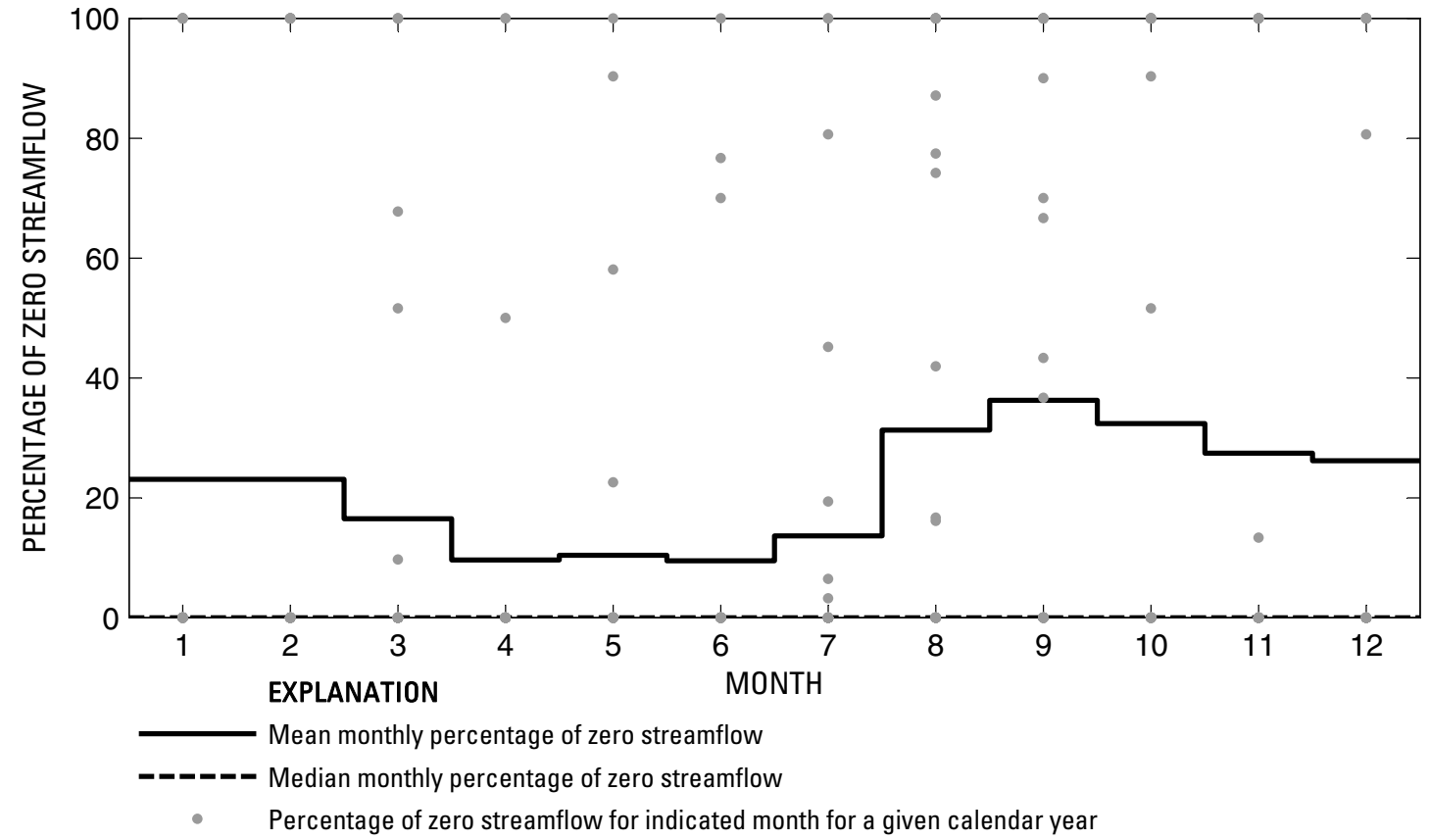

Figure 474. Analysis of percentage of zero daily mean streamflow for U.S. Geological Survey streamflow-gaging station 08129300 Spring Creek above Tankersley, Texas. 


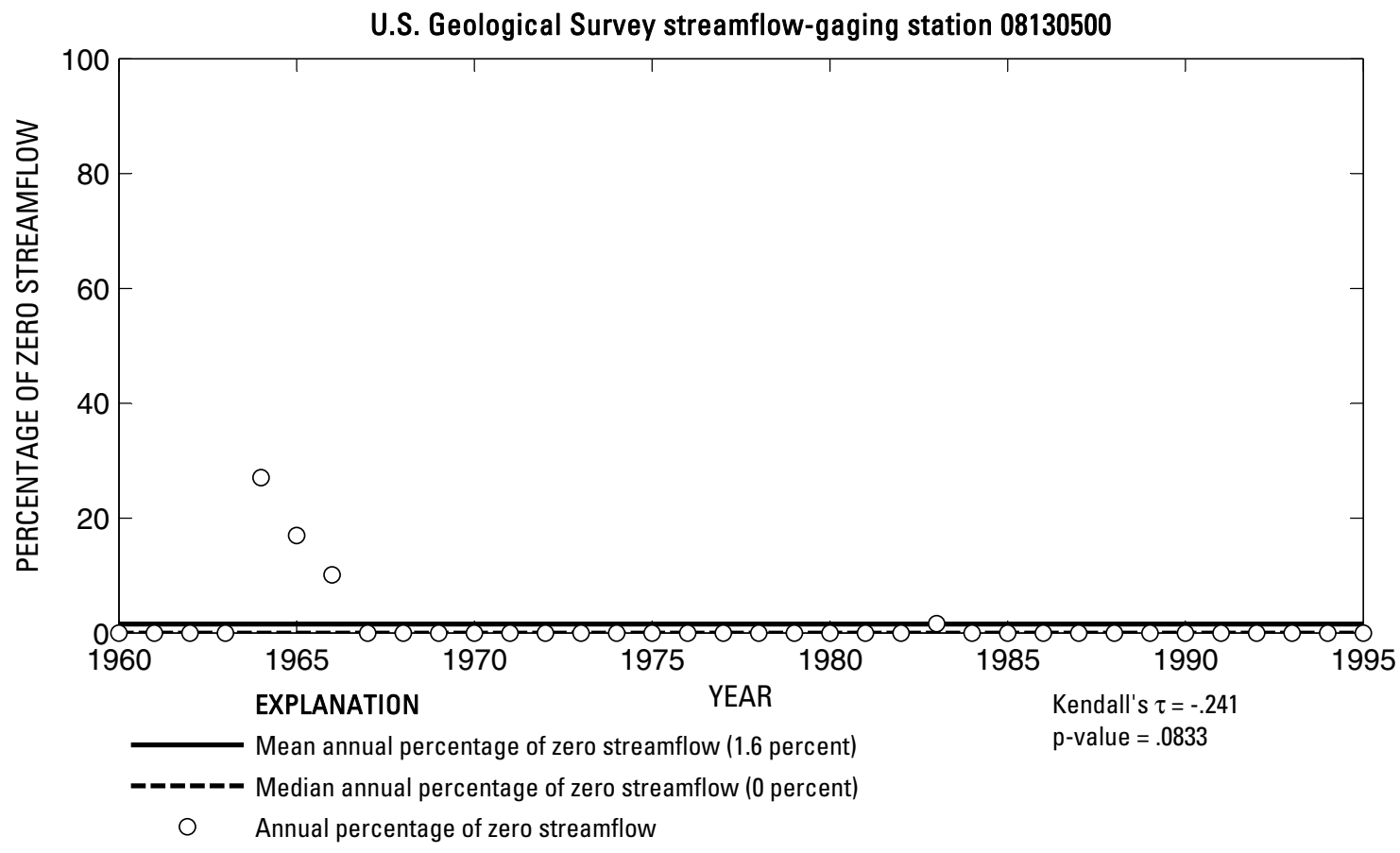

U.S. Geological Survey streamflow-gaging station 08130500

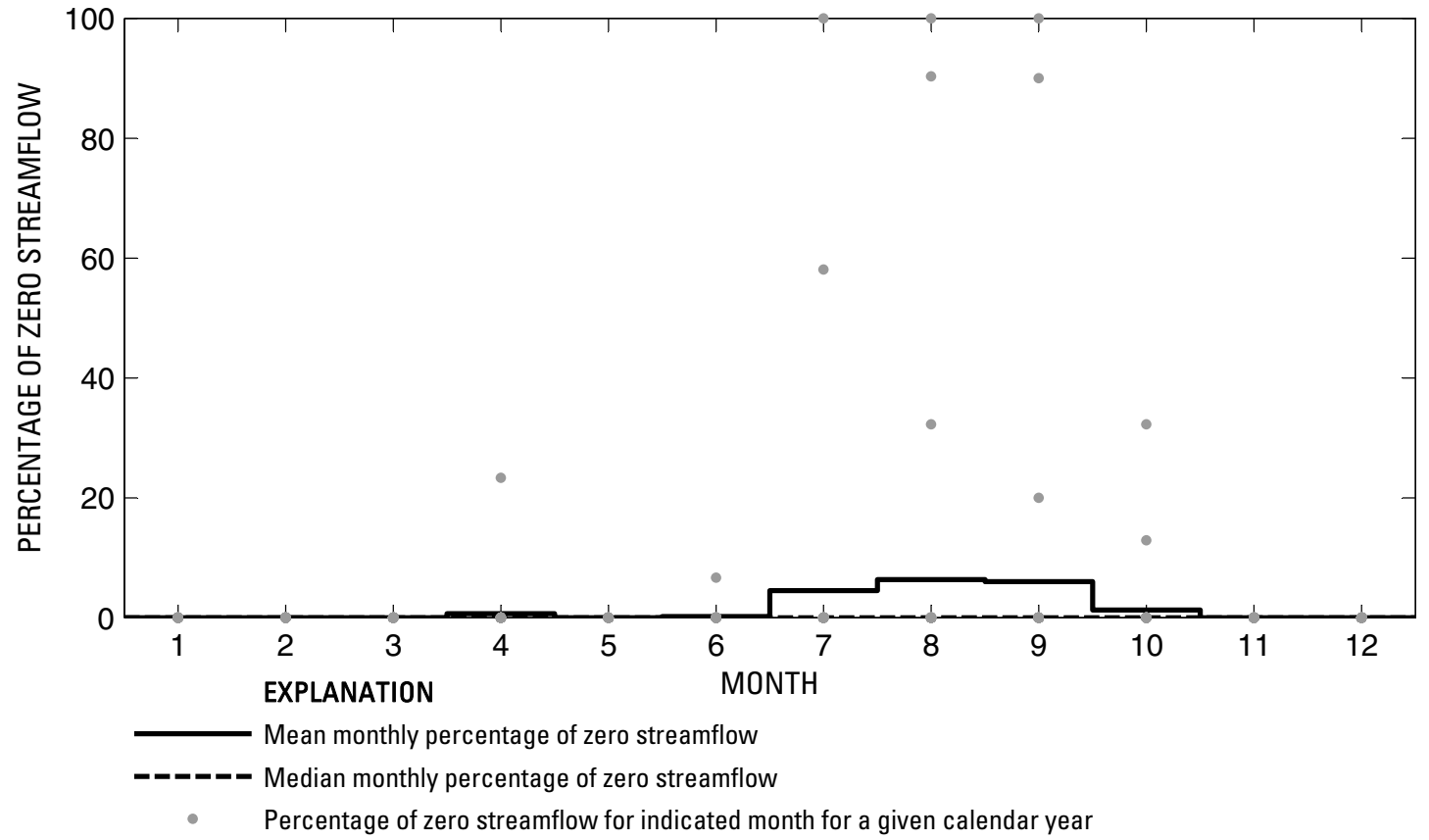

Figure 475. Analysis of percentage of zero daily mean streamflow for U.S. Geological Survey streamflow-gaging station 08130500 Dove Creek at Knickerbocker, Texas. 
U.S. Geological Survey streamflow-gaging station 08130700

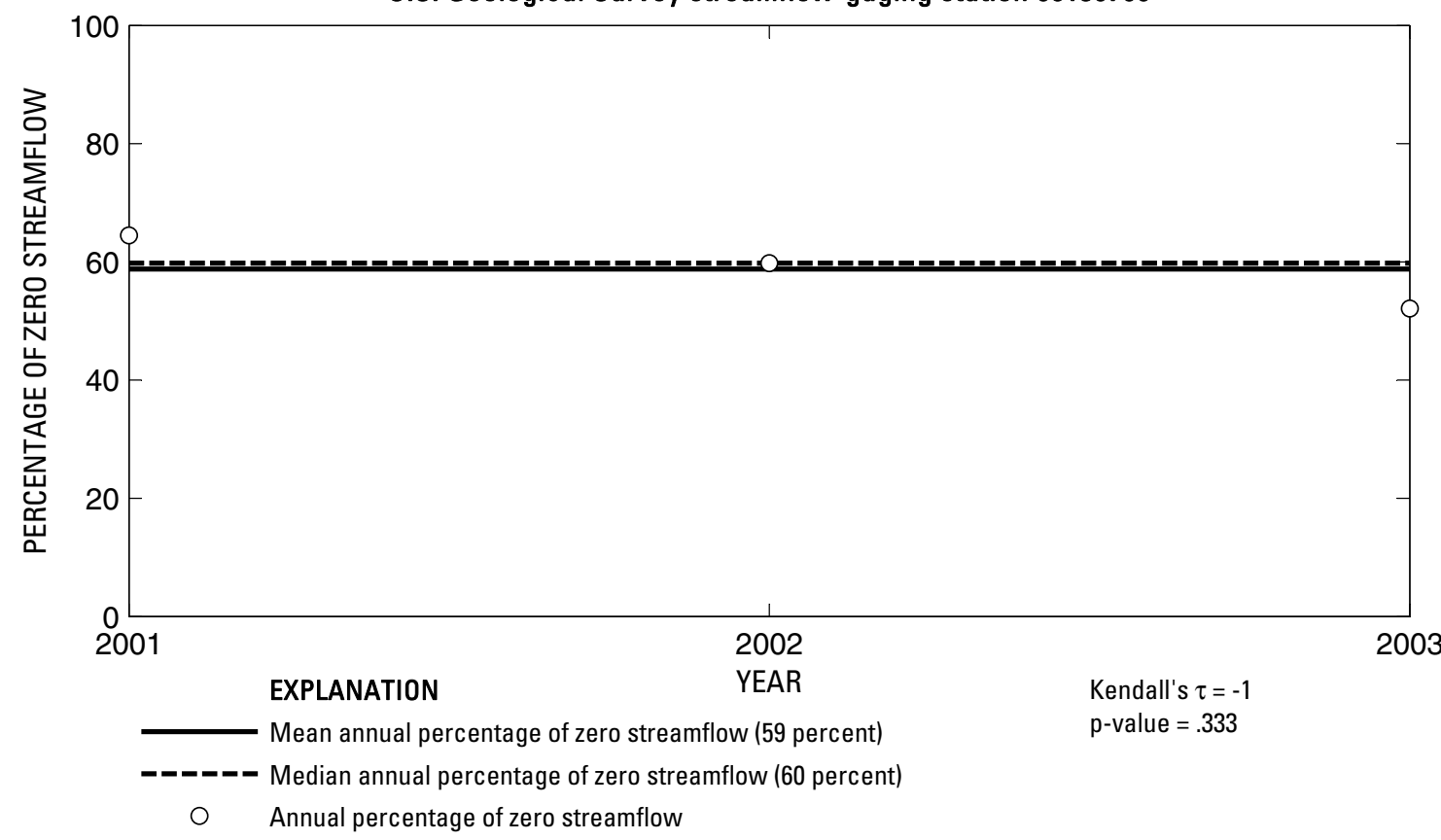

U.S. Geological Survey streamflow-gaging station 08130700

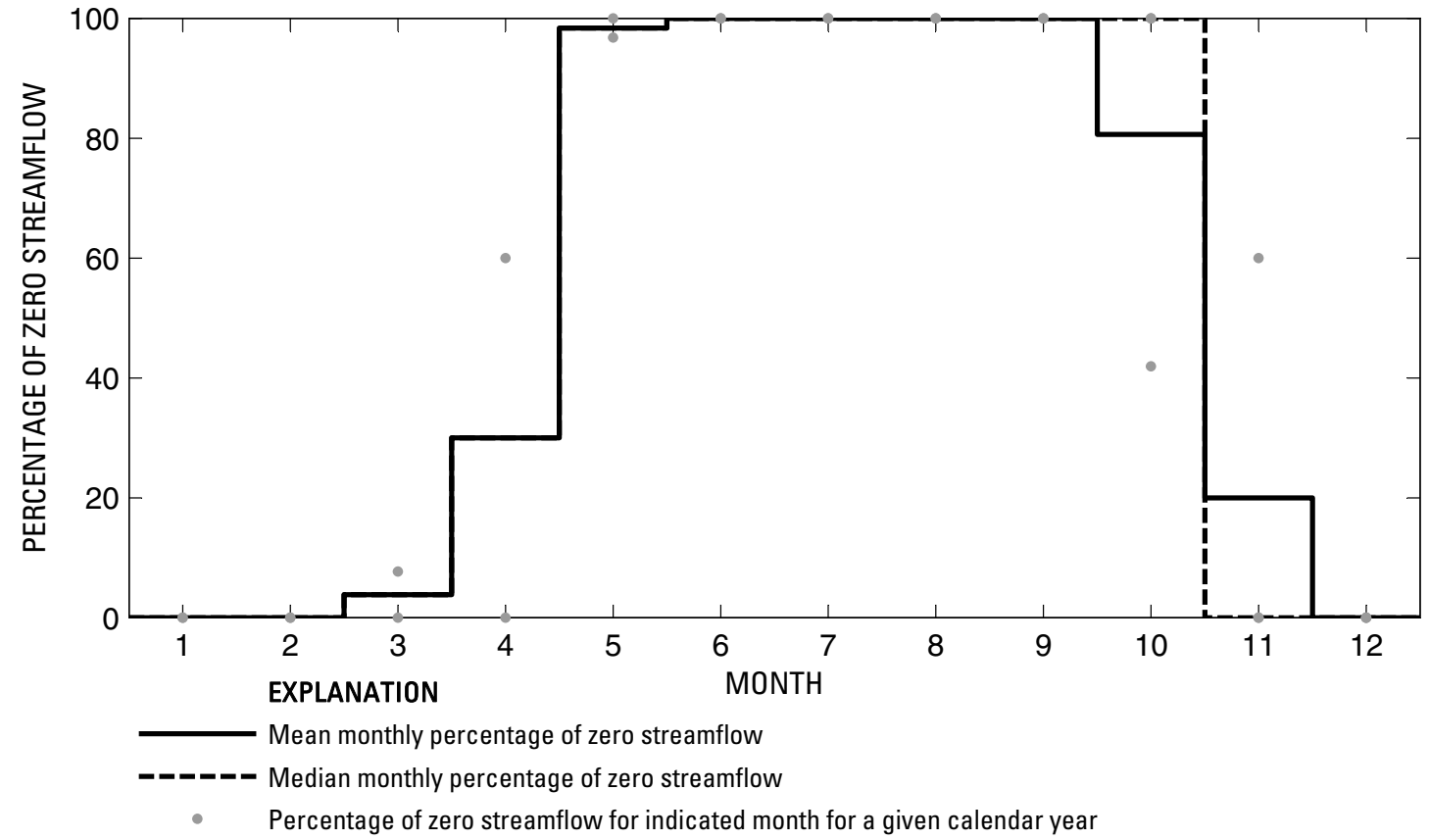

Figure 476. Analysis of percentage of zero daily mean streamflow for U.S. Geological Survey streamflow-gaging station 08130700 Spring Creek above Twin Buttes Reservoir near San Angelo, Texas.

Index of Station Numbers 719 

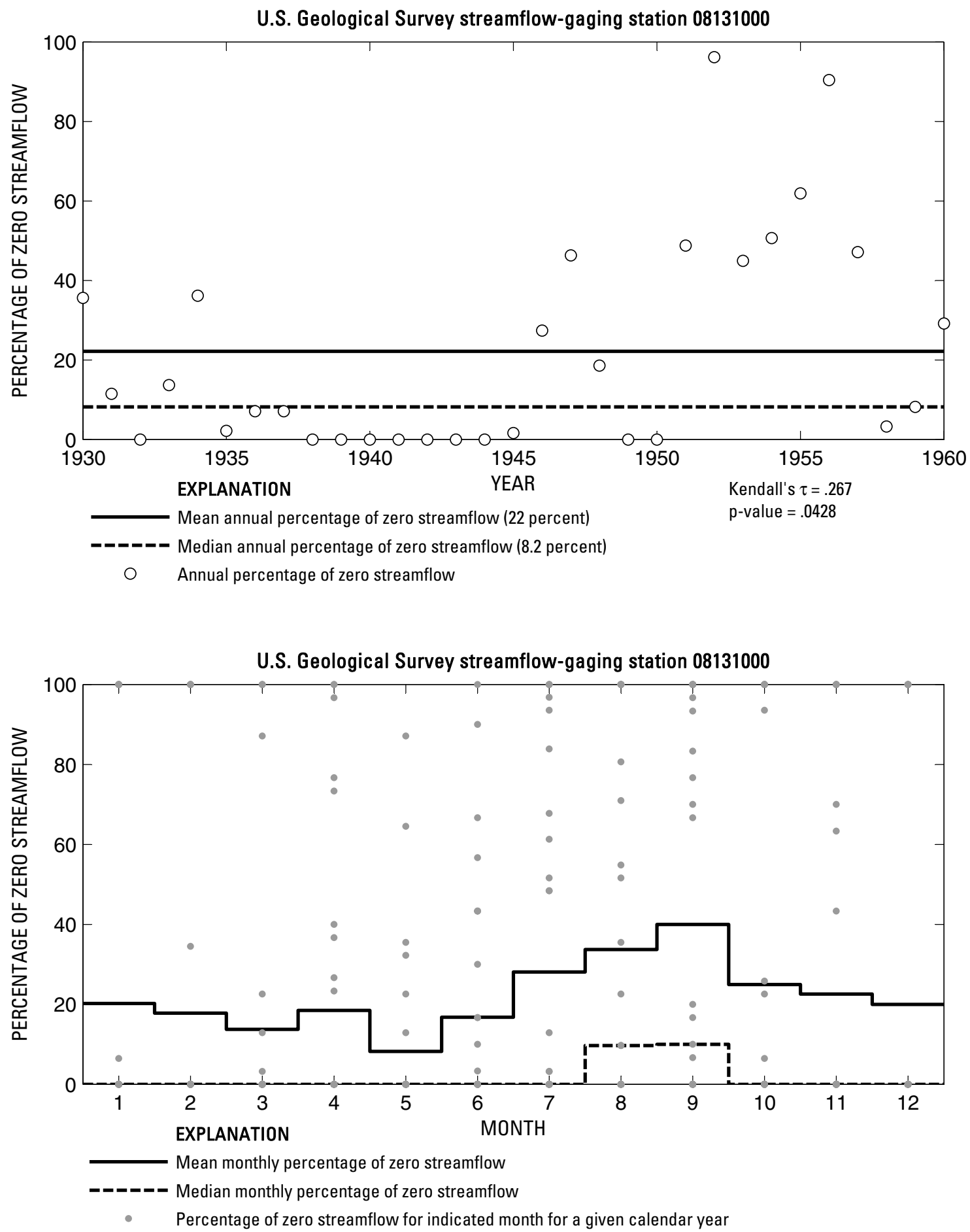

Figure 477. Analysis of percentage of zero daily mean streamflow for U.S. Geological Survey streamflow-gaging station 08131000 Spring Creek near Tankersley, Texas. 
U.S. Geological Survey streamflow-gaging station 08131400

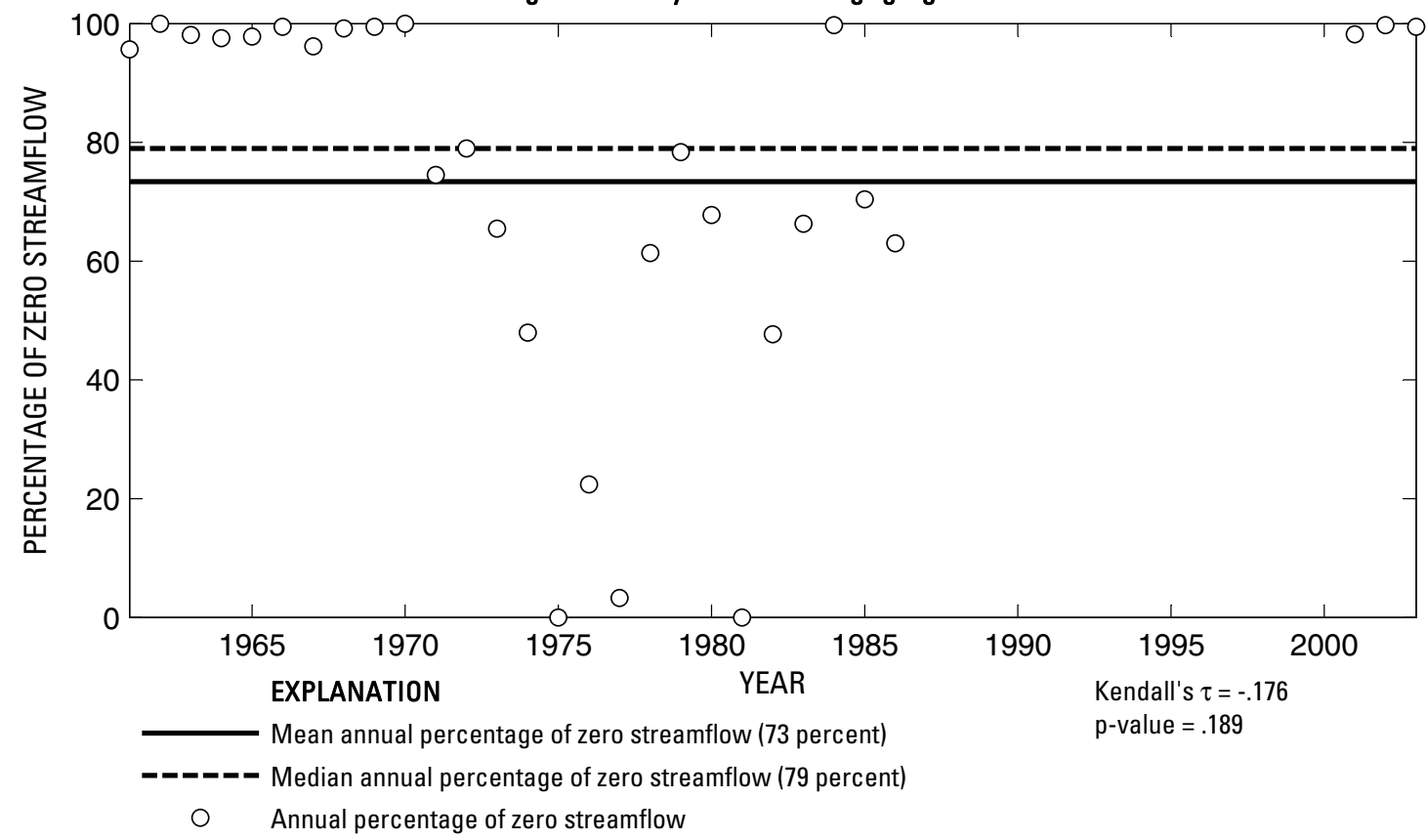

U.S. Geological Survey streamflow-gaging station 08131400

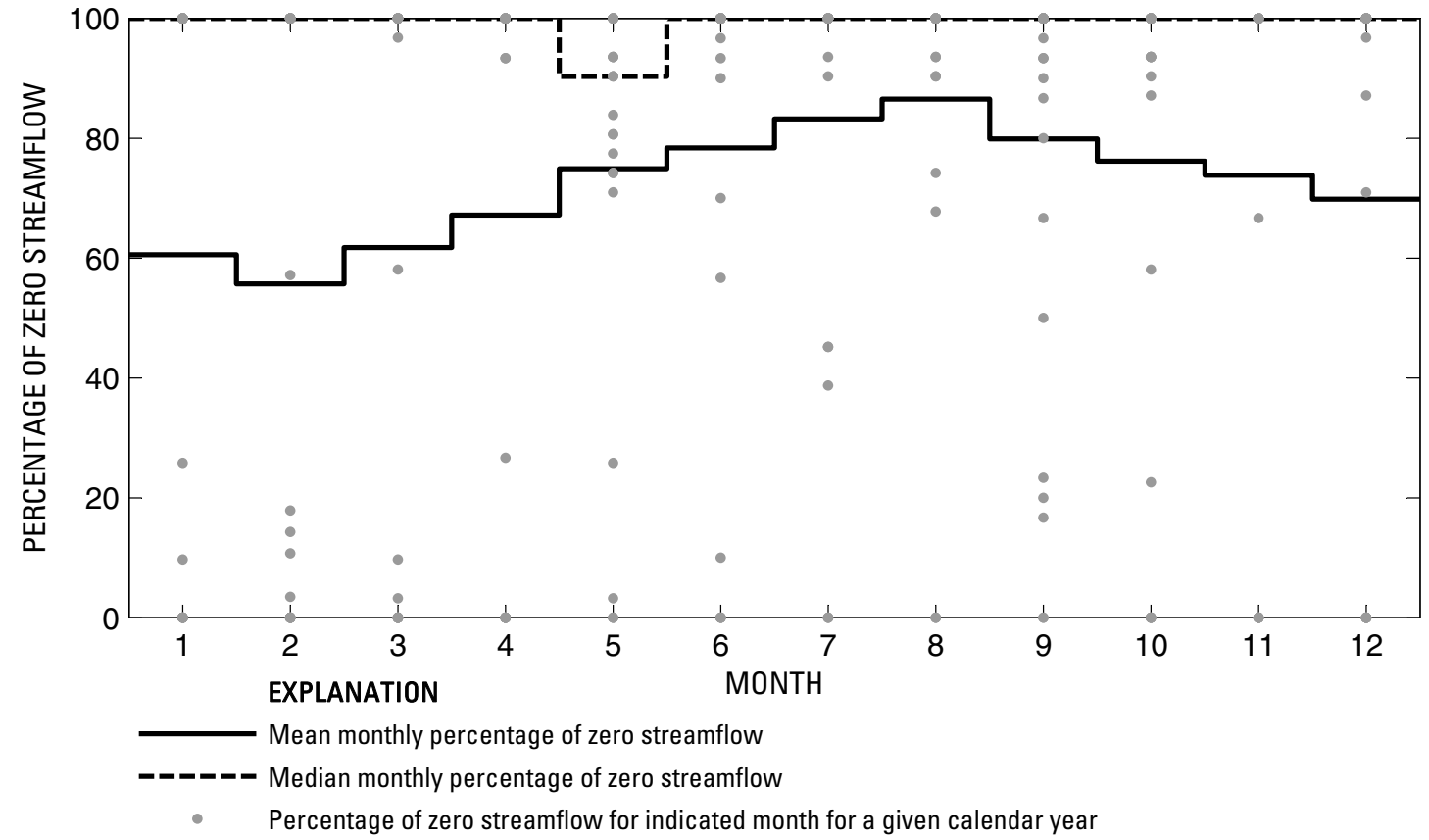

Figure 478. Analysis of percentage of zero daily mean streamflow for U.S. Geological Survey streamflow-gaging station 08131400 Pecan Creek near San Angelo, Texas.

Index of Station Numbers 719 


\section{U.S. Geological Survey streamflow-gaging station 08132500}

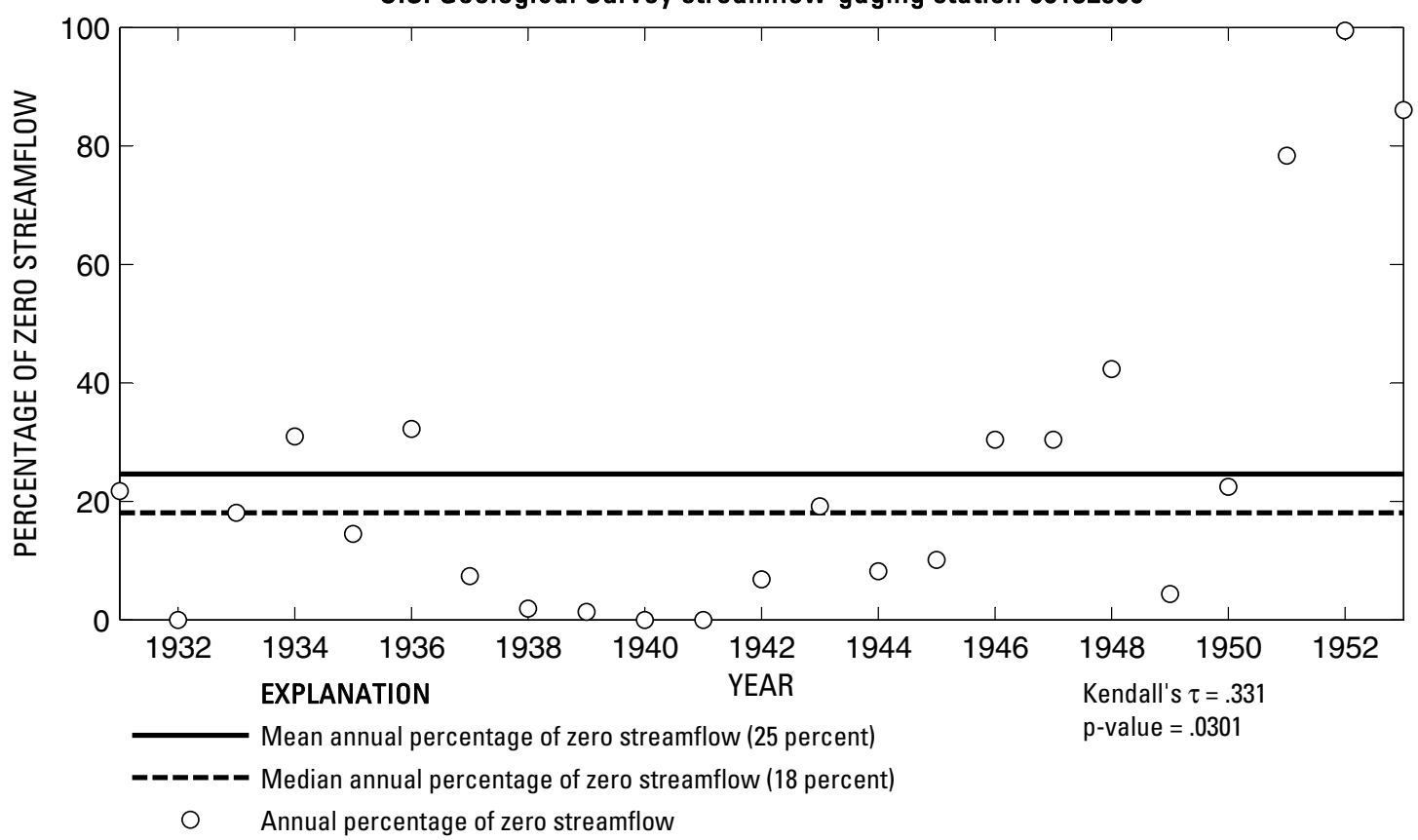

U.S. Geological Survey streamflow-gaging station 08132500

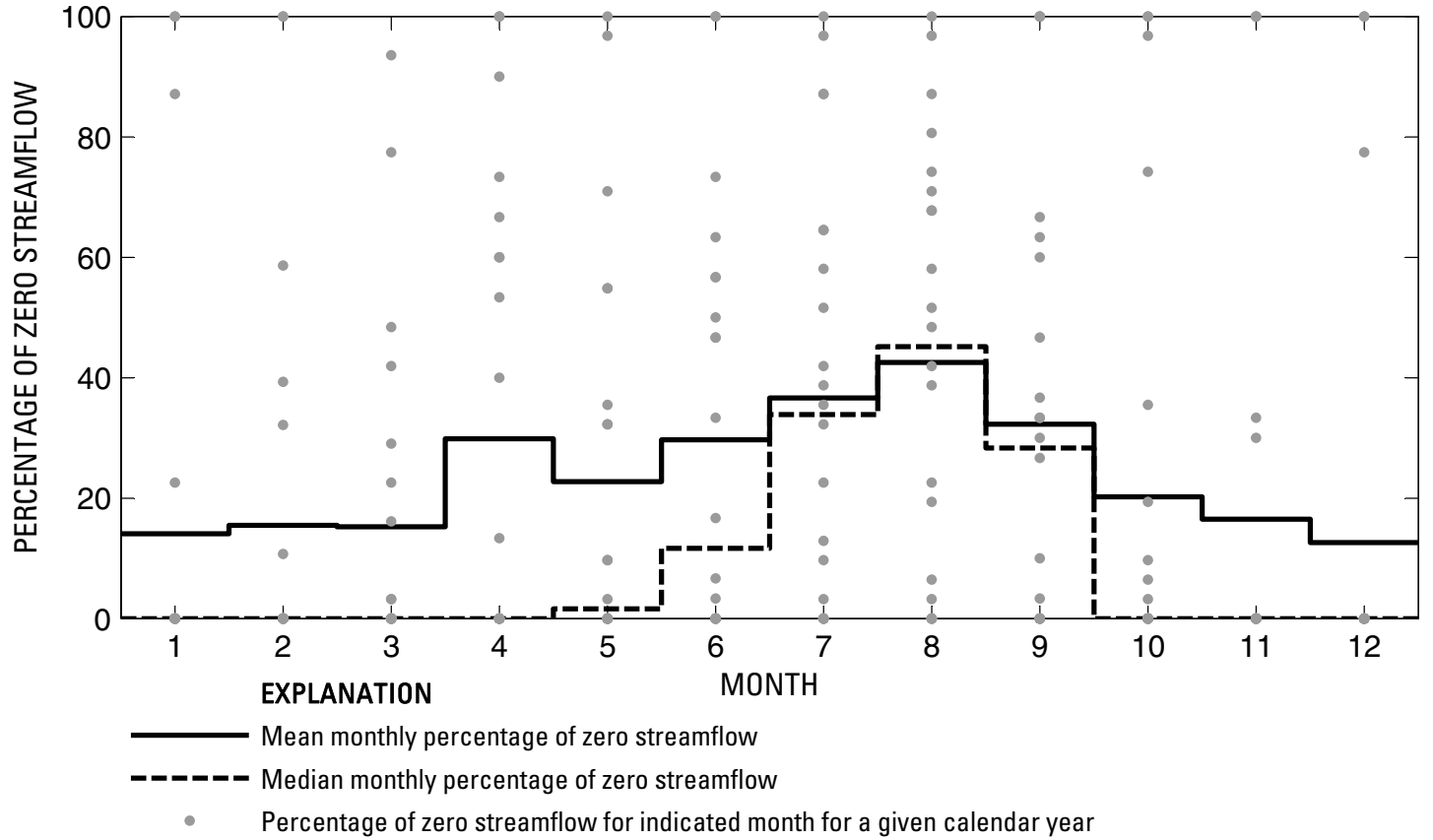

Figure 479. Analysis of percentage of zero daily mean streamflow for U.S. Geological Survey streamflow-gaging station 08132500 South Concho River at San Angelo, Texas. 
U.S. Geological Survey streamflow-gaging station 08133250

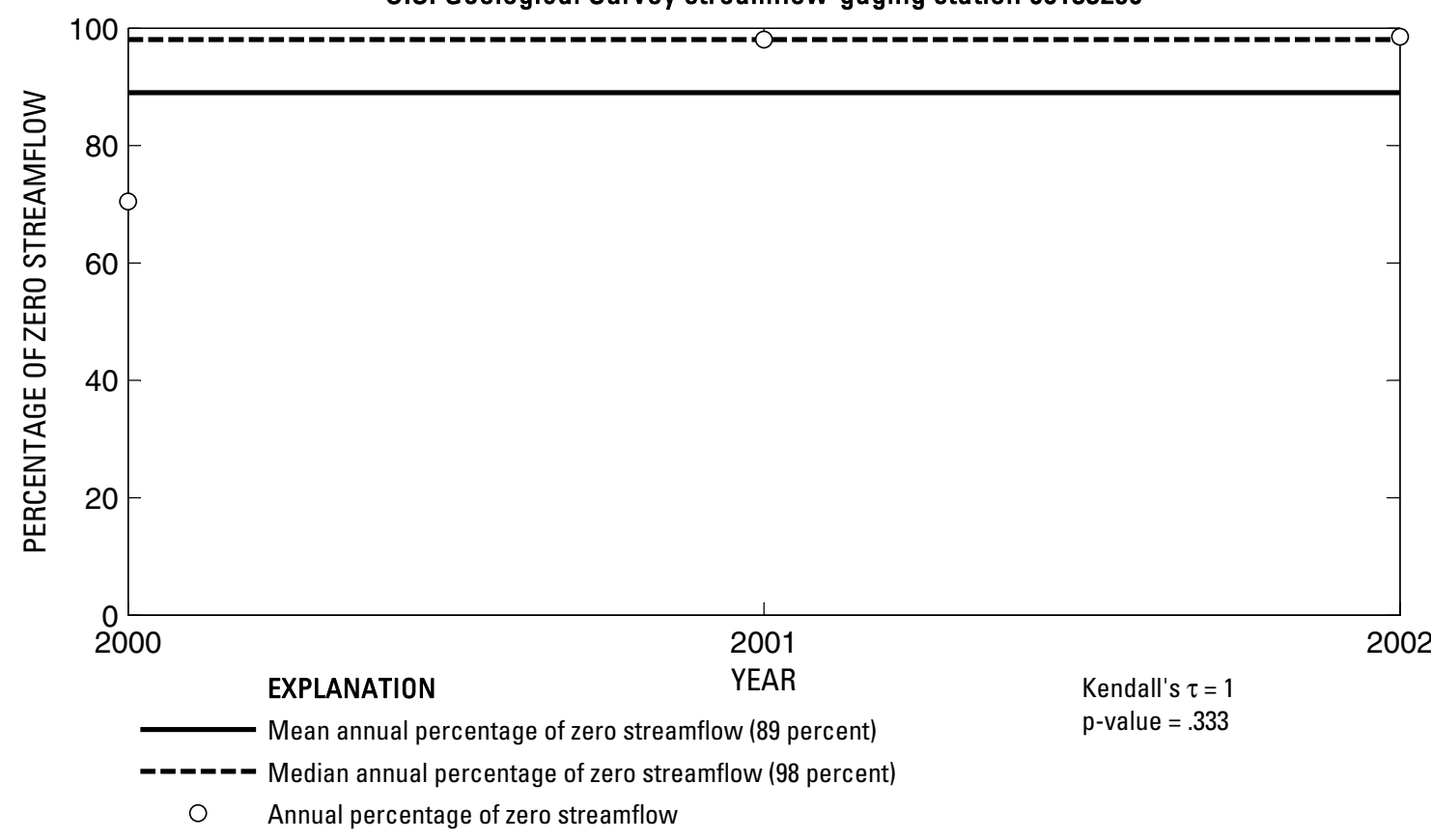

U.S. Geological Survey streamflow-gaging station 08133250

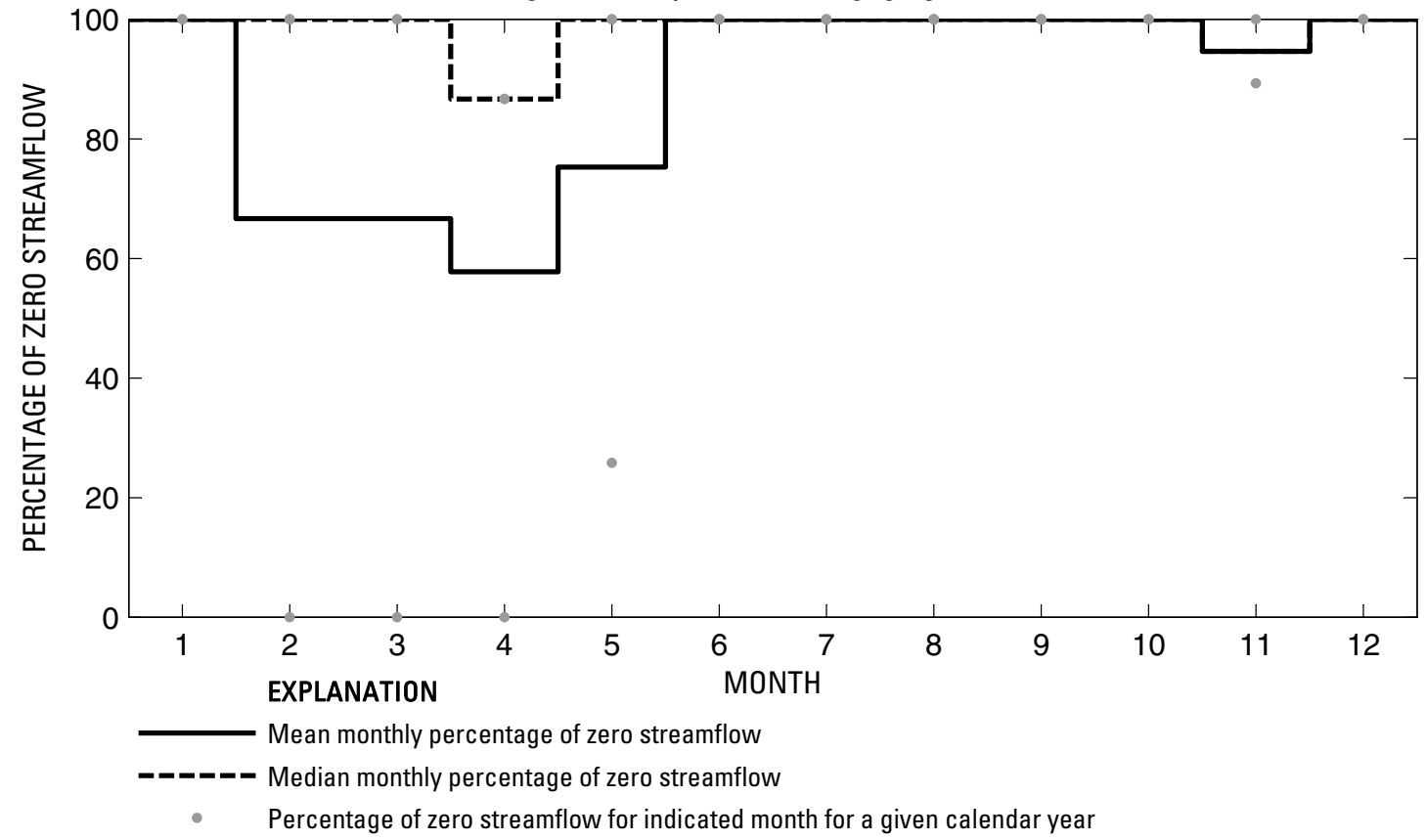

Figure 480. Analysis of percentage of zero daily mean streamflow for U.S. Geological Survey streamflow-gaging station 08133250 North Concho River above Sterling City, Texas. 
U.S. Geological Survey streamflow-gaging station 08133500

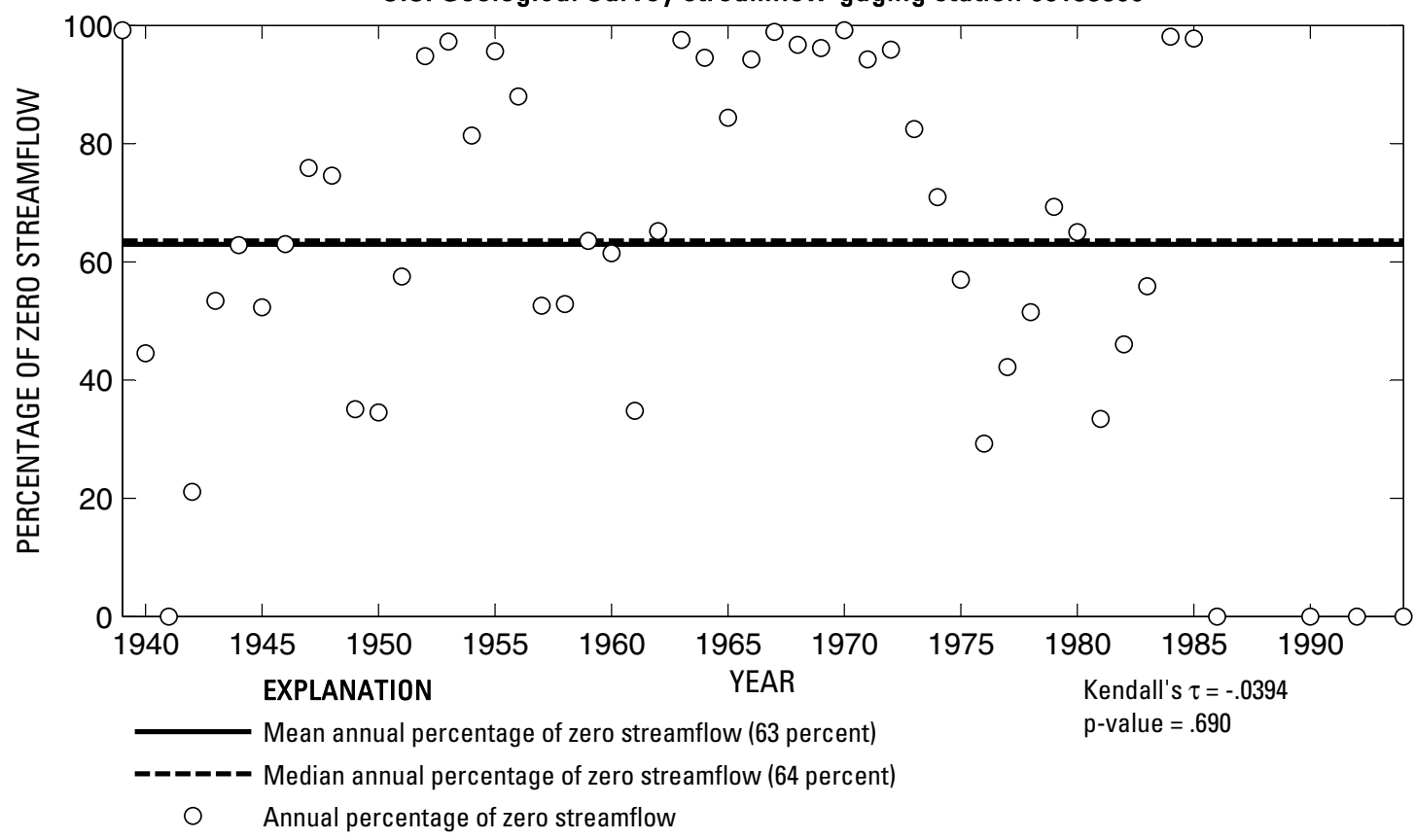

U.S. Geological Survey streamflow-gaging station 08133500

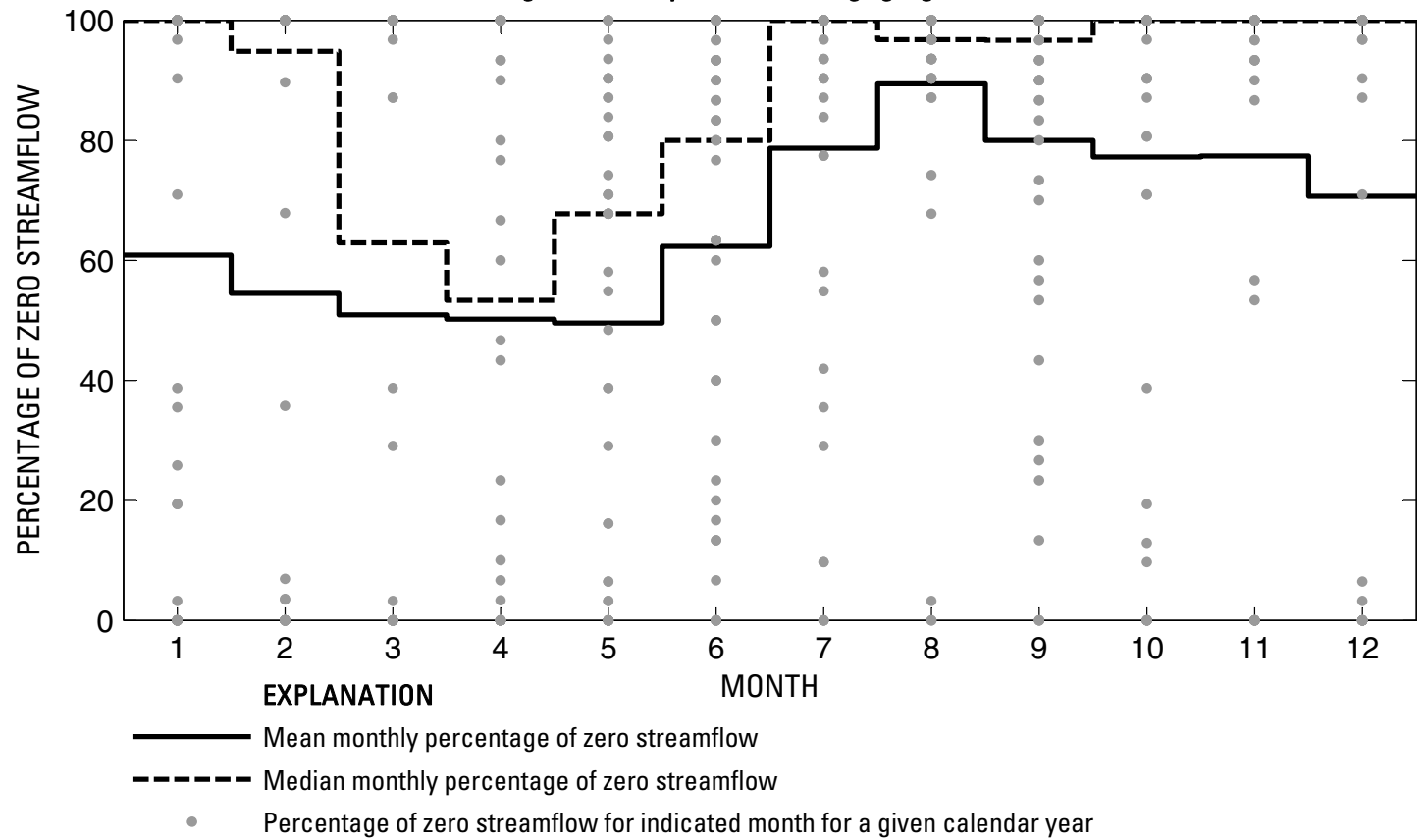

Figure 481. Analysis of percentage of zero daily mean streamflow for U.S. Geological Survey streamflow-gaging station 08133500 North Concho River at Sterling City, Texas. 

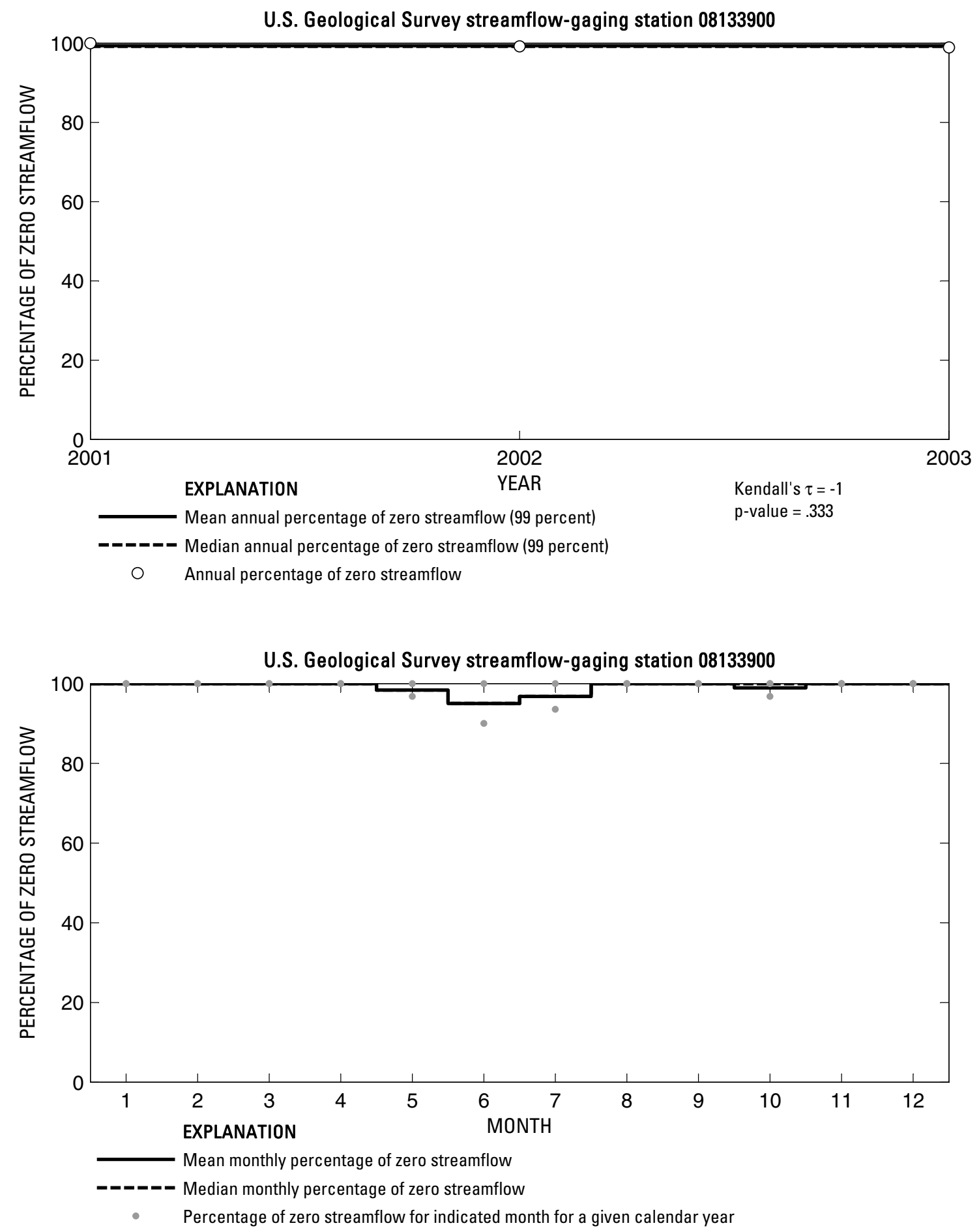

Figure 482. Analysis of percentage of zero daily mean streamflow for U.S. Geological Survey streamflow-gaging station 08133900 Chalk Creek near Water Valley, Texas. 
U.S. Geological Survey streamflow-gaging station 08134000

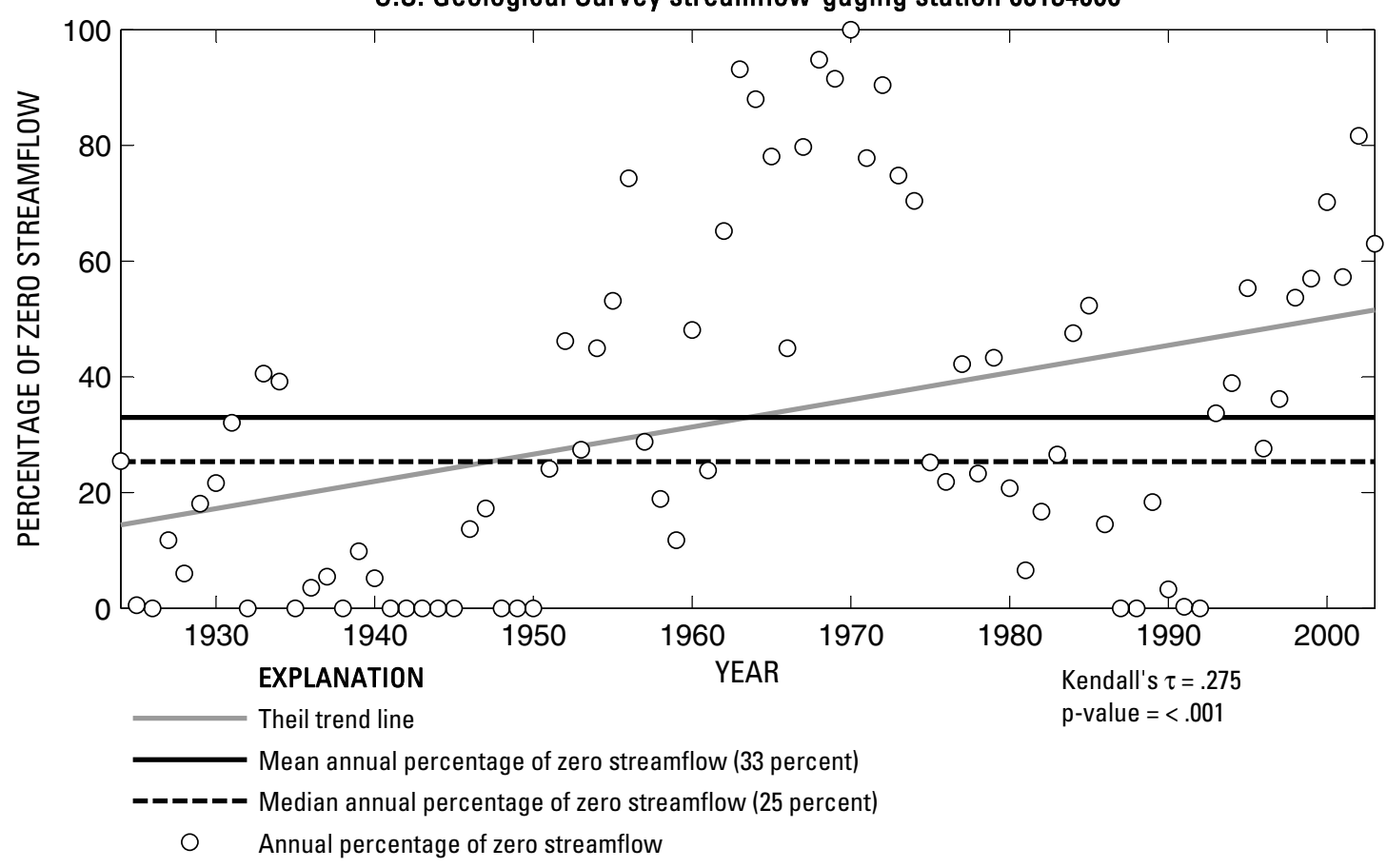

U.S. Geological Survey streamflow-gaging station 08134000

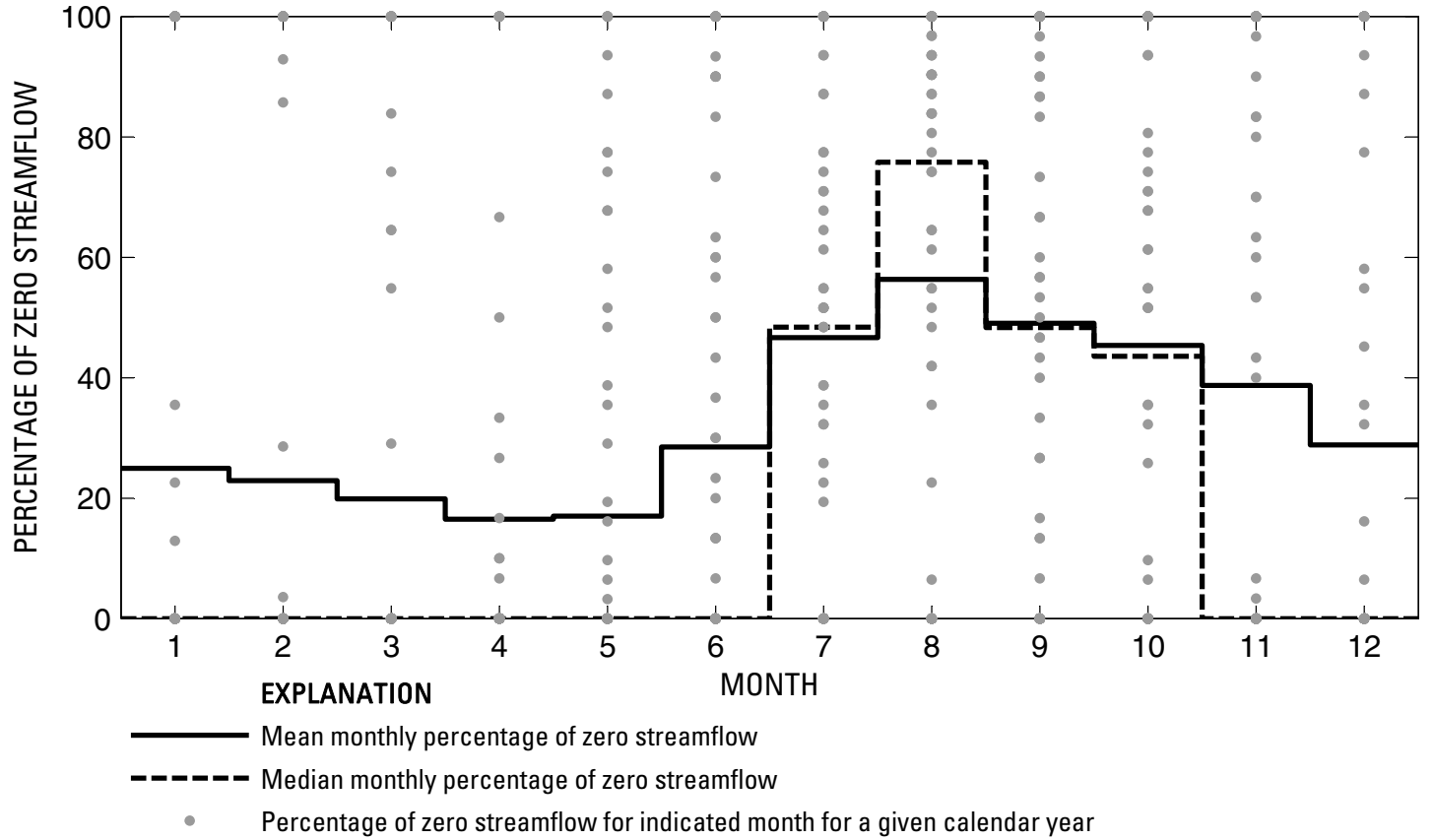

Figure 483. Analysis of percentage of zero daily mean streamflow for U.S. Geological Survey streamflow-gaging station 08134000 North Concho River near Carlsbad, Texas. 
U.S. Geological Survey streamflow-gaging station 08134230

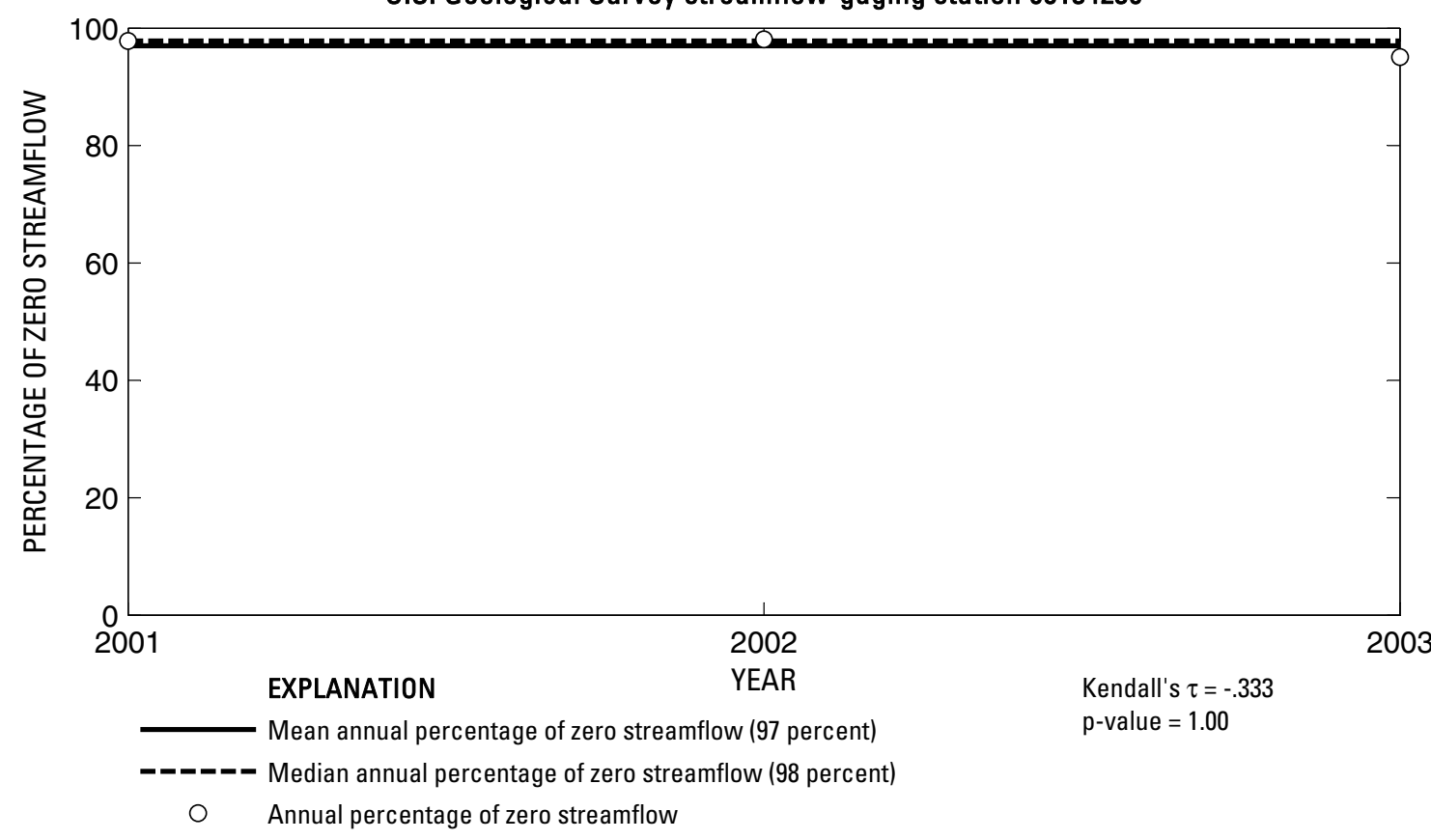

U.S. Geological Survey streamflow-gaging station 08134230

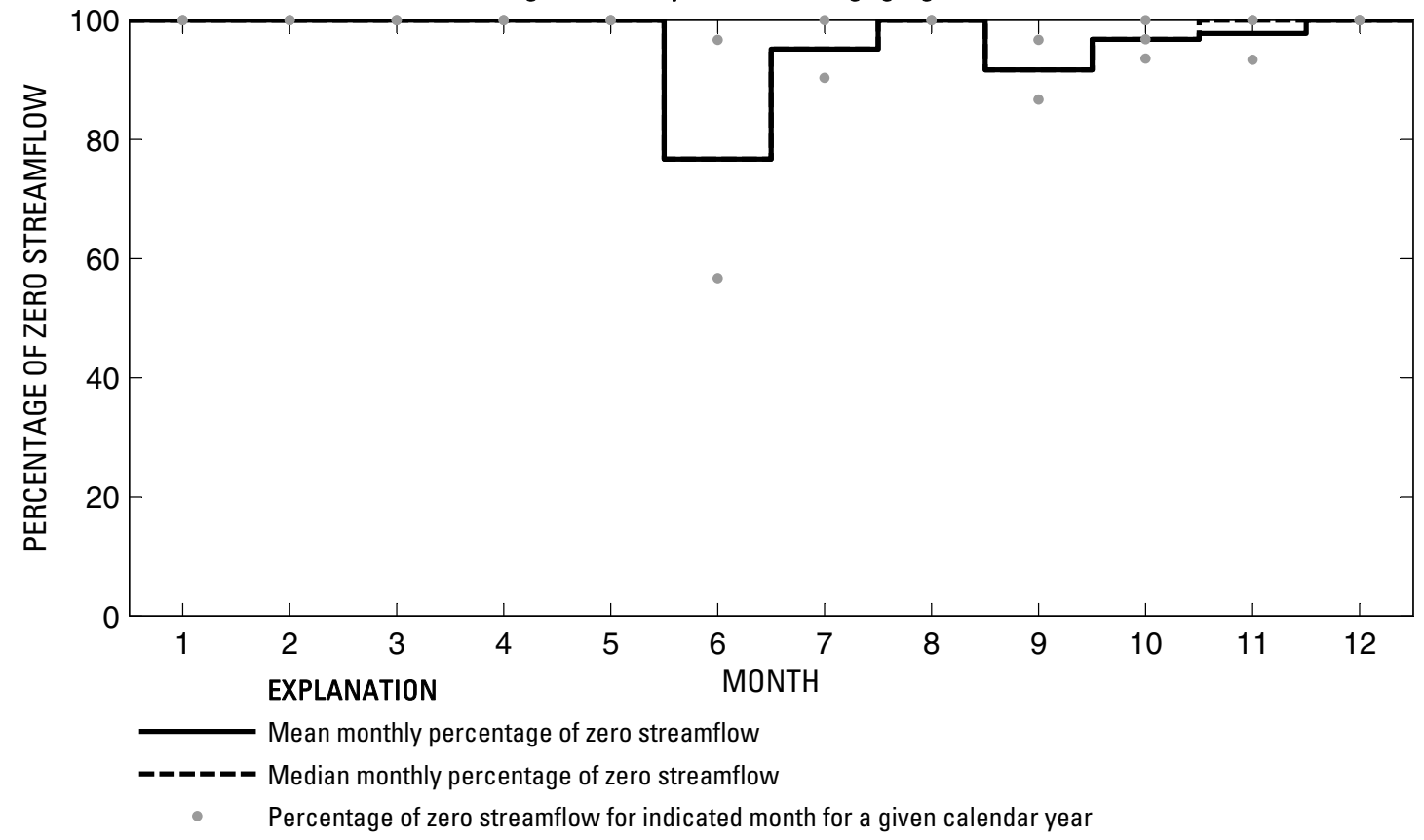

Figure 484. Analysis of percentage of zero daily mean streamflow for U.S. Geological Survey streamflow-gaging station 08134230 Grape Creek near Grape Creek, Texas. 
U.S. Geological Survey streamflow-gaging station 08134250

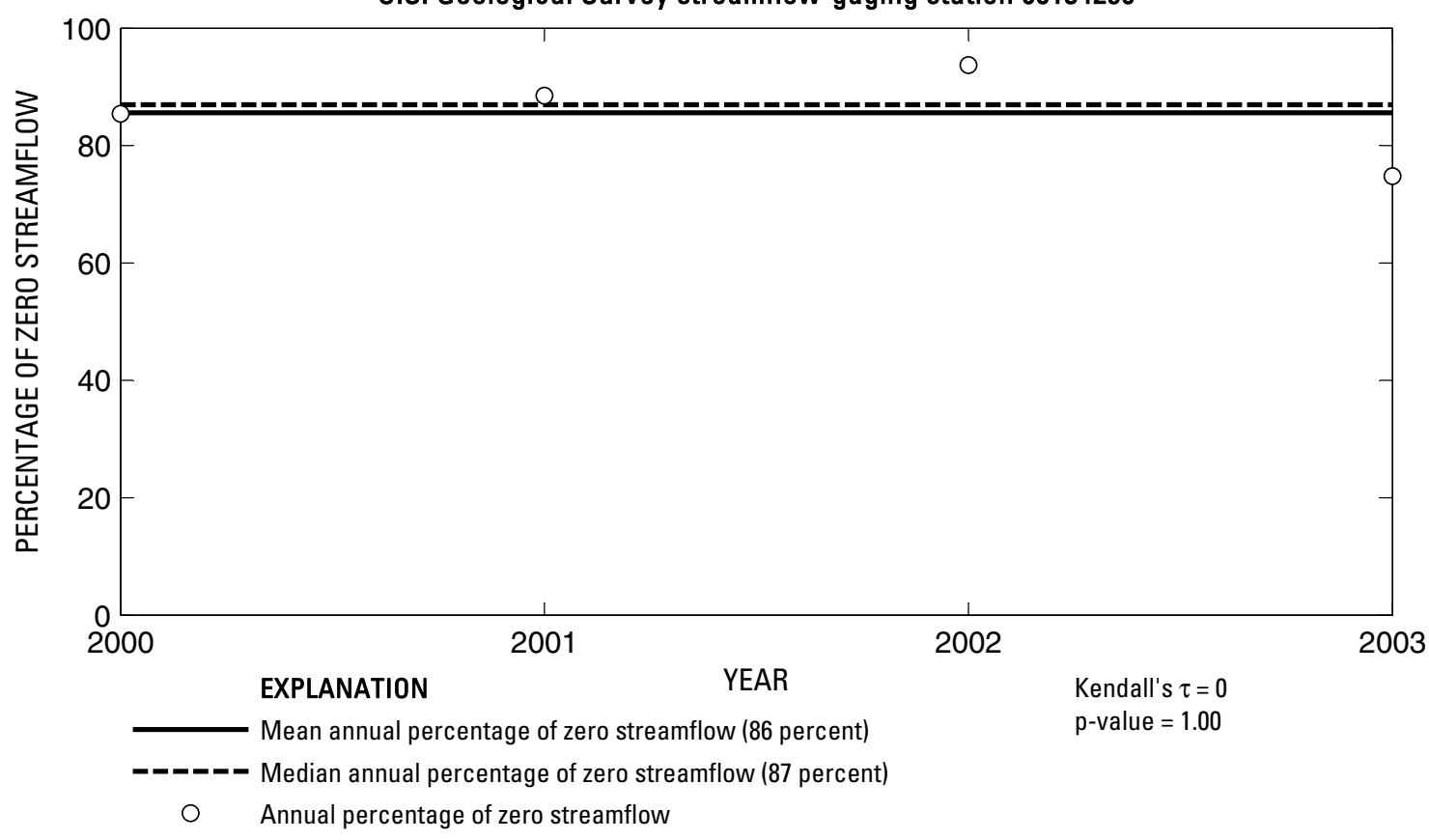

U.S. Geological Survey streamflow-gaging station 08134250

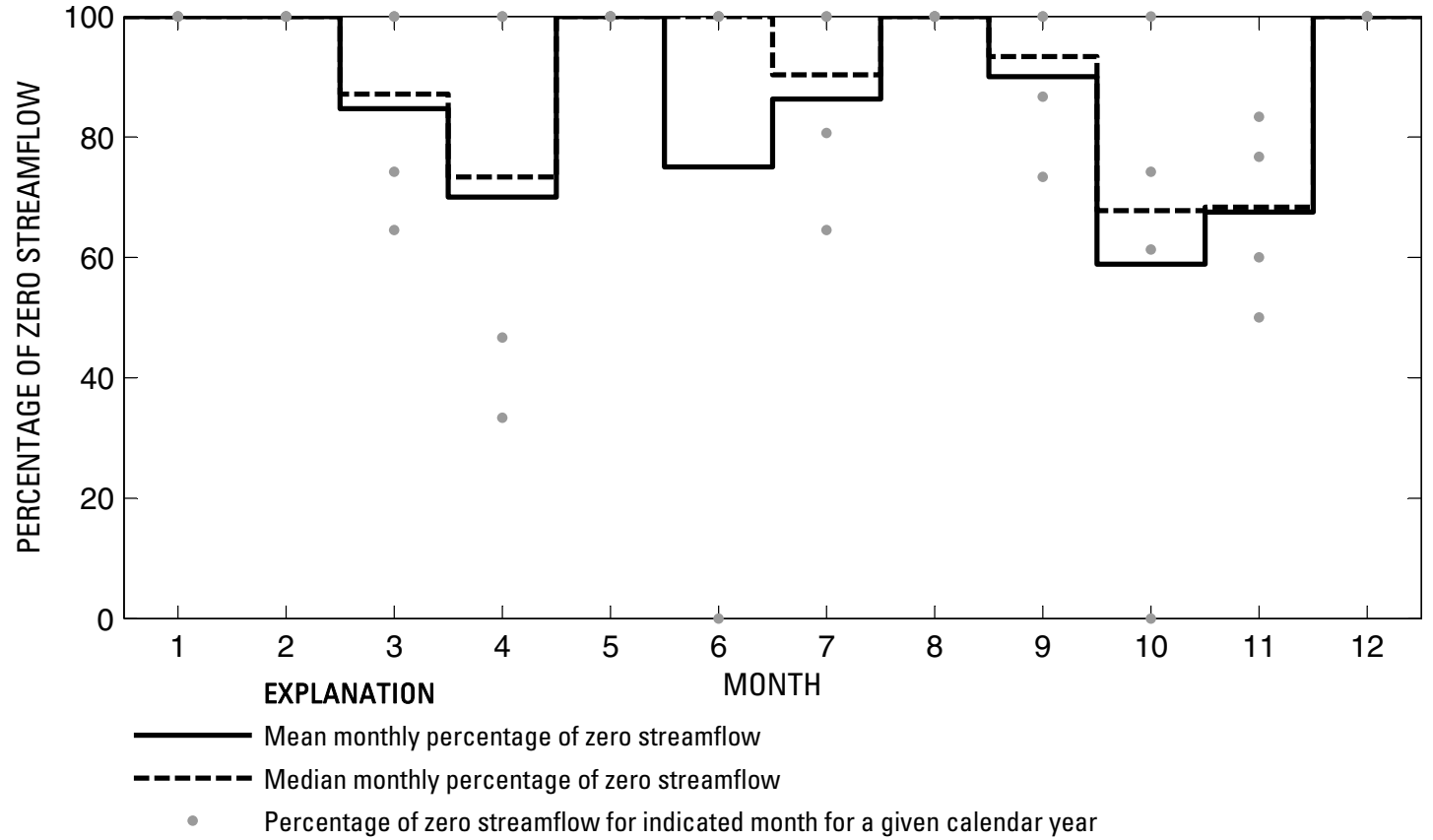

Figure 485. Analysis of percentage of zero daily mean streamflow for U.S. Geological Survey streamflow-gaging station 08134250 North Concho River near Grape Creek, Texas. 
U.S. Geological Survey streamflow-gaging station 08135000

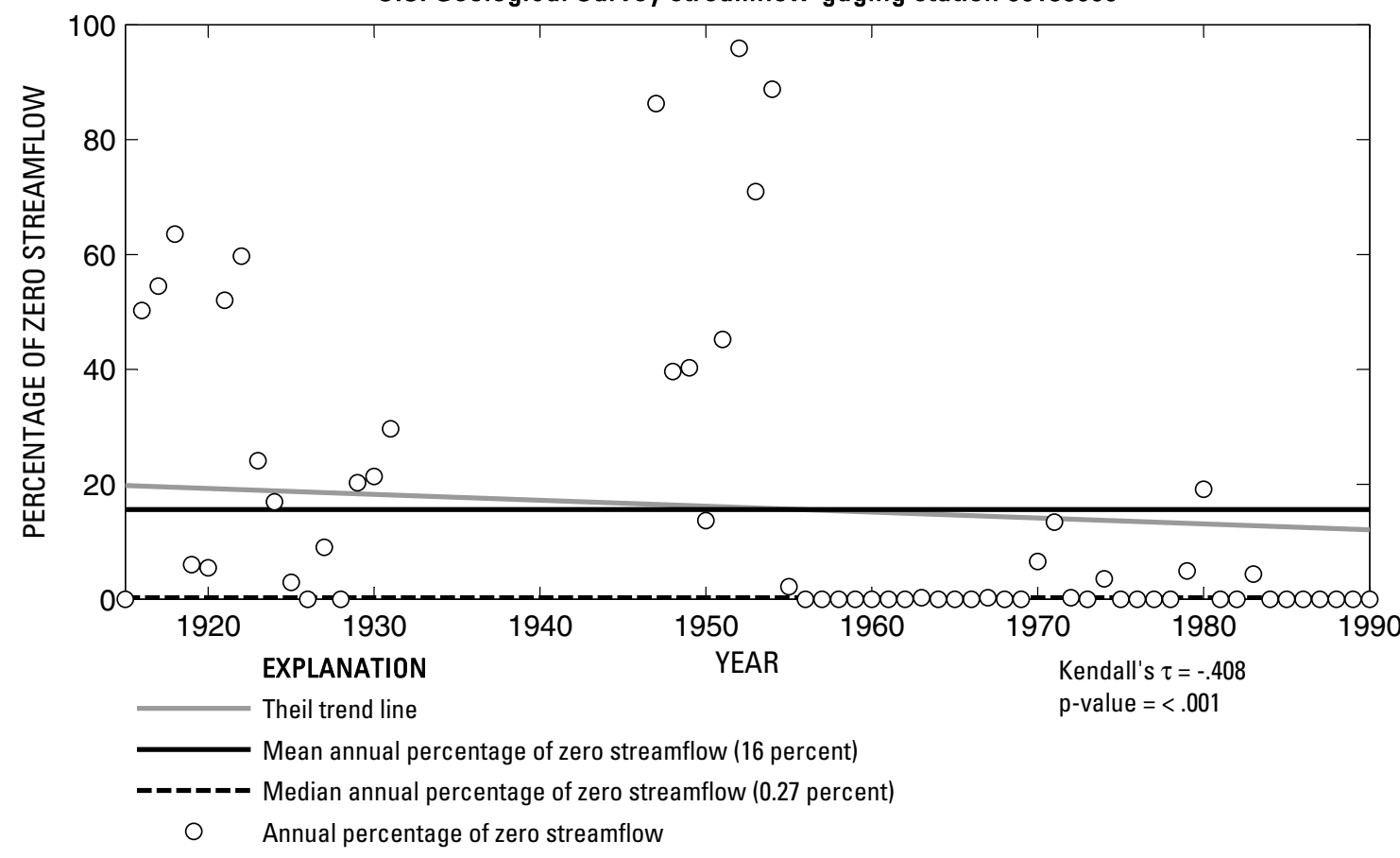

U.S. Geological Survey streamflow-gaging station 08135000

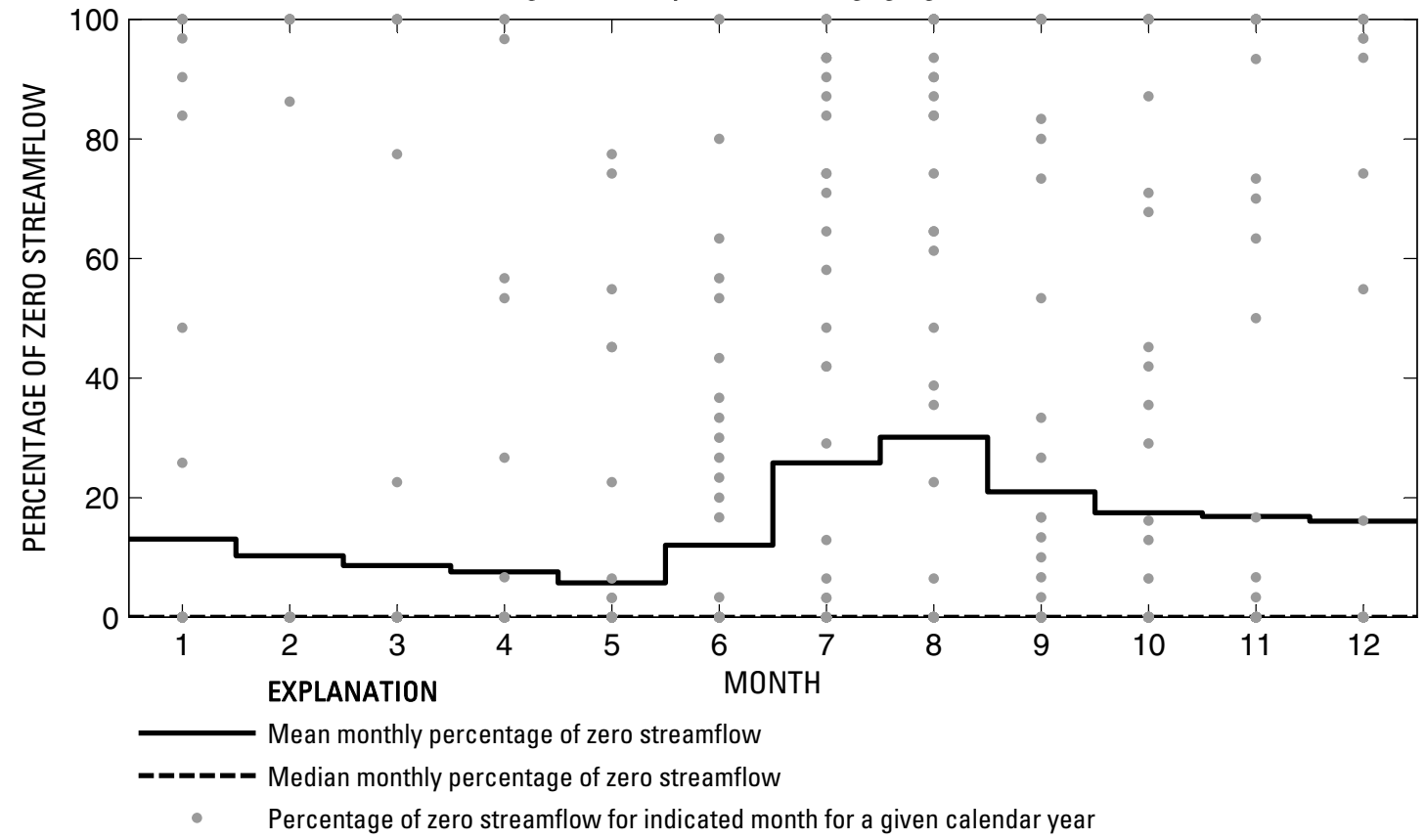

Figure 486. Analysis of percentage of zero daily mean streamflow for U.S. Geological Survey streamflow-gaging station 08135000 North Concho River at San Angelo, Texas.

Index of Station Numbers 719 


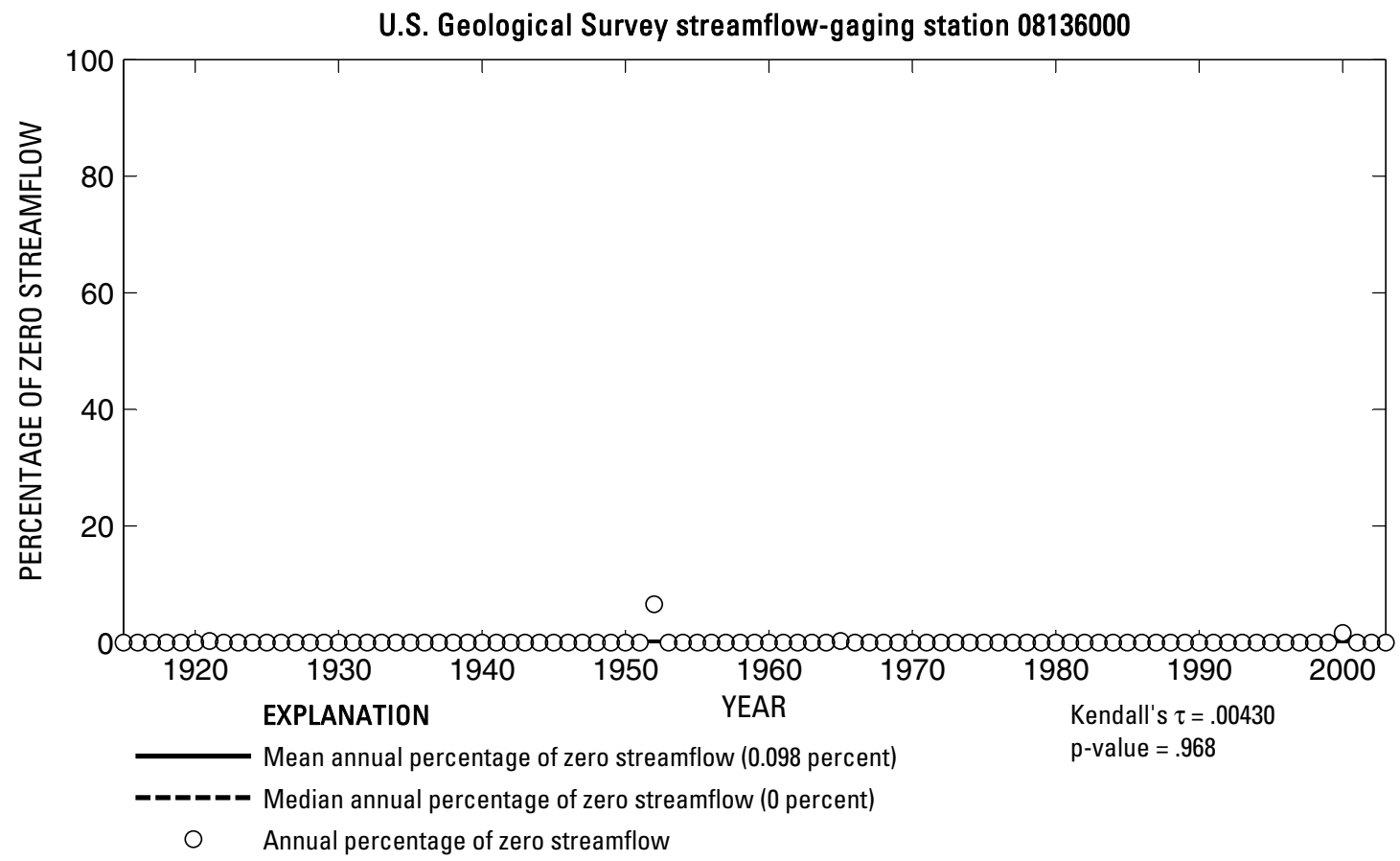

U.S. Geological Survey streamflow-gaging station 08136000

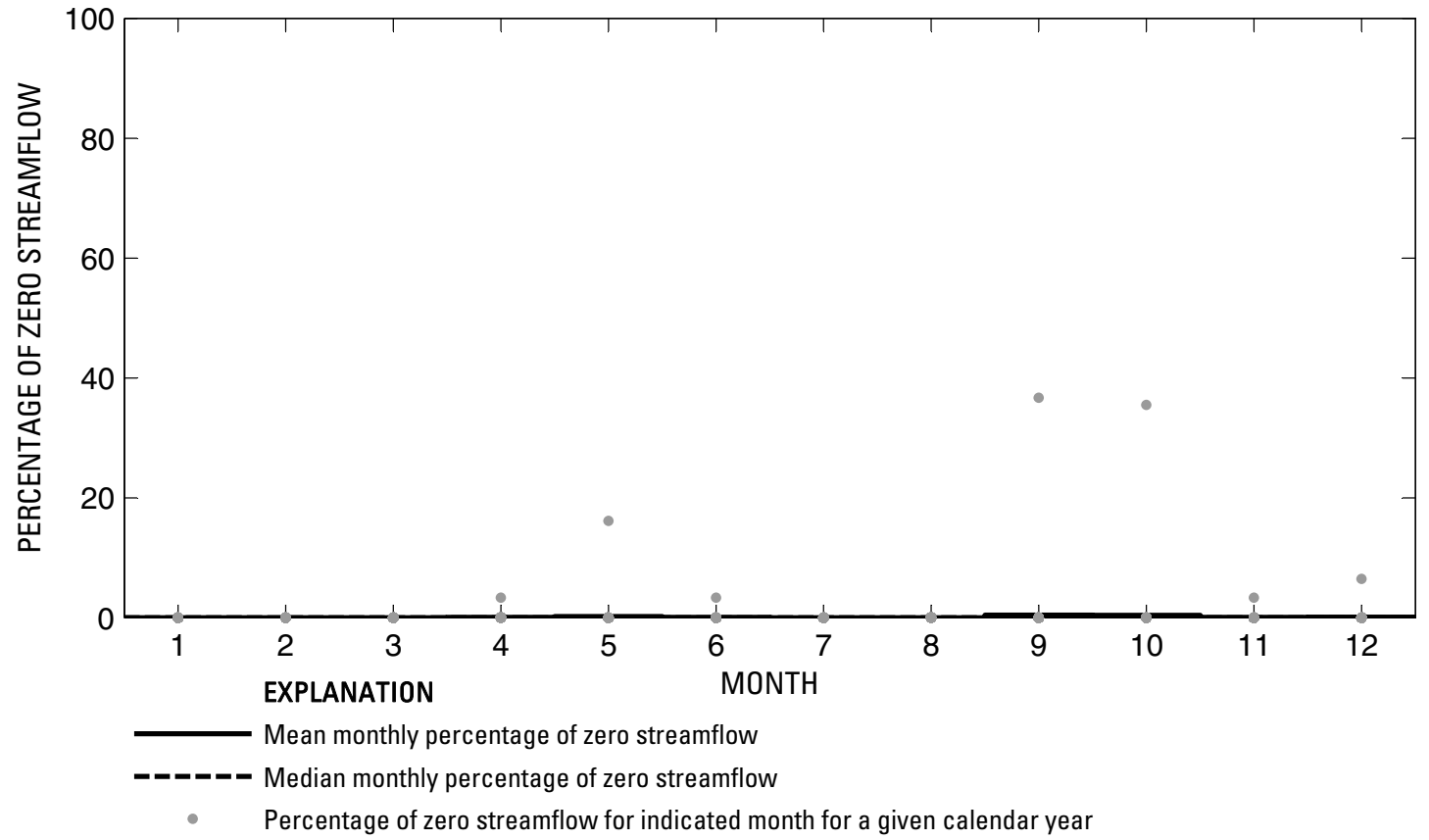

Figure 487. Analysis of percentage of zero daily mean streamflow for U.S. Geological Survey streamflow-gaging station 08136000 Concho River at San Angelo, Texas. 
U.S. Geological Survey streamflow-gaging station 08136500

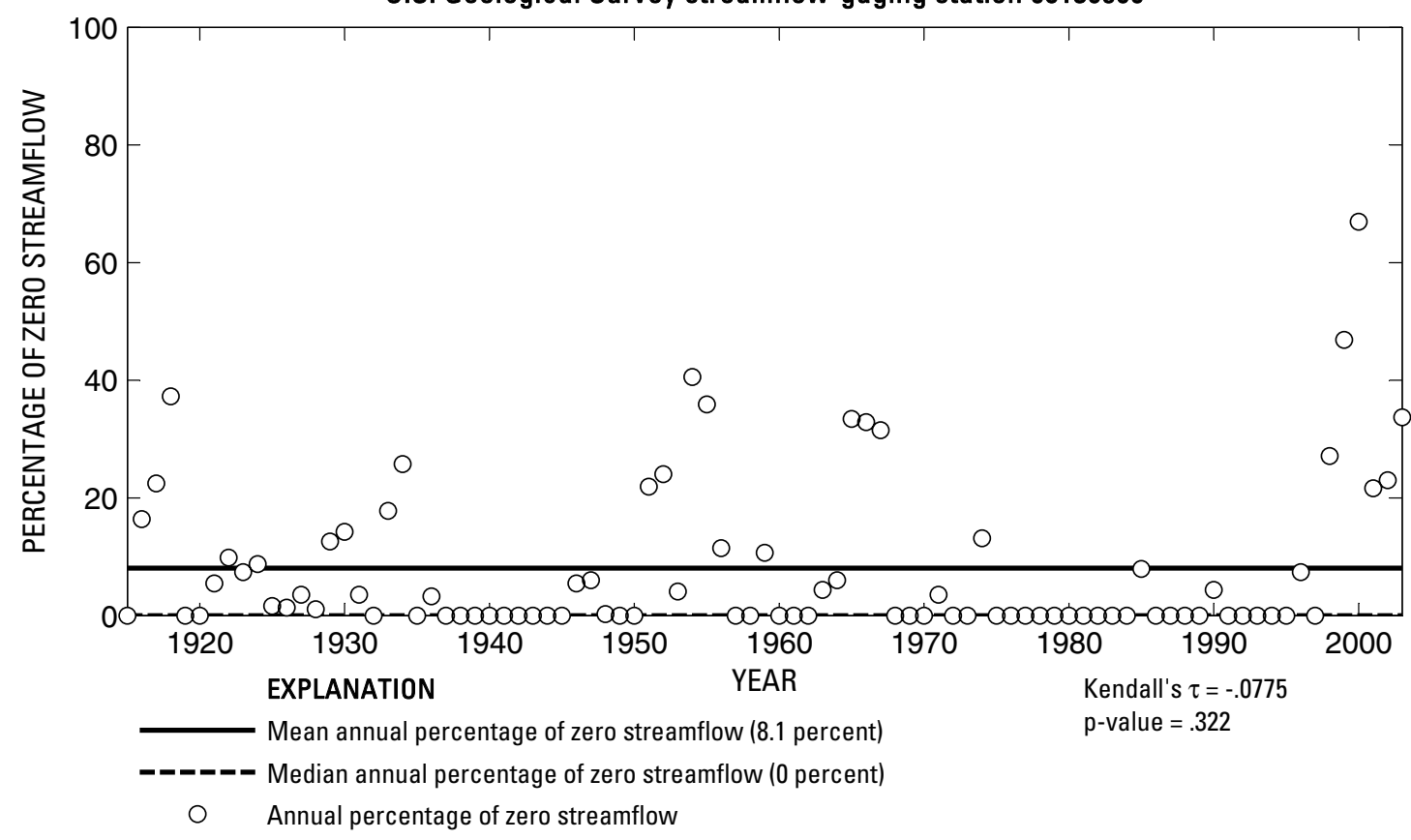

U.S. Geological Survey streamflow-gaging station 08136500

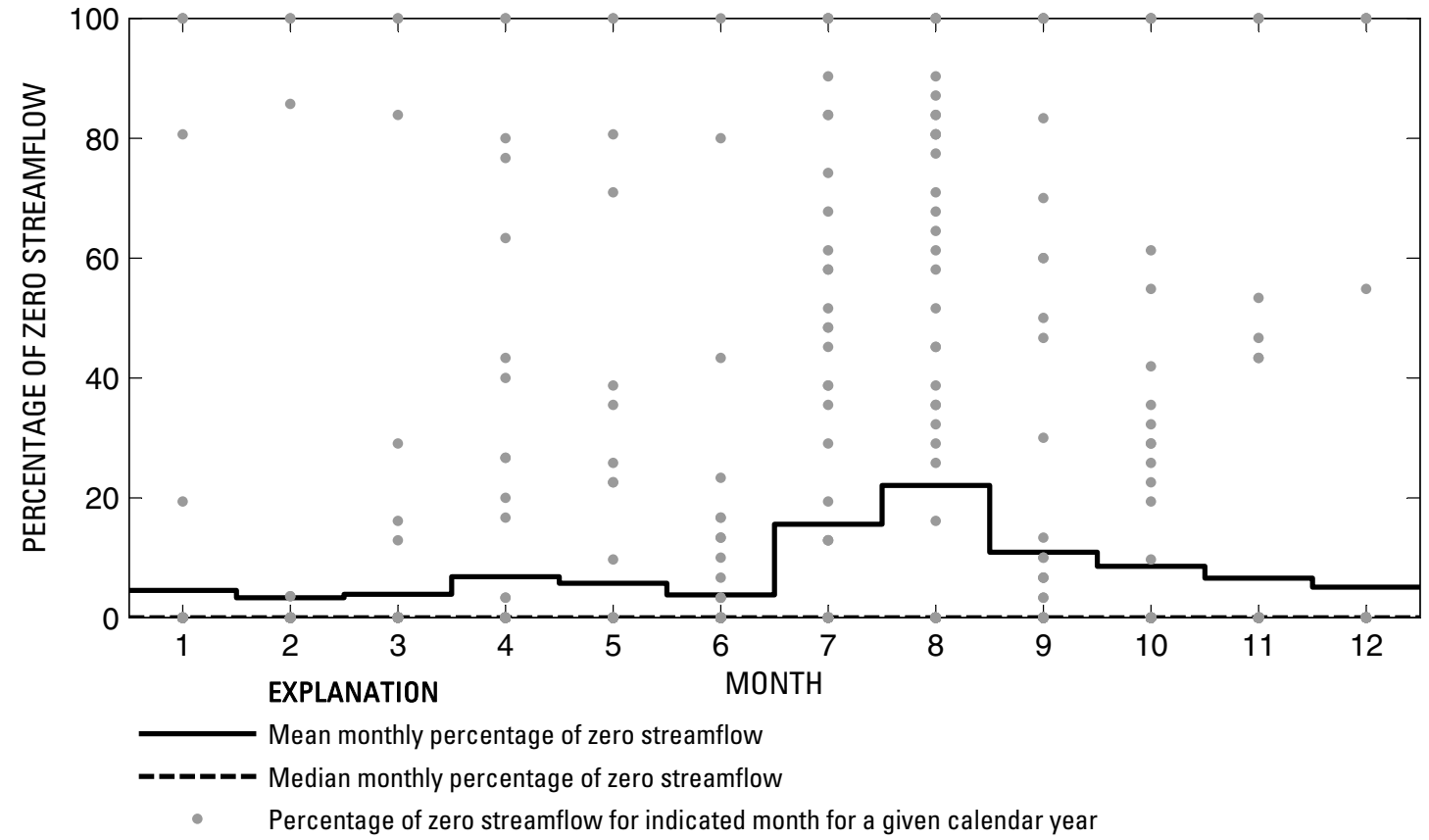

Figure 488. Analysis of percentage of zero daily mean streamflow for U.S. Geological Survey streamflow-gaging station 08136500 Concho River at Paint Rock, Texas.

Index of Station Numbers 719 
U.S. Geological Survey streamflow-gaging station 08136700

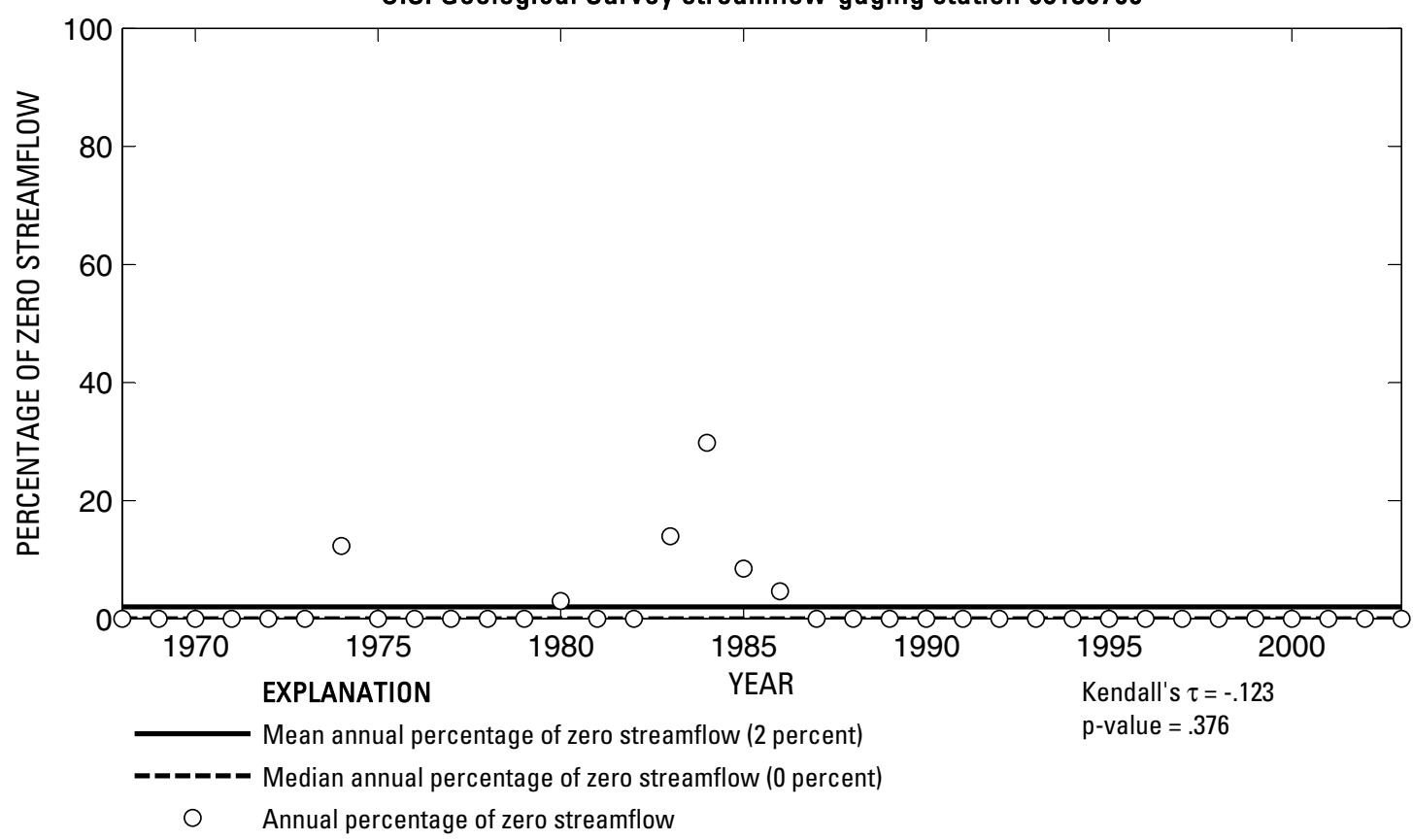

U.S. Geological Survey streamflow-gaging station 08136700

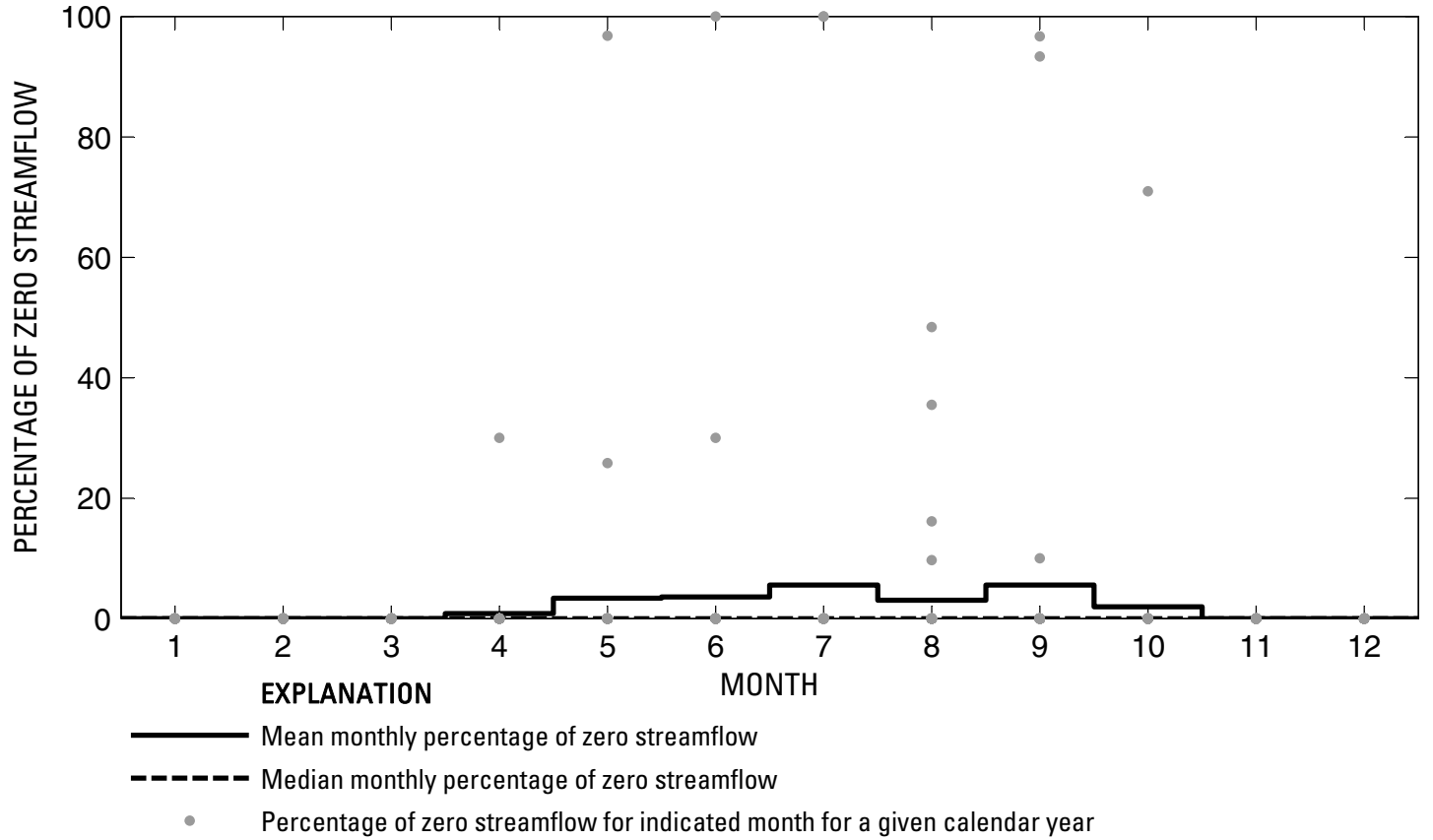

Figure 489. Analysis of percentage of zero daily mean streamflow for U.S. Geological Survey streamflow-gaging station 08136700 Colorado River near Stacy, Texas. 
U.S. Geological Survey streamflow-gaging station 08138000

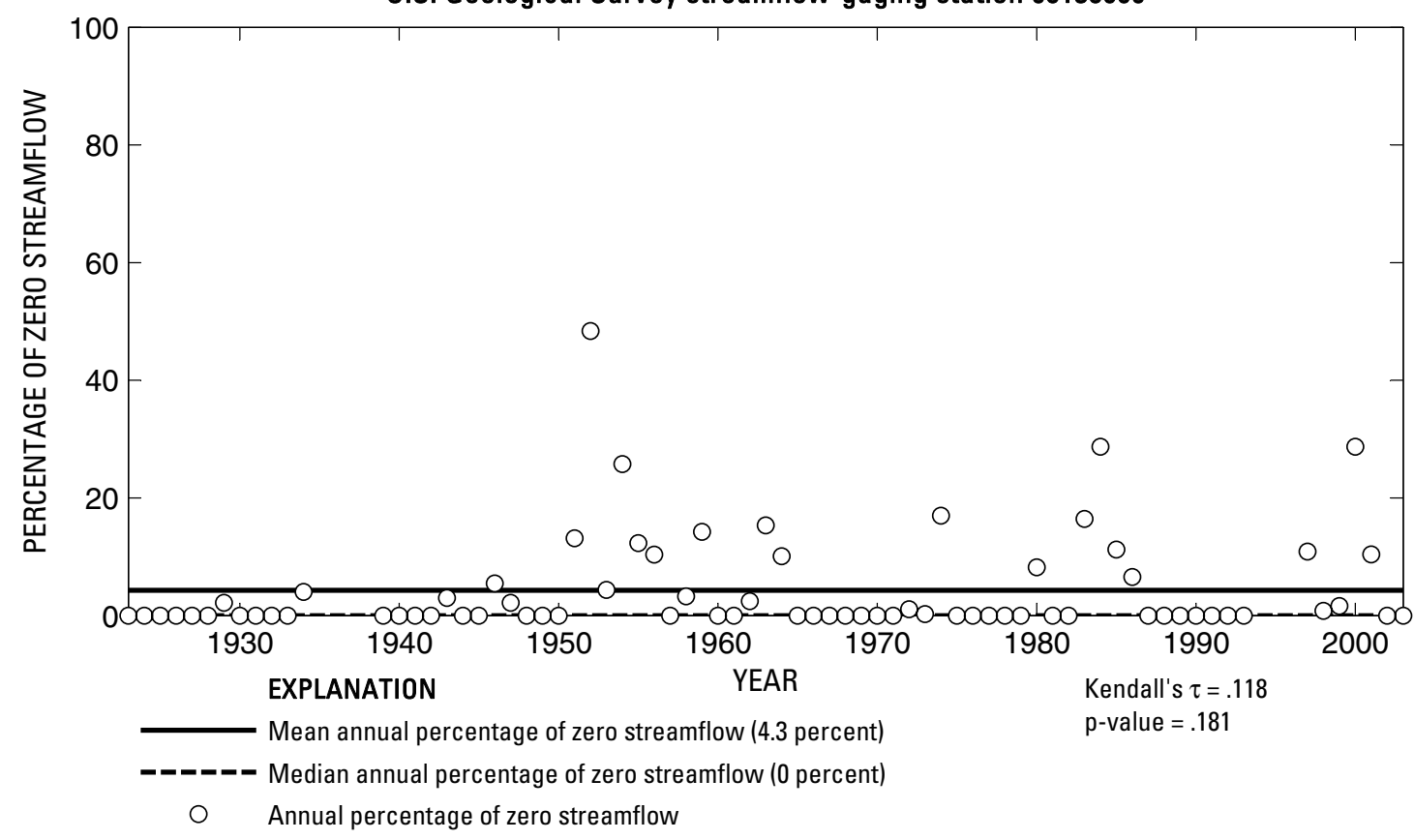

U.S. Geological Survey streamflow-gaging station 08138000

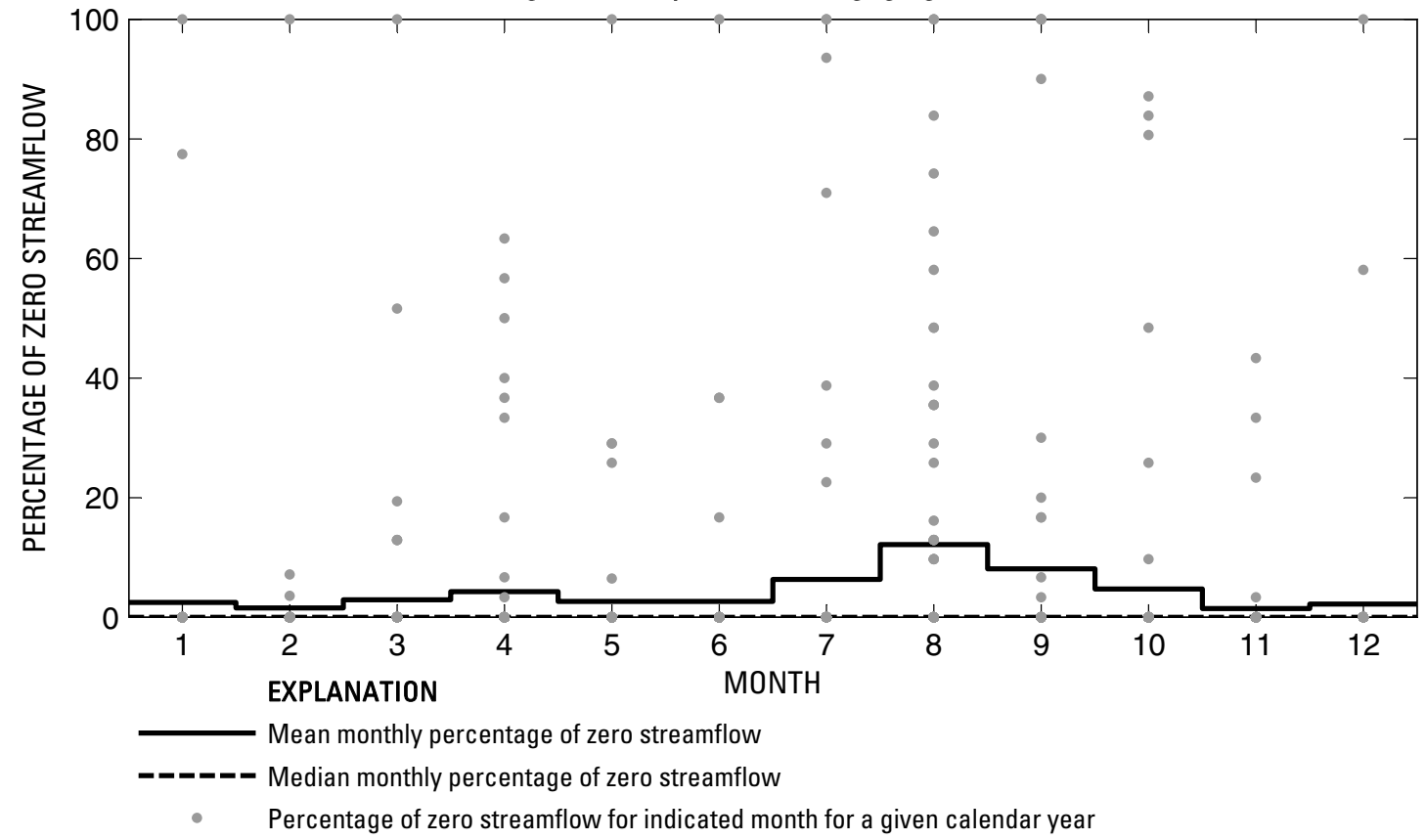

Figure 490. Analysis of percentage of zero daily mean streamflow for U.S. Geological Survey streamflow-gaging station 08138000 Colorado River at Winchell, Texas.

Index of Station Numbers 719 


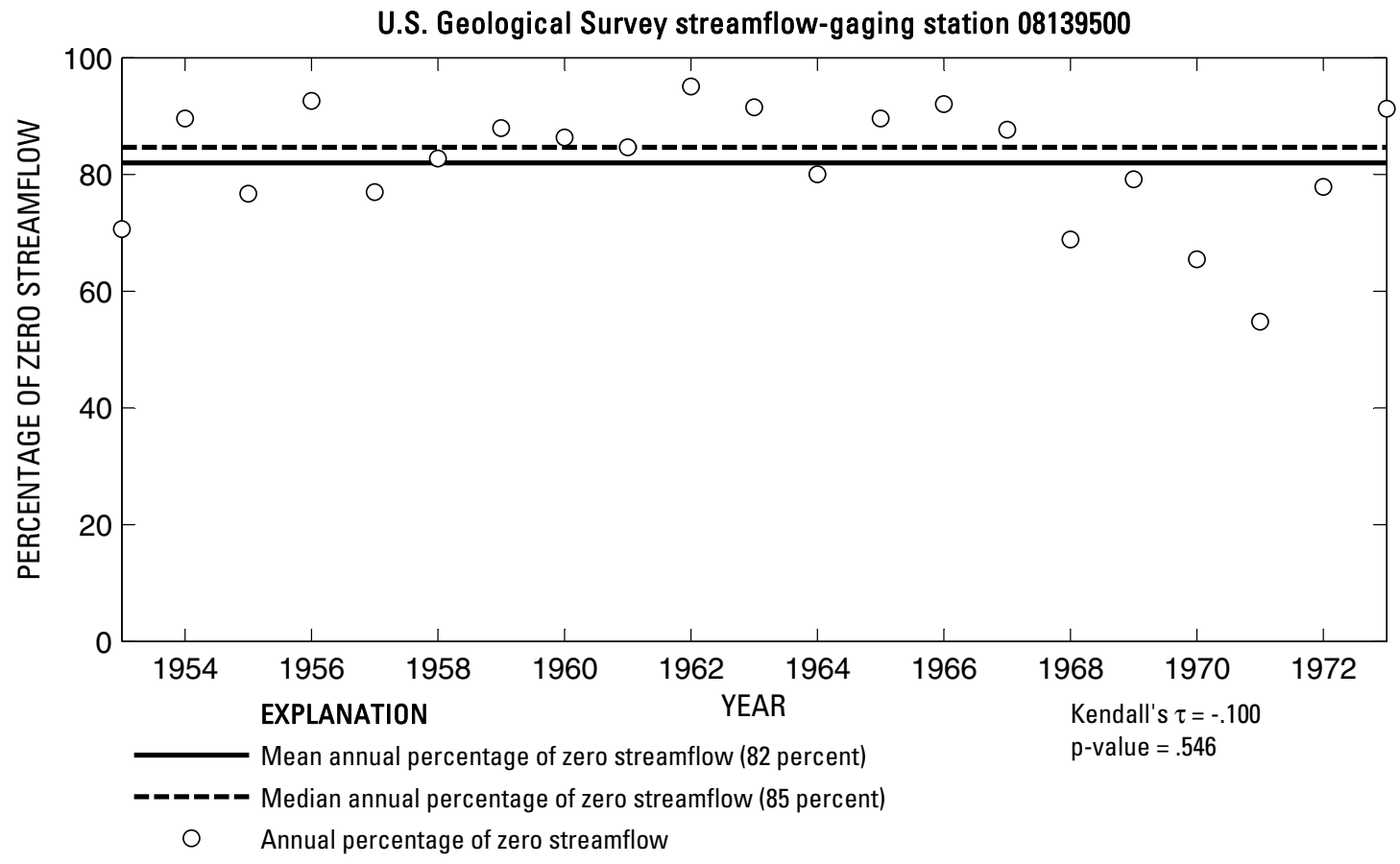

U.S. Geological Survey streamflow-gaging station 08139500

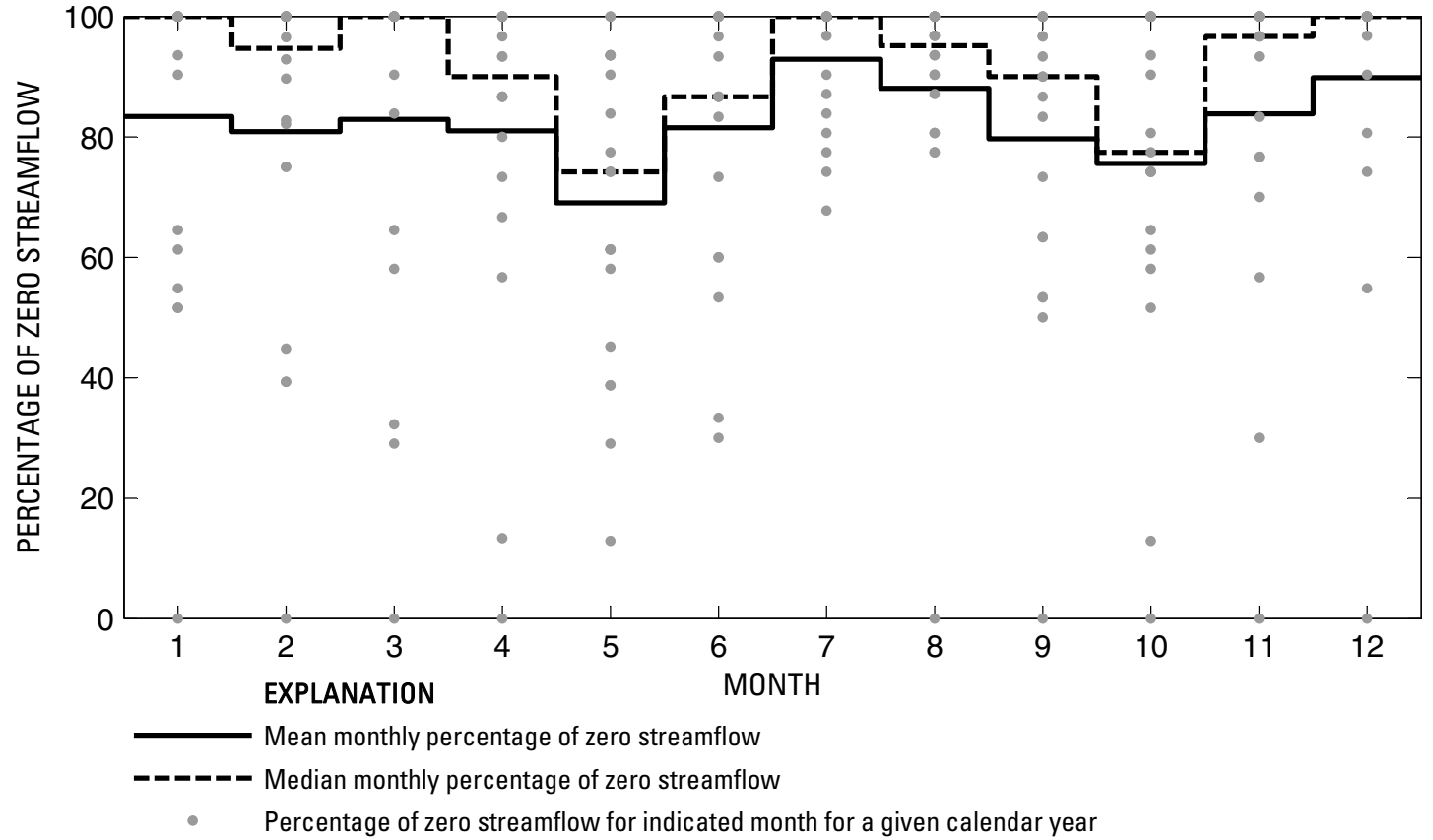

Figure 491. Analysis of percentage of zero daily mean streamflow for U.S. Geological Survey streamflow-gaging station 08139500 Deep Creek near Mercury, Texas. 
U.S. Geological Survey streamflow-gaging station 08140500

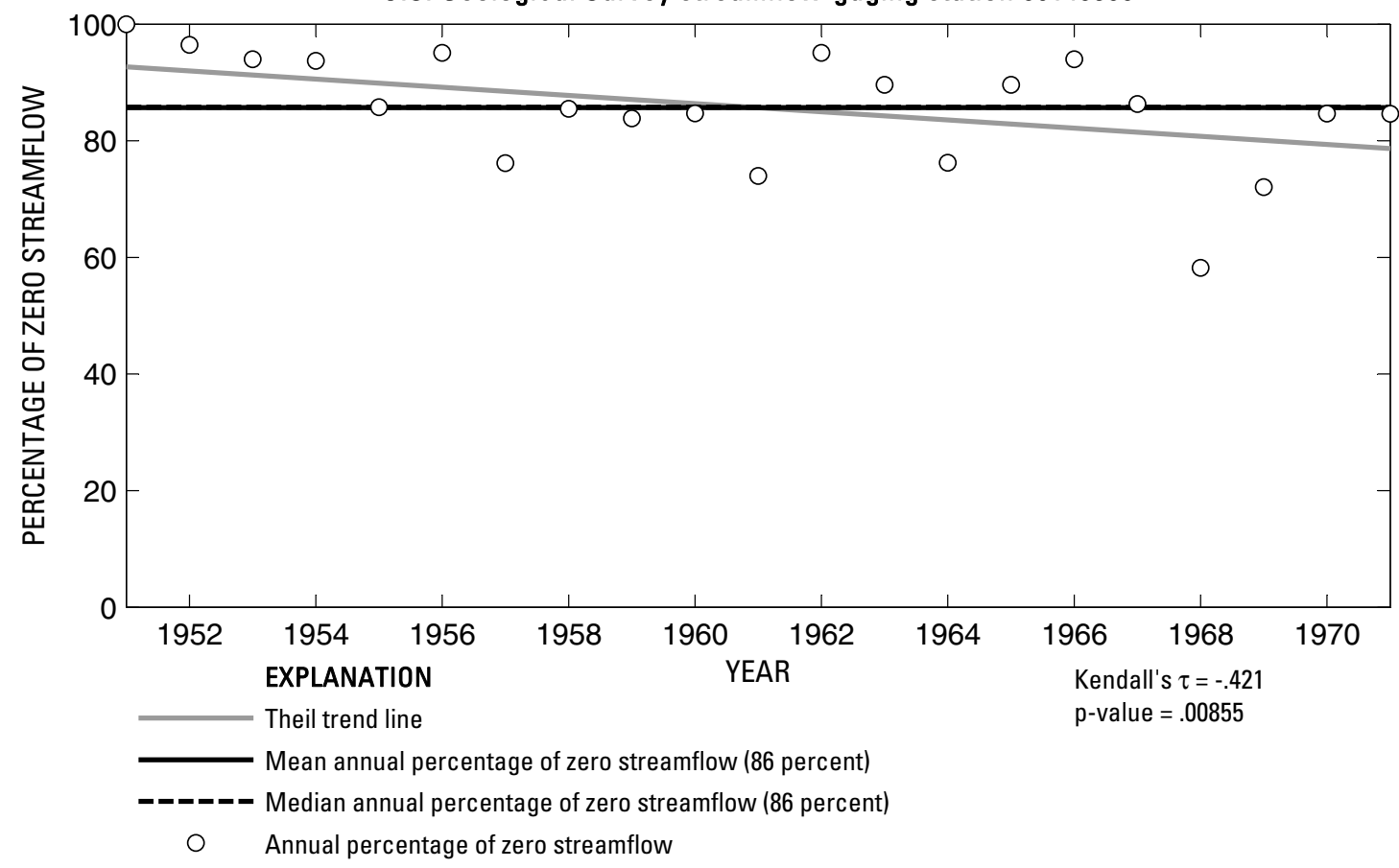

U.S. Geological Survey streamflow-gaging station 08140500

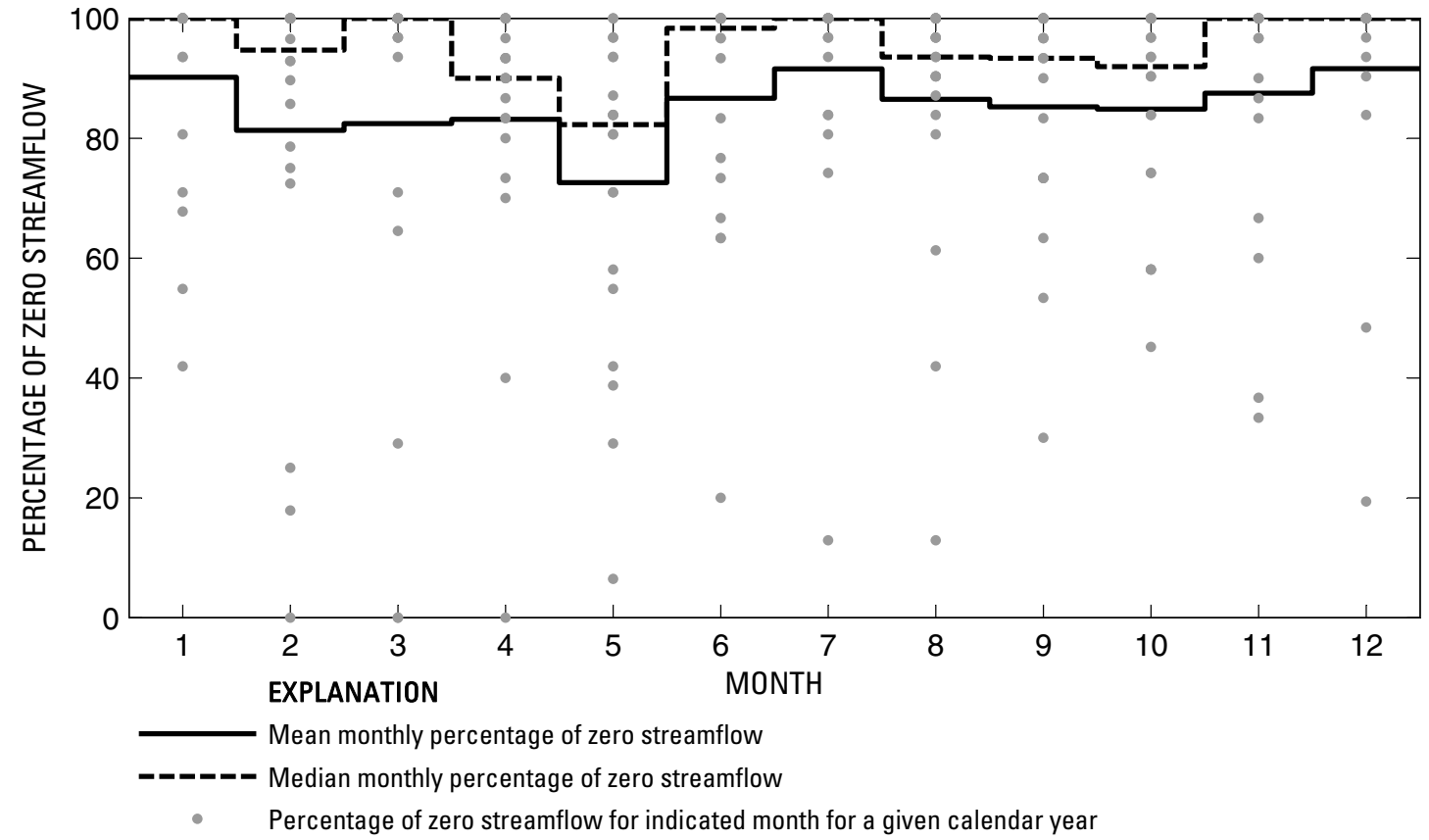

Figure 492. Analysis of percentage of zero daily mean streamflow for U.S. Geological Survey streamflow-gaging station 08140500 Dry Prong Deep Creek near Mercury, Texas.

Index of Station Numbers 719 

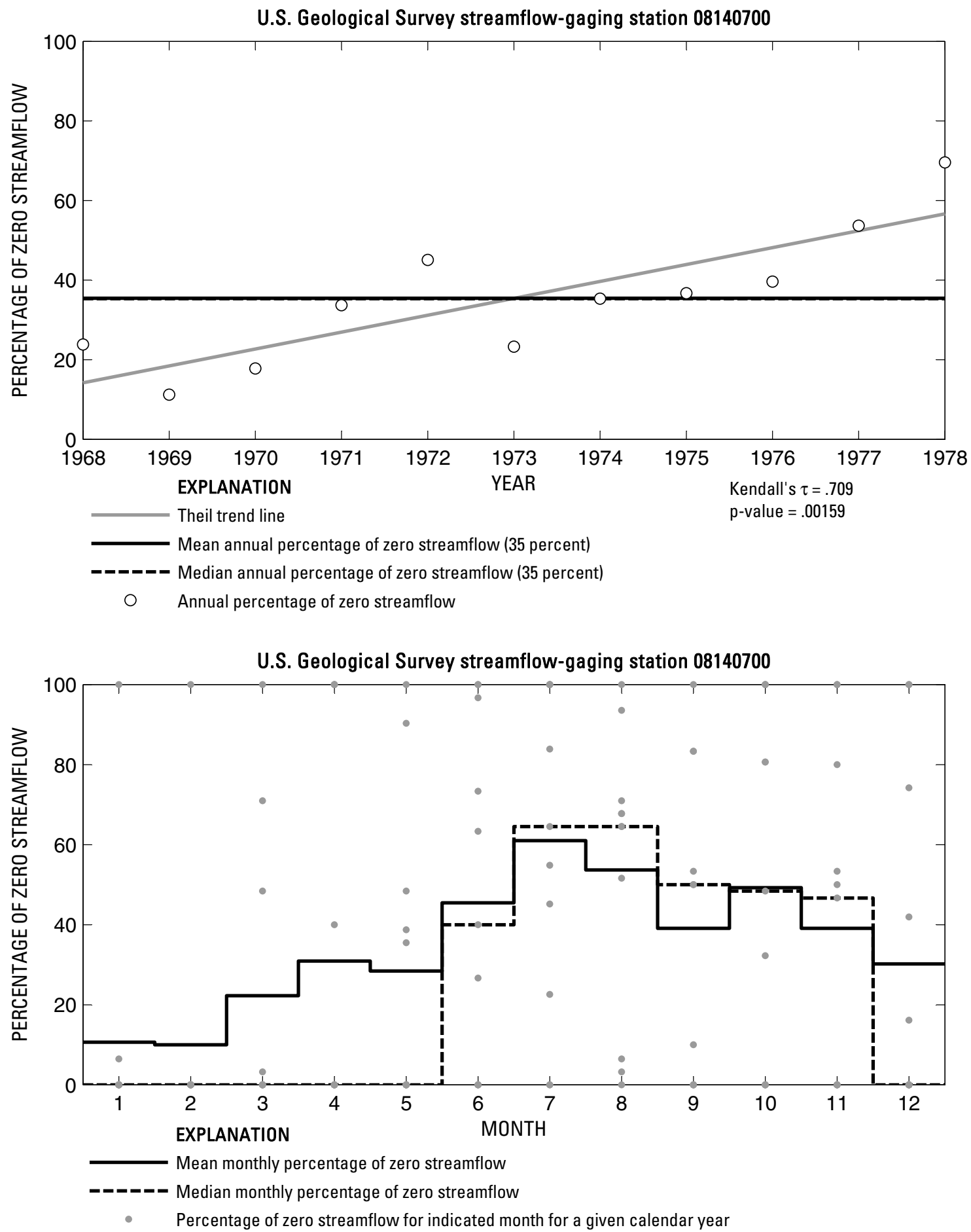

Figure 493. Analysis of percentage of zero daily mean streamflow for U.S. Geological Survey streamflow-gaging station 08140700 Pecan Bayou near Cross Cut, Texas. 

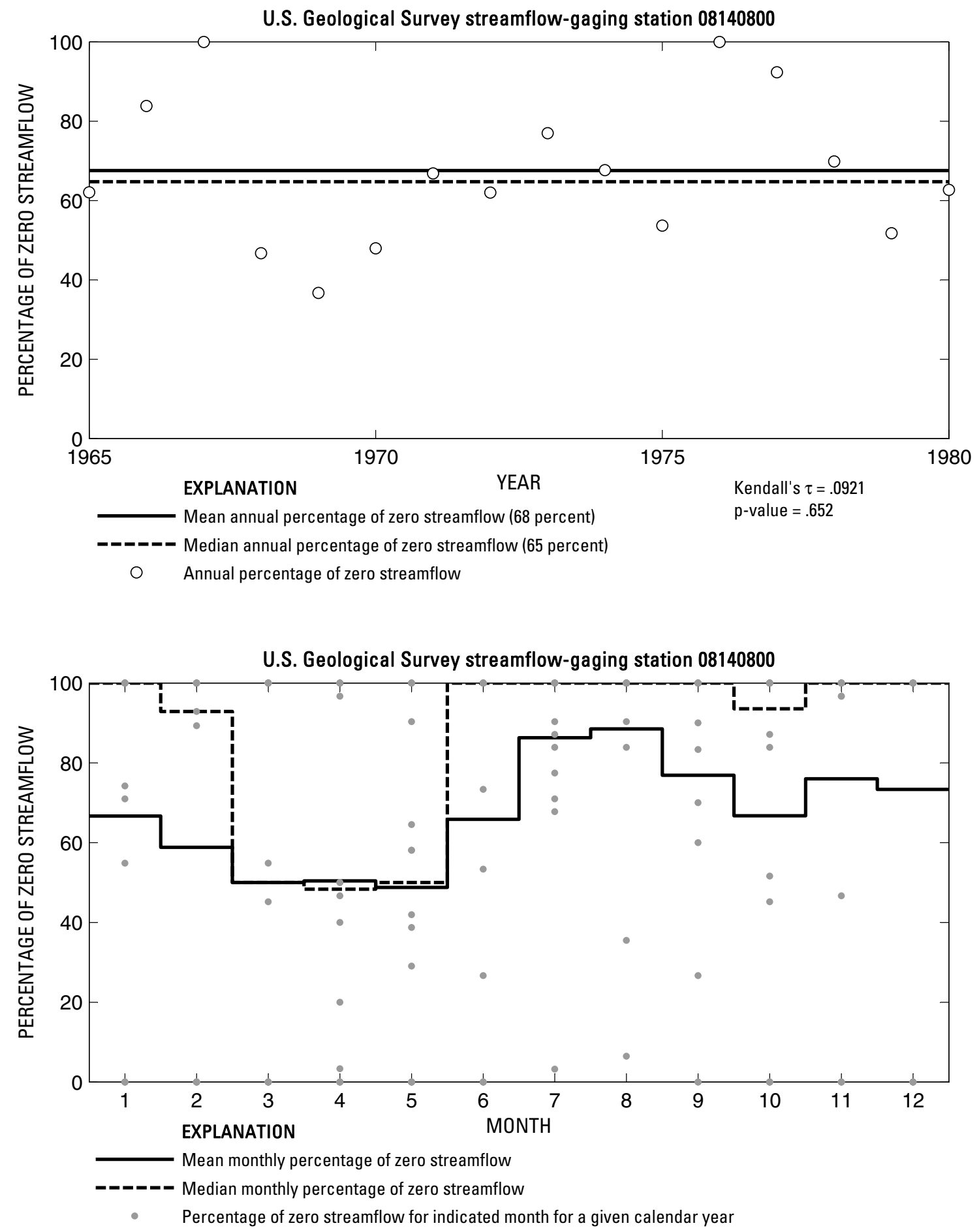

Figure 494. Analysis of percentage of zero daily mean streamflow for U.S. Geological Survey streamflow-gaging station $08140800 \mathrm{Jim}$ Ned Creek near Coleman, Texas. 
U.S. Geological Survey streamflow-gaging station 08141500

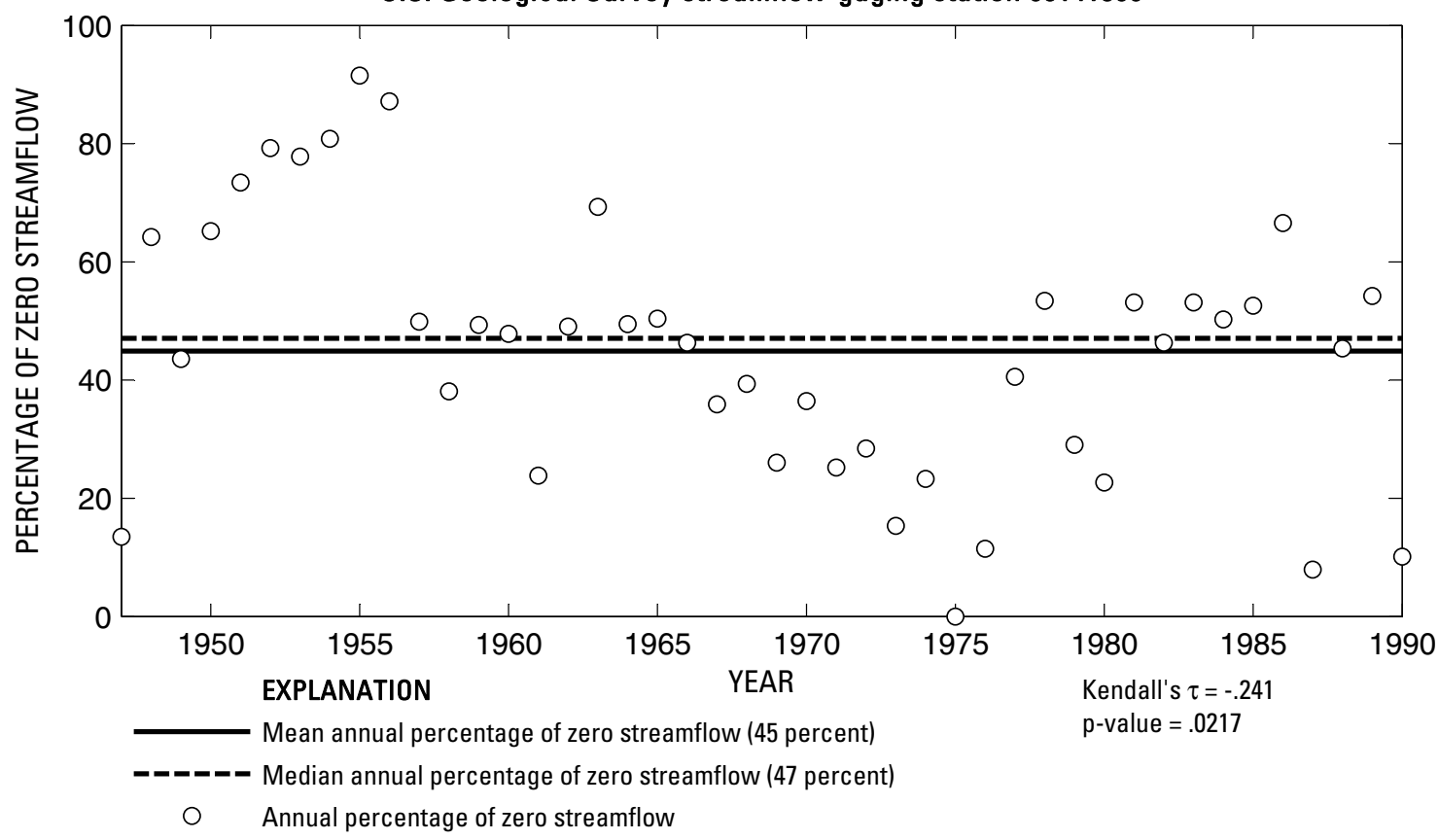

U.S. Geological Survey streamflow-gaging station 08141500

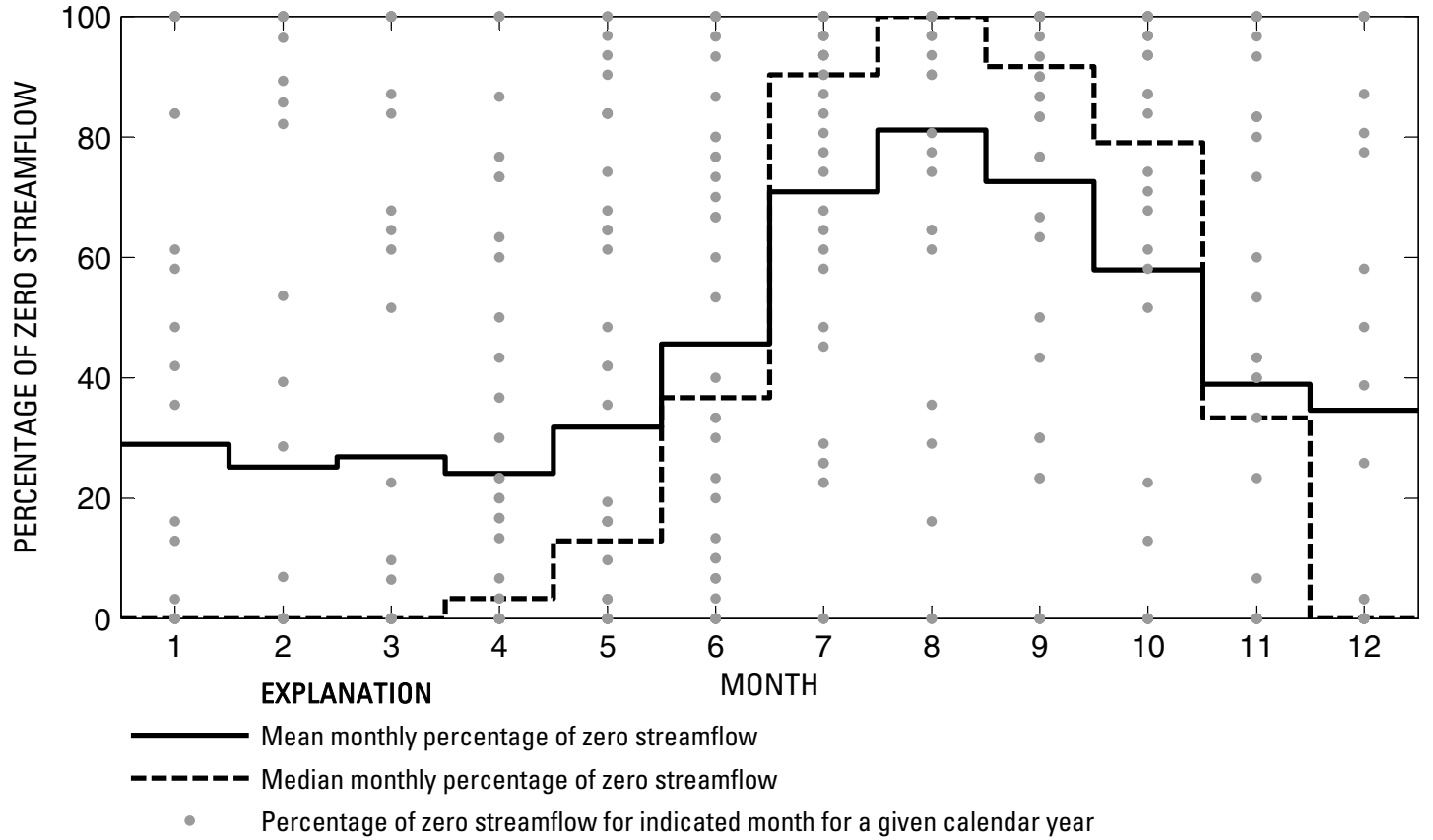

Figure 495. Analysis of percentage of zero daily mean streamflow for U.S. Geological Survey streamflow-gaging station 08141500 Hords Creek near Valera, Texas. 
U.S. Geological Survey streamflow-gaging station 08142000

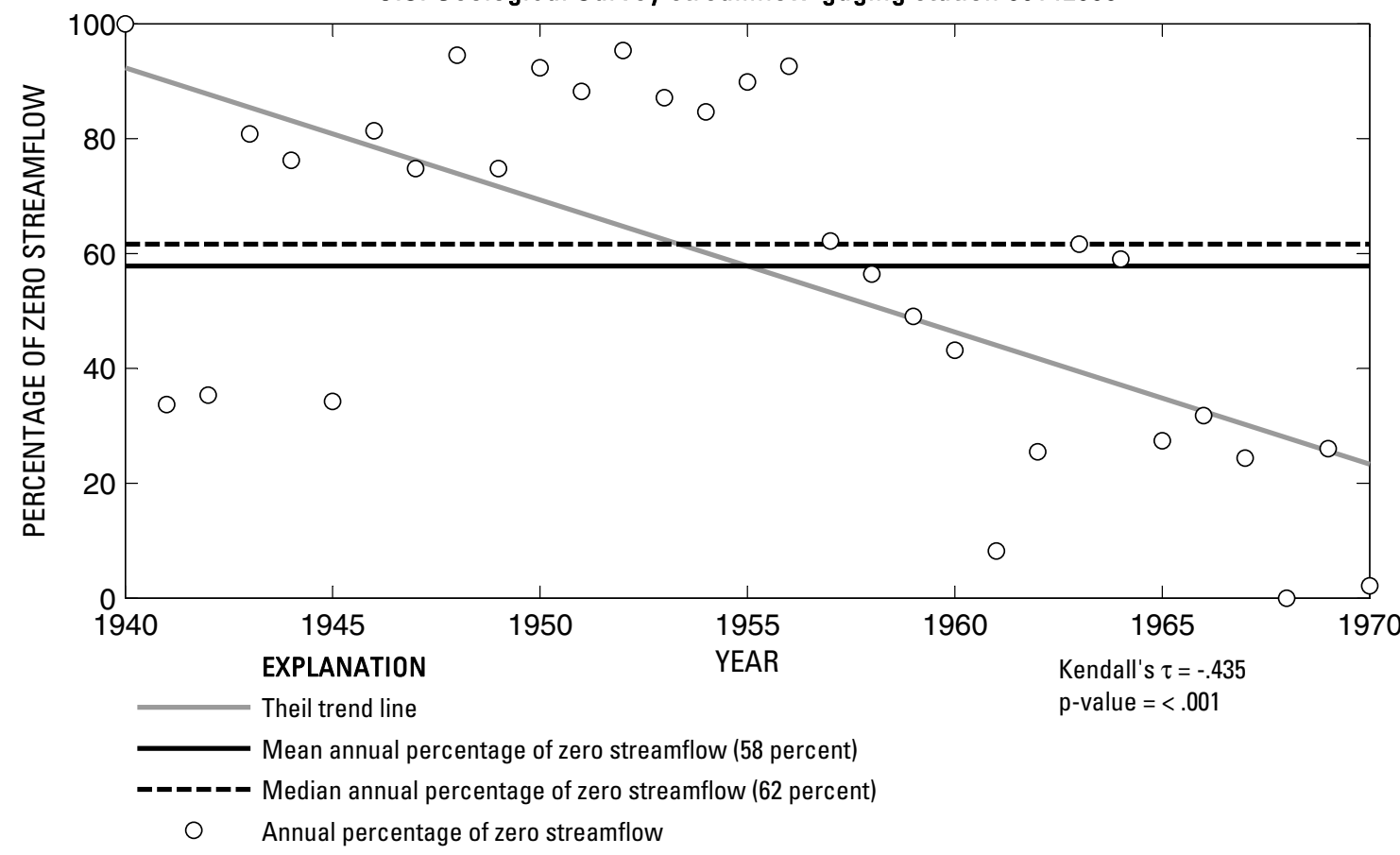

U.S. Geological Survey streamflow-gaging station 08142000

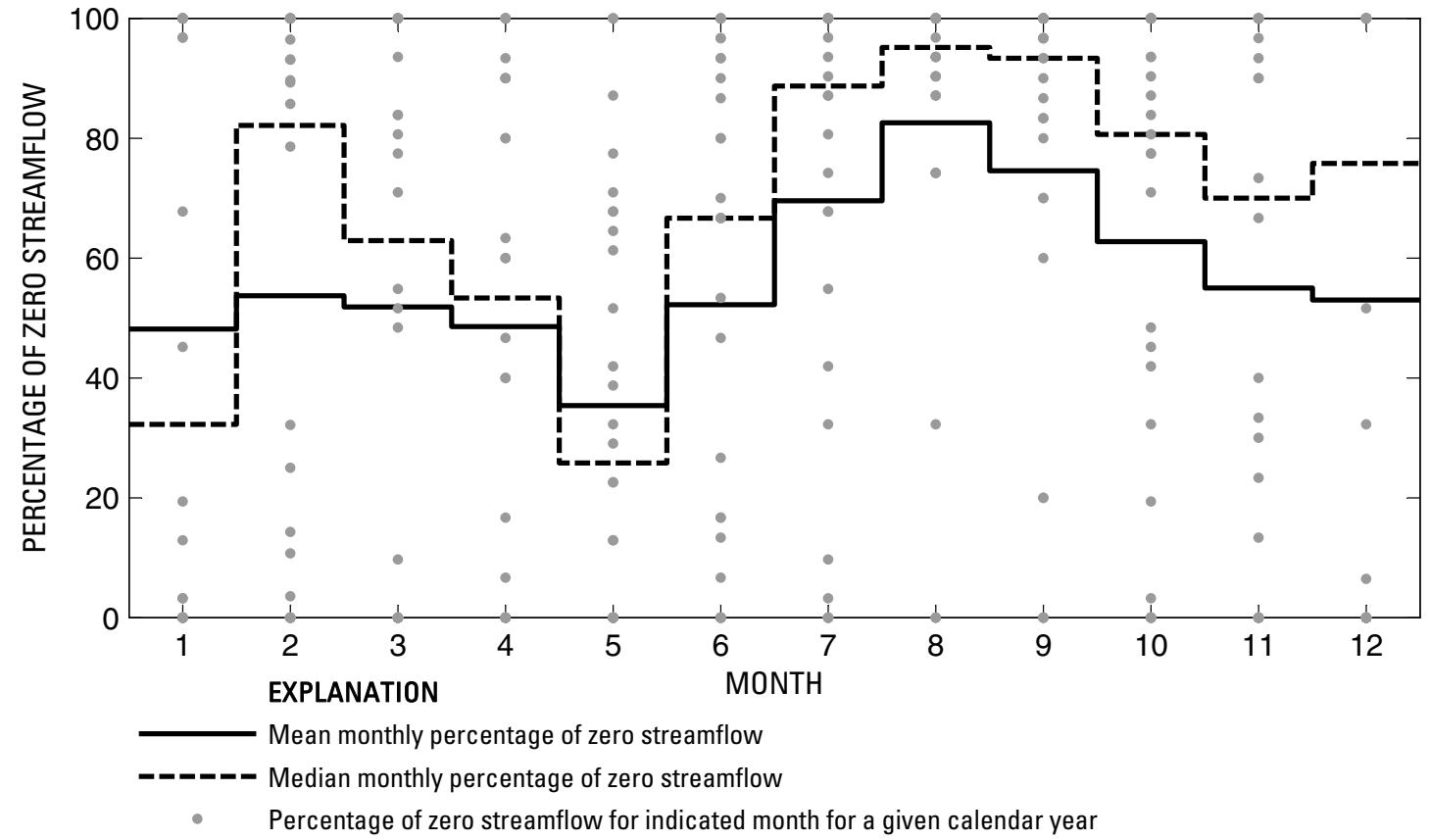

Figure 496. Analysis of percentage of zero daily mean streamflow for U.S. Geological Survey streamflow-gaging station 08142000 Hords Creek near Coleman, Texas.

Index of Station Numbers 719 

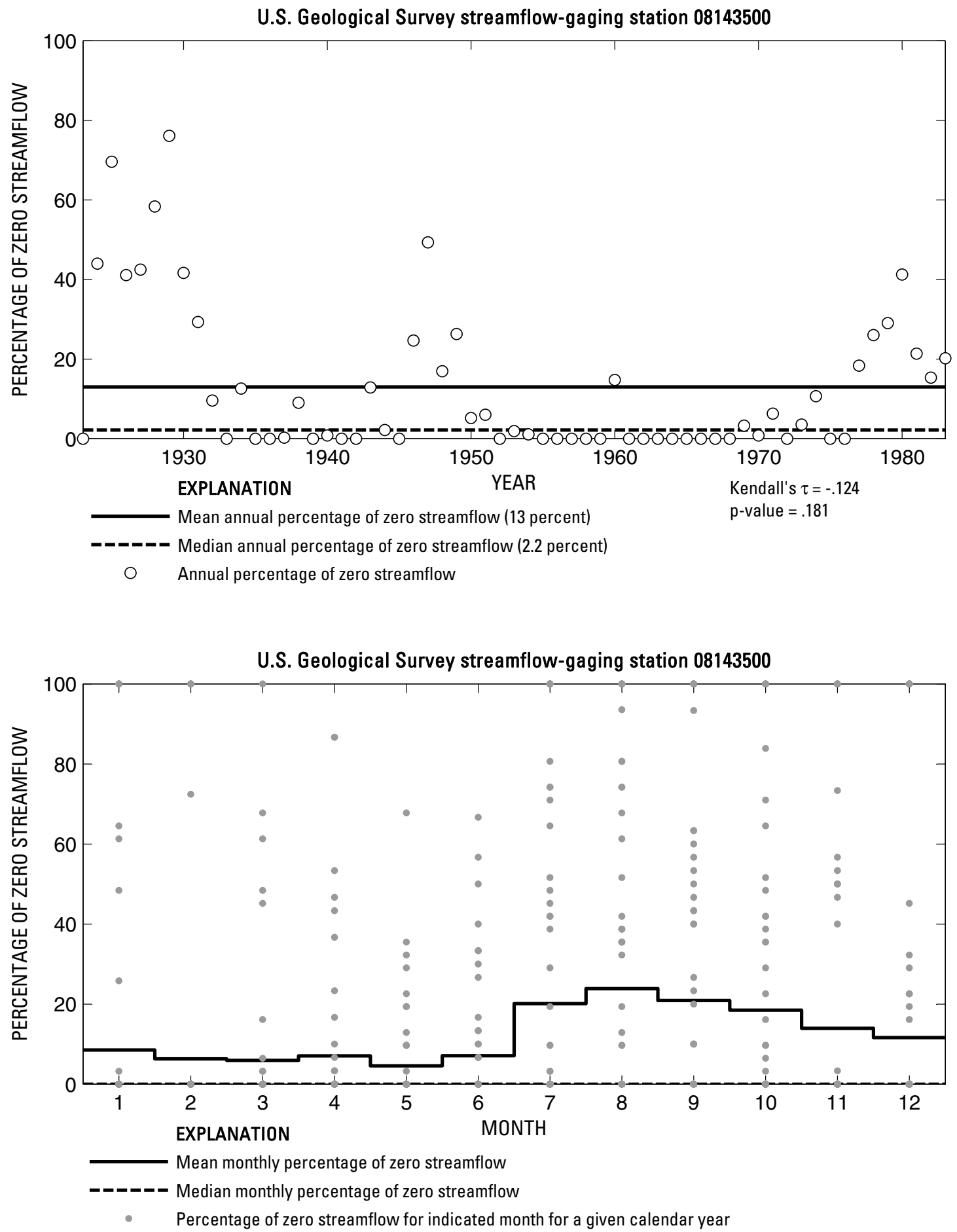

Figure 497. Analysis of percentage of zero daily mean streamflow for U.S. Geological Survey streamflow-gaging station 08143500 Pecan Bayou at Brownwood, Texas. 
U.S. Geological Survey streamflow-gaging station 08143600

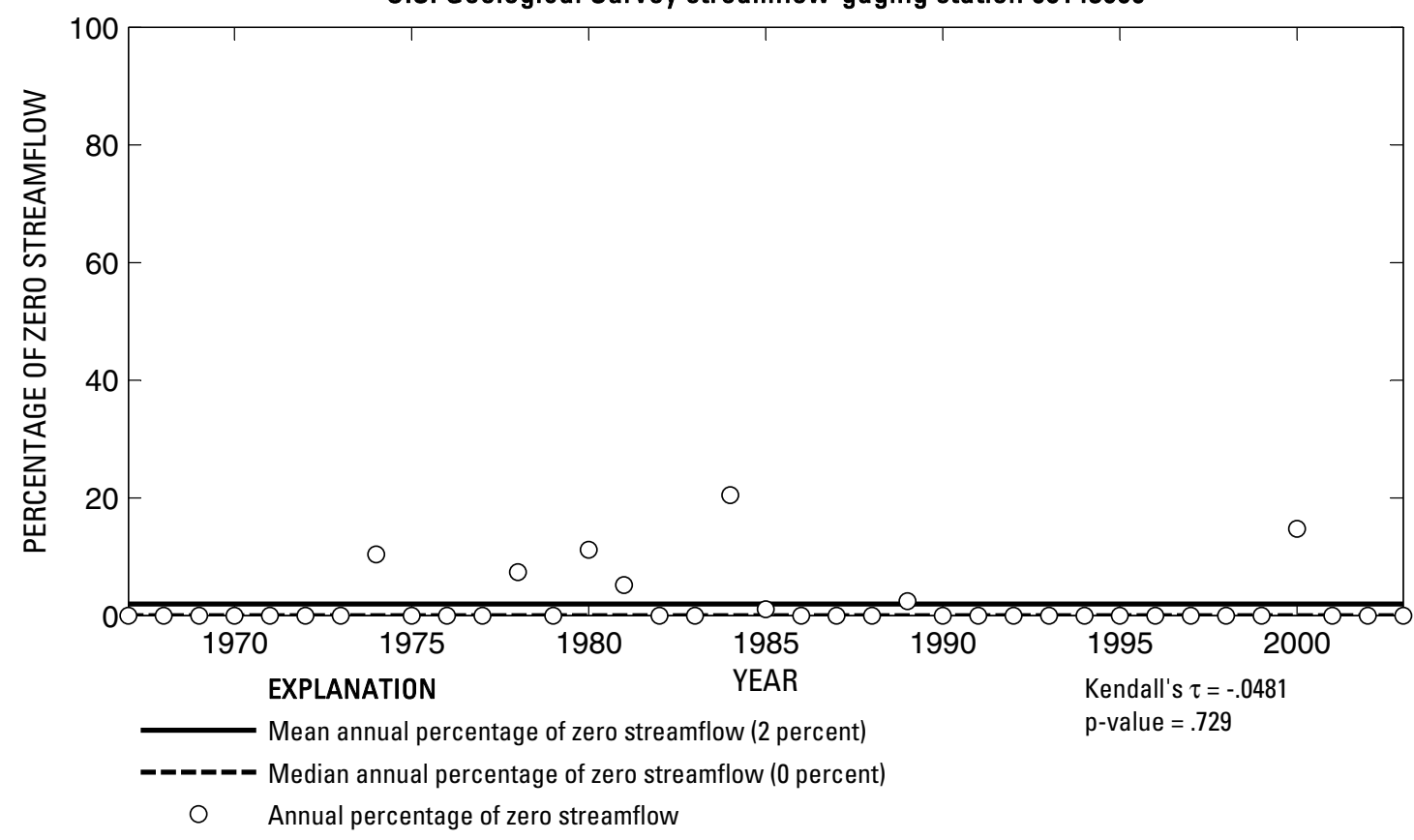

U.S. Geological Survey streamflow-gaging station 08143600

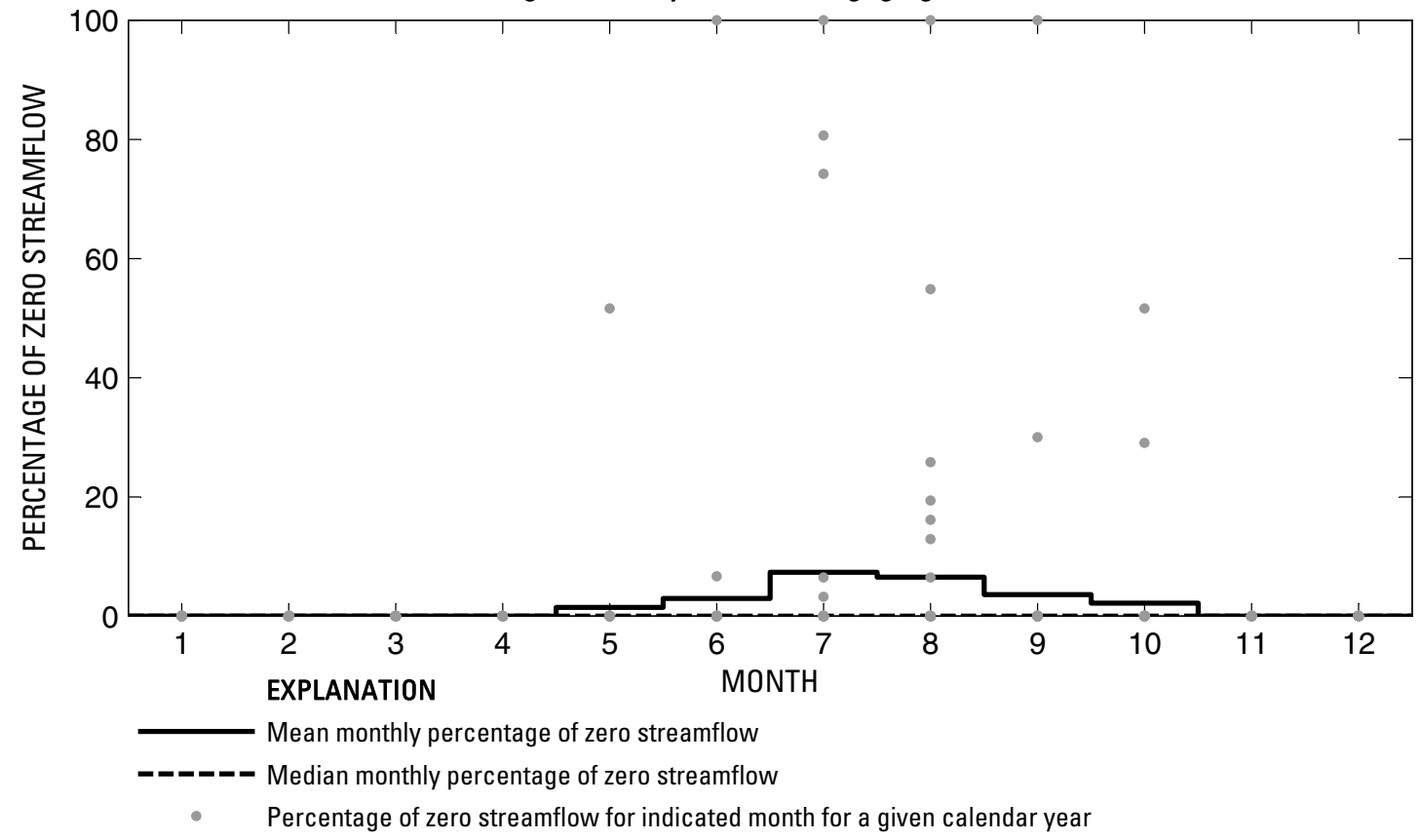

Figure 498. Analysis of percentage of zero daily mean streamflow for U.S. Geological Survey streamflow-gaging station 08143600 Pecan Bayou near Mullin, Texas. 
U.S. Geological Survey streamflow-gaging station 08144500

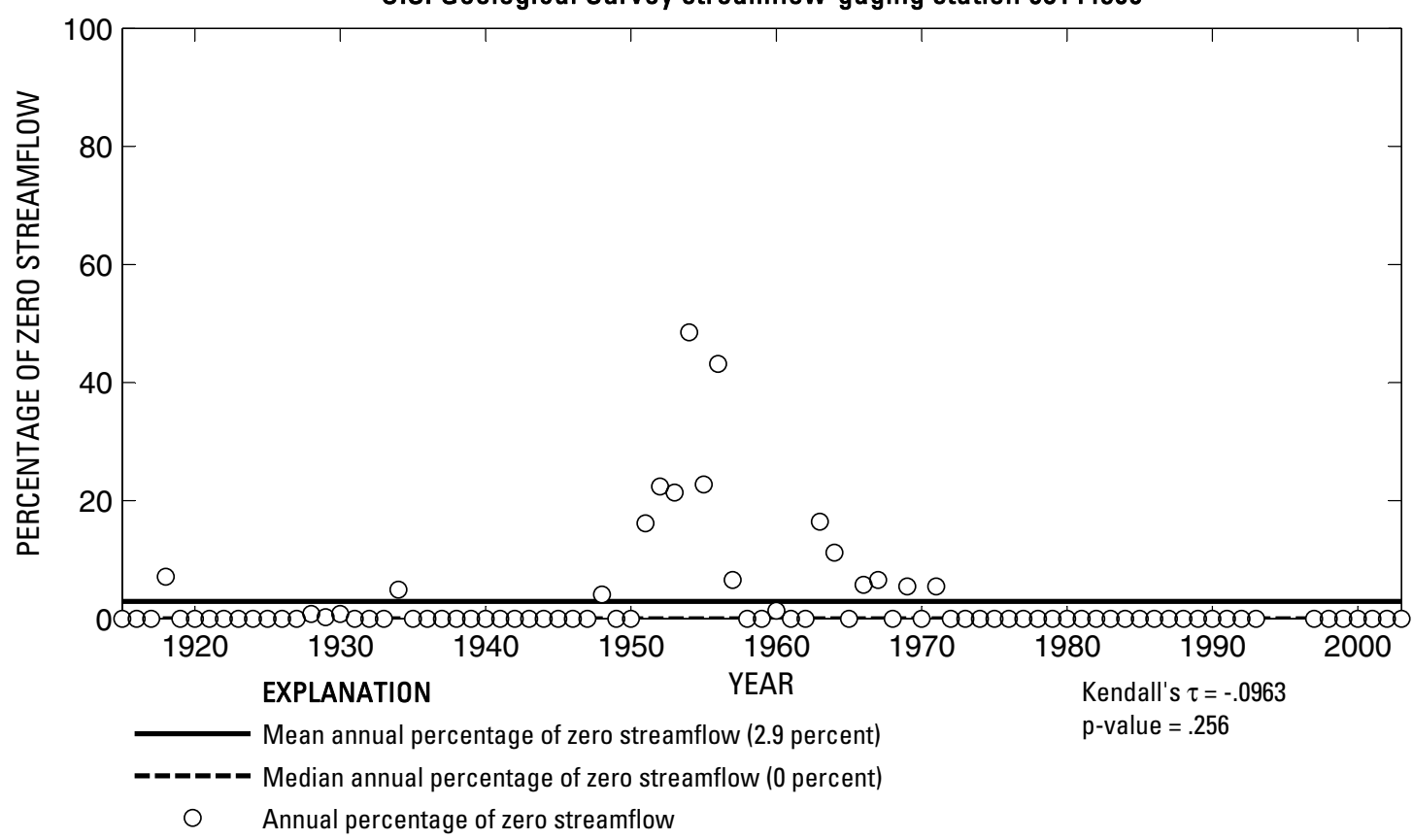

U.S. Geological Survey streamflow-gaging station 08144500

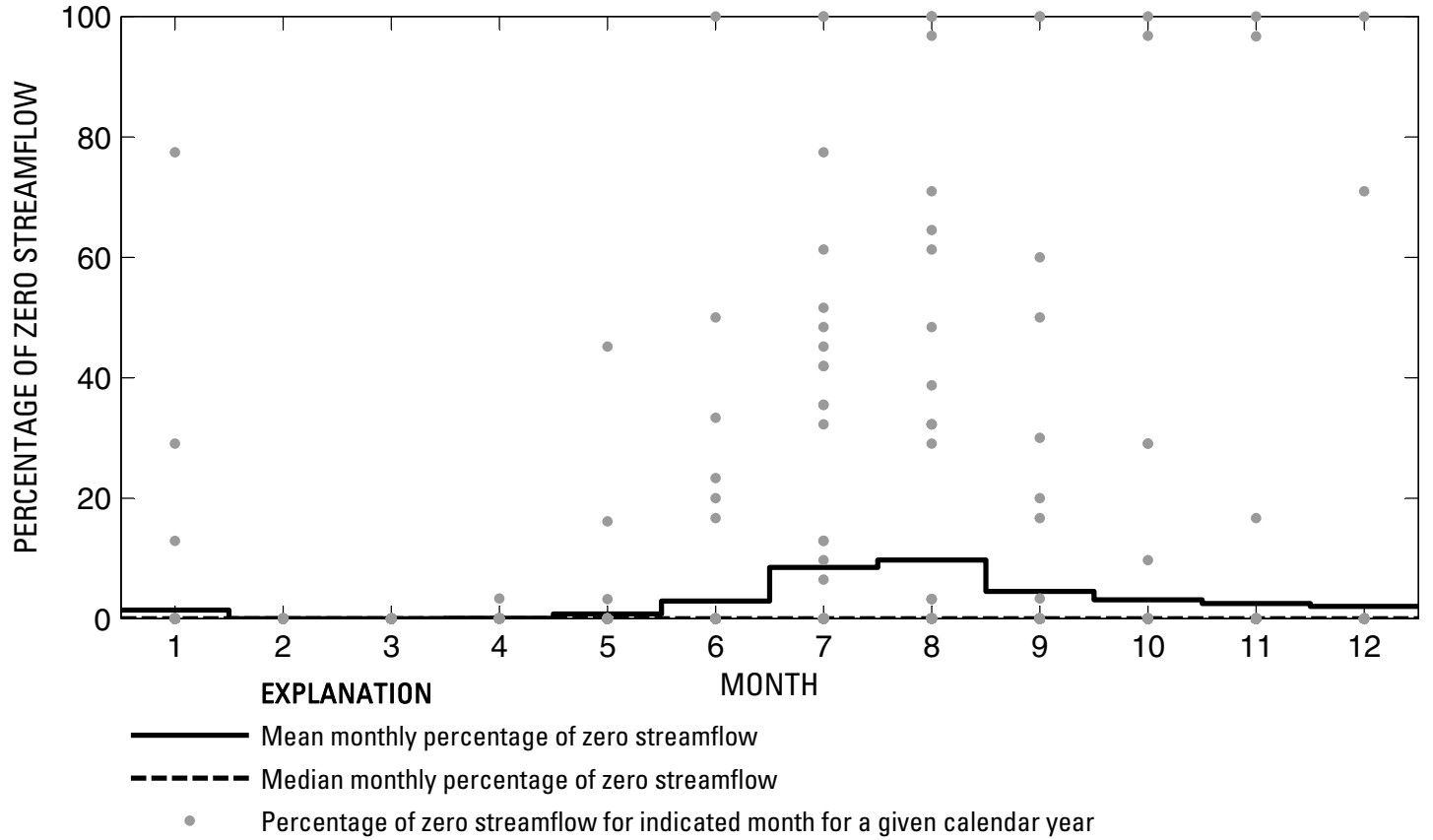

Figure 499. Analysis of percentage of zero daily mean streamflow for U.S. Geological Survey streamflow-gaging station 08144500 San Saba River at Menard, Texas. 

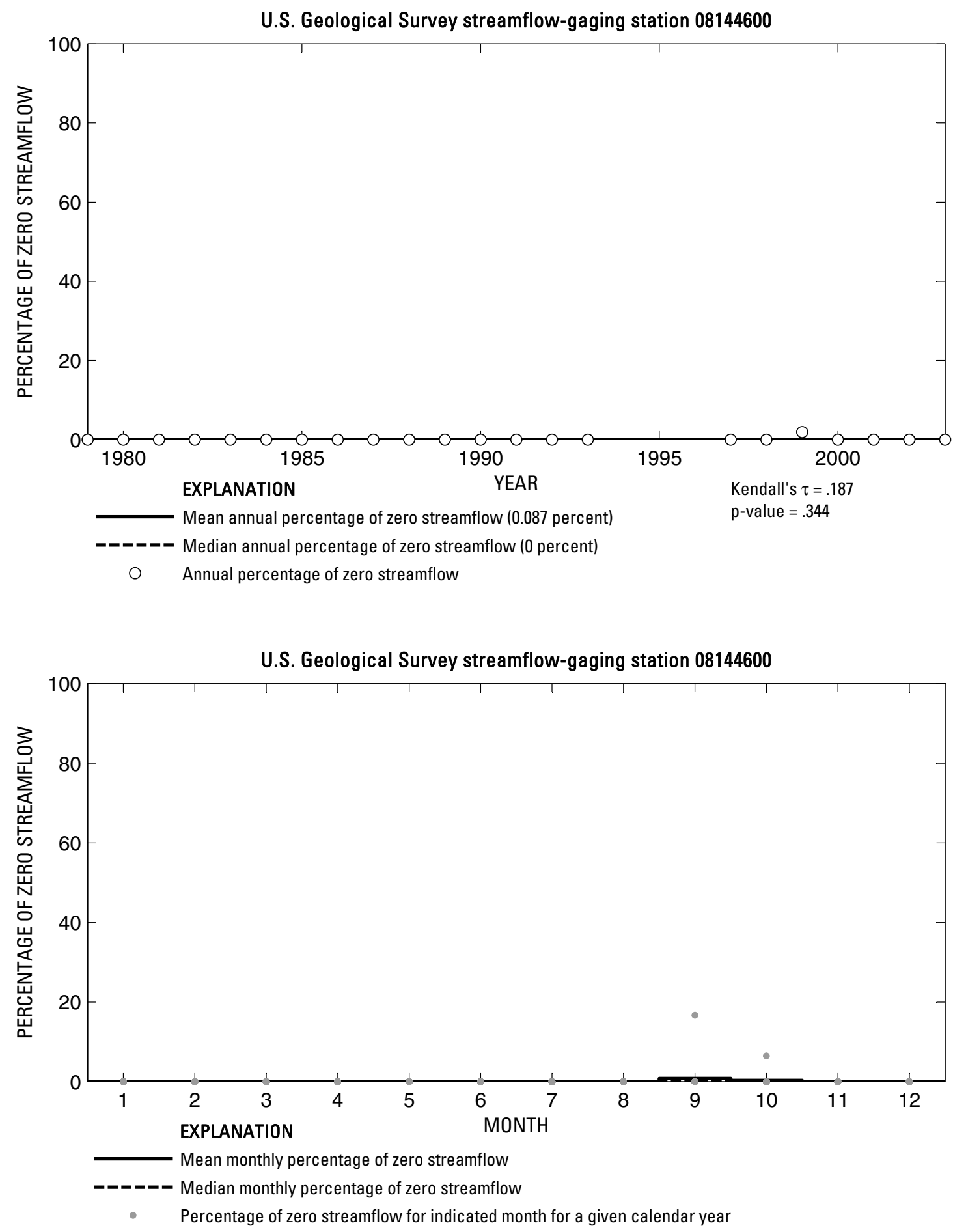

Figure 500. Analysis of percentage of zero daily mean streamflow for U.S. Geological Survey streamflow-gaging station 08144600 San Saba River near Brady, Texas. 

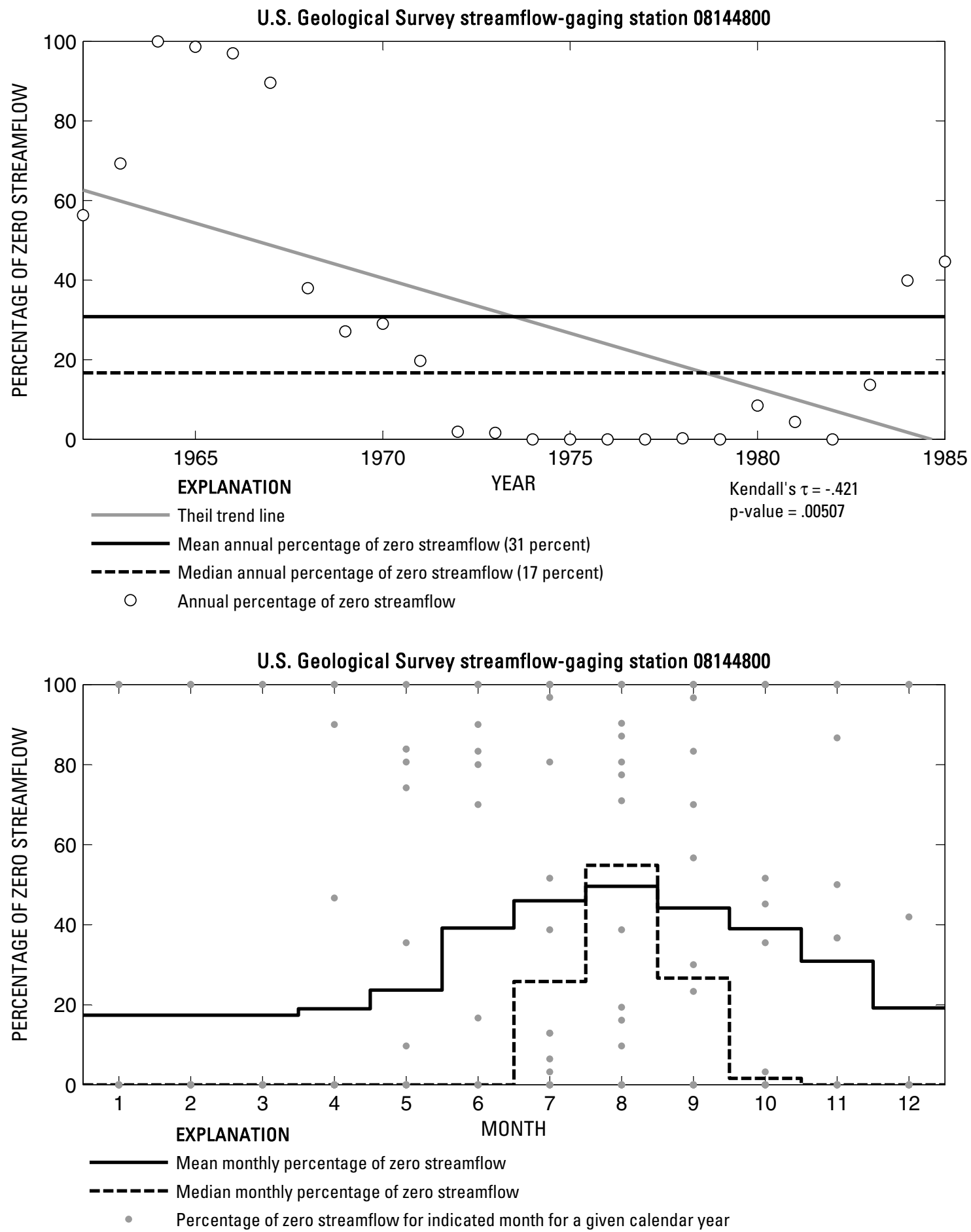

Figure 501. Analysis of percentage of zero daily mean streamflow for U.S. Geological Survey streamflow-gaging station 08144800 Brady Creek near Eden, Texas. 
U.S. Geological Survey streamflow-gaging station 08145000

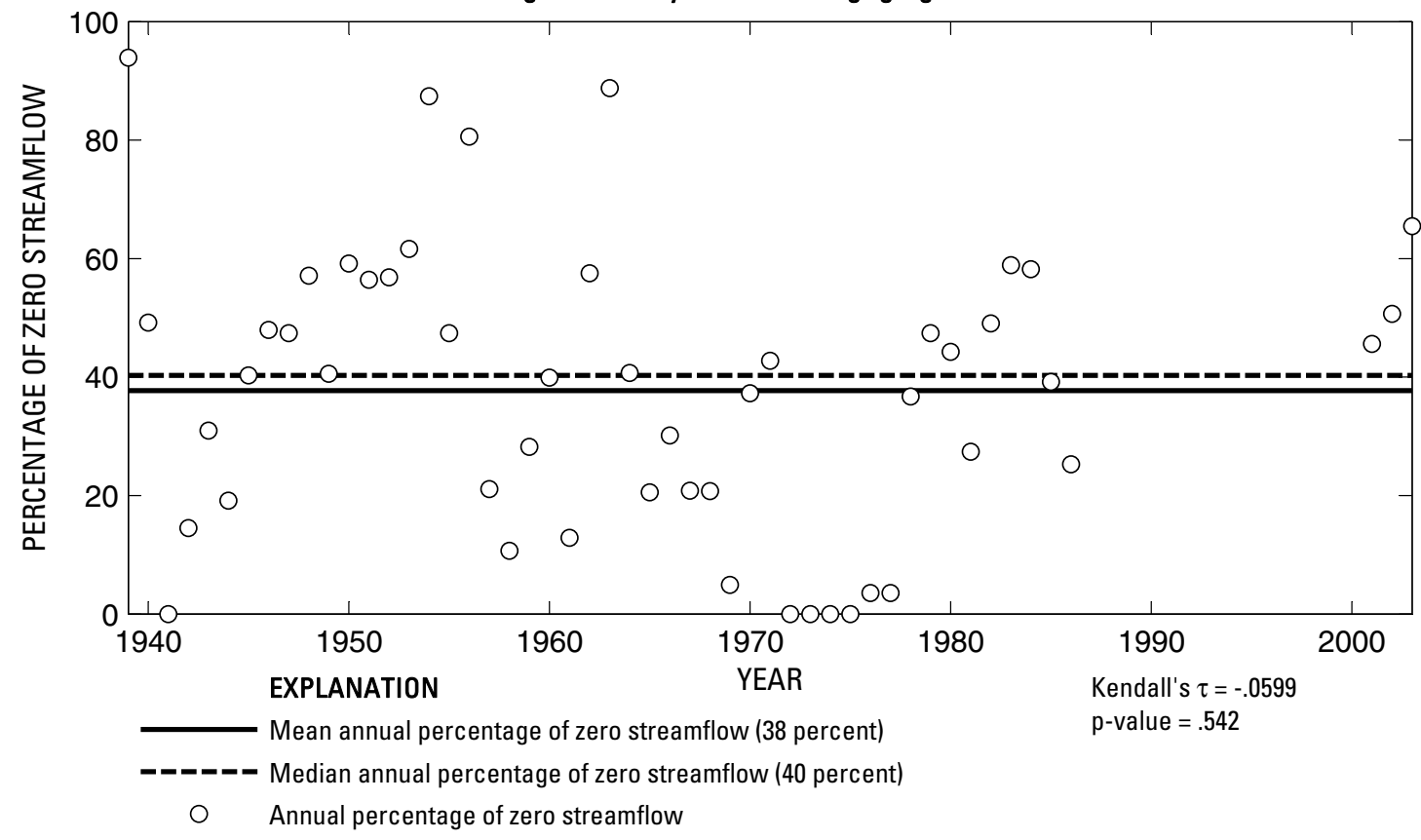

U.S. Geological Survey streamflow-gaging station 08145000

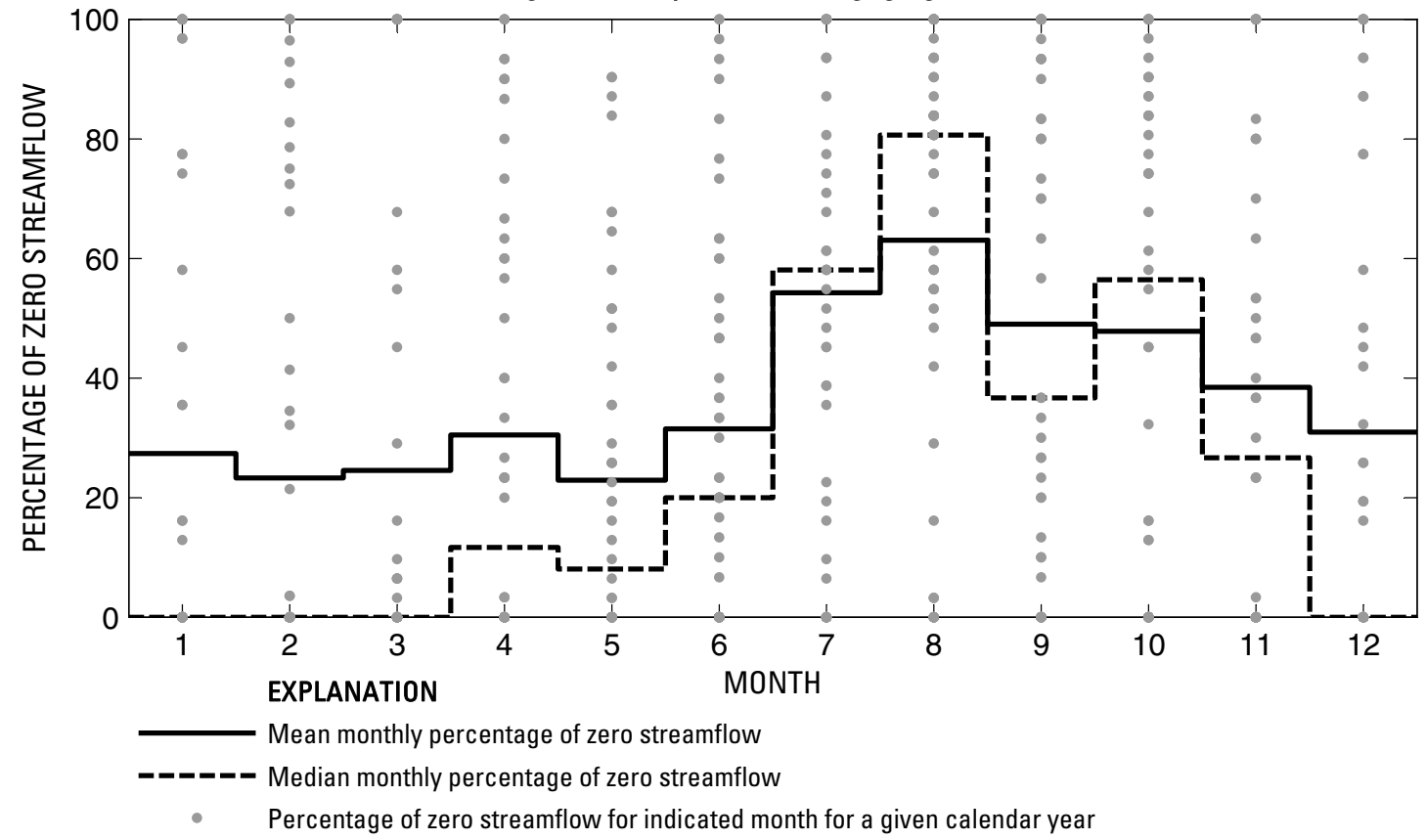

Figure 502. Analysis of percentage of zero daily mean streamflow for U.S. Geological Survey streamflow-gaging station 08145000 Brady Creek at Brady, Texas.

Index of Station Numbers 719 


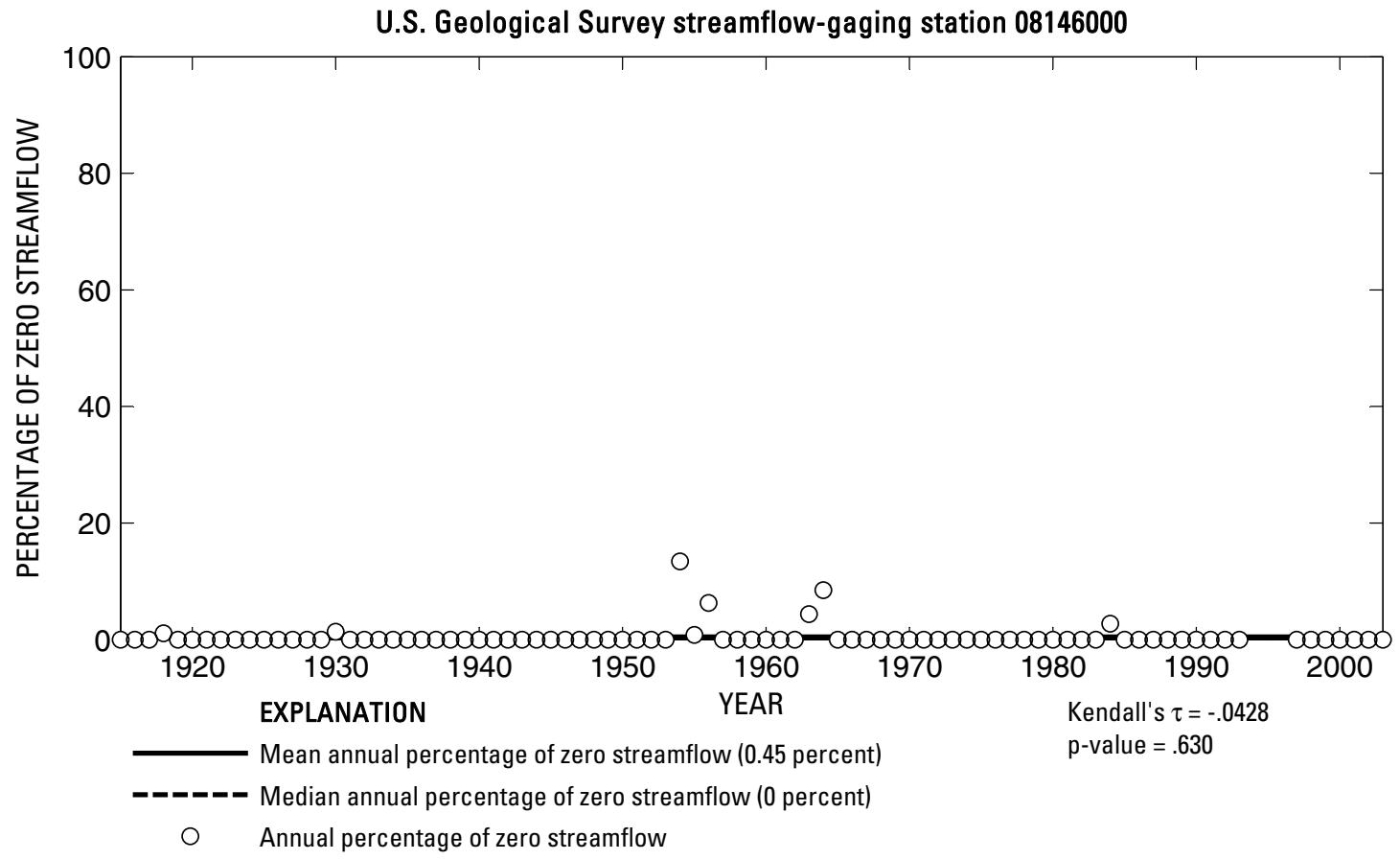

U.S. Geological Survey streamflow-gaging station 08146000

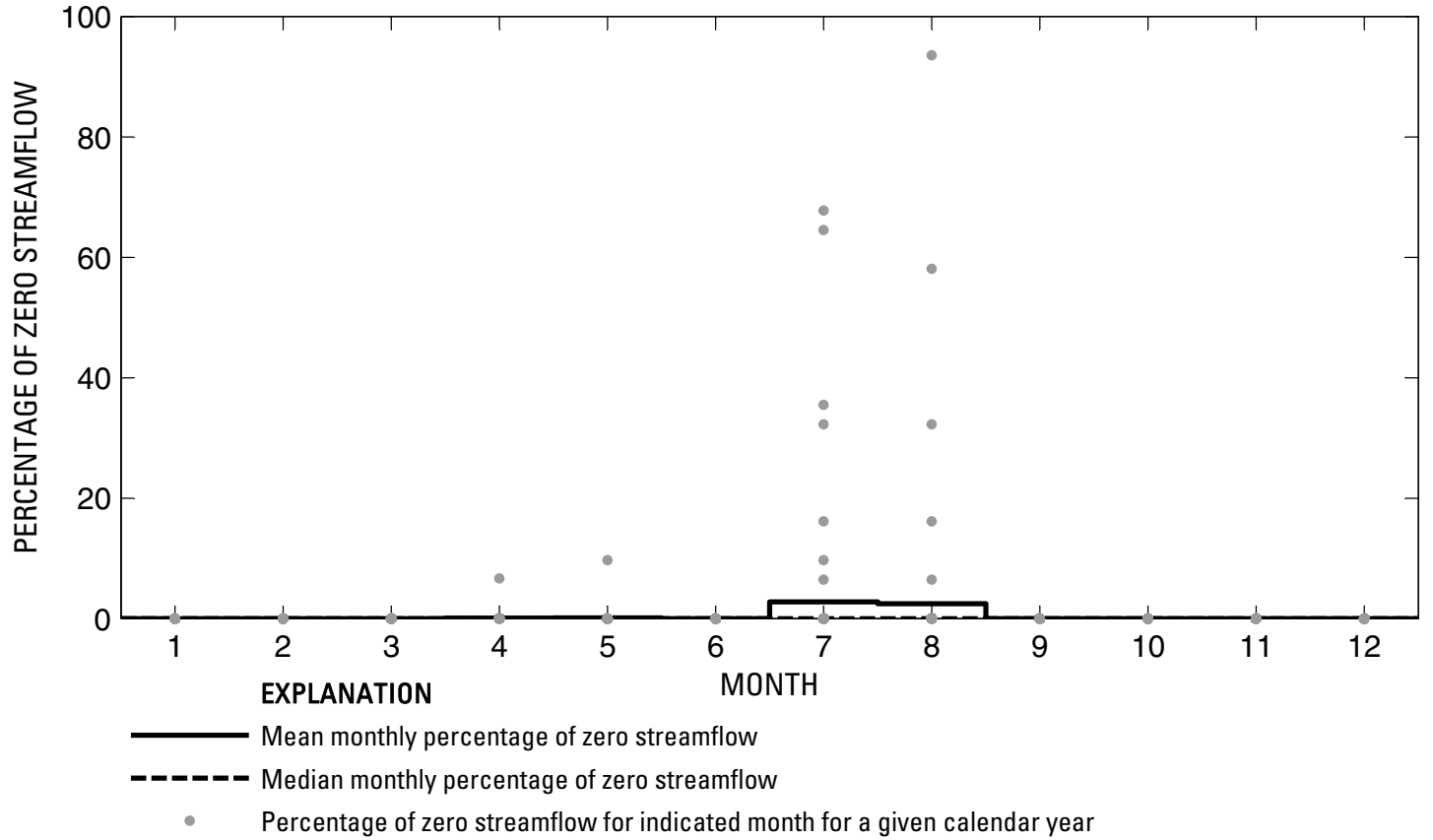

Figure 503. Analysis of percentage of zero daily mean streamflow for U.S. Geological Survey streamflow-gaging station 08146000 San Saba River at San Saba, Texas. 
U.S. Geological Survey streamflow-gaging station 08147000

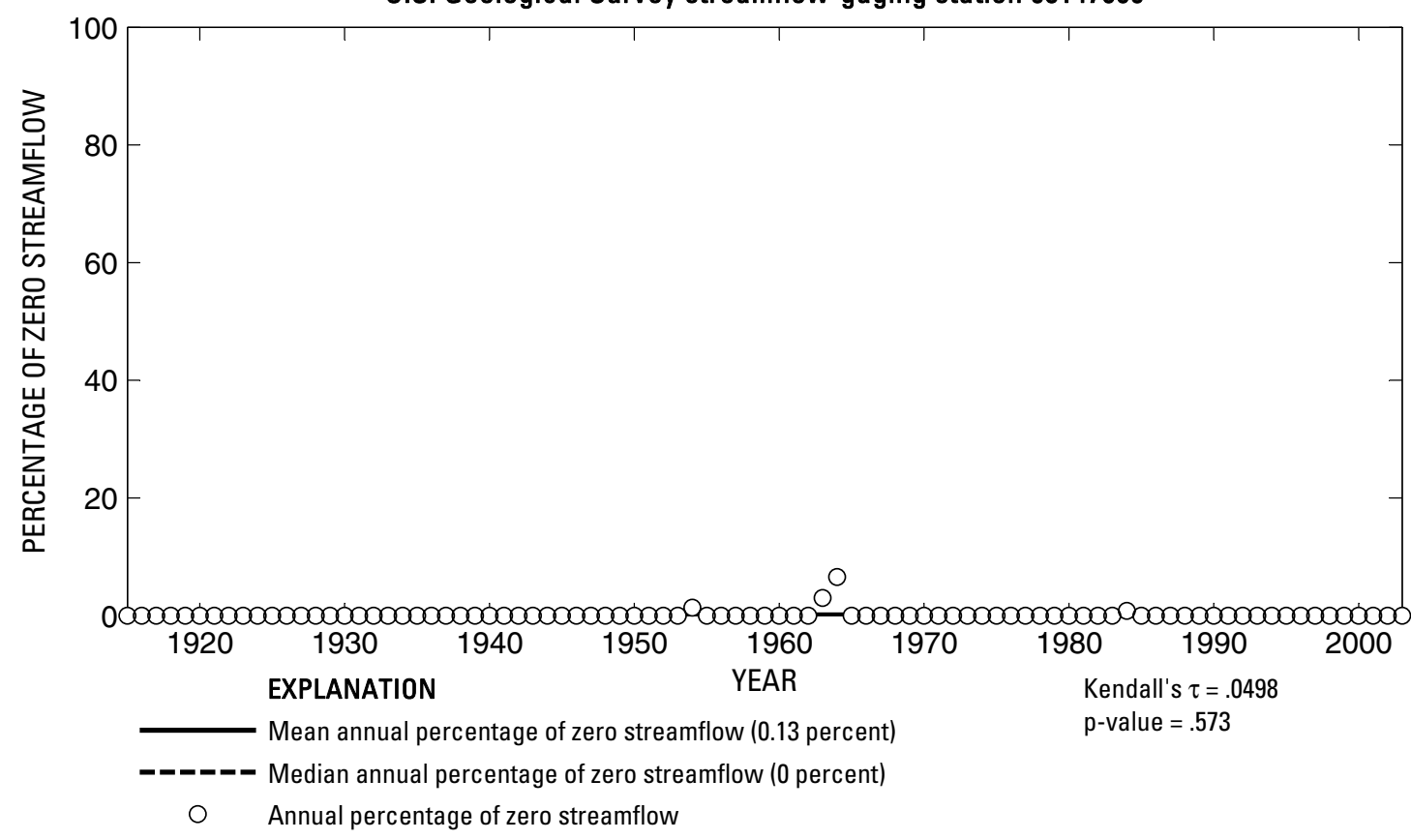

U.S. Geological Survey streamflow-gaging station 08147000

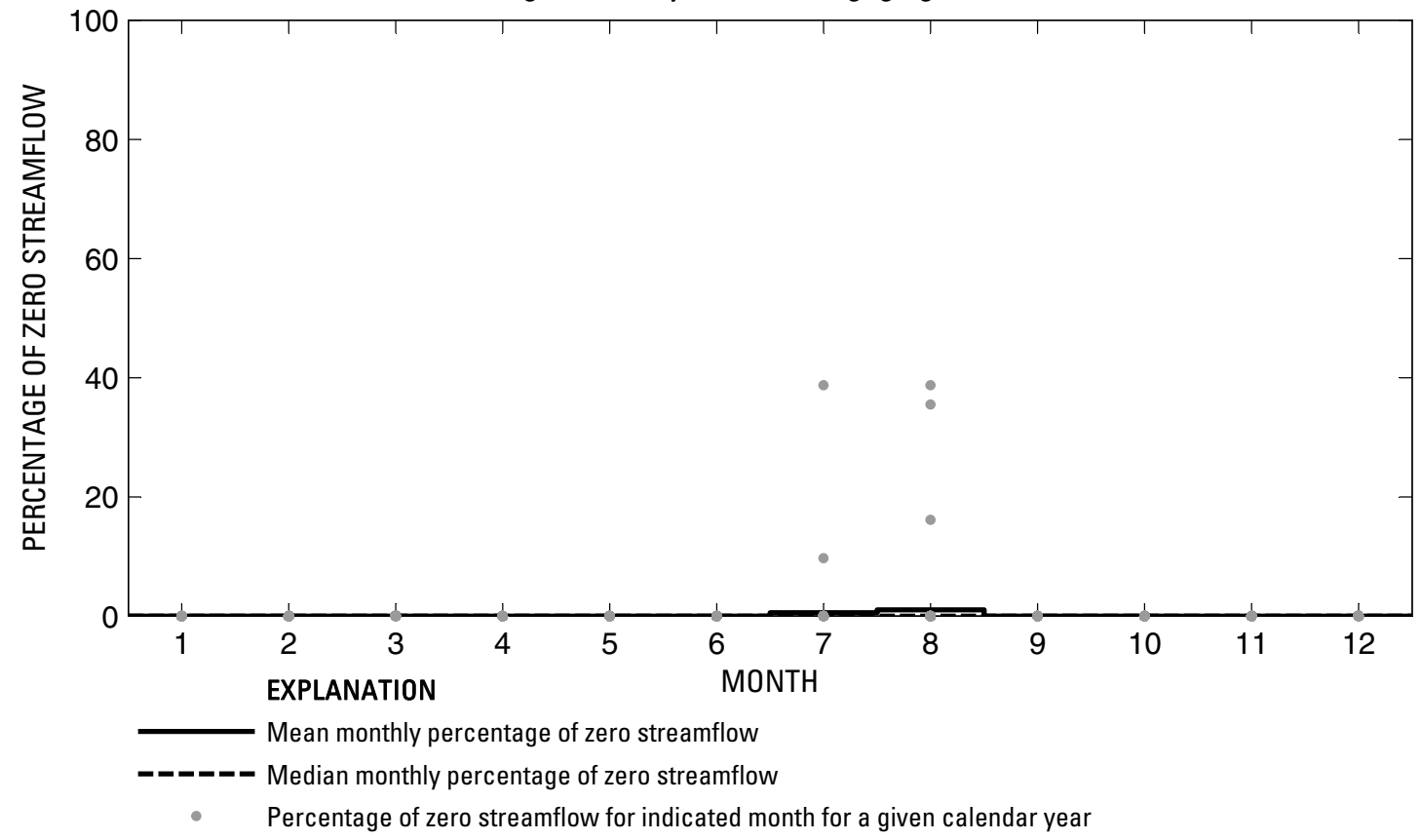

Figure 504. Analysis of percentage of zero daily mean streamflow for U.S. Geological Survey streamflow-gaging station 08147000 Colorado River near San Saba, Texas. 
U.S. Geological Survey streamflow-gaging station 08148500

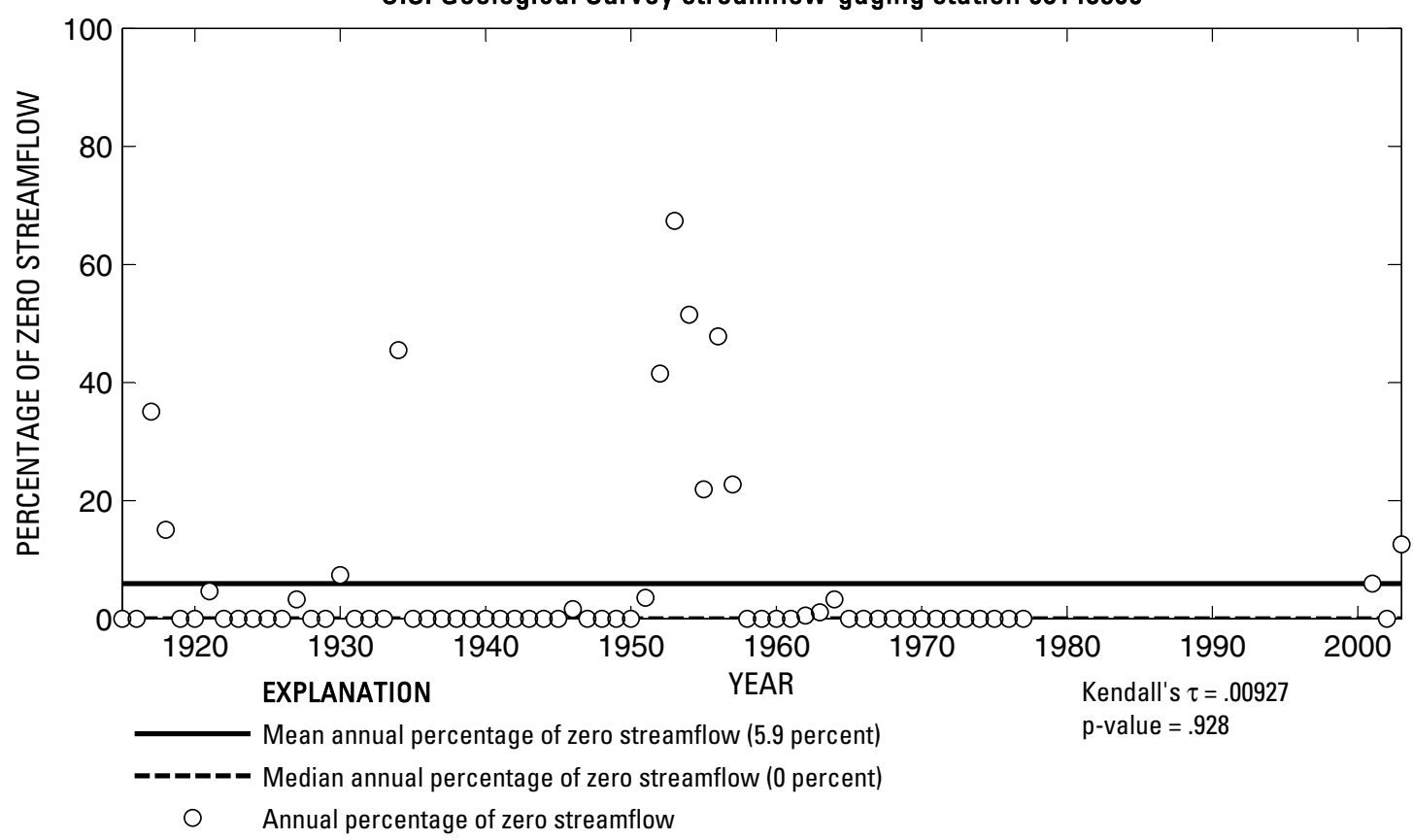

U.S. Geological Survey streamflow-gaging station 08148500

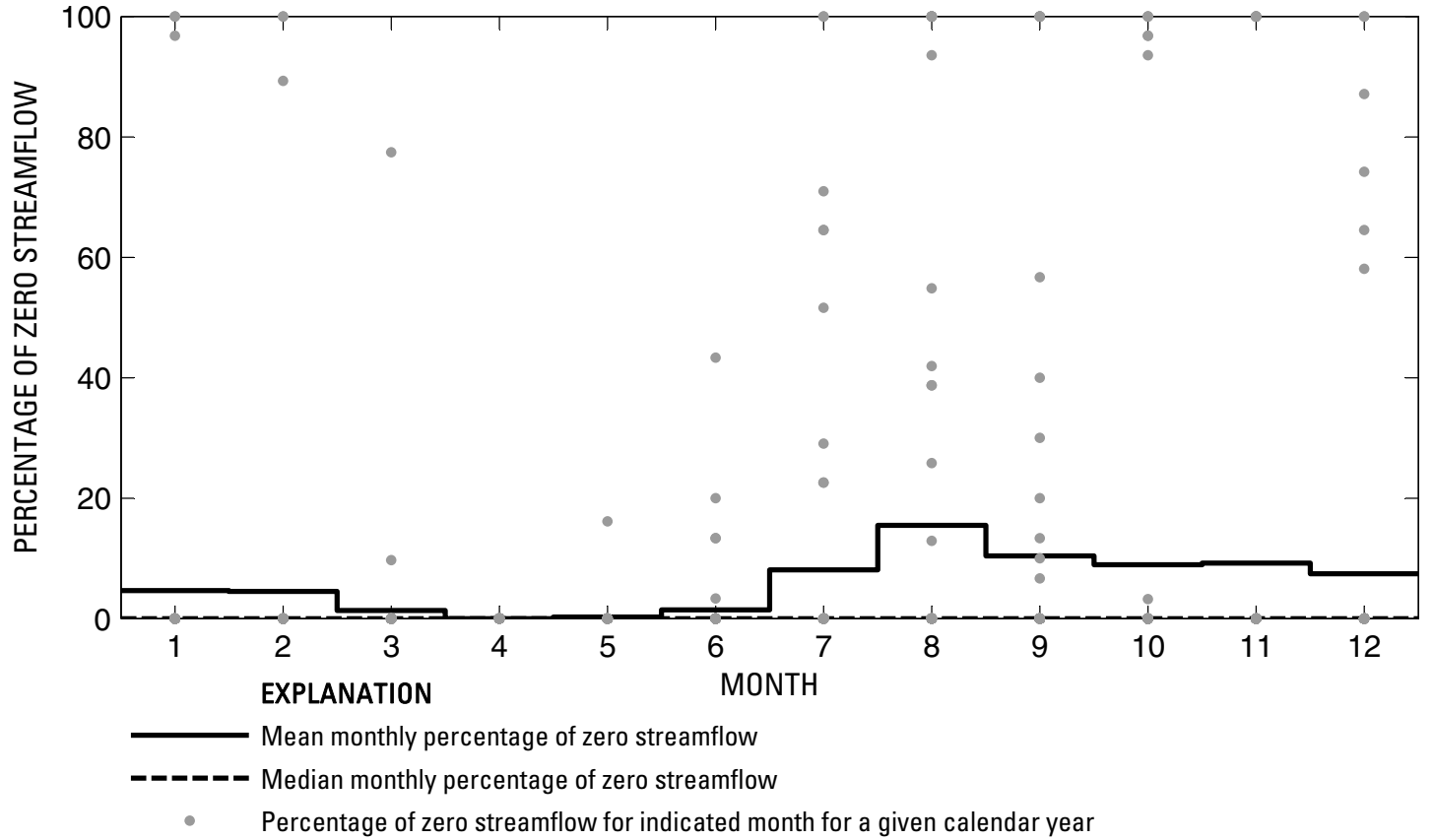

Figure 505. Analysis of percentage of zero daily mean streamflow for U.S. Geological Survey streamflow-gaging station 08148500 North Llano River near Junction, Texas. 
U.S. Geological Survey streamflow-gaging station 08150000

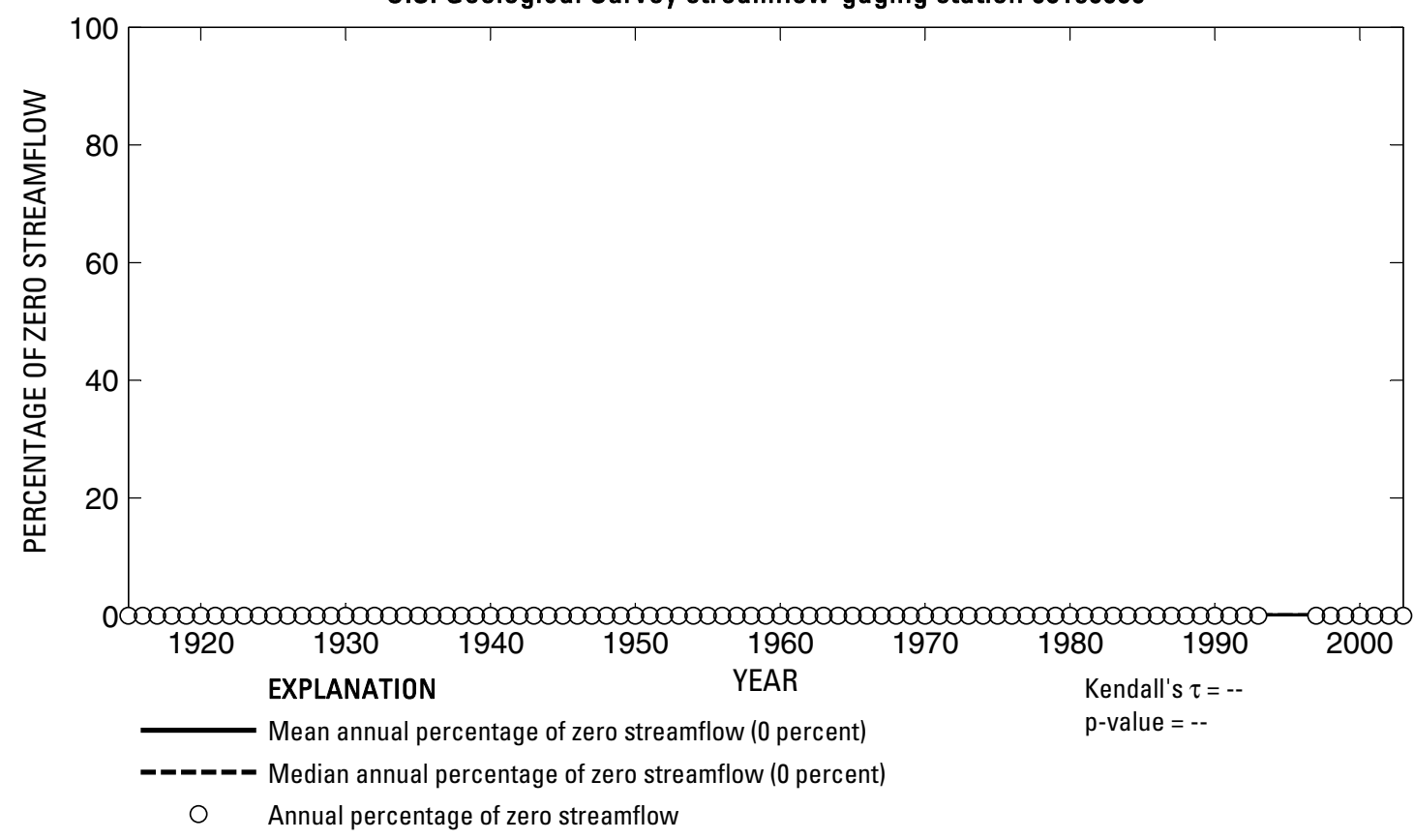

U.S. Geological Survey streamflow-gaging station 08150000

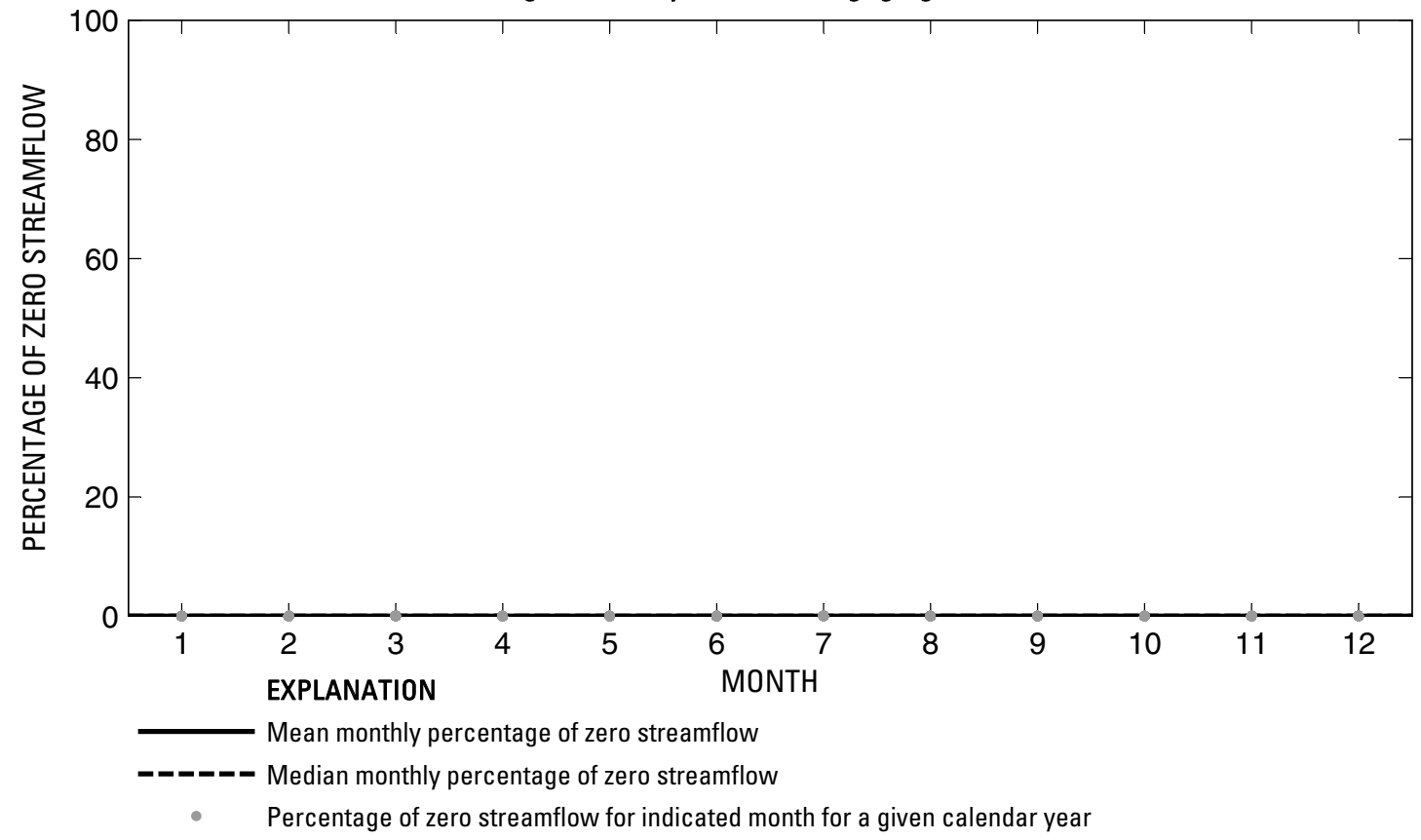

Figure 506. Analysis of percentage of zero daily mean streamflow for U.S. Geological Survey streamflow-gaging station 08150000 Llano River near Junction, Texas. 
U.S. Geological Survey streamflow-gaging station 08150700

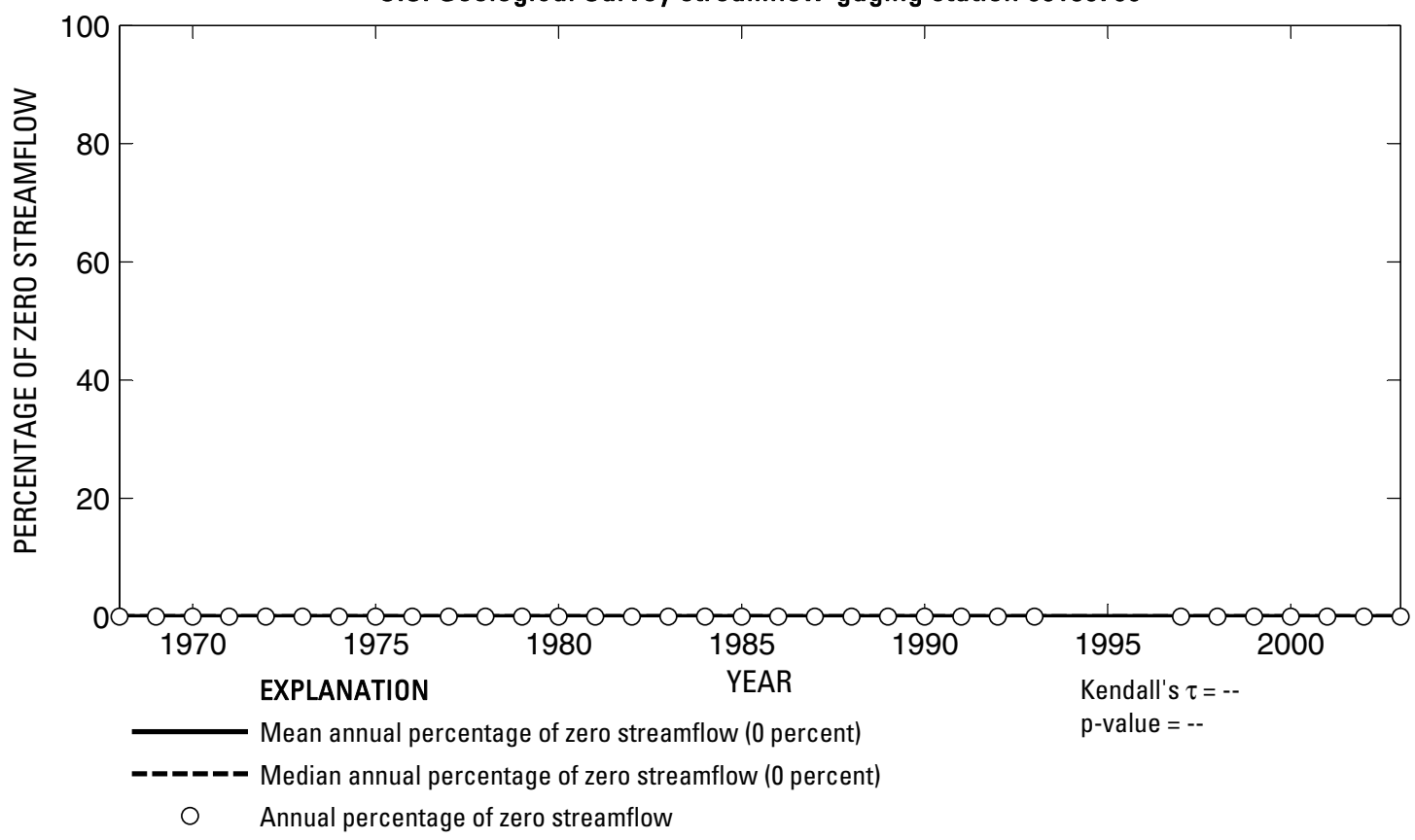

U.S. Geological Survey streamflow-gaging station 08150700

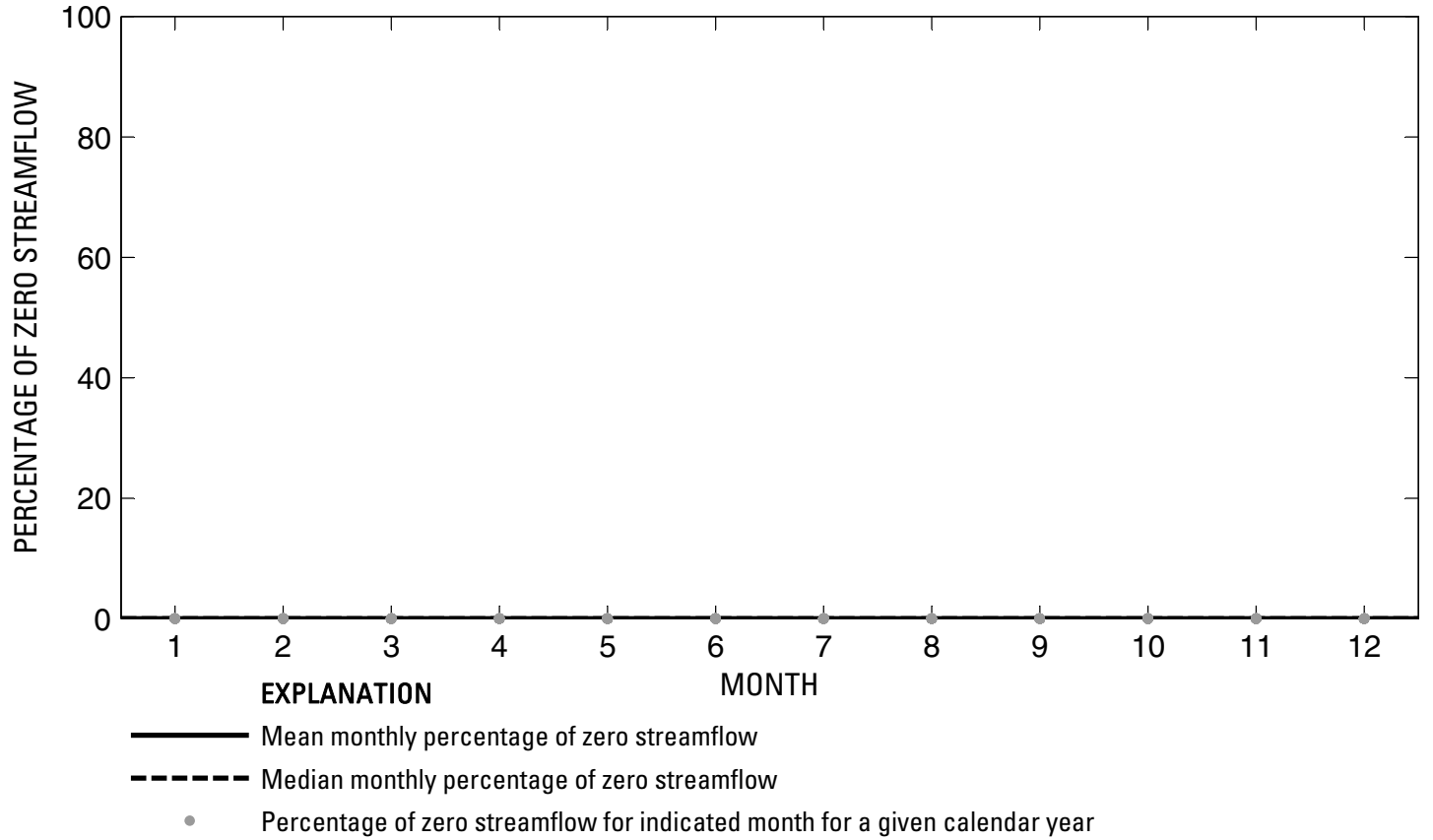

Figure 507. Analysis of percentage of zero daily mean streamflow for U.S. Geological Survey streamflow-gaging station 08150700 Llano River near Mason, Texas. 
U.S. Geological Survey streamflow-gaging station 08150800

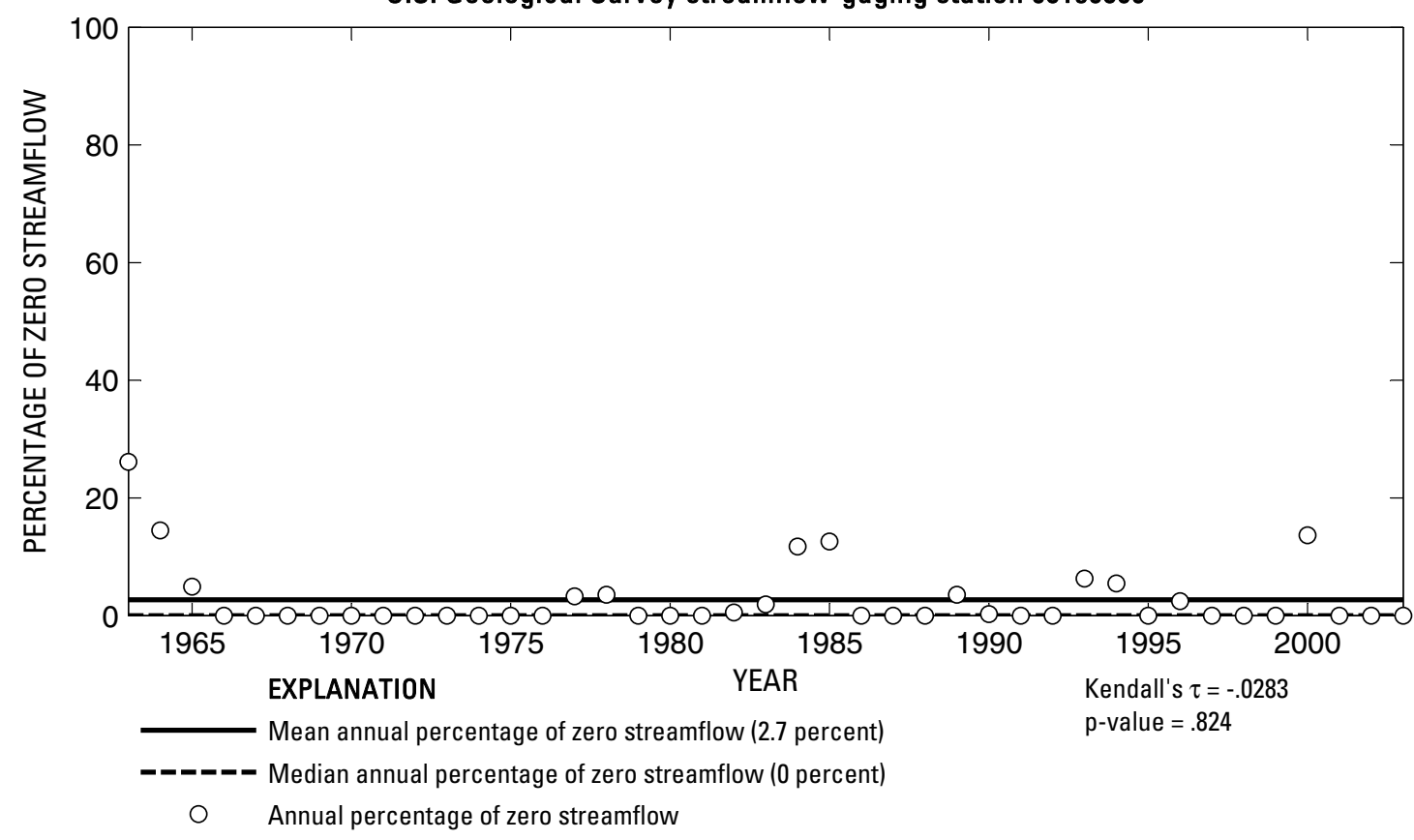

U.S. Geological Survey streamflow-gaging station 08150800

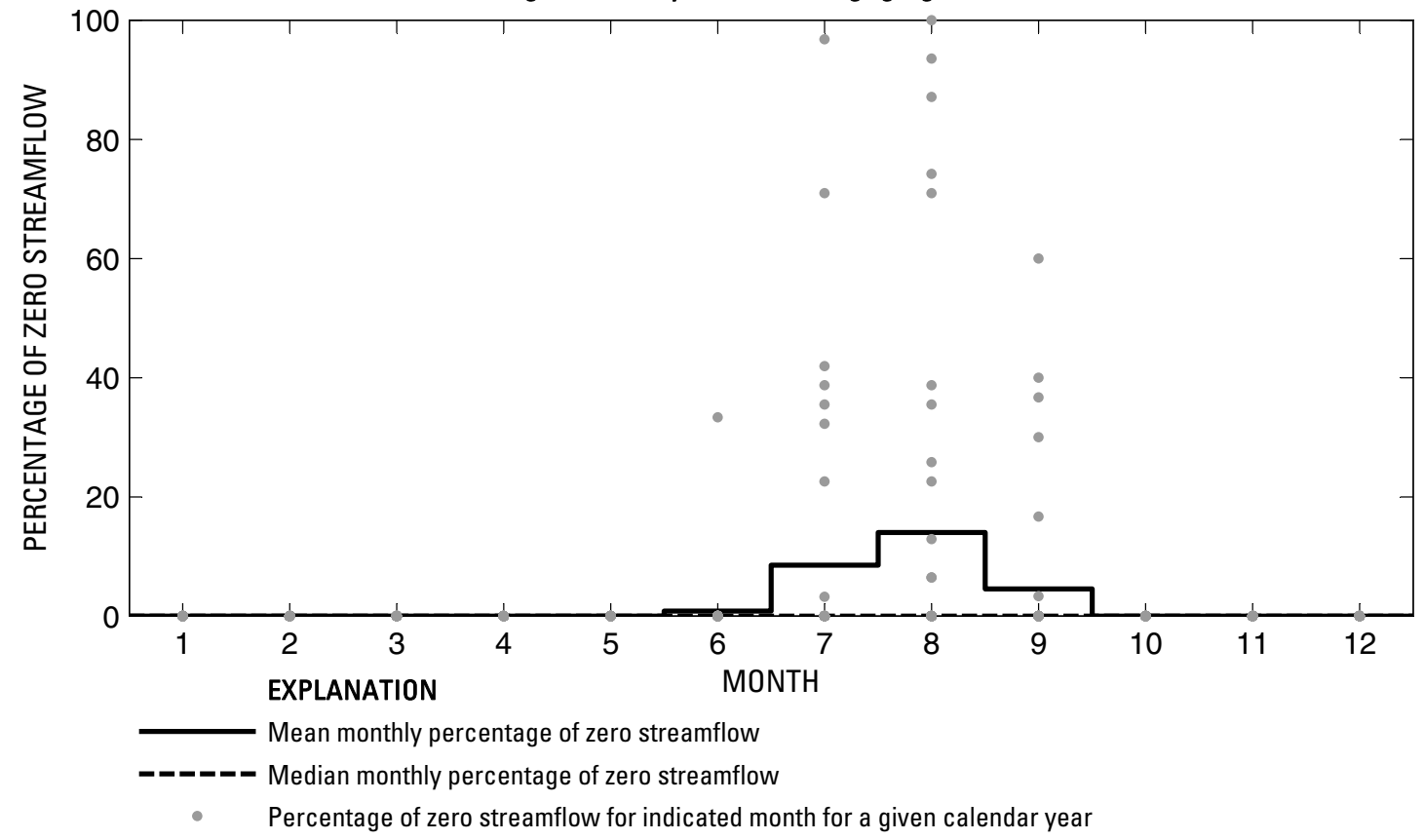

Figure 508. Analysis of percentage of zero daily mean streamflow for U.S. Geological Survey streamflow-gaging station 08150800 Beaver Creek near Mason, Texas. 


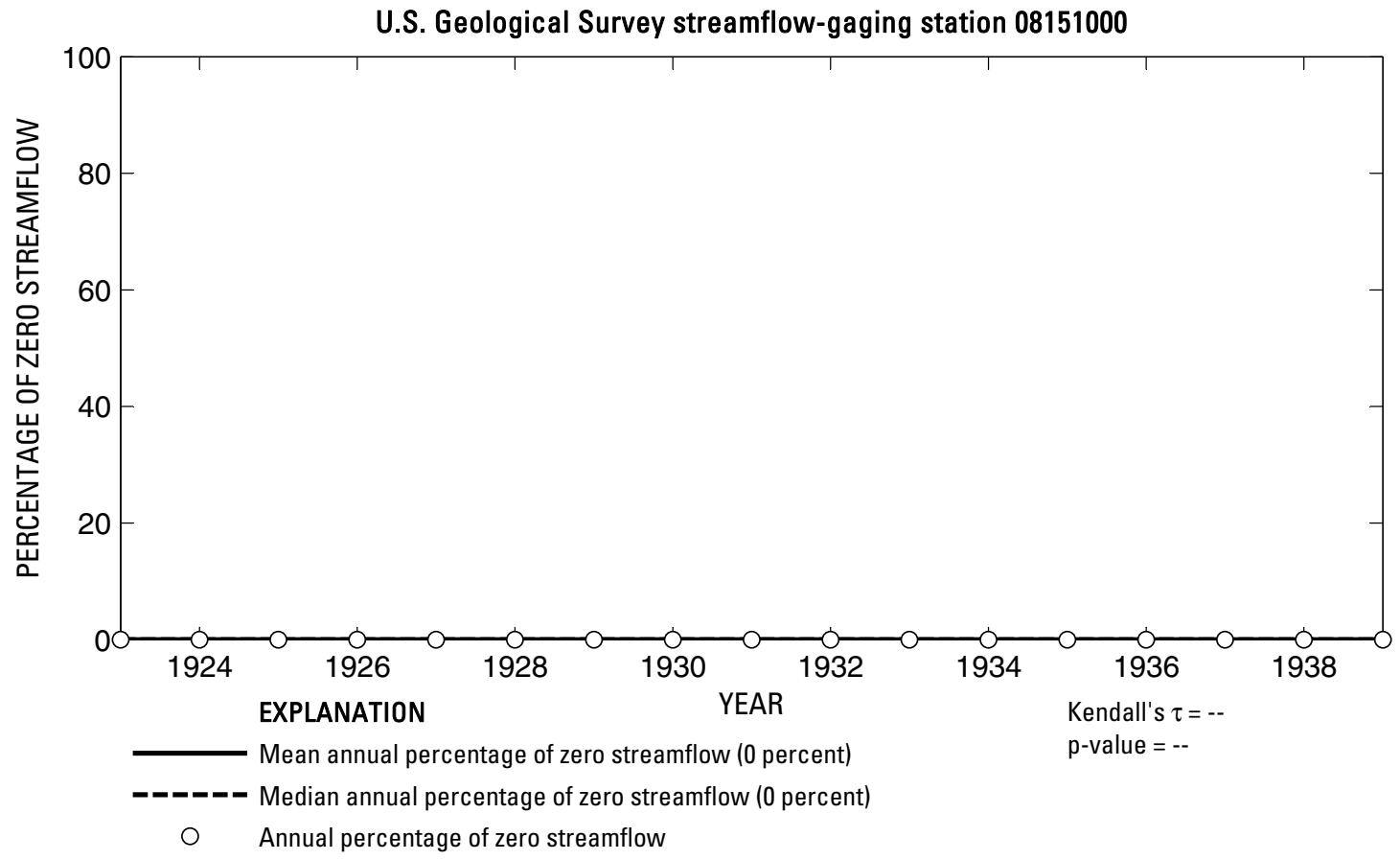

U.S. Geological Survey streamflow-gaging station 08151000

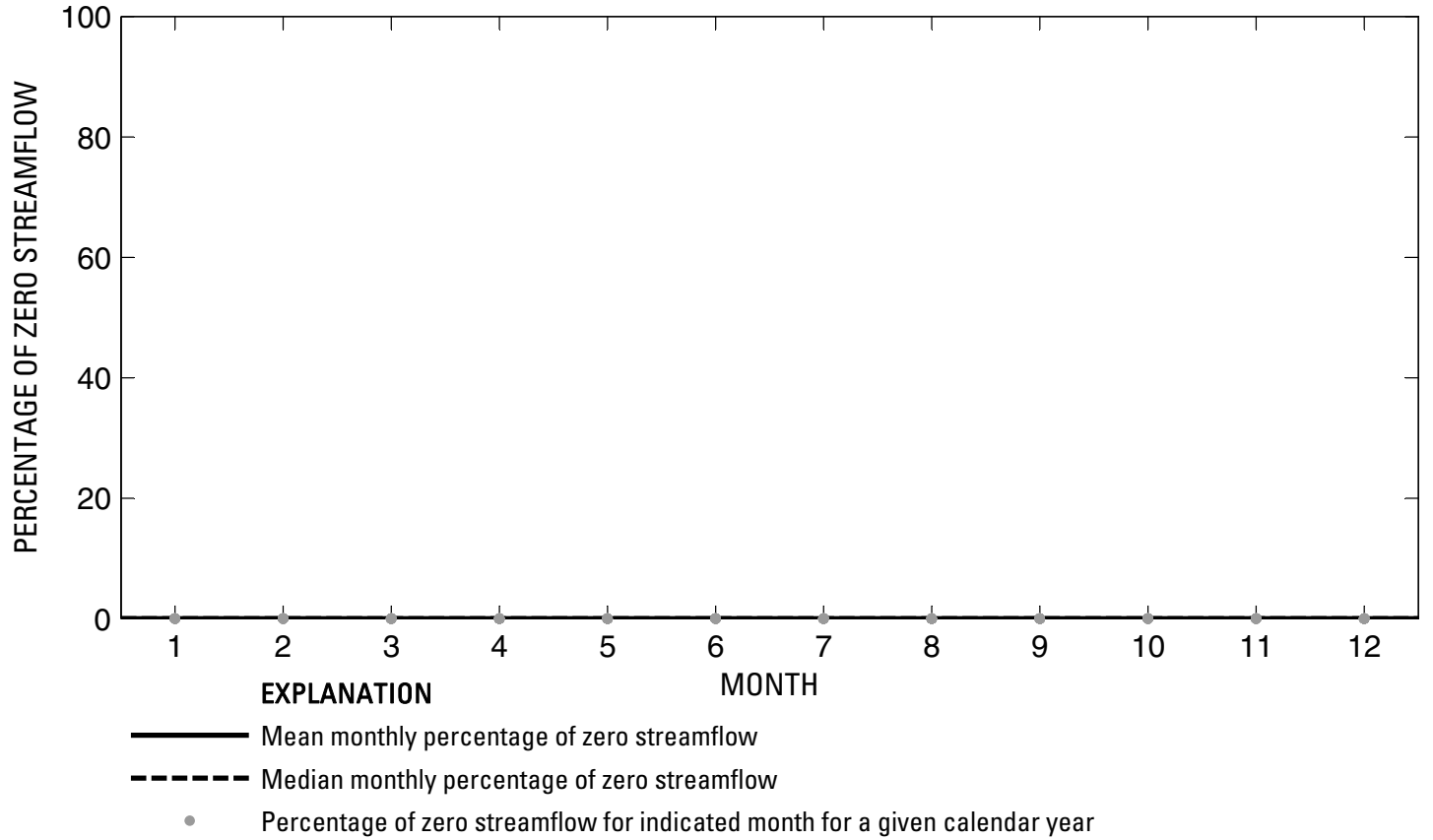

Figure 509. Analysis of percentage of zero daily mean streamflow for U.S. Geological Survey streamflow-gaging station 08151000 Llano River near Castell, Texas. 
U.S. Geological Survey streamflow-gaging station 08151500

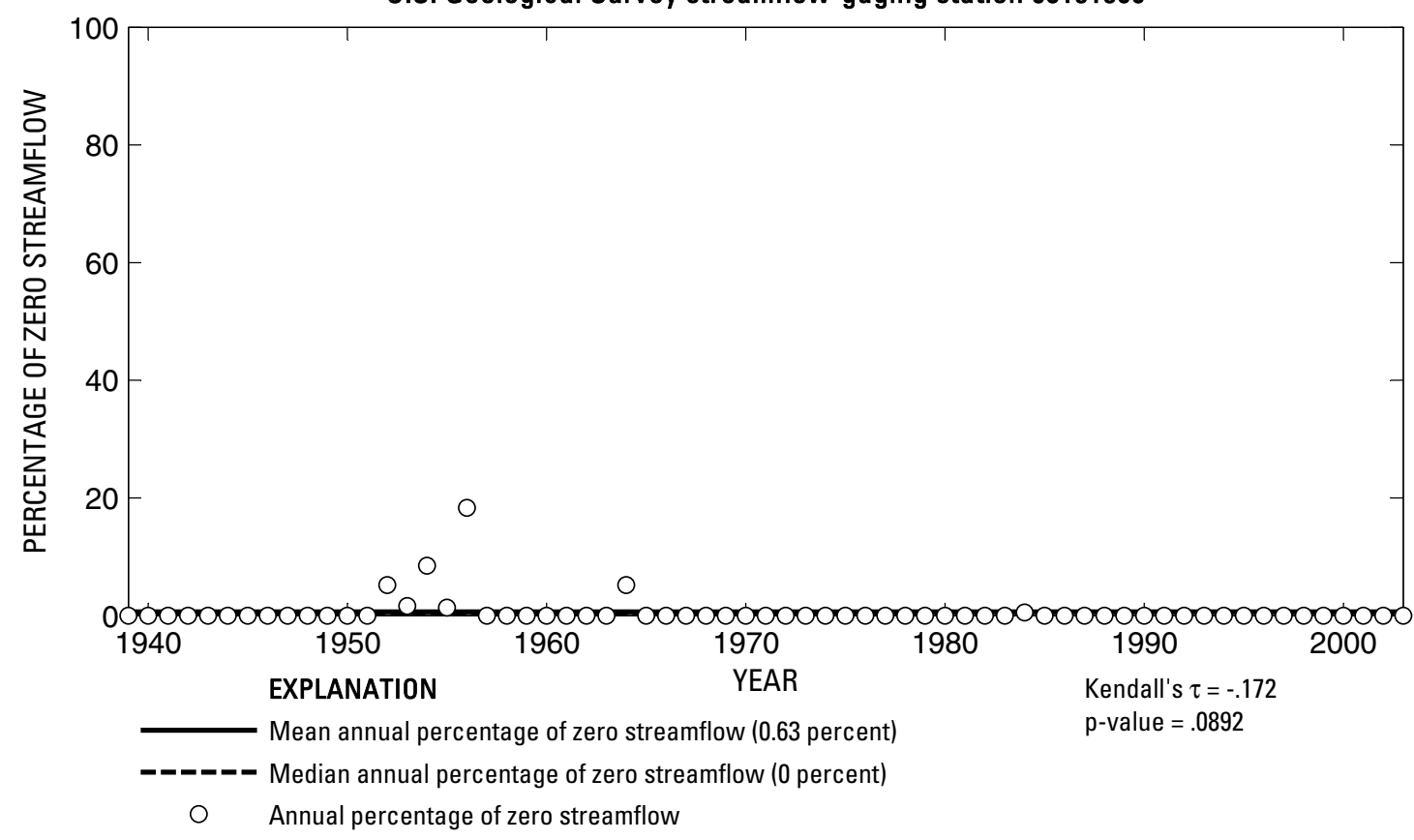

U.S. Geological Survey streamflow-gaging station 08151500

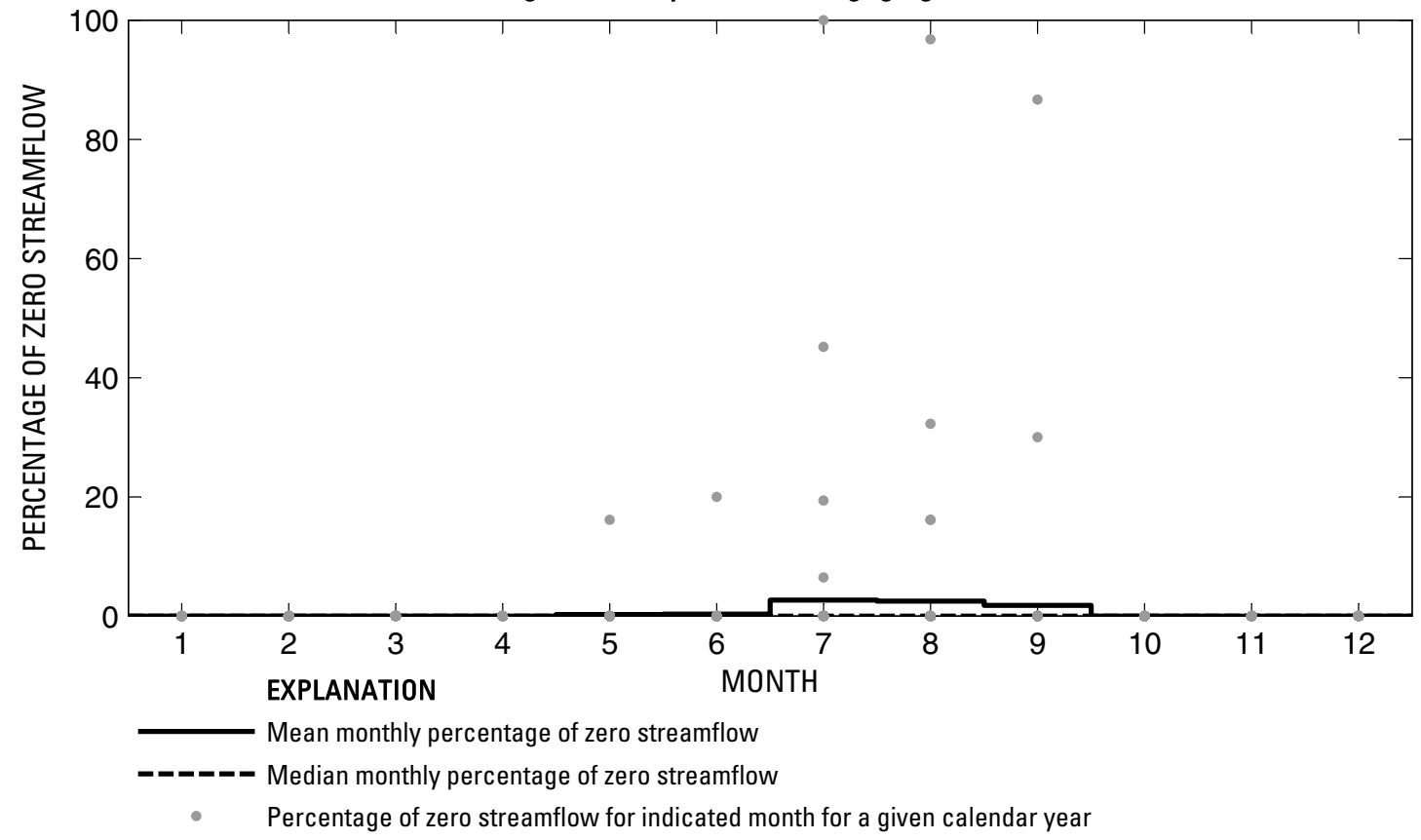

Figure 510. Analysis of percentage of zero daily mean streamflow for U.S. Geological Survey streamflow-gaging station 08151500 Llano River at Llano, Texas. 
U.S. Geological Survey streamflow-gaging station 08152000

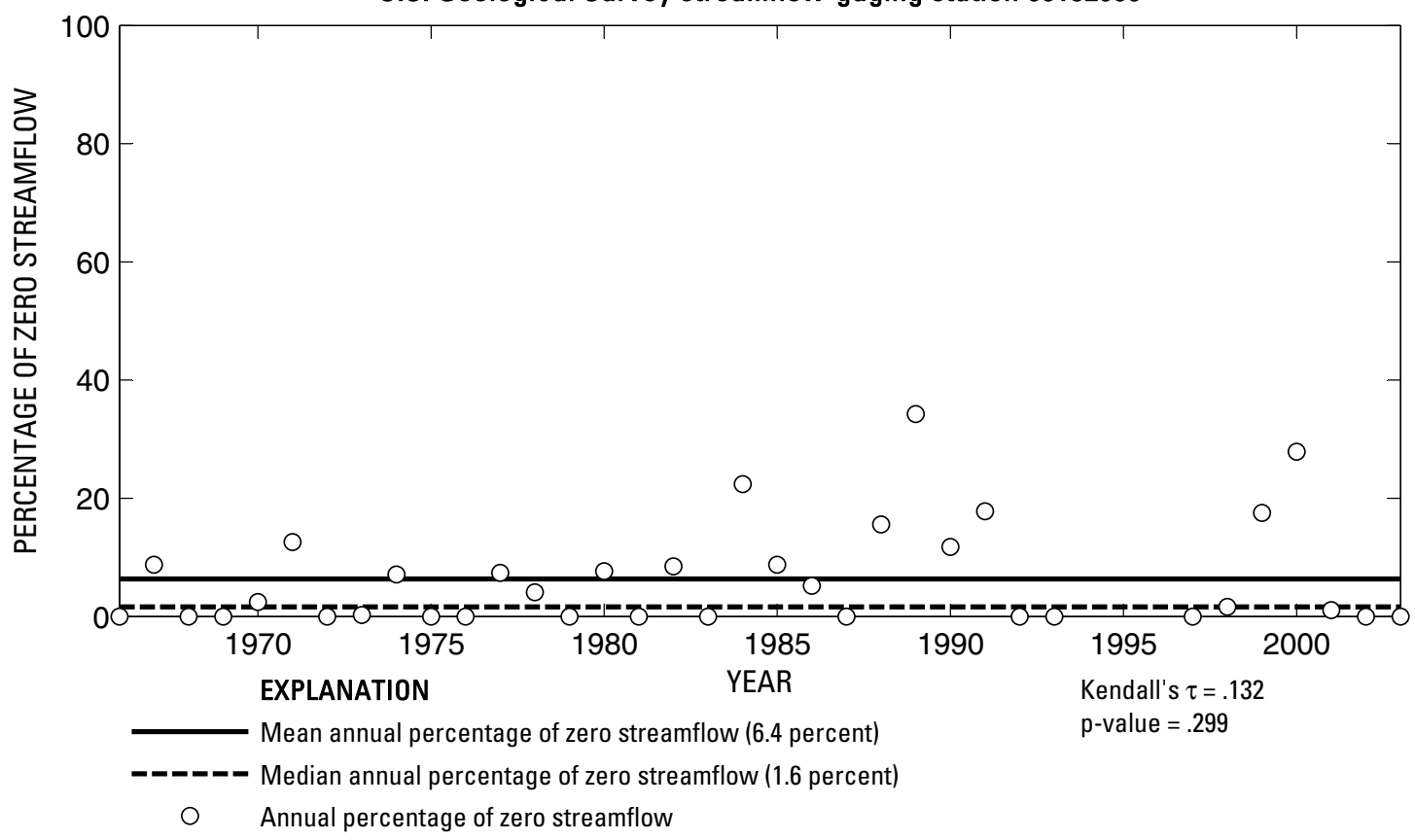

U.S. Geological Survey streamflow-gaging station 08152000

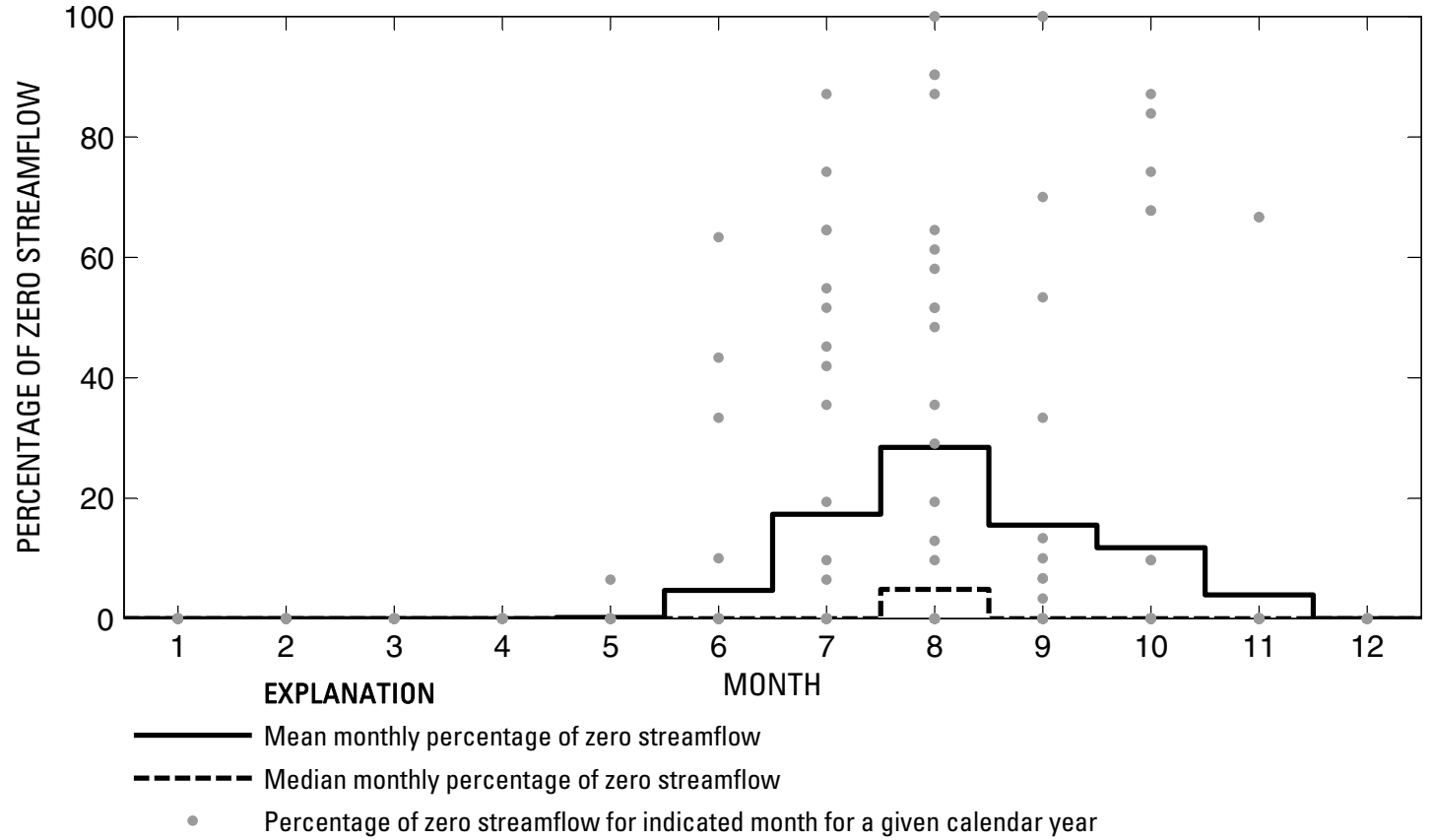

Figure 511. Analysis of percentage of zero daily mean streamflow for U.S. Geological Survey streamflow-gaging station 08152000 Sandy Creek near Kingsland, Texas. 
U.S. Geological Survey streamflow-gaging station 08152900

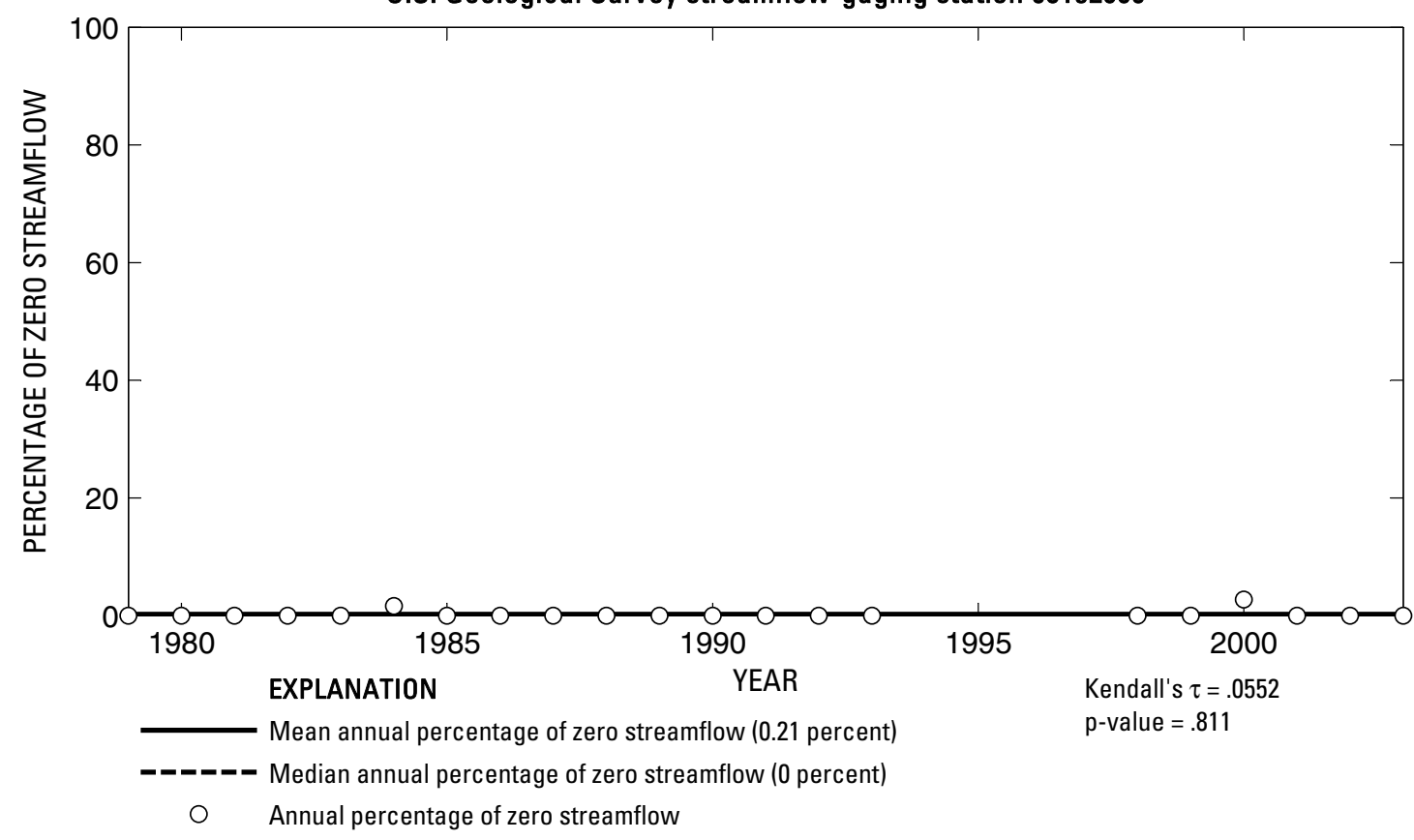

U.S. Geological Survey streamflow-gaging station 08152900

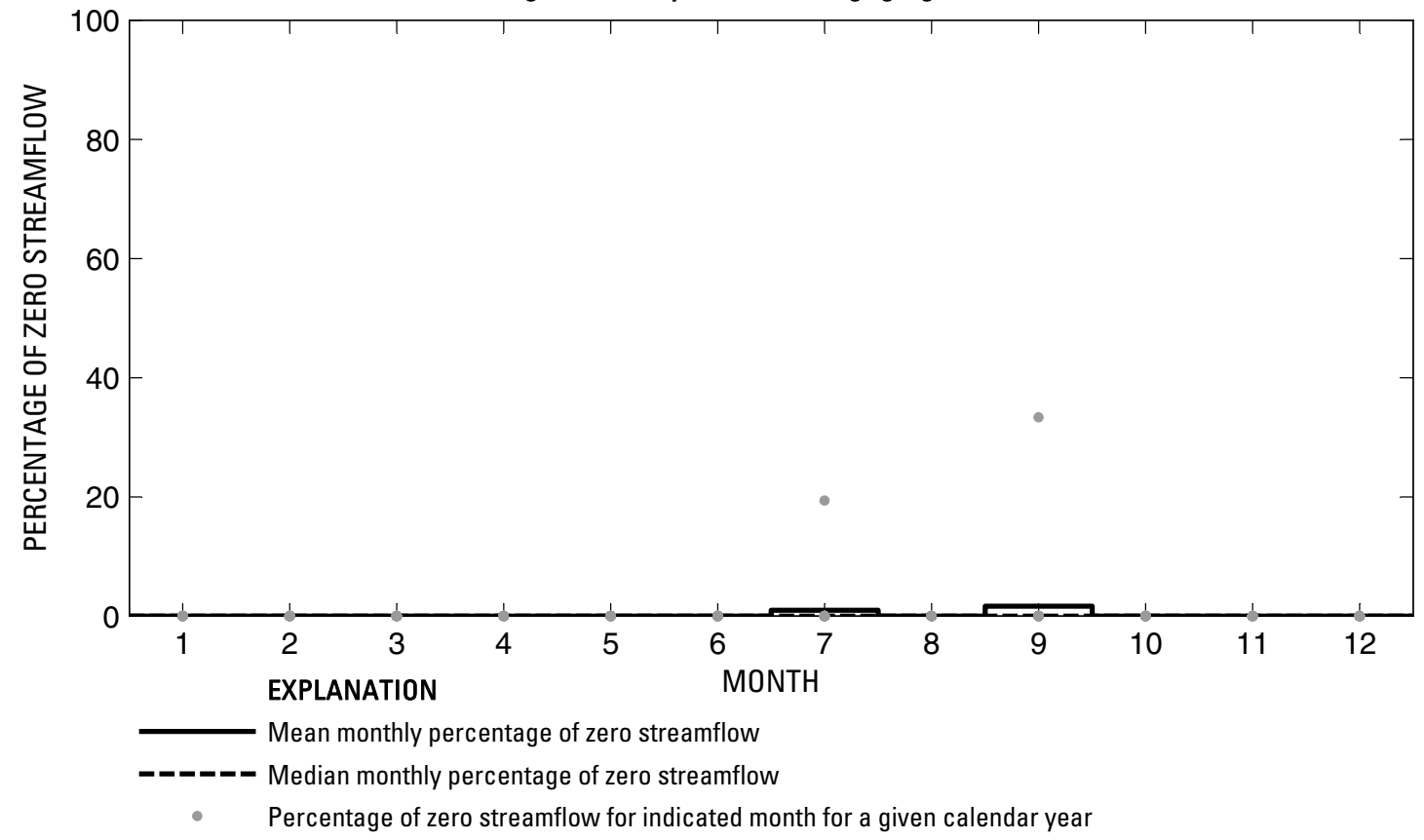

Figure 512. Analysis of percentage of zero daily mean streamflow for U.S. Geological Survey streamflow-gaging station 08152900 Pedernales River near Fredericksburg, Texas. 


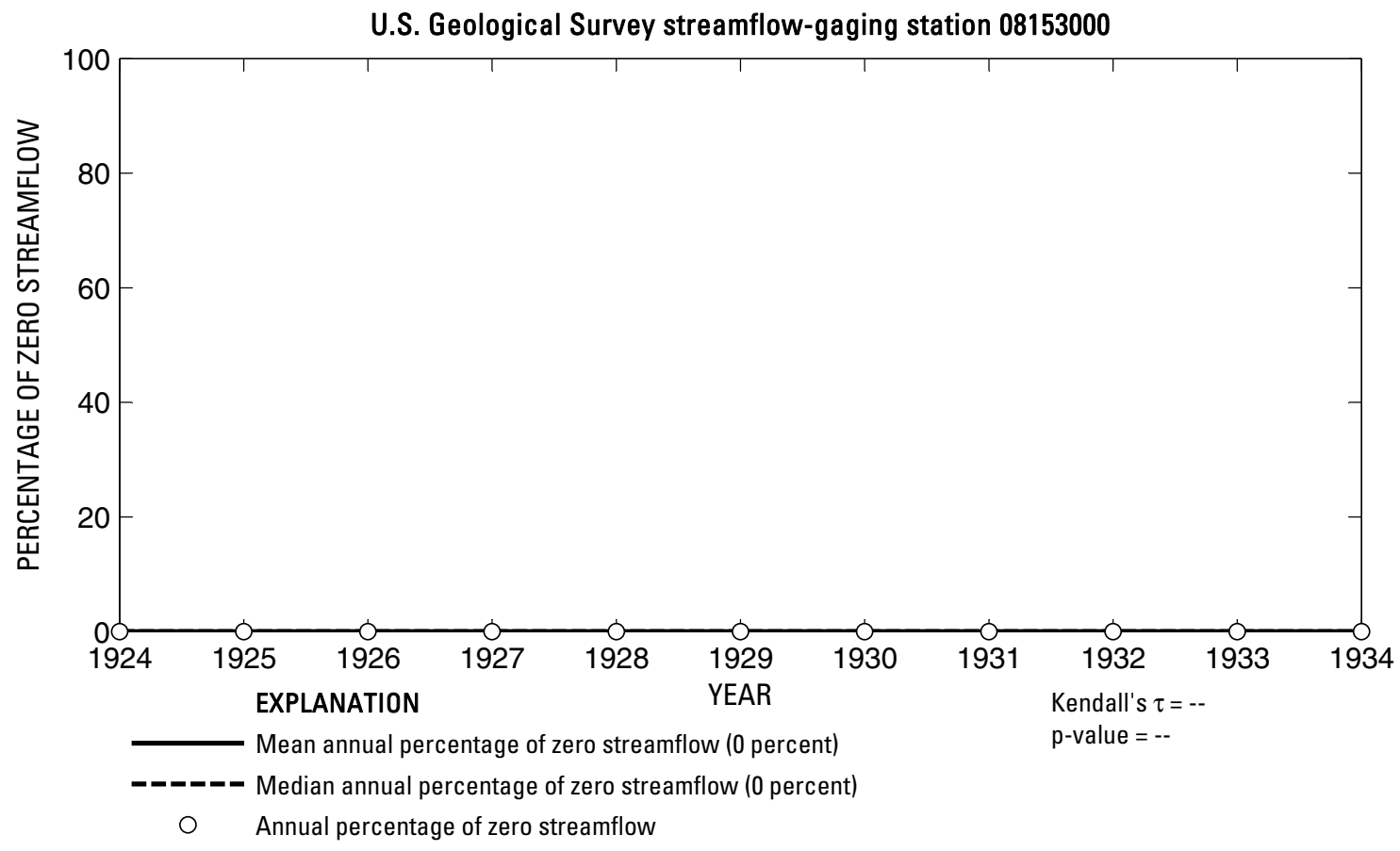

U.S. Geological Survey streamflow-gaging station 08153000

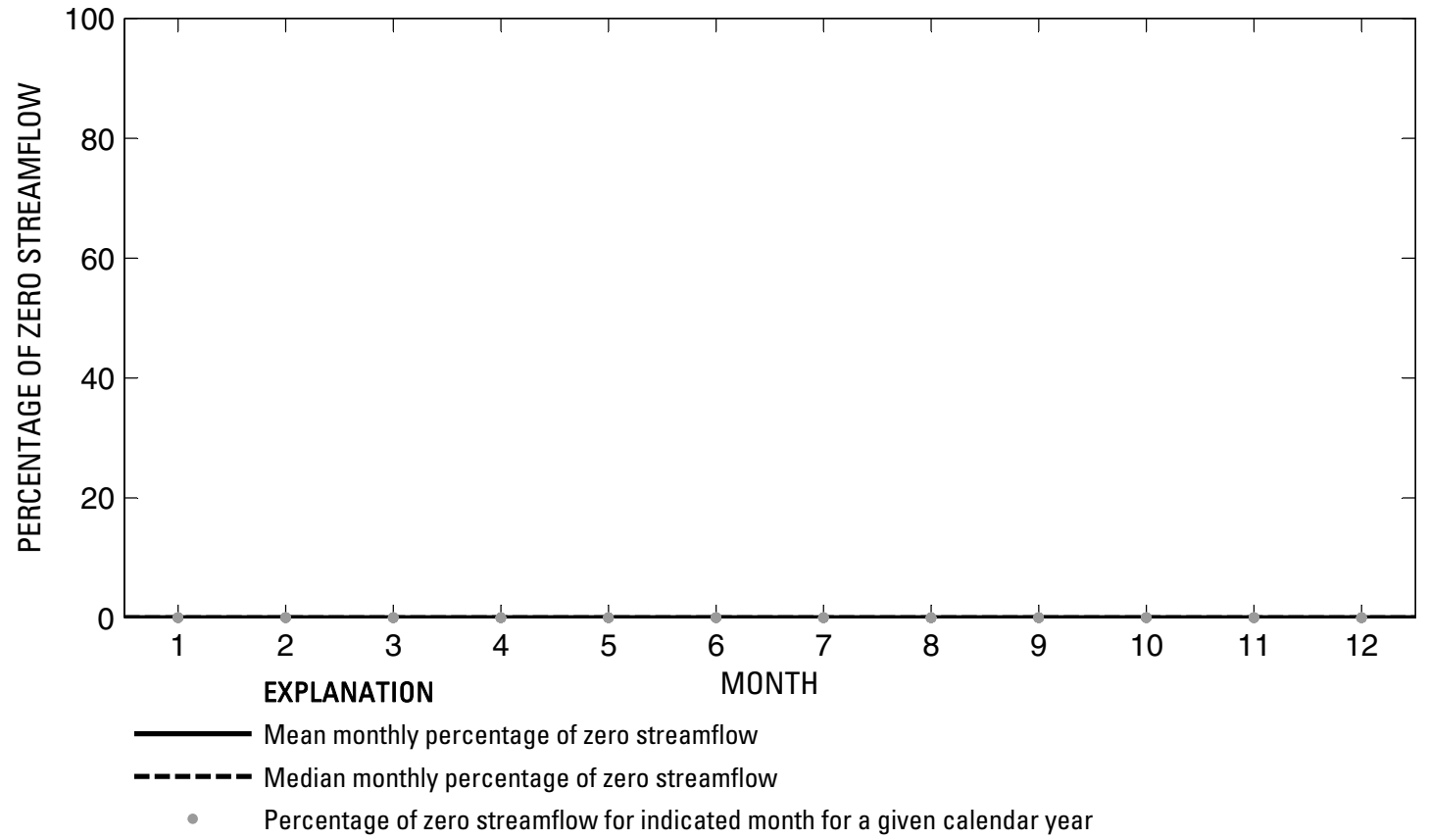

Figure 513. Analysis of percentage of zero daily mean streamflow for U.S. Geological Survey streamflow-gaging station 08153000 Pedernales River at Stonewall, Texas. 
U.S. Geological Survey streamflow-gaging station 08153500

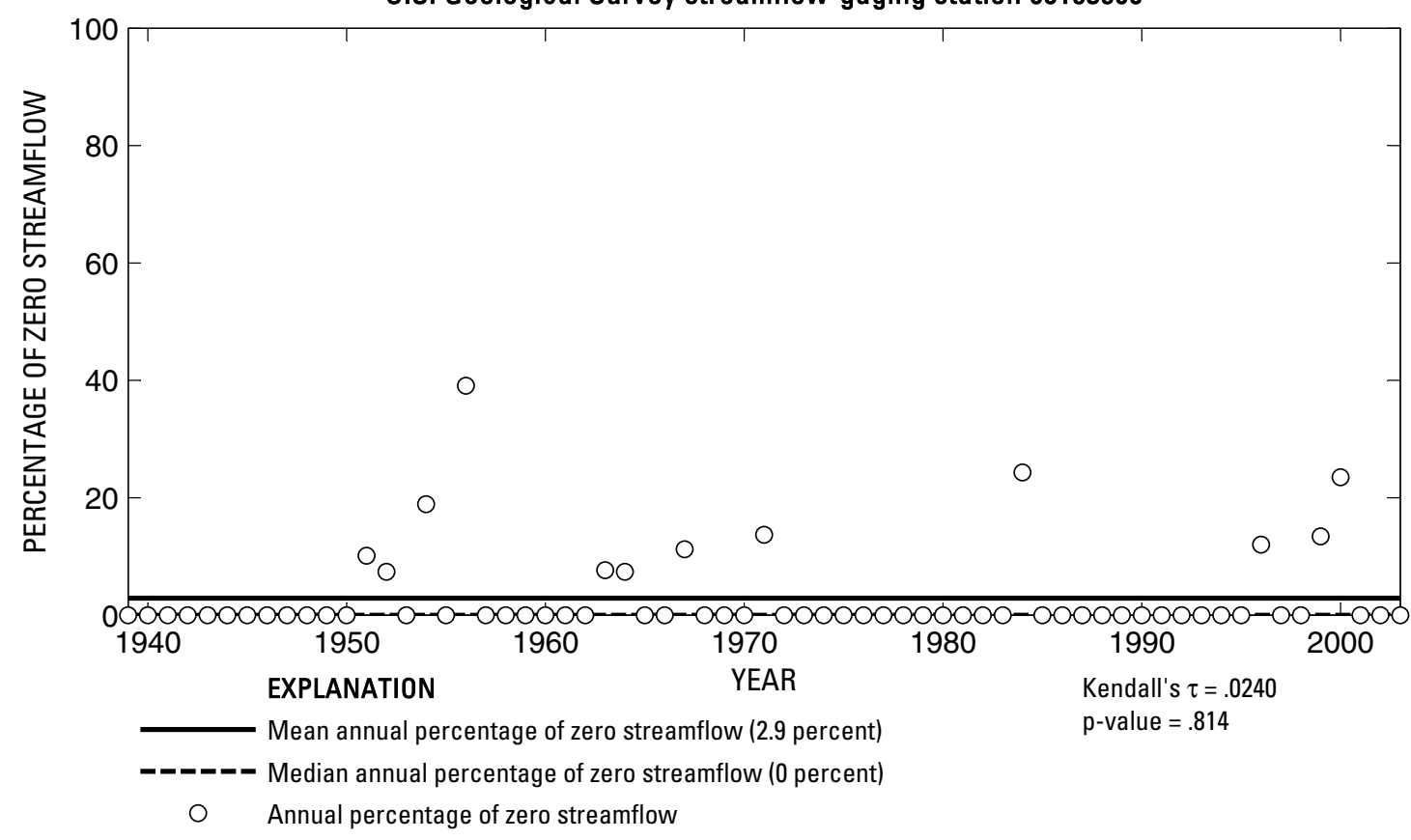

U.S. Geological Survey streamflow-gaging station 08153500

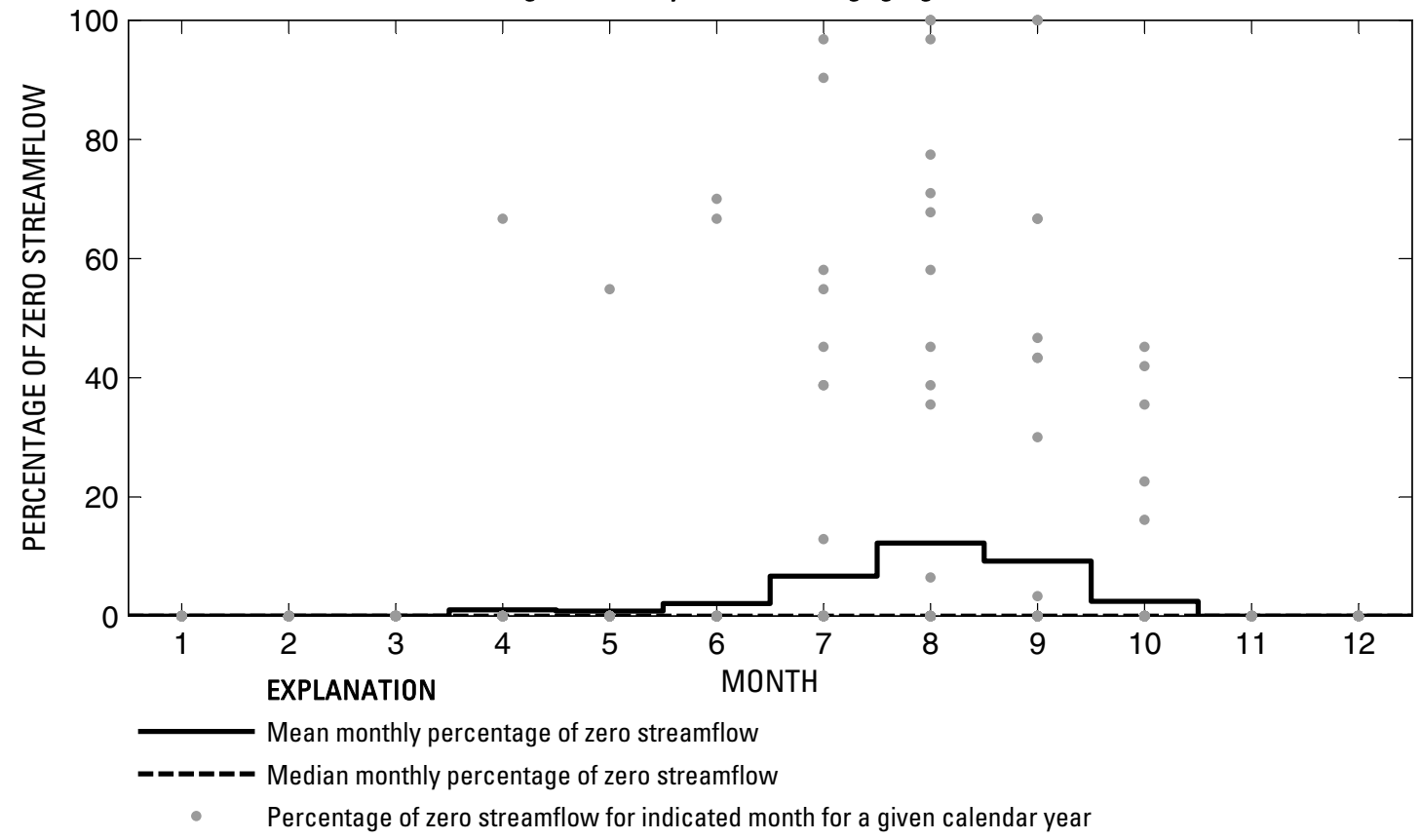

Figure 514. Analysis of percentage of zero daily mean streamflow for U.S. Geological Survey streamflow-gaging station 08153500 Pedernales River near Johnson City, Texas. 
U.S. Geological Survey streamflow-gaging station 08154000

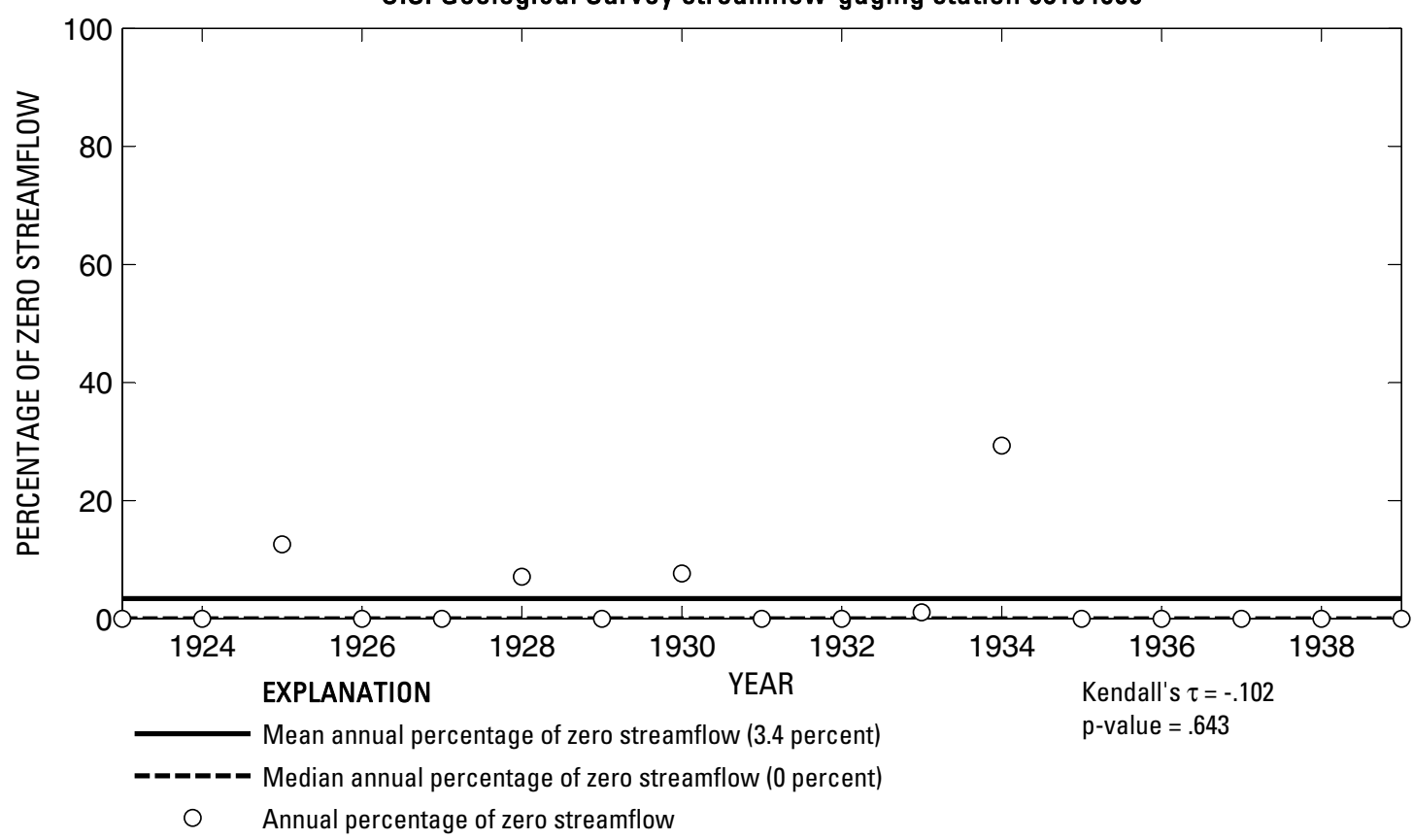

U.S. Geological Survey streamflow-gaging station 08154000

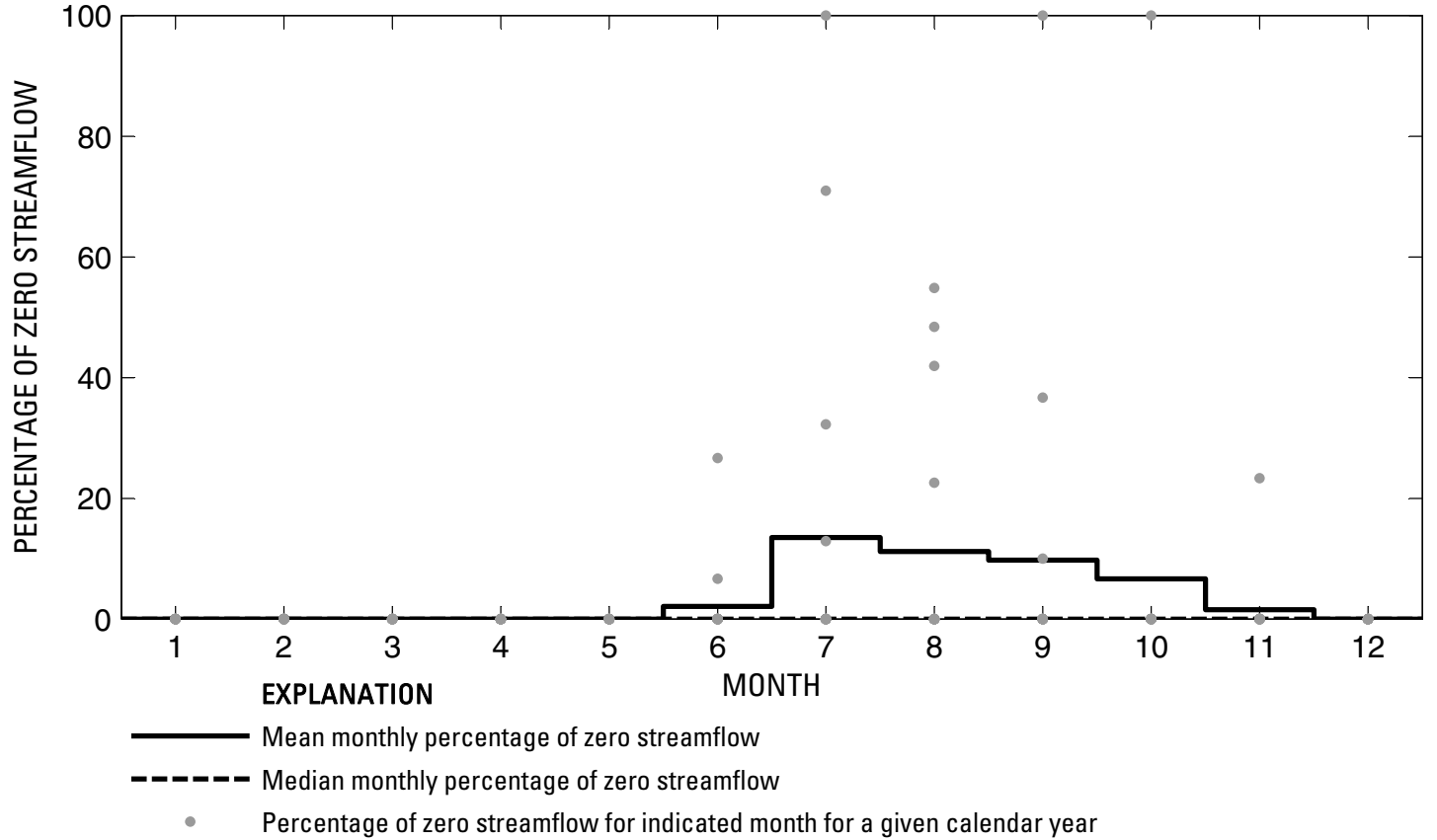

Figure 515. Analysis of percentage of zero daily mean streamflow for U.S. Geological Survey streamflow-gaging station 08154000 Pedernales River near Spicewood, Texas. 
U.S. Geological Survey streamflow-gaging station 08154510

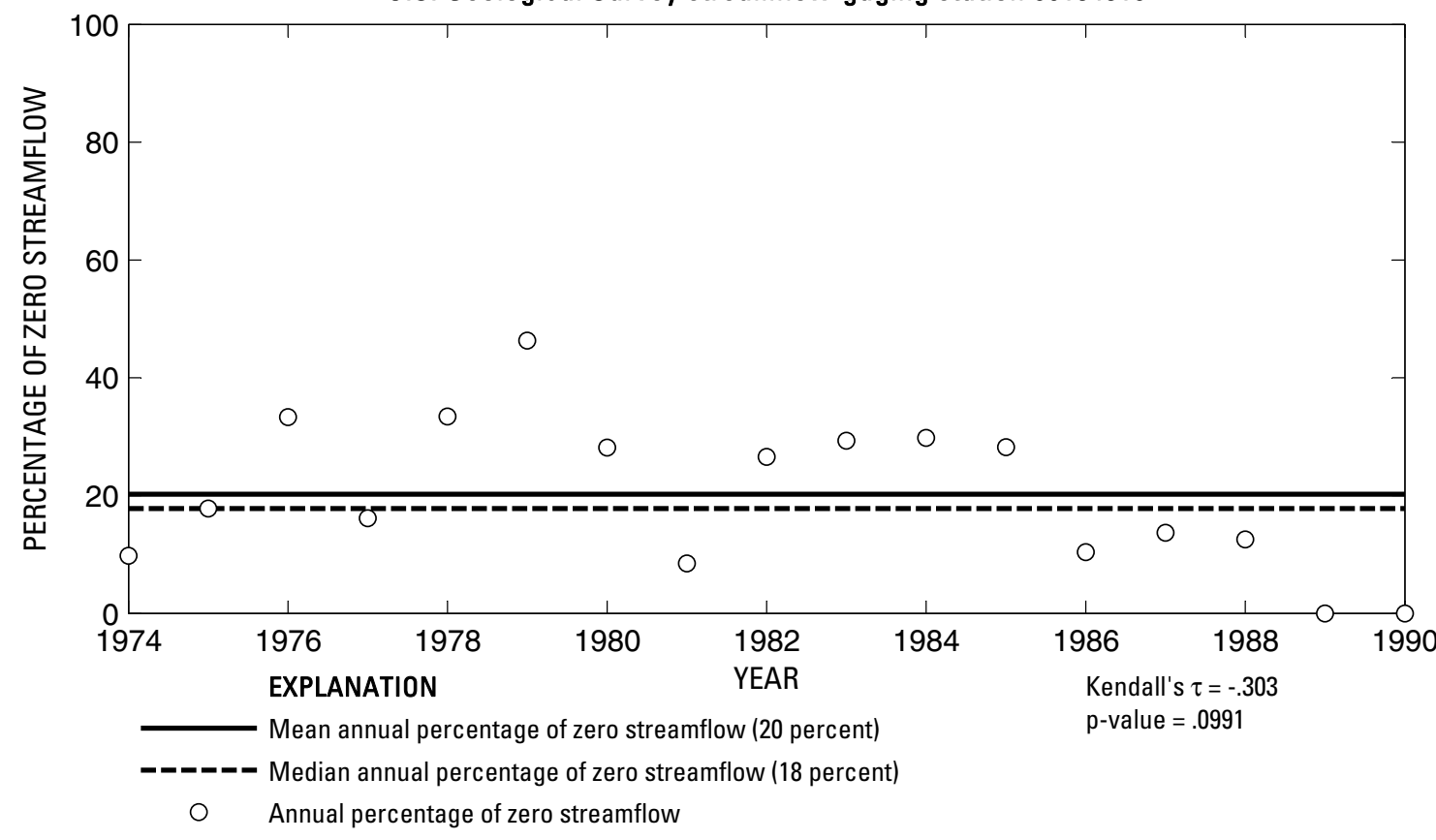

U.S. Geological Survey streamflow-gaging station 08154510

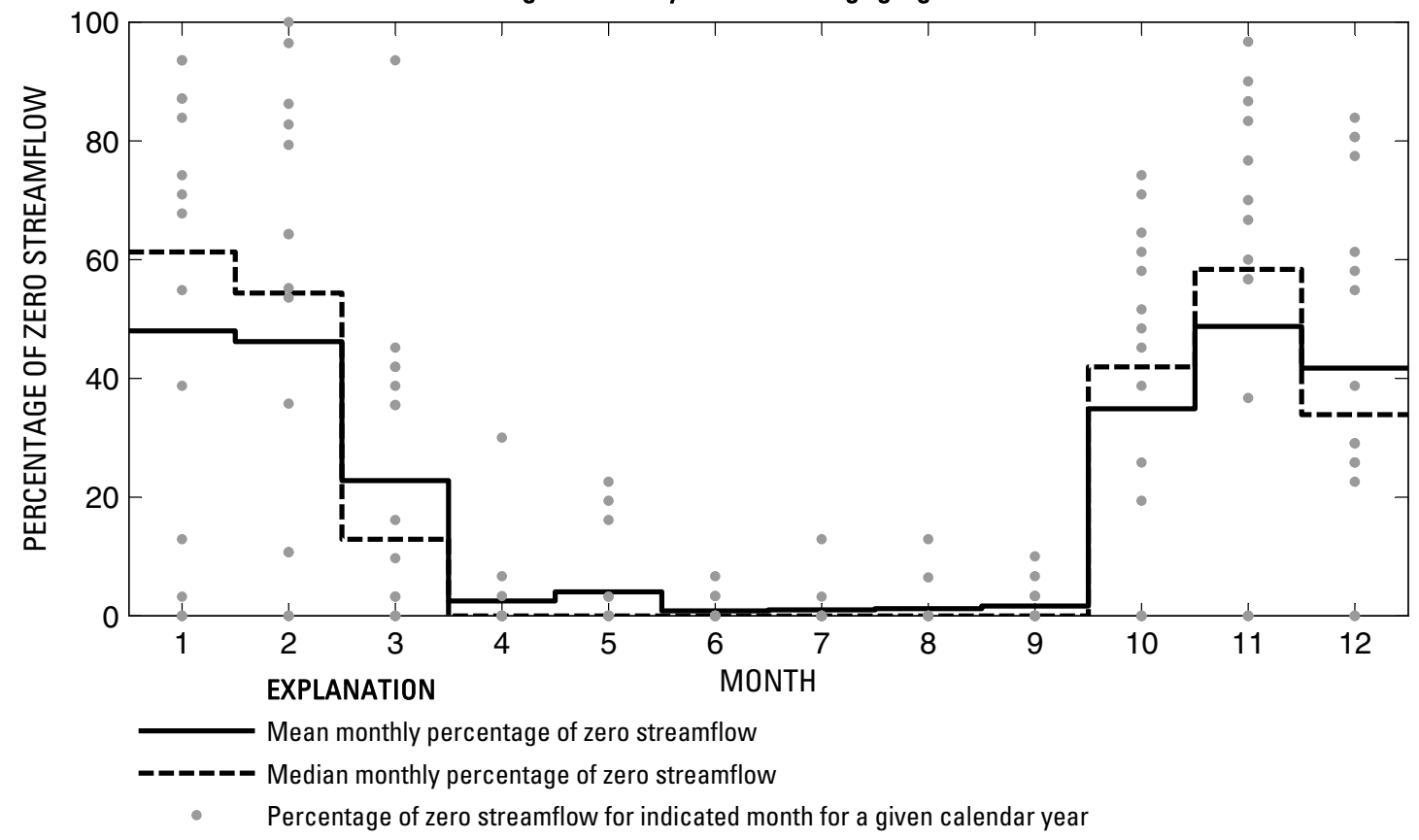

Figure 516. Analysis of percentage of zero daily mean streamflow for U.S. Geological Survey streamflow-gaging station 08154510 Colorado River below Mansfield Dam, Austin, Texas.

Index of Station Numbers 719 


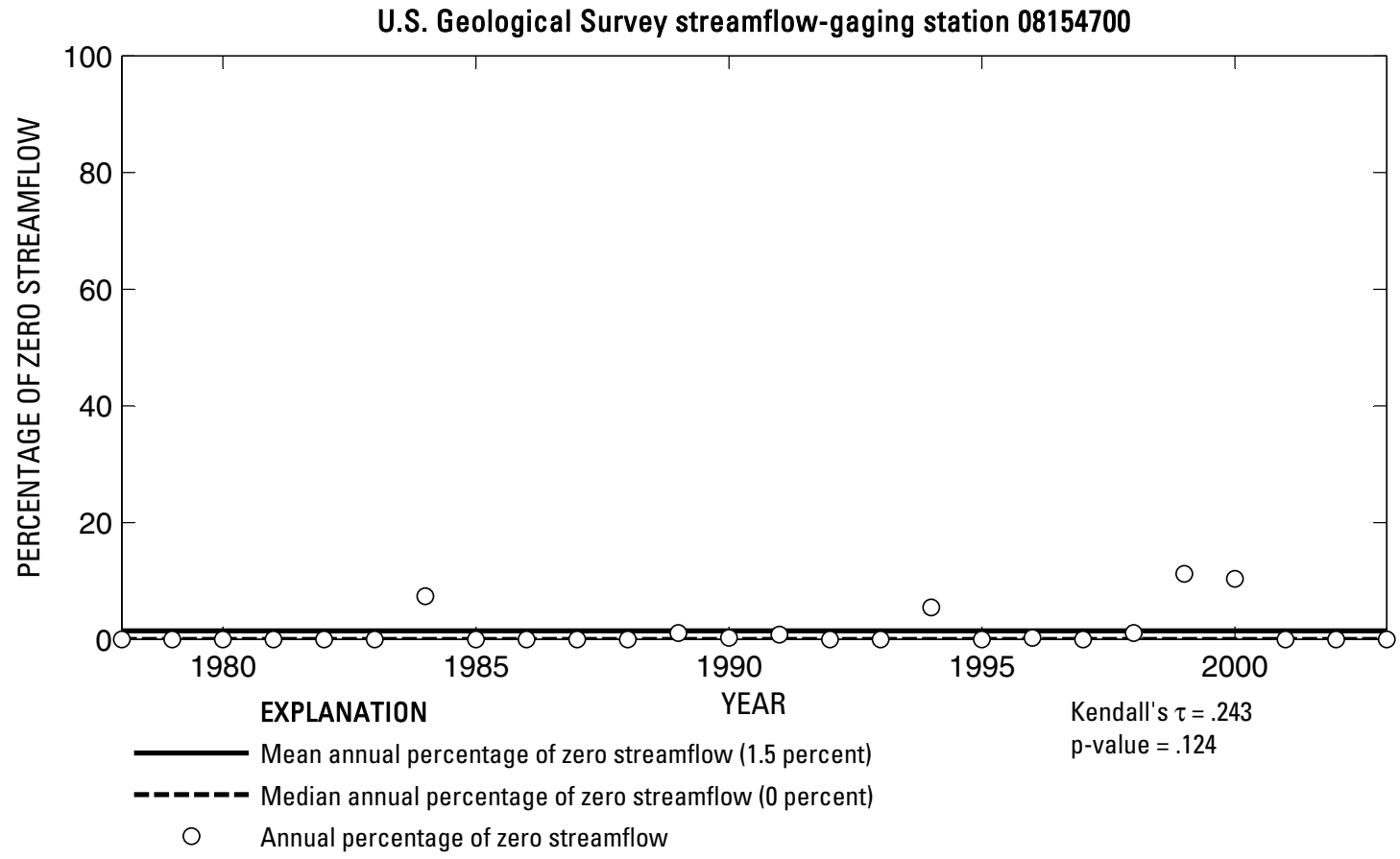

U.S. Geological Survey streamflow-gaging station 08154700

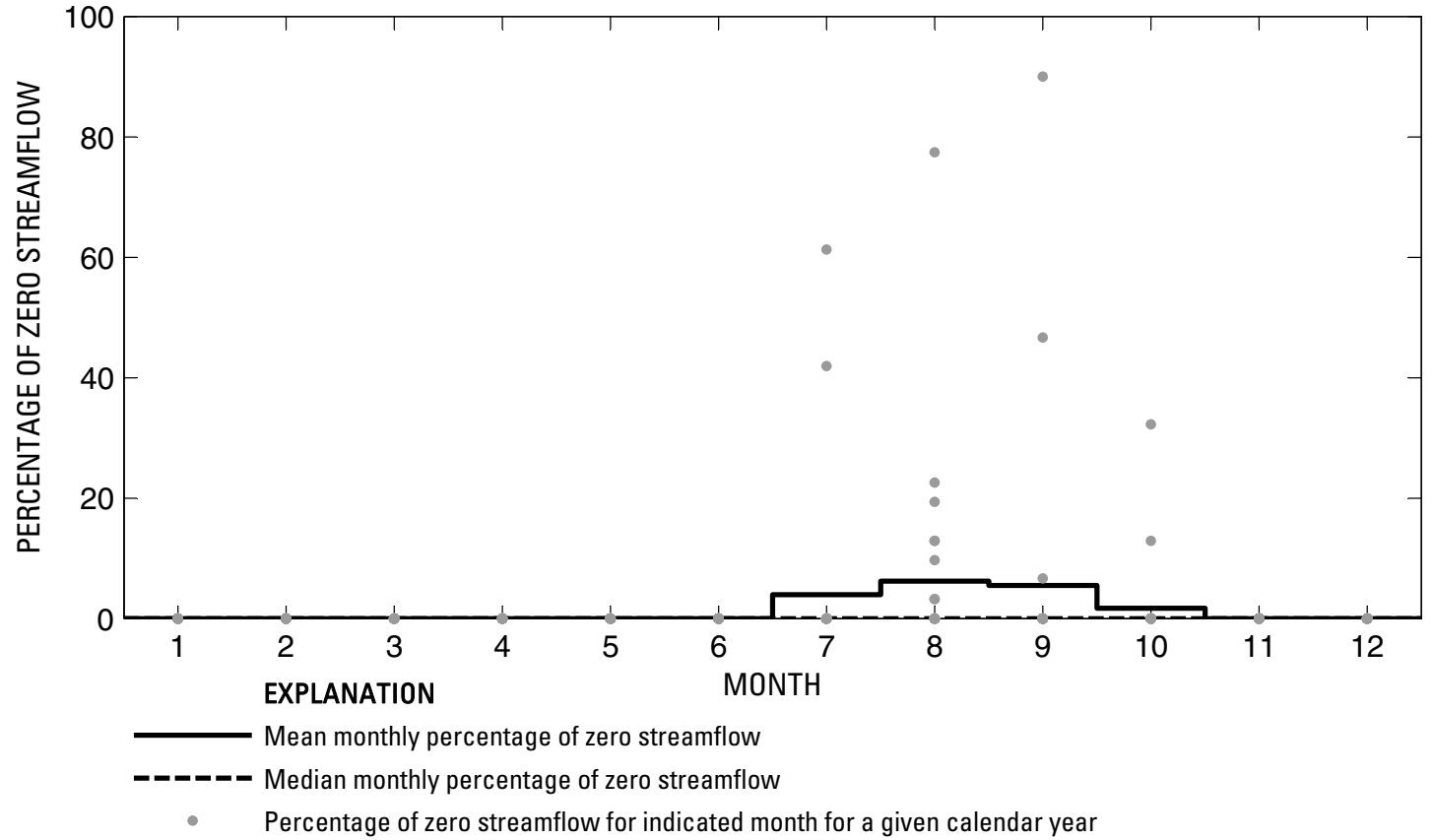

Figure 517. Analysis of percentage of zero daily mean streamflow for U.S. Geological Survey streamflow-gaging station 08154700 Bull Creek at Loop 360 near Austin, Texas. 
U.S. Geological Survey streamflow-gaging station 08155200

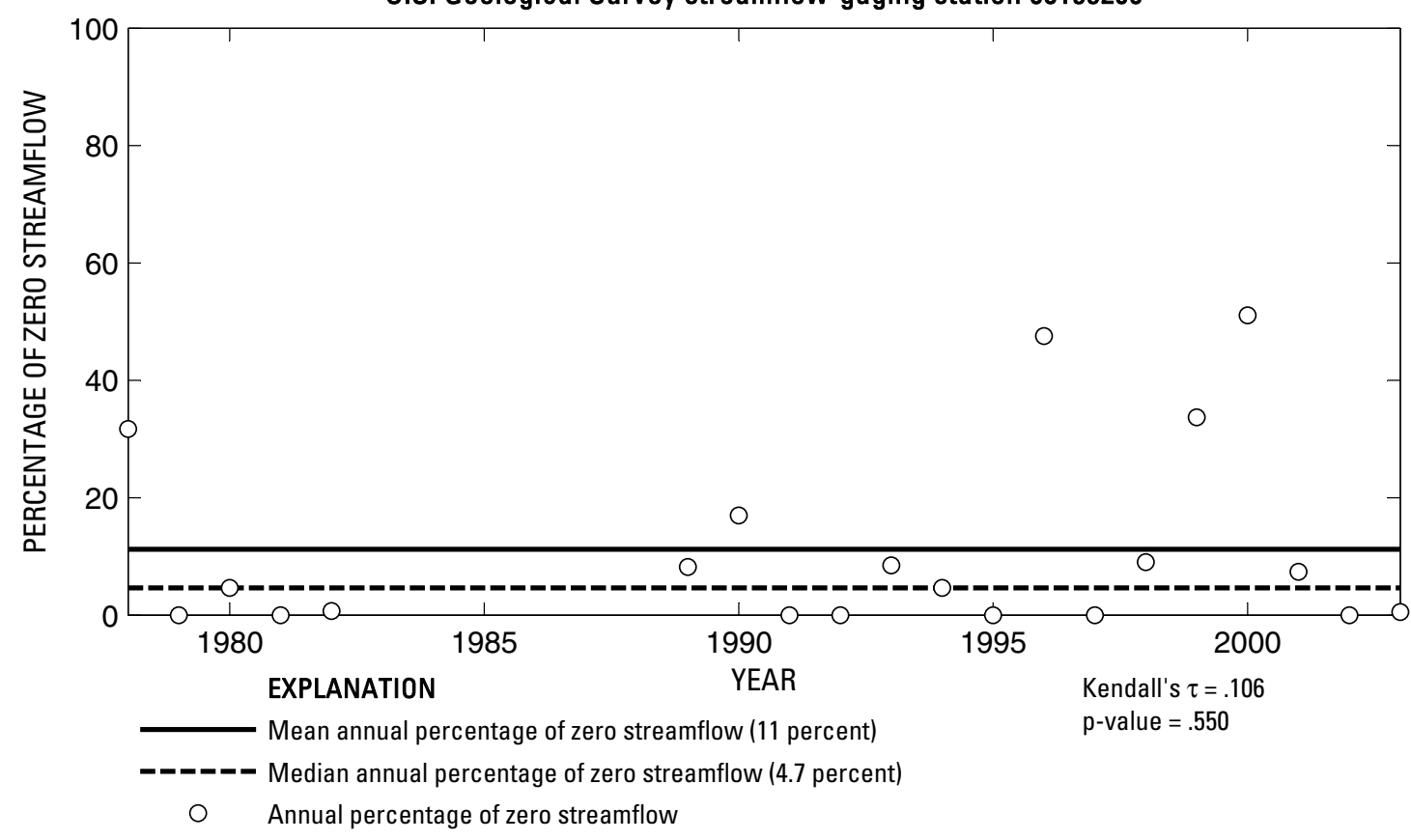

U.S. Geological Survey streamflow-gaging station 08155200

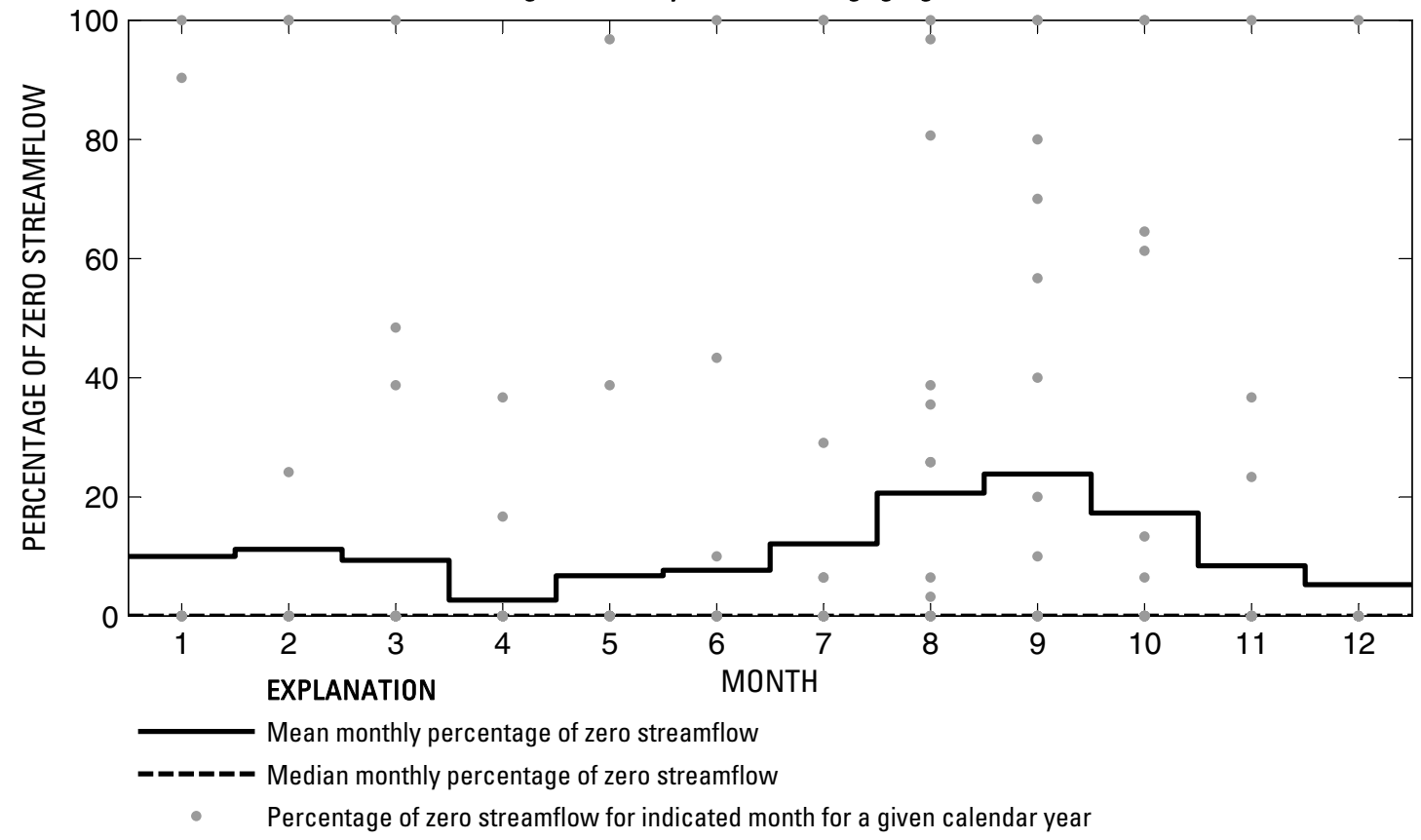

Figure 518. Analysis of percentage of zero daily mean streamflow for U.S. Geological Survey streamflow-gaging station 08155200 Barton Creek at State Highway 71 near Oak Hill, Texas.

Index of Station Numbers 719 


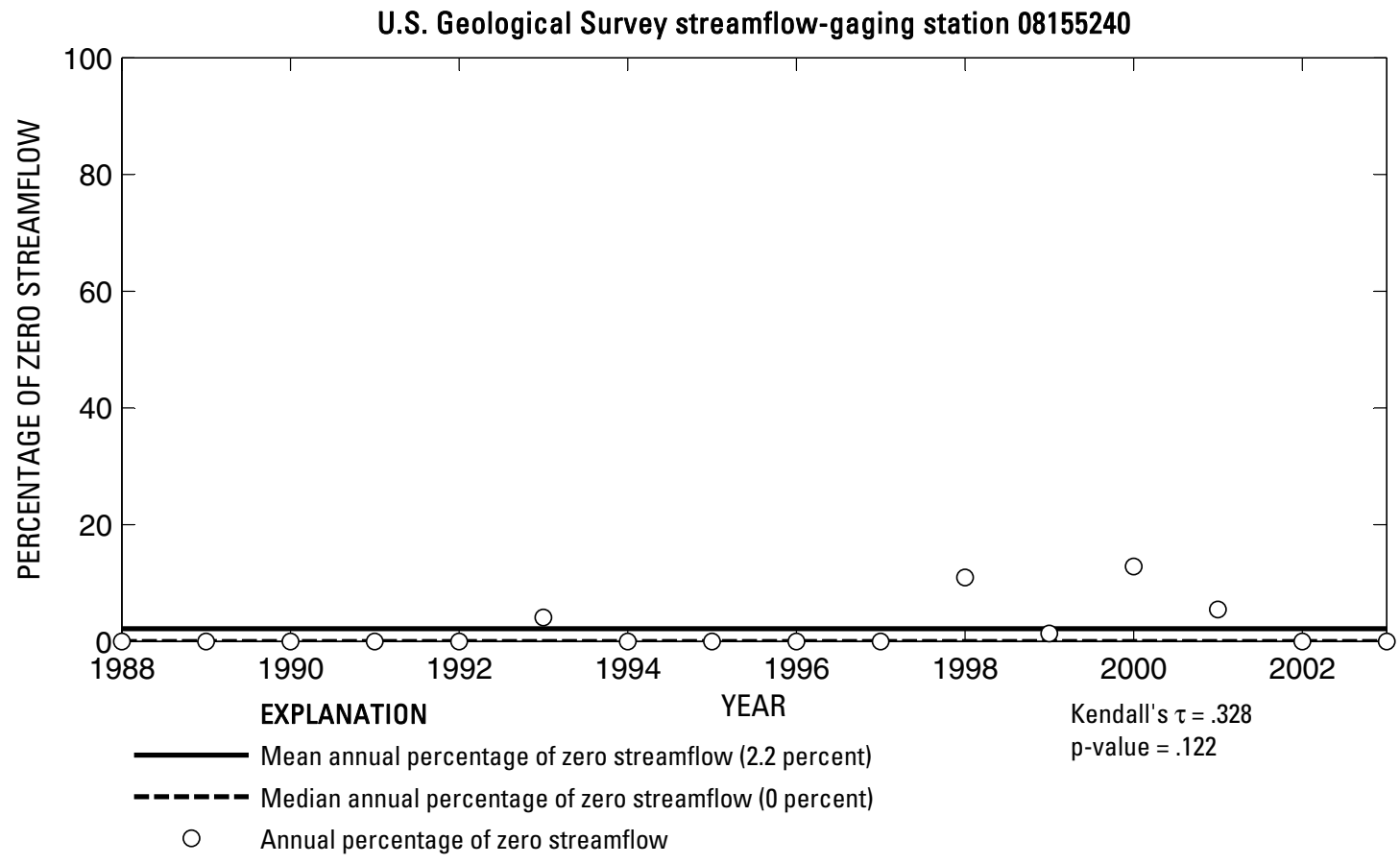

U.S. Geological Survey streamflow-gaging station 08155240

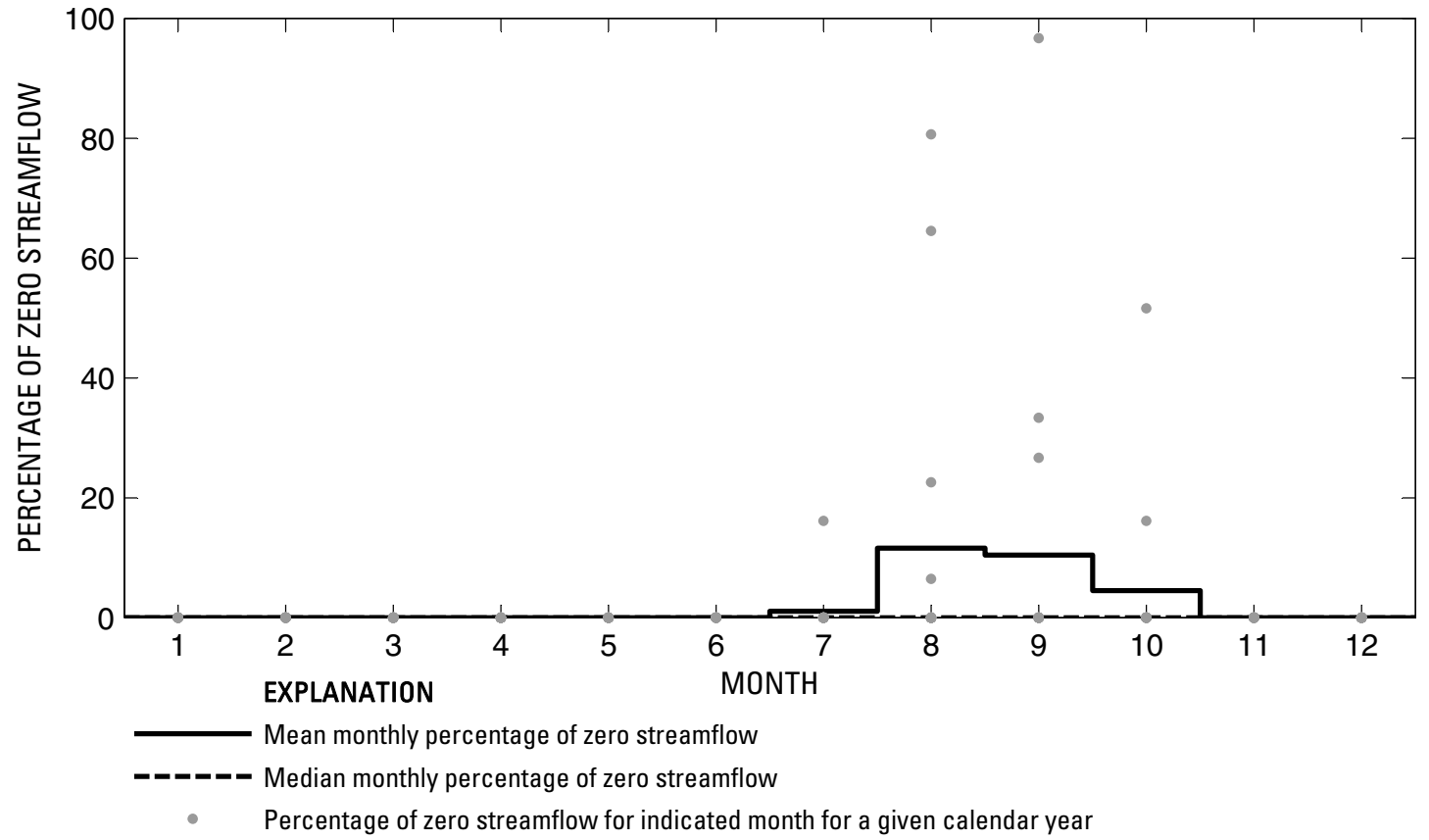

Figure 519. Analysis of percentage of zero daily mean streamflow for U.S. Geological Survey streamflow-gaging station 08155240 Barton Creek at Lost Creek Boulevard near Austin, Texas. 
U.S. Geological Survey streamflow-gaging station 08155260

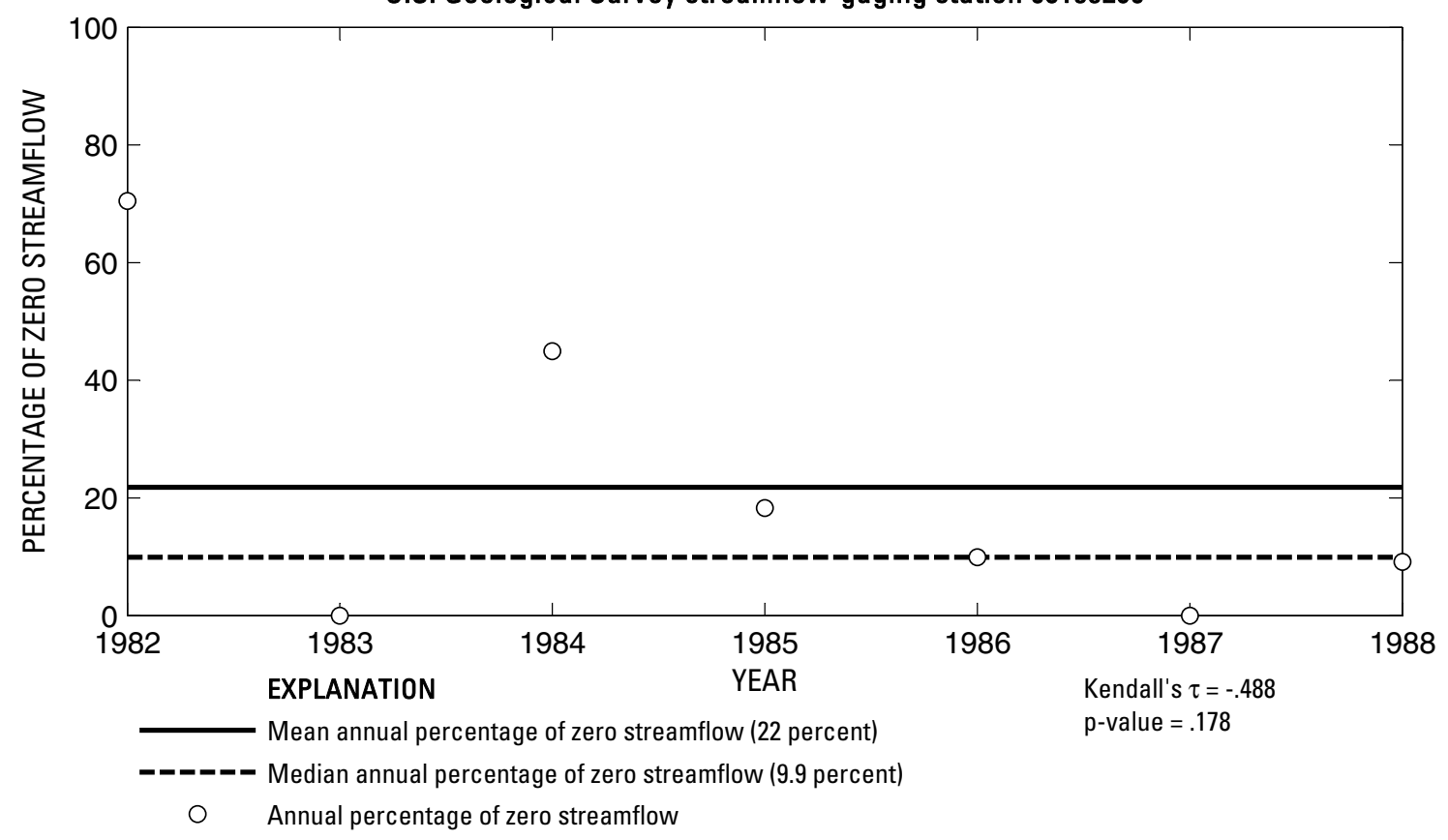

U.S. Geological Survey streamflow-gaging station 08155260

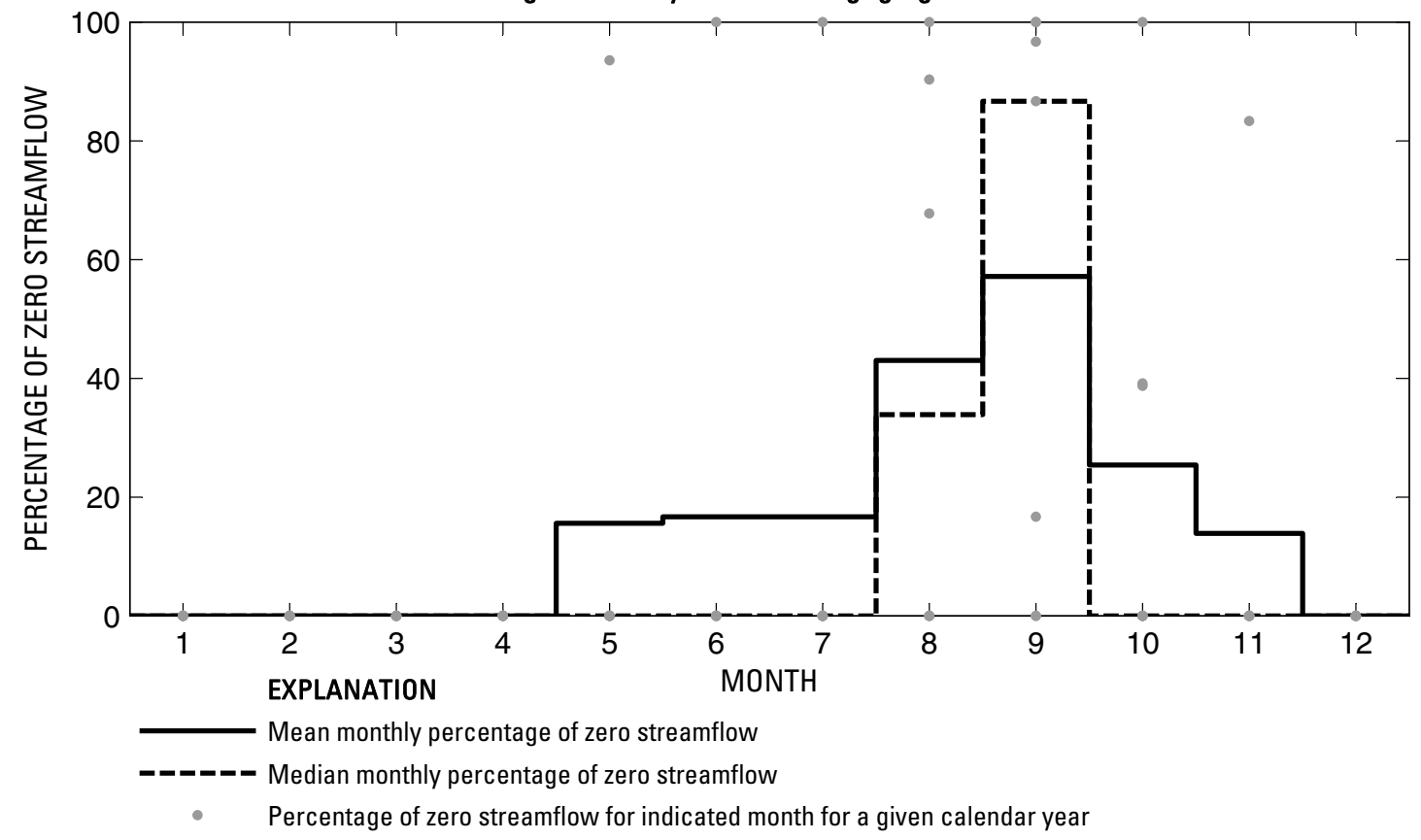

Figure 520. Analysis of percentage of zero daily mean streamflow for U.S. Geological Survey streamflow-gaging station 08155260 Barton Creek near Camp Craft Road near Austin, Texas.

Index of Station Numbers 719 
U.S. Geological Survey streamflow-gaging station 08155300

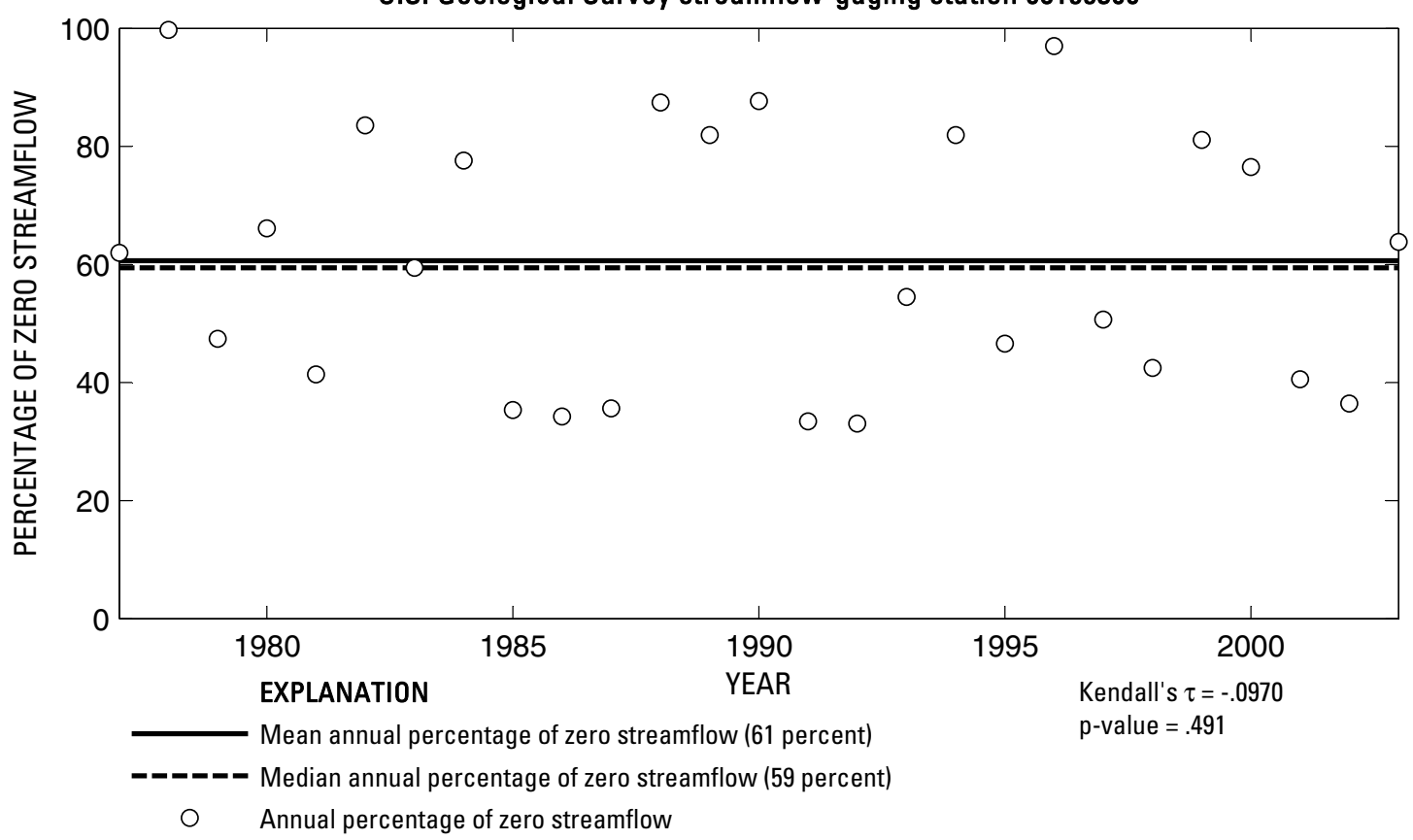

U.S. Geological Survey streamflow-gaging station 08155300

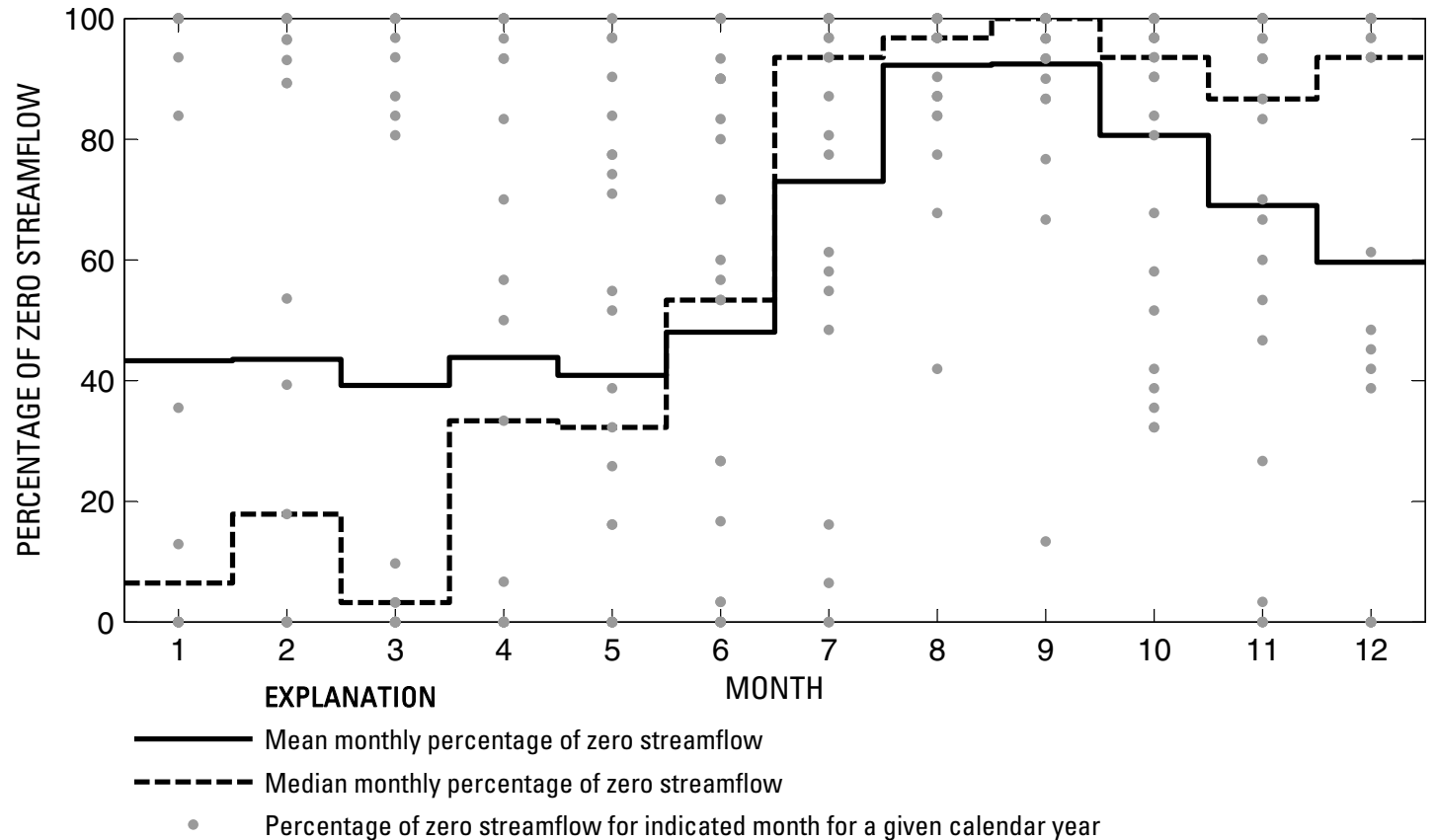

Figure 521. Analysis of percentage of zero daily mean streamflow for U.S. Geological Survey streamflow-gaging station 08155300 Barton Creek at Loop 360, Austin, Texas. 
U.S. Geological Survey streamflow-gaging station 08155400

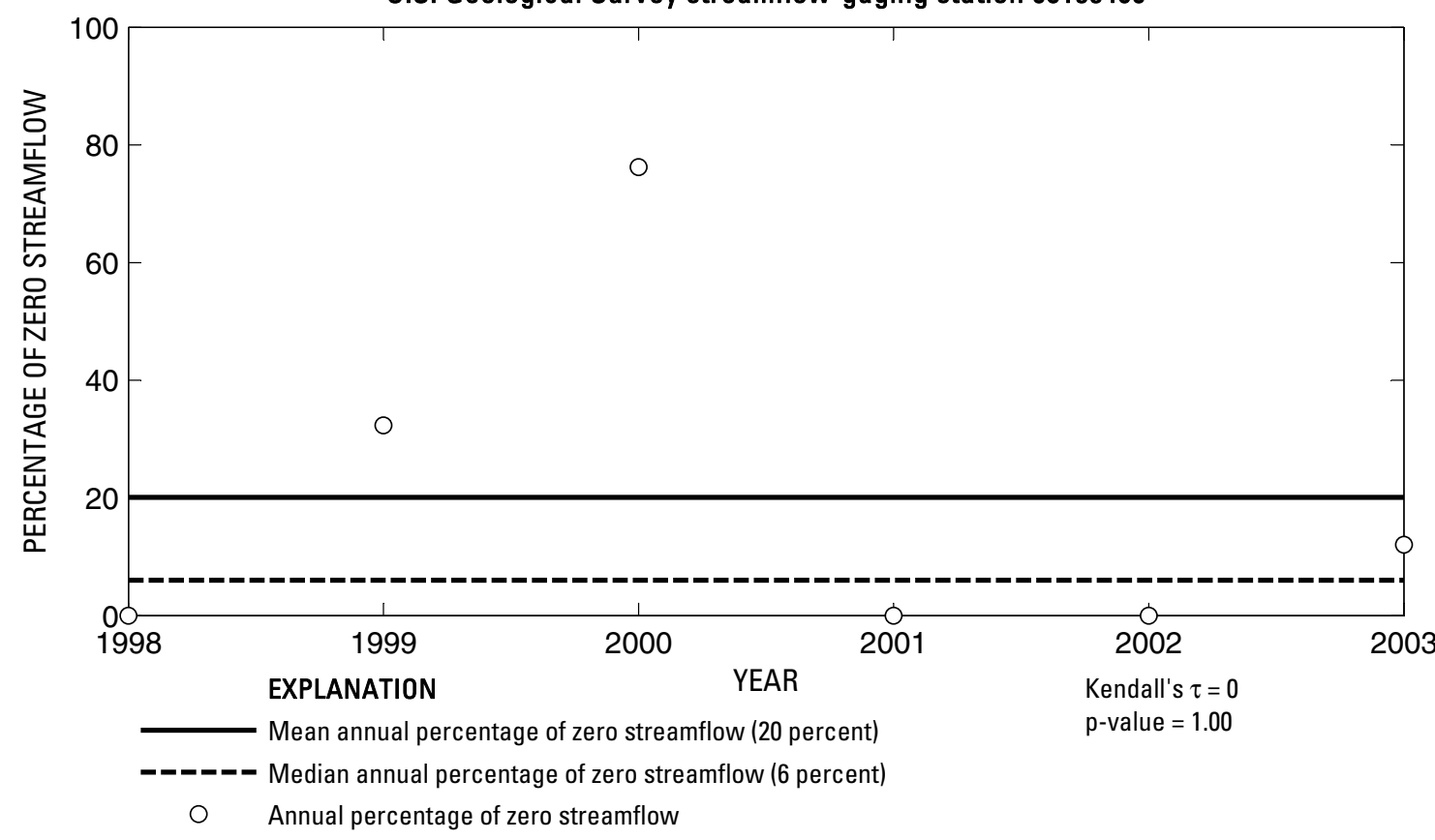

U.S. Geological Survey streamflow-gaging station 08155400

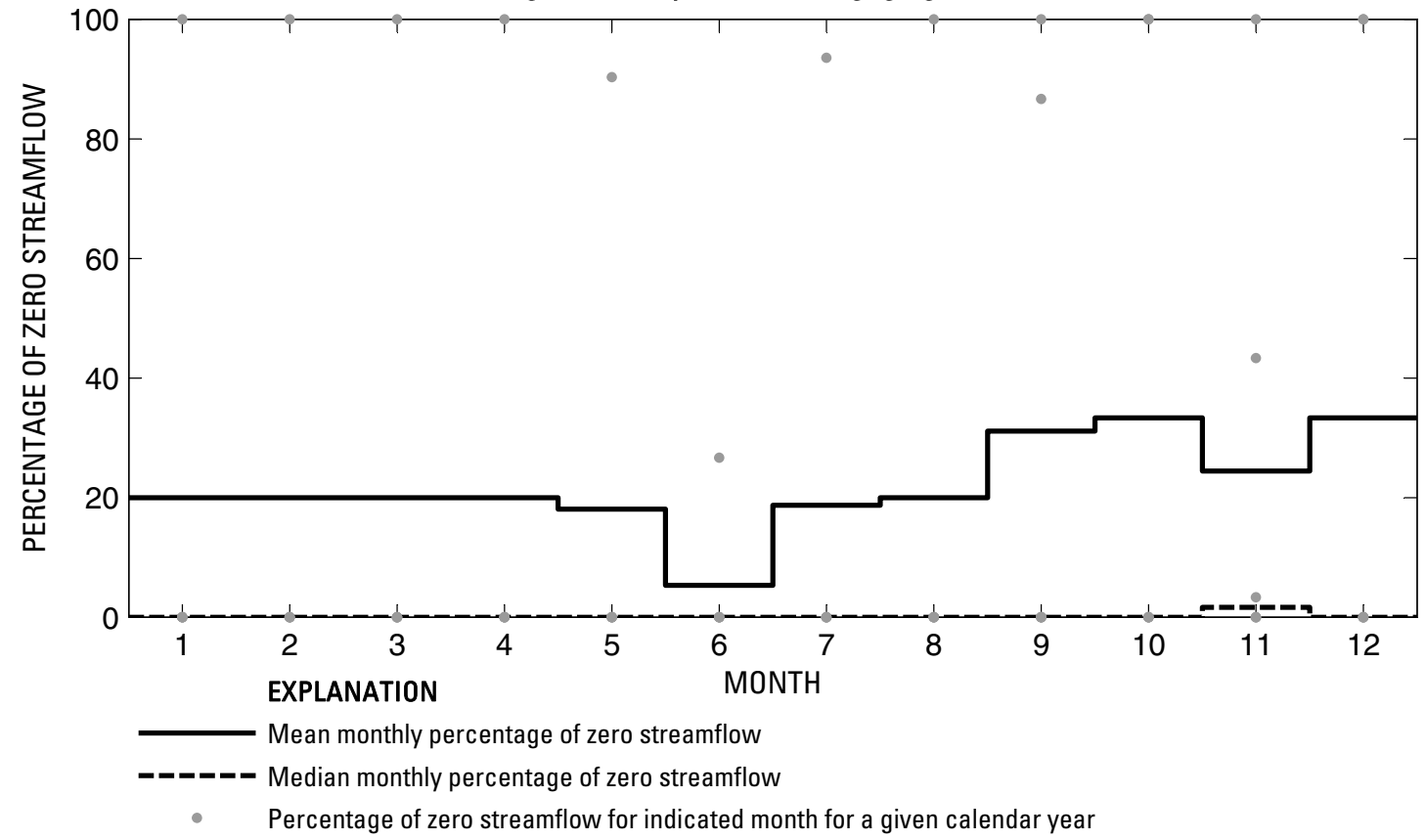

Figure 522. Analysis of percentage of zero daily mean streamflow for U.S. Geological Survey streamflow-gaging station 08155400 Barton Creek above Barton Springs at Austin, Texas.

Index of Station Numbers 719 
U.S. Geological Survey streamflow-gaging station 08156700

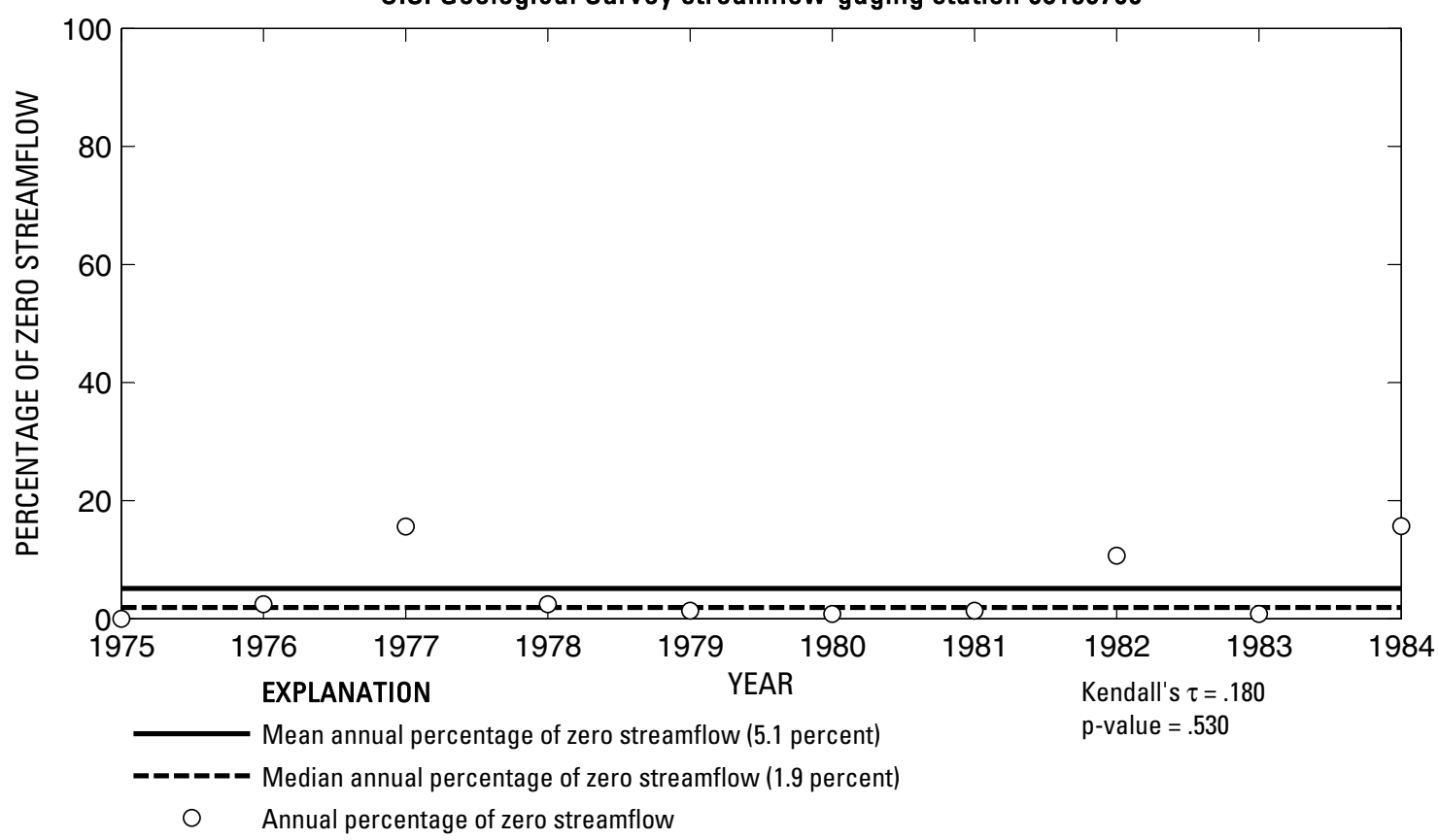

U.S. Geological Survey streamflow-gaging station 08156700

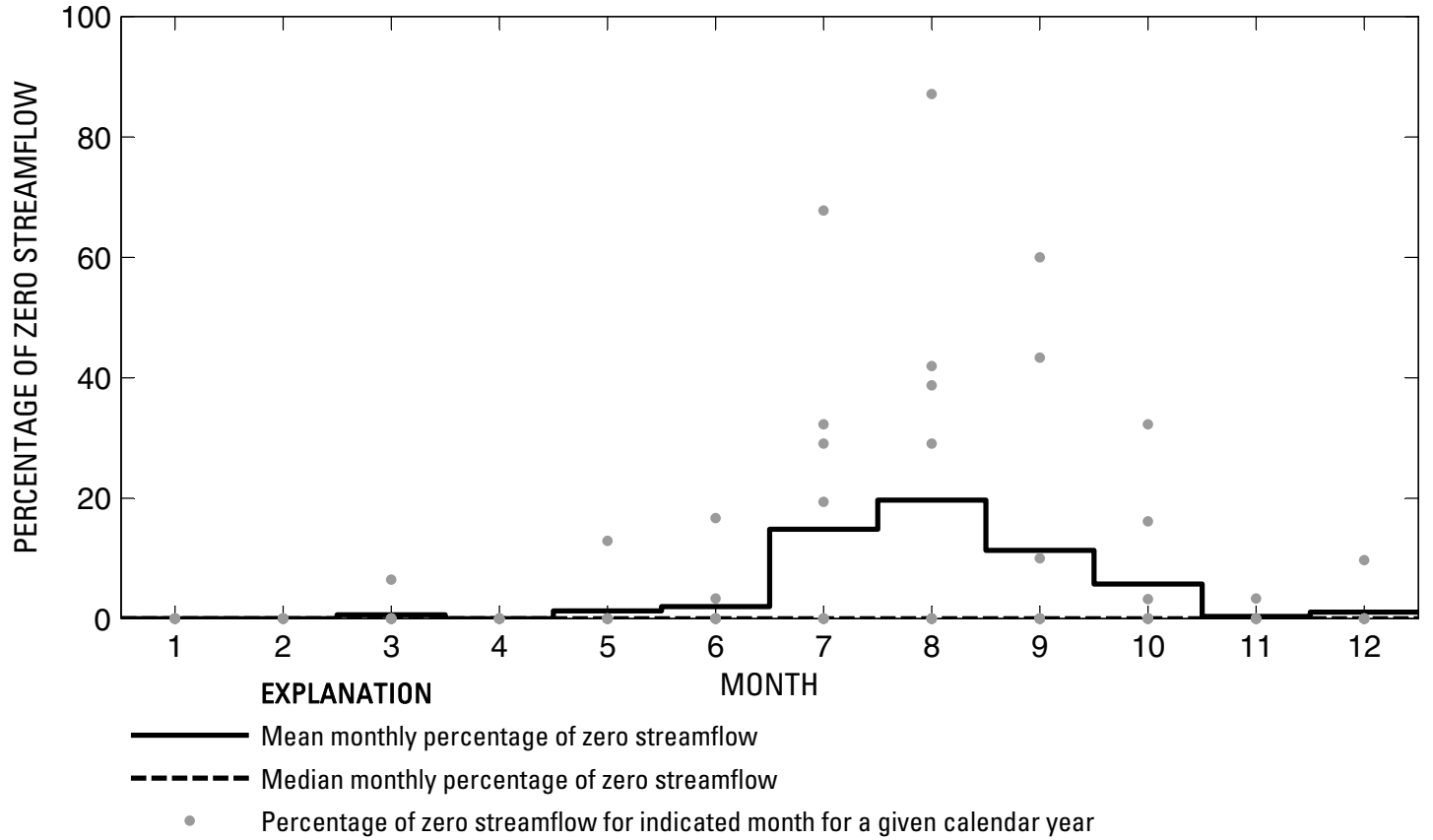

Figure 523. Analysis of percentage of zero daily mean streamflow for U.S. Geological Survey streamflow-gaging station 08156700 Shoal Creek at Northwest Park at Austin, Texas. 
U.S. Geological Survey streamflow-gaging station 08156800

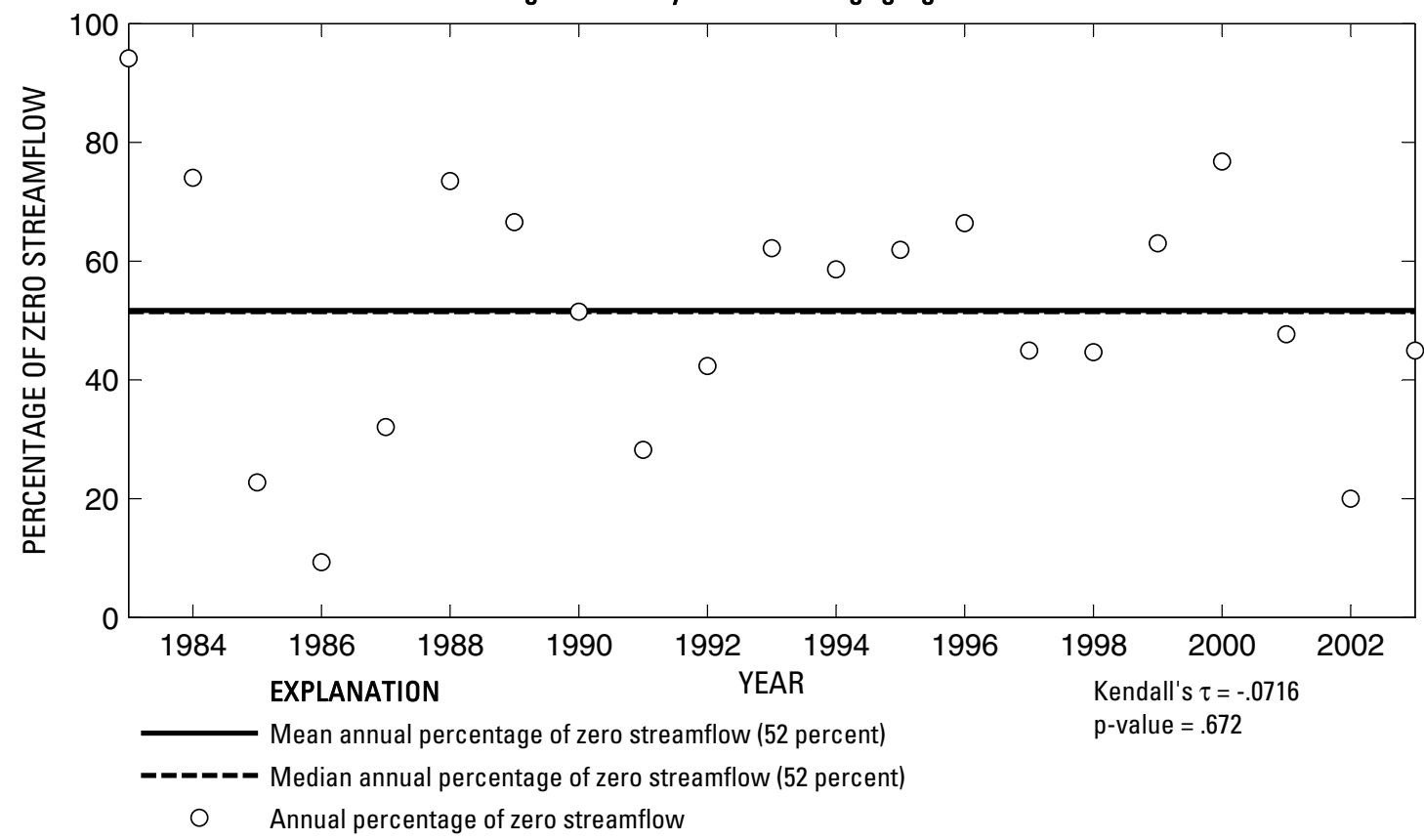

U.S. Geological Survey streamflow-gaging station 08156800

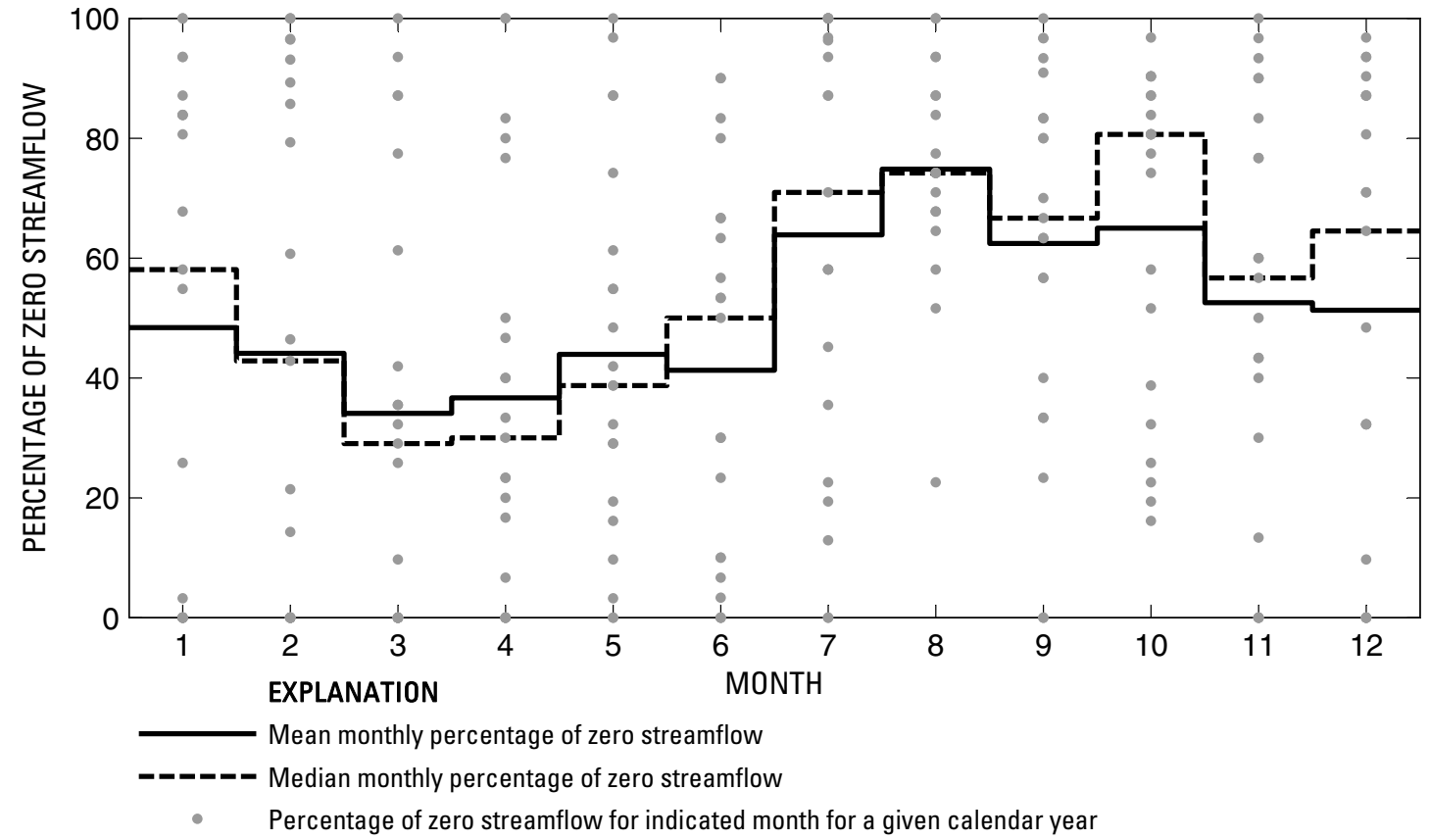

Figure 524. Analysis of percentage of zero daily mean streamflow for U.S. Geological Survey streamflow-gaging station 08156800 Shoal Creek at West 12th Street, Austin, Texas.

Index of Station Numbers 719 

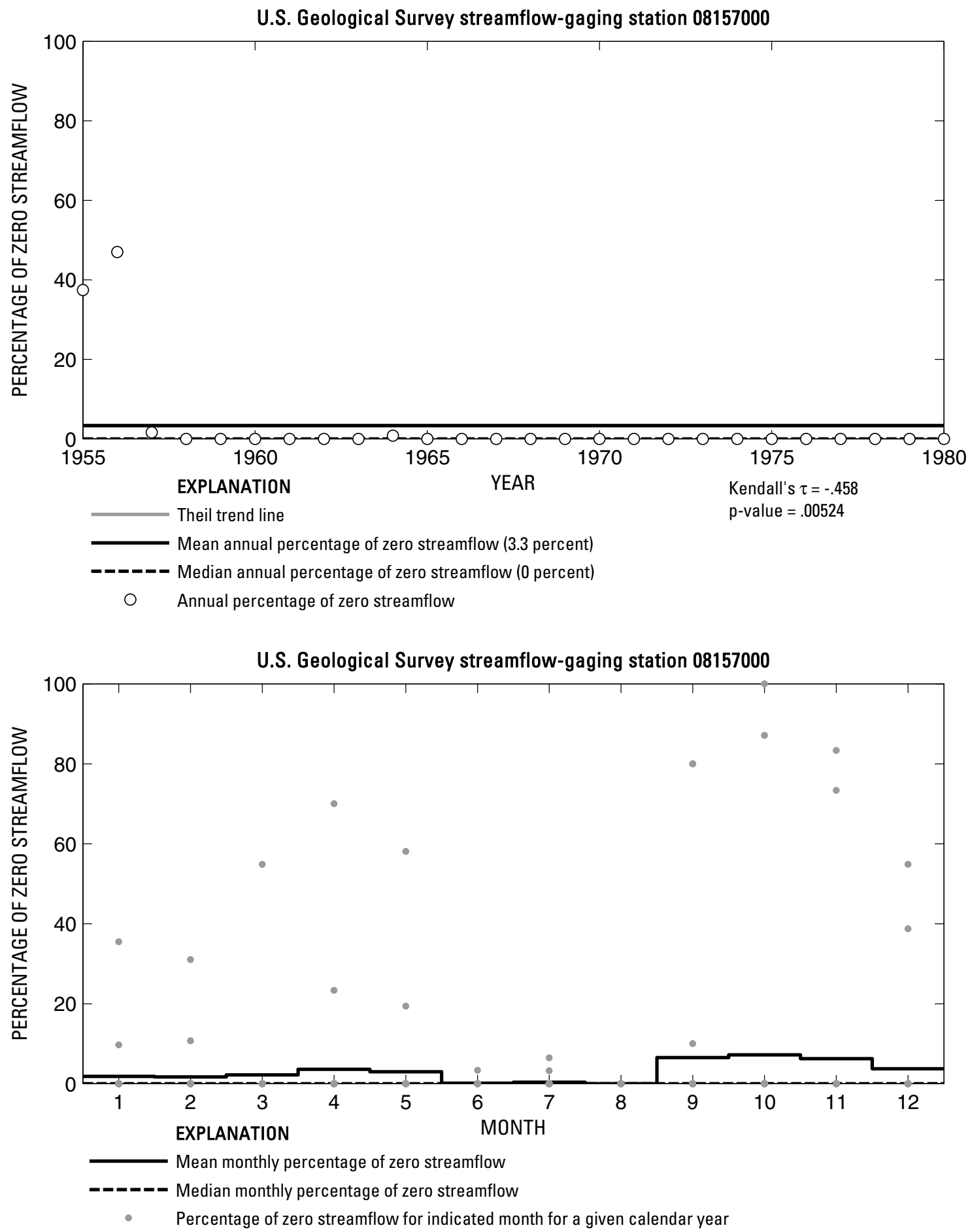

Figure 525. Analysis of percentage of zero daily mean streamflow for U.S. Geological Survey streamflow-gaging station 08157000 Waller Creek at 38th Street, Austin, Texas. 

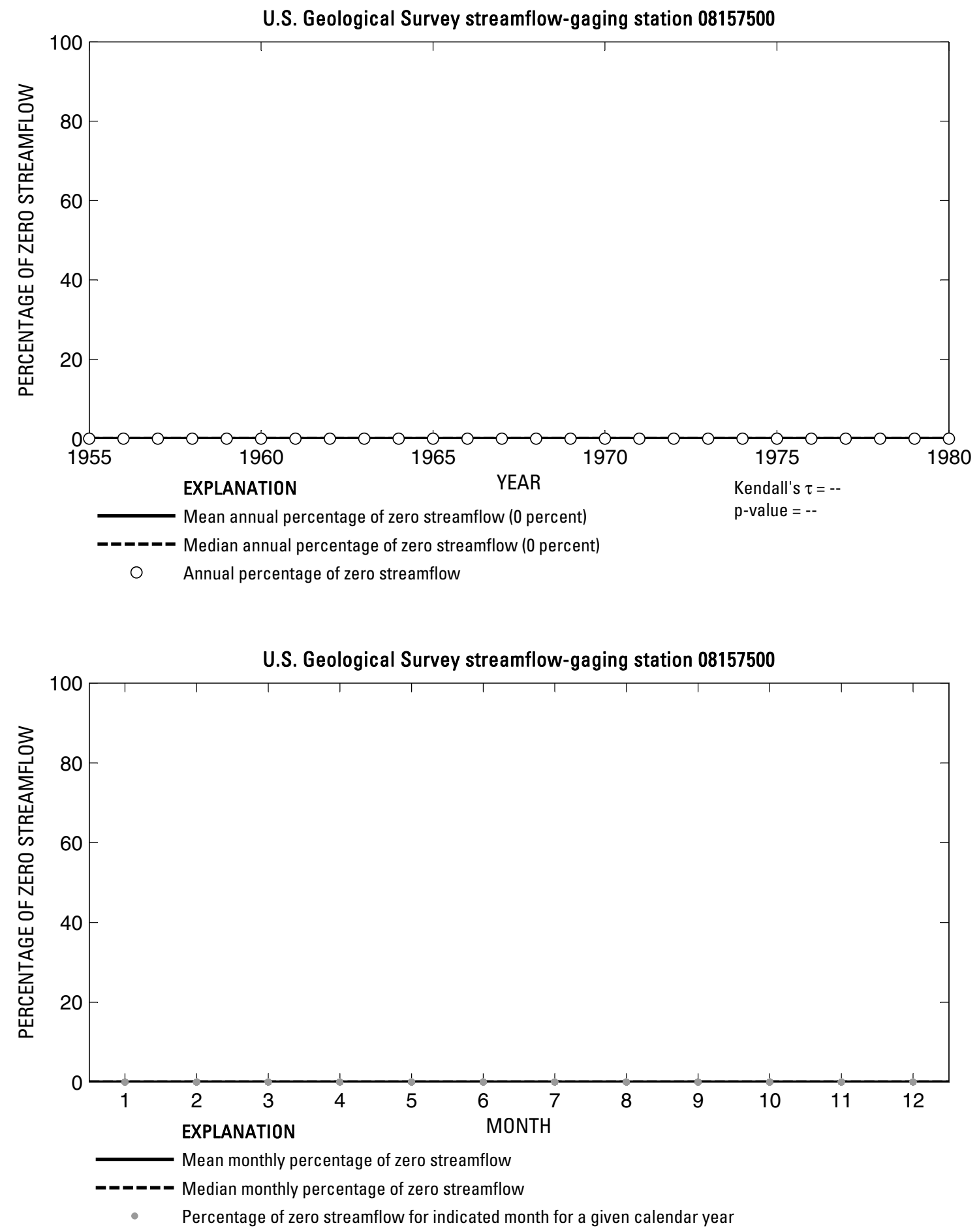

Figure 526. Analysis of percentage of zero daily mean streamflow for U.S. Geological Survey streamflow-gaging station 08157500 Waller Creek at 23rd Street, Austin, Texas. 


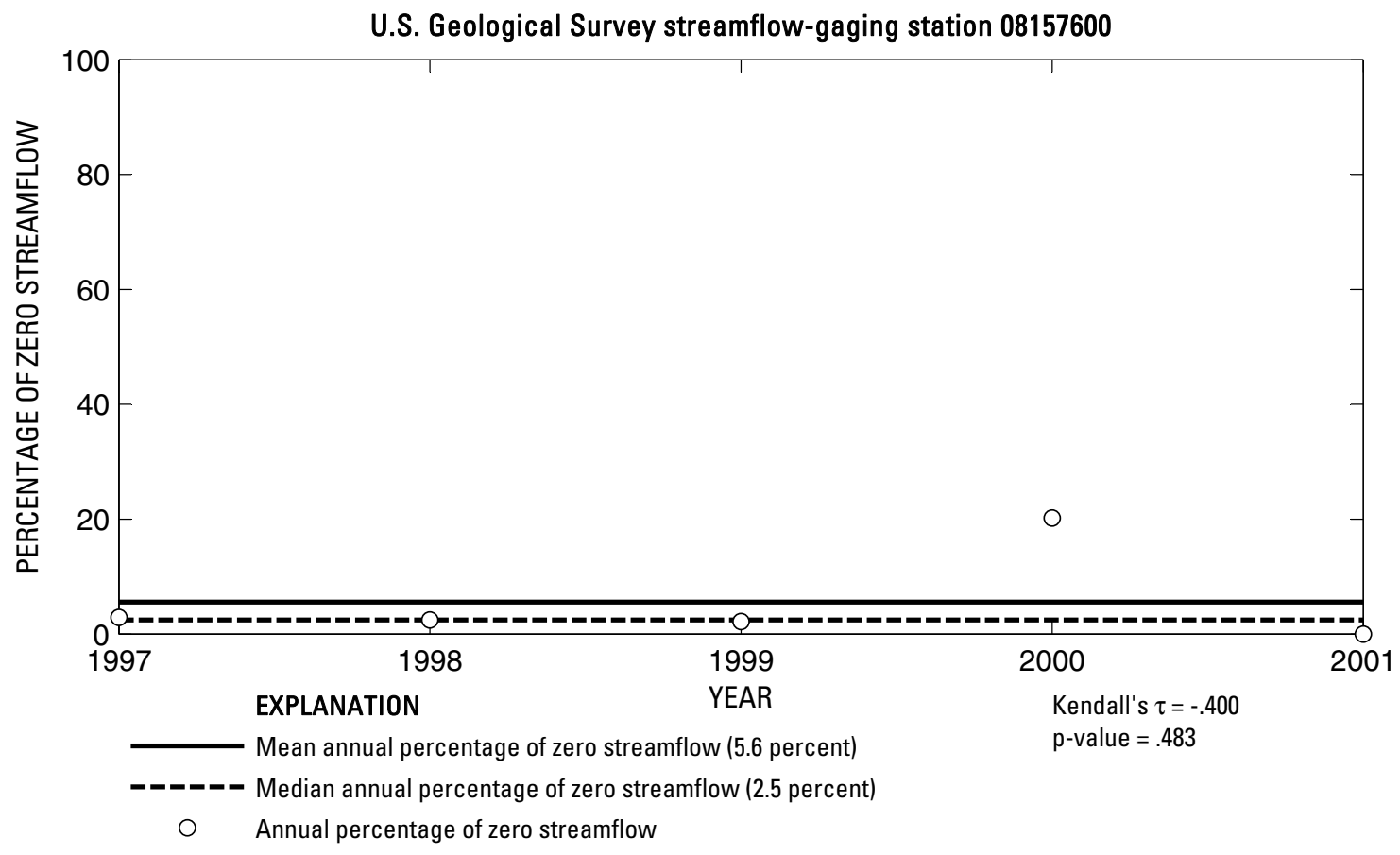

U.S. Geological Survey streamflow-gaging station 08157600

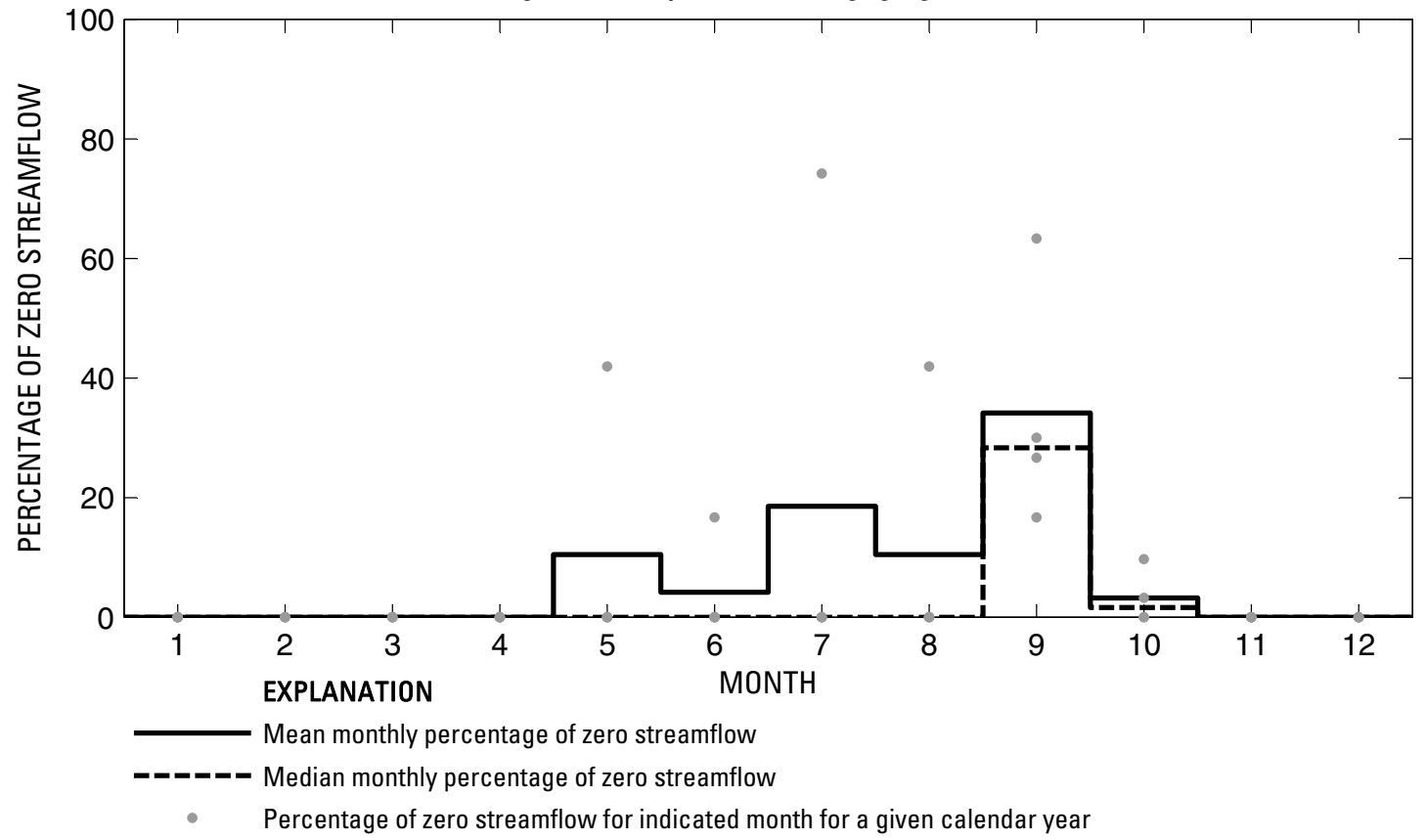

Figure 527. Analysis of percentage of zero daily mean streamflow for U.S. Geological Survey streamflow-gaging station 08157600 East Bouldin Creek at South 1st Street, Austin, Texas. 
U.S. Geological Survey streamflow-gaging station 08157700

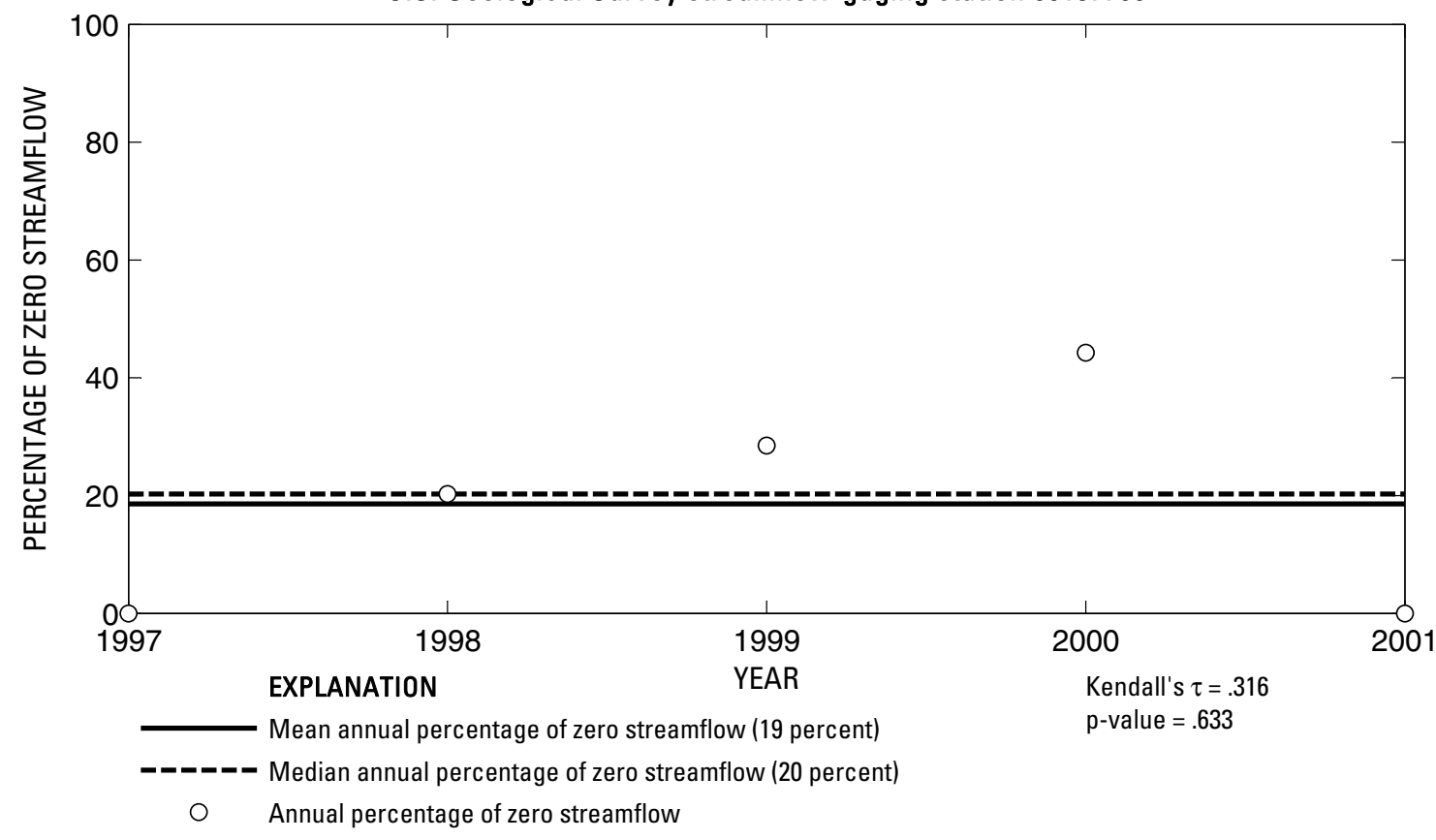

U.S. Geological Survey streamflow-gaging station 08157700

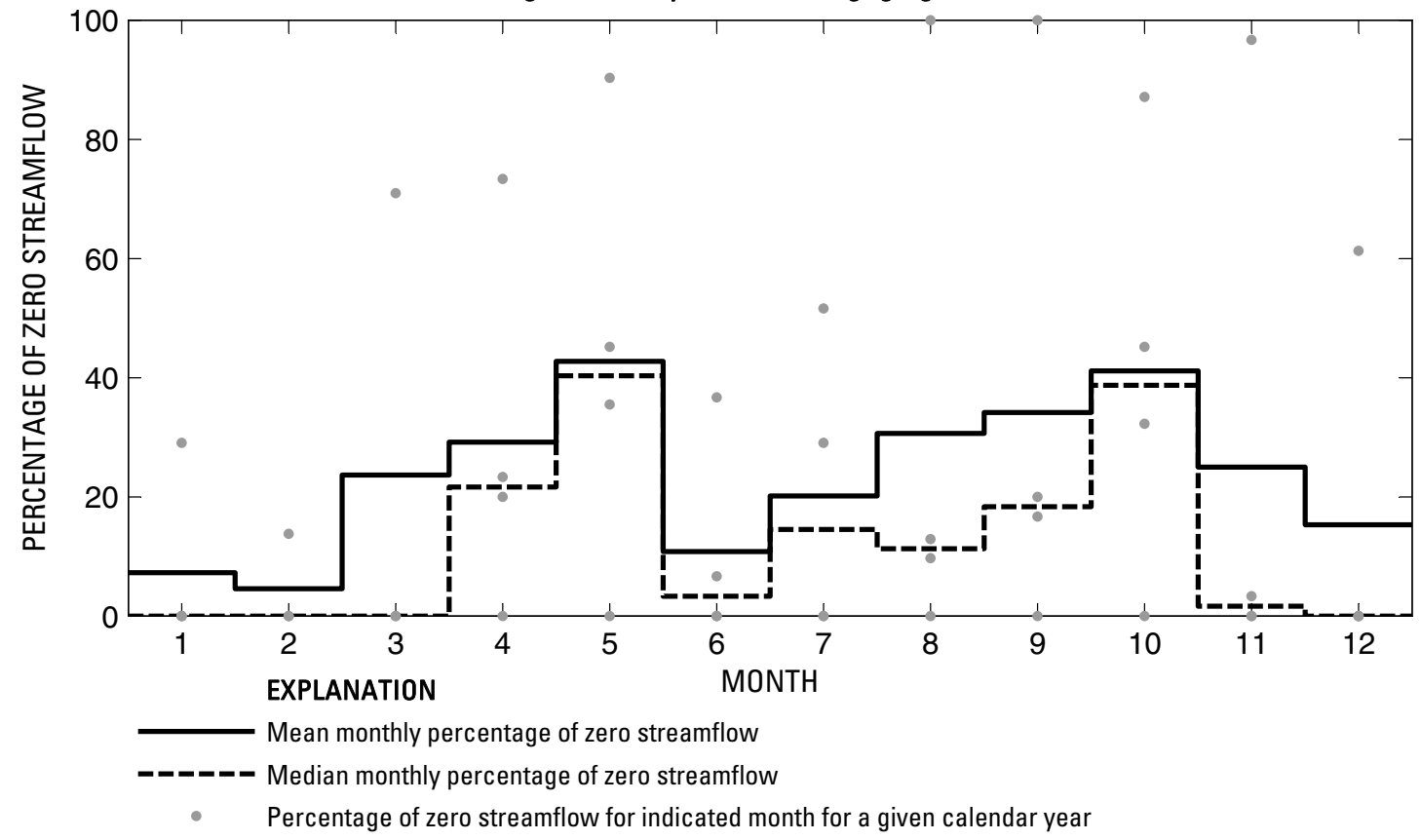

Figure 528. Analysis of percentage of zero daily mean streamflow for U.S. Geological Survey streamflow-gaging station 08157700 Blunn Creek near Little Stacy Park, Austin, Texas. 
U.S. Geological Survey streamflow-gaging station 08158000

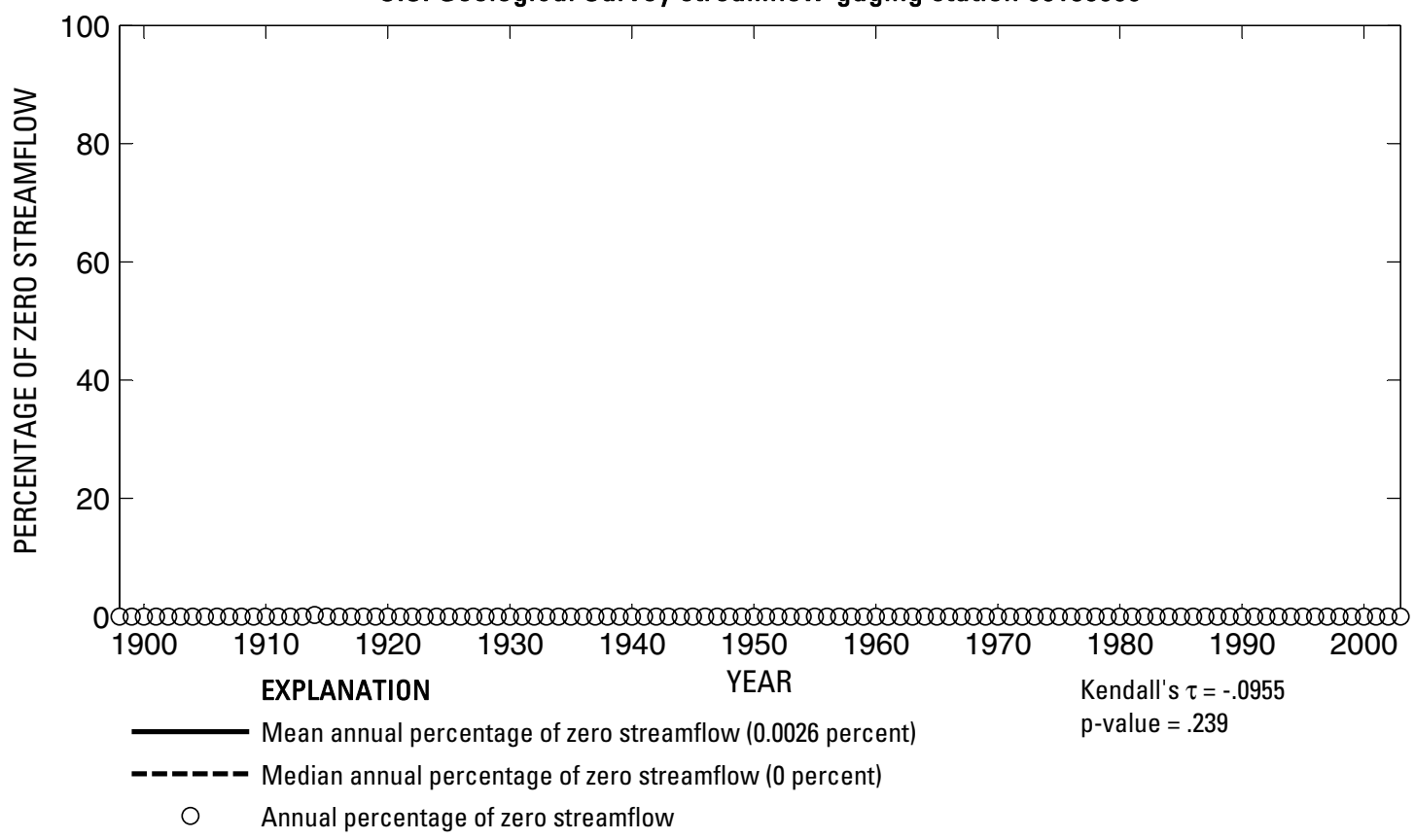

U.S. Geological Survey streamflow-gaging station 08158000

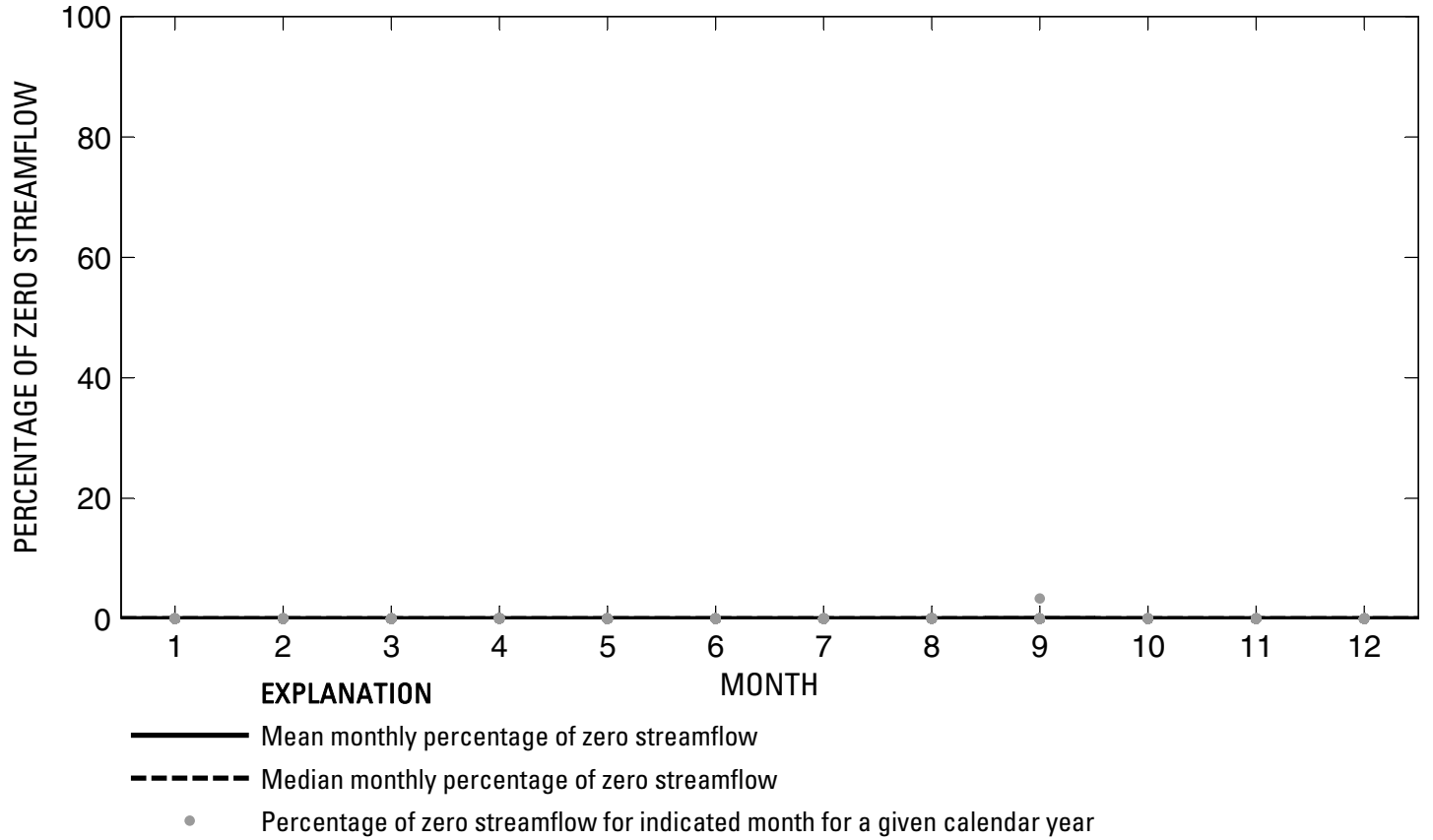

Figure 529. Analysis of percentage of zero daily mean streamflow for U.S. Geological Survey streamflow-gaging station 08158000 Colorado River at Austin, Texas. 
U.S. Geological Survey streamflow-gaging station 08158050

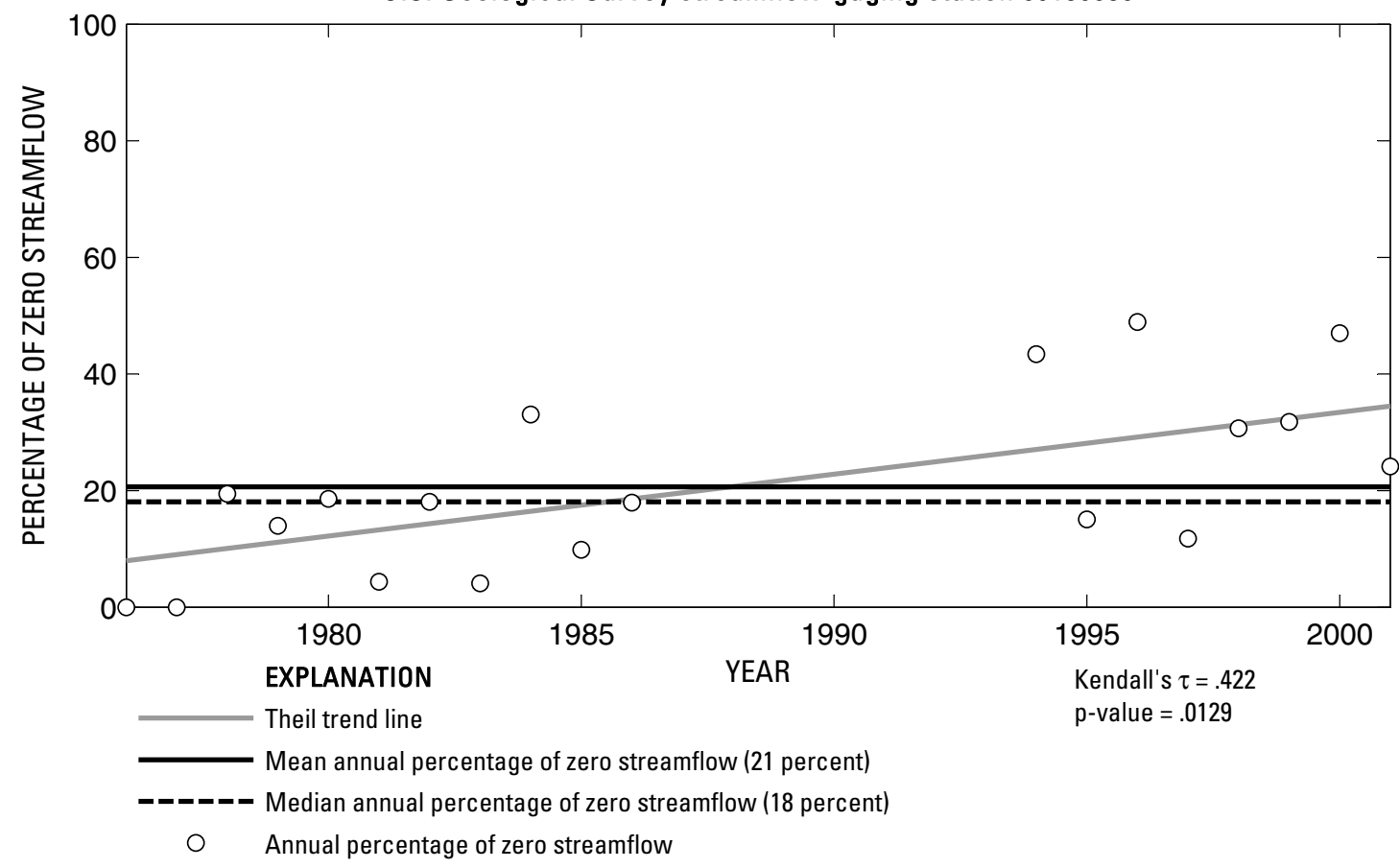

U.S. Geological Survey streamflow-gaging station 08158050

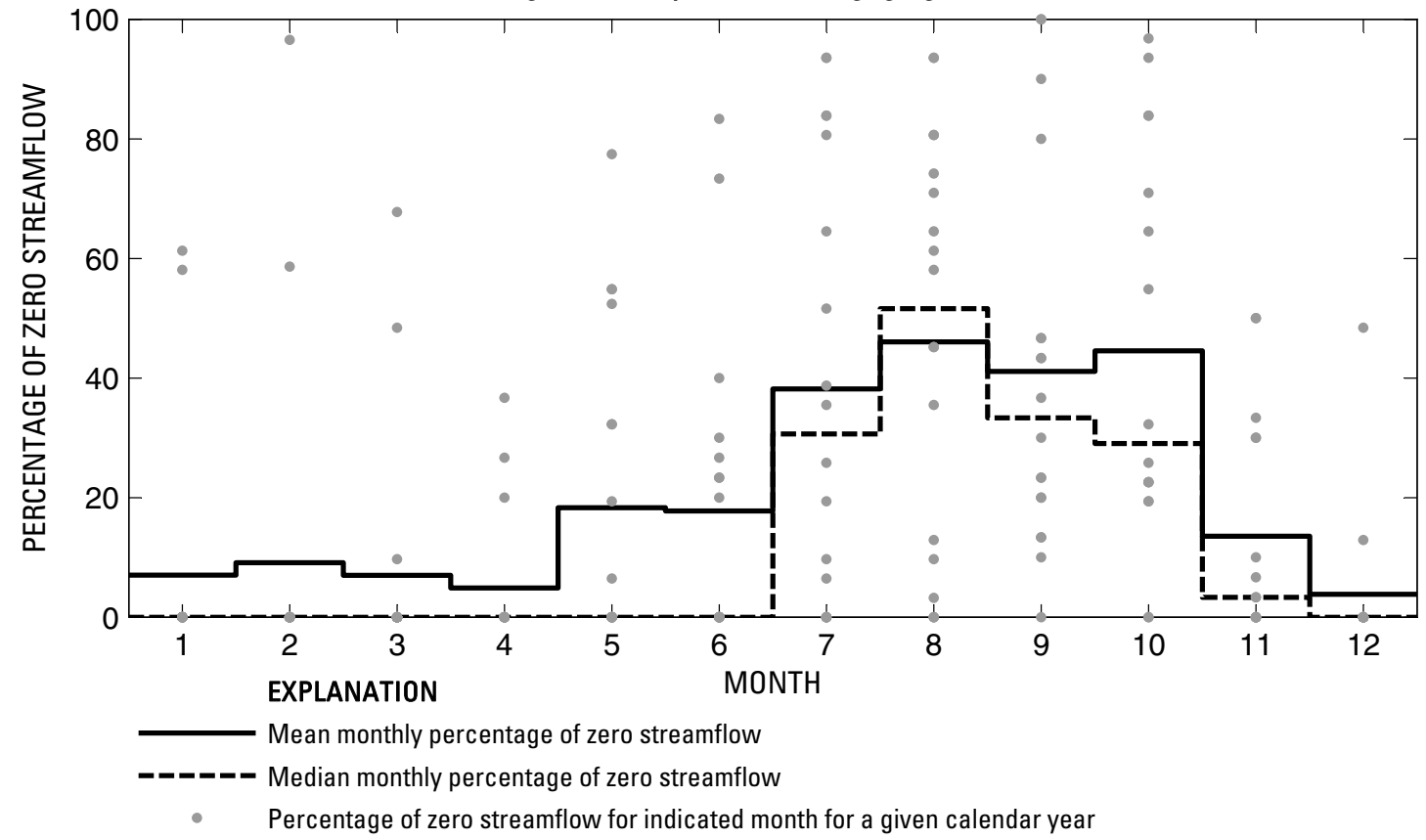

Figure 530. Analysis of percentage of zero daily mean streamflow for U.S. Geological Survey streamflow-gaging station 08158050 Boggy Creek at U. S. Highway 183, Austin, Texas.

Index of Station Numbers 719 
U.S. Geological Survey streamflow-gaging station 08158600

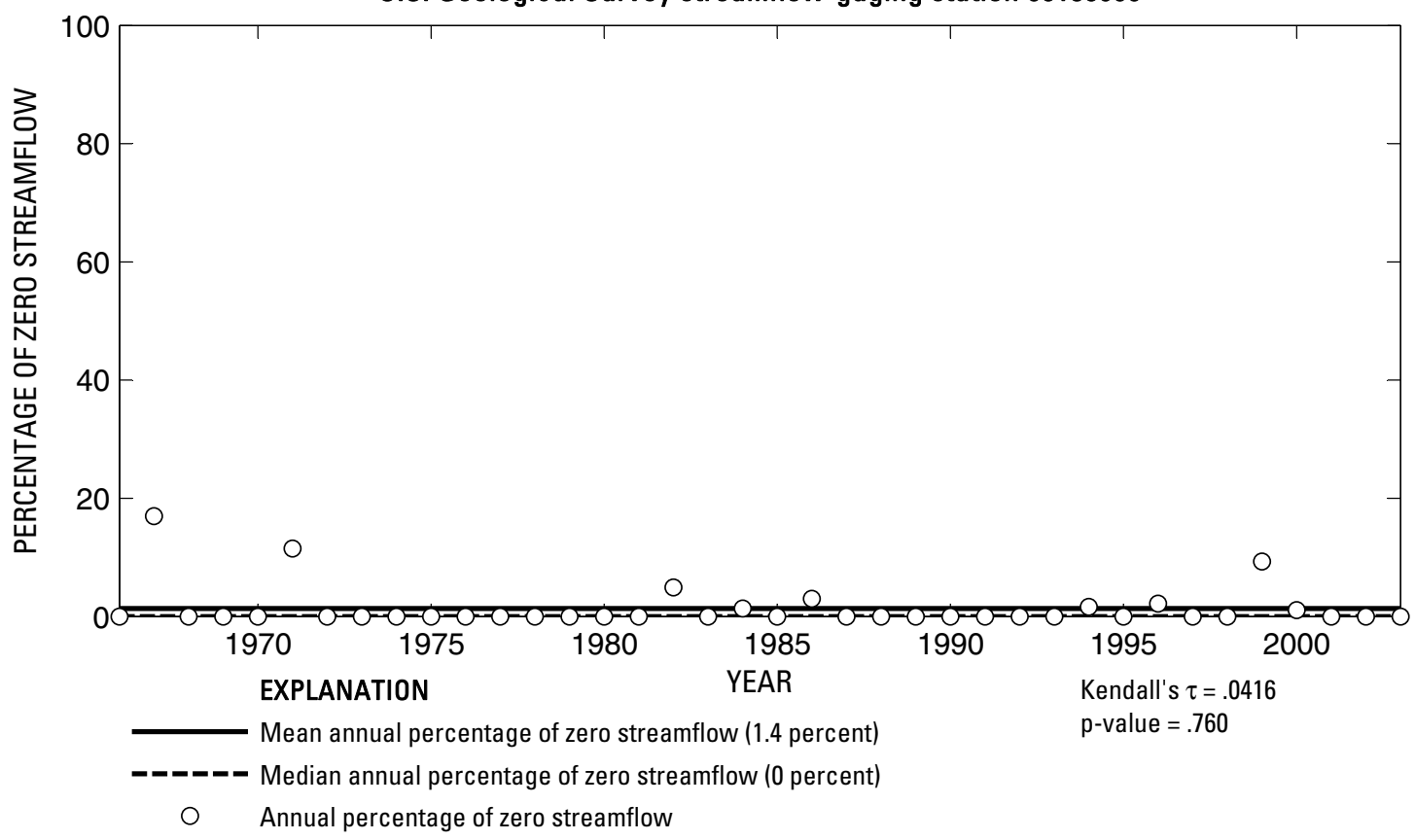

U.S. Geological Survey streamflow-gaging station 08158600

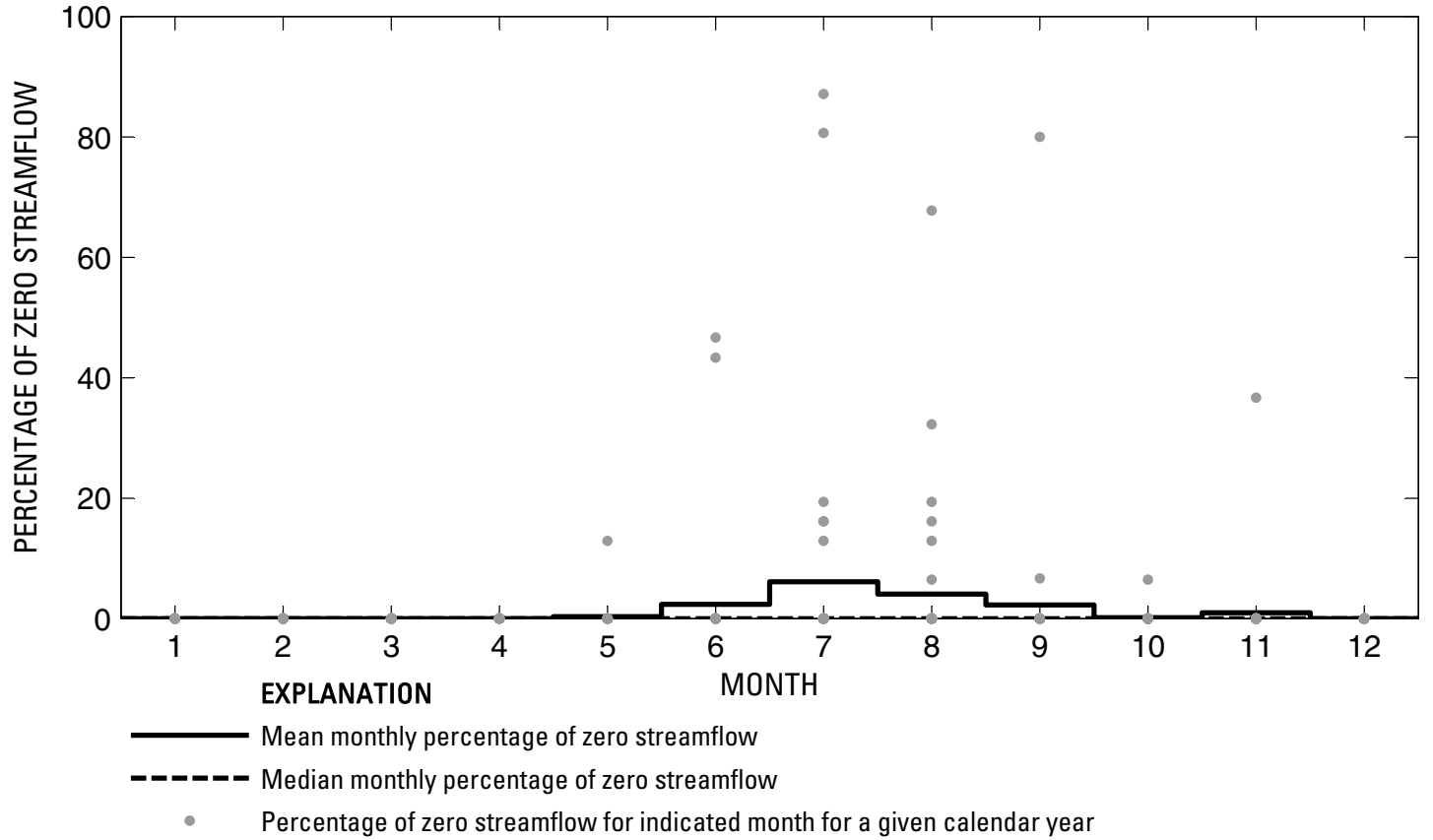

Figure 531. Analysis of percentage of zero daily mean streamflow for U.S. Geological Survey streamflow-gaging station 08158600 Walnut Creek at Webberville Road, Austin, Texas. 
U.S. Geological Survey streamflow-gaging station 08158700

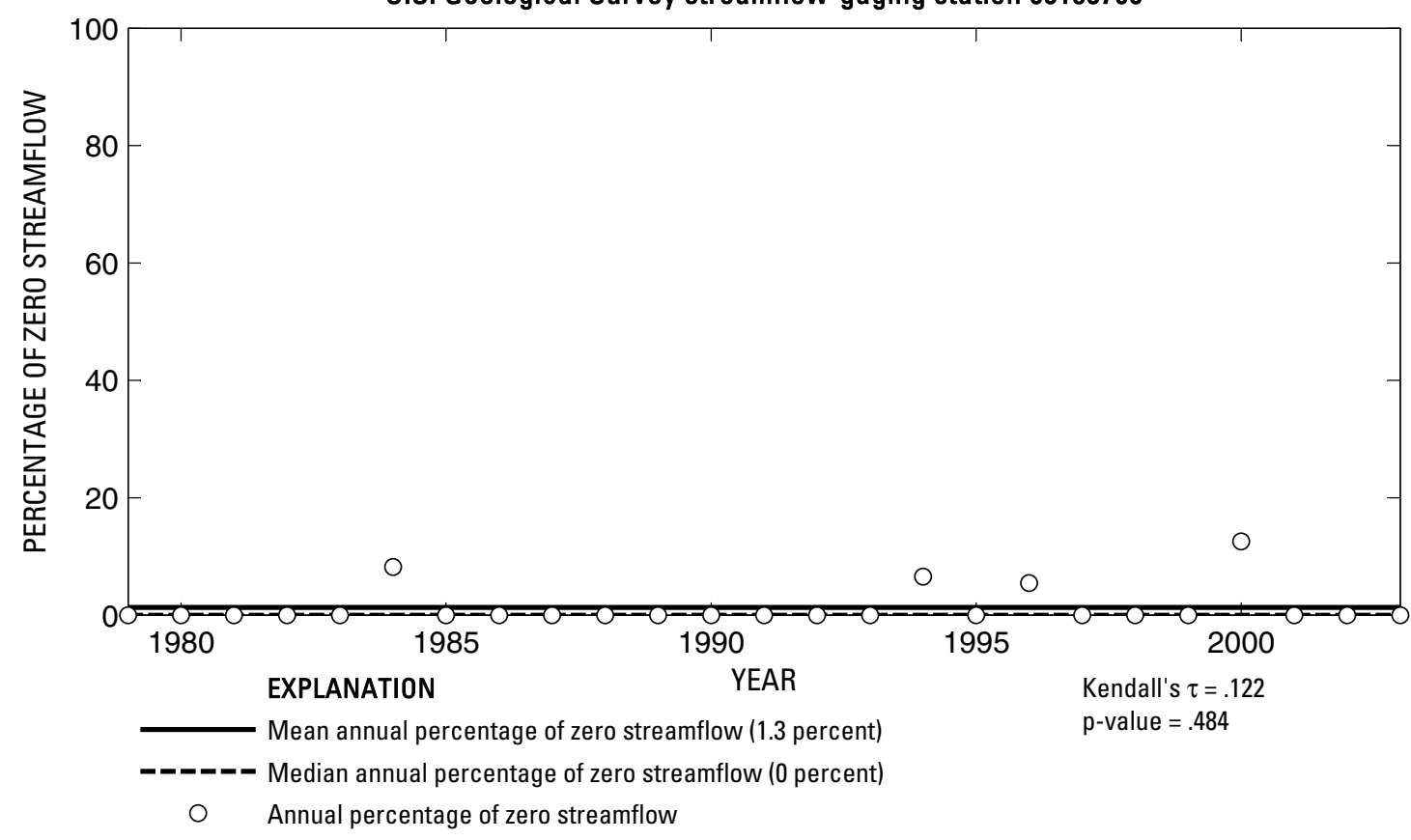

U.S. Geological Survey streamflow-gaging station 08158700

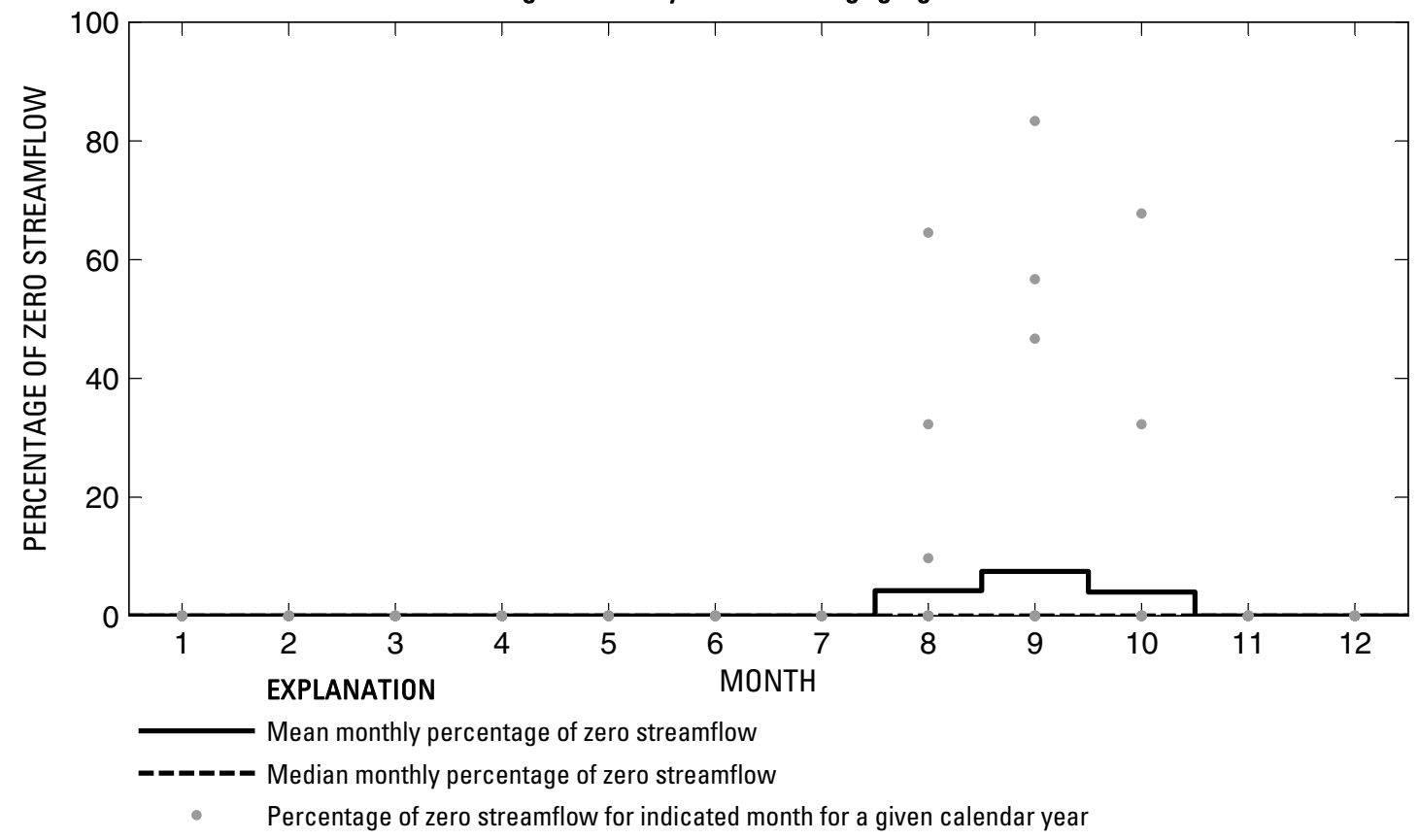

Figure 532. Analysis of percentage of zero daily mean streamflow for U.S. Geological Survey streamflow-gaging station 08158700 Onion Creek near Driftwood, Texas. 
U.S. Geological Survey streamflow-gaging station 08158800

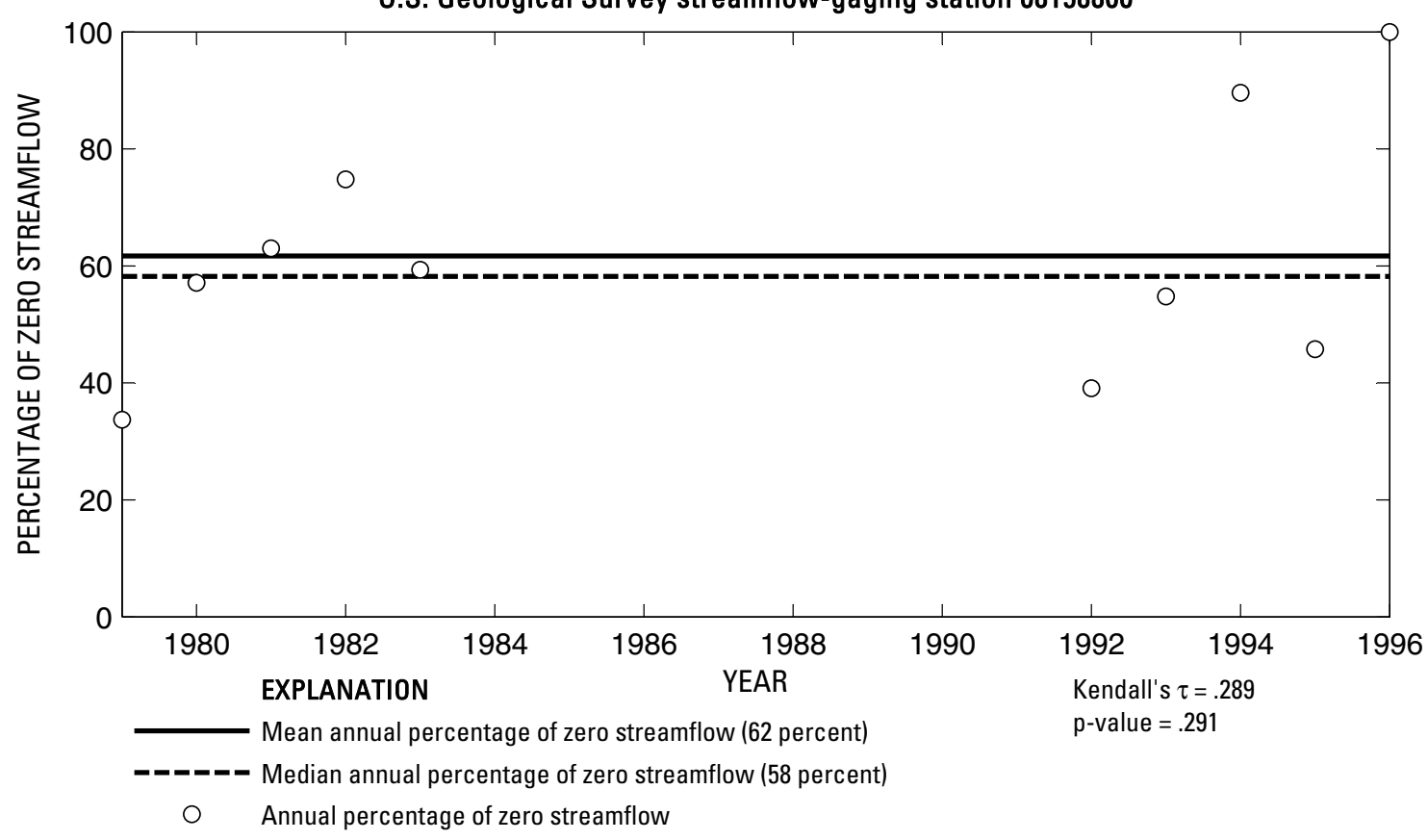

U.S. Geological Survey streamflow-gaging station 08158800

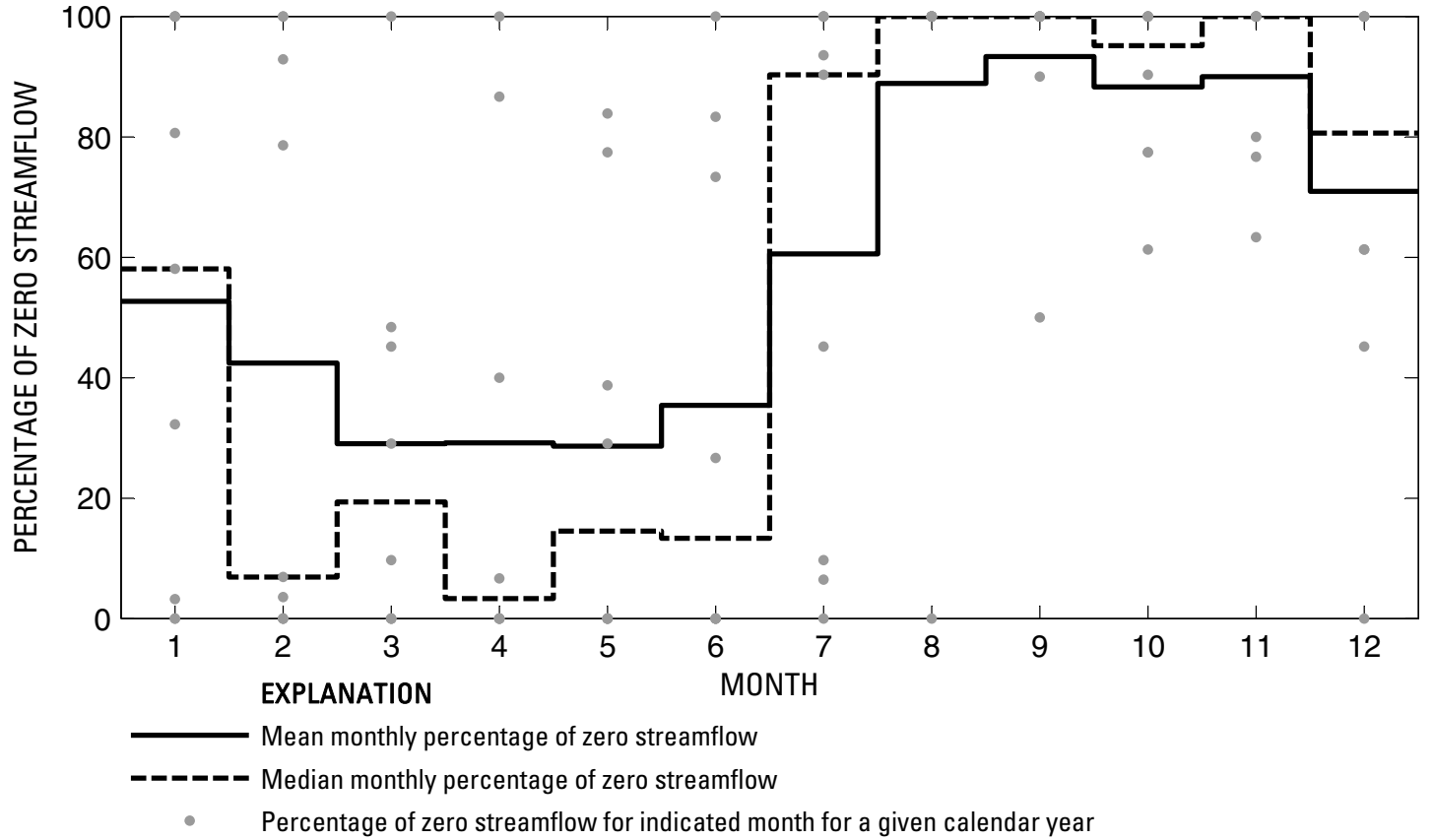

Figure 533. Analysis of percentage of zero daily mean streamflow for U.S. Geological Survey streamflow-gaging station 08158800 Onion Creek at Buda, Texas. 
U.S. Geological Survey streamflow-gaging station 08158810

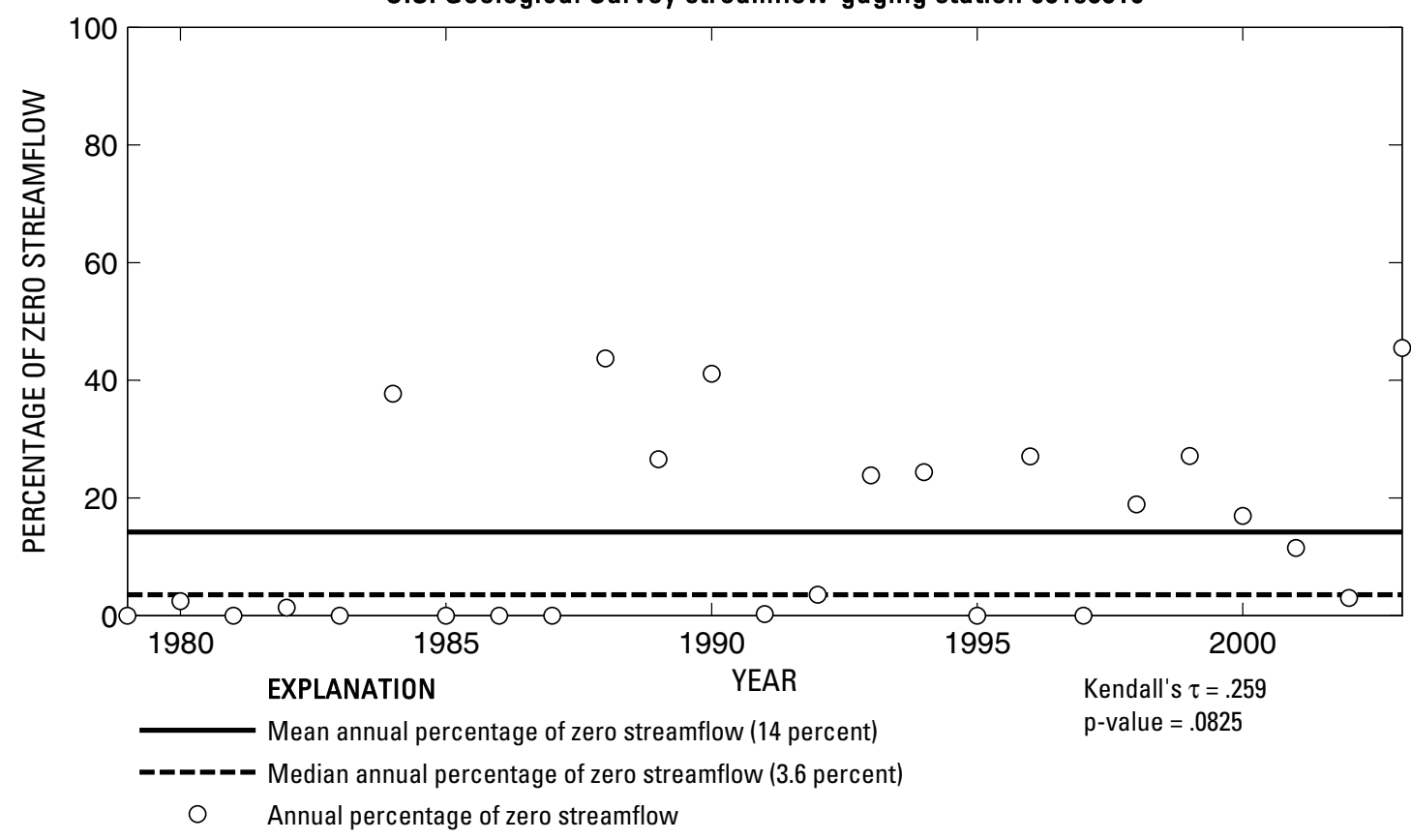

U.S. Geological Survey streamflow-gaging station 08158810

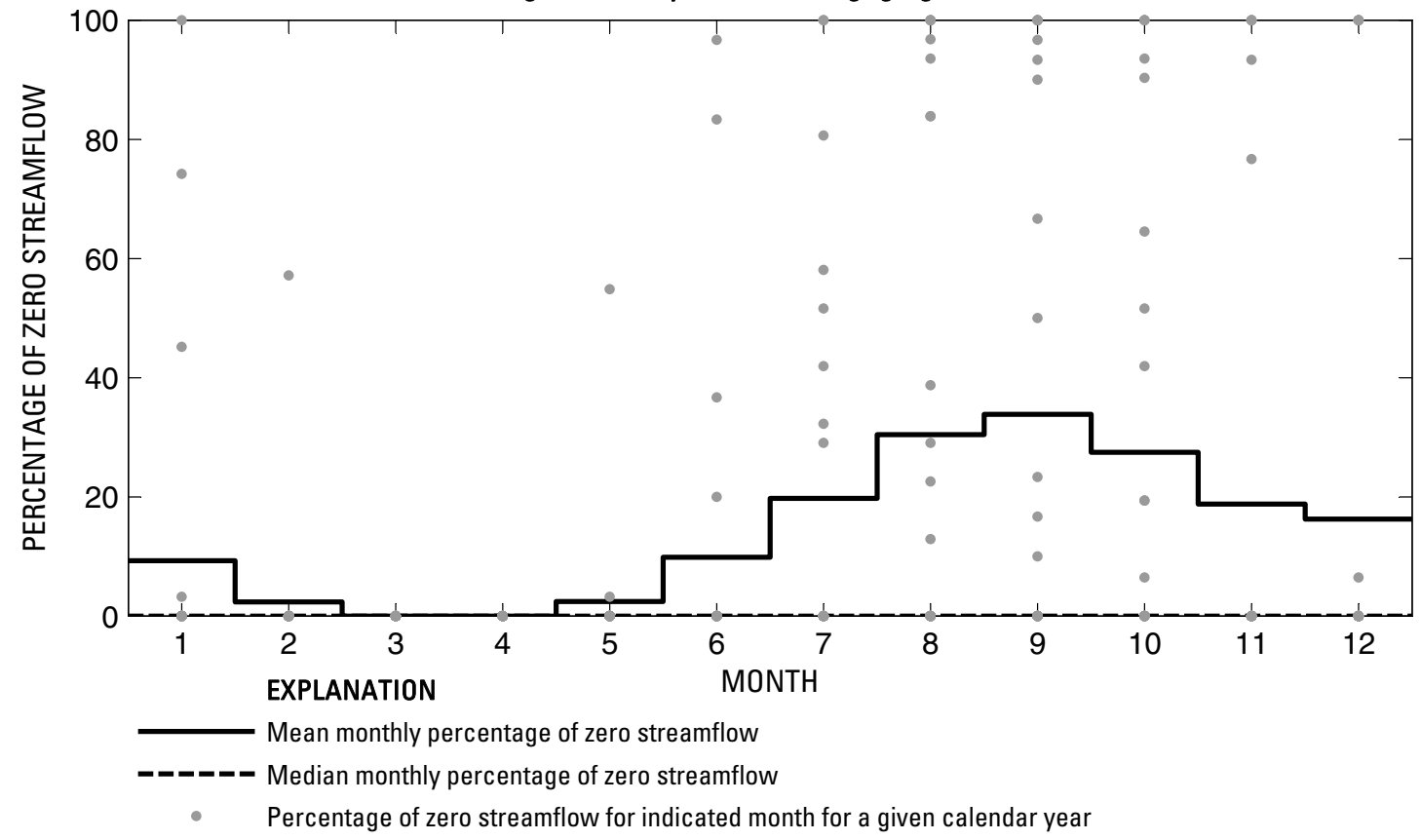

Figure 534. Analysis of percentage of zero daily mean streamflow for U.S. Geological Survey streamflow-gaging station 08158810 Bear Creek below Farm to Market Road 1826 near Driftwood, Texas.

Index of Station Numbers 719 
U.S. Geological Survey streamflow-gaging station 08158840

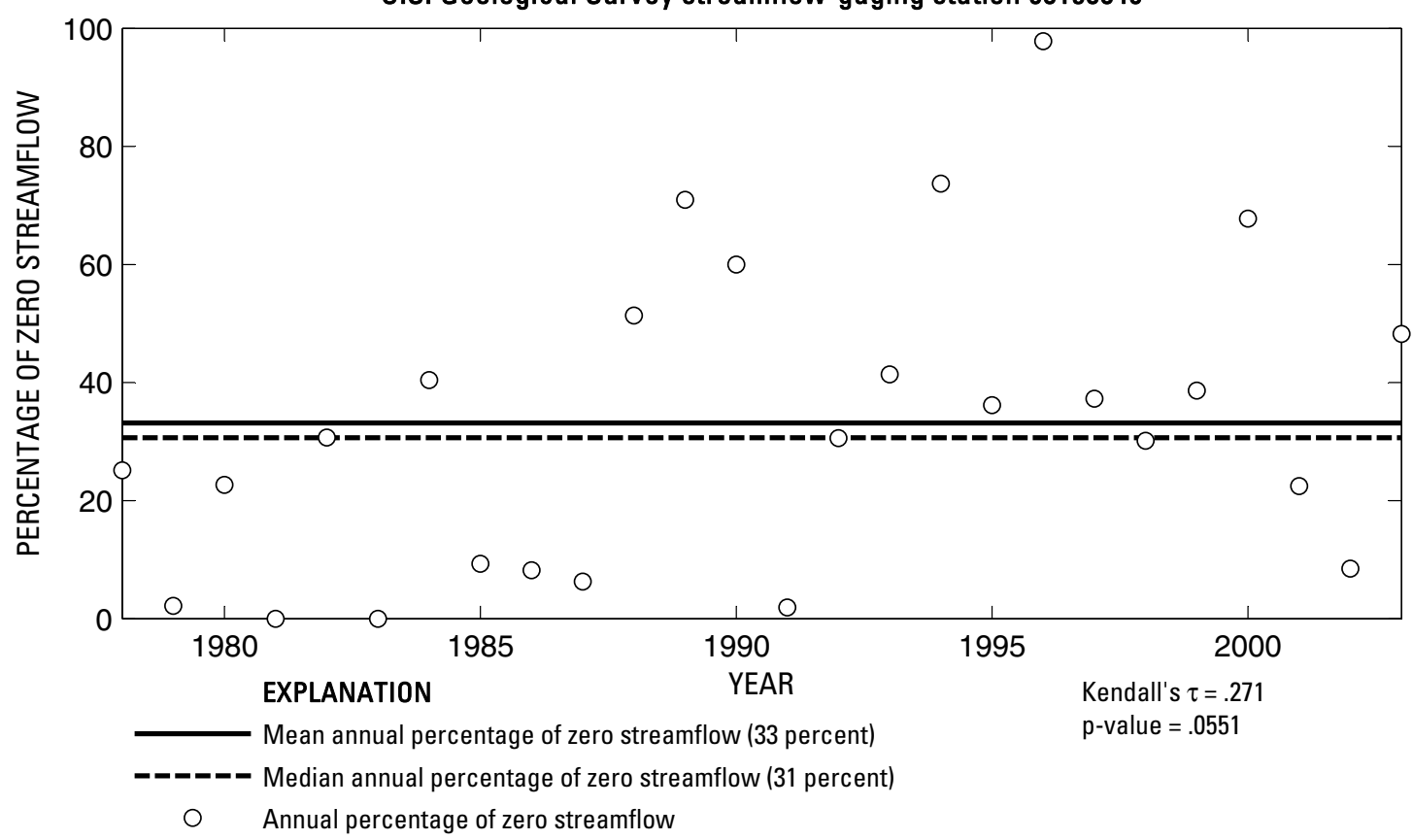

U.S. Geological Survey streamflow-gaging station 08158840

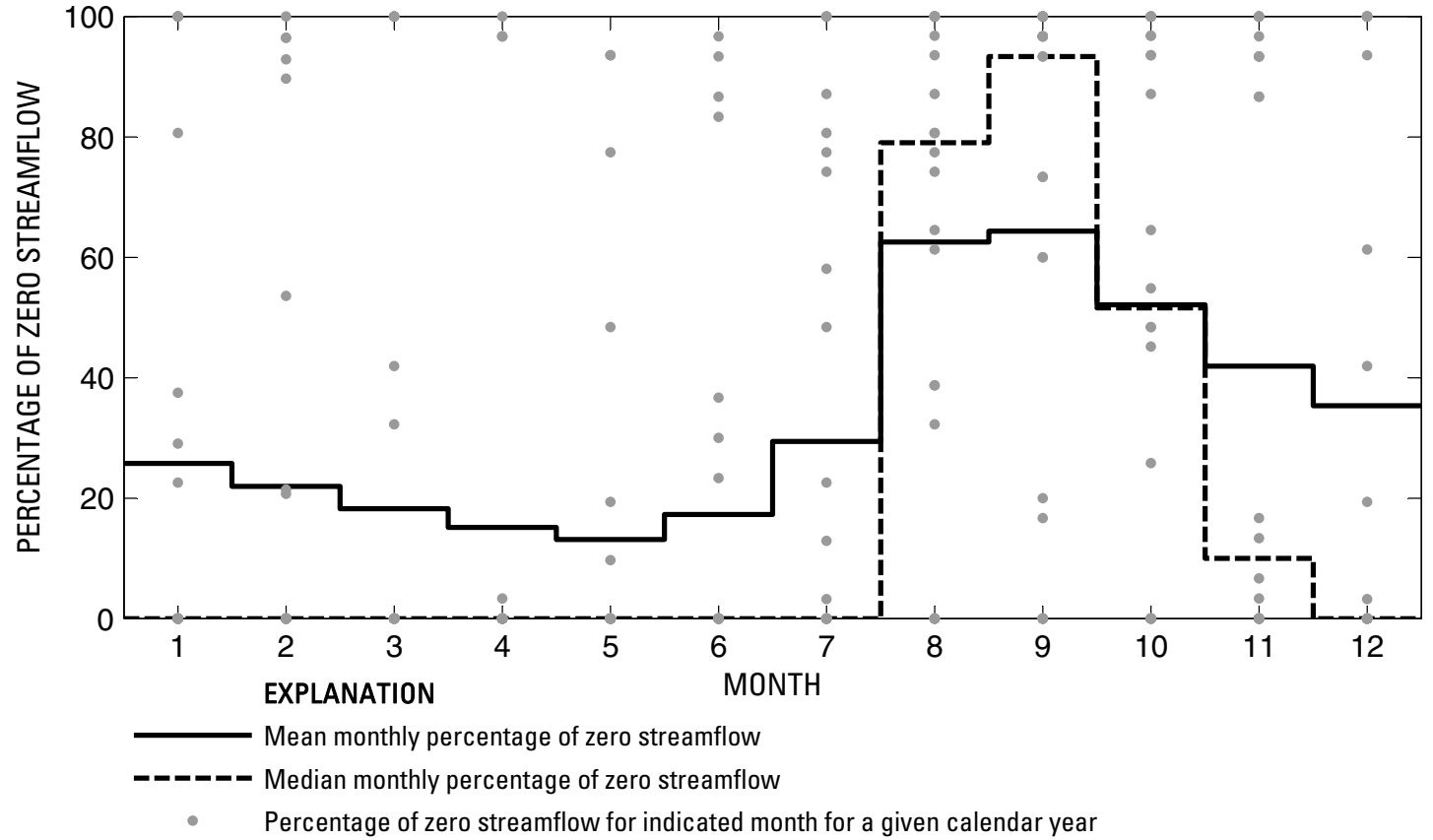

Figure 535. Analysis of percentage of zero daily mean streamflow for U.S. Geological Survey streamflow-gaging station 08158840 Slaughter Creek at Farm to Market Road 1826 near Austin, Texas. 
U.S. Geological Survey streamflow-gaging station 08158920

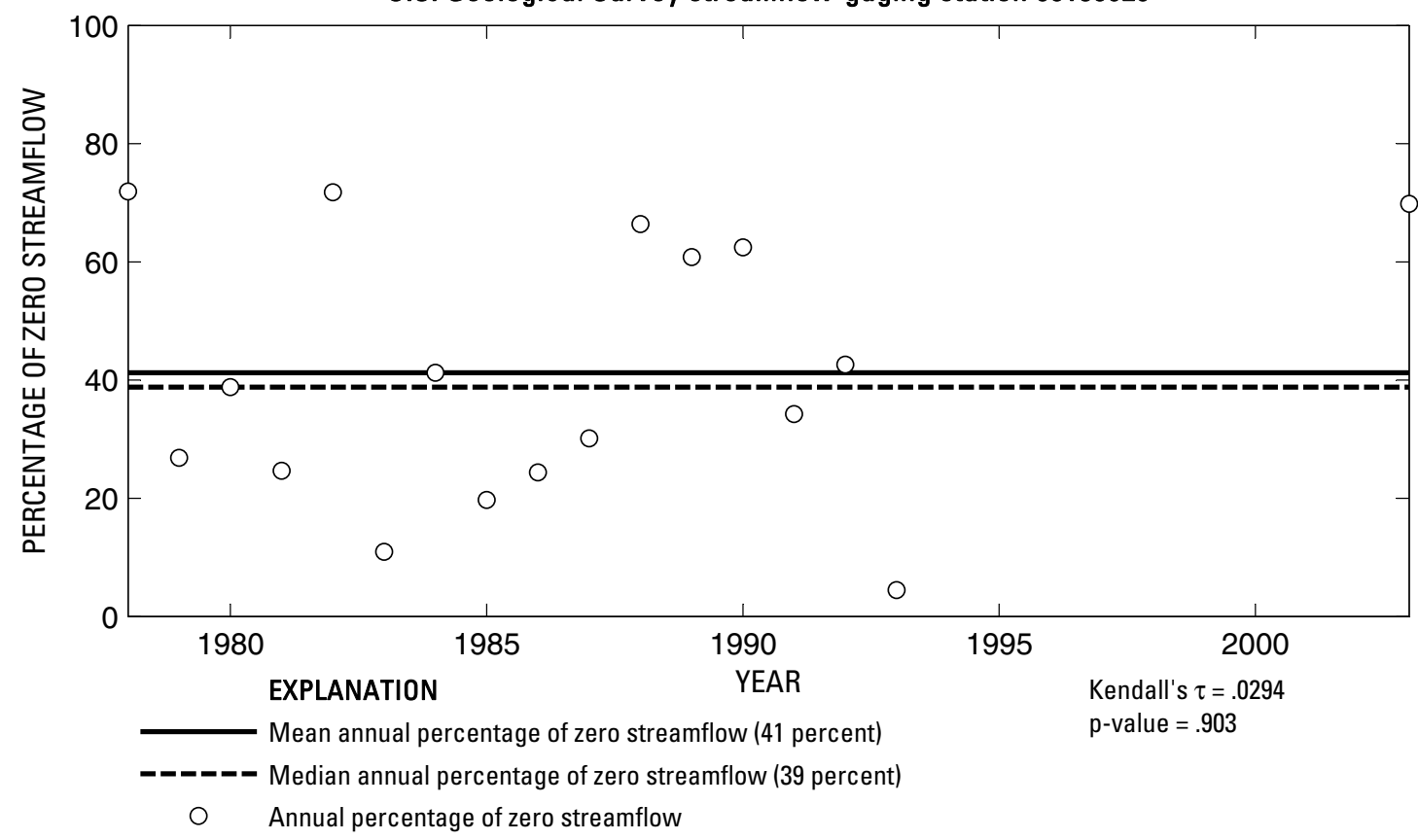

U.S. Geological Survey streamflow-gaging station 08158920

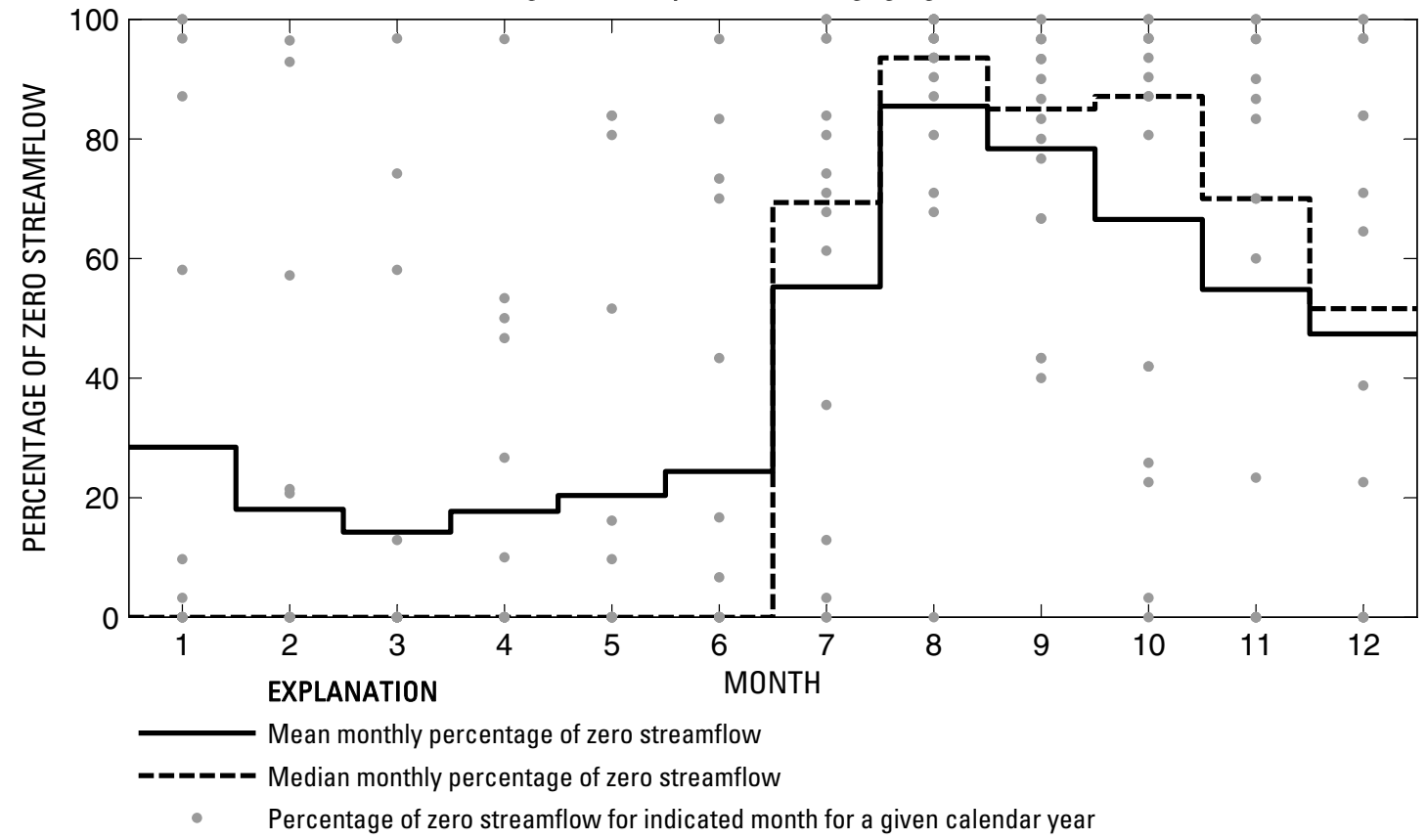

Figure 536. Analysis of percentage of zero daily mean streamflow for U.S. Geological Survey streamflow-gaging station 08158920 Williamson Creek at Oak Hill, Texas. 


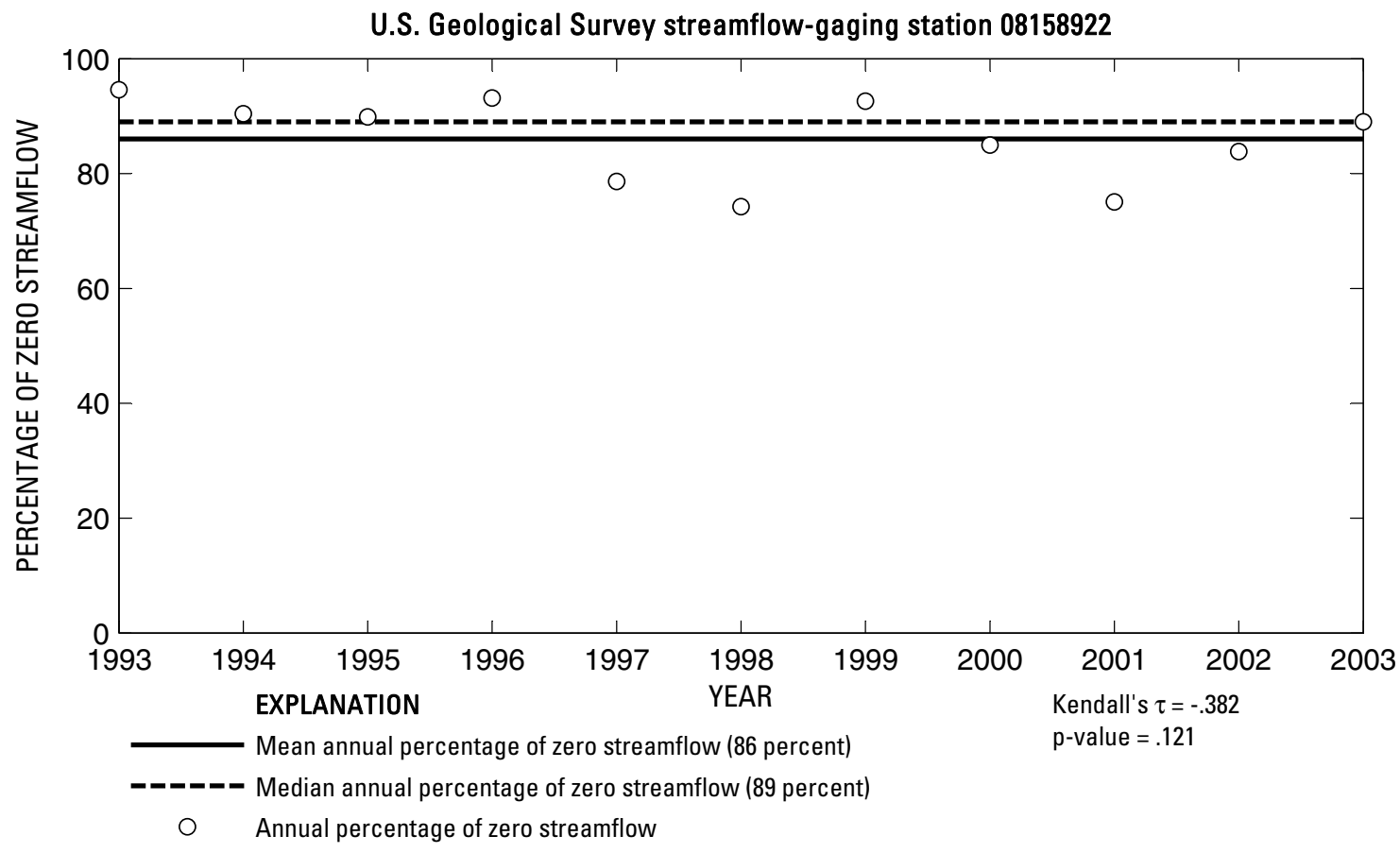

U.S. Geological Survey streamflow-gaging station 08158922

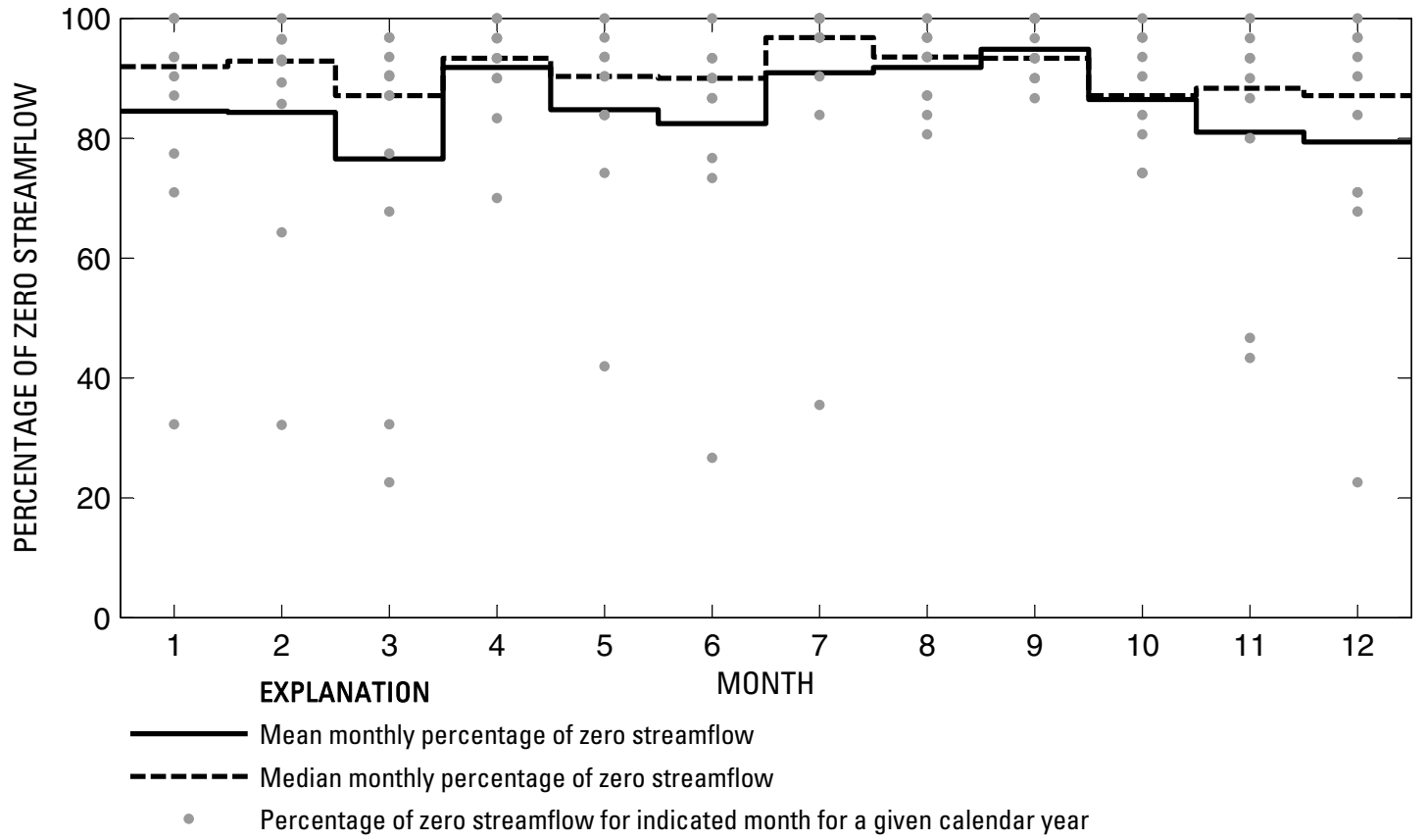

Figure 537. Analysis of percentage of zero daily mean streamflow for U.S. Geological Survey streamflow-gaging station 08158922 Williamson Creek at Brush Country Boulevard, Oak Hill, Texas. 
U.S. Geological Survey streamflow-gaging station 08158930

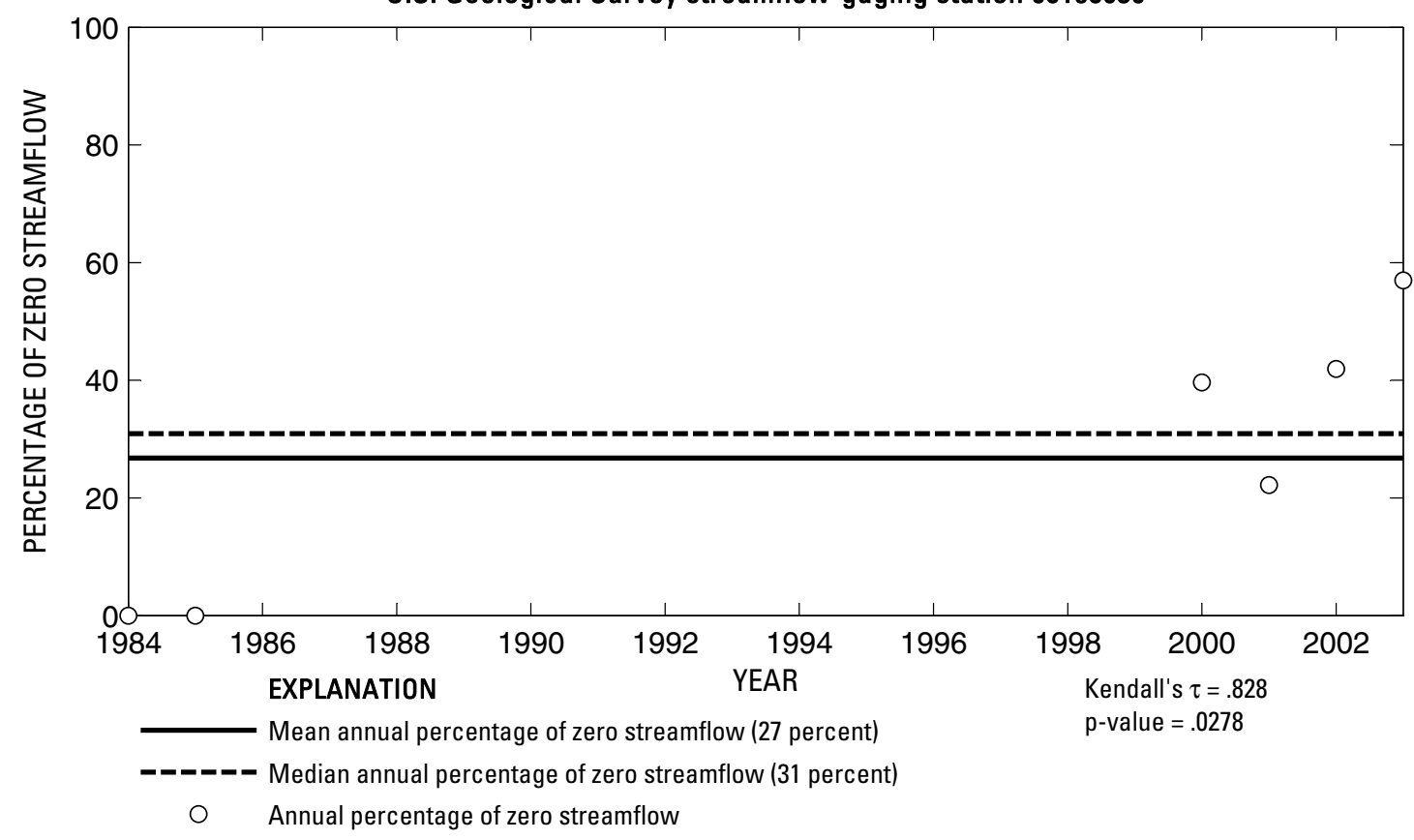

U.S. Geological Survey streamflow-gaging station 08158930

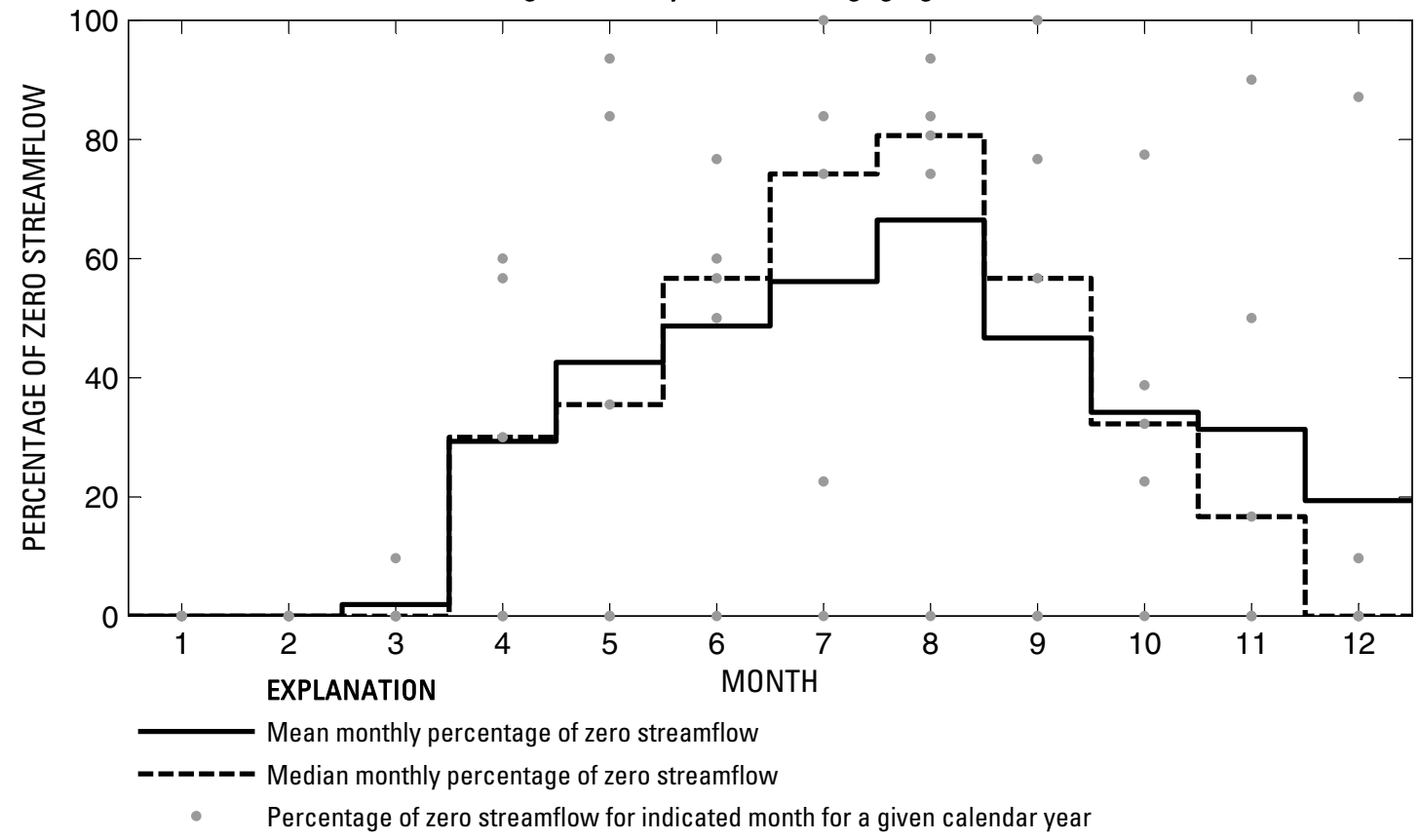

Figure 538. Analysis of percentage of zero daily mean streamflow for U.S. Geological Survey streamflow-gaging station 08158930 Williamson Creek at Manchaca Road, Austin, Texas. 


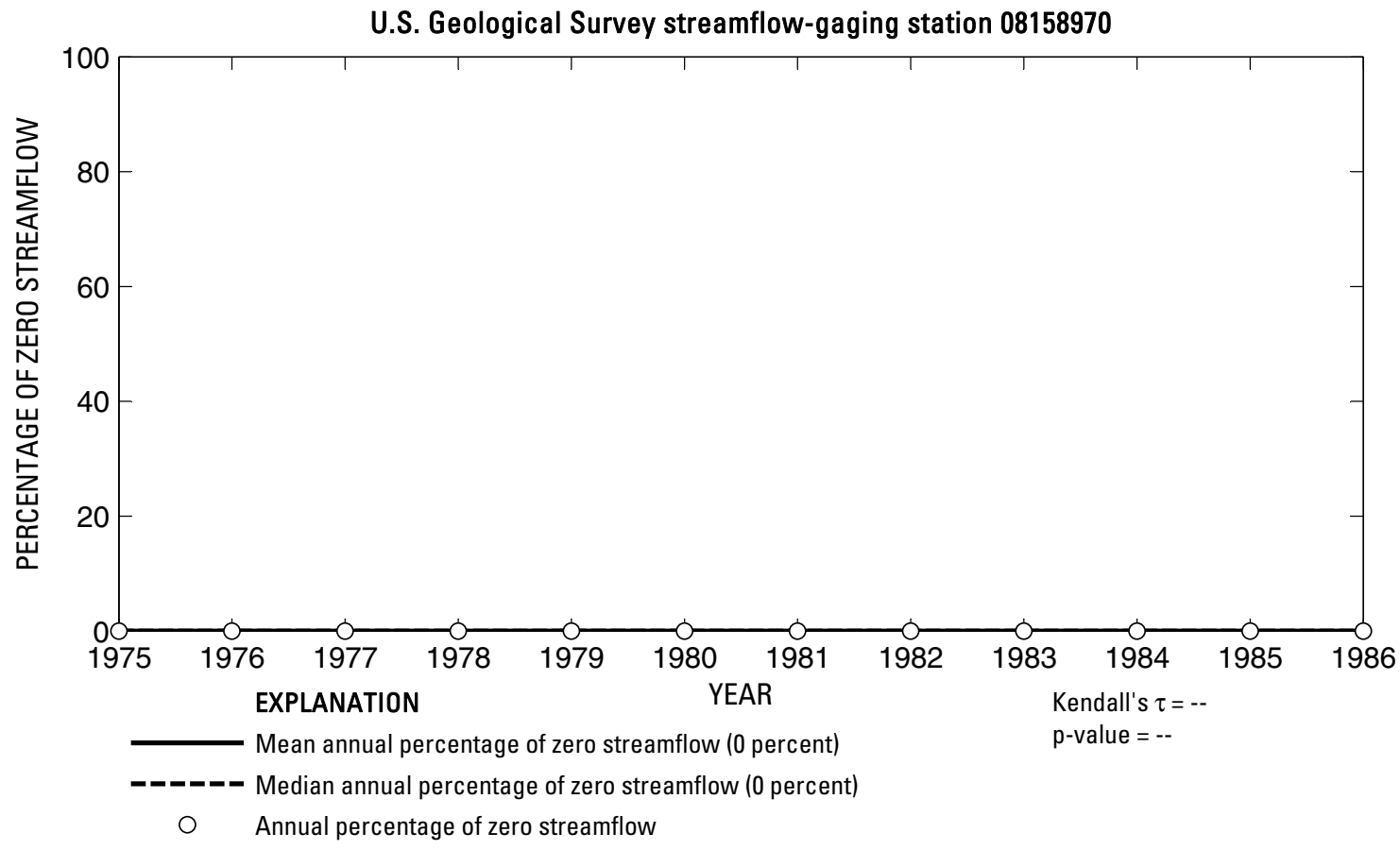

U.S. Geological Survey streamflow-gaging station 08158970

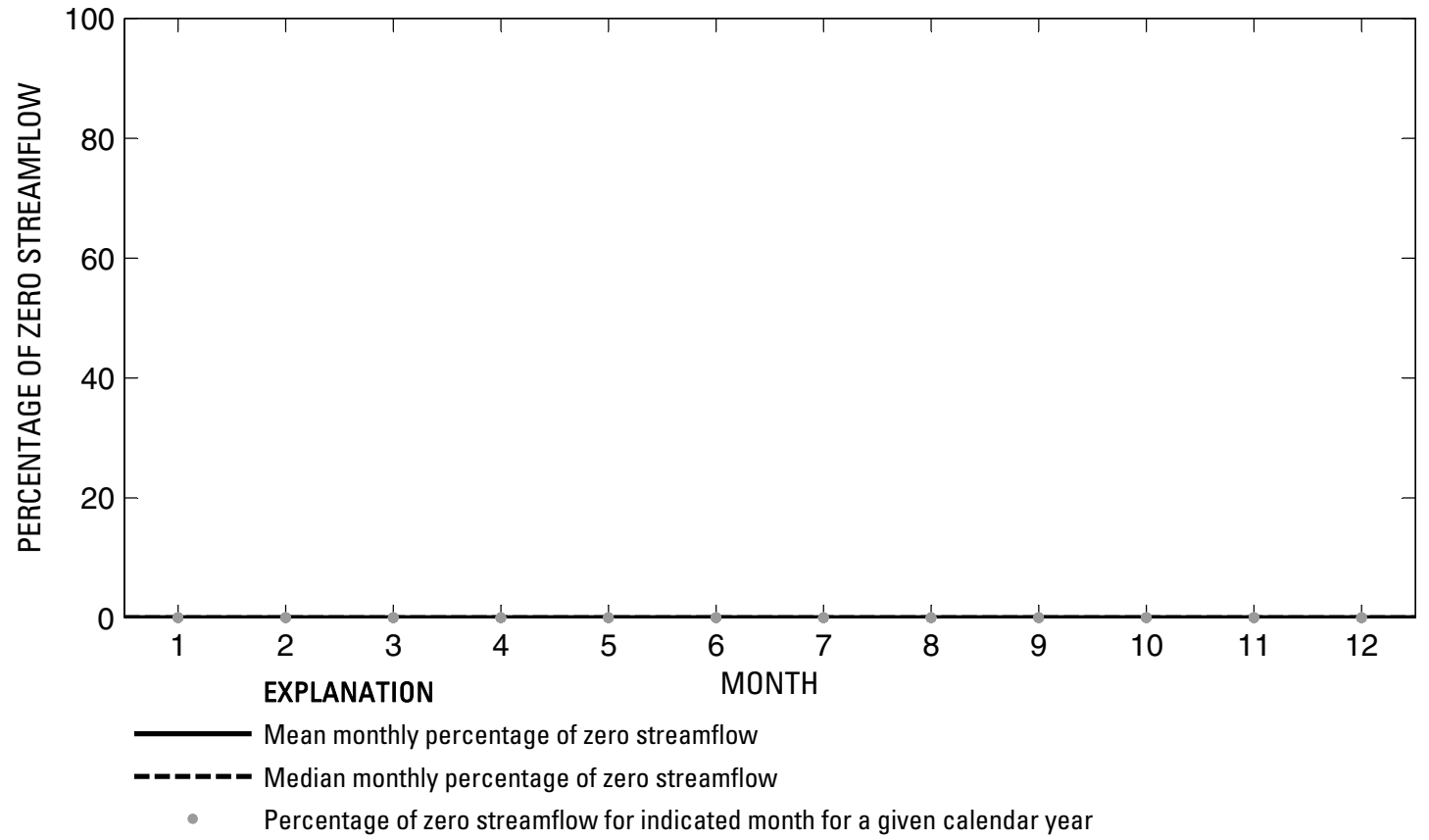

Figure 539. Analysis of percentage of zero daily mean streamflow for U.S. Geological Survey streamflow-gaging station 08158970 Williamson Creek at Jimmy Clay Road, Austin, Texas. 
U.S. Geological Survey streamflow-gaging station 08159000

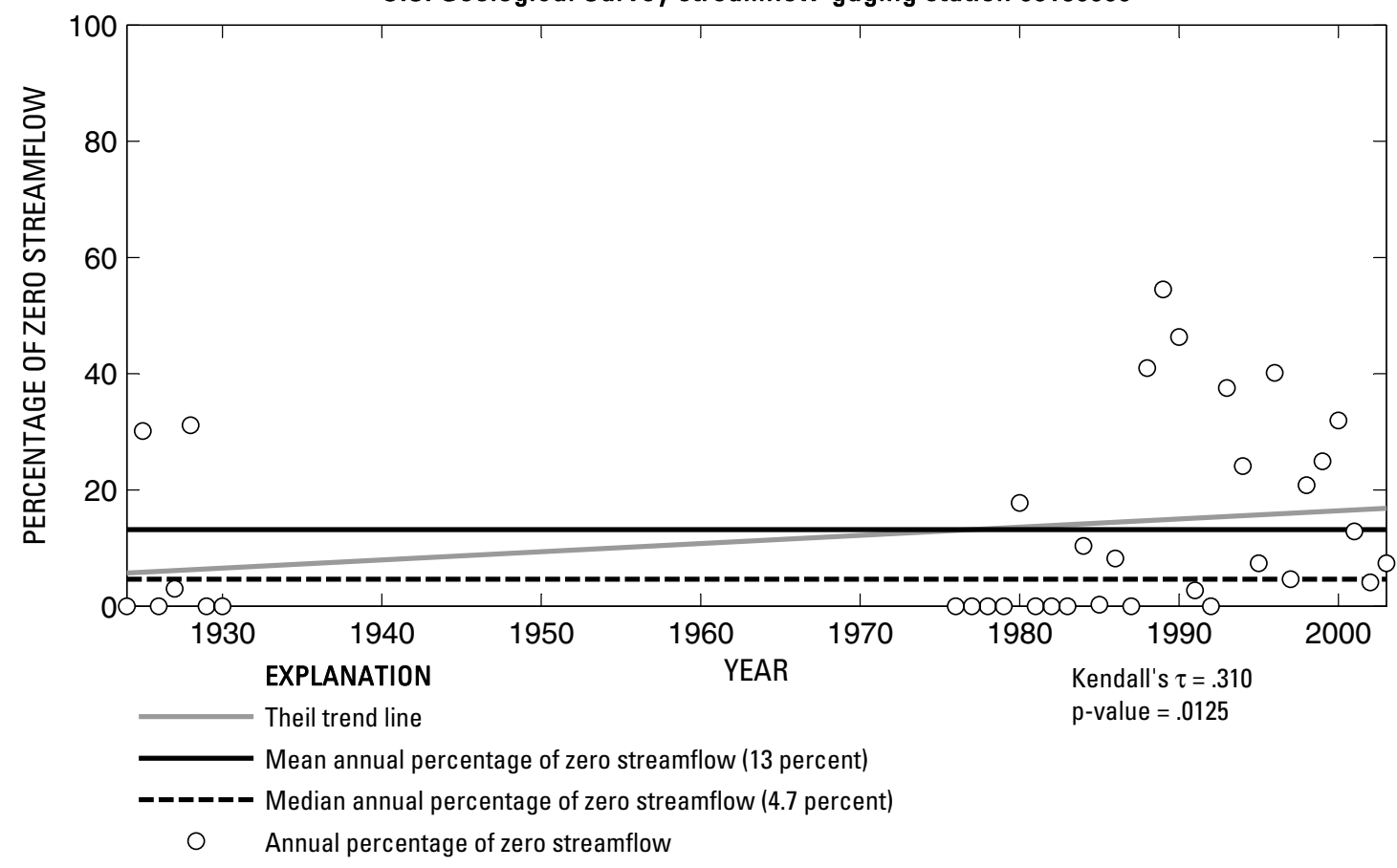

U.S. Geological Survey streamflow-gaging station 08159000

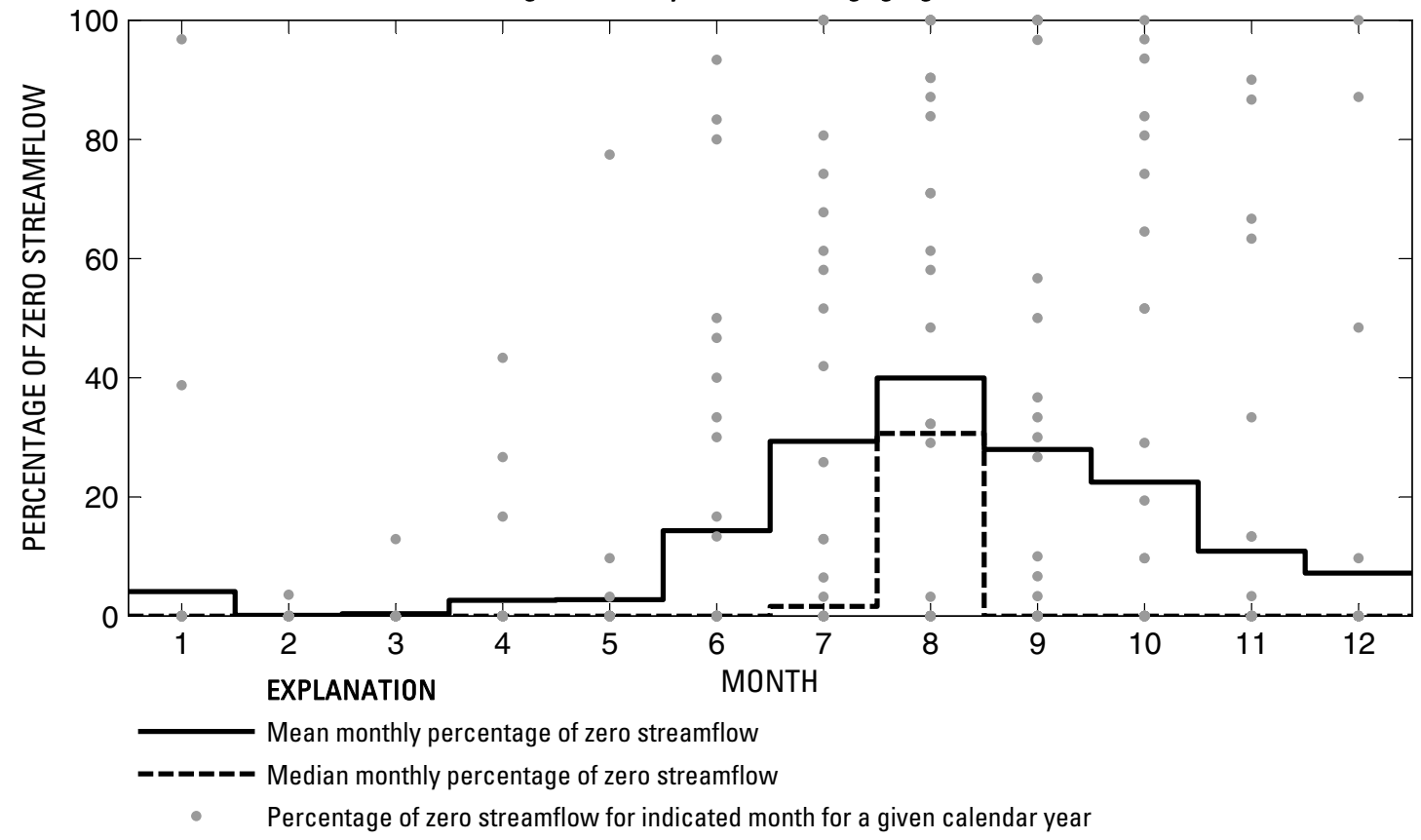

Figure 540. Analysis of percentage of zero daily mean streamflow for U.S. Geological Survey streamflow-gaging station 08159000 Onion Creek at U. S. Highway 183, Austin, Texas.

Index of Station Numbers 719 
U.S. Geological Survey streamflow-gaging station 08159150

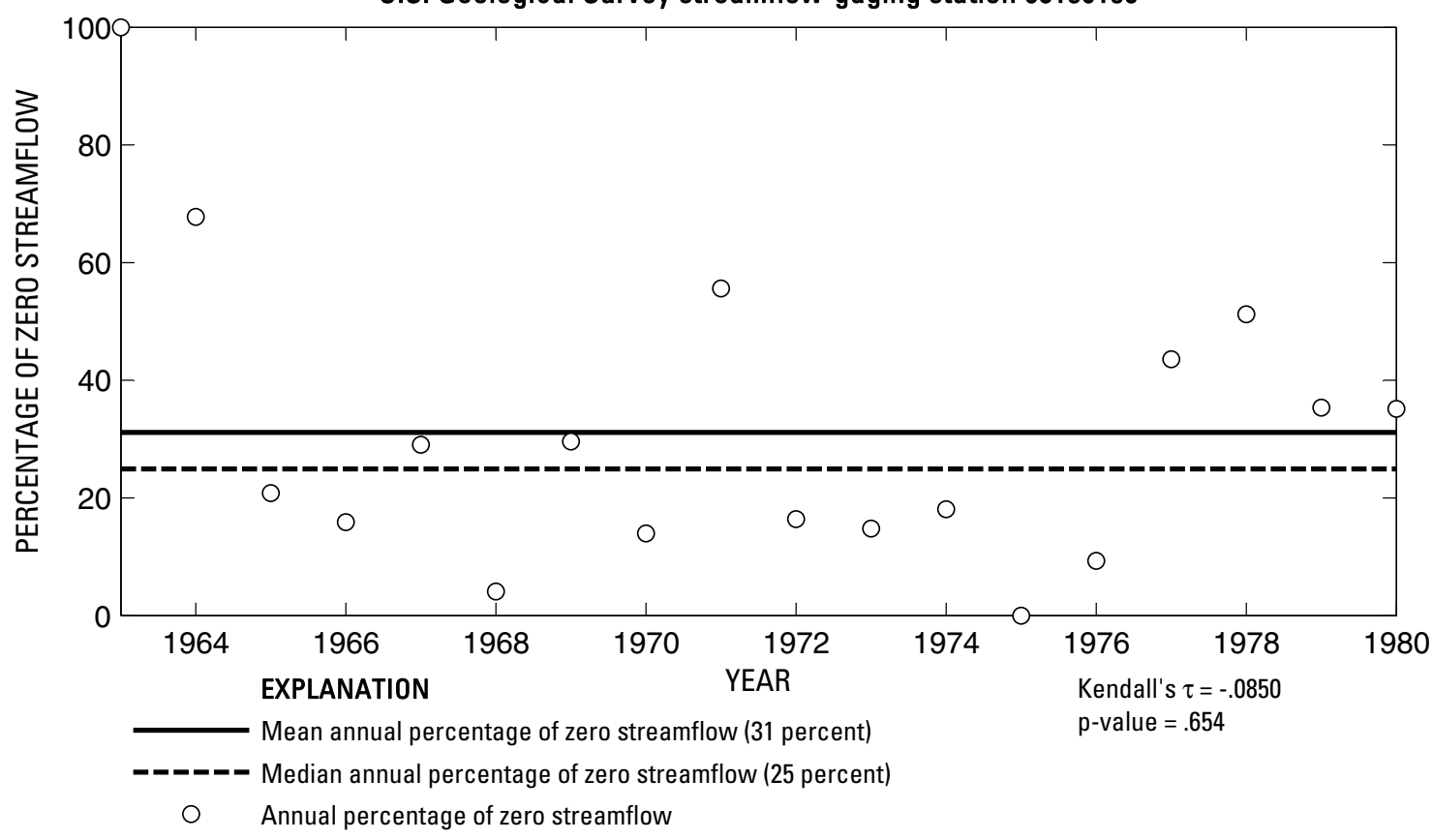

U.S. Geological Survey streamflow-gaging station 08159150

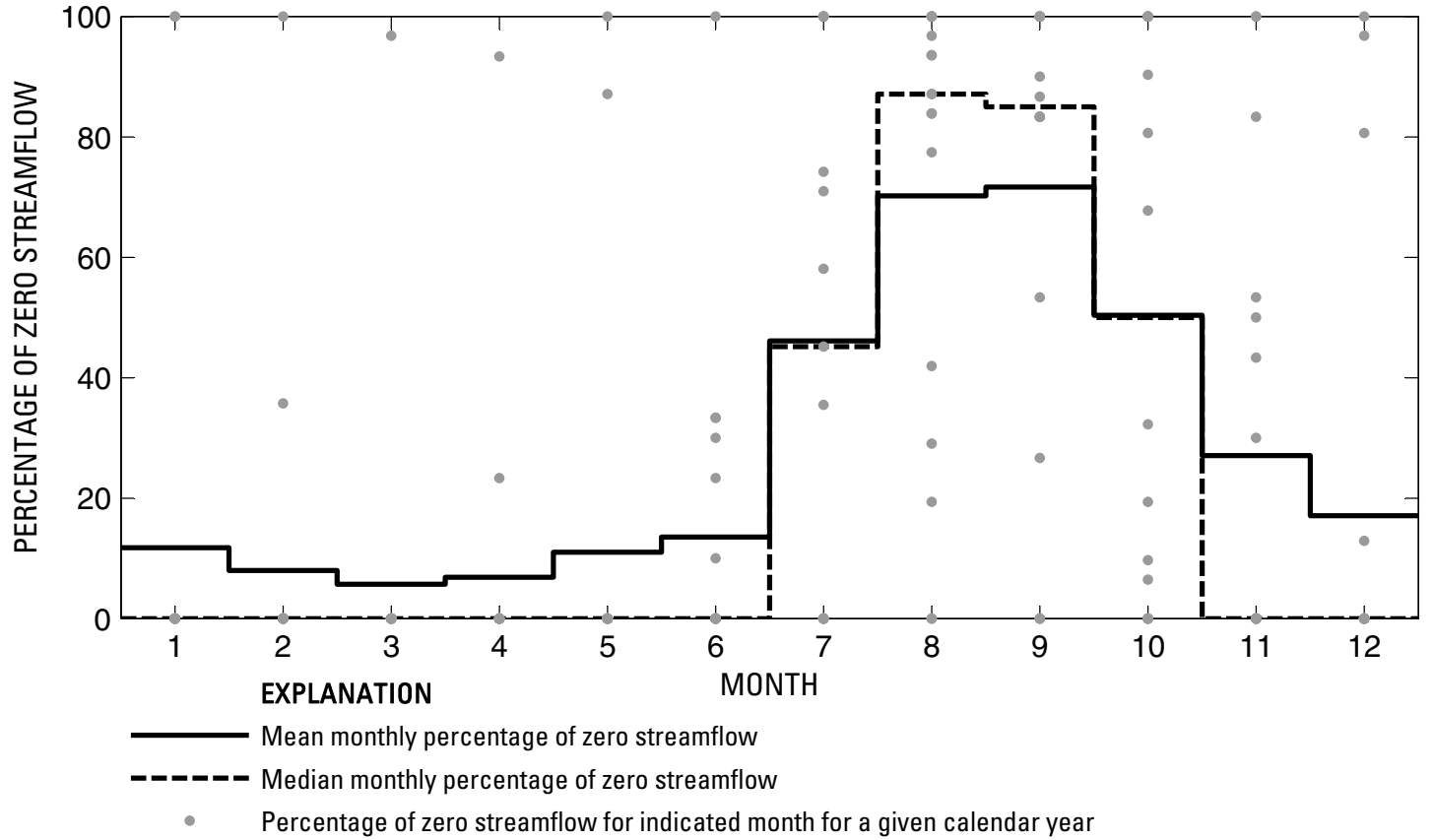

Figure 541. Analysis of percentage of zero daily mean streamflow for U.S. Geological Survey streamflow-gaging station 08159150 Wilbarger Creek near Pflugerville, Texas. 
U.S. Geological Survey streamflow-gaging station 08159165

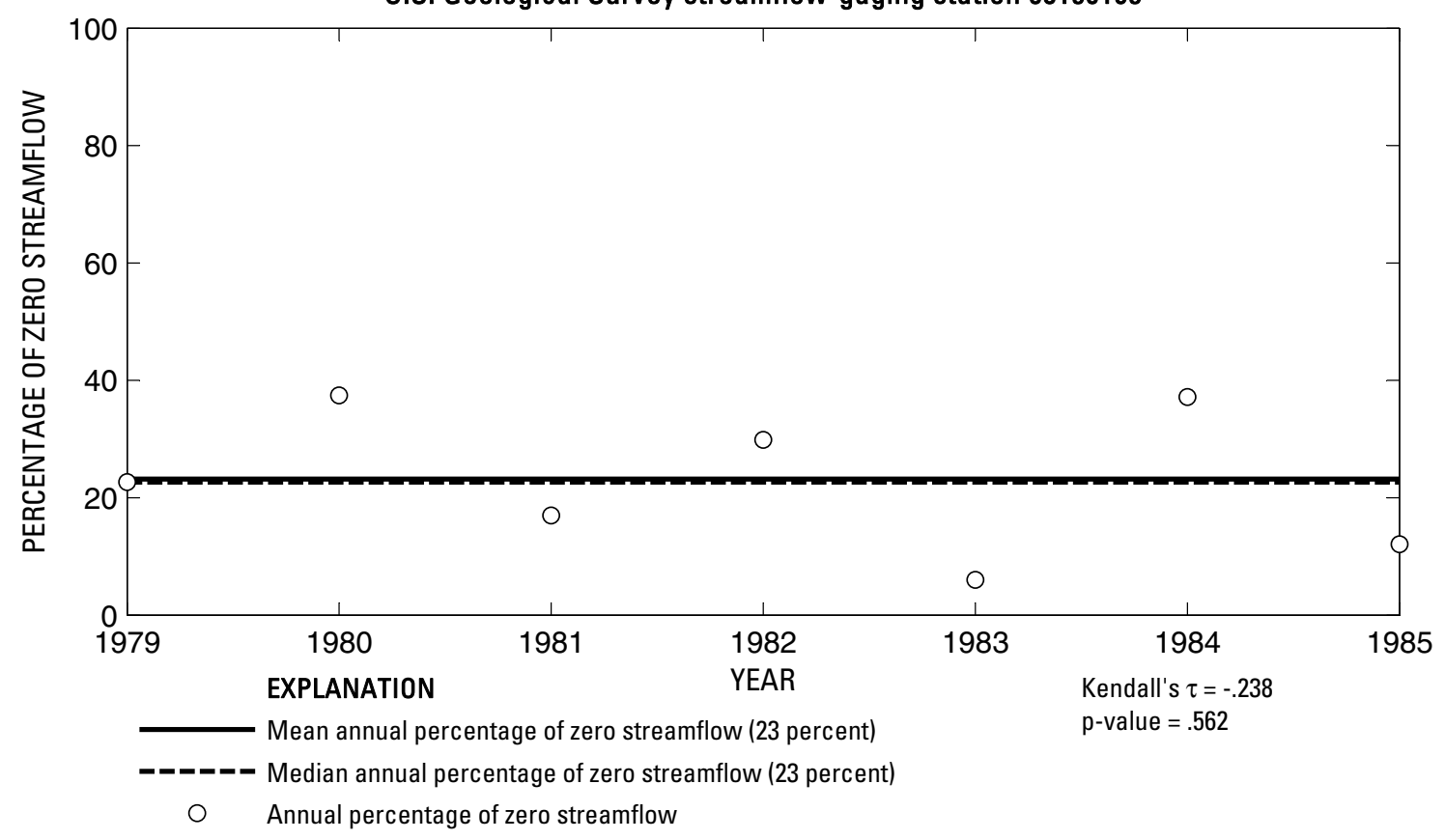

U.S. Geological Survey streamflow-gaging station 08159165

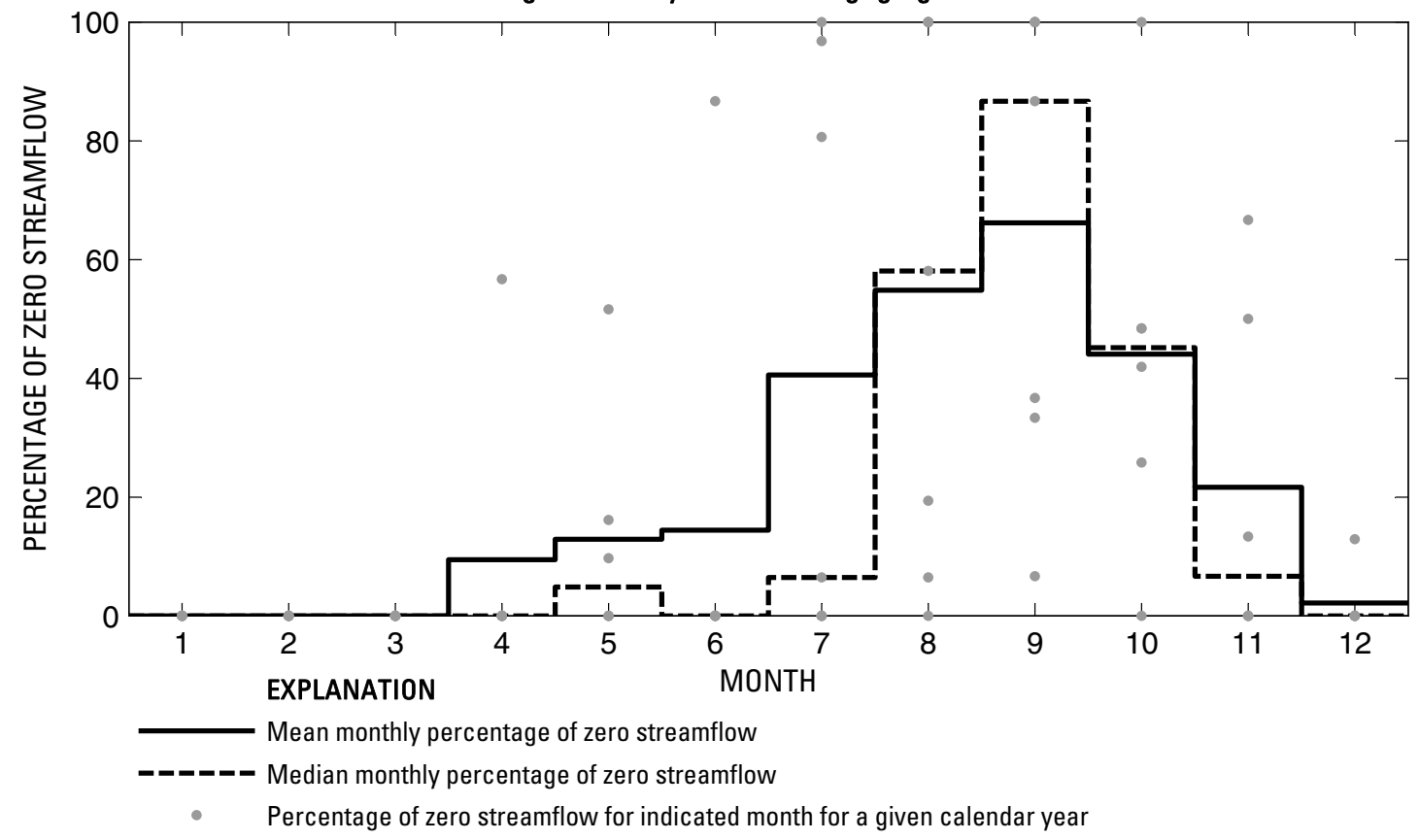

Figure 542. Analysis of percentage of zero daily mean streamflow for U.S. Geological Survey streamflow-gaging station 08159165 Big Sandy Creek near McDade, Texas. 
U.S. Geological Survey streamflow-gaging station 08159170

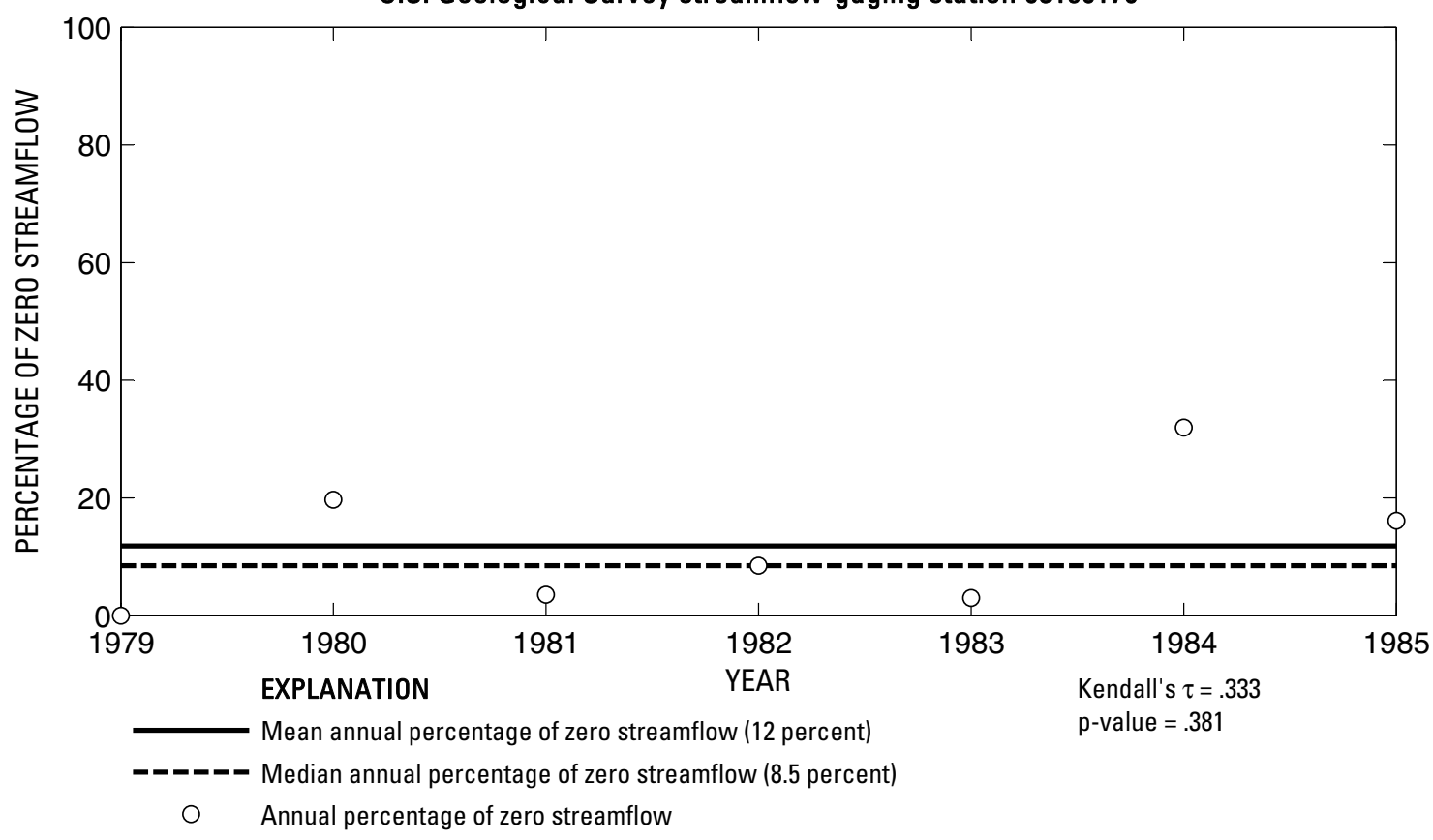

U.S. Geological Survey streamflow-gaging station 08159170

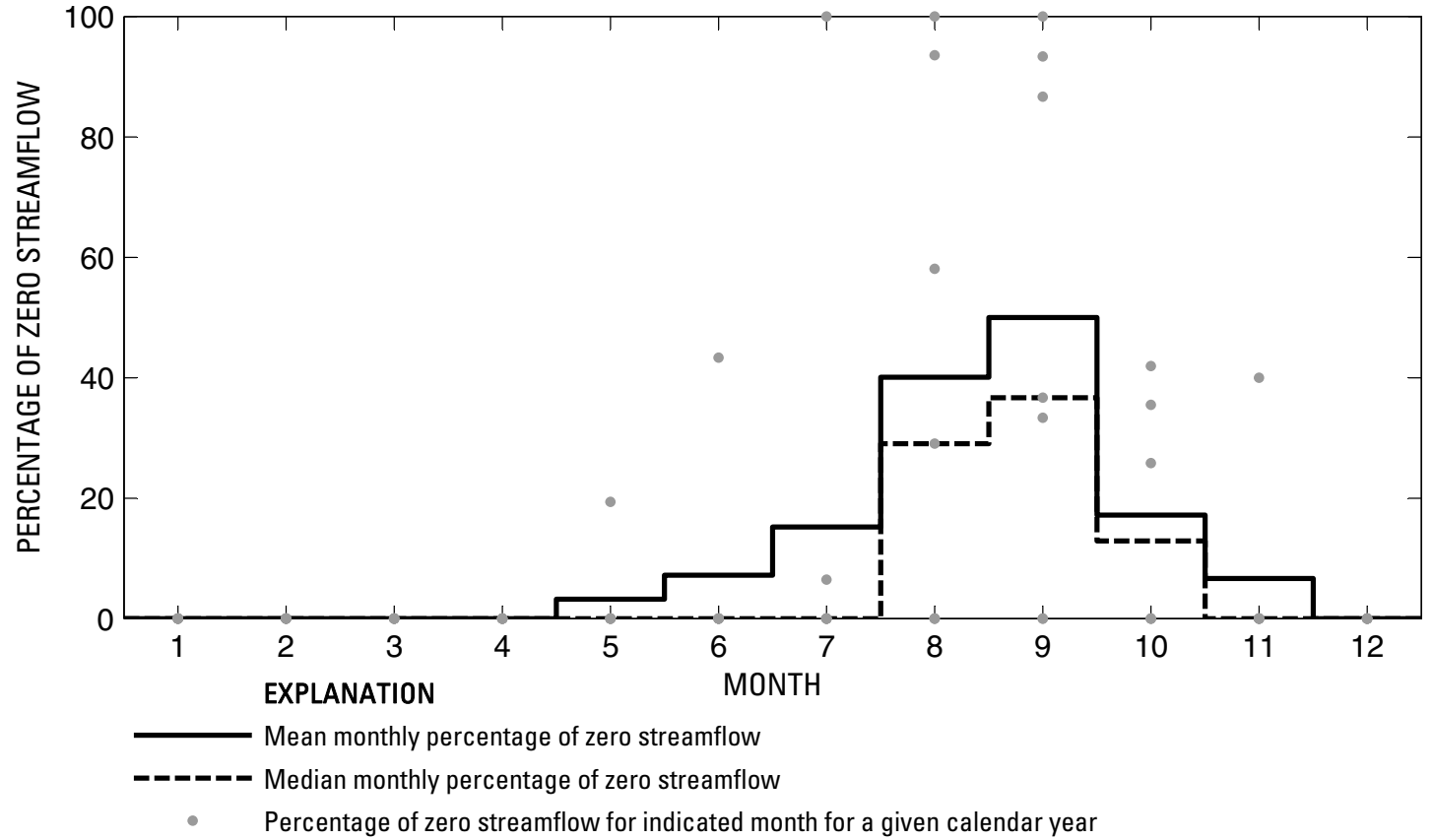

Figure 543. Analysis of percentage of zero daily mean streamflow for U.S. Geological Survey streamflow-gaging station 08159170 Big Sandy Creek near Elgin, Texas. 
U.S. Geological Survey streamflow-gaging station 08159200

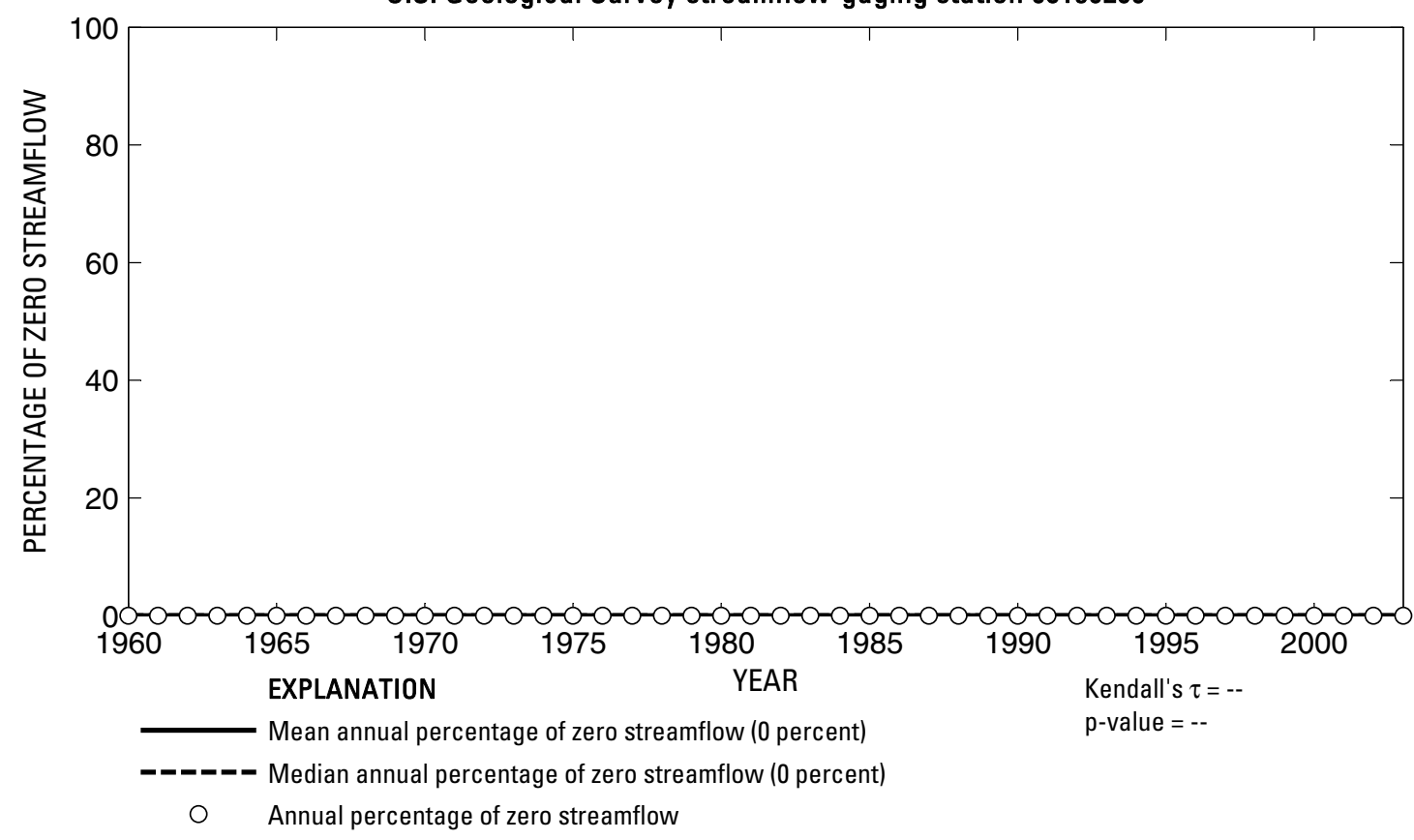

U.S. Geological Survey streamflow-gaging station 08159200

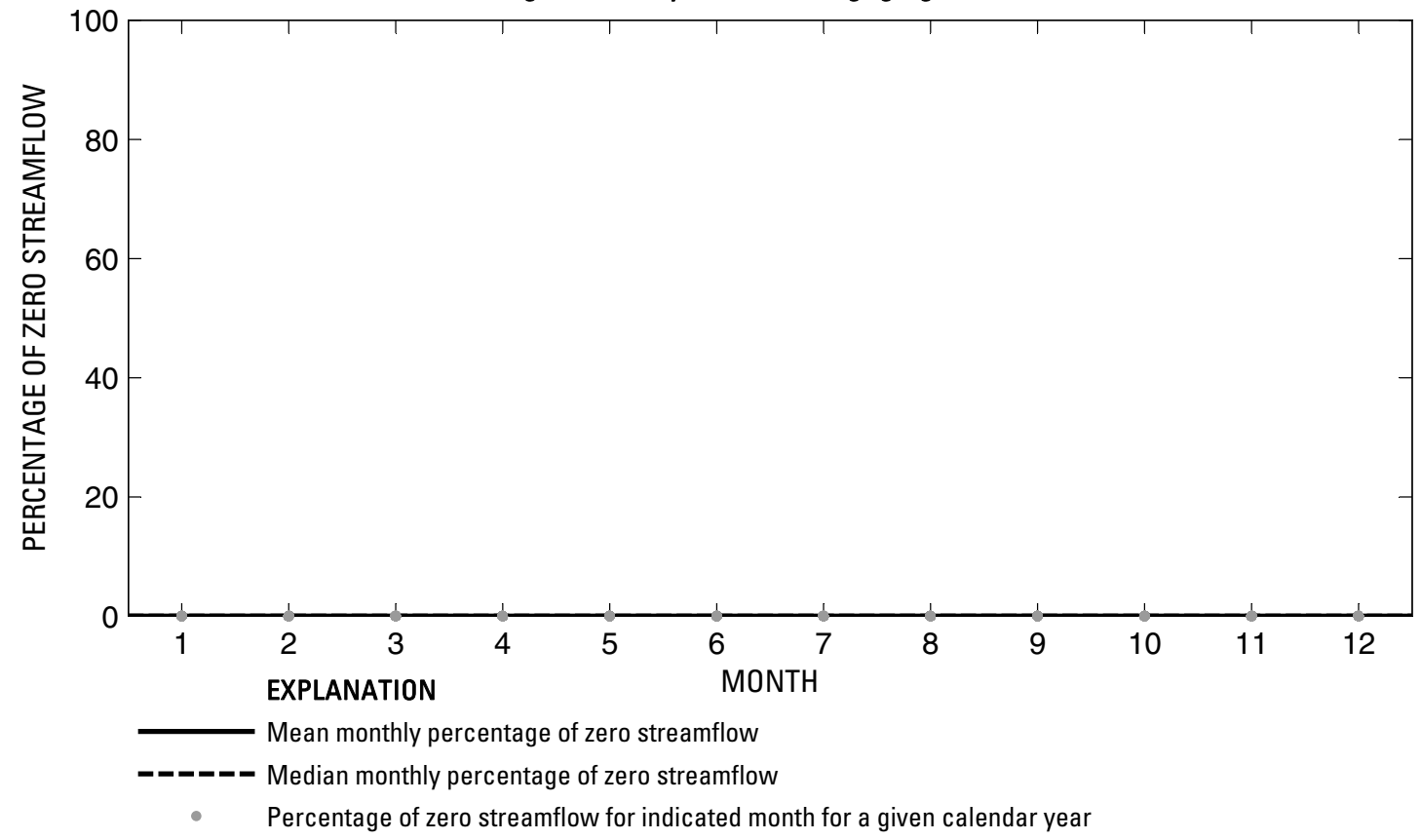

Figure 544. Analysis of percentage of zero daily mean streamflow for U.S. Geological Survey streamflow-gaging station 08159200 Colorado River at Bastrop, Texas. 


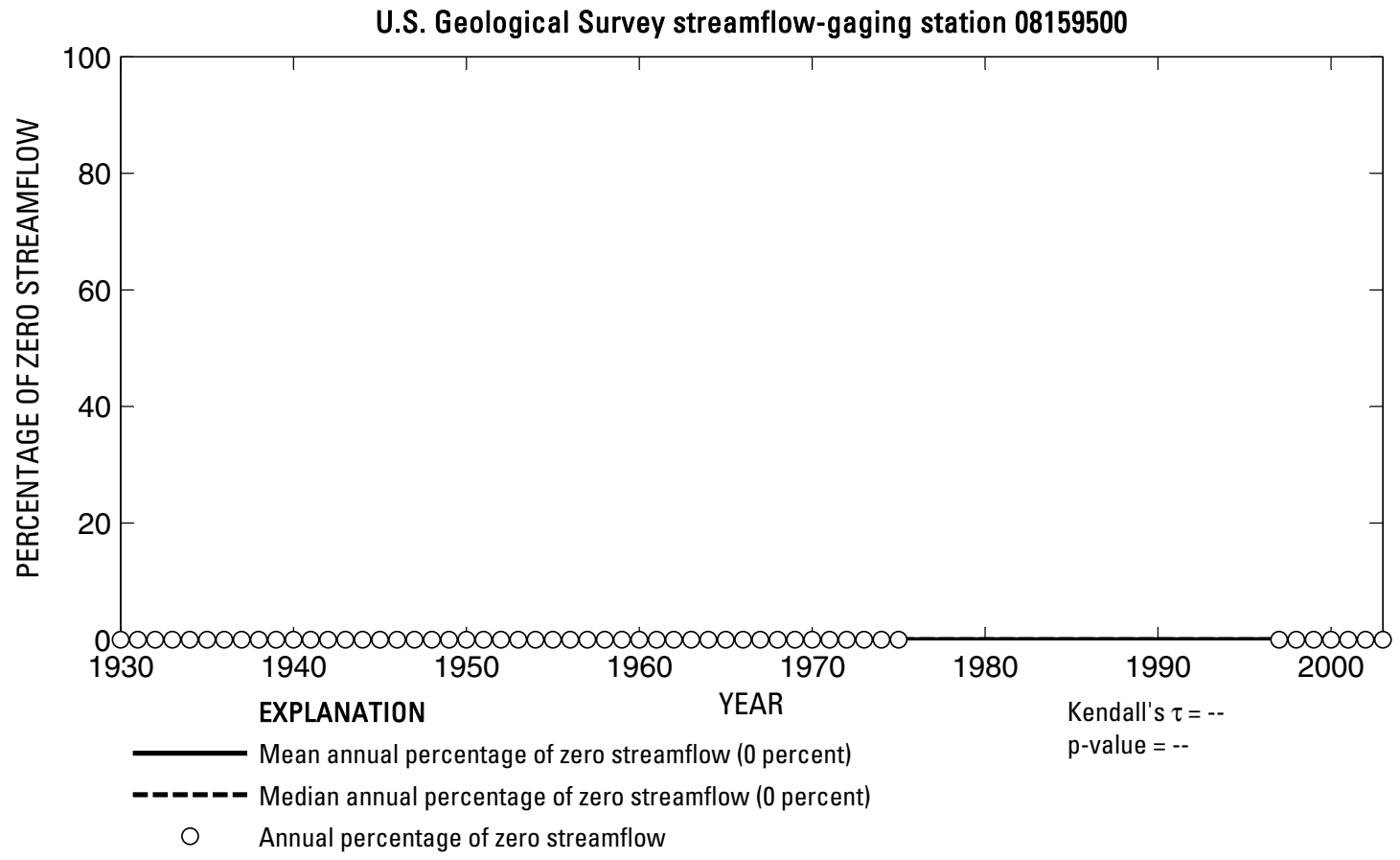

U.S. Geological Survey streamflow-gaging station 08159500

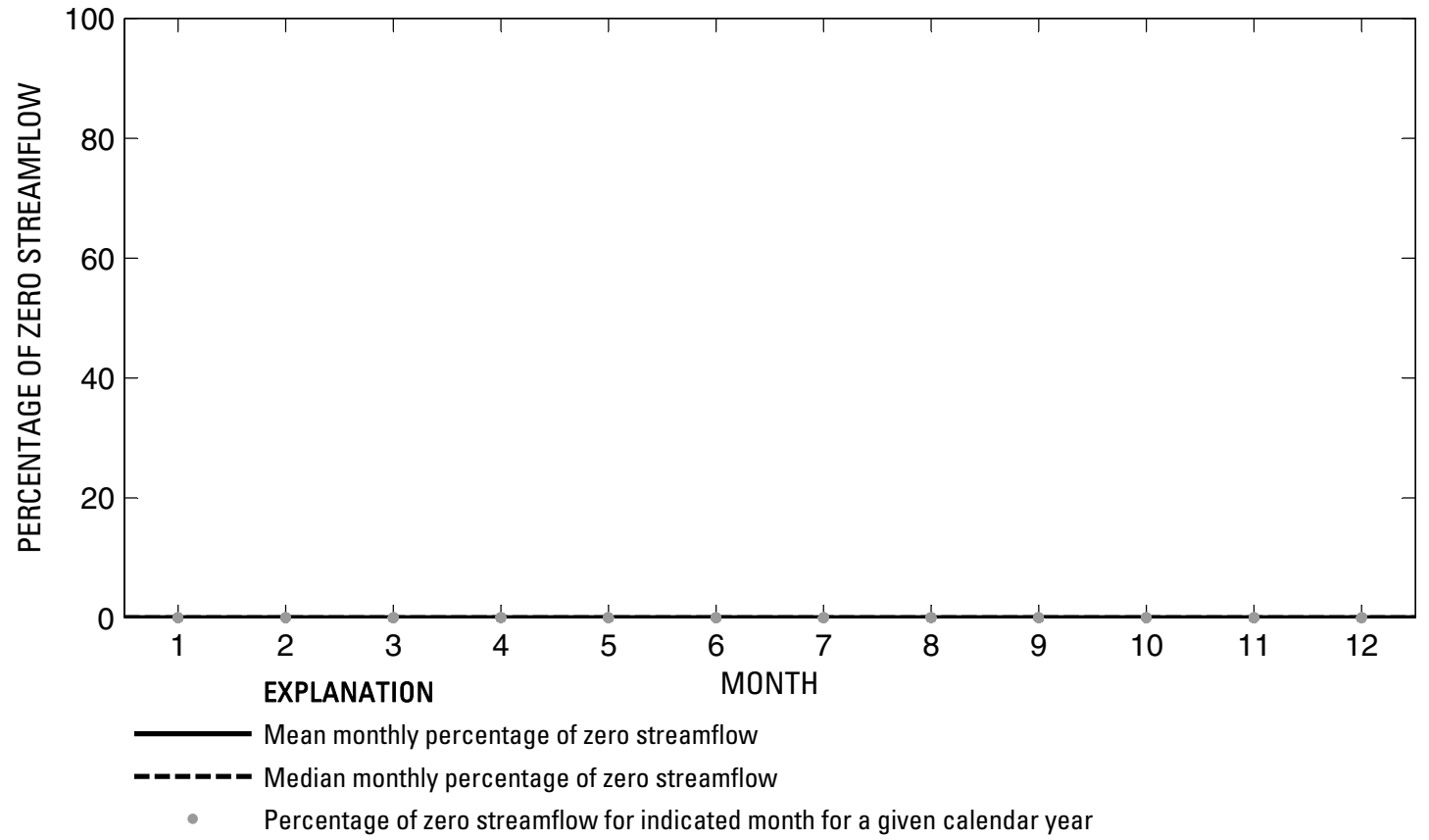

Figure 545. Analysis of percentage of zero daily mean streamflow for U.S. Geological Survey streamflow-gaging station 08159500 Colorado River at Smithville, Texas. 

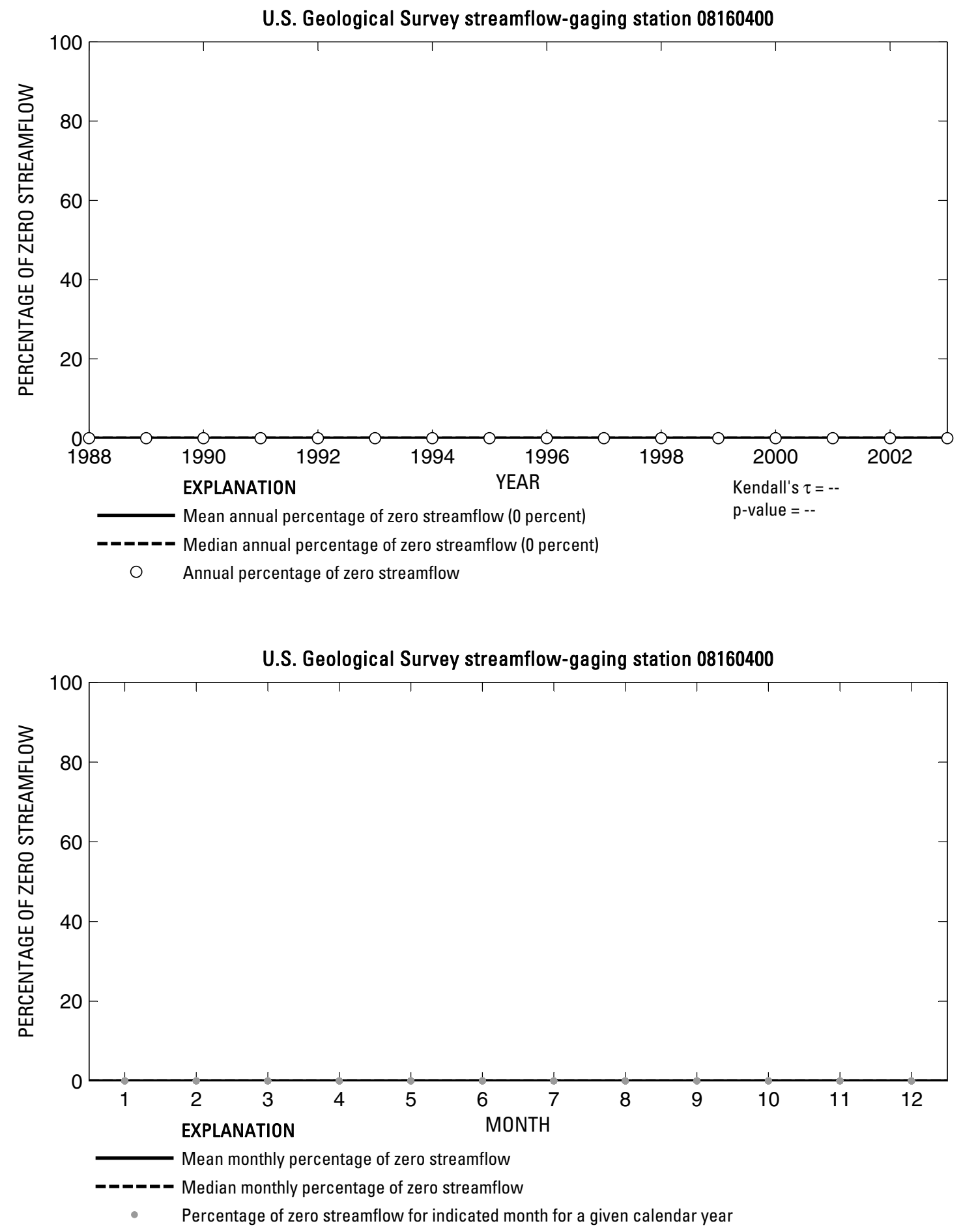

Figure 546. Analysis of percentage of zero daily mean streamflow for U.S. Geological Survey streamflow-gaging station 08160400 Colorado River above La Grange, Texas. 


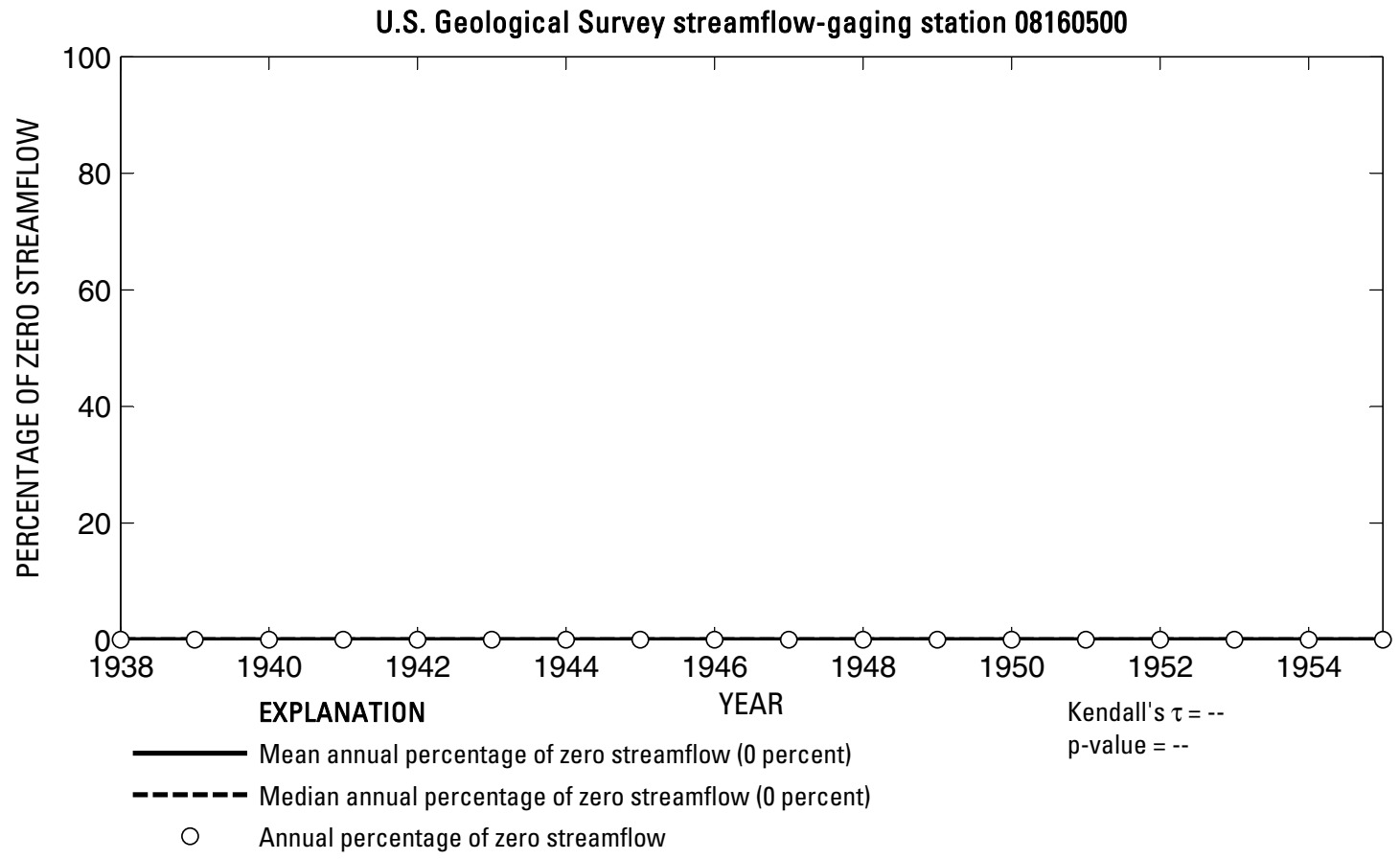

U.S. Geological Survey streamflow-gaging station 08160500

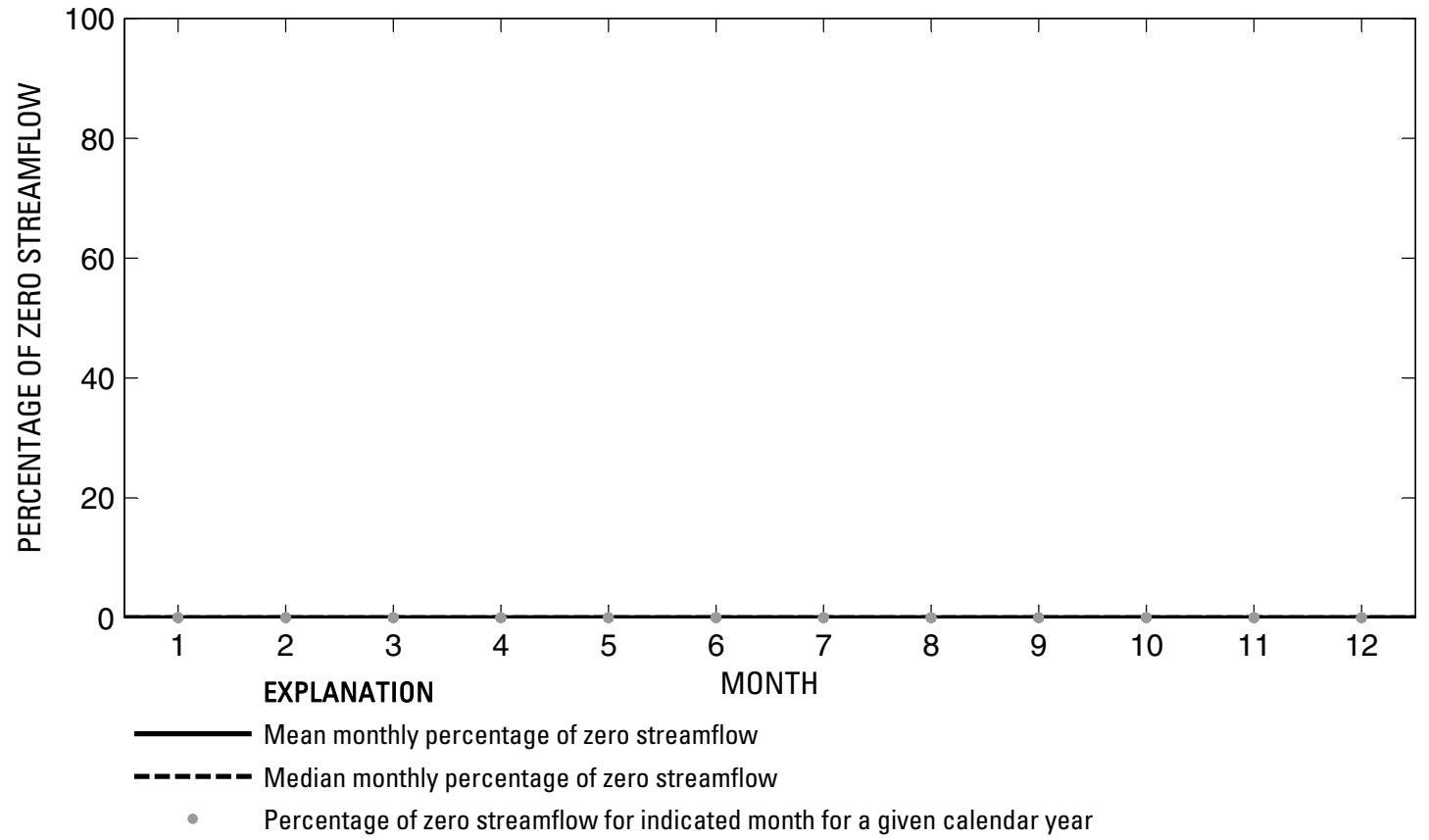

Figure 547. Analysis of percentage of zero daily mean streamflow for U.S. Geological Survey streamflow-gaging station 08160500 Colorado River at La Grange, Texas. 
U.S. Geological Survey streamflow-gaging station 08160700

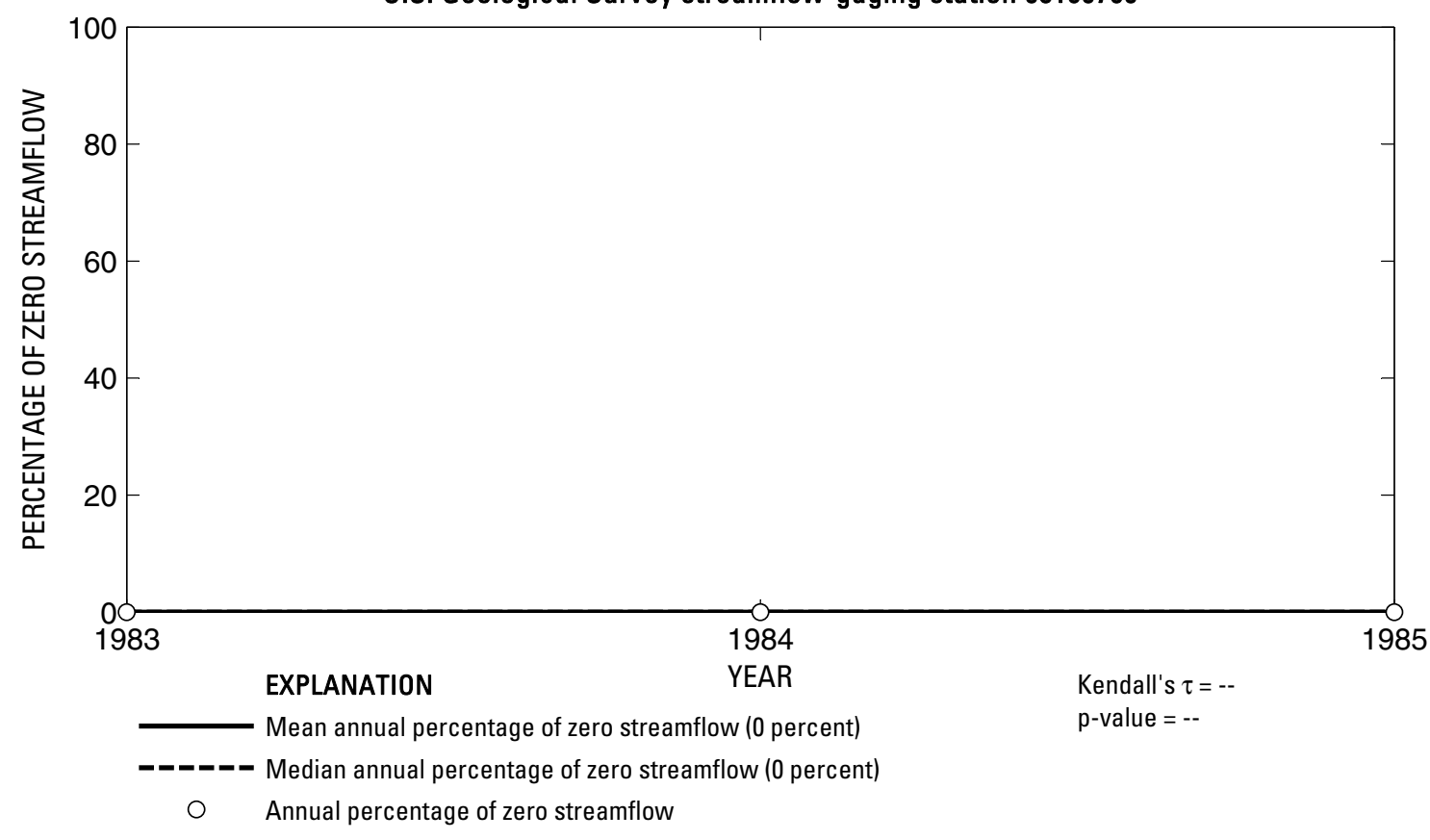

U.S. Geological Survey streamflow-gaging station 08160700

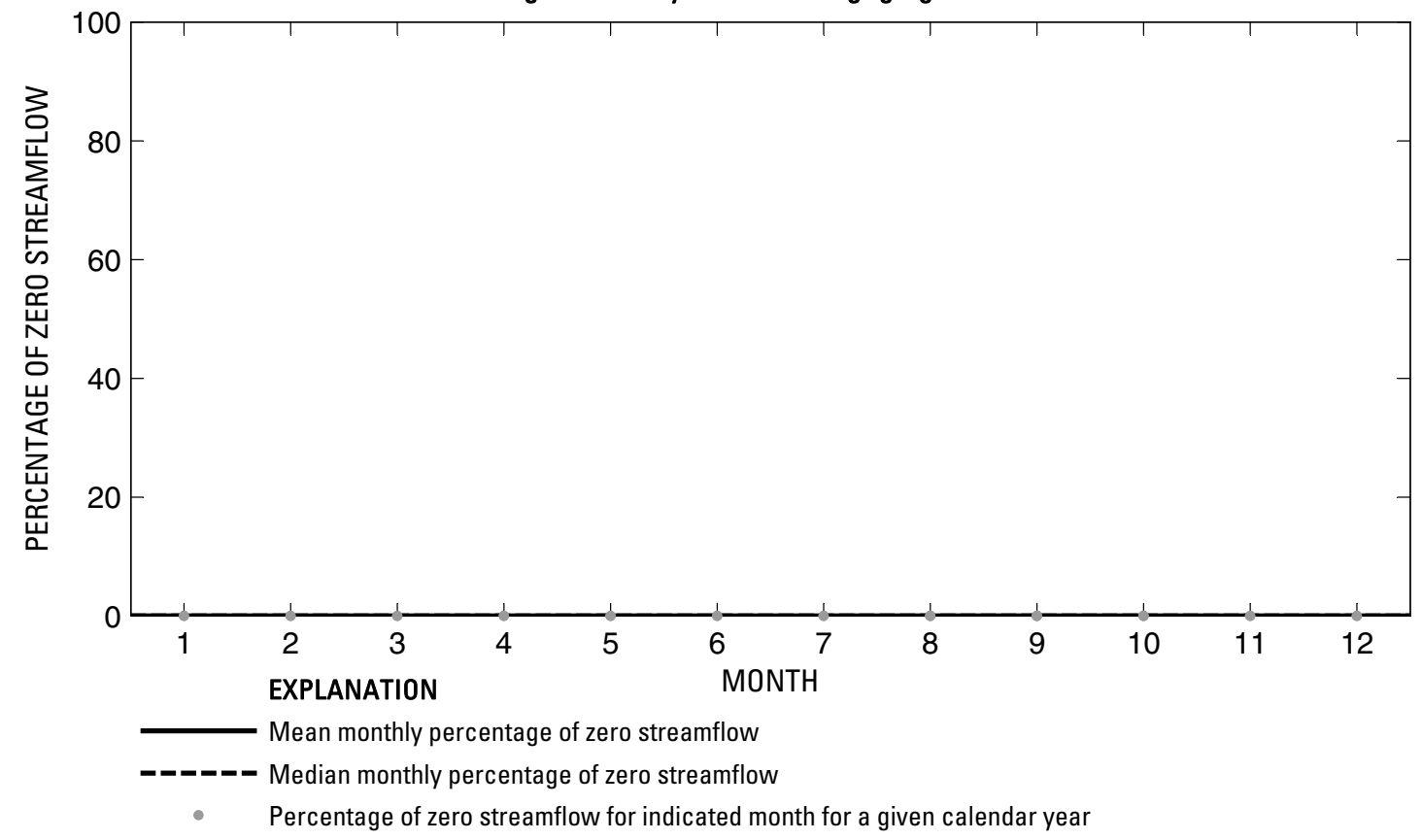

Figure 548. Analysis of percentage of zero daily mean streamflow for U.S. Geological Survey streamflow-gaging station 08160700 Colorado River above Columbus, Texas. 


\section{U.S. Geological Survey streamflow-gaging station 08160800}

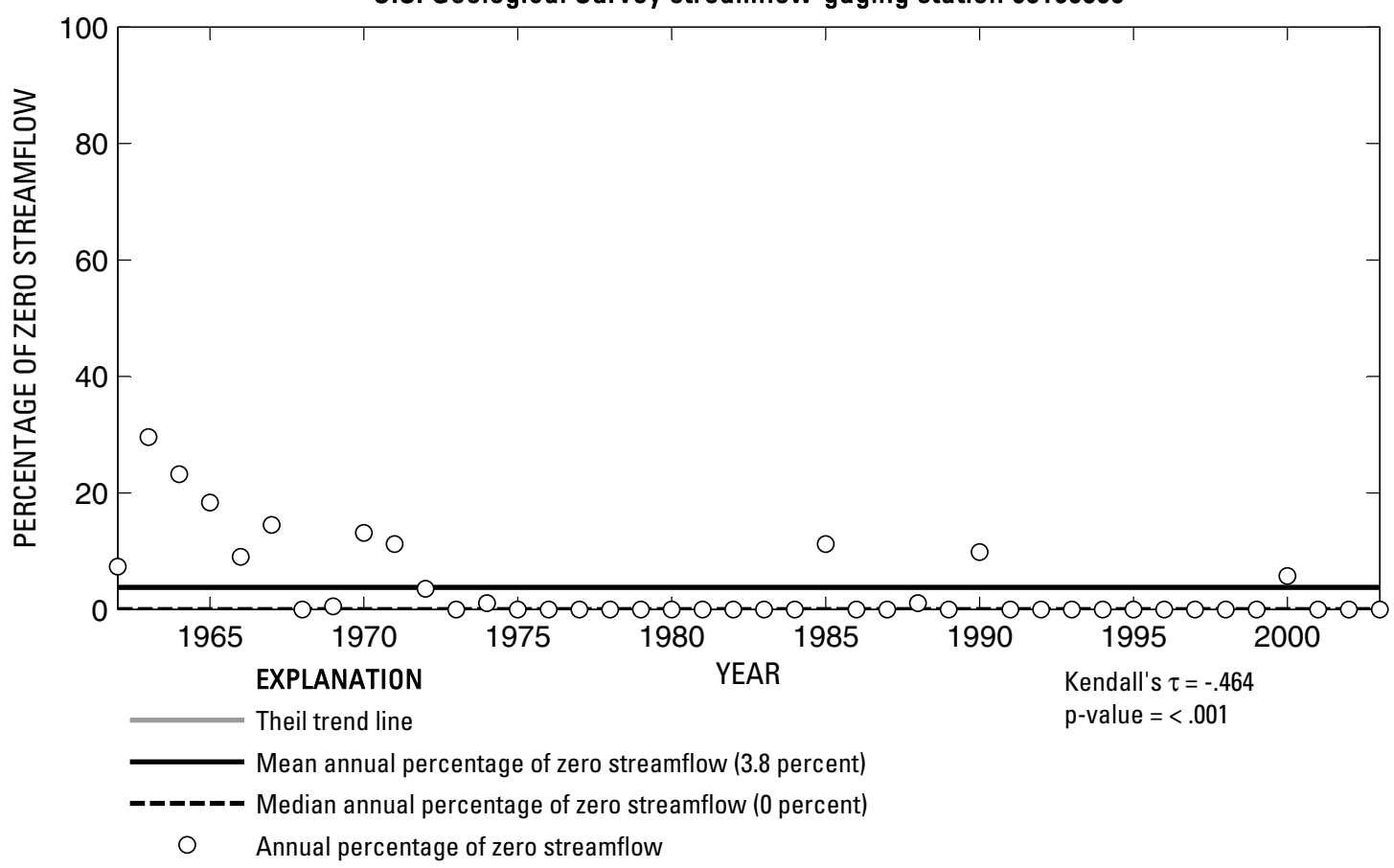

U.S. Geological Survey streamflow-gaging station 08160800

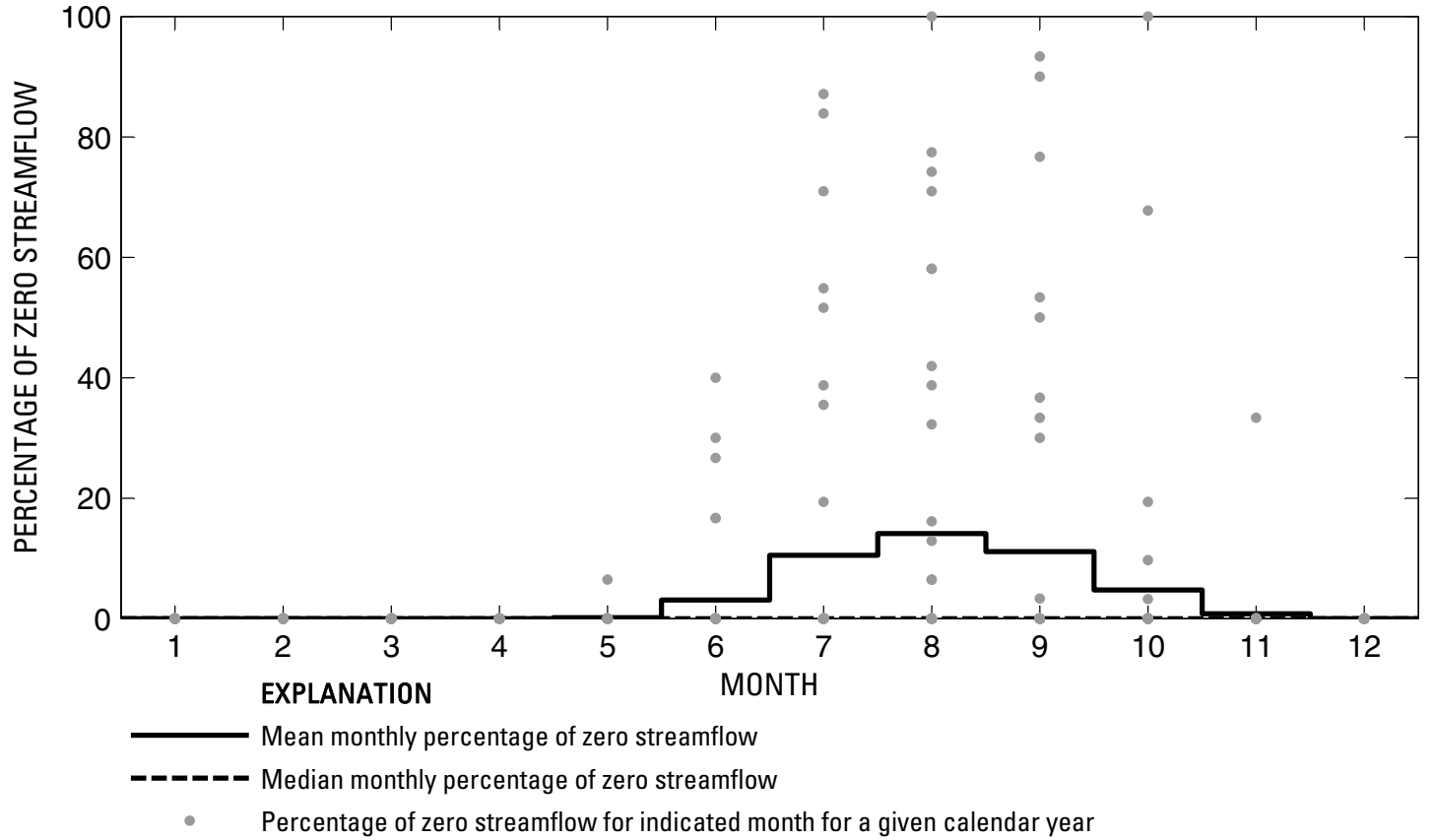

Figure 549. Analysis of percentage of zero daily mean streamflow for U.S. Geological Survey streamflow-gaging station 08160800 Redgate Creek near Columbus, Texas. 
U.S. Geological Survey streamflow-gaging station 08161000

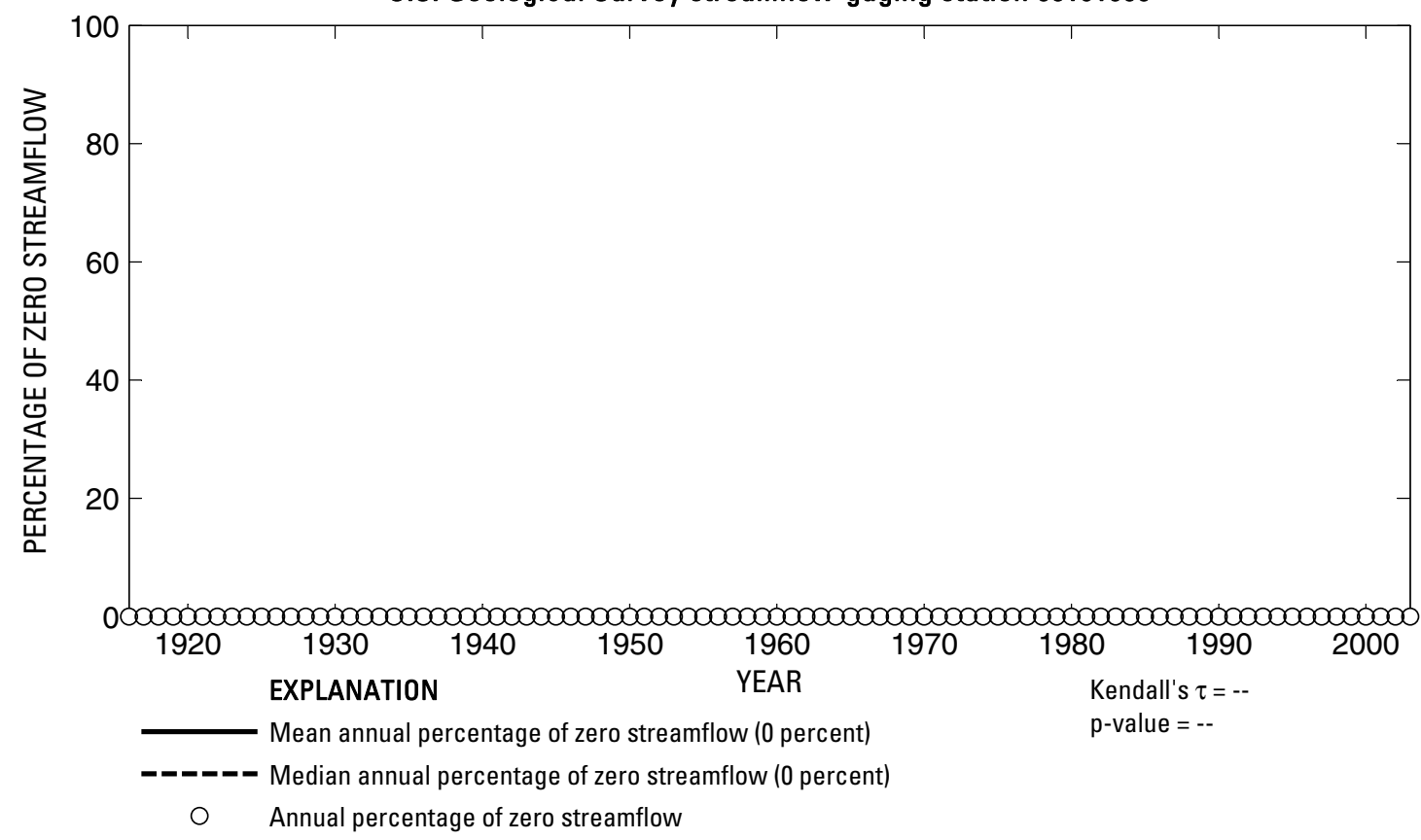

U.S. Geological Survey streamflow-gaging station 08161000

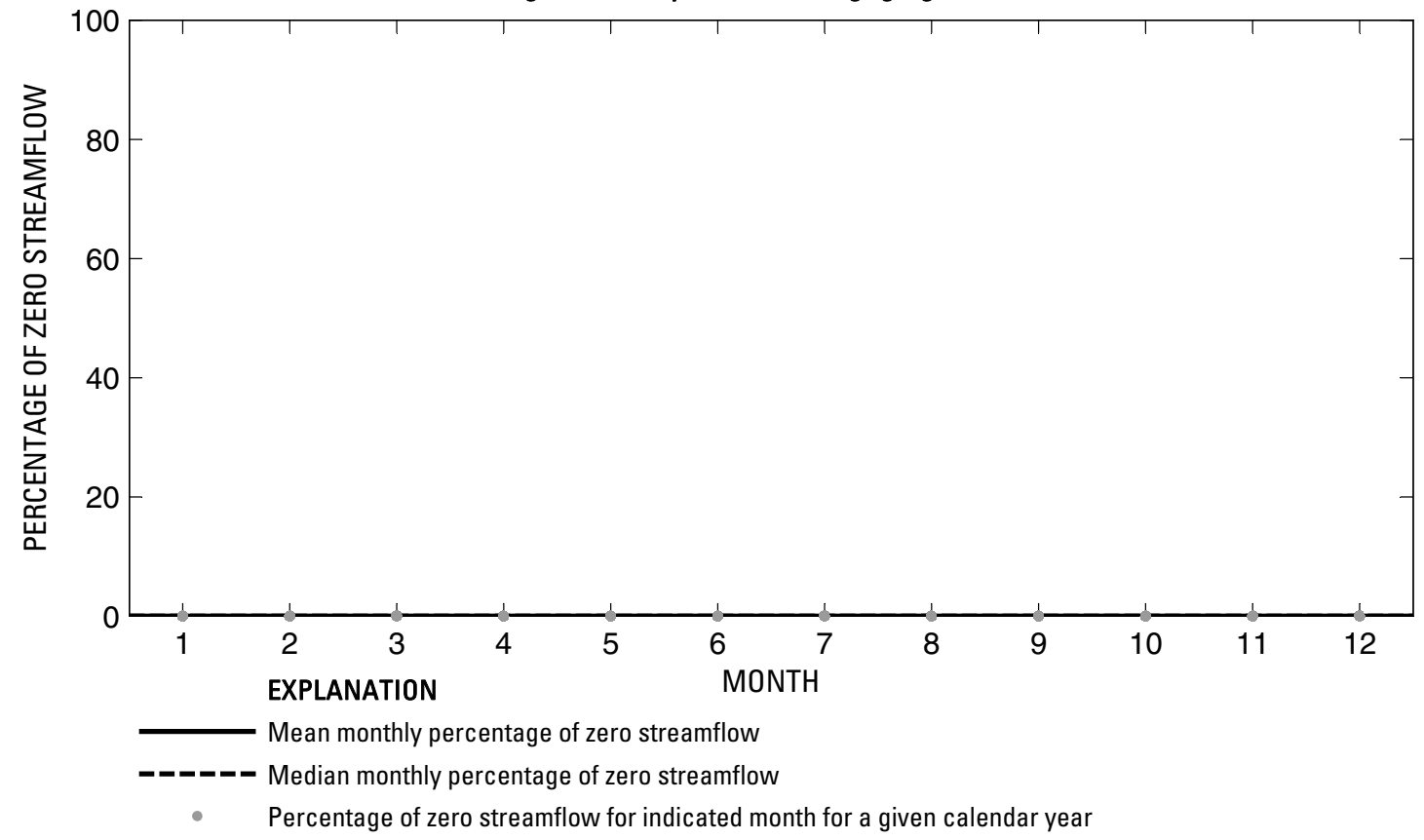

Figure 550. Analysis of percentage of zero daily mean streamflow for U.S. Geological Survey streamflow-gaging station 08161000 Colorado River at Columbus, Texas. 
U.S. Geological Survey streamflow-gaging station 08162000

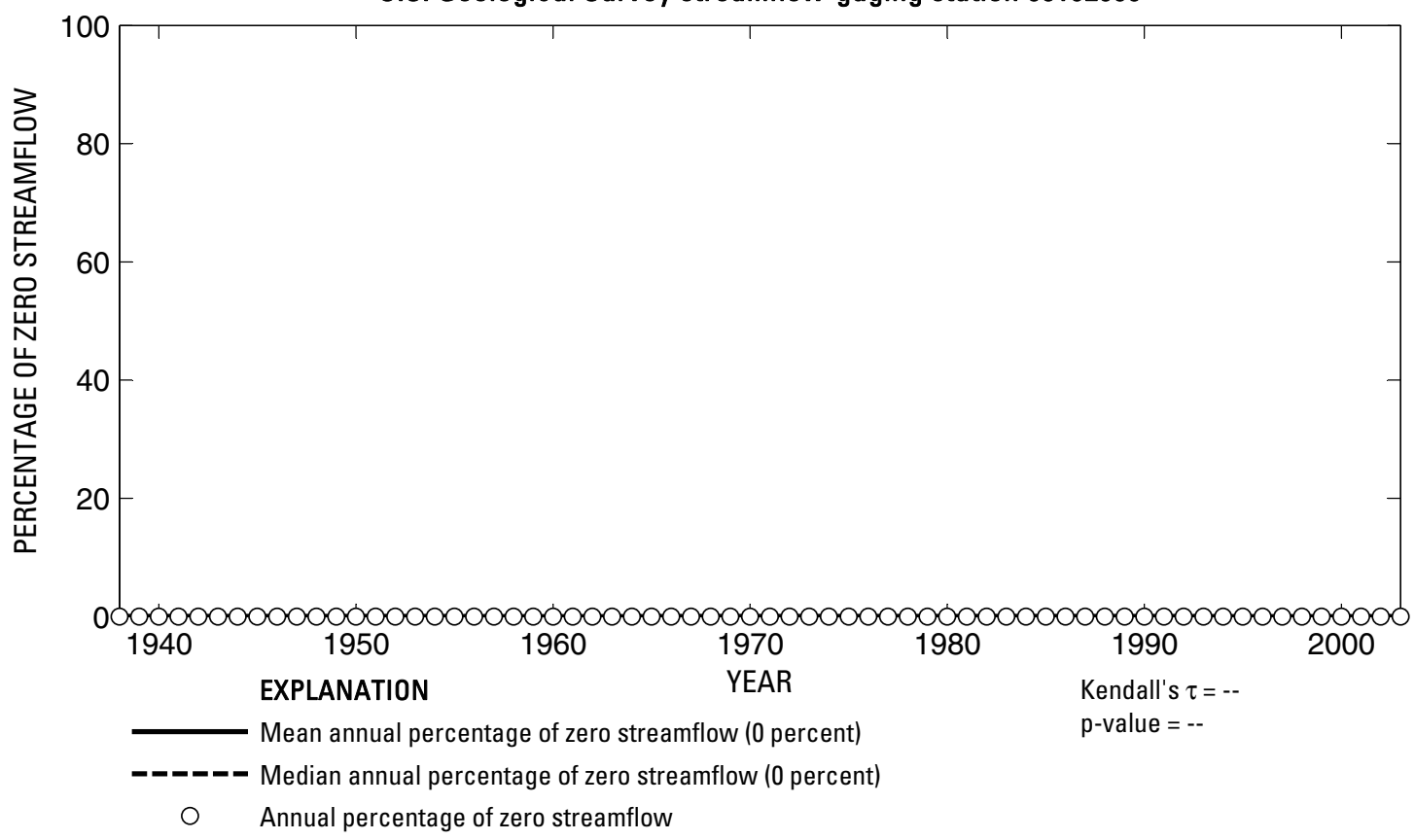

U.S. Geological Survey streamflow-gaging station 08162000

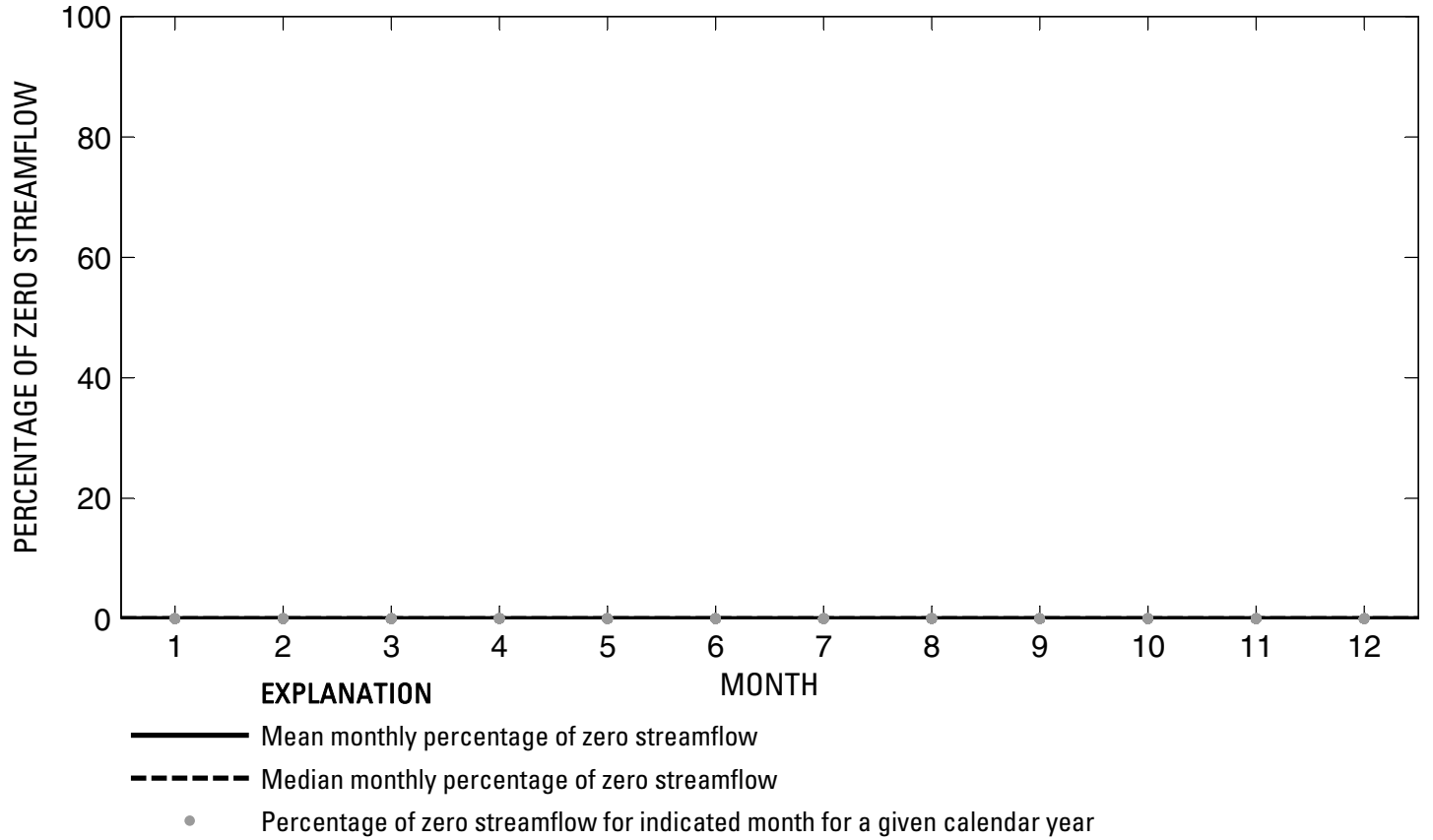

Figure 551. Analysis of percentage of zero daily mean streamflow for U.S. Geological Survey streamflow-gaging station 08162000 Colorado River at Wharton, Texas. 
U.S. Geological Survey streamflow-gaging station 08162500

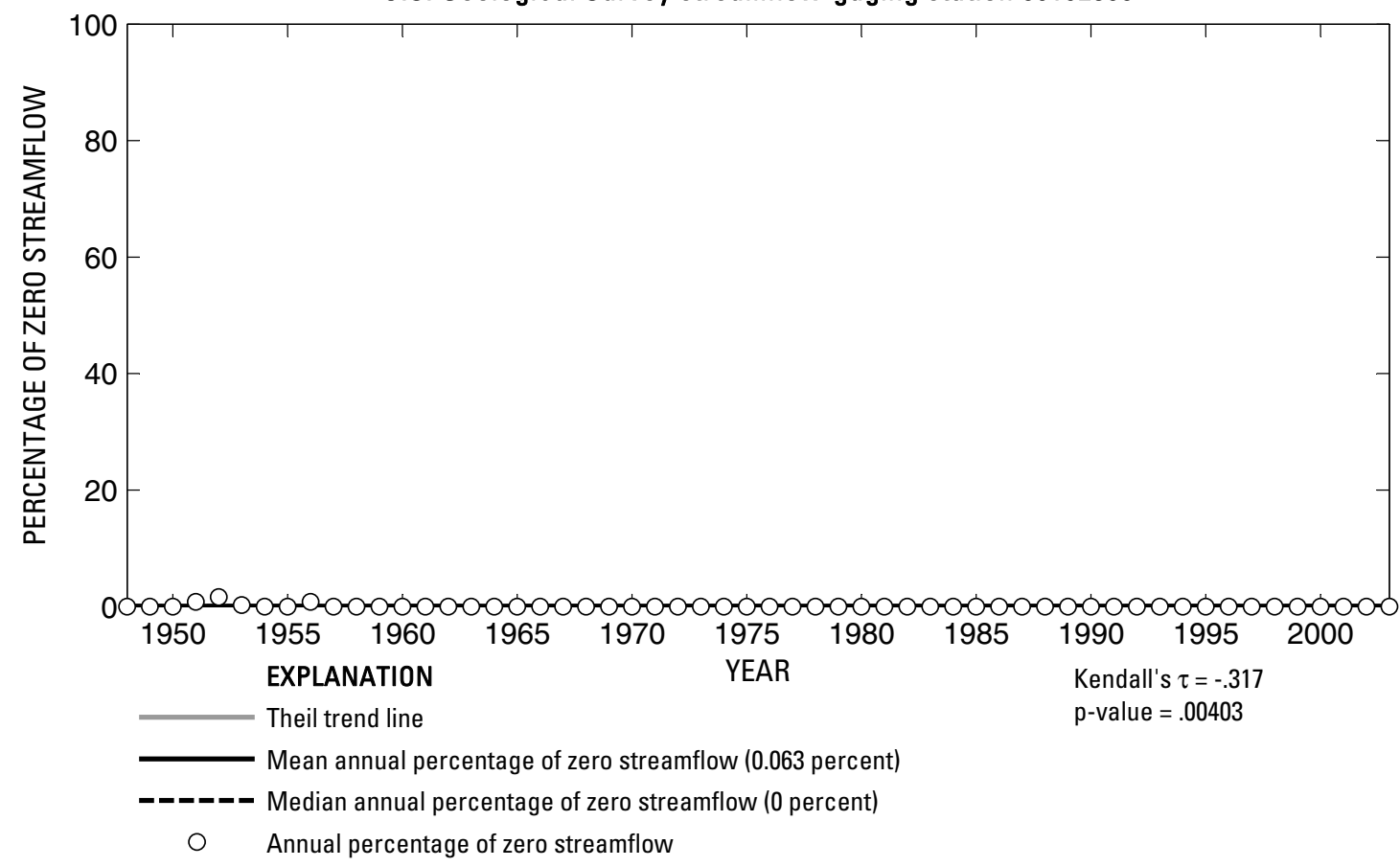

U.S. Geological Survey streamflow-gaging station 08162500

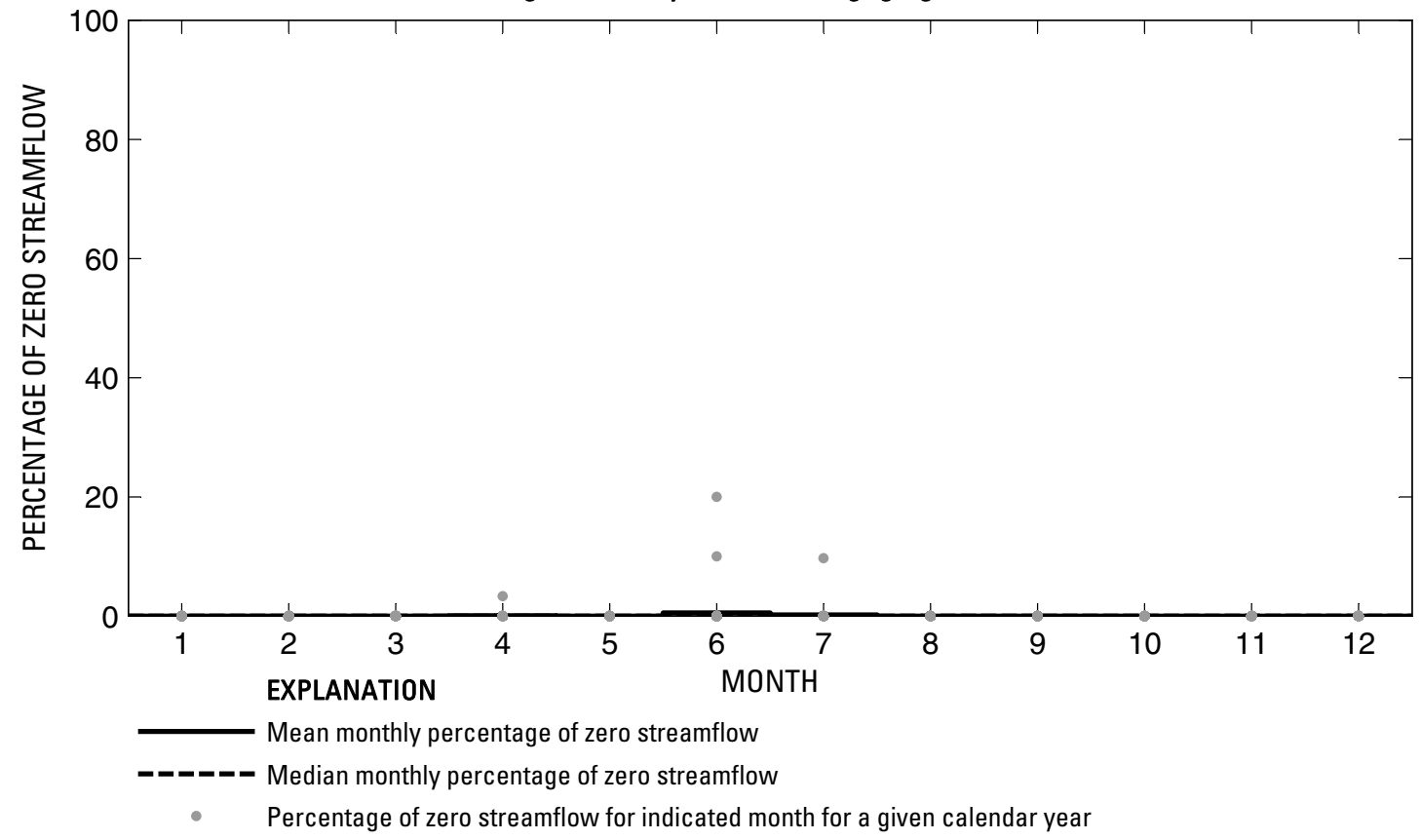

Figure 552. Analysis of percentage of zero daily mean streamflow for U.S. Geological Survey streamflow-gaging station 08162500 Colorado River near Bay City, Texas. 


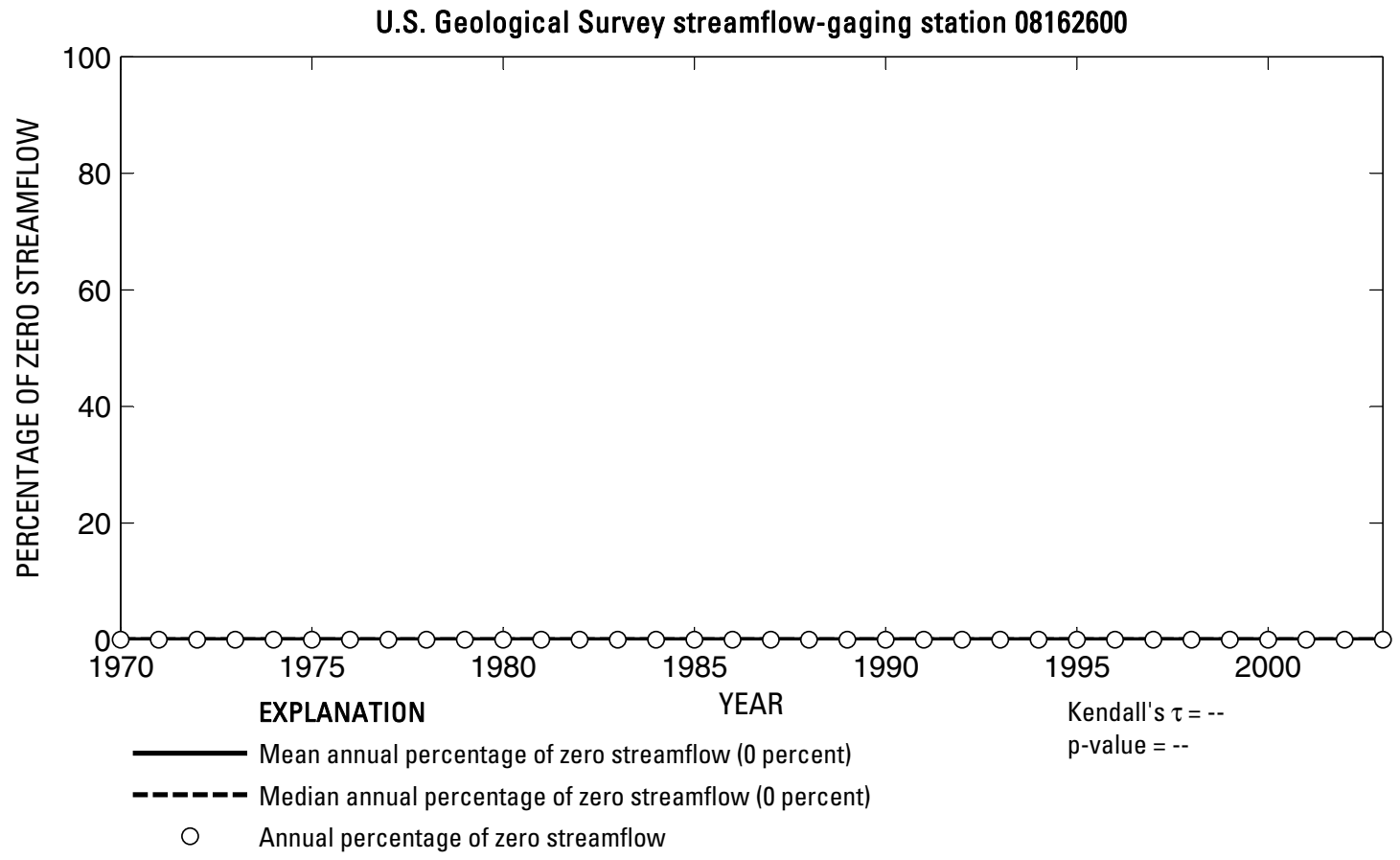

U.S. Geological Survey streamflow-gaging station 08162600

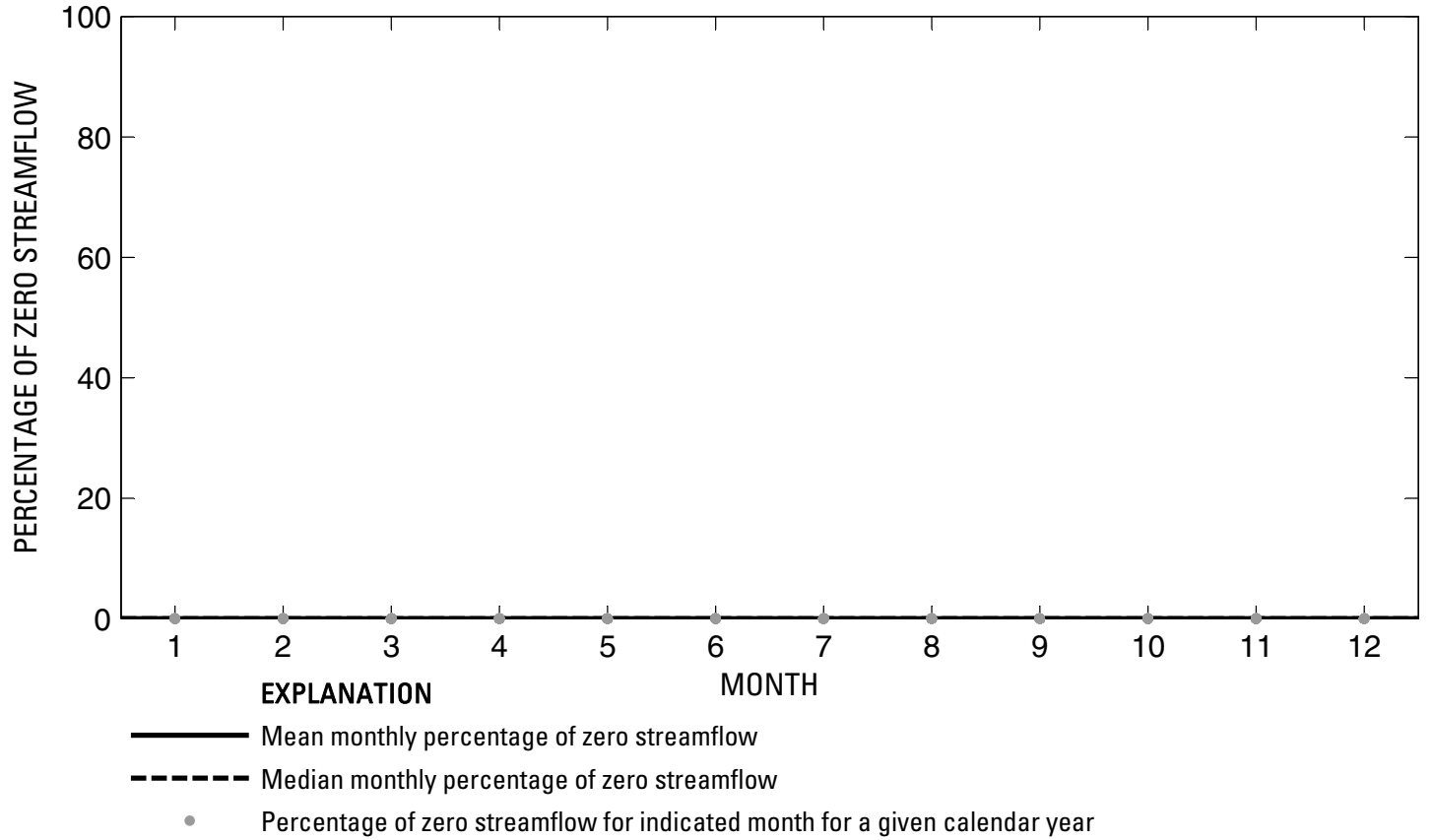

Figure 553. Analysis of percentage of zero daily mean streamflow for U.S. Geological Survey streamflow-gaging station 08162600 Tres Palacios River near Midfield, Texas. 
U.S. Geological Survey streamflow-gaging station 08164000

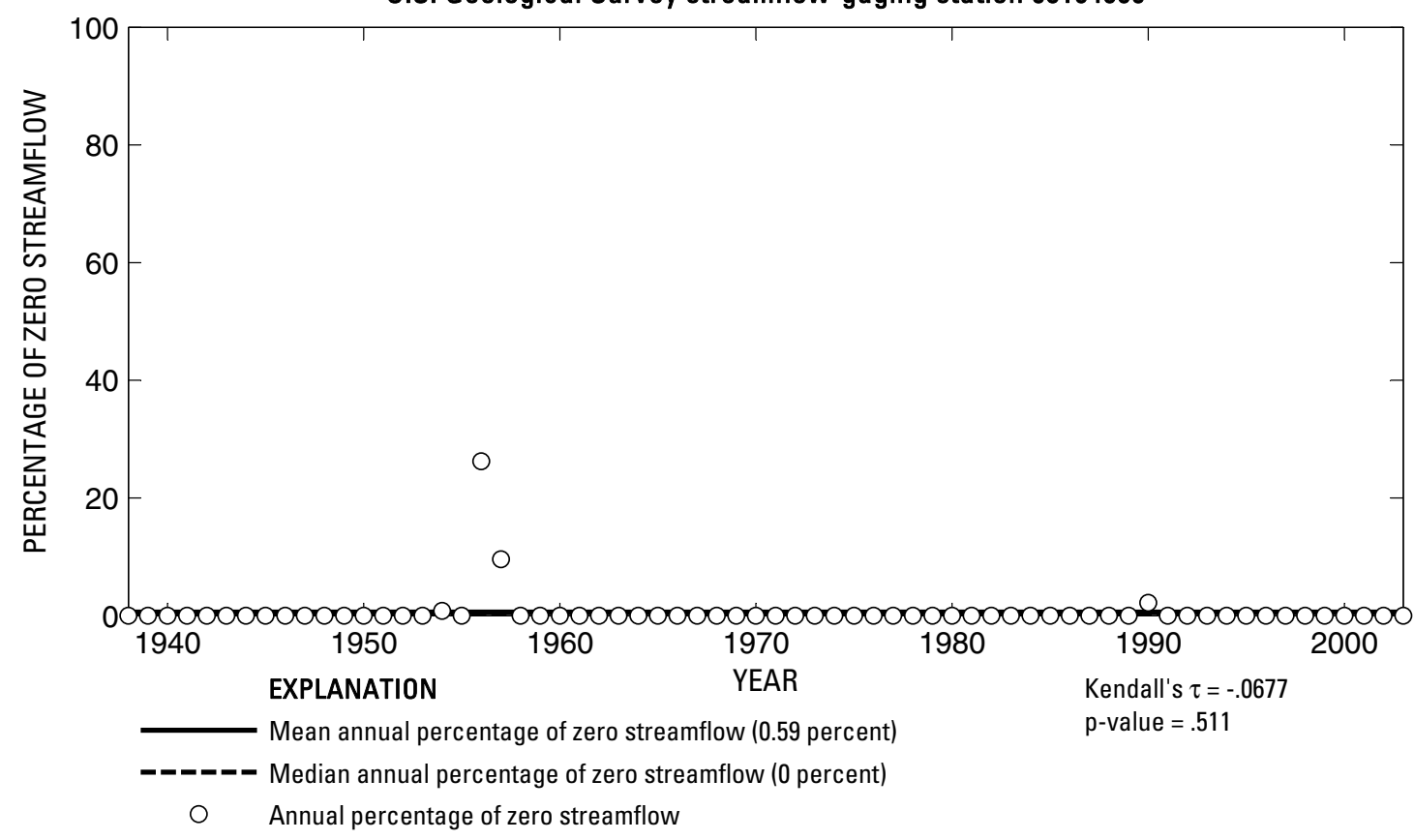

U.S. Geological Survey streamflow-gaging station 08164000

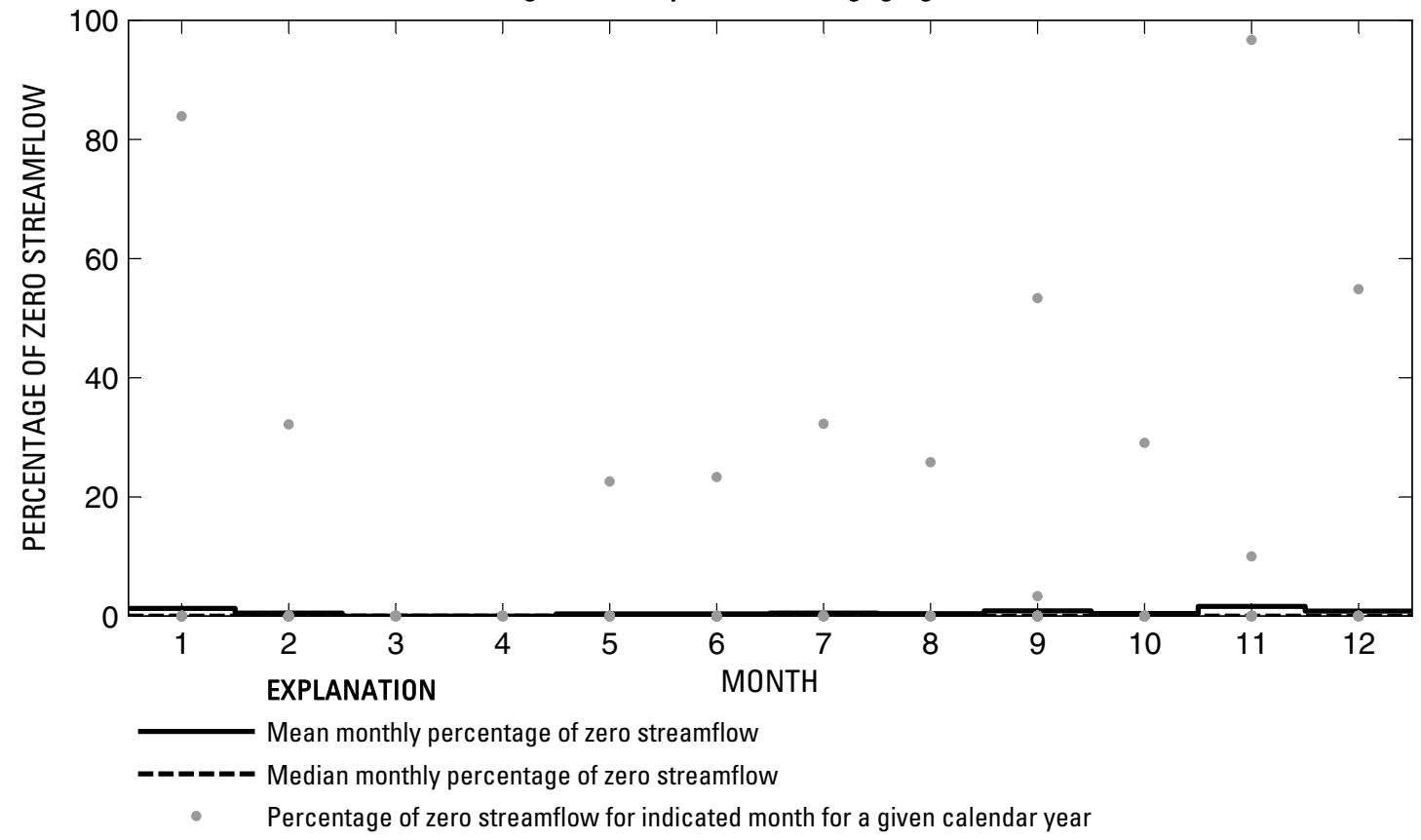

Figure 554. Analysis of percentage of zero daily mean streamflow for U.S. Geological Survey streamflow-gaging station 08164000 Lavaca River near Edna, Texas. 
U.S. Geological Survey streamflow-gaging station 08164300

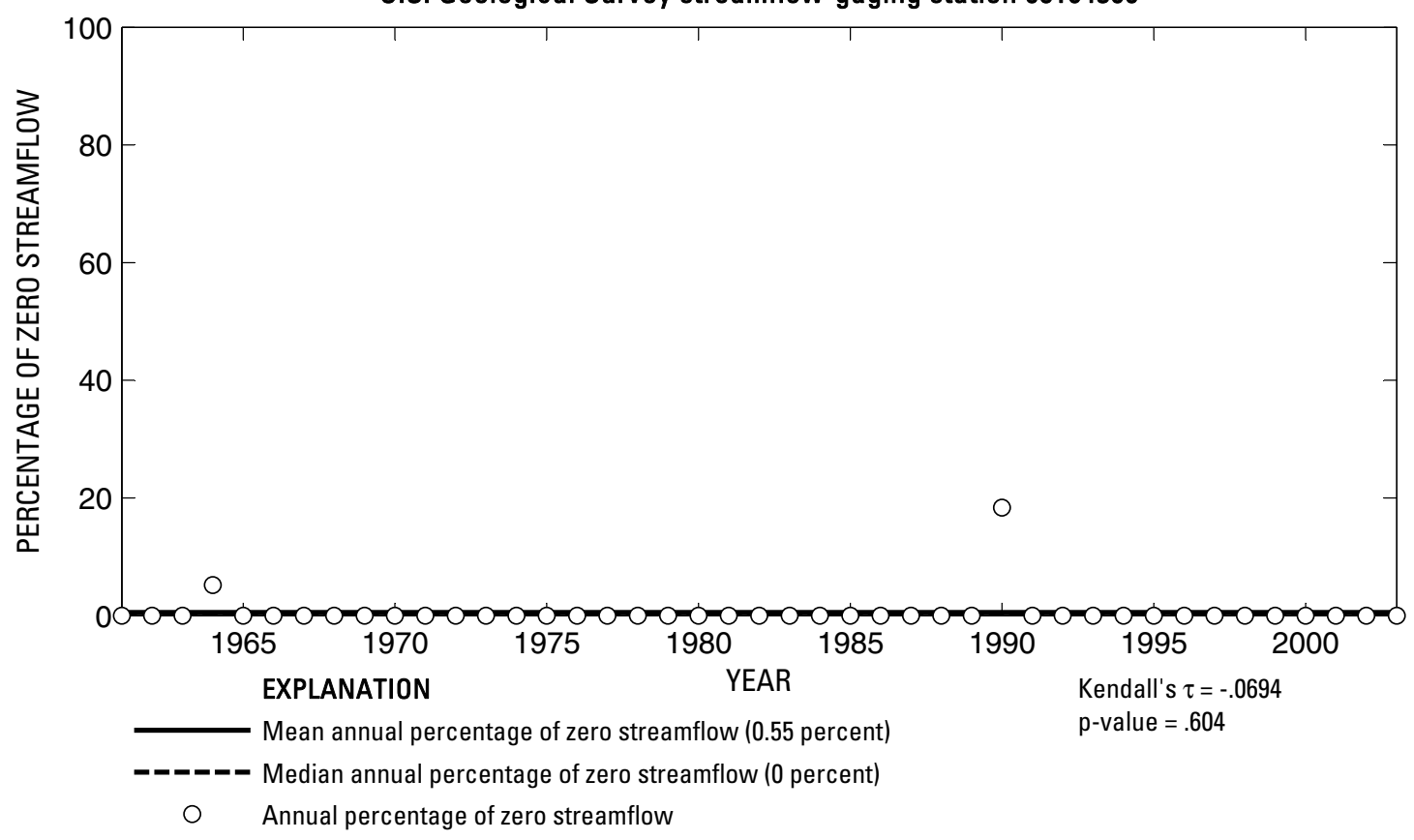

U.S. Geological Survey streamflow-gaging station 08164300

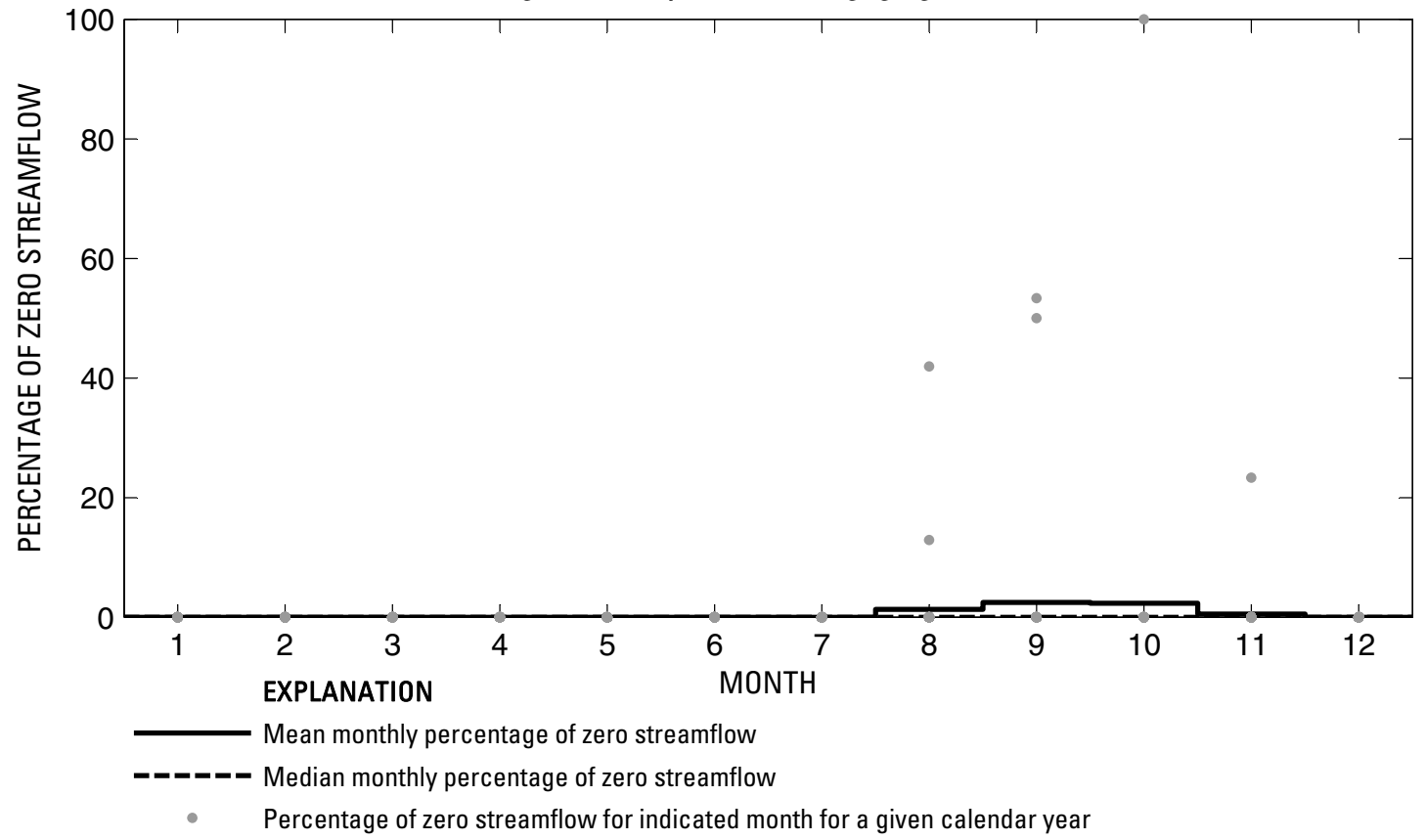

Figure 555. Analysis of percentage of zero daily mean streamflow for U.S. Geological Survey streamflow-gaging station 08164300 Navidad River near Hallettsville, Texas. 
U.S. Geological Survey streamflow-gaging station 08164350

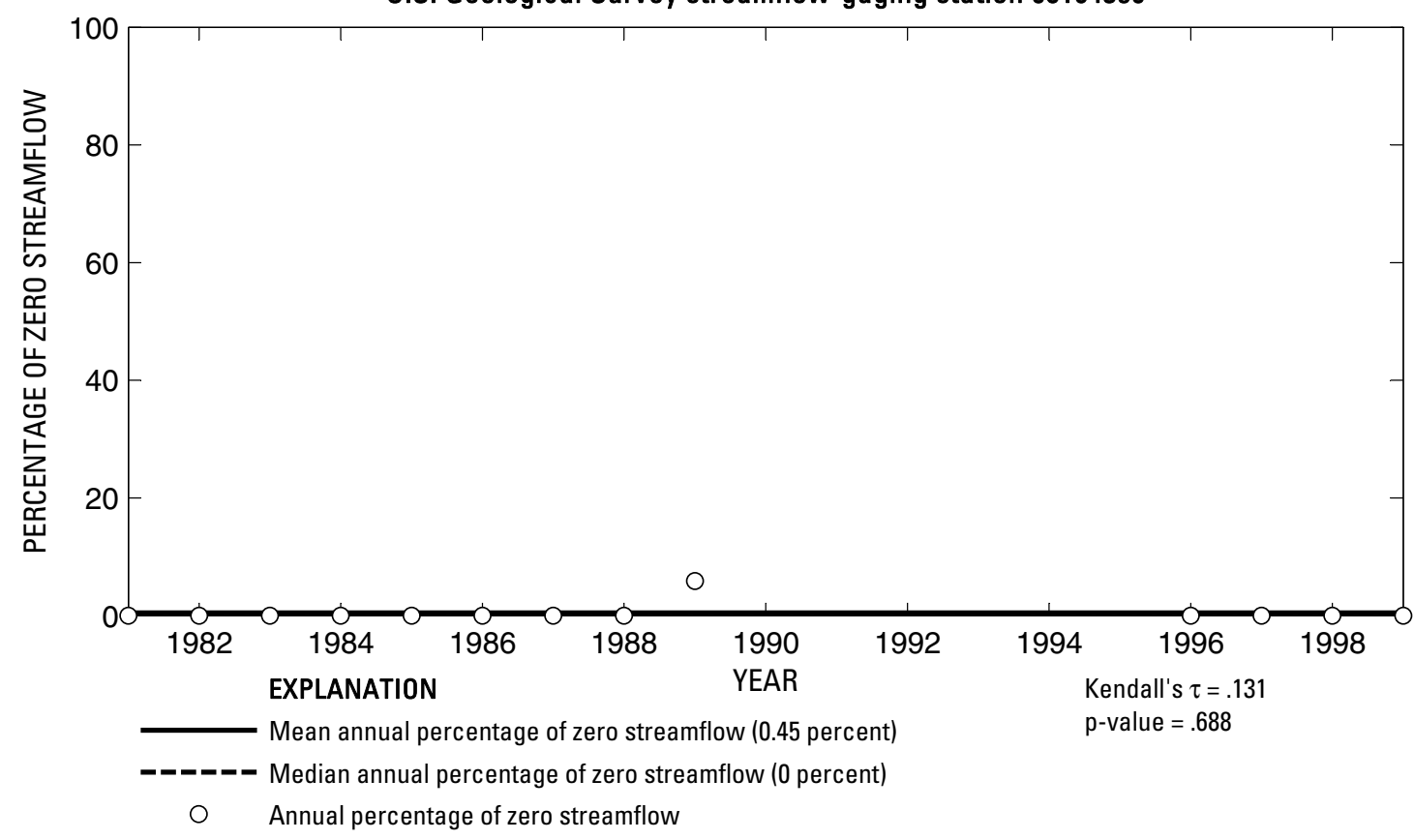

U.S. Geological Survey streamflow-gaging station 08164350

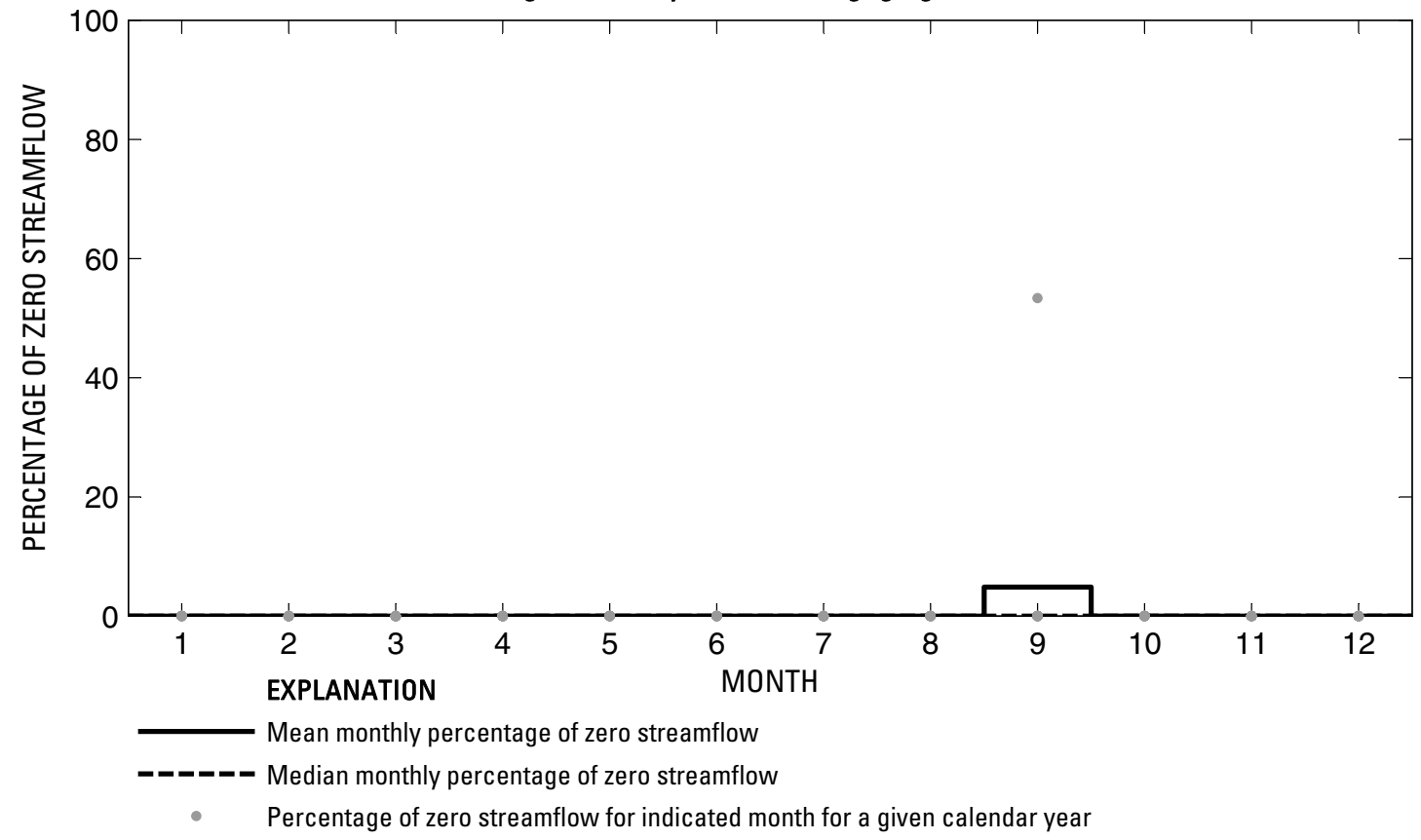

Figure 556. Analysis of percentage of zero daily mean streamflow for U.S. Geological Survey streamflow-gaging station 08164350 Navidad River near Speaks, Texas. 
U.S. Geological Survey streamflow-gaging station 08164370

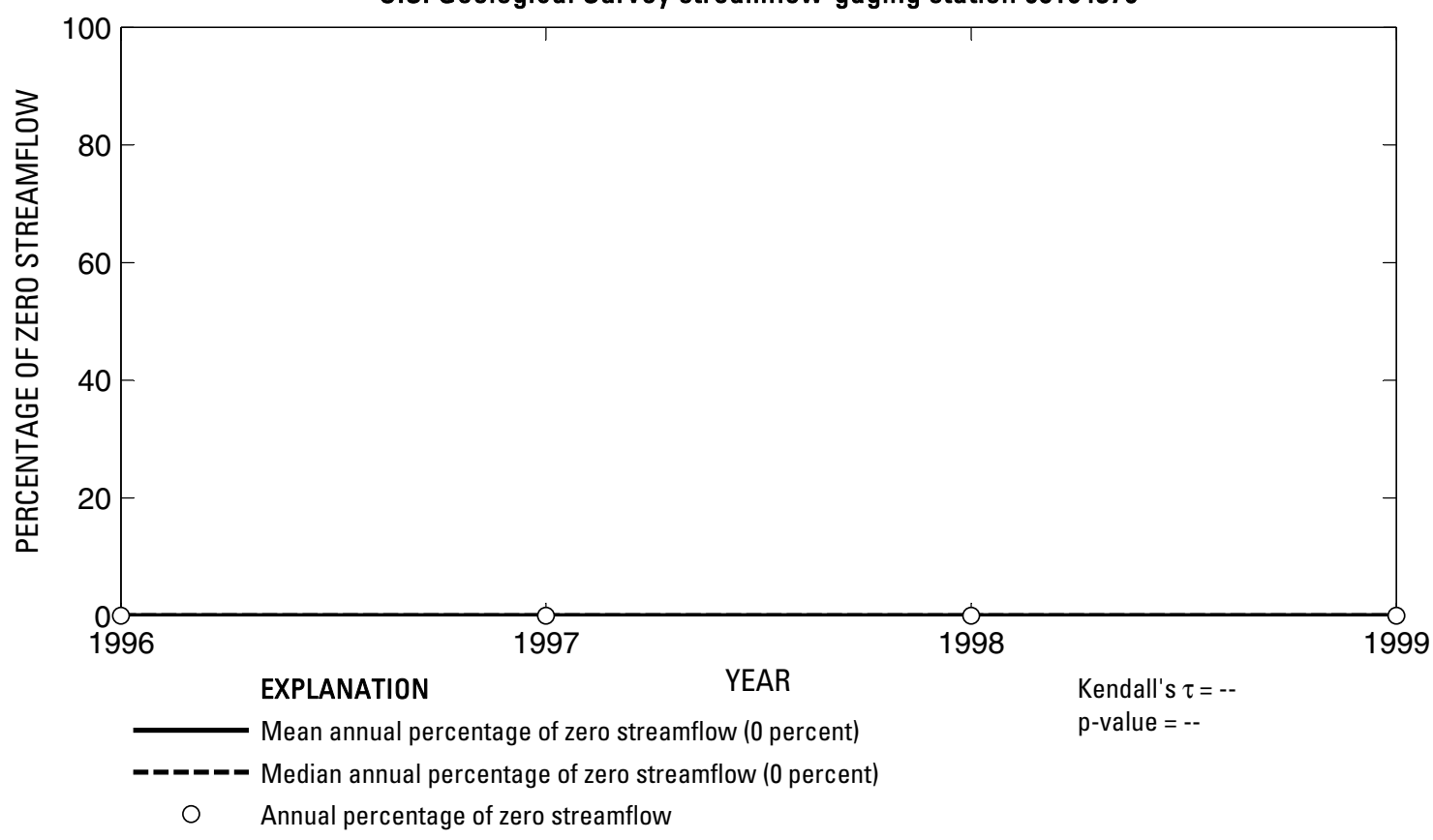

U.S. Geological Survey streamflow-gaging station 08164370

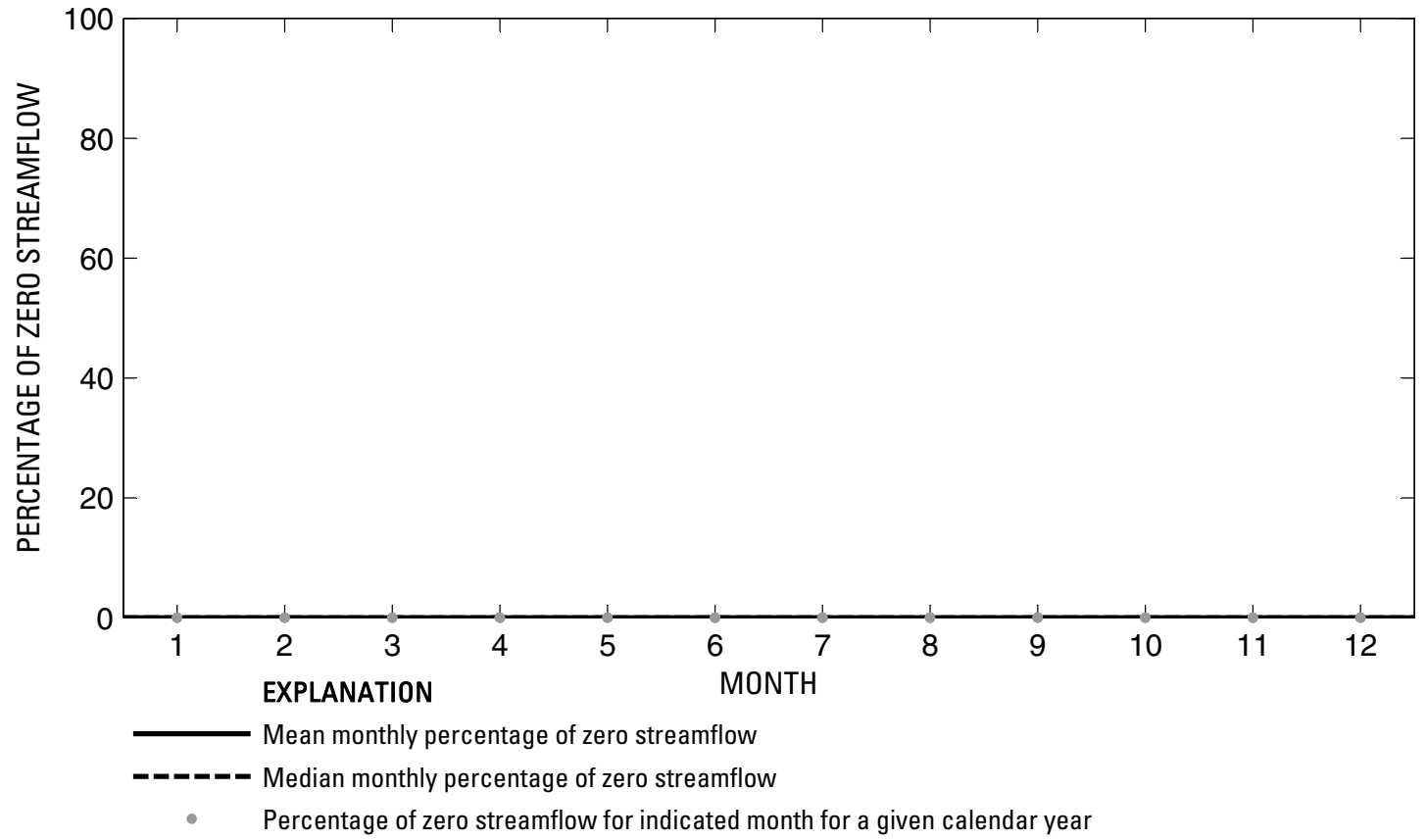

Figure 557. Analysis of percentage of zero daily mean streamflow for U.S. Geological Survey streamflow-gaging station 08164370 Navidad River at Morales, Texas. 
U.S. Geological Survey streamflow-gaging station 08164390

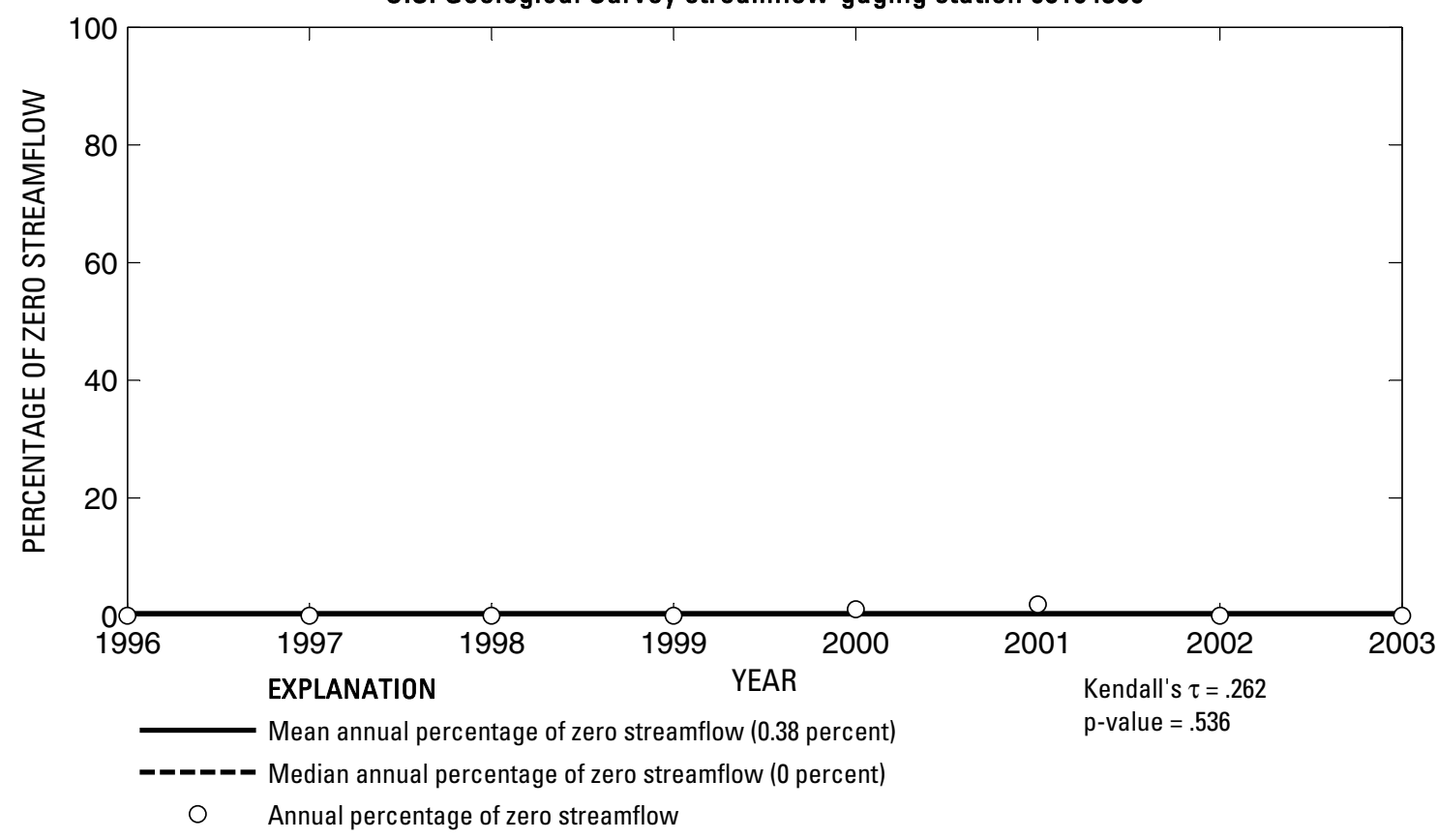

U.S. Geological Survey streamflow-gaging station 08164390

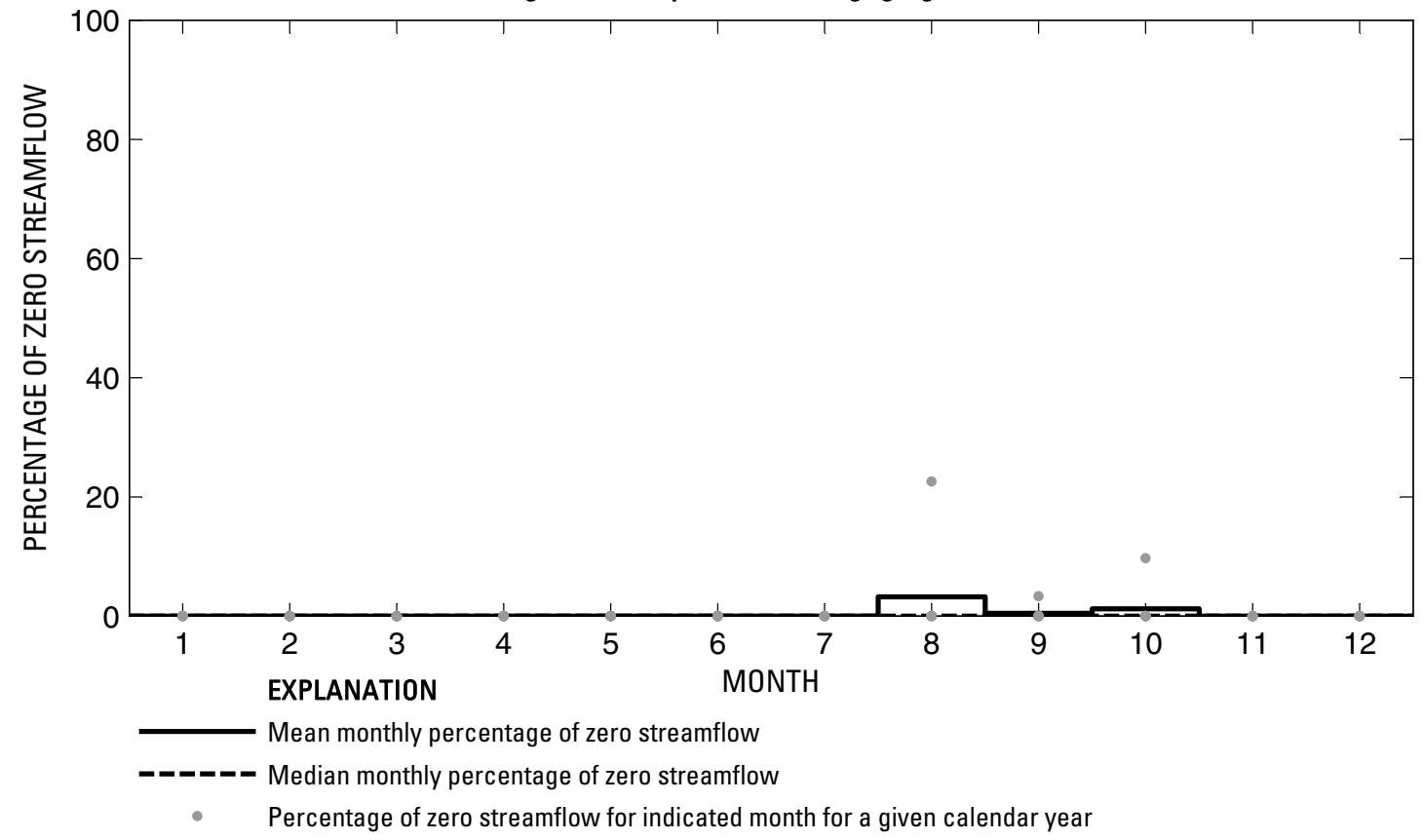

Figure 558. Analysis of percentage of zero daily mean streamflow for U.S. Geological Survey streamflow-gaging station 08164390 Navidad River at Strane Park near Edna, Texas. 


\section{U.S. Geological Survey streamflow-gaging station 08164450}

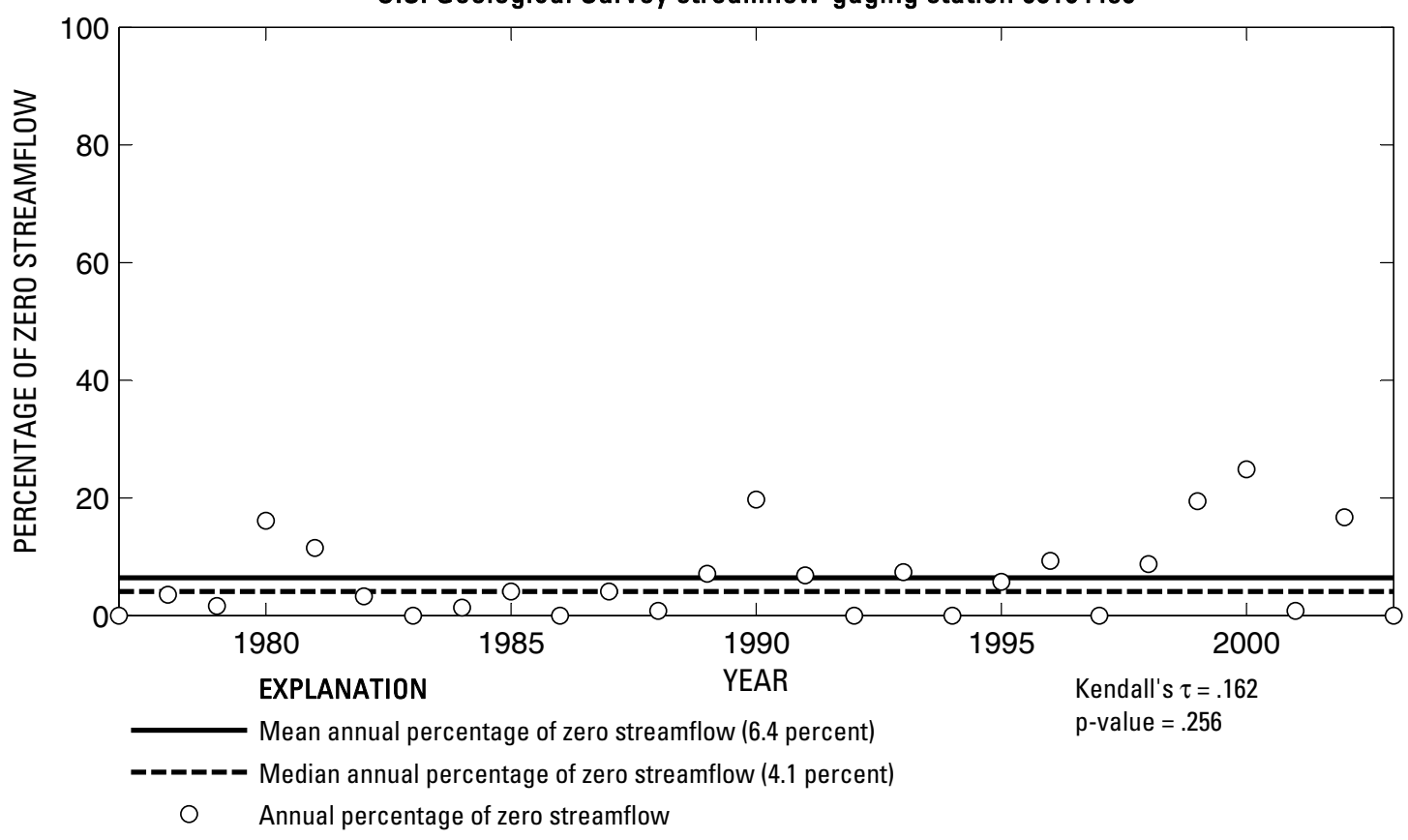

U.S. Geological Survey streamflow-gaging station 08164450

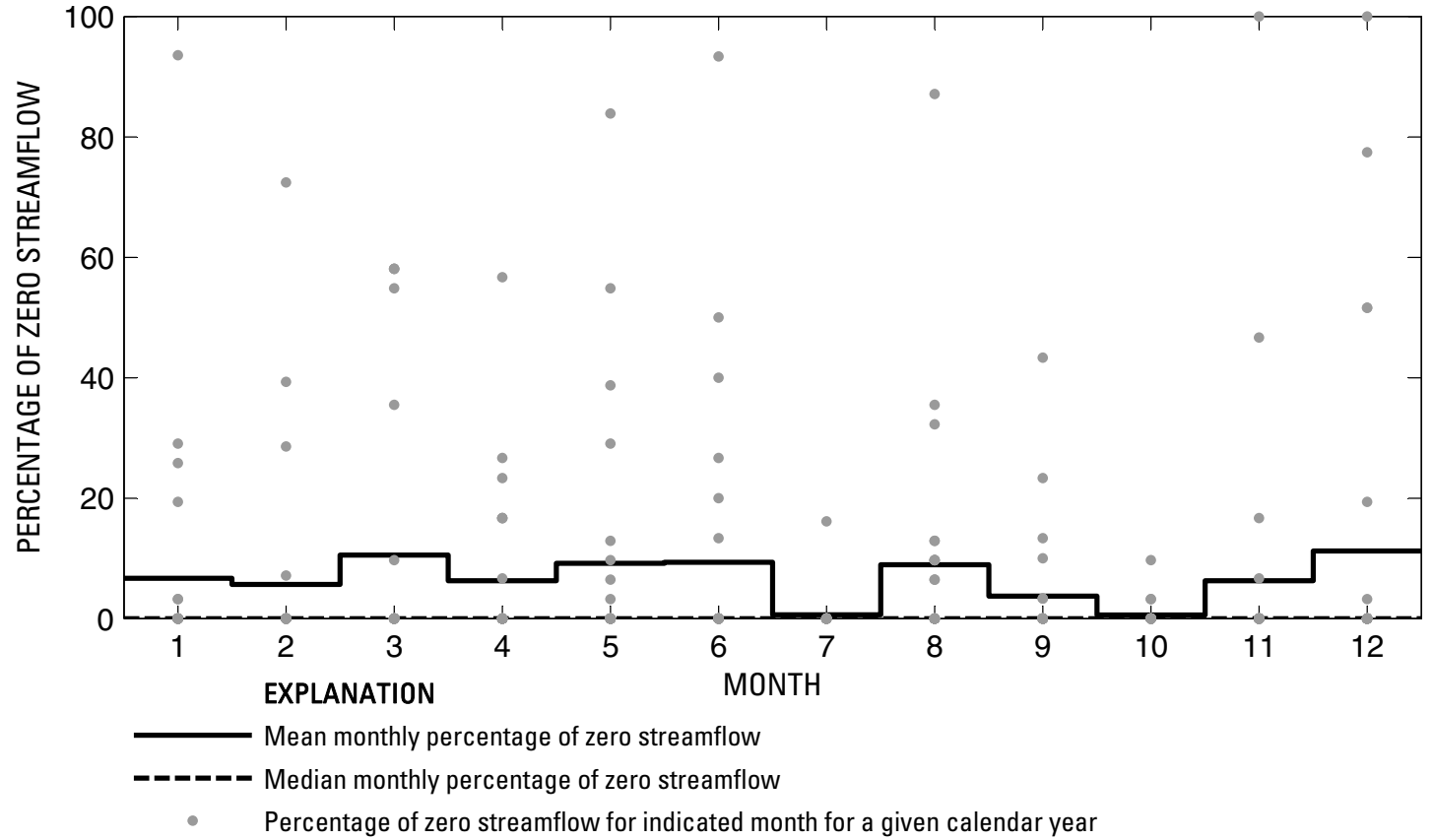

Figure 559. Analysis of percentage of zero daily mean streamflow for U.S. Geological Survey streamflow-gaging station 08164450 Sandy Creek near Ganado, Texas. 
U.S. Geological Survey streamflow-gaging station 08164500

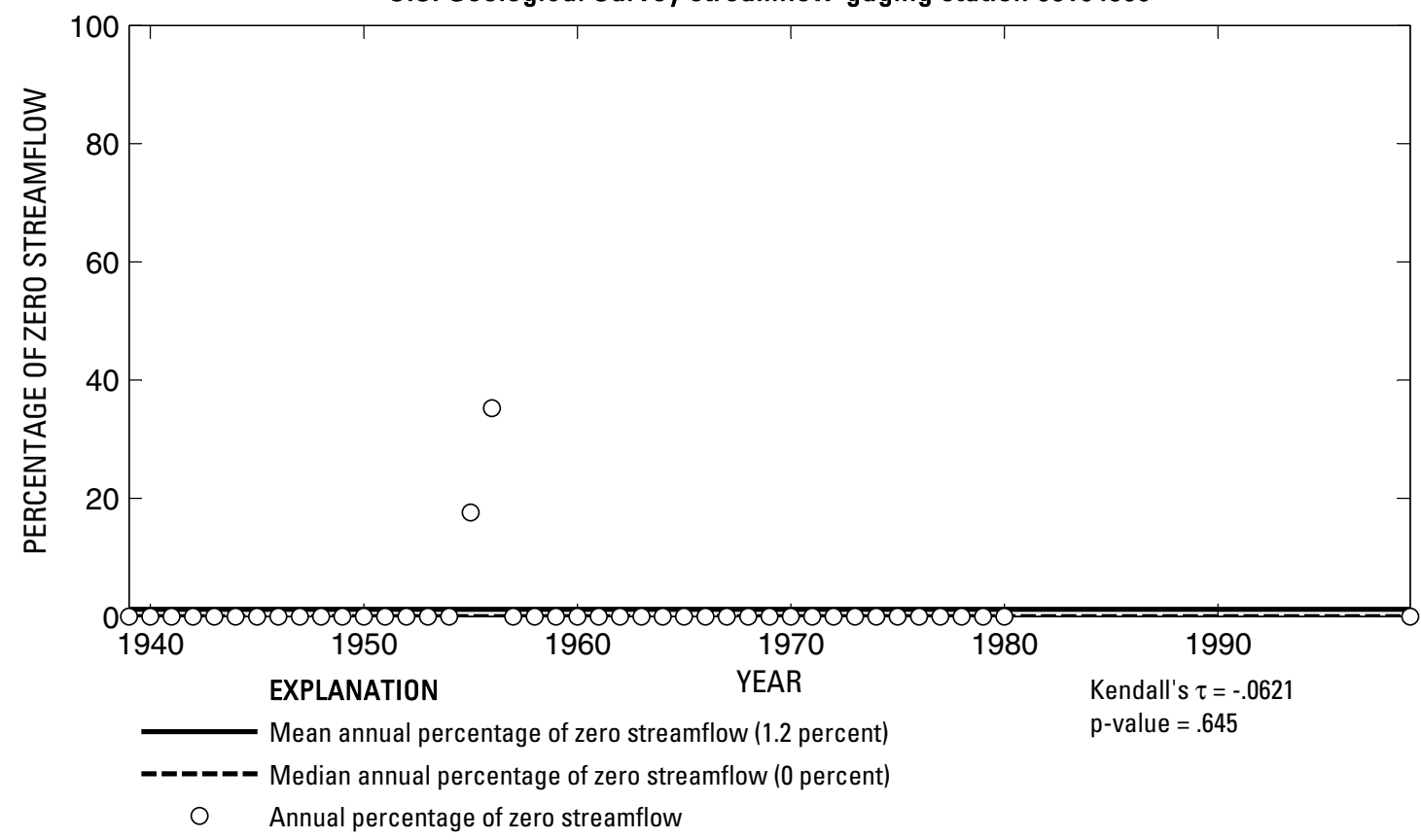

U.S. Geological Survey streamflow-gaging station 08164500

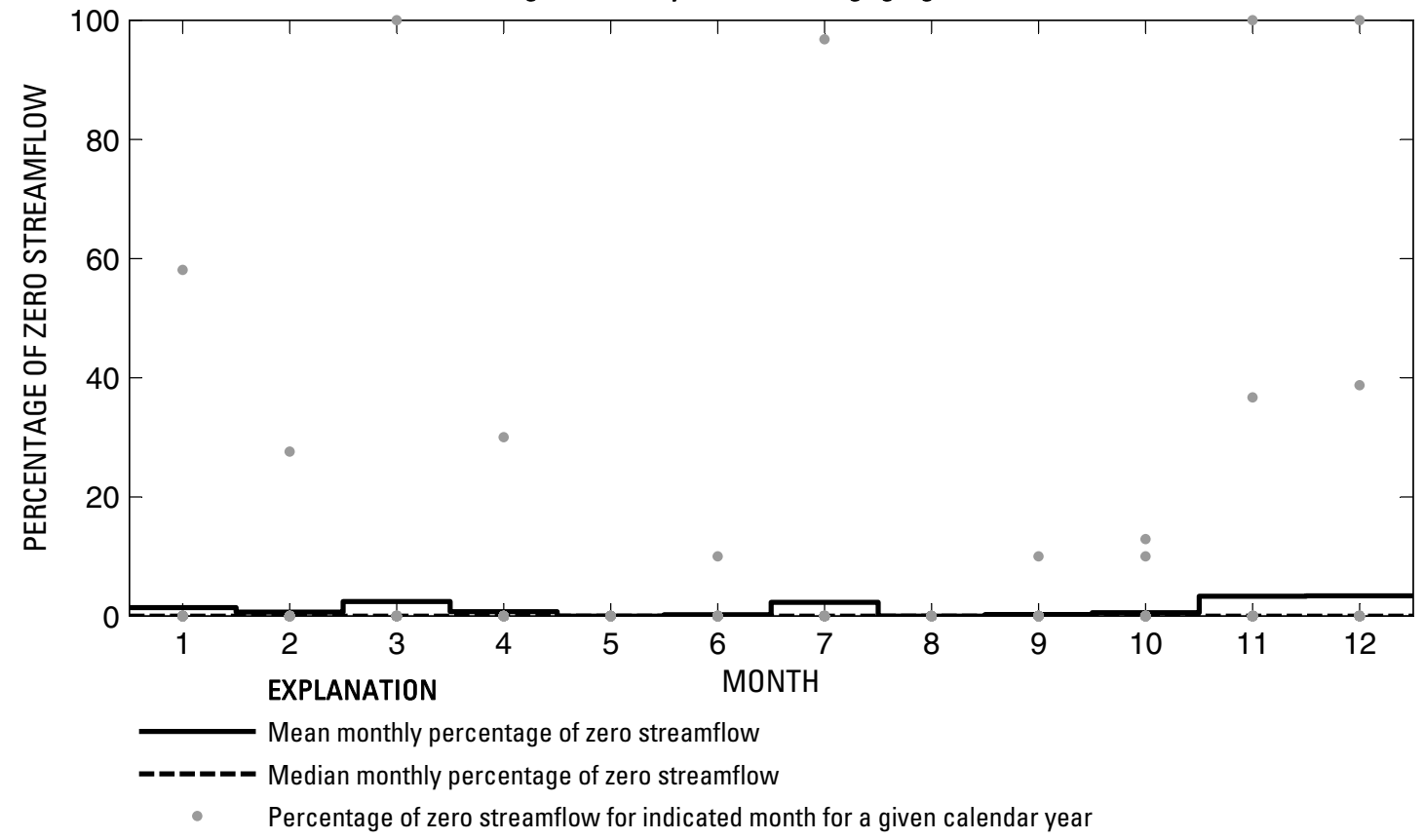

Figure 560. Analysis of percentage of zero daily mean streamflow for U.S. Geological Survey streamflow-gaging station 08164500 Navidad River near Ganado, Texas. 


\section{U.S. Geological Survey streamflow-gaging station 08164503}

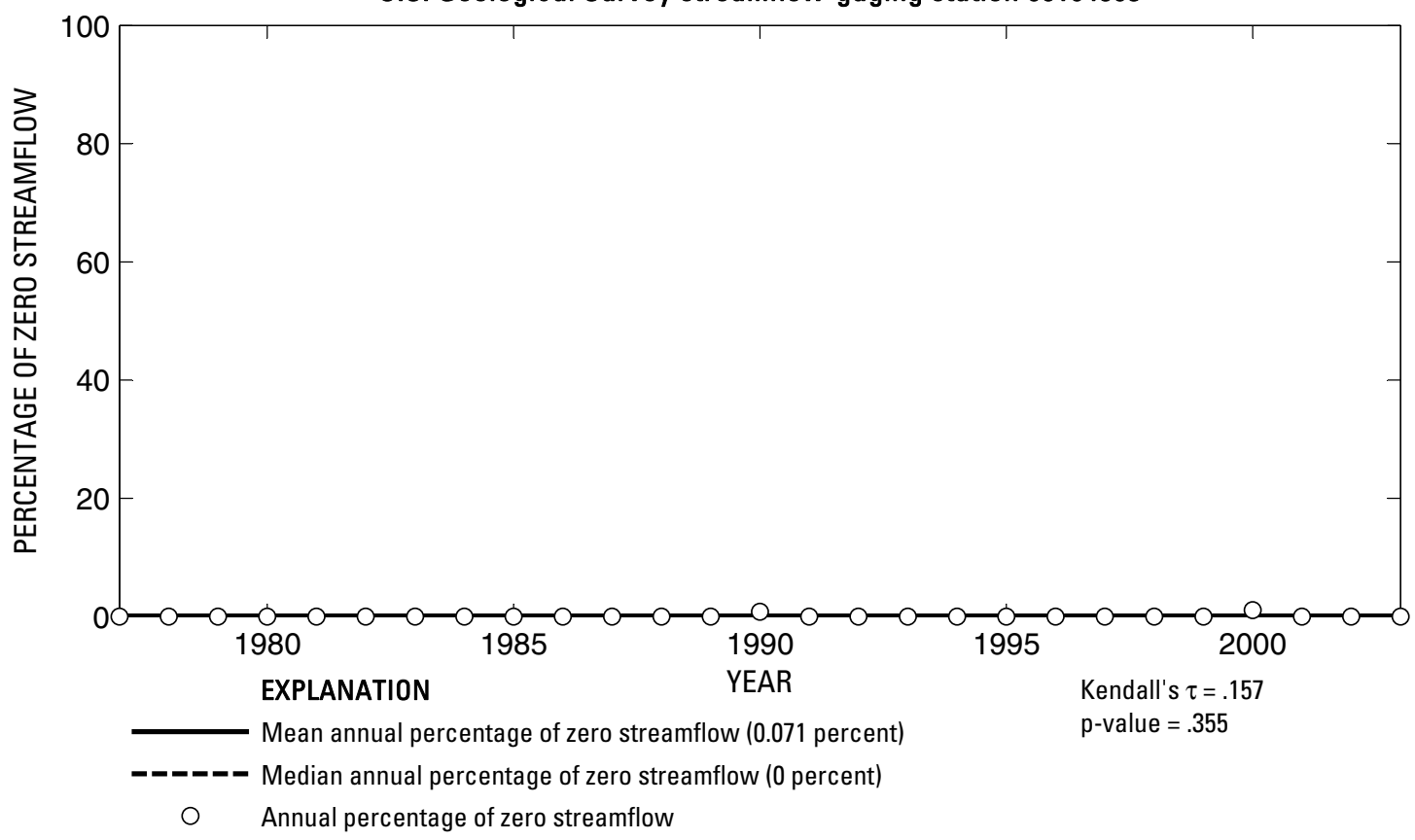

U.S. Geological Survey streamflow-gaging station 08164503

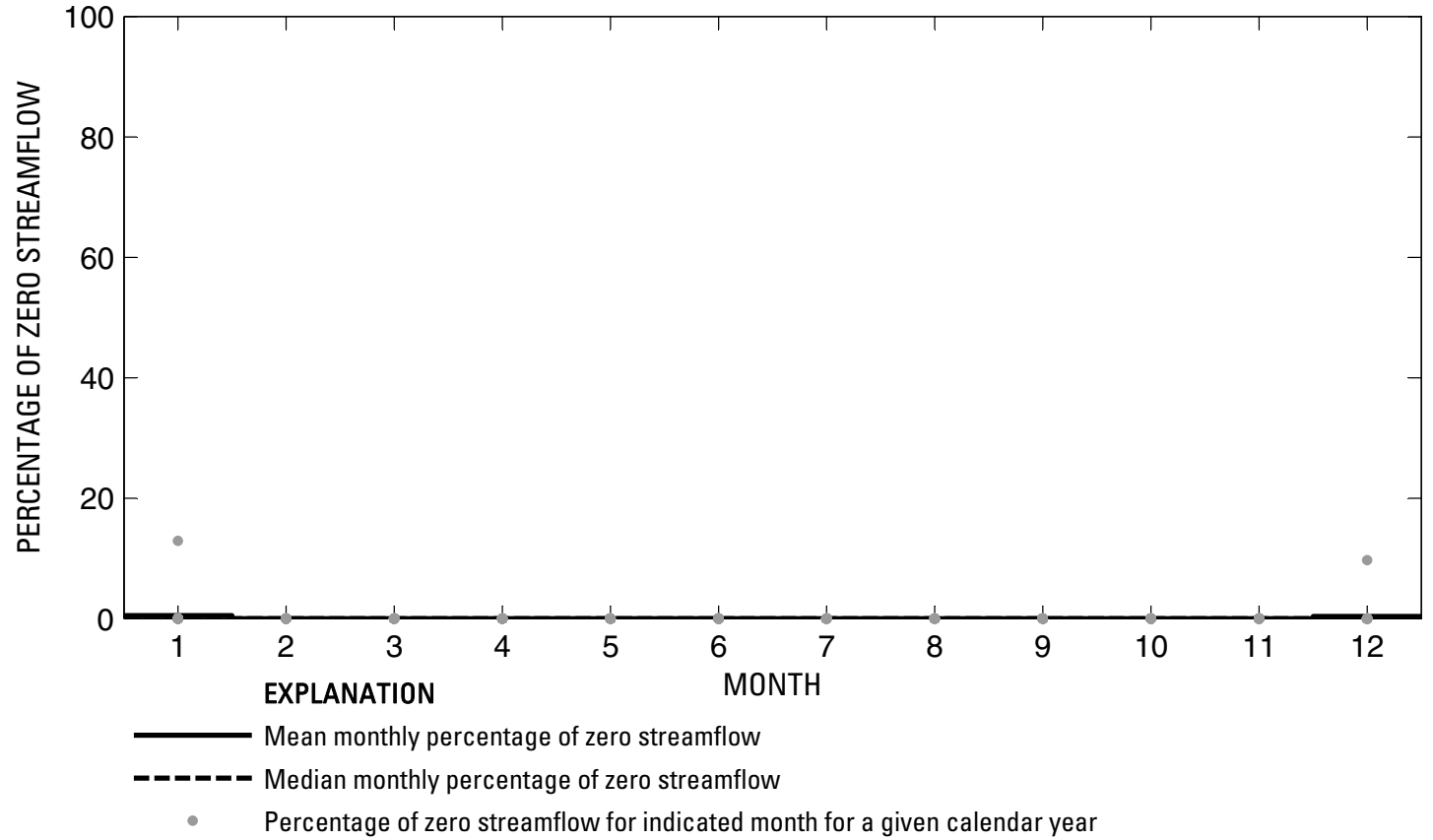

Figure 561. Analysis of percentage of zero daily mean streamflow for U.S. Geological Survey streamflow-gaging station 08164503 West Mustang Creek near Ganado, Texas. 
U.S. Geological Survey streamflow-gaging station 08164504

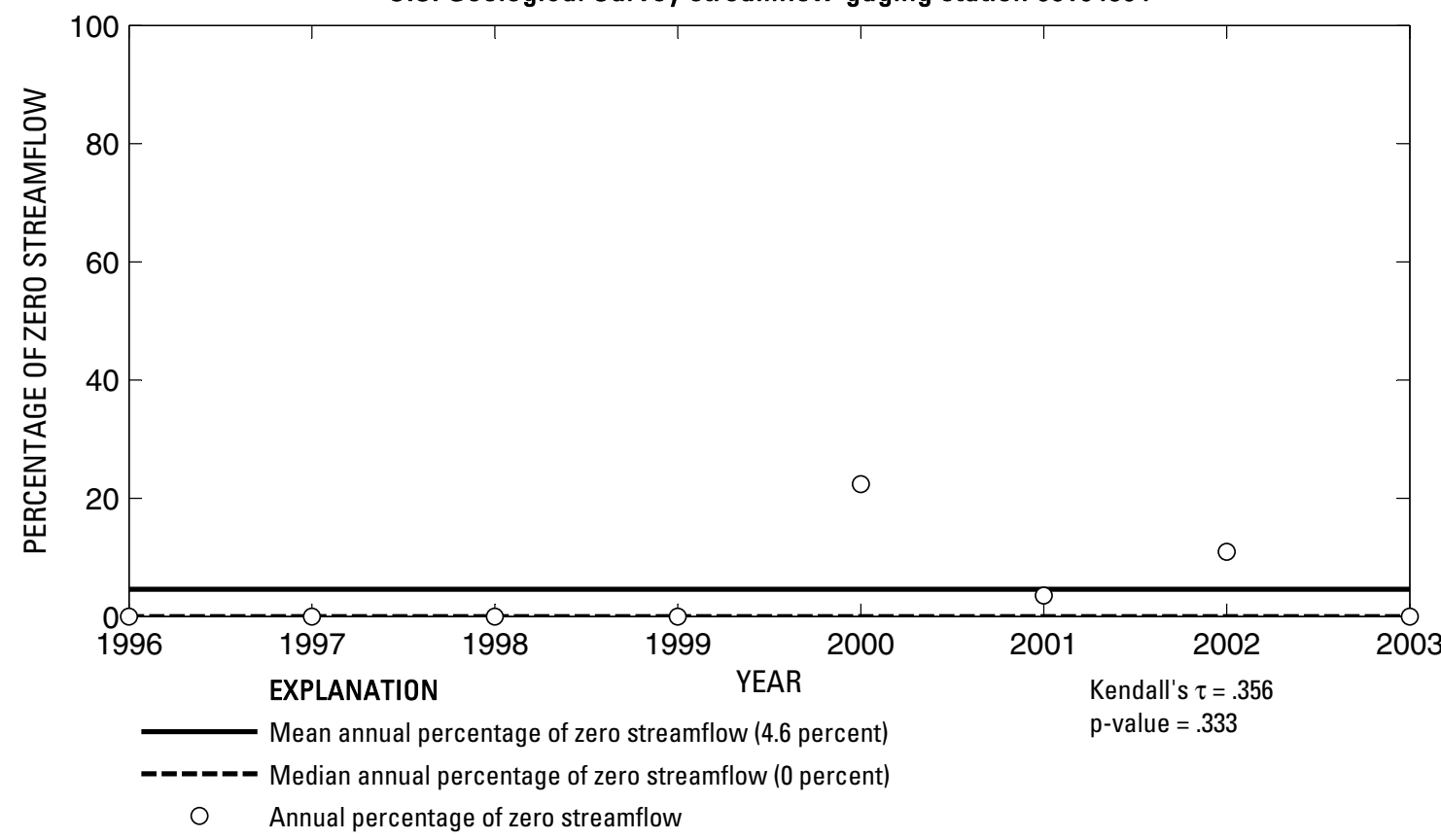

U.S. Geological Survey streamflow-gaging station 08164504

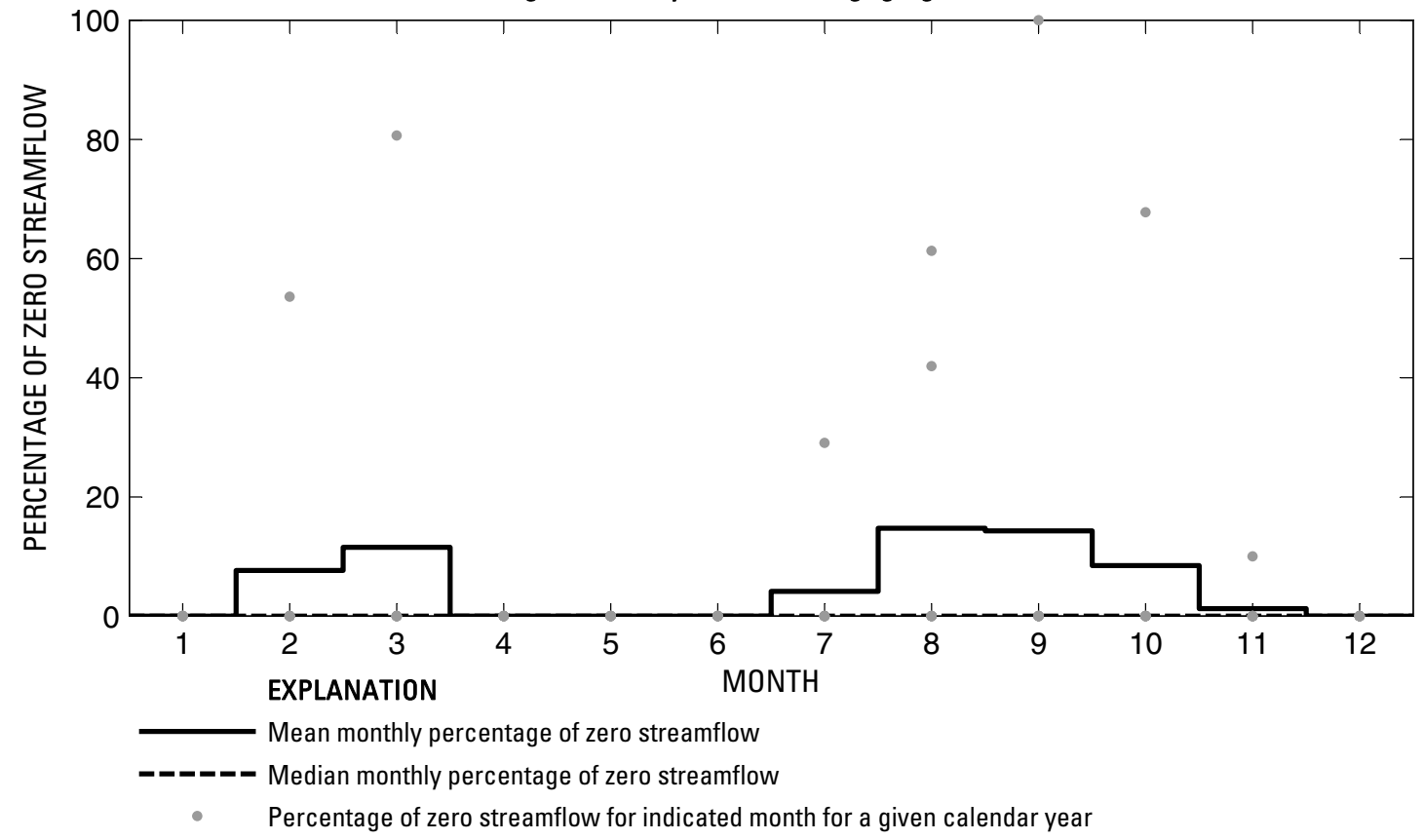

Figure 562. Analysis of percentage of zero daily mean streamflow for U.S. Geological Survey streamflow-gaging station 08164504 East Mustang Creek near Louise, Texas. 


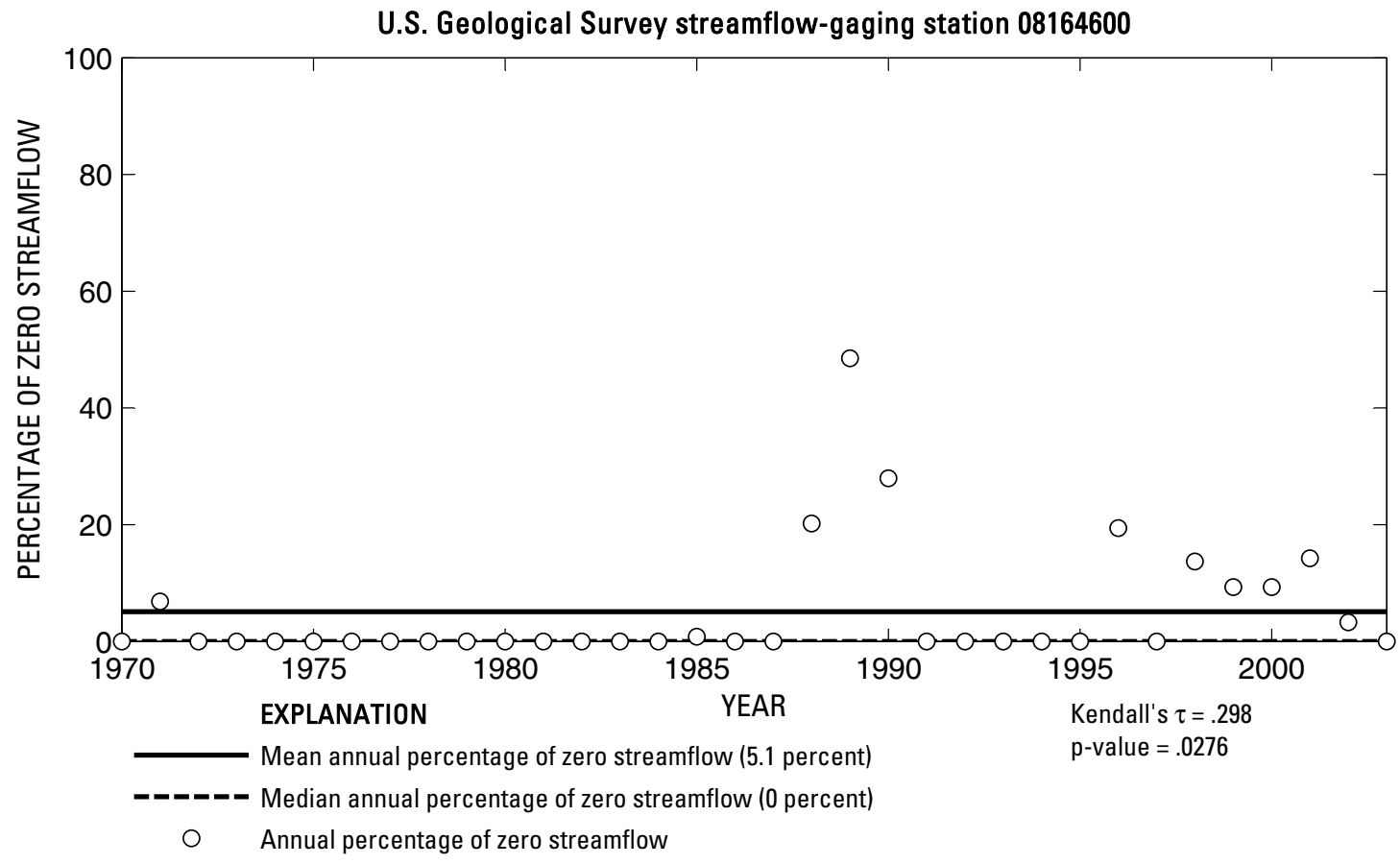

U.S. Geological Survey streamflow-gaging station 08164600

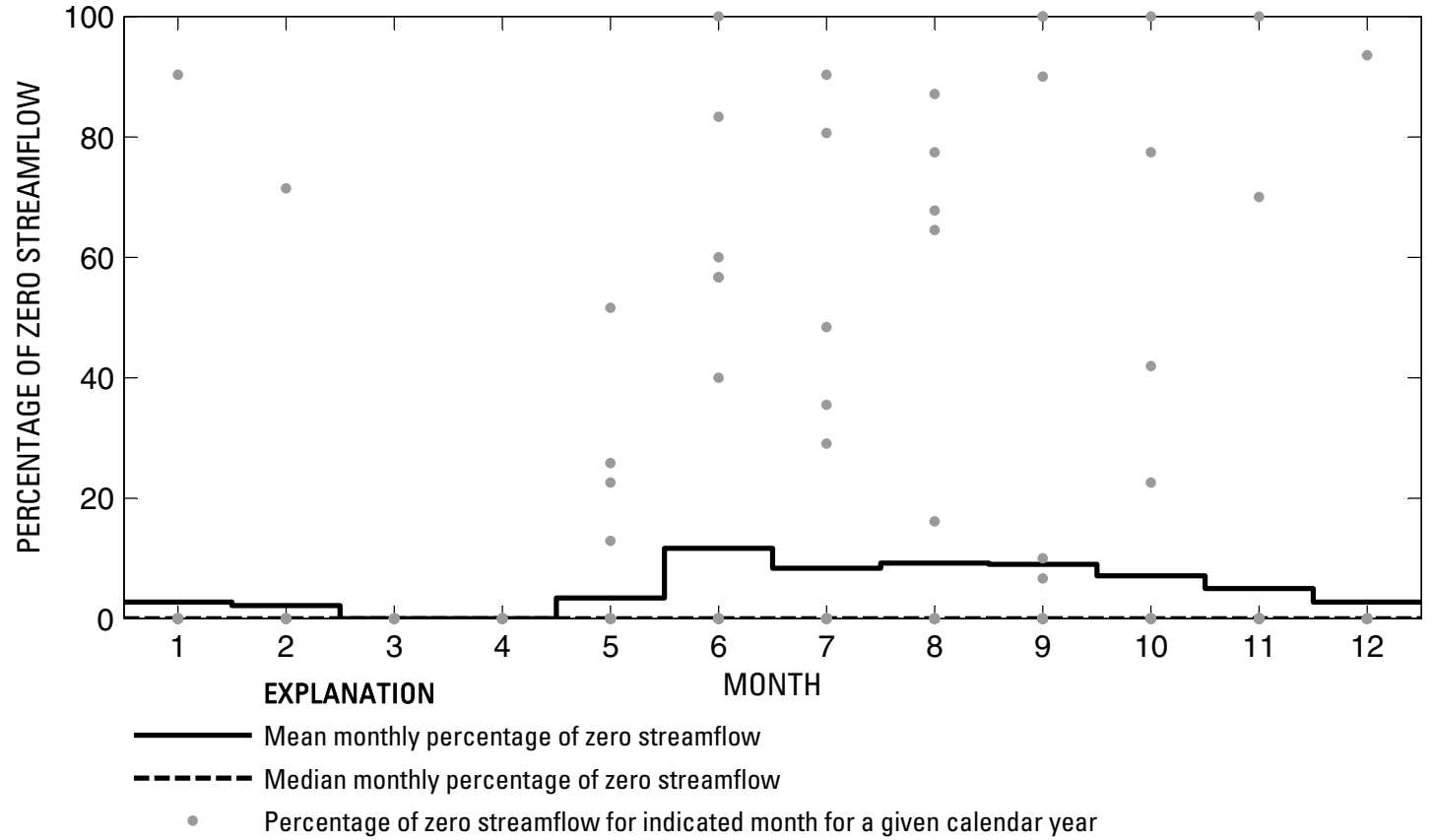

Figure 563. Analysis of percentage of zero daily mean streamflow for U.S. Geological Survey streamflow-gaging station 08164600 Garcitas Creek near Inez, Texas. 
U.S. Geological Survey streamflow-gaging station 08164800

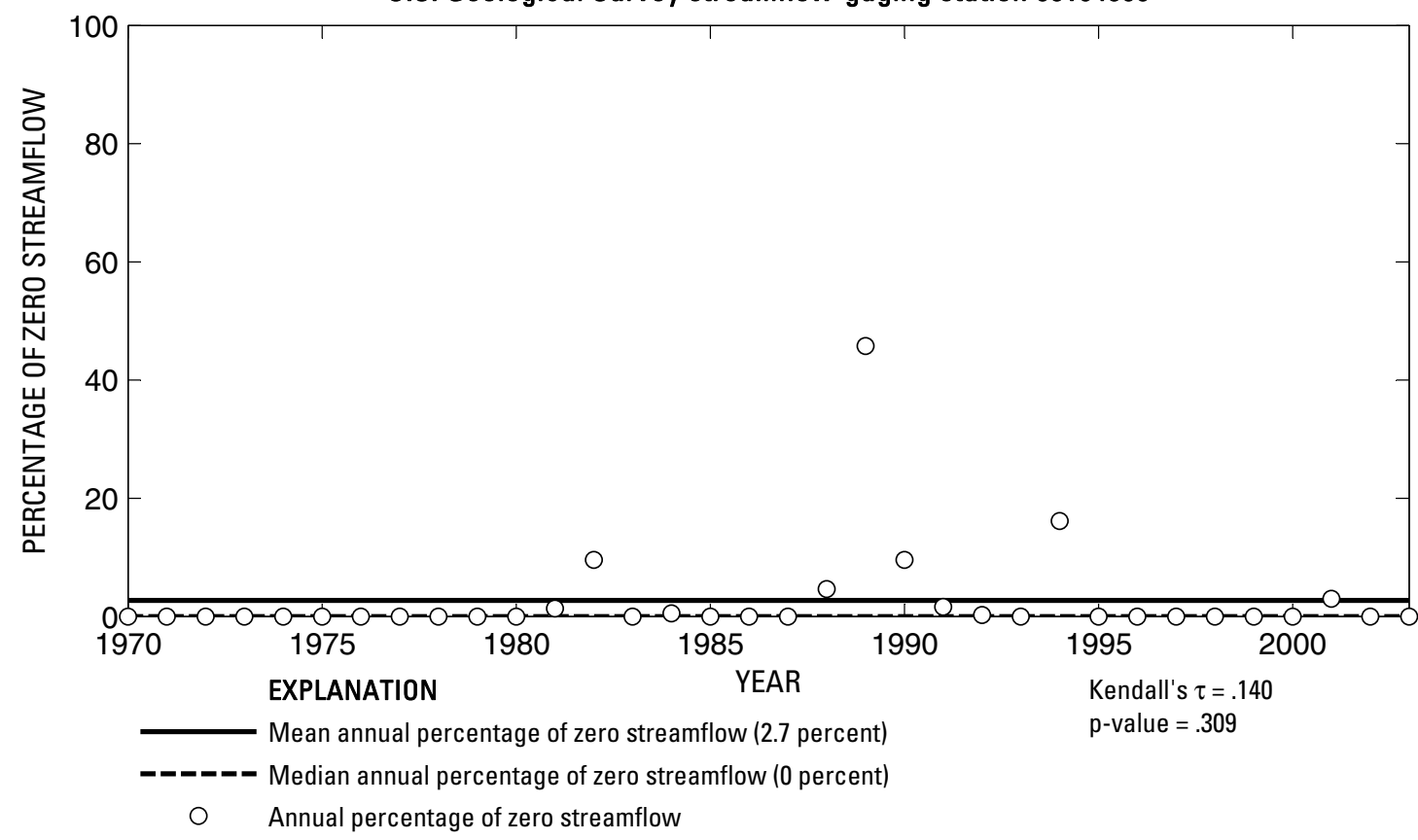

U.S. Geological Survey streamflow-gaging station 08164800

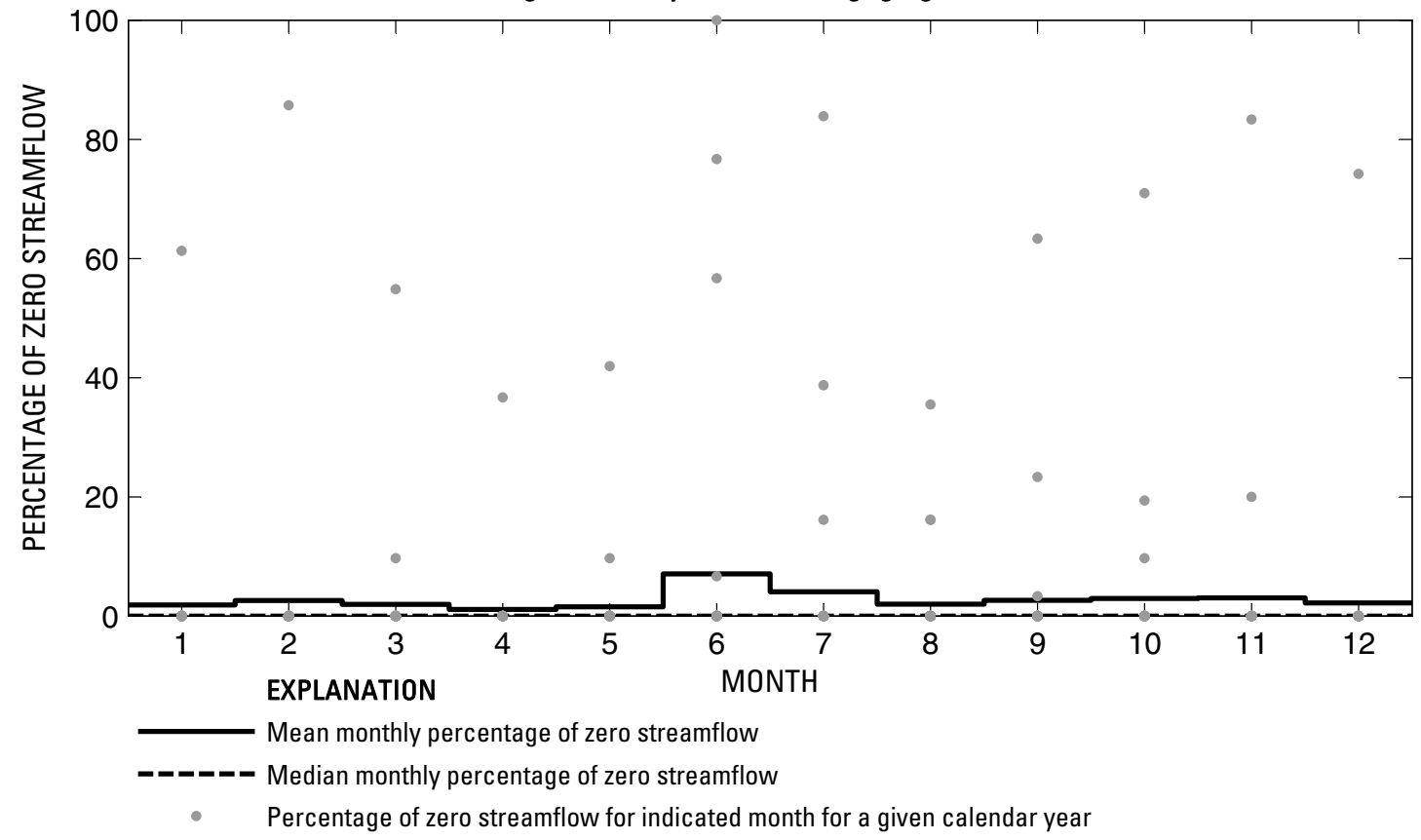

Figure 564. Analysis of percentage of zero daily mean streamflow for U.S. Geological Survey streamflow-gaging station 08164800 Placedo Creek near Placedo, Texas. 
U.S. Geological Survey streamflow-gaging station 08165300

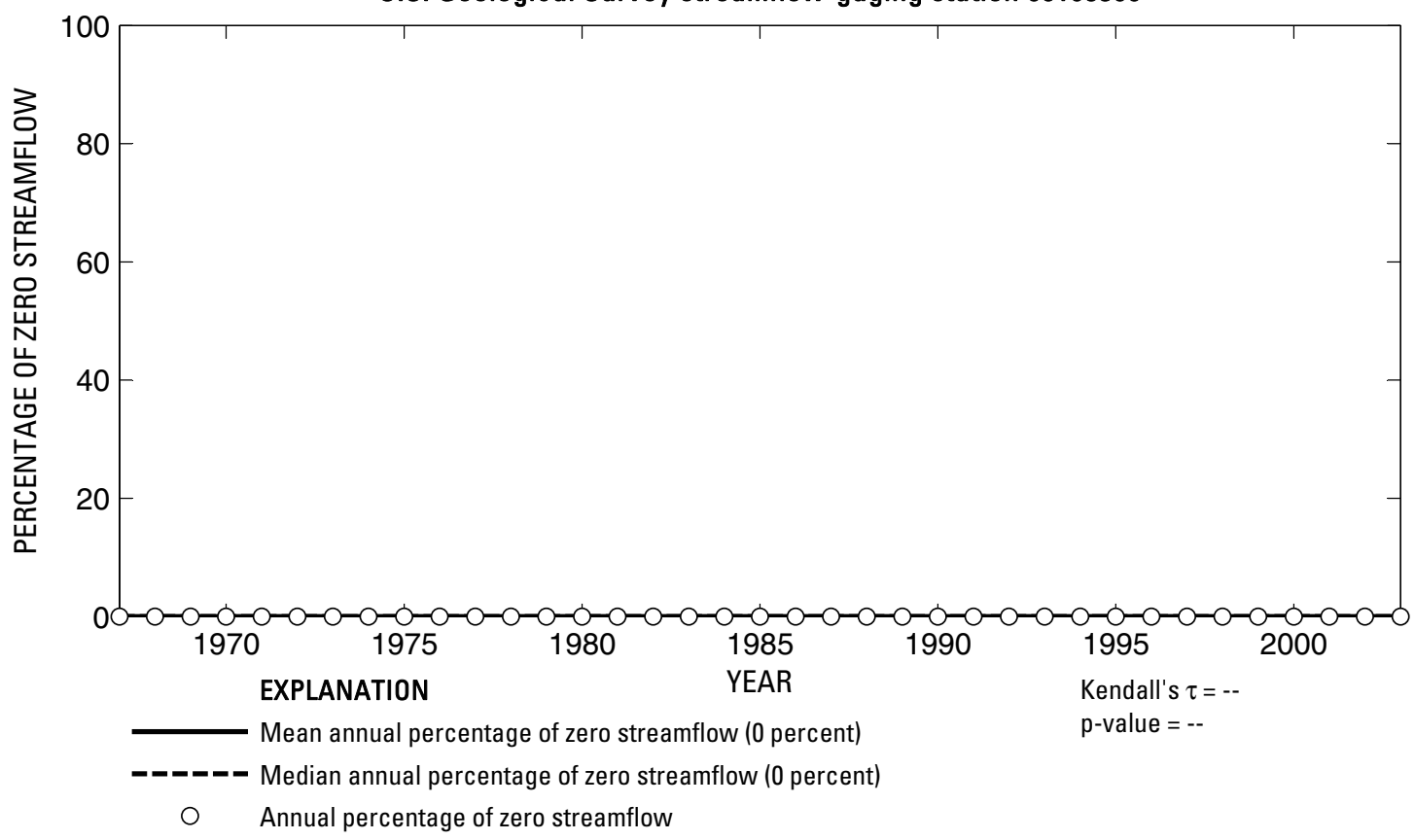

U.S. Geological Survey streamflow-gaging station 08165300

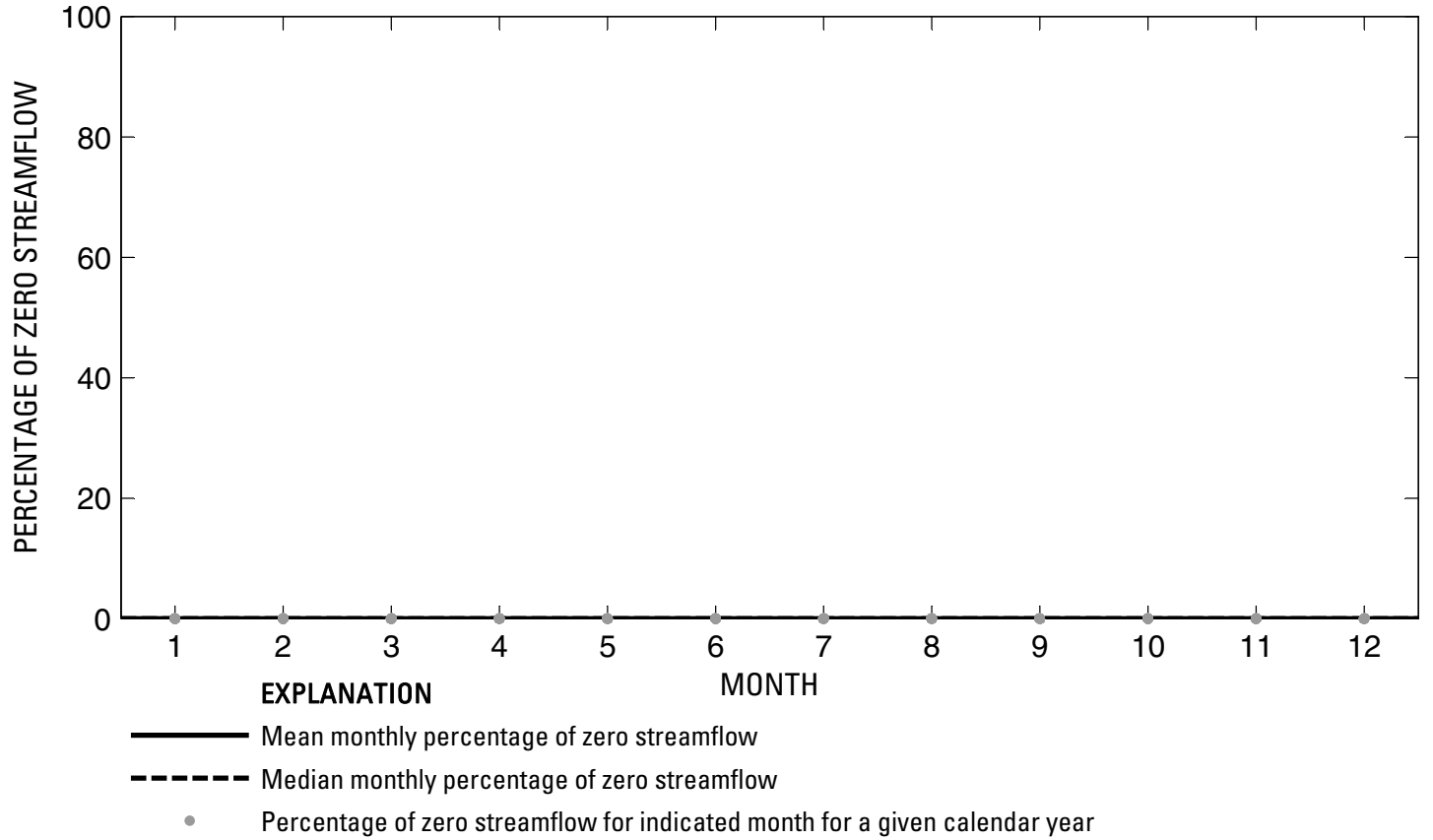

Figure 565. Analysis of percentage of zero daily mean streamflow for U.S. Geological Survey streamflow-gaging station 08165300 North Fork Guadalupe River near Hunt, Texas. 
U.S. Geological Survey streamflow-gaging station 08165500

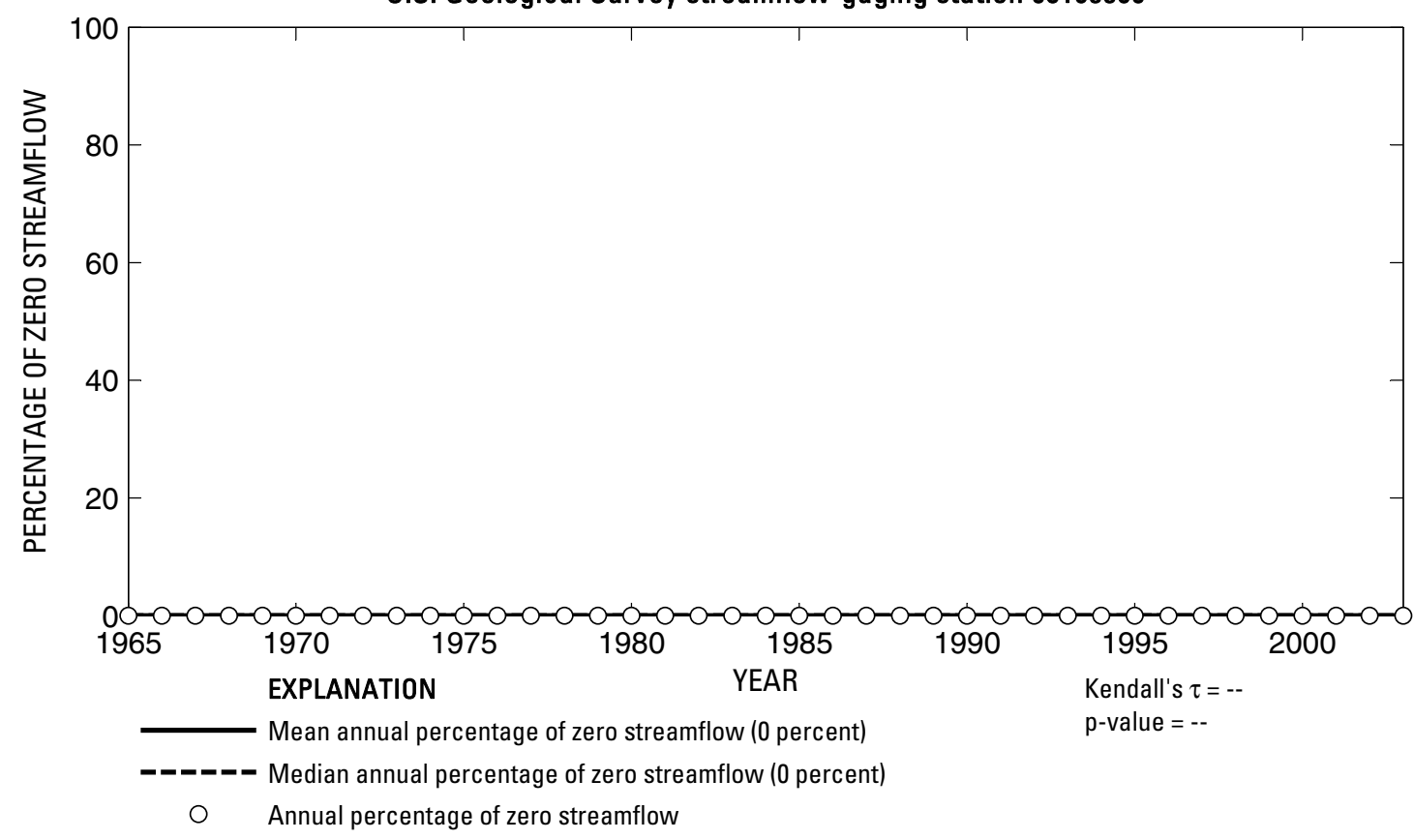

U.S. Geological Survey streamflow-gaging station 08165500

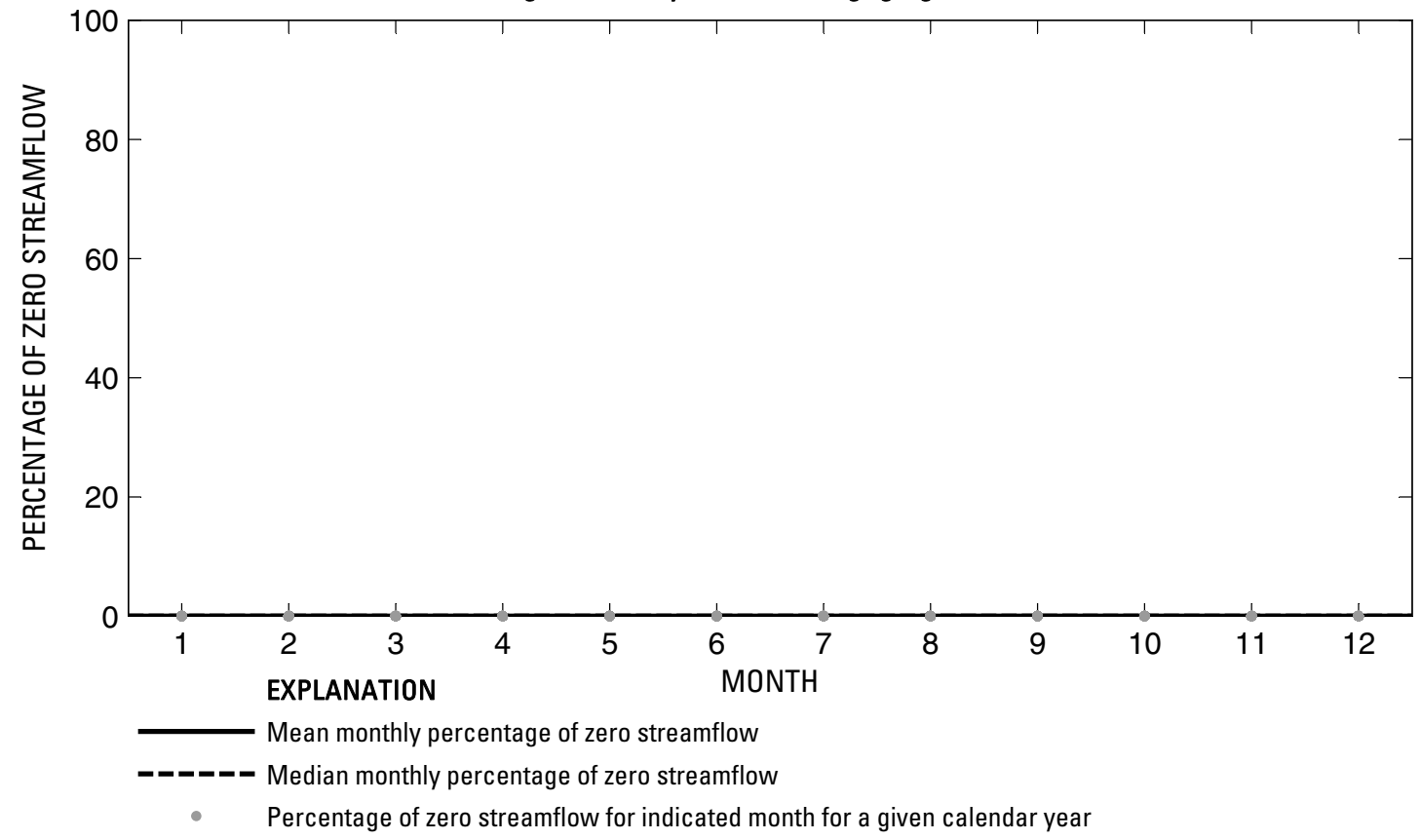

Figure 566. Analysis of percentage of zero daily mean streamflow for U.S. Geological Survey streamflow-gaging station 08165500 Guadalupe River at Hunt, Texas. 


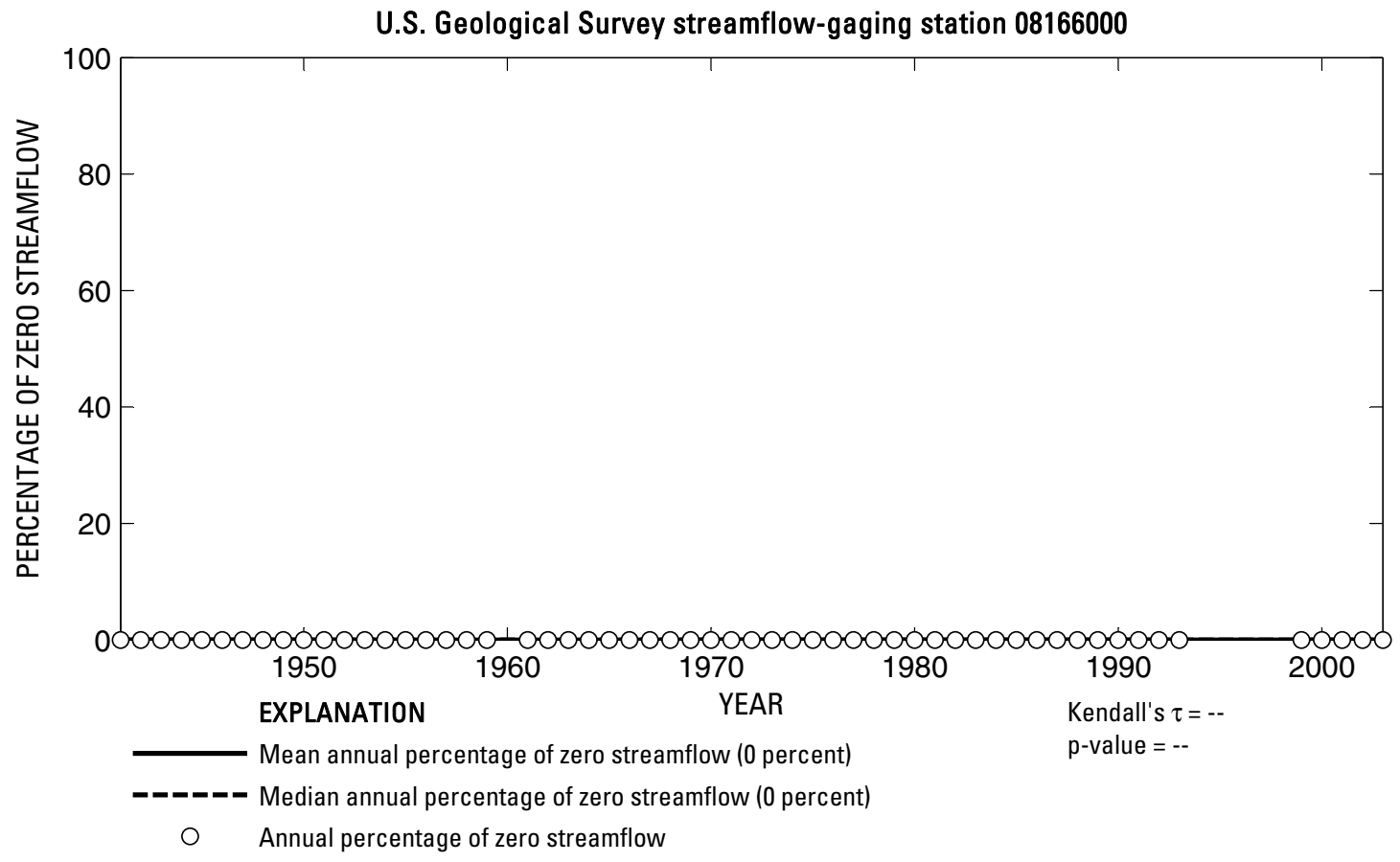

U.S. Geological Survey streamflow-gaging station 08166000

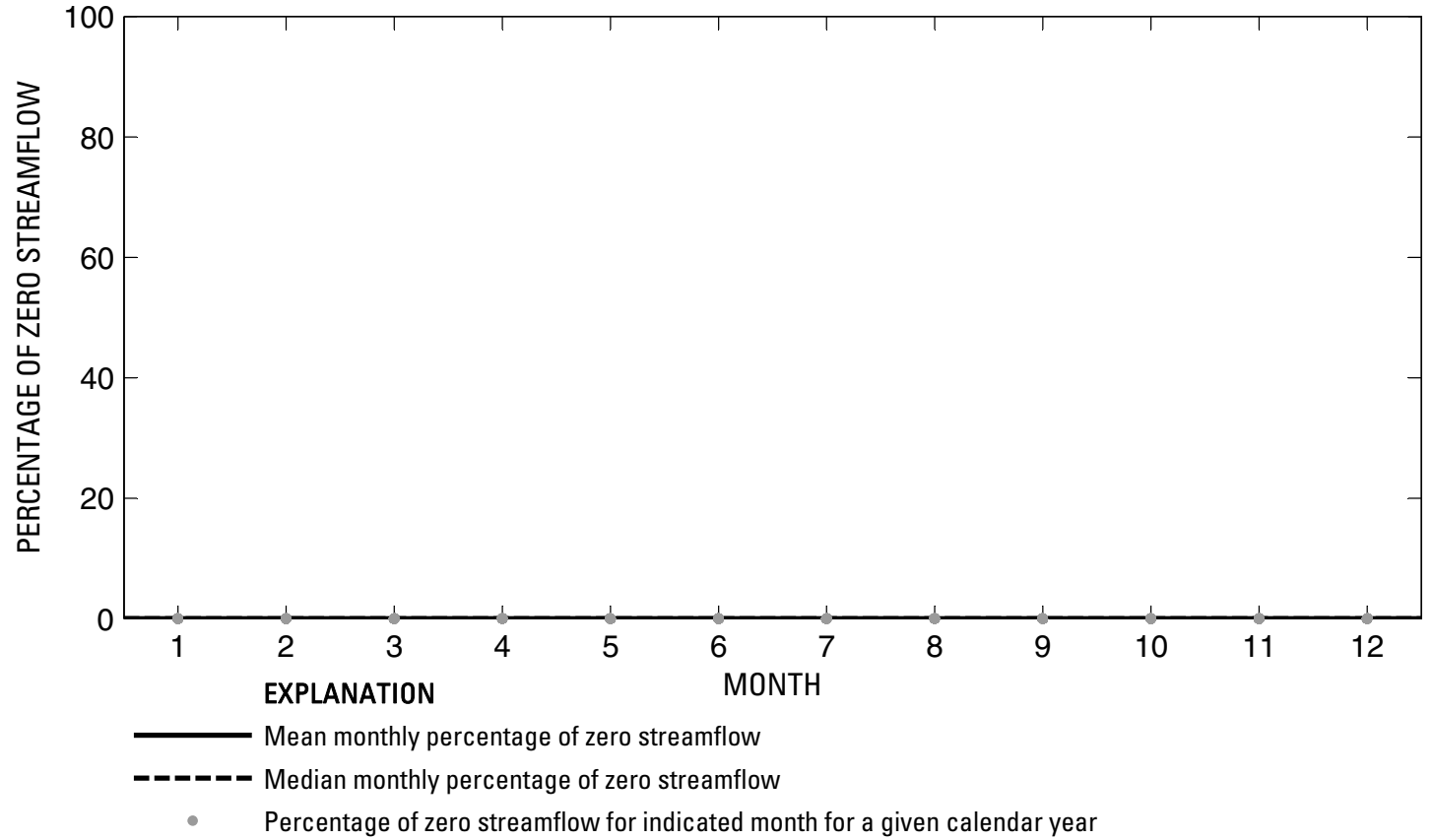

Figure 567. Analysis of percentage of zero daily mean streamflow for U.S. Geological Survey streamflow-gaging station 08166000 Johnson Creek near Ingram, Texas. 
U.S. Geological Survey streamflow-gaging station 08166140

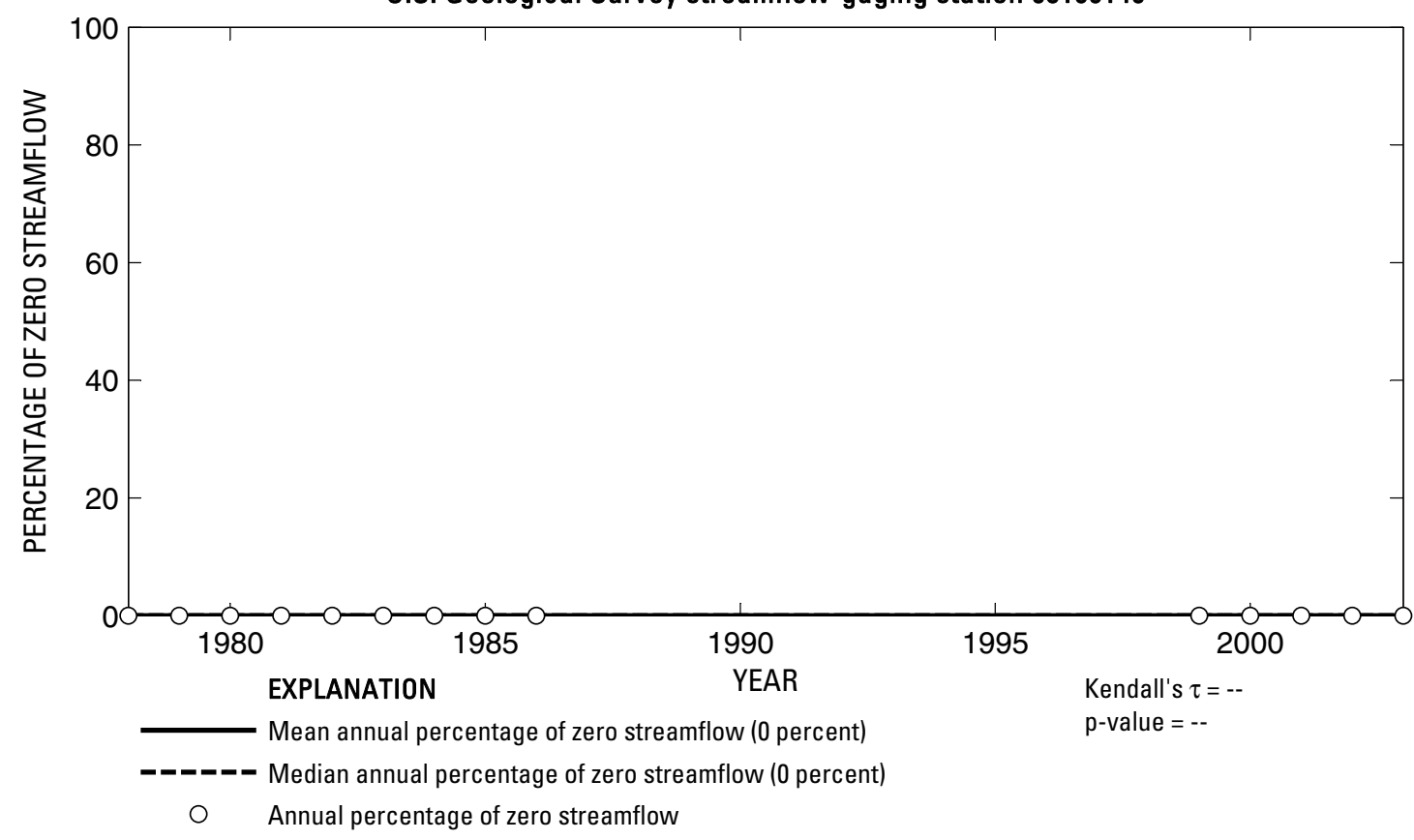

U.S. Geological Survey streamflow-gaging station 08166140

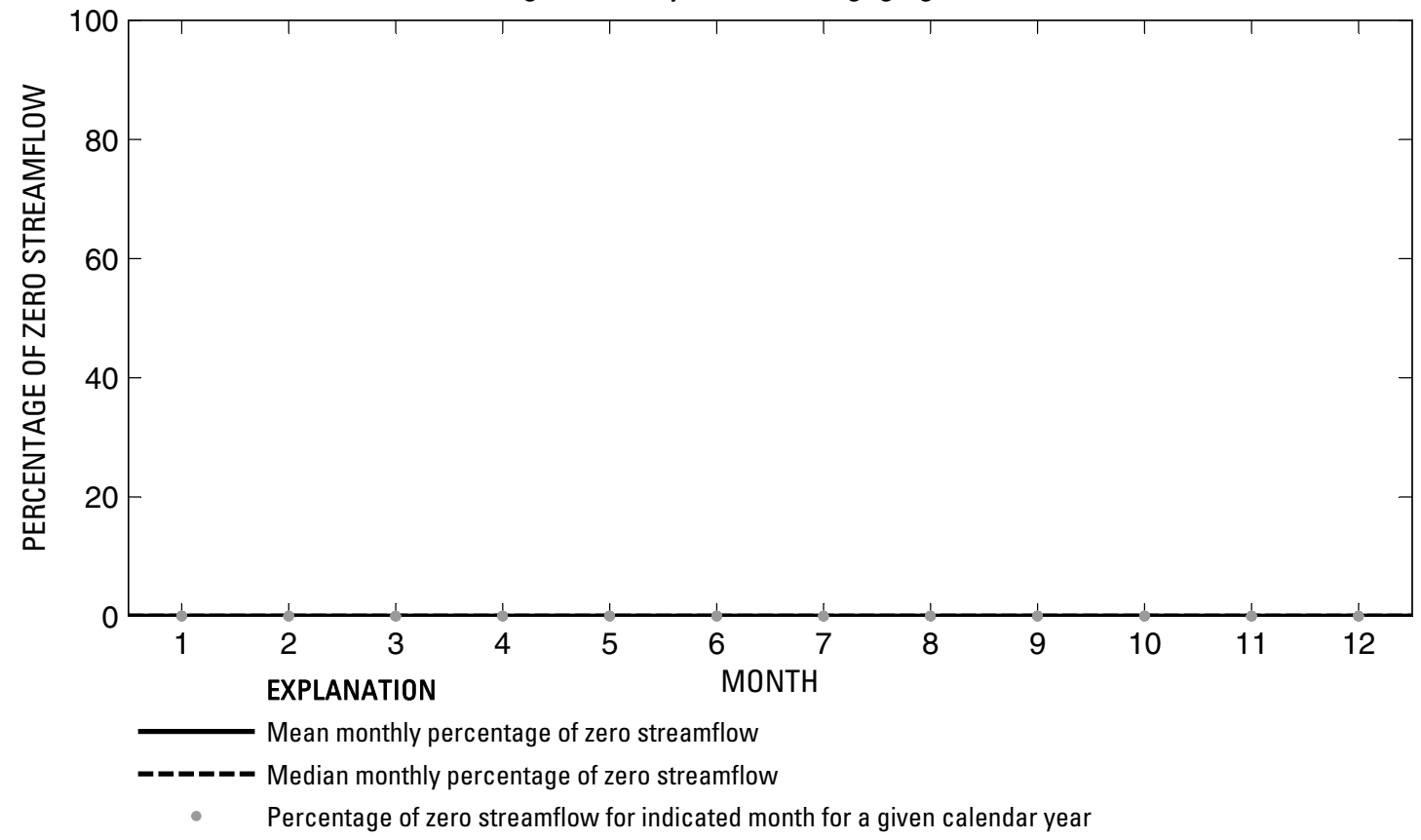

Figure 568. Analysis of percentage of zero daily mean streamflow for U.S. Geological Survey streamflow-gaging station 08166140 Guadalupe River above Bear Creek at Kerrville, Texas. 
U.S. Geological Survey streamflow-gaging station 08166200

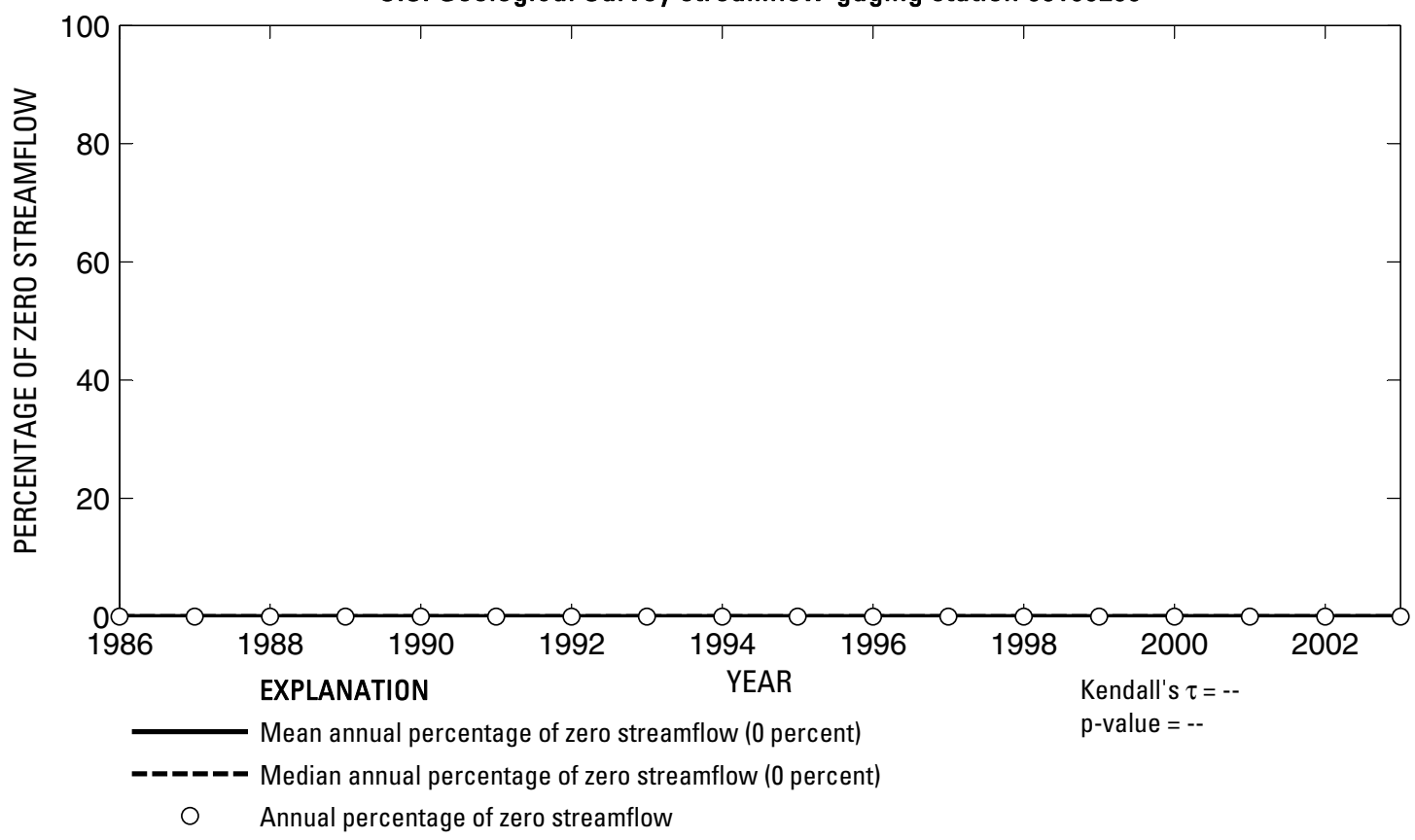

U.S. Geological Survey streamflow-gaging station 08166200

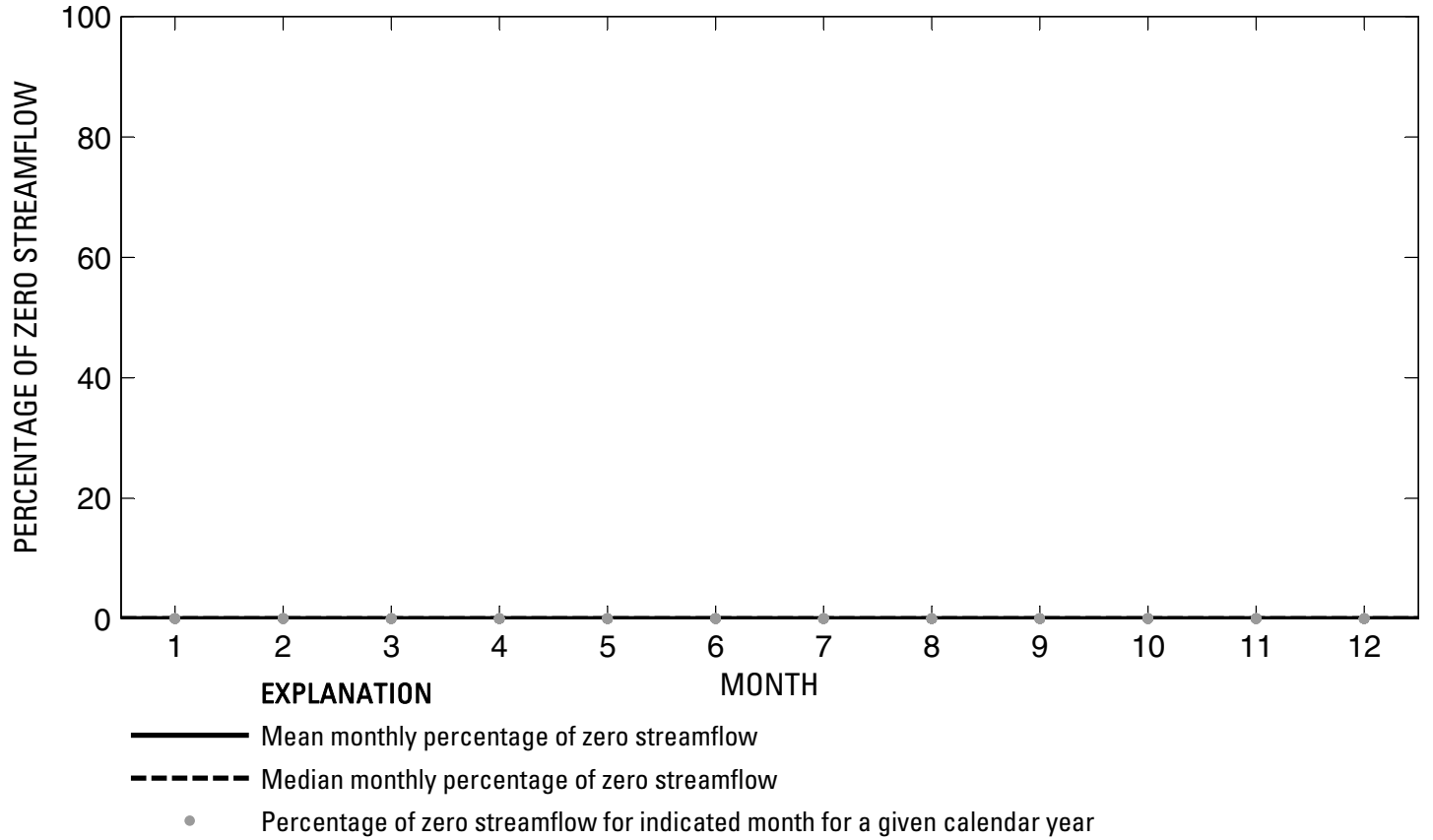

Figure 569. Analysis of percentage of zero daily mean streamflow for U.S. Geological Survey streamflow-gaging station 08166200 Guadalupe River at Kerrville, Texas. 

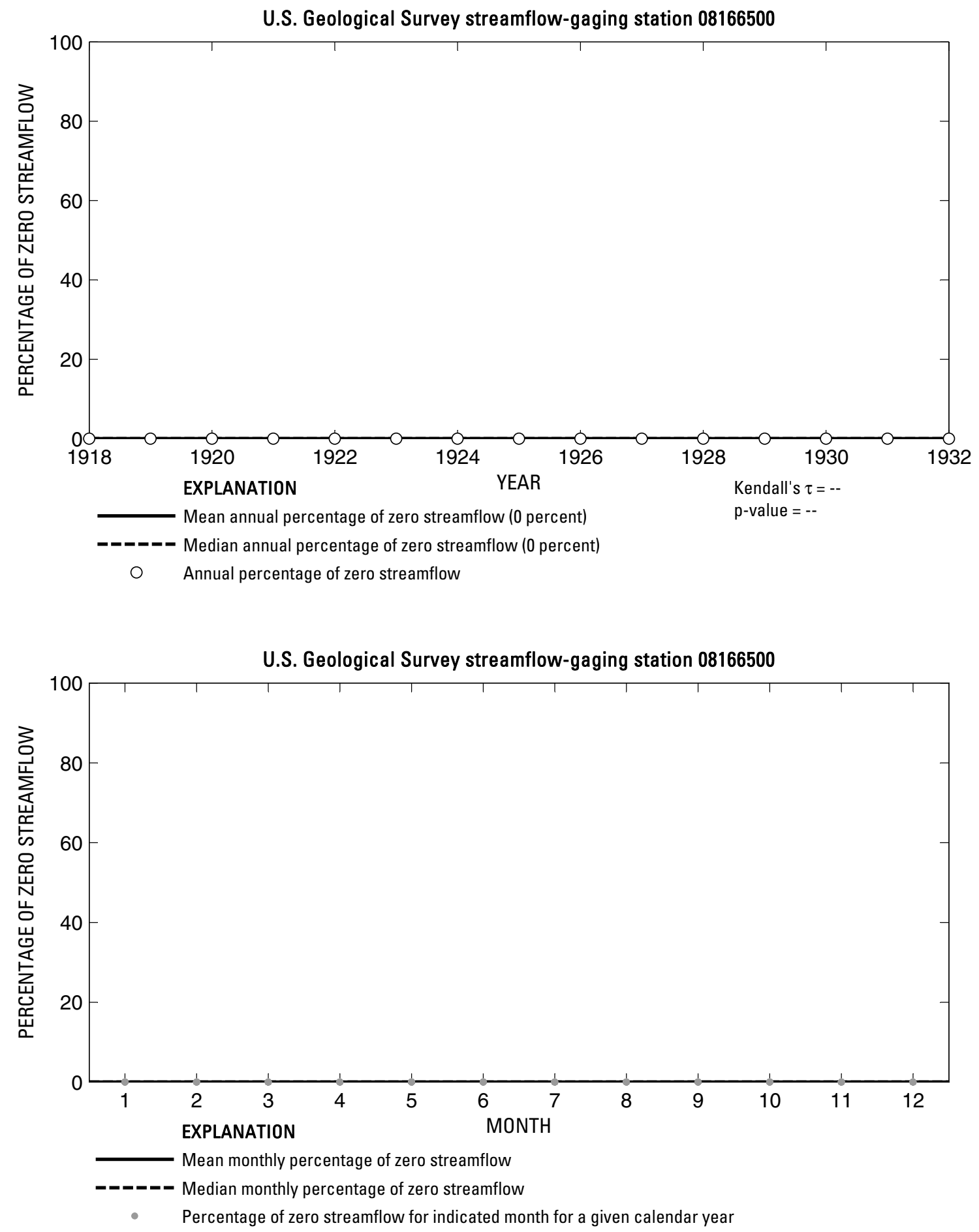

Figure 570. Analysis of percentage of zero daily mean streamflow for U.S. Geological Survey streamflow-gaging station 08166500 Guadalupe River near Comfort, Texas. 


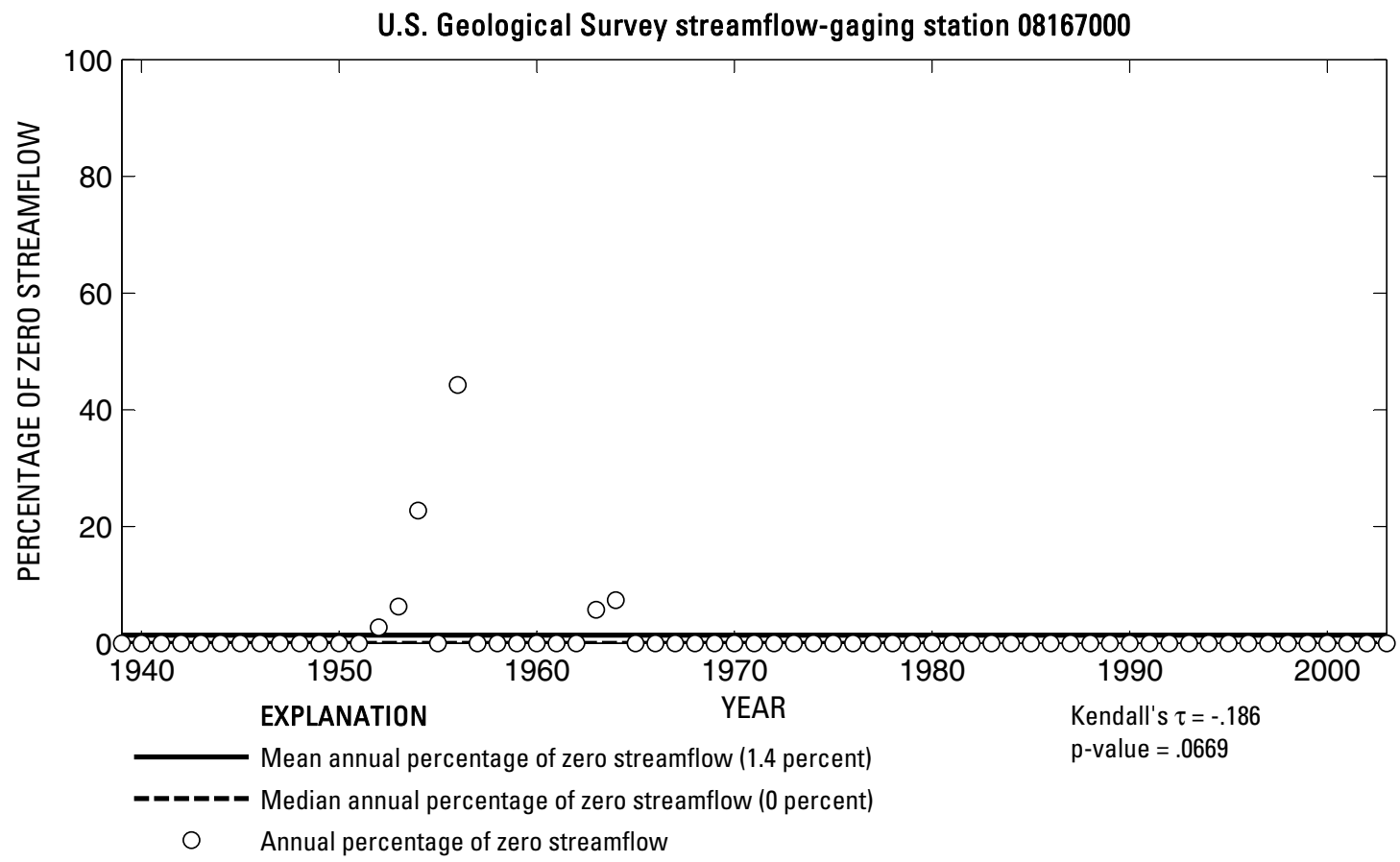

U.S. Geological Survey streamflow-gaging station 08167000

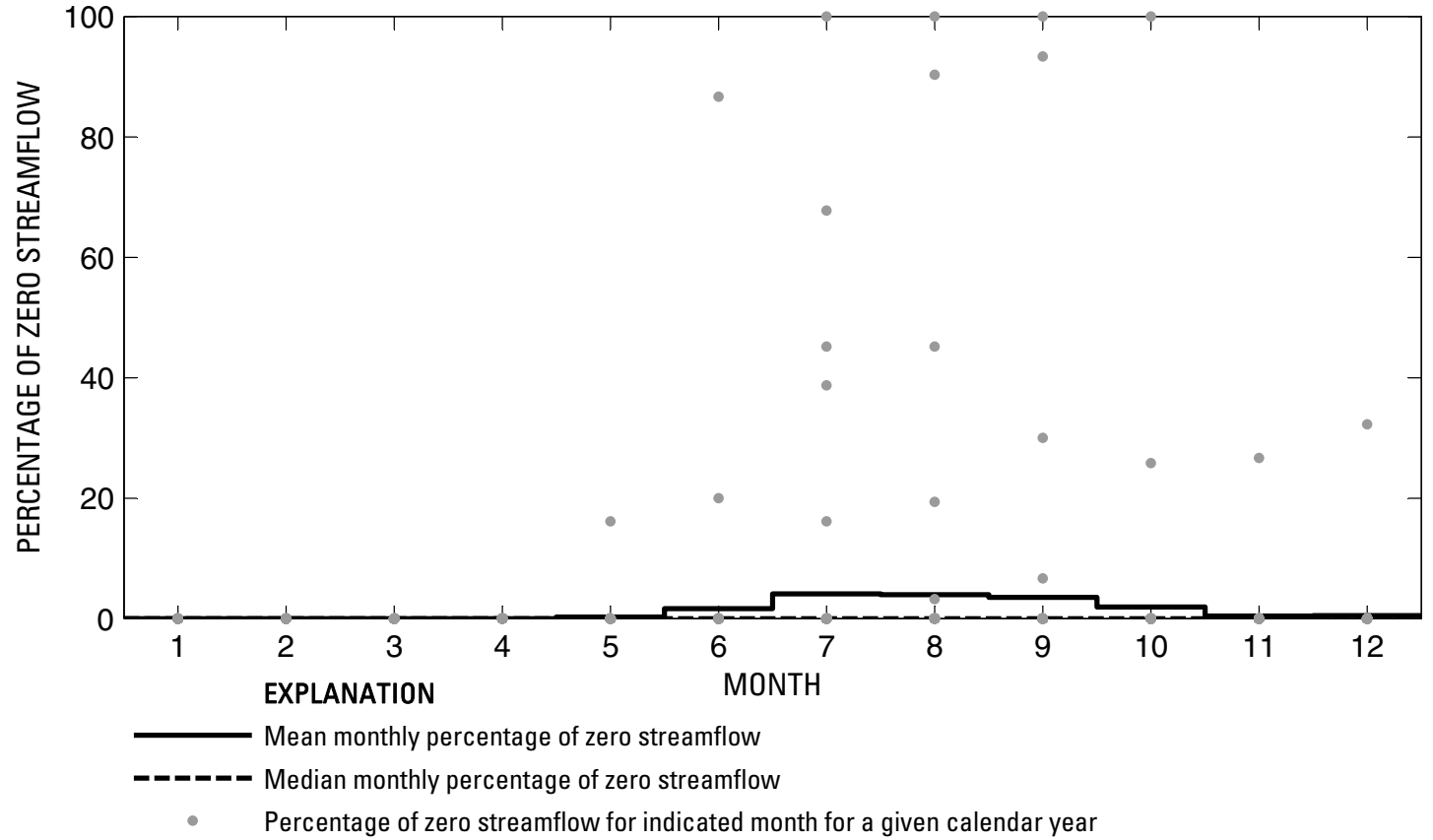

Figure 571. Analysis of percentage of zero daily mean streamflow for U.S. Geological Survey streamflow-gaging station 08167000 Guadalupe River at Comfort, Texas. 
U.S. Geological Survey streamflow-gaging station 08167500

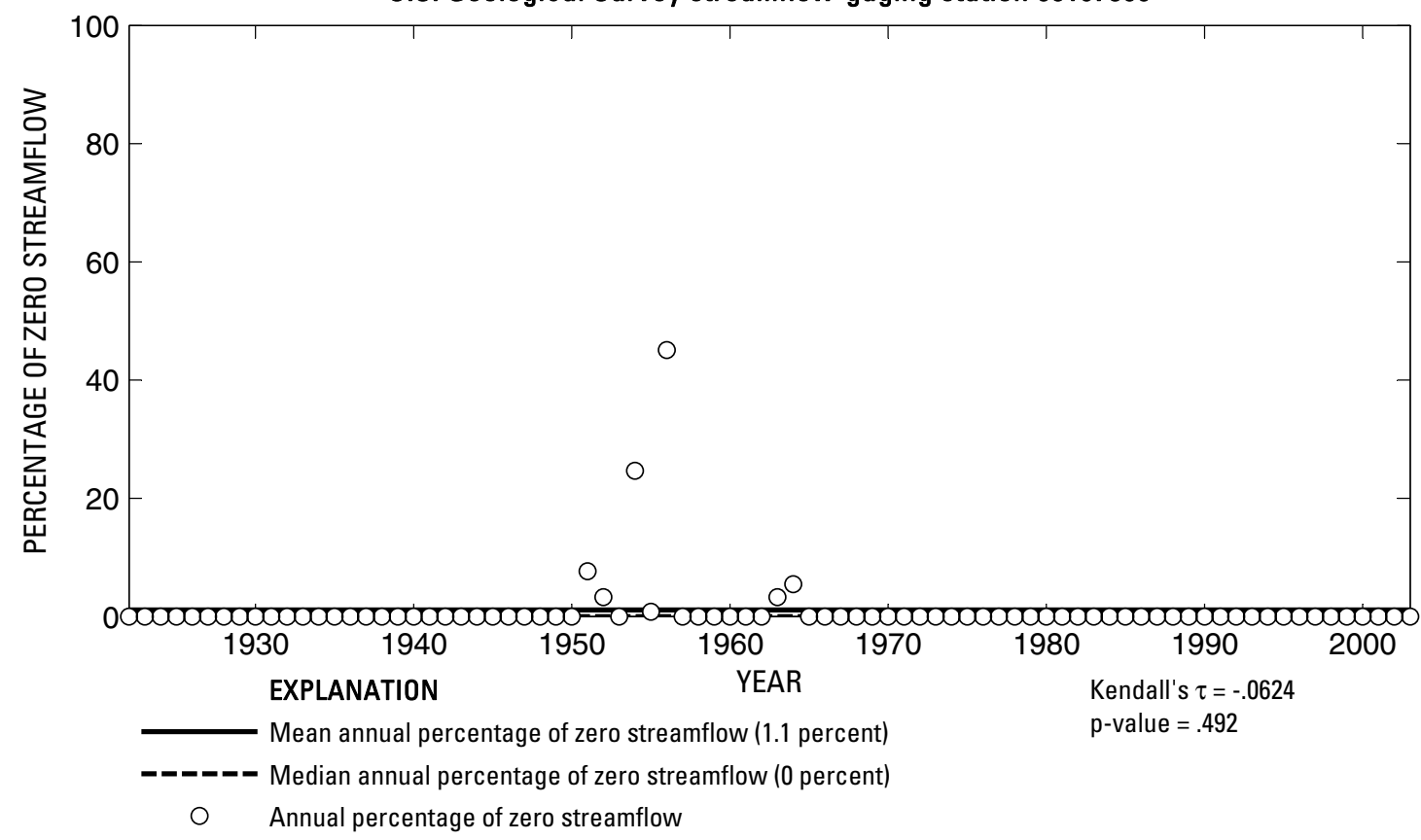

U.S. Geological Survey streamflow-gaging station 08167500

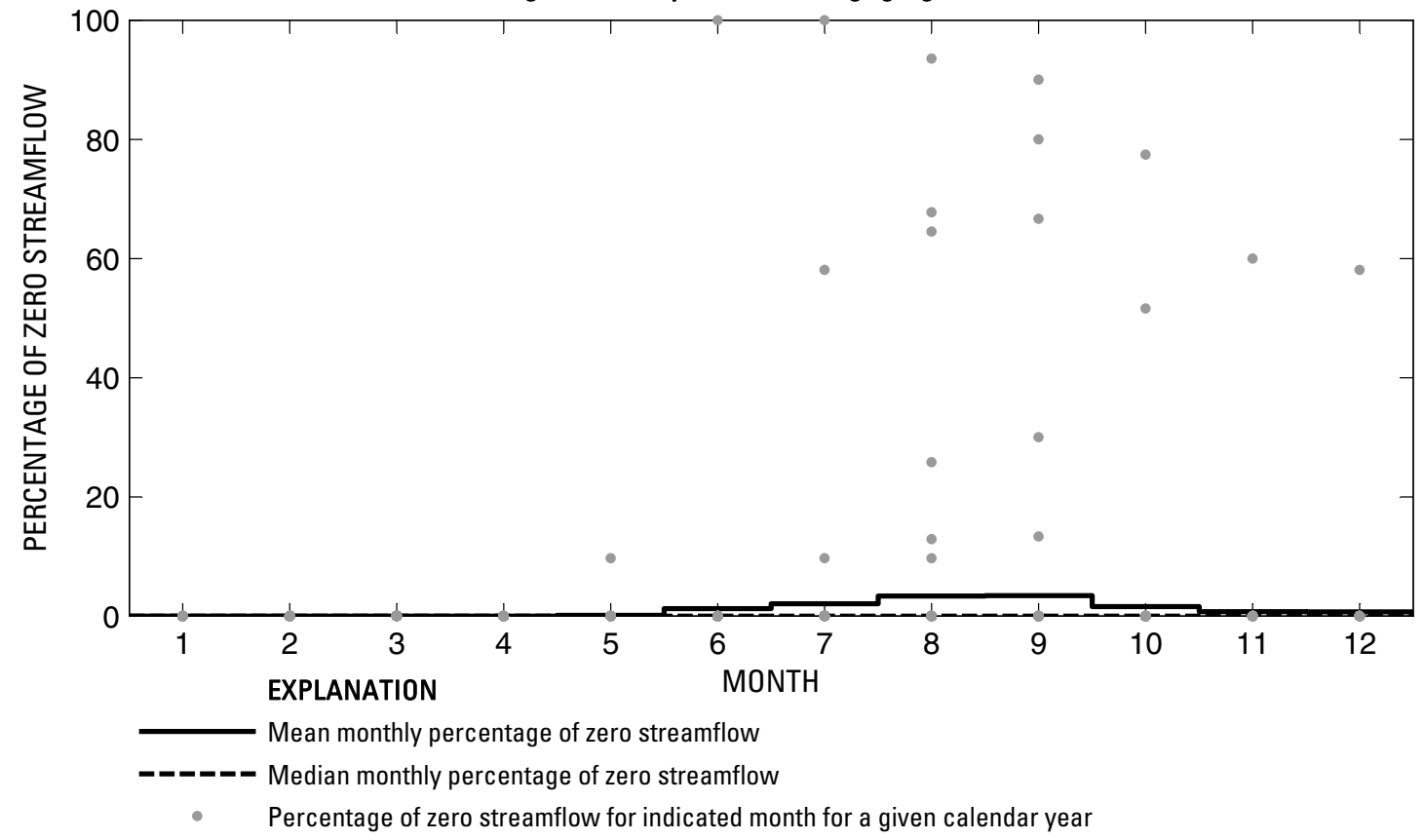

Figure 572. Analysis of percentage of zero daily mean streamflow for U.S. Geological Survey streamflow-gaging station 08167500 Guadalupe River near Spring Branch, Texas. 


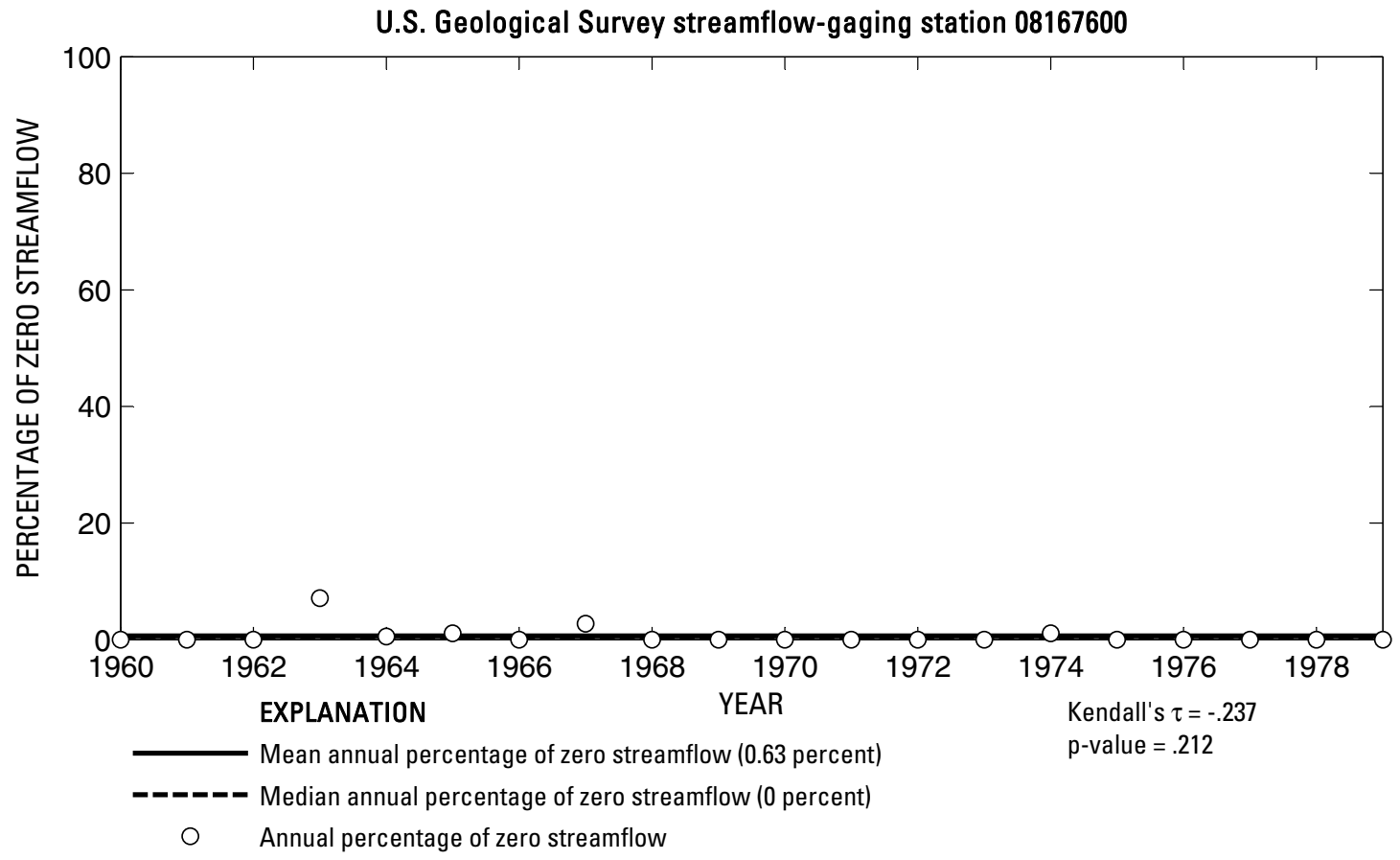

U.S. Geological Survey streamflow-gaging station 08167600

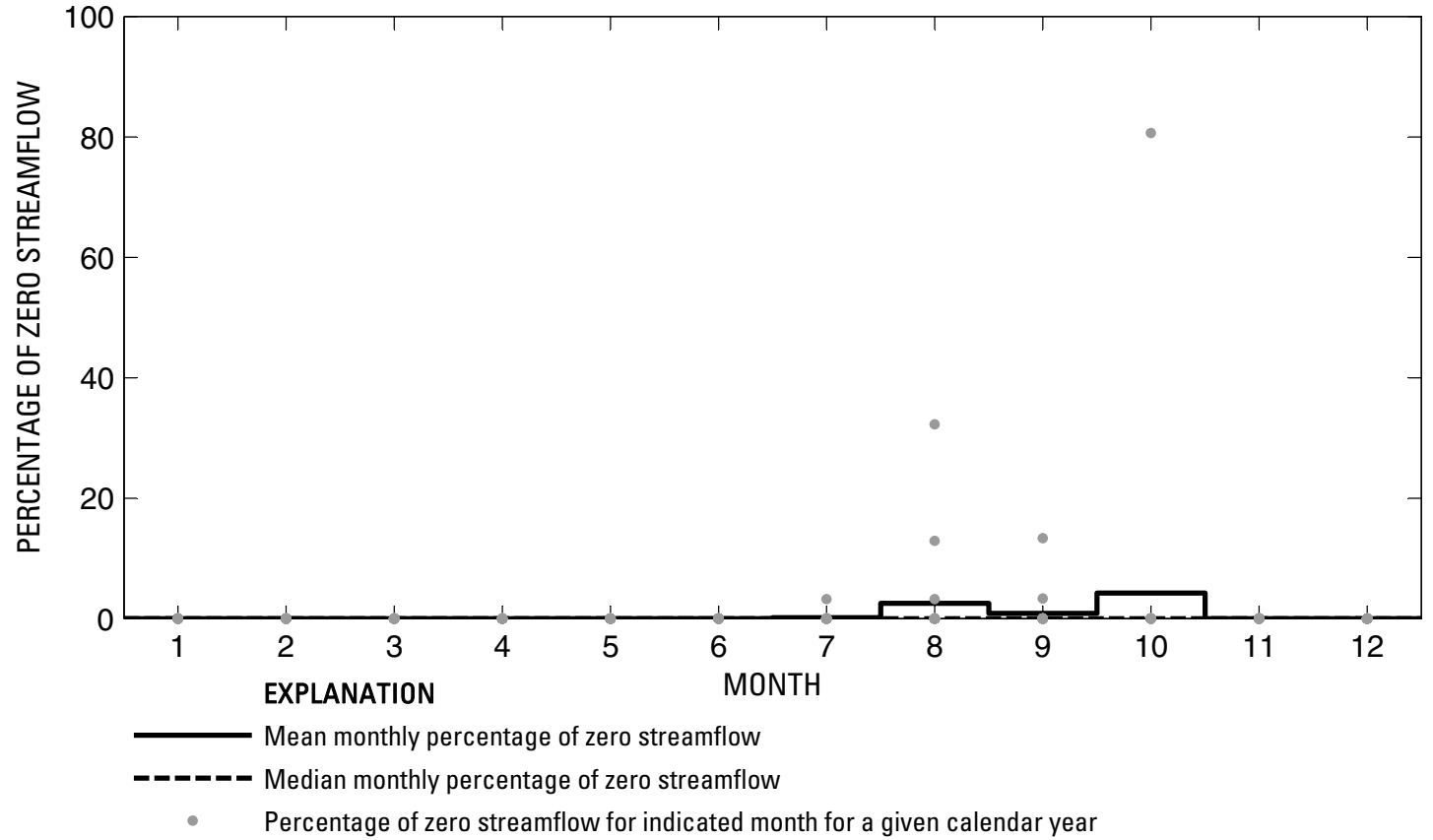

Figure 573. Analysis of percentage of zero daily mean streamflow for U.S. Geological Survey streamflow-gaging station 08167600 Rebecca Creek near Spring Branch, Texas. 
U.S. Geological Survey streamflow-gaging station 08167800

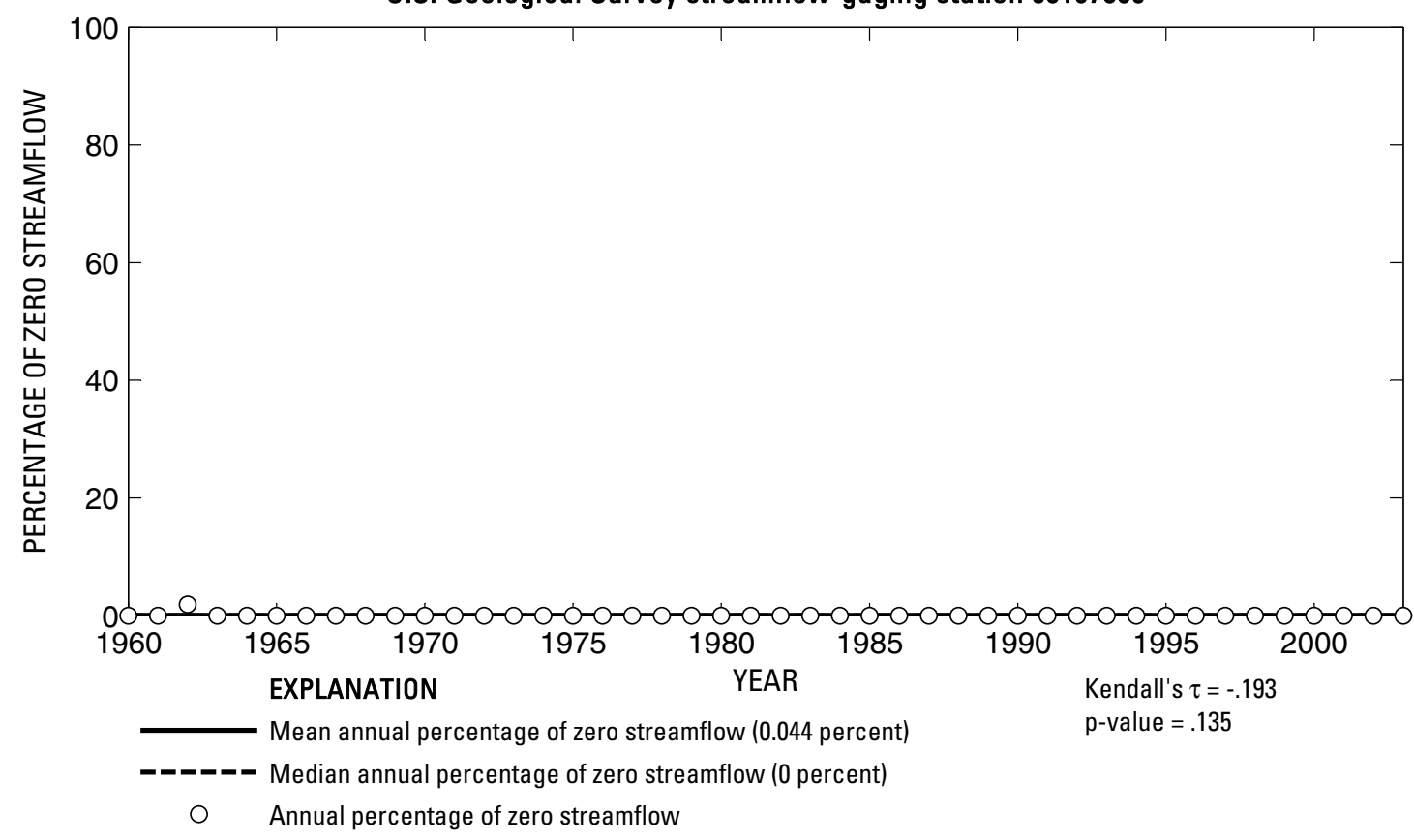

U.S. Geological Survey streamflow-gaging station 08167800

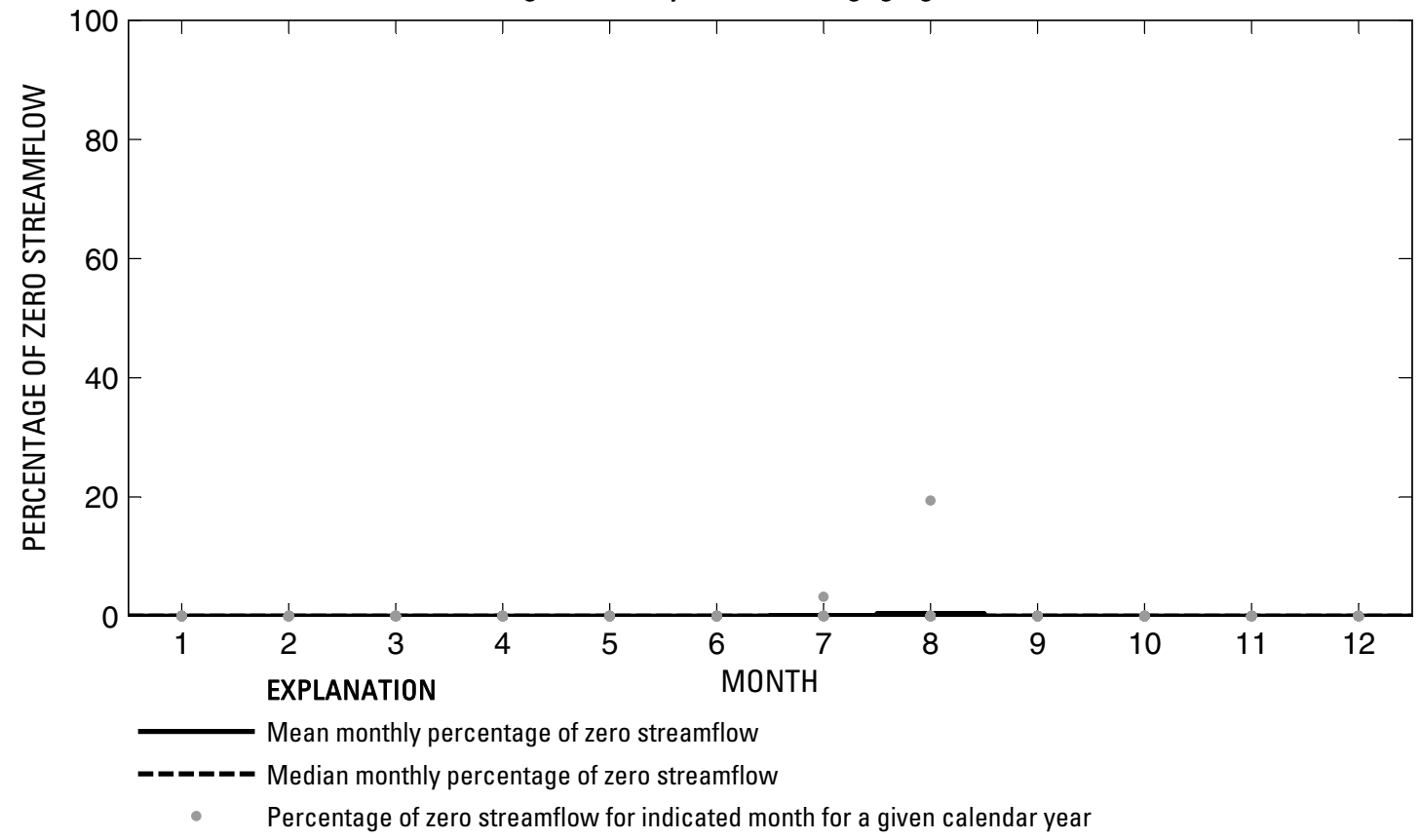

Figure 574. Analysis of percentage of zero daily mean streamflow for U.S. Geological Survey streamflow-gaging station 08167800 Guadalupe River at Sattler, Texas. 


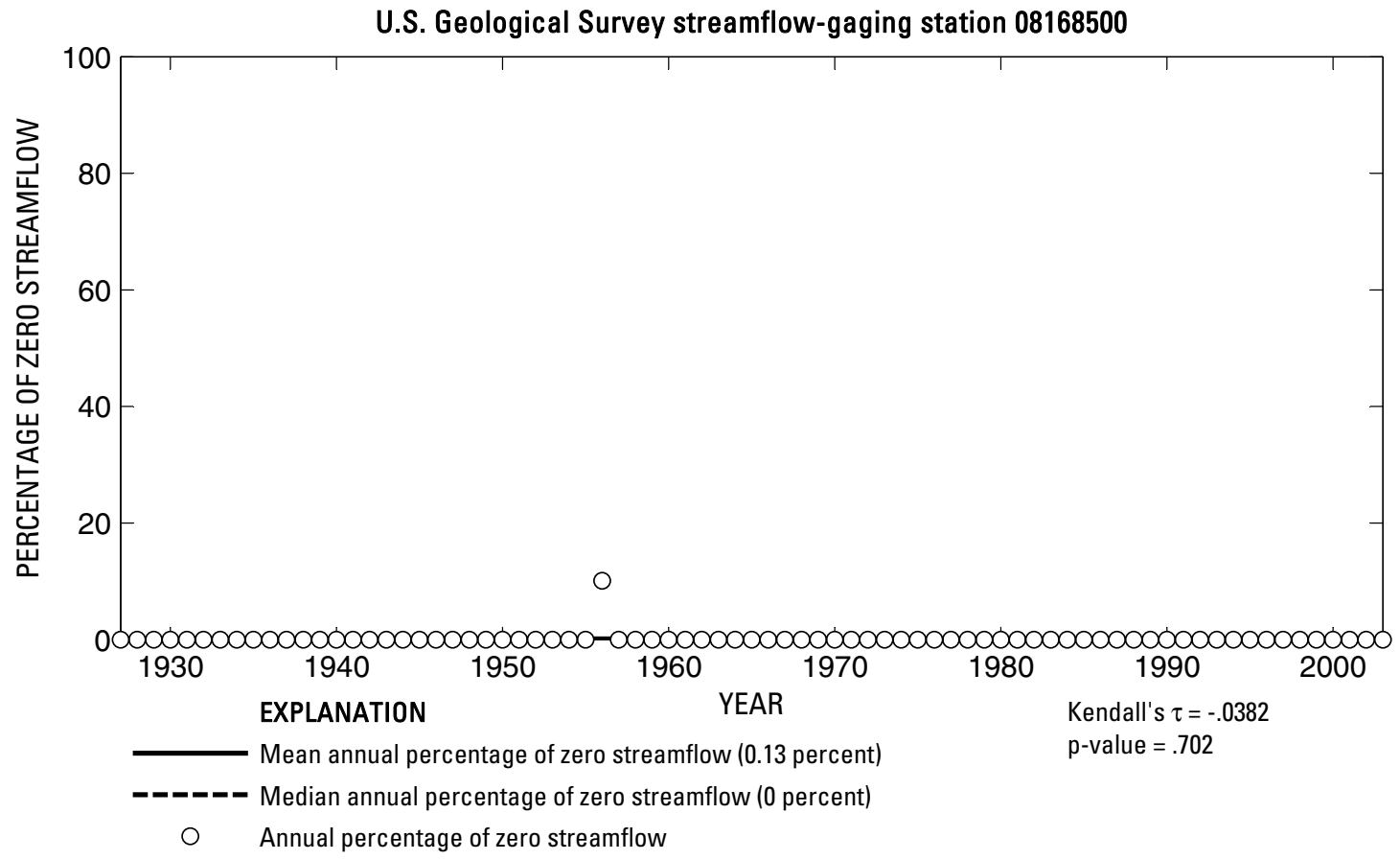

U.S. Geological Survey streamflow-gaging station 08168500

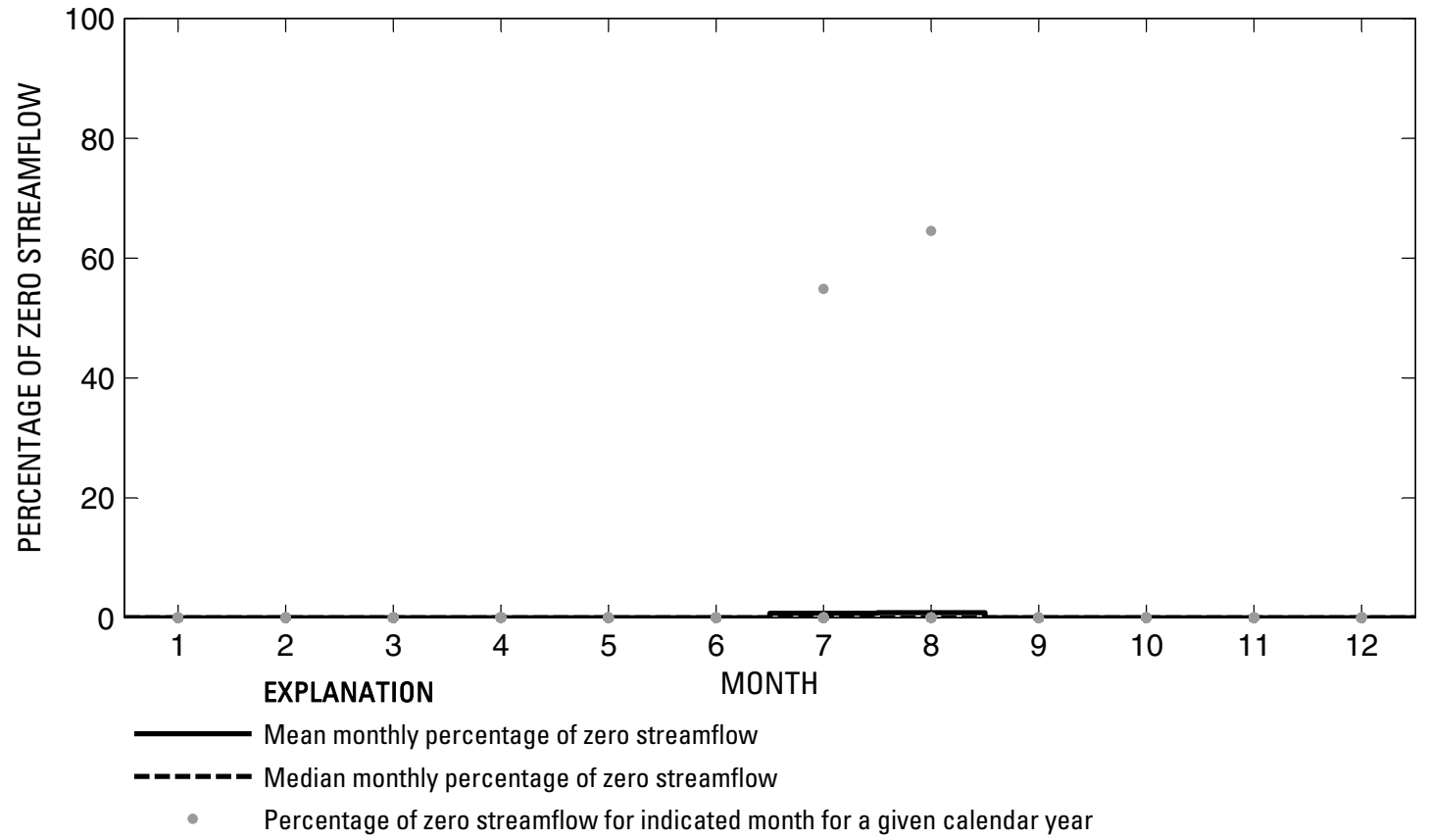

Figure 575. Analysis of percentage of zero daily mean streamflow for U.S. Geological Survey streamflow-gaging station 08168500 Guadalupe River above Comal River at New Braunfels, Texas. 
U.S. Geological Survey streamflow-gaging station 08169000

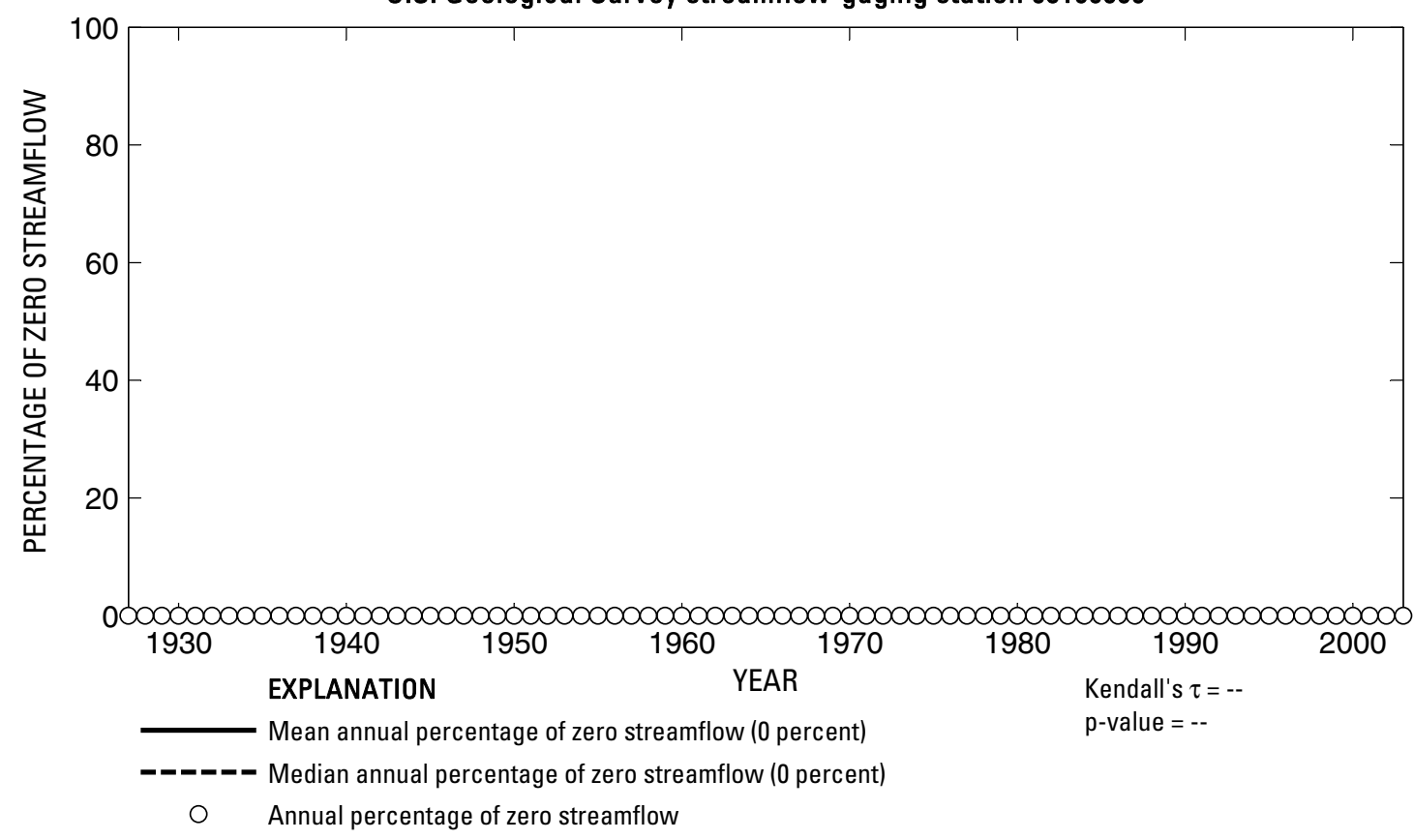

U.S. Geological Survey streamflow-gaging station 08169000

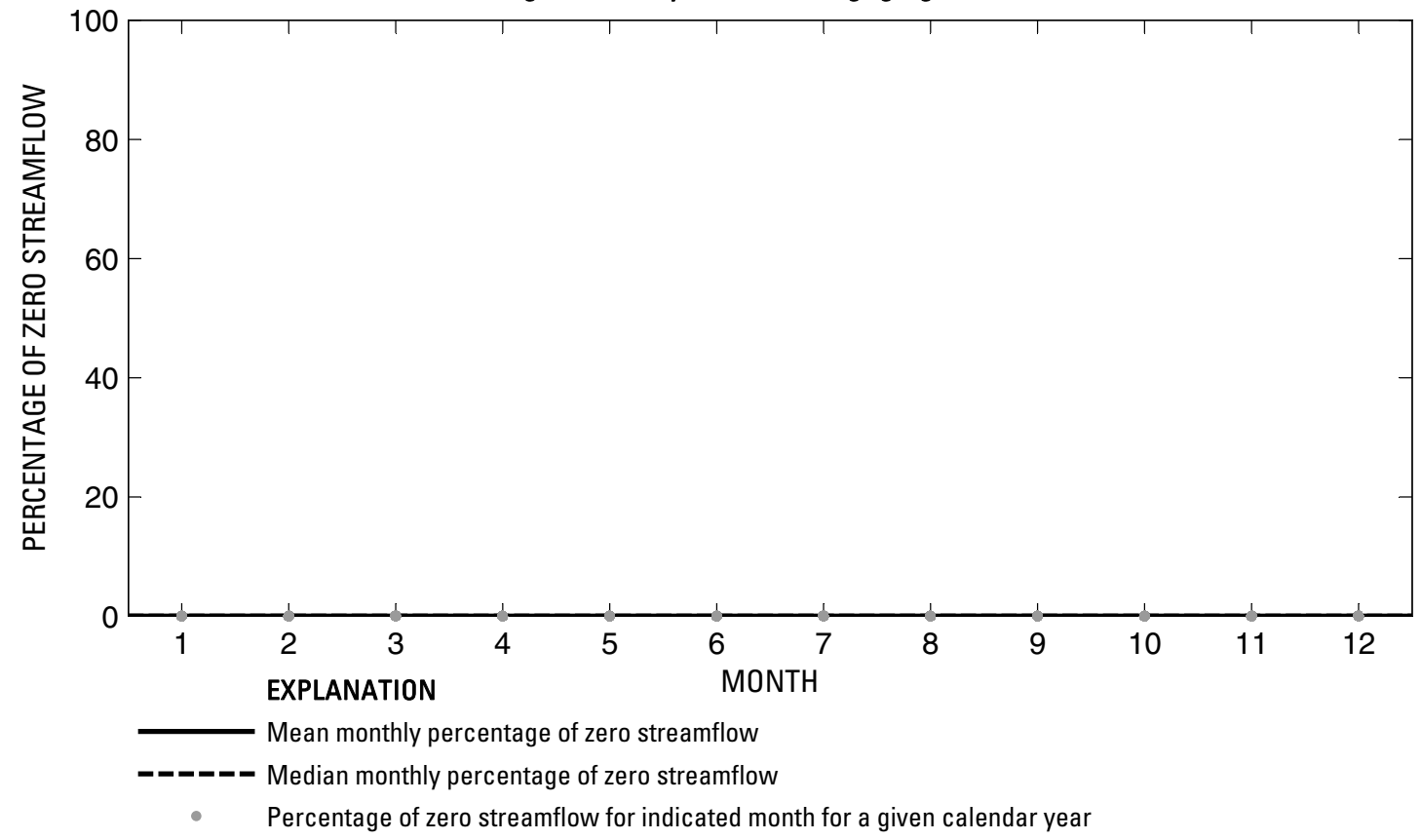

Figure 576. Analysis of percentage of zero daily mean streamflow for U.S. Geological Survey streamflow-gaging station 08169000 Comal River at New Braunfels, Texas. 


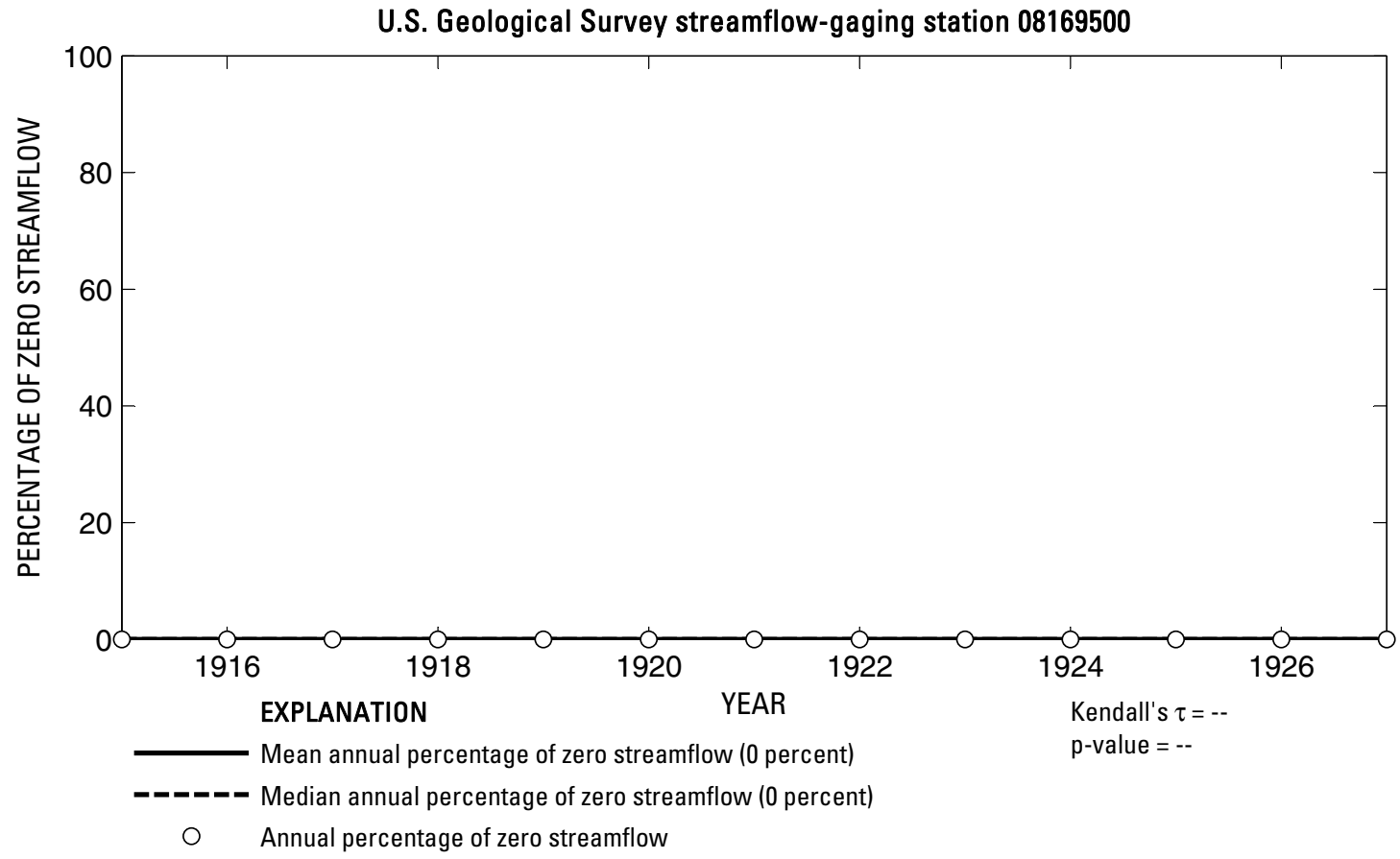

U.S. Geological Survey streamflow-gaging station 08169500

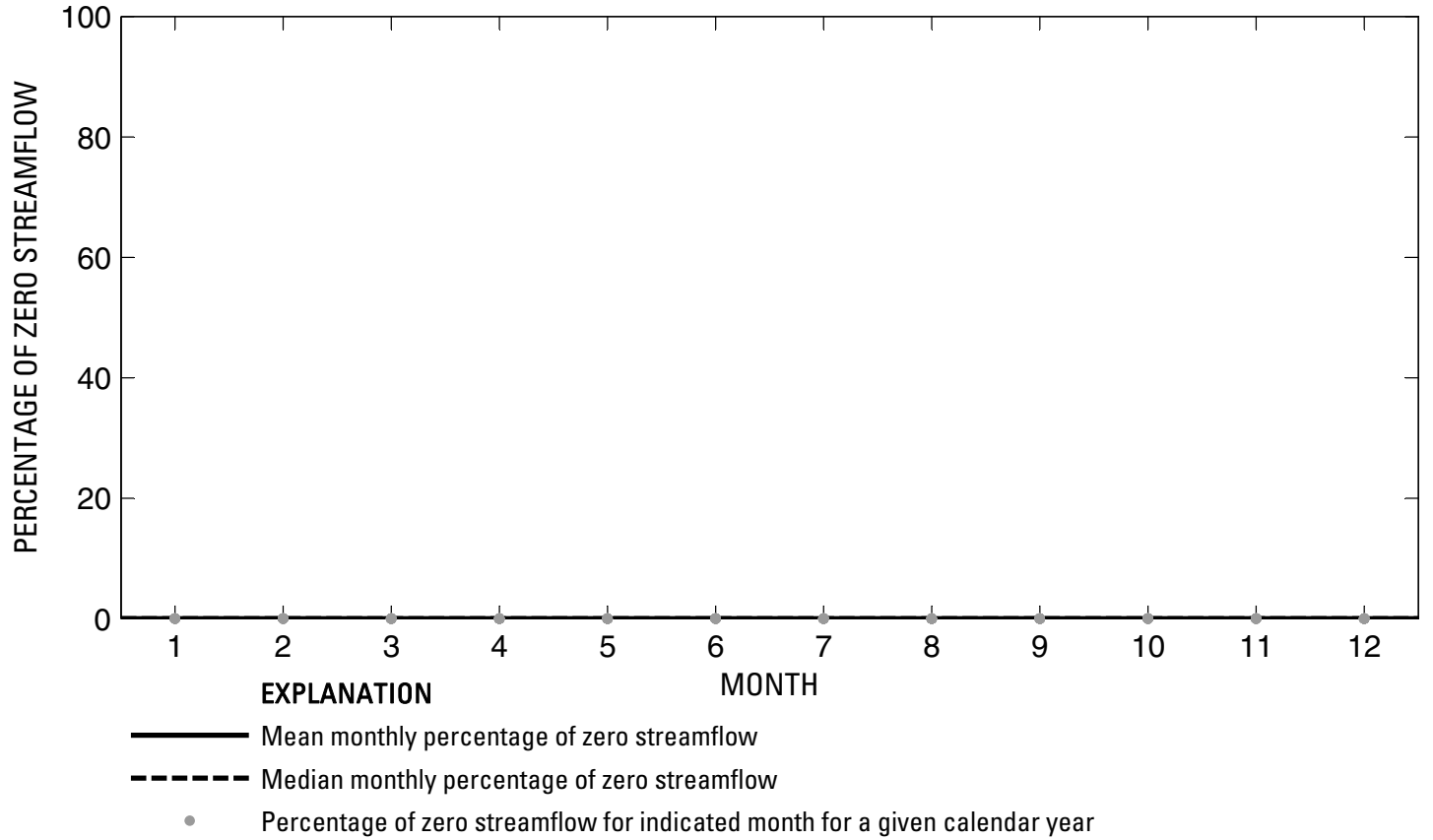

Figure 577. Analysis of percentage of zero daily mean streamflow for U.S. Geological Survey streamflow-gaging station 08169500 Guadalupe River at New Braunfels, Texas. 
U.S. Geological Survey streamflow-gaging station 08170500

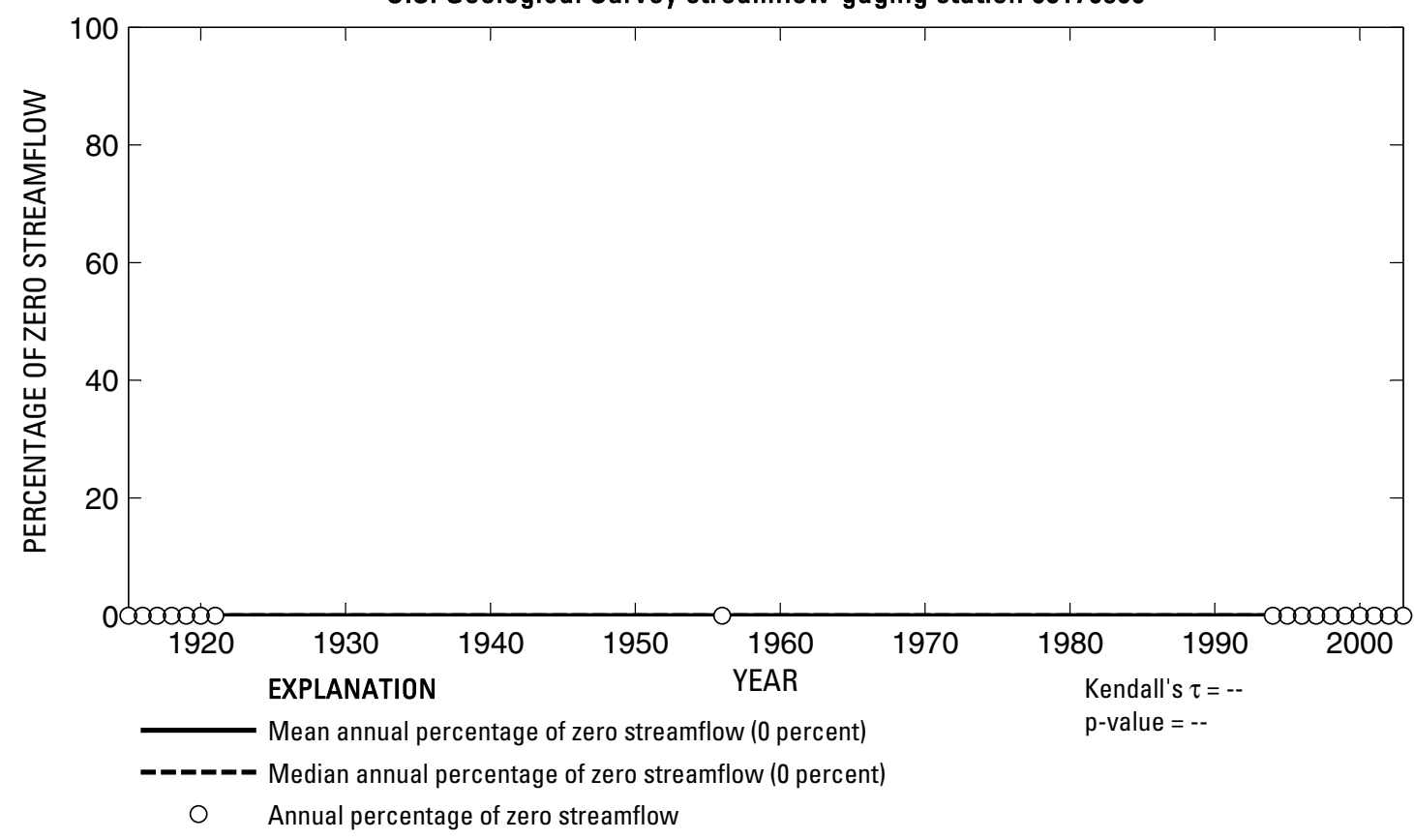

U.S. Geological Survey streamflow-gaging station 08170500

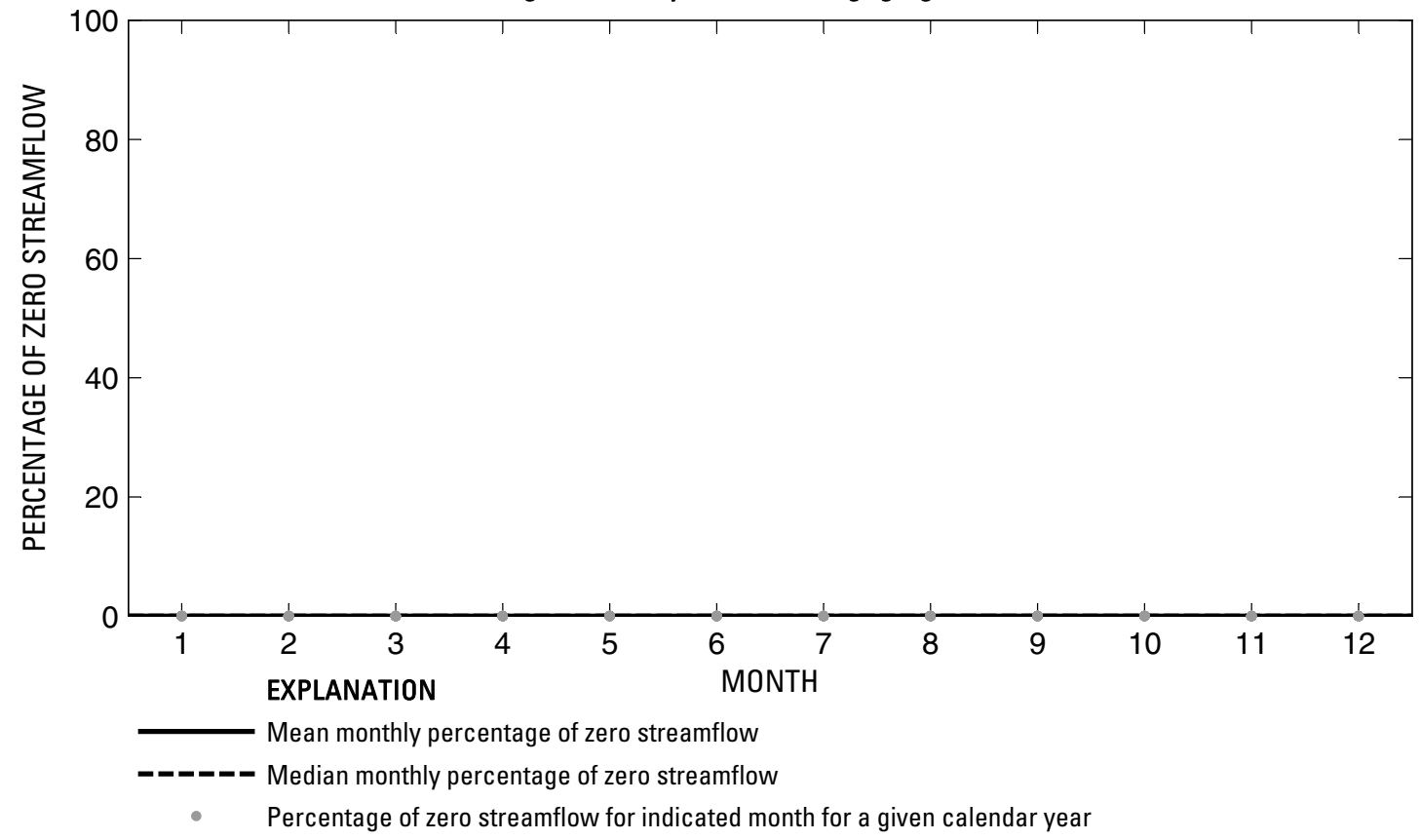

Figure 578. Analysis of percentage of zero daily mean streamflow for U.S. Geological Survey streamflow-gaging station 08170500 San Marcos River at San Marcos, Texas. 
U.S. Geological Survey streamflow-gaging station 08171000

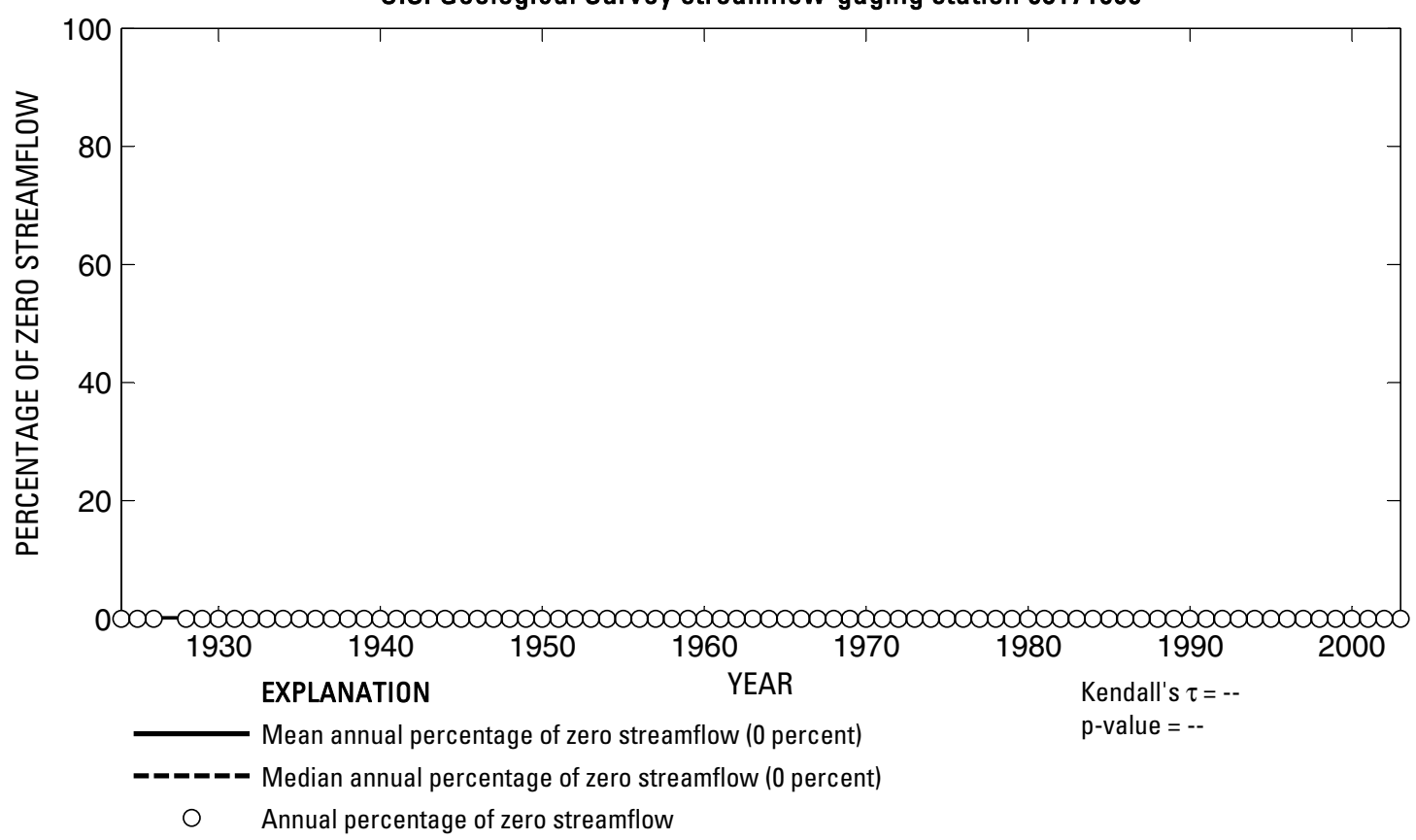

U.S. Geological Survey streamflow-gaging station 08171000

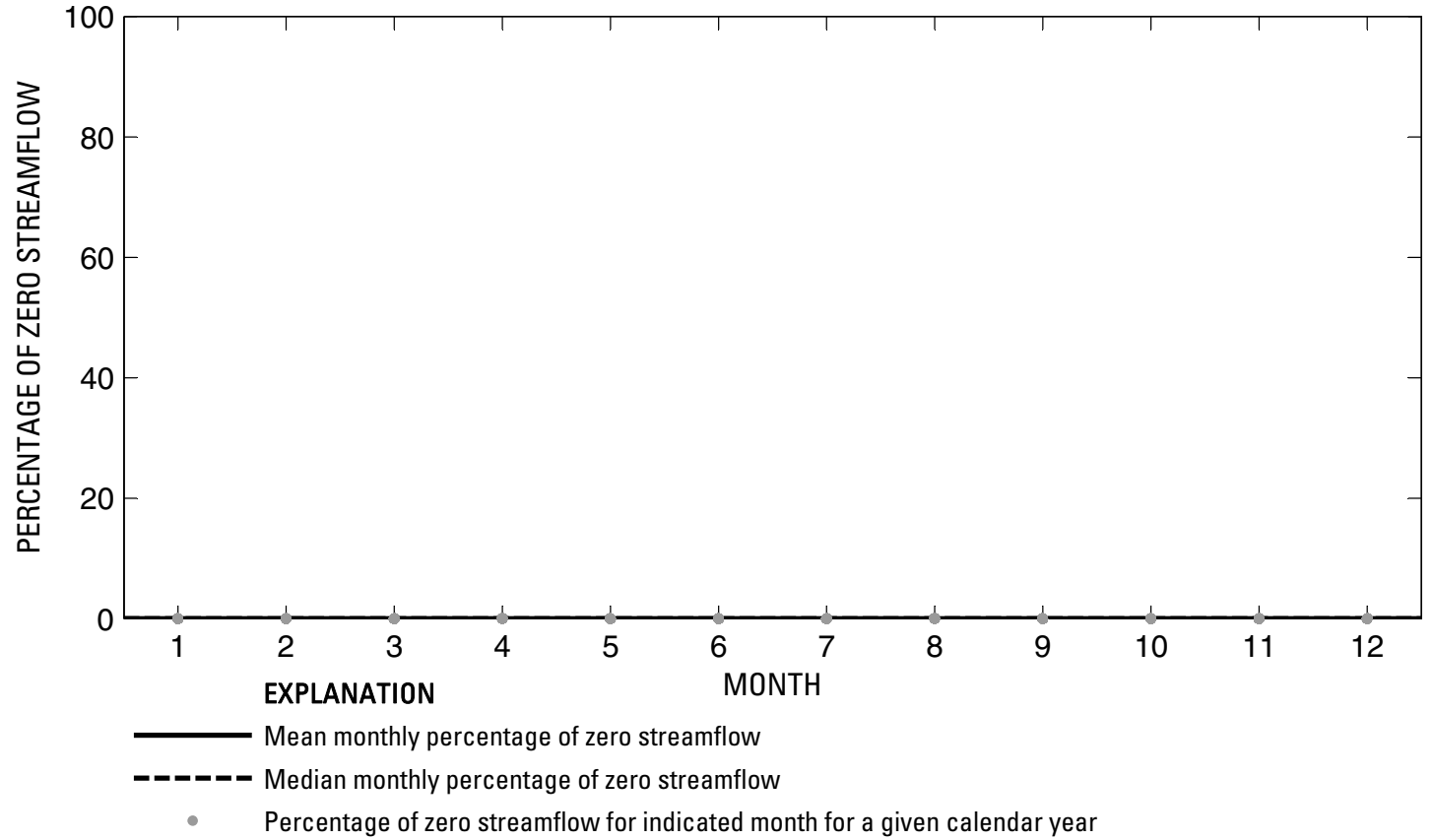

Figure 579. Analysis of percentage of zero daily mean streamflow for U.S. Geological Survey streamflow-gaging station 08171000 Blanco River at Wimberley, Texas. 
U.S. Geological Survey streamflow-gaging station 08171300

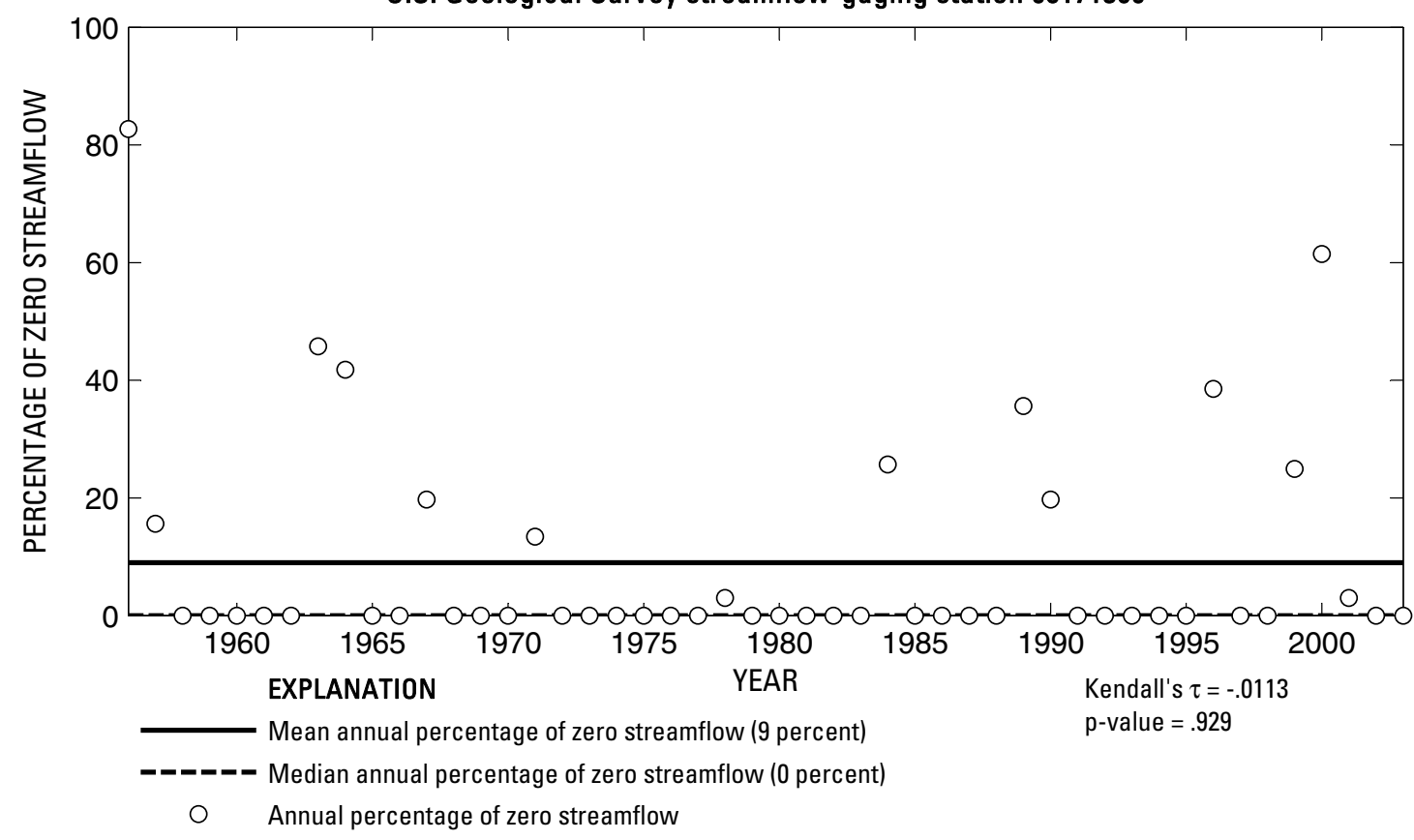

U.S. Geological Survey streamflow-gaging station 08171300

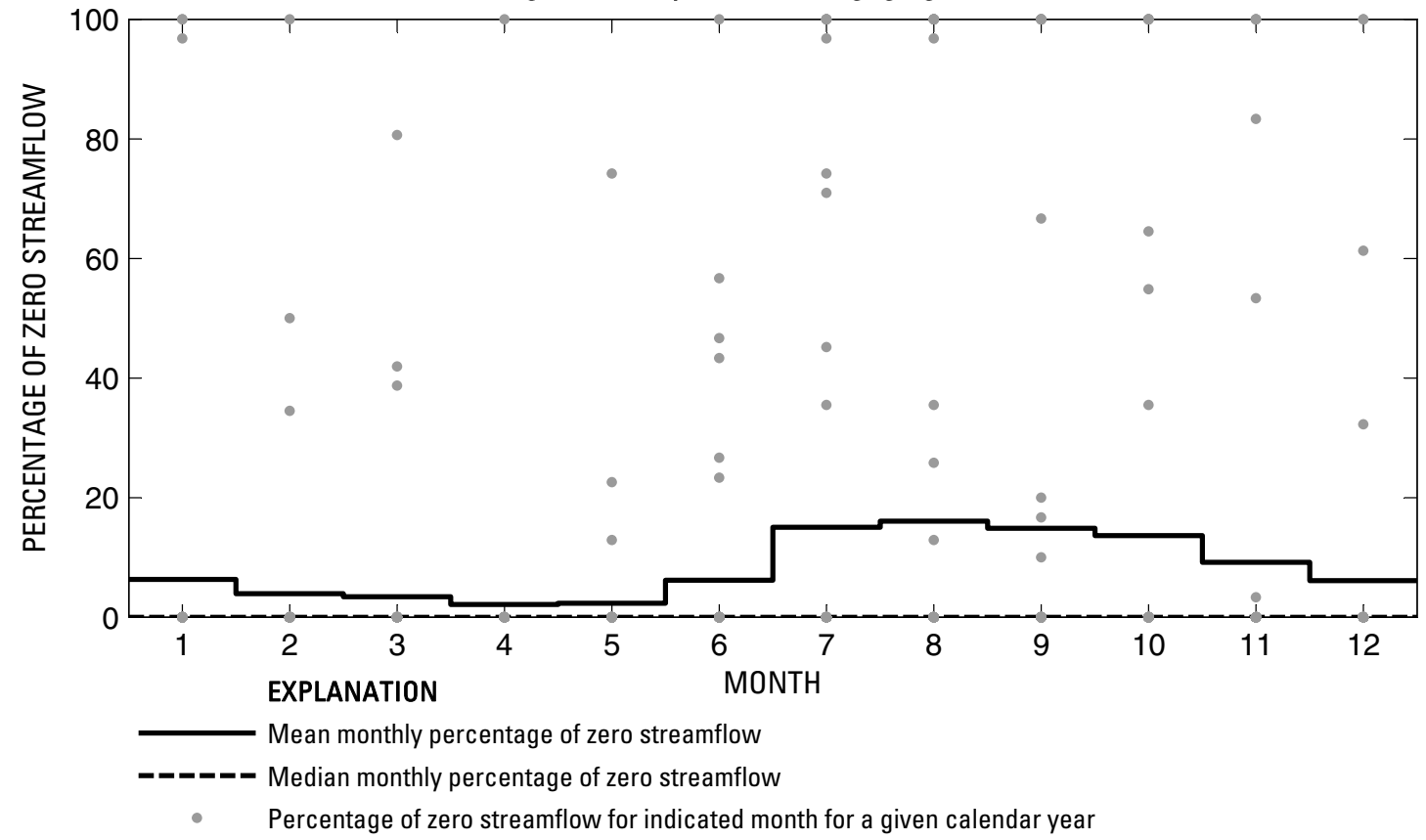

Figure 580. Analysis of percentage of zero daily mean streamflow for U.S. Geological Survey streamflow-gaging station 08171300 Blanco River near Kyle, Texas. 
U.S. Geological Survey streamflow-gaging station 08172000

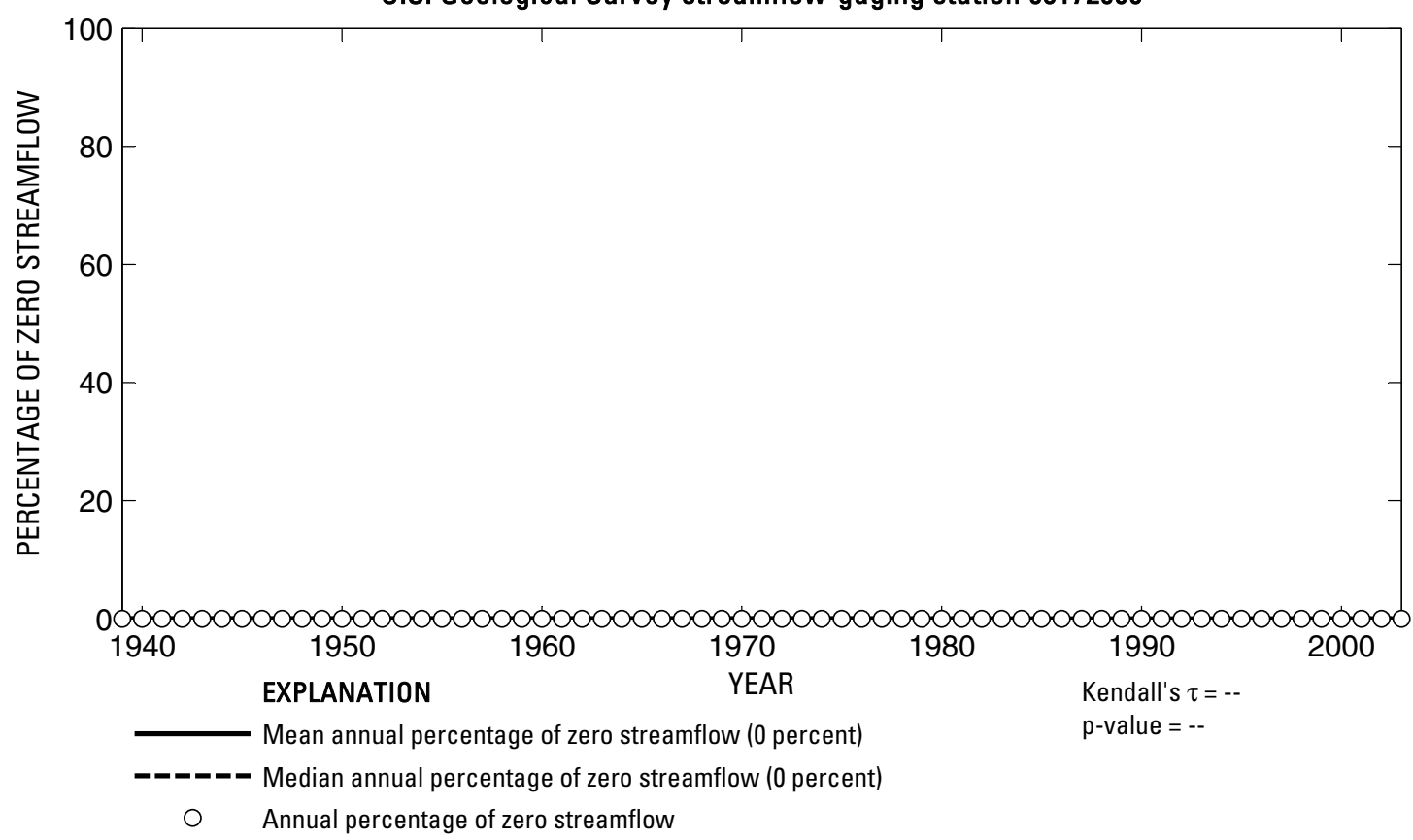

U.S. Geological Survey streamflow-gaging station 08172000

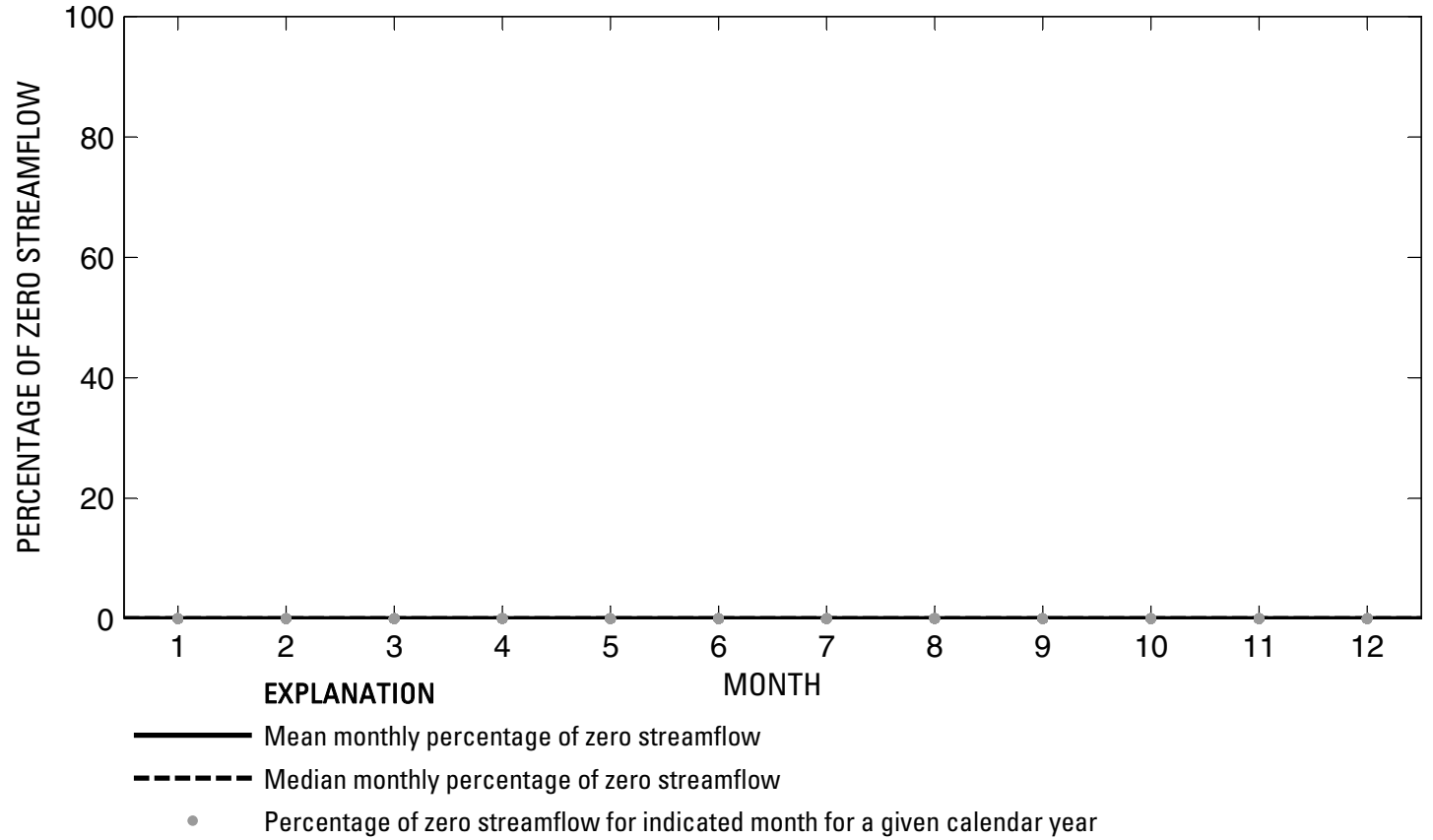

Figure 581. Analysis of percentage of zero daily mean streamflow for U.S. Geological Survey streamflow-gaging station 08172000 San Marcos River at Luling, Texas. 
U.S. Geological Survey streamflow-gaging station 08172400

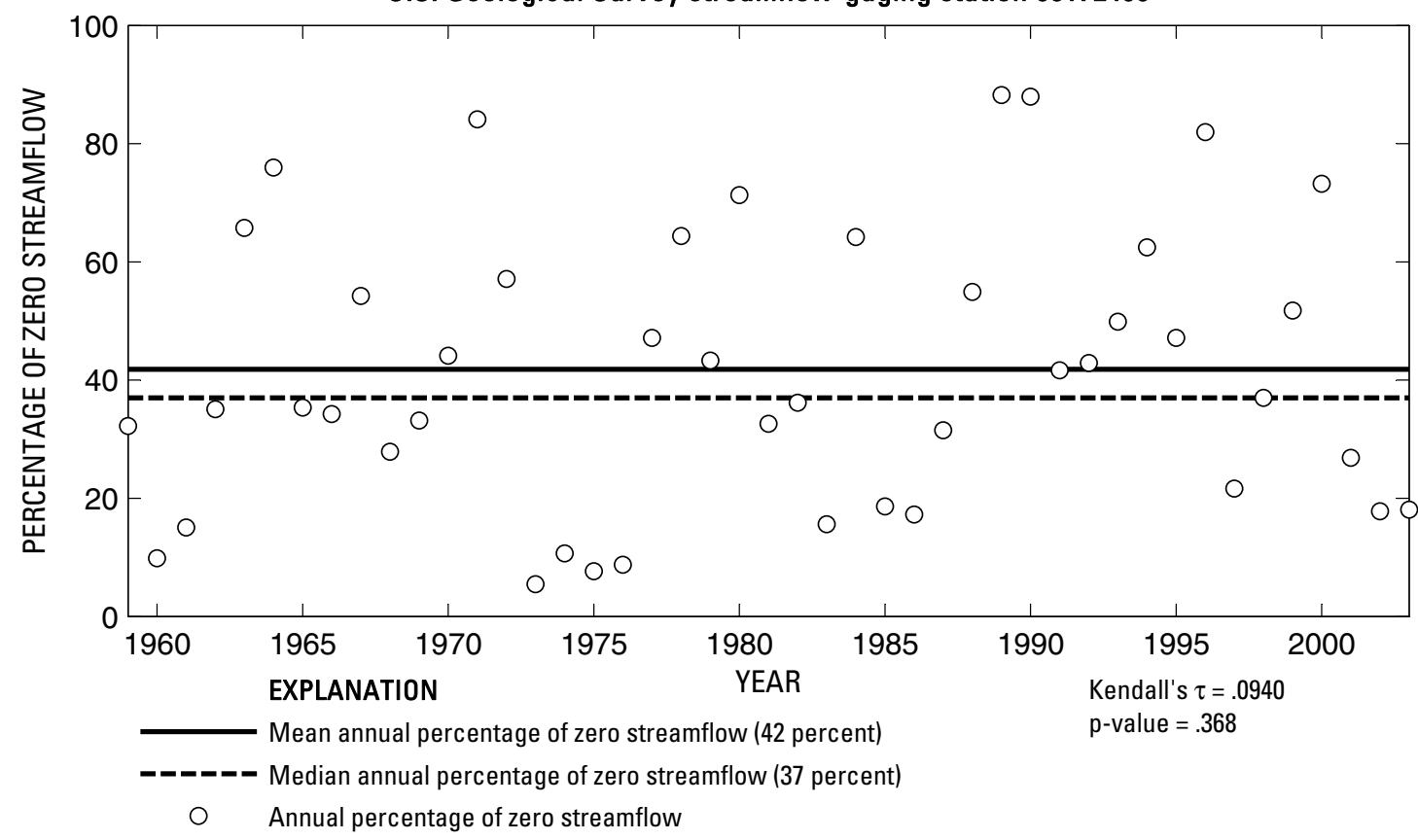

U.S. Geological Survey streamflow-gaging station 08172400

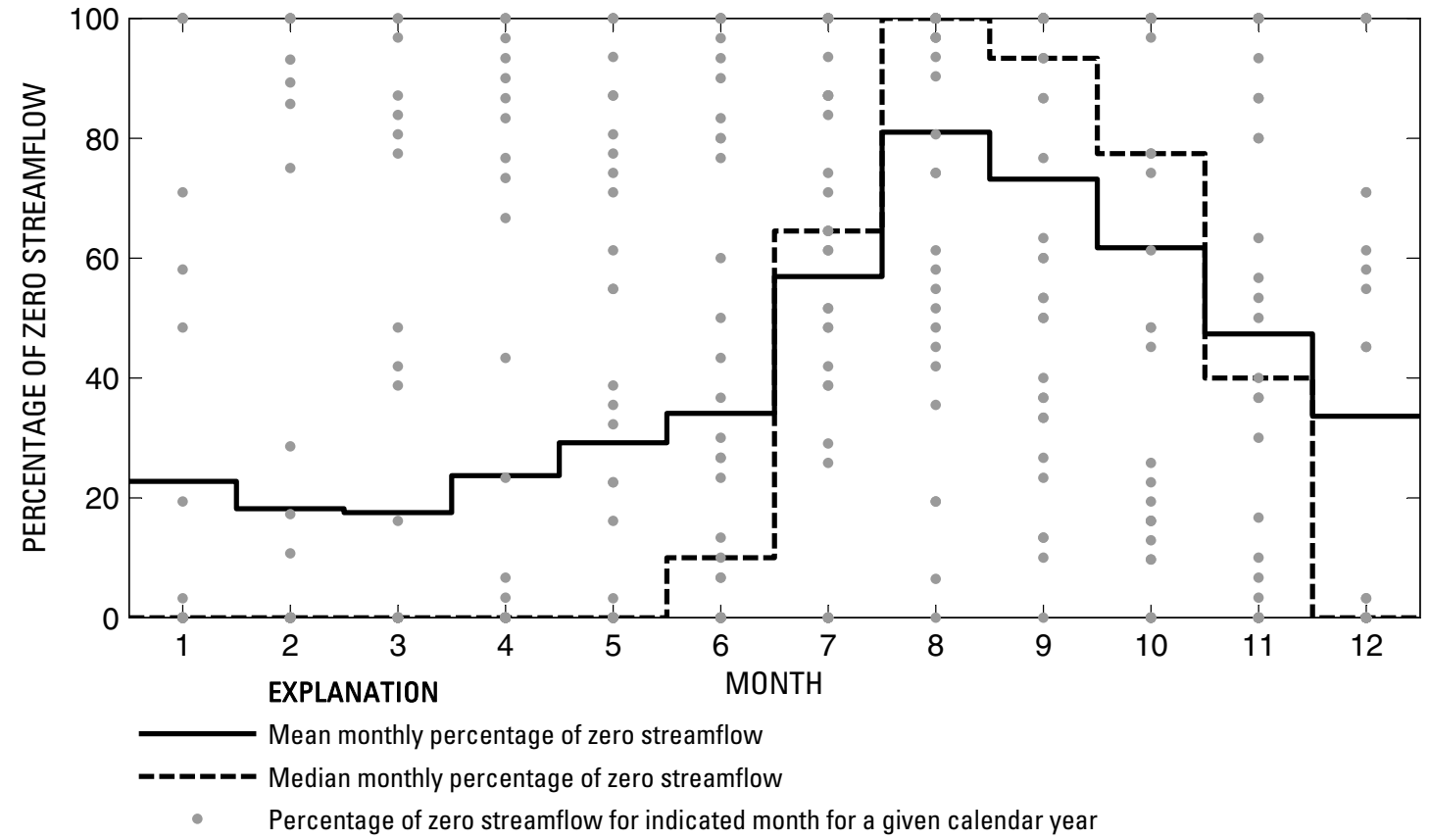

Figure 582. Analysis of percentage of zero daily mean streamflow for U.S. Geological Survey streamflow-gaging station 08172400 Plum Creek at Lockhart, Texas.

Index of Station Numbers 719 
U.S. Geological Survey streamflow-gaging station 08172500

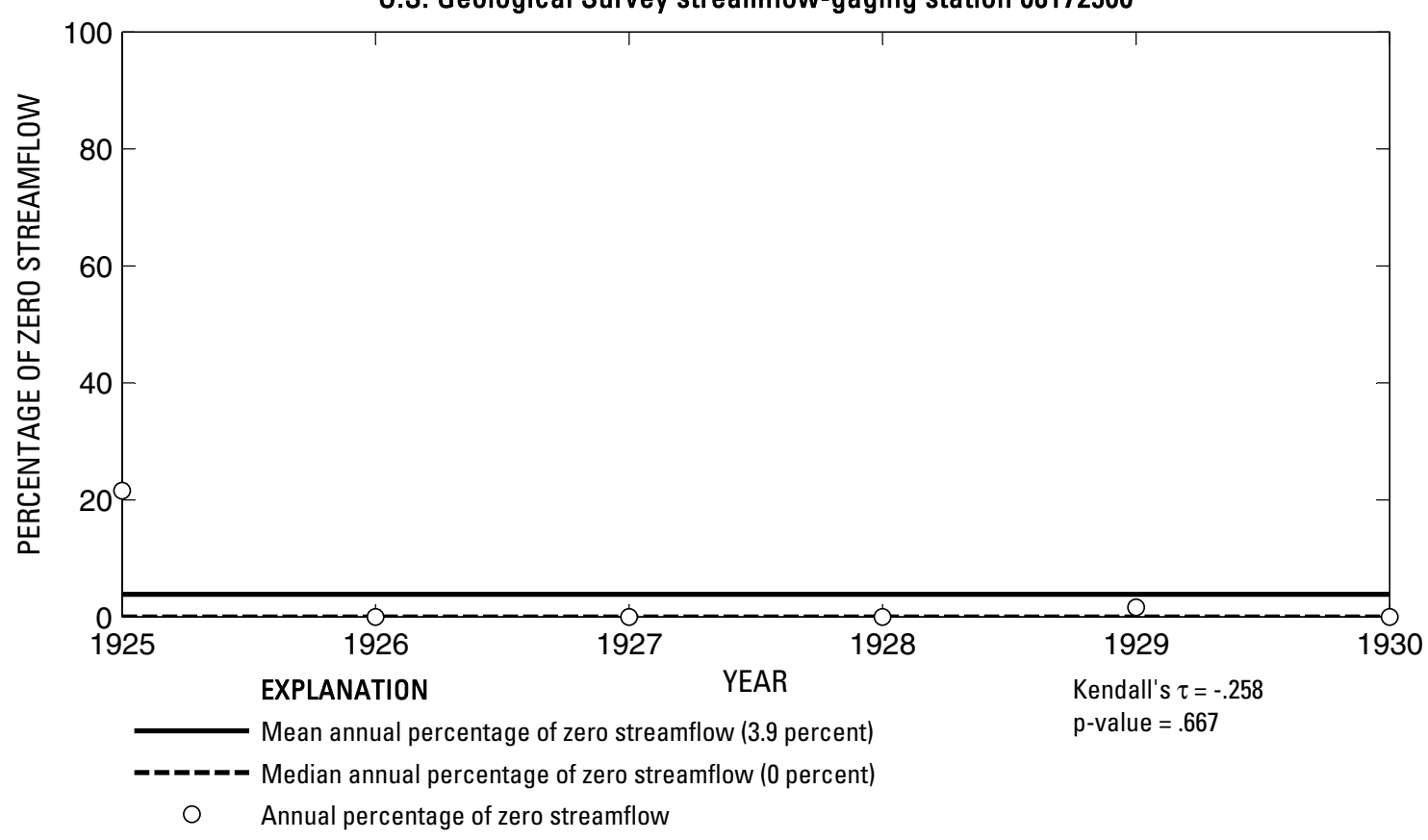

U.S. Geological Survey streamflow-gaging station 08172500

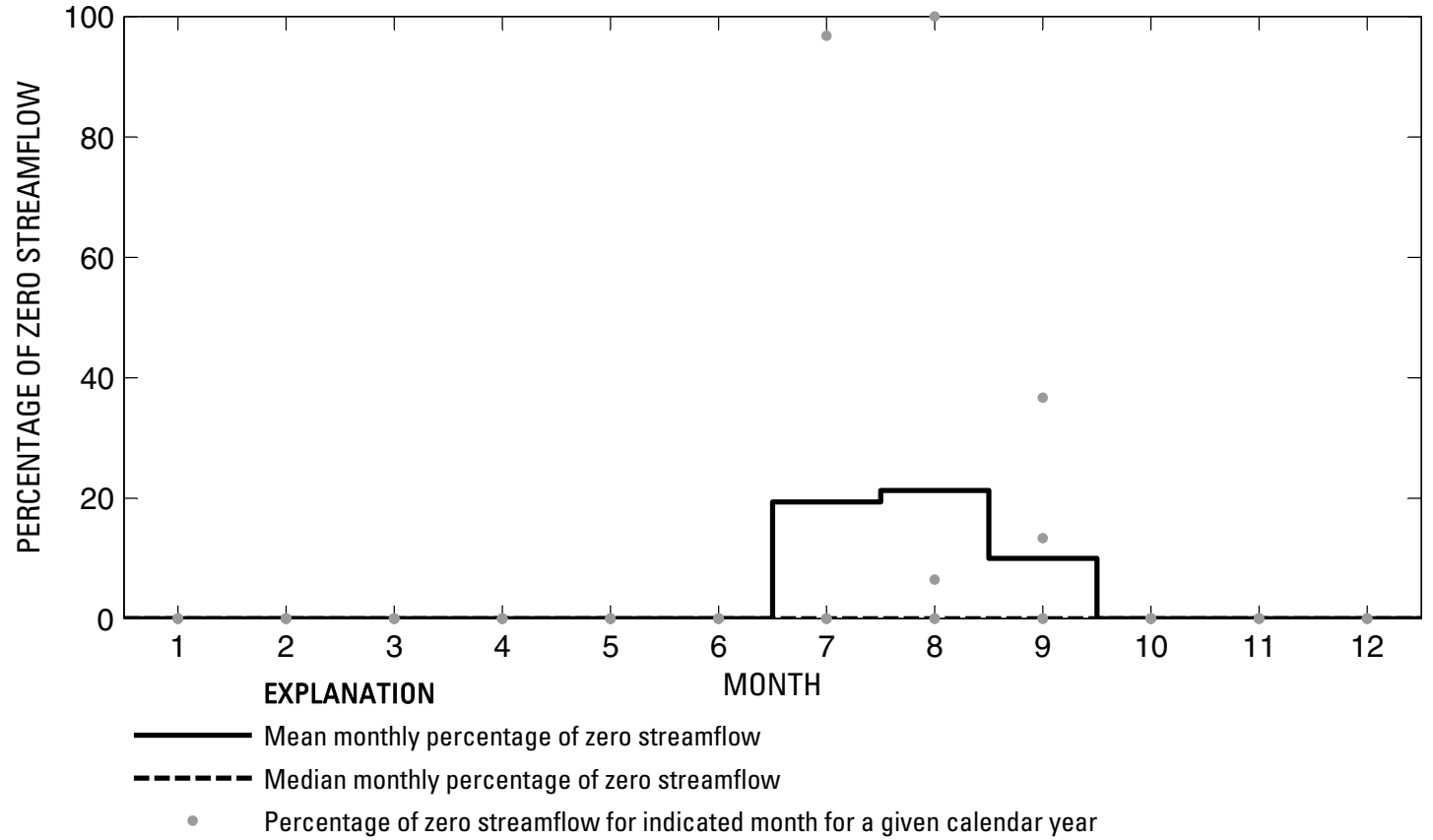

Figure 583. Analysis of percentage of zero daily mean streamflow for U.S. Geological Survey streamflow-gaging station 08172500 Plum Creek near Lockhart, Texas. 
U.S. Geological Survey streamflow-gaging station 08173000

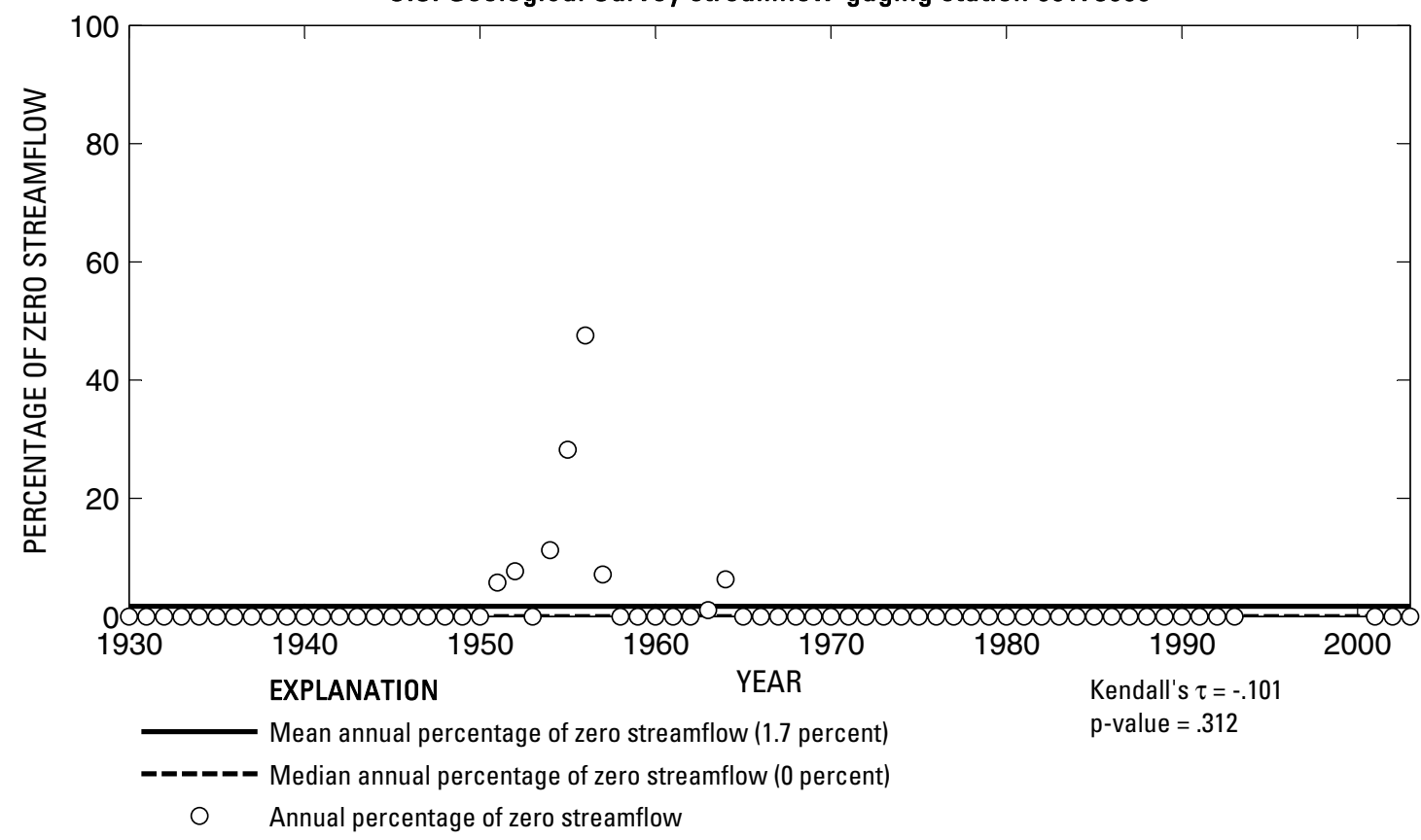

U.S. Geological Survey streamflow-gaging station 08173000

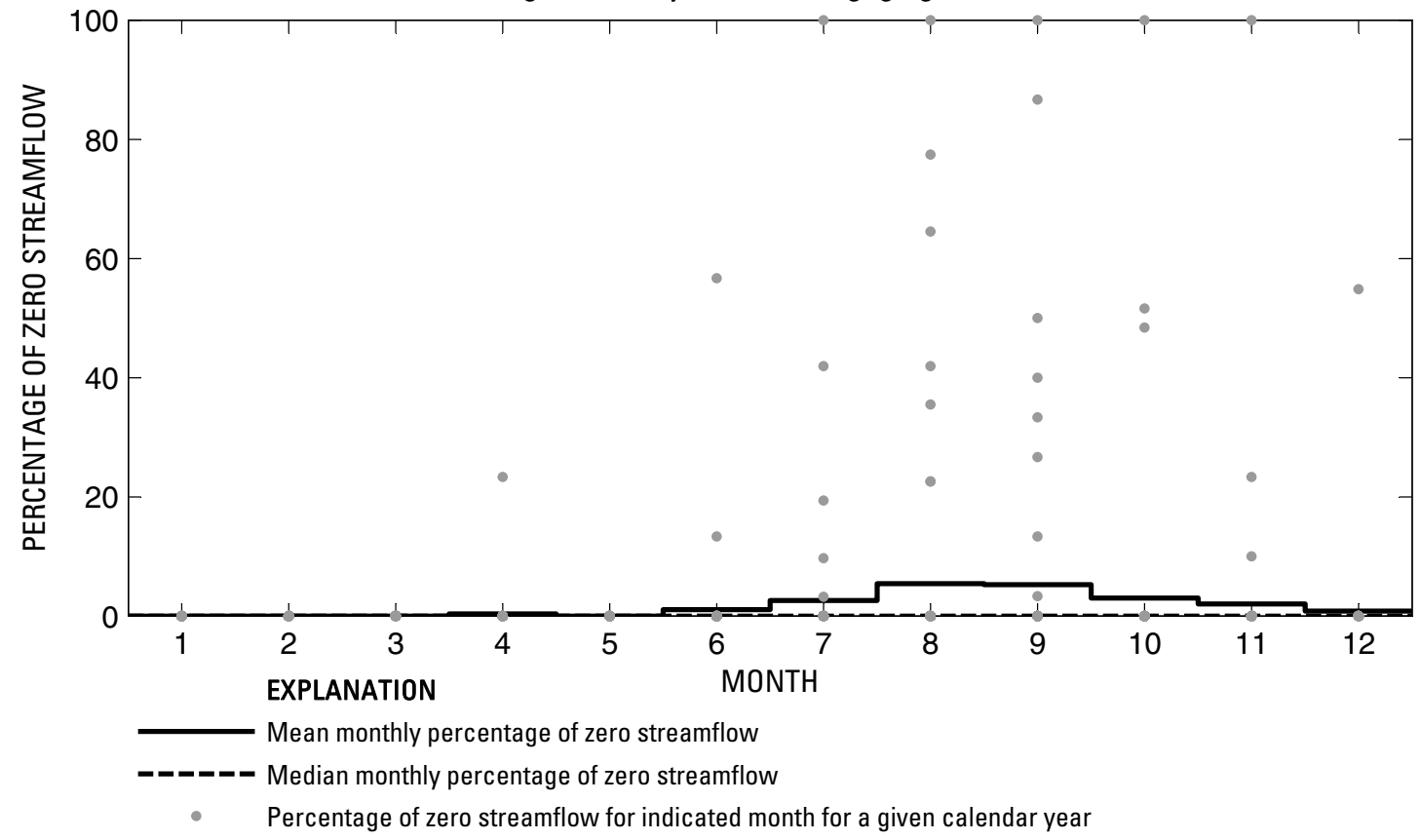

Figure 584. Analysis of percentage of zero daily mean streamflow for U.S. Geological Survey streamflow-gaging station 08173000 Plum Creek near Luling, Texas. 


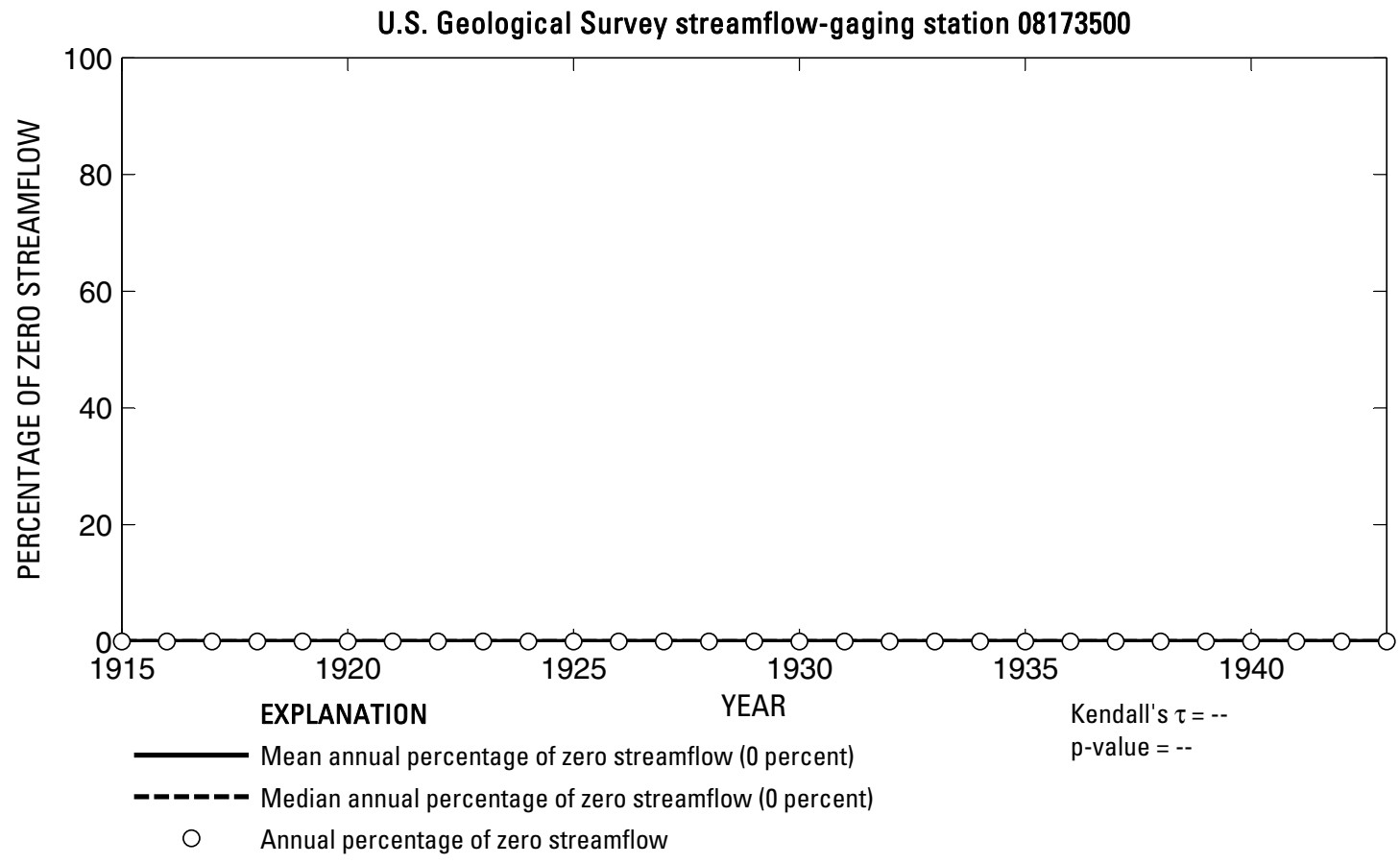

U.S. Geological Survey streamflow-gaging station 08173500

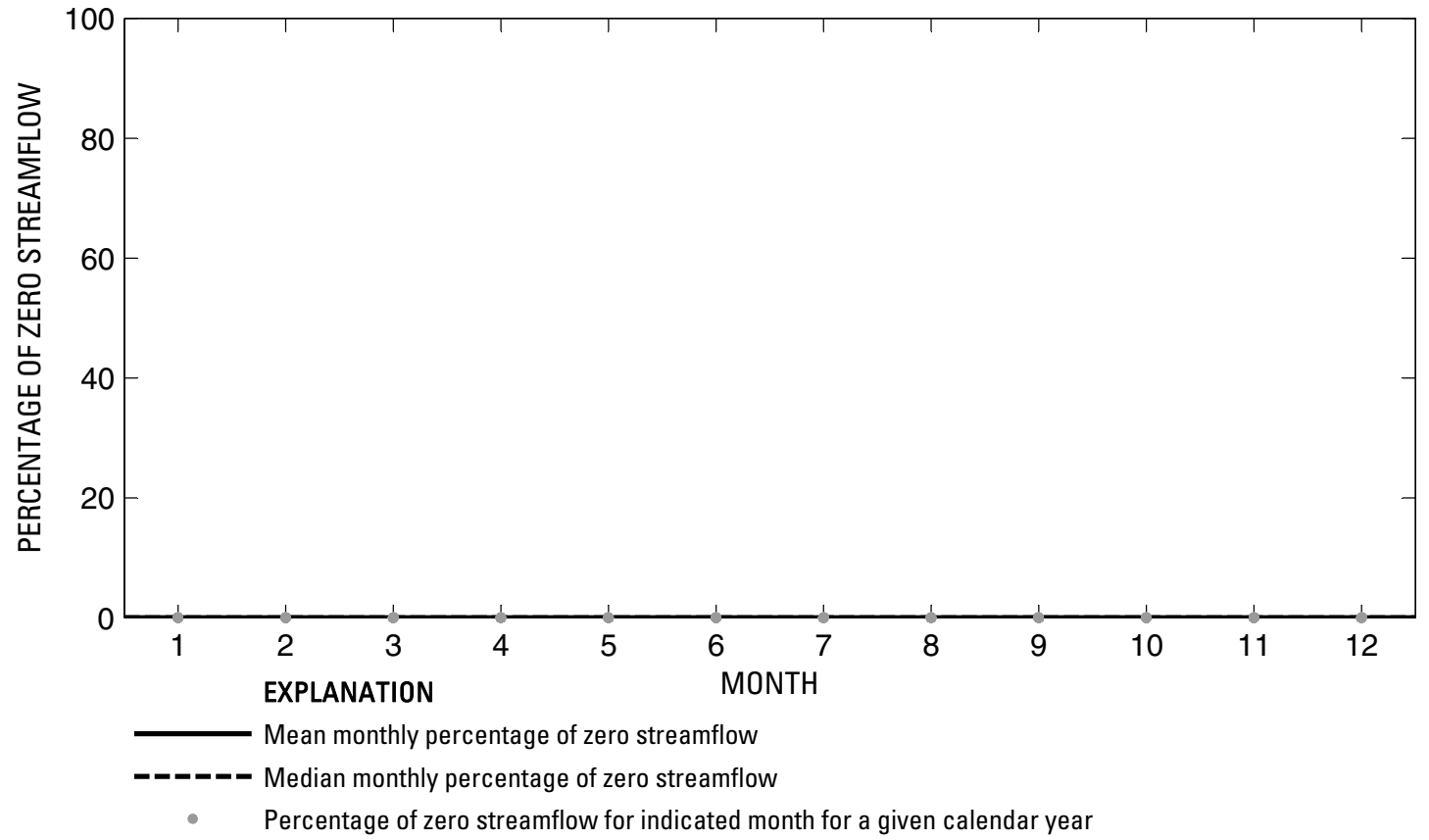

Figure 585. Analysis of percentage of zero daily mean streamflow for U.S. Geological Survey streamflow-gaging station 08173500 San Marcos River at Ottine, Texas. 

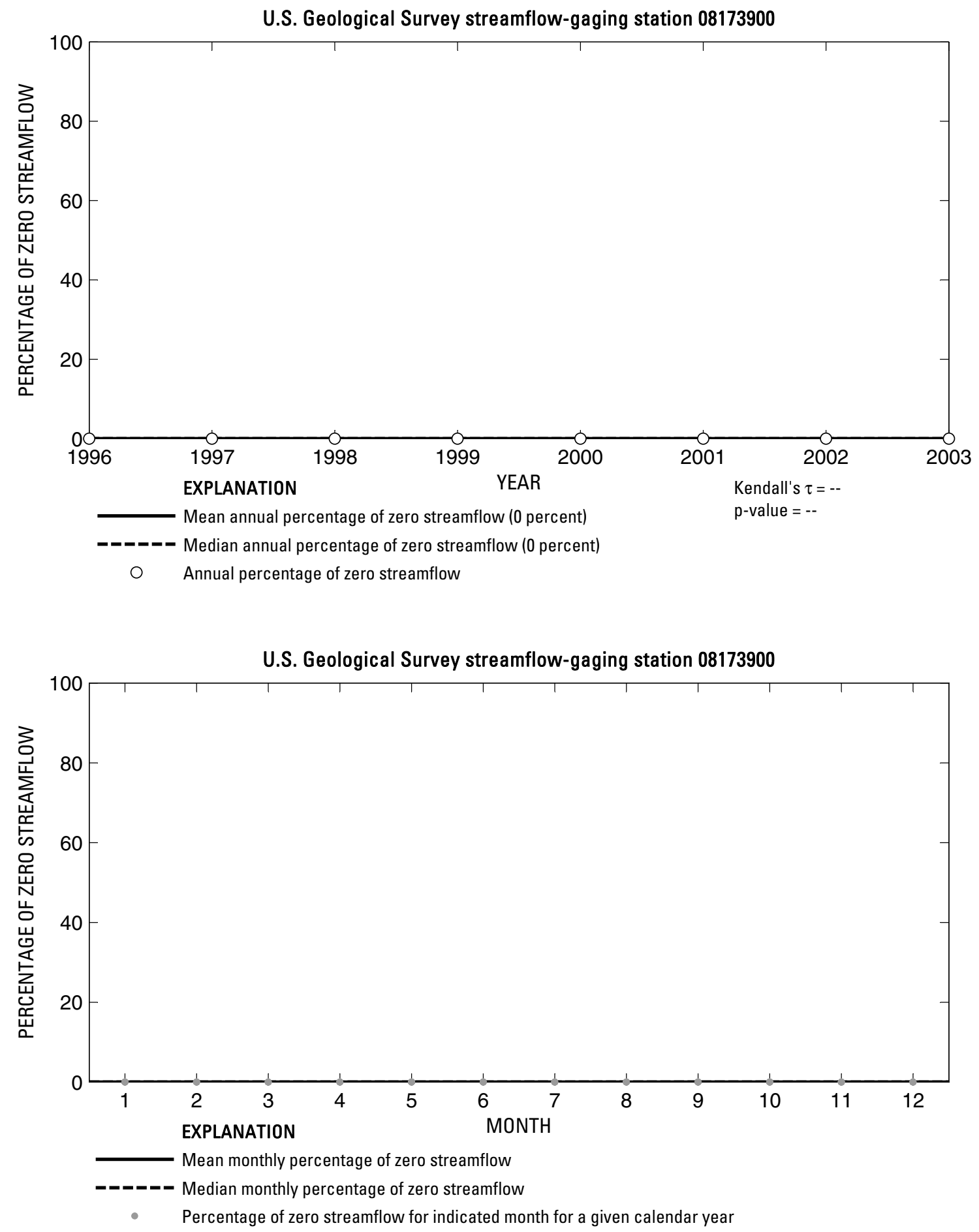

Figure 586. Analysis of percentage of zero daily mean streamflow for U.S. Geological Survey streamflow-gaging station 08173900 Guadalupe River at Gonzales, Texas. 

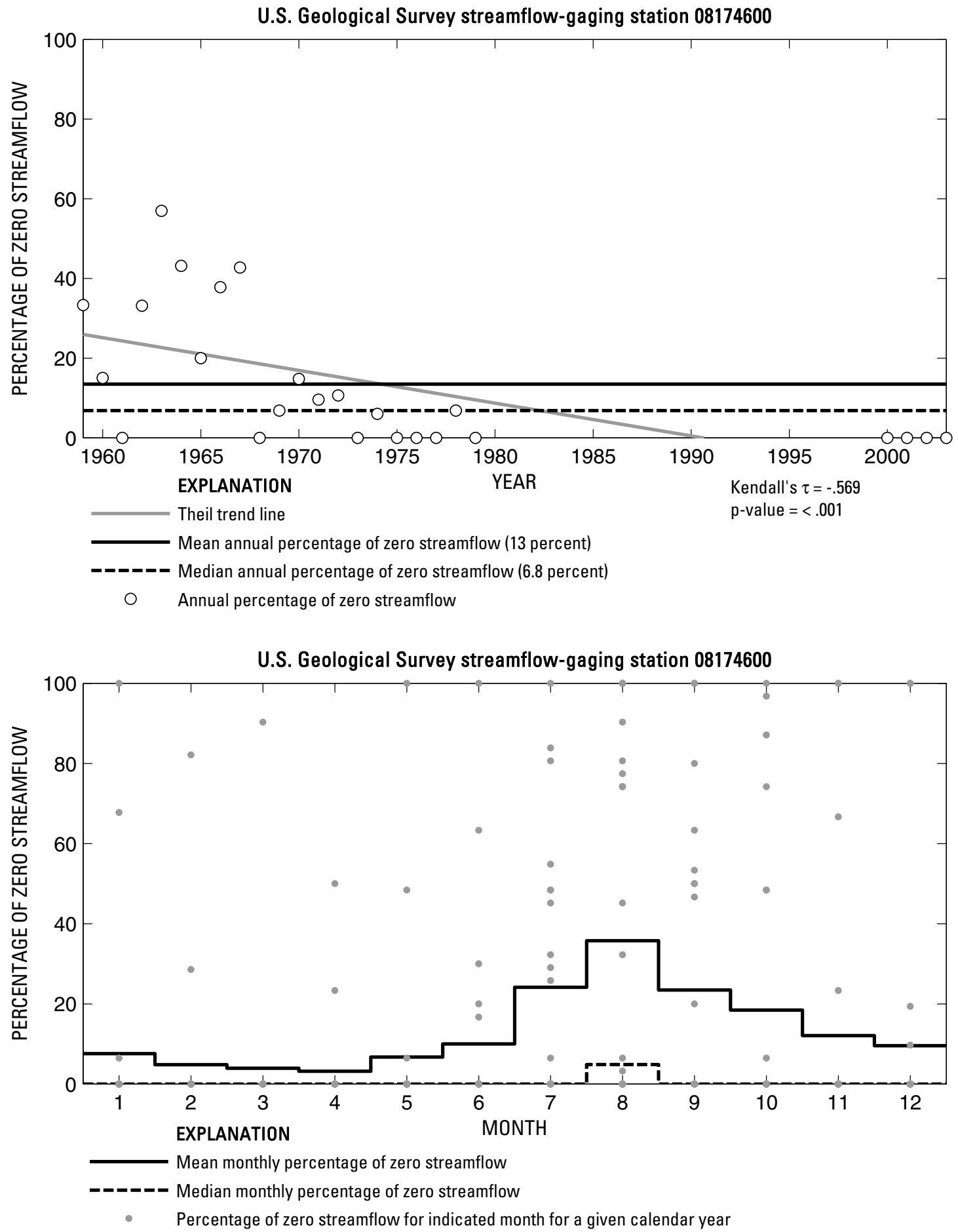

Figure 587. Analysis of percentage of zero daily mean streamflow for U.S. Geological Survey streamflow-gaging station 08174600 Peach Creek below Dilworth, Texas. 
U.S. Geological Survey streamflow-gaging station 08175000

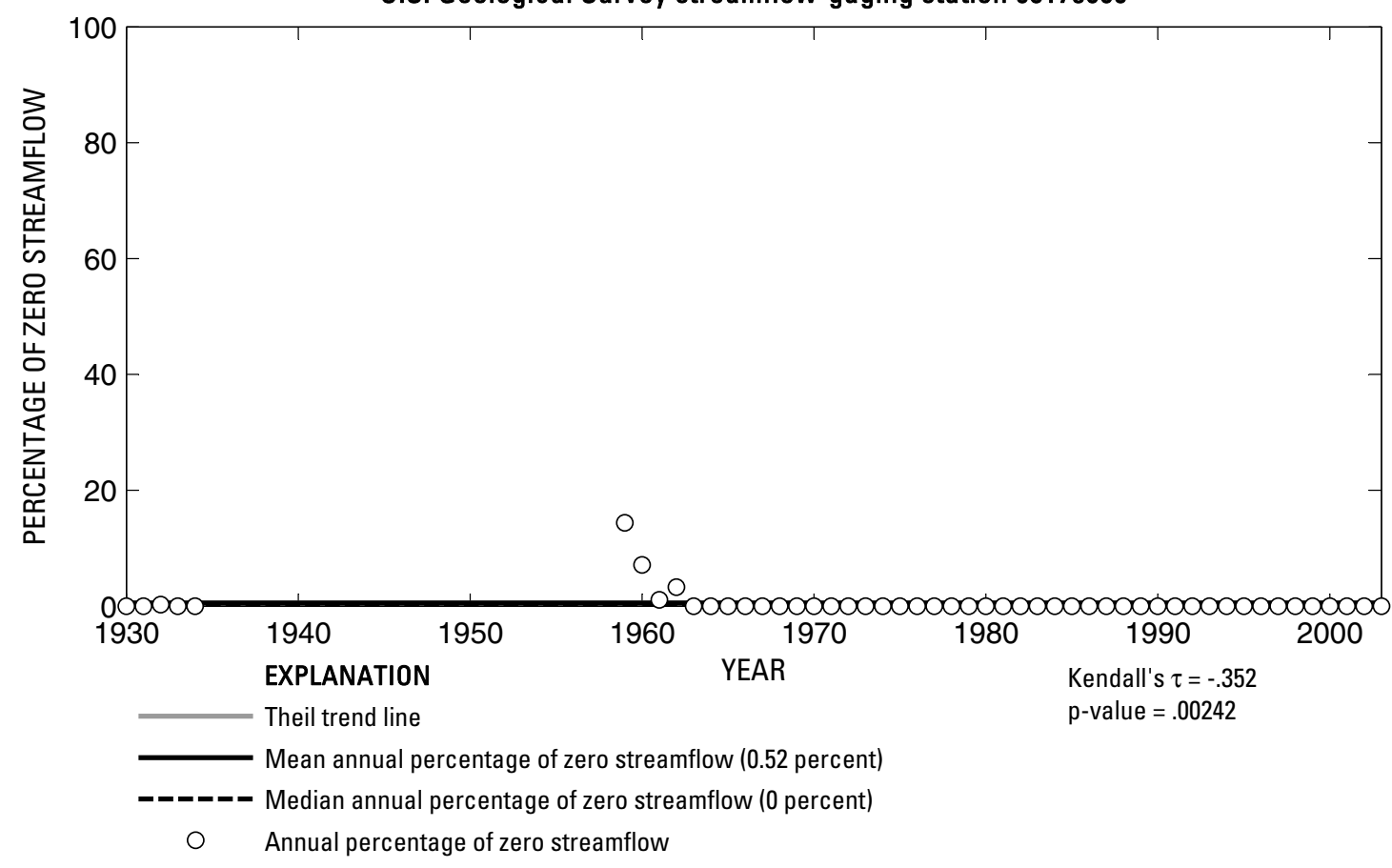

U.S. Geological Survey streamflow-gaging station 08175000

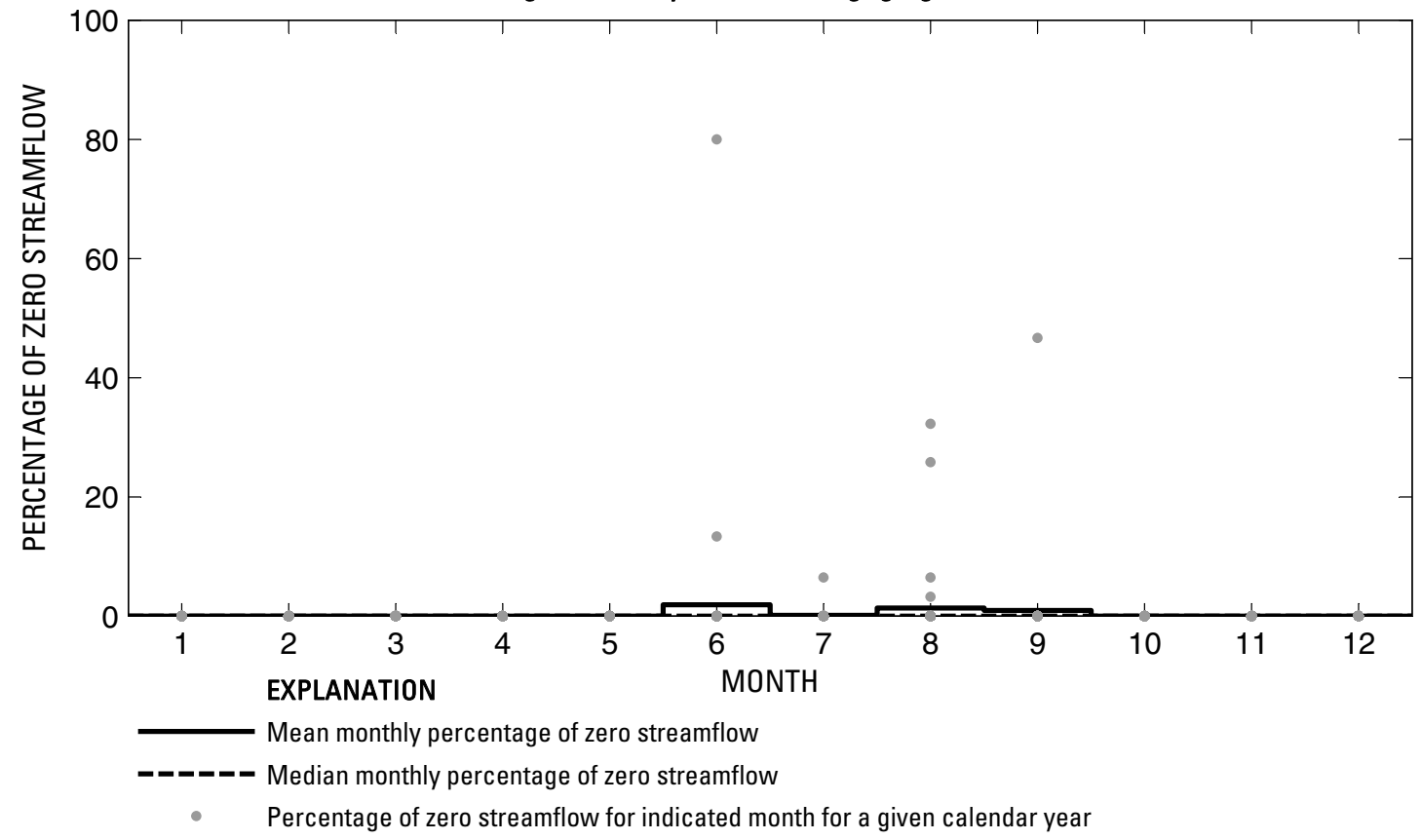

Figure 588. Analysis of percentage of zero daily mean streamflow for U.S. Geological Survey streamflow-gaging station 08175000 Sandies Creek near Westhoff, Texas. 


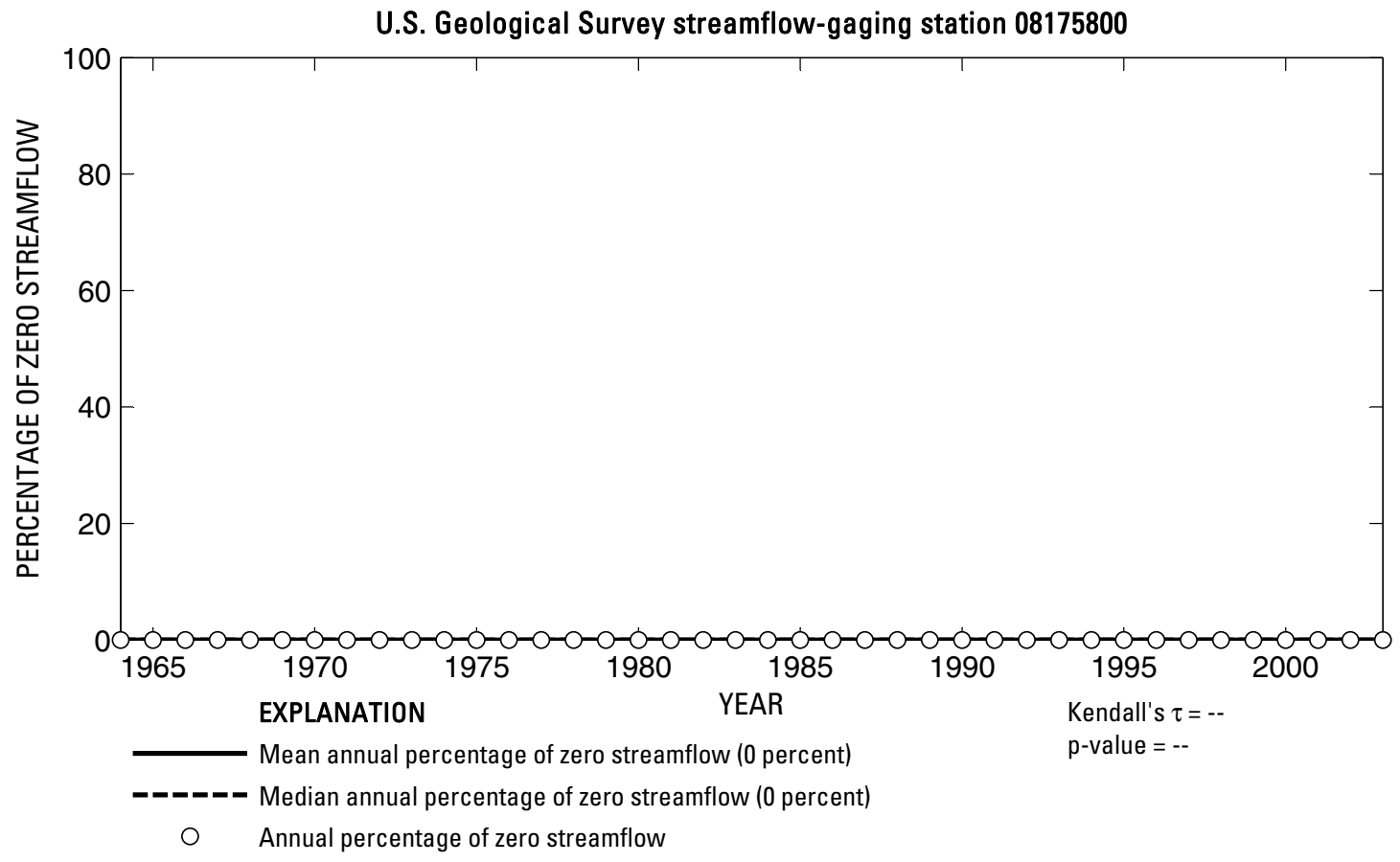

U.S. Geological Survey streamflow-gaging station 08175800

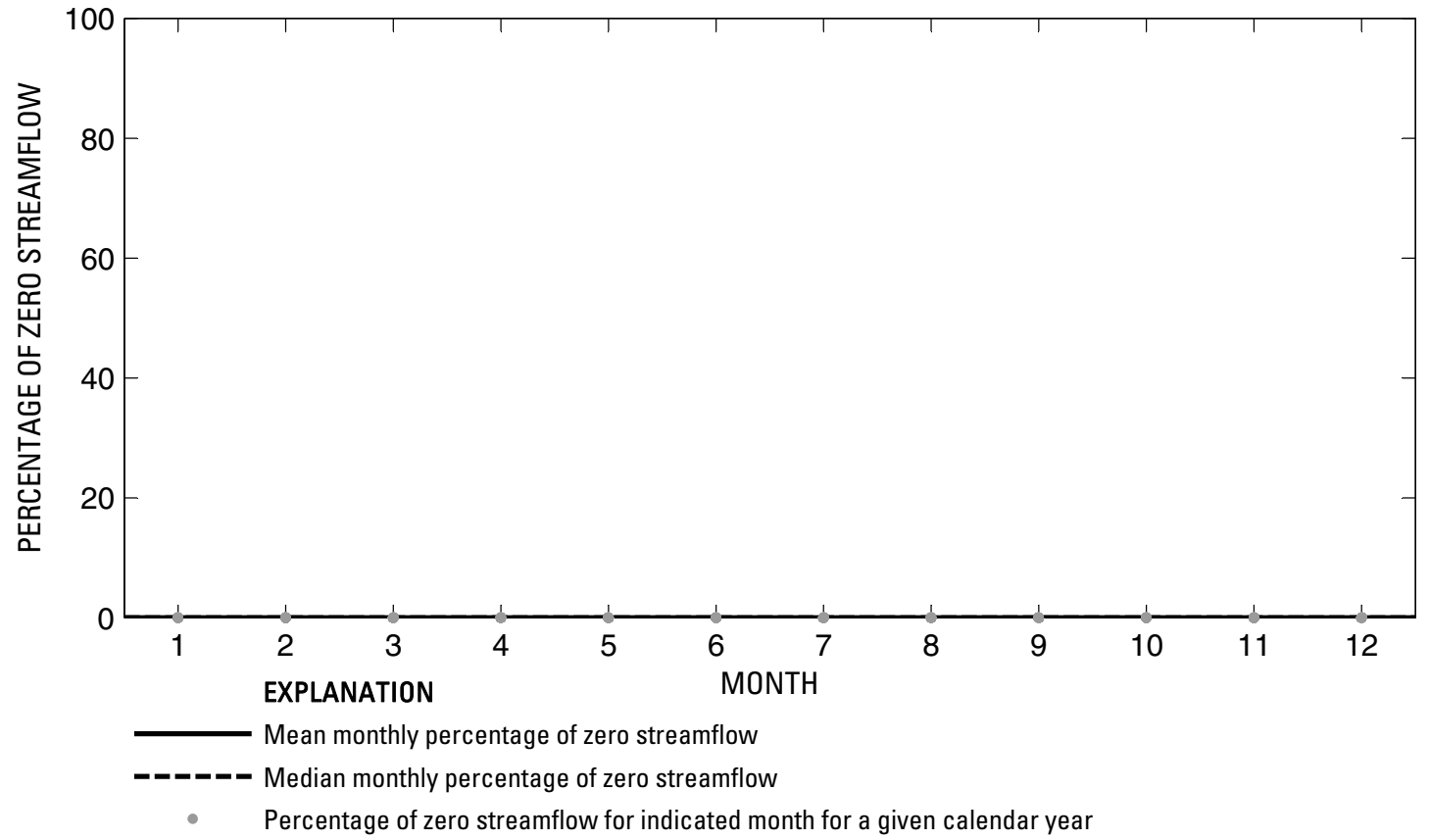

Figure 589. Analysis of percentage of zero daily mean streamflow for U.S. Geological Survey streamflow-gaging station 08175800 Guadalupe River at Cuero, Texas. 
U.S. Geological Survey streamflow-gaging station 08176000

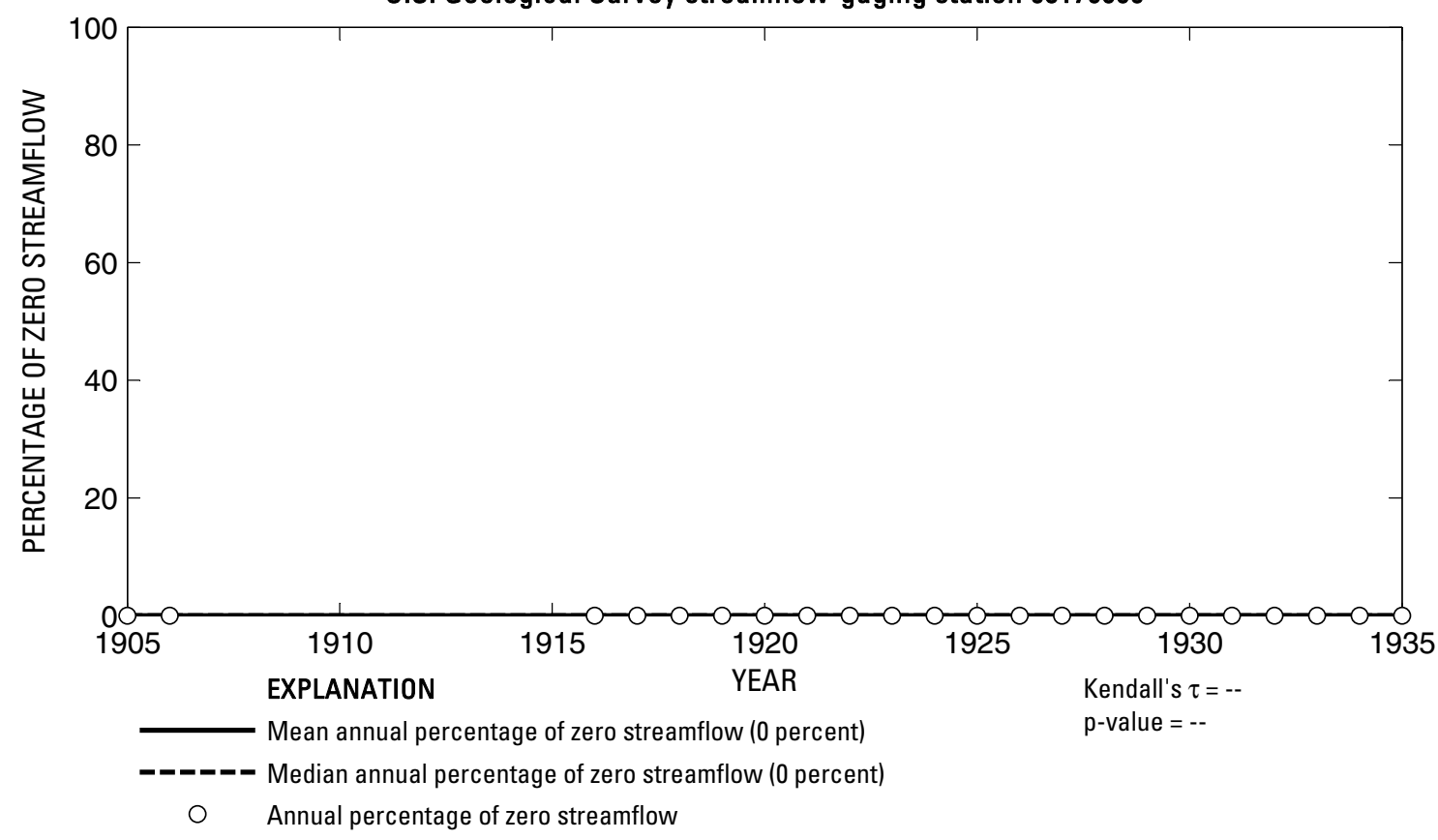

U.S. Geological Survey streamflow-gaging station 08176000

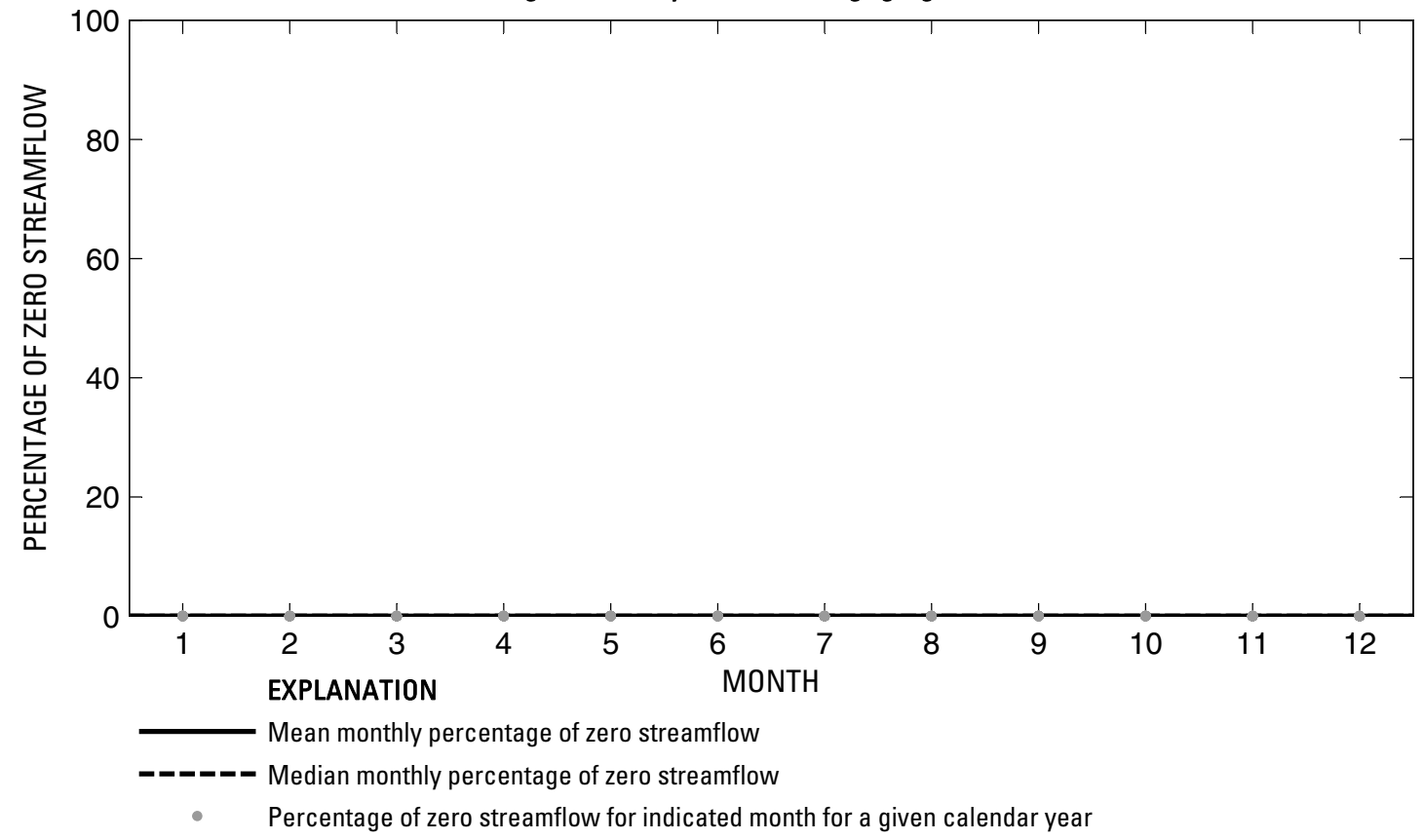

Figure 590. Analysis of percentage of zero daily mean streamflow for U.S. Geological Survey streamflow-gaging station 08176000 Guadalupe River below Cuero, Texas. 


\section{U.S. Geological Survey streamflow-gaging station 08176500}

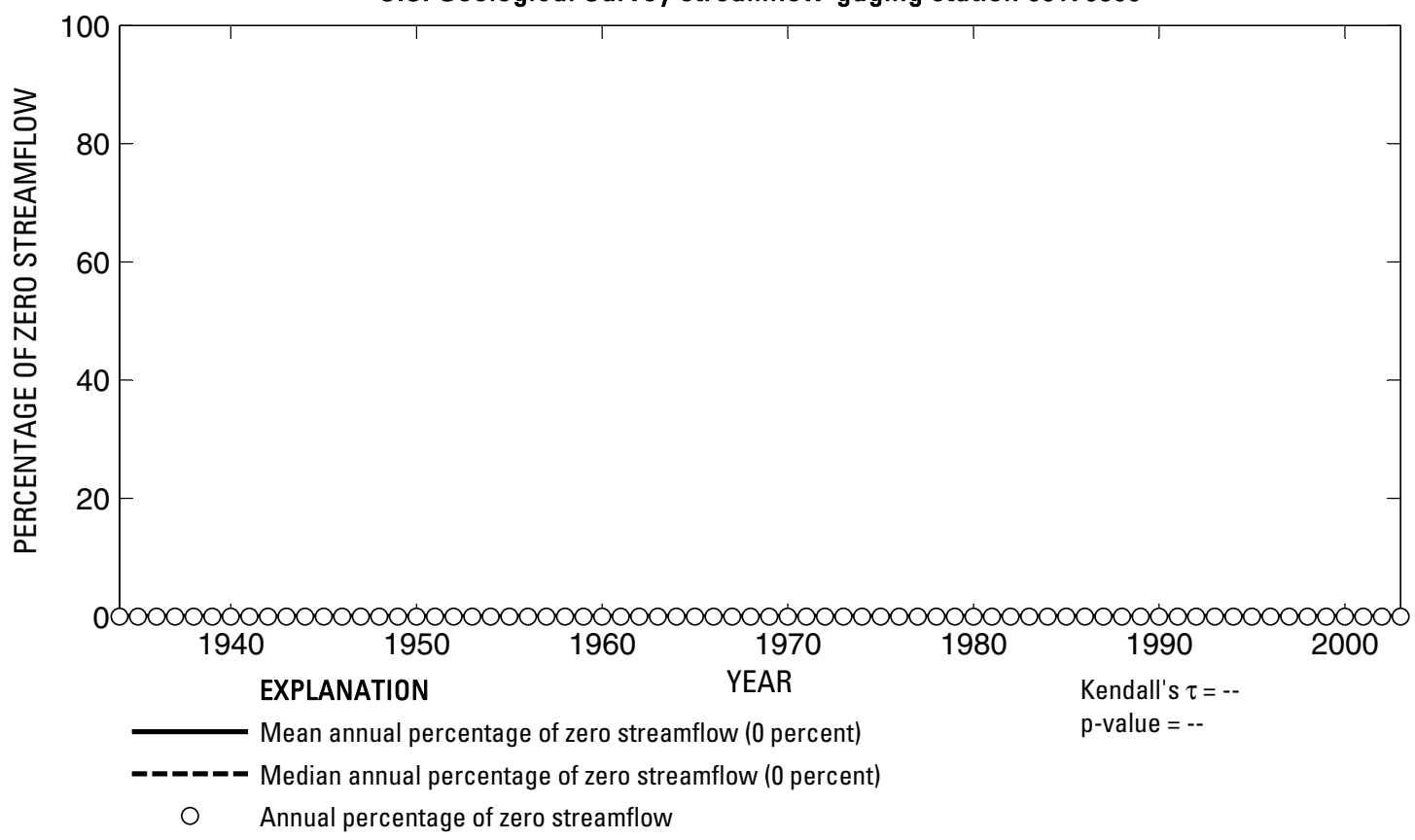

U.S. Geological Survey streamflow-gaging station 08176500

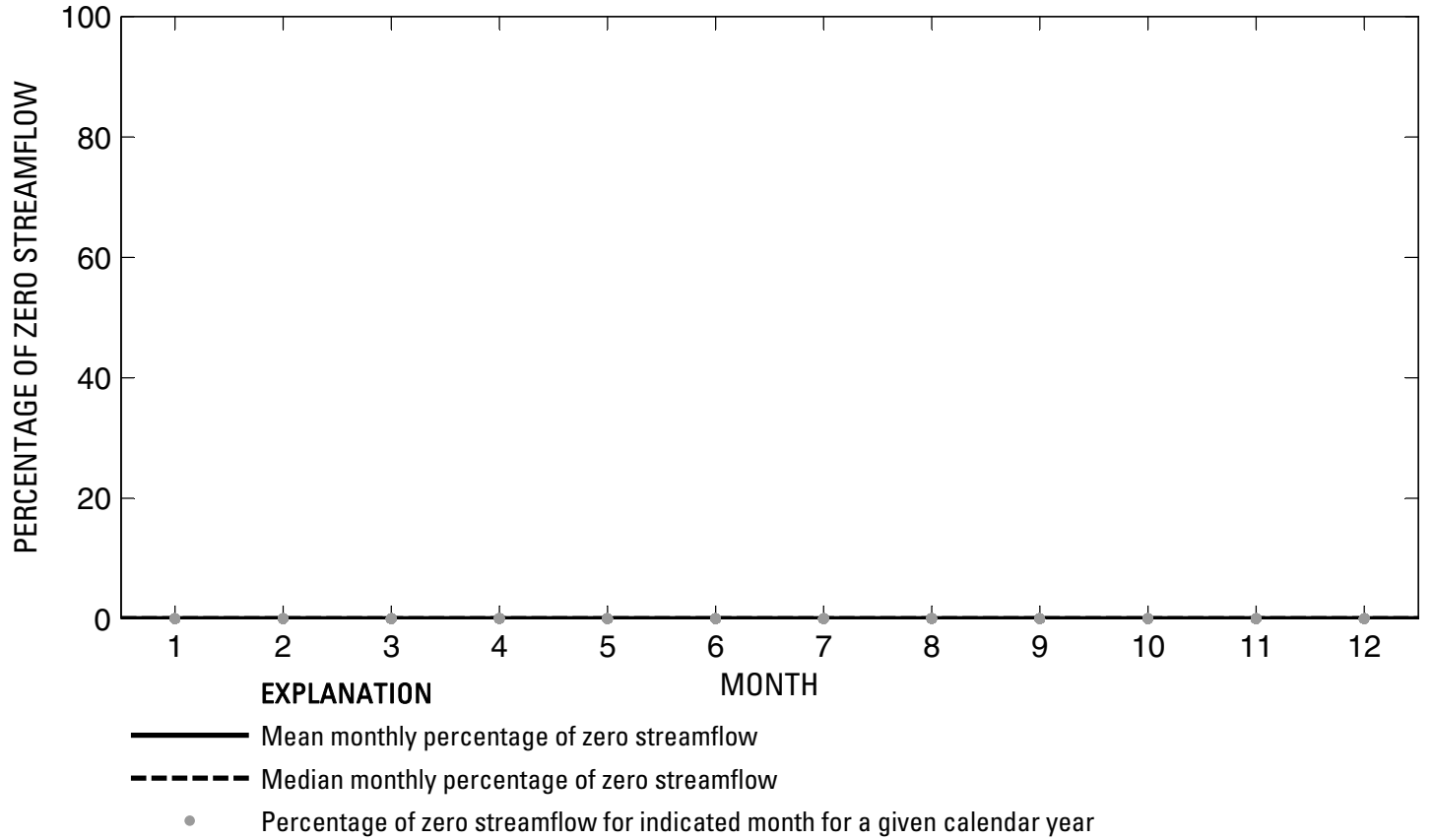

Figure 591. Analysis of percentage of zero daily mean streamflow for U.S. Geological Survey streamflow-gaging station 08176500 Guadalupe River at Victoria, Texas. 
U.S. Geological Survey streamflow-gaging station 08176550

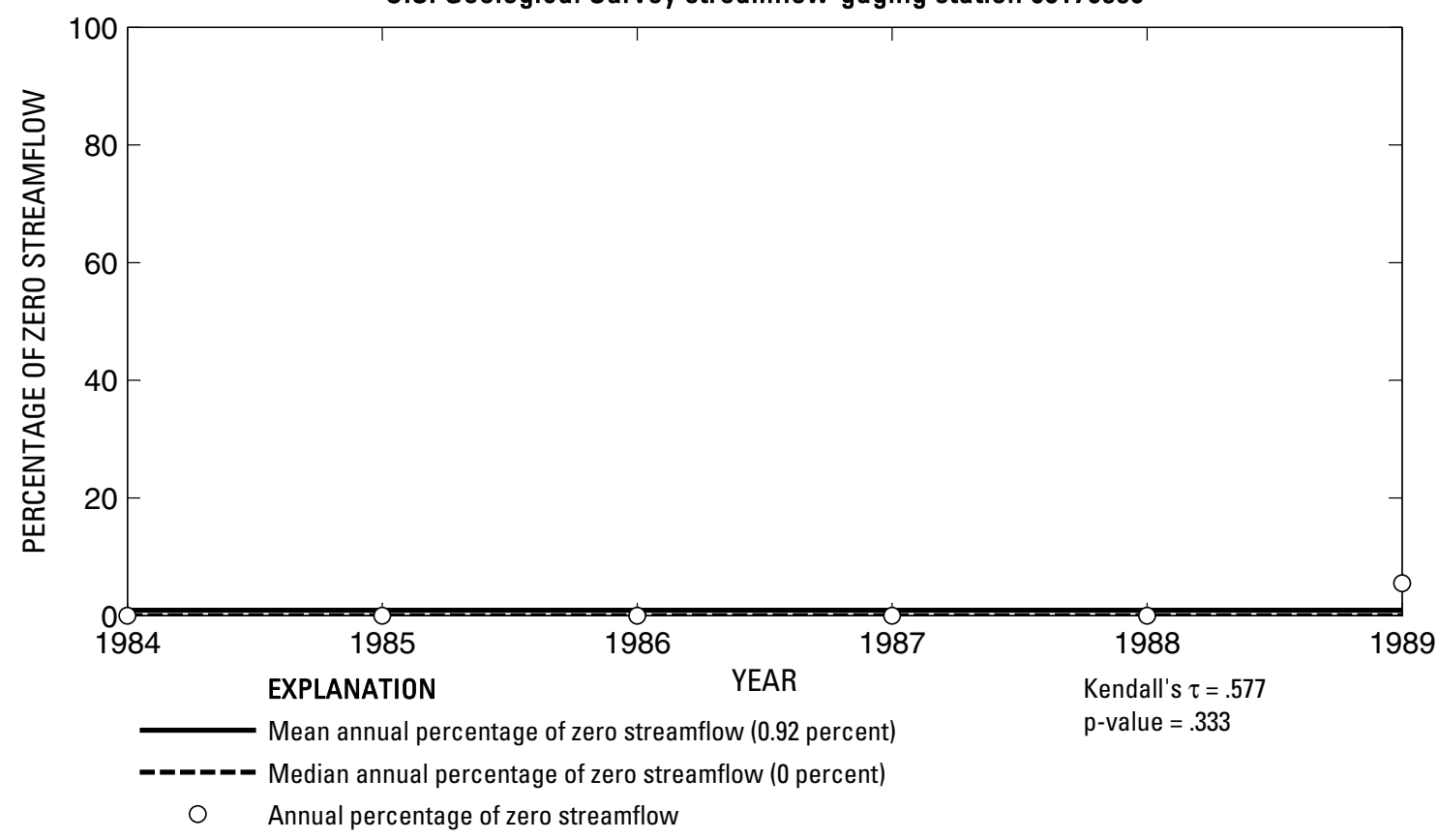

U.S. Geological Survey streamflow-gaging station 08176550

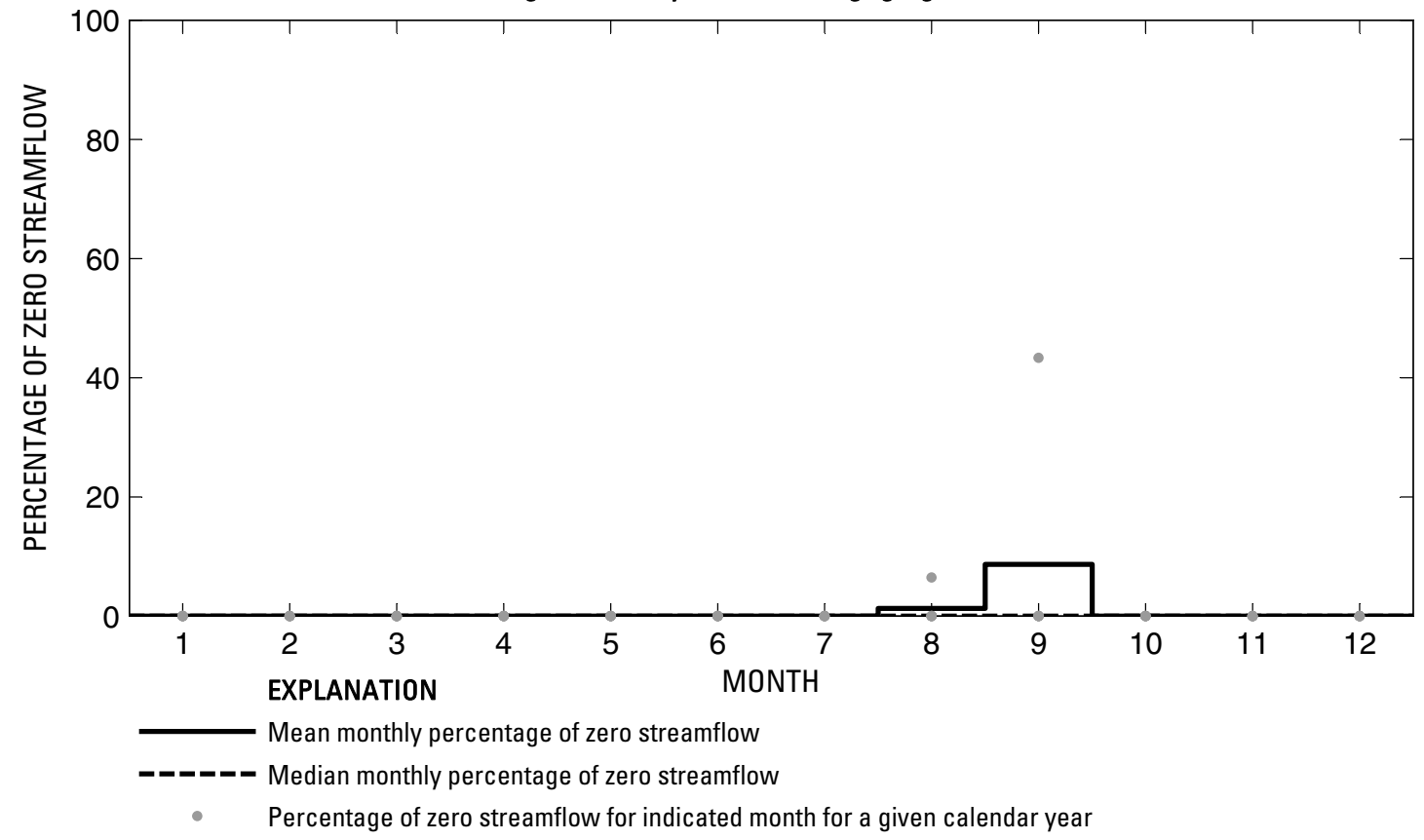

Figure 592. Analysis of percentage of zero daily mean streamflow for U.S. Geological Survey streamflow-gaging station 08176550 Fifteenmile Creek near Weser, Texas. 
U.S. Geological Survey streamflow-gaging station 08176900

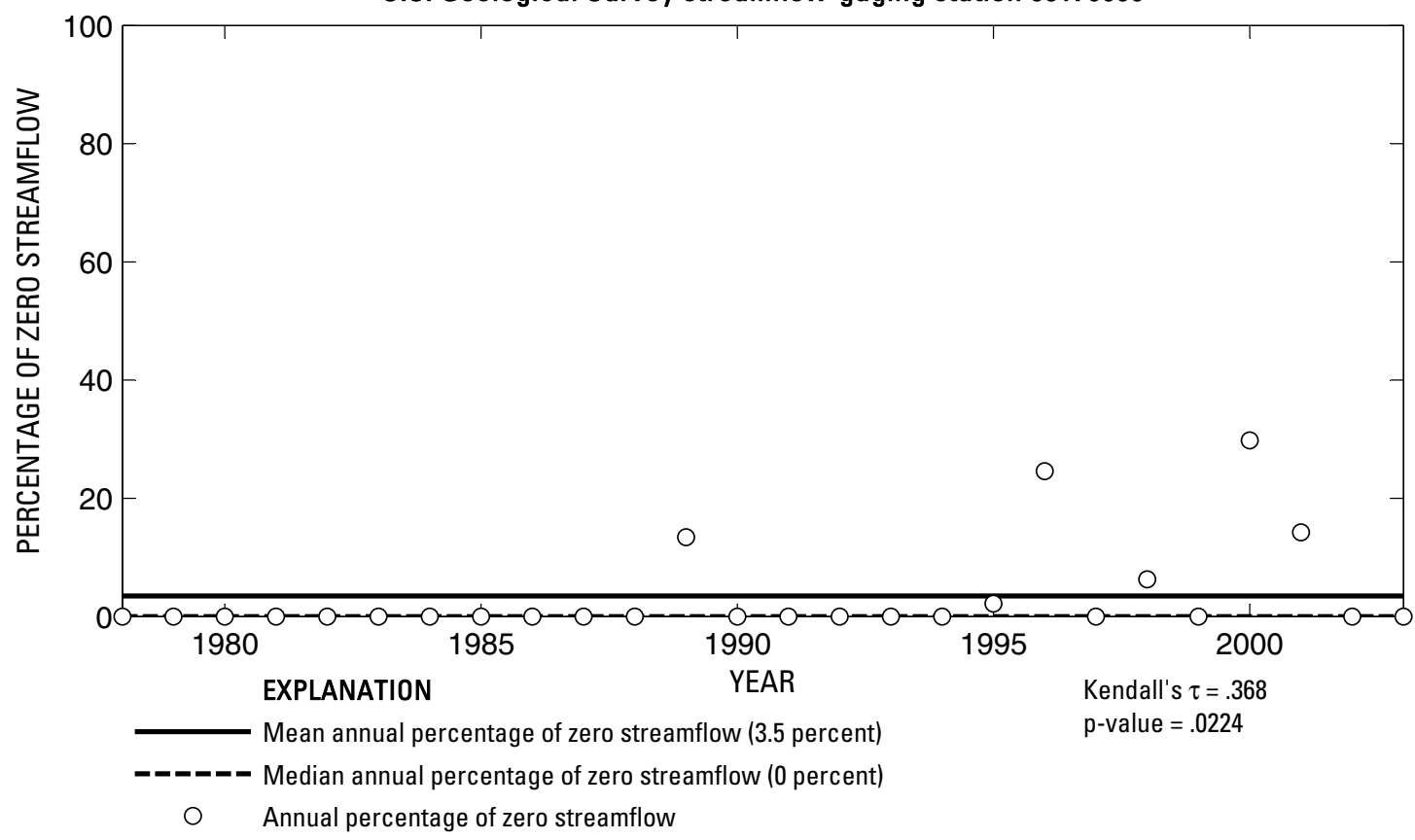

U.S. Geological Survey streamflow-gaging station 08176900

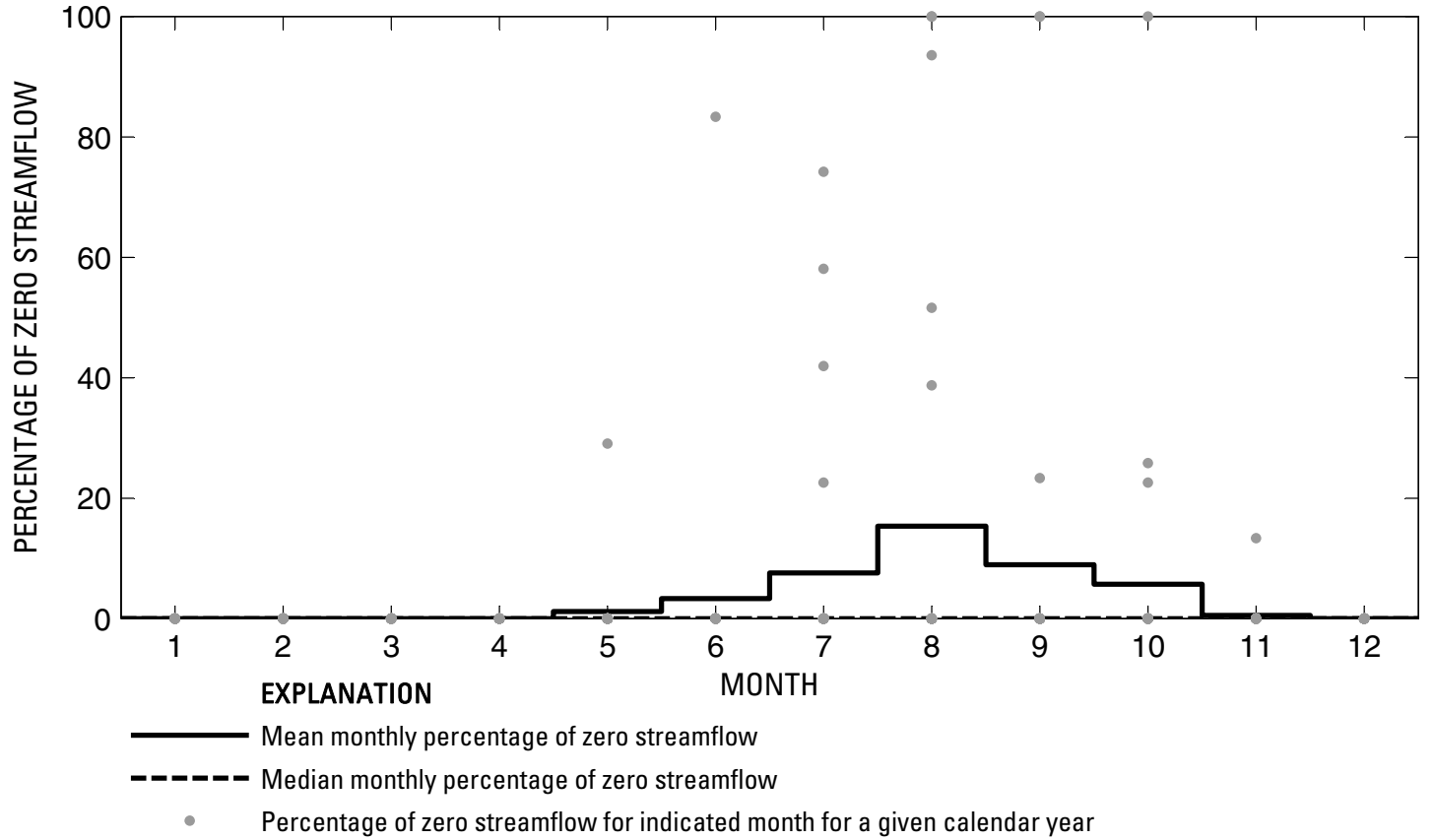

Figure 593. Analysis of percentage of zero daily mean streamflow for U.S. Geological Survey streamflow-gaging station 08176900 Coleto Creek at Arnold Road near Schroeder, Texas. 
U.S. Geological Survey streamflow-gaging station 08176990

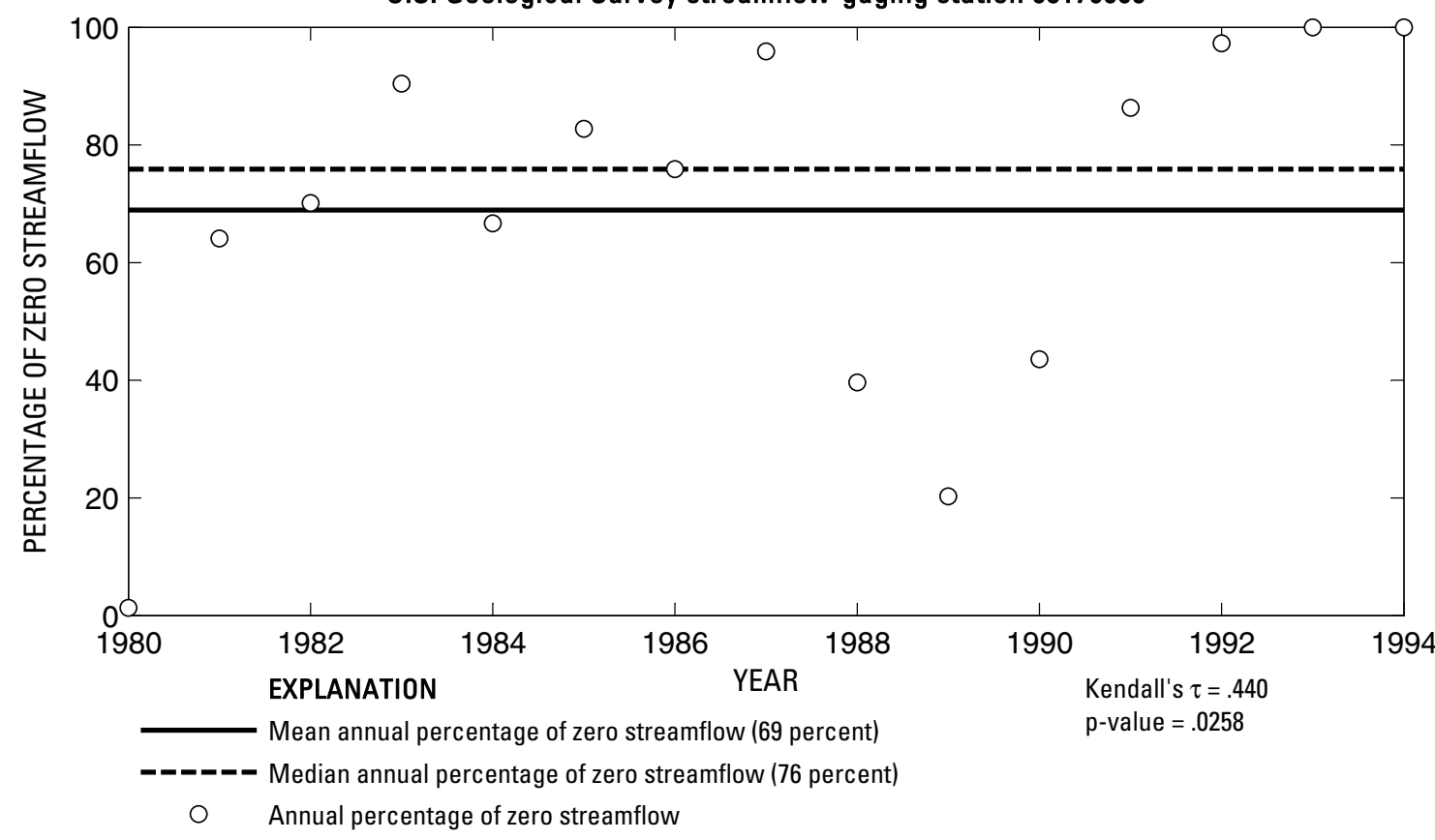

U.S. Geological Survey streamflow-gaging station 08176990

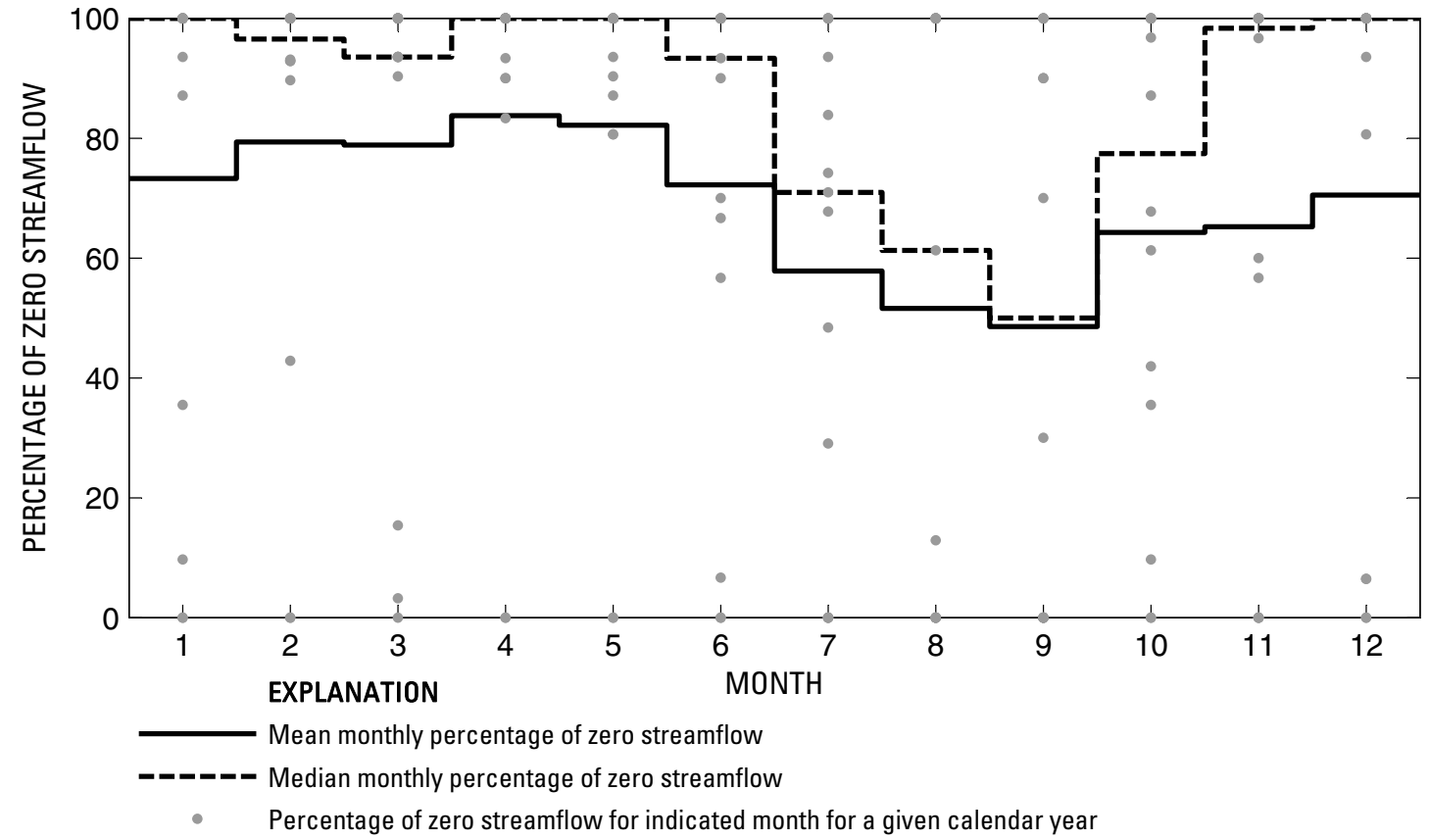

Figure 594. Analysis of percentage of zero daily mean streamflow for U.S. Geological Survey streamflow-gaging station 08176990 Coleto Creek Reservoir Inflow (Guadalupe Diversion) near Schroeder, Texas.

Index of Station Numbers 719 
U.S. Geological Survey streamflow-gaging station 08177000

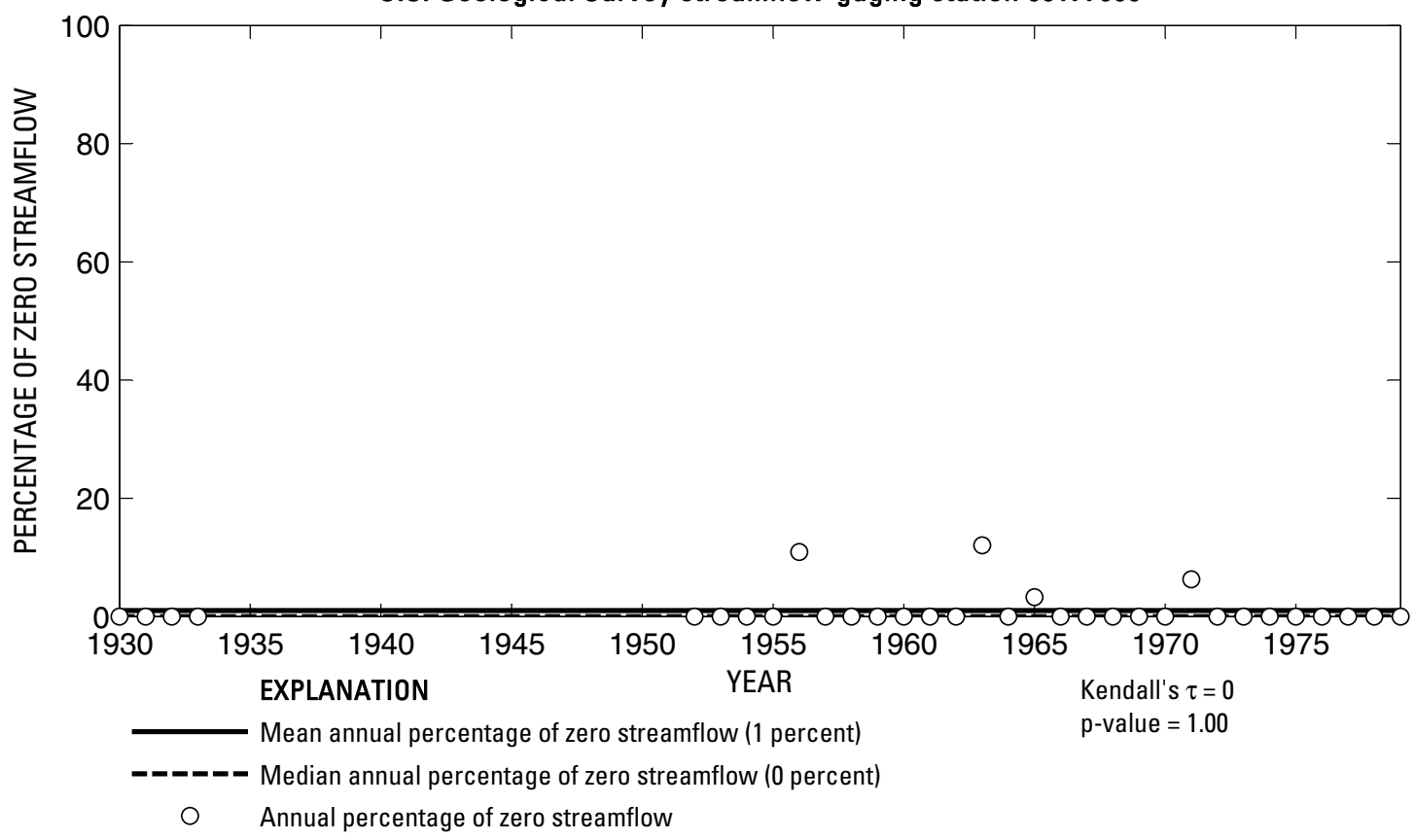

U.S. Geological Survey streamflow-gaging station 08177000

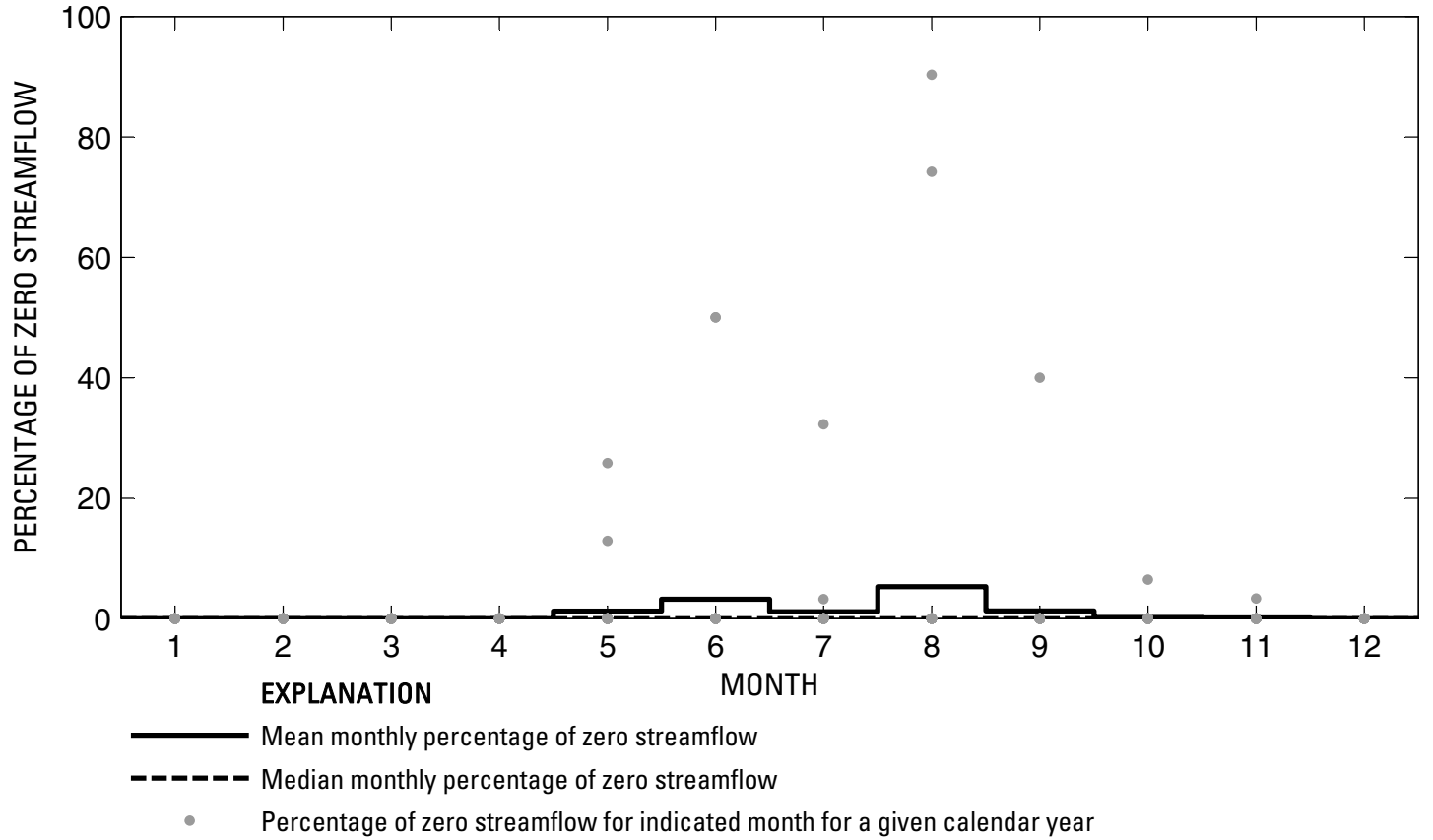

Figure 595. Analysis of percentage of zero daily mean streamflow for U.S. Geological Survey streamflow-gaging station 08177000 Coleto Creek near Schroeder, Texas. 
U.S. Geological Survey streamflow-gaging station 08177300

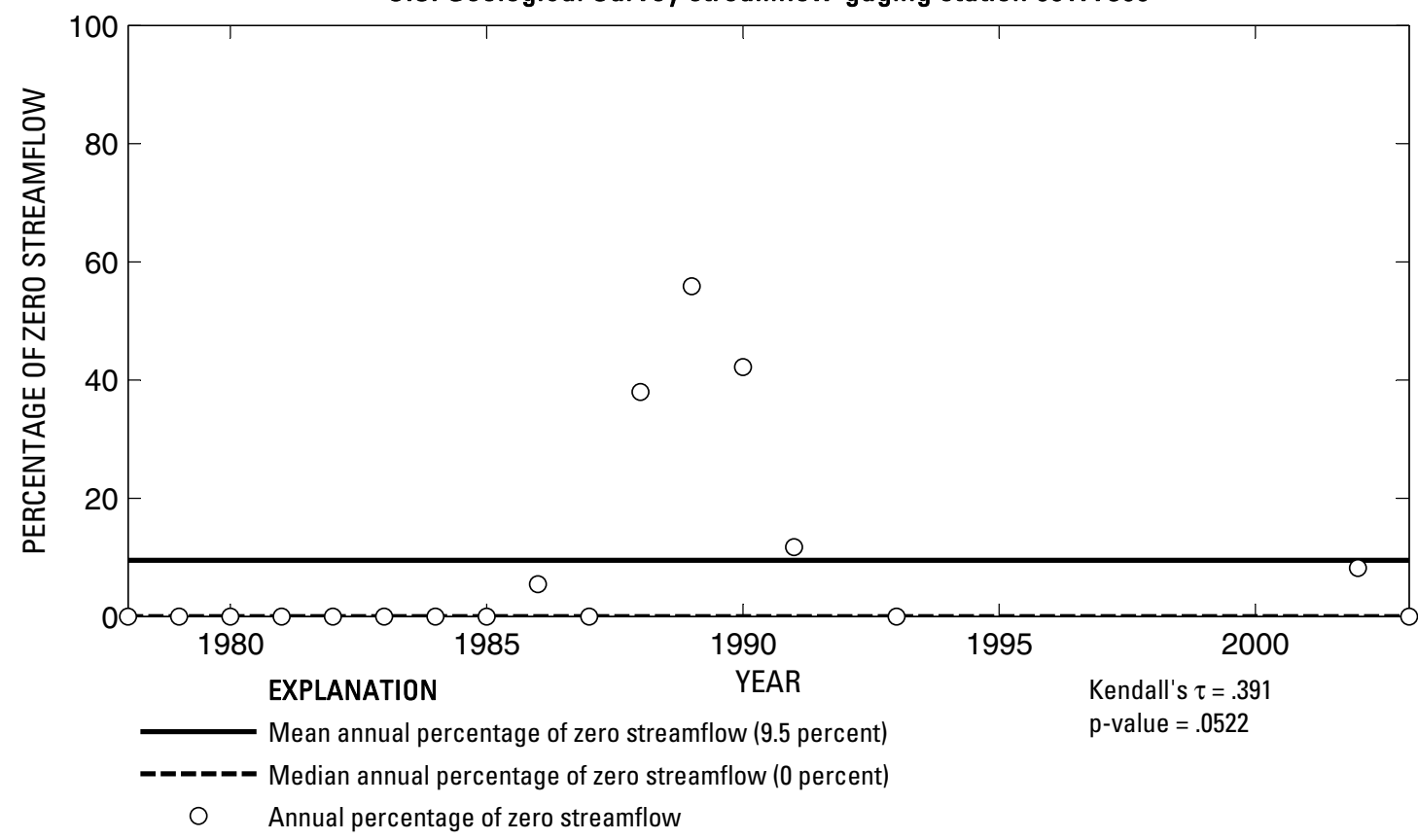

U.S. Geological Survey streamflow-gaging station 08177300

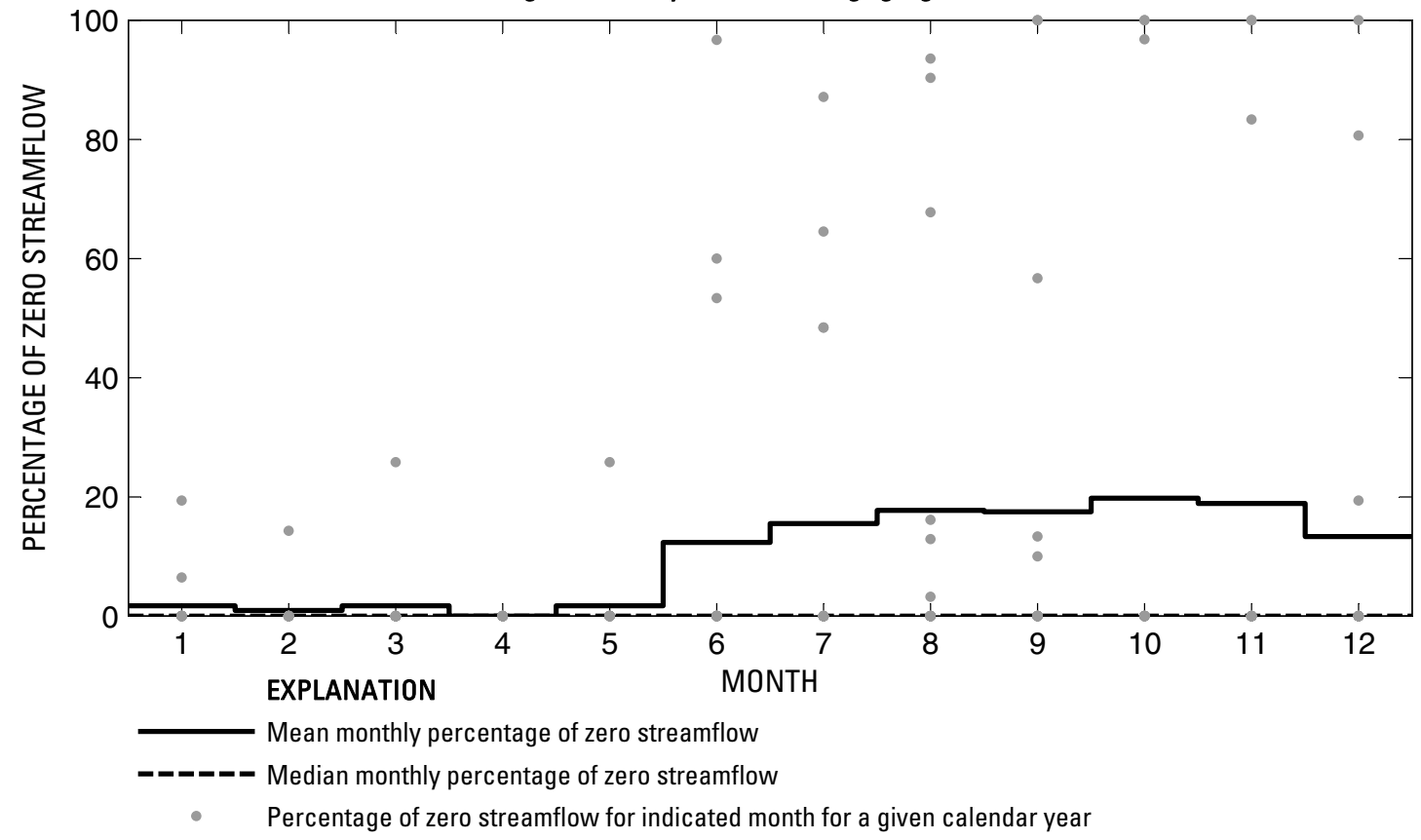

Figure 596. Analysis of percentage of zero daily mean streamflow for U.S. Geological Survey streamflow-gaging station 08177300 Perdido Creek at Farm to Market Road 622 near Fannin, Texas. 


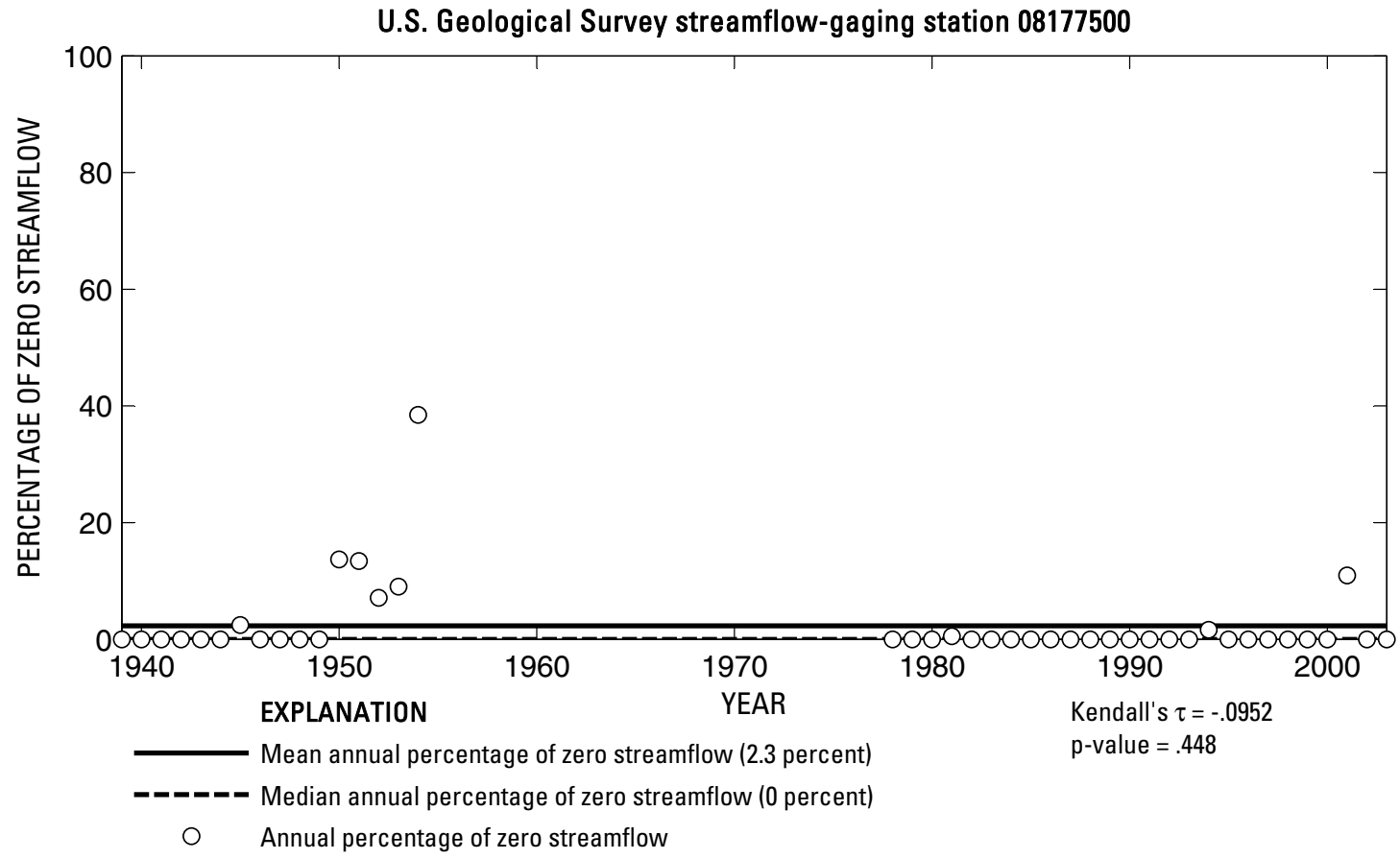

U.S. Geological Survey streamflow-gaging station 08177500

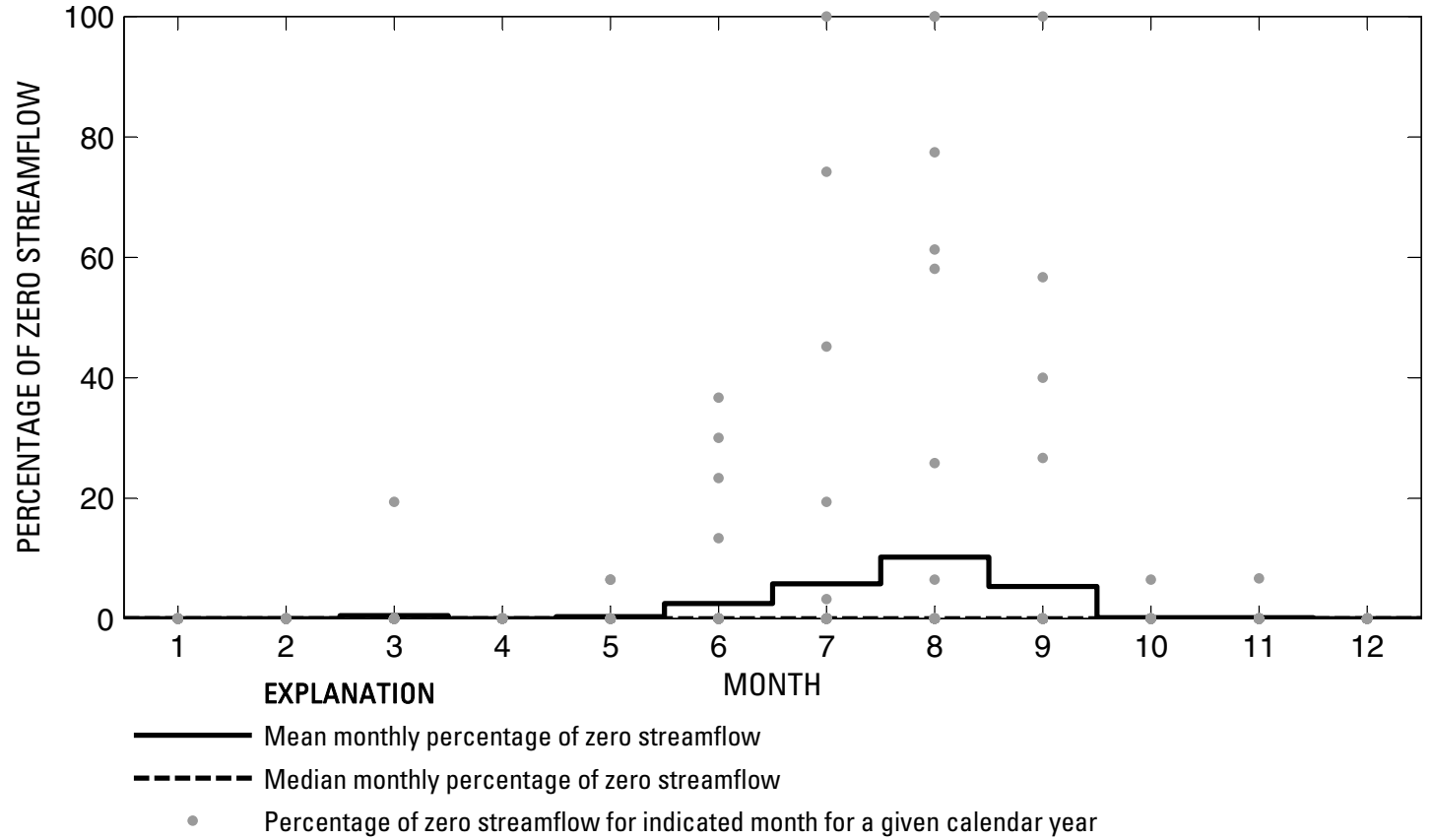

Figure 597. Analysis of percentage of zero daily mean streamflow for U.S. Geological Survey streamflow-gaging station 08177500 Coleto Creek near Victoria, Texas. 
U.S. Geological Survey streamflow-gaging station 08177700

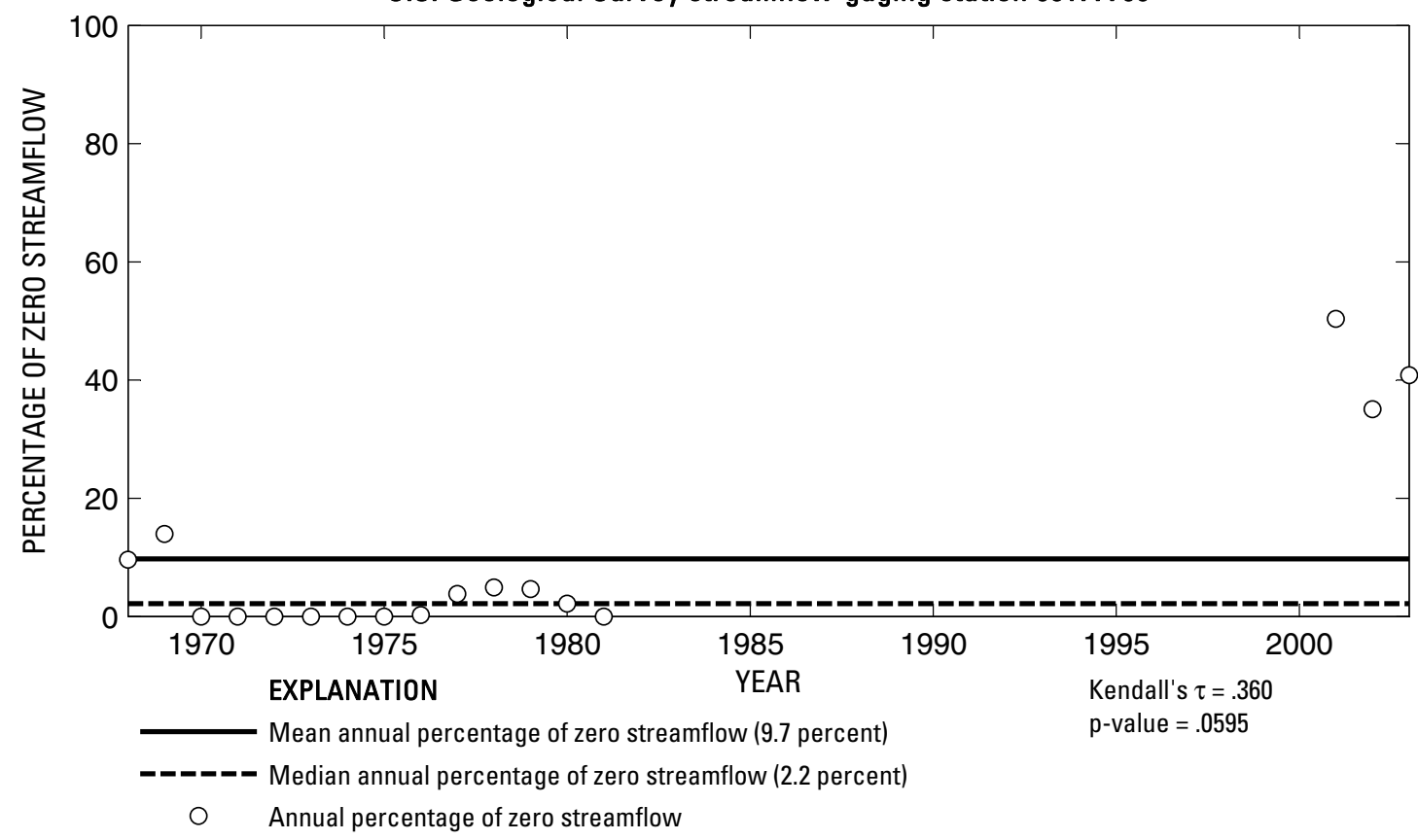

U.S. Geological Survey streamflow-gaging station 08177700

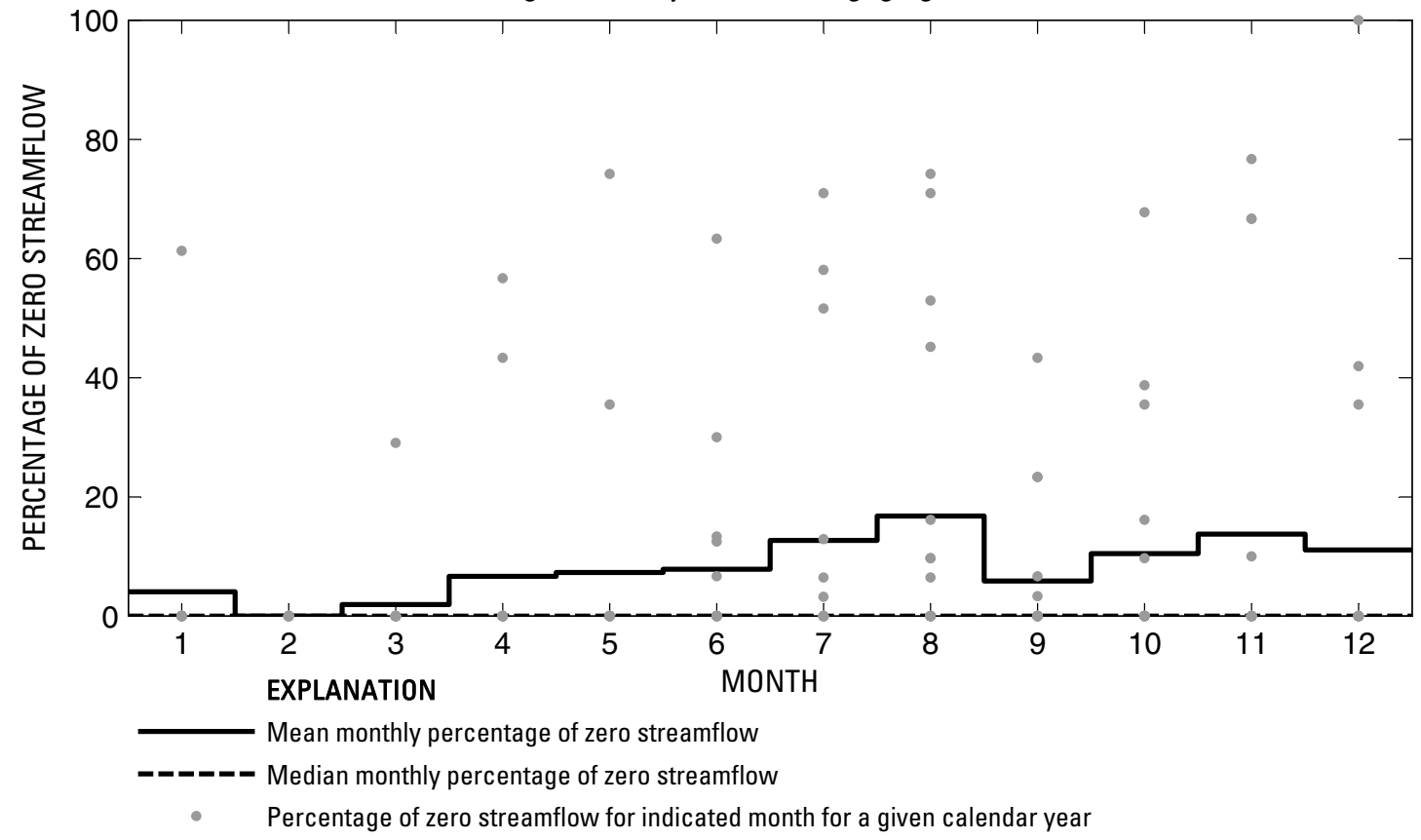

Figure 598. Analysis of percentage of zero daily mean streamflow for U.S. Geological Survey streamflow-gaging station 08177700 Olmos Creek at Dresden Drive, San Antonio, Texas.

Index of Station Numbers 719 
U.S. Geological Survey streamflow-gaging station 08177860

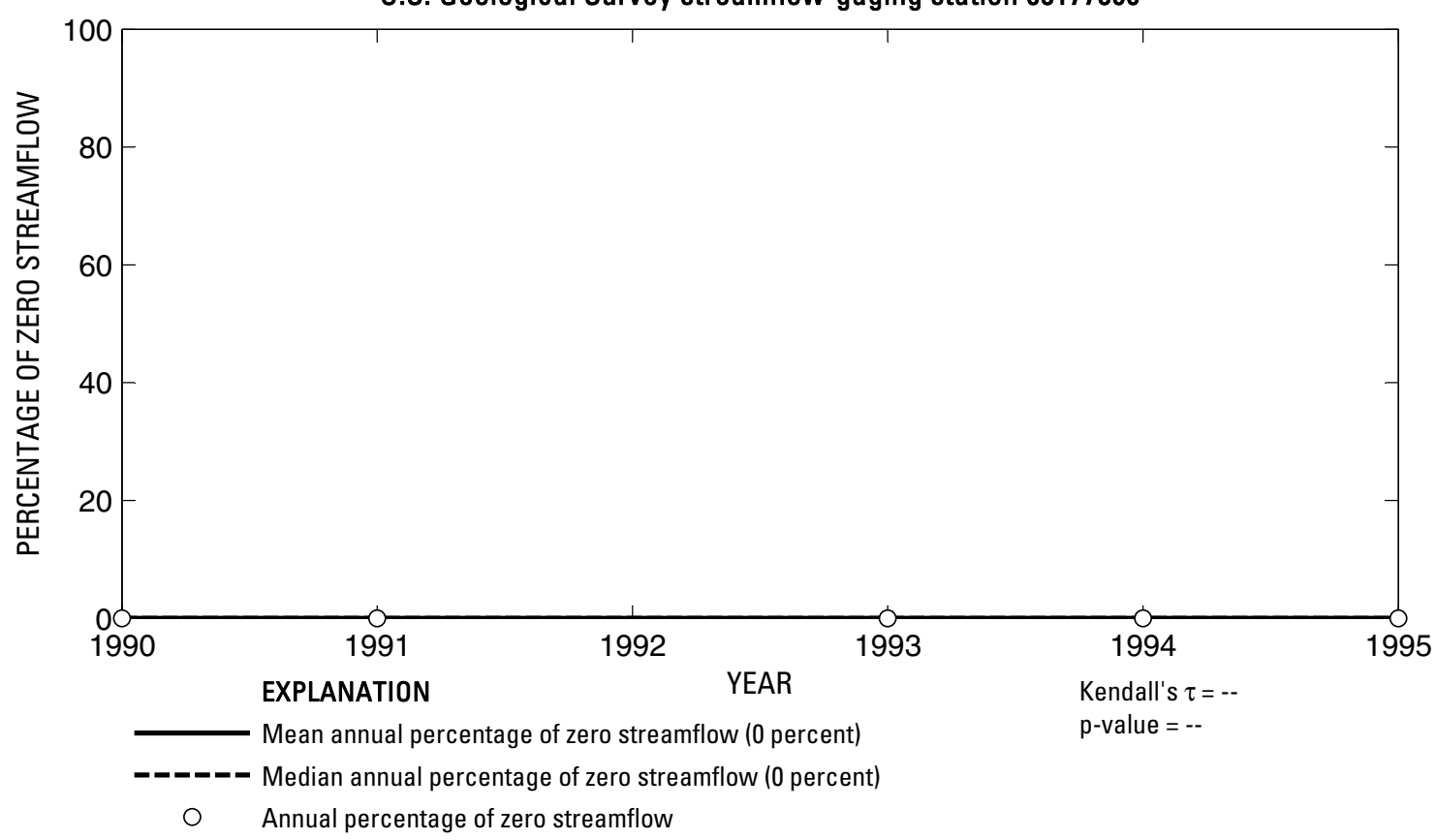

U.S. Geological Survey streamflow-gaging station 08177860

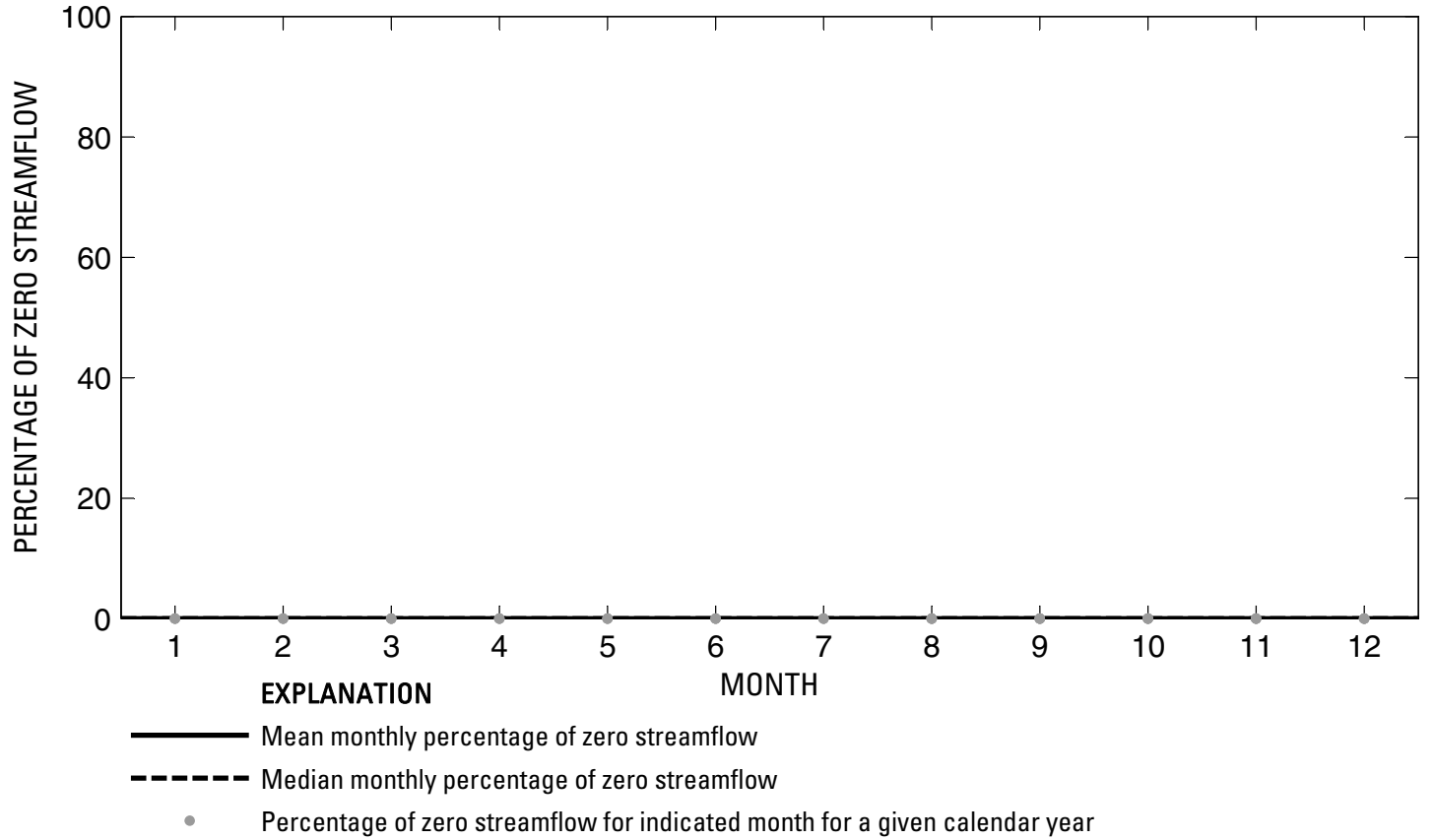

Figure 599. Analysis of percentage of zero daily mean streamflow for U.S. Geological Survey streamflow-gaging station 08177860 San Antonio River at Woodlawn Avenue, San Antonio, Texas.

Index of Station Numbers 719 

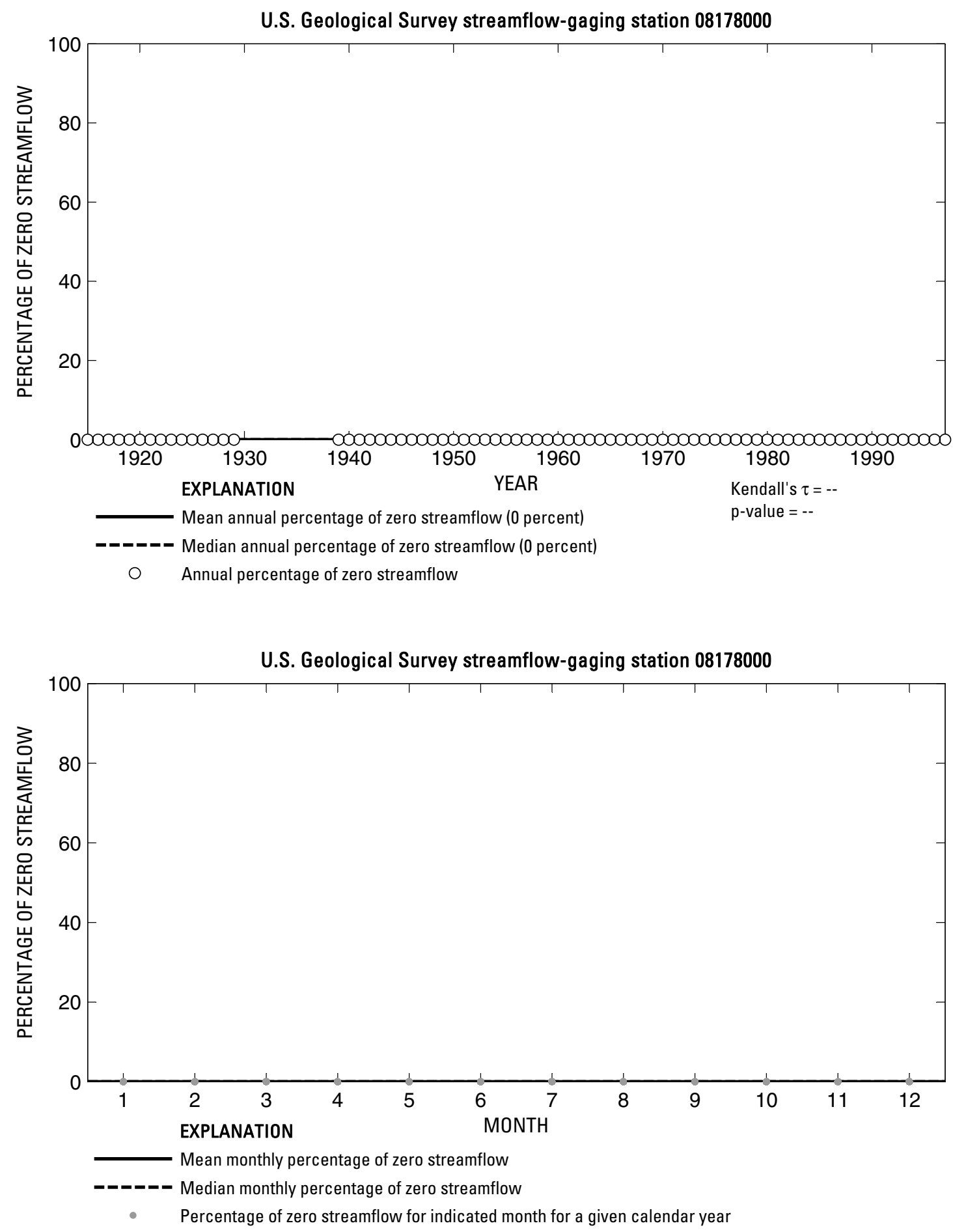

Figure 600. Analysis of percentage of zero daily mean streamflow for U.S. Geological Survey streamflow-gaging station 08178000 San Antonio River at San Antonio, Texas. 
U.S. Geological Survey streamflow-gaging station 08178050

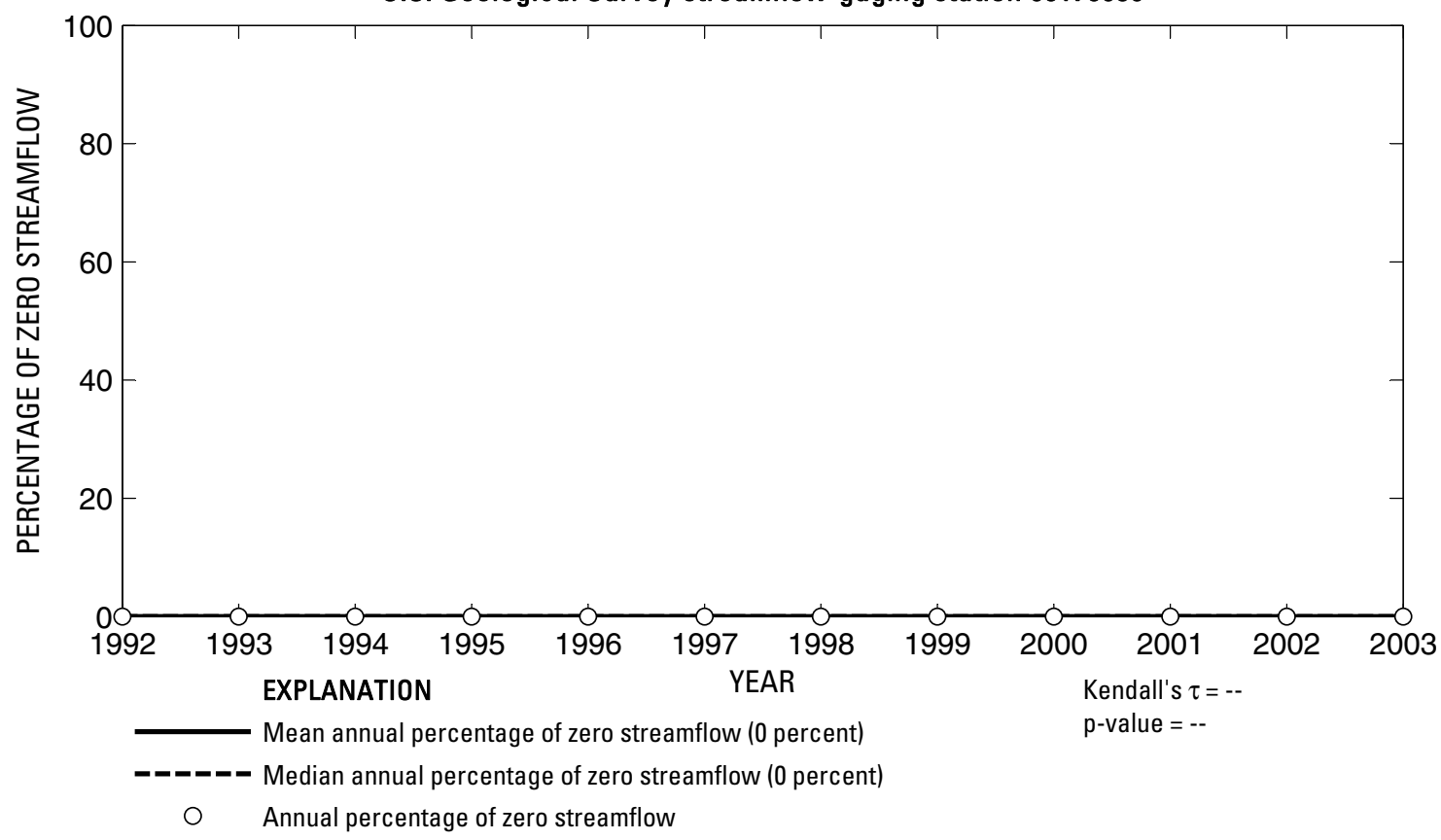

U.S. Geological Survey streamflow-gaging station 08178050

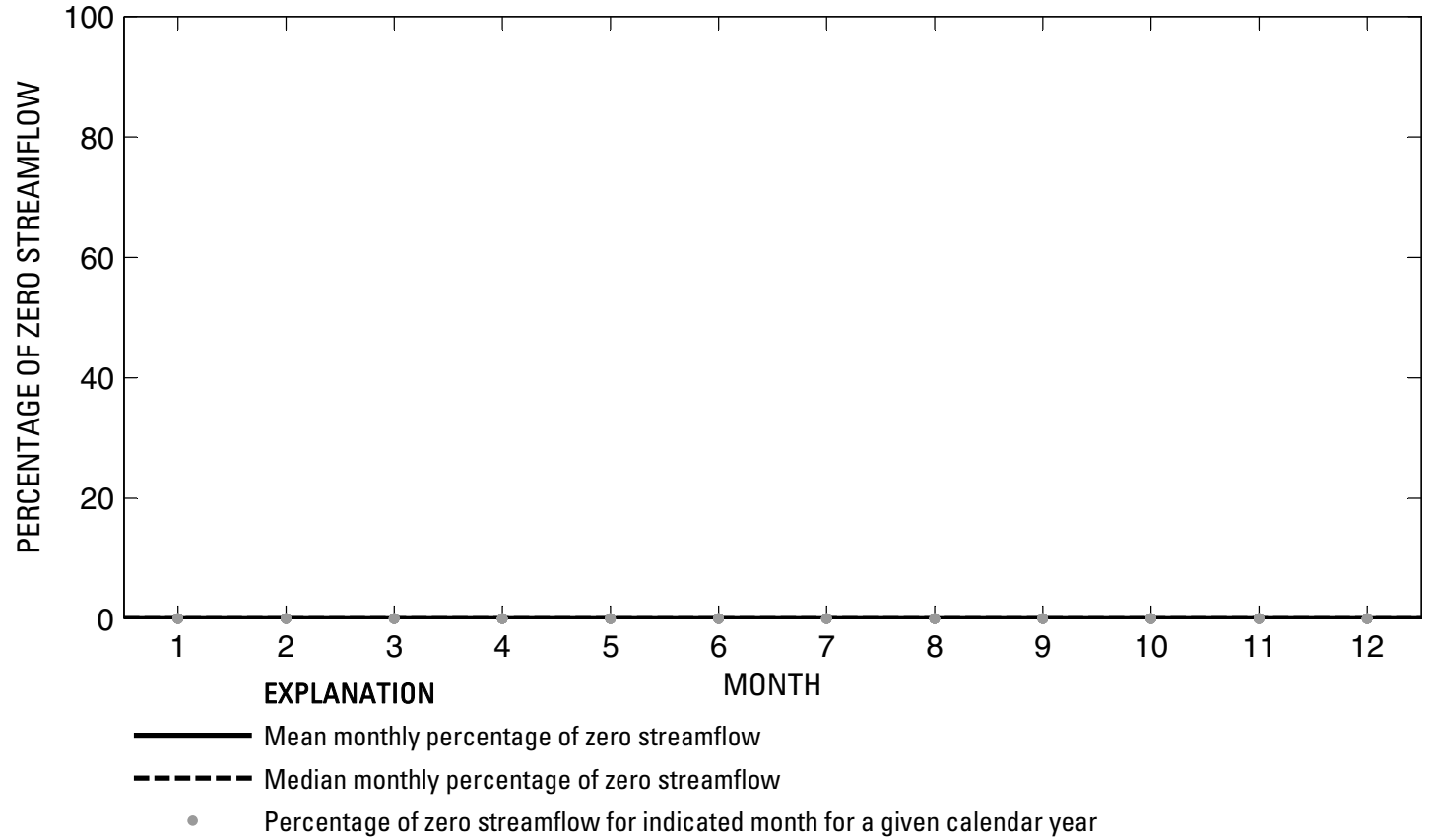

Figure 601. Analysis of percentage of zero daily mean streamflow for U.S. Geological Survey streamflow-gaging station 08178050 San Antonio River at Mitchell Street, San Antonio, Texas.

Index of Station Numbers 719 
U.S. Geological Survey streamflow-gaging station 08178500

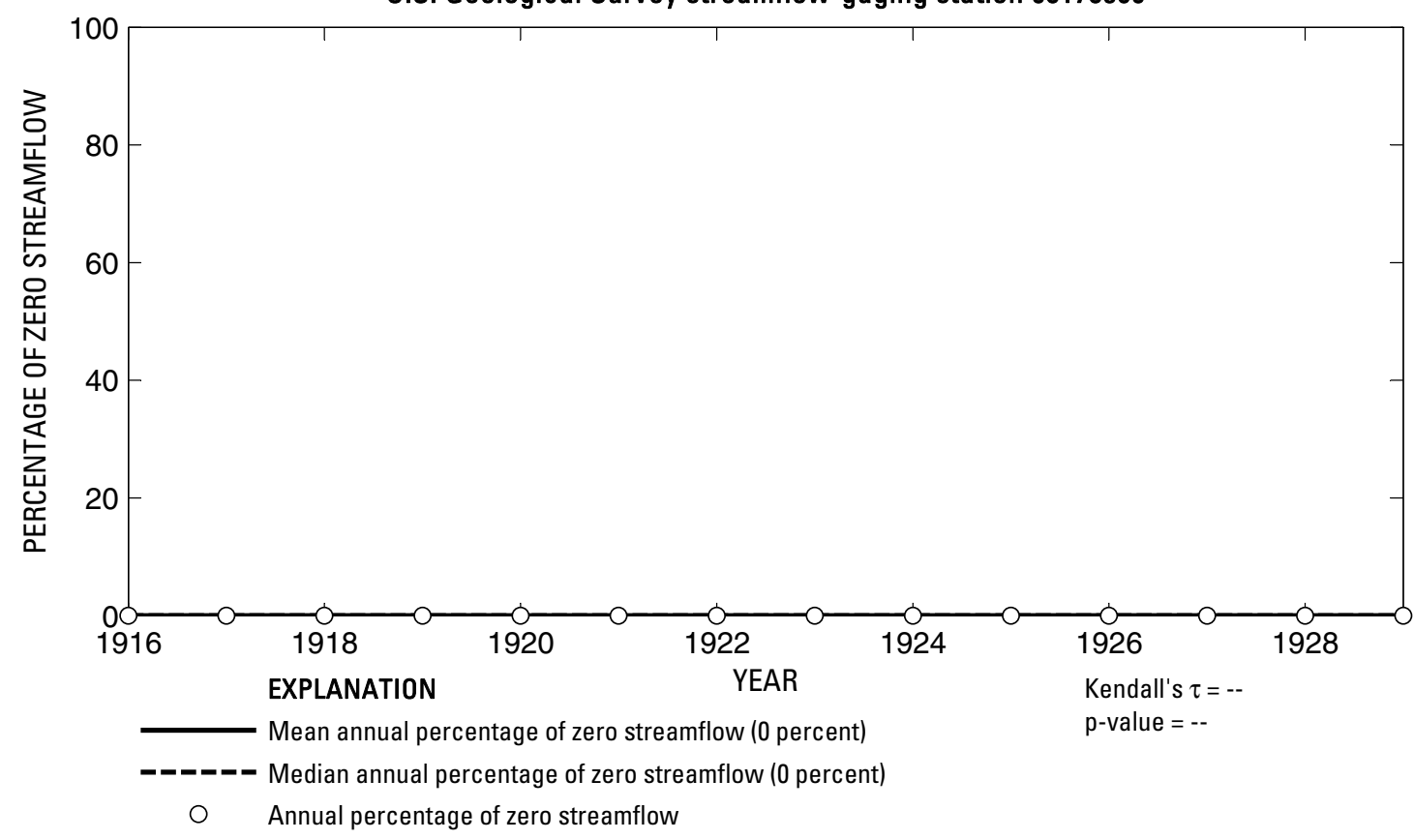

U.S. Geological Survey streamflow-gaging station 08178500

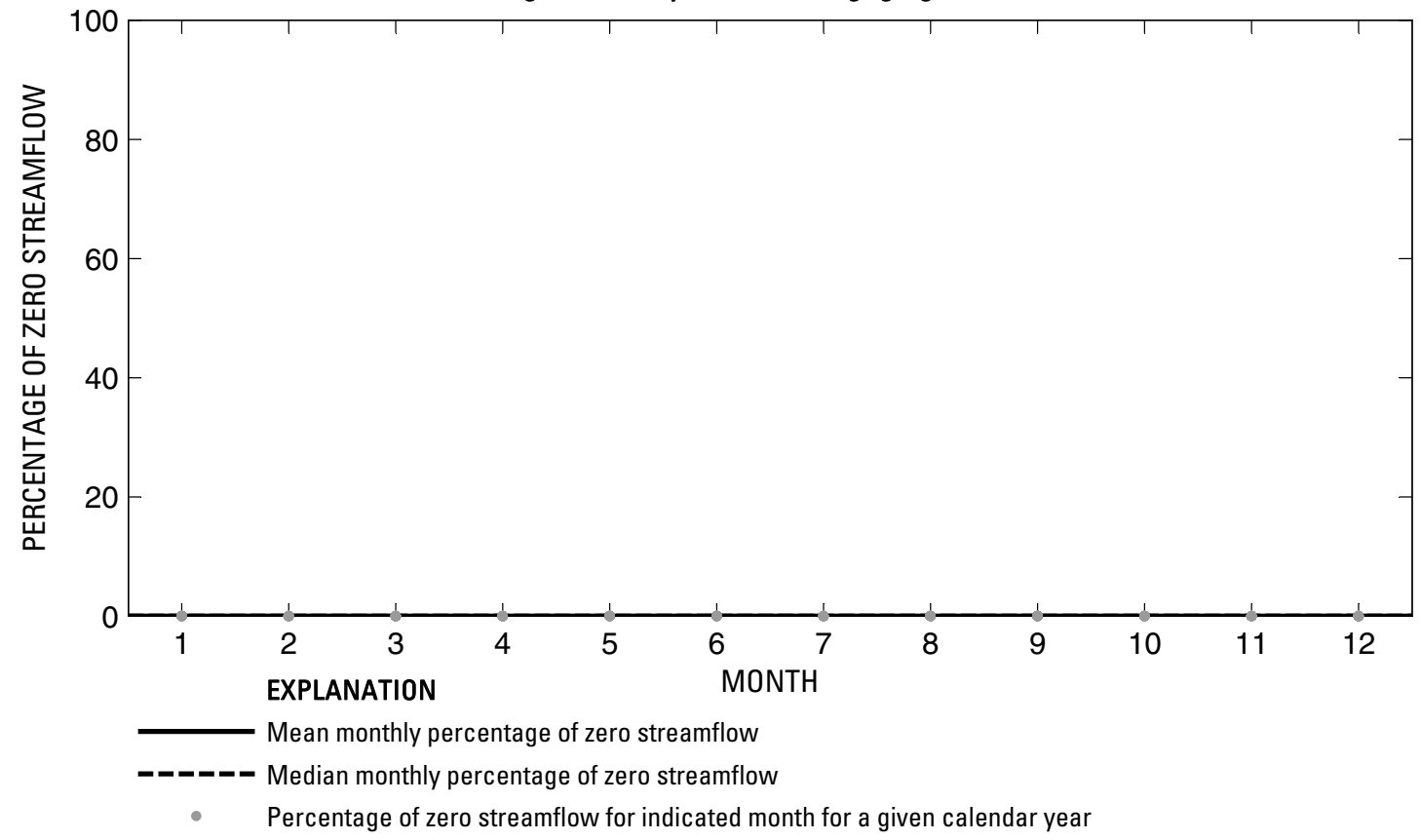

Figure 602. Analysis of percentage of zero daily mean streamflow for U.S. Geological Survey streamflow-gaging station 08178500 San Pedro Creek at Furnish Street, San Antonio, Texas.

Index of Station Numbers 719 
U.S. Geological Survey streamflow-gaging station 08178565

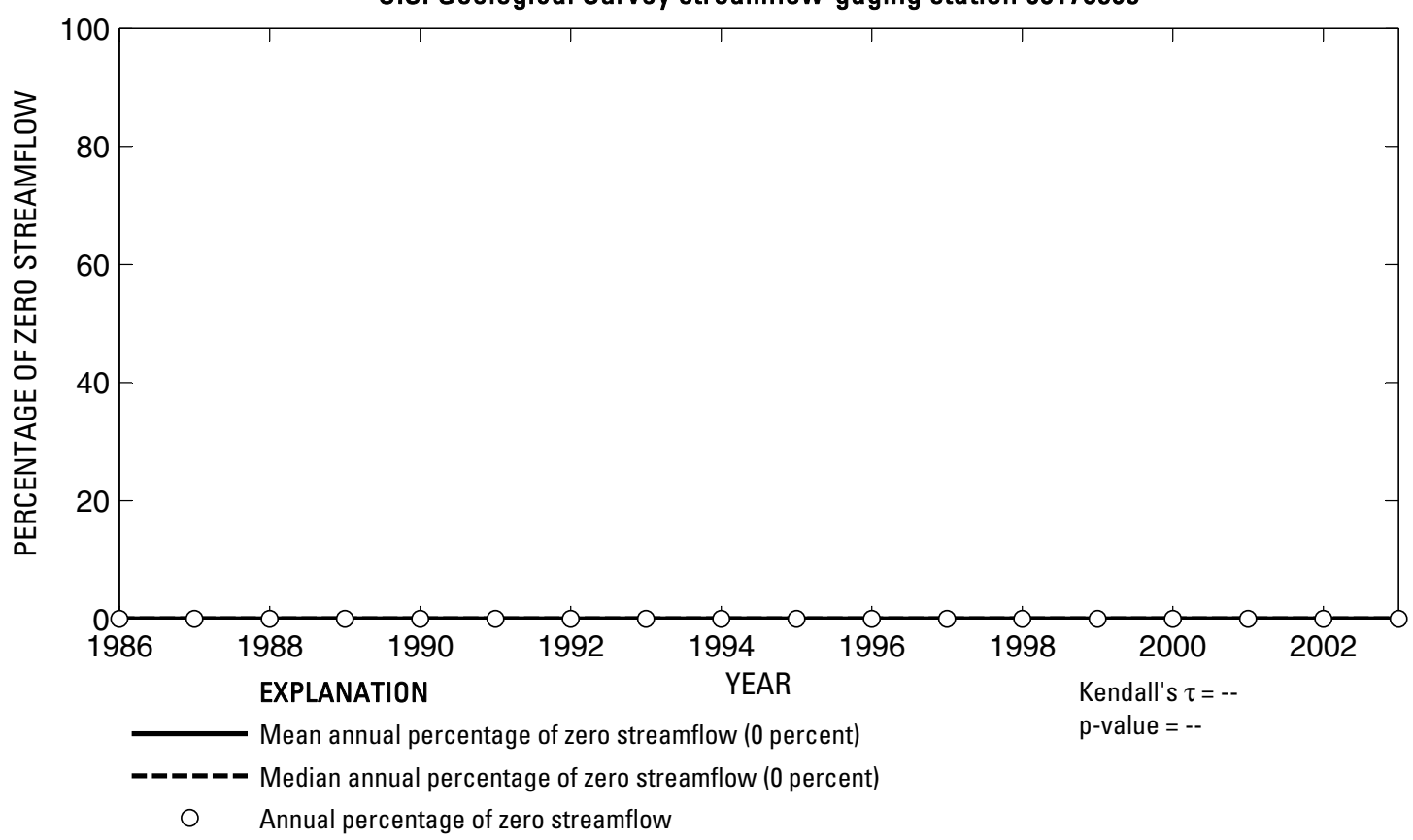

U.S. Geological Survey streamflow-gaging station 08178565

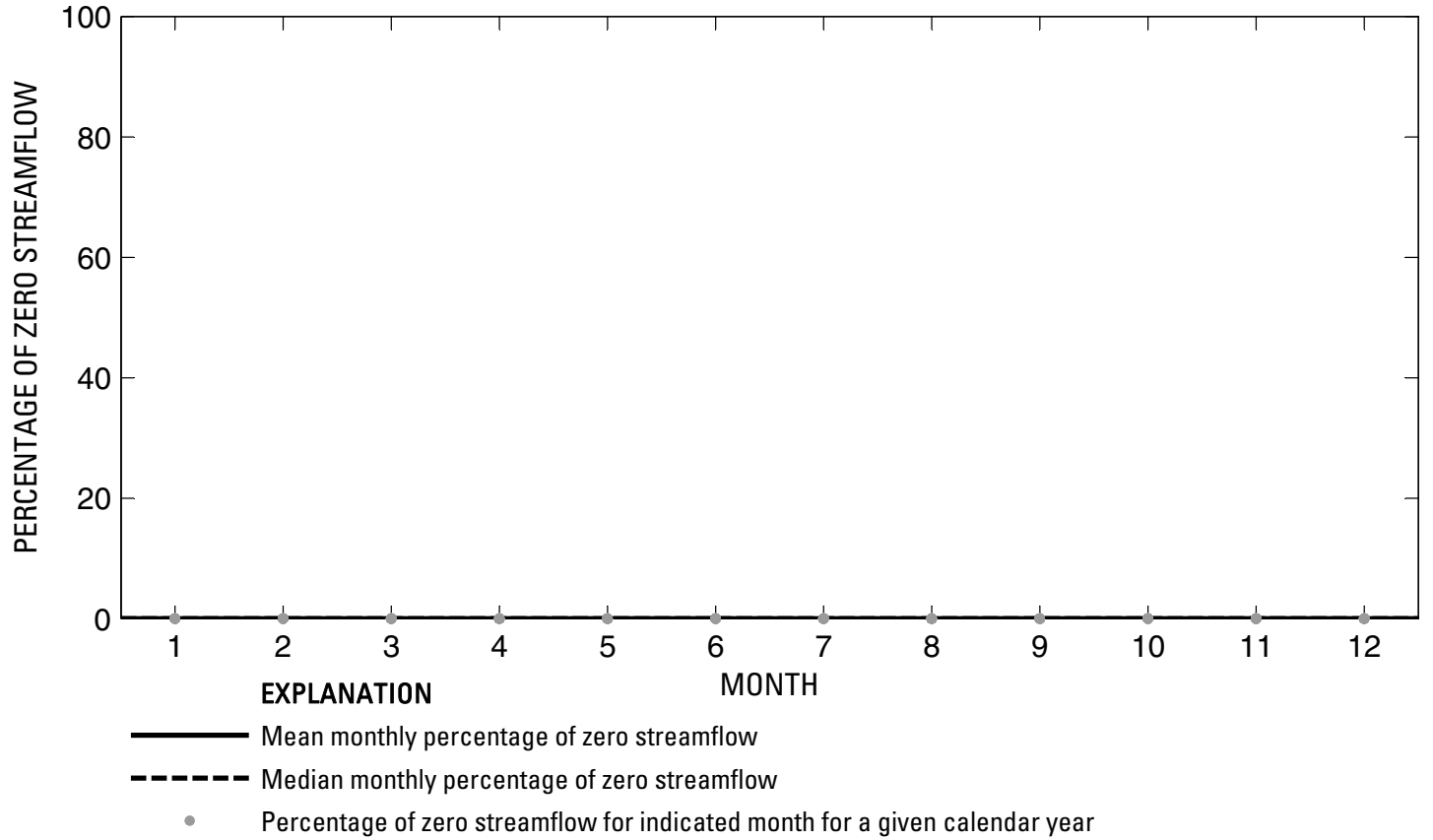

Figure 603. Analysis of percentage of zero daily mean streamflow for U.S. Geological Survey streamflow-gaging station 08178565 San Antonio River at Loop 410, San Antonio, Texas.

Index of Station Numbers 719 
U.S. Geological Survey streamflow-gaging station 08178585

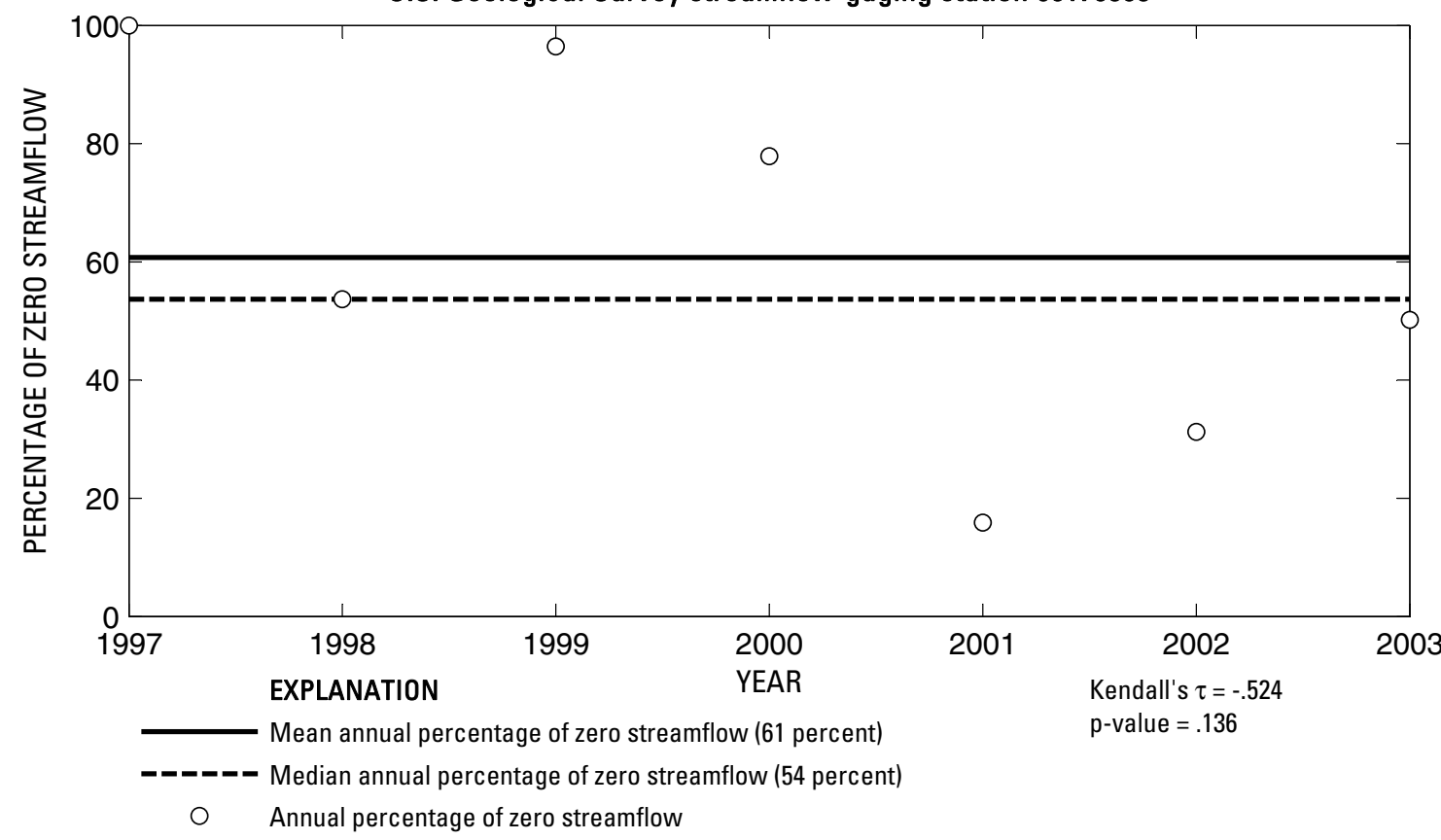

U.S. Geological Survey streamflow-gaging station 08178585

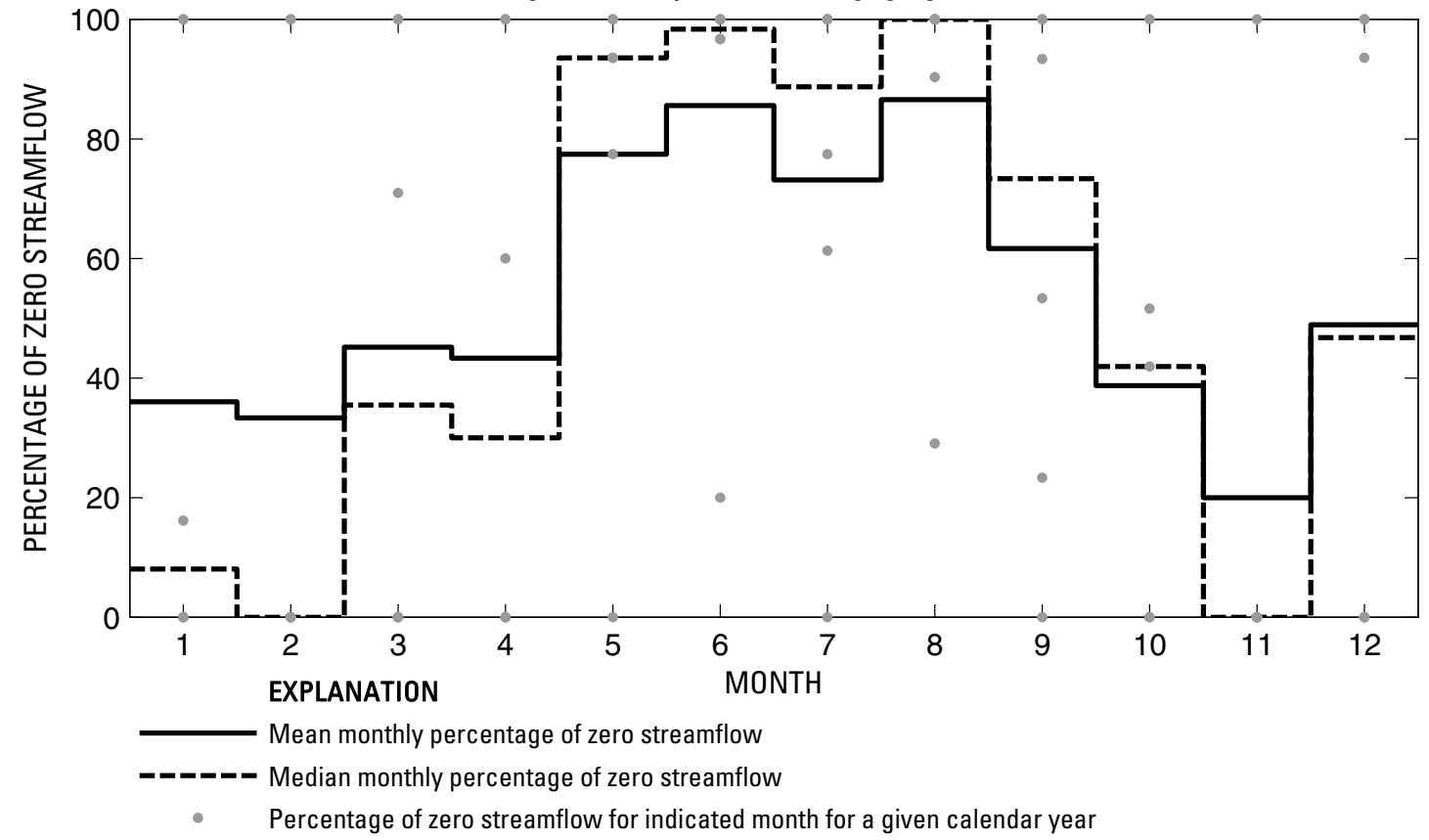

Figure 604. Analysis of percentage of zero daily mean streamflow for U.S. Geological Survey streamflow-gaging station 08178585 Salado Creek at Wilderness Road, San Antonio, Texas.

Index of Station Numbers 719 
U.S. Geological Survey streamflow-gaging station 08178700

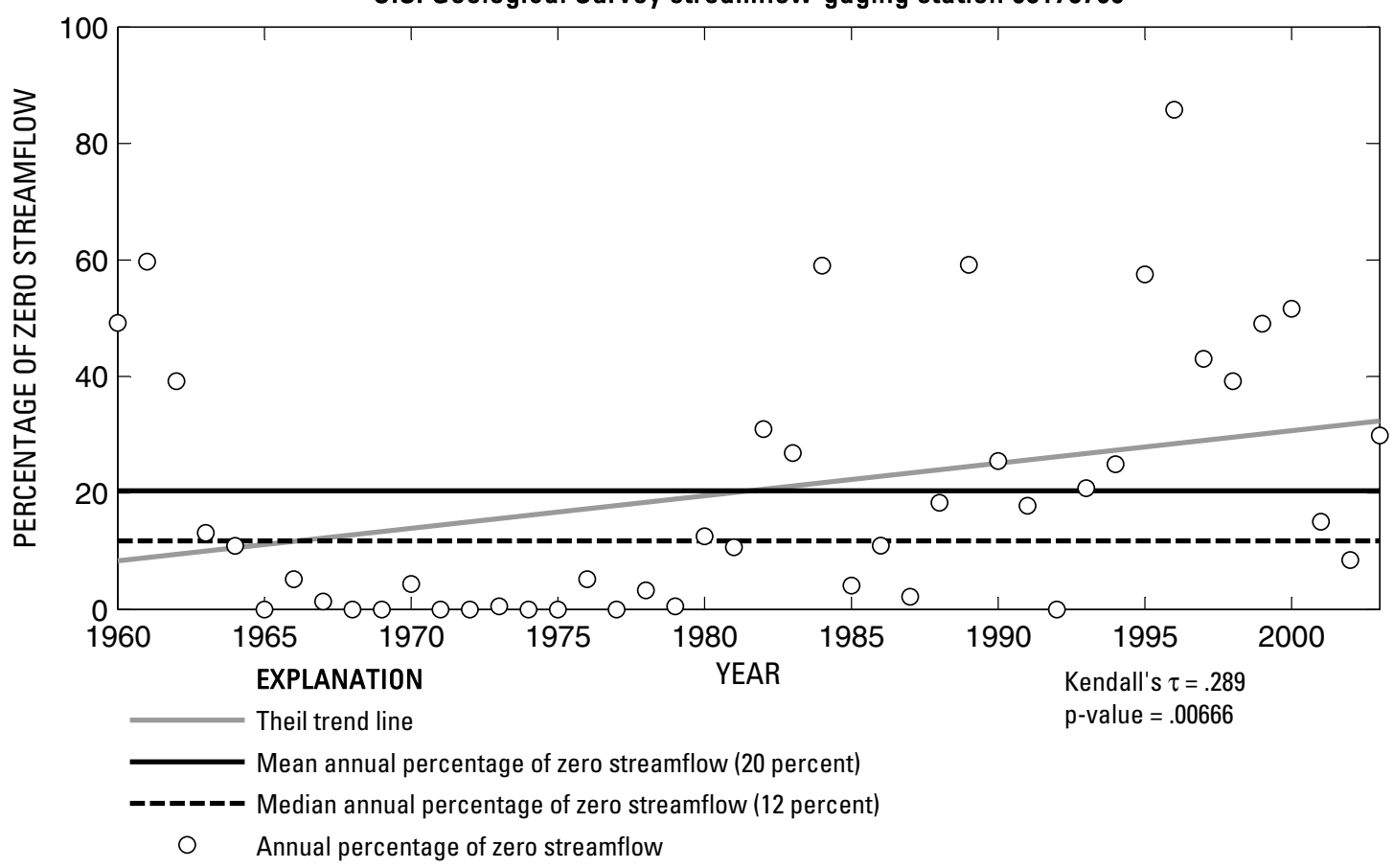

U.S. Geological Survey streamflow-gaging station 08178700

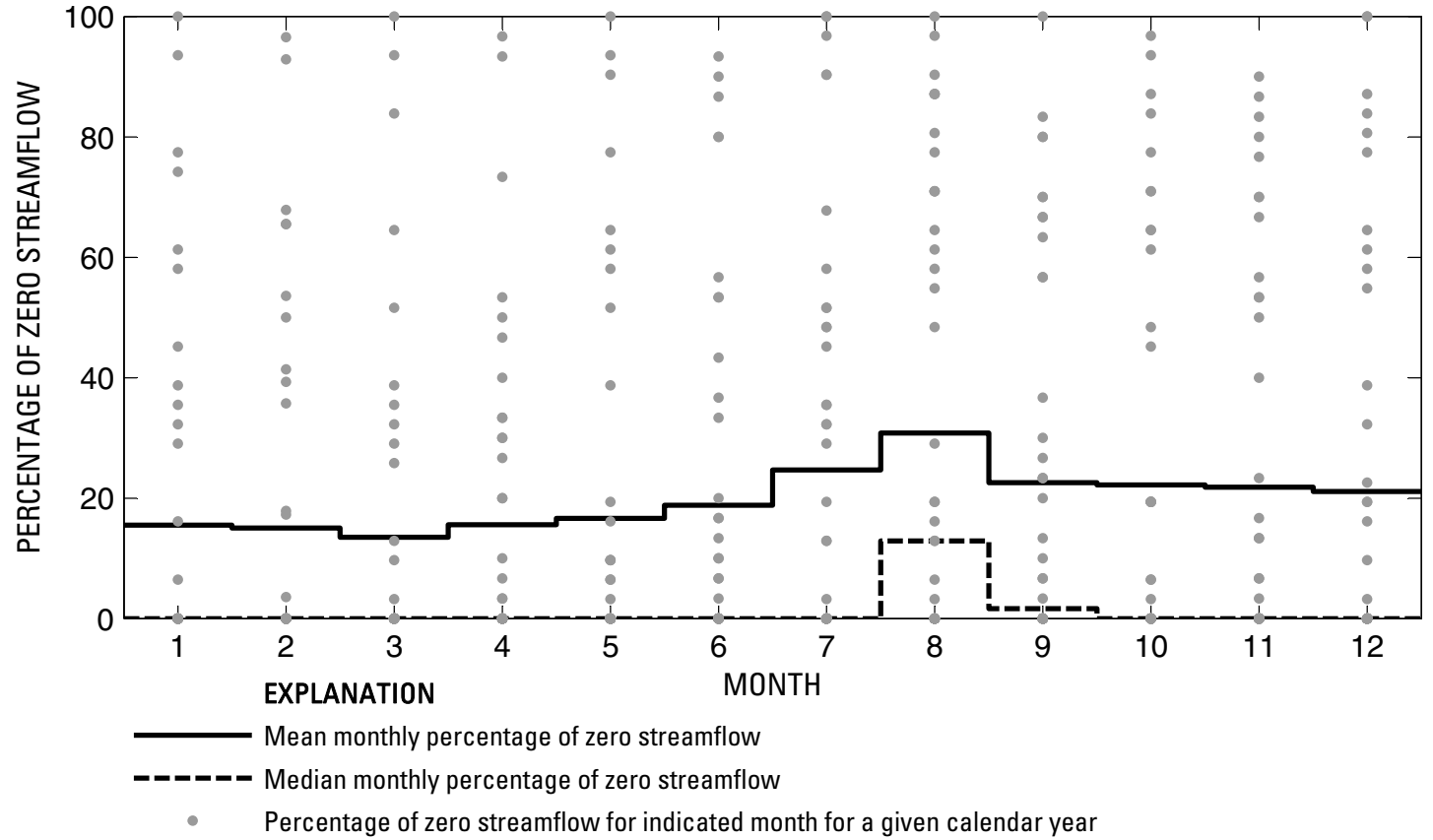

Figure 605. Analysis of percentage of zero daily mean streamflow for U.S. Geological Survey streamflow-gaging station 08178700 Salado Creek at Loop 410, San Antonio, Texas.

Index of Station Numbers 719 
U.S. Geological Survey streamflow-gaging station 08178800

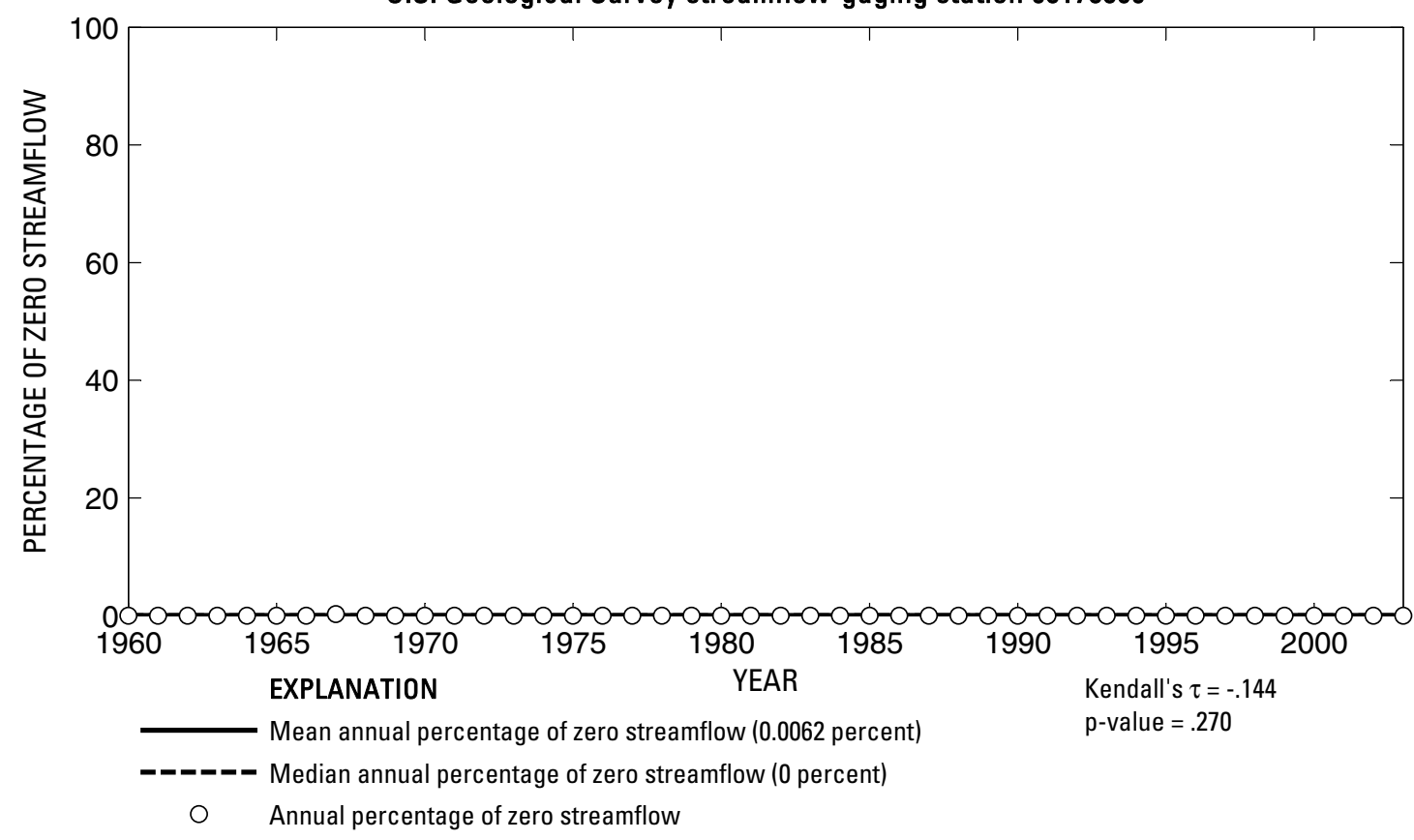

U.S. Geological Survey streamflow-gaging station 08178800

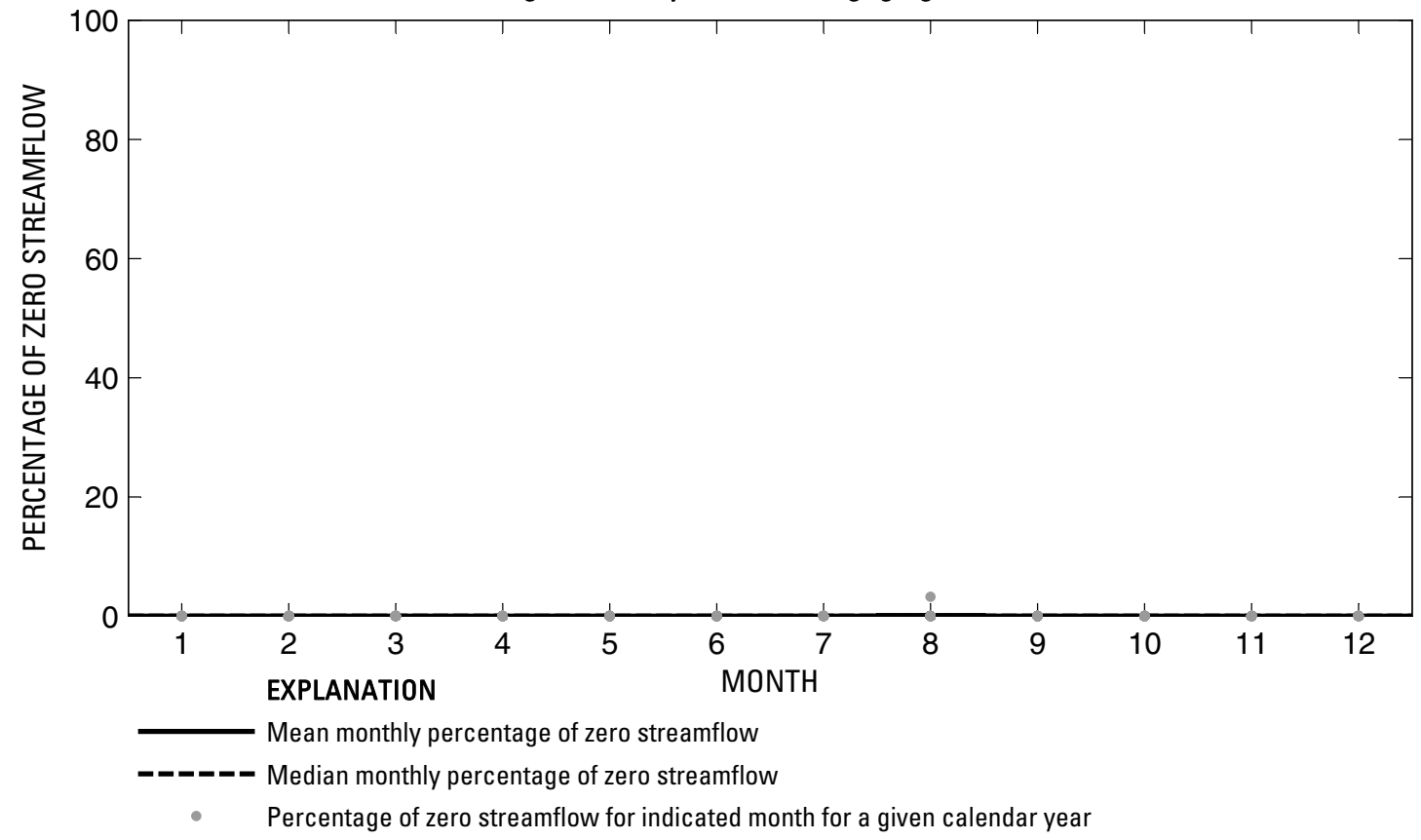

Figure 606. Analysis of percentage of zero daily mean streamflow for U.S. Geological Survey streamflow-gaging station 08178800 Salado Creek at Loop 13, San Antonio, Texas.

Index of Station Numbers 719 


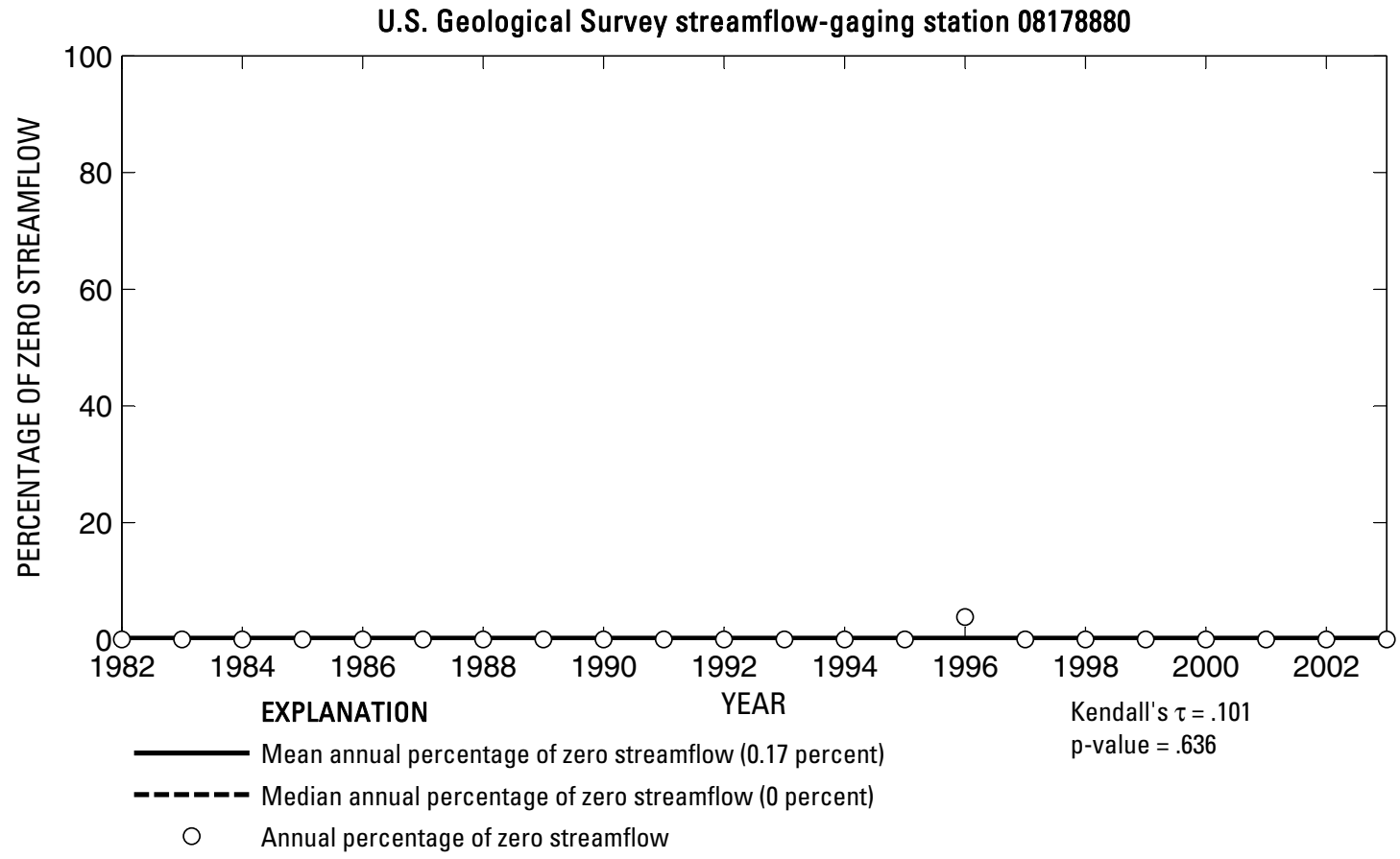

U.S. Geological Survey streamflow-gaging station 08178880

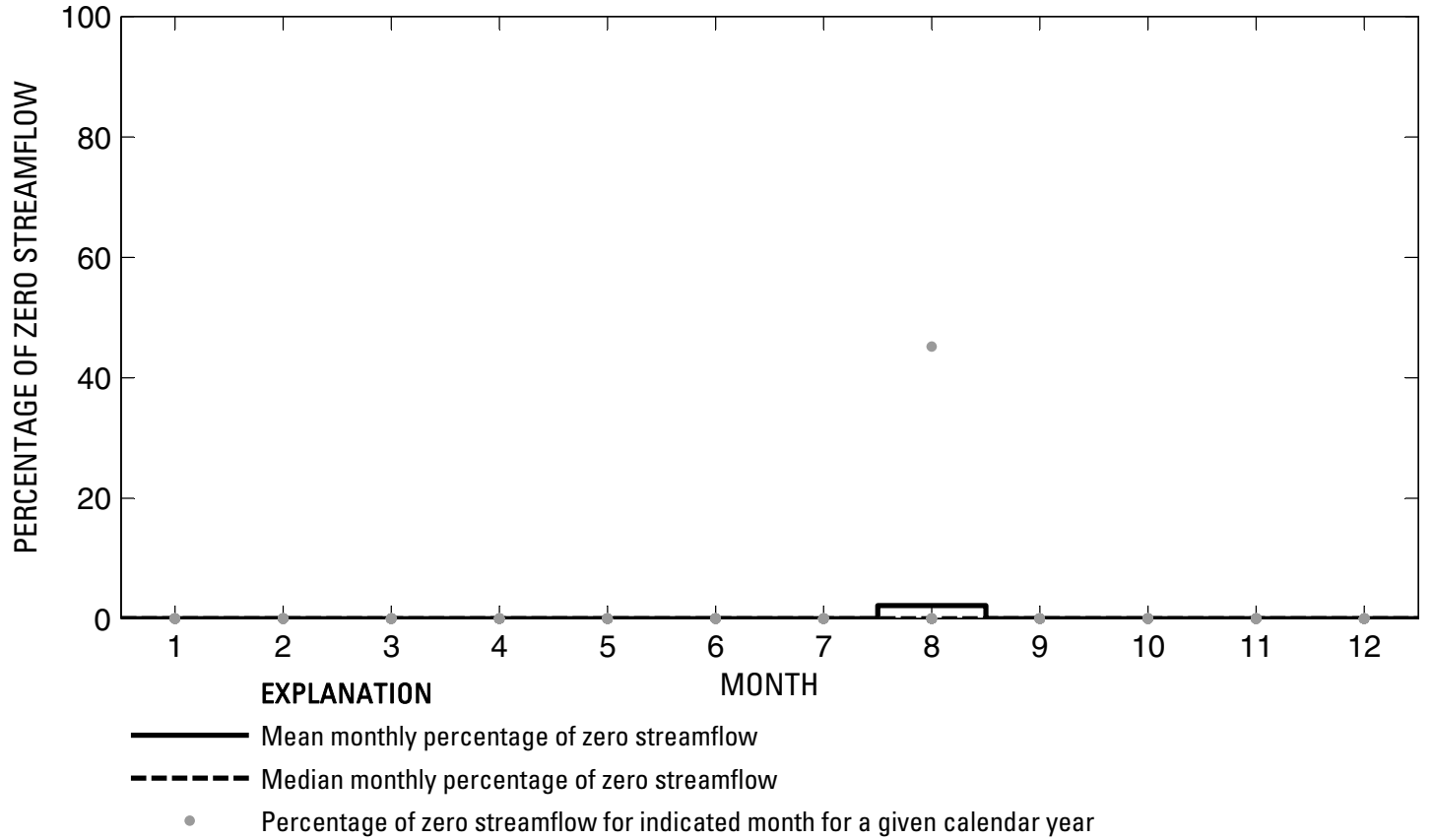

Figure 607. Analysis of percentage of zero daily mean streamflow for U.S. Geological Survey streamflow-gaging station 08178880 Medina River at Bandera, Texas.

Index of Station Numbers 719 
U.S. Geological Survey streamflow-gaging station 08179000

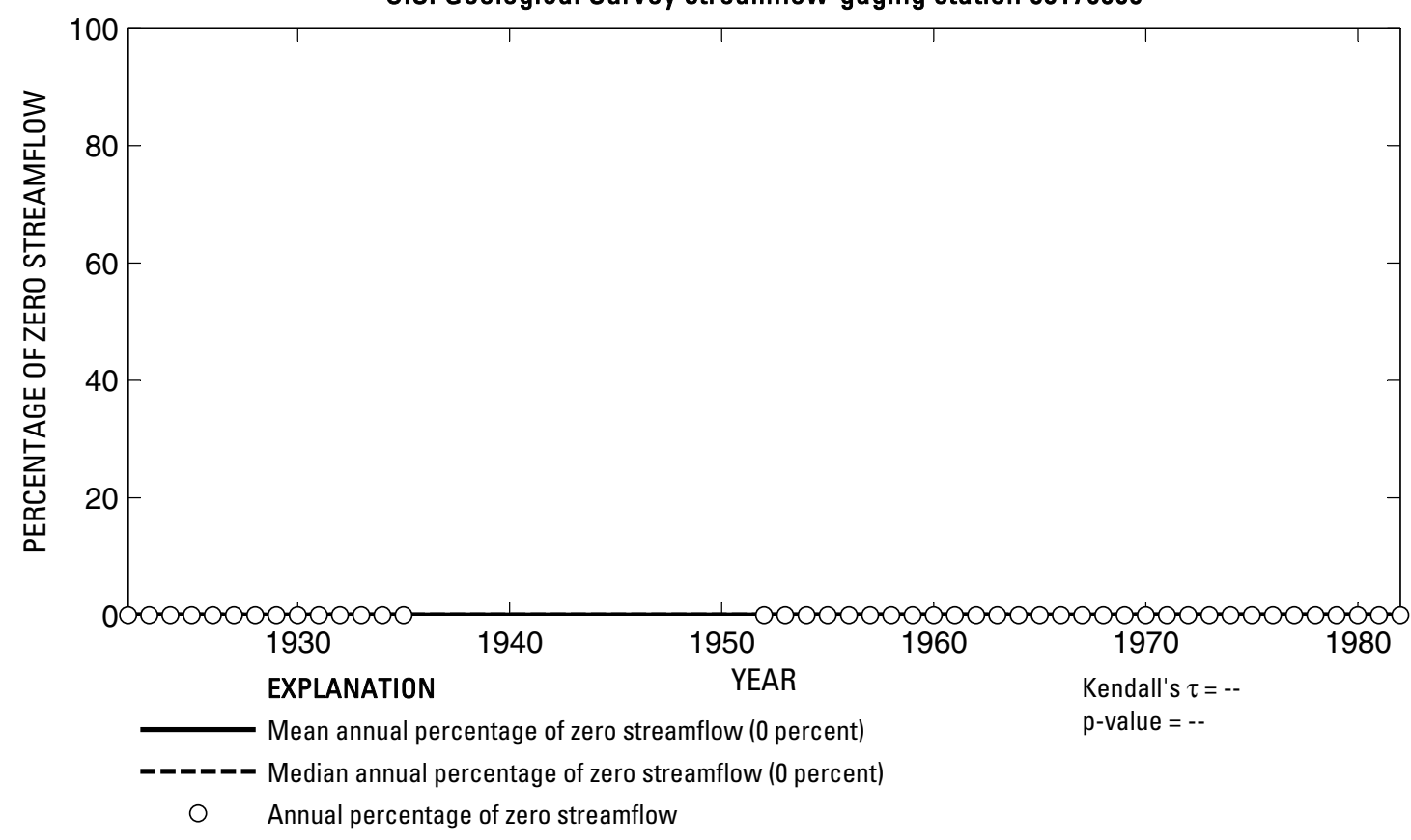

U.S. Geological Survey streamflow-gaging station 08179000

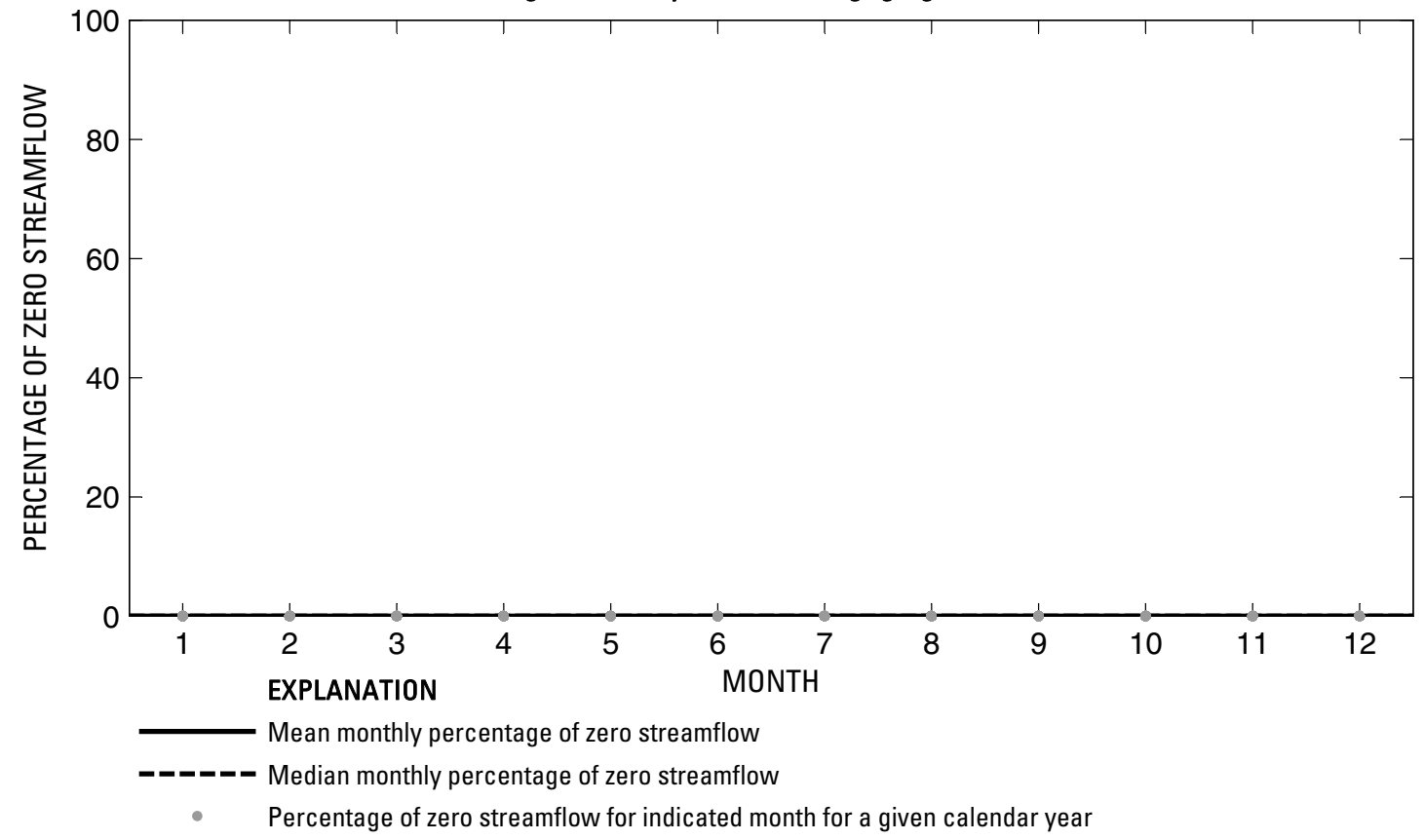

Figure 608. Analysis of percentage of zero daily mean streamflow for U.S. Geological Survey streamflow-gaging station 08179000 Medina River near Pipe Creek, Texas. 


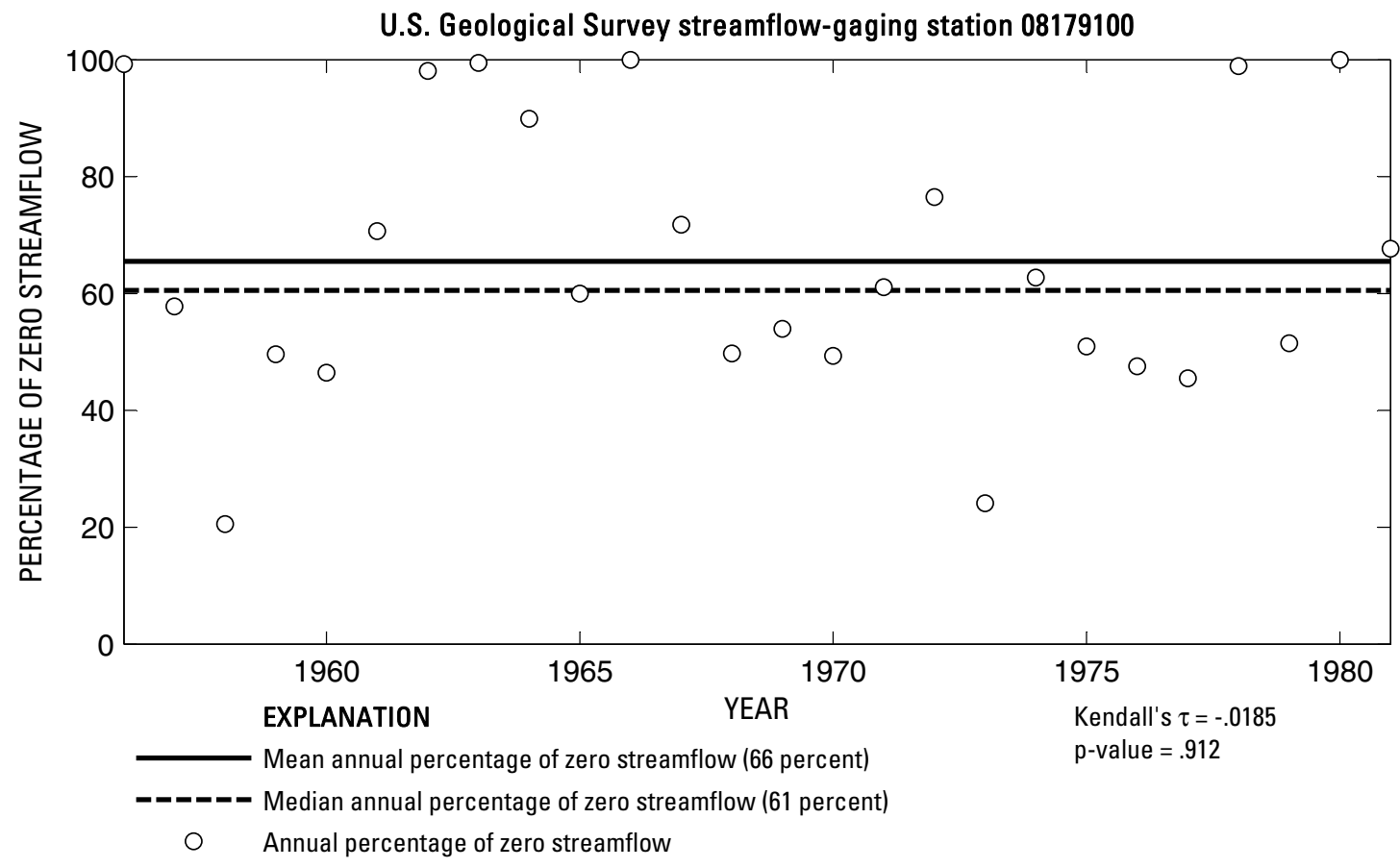

U.S. Geological Survey streamflow-gaging station 08179100

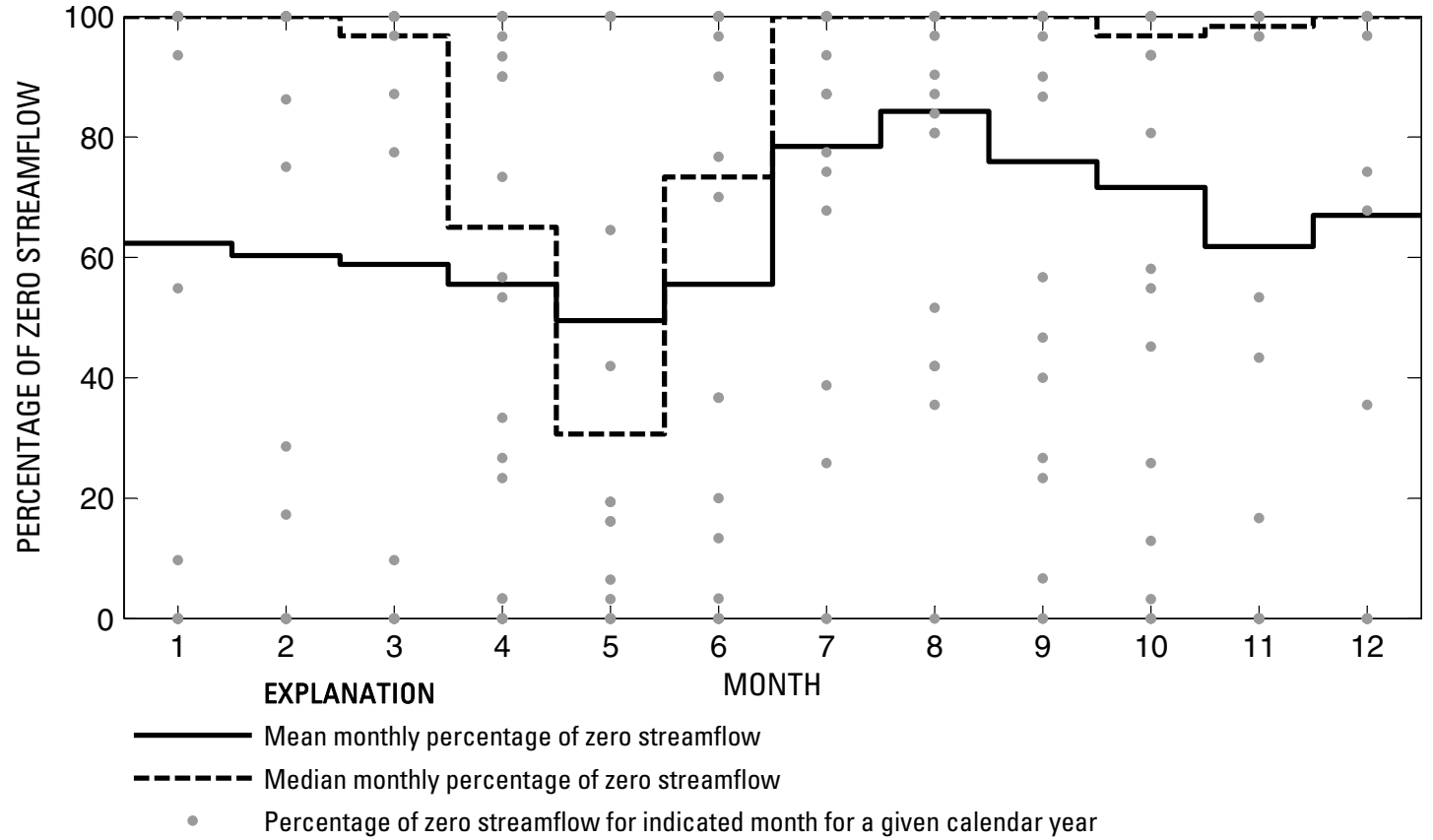

Figure 609. Analysis of percentage of zero daily mean streamflow for U.S. Geological Survey streamflow-gaging station 08179100 Red Bluff Creek near Pipe Creek, Texas.

Index of Station Numbers 719 
U.S. Geological Survey streamflow-gaging station 08179520

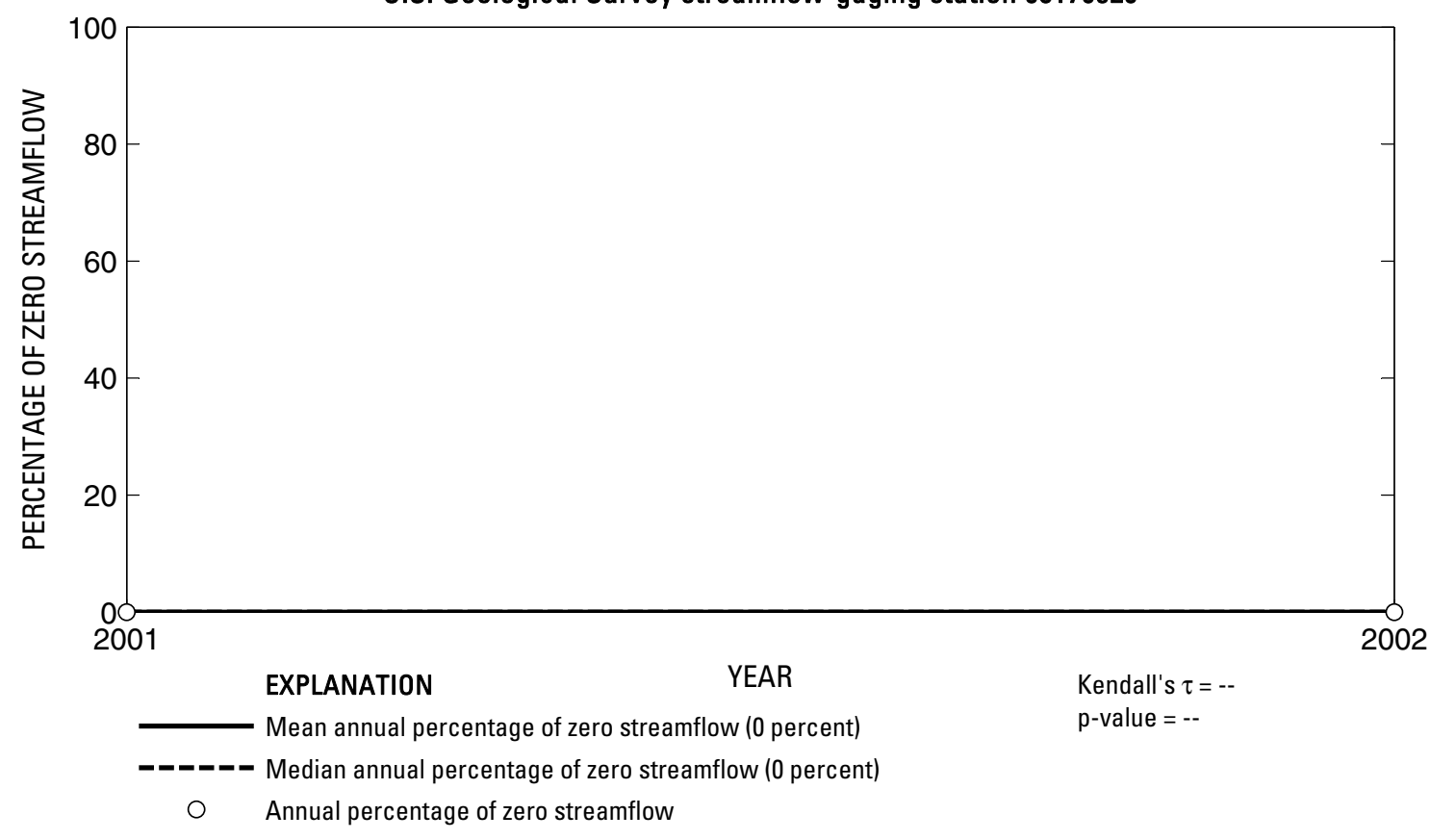

U.S. Geological Survey streamflow-gaging station 08179520

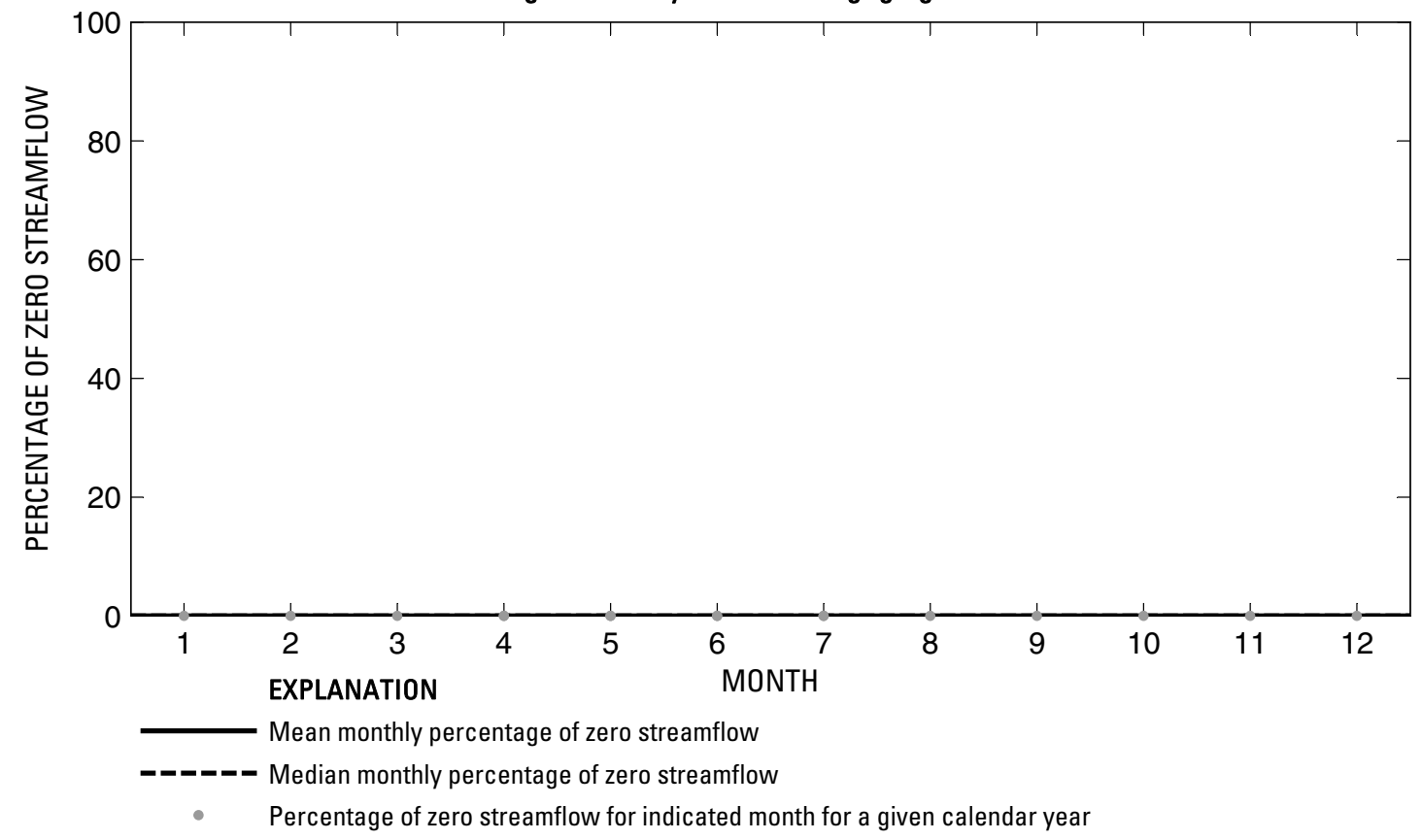

Figure 610. Analysis of percentage of zero daily mean streamflow for U.S. Geological Survey streamflow-gaging station 08179520 Medina River below Medina Lake near San Antonio, Texas.

Index of Station Numbers 719 
U.S. Geological Survey streamflow-gaging station 08180500

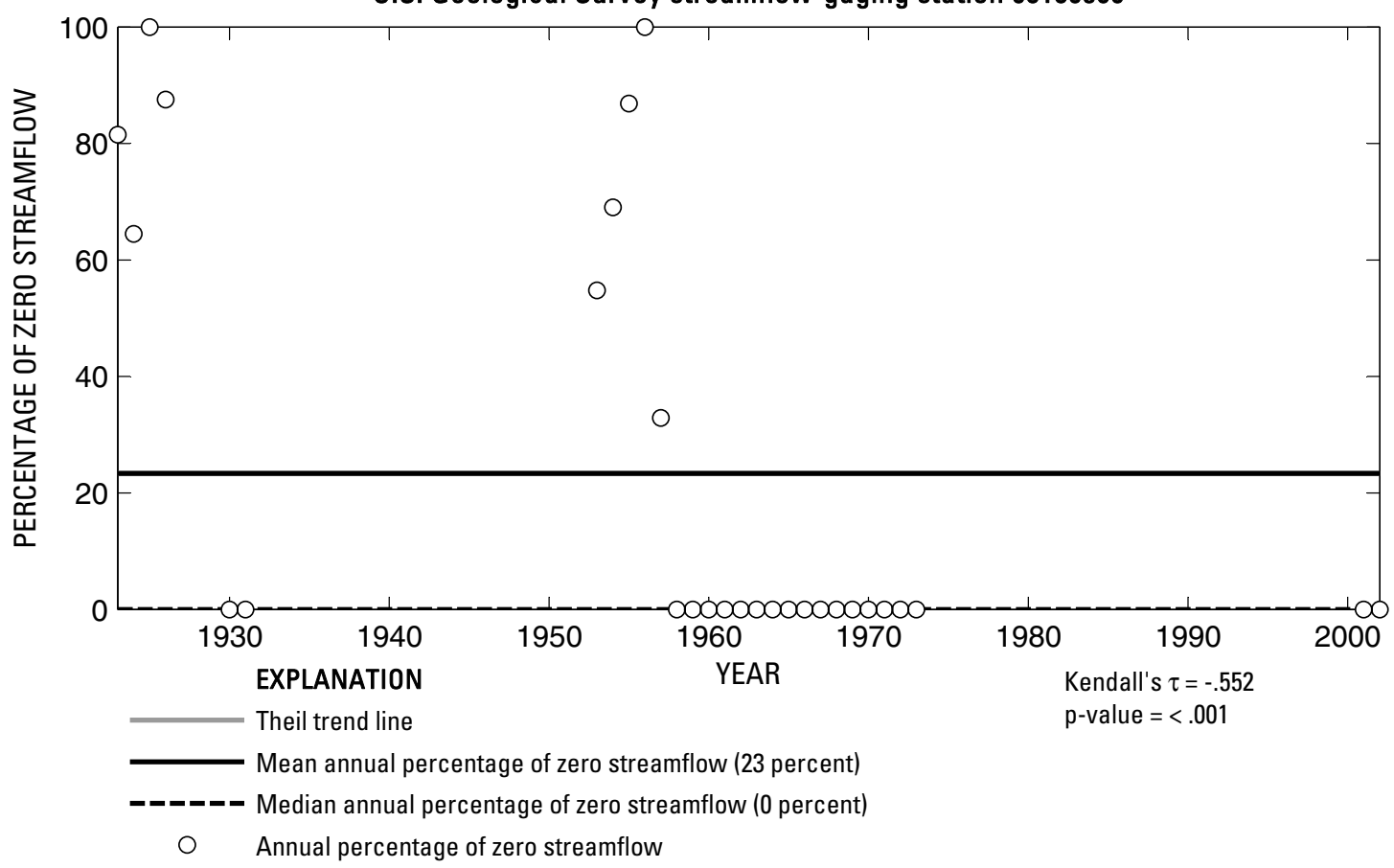

U.S. Geological Survey streamflow-gaging station 08180500

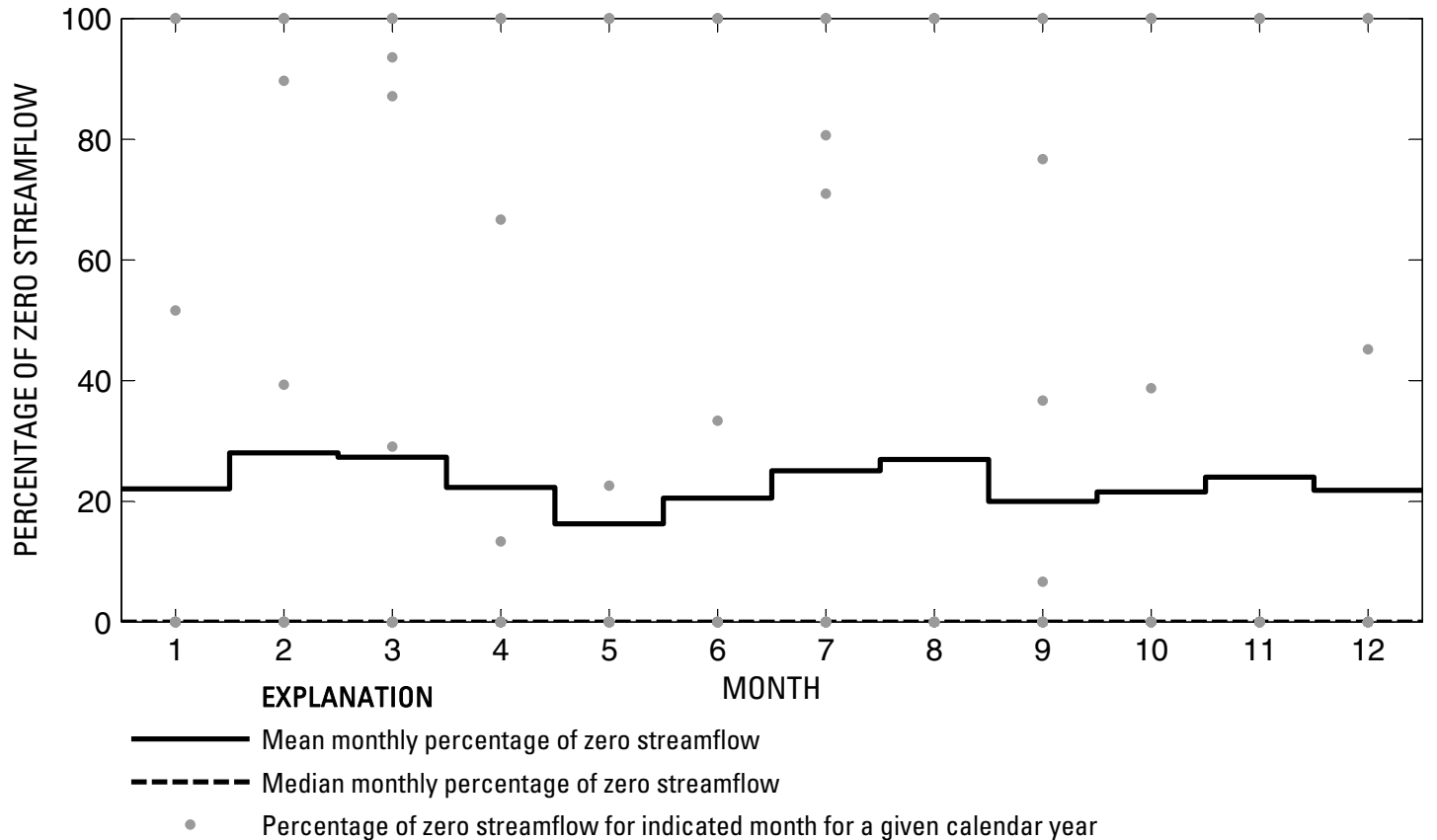

Figure 611. Analysis of percentage of zero daily mean streamflow for U.S. Geological Survey streamflow-gaging station 08180500 Medina River near Riomedina, Texas.

Index of Station Numbers 719 
U.S. Geological Survey streamflow-gaging station 08180640

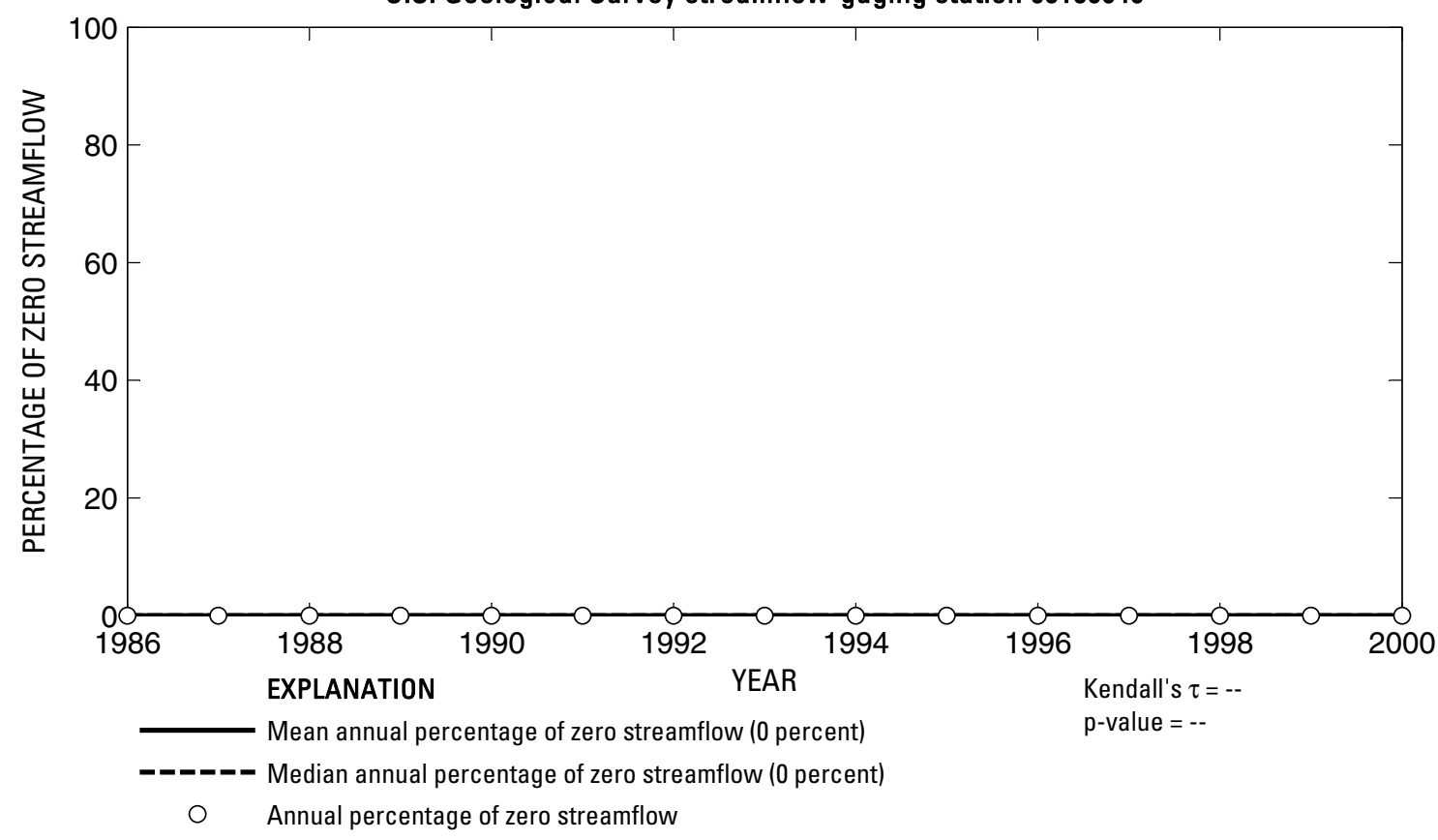

U.S. Geological Survey streamflow-gaging station 08180640

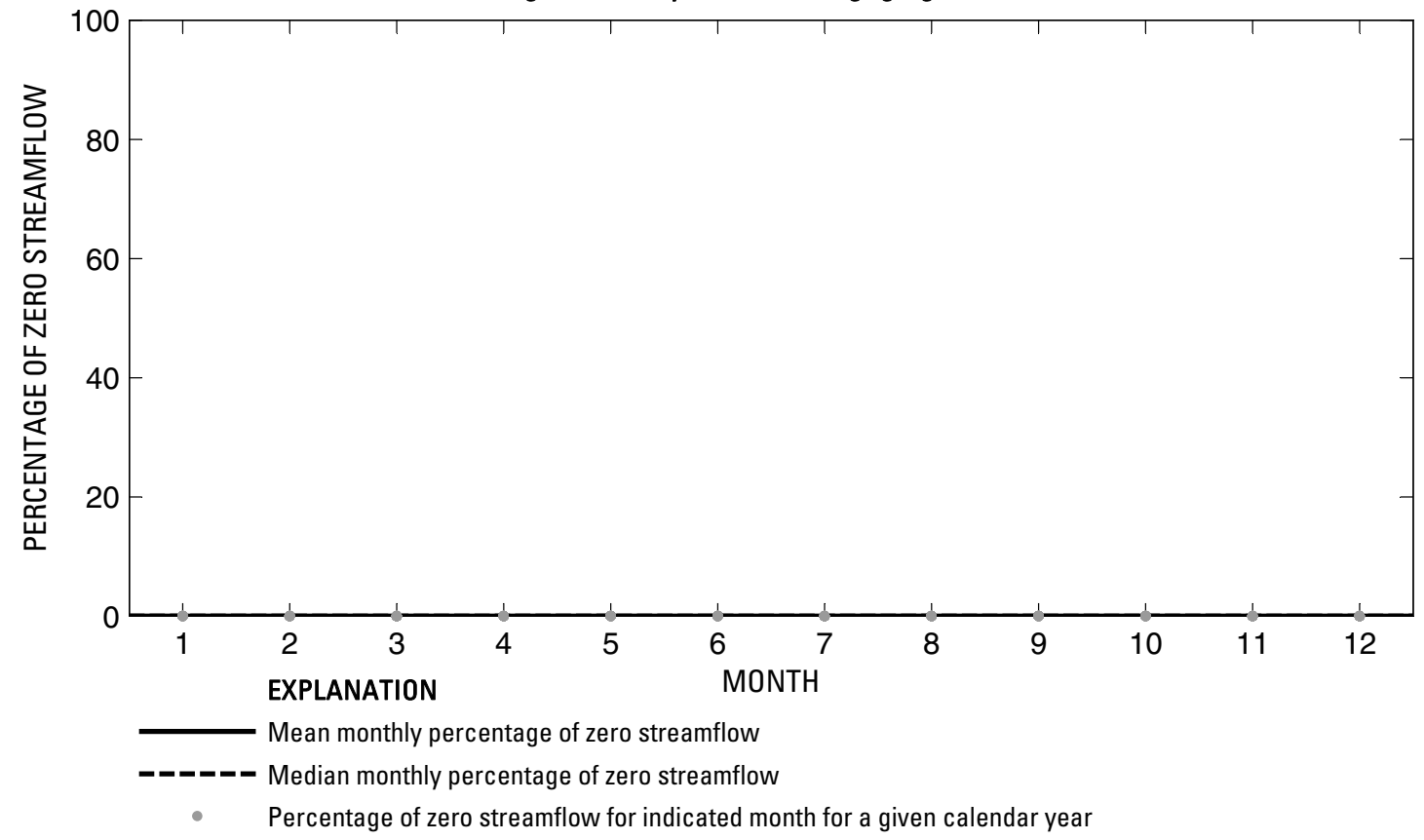

Figure 612. Analysis of percentage of zero daily mean streamflow for U.S. Geological Survey streamflow-gaging station 08180640 Medina River at La Coste, Texas. 
U.S. Geological Survey streamflow-gaging station 08180700

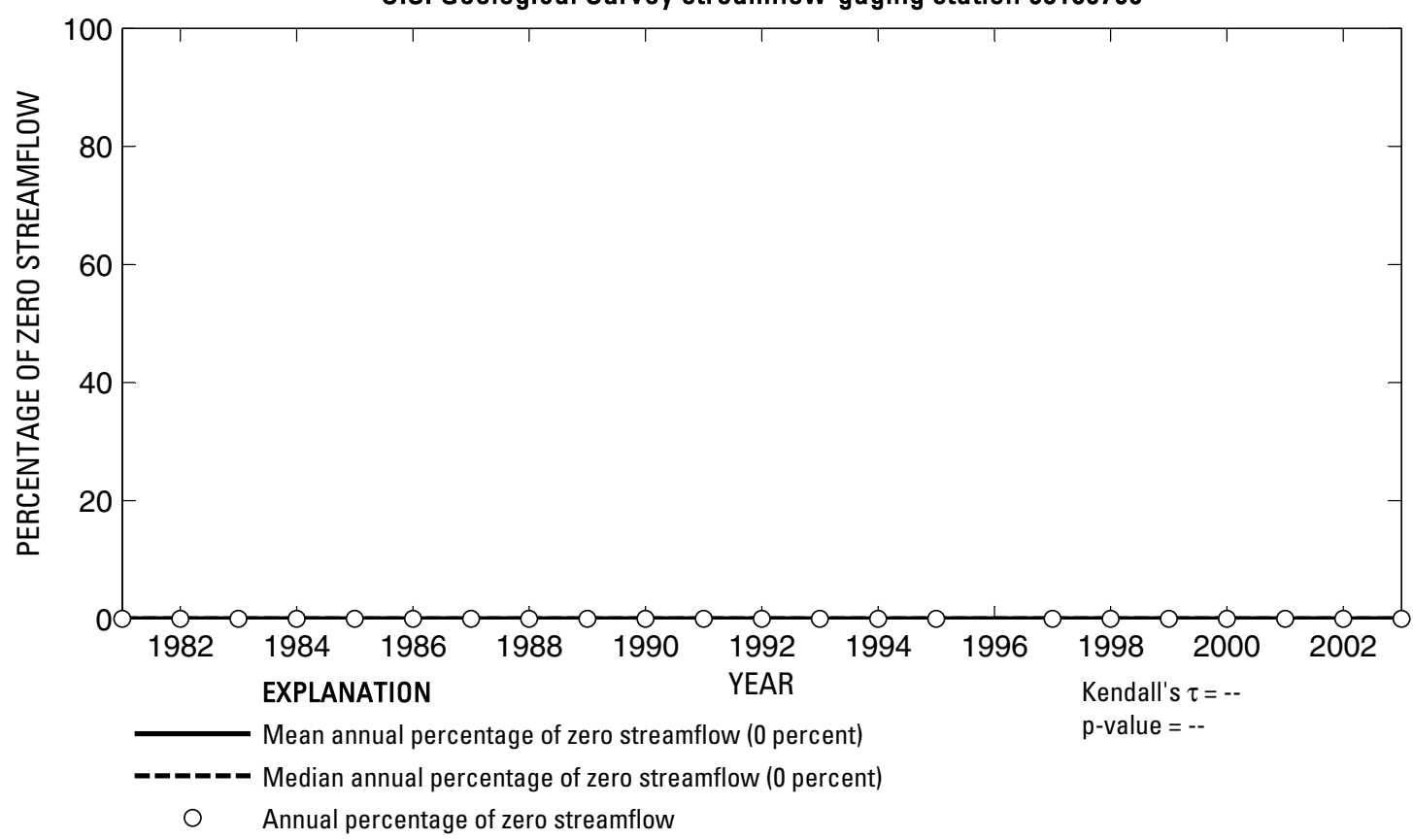

U.S. Geological Survey streamflow-gaging station 08180700

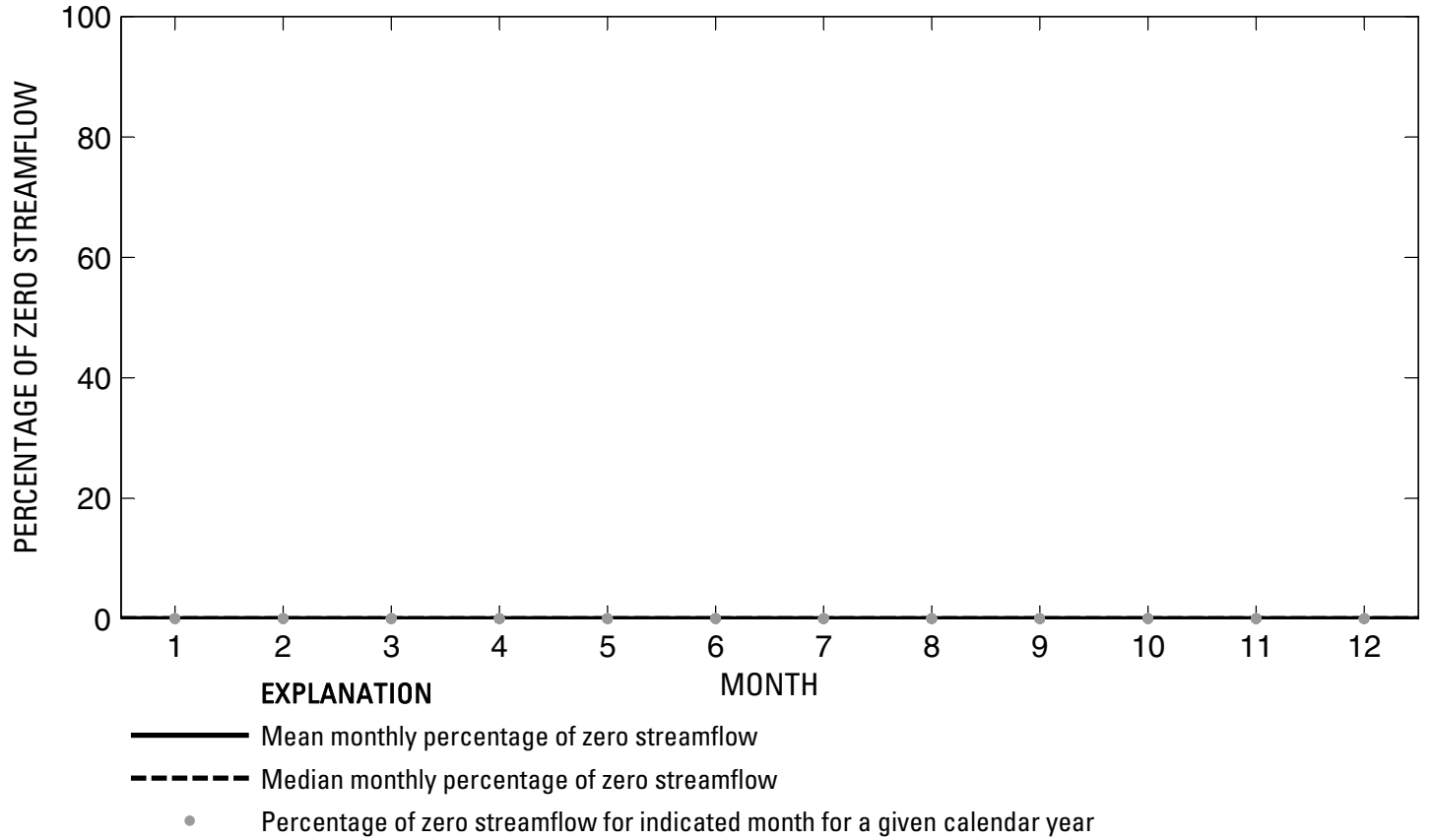

Figure 613. Analysis of percentage of zero daily mean streamflow for U.S. Geological Survey streamflow-gaging station 08180700 Medina River near Macdona, Texas.

Index of Station Numbers 719 
U.S. Geological Survey streamflow-gaging station 08180750

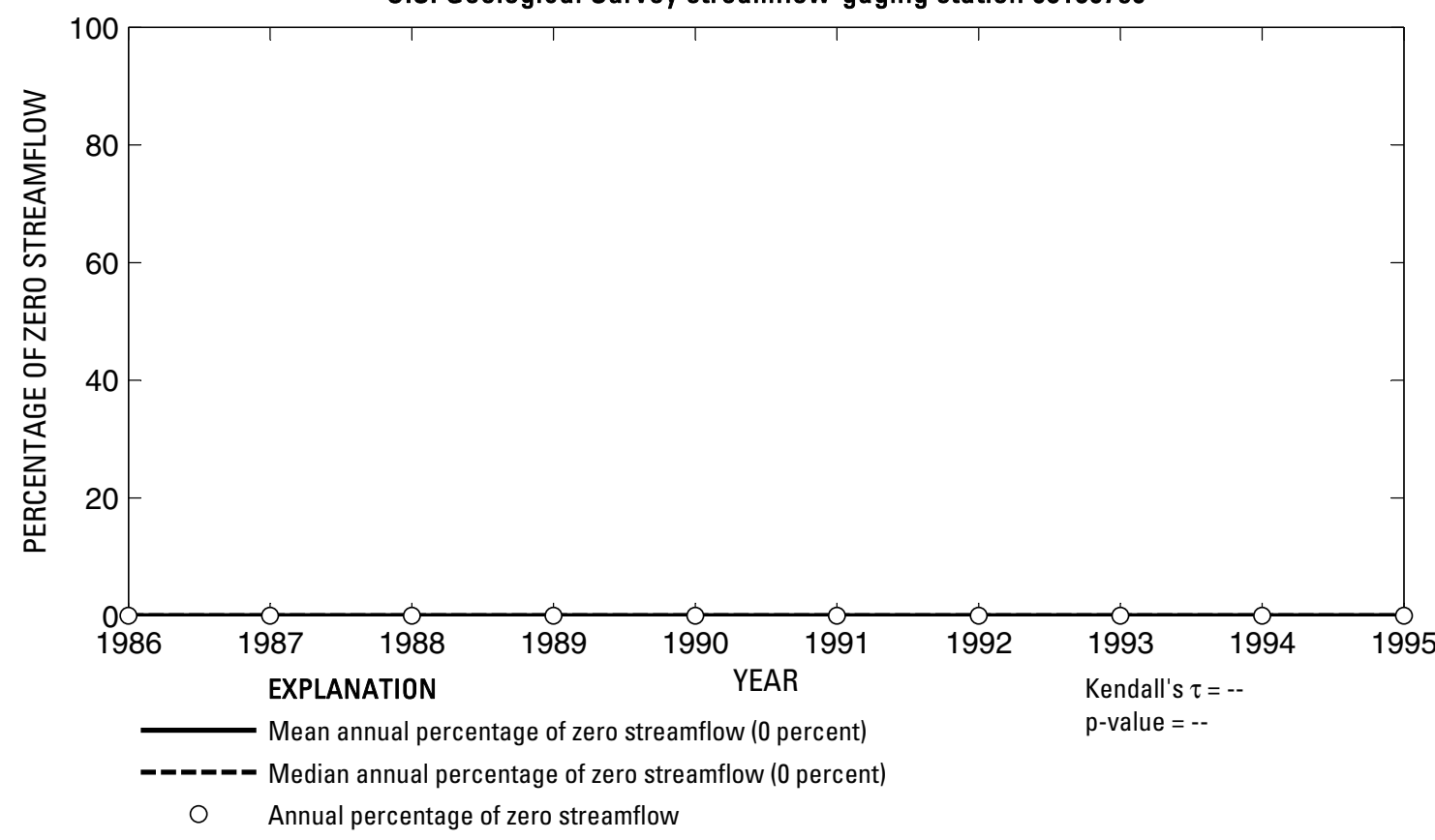

U.S. Geological Survey streamflow-gaging station 08180750

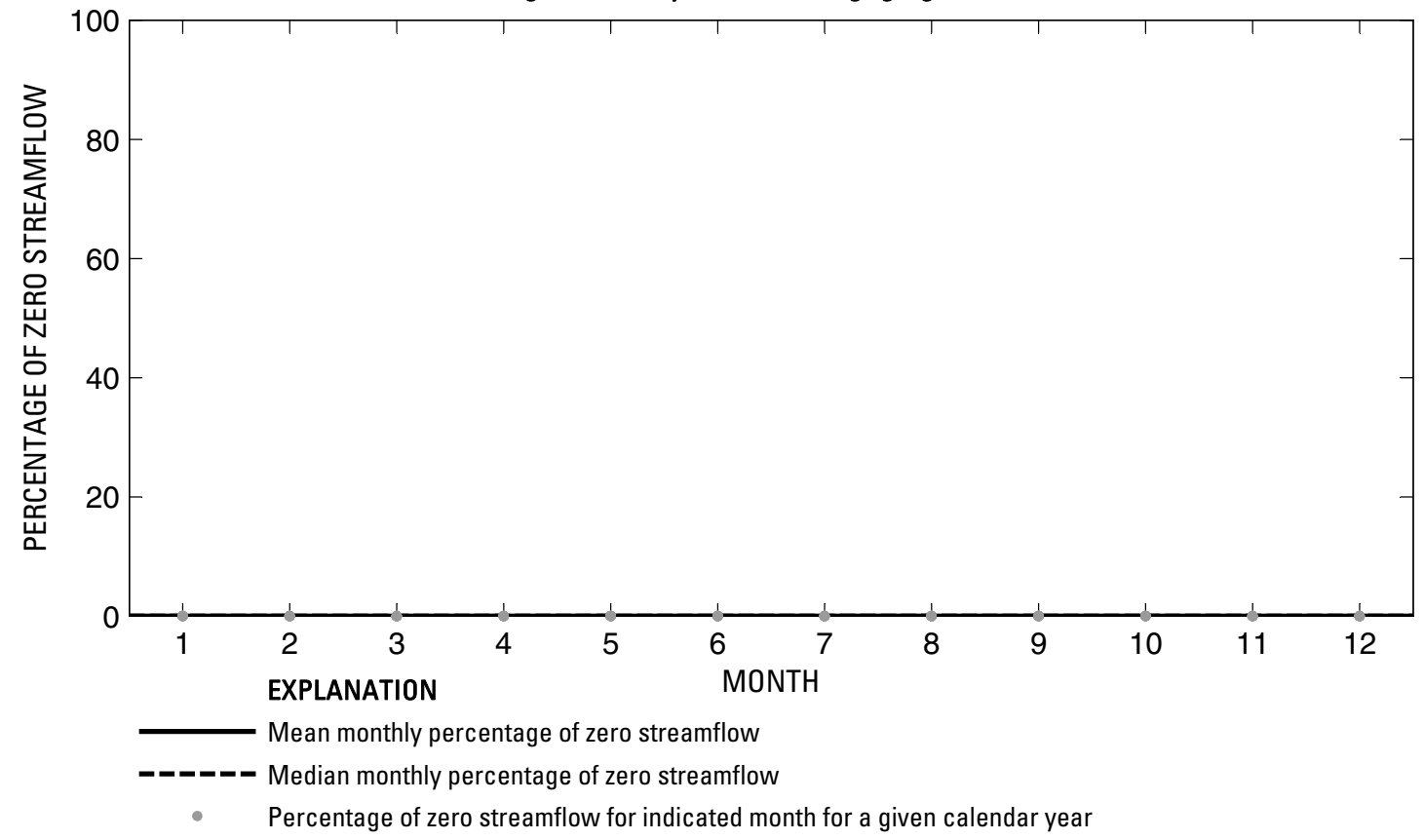

Figure 614. Analysis of percentage of zero daily mean streamflow for U.S. Geological Survey streamflow-gaging station 08180750 Medio Creek at Pearsall Road, San Antonio, Texas.

Index of Station Numbers 719 


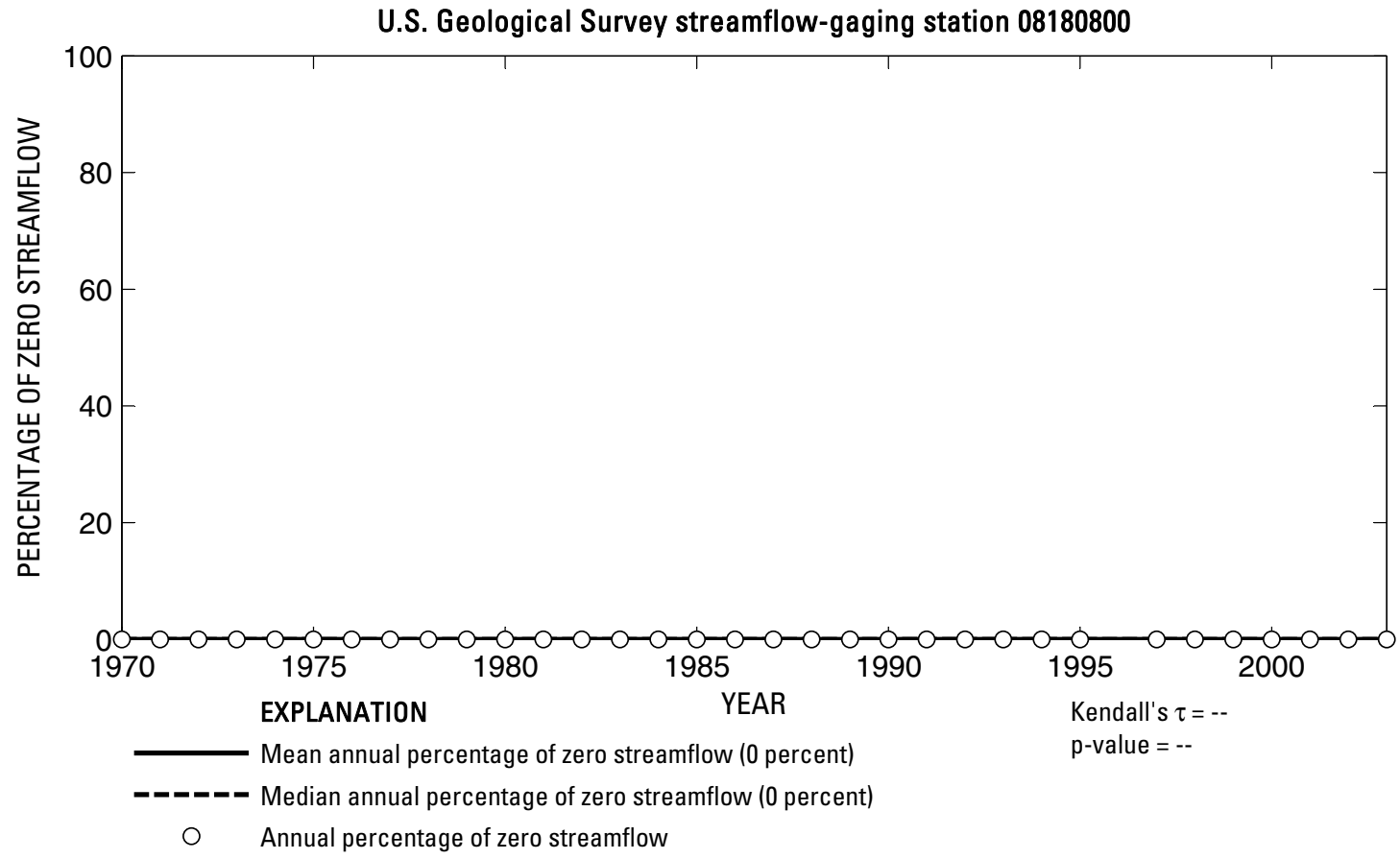

U.S. Geological Survey streamflow-gaging station 08180800

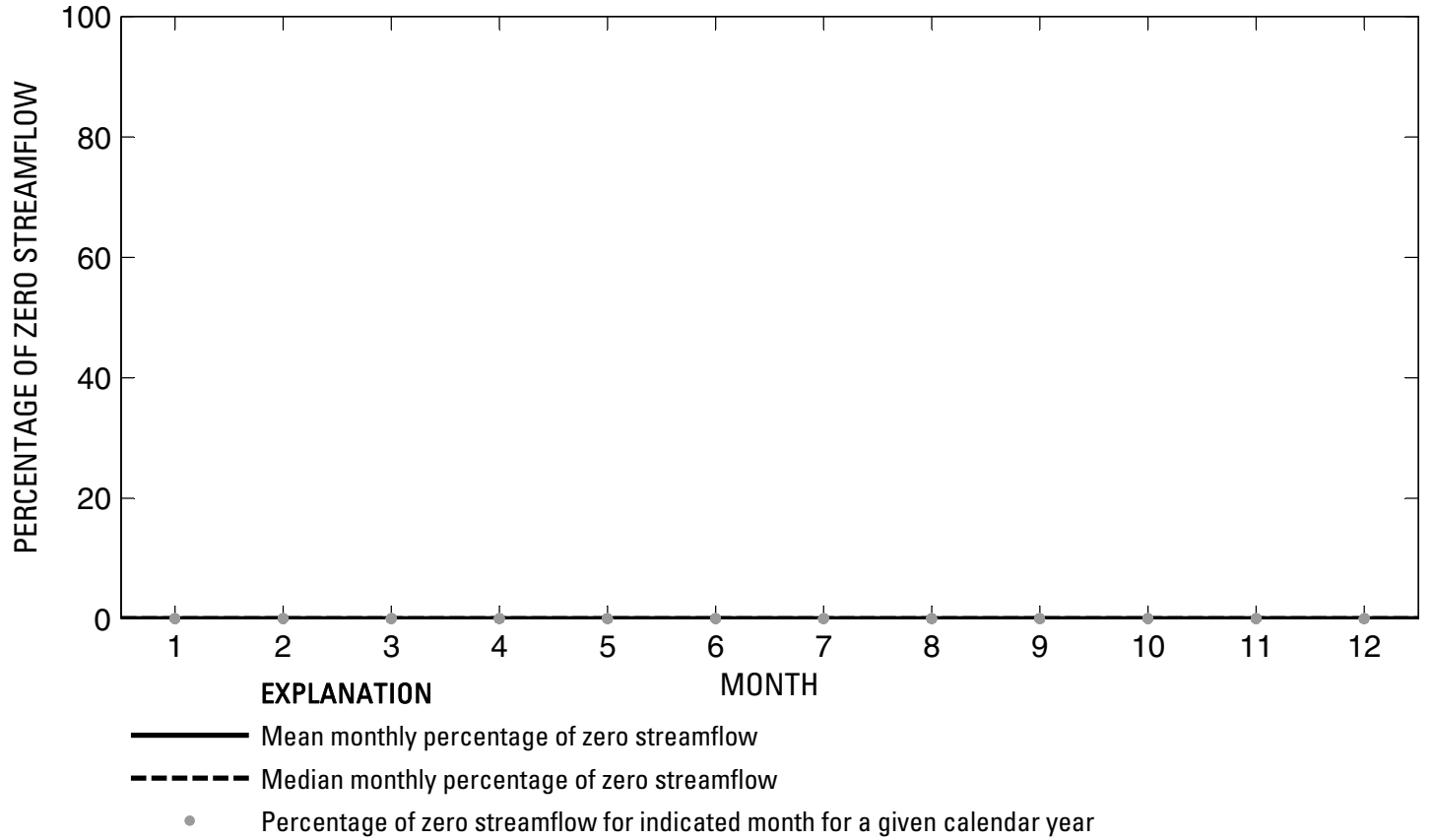

Figure 615. Analysis of percentage of zero daily mean streamflow for U.S. Geological Survey streamflow-gaging station 08180800 Medina River near Somerset, Texas.

Index of Station Numbers 719 
U.S. Geological Survey streamflow-gaging station 08181400

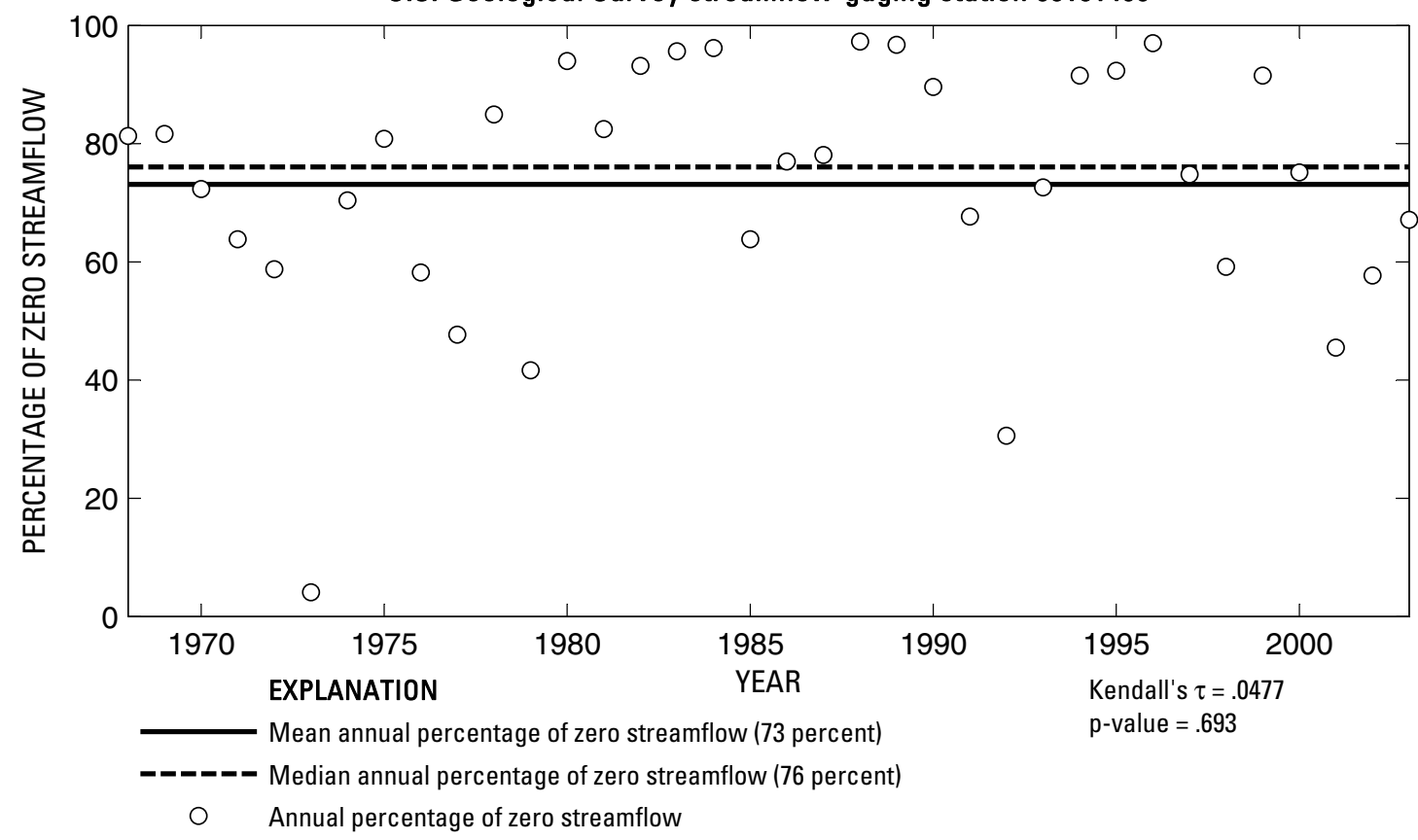

U.S. Geological Survey streamflow-gaging station 08181400

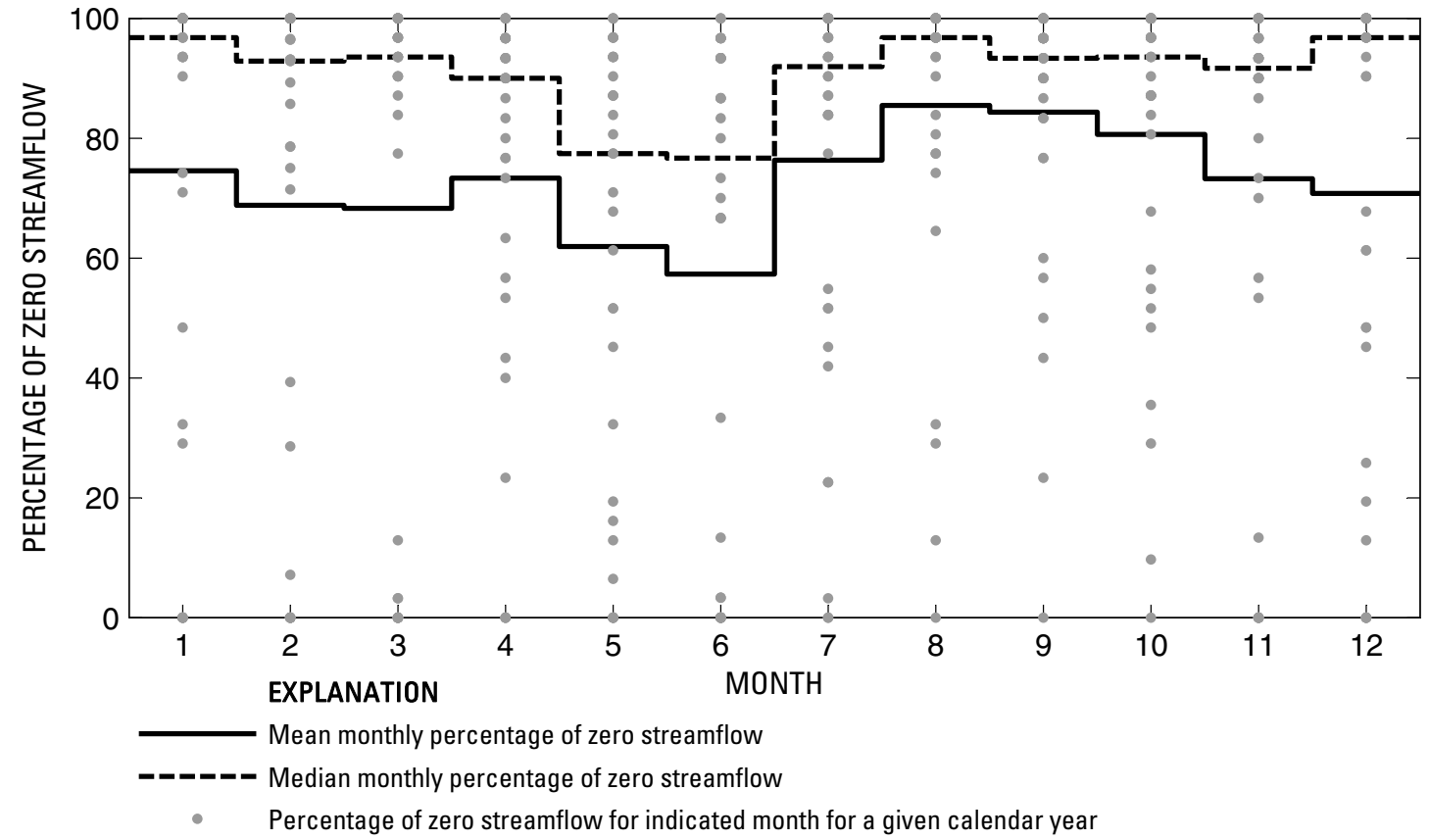

Figure 616. Analysis of percentage of zero daily mean streamflow for U.S. Geological Survey streamflow-gaging station 08181400 Helotes Creek at Helotes, Texas.

Index of Station Numbers 719 
U.S. Geological Survey streamflow-gaging station 08181410

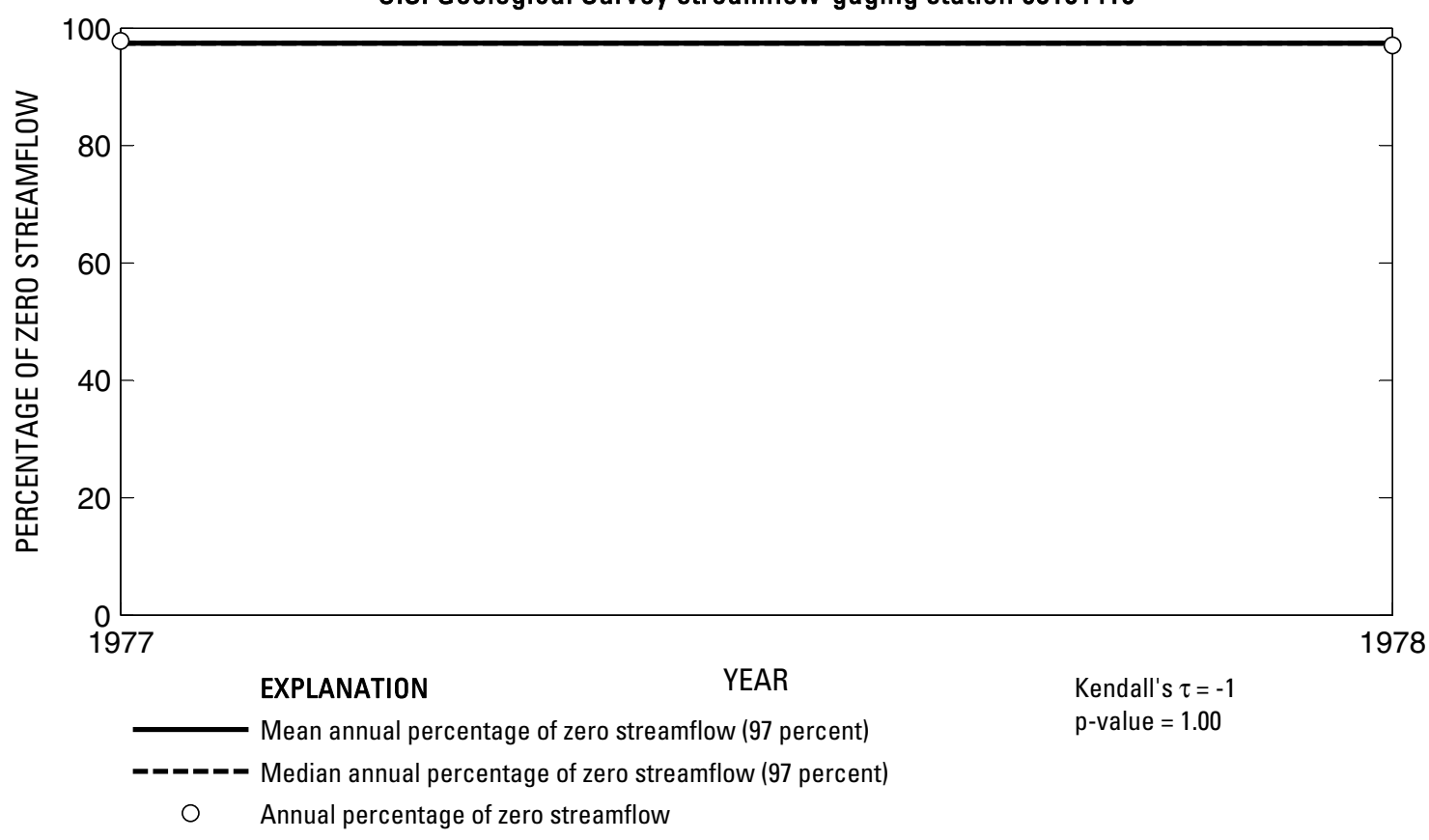

U.S. Geological Survey streamflow-gaging station 08181410

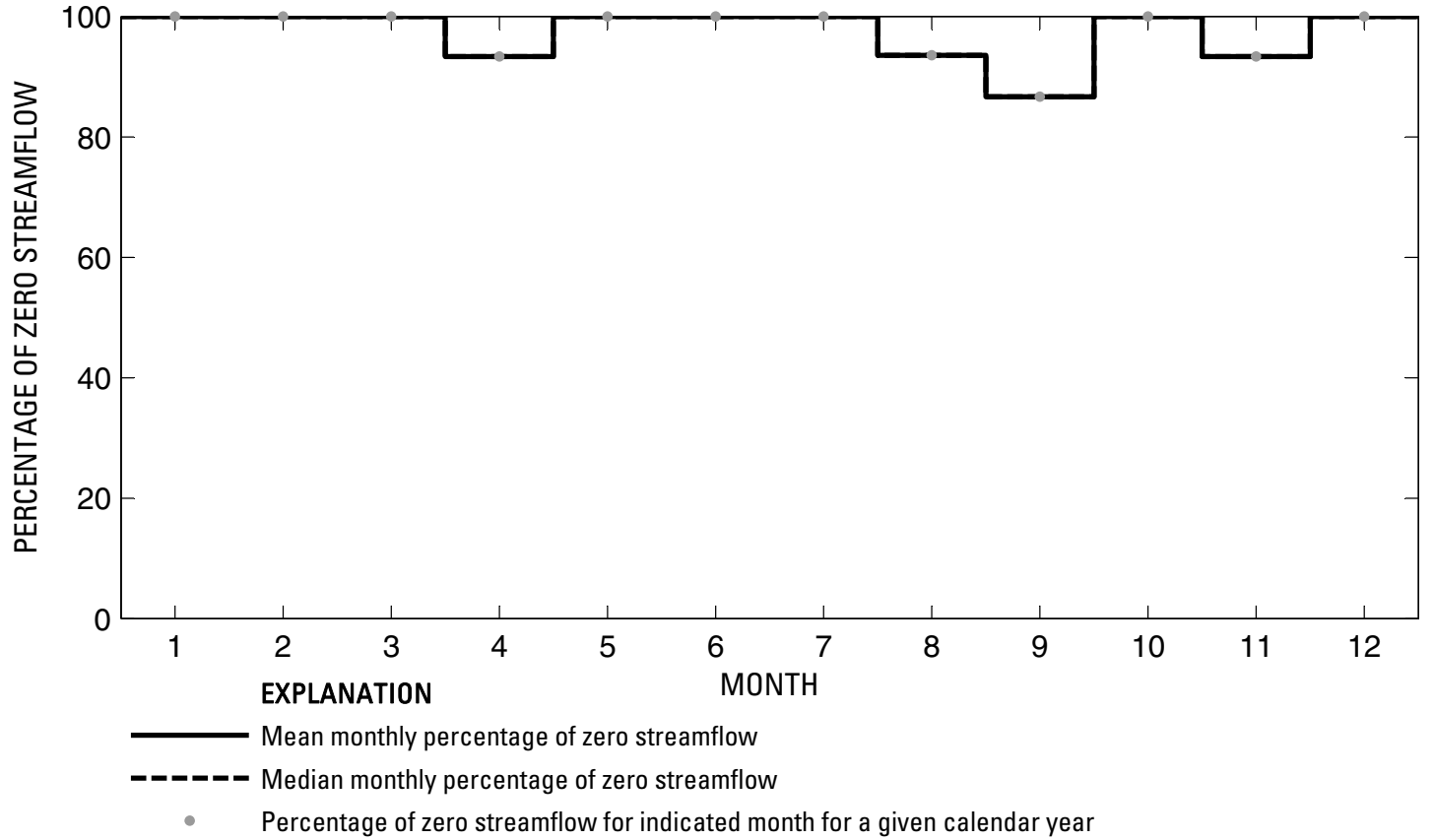

Figure 617. Analysis of percentage of zero daily mean streamflow for U.S. Geological Survey streamflow-gaging station 08181410 Ranch Creek near Helotes, Texas.

Index of Station Numbers 719 
U.S. Geological Survey streamflow-gaging station 08181450

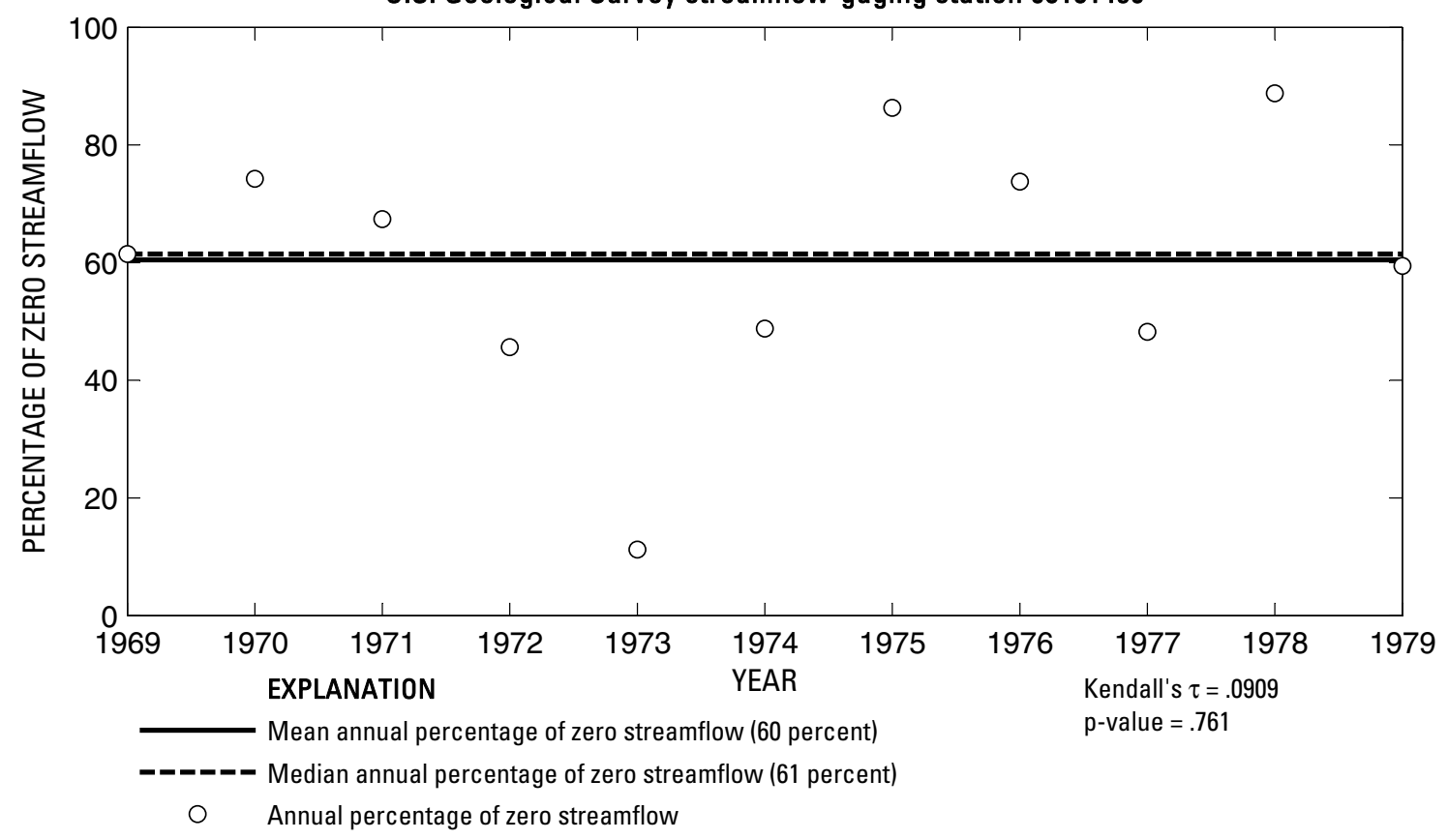

U.S. Geological Survey streamflow-gaging station 08181450

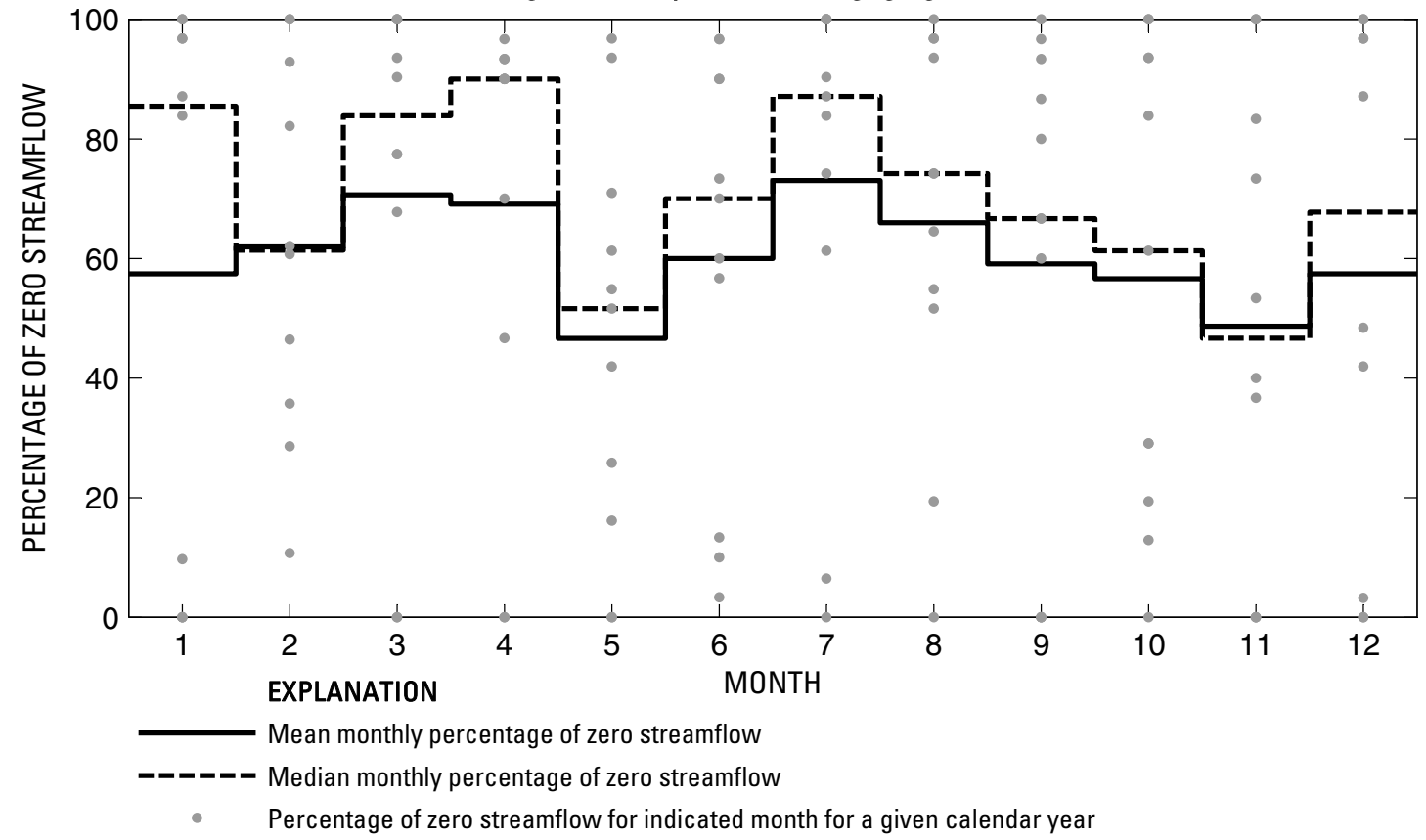

Figure 618. Analysis of percentage of zero daily mean streamflow for U.S. Geological Survey streamflow-gaging station 08181450 Leon Creek Tributary at Kelly Air Force Base, Texas.

Index of Station Numbers 719 
U.S. Geological Survey streamflow-gaging station 08181480

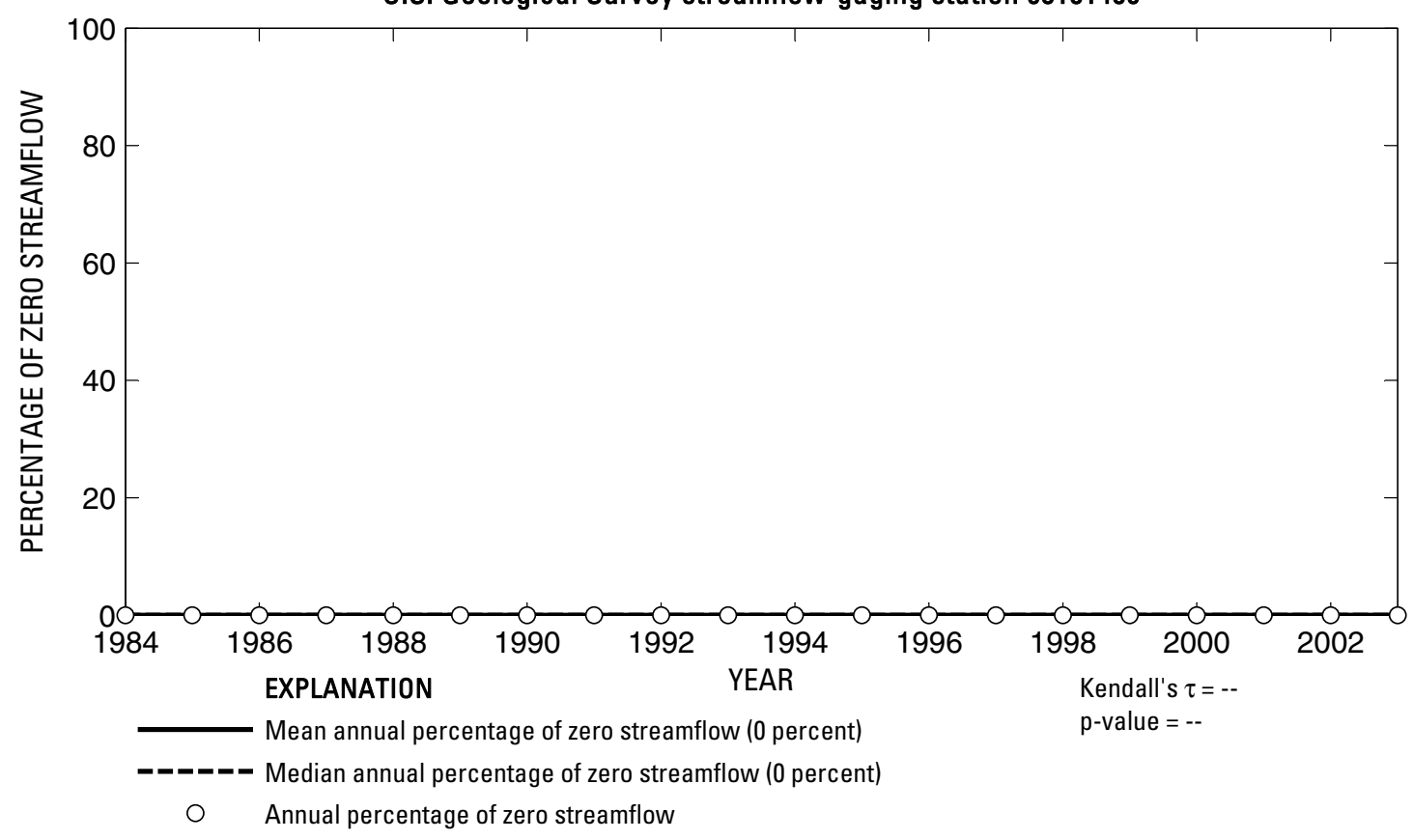

U.S. Geological Survey streamflow-gaging station 08181480

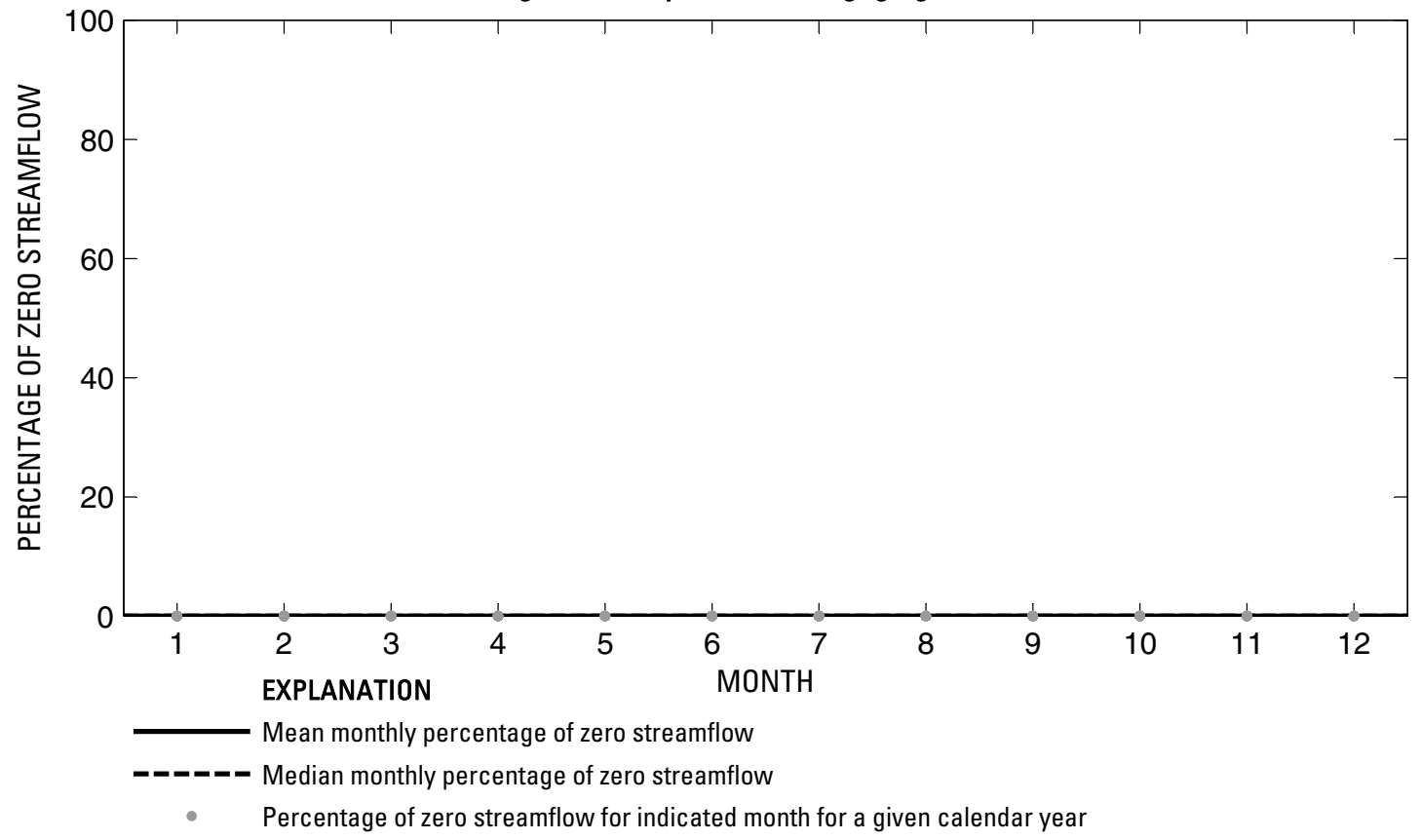

Figure 619. Analysis of percentage of zero daily mean streamflow for U.S. Geological Survey streamflow-gaging station 08181480 Leon Creek at Interstate Highway 35, San Antonio, Texas.

Index of Station Numbers 719 
U.S. Geological Survey streamflow-gaging station 08181500

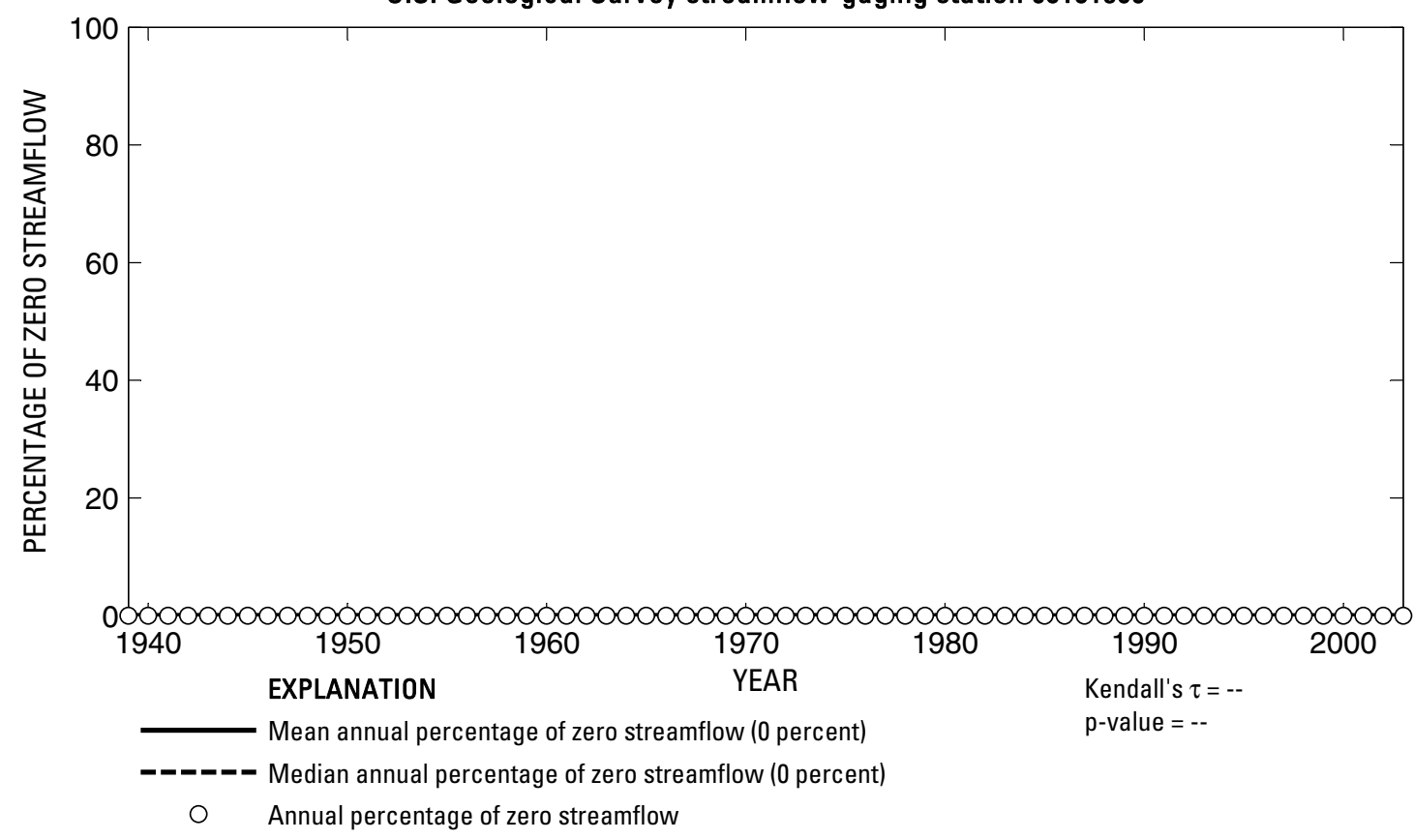

U.S. Geological Survey streamflow-gaging station 08181500

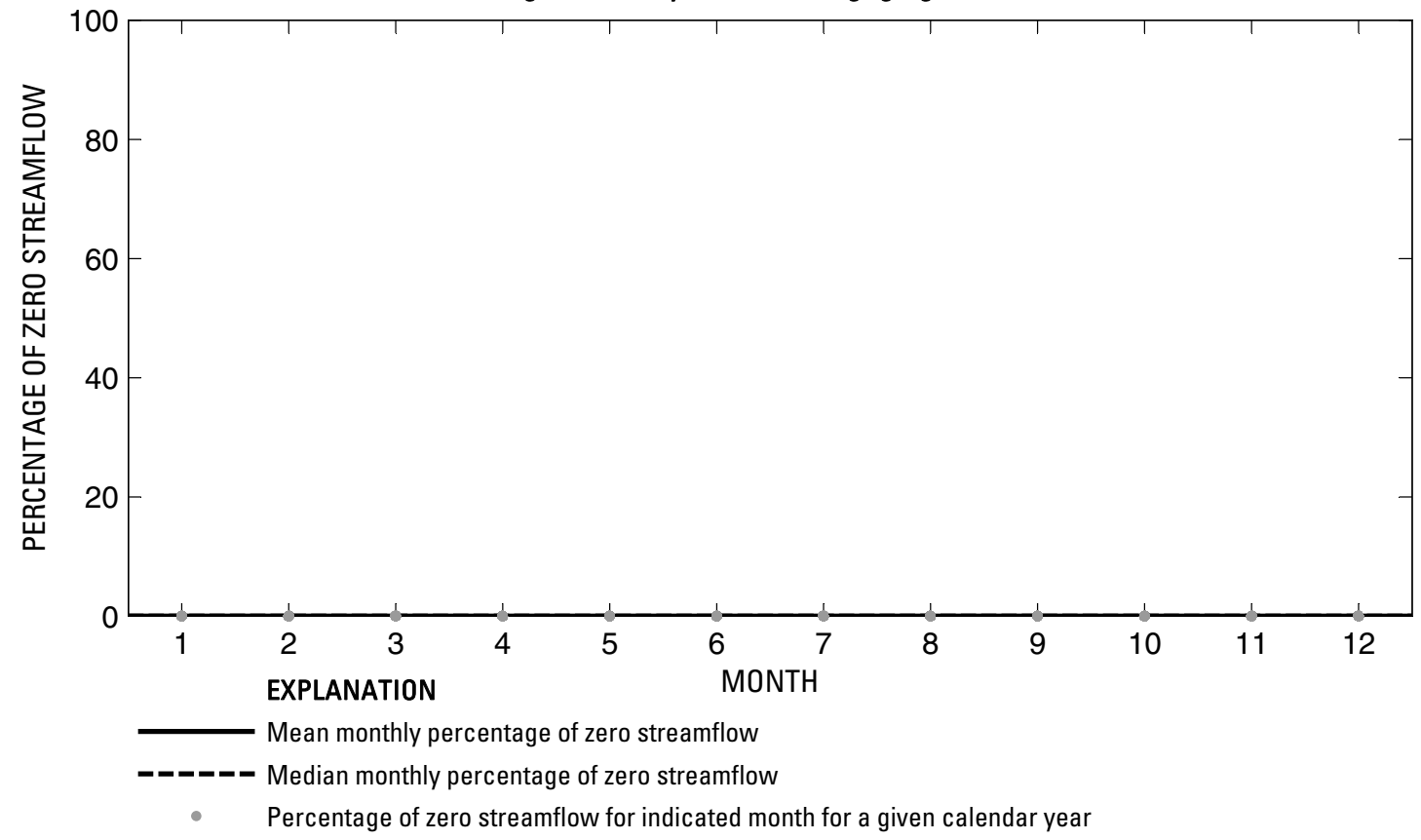

Figure 620. Analysis of percentage of zero daily mean streamflow for U.S. Geological Survey streamflow-gaging station 08181500 Medina River at San Antonio, Texas.

Index of Station Numbers 719 
U.S. Geological Survey streamflow-gaging station 08181800

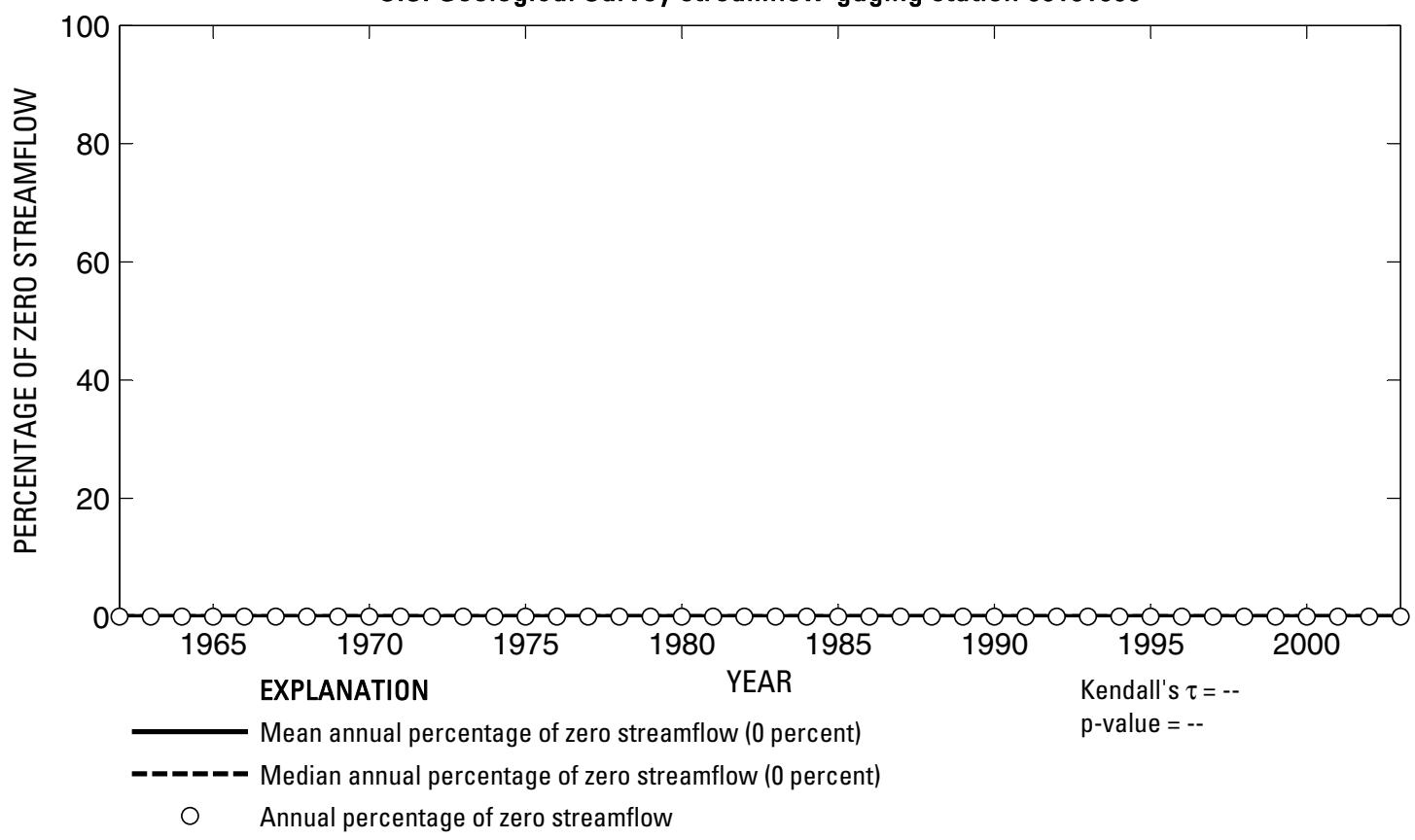

U.S. Geological Survey streamflow-gaging station 08181800

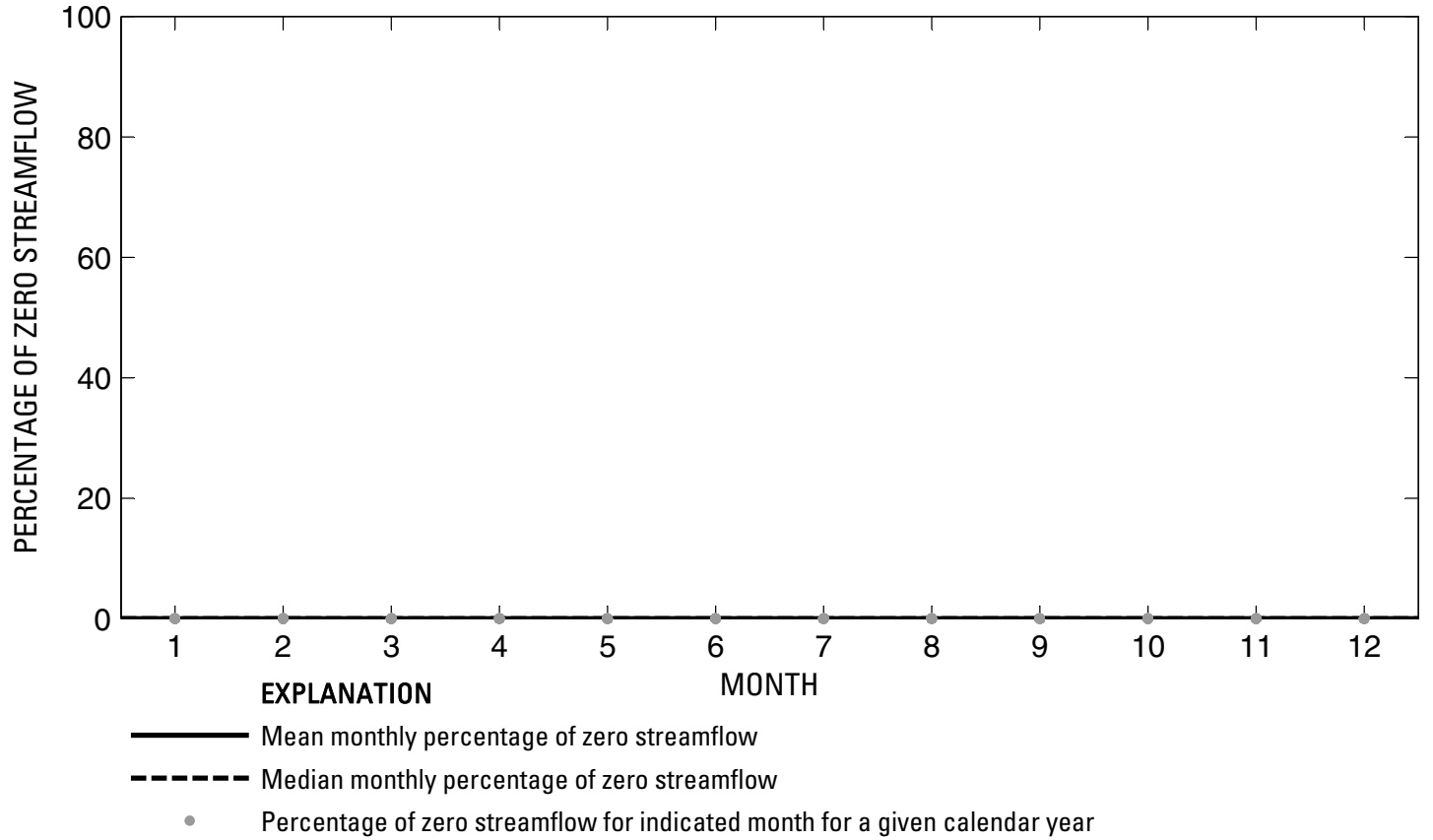

Figure 621. Analysis of percentage of zero daily mean streamflow for U.S. Geological Survey streamflow-gaging station 08181800 San Antonio River near Elmendorf, Texas.

Index of Station Numbers 719 
U.S. Geological Survey streamflow-gaging station 08182500

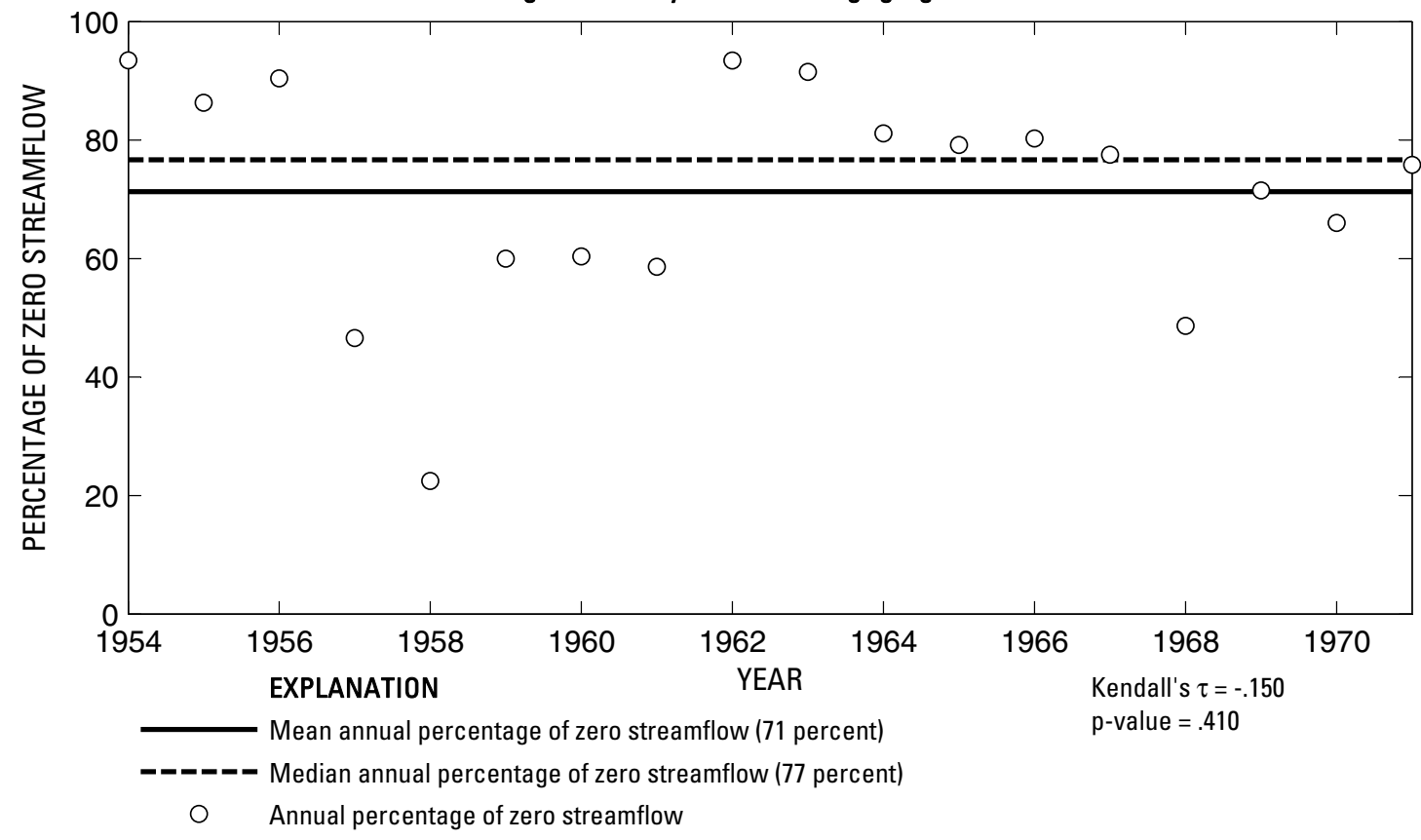

U.S. Geological Survey streamflow-gaging station 08182500

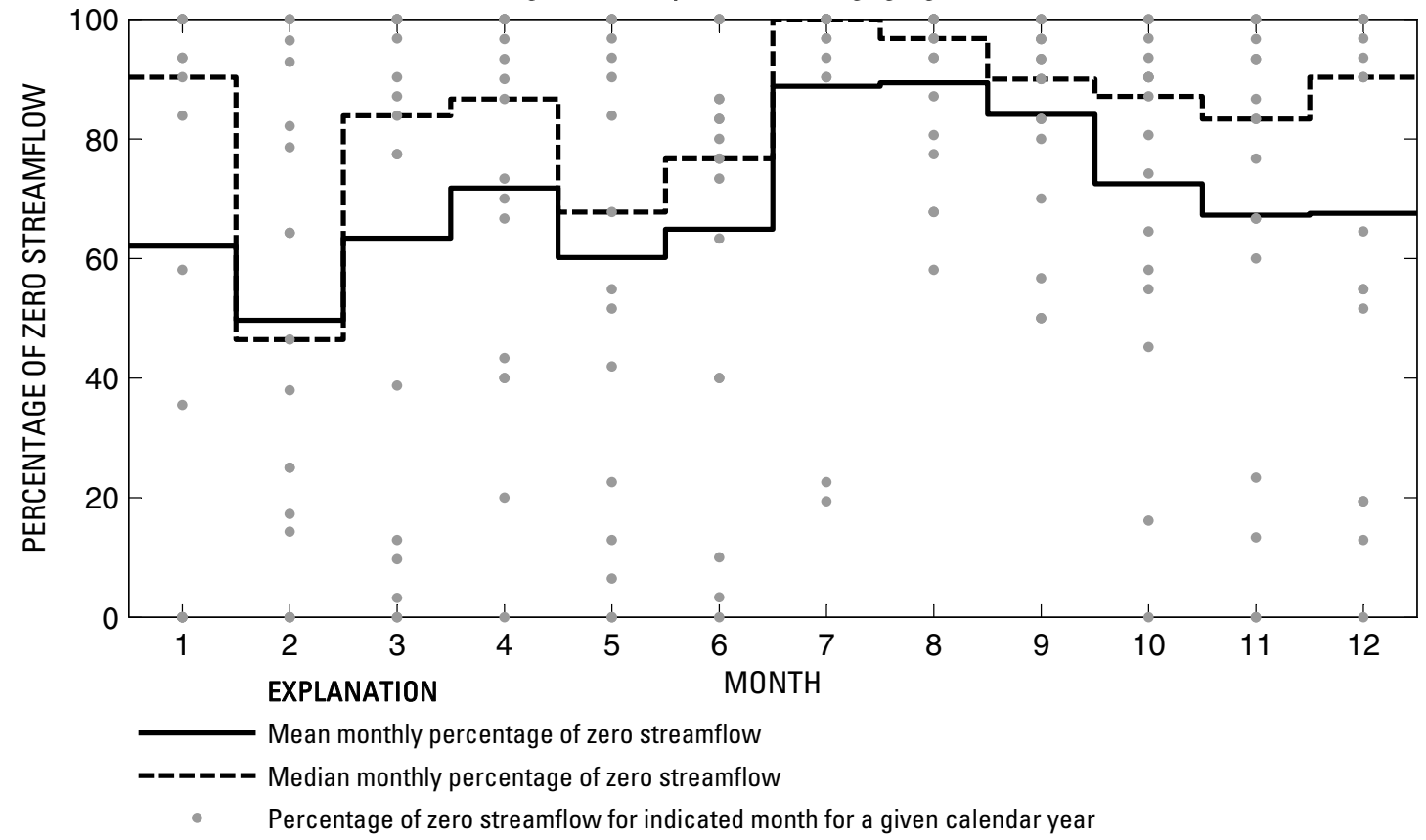

Figure 622. Analysis of percentage of zero daily mean streamflow for U.S. Geological Survey streamflow-gaging station 08182500 Calaveras Creek near Elemendorf, Texas.

Index of Station Numbers 719 


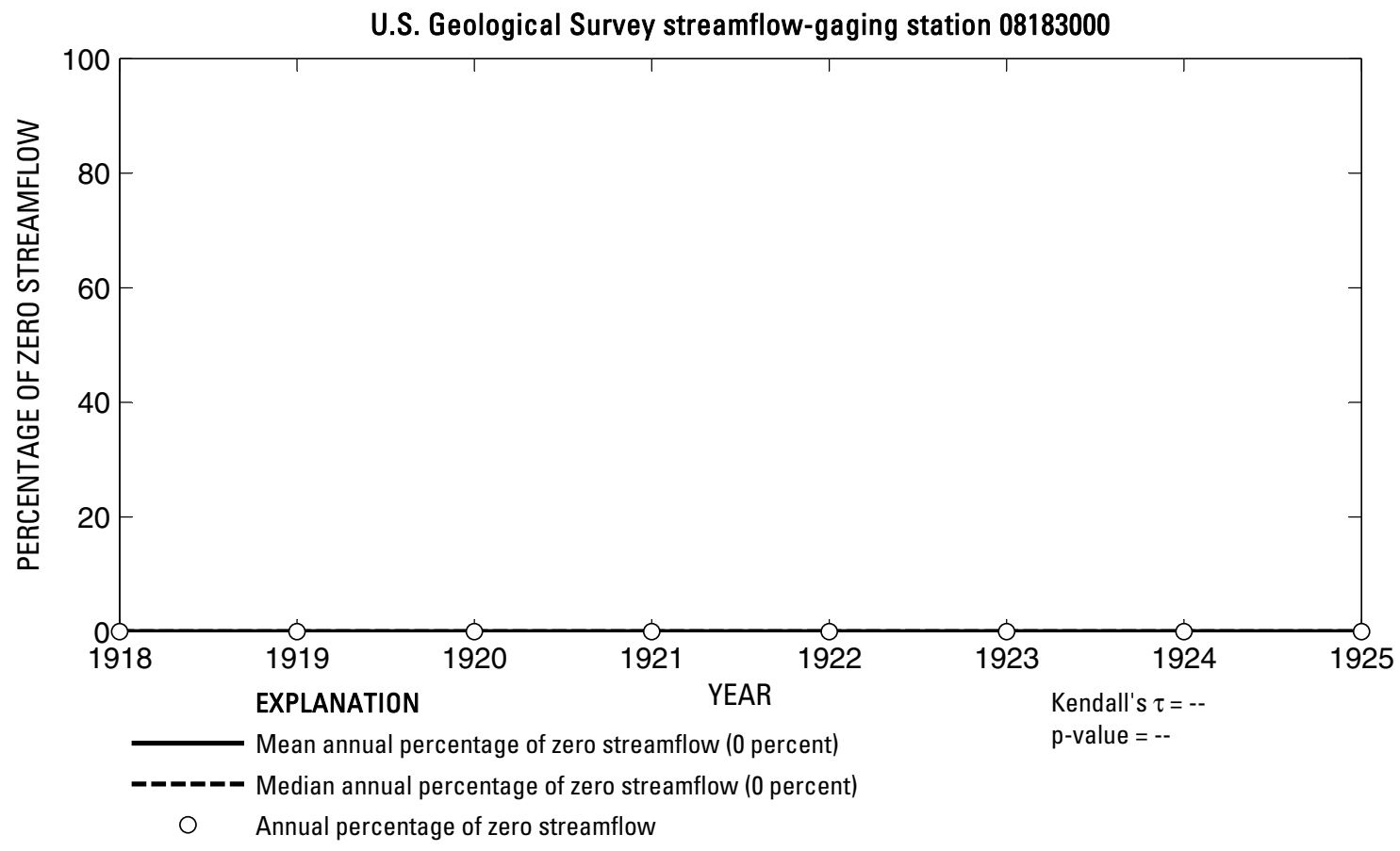

U.S. Geological Survey streamflow-gaging station 08183000

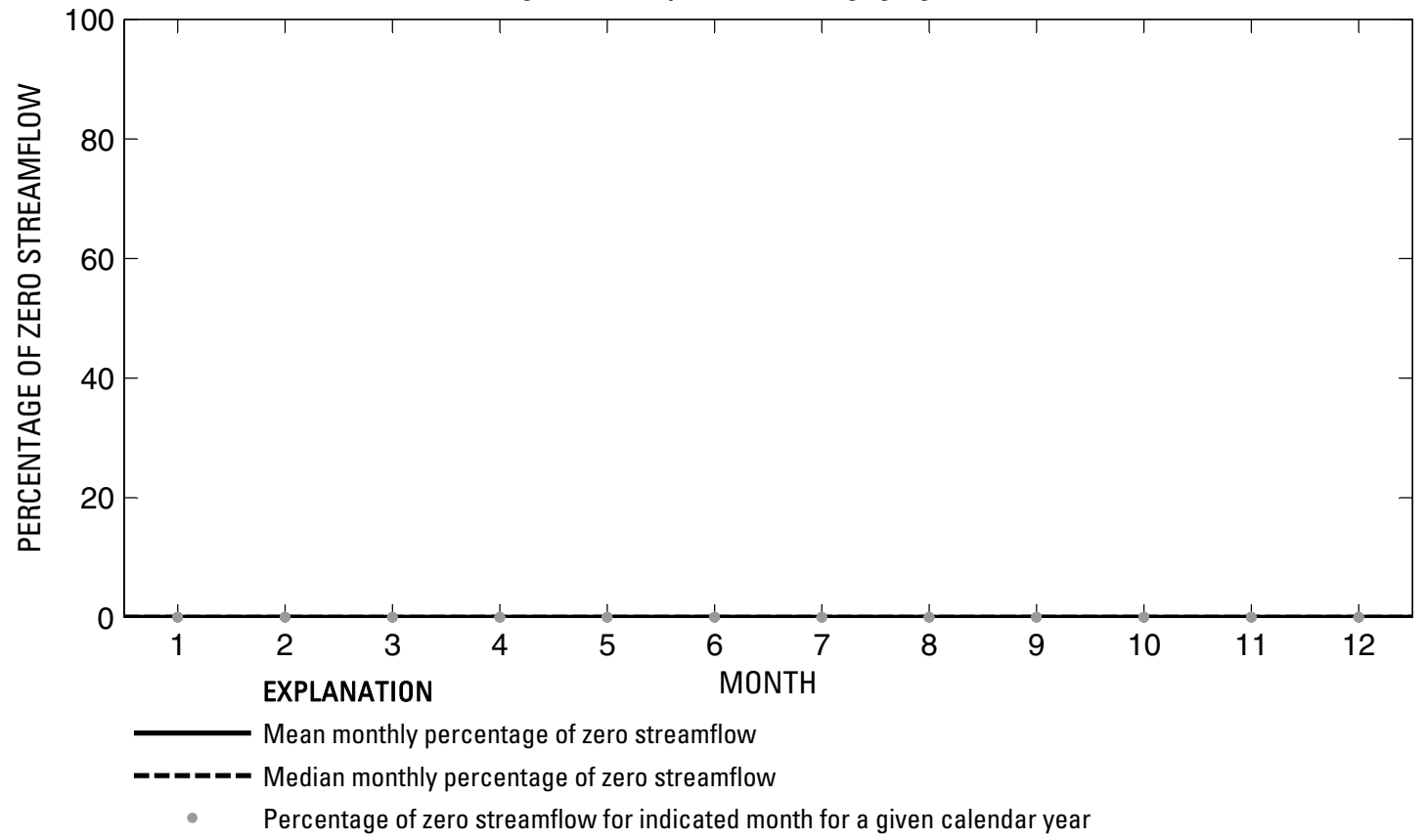

Figure 623. Analysis of percentage of zero daily mean streamflow for U.S. Geological Survey streamflow-gaging station 08183000 San Antonio River at Calaveras, Texas.

Index of Station Numbers 719 
U.S. Geological Survey streamflow-gaging station 08183500

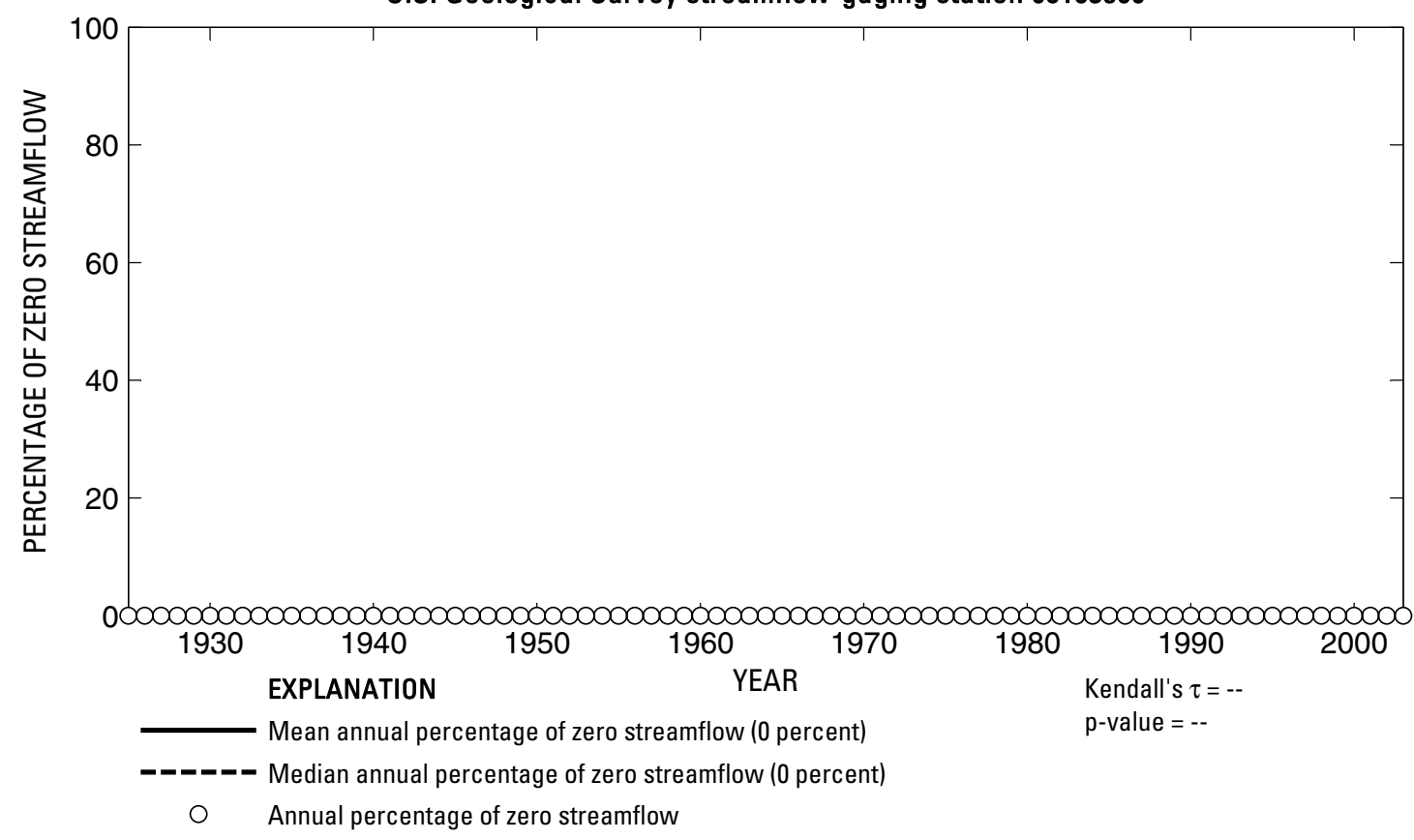

U.S. Geological Survey streamflow-gaging station 08183500

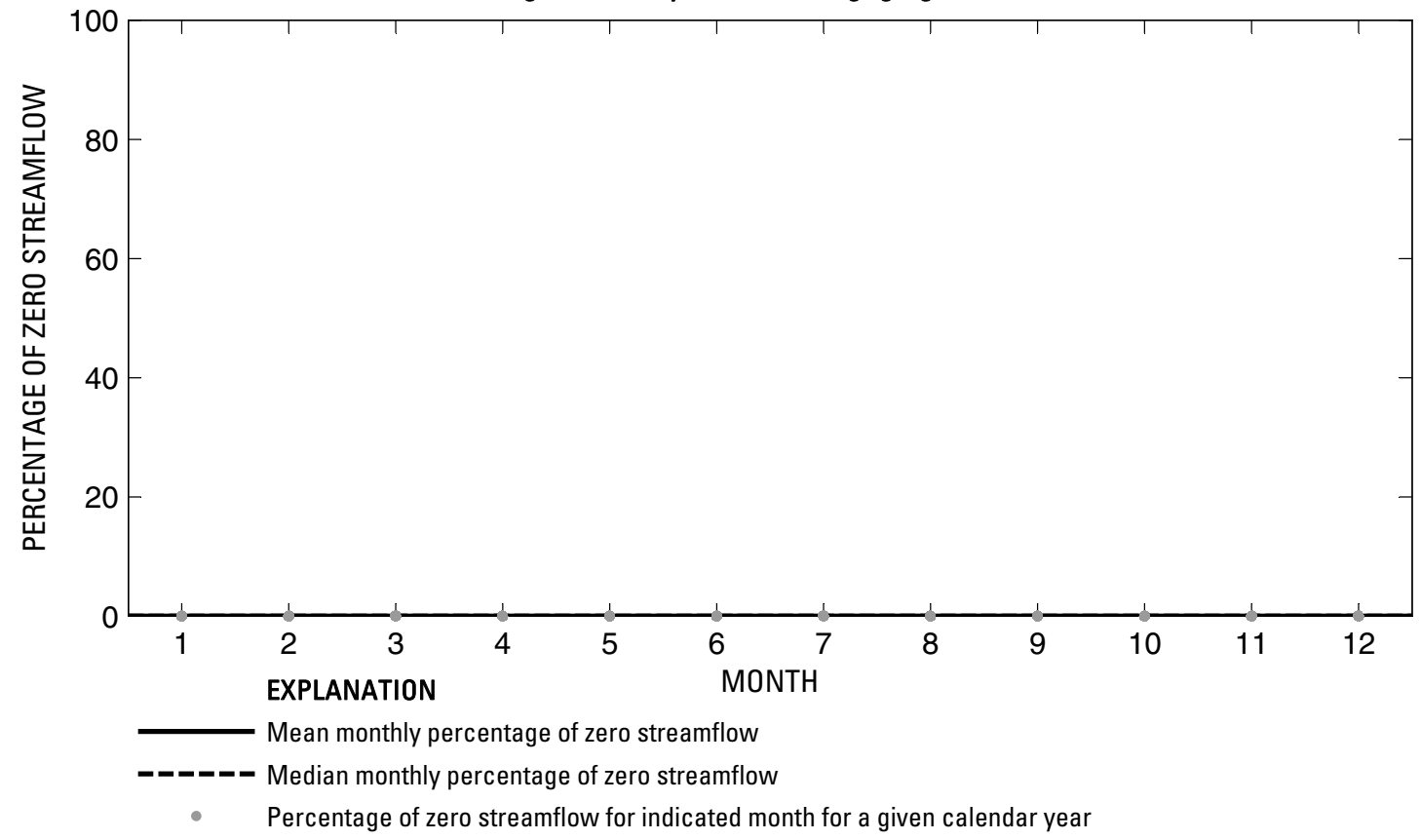

Figure 624. Analysis of percentage of zero daily mean streamflow for U.S. Geological Survey streamflow-gaging station 08183500 San Antonio River near Falls City, Texas.

Index of Station Numbers 719 


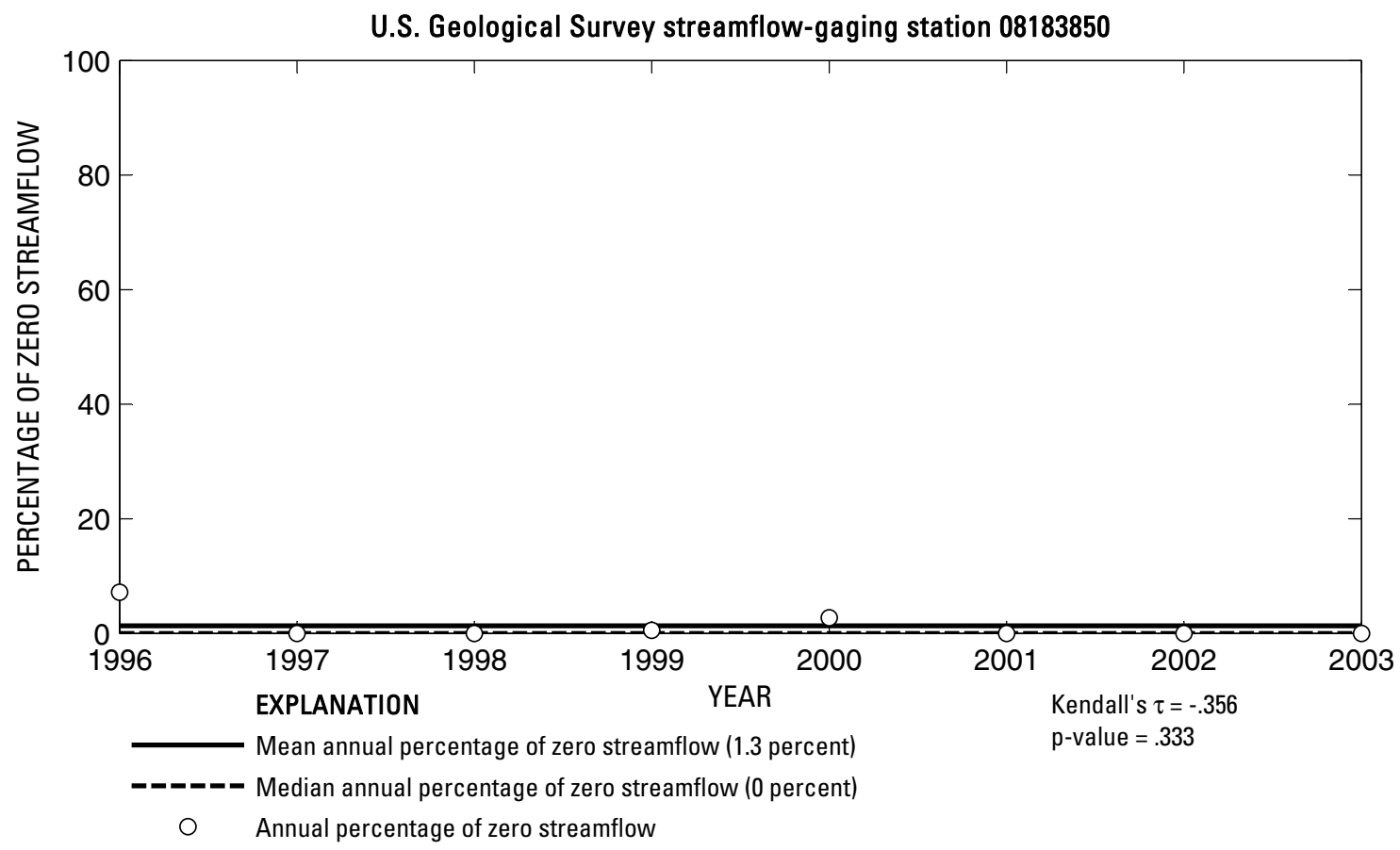

U.S. Geological Survey streamflow-gaging station 08183850

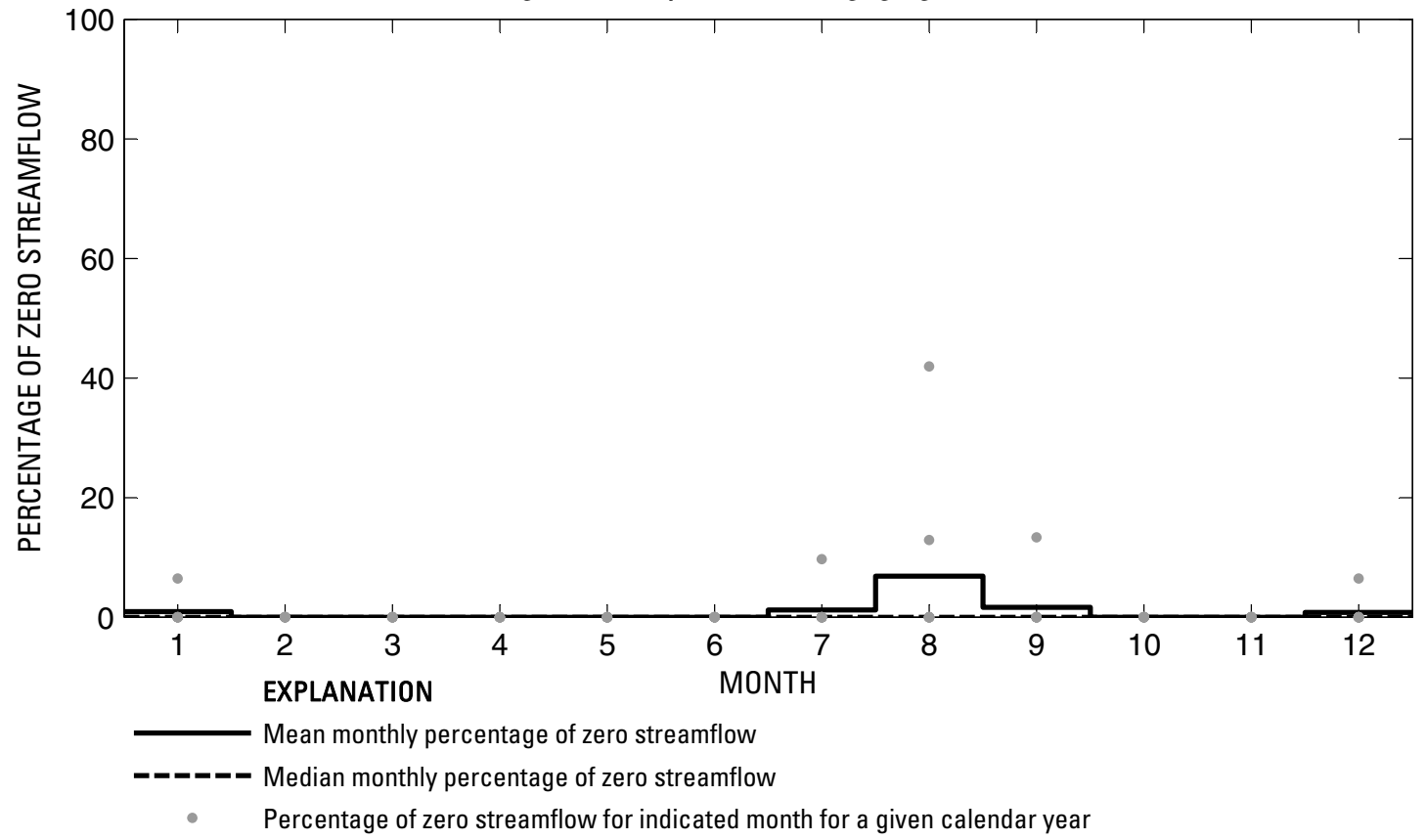

Figure 625. Analysis of percentage of zero daily mean streamflow for U.S. Geological Survey streamflow-gaging station 08183850 Cibolo Creek at Interstate Highway 10 above Boerne, Texas.

Index of Station Numbers 719 
U.S. Geological Survey streamflow-gaging station 08183900

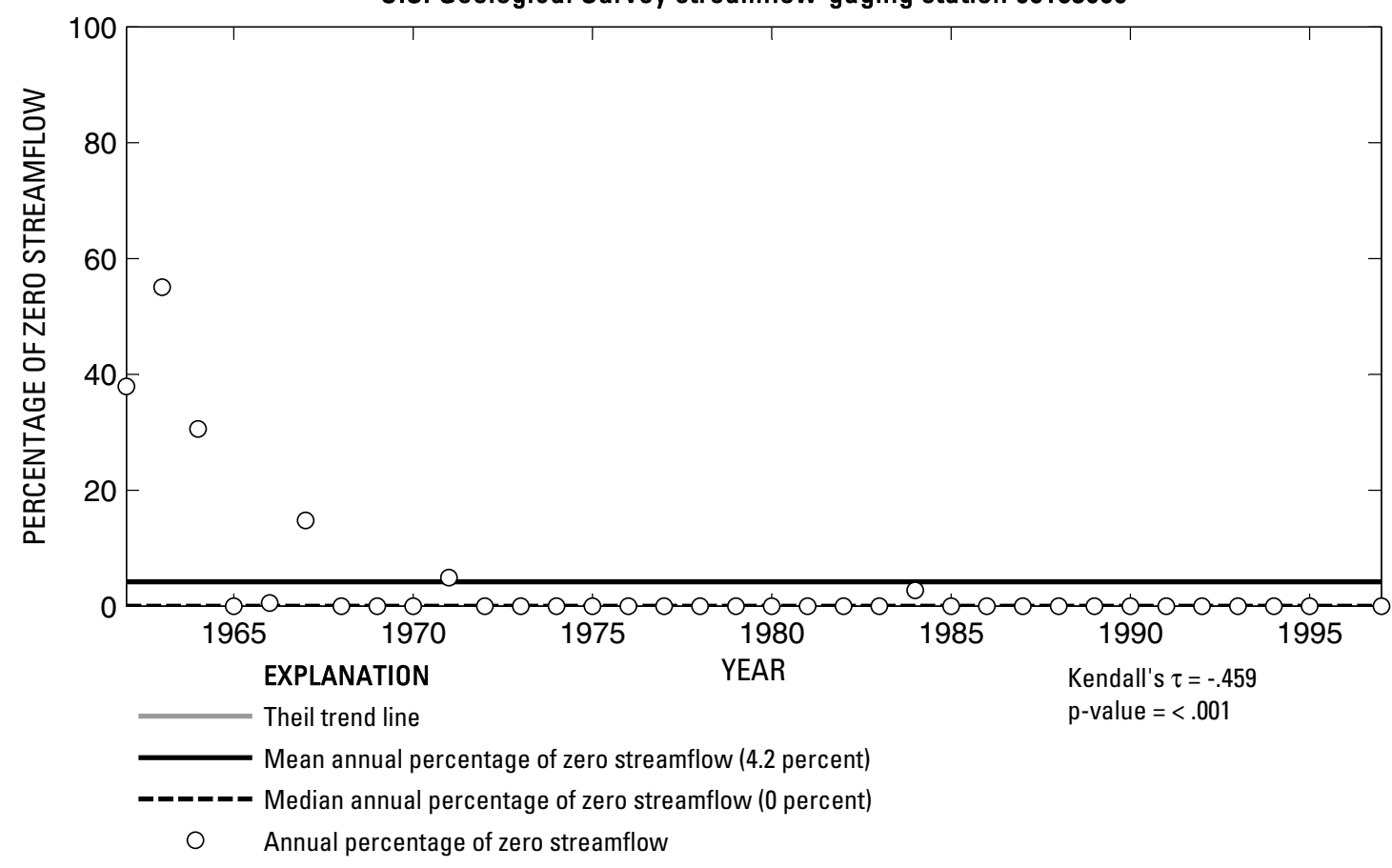

U.S. Geological Survey streamflow-gaging station 08183900

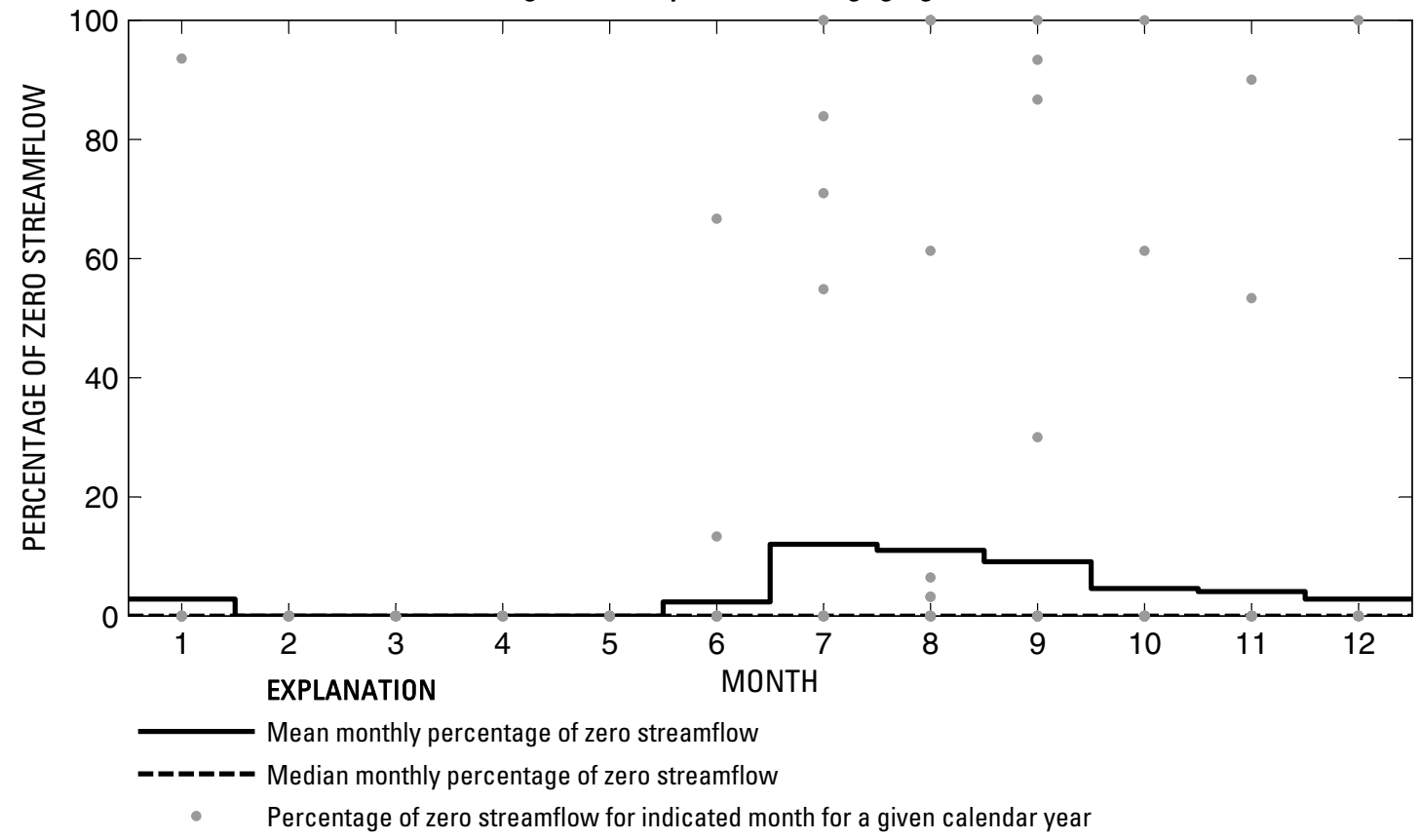

Figure 626. Analysis of percentage of zero daily mean streamflow for U.S. Geological Survey streamflow-gaging station 08183900 Cibolo Creek near Boerne, Texas. 
U.S. Geological Survey streamflow-gaging station 08184000

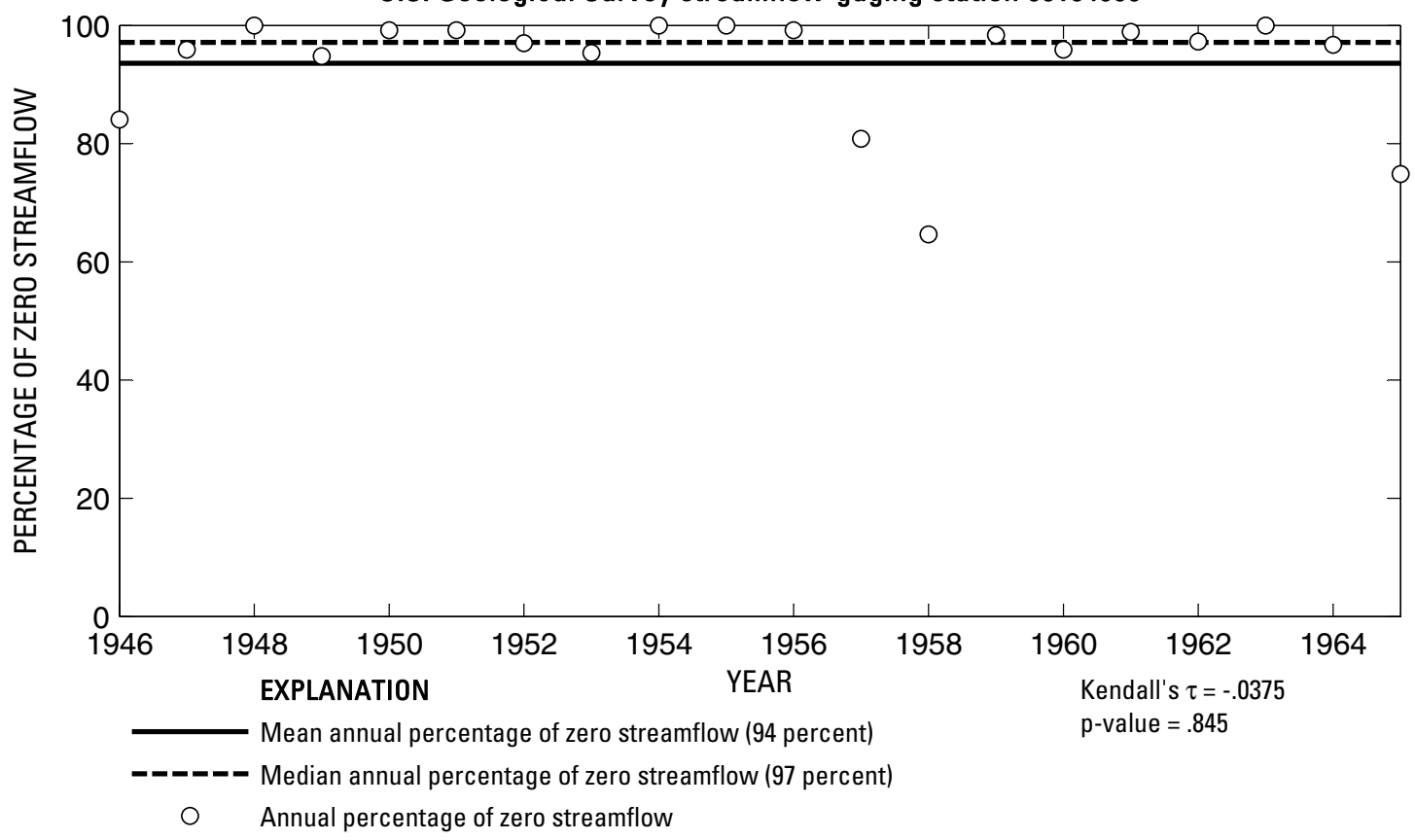

U.S. Geological Survey streamflow-gaging station 08184000

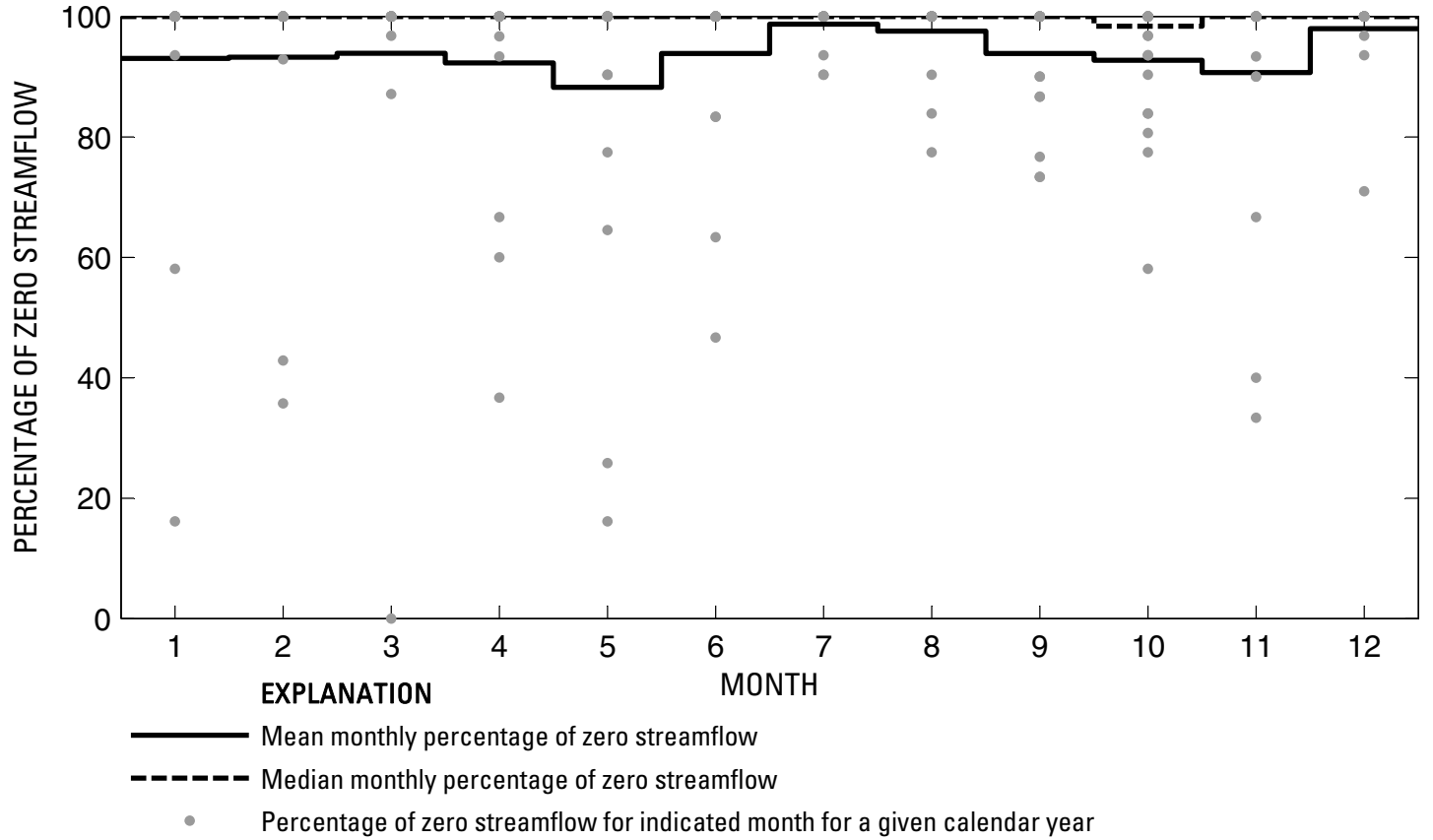

Figure 627. Analysis of percentage of zero daily mean streamflow for U.S. Geological Survey streamflow-gaging station 08184000 Cibolo Creek near Bulverde, Texas.

Index of Station Numbers 719 
U.S. Geological Survey streamflow-gaging station 08184500

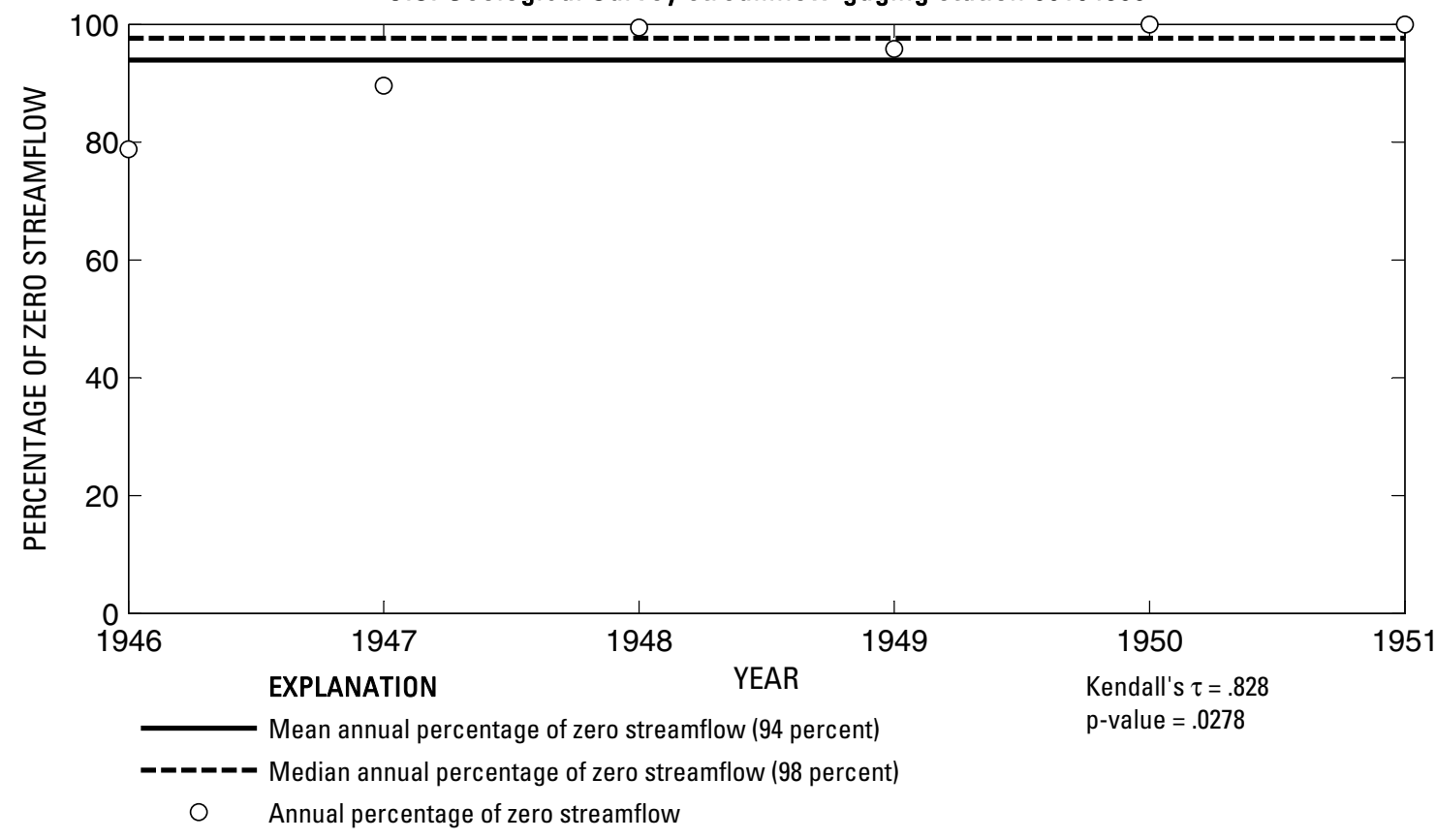

U.S. Geological Survey streamflow-gaging station 08184500

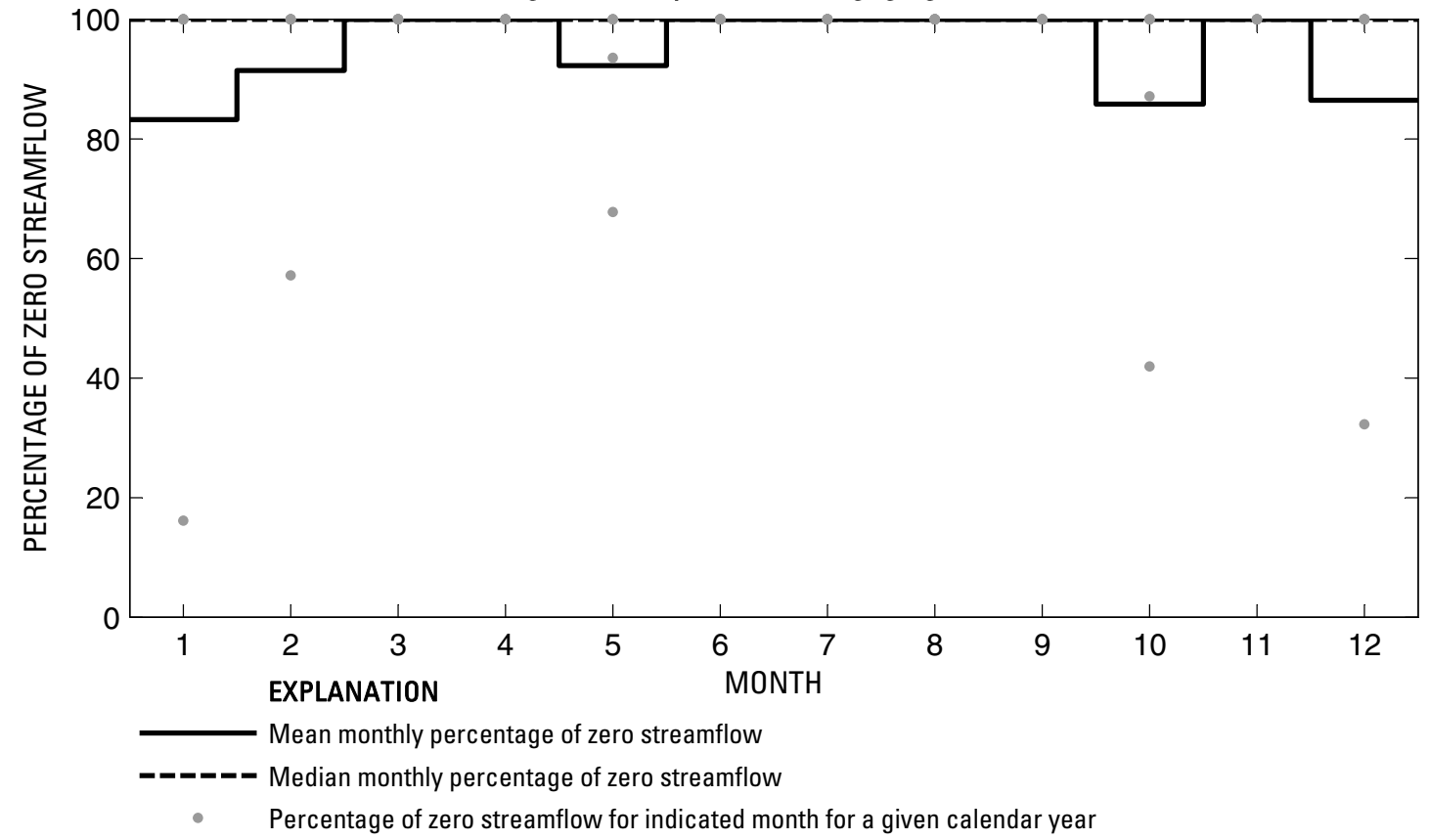

Figure 628. Analysis of percentage of zero daily mean streamflow for U.S. Geological Survey streamflow-gaging station 08184500 Cibolo Creek above Bracken, Texas. 
U.S. Geological Survey streamflow-gaging station 08185000

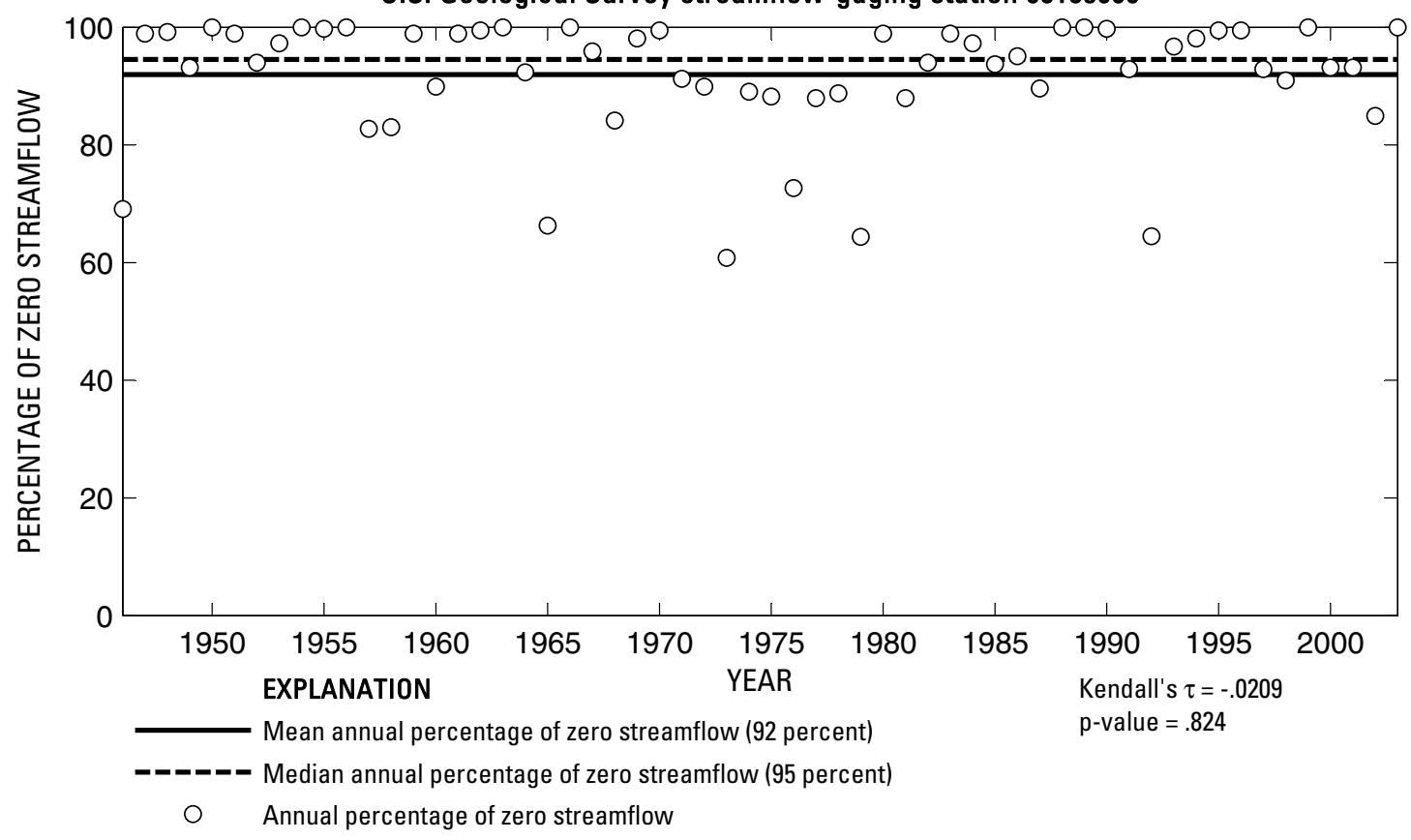

U.S. Geological Survey streamflow-gaging station 08185000

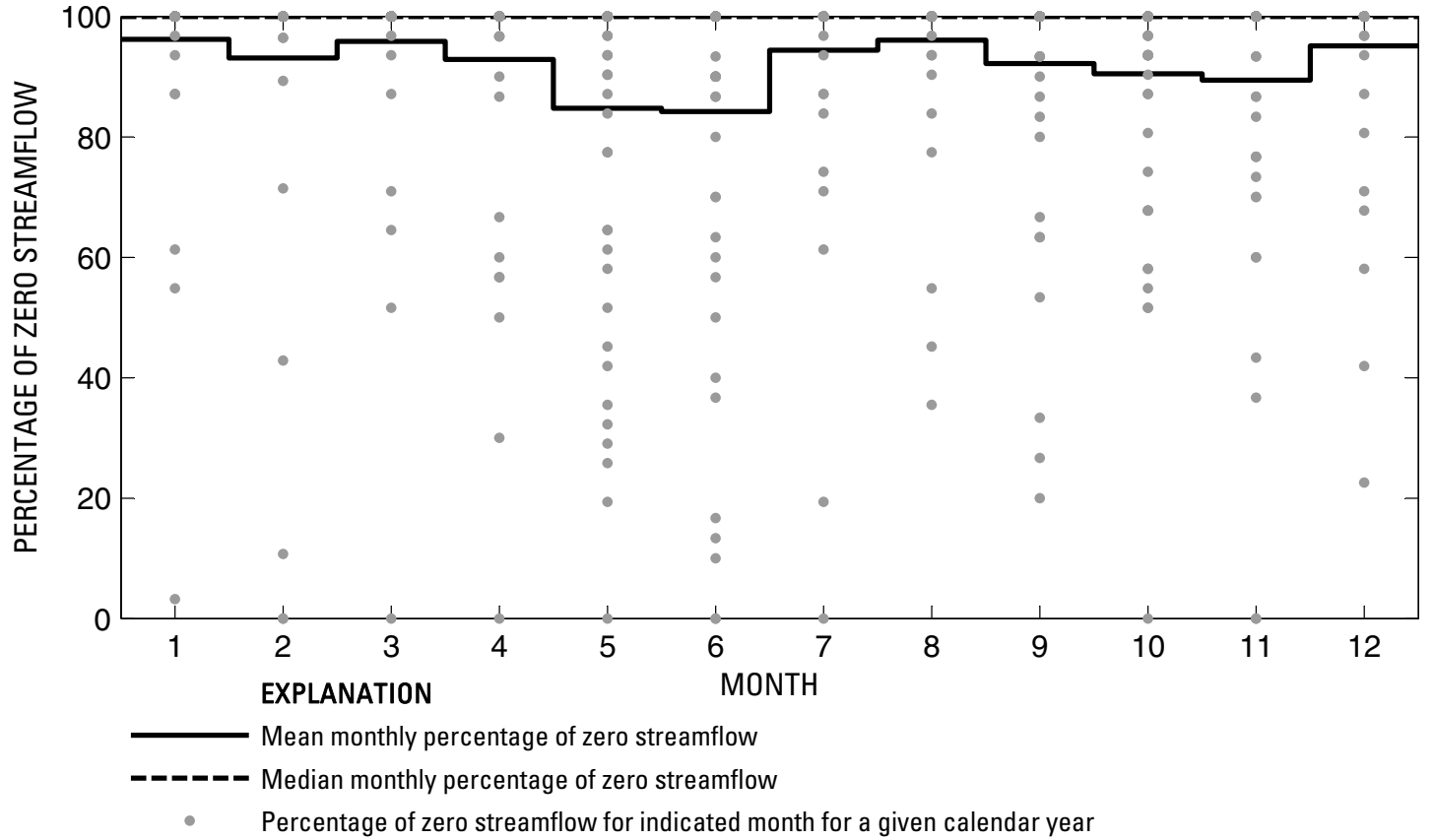

Figure 629. Analysis of percentage of zero daily mean streamflow for U.S. Geological Survey streamflow-gaging station 08185000 Cibolo Creek at Selma, Texas.

Index of Station Numbers 719 

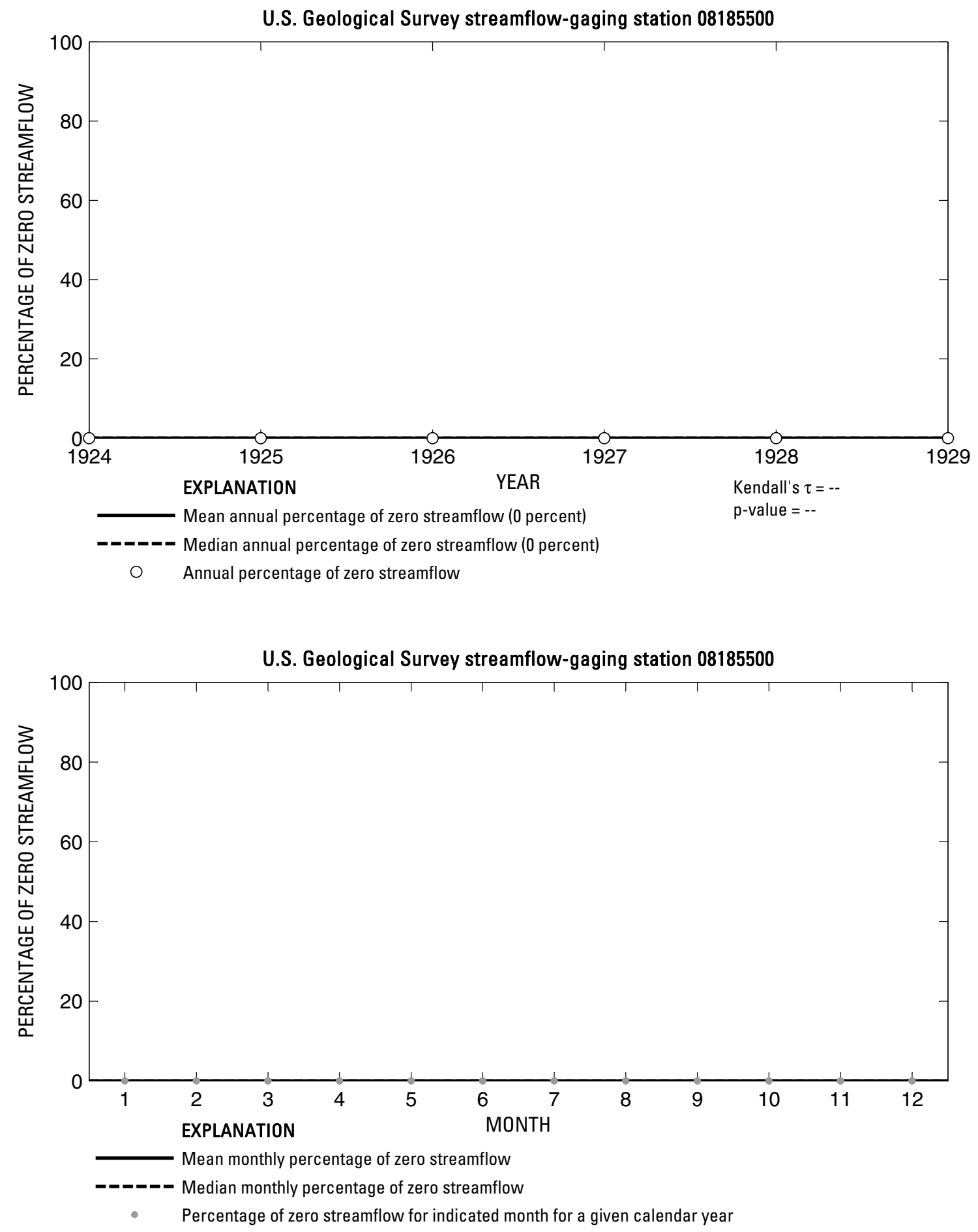

Figure 630. Analysis of percentage of zero daily mean streamflow for U.S. Geological Survey streamflow-gaging station 08185500 Cibolo Creek at Sutherland Springs, Texas. 


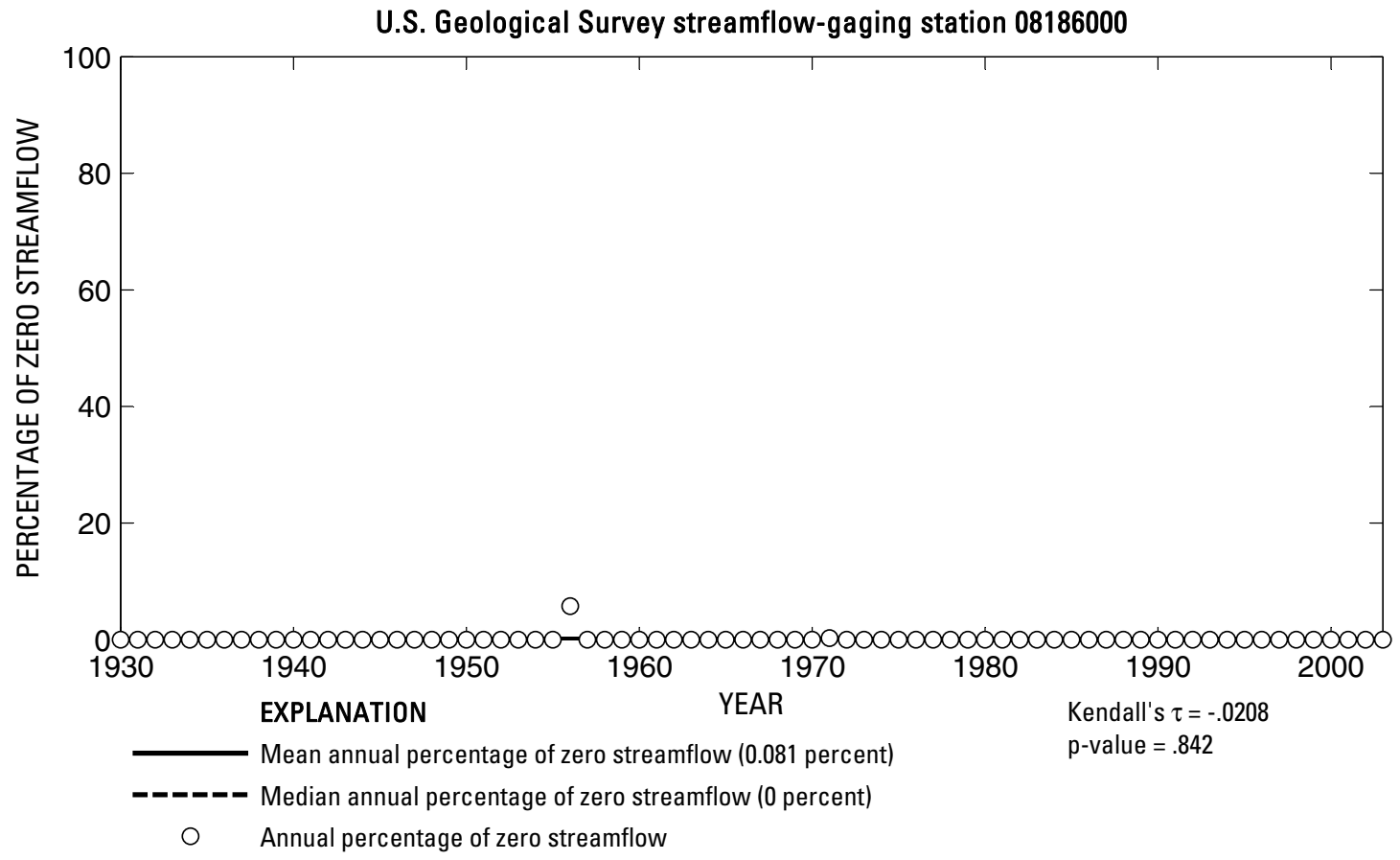

U.S. Geological Survey streamflow-gaging station 08186000

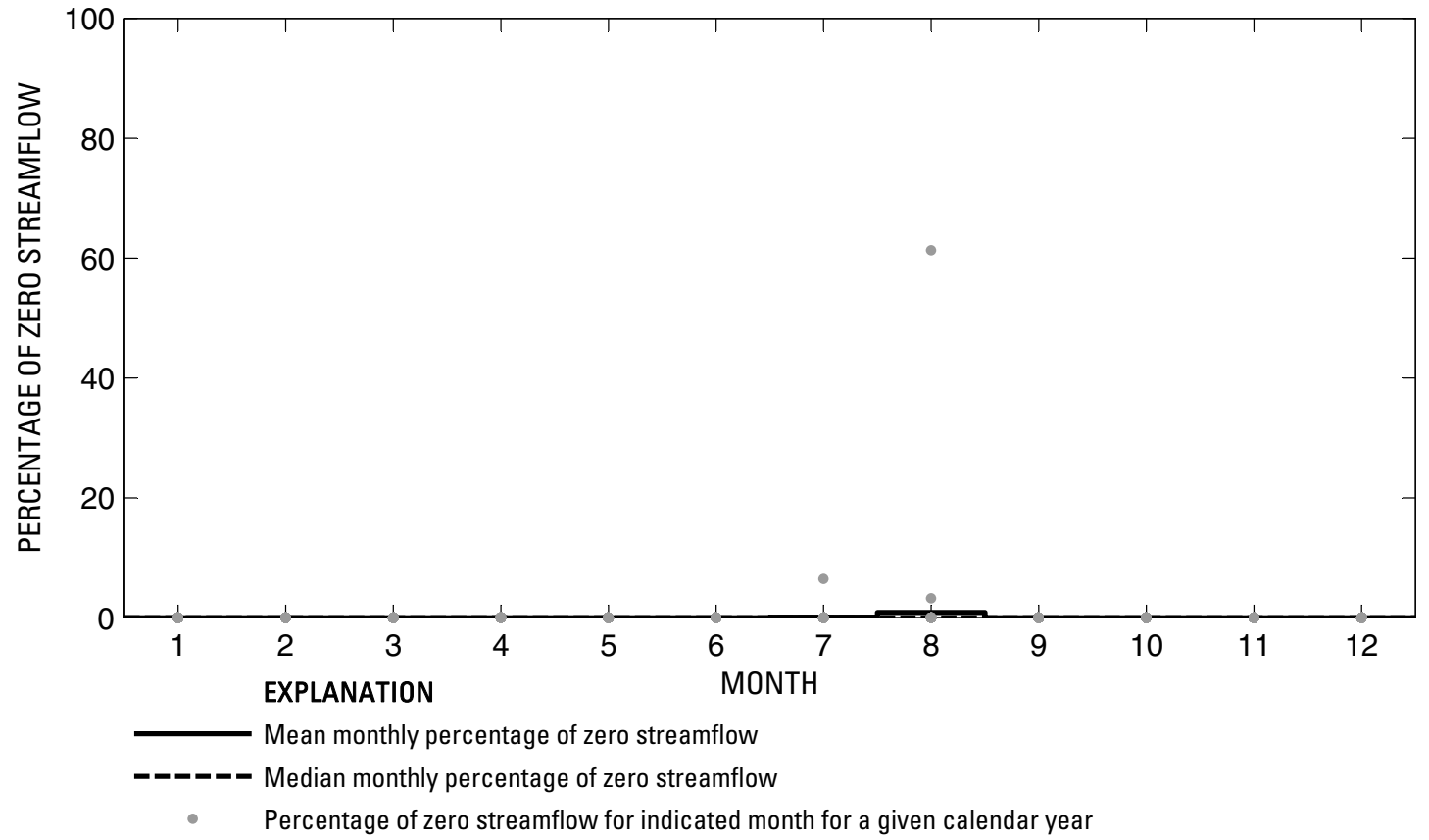

Figure 631. Analysis of percentage of zero daily mean streamflow for U.S. Geological Survey streamflow-gaging station 08186000 Cibolo Creek near Falls City, Texas.

Index of Station Numbers 719 
U.S. Geological Survey streamflow-gaging station 08186500

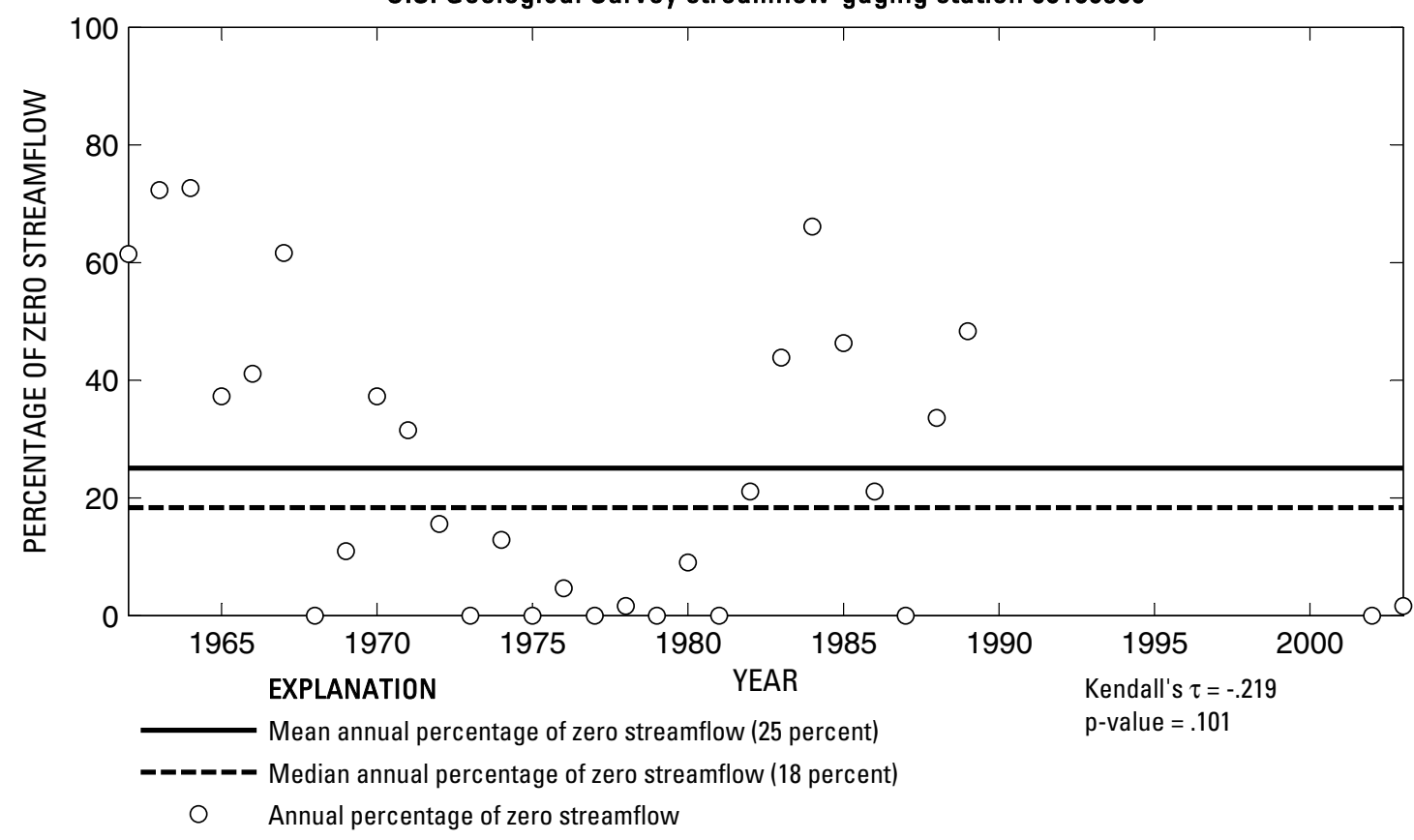

U.S. Geological Survey streamflow-gaging station 08186500

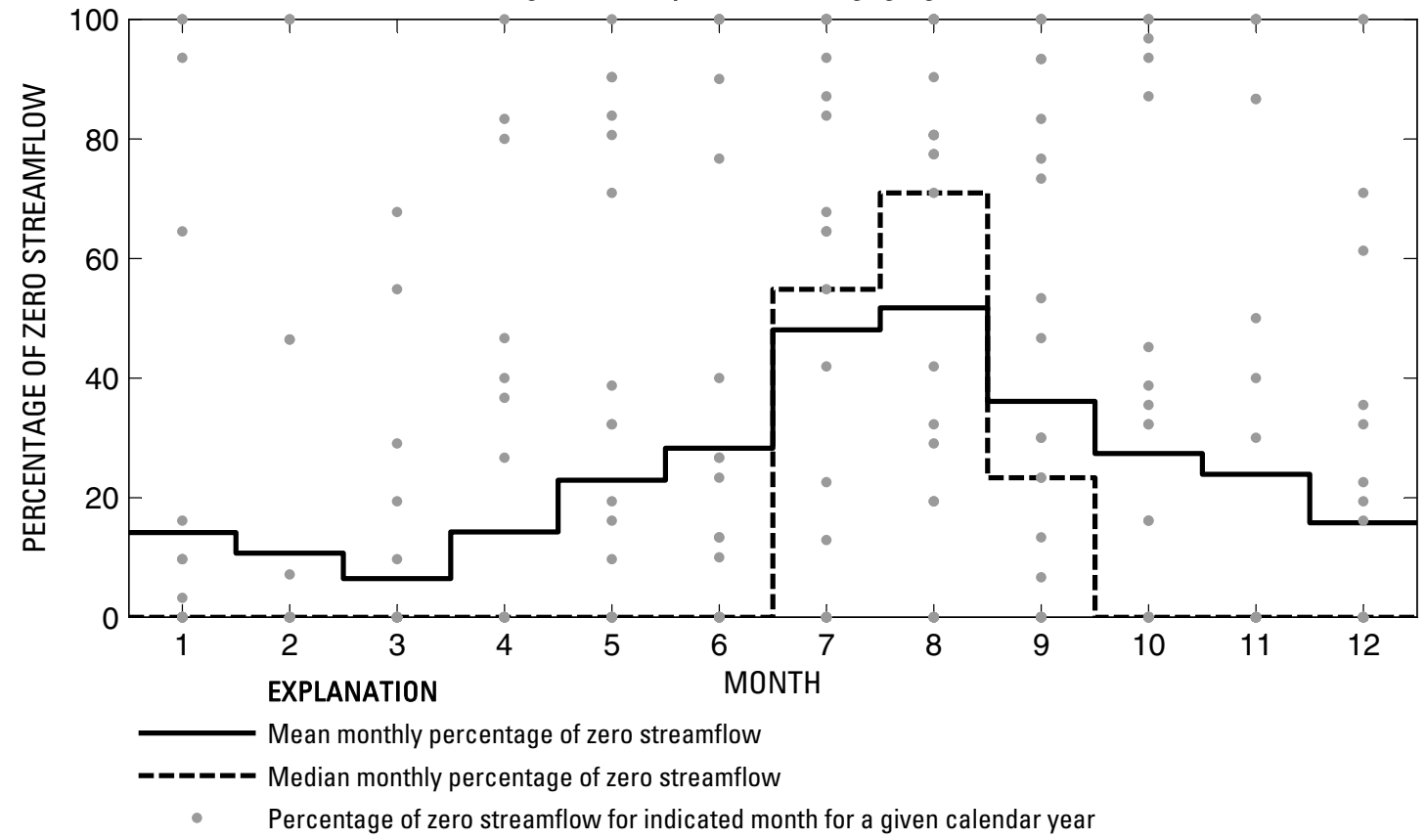

Figure 632. Analysis of percentage of zero daily mean streamflow for U.S. Geological Survey streamflow-gaging station 08186500 Ecleto Creek near Runge, Texas.

Index of Station Numbers 719 
U.S. Geological Survey streamflow-gaging station 08187500

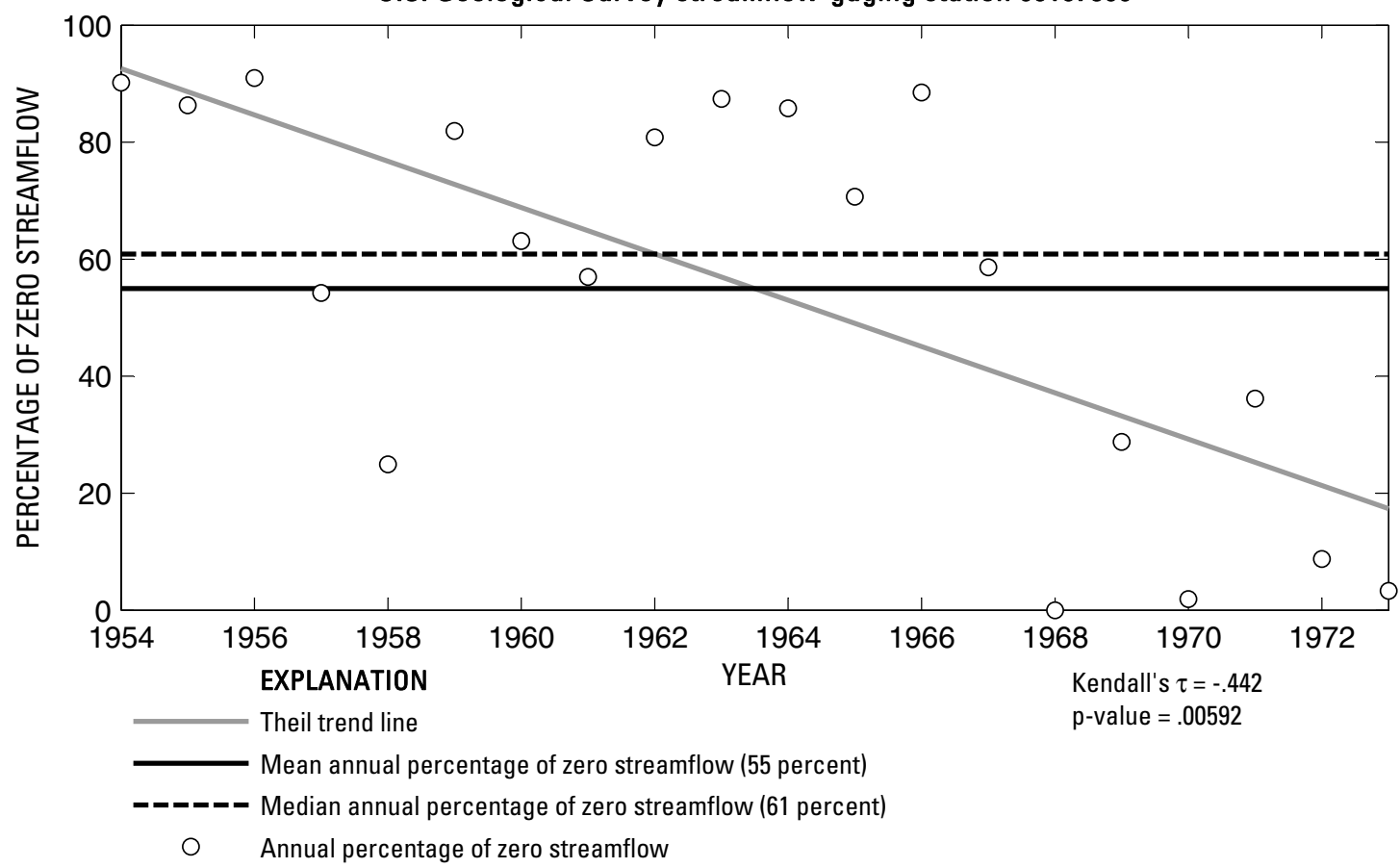

U.S. Geological Survey streamflow-gaging station 08187500

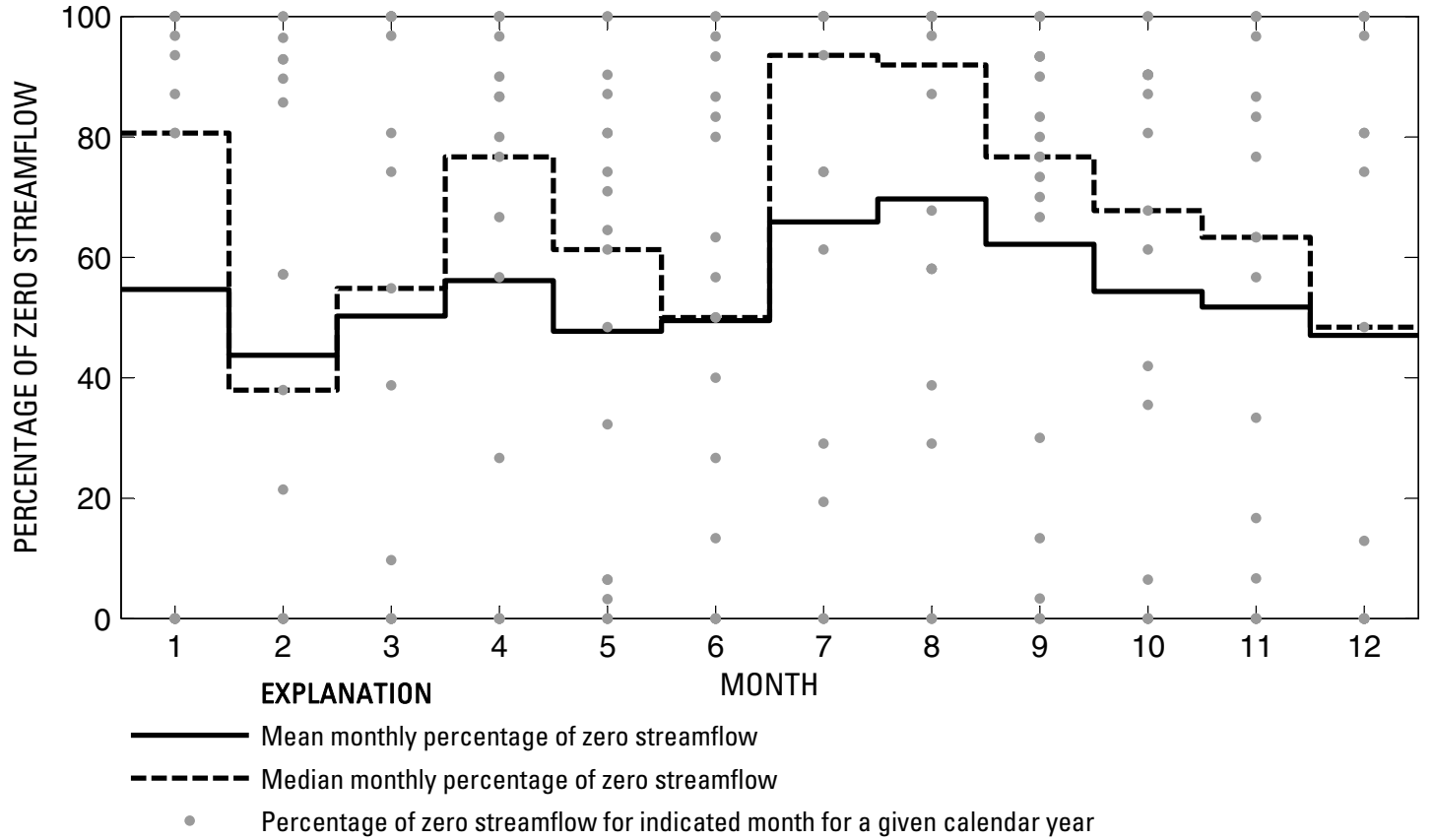

Figure 633. Analysis of percentage of zero daily mean streamflow for U.S. Geological Survey streamflow-gaging station 08187500 Escondido Creek at Kenedy, Texas.

Index of Station Numbers 719 
U.S. Geological Survey streamflow-gaging station 08188500

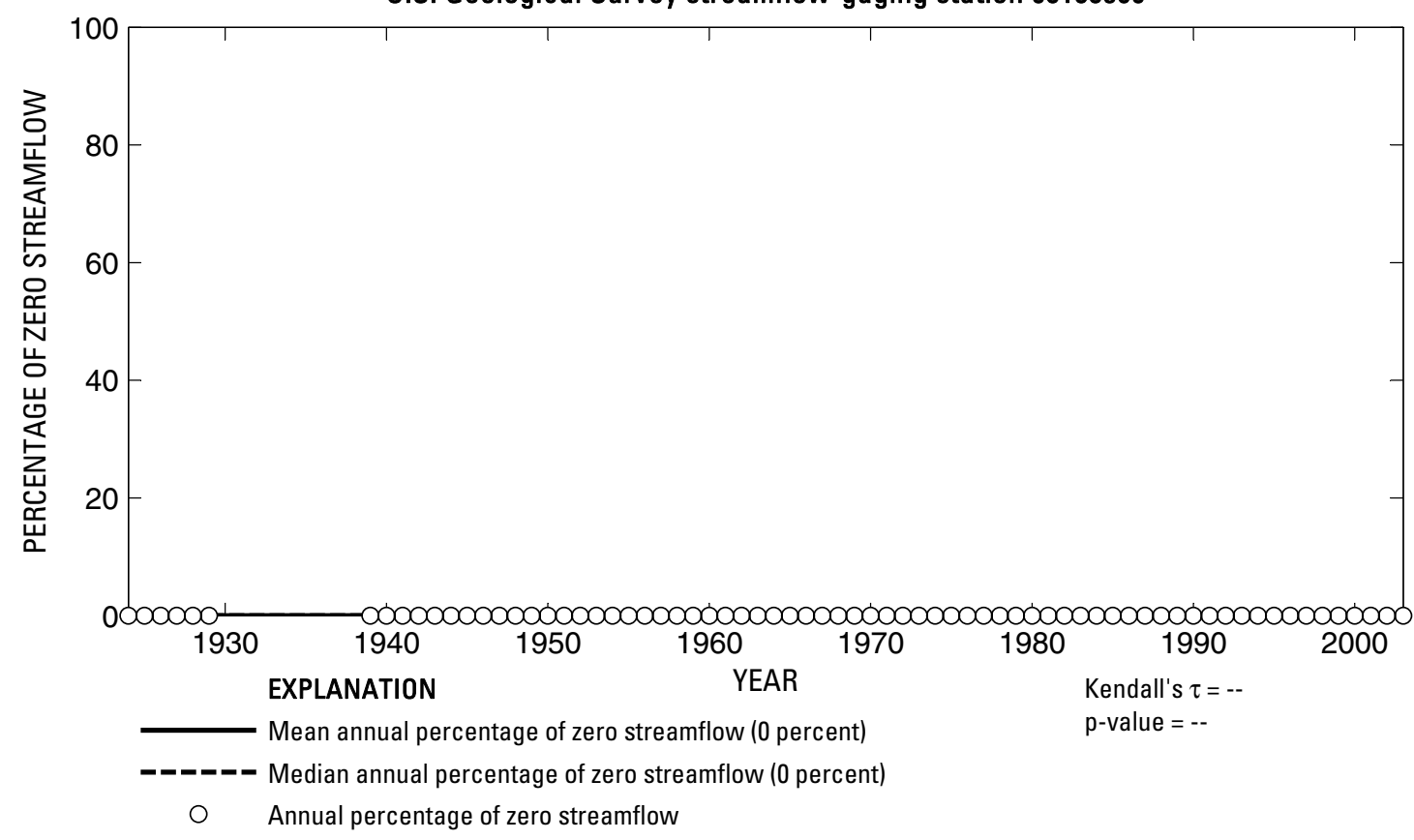

U.S. Geological Survey streamflow-gaging station 08188500

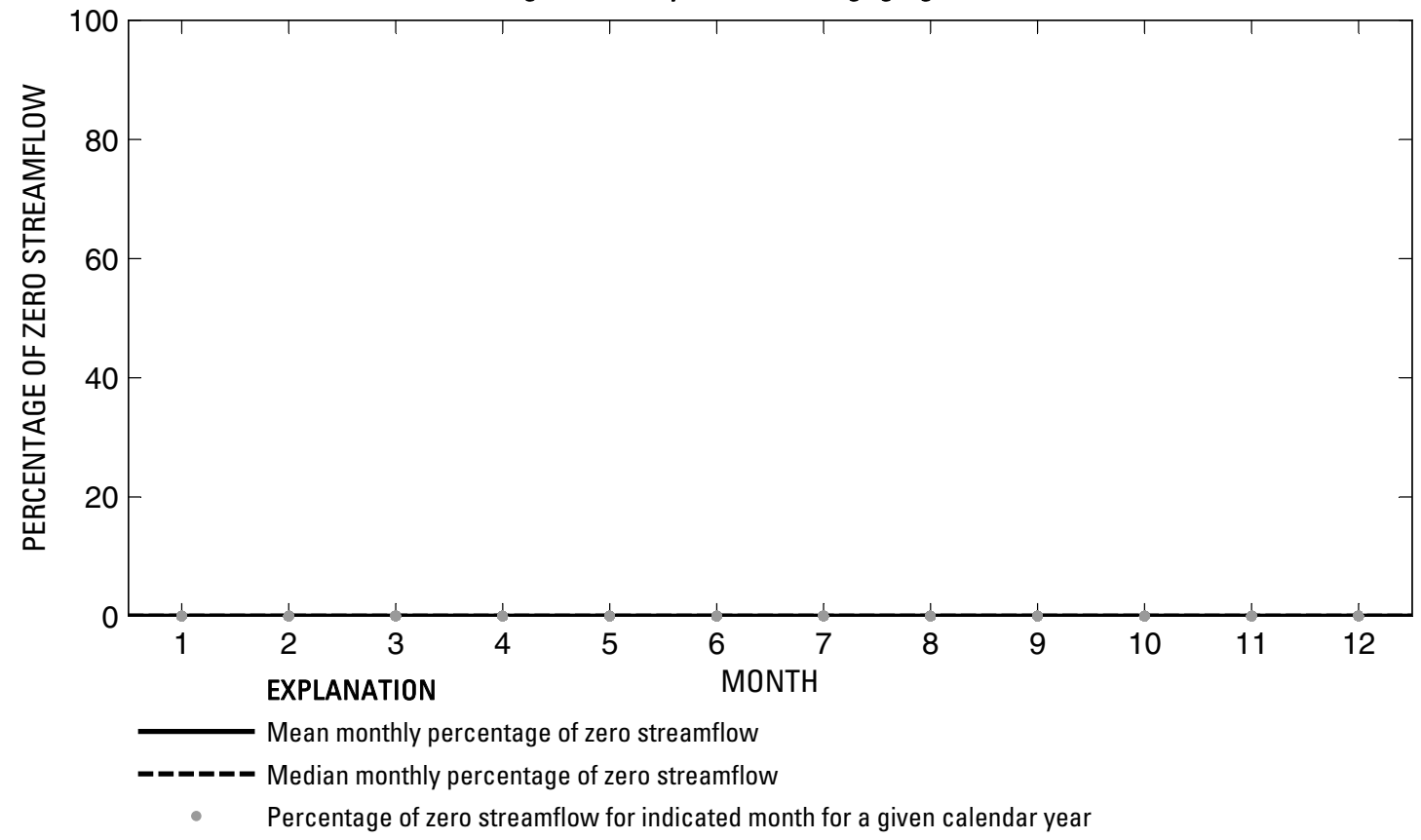

Figure 634. Analysis of percentage of zero daily mean streamflow for U.S. Geological Survey streamflow-gaging station 08188500 San Antonio River at Goliad, Texas.

Index of Station Numbers 719 

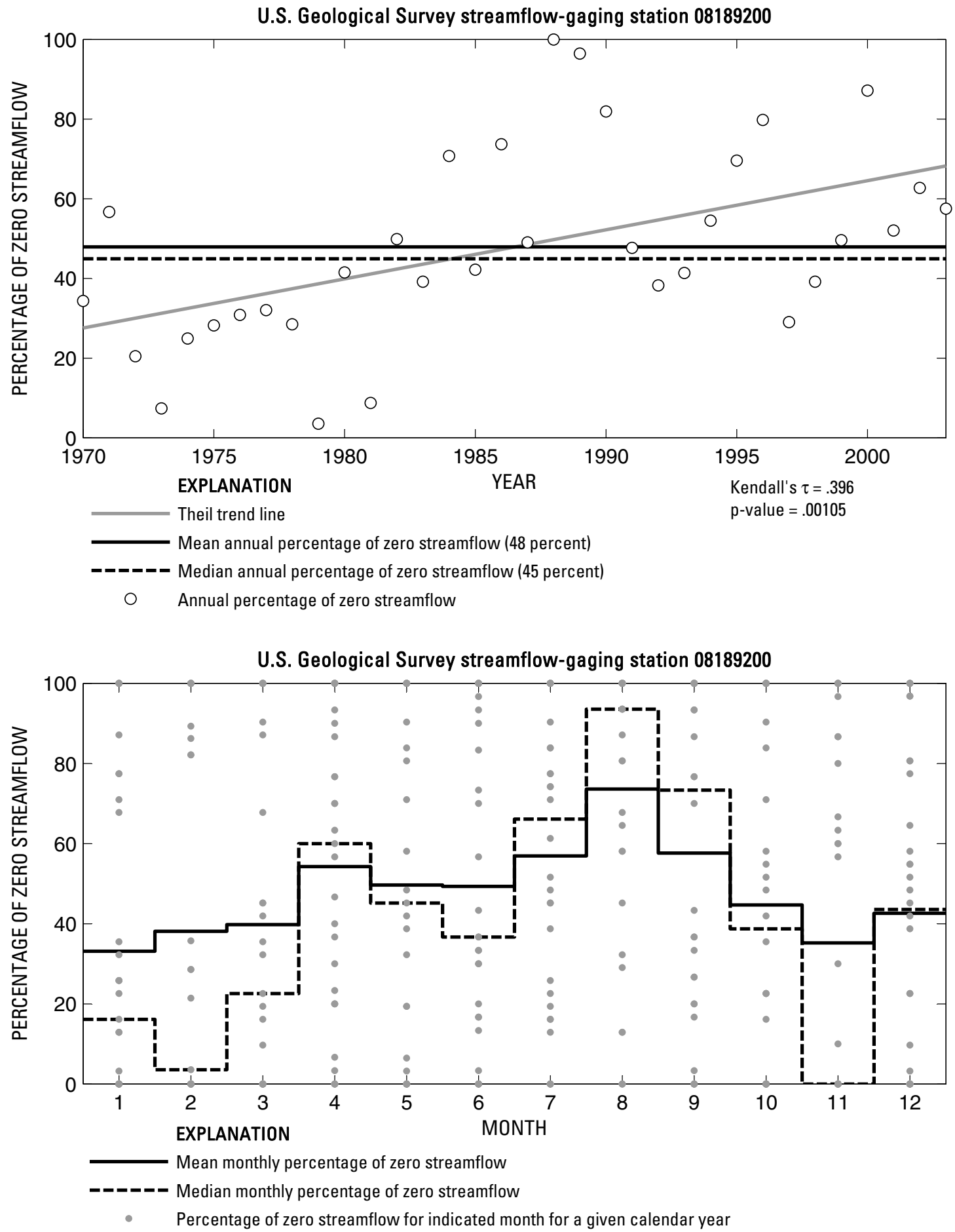

Figure 635. Analysis of percentage of zero daily mean streamflow for U.S. Geological Survey streamflow-gaging station 08189200 Copano Creek near Refugio, Texas. 
U.S. Geological Survey streamflow-gaging station 08189300
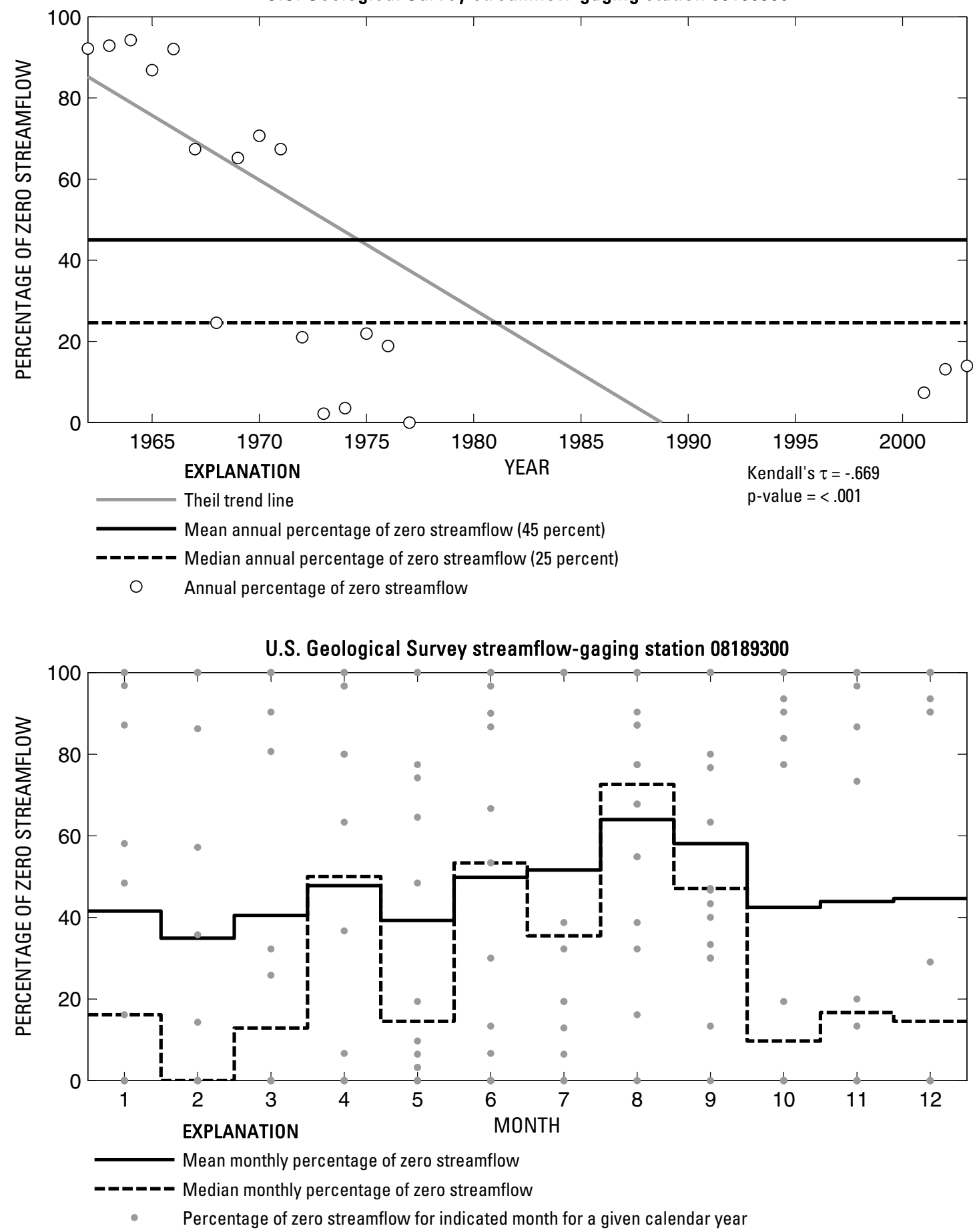

Figure 636. Analysis of percentage of zero daily mean streamflow for U.S. Geological Survey streamflow-gaging station 08189300 Medio Creek near Beeville, Texas.

Index of Station Numbers 719 


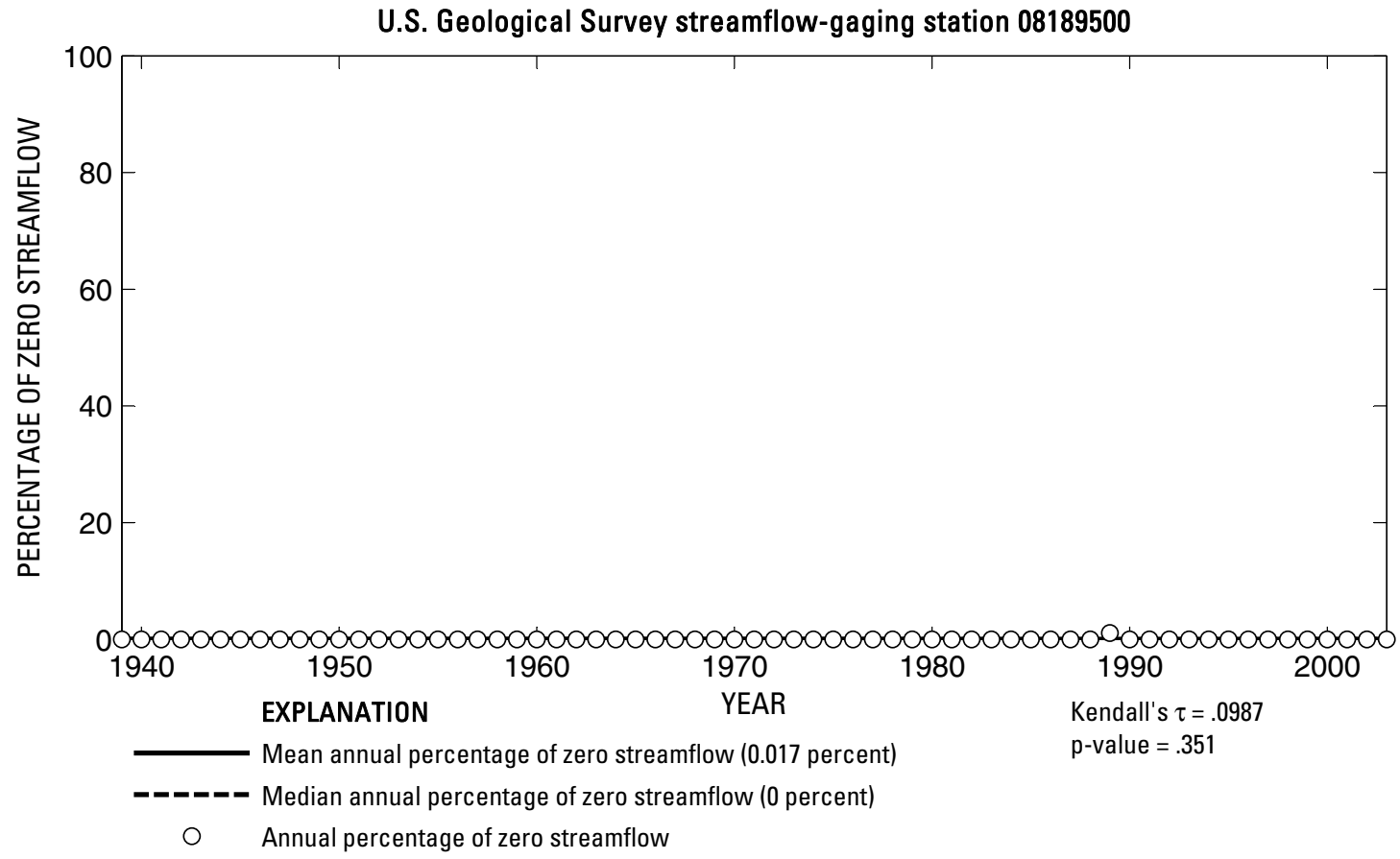

U.S. Geological Survey streamflow-gaging station 08189500

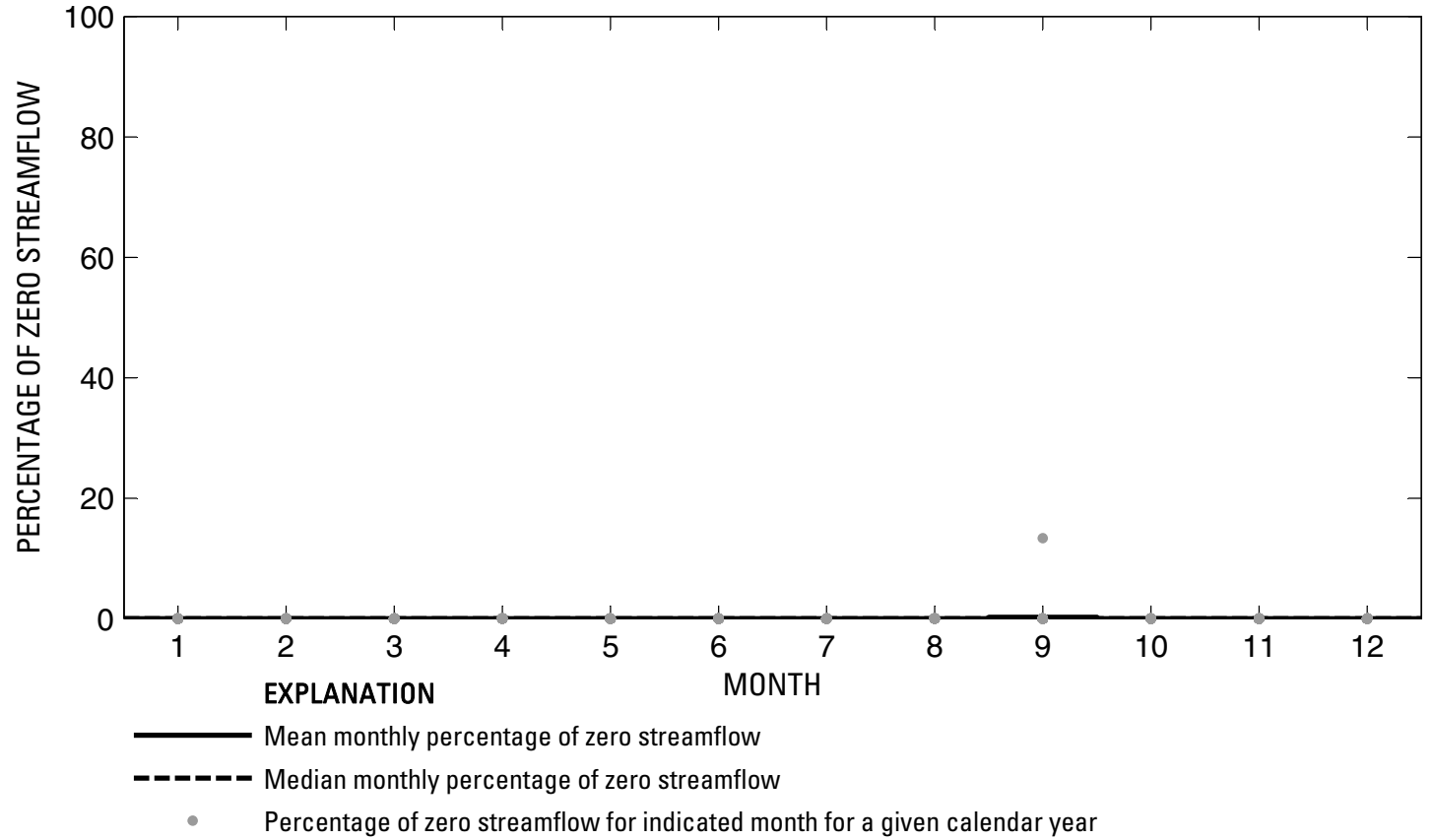

Figure 637. Analysis of percentage of zero daily mean streamflow for U.S. Geological Survey streamflow-gaging station 08189500 Mission River at Refugio, Texas. 
U.S. Geological Survey streamflow-gaging station 08189700

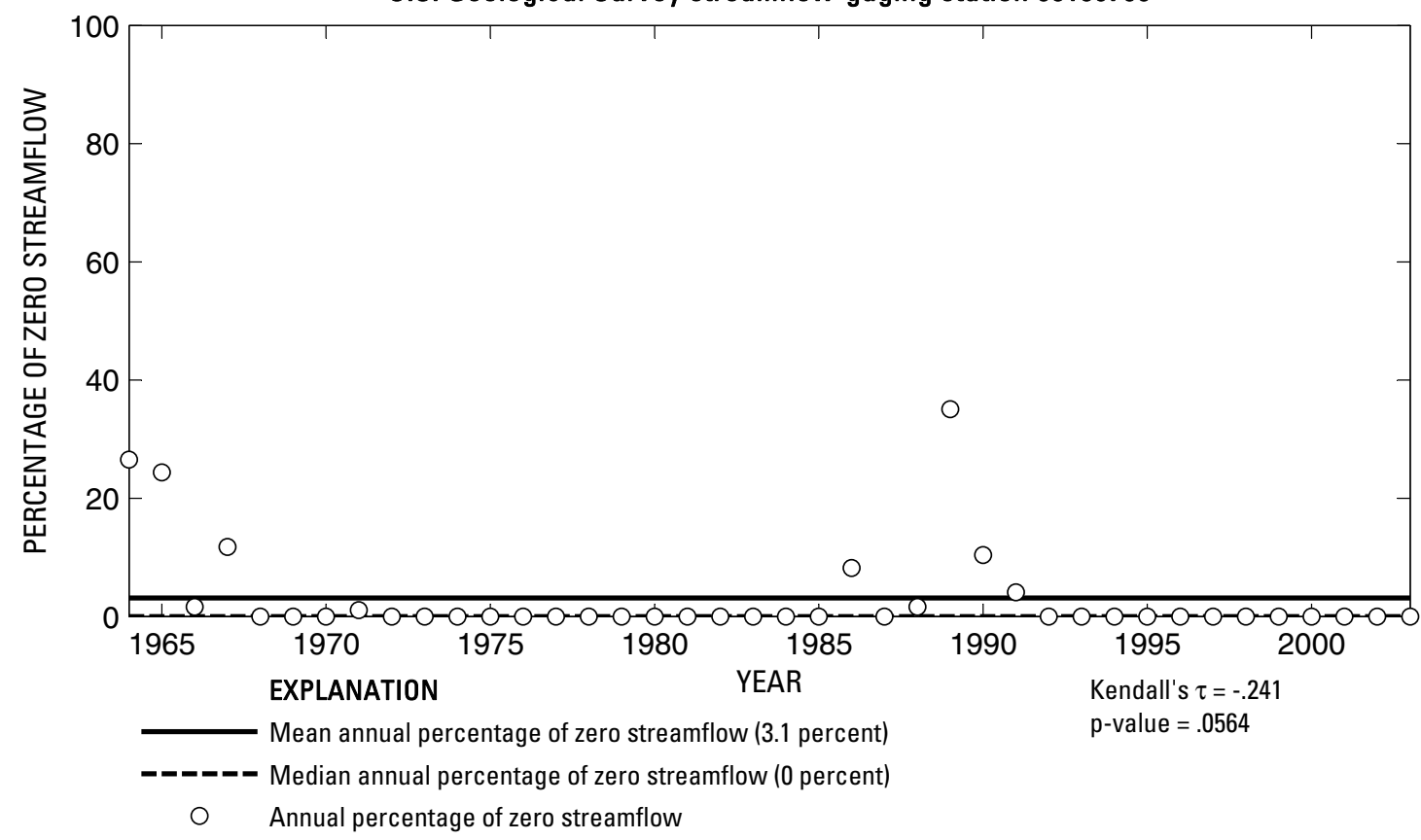

U.S. Geological Survey streamflow-gaging station 08189700

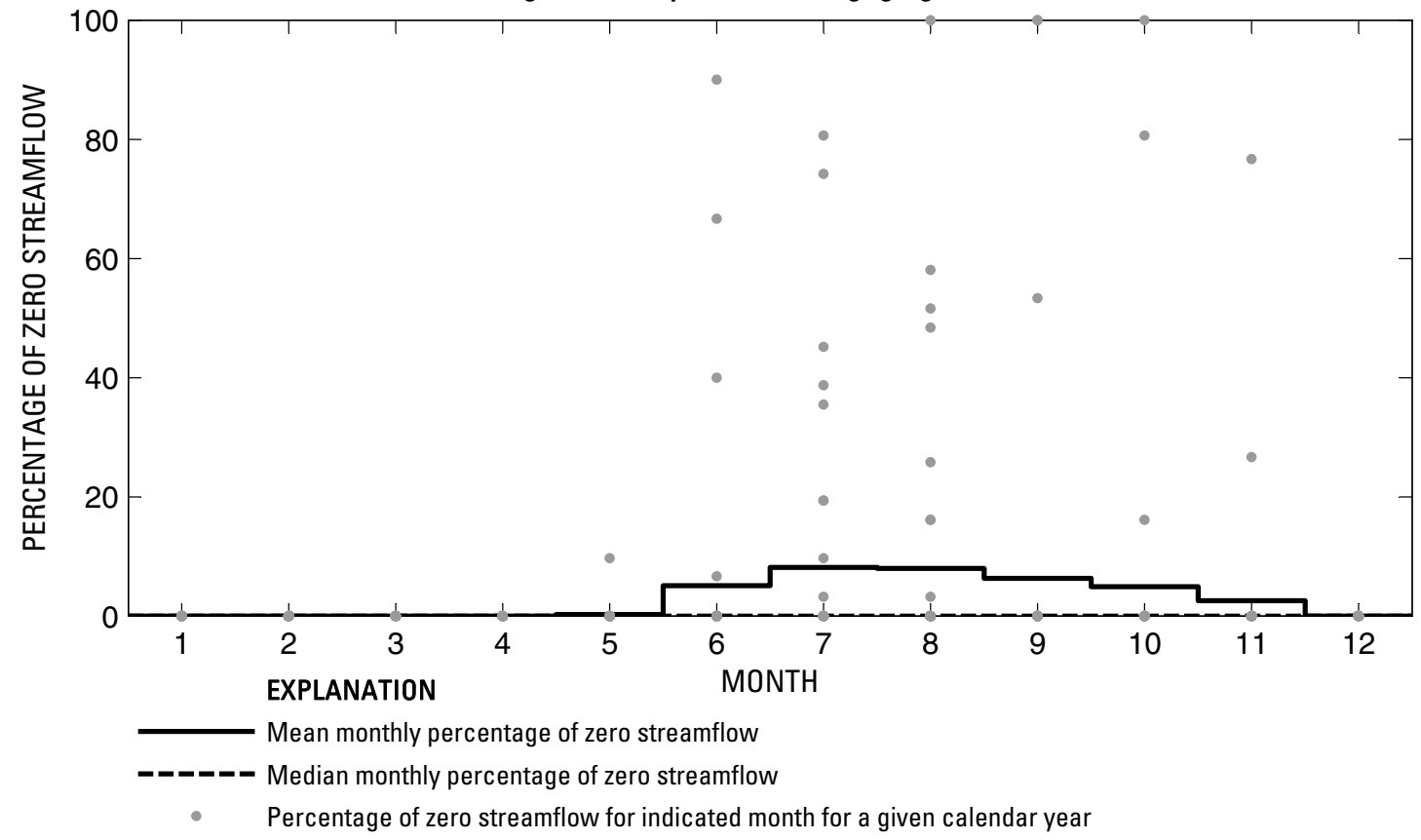

Figure 638. Analysis of percentage of zero daily mean streamflow for U.S. Geological Survey streamflow-gaging station 08189700 Aransas River near Skidmore, Texas. 

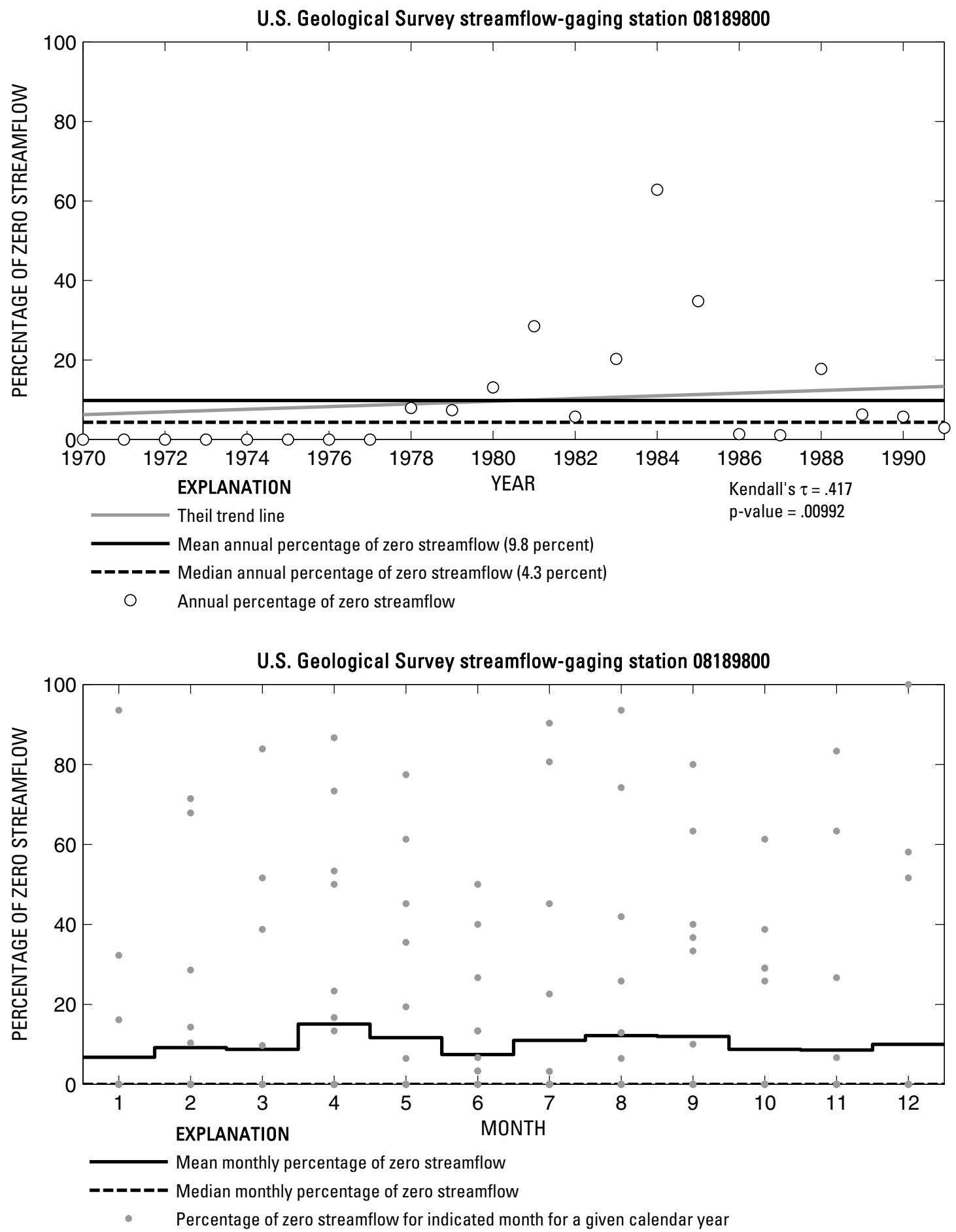

Figure 639. Analysis of percentage of zero daily mean streamflow for U.S. Geological Survey streamflow-gaging station 08189800 Chiltipin Creek at Sinton, Texas. 
U.S. Geological Survey streamflow-gaging station 08190000

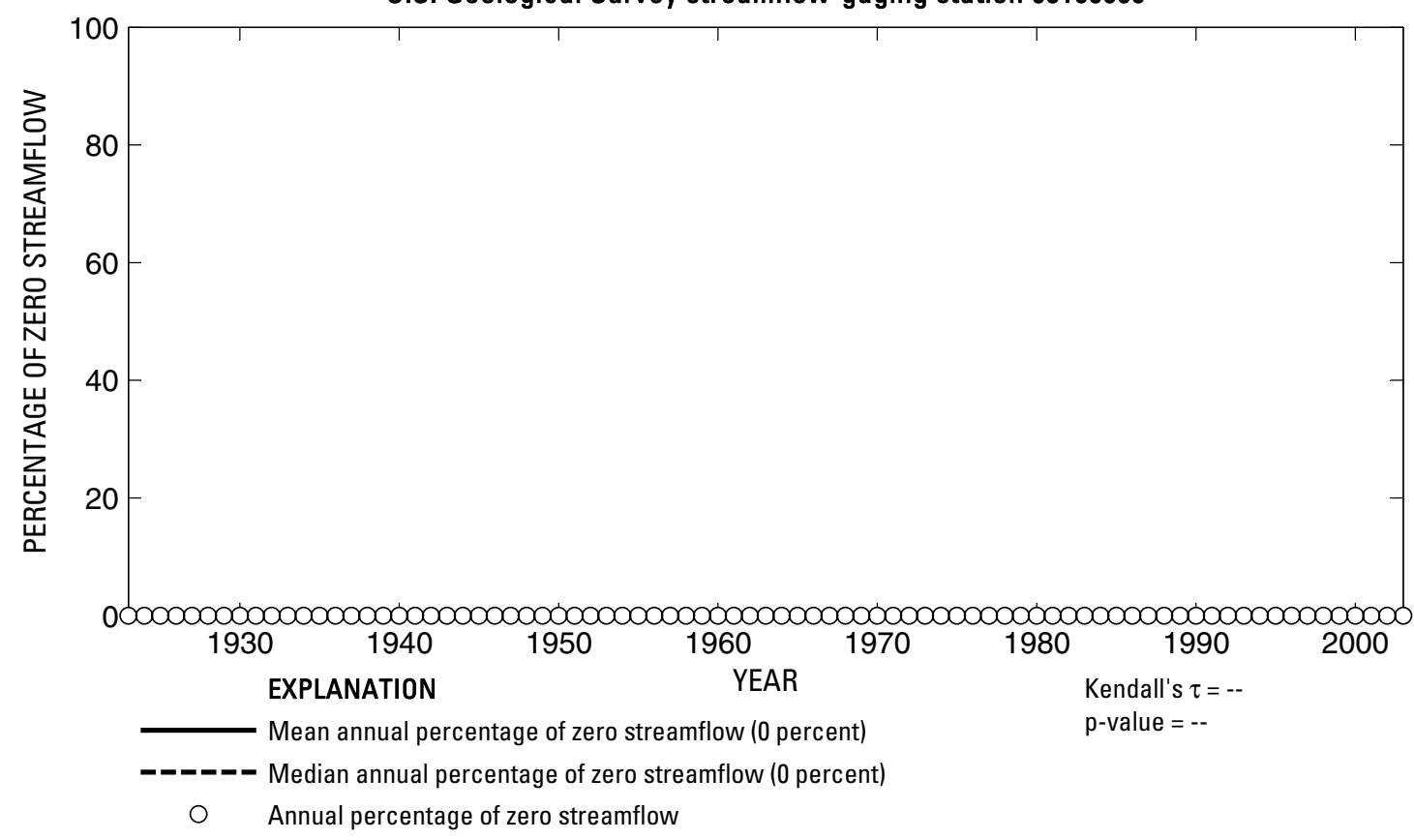

U.S. Geological Survey streamflow-gaging station 08190000

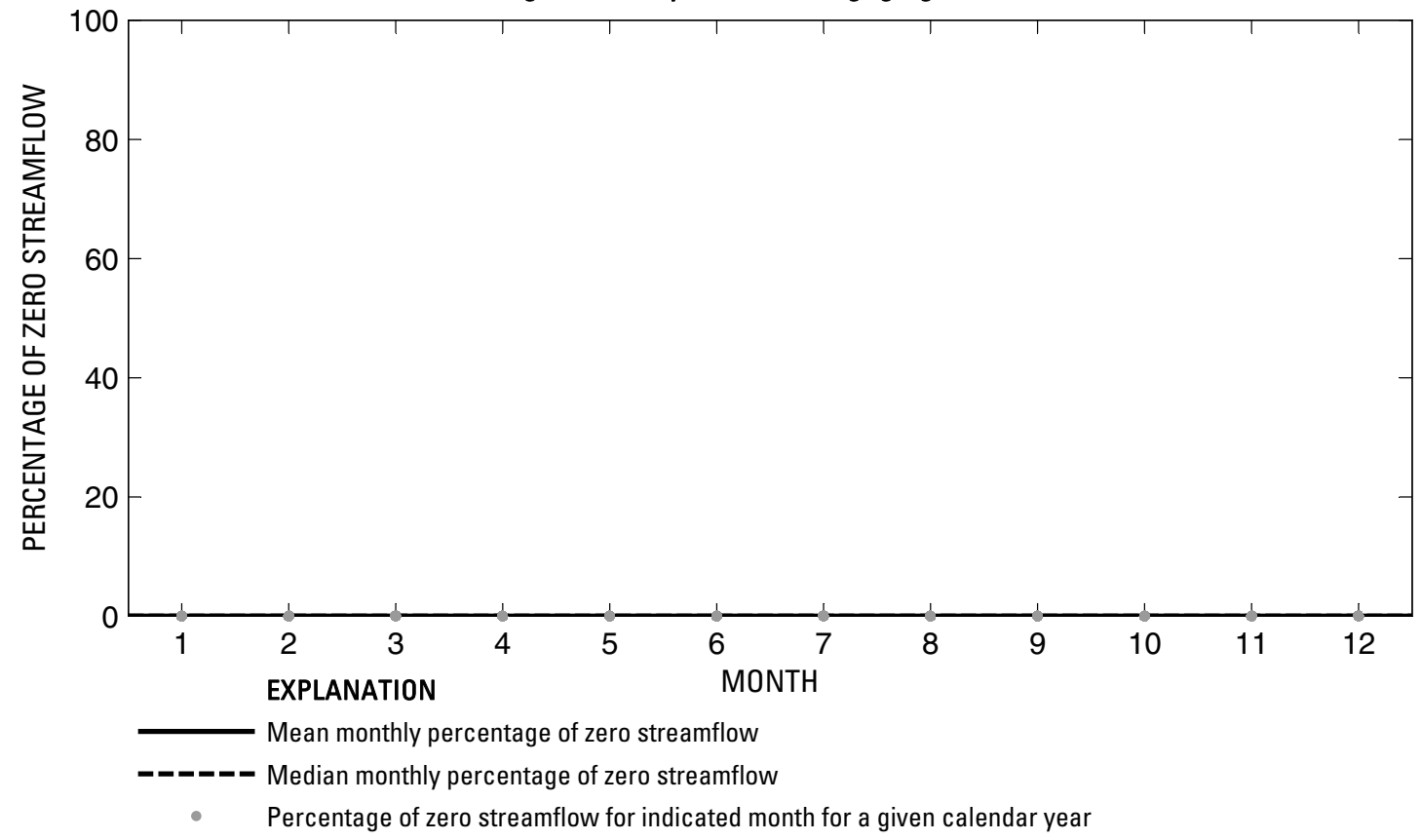

Figure 640. Analysis of percentage of zero daily mean streamflow for U.S. Geological Survey streamflow-gaging station 08190000 Nueces River at Laguna, Texas. 
U.S. Geological Survey streamflow-gaging station 08190500

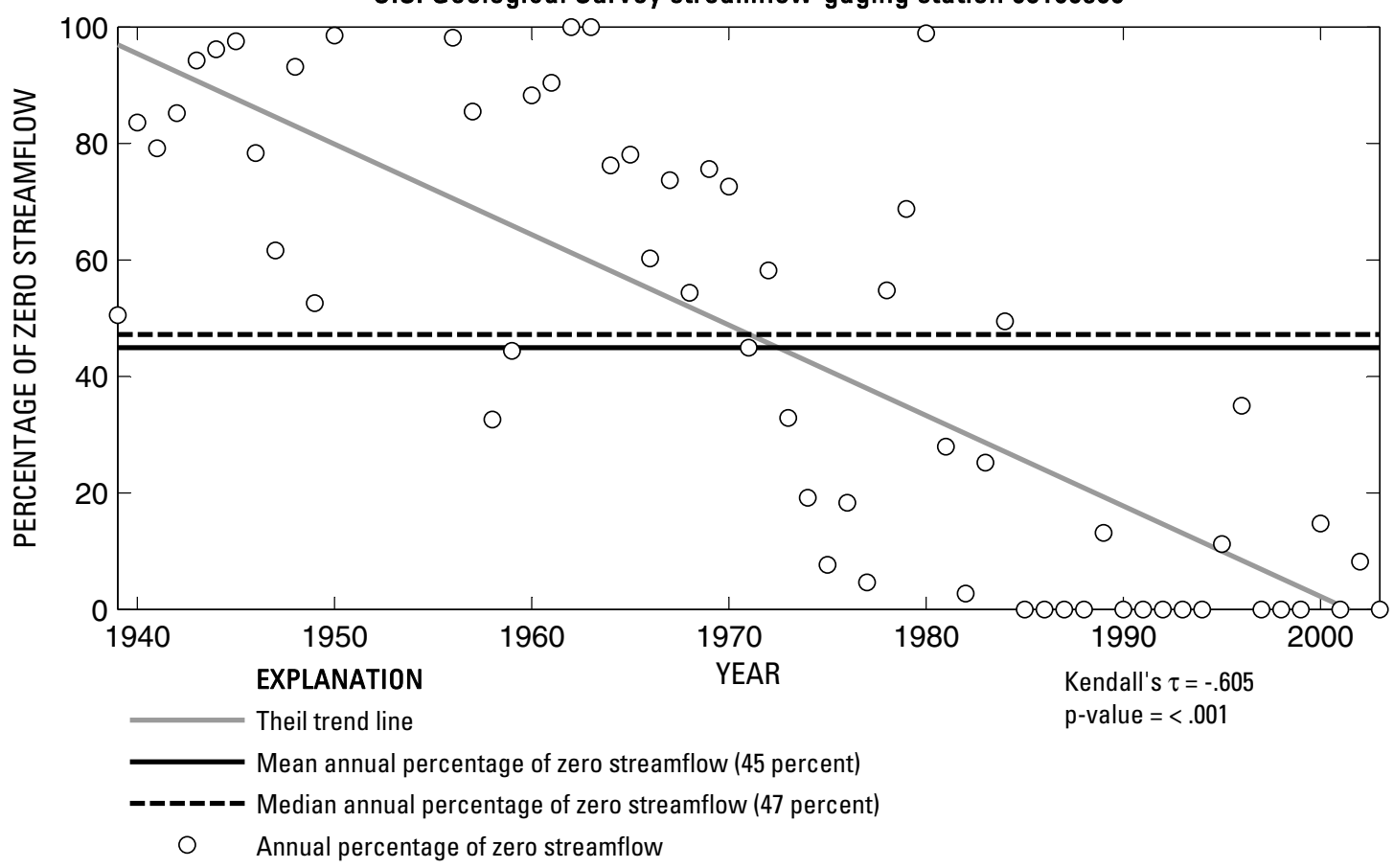

U.S. Geological Survey streamflow-gaging station 08190500

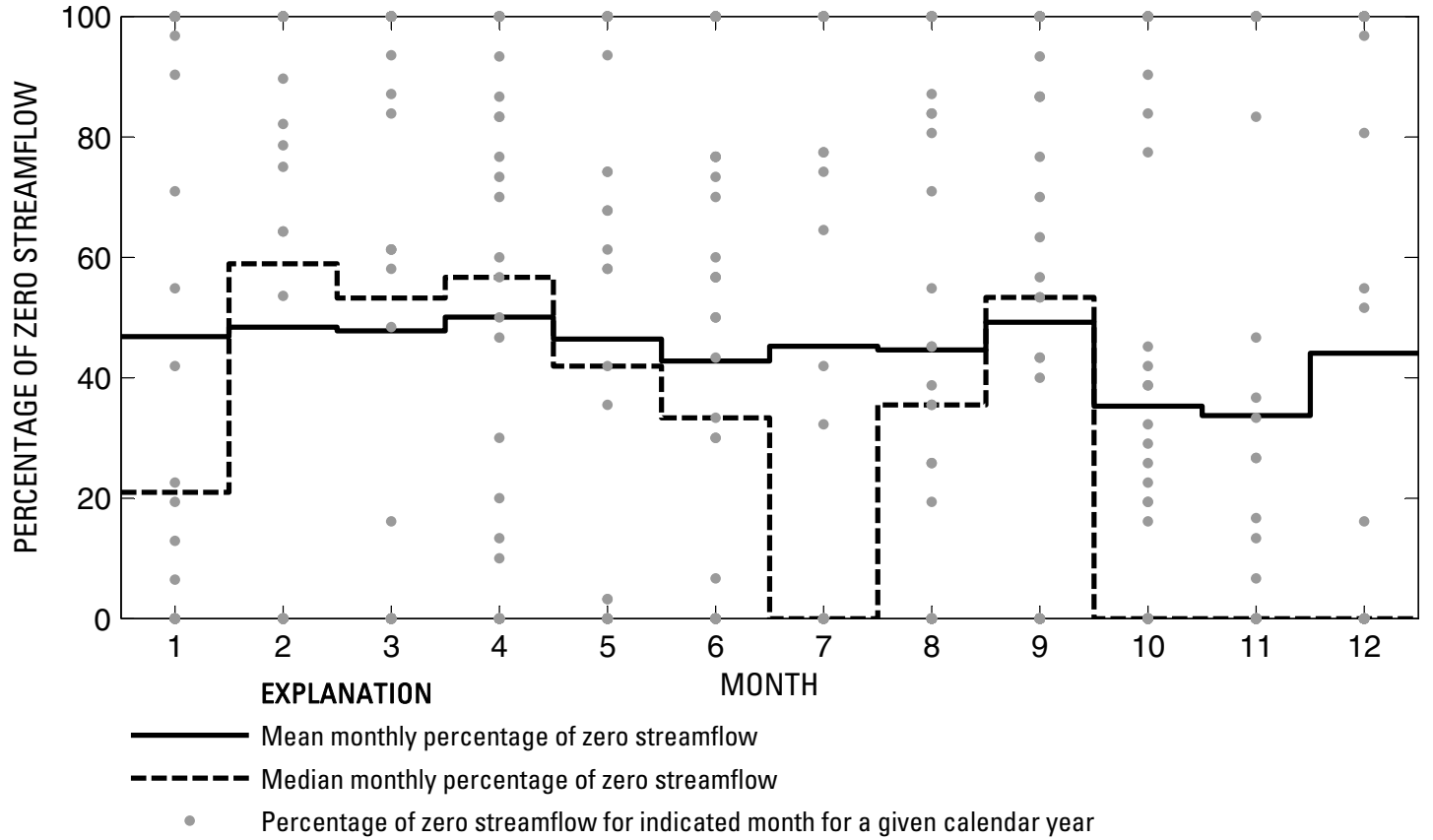

Figure 641. Analysis of percentage of zero daily mean streamflow for U.S. Geological Survey streamflow-gaging station 08190500 West Nueces River near Brackettville, Texas. 

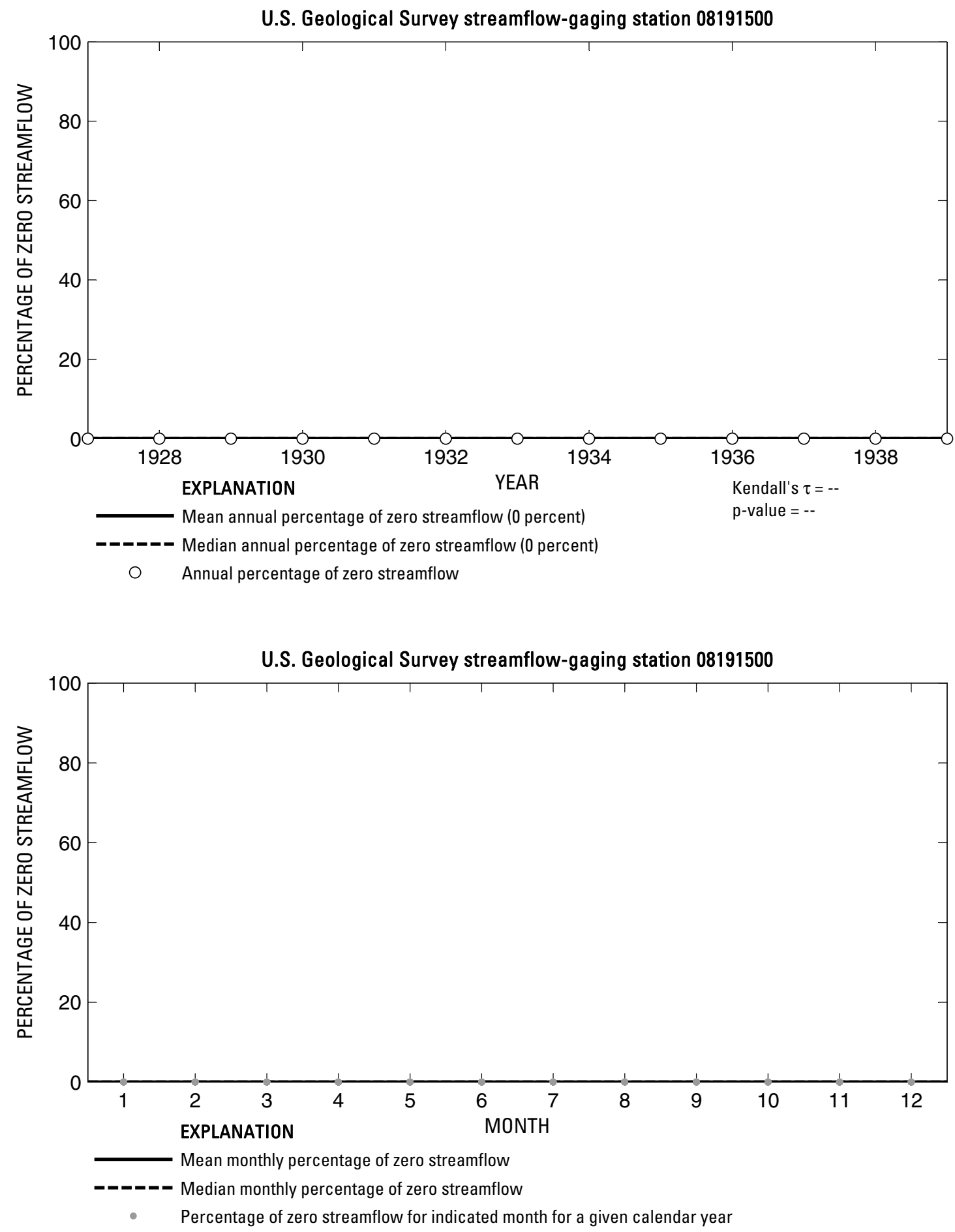

Figure 642. Analysis of percentage of zero daily mean streamflow for U.S. Geological Survey streamflow-gaging station 08191500 Nueces River near Uvalde, Texas. 
U.S. Geological Survey streamflow-gaging station 08192000

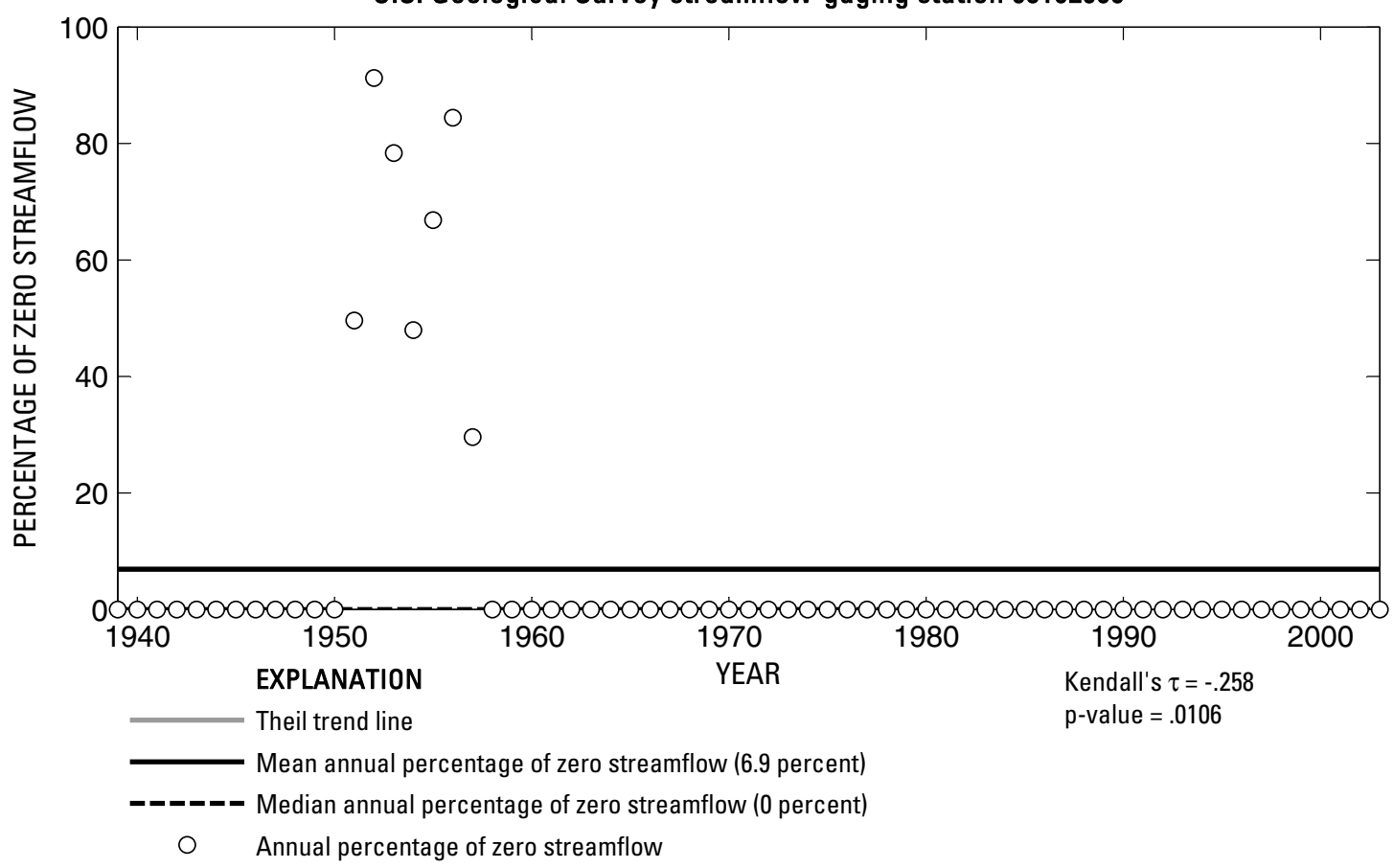

U.S. Geological Survey streamflow-gaging station 08192000

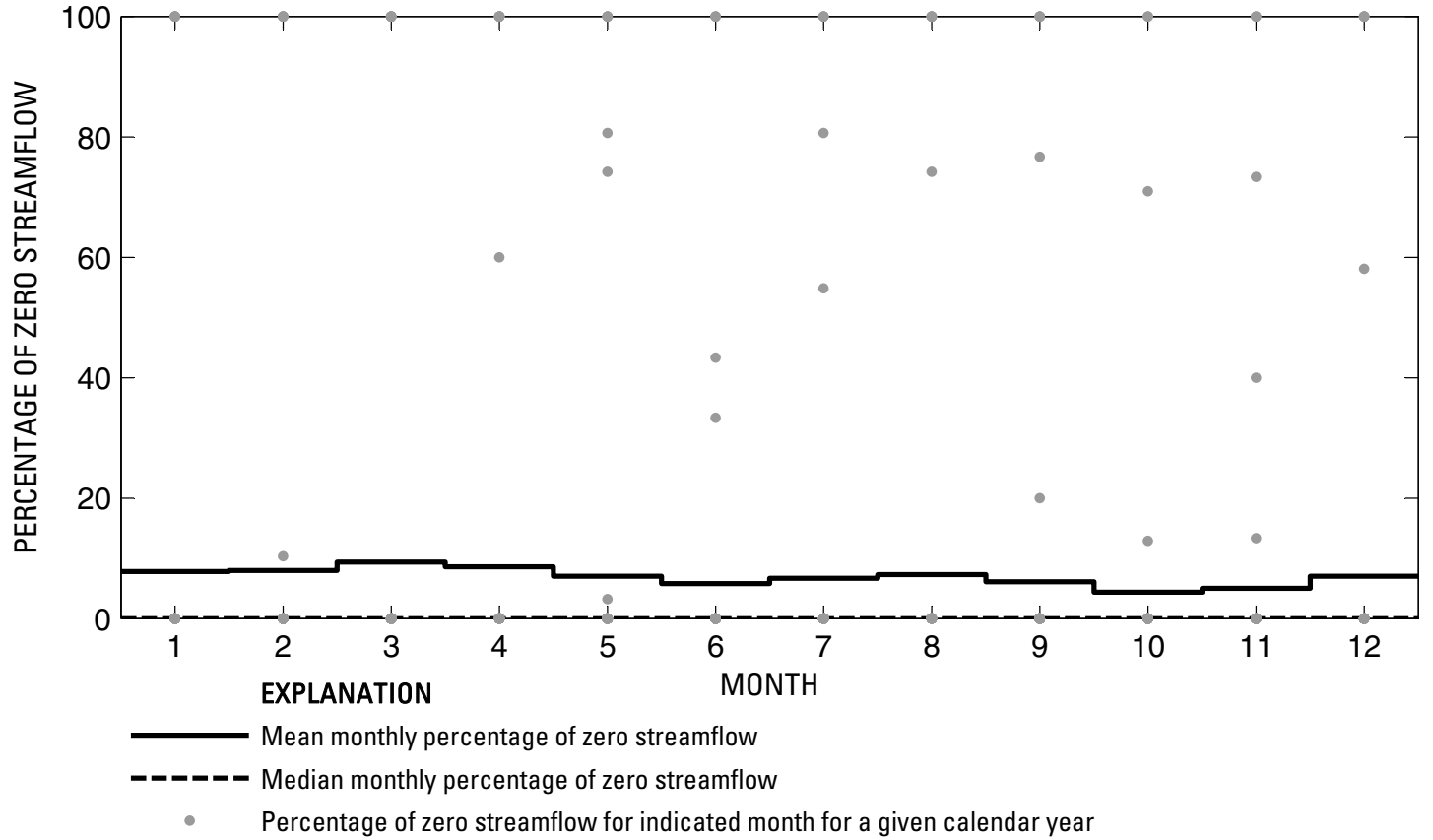

Figure 643. Analysis of percentage of zero daily mean streamflow for U.S. Geological Survey streamflow-gaging station 08192000 Nueces River below Uvalde, Texas. 
U.S. Geological Survey streamflow-gaging station 08192500

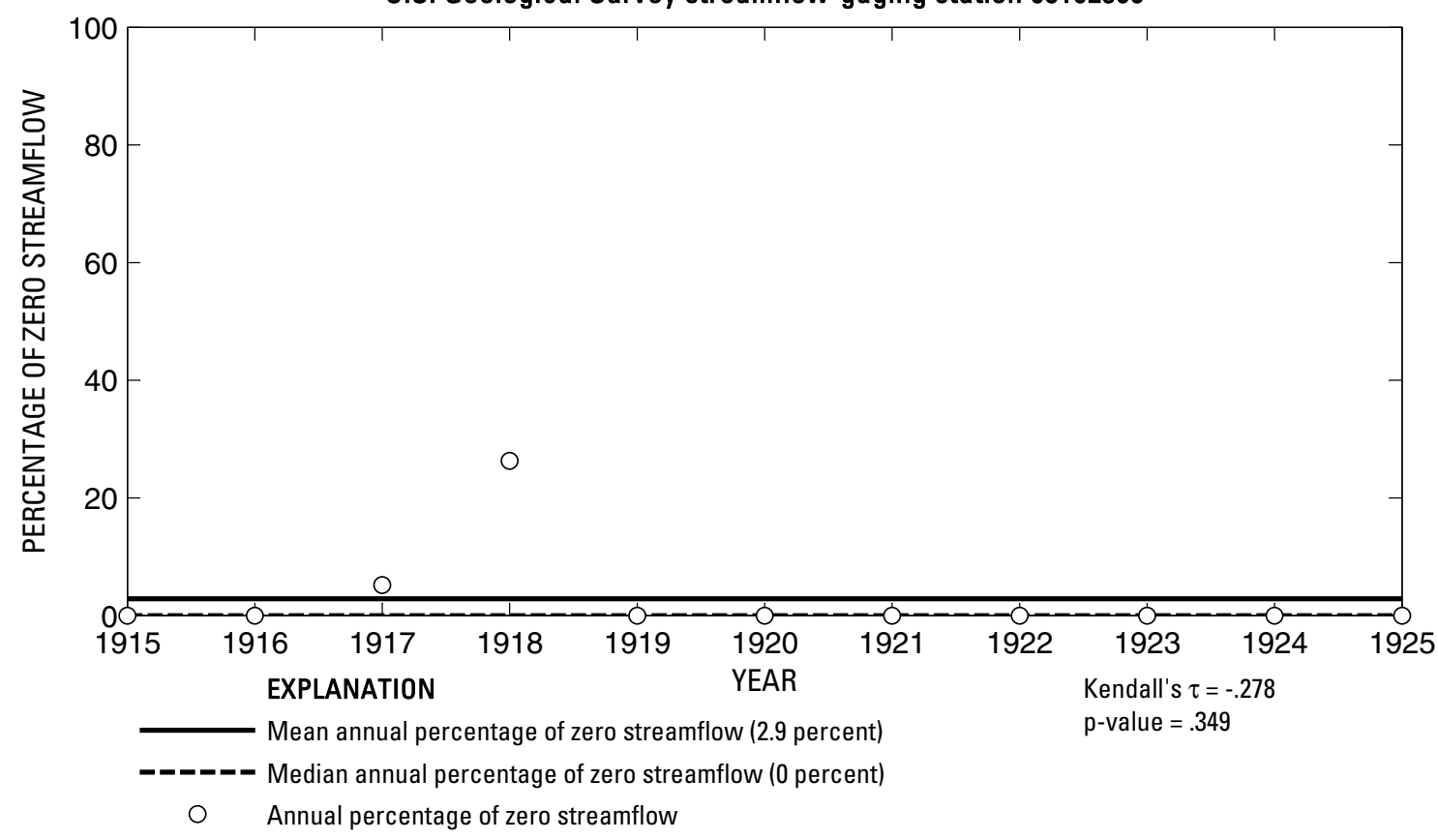

U.S. Geological Survey streamflow-gaging station 08192500

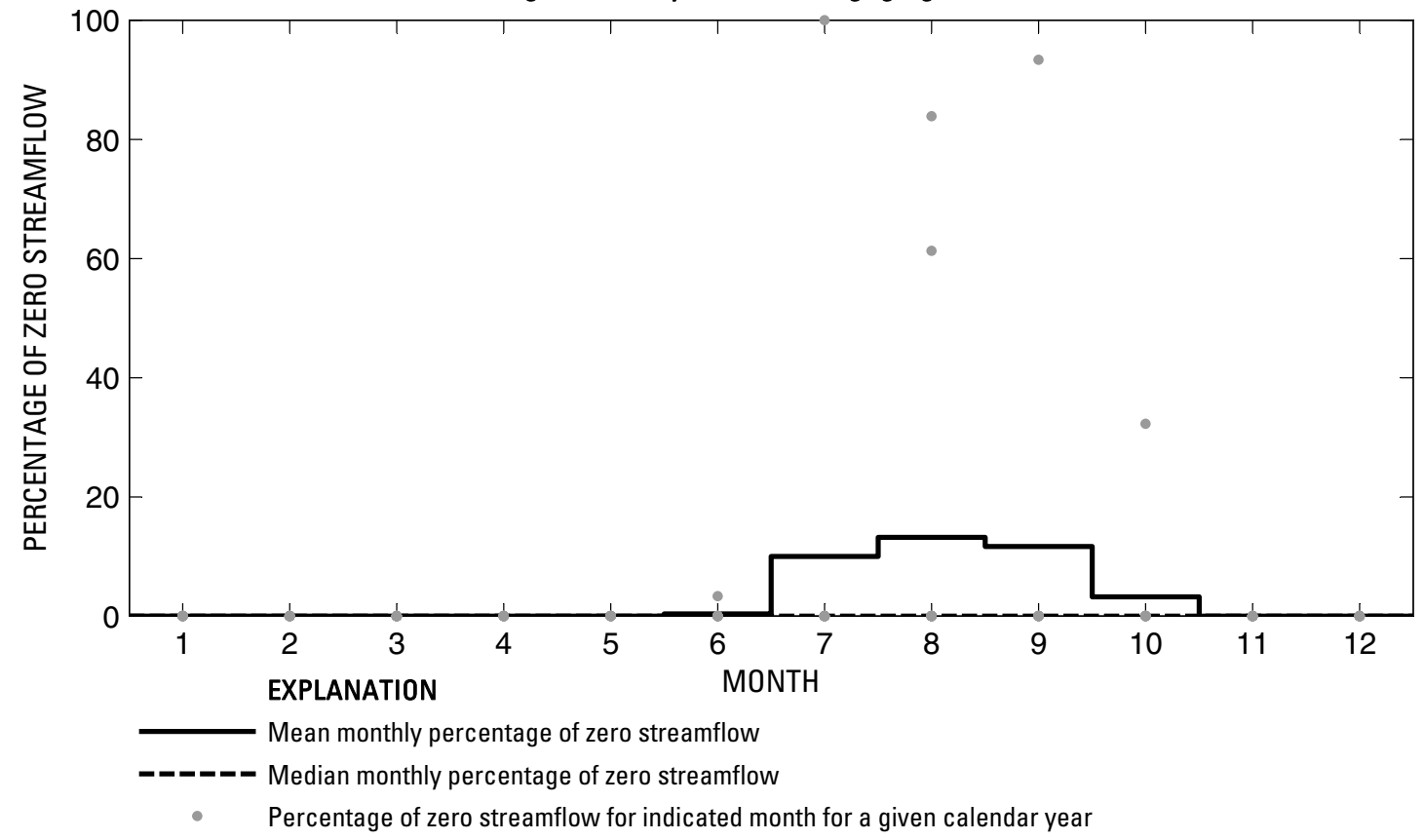

Figure 644. Analysis of percentage of zero daily mean streamflow for U.S. Geological Survey streamflow-gaging station 08192500 Nueces River near Cinonia, Texas. 
U.S. Geological Survey streamflow-gaging station 08193000

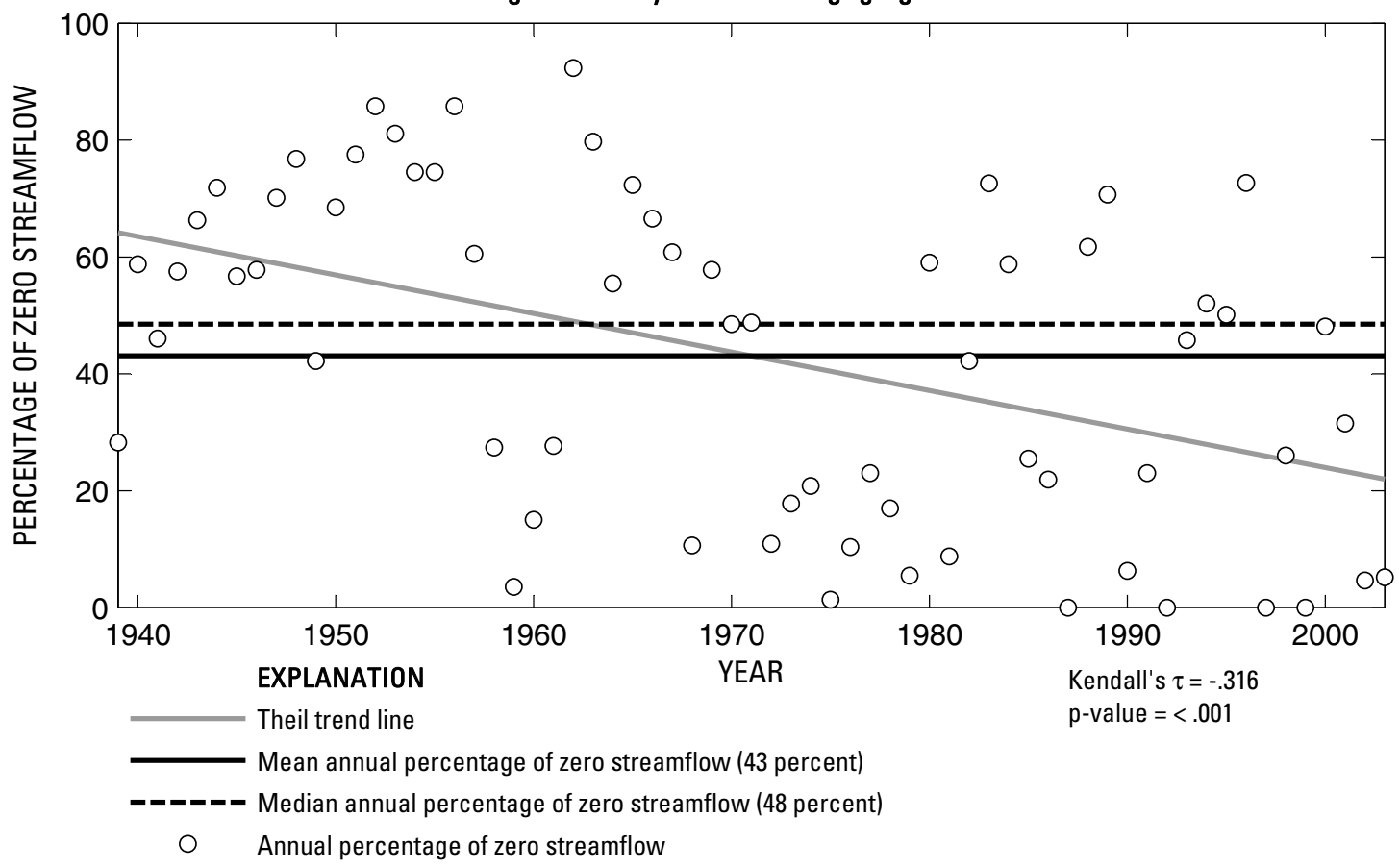

U.S. Geological Survey streamflow-gaging station 08193000

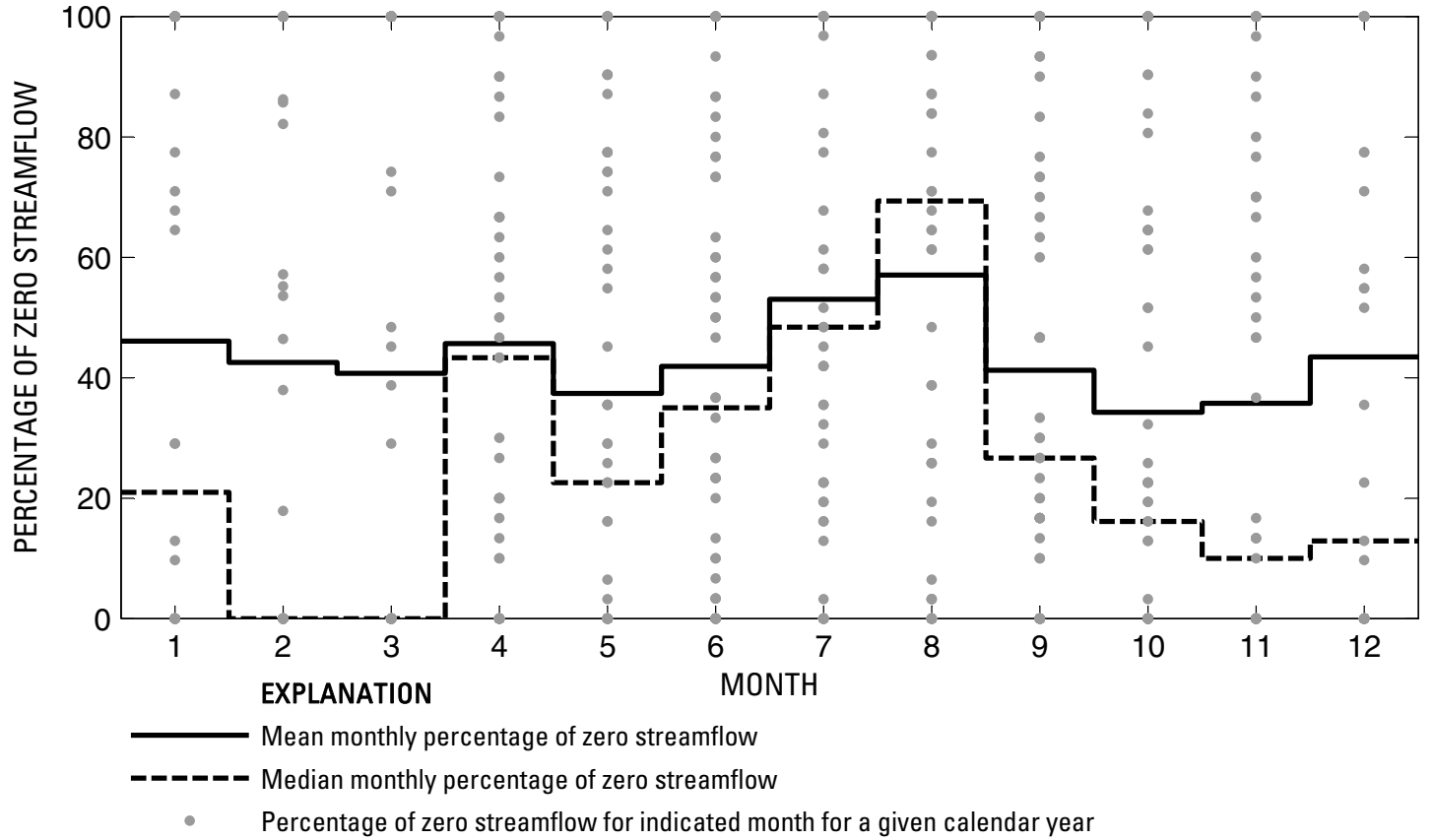

Figure 645. Analysis of percentage of zero daily mean streamflow for U.S. Geological Survey streamflow-gaging station 08193000 Nueces River near Asherton, Texas. 
U.S. Geological Survey streamflow-gaging station 08194000

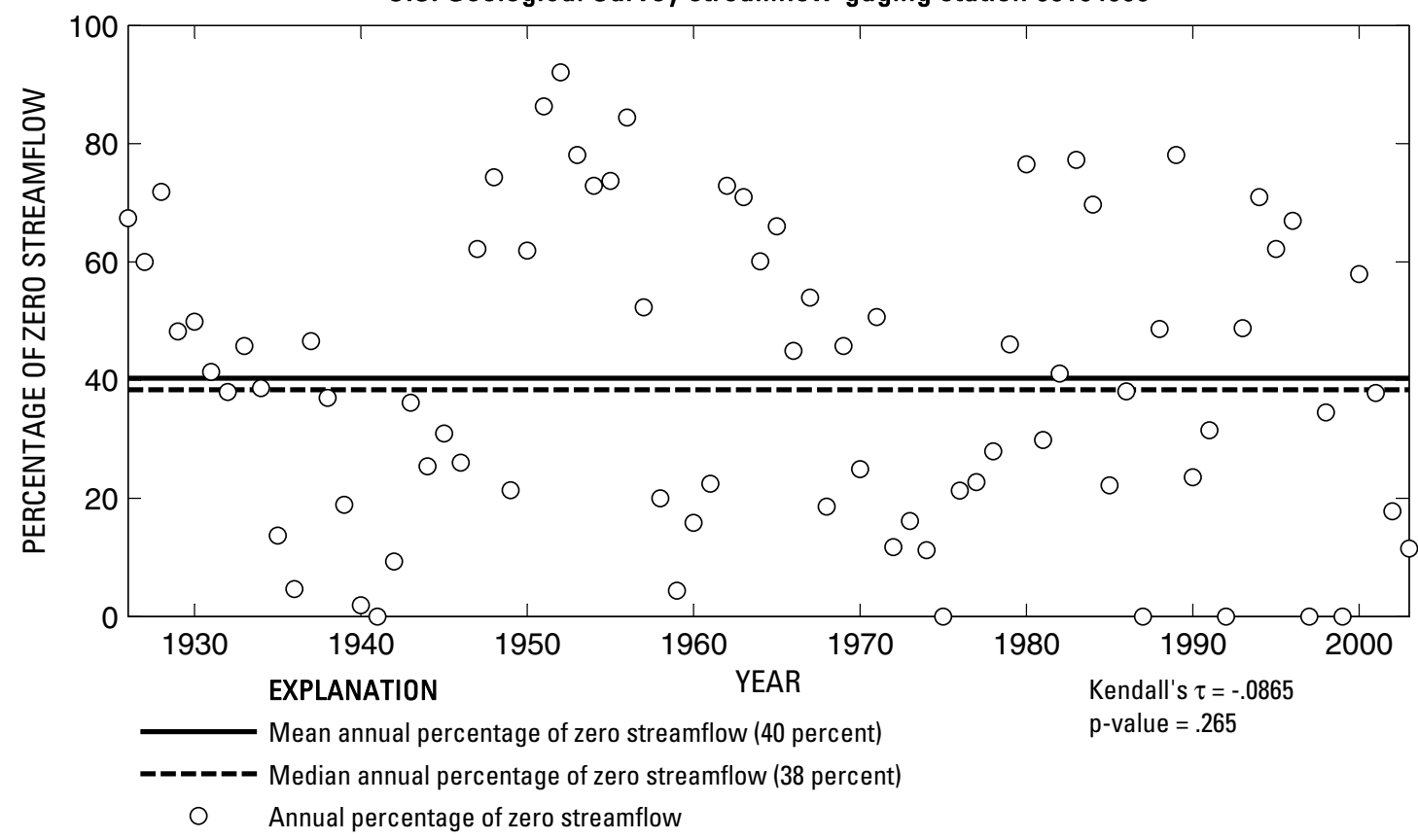

U.S. Geological Survey streamflow-gaging station 08194000

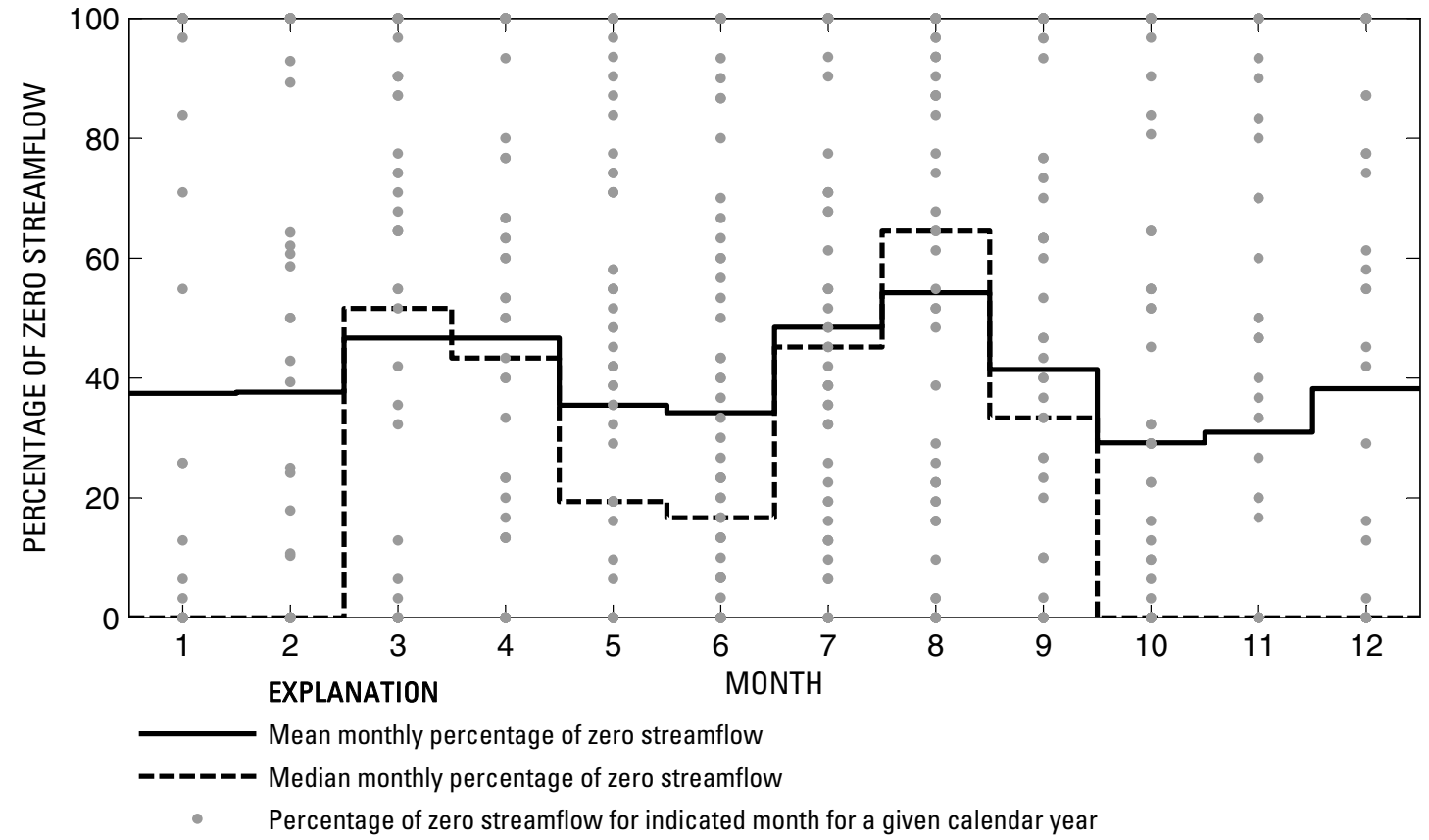

Figure 646. Analysis of percentage of zero daily mean streamflow for U.S. Geological Survey streamflow-gaging station 08194000 Nueces River at Cotulla, Texas.

Index of Station Numbers 719 
U.S. Geological Survey streamflow-gaging station 08194200

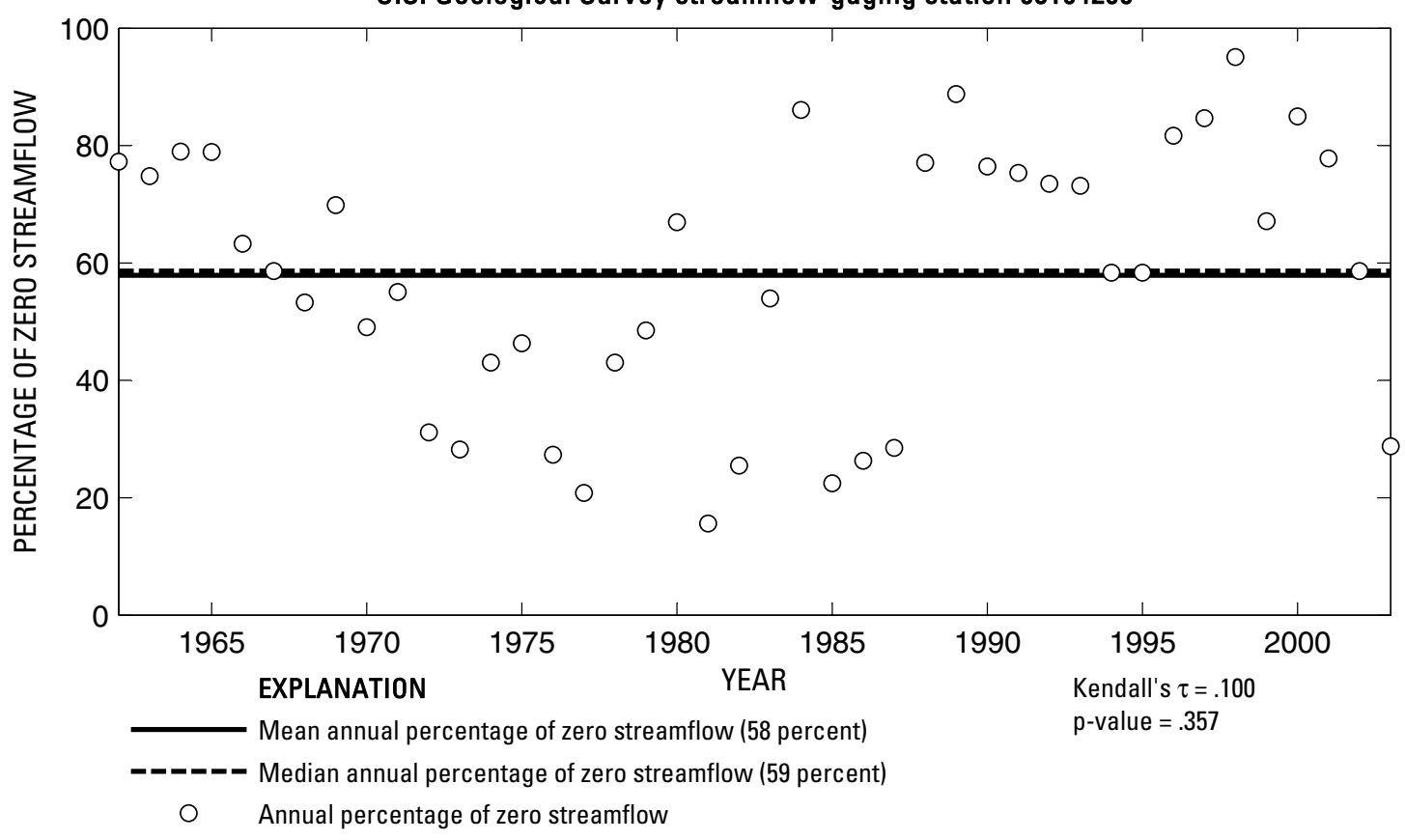

U.S. Geological Survey streamflow-gaging station 08194200

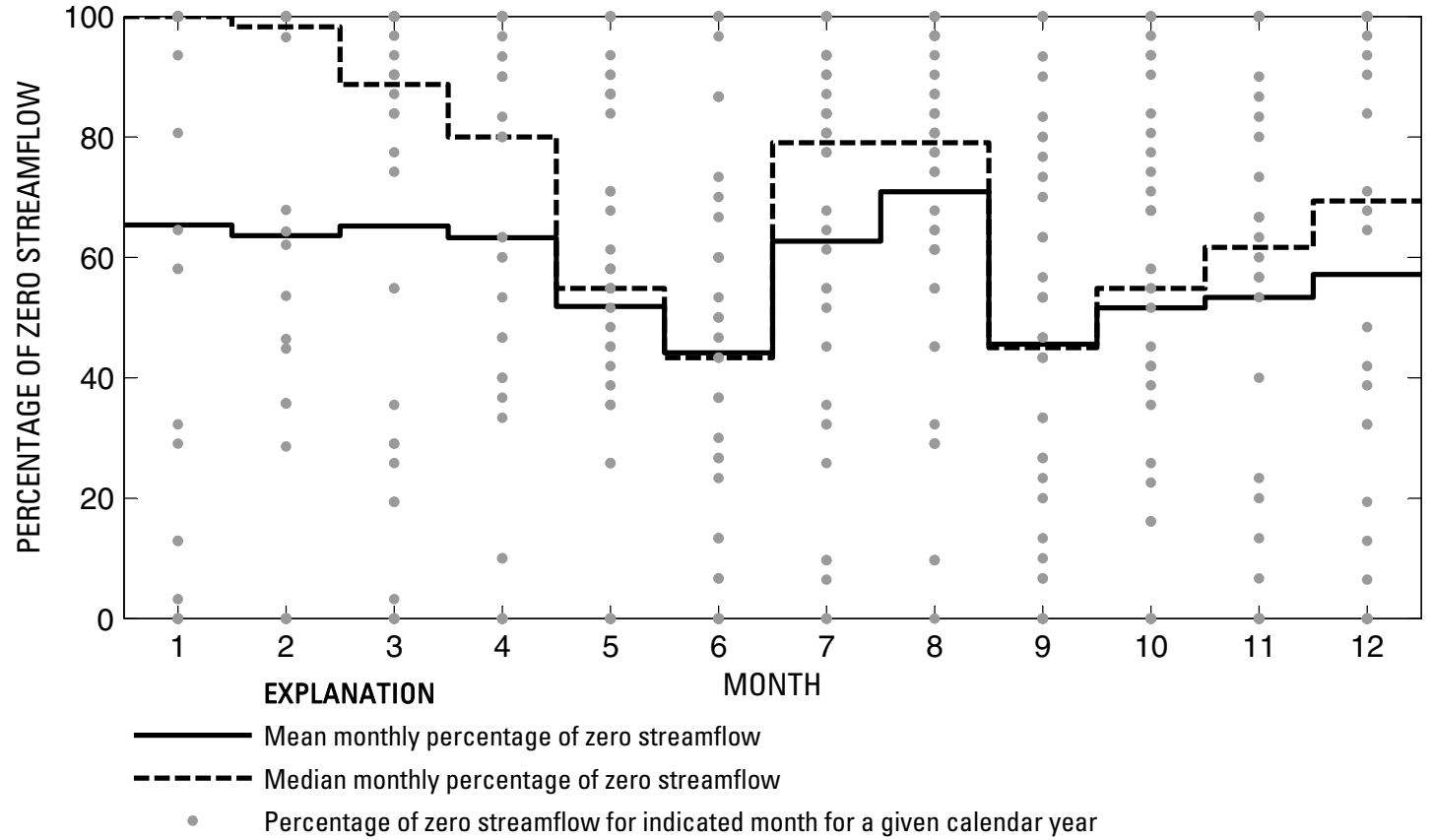

Figure 647. Analysis of percentage of zero daily mean streamflow for U.S. Geological Survey streamflow-gaging station 08194200 San Casimiro Creek near Freer, Texas. 
U.S. Geological Survey streamflow-gaging station 08194500

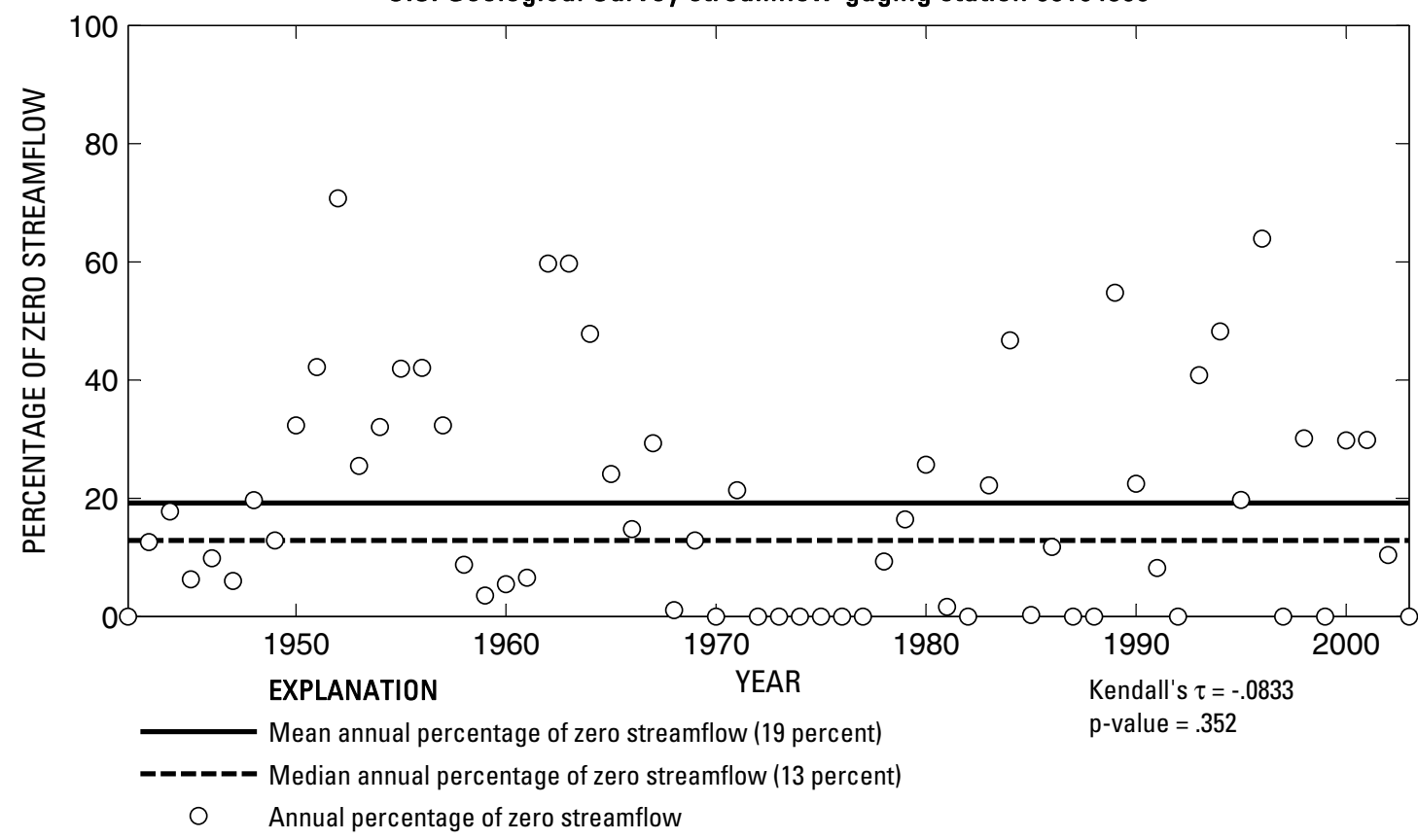

U.S. Geological Survey streamflow-gaging station 08194500

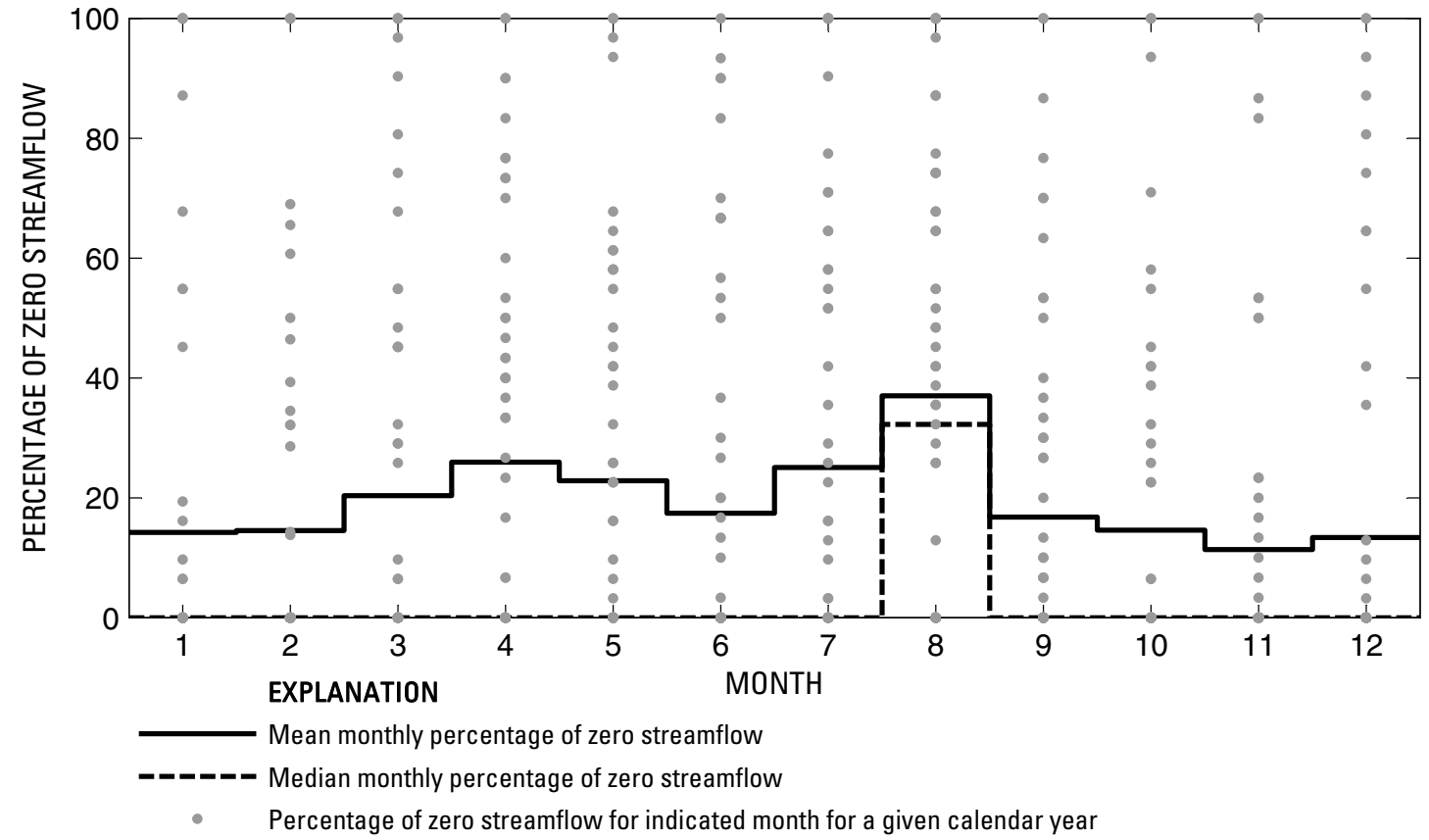

Figure 648. Analysis of percentage of zero daily mean streamflow for U.S. Geological Survey streamflow-gaging station 08194500 Nueces River near Tilden, Texas.

Index of Station Numbers 719 
U.S. Geological Survey streamflow-gaging station 08194600

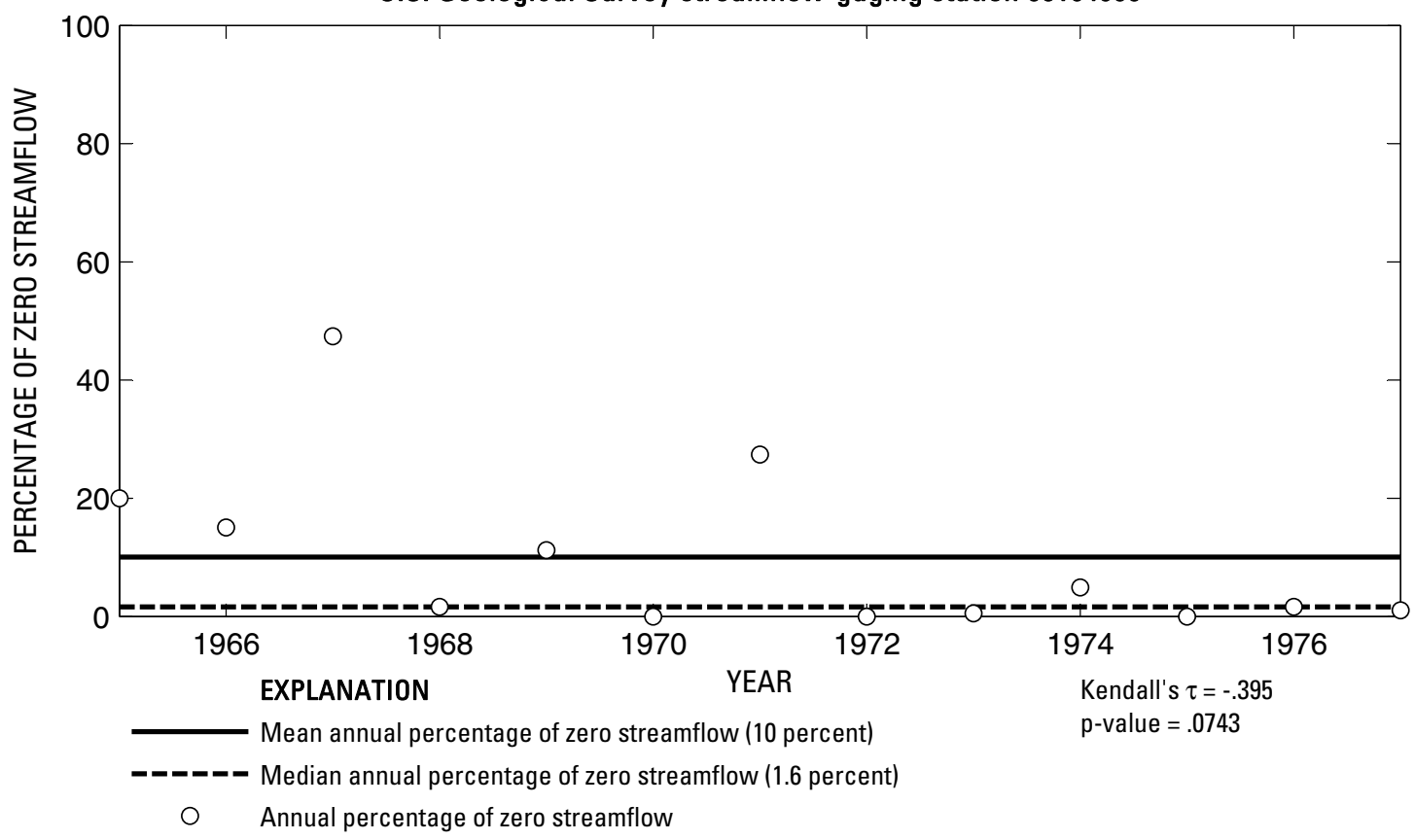

U.S. Geological Survey streamflow-gaging station 08194600

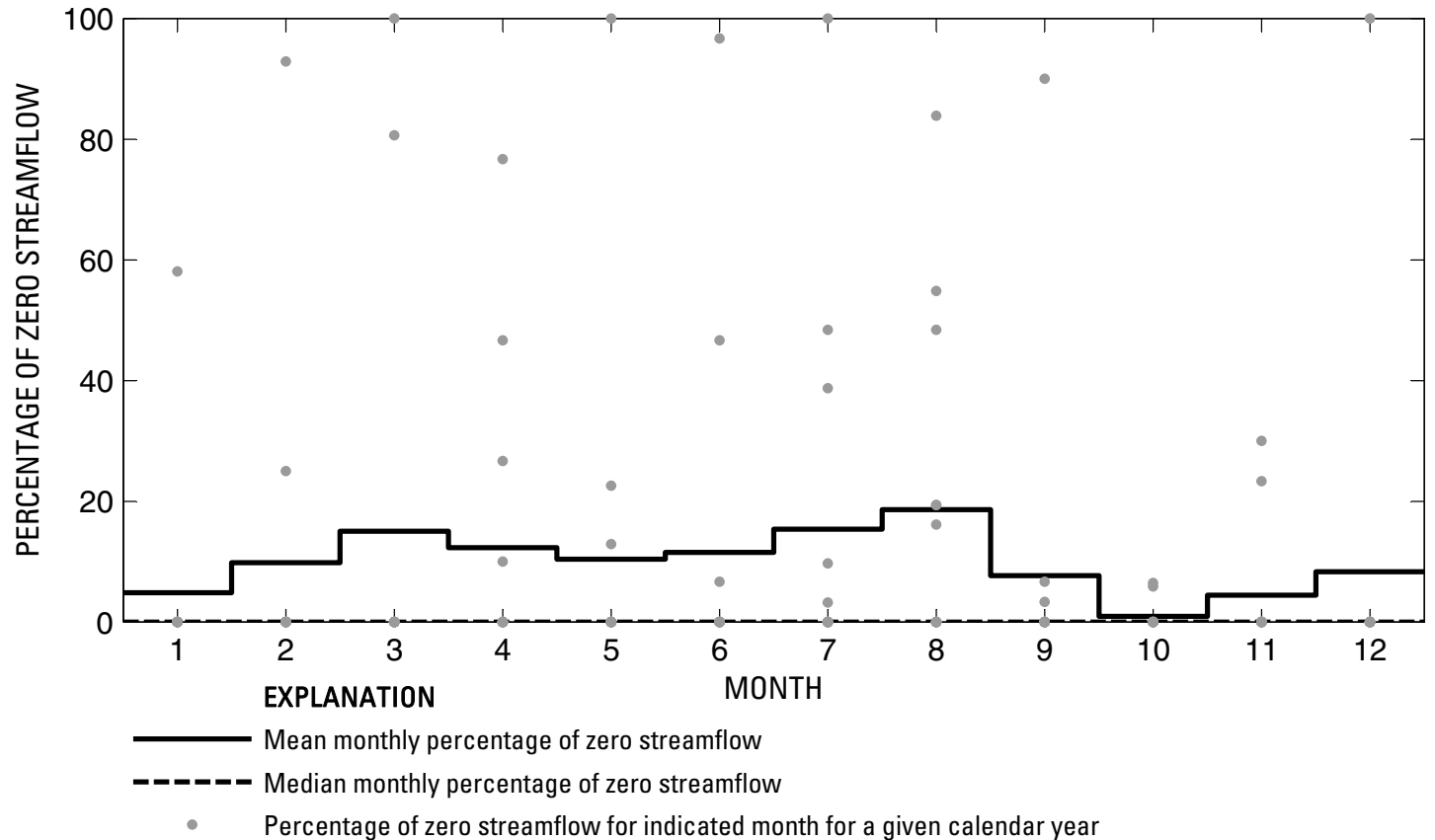

Figure 649. Analysis of percentage of zero daily mean streamflow for U.S. Geological Survey streamflow-gaging station 08194600 Nueces River at Simmons, Texas. 
U.S. Geological Survey streamflow-gaging station 08195000

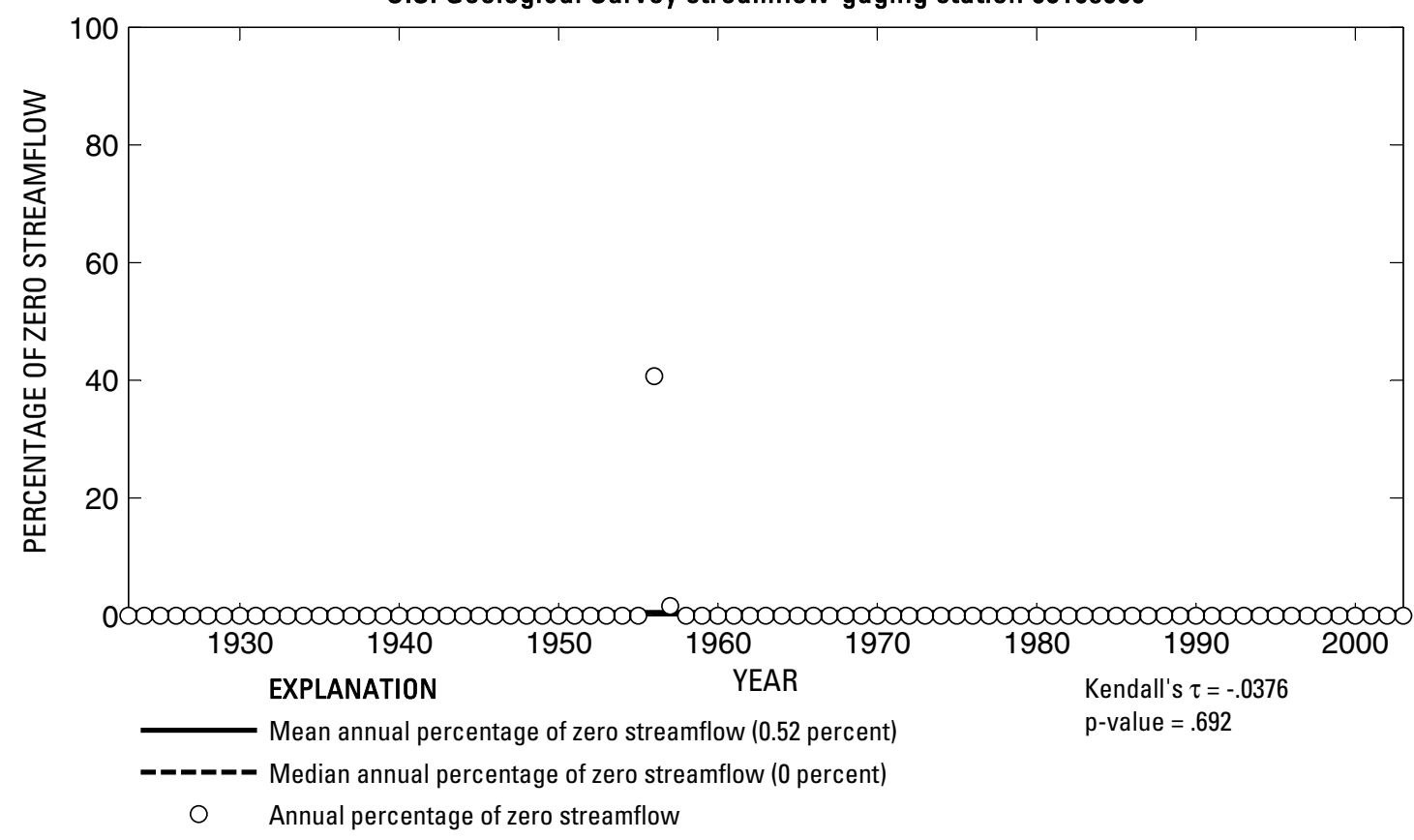

U.S. Geological Survey streamflow-gaging station 08195000

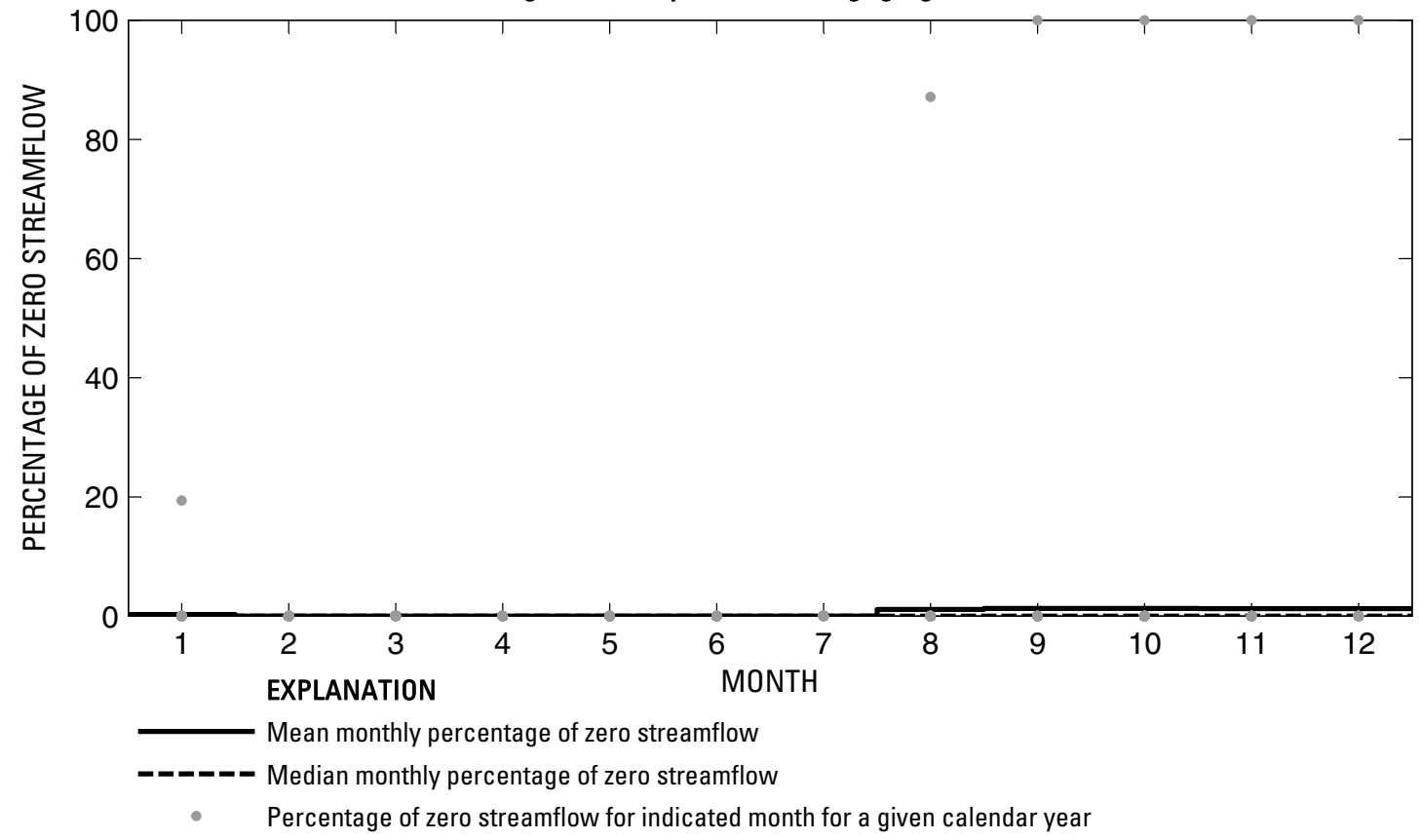

Figure 650. Analysis of percentage of zero daily mean streamflow for U.S. Geological Survey streamflow-gaging station 08195000 Frio River at Concan, Texas. 


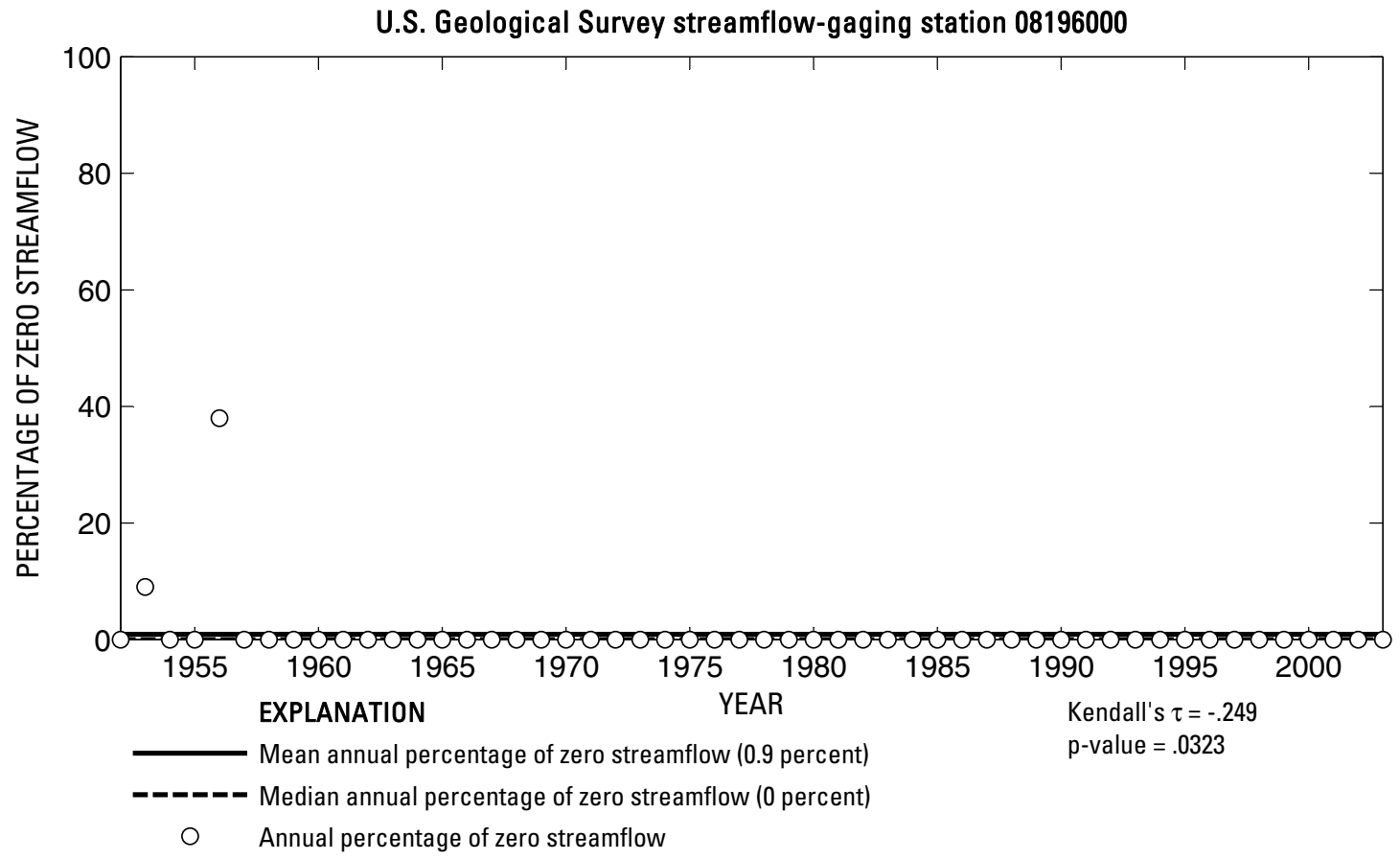

U.S. Geological Survey streamflow-gaging station 08196000

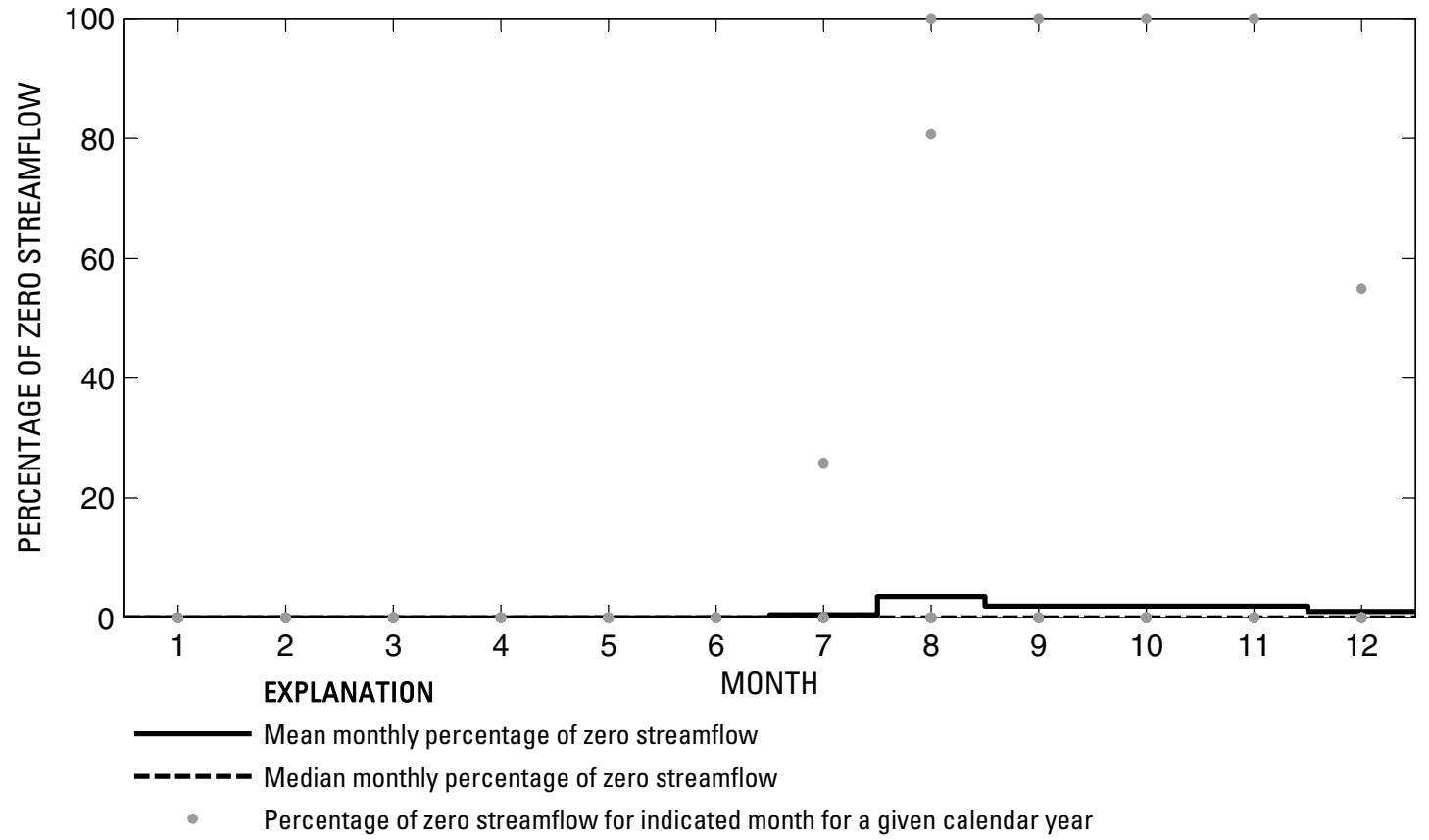

Figure 651. Analysis of percentage of zero daily mean streamflow for U.S. Geological Survey streamflow-gaging station 08196000 Dry Frio River near Reagan Wells, Texas. 

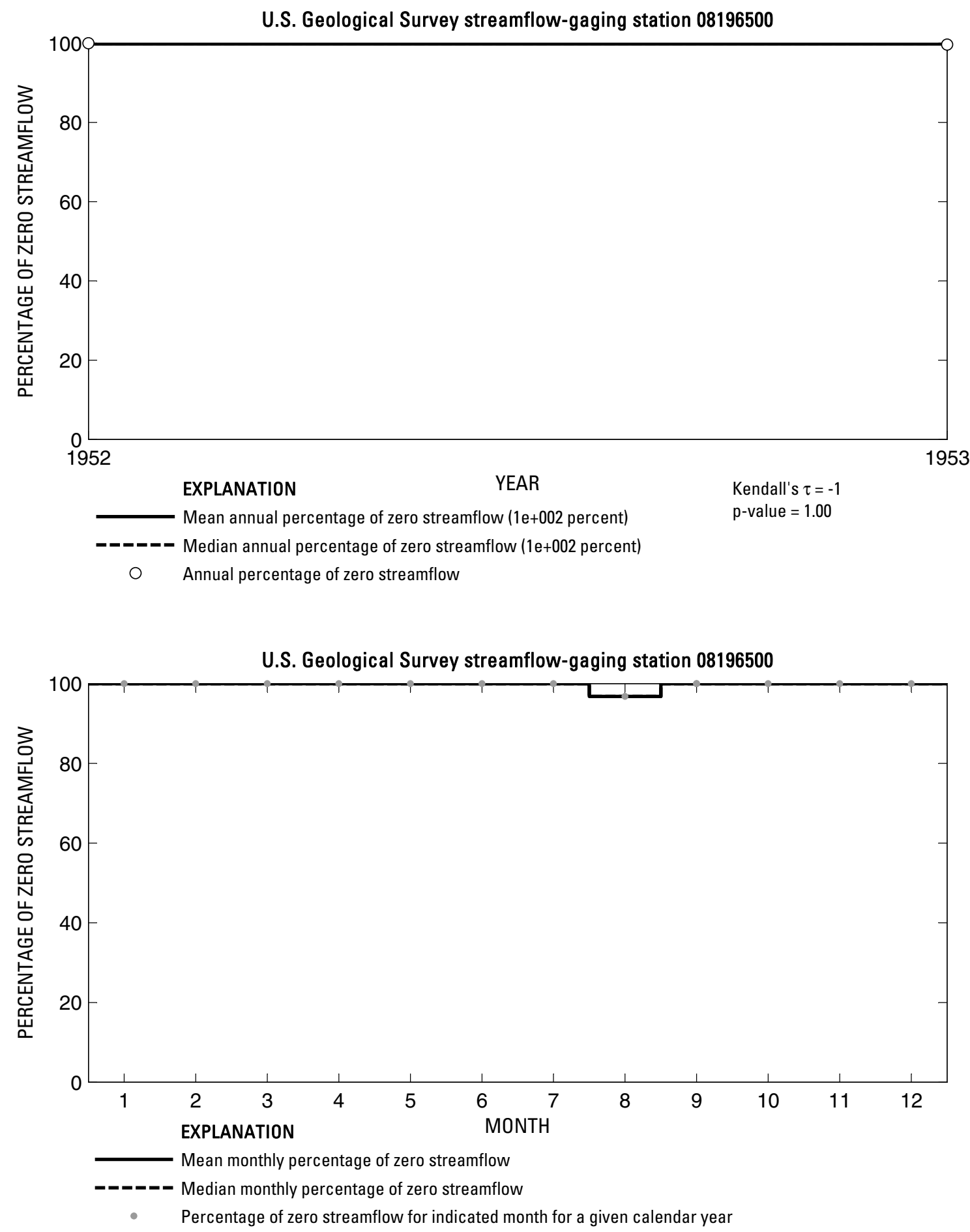

Figure 652. Analysis of percentage of zero daily mean streamflow for U.S. Geological Survey streamflow-gaging station 08196500 Dry Frio River at Knippa, Texas. 
U.S. Geological Survey streamflow-gaging station 08197500

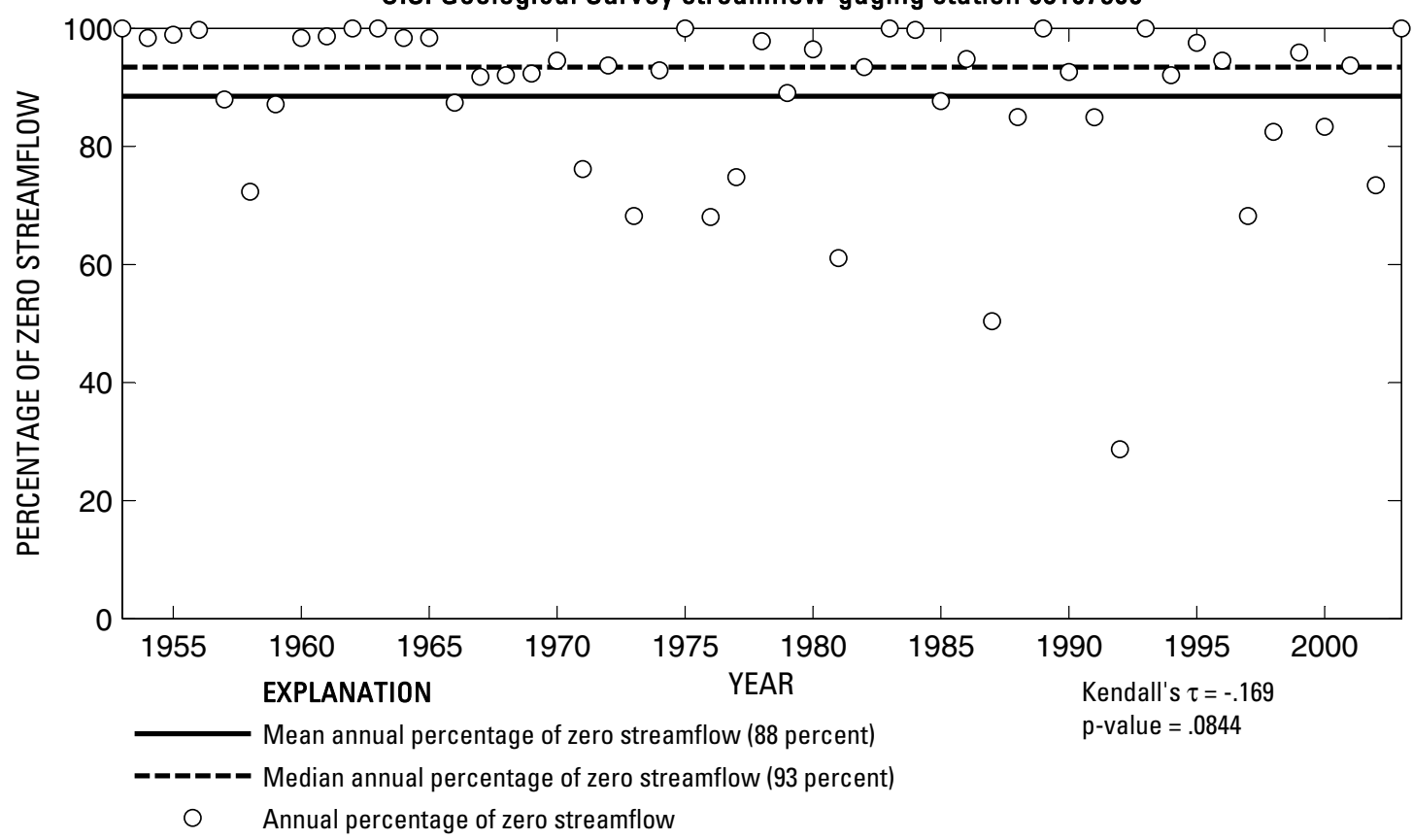

U.S. Geological Survey streamflow-gaging station 08197500

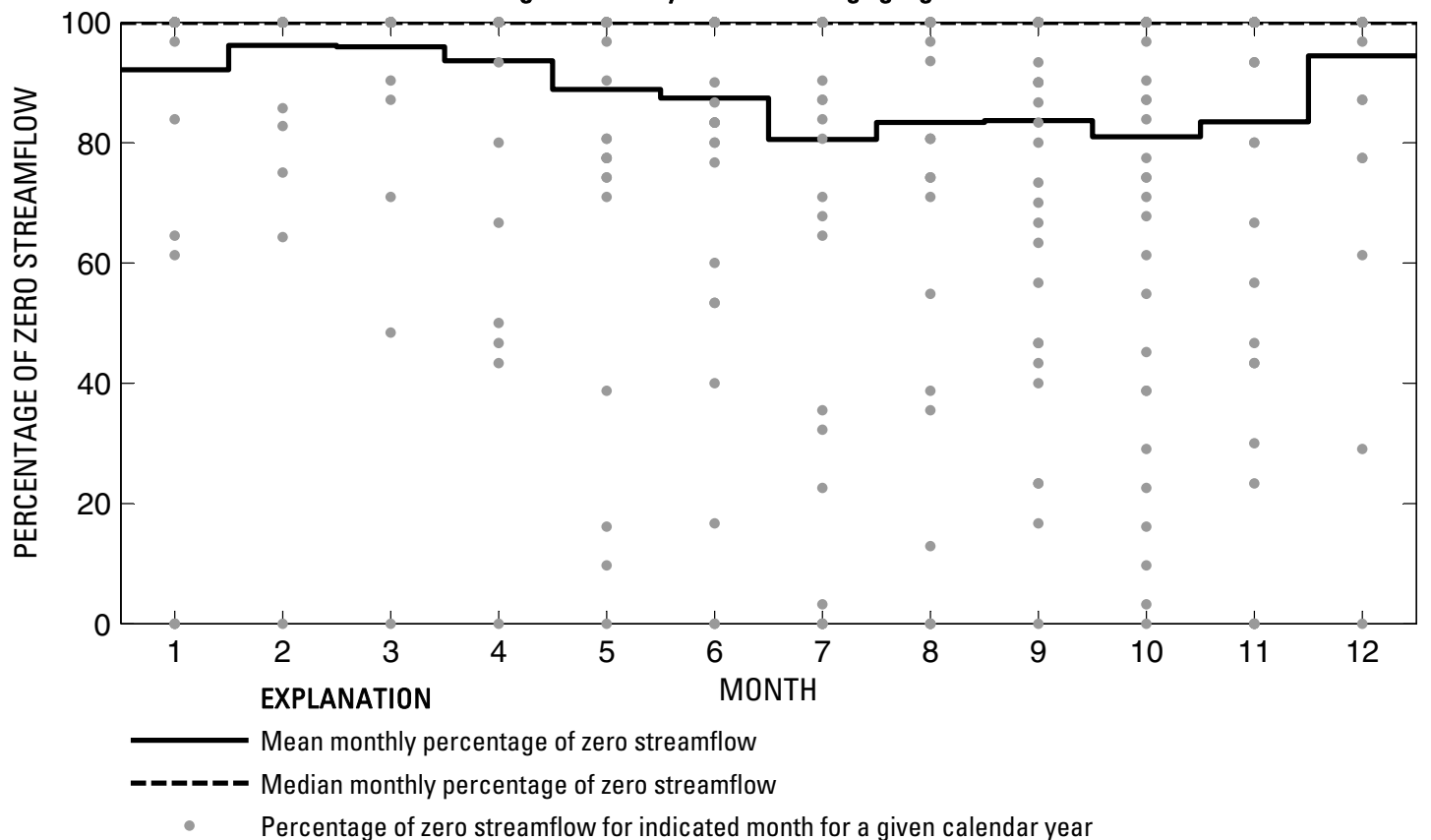

Figure 653. Analysis of percentage of zero daily mean streamflow for U.S. Geological Survey streamflow-gaging station 08197500 Frio River below Dry Frio River near Uvalde, Texas. 
U.S. Geological Survey streamflow-gaging station 08198000

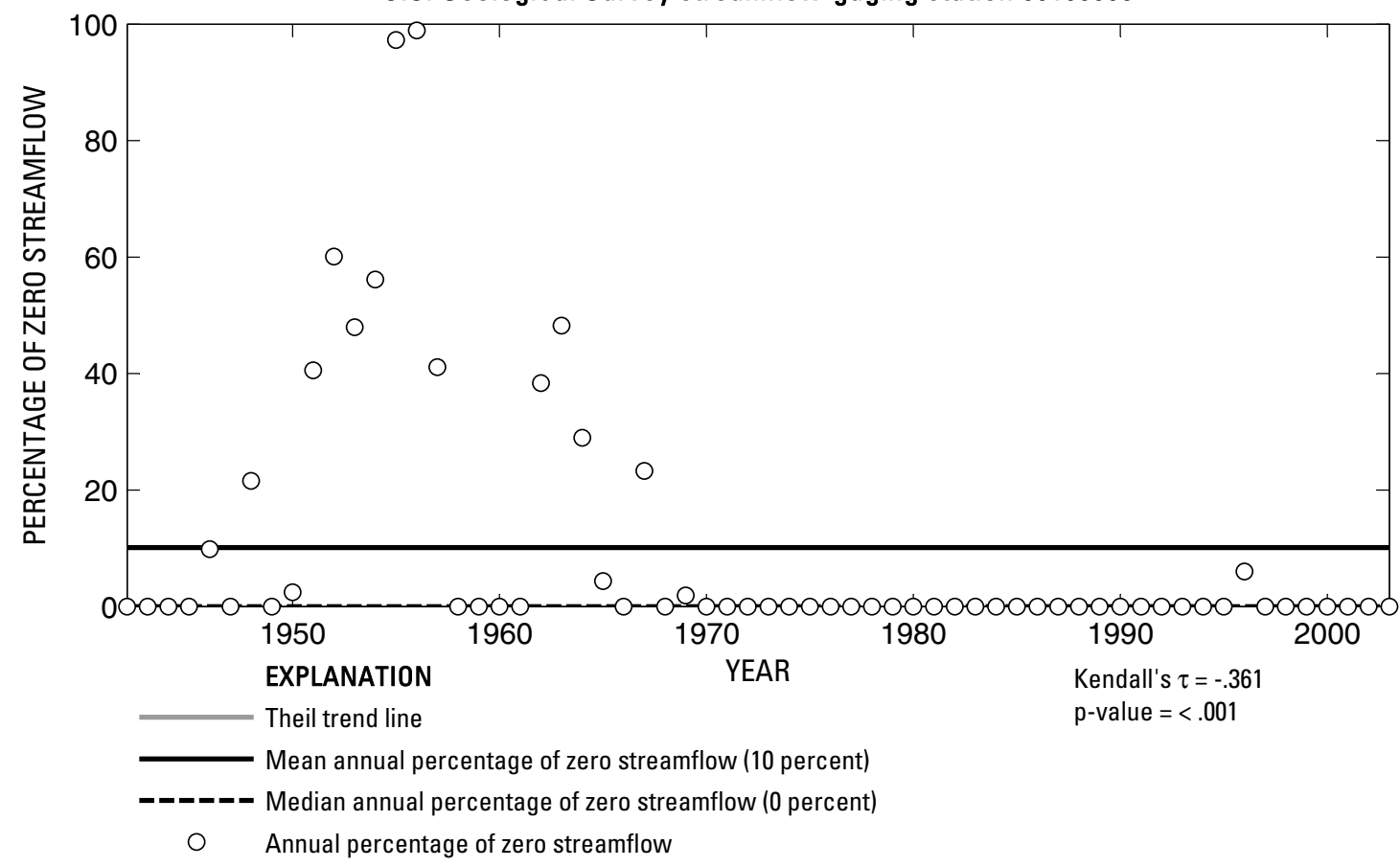

U.S. Geological Survey streamflow-gaging station 08198000

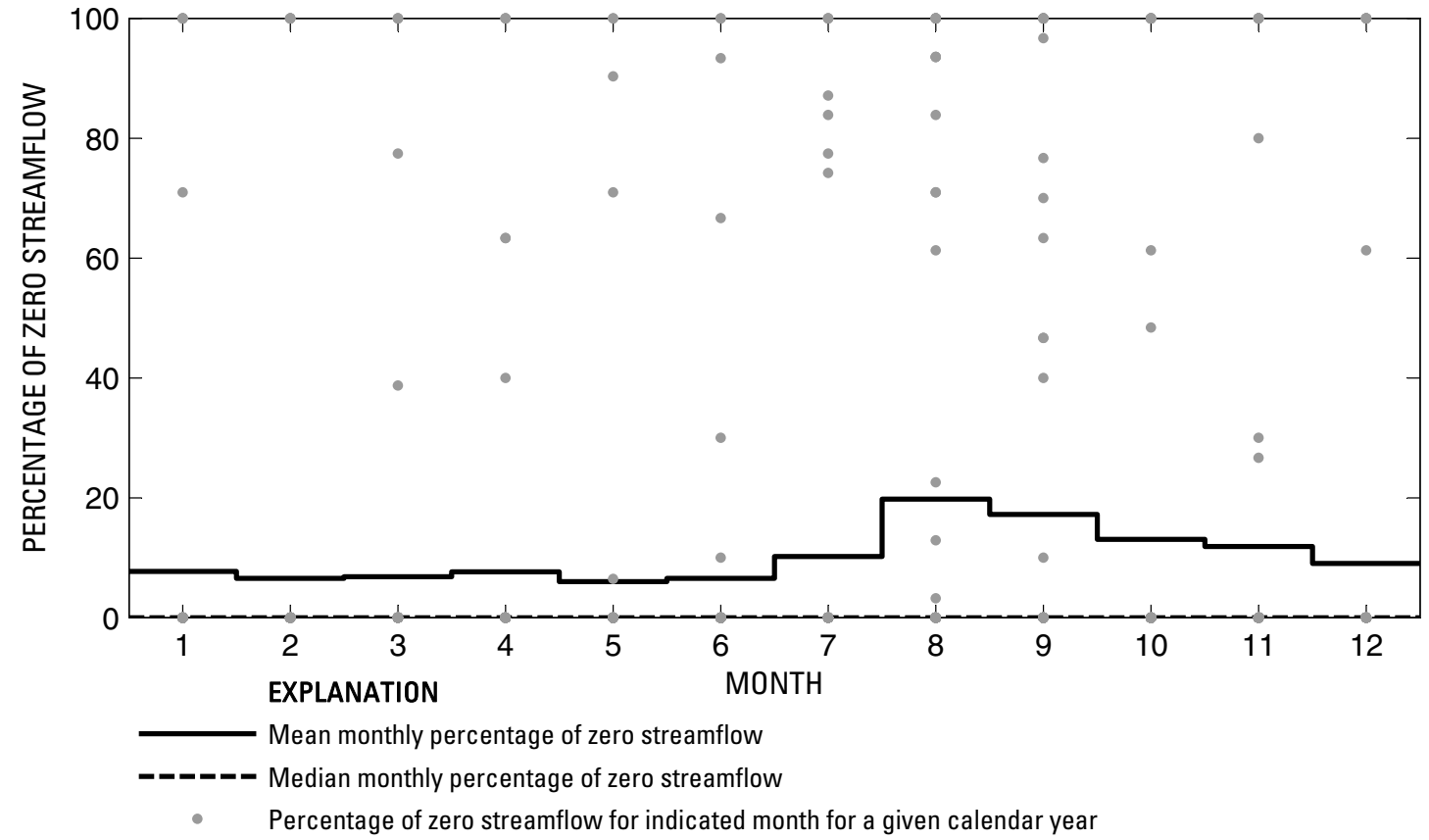

Figure 654. Analysis of percentage of zero daily mean streamflow for U.S. Geological Survey streamflow-gaging station 08198000 Sabinal River near Sabinal, Texas.

Index of Station Numbers 719 
U.S. Geological Survey streamflow-gaging station 08198500

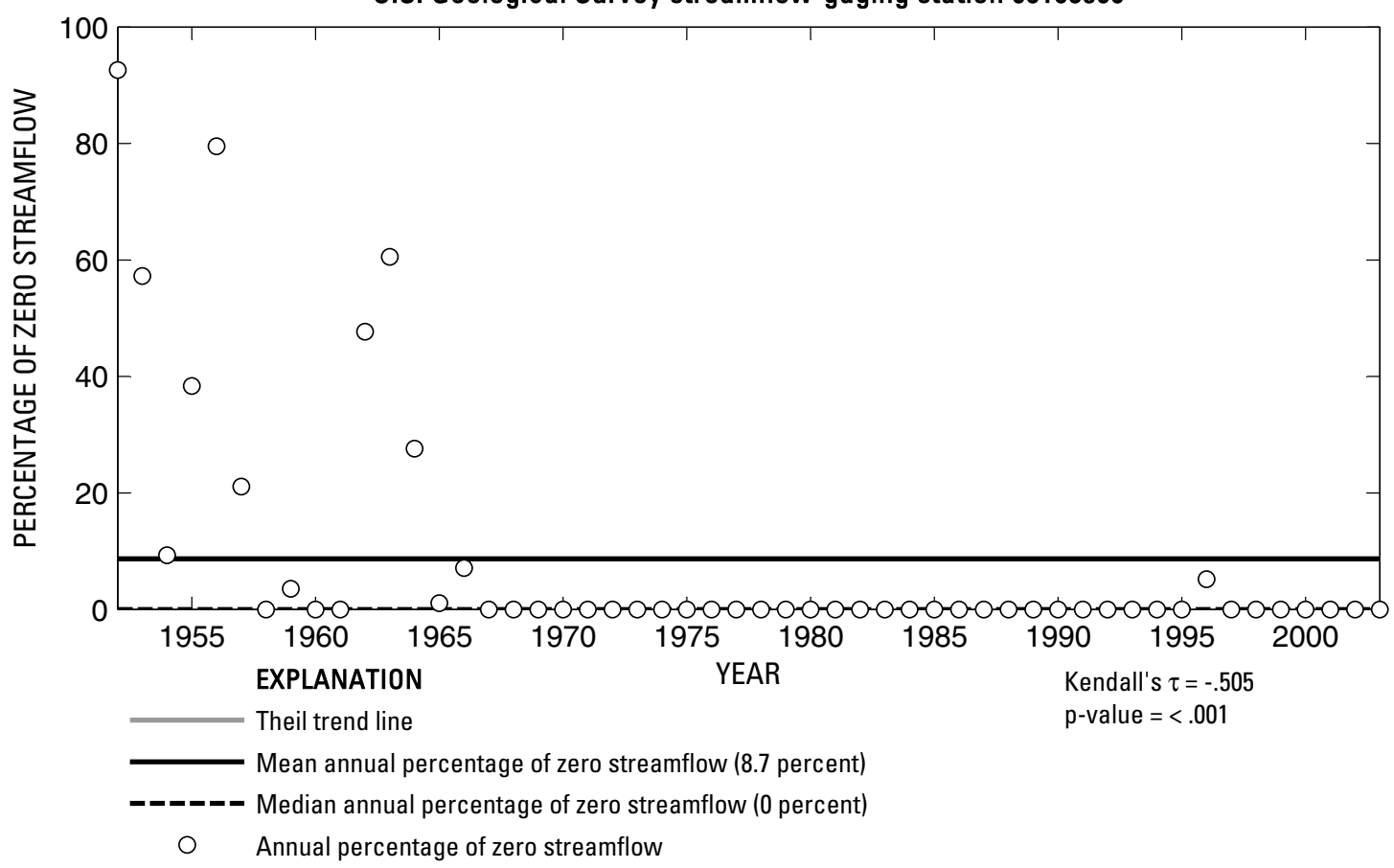

U.S. Geological Survey streamflow-gaging station 08198500

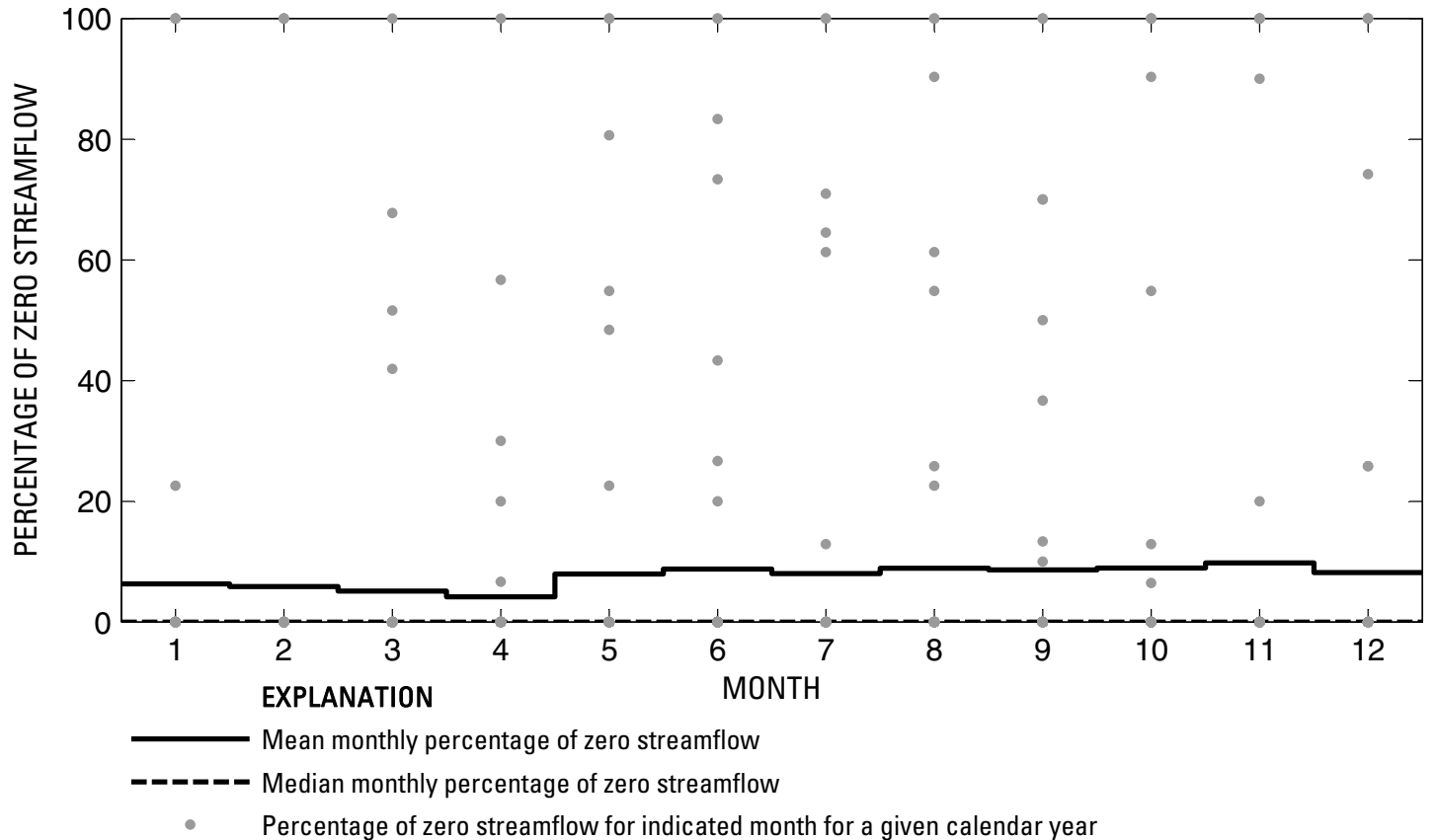

Figure 655. Analysis of percentage of zero daily mean streamflow for U.S. Geological Survey streamflow-gaging station 08198500 Sabinal River at Sabinal, Texas. 


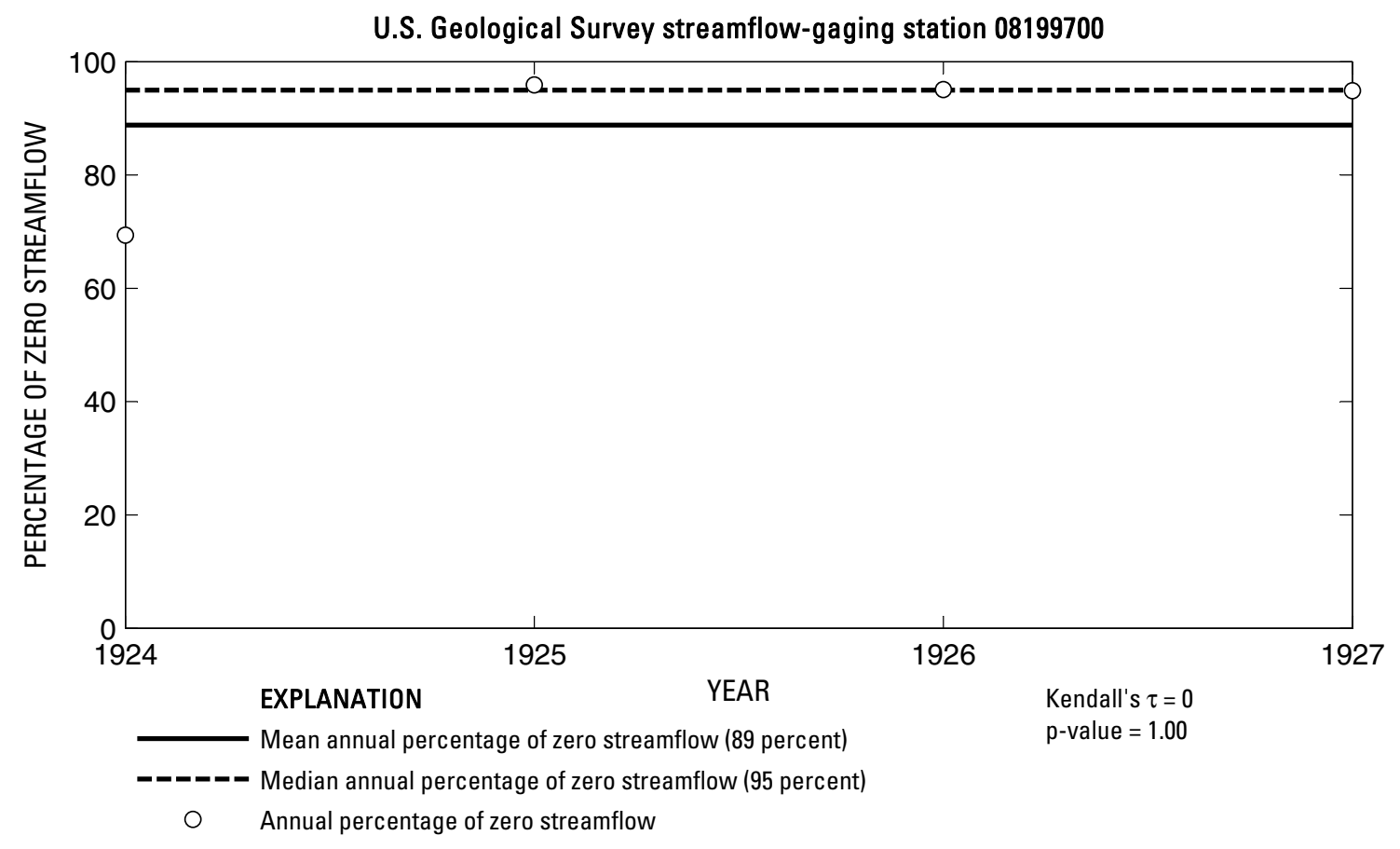

U.S. Geological Survey streamflow-gaging station 08199700

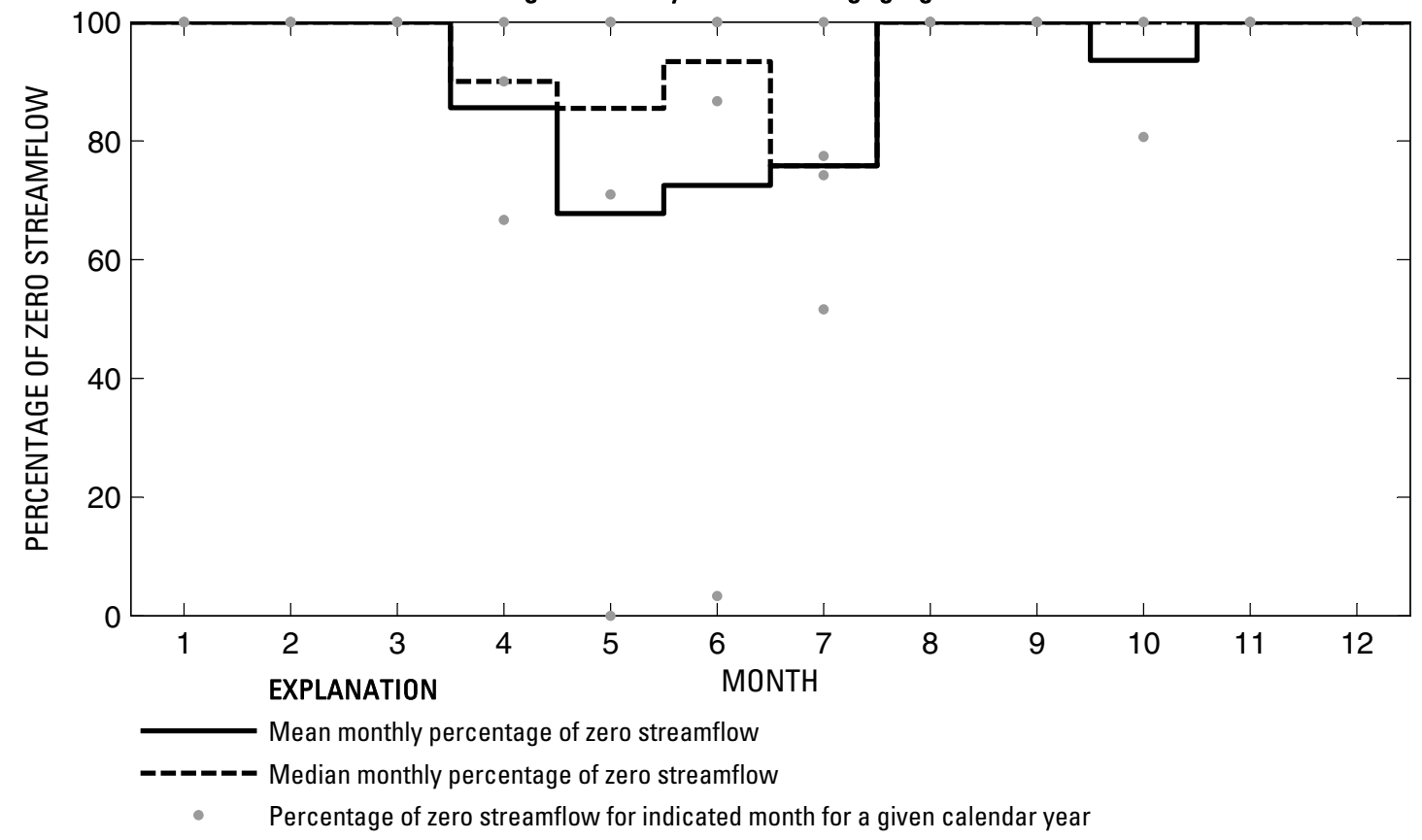

Figure 656. Analysis of percentage of zero daily mean streamflow for U.S. Geological Survey streamflow-gaging station 08199700 Frio River near Frio Town, Texas. 

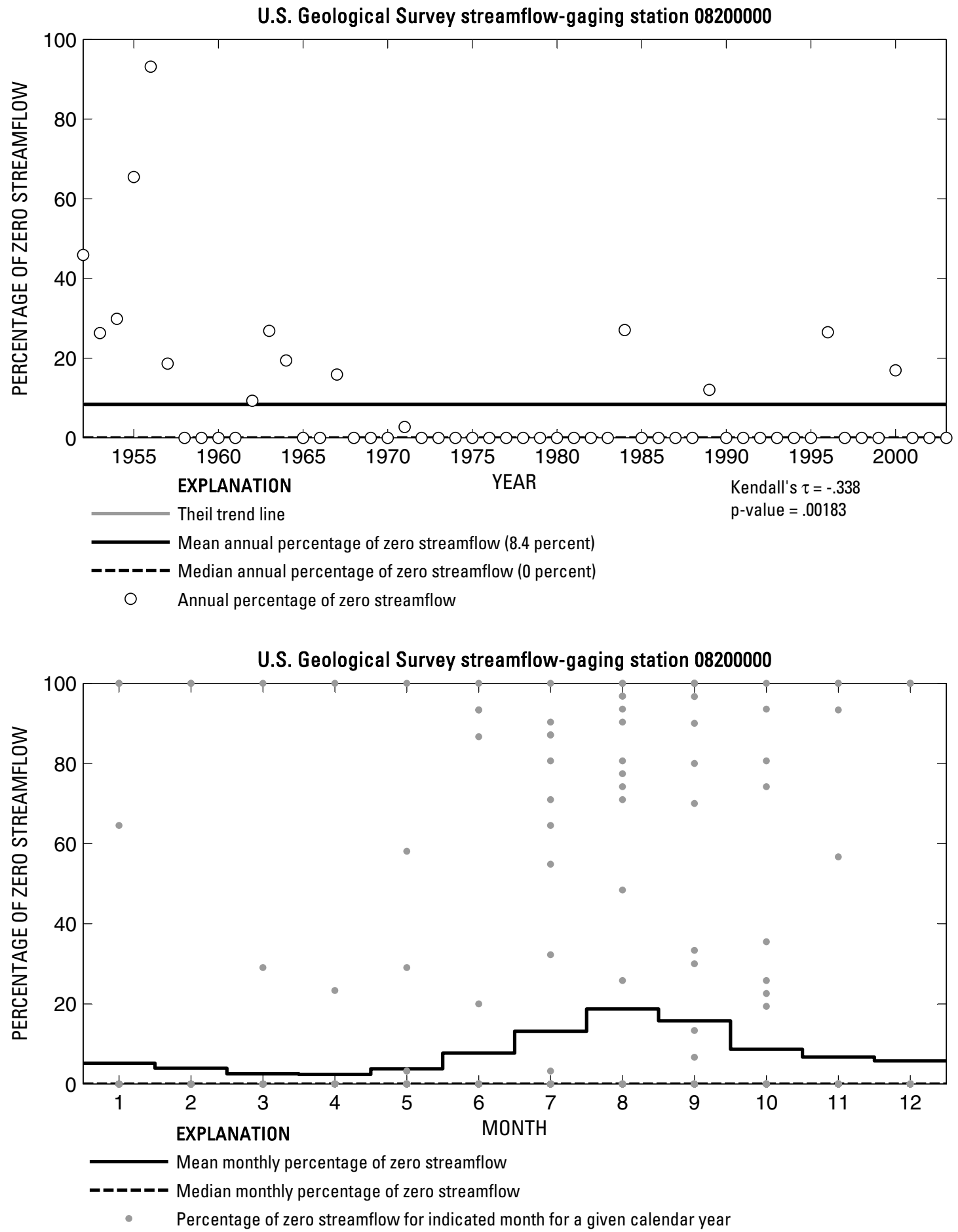

Figure 657. Analysis of percentage of zero daily mean streamflow for U.S. Geological Survey streamflow-gaging station 08200000 Hondo Creek near Tarpley, Texas. 

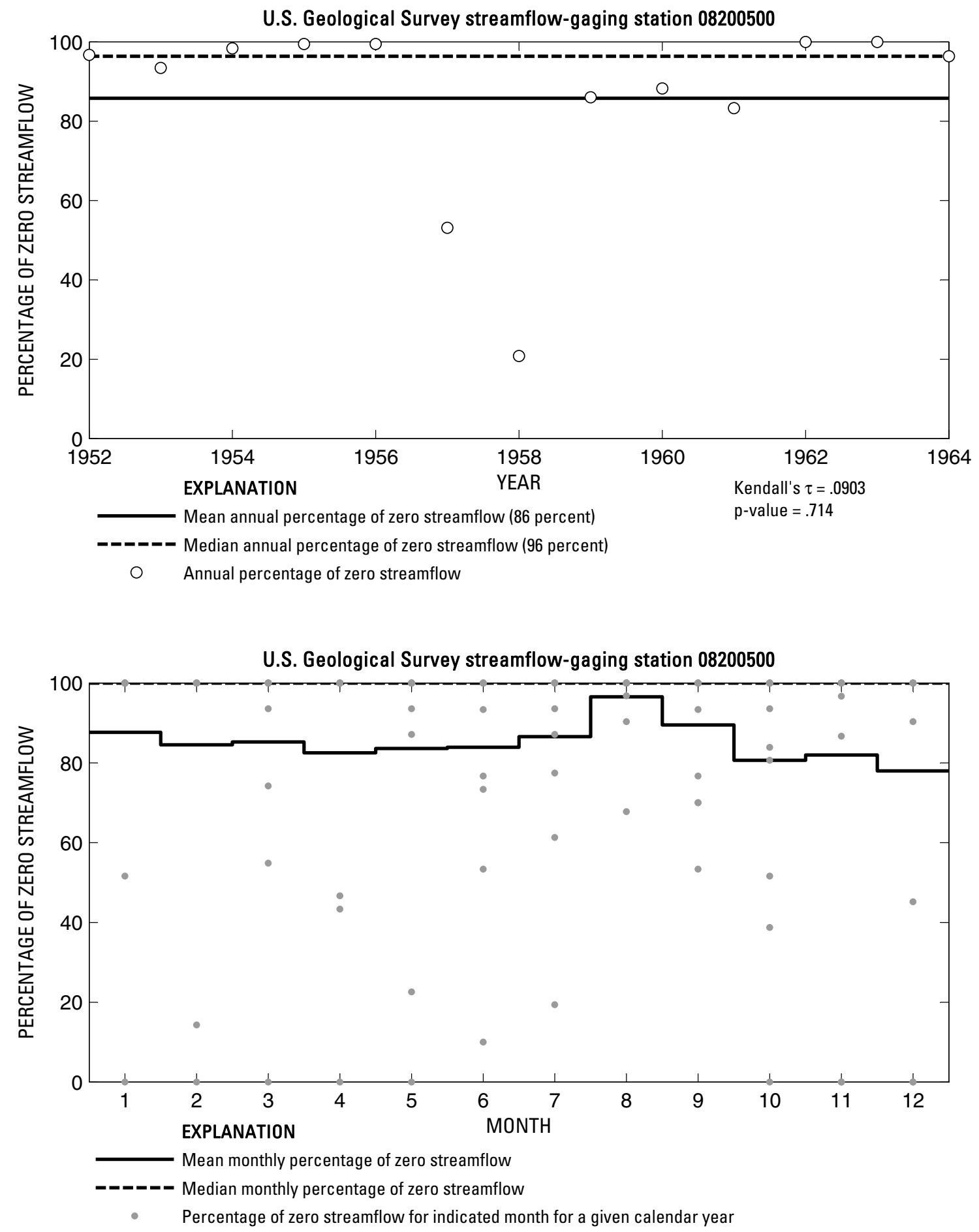

Figure 658. Analysis of percentage of zero daily mean streamflow for U.S. Geological Survey streamflow-gaging station 08200500 Hondo Creek near Hondo, Texas. 


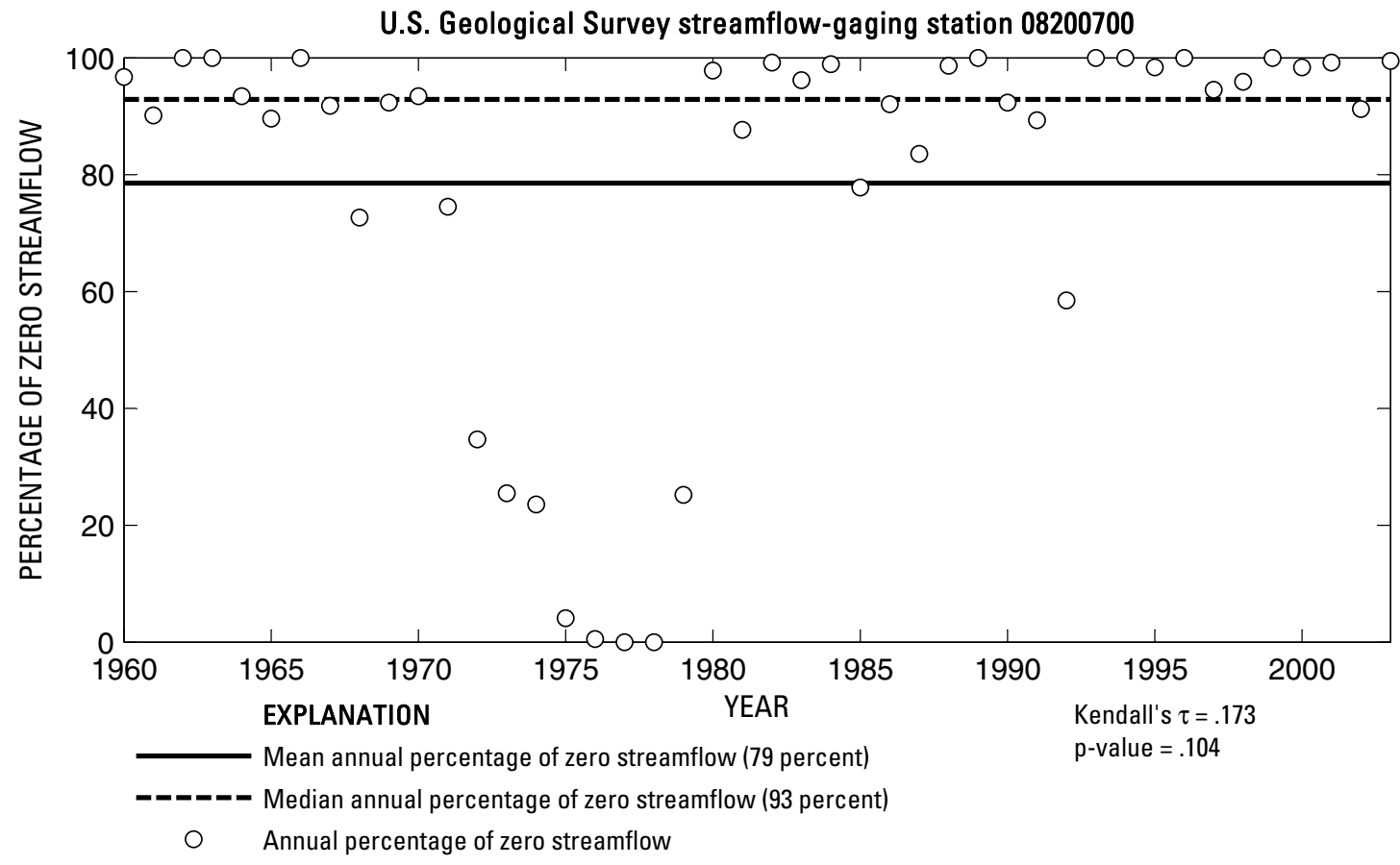

U.S. Geological Survey streamflow-gaging station 08200700

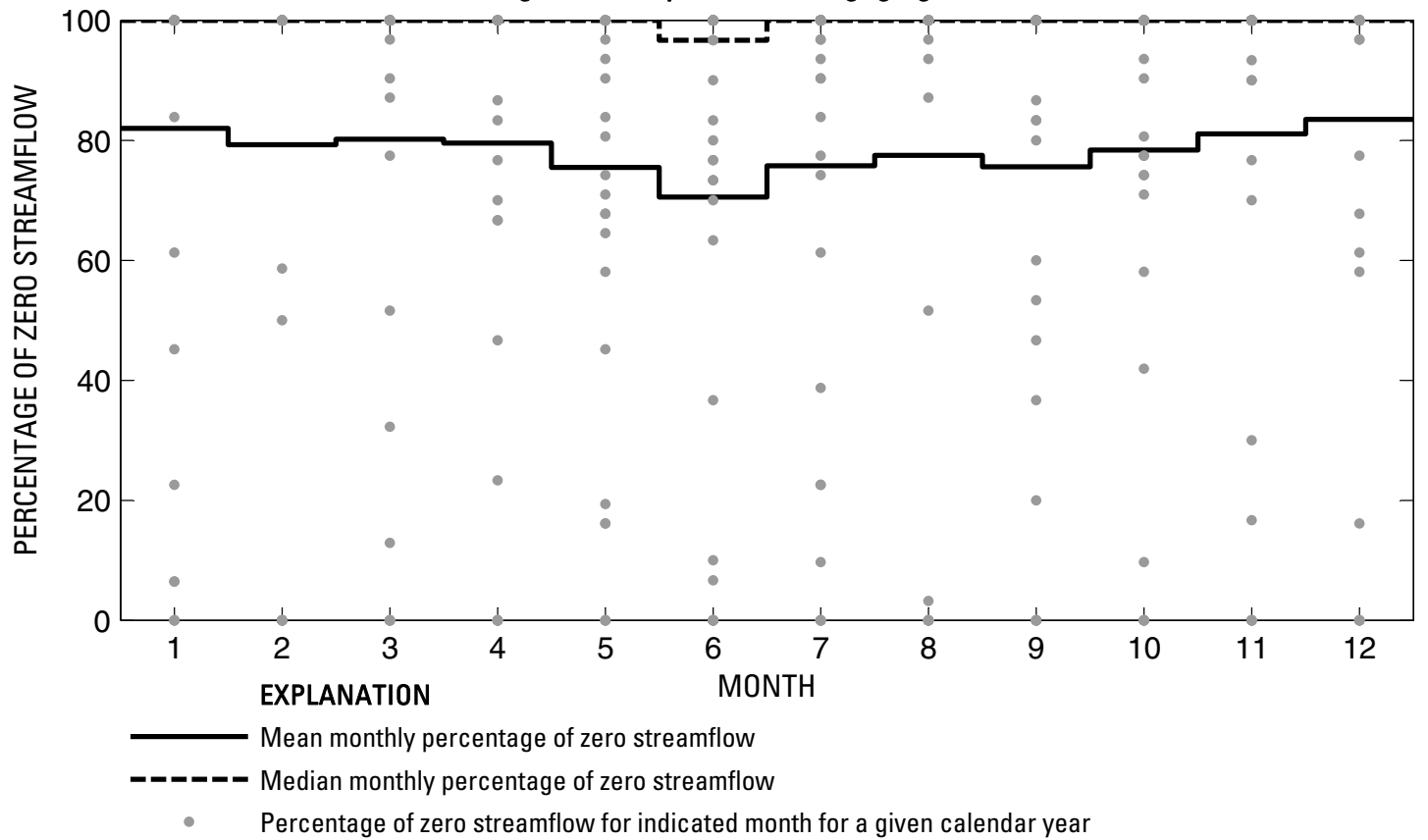

Figure 659. Analysis of percentage of zero daily mean streamflow for U.S. Geological Survey streamflow-gaging station 08200700 Hondo Creek at King Waterhole near Hondo, Texas. 
U.S. Geological Survey streamflow-gaging station 08201500

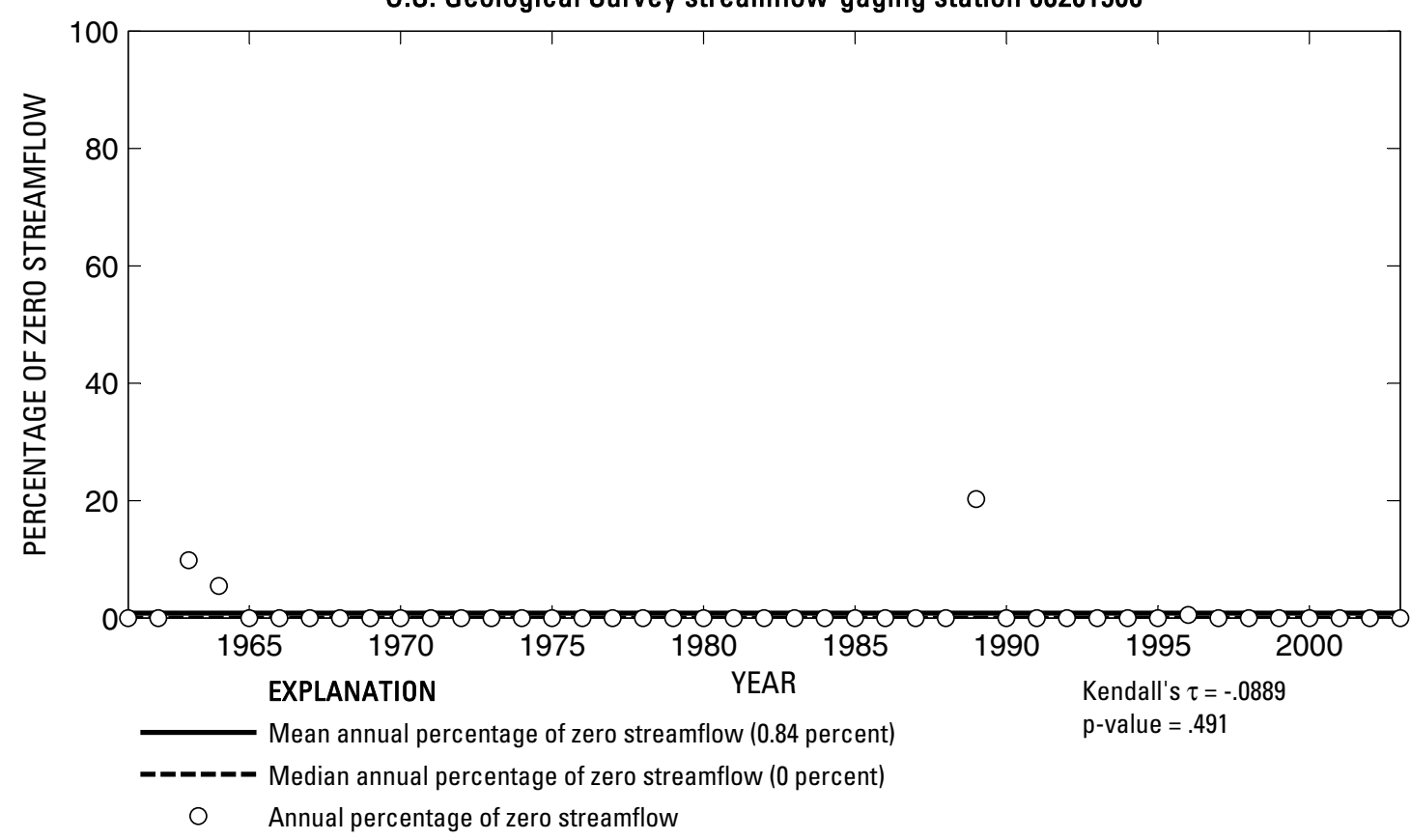

U.S. Geological Survey streamflow-gaging station 08201500

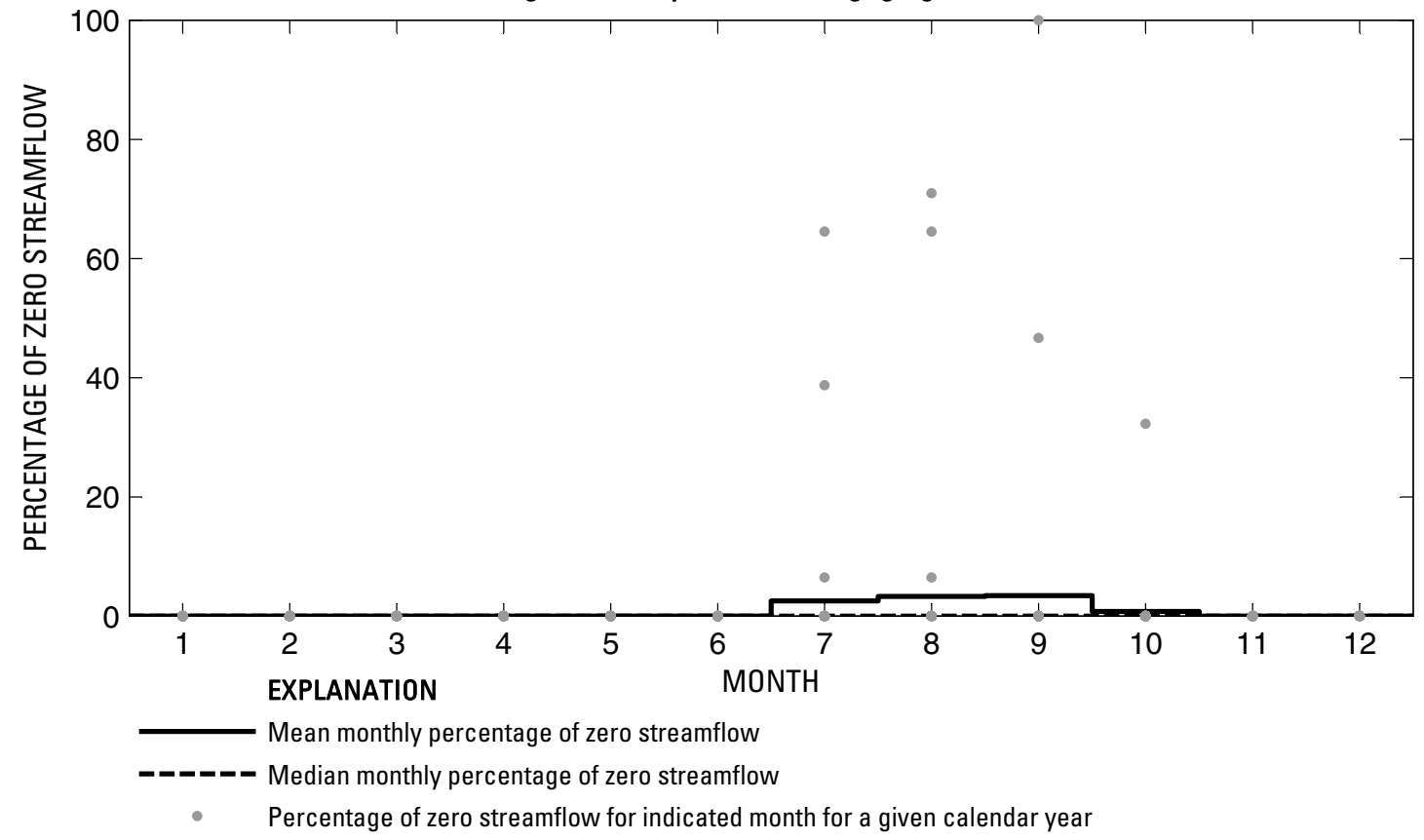

Figure 660. Analysis of percentage of zero daily mean streamflow for U.S. Geological Survey streamflow-gaging station 08201500 Seco Creek at Miller Ranch near Utopia, Texas. 
U.S. Geological Survey streamflow-gaging station 08202000

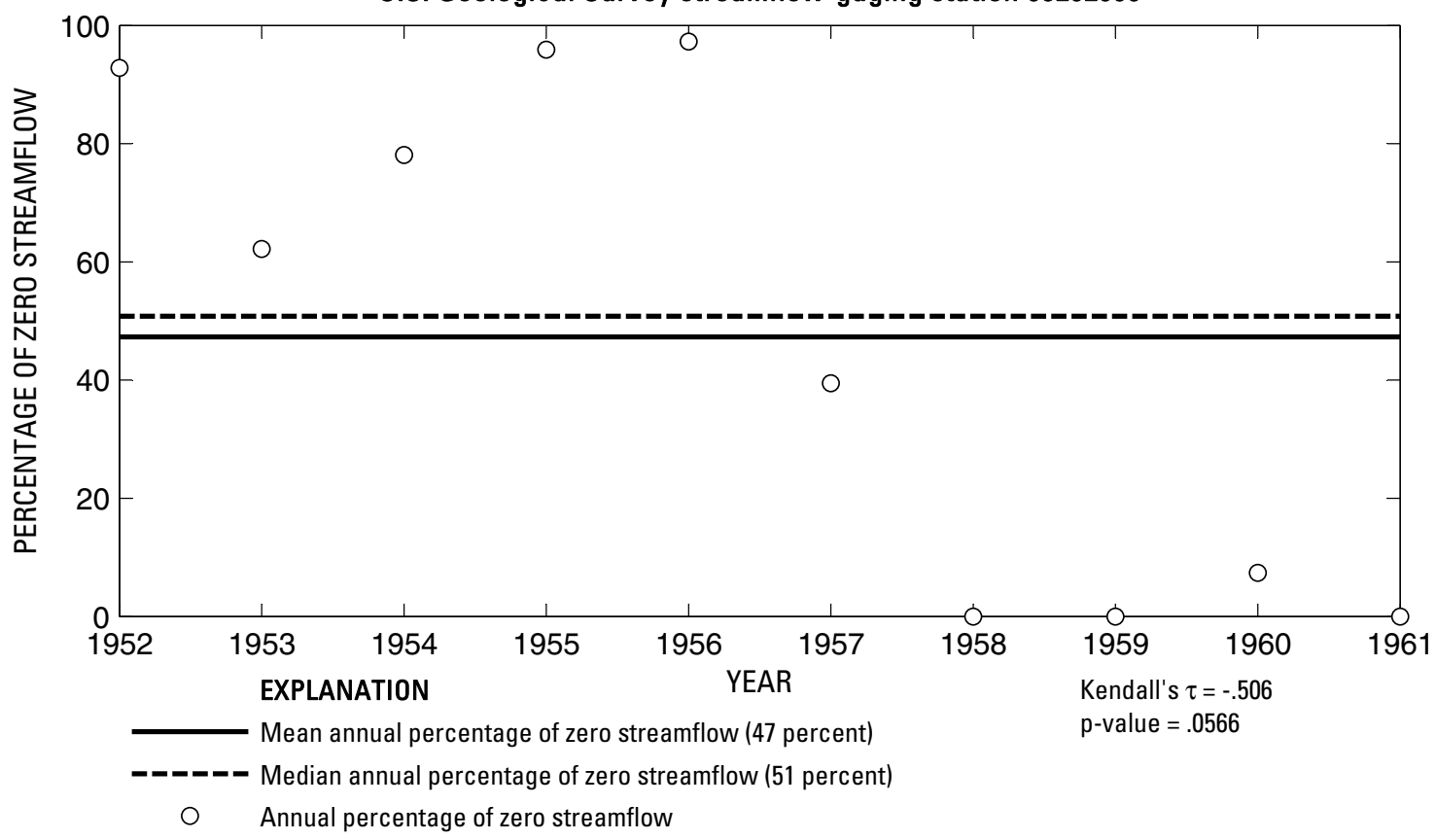

U.S. Geological Survey streamflow-gaging station 08202000

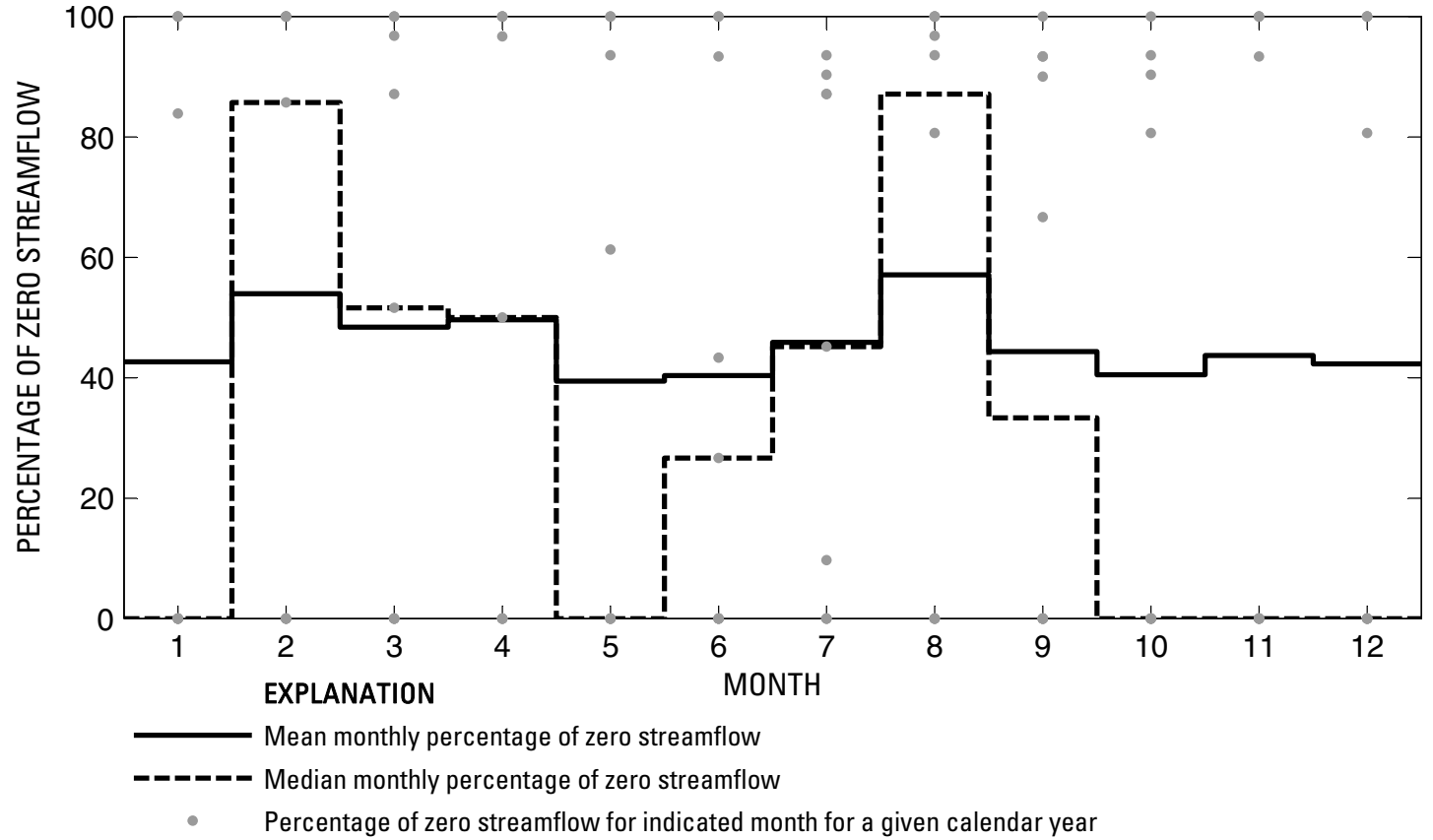

Figure 661. Analysis of percentage of zero daily mean streamflow for U.S. Geological Survey streamflow-gaging station 08202000 Seco Creek near Utopia, Texas. 
U.S. Geological Survey streamflow-gaging station 08202500

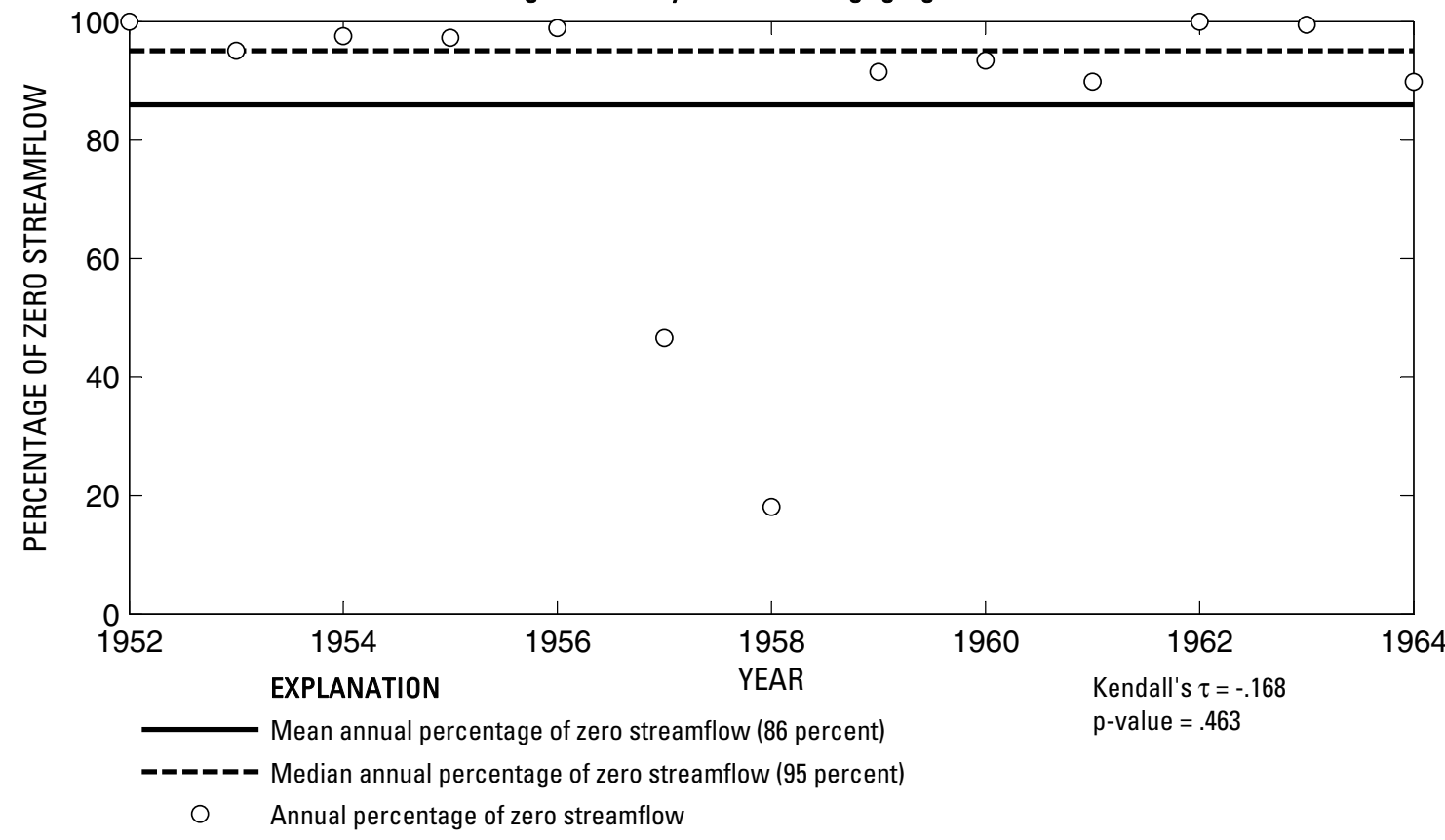

U.S. Geological Survey streamflow-gaging station 08202500

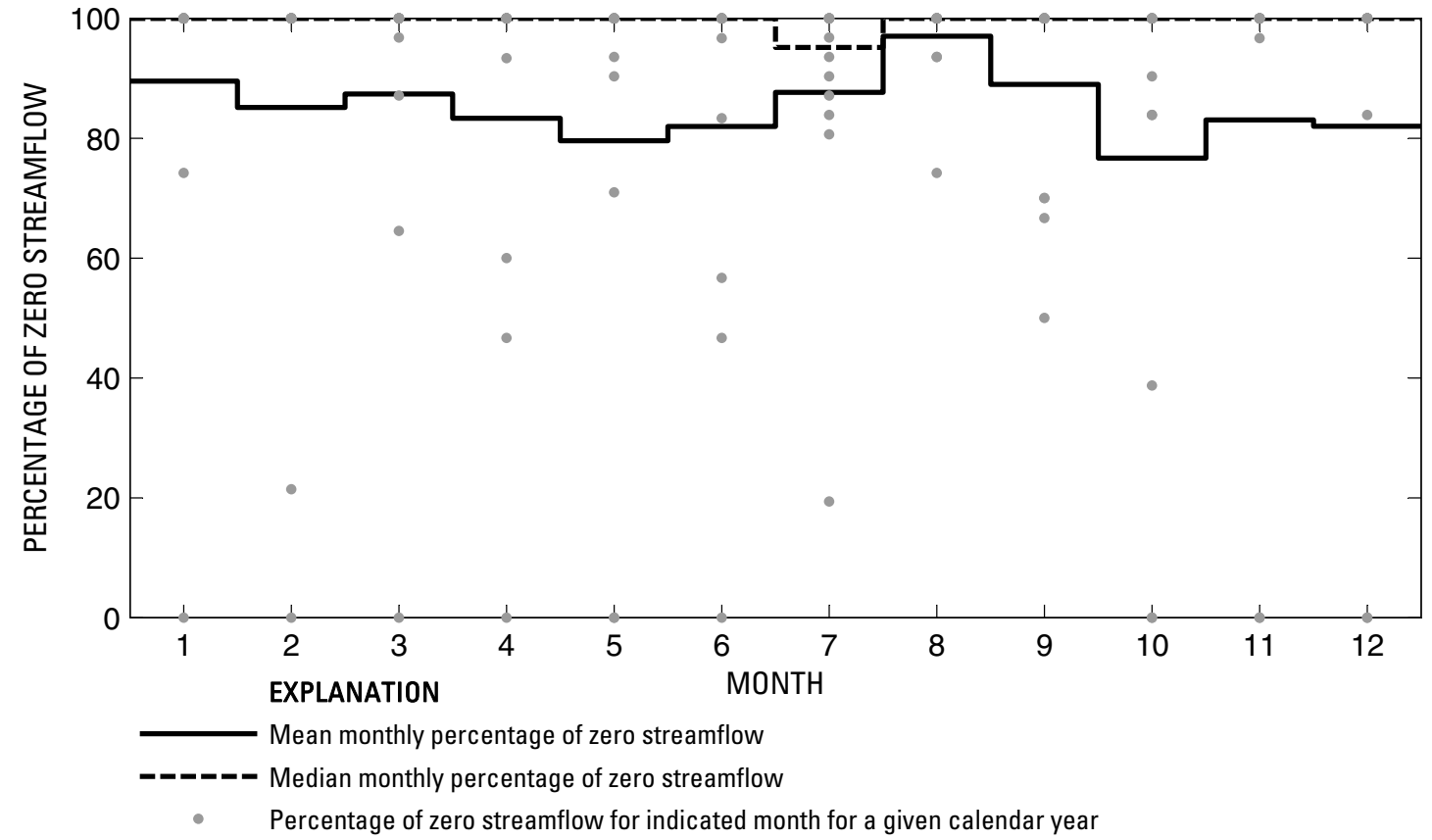

Figure 662. Analysis of percentage of zero daily mean streamflow for U.S. Geological Survey streamflow-gaging station 08202500 Seco Creek near D’Hanis, Texas. 
U.S. Geological Survey streamflow-gaging station 08202700

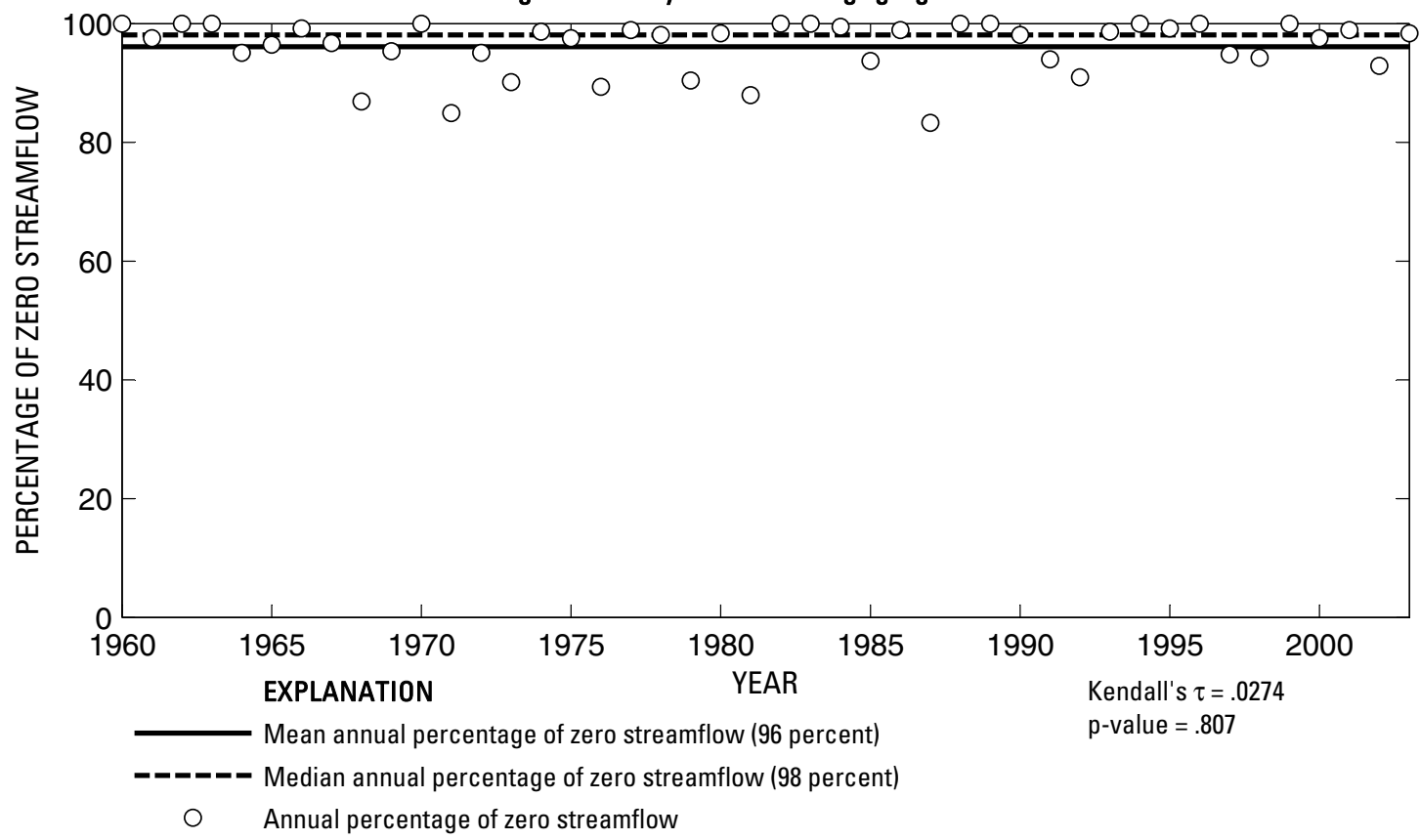

U.S. Geological Survey streamflow-gaging station 08202700

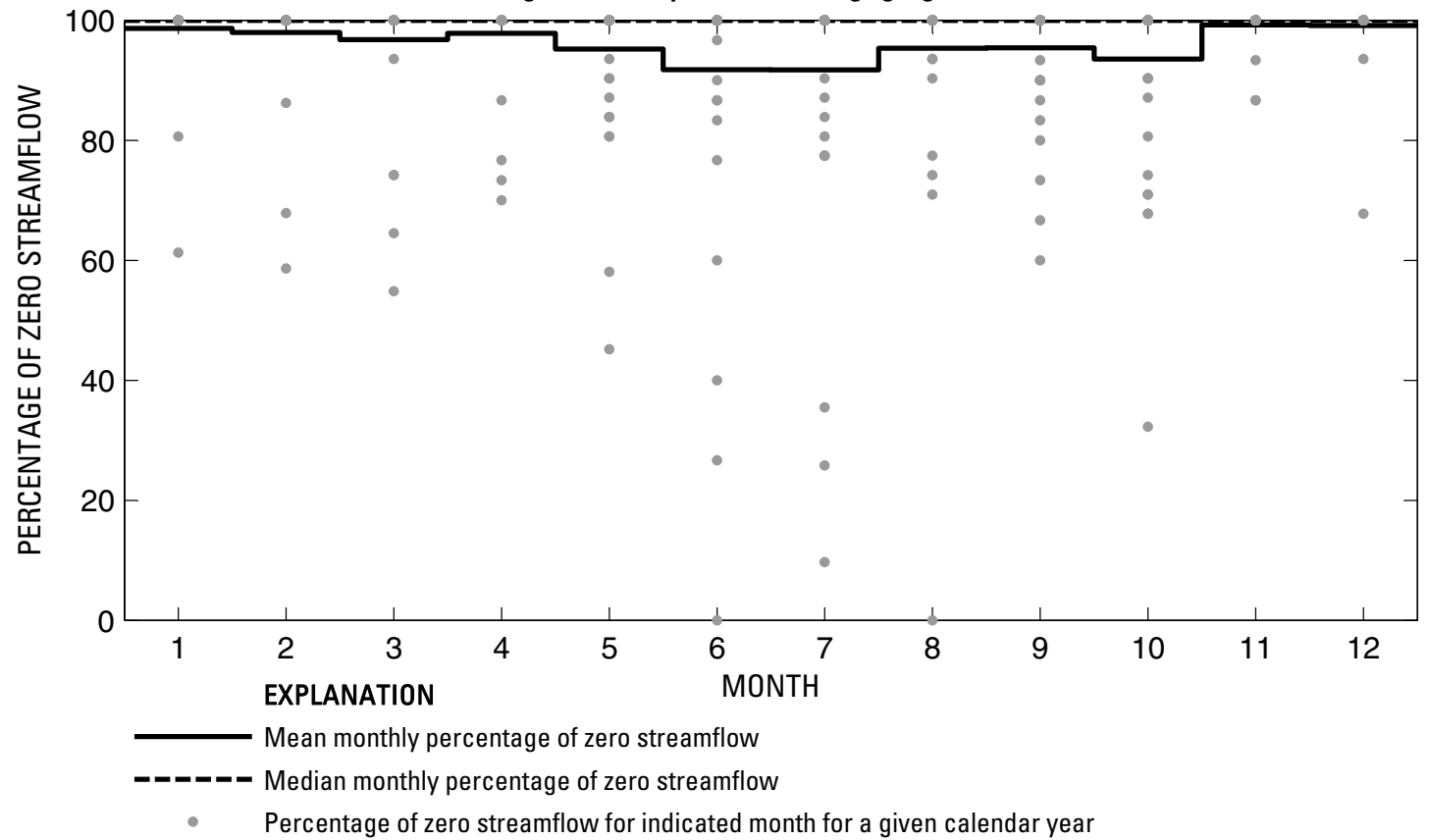

Figure 663. Analysis of percentage of zero daily mean streamflow for U.S. Geological Survey streamflow-gaging station 08202700 Seco Creek at Rowe Ranch near D'Hanis, Texas. 
U.S. Geological Survey streamflow-gaging station 08204005

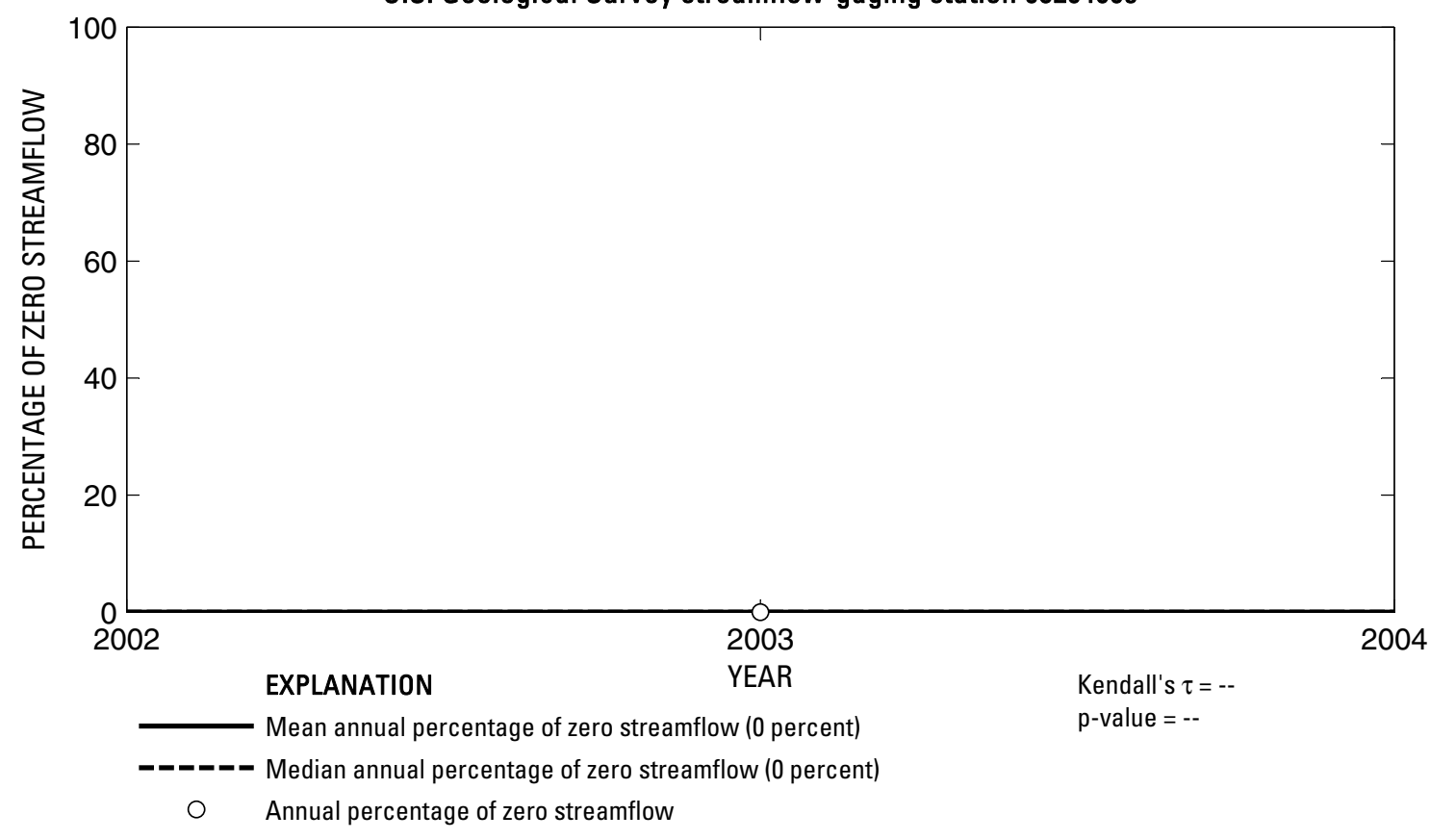

U.S. Geological Survey streamflow-gaging station 08204005

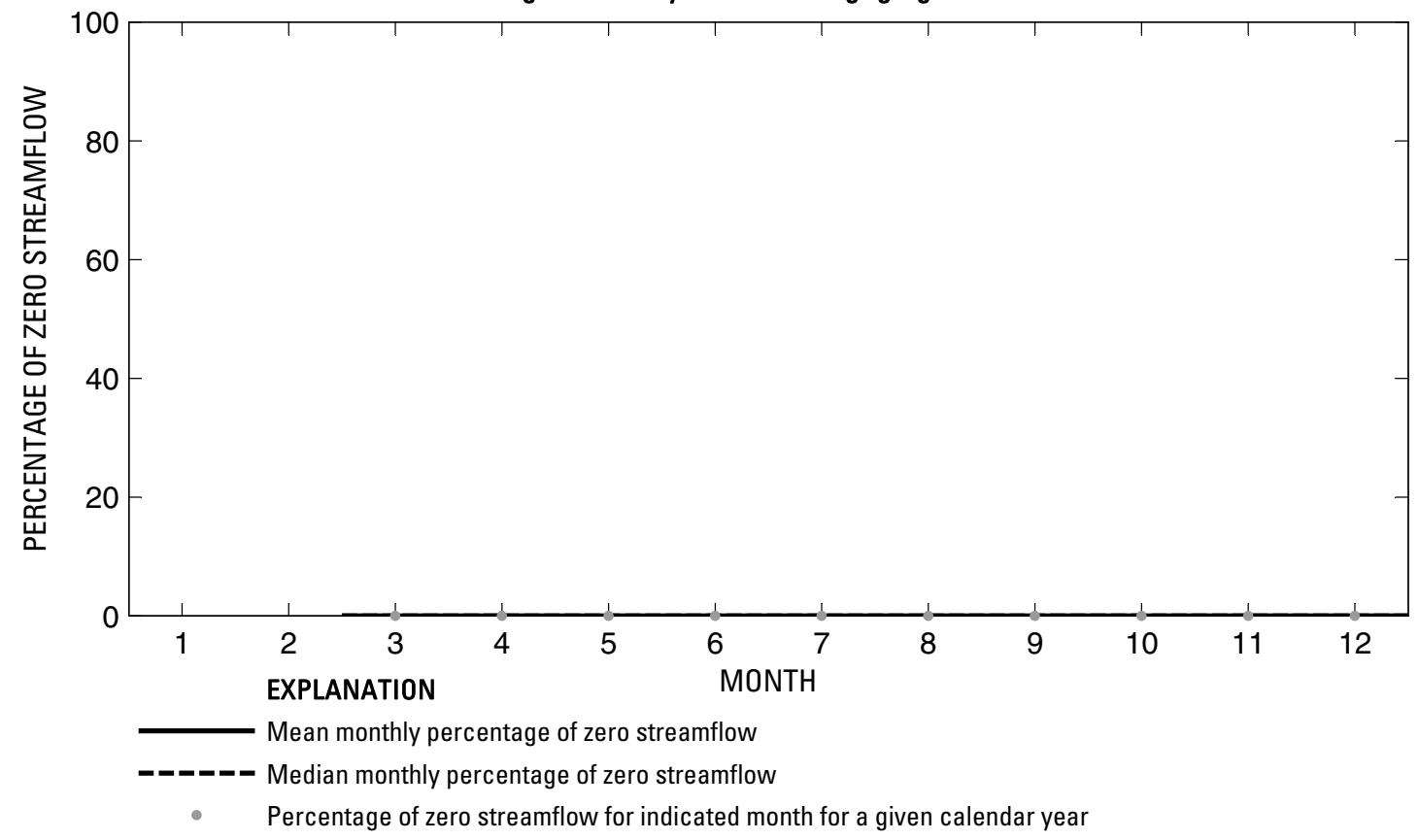

Figure 664. Analysis of percentage of zero daily mean streamflow for U.S. Geological Survey streamflow-gaging station 08204005 Leona River near Uvalde, Texas. 


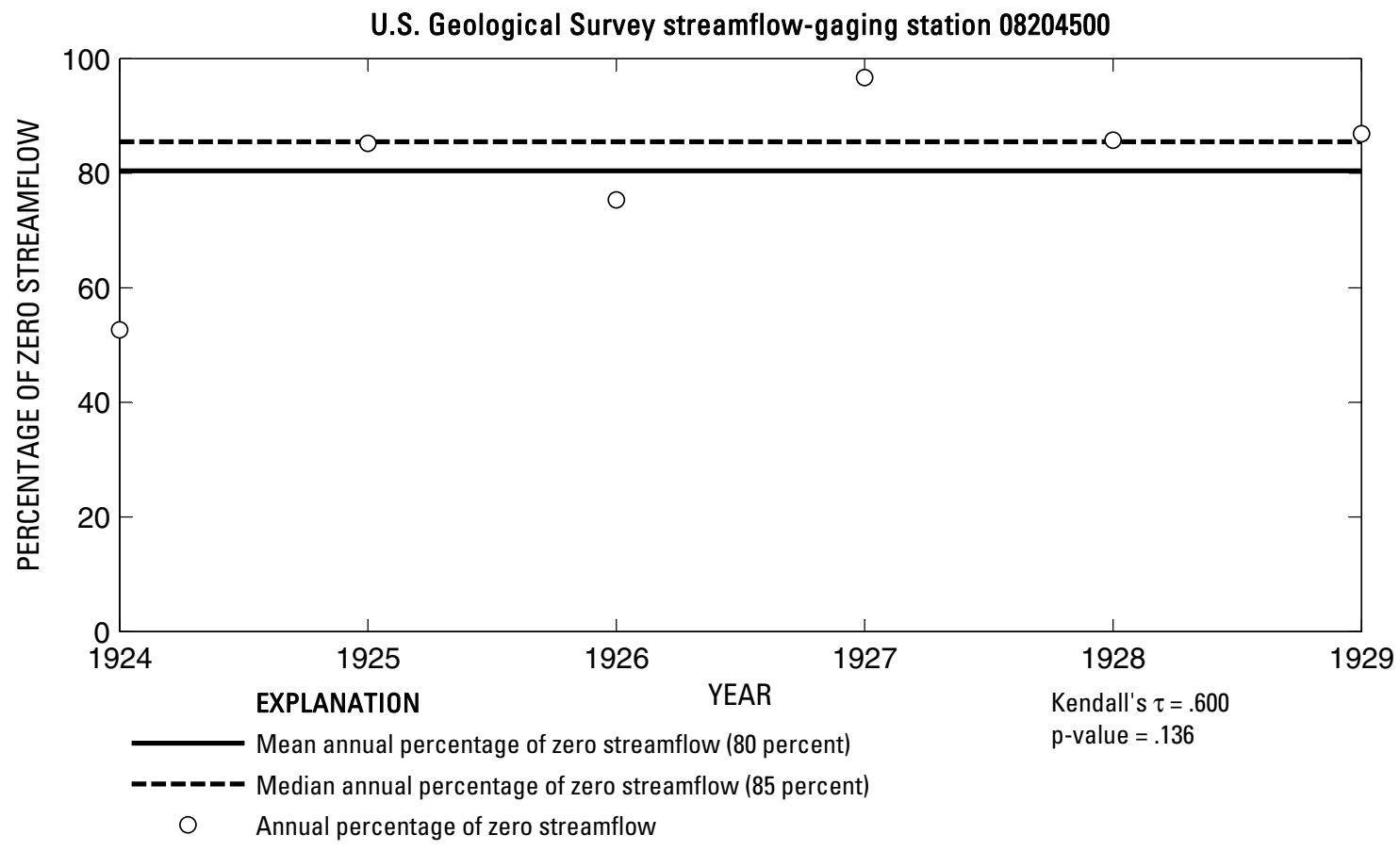

U.S. Geological Survey streamflow-gaging station 08204500

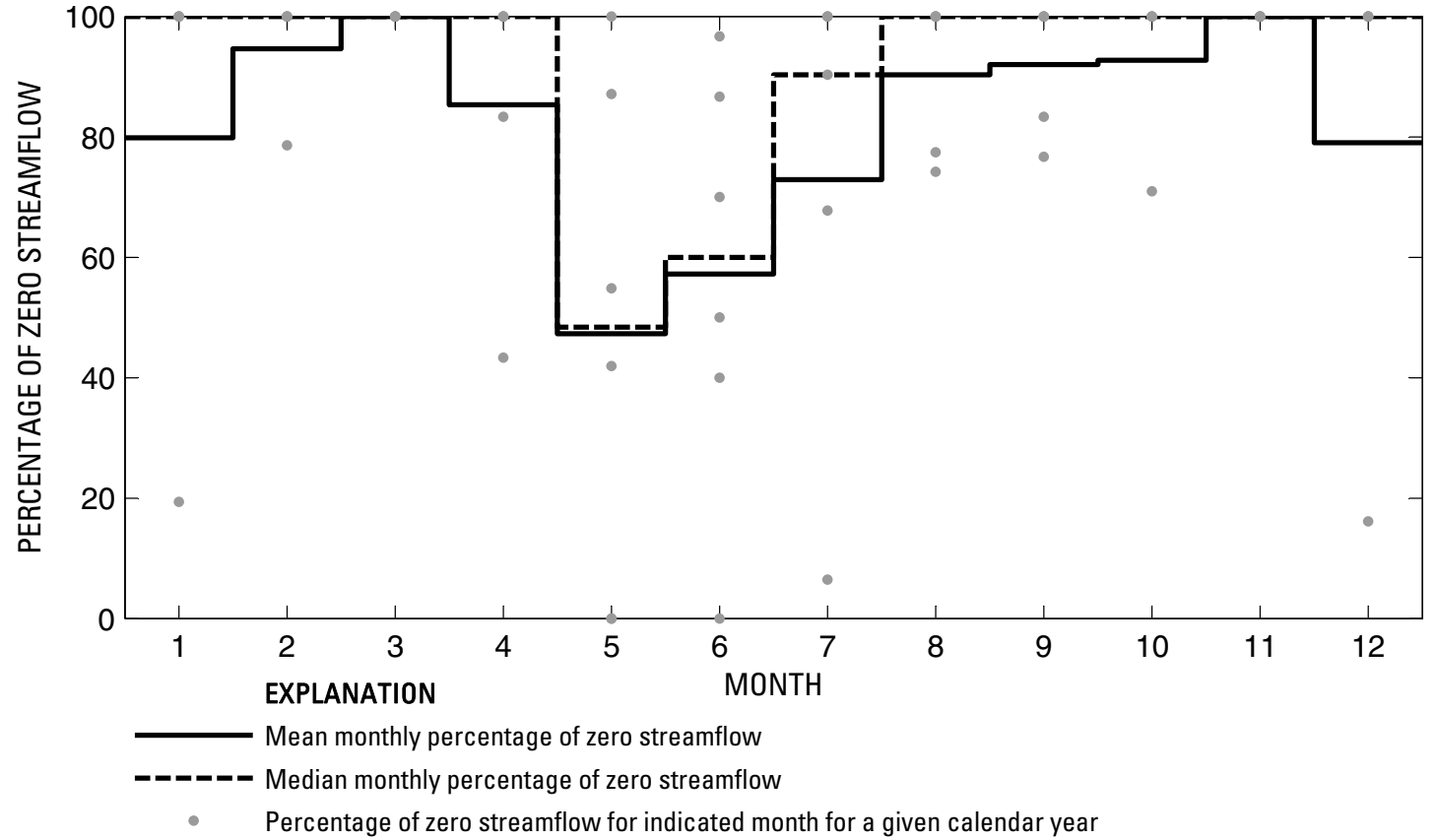

Figure 665. Analysis of percentage of zero daily mean streamflow for U.S. Geological Survey streamflow-gaging station 08204500 Leona River near Divot, Texas. 
U.S. Geological Survey streamflow-gaging station 08205500
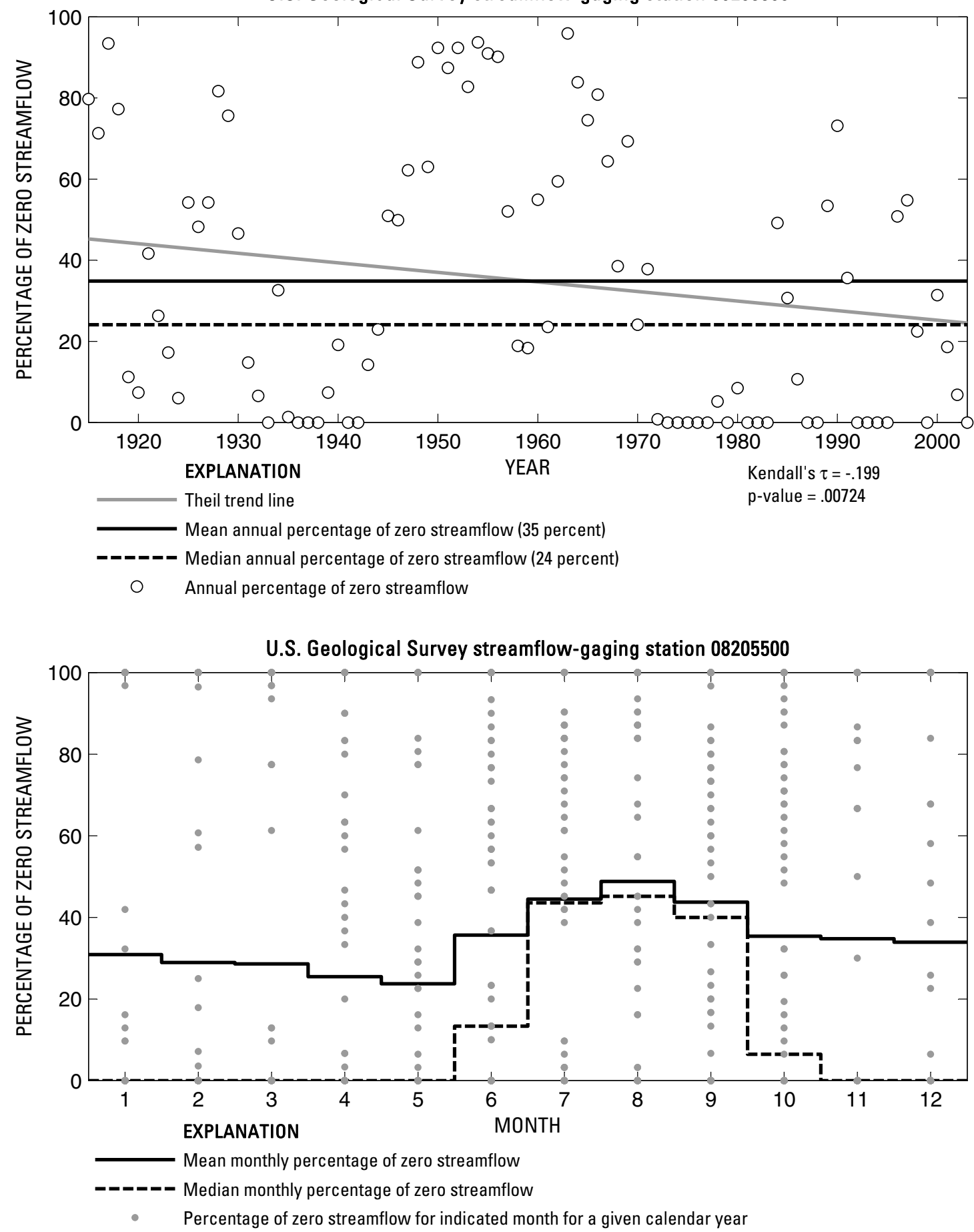

Figure 666. Analysis of percentage of zero daily mean streamflow for U.S. Geological Survey streamflow-gaging station 08205500 Frio River near Derby, Texas.

Index of Station Numbers 719 


\section{U.S. Geological Survey streamflow-gaging station 08206600}

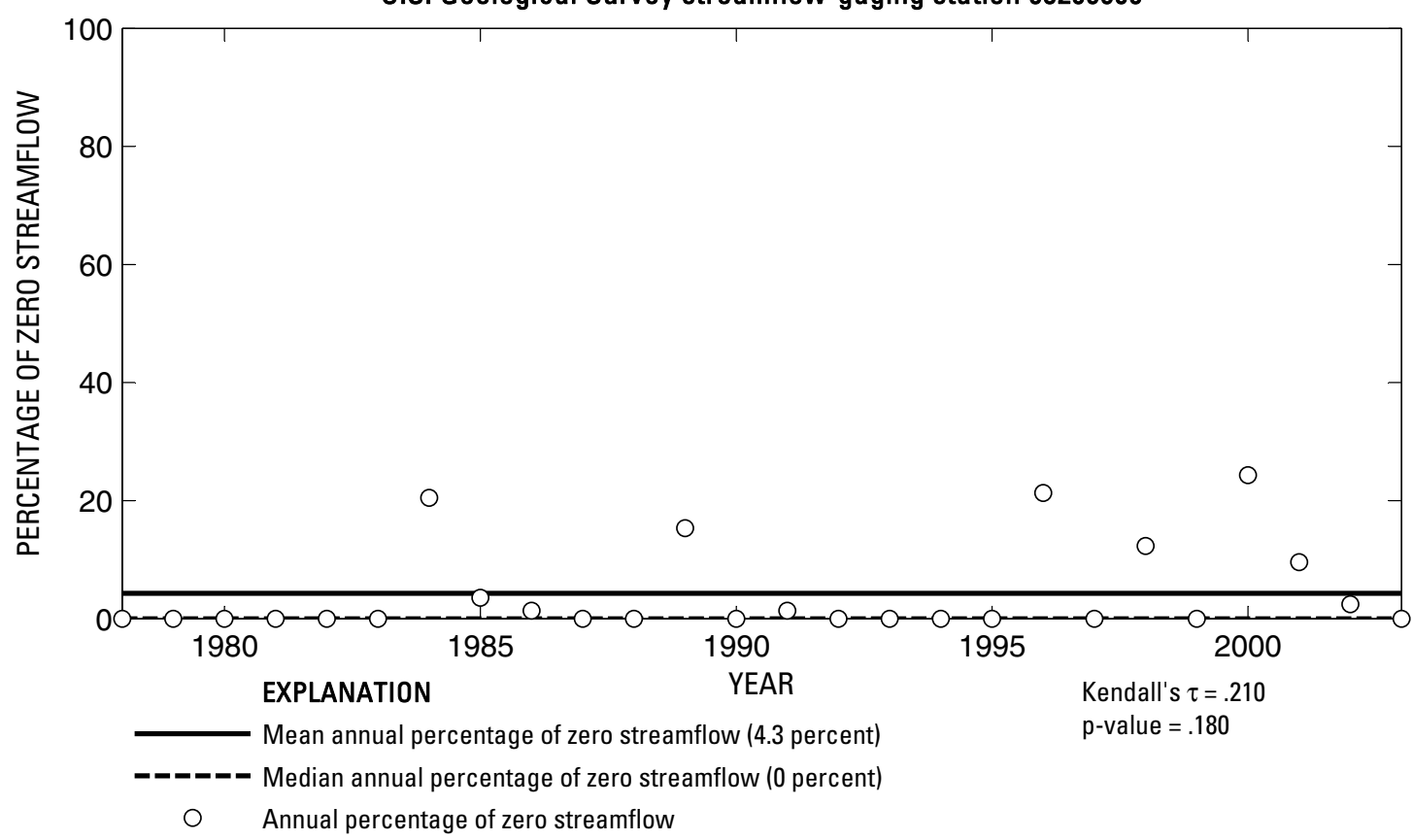

U.S. Geological Survey streamflow-gaging station 08206600

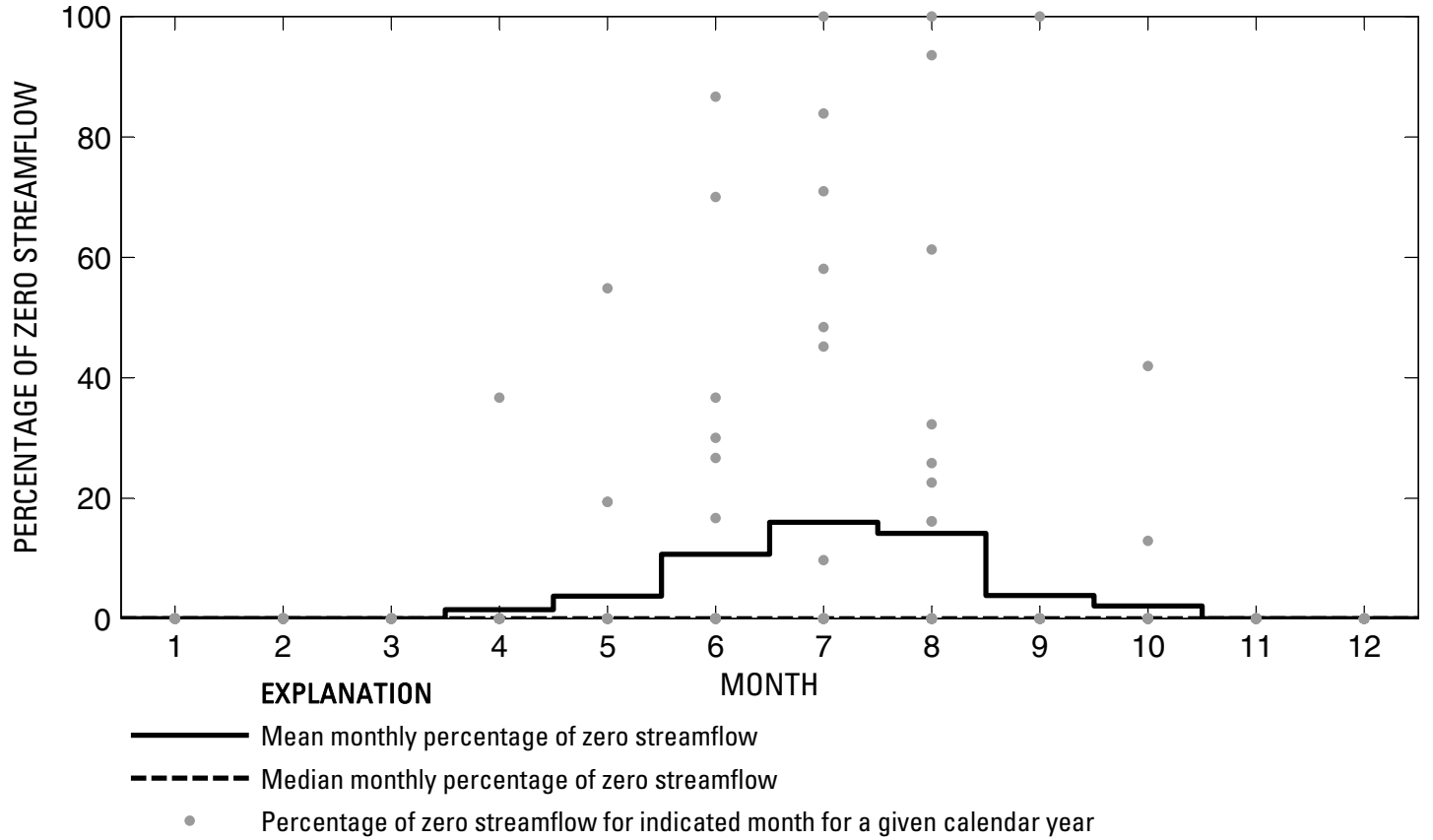

Figure 667. Analysis of percentage of zero daily mean streamflow for U.S. Geological Survey streamflow-gaging station 08206600 Frio River at Tilden, Texas. 
U.S. Geological Survey streamflow-gaging station 08206700
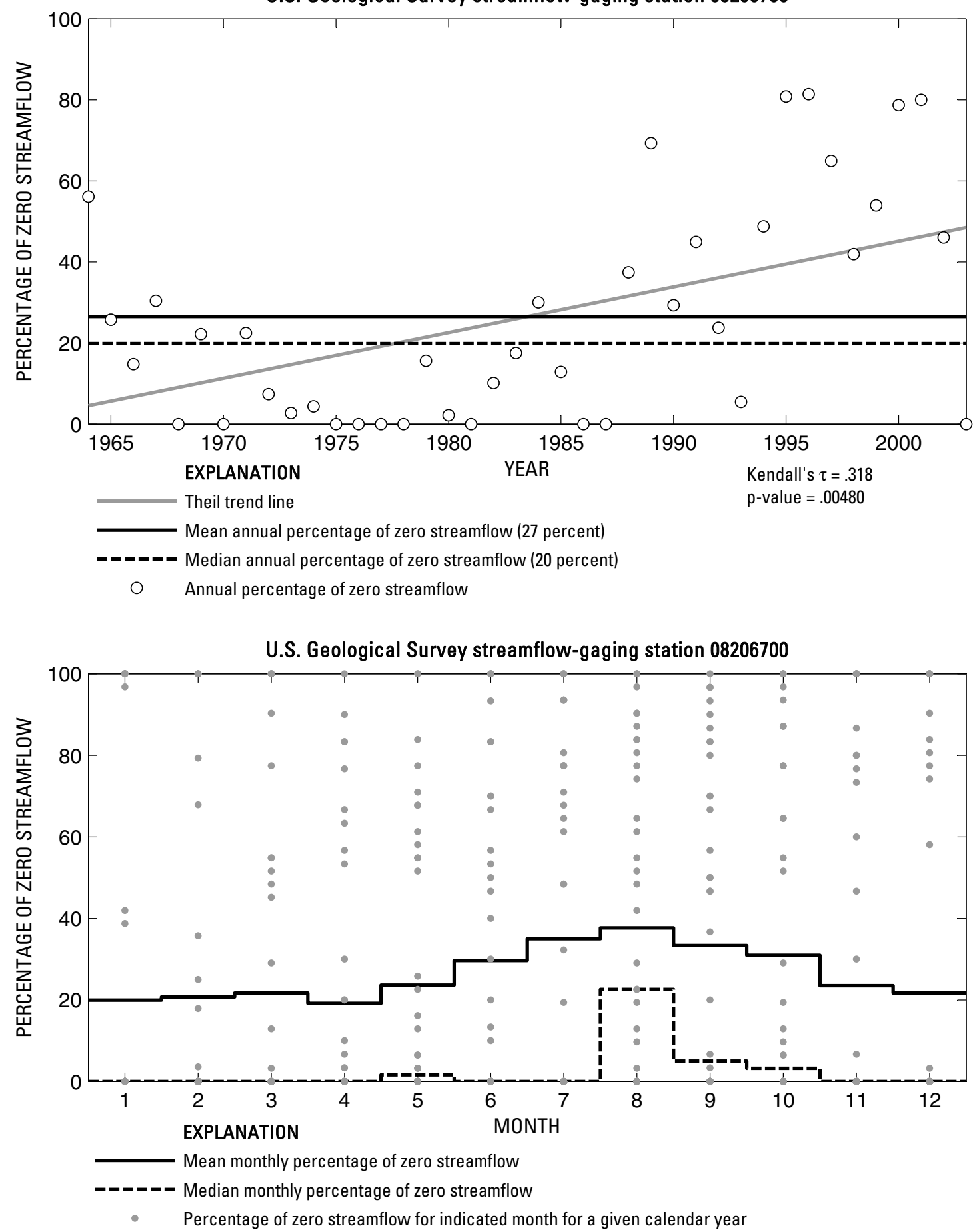

Figure 668. Analysis of percentage of zero daily mean streamflow for U.S. Geological Survey streamflow-gaging station 08206700 San Miguel Creek near Tilden, Texas.

Index of Station Numbers 719 
U.S. Geological Survey streamflow-gaging station 08206910

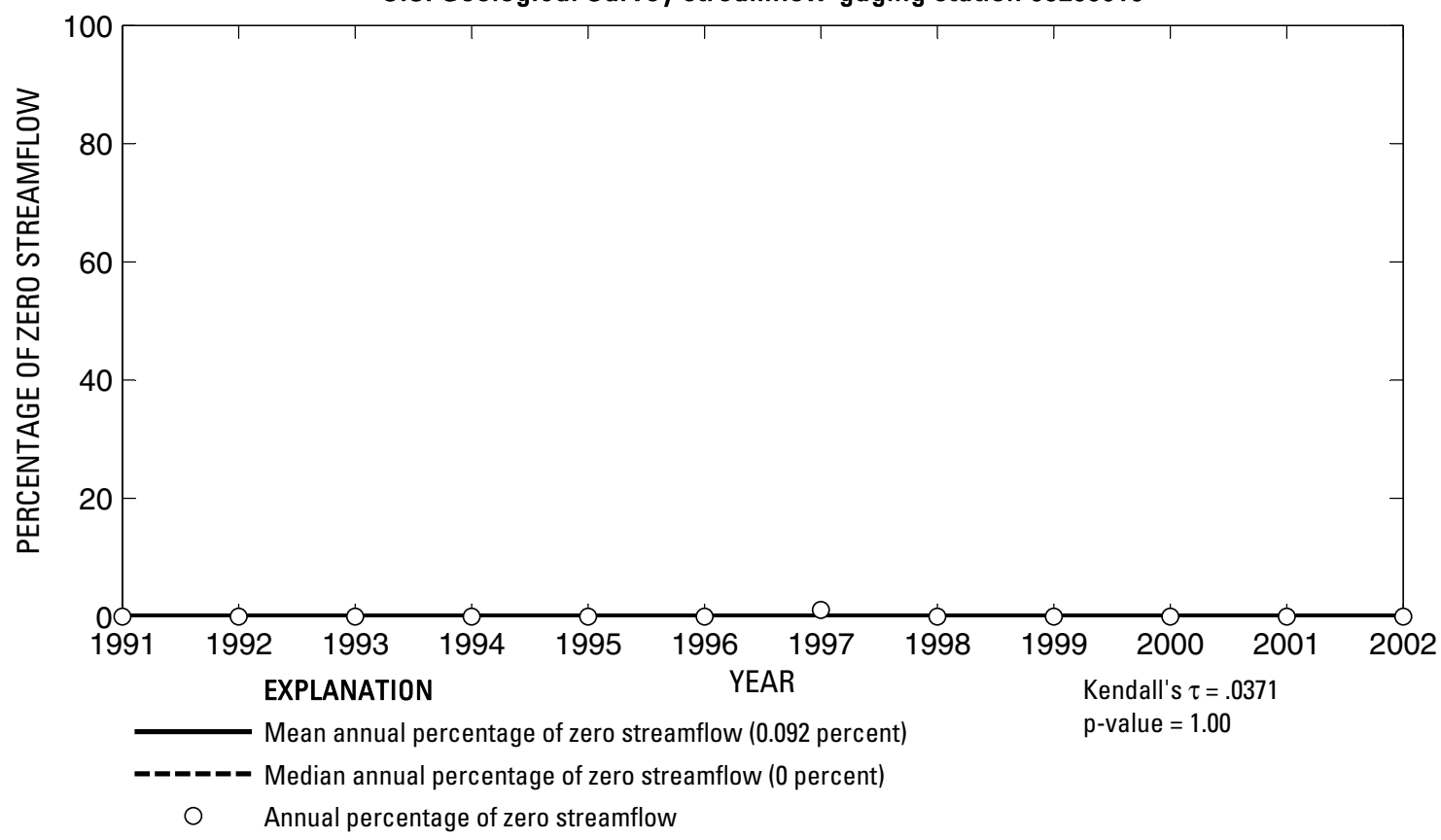

U.S. Geological Survey streamflow-gaging station 08206910

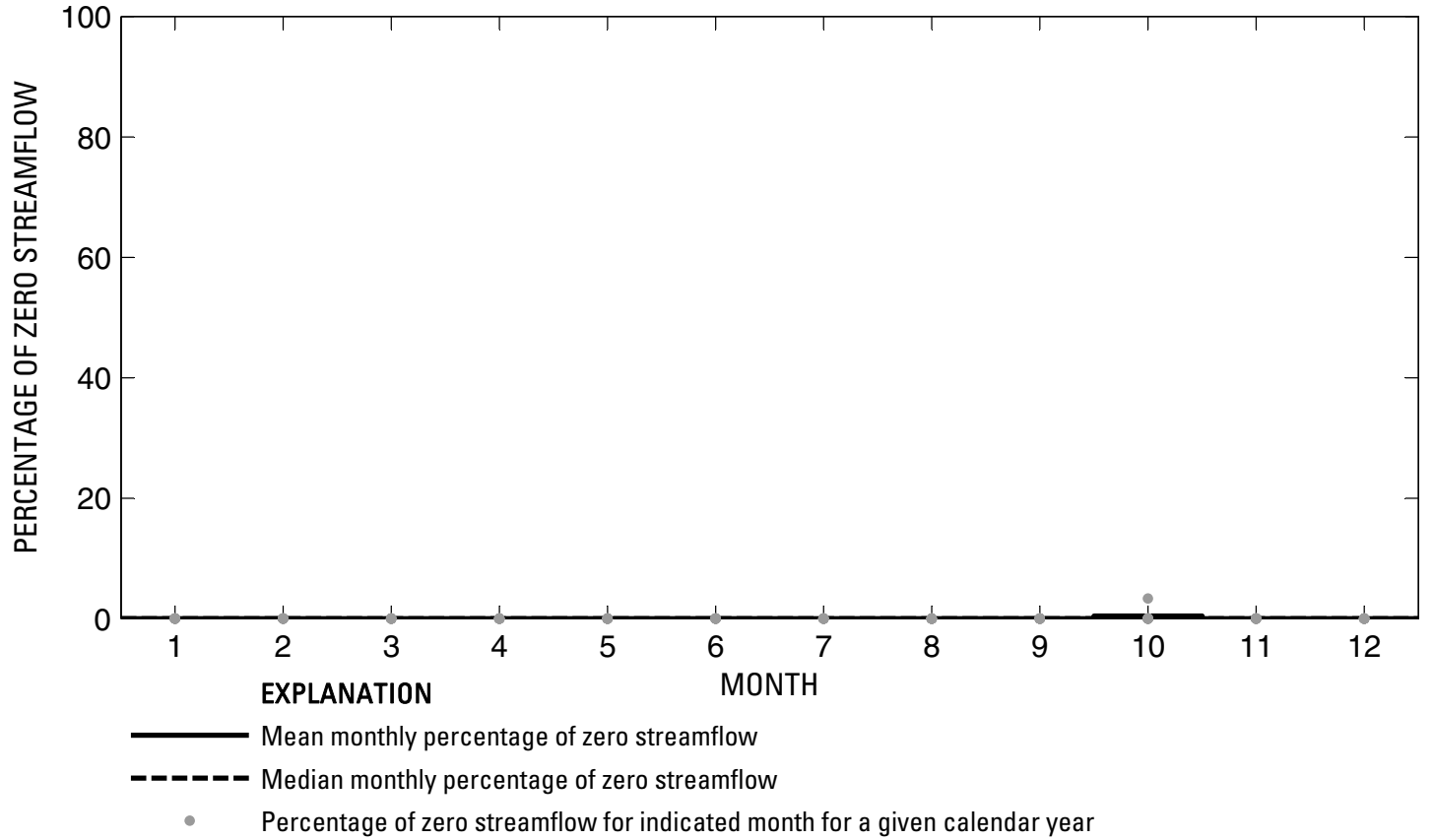

Figure 669. Analysis of percentage of zero daily mean streamflow for U.S. Geological Survey streamflow-gaging station 08206910 Choke Canyon Reservoir (Outlet Works Control) near Three Rivers, Texas. 
U.S. Geological Survey streamflow-gaging station 08207000

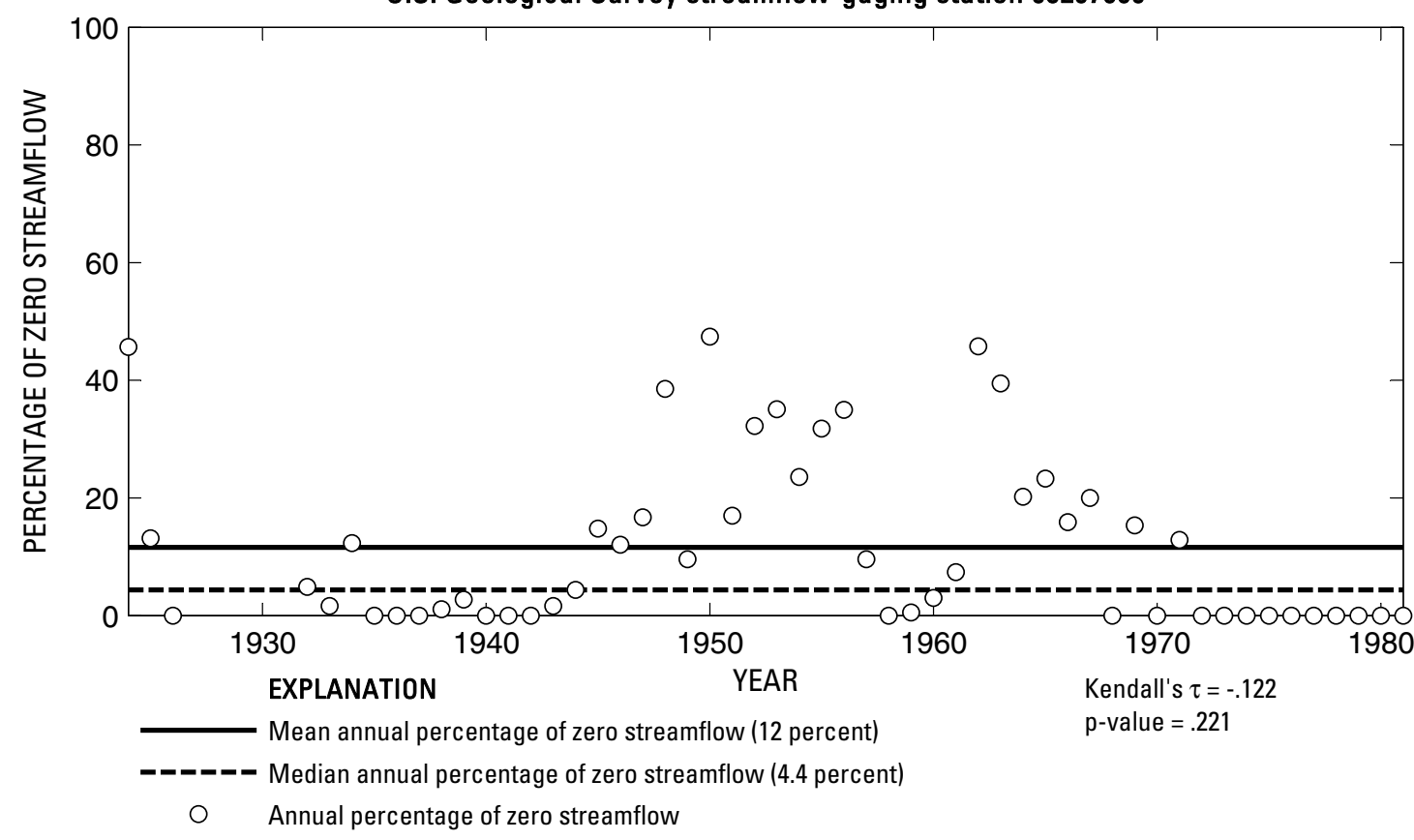

U.S. Geological Survey streamflow-gaging station 08207000

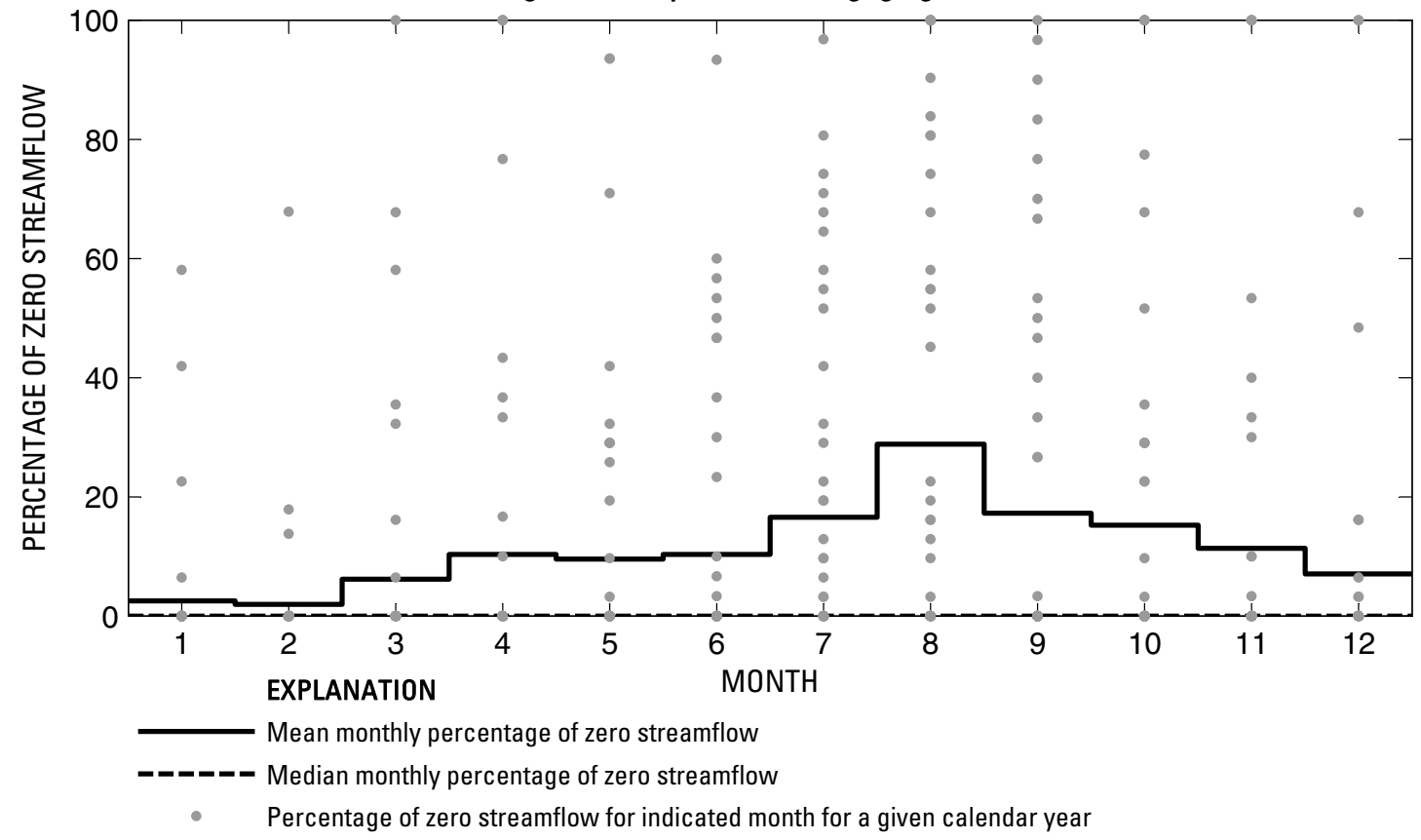

Figure 670. Analysis of percentage of zero daily mean streamflow for U.S. Geological Survey streamflow-gaging station 08207000 Frio River at Calliham, Texas.

Index of Station Numbers 719 
U.S. Geological Survey streamflow-gaging station 08207500

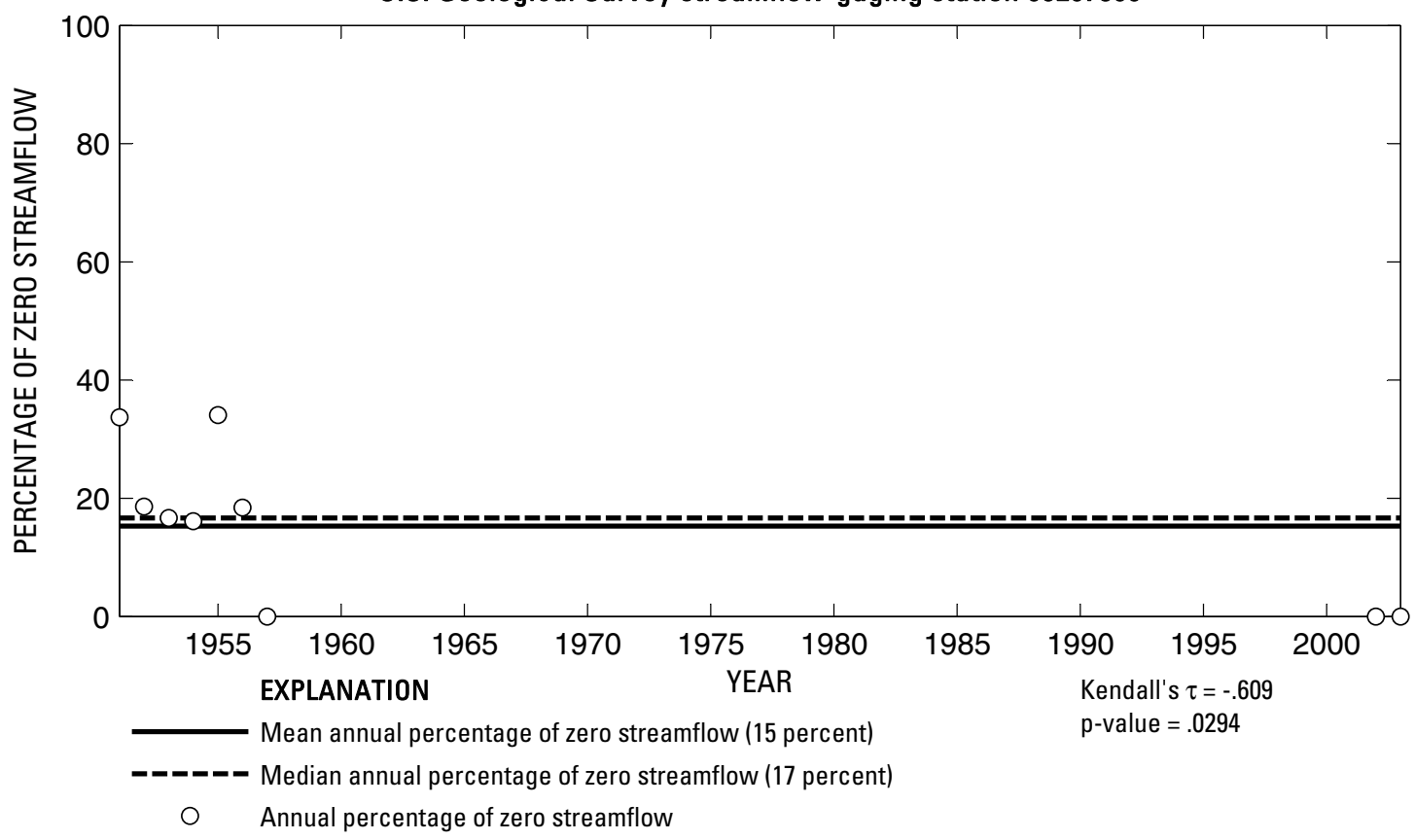

U.S. Geological Survey streamflow-gaging station 08207500

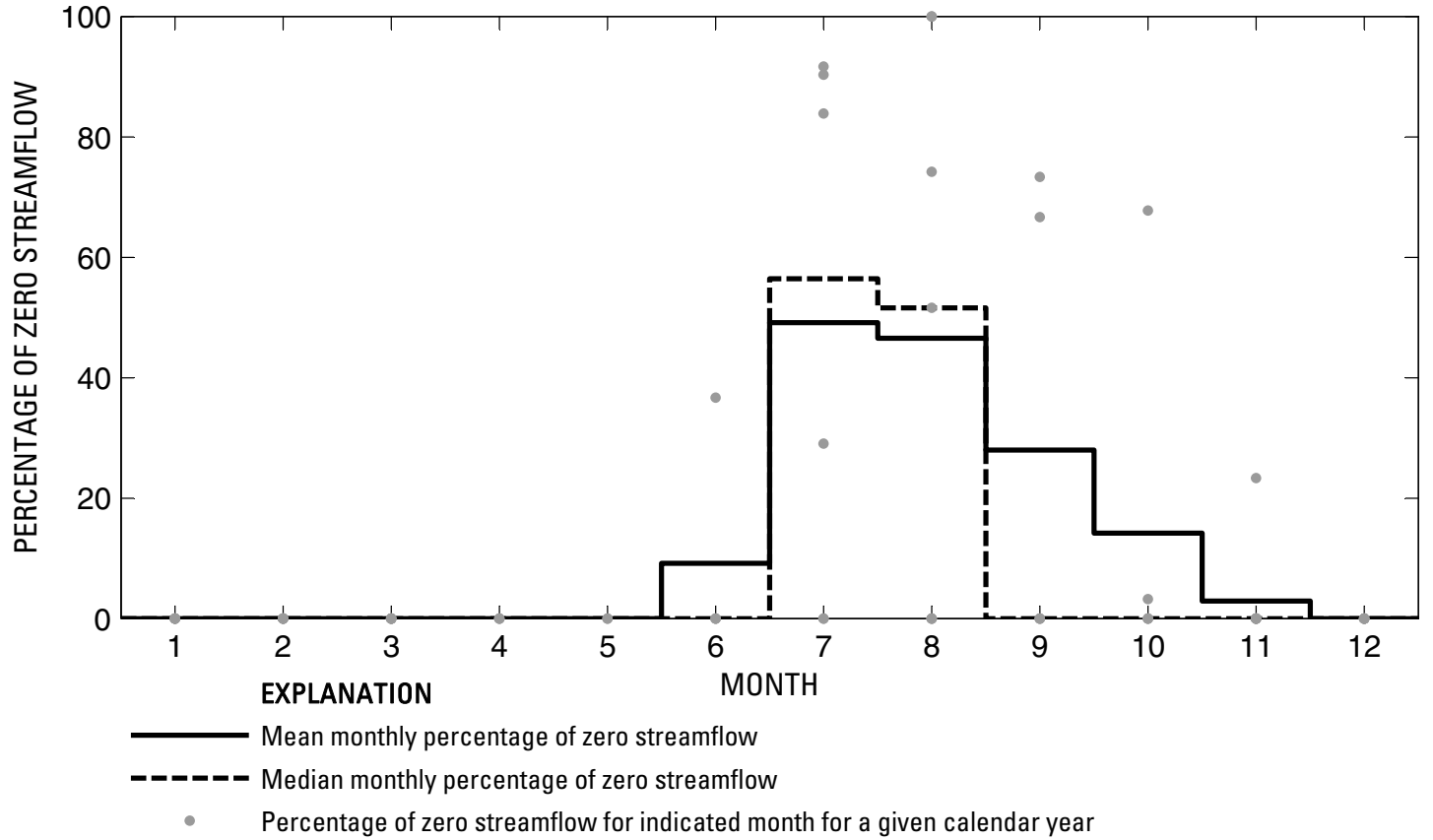

Figure 671. Analysis of percentage of zero daily mean streamflow for U.S. Geological Survey streamflow-gaging station 08207500 Atascosa River near McCoy, Texas. 
U.S. Geological Survey streamflow-gaging station 08208000

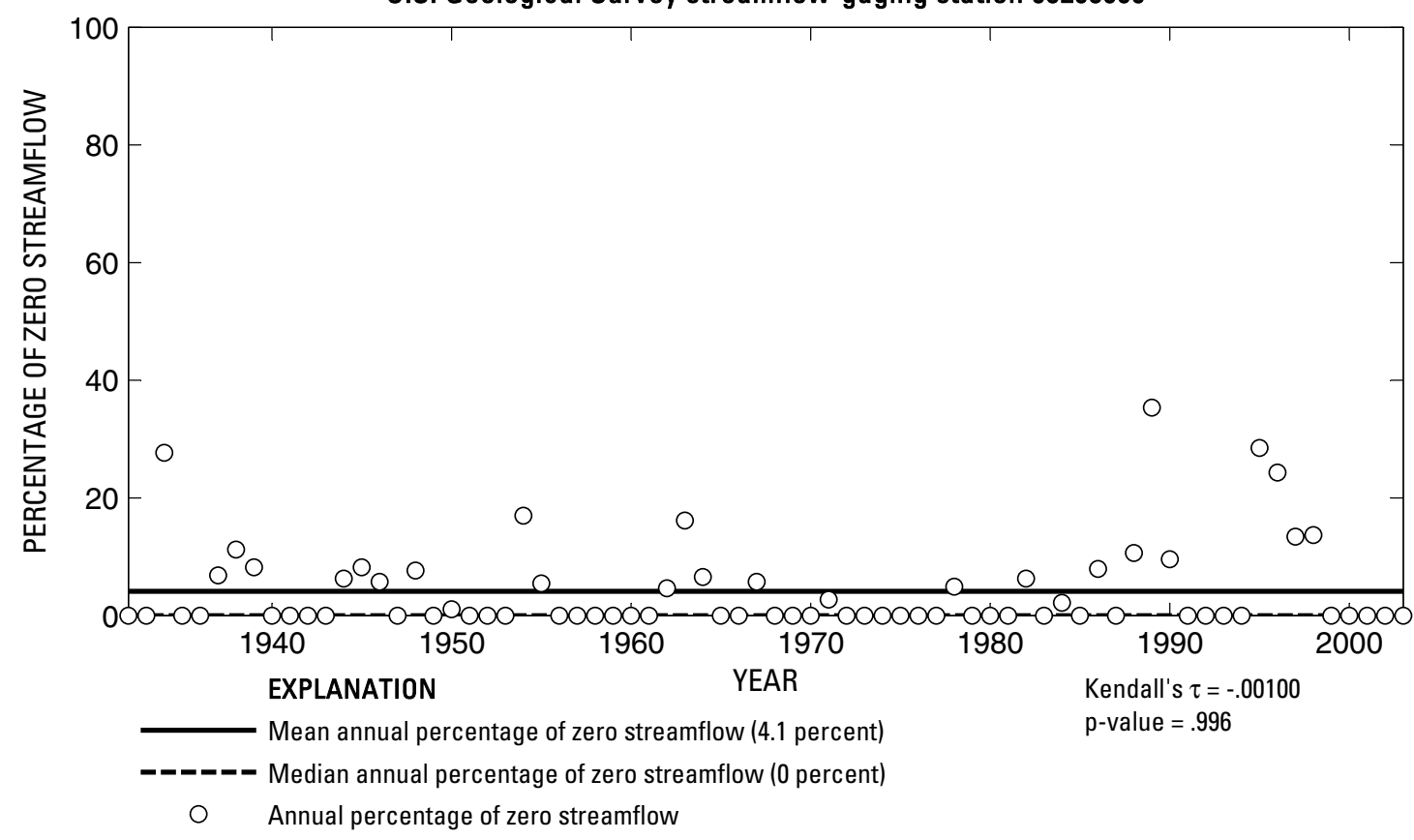

U.S. Geological Survey streamflow-gaging station 08208000

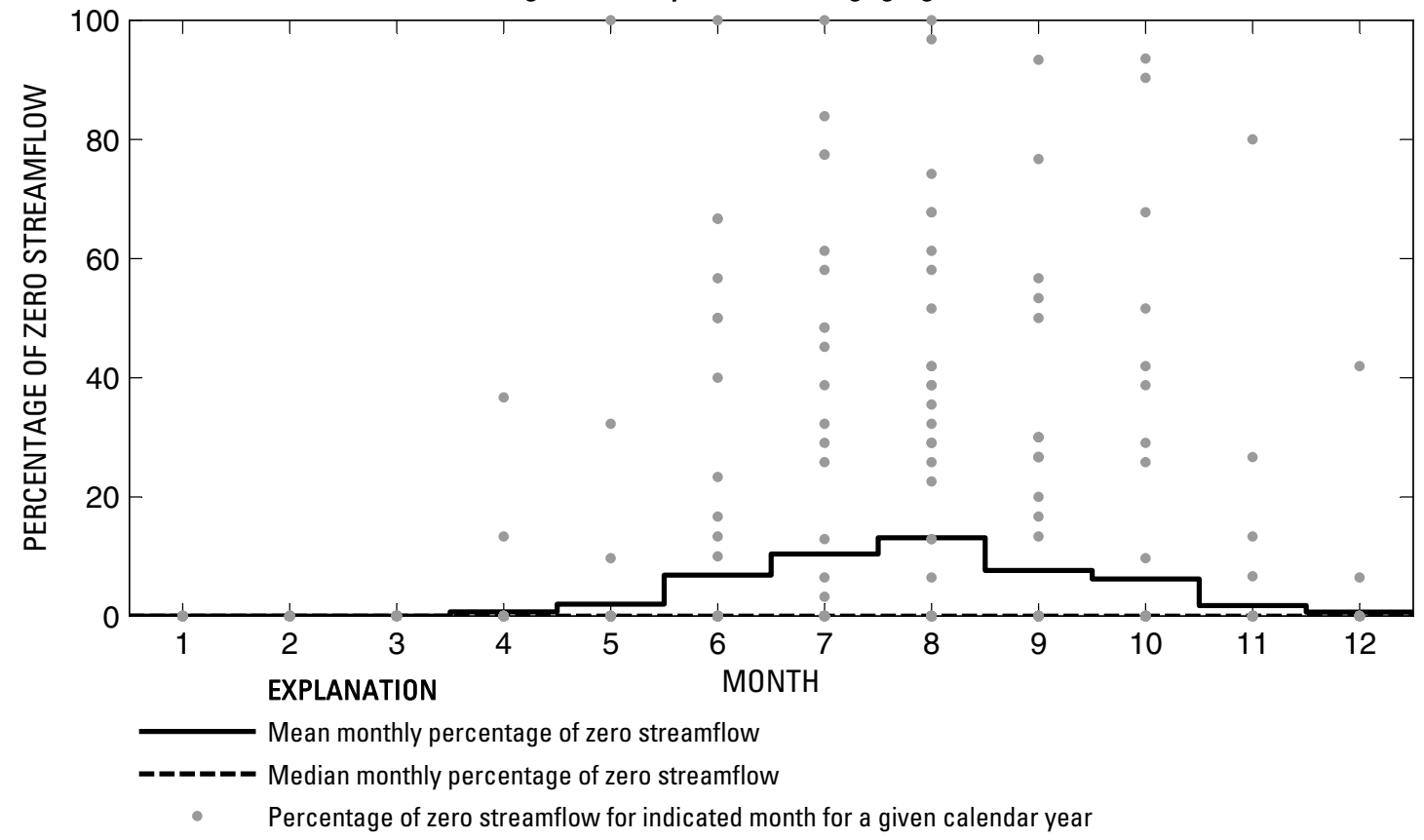

Figure 672. Analysis of percentage of zero daily mean streamflow for U.S. Geological Survey streamflow-gaging station 08208000 Atascosa River at Whitsett, Texas. 

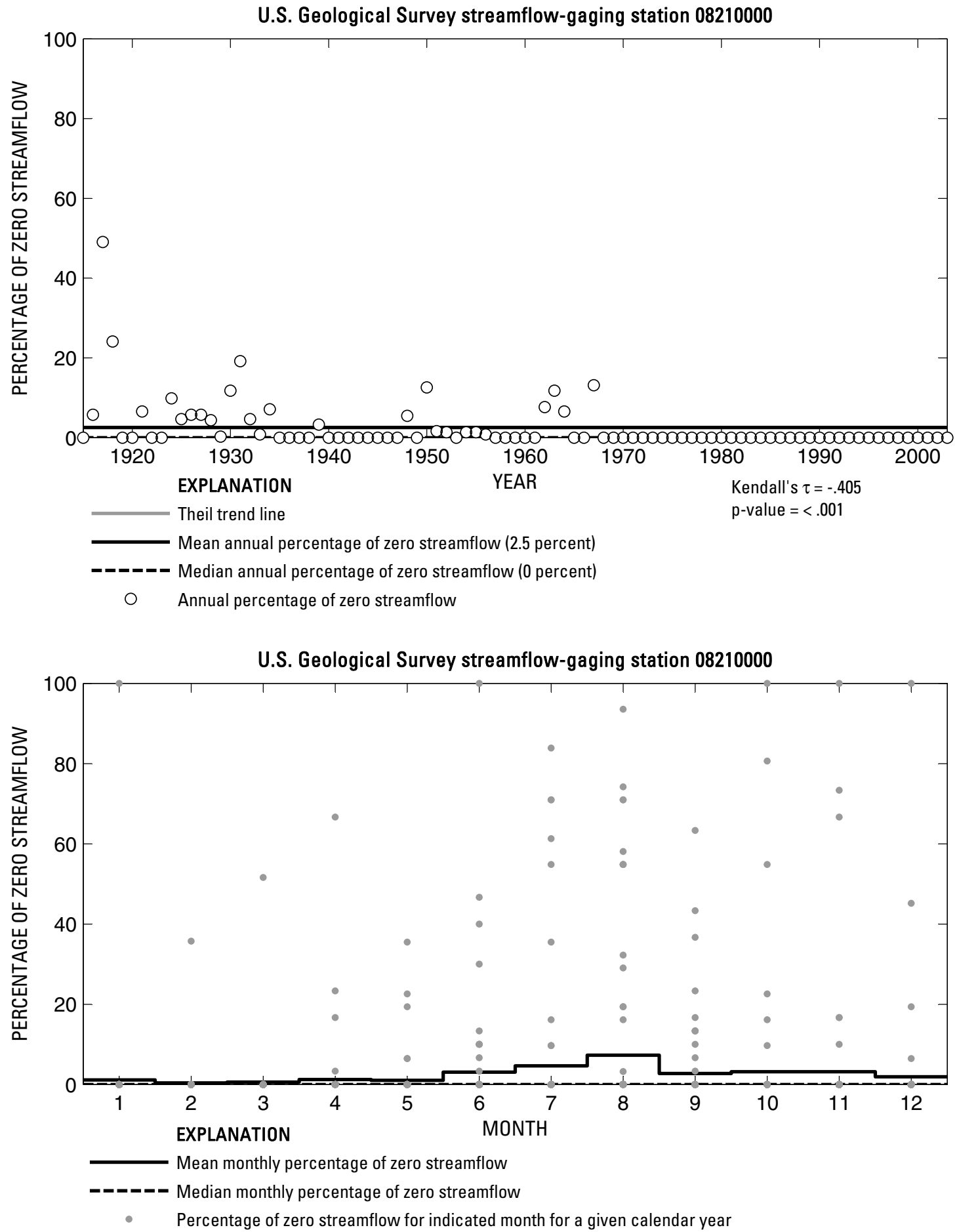

Figure 673. Analysis of percentage of zero daily mean streamflow for U.S. Geological Survey streamflow-gaging station 08210000 Nueces River near Three Rivers, Texas. 


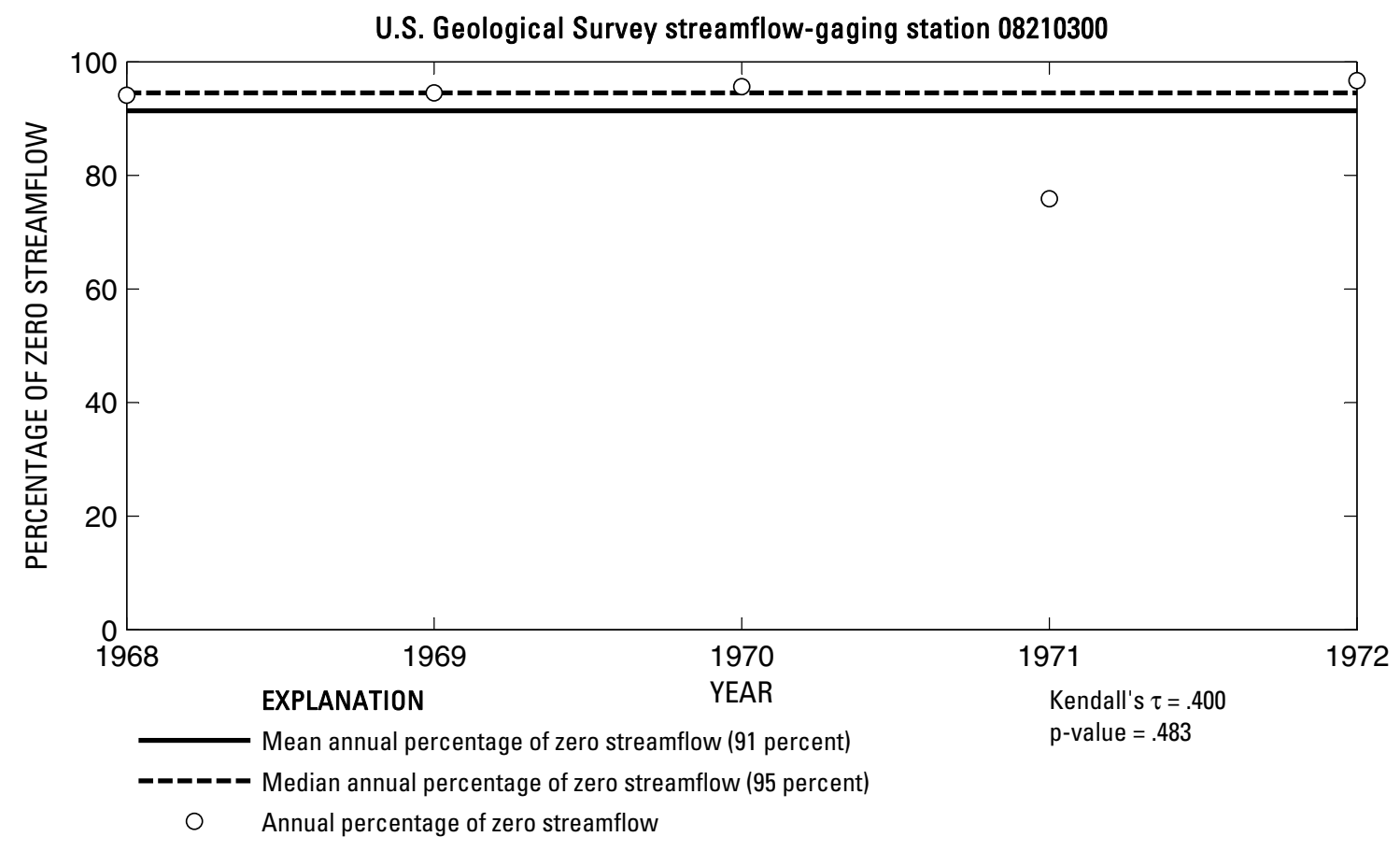

U.S. Geological Survey streamflow-gaging station 08210300

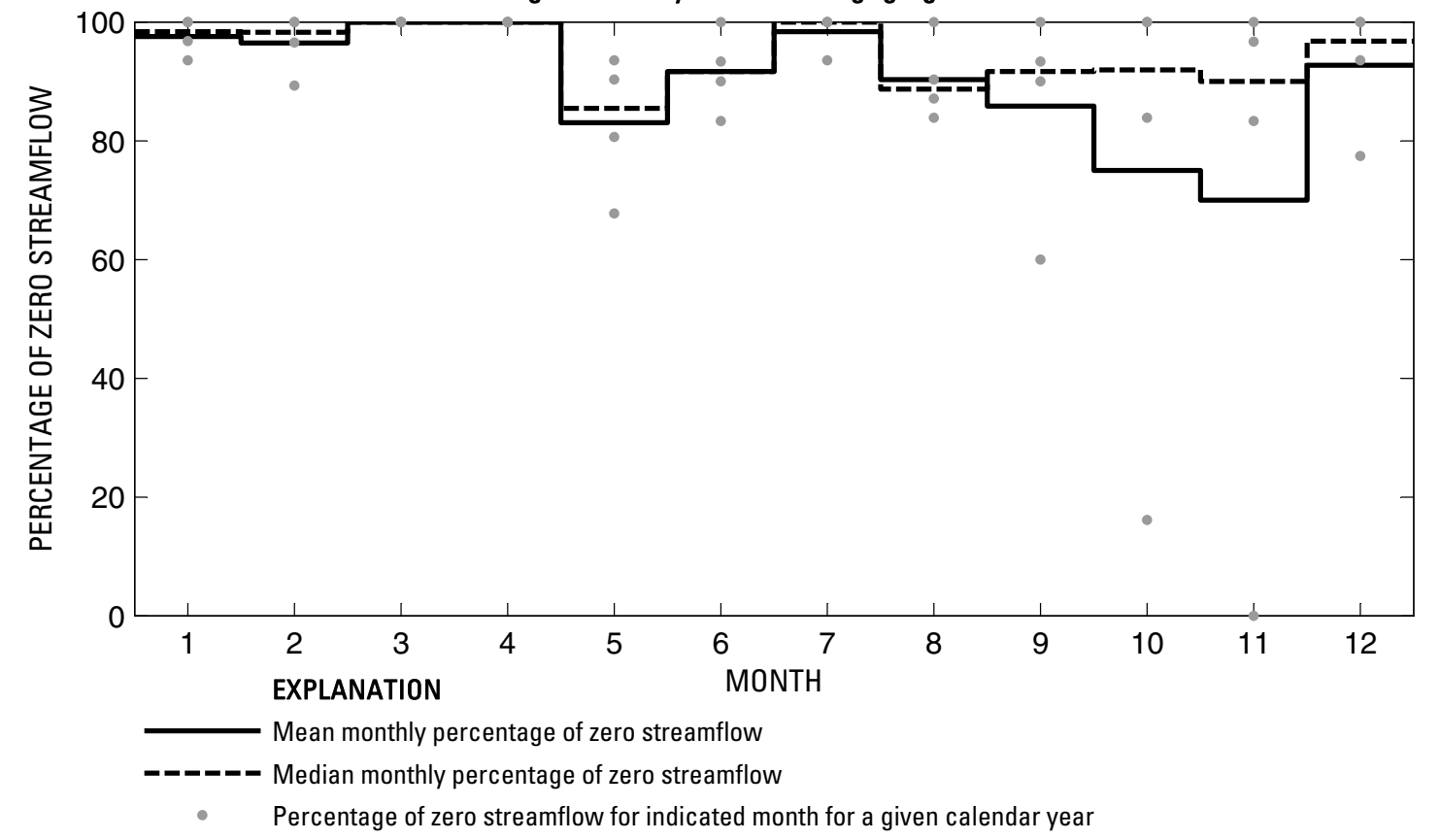

Figure 674. Analysis of percentage of zero daily mean streamflow for U.S. Geological Survey streamflow-gaging station 08210300 Ramirena Creek near George West, Texas. 
U.S. Geological Survey streamflow-gaging station 08210400

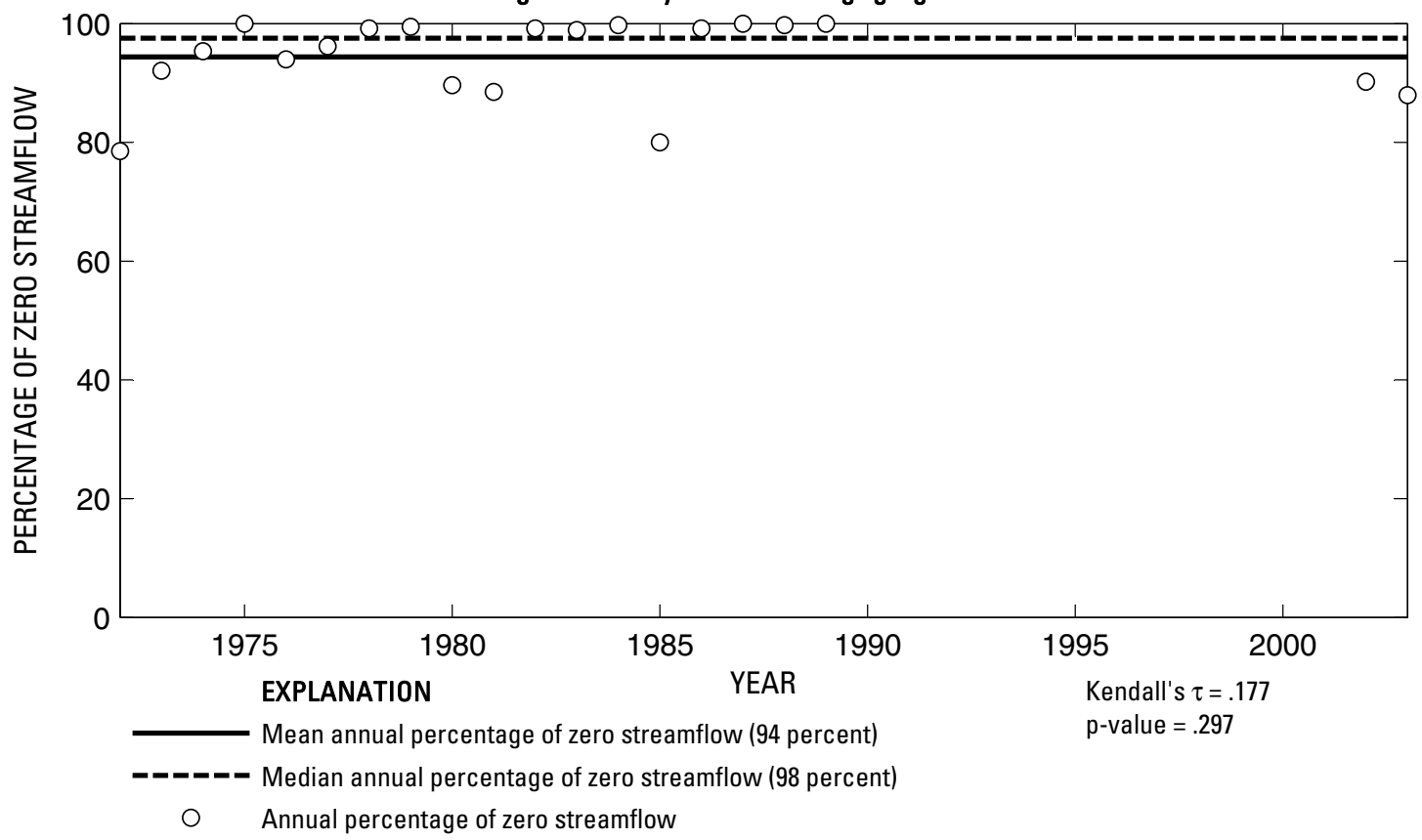

U.S. Geological Survey streamflow-gaging station 08210400

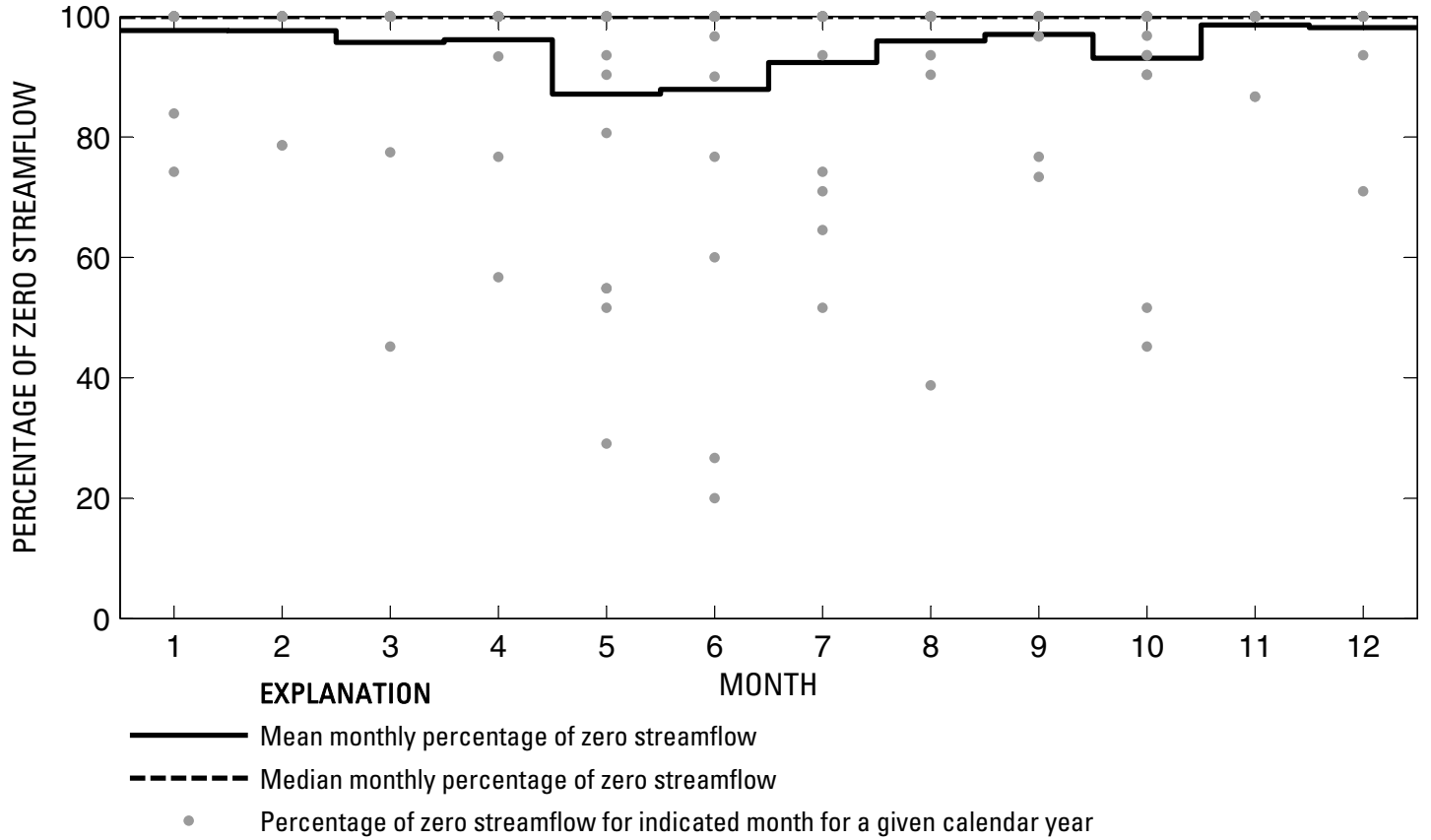

Figure 675. Analysis of percentage of zero daily mean streamflow for U.S. Geological Survey streamflow-gaging station 08210400 Lagarto Creek near George West, Texas. 
U.S. Geological Survey streamflow-gaging station 08211000

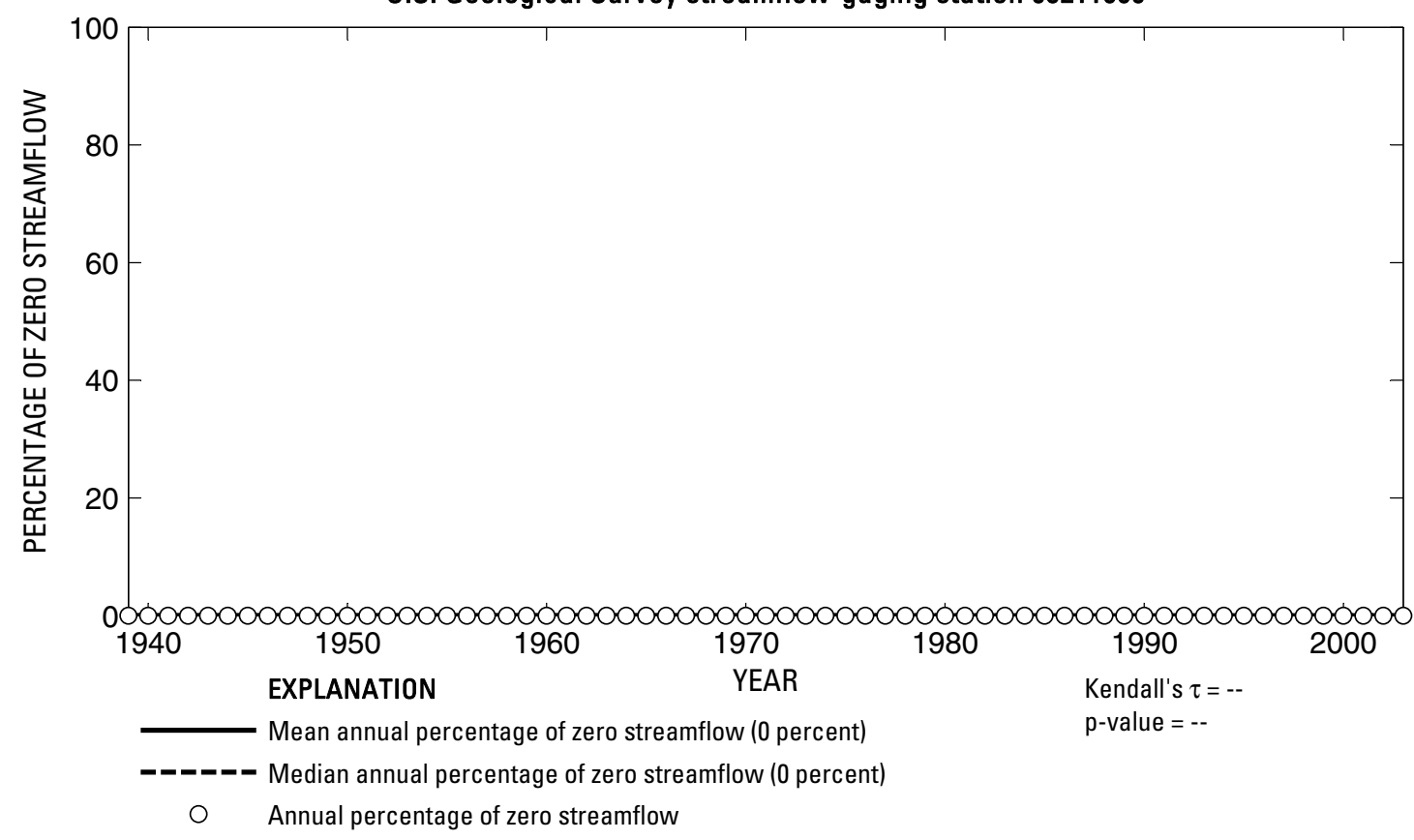

U.S. Geological Survey streamflow-gaging station 08211000

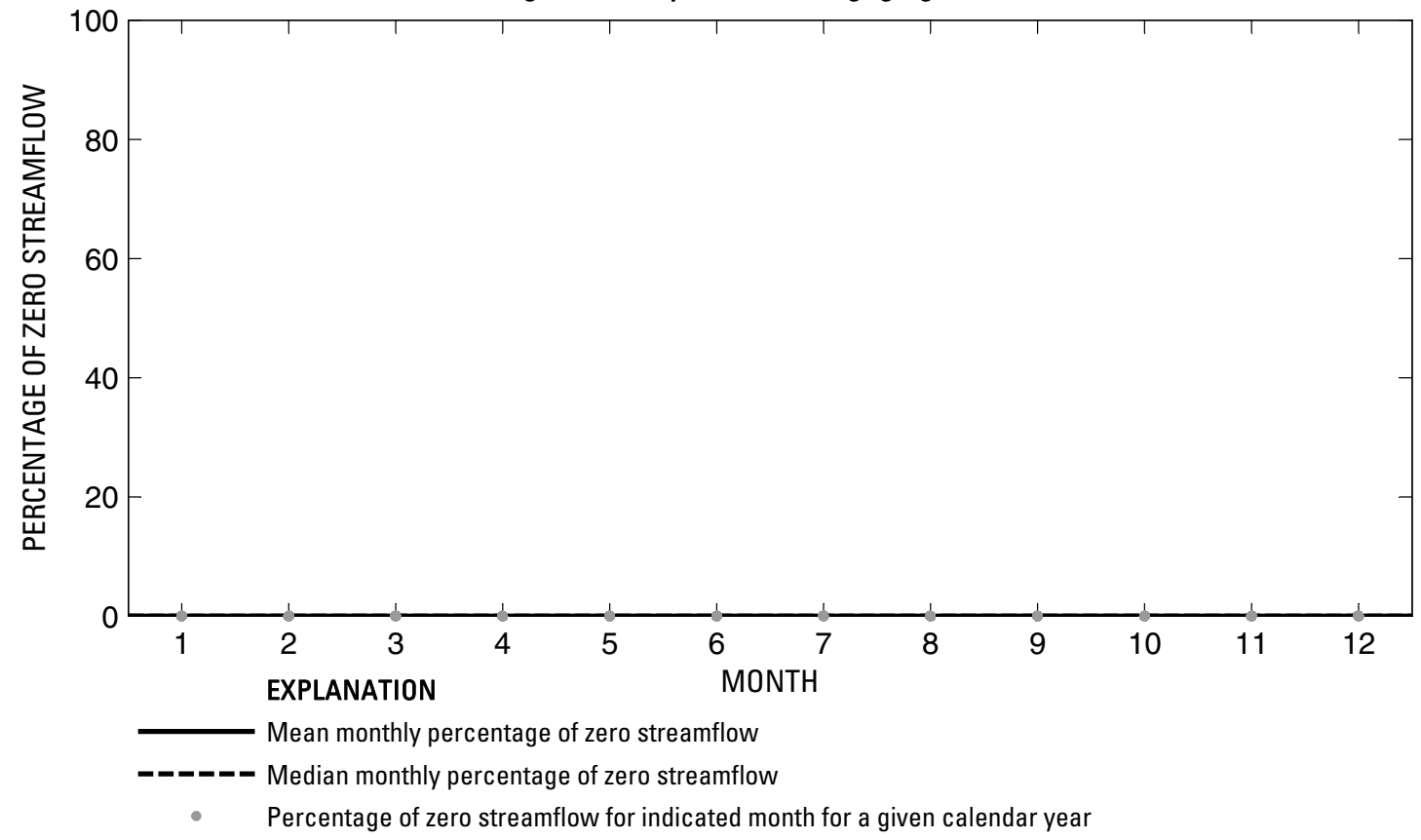

Figure 676. Analysis of percentage of zero daily mean streamflow for U.S. Geological Survey streamflow-gaging station 08211000 Nueces River near Mathis, Texas. 


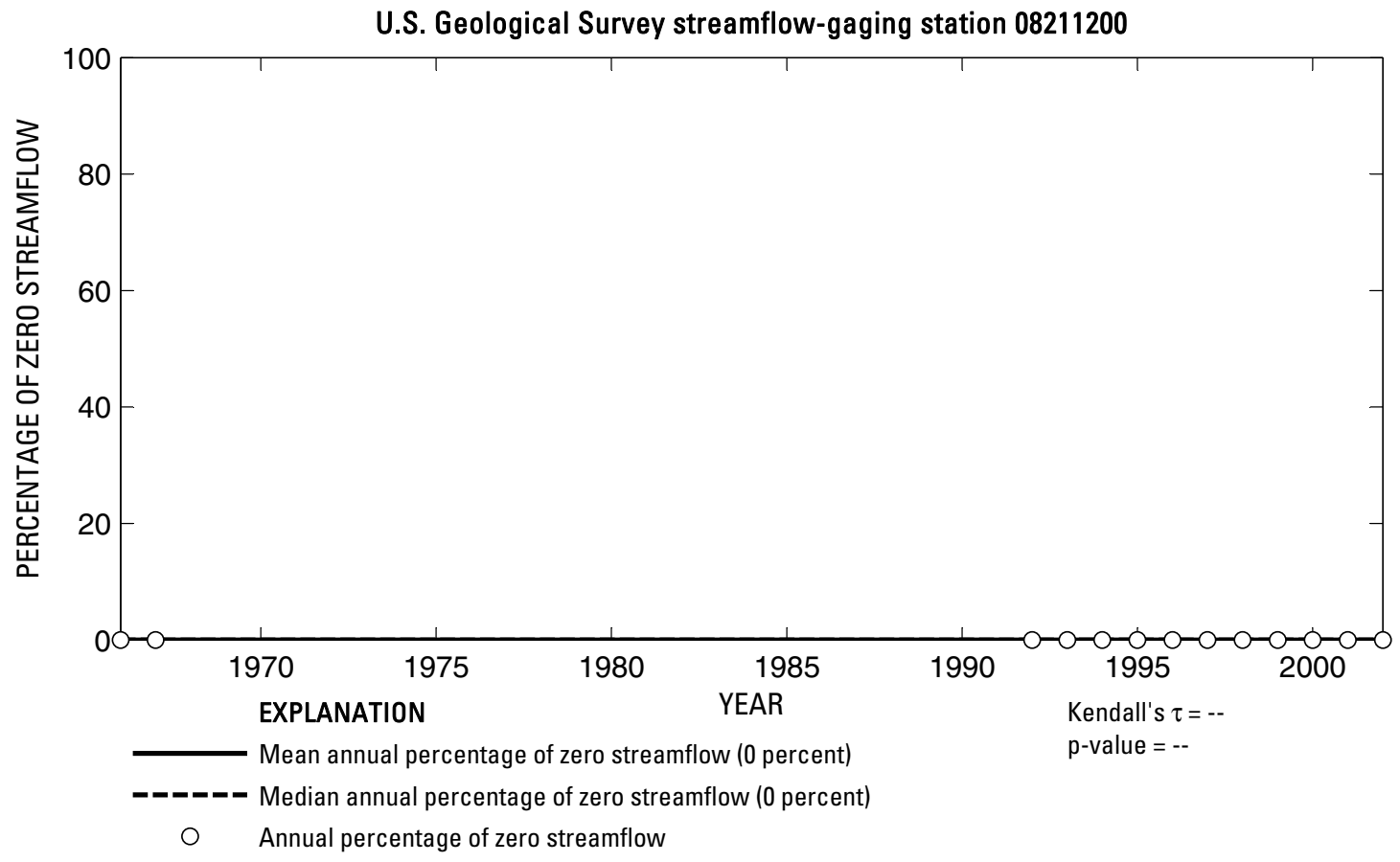

U.S. Geological Survey streamflow-gaging station 08211200

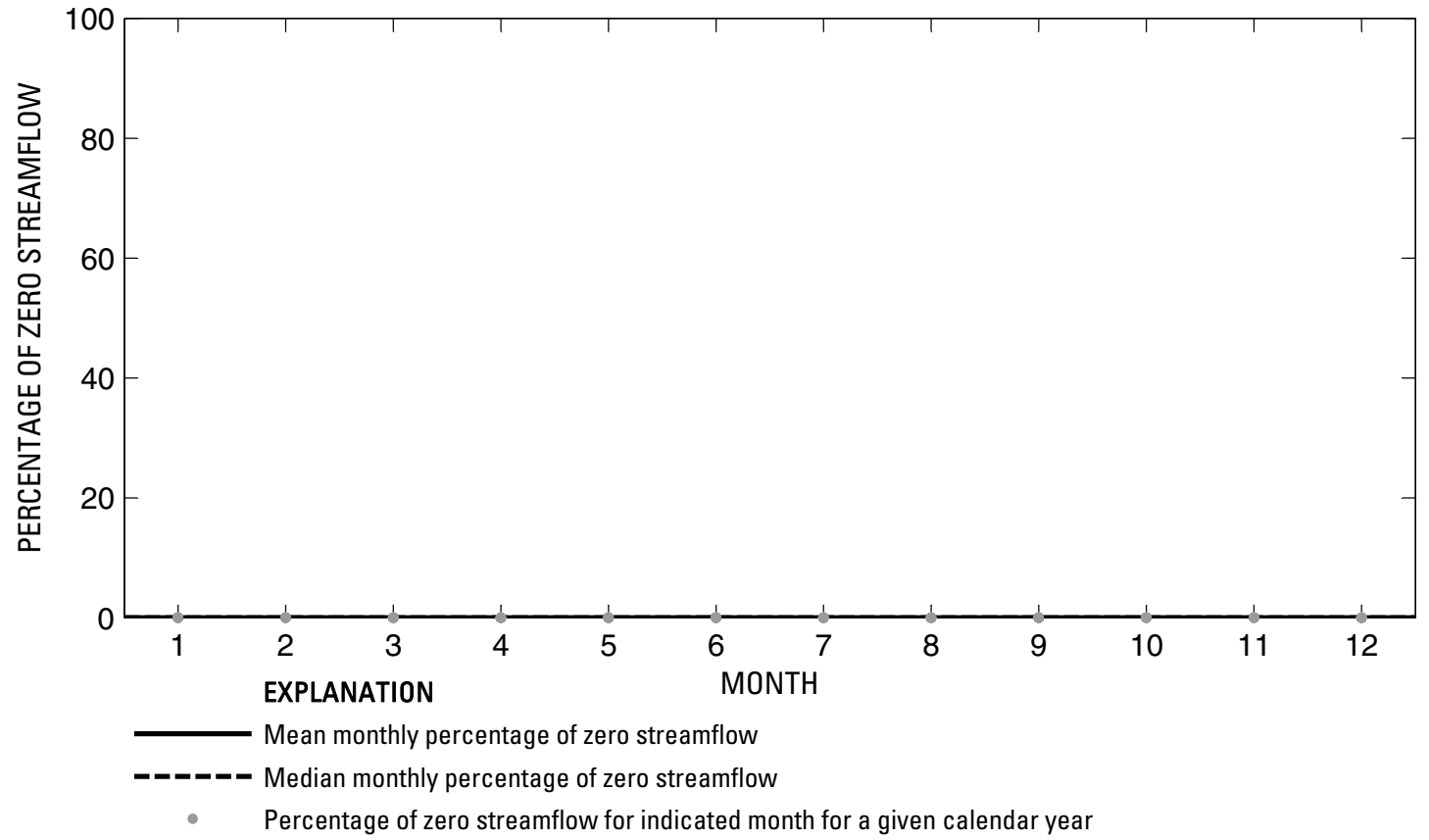

Figure 677. Analysis of percentage of zero daily mean streamflow for U.S. Geological Survey streamflow-gaging station 08211200 Nueces River at Bluntzer, Texas. 

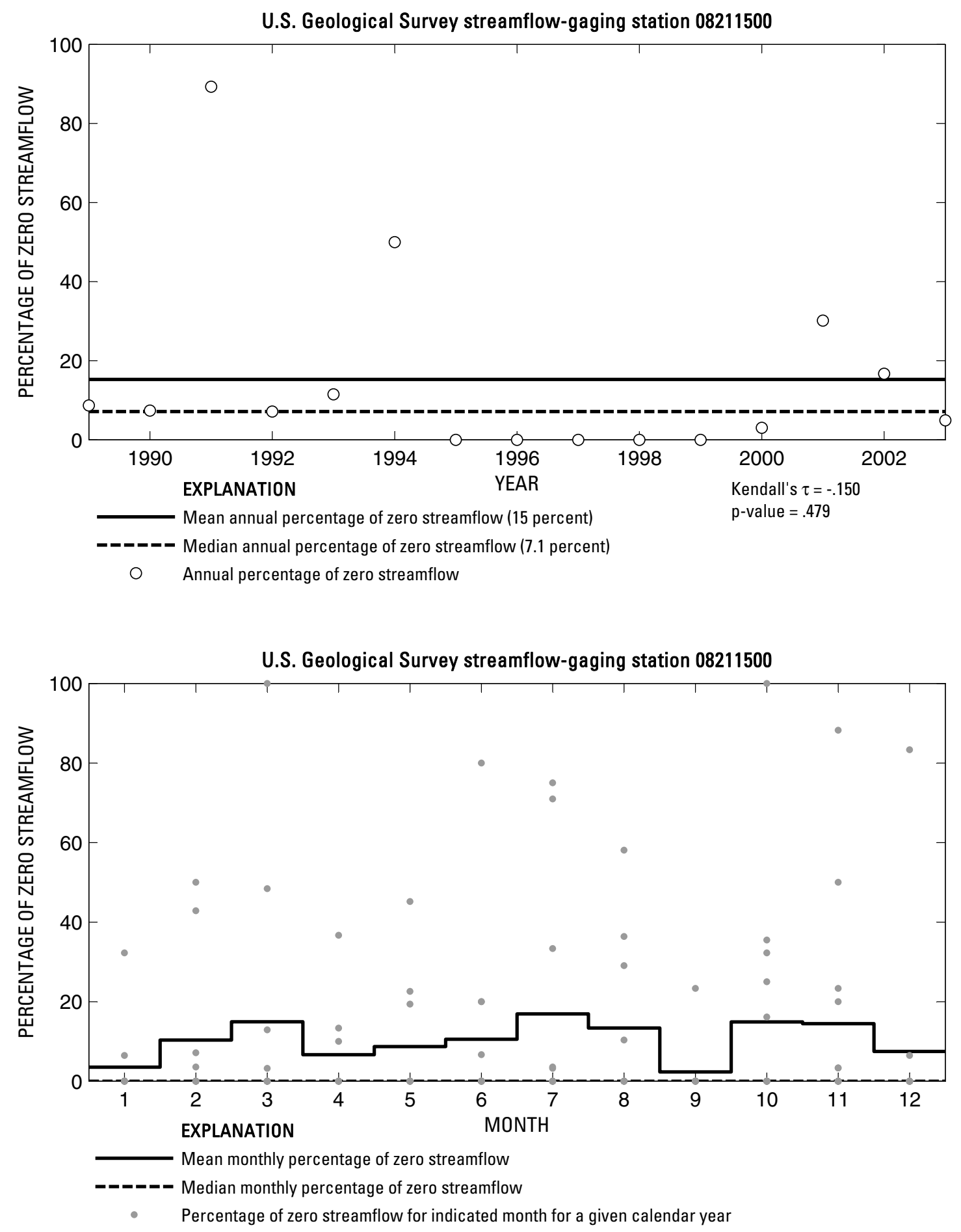

Figure 678. Analysis of percentage of zero daily mean streamflow for U.S. Geological Survey streamflow-gaging station 08211500 Nueces River at Calallen, Texas. 
U.S. Geological Survey streamflow-gaging station 08211520

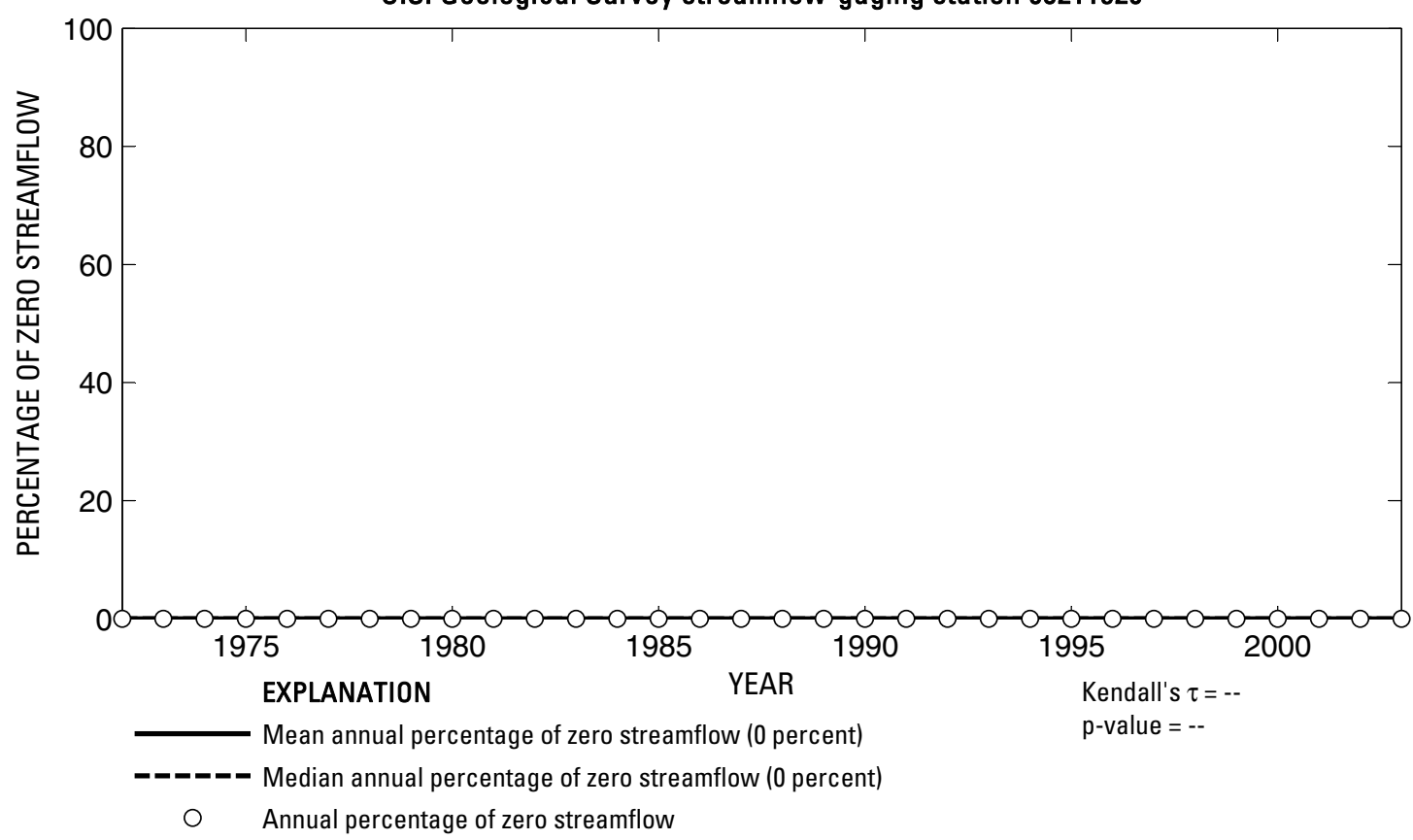

U.S. Geological Survey streamflow-gaging station 08211520

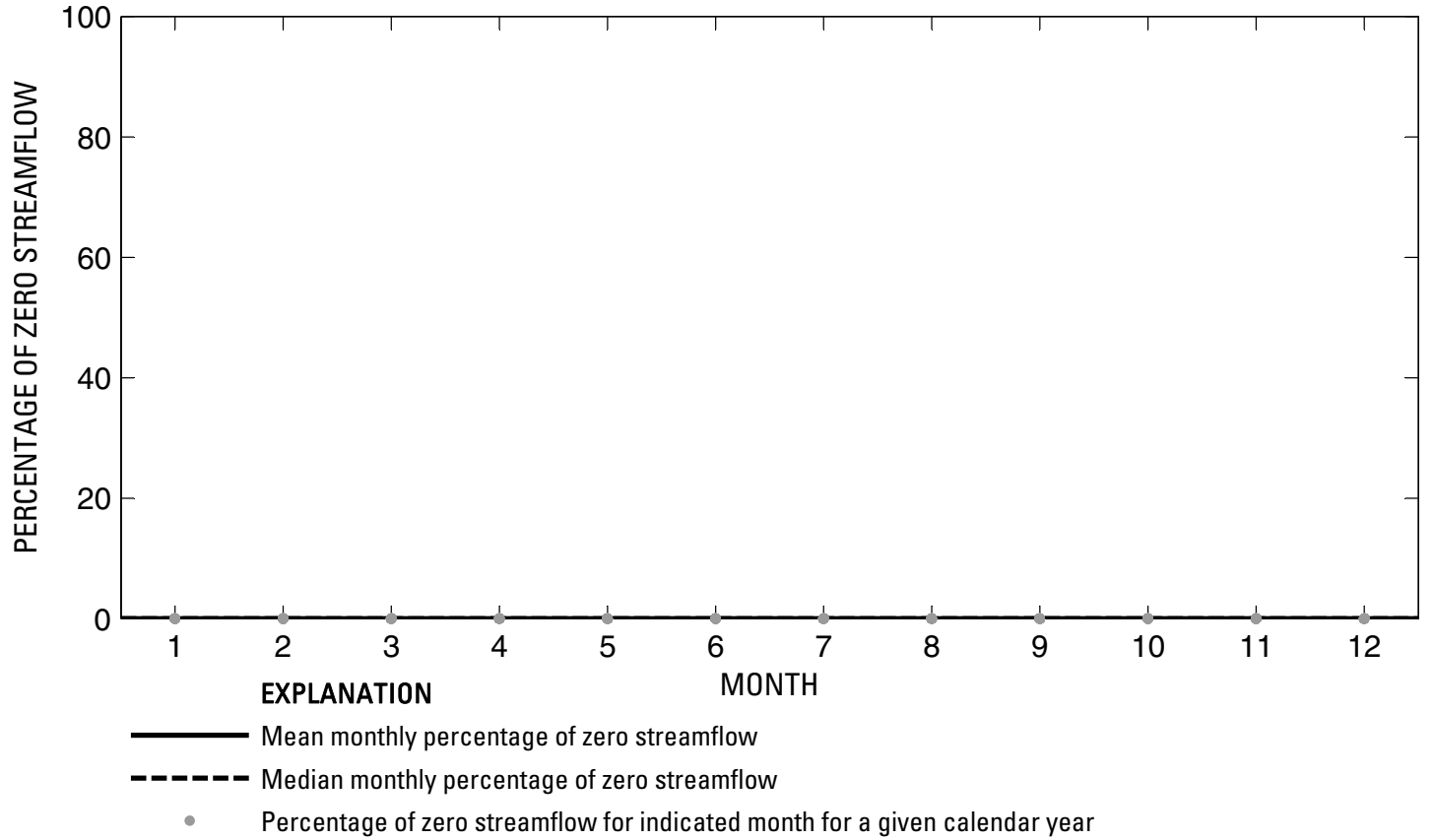

Figure 679. Analysis of percentage of zero daily mean streamflow for U.S. Geological Survey streamflow-gaging station 08211520 Oso Creek at Corpus Christi, Texas. 
U.S. Geological Survey streamflow-gaging station 08211800

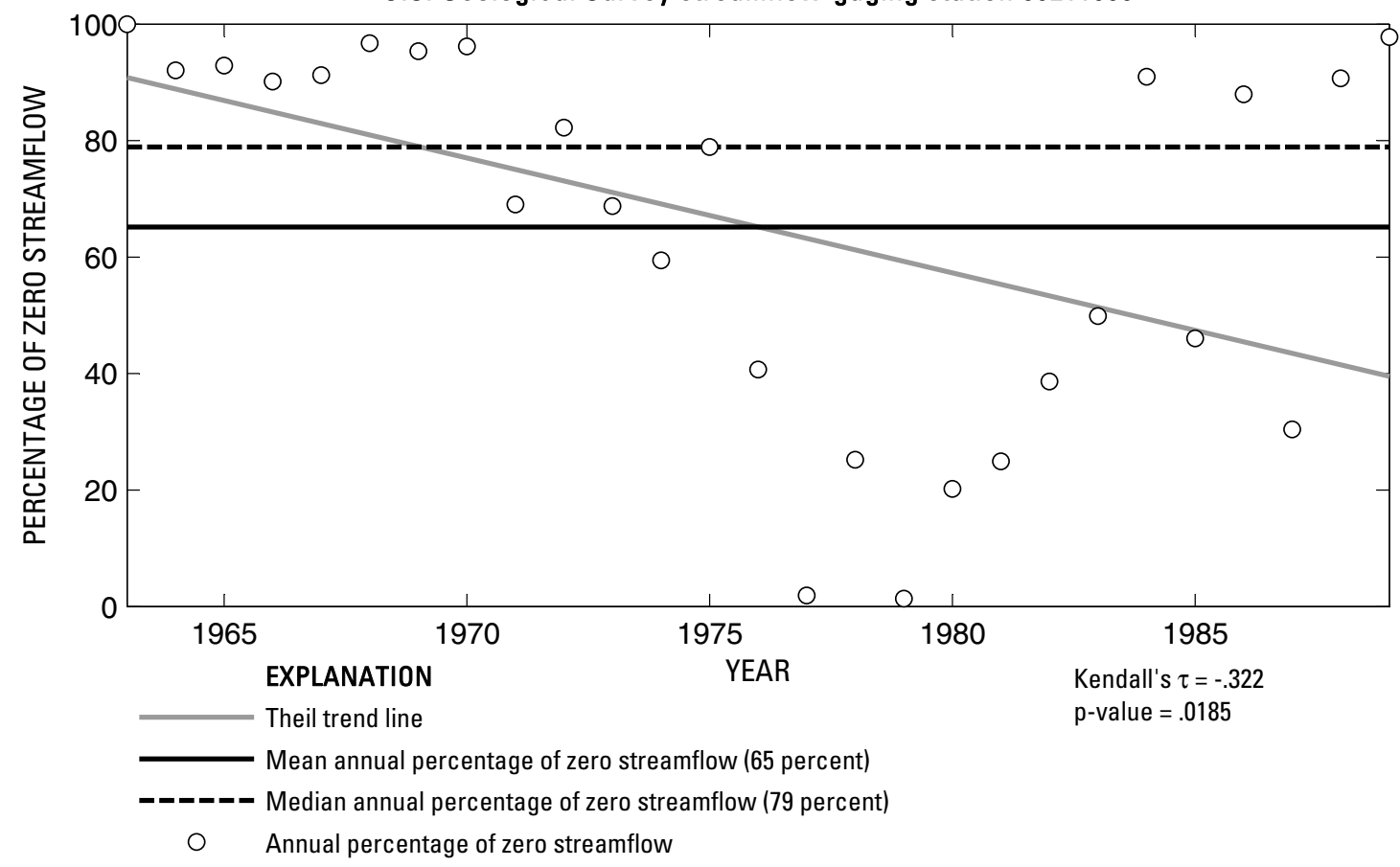

U.S. Geological Survey streamflow-gaging station 08211800

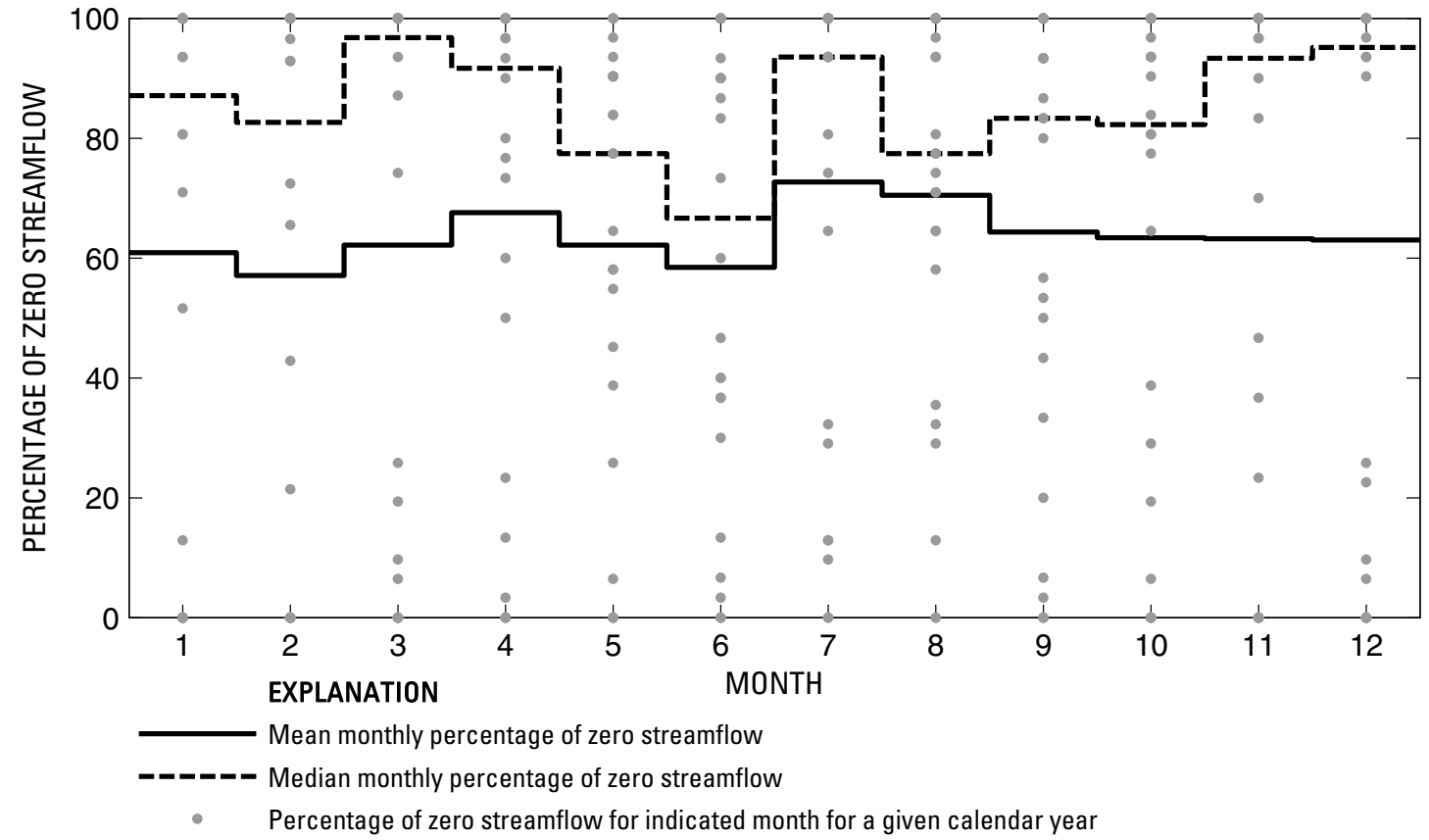

Figure 680. Analysis of percentage of zero daily mean streamflow for U.S. Geological Survey streamflow-gaging station 08211800 San Diego Creek at Alice, Texas.

Index of Station Numbers 719 


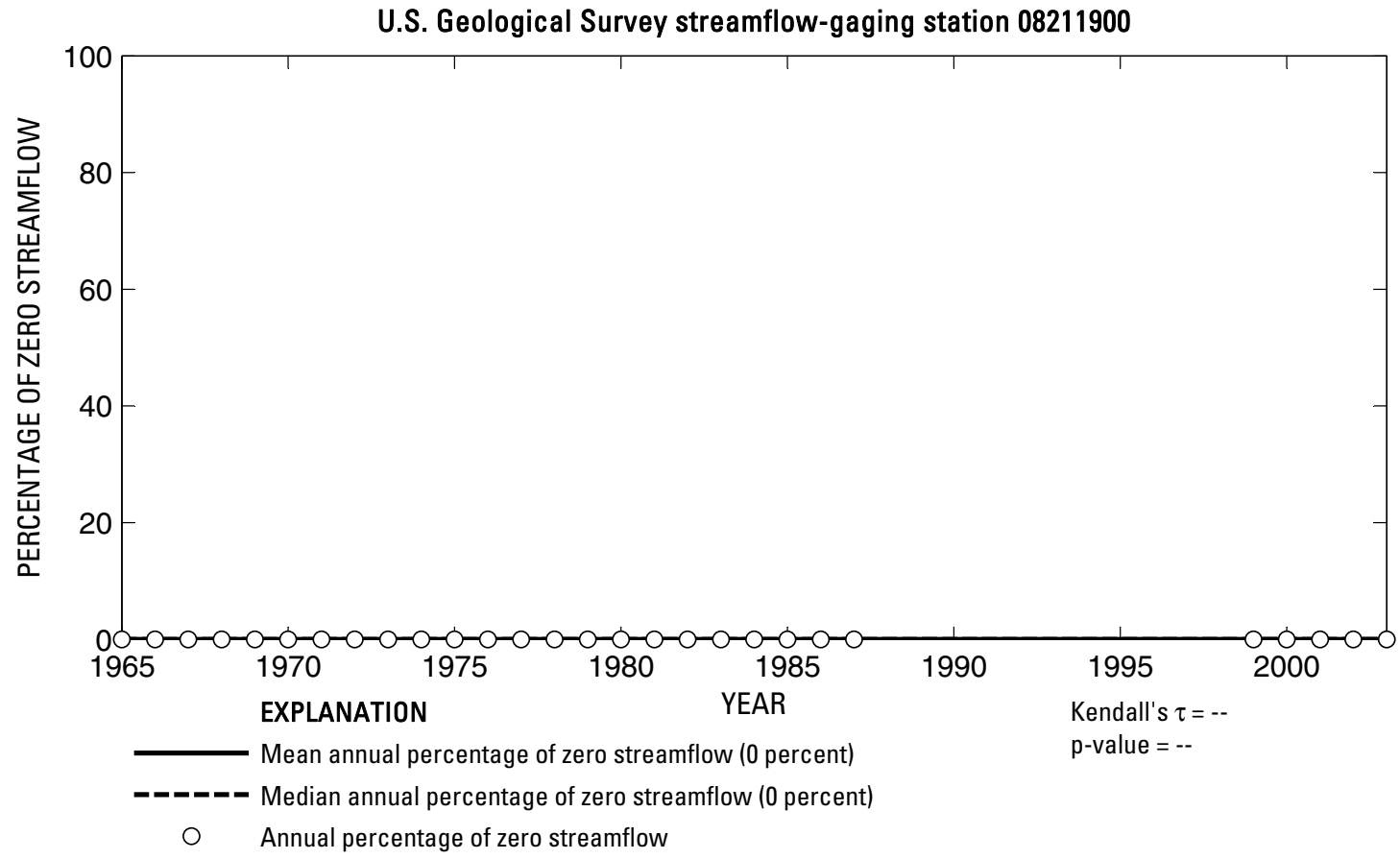

U.S. Geological Survey streamflow-gaging station 08211900

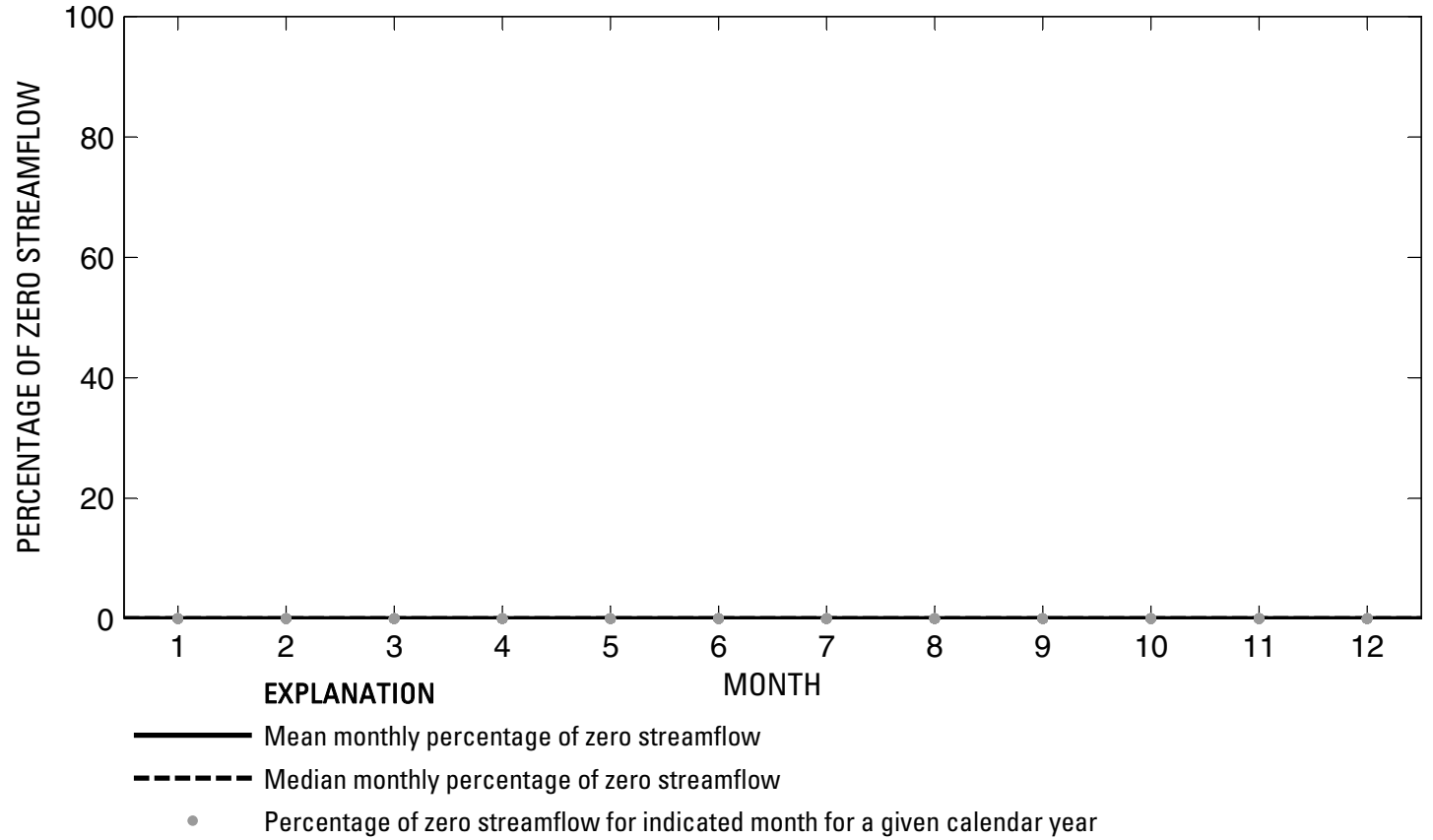

Figure 681. Analysis of percentage of zero daily mean streamflow for U.S. Geological Survey streamflow-gaging station 08211900 San Fernando Creek at Alice, Texas. 
U.S. Geological Survey streamflow-gaging station 08212000

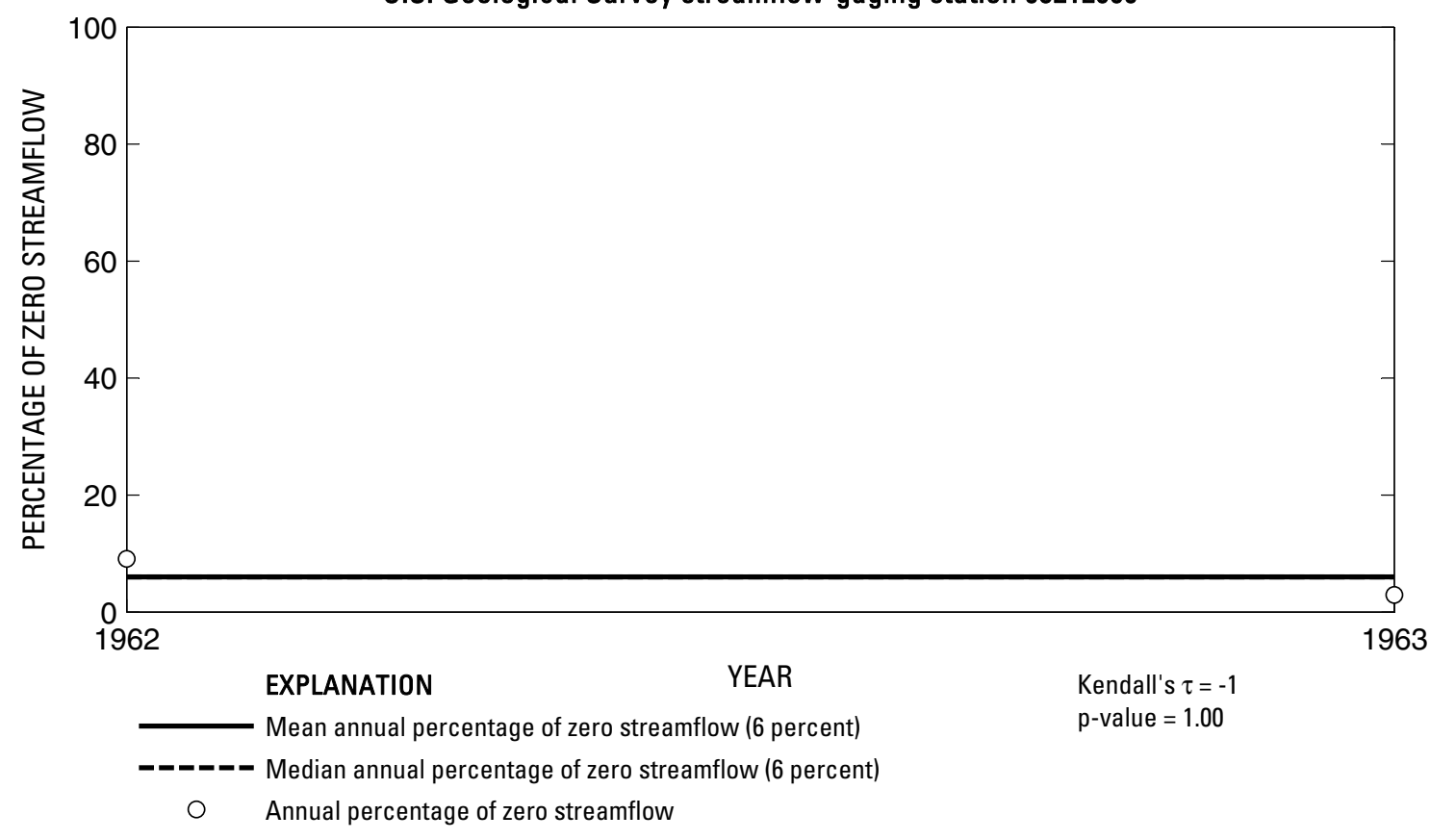

U.S. Geological Survey streamflow-gaging station 08212000

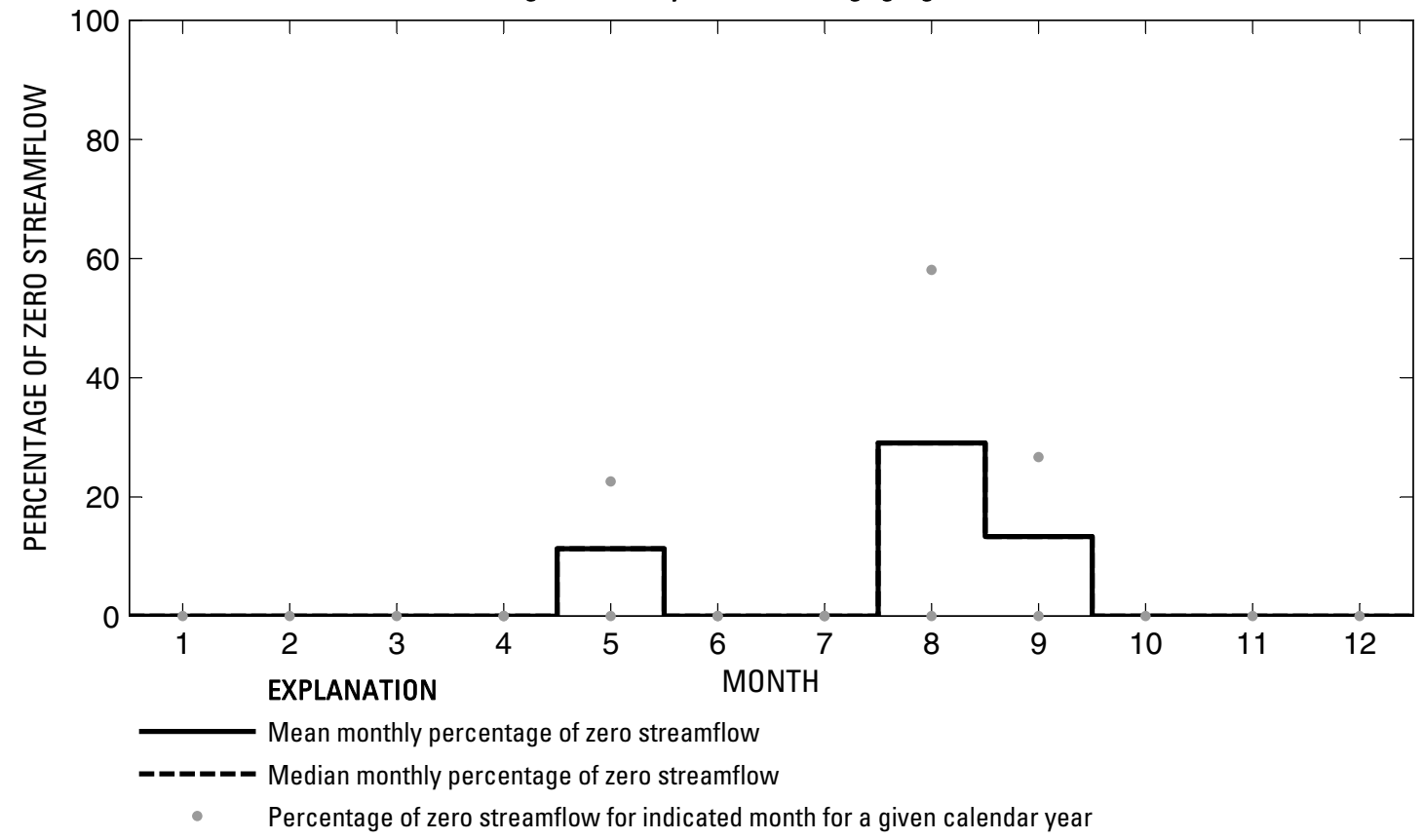

Figure 682. Analysis of percentage of zero daily mean streamflow for U.S. Geological Survey streamflow-gaging station 08212000 San Fernando Creek near Alice, Texas.

Index of Station Numbers 719 


\section{U.S. Geological Survey streamflow-gaging station 08212400}

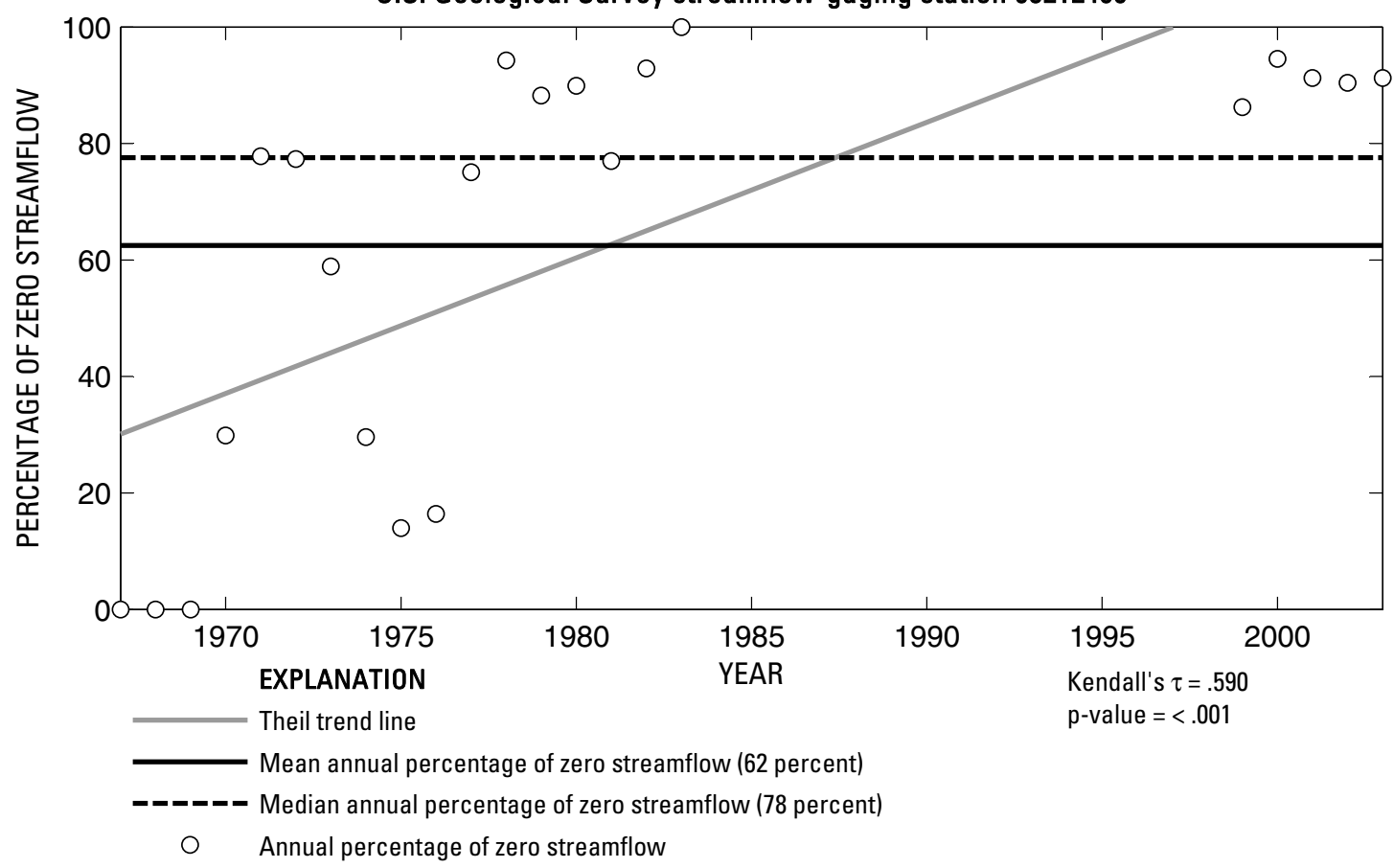

U.S. Geological Survey streamflow-gaging station 08212400

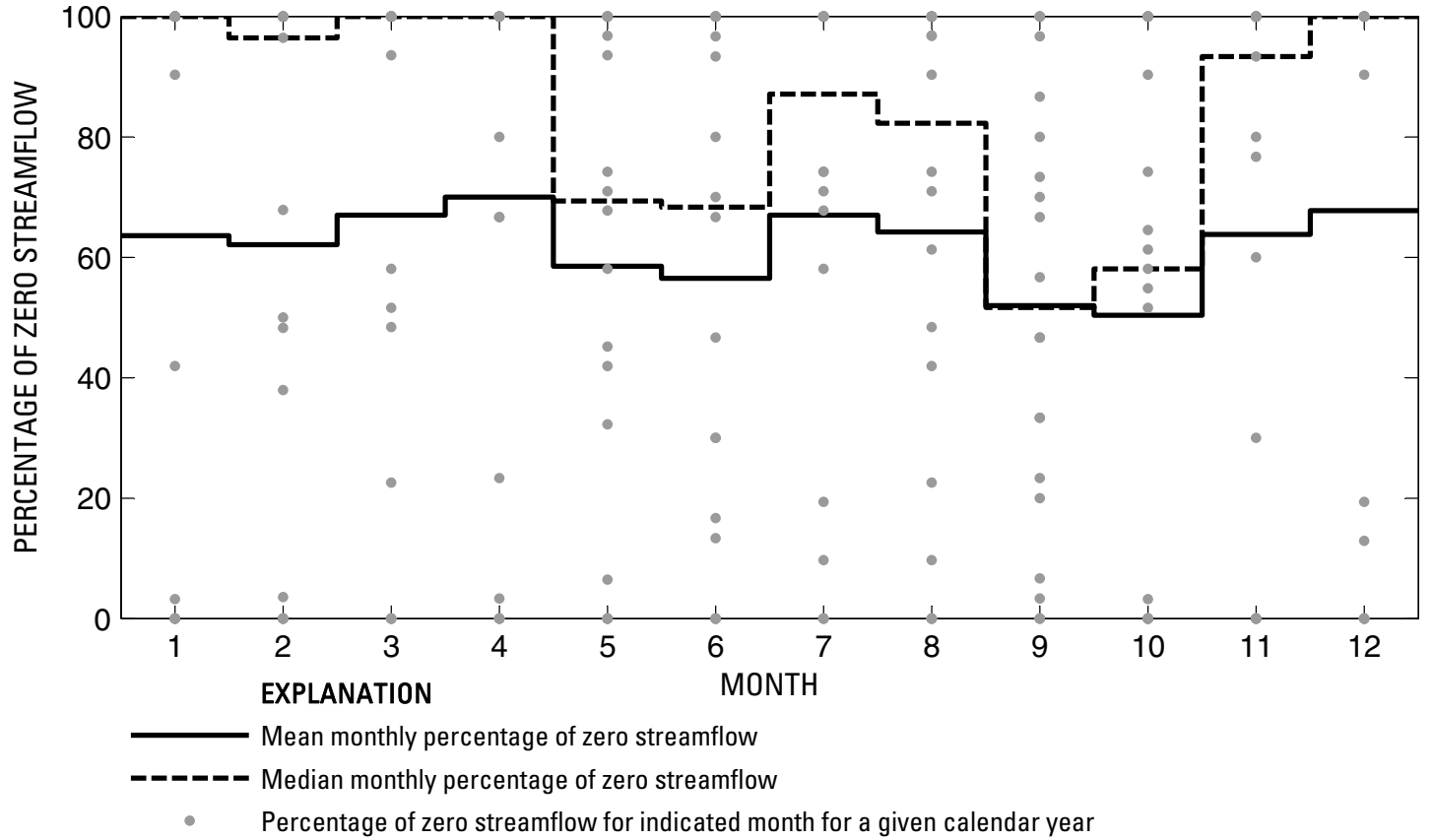

Figure 683. Analysis of percentage of zero daily mean streamflow for U.S. Geological Survey streamflow-gaging station 08212400 Los Olmos Creek near Falfurrias, Texas. 

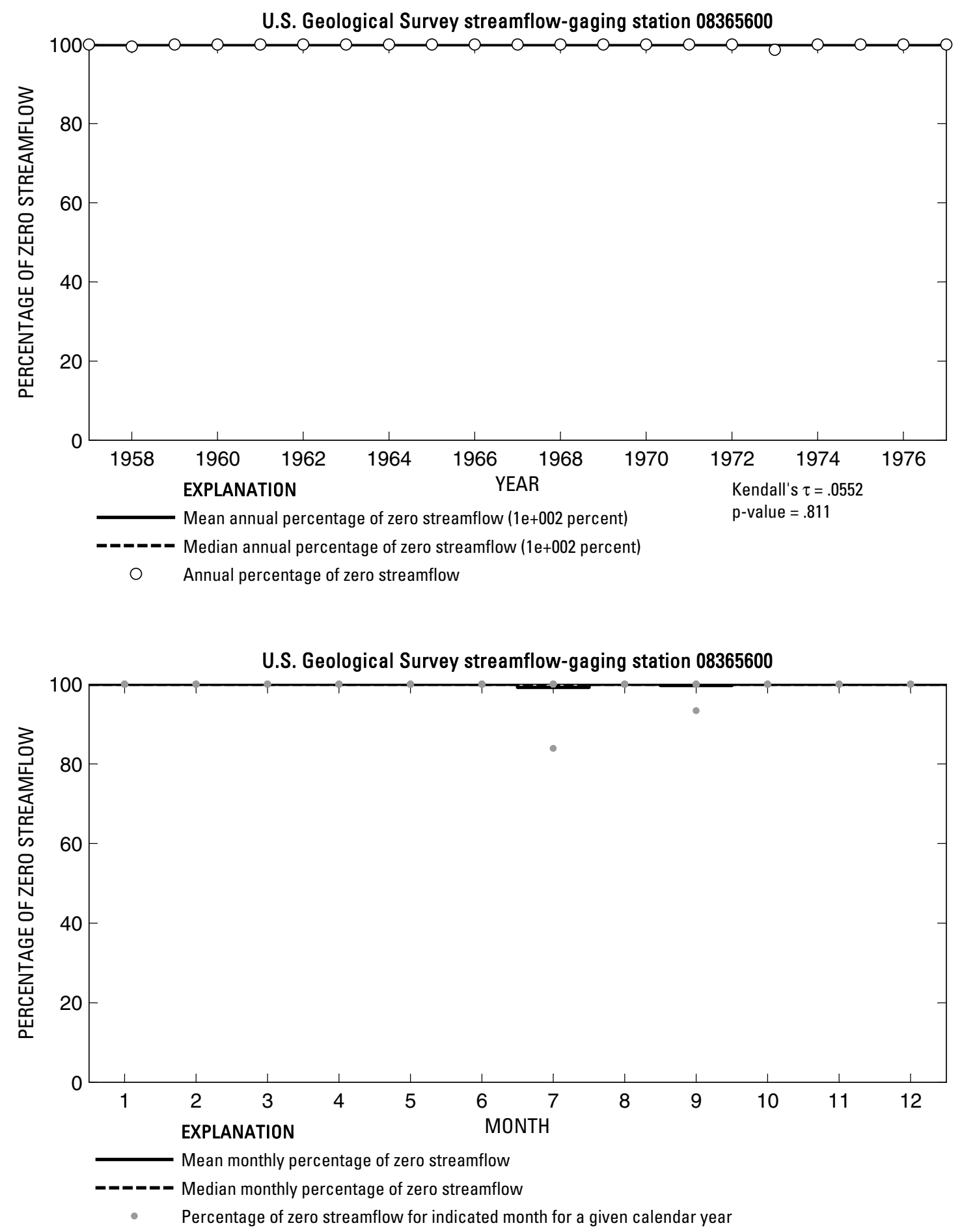

Figure 684. Analysis of percentage of zero daily mean streamflow for U.S. Geological Survey streamflow-gaging station 08365600 McKelligon Canyon at El Paso, Texas. 
U.S. Geological Survey streamflow-gaging station 08365800

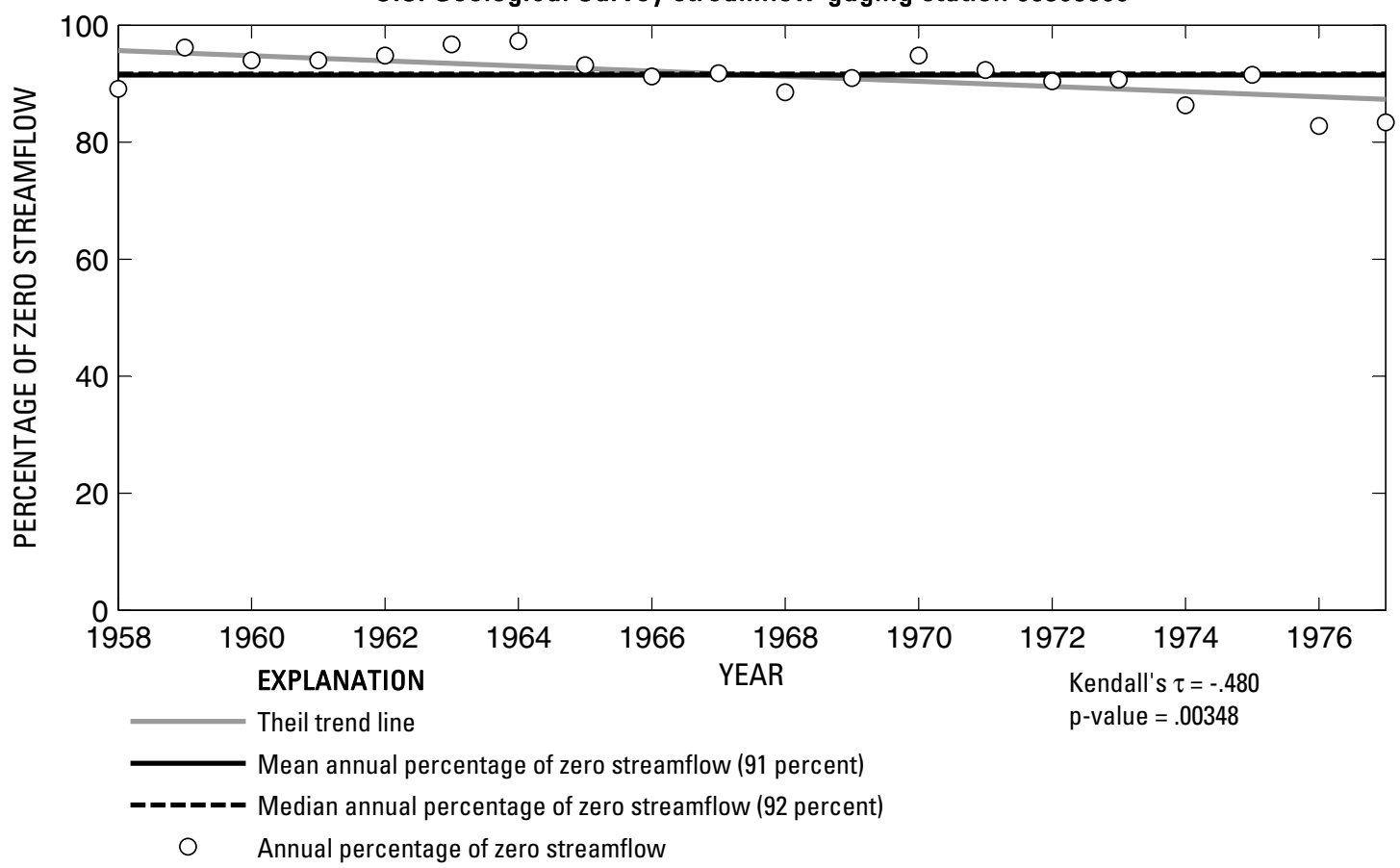

U.S. Geological Survey streamflow-gaging station 08365800

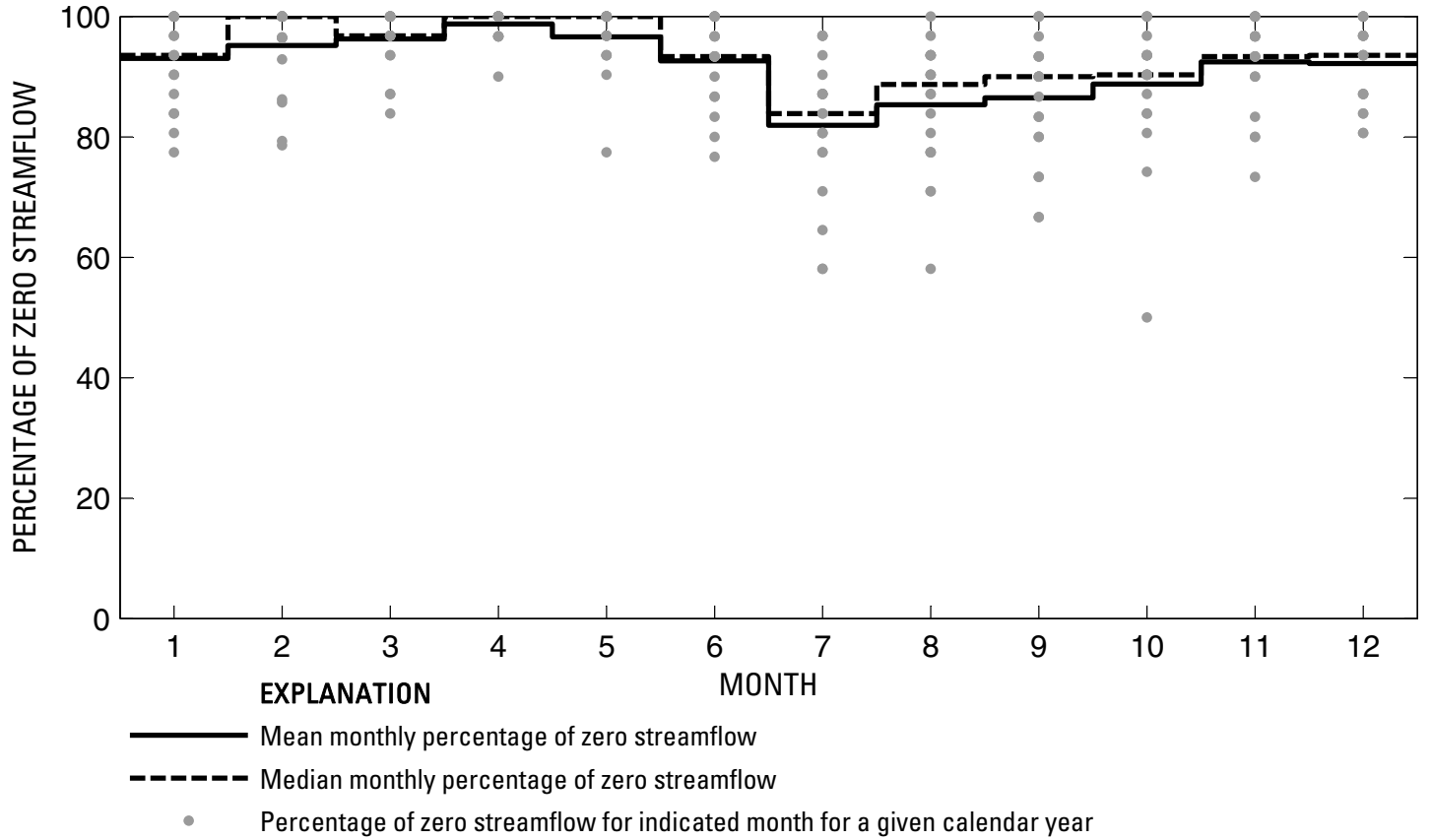

Figure 685. Analysis of percentage of zero daily mean streamflow for U.S. Geological Survey streamflow-gaging station 08365800 Government Ditch at El Paso, Texas. 
U.S. Geological Survey streamflow-gaging station 08373200

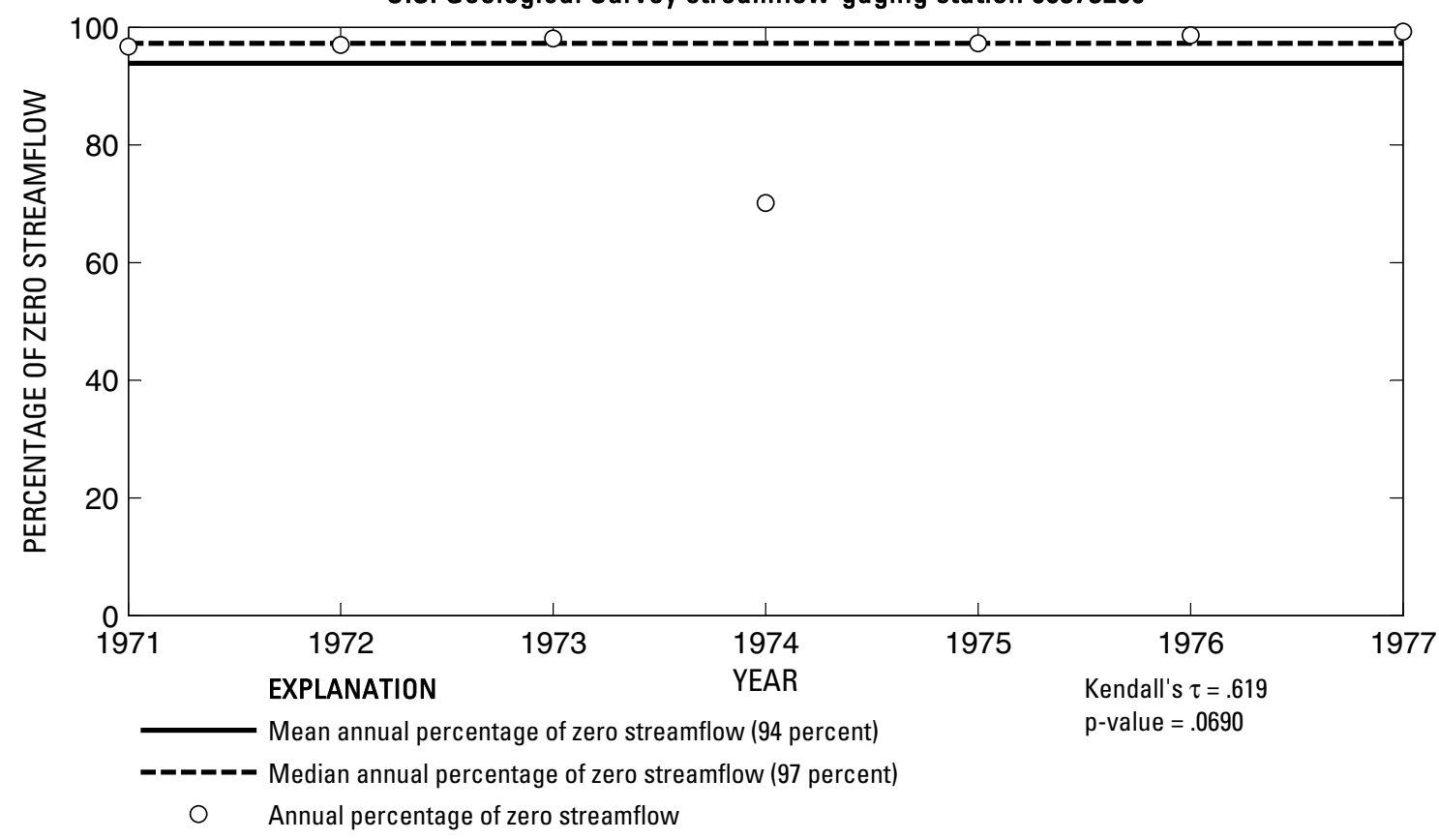

U.S. Geological Survey streamflow-gaging station 08373200

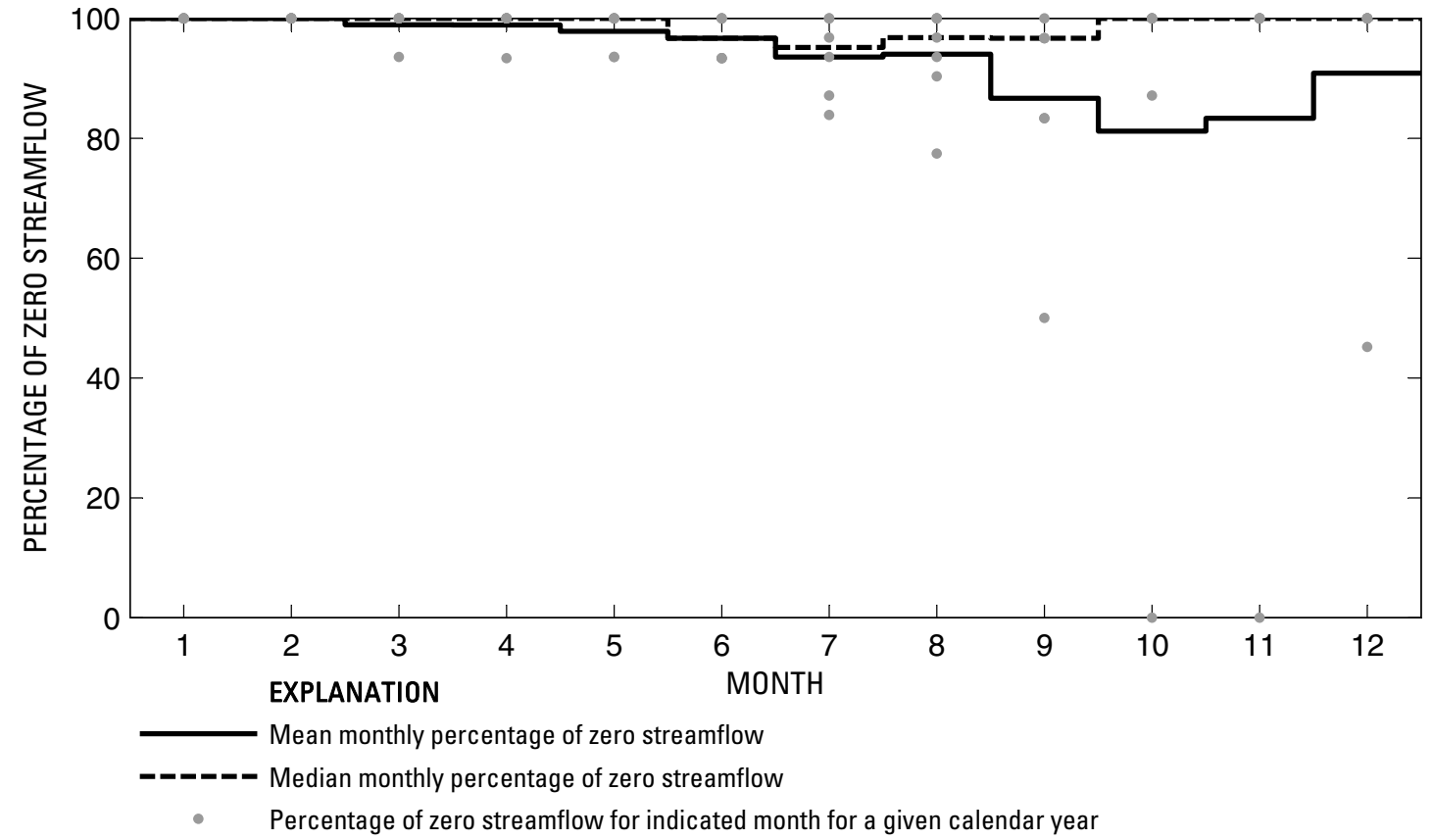

Figure 686. Analysis of percentage of zero daily mean streamflow for U.S. Geological Survey streamflow-gaging station 08373200 Cibolo Creek near Presidio, Texas. 


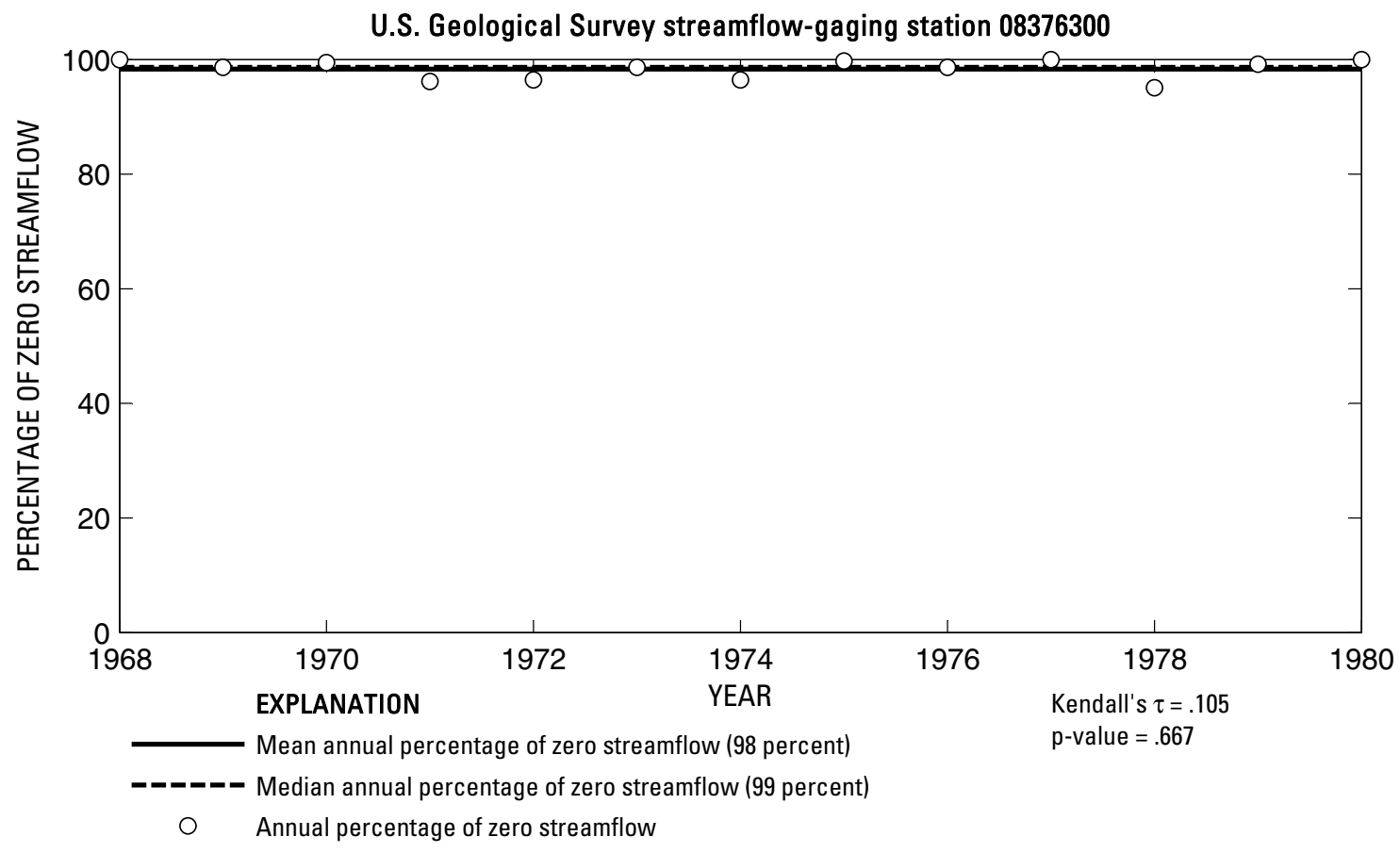

U.S. Geological Survey streamflow-gaging station 08376300

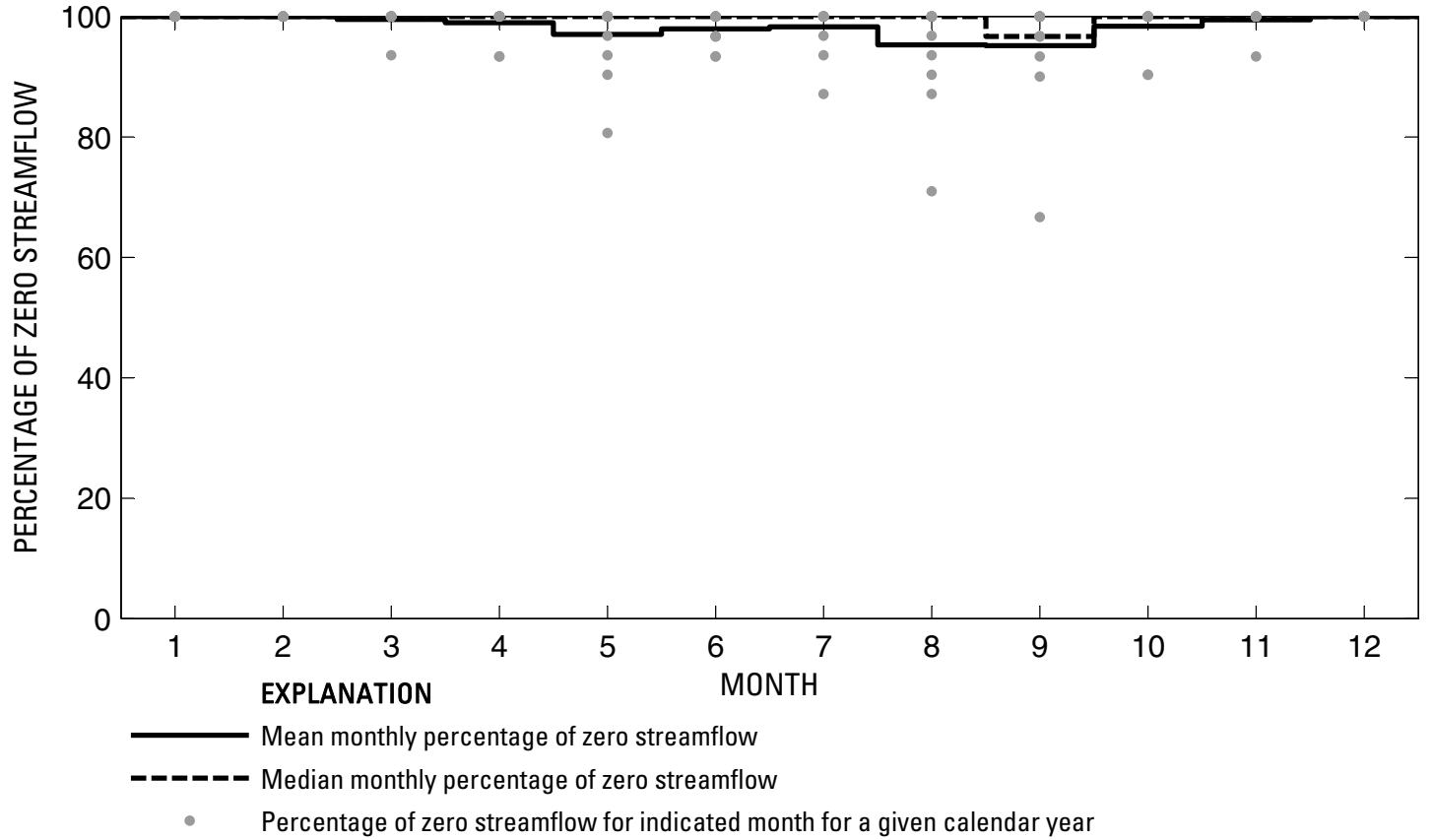

Figure 687. Analysis of percentage of zero daily mean streamflow for U.S. Geological Survey streamflow-gaging station 08376300 Sanderson Creek at Sanderson, Texas. 
U.S. Geological Survey streamflow-gaging station 08411500

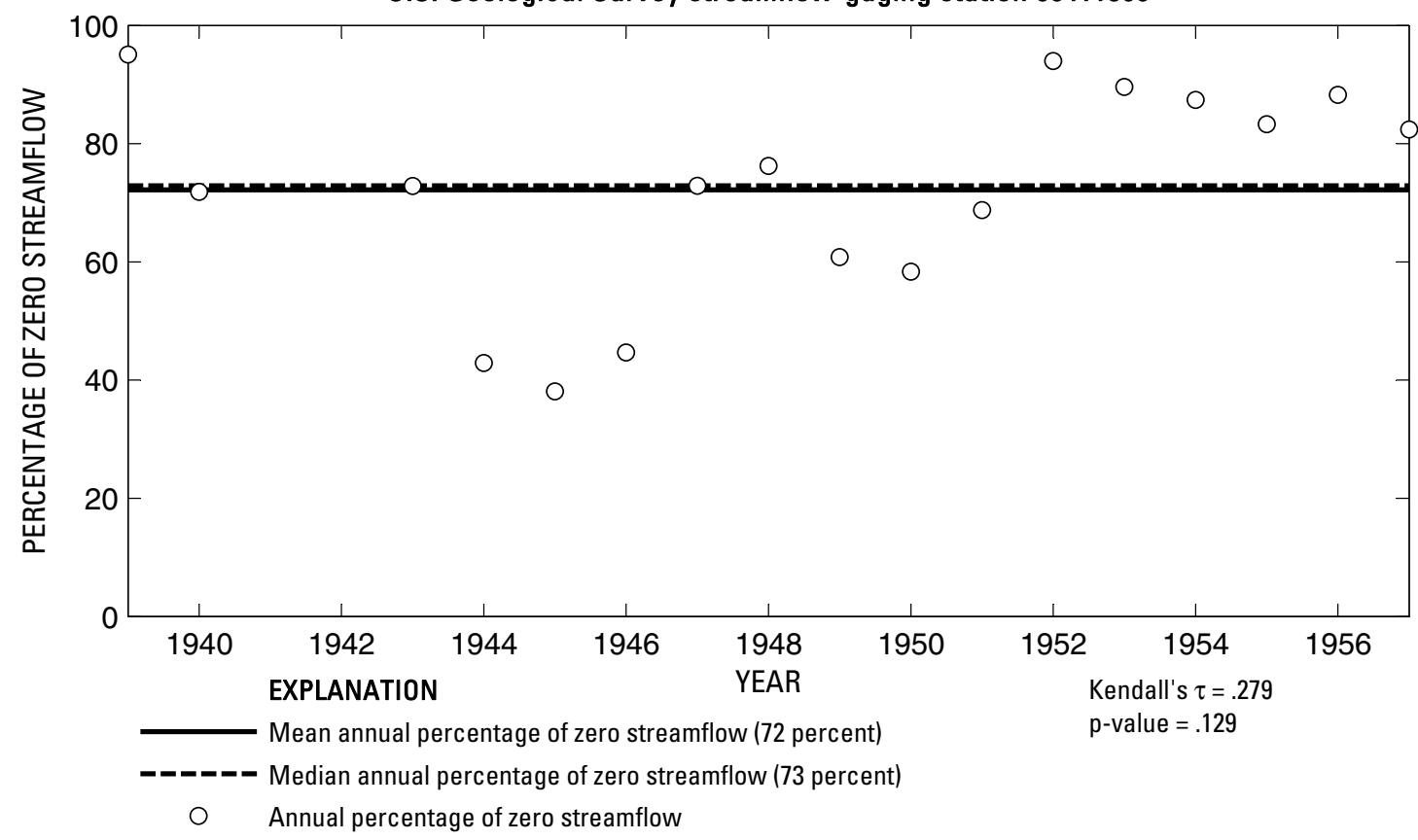

U.S. Geological Survey streamflow-gaging station 08411500

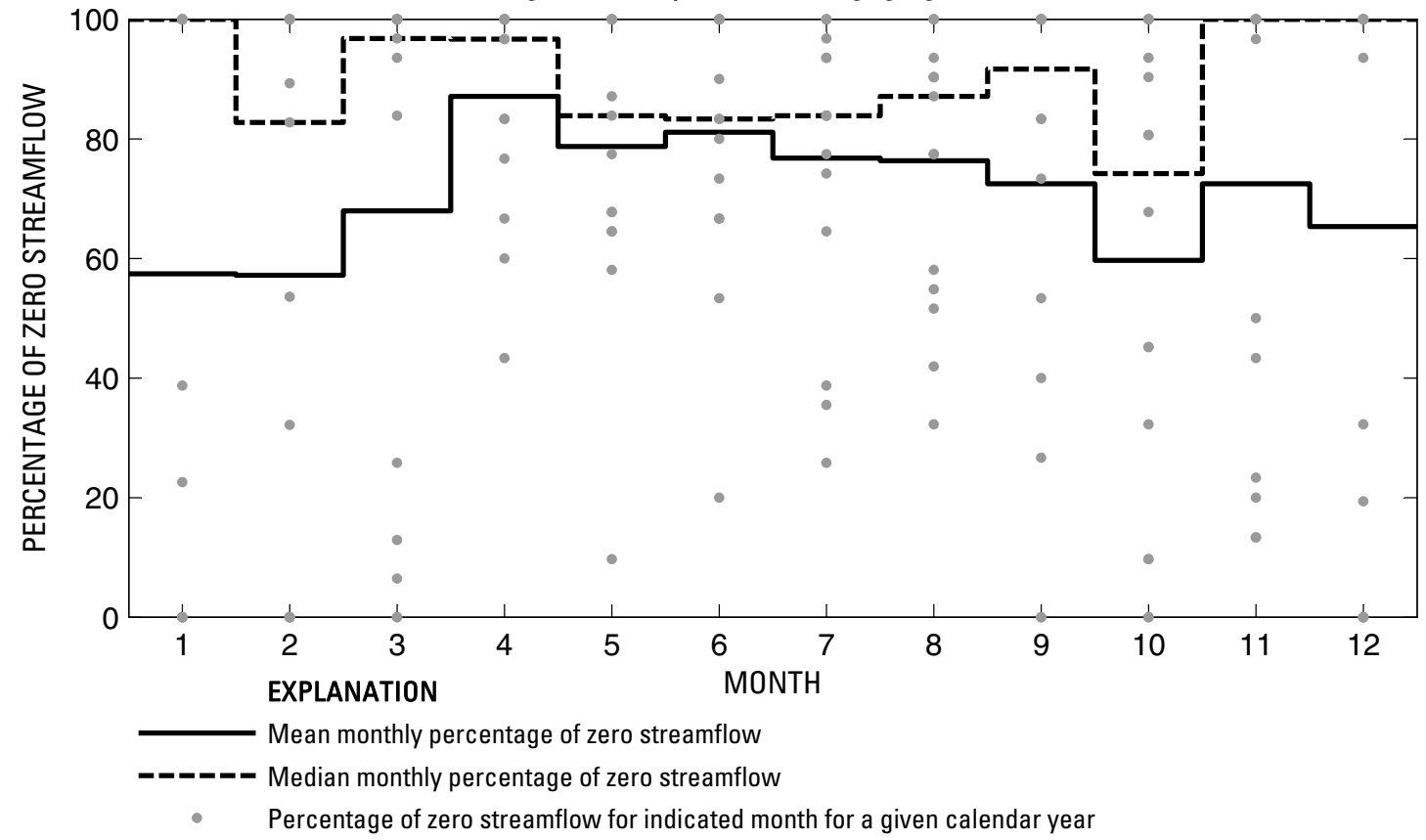

Figure 688. Analysis of percentage of zero daily mean streamflow for U.S. Geological Survey streamflow-gaging station 08411500 Salt Screwbean Draw near Orla, Texas.

Index of Station Numbers 719 
U.S. Geological Survey streamflow-gaging station 08412500

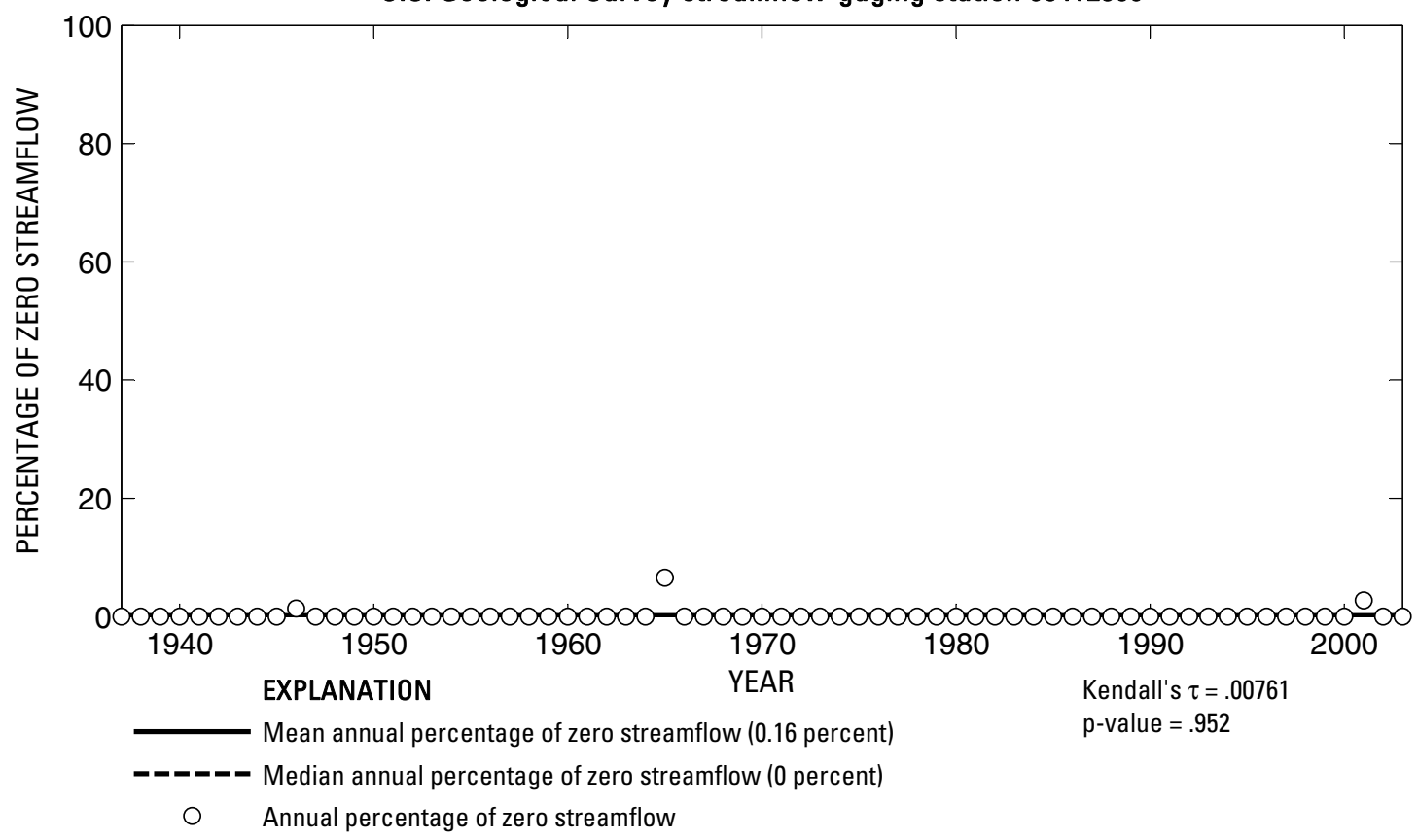

U.S. Geological Survey streamflow-gaging station 08412500

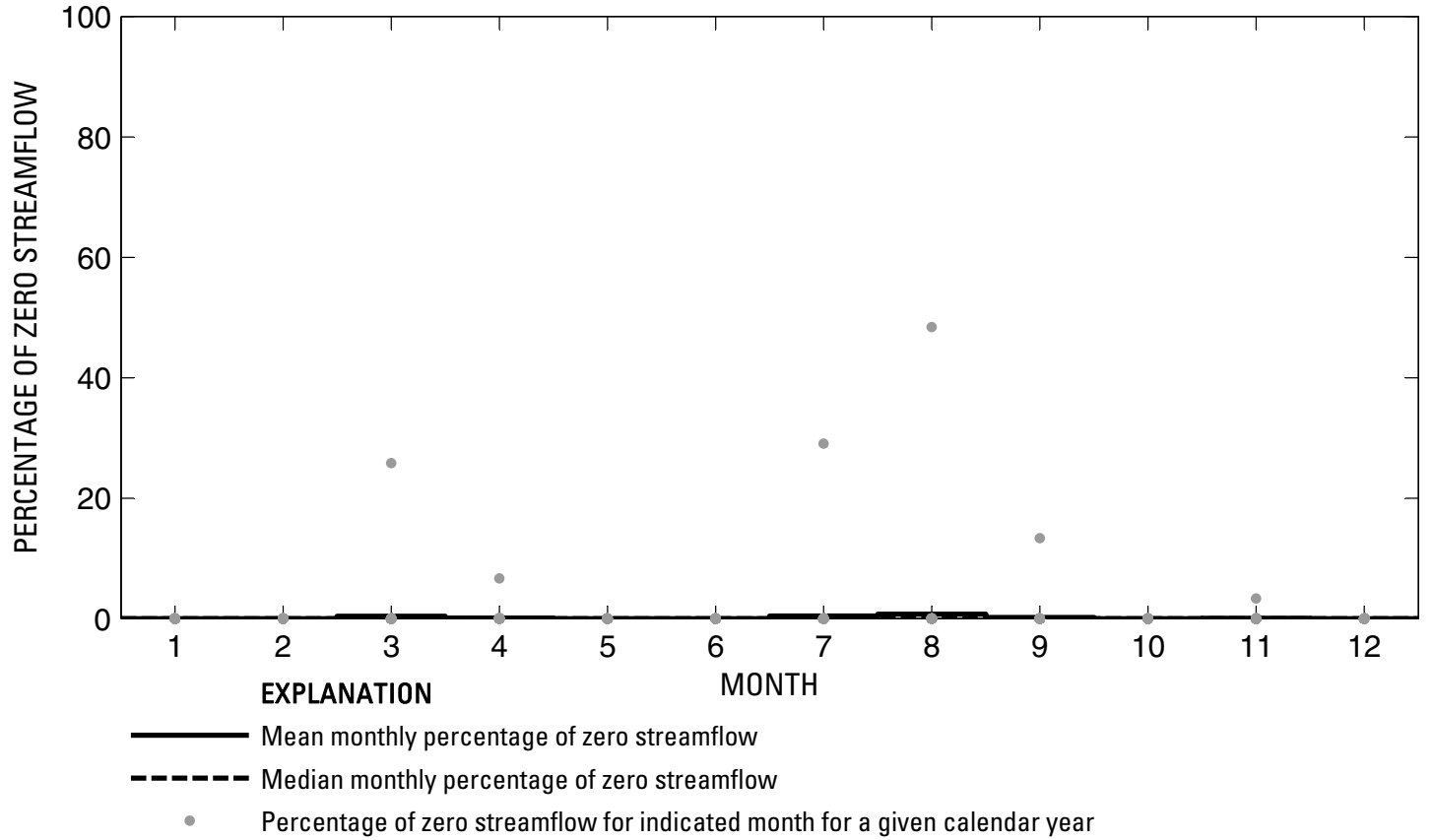

Figure 689. Analysis of percentage of zero daily mean streamflow for U.S. Geological Survey streamflow-gaging station 08412500 Pecos River near Orla, Texas. 

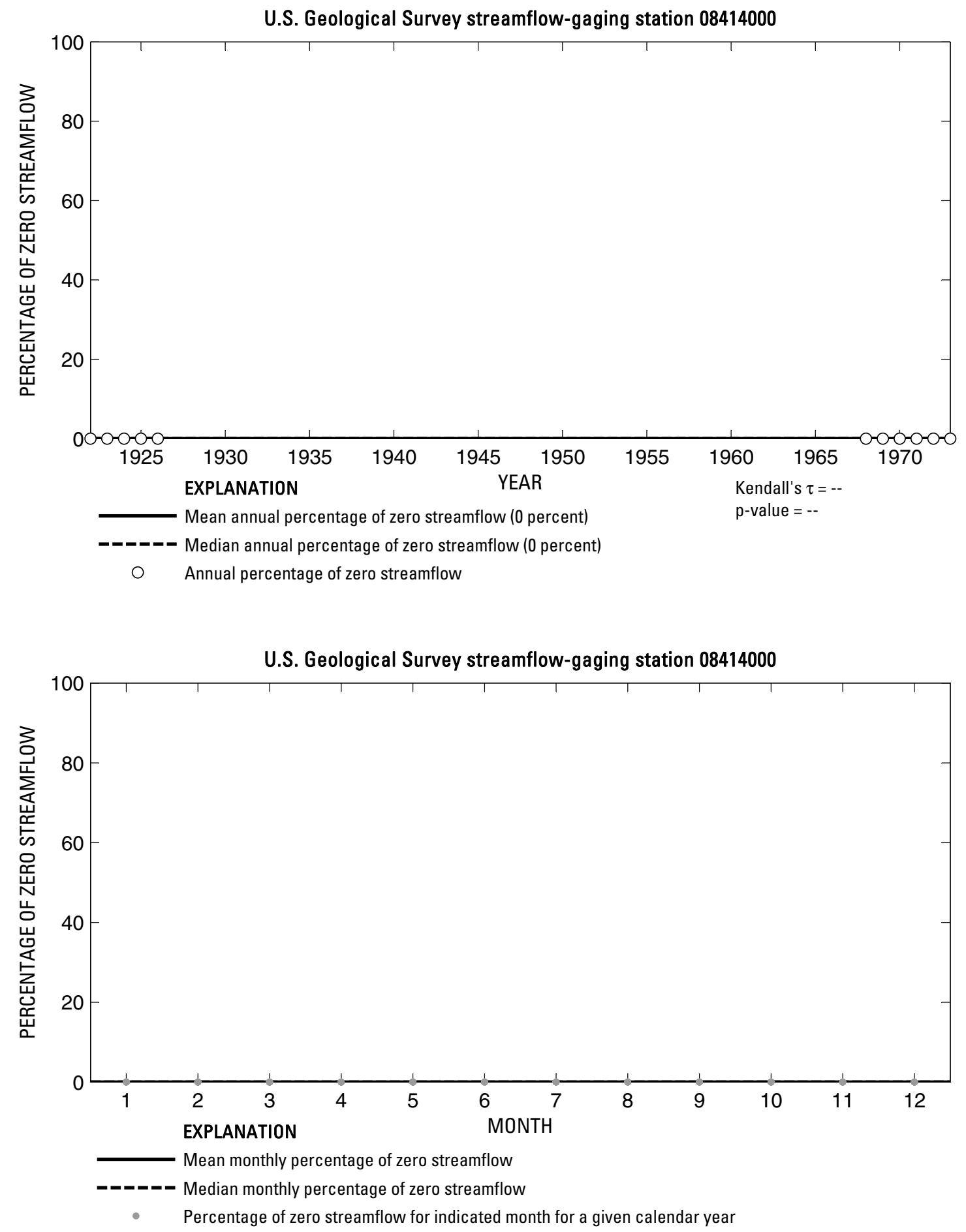

Figure 690. Analysis of percentage of zero daily mean streamflow for U.S. Geological Survey streamflow-gaging station 08414000 Pecos River near Mentone, Texas. 


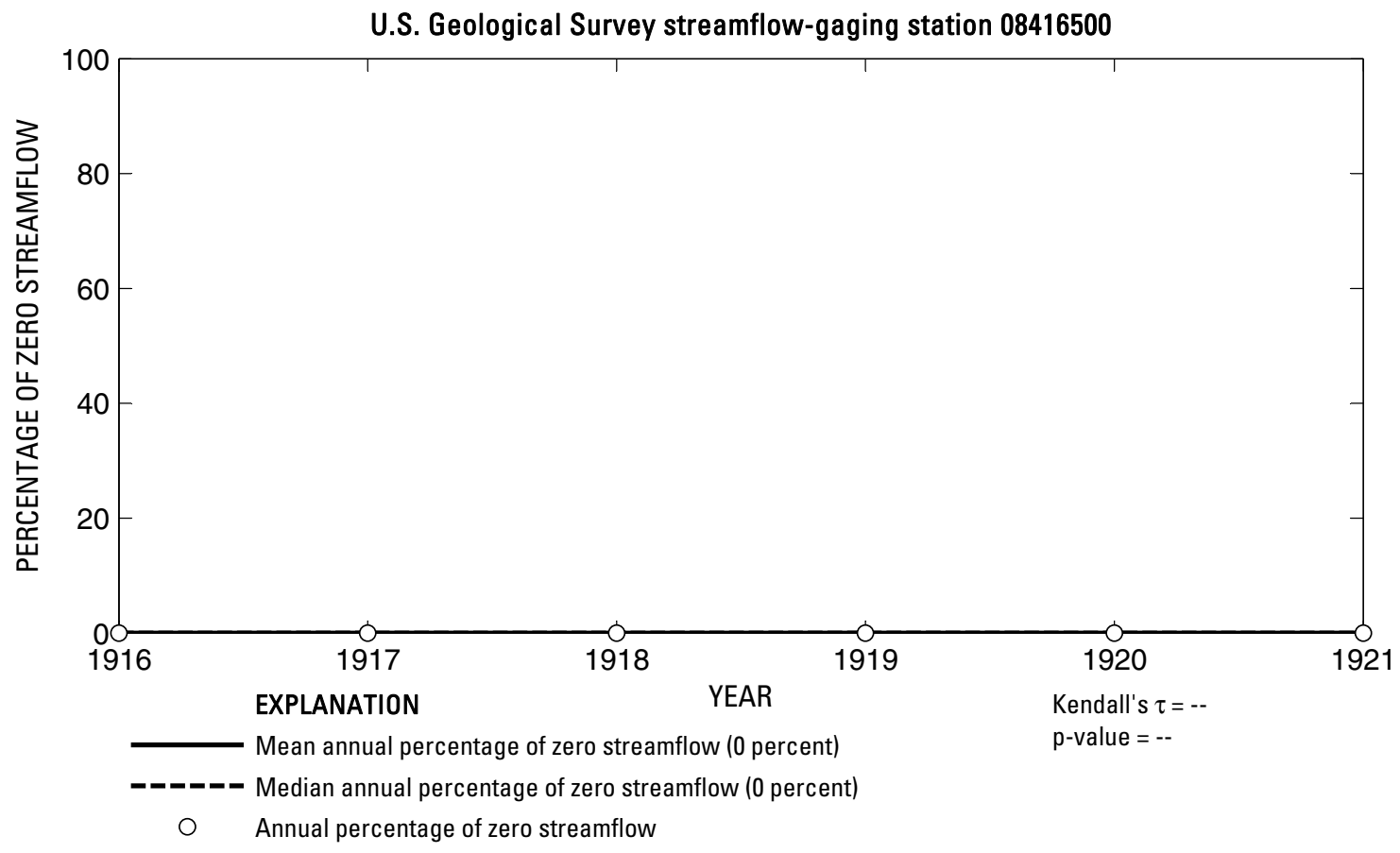

U.S. Geological Survey streamflow-gaging station 08416500

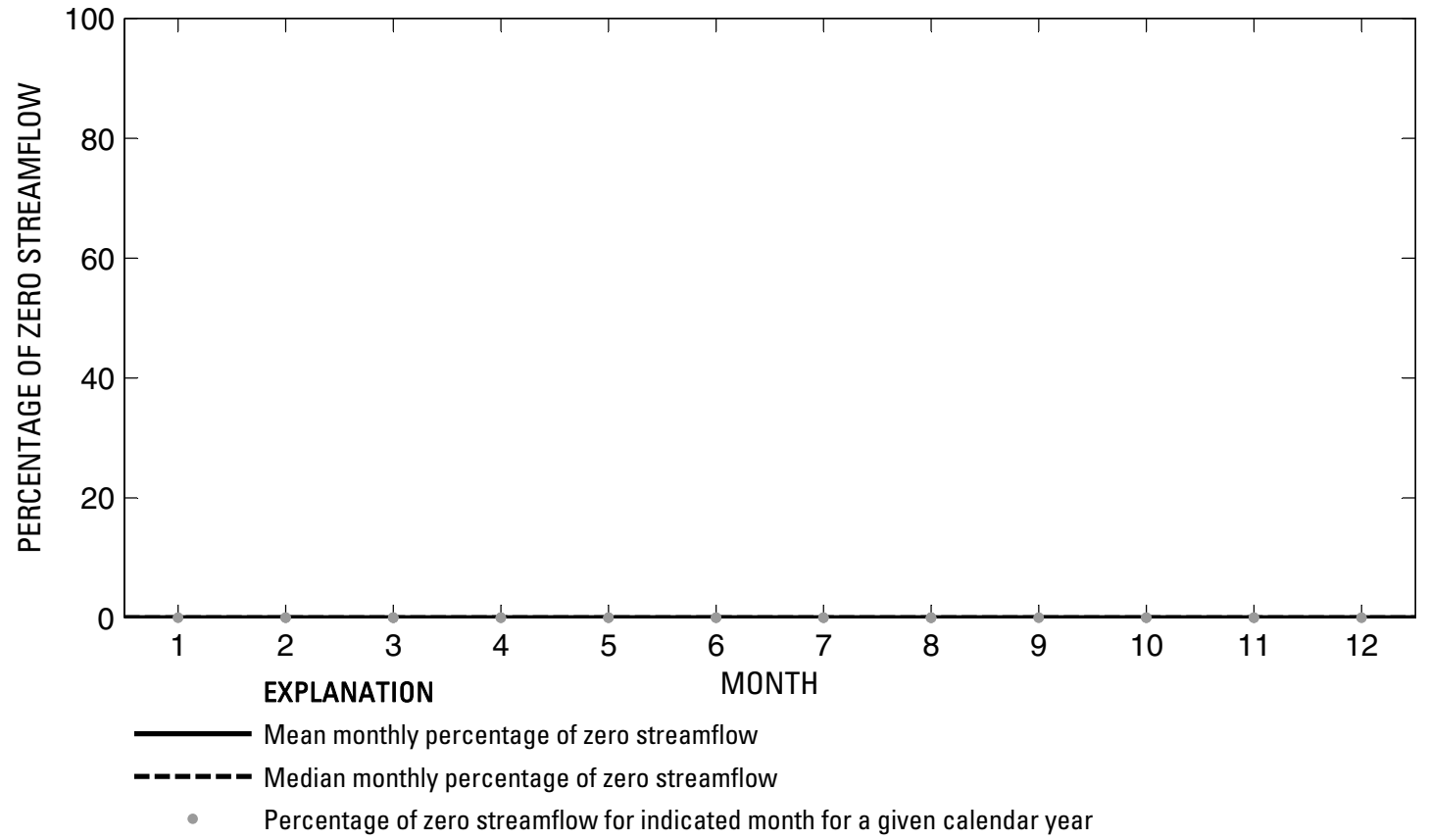

Figure 691. Analysis of percentage of zero daily mean streamflow for U.S. Geological Survey streamflow-gaging station 08416500 Pecos River above Barstow (Barstow Canal), Texas. 
U.S. Geological Survey streamflow-gaging station 08420500

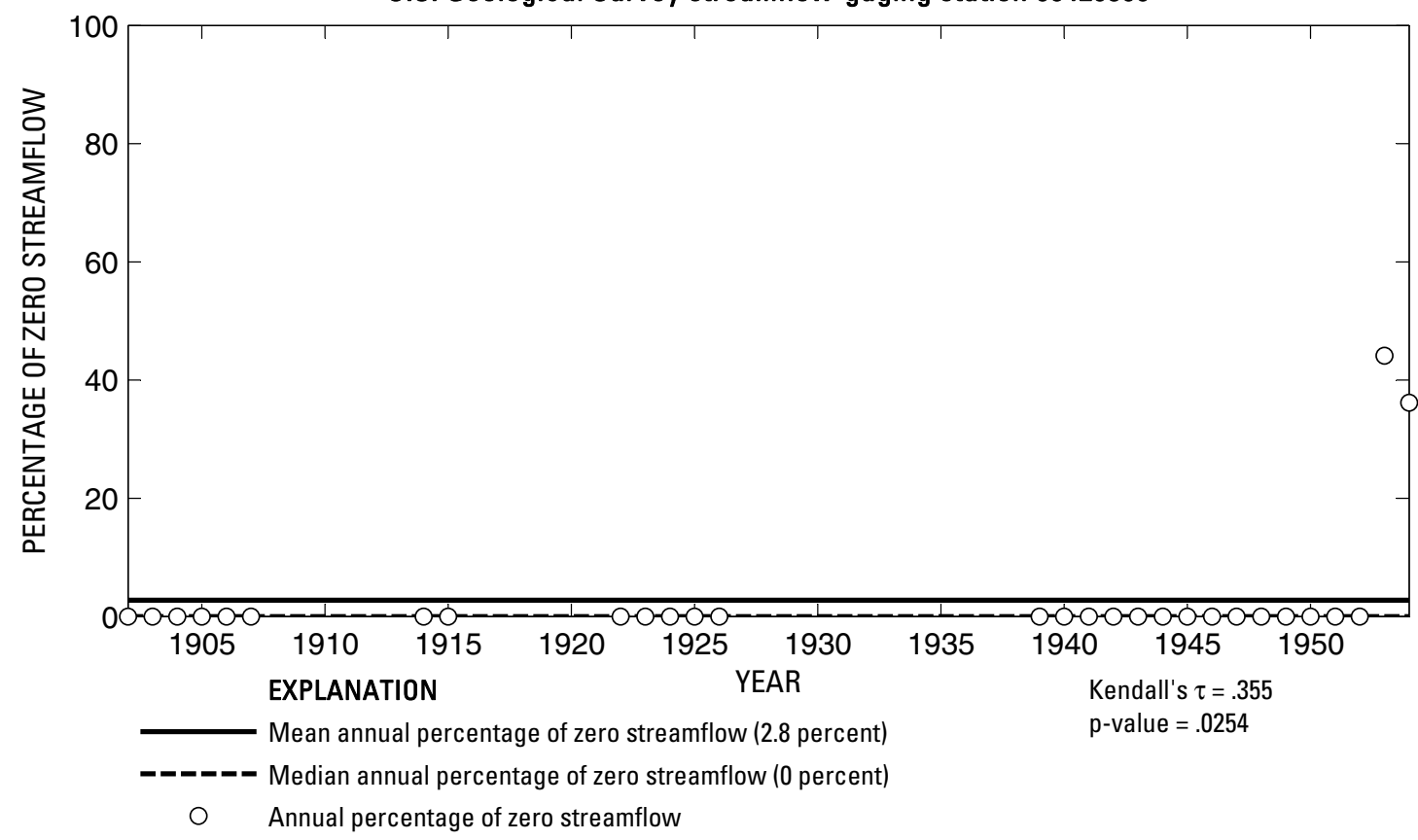

U.S. Geological Survey streamflow-gaging station 08420500

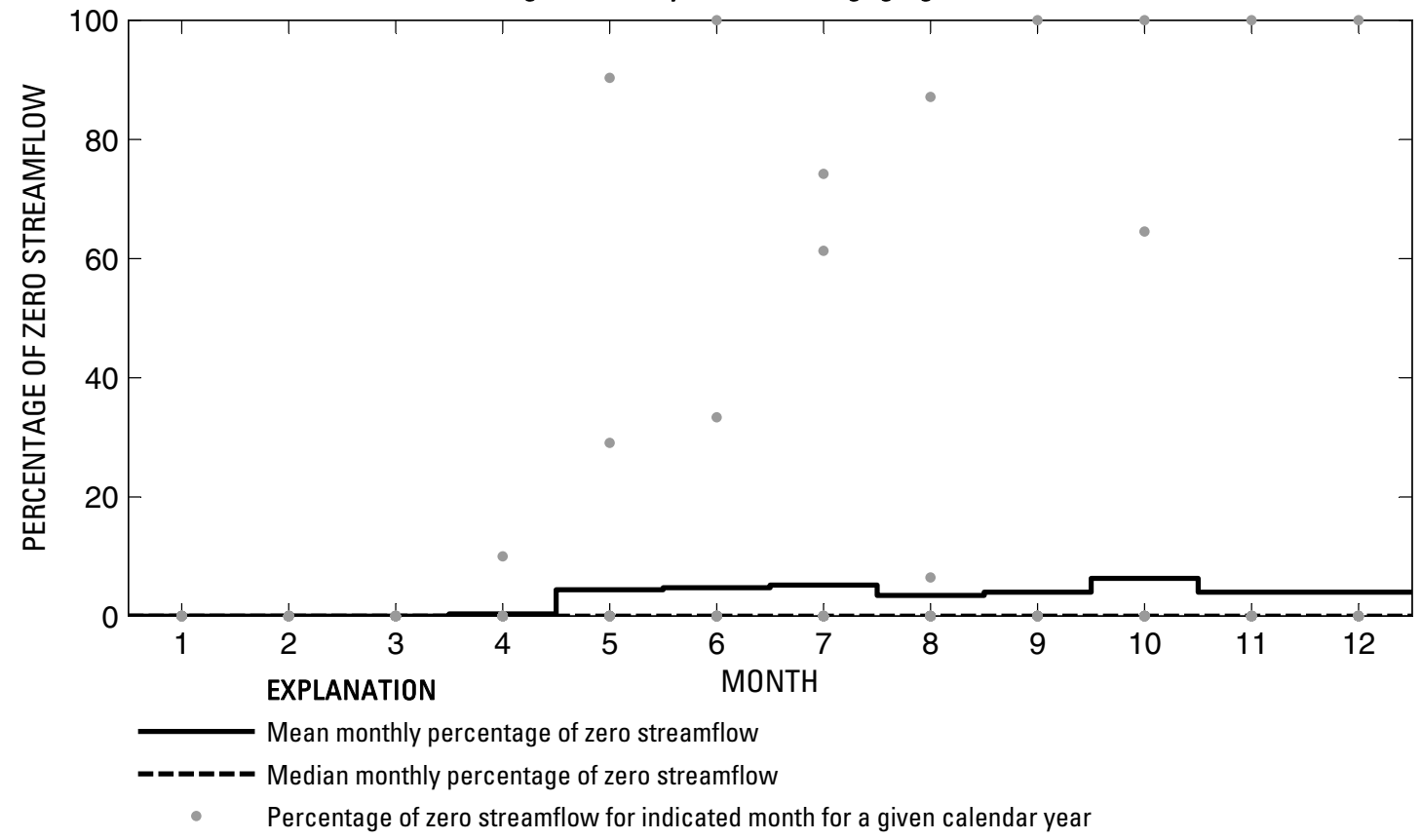

Figure 692. Analysis of percentage of zero daily mean streamflow for U.S. Geological Survey streamflow-gaging station 08420500 Pecos River at Pecos, Texas. 


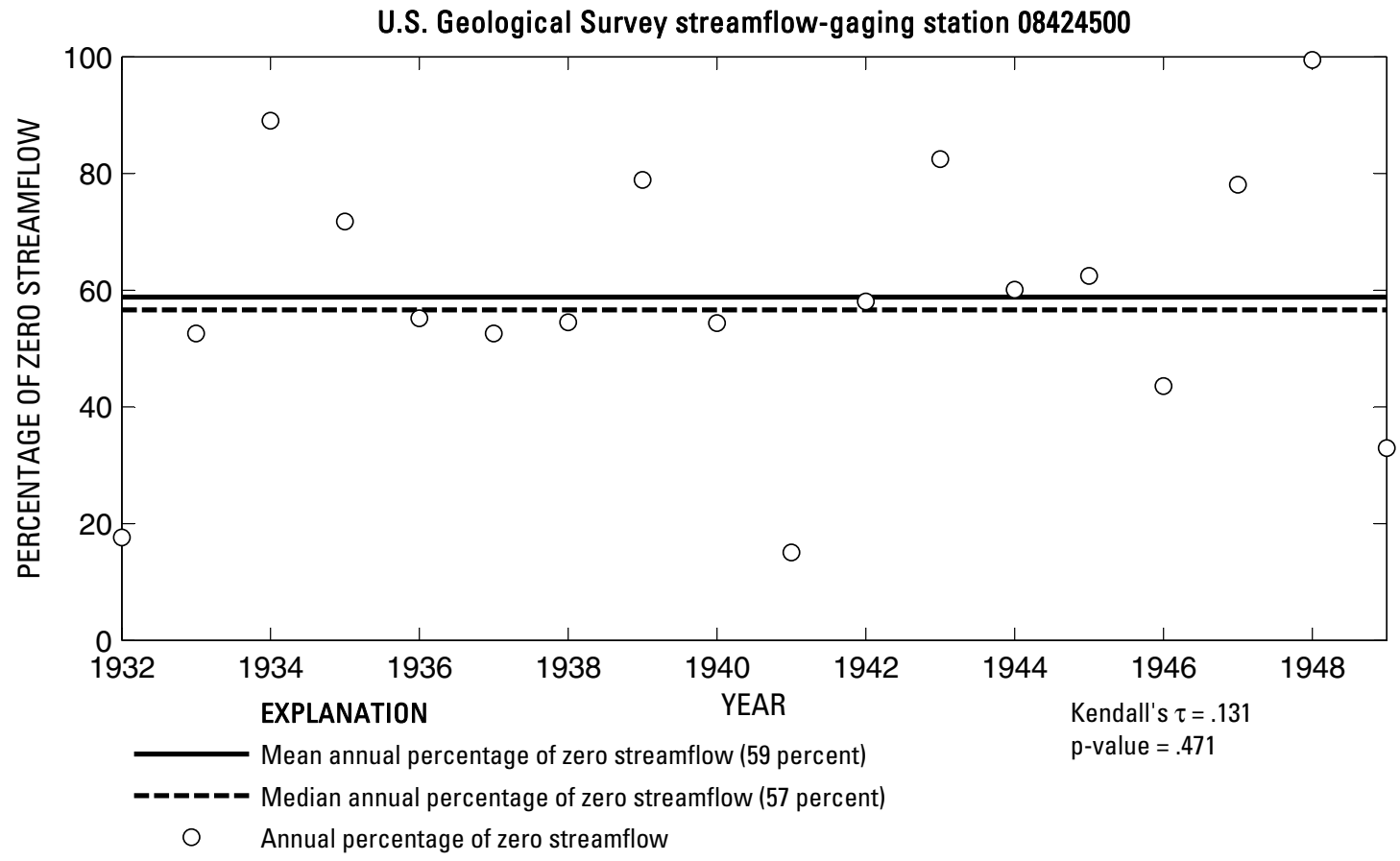

U.S. Geological Survey streamflow-gaging station 08424500

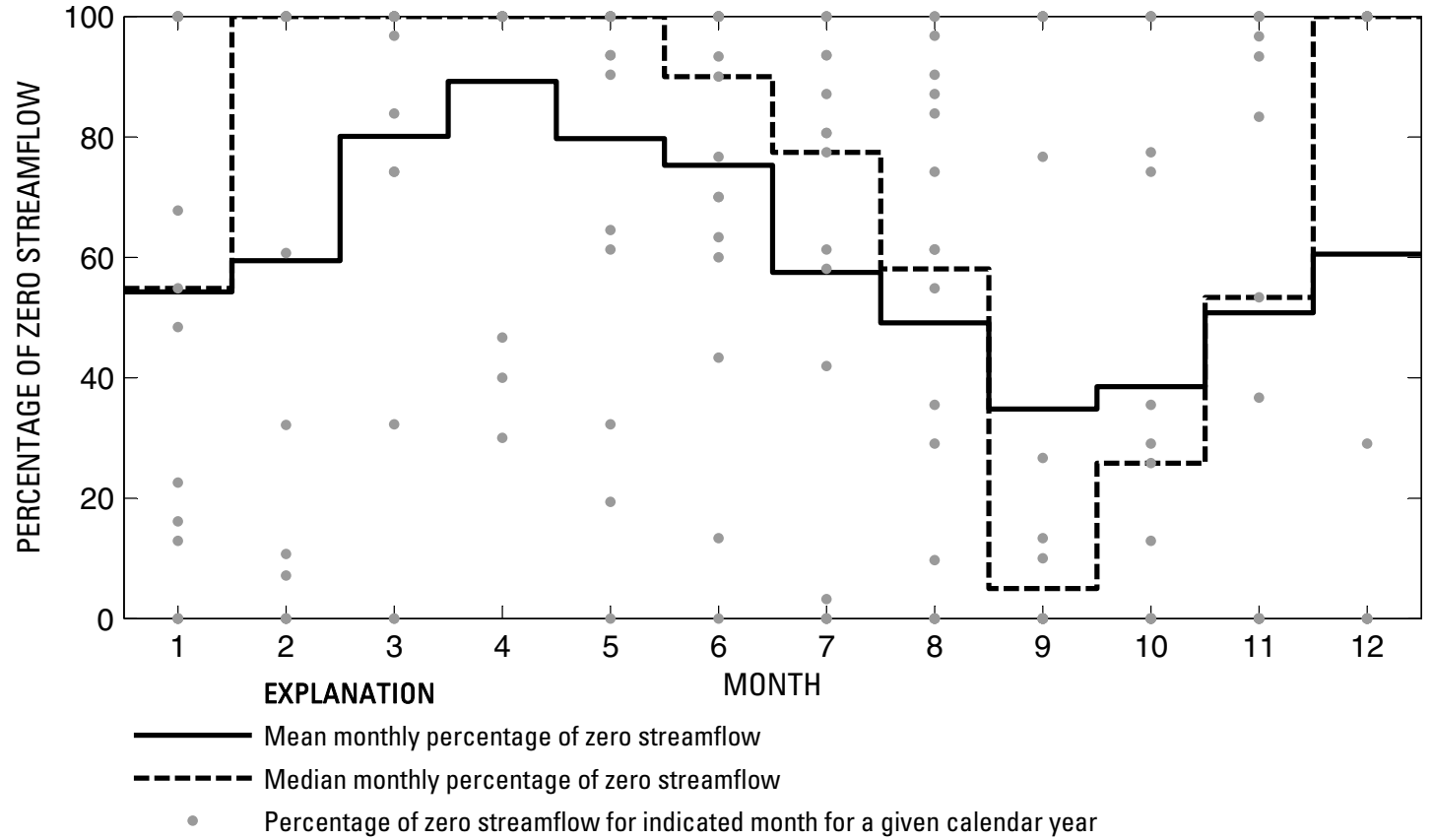

Figure 693. Analysis of percentage of zero daily mean streamflow for U.S. Geological Survey streamflow-gaging station 08424500 Madera Canyon near Toyahvale, Texas. 
U.S. Geological Survey streamflow-gaging station 08431000

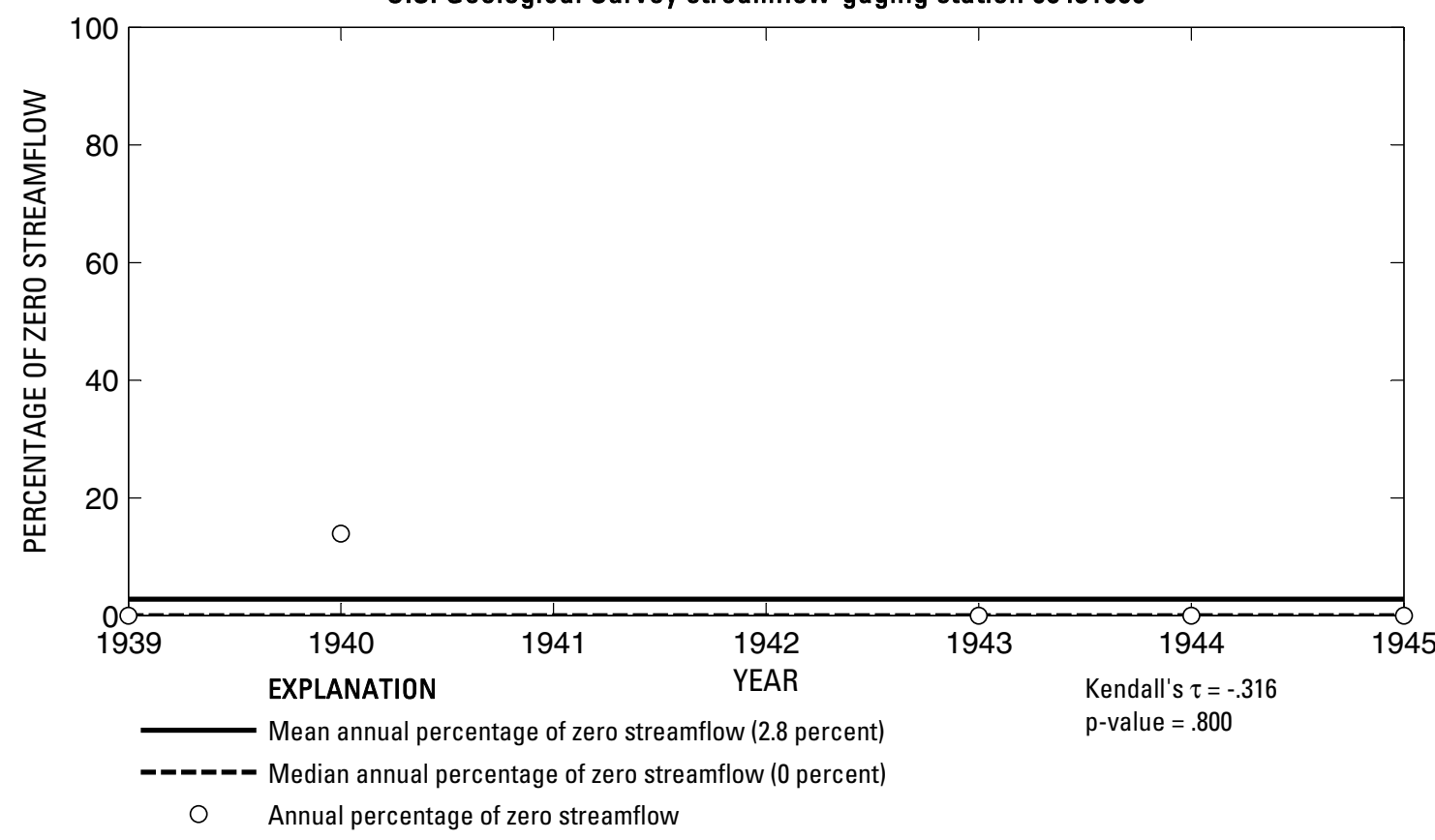

U.S. Geological Survey streamflow-gaging station 08431000

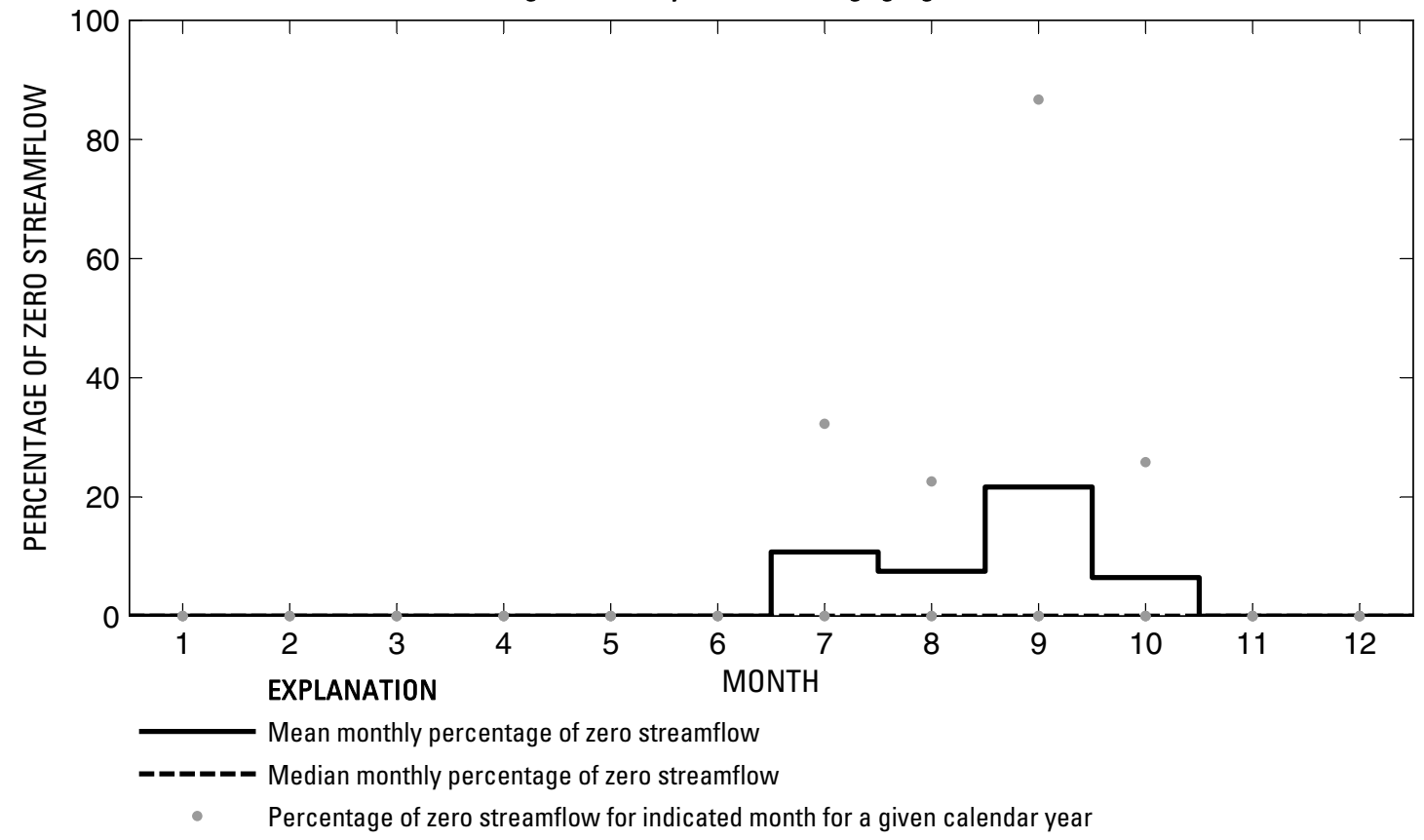

Figure 694. Analysis of percentage of zero daily mean streamflow for U.S. Geological Survey streamflow-gaging station 08431000 Toyah Creek near Pecos, Texas. 


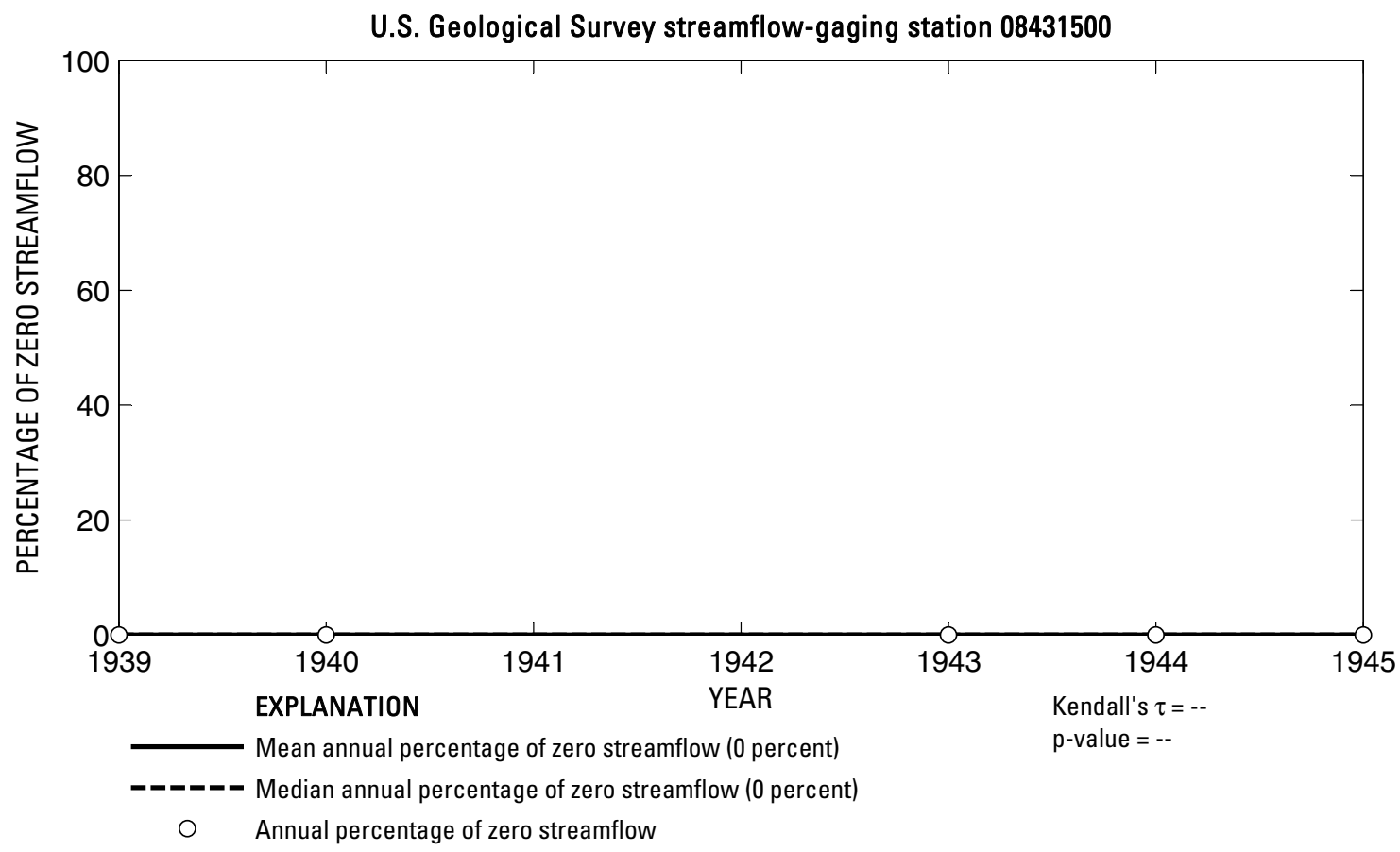

U.S. Geological Survey streamflow-gaging station 08431500

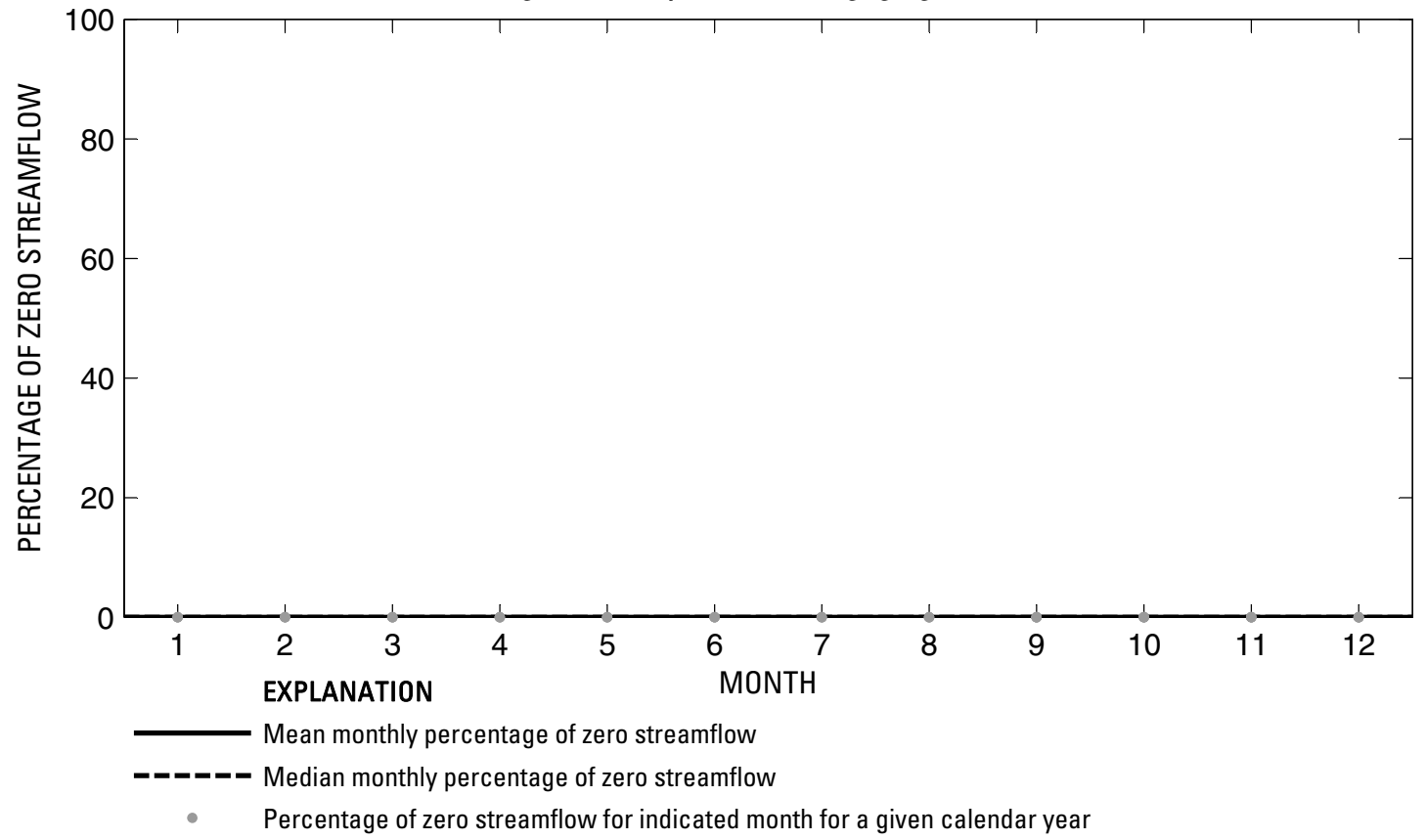

Figure 695. Analysis of percentage of zero daily mean streamflow for U.S. Geological Survey streamflow-gaging station 08431500 Salt Draw near Pecos, Texas. 

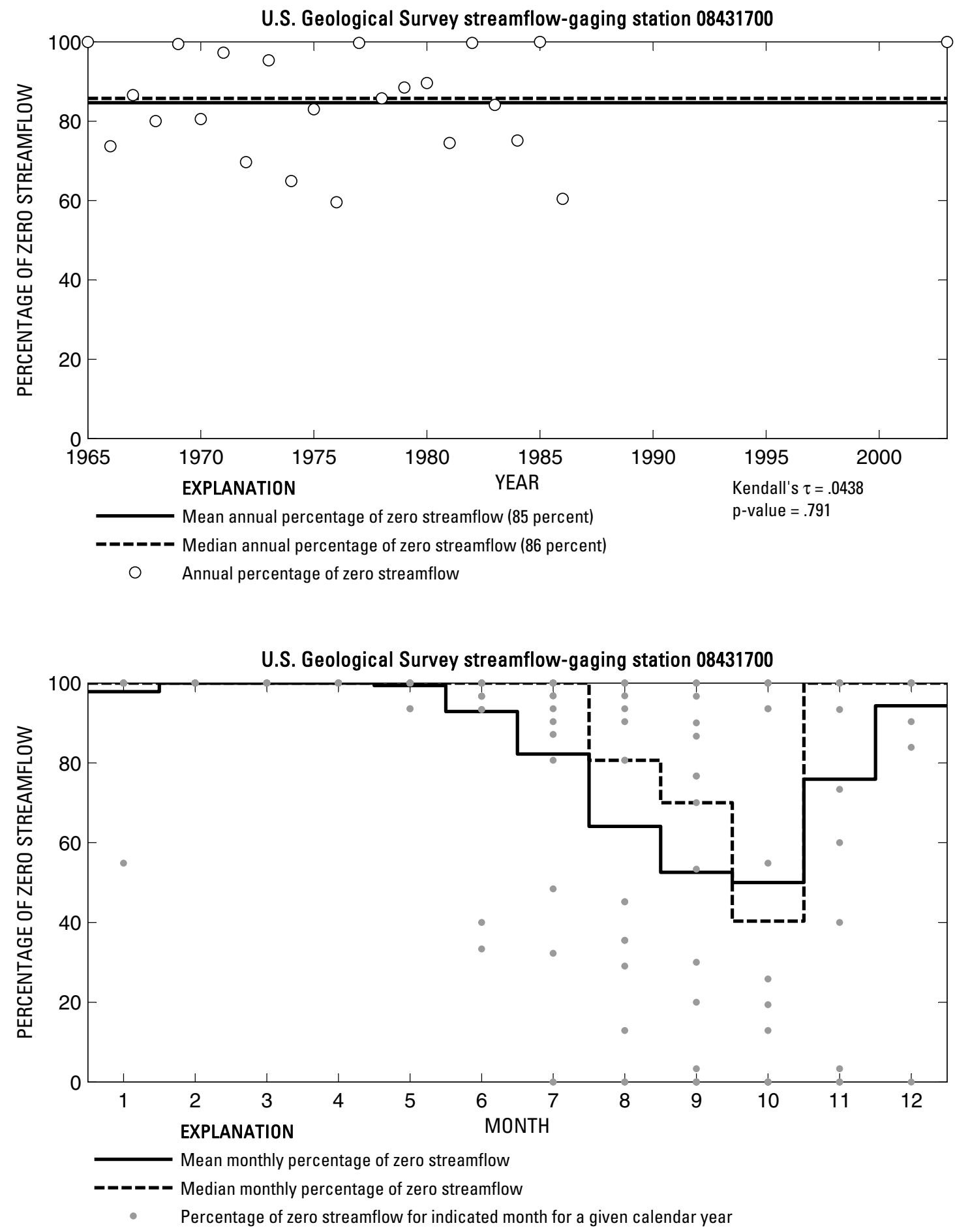

Figure 696. Analysis of percentage of zero daily mean streamflow for U.S. Geological Survey streamflow-gaging station 08431700 Limpia Creek above Fort Davis, Texas.

Index of Station Numbers 719 

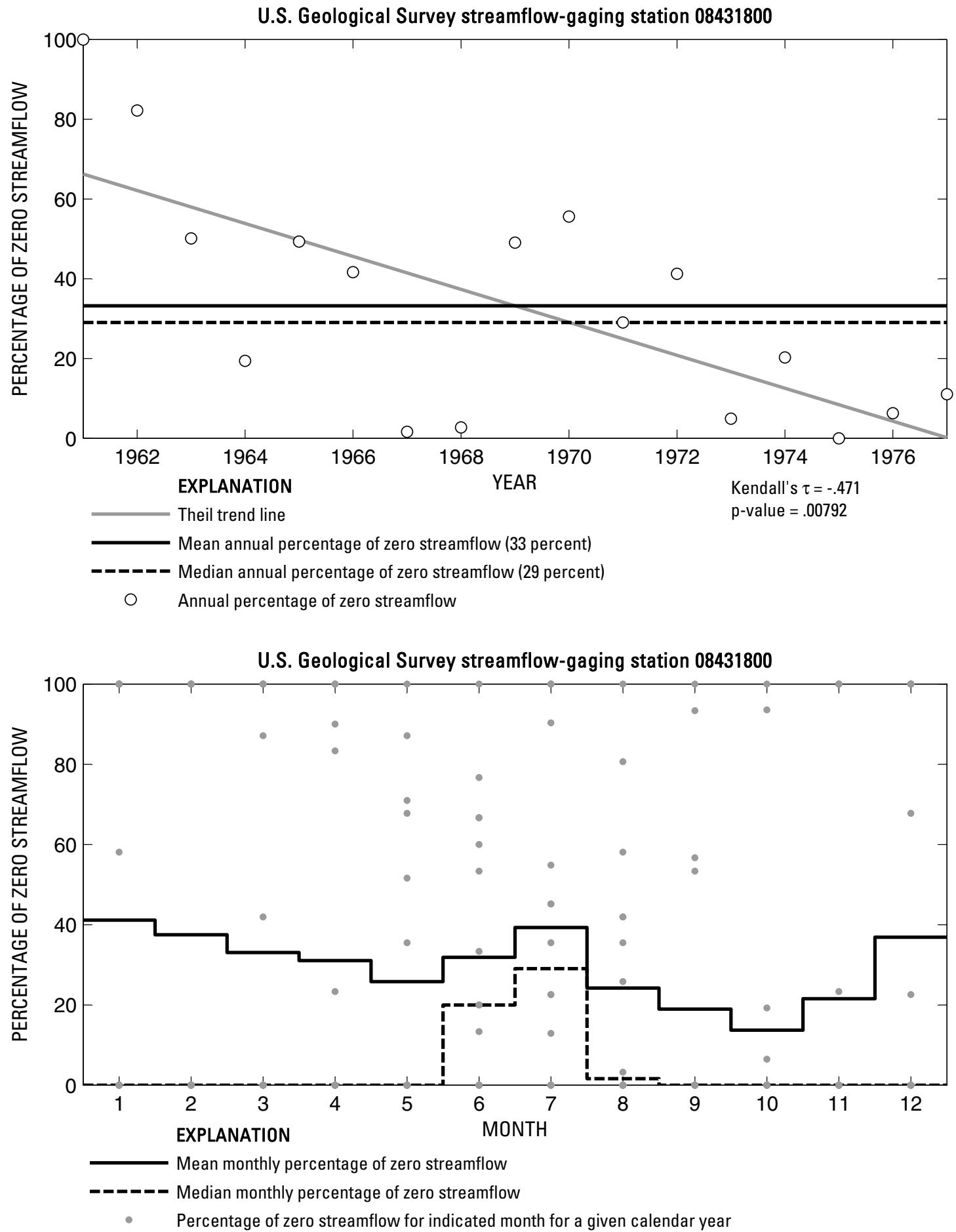

Figure 697. Analysis of percentage of zero daily mean streamflow for U.S. Geological Survey streamflow-gaging station 08431800 Limpia Creek below Fort Davis, Texas. 
U.S. Geological Survey streamflow-gaging station 08432000

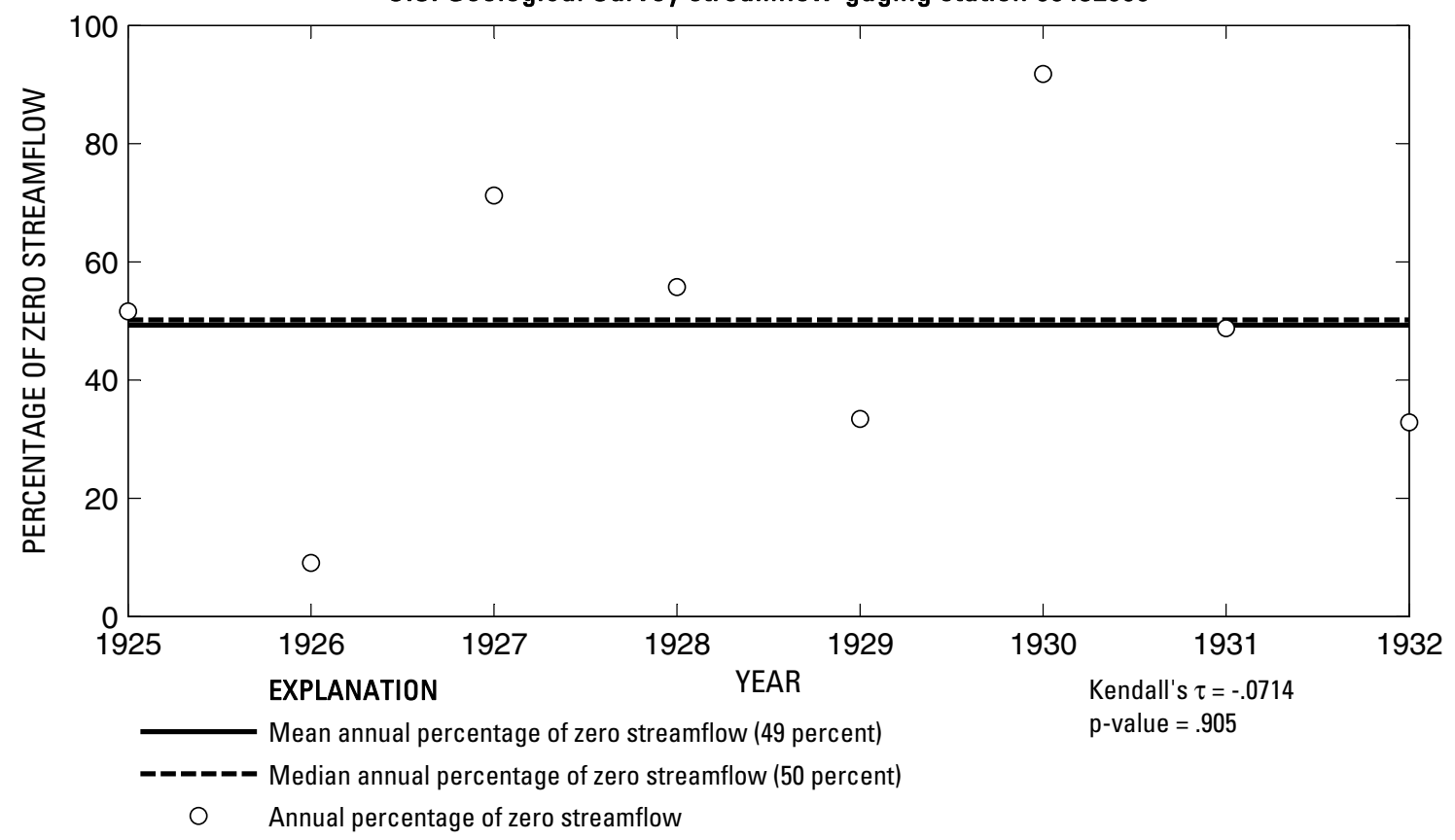

U.S. Geological Survey streamflow-gaging station 08432000

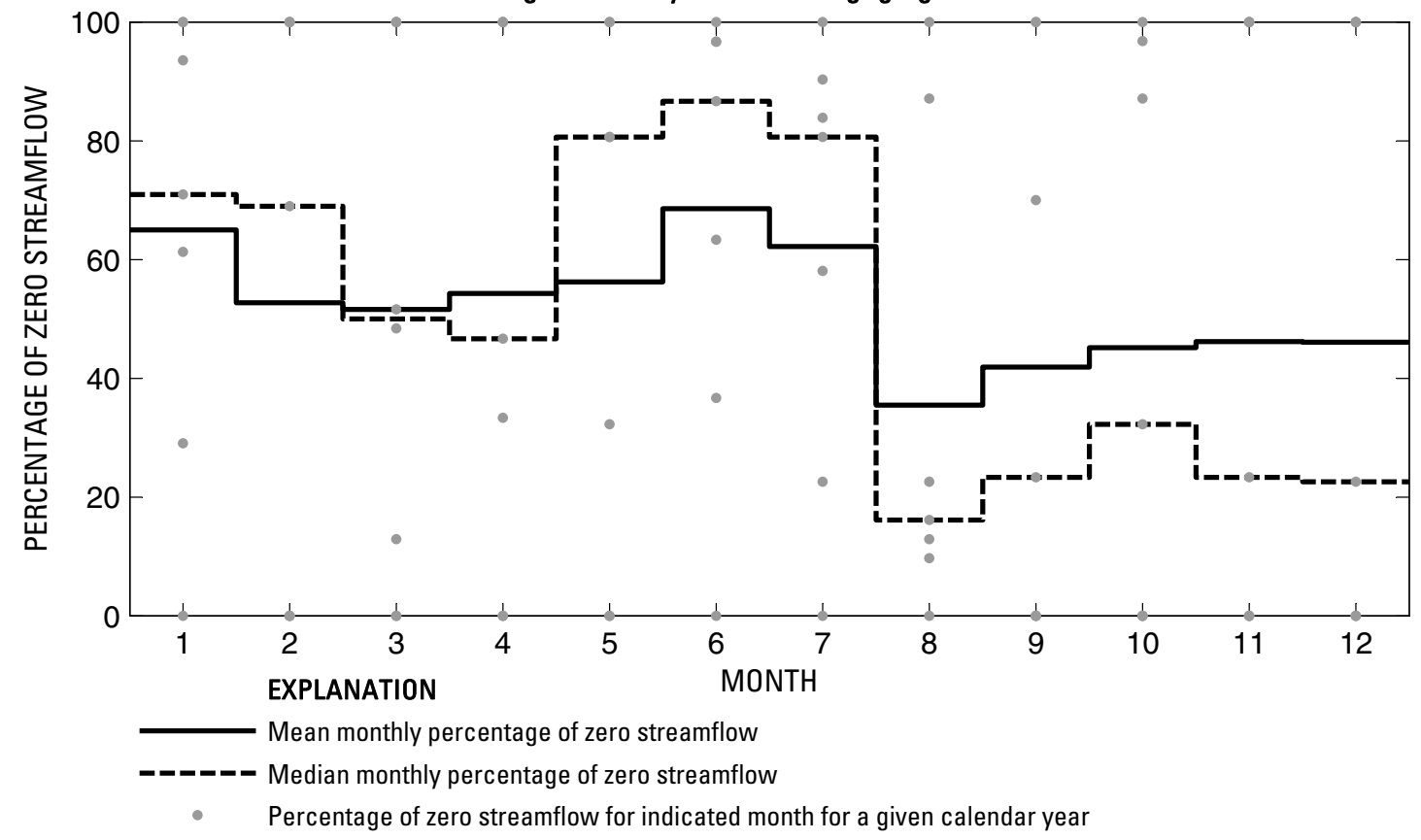

Figure 698. Analysis of percentage of zero daily mean streamflow for U.S. Geological Survey streamflow-gaging station 08432000 Limpia Creek near Fort Davis, Texas.

Index of Station Numbers 719 
U.S. Geological Survey streamflow-gaging station 08433000

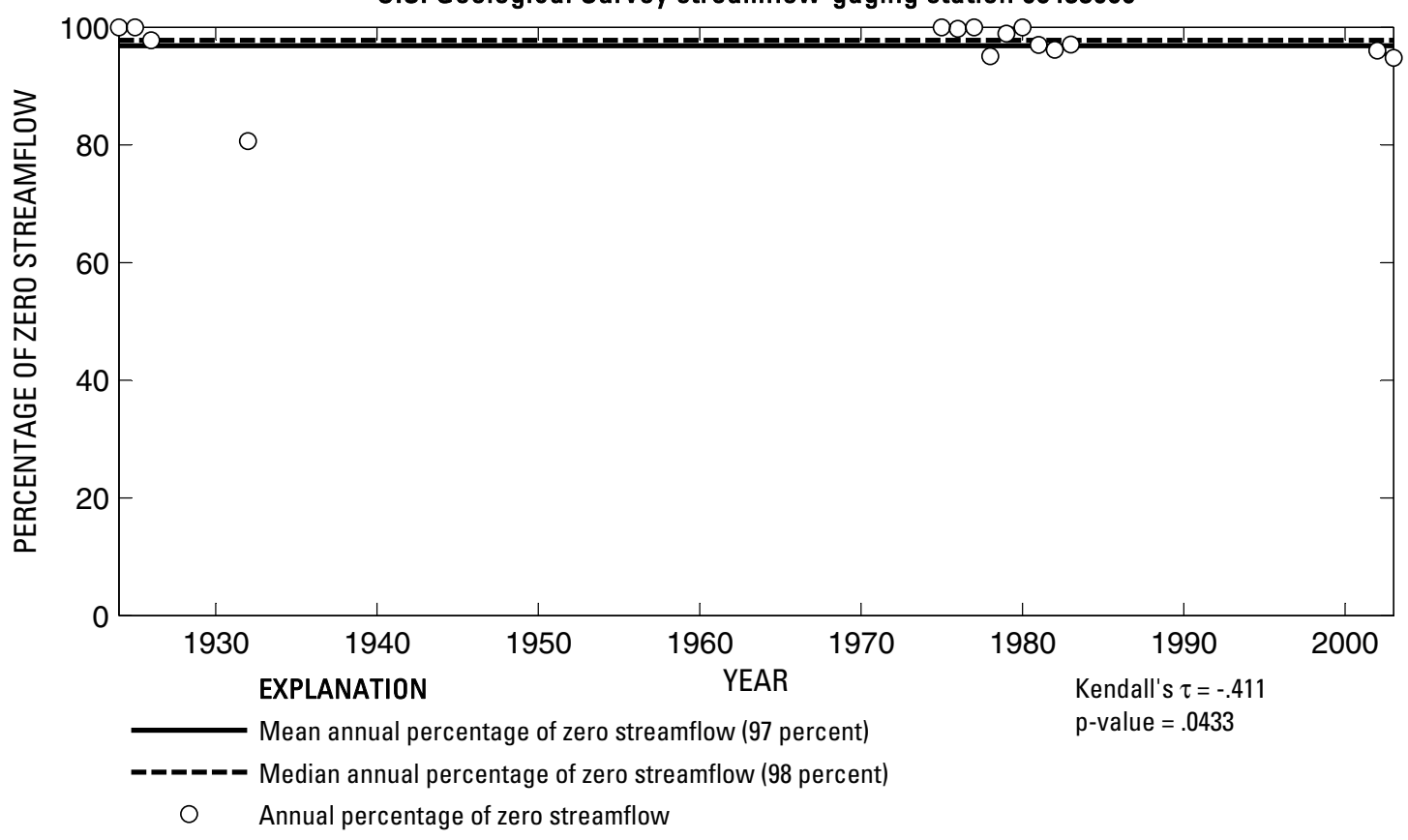

U.S. Geological Survey streamflow-gaging station 08433000

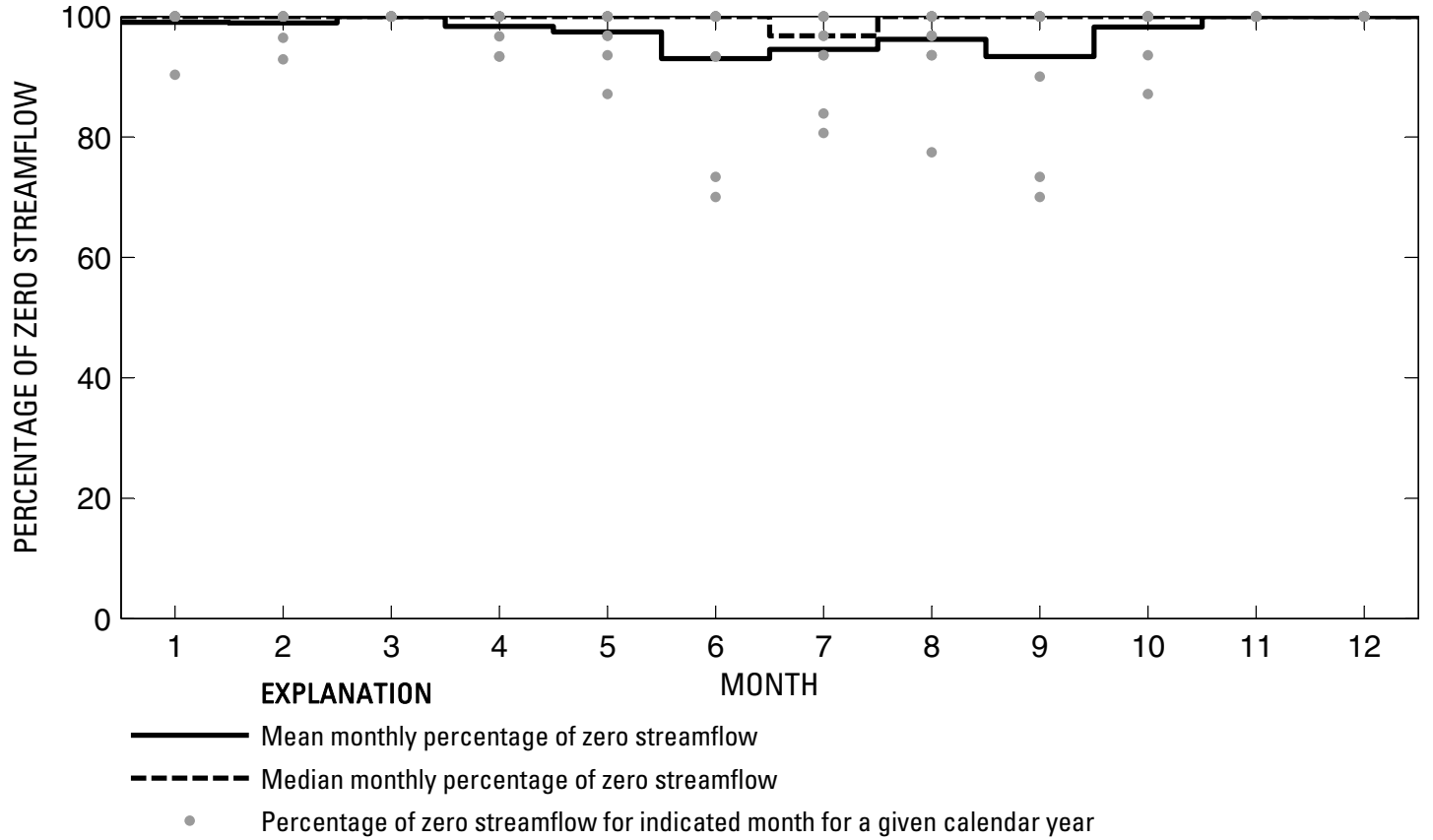

Figure 699. Analysis of percentage of zero daily mean streamflow for U.S. Geological Survey streamflow-gaging station 08433000 Barrilla Draw near Saragosa, Texas. 

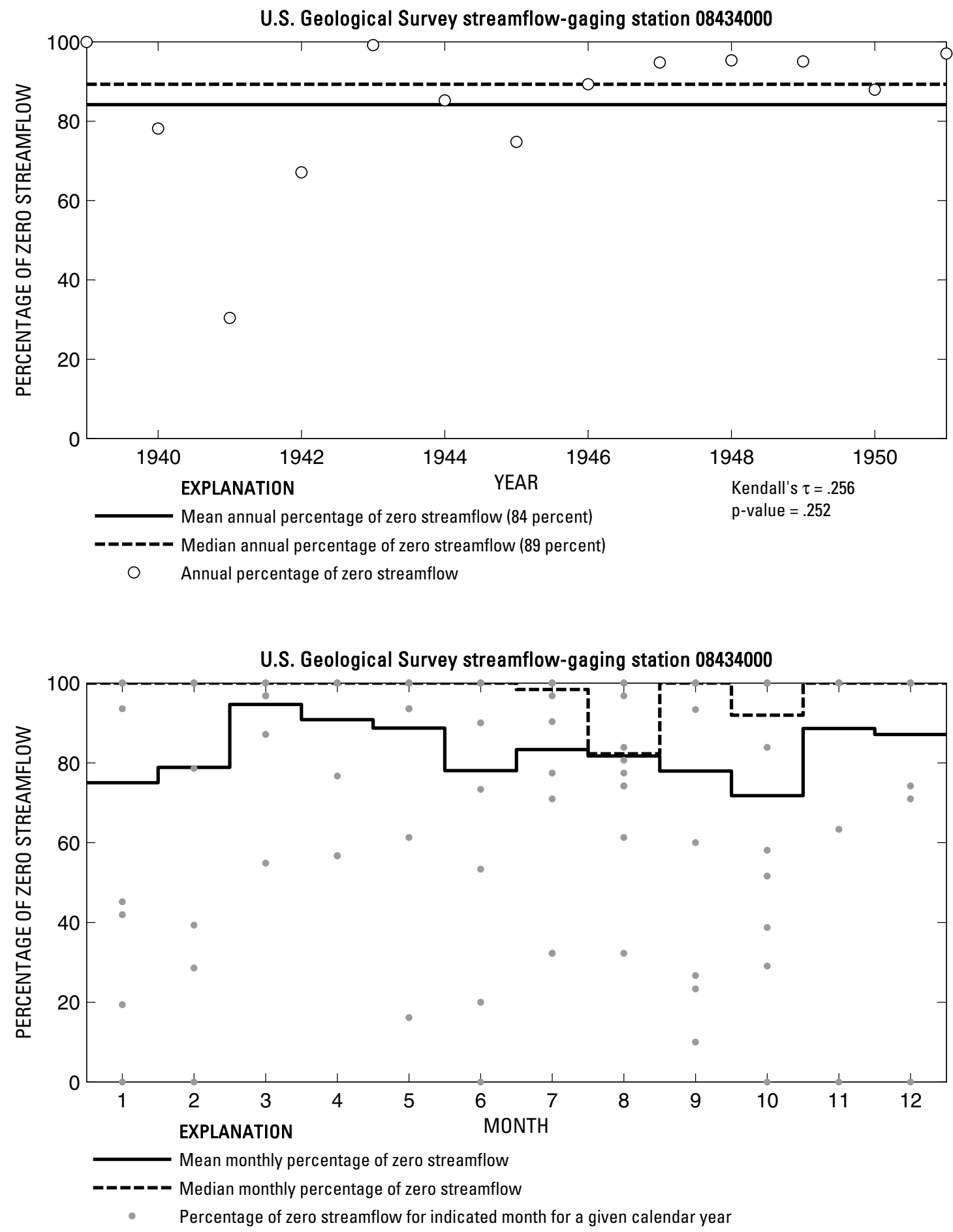

Figure 700. Analysis of percentage of zero daily mean streamflow for U.S. Geological Survey streamflow-gaging station 08434000 Toyah Creek below Toyah Lake near Pecos, Texas. 
U.S. Geological Survey streamflow-gaging station 08435500

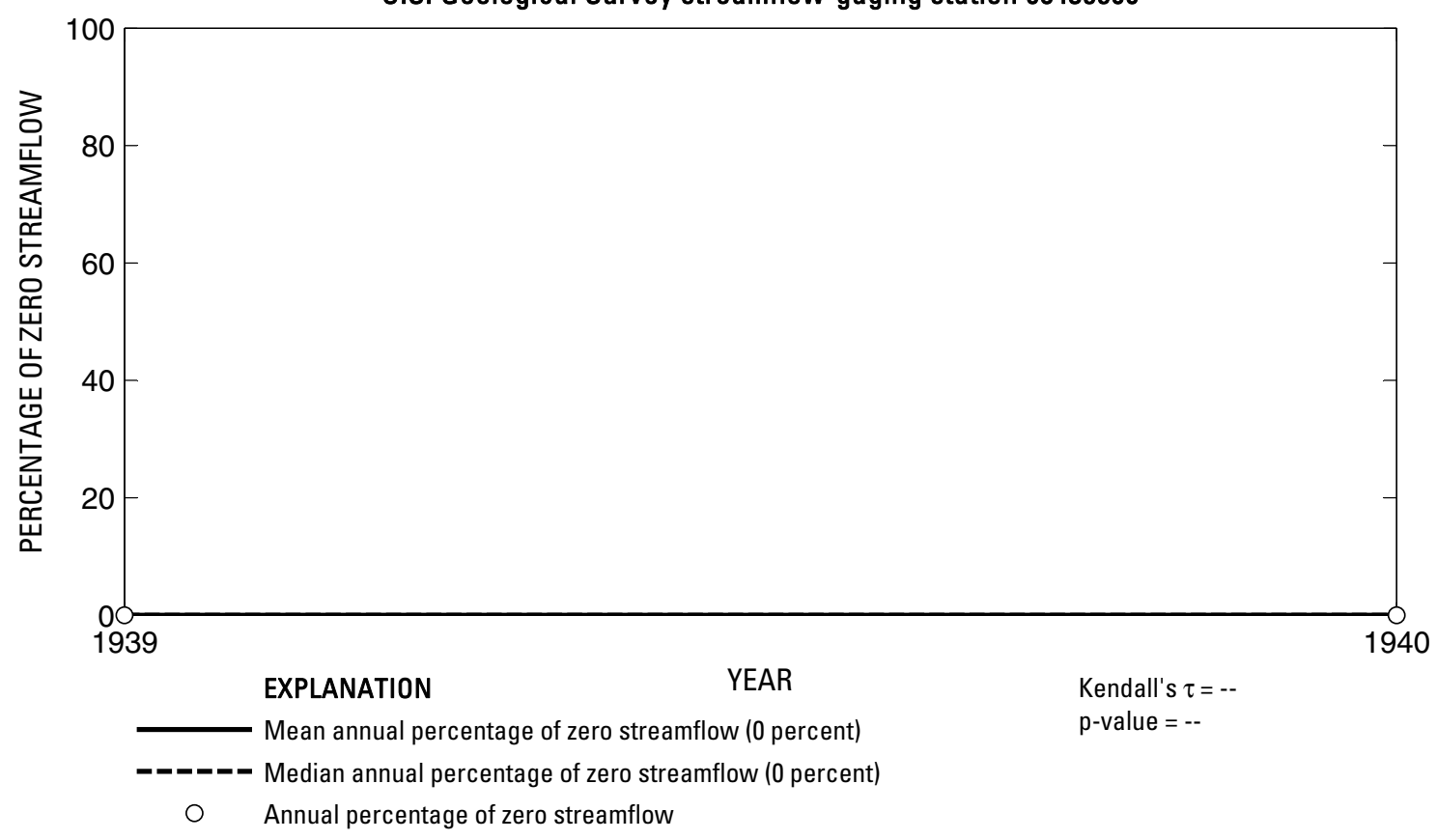

U.S. Geological Survey streamflow-gaging station 08435500

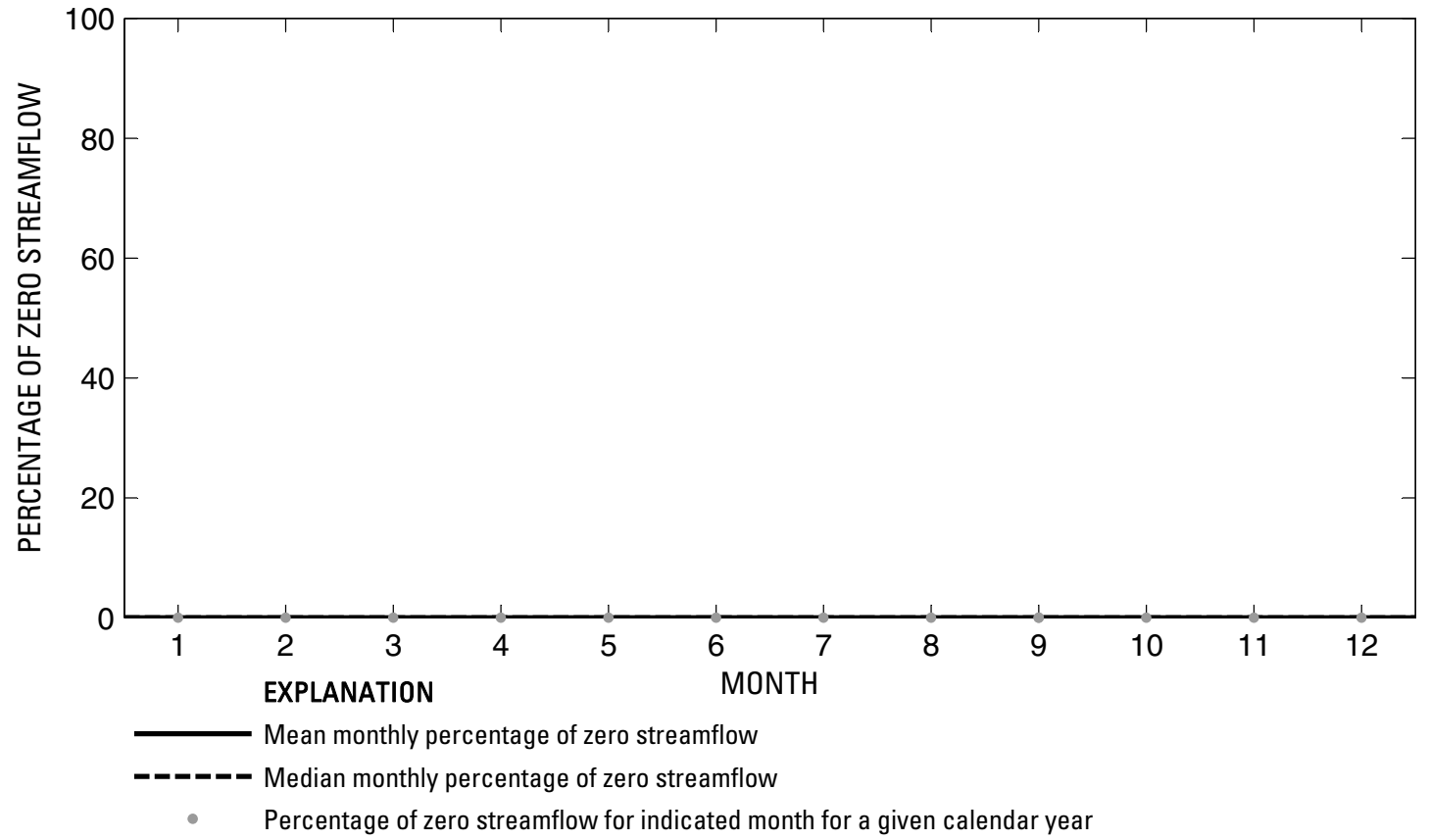

Figure 701. Analysis of percentage of zero daily mean streamflow for U.S. Geological Survey streamflow-gaging station 08435500 Pecos River below Barstow, Texas. 
U.S. Geological Survey streamflow-gaging station 08435600

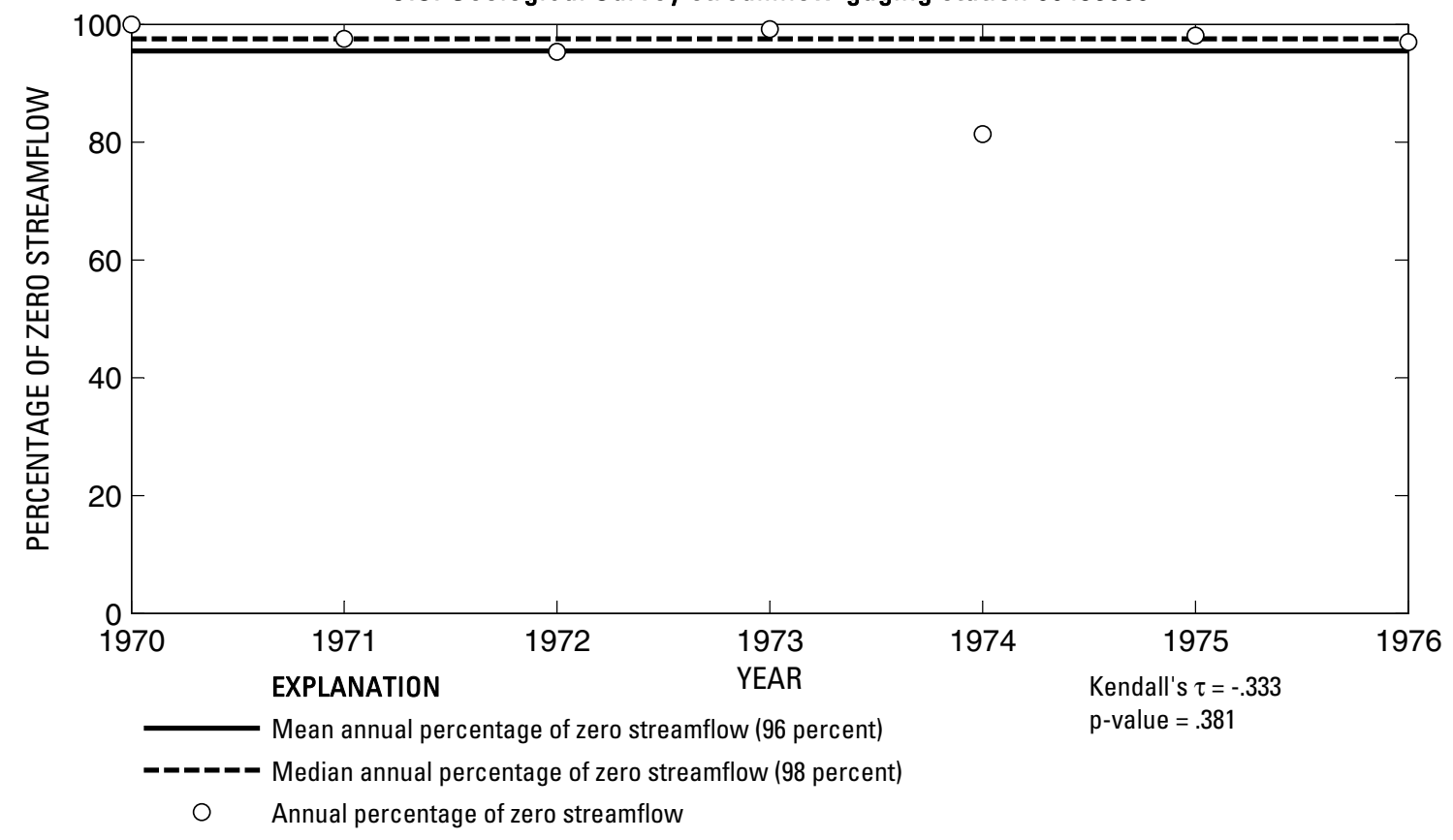

U.S. Geological Survey streamflow-gaging station 08435600

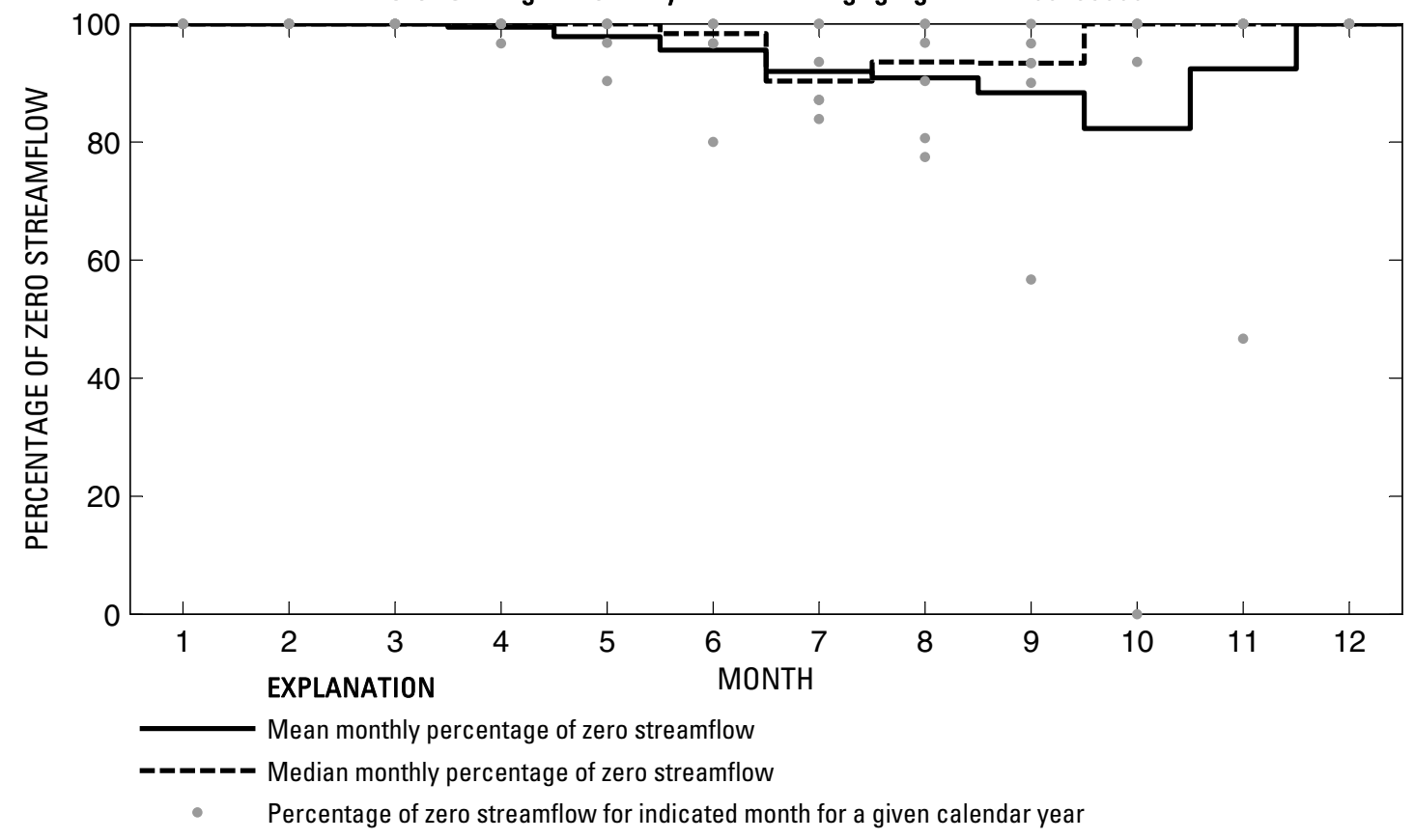

Figure 702. Analysis of percentage of zero daily mean streamflow for U.S. Geological Survey streamflow-gaging station 08435600 Toronto Creek near Alpine, Texas.

Index of Station Numbers 719 


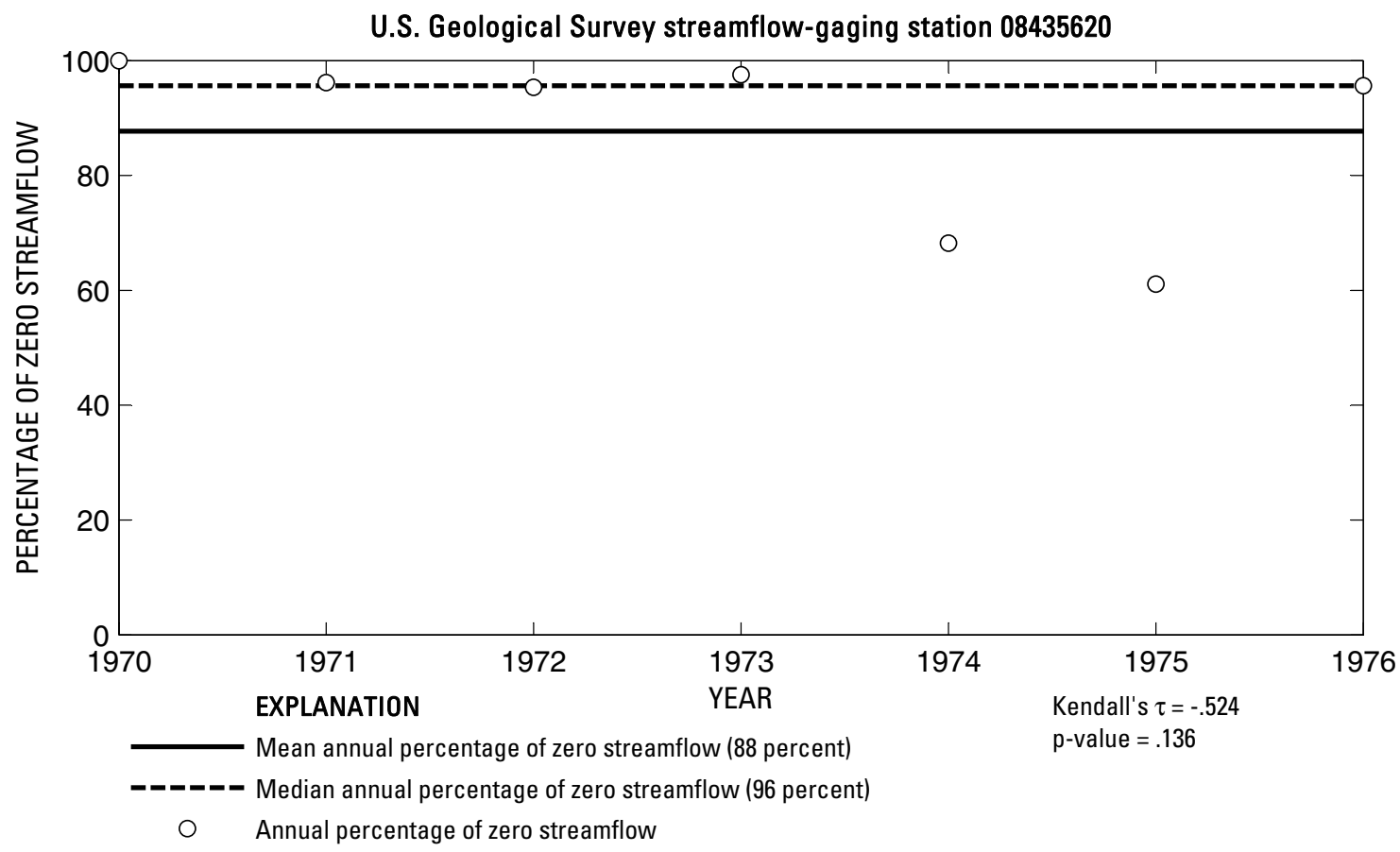

U.S. Geological Survey streamflow-gaging station 08435620

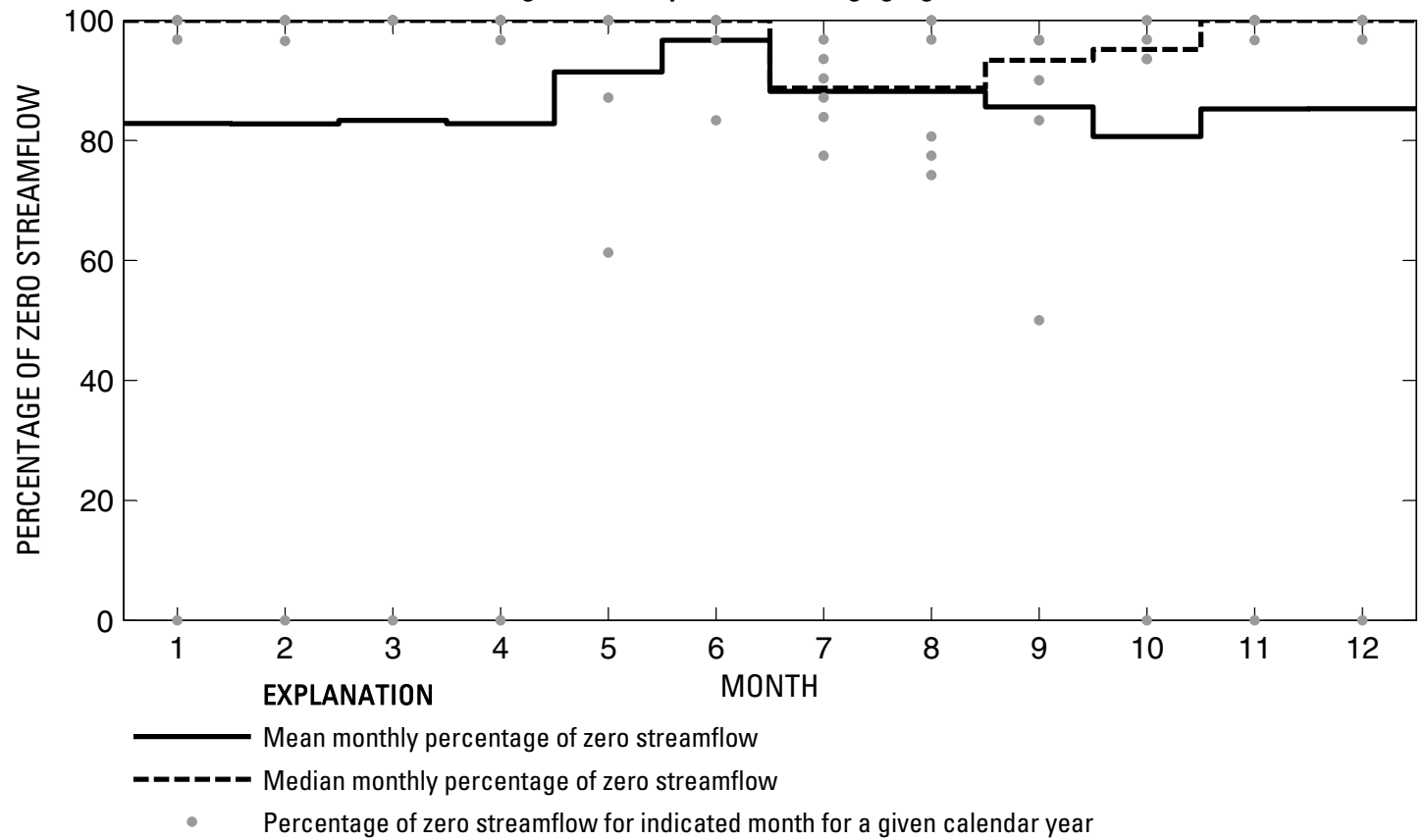

Figure 703. Analysis of percentage of zero daily mean streamflow for U.S. Geological Survey streamflow-gaging station 08435620 Alpine Creek at Alpine, Texas. 


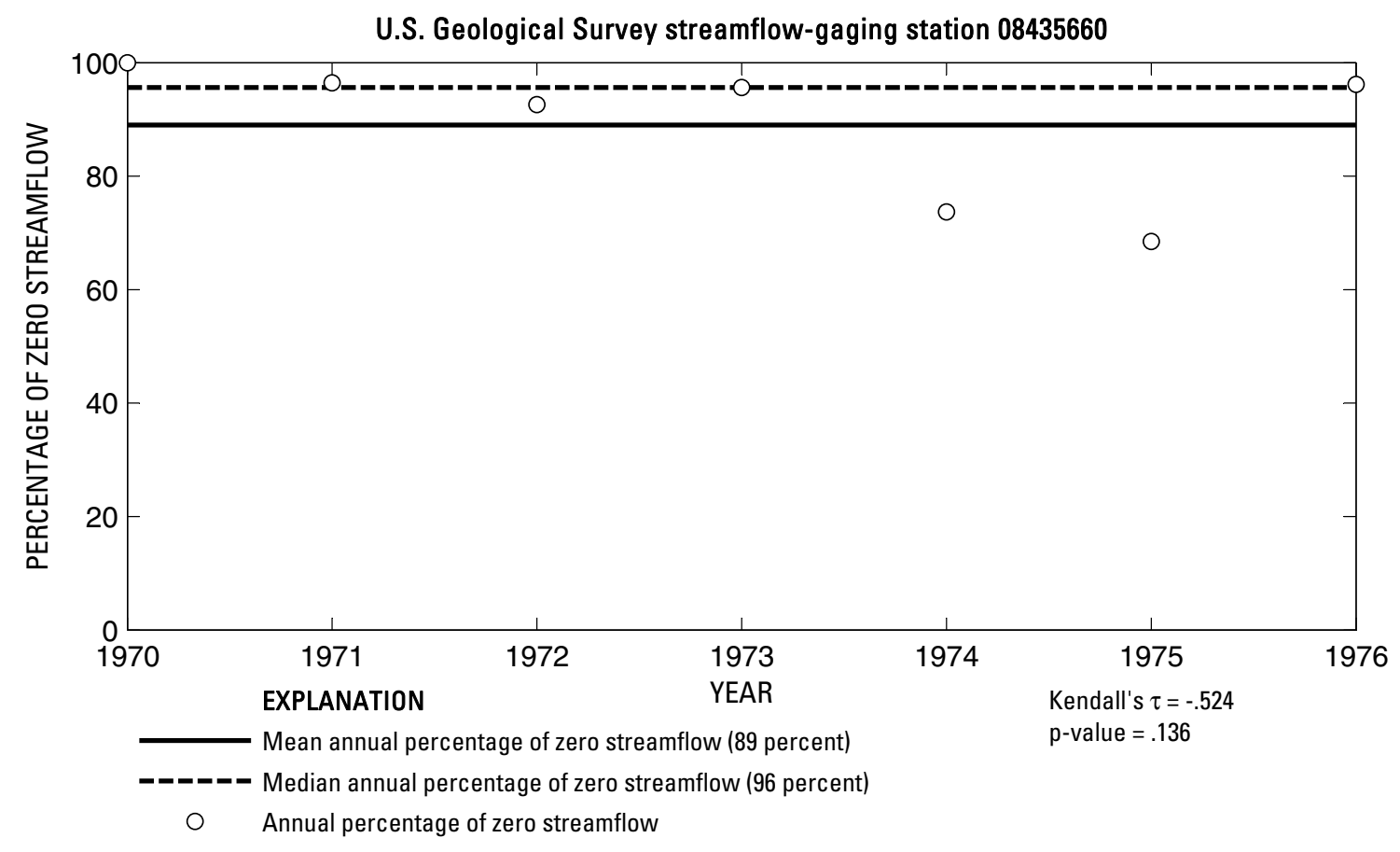

U.S. Geological Survey streamflow-gaging station 08435660

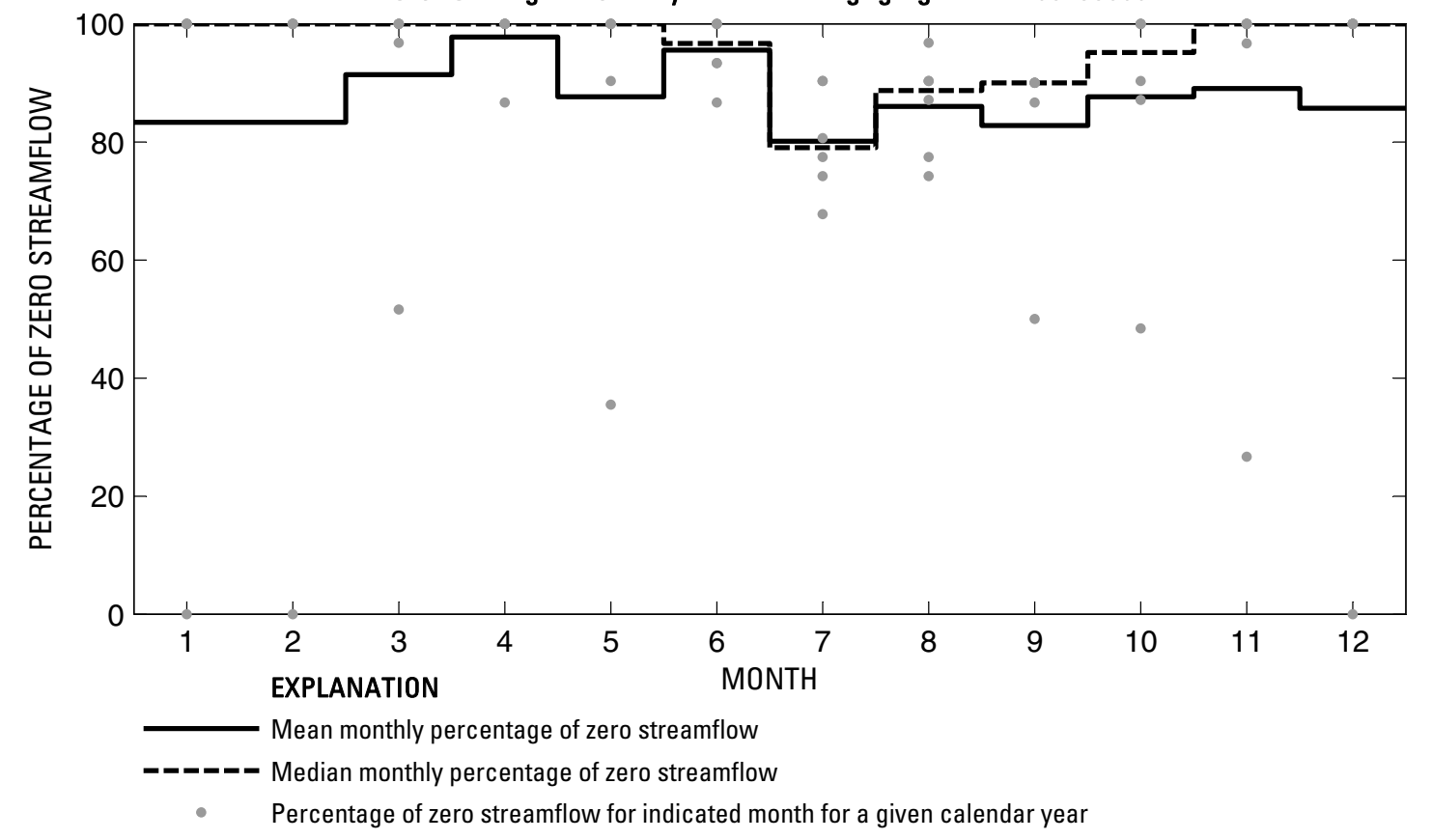

Figure 704. Analysis of percentage of zero daily mean streamflow for U.S. Geological Survey streamflow-gaging station 08435660 Moss Creek near Alpine, Texas.

Index of Station Numbers 719 


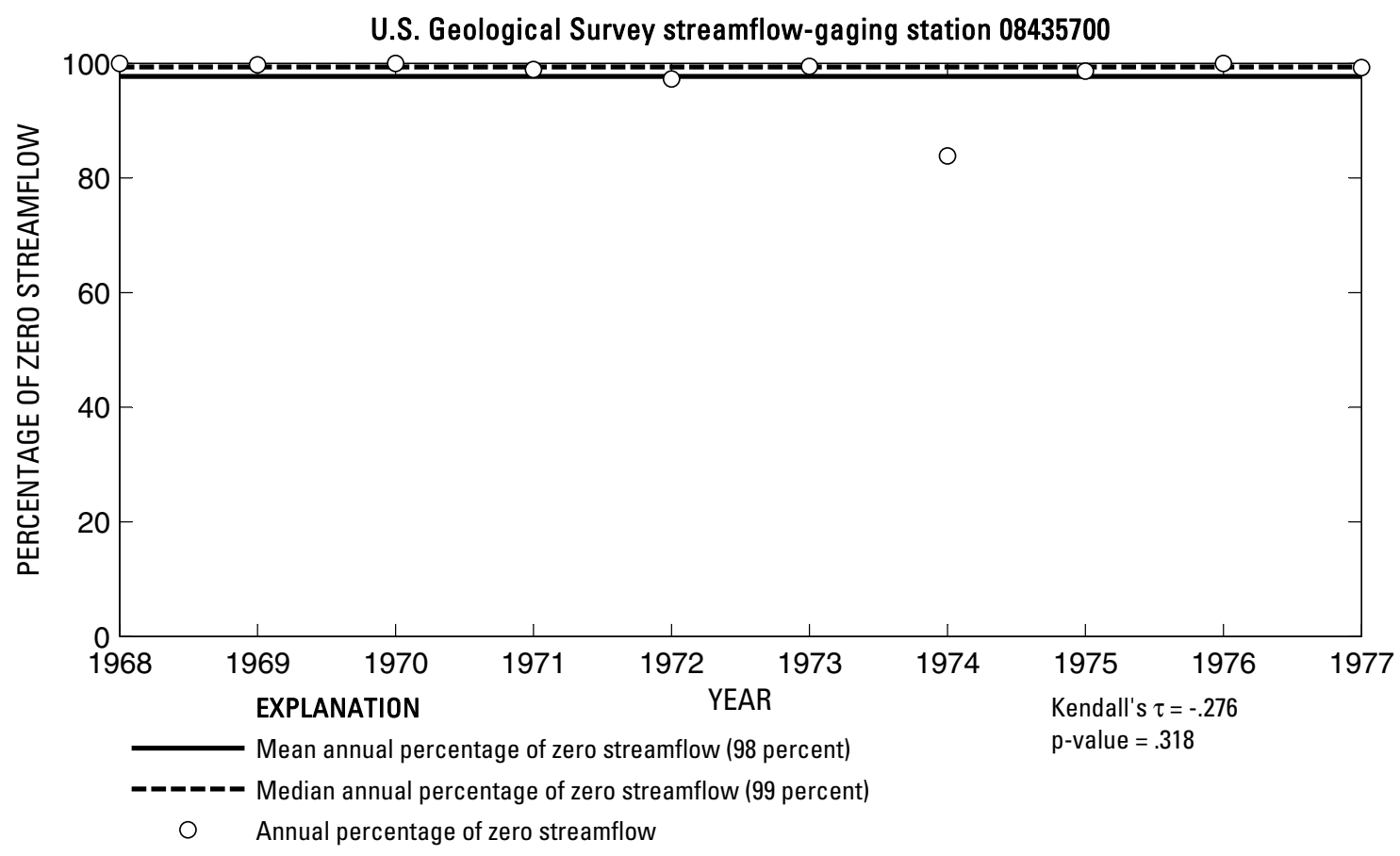

U.S. Geological Survey streamflow-gaging station 08435700

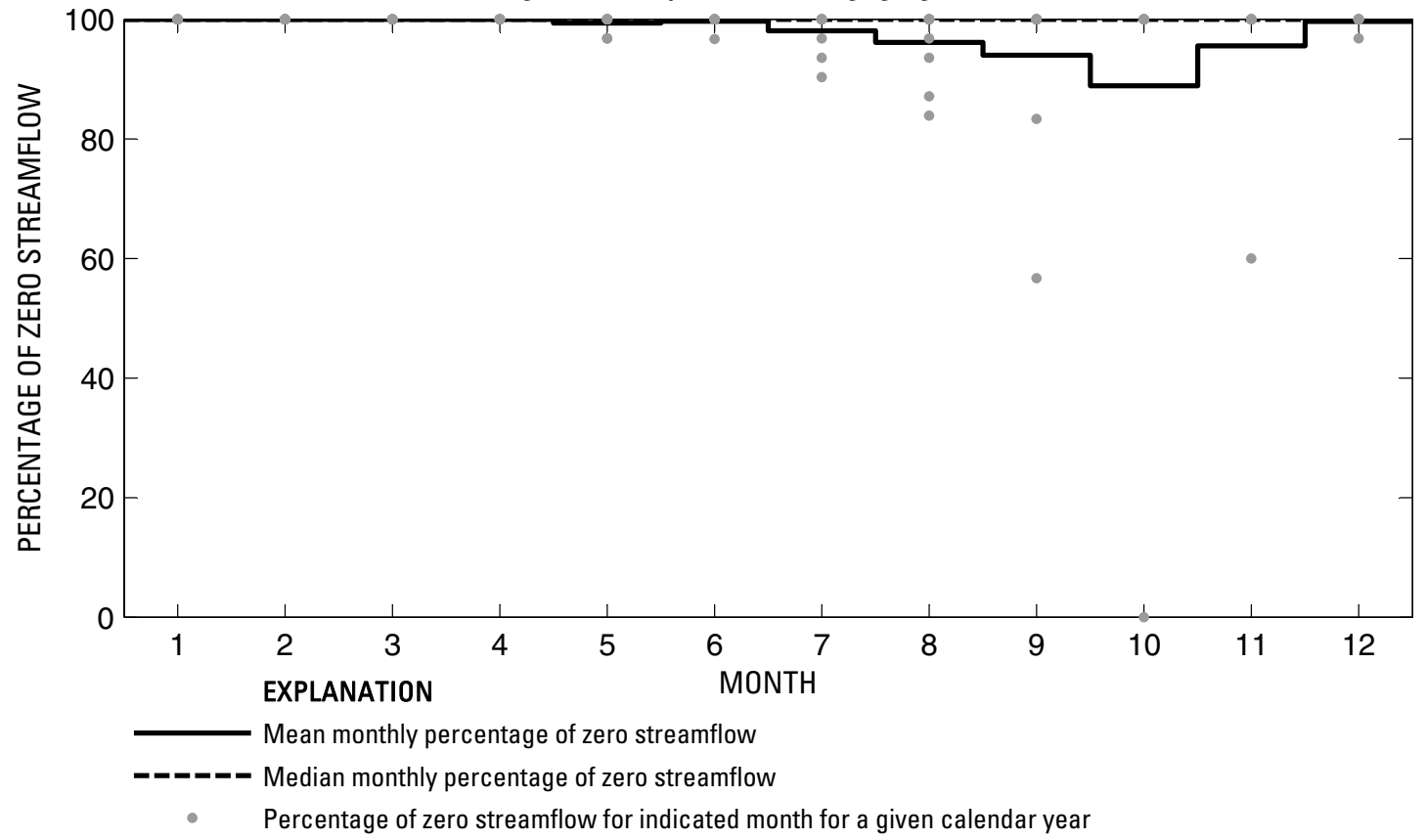

Figure 705. Analysis of percentage of zero daily mean streamflow for U.S. Geological Survey streamflow-gaging station 08435700 Sunny Glen Canyon near Alpine, Texas. 
U.S. Geological Survey streamflow-gaging station 08435800

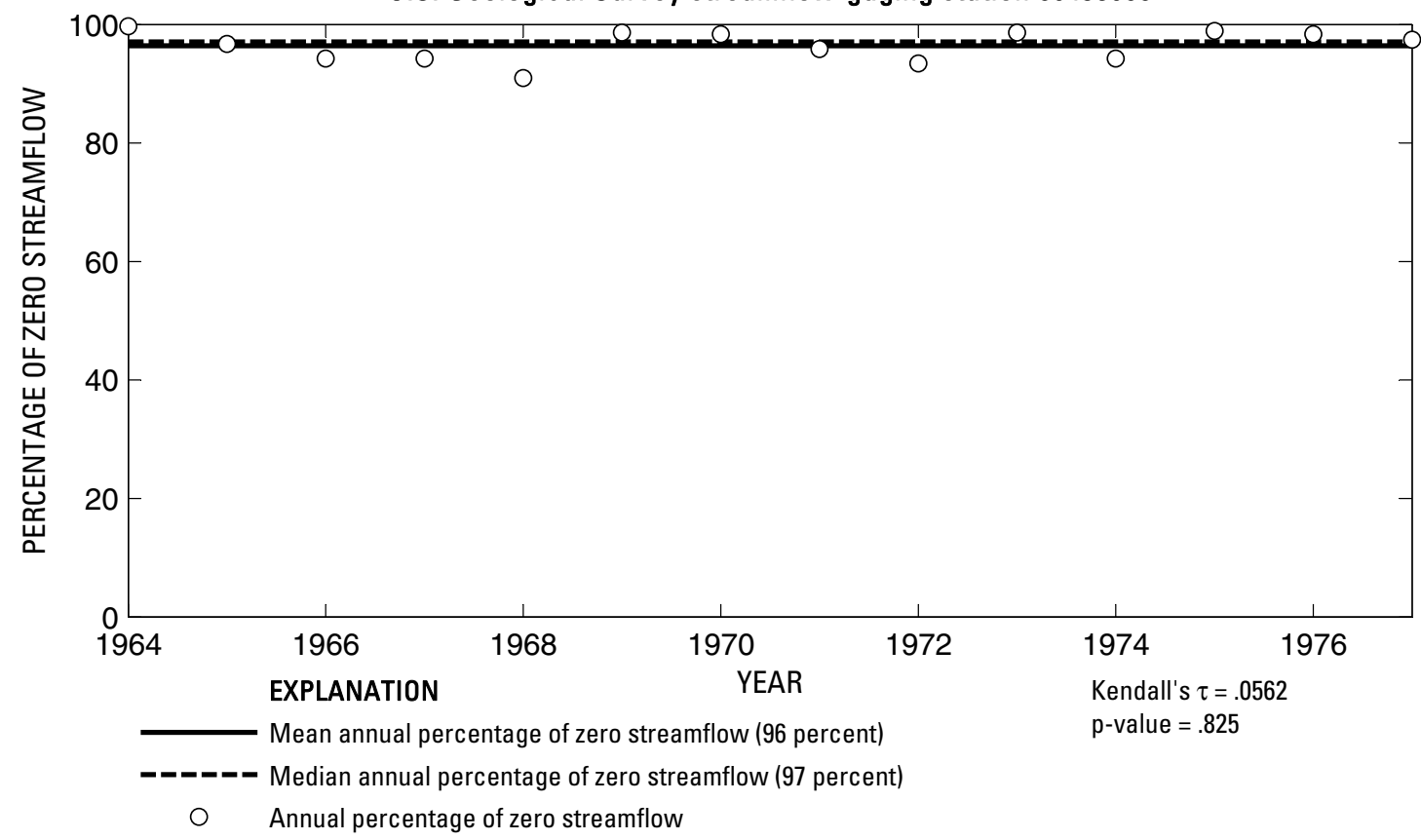

U.S. Geological Survey streamflow-gaging station 08435800

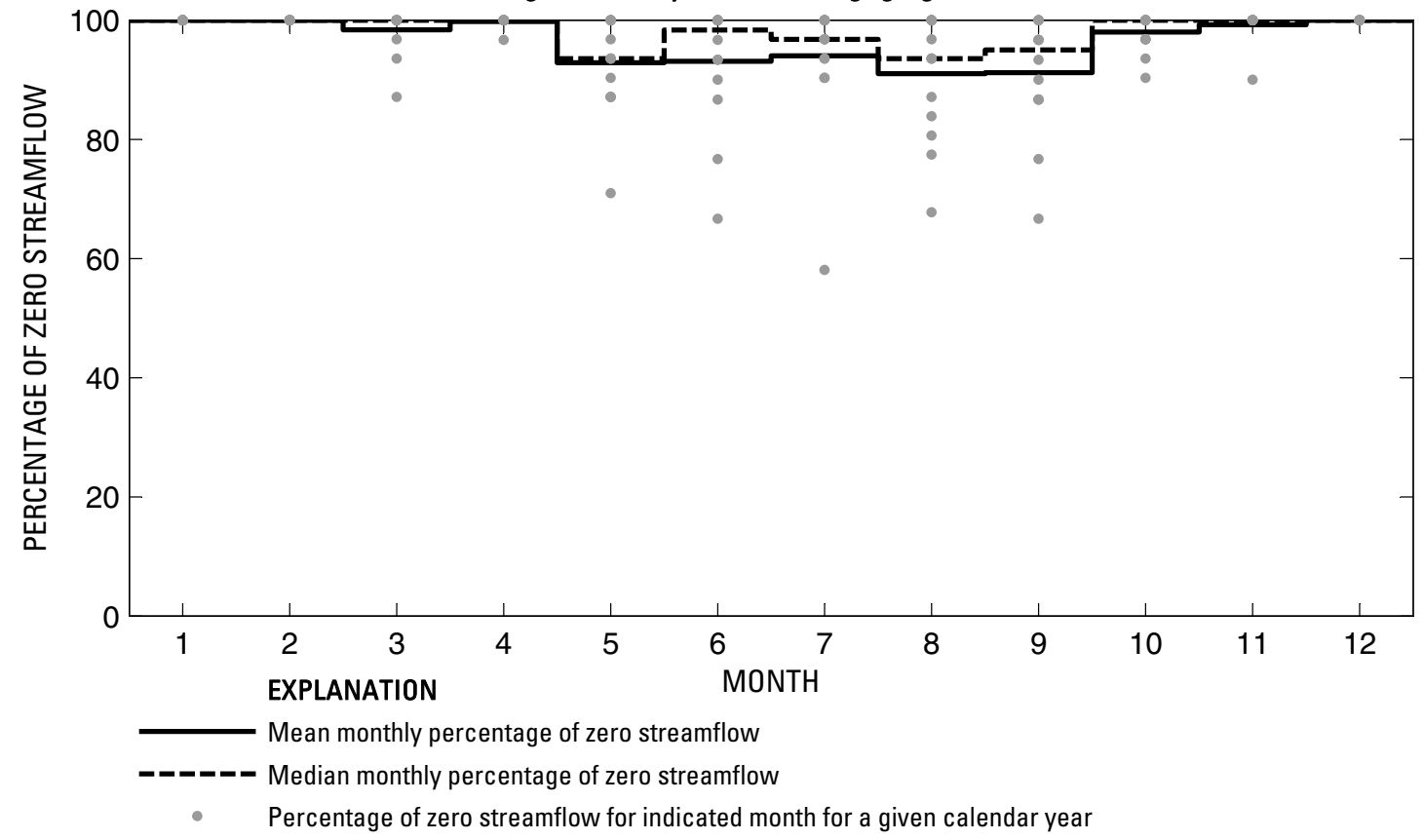

Figure 706. Analysis of percentage of zero daily mean streamflow for U.S. Geological Survey streamflow-gaging station 08435800 Coyanosa Draw near Fort Stockton, Texas. 


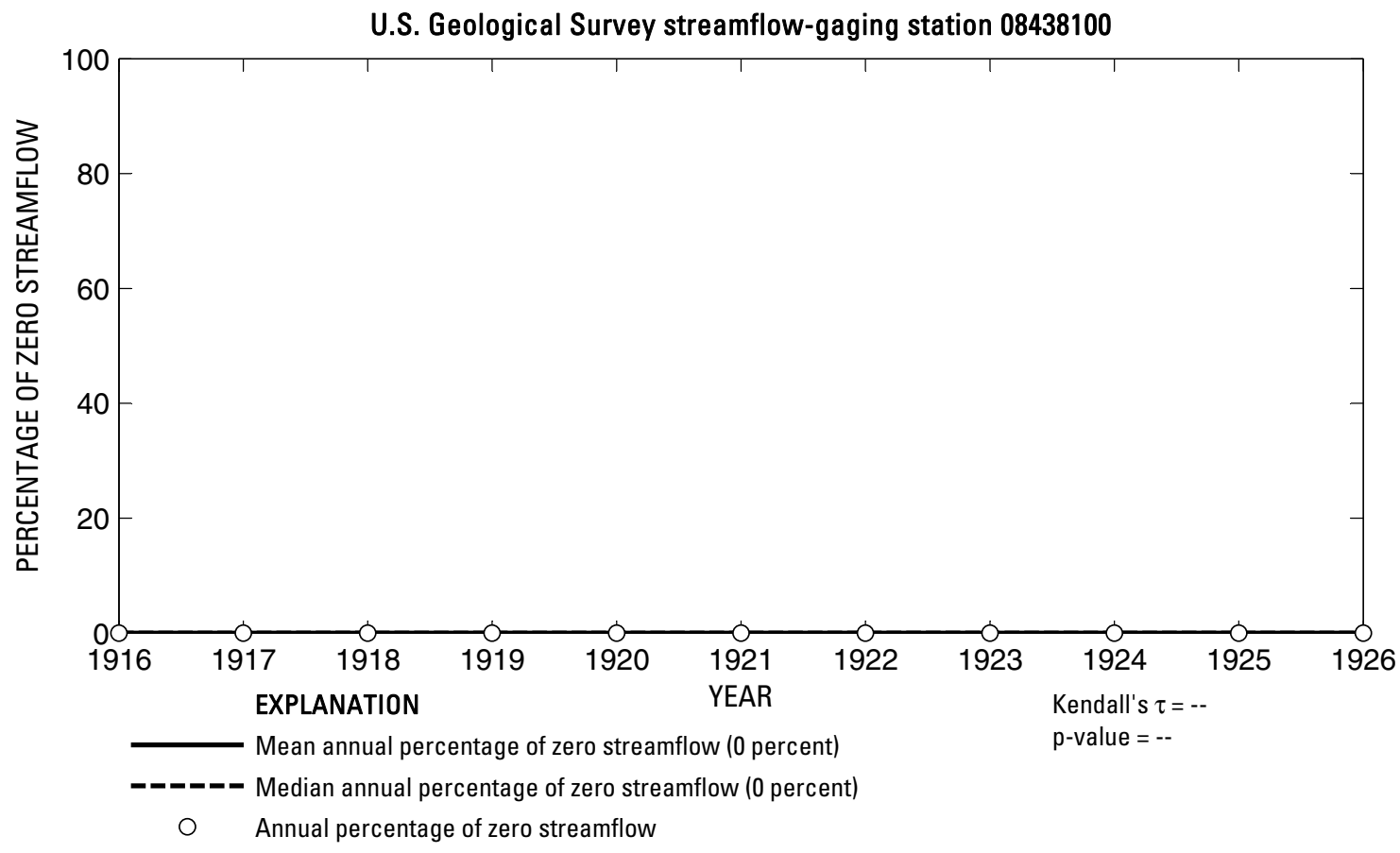

U.S. Geological Survey streamflow-gaging station 08438100

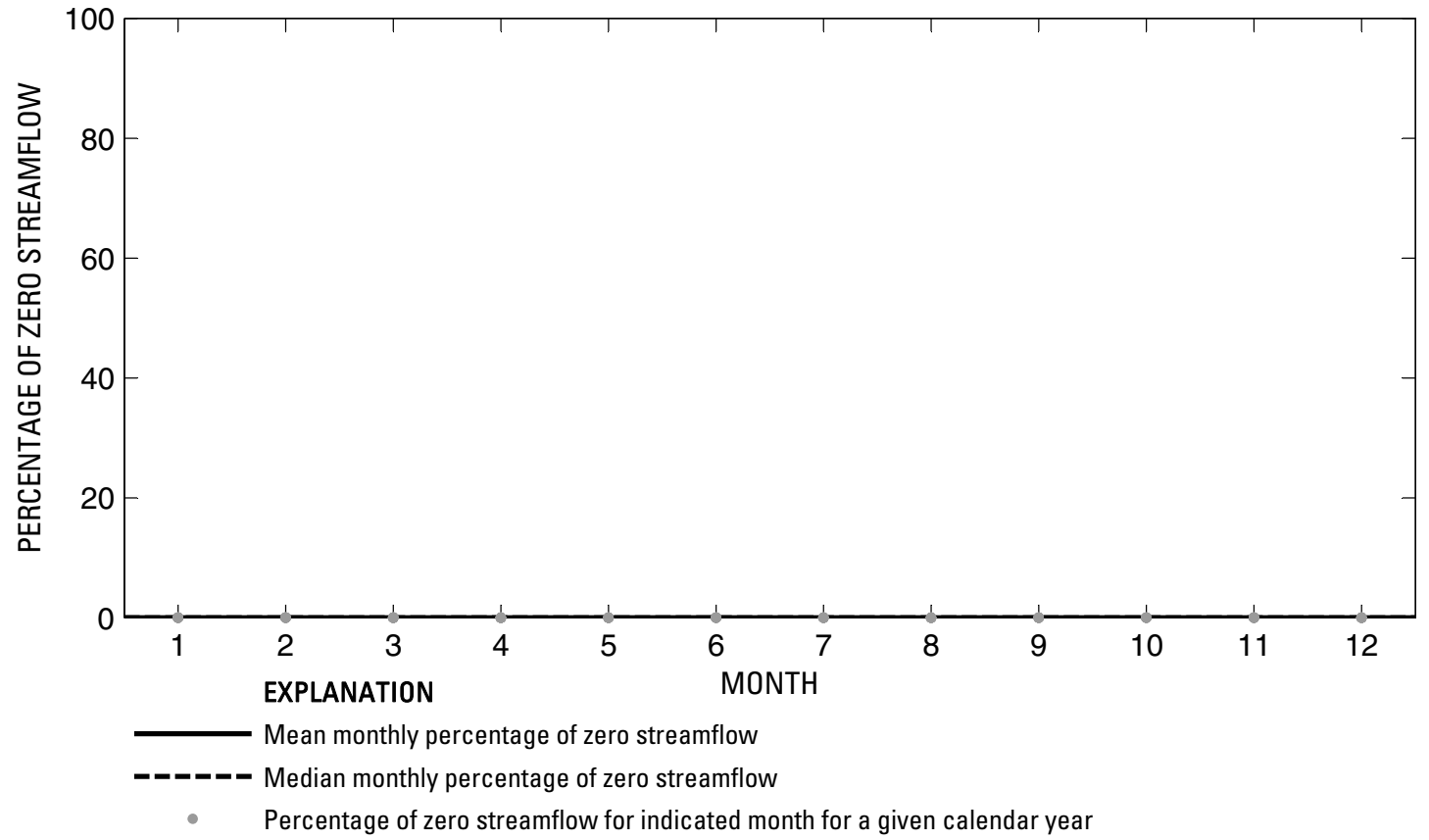

Figure 707. Analysis of percentage of zero daily mean streamflow for U.S. Geological Survey streamflow-gaging station 08438100 Pecos River near Grandfalls, Texas. 
U.S. Geological Survey streamflow-gaging station 08441500

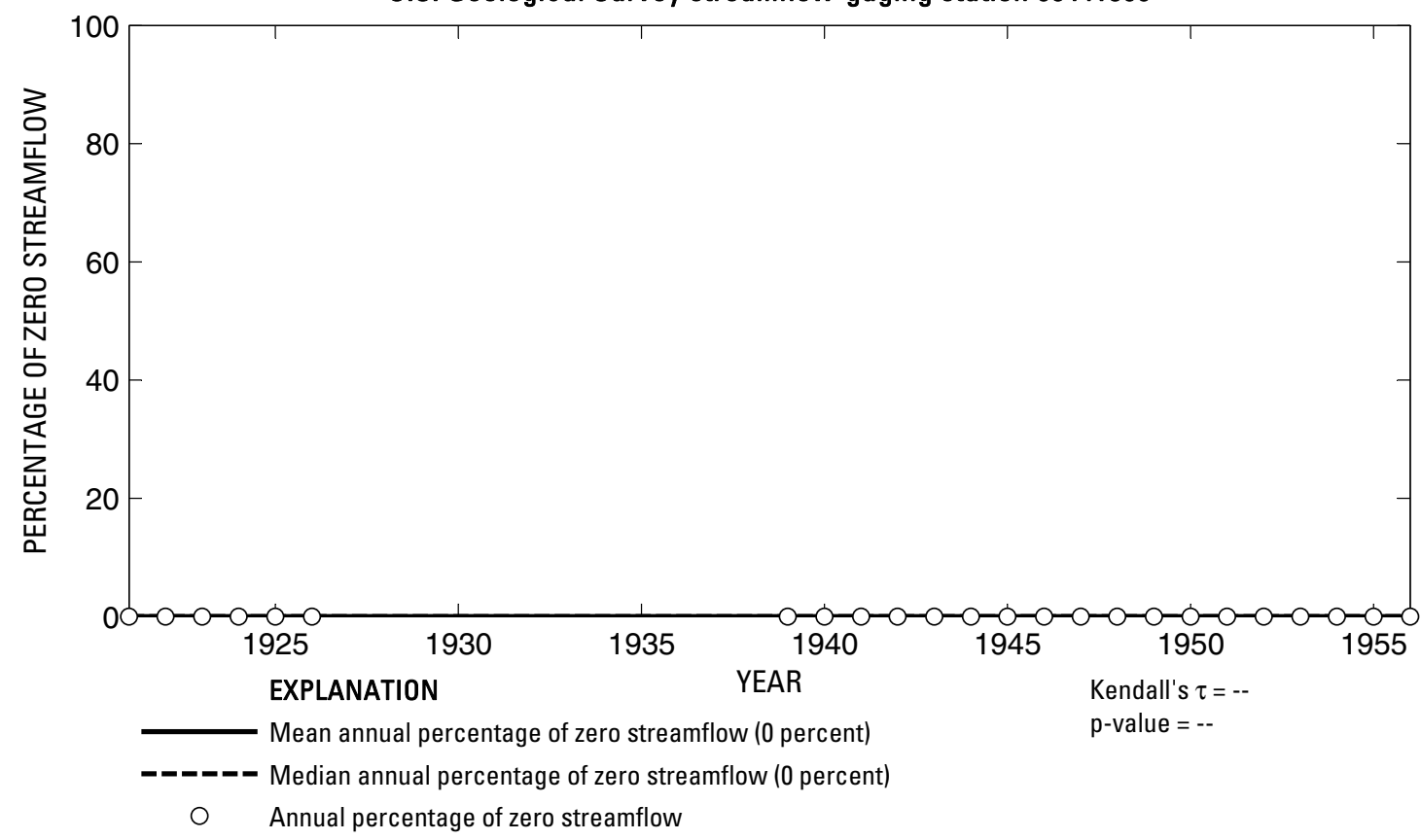

U.S. Geological Survey streamflow-gaging station 08441500

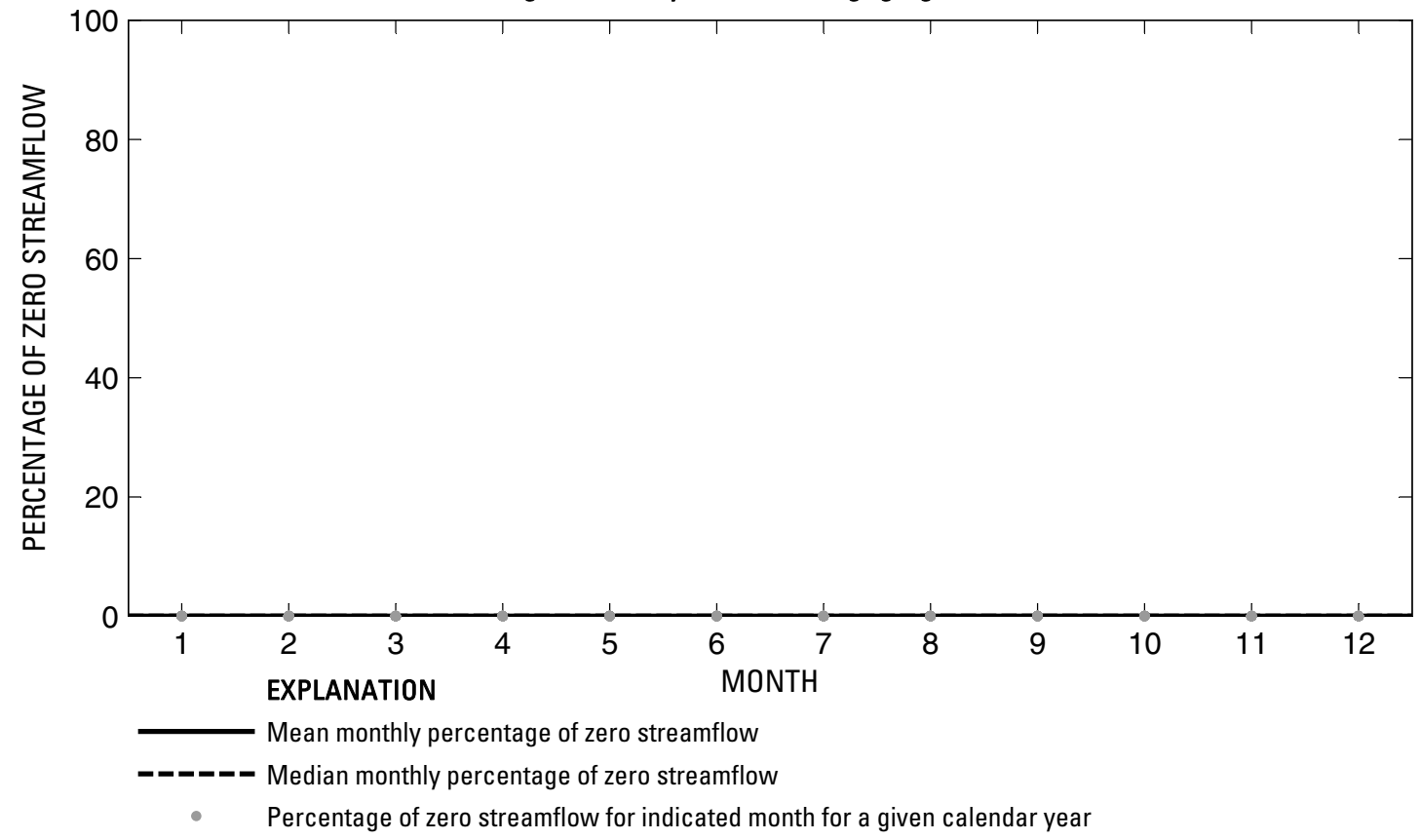

Figure 708. Analysis of percentage of zero daily mean streamflow for U.S. Geological Survey streamflow-gaging station 08441500 Pecos River below Grandfalls, Texas.

Index of Station Numbers 719 


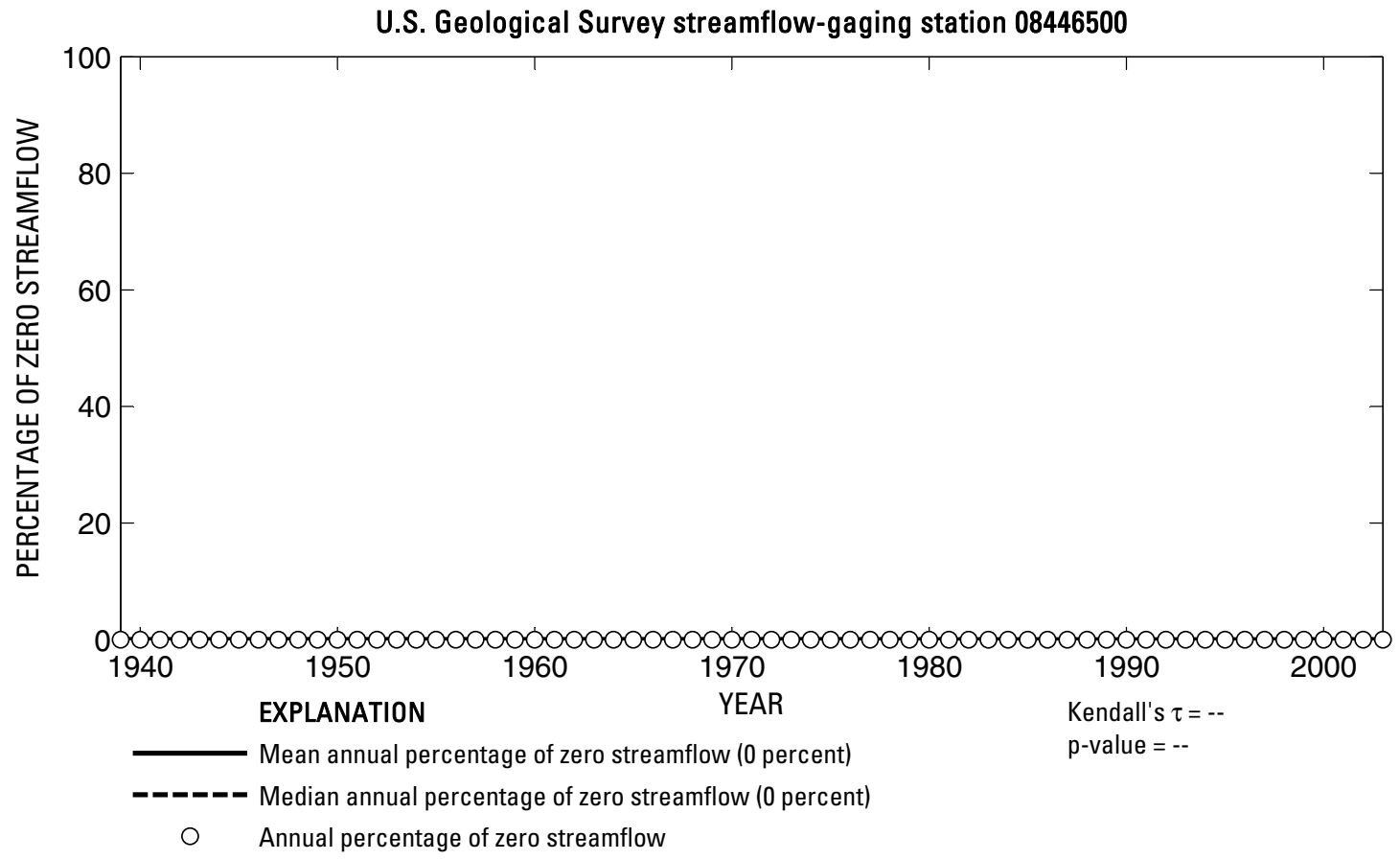

U.S. Geological Survey streamflow-gaging station 08446500

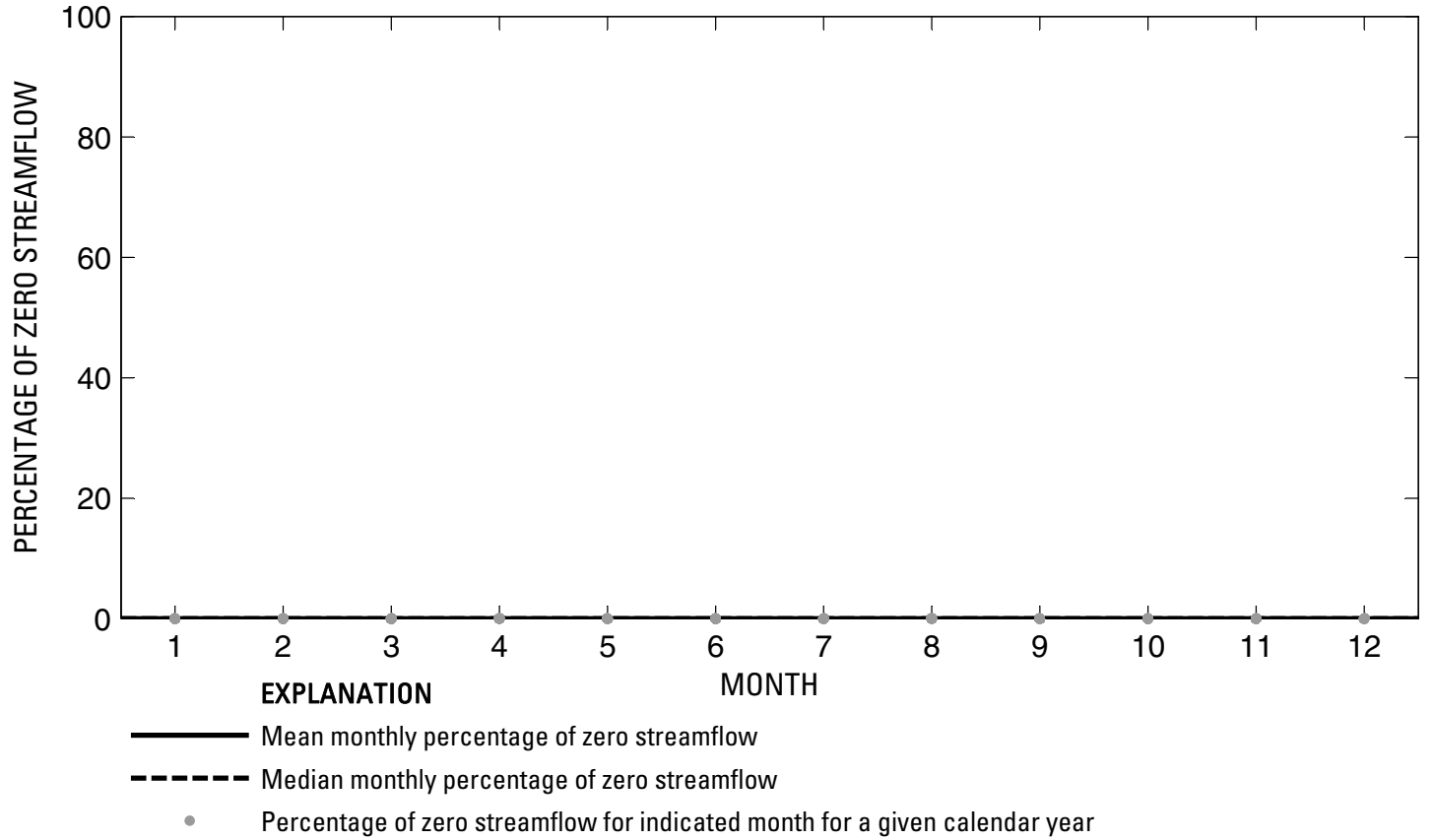

Figure 709. Analysis of percentage of zero daily mean streamflow for U.S. Geological Survey streamflow-gaging station 08446500 Pecos River near Girvin, Texas. 

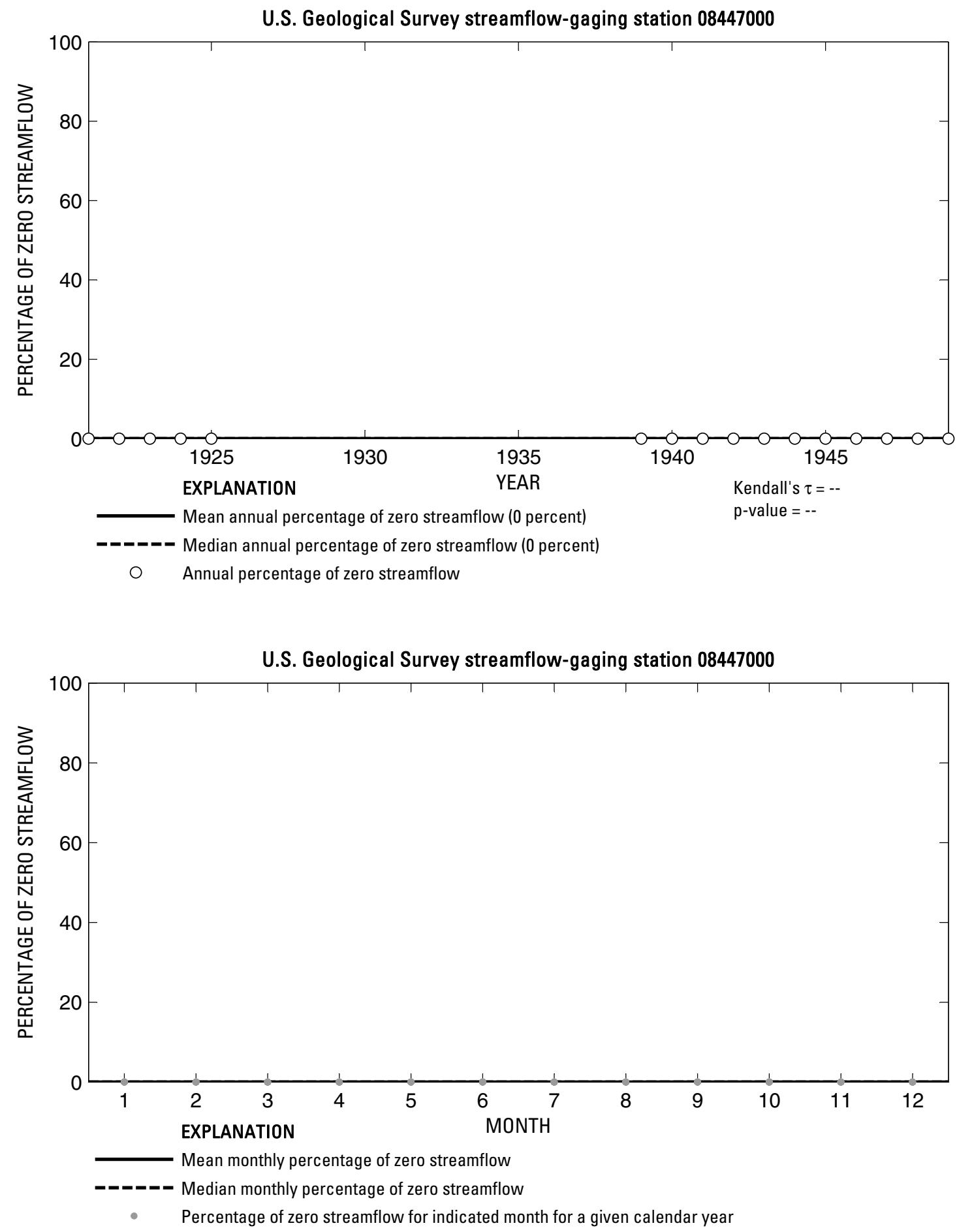

Figure 710. Analysis of percentage of zero daily mean streamflow for U.S. Geological Survey streamflow-gaging station 08447000 Pecos River near Sheffield, Texas. 
U.S. Geological Survey streamflow-gaging station 08447020

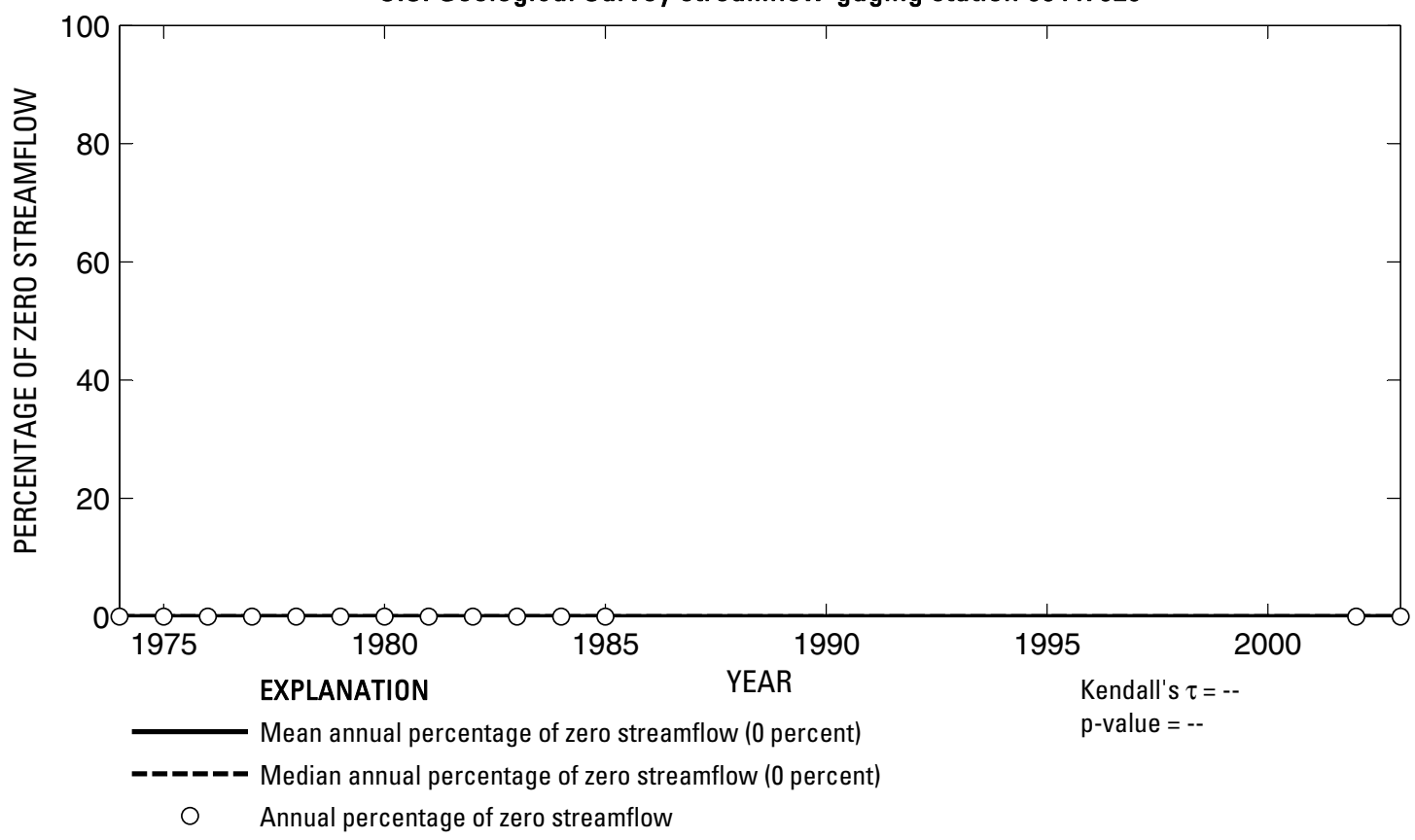

U.S. Geological Survey streamflow-gaging station 08447020

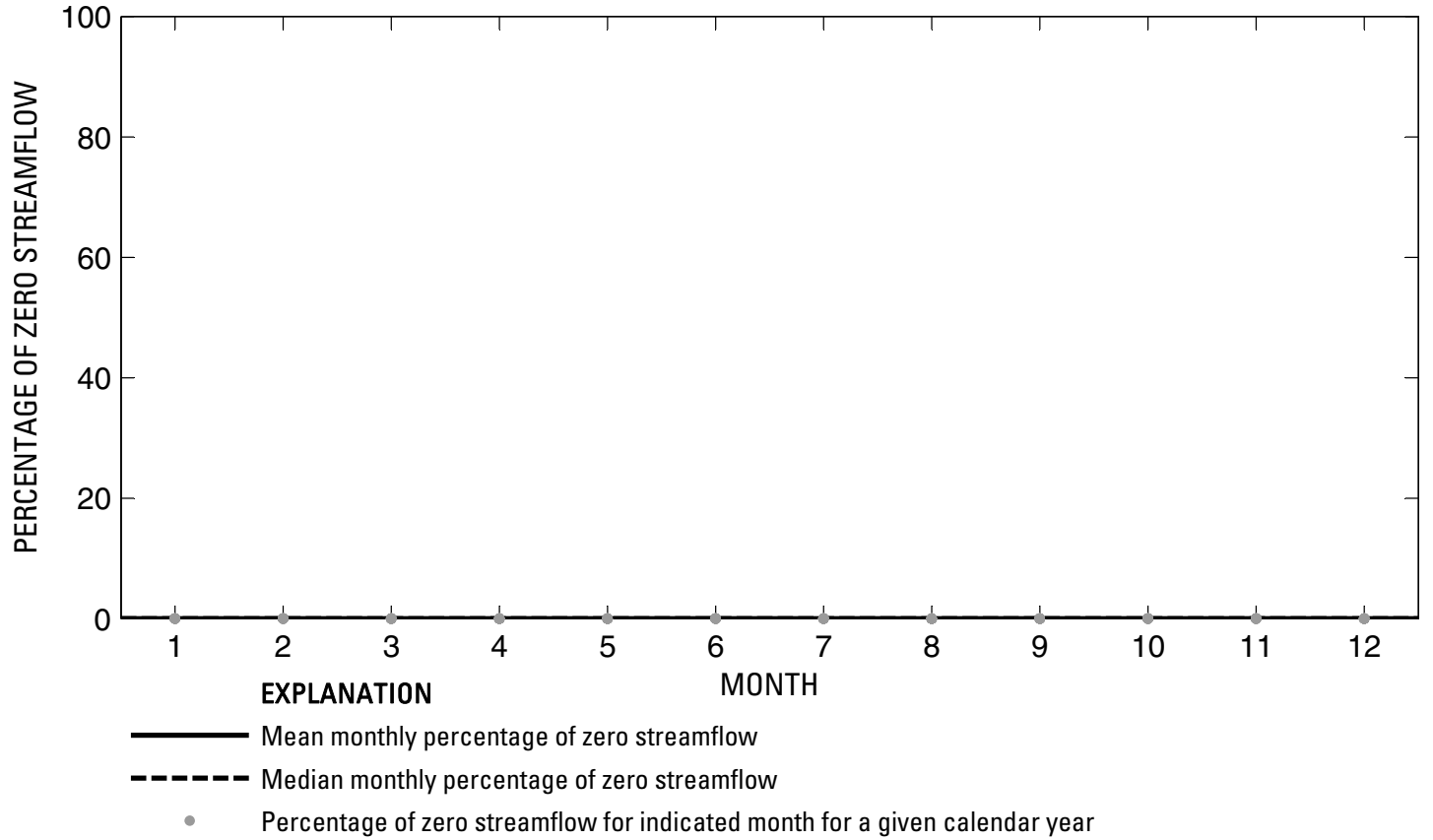

Figure 711. Analysis of percentage of zero daily mean streamflow for U.S. Geological Survey streamflow-gaging station 08447020 Independence Creek near Sheffield, Texas. 

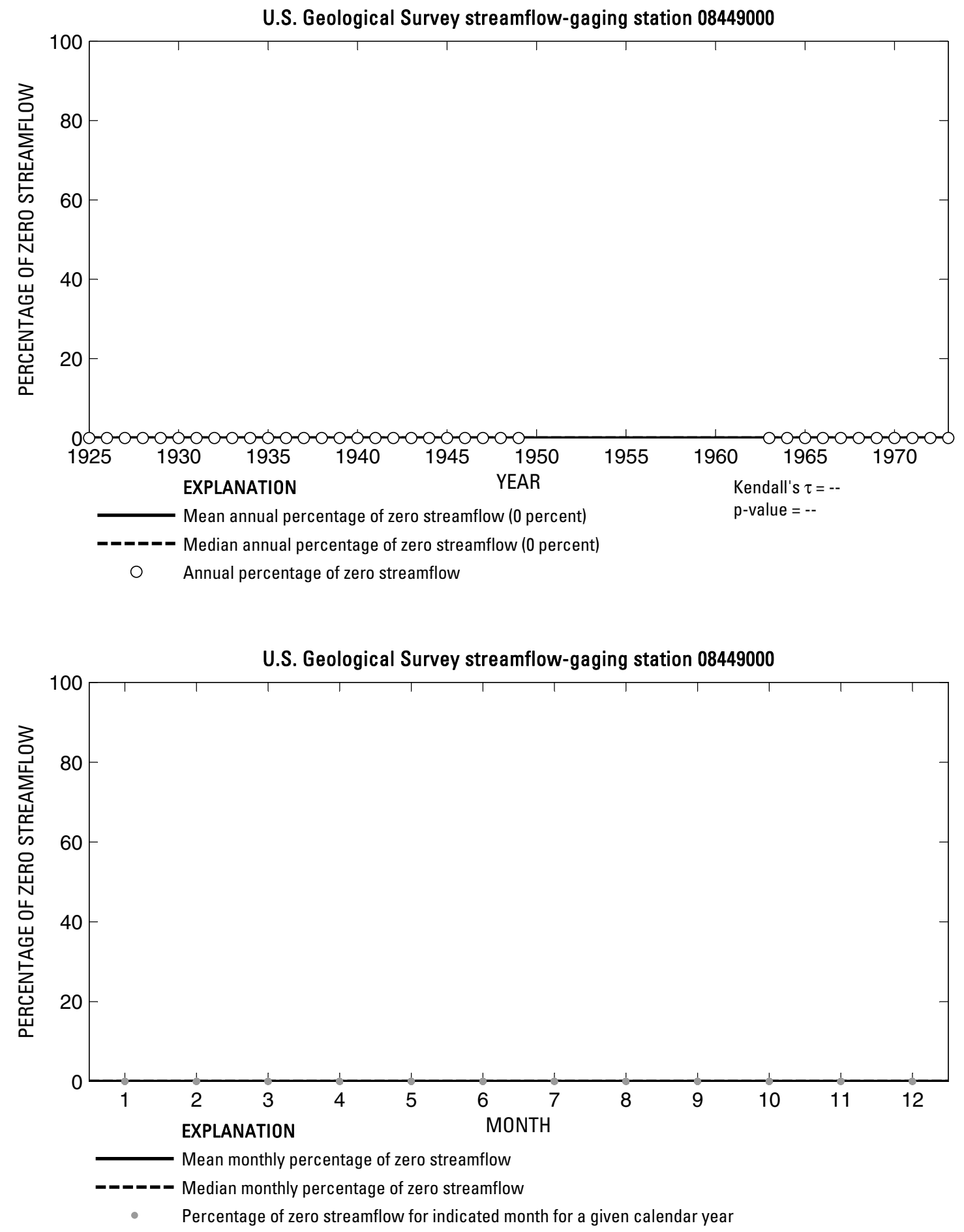

Figure 712. Analysis of percentage of zero daily mean streamflow for U.S. Geological Survey streamflow-gaging station 08449000 Devils River near Juno, Texas. 
U.S. Geological Survey streamflow-gaging station 08455000

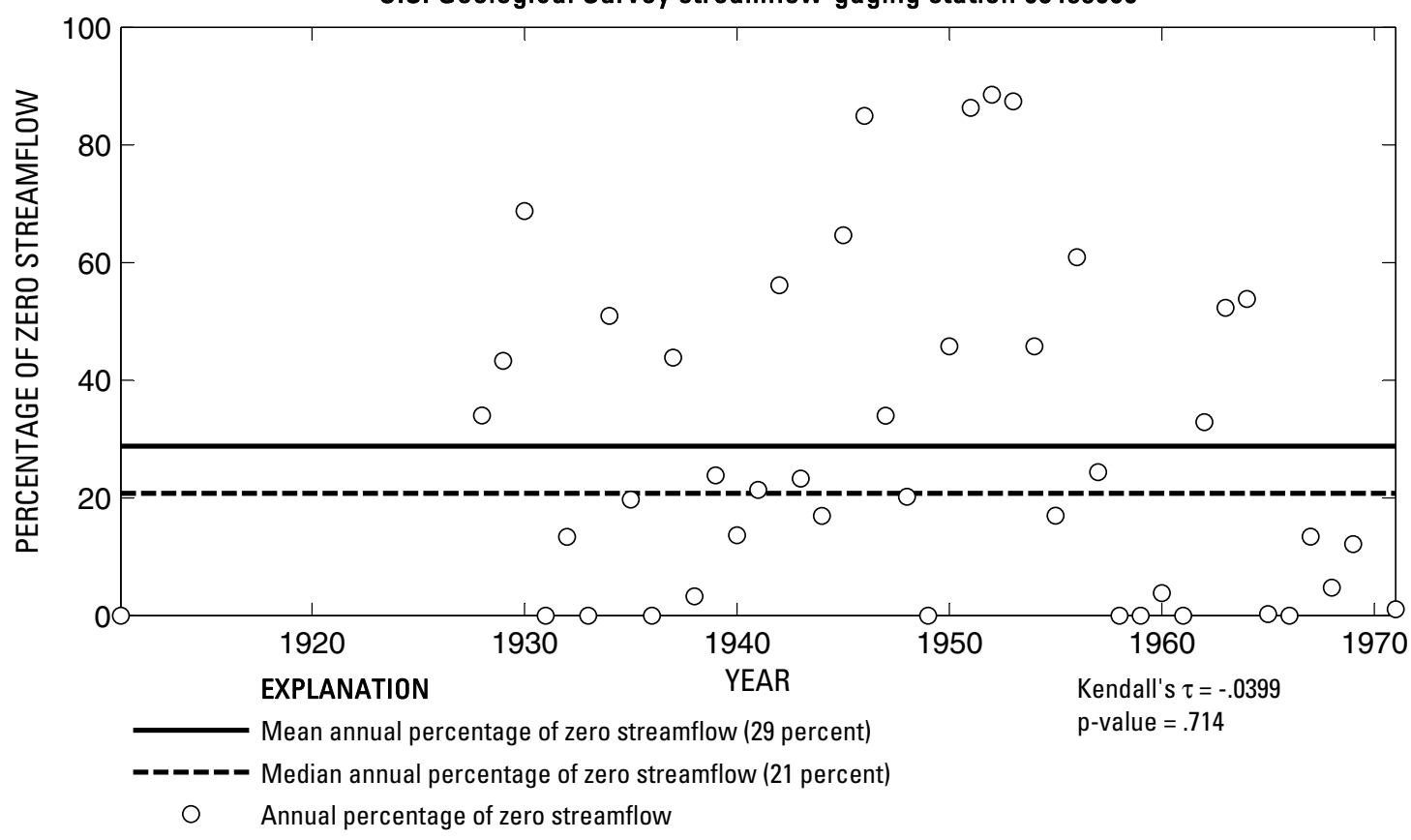

U.S. Geological Survey streamflow-gaging station 08455000

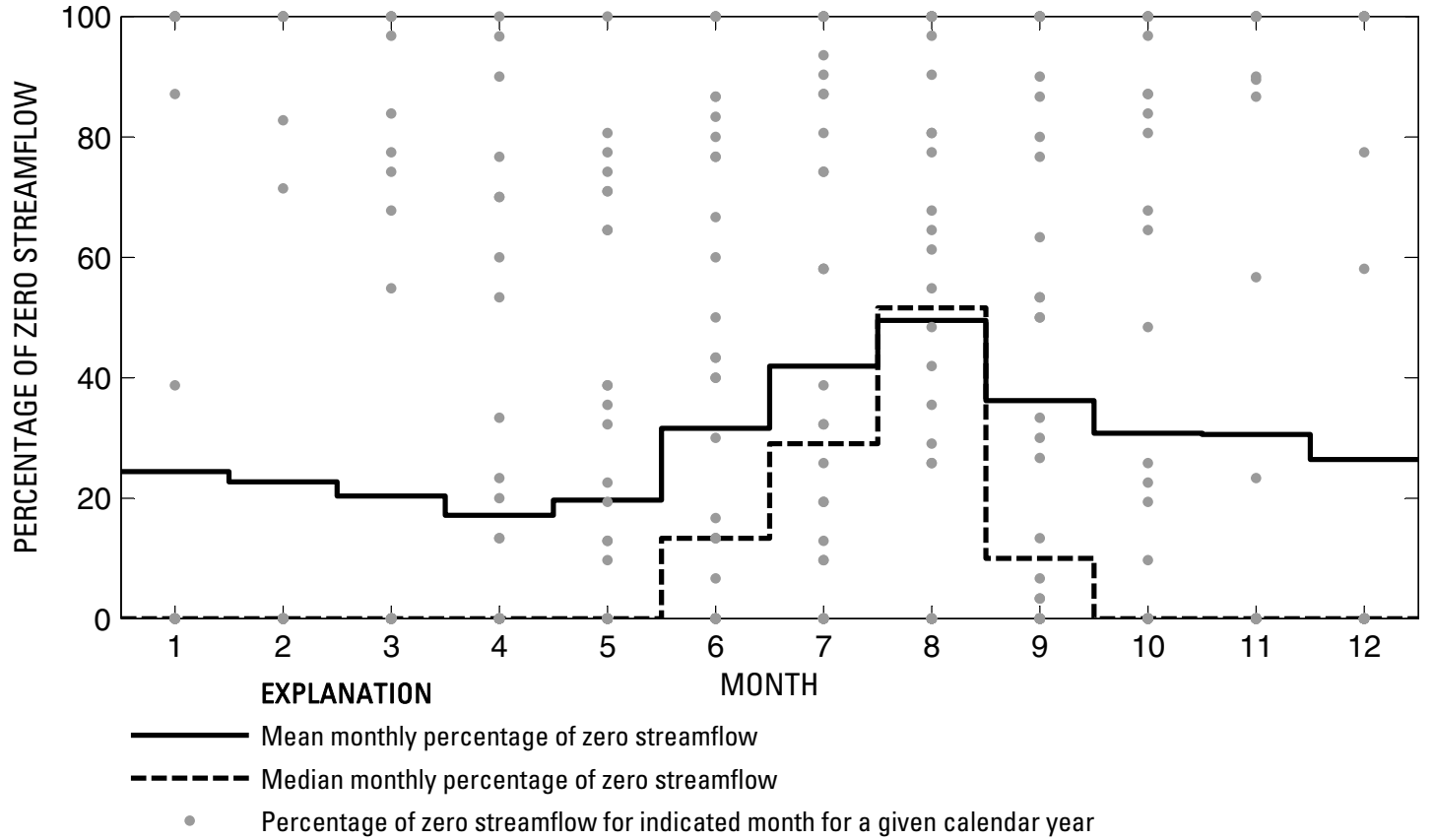

Figure 713. Analysis of percentage of zero daily mean streamflow for U.S. Geological Survey streamflow-gaging station 08455000 Pinto Creek near Del Rio, Texas. 


\section{Index of Station Numbers (hyperlinked)}

The page numbers of this index are hyperlinked to provide navigational convenience to the portable document format version of this report. A return link is provided at the bottom right of the linked page.

\begin{tabular}{|c|c|}
\hline 07227470 . & 07311782 \\
\hline 07227500 & 07311783 \\
\hline 07227920 & 07311790 \\
\hline 07228000 & 07311800 \\
\hline 07233500 & 07311900 \\
\hline 07235000 & 07312100 \\
\hline 07295500 & 07312130 \\
\hline 07296100 & 07312200 \\
\hline 07297500 & 07312500 \\
\hline 07297910 & 07312700 \\
\hline 07298000 & 07314500 \\
\hline 07298200 & 07314900 \\
\hline 07298500 & 07315200 \\
\hline 07299000 & 07315400 \\
\hline 07299200 & 07316200 \\
\hline 07299300 & 07332600 \\
\hline 07299500 & 07335400 \\
\hline 07299512 & 07336750 \\
\hline 07299514 & 07336800 \\
\hline 07299530 & 07336820 \\
\hline 07299540 & 07342465 \\
\hline 07299570 & 07342470 \\
\hline 07299670 & 07342480 \\
\hline 07299850 & 07342500 \\
\hline 07299890 & 07343000 \\
\hline 07300000 & 07343200 \\
\hline 07301200 & 07343300 \\
\hline 07301300 & 07343500 \\
\hline 07301410 & 07344000 \\
\hline 07307500 & 07344482 \\
\hline 07307600 & 07344486 \\
\hline 07307750 & 07344500 \\
\hline 07307760 & 07345000 \\
\hline 07307800 & 07346000 \\
\hline 07308000 & 07346045 \\
\hline 07308200 & 07346050 \\
\hline 07308500 & 07346070 \\
\hline 07311600 & 07346140 . \\
\hline 07311622 & 08017200 \\
\hline 07311630 & 08017300 \\
\hline 07311648 & 08017410 \\
\hline 07311700 & 08017500 \\
\hline 07311780 . & 08018500 \\
\hline
\end{tabular}

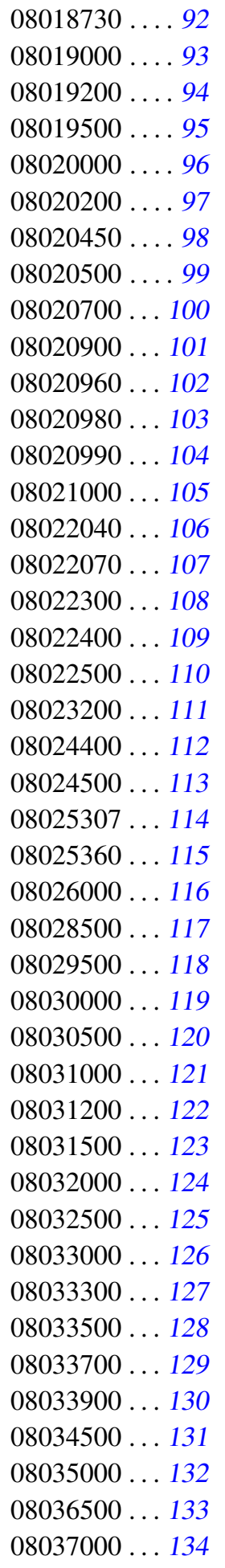

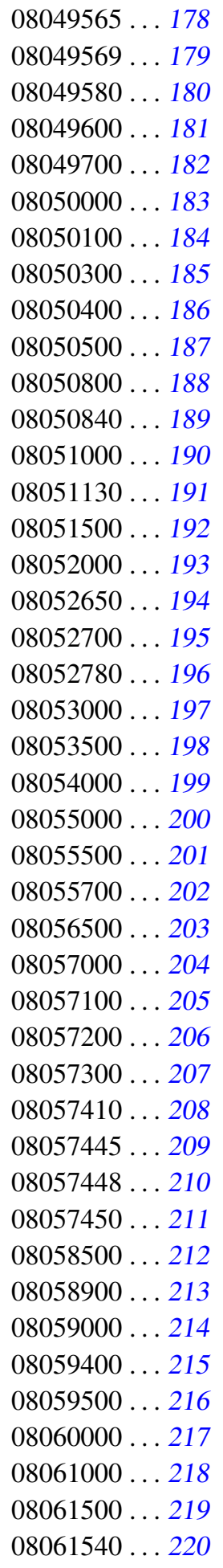




\begin{tabular}{|c|c|}
\hline $08061700 \ldots 221$ & $08068500 \ldots 270$ \\
\hline $08061750 \ldots 222$ & $08068520 \ldots 271$ \\
\hline $08061950 \ldots .223$ & $08068720 \ldots 2$ \\
\hline $08062000 \ldots 224$ & $08068740 \ldots 2$ \\
\hline $08062500 \ldots 225$ & $08068780 \ldots 274$ \\
\hline $08062650 \ldots 226$ & $08068800 \ldots$ \\
\hline $08062700 \ldots 227$ & 08068900 . \\
\hline $08062800 \ldots 228$ & $08069000 \ldots$ \\
\hline $08062900 \ldots 229$ & $08069500 \ldots 278$ \\
\hline $08062980 \ldots 230$ & $08070000 \ldots$ \\
\hline $08063000 \ldots 231$ & $08070200 \ldots[2$ \\
\hline $08063003 \ldots \overline{232}$ & $08070500 \ldots$ \\
\hline $08063020 \ldots 233$ & $08071000 \ldots$ \\
\hline $08063100 \ldots 234$ & $08071280 \ldots 283$ \\
\hline $08063200 \ldots 235$ & 08071500 . \\
\hline $08063500 \ldots \overline{236}$ & $08072300 \ldots$ \\
\hline $08063800 \ldots 237$ & 08072730 . \\
\hline $08064100 \ldots 238$ & $08072760 \ldots 287$ \\
\hline $08064500 \ldots 239$ & 08073500 . \\
\hline $08064700 \ldots . \overline{240}$ & 08073600. \\
\hline $08064800 \ldots 241$ & 08073700 . \\
\hline $08065000 \ldots 242$ & $08074000 \ldots 291$ \\
\hline $08065200 \ldots 243$ & 08074020 . \\
\hline $08065350 \ldots . \overline{244}$ & 08074150 . \\
\hline $08065500 \ldots 245$ & 08074250 . \\
\hline $08065700 \ldots 246$ & $08074500 \ldots$ \\
\hline $08065800 \ldots 247$ & 08074760 . \\
\hline $08066000 \ldots . \overline{248}$ & 08074780 . \\
\hline $08066100 \ldots 249$ & 08074800 . \\
\hline $08066170 \ldots 250$ & $08074810 \ldots 299$ \\
\hline $08066191 \ldots 251$ & $08075000 \ldots 300$ \\
\hline $08066200 \ldots 252$ & 08075400 . \\
\hline $08066250 \ldots 253$ & 08075500 . \\
\hline $08066300 \ldots 254$ & $08075650 \ldots 303$ \\
\hline $08066500 \ldots 255$ & 08075730 . \\
\hline $08067000 \ldots 256$ & 08075770 . \\
\hline $08067500 \ldots 257$ & 08075780 . \\
\hline $08067525 \ldots 258$ & 08075900 . \\
\hline $08067610 \ldots 259$ & 08076000 . \\
\hline $08067650 \ldots 260$ & 08076180 . \\
\hline $08067700 \ldots 261$ & 08076500 . \\
\hline $08067900 \ldots 262$ & $08076700 \ldots 311$ \\
\hline $08068000 \ldots 263$ & 08077000 . \\
\hline $08068090 \ldots 264$ & $08077540 \ldots 313$ \\
\hline $08068275 \ldots .265$ & 08078000 . \\
\hline $08068325 \ldots 266$ & $08079000 \ldots$ \\
\hline $08068390 \ldots 267$ & $08079500 \ldots$ \\
\hline $08068400 \ldots 268$ & $08079575 \ldots$ \\
\hline 08068450 . & 08079600 \\
\hline
\end{tabular}

$08080000 \ldots 319$

$08080500 \ldots 320$

$08080540 \ldots 321$

$08080700 \ldots 322$

$08080950 \ldots 323$

$08081000 \ldots 324$

$08081200 \ldots 325$

$08081500 \ldots 326$

$08082000 \ldots 327$

$08082100 \ldots 328$

$08082180 \ldots 329$

$08082500 \ldots 330$

$08082700 \ldots 331$

$08083000 \ldots 332$

$08083100 \ldots 333$

$08083230 \ldots 334$

$08083240 \ldots 335$

$08083245 \ldots 336$

$08083300 \ldots 337$

$08083400 \ldots 338$

$08083420 \ldots 339$

$08083430 \ldots 340$

$08083470 \ldots 341$

$08083480 \ldots 342$

$08084000 \ldots 343$

$08084800 \ldots 344$

$08085000 \ldots 345$

$08085500 \ldots 346$

$08086000 \ldots 347$

$08086015 \ldots 348$

$08086050 \ldots 349$

$08086100 \ldots 350$

$08086120 \ldots 351$

$08086150 \ldots 352$

$08086200 \ldots 353$

$08086210 \ldots 354$

$08086212 \ldots 355$

$08086235 \ldots 356$

$08086260 \ldots 357$

$08086290 \ldots 358$

$08086500 \ldots 359$

$08087300 \ldots 360$

$08088000 \ldots 361$

$08088100 \ldots 362$

$08088200 \ldots 363$

$08088300 \ldots 364$

$08088450 \ldots 365$

$08088600 \ldots 366$

$08088610 \ldots 367$
$08089000 \ldots 368$

$08090500 \ldots 369$

$08090800 \ldots 370$

$08091000 \ldots 371$

$08091500 \ldots 372$

$08091750 \ldots 373$

$08092000 \ldots 374$

$08092600 \ldots 375$

$08093100 \ldots 376$

$08093250 \ldots 377$

$08093360 \ldots 378$

$08093400 \ldots 379$

$08093500 \ldots 380$

$08093700 \ldots 381$

$08094800 \ldots 382$

$08095000 \ldots 383$

$08095200 \ldots 384$

$08095300 \ldots 385$

$08095400 \ldots 386$

$08095500 \ldots 387$

$08095600 \ldots 388$

$08096500 \ldots 389$

$08097500 \ldots 390$

$08098000 \ldots 391$

$08098290 \ldots 392$

$08098300 \ldots 393$

$08099100 \ldots 394$

$08099300 \ldots 395$

$08099500 \ldots 396$

$08100000 \ldots 397$

$08100500 \ldots 398$

$08101000 \ldots 399$

$08101500 \ldots 400$

$08102500 \ldots 401$

$08102600 \ldots 402$

$08103800 \ldots 403$

$08103900 \ldots 404$

$08104000 \ldots 405$

$08104100 \ldots 406$

$08104310 \ldots 407$

$08104500 \ldots 408$

$08104700 \ldots 409$

$08104900 \ldots 410$

$08105000 \ldots 411$

$08105095 \ldots 412$

$08105100 \ldots 413$

$08105200 \ldots 414$

$08105300 \ldots 415$

$08105400 \ldots 416$
$08105700 \ldots 417$

$08106300 \ldots 418$

$08106310 \ldots 419$

$08106350 \ldots 420$

$08106500 \ldots 421$

$08107000 \ldots 422$

$08107500 \ldots 423$

$08108000 \ldots 424$

$08108200 \ldots 425$

$08108700 \ldots 426$

$08109000 \ldots 427$

$08109700 \ldots 428$

$08109800 \ldots 429$

$08110000 \ldots 430$

$08110100 \ldots 431$

$08110200 \ldots 432$

$08110325 \ldots 433$

$08110400 \ldots 434$

$08110430 \ldots 435$

$08110500 \ldots 436$

$08110800 \ldots 437$

$08111000 \ldots 438$

$08111010 \ldots 439$

$08111025 \ldots 440$

$08111050 \ldots 441$

$08111500 \ldots 442$

$08111700 \ldots 443$

$08114000 \ldots 444$

$08114500 \ldots 445$

$08115000 \ldots 446$

$08115500 \ldots 447$

$08116000 \ldots 448$

$08116400 \ldots 449$

$08116500 \ldots 450$

$08116650 \ldots 451$

$08117500 \ldots 452$

$08117900 \ldots 453$

$08117995 \ldots 454$

$08118500 \ldots 455$

$08119000 \ldots 456$

$08119500 \ldots 457$

$08120500 \ldots 458$

$08120700 \ldots 459$

$08121000 \ldots 460$

$08121500 \ldots 461$

$08122000 \ldots 462$

$08122500 \ldots 463$

$08123500 \ldots 464$

$08123650 \ldots 465$ 


\begin{tabular}{|c|c|c|c|}
\hline $08123700 \ldots 466$ & $08153000 \ldots 517$ & $08164800 \ldots 568$ & $08180800 \ldots 619$ \\
\hline $08123720 \ldots 467$ & $08153500 \ldots 5$ & $08165300 \ldots 569$ & $08181400 \ldots 620$ \\
\hline $08123800 \ldots 468$ & $08154000 \ldots 519$ & $08165500 \ldots 570$ & 08181410 . \\
\hline $08123850 \ldots .469$ & $08154510 \ldots \overline{520}$ & $08166000 \ldots 571$ & $08181450 \ldots .62$ \\
\hline $08123900 \ldots \overline{470}$ & $08154700 \ldots 521$ & $08166140 \ldots 572$ & $08181480 \ldots .623$ \\
\hline $08124000 \ldots .471$ & $08155200 \ldots . \overline{522}$ & $08166200 \ldots 573$ & $08181500 \ldots$ \\
\hline $08126380 \ldots 472$ & $08155240 \ldots 523$ & $08166500 \ldots 574$ & 08181800 . \\
\hline $08126500 \ldots 473$ & $08155260 \ldots 524$ & $08167000 \ldots 575$ & 08182500 . \\
\hline $08127000 \ldots 474$ & $08155300 \ldots 525$ & $08167500 \ldots 576$ & $08183000 \ldots$ \\
\hline $08128000 \ldots \overline{475}$ & $08155400 \ldots \overline{526}$ & $08167600 \ldots \overline{577}$ & 08183500 . \\
\hline $08128400 \ldots 476$ & $08156700 \ldots 527$ & $08167800 \ldots 578$ & 08183850 . \\
\hline $08128500 \ldots 477$ & $08156800 \ldots 528$ & $08168500 \ldots 579$ & $08183900 \ldots$ \\
\hline $08129300 \ldots \overline{478}$ & $08157000 \ldots 55$ & $08169000 \ldots 5 \overline{580}$ & $08184000 \ldots$ \\
\hline $08130500 \ldots \overline{479}$ & $08157500 \ldots \overline{530}$ & $08169500 \ldots . \overline{581}$ & 08184500 . \\
\hline $08130700 \ldots 480$ & $08157600 \ldots 531$ & $08170500 \ldots 582$ & $08185000 \ldots$ \\
\hline $08131000 \ldots 481$ & $08157700 \ldots 532$ & $08171000 \ldots 583$ & $08185500 \ldots 6$ \\
\hline $08131400 \ldots$. & $08158000 \ldots 533$ & $08171300 \ldots 584$ & $08186000 \ldots$ \\
\hline $08132500 \ldots \overline{483}$ & $08158050 \ldots 5$ & $08172000 \ldots \overline{585}$ & 08186500 . \\
\hline $08133250 \ldots 484$ & $08158600 \ldots 535$ & $08172400 \ldots 586$ & 08187500 . \\
\hline $08133500 \ldots .485$ & $08158700 \ldots \overline{536}$ & $08172500 \ldots \overline{587}$ & $08188500 \ldots$ \\
\hline $08133900 \ldots . \overline{486}$ & $08158800 \ldots 537$ & $08173000 \ldots 588$ & 08189200 . \\
\hline $08134000 \ldots \overline{487}$ & $08158810 \ldots \overline{538}$ & $08173500 \ldots 5 \overline{589}$ & 08189300 . \\
\hline $08134230 \ldots 488$ & $08158840 \ldots 539$ & $08173900 \ldots 590$ & 08189500 . \\
\hline $08134250 \ldots .489$ & $08158920 \ldots \overline{540}$ & $08174600 \ldots 591$ & $08189700 \ldots$ \\
\hline $08135000 \ldots \overline{490}$ & $08158922 \ldots 541$ & $08175000 \ldots 592$ & 08189800 . \\
\hline $08136000 \ldots 491$ & $08158930 \ldots 5$ & $08175800 \ldots 593$ & 08190000 . \\
\hline $08136500 \ldots 492$ & $08158970 \ldots 543$ & $08176000 \ldots 594$ & 08190500 . \\
\hline $08136700 \ldots .4993$ & $08159000 \ldots 5$ & $08176500 \ldots 5$ & $08191500 \ldots$ \\
\hline $08138000 \ldots$. & $08159150 \ldots 5$ & $08176550 \ldots 596$ & 08192000 . \\
\hline $08139500 \ldots .4995$ & $08159165 \ldots 5$ & $08176900 \ldots 597$ & 08192500 . \\
\hline $08140500 \ldots 496$ & $08159170 \ldots 547$ & $08176990 \ldots 598$ & 08193000 . \\
\hline $08140700 \ldots . \overline{497}$ & $08159200 \ldots \overline{548}$ & $08177000 \ldots 559$ & $08194000 \ldots$ \\
\hline $08140800 \ldots \overline{498}$ & $08159500 \ldots 5$ & $08177300 \ldots 600$ & 08194200 . \\
\hline $08141500 \ldots . \overline{499}$ & $08160400 \ldots 550$ & $08177500 \ldots 601$ & 08194500 . \\
\hline $08142000 \ldots 500$ & $08160500 \ldots 551$ & $08177700 \ldots 602$ & 08194600 . \\
\hline $08143500 \ldots 501$ & $08160700 \ldots 55$ & $08177860 \ldots 603$ & $08195000 \ldots$ \\
\hline $08143600 \ldots 502$ & $08160800 \ldots 553$ & $08178000 \ldots 604$ & 08196000 . \\
\hline $08144500 \ldots 503$ & $08161000 \ldots 5$ & $08178050 \ldots 605$ & 08196500 . \\
\hline $08144600 \ldots 504$ & $08162000 \ldots 555$ & $08178500 \ldots 606$ & 08197500 . \\
\hline $08144800 \ldots \overline{505}$ & $08162500 \ldots \overline{556}$ & $08178565 \ldots \overline{607}$ & 08198000 . \\
\hline $08145000 \ldots \overline{506}$ & $08162600 \ldots 557$ & $08178585 \ldots 608$ & 08198500 . \\
\hline $08146000 \ldots .5$ & $08164000 \ldots 5$ & $08178700 \ldots 609$ & 08199700 . \\
\hline $08147000 \ldots 508$ & $08164300 \ldots 559$ & $08178800 \ldots 610$ & 08200000 . \\
\hline $08148500 \ldots \overline{509}$ & $08164350 \ldots 5 \overline{560}$ & $08178880 \ldots .611$ & 08200500 . \\
\hline $08150000 \ldots \overline{510}$ & $08164370 \ldots 561$ & $08179000 \ldots 612$ & 08200700 . \\
\hline $08150700 \ldots \overline{511}$ & $08164390 \ldots . \overline{562}$ & $08179100 \ldots .6$ & $08201500 \ldots$ \\
\hline $08150800 \ldots 512$ & $08164450 \ldots 563$ & $08179520 \ldots 614$ & $08202000 \ldots$ \\
\hline $08151000 \ldots \overline{513}$ & $08164500 \ldots 564$ & $08180500 \ldots . \overline{615}$ & $08202500 \ldots$ \\
\hline $08151500 \ldots \overline{514}$ & $08164503 \ldots 565$ & $08180640 \ldots 616$ & $08202700 \ldots$ \\
\hline $08152000 \ldots .515$ & $08164504 \ldots 5$ & $08180700 \ldots .617$ & $08204005 \ldots$ \\
\hline $08152900 \ldots 516$ & $08164600 \ldots 567$ & $08180750 \ldots 618$ & 08204500 . \\
\hline
\end{tabular}

\begin{tabular}{|c|c|}
\hline $205500 \ldots 670$ & \\
\hline $08206600 \ldots 671$ & 71 \\
\hline $08206700 \ldots 672$ & 72 \\
\hline $08206910 \ldots 673$ & 73 \\
\hline 08207000 . & 74 \\
\hline 08207500 . & 75 \\
\hline 08208000 . & 7 \\
\hline $08210000 \ldots 677$ & 77 \\
\hline $08210300 \ldots 678$ & 78 \\
\hline 08210400 . & 79 \\
\hline 08211000 . & 80] \\
\hline $08211200 \ldots 681$ & 81 \\
\hline 08211500 . & 87 \\
\hline 08211520 . & \\
\hline 08211800 . & \\
\hline $08211900 \ldots 685$ & \\
\hline 08212000 . & \\
\hline 08212400 . & \\
\hline 08365600 . & \\
\hline $08365800 \ldots$ & \\
\hline 08373200 . & \\
\hline 08376300 . & \\
\hline $08411500 \ldots$ & \\
\hline $08412500 \ldots$ & \\
\hline 08414000 . & \\
\hline 08416500 . & \\
\hline 08420500 . & \\
\hline 08424500 . & \\
\hline 08431000 . & \\
\hline 08431500 . & \\
\hline $08431700 \ldots 700$ & \\
\hline $08431800 \ldots 701$ & \\
\hline 08432000 . & \\
\hline 08433000 . & \\
\hline $08434000 \ldots 704$ & \\
\hline $08435500 \ldots$ & \\
\hline 08435600 . & \\
\hline 08435620 . & \\
\hline $08435660 \ldots 708$ & \\
\hline 08435700 . & \\
\hline 08435800 . & \\
\hline 08438100 . & \\
\hline 08441500 . & \\
\hline 08446500 . & \\
\hline 08447000 . & \\
\hline 08447020 . & \\
\hline [ & \\
\hline
\end{tabular}

$08205500 \ldots 670$

$08206600 \ldots 671$

$08206700 \ldots 672$

$08206910 \ldots 673$

$08207000 \ldots 674$

$08207500 \ldots 675$

$08208000 \ldots 676$

$08210000 \ldots 677$

$08210300 \ldots 678$

$08211000 \ldots 680$

$08211200 \ldots 681$

$08211500 \ldots 682$

$08211520 \ldots 683$

$08211800 \ldots 684$

$08211900 \ldots 685$

$08212000 \ldots 686$

$08212400 \ldots 687$

$08365600 \ldots 688$

$08365800 \ldots 689$

$08373200 \ldots 690$

..691

$08412500 \ldots 693$

$08414000 \ldots 694$

$08416500 \ldots 695$

$08420500 \ldots 696$

$08424500 \ldots 697$

$08431000 \ldots 698$

$08431500 \ldots 699$

$08431700 \ldots 700$

$08431800 \ldots 701$

$08432000 \ldots 702$

$08434000 \ldots 704$

$08435500 \ldots 705$

$08435600 \ldots 706$

$08435620 \ldots 707$

$08435660 \ldots 708$

$08435700 \ldots 709$

$08435800 \ldots 710$

$08438100 \ldots 711$

$08441500 \ldots 712$

$08446500 \ldots 713$

.71

$08455000 \ldots 717$ 

Prepared by William H. Asquith and the USGS Publishing Service Center 9 Edited by Gail J. Sladek

Illustrations by Laura S. Coplin (fig.11 and Joseph Vrabel (the rest)

Layout and typesetting by William $\mathrm{H}$. Asquith using $\mathrm{LTT}_{\mathrm{E}} \mathrm{X}$

Final portable document format preparation by Gloria J. Smith

For information regarding this report or water resources in Texas, contact:

U.S. Geological Survey

8027 Exchange Drive

Austin, Texas 78754-4733

(512) $927-3500$

http://tx.usgs.gov 


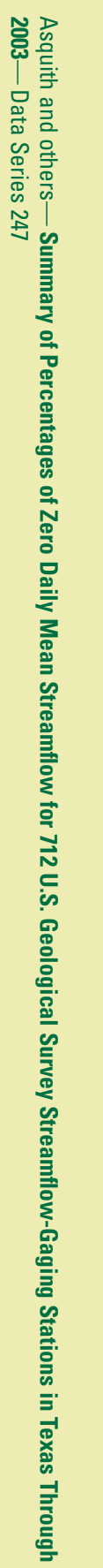

